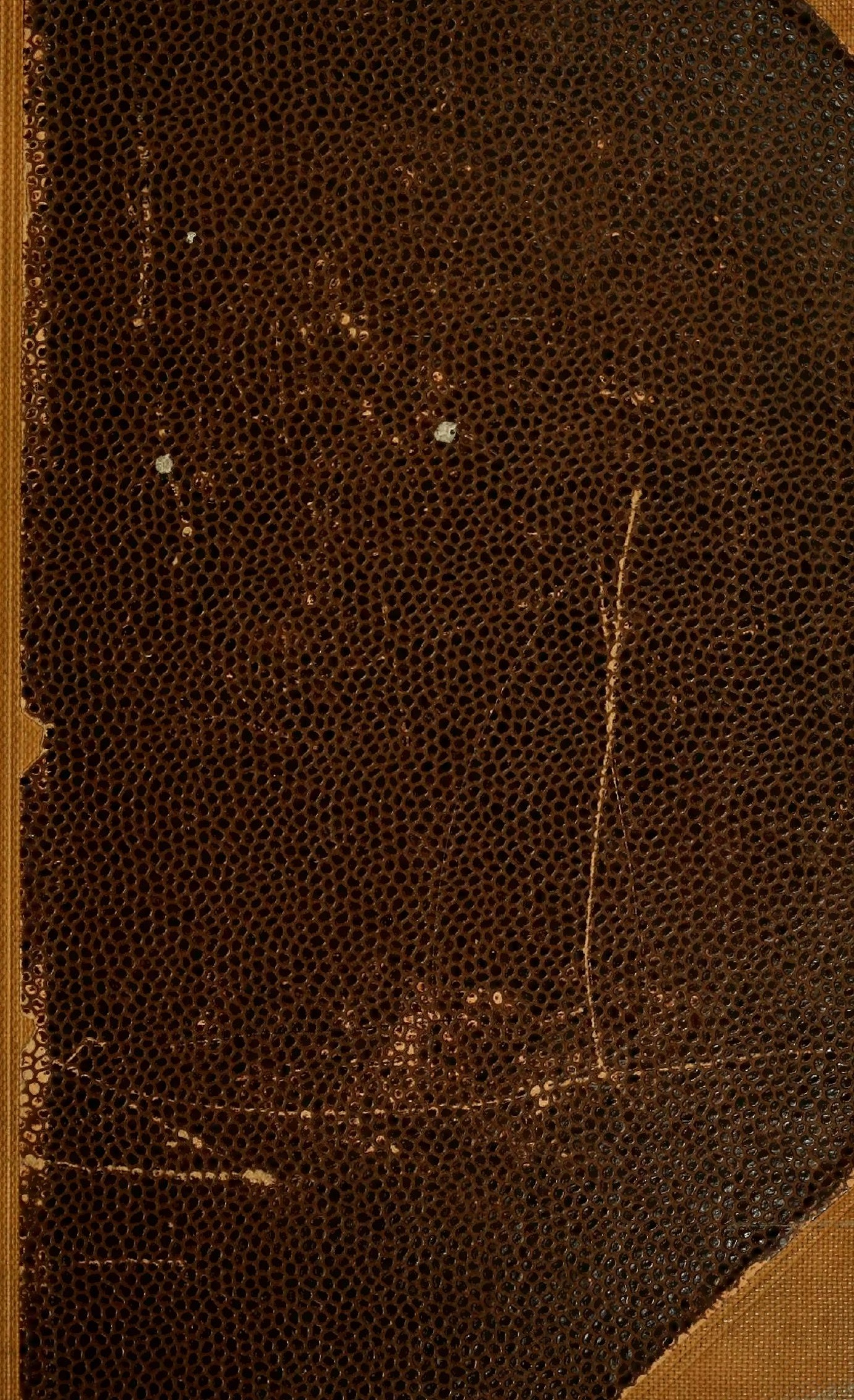


PURCHASED BY THE

Maky STUART Book Fund

ESTABLISHED 1893

The Cooper Union Library 




DIE LITURGISCHE GEWANDUNG. 



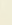




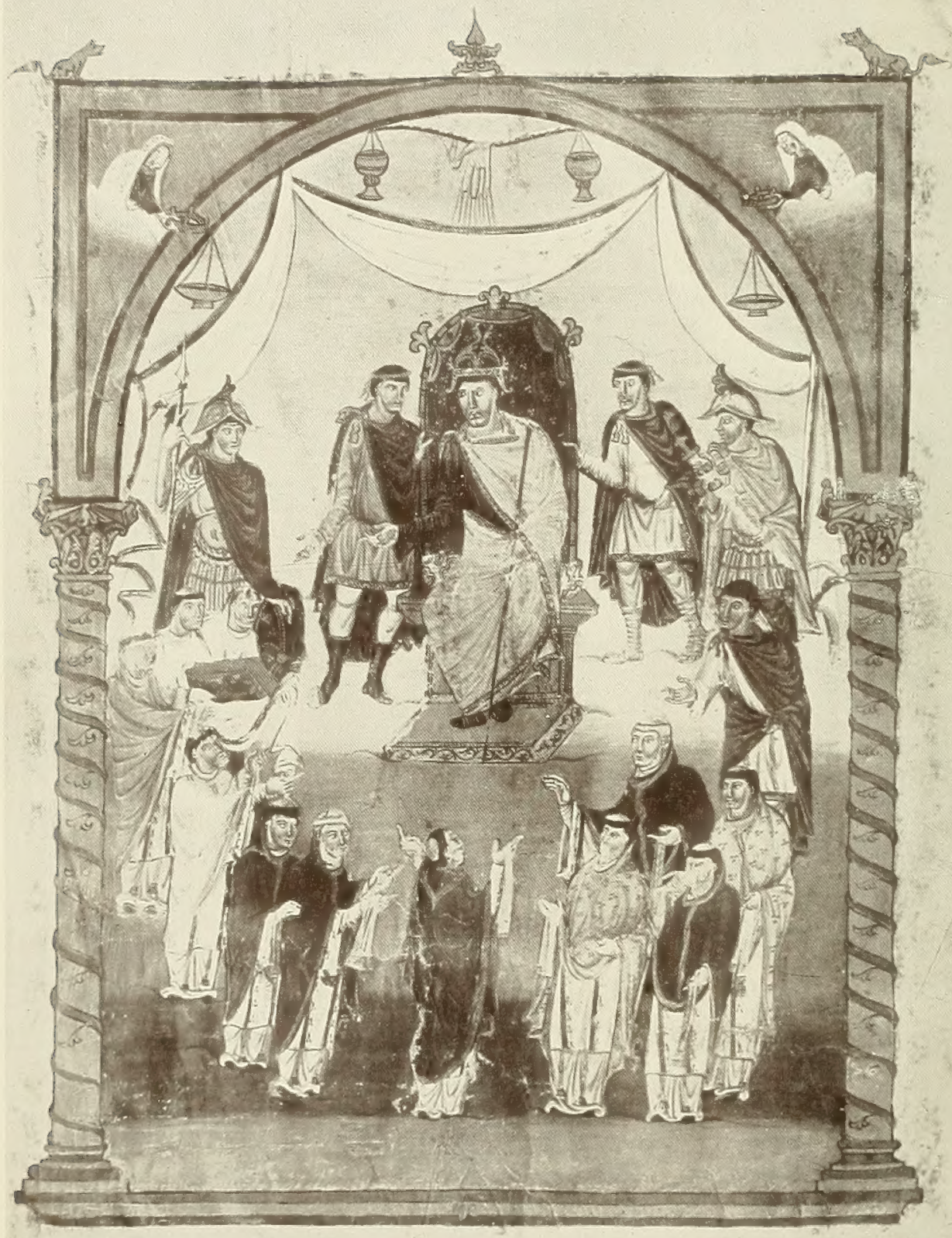

Widmungsbild der Viviansbibel:

Abt Vivian und die Mönche von St Martin zu Tours überreichen die Bibel Karl dem Kahlen. Paris, Bibl. Nat. (ms. lat. 1, f. 423). 


\section{IE LITURGISCHE GEWANDUNG}

\section{IM OCCIDENT UND ORIENT}

NACH URSPRUNG UND ENTWICKLUNG, VERWENDUNG UND SYMBOLIK.

VON

JOSEPH BRAUN S. J.

MIT 316 ABBILDUNGEN.

FREIBURG IM BREISGAU.

HERDERSCHE VERLAGSHANDLUNG.

1907.

BERLIN, KARLSRUHE, MÜNCHEN, STRASSBURG, WIEN UND ST LOUIS, MO. 


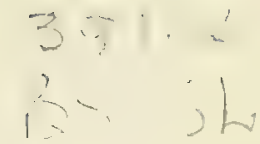

Cum opus, cui titulus est: Die liturgisehe Gewandung in der Gegenwart und Vergangenheit, a P. Josepho Braun, sacerdote societatis Iesu compositum aliqui eiusdem societatis revisores, quibus id commissum fuit, recognoverint et in lucem edi posse probaverint, facultatem concedimus, ut typis mandetur, si ita iis, ad quos pertinet, videbitur. tas dedimus.

In quorum fidem has litteras manu nostra subscriptas et sigillo muneris nostri muni-

Luxemburg, die 8. Januarii 1905.

P. C. Schaeffer S. J.

\section{Imprimatur.}

Friburgi Brisgoviae, die 29 Ianuarii 1907.

† Thomas, Archiepps.

Alle Rechte vorbehalten. 


\section{VORWORT.}

Das vorliegende Werk ist die Frucht vieljähriger, eingehendster Beschäftigung mit der Geschichte der liturgischen Gewandung. Es will nicht lediglich in grosen Zügen, sondern nach Möglichkeit bis ins einzelne ein Bild des Werdens der liturgischen Gewänder nach Form, Beschaffenheit, Verwendung und Symbolik geben. Nach Möglichkeit; denn nur zu oft geschieht es, daf die Quellen entweder ganz schweigen oder doch nicht in wünschenswertem Maße Auskunft gewähren. Das gilt namentlich für die vorkarolingische Zeit. Aber auch noch später sieht man sich, sobald man Einzelfragen nachforscht, nur zu oft vor mehr oder weniger dichtem Dunkel. Je eingehender sich jemand mit der liturgischen Gewandung der Vergangenheit befast, um so mehr wird er inne, wie vieles wil im einzelnen nicht oder doch blobs mangelhaft wissen und zum großen Teil wahrscheinlich auch in Zukunft niemals vollkommener wissen werden. Der allein kann wähnen, es herrsche in der Geschichte der Sakralkleidung allerwegen lauter Licht und der hellste Tag, wer sich nur oberflächlich mit derselben beschäftigt hat.

Der Hauptgegenstand der Arbeit sind die liturgischen Gewänder des Abendlandes. Indessen wurde auch die Kultgewandung der orientalischen Riten in den Kreis der Untersuchungen gezogen, und es darf ohne Bedenken versichert werden, daß dieser bislang noch keine so ausgiebige Behandlung zuteil wurde wie in dem vorliegenden Werke. Leider ist es ganz unmöglich, ihre Entwicklung über die Hauptzüge hinaus zu verfolgen. Ja für die Geschichte der liturgischen Kleidung der Syrer, Armenier, Nestorianer und Kopten läßst sich aus Mangel des dazu erforderlichen Materials nicht einmal das leisten. Es darf daher nicht wundernehmen, wenn den Kultgewändern der orientalischen Riten nur ein verhältnismäßig kleiner Raum gewidmet ist und von einer Schilderung ihrer einzelnen Entwicklungsstadien fast ganz Abstand genommen werden mußste.

Die Darstellung baut sich auf den Quellen selbst auf, den Schriften der Liturgiker, den gelegentlichen Angaben der alten Historiker, den offiziellen liturgischen Büchern und Gottesdienstordnungen, den einschlägigen synodalen Bestimmungen, den mittelalterlichen Schatzverzeichnissen, den Monumenten jeglicher Art und dem noch vorhandenen Bestand an liturgischen Gewandstücken aus früherer Zeit. Namentlich wurden im weitesten Umfang diese alten Paramente und die Inventare, deren Wichtigkeit nicht hoch genug gewertet werden kann, ausgenutzt. Die zahlreichen durch das Werk verstreuten Auszüge aus den mittelalterlichen Schatzverzeichnissen und die am Schlusse gebotene Zusammenstellung der in ihm berücksichtigten liturgischen Gewänder legen dafür reichlich Zeugnis ab. Natürlich wurde auch zu Rate gezogen, was andere über die Geschichte der Sakralkleidung geschrieben haben, und 
es gilbt solcher Arbeiten sehr viele und sehr gute. Allein nichts wurde daraus herübergenommen, das nicht zuvor, soweit nur eben tunlich, an den Quellen selbst nachgeprüft worden wäre. Wirklich erwiesen sich nicht wenige Angaben als ungenau, ja geradezu als irrig, darunter auch solche, welche wie ein Erbübel sich bereits durch eine Reihe von Schriften hingezogen hatten. Sie wurden teils ausdrücklich teils, und dies in den meisten Fällen, stillschweigend richtiggestellt.

Bei Benutzung der schriftlichen und monumentalen Quellen war leitender Grundsatz sorgfältige Wertung und Sichtung des Materials; im Vorlegen der Resultate seiner Forschung aber suchte der Verfasser sich vorsichtiger Zurückhaltung zu befleißigen. In zahlreichen Fällen war er daher veranlajt, sich mit einem gröferen oder geringeren Grad von Wahrscheinlichkeit, mit einem "könnte“, „dürfte" u. a. zu begnügen. Fr hegt nicht die Besorgnis, daßs solches dem Werk zum Nachteil gereicht. Gegenteiligen Meinungen von irgend einer Bedeutung wurde volle Rechnung getragen und keine Schwierigkeit wurde unberiicksichtigt gelassen. Dem Verfasser scheint es ein Gebot wissenschaftlicher Ehrlichkeit, auch abweichende Auffassungen, soweit sie nur eben der Beachtung wert sind, samt ịhren Gründen anzuführen. Er könnte es sich nicht verzeihen, wollte er in Fragen, über die man streitet, lediglich seine persönliche, wenn auch noch so begründete Meinung vortragen. Ist ja doch auch nur bei Anwendung des Grundsatzes: Audiatur et altera pars, die erwünschte Klärung möglich.

Ein allseitig abgeschlossenes Werk zu schaffen, das gleichsam in Sachen der liturgischen Gewandung das letzte Wort gewesen wäre, konnte angesichts des in so vieler Hinsicht beschränkten Quellenmaterials unmöglich als Ziel in Aussicht genommen werden. Der Verfasser erwartet daher auch trotz aller Sorgfalt, mit der er vorgegangen ist, keineswegs, dafs seine Aufstellungen in allem und jedem die Zustimmung des Lesers finden werden. Möge man dieselben prüfen und, wo es am Platze ist, richtigstellen. Niemand wird sich über jede wirkliche Verbesserung aufrichtiger freuen als der Verfasser, dem es nicht um seine persönliche Meinung, sondern einzig um die Wahrheit zu tun ist. Bei längerem Zögern hätte er selbst wohl noch dem Bilde, das er von der liturgischen Gewandung und ihrer Geschichte entworfen hat, den einen oder andern Strich hinzufügen können. Allein es schien an der Zeit, einen Abschluf zu machen. Um Wesentliches hätte er, solange kein neues Material zu Tage kommt, seine Ausführungen ja doch nicht bereichern können; lediglich aber die Belege für die Einzelheiten zu mehren, erschien unzweckmäßrig, weil das zu einer Breite geführt hätte, die der Klarheit und Übersichtlichkeit nur geschadet haben würde. Zudem bietet ja das Buch auch so, wie es vorliegt, die umfassendste und eingehendste von allen Bearbeitungen der Geschichte der Sakralkleidung, die bisher erschienen. Vielleicht wird der eine oder andere wünschen, dafs in der Darstellung der Entwicklung der liturgischen Gewandung noch mehr, als es geschehen ist, auf deren Zusammenhang mit den jeweiligen äußeren Verhältnissen hingewiesen worden wäre. Soweit sich darüber etwas Zuverlässiges sagen liefi, ist das Milieu, in dem und unter dessen Einflut die Ausgestaltung der Sakralkleidung sich vollzog, 
gegebenenorts genügend gezeichnet worden. Im übrigen aber schien es nicht angebracht, Lücken durch Phantasien und geistreiche Mutmaßungen auszufüllen und so künstlich einen Zusammenhang zu schaffen, wo für den nüchternen Forscher ein solcher nicht ersichtlich ist.

Große Sorgfalt wurde auf die Auswahl der Abbildungen gelegt. Ein Bilderbuch sollte und durfte nicht geschaffen werden, doch muste alles irgendwie Belangreiche durch eine entsprechende Illustration belegt und erläutert werden. Auch sollte, soviel wie eben möglich, neues, jedenfalls aber blof minder leicht zugängliches Material genommen werden. Bevorzugt wurden Wiedergaben von noch erhaltenen alten Paramenten, welche, weil Photographien davon nur selten zu haben sind, zumeist vom Verfasser selbst an Ort und Stelle aufgenommen wurden. Überhaupt stammt von diesem die Mehrzahl der in dem Werk verwendeten photographischen Abbildungen.

Die Arbeit will vor allem einen Beitrag zur Geschichte der Liturgie bilden; doch dürfte sie auch für die Kenntnis der mittelalterlichen Textilien und Stickereien, für die Archäologie, für die Kunstwissenschaft und für die Geschichtsforschung von Wert sein, für die letzten Disziplinen, von anderem abgesehen, namentlich auch deshalb, weil die in ihr niedergelegten Ergebnisse manchen Anhaltspunkt zur Datierung von Monumenten und illuminierten Handschriften gewähren.

Bei meinen dem mittelalterlichen Paramentenbestand gewidmeten Reisen habe ich mich allenthalben des freundlichsten Entgegenkommens zu erfreuen gehabt. Ich fühle mich gedrungen, solches hier mit herzlichstem Dank gegen alle, die mir gütige Unterstützung liehen, zum Ausdruck zu bringen. Einzig das Kapitel des Domes zu Brandenburg schlug mir kurzer Hand eine nähere Besichtigung der dortigen Paramente ab, während mir die Herren Superintendent Oberdomprediger Dr Hermes und Diakonus Brausewetter mit bereitwilligster Zuvorkommenheit die Paramentenschätze des Domes zu Halberstadt bzw. der St Marienkirche zu Danzig zum Zwecke eines Studiums der darin geborgenen kostbaren Gewandstücke öffneten. Aber auch sonst haben mich manche durch die Auskünfte, die sie mir auf meine Bitte gaben, oder das Material, das sie mir zur Verfügung stellten, Ordensgenossen wie Nichtordensgenossen, vielfältig verpflichtet. Auch ihnen meinen herzlichsten Dank.

Luxemburg, am Feste der Geburt des Herrn 1906.

JOS. BRAUN S. J. 



\section{INHALTSVERZEICHNIS.}

Vorwort

Illustrationsverzeichnis

Literaturverzeichnis

Einleitung.

I. Gegenstand und Methode

II. Quellen

III. Bearbeitungen

Erster Abschnitt.

\section{Die liturgischen Untergewänder.}

Erstes Kapitel.

Der A mikt.

I. Der Amikt nach heutiger Praxis . . . . . . . . . . . 21

II. Der Amikt als Bestandteil der liturgischen Kleidung im Mittelalter . . . 23

III. Die Gebrauchsweise des Amikts . . . . . . . . . . 28

IV. Beschaffenheit und Ausstattung des Humerale . . . . . . . . 32

V. Ursprung des Schultertuches. Seine Namen . . . . . . . . 44

VI. Das Schultertuch in den orientalischen Riten . . . . . . . . . . 49

Zweites Kapitel.

Der Fanone.

I. Der Fanone nach gegenwärtigem Brauch . . . . . . . . . 52

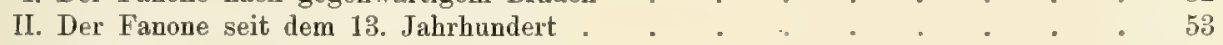

III. Der Fanone vor dem 13. Jahrhundert . . . . . . . . . . 56

Drittes Kapitel.

D i e $A 1$ b e.

I. Die Albe in der Gegenwart .

\section{Die Albe.}

II. Name des Gewandes

III. Die Albe in karolingischer Zeit

IV. Die Albe in vorkarolingischer Zeit

V. Form der Albe

VI. Beschaffenheit und Ausstattung der Albe

VII. Die liturgische Tunika in den orientalischen Riten. Die Epimanikien

Viertes Kapitel.

D a s Cingu 1 u m.

I. Das Cingulum nach gegenwärtigem Brauch . . . . . . . . . 101

II. Das Cingulum als Bestandteil der liturgischen Gewandung in der Vergangenheit 102

III. Beschaffenheit des liturgisehen Gürtels im Mittelalter . . . . . . 105

IV. Der liturgische Gürtel in den Riten des Orients . . . . . . . . 115 
Fünftes Kapitel.

\title{
Das Subcinctorium.
}

I. Das Subcinctorium nach gegenwärtigem Brauch

II. Das Subcinctorium im Mittelalter. Sein Alter, seine Beschaffenheit. Weise, es anzulegen

III. Balteus, Praecinctorium und Semicinetium

IV. Zweck, Ursprung und Bedeutung des Subcinctorium

Sechstes Kapitel.

\section{Rochett und Superpelliceum.}

I. Vorbemerkung:

II. Rochett als Name eines geistlichen Gewandes

III. Charakter des Gewandes zu Rom und auferhalb Roms

IV. Erste Spuren des Gewandes.

$\nabla$. Beschaffenheit des Gewandes

VI. Auftreten des Superpelliceum

VII. Name und Gewand in ihrem Ursprung

VII. Das Superpelliceum im Ordinationsritus

IX. Beschaffenheit des Superpelliceum

Zweiter Abschnitt.

\section{Die liturgischen Obergewänder.}

\author{
Erstes Kapitel.
}

\section{D i e K a s e 1.}

I. Die Kasel in der Gegenwart .

II. Die Namen des Mefsgewandes 152

1II. Die Kasel als liturgisches Gewand 155

IV. Die Kasel bei den Subdiakonen und Minoristen . . . . . . . . . , 160

V. Die Kasel bei den Diakonen. . . . . . . . . . . . . 163

VI. Anlegungsweise der Kasel béi den Diakonen, Subdiakonen und Akolythen. Die planeta plicata

VII. Die Kasel im liturgischen Gebrauch

VIII. Die Kasel im Weiheritus

IX. Form der Kasel im Mittelalter bis zum 13. Jahrhundert

$X$. Änderungen in der Form des Gewandes seit dem 13. Jahrhundert

XI. Die Kasel in der neuesten Zeit

XII. Stoff des Mefigewandes.

XIII. Verzierung des Mefigewandes

XIV. Bestickte Meßgewänder .

XV. Das Mébgewand in den Riten des Ostens

XVI. Ursprung des Mefigewandes.

Zweites Kapitel.

\section{Dalmatik und Tunicella.}

I. Dalmatik und Tunicella nach gegenwårtigem Brauch . . . . . . . 247

II. Alter des Gebrauches der Dalmatik . . . . . . . . . . 249

III. Der Gebrauch der Dalmatik seit dem 9. Jahrhundert . . . . . . 255

IV. Beschaffenheit der Dalmatik in vorkarolingischer Zeit . . . . . . 258

V. Beschaffenheit der Dalmatik vom 9. Jahrhundert bis zum späten Mittelalter . 261 Beschaffenheit der Dalmatik seit dem späten Mittelalter . . . . . 270

VI. Die Dalmatik in der Neuzeit . . . . . . . . . . 280

VII. Alter der Verwendung der Tunika bei den Subdiakonen und Bischöfen . . 283

VIII. Namen der Levitengewänder . . . . . . 287

IX. Beschaffenheit der Tunika im Mittelalter und in der Neuzeit . . . . 289

X. Liturgische Verwendung der Dalmatik und Tunicella . . . . . . . 293

XI. Ursprung der Dalmatik und Tunicella . . . . . . . . . . 299

XII. Die Tunika der Diakone und Subdiakone in den Riten des Ostens. Der Sakkos 302 
Drittes Kapitel.

Das Pluviale.

I. Das Pluviale nach gegenwärtigem Brauch

II. Name des Gewandes . . . . . . . . . . 307

III. Alter des Gewandes . . . . . . . . . . . . . 310

IV. Gebrauch des Gewandes . . . . . . . . . . . 314

V. Form und Beschaffenheit des Gewandes . . . . . . . . 317

VI. Verzierung des Pluviale . . . . . . . . . . . 329

VII. Ursprung des Gewandes. Das päpstliche Mantum. Die Cappa magna und Almutia 348

Dritter Abschnitt.

\title{
Die liturgischen Bekleidungsstücke der Hände, der Füße und des Kopfes.
}

\author{
Erstes Kapitel.
}

Die Pontifikalhandschuhe.

I. Name der liturgischen Handschuhe. Die Pontifikalhandschuhe in der Gegenwart 359

II. Alter des Gebrauches der Pontifikalhandschuhe . . . . . . . 361

III. Die Pontifikalhandschuhe im 12. und 13. Jahrhundert . . . . . 366

IV. Verleihung des usus chirothecarum an Nichtbischöfe . . . . . . . . 367

V. Form und Herstellungsweise der Pontifikalhandschuhe . . . . 369

VI. Ausstattung der liturgischen Handschuhe . . . . . . . . . 374

VII. Stoff und Farbe der Pontifikalhandscluhe . . . . . . . . . 378

VIII. Die liturgische Verwendung der Handschuhe . . . . . . . . 380

IX. Ursprung der pontifikalen Handbekleidung . . . . . . . . . . 382

Zweites Kapitel.

\section{Die pontifikale Fußbekleidung.}

I. Die pontifikale Fußbekleidung in der Gegenwart. Ihre Bestandteile: Sandalen und Caligae

II. Die liturgische Fußbekleidung in der römischen Kirche bis zur Wende des ersten Jahrtausends.

III Die liturgische Fußbekleidung auferhalb Roms bis zum 11. Jahrhundert

IV. Die Bestandteile der liturgischen Fußbekleidung.

$\nabla$. Beschaffenheit der beiden Bestandteile der liturgischen Fuß̉bekleidung bis zum 11. Jahrhundert

VI. Die Träger der Sandalen und Caligae seit dem Ende des ersten Jahrtausends

VII. Verleihung der pontifikalen Fuß̧bekleidung an Nichtbischöfe

VIII. Beschaffenheit der Sandalen und Caligae vom 11. bis 14. Jahrhundert . 399

IX. Beschaffenheit der Sandalen und Caligae im späten Mittelalter und der Neuzeit 410

$X$. Verwendung der sakralen FußBbekleidung im liturgischen Dienst. . . . 419

XI. Ableitung der liturgischen Fußbekleidung . . . . . . . . . 421

Drittes Kapitel.

\section{D i e $M$ it r a.}

I. Name des Ornatstückes. . . . . . . . . . . . . . 424

II. Die Mitra in der Gegenwart . . . . . . . . . . . . . . . 429

III. Erstes Auftreten der pontifikalen Mitra . . . . . . . . . . . . 431

IV. Weitere Verleihungen unter Leo IX. Die Mitra wird bischöflicher Ornat . $\quad 448$

V. Die Mitra bei Kanonikern, bei Äbten und bei den Kardinälen . . . . 452

VI. Älteste Form der Mitra . . . . . . . . . . . 458

VII. Änderungen in der Form der Mitra . . . . . . . . . . . . . 463

VIII. Die Mitra im späten Mittelalter und in der Neuzeit . . . . . . . 474

IX. Liturgische Verwendung der Mitra . . . . . . . . . . . . . . . 485

X. Die liturgische Kopfbedeckung in den orientalischen Riten . . . . . . 487

XI. Ursprung der Mitra . . . . . . . . . . . . . . . . . . 495 
Viertes Kapitel.

Tiara, Pileolus, Birett.

I. Die Tiara

II. Der Pileolus

III. Das Birett

Vierter Abschnitt.

\section{Die Insignien.}

Erstes Kapitel.

\section{Der $M$ anipel.}

I. Der Manipel in der Gegenwart

II. Namen des Ornatstïckes . . . . . . . . . . . . 517

III. Der Manipel seit der Karolingerzeit . . . . . . . . . . . . 520

IV. Die ältesten Nachrichten über die Verwendung des Manipels . . . . . 523

V. Beschaffenheit des Manipels zur Karolingerzeit. Seine Umwandlung in einen Zierstreifen . . . . . . . . . . . 530

VI. Der Manipel seit dem 12. Jahrhundert bis zur Neuzeit . : . . . 535

VII. Der Manipel in der Neuzeit . . . . . . . . . . . . 541

VIII. Tragweise des Manipels . . . . . 543

IX. Verwendung des Manipels . . . . . . . . . . . 545

X. Die Überreichung des Manipels in Ritus der Subdiakonatsweihe . . $\quad .548$

XI. Das Gegenstück des Manipels in den Riten des Ostens . . . . 550

XII. Ableitung des Manipels . . . . . . . . . . . . 554

Zweites Kapitel.

\section{$D$ i e $S$ tola.}

I. Die Stola nach der gegenwärtigen Praxis . . . . . . . . . 562

II. Namen des Ornatstückes . . . . . . . . . . . . . . 563

III. Die ältesten Nachrichten übor die Stola im Abendland . . . . . 569

IV. Die Stola als liturgisches Ornatstück zur Karolingerzeit . . . . . . 578

V. Gebrauch der Stola . . . . . . . . . . . . . 582

VI. Die Überreichung der Stola im Weiheritus _ . . . . . . . . . . 589

VII. Beschaffenheit der Stola im Mitteialter . . . . . . . . . . 590

VIII. Die Stola in den Riten des Ostens . . . . . . . . . . . 601

IX. Ursprung der Stola . . . . . . . . . . . . . . 608

Drittes Kapitel.

Das Palli u m.

I. Das abendländische Pallium in der Gegenwart . . . . . . . . 620

II. Alter des römischen Palliums

III. Die Verleihung des Palliums .

IV. Liturgischer Charakter des römischen Palliums. Seine Verwendung beim Gottes* dienst . . . . . . . . . . . . 631 634

V. Die Palliumverleihungen im 6. Jahrhundert und der Kaiser . . . 634

VI. Bedeutung des Palliums . . . . . . . . . . . . 639

VII. Gestalt und Beschaffenheit des Palliums . . . . . . . . . 642

VIII. Ursprung des Palliums . . . . . . . . . . . . . 652

IX. Das bischöfliche Schultergewand in den Riten des Ostens . . . . . 664

X. Die bischöfliche Insignie in den Kirchen Galliens, Spaniens und Nordafrikas . 674

Viertes Kapitel.

\section{Das Rationale.}

I. Das Rationale in der Gegenwart . . . . . . . . . . . 676

II. Das erste nachweisbare Auftreten des Rationale . . . . . . . . . 678

1II. Verbreitung des Gebrauches des Pationale . . . . . . . . . 680 
IV. Form und Ausstattung des Rationale . . . 687

V. Ursprung des Rationale . . . . . . . . . . . . . 694

VI. Das Rationale als bischöflicher Brustschmuck . . . . . . . . . 697

Fünfter Abschnitt.

\section{Symbolik, Farbe und Segnung der liturgischen Gewänder.}

Erstes Kapitel.

Die mystische Deutung der liturgischen Gewänder.

I. Die mystische Deutung im Abendland . . . . . . . . . 701

II. Die mystische Dentung der liturgischen Gewänder in den Riten des Ostens . 707

III. Die symbolische Bedeutung der priesterlichen Gewänder im Abendland . $\quad 710$

IV. Die Symbolik der bischöflichen Ornatstücke . . . . . . . . . 719

V. Die symbolische Bedentung des Superpelliceum, der Levitengewänder und des Plnviale.

Zweites Kapitel.

Die liturgischen Farben.

I. Die liturgischen Farben nach del gegenwärtigen Praxis . . . . . 728

II. Das erste Auftreten des liturgischen Farbenkanons . . . . . . . 729

III. Mannigfaltigkeit der liturgischen Farbenregeln in der Vergangenheit . . . 737

IV. Ursprung und Symbolik der liturgischen Farbenregel . . . . . . . 749

V. Die Riten des Ostens und die liturgische Farbe . . . . . . . . 753

VI. Weiß als liturgische Farbe in der vorkarolingischen Zeit . . . . . 754

Drittes Kapitel.

Segnung der liturgischen Gewänder. . . . 760

\section{Schlußabschnitt.}

\section{Die liturgische Gewandung in ihrer Gesamtentwicklung.}

I. Die liturgische Kleidung in ihrer Beziehung zur alttestamentlichen Kulttracht . 765

II. Die liturgische Gewandung in vorkonstantinischer Zeit . . . . . . 767

III. Die liturgische Kleidung vom 4, bis 9. Jahrhundert . . . . . . 771

IV. Die liturgische Gewandung vom 9. bis 13. Jahrhundert . . . . . $\quad 779$

V. Die liturgische Gewandung im späten Mittelalter und in der Neuzeit . . 781

I. Verzeichnis der besprochenen alten Gewänder . . . . . . . 787

II. Übersicht über die dem Werke zu Grunde liegenden monumentalen und schriftlichen Quellen . . . . . . . . . . 789

HII. Sachregister. . . . . . . . . . . . . . 793 


\section{ILLUSTRATIONSVERZEICHNIS.}

Bild Titelbild: Widmungsbild. der Vivianslbibel

1. Heutiger Amikt.

2. Spanischer goldbestickter Amiktkragen

3. Amikt und Cingulum

4. Anlegungsweise des Amikts nach mittelalterlicher Weise

5. Von der Grabplatte des Kanonikus Joh. Peter von Seckendorf

6. Vom Grabmal des bischofs Gottfried von Limburg

7. Anik thesatz

8. In Seide und Perlen gestickter Amiktbesatz

9. Amiktparura

10. In Perlen- und Reliefstickerei ausgeführte Amiktparuia

11. Amiktkragen nach Miländer Gebrauch

12 1. 13. Reliefs der Trajanssäule zu Rom

14. Grabstele des Centurio Faltonius

15. Schultertuch und liturgische Stauchen im armenischen Ritus

16. Bischofsweihe. Miniatur eines syrischen Pontifikale

17. Fanone

18. Grabmal Bonifatius' VIII

19. Grabfigur Sixtus' IV.

20. Cosimo Roselli: Papst Silveste

21. Papst Innozenz II.

22. Mit Besätzen verzierte Albe nach ambrosianischem Ritus

23. Albe von maittelalterlicher Form u. Verzierung

24. Subdiakon und Minoristen. Miniatur eines Sakramentars in Autun

25. siog. Camillus in sackformiger, gegürteter Tunika

26. Albe des 12], Bernulf

27. Albe

28-31. Alben

32. Albe mit herabfallenden Giren

33. Albe

iit.

35.

36. Albenparura" mit Eigurenstickerei

37. Albenparur:

38. Albenparura

39. Albe

40. Armeniseher Diakon und Subdiakon

41. Armenische Diakonentunika

42. St Nikolaus. Griechische Miniatur

43. Teil eines Ledergürtel

44. Schnalle eines Gürtels

45. Cingulum

46. Cingulum

47. Cingulum

48. Kaiserüurtel

49. Witgarjusgiirtel

50. Detail dess Witgariusgürtels

51. Ankleidung zur Messo. Miniatur eines ManttBhriptes von 1380

52. Priesterliclıer Gürtel im rrechischen Ritus

53. Giturtel des Sibbdiakons im griechisehen Ritus

54. Subcinctorium

55. Rochett des hl. Thomas Precket

56. Melozzo da Forli: Platinas Audienz bei Sixtus IV.

Seite | Bild

57. Stiftsherr aus Oberwesel in Pelzkleid, Superpelliceuna und Almutia

59. Stifter, Ausschnitt aus einem Tafelbild Barthel Bruyns . . . . .

60. Weihe des Bischofs von Bamberg Veit Truchsef von Pommersfelden. Miniatur aus den Gundekarpontifikale

61. Kaselformen

62. H. Ambrosius .

63. Kaiser Justinian mit Erzbischof Maximian und Gefolge

64. Papst Honorius I, Mosaik . * . 160

65. Elfenbeintafel

66. Elfenbeintafel . . . . . . 168

67. Elfenbeinplatte vom Sakramentar des Drogo 170

68.

69. Elfenbeintafel . . . . . . ${ }^{n},{ }^{n}, 177$

70. Glockenkasel . . 178

71.

72.

73. 181

74. Sehnitt der Glockenkasel . . . . 183

75. Kasel . . . 185

76. Kasel Kalixtus' III. . . , , . . 187

77. Kasel des hl. Karl Borromäus . . . 190

78. Kasel Pius' V. . . . . 190

79. Kasel des sel. Petrus Canisius . . . 191

80. Kasel. . . . . . . . 192

81. 193

82-87. Kaseln, die Entwicklung der Kasel vom 12. Jahrh. an bietend . . . . . 195

88. Leinwandkasel. 202

89. Musterung der Bernwardskasel : . . 204

90. Lederkasel . 207

91. Kasel aus Stroh . . . . . . 208

92. Elfenbeinrelief von der Kathedra Maximinns

zu Ravenna

93. Miniatur eines Registers Gregors des Grofen 211

94, Kasel. . . . . . . 212

95. . . 213

96. Miniatur in Hrabans Laudes is. Crucis 214

97. Kaselkreuz

98. 218

99. Kasel. . . 219

100. Kasel mit Kreuz in Perlen . . . 220

101. Kaselkreuz in Perlenstickerei . . . . 221

102. Kasel. . . . . . . 222

103. . . . . . . . . . . . . . .

104. ${ }^{n} \cdot{ }^{\circ} \cdot{ }^{2} \cdot 28$ und seiner Gemahlin Gisela, jetzt ungariseher Krönungemantel

107. Kasel des Ornats des Ordens vom Goldenen Vlies

108. Griechisehe Kaselvervierume -

109. Armenischer Priester . . . . . " 235

110. Prozession. Miniatux im Menologium Basilius' II. . . . . . . . . 236

111. Chor der Bischöfo. Miniatur niner Şammlung griechischer Marienpredigten . . 237

112. Einsegnung des Archipresbyter. Miniatur eines syrischen Pontifikale 
Bìld

113. Sarkophagskulptur (altelıristlich) .

11. Relief von der Trajanssäulo zu Rom

115. Grabstele eines Centurio

116. Grabstele des Schiffers Blussus

117. Buddha mit Tunika, Kasel und Sudarium

118. Hl. Septimius. Mosaik

119. Der hl. Optatus

120. Dalmatik .

121. St Laurentius. Miniatur eines Tropars von Prüm.

122. Translation der Reliquien des hl. Stephanus Miniatur eines Evangeliars

123. Siegel des Mainzer Domstifts

124. Sigebert von Minden mit seinen Klerikern. Miniatur eines Mindener Codex

125. Der Subdiakon Juvenianus, Miniatur eines Codex

1:6. Dalmatik

127.

128.

129.

130.

131.

132. Papst Silvester zeigt Kaiser Konstantin die Bilder der Apostelfürsten. Fresko

133. Spanische Dalmatik

134. Dalmatikflügel

135. Dalmatik

136.

137.

138. Tunicella

139. Ädil, das Zeichen gebend

140. Diptychon des Konsuls Felix

141. St Johannes Chrysostomus. Mosaik

142. Griechisehe Tafelmalerei

143. Relief vom Deckel des Drogosakramentar's

144. Piuviale

145. Übersicht über die Entwicklung des Pluvialschildes

146. Pluvialschliefie .

147.

148 .

149 .

150.

151.

152.

153

$15 \pm$

155. Pluvialscbild

156. Schild und Teile des Besatzes eines Pluviale

157. Szenen aus dem Leben der hl. Magdalena. Pluvialbesatz

158. Pluvialstäbe mit Totentanzszenen

159. Pluviale Nikolaus' IV.

160. Pluviale aus Syon.

161. Pluviale aus Hildesheim

162. Pluviale

163. Pluviale, (Rekonstruktion)

16t. Pluviale des Kardinals Albornoz

165. Pluviale

166. Pluviale des Ornats des Ordens vom Goldenen Vlies

167. Kanonisation der hl. Katharina. Fresko Pinturicehios

168. Der hl, Franziskus vor Honorius III. Fresko Giottos

169. Bischof Albert von Hohenfels und seine Canonici. Miniatur des Gundekarpontitikale

170. Grabplatte des Georg von Schaumburg

171. Armreliquiar

172. Pontifikalhandschuh

173. Pontifikalbandschuh Peters "on Courpalay

174. Pontifikalhandschuh im Domschatz zu Prag

175-177. Pontifikalbandschuhe

$178-179$.

180. Pontifikalhandschuh
Seite Bild

240 181. Stulpen eines Handschuhpares aus einem

Bischofsgrab . . .

241 182. Pontifikalhandschuh mit Zipfeln.

242 183. Pontifikalhandschuh . . . . 375

$243184 . \quad 37 b^{\circ}$

258 185. Grabtigur des Bischofs Johannes von Lübeck 376

259 186-187. Handschuhfibeln aus einem Bischofs-

280 grabe. Emailplättchen

188. Zierscheibchen in itickerei

262 189. S. Felicissimus. Mosaik.

190. Pontifikalschuhe der Grabfigur des Bisehofs Otto von Braunschweig

263 191-192. Pontifikalstrümpfe .

193. Pontifikalschuh St Godehards

266 194. Pontifikalschuh des Bischofs bernhard von Hildesheim

267

239

870

$271 \quad 19$

272198

234. Entwicklung der Mitra vom 11. Jahrhundert bis heute.

235. Mitra des Jean de Marigny -

353

236. Mitra

237.

354238

239.

240.

355241

Pontifikalschuh des Bischofs Konrad II. von Worms

Pontifikalschuln

90. Pontifikalstrumpf des Arnold de la Vie

. Pontikikalstrump.

Pontitikalschal

5. Stiefelartiger Pontifikalschul

208. Pontifikalschuhe aus den Trierer Bi-

9. Pontifikalschuh des Erzbischofs Arnold I. von Trier.

-212. Pontifikalschuhe aus den Trierer Bi-

3. Pontifikalschuhe der Grabfigur Martins V

4. Segnung des Taufwassers. Miniatur eines Taufrotels .

5. Erzbisch of Friedrich von Köln. Miniatur einer Sammlung der Hieronymusbriefe

Die Bischöfe Felicius, Fanstinus und $J_{0}$ hannes. Miniatur einer Kanonessammlung

- Hajestätssiegel Kaiser Karls IV. . Albero

21. Siegel Gottfrieds von Nevers

24.

26.

Herstellungsweise der Mitra in 12" und 13. Jahrhundert

377

377
393

401

403

406

406

407

409

409

411

411

412

413

413

413

414

415

416

417

418

447

450

451

459

460

463

464

465

466

466

467

467

468

469

470

471

472

473

370 244. Liturgische Kopfbedeckung der armenischen Priester

245. Atbanasius. Minjatur im Menologium Basilius' II.

246. Spiridion. Miniatur im Menologium Basilius' II.

\section{7}


247. Papst. Miniatur eines Exultetrotels.

248. St Gregor d. Gr. Von der Bronzetüre des Luca della Robbia.

249. St Silvester. Fresko

250. Tiara der Grabstatue Benedilts XI.

251. Fragment der Grabstatue Benedikts xil.

252. Tiara Julius' II.

253 Vom Grabmal Klemens' VI.

254. Vom Grabmal des Kardinals Alanus

255. Grabstein Peters ron Thure

256. Übersicht über die Entwicklung des Biretts an Hand der Grabplatten in den Domen zu Augsluurg, Bamberg, Regensburg und Wûrzburg

257. Anonymes Konsulardiptyehon

258. Relief voru Palliotto zu Nailand

259. Ausschnitt aus eines Miniatur des Geroerangeliars

260. Manipel des bl. Bernulf .

261. Elemalige Bindevorrichtung am Manipel

262. Manipel

263. Manipel des hl. Edmund

264. Manipel

265. Manipel und Stola

266. Manipel

267. Manipel in Goldstickerei. Slavische Arbeit des 16,-17. Jahrh.

268. Epigonation

269. St Gregor der Wundertäter, Miniatur des Menologium Basilius' II.

270. St Nikolaus, (Tauschierarbeit)

271. St Athanasius. Mosaik

272. Doigtier

273. Bischof Ecelesius. Mosaik

274. Aitar des Ratchis

275. Taufszene. Miniatur in einer Wessobrunner Handschrift

276. Segnung der Osterkerze. Miniatur eines Exultetrotels

277. Diakon, Marmorrelief

278. Stola

279. Stola ans dem Grabe Theodorichs II von Triei

280. Stola

281. Stola (Mittelstiick)

282, Stola
283. Stola (oberes Stuick)

284. Weihe der Subdiakone, Miniatur eines syrisehen Pontifikale . . . . .
Seite 599 601 


\section{VERZEICHNIS DER HÄUFIGER BENUTZTEN MITTELALTERLICHEN WERKE.}

Admonitio synodalis ${ }^{1}$. M. $115,675 \mathrm{ff}$.

Alcuini (Pseudo-) De divinis officiis c. 38 39. MT. 101, $1238 \mathrm{ff}$.

Amalarii Symphos. De ecclesiasticis officiis 1. 2, c. $15 \mathrm{ff} ; 1.3$, c. 4. M. $105,1093 \mathrm{ff} 1107$.

Bedae (Pseudo-) De septem ordinibus. M. 94, $553 \mathrm{ff}$.

Belethi Ioannis Rationale divinorum officiorum c. 32. M. 202, 43.

Berthold von Regensburg, Predigt ihber die heilige Messe: Wackernagel, Altdeutsche Predigten Nr 41, Basel 1876, 70.

Brunonis Signiensis Tractatus de sacramentis eeclesiae. M. 165, $1103 \mathrm{ff}$.

Durandi Rationale divinorum officiorum 1. 3, c. $1 \mathrm{ff}$, ed. Lugdun. $1612 \mathrm{f}, 63 \mathrm{ff}$.

Expositio brevis antiquae liturgiae gallicanae ep. 2. M. $72,95 \mathrm{ff}$.

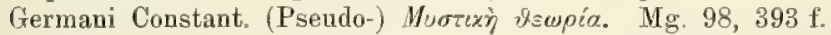

Gilberti Lunic. De statu ecclesiae, M. 159, $997 \mathrm{ff}$.

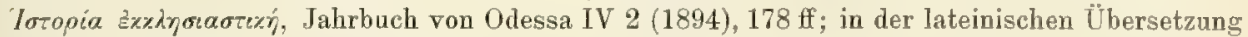
des Anastasius Bibliothecarius, Revue de l'Orient chrétien 1905, $301 \mathrm{ff}$.

Honorii Augustod. Gemma animae 1. 1, c. 199 ff. M. 172, 604 ff.

Honorii Augustod. Sacramentarium c. $25 \mathrm{ff}$. M. 172, $760 \mathrm{ff}$.

Innocentii III. P. De sacro altaris mysterio I. 1, c. $10 \mathrm{ff}$. M. 217, $780 \mathrm{ff}$.

Ioannis Abrincensis De officiis ecclesiasticis. M. 147, 62210.

Isidori Hispal. Etymologiarum 1. 19, c. 24 ff. M. $82,689 \mathrm{ff}$.

Ivonis Carnot. Sermo 3. M. 162, $524 \mathrm{ff}$.

Liber Patrum: La science catholique, année 1890, 450.

Nerses von Lampron, Kommentare zur heiligen und göttlichen Liturgie c. 52527 (ed. Venet. $1847,80140145)$.

Ordo Romanus I, n. 6. M. 78, 940.

Ordo Romanus III, n. 6. M. 78, 978.

Ordo Romanus IX, n. 4. M. 78, 1005.

Ordo Romanus XIII, n. 2-6. M. 78, $1105 \mathrm{ff}$.

Ordo Romanus XIV, n. $48 \mathrm{ff}$, c. 103 . M. $78,1153 \mathrm{ff} 1233 \mathrm{f}$.

Ordo Romanus XV, n. 8. M. 78, 1276.

Rabani Mauri De institutione clericorum 1. 1, c. $14 \mathrm{ff}$. M. 107, $306 \mathrm{ff}$.

Riculfi Statuta. M. 131, 15 ff.

Roberti Paululi De caeremoniis, sacramentis et officis ecclesiasticis 1. 1, c. $45 \mathrm{ff}$. M. 177, $403 \mathrm{ff}$. Ruperti Tuitiens. De divinis officiis 1. 1, c. $18 \mathrm{ff} ; 1.2$, c. 24 . M. 170, 2154.

S. G. K. (St Gallener Kleiderkatalog), S. $777 \mathrm{f}$ dieses Werkes.

Sermonum C sermo XIV. M. $177927 \mathrm{f}$.

Sicardi Cremon. Mitralis 1. 2, c. 5 ff. M. $213,72 \mathrm{ff}$.

Simeonis Thessalon. De sacra liturgia c. $80 \mathrm{ff}$. $\mathrm{Mg} .155,257 \mathrm{ff}$.

Simeonis Thessalon. De divino teinplo c. $33 \mathrm{ff}$. Mg. 155, $712 \mathrm{ff}$.

Sophronii Hierosolym. (Pseudo-) Commentarius liturgicus. $\mathrm{Mg} .87,3,3986 \mathrm{f}$.

Speculum de mysteriis ecclesiae c. 6. M. 177, $352 \mathrm{ff}$.

'Theodulphi Aurelian. Paraenesis ad episcopos carm. 1. 5, n. 3. M. 105, $354 \mathrm{ff.}$

Tractatus de sacramento altaris c. 5 ff. M. $172,1277 \mathrm{ff}$.

Walafriedi Strabonis De exordiis et incrementis quarundam in observationibus ecclesiasticis rerum c. 24 . M. $114,951 \mathrm{f}$.

1 Um die Fufnnoten möglichst zu beschränken, werden in der Arbeit die folgenden Werke nur dann unter dem Text zitiert, wo solches aus besondern Gründen zweckmäßig ist; im übrigen muB auf das hier gegebene generelle Verzeichnis verwiesen werden. Es kann das aber auch um so eher geschehen, als die in ibnen den liturgischen Gewändem gewidmeten Abschnitte nur kürzeren Umfanges und auferdem meist in Kapitel mit besondern Überschriften eingeteilt sind, so daf ein Vergleich keinerlei Schwierigkeiten bietet. 


\section{VERZEICHNIS BEMERKENSWERTER FÜR DIE ARBEIT BENUTZTER INVENTARE.}

A bdingh of, Abteikirche. Inventar von $1031^{\prime}$. M. G. SS. XI $156 \mathrm{f}$.

- - Inventar von ca 1105. Voyage littéraire de deux religieux Bénédictins de la congrégation de St-Maur (Paris 1724) $241 \mathrm{f}$.

A berdeen, Kathedrale (1436 1465 1550). Innes C., Registrum episcopatus Aberdonensis II (Edinburg 1845: Publikation des Spalding Club) $127 \mathrm{ff}$.

Alban's, St-, Abteikirche (ca 1400). Riley O. H., Annales monasterii S. Albani (Chronicles and Memorials) II (London 1871) $322 \mathrm{ff}$.

Allenstein, Pfarrkirche (1581). Hipler, Die ältesten Schatzverzeichnisse der ermländischen Kirchen (Braunsberg 1886) $40 \mathrm{ff}$.

Altenburg, Pfarrkirchen (1527). Mitteilungen der geschichts- und altertumsforschenden Gesellschaft des Osterlandes zu Altenburg. V (1862) 354.

- Bergerkloster (1528). Ebd. $453 \mathrm{f}$.

A miens, Kathedrale (1419). Garnier J., Mémoires de la Soc. des Antiquaires de Picardie $\mathrm{X}(1850) 277 \mathrm{ff}$.

Anagni, Gaben Bonifaz' VIII. (ca 1300). Annales archéologiques XVIII (1858) $22 \mathrm{ff}$.

Angers, Kathedrale (1297 13911421 ff). Revue de l'art chrétien, 3e série III (1885) 168 ff $299 \mathrm{ff} ;$ IV (1886) $170 \mathrm{ff}$.

A quileja, Kathedrale (1858-1378 1408). Joppi V., Archivio storico per Trieste, l'Istria ed il Trentino II (1883) $56 \mathrm{ff}$; III (1884) $58 \mathrm{ff}$.

Arles, St-Césaire (1473). Revue des Sociétés savantes, 7e série I (1879) $168 \mathrm{ff}$.

Assisi, S. Francesco. Inventar von 1320. Abschrift in Dr Bocks Sammlung mittelalterlicher Inventare im städtischen Suermondt-Museum zu Aachen.

- - Inventar von 1341. Fratini G., Storia della Basilica di S. Francesco in Assisi $168 \mathrm{ff}$. Bajos (Diöz. Vich), S. Benito (972). Marca P. de, Marca Hispanica (Parisiis 1688) c. 899. Bamberg, Kathedrale (1127). Weber H., Die St-Georgenbrüder am alten Domstift zu Bamberg (Bamberg 1883) $38 \mathrm{ff}$.

- Abtei Michelsberg (1488). Abschrift in Dr Bocks Sammlung mittelalterlicher Inventare im Besitz des städtischen Suermondt-Museums zu Aachen.

Beauvais, Kathedrale (1464). Desjardins, Histoire de la cathédrale de Beauvais (Beauvais 1865$)$, Documents $159 \mathrm{ff}$.

Benediktbeuren, Abteikirche (1032). M. G. SS. IX 223.

Braunsberg, St Marien (1565). Hipler, Die ältesten Schatzverzeichnisse der ermländischen Kirchen $48 \mathrm{ff}$.

Braunschweig, St Gertrud (Ende des 15. Jahrh.). Vaterländisches Archiv des histor. Vereins für Niedersachsen Jahrg. 1836, $380 \mathrm{ff}$.

Breslau, St Elisabeth (1483). Ablandlungen der schlesischen Gesellschaft für vaterländische Kultur, philosoph.-histor. Abteil., Jahrg. 1867, 6 ff.

- St Bernhardin und St Jakob (1521). Ebd. $18 \mathrm{ff}$.

- St Nikolai (1529). Ebd. $22 \mathrm{ff}$.

Brö żge , St Donat (1347). Dehaisnes, L'art dans la Flandre, Documents (Lille 1886) $359 \mathrm{f}$. Cambrai, Notre-Dame (1359 u. 1401). Ebd. $402 \mathrm{ff} 799 \mathrm{ff}$.

Cambridge, King's College (1452). The Ecclesiologist XX (1859) $311 \mathrm{ff} ;$ XXI (1860) $5 \mathrm{ff} ;$ XXIV (1863) $100 \mathrm{f}$.

1 Wie die Hinweise auf die Angaben der mittelalterlichen Liturgiker, so werden auch die Verweise auf die Inventare und die ihnen entnommenen Ausziige und Daten der Vereinfachung des Fufanotenmaterials halber nur in besondern Fällen ausdrücklich durch genaue Stellenangabe belegt. Da die Inventare in der Regel nur geringen Umfang haben, größere aber in Rubriken geschieden zu sein pflegen, ist anch so ein Vergleich ohne Mühe zu bewerkstelligen. Das obige Verzeichnis gibt die alteren gedruckten Inventare von irgend einer Bedentung vollständig, die späteren mit Auswahl. Aus den meisten derselben werden im Verlauf der Arheit Exzerpte geboten. Eine reichhaltige, fast vollständige Zusammen. stellung aller bisher im Druck erschienenen Inventare aus dem Mittelalter und der Nenzeit bietet Ferd. de $\mathrm{M} e ́ 1 \mathrm{y}$ et $\mathrm{E} d$. Bishop, Bibliographie générale des Inventaires imprimés, 2 vols., Paris 1892-1895. 
Canterbury, Kathedrale (1316). Dart, The history and antiquities of the Cathedral Church of Canterbury (London 1726), App. Iv fi.

Chartres, Kapelle des Bischofs Robert von Joigny (1327). Bulletin du Comité de la langue IV (1857) $309 \mathrm{ff}$.

- Kathedrale (1322 1353). Mély F. de, Trésor de Chartres (Paris 1885) 101 f.

- St-Père-en-Vallée (10. Jahrh.). Revue de l'art chrétien, $3^{e}$ série IV (1886) 308.

Chemnitz, Abteikirche (1541). Ermisch, Urkundenbuch der Stadt Chemnitz (Leipzig: 1879) $436 \mathrm{f}$.

- Franziskanerkirche (1539). Ebd. 451.

Chester-le-Street, Gaben Athelstans (ca 930). Dugdale, Monasticon anglicanum, nova editio (1846) I 234.

Chieti, S. Liberatore (1019). Muratori, Antiquitates Italicae medii aevi IV (Milano 1741) $767 \mathrm{ff}$.

Cla irvaux, Abteikirche (1405). Lalore Ch., Le trésor de Clairvaux du XIIe au XVIIJe siècle (Troyes 1875) $98 \mathrm{ff}$.

Clexmont-Ferrand, Kathedrale (10. Jahrh.). Revue archéologique X (1853) $172 \mathrm{ff}$.

Cluny, Abteikirche (1382). Revue de l'art chrétien, $3^{\circ}$ série VI (1888) 195 ff.

Coldinghham, Klosterkirche (1362-1374). Raine J., The Priory of Coldingham (Surtees Society XII, London 1841) xL ff.

Cremona, Kathedrale (984). Historiae patriae monumenta. Codex diplom. Langobardiae $1442 \mathrm{ff}$.

Dijon, Ste-Chapelle (1563). Arbaumont J. d', Le trésor de la Sainte-Chapelle de Dijon (Dijon 1887) 1 ff.

Dol (Bretagne), Kathedrale (1410). Bulletin du Comité de la langue II (1853-1855) 64 ff.

Douai, St-Amé (13. Jahrh.). M. G. SS. XXIV 28.

- - Inventar von 1377 und 1386. Dehaisnes, L'art dans la Flandre, Documents $541 \mathrm{ff}$.

Dover, St Martin (1535). Dugdale, Monasticon anglicanum, nova editio IV 542.

Durham, Kathedrale (1418). Raine J., St Cuthbert (Durham 1828) $142 \mathrm{ff}$.

- Nachlaß der Bischöfe (12. bis 14. Jahrh.), Raine J., Durbam Wills and Inventories I (London 1835) $1 \mathrm{ff}$.

Ecouis (Eure), Stiftskirche (1565). Bulletin de la Société des Antiquaires de la Normandie XIV (1888) $390 \mathrm{ff}$.

Egmond, Abteikirche, Gaben Egberts von Trier (976-993). Miraeus, Codex donationum piarum I (Lovanii 1723) 71.

Elb ing, Kirchen und Kapellen (1544-1547). Hipler, Die ältesten Schatzverzeichnisse der ermländischen Kirchen $6 \mathrm{ff}$.

Fln e (915), Testament Riculfs von Elne. Migne, P. lat. 132, 468.

Ely, Kathedrale (1079). Monasticon anglicanum, nova editio I 477.

Enger (10. bis 11. Jahrh.). Diekamp W., Westfälisches Urkundenbuch $92 \mathbf{f}$.

Exalata (Coxan), Klosterkirche (855). Marca P. de, Marca Hispanica (Parisiis 1688) $788 \mathrm{f}$.

Exeter, Kathedrale (1277 1327 1506). Oliver, Lives of the Bishops of Exeter (Exeter 1861) $297 \mathrm{ff}$.

- Schenkung Leofrics von Exeter (vor 1073). Warren F. E., The Leofric Missal (Oxford 1883) xxII.

Farfa, Abteikirche (ca 9471119 1122). M. G. SS. XI 536578582.

Fécamp, Abteikirche (1362-1375). Bibliothèque de l'École des Chartes, $4^{\ominus}$ série $\nabla$ (1859) $160 \mathrm{ff} 399 \mathrm{ff}$.

Fontenelle (823-833), Gaben des hl. Ansegisus. M. G. SS. II 295.

Franenburg, Kathedrale (1578). Hipler, Die ältesten Sehatzverzeichnisse der ermländischen Kirchen $25 \mathrm{ff}$.

Freiberg (Sachsen), Franziskanerkirche (1530), Jungfernkloster (1542), Dom (1535). Ermisch, Urknndenbuch der Stadt Freiberg in Sachsen I 394519623.

Freising, Inventar des Chorbischofs Herold (855). Meichelbeck, Histor. Frising. $I_{2} 351$.

- Kathedrale, Inventar yon 1352. Anzeiger für Kunde der deutschen Vorzeit XIV (1867) $303 \mathrm{f}$.

- Inventar von 1456. Ebd. XV (1868) $14 \mathrm{f}$.

Gandersheim, Klosterkirche (12. Jahrh.). Ebd. XX (1873) 345.

Genf, Kathedrale (1535). Mémoires et documents publiés par la Société d'histoire et d'archéologie de Genève V (1849) 126 ff.

Gent, St Bavo (860). Neues Archiv VIII (1882) 374.

Genua, S. Maria di Castello (1253). Vigna R. A., Liantica Collegiata di S. Maria di Castello in Genova (1859) $184 \mathrm{f}$. 
Georgenberg bei Goslar, Klosterkirche (ca 1125-1150). Heinemann O. v., Die Handschriften der herzoglichen Bibliothek zu Wolfenbüttel, 1. Ahteil., I 175.

Gerona, St Felix (1310). Florez H., España sagrada XLV (1832) 255 ff.

GI as gow, Kathedrale (1433). Innes C., Registrum episcopatus Glasguensis. Publikation des Bannatyne Club und des Maitland Club (Edinburg 1843) $329 \mathrm{ff}$.

Gnesen, Kathedrale (1450). Monumenta Poloniae historica V (1888) $950 \mathrm{ff}$.

Gottesthal (Rheingau, 1499). Roth, Geschichtsquellen aus Nassau III 202.

Gran, Kathedrale (1528 15531592 1609). Dankó J., Geschichtliches aus dem Graner Domschatz 142 ff.

Gubbio, Augustinerkirche (1341). Mazzatinti G., Archivio storico per le Marche e per l' Umbria III (1886) 570 ff.

Ha l berstadt, Kathedrale, Gaben des Bischofs Konrad (1208). Riant, le comte.P., Exuviae sacrae Constantinopolitanae I $20 \mathrm{ff}$; II $84 \mathrm{f}$.

Heilsberg, Pfarrkirche und Schloßkapelle (1581). Hipler, Die ältesten Schatzverzeichnisse der ermländischen Kirchen $58 \mathrm{f}$.

Hereford, Kathedrale (1317). Welb J., A roll of the household expenses of Richard de Swinfield, Bishop of Exeter (Camden Society 1854) xxxvi f.

Hermannstadt (Siebenbürgen), St Marien (1440). Serapeum IX (1848). $227 \mathrm{ff}$.

Hildesheim, Dom (1409). Anzeiger für Kunde deutscher Vorzeit XXV (1878) $207 \mathrm{ff}$.

Karl der $\mathrm{K}$ ï h ne von Burgund (1467). Laborde, comte de, Les dues de Bourgogne II $1 \mathrm{ff}$.

Karl V. von Frankreich (1379): Labarte J., Documents inédits de l'histoire de la France (Paris 1879).

Kiedrich (Rheimgau), St Valentin (1583). Annalen des Vereins für nassanische Altertumskunde und Geschichtsforschung XXIX (1898) $220 \mathrm{f}$.

Kolbatz, Klosterkirche (1509). Baltische Studien XXVII (1877) $267 \mathrm{f}$.

Köln, St Brigiden (1508 $1541 \quad 15781597$ 1612). Annalen des historischen Vereins für den Niederrhein XLV (1886) $118 \mathrm{ff}$.

- St Georg (ca 1100). Bock, Das heilige Köln (Leipzig 1858), St Jakob 8 ff.

- - (14. Jahrh.). Ebd. $14 \mathrm{ff}$.

- St Johann (1406). Ebd., St Johann 14.

Königsberg, Schloßkirche (1518). Hipler F., Mitteilungen des ermländischen Kunstvereins III (1875) $56 \mathrm{ff}$.

Kraka u, Kathedrale (1101 u. 1110). Essenwein A., Die mittelalterlichen Kunstdenkmale der Stadt Krakau (Leipzig 1869), Anhang xxxm.

Kremsmünster, Klosterkirche (1. Hälfte des 11. Jahrh.). M. G. SS. XXV 669.

I a mspringe (?), Klosterkirche (10. Jahrh.). Heinemann O. v., Die Handschriften der herzoglichen Bibliothek zn Wolfenbüttel, 1. Abteil., I 333.

L a u s a n ne, Kathedrale (1536). Chavannes F., Le trésor de l'église cathédrale de Lausanne 50 ff.

Leon, Kathedrale (1063), Gaben des Königs Ferdinand. Florez H., España sagrada XXXVI (1787) cLXXXix. (1073), Gaben des Bischofs F'elagius. Ebd. I.IX f:

Lerez, S. Salvador (ca 916). Schenkung König Ordoños II. von Leon. Ebd. XIX (1765) 355.

Lichfield, Kathedrale (1346). Journal of the Derbyshire Archaeological Society IV (1882) $107 \mathrm{ff}$.

Lille. St Pierre (1397). Dehaisnes, L'art dans la Flandre, Documents 751 ff.

L imoges, St Martial (12. Jahrh.). Bulletin archéologique IV (1847/1848) $100 \mathrm{f}$.

- Inventar von 1226-1245. Bibliothèque de l'école des Chartes, $4^{\ominus}$ série (1855) I 29 ff.

Lincoln, Kathedrale (1536 u. 1553). Monasticon anglicanum, nova editio VI $1278 \mathrm{f} 1287 \mathrm{ff}$.

London, St Paul (1245 1295 1402). Archaeologia L (1887) $464 \mathrm{ff}$.

Lüttich, St Laurent (1034). Helbig J., La sculpture au pays de Liège (Bruges 1890) $8 \mathrm{f}$. L y o n (1448). Valois V. de, Inventaire du trésor de l'église de Lyon (Iyon 1877) $1 \mathrm{ff}$.

Mailand, S. Ambrogio (11. Jahrh.). Magistretti M., Delle vesti ecclesiastiche in Milano (Milano 1897) $79 \mathrm{ff}$.

M a inz, Altmünster (12. Jahr.). Serapeum, Zeitschrift für Bibliothekswissenschaft XVIIL (1857) 363.

- Kathedrale (12.-13. Jahrh.). M. G. SS. XXV 239 ff.

- St Quintin. Laib und Schwarz, Kirchenschmuck XXVII (1870) 30.

Marchiennes, Klosterkirche (9. Jahrh.). Dehaisnes, L'art dans la Flandre, Documents 14.

Martinsberg, Klosterkirche (12. Jahrh.). Mitteilungen der k. k. ZentraI-Kommission V (1860) $350 \mathrm{ff}$.

Mehlsack, Pfarkirche (1581). Hipler, Die ältesten Schatzverzeichnisse der ermländischen Kirchen $65 \mathrm{f}$. 
Meschede (Westfalen), Gaben der Äbtissin Hidda. Neues Archiv XI (1886) 409.

Milz, Klosterkirche (ca 800). Schannat, Corpus traditionum Fuldensium (Lipsiae 1724) 69. Mittel heim (1492). Roth F. W., Geschichtsquellen aus Nassau III (Wiesbaden 1880) 419. M onte Cassino. Erwerb des Abtes Desiderius. Chronicon Cassinense 1. 3, c. 18 (M. G. SS. VII 710 ).

Hinterlassenschaft Viktors III. Ebd. c. 74 (M. G. SS. VII 753).

Monza, S. Giovanni. Inventar von ca 910 . Bulletin monumental XLVI (1880) $313 \mathrm{f} 464 \mathrm{ff}$. - Inventar von 1275. E'bd. $627 \mathrm{ff}$.

Muri, Klosterkirche (12. Jahrh.). Hergott M., Genealogia diplomatica Augustae Domus Habsburgicae I (Viennae 1737) $313 \mathrm{ff}$.

N am ur, St Aubin (1218). Le Beffroi III (1871) $129 \mathrm{ff}$.

Nevers, Kathedrale (11. Jahrh.). Revue de l'art chrétien, 4e série (1890) 247.

Novara, Kathedrale (1212). Historiae patriae monumenta, Chartarum I $1192 \mathrm{ff}$.

O bon a, Stiftungsurkunde Adelgasters von Asturien (ca 790). Florez, España sagrada XXXVIl (1789) 308.

Oberaltaich, Klosterkirche (ca 1150). Mitteilungen des Instituts für österreichische Geschichtsforschung IV (1883) 288.

Oldesloe, St Peter und Paul (1489). Jahresbericht des Realprogymnasiums in Oldesloe $1889-1890,4$ ff.

$01 \mathrm{mütz}$, Kathedrale. Inventar von ca 1100. Notizenblatt, Beilage zum Archiv für Kunde der österreichischen Geschichtsquellen II (1852) 231.

- Inventar von 1435. Ebd. $170 \mathrm{ff}$.

Os imo, Kathedrale. Inventar von 1267. Zaccaria F. A., Excursus litterarii per Italiam ab auno 1742 ad annum $1752 \mathrm{I}$ (Venetiis 1754) 255.

- Inventar von 1379. Compagnoni P., Memorie istorico-critiche della chiesa di Osimo V (Roma 1783) $146 \mathrm{ff}$.

Oxford, Lincoln College (1480). Second report of the Royal Commission on historical manuscripts $130 \mathrm{f}$.

- New College (ca 1450). Ebd. 135.

- St Frideswide (1545). Monasticon anglicanum, nova editio II 166.

Padua, S. Antonio (1396). Abschrift in der Dr Bockschen Sammlung mittelalterlicher Inventare im Besitz des städtischen Suermondt-Museums zu Aachen.

Palermo, Pfalzkapelle (1309). Annales archéologiques XXV (1865) 296.

$\mathrm{P}$ ar is, Inventar der Königin Klementine, Witwe Ludwigs X. (1328). Revue de l'art chrétien, $4^{\text {e }}$ série (1892) $415 \mathrm{f}$.

Parma, Kathedrale (1483). Pezzana, Storia della città di Parma IV, app. 72 ff.

Passau, Gaben des Chorbischofs Madalwin (903). Monumenta Boica XXVIII 2, 201.

Perugia, Inventar des Schatzes des Apostolischen Stuhles (1311). Regesta Clementis Papae V, app. I (Romae 1892) $369 \mathrm{ff}$.

Peterborough, Gaben des Bischofs Ethelwold (ca 970). Monasticon anglicanum, nova editio I 365382.

- Infirmary Chapel (1539). Ebd. I 365.

- Kathedrale (1539). Ebd. I 382.

Pfäffers, Klosterkirche (Ende 9. Jahrh., 10. Jahrh.; ca 10201067 1155). M. G. Libri confrat. $396 \mathrm{ff}$.

Philipp der Gute von Burgund (1420). Laborde, comte de, Les ducs de Bourgogne II 235 ff.

Philipp der Kühne von Burgund (1404). Dehaisnes, L'art dans la Flandre, Documents $835 \mathrm{ff}$.

Pisa, S. Michele (ca 1048). Muratori, Antiquitates Italicae medii aevi IV $789 \mathrm{ff}$.

Poitiers, Kathedrale (1406). Auber, Histoire de la cathédrale de Poitiers (Paris 1849) II 139 ff.

- Kathedrale (1469). Bibliothèque de I'École des Chartes, 3e série I (1849) 495 ff.

Polnische Kirchen (1522). Lukowski J. et Korytkowski J., Toannis de Lasco, Gnesn. archiep., Liber beneficiorum II (Gnesnae 1880).

Prag, Dom (1354 13551387 1396-1512). Chrámový poklad u sv. Vita u Praza (Prag 1903). Anhang III ff.

Prefburg, Kathedrale (1425). Mitteilungen der k. k. Zentral-Kommission II (1857) $151 \mathrm{ff}$.

Prüfening, Klosterkirche (12. Jahrh.). Neues Archiv XIII (1888) 560 ff.

Prüm, Klosterkirche (1003). Beyer H., Mittelrhein. Urkundenbuch (Koblenz 1860) 717.

Ravensburg, Stadtkirche (15. Jahrh.). Diözesanarchiv von Schwaben III (1886) 23.

Reading, Abteikirche (13. Jahrh.). Barfield S., 'The English historical Review 1888, $116 \mathrm{f}$.

Ribe, Kathedrale (1213). Terpager P., Ripae cimbricae descriptio (Flensburgi 1736, $211 \mathrm{ft}$. 
Riquier St-, Klosterkirche, Inventar aus der Zeit Angilberts (ca 800). M. G. SS. XV 177.

- Inventar von 831. Chronicon Centul. 1. 3, c. 3 (M. P. lat. 174, $1257 \mathrm{ff}$ ).

Rochester, Kathedrale (11.-13. Jahrh.). Registrum Roffense, Revue de l'art chrétien, 3 série $\mathrm{V}$ (1887) 332 .

Rom, St Johann in Lateran (1455). Müntz E., Mélanges d'archéologie et d'histoire IX (1889) 165 㚏.

- St Peter (1361 14361454 1489). Miintz e Frothingham, Il tesolo di S. Pietro, in Archivio della Societż Romana di storia patria VI (1883) $11 \mathrm{ff}$.

- Inventar des Schatzes des Apostolischen Stuhles (1295). Bibliothèque de l'École des Chartes XLVI (1885) $16 \mathrm{ff}$

Rou en, Kathedrale (Ende des 12. Jahrh.). Revue de l'art chrétien, 3e série IV (1886) 460 ff. Saint-O mer, St-Bertin (867). M. G. SS. XIII 634.

Sa lis b ury, Kathedrale (1212 1222). Jones W. H. R., Registrum S. Osmundi II (Iondon 1884) $127 \mathrm{ff}$.

- Kleinere Kirchen in Wilts und Berks (Ruscombe, Sonning, Hurst etc.). Ebd. I 275 ff.

Sankt Gallen (11. Jahrh.). Stimmen aus Maria-Laach LXVIII (1904) 354.

Schweidnitz (Schlesien), Stadtkirche (1471). Anzeiger für Kunde der deutschen Vorzeit XXI (1874) $169 \mathrm{ff}$.

Siena, Dom (1467). Annales archéol. XXV $263 \mathrm{ff}$.

Sitten und Valeria (1364). Mémoires et documents publiés par la Société de la Suisse romande XXXIII (Lausanne 1884) $254 \mathrm{ff.}$

Soignies (1382). Dehaisnes, L'art dans la Flandre, Documents 592.

Speier, Dom (1051). Schannat, Vindemiae litterariae (Lipsiae 1723) $9 \mathrm{f}$.

Staffelsee, St Michael (ca 810). M. G. Leg. sect. II, I 251.

Sternberg, Angustinerkirche (1527). Jahrbücher des Vereins für mecklenburgische Geschichte XII (1847) $276 \mathrm{ff}$.

Stolp, Dominikanerkirche (1523 1525). Bau- und Kunstdenkmäler des Regierungsbezirks Köslin II, Kreis Stolp (Stettin 1894) 81.

Susteren, Klosterkirche (1174). Fisenne L. v., L'art monumental du moyen-âge (Aachen 1880), $1^{\text {re }}$ série, 1. 2, 7.

Todi, S. Fortunato (ca 1300). Archivio storico italiano II (Firenze 1888) $261 \mathrm{ff}$.

Toledo, Inventar der Kirchensachen des Kardinals Gonzalo, Erzbischofs von Toledo ( $\dagger$ 1275). El arte en España, Revista mensual del arte y'de su historia VII (1868) 45 ff.

- Inventar der Kirchensachen des Erzbischofs Albornoz von Toledo (ca 1350). Ebd. $101 \mathrm{f}$.

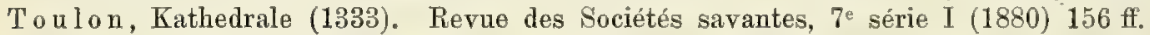

Toulouse, St Sernin (1489). Mémoires de la Société archéologique du midi de la France IV (1840) $158 \mathrm{ff}$.

Tréguier, Kathedrale (1620). Revue de l'art chrétien III (1859) $451 \mathrm{ff}$.

Trier, Dom (1238). Abschrift in der Dr Bockschen Sammlung mittelalterlicher Inventare im Besitz des städtischen Suermondt-Museums zu Aachen.

Trond St-, Klosterkirche. M. G. SS. X $230 \mathrm{f}$.

Venedig, S. Marco (1519). Pasini, Il tesoro di S. Marco in Venezia (Venezia 1886), app. CI ff.

W estminster, Abteikirche (1388). Archaeologia LII (1890) $213 \mathrm{ff}$.

Wien, St Stephan, Kapelle des hl. Morandus. Mitteilungen der k. k. Zentral-Kommission XIV (1869), Anh. c.

IV in chester, Kathedrale. Gaben des Bischofs Heinrich von Blois (ca 1170). The Downside Review III 41.

W indsor, Königl. Kapelle (1384). Monasticon anglicanum, nova editio VI 1362 ff.

Wormditt, Pfarrkirche (1584). Hipler, Die ältesten Schatzverzejchnisse der ermländischen Kirchen $83 \mathrm{ff}$.

Wörthsee (Kärnten), Pfarrkirche (ca 1000). Anzeiger für Kunde der deutschen Vorzeit $\mathrm{XV}(1868) 95 \mathrm{f}$.

W ù r zburg, Dom (1448). Archiv des historischen Vereins von Unterfranken und Aschaffenburg IV (1838) $131 \mathrm{ff}$.

- Neumünster (1230). Ebd. XVI (1863), 2. TI $246 \mathrm{ff}$.

- Schottenkloster (1535). Ebd. $45 \mathrm{f}$.

York, Kathedrale (ca 136013641483 ca 1500). Raine, The fabric rolls of York Minster (Durham 1858) 212 ff $275 \mathrm{ff}$.

Zeitz, St Michael (1514). Bau- und Kunstdenkmäler der Provinz Sachsen I, Kreis Zeitz (Halle 1879) $70 \mathrm{f}$. 


\section{VERZEICHNIS DER TITELABKÜRZUNGEN ÖFTER ZITIERTER WERKE.}

A. E. Med. = Acta Ecclesiae Mediolanensis. Frederici Card. Borromaei archiepiscopi Mediolan. iussu edita. Mediolani 1599.

A. SS. = Acta Sanctorum Bollandiana. Editio novissima. Parisiis $1863 \mathrm{ff}$.

A. SS. O. S. B. = Acta Sanctorum Ordinis S. Benedicti. Venetiis 1733 ff.

Ag. = Seroux d'Agincourt (J.-B.), Sammlung von Denkmälern der Architektur, Skulptur und Malerei. Deutsch v. F. von Quast. Frankfurt am Main 1840.

Ann. = Didron, Annales archéologiques. Paris $1844 \mathrm{ff}$

Ann. O. S. B. = Mabillon (I.), Annales Ordinis S. Benedicti. Lucae 1739-1745.

Arts sompt. = Maugé-Ciappori-Louandre, Les arts somptuaires. Paris 1857.

Ass., C. 1. = Assemani (J. A.), Codex liturgicus. Romae 1749-1766.

Ass., Bibl. = Assemani (I. S.), Bibliotheca orientalis Clementino-Vaticana. Romae 1719-1728.

Bock, Gesch. = Bock (Dr Fr.), Geschichte der liturgischen Gewänder des Mittelalters. Bonn 1856-1871.

Bock, Reichskl. = Die Kleinodien des heil. römischen Reiches deutscher Nation. Wien 1864.

Bona = Bona (Card. I.), Rerum liturgicarum libri duo, editio aucta abservationibus D. Roberti Sala. Augustae 'Taurinorum 1747-1753.

Braun, Winke = Braun (Joseph) S. J., Winke für die Anfertigung und Verzierung der Paramente. Freiburg 1904.

Bullet. mon. = Bulletin monumental, ou Collection de mémoires et de renseignements sur la statistique monumentale de France. Paris $1835 \mathrm{ff}$.

Caerem. = Caeremoniale episcoporum Clementis VIII, Innocentii $X$ et Benedicti XIII iussu editum.

Cahiex $=$ Cahier (P. Ch.) S. J., Nouveaux mélanges d'archéologie. Paris 1874-1877.

Cahier et Martin = Cahier (P. Ch.) S. J. et Martin (P. A.) S. J., Mélanges d'archéologie. Paris $1847-1856$.

Chambers $=$ Chambers (J. D.), Divine Worship in England in the XIII ${ }^{\text {th }}$ and $X I V^{\text {th }}$ centuries. London 1877.

Coll. Lac. = Acta et Decreta sacrorum conciliorum recentium sive Collectio Lacensis. Friburgi $1870-1890$.

Corp. SS. eccl. = Corpus Scriptorum ecclesiasticorum latinorum. Vindob. $1866 \mathrm{ff}$.

D. C. = Du Cange, Glossarium mediae et infimae latinitatis, editio nova. Niort $1883-1887$.

Decret. auth. = Decreta authentica Congr. SS. Rituum edita sub auspiciis SS. D. N. Leonis PP. XIII. Romae $1898 \mathrm{ff}$.

Delisle, Mém. = Delisle (Leop.), Mémoire sur d’anciens sacramentaỉres. Paris 1886.

De Farcy = Farcy (L. de), La broderie du XI siècle jusqu'à nos jours. Angers 1890; Supplément. Angers 1900.

De Linas = Linas (Ch. de), Anciens vêtements sacerdotaux et anciens tissus conservés en France, $3^{\circ}$ série, Paris $1860-1863$.

De Rossi, Mus, = Rossi (G. B. de), I Musaici cristiani delle chiese di Roma. Roma $1899 \mathrm{ff}$.

De Vert - Vert (Cl. de), Explication simple, littérale et historique des cérémonies de l'Église. Paris $1706-1708$.

Duch., Orig. = Duchesne (L.), Origines du culte chrétien. Paris 1903.

Duch., L. P. = Duchesne (L.), Liber Pontificalis. Parisiis 1886.

Forcell. = Forcellini, Totius latinitatis lexicon. Lipsiae 1839.

Franz $=$ Franz (A.), Die Messe im deutschen Mittelalter. Freiburg 1902.

Garr. = Garrucci (P. R.) S. J., Storia dell' arte cristiana nei primi otto secoli della Chiosa. Prato 1872-1880.

Gav. = Gavanti (B.), Thesaurus sacrorum rituum cum novis observationibus C. Merati. Venetiis 1823.

Gay = Gay (Victor), Glossaire archéologique. Paris 1887.

Gräven = Gräven (D. H.), Frühchristliche und mittelalterliche Elfenbeinwerke. Rom 1898 und 1900. 
Hard. = Harduini (P. T.) S. J. Conciliorum collectio regia maxima. Parisiis 1715.

Hartzh. = Hartzheim (P. J.) S. J., Concilia Germaniae. Colon. Agripp. 1759-1775.

Hef., Beitr. = Hefele (K. J.), Beiträge zur Kirchengeschichte, Archäologie und Liturgik. Tübingen 1864.

Hef., Concilien $=$ Hefele (K. J. v.), Conciliengeschichte, 2. Aufl., Freiburg 1873 ff; VIII u. IX, 1. Aufl., Freiburg $1887-1890$.

Hefner-Alt. = Hefner-Alteneck (Dr J. H. v.), Trachten, Kunstwerke und Gerätschaften vom frühen Mittelalter bis zum Ende des 18. Jahrhunderts. Frankfurt a. M. 1879-1889.

Hitt. = Hittorpii (M.) De divinis catholicae ecclesiae officiis. Parisis 1610.

J. = Jaffé (Ph.), Regesta Pontificum Romanorum, editio altera. Lipsiae 1888.

Firchenlex. = Kaulen (Dr Fr.), Wetzer und Weltes Kirchenlexikon, 2. Autl. Freiburg 1882-1901.

Kirchenschmuck = Kirchenschmuck, herausgegeben unter der Leitung des christlichen Kunstvereins der Diözese Rottenburg. Stuttgart 1857-1870.

Le Brun = Le Brun (Pierre), Explication littérale, historique et dogmatique des prières et des cérémonies de la Messe, t. I, Lyon 1850; t. II-IV, ibid. 1843.

M. = Migne, Patrologia latina. Parisiis 1844-1864.

Magistretti $=$ Magistretti (M.), Delle vesti ecclesiastiche in Milano. Milano 1897.

Magistretti, Monumenta = Magistretti (M.), Monumenta veteris liturgiae Ambrosianae, Pon tificale in usum ecclesiae Mediolanensis. Mediolani 1897.

Marr. = Marriot (B.), Vestiarium christianum. Londini 1868.

Mart. = Martène (E.), De antiquis ecclesiae ritibus libri tres. Antverpiae 1763-1764.

Mart., Mon. = Martène (E.), De monachorum ritibus libri quinque. Antverpiae 1764. Bildet den vierten Band der Antwerpener Ausgabe von Martènes Werk: De antiquis ecclesiae ritibus.

Mart, SS. Vet. = Martène (E.) et Durand (U.), Veterum Seriptorum amplissima collectio. Parisiis $1724-1738$.

Mart., Thes. = Martène (E.) et Durand (U.), Thesaurus novus anecdotorum. Parisiis 1717. $\mathrm{Mg}$, = Migne, Patrologia graeca, Parisiis 1857-1866.

M. G. Conc. = Monumenta Germaniae historica, Legum sect. III, concilia.

M. G. Confr. = Monumenta Germaniae historica, Antiquitates, Libri confraternitatum.

M. G. Epp. = Monumenta Germaniae historica, Epistolae.

M. G. LL. = Monumenta Germaniae historica, Leges.

M. G. SS. = Monumenta Germaniae historica, Scriptores.

M. G. SS. Langob. = Monumenta Germaniae historica, Scriptores rerum Langobardicarum.

M. G. SS. M. = Monumenta Germaniae historica, Scriptores rerum Merovingicarum.

Miss. = Missale Romanum S. Pii V P. M. iussu editum.

Mitt. = Mitteilungen der k. k. Zentral-Kommission zur Erforschung und Erhaltung der Baudenkmale. Wien $1856 \mathrm{ff}$.

Mor. = Moroni (G.), Dizionario di erudizione storico-ecclesiastica. Venezia 1840-1879.

Mühlb. = Mühlbaner (Wolfg.), Decreta auth. Congreg. SS. Rituum. München 1865-1867. Supplementum, ibid. 1876-1885.

Mur., Ant. = Muratori (I. A.), Antiquitates Italicae medii aevi. Mediolani 1738-1742.

Mur., SS. = Muratori (L. A.), Rerum Italicarum scriptores, Mediolani 1723-1738.

Pflugk-Harttung = Pflugk-Harttung (J. v.), Acta Pontificum Romanorum. Tübingen 1881 bis 1886 .

Realenc. := Kraus (F. X.), Realencyklopädie der christlichen Altertümer. Freiburg 18821886. Revue = Revue de l'art chrétien I-XXX. Paris 1857-1880; dann Lille $1883 \mathrm{ff}$.

Roh. = Rohault de Fleury (Ch.), La Messe. Paris 18×3-1889.

Thalhofer $=$ Thalhofer (Dr V.), Handbuch der kath. Liturgik. Freiburg 1883.

Ebner = Thalhofer (Dr V.), Handbuch der kath. Liturgik, 2. Aufl, besorgt von Dr A. Ebner. Freiburg 1894.

Wilp., Cap. = Wilpert (G.), Un capitolo di storia del vestiario. Roma 1898.

Wilp., Gew. - Wilpert (J.), Die Gewandung der Christen in den ersten Jahrhunderten. Köln 1898.

Wilp., Kat. = Wilpert (J.), Die Malereien der Katakomben Roms. Freiburg 1903.

Wilp., Sakr. = Wilpert (J.), Malereien der Sakramentskapellen. Freiburg 1897.

Zeitschuift $=$ Zeitschrift für christliche Kunst. Düsseldorf $1888 \mathrm{ff}$. 


\section{EINLEITUNG.}

\section{GEGENSTAND UND METHODE.}

Unter liturgischer Gewandung versteht man diejenige Kleidung, deren sich die Geistlichen bei Ausübung ihrer gottesdienstlichen Funktionen zu bedienen haben. Es gibt nicht bloß̊ im lateinischen, sondern auch in den orientalischen Riten eine besondere Kulttracht. Selbst der Protestantismus hat nicht einmal völlig auf sie Verzicht geleistet.

Die liturgische Kleidung ist bei den verschiedenen Weihestufen eine verschiedene. Am reichsten erscheint sie im abendländischen Ritus, wie leicht begreiflich, beim obersten aller Liturgen, beim Papst, ausgestaltet. Sie besteht bei ihm aus dem Amikt, der Albe, dem Cingulum, dem Subcinctorium, der Stola, der Tunicella, der Dalmatik, der Kasel, dem Fanone, dem Pallium, der Mitra und dem Manipel. Bei den Erzbischöfen fehlen von diesen Gewandstücken Subcinctorium und Fanone, bei den Bischöfen auch das Pallium, doch ist bei einigen wenigen der letzteren ein Gegenstück des Palliums, das sog: Rationale, in Gebrauch. Die priesterliche liturgische Gewandung setzt sich aus Amikt, Albe, Cingulum, Manipel, Stola und Kasel zusammen, die der Diakone aus Amikt, Albe, Cingulum, Manipel, Stola und Dalmatik, die der Subdiakone aus Amikt, Albe, Cingulum, Manipel und Tunicella. Die niederen Kleriker tragen nach gegenwärtigem Gebrauch bei ihren Funktionen das Superpelliceum.

Ubrigens wird die liturgische Kleidung in ihrer Vollständigkeit von den Geistlichen nur bei der Vornahme der vorzüglichsten aller ihrer Amtshandlungen, bei der Feier des heiligen Opfers, und bestimmten mit derselben in unmittelbarer Verbindung stehenden Verrichtungen verwendet. Bei andern Gelegenheiten bedienen sie sich einer vereinfachten liturgischen Gewandung, bei welcher insbesondere die Albe durch das Superpelliceum und die Kasel durch das Pluviale ersetzt wird. So trägt der Priester z. B. bei Spendung der heiligen Taufe Superpelliceum und Stola, der Bischof bei Erteilung der heiligen Firmung Rochett bzw. Superpelliceum, Amikt, Stola und Pluviale, bei Abhaltung feierlicher Vespern Amikt, Albe, Cingulum, Stola und Pluviale.

Die liturgische Kleidung in den Riten des Ostens ist derjenigen des lateinischen Ritus durchaus verwandt. Aber auch untereinander ist der Unterschied in Bezug auf die liturgische Gewandung in den verschiedenen dortigen Riten kein wesentlicher. Vergleichen wir die orientalischen Kultgewänder mit denen des Abendlandes, so finden wir, wenngleich mit einigen Abweichungen in Bezug auf Form, Beschaffenheit und Verwendung, allenthalben eine Unteltunika (Albe), das Cingulum, die Stola, einen liturgischen Mantel (Kasel) und das Pallium. Nur vereinzelt sind ein Schultertuch (Armenier, Syrer, unierte 
Kopten) und die Mitra (Almenier, Maroniten, unierte Chaldäel und unierte Kopten) gebräuchlich. Das Schultertuch fehlt in den übrigen Riten des Orients vollständig; anstatt der Mitra trägt man bald einen der Tiara ähnlichen Hut (Griechen, armenische Priester), bald eine turbanartige Kopfbedeckung (nicht unierte Kopten). bald endlich eine Art von Kapuze oder Schleier (nicht unierte Chaldäer). Unbekannt sind im Osten der Manipel — den armenischen Ritus ausgenommen —, die bischöflichen Handschuhe, Strümpfe und Schuhe, das päpstliche Subcinctorium, der päpstliche Fanone, das Superpelliceum, das Plnviale, someit es ein Gegenstuick und ein Ersatz der Kasel ist, die Tunicella und Dalmatik. Eigentïmlich sind den orientalischen Riten dagegen der Sakkos des griechischen Ritus, eine der Dalmatik formverwandte und den liturgischen Mantel vertretende Obertunika der Metropoliten und Bischöfe, das Epigonation der Bischöfe und Prälaten (Griechen, Armenier) und die Epimanikien oder liturgische Stauchen, die sich in allen Riten des Orients finden ${ }^{1}$.

Im einzelnen gilt von der liturgischen Gewandung der Riten des Ostens folgendes:

In allen haben die Lektoren nur eine Tunika. Die Subdiakone tragen aufer der Tunika einen Gürtel bei den Griechen, den Manipel bzw. Epimanikien bei den Armeniern, eine Stola bei den Syrern, Chaldäern und Kopten. Die Diakone sind nach allen Riten mit Tunika und Stola (Orarion) ausgestattet; der Epimanikien bedienen sie sich in allen Zweigen des griechischen Ritus, einer liturgischen Kopfbedeckung in einzelnen Fällen bei den Armeniern. Die wenigste Versehiedenheit offenbart sich hinsichtlich der priesterlichen Gewandung. Sie besteht bei allen Orientalen aus Tunika, Stola, Gürtel und Epimanikien. Einen Amikt tragen die armenischen und die unierten koptischen, einen sakralen Kopfschmuck die armenischen und nicht unierten koptischen Priester. Das Obergewand ist zweifacher Art, entweder ein vorn geschlossener oder ein vorn geöffneter Mantel. Ersterer eignet dem griechischen, letzterer allen übrigen Riten.

Ein erheblicherer Unterschied besteht zwischen den spezifisch pontifikalen Gewandstücken der verschiedenen orientalischen Riten. Das Epigonation kennen nur Griechen und Armenier, das Omophorion Griechen, Armenier, Syrer und die katholischen Kopten. Eine Mitra in abendländischer Form begegnet uns im armenischen Ritus sowie bei den unierten Kopten, Syrern und Chaldäern, eine sonstige Kopfbedeckung, sei ès in Gestalt einer Krone, eines Hutes, Turbans oder Schleiers, bei den Griechen, nicht unierten Chaldäern und Kopten. Der Sakkos ist nur dem griechischen Ritus eigen.

Der Vergleich zeigt ein Doppeltes.

Erstens läbt sich eine wesentliche Übereinstimmung zwischen der Sakralgewandung der verschiedenen orientalischen Riten nicht verkennen. Die Hauptstücke derselben sind überall die nämlichen, wenn sie auch in Bezug auf die Ausstattung und die Tragweise im einzelnen voneinander abweichen. Es erhellt daraus, dak die Sakraltracht der Riten des Ostens einen gemein-

1 Hier wie im folgenden unterscheiden wir den griechischen Ritus, zu dessen Schattierungen auch die Russen, Ruthenen, Bulgaren, Melchiten und Italo-firjechen gehören, den armenischen. den syrischen, den chaldäischen und koptischen und zählen zu dem syrischen die monophysitischen Syrer oder Jakobiten, die unierten Syrer oder sog. reinen Syrer und die Maroniten, die in der Liturgie vieles aus dem römischen brauch heribergenommen haben (vgl. Die Synode vom Berge Jibanon aus dem Jahre 1736, in Coll. Lac. II 1к8), zum chaldisischen die nicht unierten
Nestorianer und die unierten Nestorianer, die eigentlichen Chaldäer. Zum koptischen Ritus rechmen wir die nicht unierten Kopten Ägyptens, die abessinischen Kopten und die unierten Kopten Ägyptens. Prinzip dieser Unterscheidung ist die Übereinstimmung im Ritus. Eine etwas andere Teilung, wabei indessen nicht der Ritus, sondern der Gesamtcharakter der verschiedenen Zweige del Kirche des Ostens makgebend ist, bei J. Silbernagl, Verfassung und gegenwärtiger Bestand sämtlicher Kirchen des Orients, Regensburg 1904. 
samen Ursprung und Ausgang haben muk, der angesichts des zwischen den einzelnen Riten bestehenden Gegensatzes unzweifelhaft in eine Zeit hinaufreicht, da die Ostkirche noch nicht in Sekten zerklüftet war.

Auf der andern Seite ergibt sich aber aus dem Vergleiche auch, das die Kultgewandung bei den einzelnen Riten ihre eigene Entwicklung durchgemacht hat. Es fehlt ja nicht an mancherlei Unterschieden. Es sind weder alle Gewänder in allen Kirchen des Ostens Brauch, noch stimmen sie in Bezug auf die Beschaffenheit und die Weise, wie sie angelegt werden, völlig überein. Indessen ist auch das durchaus erklärlich. Bei dem selbständigen Charakter der orientalischen Kirchengemeinschaften konnte ebensowenig wie in Bezug auf den Ritus hinsichtlich der Kulttracht eine selbständige Fortentwicklung und Ausbildung ausbleiben.

Aufer den bisher erwähnten gibt es aber auch noch eine Anzahl von Gewandstücken, welche zwar nicht zu den liturgischen Gewändern in eigentlichen sinne gehören, jedoch entweder im weiteren Sinne der liturgischen Kleidung beigezählt werden können oder durch ihre $V$ erwandts chaft mit bestimmten Bestandteilen der letzteren eine kurze Behandlung oder doch Erwähnung verdienen. Es sind das Rochett, die Cappa magna, die Almutia, die Mozetta, der griechische Mandyas, die Tiara, der Pileolus und das Birett. Namentlich erheischt das Rochett eine Besprechung, weil es nicht nur ehedem vielfach als Ersatz des Superpelliceums verwendet wurde, indem man beim Gebrauch nicht zwischen hochett und Superpelliceum unterschied, sondern auch noch jetzt hie und da in dieser Eigenschaft Verwertung findet.

Was den Gewandcharakter der einzelnen Stiicke der Sakralkleidung anlangt, so kann man diese in vier Gruppen scheiden: Untergewänder, (Ohergewänder, Bekleidung der Hände, des Fubes und des Kopfes und Abzeichen. Zu den Untergewän dern zählen der Amikt, der päpstliche Fanone, die Albe mit ihrem Zubehör, dem Cingulum und den Epimanikien, das päpstliche Subcinctorium und, als Ersatz der Albe, das Superpelliceum (Rochett). Zn den Obergewändern rechnen die Kasel, die Dalmatik, die Tunicella und das Pluviale, welch letzterem passend die Cappa magna, die Almutia und die Mozetta angeschlossen werden. Die Almutia war ursprünglich allerdings eine Kopfbedeckung, nicht mantelartiges Bekleidungsstück; später wurde sie jedoch jenem ersteren Zwecke ganz entfremdet und zum bloken Schultermäntelchen. Der dritten Gruppe gehören an die Pontifikalhandschuhe, die Pontifikalstrümpfe, die Pontifikalsandalen und die Mitra, von den liturgischen Ornatstiicken im weiteren Sinne aber Tiara, Pileolus und Birett. Die vierte endlich umfafit den Manipel, die Stola, das Pallium und das Rationale.

Die Punkte, welche bei Behandlung der einzelnen Gewänder in Betracht kommen, sind Ursprung, formelle Entwicklung, stoffliche Beschaffenheit, Ausstattung, Träger, Verwendung im liturgischen Dienst, Farbe, mystische Deutung und Segnung. Auf die ersten sechs muk bei jedem der verschiedenen Ornatstücke eingegangen werden; dagegen empfiehlt es sich, die drei letzten erst nach Abschluf der den Gewändem gewidmeten Lntersuchungen zusammenfassend zu besprechen. Die kirchliche Farbenregel, die mystische Deutung und die Segnung der liturgischen Kleidung bedeuten nicht nur für diese eine äuferliche, durch die Beschaffenheit der Gewänder und ihre Verwendung an sich noch nicht gegehene Zutat, sie haben obendrein auch ihre eigene freschichte, die sich übersichtlich nur behandeln läfist, wenn sie losgelöst von den einzelnen Oruatstücken im Zusammenhang dargestellt werden. Demgemäf folgt den Abschnitten, welche den Untergewändern, den Obergewändern, der Bekleilung der Hände, der Füßße, des Hauptes und den liturgischen. Abzeichen gewidmet sind, ein weiterer, der sich mit der kirchlichen Farbenregel, rer mystischen Deutung und der Segnung der heiligen Gewänder beschäftigt. 
Was die Methode der Behandlung der einzelnen Gewandstücke anlangt, so werden diese zunächst nach Beschaffenheit und Verwendung geschildert, wie es der gegenwärtige Brauch will. Die heutige liturgische Kleidung ist ja das Elgebnis nicht des Zufalls, sondern einer langen Entwicklung. Wer daher an das Studium ebendieses Prozesses herantreten will, tut gut, vor allem sich mit dem Resultat desselben recht vertraut zu machen. Je klarer und bestimmter dieses vor seinem Geiste steht, um so besser wird er die verschiedenen Phasen in der Ausgestaltung der liturgischen Gewandung und die in ihr jeweilig zum Ausdruck kommende Tendenz verstehen.

Die Untersuchung über dje Entwicklung der Kultgewänder selbst knüpft an das nachweisbar früheste Auftreten der letzteren an, um dann ron da bis zur Gegenwart herabzusteigen. Die Erörterung über ihren Ursprung und ihre Ableitung macht in der Regel den Beschluf. An sich wäre es freilich natürlicher, hiermit zu beginnen. Allein so klar im allgemeinen der Ursprung der liturgischen Kleidung ist, so läbt sich das doch nicht in gleichem Maßse von allen und den einzelnen Bestandteilen derselben sagen. Es genügt, auf die verschiedenen Meinungen hinzuweisen, welche hinsichtlich der Herleitung z. B. des Manipels, der Stola, des Palliums bestehen. Aufierdem verliert sich bei manchen der Gewänder die älteste Geschichte zu sehr ins Dunkle, so daf3 wir weniger durch positive Nachrichten, als vielmehr durch die Verwandtschaft, die zwischen ihnen und den entsprechenden profanen Kleidungsstuicken in Bezug auf Charakter und Form besteht, auf ihren Ursprung hingewiesen werden. Man denke nur an den Amikt, die Albe, das Cingulum, die Mitra, die Pontifikalhandschuhe usw. Unter solchen Umständen erschien es nicht bloß als zweckmäßig, sondern zur möglichsten Klarstellung der Sachlage als notwendig, die Frage nach der Ableitung der einzelnen Ornatstücke für gewöhnlich erst an den Schlußs der betreffenden Untersuchung zu setzen. Manche Irrtümer hinsichtlich des Ursprungs der liturgischen Gewandung haben ihren Grund vornehmlich in einem allzu aprioristischen Vorgehen. Sie wären vermieden worden, wenn man mehr von der Erscheinung ausgegangen wäre, welche die einzelnen Gewänder bei ihrem ersten Auftreten und dann in der Folge gewähren.

Wenn in der Arbeit die Bestandteile der liturgischen Kleidung jeder für sich, nicht im Zusammenhang miteinander nach bestimmten Epochen besprochen werden, so liegt die Ursache hierfür teils in den unleugbaren Vorteilen, welche diese Methode zunächst für das Verständnis der Entwicklung der einzelnen Ornatstücke, dann aber indirekt auch für das der Ausgestaltung der ganzen Kulttracht bietet, teils in der ungemeinen quantitativen und qualitativen Ungleichheit des Nachrichtenmaterials, welches aus den verschiedenen Zeiten über die Sakralkleider vorliegt. Das gilt besonders für die vorkarolingische Periode, zum Teil aber selbst noch für die Frühe des zweiten Jahrtausends. Es geschah sonach nicht ohne Grund, wenn bisher fast allgemein die Geschichte der liturgischen Gewandung in eine Geschichte der liturgischen Gewänder aufging. Von Nachteil war hierbei, daf gewisse Fragen allgemeiner Art nicht oder nicht hinlänglich zur Erörterung kommen konnten und dala dem Zusammenhang in der Ausgestaltung der Kultkleidung zu wenig Aufmerksamkeit geschenkt wurde. Um diesen Übelstand in der vorliegenden Arbeit nach Möglichkeit zu vermeiden, wird ihren Abschlus eine zusammenfassende Übersicht über die Entwicklung der liturgischen Gewandung in den verschiedenen Epochen bilden. Sie wird eine Ergänzung der Untersuchungen 
sein, welche deren einzelnen Bestandteilen gewidmet waren, zugleich aber auch in einem Gesamtbild das Ergebnis dieser Untersuchungen nach Maßgabe der einander folgenden Perioden vorführen.

\section{QUELLEN.}

Die Quellen für die nachfolgende Geschichte der liturgischen Gewänder sind vor allem Bestimmungen von Konzilien oder sonstige Verordnungen der mafigebenden kirchlichen Autoritäten betreffs der sakralen Kleidung, die liturgischen Bücher, die Schriften der Liturgiker, die Inventare, die Monumente mit Darstellungen geistlicher Personen in ihrer liturgischen Tracht und endlich die a us früherer Zeit noch erhaltenen Ornatstücke. Es erscheint angebracht, auf diese Quellen etwas näher einzugehen und sie nach Wert und Bedeutung zu würdigen.

Die erste bietet wenig zu bemerken. Eingehendere Bestimmungen über die liturgischen Gewänder, ihre Beschaffenheit, Form und die für sie zu nehmenden Stoffe fehlen im Mittelalter vollständig. Es gibt deren weder, die für die ganze Kirche oder doch das ganze Abendland erlassen wurden, noch solche für einzelne Diözesen oder Kirchenprovinzen. Selbst Verordnungen, in denen die Zahl der zur liturgischen Gewandung gehörenden Einzelstücke aufgeführt werden, sind selten. Sehen wir von der "Synodalermahnung “ (9. Jahrhundert) $a b$, so beschränken sie sich anf die Statuten Riculfs von Soissons (889), der Synode von Coyaca $\left(1050^{1}\right)$ und der Synoden von Lüttich $\left(1287^{2}\right.$ ) und Cambrai (ca $1300^{3}$ ). Aber auch die Neuzeit brachte im ganzen. wenig ausdrückliche Bestimmungen über die Sakralkleidung. Die eingehendsten Torschriften erlief über dieselbe der hl. Karl Borromäus, Vorschriften, die zwar in Rom approbiert wurden, indessen auch so ihre lediglich partikuläre Bedeutung behielten, ein Punkt, der bei den Reformbestrebungen, wie sie die Mitte des 19. Jahrhunderts bezïglich des Paramentenwesens hervorbrachte, häufig übersehen wurde. Aufer dem hl. Karl er-

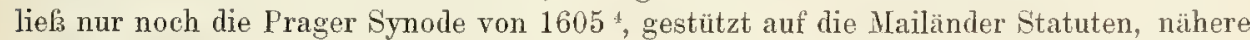
Bestimmungen, Bestimmungen, welche dann von der Prager Synode von $1860^{\circ} \mathrm{im}$ wesentlichen wieder erneuert wurden. Was in den Generalrubriken des Missale und den Rubriken des römischen Caeremoniale, des Pontificale und Rituale bezüglich der liturgischen Ornatstücke festgesetzt wird, betrifft fast nur deren Verwendung. Auch was die Ritenkongregation seit ihrem Entstehen an Entscheidungen erließ, bezieht sich auf kaum etwas anderes denn auf Zweifel, die ihr bezüglich des Gebrauches der Gewänder vorgelegt worden waren. Erst die neueste Zeit brachte verschiedene Dekrete über den Stoff, die Verzierung und die Form einzelner der letzteren. Wie der Ritus uiberhaupt, so beruhte demnach auch die Sakralkleidung mehr auf Brauch und Herkommen als auf ausdrücklichen kirchlichen Bestimmungen, ein Umstand, der für die Geschichte ihrer Entwicklung von großer Bedeutung ist. Denn er erklärt, wie die liturgischen Gewänder im Laufe der Zeit fast unmerklich und ohne dafo die kirchlichen Autoritäten sich gegen ein solches Vorgehen erhoben, die tief eingreifenden Veränderungen erleiden konnten, welche mit ihnen vorgingen. Man denke nur an die Kasel, die Dalmatik, Tunicella, Mitra. Aber auch für die Verwendung der Sakralkleidung war mehr die jeweilige, nach Ort und Zeit wechselnde Praxis denn bestimmte Satzungen makgebend. Nur für die Feier der Messe hatte sich schon im 9. Jahrhundert ein Kanon gebildet, wiewohl noch um die Wende des Jahrtausends in der Praxis bezüglich des Amikts, wie es scheint, ein Schwanken statthatte. Von besonderer Wichtigkeit sind eine freilich nicht große Zahl von konziliaren Bestimmungen aus vorkarolingischer Zeit hinsichtlich einzelner liturgischer Gewänder.

${ }^{1} \mathrm{Hard}$. VI 1, 1025.

${ }^{2} \mathrm{Hartzh}$. III 690.
${ }^{3}$ Ib. IV 70.
${ }^{4}$ Ib. VIII 691.

${ }^{5}$ Coll. Lac. V 538. 
Die liturgischen Bücher, Sakramentare, Pontifikalien, Missalien, Ordines sind besonders wertvoll für die Kenntnis der Verwendung der sakralen Kleidung und die Symbolik, welche man mit dieser verband. Über die Beschaffenheit geben sie meist nur indirekt einigen Aufschluf. Namentlich sind für die Geschichte der Sakrallileidung ron Bedleutung die Ordines, Gottesdienstordnungen, Zusammenstellungen von Angaben über die Feier der liturgischen Verrichtungen, auch Konsuetudinare, Consuetudines, Ordinare, Agenden u. ä. genannt, vor allem die sog. römischen Ordines. Sie sind, nachdem schon früher einige derselben herausgegeben worden waren, am rollständigsten durch Mabillon veröffentlicht worden '. Seine Publikation umfaft im ganzen 15 Ordines, von denen nux der vierte (ein kurzes Fragment) und der sicbence (ein Taufordo) für die liturgische Gewandung nicht in Betracht kommen. Der achte und neunte sind Weiheordines, $d . h$. sie geben den Ritus wieder, nach dem zu Rom die heiligen Weihen statthatten. Die Mabillonsche Ordinessammlung ist eine überaus schätzenswerte Quelle für die Geschichte der römischen Liturgie im allgemeinen wie der römischen Sakraltracht im besondern. Sie entspricht indessen nicht mehr allerwegen dem heutigen Stand der kritischen Forschung, weshalb eine Neuherausgabe der römischen Ordines dringend zu wünschen wäre.

Was das Alter der Mabillonschen Ordines anlangt 2, so stammt der erste, von dem Anhang abgesehen, in seiner jetzigen Form, wie es scheint, etwa aus der Mitte, der zweite und dritte aus dem Ende des 8. Jahrhunderts. Der einem St Gallener Kodex entnommene fünfte Ordo ist von hervorragender Bedentung durch das Verzeichnis der Bestandteile der liturgischen Kleidung der verschiedenen römischen Geistlichen, vom Papst angefangen bis zu den Akolythen. Der Kodex, in dem er sich findet, gehört dem 10. Jahrhundert an, doch ist der Katalog selbst älteren Datums und schon im Lauf des 9. Jahrhunderts entstanden. Wir werden die Aufstellung, auf die wir uns des öfteren beziehen müssen, der Kürze halber mit S. G. K. (St Gallener Kleiderkatalog) bezeichnen. Der sechste Ordo gibt den Ritus der römischen Pontifikalmesse wieder, wie er um 1000 an manchen Orten außer Rom rezipiert war, von den beiden Weiheordines stanmt der erste, der achte Mabillons, etwa aus der zweiten Hãlfte des 8., der zweite aus dem 9. Jahrhundert. Der zehnte Ordo gehört dem 11.-12. Jahrhundert an, der elfte wurde zwischen 1140-1143 von einem Kanonikus von St Peter, Benedikt mit Namen, der zwölfte zu Lebzeiten Cölestins III. (1191-1198) von dem Kardinal Cencius de Sabellis und späteren Papst Honorius III. verfafit. Der dreizehnte Ordo wurde unter dem Titel Caeremoniale Romanum auf Befehl Gregors X. (1271-1276) herausgegeben. Der vierzehnte Ordo ist eine im 16. Jahrhundert entstandene Kompilation ${ }^{3}$, die aufer Auszügen aus Diarien, dem ebengenannten Caeremoniale und dem gleich zu erwähnenden Ordo des Petrus Amelii auch das in mancher Beziehung wichtige, von Kardinal Jakob Gajetanus Stefaneschi um 1311 verfafite Ordinar enthält. Der fünzehnte Ordo endlich hat zum Urheber den Bischof Petrus Amelii von Sinigaglia, 1401 als Patriarch von Grado gestorben. Er führt den Titel: Liber de caeremoniis ecclesiae Romanae. Ein Mabillon unbekannt gebliebener römischer Ordo aus dem 9. Jahrhundert, der für die Geschichte der liturgischen Gewandung verschiedene sehr bemerkenswerte Notizen enthäl, wurde von L. Duchesne herausgegeben ${ }^{4}$.

Von auferrömischen Ordines ist bisher im ganzen nur wenig veröffentlicht worden, wenigstens harrt ungleich mehr noch des Augenblicks, da es ans Licht treten soll. Obendrein ist die Ausbeute, welche sie für die Geschichte der Sakralkleidung liefern, im allgemeinen nicht in gleichem Maßse erheblich wie die, welche die römischen $\mathrm{Or}^{\mathrm{r}}$ -

1 Museum Ital. II, Paris. 1689, $1 \mathrm{ff}$; bei M. $88,937 \mathrm{ff}$.

2 Über die römischen Ordines vgl. besonders auch $\mathrm{Eb}$ ner $47 \mathrm{ff}$. Beim fünften Ordo wird hier nicht zwischen dem Kleiderverzeichnis und dem eigentlichen Meßordo unter- schieden, und doch gehören beide verschiedenen Zeiten an. Sie sind nur deshalb bei Mabillon zusammengestellt worden, weil sie im St Gallener Kodex einander folgen.

${ }^{8}$ Cod. Vat. Urbin. 469.

"Duch., Orig. $456 \mathrm{ff}$. 
dines gewähren. Am ergiebigsten sind noch einzelne der alten monastischen Konsuetudinare, namentlich die Consuetudines Farfenses ".

Von den vorkarolingischen Sakramentaren tut lediglich das altirische sog. StoweMissale, und zwar nur gelegentlich in einem Vorbereitungsgebet, zweier liturgischer Gewänder, der Albe und des Cingulums, Erwähnung 2. Erst im 9. Jahrhundert wird der Sakralkleider in den Sakramentaren etwas häufiger gedacht, doch ist in diesen sowie den mittlerweile in Gebrauch gekommenen bischoflichen Pontifikalien noch in 10., ja 11. Jahrhundert im ganzen von ihnen blos selten die Rede. Werden sie aufgeführt, so geschieht es entweder im Ankleideritus oder bei Darstellung der Weihezeremonien, hie und da auch in den Rubriken des Gründonnerstags oder Karfreitags. Auch als die Missalien und Pontifikalien durch Aufnahme reichlicherer Rubriken sich vervollständigt hatten, werden sie kaum anders als bei diesen Gelegenheiten erwähnt.

Was an Liturgien und Weiheordines der orientalischen Riten herausgegeben wurde, bietet für die Geschichte der liturgischen Kleirlung entweder kein oder doch nur sehr geringes Material. Obendrein entstammen dieselben meist entweder recht später Zeit oder sind sehr unsichern Datums. Die meiste Bedentung haben noch die von Joh. Morinus $(\dagger$ 1659), den Brüdern Joseph Alois († 1782) und Joseph Simon († 1768) Assemani und H. J. Dom. Denzinger ( $\dagger$ 1883) veröffentlichten Weiheordines ${ }^{3}$.

Von größster Bedeutung sind für die Kenntnis der mittelalterlichen Sakralkleidung die Schriften der alten Liturgiker, allerdings nur für die Zeit von dem Beginn des 9. bis zum letzten Viertel des 13. Jahrhunderts. Was nach dem letzteren liegt, ist teils infolge seiner Knappheit, teils weil es fast nur auszugsweise das Rationale des Durandus wiedergibt, ohne Bedeutung. Aus vorkarolingischer Zeit liegt nur eine kurze liturgische Schrift, die vielleicht noch bis zum 6. Jahrhundert hinaufreichende gallikanische Meferklärung t,

1 Ed. P. Bruno Albers, Stuttgart 1900. Andere Ordines werden im Laufe der Arbeit erwälnt.

\& Über das Stowe-Missale, dessen ältester Teil, wozu jenes Gebet gehört, nicht ohne Grund dem zweiten Viertel des 7. Jahrhunderts zugeschriehen wird, vgl. namentlich M ac Carthy, On the Stowe Missal, in Transactions of the Royal Irish Academy XXVII, Dublin 1886, $135 \mathrm{ff}$ und den hieran sich anschlieBenden Aufsatz von P. S. B a e umer O. S. B., Das Stowe-Missale, in Zeitschrift für kath. Theologie XVI, Innsbruck 1892, $446 \mathrm{ff}$.

${ }^{3}$ Die sog. Liturgie des hl. Joh. Chrysost. unter anderem bei Mg. 63, $901 \mathrm{ff}$. Eine syrische Meßliturgie gab Fabricius Boderianus im Anhang zur Taufliturgie des Severus von Antiochien (Antverp. 1572) heraus; die armenische bei Le Brun III 58 ff. Wegen der koptischen Mefkkleidung vgl. die Angaben des Rituale des Patriarchen Gabriel (ca 1140) bei Renaudot, Collectio liturgiarum orientalium I, Francofordi 1847, 160. Weiheordines bei Mor in us in De sacris ecclesiae ordinationibus $\mathrm{I}$, Paris. 1655, bei Jos. Alois Asse$\mathrm{mani}$ in dessen Codex liturgicus ecclesiae universae VIII, 2-5, Romae $1749 \div 1766$, bei Jos. Sim. Assemani in Bibliotheca orientalis Clementino-Vaticana II III, Romae 1719-1728, und bei Denzinger in Ritus orientalium, Coptorum, Syrorum et Armenorum in administrandis sacramentis II, Wirceburgi 1863 und
1864; vgl. auch A. von Maltzew, Die Sakramente der orthodox-katholischen Kirche des Morgenlandes, Berlin 1898, $301 \mathrm{ff}$.

4 Über das Alter und den Verfasser der gallikanischen Mefaerklärung sind die Ansichten sehr geteilt. Martèn e, ihr erster Herausgeber (M. 72, 87), hält es nicht für unwahrscheinlich, daf3 der lıl. Germanus ihr Verfasser sei oder daß sie doch einen Auszug aus einer Schrift des Heiligen darstelle. Jedenfalls glaubt er sie dem 6. Jahrhundert zuschreiben zu diurfen. M a r r i o t t (Vest. christ. 204, Note 421) weist die Meferklärung mit der kurzen Bemerkung: Internal evidence points to the $\mathrm{IX}^{\text {th }}$ or $\mathrm{X}^{\text {th }}$ century as the earliest, at which the Ms. could have been actually written, frühestens dem 9. oder 10. Jahrhundert zu, worin ihm Krieg (Realenc. II 200) folgt. Thalhofer und Ebner bemerken, die Expositio brevis antiquae liturgiae gallicanae werde mit guten Gründen dem Bischof Ger. manus beigelegt ( $\mathrm{Tha}$ h h ofer I 59: E b n e r I 70). Duchesne (Orig. 155) sagt: Je ne vois pas la moindre raison, de contester cette attribution. Ähnlich entscheidet sich Propst (Die abendländische Messe 316). Nirschl hält die Autorschaft des hl. Germanus für zweifelhaft (Patrologie III, Mainz 1885, 517). Franz meint (Die Messe 340), die Schrift sei; wean nicht vom hl. Germanus, so doch nolil noch aus dem 6. Jahrhundert. Koch. (Tübinger 
vor, welche den gallikanischen Ritus samt dessen liturgischer Kleidung behandelt. Denn das angebliche Schriftchen Bedas des Ehrw. De septem ordinibus ist nichts als eines der vielen frühen Exzerpte aus Hrabans und Amalars Erörterungen über die liturgischen Gewänder, n i ch t aber die Vorlage derselben.

Die Liturgiker des 9. Jahrhunderts, welche von der liturgischen Kleidung handeln, sind Hraban $(\dagger 856)$, Amalar († ca 850), Walafried Strabo $(\dagger$ 849) und PseudoAlkuin '. Hrahan schrieb 819, Amalar 820, Walafried um 841, die unter dem Namen Alkuins gelende schrift De divinis officiis aber entstand um den Ausgang des Jahrhunderts. Hraban behandelt nur die priesterlichen bzw. bischöflichen Gewänder, und zwar knilz und nüchtern, Amalar gibt dagegen eine ausführliche Schilderung der gesamten liturgischen Tracht. Allerdings bezweckt er keineswegs, eine Kenntnis der formellen und qualitativen Beschaffenheit der Sakralgewänder zu vermitteln, er will diese Fielmehr lediglich mystisch erklären; allein der Umstand, daß er bei ihrer Ausdeutung auf die Einzelheiten die größte Rücksicht nimmt, macht aus den fraglichen Abschnitten seiner Schrift eine tatsächliche, zum Teil sehr eingehende Beschreibung der liturgischen Kleidung. Amalar hat zu seiner Zeit wie bezüglich der mystischen Deutung im allgemeinen, so bezüglich seiner Auslegung der liturgischen Gewandung heftigsten Widerspruch gefunden. Es wurde sogar auf das perfide Betreiben des Lyoner Diakons Florus hin, der Sätze aus dem Zusammenhang rif und ihnen einen falschen Sinn unterlegte, seiner Deutungsweise von der Synode zu Quiercy 838 eine entschiedene Verurteilung $z u$ teil. Aber auch in unserer Zeit hat man über Amalar zu hart abgeurteilt, ohne zu bedenken, daßs man einen Mann des 9. Jahrhunderts nicht schlechthin nach den Gepflogenheiten und dem Geschmack des 20. bemessen darf. Amalar war bei aller überströmenden Phantasie und bei manchen unserem Empfinden schlecht zusagenden Gedankenflügen und Einfällen ohne Zweifel ein scharfsinniger, groß angelegter Geist, dem es nur an Schulung fehlte, ein Geist, der die Ideenrichtung der Zeit klar erfaft hatte, dessen Schöpfungen daher auch trotz ihrer Verurteilung das ganze übrige Mittelalter hindurch von gröftem Einfluf auf die Auffassung der liturgischen Verrichtungen waren, ein Geist, der jahrhundertelang auf dem Felde der Deutung der Liturgie und alles dessen, was in ihren Bereich gehört, wie kein anderer die Herrschaft ausüben sollte, und

theol. QuartalschriftLXXXII [1900]528) glaubt dis Expositio dem Heiligen mit Rücksicht darauf, daß sie die Ausweisung der Katechumenen als nicht mehr in Brauch befindlichen Ritus darstelle, während dieser doch noch im frühen 6. Jahrhundert in Gallien bekannt gewesen sei, entschieden absprechen zu sollen. Die Ansicht Marriotts und Kriegs ist nnter allen Umständen abzuweisen; der Umstand, daßB die Schrift eine Erklärung des gallikanischen Meßritus gibt, läßst keinen ernsten Zweifel, daß3 sie vorkarolingisch ist. Die Anuahme, dafi sie vom hl. Germanus herrühre, stützt sich auf die Eingangsworte der Schrift. Indessen bieten diese, wie Koch mit Recht betont, keine genügende Unterlage für eine solche Zueignung. Auch wenn man sie nicht lediglich als Zitat aus einer verloren gegangenen Schrift des Heiligen auffafst, so gewähren sie bei der Unzuverlässigkeit so mancher mittelalterlichen Aufschriften doch zu wenig Bürgschaft für ihre Richtigkeit. Eine andere Frage ist freilich, ob der von Koch geltend gemachte Grund stichhaltig genug ist, um die Schrift schlechthin dem hl. Germanus absprechen zu können. Wie dem indessen sein mag, jedenfalls ist diese, und darauf kommt es vor allem an, vorkarolingisch. Auch mag sie immerhin, wenn nieht ins 6. Jahrhundert hinein, so doch bis gegen dasselbe hinaufreichen.

1 Die Schriften dieser und der späteren Liturgiker sind bereits früher in einem der Vorrede folgenden besondern Verzeichnis unter gleichzeitiger Angabe des Bandes und Ortes, wo sie in der Migneschen Vätersammlung zu finden sind, zusammengestellt. Es ist daher überflüssig, hier noch einmal die Titel der Schriften anzuführen. Die Schrift Hrabans De institutione clericorum libri tres und $W$ alafrieds De exordiis et incrementis quarundam in observationibus ecclesiasticis rerum wurden jüngst in vortrefflicher Weise neu ediert von A. Knöpfler, München 1899 und 1901; nur geht es wohl nicht an, mit dem Herausgeber die Schrift De septem ordinibus als Werk Bedas und als Vorlage für Hraban zu betrachten. Ausführlicheres über die karolingischen Liturgiker, als der Raum hier gestattet, bei $\mathrm{Ebn} \theta \mathrm{r} 73 \mathrm{ff}$. 
selbst bei IIännern wie Innozenz III. Anerkennung und Ausnutzung fand. Amalar war aber auch, und das macht hier seine besondere Bedeutung aus, ein guter Beobachter, und darum verdanken wir ihm einen grofen Teil der eingehenden Kenntnisse, welche wir von der liturgischen Gewandung des 9. Jahrhunderts besitzen. PseudoAlkuin bietet in seiner Abhandlung über die sakrale Kleidung des Neuen Bundes nichts von Belang. Was er vorbringt, ist nur ein Exzerpt aus Amalar und Hraban. Dagegen enthält das Kapitel über die jüdische Kultkleidung verschiedene sehr wertvolle Notizen über einzelne neutestamentliche liturgische Ornatstücke, die sich bei keinem der früheren Liturgiker finden und ganz das Eigentum Pseudo-Alkuins sind. Walafried sagt nur wenig von den liturgischen Gewändern. Mystische Deutungen meidet er, dagegen macht er einige Bemerkungen über den Ursprung derselben, ein schwacher Ansatz zu einer Geschichte der Sakralgewandung, der freilich noch für Jahrhunderte auch nur Ansatz bleiben sollte.

Pseudo-Alkuin ist der letzte Liturgiker der Karolingerzeit, dem wir Angaben über die liturgischen Gewänder verdanken. Erst die zweite Hälfte des 11. Jahrhunderts bringt neve liturgische Schriften, die sich mit denselben beschäftigen, im 12. folgt dann eine reiche Literatur über die Kultkleider freilich ganz im Geist der Zeit, deren Streben vor wie nach völlig in der herkömmlichen mystischen Betrachtung und Deutung der liturgischen Gewänder aufging. Es waren die alten von Hraban und namentlich Amalar eingefahrenen Pfade, auf denen die Liturgiker auch jetzt voranzogen. Immerhin spiegelt sich in den betreffenden Schriften, sofern sie nicht lediglich Exzerpte ans den karolingischen Liturgikern sind, der mehrfach veränderte stand der Sakralgewandung im 11. und 12. Jahrhundert, genügend wider, so daß sie bei allem Festhalten an der alten Deutungsweise manchen wertvollen Beitrag zur Geschichte der liturgischen Kleidung jener Tage liefern.

Der erste, dem wir im 11. Jahrhundert eine Abhandlung über die Sakralkleider verdanken, ist Johannes von Avranches († 1079 ). Sie findet sich im Anhang zu dem von ihm abgefafiten Ordo. Dann folgen Ivo von Chartres ( $\dagger$ ca 1117), Bruno von Segni († 1123), Rupert von Deutz († 1185), Honorius (schrieb um 1120). Der zweiten Hälfte des 12. Jahrhunderts gehören an Robert Paululus († ca 1184), Johannes Beleth $(†$ nach 1165), der indessen nur wenig über die liturgische Kleidung sagt und selbst dies wörtlich aus der Gemma animae des Honorius oder einer äIteren Quelle entnommen hat, aus der auch dieser geschöpft haben mag. In dieselbe Zeit fallen anch das Speculum de mysteniis ecclesiae mit seinem der Sakralkleidung gewidmeten sechsten Kapitel, der 14. der hundert Sermones im Anhang der Werke Hugos von St Viktor, und der irrig Stephan von Bauge zugeschriebene Tractatus de sacramento altaris. Am Schlufs des Jahrhunderts stehen Sicard von Cremond ( $\uparrow 1215)$ und Innozenz III. († 1216). Am selbständigsten von allen erscheinen Rupert von Deutz und namentlich Bruno von Segni sowie der angeführte Sermo XIV; am ansführlichsten behandelt die liturgische Kleidung Honorius. Was Robert Paululus schreibt, ist fast nur Auszug aus des Honorius Gemma. Auch Sicard ist in hohem Maßse Kompilator, während Innozenz III. zwar ebenfalls nur wenig Neues bringt, immerhin aber das Alte in ansprechender Weise zu verarbeiten gewußt hat. Der Wende des Jahrhunderts gehört auch eine gereimte deutsche Meßerklärung an, in welcher die liturgische Gewandung eine zum Teil recht eigenartige Deutung erfährt ${ }^{2}$.

Was das 13. Jahrhundert an Werken über die Liturgie schuf, ist für die Geschichte der liturgischen Gewandung fast ohne Bedeutung. Das gilt selbst von dem Rationale des Durandus, einer ungemein fleißigen, im einzelnen aber wenig geordneten Sammlung alles dessen, was frommer Sinn bis dahin über die Messe, das Offizitum,

1 Näheres über die Liturgiker des 11 . bis 13. Jahrhunderts bei $\mathrm{Ebn}$ er 79 ff und Franz 407 ff. Über Honorius und die Streitfrage betreffs seiner Nationalität, Sicardus und Durandus namentlich die vor- zügliche Schrift von J. S a u er. Symhnlik des Kirchengebäudes, Freiburg 190\%, $12 \mathrm{ff}$.

${ }^{2}$ Kelle, Speculum de mysteris ecclesiae, München $1858,149 \mathrm{ff}$. 
das Kirchenjahr usw. und auch die Sakralkleidung Erbauliches und Nystisches ersonnen und geschrieben hatte. Teraltetes und im Brauch Stehendes wird in einer Weise vermengt, daß es in manchen Fällen schwer ist, Vergangenheit und Gegenwart zu sondern. Für die mittelalterliche Anschaungsweise freilich, die nur an mystische Ergründung des Sinnes der litmgischen Gewänder wie der liturgischen Verrichtungen überhaupt dachte, war das Rationale das ganze noch übrige Mittelalter das Universalhandbuch der Liturgik ${ }^{1}$.

Der liturgischen $\Delta$ bhandlungen aus den Riten des 0 stens, welche sich mit Erklärung der Kútgewänder beschäftigen, sind nur sehr wenige.

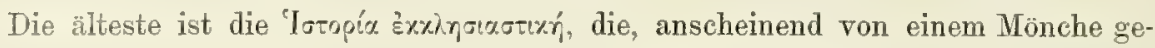
schriehen. sehr wahrscheinlich noch in die vorkarolingische Zeit fällt ${ }^{2}$. Eine Erweiterung:

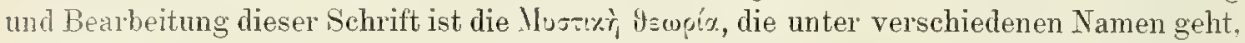
namentlich dem des hl. Germanus von Konstantinopel († 733), daher auch wohl PseudoCermanus genannt ${ }^{3}$. Thr Alter mit Sicherheit festzustellen, ist nicht möglich; jedenfalls fällt sie aber noch in das erste Jahrtausend. Ebenfalls auf der Irrór gründet die von dem Herausgeber, Kard. Angelo Mai, dem hl. Sophronius von Jerusalem ( $†$ 638) zugeschriebene Meßerklärung ${ }^{4}$. Sie entstand, wie Krasnojeljcev nachgewiesen, im 11.-12. Jahrhundert. Eine in Fragen und Antworten abgefaßste kurze Erklärung der heiligen Kleidang, bei welcher St Basilius der Fragesteller ist, St Gregor der Theolog aber antwortet, scheint ebenfalls aus der Frühe des Jahrtausends herzurühren `. Der Wende des 14. Jahrhunderts entstammen die auch für die Kenntnis der damaligen sakralen Gewandung des griechischen Ritus wichtigen liturgischen Traktate des schismatischen Metropoliten Simeon von Saloniki $\left(\dagger 1429^{\circ}\right.$ ). Eine Deutung der Gewänder des syrisch-nestorianischen Ritus findet sich in dem "Buche der Väter", das dem 12. Jahrhundert zugeschrieben wird ${ }^{7}$, Angaben über die liturgischen Gewänder der Kopten enthält die Schrift Ibn Sabaas (14. Jahrh.): Monile pretiosum in scientia

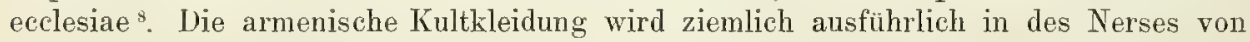
Lampron ( $\dagger$ 1198) Kommentaren zur heiligen und göttlichen Liturgie behandelt 9

Eine wichtige Ergänzung der schriftlichen Nachrichten, welche über die liturgische Gewandung aus dem Mittelalter vorliegen, bilden die Inventare. Sie reichen bis in das Ende des 8. Jahrhunderts hinauf, im ganzen ist indessen, wie leicht begreiflich, ihre Zahl bis zum 13. nicht allzu grof. Aus dem späten Mittelalter hat sich eine lange Reihe von Schatzverzeichnissen erhalten. Die älteren Inventare sind sehr knapp abgefaft und gehen leider häufiger als wünschenswert über Stoff und Verzierung der Gewänder stillschweigend hinweg. Doch gibt es kaum eines dieser älteren Inventare, das nicht von Bedeutung wäre. Die späteren Schatzaufnahmen sind vielfach sehr eingehend und geben oft umständliche Beschreibungen der Stoffe und Verzierungen der Paramente nach Qualität und Darstellungen. Beispiele sind die Inventare von St Paul zu London (1245, 1402), des Schatzes des Apostolischen

1 Betreffs der Meferklärungen des 14. und 15. Jahrhunderts, wobei gewöhnlich auch die Gewånder gedeutet werden, vgl. das bereits erwähnte, für die Geschichte der Meßerklärungen des späten Mittelalters unentbehrliche Werk von A. Franz über die Messe im deutschen Mittelalter $515 \mathrm{ff}$.

2 Jahrbuclı von Odessa IV 2 (1894) $178 \mathrm{ff}$. Krasnojeljcev hält es für möglich, daß die Schrift vom hl. Basilius herrühre, doch ist das blofs eine Vermutung. Der Umstand, daf sie wie die von ihr ahhängige Hestexy Newpic auch den hl. Basilius zugeeignet wird, ist für eine solche Annahme nicht Grund genug.
${ }^{3} \mathrm{Mg} .98,393 \mathrm{ff} . \mathrm{Da}$ in der Schrift die Ankunft des Antichrist auf das Jahr 6500 $=992$ n. Chr. festgesetzt wird, muß sie vor diesem Termin geschrieben sein.

4 Mg. 87, 3, $3985 \mathrm{ff}$.

${ }^{5} \mathrm{~N}$. Krasnojeljeer, Addenda et Anecdota graecobyzantina, Odessa 1898, Nr 13.

${ }_{6} \mathrm{Mg} .155,257 \mathrm{ff} 712 \mathrm{ff}$.

7 Dom Jean Parisot, Le livre des Pires. in La Science cath. $1890,450$.

8 Puenaudot, Collectio liturg. orient. I, Francof. 1847, 161.

${ }^{9}$ c. 52527 (ed. Venet. 1847, p. 80140145 ). 
Stuhles von 1295, des Domes zu Prag (1387, 1396, 1476), der Kathedrale zu York (1500), des Santo zu Padua (1396), von S. Francesco zu Assisi (1320), des Domes zu Olmütz (1435) u. a. Die Angaben sind bisweilen so vollständig und bestimmt, daf man sich ohne Mühe ein klares Bild des betreffenden Gegenstandes machen kann, zumal wenn man mit den noch erhaltenen Paramenten und Paramentenresten aus dem Mittelalter vertraut ist. Es ist bereits eine grobe Anzahl mittelalterlicher Inventare herausgegeben worden.

Eine ziemlich vollständige Zusammenstellung derselben bietet nebst freilich zu knapper Inhaltsangabe und unter Bezeichnung der Werke, in denen sie Veröffentlichung gefunden haben, Ferd. de Mély und Ed. Bishop in dem schätzenswerten Werk Bibliographie générale des inventaires imprimés (Paris 1892-1895).

Die Monumente sind ebenso wichtig als Zeugnisse für den Gebrauch der liturgischen Kleidung bzw. ihrer einzelnen Bestandteile wie für die Kenntnis der Form und Beschaffenheit der letzteren. Besondere Bedeutung haben sie, wo schriftliche Angaben mangeln. Aber auch da, wo deren vorliegen, sind sie immerhin eine wertvolle Ergänzung derselben. Allerdings erheischt das Studium der Monumente einige Vorsicht.

Das Bestreben, das Alter derselben möglichst hoch hinaufzurücken, ist noch keineswegs ausgestorben, und es fehlt darum noch immer nicht an Bildwerken, die mehr oder weniger weit über ihre wirkliche Entstehungszeit hinaus datiert werden. Aber auch bei solchen, bei welchen die früheren Altersbestimmungen als unzutreffend nachgewiesen wurden, dauert es oft recht lange, bis die richtige Erkenntnis durchdringt, so daßs die falschen Altersbestimmungen vor wie nach noch eine gute Weile in den Büchern herumzuspuken pflegen. Wer die Monumente für das Studium der liturgischen Gewandung ausnutzen will, muf daher, wie überhaupt jeder, der auf ihnen aufbauen möchte, vor allem sich nach Möglichkeit über das Alter derselben zu vergewissern suchen, wo nicht klare, bestimmte innere oder noch besser äufere Anhaltspunkte vorliegen, allerdings eine schwierige Sache, bei der man nur zu häufig über eine gewisse Wahrscheinlichkeit nicht hinauskommt'. Sichere Schlüsse können sich nur auf sicher datierten Bildwerken aufbauen. Auferdem aber ist zu beachten, dak die mittelalterlichen Bildwerke in Bezug auf Genauigkeit, Tollständigkeit und Korrektheit der auf ihnen dargestellten liturgischen Gewänder vieles zu wünschen ühriglassen. Hier hat es dem Künstler an Beobachtung dex. Wirklichkeit gefehlt, dort ist es eine überquellende, dekorationslustige Phantasie, welche Feder, Pinsel oder Meifel geführt hat, anderswo ist es jene den mittelalterlichen Meistern eigene Sorglosigkeit, welcher die Verstöße und Vängel zuzuschreiben sind. Auch das Stilisieren von Personen und Gewändern trägt seinen guten Teil an den Eigenarten Schuld, welche wir auf den alten Bildwerken bei der liturgischen Kleidung antreffen. Gewifs herrschte im Mittelalter in Bezug auf die liturgische Gewandung nicht die straffe Einheit, welche heute, wo alles durch bestimmte Torschriften geregelt ist und eine besondere Kongregation über die Einhaltung des einmal festgelegten Ritus wacht, alle bindet. Allein so bunt, wie es nach den Biläwerken scheinen könnte, sah es zu keiner Zeit in Bezug auf Crebrauch, Form, Ausstattung usw. der Sakralkleidung aus. Im allgemeinen darf als Erfahrungssatz aufgestellt werden, daf die mittelalterlichen Künstler am z uverlïsigsten sind in Bezug auf das Gesamtbild der Kleidungoder der einzelnen Gewänder, daßs sie dagegen in Bezug auf das Detail aus den vorhin angeführten Gründen weniger Glauben verdienen. Nichts wäre verkehrter, als in den Schöpfungen der alten Niniatoren, Glasmaler, Sticker, Bildhauer, Maler eine Art

1 Gerade die Beschaffenheit der liturgischen Gewandung bildet, wo sie fü eine bestimmte Zeit auf Grund zurerlässiger
Monumente oder sonstwie festgestellt wurie, ein wextrolles Mittel zur Datierung mancher andern Monumente. 
von Photographien zu sehen '. Zu den für die Geschichte der liturgischen Gewänder bedeutsamsten Bildwerken genören die Bischofssiegel des 12. und 13. Jahrhunderts sowie die Grabfiguren des 12. und der folgenden Jahrhunderte.

Je häufiger eine bestimmte Eigentümlichkeit in Bezug auf die liturgische Gewandung auf den Monumenten bezeugt ist, um so mehr darf sie als den tatsächlichen Verhältnissen entsprechend angesehen werden. Vereinzelten Darstellungen wird man nur dann wirklichen Wert und wirkliches Gewicht beizumessen berechtigt sein, wenn die ganze Ausführung darauf schließsen läßst, daß der Künstler die Wirklichkeit wiedergebe. Wo an allen Enden die Phantasie und Laune des Künstlers durchscheint, haben sie eine recht zweifelhafte Bedeutung.

Wir machen noch auf eine letzte wichtige Wahrnehmung aufmerksam. Danach darf es im allgemeinen als Regel angesehen werden, daßi Veränderungen, die mit den liturgischen Gewändern vor sich gingen, nicht auch schon ohne weiteres und alsbald auf den Monumenten zum Ausdruck kommen. Die Tradition, die im Mittelalter einen ungleich gröferen Einflufs auf das Kunstschaffen hatte als gegenwärtig; wo in der Kunst alles im Fluf ist und alle Welt nach Neuem strebt, machte sich nicht selten noch eine Reihe von Jahren geltend, und es daterte bisweilen eine verhältnismäfỉg geraume Zeit, ehe die Künstler die alte Weise verließsen und die Neuerung zur Darstellung brachten. Aus demselben Grunde aber sehen wir nicht selten umgekehrt Eigentümlichkeiten auf den Monumenten auftreten, die in Wirklichkeit bereits einige fünfzig Jahre vom Schauplatz verschwunden waren. Ein geradezu klassisches Beispiel bietet die Wiedergabe der Mitra. Trotzdem diese schon in der zweiten Hälfte des 11. Jahrhunderts weithin in Gebrauch war, sind Darstellungen derselben auf den Bildwerken noch bis 1100 sehr selten. Anderseits aber kommen auf den Monumenten noch nach der Mitte des 13. Jahrhunderts bei Bischofsfiguren Mitren von einer Form vor, welche einer um 50-100 Jahre früheren Periode angehört und längst durch eine neue abgelöst worden war.

Am allerwichtigsten sind, wie leicht ersichtlich, für die Geschichte der Entwicklung der liturgischen Kleidung die a us dem Mittelalter noch vorhandenen Gewänder. Was die Inventare beschreiben oder oft nur andeuten, was die Monumente in ihrer Weise mehr oder weniger künstlerisch umgestaltet wiedergeben, sehen wir bei ihnen leibhaftig vor uns. Um so mehr ist zu bedauern, daß die Zahl derjenigen liturgischen Gewänder, welche mit Sicherheit dem ersten Jahrtausend zugewiesen werden können, äußerst gering ist. Will man freilich den laufenden Traditionen glauben, dann gibt es noch eine ziemliche Anzahl von Paramenten aus dieser Periode. Indessen lassen Form, Stoff, Ausstattung und was wir sonst von der Geschichte der liturgischen Gewänder Sicheres wissen, keinen Zweifel übrig, daßs sie einer weit späteren Zeit ihre Entstehung verdanken. Pontifikalhandschuhe eines hl. Cassius († 558) zu Narni und eines hl. Sabinus $(\dagger$ ca 566) zu Canosa, die Mitra des hl. Silvester I. († 335) in S. Martino ai Monti und des hl. Gildas (um 547) zu St-Gildasde-Rhuys, die Pontifikalschuhe des heiligen Abtes Germanus ( $†$ ca 677) zu Delsberg u. a. sind, ganz abgesehen von ihrer Beschaffenheit, welche sie evident dem zweiten Jahrtausend zuweist, für die Zeit, welcher sie angehören sollen,

1 Man führt wohl, wemn sich auf den Bildwerken scheinbar altertümelnde Eigenarten in Bezug auf die liturgische Gewandung zeigen, solche auf den Umstand zurück, daß dem Künstler Vorlagen aus früherer Zeit zum Muster dienten. Wirklich mögen sie sich in solchen Fällen hie und da auf diese Weise am besten erklären lassen. Immerhin wird man sehr wohl zusehen můssen, um nicht Gefahr zu laufen, sich in leere Hypothesen zu verlieren und eine Phantasie des Künstlers als Reminiszenz an alte Zeiten oder ältere Monumente auszugeben. Man sollte nur dort so vorgehen, wo Bildwerke aus früherer Zeit und andere sichere Grínde genügenden Anhalt für eine solche Erklärung bieten. 
Anachronismen. Bei andern, wie z. B. bei der Kasel des hl. Johannes Angeloptes $(\dagger 432)$ in S. Urso zu Ravenna, schlieft wenigstens die Beschaffenheit durchaus den Ursprung aus, den die Überlieferung will. Übrigens sind ebendiese Überlieferungen bei genaueren Nachforschungen bisweilen relativ recht jungen Datums.

Manche Erwartungen knüpften sich an die koptischen Gräberfunde in den Gräberfeldern der Provinz Fajûm, zu Antinoe in Mittel- und zu Achmîm in Oberägypten. Indessen haben diese über die liturgische Gewandung leider keinerlei Aufschlufs gebracht, so belehrend sie auch hinsichtlich der Form und Beschaffenheit der profanen Tracht gewesen sind '.

Recht stattlich ist die Zahl der liturgischen Gewänder, die sich aus dem 11. bis 16. Jahrhundert erhalten haben; insbesondere gilt das von den Kaseln, den Pontifikalschuhen, der Mitra und auch der Albe. Freilich gibt es auch hier manche unzutreffende Traditionen, indessen fallen die betreffenden Stücke doch immer noch in Wirklichkeit ins Mittelalter, mögen sie auch um ein, zwei oder vielleicht drei Jahrhunderte später zu datieren sein, als die örtliche Überlieferung will. Sehen wir von den Gewändern $a b$, die sich in protestantischen Kirchen, namentlich in St Marien zu Danzig, im Dom zu Brandenburg und im Dom zu Halberstadt, in die Gegenwart gerettet haben und die fast ausnahmslos dem späten Mittelalter angehören, so verdanken die übrigen noch vorhandenen mittelalterlichen Paramente in den meisten Fällen ihre Erhaltung dem Umstande, daf sie Reliquien waren oder doch als solche galten, ein Umstand, dessen glückliche Wirkung namentlich ist, daf wir aus der Frühe des Jahrtausends, d. i. dem 11., 12. und beginnenden 13. Jahrhunderts, noch die bedeutende Zahl von etwa dreifig Glockenkaseln besitzen. Wenn es in den katholischen Kirchen Deutschlands aus dem Ende des Mittelalters zwar noch ungemein viele Reste alter Paramente, aber äußerst wenig unversehrte gibt, so kommt das daher, dafs die fraglichen Gewänder nicht als Reliquien betrachtet wurden und dafs man deshalh kein Bedenken trug, bei veränderter Mode sie dem neuen Geschmack gemäß umzugestalten.

Übrigens mußs betont werden, daß in den Fällen, wo die Tradition hinsichtlich des einen oder andern Ornatstückes nach Ausweis der Form und Beschaffenheit desselben linzutreffend ist, in der Regel immerhin irgend eine Beziehung des fraglichen Gewandes zu dem Heiligen, dessen Namen es trägt, vorliegt. Insbesondere stellt ein grofer Teil solcher Paramente Gewandstücke dar, mit denen der Leib eines Heiligen bei seiner ersten Erhebung oder einer andern späteren Gelegenheit neu bekleidet wurde. Es sind das also Gewänder, die, wenn auch erst in späterer Zeit. wirklich mit dem heiligen Leib in Berührung kamen und darum mit Recht als eine Art von Reliquien verehrt werden können und als solche offenbar mit mehr Recht verehrt werden als die altchristlichen Brandea, Tücher, die man auf die Schreine

1 Wenn F. X. Kraus die Erwartung aus. sprach, daf, wie schon jetzt abzusehen sei, die koptischen Grabfunde wesentliche Veränderungen der Geschichte der liturgischen Gewandung zur Folge haben würden (Geschichte der christl. Kunst I 534), so beruht das auf einer sehr mangelhaften Kenntwis der wirklichen Ergebnisse der Nachforschungen in den koptischen Gräbern. Allerdings hat mau unter den Textilien, welche ans Licht kamen, auch Reste von Pallien, einer Stola $\mathrm{bzw}$. eines Manipels und altchristlicher Infulae zu entdecken geglaubt. Man wird indessen gut tun, über derartige Funde, bei deren Bestimmung, wie wir fuirchten, die Phantasie eine größere Rolle gespielt hat als die Archäologie, zur Tagesordnung überzugehen. Wenn man aus Heiligendarstellungen auf koptischen Gewandstioken auf deren liturgischen Gebrauch und Charakter einen Schluß machen möchte, so übersieht man, daß solche im Orient keineswegs eine Eigentümlichkeit der Sakralkleidung waren, da es bei den Reichen Sitte war, anch profane Gewänder mit ihnen zu schmücken. Vgl. die lehrreiche Rede des Asterius von Amasea (5. Jahrh.) De divite et Lazaro (Mg, 40, 167). Heiligenbilder anf koptischen Grabfunden beweisen also keineswegs, daf diese eiust liturgischen Zwecken dienten. 
oder die Confessio legte, um sie dann als Reliquien zu versenden. Andere Ornatstücke haben mit Reliquienbüsten oder Statuen eines Heiligen in Verbindung gestanden; denn die Sitte, Büsten oder Statuen mit Gewändern zu schmücken, entstand nicht erst in der Zeit der Renaissance. So stammt die Mitra Silvesters I. in S. Martino zu Rom, wie kaum zu bezweifeln, von einer Reliquienbüste des Heiligen, die Mitra und Dalmatik des hl. Ludwig zu Brignoles aber von einer damit geschmückten Statue. Die Maßse beweisen das hier wie dort. Wieder bei andern Gewändern erklärt sich die Zuweisung an einen Heiligen durch den Umstand, daß sie Votivgaben zu Ehren dieses Heiligen waren oder für einen Altar, eine Kapelle desselben gestiftet wurden. Aus der casula S. N. im Sinne eines zu Ehren des betreffenden Heiligen geschenkten Mefigewandes murde im Lauf der Zeit bei zunehmender VerdunkIung des Ursprungs eine casula S. N. im Sinne einer von dem Heiligen herrührenden Kasel. Anderswo waren ursprünglich authentische Ornatstücke vorhanden. Es trat aber infolge von Wirren eine Verwechslung ein, und während die echten zu Grunde gingen, erhielten sich die unechten. Auch kam es wohl vor, daf da, wo man irgend eine wirkliche Gewandreliquie besaß, sich durch Zufall im Laufe der Zeit andere Ornatstücke zu dieser gesellten, die dann auch den Namen jenes Heiligen erhielten.

Solche und ähnliche Irrtümer waren um so eher möglich, als unsere Vorfahren auf der einen Seite große Freunde alles dessen waren, was den Namen Reliquie trug, anderseits aber in ihrer schlichten, kindlichen Frömmigkeit weiter, als gerade gut, davon entfernt waren, einen Zweifel an der Authentizität der Reliquien zu hegen, die kritische Sonde anzusetzen und eine Untersuchung über Echtheit oder Unechtheit der Reliquien vorzunehmen. Freilich wären sie dazu auch in vielen Fällen schlechterdings nicht im stande gewesen. Denn sie waren weder so kritisch geschult, wie es meistens nötig ist, noch hatten sie die reichen wissenschaftlichen Hilfsmittel, die heute dem Forscher bei seinen Prüfungen zu Gebote stehen. Es wäre sehr töricht, mit unsern Vorfahren deshalb zu rechten, weil sie irrtümlich unechte Gewandreliquien für echte angesehen haben. Wenn wir jetzt die Datierungen. der Textilien durchgehen, die vor fünfzig Jahren erfolgten, werden wir manche als zu hoch gegriffen bezeichnen müssen, und doch waren sie ihrerzeit das Werk von Fachleuten. Um wieviel mehr war also ein Irrtum im Mittelalter möglich. Und noch jetzt, wo wir die grofen Sammlungen von Textilien besitzen und photographische Abbildungen die letzteren zum wissenschaftlichen Gemeingut machen, ereignet es sich oft genug, dafs der Fachmann sich täuscht, falls er nicht, um der Gefahr eines Mißgriffes zu entgehen, nur unter Vorbehalt und mit vielen Fragezeichen eine Zeitbestimmung versucht. Nur wer von den tatsächlichen Verhältnissen keine Ahnung hat und von den Schwierigkeiten nichts weißs, welchen noch jetzt die Datierung von Stoffen begegnet, kann über unechte Gewandreliquien lächeln oder witzeln. Wissenschaft ist das jedenfalls nicht. Der Forscher aber wird sich freuen, daf infolge solcher leicht verzeihlichen. Irrtümer manches auf unsere Tage gekommen ist, was sonst wie tausend andere Sachen rettungslos im Strom der Zeit untergegangen wäre. und zugleich den kindlich-frommen, glïubigen Sinn bewundern, der sich, wie überhaupt in Reliquienkultus, so insbesondere auch in Bezug auf die Gewandreliquien im Mittelalter vielfach so anheimelnd und erbauend äukerte.

\section{BEARBEITUNGEN.}

Das Mittelalter hat keine Geschichte der liturgischen Gewandung hervorgebracht. Eine geschichtliche Betrachtung derselben lag seinen Ideen zu fern. Die ersten Keime einer solchen, welche sich bei Walafried Strabo finden, blieben nur Keime. Erst die Nenzeit wandte sich bei dem erwachten historischen Sinn und dem immer mehr zunehmenden Interesse an der Vergangenheit, wie der Geschichte der Liturgic überhaupt, so auch derjenigen der liturgischen Gewandung zu. Ein äußserer Anlaf und Antrieb dazu lag freilich auch in den Teitumständen, sofern es galt, die alten katholischen Einrichtungen und Riten 
gegenüber den Neuerern, welche diese gemäßs ihrem Grundirrtum betreffs der priesterlichen Mittlerschaft aus dem Gotteshause ganz oder fast ganz verbannt hatten, als altkirchlich und berechtigt $\mathrm{zu}$ begründen und zu verteidigen.

Die Untersuchungen bezüglich der liturgischen Kleidung waren übrigens bis zum 19. Jahrhundert nach alter Weise fast immer mit der Darstellung der Liturgie verbunden. Besondere schriften erschienen über dieselbe nur in geringer Zahl. Eigentümlich ist allen, daf sie sich kaum auf andern als den schriftlichen Quellen aufbauen. Aufer der einen oder andern Angabe des Papstbuches, einiger Heiligenbiographien und sonstigen historischen Quellenwerke sind es namentlich die Ordines, die kirchlichen Bestimmungen und die mittelalterlichen liturgischen Schriften, die ihren Ausführungen zu Grunde liegen. Die Inventare sind so gut wie ganz unberücksichtigt geblieben. Auch die Monumente sind nur in sehr geringem Mab verwertet. Obendrein sind sie, wo sie herangezogen werden, recht oft mifsverstanden oder falsch datiert. Nicht besser verhält es sich mit den Überresten an liturgischen Gewändern aus früherer Zeit, was um so mehr zu bedauern ist, als seitdem manche derselben leider für immer zu Grunde gegangen sind. Abbildungen, die zur Illustration des Textes hie und da gebracht werden, sind meist sehr ungenau und stilistisch völlig umgearbeitet, daher fast stets ohne Wert. Eine rïlmmliche Ausnahme machen die für ihre Zeit ungemein treuen Wiedergaben in Gerberts, des gelehrten Abtes von St Blasien, Vetus liturgia alemannica, von der weiter unten die Rede sein wird.

Es würde zu weit führen, auf alle diese äIteren Abhandlungen einzugehen, zuma] die meisten jedes selbständigen wissenschaftlichen Wertes entbehren und meist nur bereits Gesagtes zu wiederholen pflegen. Es ist uns auch hier mehr darum zu tun, die Art der Bearbeitung der Sakralgewandung im 17. und 18. Jahrhundert im allgemeinen zu charakterisieren, als eine Anzahl einzelner Schriften anfzuführen. Immerhin müssen einige Namen genannt werden. Zu ihnen gehört vor allem der des Kardinals . o h a nu es Bona $(† 1674)$, dessen bündige, verständige Untersuchungen über die liturgischen Gewänder lange den Liturgikern als Grundlage dienten und auch jetzt noch Beachtung verdienen. Erweitert und kommentiert wurden sie in der von dem Cistercienser Robert Sala veranstalteten Ausgabe der Rerum liturgicarum libri duo (Aug. Taur. 1747-1753). Dann erheischt Erwähnung der Cluniacenser Claudius de Vert († 1708), dessen Erörterungen über die Sakralkleidung in dem Werk Explication simple littérale et historique des cérémonies de l'église (2. Aufl. Paris 1707-1708) zwar kurz sind, aber immerhin manche interessante Angabe über den älteren Brauch in französischen Kirchen bieten. Bemerkenswert ist, dak, während Bona zwar die mystische Bedeutung der liturgischen Gewänder beiseite läßt, aber nicht verwirft, de Tert ein abgesagter Feind aller mystisch-symbolischen Auslegung ist. Auch der Oratorianer Peter Le Brun $(\dagger$ 1729) mufs genannt werden, sofern auch er in seiner Explication littérale, historique et dogmatique des prières et des cérémonies de la Messe (jüngste Ausgabe Lyon 1843 u. 1850) in seiner Darstellung der Mefskleidung Notizen aus französischem Brauche bringt. Was B. Gavanti ( $\dagger$ 1638) im Thesaurus sacrorum rituum über die Geschichte der liturgischen Kleidung bietet, ist selbst in der von dem Theatiner C. Merati besorgten erweiterten Form (Romae 1736-1738 u. ö.) kaum der Anführung wert; dagegen ist durchaus der Erwähnung würlig die Abhandlung; welche Benedikt XIV. seiner oft herausgegebenen Schrift De sacrosanctae missae sacrificio (neueste Ausgabe Mainz 1874) über die Meßsgewänder eingegliedert hat, nicht zwar, als ob hier Neues geboten würde, wohl aber wegen der vortrefflichen Behandlung des Gegenstandes. Ungleich einlässiger ist, was der Dominikaner Augustinus Kratzer in seiner Schrift De apostolicis necnon antiquis ecclesiae occidentalis liturgiis (Augustae Vindel. 1786) über die 
liturgische Gewandung schreibt. Es gehört zum Besten, was bis zum Ende des 18. Jahrhunderts in liturgischen Werken über diesen Gegenstand gesagt worden ist. Auch der Traktat über die Sakralkleidung, den Abt M artiri Gerbert von St Blasien $(\dagger$ 1793) seiner Vetus liturgia alemannica, disquisitionibus praeviis, notis et observationibus illustrata (S. Blasii 1776) eingeflochten hat, verdient alle Anerkennung. zumal hier mehr als sonst die Bildwerke und noch vorhandene mittelalterliche liturgische Gewïnder berücksichtigt sind. Einige Jahrzehnte älter ist die Schrift des Dominikus Giorgi ( $\$ 1764)$ : Liturgia Romani Pontificis in celebratione missarum sollemni (Romae 1731--1744), worin auch die Pontifikalkleidung eine eingehende Behandlung findet, vielleicht das Vorzüglichste, was bis zum 19. Jahrhundert über dieselbe geboten wurde. In enzyklopädischer Art werden die liturgischen Gewänder erörtert in des Dominikus $\mathrm{Macri}(\dagger 1672)$ Hierolexicon sive sacrum dictionarium (ursprünglich italienisch; lateinisch Romae 1677), das später von dessen Bruder Karl Macri vervollständigt wurde (Venetiis 1712). Ganz der sakralen Kleidung gewidmet sind die drei Bände des Tonler Bischofs Andreas du Saussay († 1675): Panoplia episcopalis seu de sacro episcopi ornatu (Paris. 1646), Panoplia clericalis seu de clericorum tonsura et habitu (Paris. 1649) und Panoplia sacerdotalis seu de venerando sacerdotum habitu (Paris. 1653), alle in Folio, ein höchst umfangreiches Werk, das aber aufser dem allgemeinen Mangel an der nötigen Berücksichtigung der Monumente obendrein an starker Kritiklosigkeit und ermüdender, nichtssagender Breite der Darstellung leidet, für seine Zeit allerdings eine sehr bemerkenswerte Leistung ${ }^{1}$.

Die Kultkleidung der orientalischen Riten hat bis zum 19. Jahrhundert keine zusammenfassende Bearbeitung gefunden. Einzelne Angaben sind gelegentlich den vorhin erwähnten Abhandlungen über die abendländischen Sakralgewänder eingefügt, einlässigere Notizen enthalten des Dominikaners Jakob Goar († 1653) Euchologium (Paris. 1647), des Eusebius Renaudot $(\uparrow 1720)$ Collectio liturgiarum orientalium (neneste Ausgabe Frankfurt 1847), der Codex liturgicus Ecclesiae universae (Romae 1749-1766) des Maroniten Jos. Alois Assemani $(†$ 1782) und die Bibliotheca orientalis Clementino-Vaticana (Romae 1755-1757) des Jos. Simon Assemani $(†$ 1768), Jos. Mich. Wansleben ( $†$ 1679) oder Vansleb, Histoire de l'église d'Alexandrie (Paris 1677), Kap. 16 der Noten Jak. Gretsers S. J. $(† 1625)$ und Goars zu Codinus, De officiis magnae ecelesiae et aulae constantinopolitanae 2, John Glen King, Gebräuche und Zeremonien der griechischen Kirche Rufilands (aus dem Englischen, Riga 1773) u. a., von denen einige schon früher erwähnt worden sind.

Neues Leben brachte in das Studium der geschichtlichen Entwicklung der liturgischen Gewandung das 19. Jahrhundert. Die Reformbestrebungen, welche gegen die Mitte desselben in Bezug auf Gestalt und Ausstattung, auf Stoff und Ornamentierung der Sakralkleidung einsetzten, lenkten immer mehr

1 Was an Monographien ủber einzelne Gewänder aus dem 17. und 18. Jahrhundert vorliegt - sie betreffen meist die Mitra (Tiara) und namentlich das Pallium - ist zu unbedeutend, als daß es hier besondere Erwähnung erheischte; einiges Brauchbare wird ohnehin gelegentlich genannt werden. Eine Ausnahme sei nur mit der vorzüglichen Abhandlung Puinarts Disquisitio hist. de pallio archiepiscopali, inOuvrages posthumes II, Paris 1724 , gemacht. Die mehrgenannte Schrift M. Sart is De veteri casula diptycha (Faenza 1753) soll nicht sowohl, wie der Titel vermuten lassen könnte, ein Beitrag zur Geschichte der liturgischen Gewänder als vielmehr zur Bischofsgeschichte Veronas sein. Sie handelt nämlich von den Bildern veronesischer Bischöfe, die sich auf den Zierbesätzen der fraglichen Kasel befanden. Der Name casula diptycha, den Sarti deshalb dieser gab, ist ein Unsinn. Auch hat Sarti übersehen, daß die fraglichen Stäbe ihr nicht ursprünglich, sondern von einem älteren Antipendium (10. Jahrh.) hergenommen waren. 2 M. $157,181 \mathrm{ff}$. 
den Blick auf deren große Vergangenheit. Man sah in der Rückkehr zu den Traditionen des Mittelalters den einzigen Weg, den Paramenten wieder eine geziemendere Form und einen geziemenderen Schmuck zu geben. Kein Wunder, daf unter solchen Umständen auch das Interesse an der Geschichte der liturgischen Gewandung von neuem erwachte und dann im Kampf um die Ideale, die man anstrebte, immer mehr erstarkte. So kam es bald zu größeren und kleineren Aufsätzen und nicht lange nachher auch zu gröferen Monographien über die Sakralkleidung im allgemeinen oder einzelne ihrer Bestandteile. Von besonderem Wert war, daf man sich nicht mehr vornehmlich auf die schriftlichen Nachrichten gründete, sondern auch in ungleich ausgedehnterem Mafe die zahlreichen Bildwerke früherer Zeit mit Darstellungen liturgischer Gewänder und ganz besonders das noch vorhandene Material an mittelalterlichen Paramenten und Paramentenresten verwertete. Man gewann dadurch gegenüber den älteren Arbeiten über die Sakralkleider ebenso an Gründlichkeit wie an Weite und Sicherheit.

Manche Momente wirkten fördernd auf diese stärkere Berücksichtigung der Monumente und der noch erhaltenen Gewänder des Mittelalters ein: die allgemein erhöhte Wertschätzung der mittelalterlichen Kunst und ihrer Produkte, auf die man vordem sehr verächtlich herabgesehen hatte, und im Zusammenhang damit eine große Pietät gegenüber den Erzeugnissen der Kunst einer vom christlichen Geist ganz durchdrungenen Vorzeit, die von kirchlichen, staatlichen und städtischen Behörden, sowie von manchen für die Werke der Vorzeit begeisterten Privaten angelegten Sammlungen, worin auch die Textilien, kirchlichen Stickereien und Gewänder einen ihrer Bedeutung entsprechenden Platz erhielten, die ungleich vervollkommnete Reproduktionstechnik, bei welcher es möglich wurde, die Gegenstände in gröbter Naturtreue wiederzugeben, die außerordentlich erhöhte Leichtigkeit des Verkehrs, welche ohne allzu große Beschwerden eine persönliche Einsichtnahme der Monumente und mittelalterlichen Gewänder ermöglichte, Sammelwerke mit guten Abbildungen der alten Kunstdenkmale u. a. Vornehmlich war es die Entwicklung der liturgischen Gewänder nach Form und Beschaffenheit, welche den Gegenstand der Abhandlungen bildete. Eine eingehende Untersuchung über ihre Verwendung und ihre Symbolik, die bis dahin minder berücksichtigt worden waren, unternahm namentlich der Verfasser dieses Werkes in seinen beiden Monographien über die priesterliche und pontifikale Gewandung.

Es ist unmöglich, die zahlreichen größeren oder kleineren Aufsätze auch nur zum Teil zu nennen, welche seit der Mitte des vorigen Jahrhunderts in den verschiedensten Zeitschriften über die liturgische Gewandung, über einzelne Bestandteile derselben oder noch erhaltene Paramente aus früherer Zeit erschienen. Manche sind ohne Wert, manche andere wichtige Beiträge zur Geschichte der Sakralkleidung. Besonders reich an Abhandlungen dieser Art ist der freilich hesonders mit Hinblick auf die Pflege der Paramentik von Dr Fl. Rief, Pfarrer Laib und Pfarrer Dr Schwarz gegründete Rottenburger "Kirchenschmuck" (Stuttgart 1857-1870). Zahlreiche andere Aufsätze enthalten die ,Mitteilungen der k. k. Zentralkommission zur Erforschung: und Erhaltung der Baudenkmale* (Wien $1856 \mathrm{ff}$ ), doch nur in ihren älteren Jahrgängen, die jüngere, von dem durch seine ausgebreiteten Kenntnisse der mittelalterlichen Kunst und speziell der mittelalterlichen Textilien und Paramente ausgezeichneten und durch seine kostbare, mit großer Feinsinnigkeit hergerichtete Sammlung bekannten Domkapitular Prof. Dr A lex. Sehnütgen trefflich redigierte "Zeitschrift für christliche Kunst" (Düsseldorf 1888 ff) und die Revue de l'art chrétien (Paris $1857 \mathrm{ff}$; Lille $1883 \mathrm{ff}$ ), welche namentlich aus der Feder der tüchtigen $\mathrm{Ch}$ arles de Lin as 
und Louis de Farcy, sowie des überaus fleißigen, aber zu breitspurigen und bis* weilen der nötigen Kritik entratenden $\mathrm{X}$. Barbier de Montault viele schätzenswerte Bausteine zur Geschichte der liturgischen Gewandung brachte. Auch der Grazer "Kirchenschmuck" (Graz 1870 ff), das Rottenburger "Archiv für christliche Kunst" (Stuttgart $188 \pm \mathrm{ff}$ ), T. Didrons Annales archéologiques (Paris 1844-1881) und das von A. de Caumont begründete Bulletin monumental lieferten eine größsere oder geringere Zahl sehr brauchbarer Aufsätze über die Sakralkleidung im allgemeinen und mehr noch über einzelne Gewandstücke. Desgleichen boten eine Reihe guter Beiträge die PP. Ch. Cahier S. J. und Arthur Martin S. J. in den Mélanges de l'archéologie (Paris $1847 \mathrm{ff}$ ) und nach dem Tode des letzteren ( $\dagger$ 1856) P. Ch. Cahier († 1882) allein in den Nouveaux mélanges (Paris 1874 ff).

Der Raum gestattet leider nicht, auch nur die hervorragendsten der Arbeiten hier anzuführen, welche in diesen Zeitschriften ans Licht traten. Soweit sie nicht über die Sakralkleidung als Ganzes handelten, sind es namentlich Albe, Kasel, Pluviale, die pontifikalen Ornatstücke, das Pallium und die liturgischen Farben, denen sie gewidmet waren. Von Abhandlungen, die in sonstigen Zeitschriften erschienen, heben wir hervor die in der "Linzer Theol. Quartalschrift" (1897 und 1898) von P. Beda Kleins chmidt 0 . S. Fr. veröffentlichte Serie von Artikeln über die priesterlichen Gewänder, eine vorzügliche Popularisierung und Verarbeitung der bis dahin erzielten Resultate der diese betreffenden Forschungen, sowie ebendesselben Aufsätze über Manipel und Pallium im ,Katholik“ (1899 und 1900), ferner eine die Tiara und Mitra betreffende Arbeit des Archäologen E. Wüscher-Becchi in der „Römischen Quartalschrift" (1899), die für die spätere Entwicklungsgeschichte der Tiara geradezu erschöpfende Monographie Eu gène Müntz' La 'Tiare pontificale in Mémoires de l'Académie des Inscriptions et Belles-Lettres XXXVI (1898), der für die ältere Geschichte des Pluviale bedeutungsvolle Artikel Ed. Bishops: The origin of the cope as a church vestment, in Dublin Review CXX (1897) und endlich die an die Mosaiken in S. Venanzo beim Lateran anknüpfenden, ebenso soliden wie lehrreichen Ausführungen P. H. Grisars S. J. über die auf jenen vorkommenden liturgischen Gewandstücke in Civiltà cattolica Jahrg. 1898, I, die erweitert mit Recht in des Verfassers Analecta Romana n. XII (Rom 1899) aufgenommen zu werden verdienten.

Was im 19. Jahrhundert über die Geschichte der liturgischen Gewandung in Liturgiken, Archäologien und Kunstgeschichten erschien, ist zum großen Teil von wenig oder keinem Belang. Das Beste lieferten D. Rock († 1871) in Hierurgia or the holy sacrifice of the mass (3. Aufl. London 1892-1893) und The faith of our fathers (London 1849), P. Raffaele Garrucci S. J. († 1885) in Storia della arte cristiana nei primi otto secoli della chiesa I (Prato 1873-1881), der gelehrte Herausgeber des Liber Pontificalis L. Duchesne in Origines du culte chrétien (3. Aufl. Paris 1903), der Löwener Professor Can. Reusens in Éléments de l'archéologie chrétienne (2. Aufl. Aachen 1885) und namentlich der ebenso gelehrte wie gemütrolle und fromme V.Thalhofer († 1891) im „Handbuch der katholischen Liturgik" (Freiburg 1883), unzweifelhaft das Vortrefflichste, was über die Sakralkleidung in Werken dieser Art in neuerer Zeit geschrieben wurde.

Von enzyklopädischen und Nachschlagewerken, welche wegen ihrer Behandlung der liturgischen Gewänder Erwähnung verdienen, nemnen wir Viktor Gays († 1887) leider unvollendet gebliebenes Glossaire archéologique (Paris 1887), ferner E. Viollet-le-Duc $(\dagger$ 1879), Dictionnaire raisonné III IV (Paris $1873 \mathrm{ff}$ ), R. Atz, Die christliche Kunst in Wort und Bild (Regensburg 1899), Wetzer und

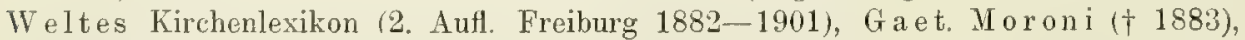
Dizionario di erudizione storico-ecclesiastica (Venedig 1840-1861), dessen ausführliche Artikel über die liturgischen Gewänder zwar nur wenig geordnete und großen Mangel an Kritik verratende Kompilationen sind, aber von riesigem Fleif zeugen und manches Material aus weniger leicht erhältlichen älteren Werken enthalten. Eine gute zusammenfassende Darstellung der Sakralkleidung bieten C. Krieg in Fr. X. Kra us, Realencyklopädie der christlichen Altertümer (Freiburg 1882-1886) unter Kleidung 
und V. Schultze in Realencypklopädie für protestantische Theologie (Leipzig 1896 ff) unter Kleider. Über die gegenwärtige liturgisehe Gewandung und ihre Bestandteile im lateinischen und den orientalischen Riten unterrichtet in vorzüglicher Weise unter Beigabe ausgezeichneter farbiger Abbildungen nach photographischen Aufnahmen Herders Konversations-Lexikon.

Von selbständigen größeren oder minder ausführlichen Arbeiten über die liturgische Kleidung verzeichnen wir vor allem das für die Neubelebung und das Studium der Paramentik so bedeutungsvolle und verdienstliche Werk Dr Fr. Bocks († 1899) „Geschichte der liturgischen Gewänder des Mittelalters“ (Bonn 1856-1871). Ist es auch jetzt zum großen Teil veraltet, so hat es doch das Verdienst, wesentlich dazu beigetragen zu haben, die Sakralkleidung in gründlicherer Weise nach den Monumenten und den noch erhaltenen Gewändern früherer Zeit zu erforschen und dem Stoff und der Ausstattung der Paramente eine bis dahin ungekannte Aufmerksamkeit zuzuwenden. Wenn es in Bezug auf die schriftlichen Nachrichten noch ganz auf den nicht immer kritischen Arbeiten des 17. und 18. Jahrhunderts fußst und auch die Datierungen von Stoffen und Gewändern nicht selten fehlgehen, so wird man diese Mängel unzweifelhaft milde beurteilen, wenn man an den bedeutenden Fortschritt denkt, welche die Kritik in der Ausgabe der historischen Quellen, in Erforschung der Denkmäler und der damals noch in den Kinderschuhen steckenden Textilkunde gemacht hat. Das Werk bedeutet einen Markstein in der wissenschaftlichen Darstellung der Geschichte der liturgischen Gewandung. Eine mit guten Noten versehene und mit einer geistreichen Einleitung über die Entwicklung der Sakralkleidung versehene, sehr brauchbare Materialiensammlung in Wort und Bild schuf der Anglikaner Wharton B. Marriott in seinem Vestiarium ehristianum (London 1868). Die Schrift des Anglikaners R. A. S. Macalister Ecelesiastical vestments (London 1896) ist von weit geringerer Bedeutung. Die beiden von dem Verfasser herausgegebenen Ergänzungshefte zu den "Stimmen aus Maria-Laach": "Die priesterlichen Gewänder des Abendlandes" (Freiburg 1897) und „Die pontifikalen Gewänder des Abendlandes" (Freiburg 1898) setzten sich zum Ziel eine möglichst allseitige Untersuchung der betreffenden liturgischen Ornatstücke. Für die ältere Geschichte der liturgischen Kleidung ist sehr wichtig die kleine, aber inhaltreiche Arbeit J. Wilperts "Die Gewandung der ersten Christen" (Köln 1898). Wertlos ist die Schrift P. J. Rinaldi-Buceis De insignibus episcoporum commentaria (Regensburg 1891), für welche die Forschungen des 19. Jahrhunderts spurlos vorübergezogen sind, die sich in rührender Bescheidenheit auf das, was das 17. und 18. Jahrhundert dachte, beschränkt und selbst noch die sog. Silvestermitra in S. Martino zu Rom als echt behandelt. Eine sehr fleifige und in mancher Beziehung sehr brauchbare Leistung sind die beiden von den liturgischen Ornatstücken handelnden Bände VII und VIII des großartig angelegten Werkes La messe (Paris $1883 \mathrm{ff}$ ) von G. R o hault de Fleury († 1904). Sie bieten aber nur unverarbeitete Materialien, die in Text nach Jahrhunderten geordnet sind und blow bis zum 14. Jahrhundert reichen. Ein empfindlicher Mangel ist die Kritiklosigkeit, die sich oft in ihnen offenbart und um so unangenehmer ist, als die Zitate nur zu häufig sehr ungenau sind. Angaben aus Rohault ungeprüft benutzen, heift sich der Gefahr aussetzen, fehlzugehen. Der Hauptwert des Werkes liegt übrigens in den Tafeln, die eine Fülle meist sehr guter Abbildungen bringen. Leider fehlte es bei der Auswahl an einem festen System, weshalb für manche Punkte die monumentalen Belege übermäßig gehäuft sind, während anderswo Abbildungen mangeln. Außserdem sind die Datierungen der Bildwerke mit Vorsicht hinzunehmen, weil nicht immer zuverlässig. Immerhin bieten die beiden Bände bei allen ihren Mängeln durch das mit Riesenfleiß gesammelte Material manchen wertvollen Ausgangspunkt für weiteres Studium. Eine treffliche Arbeit ist $\mathrm{Ch}$. de Linas ( $\dagger$ 1887), Anciens vêtements sacerdotaux (Paris 1860-1863) in $2 \mathrm{Bdn}$, trefflich sowohl durch das reiche Material, wobei namentlich Frankreich und die daselbst noch vorhandenen mittelalter. lichen Gewänder berücksichtigt sind, wie durch die sorgfältige, durchwegs kritische Verarbeitung desselben. Die Schrift des Mailänder Kanonikus Dr M. Magistretti 
Delle vesti ecclesiastiche in Milano (Mailand 1897) enthält gute Notizen über die Geschichte der liturgischen Gewandung zu Mailand.

Nicht unmittelbar eine Geschichte der liturgischen Gewandung und doch eine für diese höchst wichtige, ja unentbehrliche Arbeit ist das große Werk des französischen Gelehrten Louis de Farey, La broderie du XIe siècle jusqu'aux nos jours (Angers 1390; Supplement 1900) mit seinen vorzüglichen Tafeln und dem kaum minder wertvollen Text. Die zahlreichen phototypischen Wiedergaben liturgischer Ornatstücke aus Mittelalter und Neuzeit bilden eine ungemein lehrreiche Illustration zur Entwicklung, welche diese sowohl bezüglich der Form als namentlich der Ornamentation seit dem 11. Jahrhundert nahmen.

An selbständigen Monographien über einzelne Stücke der Sakralkleidung erschien im ganzen nicht viel; wir nennen davon E. Berriseh, „Die Stola in ihrer Entstehung* (Köln 1867), eine allerdings wenig bedeutende Schrift; $G$. Wilpert, Un capitolo della storia del vestiario (Roma 1898-1899), für die ältere Geschichte von Manipel, Stola und Pallium von grofem Wert; H. Grisar S. J., Das römische Pallium in „Festschrift zum 1100jährigen Jubiläum des dentschen Campo Santo" (Freiburg 1897), eine vortreffliche Arbeit; H. Thurston, The Pallium (London 1892); Dr L. E is enh o fer, „Das bischöfliche Rationale (München 1904), eine sehr beachtenswerte Studie. Die Schrift des Anglikaners J. Wickham-Legg, The liturgical colours (London 1882), ist eine ungemein fleißige Untersuchung über die liturgischen Farben im lateinischen Ritus.

Die Geschichte der liturgischen Gewandung in den Riten des Ostens hat im 19. Jahrhundert keine eingehendere Bearbeitung gefunden. Allerdings bietet sie auch die äußersten Schwierigkeiten, da schriftliche wie monumentale Quellen nur sehr spärlich fließen, zum zroßen Teil sogar ganz fehlen. Über die Sakralkleidung, wie sie gegenwärtig in den Riten des Ostens in Brauch ist, handelt eingehend der Artikel der "Stinmen aus Maria-Laach“ LIX (1900): „Die liturgische Gewandung in den Riten des Ostens". Kurze Angaben bieten darüber auch A. v. Maltzew, Die Sakramente der orthodox-katholischen Kirche des Morgenlandes (Berlin 1898), sowie J. Silbernagl († 1904), "Verỉassung und gegenwärtiger Bestand sämtlicher Kirchen des Orients" (2. Aufl. Regensburg 1904), der indessen die neueste Literatur nicht genug berücksichtigt hat, ferner M. Rajew ski, Euchologion der orthodox-griechischen Kirche (Wien 1861) u. a. Über ihre Geschichte findet sich einiges in des Verfassers Schriften "Die priesterliche Gewandung des Abendlandes" und "Die pontifikalen Gewänder des Abendlandes", ferner bei Wilpert, Un capitolo, bei Rohault de Fleury, La Messe VII VIII, bei C. Krieg in Fr. X. Kraus, Realencyklopädie, unter Kleidung, bei A.J Butler, The ancient coptic churches of Egypt (Oxford 1884), besonders aber bei dem Anglikaner J. Neale († 1866), History of the holy eastern church I (London 1850).

Wir können damit schließen. Es sind nur die bemerkenswertesten Arbeiten hinsichtlich der liturgischen Gewandung, die wir verzeichneten. Auf andere zu verweisen werden wir in der Arbeit selbst Gelegenheit finden. 


\title{
DIE LITURGISCHEN UNTERGEWÄNDER.
}

\author{
ERSTES KAPITEL.
}

\section{DER AMIKT.}

\section{DER AMIKT NACH HEUTIGER PRAXIS.}

Der Amikt (amictus, von amicire, umhüllen) ist ein rechteckiges oder quadratisches Tuch, welches um Hals, Schultern und Brust geschlungen wird. Weil er den Schultern aufliegt, heist er auch Humerale (von humerus, Schulter), Schultertuch.

Der Amikt muf aus Linnen oder Hanftuch angefertigt werden. Die Verwendung von Baumwollstoffen, welcher Art dieselben auch sein mögen, wurde durch das von Pius VII. ausdrücklich approbierte Dekret der Ritenkongregation vom 18. Mai $1819^{1}$ verboten. In der Mitte soll dem Amikt, wie aus der Rubrik des römischen Missale, welche die Anlegung desselben beschreibt, hervorgeht, ein Kreuzchen aufgenäht oder eingestickt sein. Natürlich braucht selbiges nicht mathematisch genau in der Mitte des Tuches zu stehen. Es kann vielmehr nach dem oberen Rande zu angebracht werden. Reiche Verzierung pflegt der Amikt nicht zu erhalten. Sie wäre auch angesichts der Weise, wie er jetzt getragen wird, zwecklos. Insbesondere ist eine Wiedereinführung der mittelalterlichen Besatzweise des Schultertuches, wonach sich der aufgenähte Zierbesatz über der Kasel bzw. Dalmatik kragenartig um den Hals legte, untunlich. Sie wïrde voraussetzen, dafz der Amikt, wie einst im Mittelalter, bis nach Anlegung der Kasel bzw. Dalmatik auf dem Kopfe ruhen bleibe, was indessen der Anweisung des Missale direkt entgegen ist. Den Besatz aber, die sog. Parure, als eine Art selbständigen Kollars behandeln, das man nachträglich an dem Humerale oder auch der Kasel bzw. Dalmatik befestigt, ist, wo solches nicht auf altem Herkommen beruht, wie zu Lyon, zu Mailand und in spanischen Kirchen, unzulässig. Immerhin mag man an dem oberen Saum des Schultertuches eine schmale Bordüre etwa in Rotstickerei anbringen, da es sich ohne Schwierjgkeit so anlegen läft, daßs dieselbe sichtbar bleibt.

Über die Größenverhältnisse des Amikts ist nichts Bestimmtes vorgeschrieben. Er muß eine solche Ausdehnung in die Länge und Breite haben, daß er, wie es das Missale vorschreibt, um Hals und Schultern gelegt werden kann ${ }^{2}$. Zum Zweck der Befestigung des Humerale müssen an

1 C. R. decret. gen. 18. Maii 1819 (D. auth. Nr. 2600).
2 Braun, Winke 28 werden für die Länge $0,80-0,90 \mathrm{~m}$, fuir die Breite $0,60-0,70 \mathrm{~m}$ angesetzt. 
seinen beiden vorderen Ecken Schnüre oder Bänder vorgesehen werden. Über die Weise, wie sie dort angebracht werden, ist nichts angeordnet. Man kann sie annähen, kann sie aber auch, falls man sie beim Waschen vom Schultertuch zu trennen wünscht, Ösen oder Schleifen einschlingen, mit welchen man die vorderen Ecken des Amikts versehen hat.

Wie man sich mit dem Amikt zu bekleiden habe, ist in den Generalrubriken des Missale ausführlich beschrieben 1. Man soll ihn an seinen Enden, und zwar an den Schnüren anfassen, ihn in der Mitte, wo das Kreuzchen

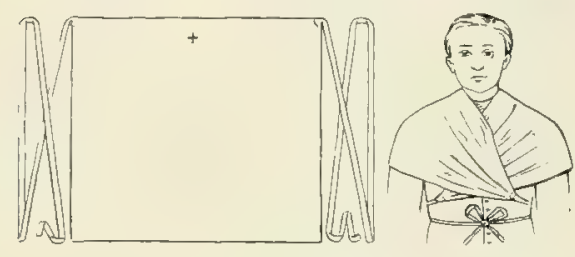

Bild 1. Heutiger Amikt. angebracht ist, küssen, dann auf den Kopf legen, aber alsbald ihn auf die Schultern herablassen, den Kragen des Kleides ringsum mit ihm bedecken, hierauf die Schnüre von vorn unter den Armen her zum Rücken führen, sie von dort wieder zur Brust bringen und endlich hier zusammenbinden (Bild 1).

Nach dem römischen Ritus muf das Schultertuch vor der Albe angelegt werden. Anders nach dem zu Mailand geltenden ambrosianischen Ritus, nach welchem erst die Albe und dann der Amikt angezogen wird.

Auch darin hat der ambrosianische Ritus etwas Eigenartiges, daf er die sog. Amiktparure beibehalten hat. Nur ist diese nicht mehr am Amikt selbst befestigt. Sie wird vielmehr jetzt an der Kasel oder Dalmatik mittels Knöpfen festgemacht, jedoch so, daß ihre ursprüngliche Zugehörigkeit zum Schultertuch noch wohl erkennbar ist und sie einen die Halsöffnung der Kasel bzw. Dalmatik umgebenden Kragen bildet.

Wie der ambrosianische, so hat auch der Lyoner Ritus das Eigentümliche, dafs der Amikt über der Albe getragen werden kann und an den drei Kartagen sogar in dieser Weise getragen werden muf. Ebenso kennt er den aus der Amiktparure entstandenen Kragen, nur daß dieser nie zur Kasel, son-

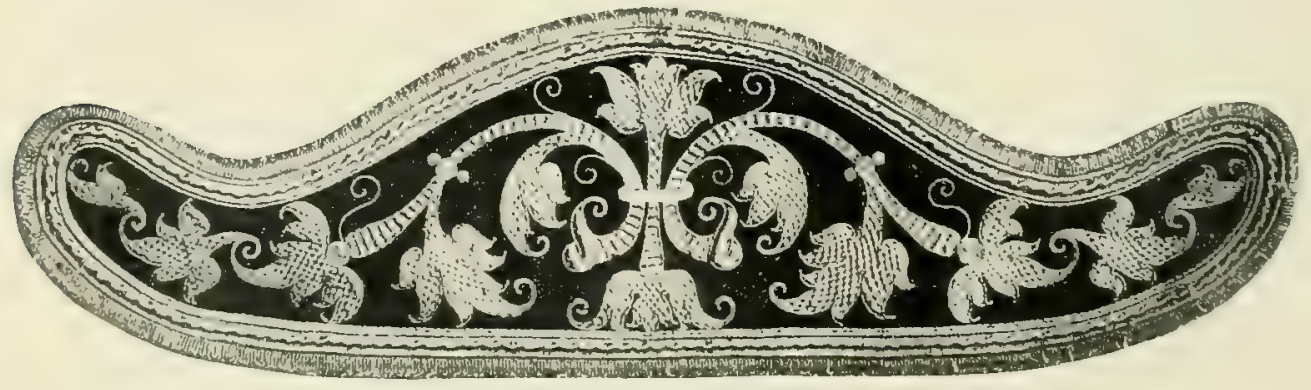

Bild 2. Spanischer goldbestickter Amiktkragen (17. Jahrh.).

Berlin, Kunstgewerbemuseum.

dern blok zur Dalmatik und Tunicella benutzt wird. Ehedem, d. i. bis 1868, bedienten sich sogar Diakon und Subdiakon überhaupt keines Amikts, indem man den Kragen, collet oder colletin genannt, als Ersatz des Schultertuches betrachtete?

Auch in Spanien hat sich die Amiktparure bei den Ministri als ein über Dalmatik und Tunicella gelegter Kragen, collarín, erhalten (Bild 2). Der

1 Miss, ritus celebr. I 2.

2 Nach gütigen Mitteilungen meines Ordensgenossen P. A. Feder S. J. 
Amikt selbst wird dort jedoch allgemein, den mozarabischen Ritus nicht ausgenommen, unter der Albe getragen. Selbständiger Ornat geworden, hat hier die Parure eine ungewöhnliche Form erhalten, während sie z. B. in Mailand noch ganz die rechteckige Gestalt, die ihr ehedem eigen war, bewahrt hat.

Bei der Subdiakonatsweihe mub der Ordinandus nach der Vorschrift des römischen Pontifikale in gewöhnlicher Weise mit Amikt und gegürteter Albe bekleidet sein. Am Schlus der feierlichen Handlung zieht dann der Bischof den Amikt uiber den Kopf des neuen Subdiakons, indem er dabei die Worte spricht: "Nimm hin den Amikt, welcher die Zucht im Reden bedeutet, im Namen des Vaters usw. Amen." Die Zeremonie ist eine Reminiszenz aus der Zeit, da man noch das Humerale über den Kopf zu legen und erst nach Anlegung aller andern Gewänder auf die Kasel bzw. Dalmatik und Tunicella zurückzuschlagen pflegte.

Erscheint der Amikt in den diesen Ritus begleitenden Worten des Bischofs als Symbol der Wachsamkeit beim Reden, so ist er in dem Gebet, welches man beim Anlegen spricht, Sinnbild des Helmes des Heiles, von dem der Apostel im Epheserbrief $(6,17)$ redet, d. i. der Hoffnung auf den himmlischen Lohn, die uns im Kampfe gegen die Feinde des Heiles einem festen Helm gleich Schutz und Schirm gewährt. "Setze auf mein Haupt", so betet der Priester, „den Helm des Heiles, auf daßs ich abwehren möge alle Angriffe Satans."

\section{DER AMIKT ALS BESTANDTEIL DER LITURGISCHEN KLEIDUNG IM MITTELALTER.}

Das Schultertuch wird im römischen Ritus zuerst gegen Ausgang des 8. Jahrhunderts erwähnt.

Die früheste Mitteilung erhalten wir von ihm im 1. römischen Ordo, welcher, im Kern gregorianisch, in seiner jetzigen Gestalt dem 8. Jahrhundert angehört. Dieser bemerkt, wo er den Ritus der feierlichen Papstmesse beschreibt: „Der Pontifex wechselt mit Hilfe der Subdiakonen seine Kleidung: in folgender Weise.... Die Regionarsubdiakonen nehmen, um den Papst anzuziehen, nach ihrer Ordnung diese Gewänder: der eine das Linnenkleid, der andere das Cingulum, wieder ein anderer das anagolaium, d. i. den Amikt, ein weiterer die linnene Dalmatik, ein fernerer die größere Dalmatik, ein letzter endlich die Planeta, und so bekleiden sie der Reihe nach den Pontifex." In der römischen Kirche zählte sonach schon wenigstens seit der Mitte des 8. Jahrhunderts das Schultertuch zu den liturgischen Gewandstücken ${ }^{1}$.

Auffallend ist, dafs der S. G. K. bei Aufzählung der liturgischen Gewänder der Hebdomadarbischöfe und Priester keines anagolaium gedenkt. Es ist das um so befremdender, als doch sowohl nach dem von Duchesne herausgegebenen Ordo wie nach dem S. G. K. selbst die Diakone und Subdiakone sich des anagolaium (anagolagium) bedienten. Nichtsdestoweniger scheinen jene wirklich bis ins 9 . Jahrhundert kein Schultertuch benutzt zu haben. Aber auch die Ministri trugen es damals noch keineswegs allzeit beim Gottesdienst. Denn es heift im Ordo Duchesnes: Quando (pontifex) dalmaticas induit, et diaconi et subdiaconi similiter induunt se et subdiaconi involvunt se anagolagio circa collo et induunt se tunicas albas, quales habent, sericas aut lineas. Et si pontifex dalmaticas non induerit, diaconi vel subdiaconi non se involvunt anagolagio, sed cum tunicis albis et planitis

1 V. Exmoni läft (D. Cabrol, Diction. d'arch. chrét. I [Par. 1904] 1597) schon Hieronymus vom Amikt reden, hat aber die Stellen, die er dafür zitiert, durchaus mißsverstanden. 
ambulant ${ }^{1}$. Sie hatten also das anagolagium nur an, wenn der Papst bei der Liturgie außer den übrigen Gewändern auch eine Dalmatik anlegte und sie dann ebenfalls mit der Dalmatik und Tunika ausgestattet waren, d. i. bei feierlichen Gelegenheiten. Sie gebrauchten dagegen das Schultertuch nicht, wenn der Papst ohne Dalmatik fungierte und sie selbst statt mit der ibnen eigenen Obertunika mit der Planeta (Kasel) bekleidet waren, d. i. an den Tagen, welche einen Bußscharakter hatten, sowie den gewöhnlichen Ferialtagen, den quotidianis diebus des S. G. K.

Aber selbst der Papst trug den Amikt nicht an allen Tagen; denn unter den Gewändern, die er nach dem S. G. K. quotidianis diebus anzog, fehlt nicht nur die Dalmatik, sondern auch das Schultertuch. Auch er benutzte also dieses ursprünglich bloß 3 in Verbindung mit der Dalmatik. Das anagolagium war demnach gemäß römischer Anschauung nur Zubehör der Dalmatik, das wie diese allein vom Papste und seinen Ministri, und zwar blok an Festtagen, wenn sie in liturgischer Gala erschienen, gebraucht wurde. Die Priester und Hebdomadarbischöfe trugen nach dem S. G. K. nie die Dalmatik, letztere wohl zum Unterschied vom Papste, aber eben darum auch keinen Amikt. Außerhalb Roms fand bei der Adoption der römischen Gewandung eine solche Beschränkung keine Nachahmung, doch auch zu Rom verlor sie sich noch im 9. Jahrhundert ${ }^{2}$, vielleicht unter dem Beispiel von aufen her.

Auf den römischen Monumenten des 9. und der vorhergehenden Jahrhunderte gewahrt man kein liturgisches Schultertuch. Man betrachte nur die Mosaiken und Fresken aus dieser Zeit. Wohl erblickt man innerhalb des Kopfdurchlasses des Obergewandes mehrfach einen hellen Streifen, der sich rings um den Hals zieht; allein es ist völlig unklar, ob dieser die Untertunika oder einen Amikt andeuten soll. Den Monumenten läßst sich daher kein Beweis dafür entnehmen, daß im römischen Ritus schon etwa im 6. und 7. Jahrhundert das Schultertuch im Gebrauch gewesen sei. Man kann sich freilich auch nicht für das Gegenteil auf sie berufen. Denn noch zu einer Zeit, da das Humerale schon Iange allgemein Verwendung fand, im 10., 11. und 12. Jahrhundert, ist auf der römischen Monumenten von ihm fast nie etwas zu sehen. Es liegt das zum Teil in dem Charakter und der Anlegungsweise des Schultertuches. Erst als man auch zu Rom angefangen hatte, dieses wie eine Art von Kopftuch zu behandeln und statt völlig unter, teilweise sichtbar über dem Obergewand (Kasel, Dalmatik) zu tragen, kommt es nach und nach auch auf den Bildwerken häufiger zum Vorschein.

Ob es in vorkarolingischer Zeit da, wo der römische Ritus nicht in Gebrauch war, ein liturgisches Schultertuch gegeben, ist mit Sicherheit nicht festzustellen. Nichts wissen wir von dem Brauch in Spanien. Das Anabolium, von dem der hl. Isidor in seinen Etymologien redet, ist nicht das sakrale Gewandstück, welches in den römischen Ordines mit anaboladium, anagolagium, anagolaium bezeichnet wird ${ }^{3}$. Denn der Heilige beschreibt es als einen linnenen Umwurf, mit dem die Frauen ihre Schultern bedeckten und den die Griechen wie die Lateiner auch wohl sindon hiefen. Ebensowenig ist es bekannt, wie es auf den britischen Inseln gehalten wurde. Zwar behandelt die dem ehrwürdigen Beda $(† 735)$ zugeschriebene Schrift De septem ordinibus das Schultertuch als eines der priesterlichen Gewänder; sie ist indessen, wie früher schon gesagt wurde, unecht und ehestens im 9. Jahrhundert, wenn nicht später entstanden.

Was endlich den gallikanis chen Brauch anlangt, so hängt die Antwort auf die Frage, ob derselbe ein liturgisches Schultertuch gekannt, ganz von
${ }^{1}$ Duch, , Orig. 456.
${ }^{2}$ Ordo 9 n. 4 (M. 88, 1006).
${ }^{3}$ L. 19, c. 25 (M. 82,693 ). 
der Bedeutung ab, welche das Wort pallium in dem 6. Kanon des ersten Konzils von Mâcon (583) und in der vor der karolingischen Reform entstandenen gallikanischen Meßerklärung hat.

Das Konzil von Màcon verbietet in dem genannten Kanon den Bischöfen, ohne pallium die Messe zu feiern '. In der gallikanischen Meferklärung aber lesen wir da, wo die liturgische Kleidung beschrieben und gedeutet wird: „Das Pallium, das rings um den Hals bis zur Brust geht, hieß im Alten Bunde Rationale... Daß es den Hals umgibt, ist alten Brauches, weil die Könige und Priester von einem Pallium, einem glänzenden Gewande umgeben waren.... Daf aber Fransen an den priesterlichen Gewändern angebracht werden, hat seinen Grund darin, daß der Herr dem Moses befahl, es sollten die Kinder Israels an den vier Ecken ihrer Mäntel (palliorum) Fransen machen, damit das Volk des Herrn nicht bloß im Werk, sondern anch in der Kleidung Gottes Gebote zum Ausdruck bringe."

Man hat in dem pallium des Konzils von Màcon und der gallikanischen Meßerklärung ein bischöfliches Gewandstück, also nicht das gewöhnliche Schultertuch, sondern etwa ein Gegenstück des erzbischöflichen Palliums gesehen. Es lag das um so näher, als der 6. Kanon der genannten Synode in der früher bekannten Fassung lautete: ut archiepiscopus (irrig statt episcopus) sine palleo (sic) missas dicere non praesumat. Neuerdings hat man dagegen gesagt, unter dem pallium sei an beiden Stellen lediglich ein Hals- oder Schultertuch, also eine Art von Amikt zu verstehen ". Allein diese Auffassung dürfte weder dem Kanon der Synode von Wàcon noch der Meßerklärung genügend gerecht werden.

Wenn es sich blok um ein Halstuch handelt, warum schreibt der Kanon dann nur den Bischöfen und nicht auch den Priestern und Diakonen den Gebrauch eines solchen bei der Messe vor? Im 5. Kanon verbietet doch das Konzil allen Klerikern, das Sagum oder sonstige weltliche Kleidung sowie weItliches Schuhwerk zu tragen. Wenn nun das pallium nur ein gewöhnliches Halstuch ist, warum wird dann im folgenden Kanon blof den Bischöfen sein Gebrauch bei der Messe zur Pflicht gemacht? Eine Dalmatik, als deren Ergänzung es hätte gelten können, war im gallikanischen Ritus unbekannt. Warum überhaupt in diesem Falle eine so strenge Vorschrift, da doch das Schultertuch nach dem Ordo Duchesnes und dem S. G. K. nicht einmal zu Rom an allen Tagen beim Gottesdienst angelegt wurde? Es sind zudem alles höchst wichtige Sachen, die in den übrigen Kanones zum Ausdruck kommen. Kann man demnach den 6. Kanon bloß dahin verstehen, es sollten die Bischöfe bei der Messe ein Halstuch brauchen? Was aber die gallikanische Mefserklärung anlangt, so mufs auffallen, daß sie von allen priesterlichen bzw. bischöflichen Gewändern nur drei erwähnt, die Kasel, das pallium und die manicae. Würde das Wort nur ein Halstuch hedeuten, so ist nicht einzusehen, warum die Meferklärung gerade diesem mit Übergehung z. B. der liturgischen Tunika und des Orariums (der Stola) eine so ausgiebige Deutung und Beschreibung widmet. Ein Schultertuch (Halstuch) ist also das pallium des Konzils von Mâcon und der Meßerklärung wohl nicht.

Der französische Cluniacenser Claudius de Vert $(\dagger 1708)$ wollte das Schultertuch schon bei einer, wie man sagte, im 7. Jahrhundert in Relief ausgeführten Figur des hl. Firmin gefunden haben, mit welcher das unter dem Hochaltar der Abteikirche von St-Acheul bei Amiens gelegene steinerne Grabmal des Heiligen geschmückt war ${ }^{3}$. Leider besteht keine Möglichkeit, seine Angaben am Monument selbst auf ihre Richtigkeit zu prüfen, weil dasselbe mitsamt dem fraglichen Bilde mittlerweile zu Grunde ging. Indessen ist genugsam bekannt, was man von Datierungen wie der-

1 M. G. Leges III, Conc. I 157.

2 Wilp., Cap. II 50.

3 D e Vert II 242. Er hält das Denkmal für einen Beweis, daß schon vor dem 9. Jahrhundert der Amikt in Gebrauch gewesen:
Qu'on juge après cela, quelle foi on doit ajouter à ce qu'avance M. Thiers ... qu'on n'a commencé à se servir de l'amict dans l'église latine qu'au IX ${ }^{e}$ siècle. 
jenigen de Yerts zu halten hat. Es ist nicht zweifelhaft, daf dieser geirrt und ein Denkmal etwa aus dem 12. bis 13. Jahrhundert in das 7, versetzt hat. Ein Grabmal, wie es dasjenige des hl. Firmin gewesen sein muf, wäre, wie jeder, der einen Einblick in die Kunstgeschichte hat, im 7. Jahrhundert ein Anachronismus. Der Irrtum de Verts erhellt übrigens zur Genüge schon aus der Angabe, es habe der Amikt den Kopf des Bildes eingehüllt en forme de capuchon fort serré. Denn die Gepflogenheit, das Humerale um den Kopf zu legen, kam frühestens erst gegen Ende des 9. Jahrhunderts auf.

Wie es aber auch immer in vorkarolingischer Zeit a f ferhalb Roms um den Gebrauch eines liturgischen Schultertuches bestellt gewesen sein mag, im 9. Jahrhundert bildet das anabolagium ${ }^{1}$, id est amictus, quod dicitur humerale, wie es im 3. Ordo Mabillons heift, wenigstens de iure überall da, wo durch die karolingische Reform der römische Ritus Eingang erhalten hatte, einen Teil der sakralen Gewandung. Darum ist denn auch seit dieser Zeit von ihm häutig als von einem der liturgischen Gewandstücke die Rede, namentlich bei den Liturgikern. Schon bald nach Beginn des 9. Jahrhunderts geschieht das in des Hrabanus Maurus Schrift De clericorum institutione. Es heifst darin im Anschluf an das ephod bath, von dem $1 \mathrm{Kg} 2,18$ spricht, superhumerale. Etwas früher noch begegnen uns Amikte in dem Inventar der Gegenstände, mit welchen Abt Angilbert $(\dagger 814)$ die Kirche des Klosters Centula (St-Riquier, Somme) die er neu erbaut, bereichert hatte. Walafried Strabo († 849) schweigt auffälligerweise von dem Schultertuch, ja er stellt sogar dem Superhumerale des levitischen Hohenpriesters die mappula, den Manipel, entgegen, falls nicht etwa unter der mappula eben der Amikt $\mathrm{zu}$ verstehen ist. Sein Verhalten ist um so merkwürdiger, als ja doch schon sein Lehrer Hraban eine Weile vorher das Schultertuch unter den liturgischen Gewändern behandelt hatte. Indessen läbt sich aus Walafrieds Schweigen um so weniger etwas gegen die Verwendung des Schultertuches folgern, als sein Zeitgenosse Amalar von Metz ( $†$ zwischen 850 und 853) dasselbe, und zwar unter dem Namen Amictus, bestimmt und wiederholt zu der liturgischen Kleidung rechnet. Vielleicht liegt die Erklärung für die Nichterwähnung des Amikts bei ihm darin, daf der Amikt zwar bereits de iure einen Bestandteil der liturgischen Tracht ausmachte, in der Praxis aber noch keineswegs immer zur Verwendung kam. Daf er selbst im 10. Jahrhundert noch nicht allgemein gebraucht wurde, ergibt sich beispielsweise aus Gerhards Miracula S. Udalrici?

In der Folge begegnet uns der Amikt bei Pseudo-Alkuin, bei PseudoBeda, in der weit verbreiteten und einflußreichen Admonitio synodalis und den Statuten Riculfs von Soissons. Überall erscheint er hier als eines der bei der Feier der Liturgie vorschriftsmäßig zu tragenden sakralen Gewandstücke. Insbesondere bestimmt die Synodalermahnung ausdrücklich: "Niemand singe die Messe ohne Amikt, Albe, Stola, Fano (Manipel) und Kasel." Riculf aber verordnet 889 in seinen Statuten unter anderem, es solle der Priester für die Feier des heiligen Opfers außser den sonstigen liturgischen Kleidern, die im einzelnen aufgeführt werden, auch zwei reine Amikte vorrätig haben. In den liturgischen Büchern werden im 9. und 10. Jahrhundert sehr selten die sakralen Ǩleider erwähnt, weil selbige fast nur die bei der Messe und

I Bei Mabillon heifst das Schultertuch hier ambolagium, wofür ohne Zweifel anabolagium zu lesen ist.
2 Nr 20 (M. G. SS. IV 422). Die Schrift entstammt noch dem 10. Jahrhundert. 
den sonstigen gottesdienstlichen Handlungen gebräuchlichen Gebete enthalten. Wo sie aber genannt werden, finden wir regelmäßig auch das Schultertuch darunter. 915 ist von Amikten im Testamente Riculfs von Elne die Rede.

Leider geben uns die Quellen nur wenig Aufschluf darüber, wer v on den liturgischen Personen auferhalb Roms sich des Amikts zu bedienen pflegte. Dafe der Bischof es trug, geht aus Hrabans und Amalars Angaben hervor. Dafs aber auch die Priester den Amikt gebrauchten oder doch gebrauchen sollten, daran lassen die "Synodalermahnung“ und die Statuten Riculfs von Soissons keinen Zweifel. Dagegen erfahren wir nicht, wie es sich mit den Diakonen, Subdiakonen und Akolythen verhielt. Immerhin darf es als sicher betrachtet werden, dafs auch auferhalb Roms schon zur Karolingerzeit die Diakone und Subdiakone ein Schultertuch verwendeten. Die Gründe, welche hier Anlafs waren, dem Priester bei der Messe den Gebrauch desselben vorzuschreiben, wie es die "Synodalermahnung" tat, galten ja doch auch zuletzt für die Ministri. Obendrein war die liturgische Gewandung, wie sie fast überall auferhalb Roms in Aufnahme gekommen war, nur das Nachbild römischen Brauches. Auffällig ist zwar, dafs noch Johannes von Avranches $(\dagger$ 1079) in seiner Gottesdienstordnung bei Angabe der liturgischen Gewänder der Ministri von einem Schultertuch völlig schweigt; indessen ist zu beachten, daf er ebensowenig von einem Cingulum redet, obschon es nicht zweifelhaft sein kann, dafi die Albe bei den Diakonen, Subdiakonen und Akolythen gegürtet war. Amikt und Gürtel waren eben mittlerweile zu einem ständigen Zubehör der Albe geworden, das selbst in den Inventaren nicht einmal immer einzeln aufgeführt wurde. Es mochte daher Johannes von Avranches überflüssig erscheinen, sie, weil selbstverständlich besonders zu nennen. Es ist wohl nur Zufall, wenn wir auferhalb Roms erst spät von einem Schultertuch der Diakonen, Subdiakonen und Akolythen hören. Das liegt, wie es scheint, blof daran, daf keiner der älteren Liturgiker sich eingehender mit den einzelnen Gewändern der Ministri befafit. Hraban, Pseudo-Alkuin, Walafried und Pseudo-Beda handeln lediglich von der liturgischen Kleidung des Priesters bzw. der Bischöfe. Einzig Amalar beschäftigt sich mit der Gewandung der Ministri, indessen auch er nur in einigen gelegentlichen Bemerkungen. Seine früheste Erwähnung findet auferhalb Roms das Schultertuch der Diakonen im dritten Kapitel der Synode von Coyaca in Spanien aus dem Jahre 10501. Die ersten Liturgiker, welche ausdrücklich den Amikt als ein den Bischöfen, Priestern, Diakonen, Subdiakonen und Akolythen, also allen am Altar fungierenden Klerikern zustehendes Gewand bezeichnen, sind Gilbert von Limerick ${ }^{2}$ und Honorius.

Eine der ältesten oder gar die älteste der Darstellungen, auf welcher das liturgische Schultertuch auftritt, ist eine Miniatur der Bibel, welche von den Insassen des Klosters vom hl. Martinus von Tours zu Metz Karl dem Kahlen geschenkt wurde und den Akt der Übergabe des Buches darstellt. Das Gewandstück nämlich, welches besonders bei einem der auf ihr in ihrer liturgischen Kleidung abgebildeten Mönche am Hals unter der Kasel hervortritt, ist augenscheinlich der Amikt und nicht der Saum der Albe?

1 Hard. VI 1026.

${ }^{2}$ De statu eccl. (M. 159, 999): Atque hi quattuor ordines (ostiarii, exorcistae, lectores, acolythi) in officiis suis solent indui superhumera li, alba et cingulo.
3 Vgl. auf dem Titelbild den obersten Geistlichen rechts. Die Photographie der Miniatur verdanke ich der Güte des Herrn Prof. Dr A. Haseloff. Eine brauchbare farbige Wiedergabe in Arts sompt. pl. 16. 


\section{DIE GEBRAUCHSWEISE DES AMIKTS.}

Hraban bezeichnet, wie auch die Pastoralhomilie es tut, das Schultertuch als erstes Gewand der Priester des Neuen Bundes. Auch nach Amalar ist der Amikt, von dem er sagt: amictus ideo dicitur, quia circumicitur, das erste Gewandstück. Dagegen mußs auffallen, daß er im 1. römischen Ordo in der Reihe der Pontifikalkleider an dritter Stelle genannt wird. Auch für die Folgezeit verhält es sich ähnlich. Alle mittelalterlichen Liturgiker bezeichnen das Humerale als erstes Gewand, nur wenige, z. B. Ivo von Chartres († ca 1117) und den Verfasser des Speculum de mysteriis ecclesiae, ausgenommen. Ebenso wird in den alten Pontifikalien und Sakramentaren stets zunächst der Amikt genannt; eine Ausnahme bildet fast nur das ambrosianische Missale ${ }^{1}$. Umgekehrt wird nach dem 3. und 9. römischen Ordo und dem S. G. K. erst die Albe und dann das Schultertuch angelegt. Beim Papst finden wir diesen Brauch nach Ausweis des 15. Ordo noch gegen Ende des 14. Jahrhunderts ${ }^{2}$. Ja noch jetzt trägt derselbe, so oft er feierlich pontifiziert, ein Schultertuch über der Albe, den sog. fanone, von dem später besonders die Rede sein wird. Es ist, wie aus einem Vergleich mit dem 13., 14. und 15. Ordo Mabillons und den Angaben Innozenz' III. und des Durandus erhellt, identisch mit dem fano des 13. und dem fanum des 15. Ordo, dem orale der beiden genannten Liturgiker und dem anabolagium des 1. und 3. Ordo Mabillons und des S. G. K. Allerdings hat der Papst heute nicht mehr wie ehedem blof den fanone, sondern außerdem den gewöhnlichen Amikt, diesen unter, jenen über der Albe. Es wurde das im Verlauf des 15. Jahrhunderts Sitte als der Fanone seinem praktischen Zweck ganz entfremdet und zum bloßen Schmuckstiuck geworden war. In der Privatmesse bedient sich der Papst lediglich des allgemein gebräuchlichen Schultertuches; seit wann, konnten wir nicht feststellen. Bei den Bischöfen, Priestern und Ministri muß zu Rom der Brauch, den Amikt über der Albe zu tragen, etwa um das Ende des ersten oder in der Frühe des zweiten Jahrtausends abhanden gekommen sein. Jedenfalls bestand er bei ihnen daselbst, wie aus der Schrift Innozenz' III. De sacro mysterio altaris erhellt ${ }^{3}$, schon wenigstens um die Wende des 12. Jahrhunderts nicht mehr.

Die Sitte, den Amikt über der Albe zu tragen, erhielt sich, wie vorhin gesagt wurde, in der ambrosianischen Liturgie und zu Lyon bis auf die Gegenwart. Übrigens findet sich auch noch im römischen Ritus eine schwache Erinnerung an die ursprüngliche Tragweise des Schultertuches. Beim Pontifikalamt und den Pontifikalvespern legen nämlich nach dem Caeremoniale für die Bischöfe der assistierende Priester, die Ehrendiakone und die Ehrensubdiakone, ehe sie das Pluviale bzw. die Dalmatik und Tunicella anziehen, über ihr Rochett bzw. ihr Superpelliceum (Cotta) ein Schultertuch an*. Daß aber diese Sitte nicht erst durch das Caeremoniale eingeführt wurde, sondern dem Mittelalter entstammt, beweisen der 14. und 15. Ordo Mabillons ${ }^{5}$.

\footnotetext{
1 Mart. 1. 1, c. 4, art. 12, ordo 3; I 173. Magistretti 45 . Magistretti int übrigens, wenn er (ebd. 44) meint, Innozenz III. lasse den Papst zwei Amikte tragen. Das Gegenteil ist der Fall. Vgl. De sacrificio missae 1. 1, c. 3553 (M. 217, 787793 ).

${ }^{2}$ C. 8 (M. 78,1277 ).

${ }^{3}$ L. 1, c. 1053 (M. 217, 780 793). Vgl.
}

auch den 13. römischen Ordo nr 56 (M. 78, 11061107 ) und namentlich betreffs der Karđinalbischöfe den 14. Ordo c. 4853 (ebd. 11531157 ).

4 L. 1 , c. 7, n. 1 ; c. 8, n. 2 ; L. 2 , c. 1 , n. $4 ;$ c. 2, n, 4 .

5 Ordo 14, c. 464878 u. a.; ordo 15, c. 20 54 u. a. (M. 78, 11451153119612821300. 
Wer dem Gottesdienst in einer Kirche der Franziskaner oder Dominikaner beigewohnt hat, wird bemerkt haben, daf der Priester beim Austritt aus der Sakristei mit dem Amikt wie mit einem Kopftuch das Haupt bedeckt hatte und ihn erst am Altar auf die Schulter niederliefs. Es ist diese Sitte, die uns auch noch bei einigen andern älteren Orden, wie den Trinitariem, Serviten u. a., begegnet, der Rest eines ehedem allgemeinen Brauches. Nur war es nicht überall Gepflogenheit, das Schultertuch erst am Altar herabzuschlagen. Das gewöhnliche war vielmehr, das Humerale gleich nachdem man alle liturgischen Gewänder angelegt hatte, und bevor man die Sakristei verliek, vom Kopf auf die Schultern herabzuziehen und rings um den Hals zu ordnen.

Bei dieser Anlegungsweise wurde also der Amikt nicht, wie das heute nach dem römischen Missale geschehen soll, gleich von Anfang um den Hals gelegt. Man bedeckte vielmehr zunächst mit ihm in der Weise den Kopf, daß er wie ein Schleier über die Schultern, den Nacken und die Brust herabhing, und belief ihn so, bis man alle andern Paramente, die Kasel eingeschlossen, angezogen hatte.

Wann der fragliche Brauch aufgekommen, läßt sich nicht genau bestimmen. Hraban und Amalar, Pseudo-Beda und Pseudo-Alkuin haben ihn ersichtlich noch nicht gekannt. Denn sonst würden sie schwerlich unterlassen haben, seiner Erwähnung zu tun und ihn mystisch zu deuten. Für Hraban und Pseudo-Alkuin sinnbildet der Amikt nur die Reinheit der guten Werke, für Amalar und Pseudo-Beda aber die Wachsamkeit im Reden. Auch der Ordo Duchesnes weif noch nichts von der fraglichen Geptlogenheit. Im Gegenteil sagt er ausdrücklich, man habe das anagolagium um den Hals gewunden: involvunt se anagolagio circa collo (sic).

Es scheint, daß die Sitte, mit dem Humerale beim Ankleiden zunächst den Kopf zu bedecken, etwa gegen Ende des 9. Jahrhunderts aufzutauchen begann. Ankleidegebete, in denen der Amikt als ein geistlicher Helm oder als Schirm des Hauptes bezeichnet wird, die also auf die uns beschäftigende Gewohnheit hinweisen bzw. sie als bestehend voraussetzen, finden sich schon in einigen Sakramentaren des 10. Jahrhunderts ${ }^{1}$.

Anfänglich wie alles Neue nur vereinzelt in Übung, erlangte der Brauch allmählich immer weitere Verbreitung. Davon zeugen insbesondere auch die Sakramentare und Pontifikalien des 11. und 12. Jahrhunderts, in denen um diese Zeit auf ihn hindeutende Ankleidegebete immer häufiger werden ${ }^{2}$. Von den damaligen Liturgikern tun Johannes von Avranches ( $†$ 1079), Ivo von Chartres († ca 1117) und Bruno von Segni $(\dagger 1123)$ seiner noch keine Erwähnung. Die ersten unter ihnen, die von ihm reden, sind Rupert von Deutz († 1135) und Honorius (schrieb ca 1120). "Der Priester", so bemerkt jener, "bedeckt mit einer Sorte von Umwurf sein Haupt, bis er ihn über die Halsöffnung der Kasel zurückschlägt und wie ein Kopfstück oder eine Bekrönung

1 Mart., L. 1, c. 4, art. 12, ordo 7; I 192 (ca 900). St Gallen, Stiftsbibliothek Cod. 389 (s. X). Vgl. auch M a r t., l. c., ordo 6; I 190; wo indessen das betreffende Pontificale zu hoch hinauf datiert sein dürfte.

$2 \mathrm{Maxt}$, L. 1, c. 4, art. 12, ordo 1213 16; I 204207 214. Flore nz, Bibl. Riccard. Cod. 299 (s. XI) 300 (s. XI). Mailand,
Ambrosiana Cod. D, 84 (ca 1000). Rom, Bibl. Vaticana Cod. lat. 7231 (s. XII-XIII) ebd. Ottob. Cod. 576 (s. XII) und ebd. Barb. Cod. XII 2 (ca 1200); ferner Rom, Bibl. Angelica Cod. 477 (s. XII) 1092 (s. XII-XIII). Modena, Bibl. Capit. Cod. I 8 (s. XII ex.); II 20 (s. XII). P aris, Bibl. nat. f. lat. 10500 (s. XI), 821 (s. XI), 2293 (s. XI in.) u. aa. 
derselben anpafst." 1 Seit etwa der Mitte des 12. Jahrhunderts ist dann von der Sitte bei den Liturgikern regelmäßig die Rede: so bei Robert Paululus († ca 1184), bei dem Verfasser des Tractatus de sacramento altaris, bei Sicard von Cremona († 1215), Innozenz III. († 1216) und Durandus $(\dagger 1296)$, welche sie als allgemein in Übung stehend behandeln. Eine sehr interessante und eingehende Beschreibung, wie das Schultertuch auf Grund jener Gepflogenheit angelegt wurde, findet sich im 14. römischen Ordo ${ }^{2}$.

Der Gebrauch, den Amikt beim Ankleiden zunächst aufs Haupt zu legen und erst, nachdem die Kasel übergeworfen war, auf die Schultern zurückzuschlagen, hörte in Rom schon gegen Ende des Mittelalters auf. Der Ordo missae Burchards von Straß̧burg, des Zeremonienmeisters Sixtus' IV., Innozenz' VIII. und Alexanders VI., kennt ihn nicht mehr. Die Weise, wie in ihm die Anlegung des Schultertuches beschrieben wird, entspricht schon ganz den Anweisungen, welche darüber das römische Missale gibt. Dasselbe hat demnach in die Generalrubriken hinsichtlich des Amiktes nur aufgenommen, was sich schon seit einer Weile als römischer Brauch herausgebildet hatte. Zweierlei erinnert jedoch noch im römischen Ritus an die alte Sitte. Das eine ist das Gebet, welches der Priester bei Anlegung des Schultertuches spricht: "Setze, o Herr, auf mein Haupt den Helm des Heiles, auf daf ich alle teuflischen Angriffe abschlagen möge", in Verbindung mit der Gewohnheit, dasselbe beim Ankleiden einen Angenblick über dem Kopf ruhen zu lassen. Das andere ist die Zeremonie bei der Subdiakonatsweihe, daßs der Bischof den Amikt von den Schultern des Ordinanden über dessen Kopf zieht und dabei spricht: "Nimm hin den Amikt, durch den die Zucht im Reden bezeichnet wird, im Namen des Vaters und des Sohnes und des Heiligen Geistes. Amen." Dieser Ritus entstammt dem späten Mittelalter. Solange die Minoristen noch Albe mit Humerale trugen, hatte er keine Bedeutung. Seitdem dieselben jedoch bei Ausübung ihrer Funktionen sich des Superpelliceums bedienten - in Rom war das sicher schon in der zweiten Hälfte des 13. Jahrhunderts der Fall - und Humerale samt Albe der Regel nach erst von den Subdiakonen gebraucht wurden, konnte man in jener Zeremonie einen Hinweis auf den Ordo des Subdiakonats erblicken.

Mit der Aufnahme des neuen römischen Missale verschwand auch auferhalb Roms nach und nach die Sitte, das Humerale bis nach Anlegung der Kasel auf dem Haupte zu belassen. Doch war sie noch bis gegen Ende des 16. Jahrhunderts häufig. In einem Inventar der St Brigidenkirche zu Köln heifen die Humeralien noch im Jahr 1578 heubtdoecher ${ }^{3}$, offenbar wegen des Brauches, mit ihnen beim Ankleiden den Kopf zu bedecken. Auch der Um-

${ }^{1}$ De off. div. 1. 1, c. 19 (M. 170, 22). Die gewöhnliche Lesart ist: Quidam amictu caput suum obnubit. Statt dessen ist richtiger zu lesen: Quodam amictu... obnubit (sc. sacerdos). So lautet die Stelle in der Tat in Cod. 246 der St Gallener Stiftsbibliothek, in dessen explicit die Schrift irrig Beda zugeschrieben wird.

${ }^{2}$ c. 53 (M. 78,1157 ): In primis ergo acolythi deferant amictum, quem ponat super caput pontificis diaconus et einsdem amictus chordulam sinistram diaconus, dextram subdiaconus accipiat et post tergum pontificis ducant et reducant ad anteriorem partem super cingulum, quas invicem colligare poterit ipse pontifex. ... Planeta complicata, diaconus de capite pontificis amictum deponat et aptet circa collum eius.

${ }^{3}$ A. D itges, Eine Kölner Gerkammer, in ${ }_{n} \mathrm{An}-$ nalen des hist. Vereins für den Niederrhein ${ }^{*}$ XLV 130. Eine der Bezeichnung heubtdoecher verwandte Benennung findet sich in Inventaren der Kathedrale von Lincoln aus dem 16. Jahrhundert, wo der Amikt ammis kerchif heist (kerchif = couvre-chef = Kopftuch). 
stand, daß in diesem wie in andern Schatzverzeichnissen des ausgehenden 16. Jahrhunderts noch immer Amiktparuren aufgeführt werden, beweist, daf.3 die alte Gepflogenheit damals vielfach noch bestand. Wir finden deren z. B. noch in einem Schatzverzeichnis von St Valentin zu Kiedrich im Rheingau aus dem Jahre 1583, in Inventaren ermländischer Kirchen aus den Jahren 1597 und $1598^{\prime}$ und einem Graner Inventar vom 30. Mårz 1609. Am längsten erhielt sich beim Weltklerus in Frankreich die Sitte. Sie dauerte daselbst an manchen Orten, wenngleich mit mehr oder weniger Einschränkungen und verschiedenen Eigenheiten, bis ins 18. Jahrhundert fort, so zu Langres, Narbonne, Angers, Auxerre, Paris, Rochelle, Dijon, Puy. Zu Langres und Narbonne trugen die Kanoniker das Humerale auf dem Kopf, bis sie zum Altare kamen. Zu Auxerre war es nur von Allerheiligen bis Ostern gebräuchlich, den Amikt in Form eines Kopftuches zu tragen. Zu Paris behielt man ihn im Winter bis zur Secret, zu Rochelle bis zum Beginn des Kanons auf dem Haupt. Zu Angers schlug man ihn das ganze Jahr hindurch nur während des Kanons auf die Schultern. Blof in Messen vor ausgesetztem hochwürdigsten Gute trug man ihn während der ganzen heiligen Handlung um den Hals. In St-Benigne zu Dijon wurde das Humerale über das Birett gelegt. Ähnlich geschah es vereinzelt auch in der Diözese Puy ${ }^{2}$.

Da: es bei verschiedenen Mönchsorden noch jetzt Gewohnheit ist, mit dem Schultertuch auf dem Kopf zum Altar zu treten und erst dort selbiges herabzulassen, wurde vorhin schon bemerkt.

Auf die Frage, wo die Gepflogenheit, den Amikt auf den Kopf zu legen, ihren Ursprung genommen habe, läft sich eine sichere Antwort, nicht geben. Sollte jedoch der Umstand, dafs uns das Ankleidegebet, in welchem das Gewand als Helm des Heiles und Schutz des Hauptes gedeutet wird, zuerst, soweit sich darüber ein Urteil bilden läkit, in fränkischen Sakramentaren auftritt, nicht darauf hinweisen, daf sie im nördlichen Frankreich aufgekommen sei? Römischer Herkunft ist sie allem Anschein nach wohl nicht.

Auch für die andere Frage, was zu dem fraglichen Brauch geführt, fehlt noch eine genügende Lösung. Als zweifellos darf betrachtet werden, daf nicht eine mystische Erwägung ihn veranlafite, sondern die mystische Deutung hier wie auch sonst der Praxis folgte. Auch scheint es wenig wahrscheinlich, das der Amikt auf dem Wege zum Altar und bei etwaigen mit der Messe in Verbindung stehenden Prozessionen statt der sonst üblichen Kapuze oder in Verbindung mit ihr als eine Art Kopfbedeckung dienen sollte. Wenn etwas für diese Erklärung sprechen könnte, so ist es die später in manchen Orden herrschende Gewohnheit, das Schultertuch über die Kapuze anzulegen. Indessen ist eine solche Gepflogenheit allem Anschein nach weit jünger als der Brauch, den Amikt bis nach Anlegung der Kasel auf dem Kopf zu belassen und wohl erst spätmittelalterlich. Auferdem belehrt uns Rupert von Deutz, dab man das Humerale herabzog, sobald man die Kasel übergeworfen hatte.

Vielleicht daf der Wunsch, das vielfach kostbare Obergewand, zumal die Kasel, die infolge ihres Schnittes im Nacken einen Bausch zu bilden pflegte, besser zu schützen, der Grund für die Einführung der Sitte war.

1 Fr. H i ple r, Die ältesten Schatzverzeichnisse der ermländischen Kirchen, Braunsberg 1886, 68 ff und Fr. Dittric h, Inneres Aussehen und Ausstattung der Kirchen des aus- gehenden Mittelalters im deutschen Nordoster (Zeitschrift III [1890] 246).

2 De Vert II 243 261. Roh. VII 19.

Le Brun I, traité prélim. art. 4, 1 ; I 39. 
Vielleicht auch, daf ästhetische Erwägungen den Anlaf gaben. Die Bemerkung Ruperts, daßs man den Amikt wie ein Kopfstück und eine Krone, d. i. einen bekrönenden Abschluß, um den Kopfdurchlaf der Kasel herumlege, und die Angabe des Tractatus de sacramento altaris, der Amikt werde der Zierde halber über der Kasel zusammengefaltet, dürften darauf hinweisen. Insbesondere mag aber das Bestreben, an dem Saum des Amikts angebrachte Verzierungen besser zur Geltung zu bringen, auf die Entstehung des Brauches von Einfluf getresen sein. Indessen sind alle diese Erklärungen zuletzt kaum mehr als bloke Vermutungen.

Wie es sich aber auch mit dem Ursprung der in Frage stehenden Sitte verhalten mag, jedenfalls war es eine unbedingte Notwendigkeit, das Humerale in der beschriebenen Weise anzulegen, seitdem man damit begann, das Schultertuch mit dem im späteren Mittelalter so beliebten kragenartigen Zierbesatz zu versehen.

\section{BESCHAFFENHEIT UND AUSSTATTUNG DES HUMERALE.}

Das Schultertuch der ältesten Zeit haben wir uns als ein einfaches rechteckiges oder quadratisches Tuch zu denken, das je nach der Würde des Trägers größer oder kleiner sein mochte ${ }^{1}$. Mit Bändern, die um Brust und Rücken geschlungen werden konnten, scheint es ursprünglich nicht ausgestattet gewesen zu sein. Weder Hraban noch Amalar noch Pseudo-Alkuin sagen davon das geringste, und doch hätten sie, falls der Amikt zu ihrer Zeit mit solchen versehen gewesen wäre, es schwerlich unterlassen, von ihnen zu reden und sie mystisch zu deuten ${ }^{2}$. Man vergleiche nur, wie eingehend sie die Dalmatik und die.Sandalen nach allen ihren Teilen erörtern. Weiß doch z. B. Amalar für jedes Riemchen der Fufbekleidung eine entsprechende Auslegung. Wir dürften um so mehr erwarten, daf sie von ihnen geredet hätten, als die Liturgiker seit dem 12. Jahrhundert getreulich anmerken, daf das Schultertuch mit Schnüren ausgestattet sei, und was selbige besagten. Der erste, welcher die Bänder ausdrücklich erwähnt - Ivo von Chartres scheint sie nur anzudeuten - , ist Honorius. Ihm folgen Robertus Paululus, Sicard von Cremona, Innozenz III., welcher sie vasculi nennt, und natürlich auch Durandus. Es scheint fast, als seien Bänder zur Befestigung des Schultertuches demselben erst angefügt worden, als die Sitte aufkam, den Amikt über den Kopf zu legen und allda bis nach Annahme der Kasel zu belassen.

Von einer Verzierung des Humerale vernehmen wir schon im Testament Riculfs von Elne († 915); denn unter den verschiedenen liturgischen Gewändern, welche er darin seinem Nachfolger hinterläbt, werden auch vier goldgeschmückte Amikte genannt. Dafi aber kostbare Schultertücher dieser Art im 10. Jahrhundert keine vereinzelte Erscheinung bildeten, zeigen beispielsweise das Inventar von Clermont-Ferrand, das 15 bonos amictos (sic), cum auro 5 optimos, alios amictos cum auro 10 verzeichnet, und das von St-Père-enVallée zu Chartres, das von 12 collaria auri (nach dem Zusammenhang = humeralia) berichtet. 1051 erwähnt ein Speierer Inventar humeralia cum

\footnotetext{
${ }^{1}$ Ordo 9, n. 4 (M. 88, 1006) ist von einem anagolagium grande des Bischofs die Rede. Es scheint hiernach, dak das Schultertuch des Bischof gröber war als das der Priester und Diakonen.
}

2 Auch die Worte des von Duchesne (Orig. 456) herausgegebenen Ordo: involvunt se anagolagio circa collo et induunt se tunicas, scheinen nicht für eine Bindvorrichtung zu sprechen. 
auro texta, 1077 eine Schenkungsurkunde Hugos von Burgund 10 amicti aurei ${ }^{1}$. Auch ein noch dem 11. Jahrhundert entstammendes Schatzverzeichnis von Enger nennt 2 superhumeralia auro parata.

Ein kostbares, örtlicher Überlieferung zufolge dem 11. Jahrhundert entstammendes Humerale befand sich bis zur Aufhebung des Stiftes im Jahre 1802 in der Stiftskirche des hl. Andreas zu Freising. Es sollte wie einige andere dort aufbewahrte Paramente vom Bischof Ellenhard von Freising (1052-1078), einem geborenen Grafen von Meran und dem Gründer des Stiftes, herrühren. In einer Handschrift vom Jahre 1728 wird es folgendermafen beschrieben : „Auf dem Humerale, welches der Priester auf die Schultern und um den Hals zu nehmen pflegt, ist in der Mitte angebracht das Lamm Gottes, und an den Ecken sieht man die vier Tiere der Evangelisten mit Edelsteinen und Gemmen prachtvoll gestickt." 2 Welche Verbreitung im 10. und 11. Jahriundert der Brauch hatte, das Schultertuch in dieser oder ähnlicher Weise auszustatten, läst sich nicht bestimmen. Bei den Bildwerken aus jener Zeit, namentlich den allerdings vielfach unvollkommenen Miniaturen, sind die Humeralien durchweg nur wenig, meist aber gar nicht sichtbar, so daf aus ihnen ein Urteil ïber die Ausstattung des Amiktes nicht zu gewinnen ist. Die Inventare ans dem Ende des 1. und dem Beginn des 2. Jahrtausends aber erwähnen im ganzen nux selten Humeralien besserer Art.

Einen besondern Aufschwung nahm die Verzierung des Amiktes im 12. Jahrhundert, und bald kam es zu jenem kragenartigen Humeralbesatz, der für die ganze übrige Zeit des Mittelalters die Herrschaft behaupten sollte. Er bestand in einem melır oder minder breiten Zierstück von kostbarem Stoff (Bild 3), welcher häufig mit reichen Stickereien und selbst aufgesetzten Perlen und Edelsteinen versehen war, oder, wenngleich seltener, in einem dem Humerale unmittelbar eingestickten Zierstreifen. Angebracht war er an einer der Langseiten, und zwar an derjenigen, an der sich die Bänder zum Anbinden befanden. Seine Länge schwankte gewöhnlich zwischen 0,40 bis $0,50 \mathrm{~m}$. Beim Ankleiden wurde der Amikt so auf den Kopf gelegt, daß der Besatz sich von Schläfe zu Schläfe erstreckte, und zwar entweder einfach oder in der Breite des Besatzes umgeschlagen. Dann wurden die Bänder um die Brust geschlungen, die Albe, Stola und Kasel

1 d'A chéry, Spicileg. III, Paris. 1723, 412. Von einem sehr kostbaren Amikt ist auch in der Vita des Bischofs Hugo von Auxerre (1000-1039) die Rede (Hist. episc. Autissiod. c. 49 ; M. 138,277 ) : In amictu lamina aurea margaritis et lapidibus pretiosis intertexta quasi regali diademate summi sacerdotis caput illustrabat. Der Bischof soll ihn samt andern prächtigen Paramenten von Kaiser Otto III. erhalten haben. Sowohl die Beschreibung des Amikts, bei der dem Verfasser der Vita ersichtlich ein mit Parura verziertes Humerale vorschwebte, als auch was über seine Herkunft gesagt wird, lassen die Angaben der Historia als spätere Fabel erscheinen, welche auf Zuverlässigkeit keinen Anspruch erheben kann. Man vergleiche auch den Widerspruch zwischen der Erzählung der Vita Hugonis von den kostbaren

Braun, Die liturgische Gewandung.
Gewändern, mit denen Hugo am Ende seines Lebens seine Kathedrale bereicherte, und dem Bericht der Vita Godofredi, der etwa ein Dezennium später Bischof wurde, über den damaligen armseligen Zustand der Paramente in der Kathedrale: Nulla denique pontificalia, in quibus missam ipse decenter celebraret, habebantur indumenta. Die Lebensbeschreibung Hugos wurde allem Anschein nach erst spät im 12. Jahrhundert geschrieben.

2 Kirchenschmuck I (1857) 15. Vgl, auch Meichelbeck, Hist. Frising. I 257. Übrigens geben wir obige Daten nicht wieder, ohne unser Bedenken an der Echtheit des fraglichen Amiktes zum Ausdruck zu bringen. Die angeblich ebenfalls von Bischof Ellenhard herrührende und ebendort beschriebene Albe stammte sicher erst aus späterer Zeit. 
angezogen und num das Schultertuch so über den Hinterkopf herabgelassen, daßs die Terzierung kragenförmig den Hals umgab. Bild 4 veranschaulicht den Vorgang. Wurde der Amikt auf den Kopf gelegt, wie es Bild 4 andeutet, d. i. ungedoppelt, so hatte der Besatz, wenn um den Hals geordnet, das Aussehen eines umgeschlagenen Kragens. Brachte man jenen in der Breite der letzteren gedoppelt oder zusammengefaltet auf den Kopf, so ähnelte er nach dem Herablassen des Humerale einem Stehkragen ${ }^{1}$.

Belege für das Gesagte liefern die Monumente seit etwa der Mitte des 12. Jahrhunderts bis zum 16. Jahrhundert und selbst darüber hinaus die Hülle und Fülle. Auf französischen Bischofssiegeln erscheint der Besatz schon um 1150, auf englischen gegen Ende des Jahrhunderts 2. Auf den Siegeln der Mainzer Erzbischöfe ist er mit Sicherheit erst bei Heinrich II. $(1286-1288)^{3}$ nachweisbar, auf den Siegeln der Bischöfe von Paderborn, Münster, Osnabrück und Minden begegnet er uns ebenfalls kaum vor der Mitte des 13. Jahrhunderts. Regelmäßig tritt er auf denselben erst um 1300 auf ${ }^{4}$. Auf Kölner Siegeln gewahren wir das Zierstück vielleicht schon bei Philipp

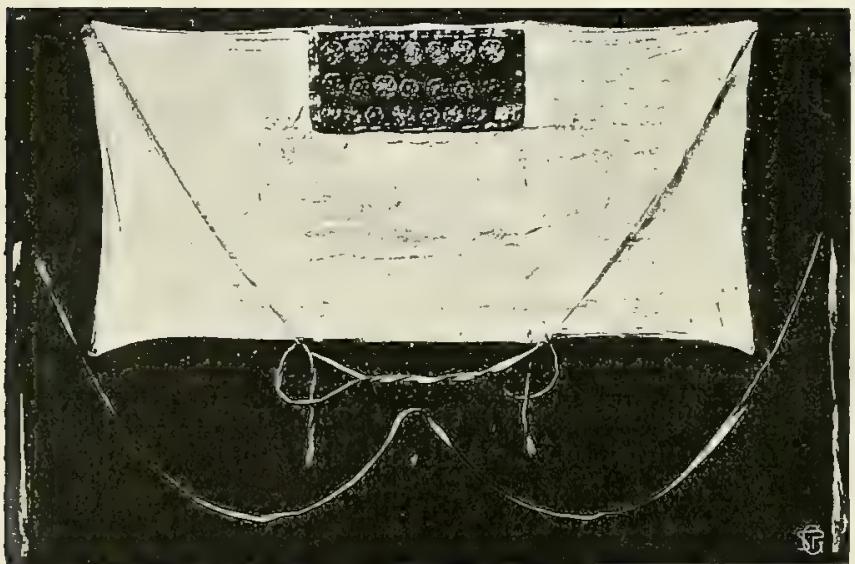

Bild 3. Amikt und Cingulum. Danzig, Marienkirche, (Nach Hinz.) von Heinsberg (1167 bis 1191) und Dietrich von Bergen (1208-1212), falls das, was einem Besatz ähnelt, nicht etwa der Amikt selbst ist. Unzweifelhaft findet es sich auf dem Siegel Siegfrieds von Westerburg (1275-1297). Auf den Trierer Siegeln mag es schon bei Dietrich (1212 bis 1242) vorkommen. Um 1275 treffen wir die fragliche Verzierung des Amiktes auf dem Siegel des Abtes Adolf von Siegburg und um 1300 auf dem des tüchtigen Abtes

Arnold von St Martin zu Köln, um 1250 auf dem Siegel des Domes zu Hildesheim. Um dieselbe Zeit kommt sie auch auf den Hildesheimer, den Halberstädter und Würzburger Bischofssiegeln vor.

Auf den italienischen Bischofssiegeln dürfte der Amiktbesatz kaum vor 1250 auftreten. Regel wird er auf ihnen erst gegen Ende des Jahrhunderts. Als noch fraglich vermerken wir ihn auf dem Siegel des Bischofs Egidius von Foligno (1208 bis 1243). Sicher finden wir dagegen das Zierstück auf den ersichtlich unter franzüsischem Einflußs stehenden Siegeln der Bischöfe Johannes von Ferrara (1252-1257)

${ }^{1}$ Bock (Gesch. II 30) beschreibt auch noch eine zweite im Mittelalter gebräuchliche Anlegungsweise des Amikts ( $\mathrm{vgl}$, dazu a. a, O. Tl 2,2). Wir haben indessen für dieselbe keine Bestätigung gefunden, es spricht vielmehr alles, was wir vom mittelalterlichen Amikt und seiner Beschaffenheit wissen, gegen sie. Jedenfalls ist das Untertücblein, das nach Bock bei der oben im Text heschriebenen Weise nütig und Anlaßs zu der von ihm an zweiter Stelle geschilderten Anlegungsweise gewesen sein soll, eine Fabel.
2 Man vergleiche die zahlreichen Abbildungen französischer und englischer Siegel bei Roh. VII VIII sowie unter andern L. Blancard, Iconographie des Sceaux des arch. départ. des Bordes - du-Rhône, Paris 1860.

${ }^{3}$ W ü r d tw e in, Nova subsidia dipl. t. IV, tab. $21 ; \mathrm{V}$, tab. $22 \mathrm{ff}$.

${ }^{4}$ G. T u mbült, Die westfälischen Siegel des Mittelalters 2. Hft, 1. Abtl: Die Siegel der Bischöfe, Münster 1885 (Münster, Paderborn, Osnabrück, Minden). 
Jakobus von Feltre (1291 bis ca 1298), Vivianus von Faënza (1282-1287), Otto von Ventimiglia (1304-1319), Hubertus von Montefeltro (1288-1318), Maurus von Amelia (1286-1300), Monaldus von Civita Castellana (1288-1300), des Kardinals Berengar von Frascati (1309-1323) und des Patriarchen Egidius von Grado (1296-1311). Ebenso weisen den Besatz auf die Siegel des Bischofs Magnus von Vexiö in Schweden (1295-1320), des Bischofs Roderich vou Mondoñedo in Spanien (1297-1318) und des Erzbischofs Martin von Braga in Portugal (1295-1313) ${ }^{1}$.

Es kann hiernach wohl keinem Zweifel unterliegen, daf die fragliche Amiktverzierung aus Frankreich stammt; sie begegnet uns also da zuerst, wo auch die Wiege der Gotik gestanden hat. Es ist bemerkenswert - die Siegel bekunden das auf das deutlichste -, wie die Ausbreitung ihrer Verwendung gleichen Schritt mit der Verbreitung der Gotik hält. Wie diese, so nimmt auch das Zierstück des Amikts zunächst seinen Weg über den Kanal, während in Deutschland beide erst eine geraume Weile später ihren Einzug halten und sich einbiirgern. Nicht anders verhält es sich hinsichtlich Italiens und Spaniens.
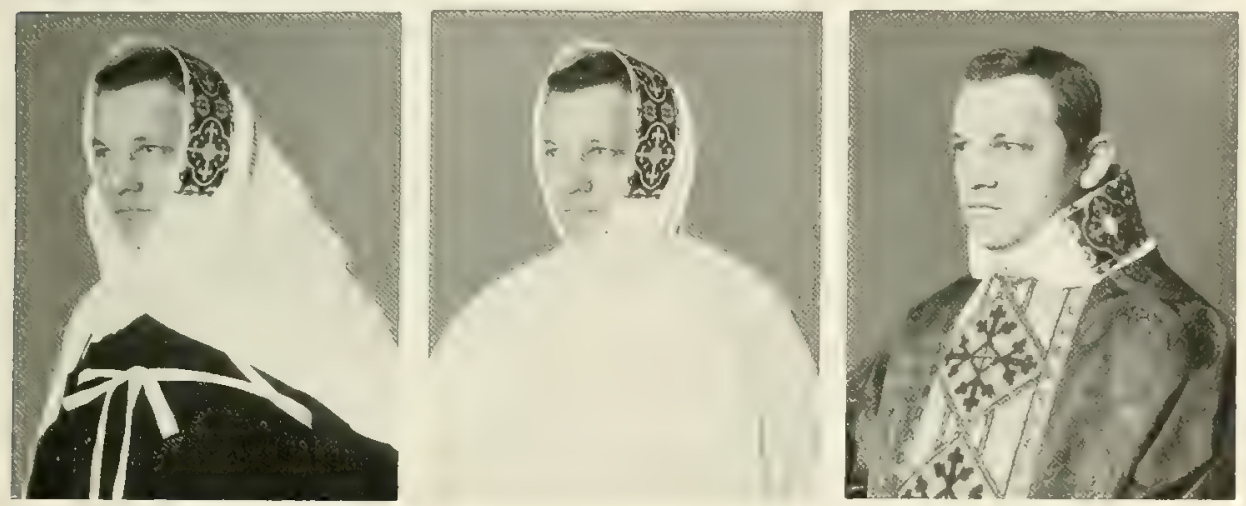

Bild 4. Anlegungsweise des Amikts nach mittelalterlicher Weise.

Der Besatz umgibt, wie schon gesagt, entsprechend der vorhin geschilderten Anlegungsweise auf den Bildwerken den Hals bald nach Art eines anliegenden umgeschlagenen Kiragens (Bild 5, S. 36), bald gleicht er, zumal im 14. und 15. Jahrhundert, einem Stehkragen (Bild 6, S. 36). Nicht selten machen die Monumente den Eindruck, als sei er nicht am Amikt, sondern an der Kasel bzw. der Dalmatik befestigt. Es ist das namentlich bei Bildwerken aus dem ausgehenden Mittelalter der Fall. Gewöhnlich wird das jedoch nur bloßer Schein oder künstlerische Lizenz sein. Dafs er indessen wirklich hie und da statt am Amikt der Einfachheit halber an dem Mefgewand (bzw. dem Levitengewand) angebracht wurde, beweist z. B. die Notiz eines Pontifikale von Montecassino in der vatikanischen Bibliothek, wonach der Abt für die Messe casula cum collari ${ }^{2}$ bekleidet werden soll, falls man nicht lieber die Rubrik von einer Kasel und einem vom Amikt losgelösten selbständigen Kragen,

1 Nach Originalsiegeln oder Kopien in der dem Skriptorenhaus der deutschen Ordensprovinz gehörenden Siegelsammlung. Die den Bischöfen beigefügten Daten beruhen hier wie auch sonst in diesem Werke auf $\mathrm{P}$. P i us
Gams, Series episcoporum (Regensburg 1873) mit Benutzung der Korrekturen bei P. K. Eube 1 O. Min. Conv., Hierarchia catholica medii aevi, Münster 1898.

2 Vatic. Cod. lat. 9340, $4 \mathrm{v}$. 
wie dieser noch jetzt in Mailand gebräuchlich ist, verstehen will. Hinsichtlich der Farbe richtete sich das Zierstiick, seitdem und wo es einen liturgischen Farbenkanon gab, gewöhnlich, wenngleich keineswegs ausschlieflich, nach der Farbe des Tagesoffiziums. Insbesondere wurden bessere, reichere und kunstrollere Besätze ohme strenge Rücksicht auf die jeweilige Tagesfarbe gebraucht. Bei dem Amiktbesatz konnte um so eher davon abgesehen werden, als er ja nicht einen wesentlichen Teil des Gewandes ausmachte, sondern blos Verzierung war.

In den Inventaren heift der Besatz des Schultertuches bald parura oder collare, bald plaga, plagula oder plica, bald gemma, praetexta, truncus ${ }^{1}$ oder aurifrisium (a uriphrygium), frisium, in deutschen schilt, brederken (Kragen) und ähnlich. Nicht selten wird er indessen auch vom ganzen Gewand humerale genannt. So lesen wir z. B. in einem Olmuitzer Inventar aus dem Jahre 1435 von gelben oder goldenen Humeralien, von einem Humerale aus schwarzem Samt, in einem Schatz-

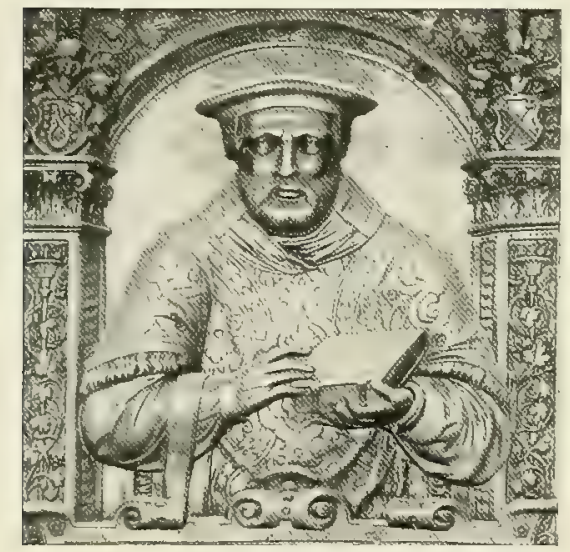

Bild 5. Von der Grabplatte des Kanonikus Joh. Peter von Seckendorf ( $†$ 1557). Bamberg, Dom.

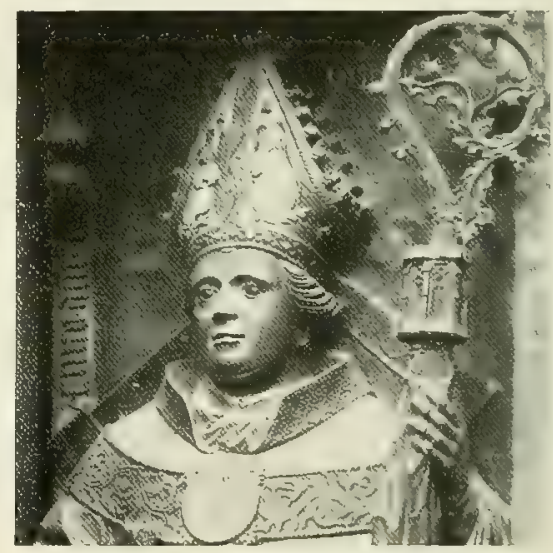

Bild 6. Vom Grabmal des Bischofs Gottfried von Limburg ( $†$ 1455). Würzburg, Dom.

verzeichnis von Flbing von grünen, braunen Humeralien, von schwarzen Humeralien, von einem "silbern übergult humeral cum radice Iesse", einem "silbern übergult humeral mit einem übergulten Marienbild“, einem „rot humeral mit gelben spangen" (Metallplättchen, die als Schmuck aufgesetzt wurden) und einem weifen Kreuz usw. ${ }^{2}$ Selbstredend kann sich eine derartige Benennung nicht auf den ganzen Amikt, sondern nur auf den Besatz beziehen, der ja auch in der Tat, weil sich um die Schultern legend, ein Humerale war. Es ist die Ausdrucksweise wohl zu beachten, andernfalls kommt man zum Irrtum, es habe ehedem schwarze, rote usw. Schultertücher gegeben.

Von mittelalterlichen Schultertüchern sind nur einige wenige auf uns gekominen. Es gibt deren ja eines zu Valsainte bei Bulle in der Schweiz, Neresheim (Württemberg), Rostock (Museum) und Eichstätt, zwei zu Halberstadt und drei zu Danzig. Bei dem Neresheimer Amikt besteht der Besatz aus einer Goldborte mit schönem, farbigem

\footnotetext{
1 Inventar von Frauenburg vom Jahre 1598 (Zeitschrift III [1890] 246).
}

2 Hipler, Die ältesten Schatzverzeichnisse 712 13. Vgl, namentlich auch S. 29. 
Vogel- und Pflanzenmuster ${ }^{1}$, der Eichståtter hat einen einfach gelbseidenen Besatz.

Von den drei Humeralien im Dom zu Halberstadt ist eines mit rotseidener Parura versehen, welche mit silbervergoldeten Zierplättchen (fibulae, Spangen) geschmückt ist. Ein zweites weist einen blauseidenen, mit blauen, weifen und roten Perlen bestickten Besatz auf.

Von den drei Schultertüchern in der St Marienkirche zu Danzig sind zwei mit rotsamtener Parura, die über und über mit silbervergoldeten Rosettchen und Blättchen besät ist, ausgestattet(Bild 3, S. 34). Bei einer derselben sind auf den Rosettchen kleine, frei herabbaumelnde Anhängsel aus vergoldetem Silber angebracht (Bild 7), in

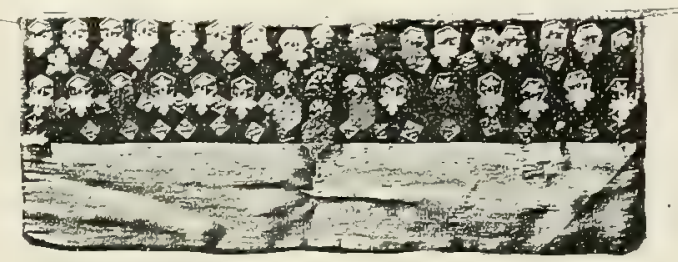

Bild 7. Amikthesatz. Danzig, Marienkirche.

einem Inventar von St Elisabeth zu Breslau aus den Jahren 1483-1498 flatterchen genannt 2. Das glänzendste Stück ist aber das dritte Humerale, dessen Parura mit einer in Ausführumg, Zeichnung und Technik gleich vorzüglichen Stickerei in Seide und Perlen, Christi Auferstehung darstellend, geschmückt ist (Bild 8). Der im Besitz der Kartäuser zu Valsainte befindliche Amikt entbehrt der Parura ${ }^{3}$

Lose Amiktbesätze sind, wenngleich etwas häufiger als vollständige Amikte, doch im ganzen gleichfalls nur in geringer Zahl erhalten. Die ältesten sind die schön in farbiger Seide und Gold gestickte Parura im Schatz der Kathedrale zu Sens, welche als Reliquie des hl. Thomas von Canterbury von dessen Aufenthalt zu Sens her gilt, jedenfalls aber spätestens aus der Frühe des 13. Jahihunderts stammt, und ein der gleichen Zeit angehörender, hochinteressanter Besatz im Dom zu Halberstadt, der in späterer Zeit als Einfassung des Kopfdurchschlupf's einer Kasel verwendet wurde und sich noch jetzt als solche an dieser befindet. Die Parura in der Kathedrale zu Sens ist $0,67 \mathrm{~m}$ lang, 0,125 hoch und mit Kreisen gemustert, die einander überschneiden und in der Yitte mit einem kreuzförmigen Ornament gefüllt sind. Der Halberstädter

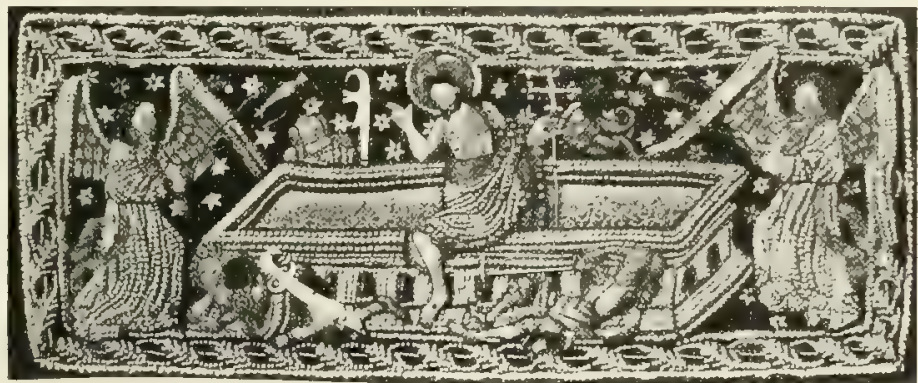

Bild 8. In Seide und Perlen gestickter Amiktbesatz. Danzig, Marienkirche. (Nach Hinz.)

Amiktbesatz ist ca $0,55 \mathrm{~m}$ lang und ca $0,08 \mathrm{~m}$ hoch und enthält auf tiefblauem Fonds von schwerem Seidenköper in der Mitte eine Darstellung der Najestas, rechts und

1 Nach gütiger Mitteilung des Herrn Pfarrers von Neresheim, Schulinspektor K. Schips.

2 Alwin Selu ultz, Schatzverzeichnisse Breslauer Kirchen 10 f: Lobwerg mit silberen vorgulten flatterchen ... mit obergulten span- geleyn und flatterchen... mit silbern spangeleyn und flatterchen vorgultet beslagen.

${ }^{3}$ Nach freundlicher Angahe des hochw Herrn Bibliothekars Dom Louis Maria de Massiac. 


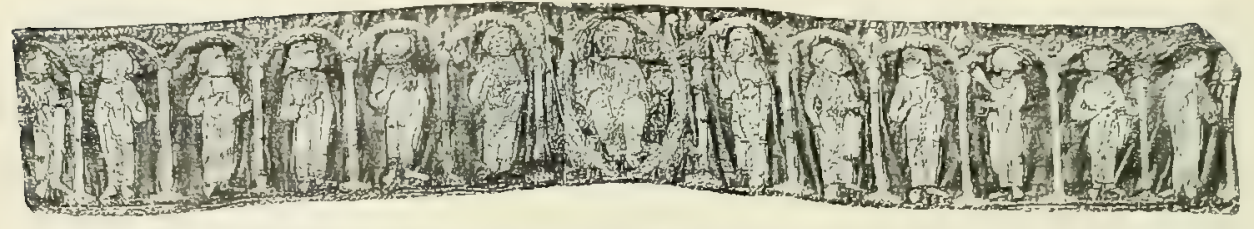

Bild 9. Amiktparura (ca 1200). Halberstadt, Dom.

links unter rundbogigen Arkaturen die Bilder von je sechs Aposteln. Die Fleischteile ausgenommen, ist alles übrige in Goldstickerei ausgeführt, wobei die Abheftfäden so tief in den Stoff hineingezogen wurden, dafà sie für das Auge völlig verschwinden (Bỉld 9), eine kunstvolle, im Mittelalter sehr beliebte und geübte Art der Abhefttechnik ${ }^{3}$.

Von sonstigen Amiktparuren finden sich bei weitem die meisten und vorzüglichsten in St Marien zu Danzig, darunter solche von ausnehmender Pracht und Kostbarkeit ${ }^{2}$. Dieselben entstammen teils dem 15., teils dem beginnenden 16. Jahrhundert. Echte Perlen sind bei einzelnen von ihnen in geradezu verschwenderischer Fülle angebracht. Das Verderben des guten Geschmackes tritt aber auch schon bei verschiedenen deutlich zu Tage (Bild 10). Reliefstickereien mit fast freistehenden Darstellungen sind auf einem Amiktbesatz trotz aller Kostbarkeit und trotz aller Kunst oder besser Kunstfertigkeit, mit der sie hergestellt wurden, widersinnig, weil ihrem Zwecke durehaus zuwider.

Es ist, was wir noch von mittelalterlichen Humeralien und ihren Besätzen besitzen, nur ein winziger Bruchteil der alten Herrlichkeit und keineswegs geeignet, uns ein vollständiges Bild von dem Reichtum und der glänzenden Ausstattung des mittelalterlichen Schultertuches zu geben. Indessen haben wir einen, wenngleich nur unvollkommenen Ersatz in den zahlreichen Bildwerken des 13., 14. und 15. Jahrhunderts, welche uns Bischöfe, Priester, Diakone und Subdiakone mit bald mehr bald minder reich verziertem Amikt ausgestattet zeigen.

Hier stellt der Besatz ein ungemustertes Zeug dar, dort ist er mit Perlen und Edelsteinen aufs glänzendste geschmückt; anderswo gewahren wir auf ihm Inschriften, Rankenwerk oder gar hildliche Darstellungen. Ein Blick auf die zahlreichen Statuen an den herrlichen Portalen der mittelalterlichen Dome in Frankreich, Deutschland und Spanien, auf die Glasgemälde, die sich aus dem späteren Mittelalter noch in reicher Fülle erhalten haben, auf die Werke des Pinsels, mit denen die alten Meister die Wände und Altäre der Gotteshäuser schmückten und ganz besonders die prächtigen Grabmonumente, die uns seit dem 13. Jahrhundert in grofer Menge in Deutschland (Köln, Paderborn, Würzburg, Bamberg, Regensburg usw.), in England, Frankreich, Spanien und Italien begegnen, zeigt uns, mit welch verschwenderischer Pracht die Humeralien im Mittelalter ausgestattet zu werden pflegten. Zugleich belehrt er uns, welche große Verbreitung die Gepflogenheit gewonnen hatte, den Amikt mit dem kragenartigen Zierbesatz zu versehen.

Den besten Begriff von dem Reichtum der mittelalterlichen Paruren gewähren aber die Schatzverzeichnisse des 13., 14., 15. und 16. Jahrhunderts, von denen zwar nicht alle, aber doch sehr viele von den Humeralien ausführliche Beschreibungen gebell. Wir lernen aus ihren nicht selten bis ins einzelne gehenden Angaben, dacis die Meister, welche die alten Monumente schufen,

$1 \mathrm{Vg}$. über diese T'echnik Br a un, Winke 132. BeiVerwendung feiner Goldfäden gleichen die Stickereien täuschend einem Goldgewebe.
2 Abbildungen der meisten bei Hinz, Die Schatzkammer von St Marien zu Danzig, Danzig 1870. 
keineswegs übertrieben haben, wenn sie so prächtige Amikte zur Darstellung brachten, und daf man ehedem wirklich nichts gespart hat, um dem Amikt eine würdige, ja oft fast zu glänzende Ausstattung zu geben. Hören wir nur, was uns das eine oder andere Inventar zu erzählen weiß.

Im Schatzverzeichnis der Kirche von Salisbury aus dem Jahre 1212 werden zwei goldverzierte und mit Edelsteinen besetzte Amikte und außerdem fünf andere, die mit Stickereien, und zehn, die mit Aurifrisien versehen waren, erwähnt. Das Inventar des päpstlichen Sehatzes von 1295 nennt unum amictum laboratum ad aurum tractitium et perlas et flores de serico diversorum colorum, unum amictum laboratum ad aurum et perlas, unum amictum cum frixio de Romania (Besatz byzantinischer Herkunft) ad aurum tractitium, unum amictum ad aurum filatum de opere anglicano cum media imagine Salvatoris in medio et sex aliae circa eam, unum amictum cum frixio anglicano ad imagines medias, unum amictum cum frixio de Alamania $u$. a., also Amikte, die mit Perlen und Goldstickerei und aufgestickten Halbhildern prächtig verziert waren ${ }^{1}$.

Ein Schatzverzeichnis des Prager Doms vom Jahre 1387 verzeichnet vier mit Perlen geschmückte Humeralien, von denen eines in großen Perlen die Inschrift Maria Virgo trug.

In dem Inventar des Domes zu 01 mütz von 1435 findet sich neben sonstigen kaum minder kostbaren Schultertüchern ein Amikt mit einerpraetexta aus Goldstoff, auf welcher aufer vier andern Bildern Mariä Krönung dargestellt war.

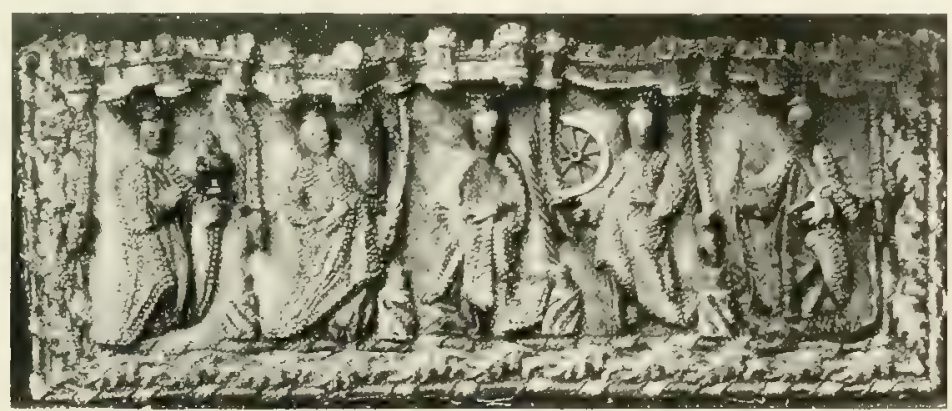

Bild 10. In Perlen- und Reliefstickerei ausgeführte Amiktparura. Danzig, Marienkirche. (Nach Hinz)

Ebendort treffen wir auch Besätze aus Coldstoff und aus schwarzem Samt für Humeralien ohne Leinwand, d. i. losgetrennt vom Schultertuch, wofür sie bestimmt waren, an. Sehr reich an Amikten mit kostbaren Besätzen war auch die Schatzkammer der Peterskirche in Rom. Dort fand sich beispielsweise dem Schatzverzeichnisse von 1361 zufolge unter sonstigen ein Amikt mit einem aus Gold und Perlen gearbeiteten Aurifrisium. Die Parura eines andern enthielt in sechs Feldern die Bilder verschiedener Heiligen, Wappen und Blattwerk. Das Aurifrisium eines dritten Humerale bestand aus drei Feldern, war aber im übrigen ähnlich wie das letztgenannte eingerichtet. Auch treffen wir neben diesen und andern Schultertüchern gleicher Art im Schatz von St Peter einen alten Amiktbesatz, der mit sieben Heiligenfiguren geschmückt war und als sehr reich mit Perlen verziert beschrieben wird. Sehr viele kostbar ausgestattete Humeralien weist das Inventar des Graner Domschatzes aus dem Jahre 1609 auf. Ausdrücklich erwähnt und näher beschrieben werden ihrer dreizehn. Da gibt es z. B. ein Schultertuch mit einem Besatz aus Goldstoff; die Parura eines zweiten ist mit dem aus roten und grünen Edelsteinen gebildeten Namen Jesu geschmückt. Auf andern waren der Weltheiland mit zwei Engeln, die auf der Brust einen Edelstein trugen, die Verkündigung, Naria mit Hei-

1 C. 54 (Bibl. de l'École des Chartes XLVI 36). Frixium ist gleich frisium oder aurifrisium (auriphrygium); aurum tractitium bezeichnet einen mit goldenem oder silbervergoldetem
Lahn hergestellten, aurum filatum dagegen, wie es scheint, den in neuerer Zeit irrig , Cyprisches Gold genannten Goldfaden. Näheres über Goldfäden bei Braun, Winke 7 . 
ligen, das Lamm Gottes largestellt oder die Namen Mariä und des hl. Johannes in Edelsteinen angebracht usw. Es waren diese Humeralien offenbar wie die Kaseln und Dalmatiken, wozu sie gehörten, meist Erbstücke des ausgehenden Mittelalters oder auch der ersten Hälfte des 16. Jahrhunderts.

Dafs aber anch in kleineren Kirchen zahlreiche glänzend ausgestattete Amikte sich vorfanden, heweist ein Einblick in die meist der zweiten Hälfte des 16. Jahrhunderts entstammenden Schatzverzeichnisse ermländischer Kirchen. So nennt das Inventar von Allenstein fünf mit fibulae geschmückte Humeralien, dasjenige der Liebfra un kirche in Braunsberg septem humeralia fibulata, octo aurata, varii coloris auro intertexta quatuor, ex serico et holoserico varii coloris duodecim. Das Schatzverzeichnis von Heilsberg vermerkt mehr als zehn mit fibulae versehene Schultertïcher, in Wormditt treffen wir ihrer sieben an. Daßs wir erst recht im Dom zu Fra u en burg einer Reihe prächtiger Humeralien begegnen, ist unter solchen Umständen nicht zu verwundern. Nach dem Inventar von 1578 waren hier zehn mit Perlen, drei mit Heiligenbildern, drei mit Laubwerk, eines mit dem Lamm Gottes innerhalb Laubwerk, zwei alte mit Zierplättchen (fibulae) geschmückt. Eines war mit einem Besatz aus Goldbrokat versehen, der in der Mitte ein Lamm aus Perlen aufwies, bei dreien bestand die Parura ganz aus vergoldetem Silber, bei füfen war sie mit vergoldeten Spangen und Kügelchen besetzt usw. Bei einfachen Humeralien war der Besatz aus Samt, aus rotem Brokat und ähnlichen Stoffen angefertigt.

Noch grofartiger war der Bestand an kostbaren Amikten im Dom zu Frauenburg im Jahre 1598. Das Inventar aus diesem Jahre verzeichnet: Humerale unum totum margaritis contextum cum imagine Agnus Dei - Humeralia duo tota gemmatis floribus frondeis similis operis decorata - Humerale unum cum imaginibus B. V., S. Catharinae et Dorotheae ex gemmis effigiatis - Humerale cum imaginibus Salvatoris, S. Petri et Pauli ex gemmis paratum -. Humeralia duo ex argento solido tota deaurata cum imaginibus coronationis B. V. et Sanctorum - Humeralia tria ex serico viridi cum bullis maioribus et minoribus argenteis deauratis numero 89 etc. ${ }^{1}$ Beliebt war es, besonders im ganzen Norden und Nordosten von Deutschland, den Humeralbesatz mit silbervergoldeten Zierplätchen zu schmücken, fibulae, Spangen, Löbern, Berlein u. ä. genannt. Eine zu Heilsberg befindliche Amiktparura zählte deren nicht weniger als $132^{2}$. Es gab sogar Besätze, die ganz aus Silber gearbeitet und, um sich dem Hals anpassen zu können, in Glieder abgeteilt waren. So besaf3 die St Nicolauskirche zu Elbing nach dem Inventar von 1544 „3̂ silberne überguldete gefaltete Humeralia, davon 2 haben zu 11 und 1 zu 10 gliedern", die Kirche zum heiligen Leichnam nach dem Inventar von 1547,1 silbern vergult grof humeral mit beumen und bildern von silber in sieben fachen", der Altar der hl. Katharina, welcher der Trägerzunft zngehörte, „1 silbern übergult humeral cum radice Iesse mit 3 gliedern und 1 silbern übergult humeral mit einem übergulten Harienhild und 7 übergulten gliedern". Ein zu Allenstein befindlicher Humeralbesatz aus vergoldetem Silber wog mehr als $1 \frac{1}{2} \mathrm{~m}(=3 / 4 \mathrm{Pfd} \text {. })^{3}$.

Zum Schlus noch einige Angaben aus einem Stolper und einem Breslauer Inventar.

Das Inventar von Stolp verzeichnet die Gegenstände, welche 1525 den Dominikanern zu Stolp heim Bildersturm "mith gewalt genamen“ wurden; darunter 17 Amikte, die alle mehr oder weniger reich mit Spangen besetzt waren. Item, heifst es in ihm, 1 amith resurectio van Perlen und golde, de Forstynne gegeven heft. Item 1 amith van sroten Spangen und 34 kleynen dartho. Item een grüen amith, Moria (sic) genannt, mit 40 Spangen. Item 1 amith ave mit 51 Spangen. Item 1 amith 10 grote Spangen und 40 kleyne. Item 1 amith mit 12 grote Spangen und 36 kleyne. Item noch

2 Dittrich, Inneres Aussehen und innere Ausstattung (Zeitschrift III [1890] 246).

2 Ebd. 245 .
${ }^{3}$ Hipler, Die ältesten Schatzverzeichnisse 91241 . Dittrich a. a, 0.246. 
1 amith 4 grote Spangen und 37 kleyne. Item 1 amith roth Sammith mit 3 groten Spangen und 20 kleynen u. a. ${ }^{*}$

Das Breslauer Inventar entstammt dem Ausgang des 15. Jahrhunderts und gibt den Befund an Paramenten in der St Elisabethenkirche zu Breslau wieder. Auch hier ist die Zahl der mit kostbaren Besätzen geschmückten Humeralien eine sehr grofie. Wir heben aus ihr hervor: Item Eyn Humeral Rot Samath mit Perlen mit vorgulten Cron. Item Czwee Humeral gulden mit Perlenn gehafft mit den nahmen Maria und mit 18 vorspan (Zierplättchen). Item eyn Humeral gulden mit Perlen gehaft mit dreyen bilden mitten Imago Salvatoris in Majestate. Item Eyn humeral gulden mit Perlen gehafft mit dreyen Bilden Mitten imago Beate Harie virginis eum infantulo. Item eyn humeral Rot Samath mit fünf Silbern hilden mitten Signum Crucifixi mit Silbern Sternen... Item Czwee humeralia Roth Samath mit perlen gehafft lobwerg mit Silberen vorgulten flatterchen. Item eyn Humeral uff grwhner Zeyde mit Silberen großen Spangen gehaft und mitten an den spangen der Buchstabe A mit swartzem gesmeltze. Item Eyn Humeral von Kempehen Rot und geel mit kleynen vorgulten Spangeleyn silveren und glackeleyn (Glückchen an den Zierplättchen) daran.... Item eyn humeral bloe mit 4 grossin silberen spangyn dor off synt bilde mit bloenn grünen und brawen gesmelcze off den renden silberne ohirgulthe pockiln und Korallyn dartwischen ${ }^{2}$.

In Rom kam die Amiktparura um die Wende des 15. Jahrhunderts auker Gebrauch. Der Ordo missae Burchards von Straßburg kennt sie nicht mehr, wie ihm ïberhaupt die Sitte, den Amikt bis nach Anlegung der Kasel auf dem Haupt zu belassen, bereits fremd geworden ist. Immerhin gibt es zu Rom noch aus der Frühe des 16. Jahrhunderts verschiedene Monumente, welche den Amiktbesatz, wenngleich anscheinend in Form eines Kragens, aufweisen. Dazu gehören z. B. die Grabfiguren der Kardinäle Ascanius Sforza († 150.5) und Hieronymus Basso $(\uparrow 1507)$ in S. Maria del Popolo, des Bischofs Pietro de Vincentia († 1504) in der seitlichen Vorhalle von Ara Celi, des Kardinals Johannes Michaeli $(\uparrow 1503)$ in S. Marcello al Corso, des Kanonikus von St Peter Bernardo Capella ( $†$ 1524) in S. Stefano Rotondo und das eines 1538 verstorbenen Bischofs in S. Cecilia. Allerdings sind das nur vereinzelte Erscheinungen, bei denen obendrein zum Teil Einflüsse von auswärts maßgebend gewesen sein mögen. Zur Zeit, da das offizielle römische Missale erschien,

1 L. Böttger, Die Bar- und Kunstdenkmäler des Regierungsbezirks Köslin II 81. In einer Anmerkung werden die ${ }_{n}$ Amithe ${ }^{*}$ irrig als Kleider des Marienbildes bezeichnet.

2 Auch die bei Alwin Sebultz (Schatzverzeichnisse Breslauer Kirchen) mitgeteilten Inventare aus andern Kirchen zu Breslau enthalten Angaben über kostbar geschmückte Amikte. Von sonstigen sei noch besonders auf die Schatzverzeichnisse der Kathedralen zu London (1245) and zu Prefourg (1416), die Inventare der Pfarrkirche zu Altenburg (1527), der Kapelle des hl. Morand in St Stephan zu Wien (1426), der Königsberger Schloßkirche (1518) und der St Michaelskirche zu Zeitz (1514) verwiesen. Überall eine Füille kostbarer Amiktbesätze. Bock und andere haben geglaubt, in den fibulae, Spangen, in den englischen Inventaren tasselli genannt, das opus anglicanum wiedererkennen zu sollen, von dem in mittelalterlichen Schatzverzeichnissen öfters die Rede ist. Sie irren indessen.
Die Verwendung von Zierplättchen zur Ausstattung der Paramente war nichts, das England eigenartig gewesen wäre. Sie war seit etwa dem 13. Jahrhundert allenthalben gebräuchlich, in Frankreich wie in Italien, in England wie in Deutschland. Neben dem opus anglicanum wird in den Inventaren auch ein opus theotonicum, opus Alamaniae, opus Romanum, opus Lucanum usw. genannt. Meist handelt es sich bei diesen Bezeichnungen um Stickereien, doch nicht ausschließlich. So wird der Ausdruck opus anglicanum auch oft von Metallarbeiten gebraucht. Beispiele bei Gay I 3:. Wenn dort aus einem Inventar Karls V. ein Pluviale de points d'Angleterre angeführt wird, so heikt das nur ein Plnviale mit englischer Stickerei. Dak es sich um eine besondere Stickart handelt, folgt nicht aus der Angabe. Der richtige Sinn von opus anglicanum, Lucanum, Romanum (= de Romania) usw. ist: englische Arbeit oder Ware, Fabrikat von Lucca, Ware aus Byzanz. 
d. i. 1570, hatte die Verwendung des Amiktbesatzes zu Rom völlig aufgehört. In dem jenem vorgedruckten Ritus celebrandi ist nur von einem Kreuz die Rede, das in der Mitte des Schultertuches angebracht sein soll.

A uferhalb Roms tritt das Zierstück zu sehr verschiedenen Zeiten rom Schauplatz ab. Auf den Mainzer Bischofsmonumenten verschwindet es bald nach Beginn des 16. Jahrhunderts. Jakob von Liebensteins (1504-1508) Grabfigur ist die letzte, welche die Amiktparura aufweist. Damit stimmt das Zeugnis der Mainzer Bischofssiegel, auf denen die Parura um dieselbe Zeit aufhört. Anderswo in Deutschland erhält sich die Verzierung des Amikts bis nahe dem 17. Jahrhundert. So in Ermland, wie die angeführten Inventare beweisen, in Miunster und Paderborn, wie aus dem Grabmal Rembolds von Kerssenbroich $(\dagger$ 1568) im Dom zu Paderborn und der Grabplatte Johannes' von Hoya († 1574) im Dom zu Münster erhellt, in Köln, wie sich aus dem Inventar der St Brigiden-Kirche vom Jahre 1578 ergibt. "Item “, heifst es in letzterem, „noch 5 alven mit ihr heubtdoecher geristet und die brederkens daran geneit." Auch im Rheingau war um den Ausgang des 16. Jahrhunderts der Amiktbesatz noch nicht ganz auser Gebrauch gekommen. Denn das Inventar der St Valentinskirche zu Kiedrich verzeichnet unter anderem auch noch, 2 humeral mit guldenen kragen mit perlen und silber bestickt, 2 bloenn sammat humeral, 1 grunen humeral". In Brixen verordnet die Synode von 1603, es sollten die scutella (Schilde, Paruren) aus den Alben und Humeralien entfernt und ein gesticktes Kreuz auf dem Amikt, der Stola und dem Manipel angebracht werden ${ }^{1}$.

In den Niederlanden war das Zierstück noch wenigstens bis gegen die Mitte des 16. Jahrhunderts in Gebrauch, wie die aus Breda stammende Grabplatte des Priesters Wilhelm († 1539) im Rijksmuseum zu Amsterdam beweist. Zu Gran begegneten wir mit Paruren versehenen Humeralien noch beim Ausgang des ersten Jahrzehnts des 17. Jahrhunderts.

In Frankreich fand der Besatz des Schultertuches, wenngleich nur in beschränktem Maße, an verschiedenen Orten, wie z. B. zu Angers, bis ins 18. Jahrhundert hinein Verwendung ${ }^{2}$. In der ersten Hälfte des 17. Jahrhunderts mufs er daselbst noch recht häufig benutzt worden sein. So war die Amiktparura, das collet, damals, wie du Saussay berichtet, zu Paris aufier in Notre Dame auch noch in den bedeutenderen Stifts- und Pfarrkirchen in Gebrauch ${ }^{3}$. Namentlich erhielt sie sich lange in den Kathedralen Frankreichs; im Lyoner Ritus kam sie, wie früher bereits bemerkt wurde, bei den Diakonen und Subdiakonen in Gestalt eines Kragens sogar bis in die Gegenwart.

$\mathrm{Zu}$ Mailand schrieb der hl. Karl den Zierbesatz für die ganze mailändische Kirchenprovinz vor. "Das Humerale", so lautet seine Verordnung, „soll in alter Weise angefertigt werden. Es soll nämlich mit einem Besatz (fascia) versehen werden, welcher über dem Mefagewand wie ein Kragen den Hals umgibt. Die Ränder dieses Zierstückes sollen passend geschmückt und drei Kreuze auf demselben angebracht werden, eines in der Mitte, die beiden übrigen an den Enden. Die Länge des Besatzes betrage $1 \mathrm{cub}, 2$ unc。 $=0,53 \mathrm{~m}$, seine Breite 7 unc. $=0,13 \mathrm{~m}$... Wird das Humerale aber ohne Parura gebraucht, so muß ein Ḱreuz, das ca $0,035 \mathrm{~m}$ grof ist, etwa zwei Finger vom oberen Rand entfernt eingestickt oder eingenäht werden." + Auch im ambrosia-

1 C. de eccl. n. 16 (Hartzh. VIII 565).

2 Revue 1886, 172.
3 Panoplia episc. 56.

4 A. E. Med. 626. 
nischen Ritus hat sich die Amiktparura, wie vorhin schon gesagt wurde, in Form eines Kragens bis in die Gegenwart erhalten (Bild 11). Unter solchen Umständen kann es natürlich nicht wundernehmen, wenn uns das Zierstiick auf den Bildwerken im Gebiet der mailändischen Kirchenprovinz nicht nur im ganzen 16. Jahrhundert, sondern auch noch später immer wieder begegnet.

Auch im übrigen Italien scheint sich die Amiktparura an verschiedenen Orten länger als zu Rom im Gebrauch erhalten zu haben. So wenigstens nach den Bildwerken zu urteilen. Zu Venerlig begegnet sie uns z. B. noch beim Mosaikbild des hl. Geminianus im Portikus von S. Marco, einem Werke des Jahres 1535, und in der Accademia bei einem hl. Augustinus von Girolamo da S. Croce (arbeitete ca 1520-1549), zu Florenz aber treffen wir sie nicht nur im Beginn des 16. Jahrhunderts bei Arbeiten aus der Schule Robbias, z. B. einem hl. Zenobius in der Opera del Duomo, und einem hl. Laurentius am Chorgestühl von S. Maria Novella, einer Schöpfung Baccio d'Agnolos (1460 bis 1543), sondern auch beim Grabmal des Bischofs Paulus Jovius von $1574 \mathrm{im}$ Kreuzgang von S. Lorenzo, dem Fresko Passignanos (1560-1638) „Die Übertragung des hl. Antonin" in S. Marco und der "Gründung des Servitenordens", einem Fresko im Kreuzgang der Annunziata. Auch schreibt noch im 17. Jahrhundert Kard. Bona († 1674): Sunt quidam, qui amictui ex holoserico vel aurea textura plagulam assuunt colori et opificio casulae sive stolae consimilem. Ambrosiani tertio loco amictum sumunt 1. Es waren also zu Bonas Zeiten wohl nicht blof die Ambrosianer, welche die Parura noch beibehalten hatten. Wenn freilich Benedikt XIV. ein Jahrhundert später von der in Rede stehenden Gepflogenheit spricht ${ }^{2}$, so denkt er wahrscheinlich nur an die Ambrosianer. Denn aufer ihnen dürfte sich damals sonst niemand mehr in Italien der Amiktparura bedient haben. Wie in Mailand und Lyon, so starb auch in Spanien der Gebrauch der Parura nicht ganz aus.

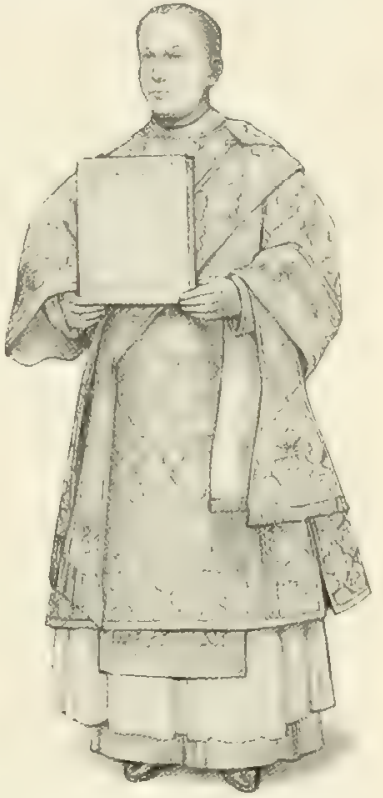

Bild 11. Amiktkragen nach Mailänder Gebrauch.

Übrigens wäre es irrig, wollte man glauben, es sei, seitdem einmal die Amiktbesätze aufgekommen waren, das Schultertuch stets mit solchen ausgestattet gewesen. Die Inventare, die neben amictus parati auch von einfachen Humeralien sprechen, beweisen das Gegenteil. Wie es scheint, wurden die mit Besätzen versehenen Amikte vornehmlich von höher stehenden Geistlichen oder an Festtagen getragen.

Nach Hraban, Pseudo-Alkuin und Pseudo-Beda wurde das Superhumerale, wie sie das Schultertuch nennen, aus Linnen angefertigt. So blieb es auch, wie wir aus den späteren Liturgikern des Mittelalters sehen, in der Folgezeit. Wohl hören wir in den Inventaren hie und da von seidenen Humeralien. Doch ist dann meist der Besatz gemeint. Ganz aus Seidenstoff verfertigte Amikte kommen zwar auch hie und da in mittelalterlichen Inventaren vor, doch blieben sie stets Ausnahme. Eine strenge Vorschrift, das Humerale aus Linnen 
anzufertigen, scheint übrigens nicht bestanden zu haben. Es ist uns weder eine allgemeine noch eine partikulare Bestimmung dieser Art bekannt. Eine der ersten ausdrücklichen Terordnungen, welche das Humerale aus Linnen gemacht wissen will, dürfte diejenige des hl. Karl Borromäus sein. In die Fußstapfen dieses grofen Reformators im guten Sinn eintretend, bestimmte ein Vierteljahrhundert später auch die Provinzialsynode von Prag vom Jahre 1605, es sollte der Amikt aus weiker Leinwand gemacht werden 1 .

\section{URSPRUNG DES SCHULTERTUCHES. SEINE NAMEN.}

Über die Ursachen, welchen der Amikt seine Aufnahme unter die liturgischen Gewänder verdankt, finden sich verschiedene Ansichten.

Mittelalterliche Liturgiker und mit ihmen einzelne neuere sahen in ihm eine Nachbildung des Schulterkleides (ephod, ¿̇ंroric, superhumerale) des jüdischen Hohenpriesters, weshalb jene den Amikt nicht selten Ephod oder Superhumerale nennen. Daf jedoch der Ephod des Alten Bundes Anlaf zur Einführung des Humerale gewesen, ist abgesehen von der verschiedenen Gestalt und Beschaffenheit beider Gewänder schon darum zu verneinen, weil er mitsamt dem sog. Richtschmuck (chosen, hígrov, rationale) das oberste und vornehmste Kleid des alttestamentlichen Pontifex bildete, der Amikt aber, mag er nun anfänglich über oder unter der Albe getragen worden sein, stets nur ein nebensächliches Untergewand darstellte. Nachher freilich, als man einmal anfing, die Kultgewänder des Neuen Bundes mit denen des Alten Bundes zu vergleichen, hat man, um eine Analogie für das Schultertuch zu finden, dasselbe wohl oder übel mit dem Ephod in Verbindung gebracht. Der einzige Anhaltspunkt hierfür lag in dem Umstande, daf beide über den Schultern getragen wurden (superhumerale - humerale).

Rohault de Fleury ${ }^{2}$ scheint unter der Voraussetzung, daf der Amikt vor allem Hauptbedeckung habe sein sollen, zur Annahme zu neigen, das Kopftuch heidnischer Priester habe zu seinem Gebrauch geführt, wobei der Schleier, den der Apostel den Frauen für den Gottesdienst vorschreibt, gleichsam das Zwischenglied gewesen sei. Allein er übersieht, daf er kurz vorher selbst den Kanon des unter Zacharias 743 gefeierten römischen Konzils anführt, der - also noch in der Mitte des 8. Jahrhunderts -- unter Berufung auf 1 Kor 11, 4 bestimmt, kein Bischof, Priester und Diakon dürfe am Altare bedeckten Hauptes erscheinen ${ }^{3}$. Obendrein sei daran erinnert, daf das Schultertuch ursprünglich nur ein Halstuch war und die Sitte, es beim Ankleiden auf den Kopf zu legen, erst nachträglich aufkam. Aber auch dann war der Amikt noch immer blok im weiteren Sinne eine Kopfhülle. Der in Frankreich vorkommende Brauch, ihn bei der Messe bis zu der Sekreta oder dem Kanon auf dem Kopf zu behalten, ist sehr späten Ursprungs und durchaus unrömisch.

Eine dritte Ansicht geht dahin, das Humerale verdanke seine Aufnahme unter die liturgischen Gewänder mystischen Erwägungen. So hat man gemeint, es habe vielleicht der Umstand, daf man symbolisch den Helm des Heiles oder den S'chirm gegen die Versuchungen habe darstellen wollen, dazu

1 C. 13 (Hartzh. VIII 691).

2 La messe VII 410.

3 C. 13 (Hard. III 1929): Ut nullus episcopus, preshyter aut diaconus ad celebrandum missarum sollemnia praesumat cum baculo introire aut velato capite altario assistere (quoniam et apostolus prohibet viros velato capite orare in ecclesia). Hef., Concilien III 517. 
geführt, es der gottesdienstlichen Kleidung einzufügen, während von anderer Seite die Vermutung ausgesprochen wurde, der Amikt sei anfänglich nur für den Priester bestimmt gewesen und habe demselben das sein und symbolisieren sollen, was das erzbischöfliche Pallium ist und bedeutet, eine Insignie und ein Symbol des Hirtenamtes.

Allein auch diese Erklärungen können nicht befriedigen. Wer die Geschichte der liturgischen Gewänder verfolgt hat, weis, daf nicht mystische Anschauungen und Grübeleien die Sakralkleidung geschaffen haben, sondern daßs sich diese naturgemäfs aus der Volkstracht herausgestaltete, und daßs die mehr oder minder tiefsinnigen und ansprechenden Deutungen, welche die liturgischen Kleider erfahren haben, nicht denselben vorausgingen, sondern an das Bestehende anknüpften. Der zweiten Erklärung gegenüber aber ist noch insbesondere zu bemerken, daf sich unter den mystischen Deutungen des Humerale niemals eine findet, welche dieses als Symbol des Hirtenamtes betrachtet. Auferdem widerspricht sie völlig dem Charakter des Schultertuches. Dasselbe erscheint stets als minder bedeutsames Untergewand, während das Pallium als auszeichmendes Abzeichen der erzbischöflichen Würde über allen andern Gewändern getragen wurde. Auferdem kam es ursprïnglich so wenig nur den Priestern zu, dafs diese vielmehr nach römischem Brauch noch bis ins 9. Jahrhundert hinein kein anagolagium getragen zu haben scheinen; denn der S. G. K. vermerkt es blof: bei dem Papst, den Diakonen und Subdiakonen, nicht aber den Priestern.

Eine vierte Meinung endlich leitet wie die übrigen liturgischen Gewänder so auch den Amikt von einem entsprechenden Bestandteil der Alltagstracht ab. Sie ist zweifellos die richtige. Man braucht in der Tat nicht weit zu gehen, um den Ursprung des Amiktes zu erklären. Er ist nichts anderes als das im profanen Leben unter Namen wie amictus, focale, palliolum, pallium, mappula, orarium bekannte und gebräuchliche Hals- oder Schultertuch. Es fand bei allen Klassen der Bevölkerung Verwendung, bei hoch und niedrig, arm und reich, vornehm und gering, natürlich in verschiedener Beschaffenheit und Ausstattung. Bedienten sich doch selbst die römischen Soldaten der Halstücher, wie wir aus verschiedenen interessanten Reliefs der Trajanssäule entnehmen. Wir geben zwei derselben (Bild 12 und 13, S.46) wieder. Das eine stellt Soldaten mitten im Kampfe dar. Sie tragen das Koller und um den Hals ein Halstuch, das unter dem Kinn in einen Knoten geschlungen ist. Das zweite, einer Belagerungsszene entnommen, zeigt uns zwei Soldaten im Kürafs und eine Anzahl mit der Pänula bekleideter Soldaten. Die einen wie die andern sind, wie sich deutlich erkennen läfst, mit dem Halstuch versehen.

Häufig trifft man namentlich Halstuch und Pänula zusammen, so z. B. zweimal auf der Trajanssäule bei Trajan selbst, das eine Mal bei seiner Einschiffung zum zweiten Feldzug gegen die Dacier, das andere Mal bei einer Opferszene ${ }^{1}$, ferner auf Skulpturen der Rostrabrïstung, auf Reliefs des Triumphbogens des Septimius Severus auf dem römischen Forum u. a., und zwar beweisen die Bildwerke der Rostrabrüstung mit aller Bestimmtheit, daf man sich des Halstuches nicht blof beim Militär, sondern auch im bürgerlichen Leben zur Pänula bediente. Auch die römischen Monumente im Norden weisen treffliche Beispiele für den Gebrauch des Halstuches auf. Es findet sich auch hier bei Militär- wie bei Zivilpersonen, und zwar ebensowohl zur Pänula wie unter der Tunika. Zwei der trefflichsten Beispiele finden sich im römisch-germanischen

1 Vgl. die Abbildung der Szene weiter unten in dem der Kasel gewidmeten Kapitel. 
Zentralmuseum zu Mainz. Es sind die Grabstelen des Centurio Faltonius (Bild 14) und eines Schiffers namens Blussus ${ }^{1}$. Ein Sklave Peregrinus in Pänula und Halstuch erscheint auf einem Speierer Grabstein ${ }^{2}$, eine Frau mit Halstuch auf dem Grabmonument $\mathrm{Nr} 51$ im Museum römischer Altertümer des Historischen Vereins zu Regensburg. Andere Beispiele bieten die römischen Altertůmer zu Luxemburg. Daf aber Halstücher nicht blok in den drei ersten Jahrhunderten, sondern auch noch in den folgenden in Gebrauch waren, dafür haben wir mancherlei Zeugnisse. Hieronymus redet z. B. in dem Brief an Nepotian von einem limenen Amikt, den er gleich darauf sudarium orariumque nennt $^{3}$. Es ist also eine Art von Halstuch, wovon er spricht. Von dem hl. Fulgentius, Bischof von Ruspe ( $†$ 533), berichtet sein Biograph, es habe derselbe unter der Kasel ein schwärzliches oder weißliches Umschlagtuch getragen, ja bei gutem Wetter innerhalb des Klosters sich auch wohl blob dieses
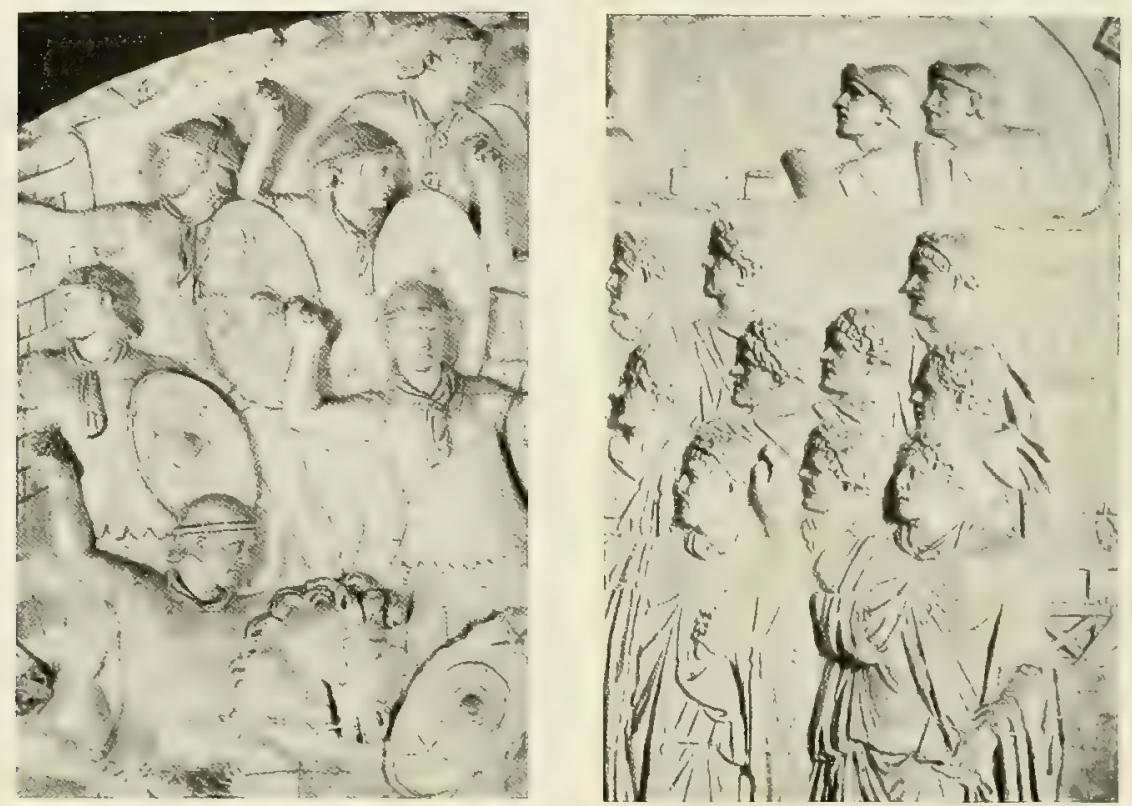

Bild 12 und 13. Reliefs der Trajanssäule zu Rom.

Tuches zur Tunika bedient". Wiederholt ist ferner von dem Schultertuch in den alten Mönchsregeln die Rede, wie z. B. in des Hieronymus Übersetzung der Regel des hl. Pachomius, wo zu den Kleidern, die ein jeder Mönch erhalten solle, auch ein linnener Amikt gerechnet wird, und in den Regeln des hl. Isidor, in denen jedem Klosterinsassen außer zwei pallia eine mappula zugestanden und bestimmt wird, man solle, falls man nicht das pallium trage, mit der mappula die Schultern bedecken. Von einem palliolum lineum bzw. einem palliolum lesen wir in den Regeln des hl. Orsiesius und des hl. Fruc-

1 Eine Abbildung des Grabsteines des Blussus s. unten im Kapitel, welches die Kasel behandelt. Die Photographien beider Monumente erhielt ich durch die Güte des Herrn Prof. E. Neeb zu Mainz.
2 Abbildung in Bonner Jahrbiicher 1902, Tl 5, Fig. 3.

${ }^{3}$ Ep. 52 ad Nepot. n. 9 (M. 22, 535).

4 C. 18, n. 37 (M. 65, 135). 
tuosus ${ }^{1}$. Es diente, wie wir von Cassian vernehmen, als Ersatz des Obergewandes ${ }^{2}$. Auch unter dem orarium, von dem bei Behandlung der Stola die Rede sein wird, ist verschiedentlich ein Halstuch zu verstehen.

Was aber war der Anlas, daf man zu Rom - denn hier geschah das ohne Zweifel zuerst - das profane Schultertuch der liturgischen Kleidung einreihte: Waren es, wie man gesagt hat, praktische Gründe, etwa das Bestreben, die oft kostbaren Oberkleider gegen Schweif zu schützen, Forderungen des Anstandes, welcher eine Enthlöfung des Halses bei der Liturgie als wenig geziemend erscheinen lassen mochte, das Bedürfnis nach wärmerer Kleidung bei den heiligen Funktionen in den oft kalten und zugigen Kirchen, die Notwendigkeit, für Erhaltung der Stimme Sorge zu tragen? Wie es scheint, kaum. Die nach Personen und Zeit so beschränkte Verwendung, welche der Amikt bis ins 9. Jahrhundert zu Rom fand, spricht dagegen. Denn jene praktischen Gründe galten ja doch nicht blof in Bezug auf den Papst und seine Ministri, sondern auch in Bezug auf die andern Geistlichen, nicht bloß hinsichtlich der Dalmatik, sondern auch hinsichtlich der Kasel und Tunika, und nicht blok für die Feste, sondern auch für die sonstigen Tage. Höchstens liefe sich denken, daß die Rücksicht auf Schonung der wertvollen weisen Obertunika des Papstes, seiner Diakone und Subdiakone auf die Ingebrauchnahme des Amiktes von einigem Einflufiggewesen sei. Es dürfte daher wohl zutreffender sein, wenn wir seine Aufnahme unter die liturgischen Gewänder des römischen Ritus nicht sowohl praktischen Erwägungen als vielmehr dem Umstande zuschreiben, daf zur Zeit, da die sakrale Galakleidung des Papstes und seiner nächsten Ministri ihre Ausgestaltung erhielt, ein

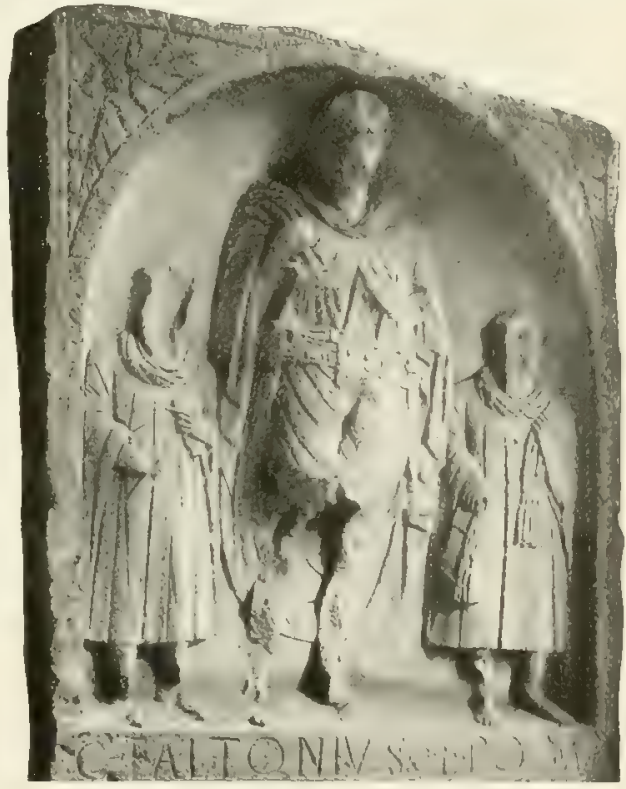

Bild 14. Grabstele des Centurio Faltonins. Mainz, Rümisch-german. Zentralmuseum.

Amikt überhaupt zum Bestand einer hochvornehmen Festgewandung gehörte, und es darum angezeigt schien, ihn auch der Festkleidung des obersten Liturgen und seiner unmittelbaren Altargehilfen einzureihen.

Das liturgische Schultertuch begegnet uns mit Sicherheit erst im Verlauf des 8. Jahrhunderts. Die obigen Ausführungen machen es jedoch mehr als wahrscheinlich, daß es schon eine gute Weile vorher in Gebrauch gewesen sei. Sollte der Abschnitt, in welchem der erste Ordo Mabillons die Weise und Reihenfolge beschreibt, in denen der Papst mit den liturgischen Gewändern bekleidet werden mulite, dem gregorianischen Kern des Ordo angehören, so hätte der Amikt schon um das Ende des 6. Jahrhunderts zu Rom den Charakter eines

Hi eron., Transl. reg. S. Pachom., praefatio 4 (M. 22, 64); reg. S. Isidori (Concord. reg. S. Benedict. Anian. c. $62, \S 10$ [M. 103, 1244]); ebendort auch $\$ 13$ ex doctr.
S. Orsiesii (ebd. 1245) und $\$ 17$ reg. S. Fructuosi ep. Brace. (ebd. 1248).

2 De coenobiorum institutis 1. 1, c. 7 (M. 49, 72). 
Kultgewandes gehabt. Allein er ist sehr wahrscheinlich nur ein Einschiebsel aus der Zeit der Redaktion des Ordo, d. i. dem 8. Jahrhundert.

Was die Xamen des liturgischen Schultertuches anlangt, so heißst es auffälligerweise in den ältesten römischen Ordines überall an agolaium, anagolagium, a nabolagium: es mufs das daher die offizielle Bezeichnung gewesen sein, welche man im 9. und 10. Jahrhundert zu Rom für das Gewandstück hatte. Das Wort dürfte

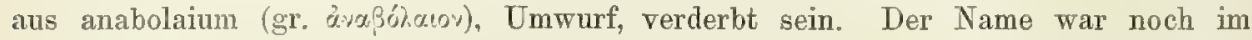
11. Jahrhundert die eigentlich römische Benennung des Schultertuches. Denn in der Bulle vom Jahre 1049, worin Leo IX. dem Stifter das Klosters Heiligkreuz zu Donauwörth, Mangold von Kyburg, und dessen Nachkommen die Vogtei üher dasselbe überträgt, wird als jährlich nach Rom zu entrichtende Abgabe neben einer goldverzierten Stola, einem Manipel und einem Cingulum auch ein anabolagium, das bezeichnenderweise für die Adressaten durch das ihnen verständlichere fano erläutert wird, genannt: anabolagium i. e. fanonem ${ }^{1}$. Anderthalb Jahrhundert später war die Bezeichnung ganz abgekommen, um dem aus dem Norden stammenden Namen amictus für immer Platz zu machen. Schon Innozenz III. bezeichnet das Schultertuch nur noch mit amictus. Auch in den Ordines des 13., 14. und 15. Jahrhunderts führt dasselbe ausschließlich diesen Namen. Statt anagolagium war amictus die offizielle römische Benennung des Gewandes geworden, die denn auch in das römische Missale, in das Pontifikale und in das Caeremoniale überging. Auferhalb Roms scheint die Bezeichnung anagolagium nirgends gebräuchlich gewesen zu sein. Hier hief es bald in Erinnerung an das Ephod des alttestamentlichen Hohenpriesters superhumerale, bald einfach humerale, Schultertuch, bald amictus, vereinzelt auch fano.

Am gewöhnlichsten war der Name amictus. Im klassischen Latein bezeichnet das Wort allgemein jede Verhüllung, im besondern Simne aber einen mantelartigen Umwurf ${ }^{2}$. Der Etymologie nach von derselben Bedeutung wie ja, ohne ein guter Ersatz für das griechisch-römische verderbte anagolagium. Als Bezeichnung des Schultertuches kommt der Ausdruck schon in dem aus dem Beginn des 9. Jahrhunderts stammenden Verzeichnis der von Angilbert dem Kloster des hl. Richarius zu Centula (St-Riquier, Somme) geschenkten Paramente vor. Auf die Verbreitung, welche er gewann, dürfte nicht ohne Einfluf gewesen sein, dafs er hei Amalar, dessen liturgische Schriften für die Folgezeit von so großer Bedeutung waren, als Name des Schultertuches gebraucht ist.

Die Bezeichnungen superhumerale und humerale ${ }^{3}$ waren namentlich in Deutschland beliebt, anderswo scheinen sie nur wenig angewandt worden zu sein. Wo immer in deutschen Inventaren vom Schultertuch die Rede ist, heifat es fast regelmäfigig superhumerale und humerale, verdeutscht humeral, umbral, umbalar $u$. ä. Superhumerale begegnet uns schon bei Hraban, humerale in einem Inventar von Pfäffers

1 J. 4207. Über die Form ambolagium statt anaholagium s. oben S. 26. V. Ermoni führt anagolagium auf gula zurück, ein Verfahren, das ein wenig an die im Mittelalter beliebte Ableitungsweise erinnert. (Dom F. Cabrol, Dictionnaire d'archéologie chrét. I, Paris 1904, 1597). Schon die Endung agium beweist das Unzutreffende einer solchen Etymologie. Anagolagium ist verderbt aus anabolagium und dieses aus anabolaion. In einem griech.-latein. Schulgespräch (Corp. Gloss. III 645, 2, bei Momm sen-Blumner, Der Maximaltarif des Diokletian, Berlin 1893, 170) wird das mit anagolaium sachlich identische à

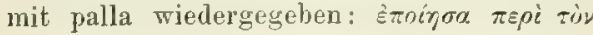

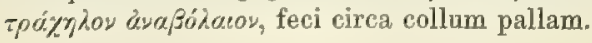

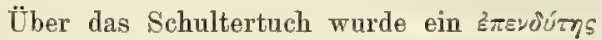

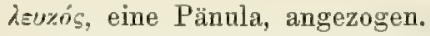

2 Vgl. Forcell. unter amictus I 154 und namentlich Thesaurus linguae latinae (Leipzig 1904) unter amictus I 1899 ff.

3 Beim römischen Juristen Paulus (Dig. 49, $16,14)$, der unter Septimius Severus, also ca 200 lebte, ist von einem humerale der Soldaten die Rede. Dem Soldaten, heißt es dort, welcher das tibiale und humerale verkaufe, sollten dafür Prügel als Strafe zu teil werden. Wie es scheint, ist unter dem humerale eben das Schultertuch zu verstehen, welches wir auf den früher erwähnten römischen Monumenten bei Soldaten unter der Pänula um den Hals herum hervorkommen sehen. 
(Schweiz) aus der Wende des 9. Jahrhunderts. Superhumerale kam uibrigens, wohl weil zu langatmig, schon seit Ausgang des 11. Jahrhunderts bald in Abgang.

Fano (fanum) ward später zur Benennung des päpstlichen Sonderschultertuches, das den Gegenstand des folgenden Kapitels bilden wird. Bereits im 13. Jahrhundert hief dasselbe fano (fanum).

\section{DAS SCHULTERTUCH IN DEN ORIENTALISCHEN RITEN.}

Was die Ostkilche anlangt, so gibt es ein liturgisches Schultertuch nur im armenischen, syrischen und koptischen Ritus.

Das Schultertuch der Armenier, Vakas (Bild 15), stellt einen Amikt genau von der Art dar, wie er im Abendland seit Mitte des 12. Jahrhunderts üblich war, nur daß dem Besatz am oberen Saum durch eingelegten Karton eine fast bretterne Steifheit gegeben ist. Über Stoff und Farbe bestehen keine Vorschriften. Der Besatz ist in seiner Mitte mit einem Kreuz geschmückt. Wie im ambrosianischen Ritus wird das Schultertuch über der Tunika getragen, es bedienen sich seiner aber nur die Bischöfe und Priester, nicht die Diakone und Subdiakone. Angelegt wird es vollständig in derselben Weise wie ehedem der abendländische amictus paratus. Es kommt nämlich ebenfalls zunächst auf den Kopf zu liegen, und zwar so, dafs der Besatz sich von der einen Schläfe zur andern zieht; dann wird es mittelst der Schnüre angebunden; hierauf wird der liturgische Mantel umgeworfen und nun das Tuch auf die Schultern herabgelassen und kragenförmig um den Hals gelegt. Im syrischen Ritus ist zwischen Maroniten und Jakobiten (unierten und nicht unierten) zu unterscheiden. Bei ersteren ist das Schultertuch, maçnaftâ, in allem dem armenischen Amikt gleich. Bei letzteren

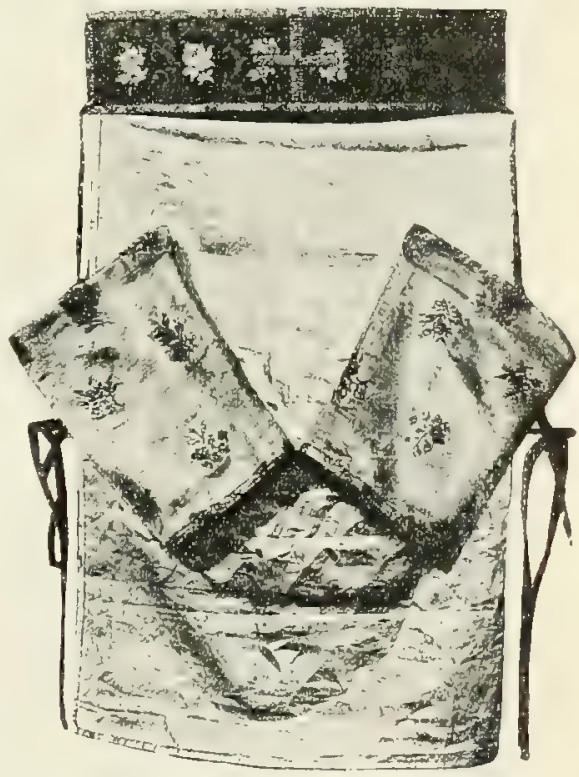

Bild. 15. Schultertuch und liturgische Stauchen im armenischen Ritus. ist es in zweifacher Hinsicht von diesem verschieden. Erstens hat nämlich der Besatz nicht rechteckige Gestalt, sondern die Form eines Kreisabschnittes. Dann ist das Schultertuch bei den Jakobiten nicht Bischöfen und Priestern gemeinsam, sondern ein privilegiertes Gewand der Bischöfe. Keinen Amikt gibt es bei den schismatischen Kopten; denn die lange, mit Kreuzen versehene Binde (ballin, tailasan), welche die Priester und Bischöfe derselben nach Art eines Turban so um den Kopf schlingen, daf die Enden über die Schultern herabfallen, ist nicht ein Schultertuch, sondern eine Kopfbedeckung. Wohl aber ist er bei den unierten Kopten in Gebrauch. So wie er hier jetzt beschaffen ist, unterscheidet er sich in keiner Weise von dem lateinischen Humerale. Insbesondere wird er auch wie dieses unter der Tunika getragen. Ehedem bedeckte man jedoch mit ihm den Kopf, weshalb er mit reichen Stickereien in Seide, Silber und Gold versehen zu werden pflegte. Nur während des Evangeliums und des Kanons lief man ihn auf die Schultern herab 1.

- Nach gütigen Mitteilungen des koptischen Bischofs von Minieh, Mons. Maximos Sedfaui. Braun, Die liturgische Gewandung. 
Über die Geschichte des liturgischen Schultertuches des armenischen Ritus läß3t sich nichts feststellen. Fände es sich nur bei den Armeniern, so ließse sich vielleicht ammehmen, es sei durch die Bemühungen der sog. Unitores im 14. Jahrhundert oder schon bei den Unionsbestrebungen im Beginn des 13. Jahrhunderts bei ihnen eingeführt worden und demgemä6 dem abendländischen Ritus entnommen. Allein wir treffen es auch bei den Maroniten und Syrern, bei welch letzteren es sogar den Charakter eines spezifisch pontifikalen Gewandstückes hat. Seine Heimat ist daher zweifelsohne im Orient selbst zu suchen, und zwar hat es sich aller Wahrscheinlichkeit nach aus einer kapuzenartigen Kopfbedeckung herausgebildet, so daß es also ursprünglich nicht eine Art Schultertuch, sondern ein Kopftuch gewesen wäre. Nerses von Lampron erwähnt den Vakas in seiner Erklärung der göttlichen Liturgie noch nicht; er ist ihm offenbar noch unbekannt. Aber er gedenkt auch in ihr keiner liturgischen Kopfbedeckung. Indessen redet schon einige Jahrzehnte früher der Katholikos Isaak in seinen Invectivae adversus Armenos ${ }^{1}$ von einem

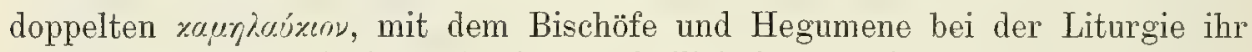
Haupt bedeckten, ein Brauch, den er freilich in scharfen Worten als durchaus unstatthaft rügt. Man wird wohl nicht fehl gehen, wenn man das eine

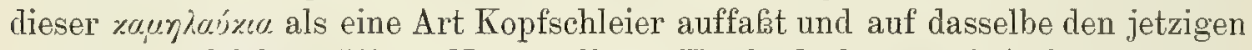
Vakas zurückführt. Wenn Nerses dieser Kopfbedeckung bei Aufzählung und Beschreibung der liturgischen Gewänder nicht gedenkt, so dürfte das darin seinen Grund haben, daf auch er, der von der Erhabenheit der Liturgie so

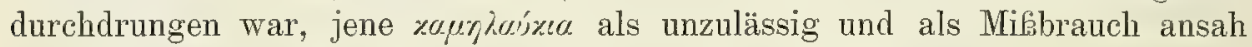
und darum der gottesdienstlichen Kleidung nicht zurechnete.

Bei den Nestorianern, welche ein Schultertuch nicht kennen, tragen die Bischöfe noch jetzt eine Kopfhülle, biruna, von welcher Assemani sagt: ,cidaris, phrygio opere ornata, qua caput tegitur estque instar amictus latini, quo fratres minores cucullum tegunt, dum e sacrario ad altare pergunt, liturgiam celebraturi 2. Sie ist dieser Beschreibung zufolge allem Anschein nach dasselbe Gewandstück wie die syrische Maçnaftâ und der armenische Vakas. Auf das Alter der biruna wirft Licht, daf nicht nur Amru (ca 1340) in seiner Geschichte der nestorianischen Patriarchen ${ }^{3}$, Ebedjesu $(\dagger 1318)$ in seinem Abrib der Synodalkanones ${ }^{4}$ und Barhebräus $(\uparrow 1286)$ in seiner Chronik ${ }^{5}$ sie erwähnen, sondern auch schon "das Buch der Väter" (12. Jahrh.) in seiner Auslegung der liturgischen Gewänder von ihr spricht. Sie wird jedoch nach einer $\ddot{A} u$ ferung Georgs von Arbela ( $\dagger$ ca 990) noch viel weiter hinaufreichen ${ }^{6}$.

Daf́ die Maçnaftâ der syrischen Bischöfe — und somit auch wohl der Vakas der Armenier - ursprünglich in der Tat eine Kopfbedeckung gewesen ist, geht aus den Miniaturen eines syrischen Manuskriptes der Pariser Nationalbibliothek ${ }^{7}$ aus dem Jahre 1239 hervor (Bild 16). Dieselben stellen die Erteilung der heiligen Weihen dar. Dabei tragen die Bischöfe um den Kopf eine weiße, kapuzenartige, über der Stirn mit einem Kreuz geschmückte Hülle, wie man sie auch wohl bei den orientalischen Mönchen, aus denen die Bischöfe genommen zu werden pflegten und pflegen, auf den Miniaturen antrifft. Auf den Nacken zurückgeschlagen und oben mit

\footnotetext{
1 Orat. II, n. 29 (Mg. 132, 1236).

2 Ass., Bibl. III, 2, 683. ${ }^{3}$ Ebd. 666.

4 Pars 6, c. 6. De privilegiis monasteriorum (ebd. III, 1, 343).
}

5 Ebd. II 423.

6 De off. bapt. c. 4 (ebd. III, 2, 257). Der Kopfschleier heift hier maaphra.

7 f. Syriaques 112. 
einer steifen Einlage versehen, wäre sie ganz dasselbe Gewandstiick, welches uns in der Maçnaftâ und dem Vakas entgegentritt ${ }^{1}$.

Es mufs auffallen, daß man bei der Maçnaftâ des syrischen und dem Vakas des armenischen Ritus eine Verzierungsweise antrifft, welche uns seit der Mitte des 12. Jahrhunderts auch bei dem liturgischen Amikt des lateinischen Ritus begegnet. Ob zwischen dem eigenartigen Besatz der einen und der Parura des letzteren eine nähere Beziehung, eine Verwandtschaft besteht? Der Gedanke drängt sich unwillkïrlich auf. Allein so auffällig auch die Übereinstimmung ist, so wird es sich zuletzt doch wohl nur um eine zufällige Ähnlichkeit und eine nur scheinbare Verwandtschaft handeln. Ïhnliche Verhältnisse und Umstände führen zu ähnlichen Resultaten. Auker der blofen äußseren Übereinstimmung der Besätze fehlt es an irgend einem weiteren Anhalt für die Annahme einer wirklichen verwandtschaftlichen Beziehung derselben. Die bloke äufere Ähnlichkeit reicht aber offenbar nicht aus, eine innere Beziehung und Abhängigkeit der abendländischen Amiktparura und des Besatzes der Maçnaftâ bzw. des Vakas mit Grund behaupten zu können. Jedenfalls stammt die Parura nicht von einem Zierbesatz der Maçnaftâ, da die Kopfhülle, mit der die Bischöfe auf den Miniaturen des vorhin erwähnten syrischen Kodex der Pariser Nationalbibliothek ausgestattet sind, zwar ein Kreuz, aber noch keine Spur eines pa-

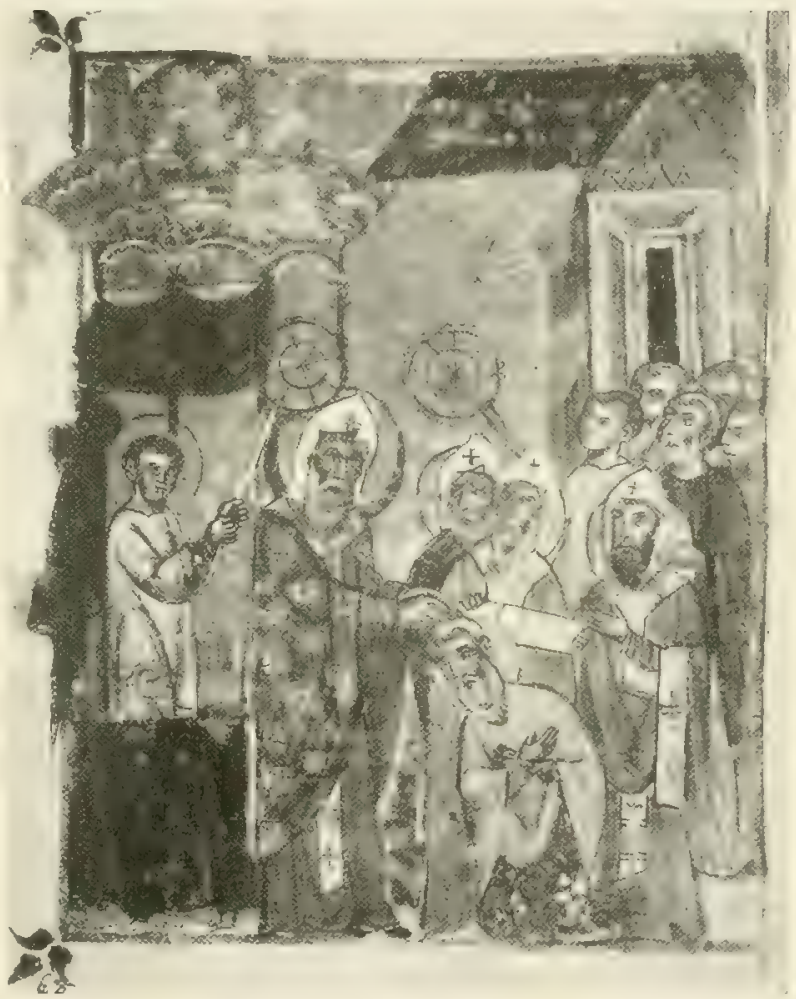

Bild 16. Bischofsweihe. Miniatur eines syrischen Pontifikale (1239). Paris, Bibl. Nat. ruraartigen Zierbesatzes aufweisen. Am ehesten lieke sich noch denken, es sei die abendländische Verzierungsweise des Amiktes zunächst etwa von den Maroniten oder Armeniern, welche infolge ihrer Beziehungen zu Rom und zum Abendland auch sonstige Einzelheiten aus dem abendländischen Ritus sich aneigneten, oder von beiden zugleich herübergenommen und von ihnen dann auch zu den jakobitischen Syrern verpflanzt worden. Indessen ist das kaum mehr als eine blofe Vermutung.

Bei den Kopten begegnet uns unter den liturgischen Kleidern im 12. Jahrhundert im Rituale des Patriarchen Gabriel ein epomis genanntes

1 Auch der Name des Gewandes, identisch mit dem hebräischen miznephet, womit der Kopfbund des alttestamentlichen Hohenprie- sters bezeichnet wird, dürfte darauf hinweisen, dak das Schultertuch ehedem eine Kopfbedeckung war. 
Gewandstück, das der Priester über der Tunika anlegte, ehe er die Stola und den Gürtel annalım ${ }^{1}$. Dasselbe wird auch im 14. Jahrhundert in des Ibn Sabaa Traktat über die kirchliche Wissenschaft bei Aufzählung der priesterlichen Kleider erwähnt ${ }^{2}$. Es handelt sich bei ihm, wie es scheint, um das Schultertuch, welches noch jetzt bei den unierten Kopten in Gebrauch ist, so daf letzteres nicht erst in der Folge der Union im koptischen Ritus Aufnahme gefunden hätte.

In dem verbreitetsten aller orientalischen Riten, dem griechischen, gilht es weder ein liturgisches Schultertuch, noch hat es jemals in demselben, soweit sich erkennen läst, ein solches gegeben. Man hat freilich gesagt, es habe sich die priesterliche und bischöfliche Stola bei den Griechen aus einem Halstuch entwickelt; doch ist das mehr behauptet als bewiesen worden. Wäre dem wirklich so, so darf man mit Recht fragen, warum man, als man aus dem Halstuch ein bloßes Zierstick gemacht hatte, kein anderes dafür wieder eingeführt habe, da ja doch die Gründe für den Gebrauch eines solchen vor wie nach dieselben blieben.

\section{ZWEITES KAPITEL.}

\section{DER FANONE.}

\section{DER FANONE NACH GEGENWÄRTIGEM BRAUCH.}

Dem Amikt reiht sich passend der päpstliche Fanone an, da er wie jener ein Schultertuch ist. Wenn der Papst feierlich pontifiziert, so trägt er aufaer dem gewöhnlichen linnenen Humerale noch ein zweites, ihm ausschliefslich eigenes Schultergewand, das den Namen fano, ital. fanone, führt.

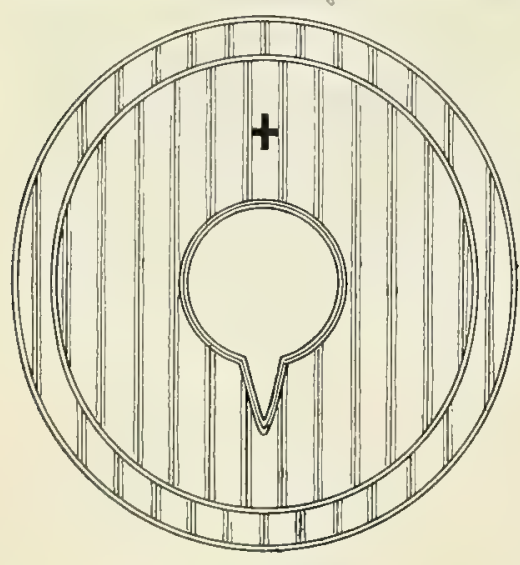

Bild 17. Fanone.

Der Fanone stellt flach ausgebreitet ein der Kreisform sich näherndes Oval dar, dessen größter Durchmesser ca $92 \mathrm{~cm}$ beträgt, und besteht aus zwei übereinander liegenden Blättern Seidenstoff. Dieselben sind nur in der Mitte, wo sich die Öffnung für den Kopf befindet, aneinandergenäht. Das obere Blatt ist ringsum etwa eine Handbreit kleiner als das untere. Mit Futterstoff ist der Fanone nicht versehen. Die beiden Seidenstücke sind von weißer Farbe, mit roten und goldenen Streifen verziert und auferdem rundum mit einer schmalen Goldborde eingefast. Auf dem Vorderteil des Fanone befindet sich ein goldgesticktes Kreuz; an der hinteren Seite ist im Anschluß an die Halsöffnung des leichteren Anziehens halber ein Einschnitt angebracht. Bänder zum Zwecke des Anbindens wie am gewöhnlichen Amikt befinden sich nicht an ihm (Bild 17).

Die Anlegung des Gewandstückes vollzieht sich in folgender Weise. Nachdem der Diakon den Papst mit dem linnenen Amikt, der Albe, dem Cingulum samt Subcinctorium und dem Brustkreuz versehen hat, zieht er

\footnotetext{
1 Renaudot, Liturg. orient. coll. I 160.2 Ebd. 161.
} 
ihm den Fanone mittels der in demselben angebrachten öffnung so über den Kopf, daf dieser wie ein Kragen die Schultern, den Rïcken und die Brust bedeckt, und der Teil, welcher mit dem Kreuze geschmïckt ist, nach vorn gerichtet ist. Dann schlägt der Diakon die hintere Hälfte des oberen Blattes über das Haupt des Papstes, bekleidet diesen mit Stola, Tunicella, Dalmatik und Kasel, läfst hierauf den über den Kopf des Papstes geschlagenen Teil des Fanone wieder herab, zieht die vordere Hälfte des oberen Blattes unter dem Mefagewand hervor und ordnet schließlich das Ganze so um die Schultern an, daf das Ornatstück diese wie ein Kragen bedeckt.

\section{DER FANONE SEIT DEM XIII. JAHRHUNDERT.}

Der Fanone war ein liturgisches Sondergewand des Papstes schon im 13. Jahrhundert, wie Durandus und vorher schon Innozenz III. bezeugen. "Der römische Bischof", sagt letzterer", "legt nach der Albe und dem Cingulum das Orale an, welches er um den Kopf wickelt und auf die Schultern zurückschlägt; er folgt hierbei der Gepflogenheit des alttestamentlichen Hohenpriesters, welcher über die Limnentunika und den Gürtel den Ephod (das Schultergewand) anzog." Ähnlich lauten die Worte des Bischofs von Mende. Das Recht, den Fanone zu tragen, war dem Papst schon damals so ausschlieflich vorbehalten, daß es, wie sich aus dem Ordo des Jakobus Gaietanus Stefaneschi ergibt, nicht einmal den Kardinalbischöfen zustand, sich desselben zu bedienen ${ }^{1}$. Ja selbst der papa electus legte das Ornatstiick erst an, wenn er sich zum Empfang der Bischofsweihe ankleidete?, nicht aber auch schon, wenn er sich zu dem der Priesterweihe rủstete.

In den Ordines Gregors X., des Kardinals Gaietanus und des Bischofs Petrus Amelii, d. i. im 13., 14. und 15. der Ordines Mabillons, heifst das Gewandstuick nicht orale, sondern wie gegenwärtig fano (fanum). Die letztere Bezeichnung scheint die vorwiegendere gewesen zu sein. Nach den genannten Ordines trug der Papst den Fanone bei seiner Konsekration ${ }^{3}$, bei den Feierlichkeiten, die sich an seine Konsekration anschlossen, und dem feierlichen Krönungsmahl ${ }^{4}$, bei der feierlichen Messe ${ }^{5}$, bei der Fubwaschung am Gründonnerstag, dem sog. Mandatum ${ }^{6}$, und dem Mahl desselben Tages ${ }^{7}$. Am Karfreitag bediente er sich keines Fanone ${ }^{3}$, wohl aber wurde die Leiche des Papstes mit ihm ausgestattet ${ }^{9}$.

Bei der Messe umgab das Gewandstück nicht blofs den Hals, sondern fiel auch, abweichend vom gewöhnlichen Amikt, auf die Schultern, den Nacken uni den oberen Teil der Brust herab. Partem illam fanonis, quae dependet ante pectus pontificis, aptet (cardinalis) decenter sub cruce pallii, sagt der 14. Ordo ${ }^{10}$. So sehen wir es denn auch auf den Bildwerken des 13., 14, und 15. Jahrhunderts. Bei den älteren Darstellungen pflegt sich das Orale wohl in einem Bausch oder in einem spitzen Winkel tief über die Brust hinabzuziehen, während es Nacken und Schultern fast ganz unbedeckt lälit. Das ist z. B. der Fall bei den Statuen Bonifaz' VIII. im Lateran (Bild 18, S. 54) und

1 Ordo 14, c. 4853 (M. 78, 1153 1157).

2 Ordo 13; n. 56 (ebd. 11061107 1108).

3 Ordo 13, n. 6 (ebd. 1108).

4 Ordo 14, c. 2343 (ebd. 1133 1139).

5 Ordo 14 , c. 47 ; ordo 15 , c. 8 (ebd. 1151 1277).
${ }^{6}$ Ordo 14, c. 84 (ebd. 1207).

7 Ordo 14, c. 87 ; ordo 15 , c. 70 (ebd. 1209 1312).

8 M or. XXIII 176.

9 Ordo 15, c. 144 (ebd. 1351).

10 Ordo 14, c. 47 (ebd. 1151). 


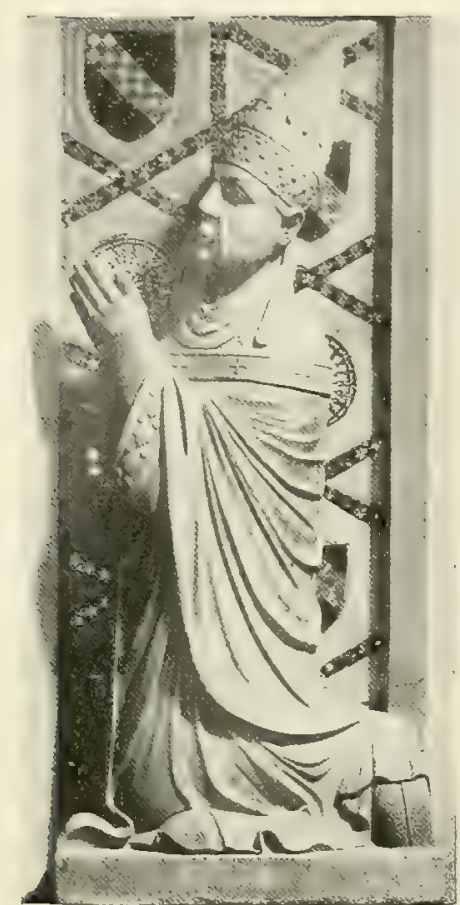

Bild 18. Grabmal Bonifatius' VIII. Rom, Lateranbasilika.

im Dom zu Florenz, bei der Grabstatue desselben Papstes in der Krypta von St Peter sowie der Grabfigur Honorius' IV. in Ara Celi. Bei andern, namentlich den späteren Bildwerken, bedeckt es gleichmäßig Brust, Nacken und Schultern. So z. B. auf einem der Bilder des Fra Angelico in der Kapelle Nikolaus' V. im Vatikan (der hl. Laurentius wird von Papst Sixtus zum Diakon geweiht) ${ }^{1}$, einem Gemälde Simone Martinis (St Gregor d. Gr.) im Museo civico zu Pisa (sala III, n. 17), dem Gewölbefresko Taddeo Gaddis in der Sakramentskapelle von Santa Croce zu Florenz (St Gregor d. Gr.), den Grabstatuen Martins V. im Lateran, Sixtus' IV. (Bild 19) und Innozenz' VIII, in St Peter u. a.

Bei den feierlichen Mahlzeiten und dem Mandatum wurde der Fanone nach Art einer Kapuze auf den Kopf gezogen.

Den gewöhnlichen Amikt trug der Papst im 13. Jahrhundert, wenn er in Pontifikalkleidung war, aufer dem Fanone nicht. Es geht das aus dem Ordo Gregors X. mit Bestimmtheit hervor. Wo darin von einer etwa vorzunehmenden Bischofsweihe des erwählten Nachfolgers Petri die Rede ist, heifst es: „Hat er die Hände gewaschen, so soll er allen Schmuck mziehen, nämlich zuerst die Albe und das Cingulum mit dem Subcinctorium, dann das Pektorale, hierauf den Fanone, weiterhin die Stola, die Tunicella und die Dalmatik. Ferner nimmt er die Handschuhe und endlich die Kasel und die Mitra. Pallium und Ring empfängt er später zu seiner Zeit." Wie man sieht, ist hier vom Amikt nicht nur keine Rede, derselbe wird sogar durch den Wortlaut (allen Schmuck - zuerst) völlig ausgeschlossen ${ }^{2}$. Umgekehrt soll der papa electus, falls er noch zum Priester zu weihen wäre, für die Priesterweihe mit einem Amikt unter der Albe bekleidet sein, aber weder eine Tunicella noch eine Dalmatik, noch die Sandalen, noch das Brustkreuz, noch endlich den Fan one tragen ${ }^{3}$.

Der Amikt fehlt noch am Ende des 14. Jahrhunderts in der Pontifikalkleidung des Papstes. Es erhellt das aus der Beschreibung, welche der Ordo des Petrus Amelii von derselben gibt. Auch hier ist es die Albe, mit welcher die Kardinaldiakone den Papst, der sich zur feierlichen Nachtmesse am Weihnachtsfest rüstet, zuerst und vor allen andern Gewändern bekleiden. Dann folgen Cinctorium (Cingulum) und Subcinctorium, weiterhin das Pektorale und erst an vierter Stelle der Fanone 4.

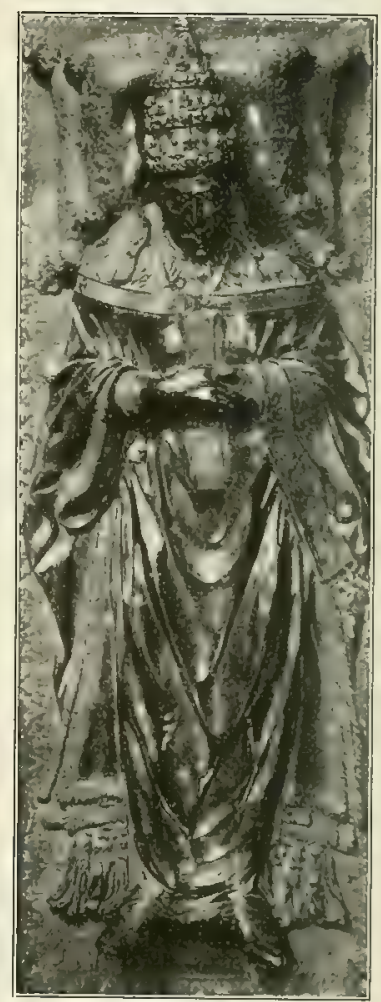

Bild 19.

Grabfigur Sixtus' IV.

Rom, Peterskirclie.

(Phot. Alinari.)
1 Vgl. die Wierlergabe des Bildes weiter unten im Kapitel : Rochett und Superpelliceum.

2 Ordo 19, n. 6 (78 1108).
3 Ebd. 1107.

4 Ordo 15, c. 8 (ebd. 1277); vgl. auch c. 144 (ebd. 1351). 
Um den Beginn des 16. Jahrhunderts trägt der Papst, wie sich das aus den Angaben des Christoph Marcellus in dem 1516 herausgegebenen Caeremoniale der päpstlichen Kapelle ergibt, Amikt und Fano zugleich ${ }^{1}$. Die Aufnahme des gewöhnlichen Amikts in die päpstliche Pontifikaltracht mufs sich demnach im Lauf des 15. Jahrhunderts vollzogen haben.

Zum Pluviale nahm um 1500 der Papst ebenfalls den gewöhnlichen Amikt, nicht den Fanone ${ }^{2}$. Wie er es vorher gehalten, jst aus den römischen Ordines nicht ersichtlich. Nur so viel läßst sich aus ihnen feststellen, dafs der Papst dann zum Pluviale den Fanone behielt, wenn er nach der Pontifikalmesse für irgend eine an dieselbe sich anschlieliende Funktion, wie z. B. die Fufwaschung am Gründonnerstag, unter Beibehaltung der übrigen Melsgewänder die Planeta mit dem Mantum (dem päpstlichen Pluviale) vertauschte ${ }^{3}$.

Über die Beschaffenheit und Form, welche das Orale im 13., 14. und 15. Jahrhundert besak, liegen nur wenige Nachrichten vor. Innozenz III. schweigt von derselben; Durandus beschränkt sich darauf, es sindon zu nennen.

Der Fanone, mit welchem einst die Leiche Bonifaz' VIII. bekleidet worden war, bestand nach dem bei der Eröffnung des Grabes im Jahre 1605 über den Befund abgefaßiten Protokoll aus einem höchst zarten weißen Tuch aus reiner Seide, ohne Goldverzierung und sonstigen Schmuck. Für seine Gestalt ist die Bemerkung von Belang, er sei mehreremal über der Albe um die Schultern gewickelt und dann über der Kasel rings um den Hals geschlagen gewesen ${ }^{4}$. Im Inventar des päpstlichen Schatzes aus dem Jahre 1295 werden angeführt 4 große Oralien, welche mit je 3 Goldstreifen an den Enden und in der Mitte und auferdem mit sonstigen schmäleren Streifchen verziert waren, 14 Oralien mit breiten, roten oder grünen Seidenstreifen an der Seite, 4 Oralien mit schwarzen Längsstreifen, 1 Orale mit 3 Goldstreifen an jedem Ende und einem Goldstreifen an der einen Seite, sowie 13 teils einfachere teils ganz

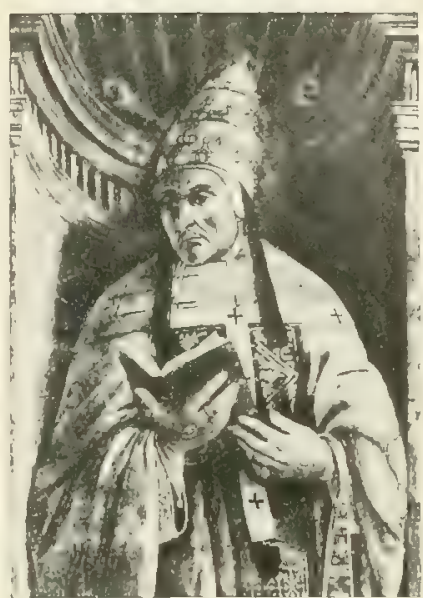

Bild 20. Cosimo Roselli :

Papst Silvester.

Rom, Sistina. schmucklose Oralien. Nach dem handschriftlichen Caeremoniale des Paris de Grassis bestand der Fanone zur Zeit dieses päpstlichen Zeremonienmeisters aus Linnen, das mit Goldfäden durchwirkt war ${ }^{5}$. Das Orale, welches Papst Sixtus auf dem vorhin erwähnten Gemälde des Fra Angelico trägt, ist mit breiten und schmalen Längsstreifen verziert. Ähnlich das Bild Silvesters von Cosimo Roselli in der Sistina (Bild 20). Auf dem Gemälde Simone Martinis im Museo civico zu Pisa ${ }^{6}$ ist es mit goldenen Doppelstreifen geschmüickt; meist tritt es aber auf den bildlichen Darstellungen als einfaches weißes Tuch auf. Ein erschöpfendes, völlig klares Bild des mittelalterlichen Fanone des Papstes gewähren alle diese Angaben nicht; doch war er jedenfalls nicht ein

1 L. II, c. 14.

2 Burchard. Argent. bei Cancellieri, Storia de' solenni possessi, Roma 1802, 57.

3 Ordo 12 , n. 25 ; ordo 14 , c. 91 ; ordo 15 ,

c. 78 (M. 78,107412101311 ).

4 Bzovius, Annal. ad 1303; XIV 51.

${ }^{5}$ Giorgi, Liturgia Rom. Pontif. I 148. Die
Ausstattung mit Streifen wurde dem Finnone vielleicht in Erinnerung an den mehrfarbigen Ephod (Schulterkleid) des jüdischen Hohenpriesters zu teil, als dessen Abbild das Ornatstück gelten konnte, seitdem es in Rom päpstliches Sondergewand geworden war.

${ }^{6}$ S. oben S. 54. 
kragenartiges Ornatstïck wie gegenwärtig. Er hatte vielmehr wie der gewöhnliche Amikt noch im 15. Jahrhundert die Gestalt eines Tuches. Das beweisen die Bildwerke auf das bestimmteste. Wann der Fanone Kragenform erhielt, läßst sich kaum näher bestimmen, da seit dem 16. Jahrhundert die Päpste im Pluviale dargestellt zu werden pflegen. Als die Papstfiguren der Cappella Sistina entstanden (vgl. Bild 20) und Raffael die Stanzen ausmalte, scheint er noclı kein förmlicher Kragen gewesen $z u$ sein; doch war er damals jedenfalls schon auf dem besten Wege dazu.

\section{DER FANONE VOR DEM XIII. JAHRHUNDERT.}

Nicht ohne Grund wurde vorhin darauf hingewiesen, daf der Papst bis zum 15. Jahrhundert bei dem Pontifikalamt nur den Fanone, d. i. ein über die Albe gelegtes Schultertuch, getragen, nicht aber auferdem noch unter

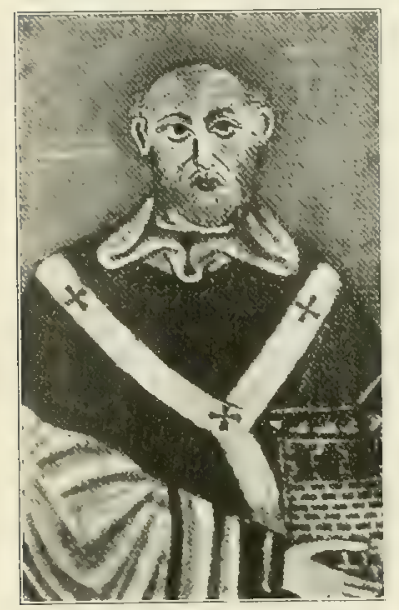

Bild 21. Papst Innozenz II.

Vom Apsidalmosaik in S. Maria in Trastevere. (Nach Photographie.) der Albe sich des gewöhnlichen Amikts bedient habe. Es beweist das nämlich, daßs das anagolagium (anagolaium, anabolagium), von dem im 1. und 3. römischen Ordo Mabillons, im S. G. K. und im Ordo Duchesnes die Rede ist, mit dem späteren Orale (Fanone) im wesentlichen eins ist und daf somit dieses, wenn auch unter anderem Namen, bereits im 8. Jahrhundert in Gebrauch war.

Nach dem 1. Ordo bekleiden die Regionarsubdiakone den Papst der Reihe nach mit der linea (Albe), dem Cingulum, dem anagolaium, d. i., wie erklärend bemerkt wird, mit dem amictus, der linnenen Dalmatik, der größeren Dalmatik und der Planeta. Ähnlich lauten die Angaben in dem 3. Ordo, in welchem das anabolagium nicht nur durch amictus, sondern auch durch humerale erläutert wird. Der S. G. K. beschreibt die päpstliche Sakralkleidung wie folgt: In primis cam.(isia) et cingitur supra. Dein linea cum cottis, serica et cingulum. Post haec mittitur an agolagi; exinde dalmatica minore, postea maiore dalmatica et supra orarium. Post haec planeta et supra mittitur pallium. Die camisia bedeutet eine Art Rochett, die linea die Albe. Was cum cottis, serica besagt, ist unklar ${ }^{1}$. Das anagolagi ist offenbar das anagolaium des 1. und das anabolagium des 3. Ordo. Wie aus den drei Stellen hervorgeht, trug der Papst im 8., 9. und 10. Jahrhundert nur ein Schultertuch über der Albe, aber keines unter ihr, gerade wie es noch im 13. und 14. Jahrhundert der Fall war. Es kann also nicht zweifelhaft sein, daßs das anagolagium des 1., 3. und 5. Ordo und der spätere Fanone ein und dasselbe Gewandstück darstellen.

Beachtenswert ist indessen, daf im Gegensatz zum Orale des 13. Jahrhunderts das Schultertuch des 1. und 3. Ordo sowie des S. G. K. noch kein dem Papst ausschließlich vorbehaltenes Ornatstück war ${ }^{2}$.

Wann zu Rom bei den andern Bischöfen, den Priestern, Diakonen und Subdiakonen die Sitte aufkam, das Schultertuch eher als die Albe anzulegen, mit andern Worten, wann das anagolagium dort zu einem dem Papst vorbehaltenen Gewandstück, also zum päpstlichen Orale oder Fanone wurde, ist, wie friiher gesagt wurde, nicht genau festzustellen; der Wechsel muf sich

\footnotetext{
1 Statt des unverständlichen cum cottis, serica ist vielleicht cum costis sericis, mit seidenen Besatzstreifen zu schreiben.

2 Vgl, oben S. $23 \mathrm{f}$.
} 
in der Zeit zwischen dem 10. und Ende des 12. Jahrhunderts vollzogen haben. Auf den Mosaiken der Apsis in S. Maria in Trastevere ist Papst Innozenz II. (1130-1143), der Stifter des Bildwerkes, mit einem weißen Schultertuch dargestellt, das rings um den Hals ỉber der Planeta gelagert ist (Bild 21). Ob damals schon das anagolagium zum Orale geworden war? ${ }^{1}$

Die Frage nach dem Ursprung des römischen anagolagium, des Vorläufers des späteren Orale (Fano) und jetzigen päpstlichen Fanone, kann hier übergangen werden. Da es Schultertuch war, gilt von ihm in dieser Hinsicht, was über die Entstehung des liturgischen Amikts gesagt wurde.

\section{DRITTES KAPITEL.}

\section{I E A L B E.}

\section{DIE ALBE IN DER GEGENWART.}

Die Albe ist eine Tunika, d. h. ein mit engen Ärmeln und einem Durchschlupf für den Kopf versehenes, vorn geschlossenes, sackartiges Gewandstück.

Wie der Amikt muf sie kraft des Dekretes vom 18. Mai 1819 aus weifem Linnen oder Hanfstoff gemacht werden. Das gilt jedoch nur von der Albe selbst, nicht aber von den Besätzen oder Spitzen, mit denen sie etwa verziert wird. Es ist weder verboten, eine Bordüre aus Seidenstoff am Saum oder den Ärmeln des Gewandes anzubringen, noch mittels Seide oder Baumwollengarn einen Zierstreifen dem Albenrand einzusticken, noch endlich selbst, mit Spitzen aus Baumwolle das Gewand zu verzieren, wiewohl solche keineswegs hier empfohlen werden sollen. Über die sonstige $\mathrm{Be}-$ schaffenheit und die Breite der Spitzen und Besätze gibt es ebenfalls keine bestimmten kirchlichen Vorschriften. Es muß darüber aufer dem Brauch und der gebührenden Rücksicht auf den Ernst des Gottesdienstes und die Natur des Gewandes vornehmlich der gute Geschmack entscheiden ${ }^{2}$. Spitzen dürfen nach neueren Entscheidungen der Ritenkongregation mit farbigem Stoff unterlegt werden, damit sie besser wirken ${ }^{3}$.

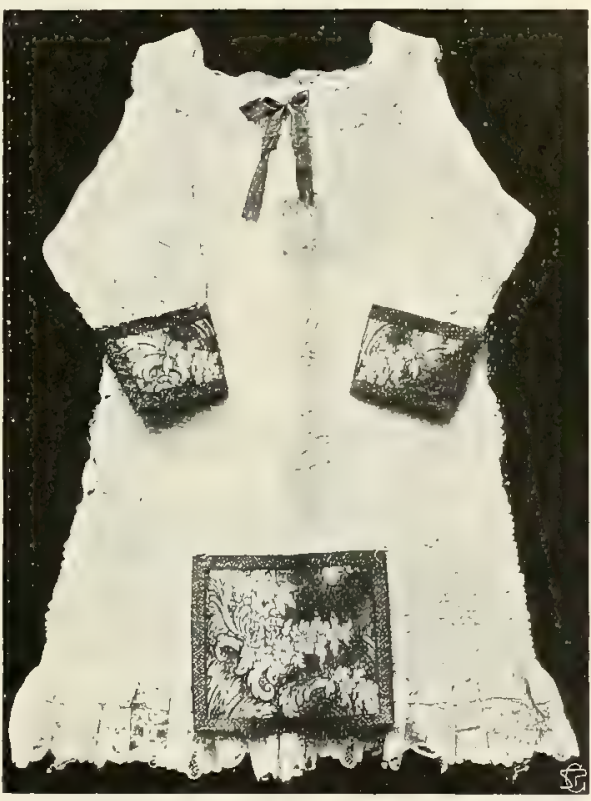

Bild 22. Mit Besätzen verzierte Albe nach ambrosianischem Ritus.

Im Mittelalter versah man (seit etwa dem 12. Jahrh.) die Alben am Saum und auch wohl an dem Ärmelrand nicht sowohl mit durchlaufenden Besätzen, als vielmehr mit kurzen Zierstuicken, die bei den Ärmeln auf der

1 de Rossi, Musaici fasc. VII und VIII.

2 Über die Beschaffenheit der Albenbesätze und Spitzen findet sich Näheres in Brau $\mathrm{n}$, Winke $34 \mathrm{f}$.
${ }^{3}$ C. R. 12. Juli 1892 und 24. November 1899 (Decret. auth. n. 3780 4048). Es steht also auch nichts im Wege, farbige Stickereien am Saum der Albe anzubringen. 
oberen Hälfte, beim Saum aber in der Mitte der Vorder- und Rückseite angebracht waren. Gegenwärtig ist diese Verzierungsweise des Gewandes nur noch in Mailand (Bild 22, S.57) und einigen Kirchen Spaniens in Gebrauch ${ }^{1}$. Doch hat man in newester Zeit versucht, sie auch anderswo wieder einzuführen (Bild 23).

Bezüglich der Ma ڤaverhältnisse der Albe gibt es keine allgemein gültigen kirchlichen Bestimmungen. Die Verordnung, welche der hl. Karl betreffs derselben erlie: ${ }^{2}$, war, obwohl von Rom approbiert, nur partikulärer Natur; ihre Geltung ging nie über den Rahmen eines Diözesan- bzw. Provinzialdekretes

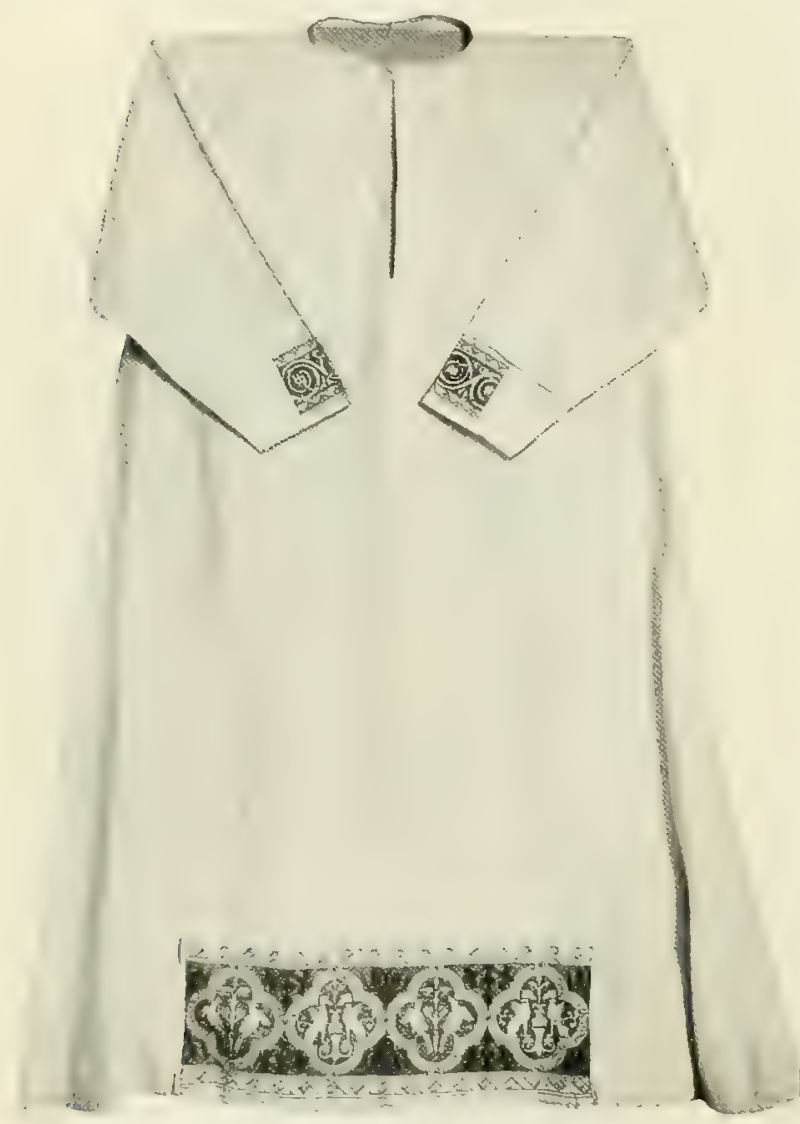

Bild 23. Albe von mittelalterlicher Form und Verzierung. (Gearbeitet von $\div$ Frl. J. Nellessen zu Kornelimünster.) hinaus. Obendrein wird sie selbst nicht einmal in Mailand mehr in allem beobachtet. Die Maße aber, welche Gavanti für die Albe angibt, sind lediglich dem Mailänder Synodalstatut entnommen, also nicht einmal die seinerzeit in Rom üblichen ${ }^{3}$. Auch sind dieselben niemals von der kirchlichen Autorität für masigebend erklärt worden.

Genaue Maße lassen sich überhaupt für das Gewand nicht angeben, da dieselben zu sehr durch die Größe desjenigen bedingt sind, welcher das Gewand zu benutzen hat. Für die Länge bietet einen ungefähren Anhalt die Bemerkung des Missale, es solle die Albe, wenn gegürtet und aufgeschürzt, ringsum gleichmäfig etwa eine Fingerbreite vom Boden abstehen (in latitudinem digiti vel circiter super terram aequaliter fluat). Für gewöhnlich dürfte zu dem

Ende eine Durchschnittslänge von 1,50-1,60 m völlig ausreichen. Die Weite der Albe mufs der Art sein, dak sowohl das Schreiten und Knien ohne Beschwerde und ohne Beschädigung des Gewandes erfolgen, als auch ein schöner Faltenflußs sich bilden kann. Für beides genügt es, wenn die Alben einen

1 Die Photographie der Albe verdanke ich der Liebenswürdigkeit des Herrn Can. Dr M. Magistretti zu Mailand.

2 A. E. Med. 626.

3 Gav. II v; II 272. Die Maßsverhältnisse, wie sie in der Verordnung des hl. Karl und bei Gavanti sich finden, können nicht einmal als Norm empfohlen werden. Die gewöhnliche Albe soll nach beiden 16 Ellen, d. i. 7-8 $\mathrm{m}$ weit sein, gewifs des Guten zu viel. Eine mit Zierbesätzen versehene Albe braucht nach dem Mailänder Statut dagegen nur 4 Ellen, also nur ca 2 m Umfang zu liaben, gewif eine minimale Weite. 
Umfang ron ca $3,20 \mathrm{~m}$ besitzen, eine Weite, die sie denn auch heute gewöhnlich erhalten.

Was den Schnitt der Alben betrifft, so ist heutzutage diejenige Form wohl die gewöhnlichste, bei welcher der Albenkörper einen überall gleichweiten Sack darstellt. Die am oberen Ende zum Zweck eines guten Sitzens des Gewandes nötige Verengerung erreicht man bei ihr dadurch, daf man den Albenstoff oben an dem Durchlaß̉ für den Líopf nach Bedürfnis einkräuselt. Von ganz anderem Schnitt ist eine zweite, der mittelalterlichen Albe nachgebildete Albenform, die sog. Girenalbe, während eine dritte Albenart, die sog. Spatelalbe, eine Vermittlung zwischen dieser und der erstgenannten Albenform darstellt ${ }^{1}$.

Die Albe kommt den Bischöfen, Priestern, Diakonen und Subdiakonen zu, sie kann indessen auch von den Minoristen getragen werden, wenn auch das den letzteren eigentiumliche Gewand nicht die Albe, sondern das Superpelliceum ist. Gebraucht wird sie für gewöhnlich nur bei der Messe und den damit in Verbindung stehenden Funktionen. Bei andern wird sie in der Regel durch das Superpelliceum ersetzt.

Gegenstand einer besondern Zeremonie bei einer der heiligen Weihen ist die Albe nicht. Die mystische Deutung, welche die Kirche mit ihr verknüpft, erhellt aus dem Gebet, welches der Priester bei Anlegung des Gewandes zu sprechen hat: "Mach mich weib und reinige mein Herz, o Herr, auf daf3 ich geläutert im Blute des Lammes die ewigen Freuden geniefsen möge." Rein soll der Priester sein, wenn er zum Altar tritt, um denjenigen zu empfangen, den er einst, geläutert ehen durch das Blut des Lammes, das er beim heiligen Mahl geniefst, im Himmel in ewig seligem Jubel zu schauen hofft und verlangt.

\section{NAME DES GEWANDES.}

Bei den Liturgikern des Mittelalters, in den römischen Ordines, den mittelalterlichen Inventaren usw. begegnen wir einer mehrfachen Benennung des Gewandes. Bald heift es in Anbetracht des Materials, aus dem es angefertigt ist, einfach linea, bald mit Rücksicht auf den Stoff und den Charakter des Gewandes tunica linea, bald, weil es bis auf die Füfe oder bis zu den Knöcheln reicht, also der Länge wegen, poderes, talaris oder tunica talaris, bald wieder, vielleicht im Anschluß an eine Äußerung des hl. Hieronymus, camisia, bald endlich um der Farbe willen alba. Die Bezeichnung alba romana, die uns hie und da begegnet, bedeutet, wo damit eine wirkliche Albe gemeint ist, entweder eine zu Rom gebräuchliche Albenform oder besagt nur, daf es sich um Alben handelt, die aus Rom gekommen waren. Von den verschiedenen Namen, mit denen ehedem das zweite liturgische Gewand bezeichnet wurde, hat sich fast nur das Wort alba im kirchlichen Gebrauch erhalten.

Es ist bemerkenswert, dafs das Wort alba, welches in der Vita Claudii c. 14 und c. 19 des Trebellius Pollio zur Bezeichnung einer profanen Tunika angewandt wird, als Terminus eines liturgischen Gewandes zuerst in Afrika, Spanien und Gallien auftritt. In Rom scheint es bis zum 2. Jahrtausend, wie aus dem 1. und 3. Ordo Mabillons und dem S. G. K. hervorgeht, als Name unserer Albe nicht oder kaum in Brauch gewesen zu sein. Diese hiek hier linea oder camisia. Der Zusatz: quam dicinus

1 Näheres über den Schnitt der drei Albenarten in Prann, Winke $31 \mathrm{ff}$. 
albam, der in dem 3 . Ordo bei Aufzählung der Pontifikalgewänder irrig statt der linea der dalmatica linea angefügt wurde, ist ersichtlich nur Glosse des Kopisten. Später erscheint freilich auch in der römischen Kirche das Wort alba als Name des Gewandes. Es muf schon zu Innozenz III. Zeit daselbst mit Vorzug so geheiß̉en haben. Jedenfalls war gegen Ende des 13. Jahrhunderts zu Rom alba die vorherrschende Bezeichnung, wie dies bestimmt aus dem 13., 14. und 15. Ordo Mabillons hervorgeht. Üherall heifst das Gewand darin alba. Wo einer camisia gedacht wird, ist stets die Rede von der anferliturgischen linnenen Tunika, dem jetzigen Rochett. Im Italienischen hat sich jedoch bis jetzt der alte Ausdruck camisia in der Umbildung camice als Albenname erhalten. Der Benennung des Gewandes in den meisten übrigen Sprachen liegt das Wort alba zu Grunde (deutsch Albe, französisch aube, englisch alb, spanisch alba).

Übrigens ist wohl zu beachten, dafs der Ausdruck alba im Mittelalter noch keineswegs bloß für das sakrale Gewand gebraucht wurde, welchem dieser Name gegenwärtig ausschlieflich zukommt. Im spanischen und gallikanischen Ritus bezeichnete man mit ihm die liturgische Tunika der Diakone und der Lektoren. Es geschieht das z. B. in der gallikanischen Mefarklärung und im 28. Kanon der vierten Synode von Toledo ${ }^{1}$. Später verstand man unter alba nicht selten die Tunicella, das Amtskleid des Subdiakons, wohl wegen der engen Ärmel, welche dieselbe gewöhnlich mit der Albe im Sinne der camisia gemeinsam hatte. So wird z. B. in des Beroldus Ordo für S. Ambrogio in Mailand aus der ersten Hälfte des 12. Jahrhunderts die subdiakonale Tunika regelmäbig alba genannt. Selbst die rote diakonale Tunika, deren sich die Diakone beim Absingen der Passion bedienten, heist darin alba (rubea) ${ }^{2}$. Auch in dem Ordo romanus officiorum totius anni, wie er im 11. und 12. Jahrhundert weit verbreitet war, wird die Tunika des Subdiakons mit alba bezeichnet ${ }^{3}$. Teils bischöfliche, teils diakonale oder subdiakonale Tuniken waren wohl die alba nigra cum minutis lineis aureis aus der Hinterlassenschaft des Bischofs Galfried von Durham $(\dagger 1140)$ und die 10 albae brudatae (bestickt), welche aus dem Nachlaßs des Bischofs Hugo († 1195) der Kathedrale zufielen, darunter eine rubea cum aquilis deauratis, duo capita habentibus in parvis rotis, eine alba magna viridis cum griffonibus, eine alba indici coloris cum griffonibus, leonibus et floribus in parvis rotis, eine alba viridis cum apostolis, eine alba nigra cum largis orariis (Saumbesätzen) deauratis *. Denn es scheint nicht, đaß in diesen Fällen; wie das allerdings sonst in den Inventaren hie und da vorkommt, die Alben lediglich wegen der Farbe und Beschaffenheit der Besätze als nigrae, brudatae usw. bezeichnet werden ${ }^{5}$. Die in einem Inventar von Peterborough aus dem Jahre 1539 erwähnten 7 albes called ferial black, 40 blue albes of divers sortes, 27 red albes for Passion week waren entweder Alben mit Paruren oder wohl richtiger Tuniken für Akolythen, Ministrantenröcke ${ }^{6}$, wie deren z. B. in einem Inventar des Mainzer Domes aus der ersten Hälfte des 13. Jahrhunderts aufgeführt werden: Multae tunicae diversorum colorum videlicet rubei, virides et violacei coloris, virgulatae, crocei, albi coloris, quibus utebantur ministri altarium et acolythi et chrismatis portatores. In einem Inventar von Angers begegnen uns solche unter dem Namen dalmaticae pro pueris?

1 Hald. III 586.

I Mur., Ant. IV 867891896899.

3 Hitt. 61 76. Man vergleiche auch das Pontifikale von Besançon bei Mart. 1. 4, c. 22; Ill 109, das Puntifikale von St-Germaindes-Près (ebd. III 114), ein Kölner Pontifikale der Vaticana (Ottob. Cod. 167) u. a.

4 Vgl. auch die Hinterlassenschaften del Bischöfe Philipp († 1208), Pichard II. († 1237): 2 albae, una nigra brudata cum vinea, in qua sedent aves et alia de serico non brudata, Anton († 1310); 3 albae de uno panno aureo indici coloris cum ramis arborum et floribus et aviculis super ramos et flores consedentes. (Raine, Durham wills I $1 \mathrm{ff}$ ).

5 So sind z. B. in dem Würzburger Inventar von 1448 unter den darin aufgeführten "grïnen" Alben mit ihren Umbralen nach dem Zusammenhang Alben mit ,grünen" Schilten (Paruren) zu verstehen.

6 Tunicellen sind jedenfalls nicht gemeint, da diese in dem Inventar tunicles genannt werden.

7 Revue 1886, 176. Vgl. auch ebd. zu einem Inventar von Rouen p. 464, nota 4, ferner das Inventar von St Paul zu London von 1245: 
Es gibt da weife, rote, grüne, schwarze usw. Dalmatiken für die Chorknaben. In Spanien waren an verschiedenen Orten noch bis in die neueste Zeit dalmatikartige Obergewänder bei den Akolythen in Gebrauch.

Es ist wichtig, auf die versehiedenen Bedeutungen zu achten, welche das Wort alba hat. Nicht überall, wo eine alba genannt wird, ist die Albe in dem heutigen Sinne gemeint. Man wird daher in den einzelnen Fällen nachzusehen haben, was dem Zusammenhang nach darunter verstanden werden mufs und zwar gilt das ehensowohl für das späte Mittelalter als auch schon für die ältere Zeit. Anciernfalls wird man sich unvermeidlich der Gefahr aussetzen, der Albe in Beziehung auf Stoff und Farbe Eigenschaften beizulegen, welche sie nicht oder nur ausnahmsweise und gegen den gewöhnlichen Brauch hatte oder Stellen auf sie zu beziehen, die zwar von einer alba, nicht aber von unserer Albe reden.

Es verdient hervorgehoben zu werden, dab der jetzige Name des Gewandes ursprünglich nicht im römischen Ritus in Gebrauch war und daf er unter Verdrängung der einheimischen Bezeichnung von auswärts in Rom eingeführt wurde. Es ist derselbe Vorgang, den wir schon hinsichtlich der Benennung des Schultertuches sich abspielen sahen, ein Vorgang, der auch bei den Namen verschiedener anderer liturgischen Gewänder wiederkehrt. Rom hat sich in liturgischen Dingen nicht blok gebend, sondern auch nehmend verhalten. Es gab dem Abendland seine eigenen Kultgewänder, es nahm aber dafür im Laufe der Zeit von ihm die Namen derselben unter Aufgabe der ursprünglich römischen an.

\section{DIE ALBE IN KAROLINGISCHER ZEIT.}

Von der Geschichte der Albe oder der liturgischen, d. h. den gottesdienstlichen Funktionen allein vorbehaltenen Tunika wissen wir für die acht ersten Jahrhunderte im ganzen nur wenig. Es empfiehlt sich daher, bevor wir unsern Blick der vorkarolingischen Zeit zuwenden, uns mit dem Stande der Dinge im 9. Jahrhundert zu beschäftigen.

Im 9. Jahrhundert war unzweifelhaft eine liturgische Tunika im Sinne unserer heutigen Albe sowohl in Rom wie überall, wo der römische Ritus Aufnahme gefunden hatte, in Gebrauch. Es ergibt sich dies aus den Angaben eines Hraban, eines Amalar von Metz, eines Theodulf von Orleans ${ }^{1}$, eines Walafried Strabo, aus dem 1. und 3. römischen Ordo, dem S. G. K., aus den Sakramentaren und Pontifikalien jener Zeit², aus der "Synodalermahnung", den Statuten Riculfs von Soissons und Reginos Schrift De ecclesiae disciplina ${ }^{3}$. "Keiner", schreibt die Synodalermahnung vor, "feiere ohne Albe die Messe." Riculf will, es solle der Priester für die Feier des heiligen Opfers eine oder zwei Alben bereit halten. Nach Regino hat der Bischof bei der Visitation sich zu erkundigen, ob man sich unterfange, ohne Albe oder in der Alltagsalbe die Messe zu halten.

In fast allen der angeführten Belege ist nur von der priesterlichen und bischöflichen Albe die Rede. Daf die als Cantores fungierenden Kleriker diese bei Ausübung ihres Amtes trugen und der Subdiakon bei Ablesung der Epistel mit ihr versehen war, sagt uns Amalar ${ }^{4}$. Als Bestand-

7 dalmaticae puerorum, das von St Amé zu Douai (13. Jahrhundert) octo tunicae puerorum neben 11 albae puerorum, die Consuetudines von Farfa (ed. B. Albers, Stuttgart 1900) 1014 und sonst (vgl. Ind. III sub tunica) u. a.

${ }^{1}$ Carm. 1. 5, n. 3. Par. ad episc. (M. 105355 ).
2 Vgl. z. B. Mart. l. 1, c. 4, art. 12. ordo $5 \mathrm{ff}$, I $186 \mathrm{ff}$.

${ }^{3}$ De discipl. eccl. inquisitio n. 66 und 1. 1, can. 80 (M. 132, 190 207).

4 De eccl. offic. 1. 3, c. 415 (M. 105, 1107 1122). 
teil der liturgischen Kleidung aller Ordines, des Papstes, der Bischöfe, der Priester, der Diakone, der Subdiakone und sonstigen Kleriker erscheint die Camisia im st Gallener Kleiderverzeichnis. Auch auf einer höchst interessanten Miniatur des der Mitte des 9. Jahrhunderts angehörig'en Sakramentars von Autun ${ }^{1}$, welche die verschiedenen Weihestufen in der ihnen eigenen liturgischen Kleidung darstellt, tragen nicht nur der Bischof und Priester, sondern auch der Diakon und Subdiakon, Akolyth und Lektor, Exorzist und Ostiarius die Albe (Bild 24). Ebenso gervahrt man auf den Elfenbeintafeln der Deckel des bekannten Drogosakramentars und auf seinen Miniaturen diese nicht blob; beim Bischof, sondern auch bei den übrigen Klerikern ${ }^{2}$. Die Albe war sonach zur Karolingerzeit ein allen Ordines zukommendes liturgisches Gewand, ohne das keiner der am Gottesdienst Beteiligten, vom opfernden Papst oder Bischof an bis zum letzten Kleriker, am Altare erscheinen durfte.

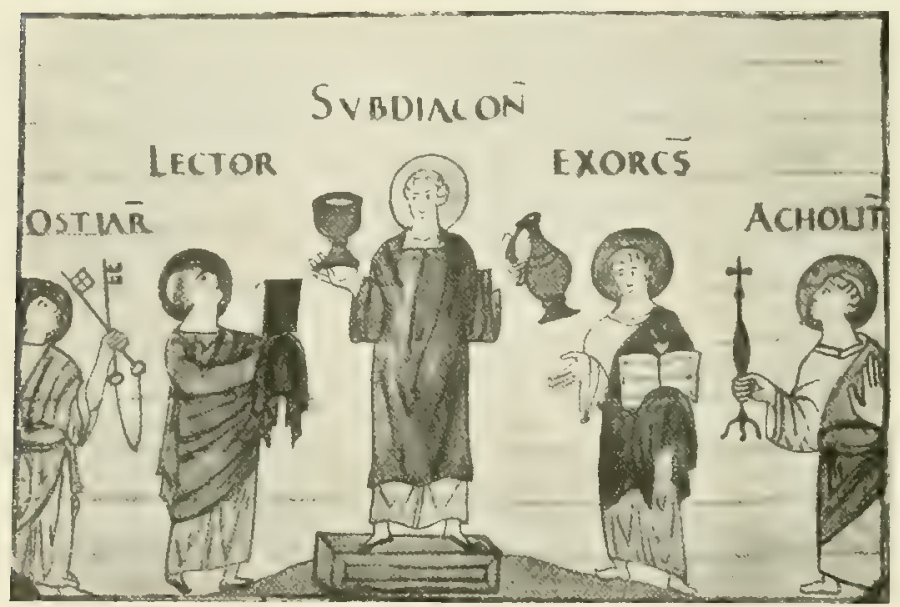

Bild 24. Subdiakon und Minoristen. Miniatur eines Sakramentars in Autun (9. Jahrh.).

Es ist indessen nicht aufer acht zu lassen, dak man im 9., ja selbst 10. Jahrhundert unter "Albe" nicht nur die zur liturgischen Kleidung gehörende Linnentuni$\mathrm{ka}$, sondern auch den entsprechenden $\mathrm{Be}$ standteil der gewöhnlichen klerikalen Tracht verstand. Es scheint aber, dafs man sich in der Praxis mißbräuchlich dieser auferliturgischen Albe nicht selten statt der liturgischen bediente bzw. es sich bei der Messe mit der Alltagsalbe genug sein lief. Es bestimmt nämlich im Jahre 889 Riculf von Soissons: "Wir untersagen aber allerwegen, daf man sich jener Albe bei der Feier der heiligen Geheimnisse bediene, die man im Alltagsleben anzieht." Auch die "Synodalermahnung" sagt: "Niemand soll sich vermessen, in der Albe die Messe zu singen, die er für gewöhnlich trägt." Dementsprechend soll auch, wie bereits gesagt wurde, nach Regino von Prüm $(\dagger 915)$ der Bischof bei der Visitation sich erkundigen, nicht nur ob der Priester ohne Albe, sondern auch ob er in seiner Alltagsalbe die Messe zu singen sich unterfange. Allerdings erhellt aus diesen Verordnungen nicht minder, daf die maßgebende kirchliche Auffassung im 9. und 10. Jahrhundert sehr wohl zwischen der Albe, die im Dienst des Kultus stand, und derjenigen des Alltagslebens, wie sehr dieselben auch im übrigen einander gleichen mochten, unterschied und die praktische Nichtbeachtung dieses Unterschiedes als Mikbrauch betrachtete.

1 Das Sakramentar befindet sich im Besitz des Seminars von Autun (Ms. n. 19 bis). Delisle, Mém. 96. Abbildungen der Miniatur schon bei Gerbert, Vetus liturgia alleman. I 264, und Realenc. II 556; seitdem genauer bei $\mathrm{R}$ oh. I, pl. VII und neuestens bei Wilp., Cap. 77.
2 Bibl. nat. f. lat. 9428. Abbildungen bei Cahier, Miniatures $116 \mathrm{ff}$ und Roh. I, pl. IV ff. Man vergleiche unter anderm auch die Reliefs des Palliotto in S. Ambrogio zu Mailand (Abbildung bei Roh. I, pl. VIII). Über das Alter des Palliotto $\vee$ gl. Stimmen aus Maria-Laach LVII (1899) 311 ff. 


\section{DIE ALBE IN VORKAROLINGISCHER ZEIT.}

Die Schwierigkeit, welche diese Epoche für die Geschichte der Albe bietet, betrifft nicht den Nachweis, dafs man damals bei der Liturgie sich ïberhaupt einer Tunika berlient habe, sondern dafs bereits eine liturgische, d. i. einzig für die gottesdienstlichen Verrichtungen bestimmte Tunika in Gebrauch gewesen sei, die bei andern Gelegenheiten zu benutzen als ungeziemend und unstatthaft galt. Nicht jedes Gewand, das beim Gottesdienst getragen wird, ist ja darum auch schon ohne weiteres ein liturgisches Gewand. Andernfalls würde ja auch die Soutane oder die vestis talaris, mit welcher der Priester bei der Messe unter der Albe nach der Vorschrift des römischen Missale bekleidet sein soll, zur Sakralgewandung zählen. Was ein Obergewand (Kasel, Dalmatik) oder Untergewand (Tunika) zu einem Sakralkleid macht, ist die ausschliefliche Bestimmung für liturgische Funktionell. Aber auch aus dem L'mstand, daf das Obergewand liturgischen Charakter hat, folgt noch nicht sofort das gleiche für das Untergewand, da ein liturgisches Obergewand keineswegs notwendig als Ergänzung ein sakrales Untergewand fordert.

Daßs es von jeher und nicht bloß erst seit dem 4. Jahrhundert Brauch war, bei der Feier der Liturgie sich einer Tunika zu bedienen, ist zu selbstverständlich, als daßs solches auch nur im geringsten zweifelhaft sein könnte. War doch die Tunika das allernotwendigste und unentbehrlichste Gewandstück, das Allerweltskleid, dessen sich jedermann, hoch wie niedrig, arm wie reich im gewöhnlichen Leben zu bedienen pflegte. Ein Obergewand trug. man nicht immer, namentlich nicht zu Hause oder bei der Arbeit. Auf das Untergewand aber verzichtete, abgesehen von den Leuten, deren Beschäftigung eine Beschränkung der Kleidung auf den Leibschurz orler etwa einen um den Unterkörper geschlungenen Mantel mit sich brachte, kaum jemand anders als Bettler und gewisse Philosophen. Freilich sollte man, nach den zahlreichen nackten oder halbbekleideten Figuren der antiken Bildwerke zu urteilen, glauben, eine Tunika sei bei den Alten nicht eben ein großes Bedürfnis gewesen. Indessen galten die Grundsätze der antiken $̈$ sthetik glücklicherweise nicht auch im Alltagsleben. Man trug sogar, wenn die Witterung oder die körperliche Verfassung solches erheischten, eine innere und eine äufere Tunika oder gar mehrere. So wissen wir z. B. aus Sueton, daf Augustus sich im Winter außer mit einer Toga aus dickem Stoff noch mit vier Tuniken, einem Hemd und einer Wolljacke bekleidete ${ }^{1}$. Mögen auch die meisten genügsamer gewesen sein, die paradiesischen Zustände, wie sie auf den Bildwerken uns entgegentreten, entsprachen gewif nicht dem realen Leben. Überall, wo dieses dargestellt wird, fehlt die Tunika nimmer. Daf insbesondere in kälteren Gegenden ein Untergewand dringendstes Bedürfnis war und zum eisernen Bestand der Kleidung gehörte, liegt auf der Hand.

Die Anschauung der Christen hinsichtlich des Gebrauches der Tunika erhellt deutlich aus den Fresken der römischen Katakomben. Es sind nur ganz bestimmte Persönlichkeiten, wie z. B. Jonas, oder allegorische Wesen, welche ohne Kleider auftreten. Blof ein Lendenschurz kommt einmal bei Johannes dem Täufer und einigemal bei Daniel vor ${ }^{2}$. Die sog. Philosophentracht, das unmittelbar ohne Tunika über dem Leibe getragene Pallium, hei 
welchem der rechte Arm, die rechte Schulter und teilweise auch die rechte Seite des Körpers sichtbar blieb, kommt nur sehr vereinzelt ror, und zrar außer bei dem Propheten Isaias auf der bekannten Darstellung der Mutter Gottes in S. Priscilla auffallenderweise blol 3 in zweien der sog. Sakramentskapellen in S. Callisto ${ }^{1}$. Es sind dort - und zwar entgegen der sonstigen Gewohnheit - Moses, Christus und ein Heiliger so dargestellt; dab hier das Obergewand ohne eine Tunika auftritt, mag eine Reminiszenz an Gepflogenheiten der profanen Kunst sein, wie eine solche auch sonst wohl in der altchristlichen Kunst sich bemerklich macht.

Im übrigen fehlt auf den Grabgemälden der Katakomben nie die Tunika. Dieselbe ist bald gegürtet, bald ungegürtet, bald kurz, bald länger, bald ärmellos, bald mit kurzen, bald mit langen Ärmeln versehen, bald eine exomis, welche die rechte Schulter freilief, bald von gewöhnlicher Form, je nachdem es dem Brauch der Zeit, in welcher die Bildwerke entstanden, oder dem darzustellenden Gegenstand entsprach . Dieselbe Wahrnehmung wie die Katakombengemälde gestatten im wesentlichen auch die andern christlichen Monumente der drei ersten Jahrhunderte. Unter solchen Umständen ist es klar, daß, wenn irgend jemand, dann sicher der christliche Liturg bei der Darbringung des heiligen Opfers stets, und nicht erst in nachkonstantinischer Zeit, sich einer Tunika bediente. So weitherzig und so wenig feinfühlend man auch in der antiken Welt in mancher Beziehung in Sachen des Anstandes gewesen sein mag, es wäre unter normalen Verhältnissen unzweifelhaft als grobe Ungehörigkeit betrachtet worden, hätte ein Bischof nur in Pallium ohne Tunika, die rechte Seite mitsamt der Schulter und dem Arm entblößst, den heiligen Dienst verrichtet.

Wirklich gewahren wir auf den freilich wenig zahlreichen liturgischen Darstellungen, welche uns auf den Sepulkralgemälden begegnen, unter der Pänula bzw. dem Pallium überall die Tunika, so bei der Einkleidung einer gottgeweihten Jungfrau, in S. Priscilla an der alten Via Salaria ${ }^{3}$ und einigen Taufdarstellungen ${ }^{4}$. Auch die Statue des Hippolytus, um von andern Darstellungen, wie z. B. den Papstbildern auf den Goldgläsern abzusehen, zeigt eine Tunika unter dem Pallium. In der sog. Konsekrationsszene ${ }^{5}$ in einer der Sakramentskapellen von S. Callisto soll allerdings ein Priester in der Philosophentracht auftreten ${ }^{6}$. Allein gibt denn wirklich dieses Fresko die Darstellung der Konsekration wieder? Weist nicht vielmehr der Umstand, daf auf dem Tisch, neben welchem rechts die weibliche Orans, links die männliche Person im Philosophengewand steht, nur Brot, nicht aber auch Wein sich findet, samt der Haltung und dem Gestus des sog. Liturgen die Deutung des Bildes auf den Wandlungsmoment entschieden ab? Es kann das Fresko nicht einmal als realistische Wiedergabe der Austeilung der heiligen Kommunion gelten. Denn auch in diesem Falle würde man auf dem Tische neben der Brotsgestalt die des Weines erwarten, da ja ehedem die Himmelsspeise den Gläubigen unter beiden Gestalten gereicht wurde. Die Darstellung hat vielmehr, wie auch die Orans beweist, durchaus einen symbolischen Charakter. Sie will zum Ausdruck bringen, dafs der Heiland der gläubigen Seele, hier durch die Verstorbene als Orans symbolisiert, sich selbst als das Brot des Lebens zur Speise gibt. Darum auch der Fisch neben dem Brote auf dem Tische. Oder aber es soll, wie Wilpert meint, in treier Weise natürlich, Christus dargestellt werden, wie er das Wunder der Vermehrung an einem Fisch und einem Laib Brot wirkt. Daßs

1 Ebd. 11 bzw. 19 u. 74.

2 Wilp., Kat. $65 \mathrm{ff}$ und Gew: $1 \mathrm{ff}$.

${ }^{3}$ Abbildung in Wilp., Die gottgeweihten Jungfrauen Tl 1 und besser in Wilp., Kat. Taf. 79 .
Wilp., Kat. 260.

${ }^{5}$ Abbildungen bei Kraus, Roma sotterranea ${ }^{2}$ T'af. VIII, und G a $r$ r. Thf. 7, besser bei W ilpert, Kat. Taf. 41 und Sakr. 17.

C Kraus a. a. O. 314 f; Realene. II 179. 
hierbei der Fisch und das Brot auf einem Tisch liegen, soll andeuten, daf durch das Wunder symbolis ch die Konsekration dargestellt werde ${ }^{1}$.

Allerdings ist richtig, daß etwa in der Zeit von 150 bis 250 hie und da bei Geistlichen die Philosophentracht, d. i. ein Pallium ohne Untertunika, in Gebrauch kam. Am häufigsten scheint das im Osten geschehen zu sein, wenngleich wir nur von wenigen bestimmten Fällen wissen. So nahm z. B. der alexandrinische Presbyter Herakles die Philosophengewandung an ${ }^{2}$. Im Abendlande dürfte die Philosophentracht kaum Verbreitung gefunden haben ${ }^{3}$.

Jedenfalls folgt daraus, daf einige Geistliche im Alltagsleben sich des Palliums ohne Tunika bedienten, nicht auch schon, dafs dieselben je in diesem Anzug an den Altar getreten seien. Lnd wenn zuletzt die absolute Möglichkeit, lafs der eine oder andere das aus falsch verstandener Aszese oder aus Philosophendünkel wirklich getan, nicht verneint werden kann - denn was ist nicht alles schon vorgekommen -, ein Beweis, daß tatsächlich solches geschehen sei, ist nicht zu erbringen. Es ist deun doch allzu

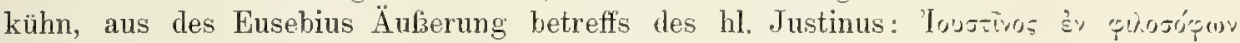

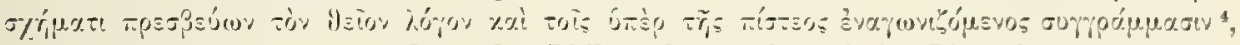
auf eine liturgische Verwendung der Philosophentracht bei der Liturgie zu schliefen. Abgesehen davon, daßs es bekanntlich mehr als fraglich ist, ob Justinus überhanpt je Priester war, sind denn doch das Wort Gottes verkünden und das heilige Opfer darbringen zwei grundverschiedene Dinge. Noch heute kann man das erste ohne alle sakrale Kleidung tun. Wirklich will Eusebius anch nur sagen, der hl. Justinus habe als Philosoph die göttliche Wahrheit gepredigt.

Als der hl. Cyprian († 258) zum Tode geführt wurde, war er nach den Prokonsularakten mit einer Untertunika (linea), einer Obertunika (dalmatica, tunica) und dem Mantel (lacerna, byrrus) bekleidet ${ }^{5}$. Es war das, wie aus dem Zusammenhang hervorgeht, seine gewöhnliche Kleidung. Es liegt aher auf der Hand, daf der Heilige bei der Feier der heiligen Geheimnisse nicht weniger Gewänder angezogen hat wie im Alltagsleben.

Daßs man also in vorkonstantinischer Zeit auch eine Tunika bei der Feier der heiligen Geheimnisse getragen, kann vernünftigerweise nicht im geringsten bezweifelt werden. Da jedoch eine Tunika, welche beim Gottesdienst gebraucht wird, noch nicht darum allein schon das ist, was wir eine liturgische Tunika nennen, so bleibt die Frage, ob es damals auch bereits eine eigentlich liturgische Tunika gegeben habe.

Die einzigen Stellen von einiger Bedeutung, auf welche man sich zu Gunsten einer bejahenden Antwort etwa berufen könnte, sind erstens die Worte des hl. Irenäus, in denen er den poderes, die Talartunika des Menschensohnes (Offb 1, 13), „etwas Priesterliches“, aliquid sacerdotale nennt6, und dann das bekannte, im Liber Pontificalis Papst Stephan I. (255-257) zugeschriebene Dekret, wonach die vestes sacratae nur in der Kirche, nicht aber im Alltagsleben getragen werden sollten ${ }^{7}$. Allein der hl. Irenäus be-

1 Über die sog. Konsekrationsszene in S. Callisto vgl. namentlich Wil p., Sakr. $15 \mathrm{ff}$ sowie Kat. 289.

${ }^{2}$ Euseb., Hist. eccl. 1. 6, c. 19 (M g. $20,569)$.

${ }^{3}$ So adoptierte Tertullian den Philosophenmantel, wie aus seiner Schrift De pallio erhellt, einer von Witz und Spott überfließenden Verteidigung des pallium. Übrigens ist die Behauptung, Tertullian empfehle dasselbe als für den christlichen Priester einzig passend (Kraus, Roma sotterr. 314), durchaus unBraun, Die liturgische Gewandung. zutreffend. In der ganzen Schrift findet sich davon kein Wort. Zudem verteidigt Tertullian keineswegs schlechthin die Philosophentracht im Sinne eines pallium ohne Tunika, wie aus c. 1 u. 5 (M. 2, 1084 1102) hervorgeht. Er will nur keine Tunika, die aufgeschïrzt und gegürtet werden müßte.

4 Euseb., Hist. eccl. 1. 4, c. 11 (M g. 20, 329).

5 C. 5 (Corp. SS, eccl. III, app. cXIII).

' Adv. haer. 1. 4, c. 20, n. 11 (M g. 7, 1040).

${ }^{7} \mathrm{Duch}$., L. P. I 154. 
zeichnet allem Anschein nach jenen poderes als „etwas Priesterliches" lediglich im Hinblick auf die Talartunika des jüdischen Priestertums; denn er fiigt ummittelbar an: "Und darum hat Moses nach dieser Weise den Hohenpriester bekleidet." Was aber das angebliche Dekret Stephans I. anlangt, so ist es sehr fraglich, ob dasselbe wirklich von diesem herrührt oder ob es nicht vielmehr erst aus nachkonstantinischer Zeit stammt.

Auch im vierten und den nächstfolgenden Jahrhunderten fehlt es noch sehr an den wünschenswerten Belegen für die Verwendung einer eigentlich liturgischen Tunika. Was zunächst die Monumente anlangt, so lassen allerdings die Darstellungen von Päpsten, Bischöfen, Priestern und Diakonen auf den römischen und ravennatischen Monumenten des 6. und 7. Jahrhunderts deutlich unter der Planeta oder Dalmatik eine Tunika erkennen; allein sie sagen uns nicht, daf es sich bei dieser um ein wirklich liturgisches Gewand und nicht um die Alltagstunika handelt.

Was aber die schriftlichen Zeugnisse betrifft, so mus man sehr wohl zusehen und untersuchen, ob in ihnen wirklich von einer liturgischen Tunika im Sinne unserer Albe, von der Tunika der gewöhnlichen Kleidung oder von einer Obertunika nach Art der Dalmatik die Rede ist. Am ehesten scheint noch von einem der späteren Albe analogen Gewand die Rede zu sein, wenn im Brief des hl. Hieronymus an Heliodor ${ }^{1}$ erzählt wird, der Presbyter Nepotian habe sterbend seinem Onkel den Auftrag gegeben, seine Tunika, die er "im Dienste Christi“ getragen, Hieronymus als Andenken zu ïbersenden. Und doch wird auch hier bei näherem Zusehen die Sache zweifelhaft. Denn es ergibt sich weder aus den Worten Nepotians noch aus dem Zusammenhang, ob dieser das fragliche Gewand bei seinen Amtsverrichtungen bloßs verwendet hatte wegen seiner besseren Beschaffenheit oder, weil es als unstatthaft galt, im Altardienst sich anderer Kleider als solcher zu bedienen, die ausschlieblich für die liturgischen Amtshandlungen bestimmt waren. Das letzte mag freilich das wahrscheinlichere sein. Denn die Anschauung, welche Hieronymus in seiner Erläuterung von Ez 44, 19 in die Worte kleidet: „Hieraus lernen wir, daßs wir nicht mit den alläglichen und mit beliebigen, durch die Verwendung im gewöhnlichen Leben beschmutzten Kleidern in das Allerheiligste eintreten, sondern nur mit reinem Gewissen und in reinen Gewändern des Herrn Geheimnisse in den Händen halten dürfen.... Die göttliche Religion hat ein anderes Gewand im heiligen Dienst, ein anderes im Alltagsleben" 2, war zweifelsohne nicht blob die des Schreibers, sondern auch die seines Schülers und geistigen Sohnes Nepotian.

VerhältnismäßBig früh wird uns aus Gallien von einer liturgischen Tunika der Diakone und Lektoren berichtet. Es ist von ihr schon bei Gregor von Tours, in den Kanones der Narbonner Synode von 589, ja bereits in den neuerdings dem 5. Jahrhundert zugeschriebenen Statuta ecclesiae antiqua die Rede. Sie hieb alba und war nach den Statuta zweifellos ein eigentlich liturgisches Gewand, war aber wohl eher ein Gegenstück der römischen Dalmatik als eine Tunika von der Art unserer Albe, weshalb auch erst bei der Dalmatik näher auf sie eingegangen werden soll. Unsicher ist, seit wann es in Gallien bei den Priestern und Bischöfen eine liturgische Tunika gegeben hat. Um das Ende des 4. Jahrhunderts scheint die Tunika derselben noch nicht den Charakter eines sakralen Gewandes besessen zu haben. Sulpicius

${ }^{2}$ Ep. 60, n. 13 (M. 22, 597). ${ }^{2}$ In Ezech. 1. 13, c. 44 (M. 25, 437). 
Severus erzählt nämlich, als eines Tages der hl. Martin von Tours sich bereit gehalten habe, an den Altar zu treten, um das heilige Opfer darzubringen, sei ein Bettler in die Sakristei gedrungen und habe dringend um ein Gewand zum Schutz gegen den Frost gebeten. Darauf habe der Heilige unter seinem Amphibalus, einer Glockenkasel, seine Tunika ausgezogen und dieselbe dem Armen gereicht, damit er sich damit bekleide. Dann habe er den Archidiakon gerufen und ihm befohlen, eine Tunika für einen Armen, worunter der Heilige sich selbst verstanden, herbei zu besorgen. Unwillig habe jener, da er vom Sachverhalt keine Kenntnis gehabt, um weniges Geld eine schlechte, rauhe und schäbige Tunika in der Nachbarschaft gekauft und dem Bischof gebracht. Dieser habe ihn herausgehen heißen, alsbald das Gewand angezogen und sich so zum Altar begeben ${ }^{1}$. Hätte, so sollte man glauben, zur Zeit des hl. Martin in Gallien die Tunika einen ausgesprochen liturgischen Charakter besessen, so hätte der Heilige schwerlich so handeln können noch auch gehandelt, wie es Sulpicius Severus berichtet.

Es mag sogar im dortigen Ritus die priesterliche Tunika noch eine gute Weile länger nicht zu den eigentlich sakralen Gewändern gehört haben. Denn es ist auffällig, dafs die gallikanische Mefarklärung sie bei der Deutung der liturgischen Kleider vollständig unberücksichtigt läßst, ja sie überhaupt nur ganz zufällig und nur ganz nebenher nennt ${ }^{2}$.

Auf den Stand der Dinge in Nordafrika wirft ein bezeichnendes Licht, was von dem hl. Fulgentius von Ruspe dessen Biograph berichtet. Der Heilige, so erzählt dieser, habe in der Tunika, in welcher er geschlafen, das heilige Opfer dargebracht und gesagt, zur Zeit des Opfers solle man lieber die Herzen als die Kleider wechseln ${ }^{3}$. Die Handlungsweise des Bischofs war, wie aus dem Zusammenhang hervorgeht, nicht das Gewöhnliche; man kann sie als aszetische Sonderbarkeit bezeichnen, sie setzt aber ersichtlich voraus, daf es zu Lebzeiten des hl. Fulgentius, also im Beginn des 6. Jahrhunderts, in der afrikanischen Kirche noch keine eigentlich liturgische Tunika gab, wenigstens nicht allgemein und nicht kraft Vorschrift oder bindender Gewohnheit. Wäre ihr sakraler Charakter dort schon über allen Zweifel erhaben gewesen, hätte der Heilige gewiß̧ bei der Messe sich nicht seiner gewöhnlichen Tunika bedient.

Aus Spanien besitzen wir nur Nachrichten über eine liturgische Albe der Diakone und eine sakrale Tunika der Subdiakone". Dak es in Irland im 7. Jahrhundert eine priesterliche liturgische Tunika gab, dürfte vielleicht aus dem Gebet des Stowe-Missale, welches der Priester bei der Vorbereitung auf die heilige Messe zu sprechen hatte, gefolgert werden. „Ich bitte dich, allerhöchster Gott Sabaoth, heiliger Vater, du wollest mich mit der Tunika der Keuschheit gnädigst umgeben und meine Lenden mit dem Gïrtel deiner

1 Dialog. 1. 2, c. 1 (Corp. SS. eccl. I 180).

2 M. 72, 98: Probibet autem manica tonica (= tonicae), ne appareat vile vestimentum (wohl die Alltagskleidung). In der Biographie des hl. Cäsarius von Arles († 542) wird erzählt, es habe der Heilige eines Tages einem Armen, da er sonst nichts gehabt, casulam quam processoriam habebat, albamque paschalem mit der Weisung gegeben, dieselben an jemanden aus dem Klerus zu verkaufen ( $\mathrm{C} y$ - prian., Episc. Tol., Vita S. Caesar. 1. 1, c. 4 [M. 67, 1017]). Der letzte Umstand und die Wendung: quam processoriam habebat, lassen wohl in jenen Kleidern wirklich liturgische Stücke erkennen, doch ist unklar, ob alba paschalis eine Obertunika, die gewöhnliche Tunika oder (mit Ergänzung von casula) eine Kasel bedentet.

3 Vita S. Fulgentii c. 18, n. 37 (M. 65, 136).

* Näheres auch über sie unter Dalmatik. 
Liebe umschliefien" usw., so lautet dasselbe ${ }^{1}$. Es scheint darauf hinzudeuten, daf der Priester, während er dieses Gebet sprach, sich mit einer eigenen, nur für die gottesdienstlichen Funktionen bestimmten Untertunika bekleidete.

Zu Rom muß es eine liturgische Tunika im Sinne der heutigen Albe schon eine geraume Weile vor dem 6. Jahrhundert gegeben haben. Denn das vorhin erwähnte angebliche Dekret Papst Stephans I. gibt unzweifelhaft den liturgischen Brauch wieder, wie er zur Zeit der Abfassung des ersten Teiles des Papstbuches, d. i. in dem Anfange des 6. Jahrhunderts, bereits seit langem bestanden haben muf. Andernfalls hätte ja der Schreiber der Vita Stephani es unmöglich als von diesem Papst herrührend hinstellen können. Freilich spricht das Dekret nicht ausdrücklich von der Albe, sondern begnügt sich, generell den Gebrauch der vestes sacratae im Alltagsleben zu verbieten. Indessen lautet es so allgemein und ohne jede Einschränkung, dafs es wohl von der Gesamttracht verstanden werden muß, in welcher die an der Feier der Liturgie beteiligten Geistlichen am Altare erschienen, also nicht blob von der Planeta, dem mantelförmigen Obergewand, und der Dalmatik, der Obertunika des Papstes und der Diakone, sondern auch von der Tunika, dem nach römischem Begriff zur Planeta und Dalmatik unumgänglich notwendigen Untergewand, dem nie fehlenden, weil unentbehrlichsten Teil eines anständigen Anzuges.

Nach der um 500 entstandenen Vita S. Silvestri könnte es sogar scheinen, als $\mathrm{ob}$ es bereits im 4. Jahrhundert zu Rom eine liturgische Albe gegeben habe. Dieselbe erzählt: Zur Zeit dieses Papstes sei ein heiliger Bischof Pamphiliens, Euphrosinus mit Namen, nach Rom gekommen und habe dort am Altar ein colobium, eine ärmellose, wallende Tunika, getragen, die ehedem dem Apostel Jakobus gehört habe. Daraufhin hätten dann auch Silvester, seine Presbyter und seine Diakone Kolobien in Gebrauch genommen, und so sei es geblieben unter Markus, Julius und Liberius. Da aber dann die Nacktheit der Arme getadelt worden sei, habe man die Kolobien mit Dalmatiken vertauscht. Visum est enim melius huic proposito convenire, quod accuratius magis aspectibus placere valeat populorum ${ }^{2}$.

Indessen ist die Silvesterbiographie zu voll des Fabelhaften, um als zuverlässig gelten zu können ${ }^{3}$. Dann scheint es sich in ihr nicht sowohl um eine Unter-wie um eine Obertunika zu handeln. Ferner steht die obige Erzählung im Widerspruch mit der Notiz des L. P., dem zufolge bereits Silvester bestimmte, es sollten sich die Diakone der Dalmatik bedienen. Auferdem ist es unzutreffend; wenn die Vita auch den Presbytern die Dalmatik zuweist, da diesen nach römischem Brauch das Gewand nie zustand. Endlich redet die Biographie nicht sowohl von dem liturgischen Charakter als der Form der Tunika. Ihre Angaben sind also für den Nachweis, daf es bereits im 4. Jahrhundert zu Rom eine liturgische Tunika im Sinne der späteren Albe gegeben habe, ohne Belang.

Ausdrücklich genannt wird die Albe als Bestandteil der römischen Sakraltracht zuerst in dem 1. Ordo Mabillons.

Seit dem 9. Jahrhundert bietet die Geschichte der Albe, was deren Charakter als liturgisches Gewand und deren Verwendung im Kultus anlangt,

1 Propst, Die abendländische Messe 44. ¿her das Alter des Stowe-Missale vgl. oben S.7. Dieses Gebet findet sich auch im Sacramentarium Ambros. (ed. Pamelius 293) und in manchen späteren Missalien. Nach einem Pontifikale von Troyes (s. XI) bei Mart. 1. 1, c. 4, art. 12 , ordo 6 ; I 190 und einem Sakramentar von Amiens (s. IX; Bibl. nation. f. lat. 9432 , f. 10) betet es der Bischof, wenn er die bischöfliche Tunika anzieht. Nach dem Cod. Vatic. 1. 4770 (s. X-XI) spricht der Priester es bei Anlegung des Gürtels. Propst (a. a. 0.59 ) scheint anzunehmen, daf das Gebet aus Rom stammt.

${ }^{2}$ D uch., L. P. I 189.

$s$ Ebd. I, Introduct. cxIv ff. 
bis gegen das 13. Jahrhundert hin kaum etwas Bemerkenswertes. Die Angaben, die wir über dieselbe bei Pseudo-Beda, Pseudo-Alkuin, Johannes von Avranches und in sonstigen Quellen finden, decken sich ganz mit dem, was wir von ihr durch Hraban, Amalar usw. erfuhren. Von einigem Interesse ist zuletzt nur eine Notiz bei Rupert von Deutz ${ }^{1}$, die uns belehrt, daß in manchen Klöstern von der Regel des hl. Benedikt an gewissen Festen nicht nur die beim Gottesdienst unmittelbar tätigen Kleriker, sondern überhaupt alle, die im Chor safien, eine Albe trugen. Die Sitte bestand nach den Consuetudines Cluniacenses z. B. bei den Cluniacensern ${ }^{2}$. Andeutungsweise spricht von ihr auch Lanfrank in einem Briefe an Johannes von Avranches?. Von den Alben, welche an diesen Tagen von allen Klosterinsassen, auch den infantes, getragen wurden, hiebien die betreffenden Feste schJechthin festa in albis", der Ausdruck festa in albis aber galt hinwienlerum als gleichbedeutend mit "hohe Feste“. Es ist nicht so unwahrscheinlich, dafs diese Gepflogenheit bereits schon im 9. Jahrhundert bestand. Wenigstens scheinen die 260 Alben, welche Angilbert für das Kloster Centula beschaffte, auf einen ähnlichen Brauch hinzuweisen. Daf selbe lediglich für die Priester und ihre Ministri bestimmt waren, dürfte die grofe Zahl der Alben ausschliefen.

Auch die Geschichte der Albe seit dem 13. Jahrhundert bringt, was den Gebrauch des Gewandes bei den gottesdienstlichen Funktionen anlangt, keinen wesentlichen Wechsel im bisherigen Stand der Dinge. Die einzige Veränderung von Bedeutung, die in dieser Hinsicht seit etwa 1150 vor sich geht, besteht darin, dafs sich für eine Anzahl von priesterlichen Funktionen und als liturgisches Gewand der Minoristen anstatt der Albe allmählich ein Ersatz derselben, das Superpelliceum, einbürgerte. WVir müssen auf diese Sache bei Behandlung des Superpelliceums näher eingehen und können deshalb hier von einer Schilderung dieses Wechsels Abstand nehmen. Wir bemerken daher blok, daf die Albe bereits im 15. Jahrhundert für gewöhnlich nur noch bei der Messe und etwaigen mit derselben in Verbindung stehenden Funktionen getragen zu werden pflegte. Sehr belehrend ist in Bezug auf den damaligen römischen Brauch der 15. Ordo Mabillons.

\section{FORM DER ALBE.}

Auf den liturgischen Darstellungen der Katakombenfresken tritt die Tunika des Liturgen, von der wir allerdings nicht wissen, ob sie ein sakrales Gewand darstellen soll, in verschiedener Form auf. Der taufende Priester in der Sakramentskapelle trägt, wie es scheint, eine mittelkurze, geschürzte, mit Halbärmeln versehene Tunika. Auf der sog. „Einkleidung einer gottgeweihten Jungfrau " finden wir dagegen bei dem Bischof eine lange, weitärmelige, ungegiirtete Tunika, ähnlich der späteren Dalmatik. Es wäre in der Tat unzutreffend, wollte man annehmen, es habe sich der Liturg in den ersten Jahrhunderten einer bestimmten Form der Tunika beim Gottesdienst bedient. Die Tunika, die er unter dem Obergewand trug, entsprach in Bezug auf Form und Beschaffenheit unzweifelhaft dem gerade herrschenden Brauch.

1 De off. div. 1. 2, c. 23 (M. 170, 54).

g L. 1, c. 11 (M. 149, 653). Vgl. M a rt, De antiquis monach. rit. 1.3, c. $4, n .28$; c. 16, n. 227 ; c. 22 , n. 1 ; 1.4 , c. 1, n. 9 ; c. 2 , n. 2 ; c. 3 , n. 11 ; с. 5 , n. 1 und sonst;
IV 97145148160178186189194 . Constret. Farfens. (ed. A lbers) 43577086 .

${ }^{3}$ Ep. 13 (M. 150, 520).

4 Vgl. z. B. den Auszug aus dem Re-istrum Roffense in Revue 1887, $332 \mathrm{ff}$. 
Die römische Tunika war in der Regel gegürtet; eine Ausnahme bildete die tunica laticlaria der Senatoren. Die afrikanische Tunika wurde ursprünglich nicht aufgeschürzt. wie aus Tertullians Schrift De pallio ${ }^{1}$ erhellt. Die gegürtete Tunika erhielten die Afrikaner von den Römern. In der ersten Liaiserzeit hatte der Leibrock in der Regel kurze Ärmel, falls er nicht ganz ärmellos war. Wir haben ihn uns nach den Bildwerken aus dieser Epoche als eine Art rou weitem, unten offenem Sack vorzustellen, der oben in der Mitte einen Durchlaf für den Kopf besab, oben an den Seiten mit einem Schlitz zum Durchstecken der Arme versehen war und bei Erwachsenen etwa eine Breite ron 1,00 bis 1,50 $\mathrm{m}$ haben mochte (vgl. Bild 14, S. 47). Durch die Gürtung bildete sich bei ihm so etwas wie Ärmel (Bild 25). Wir begegnen dieser Tunikaform auf den Monumenten äußerst häufig, und zwar finden wir sie bei

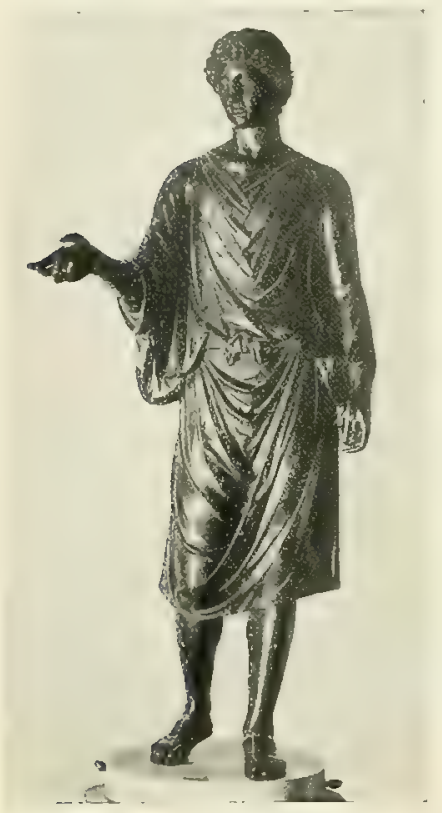

Bild 25. Sog. Camillus in sackförmiger, gegürteter Tunika. Personen aus allen Ständen, ein Beweis für ihre weite Verbreitung.

Die tunica manicata oder manuleata, Iangärmelige Tunika, kommt auf den Fresken der Katakomben in den beiden ersten christlichen Jahrhunderten sehr selten und nur bei bestimmten Personen, namentlich den Magiern und den babylonischen Jünglingen, also besonders bei Orientalen, vor ${ }^{2}$. Auch auf den Profanmonumenten dieser Zeit hat die Tunika für gewöhnlich entweder keine oder nur kurze Ärmel. Langärmelige Tuniken zu tragen, galt eben für Männer damals noch als ungeziemend. Bald nahm die nimmer rastende Mode den langen Ärmeln freilich das Unschickliche; in der späteren Kaiserzeit waren langärmelige Tuniken sehr gewöhnlich. Schon Tertullian will, daß die Ärmel weder zu kurz noch an den Händen zu eng seien, nec brachiis parcae, nec manibus arctae ${ }^{3}$. Zur Zeit des hl. Augustinus galt es für Leute von Stand sogar als ungeziemend und schimpflich, kurzärmelige zu tragen. Talares et manicatas tunicas habere, apud Romanos veteres flagitium erat, nune autem honesto loco natis, cum tunicati sunt, non eas habere flagitium est ${ }^{4}$.

Was die Länge des Gewandes anlangt, so reichte die Tunika in der ersten Kaiserzeit bei den Mämnern regelmälig nur bis mitten vor das Knie, jedenfalls aber nicht weit über dasselbe ${ }^{5}$. Lang herabwallende Tuniken zu tragen, galt als weibisch und unpassend. Ein Wechsel konnte aber bei der zunehmenden Verweichlichung auch hier nicht ausbleiben und es scheint, dal rlie Kaiser selbst mit gutem Beispiel vorangingen. Im 3. Jahrhundert hatte die Sitte, wonach auch Männer sich lang herabfallender Tuniken bedienten - die Dalmatik ist eine Abart derselben - , bereits eine weite Verbreitung gefunden, im 4. war sie nach rem angeführten Zeugnis des hl. Augustinus bei Leuten

1 c. 1 (MI 2, 1081).

$2 \mathrm{Wilp.,} \mathrm{Gew.} 4$ und Kat. 67.

De píllio c. 1 (M. 2, 10:4).
4 De doetr. christ. 1. 3, c. 12, n. 20 (M.

$34,74)$.

5 Vgl. die Monumente aus jener Zeit. 
von Stand herrschend. Auf dem Triumphbogen Konstantins sind der Kaiser wie die Vornehmen, die in der Toga zur Entgegennahme der Geldspende vor dem Kaiser stehen, mit langer Tunika versehen. Treffliche Beispiele für. den Gebrauch der Talartunika liefern auch die Konsulardiptychen, namentlich das noch dem 4. Jahrhundert angehörende des Rufinus Probianus. Auch mit dem Stoff, ans dem die Männertuniken angefertigt wurden, ging im Laufe der Zeit eine Veränderung vor sich. Trsprünglich wurden sie nach römischem Brauch für gewöhnlich aus ungefärbter, weifer Wolle gemacht; Leinwand scheint bei ihrer Anfertigung erst im 3. Jahrhundert eine ausgedehntere Anwendung gefunden zu haben. Gegen Ende des 4. Jahrhunderts aber bestand die Tunika meist aus Linnen und nur noch die äußeren Kleider aus Wolle: Interiora sunt enim linea vestimenta, lana exteriora ${ }^{1}$, sagt der hl. Augustinus.

Es ist wohl nicht zweifelhaft, daf die Geistlichen, seitdem die Talartunika in Gebrauch gekommen war, sich wenigstens heim Gottesdienst dieser Art von Tunika zu bedienen pflegten. Namentlich darf das mit aller Bestimmtheit für die nachkonstantinische Zeit, als die Kirche den Frierlen ellangt hatte, frei auftreten, sich ungehindert entfalten und die Opferfeier mit dem geziemenden Glanz ungeben durfte, als Regel angesehen werden. Die wallende, die Blöfe der Arme bedeckende tunica talaris manicata mufte der hohen Würde der christlichen Liturgie wie des christlichen Liturgen und seiner Gehilfen am entsprechendsten erscheinen. War ja doch auch eine Talartunika auf Gottes Geheifs von Moses dem alttestamentlichen Priester als Kultgewand vorgeschrieben worden in gloriam et decorem, zur Zier und zum Schmuck ${ }^{2}$. Es ist wohl keine Übertreibung der Einwirkung der alttestamentlichen Kulttracht auf die Bildung der neutestamentlichen, wenn man der Erinnerung an den Poderes des Alten Bundes auch irgend einen Einfluf auf die Annahme der Talartunika für den christlichen Kultus seitens der Geistlichen zuschreibt. Heißt es doch in der Kanonessammlung des hl. Martin, Bischof von Braga († 580): „Die Geistlichen sollen nicht mit wohlgepflegtem Haar ihren Dienst verrichten, sondern mit geschorenem Haupte und sichtbaren Ohren, und nach dem Vorbilde Aarons eine Talartunika anziehen, auf dafi sie so mit dem für sie passenden Gewande ausgestattet sind." 3

Bei den Laien hielt sich die Talartunika auf die Dauer nicht im Gebrauch. Sie hatte für dieselben wirklich zu viel Unbequemlichkeiten und Schattenseiten. Die Mode machte darum, wie das auch sonst nicht selten vorkommt, eine rückläufige Bewegung, und man kehrte nach und nach zur kurzen Tunika zurück. Man hat das mit dem Hereinbrechen der germanischen Völker und Einflïssen des Auslandes in Verbindung gebracht. Ohne Grund. Bei einer großen, vielleicht der grösten Masse des Volkes, der arbeitenden Klasse und dem Militär, war die kurze Tunika, wie leicht begreiflich, überhaupt nie auker Brauch gekommen. Es ist daher nicht von nöten, den Blick auf die nordischen Barbaren zu richten, um den Wechsel der Mode zu erklären.

Lehrreich sind für den Stand der Dinge im 6. und 7. Jahrhundert namentlich die aus jener Zeit stammenden römischen und ravennatischen Mosaiken. Wo auf denselben Laien in realistischer Weise dargestellt werden, und es sich also nicht um einen blofien Typus oder etwa einen Heiligen im Kleide der Seligkeit handelt, gewahren wir bei denselben regelmäfig ein kurzes Unter- 
gewand. Ein treffliches Beispiel bietet namentlich die Tracht eines Justinian und seiner wie seiner Gemahlin Höflinge auf den Mosaiken in S. Vitale zu Ravenna.

Anders wie bei den Laien und im profanen Treiben verhielt es sich jedoch bei den Geistlichen und im Kultleben. Hier blieb die Talartunika. Was die Laien zu einer Änderung in der Tracht führen muste, fiel bei dem Kilerus weg. Zudem mußste die Talartunika vor wie nach als die für den Gottesdienst und die gottesdienstlichen Personen passendiste, weil würdigste Tunikaart erscheinen. Versuche von Klerikern, es im außierkirchlichen Leben und selbst in der Kirche den Laien gleichzutun, begegnen uns nur sehr vereinzelt und nur in Gallien und Spanien ${ }^{1}$.

Über die nähere Beschaffenheit der Talartunika, wie sie seit etwa den Tagen Konstantins beim Klerus in Gebrauch war - von ihrem liturgischen Charakter sehen wir hier ab -, erhalten wir vor dem 9. Jahrhundert aus schriftlichen Quellen keine Auskunft. Von den Monumenten aber geben uns darüber nur wenige Aufschluf und selbst diese blof einen recht kümmerlichen. In den meisten Fällen ist das Gewand, weil es sich um Darstellungen von Bischöfen und Diakonen handelt, auf den Bildwerken durch die Dalmatik so sehr verdeckt, daf wir im besten Falle bloß die Mündungen der Ärmel sehen. Vollständiger erscheint es auf den Mosaiken in S. Venanzo bei dem Presbyter Asterius und auf dem Fresko in der Katakombe des hl. Pontian beim hl. Vinzenz, die beide ohne Dalmatik abgebildet sind. Es reicht hier, wie die Dalmatik, bis zu den Füfen, ist aber statt mit weiten, mit engen Ärmeln versehen.

Die erste, freilich sehr unzureichende Beschreibung unserer Albe erhalten wir durch Hraban und Amalar im Beginn des 9. Jahrhunderts.

Nach Hraban ist das zweite Gewand, mit dem sich der Priester bekleidet, eine tunica linea, welche im Griechischen poderes, im Lateinischen aber talaris genannt werde. Den Grund dafür, dafs es aus Linnen verfertigt werde, findet er in der Symbolik desselben; wegen seiner Weiße sinnbilde es nämlich die Enthaltsamkeit und Keuschheit. Dadurch, dał es bis zu den Kinöcheln heruntergehe, ermahne es den Priester, bis zum Ende des Lebens guten Werken obzuliegen.

Eigentümlicherweise bezeichnet Hraban die linea der Priester des Neuen Bundes als eng anschliefsend. Amalar betont nämlich im Gegenteil ausdrücklich, daf die camisia, die man Albe nenne, d. i. das liturgische Gewand des christlichen Kultus, sich von der linnenen Tunika des jüdischen Opferdienstes durch die Weite unterscheide. Diese sei eng gewesen, jene aber sei weit.

Den mystischen Grund hierfür findet er in den Worten des Apostels: Non enim accepistis spiritum servitutis in timore. Die Juden waren durch das Gesetz eingeengt und wie in Knechtschaft geschlagen, wir aber, die der Sohn Gottes befreit, seien als Gotteskinder frei.

Das Bild, welches die Monumente des 9. Jahrhunderts von der Gestalt der Albe vermitteln, lúfit sie als eine schlichte Ärmeltunika, die bis zu den Füßzen reicht, erscheinen. Unten von ziemlicher Weite, hat sie meist sehr enge Ärmel, namentlich dann, wenn eine zweite Tunika bzw. eine Dalmatik darüber getragen wird. Man vergleiche die schon früher erwähnte Miniatur in der Bibel Karls des Kahlen

$1 \mathrm{Vgl}$. Synode von Agde (a. 506) can. 20 (Hard. II 1000); Synode von Mâcon (a. 583) can. 6 (M. G. Conc. I 156); den vorhin angeführten Kanon 66 der Kanonessammlung des hl. Martin von Braga und can. 11 des zweiten Konzils von Braga (a. 563) ( $\mathrm{H}$ ar d. III 351): Item placuit, ut lectores in habitu saeculari ordinati non psallant. 
(s. Titelbild), die Miniatur des Sakramentars von Autun (vgl. Bild 24, s. 62), die Reliefs der Rückseite des herrlichen Pallioto in S. Ambrogio zu Mailand u. a. Die Erklärung des Widerspruches, in dem sich Hraban und Amalar bezüglich der Albenweite befinden, ist wohl darin zu suchen, daf Hraban seine Angabe wörtlich aus Bedas Schrift De Tabernaculo 1. 3, c. 8, wo vom jüdischen poderes die Rede ist, abschrieb.

Von der Gestalt der Albe, wie sie dem Gewande im Beginn unseres Jahrtausends eignete, gewährt eine dem hl. Bernulf, Bischof von Utrecht $(†$ 1056), zugeschriebene und in der bischöflichen (jansenistischen) Kanzlei zu Utrecht aufbewahrte Prachtalbe ein Bild. Dem Stoff nach besteht sie aus ziemlich grober Leinwand; dabei ist sie jedoch, wie Bild 26 zeigt, am unteren Saum, um den Rand der Ärmel, um den Lopfuurchlafs usw. reich mit Goldborten besetzt ${ }^{1}$.

Die Liturgiker des 12. und 13. Jahrhunderts geben uns von der Albe eine ziennlich ausführliche Beschreibung. Was wir von ihnen uber

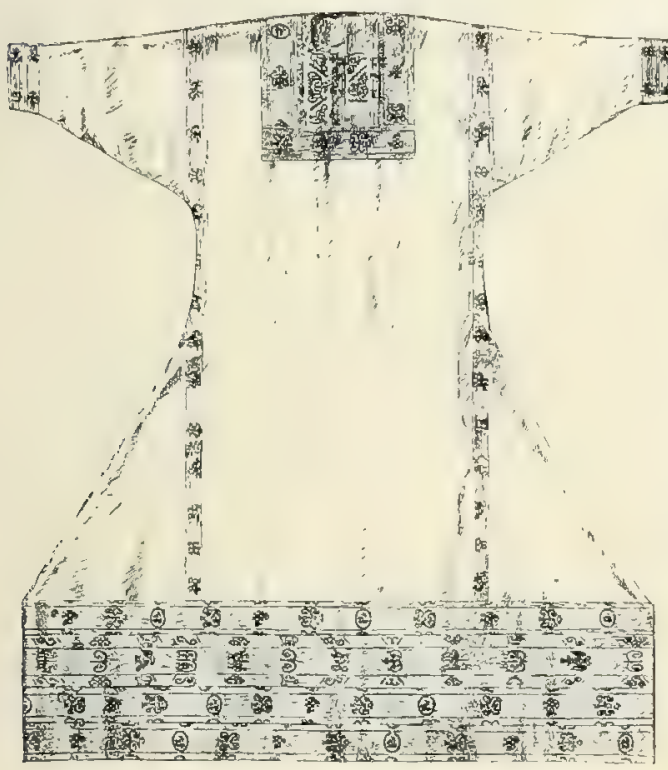

Bild 26. Albe des hl. Bernulf. Utrecht. die Gestalt und Beschaffenheit des Gewandes hören, ist etwa folgendes: Die Albe steigt bis zu den Knöcheln hinab; ihre Ärmel sollen eng sein. Oben ist sie mit einem caputium, d. h. einer Öffnung zum Durchstecken des Kopfes, versehen. An diesem caputium ${ }^{2}$ ist eine lingua, lingula, ligula ${ }^{3}$, d. i. eine Schliefe oder Bindevorrichtung, angebracht, welche zum Schlieken des Durchlasses dient. In der Mitte verengert sich die Albe, erweitert sich aber nach unten wieder und wallt in reichem Faltenfluf auf die Füße des Trägers hernieder.

Daß diese Schilderung der Albe des 12 . und 13 . Jahrhunderts zutreffend ist, zeigt Bild 27, S. 74. Es stellt eine Albe dar, welche als ein Andenken an ten hl. Thomas von Canterbury, der sich ihrer während seiner Verbannung bedient haben soll, mit andern Mefgewändern desselben Heiligen (Kasel, Stola, Manipel) in der Kathedrale von Sens autbewahrt wird.

1 Het Gildeboek (Utrecht 1877) 1 ff. Zu Mainz wurde in St Stephan bis gegen Ende des vorigen Jahrhunderts eine angeblich vom hl. Willigis herrührende Albe aufbewahrt. Sie wird von P. J. Gamans S. J. näher beschrieben (Kirchenschmuck XXVI [1869] 12). Interessant ist, was derselbe über den Schnitt des Gewandes sagt. Es war offenbar eine Albe von der Form, wie sie seit wenigstens dem Ende des ersten Jahrtausends bis in die Neuzeit hinein gang und gäbe war. Der Umstand, dak die Albe mit Paruren versehen war, scheint dafür zu sprechen, daß sie nicht dem hl. Willigis an- gehört hat, es sei denu, daß̧ diese Besätze nachtraglich angebracht wurden.

${ }^{2}$ Rohault de Fleury (VII 17) versteht unter dem caputium cum lingula un étroit capuce avec oreilles. Allein Honorius sagt ausdrücklich: caputium, $q u$ u $1 \mathrm{~b}$ a induitur... lingula, quae in caputio nunc innectitur, nunc resolvitur.

3 Daf die lingula als Schliefe oder Bindevorrichtung aufzufassen ist, folgt auch ans Ans. von Havelberg (Liber de ord. canonic. c. 12; M. 188, 1104), wo die lingua der tunica pellicea der snalla gleichgesetzt wird: lingua seu snalla. 


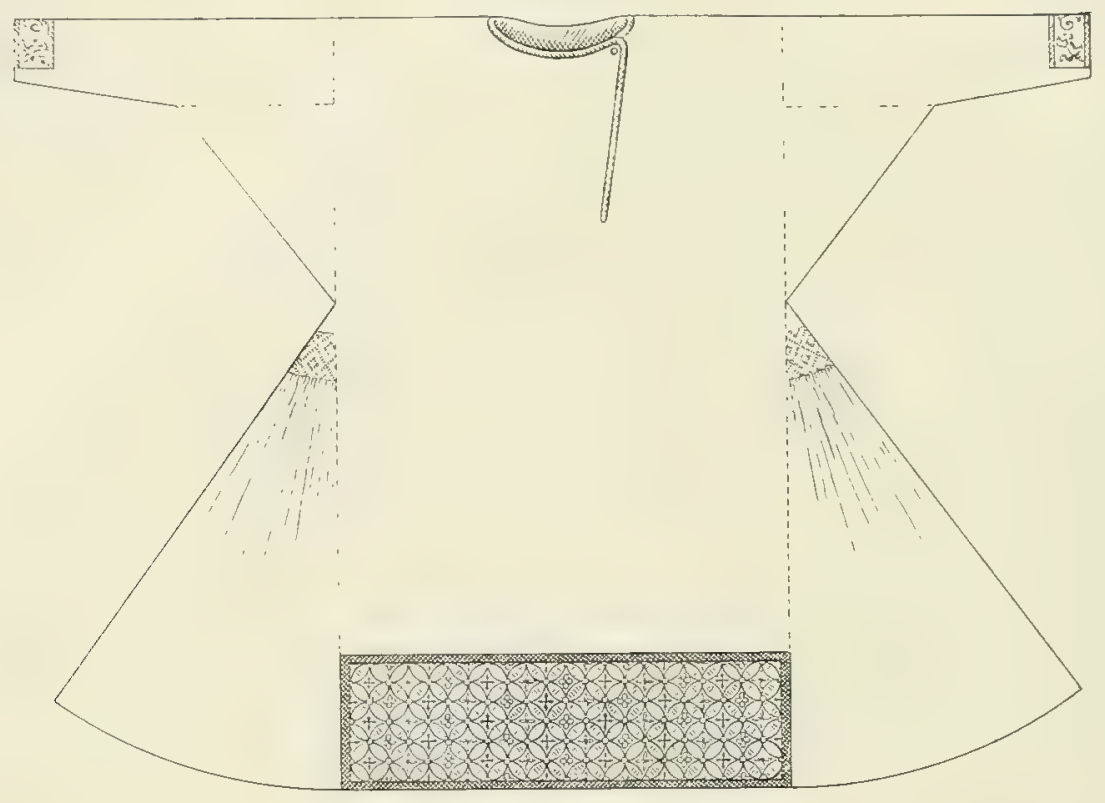

Bild 27. Albe. Sens, Kathedrale.

Bei dem Gewande fällt die eigentümliche Form des Oberteils auf. Das Bruststück ist verhältnismäßig eng; die Ärmel sind nach den Händen zu so schmal, daf hier ein Schlitz angebracht wurde, um das Anziehen zu erleichtern, eine Eigentümlichkeit, die wir übrigens nur bei dieser Albe zu beobachten Gelegenheit hatten. Dagegen haben sie dort, wo sie an den Albenkörper angenäht sind, eine sehr bedeutende Weite. Sehr weit ist der untere Teil des Gewandes. Um dem Träger eine freiere Bewegung zu ermöglichen und einen volleren Faltenfluf zu erzielen, hat man beiderseits zwischen die rechteckig geschnittenen Mittelbahnen große Zwickel eingesetzt. Es leuchtet ein, das bei dieser Einrichtung in der Tat ein reicher Faltenwurf entstehen mufte. Alba descendens usque ad talos, medio angustatur, in extremitate multis commissuris dilatatur, stringet manus et brachia, sagt Sicard von Cremona; seine Worte klingen wie ein genauer Kommentar zu Bild 26.

Eine der Albe von Sens verwandte, einst dem hl. Thomas von Cantilupe, Bischof von Hereford in England († 1282), zugehörige Albe befindet sich im Hospiz zu Lisieux. Ihre Rumpfbreite beträgt 1,05 m, der Umfang am unteren Saum 4,76 m und die Länge 1,90 m. Die Giren an den Seiten sind 1,05 m hoch und dicht gefältelt. Die Besätze, mit denen das Gewand einst geschmückt war, sind verschwunden ${ }^{1}$.

Die Form und Machweise der Albe, wie dieselben im 12. und 13. Jahrhundert üblich waren, erhielten sich das ganze übrige Mittelalter. Es ist im wesentlichen eine und dieselbe Erscheinung, welche uns in dieser Hinsicht alle aus dem ausgehenden 12., dem 13., 14. und 15. Jahrhundert noch ror-

1 Die Albe galt früher als Reliquie des hI. Thomas von Canterbury; de Mély hat indessen nachgewiesen, daß sie mit einigen andern Paramenten, einer Kasel und drei Dalmatiken (Tunicellen), vom hl. Thomas von Cantilupe herrührt (Revue 1891, 91 ff). Die
Beschaffenheit der Dalmatiken hätte übrigens auch ohne den von de Mély gelieferten Nachweis eine Zuweisung der Gewănder an den hl. 'I'homas Becket und jede die zweite Hälfte des 13. Jahrhunderts ïberschreitende Datierung entschieden verboten. 
handenen Alben bieten. Die Veränderungen sind so wenig bedeutend und so wenig charakteristisch, daf es in den meisten Fällen schwer, wenn nicht gar unmöglich ist, lediglich aus Schnitt und Gestalt einen sichern Anhaltspunkt für die Bestimmung des Alters zu gewinnen.

Ein interessantes Bild der Alben, wie sie im ausgehenden 13., dem 14., und 15. Jahrhundert im Gebrauch waren, bieten fünf Alben in dem Paramentenschatz ron Castel S. Elia bei Nepi in der römischen

Campagne ${ }^{1}$, von denen vier in Bild $28-31$ skizziert sind,

Über die höchst bemerkenswerten

\begin{tabular}{|c|c|c|c|c|c|c|}
\hline \multirow[b]{2}{*}{ Allue } & \multicolumn{3}{|c|}{ Breite } & \multirow[b]{2}{*}{ Linge } & \multirow{2}{*}{$\begin{array}{l}\text { Ârnel- } \\
\text { länge }\end{array}$} & \multirow{2}{*}{$\begin{array}{c}\text { Vordere } \\
\text { Ärmel- } \\
\text { weite }\end{array}$} \\
\hline & unters & $\begin{array}{l}\text { in der } \\
\text { Mitte }\end{array}$ & oben & & & \\
\hline 1 & 9 & 1.1 & 29 & 1,7 & 0,73 & 0,17 \\
\hline 2 & & & & & & \\
\hline 3 & 2,04 & 1,00 & 2,0 & 1,9 & 0,70 & 0,2 \\
\hline 4 & 2,38 & 0,90 & 2,16 & 1,70 & 0,75 & 0,1 \\
\hline 5 & 2,46 & 0,80 & 2,38 & 2,17 & 0,66 & 0,14 \\
\hline
\end{tabular}

Maßsverhältnisse dieser Gewandstücke gibt dienebenstehende Tabelle Auskunft, bei welcher die beiden Gewandhälften aufeinander gelegt zu denken sind.

Bei allen Alben ist die untere Breite sehr auffallend. wenn man mit

ihr die der modernen Albe vergleicht, welche am Saume allerhöchstens etwa 3,00 m bis $3,20 \mathrm{~m} \mathrm{zu}$ messen pflegt. Ist doch die Saumweite von $\mathrm{Nr} 4$ und 5 (Bild 31 und 29) gerade um die Hälfte größer als diejenige unserer heutigen Albe. Selbst bei Nr 1 (Bild 30) ist sie noch bedeutender, als es jetzt bei den Alben, namentlich wie sie in Italien in Gebrauch sind, der Fall ist. Dagegen ist umgekehrt bei den Alben von Castel S. Elia die Brustweite um vieles geringer als hei der gegenwïrtig üblichen Alben-
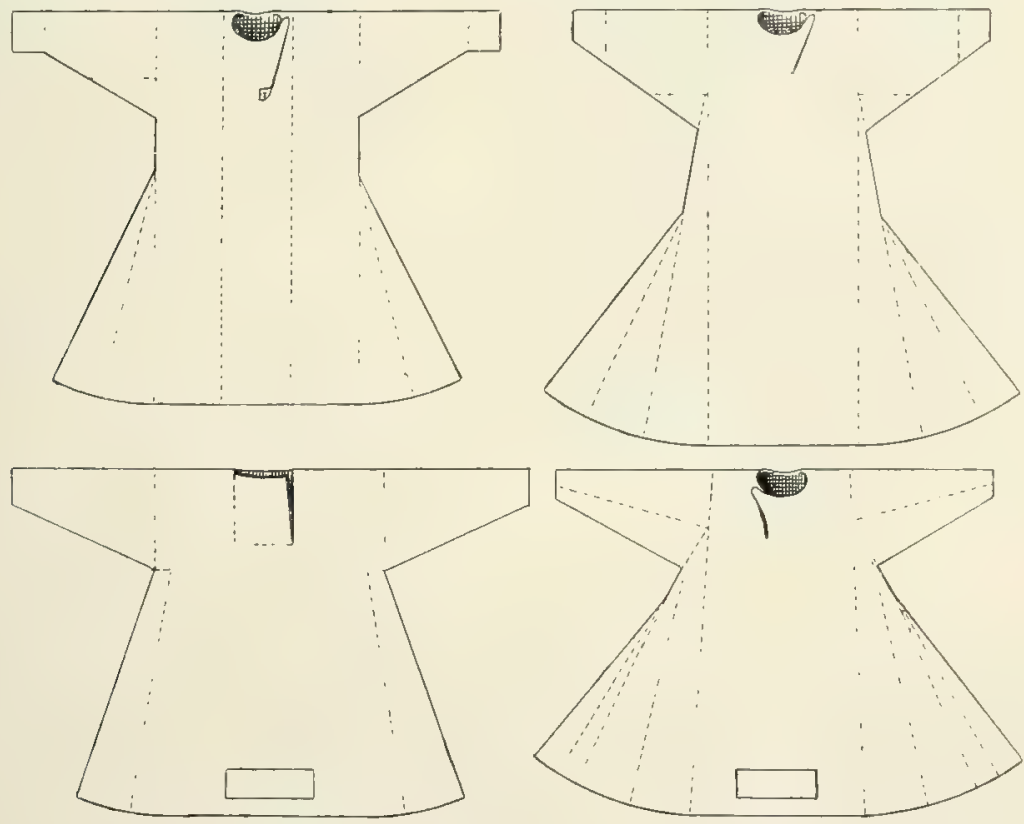

Bild 28-31. Alben. Castel S. Elia. Die punlitierten Linien deuten die Nihte an. Bild $28 \cdots$ Nr 3 , Bild $29=\$ 15$, Bild $30 \cdot$ Ni 1 , Bild 31 - Nr 4 der Tabelle.

form. Tamentlich fällt das bei Nr 5 (Bild 29) auf. Die Ärmellänge schwankt bei den Alben zwischen $73 \mathrm{~cm}$ und $66 \mathrm{~cm}$, die vordere Ärmelweite zwischen $11 \mathrm{~cm}$ und $20 \mathrm{~cm}$.

Die eigenartigen Maßverhältnisse der miltelalterlichen Alben sind die Folge ihrer Anfertigungsweise. Die Abbildungen 28-31, auf denen die Nähte durch punktierte

1 Vgl. über den Paramentenschatz von Castel S. Elia die diesbezüglichen Aufsätze des Verfassers in "Zeitschrift" 1899, $291 \mathrm{ff}$ $343 \mathrm{ff}$, über die Alben $352 \mathrm{ff}$. 
Linien angedeutet sind, erlüutern besser als eine lange Beschreibung den Schnitt der mittelalterlichen Alben. Dieser ist allerdings bei den vier Alben im einzelnen einigermaßen verschieden. Tesentlich ist aber allen die geringe Breite der Mittelbahnen, die Giren zur Seite des Mittelstückes, deren es bei Nr 4 (Bild 31) rechts wie links sogar je zweimal vier, im ganzen also je acht gibt, die durch diese Einrichtung bedingte Enge in der Körpermitte bei auffallend grofer unterer Breite und endlich die Weite der Ärmel da, wo sie an den Rumpfteil des Gewandes angesetzt sind. Bei $\mathrm{N}_{2}: ;$ und 5 (Bild 28 and 29) ist diese Ärmelweite, wie die Skizze zeigt, durch Zwickel, bei $\mathrm{Nr} 4$ (Bild 31) durch eine eigenartige Bildung der Ärmel erzielt worden.

Das Charakteristische der mittelalterlichen Alben ergibt sich hieraus von selbst. Es liegt einerseits in der Bildung der Ärmel und anderseits, und zwar besonders in der verhältnismäßig geringen mittleren und großen unteren Weite.

Zwei weitere Eigentümlichkeiten der Alben von Castel S. Elia sind nur die Folge der eigenartigen Machweise. Die erste besteht in dem Mangel einer Einkräuse-

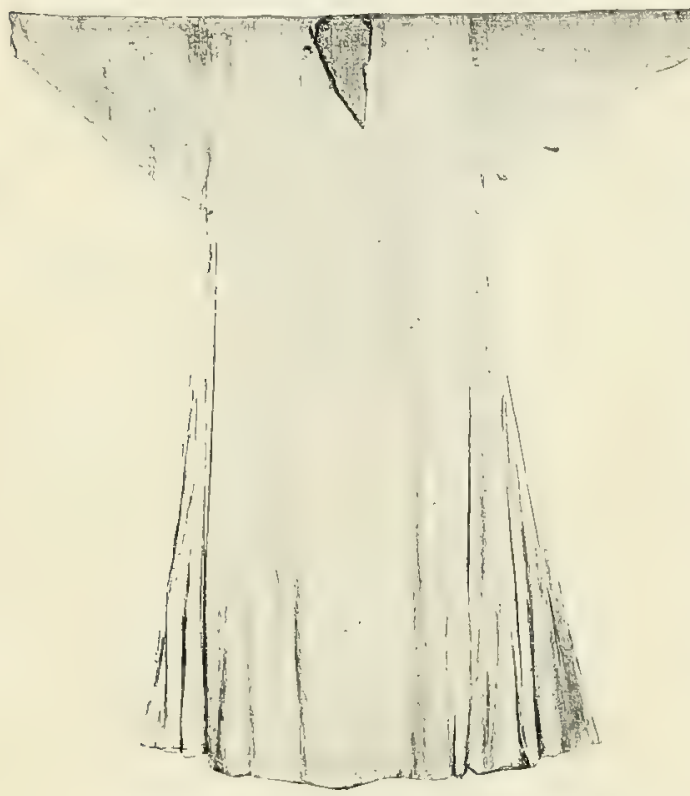

Bild 32. Albe mit herabfallenden Giren. Castel S. Elia. lung, wie dieselbe bei der modernen sackförmigen Albe rings um den Kopfdurchlaf herum gebräucblich, ja notwendig ist, damit dieselbe dem Oberkörper sich besser anpasse. Infolge des Schnittes der Alben von Castel S. Elia war bei denselben das Einkräuseln überflüssig. Diezweite bemerkenswerte Eigentümlichkeit liegt in dem Faltenwurf. Vorn und hinten fallen nämlich die Alben fast ganz glatt herunter (Bild 32). Dagegen gewahren wir an den Seiten infolge der eingesetzten Giren einen dichten, malerischen Faltenflufs, Es war daher auch nicht notwendig, beim Ankleiden das Gewand, wie das heute zu geschehen pflegt, auf dem Rücken in einen massigen, schweren Faltenbausch zusammenzulegen. Denn es war schon in der Machweise ein natürlicher, schöner Faltenwurf gegeben.

An die Halsöffnung schlie ist sich bei $\mathrm{Nr} 2$ bis 5 ein über die Brust sich hinabziehender Schlitz an, welcher das Durchstecken des Kopfes exleichtern soll. Er findet sich nicht in der Mitte des Durchschlupfs, sondern bald an iler rechten, bald an der linken Seite desselben, so daf auf der Brust sich eine Art von schliefbarer Klappe bildet. Dieselbe läuft bei einigen in eine Zunge aus. Es ist die lingua, von der bei den Liturgikern des 12. und 13. Jahrhunderts wiederholt die Rede ist.

Ein vorzügliches Gegenstück der Alben zu Castel S. Elia bilden sechs Alben

\begin{tabular}{|c|c|c|c|c|c|}
\hline \multirow[b]{2}{*}{ Albe } & \multicolumn{3}{|c|}{ Breite } & \multirow[b]{2}{*}{ Länge } & \multirow{2}{*}{$\begin{array}{c}\text { Ärmel- } \\
\text { linge }\end{array}$} \\
\hline & unten & $\begin{array}{l}\text { in cler } \\
\text { Mitte }\end{array}$ & oben & & \\
\hline 1 & 1,84 & 1,10 & 2,24 & 1,81 & 0,56 \\
\hline 2 & 1,84 & 1,05 & 2,24 & 1,61 & 0,58 \\
\hline 3 & 1,68 & 1,16 & 2,32 & 1,67 & 0,58 \\
\hline 4 & 2,50 & 1,38 & 2,56 & 1,63 & 0,59 \\
\hline 5 & 2,00 & $\mathbf{1}, 14$ & 2,22 & $1,8 \mathrm{I}$ & 0,53 \\
\hline 6 & 2,18 & 1,16 & 2,34 & 1,58 & 0,59 \\
\hline
\end{tabular}
in der St Marienkirche zu Danzig. Es ist durchaus ein und dasselbe Bild, welches diese wie jene von dem Gewande gewähren. Die Unterschiede, welche zwischen beiden bestehen, sind nur unwesentlich. Sie beschränken sich lediglich auf die etwas abweichenden Mafverhältnisse und auf die Bildung des Kopfdurchlasses, der bei den Alben zu Danzig blok aus einem wagerechten Ausschnitt besteht. Über deren Maße gibt die beifolgende Aufstellung Auskunft. 
Wie man sieht, ist die Höhe, die Ärmellänge und die Saumbreite bei den Alben der St Marienkirche etwas geringer, der Albenrumpf dagegen etwas breiter als bei den Alben von Castel S. Elia. Die obere Breite ist bei beiden ziemlich die gleiche.

Die Danziger Alben werden allesamt aus dem 15. Jahrhundert stammen, während die Alben von Castel S. Elia zum Teil noch in das 14. und 13. Jahrhundert hinaufreichen mögen. Sie zeigen, daßs das Gewand in späteren Mittelalter denselben Typus im äufiersten Nordosten Deutschlands aufwies, der ihm im Herzen Italiens eignete. Es handelt sich ja hier nicht um eine vereinzelte Albe, sondern um eine verhältnismäfig bedeutende Zahl derselben.

Von andern mittelalterlichen Alben seien noch erwähnt eine Albe im Kartäuserkloster Valsainte bei Bulle (Schweiz), eine Albe in Santa Chiara zu Assisi, gewöhnlich als Albe des hl. Franziskus bezeichnet, doch wahrscheinlich aus späterer Zeit, eine Albe im Dom zu Eichstätt, welche unter dem Namen der Albe des hl. Willibald läuft, eine Albe zu Neresheim in Württemberg; ferner je eine Albe im Dom zu Brandenburg, im Königlich bayrischen Nationalmuseum zu München, im Museum zu Rostock, im Kensington Museum zu London, ehedem in der Sammlung Bock, im Dom zu Viterbo und in St Bertrand zu Comminges. Zwei gibt es im Provinzialmuseum zu Hannover, drei im Dom zu Ratzeburg. Alle folgen dem Typus der Alben von Castel S. Elia und Danzig ${ }^{1}$. Nur die Albe von Comminges bildet eine Ausnahme, doch ist es mehr als wahrscheinlich, daß das Gewand im Laufe der Zeit Veränderungen erlitten und seine ursprüngliche Form eingebüft hat.

Die Albe in S. Chiara zu Assisi, durch ihre Besätze und die oben an den Giren angebrachten Weifstickereien eine der hervorragendsten unter den noch erhaltenen mittelalterlichen Alben,

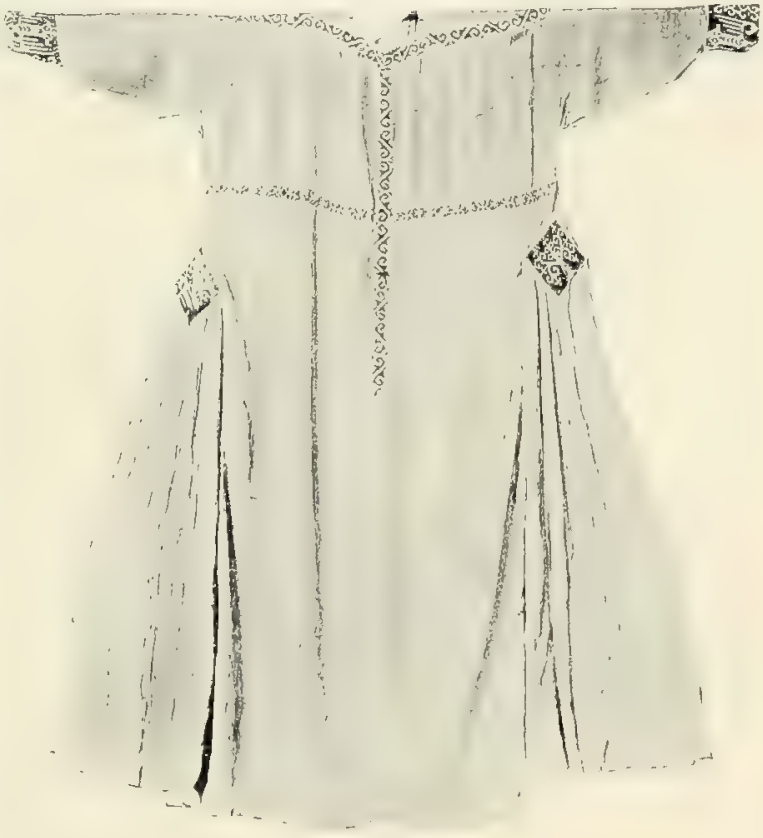

Bild 33. Albe.

München, bayrisches Nationalmuseun. ist bemerkenswert durch ihre große Weite von $5,40 \mathrm{~m}$. Sie wird indessen noch durch die Albe im Dom zu Brandenburg übertroffen, deren unterer Umfang sich bei einer Länge von ca $1,80 \mathrm{~m}$ auf volle $6 \mathrm{~m}$ beläuft. Recht anormal sind die Makverhältnisse der Albe im Königl, bayrischen Nationalmuseum (Bild 3:3); denn bei einer Länge von $1,90 \mathrm{~m}$ und einem Saumumfang von $4,56 \mathrm{~m}$ beträgt hier die obere Breite nur $1,79 \mathrm{~m}$, die Brustweite $0,87 \mathrm{~m}$ und die Ärmellänge $0,46 \mathrm{~m}$. Auch die Maße der Alben im Dom zu Ratzeburg sind ungewöhnlich; 1,63 $\mathrm{m}$ lang und am

1 Bezüglich des Schnittes der Albe zu Viterbo liefs sich nichts Näheres feststellen. Von früher vorhandenen, im Strudel der Revolution aber vernichteten Alben aus dem Mittelalter seien kurz genannt eine Albe zu Angers (Abbildung bei de Far cy, Broderies et tissus, conservés autrefois dans la Cathédrale d'Angers, in Revue 1886, 173), eine
Albe zu Toul (Abbildung und Beschreibung bei Roh. VII 16 und pl. DXIX), eime Albe zu Montreuil (Diözese Amiens) und zu Sen]is (ebd. 13). Es waren das alles Alben voun Typus der Alben zu Castel S. Elia und Danzig und nach Ausweis des Schnittes und der Ausstattung Erzengnisse etwa des 13. oder 14. Jahrhunderts. 
Saum 4,20 m weit, sind sie in der Brust nicht weniger denn $1,63 \mathrm{~m}$ breit, so daf die Giren an den Seiten unten nur ca $0,25 \mathrm{~m}$ messen. Sehr bedeutend sind die Mafie der Neresheimer Albe. Hat dieselbe doch eine Länge von $1,96 \mathrm{~m}$, eine untere Weite von $4,63 \mathrm{~m}$, eine obere Breite von $2,35 \mathrm{~m}$, eine Ärmellänge von $0,60 \mathrm{~m}$ und eine Brustbreite von $1,15 \mathrm{~m}$. Die geringsten Mafe haben die beiden Alben im Provinzialmuseum zu Hannover. Die obere Breite ist allerdings noch grok $(2,30$ bzw. 2,14 m), dagegen beläuft sich die Länge nur auf 1,75 bzw. $1,38 \mathrm{~m}$ und die untere Weite auf 3,12 bzw. $3,10 \mathrm{~m}$. Die Albe zu Valsainte, welche sich durch interessante Weifstickereien an den Ärmeln, auf den Schultern, unter den Achseln und um den Kopfdurchschlupf auszeichnet, ist 1,92 m lang und bei einer Brustweite von $2,40 \mathrm{~m}$ unten $4,76 \mathrm{~m}$ weit 1

Den Entwicklungsgang, den die Machweise der Albe im 14. und 15. Jahrh undert genommen, in seinen einzelnen Stadien zu verfolgen, ist unmöglich, weil die Zahl der noch vorhandenen Alben dafür zu gering ist. Es läfit sich nur so viel feststellen, daf gegen Ausgang des Mittelalters die Mittelbahn des Albenkörpers durchweg an Breite zunahm, die Giren dagegen schmäler wurden.

Die Vorschriften, welche der hl. Karl Borromäus hinsichtlich der Anfertigung der Alben erlief, setzen offenbar noch die alte Machweise roraus. Die Albe sollte 4 cubiti = ca 1,72 m lang sein, so daf sie, aufgeschürzt und gegürtet, noch bis zu den Füben reiche. Unten sollte sie, falls sie nicht mit Paruren verziert werde, die - enorme - Weite von 16 cubiti $=$ ca $7 \mathrm{~m}$ haben, damit sie, aufgegürtet und oberhalb des Cingulums im Bausch sich um den Körper legend, unten einen reichen und schönen Faltenwurf bilde. Mit Zierbesätzen versehen, sollte sie etwas kürzer und nur 4 cubiti oder etwas mehr weit sein. Die Ärmel sollten an den Schultern etwa 1 cubitus = ca $0,43 \mathrm{~m}$ breit sein, nach den Händen zu sich jedoch verengern ${ }^{2}$. Ihre Länge wird auf $1 \frac{1}{2}$ cubitus $=$ ca $0,65 \mathrm{~m}$ angesetzt.

Nach den Statuten des Prager Konzils vom Jahre 160อ, des einzigen deutschen, welches über die Maße der liturgischen Gewänder nähere Bestimmungen erließ, soll die Albe drei (böhmische) Ellen = ca 1,70 m lang: und am unteren Saum ebenfalls drei Ellen weit sein ${ }^{3}$.

\section{BESCHAFFENHEIT UND AUSSTATTUNG DER ALBE.}

In dem 1. und 3. römischen Ordo heist die Albe linea. Sie wurde also damals aus Linnen gemacht, sonst hätte man sie nicht schlechthin linea genannt. Aber auch von Hraban hörten wir bereits, daf3 das Gewand aus Linnen hergestellt werde, und ebenso versichert Amalar, daf die camisia aus Leinwand bestehe. Wenn daher in dem Inventar von St-Riquier, in

1 Die Daten über die Ratzeburger Alben schulde ich dem liebenswürdigen Entgegenkommen des Herrn Dompropstes Ohl, die Angaben über die Maße der Albe zu Neresheim den freundlichen Bemuihungen des Herrn Pfarrers Schulinspektor Schips zu Neresheim; izber die Alben zu Hannover gab mir in zuvorkommendster Weise Herr Direktorialassistent Runde Auskunft. Ich verfehle nicht, diesen Herren auch hier den gebührenden Dank auszusprechen. Abbildung der Albe zu Valsainte in Revue 1905, 407.

2 A. E. Med. 626. Die Angabe, es solle die Albe, falls Besaitze zur Anwendung kämen, unten 4 cubiti - ca 1,72 m weit sein, scheint schlecht zu der späteren Bestimmung zu passen, daf Alben ohne Parura 16 cubiti weit und so p a ulo latiores sein sollten als albae grammatis ornatae. Vielleicht ist statt quattuor quattuordecim oder statt sedecim sex zu Iesen. Selbst ein gutes Stick des Umfanges für das Fülteln gerechnet, bleibt der Unterschied zwischen 2 und 16 Ellen immer noch zu yrof3.

\& C. 13 ( $\mathrm{Har}$ tzh, VllI 691). Mit 8 Ellen Weite ist der ganze, nicht der halbe ITmfang gemeint: longe tros ultris producta et late tres item circumquaque appareat. 
welchem von 260 linnenen Alben berichtet wird, mit denen Angilbert das Kloster beschenkte, auch 6 sericae albae romanae cum amictibus suis auro paratae aufgeführt werden, so dürften darunter nicht sowohl gewöhnliche Alben als vielmehr das Gegenstück der Dalmatik, subdiakonale Tuniken zu verstehen sein. Freilich könnte man dem entgegen auf den Zusatz cum amictibus suis verweisen, allein es handelt sich im Inventar um albae romanae, nach rümischem Brauch aber gehörte im Beginn des 9. Jahrhunderts das anagolaium, der Amikt, nicht sowohl zur Albe als zur Dalmatik und Tunicella ${ }^{1}$.

Noch viel weniger ist eine Albe, wie man überall liest, die camisia alba sigillata olosyrica cum chrisoclavo, welche der angelsächsische König Ethelwolf der Peterskirche unter Benedikt III. (855-858) zum Geschenk machte 2 es handelt sich bei ihr vielmehr um eine Decke. Da nämlich in Rom nach Ausweis der Monumente Bischof und Diakon eine so lange Dalmatik trugen, daf die Tunika ganz von dieser bedeckt wurde, ist es von vornherein unwahrscheinlich, daß man daselbst Alben mit kostbaren Goldbesätzen getragen habe. Dann aber lälist auch die Gesellschaft von Kirchenutensilien wie corona, baucae, spata, imagines, gabathae, saraca, vela maiora, unter denen sich die fragliche camisia befindet, nur an eine Decke denken. Wirklich kommt das Wort in diesem Sinne auch sonst mehrfach vor. So begegnet es uns in der Bedeutung von Buchdecke, Altardecke, Decke eines Behälters, ja sogar von Schabracke (Pferdedecke) ${ }^{3}$. Endlich ist der Umstand selır beachtenswert, dafs nirgends im L. P. sonst einer. Schenkgabe liturgischer Kleider an Kirchen gedacht wird. Wohl hören wir, wie die Päpste in einzig dastehender Weise die römischen Basiliken und sonstige Gotteshäuser bedenken, aber unter den zahllosen Altargeräten, Schaustücken, gottesdienstlichen Einrichtungsgegenständen, Behängen, Decken, Altarverhüllungen (vestes) aus edlem Metall und den prächtigsten Stoffen findet sich nirgends ein liturgisches Gewand genannt. Daßs der L. P. nicht von einer Schenkung liturgischer Kleider berichtet, erklärt sich wohl durch den Umstand, daf damals die Beschaffung der nötigen Sakralgewänder den einzelnen Klerikern selbst, nicht der Kirche oblag 4 .

Wie es sich aber immer mit den 6 sericae albae romanae des Inventars von St-Riquier und der "seidenen, mit runden Zierflecken und Goldborten geschmückten camisia" Ethelwolfs verhalten mag', Alben aus Seide waren nicht blob im 9. Jahrhundert, sondern auch in der Folgezeit nicht nur sehr selten, sondern stets Ausnahme. Die Liturgiker des 12. und 13. Jahrhunderts betonen immer wieder, daf das Gewand aus Limnen gemacht werde. Wenn in den Schatzverzeichnissen des Mittelalters mehrfach von albae de serico die Rede ist, so darf man sich dadurch nicht täuschen lassen. In manchen Fällen ist, wie früher des näheren ausgeführt wurde, gerade wie im Ordo officiorum bei Hittorp die subdiakonale Tunicella ge-

1 S. oben S. $23 \mathrm{f}$.

${ }^{2}$ D u ch., L. P. II 148.

3 D. C. II 53. Als Hülle des Evangeliars und Missale finden wir z. B. das Wort im Testament Riculfs von Elne : camisiae ad textum et missale 4, unum de auro purpureum, als Altardecke in der Stiftungsurkunde des Klosters Tuñon (Spanien) von 891: camisiae altaris 3 (Florez, España sagr. XXXVII 339). In einem Verzeichnis der von Alfons II. $81 \%$ der
Kathedrale von Oviedo geschenkten Gegenstände heiken diese camisiae tunicae de altaria (sic) (ebd. 313), in einem Inventar der Kathedrale von Lugo von 998 (F lor ez a. a. O. XL 409): mitrae de mensa.

4 Betreffs der einzigen Schenkung von liturgischen Gewändern an geistliche $P$ (i) sonen $\nabla g l$. die Vita Stephani (Duch. L. P. I 443). In Klöstern war deren Beschaffung natürlich Sache der Kirche. 
meint ${ }^{1}$, in andern handelt es sich um eine ungenaue Bezeichnung einer mit seidenen Zierbesätzen versehenen Albe, ähnlich wie amictus de aurifrigiis mit Paruren aus Borten geschmückte Schultertücher bedeuten. Man muf in jedem einzelnen Falle, wo es sich um albae de serico handelt, zusehen, was darunter nach dem Zusammenhang oder der Sprechweise des betreffenden Inventars zu verstehen ist.

Immerhin kommen tatsächlich hie und da wirkliche Alben aus Seide in den Schatzverzeichnissen vor. Es wurde eben ehedem mit dem Stoff der Paramente, wie mit manchen andern liturgischen Fragen, nicht so genau genommen wie jetzt, wo eine Ritenkongregation über die Beobachtung dessen, was Rechtens und kirchlichen Herkommens ist, wacht. Solche Alben waren indessen auch im Mittelalter nur vereinzelte Erscheinungen. Wirkliche aus Seide gemachte Alben, also keine bischöfliche oder subdiakonale Tunicellen sind wohl die quattuor albae de serico des Inventars von Angers vom Jahre $1297^{2}$, die zwei vestimenta (= albae) de serico im Inventar von St Paul zu London von 1245 und die tres albae de serico brosdatae (bestickte) des Schatzverzeichnisses der Kathedrale von Rouen aus dem Ende des 12. Jahrhunderts ${ }^{3}$, kaum aber die alba de serico pretiosissima, welche Bischof Brithwold von Wilton ( $\dagger$ 1045) als Geschenk dem hochberühmten Kloster Glastonbury in Somersetshire übersandte: $\mathrm{Ob}$ alle die seidenen Alben, welche Chambers erwähnt ${ }^{5}$, Alben im heutigen Sinne gewesen, scheint sehr fraglich, dagegen dürfte die alba de tenui serico vetus im Schatzverzeichnis von St Veit zu Prag aus dem Jahre 1354, weil mitten unter linnenen Alben genannt, wohl eine Albe der gewöhnlichen Art bedeuten. Dasselbe gilt von 8 albae de serico im Inventar der Kathedrale von Salisbury von 1212. Die 12 albae consutae de serico, welche im Registrum Roffense, dem Gabenverzeichnis der Kathedrale von Rochester in England, für den Beginn des 13. Jahrhunderts als der Kirche geschenki vermerkt werden, sind zwar richtige Alben - denn die subdiakonale Tunicella heifst darin tunica oder tunica epistolaria -, aber mit Seide besetzte Alben, nicht seidene Alben.

Eine reichere Ausstattung scheint die Albe bis in den Beginn des 12. Jahrhunderts für gewöhnlich nicht erhalten zu haben. Reich verzierte Alben sind bis dahin eine seltene Erscheinung. Immerhin kommen solche vor. So begegnen wir im Testament Riculfs von Elne neben zwei albae planae auch drei albae clarae. Das Inventar von Clermont-Ferrand aus dem 10. Jahrhundert verzeichnet zwei goldverzierte Alben zum Gebrauch für den Bischof und eine mit Seide besetzte Albe. Gegen Ende des Jahrhunderts verehrte Herzogin Hadawiga von Schwaben dem Kloster St Gallen eine Albe, die in Goldstickerei mit der Hochzeit der Philologie und Merkurs geschmückt war ${ }^{6}$. Die Albe, welche die Kaiserin Agnes dem Kloster Monte Cassino schenkte, hatte nicht nur um den Halsausschnitt und die Ärmelsäume eine reich verzierte Borte, es zog sich auch ein kostbarer Besatz über die Schultern. Den Saum des Gewandes aber umgab ein Aurifrisium, das fast die Breite einer Elle hatte ${ }^{7}$. Eine andere glänzende Albe aus dem Beginn des 11. Jahrhunderts wird in der Geschichte der Bischöfe von Auxerre erwähnt8. Auf der Brust war dieselbe mit einem Zierstück aus Goldstoff, unten aber mit

1 Hitt. 61: subdiaconi albis sericis induantur; 76: subdiaconi lineis aut sericis albis. Vgl. auch oben S. 60 .

2 Revue 1886, 173.

3 Ebd. 464. Unmittelbar nach den 3 albae de serico et brosdatae werden aufgeführt 14 albae paratae et 13 sine paraturis.
- Wilh. Malmesbury, De antiq. Glaston. (M. 179, 1722)

${ }^{5}$ Divine worship p. 31 .

* Ekkeh. IV. Casus c. 10 (M. G. SS. II 123).

7 Chron. Casin. 1. 3, n. 31 (M. G. SS. VII 722).

${ }^{8}$ C. 49 (M. 138, 277). Die Albe heift hier palla. Siehe übrigens oben S. 33, Anm. 1. 
einer Borte aus Brokat, die von den Kinien bis zu den Tinöcheln reichte, geschmiickt. Die Albe des hl. Bernulf zu Utrecht, von der oben schon die Rede war (Bild 26, S. 73), ist ein Prachtstück dieser Art. Kostbare Goldborten fassen die Ärmelmündungen, den Saum und den Kiopfdurchlaf des Gewandes ein. Aufierdem ziehen sich vorn und hinten zwei Goldborten von oben nach unten. Der Besatz am unteren Rande der Albe, eigentlich mehrere nebeneinander gelegte Borten, hat eine Breite von etwa 0,40 m. Das Gewand ist ersichtlich ein ausgezeichnetes Gegenstück sowohl der Albe, welche Kaiserin Agnes den Mönchen zu Monte Cassino gal, als auch derjenigen, von welcher die Geschichte der Bischöfe von Auxerre erzählt. Von zwei albae auro insignes berichtet ein Inventar von St Gallen aus dem 11. Jahrhundert; ein Speierer Schatzverzeichnis aus dem Jahre 1051 erwähnt albam unam, auro texto (Goldstoff) optime ornatam, ein Inventar von Ely (England) aus dem Jahre 1079 octo albas, una est de serico cum aurifrisio et cum amictu, sex cum amictibus et aurifrisio ...., tres sine amictu cum aurifrisio. Der Dom zu Bamberg besafs laut Inventar von 1127 im Beginn des 12. Jahrhunderts acht mit Goldborten besetzte Alben: albae 46, ex his 8 cum aurifrigio.

Auf den Bildwerken des 9., 10. und 11. Jahrhunderts, namentlich den Miniaturen, ist die Albe fast stets schmucklos. Prachtalben, uiberhaupt mit Zierbesätzen versehene Alben, dürften damals wohl nur bei Bischöfen und sonstigen Würdenträgern als Festalben in Gebrauch gewesen sein. Das deutet das Inventar von Clermont zur Genüge an. Auch die „Geschichte der Bischöfe von Auxerre" läßst das durchblicken.

Das 12. Jahrhundert brachte einen um ein bedeutendes gesteigerten Verkehr mit dem Osten. Die kostbaren Stoffe und Borten, welche der Orient erzeugte, wurden infolgedessen im Abendlande läufiger als bis dahin. Zum Überfluli begannen gleichzeitig die Seidenmanufakturen in Sizilien eine grofartige Tätigkeit zu entfalten und überallhin ihre prächtigen Zeuge, köstlichen Borten und glänzenden Stickereien auszuführen. Auch die Albe hatte ihren Nutzen davon. Die Zierbesätze werden auf ihr nun immer gewöhnlicher und bei besseren Alben allmählich Regel.

Anfangs hielt man sich bei der Ausstattung der Albe noch an die alte Weise, wonach man das Gewand am Saum und an den Ärmeln mit einer den ganzen Rand umziehenden Borte versah. Bald aber bildete sich eine eigenartige Verzierungsweise der Alben aus. Statt mit einem Vollbesatz wurde die Festalbe nunmehr mit vier oder fünf kurzen quadratischen oder rechteckigen Zierstücken (parurae, plagulae, grammata, gemmata, aurifrisia, frisia, fimbriae, plicae, fasciae u. ä. genannt) versehen (Bild 34, S. 82), die entweder blof aus kostbarem Stoff (Damast, Brokat, Samt, Goldtuch) bestanden, oder bald mehr, bald minder reich und kunstvoll bestickt waren. Bei Prachtalben wurde füx die Besätze weder Gold noch Perlenschmuck noch edles Gestein geschont, wie aus den Beispielen erhellt, die wir aus Schatzverzeichnissen anführen werden. Je einer der Besätze erhielt vorn auf den Ärmeln seinen Platz: ein drittes Zierstück hatte seine Stelle an der Vorderseite der Albe unten in der Mitte, ein wenig über dem Saum; ein viertes war entsprechend unten an der Rückseite des Gewandes befestigt. Wurde eine fünfte plagula verwendet - und solches scheint in Italien nicht selten vorgekommen zu sein so befand sich dieselbe vorn auf der Brust unterhalb des Schlitzes, der zum Durchlassen des Kopfes diente. Die Besätze der Ärmel umzogen entwerler 
den ganzen Rand derselben oder waren nur auf der oberen Hälfte angebracht. Das letztere scheint in Frankreich und Deutschland, das erstere in Italien das Torherrschendere gewesen zu sein. Die Parurae oder Grammata, wie sie bei Durandus und in den italienischen Inventaren gern genannt werden, waren meist der Albe aufgenäht, damit sie von ihr getrennt werden konnten, wenn die Notwendigkeit eintrat, das Gewand zu waschen ${ }^{1}$. Doch finden sie sich auch dem Albenstoff eingestickt oder eingesetzt, so daf ein Loslösen nicht möglich war. Ein vorzügliches Beispiel für eine Albe der letzteren Art ist die Albe in S. Chiara zu Assisi (Bild 35). Die Paruren bestehen bei derselben aus kanevasartigen Linnenstiicken, die mittelst des sog. Gobelinstiches mit geometrischer Musterung versehen, dann dem Stoff der Albe eingenäht und zuletzt mit einem Goldbörtchen eingefafit wurden.

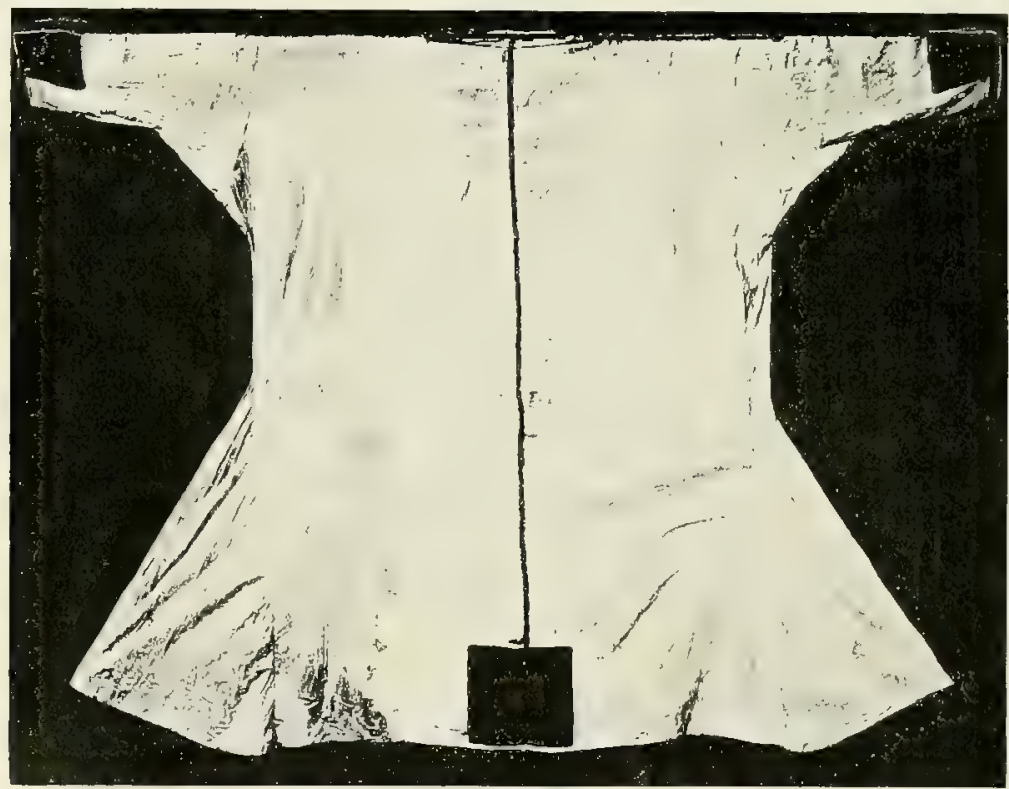

Bild 34. Albe. Danzig, Marientirche.

Seitdem sich die kirchlichen Farben fixiert hatten, d. i. seit dem Ende des 12. Jahrhunderts, pflegte man die Besatzstücke der Albe der Farbe der Kasel entsprechen zu lassen. Eine allgemeine Vorschrift war das jedoch nicht. Insbesondere brauchte man Alben mit besseren Paruren häufig ohne Rücksicht auf deren Farbe.

Es ist nicht möglich, zu bestimmen, wann die neve Ausstattung der Albe zum erstenmal aufgetreten ist. Sie scheint sich in der ersten Hälfte des 12. Jahrhunderts ausgebildet zu haben.

Was aber die Heimat der Albenparuren anlangt, so glauben wir nicht fehlzugehen, wenn wir, wie die Heimat der Parura des Amiktes, so auch

1 Eine hierauf bezügliche Notiz bei II a $\mathrm{c}$ alister (Ecclesiastical vestments, London $\mathbf{1 8 9 6 ,}$ (;7) aus der Kirclienrochuung von St Peter zu Sandwich: For washing of an awbe and an amyce... and for sewing on of the parelles of the same, $\mathrm{V}$ d. $\mathrm{Vgl}$. auch Annalen des histor.
Vereins für den Niederrhein XLV 130: „Item noch 5 alven mit ir heubtdoecher geriistet (gewaschen) und die brederkens (die Paruren) daan geneit." Oft ist in den Inventaren von losen Besätzen die Rede, die auf eine gelegentliche Verwendung warteten. 
die der Grammata der Alben im nördlichen Frankreich suchen. Wie die Gotik zuerst auf französischem Boden, so erscheint auch die neue Besatzweise beider Gewänder zuerst auf französischen Monumenten. Woher aber die Idee zu derselben, vermögen wir nicht zu sagen. Scheibenförmige und viereckige Zierstücke (segmenta, sigilla) treffen wir schon auf Tuniken des 3. und 4. Jahrhunderts und selbst früherer Zeit an. Bekannt ist ihre ausgiebige Verwendung auf koptischen Gewandstïcken. Auch auf Prachtmåntel des 11. und 12. Jahrhunderts wurden solche Zierstücke aufgenäht, zumal auf solche sizilischen oder byzantinischen Ursprungs. Mit der eigentümlichen Ausstattung der Albe des späteren Mittelalters steht diese Verzierungsweise, die einen durchaus profanen Charakter hatte, abgesehen von dem entscheidenden Umstand, daf, jene Zierbesätze in ganz anderer Anordnung wie die Pa-

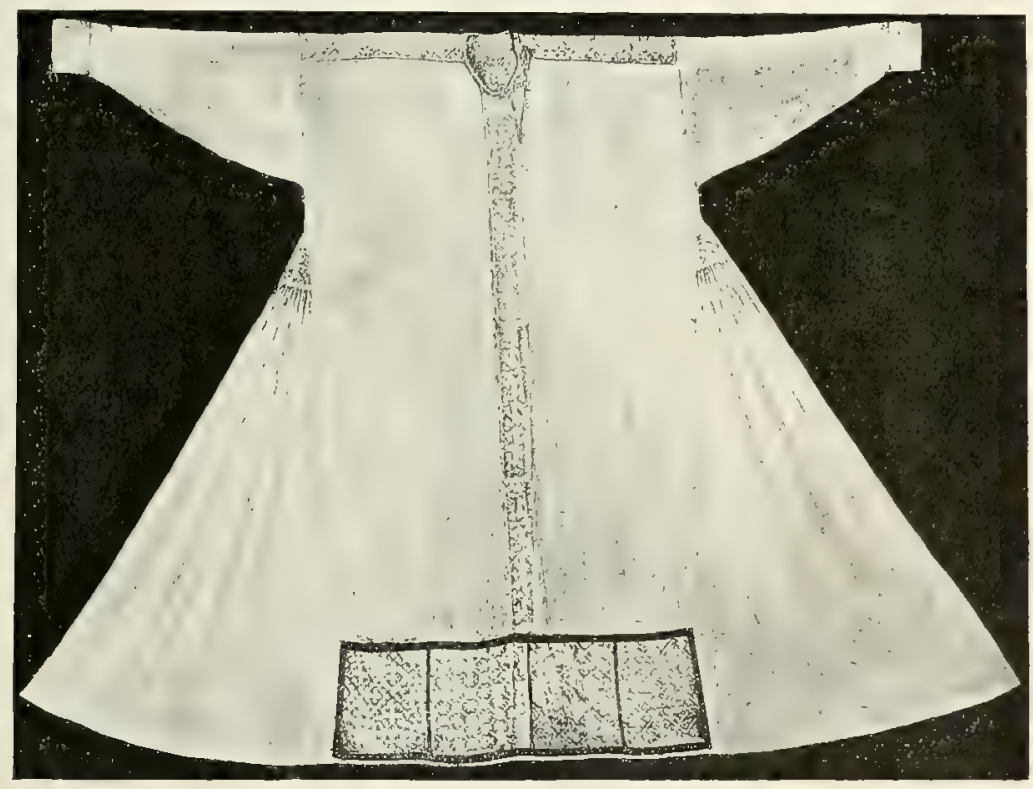

Bild 35. Albe. Assisi, \& Chiara.

ruren aufgesetzt wurden, schon darum in keinem Zusammenhang, weil die Albe vor dem 12. Jahrhundert niemals derartige Besätze aufweist.

Besondern mystischen Erwägungen, wie man sie später mit dieser eigenartigen Verzierungsweise der Albe verband, dürften die Paruren ebenfalls ihre Entstehung nicht verdanken. Denn in diesem Falle würde wohl bei den zahlreichen Liturgikern des 12. Jahrhunderts sich irgend etwas darüber finden, während diese doch in Wirklichkeit nicht nur nicht von der Bedeutung der Besätze, sondern auch ron den Besätzen selbst, ja jeder Ausstattung der Albe schweigen.

Von den Liturgikern des Mittelalters erwähnt zuerst Innocenz III. unsere Albenbesätze. Der Priester stellt nach ihm Christi Braut dar, und so geziemt ihm gemäbs den Worten des Psalmisten (Ps 44, 10): Astitit regina a dextris tuis in vestitu deaurato, circumdata varietate, ein herrliches Gewani. Deshalb das Aurifrisium und die Gemmata (Grammata), "welche an verschiodenen Stellen und in mannigfaltiger Arbeit der Zierde halber an der Albu angebracht sind". Ein Echo des großen Papstes bildet Durandus. 
Die Paruren gewannen rasch eine grole Beliebtheit, wie aus den Bildwerken und nicht minder aus den Schatz- und Gabenverzeichnissen hervorgeht. Am beliebtesten waren sie im Norden, wo allerdings auch die Form der liturgischen Obergewänder, namentlich die gröfere Küurze der Dalmatik, ihre Verwendung begünstigte. In Italien, wo die Dalmatik bis in eine weit spätere Zeit als in Frankreich, Deutschland und England eine sehr ansehnliche Länge bewahrte, und wo infolgedessen die Albe beim Bischof und den Diakonen durch die Obertunika ganz oder fast ganz verdeckt wurde, ging man bald dazu über, statt die Albe eben die Dalmatik mit Zierbesätzen nach Art der Albenparuren zu versehen. Immerhin kamen auch im Süden, wie die Schatzverzeichnisse, die Bildwerke und verschiedene noch vorhandene mittelalterliche Alben beweisen, die Grammata, wie sie hier gern genannt wurden, bei den Alben recht häufig zur Anwendung. Wie die Parura des Humerale und die Albenparuren gleichzeitig oder doch fast g]eichzeitig auf dem Plane erscheinen, so ging auch ihre Verbreitung im ganzen in gleichem Schritt vor sich. Bildeten sie ja auch in der Tat eine gegenseitige Ergänzung. Was über das erste Auftreten des Amiktbesatzes in den einzelnen Ländern gesagt wurde, gilt daher auch von dem der Paruren der Albe. Um die Mitte des 13. Jahrhunderts waren auch diese nach Ausweis der Inventare und Bildwerke fast allgemein gebräuchlich.

Um einen Begriff von der Kostbarkeit und Pracht so mancher mittelalterlichen Albenparturen zu erhalten, braucht man nur einen Blick auf die Monumente des 13., 14. und 15. Jahrhunderts zu werfen. Daf aber die Iünstler wirklich nichts anderes darstellten, als was sie sahen, beweisen die eingehenden Angaben, welche wir über die Besätze der Alben in manchen Inventaren aus damaliger Zeit finden.

Es kann nicht unsere Aufgabe sein, noch gestattet es uns der Raum, an dieser Stelle lange Auszüge aus mittelalterlichen Schatzverzeichnissen über die Albenparuren zu geben; immerhin empfiehlt es sich, wenigstens einiges von dem hier mitzuteilen, was uns die Inventare von deren Pracht erzählen.

So hatte eine Albe gemäf einem gegen Ende des 13. Jahrhunderts aufgestellten Schatzverzeichnis von Anagni einen Brustbesatz von Gold und dicken Perlen, auf dem die Bilder des Erlösers und der allerseligsten Jungfrau dargestellt waren. Die Besätze am unteren Saume (fimbriae) bestanden aus gemustertem Seidenstoff, dem Papageien und anderes Ornament eingewebt waren, während die Paruren der Ärmel Bildwerk aufwiesen. Eine andere Albe desselben Verzeichnisses enthielt auf dem Bruststück eine Darstellung der Flucht nach Ägypten; ihre Ärmelbesätze waren mit je drei Bildern geziert. Die aufgesetzten Stoffstücke am unteren Rand der Albe waren aus Goldstoff gemacht und gleichfalls mit Figuren bestickt. Eine Albe in St Peter zu Rom hatte nach dem Inventar von 1361 Besätze aus indigofarbigem Stoff. Auf den Stoffstücken, die unten an der Vorder- und Rückseite aufgenäht waren, befanden sich zwei am Hals gekoppelte, goldene Drachen, deren Schweif in Ranken auslief. Lie Paruren (mappuli) der Ärmel waren mit Blattwerk verziert; an jedem Ärmel befanden sich - wohl als Verschlubvorrichtung der geschlitzten Ärmel — acht silbervergoldete Knöpfe. Um die Halsöffnung lief eine einfachere Borte; der Knopf, der dort \}rehufs Schließung des Schlitzes angebracht war, bestand wie die Knöpfe an den Ärmeln aus vergoldetem Silber. Ein prächtiges Stück war auch die Albe, in der Bonifaz VIII. († 130:3) hegraben wurde ${ }^{1}$. Sie bestand aus flandrischer Leinwand und hatte fünf Paruren, auf denen in Gold- und Seidenstickerei die Verkündigung, Heimsuchung, Geburt und rahlreiche andere heilige Geheimnisse dargestellt waren.

1 lizovius, Annales ad a. 1303, n. 8: XIV 50. Die Rekognition der Leiche fand 1605 statt. 
Diejenigen, welche sich am Albensaum hefanden, waren $3 \frac{1}{2}$ Hand breit und eine Hand hoch.

Eine reiche Albe, die vordem in der nunmehr verschwundenen Stiftskirche zum hl. Andreas zu Freising aufbewahrt wurde, wird von einem Kanonikus des Stifts 1728 folgendermafen beschrieben ". "Die Albe ist vom feinsten Linnen und sehr lang. An den Teil der Albe, welcher vom Halse bis zur Brust reicht, hat der Nadelmaler mit Gold- und Seidenfäden von verschiedener Arbeit das Bild Christi ausgeführt, welchen Nikodemus vom Kreuze abnimmt, während Maria, die Yutter Jesu, und sein Lieblingsjünger Johannes zur Seite stehen. Gegen den Saum der Vorderseite sehen wir mit ïhnlicher Kunst dargestellt Christum mit den zwölf Aposteln; Christus sitzt in ihrer Mitte; zu seiner Rechten steht Petrus, den Schlüssel in der Rechten, das Buch in der Linken haltend, zur Linken Paulus mit einem Buche. An diese reihen sich Andreas mit einem Buche usw. an, alle prachtvoll, wenn auch nicht künstlich für unsere Zeit (!) ausgeführt. In der Mitte der Albe auf der Rückseite sieht man die Gestalt eines Weibes, das in der rechten Hand ein Messer trägt, in der Linken aber eine große Rolle. Über ihrem Haupte steht die Inschrift Synagoga. Zu ihrer Rechten erblicken wir den König David mit einer Krone auf dem Haupte und einer gleichen Rolle, zur Linken aber den Propheten Isaias usw., ein anmutiges Schaustück für Liebhaber des Altertums." Man beachte die sinnvolle Wahl der Darstellungen auf den Besätzen. Wie nüchtern und geistlos erscheint dieser Albe gegenüber so manche prunkende Albe einer späteren Zeit mit ihrer meterbreiten spitze! Besonders kustbare Albenparuren enthält das Schatzverzeichnis des Apostolischen Stuhles vom Jahre 1295. Da heibt es z. B.: Item unum camisum cum gramitis ad argentum deauratum tractitium et per diversas partes earum sunt aves, pectorale (der Brustbesatz) autem est in xamito rubeo, ornato de uno esmalto (Emailplättchen) in auro in medio eum uno angelo et ad alia esmalta et rosas de auro et sunt ibi una amatissa (Amethyst), unus smaragdus, unus topacion (Topas), plures fragae (erdbeerartige Verzierungen) aureae, diversae perlae grossae; deficiunt tamen plures lapides et topacion. Eine zweite Albe hatte Paruren aus Goldbrokat, auf ihrem Brustbesatz aber fanden sich außer sonstigem Schmuck vier Nedaillons aus Gold und Email mit Blumen, vier in Gold gefafite Saphire, drei große, gleichfalls in Gold gefafite Smaragde, sechs Rubine und sieben Granate. Eine dritte wies auf den Paruren teils Heiligenfiguren nnter Arkaturen, teils in Goldstickerei ausgeführtes Rankenwerk, auf dem Pektorale aber eine Darstellung des letzten Abendmahles auf. Bei einer vierten war dem Brustbesatz die "Sendung des Heiligen Geistes" und den Saumparuren die "Verkündigung" und "Geburt" aufgestickt. Die Ärmelparuren sowie ein Schulterbesatz waren in Perlenstickerei gearbeitet. Von einer andern Albe sagt das Inventar: Item unum camisum cum fimbriis (Paruren) de opere anglicano eum historia B. Nicolai et pectorali laborato ad aurum cum imagine Salvatoris in medio et 4 evangelistis. Im ganzen werden 20 Alben mit mehr oder minder kostbaren Zierbesätzen aufgezählt.

Um etwa dieselbe Zeit führt ein Inventar von Peterborough fünf Alben auf, quarum parurae sunt de rubeo samito cum ymaginibus, clavibus et rosis ex aurifrigio bene brusdatis, 11 Alben, quarum parurae sunt de panno Turky (orientalisches Gewebe), quae quasi aurum resplendent, eine Albe, deren aus rotem Samt bestehende Paruren mit Bildwerk und großen in Silber gefaßsten Steinen geschmückt waren, eine weitere Albe, deren seidene Besätze mit Bildern in Gold bestickt waren, und schlieflich eine Albe, die auf den Paruren in kunstvollster Stickerei Szenen aus Christi Leiden aufwies ${ }^{2}$.

Ein Inventar von St Viktor zu Marseille aus dem Jahre 1358 verzeichnet eine Albe paratam ante et retro in fimbriis et in pectore et in summitatibus

1 Kirchenschmuck I (1857) 15 . Ähnlich $\mathrm{M}$ e i chelbeck, Hist. Frising. 1 257. Die Albe sollte von Bischof Ellenhard $(\dagger 1078)$ herrihren. Indessen beweisen die Besätze, da 3 sie frühestens dem 12. bis 13 . Jahrhundert entstammte (vgl. oben S. 33 Aum. 2).

${ }^{2}$ Gay 83. Vgl. dort auch die Auszuige ans Inv, von N.-D. zu Paris u. der Kath, zu Amiens. 
pugnorum. Die Samparuren waren mit je fünf Ganzbildern verziert, auf dem Brustbesatz war der Erlöser zwischen zwei Engeln dargestellt, auf den Ämelparuren aber befanden sich je fünf Halbbilder. Dazu kam ein Amiktbesatz mit sieben Halbbildern, in ihrer Mitte Christus. Geschlossen wurden die Ärmel cordello viridi cum acu argenteo (sic), qui est in eius summitate ${ }^{1}$.

Besonders grof ist die Zahl der Alben, die reich mit Paruren verziert waren, in den Inventaren von St Paul zu London aus den Jahren $1245^{2}$ und 1402 , zumal im letztgenannten, welches deren über 120 notiert. Viele waren mit figürlichen Darstellungen bestickt, z. B. mit Szenen aus dem Leben des hl. Thomas Becket, mit Brustbildern der Apostelfürsten, mit den Figuren der Apostel, mit Begebenheiten aus dem Leben des Heilandes und der allerseligsten Junghrau, mit Heiligenbildern u. ä. Interessant sind im Inventar von 14028 albae cum paruris albis de panno lineo depictis cum rosis rubeis, ordinatae pro pueris choristis und 4 albae cum paruris de panno lineo nigri coloris, ordinatae pro pueris choristis.

Wie beliebt schon früh die albae paratae waren, ergibt sich z. B. aus dem Registrum Roffense. Unter der endlosen Reihe der Geschenke an Paramenten, welche darin aufgezählt werden, spielen eine Hauptrolle mit Paruren versehene Alben. Immer und immer wieder heifst es darin: Dedit albam paratam, albam cum parura, albam cum parura de cendal (taftartiger Seidenstoff), albam paratam cum aureis leunculis $\mathbf{u}$. ä. Daf3 es sich aber in diesen Fällen wirklich um einen Albenbesatz im Sinne unserer Paruren und nicht um Vollborduren handelt, geht daraus hervor, daßs in Fällen, wo letztere gemeint sind, ausdrücklich solches bemerkt wird, so wenn es heifst: duas albas cum nigris paruris, quae parurae circumdant totam albam, oder albam circumdatam de pallio optimo. Es erhellt ferner aus der interessanten Angabe des Registrum: Walterus episcopus (1148-1182) dedit... sandalia brustata, de quibus facta est parura ad albam. Denn der Besatz, den man aus diesen sandalia machte, kann unmöglich eine Vollbordüre gewesen sein, auch wenn man unter ihnen die Pontifikalstrümpfe verstehen sollte. Lehrreich für den Umfang, den die Verwendung der Paruren im 14. und 15. Jahrhundert gewonnen hatte, sind namentlich die Schatzverzeichnisse von Cluny (1382), Prag (1354 und 1387), Olmütz (1435), das oben erwähnte Inventar von St Paul zu London (1402) u. a. Wie bedeutend sie selbst hie und da noch gegen Ausgang des 16. Jahrhunderts war, bekundet das Inventar von St Brigiden zu Köh aus dem Jahre 1578, worin neben einer Anzahl von Alben, denen die Besätze angenäht waren, auch erwähnt werden: "Item zu 77 alven Bretger ohne angeneit", sowie das Inventar von Kiedrich von 1583 , das , 3 alpenn mitt bloen sammat schilten, 2 alpenu mitt rodt verblömet sammat schilten, eyn alb mit rod verblömet damasten schilten, eyn alb mitt gulden schilten, eyn alb mit weysem damast, eyn alb mit rodem bursatt" (Brokat) und "eyn alb mit sehwarzen duch" zu verzeichnen hat ${ }^{3}$.

Natïrlich waren im Mittelalter ebensowenig alle Alben mit Paruren versehen, wie heute alle mit Spitzen ausgestattet sind. Es gab auch einfache Alben, zumal in Landkirchen und für den werktäglichen Gottesdienst. Von den fünf Alben zu Kastel S. Elia zeigen beispielsweise nur zwei Spuren oder Reste von Besätzen.

Üherhaupt scheint im allgemeinen auf die Albenbesätze nicht der Fleif und Wert gelegt worden zu sein wie auf die Parura des Amiktes. Der Grund hierfür dürfte vor allem in dem stärkeren Verschleisen liegen, dem die Albemparuren naturgemäfs ansgesetzt waren. Dann aber mochte der Umstand darauf einwirken, dal; dieselben weniger in die Augen fielen als der Zierhesatz des Schultertuches, welcher wie ein Kragen das Meligewand

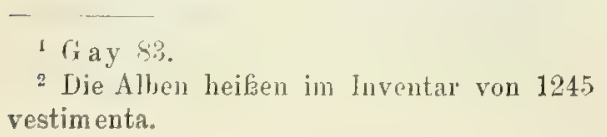

1 liay $8: 3$. vestimenta.

$3 \mathrm{Vgl}$. auch dic Inventare von St Martin zu Dover (1536) und der Infirmary chapel zu Peterborough (1539). 
wirkungsvoll abschlof. Auffallend ist diese Verschiedenheit in der Behandlung der Albe und des Amiktes namentlich in den späteren Inventaren. So wird man in den ermländischen Schatzverzeichnissen nirgends einem Albenbesatz begegnen, der sich auch nur in etwa mit einer der vielen darin erwähnten Amiktparuren vergleichen ließe. Es ist überhaupt darin kaum irgendwo von Albenparuren die Rede. Selbst von den Alben schweigen diese Inventare zum Teil, da dieselben als selbstverständliches Zubehör zur Kasel und den Levitengewändern angesehen wurden. Ähnlich verhält es sich in dem Stolper Inventar aus dem Beginn des 16., dem Breslauer aus dem Ende des 15. Jahrhunderts und dem Schatzverzeichnis des Graner Doms. Wie es scheint, bestanden die Albenparuren hier überall lediglich aus Stoffstücken vom Material des Mefigewandes, der Dalmatik und der Tunicella, so daf eine besondere Erwähnung ïberflüssig erscheinen mochte. Wirklich stellen die zahlreichen Albenbesätze, welche sich aus dem Ende des Mittelalters in St Marien zu Danzig erhalten haben, blofe Damaste, Brokate und Samte von der gleichen Beschaffenheit dar, wie sie sich an den zahlreichen alten Kaseln der Kirche finden, so daßs es nicht schwer sein würde, für manche der letzteren aus dem Haufen der Albenparuren die einst zu ihnen gehörenden Albenbesätze wieder herauszulesen.

Von den Alben, die sich aus dem Mittelalter in unsere Zeit herübergerettet haben, weisen nur wenige Paruren von Bedeutung auf. $\mathrm{Zu}$ ihnen gehört namentlich die Albe des hl. Thomas Becket zu Sens mit prächtigen Goldstickereien auf den Besätzen, wie sie ähnlich die im Grabe Theodorichs von Trier († 124:3) aufgefundenen Kaselreste aufweisen. Die Albe in St Chiara zu Assisi besitzt Paruren mit den im 13., 14. und 15. Jahrhundert so beliebten Hakenmustern.

Die meisten der noch vorhandenen alten Alben entbehren gegenwärtig der Besätze, doch lassen sich bei verschiedenen noch deutlich die Spuren derselben erkennen. Die Albe im Dom zu Brandenburg ist mit Zierstücken aus Samtbrokat, die Eichstätter Albe mit Paruren aus gelber Seide geschmückt, Die einzige Albe in St Marien zu Danzig, welche noch ihre ursprüngliche Ausstattung besitzt, hat Paruren aus dunkelblanem, fast schwarzem Samt (vgl. Bild 34, S. 82). Die Paruren der drei Alben im Dom zu Ratzeburg bestehen aus rotem, grünem und blauem Samt.

Von losen Albenparuren besitzt ein einfaches, aber schönes, in der Applikationstechnik ausgeführtes Exemplar der Dom zu Xanten ${ }^{1}$. Es stammt etwa aus dem Anfang des 15. Jahrhunderts. Etwas reicher ist eine Parura im Königl. Kunstgewerbemuseum zu Berlin, ein Muster schlichter Eleganz. Aus grünem Taft angefertigt, ist sie durch Zickzacklinien in über Eck stehende Quadrate eingeteilt, welche ringsum von einem zierlichen Rankenfries eingefaft werden. Die Quadrate sind mit je zwei einander zugewandten Vöglein, welche durch ein Bäumchen geschieden werden, ausgefültt. Die Halbquadrate an den Lang- und Schmalseiten und die Viertelquadrate in den Ecken enthalten Blattwerk oder Ranken. Die Parura ist von bester Wirkung, obwoll die Ausführung der Ornamente fast nur in gelber, gelbgrüner und weifer Seide und fast blof unter Anwendung einfacher Konturenstickerei erfolgte.

Auch das k. k. Museum für Kunst und Industrie zu Wien besitzt einige hübsche Alhenparuren. Eine erinnert durchaus an die Xantener, nur ist die Ausführung eine andere (Gold- und Seidenstickerei) ${ }^{2}$. Drei andere haben hinsichtlich ihrer Musterung einige Verwandtschaft mit den eigenartigen Dessins der sog. Kölner Borten ${ }^{3}$. Zwei in reicher Figurenstickerei gearbeitete Paruren befinden sich im Schatz der Kathedrale

1 Abbildung in Zeitschrift III (1890) 289. Aus der Parura ist später unter Zuhilfenahme des zu ihr gehörenden Amiktbesatzes ein Behang angefertigt worden.
2 Abbildung und Beschreibung ebd. XIII (1900) 213.

${ }^{3}$ Ebd. XII (1899) 189. Über die "Külner Borten" ebd. XIII 1 ff und Braun, Winke 19. 
zu Sens; sie gehören dem 13. Jahrhundert an und weisen unter reizenden Arkaturen den Erlöser und die allerseligste Jungfrau mit dem Kind inmitten von je sechs Aposteln auf ${ }^{1}$. Eine andere mit Bildwerk verzierte Parura besitzt St-Bertrand zu Comminges; sie enthält unter gotischen Bogen die Apostel Philippus, Petrus, Johannes, Matthias und Jakobus und ist den Inschriften zufolge italienischen Ursprungs (Bild 36).

Die vorzïglichsten von allen noch vorhandenen mittelalterlichen Albenparuren besitzt aber der st Veitsdom zu Prag (Bild 37 u. 38) ${ }^{2}$. Es sind ihrer vier. Jede enthält auf einem Goldfond, der durch abgeheftete Goldfäden hergestellt und mit Ranken in feinster Perlenstickerei belebt ist, aufer dem Halbbild des Heilandes bzw. seiner jungfräulichen Mutter die Halbbilder von je zwei männlichen bzw. je zwei weiblichen Heiligen. Alle Figuren sind, nur die Fleischteile, das Haar, die Unterseite der Gewänder und einiges andere kleinere Detail ausgenommen, ganz in Perlen ausgeführt. Umrahmt ist das Bildwerk von einem Blattfries, bei welchem gleichfalls echte Perlen in reichstem Maß̧e zur Verwendung gelangt sind. Die Länge der Paruren, die aus der letzten Hälfte des 14. Jahrhunderts herrühren mögen, beträgt ca $0,31 \mathrm{~m}$, ihre Höhe ca $0,18 \mathrm{~m}$.

Aufer den Paruren kamen übrigens nicht selten auch noch Zierstreifen als Albenornament zur Verwendung. Beliebt war es namentlich, solche

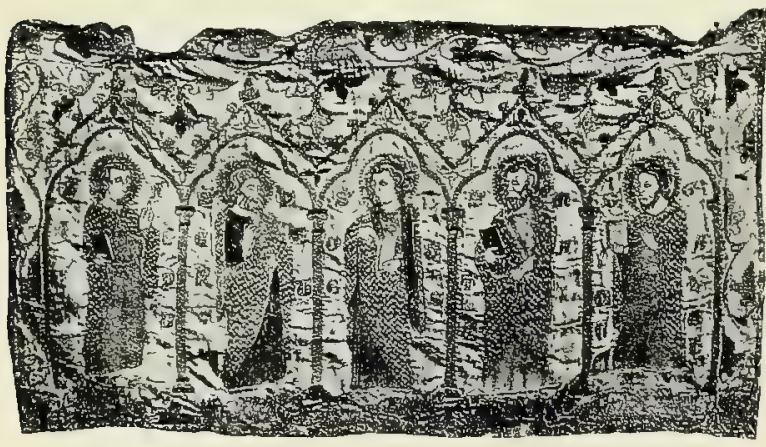

Bild 36. Albenparura mit Figurenstickerei. Comminges, St-Bertrand. auf den Schultern anzubringen. Sie liefen hier entweder bloks rechts und links von dem Ärmelansatz bis zum Kopfdurchlae oder an diesem vorbei von Ärmel zu Ärmel. Auch umgab man wohl den Kopfdurchschlupf selbst mit einem Börtchen. Dann finden wir mehrfach einen, zwei, ja selbst drei Vertikalstreifen auf der Vorder- und Rückseite oder doch wenigstens der Vorderseite des Gewandes. Bei drei Vertikalstreifen befand sich einer in der Mitte, während die andern sich den Rand der Mittelbahn herabzogen (Bild 39, S. 91).

Auf der Albe im Königl. bayrischen Nationalmuseum zu München (vgl. Bild 33, S. 77) geht ein Zierstreifen über die Schultern, ein anderer um den Kopfdurchlaf. Ein dritter steigt über die Brust vom Kopfdurchlak bis zur Mitte des Gewandes herab, ein vierter endlich verläuft quer über die Brust, bildet also mit dem senkrechten Streifen ein förmliches Kreuz. Eine Saumparura scheint die Albe nie besessen zu haben, dagegen findet sich bei ihr am oberen Ende der Giren ein Zierstück in Form eines über Eck stehenden Quadrates angesetzt, von dem die Fältelung der Giren ausgeht, eine Einrichtung, welche sich ähnlich auch sonst bei mittelalterlichen Alben findet, wie z. $B$. bei den Alben im Hospiz zu Lisieux, in S. Chiara zu Assisi, zu Valsainte und im Kensington Museum. Das Zierstück ist hier überall dreieckig. Bei den drei ersten ist es in Weifsstickerei mit Rhomben gemustert, bei der letzten mit einem Kreuz bestickt.

Alben, die einen Vollbesatz am Saum aufweisen, scheinen nach Ausweis der Inventare und Bildwerke im 13., 14. und 15. Jahrhundert im Ganzen nur selten vorgekommen zu sein. Von allen aus jener 'Leit noch erhaltenen Alben

1 Abbildungen in de F a r e y pl. 23. Die Parura in St-Bertrand zu Comminges auf pl. 31.

2 Abbildung aller vier Paruren bei A.PodI a h a und E. Sittler, Topographie der histor. und Kunstdenkmale Böhmens. Der Domschatz in Prag, Prag 1903, $185 \mathrm{ff}$. Eine ist gut in Farben wiedergegeben bei Bock, Gesch. I, Tfl 11. 


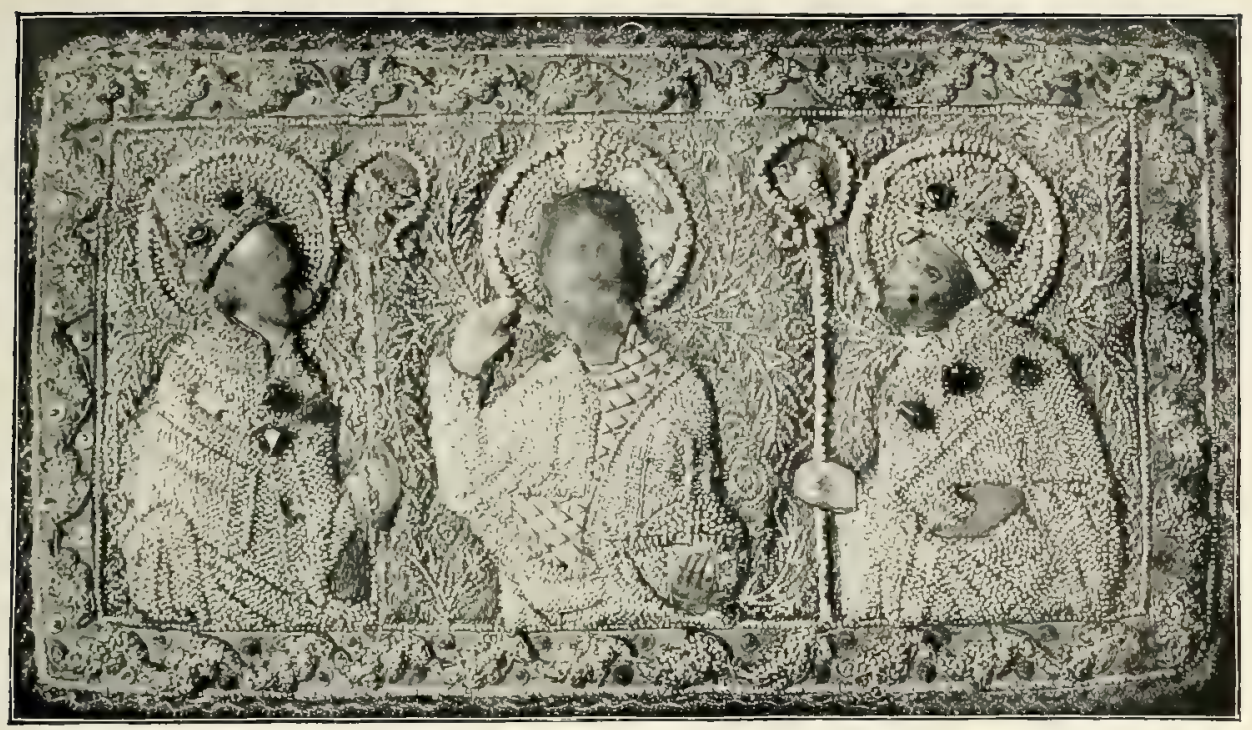

Bild 37. Albemparura. Prag, Domschatz.

(Aus Podlaha n. Sittler, Der Domschatz zu Prag

ist blof eine mit einem solchen ausgestattet, die aus der Neustädter St JohannesKirche zu Hannover stammende, mit M. XX 6 bezeichnete Albe im Provinzialmuseum daselbst. Die Bordüre setzt sich aus Vierpässen zusammen, welche mit einem Wappenschild gefüllt sind und durch Blattwerk voneinander geschieden werden. Bemerkenswert ist, daf aber auch hier in der Mitte des Saumes die Paruren nicht fehlen.

In der Neuzeit ging es den Albenparuren ähnlich wie dem Besatz des Amiktes. Während indessen bei letzterem die Verzierung ganz aufhörte, be-

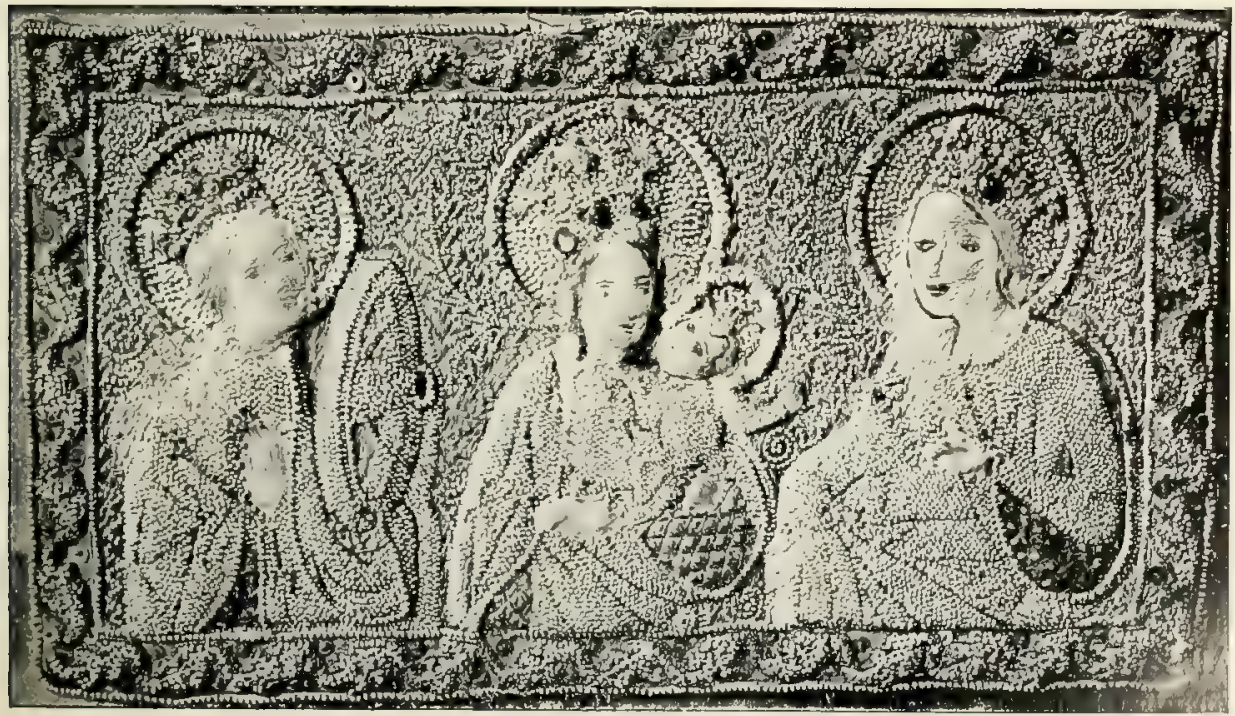

Bild 38. Albenparura. Prag, Domschatz. (Aus Podlaha u. Šitller, Der Domschatz zu Prag.) 
gann bei der Albe eine rückläufige Bewegung, indem wieder Vollbordüren an Stelle der Paruren traten.

Ein gutes Beispiel einer solchen Albe, eine Schöpfung des 16. Jahrhunderts, findet sich in der ehemaligen Stiftskirche zu Göß in Steiermark. Der breite Besatz, der sich um den ganzen Rand derselben hinzieht, ist teils in mehrfarbiger Seide teils in Goldstickerei ausgeführt 1 .

Im allgemeinen hielt das Aufermodekommen der Alben- und Amiktparura gleichen Schritt, wie sie ja auch so ziemlich zur gleichen Zeit aufgetreten waren und in gleichem Maßs sich verbreitet hatten. Freilich auch nur im allgemeinen. Denn wie wir noch gegen Ende des 16. Jahrhunderts dort Amiktbesätze antreffen, wo die Zierstücke der Alben, wie es scheint, schon aufer Gebrauch gekommen waren, so begegnen uns umgekehrt diese hie und da noch, nachdem jene bereits eine Weile von der Bildfläche verschwunden waren. So hört z. B. auf den Mainzer Bischofsmonumenten die Amiktparura, wie früher ausgeführt wurde, schon im Beginn des 16. Jahrhunderts auf, während die Albe noch bei Albrecht von Brandenburg († 1545), Sebastian von Heussenstamm $(† 1555)$ und selbst Daniel Brendel von Homburg $(\dagger 1582)$ die alte Besatzart aufweist. Ähnlich gewahrt man auf dem Grabstein eines Willem Symoens zu Gent († 1570) nicht mehr die Amikt-, wohl aber noch die Albenparura.

In Deutschland bleibt die Albenparura teilweise noch bis gegen Fnde des 16. Jahrhunderts in Gebrauch. Aufer den schon angeführten Grabmälern der Mainzer Erzbischöfe verweisen wir zum Beweis hierfür auf die Grabplatten der Bischöfe Rembert von Kerssenbroich († 1568) im Dom ron Paderborn und Johannes von Hoya $(\dagger$ 1574) im Dom zu Münster. Noch später treffen wir die Zierstiicke als Albenschmuck auf der Grabplatte des Bischofs Johannes Nasius († 1590) in der Franziskanerkirche zu Innsbruck. Von den 77 Albenparuren, die unter dem Namen „bretgen, brederken“ im Inventar der St Brigidenkirche zu Köln von 1578 erwähnt werden, war schon die Rede. In demselben Schatzverzeichnis heifst es: "Item noch 5 alven mit ir heubtdoecher gerüstet (gewaschen) und die brederkens daan geneit." An einer andern Stelle findet sich der Vermerk, es seien einer Albe "roth kamelotte (Wollstoff) bretgen " aufgenäht. Zu Kiedrich im Rheingau waren die "Albenschilde" noch $1583 \mathrm{im}$ Gebrauch. Zu Brixen untersagte erst die Synode ron 1603, ferner scutella (Schilde) zur Verzierung der Alben zu gebrauchen?2. Die Prager Synode vom Jahre 1605 scheint die Paruren nicht mehr zu kennen. Was sie über die Albe sagt, beruht ersichtlich, wie ihre Verordnungen hinsichtlich der Beschaffenheit der übrigen Paramente, auf den Bestimmungen des hl. Karl Borromäus. Ausgelassen ist aber, was der Heilige über die Albenparuren sagt, wohl ein Zeichen, daf diese in der Prager Erzdiözese aufer Verwendung gekommen waren.

In Italien war die Parura, wenn wir von Norditalien, namentlich der mailändischen Kirchenprovinz, absehen, schon um den Beginn des 16. Jahrhunderts kaum mehr gebräuchlich. Zu Venedig treffen wir sie noch auf dem 1535 angefertigten Mosaikbilde des hl. Geminianus im Portikus von S. Marco und einem GemäIde des Girolamo da S. Croce in der Accademia bei St Augustinus. Zu Mailand verordnete der hl. Karl Borromäus: „Unten an der Albe vorn und rückwärts und ebenso an den Ärmelenden mögen quadratförmige Seidenstücke, welche man Grammata oder Auriphrygium nennt, in

\footnotetext{
1 Mitt. III (1885) 94. 2 C. De eccl. n. 16 (Hartzh. VIII 565).
} 
der Farbe und vom Stoff der Kasel aufgenäht werden." ... Wer nach Mailand kommt und im Dome daselbst dem Hochamt beiwohnt, wird bemerkt haben, daßs die Verordnung des hl. Karl bezüglich der Albenbesätze noch immer befolgt wird (vgl. Bild 11, S. 43 und 22, S. 57). Freilich passen dieselben herzlich schlecht zu der häflichen Albenform, wie sie dort gegenwärtig in Gebrauch ist.

Auch in Spanien hat sich hie und da, wie z. B. zu Sevilla ${ }^{1}$ und Toledo, eine wenngleich sehr beschränkte Verwendung der alba parata erhalten. So tragen zu Toledo am Káarfreitag die Sänger der Passion mit Paruren ausgestattete Alben ${ }^{2}$, wohl im Festhalten an der mittelalterlichen Symbolik, welche die Albenbesätze auf die Wunden des Heilandes deutete.

In Frankreich ist der mittelalterliche Albenbesatz heute ganz verschwunden. Im vorigen Jahrhundert gah es daselbst jedoch noch einzelne Kirchen, in denen man sich an hohen Festen der albae paratae bediente. So geschah es z. B., wie Montfaucon berichtet, zu Angers, wo allerdings derartige Alben gerade wie die amictus parati ein Vorrecht der Kanoniker der dortigen Kathedrale bildeten ${ }^{3}$. Wie die Revolution in Frankreich leider eine Menge der kostbarsten und interessantesten Paramente aus dem Mittelalter vernichtet hat, so hat sie auch den traurigen Ruhm, mit manchen andern mittel-

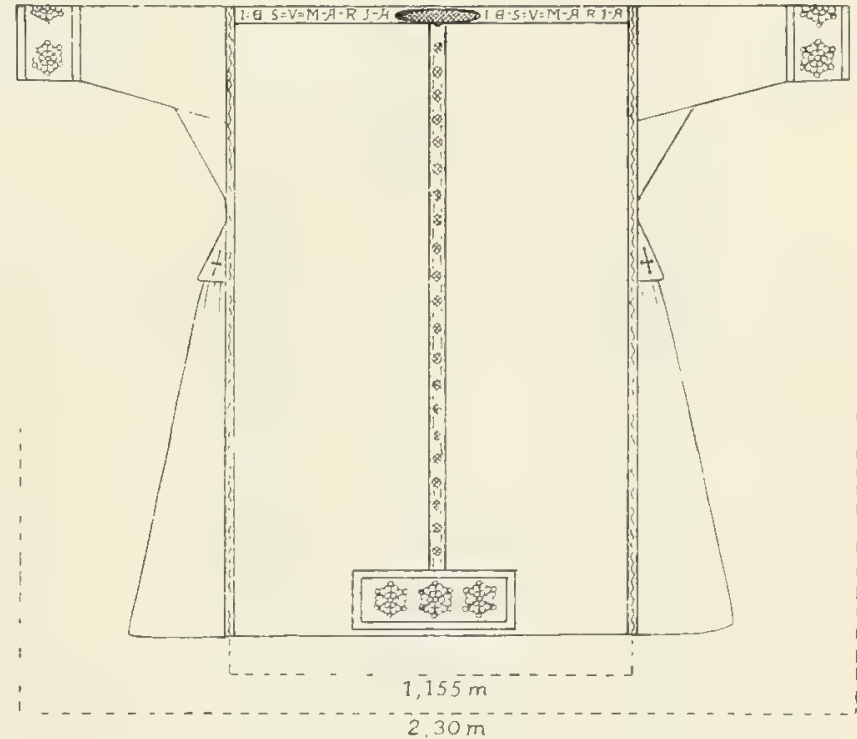

Bild 39. Albe. London, Kensington-Museum.

alterlichen Überbleibseln im Kultus auch die Albenparuren ganz weggeschwemmt zu haben. Auf den Wandel in der Verzierungsweise der Alben wird übrigens das Aufkommen und die Entwicklung der Spitzenindustrie im 10. Jahrhundert nicht ohne Einfluf gewesen sein. Die prächtigen Spitzen, welche diese schuf, waren zu einladend, um nicht auch zur Verzierung bei den Alben verwendet zu werden. In der Tat kamen sie bald als Ausstattung bei denselben in Gebrauch. Die Verbreitung, die sie hierbei nach und nach gewamnen, bedeutete natürlich das Ende der Paruren. Alben mit Spitzen werden in einem Inventar von Angers aus dem Jahre 1644 erwähnt

Die Albenspitzen haben sich bis auf unsere Tage erhalten und werlen auch wohl nimmermehr aus dem Gebrauche verschwinden. In der Tat wäre es verkehrt, die Spitzen, oft genug Werke vollendetsten Kunstfleifes, als Schmuck der Albe zu verschmähen. Richtig und mit gutem Geschmack angewendei.

'W iseman, Vermischte Schriften I (deutsch Köln 1857) 63.
2 Nach Mitteilungen aus Toledo.

${ }^{3}$ Revue 1886, 172. 4 Ebd. 181. 
sind sie ein sehr brauchbares Mittel zu deren würdiger Verzierung. Es ist allerdings vielfach mit ihnen Misbrauch getrieben worden. Sie standen nicht nur oft genug im Widerspruch zum Stoff der Albe - man denke an die duftigen Tüllspitzen, die großlöcherigen Guipuren $u$. ä., sondern erhielten auch häufig zum Schaden der Würde und des Charakters des Gewandes eine unverhältnismäßsige Länge; gab es doch genug Albenspitzen, die bis zu einem Meter breit waren. Der Kampf, den man in den fünfziger Jahren beim Wiedererwachen der religiösen Kunst gegen die Spitzen begann, war daher nicht unberechtigt. Es waren in der Tat Mißbbräuche zu beseitigen. Es läfst sich aber nicht verkennen, daf in der ersten Begeisterung und im heiligen Kampfeseifer nicht selten die Kugeln, die man abschoß, weit ïber das Ziel hinausflogen ${ }^{1}$. Man verwechselte Mifbräuche mit der Sache selbst und gab nur zu oft einseitig den eigenen Geschmack für das allein Richtige, allein Kirchliche aus. Immerhin fiel manches gute Wort, manche treffende Bemerkung, mancher begründete Tadel, manche aufmunternde Anregung. Die erfreuliche Frucht der Bewegung war denn auch, daf wenigstens in Deutschland in Bezug auf die Verwendung der Albenspitzen eine nicht unerhebliche Besserung eintrat.

Der freilich nur vereinzelt gemachte Vorschlag, unter Rückkehr zur mittelalterlichen Gepflogenheit wieder Paruren zur Verzierung der Alben zu verwenden, verhallte jedoch leider so gut wie ergebnislos. Nur in England begann man dieselben von neuem zu verwerten, doch hatten die diesbezüglichen Bemühungen auch hier weder einen durchschlagenden noch einen nachhaltigen Erfolg. Dagegen gelang es, zumal in Deutschland, statt der Spitzen gestickte Bordüren einzuführen, ein Ergebnis, das man immerhin mit Freuden begrüßien kann. Allerdings gilt auch hier, dafi nicht jede gestickte Bordüre als solche schon ein Muster von Schönheit und eine geeignete Verzierung der Albe ist. Wer den Inhalt mancher Sakristeischränke mustert und die Dutzendware nicht blok einer der sog. Anstalten für christliche Kunst beschaut, wird manches finden, das weit weniger zur Albe pabit als zahlreiche der vielgelästerten Spitzen. Das gilt besonders von den in jüngster Zeit so beliebt gewordenen, auf schwerem Kanevas gestickten Albenbordüren, die zu einer Tischdecke und ähnlichem oder als Tischläufer passen mögen, für ein leichtes Linnengewand aber zu steif und massig sind.

\section{DIE LITURGISCHE TUNIKA IN DEN ORIENTALISCHEN RITEN. DIE EPIMANIKIEN.}

Bei allen Riten des Ostens gibt es eine liturgische Tunika, griechisch sticharion, slavisch stichar, armenisch schapik, syrisch (chaldäisch) kutīnã, koptisch stoicharion, tuniah. Sie kommt allen Klerikern zu, vom Patriarchen angefangen bis zum Lektor.

Bei den Priestern und Bischöfen wird die Tunika zwar gegürtet, aber in der Piegel nicht auch aufgeschürzt. Sie pflegt daher etwas kürzer zu sein als die abendländische Albe. Die Tunika der Diakone wird in keinem Ritus gegürtet, diejenige der Subdiakone und Lektoren nur im griechischen und koptischen. Eine Obertunika der Diakone und Subdiakone von der Art der abendländischen Dalmatik und Tunicella ist den Riten des Ostens unbekannt.

\footnotetext{
1 Man vergleiche namentlich die diesbezüglichen Aufsätze in den älteren Jahrgängen des ${ }_{\pi}$ Kirchenschmuck*, der sich tiberhaupt
}

um die Besserung und Hebung des Paramentenwesens die größten Verdienste erworbeu hat. 
Diakon und Subdiakon tragen nur eine Tunika, die bei ihnen freilich in gewisser Hinsicht ein Mittelding zwischen Albe und Dalmatik ist. Die priesterliche und bischöfliche Tunika hat allenthalben enge Ärmel. Bei den Diakonen und teilweise auch den Minoristen pflegen die Ärmel der Tunika dagegen fast mittelweit zu sein, namentlich bei den Griechen (Russen) und Armeniern (Bild f0).

In Bezug auf die Farbe der Tunika herrscht in der Ostkirche durchweg die gröfte Freiheit. Wenn wir von Schwarz absehen, ist keine Farbe von ihr ausgeschlossen. Immerhin bevorzugt man für die priesterliche und bischöfliche Tunika Weif. Vorgeschrieben ist dies für selbige bei den Kopten. Ein buntes Farbenspiel gewähren die Tuniken der Diakone und Minoristen bei den Armeniern, wie jeder bemerkt haben wird, der Gelegenheit hatte, dem armenischen Gottesdienst beizuwohnen. Da sieht man z. B. rote Tuniken mit breiten gelben oder blauen Besätzen und gleich daneben blane Tuniken mit roten oder gelben Besätzen.

Die Verzierung der Tuniken ist durchweg recht dürftig. Der Regel nach beschränkt sie sich auf ein oben auf der Rückseite angebrachtes gleicharmiges Kreuz. Reicheren Schmuck erhält die Tunika nur bei den schismatischen Kopten und den Armeniern, doch ist es bei letzteren blok die Tunika der Diakone und Minoristen, welcher eine besondere Ausstattung zu teil wird. Sie besteht in einer breiten Bordüre, welche die Ärmelmündungen und den Saum des Gewandes umgibt, sowie in einem kragenförmigen Besatz, welcher den Durchlaf für den Kopf umzieht. Auferdem bringt man gern vor den beiden Schultern bzw. auf den beiden Oberarmen ein Kreuz bzw.

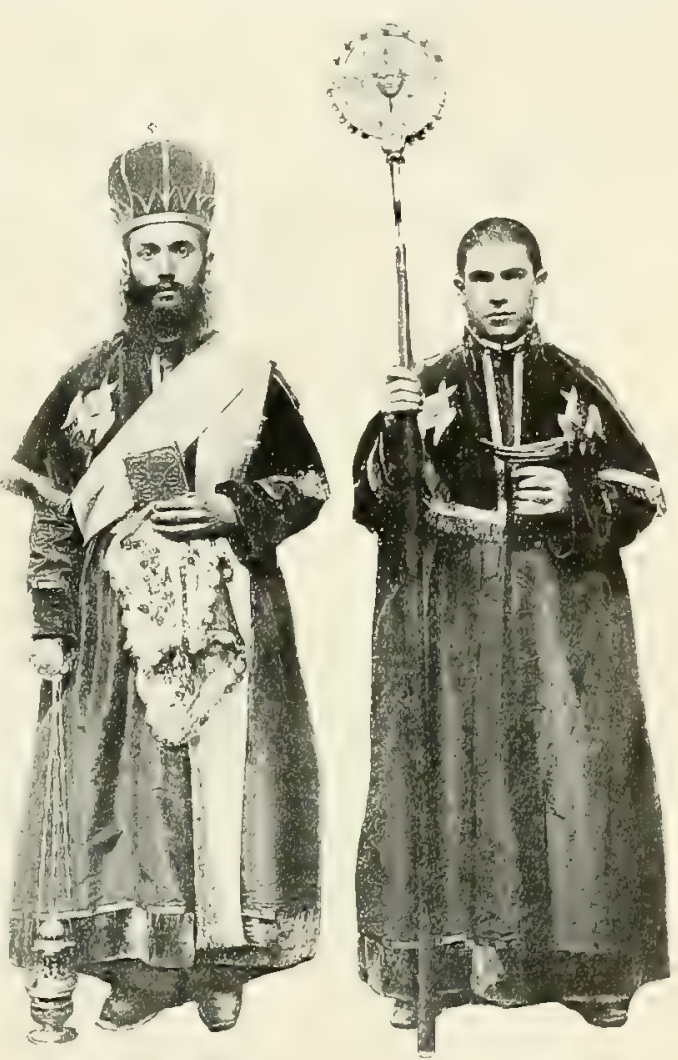

Bild 40. Armenischer Diakon und Subdiakon. einen Cherub an, wie man sagt, um die Stelle für den Friedenskufs zu bezeichnen. Statt des kragenähnlichen Besatzes trägt man übrigens auch wohl einen förmlichen, rings mit Fransen versehenen Kragen (Bild 40).

Bordüren und Besatz werden bei einfachen Tuniken blok aus andersfarbigen, stark kontrastierenden Stoffen gemacht, bei besseren aber durch Stickerei hergestellt. Ein interessantes Exemplar einer Tunika der letzteren Art besitzt das Düsseldorfer Gewerbemuseum (Bild 41, S. 95). Der die Halsüffnung derselben umrahmende kragenförmige Besatz weist im Nacken in reicher Goldstickerei das letzte Abendmahl, vorn die Verkündigung und Cherubim anf́.

Die Tunika der schismatischen Kopten soll auf dem Rücken ein Kíleuz. auf den Ärmeln das Bild des hl. Georg und des hl. Michael und ror der I'ruse das der allerseligsten Jungfrau mit dem Jesuskinde und darüber ein zweites 
Kreuz tragen. Doch kann auf den Ärmeln auch ein Cherub angebracht werden. In diesem Fall kommt die Darstellung des hl. Georg unter diejenige der Gottesmutter zu stehen.

Die bischöfliche Tunika des griechischen Ritus soll mit roten Vertikalstreifen ( $\pi \circ \tau_{\alpha \mu o \ell}$ ) verziert sein.

Betreffs des Stoffes der liturgischen Tunika besteht in den Kirchen des Ostens keine streng bindende Vorschrift. Es kann ebensowohl Seide und Wolle wie Linnen oder Baumwolle für sie genommen werden, doch pflegt man bei den liopten die Tunika des Priesters und Bischofs gewöhnlich aus Linnen anzufertigen; ähnlich verhält es sich im chaldäischen Ritus. Die diakonale Tunika wird allgemein, wenn möglich, aus Seide hergestellt.

Die Tunika wird in den Riten des Ostens fast nur bei dem heiligen Opfer und bei liturgischen Handlungen getragen, die, wie die Erteilung der heiligen Weihen, in engster Verbindung mit demselben verrichtet werden. Aufserhalb der Messe ist ihr Gebrauch beschränkter als derjenige der Iateinischen Albe bzw. ihres Surrogates, des Superpelliceum, weil da, wo man im abendländischen Ritus Albe und Stola bzw. Superpelliceum braucht, bei den Orientalen gewöhnlich nur die Stola oder die Stola mitsamt dem liturgischen Obergewand zur Verwendung kommt.

Bei den Griechen sollte der Lektor an sich keine Tunika, sondern ein kurzes Phelonion (Kasel) tragen und mit diesem zum Zeichen, dafs es sein Amtskleid sei, bei der Weihe bekleidet werden. In der Wirklichkeit hat sich aber die Sache schon seit langer Zeit dahin gestaltet, dab auch der Lektor das Sticharion hat und ihm demgemäp bei der Weihe anstatt des Phelonion das Sticharion angelegt wird. Ein Rest der alten Praxis hat sich indessen im russisch-griechischen Ritus erhalten. Denn obwohl auch in ihm die Lektoren für gewöhnlich das Sticharion benutzen, wird ihnen doch bei der Weihe zunächst das Phelonion und erst am Schluf das Sticharion angezogen ${ }^{1}$.

Auch in den übrigen Riten der Ostkirche pflegt der Lektor bei seiner Ordination mit der Tunika bekleidet zu werden, wenngleich nicht bei allen durch den Bischof selbst. Bei den Maroniten, bei welchen die eigenartige Sitte besteht, bei der Weihe nicht nur dem Lektor, sondern auch dem Subdiakon, Diakon und selbst dem Bischof die Tunika anzulegen, spricht der Konsekrator, während er den Ordinanden mit derselben bekleidet: "Zieh an, o Herr, diesem deinem Diener die Tunika des Lektorats (Subdiakonats usw.) zum Lob und Preis der heiligen Dreifaltigkeit und zur Erbauung und Kräftigung der heiligen Kirche und all ihrer Kinder, auf den Titel des Altares der Kirche des hl. N., im Namen des Vaters usw." 2

ITas die Geschichte der liturgischen Tunika in den orientalischen Riten anlangt, so läfst sich darüber wenig feststellen. Es sind nur ganz vereinzelte und zudem meist späte Angahen, die wir betreffs derselben erhalten. Auch die Monumente bringen wenig Aufschluf, zumal aus früher Zeit kaum etwas an solchen vorhanden ist. Obendrein ist es fast nur die Tunika des griechischen Ritus, über deren Geschichte wir einige nähere Auskunft erhalten.

Die Hauptfrage ist natürlich, seit wann es in den orientalischen Riten eine liturgische Tunika in dem früher erklärten Sinne ${ }^{3}$ gegeben habe. Möglich,

1 v. Maltzew, Die Sakramente der orthodox-katholischen Kirche, Berlin 1898, 309 311. Das Phelonion wird ihnen vor Anlesung des Sticharion wieder ausgezosen.
${ }^{2}$ A ss., C. 1. 1. 8, p. 2 praef. n. $38 \mathrm{ff}$ (p. Lxxix ff), sowie die dort abgedruckten einzelnen Ordines p. 284780.

3. S. oben S. 63 . 
dałs schon der heilige Poderes (eine bis zu den Füß3en herabwallende Talartunika), der uns in der bei Gelegenheit der Einweihung der Basilika zu Tyrus an die anwesenden Bischöfe gehaltenen Ansprache des Eusebius von Cäsarea begegnet, als solche aufzufassen ist. "Freunde Gottes und Priester", so begrüfte der" Redner seine Mitbischöfe, „die ihr bekleidet seid mit der Talartunika und dem himmlischen Ruhmeskranze." 1 Indessen ist es nicht unwahrscheinlich, dafis Eusebius nur im Bilde gesprochen hat, indem er im Hinblick auf die alttestamentliche sakrale Talartunika, statt zu sagen: „mit der Priesterwiurde bekleidet", die Metapher brauchte: "mit dem heiligen Poderes bekleidet". Denn eine ähnliche, hier jedoch unzweifelhaft bildliche Redeweise finciet sich bei Gregor von Nazianz in der Rede auf seine Bischofsweihe ${ }^{2}$. Nicht minder läßst die Wendung "mit dem himmlischen Ruhmeskranze" die allegorische Auffassung der Worte Eusebius" als die wahrscheinlichste erscheinen.

Wie dem indessen auch sein mag, jedenfalls können die linnenen Sticharien, wegen deren sich der hl. Athanasius gegenüber den Anschuldigungen der Arianer zu verteidigen veranlast $\operatorname{sah}^{3}$ - man hatte dem Heiligen vorgeworfen, er habe als der erste linnene Sticharien unberechtigterweise als Abgabe verlangt -, nicht zum Beweise dienen, dafs es zu des großen Bischofs Zeit bereits eine Sakraltunika im Osten gegeben habe, wiewohl man sie oft genug zu diesem Zweck herangezogen hat. Denn wenn es sich auch bei denselben um Tuniken für Athanasius und seine Kleriker

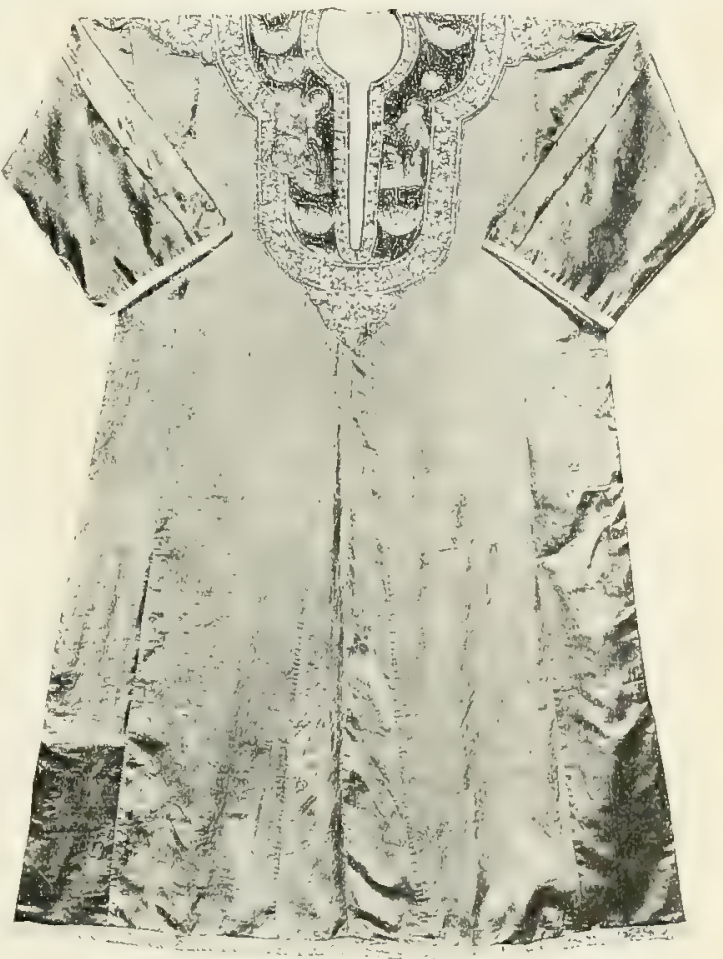

Bild 41. Armeuische Diakonentunika. Düsseldorf, Kunstgew rhemuseum. handelt, so liegt doch kein Grund vor, sie als liturgische Tuniken aufzufassen. Noch viel weniger aber beweist das Sticharion, von dem in des Palladius Historia Lausiaca die Rede ist ${ }^{4}$, die Existenz einer liturgischen Tunika. Denn wenn dort erzählt wird, es habe der hl. Athanasius, als die Häscher zur Nachtzeit in seine Wohnung eindrangen, um sich seiner zu bemächtigen, sein Sticharion und seinen Birrus (Tunika und Mantel) genommen und ein Versteck aufgesucht, so ist hier offenbar nur die gewöhnliche Tunika gemeint.

Einer diakonalen Tunika, die, wie es scheint, eine liturgische Tunika darstellt, geschieht in der 83. Homilie des hl. Johannes Chrysostomus zu

1 Hist. eccl. 1. 10, c. 4 ( $\mathrm{Mg} .20,849)$.

2 Or. 10, n. 4 (Mg. XXXV 829). Er schildert hier seine Weihe im Bilde der aronitischen Priesterweihe ( $\mathrm{Lv} 8,6 \mathrm{ff}$ ).
3 Apologia contra Arianos n. 60 (119. 25, 357). Vgl. Soz o m en us, Hist. eccl. 1. ¿2, c. 22 ( $\mathrm{Mg} .67,992)$.

+ C. 136 ( $\mathrm{Mg} .34,1235$ ). 
Matthäus Erwähnung: „Das ist eure Ehre, eure Sicherheit und eure Krone (nämlich zu unterscheiden, wem sie den Leib des Herrn zu reichen haben), nicht aber, daf ihr in weißer, hellschimmernder Tunika einherzieht", mahnt dort der Heilige die Diakone 1. Auch im Testamentum Domini Iesu Christi dïrfte unter dem weißen Gewand, in dem der Diakon im Hospiz sitzen soll, um sich der Fremden anzunehmen, nach dem Zusammenhang die diakonale Amtstunika zu verstehen sein ${ }^{2}$.

Etwas Bestimmtes läbt sich also über das Alter und die Urgeschichte einer liturgischen Untertunika in den Riten des Ostens nicht feststellen.

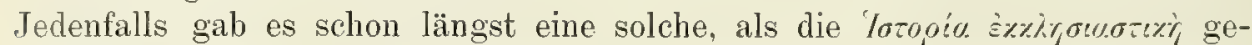
schrieben wurde, und nicht erst zur Zeit, da die unter dem Namen des hl. Germanus von Konstantinopel gehende Mefierklärung entstand. Die Yoropía redet allerdings nur von dem Sticharion des Bischofs ${ }^{3}$, indessen gestattet natürlich die Verwendung einer liturgischen Tunika bei diesem einen Rückschluß überhaupt auf den Gebrauch einer solchen. Bemerkenswert ist, was die Schrift über die Ausstattung des bischöflichen Sticharion mitteilt. Sie erzählt nämlich, es sei vorn an den Ärmeln mit Zierstreifen versehen gewesen, welche sie anf die Handfesseln Christi deutet. Auferdem erfahren wir, dal.3 seitlich am Gewand Streifen angebracht waren, durch welche das am Kreuz aus den Wunden des Heilandes rimnende Blut versinnbildet werde; es sind die bekannten antiken clavi, die sich als Reminiszenz auch noch in den Besätzen unserer Dalmatiken erhalten haben.

Von der Farbe des Sticharion sagt die Schrift nichts. Erst die unter dem Namen des hl. Germanus gehende Meferklärung tut ihrer Erwähnung, wenn sie das Gewand als weiß bezeichnet. Weils war auch das Sticharion, das Patriarch Nicephorus von Konstantinopel mit andern Meßsgewändern Papst Leo III. zum Geschenk machte ${ }^{4}$.

Seit wann es neben weifsen auch farbige Sticharien gab, lä fat sich nicht bestimmen. Auf den Miniaturen kommen deren schon ziemlich früh vor, doch sind diese, was die Farbe der Gewänder anlangt, nicht gerade besonders zuverlässig. Gegen Ende des Mittelalters waren jedenfalls nicht mehr ausschliefilich weife Tuniken in Gebrauch; denn Simeon von Saloniki redet bestimmt von purpurnen bischöflichen Sticharien ${ }^{5}$. Weils oder purpurn war nach Simeon auch das xauiaroy. das Amtskleid der Lektoren, das entweder dem Phenolion, der Kasel, gleichen oder auch die Form eines Sticharion haben konnte ${ }^{6}$. Immerhin scheint das Sticharion im Mittelalter vorherrschend von weiker Farbe gewesen zu sein, besonders bei den liopten, bei welchen nach der Kanonessammlung des Ibn 'Assal und den Canones imperiales sogar die ganze liturgische Gewandung aus weißen Stoffen gemacht sein sollte?

Die Besätze, mit denen nach der Koropía die Tunika geschmückt wurde,

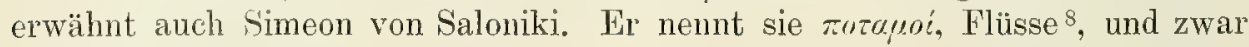

I Mg. 58, 745 .

2 L. 1, c. 24 (ed. Rahmani), p. 89.

3 Jahrb. von Odessa IV 2 (1894) 245. In den Handschriften wechseln die Lesearten. Sie haben teils jozórous, teils icosis, teils ispeis braxirous; allein der Zusammenhang ergibt mit Bestimmtheit, dafs nur ispeis, und zwar im Sinne von Bischöfen, gemeint sein können, und daß die erste Leseart ein Schreibfehler, die zweite ein unglïcklicher

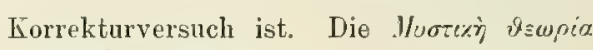
gibt richtig ispeis.

4 M. 102, 1068.

${ }^{5}$ De sacra liturgia c. 79 (Mg. 155, 256).

6 De sacra ordinatione c. 186 (ebd. 396).

7 Renaudot, Goll. lit, orient. I 160 Can. S. Bas. c. 99 (W. Rie d el, Kirchenrechtsquellen des Patr. von Alexandrien, Leipzig 1900, 272).

8 De sacra liturgia c. 79 ( $\mathrm{Mg} .155,256)$; De divino templo q. 37 (ebd. 712). 
war es zu seiner Zeit noch immer ein Vorrecht der Bischöfe, ihr Sticharion mit denselben $\mathrm{zu}$ schmücken. $\mathrm{Ob}$ es immer so gehalten worden, ist nicht mit Sicherheit zu bestimmen, doch ist das wohl am wahrscheinlichsten. Es ist uns keine Darstellung bekannt, auf der die priesterliche oder diakonale Tunika mit den fraglichen Streifen geschmückt wäre. Nach Balsamon, also im 12. Jahrhundert, galten sogar die nozuurí auf dem Sticharion als Vorrecht der Patriarchen ${ }^{1}$. Auf den Monumenten sind die zotuuo' bald von roter, bald von dunkelvioletter, meistens aber von schwarzer oder schwärzlicher Farbe. In der Regel bestehen sie aus zwei parallel nebeneinander laufenden Streifen (Bild 42). Die rotupó dienten sicher im griechischen Ritus zur Verzierung der bischöflichen Tunika. Ob und in welchem Umfang sie auch in den andern Riten des Ostens als Schmuck derselben zur Verwendung kamen, läßt sich nicht feststellen.

Wie die Funde in den koptischen Gräberfeldern beweisen, bedienten sich die Altkopten im Alltagsleben zur Verzierung der Tunika aufer Längsstreifen, die von oben bis unten reichten, auch breiterer oder schmalerer Saumeinfassungen, runder, viereckiger oder herzförmiger Flecke sowie streifenförmiger Besätze, die sich von den Schultern bis etwa in die Mitte des Rückens bzw. unter die Brust herabzogen und unten mit einem runden oder ovalen Anhängsel endigten. Es ist beachtenswert, dafs auf diesen Zierstücken vielfach auch religiöse Motive zur Darstellung gekommen sind ${ }^{2}$. Ohne Zweifel wird man sich ähnlicher Ornamente, die in Gobelinwirkerei hergestellt und teils dem Gewandstoff aufgesetzt teils eingearbeitet waren, auch zur Ausstattung der liturgischen Tunika bedient haben. Die Sitte der schismatischen Kopten, die tuniat

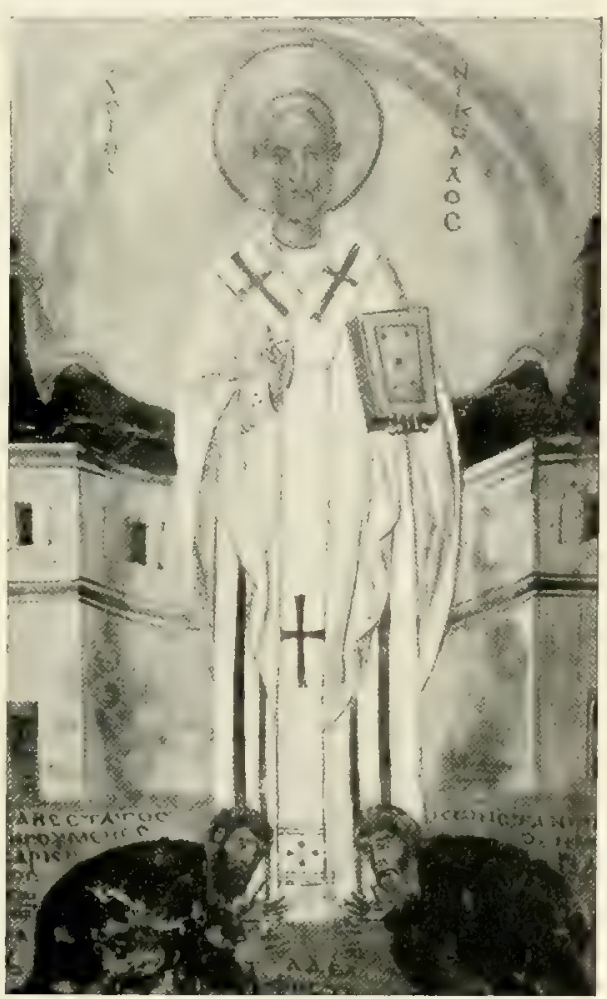

Bild 42. St Nikolaus. Griechische Miniatur. Rom, Vaticana. noch jetzt auf den Ärmeln, der Brust und dem Rücken mit Bildwerk zu versehen, mag ein Überbleibsel der alten Gepflogenheit sein, von der uns die Gräber Kunde brachten.

Auf den Miniaturen des syrischen Pontifikale der Pariser Nationalbibliothek ist weder bei den Bischöfen noch Priestern noch Diakonen von einer Verzierung der Tunika mittelst der zozupó etwas zu sehen. Dagegen gewahrt man wohl an dem Oberarm der diakonalen Tunika einen Zierbesatz. Der Farbe nach sind hier die Tuniken meistens rot, blau oder grün, doch kommen auch weike vor. Ob die Darstellungen Zeugnis von dem damaligen Tatbestand ablegen?

\footnotetext{
1 Meditata. Mg. 138, 1022.

2 S. oben S. 13, Anm. 1. 
Bezüglich der Verwendung, welche die liturgische Tunika beim Gottesdienst in den Riten des Ostens erfährt, dürfte es sich in der Vergangenheit nicht anders denn in der Gegenwart verhalten haben.

Im griechischen Ritus trugen in älterer Zeit nur die Bischöfe, die Priester und Diakone das Sticharion; die Subdiakone und Lektoren bedienten sich bei ihren Funktionen statt seiner einer Art von Kasel, des Phelonion. Taun sich auch bei ihnen das Sticharion einbürgerte, läbt sich nicht genau angehen. Bis gegen das 12. Jahrhundert war solches wohl noch kaum erfolgt. Denn in zwei Weiheordines aus der Wende des 1. und der Frühe des 2. Jahrtausends treten die Ordinanden zum Empfang der Diakonatsweihe noch im Phelonion hin, das ihnen dann bei dieser ausgezogen wird ${ }^{1}$. Im 1400 dagegen war bei den Subdiakonen das Phelonion schon eine Weile völlig aufer Gebrauch gekommen und ganz durch das Sticharion ersetzt. Aber auch bei den Lektoren finden wir dieses bereits um die Wende des 14. Jahrhunderts, wenngleich bei ihnen nur neben dem althergebrachten Gewand 2. Der Wechsel, durch den bei den Minoristen des griechischen Ritus das Sticharion ganz oder teilweise an die Stelle des Phelonion trat, mag sich demnach etwa im 12. oder 13. Jahrhundert vollzogen haben.

Seit wann in den übrigen Riten des Ostens die Subdiakone und Lektoren eine liturgische Tunika tragen, ist aus Mangel an diesbezüglichen Nachrichten nicht näher zu bestimmen. Dał es in der zweiten Hälfte des 12. Jahrhunderts im armenischen Ritus bei ihnen eine solche gab, ersehen wir aus den Angaben des Nerses von Lampron, der ausdruicklich die Tunika als das allen Geistlichen zukommende gottesdienstliche Gewand bezeichnet ${ }^{3}$. Freilich bestand damals bei den Armeniern auch eine Richtung, welche sich um eine besondere liturgische Ḱleidung nicht kümmerte und keinen Anstok nahm, die heiligen Geheimnisse in der Alltagstracht zu feiern. Nerses von Lampron deutet selbst solches an ${ }^{4}$.

Eine Ergänzung der sakralen Tunika bilden in der Ostkirche die sog.

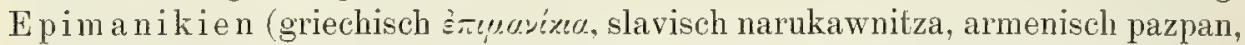
syrisch zendo, chaldäisch zendā, koptisch kimam). Sie sind, wenngleich mit einigen geringfügigen Unterschieden, bei allen Riten des Ostens in Gebrauch. Bei den Armeniern, Syrern, Chaldäern und Kopten bedienen sich ilırer nur die Bischöfe und Priester, bei den Griechen aller Schattierungen, den Russen, den eigentlichen Griechen, den Syro-Melchiten, den Italo-Griechen, Bulgaren, Serben usw. tragen auch die Diakone die Epimanikien. Bei den Maroniten scheinen, nach dem Ordinationsritus zu schlieken, nur die Bischöfe die Stauchen anzulegen. Ihrem Gewandcharakter nach sind die Epimanikien eine Art von Stauchen, Manchetten oder Stulpen (s. Bild 15, S. 49). Sie sind etwa $0,15-0,18 \mathrm{~m}$ lang und so weit, daf sie, ohne auf die Hände zu rutschen, üher den Ärmeln der Tunika getragen werden können. Die liturgischen Stauchen des griechischen Ritus sind gerade wie unsere Manchetten an der Unterseite offen. Sie werden am Arm mittelst einer an den beiden Schmalseiten angebrachten Schnur befestigt. In den übrigen Riten des Ostens sind die Epi-

\footnotetext{
1 Vgl. die griechischen Weiheordines bei Ass., C. l. I. VIII 4114140141143.

2 Simeon Thess., De ordinatione c. 162 186 ( Mg, 368 396). Näheres siehe Absch, 2, Kap. :, \$1: Las Mefigewand in den Riten des Ostens.
}

3 Kommentar zur göttl. Lit. c. 527 (ed. Venet. $80 \mathrm{ff} 145 \mathrm{ff}$ ).

* Ehd. Vgl. auch Isaaci Cath. Invect. adv.

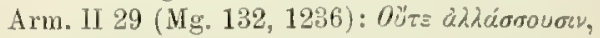

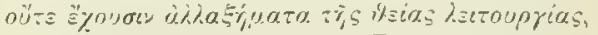

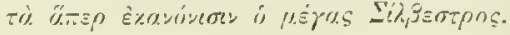


manikien ringsum geschlossen, so daß sie nur über den Tunikaärmel gestreift zu werden brauchen.

Ein bestimmter Stoff und eine bestimmte F arbe ist für die liturgischen Stauchen nicht vorgeschrieben. Bei den Priestern und Bischöfen sind diese indessen gewöhnlich von der Farbe und möglichst auch dem Material des Obergewandes, des Phelonion. Die Verzierung der Epimanikien besteht in einem den Rand derselben umsäumenden Börtchen und einem auf der Oberseite angebrachten gleicharmigen Kreuzchen.

Die geschichtlichen Nachrichten über den Gebrauch der Epimanikien sind im ganzen spärlich. Bei den Kopten bezengt ihn nicht blof Ibn Sabaa im 14. Jahrhundert, sondern auch schon Patriarch Gabriel im $12{ }^{1}$. Dak sie auch bei den Syrern bereits im Mittelalter Verwendung fanden, beweisen die syrischen Weiheordines; demn ist es auch beim jetzigen Stand der Dinge noch nicht möglich, sicher das Alter dieser Weiheformulare zu bestimmen, so ist es doch wohl unzweifelhaft, daf sie nicht erst der Neuzeit entstammen. Es erhellt das ferner aus der zuerst von Fabricius Boderianus 1572 zu Antwerpen veröffentlichten syrischen Melsliturgie, welche der Stauchen als eines der liturgischen Gewänder des Priesters Erwähnung tut. Allerdings irrt der Herausgeber, wenn er dieselbe dem Patriarchen Severus von Antiochien († 5:39) zuschreibt. Allein kann sie auch nicht dem 6. Jahrhundert zugewiesen werden, so ist sie sicher nicht unmittelbar vor dem 16. entstanden. In der Tat erscheinen die Stauchen schon in aller Klarheit auf einigen der Miniaturen des syrischen Pontifikale von 1239 in der Nationalbibliothek zu Paris, so auf der Darstellung der Bischofsweihe beim Konsekrator (vgl. Bild 19, S. 51). Bei den Armeniern waren sie bereits in der zweiten Hälfte des 12. Jahrhunderts in Gebrauch, wie Nerses von Lampron bekundet. Sie waren bei ihnen ein privilegiertes Ornatstück der Bischöfe?

Am günstigsten steht es im griechischen Ritus. Hier vermögen wir die Epimanikien nicht blof mit Bestimmtheit bis zum Beginn des Jahrtausends zu verfolgen, sondern auch zur Genüge ihren Ursprung nachzuweisen. Die erste Nachricht erhalten wir über sie um 1054 in dem Briefe des Patriarchen Peter von Antiochien an den Patriarchen Michael Cärularius ${ }^{3}$. Sie erscheinen hier wie

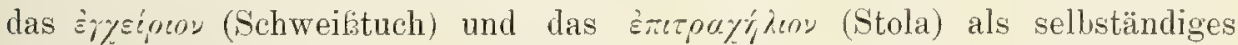
Ornatstück, also nicht als bloker Besatz der Tunika. Auch erhellt aus dem Briefe, dafs sie mit Goldverzierungen versehen zu werden pflegten. Da die Epimanikien vom Patriarchen als allbekannter Bestandteil der liturgischen Tracht behandelt werden, müssen sie schon eine geraume Weile im Gebrauch gewesen sein. Wirklich finden wir bereits in dem Menologium des Basilius II. $\left(\dagger\right.$ 1025) in der vatikanischen Bibliothek ${ }^{4}$ genug Abbildungen der Epimanikien. Auch die Darstellung des hl. Nikolaus in einem vielleicht noch ins 10. Jahrhundert hineinreichenden, spätestens aber dem 11. entstammenden Alten Testament ${ }^{5}$ der Vaticana liefert ein gutes Beispiel (vgl. Bild 42, S. 97).

Seit dem 11. Jahrhundert ist dann wiederholt von den Epimanikien die Rerle. Besonders beachtenswert ist, daf es noch um das Ende des 12. Jahrhunderts ein ausschliefliches Vorrecht der Bischöfe war, sich der liturgischen Stauchen zu bedienen. Denn auf die Frage, ob es den Hegumenen und

Re na u dot, Liturg. orient. collect. I (Frankfurt 1847) 160161.

${ }^{2}$ Kommentar zur heiligen und göttlichen Liturgie c. 27 (ed. Venet. 145 ff). Die Stauchen wurden in die übrigen orientalischen Rituil wohl aus dem griechischen herübergenommen.

${ }^{3}$ Mg. 120, 800.

5 Vat. reg. gr. 1.
4 Vat. gr. n. 1613.

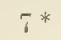


Protopopen (Äbten und Erzpriestern) gestattet sei, die Epimanikien zu tragen, antwortet Balsamon, seit 1193 Patriarch von Antiochien, dem Patriarchen Marius von Alexandrien schlechthin verneinend 1.

Die Sache änderte sich jedoch allmählich. Schon um 1400 fanden, wie wir von Simeon von Saloniki vernehmen, die Epimanikien auch bei den Priestern Verwendung ". Bei den Diakonen waren sie aber damals noch nicht in Gebrauch. Bei ihnen haben sie sich also frühestens im Verlauf des 15. oder 16. Jahrhunderts eingebürgert.

Die /orogia und die unter dem Namen des hl. Germanus gehende Mefaerklärung kennen die Epimanikien noch nicht. Ebenso weib das von Krasnojeljcev veröffentlichte liturgische Fragment nur erst von dem Sticharion, dem Gürtel, dem Epitrachelion, dem Phelonion und dem Omophorion des Bischofs ${ }^{3}$.

Man hat wohl gemeint, die Epimanikien hätten einen ähnlichen Ursprung wie der abendländische Manipel, d. h. sie seien ursprünglich Schweisstücher gewesen. Indessen mußs eine solche Hypothese schon darum abgelehnt werden, weil die Epimanikien stets an beiden Armen getragen wurden, ein doppeltes Schweifstuch aber, eines auf dem rechten und ein anderes auf dem linken Arm, weder jemals üblich war, noch überhaupt einen Sinn gehabt hätte. Der Ursprung der liturgischen Stauchen ist aber auch tatsächlich ein anderer. Sie sind lediglich die von den Ärmeln losgelösten und zum selb-

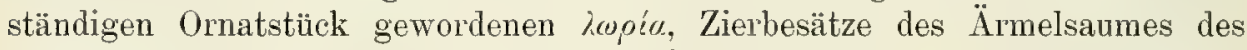
bischöflichen Sticharion, von denen die Yaropio und die von ihr abhängige Meferklärung des hl. Germanus erzählen. Dak diese iwpic noch kein für sich bestehender Gewandteil waren, beweist mit aller Bestimmtheit der Umstand, dafis die beiden Schriften alsbald auch die purpurnen Vertikalstreifen der Tunika io ota nennen.

Anfänglich den Ärmeln aufgenäht, wurden diese Zierbesätze, sei es, um sie mehr zu schonen, oder um sie zu verschiedenen Sticharien brauchen zu können, oder um der Notwendigkeit überhoben zu sein, sie beim Waschen der Sticharien abzutrennen, in der Folge von den Ärmeln dauernd losgelöst und in der Form von Stauchen zu einem selbständigen Ornatstück umgestaltet. Als solches folgten sie dann hinsichtlich der Farbe auch nicht mehr der Farbe der Vertikalbesätze des Gewandes, sondern derjenigen des liturgischen Obergewandes. Es ist ein ähnlicher Vorgang, wie er sich in der Neuzeit im Abendland zu Mailand, Lyon und in Spanien mit der Amiktparura vollzog: Wie hier sich der Besatz von dem Schultertuch trennte und zu einem förmlichen Kragen (collare, collarín, collet) wurde, so bildeten sich im Osten die $\lambda$ wo éc der Sticharionärmel zu förmlichen Manschetten um.

Die angegebene Erklärung der Entstehung der Epimanikien erklärt es denn auch, warum dieselben anfangs ein Privileg der Bischöfe waren. Waren

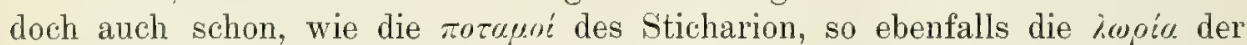
Ärmel desselben ohne Zweifel den Bischöfen als Auszeichnung vorbehalten.

Leider läßt sich auf die Frage, wann sich die so interessante Umbildung der iogí. vollzogen habe, nicht einmal eine annähernd genaue Antwort geben,

1 Resp. 37 ( $\mathrm{Mg} . .138,987)$. Wenn uns daher in der sog. Liturgie des hl. Johannes Chrysostomus (Mg, 63, 903) bei der Vorbereitung zur Messe heim Priester die liturgischen Stauchen begegnen, so ist klar, daß der fragliche Passus erst seit dem Ende des 12. Jahrhunderts in dieselbe hineingekommen sein kann.

2 De sacra liturg. c. 83 ( $\mathrm{Mg} .155,261)$.

${ }^{3}$ N. Krasnojelj cev, Addenda ad anecdota graeco-byzantina (Odessa 1898) n. 13 . 
weil wir zu wenig über das Alter der 'Vatonía und der beiden andern erwähnten liturgischen Schriften wissen. Um die Wende des Jahrtausends war sie jedenfalls schon erfolgt. Vielleicht, daß sie erst im 10. Jahrhundert vor sich ging. Wenigstens scheinen die Miniaturen der zwischen 867 und 886 für Kaiser Basilius I. angefertigten Pariser Homiliensammlung des hl. Gregor von Nazianz ${ }^{1}$ mit ihren Bischofsbildern die Epimanikien noch nicht zu kennen. Die Verzierung am Saum der Sticharionärmel macht hier noch ganz den Ein-

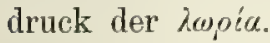

Ein Gegenstück zu den Epimanikien hat es im römischen Ritus zu keiner Zeit gegeben; denn die mittelalterlichen Ärmelbesätze der Alben sind nie ein selbständiges Ornatstück geworden. Dagegen hat der dem griechischen in vielem verwandte altgallikanische Ritus allem Anschein nach ein Pendant zu den liturgischen Stauchen der Riten des Ostens gekannt, da die manicae, von denen in der gallikanischen Mekerklärung die Rede ist, wohl nur als Stauchen, die zum Schmuck der Ärmel der Tunika dienten, aufgefast werden können 2 .

\section{VIERTES KAPITEL}

\section{DAS CINGULUM.}

\section{DAS CINGULUM NACH GEGENWÄRTIGEM BRAUCH.}

Die Albe muf nach der Vorschrift des Missale und uraltem Brauch gegürtet werden. Es gehört daher zur sakralen Gewandung als Ergänzung der Albe das Cingulum, der liturgische Gürtel.

Dasselbe pflegt gewöhnlich aus Linnen (oder Hanf) gemacht zu werden. Doch kann es nach einer Entscheidung der Ritenkongregation vom 22. Januar $1701^{3}$ auch aus Seide, und nach einem Responsum vom 23. Dezember $1862^{4}$ selbst aus Wolle angefertigt werden, wenngleich es als passender bezeichnet wurde, das Cingulum aus Linnen herzustellen (22. Januar 1701).

Was die Farbe anlangt, so ist es gleich statthaft, weife wie farbige Cingula zu gebrauchen, wenn nur im letzten Fall die Farbe des Gürtels mit derjenigen des jeweiligen Offiziums übereinstimmt. Wirklich sind denn auch verschiedenenorts Cingula von der Tagesfarbe in Gebrauch. Unzulässig sind gelbe Cingula, weil Gelb nicht zu den liturgischen Farben zählt, obwohl man auch solche wohl antrifft. Das Cingulum tritt in drei Formen auf. Bei der ersten ist es ein Strick. Bei der zweiten stellt es ein Band von etwa $3 \mathrm{~cm}$ Breite dar, welches entweder auf dem Bandstuhl gewebt oder durch Zusammennähen von Zeugstreifen hergestellt ist. Bei der dritten Art sind an der Innenseite des Gürtels Bänder angenäht, mit welchen derselbe, statt mit seinen Enden, angebunden wird.

Wie leicht ersichtlich, braucht bei dieser letzten Art das eigentliche Cingulum bei weitem nicht so lang zu sein wie bei den beiden andern, auch wenn man diese nicht gedoppelt anwenden sollte. Ein weiterer Vorteil besteht darin, das die Cingula dieser Form weit weniger dem Verbrauch ausgesetzt, ja fast unverwüstlich sind. Es verschleifien oder zerreifien höchstens die inwendig angenähten Bänder, ein Schaden, der leicht reparierbar ist.

1 Bibl. nat. m. gr. 510 f. $71^{\mathrm{v}}$; vgl. auch f. $409^{\mathrm{v}}$.

\& Näheres darüber bei Behandlung der Pontifkalhandschuhe.
3 C. R. 22. Januar 1781 ad 7 und 23. [ezember 1862 (Decret. auth. 2067 3118).

4 C. R. 8. Juni 1709 ad 3 (ebd. 2194). 
Diese dritte Art des Cingulum, welche eine Verzierung in ausgiebigstem Maßze gestattet, ist gegenwärtig nur mehr in einzelnen wenigen Diözesen, wie zu Genua, Pisa und Siena, wo wir sie noch vor einigen Jahren antrafen, in Gebrauch. Ehedem, d. i. in der zweiten Hälfte des Mittelalters, war sie dagegen sehr gewöhnlich. Als gegen Ende der fünfziger Jahre die Anregung zur Besserumg des Paramentenwesens erging und auf die mittelalterliche Form der liturgischen Gewänder als nachahmenswerte Vorbilder hingewiesen wurde, machte man auch den Vorschlag, das Cingulum nach Weise früherer Zeiten herzustellen. Indessen wurde ihm nur vereinzelt und nur vorübergehend Folge gegeben.

Die Cingula der ersten und zweiten Art können einfach und gedoppelt gebraucht werden. Es hängt davon natürlich ihre Länge ab. Im ersten Falle genügt es, wenn sie $2,50 \mathrm{~m}$ lang sind, im zweiten ist dagegen wohl mindestens eine Länge von ca $3 \mathrm{~m}$ erforderlich.

An das Ende der Cingula pflegen Quasten oder Fransen angesetzt zu werden. Sie bilden in der Tat einen passenden Abschluf, doch sollten sie nie zu gros und schwer sein.

\section{DAS CINGULUM ALS BESTANDTEIL DER LITURGISCHEN GEWANDUNG IN DER VERGANGENHEIT.}

"Die Albe mus", sagt Durandus, "rings um die Lenden des Bischofs oder Priesters mit der Zona oder dem Cingulum gegürtet werden, sowohl damit das herabwallende Kileid das Ausschreiten nicht hindere, als auch, damit der Priester dadurch gemahnt werde, Sorge zu tragen, daß die durch das weiße Gewand versinnbildete priesterliche Keuschheit durch keine Stacheln sündhafter Reize gelöst werde." Entsprechend dem Worte des Herrn: "Eure

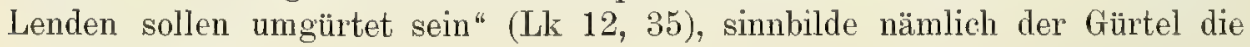
Enthaltsamkeit.

Der Verfasser des Rationale ist nicht der erste, der das Cingulum den liturgischen Gewändern einreiht. Seit 800 behandeln es alle Liturgiker als eines der Gewandsticke, deren sich der Priester bei der Feier des heiligen Opfers zu bedienen habe.

"Das dritte Gewand“ - nämlich des Priesters bei der Messe — „ist das Cingulum oder der balteus", so belehrt uns beispielsweise Hraban; derselbe umgürte sich mit ihm, damit die Tunika (Albe) nicht auf die Füfe herabfliefe und das Gehen erschwere. Der Gürtel sinnbilde die Bewachung des Geistes. Ebenso erwähnt Amalar das Cingulum unter den heiligen Gewändern; dabei bemerkt derselbe besonders, es werde nicht über die Tunika (= Dalmatik) angelegt - denn diese werde nicht gegürtet - , sondern blof über die Camisia (= Albe). Fast zur gleichen Zeit setzt Walafried Strabo in der Parallele, die er zwischen den Kultkleidern des Alten und des Neuen Bundes zieht, den Gürtel der neutestamentlichen Liturgen dem balteus gegenüber, dessen sich die jüdischen Priester bei Verrichtung ihres Amtes nach Gottes Anordnung bedienen mufiten.

Ejgentümlicherweise scheint die Admonitio synodalis ein liturgisches Cingulum nicht zu kennen, da ein solches unter den Gewändern, welche der Priester ihr zufolge am Altare tragen soll, gar nicht genannt wird. Weil jedoch der Gebrauch eines liturgischen Gürtels durch Hraban, Amalar und Walafied völlig aulier Zweifel gestellt ist, kann sein Fehlen in der "Synodal- 
ermahnung" nichts gegen seine Verwendung bei der Liturgie beweisen. Wie es scheint, ist der Gürtel übergangen, weil man ihn entweder für selbstverständlich hielt, oder weil er zwar gebraucht wurde, aber noch nicht eigentlich den Charakter eines förmlichen liturgischen Gewandstückes hatte. Doch ist es zuletzt auch möglich, daß eine allgemeine Vorschrift, das Gewand hei der Messe aufgeschürzt zu tragen, im 9. und 10. Jahrhundert noch nicht bestand, wenngleich solches damals jedenfalls die Regel und das Gewöhnliche war. 889 bestimmt Riculf von Soissons, es sollten - neben den andern Mebkleidern, als Albe, Stola, Mappula usw. - die Priester auch zwei zonae i. e. cinctoria zur Mefafeier vorrätig halten. Als für die Feier des heiligen Opfers vorgeschriebenes und somit pflichtmäßsig bei demselben zu tragendes Gewandstück erscheint der Gürtel auch etwa 150 Jahre später in den Bestimmungen der spanischen Synode, welche $1050 \mathrm{zu}$ Coyaca, Diözese Oviedo, gehalten wurde 1.

Aus vorkonstantinischer Zeit haben wir keine Nachricht über die Verwendung eines Gürtels im liturgischen Dienst. Da die Altarkleidung damals der Form und Zusammensetzung nach der Alltagskleidung gleich war, wird man es mit dem Gebrauch eines Cingulum bzw. der Gürtung der Tunika gehalten haben, wie das eben die Sitte im gewöhnlichen Leben verlangte. Wo es als geziemend galt, die Tunika aufzuschürzen, wird solches auch am Altar geschehen sein; wo die entgegengesetzte Sitte herrschte, wie etwa in Afrika, wird auch bei den liturgischen Verrichtungen die Gürtung unterblieben sein.

Allein auch in der nachkonstantinischen Zeit hören wir bis zum 9. Jahrhundert nur sehr wenig von dem Gebrauch eines Cingulum. Was Irland anlangt, so läfst das Gebet Rogo te, von welchem schon gelegentlich der Besprechung der Albe die Rede war, es als zweifellos erscheinen, dás dort der Priester im 7. Jahrhundert gegürtet zum Altar trat.

Im gallikanischen Ritus war keinesfalls die Alba des Diakons gegürtet; das sagt die gallikanische Meferklärung ausdrücklich. Von einer Gürtung oder Nichtgürtung der priesterlichen Tunika schweigt die Schrift. Wohl heift es darin: Praecinctio autem vestimenti candidi, quod sacerdos baptizaturus praecingitur, in signa Ioannis agetur, qui praecinctus baptizavit Dominum 2. Allein daraus, dafs der Priester bei der Taufe - die durch Intertauchen statthatte - seine T'unika gürtete, folgt nicht, daf er das auch beim Altardienst getan. Immerhin läfst der Umstand, dafs die Mefaerklärung die Nichtschürzung der diakonalen Alba hervorhebt, vermuten, daßs beim Priester ein Gürtel zur Verwendung kam. Wirklich wird in den Acta S. Salvii unter den goldenen Kirchengefälien und den mit Gold und Edelsteinen geschmückten Gewändern, deren sich der Heilige bei der Feier der Messe bediente, ein kostbarer, mit blinkenden Gemmen und Perlen verzierter Gürtel erwähnt ${ }^{3}$. $O b$ auch das lederne Cingulum in St-Trophime zu Arles, welches der Überlieferung nach dem hl. Cäsarius († 542) gehört haben soll ${ }^{4}$, liturgischen Zwecken gedient hat oder ob es von dem Heiligen nur im Alltagsleben verwendet worden ist, mufs dahingestellt bleiben. Das Monogramm $\ngtr$ nebst den beigefügten $\perp$ und $\Omega$, mit denen es bestickt ist (Bild 43, S. 104), und das Bild-

1 C. 3 (Hard. VI 1026).

M. 72,97 .

3 Vita S. Salvii c. 1, n. 3 (A. SS. 26. Juni,
VII 176). Salvius lebte zur Zeit Karl Martells. Die Vita stammt von einem Zeitgenossen.

4 Bullet. mon. 1877, $240 \mathrm{ff}$. 
werk der Elfenbeinschliefse, die Wächter am Grabe (Bild 44), sind nicht entscheidend, da derartige religiöse Darstellungen in fränkischer Zeit auch an profanen Gürteln angebracht wurden.

Aus der spanischen Kirche haben wir kein bestimmtes Zeugnis für den Gebrauch eines Cingulum bei der Liturgie. Insbesondere herrscht bei Isidor über

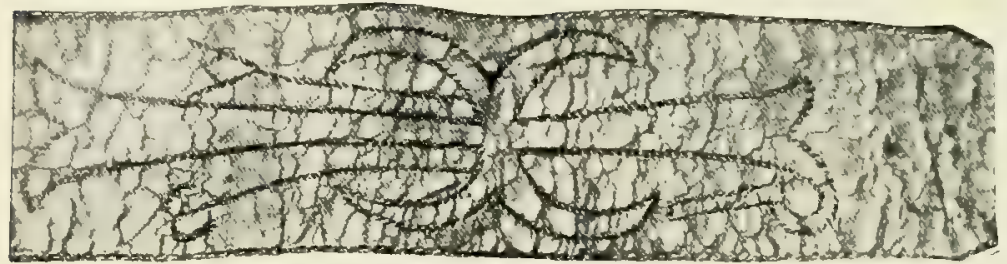

Bild 43. Teil eines Ledergürtels. Arles, St-Trophime, ein solches tiefes Schweigen, wo er in den Etymologien die verschiedenen Arten der Gürtel bespricht. Immerhin dürfte

die Vorschrift des Konzils von Braga vom Jahre 675, welche den Priestern gebietet, die Stola gekreuzt über der Brust zu tragen, durchaus auf den Gebrauch eines Cingulum hinweisen ${ }^{1}$, da es nur so möglich war, die Stola haltbar im Kreuz über die Brust zu legen.

Aus Afrika wird uns berichtet, der hl. Fulgentius habe nie ein Orarium wie alle Bischöfe, wohl aber wie ein Mönch ein ledernes Cingulum getragen ${ }^{2}$. Es seheint hiernach, dafs dort die Weltgeistlichkeit im gewöhnlichen Leben und darum auch wohl beim Gottesdienst im 6 . Jahrhundert einen Gürtel nicht zu benutzen pflegte. Indessen will die Angabe der Vita S. Fulgentii vielleicht nur sagen, es sei Eigentümlichkeit der Mönche gewesen, sich eines Ledergurtes zu bedienen, nicht aber, es habe das Cingulum ausschlieflich bei den Klosterleuten in Gebrauch gestanden.

Aus Rom kommt die früheste Nachricht über einen liturgischen Gürtel uns erst in der zweiten Hälfte des 8. Jahrhunderts. Er erscheint als das zweite Stück in der Reihe der päpstlichen Pontifikalgewänder ${ }^{3}$.

Freilich wird uns durch Johannes Diakonus von einem Gürtel Gregors des Grofen erzählt, der bei den Gläubigen eine große Verehrung genossen habe ${ }^{4}$. Doch läfst sich aus seinem Bericht nicht entnehmen, ob der Papst sich desselben auch bei der Liturgie bedient, und noch weniger, ob schon

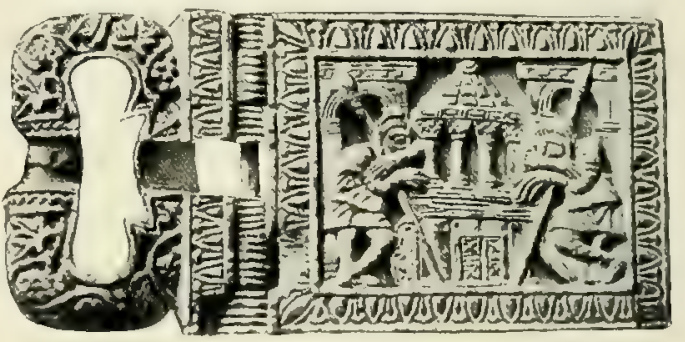

Bild 44. Schnalle eines Gürtels. Arles, St-Trophime. damals ein Cingulum in Rom zum notwendigen Bestand der gottesdienstlichen Gewandung gehört habe.

Dafs auf den römischen Monumenten bei den Geistlichen kein Cingulum wahrnehmbar ist, liegt an dem Umstand, daf die Tunika hier durch die Dalmatik und Planeta oder doch wenigstens durch die letztere fast völlig verdeckt wird.

Das Bild, welches wir von der Verwendung eines Cingulum bei den gottesdienstlichen Funktionen in der abendländischen Kirche für die vorkaro-

\footnotetext{
1 C. 4 ( $\mathrm{H}$ ard. III 1034).

2 Vita S. Fulgentii c. 18, n. 37 (M. 65, 136).
}

8 Ordo 1, n. 6 (M. 78, 940).

4 Vita S. Gregorii M. 1. 4, n. 80 (M. 75, 
lingische Zeit erhalten, ist ersichtlich mehr als mangelhaft. Ja man kann kaum von einem Bild, sondern nur von einigen Strichlein reden, von denen es obendrein sehr zweifelhaft ist, ob sie je auch nur zu einer halbwegs befriedigenden Skizze ergänzt werden können. Namentlich erhalten wir auf die Hauptfrage, wann der Gürtel ein offizieller Bestandteil der Altarkleidung geworden, keinen Aufschlus.

\section{BESCHAFFENHEIT DES LITURGISCHEN GÜRTELS IM MITTELALTER.}

In Gallien stellte der Gürtel, wie er allgemein bei hoch und niedrig gebräuchlich war, einen Gurt von Leder oder starkem Zeug dar, welcher mit einer Schnalle geschlossen wurde. Die Museen besitzen zahlreiche Beispiele solcher Gürtelschließen. Man legte großen Wert auf kostbare Gürtel, namentlich aber auf reichverzierte Schnallen.

Ein Gürtel dieser Art ist das Cingulum des hl. Cäsarius, von welchem vorhin die Rede war (Bild 43). Der Gürtel kann als Typus jener Gürtel gelten, deren man im gallikanischen Ritus sich bedient liaben wird. Denn es ist schwer anzunehmen, daf man in einer Zeit, wo die liturgische Gewandung noch in der Ausbildung begriffen war und der Volkstracht noch nach Schnitt und Ausstattung viel näher stand als jetzt, dem Gürtel im gallikanischen Ritus eine andere als die heimatliche Gürtelform und Ausstattung gegeben habe.

Das römische Cingulum des Alltagslebens war, wenn wir von dem Soldatengürtel absehen, in der Regel nicht mit einer Schliefie versehen. Es bestand vielmehr für gewöhnlich nur aus einem Band, dessen Enden miteinander verknotet wurden. Es ist die Form, welche das liturgische Cingulum in der zweiten Hälfte des Mittelalters überall im Okzident besaß und die zu Rom wohl von jeher für den liturgischen Gürtel gebräuchlich war. Nach Gallien mus sie bei Gelegenheit der karolingischen Reform gekommen sein; sie hieb hier im Unterschiede von der gallikanischen Gürtelform zona romana. Zur Gürtung der heiligen Kleider des Alten Bundes habe man, sagt uns PseudoAlkuin, sich des balteus bedient, d. i. einer Gürtelart, die aus gezwirntem Byssus, aus Hyazinth (Blaupurpur), aus Rotpurpur und endlich aus Scharlach in Buntwirkerei nach Weise eines Schlangenfelles in einer Breite von vier Fingern angefertigt gewesen sei; nun aber seien anstatt des balteus die sog. römischen Gürtel in Gebrauch gekommen, zonae quas appellant romanas ${ }^{1 .}$

Man hat geglaubt, unter zonae, quas romanas appellant, seien reich ausgestattete und kostbare Cingula zu verstehen, und es seien diese Gürtel, welche Bischöfe und höhere Geistliche getragen, nicht liturgisch im eigentlichen Sinne, sondern nach Durandus nur saecularia ornamenta gewesen, womit die damaligen Grofen des Reiches prunkten, ähnlich den hohen Beamten, namentlich den Militärbeamten früherer Jahrhunderte, bei denen die reich verzierte zona hauptsächlichstes Abzeichen der Würde war?. Allein mit Unrecht. Die sog. römischen Gürtel PsendoAlkuins sind, wie aus dem ganzen Zusammenhang sich ergibt, wirkliche liturgische Cingula, und zwar erscheinen sie als ein allgemein gebräuchliches liturgisches Gewandstiick. Sie sind ebendarum jedenfalls nicht immer kostbar verziert gewesen, wenngleich einzelne, zumal die der Prälaten, mit reichem Schmuck ausgestattet gewesen sein mögen. Man wird daher den Ausdruck „römische Gürtel" auf die Form zu. heziehen und unter den zonae romanae im Gegensatz zu den gallischen oder profann

\footnotetext{
1 De offic. div. c. 38 (M. 101, 1239). ${ }^{2}$ Realenc. II 193.
} 
Cingula, die mit einer Schließse, einer Krampe oder einer ähnlichen Befestigungsvorrichtung versehen zu sein pflegten, Gürtel zum Binden, wie sie später uns tatsächlich ausschlieklich entgegentreten, zu verstehen haben.

In dem Verzeichnis der Paramente, welche Abt Ansegisus ( $†$ 883) dem. Kloster Fontanelle schenkte, heißen die zonae romanae cingula romano opere facta : Denn wenn romano opere facta an sich auch bedeuten könnte: zu Rom gemacht und aus Rom eingeführt, so ist hier damit doch wohl gemeint: nach römischer Art angefertigt, und cingula romano opere facta sonach gleichbedeutend mit zonae romanae.

Seit wann die im späteren Mittelalter so beliebte Einrichtung, an der Innenseite der Cingula zum Zwecke des Anbindens besondere Schnüre oder Bänder anzubringen, im Gebrauch gewesen ist, läfst sich nicht bestimmen.

Die Liturgiker, von Hraban und Amalar angefangen bis auf Durandus, sagen von dieser Binderorrichtung wie überhaupt von der Form des liturgischen Giurtels gar nichts. Ebenso lassen uns die Monumente in jener Frage völlig im Stich. Meist schauen auf den Bildwerken nur die Enden des Cingulum unter dem Saum der Dalmatik oder Kasel hervor, wenn es überhaupt zum Vorschein kommt. Darstellungen, auf denen es ganz sichtbar ist - es handelt sich bei ihnen entweder um Akolythen in der Albe oder um Priester in Albe und Pluviale - sind äußserst selten. Aber selbst in diesen ganz vereinzelten Fällen fehlt stets eine Andeutung besonderer zur Befestigung des Cingulum vorgesehener Bänder oder Schnüre, mit Ausnahme vielleicht einer Miniatur der Miracula ${ }^{5} \mathrm{~S}$. Benedicti in der Stadtbibliothek zu Troyes, auf der die weit voneinander entfernt herabfallenden Enden des Gürtels auf die in Rede stehende Bindevorrichtung hinweisen mögen. Der Codex soll nach Rohault de Fleury dem 11. Jahrhundert angehören ${ }^{2}$.

Auch die Inventare geben keinen Aufschluk, da sie von der Einrichtung des Cingulum in der älteren Zeit nie und selbst später nur ausnahmsweise sprechen. So heißt es einmal im Inventar des Schatzes des Apostolischen Stuhles von 1295: Unum cingulum rubeum laboratum ad aurum cum cordone de serico rubeo et viridi. Der Grund hierfür liegt indessen nicht etwa in einer äuberst seltenen Anwendung dieser Bindevorrichtung, sondern in ihrer Alltäglichkeit. Wie gewöhnlich sie gewesen sein muf, erhellt aus dem 14. Ordo Mabillons, wo die chordulae als selbstverständlicher Bestandteil des Cingulum erscheinen: Subsequenter subcingat (diaconus) eum (pontificem) cingulo cum subcinctorio... et ipsius cinguli chordulas diaconus invicem liget et stringat vel ipse pontifex stringere poterit, sicut ei placuerit ${ }^{3}$. Es hat darum auch nichts Auffälliges und Besonderes, wenn man gelegentlich des Neubaues der Peterskirche bei der Leiche Bonifaz' VIII. gemäf dem über den Leichenbefund aufgenommenen Protokoll ein cingulum ex serico rubro et viridi pulchre quidem intertextum cum suis chordulis sericis ante pendentibus suisque globulis et floccis antraf ${ }^{4}$.

Von den Cingula, welche sich aus dem Mittelalter erhalten haben, gehören alle, bei welchen besondere Schnüre an der Innenseite des Cingulum zum Zweck des AnFindens angebracht sind, der späteren Zeit desselben an. Das älteste von innen ist das Cingulum im Sichatz der Kathedrale zu Sens (Bild 45) ${ }^{5}$. Es wurde 1749 im Schrein des hl. Edmund von Canterbury $(\dagger$ 1240) zu Pontigny, in den es 1247 bei der Erhebung des heiligen Leibes gekommen war, vorgefunden und gelangte 1884 durch die

$1 \mathrm{Nr} 7$ (M. 105, 739): Cingula romano opere facta auro decorata duo.

2 Ro h. I, 73. Abbildung pl. X.
${ }^{8}$ C. 53 (M. 78, 1157).

4 Brovius, Annales ad an. 1303; XIV 51.

$5 \mathrm{Vgl}$. auch de Farcy Taf. 13. 
Erben des Grafen de Bastard, der es durch Kauf erworben, in den jetzigen Besitz. Bei einer Länge von $0,87 \mathrm{~m}$ ist es $0,032 \mathrm{~m}$ breit und endet beiderseits in je drei schmale Bändchen von verschiedener Länge, von denen die längsten ebenfalls ca $0,87 \mathrm{~m}$ messen. Auferdem ist jedem Ende eine starke Schnur zum Festbinden angenäht.

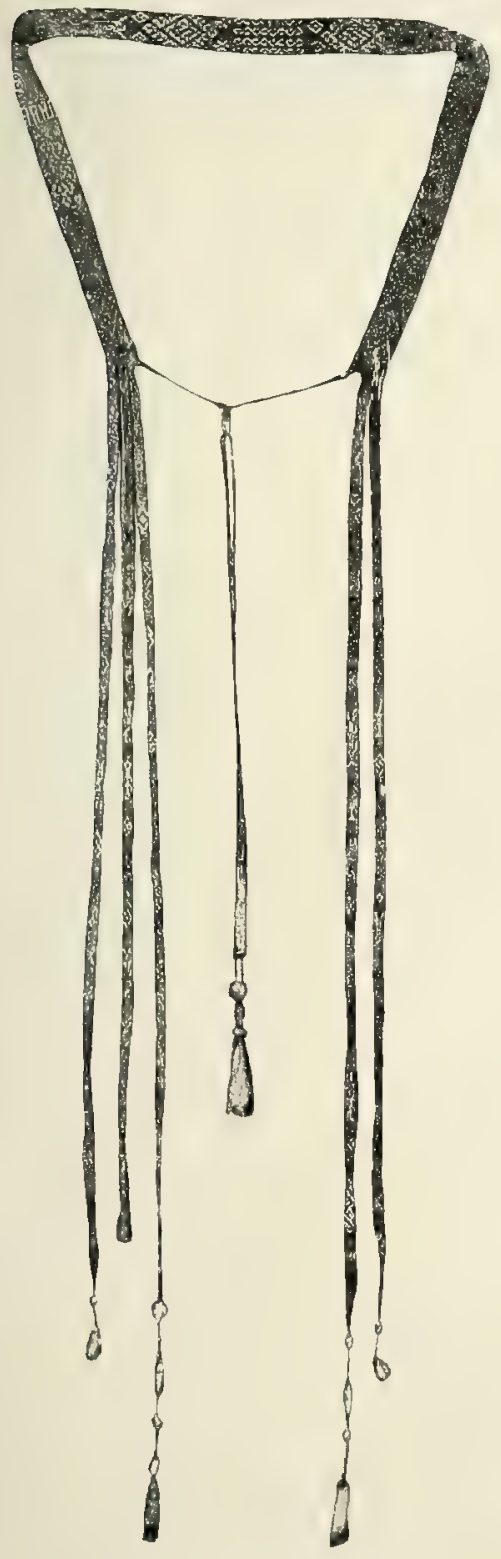

Bild 45. Cingulum. Sens, Kathedrale.
Cingulum wie Behänge bestehen aus roter Seide, sind mit Lilien, Fischen, Vögeln, Vierfüßlern,

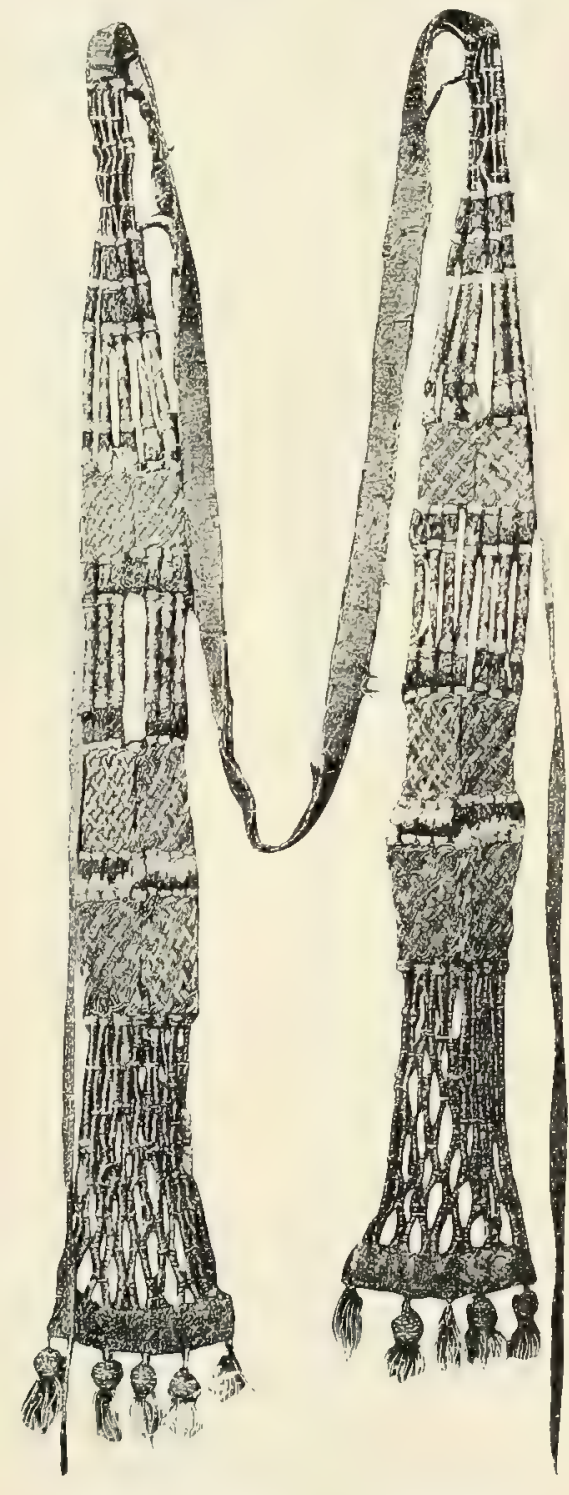

Bild 46. Cingulum. Halberstadt, Dom.

Ranten und anderem geometrischen Gebilde sowie den Buchstaben E und M in Gold durchwirkt und mit gelbem Seidenzeug gefüttert ${ }^{1}$.

${ }^{1}$ Die Angaben L. de Farcys (Broderie 123), das Cingulum stelle ein Trikotgewebe dar, ist unrichtig. Dem Anschein nach gleicht es allerdings einem solchen, allein in Wirk- lichkeit ist es in derselben Weise gearbeitet wie so manches andere mittelalterliche $B a n d$, d. i. mittelst zweier Ketten. deren Fäden sich nach Aufnahme des Einschusses umeinander 
Drei Cingula im Dom zu Halberstadt sind jüngeren Datums, doch mag eines von ihnen, ein wahres Pracht-, um nicht zu sagen Prunkstück, immer noch in das 13. Jahrhundert hinaufreichen (Bild 46, S. 107). Es besteht aus einer 1,08 m langen und $0,016 \mathrm{~m}$ breiten, grünseidenen Borte, der in Gold Löwen, Rosetten und ähnlich

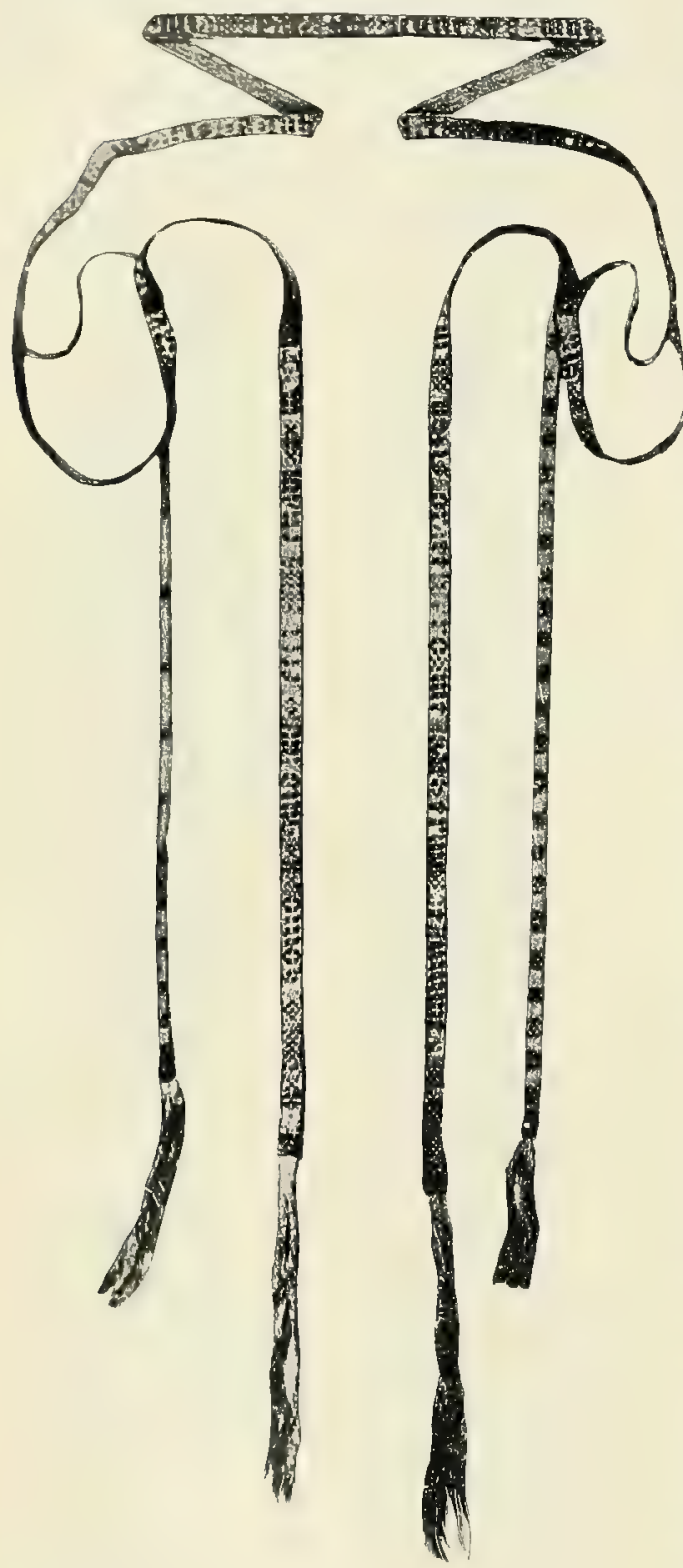

Bild 47. Cingulum. Danzig, Marienkirche. stilisierte Ornamente eingewebt sind. Als Innenfutter ist roter Taft, als Einlage ein Pergamentstreifen verwendet worden. An den Enden des Gürtels sind kostbare, in Posamentierarbeit hergestellte Behänge angebracht, welche eine Länge von $0,76 \mathrm{~m}$ haben, in Gold und farbigen Seidenfäden ausgeführt sind und unten in Quästchen ausmünden. Zum Zweck des Anbindens des Gürtels dienen zwei nahe den beiden Enden des eigentlichen Gürtels an der Innenseite angesetzte kråftige, aus blauleinenem Garn gewirkte Bändchen, von denen das eine gegenwärtig eine Länge von $0,63 \mathrm{~m}$, das andere von $0,97 \mathrm{~m}$ hat. Die beiden andern Cingula im Schatz des Domes von Halberstadt werden wohl kaum weit über das späte 15. Jahrhundert hinausgehen. Bei dem einen besteht der eigentliche Gürtel aus einem $3,10 \mathrm{~m}$ langen und $0,063 \mathrm{~m}$ breiten schlichten Linnenstreifen, bei dem andern aus einem $0,075 \mathrm{~m}$ breiten, $2,75 \mathrm{~m}$ langen, grünseidenen Bande, dessen beide Enden ein rotseidenes, mit silbervergoldeten Plättchen geschmücktes Zierstück von fast quadratischer Form angesetzt ist.

Ein sehr interessantes Cingulum in St Marien zu Danzig (Bild 47) gehört ebenfalls dem 15. Jahrhundert an. Es ist $2,43 \mathrm{~m}$ lang, $0,015 \mathrm{~m}$ breit, an den Enden mit Fransen von 0,15 m Länge verziert, aus Linnen gemacht und mit rotem Leder gefüttert. Auf der Außenseite ist dem Linnengrund eine Inschrift eingewebt, deren einzelne Worte durch geometrische Gebilde voneinander getrennt sind. Inschrift und Ornamente sind in Gold und farbiger Seide (blau, rot, braun, grün) ausgeführt. Die Inschrift lautet: Homo + quidam + fecit + cenam + magnam + vocavit + multos + et + misit $+\operatorname{servum}+\operatorname{suu}(\mathrm{m})+\mathrm{h}($ ora $)+$ cene + dicere + invitatis + ut + venirent + . quia + iam + parata + sunt + omnia + venite + comedite + panem + meum

rrehten. Auch ist es nicht zutreffend, wenn gesagt wird, die Musterung sei in Gold und Silber ausgeführt. Sie besteht nur aus Gold.
Was jetzt als Silber erscheint, ist bloß die infolge Abschleifens der Goldschicht sichtbar gewordene Silberunterlage des Lahns. 
+ et + bibite + vinum + quod + miscui + vobis - orate + pro + me + Katharina $+\mathrm{de}+$ ummen. Die ca $0,50 \mathrm{~m}$ langen und ca $0,01 \mathrm{~m}$ breiten linnenen Schnüre an der Innenseite sind mit Kreuzehen, Hakenfiguren, geometrisch stilisierten Tiergebilden und Rosetten in farbiger Seide verziert und an den Enden mit ca $0,07 \mathrm{~m}$ langen Fransen besetzt. Das Cingulum ist kein Prachtstück, aber in seiner edeln Einfachheit ungemein gefällig.

Ein Cingulum der ehemaligen Bockschen Sammlung war auf seiner Außsenseite mit kleinen, durch Silberfäden gebildeten Quadraten geschmückt, innerhalb deren sich auf violettem Fond ein aus Goldfäden hergestelltes Kreuzchen befand, und an den Enden mit einer aus Goldfäden gearbeiteten Quaste versehen. Im Innern war es mit violetter Seide gefütert, seine Länge belief sich auf $1,68 \mathrm{~m}$, die Schnüre zum Festbinden waren, nach der Abbildung des Cingulum zu urteilen, ca $0,45 \mathrm{~m}$ entfernt von den Enden angesetzt ${ }^{1}$.

Ein Gegenstück zu den genannten Cingula bildet ein Gürtel, welcher im Schatze der Hofburg zu Wien unter den Reichskleinodien aufbewahrt wird. Bock, der in dem Werke "Die Kleinodien des heiligen römischen Reiches deutscher Nation" eine gute Abbildung und Beschreibung von demselben gegeben hat, setzt ihn in das 12. Jahrhundert, doch wohl mit Unrecht, da er schwerlich über das 14. Jahrhundert hinaufreicht. Der Gürtel kann aber auch ursprünglich nicht zu den Reichskleinodien gehört haben, sondern erst seit dem Ende des 18. Jahrhunderts, d. i. seitdem sie von Nürnberg über Prag nach Wien gebracht wurden, ihnen zugesellt worden sein, da weder v. Murr in seiner ausführlichen Beschreibung sämtlicher Reichskleinodien vom Jahre 1790 seiner Erwähnung tut, noch Delsenbach in seinen Abbildungen der Kleinodien ihn wiedergibt. Wie es scheint, zählte er bis dahin zu dem böhmischen Krönungsschatze (Bild 48).

Der Gürtel besteht an der Innen- wie Aukenseite aus einem schweren, hellblauen Seidenköper und hat bei einer Breite von $0,035 \mathrm{~m}$ eine Länge von $1,52 \mathrm{~m}$. Etwa $0,34 \mathrm{~m}$ von den beiden Enden ist inwendig eine kräftige Seidenschnur von roter Farbe angenäht, welche eine Länge von $0,67 \mathrm{~m}$ besitzt und unten in eine rotseidene Quaste ausläuft. Eigenartig ist, daß sich die beiden Schnüre nicht weit vom oberen Ende in je zwei und diese sich dann nochmals in je vier Schnüre teilen. Ringsum ist der Gürtel mit einer kordelartigen Einfassung versehen; seine beiden frei herabfallenden Enden sind auf beiden Seiten mit Perlen, Edelsteinen und einem mit Goldfiligran bedeckten Plättchen geschmüekt?.

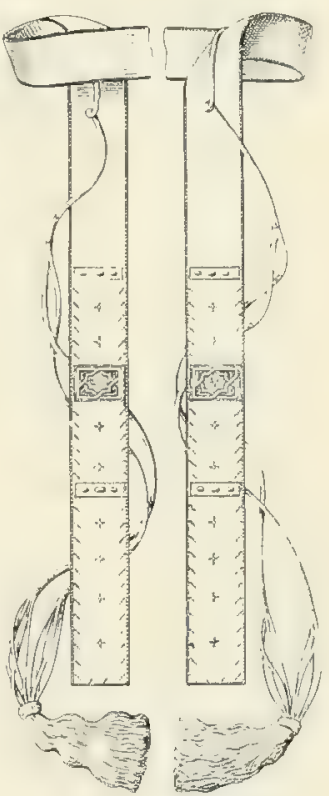

Bild 48. Kaisergïrtel. Wien, Hofburg.

Was von mittelalterlichen Cingula noch dem ersten Jahrtausend oder dem Beginn des zweiten angehört, weiß uns nichts von der fraglichen Bindevorrichtung zu erzählen. Von zwei Gürteln in St Peter zu Salzburg, welche als Reliquien der hll. Rupert (ca 700) und Vitalis (ca 730) gelten und etwa 0,025 bzw. $0,03 \mathrm{~m}$ breit sind, wird der eine mittelst Haken und Ösen, der andere mittelst einer Krampe geschlossen ${ }^{3}$. Es ist zudem sehr fraglich, ob sie jemals als liturgische Cingula gedient haben. Das Cingulum des hl. Godehard von Hildesheim ( $\dagger$ 1038) zu Niederaltaich (Niederbayern), wenn wirklich von diesem Heiligen herrührend, ist ein schmales, schlichtweifses Band

I Bock II 59 u. Tl V, 2. Wohin das Cingulum gekommen, lief sich nicht ermitteln. Ob auch die vier andern Cingula der ehemaligen Bockschen Sammlung, welche ebendort beschrieben werden, mit Bindevorrichtung versehen waren, ist nicht angegeben.
Ihre Breite von $5-6 \mathrm{~cm}$ und die Seidenstickereien, mit denen sie verziert waren, lassen jedoch darauf schließen.

2 Bock, Reichskl. 64 u. TI XIIL,

3 Gute Abbildungen nach Photographien bei Roh. VII, pl. DXXII. 
ohne S̈chliefse oder sonst eine besondere Einrichtung zum Befestigen. Der prächtige Witgarinsgürtel im Dommuseum zu Angsburg und das dem Schrein des hl. Kuthbert entnommene Cingulum im Museum der Kathedrale zu Durham (Nordengland) ${ }^{1}$ sind nur Fragmente, die keine Spur einer Bindevorrichtung mehr erkennen lassen. Das schöne, vollstïndig erhaltene Cingulum im Reliquiensehatz zu Andechs endlich, das noch ins 11. Jahrhundert hinaufreichen mag, ist ohne Schnüre an der Innenseite. Es scheint sogar, daß es nie als Gürtel, sondern stets als Stola gebraucht wurde, worauf auch die Bezeichnung Stola S. Ioannis Ev. hinweisen dürfte.

Übrigens wird der Brauch, im Innern des Cingulum eine besondere Bindevorrichtung anzubringen, sicher bis

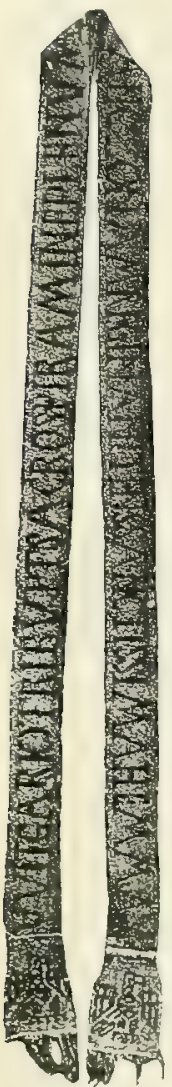

Bild 49.

Witgariusgürtel.

Augsluurg, Dommuseum. ins erste Jahrtausend hinaufreichen. Denn wenn wir eine solche an einem aus der Ottonenzeit stammenden, mit den liturgischen Cingula durchaus verwandten profanen Gürtel antreffen, so wird sie zweifelsohne auch an besseren liturgischen Cingula zur Anwendung gekommen sein. Der fragliche Gürtel ist heute leider nur mehr in Abbildung' vorhanden. Er gehörte einst $\mathrm{zu}$ den Reichskleinodien, unter welchen ihn noch v. Murr gesehen und beschrieben hat, und kam mit einigen andern Stücken derselben abhanden, als er Ende des 18. Jahrhunderts von Nürnberg vor den einziehenden Franzosen geflüchtet wurde. Die Inschrift wie die stoffliche Beschaffenheit des Gürtels lassen keinen Zweifel, daf er von einem der Ottonen herrührte.

In der Tat ist es auch kaum anders denkbar, als daf Gürtel wie das jetzt leider nur mehr als Frag. ment vorliegende Cingulum im Dommuseum zu Augsburg (Bild 49 u. 50), laut der Inschrift: Witgario tribuit sacro spiramine plenum (sic) + hanc zonam regina nitens sanctissima Hemma, ein Geschenk der Königin Hemma, Gemahlin Ludwigs des Deutschen, an Bischof Witgarius von Augsburg (858-887), an der Innenseite Schnüre zum Anbinden besaßen. Der eigentliche Gürtel ist nicht mehr vorhanden, nur die beiden Endstücke sind erhalten geblieben. Sie sind $0,035 \mathrm{~m}$ breit und zusammen $1,34 \mathrm{~m}$ lang und münden in einen trapezförmigen Zieransatz von $0,067 \mathrm{~m}$ Höhe und $0,047 \mathrm{~m}$ unterer Breite aus, dem ein Adler eingewebt und als Abschluf eine Reihe zierlicher Quästchen an-

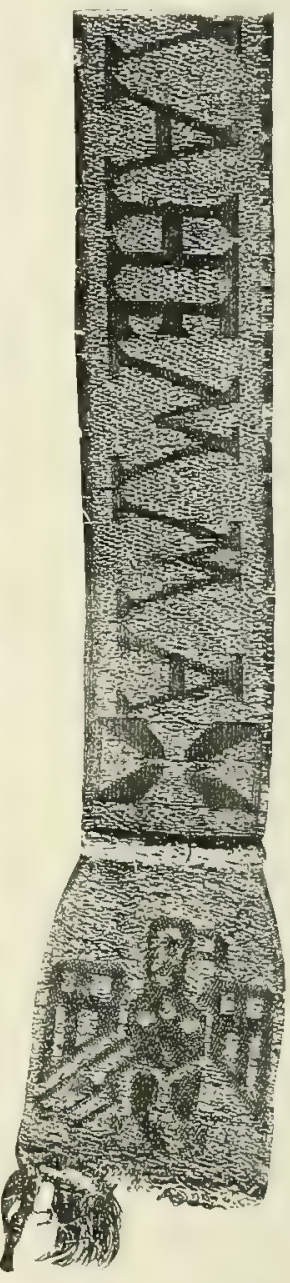

Bild 50. Detail des Witgariusgürtels.

gefügt ist. Inschrift und Adler heben sich in prächtigem Rot von einem aus kostbarem Goldgespinst, bei welchem der Lahn ganz ans Gold besteht, hergestellten

I Der Giurtel wurde grefunden, als man 1827 den bei der Reformation in die Erde versenkten Schrein des Heiligen aufdeckte und offnete. Er scheiut mit rerschiedenen andern Paramenten im Laufe des 11. oder im Beginn des 12. Jahrhunderts den Reliquien des Heiligen beigegehen worden zu sein. Die
Länge des noch erhaltenen Stiuckes beträgt ca $76 \mathrm{~cm}$, seine Breite ca $0,022 \mathrm{~m}$. Der Guirtel ist aus roter Seide gewirkt und mit Goldfiden duchweht. Den Rand entlang laufen $\mathrm{zwei}$ Längslinien. Das Futter besteht aus gruner Seide (Raine, St Cuthbert [Durham 1820] 209). 
Fond ab. Schließsen, wie die frinkischen Gürtel sie aufzuweisen pflegten, kann es an dem Witgariusgürtel nicht gegeben haben. An ein unmittelbares Verknüpfen, wie es jetzt Brauch ist, ist angesichts der äußerst wertvollen Beschaffenheit desselben ebensowenig zu denken. Es bleibt also nur übrig, anzumehmen, es sei das Cingulum, ähnlich wie der eben erwähnte kaiserliche Gürtel aus der Ottonenzeit, inwendig mit Bänderu zum Anbinden versehen gewesen ${ }^{1}$.

Strickförmige Cingula sollen nach Bock erst im 16. und 17. Jahrhundert in Aufnahme gekommen sein. Der eigentlich liturgische Gürtel wäre ihm zufolge das Bandcingulum, das strickcingulum aber das Ergehnis des entstellenden, profanierenden Einflusses, den der moderne Zeitgeschmack wie auf die übrigen liturgischen Gewänder, so auch auf die Jahrhunderte hindurch feststehende Gestalt und Beschaffenheit des kirchlichen Gürtels ausülote? Das eine wie das andere ist jedoch irrig. Das Strickcingulum war bereits um den Ausgang des 15. Jahrhunderts in Italien und speziell in Rom in Gebrauch. Die Bildwerke dieser Zeit lassen daran keinen Zweifel. Beispiele bieten z. B. Ercole di Robertis $(1450-1496)$ "St Augustinus" und Cima da Coneglianos (1489-1508) "St Petrus" in der Brera zu Mailand, Benozzo Gozzolis (1420-1498) "St Sixtus II." in der Sixtinischen Kapelle u. a. Ja wir finden schon im Inventar des Apostolischen Stuhles von 1295 mit klaren Worten ein strickförmiges Cingulum verzeichnet: unum cingulum de cordone rotundo violaceo cum tribus bottonibus grossis (dicken Krnäufen) et appendiciis ad nodos (Quasten) per totum ad aurum ${ }^{3}$. Die Wahreit dïrfte wohl

1 Im Dommuseum zu Augsburg finden sich auch noch zwei Fragmente eines zweiten Cingulum aus dem 9. Jahrhundert, falls sie nicht etwa Überbleibsel einer Stola sind. Das kleinere Stück trägt die Inschrift: OMINE DOMINI NO, das gröfere IN NOMINE DOMINI AILBECVND VE. V SPI IHEV NOSTRI IN NOMINE DOM. Die Inschrift ist leider nicht ganz lesbar, immerhin geht aus ihr zur Genuige hervor, dafs das Cingulum die Gabe einer gewissen Ailbecund ist. Der Name kommt auch in den Libri Confraternitatum von St Gallen (M. G. Confr. 334, 12), von Reichenau (ebd. 42, 36; $65,17 ; 97,16 ; 276,32 ; 466,11)$ und Pfäffers (ebd. 44, 13) vor. Vgl. ferner M. G., Necrolog. dioec. Salisburg. ind. sub Albegund 485. Die Fragmente sind mit dem Witgariusgiurtel so sehr verwandt, daß sie zweifellos derselben Werkstätte zugewiesen werden müssen. Nicht blof das Material, kräftiges karminrotes Seidengarn, sondern auch die Technik und die Formgabe der Inschrift sind hier wie dort völlig gleich. Die Fragmente unterscheiden sich von dem Gürtel lediglich Iurch ihre un ca $2 \mathrm{~mm}$ größrere Breite und ihre einfachere Ausführung, sofern die Inschrift auf ihnen nicht mittelst eines Einschlages von Goldfäden in den Fond, sondern nur durch anders gerichtete Drehung der Kettenfäden hergestellt ist.

2 Bock II 61. Wenn derselbe ebd. 51 lvgl. anch Hef., Beitr. II 179; Ann.
VI 168; Roh. VII 29, note 2) auf Grund einer Notiz im Papstbuch meint, der Pontifikalgürtel des 8. und 9. Jahrhunderts scheine noch analog mit dem balteus des Hohenpriesters rund, älnnlich einer Schlangenhaut, gewebt gewesen zu sein, so ist zu bemerken, daf der L. P. an dem fraglichen Ort nicht ron Gürteln und noch viel weniger von liturgischen Gürteln spricht (vgl. die Stelle bei Duch., L. P. II 78). Wenn dort nämlich. von einem von Gregor IV. $(827-844)$ für das auf seine Kosten hergestellte Praesepium in S. Maria in Trastevere gestifteten Bild die Rede ist, babentem morenas prasinales pretiosissimas II ... item morenam trifylem auream ... morenam in quo pendent gemmas jachinctas XIII ... item morenam fylata... omnes morenas cum petinantes eornm, so kann man unter diesen morenae doch nimmer Gürtel und am wenigsten Pontifikalgürtel verstehen.

${ }^{3}$ Im Schatz der Kathedrale zu Sens befindet sich ein strickförmiges Cingulum, welches als dasjenige des hl. Thomas Becket ausgegeben wird und sonach aus dem 12. Jahr hundert stammen würde. Es ist aus roter Seide und Goldfäden gemacht und an den Enden mit kräftigen Quasten geschmüickt Seine Beschaffenheit weist jedoch durchaus auf eine jüngere Entstehungszeit hin. Es ent spricht aber auch nicht der Beschreibung welche das Inventar von 1446 von dem ia zwischen offenbar verloren gegangenen Cin- 
sein, daf es schon früh, um nicht zu sagen stets, neben bandförmigen auch strickförmige Cingula gegeben hat, daß aber bei Gürteln besserer Qualität bis gegen Ausgang des Mittelalters die Bandform vorgezogen wurde. So selbst zu Rom, wo dann jedoch die Bandcingula sich rasch aus dem Gebrauch verloren. Man trifft darum auf den römischen Bildwerken des 16. und 17. Jahrhunderts nur mehr strickförmige an, die an den Enden mit kräftigen Quasten rerselien sind. Gute Beispiele bieten die Statuen Leos $\mathrm{X}$., Pauls III, und Gregors VIII. in Ara Celi und Klemens' VIII. in S. Maria Maggiore. In der Stanza della Segnatura trägt Gregor IX. auf Raffaels Fresko „Das kanonische Recht" ein solches von roter Farbe, das in mächtige Quasten endet. Die Strickform bürgerte sich in Rom beim Cingulum in dem Mafe ein, daf sie daselbst zur offiziellen Cingulumform wurde und die Ritenkongregation demgemäß in einem partikulären Falle in ihrer Antwort auf eine Anfrage aus Spanien die Bandform als unzulässig bezeichnete ${ }^{1}$. A u B erhalb Roms erhielten sich bandförmige Cingula vielerorts bis in die Gegenwart im Gebrauch, nur wurden sie im allgemeinen nicht mehr mit besondern Bändern oder Schnüren zum Anbinden versehen.

Nach der Verordnung des hl. Karl Borromäus soll das Cingulum 7 cubiti = ca $3 \mathrm{~m}$ lang, aus weifem Linnen oder zartem Hanf verfertigt und an den Enden mit Linnenquasten ausgestattet sein?. Von der Form des Ornatstückes spricht der Heilige nicht. Seine Bestimmungen wurden fast wörtlich von der Prager Synode vom Jahre 1605 adoptiert. Cingulum e candido filo conficiatur longitudinis ulnarum quinque. Eius autem capita globulis eiusdem materiae inserantur, filamentorum manipulis floccisve appensis ${ }^{3}$. Auch Gavanti nahm in seinen Thesaurus rituum die Vorschriften des hl. Karl ïber die Anfertigung des liturgischen Gürtels herüber.

Hinsichtlich des Materials des liturgischen Gürtels gab es im Mittelalter keine Bestimmungen. Gewöhnliche Gürtel dürften der Regel nach aus Linnen gemacht worden sein. Sieben solcher weiflinnenen Cingula besitzt noch die St Marienkirche zu Danzig (Bild 3, S. 34). Sie sind ganz unverziert, 2,23-2,87 m lang und 0,01-0,015 $\mathrm{m}$ breit und stellen ein kräftiges, festes, auf dem Bandstuhl hergestelltes Band dar. An den Enden münden sie in Fransen aus. Das zu Niederaltaich befindliche Cingulum, welches vom hl. Godehard, dem späteren Bischof von Hildesheim (1022-1038), herrühren soll, ist anscheinend aus Wolle gemacht und bei einer Breite von ca $0,02 \mathrm{~m}$ etwa $2,25 \mathrm{~m}$ lang 4 .

gulum des hl. Thomas gibt. Ihr zufolge war nämlich das Cingulum des Heiligen, welches man in 15. Jahrhundert zu Sens besak, nicht strickförmig, sondern bandförmig: une sainture de soye faite en manière de sangle, Piemen, Gurt. Band. (E. Chartraire, Inventaire du trésor de l'église métropolitaine de Sens 42, Es ist auffallend, daf der Verfasser, der das fragliche Cingulum ebenfalls dem hl. Thomas zuschreibt, den Widerspruch. nicht beachtet hat, in dem dessen Beschaffenheit zur Angabe des Inventars von 1446 steht.)

I C. R. 24. Nov. 1899 (Decl. auth. Nr 4048 ad 6).
2 A. E. Med. 626 .

${ }^{3}$ C. 13 (Hartzh. VIII 691).

- Die für eine Untersuchung höchst ungünstige Aufbewahrungsweise des Cingulum (hoch oben im Altar hinter Glas) lief eine sichere Feststellung des Stoffes nicht zu. Ein anderes dem hl. Godehard zugeschriebenes Cingulum ist in Niederaltaich nicht mehr vorhanden. Eine wenngleich sehr mangelhafte Abbildung desselben findet sich in den Monumenta boica IX 24. Es war mit Schlieke versehen und wies als Verzierung die stets sich wiederholende Inschrift Sola fides auf. Die ungenaue Abbildung gestattet kein Urteil über das Alter des Guirtels. 
Bessere Cingula bestanden aus Seide. So verzeichnet ein dem Ende des 11. Jahrhunderts angehörendes Inventar des St Georgstiftes zu KöIn unter sonstigen auch ein cingulum de pallio und ein anderes de serico, ein Inventar von Salisbury aus dem Jahre 1212 neben aliae 12 und 8 zonae nullius pretii für die Chorknaben 9 zonae de serico, ein Schatzverzeichnis der Kathedrale von Chartres aus dem Jahre 1337: 2 zonae de serico. Das Inventar von St Peter aus dem Jahre 1361 führt tria cinctoria de serico diversorum colorum und 6 cinctoria sacerdotalia de serico diversorum colorum et aliqua laborata de serico ad aurum, dasjenige aus dem Jahre 1436 Cingula von schwarzer und karminfarbiger Seide auf. Ein um 1200 aufgestelltes Schatzverzeichnis der Kathedrale von Rouen weifs von 2 albae cum zonis de serico und einem balteus (Subcinctorium) mit dazu gehörigen 2 zonae sericae una alba, altera rubea, zu berichten. Ein Inventar von Angers vermerkt zum Jahre 1418 eine zona de serico rubri coloris ${ }^{1}$, ein Inventar von St Fortunat zu Todi (ca 1300) unum cingulum latum de serico et auro, item unum cingulum de serico rubeo, item unum cingulum de serico viridi, item unum cingulum de serico albo, item unum cingulum de serico gallo. Bonifaz VIII. schenkte der Peterskirche, deren Kanonikus er gewesen war, sieben cingula de serico 2 .

Auch die scharlachfarbenen Cingula, die in älteren Schatzverzeichnissen genannt werden, und mehr noch die goldverzierten Cingula, die sich darin finden, haben wir uns nach dem Beispiel der Gürtelfragmente im Dommuseum zu Augsburg und in der Bibliothek der Kathedrale von Durham als aus Seide gewebt zu denken. Scharlachfarbene erwähnt z. B. ein Inventar von Benediktbeuren aus dem Jahre 1032: zonae coccinae 4, ein Inventar des Klosters Abdinghof aus der Zeit des Bischofs Meinwerk: cinctorium coccineum 1, das Inventar desselben Klosters unter Abt Gumbertus: 10 cingula coccinea, mit Gold durchwebte ein Inventar von Clermont-Ferrand (10. Jahrh.): zonae 2 aureae, ein Speierer Schatzverzeichnis von 1051: cingula :3 auro parata, ein Inventar von St Gallen (11. Jahrh.): cingula 5 aurata, und ein Inventar von Enger (11. Jahrh.): praecingula auro ornata 6. Auch die beiden Cingula, welche Abt Ansegisus († 833) dem Kloster Fontanelle schenkte, waren auro decorata, desgleichen die neun Gürtel, welche Bischof Riculf von EIne 915 seiner Kathedrale hinterließ ${ }^{3}$.

Für reiche Ornamentierung bot das Cingulum bei seiner geringen Breite nur wenig Raum. Insbesondere waren figürliche Darstellungen, welche stets größrere Flächen beanspruchen, als dasselbe zu bieten im stande ist, von vornherein ausgeschlossen. Das einzig entsprechende Ornament bildeten kleine geometrische Muster, einfache stilisierte Pflanzen- und Tiermotive, Wappenschildchen und Inschriften, wie sie auch bei schmalen Borden zur Anwendung kamen.

Inschriften finden sich auf dem Witgariusgürtel und dem vorhin besprochenen Cingulum in St Marien zu Danzig. Ein ferneres Beispiel bietet das Cingulum im Reliquienschatz des Klosters Andechs, dessen Aufenseite die auf den Zweck und die mystische Bedeutung des Ornatstückes hinweisenden Verse eingewebt sind: Zona iustitiae sic te, pater optime, cinge, + Ut digne benedicas panem mysterialem, während die Innenseite Felder mit romanischem Rankenwerk und phantastischen Tiergestalten aufweist. Der Gürtel ist $2,80 \mathrm{~m}$ lang und $0,03 \mathrm{~m}$ breit. Ein Inventar von Angers

Revue 1886, 176.

2 Miitz e Frothingham, Il Tesoro 12.

Braun, Die liturgische Gewandung.
3 M. 132, 468: zonae 5, una cum auro e? gemmis pretiosis, aliae 4 cum auro. 
aus dem Jahre 1467 vermerkt ein schönes, aus Seide und Goldfäden gemachtes Cingulum, dem das ganze Evangelium In principio erat verbum eingewirkt war.

Geometrische Gebilde und geometrisch umgeformte Tier- und Pflanzenmotive finden sich auf dem Prachtcingulum im Dom zu Halberstalt, dem Danziger Cingulum und dem hochinteressanten Gürtel im Schatz der Kathedrale zu Sens. Das Inventar des päpstlicheu Schatzes vom Jahre 1295 verzeichnet unum cingulum album ad castella et senta cum appendiciis amplis, factis de vernicibus (Zierplättchen) und unum cingulum antiquiom rubeum ad castra, scuta et rosas auri.

Außer eingewebten und eingestickten Ornamenten dienten zur Ausstattung des Cingulum auch wohl Perlen, Edelsteine und silbervergoldete oder goldene Zierplättchen. Natürlich kamen solche nur bei Prachtcingula zur Anwendung, und zwar wurden sie bei denselben namentlich an den vorn frei herabfallenden Streifen angebracht. Das Inventar des päpstlichen Schatzes von 1295 führt eine Anzahl derartiger kostbarer Cingula an. So heifst es darin: unum cingulum de stri(a)to (gestreifter Stoff) viridi cum appendiciis factis de vernicibus et cum bottone de crystallo, unum cingulum de serico albo cum bottonibus et vernicibus ad aurum (Knöpfchen und Plättchen

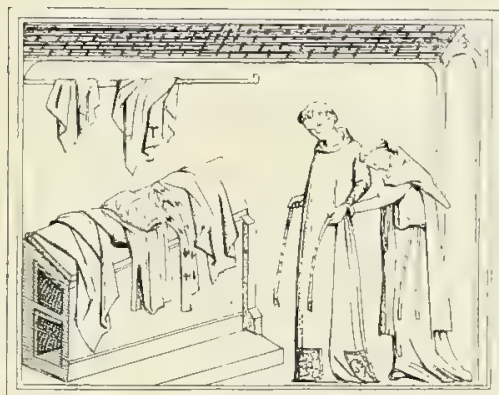

Bild 51. Ankleidung zur Messe. Miniatur eines Manuskriptes von 1380. (Nach Roliault de Fleury.) aus Gold) cum appendiciis, unum cingulum album ad aurum cum perlis albis et indicis et nodis de auro tilato. Ein Inventar von St Peter von 1436 vermerkt ein cingulum maspillatum de serico rubeo et auro, ein rotseidenes, golddurchwirktes Cingulum, dem maspilli, kleine Ornamente aus Edelmetall oder Kristall, aufgenäht waren ${ }^{1}$. Ein Bild solcher Gürtel gewährt das Cingulum im Schatz der Wiener Hofburg (Bild 50, S. 110).

Die Enden des Cingulum lief man gern in Fransen, Quasten oder Trodeln ausmünden. Bessere Cingula besetzte man unten auch wohl mit Schellchen, Metallkügelchen und ähnlichen Behängseln. Unum cingulum de serico diversorum colorum cum campanellis de argento, heist es unter $\mathrm{Nr} 1082 \mathrm{im}$ Inventar des päpstlichen Schatzes. Auch brachte man wohl an den Enden ein besonderes quadratisches oder trapezförmiges Kopfstück an, wie es beim Manipel und der Stola zu geschehen pflegte. Ein Beispiel bietet aufer dem Witgariusgürtel eines der beiden einfacheren Cingula im Dom zu Halberstadt, das in fast quadratische, mit vergoldeten Silberplättchen besetzte Abschlusstücke ausmündet. Diese Verzierungsweise muls namentlich im 12. und 13. Jahrhundert beliebt gewesen sein. Die Monumente dieser Zeit bieten mehrfach Darstellungen von Cingula, die mit derartigen Endstücken versehen sind. Natürlich waren solche nur bei Bandcingula anwendbar.

Betont sei übrigens, dafs reichere Cingula auch im Mittelalter zwar nicht selten, doch keineswegs das Gewöhnliche waren. Es mufs auffallen, dals in den Inventaren derartiger Gürtel im ganzen nicht allzuhäufig Erwähnung geschieht. Beispielsweise führt das Inventar von St Peter von 1361 nur sechs bessere Cingula auf.

Die Anlegung des Cingulum zeigt eine interessante Miniatur eines dem 1\%. Jahrhundert entstammenden Manuskriptes. Ein Priester ist im Begriff,

\footnotetext{
1 Ii ntz e Frothingham, Il Tesoro 78 .
} 
sich für das heilige Opfer anzukleiden. Den Amikt und die mit Paruren versehene Albe hat er schon angezogen, und nun sucht er sich mit Hilfe des Akolythen das Cingulum umzugürten. Auf dem Betstuhl, der vor dem Priester steht, liegen die noch übrigen Paramente. Die Darstellung ist ganz aus dem Leben gegriffen (Bild 51) ${ }^{1}$.

\section{DER LITURGISCHE GÜRTEL IN DEN RITEN DES ORIENTS.}

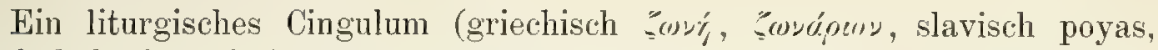
armenisch koti, syrisch zūnārā, zunnār, koptisch zounarion) ist in keinem der verschiedenen Riten bei den Diakonen im Gebrauch, dagegen bedienen sich in allen seiner die Priester und Bischöfe. Die Subdiakone tragen einen Gürtel nicht bei den Armeniern, Syrern und Chaldäern, wohl aber bei den Griechen und Kopten.

Der Gürtel der Priester und Bischöfe ist ein ca 1,00 m langes und ca $0,06-0,07 \mathrm{~m}$ breites Band, welches entweder mit Schnüren hinter dem Riücken oder nit einer Schliefe unterhalb der Brust befestigt wird (Bild 52). In der

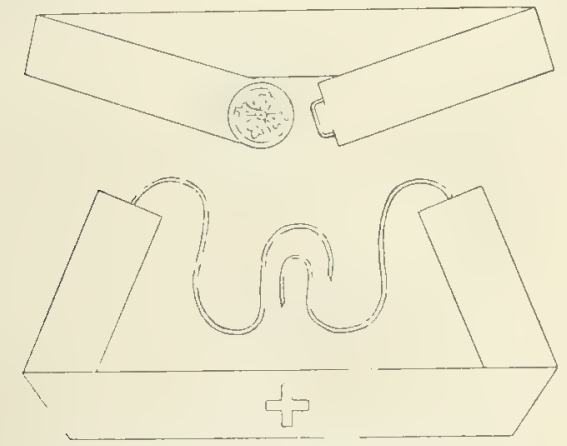

Bild 52. Priesterlicher Gürtel im griechischen Ritus.

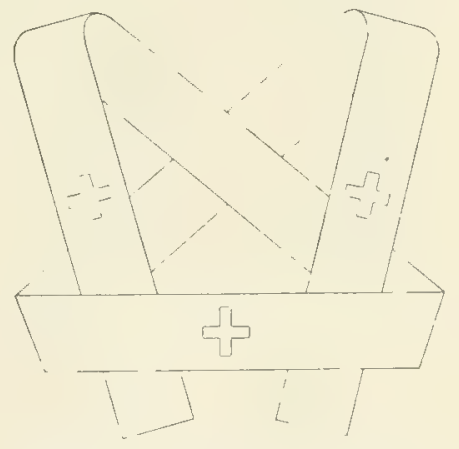

Bild 53. Gürtel des Subdiakons im griechischen Ritus.

Regel besteht er aus demselben Stoff, aus welchem das liturgische Obergewand angefertigt wird. Bindet man das Ornatstiuck hinter dem Rỉcken an, so ist vorn in der Mitte entweder eine Agraffe angebracht oder doch wenigstens ein Kreuz aufgestickt bzw. aufgenäht.

Der Gürtel der Subdiakone stellt ein ca 2,50-3,00 m langes und ca $0,09-0,10 \mathrm{~m}$ breites, mit drei Kreuzen geschmücktes Band dar. Eine bestimmte Farbe ist für ihn nicht vorgeschrieben. Von den drei Kreuzen befindet sich eines in der Mitte, die beiden andern sind nach den Enden zu angebracht. Die Anlegung des Cingulum erfolgt in eigenartiger Weise. Statt die Enden auf dem Rücken zu binden, wie es bei den Priestern geschieht, führt man sie über Kreuz zu den Schultern hinauf, wirft sie von dort nach vorn und steckt sie hier, ohne sie nochmals zu kreuzen, unter dem Teil des Cingulum durch, welcher sich unterhalb der Brust quer vorbeizieht (Bild 53). Zwischen dem priesterlichen bzw. bischöflichen Cingulum einerseits und dem Gïrtel der Subdiakone anderseits, welcher der Form, wenn auch nicht der Tragweise nach grofe Älnnlichkeit mit dem diakonalen Orarium (Stola) hat, ist sonach ein Unterschied.

'Bill. des Arsenals (Paris) n. 2002; Abbildung bei Roh. VII, pl. DXXIII. 
Über die Geschichte des Cingulum in den orientalischen Riten läßst sich nur wenig sagen, und das wenige betrifft fast nur den griechischen Ritus. Für den Gebrauch eines Gürtels bei den Mönchen liegen bereits aus dem 4. Jahrhundert Zeugnisse vor. Wie wenig sich jedoch aus dem Mönchsgürtel auf den Gehrauch eines liturgischen Cingulum schliefen läfst, geht aus der Bemerkung der Historia Lausiaca hervor: Ingredientes ad Christi communionem sabbato et dominica zonas solvant et pellem ovilem deponant 1. Die Mönche hedienten sich also nach der Regel des hl. Pachomius des Gürtels gerade dann nicht, wenn sie sich den heiligen Geheimnissen nahten.

Ziemlich dunkel ist, was im 22. (61.) der arabisch-nicänischen Kanones ïber die Gürtung der Kleriker beim Gottesdienst bestimmt wird ${ }^{2}$. Wie es scheint, wird darin verordnet, daf die Priester am Altar gegürtet, die andern Kleriker (wohl die Diakone) aber ungegürtet ihres Amtes zu walten hätten; doch ist dieser Sinn des Kanons keineswegs gewif. Obendrein ist es fraglich, aus welcher Zeit die Kanones stammen; denn daf sie nicht nicänisch sind, steht auker Zweifel.

Den ältesten sichern Beleg für den Gebrauch eines liturgischen Gürtels in den Riten des Ostens bildet die sog. Mefierklärung des hl. Germanus ${ }^{3}$. Leider erhalten wir aus ihr keine Auskunft über Form und Beschaffenheit des Cingulum. Auch in der Folge bleiben wir so gut wie ohne allen Aufschluf über diese doch so wissenswerten Punkte. Insbesondere lassen uns auch die Bildwerke nahezu gånzlich im Stich. Wo auf denselben, wie z. B. auf vereinzelten Miniaturen des Menologium des Basilius II. in der vatikanischen Bibliothek, ein Stückchen des Cingulum zum Vorschein kommt, scheint es ein Band von der Art des heutigen Bandcingulum darzustellen.

Auffällig ist, daßs die Meserklärung auch den Diakonen ein Cingulum zuzuschreiben scheint ${ }^{4}$. Indessen ist es wohl richtiger, wenn man die fragliche Stelle auf das priesterliche (bischöfliche) Cingulum bezieht. Ein Diakon mit gegürteter Tunika dürfte dem griechischen Ritus, um den es sich in der "mystischen Betrachtung" handelt, denn doch etwas gar zu fremdartig sein. Wo immer griechische Diakone abgebildet sind, wie z. B. in den "Homilien des hl. Gregor von Nazianz" der Pariser Nationalbibliothek aus dem 9.5, dem "Menologium des Basilius" der Vaticana aus dem beginnenden $11 .{ }^{6}$ oder den "Homilien des hl. Gregor" der Pariser Bibliothek aus dem 14. Jahrhundert?, ist das Sticharion stets umgegürtet.

Allerdings sagt einmal Simeon von Saloniki gelegentlich, es werde der Diakon gegürtet ${ }^{8}$; wie wir das aber zu verstehen haben, erklärt er uns selbst. Gegürtet wurden die Diakone mit ihrem Orarium, ihrer Stola - also nicht einem eigentlichen Gürtel - , und zwar bloß bei einer bestimmten Gelegenheit, nämlich bei der Kommunion". Bei den Griechen war und ist es nämlich

1 P a 11 a d., Hist. Laus. c. 38 (M g. 34, 1099).

2 Hard. I 473. Die Zählung der Kanones ist nicht in allen Ausgaben die gleiche. In dem von O. Braun (De sancta Nicaena synodo 76) iubersetzten Text hat er die Nummer 22. Die Texte des Kanons sind teilweise recht verschieden, Die Kanones werden von Braun dem 5. Jahrhundert zugewiesen. Vgl. auch $\mathrm{Hef}$., Concilien I $361 \mathrm{ff}$.
3 Mg. 98, 393. Vgl. auch Krasnoje]jeev, Addenda ad Anecdota graeco-byzantina(Odessa 1898) n. 13 und Pseudo-Sophroniosn. (Mg. $\left.87^{3}, 3988\right)$.

$4 \mathrm{Mg} .98,396$.

5 Ms. grecs 510. ${ }^{6}$ Vatic. Cod. gr. 1613.

7 Ms. grees 543, Der Codex wird von Roh. VII, pl. DXLIII irrig dem 11. Jahrhundert zugeschrieben.

${ }^{8}$ De sacra liturgia c. 81 (Mg. 155, 260).

3 De sacris ordinat. c. 173 (ebd. 381). 
Sitte, daf der Diakon in der Messe vor der Kommunion die Stola von der Schulter herunternimmt und nach Weise des subdiakonalen Gürtels umlegt, zum Ausdruck der Demut und Ehrfurcht, wie Simeon sagt.

Was die Verwendung eines Cingulum seitens der Subdiak one anlangt, so trugen diese in der Frühe unseres Jahrtausends jedenfalls noch kein solches, wie ein von Assemani mitgeteilter griechischer Weiheordo aus dieser Zeit beweist ${ }^{1}$. Im 14. Jahrhundert war es dagegen sowohl zufolge der griechischen Weiheordines des späten Mittelalters wie der ausdrücklichen Angabe Simeons von Saloniki ${ }^{2}$ bei ihnen zweifellos im Gebrauch. Das Cingulum wird also bei den griechischen Subdiakonen etwa in der Zeit zwischen dem 11. und 14. Jahrhundert aufgekommen sein. Jedenfalls ist die gegenwärtig bei den griechischen und koptischen Subdiakonen gebräuchliche Anlegungsweise des Cingulum nicht selrr alten Datums. Man wird sich vergebens auf den zahlreichen griechischen Miniaturen und sonstigen Bildwerken bis zum Ende des Mittelalters nach einem Kleriker umsehen, der so gegürtet erscheint, wie es jetzt bei den Subdiakonen im griechischen Ritus Sitte ist.

\section{FÜNFTES KAPITEL.}

\section{DAS SUBCINCTORIUM.}

\section{DAS SUBCINCTORIUM NACH GEGENWÄRTIGEM BRAUCH.}

Ein zweites päpstliches Sondergewand ist das Subcinctorium, wie schon der Name besagt, ein Zubehör des Cingulum. Dasselbe stellt wie der Manipel, dem es nach Gestalt und Beschaffenheit sehr ähnlich ist, einen in der Mitte zusammengefalteten Stoffstreifen dar, der in der Farbe mit derjenigen des Meßggewandes übereinstimmt. Nahe am oberen Ende sind die beiden Hälften durch eine Quernaht zusammengenäht. Die dadurch gebildete Masche ist so breit, daf das Cingulum bequem hindurchgezogen werden kann (Bild 54). Auf dem unteren Ende des einen Streifens ist in Gold ein Lämmchen, auf dem des andern, ebenfalls in Gold, ein Kreuz aufgestickt. Das Subcinctorium ist nicht am Cingulum angenäht, sondern stellt ein davon trennbares, selbständiges Gewandstück dar.

Der Papst bedient sich des Subcinctorium nur, wenn er feierlich pontifiziert. Man legt es ihm an, indem man es an das Cingulum streift und ihn dann mit letzterem umgürtet. Es wird

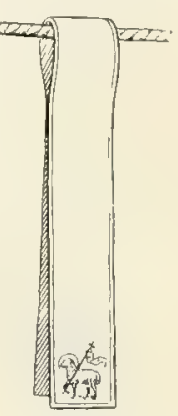

Bild 54. ubcinctorium. an der linken Seite getragen. Das Subcinctorium hat gegenwärtig keinerlei praktische Bedeutung und besitzt demgemäf bloß den Charakter eines Zierstüickes.

\section{DAS SUBCINCTORIUM IM MITTELALTER. SEIN ALTER, SEINE BESCHAFFENHEIT. WEISE, ES ANZULEGEN.}

In Rom kann das Subcinctorium bis ins 9. Jahrhundert noch nicht in Gebrauch gewesen sein, da weder der 1 . Ordo noch der 3. noch endlich der S. G. K. es unter den liturgischen Gewändern des Papstes erwähnt. Aber auch auferhalb Roms dürfte es damals wohl noch nicht zur Verwendun. gekommen sein. Denn weder Hraban, noch Amalar, noch Pseudo-Alkin

1 Codex liturg. 1. 8, p. $4141 \mathrm{f}$.

2 De sacris ordinat. c. 163 (Mg. 155, 368). 
noch Pseudo-Beda, noch endlich Walafried gedenken des Subcinctorium; sie kennen es ersichtlich nicht als Bestandteil der Pontifikaltracht. Wenn daher ein Inventar des Klosters vom heiligen Erlöser zu Stendland (bei St-Omer) aus dem Jahre 867 neben cinctoria 3 auch subcinctorium auro paratum 1 verzeichnet ${ }^{1}$, so wird es sich bei diesem wohl nicht um ein Subcinctorium im späteren Sinne, sondern um einen reichverzierten Prachtgürtel handeln. Jedenfalls war damals das Subcinctorium noch kein allgemein gebräuchliches, ja nicht einmal ein verbreitetes Ornatstück.

Seit dem 12. Jahrhundert ist wiederholt bei den Liturgikern von dem Subcinctorium, das auch wohl subcingulum genannt wird, als einem wie zu Rom so auch verschiedenenorts a $u$ ferhalb Roms gebräuchlichen sakralen Ornatstücke die Rede.

Schon bei Bruno von Segni († 1123) geschieht seiner Erwähnung; es wird von ihm ausdrücklich als spezifisch bischöflicher Ornat hingestellt. Sicard, welcher neben subcinctorium auch die Ausdrücke subcingulum und perizoma als Namen des Gewandstückes anführt, rechnet selbiges zwar nicht mit bestimmten Worten zur bischöflichen Sakraltracht, behandelt es aber doch als einen Bestandteil derselben. Ausdrücklich bezeichnen dagegen wieder Innozenz III., Durandus und auch der hl. Thomas * das Subcinctorium als ein den Bischöfen zukommendes Ornatstück. Es mufs deshalb auffallen, daf Honorius und Robert Paululus ${ }^{3}$ es auch der liturgischen Kleidung der gewöhnlichen Priester einreihen. Indessen dürften sich wirklich hie und da auch Priester des Subcinctorium bedient haben, so z. B. zu Mailand, wo es den Kardinalpriestern der Metropolitankirche zugestanden zu haben scheint *. Ein päpstliches Sondergewand war das Subcinctorium im 12. und 13. Jahrhundert nicht. Es entbehrte dieses Charakters selbst noch im Beginn des 14. Jahrhunderts, da der Ordo des Jakobus Gaietanus es um jene Zeit ausdrüicklich zu den liturgischen Kleidern der Kardinalbischöfe zählt ${ }^{5}$.

Welche Verbreitung das Subcinctorium im Mittelalter hatte, läfst sich nicht bestimmen. Mit dem Ausgang desselben scheint es bei den Bischöfen fast allgemein aufer Gebrauch gewesen zu sein. In den spätmittelalterlichen Pontifikalien ist kaum mehr von ihm die Rede. Wenn es in einem vereinzelten Falle noch erwähnt wird, mag das meist darin seinen Grund hahen, dafe das betreffende Pontifikale eine gedankenlose Kopie einer älteren Vorlage ist ${ }^{6}$. In Mailand kam es noch zur Zeit des hl. Karl Borromäus zur Verwendung, wie aus dessen Verordnungen über die liturgische Kleidung erhellt ${ }^{7}$. Das römische Caeremoniale der Bischöfe kennt das Subcinctorium nicht mehr.

1 Folcwini Gesta abb. S. Bertini Sith. n. 117 (M. G. SS. XIII 634).

${ }^{2}$ In Lombard. 1. 4, dist. 24, quaest. 3, art. 3; ed. Parm. (1858) VII 903.

${ }^{3}$ Auch Johannes Beleth rechnet in seinem Rationale c. 32 (M. 292, 43) ein subcingulum unter die priesterlichen Sakralkleider, jedoch ist es unklar, ob dasselbe mit eben dem subcingulum eins ist, dem unsere Erörterungen gelten; denn er beschreibt es als netwas an der Stola, was mit dem Cingulum verbunden werde" (est quiddam in stola, quod ligatur cum cingulo). Vielleicht ist indessen zu lesen: est quidkam in cingulo, quod ligatur cum stola. Ivo von Charties spricht in der Beschreibung der liturgischen Priesterkleidung
(Sermo 3 [M. 162, 525]) von gewissen nexus (Verknüpfungen), durch welche die Stola mit dem Gürtel verbunden werde. $\mathrm{Ob}$ er dabei das subcinctorium im Sinne hat, geht aus seinen Worten nicht hervor.

${ }^{4}$ Magistretti 43. Vgl. auch Synode von Coyaca c. 3 (1050), wo das Subcinctorium balteus heift (M a nsi, Coll. Conc. XIX, 791).

${ }^{5}$ Ordo 14, c. 4853 (M. 78, 1153 1157).

B Der Kopist eines Benediktinerpontifikale von Monte Cassino aus dem 14. Jahrhundert (Vat. lat. 9310 fol. $4 \mathrm{v}$ ) hat mit dem Worte semicinthium (= subcinctorium) so wenig mehr anzufangen gewußst, dafs er daraus das Ungehever cimicampamum machte.

7 A. E. Med. 626. 
Über die Beschaffenheit und die Gestalt des mittelalterlichen Subcinctorium erfahren wir nicht viel. Jedenfalls war dasselbe, wie auch heute noch, ein selbständiges Gewandstück; es bestand sonach nicht blok, wie man wohl geglaubt hat ${ }^{1}$, in den vorn herabhangenden Enden des Cingulum.

Bei Bruno, Sicard und Durandus könnte die Sache allerdings einigermaßen zweifelhaft sein, Honorius und Robert Paululus beschreiben das Subcinctorium jedoch klar als einen vom Cingulum verschiedenen und trennbaren Ornatteil. Während nämlich jene nur bemerken: a cinctorio (zona) duplex pendet subcinctorium (subcingulum), sagen diese: subcingulum (subcinctorium) duplicatum (duplex) suspenditur. Als ein vom gewöhnlichen liturgischen Gürtel unterschiedenes und für sich bestehendes Gewandstück erscheint das Subcinctorium auch in den Acta der Bischöfe von Le Mans (subcinctoria tria, unum pretiosis margaritis ornatum) und unter dem Namen succincta bei Johannes von Bayon (ca 1326) in den Annalen von Moyen-Moutier (cingula serica 12, succinctae de serico 2, tertiaque de auro) ${ }^{2}$.

Da Honorius und Robert Paululus sagen, es werde das Subcinctorium gedoppelt, đ. i. in der Mitte zusammengeschlagen am Cingulum aufgehängt, so $m u \hat{B}$ dasselbe wohl schon im 12. Jahrhundert ein manipelförmiges Ornatstück gewesen sein. In der zweiten Hälfte des 13. Jahrhunderts war es sicher ein solches; denn es heift im Pontifikale des Wilhelm Durandus: cingulum cum subcinctorio, quod habet similitudinem manipuli ${ }^{3}$. Auch der 14. Ordo* und ein Pontifikale von Elne ${ }^{5}$ bezeichnen das Subcinctorium als ein dem Manipel ähnliches Ornatstück. Bezeichnend für die formelle Verwandtschaft zwischen Manipel und Subcinctorium ist auch, dalis im Inventar Bonifaz' VIII. vom Jahre 1295 die letzteren zum Teil den Manipeln zugesellt sind. In einem Falle scheint es sogar dem Verfasser des Verzeichnisses schwer geworden zu sein, zu bestimmen, ob es sich um einen Manipel oder ein Subcinctorium handle; denn er bemerkt: subcinctorium vel manuale (andere Bezeichnung für den Manipel) rubeum et indicum cum nodis et manipulis (Quasten) auri filati.

Auf die Ausstattung des Subcinctorium scheint viel Wert gelegt worden zu sein. Das Inventar Bonifaz' VIII. verzeichnet beispielsweise aufier dem schon angeführten auch ein subcinctorium rubeum ad 8 imagines, ein Inventar von Prüfening (bei Regensburg) aus dem Jahre 1165 succingula 3 de auro et argento, ein unter Bischof Arnulf von Speier um 1151 abgefaftes Verzeichnis der Schätze des Speierer Domes neben cingula 3 auro texto parata et 1 sine auro baltei (= subcinctorium) 2 auro texti.

Über die Stelle des Gürtels, wo im 12. und 13. Jahrhundert das Subcingulum befestigt wurde, erfahren wir Näheres von Honorius ${ }^{6}$ und Durandus. Nach jenem wäre es mitten vor dem Körper angebracht worden; Durandus sagt dagegen in seinem Pontifikale ', es befinde sich an der rechten, und in seinem Rationale, es hange an der linken Seite herab. In Rom wurde,

1 Marr. 153, note 313: When the zona and the succinctorium are distinguished, it seems that by the latter term we must understand the long ends of the girdle, which hang down from the waist nearly to the feet. Vgl. auch Realenc. II 193.

2 Mabillon, Analecta vet. III (Paris. 1682) 390 , und D. C. sub subcinctorium VII 625 .

${ }^{3}$ M a rt. I. 1, c. 4, art. 12, ordo 23; I 221.
Auf bildlichen Darstellungen haben wir bisher nie das Subcinctorium angetroffen, allerdings begreiflich, weil es durch die Obergewänder verdeckt wurde.

4 C. 48 (M. 78, 1153).

5 Bei D. C. VII 625.

${ }^{6}$ L. 1, c. 206 (M. 78, 606): Subcingulum, quod subcinctorium dicitur, circa pudenda duplex suspenditur.

${ }_{7}$ M a t. a. a. O. 
wie aus der ausdrücklichen Vorschrift sowohl des 14. als auch des 15. Ordo hervorgeht, das Subcinctorium im Verlauf des 14. Jahrhunderts von dem Papst wie den Kardinalbischöfen an der linken Seite getragen. Dependere debet (subcinctorium) a cingulo in sinistra parte, sagt der 14. Ordo ${ }^{1}$; der 15. aber malınt den Liardinaldiakon, welcher den Papst zur Messe ankleidet, er möge darauf achten, das das Ornatstück ad latus sinistrum hange?. Wie im 14., so verhielt es sich beim Papst auch im 17. ${ }^{3}$ und 18. ${ }^{4}$ Jahrhundert und so ist es auch jetzt noch Sitte.

Dal3 es zur Zeit des hl. Karl Borromäus in der mailändischen Kirche, wo das Subcinctorium damals noch zur Verwendung kam, Brauch war, dasselbe links am Gürtel zu befestigen, beweist die diesbezügliche Verordnung des Heiligen: Cingulum episcopale a sinistro latere duplex, ut vocant, succinctorium seu succingulum, quo scilicet stola cum cingulo connectitur, habere debet pro ratione mysterii ${ }^{5}$.

\section{BALTEUS, PRAECINCTORIUM UND SEMICINCTIUM.}

Neben den gewöhnlichen Namen subcinctorium und subcingulum führte das Ornatstïck auch noch einige andere. Es erscheint nämlich auch unter den Bezeichnungen balteus, praecinctorium und semicinctium.

Balteus wird in der Vulgata der Gürtel der jüdischen Priester genannt ${ }^{6}$, doch heifst auch das Laiencingulum darin balteus. Bei den Klassikern bedeutet das Wort bald allgemein Einfassung, Rand, bald im besondern den Himmelsgürtel, den Polstergurt an den Säulenkapitälen, den Bauchgurt der Pferde, den Gurt zum Tragen des Schwertes, das Degengehenk, die Koppel ?.

Isidor von Sevilla beschreibt den balteus als cingulum militare, dictus, quod ex eo signa dependent ad demonstrandam legionis militaris summam... unde et balteus dicitur non tantum quod cingitur, sed etiam a quo arma dependent ${ }^{8}$. Zur Karolingerzeit bezeichnete das Wort die Schwertkoppel ${ }^{3}$, bei Petrus von Pisa heifst der mit sieben Schlüsseln geschmückte Gürtel, welcher dem Papst bei der Krönung angelegt wurde, balteus ${ }^{10}$.

Das gewöhnliche liturgische Cingulum wird selten balteus genannt. Von den Liturgikern gibt ihm nur Hraban diesen Namen, und zwar zweifelsohne im Anschluf an die Vulgata. Wenn Honorius, Sicard und Durandus vom balteus reden, so meinen sie den sakralen Gürtel der alttestamentlichen Priester.

1 C. 48 (M. 78, 1153).

2 C. 8 (ebd. 1277).

${ }^{3}$ Bona 1. 1, c. 24, § 15; II 268. M a cri, Notizia dei vocaboli ecclesiast. sub voce Cingulum; Mor. LXX 307.

${ }^{4}$ Chiapponi, Acta canonizat. 227. Zaccaria, Onomasticon rituale sub voce Praecinctorium; Mor. 1. c.

5 A. E. Med. 626 .

6 Ex 28, $440 ; 29,5840 ; 39,5$. T/V 8, 7. Dt 23, 13. $1 \mathrm{Kg} \mathrm{18,4.} 2 \mathrm{Kg} \mathrm{18,} 11$. $3 \mathrm{Kg} \mathrm{2,} \mathrm{5.} 4 \mathrm{Kg} \mathrm{3,21.} \mathrm{Jb} \mathrm{12,} 18$.

7 Forcell., sub balteus, I 309.

${ }^{8}$ Etymolog. 1. 19, c. 33 (M. 82, 702). Der erste Teil der Erklärung beruht auf Varro: balteum quod cingulum habebant bullatum, balteum dictum.
9 Caroli M. ep. ad Offam regem Merciae (M. G. Ep. IV, 146) : unum balteum et unum gladium hunniscum. Thegani, Vita Hludov. Imp. e. 19 (M. G. SS. II 595): balteo aureo praecinctus et ense auro fulgenti, und Vita altera n. 28 (M. G. SS. II 622): Ipsius (Ludovici) tempore coeperunt deponi ab episcopis et clericis cingula balteis aureis et gemmeis cultris onerata exquisitaeque vestes, sed et calcaria talos onerantia relinqui, wo baltei, cingula und cultei offenbar zwar als zusammengehörig, aber zugleich als voneinander verschieden erscheinen.

10 Vita Paschal. II (D u ch., L. P. II 296). Statt balteus wird auch oft baltheus geschrieben. Der Einheit halber wählen wir stets die Schreibweise balteus. 
Als Name des Subcinctorium begegnet uns das Wort balteus schon um das ausgehende 10. Jahrhundert in dem ursprünglich für St-Vast zu Arras bestimmten Sakramentar Ratolds von Corbie ${ }^{1}$. Cingulum und Balteus werden in demselben scharf voneinander unterschieden. Erst hilft der Minister dem Bischof die Albe anziehen, dann umgürtet er ihn mit dem Cingulum, und nun legt er ihm den Balteus an. Wir erhalten freilich keine Beschreibung des letzteren, indessen kann denn doch unter ihm nicht wohl ein zweiter vollständiger Gürtel, sondern nur das Ornatstück verstanden werden, welches sonst Subcinctorium genannt zu werden pflegte.

Etwas später finden wir balteus im Sinn von subcinctorium in einem Pontifikale von Besançon, in zwei Pontifikalien des Klosters Le Bec (alle drei frühes 12. Jahrh.) und in einem Pontifikale von Cambrai (Ende des 12. oder Anfang des 13. Jahrh.) ?. Hier überall ein pontifikales Ornatstück, erscheint balteus in gleicher Bedeutung als Bestandteil der priesterlichen Kleidung in c. 3 der Synode von Coyaca von 1050. Auch in Inventaren treffen wir das Wort balteus in der Bedeutung eines vom Gürtel verschiedenen, aber zum Gürtel gehörenden Ornatstiickes an, so in einem noch dem 10. Jahrhundert angehörenden Inventar von Pfäffers (Schweiz): baltei 11, cinguli insuper $13^{3}$, in dem 1051 unter Bischof Arnulf abgefabten Speierer Schatzverzeichnis: baltei 2 auro texti, cingula 3 auro texto parata et 1 sine auro, und in einem um 1200 entstandenen Inventar der Kathedrale von Rouen: balteum pretiosum eum zonis duabus sericis, una alba, altera rubea. Anderswo ist nicht ersichtlich, ob unter balteus das Cingulum oder das Subcinctorium zu verstehen ist, so z. B. wenn in einem Verzeichnis der Paramente und Geräte, welche Bischof Reginard von Liittich der Klosterkirche zum hl. Laurentius am Tage ihrer Einweihung schenkte, auch eine stola cum balteo deaurata genannt wird. Dagegen ist das Subcinctorium zweifelsolnne gemeint, wenn in einer Bulle Johannes' XV. (986-997) dem Abt von Braunau die Erlaubnis erteilt wird, sich bestimmter bischöflicher Paramente, darunter auch des Balteus, zu bedienen 4, und Gilbert von Limerick zu den pontifikalen Sakralgewändern auch einen Balteus rechnet ${ }^{5}$, ebensowohl, wenn Johannes von Salisbury Papst Alexander III. (1159 bis 1181) an den anulus proprius und balteus erinnert, mit denen derselbe ihn zu Ferentino ausgezeichnet hatte ${ }^{6}$.

Es verdient Beachtung, daf beinahe alle Stellen, in denen das Subcinctorium balteus genannt wird, französischen, normannischen und deutschen Ursprungs sind. Es scheint sonach dieser Name fast nur im Norden in Gebrauch gewesen zu sein oder doch aus dem Norden zu stammen. Er dürfte seinen

1 Biblioth. nat. f. lat. 12052. Mart. 1. 1. c. 4, art. 12, ordo 11; I 203. Über die urspriingliche Bestimmung vgl. Delisle, Mémoire sur d'anciens sacramentaires (Paris 1886) 188.

Mart.c. 18 , art. 11, ordo 1012 ; II 57 66 ; ebd. 1. 1, c. 4, art. 1; I 128.

${ }^{3}$ M. G. Confr. S. Galli 397. Das insuper bezieht sich anf Cingula, von denen vorher bei Aufführung der Alben mit ihren zugehörigen Humeralien und Cingula die Rede war. Auch in einem Inventar aus dem Beginn des 14. Jahrhunderts werden 15 baltei genannt. Cingula werden in demselben nicht erwähnt; wie es scheint, sind selbige gerade wie die Humeralien nicht eigens verzeichnet worden, weil man sie als selbstverständliches Zubehör der Alben betrachtete.

4 M. 137, 847. Die Bulle ist zweifelsohne interpoliert, so dafs es unsicher ist, ob balteus der ursprünglichen Fassung angehört. Das Wort Mitra ist sicher später eingeschoben.

5 De statu eccl. (M. 159, 1002): Utitur etiam episcopus pro dignitatis honore baculo et anulo, chirothecis et mitra, balteo, dalmatica et sandaliis.

${ }^{6}$ Ep. 42 (M. 199, 26). Der Brief wurde ca 1160 geschrieben. 
Grund in einer, wemngleich nur entfernten Formähnlichkeit des Subcinctorium mit der Schwertkoppel haben.

Praecinctorium heifst das Ornatstück in der Missa Illyrica ${ }^{1}$, einem für Sigebert von Minden um 1030 geschriebenen Mefordo. Auch hier wird zwischen dem Cingulum und einem Praecinctorium unterschieden. Die Anlegung der Gewänder beginnt mit dem Amikt; dann folgen der Reihe nach Albe, Cingulum, Praecinctorium, Stola, Subtile (Tunicella) usw. Das Praecinctorium ist hier offenbar ein vom Cingulum verschiedener, aber seinem Namen nach zum Cingulum gehörender Ornat, also zweifelsohne das Subcinctorium.

Eine mit praecinctorium verwandte Bezeichnung ist der Ausdruck praecingulum, der sich in einem Inventar von Enger aus dem 11. Jahrhundert findet: 6 praecingula auro ornata, doch scheinen hier lediglich reich geschmückte Cingula gemeint $\mathrm{zu}$ sein.

Im südlichen Italien erscheint das Subcinctorium im 11. und 12. Jahrhundert unter dem Namen semicinctium (semicinthium). Denn wenn Leo von Ostia in der Chronik des Klosters Monte Cassino berichtet, es habe Abt Desiderius 9 stolas auro textas cum manipulis et semicinthiis suis gekauft? und wenn Anaklet II., der Gegenpapst Innozenz' II. (1130-1143), dem Abt Franco vom Sophienkloster zu Benevent und dessen Nachfolgern das Recht verleiht, wie die Bischöfe Mitra, Handschuhe, Dalmatik und Semicinctium zu tragen ${ }^{3}$, so kann es kaum zweifelhaft sein, daf hier wie dort unter dem Semicinctium das Subcinctorium zu verstehen ist.

Das Wort semicinctium (gräzisiert sruxiviov und davon wieder lateinisch auch semicinthium, semicintium) erscheint in verschiedener Bedeutung. Bei M a rtial (14, 153) ist es ein Lendenschurz. I sidor v on Sevilla bemerkt: Cinctus lata zona, minus lata semicinctium, minima cingulum 4. Was die semicinctia Apg 19, 12 (virtutes non quaslibet faciebat Deus per manus Pauli, ita ut etiam super languidos deferrentur a corpore eius sudaria et semicinctia et recedebant ab eis languores) bedeuten, ist nicht klar. Papst Gregor II. erklärte sie nach dem ehrwürdigen Beda als eine Art von Schweigtuch ${ }^{5}$. Theophylakt sagt, onprivita seien Sudarien, welche Leute von konsularischem Rang in den Händen trügen ${ }^{6}$. Als Leibschurz erscheint das Semicinctium beim hl. Bernhard De moribus episc. c. $2^{7}$, in der Vita B. Hugonis de Lacerta ${ }^{8}$, bei Heribert De mirac. Cisterc. monach. ${ }^{9}$ und sonst mehrfach. Johannes Balbis († 1298) schreibt: Semicinctium dicitur eo, quod dimidium cingat. In glossa Actor. 19 dicuntur semicinctia vestes ex uno latere dependentes vel zonae sive vestes nocturnales vel genus sudarii, quo hebraei utuntur in capite ${ }^{\text {to. }}$.

Bei Leo von Ostia und in der Bulle Anaklets kann es sich offenbar nicht um ein Lendentuch handeln. Ebensowenig stellen die fraglichen Semicinctien den gewöhnlichen liturgischen Gürtel dar, weil derselbe niemals den Charakter eines privilegierten Gewandstückes hatte. Daßs sie aber auch keinen griechischen Sakralornat bedeuten, wie man vielleicht wegen der gräzisierenden Richtung in Süditalien vermuten könnte, etwa das Epigonation, damals noch Enchirion der Bischöfe, ergibt sich daraus, dafo sie in beiden Fällen als Bestandteil der abendländischen Pontifikalkleidung erscheinen

Mart. 1. 1, c. 4, art. 12, ordo 4; I 177. Wegen des Alters und Ursprungs der Missa Illyrica vgl. Stimmen aus Maria-Laach LXVIII $143 \mathrm{ff}$.

${ }^{2}$ L. 3, c. 18 (M. G. SS. VII 711); vgl. in der Fortsetzung der Chronik durch Petrus Diaconus 1. 3, c. 74 (ebd. 753) : semicintia 7. 3 J. L. n. 8428 .
4 Etymolog. 1. 19, c. 33 (M. 82, 702).

${ }_{5}^{5}$ Liber retract. in Actus apost. c. 19 (M. 92, 1027).

${ }^{6} \mathrm{Mg} .125,764$.

7 M. 182,816 .

8 M a rt., SS. Vet. VI 1145.

9 L. 1 , c. 6 (M. 185,457 ).

10 D. C. (sub semicinctium) VII 407. 
und insbesondere in der Bulle Anaklets II. auf einer Linie mit der Mitra, den Handschuhen und der Dalmatik stehen.

Es bleibt daher nur übrig, in ihnen das Subcinctorium zu sehen, welches als bischöfliches Ornatstück gemäß den Ausführungen Brunos von Segni in der Tat wenigstens im Beginn des 12. Jahrhunderts in Italien bekannt gewesen sein muf Es liegt aber um so näher, Semicinctium und Subcinctorium als ein und denselben Ornatteil zu betrachten, als einerseits Leo ron Ostia seine semicinctia als eine Art von Zubehör zur Stola hinstellt (stolae $9 \mathrm{cum}$... semicinctiis suis), und anderseits das Subcinctorium tatsächlich, wie wir sehen werden, ursprünglich keinen andern Zweck hatte, als die vorn herabhangenden Stolastreifen zu befestigen. Einen Beweis für die Identität beider bildet anch das cimicampanum, welches in einem dem 14. Jahrhundert entstammenden Pontifikale von Monte Cassino unter den bischöflichen Gewändern erwähnt wird. Denn dieses Ungeheuer von Wort, das wohl aus semicincthium verderbt ist, kann nach dem Kontext nur das Subcinctorium sein 1 .

Balteus, Praecinctorium und Semicinctium erscheinen überall, wo sie uns begegnen, als ein an sich den Bischöfen eigentümliches, aber auch andern als Auszeichnung verliehenes Ornatstück.

\section{ZWECK, URSPRUNG UND BEDEUTUNG DES SUBCINCTORIUM.}

Über die Bedeutung und den Zweck des Subcinctorium sind sonderhare Ansichten aufgestellt worden. Man hat es für das Gremiale der Bischöfe, d. i. für jene Decke gehalten, welche dem Bischof auf den Schof gelegt wird, wenn er z. B. bei dem Pontifikalamt auf seinem Thron sitzt oder wenn er bei den Weihen die Salbungen vornimmt; man hat, gestützt auf den Umstand, dafis Honorius das Ornatstück mystisch als Sinnbild des studium eleemosynae, des Eifers im Almosengeben, dentet, geglaubt, selbiges habe ehedem dazu gedient, den saccone, die Geldbörse des Papstes, zu tragen, gerade als ob dieser in der heiligen Messe die Geldtasche an der Seite gehabt habe. Ja man hat sogar in ihm ein Abbild der femoralia, d. i. des unter allen andern Kleidern auf blokem Leibe getragenen Schurzes sehen wollen, den Gott durch Moses den jüdischen Priestern anzulegen befohlen hatte? Einer näheren Erörterung und Widerlegung bedürfen diese Meinungen, deren Unhaltbarkeit auf der Hand liegt, um so weniger, weil der hl. Thomas und Durandus klar und bestinimt den 7 weck angeben, den das mittelalterliche Subcinctorium hatte. Per succinctorium, quo stola ligatur cum alba, amor honestatis significatur, sagt der hl. Thomas im Kommentar zum Lombardus ${ }^{3}$; Durandus aber bemerkt: Est subcingulum illud, quod dependet a cingulo, quo stola pontificis cum ipso cingulo colligatur ${ }^{4}$. Es bestand also noch im 13. Jahrhundert unser Gewandstück in einer am Gürtel aufgehängten Vorrichtung, welche dazu diente, die vorn haltlos herabfallenden Stolenstreifen zu befestigen und auch wohl aufzuschürzen. Man mufs nämlich vor Augen halten, daßs die mittelalterliche Stola ein Band war, das nicht selten die bedeutende Gesamtlänge von $3 \mathrm{~m}$ und selbst mehr hatte ${ }^{j}$. Angesichts dieses Zweckes,

1 Vat lat. 9340 f. $4^{*}$ : Dum supradicta dicuntus calciatus debet dictus praelatus abluere (sc. manus) sedendo super cathedram suam ; deinde servitores debent ipsum induere sicuti moris et de amito (sic), de alba et stola. Et desuper stola zona cum cimicampamis etc. Eine spätere Hand hat in Schwarz über das Wort cingulum geschrieben.
2 Das Nähere bei Mor. LXX 307 f. Moroni hält das Subcinctorium für den Gürtel, an welchem der Papst die Geldtasche behufs Almosenspenden getragen hätte.

3 S. oben S. 118.

4 Rationale 1. 3, c. 1, n. 3; f. 64.

5 Wegen der großen Länge der Stola im 11 bis 13. Jahrh. vgl. das Kapitel ỉher die Stola. 
welchem ehedem das Gewandstïck diente, begreift man auch leicht seinen Namen. War es nämlich dazu da, die Stola an- und je nachdem auch aufzuschïrzen (subcingere), so lag es nahe, dasselbe subcinctorium, subcingulum zu nennen. Da es ferner, wenn es zur Befestigung der Stola gebraucht wurde, nicht einen den ganzen Leib umgebenden Gürtel, sondern nur ein gurtartig vor der Vorderseite desselben sich hinziehendes Band darstellte, wurde es mit Recht als semicinctium (Halbgurt) und praecinctorium (Vorgurt) bezeichnet.

Das Subcinctorium des Papstes ist jetzt nur mehr ein Zierstreifen, der seine praktische Bedeutung völlig eingebübt hat. In Rom wird er das schon im Beginn des 14. Jahrhunderts gewesen sein. Denn der 14. Ordo merkt an, es sollten die Ministri, welche dem Kardinalbischof beim Ankleiden zu helfen hatten, die beiden Stolastreifen mit dem Cingulum (cingulo) aufschürzen, damit sie nicht hinabgleiten könnten ${ }^{1}$. Es wurde also nach römischem Brauch bereits zur Zeit des Jakobus Gaietanus die Stola nicht mehr mit dem Subcinctorium, welches der Pontifex trug - et subsequenter subcingat eum cingulo cum subcinctorio - , sondern mit dem Cingulum selbst befestigt. In Mailand diente das Subcinctorium noch in den Tagen des hl. Karl Borromäus seinem ursprünglichen Zweck, wie das aus der früher angeführten Verordnung des Heiligen hervorgeht: succinctorium seu succingulum, quo scilicet stola cum cingulo connectitur. Das römische Caeremoniale der Bischöfe, welches das Subcinctorium nicht mehr kennt, gibt als zweckmäligig an, die bischöfliche Stola behufs ihrer Befestigung vorn und rückwärts mit Bändchen zu versehen?

In Bezug auf die Frage, wo das Subcinctorium zuerst in Gebrauch genommen worden sei, lassen sich nur Vermutungen anstellen. Man hat das Subcinctorium mit dem Epigonation der griechischen Kirche in Verbindung gebracht und geglaubt, eine Verwandtschaft zwischen diesem zur liturgischen Ausstattung der Bischöfe und auch wohl sonstiger höheren Geistlichen gehörenden Ornat und unserem Gewandstück annehmen zu sollen ${ }^{3}$. Allein eine solche Beziehung zwischen Subcinctorium und Epigonation ist nicht nur nicht nachweisbar, es hat eine solche nie gegeben. Subcinctorium und Epigonation sind zwei ganz verschiedene Dinge.

Das griechische Ornatstück wurde stets an der rechten Seite getragen, das Subcingulum dagegen fast allzeit links. Dann erscheint ersteres schon auf Miniaturen des 14. Jahrhunderts als taschenartiger, rautenförmiger Ornat, welcher an Bändern vom Gürtel herabhängt, während letzteres immer ein streifenartiges, dem Manipel ähnliches und unmittelbar am Cingulum befestigtes Gewandstück bildete. Drittens endlich war das Epigonation ursprünglich, und zwar noch wenigstens bis ins 12. Jahrhundert, ein Enchirion (Schweifituch), während das Subcinctorium zur Befestigung der Stola diente, mit einem Schweiftuch also niemals etwas zu tun hatte.

Wie es scheint, haben wir die Heimat des Subcinctorium im Norden zu suchen, wahrscheinlich im Frankenland, wo uns dasselbe am frühesten begegnet. Im Norden erhielt es auch, soweit die Quellen ein Urteil gestatten, die grölite Verbreitung. Von dort dürfte es dann etwa um die Wende des Jahrtausends auch nach Rom seinen Weg genommen haben, um allda ein Bestandteil der römischen Pontifikalgewandung zu werden.

1 C. 53 (M. 78, 1157).

2 L. 2, c. 8, a. 14 .
${ }^{3}$ Hef., Beitr. II 180. Realenc. II 193. Bona 1. 1, c. 24, \$ 15; II 268. M or. LXX 309. 


\section{ROCHETT UND SUPERPELLICEUM.}

\section{VORBEMERKUNG.}

In den Generalrubriken des römischen Missale, welche den Ritus der Meffeier behandeln, findet sich die Bestimmung, es solle derjenige, welcher das heilige Opfer darbringen wolle, die liturgischen Gewänder, falls er weltlicher Prälat sei, über ein Rochett, falls er aber ein dem Ordensstand angehörender Prälat oder ein Weltpriester sei, über ein Superpelliceum anlegen, wofern ein solches leicht zu haben sei ${ }^{1}$. Zwischen Rochett und Superpelliceum besteht ein dreifacher Unterschied. Der erste betriffit ihre Form; das Rochett ist mit engen, das Superpelliceum mit weiten Ärmeln (bzw. mit großsen Stoffstücken, welche deren Stelle vertreten) ausgestattet. Der zweite liegt in der Verschiedenheit der Personen, welche sich der beiden Gewandstiucke bedienen. Das Superpelliceum kommt nämlich allen Klerikern ohne Unterschied der Rangordnung und der Weihestufe zu, das Rochett bildet hingegen ein Kleid, das auker den Bischöfen und Prälaten nur solchen Geistlichen zusteht, denen kraft eines Privilegs der usus rochetti verliehen wurde. Der dritte Unterschied bezieht sich auf den Charakter der beiden Gewänder. Das Superpelliceum ist liturgisches Ornatstuck im engeren Sinne, wälırend das Rochett wenigstens nach römischer Auffassung nur einen Bestandteil der auferliturgisehen klerikalen Tracht darstellt und nur im weiteren Sinne, d. i. als Chorgewand, der liturgischen Kleidung zugezählt werden kann.

"Der Gebrauch des Rochetts", so heist es diesbezüglich in einer Vorbemerkung des römischen Missale, „ist allen verboten, denen es nicht von liechts wegen zusteht" : aufierdem ist es, wie andurch bestimmt wird, niemand gestattet, bei der Feier der Messe oder beim Chorgebet im Rochett oder in einer Cotta, die nach Art des Rochetts enge Ärmel hat, zu dienen oder zu assistieren. Dasselbe ist bei den Predigten zu beobachten 2. Der Unterschied zwischen Rochett und Superpelliceum, der in dieser Bestimmung des Missale zum Ausdruck kommt, wird auch in einer Reihe von älteren und jüngeren Antworten der Ritenkongregation betont. So entschied diese unter dem 10. Januar 1852, das Rochett sei bei der Spendung der Sakramente nicht als vestis sacra zu verwenden, und demgemäf habe man sich sowohl bei der Verwaltung der Sakramente als auch beim Empfang der Tonsur und der niederen Weihen des Superpelliceum zu bedienen ${ }^{3}$. Selbst diejenigen, welche von Rechts wegen oder kraft eines Privilegs den Gebrauch des Rochetts haben, diirfen nur im Superpelliceum die Sakramente ausspenden. Kanoniker, welche sich des Vorrechtes erfreuen, Rochett und Cappa oder Mozzetta zu gebrauchen, müssen daher bei Erteilung der Sakramente ein Superpelliceum über das Rochett anlegen, andere haben sich bei diesen Funktionen blok mit dem Superpelliceum zu bekleiden *. Allerdings wird in der Praxis der Unterschied

1 Ritus celebrandi tit. 1, n. 2. Da es hier wie im Pontifikale superpelliceum heift, wird auch im folgenden diese Schreibweise angewandt und superpellicium nur in Zitaten gebraucht.

\footnotetext{
${ }^{2}$ Decret. Congreg. Rit. ex mandat. $L^{*}$ ban. VIII. in Praef. ad Missale Rom.

3 Decret. auth. 2993.

* C. R. 31. Mai 1817, 17. Sept. 1812, 16. April 1831 (c. $2578,2622,2680$ ).
} 
zwischen beiden Gewändel'n nicht allenthalben eingehalten ${ }^{1}$. Solche Geptlogenheiten sind jedoch auch da, wo sie auf altem Herkommen beruhen, nur als Ausnahme von der Regel anzusehen. Sie heben die tatsächliche Verschiedenheit der beiden Gewänder nicht auf. Immerhin erheischen sie es, daßj wir uns hice nicht blof mit dem Superpelliceum, sondern auch mit dem Rochett näher befassen.

\section{ROCHETT ALS NAME EINES GEISTLICHEN GEWANDES.}

Rochett, rochettum ist die Diminutivform des mittellateinischen roccus, das schon in karolingischen Kapitularien ${ }^{2}$ und in dem 831 aufgestellten Inventar von St-Riquier vorkommt. Roccus selbst hängt mit dem althochdeutschen roch, rocch, rogh, roc sowie dem angelsächsischen rocc und unserem Rock zusammen ${ }^{3}$.

Das Wort rochettum scheint als Name des jetzt allgemein mit demselben bezeichneten Gewandes vor dem 13. Jahrhundert kaum in Gebrauch gewesen zu sein. In Deutschland kommt es in diesem Sinne schon in der ersten Hälfte des 13. Jahrhunderts vor, wie der 10. Kanon der im Jahre 1238 gehaltenen Trierer Synode beweist: „Das oberste Kleid der Priester soll bis auf die Füfe reichen und geschlossen sein; wenn sie aber zum Gottesdienste gehen, sollen sie eine Camisia, d. i. ein Rochett, anziehen" (camisia i. e. rochetto induantur) ${ }^{\star}$. Daßs hier unter Rochett nicht das weitärmelige Superpelliceum zu verstehen ist, ergibt sich daraus, daß es der Camisia gleichgestellt wird. Camisia bezeichnete nämlich im Mittelalter stets eine Albe oder albenähnliche, d. i. engärmelige Linnentunika. Außerdem folgt das aus dem 11. Kanon derselben Synode, in welchem zwischen Camisia und Superpelliceum klar unterschieden wird.

Etwa ein halbes Jahrhundert später sprechen auch die Lütticher Synodalstatuten des Jahres 1287 von dem Rochett: "Die Priester sollen unter den Alben entweder Superpelliceen oder Linnentuniken, die den Namen saroht oder rochet (sic) führen, tragen." 5 Denn auch in diesem Falle bedeutet rochet eine engärmelige Linnentunika, d. i. ein Gewand von der Art des jetzigen Rochetts. Daf dieses rochet nämlich Ärmel hatte, folgt aus den Worten der Statuten: "Man soll unter den Achseln keine Öffnungen in die linnene Tunika... machen, um die Arme ohne die Ärmel der Linnentunika ... beim Altardienst herauszustrecken." 6 Dał es aber kein weitärmeliges Gewand war,

1 Auf eine in einem besondern Fall gestellte Anfrage, ob die Sitte, wonach der ganze Klerus einer Diözese sich auf Grund alter Gewohnheit des Rochetts bediene, beibehalten werden könne, antwortete die Rituskongregation unter dem 27. Februar 1847: Non esse inquietandos (Decret. auth. n. 2935).

2 Capit. Lud. I, De monach. n. 22 (Hartzh. II 4).

${ }^{3}$ Grimm, Deutsches Wörterbuch VIII 1093. Sonderbare Ableitungen finden sich bei Gavanti in der Erklärung der Rubriken des römischen Missale ( $G$ a v. P. 2, tit. 1, n. 2; I 168). Seinen Ausfuhhrangen zufolge soll rochettum entweder von formos (= corymbi, die Fruchtbüschel des Efeu) herkommen, weil der Saum desselben mit ähnlich gestalteten linnenen Zieraten geschmückt worden sei, oder von fiü - ziшi: (weichere, zartere Linnentunika) oder gar vom hebräischen rah (sehen) und chetam (Linnen) herzuleiten sein. Im letzten Falle würde Rochett linea vestis speciosa, linum spectabile (glänzendes Linnengewand) bedeuten. Es braucht kaum bemerkt za werden, daß diese Etymologien nichts als gelehrte Spielereien sind.

4 Harzh. III 559 .

${ }^{5}$ C. 5, n. 1 (ebd. 690).

${ }^{6}$ C. 5, n. 14 (ebd.). Vgl. Syn. von Cambrai c. Celebrans (ebd. IV, 71). 
erhellt aus dem Umstand, dab es als ein vom Superpelliceum verschiedenes Gewand erscheint ${ }^{1}$.

Früh begegnen uns auch in England rochettae. Dort werden solche schon 1222 im Inventar der Kathedrale von Salisbury als zu den Altären des hl. Paulus und Allerheiligen gehörig und noch etwas vorher 1220 in den Inventaren der Pfarrkirchen von Ruscomb und Hill Deverell erwähnt. 1240 hestimmt eine unter Walter von Cantilupe zu Worcester abgehaltene Synode, es sollten in jeder Pfarrkirche zwei Superpelliceen und zwei rochettae sich befinden ${ }^{2}$, eine Synode von Exeter aber verordnete 1287 sogar, es sollten zu jedem Altar zwei Superpelliceen und ein Rochett gehören ${ }^{3}$. 1245 ist in dem Schatzverzeichnis von St Paul in London von Rochetten die Rede; eines wird darin als vom hl. Edmund, Erzbischof von Canterbury, herrührend bezeichnet. Um 1300 rechnet Robert von Winchelsea, ebenfalls Erzbischof von Canterbury, in der Konstitution, in welcher er festsetzt, was die Parochianen für die Pfarrkirche zu leisten hätten, unter die von diesen beizubringenden Gegenstände neben drei Superpelliceen auch ein Rochett ${ }^{4}$. Es ist allerdings fraglich, ob unter den genamnten englischen Rochetten allemal gerade unser Rochett zu verstehen sei. Vielleicht, dabi die erwähnten Rochette zum Teil ärmellos statt engärmelig waren. Denn der dem 15. Jahrhundert angehörige Kanonist Lyndwoode $(† 1446)$ bemerkt in einer Glosse zur Konstitution Winchelseas: "Das Rochett enthehrt der Ärmel und unterscheidet sich dadurch vom Superpelliceum, welches mit lang herabfallenden Ärmeln ausgestattet ist; es ist zum Gebrauch für den Kleriker, welcher dem Priester dient, und auch wohl für den Priester, welcher die Taufe spendet, bestimmt, damit seine Arme nicht durch die Ärmel behindert werden." 5 Indessen kannte man in England jedenfalls bereits früh im 13. Jahrhundert ein Gewand unter dem Namen rochetta.

In Deutschland und im nördlichen Frankreich hief das Rochett wohl auch saroht, sarcos, sarcotium, sarrotus, so in den schon erwähnten Lütticher Synodalstatuten, in den Statuten der Synoden von Passau (1284) ${ }^{\circ}$ und Cambrai $(1300)^{7}$, in den Statuten Stephans von Firomonte, Abtes von St-Eloi, und noch 1419 in einem Inventar der Kathedrale von Noyon, welches 5 sarroti modici valoris zu verzeichnen hat ${ }^{8}$.

In Rom scheint das Gewand, welches in den Statuten der Trierer und Lïtticher Synode Rochett genannt wird, bis gegen Ende des 14. Jahrhunderts unter diesem Namen noch nicht bekannt gewesen zu sein. In dem auf Befehl Gregors X. (1271-1276) herausgegebenen Ordo, dem 13. Mabillons, findet sich das Wort rochettum noch nirgends. In dem 14 . Ordo kommt es zwar zweimal vor, allein die eine der beiden Stellen ${ }^{9}$ ist wörtlich dem um die Wende des 14. Jahrhunderts entstandenen 15. Ordo des Bischofs Petrus

1 C. 5 n. 1 แ. 13. Vgl, auch Conc. Budense rom Jahre 1279 c. 2 (H ard. VII 792) : Praelati deferant... camisias albas sive rosetas, quas semper sub cappis deferant.

C. 1 (Hard. VII 331).

3 C. 12 (ebd. 1088).

4 C. 4 (ebd. 1212).

${ }^{5}$ Chambers 29 f; D. C. (sub v. roceus) VII 202.

${ }^{6}$ C. 2 (Hartzh. III 67:3): Sacerdotes portantes... hostiam, chrisma et oleum superpeilicio et sarcocio sint induti.
7 C. de euch. (ebd. IV 70): tunica linea, quae Gallice dicitur Sarcos.

8 D. C. (sub sarcotium und sarrotus) VII 311 313. Die Etymologie des Wortes ist nicht sicher; es hängt wohl mit dem altdeutschen saro = Rüstung zusammen. Vgl. Grim m, Deutsches Wörterbuch (unter sarrock) VIII 1802 und E. Littré, Dictionnaire de la langue française sul, sirran (IV 182s).

${ }^{9}$ C. 78 (M. 78, 1196); vgl. ordo 15, c. 20 (ebd. 1282). 
von Sinigaglia entnommen, die andere ${ }^{1}$ ist, wie aus einem Vergleich mit der Parallelstelle des 13. Ordo hervorgeht, ersichtlich verderbt und in ihrer jetzigen Form der ursprünglichen Fassung des 14. Ordo unzweifelhaft fremd. Der erste Ordo, in dem das Wort rochettum als Name eines mit dem jetzigen Rochett identischen Gewandes vorkommt, ist der 15. Ordo Mabillons ${ }^{2}$.

Das Kleidungsstïck, welches uns im 15. Ordo unter dem Namen rochettum begegnet, heilist im 13. und 14. Ordo camisia oder alba romana. gleichviel, ron wem die Rede ist ${ }^{3}$. Im 15. Ordo wird mit diesen Ausdrücken nur noch die Linnentunika bezeichnet, welche der Papst unter der Cappa bzw. unter der Mefalbe über den Alltagskleidern trug.

Ein anderer Name des Gewandes war succa (sucta, subta). Er hegegnet uns schon in einer Bulle Nikolaus III. $(1277-1280)^{ \pm}$und einer Verordnung der Synode von Valladolid (Spanien) aus dem Jahre $1322{ }^{5}$. Erstere bestimmt, die Kanoniker von St Peter soliten nie in der Kirche erscheinen, ohne zum wenigsten die succa zu tragen, letztere, es sollten die Bischöfe und Prälaten in der Öffentlichkeit mit succae (suctae) bekleidet sein. Im 15. Ordo findet sich statt succa subta: cum subtis seu rochettis ${ }^{6}$. Sajetta heibt das Gewand neben rochetum (sic) in den Konstitutionen der Lateranensischen Basilika?.

Seit dem 15. Jahrhundert verschwinden allmählich in Rom die Namen camisia, alba romana und succa (subta). Schon der Kompilator des 14. Ordo scheint succa nicht mehr verstanden zu haben, da er aus demselben scuta gemacht hat ${ }^{*}$. Das römische Missale, das römische Pontifikale und das Caeremoniale episcoporum nennen unser Gewand nur mehr rochettum. Dieselbe Bezeichnung eignet ihm ausschlieflich jeder andern auch in den Statuten des hl. Karl Borromäus De vita et honestate episcoporum et clericorum ${ }^{9}$. In Spanien war schon nach der Mitte des 15. Jahrhunderts roquetum als Benennung desselben das gewöhnliche. Episcopi veste linea superiore, vulgariter roquetum nuncupata, in publico semper utantur ${ }^{10}$. Es ist interessant, wahrzunehmen, wie auch bei dem uns hier beschäftigenden Kileidungsstück ein im Norden ursprünglich heimischer Terminus in Rom Aufnahme fand, dort den bis dahin gebräuchlichen verdrängte und allmählich im ganzen Abendland herrschend wurde.

1 C. 10 (M. 78, 1126) : Prior diaconorum . . . ponit ei (papae electo), si non habet, albam, rochetum, camisiam et ornamentum ad modum presbyteri super humeros. Ordo 13, n. 2 (ebd. 11.05) : ponit ei ... albam romanam, camisiam (= Albe) et orarium (Stola) ad modum presbyteri super humeros. Wie es scheint, hat der Kompilator mit der alba romana und dem orarium nichts anzufangen gewußt und darum romana durch das völlig überflüssige "rochettum" und orarium durch das höchst sonderbare olnamentum ersetzt.

2 C. 92068 (ebd. 12771282 1310).

"Auch aufer Rom hief es wohl camisia; vyl. c. 1 des Konzils von Montpellier 1215 (Hard. VI 2, 2046) und c. 2 des Konzils von Buda 1279 (ebd. VII 792). Die Kölner Synode des Jahres 1260 nennt es c. 7 u. 8 vestis camisialis ( $\mathrm{Hartzh}$. III 590 591).
Vgl. zu c. 8 das c. 17 der Kölner Synode von c. 1300 (ebd. IV 42) : camisia linea. Die Provinzialsynode von Aschaffenburg von 1292 verordnet in c. 2, es solle der Priester bei Versehgängen ein Superpelliceum, die campanarii eine camisia alba tragen (ebd. IV 7).

${ }^{4}$ Bzovius, Annales ad an. 1280; XIII 912.

5 C. 6 (Hard. VII 1466).

${ }^{6}$ C. 70 (M. 78, 1312). ${ }^{7}$ C. 1 (M. 78, 1396).

8 C. 92103 (ebd. 1212 1233). C. 92 ist von einer scuta die Rede, welche die capellani unter der cotta trugen. Nach c. 48 (ebd. 1153) hatten dieselben unter dem Superpelliceum. oder der Cotta eine camisia linea (d. i. das Rochett) super communes vestes, Scuta und Rochett sind also eins.

${ }^{9}$ A. E. Med. 16132168281 und sonst.

10 Synode von Aranda (1473) c. 5 (Hard. IX 1505). 


\section{CHARAKTER DES GEWANDES ZU ROM UND AUSSERHALB ROMS.}

Der Charakter, den das Rochett gegenwärtig nach römischer Anschauung besitzt, ist ihm nicht erst in der Neuzeit zu teil geworden, es hatte ihn zu Rom zum wenigsten bereits im 15., 14., ja 13. Jahrhundert. Schon damals zählte es nicht zu der eigentlichen liturgischen Kleidung. Bei Ausübung liturgischer Funktionen mukte man stets je nachdem die Albe oder das Superpelliceum tragen. Das Rochett galt nur als auszeichnender Bestandteil der klerikalen Tracht höher gestellter Geistlichen, vor allem des Papstes, dann der Kardinäle und Bischöfe, gewisser Kanoniker, wie der von St Peter, der päpstlichen Kapläne u. a. Bezüglich der Bischöfe hatte schon das 4. Laterankonzil 1215 bestimmt: Pontifices in publico et in ecclesia superindumentis

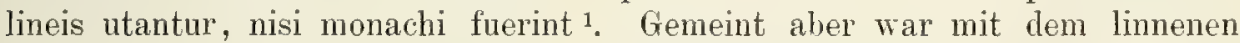
Überkleid, welches diese sowohl im öffentlichen Verkehr wie in der Kirche tragen sollten, die camisia, wie aus den Provinzialsynoden des 13. Jahrhunderts erhellt, d. i. das Rochett.

Der Papst trug nach dem römischen Brauch, wie er im 14. und 15. Jahrhundert bestand, das Gewand stets ${ }^{2}$, alle andern bedienten sich seiner wenigstens bei feierlichen Gelegenheiten und kirchlichen Funktionen ${ }^{3}$. (Camisiam lineam) semper dehet habere super laneas vestes, quando ad celebrandum vadit, etiamsi religiosus sit, heifst es im 14. Ordo vom Bischof, der sich zur Pontifikalmesse ankleidet". Es muften also selhst die dem Ordensstande angehörigen Bischöfe, welche sich für gewöhnlich der Camisia nicht zu bedienen pflegten, bei der heiligen Hesse eine solche unter der Albe haben. Das Rochett wurde bei den Bischöfen nach und nach eine Art von Insignie und ein Abzeichen der Jurisdiktion, welches darum nach dem Caeremoniale episcoporum der Papst selbst dem Neuerwählten anlegt, falls derselbe gerade zu Rom sich aufhält ${ }^{5}$.

Wie zu Rom, so verhielt es sich im 13., 14. und 15. Jahrhundert im allgemeinen auch auferhalb Roms. Auch hier wurden meistens nur die Albe und das Superpelliceum als eigentliche liturgische Gewänder angesehen, während die Camisia blok als klerikales Kleid galt. Demgemäß drängten denn auch die Synoden und Diözesanstatuten vielfach darauf, daf man bei der Feier der Messe unter der Albe eine Camisia habe ${ }^{6}$. Eine Mainzer Synode vom Jahre 1233 will sogar, daß der Priester bei der Spendung der Taufe, des Viatikum und der heiligen Ölung mit der camisia alba unter dem Superpelliceum bekleidet sei ${ }^{7}$. Ebenso betonen die Synodalverordnungen im Anschluf an die Bestimmung des 4. Laterankonzils wiederholt, daf die Bischofe

1 C. 16 (ebd. VII 34).

2 Urban. V. De curia 31 (M or. LVII 74): Rochetto lineo semper Pontifex Maximus velatus incedit. Auch ordo 13, n. 3 und ordo 14, c. 10 (M. 78, 1106 1127) erscheint die camisia als Teil der päpstlichen Alltagskleidung.

3 Ordo 14, c. 467892103 ; ordo 15, c. 9 2068 (M. 78, 114511961212123312771282 1310) u. a.

4 C. 53 (ebd. 1156).

5 L. 1, c. 1, n. 2. Vgl. schon Will. de Cham hre, Continuatio hist. Dunelmensis (Durham in England), Surtees Society 1839, 127: Bis adiit (Richard von Bury) summum pontificem Ioannem (XXII.) et recepit ab eo rochetam in loco bullae pro proximo episcopatu vacante ex post in Anglia.

Braun, Die liturgische Gewandung.
6 Stat. syn. Leod. c. 5, n. 1 ( $\mathrm{Hartzh}$. III 690); Syn. Camerac. a. 1300 , c. De euchar. (ebd. IV 70); Conc. Col. a. 1260, c. 7 (ebd. III 591). Sacerdotes ipsi quotiescunque celebraturi sunt, veste camisiali sub alba non careant, ne albam, quae consecrata est vestis, ipsorum tunicae valeant immediate contingere nec ipsae tunicae appareant, Pontif. Guiliemi Durandi apud Mart. 1. 1, c. 4, art. 12, ordo 23; I 221. Vgl. ebendort den Auszug aus dem Missale von Fécamp (c. 1300), ordo 26 (ebd. 228), wo es in der Vorbereitung auf die heilige Messe heifst: Sacerdos induat se roqueto, dicens: Actiones nostras, quaesumus Domine etc. Also selbst beim Rochett ein Ankleidegebet

7 Zeitschrift für die Geschichte des Oberrheins III, Karlsruhe 1852, 136. 
und Prülaten im öffentlichen Leben über den gewöhnlichen Kleidern stets die Camisia tragen sollten ". Immerhin gab es auch Diözesen, in welchen man von dem römischen Brauch abwich, indem man zwischen Rochett und Superpelliceum nicht unterschied und gleichmäßjig das eine wie das andere bei liturgischen Akten verwendete? Auferdem stand auferhalb Roms das Rochett nicht bloß im Dienste der Prälaten, sondern auch der Priester und der Kleriker überhaupt, selbst der Küster ${ }^{3}$.

\section{ERSTE SPUREN DES GEWANDES.}

Unzweifelhaft hat das 4. Laterankonzil durch die vorhin angeführte Bestimmung auf die Verbreitung des Rochetts einen grofien Einfluf ausgeuibt, wie aus den Provinzialsynoden des 13. Jahrhunderts hervorgeht. Irrig wäre es jedoch, wollte man den Gebrauch des Gewandes erst von jener Verordnung ableiten. Denn dafs es schon vor dem 4. Laterankonzil bekannt war, ist, so wenig Genaueres wir auch über seine frühere Geschichte wissen, durchaus sicher.

Zu Rom mufs sogar bereits im 9. Jahrhundert eine Art von Rochett in Gebrauch gewesen sein. Denn der St Gallener Kleiderkatalog belehrt uns, dak der Papst und die römischen Diakone unter den liturgischen Kleidern eine Camisia trugen ${ }^{4}$. Es wird diese allerdings als gegürtet bezeichnet, allein solches kann nicht auffallen, da selbst noch im 14. Jahrhundert die alba romana des Papstes mit einem Cingulum aufgeschürzt wurde. Es heist im 13. und 14. Ordo nämlich, der Papst müsse über seinen Tuchkleidern eine alba camisia haben et erit subcinctus cingulo de serico rubeo super camisiam ${ }^{5}$. Derselbe trug also noch gegen 1300 einen rotseidenen Gürtel über seiner Linnentunika. Wirklich fand man, als man beim Neubau der St Peterskirche 1605 das Grab Bonifaz' VIII. eröffnete, um den Überresten eine andere Ruhestätte anzuweisen, nach Angabe des Protokolls den Papst unter den liturgischen Gewändern mit einer gegürteten Camisia bekleidet ${ }^{6}$. Der Gürtel bestand aus Leder, war aber mit roter Seide überzogen und mit vier Schnüren zum Zweck der Befestigung versehen. Es scheint sogar, dalj die camisia, von welcher in dem Kleiderverzeichnis die Rede ist, bereits den Charakter eines privilegierten Gewandes hatte. Denn es ist bemerkenswert, dafis der Katalog sie aufer beim Papst nur bei den Diakonen erwähnt ${ }^{7}$, die im 9. Jahr-

1 Vgl. die Synoden von Montpellier (1215) c. 1 (Hard. VI 2 2046), Valladolid (1324) c. 6 (ebd. VII 1466), Buda (1279) c. 2 (ebd. VII 792).

2 Lütticher Synodalstatut c. 5, n, 13 (Hartzb. III 690).

${ }^{3} \mathrm{Vgl}$. die S. 128 A. 3 angeführten Stellen, dann die Bestimmungen der Synoden von Trier (1238) c. 1011 (ebd. II 1559), Cambrai (1300) c. Celebrans (ebd. IV 71) und Passau (1284) c. 2 (ebd. III 673). Nach einer Kölner Synode (1300) solleu die campanarii in der. Kirche eine camisia linea tragen c. 17 (ebd. IV 42). Die genannte Synode von Trier bestimmt c. 16 (ebd.): Campanarii sine camisia in superiori non serviant in ecclesia vel alias in divinis. Als Gewand der campanarii erscheint die Camisia auch in der friher (S. 128) mitgeteilten Verordnung der Aschaffenturger Provinzialsynode.
${ }_{4}$ N. 1 u. n. 3 (M. 78, 985). Bezüglich der Kleidung des Papstes heifst es: In primis cam. et cingitur supra. Dein linea... bezüglich derjenigen der Diakone: In primis cam. et supra cingulum. Postea tonica alba et cingulum. . . . Linea und tonica alba bedeuten hier die Albe, nicht die Tunicella oder Dalmatik, von welchen gleich darauf die Rede ist.

5 Ordo 13, n. 3 , ordo 14, n. 10 (ebd. 1106 1127).

6 Bzovius, Annal. ad an. 1303: XIV 50.

7 Nur beim Papst und bei den Djakonen ist von zwei Untertuniken die Rede, von denen die zweite offenbar die liturgische Albe darstellt. Bei den andern, den Bischüfen, Priestern, Subdiakonen, ja selbst dem Papst, wo dessen Alltagsmelskleidung heschrieben wird, verzeichnet der Katalog nux e ine Untertunika, die liturgische Albe. 
hundert in Rom bekanntlich eine ungleich bedeutendere Stellung inne hatten als selbst die römischen Hebdomadarbischöfe. Für das 11. und 12. Jahrhundert bezeugen den Gebrauch des Gewandes seitens des Papstes Leo von Ostia und Gerhoh von Reichersberg ${ }^{1}$. Die camisia oder das Rochett ist dennach zu Rom nicht erst eine Schöpfung des späteren Mittelalters, höchstens dás das zweite Jahrtausend eine Erweiterung des Kreises der zum Tragen der camisia Berechtigten brachte.

Aber auch auferhalb Roms finden sich schon lange vor dem 13. Jahrhundert Spuren des Gewandes. Nach Sicard von Cremona trugen die Kileriker cappae, tunicae laneae, stolae und auch camisiae?. Da die stolae in der Folge von Sicard mit cottae und superpellicea identifiziert werden, können unter den camisiae keine Superpelliceen verstanden werden. Ein liturgisches Gewand sind sie auch nicht; nur die stolae werden als Sakralkleid bezeichnet. Wir haben in ihnen demnach klerikale Linnentuniken, d. i. das spätere Rochett, zu sehen. Noch früher als Sicard reden Gerhoh von Reichersberg und Honorius von dem Gewand. Gerhoh bezeichnet es als das eigentliche klerikale Kleid, das ein Bischof aus dem Mönchsstande dann tragen sollte, quando clericorum choro interesse in aliquo episcopali ministerio cogetur, also wenn er inmitten des Klerus in irgend einer bischöflichen Funktion öffentlich aufzutreten habe ${ }^{3}$. Honorius führt bezüglich des Gewandes aus: Die Kleriker bedienten sich weißser Gewänder gleich denen der Senatoren, von welchen dieselben in den kirchlichen Gebrauch übergegangen seien. Die Kleider seien weit und reichten bis zu den Füßen; oben seien sie mit einer Bindvorrichtung (ligula) versehen, die camisia der Priester habe sogar zwei ligulae. Auf den Brauch, bei der Messe unter den liturgischen Kleidern eine camisia zu tragen, scheint seine Bemerkung: Primo namque (d. i. bei der Vorbereitung zur Messe) sacerdos quotidianas vestes exuit et mundas induit, hinzudeuten $\ddagger$. Diese vestes mundae sind nämlich nicht die liturgischen Kleider. Denn es heifst im Anschluf an die angeführten Worte weiter: Deinde pectit crines capitis ... aqua abluit manus, deinde a sorde eas tergit, hinc humerale sibi imponit. . . Sie können darum nur die camisia bedeuten. Klar und bestimmt spricht die vierzehnte der hundert Reden, welche sich im Anhang der Schriften Hugos von St Victor vorfinden, von der camisia, welche der Priester am Altar unter der Albe trug. Dieser soll, wenn er sich zur Mebfeier vorbereitet, die Alltagskleider ablegen, die Hände waschen und dann die candida vestimenta anziehen. Als solche werden genannt die linea interior, die linea exterior, der Amikt, der Gürtel usw. Da die linea exterior ausdrücklich als Albe bezeichnet wird (linea exterior scilicet alba), so liegt auf der Hand, dabi die interior mit der camisia, d. i. dem später Pochett genannten Gewand, eins ist. In I r land war die camisia schon wenigstens im Beginn des 12. Jahrhunderts bekannt. Denn nach Bischof Gilbert von Limerick († ca 1140) gehörten zur Alltagskleidung, welche der Priester bei der Messe unter den liturgischen Gewändern zu tragen hatte, zum mindesten Schuhe, Beinkleider, eine innere Tunika und die camisia ${ }^{5}$.

Sehr früh begegnet uns des Gewand in England, wo es den Namen oferslip führte. Der 46. Kanon der unter Edgar († 975) erlassenen kirch-

1 Chron. Cassin. 1. 3, c. 66 (M. G. SS. VII

749); Gerhoh Reichers b., De aedif. Dei c. 28 (M. 194, 1268).

2 Mitralis 1. 2, c. 1 (M. 218, 59).

3 De aedificio Dei c. 28 (M. 194, 1269).
Die Schrift ist dem Bischof Kuno von Regensburg gewidmet und entstand um 1130.

${ }^{4}$ L. 1, c. 199 (M. 172, 604).

3 M. 149, 1001: Quotidiana ad missam, camisia, tunica, femoralia, calceamentum. 
lichen Torschriften rerhietet allen Welt- und Konventualpriestern, ohme den oferslip in die Kirche oder das Sakrarium zu kommen oder doch ohne denselben am Altar zu erscheinen, um allda ihren Dienst zu verrichten ${ }^{1}$. Der oferslip ist hier ersichtlich nicht die liturgische Albe, sondern die camisia Gilberts, d. i. die Forläuferin des Rochetts. Im Franken re ich war die camisia sogar schon in 9. Jahrhundert manchenorts unter dem Namen alba im Gebrauch. Es betreisen das die bei Besprechung der Albe erwähnten Verordnungen? aus damaliger Zeit, in welchen den Priestern verboten wird, die alba, deren diese sich im gewöhnlichen Leben zu bedienen pflegten, an Stelle und als Ersatz der liturgischen Albe am Altar zu verwenden. Daf aber jene klerikale Albe der Form nach das gleiche Gewand wie das spätere Rochett darstellte und daf sie insbesondere enge Ärmel wie dieses hatte, bekundet nicht nur der Umstand, daf man sie anstatt der engärmeligen liturgischen Albe zu gebrauchen sich unterfangen hatte, sondern auch ihr Name. Denn unter alba. verstand man gerade wie unter camisia im Mittelalter stets eine engärmelige Tunika.

Es ist also die camisia in der Tat auch außerhalb Roms weit vor dem 13. Jahrhundert nachweisbar, nur war sie hier zu keiner Zeit und nirgends ein eigentlich privilegiertes Gewand, sondern lediglich allgemeine klerikale Tunika. Hatte doch das Rochett nach auferrömischem Brauch selbst im späten Mittelalter noch keineswegs ïberall den Charakter, der ihm zu Rom schon lange eigen war.

Die Herkunft des Rochetts liegt nach dem Gesagten auf der Hand. Es stammt zweifelsohne von der alten klerikalen camisia her und entstand, indem diese aus dem allgemeinen Gebrauch ausschied und zum auszeichnenden Gewand des höheren Klerus wurde, ohne dabei ihren ursprünglichen Charakter, wonach sie nur auferliturgisches Gewand war, zu verlieren. Dieser Vorgang vollzog sich am ersten zu Rom. Aufierhalb Roms folgte man erst spät dem römischen Vorbild.

\section{BESCHAFFENHEIT DES GEWANDES.}

In der Kathedrale von Arras wird ein Rochett aufbewahrt, welches der Überlieferung zufolge dem hl. Thomas Becket angehört hat ${ }^{3}$ (Bild 55). Da es nach dem Gesagten nicht bezweifelt werden kann, daf bereits das 12. Jahrhundert eine Art von Rochett gekannt hat, so kann deren Zueignung an den großen Bischof von Canterbury von dieser Seite aus nicht beanstandet werden. Es liegt aber auch sonst kein Grund vor, die Richtigkeit der Überlieferung in Frage zu ziehen. Seiner Form nach entspricht das Kleid ganz der Albe des 12. Jahrhunderts, deren Gestalt aus Beispielen und den Beschreibungen der damaligen Liturgiker bekannt ist ${ }^{4}$. Es unterscheidet sich von ihr nur durch den Umstand, daf es unten statt mit blof zwei mit vier zwickelartigen Einsätzen versehen ist. Daß wir in ihm nicht die gewöhnliche Meláalbe zu sehen haben, ergibt sich aus seiner geringen Länge von nur 1,25 $\mathrm{m}$.

Das Rochett kam zwei Jahre nach ilem Tode des Heiligen in das Kloster Dommartin, volu wo es 1709 nach Abbeville in das dortige Karmeliterkloster

1 C. 46 (W ilkins, D., Concilia Magnae Britanniae I, London 1734, 85, und M. 138 , 502, wo aher oferslip nicht ganz genau mit superpelliceum wiedergeg(hen ist). Auch unter der subucula in c. 33 (ebd.) ist wohl del oferslip zu verstehen.

2 S. oben S. 62.

Revue III (1859) 145 ff. A S. oljen S $73 \mathrm{ff}$ 
gebracht wurde. Seit der Revolution befindet es sich in der Kathedrale zu Arras. Weil einzig in seiner Art, ist das Gewand natürlich von gröbter Bedeutung. Es bietet ein verlässiges Bild eines Rochetts aus dem 12. Jahrhundert. Die Ärmel sind vorn eng; unter den Achseln sind Zwickel angebracht. Das Gewand hat in der Brust eine Weite von ca $1,40 \mathrm{~m}$. Von den vier Stoffstücken, welche dem untern Teil eingefügt sind, befinden sich zwei seitlich zwischen den beiden Linnenbahnen, aus denen das Rochett beiderseits zusammengesetzt ist, die beiden andern dagegen in der Mitte dieser Bahnen. Aus feinem Linnen angefertigt, entbehrt das Kleid jedes Ornaments.

Die camisia blieb bis ins 14. Jahrhundert hinein eine Art von Talartunika. Die päpstliche alba romana des 13 . und 14 . Ordo mubte sogar eine solche Länge haben, daf sie, aufgeschürzt, einen über das Cingulum herabfallenden Bausch bildete. Et ipsa camisia erit ita longa, quod elevata super

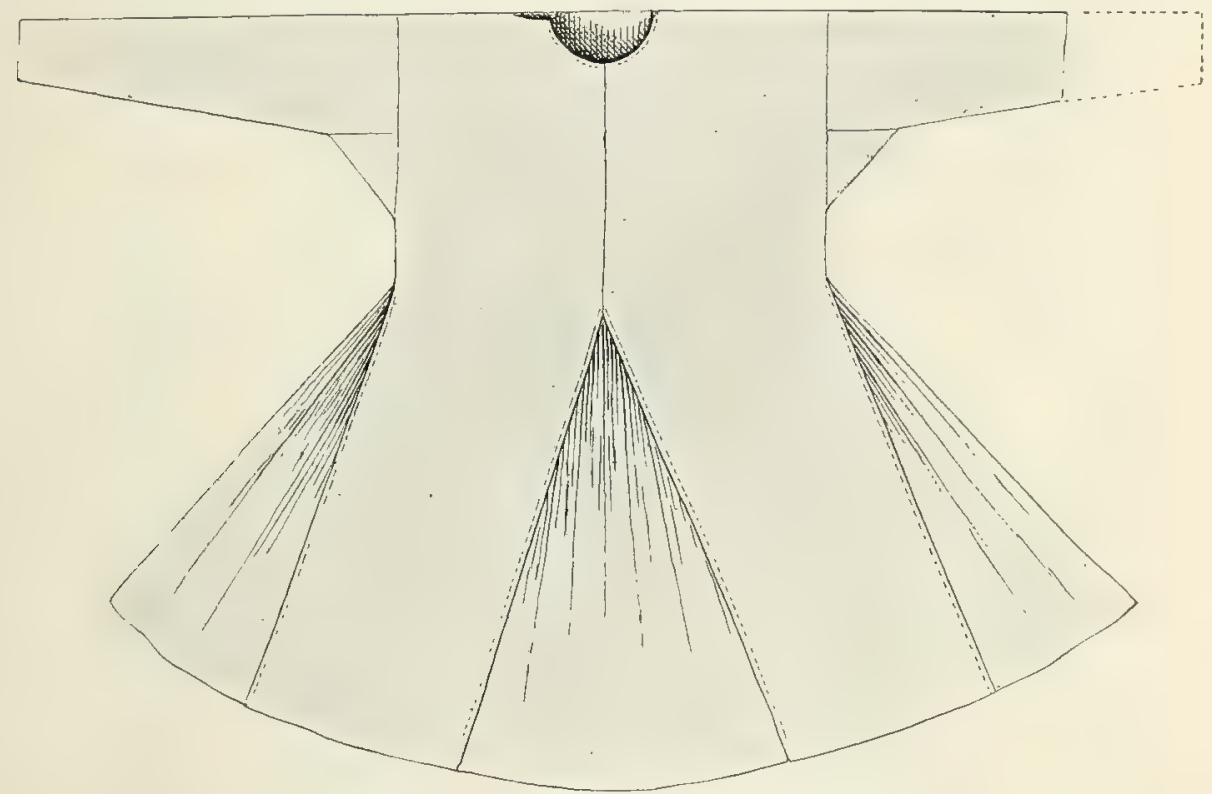

Bild 55. Rochett des hl. Thomas Becket.

ipsum cingulum reflectatur ${ }^{1}$. Nach dem Kölner Provinzialkonzil von 1260 sollte die vestis camisialis, welche jeder Celebrans unter der Albe zu tragen hatte, so lang sein, daß die gewöhnlichen Kleider unter ihr nicht zum Vorschein kämen?

Die Verkürzung des Gewandes scheint zu Rom, wo man in liturgischen Fragen stets sehr konservativ war, erst um die Zeit angefangen zu haben, als sich dort der Name rochettum einbürgerte. In der zweiten Hälfte des 15. Jahrhunderts wallte nicht einmal mehr die Camisia des Papstes bis zu den Füßsen hinunter, wie z. B. aus dem Fresko Mellozzos da Forli "Die Gründung der vatikanischen Bibliothek durch Sixtus IV." (Bild 56, S. 134) erhellt. Die Camisia reicht hier nur mehr bis etwa zur Mitte des Schienbeines herab.

${ }^{1}$ Ordo 13, n.3; ordo 14, n.10 (M.78, 11061127 ).

\& C. 7 (Hartzh. III 591): Sacerdotes, quoties celebraturi sunt missam, veste cami- siali sub alba non careant, ne albam... ipsorum tunicae valeant contingere, nec jpsae tunicae appareant. 
Dafs unter solchen Umständen eine Gürtung überflüssig wurde und darum in der Tat wegfiel, braucht kaum gesagt zu werden.

Eimmal begonnen, dauerte die Verkürzung des Rochetts nicht nur an, sondern nahm auch, wenngleich langsam, beständig zu. Im allgemeinen reichte dieses im 16. und auch wohl im 17. Jahrhundert noch bis über die

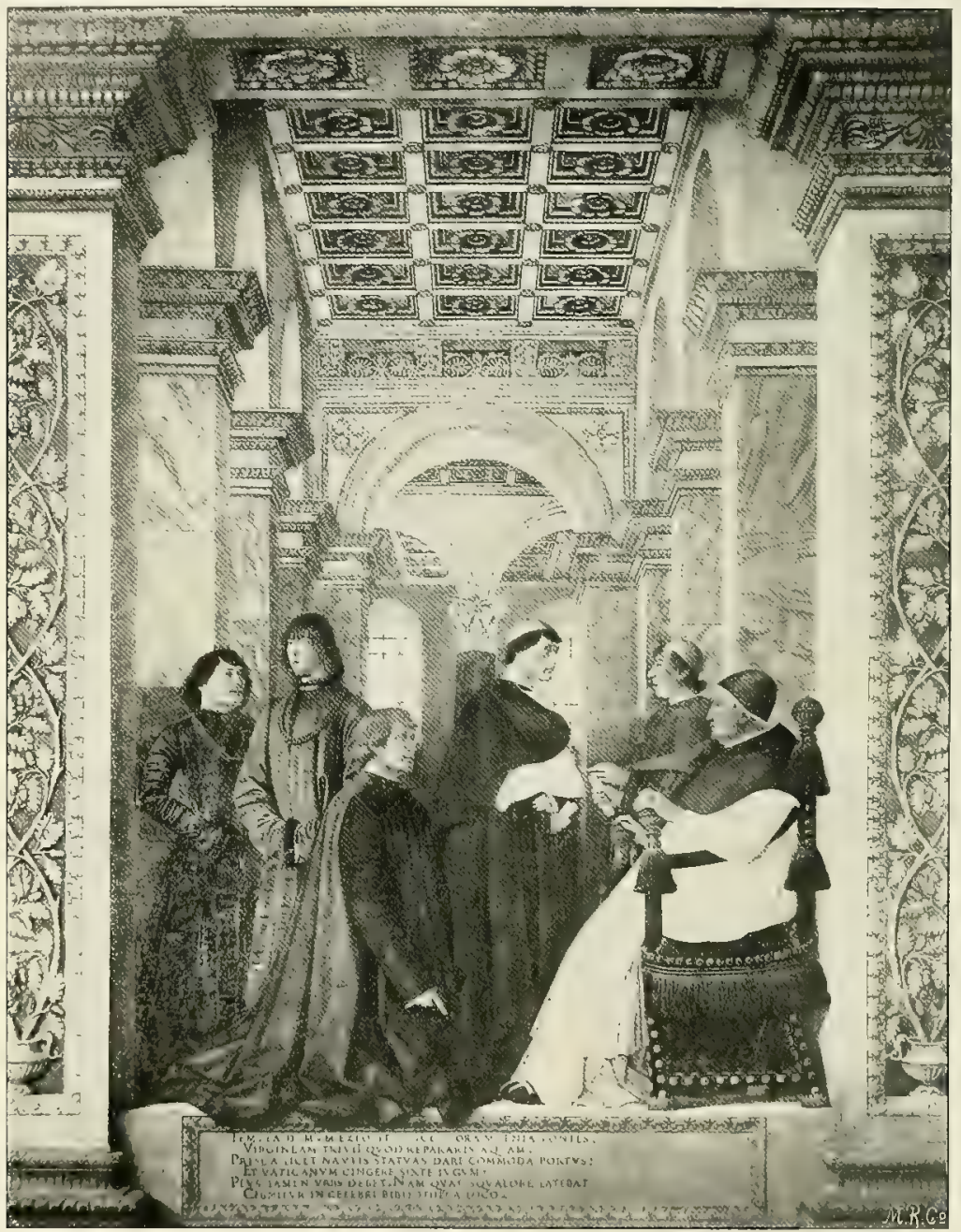

Bild 56. Melozzo da Forli: Platinas Audienz bei Sixtus IV. Rom, Vatikan. (Phot. Ainari.)

Knie, dann schrumpfte es aber dermaßen zusammen, daf es sich vielfach nur noch eben über die Hüften erstreckte.

In einem Statut Stephans de Firomonte aus dem Jahre 1276 wird denjenigen, welche in den oberen Chorstühlen saken, gestattet, sarrotes simplices et sine aliqua curiositate zu tragen ${ }^{1}$. Hiernach scheint man schon im 13. Jahrhundert reichere Rochette verwendet zu haben. Immerhin kann das

2 Bei D. C. (sub V. sarlot) VII 313. Vgl, auch eine ähnliche Bestimmung der Mailinder Statuten in A. E. M. 362 . 
nur vereinzelt geschehen sein. Nach Ausweis der Bildwerke war das Gewand bis wenigstens zum Ausgang des Mittelalters eine durchaus schlichte Linnentunika ohne alle Verzierung. Als dann freilich die Spitzenindustrie aufkam und ihre prächtigen Erzeugnisse schuf, wurden wie bei andern kirchlichen Ornatstücken, so auch bei ihm Spitzen zur Verzierung des unteren Saumes und der Ärmelränder herangezogen. Anfangs waren dieselben nur schmal, allmählich aber begannen sie, immer mehr an Breite zuzunehmen. Es verhielt sich mit ihnen gerade umgekehrt wie mit der Länge des Kleides. Je mehr die Breite der Spitzen wuchs, um so mehr verkürzte sich das Gewand selbst. Es kam zuletzt selbst dahin, dab das Fochett nicht selten zu einem kurzen, zarten, duftigen Spitzengewebe wurde, allerdings ein gewaltiger Gegensatz zur ursprünglichen Beschaffenheit des Gewandes. Die in den fünfziger Jahren unternommenen Versuche, den in kirchlichem Dienst stehenden Gewandstücken durch Annäherung an die mittelalterlichen Vorbilder eine bessere Form zu geben, blieben, wenigstens außer Deutschland, für eine Umgestaltung des Rochetts so gut wie völlig bedeutungslos.

\section{AUFTRETEN DES SUPERPELLICEUM.}

Das Superpelliceum erscheint als ein in der römischen Kirche gebräuchliches liturgisches Kleidungsstück schon in dem auf Befehl Gregors X. (1271-1276) herausgegebenen 13. Ordo. Nach n. 7 trägt es der Kardinal, welcher dem Papst bei der Messe nach der Papstweihe ministriert, unter dem Pluviale; nach n. 8 sind bei der Prozession nach der Konsekration des Papstes, in der quilibet in suo gradu indutus est, die Bischöfe mit dem Pluviale, die Priester mit der Kasel, Diakon und Subdiakon mit der Dalmatik bzw. der Tunicella, die Akolythen mit Superpelliceen bekleidet. Nach n. 22 haben die Kapläne bei der Gründonnerstagsfeier in Superpelliceen ihren Dienst zu verrichten; ebenso müssen sie nach n. 25 am Ostertag in denselben zum Offizium kommen. Überhaupt haben sie von Ostern bis Allerheiligen an allen festa duplicia, welche in der päpstlichen Kapelle gefeiert werden, sowie an den auf Ostern und Pfingsten nächstfolgenden Tagen, bei den Vespern, den Metten und der Messe im Superpelliceum sich am Gottesdienst zu beteiligen ${ }^{1}$.

Die Angaben des 13. Ordo hinsichtlich des Superpelliceum behandeln dasselbe als etwas Allbekanntes. Gewand und Name können daher nicht erst unter dem Pontifikat Gregors X. sich in Rom eingebürgert haben ${ }^{2}$. In der Tat ergibt sich aus einer Bulle Alexanders IV. (1254-1261), welche sich mit der bei der römischen Markusprozession einzuhaltenden Ordnung befast, daf

1 M. 78, 111011181119 . Wenn der Camerarius und der Kleriker, welche dem Papst nach der Krönung bei der Austeilung des Presbyteriums (Geldspende) assistierten, und die Kardinäle bei dem Mahle nach der Papstweihe und am Gründonnerstag über ihrer Camisia ein Superpelliceum trugen (ordo 13 , n. 9 ; ordo 14, n. 234345 [ebd. 11111133 1139 1145]), so erklärt sich das wohl dadurch, daß3 diese Akte Anhängsel liturgischer Funktionen waren und darum auch einen gewissen liturgischen Anstrich hatten. Auch der Papst trug bei jenen Mahlzeiten sakrale Gewänder: Et attende, quod dominus papa, dum est in mensa, est indutus omnibus paramentis missalibus, exceptis casula, pallio et chirothecis (ordo 14, n. 43).

${ }^{2}$ In einer Bulle des Vorgängers Gregors X., Klemens' IV., für die Kirche von Le Puy ist ebenfalls schon vom Superpelliceum die Rede. Es erscheint darin sogar bereits als Symbol eines kirchlichen Benefiziums, offenbar weil zu Le Puy offizieller Chorrock. So n. 38: Quod nulli in ipsa ecclesia superpellicium concedatur, nisi de legitimo matrimonio... quod clericus, cui amodo superpellicium conceditur, iuret capitulo ipsius ecclesiae fidelitatem servare (Bull. rom. [Turin 1858] III 781). 
daselbst schon 1260 das Superpelliceum als liturgisches Kleid in Gebranch war ${ }^{1}$. Bei den regulierten Chorherren in Rom muk unser Gewand sogar bereits in der zweiten Hälfte des 12. Jahrhunderts zur Verwendung gekommen sein. Denn es sendet Abt Stephan von St Genovefa (Paris), nachmals Bischof von Tournai, dem Kardinal Albinus aus dem Orden der regulierten Kanoniker ein "superpellicium novum candidum talare" 2.

Im 14. Ordo wird wiederholt neben dem Superpelliceum eine cotta erwähnt. So heist es beispielsweise c. 47: cardinalis, qui servit, assumat cottam vel superpellicium; c. 48: capellanus camisiam lineam super communes vestes, superpellicium seu cottam ... habere debet; und c. 92: capellani in scutis et cotta seu superpellicio ${ }^{3}$. Möglich, daß zwischen superpellicium und cotta - etwa bezüglich der Länge oder Weite - irgend ein Unterschied bestand, erheblich und wesentlich kann derselbe jedoch nicht gewesen sein, weil beide Gewänder durch- und füreinander gebraucht wurden. Am wahrscheinlichsten sind jedoch cotta und superpellicium, welches im 15. Ordo, wie auch anderswo nicht selten verderbt superplicium heift, nur verschiedene Namen für ein und dasselbe liturgische Gewand. Was etwa dagegen vorgebracht werden könnte, ist der Umstand, dał es im 14. Ordo bezüglich der Kleidung der Akolythen nur heist: Acolythi omnes debent esse induti cottis secundum consuetudinem sanctae romanae ecclesiae 4 . Allein es ist zu beachten, daß nach dem 13. Ordo und verschiedenen Stellen des 14. auch bei den Akolythen vom Superpelliceum die Rede ist, und dab selbst bereits in der Bulle Alexanders IV. das Superpelliceum der Kleriker der Cotta gleichgestellt wird: clerici induti ... superpelliciis sive cottis vadant processionaliter ${ }^{5}$.

Seit wann der Name cotta in Rom in Gebrauch ist, läbt sich nicht bestimmen. Daf man ihn schon im 13. Jahrhundert daselbst kannte, folgt aus den angeführten Worten Alexanders IV. und einer Bulle Nikolaus' III. $(1277-1280)^{6}$. Die costae, von welchen der S. G. K. redet: In prim. camisia et cingitur supra; dein linea cum costis serica et cingulum...., können, wie unklar auch ihre Bedeutung ist, unmöglich unser Gewand sein.

A uferhalb Roms begegnen uns bereits im 12. Jahrhundert mehrfach Nachrichten über die Verwendung des Superpelliceum bzw. der Cotta. So berichtet Wilhelm von Malmesbury († nach 1142), Walchelm, Bischof von Winchester ( $\dagger$ ca 1080) habe an seiner Kathedrale die Mönche durch Kanoniker ersetzt und diese mit Cappae und Superpelliceen ausgestattet ${ }^{7}$. Noch etwas früher erwähnt Gualter, Kanzler Rogers von Antiochien, in der Schrift Bella

1 Raynald., Annal. ad 1260, n. 13, XIV (ed. Colon. 1694) 57.

${ }^{2}$ Ep. 106 (M. 211, 395).

3 M. $78,114811531212$.

4 C. 48 .

5 Vgl. auch Sicard von Cremona (Mitralis 1. 2, c. 1; M. 123, 59), wo offenbar ein und dieselbe stola, $d$, i, ein und dasselbe sakrale Kleid der Kleriker superpellicium und cotta genannt wird. Nach Nebridius von Mündelheim bedeutet superpelliceum ein weitärmeliges, rochettum ein engärmeliges Gewand. Unter cotta versteht er ein Kleid, quod undique per circuitum clauditu et sine manicis. Sie diente bei den Augustinern von Mündelheim als Chorrock. Sarrocia hiefien nach
Nebridius dort die auferliturgisehen Linnentuniken. Sie war ebenfalls ohne Ärmel, aber an den Seiten offen. Nur unten waren sie hier etwa vier Finger breit vernäht. Beim Ausgehen trug man sog. sarrocia parva, d. i. zwei vier Finger breite, skapulierartig über Brust and Rücken herabfallende Linnenstreifen (Nebrid., Antiq. Monast. ep. CXLIII 656). Der Name cotta war im Mittelalter vornehmlich in Italien in Gebrauch, und noch jetzt heist das Superpellicium (französisch surplis) im Italienischen cotta.

${ }^{6}$ Lineis togis superpelliciis sive cottis. Bzovius, Annal. ad ann. 1280, n. 5 ; XIII 912. Vgl. auch D. C. (s. v. cota) II 596. 7 De gestis Pontif. I (M. 179, 1478). 
Antiochena, welche er als Augenzeuge (1114-1119) verfáste, das Gewand, wo er erzählt, Ebremarus, der lateinische Erzbischof von Antiochien, sei bei einem Angriff dem Feinde nicht im Panzer, sondern „im priesterlichen Superpelliceum “" das Kreuz des Herrn in seinen Händen, entgegengegangen ${ }^{1}$. Die Regel des 1146 vom hl. Gilbert gestifteten Ordens von Sempringham (England) bestimmte, es sollten die Priester unter den Mefagewänden das Superpelliceum tragen?. Aus den Angaben Anselms von Havelberg († 1158) ${ }^{3}$, Amos von Reichersberg $(\dagger 1175)^{4}$, des Prämonstratensers Adam († 1180) ${ }^{5}$, des Abtes Stephan von St Genovefa zu Paris $\left(\dagger\right.$ 1203) ${ }^{6}$ und des Hugo Metellus ( $†$ ca 1157) ${ }^{7}$ geht hervor, dafi das Superpelliceum das die regulierten Augustiner-Chorherren kennzeichnende Obergewand bildete, und daf diese es deshalb nicht blof beim Gottesdienst, sondern auch tagsüber im gewölınlichen Leben trugen. Bei den Prämonstratensern wurde es einzig bei gottesdienstlichen Verrichtungen verwendet, wie z. B. von den Akolythen, welche am Altare dienten oder den Priester auf Versehgängen begleiteten, und dem Priester, welcher einem Kranken die heilige Kommunion oder die heilige Wegzehrung brachte ${ }^{8}$. Dafs auch in Schweden um den Ausgang des 12. Jahrhunderts das Superpelliceum in Gebranch war, geht aus dem Testament Absalons, Bischofs von Lund ( $†$ 1201), hervor. Derselbe vermacht nämlich seinem Kaplan Thordo ein superpellicium cum pellicia de marturibus ${ }^{9}$.

Cottae werden im letzten Viertel des 12. Jahrhunderts in einer testamentarischen Verfügung Gregors von Antivari ( $\dagger$ ca 1199) und in einer Schenkung Tedelgars von Terracina erwähnt, in welcher bestimmt wird, es sollten die Kanoniker im Sommer in cottae die kirchlichen Tageszeiten beten ${ }^{10}$.

Von den mittelalterlichen Liturgikern erwähnt erst Sicard von Cremona um die Wende des 12. Jahrhunderts das Superpelliceum und die Cotta. Dieselben sind für ihn voneinander nicht verschieden, sondern bezeichnen ein und dasselbe liturgische Gewand, dessen sich die Kleriker an Festen anstatt der an andern 'Tagen üblichen gewöhnlichen schwarzen Cappae bedienten ${ }^{2}$.

Das 11. Jahrhundert weif nur wenig rom Superpelliceum. Die Synode von Coyaca (Diözese Oviedo) bestimmte 1050: vestes presbyterorum

1 C. 15 (M. 155, 1028).

2 D. C. (s. v. superpell.) VII 666.

${ }^{3}$ De ordine canonic. c. 10 (M. 188, 1103).

4 Scutum canonic. (M. 194, 1505).

5 De ordine et habitu canonic. Praemonst. sermo III, n. 67 (M. 198, 465 466).

6 Ep. 106 (M. 221, 395).

7 D. C. 667. Metellus tadelt die Prämonstratenser wegen ihrer Kleidung. Unter anderem sagt er: „Schau, die einen tragen Superpelliceen, die andern Tuniken, gerade, als ob man mittelst der Kleider das Reich Gottes erlange... Die tunicati haben von Norbertus, die superpelliciati abervom hl.Augustinus ihren Ursprung."

${ }^{8}$ Adam. Praemonstr., De ordine et habitu canonic. Praemonstr. 1. c. Es war in den Statuten der Prämonstratenser streng verboten, dak irgend jemand in Anwesenheit des Konvents ohne Superpelliceum oder Albe die oberen Altarstufen besteige.

9 M. 209, 760.
10 Bon a 1. 1, c. 24, § 20, nota 1; II 289. Cottus kommt als Name eines laikalen Kleidungsstückes schon im 9. Jahrhundert vor; so im 3. Kapitel der Synode von Metz des Jahres 888 (Hartzh. II 381): "Kein Kleriker daıf Laienkleidung, nämlich cotti oder mantelli sine cappa, anziehen", und in der ähnlichen Verordnung der Triburer Synode von 895: "Kleriker sollen sich keiner weltlichen Bekleidungsgegenstände, eines mantellum, eines cottus sine cappa oder kostbarer und sonderbarer Fuß̧bekleidung bedienen" (ebd. II 409). Das Wort cottus, cotta, welches in der Vita s. Meinwerci n. 37 (M. G. SS. XI 120) die Form cottis hat, ist allem Anschein nach mit Kutte, Kittel verwandt, seine $A b$ leitung ist jedoch unsicher.

11 Mitralis 1.2, c. 1 (M. 213,59) : Inter clericos tonsurandi aut illico tonsurati cappis utantur et stolis in divinis. Diese stolae werden gleich darauf cotta seu superpellicium genannt. 
sint superpilitium, amictus, alba etc. ${ }^{1}$ Die Gesta archiepiscoporum hothomagensium (geschr. ca 1080) berichten von einer linea superpellicialis, welche der Erzbischof Johamnes von Avranches († 1079) trug, als er an einem Festtage dem Gottesdienst in St-Ouen inmitten der Chorsänger wie ein Praecentor beiwohnte 2. Eine Terordnung Eduards des Bekenners endlich bestimmt, ein Hingerichteter, welcher ohne kirchliche Zeremonien beerdigt worden sei, solle, wenl sich seine Unschuld nachträglich herausstelle, ausgegraben und durch den Priestel unter Begleitung von Weihwasser, Kreuz, Kerzen und Incens tragenden, mit Superpelliceen bekleideten Klerikern nach dem üblichen Pitus von nenem bestattet werden ${ }^{3}$. Im letzten Falle hat das Superpelliceum offenbar den Charakter eines liturgischen Gewandes.

Seit dem 13. Jahrhundert ist häufig vom Superpelliceum die Rede. Durandus sagt von ihm: „Aufer den vorgenannten Gewändern (Amikt, Albe usw.) gibt es noch ein anderes Kleid, welches Superpelliceum genannt wird. Alle, welche irgend welchen Diensten am Altar und beim Gottesdienst obliegen, müssen es über den gewöhnlichen Kleidern tragen. An verschiedenen Orten macht man es aus den Chrismaltüchern, welche man über die getauften Kinder legt. Eine lobenswerte, an manchen Stellen bestehende Sitte will, daf man eine linnene Camisia oder ein Superpellicium über die Alltagskleider anzieht, ehe man den Amikt anlegt." Auferdem nennt Durandus das Superpelliceum neben Amikt, Albe und Cingulum, wo er die liturgische Kleidung der Akolythen aufzählt 4 .

Oft beschäftigen sich die Synoden des 13. Jahrhunderts mit unserem Gewand. Hier nur einige Beispiele. Die Oxforder Synode vom Jahre 12:2 ' und die Lütticher aus dem Jahre $1287^{6}$ bestimmen, der Kleriker, welcher dem Priester am Altare diene, habe ein Superpelliceum zu tragen. Nach den Verordnungen des Erzbischofs Edmund von Canterbury von $1236^{7}$ und des Bischofs Richard Poore von Sarum (Salisbury) von $1217^{\circ}$ mufte der Priester, welcher das heilige Sakrament zum Kranken brachte, mit Superpelliceum und Stola bekleidet sein. Eine gleiche Bestimmung erlief 1233 eine Mainzer ${ }^{9}, 1238$ eine Trierer ${ }^{10}, 1284$ eine Passauer Synode ${ }^{11}$ und 1292 eine Provinzialsynode zu Aschaffenburg '?2. 1280 schreibt eine Synode von Köln den Gebrauch des Superpelliceum beim Beichthören vor ${ }^{13}, 1298$ verordnet eine Würzburger Synode, es solle der Priester oder Diakon beim Waschen der Korporalien ein Superpelliceum tragen ${ }^{14}$. Die Statuten Raymunds, Bischofs von Rhodez, aus dem Jahre 1289 wollen, daf der Priester bei der Messe unter der Albe mit dem Superpelliceum bekleidet sei ${ }^{15}$. Dieselbe Verordnung erliefen auch die schon genannte Lütticher Synode, die Kölner Synode von 1280 u. a. Die Kölner Synode vom Jahre $1280^{16}$, die Lütticher" vom Jahre 1287, das Konzil von Buda vom Jahre $1279^{17}$ und eine Reihe anderer bestimmen,

2. Mansi, Coll. Conc. XIX 791. Nach der Rezension des Textes bei Hard. VI 1026 lautet die Verordnung: vestes autem presbyteri sint in sacrificio amictus alba etc. Hefele (Concilien \$ 546; IV 756) betrachtet, wie es scheint, die erste Lesart als die bessere.

2 M. 147, 13. Rer. Gall. SS. XI 72.

3 Chambers 27. Schmid, Reinh., Die Gesetze der Angelsachsen (Leipzig 1832) Anhang XVII.

4 Rationale 1. 3, c. 1, n. 1015 ; c. 2, n. 1 ; f. $65,5 \mathrm{f}$.

5 C. 10 (Hard. VII 118). Vgl, auch c. 40 der Konstitutionen des Bischofs Richard Poore von Sarum aus den Jahre 1217 ( H a r d. VII 101).
${ }^{6}$ C. 5, n. 13 (Hartzh. III 690).

7 C. 25 (H ard. VII 272).

8 C. 39 (H a r d. VII 101). Vgl. auch c. 9 der Synode von Worcester vom Jahre 1240 (ebd. VII 334).

2 Zeitschrift für die Geschichte des Oberrheins III, Karlsruhe 1852, 136.

${ }_{10}$ Can. 11 (Hartzh. III 559).

11 C. 2 (Hartzh. III 673).

12 C. 2 (Hartzh. IV 7).

13 C. 8 ( $\mathrm{Hartzh}$. III 664).

14 C. 3 (H artzh. IV 26).

15 C. 18 (Mart., Thes. IV 716).

16 Praef. (H a l tzh. III 658).

17 C. 19 (Hard. VII 796). 
dafs die Pfarrer und üherhaupt die nierlern Geistlichen in Superpelliceen anf den Synoden zu erscheinen hätten. Mehrfach findet sich auch die Torschrift, es sollten beim Chorgebet von Ostern bis Allerheiligen statt der Cappae Superpelliceen getragen werden . Man beachte, das in einzelnen dieser Verordnungen das Superpelliceum zwar als gleichartig mit der Camisia (dem Rochett) erscheint, daß es aber in den meisten den Charakter eines wirklichen Sakralgewandes und eines Ersatzes der liturgischen Albe an sich trägt. Auch in Ordinarien des 13. Jahrhunderts, wie z. B. denjenigen der Regularen von St-Lô zu Rouen ${ }^{2}$ und der Kathedrale von Bayeux ${ }^{3}$, erscheint es schon als ausgesprochen liturgisches Gewand.

Aus dem 14. und 15. Jahrhundert Zeugnisse für die Verwendung des Superpelliceum auferhalb Roms anzuführen, darf nach den aus dem 13. beigebrachten Belegen als überflüssig betrachtet werden. Schon im 14. Jahrhundert nimmt das Superpelliceum sowohl zu Rom wie fast allenthalben aufiserhalb Roms die gleiche Stellung im Kultus ein, welche es darin in der Gegenwart besitzt. Es war Chorkleid, der offizielle Sakralornat der niedern Kleriker und ein Ersatz für die Albe bei der Abhaltung von Prozessionen und Beerdigungen, der Vornahme von Segnungen, der Spendung der Sakramente, der Teilnahme an Synoden u. dgl. Die Albe wurde bereits im 14. Jahrhundert beinahe nur noch bei der Messe und etwaigen mit ihr in unmittelbarer Verbindung stehenden Funktionen getragen.

\section{NAME UND GEWAND IN IHREM URSPRUNG.}

Was den Ursprung des Wortes superpelliceum anlangt, so belehrt uns Durandus, es sei das mit diesem Namen bezeichnete Gewand so genanut worden, weil man es ehedem iiber Pelztuniken (super tunicas pellicias) getragen

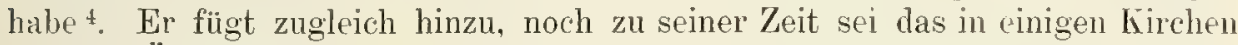
üblich. Ähnlich wie der Bischof von Mende erklärt ein englischer Grammatiker des 13. Jahrhunderts, Johannes Gerland, die Etymologie Ies Wortes superpelliceum. „Unserer Zeit Priester bedienen sich", so bemerkt er nämlich, "der superlicia oder, wie man auch wohl sagt, der superpellicia; denn die Priester pflegten Pelzkleider (pellicia) und darüber der Reinlichkeit halber jenes Gewandstück zu tragen." 5 Die Erklärung, welche Durandus und Gerland von dem Wort superpelliceum geben, ist durchaus zutreffend. Das Gewand hat zweifelsohne seinen Namen wirklich von dem TTmstand, daf es über pelliceae, Pelzröcken, getragen wurde. Der Gebrauch der pellicea war sowohl in den Kilöstern wie bei der Stiftsgeistlichkeit sehr verbreitet. Bereits die Aachener Synode rom Jahre 817 bestimmte, es soll der Abt dafür sorgen, daf jeder Mönch aufer zwei Hemden, Röcken, Cucullen und Cappae auch zwei bis zu den Knöcheln reichende Pelzkleider erhalte ${ }^{6}$. Seitdem ist oft von Pelzröcken

1 Tgl. z. B. c. 13 der Synode von Buda (Hard. VII 794) und c. 11 der Synode von Worcester vom Jahre 1240 (ebd. 334).

2 M. 147, 160 (lectio in supellicio legatur inter chorum et altare); 161 (ceroferarii cum thuriferario in supelliciis); 176 (post Nonam omnes fratres munda supellicia induant... tres in supelliciis ad aquam, crucem et thuribulum); 173 (omnes, qui legunt vel cantant vel ad altare de cande. labris serviunt, supelliciis vel albis induantur).

s Chevalier, U., Ordinain'e de l'église catb. de Bayeux (Paris 1902) 812214852 und sonst. Besonders juteressant 8: Ad vesperas et matutinas tantum, dum dicit sacerdos orationem, puer unus indutus supellicio (sic) tantum, si fiat sine festo, vel alba et amictu, si fiat $\mathrm{cum}$ festo, tenet super caput suum librum apertum coram sacerdote, in quo orationes et capitula conscribuntur. Albe mit Amikt war also feierlicher als Superpelliceum.

${ }^{4}$ Rationale 1.3, c. 1, 1. 11, f. $6 \mathrm{v}$

${ }^{5}$ Commentar. lib. Ms. Cambridge, Caius college, f. 209; B ock II 333 ; Chamber's 27.

6 C. 22 ( $\mathrm{Hartzh}$. II 4 ). 
der Geistlichen und Nönche die Rede ${ }^{1}$, und noch auf Bildwerken des späteren Vittelalters gewahren wir bei Darstellungen von Stiftsherren unter dem Superpelliceum die pellicea. Selbst im 15. Jahrhundert muf es noch hie und da üblich gewesen sein, mnter dem Superpelliceum einen Pelzrock zu tragen. Eine aus Oberwesel stammende und früher in Bockschem Besitz befindliche Skulptur aus jener Zeit, welche einen Stiftsherrn der dortigen Stiftskirche darstellt, läst unter dem Superpelliceum deutlich den pelzgefütterten Talar erkennen (Bild 57). Man bediente sich der pellicea sowohl in der Kirche wie aulierhalb derselben. So aber lag es natürlich nahe, die Linnentunika, welche man beim Gottesdienst oder, wie es bei den Augustiner-Chorherren Regel war, selbst im Alltagsleben darüber anlegte, als superpelliceum zu bezeichnen.

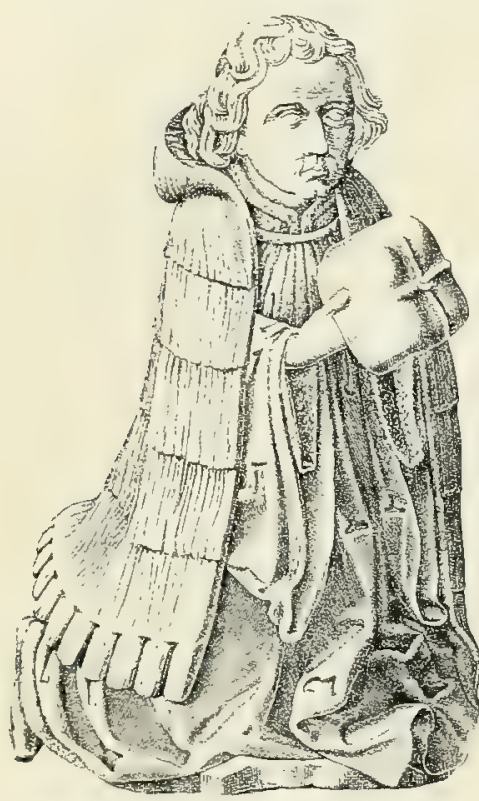

Bild 57. Stiftsherr aus Oberwesel in Pelzkleid, Superpelliceum und Almutia. Steinskulptur. (Nach Bock.)

Die Pelzkleider waren namentlich in den feuchtkalten Gegenden des Nordens heimisch ${ }^{2}$. Sie waren hier in der Tat wegen der mangelhaften Erwärmung der Wohnungen und Klosterräume ein Bedürfnis. Insbesondere aber machte sie der lange Aufenthalt in den frostigen und zugigen Kirchen, wie ihn der viele Grottesdienst und das Chorgebet bei Tag und Nacht erheischte, zur eisigen Winterszeit als Schutz gegen die Kälte notwendig. Hiermit hängt es denn wohl auch zusammen, dafi der Name superpelliceum am frühesten im Norden auftaucht, während er in Italien erst im 13. Jahrhundert nachweisbar ist. Der Name ist allem Anschein nach keine Schöpfung des Südens, sondern stammt von dort, wo vor allem die Pelzröcke bei der Mönchs- und Stiftsgeistlichkeit gebräuchlich waren. Es bildet das ersichtlich eine Bestätigung der von Durandus und Gerland gegebenen Ableitung des Wortes.

Als Zeit des Aufkommens des Gewandes dürfte etwa die Spätzeit des ersten Jahrtausends anzusetzen sein. Zum erstenmal wird es um die Mitte des 11. Jahrhunderts erwähnt. Vorher herrscht in Betreff seiner das tiefste Schweigen. Nirgends findet sich vor 1050 auch nur eine

I In der altberühmten Abtei Glastonbury in England (Somersets.) erhielten zur Zeit des Abtes 'Turstin (ca 1080) die Klosterinsassen neben den übrigen Kleidern alljährlich eine pellicea ( $\mathrm{Wilh}$. M a $1 \mathrm{mesbur}$, De antiqu. Glaston. [M. 179, 1782]). Im Kloster des hl. Martialis zu Limoges bekamen die Mönche nur alle zrvei Jahre ein neues Pelzkleid (D. C. 8. v. pellicia VI 251). Vgl. auch die Statuten von St Victor zu Paris c. 20 (Mart. III 261), die Praemonstratenserstatuten c. 14 (ebd. 335) u. a. Vgl. namentlich auch c. 56 der Statuten von St Victor, in welchen verordact wird, dab man, wemn man tagsüber obne Cappa umhergehe odel' in der Kirche diese ablege, um als Kantor zu fungieren, unter dem Superpelliceum eine tunica oder eine pellicia haben muisse (ebd.279). Statt pellicea wird auch häufig pellicia geschrieben (vgl. D. C. ebd.).

2 Strengeren Seelen, zu denen auch der hl. Bernardus gehörte, behagte es nicht, daf man in den Klöstern sich der Pelzkleider bedient. Als der grofe Abt von Clairvatix darum dem Abt Petrus von Cluny Vorwürfe darüber machte, daf man daselbst derartige Gewånder dulde, antwortete ihm dieser, daß man die Pelzröcke aus demselben Grunde trage, um dessentwillen man sich zu Clairvaux mehrerer 'Tuniken bediene, nämlich ,aus Notwendigkeit wegen der unerträglichen Strenge der Kälte" (Petri Ven. epp. 1. 1, n. 28 [M. 189, 123]). 
Spur des Gewandes, weder in den liturgischen Schriften noch in den Konsuetudinarien der Kilöster, weder bei den Liturgikern noch in den Inventaren. Ebenso kommt es auf den Bildwerken vor dieser Zeit nirgends vor. ¿ berall gewahren wir auf ihnen bei den Gelegenheiten und Personen, bei welchen wir später las Superpelliceum antreffen, an dessen Stelle noch die gegiurtete, engärmelige Albe. Man vergleiche unter andern z. B. die Bildwerke des Drogosakramentars und des Sakramentars von Göttingen 1. Auch der Umstand, daß im 11. Jahrhundert die liturgische Verwertung des Gewandes noch sehr beschrånkt war, beweist, dafo wir sein Aufkommen nicht allzuweit ïber das 11. Jahrhundert hinausschieben dürfen.

Am frühesten mus das Superpelliceum beim Chorgebet in Gebrauch genommen worden sein. Denn es erscheint bis ins 13. Jahrhundert vor allem als Chorkleid. Aber es fand hie und da auch schon bald bei den Minoristen an Stelle der gegürteten Alhe Eingang. So begegnen uns bereits in der früher erwähnten Verordnung Eduards des Bekenners die Kleriker, welche dem Begräbnisse assistieren, in superpelliceis, während es noch vom Priester, der das Begräbnis vorzunehmen hatte, heißst: cum sacerdote induto alba, manipulo et stola. Immerhin war das Superpelliceum damals bei den Akolythen und den andern niedern Klerikern noch keineswegs sehr verbreitet. Denn noch etwa 70 Jahre später bezeichnen Gilbert von Limerick und Honorius Amikt und gegürtete Albe als die jenen zukommende liturgische Kleidung, ohne auch nur mit einem Worte des Superpelliceum als eines sakralen Ornates der Minoristen zu gedenken. Aber auch als das Gewand bei diesen weithin gebräuchlich geworden war, galt die Albe bei ihnen noch längere Zeit als das feierlichere.

Bei Spendung heiliger Sakramente und bei Vornahme kirchlicher Segnungen dürfte sich das Superpelliceum erst im Laufe des 12. Jahrhunderts eingebürgert haben. Bis dahin war es noch inmer Brauch, diese Akte in der Albe zu vollziehen. Sehr lehrreich sind in dieser Bezichung besonders die

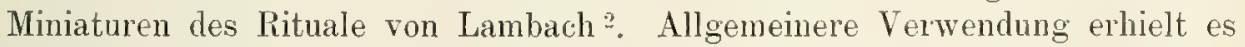
bei jenen Funktionen erst im Lauf des 13. Jahrhunderts, um dann freilich bald bei denselben die Albe ganz zu verdrängen.

Unsicher ist, was das Aufkommen des Superpelliceums veranlast hat. Wahrscheinlich war es indessen ebendasselbe, was dem Gewande seinen Namen gegeben hat, der Gebrauch der Pelzkleider. Eine engärmelige, gegürtete Albe war über diesen nicht gerade bequem. Es lag daher nahe, bei der Albe, welche von den Stiftsherren beim Chorgebet über den schweren Pelzkleidern getragen wurde, die Gürtung wegzulassen und zugleich den Ärmeln eine größere Weite zu geben. Natürlich konnte der Gebrauch solcher Alben, wegen der darunter befindlichen pellicea zum Unterschied von der gewöhnlichen Albe Superpelliceen genannt, in einer Zeit, wo die liturgische und namentlich die klerikale Gewandung noch in dem Stadium fortwährender Umbildung begriffen war, für die Dauer nicht auf eine Verwendung in Verbindung mit Pelzkleidern beschränkt bleiben. Allmählich trug man sie auch zu den sonstigen Kleidern, und nur noch der Name erinnerte an die Entstehung rles Gewandes. In diesem Stadium befand sich das Superpelliceum, als es begann. sich auch als Ersatz der eigentlich liturgischen Albe zunächst bei deı Minoristen und dann bei priesterlichen Funktionen einzubürgern.

\footnotetext{
1 Abhildung in Zeitschrift VII (1894) 75 (Darstellung eines Versehganges).

2 Franz, Das Rituale ron St Florian, Freiburg 1904, Tfl 2 ff.
} 
Was endlich die Frage anlangt, wo wir den Ursprung des Superpelliceum zu suchen haben, so ist am wahrscheinlichsten, daf es auferhalb Roms aufgekommen ist. Hier tritt es am frühesten auf, hier, wo die Pelzkleider ein ungleich grölseres Bedürfnis waren als im Süden, lag auch am ehesten eine Veranlassung vor, die Albe zum bequemeren. Superpelliceum umzubilden. Auferclem past die Änderung nicht gut zu dem konservativen Verhalten, das man zu Rom in Sachen der klerikalen und liturgischen Gewandung bewies. Eimen besonclern Einflulis auf die Verbreitung des Superpelliceum mag der Umstand ausgeübt haben, dafä es einen Bestandteil nicht bloß3 der Chorkleidung, sondern auch der gewöhnlichen Tracht der in der zweiten Hälfte des 11. Jahr'hunderts entstandenen regulierten Augustinerchorherren bildete. Die Erfinder des Superpelliceum waren diese jedoch keineswegs. Sie nahmen es als etwas bereits Bestehendes an. Similiter et in toga linea candida talari et ampla, quam superpelliceum dicimus, antiquae ecclesiae usum retinentes... nihil novitatis admittunt (sc. canonici regulares), sagt Anselm von Havelberg bezüglich des Superpelliceum ${ }^{1}$.

\section{DAS SUPERPELLICEUM IM ORDINATIONSRITUS.}

Nach dem römischen Pontifikale legt der Bischof demjenigen, welchen er unter die Kleriker aufnehmen will, nach Erteilung der 'Tonsur unter den Worten: "Es bekleide dich der Herr mit dem neuen Menschen, der nach Gott erschaffen ist in Gerechtigkeit und wahrer Heiligkeit", ein Superpelliceum an, welches der Ordinand auf dem Arme mitgebracht hat. Dieser Ritus soll zunächst zum Ausdruck bringen, daßs der Neokleriker in einen neuen Stand eintritt, indem er aus den Reihen der Laien ausscheidet und dem Klerus einverleibt wird. Dann spricht er aus, dafs dieser Standeswechsel nicht in einer blob äutserlichen Veränderung der Lebensverhältnisse bestehen dürfe, sondern von einer Umgestaltung des inneren Menschen begleitet sein müsse.

Der Gebrauch, jemand bei seiner Aufnahme unter die Kleriker die geistliche Kleidung zu ïberreichen, begegnet uns schon früh. Denn die Vita des hl. Germanus von Auxerre $(\dagger 448)$ erzählt, der Bischof Amator habe dem Heiligen, als er ihn zum Kleriker gemacht, die ornamenta saecularia ausund den hahitus religionis, hier wohl nicht die eigentlich liturgische, sondern die klerikale Gewandung, angezogen? ${ }^{2}$. Es lag in der Tat nahe, die Eingliederung in den Klerus durch Übergabe der klerikalen Kleidung äußserlich kund zu tun. Nichtsdestoweniger geschieht einer solchen Zeremonie vor 1200 in den alten Weiheordines keine Erwähnung. Erst in einem dem Beginn des 13. Jahrhunderts entstammenden Pontifikale von Sens findet sich im Ritus rer Erteilung der ersten Tonsur die Anweisung: hic induat eum cappa ${ }^{3}$. Ein Pontifikale von Senlis aus der Mitte des 14. Jahrhunderts enthält anstatt dessen die allgemeiner lautende Notiz: quando habitus datur ${ }^{4}$.

Der Bekleidung der Neokleriker mit dem Superpelliceum als dem ihnen eigentümlichen liturgischen Gewande wird erst in den aus dem 14. und 15. Jahrhundert stammenden Pontifikalion gedacht ${ }^{5}$. In älteren ist eine dies-

1 be oril. canonic. c. 10 (M. 18, 1103 ).

2 N. 5 (Acta SS. 31. Juli; VII 214).

${ }^{3}$ Mart. 1. 1, c. 8, art. 7, n. 10; II 17. Ebenso Cod. Vat. 6748 (14. Jahrh.).

4 W a t. a, a, 0.

- Bejspiele hioten Cod, Vat. lit. 1145
(15. Jahrh.); 1152 (14. Jahrh.): 4748 (14. Jahrh.) ; Ottob. 27 (15. Jahrh.) ; 501 (15.Jahrh.); Borgh. 14 A 1 (14.Jahrh.); ebenso im Pontifikale von St Blasien aus dem 14. Jahrh. (Gerbert, Honumenta vet. liturg. alem. II 45). 
bezügliche Rubrik stets nachträglicher Zusatz ${ }^{1}$. Wann die fragliche Zeremonie aufgekommen sei, ist unsicher. Schwerlich ist sie aber schon vor dem 13. Jahrhundert in Brauch gewesen; denn Sicard von Cremona belehrt uns: inter clericos tonsurandi aut illico tonsurati cappis utantur et stolis in divinis, d. i. wie aus dem Nachfolgenden erhellt, superpelliciis ${ }^{2}$. Es trugen also nach Sicard ebenso wie die Tonsurierten, so auch schon die noch zu Tonsurierenden beim Gottesdienst das Superpelliceum. Selbst Durandus redet noch nicht von der Übergabe unseres Gewandes an die Neokleriker. Diese Zeremonie dürfte demnach aus der Zeit stammen, in welcher die Albe bei den niedern Ḱlerikeru aufer Gebrauch gekommen und das Superpelliceum deren eigentliches Sakralkleid und damit zugleich deren Amtsgewand im besondern Sinn geworden war ${ }^{3}$. Nunmehr lag es in der Tat nahe, wie den Neosubdiakonen bei der Ordination die Tunicella, den Neodiakonen die Dalmatik, den Neopresbytern die Kasel, so auch den Neoklerikern bei ihrer Aufnahme in den geistlichen Stand das Superpelliceum als Zeichen der neuen Würde zu übergeben. Das Gebet, unter welchem sich jetzt die Übergabe des Superpelliceum vollzieht, begegnet uns schon in Pontifikalien aus dem 15. Jahrhundert 4

Aus der Bulle Klemens' IV. (1265-1271) für Le Puy ersehen wir, dafa "jemand ein Superpelliceum gewähren" auch wohl Symbol und Ausdruck der Übertragung einer geistlichen Pfründe war ${ }^{5}$, offenbar, weil das Superpelliceum Chorgewand war.

\section{BESCHAFFENHEIT DES SUPERPELLICEUM.}

In der Beschreibung, welche uns Anselm von Havelberg, Gerhoh und Arno von Reichersberg sowie Sicard von Cremona vom Superpelliceum des 12. Jahrhunderts geben, erscheint dasselbe als eine weite Linnentunika, welche bis auf die Füße hinabwallte ${ }^{6}$. Gegürtet war das Superpelliceum nicht. Von der Länge der Ärmel schweigen Anselm, Arno und Sicard. Die um die Wende des 12. Jahrhunderts entstandenen Statuten des St Viktorstiftes zu Paris bestimmen, es sollten die Ärmel nicht mehr als zwei Hand breit über die Finger hinausgehen ${ }^{7}$. Die Säkularkanoniker scheinen vielfach sehr lange Ärmel an ihren Superpelliceen gehabt zu haben. Denn Gerhoh von Reichersberg sagt, das Kleid der acephali -- so und pseudo-canonici nennt er die Kanoniker, welche kein gemeinsames Leben führten — sei mit Ärmeln ausgestattet, die nicht bis etwa zur Hand, sondern bis zu den Fülsen gingen oder gar zugleich mit der toga erst an der Erde endigten ${ }^{8}$. Unter dem Kleid der acephali und der toga versteht er aber, wie aus dem Zusammenhang her-

1 So in Cod, Vat. lat. 5791 und 7114 (beide aus dem 13.-14. Jahrh.) und Ottob. 330 (15. Jahrh.).

2 Mitralis 1. 2, c. 1 (M. 213,59 ).

3 In Rom war dies wenigstens schon im Beginn des 14. Jahrhunderts der Fall. Denn es heift im 14. Ordo c. 48 (M. 78, 1153): Acolythi omnes debent esse induti cottis secundum consuetudinem sanctae romanae ecclesiae.

- So in Cod. Vat. lat. 1145 und Ottob. 27.

5 N. 38 (Bull. rom. III 781).

Bezüglich der Länge des Superpelliceum sagen die Consuetudines canonic. regul.
S. Victor. Parisiens. c. 20 (M a rt. III 262): Das Superpelliceum und die wollene Tunika sollen möglichst von einer Länge sein und wenigstens eine volle Hand vom Boden abstehen. Es darf zudem kein anderes Gewand darunter hervorragen. Die Regularkanoniker mufiten das Kleid auch anfierhalb des Klosters, z. B. auf Reisen, tragen. Beim Reiten durften sie es durch ein Cingulum gürten (Consuetudines canonic. reg. ex ms. Morbacensi c. 101 102 [M a r t. III 317]).

7 M art. a. a. O.

${ }^{8}$ De aedif. Dei c. 29 (M. 194, 1270). 
vorgeht und ans der Beileutung des Wortes toga bei Anselm und Arno folgt ${ }^{1}$, das Superpellicem derselben. Von der Weite dex Ärmel hören wir weder im 12. noch auch im 13. Jahrhundert etwas. Es berechtigt ihre Länge jedoch zum Schlulis, daf sie auch entsprechend breit gewesen sein müssen ${ }^{2}$. Am Kopfdurchlals blieb das Superpelliceum bei den Augustiner-Chorherren nach Arno von Reichersberg ungeschlossen ${ }^{3}$.

Im 13. Jahrhundert beginnt für das Superpelliceum die Zeit allmählicher Ungestaltung. Denn auch ihm sollten Wandlungen ebensowenig erspart bleiben wie den andern liturgischen Gewändern. Eine der ersten Teränderungen, die mit ihm vorgingen, war seine Verkürzung. Die ersten Spuren

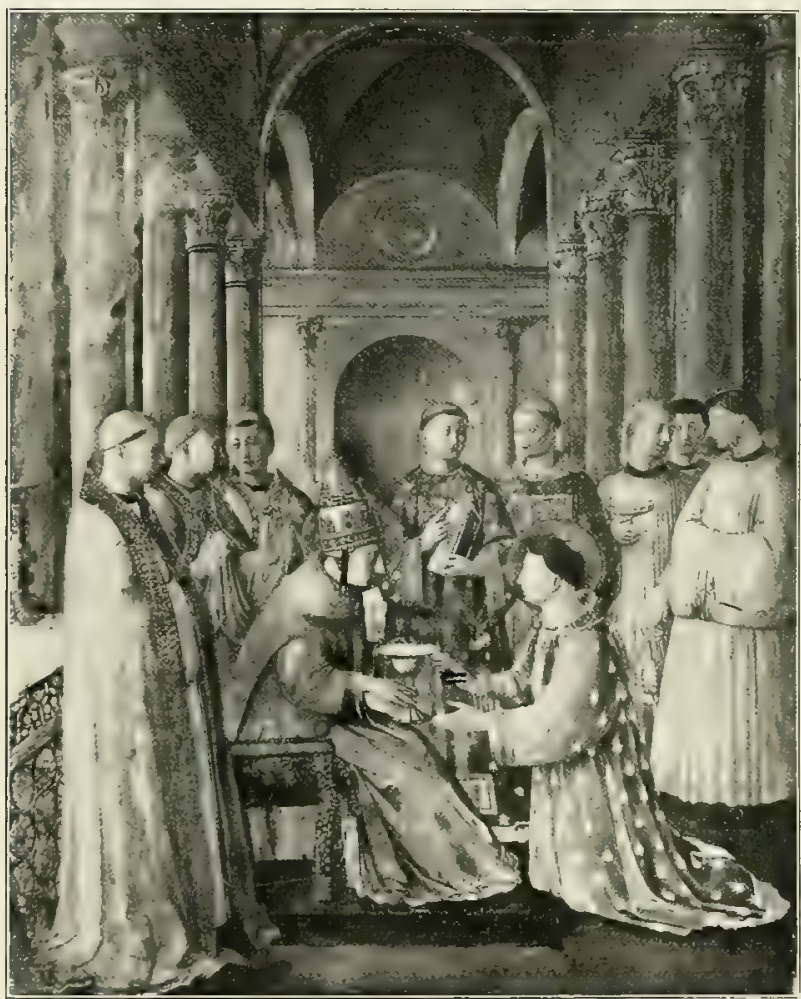

Bild 58. Fra Angelico: Weihe des hl. Laurentius. Rom, Vatikan. (Plıt. Alinaıi.) derselben finden sich bereits im 13. Jahrhundert. Traf diese Zustutzung auch zunächst nur das Superpelliceum, soweit es außerliturgisches Gewand war, so fing man jedoch allmählich an, auch an dem liturgischen Superpelliceum herumzuschneiden. Im 14. Jahrhundert war die Verkürzung noch unbedeutend; im 15. reichte das Gewand durchweg noch bis über die Mitte des Schienbeins, in Rom wie überhaupt in Italien aber sogar fast noch bis zum Saum des Talars (Bild 58). Im 16. und namentlich im 17. Jahrhundert geht es nur noch bestenfalls ein wenig über das Knie. Am schlimmsten wurde es im Verlauf des 18. Jahrhunderts. $\mathrm{Zu}$ Beginn des 19. war es so weit gekommen, dafi das Superpelliceum allerhöchstens nur noch bis zur Mitte des Oberschenkels, ja vielfach blok noch ein wenig über die Hüfte reichte. Natürlich ging die Verkürzung des Gewandes nicht überall gleich rasch vor sich. Je gröber die Neuerungssucht war und je mehr man sich von Bequem-

\footnotetext{
1 A nselmus Havelb., De ord. canonic. reg. c. 10 (M. 188, 1103); A r n o, Scutum canonic. (M. 194, 1505).

$2 \mathrm{Vgl}$, auch die Konstitution Benedikts XII. vom Jahre 13ss fiir tie resulierten Ausustiner-Chorherren zu Avignon c. 19 (Haxd. VII 1589).

${ }^{3}$ Scutum canonic. (M, 194, 1505): Cuius tunicae (sc. superpellicei) lingua soluta est...
}

sicut lingua interulae vel camisiae semper clausa est. Auch im späten Mittelalter finden sich anf den Bildwerken noch Superpelliceen, welche vom Kopfdurchlak an einen bis unter die Brust reichenden breiten, spitz zulaufenden Ausschnitt aufweisen. Ein gutes Beispiel z. B. auf einem Tafelgemålde des Meisters von St Severin im Pfarrliause vou St Lrsula zu Köln: Ecce Homo mit Stifter. 
lichkeitsrücksichten leiten lief, um so schneller vollzog sie sich. Auffallend ist, daf man auch zu Rom, wo man sich doch in Beziehung auf die andern Gewänder so konservativ verhielt, und wo das Superpelliceum noch um die Mitte des 15. Jahrhunderts fast bis zum Saum des Talars ging, bei der Zustutzung tapfer mittat. Wie man sieht, ging es mit dem Superpelliceum wie mit dem Rochett; die Verkürzung des einen hielt mit derjenigen des andern gleichen Schritt.

Eine zweite Umbildung betraf die Ärmel unseres Gewandes. Noch im 13. Jahrhundert scheinen dieselben durchweg nicht mehr als mittelweit gewesen zu sein. Dann aber nahmen sie allrnählich an Weite zu. $\operatorname{Im} 15$. und 16. Jahrhundert hatten sie nach Ausweis der Monumente sehr häufig eine so bedeutende Ausdehnung, dał sie an die Ärmel der Dalmatiken des 6. und 7. Jahrhunderts erinnerten und in langem, dichtgelagertem, malerischem Faltenwurf von den Armen sich herunterzogen (Bild 59).

Einschneidender war eine andere Wandlung, bei welcher die Ärmel ihren Ärmelcharakter einbüsten und zu losen Lappen wurden. Schon im 13. Jahrhundert hören wir davon, dafs man da, wo sich die Ärmel an den Körper des Superpelliceum ansetzen, in letzterem wohl einen Schlitz angebracht habe, um durch diesen, anstatt durch die Ärmel selbst, die Arme hinauszustecken. Bei dieser Öffnung blieb es jedoch in der Folge nicht; im weiteren Verlauf ging man dazu über, die ganzen Ärmel aufzuschlitzen, so daf dieselben lappengleich von der Schulter herabhingen und bei jedem Windzug hinter dem Träger einherflatterten. Superpelliceen dieser Art treffen wir schon im 15. Jahrhundert an (Bild 60); sie erhielten an manchen Orten, namentlich in Frankreich ${ }^{1}$ und Deutschland, das Bürgerrecht und blieben bis in die neueste Zeit im Gebrauch.

Von Superpelliceen mit aufgeschlitzten Ärmeln war nur ein kleiner Weg zu den sog. Flügelröcken, dem Gegenstück der modernen Dal-

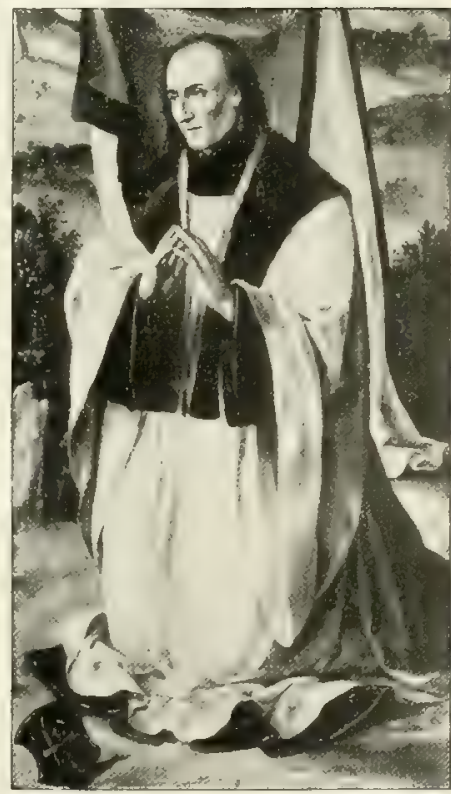

Bild 59. Stifter. Ausschnitt aus einem Tafelbild Barthel Bruyns. Köln, Mnseum. matiken und Tunicellen, welche aus einem Brust- und Rückenstück samt zwei von der Schulter auf die Arme herabfallenden Zeugstücken, den Resten der ehemaligen Ärmel, bestehen. Man brauchte nur das Gewand auch noch an den Seiten unterhalb der Armlöcher von oben nach unten aufzuschlitzen, und der Flügelrock war fertig. Daf man wirklich den Schritt nicht gescheut hat, erhellt daraus, daf in den letzten Jahrhunderten tatsächlich verschiedenenorts Superpelliceen dieser Form in Gebrauch kamen.

Der Flügelchorrock ist im Grunde genommen ebensowenig eine Tunika mehr als die modernen Dalmatiken, er erinnert nur noch an eine solche. Besser hat den Tunikacharakter eine andere Abart des Superpelliceum bewahrt, welche der Ärmel oder ihres Surrogats, der Flügel, gänzlich entbehrt und seitlich lediglich mit Schlitzen zum Durchstecken der Arme versehen ist: sie

1 De Vert II 274.

Braun, Die liturgische Gewandung. 
stellt eine dem ärmellosen Kolobium der Alten verwandte Tunika dar. Der Grund für ihre Entstehung waren offenbar Bequemlichkeitsrücksichten. In England begegnet uns diese Form des Superpelliceum bereits im 15. Jahrhundert. Sie hiels daselbst um jene Zeit, wie wir früher hörten, rochetum und stand in Diensten der Ministranten und des taufenden Priesters.

Das kolobiumförmige Superpelliceum mag wiederum den Weg zu jener seltsamen Superpelliceenart gebildet haben, bei welcher das Gewand nur noch ein Überwurf mit einer Halsöffnung zum Durchstecken des Kopfes ganz nach der Art der mittelalterlichen Kaseln war. Beispiele dieser eigenartigen Form finden sich auf den Malereien des 16. und 17. Jahrhunderts mehrfach, so auf

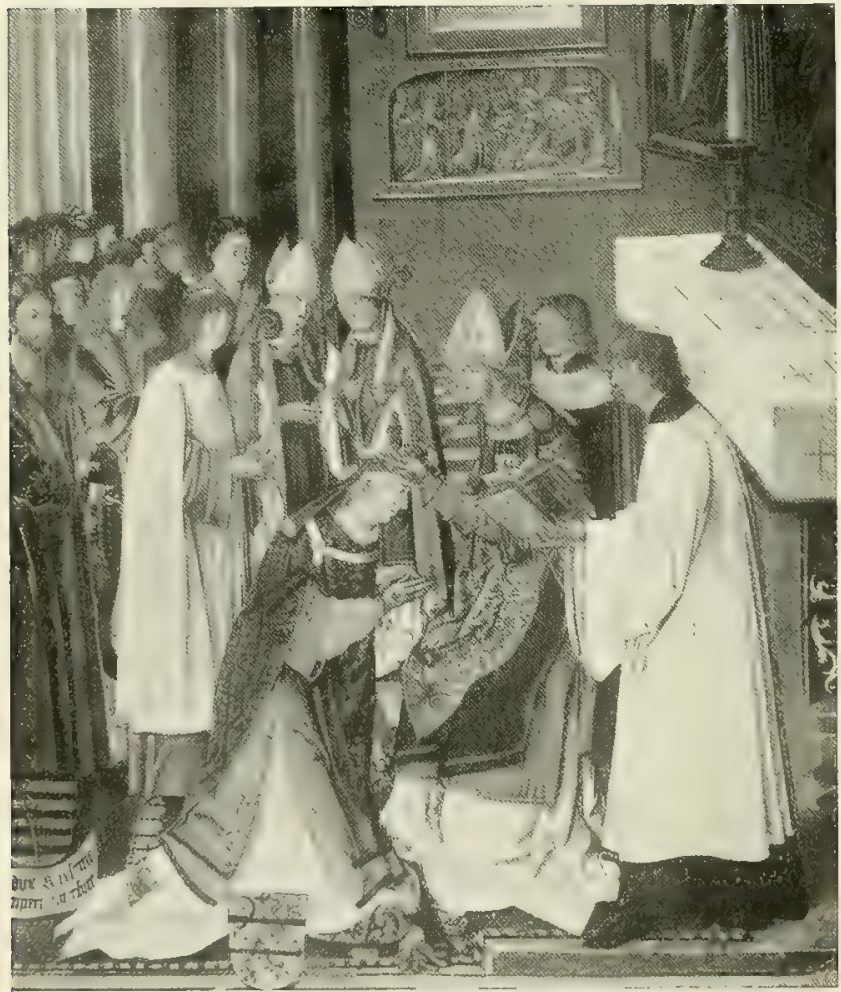

Bild 60. Weilie des Bischofs von Bamberg Veit Truchsef von Pommersfelden. Miniatur aus dem Gundekarpontifikale. Eiehstitt. einem Fresko in der Kirche degli Eremitani zu Padua, einem Gemälde im Duomo vecchio zu Brescia, einem Gemälde Bassanos in der Sala del Consiglio dei Dieci "Papst Alexander III. und der Doge Ziani " und dem Gemälde Paolo Veroneses „Rückkehr des Dogen Andrea Contarini nach dem Siege bei Chioggia" in der Sala del Maggior Consiglio des Palazzo Ducale zu Venedig, einem Mosaik in der Schatzkammer vonS. Marco u.a.

Nicht eine wirkliche Verkủmmerung des Superpelliceum, sondern nur ein Surrogat ist das skapulierartige Band, das sich bei den regulierten Augustiner-Chorherren anstatt des außerliturgischen Superpelliceum einbürgerte.

Bei dem schon fiüh auftretenden streben, das superpelliceum bequemer zu gestalten, hegreift es sich, dafí elenso früh Bestimmungen gegen ein solches Gebaren erlassen wurden. Gegen die unter dem Einflulis der wechselnden Tagesmode entstandene Gepflogenheit, an den Seiten im Gewand Schlitze zum Durchstecken der Arme anzubringen, wandten sich schon die Synodalstatuten rles Bischof's Johannes von Lüttich vom Jahre 1287 und die Synode von Cambrai aus dem Jahre $1300^{1}$. Eine Konstitution Benedikts XII, aus dem Jahre 13:39, die von der Reformation der regulierten Augustiner-Chorherren zu Avignon handelt, verordnet, es sollten die Kanoniker in der Kirche und den Klaustra

1 C. Celohraus (II artzl. IV 71). 
der Kathedralen, Konvente und Kollegien sowie überall, wo sie conventualiter aufträten, grolse und weite Superpelliceen tragen, deren Ärmel etwa vier Finger breit über die Hand hinausgingen. Kürzerer Superpelliceen sich zu bedienen, sei nur auferhalb der Kirche usw, und zwar blof bei gleichzeitiger Benutzung der Cappa oder des Mantels gestattet. Doch müfiten selbige auch in diesem Falle noch bis zur Mitte des Schienbeines reichen und Ärmel von der Breite etwa einer Elle haben ${ }^{1}$. Schon 133:3 hatte Johannes XXII. in einem Diplom für die Kanoniker von Villanova festgesetzt, alle sollten Superpelliceen von einheitlicher Form, sc. cum longis manicis, tragen ${ }^{2}$. Bezüglich des liturgischen Chorrockes verordnete das Basler Konzil, man solle zur Abhaltung des Stundengebetes in der Talartunika und reinen, bis über die Mitte des Schienbeines reichenden Superpelliceen in der Kirche erscheinen ${ }^{3}$. Eine gleiche Bestimmung erliel 1485 eine Synode von Sens *. Gegen die ärmellosen Superpelliceen wendet sich 1585 eine Synode von Aix. "Alle sollen", sagt sie, "wenn es der Dienst erfordert, sich der Superpelliceen bedienen; dieselben dürfen aber weder zerrissen noch schmutzig sein und müssen Ärmel haben. Ärmellose Superpelliceen, welche dieses Namens nicht würdig sind, sondern vielmehr Mäntelchen (mantilia) heiben sollten, verbieten wir durchaus." s Im Superpelliceum seitlich unter den Ärmeln Schlitze anzubringen, um durch dieselben statt durch jene die Arme hindurchzustecken, verbot noch 1640 das in mancher Beziehung sehr konservative Rituale von Rouen ${ }^{6}$.

Sehr eingehende Bestimmungen traf der hl. Karl Borromäus hinsichtlich des Superpelliceum. Es solle selbiges nicht nach Art des Rochetts enge, sondern weite Ärmel haben und aus reinem Linnen bzw. Hanftuch angefertigt werden. Der zur Verwendung kommende Stoff müsse weik und zart sein; ungebleichtes und allzu grobes Material dürfe zur Herstellung des Gewandes nicht gebraucht werden. Die Ärmel sollten so lang sein, daßs sie, gefältelt, noch immer bis zu den Fingerspitzen reichten, und darum etwa eine Länge von 2 cubiti ( $=0,86 \mathrm{~m}$ ) haben. Ihr vorderer Umfang solle ca 4 cubiti (= $1,70 \mathrm{~m}$ ) betragen. Die Halsöffnung sei besser rund als viereckig und habe sich bezïglich der Größe nach der Kopfdicke zu richten. Ein Schlitz dürfe vorn auf der Brust nicht angebracht werden. Unten müsse das Gewand bis über die Knie und etwa bis zur Mitte des Schienbeines reichen. Sein Umfang solle sich am unteren Ende auf etwa 13 cubiti $(=5,60 \mathrm{~m})$, an den Sichultern aber auf ungefälr 8 cubiti $(=3,40 \mathrm{~m})$ belaufen. Nirgends dürfe das Superpelliceum allzu groß̧e Künstelei und gesuchte Eleganz offenbaren ?

Sehr bemerkenswert ist auch die Verordnung, welche die Prager Synode des Jahres 1605 in Bezug auf das Superpelliceum erlief. Sie will, dal; es aus passendem Linnen gemacht werde, daß3 sein Saum höchstens eine Viertelelle vom Boden entfernt sei und dafs die Ärmel eine Gesamtweite von zwei und ein Viertel Ellen besäßzen ${ }^{8}$. Wäre das Gewand nur immer geblieben, was es nach diesen Bestimmungen sein sollte!

Eine reiche Ausstattung hat das Superpelliceum im Mittelalter im allgemeinen nicht gefunden. Bestenfalls wurde es vorn und rückwärts am unteren Saum mit einem quadratischen oder rechteckigen Besatzstuick, der sog.

I N. 19 (Hard. VII 1589 ).

2 Giorgi, Liturg. Rom. Pontif. I 333.

3 Sess. 21, c. 3 (Hard. VIII 1197).

1 C. 1 (H ard. IX 1522).
5 C. De vita et honest. cler ( $\mathrm{H}$ a r d. X 1514).

6 De Vert II 274

7 A. E. Med. 635.

8 C. 13 (H artzh. VIII 692). 
Parura, rersehen ${ }^{1}$. Doch dürfte selbst das nicht allzuhäufig vorgekommen sein. Auf den Monmmenten erscheint es durchweg als ein wenngleich faltenreiches, so doch im übrigen schlichtes Gewand. Mit Beginn der Neuzeit scheint man auf die Verzierung des Superpelliceum mehr Gewicht gelegt zu haben. Sah sich doch schon der hl. Karl Borromäus veranlafst, vor allzu kunstfertiger und eleganter Herstellung desselben zu warnen. Seitdem dann die Spitzenindustrie aufblühte, bürgerte sich die Gewohnheit ein, den unteren Rand und die Ärmelsäume des Gewandes mit Spitzen zu besetzen. Die Mißzbräuche, zu welchen eine gleiche Gepflogenheit bei der Albe und dem Rochett geführt, machten sich jedoch allmählich auch beim Superpelliceum geltend.

Die Wiedergeburt der christlichen Kunst hat in der übermäßigen und misbräuchlichen Verwendung der Spitzen einigen Wandel geschaffen. Die hierbei in Aufnahme gekommenen Borduren in Rot- oder Buntstickerei waren im Mittelalter bei den Superpelliceen wohl kaum gebräuchlich, sind aber sehr zweckentsprechend. Die neu erwachten, an bessere Zeit der kirchlichen Kunsttätigkeit anknüpfenden Bemühungen haben auch das Verdienst, dem Gewand vielfach wieder eine würdigere Form verschafft zu haben.

Von dem Gebrauch, das Superpelliceum künstlich zu fälteln, redet schon der hl. Karl Borromäus. Er bestand bereits beim Ausgange des Mittelalters, wie z. B. das Porträt des Kanonikus Salviati von Gerard Darid (Nat. Gallery zu London) beweist; eine gröfere Verbreitung und Ausbildung erlangte er aber wohl erst seit dem 17. Jahrhundert. Der Körper des Gewandes wurde dabei in zahllose, von oben nach unten laufende Parallelfalten gelegt, während die Ärmel in die Quere gefältelt wurden. Eine solche Fältelung des Superpelliceum, welche natïrlich voraussetzt, daf selbiges zuvor durch Stärken eine gewisse Steifheit erhalten hat, mag ihre Vorteile haben, übertrieben, wie es oft der Fall war und ist, artet sie aber in Spielerei und geistloses Prunken aus und macht das Superpelliceum zu einem Zerrbild eines würdevollen liturgischen Gewandes.

Von liturgischen Superpelliceen hat sich aus dem Mittelalter leider keines erhalten. Allerdings soll sich noch ein solches auf Schlol Friedenstein bei Gotha befinden, und zwar soll sich, wollen wir einer von Bock mitgeteilten Erzählung glauben, Kaiser Maximilian I. desselben bedient haben, als er angeblich gelegentlich einer Wallfahrt nach Echternach am Chordienst der Mönche teilnahm 2. Das Gewand hat indessen mit einem Superpelliceum nichts zu schaffen.

Ein interessantes Augustinersuperpelliceum wird in der Pfarrkirche zu Waldsee (Württemberg) aufbewahrt. Es hat förmliche Skapulierform, ist ungefähr $1 \mathrm{~m}$ lang und besteht aus zwei 1,96 und $1,42 \mathrm{~m}$ breiten Stücken feiner kreppartiger Leinwand, welche oben auf 0,14 bzw. 0,12 m eingekräuselt und durch zwei $0,29 \mathrm{~m}$ lange und $1 \frac{1}{2} \mathrm{~cm}$ breite Bänder miteinander verbunden sind. Das Gewand soll dem ehrwürdigen P. Kügelin, dem Beichtvater der seligen Beta ron Reute, angehört haben, doch stammt es wie eine demselben gleichfalls zugeschriebene Kasel in der Pfarrkirche zu Waldsee wohl aus späterer Zeit und nicht schon aus den 15. Jahrhundert. Immerhin ist es ein um so heachtenswerteres Stück, als sich ein derartiges Gewand sonst kaum erhalten haben dürfte.

\footnotetext{
${ }^{1}$ Ein Beispiel bei Bock, Gesch. II, Tafel XIIV.
}

2 Ebd. II 337. Kirchenschmuck IV (1858) 57 mit farbiger Abhildung. 


\title{
DIE LITURGISCHEN OBERGEW ÄNDER.
}

\author{
ERSTES KAPITEL.
}

\section{I E K A S E L.}

\section{DIE KASEL IN DER GEGENWART.}

Das liturgische Obergewand des Priesters und Bischofs ist die Kasel oder Planeta. Sie bildet mit der Albe den notwendigsten Bestandteil der Mefkleidung und kann als das Mefgewand im besondern Sinne bezeichnet werden, rla sie nur bei der Messe gebraucht wird. Denn es ist im Grunde nur eine scheinbare Ausnahme, wenn sich der Priester ihrer auch bei den Lesungen der Präsanktifikatenmesse am Karfreitag und den Prophetien am Karsamstag berlient, oder wenn sich die zwölf Priester, welche am Grïndonnerstag bei der Ölweihe assistieren, mit der Kasel bekleiden. Dem alle diese Funktionen stehen in innigster Verbindung mit der Tagesliturgie. Lediglich Schmuck ist die Kasel, wenn sie, wie das an verschiedenen Orten üblich ist, (ohne Manipel und Stola) von Priestern bei der Fronleichnamsprozession getragen wird, da die bloke Teilnahme an einer Prozession noch kein liturgischer Akt ist. Symbol der Priesterwürde ist sie, wenn sie von den Priestern, welche bei der Priesterweihe an der Händeauflegung teilnehmen, angelegt wird ${ }^{1}$. Bei der Priesterweihe wird die Kasel dem Ordinanden durch den Bischof selbst angezogen. Sie wird dabei in den Worten, mit denen der Konsekrator die Zeremonie begleitet, ausdrücklich als die vestis sacerdotalis bezeichnet. „Nimm hin", spricht derselbe, "das priesterliche Kleid, das Symbol der Liebe; Gott ist mächtig genug, dir die Liebe und vollkommenes Werk zu mehren." Eigentümlich bei diesem Ritus ist, dafí die Kasel anfangs auf dem Rïicken noch zusammengerollt bleibt. Erst am Schluf der Messe, in welcher die Weihe statthatte, wird sie ganz entfaltet, wie um anzudeuten, daf nunmeh* der Neugeweihte völlig bereit zum Altardienst ist.

Die Diakone und Subdiakone gebrauchen die Kasel nur an gewissen Tagen und bei gewissen Gelegenheiten und auch dann blok in der Form der sog. planeta plicata. Es sind die Sonn- und Wochentage der Adventund Fastenzeit, ausgenommen die Sonntage Gaudete und Laetare, der Gründomerstag und der Karsamstag (Osterkerzenweihe und Messe), die übrigen Fasttage des Kirchenjahres mit Ausnahme der Vigilien vor Weihnachten, Pfingsten (Messe), Mariä Himmelfahrt, Peter und Paul und Allerheiligen, sowie der Quatembertage der Pfingstwoche und endlich die Aschen-, Kerzenund Palmweihe samt den an die beiden letzten sich anschliefenden Prozessionell.

Planeta plicata wird die Kasel genannt, deren sich der Diakon und der Subdiakon an diesen Tagen und bei den angeführten Zeremonien bedienen,

\footnotetext{
${ }^{1}$ Pontif. Roman. in ordinat. presbyteri.
} 
weil sie, statt frei von den Schultern herunterzufallen, vorn zusammengefaltet ist. Beim Subdiakon bleibt das so die ganze Messe hindurch; nur muf er die Epistel ohne planeta plicata singen, weshalb er dieselbe vor Beginn der Lesung auszuziehen hat. Der Diakon behält die vor der Brust zusammengerollte Kasel bis zum Evangelium. Dann legt er sie ab, faltet sie, wenn er sich nicht etwa der sog. stola latior, eines breiten, stolaartigen Bandes, bedienen will, streifenartig zusammen und legt sie ganz nach Weise der diako nalen Stola wieder um. So trägt er sie bzw. ihr Surrogat, die stola latior, bis die Kommunion beendet ist; dann zieht er die planeta plicata wieder in der Gestalt an, wie er sie beim Anfang der Messe trug:

In den römischen Kirchen bedient man sich statt eines vor der Brust zusammengefalteten Mefagewandes einer vorn verkürzten Kasel, allerdings nicht ganz im Einklang mit den Rubriken des Missale und den Angaben des Caeremoniale. Die stola latior (ital. stolone) ist nicht eine Stola, sondern nur Ersatz der streifenartig zusammengerollten Kasel; sie soll deshalb auch nicht mit den drei Kreuzen versehen sein, welche man auf der eigentlichen Stola anbringt 1 . Das Missale erlaubt den Gebrauch dieses Surrogates, weil die moderne Kasel sich schlecht oder kaum in Form der diakonalen Stola zusammenfalten und benutzen läßst.

Das Missale schreibt den Gebrauch der planeta plicata nur für die Kathedralen und die sonstigen hervorragenden (Stifts-, Kloster- und Pfarr-) Kirchen vor. Kleineren Kirchen ist ihre Verwendung sogar ausdrücklich untersagt. In ihnen sollen Diakon und Subdiakon, wenn sie sich nicht der Dalmatik und Tunicella bedienen dürfen, nur in Albe, Stola und Manipel bzw. in Albe und Manipel fungieren 2. Doch ist auch in manchen Kathedralen und erst recht in vielen. größseren Kirchen die planeta plicata nicht mehr im Gebrauch. Es wäre zu wünschen, daf man sie überall wieder einführte, und wäre es auch nur im Hinblick auf das mehr als tausendjährige Alter ihrer Verwendung.

Die Kasel oder Planeta, wie sie sich gegenwärtig allenthalben im Gebrauch befindet, ist ein skapulierartiger Überwurf, der über Brust und Rücken herabfällt, an den Seiten die Arme unbedeckt läbt und in der Mitte mit einem Durchlafs für den Kopf versehen ist. Neben der vollen Übereinstimmung in der Grundform. weisen aber die Kaseln in den einzelnen Ländern cine Reihe von Verschiedenheiten auf. Dieselben betreffen teils den Schnitt, teils die Machweise, teils die Abmessungen, teils die Verzierungen des Gewandes. Es lassen sich in dieser Beziehung vier Typen unterscheiden, ein römischer (italienischer), französischer, spanischer und deutscher Typus.

Die römischen Kaseln haben durchweg eine Rückenbreite von $0,75 \mathrm{~m}$ und eine Länge von ca $1,20 \mathrm{~m}$. Die Ausschnitte an der Vorderseite können im Vergleich mit denjenigen der andern Kaseltypen als mäsig bezeichnet werden. Dor Durchlak für den Hals geht vorn weit herab (Bild $61 \mathrm{c}$ ). In der Regel besteht das Gewand aus zwei Stoffstücken, einem gröberen und einem kleineren, welche auf der Vorderscite vor der Brust aneinandergesctzt sind. Steifes Innenfutter zu verwenden, ist nicht Brauch. Die Kaseln sind darum auch durchweg leicht und biegsam. Das gilt, wenigstens in der Regel, selbst von solchen, welche mit Goldstickerei über und üher verziert sind. Kaseln von bretterhafter Steifheit sind in Italien meist Importware. 
Die Ausstattung der römischen (italienischen) Kaseln besteht in einem Stab oder, wie man gewöhnlich sagt, einer colonna (Säule) auf dem Rückteil, einer breiten Einfassung des Kopfdurchlasses und einer Art geradbalkigen Kreuzes auf der Vorderseite. Bei den gewöhnlichen Kaseln werden Säule, Halseinfassung und Kreuz regelmäßig durch Börtchen imitiert; bei besseren pflegen sie mit Vorliebe in Goldstickerei hergestellt zu werden. Die Bildstickerei kommt in Italien bei Ausschmückung der Kasel sehr wenig in Anwendung. Die immer und immer wiederkehrenden Motive der Stickereien sind Ranken, Ähren, Weinreben, Blumen, Schnörkelwerk und ähnliche. Soll eine Kasel besonders leich ausgestattet werden, so wird sie mit Goldstickereien ganz und gar wie übersponnen. Eigens zu diesem Ende gewebte Besätze werden nur wenig zur Verzierung des Mefgewandes gebraucht.

Vollkommen ist die römische Kasel nicht, sie kann indessen alles in allem noch als der würdigste und entsprechendste Typus unter den modernen Kaselformen bezeichnet werden. Ganz besonders steht sie weit über der spanischen Kasel, einem in jeder Beziehung häflichen Gewande (Bild 61 d). Man hat in neuerer Zeit die moderne Kasel vielfach Bafigeige gescholten. Irenn irgendwo, dann trifft dieser Titel bei del auf den Schultern lächerlich schmalem,
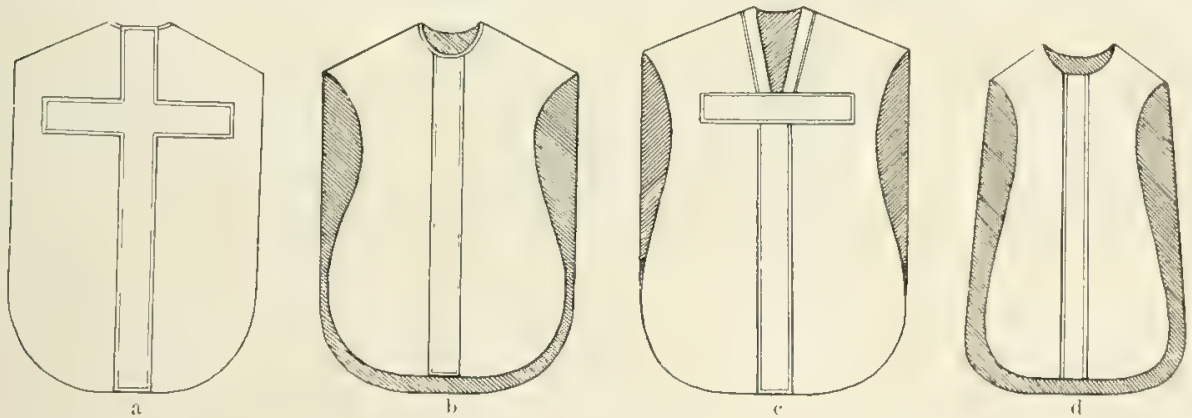

Bild 61. Kaselformen.

nach unten geigenförmig sich erweiternden spanischen Form des Melígewandes zu. Der Durchlat für den Hals ist bei dem spanischen Kaseltypus weniger lang wie bei der römischen Kasel, dafür aber sehr weit. Oben hat die spanische Kasel eben liückenbreite, sie mist also daselbst nur etwa $0,45 \mathrm{~m}$. Unten mag sich ihre Breite auf etwa $0,60 \mathrm{~m}$ belaufen. Ihre Länge beträgt bestenfalls etwa $1 \mathrm{~m}$, in der Tat zwerghafte Mafe. Ein Kreuz hat die Kasel weder auf der Brust noch auf dem Rücken; hier wie dort findet sich bloß ein einfacher Tertikalbesatz. Den Kopfdurchschlupf umsäumt bald eine breitere Einfassung, bald nur ein schmales Börtchen.

Eine Mittelstellung zwischen dem römischen und dem spanischen nimmt der französische und der deutsche Kaseltypus ein.

Eine Beschreibung der deutschen Kasel (Bild $61 \mathrm{a}, \mathrm{b}$ ) ist überflüssig, da sie allbekannt ist. Es sei daher nur bemerkt, daf ihre Länge sich gewöhnlich auf ca $1,15 \mathrm{~m}$ und ihre Rückenbreite auf ca 0,68 bis $0,70 \mathrm{~m}$ beläuft.

Die französische Kasel hat im allgemeinen etwas geringere $\mathrm{Ab}$ messungen als die deutsche, namentlich was die Länge anbetrifft. An der Vorderseite ist sie regelmälig stark ausgeschnitten. Die Halsöffnung, welche heim deutschen Typus in der Regel ovale oder elliptische Form hat, ist dem Kopfdurchlaf des römischen Typus nachgebildet, doch etwas breiter. Auf 
dem Riicken ist die französische Kasel ähnlich wie die deutsche mit einem Kreuz und auf der Vorderseite mit einem bloßen Stab verziert. Sie unterscheidet sich ron dieser durch die breite Umrahmung des Kopfdurchschlupfes sowie anch wohl durch die Ecken, welche mit Vorliebe auf französischen Kaseln in die vier von den beiden Kreuzbalken gebildeten Winkel hineingelegt werden. Die Naht, welche den Vorder- und Rückteil verbindet, liegt bald auf der Schulter, bald unterhalb des Kopfdurchlasses vor der Brust. Zur Verzierung besserer Kaseln dienen mit Vorzug Goldstickereien, namentlich solche in Gestalt von Guipés, d. i. über einen dicken, steifen Karton ausgeführte Hochstickereien.

$\mathrm{Zu}$ diesen vier Haupttypen der modernen Kasel ist in neuerer Zeit als fünfter eine Nachbildung der spätmittelalterlichen Mefsgewandform gekommen. Er hat indessen nur eine geringe Verbreitung erlangt. In Italien und Spanien hat man nicht einmal Miene gemacht, zum mittelalterlichen Kaseltypus zurückzukehren; in Frankreich, Belgien und England faud er nur vereinzelt Aufnahme; am meisten ist or in Deutschland wieder zu Ehren gekommen, wenngleich auch hier nur in beschränktem Mafe, zumal im Süden ${ }^{\text {. }}$

Über den Stoff, aus dem das Mefsgewand anzufertigen ist, geben die Rubriken keine Auskunft. Es bestehen dariber jedoch verschiedene Entscheidungen der Ritenkongregation. Hiernach ist es unzulässig, die Kaseln aus Linnen, Baumwollzeug und selbst Wollstoffen herzustellen 2. Auch dürfen dieselben nicht aus Glasbrokat, einem Surrogat für Goldbrokat, bei welchem gesponnene Glasfäden die Stelle der Goldfäden vertreten, gemacht werden ${ }^{3}$. Aus halbseidenen Stoffen darf das Mefgewand nur hergestellt werden, wenn die seidene Kette den nichtseidenen Einschlag völlig deckt ${ }^{4}$. Der eigentliche Kaselstoff ist also dem heutigen kirchlichen Gebrauch gemäß die Seide, wie Linnen für die Albe und den Amikt der liturgische Stoff im besondern Sinne ist. Die Stoffe können gemustert und ungemustert, einfarbig und mehrfarbig, glatte Zeuge und Samte, mit Gold- wie mit Silberfäden durchwoben sein. Sind sie mehrfarbig, so muk eine Farbe vorherrschen, damit sich der Farbencharakter des Gewandes nach ihr bestimmen lasse ${ }^{5}$. Der Regel nach wird das die Farbe des Stoffgrundes sein.

\section{DIE NAMEN DES MESSGEWANDES.}

Statt mit dem in der Gegenwart gebräuchlichen Namen Kasel und Planeta bezeichnete man vormals unser Gewand auch mit den Benennungen amphibalus und infula. A mphibalus hiefs es in der gallikanischen Kirche der vorkarolingischen Zeit. Es führt diesen Namen in der gallikanischen Meferklärung ${ }^{6}$, in den Dialogen des Sulpicius Severus ${ }^{7}$, den ge-

1 C̈ber dje Frage, ob die spätmittelalterliche Kaselform als zulässig gelten dürfe, was gegenwärtig wohI nicht mehr zweifelhaft sein kann, vgl. insbesondere den vortrefflichen Aufsatz des jetzigen hochw. Herrn Bischofs von Rottenhurg, P. W. v. Keppler, in dem "Archiv fül christl. Kunst" 1888, Nr 1-7; ferner Thalhofer, Liturgik I 858 und Bra u n, Winke 43.

2 Monitum C. R. 28. Juli 1881 (Acta S. Sedis XIV 144), ferner C. R. 18. Dez. 1877 und 15. April 1880 (Ballerini-Palmieri, Opus morale IV 791), 17. Dez. 1888 (Analecta Ord. Capuc. VI 182) und 23. Juni 1892 (Decret. auth. 3779).

${ }^{3}$ C. R. 11. Sept. 1847 (Decret. auth. 2949).

4 Ebd. 23. März 1882 (Decret. auth. 3543).

5 Ebd. 19. Dez. 1829, 12. Nov. 1831, 23. Sept. 1837 (Decret, auth. 26752682 2769). Ausführlicheres über die Beschaffenheit des Stoffes des Mefagewandes bei $\mathrm{Br}$ a un, Winke und 25.

${ }^{6}$ M. $72,97$.

7 Dialog. 1. 2, c. 1 (Corp. SS. eccl. I, 180). 
reimten Vitae S. Martini des Paulinus von Périgueux ${ }^{1}$ und des Venantius Fortunatus $^{2}$ u. a. Seitdem der gallikanische Meliritus aufgegeben und durch den römischen verdrängt wurde, scheint der Name, wenn er überhaupt vorher eine gröfere Bedeutung gehabt, rasch aufer Gebrauch gekommen zu sein.

Im gewöhnlichen Leben bezeichnete man mit amphibalus (amphimalus) namentlich den auferliturgischen Mantel der Geistlichen und Mönche. In diesem Simne begegnet uns das Wort in der von dem hl. Audoënus (St-Ouen, $\dagger 683$ ) verfafiten Vita S. Eligii $(\dagger 659)^{3}$, in der von einem Zeitgenossen geschriebenen Biographie des hl. Fructuosus. Erzbischofs von Braga ( $\dagger$ ca $660^{4}$ ), bei Gregorius von Tours in der Schrift De gloria confessorum " , in der von Cummeneus herrührenden Lebensbeschreibung des hl. Columba, Abtes von Jona († 598) ${ }^{6}$. Auch in der Vita S. Boniti, ep. Claromontani († 709), in der zweimal von einem amphibalus des Heiligen die Rede ist, bedeutet das Wort. wie es scheint, ein auferliturgisches Gewand? Selbst Mäntel der Laien wurden amphibalus genannt, und zwar dürfte sich der Name in diesem Sinne hie und da ziemlich lang erhalten haben. Denn wir treffen das Wort noch in der Chronik des Erzbischots Romuald von salemo ( $\dagger$ 1181) in dieser Bedeutung an ${ }^{8}$. Als Frauenmantel erscheint amphibalus in der Vita S. Wiboradae (10. Jahrh.) ${ }^{\text {? }}$.

Der Ausdruck infula ist uns in dem Sondersinn von Kasel vor 1000 bisher nirgends begegnet. Er wird erst im 11. Jahrhundert diese Bedeutung erhalten haben. Seit dieser Zeit heißst das Mebgewand freilich sehr häufig infula, vornehmlich in England und Frankreich, seltener in Deutschland und Italien.

So wird in einem dem 12. Jahrhundert entstammenden Inventar der Abtei Martinsberg (bei Raab in Ungarn) die Kasel infula genannt: 8 infulae cum stolis manipulisque. Unter demselben Namen erscheint sie ferner in denı Glossar des Engländers Johannes Gerland ${ }^{10}$. Die infula nämlich, die darin unter den priesterlichen Gewãndern aufgeführt wird, erklärt der Verfasser selbst mit cheisible (= chasuble, casula). Besonders verbreitet war aber die Benennung infula in Frankreich. His supradictis (nämlich Albe usw.) imponitur casula, qnae alio nomine planeta vel infula dicitur, heibt es in dem Speculum de mysteriis ecclesiae c. ${ }^{11}$, und bald nachher: Habeat (Priester) zonam castitatis, stolam fortitudinis et plenitudinem scientiae, i. e. charitatem, quam figurat infula. Ebenso klar und hestimmt wird das Mebgewand viermal in dem kurzen 14. Sermo, der sich im Anhang zu den Werken Hugos von St Victor befindet, mit dem Namen infula bezeichnet. Ein Schatzverzeichnis der Heiligen Kapelle zu Paris vom Jahre 1363 stellt die infula ausdrücklich der casula gleich: infula seu casula ${ }^{12}$. Dasselbe tun die Statuten der Synode von Cahors aus dem Jahre $1289^{13}$.

In den Inventaren von Angers führt das Gewand sogar noch im Jahre 15.95 diese Bezeichnung. Erst mit dem Schatzverzeichnis von 1599 heibt es hier chasuble. Den Namen infula erhielt die Kasel wohl darum, weil sie das Mefogewand in besonderem Sinne und damit zugleich das Priesterkleid mit Vorzug geworden war. Daher denn auch der Name erst auftaucht, als die Kasel nicht nur aus dem auferliturgischen

1 L. 4 in initio (M. 61, 1038).

L. 3, v. 42 (M. 88,393 ).

3 L. 2, c. 6 (M. 87, 517).

4 N. 9 (A. SS. 16. April; II 429).

5 C. 59 (M. 71, 871).

- N. 27 (A. SS. O. S. B. I 349). Vgl. auch S. Greg. M. Epp. I. XIV, n.15 (M. G. Epp. II 435).

7 N. 936 (A. SS. 15. Jan.; I 353 357).

s Mur, SS. VII 155.

N. 4 (A. SS. O. S. B. V 46).

$10 \mathrm{Chambers} 46$.

11 M. 177, 353355 . Es ist also unzutreffend, wenn es Realenc. II 213 heift, im Spec. eccl.
Hugos von st Viktor sei die Bezeichnung infula für ein Amt gesetzt. Infula besagt dort klar und bestimmt ein Gewand, und zwar nicht die Mitra, sondern die Kasel.

12 D. C. (sub Infula) IV 358.

${ }^{13}$ C. 18 (M art., Thes. IV 715). Man vergleiche auch die sehr lehrreichen Stellen bei M a r t. 1. 1, c. 4, art. 1 (Auszug aus einem Missale von Auxerre); I 127 und 1. 4, c. 23 (Auszug aus einem Rituale von Soissons); III 138; ferner Mart., Mon. 1. 3, c. 14, n. 33 35 (Ex consuet. Sti Dionysii et S. Comelii Compend.); IV 138. 
Gebrauch verschwunden war, sondern auch im liturgischen Dienst den Charakter eines spezifischen Mefornates erhalten hatte md nur noch ausschließslich der Mefafeier diente, d. i. nach Einführung des liturgischen Pluviales.

Gegenwärtig heist das Mekgewand nur noch planeta (ital. pianeta) und casula (Kasel, holl. casuifel, franz. chasuble, engl. chasuble, span. casulla).

Die Etymologie des Wortes planeta ist dunkel. Isidor bemerkt bezüglich seines Ursprungs: Graeci planetas dictos volunt, quia oris errantibus evagantur. Unde et stellae planetae $i$. e. vagae suo errore motuque discurrunt ${ }^{1}$. Danach wäre der Name vom griechischen tiavàin (errare, umherirren, umherschweifen) abzuleiten, und hatte das Gewand seine Benennung von dem Umstand, dak wegen der Stofffülle der Saum des Kleides gleichsam in regellosen Falten den Körper umirrte. Die Erklärung Isidors schmeckt jedoch zu sehr nach jener sonderbaren Deutungsweise, die man auf Schritt und Tritt bei ihm antrifft. Man hat darum neuerdings gemeint, es sei, weil die

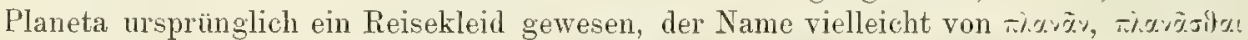
im Sinne von "reisen, umherziehen" abzuleiten. Dagegen ist indessen zu erinnern,

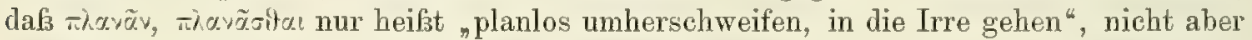
umherreisen. Auch kommt die Bezeichnung planeta erst auf, als das Gewand schon längst nicht mehr Reisegewand war. Man wird deshalb auch diesen Deutungsversuch, der scheinbar den Ursprung des Namens in einfachster Weise erklärt, auf sich heruhen lassen müssen. Eigentümlich ist, daf bei den Griechen planeta nie als Bezeichnung des Meßgewandes in Gebrauch war und ein von $\pi \lambda \alpha v a \tilde{\sigma}$ ila? gebildetes Wort bei ihnen überhaupt als Kleidername nicht vorkommt. Sie nannten das der planeta entsprechende Gewand siónos (

Was die Etymologie des Wortes casula anlangt, so leitet Isidor dasselbe von casa ab. Casula... dicta per diminutionem a casa quasi minor casa?. Casula würde also Häuschen, Hüttchen bedeuten. Die Erklärung Isidors schliefst sich an die Form des Gewandes an und klingt durchaus wahrscheinlich. Die Kasel bildete in ihrer ursprünglichen Gestalt in der Tat ein "Hüttchen", weil sie den Träger ringsum völlig umgab und nur für den Kopf einen Durchschlupf hatte.

Sehr bemerkenswert ist das Verhältnis, in welchem die beiden Bezeichnungen planeta und casula zueinander stehen. Planeta ist der eigentlich römische, casula der auferrömische Name des Gewandes. So war es indessen von jeher. Nirgends stölist man in den älteren römischen Ordines auf die Bezeichnung casula. Aber auch sonst kommt der Name, und zwar nicht blof in römischen, sondern überhaupt in italienischen Quellen, bis zur Wende des Jahrtausends nur ausnahmsweise vor. Erst seit dieser Zeit gelangte er in Italien zu größserer Verbreitung, doch hat er niemals daselbst die alte Bezeichnung aus ihrer bevorzugten Stellung verdrängen können. In den römischen Ordines des 2. Jahrtausends erscheint selbst bis ins späte Mittelalter hinein planeta stets als die vornehmste Benennung unseres Gewandes. Unter dem Namen planeta tritt es auch in der Chronik voll Monte Cassino, dem Schatzverzeichnisse von Anagni und den Inventaren der Peterskirche aus den Jahren $1303,1361,1436,1454-1455$ und 1489 und andern italienischen Schatzverzeichnissen auf. In der neueren Zeit erhielt das Wort sogar durch die Aufnahme ins römische Missale und das Caeremoniale der Bischöfe gewissermaken einen offiziellen Charakter. Noch jetzt ist in Italien "piancta" die allein gebråuchliche Bezeichnung des Mefagewandes.

Umgekehrt treffen wir außerhalb Roms seit alters nur sehr selten den Namen planeta an. Es ist eine Ausnahme, wenn das Gewand im 28. Kanon des vierten Konzils von Toledo planeta heibt ${ }^{3}$. In der Schenkungsurkunde Adel-

1 Etymol. 1. 19, c. 24 (M. 82, 691). ${ }^{2}$ Ebd. ${ }^{3} \mathrm{H}$ ard. III 586. 
gasters von Asturien aus dem Jahre 781 wird es wie sonst überall casula genannt 2 . Bei den gallischen Schriftstellern der vorkarolingischen Zeit begegnet uns nie die Bezeichnung planeta. Wenn bei ihnen vom Mefigewand die Rede ist, wird es entweder amphibalus oder casula genannt. Auch als die karolingische Reform den römischen Ritus zu den Franken brachte, blieb der Name casula vor wie nach herrschend. Bei Hraban, Amalar, Walafried, Pseudo-Alkuin und Pseudo-Beda, in der aus dem Frankenreich stammenden Synodalermahnumg, bei Regino von Prüm, Riculf von Soissons, Riculf von Eilne, in den Inventaren von St-Riquier und in andern Inventaren der Karolingerzeit heist das Mefgewand ebenso ausschließlich casula wie in den frühen römischen Ordines planeta. Allerdings gedenken Hraban und Pseudo-Beda im Anschlul an ihn auch des Namens planeta, doch erhellt aus der Weise, in der sie das tun, klar, dali er nicht die bei ihnen gebräuchliche Bezeichnung war: casula, quam Graeci planetam vocant?2. Auch in den aus fränkischen Kirchen stammenden Sakramentaren und Pontifikalien fühnt das Gewand, soweit darin seiner Erwähnung geschieht, regelmä[ỉig, um nicht zu sagen ausnahmslos, den Namen casula.

Seit Beginn des zweiten Jahrtausends wird der Name planeta aufserhalh Roms etwas häufiger, und zwar mögen darauf die Liturgiker des 12. und 13. Jahrhunderts einigen Einfluf ausgeübt haben, doch fand el dort nie gröliere Verbreitung. Gegen Ende des Mittelalters scheint er sogar daselbst wieder fast ganz aufer Gebrauch gewesen zu sein.

Aus dem Gesagten erhellt, daf es nicht zutreffend ist, wenn behauptet wurde: "Seit dem Anfang des 9. Jahrhunderts verschwindet das Wort planeta, und casula wird allgemein." Das Wort casula ist wie mancher sonstige Name liturgischer Gewänder in seinem Ursprung aulierrömisch. Es ist ihn alıer nie wie andern gelungen, in Rom die dort übliche Bezeichnung zu verdrängen und die Alleinherrschaft zu erringen.

Eine mittelalterliche deutsche Bezeichnung des Meligewandes, die noch in dem dänischen messehagel fortlebt, war meszachel (althochd. missahachul, missahahul, missihachel, angelsächs. masse hacele) ${ }^{3}$.

\section{DIE KASEL ALS LITURGISCHES GEWAND.}

Als liturgisches Kleid der spanischen Kirche erscheint unser Gewand unter dem Namen casula schon, wie vorher erwähnt wurde, in der Schenkungsurkunde Adelgasters. Unter der Bezeichnung planeta begegnen wir ihm daselbst in jener Eigenschaft bereits im 28. Kanon des vierten Konzils von Toledo (633): Presbyter... si a gradu suo iniuste deiectus in secunda synodo innocens reperitur, non potest esse, quod fuerat, nisi gradus amissos recipiat coram altario de manu episcopi ... si presbyter, orarium et planetam ... sic et reliqui ea in reparationem sui recipiant, quae, cum ordinarentur, perceperunt. In dem Make galt also damals schon die Planeta als Stück der liturgischen Tracht, dafi die Übergabe derselben einen Bestandteil des Weiheritus bildete und ihre Rückgabe zum Restitutionszeremoniell gehörte. Eigen-

1 Ann. O. S. B. II 255.

2 Die Bemerkung ist ohne allen Zweifel lediglich aus den von Hraban gern benutzten Etymologien Isidors herỉbergenommen.

${ }^{3}$ So in Bertholds von Regenshurg Predigt über die Messe. W a cker nage I, Altdeutsche Predigten (Basel 1876) 70. Das Wort Messachel
(- Melmantel) ist aus missa und dem althochdeutschen hachul, Mantel, gebildet. Bei Ulfilas ist 2 Tim 4, 13 das griechische yehóm mit hakul wiedergegeben (Heine, Ulfilas, Paderborn 1878, 210). Vgl. auch E. G. Graff, Althochdeutscher Sprachschatz (Berlin 1838) unter hachul IV 797. 
tümlich ist, dalỏ Isidor von Sevilla, der doch auf jener Synode den Vorsitz führte, in seinen Etymologien der liturgischen Verwendung der Kasel bzw. Planeta bei Erklärung dieser Namen mit keinem Wort Erwähnung tut. Der Grund hierfür mag in dem Umstand liegen, dals in jener Zeit unser Gewand in Spanien noch nicht ein ausschlieflich liturgisches Kleid war. Vielleicht aber auch, dalis Isidor darum vom Kultcharakter der casula und planeta schweigt, weil er die Erläuterung dieser wie so mancher andern Worte unverändert aus älteren Scholiasten herübernahm.

Daß3 in Gallien unter der Herrschaft des gallikanischen Ritus auch eine Kasel zur Meß̧kleidung des Priesters gehörte, beweist die gallikanische ILel3erklärung: casula, quam amphibalum vocant, quod (sic) sacerdos induitur. Nach den Angaben, welche sie von dieser casula macht, kann dieselbe sich in der Form weder von der Planeta, wie sie uns durch die römischen und ravennatischen Mosaiken des 6 . und der folgenden Jahrhunderte bekannt ist, noch von dem Mefgewand, wie es uns die älteren mittelalterlichen Liturgiker beschreiben, wesentlich unterschieden haben. Die Kasel der gallikanischen Mefoerklärung ist nämlich ein Umwurf und setzt somit ein Unterkleid voraus; vorn ist sie nicht offen, sondern geschlossen; weiterhin hat sie weder seitliche Schlitze noch Ärmel (unita utrinsecus, non scissa, non aperta; tota unita, sine manicis). Bezeichnend für den liturgischen Charakter des gallikanischen Mefamphibalus ist die allerdings auf verkehrter Voraussetzung beruhende Anmerkung der Meferklärung: "Die Kasel ist, wie man sagt, von dem Gesetzgeber Moses zuerst angeordnet worden. Der Herr befahl nämlich, ein verschiedenes Gewand anzufertigen, damit der Priester ein solches anziehe, wie es das Volk nicht anzuziehen wage."

Auch sonst hören wir vom gottesdienstlichen Gebrauch einer Kasel bzw. eines Amphibalus in Gallien. So erzählt Gregor von Tours von casulae candidae, quae per festa paschalia humeris sacerdotum imponuntur ${ }^{1}$, und Cyprian in der Vita des hl. Cäsarius von Arles von einer casula processoria ${ }^{2}$, d. i. einer Kasel, die bei Prozessionen und der Messe gebraucht wurde. Ein Amphibalus begegnet uns im Sinne eines Meligewandes bei Sulpicius Severus, Paulinus von Périgueux und Venantius Fortunatus ${ }^{3}$. Er muf nach den Umständen der hier berichteten Begebenheit ein weiter, langer, rings geschlossener Mantel und somit dasselbe Gewand gewesen sein, welches auch in der gallikanischen Meferklärung casula und amphibalus heifit. Die Kasel kam also schon gegen Ende des 4. Jahrhunderts in Gallien als Obergewand beim heiligen Opfer zur Verwendung.

Aus der nordafrikanischen Kirche besitzen wir unseres Wissens kein Zeugnis, welches bewiese, dafs allda die Kasel bzw. Planeta in der uns beschäftigenden Zeit als Meøgewand gebraucht worden sei. Beim hl. Augustinus

1 Vita PP. c. 8, n. 5 (M. 71, 1045).

2 L. 1, n. 32 (M. 67, 1017). Als Bestandteil der gewöhnlichen klerikalen Tracht erscheint die Kasel 1. 2, n. 23 (ebd. 1036), ferner Vita S. Medardi n. 2 (M. 88, 535) und Test. S. Caesarii Arel. (M. 67, 1140): casula villosa, zottige Kasel. Eine casula holoserica sed caprina lanugine mixta sandte Bonifatius, der Apostel Deutschlands, ca 742 dem Bischof Daniel von Winchester (Ep. 63 [M. G.
Epp.3,330]). Ob es sich hier um einebloß klerjkale oder um eine liturgische Kasel handelt, ist nicht klar. Der Stoff des Gewandes dürfte auf eine Meßskasel hindeuten.

${ }^{3}$ S. oben S. 67 . Die spätere Legende schmückte die Begebenheit aus, indem sie hinzudichtete, es sei ein Engel in der Messe erschienen, welcher mit goldenen Stauchen die infolge dex Kürze der Tunikaärmel entblölisten Arme des Heiligen zum Lohn hedeckt habe. 
erscheint die casula einmal als Kleidungsstück eines armen Handwerker's . ein anderes Mal als Gewand des täglichen Lebens ohne nähere Bestimmung seines Charakters ${ }^{2}$, bei Prokop als eine bei Militärpersonen ungebräuchliche Zivilistentracht, deren sich die Sklaven und gewöhnlichen Bürger hedienten ${ }^{3}$. In der Biographie des hl. Fulgentius ist eine planeta Obergewand (Mantel) vornehmer Leute, eine casula Oberkleid des Bischofs Fulgentius, der in seinem Hirtenamt die Mönchstracht beibehalten hatte, sowie seiner Mönche ${ }^{\ddagger}$. Von einem liturgischen Charakter der Kasel bzw. Planeta oder doch wenigstens ihrer Verwertung bei der Liturgie erfahren wir nichts.

Daßs zu Rom im 8. Jahrhundert die Planeta zu den liturgischen Gewändern zählte, ersehen wir aus dem 1. und 8. römischen Ordo. In jenem begegnet sie uns als liturgisches Gewand des Papstes und der Subdiakone, in diesem als das der Priester. Für die frühere Zeit fehlen bestimmte schriftliche Nachrichten über eine liturgische Planeta in der römischen Kirche. Wohl erzählt uns Johannes Diakonus in der Vita S. Gregorii M. von planetati, die sich bei einem feierlichen Aufzuge im Gefolge des Papstes Gregor d. Gr. befanden ${ }^{5}$. Allein wenn auch unter ihnen römische Kleriker in der Planeta zu verstehen sind, so braucht doch die Planeta, mit welcher diese bekleidet aufzogen, nicht als ein liturgisches Gewand angesehen zu werden; denn nach dem 1. Ordo musten die Diakone, welche den Papst zur Kirche geleitet hatten, vor dem Sekretarium, ähnlich wie der Pontifex selbst in demselben ${ }^{6}$, die Kleider, welche sie auf dem Wege getragen, mit andern - liturgischen -- vertauschen. Auch ist es nicht unwahrscheinlich, daf Johannes Diakonus blof dem Brauch seiner Zeit gemäl3 sich ausdrückt, wenn er von planetati spricht. Jedenfalls war zu Gregors d. Gr. Zeit in Rom die Planeta noch nicht ausschlielilich liturgisches Gewand. Der Biograph des Papstes erzählt nämlich 7, es habe dieser im Atrium des Klosters zum hl. Andreas zwei Bilder kunstreich malen lassen, die noch zu des Schreibers Zeit vorhanden waren. Das eine stellte den regionarius Gordianus, den Vater Gregors, stehend neben dem sitzenden hl. Petrus, das andere die Mutter des Heiligen, namens Silvia, dar. Gordianus war aber auf dem Bilde aufer mit caligae (hier wohl Senatorenschuhen) und der Dalmatik mit einer kastanienfarbigen Planeta bekleidet. Hiernach gehörte also noch zur Zeit Gregors d. Gr. die Planeta in Rom zur Laientracht; denn für die Annahme, Gordianus sei römischer Kleriker gewesen und darum mit Dalmatik und Planeta auf jenem Bilde dargestellt, fehlt die hinreichende Begründung.

Als Gewand eines persischen Abtes ${ }^{8}$, der nach Rom gekommen war, und als Kleid eines römischen Mönches ${ }^{9}$ erscheint eine casula in des Johannes Diakonus Vita Gregors d. Gr. Inwieweit allerdings der Gebrauch der Kasel seitens der Mönche, wie er an beiden Stellen zum Ausdruck kommt, nicht blob dem 9. Jahrhundert, der Zeit der Entstehung der Vita, sondern auch den Tagen Gregors d. Gr. selbst entspricht, muf dahingestellt bleiben ${ }^{10}$. Die beiden Erzählungen, in denen bei Johannes Diakonus die Kasel eine Rolle

1 A ugustin., De civ. Dei 1. 22, c. 8, n. 9 (M. 41, 765).

2 Ders., Sermo 107, c. 5 (M. 38, 630).

${ }^{3}$ Procop., De bello vandalico II, c. 26.

1 Vita S. Fulgentii c. 1829 (M. 65, 136 146).

5 L. 2, n. 43 (M. 75, 104).

${ }^{6}$ N. 5 (ebd. 939): Diaconi... egrediuntur secretarium et ante fores eiusdem mutant vestimenta sua; n. 6 : Pontifex mutat vestimenta sua.

7 Vita S. Gregor. 1. 4, n. 83 (M. 75, 229).

8 L. 4 , ฉ. 63 (M. 75, 213).

๑ L. 2, n. 45 (ebd. 106).

10 Von planeticae ist bei Cassian (De habitu monach. 1. 1, c. 7 [M. 49, 71]) die Rede, doch 
spielt, sind dem Pratum spirituale des Moschos entnommen ${ }^{1}$. In diesem aber ist im zweiten Fall nicht ron einer casula, sondern ron einer tunica die Rede, im ersten findet sich in ihm statt der casula des Biographen Gregors d. Gr.

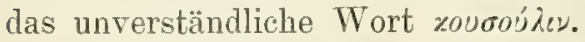

Wie für Rom, so ist auch für die andern Kirchen Italiens die liturgische Verwendung der Planeta im 7. und den vorhergehenden Jahrhunderten schriftlich nicht bezeugt. Nichtsdestoweniger kann es angesichts der bildlichen Darstellungen des 5., 6. und 7. Jahrhunderts keinem Zweifel unterliegen, daf damals in Italien, sowohl in Rom wie a u fierhalb Roms, die Planeta einen Bestandteil der Mefsgewandung bildete.

Das alteste der hier in Betracht kommenden Monumente sind die Mosaiken in der Kapelle des hl. Satyrus bei der Kirche des hl. Ambrosius zu Mailand ${ }^{2}$. Noch dem

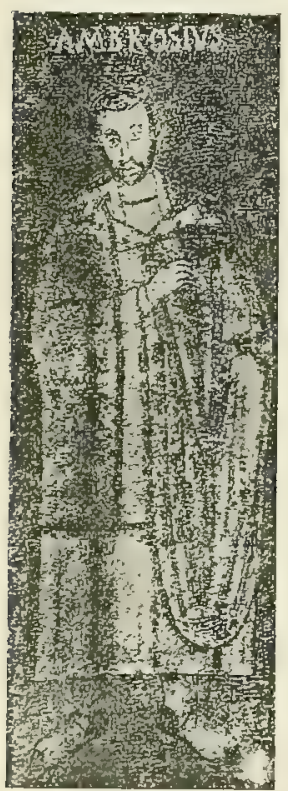

Bild 62.

HI. Ambrosius. Mrosaik, Mailand, S. Satiro. 5. Jahrhundert entstammend, stellen sie unter andern die hll. Maternus und Ambrosius in Dalmatik und Planeta dar (Bild 62). Thnen würden in Rom die musivischen Darstellungen in S. Cosma e Damiano der Zeit nach zunächst stehen, wenn die Figur des Papstes Felix III. (526-530), welche auf denselben mit der Planeta bekleidet erscheint, sich noch in ihrem anfänglichen Zustande befände; leider kann sie infolge der vorgenommenen Veränderungen nicht mehr als ursprünglich angesehen werden. Von größerer Bedeutung ist daher das noch der ersten Hälfte des 6. Jahrbunderts angehörige bekannte Mosaikbild in S. Vitale zu Ravenna ${ }^{3}$, welches den Erzbischof Maximianus mit seinen Klerikern in dem Augenblick darstellt, da er den Kaiser Justinian, den ein reiches Gefolge umgibt, am Portal der Kirche empfängt und ins Gotteshaus geleitet (Bild 63). Die Diakone Maximians sind mit Dalmatiken bekleidet. Der Bischof selbst trägt über der lang- und weitärmeligen, mit dem Clavus ausgestatteten Dalmatik noch eine Planeta und das erzbischöfliche Pallium. In der letzten Hälfte desselben Jahrhunderts entstanden auch in S. Apollinare in Classe musivische Darstellungen, welche vier Bischöfe in der Planeta aufweisen :. Es sind dies die ravennatischen Erzbischöfe Ecclesius, Severus, Ursus und Ursicinus. Auch diese tragen gerade wie Maximian in S. Vitale Dalmatik, Planeta und Pallium. Die Rechte zum Segen oder Redegestus erhoben, haben sie in der vom Obergewand verhüllten Linken das Evangelienbuch. Zu den für die Geschichte der Planeta wichtigen Bildwerken des 6. Jahrhunderts muß ferner ein Gemälde gerechnet werden, welches zwar nicht mehr vorhanden ist, das uns aber durch den Bericht eines Augenzeugen, des Johannes Diakonus, bekannt ist ${ }^{5}$. Im Kloster des hl. Andreas zu Rom betindlich, stellte es Papst Gregor d. Gr. in Dalmatik, Planeta und Pallium dar. In der Linken hielt der Papst ein Evangelienbuch, mit der Rechten machte er das Zeichen des heiligen Kreuzes ${ }^{6}$. Nach Angabe des Erzählers war das Bild, das in einer rota gypsea, in einem Nedaillon aus Gipsstuck, angebracht war, noch zu Lebzeiten des Papstes entstanden.

ist unter ihnen kein liturgisches, nicht einmal ein spezifisch klerikales Gewand verstanden. Cassian belehrt uns, dalis die Mönche (Ägyptens) keine planeticae trugen, sondern sich mit einem Umschlagtuch begnügten. Die planeticae sind ohne Zweifel identisch mit den planetae, welche Isidor von Sevilla in seinen Mönchsregeln den Mönchen zu tragen untersagt (c. 12 [M. 83, 882 J).

1 C. $151190($ H. $57,3018: 3072)$.
2 Garr. IV, tav. 236.

3 Ebd. tav. 264. Ebd. tav. 267.

5 I o an. D i a c. a. a. O. 1. 4, n. 84 (M. $75,231)$.

${ }^{6}$ Besser ist vielleicht die Angabe des Johannes Diakonus dahin $z u$ berichtigen, es habe der Papst mit der Rechten den Redegestus gemacht. Redegestus und Segensgestus sind auf den altchristlichen Monumenten uicht oder kaum unterscheidhar. 
Aus dem 7. Jahrhundert entstammen die römischen Mosaiken in S. Agnese fuori le Mura (Bild 64, S. 160) und im Oratorium des hl. Venantius bei der lateranensischen Taufkirche ${ }^{1}$. Auf jenen sind die Päpste Honorius I. und Symmachus, auf diesen Johannes IV. mit seinem Nachfolger Theodorus, die heiligen Bischöfe V'enantius und Maurus und der Presbyter Asterius mit der Planeta ausgestattet.

Dem 7. Jahrhundert, vielleicht sogar dem 6., mag auch noch ein Fresko in der Katakombe des Ponzian angehören, welches den hl. Vincentius als Priester in gelbbrauner Planeta darstellt ${ }^{2}$. $\mathrm{Ob}$ und inwieweit die mit der Planeta bekleideten Bilder der heiligen I'äpste Kornelius und Sixtus II. und der heiligen Bischöfe Cyprian und Optatus in der Korneliusgruft, wie Wilpert will, noch dem 6. Jahrhundert zuzuschreiben sind, mag auf sich beruhen bleiben ${ }^{3}$.

Der Umstand, daßs die Bischöfe und Priester auf den italienischen Bildwerken des 6. und 7. Jahrhunderts regelmäßig in der Planeta dargestellt sind, läßst keinen Zweifel daran übrig, daß diese damals in Italien zur liturgischen Tracht gehörte.

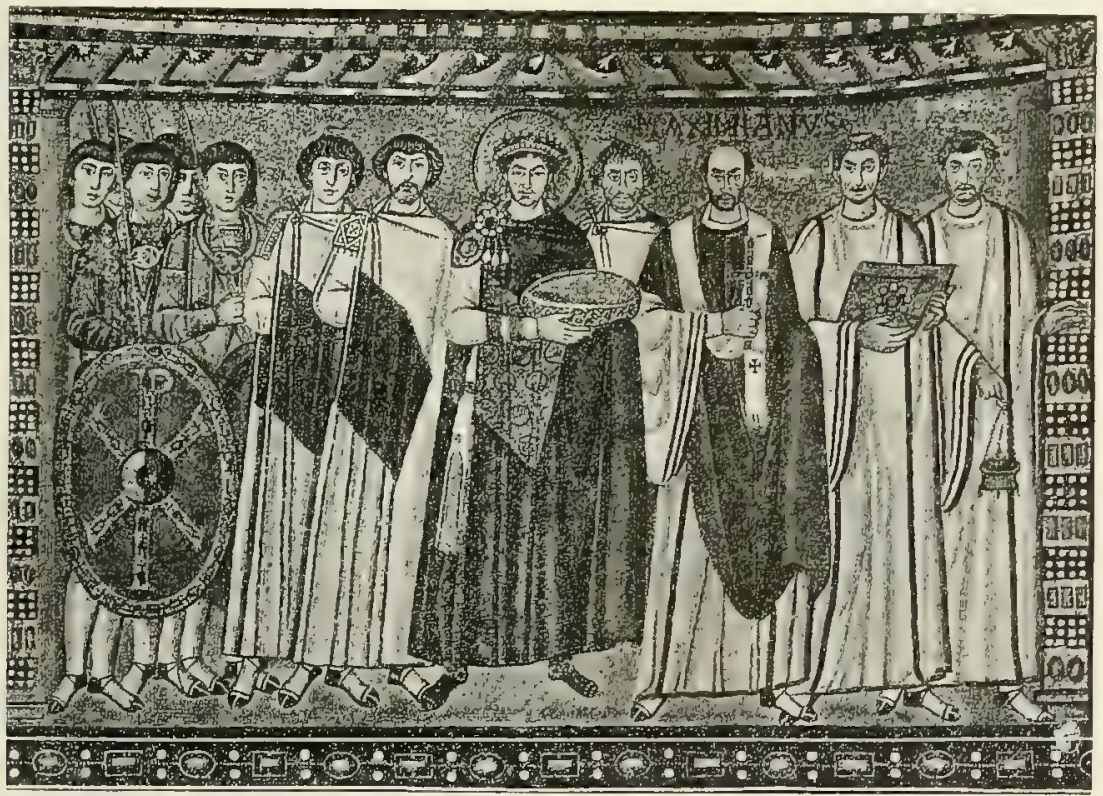

Bild 6.3. Kaiser Justinian mit Erzbischof Maximian und Gefolge.

Mosaik, Ravenna, s. Vitale, (Phot. Alinari.)

In der Folge ist es ja allgemeine Sitte, die Kleriker auf den Bildwerken in den Gewändern darzustellen, welche am meisten den jeweiligen Weiherang der abzubililenden Personen kennzeichnen, $d$. $i$. in den liturgischen. Warum sollen wir also für das 6. und 7. Jahrhundert eine andere Darstellungsweise annehmen?

Auferdem sind ja auch die Päpste und Bischöfe der römischen und ravennatischen Mosaiken über der Dalmatik und der Planeta mit dem Pallium ausgerüstet. Dieses aber galt nach römischer Anschauung als durchaus liturgisches Ornatstück ${ }^{+}$ Haben wir aber das Pallium, mit dem jene Personen versehen sind, als Sakralgewand anzusehen, warum dann nicht auch ihre Planeta?

I Garx. IV, tav. 272 274; besser bei de Rossi, Mus. fasc. 341314.

2 Wilp., Kat. TH 258.

3 Ebd. Tfl 256; dazu Textband 502 f. Was hier Wilpert zul Begründung seiner Ansicht anfiihnt, ist wohl nicht ausreichend, um die
Fresken der zweiten Hälfte des 6. Jahrhunderts zuschreiben zu können. Die Fransen an den Ärmeln und der Seite der Dalmatil scheinen vielmehr auf eine spätere Zeit hinzuweisen.

* Vgl. das Kapitel ïber das Pallizm. 
Dazu kommt, daf̧ die Päpste und Bischöfe auf den musivischen Darstellungen, wenn sie auch nirgends bei einer liturgischen Funktion beschätigt sind, so doch das Evangeliar oder das Kreuz tragen. Es weist das darauf hin, dak wir sie uns nicht als im alltäglichen Leben sich bewegend, sondern so zu denken haben, wie sie bei den heiligen Amtsverrichtungen zu erscheinen pflegten, d. i. in ihren Sakralgewändern, und daßs also auch die Planeta zu denselben zählte.

Nehmen wir endlich hinzu, daß im 8. Jahrhundert die Planeta in Rom Sakralkleid war, daß sie in Spanien als solches schon für das 7. Jahrhundert bezeugt ist, daß in Gallien der Amphibalus selbst schon im 4. Jahrhundert bei der Feier der Liturgie verwendet wurde, und beachten wir weiterhin, daf nach römischer sitte zum Feieranzug stets ein Obergewand gehört und darum auch die Bischöfe im 6. und 7. Jahrhundert nicht ohne solches zelebriert haben werden, dann ist es kein Zweifel, dafo die Planeta auf den mailändischen, römischen und ravennatischen MIosaiken, welche die

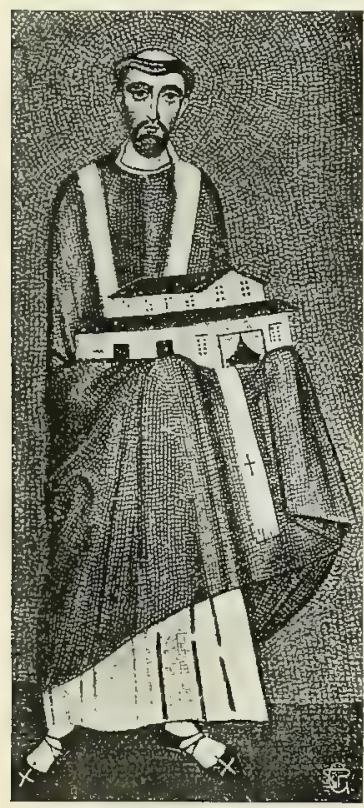

Bild 64. Papst Honorius I. Mosaik. Rom, S. Agnese. (Natli de Rossi.) Päpste und Bischöfe als planetati darstellen, die beim Gottesdienst gebräuchliche Planeta wiedergibt.

Fassen wir das Gesagte zusammen, so ergibt sich, daf wenigstens schon um die Wende des 4. Jahrhunderts die Planeta (die Kasel, der Amphibalus) in der Westkirche als Obergewand in liturgischen Diensten stand, allerdings nicht ausschlieflich, wie heutzutage. Denn Laientracht war sie verschiedenenorts noch gegen 600, wenn nicht noch länger. Als Mönchstracht begegnet sie uns im 6. Jahrhundert in Afrika und noch im 9. Jahrhundert bei Johannes Diakonus. Einen Teil der gewöhnlichen klerikalen Tracht bildete sie aber, wenn auch vielleicht nicht überall im Abendland, noch im 8. Jahrhundert, wie aus einer Verordnung des deutschen Nationalkonzils vom Jahre 742 und dem 3. und 8. Kapitel der Regel Chrodegangs hervorgeht.

Das aeutsche Nationalkonzil, welches unter dem Vorsitz des hl. Bonifatius gefeiert wurde, bestimmt, es sollten die Priester und Diakone nicht wie die Laien das sagum, sondern Kaseln nach Sitte der Diener Gottes (ritu servorum Dei), d. i., wie aus der Einleitung der Synodalakten hervorgeht, der Kleriker, tragen ". Das 3. und 8. Kapitel der Regel Chrodegangs aber besagen ${ }^{2}$ : Wer aus dem Klerus innerhalb der Klausur einen Kleriker bei sich habe - nämlich zur Bedienung -- , der solle dafür sorgen, daß dieser eine Planeta samt den übrigen Gewändern besitze, damit er an Sonnund Festtagen in der ihm geziemenden Tracht im Gotteshause sich einfinden könne; die Kleriker aber, welche außethalb des Klosters in der Stadt ihren Aufenthalt hätten, sollten an allen Sonntagen mit der Planeta bzw. ihren Amtskleidern gemäf dem Ordo romanus zum Kapitel kommen. Die letzte Bestimmung ist darum besonders interessant, weil sie zeigt, daß a uch nach römischem Brauche damals die Planeta ihren auferliturgischen Charakter noch nicht ganz verloren hatte.

\section{DIE KASEL BEI DEN SUBDIAKONEN UND MINORISTEN.}

Als liturgisches Gewand befand sich im 8. und 9. Jahrhundert und zum Teil noch längere Zeit nachher die Kasel nicht blob im Dienst des zelebrierenden Priesters, sondern überhaupt aller Kleriker. Sie war demnach in jener

1 C. 7 (M. G. Conc. II, 4).

2 Ebd. 1100 1102. Vgl. auch das S. 153 über den klerikalen Amphibalus Gesagte. 
Zeit im Unterschied von der späteren Praxis noch nicht ausschlieklich priesterliches Mefgewand. Die Sache mag heute auffallend erscheinen; sie ist aber, wenigstens für die römische Kirche bzw. den römischen Ritus, nicht zu bezweifeln.

Den Beweis liefern die römischen Ordines. Man durchgehe nur den 1. Ordo Mabillons. Da empfängt nach dem Evangelium der subdiaconus sequens das Evangelienbuch und reicht es dem Zelebranten zum Kusse hin, indem er es vor seiner Brust auf der Planeta hält; derselbe Subdiakon nimmt später die Patene, die bis dahin der Akolyth getragen, super planetam, der Regionarsubdiakon aber hat die Mappula des Pontifex, bevor er sie diesem übergibt, auf dem linken Arm über der zurückgerollten Planeta liegen. Als liturgisches Kleid der Akolythen erscheint unser Gewand im 1. Ordo, wenn es heifst: "Derjenige, welcher das Evangelium lesen wird, bereitet das Evangeliar nach Brechung des Siegels - das Evangelienbuch befand sich in einem versiegelten Behälter -- auf der Planeta tines Akolythen, oder, wenn es wegen größerer Bücher notwendig sein sollte, während zwei Akolythen es auf den Planeten halten." Auf seiner Planeta trágt ferner ein Akolyth das Evangeliar, das für die Lesung zurecht gemacht war, zum Altar; auf der Planeta hält er später auch den Scyphus, ein gröferes, becherartiges Gefüf, in welches der Opferwein gegossen wurde. Als liturgisches Gewand der Diakone erscheint die Planeta im 1. Urdo nicht; diese tragen sie zwar, wenn sie mit dem Pontifex zum Altare ziehen; sind sie aber im Presbyterium angekommen, so müssen sie dieselbe ablegen (priusquam veniant ante altare, diacones in presbyterio exuuntur planetis). Dagegen ist der Primicerius nach dem 1. Ordo mit der Planeta ausgestattet 1.

Als liturgisches Kleid des Subdiakons erscheint die Planeta auch noch im 2. Ordo ${ }^{2}$ mehrfach und einmal wohl eingangs des 3. Ordo ${ }^{3}$. Als Sakralkleidung des Akolythen begegnet sie uns im 2. Ordo einmal ${ }^{4}$, im 3, aber gar nicht. Nach dem St Gallener Kleiderkatalog ${ }^{5}$ bildet die Planeta einen Teil der liturgischen Kleidung des Papstes, der Hebdomadarbischöfe und der römischen Presbyter. Der Diakon trügt sie nur, usque dum venitur presbyterio, wo ein Akolyth sie ihm abnimmt. Unter der Gewandung des Subdiakons wird sie allda nicht mehr genannt, wohl aber dem Akolythen mit dem Bemerken zugeschrieben, wenn er am Lesepult psalliere, habe er sie abzulegen (et quando in gradu psallitur, planeta abstollitur). Auch der 1. Ordo sagt bezüglich des Klerikers, der am Karsamstag nach der Kerzenweihe die Lektionen zu singen hatte ${ }^{6}$ : Lector exuit se casula. Aus dem 8. Ordo ersehen wir, dak den Akolythen die Planeta bei der Weihe angezogen, den zu Diakonen zu Ordinierenden aber bei derselben ausgezogen wurde?

Wie lange in der römischen Kirche die Gepflogenheit sich erhalten habe, die Akolythen und Subdiakone bei der heiligen Messe mit Kaseln bekleidet amtieren zu lassen, läßst sich nicht genau bestimmen. Bei den Subdiakonen hörte sie auf, das gew öhnliche liturgische Obergewand zu sein, seitdem dieselben nach Weise der Diakone mit einer besondern Obertunika, der späteren Tunicella, ausgestattet zu sein pflegten. Wir haben uns diesen Wechsel indessen wohl nicht so zu denken, als ob die Sache mit einem Schlage geändert worden wäre. Wahrscheinlich vollzog er sich in der Weise, dafo zunächst den Subdiakonen nur für bestimmte höhere Feste die der Dalmatik ähnliche Obertunika anstatt der Planeta zugestanden, dann aber ihnen deren Verwendung allmählich auch für andere Tage gestattet wurde, bis das Gewand zuletzt das gewöhnliche Obergewand der Subdiakone an Stelle der ihnen vordem eigenen Kasel geworden war.
1 N. 57810191720 (M. 78, 939 ff).
2 N. 38 (ebd. 969 972).
${ }^{3}$ N. 5 (ebd. 978).
4 N. 2 (ebd. 969).
6 N. 40 (ebd. 955).
'N. 13 (ebd. 1000 1001).
5 Ebd. 985.

Braun, Die liturgische Gewandung. 
Um das Ende des 8. und den Beginn des 9. Jahrhunderts war die Planeta in Rom noch das gewöhnliche Amtskleid der Subdiakone. Denn so muls noch Amalar bei seinem damaligen römischen Aufenthalt die Lage der Dinge gefunden haben, da er in seiner Darstellung des römischen Ritus schreibt, es komme die Kiasel allen Klerikern insgemein zu. Der Wechsel scheint etwa seit der Mitte des 9. Jahrhunderts vor sich gegangen zu sein. Jedenfalls war er um die Wende des Jahrtausends schon vollendete Tatsache geworden.

Doch auch bei den Akolythen hat der Gebrauch der Kasel das erste Jahrtausend, wie es scheint, kaum überdauert. Wir hören allerdings von ihr als der Tracht der Leuchter- und Weihrauchfaßträger noch im 6. Ordo ${ }^{1}$. Ebenso tragen noch nach dem von Hittorp herausgegebenen Ordo officiorum eine Kasel die Akolythen, welche nach der Feier am Gründonnerstag die Altäre entblößen 2. Allein es ist sehr unsicher, ob und inwieweit der 6. Ordo und der Ordo officiorum in dieser Beziehung nicht blof den auferrömischen, sondern auch den römischen Brauch wiedergeben.

Daf im 9. Jahrhundert auch auferhalb Roms die Kasel den Minoristen als liturgisches Bekleidungsstück diente, erfahren wir mit aller Bestimmtheit von Amalar, der sie als das generale indumentum bezeichnet und von ihr sagt: pertinet generaliter ad omnes clericos ${ }^{3}$. Seine Angabe erhält eine Bestätigung durch eine interessante Notiz der ,Geschichte der Übertragung der heiligen Märtyrer Chysanthus und Daria“, die vielleicht ein Werk Markwards von Prüm († 853) ist, jedenfalls aber der Zeit der Translatio unter Lothar im Jahre 844 nahe steht. "Es ist Ortsgebrauch", so lesen wir hier, „daf auf Ostern die Kleriker bei den Vespern dieselbe Kleidung tragen, die sie sonst bei der Messe anziehen. Nun geschah es, dafis der custos - der Kleriker, der die Küsterdienste versah - , nach Sitte wie die andern gekleidet, in die Kirche ging, um die Lampen anzuzünden. Als er aber etwas unvorsichtig: zu Werke ging und unter den Lampen stand, flof das öl einer derselben heraus und beschmutzte einen Teil der Planeta, mit der er gerade bekleidet war." $*$ Der Ortsgebrauch bestand darin, daf Ostern alle Kleriker auch bei dem Abendgottesdienst die Planeta trugen, nicht aber darin, daf an diesem Tage auch die niedern Geistlichen sich ihrer bei der Messe bedienten. Das erscheint in der Erzählung vielmehr als etwas Gewöhnliches.

Es muf auferhalb Roms selbst noch im 10. und 11. Jahrhundert verschiedenenorts die Kasel bei den Akolythen in Gebrauch gewesen sein. Der viel verbreitete 6 . Ordo und der Ordo vulgatus officiorum Hittorps bekunden das. Es waren indessen wohl meist nur auliergewöhnliche Gelegenheiten, bei denen jene rlie Kasel anzogen. So ist in einem Pontifikale von Poitiers, das Martène dem 10. Jahrhundert zuschreibt, in den Rubriken der Ölweihe am Gründonnerstag von einer Planeta der Akolythen die Rede: Subdiaconus tradit (ampullam) acolytho, qui super lineam indutus planeta rotunda atque mundissima desuper sindone amicitur ${ }^{5}$. Eine andere Gelegenheit waren die Karfreitagszeremonien und die Entblöbung der Altäre am Gründonnerstag ${ }^{6}$.

1 N. 1 (M. 78, 989).

2 Hitt. 6468 .

3 De ecclesiast. off. 1. 2, c. 19 (M. 105 , 1095); cf. 1. 3, c. 15 (ebd. 1122): Ministri casula se exuunt, quando lectoris sive cantoris officium assumunt ... albam sine casula portat lector seu cantor in singulari officio.
1 Hist. Translat. SS. mm. Chrys. et Dar. n. 27 (A. SS. O. S. B. IV 1; V 582).

Mart. 1. 4, c. 22; III 106.

${ }_{6} \mathrm{Vgl}$. auch bei W arre $\mathbf{n}$, Leofric Missal 261 die Rubriken für Gründonnerstag und Karfreitag, eine Interpolation des 11. Jahr. hunderts. 
Auch war es nach dem 6. Ordo noch hie und da Brauch, daf an Festtagen alle im Chor Anwesenden Kaseln trugen: Et cum tintinnabulum ad tertiam sonuerit, omnes simul fratres in chorum ordinatim convenire debent, humeralibus et albis, apud quosdam autem casulis induti.

\section{DIE KASEL BEI DEN DIAKONEN.}

Die Verwendung der Planeta von seiten der Diakone war schon vor dem 5. Jahrhundert, d. i. seitdem die Dalmatik ihr Antsgewand geworden, in Rom natürlich nur mehr Ausnahme. Wohl trugen auch sie die Kasel auf dem Wege zur Kirche, ja selbst noch auf dem Wege zum Altare. Doch mubten sie das Gewand, sobald sie ins Presbyterium eintraten, ausziehen und es dem Regionarsubdiakon geben, der es seinerseits wieder den Akolythen der Regio anvertraute, aus der die Diakone kamen ${ }^{1}$.

Beim Gottesdienst selbst trugen die römischen Diakone die Planeta nur an bestimmten Tagen. Doch erhellt aus den Ordines nicht hiureichend, wann und nach welcher Regel solches geschah. Nach dem von Duchesne herausgegebenen Ordo waren die Diakone bei der Bittprozession am Lichtmebtage mit planetae nigrae ausgestattet; bei den grofen Litaneien und hei der Karfreitagsfeier erscheinen sie nach demselben in planetae fuscae 2 . Allem Anschein nach wurde gerade wie später so auch schon im 8. Jahrhundert die Kasel von den römischen Diakonen nur noch in der Fasten- und Adventszeit sowie an andern Bußtagen getragen.

A uferhalb Roms bestand die Sitte, wonach Diakon und Subdiakon an Fasttagen, wofern auf dieselben kein Fest fiel, sich der Kasel statt der Dalmatik bedienten, sicher hie und da bereits im 9. Jahrhundert. Denn sowohl Amalar wie Pseudo-Beda und Pseudo-Alkuin bezengen, daf der Diakon an bestimmten Tagen die Kasel statt der Dalmatik trage ${ }^{3}$. Immerhin kann diese Gepflogenheit im 9. Jahrhundert aufiserhalb Roms nicht sehr verbreitet gewesen sein. Sagt nämlich Amalar, dals der Diakon an einigen Orten von Septuagesima an und in der Adventszeit die Dalmatik nicht gebrauche ${ }^{\sharp}$, so folgt daraus, dafs sich die Diakone zu seiner Zeit für gewöhnlich auch in dieser Zeit der Buße der Dalmatik und nicht der Kasel zu bedienen pflegten. Wo der Brauch in Übung stand, war er sicher aus dem römischen Ritus herübergenommen. Unter der Herrschaft des gallikanischen Ritus hatten im Frankenreiche die Diakone in der Fastenzeit pro humiliatione die Stola ausgelassen.

Die römische Auffassung, wonach die Dalmatik (und entsprechend die subdiakonale Tunicella) Gewänder sind, welche Freude und festliche Stimmung atmen und daher für gewisse Tage als nicht passend erachtet wurden, brach sich seit dem 11. Jahrhundert immer mehr Bahn. Die Praxis, wie sie damals hinsichtlich des Gebrauches von Kasel bzw. Dalmatik und Tunicella an vielen

1 Ordo 1, n. 8 und Ordo 5 , n. 3 (= S. G. K.) (M. 78, 941985 ).

${ }^{2}$ Orjg. 468474 479. Vgl. auch die Angaben Pseudo-Alkuins, nach welchen Pontifex und Klerus am Lichtmefstag zur Bittprozession schwarze Kleider anlegen und am Karfreitag der Archidiakon und die Diakone sich zur Abhaltung der gottesdienstlichen Funktionen mit planetae fuscae ver- sehen mußsten (De offic. div. c. 718 [M. 101, 1181 1208]), desgleichen den Ordo vulgatus bei Hitt. '24 (Lichtmeß) und 71 (Karfreitag).

3 A ma lar., De offic. eccles. 1. 2, c. 21 (M. 105, 1097). Pseudo-Alcuin, De offic. div. c. 39 (M. 101, 1243). Pseudo-Beda, De septem ordinibus (M. 94, 555).

${ }_{4}$ De offic. eccles. 1. 1, c. 1 ; 1. 3, c. 40 (M. 105, 996 1159). 
Orten beobachtet wurde, beschreibt uns Johannes von Avranches mit den Worten: „Im Advent und von Septuagesima bis Gründonnerstag, ferner an den Quatembertagen und bei Totenfeierlichkeiten sollen Diakon und Subdiakon Kaseln anziehen, falls jedoch ein Festtag einfallen sollte, desgleichen am Gründonnerstag und Karsamstag Dalmatik und Tunicella." 1

Allgemein war übrigens der Brauch im 11. Jahrhundert noch keineswegs. Denn der Verfasser des Micrologus, wahrscheinlich Bernold von Konstanz († 1100), bemerkt hinsichtlich desselben ausdrücklich: Quidam infra adventum Domini casulis pro dalmaticis utuntur, quidam more solito vestiuntur. Im Kapitel De septuagesima schreibt er allerdings einfachhin: Abhine usque in coenam Domini Te Deum, Gloria in excelsis, Ite missa est, item dalmaticae et subdiaconalia antiquo more dimittuntur 2. Auch Gilbert von Limerick, der um dieselbe Zeit lebte, lä6t die Diakone blof in der Fastenzeit sich der Kasel anstatt der Dalmatik bedienen ${ }^{3}$. Man unterschied also an verschiedenen Orten in Bezug auf die Benutzung von Dalmatik und Tunicella bzw. Kasel seitens der Diakone zwischen Advent und Fastenzeit und verbannte nur in letzterer, als der Zeit größeren Bußernstes, die Dalmatik und Tunicella aus dem Gebrauch.

In den noch immer sehr unvollständigen Pontifikalien und Missalien des 11. und 12. Jahrhunderts findet sich selten eine Notiz über den Gebrauch der Kasel statt der Dalmatik und Tunika. Höchstens daf in den Rubriken für die Lichtmeßprozession und den Karfreitag sich darüber ein Vermerk findet. Bei Rupert von Deutz ist es schon allgemeine Sitte, daf man im Advent (und natürlich um so mehr in den Fasten) Dalmatik und Tunicella nicht gebrauchte, während er von der Kasel allerdings mit einer, doch wohl nur zeitlichen Einschränkung sagt: Utuntur autem interdum casulis ${ }^{4}$. Ein halbes Säkulum später spricht aber Robert Paululus von der Gepflogenheit, an Bußtagen statt der Dalmatik und Tunika die Kasel zu tragen, ohne Einschränkung ${ }^{5}$. Jedenfalls war dieselbe den Ausführungen zufolge, welche ihr Durandus angedeihen läßst, gegen Ende des 13. Jahrhunderts überall in Übung.

Der Verfasser des Rationale führt eime Reihe von mystischen Gründen an, warum der Diakon und der Subdiakon in der Fasten- und Adventszeit nicht Dalmatik bzw. Tunicella tragen, sondern statt deren die Kasel anlegen ${ }^{6}$.

Unter anderem bemerkt er, es geschehe das, um anzudeuten, es seien die Ministri des Priesters in jenen Tagen zu derselben Vollkommenheit verpflichtet, wozu dieser überhaupt; dann auch, um darauf hinzuweisen, daßs Diakon und Subdiakon aus Liebe dienen sollen, da ja die Kasel die charitas versinnbilde, nicht aher ans Furcht, wie es im Alten Bunde, dem Gesetze der Furcht, cler Fall gewesen, zumal aber zur Zeit des Fastens, das, ohne Liebe geübt, ohne Verdienst bleibe.

Des Durandus Auslegungen sind nichts als mystische Spekulationen. Über den wirklichen geschichtlichen Ursprung des Brauches geben sie keinen Aufschluf.

Einen verständigeren Versuch, ihren Grund zu erklären, hatte schon vorher Rupert gemacht. Er meint, es sei nicht als geziemend angesehen worden, daf die Ministri, welche in den Bufzeiten sich der Dalmatik und Tunicella nicht bedienen dürften, an den Sonntagen und an den einfallenden Festen immuniti, wie er kurz vor-

1 De offic eccles. (M. 147, 38), Vgl. auch W arren, Leofric Missal 261.

2 Micrologus c. 3047 (M. 151, 1003 1012).

3 De statu eccl. (M. 159, 1000).

4 De div, offic. 1. 3, c. 2 (M. 170, 58). Mit dieser letzten Bemerkung will Rupert wohl sagen, daf man die Kasel nur an jenen Tagen der Adventszeit gebrauche, an denen ein Fest bzw. ein Sonntag einfalle.

"De caerim., sacram, et offic. eccles. 1. 3, c. 89 (M. 177, 442).

${ }^{6}$ L. 2 , c. $9 ; 1.3$, c. 11 ; f. 577475. 
her bemerkt, d. i. ohne Obergewand dem Priester am Altare dienten, und darum habe man ihnen denn für die Zeit der Buße zum Ersatz gestattet, die Kasel zu tragen. Allein auch diese Deutung ist, wenn ihr auch ein richtiger Gedanke zu Grunde liegt, nicht befriedigend. Eine eigentümliche Erklärung versucht de Vert, ein geschworener Feind aller mystischen Deutung, der alles, Zeremonien wie Gewänder,

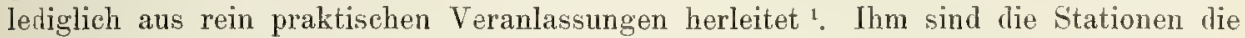
Ursache für die Einführung des fraglichen Gebrauchs. Da diese nämlich, meint er, in Zeiten fielen, in welchen es an schlechtem, unfreundlichem Wetter und häufigen Regenschauern nicht fehle, so hätten die Diakone, welche an ihnen teilzunehmen hatten, es vorgezogen, Dalmatik und Tunika zu Hause zu lassen und sich der Kasel als eines schützenden Mantels zu bedienen. Die Folge hiervon sei aber gewesen, daf sie sich auch bei der Messe in der Stationskirche dieses Gewandes hätten bedienen müssen, da sie ja doch nicht wohl Dalmatik und Tunika hätten mitnehmen können. So aber sei es nach und nach Sitte geworden, daßs die Ministri in der Fasten- und Adventszeit Kaseln trügen. Comme un homme, fügt er zur Erklärung hinzu, marchant par la pluie dans les rues en gros manteau, s'en servirait aussi dans ses visites et ne penserait pas à faire porter avec lui son habillement ordinaire. Die Erklärung de Verts ist nicht zutreffend. Denn erstens trugen die Diakone die Planeta, so oft sie mit dem Pontifex sich zur Kirche begaben, und nicht blof bei schlechtem Wetter. Zweitens aber hatten sie nach dem 1. Ordo vor der Messe die Kleider, welche sie während des Zuges zum Gotteshause getragen, mit andern zu vertauschen.

Der richtige Grund wird, wie schon vorhin angedeutet wurde, in dem Umstand zu suchen sein, daks die Tage, an welchen die Diakone eine dunkelfarbige Planeta trugen, den Charakter der Trauer und der Bußje besafien. Wenn bei den Römern weiße Kleider als Ausdruck der Freude und festlicher Stimmung, als Zeichen der Trauer aber vestes pullae galten, und wenn man deshalb nach römischer Sitte im gewöhnlichen Leben bei Gelegenheiten, die einen Trauercharakter hatten, eine toga pulla oder ein pallium pullum anlegte, so mochte es nicht angezeigt erscheinen, daß die Diakone an Buftagen in ihrem Festgewand, der weifen, mit den Purpurclavi versehenen Dalmatik, amtierten. Es mufte vielmehr als passender betrachtet werden, dafo sie sich dann bei ihren Funktionen statt der lichten Tunika eines den Ernst der Zeit verkündenden Obergewandes, also nach Lage der Dinge einer planeta fusca (nigra) bedienten. Eine solche trug ja auch, wie wir aus dem Ordo Duchesnes und den Angaben Pseudo-Alkuins² ersehen, zum Ausdruck der Bufstimmung der Pontifex. Es hätte sicher wenig gepafst, wenn der Pontifex und alle andern Kleriker in dunkler Trauergewandung, die Diakone aber in ihrer weifsen, mit den roten Clavi versehenen Dalmatik erschienen wären. Daher also wohl die römische Gepflogenheit, daf der Diakon an Bußstagen eine dunkelfarbige Kasel trug.

Der Brauch, wonach Diakone und Subdiakone an bestimmten Tagen sich der Kasel statt ihrer gewöhnlichen Gewänder bedienen sollen, erhielt sich das ganze Mittelalter und wurde auch in das römische Missale und in das Caeremoniale der Bischöfe aufgenommen, wenngleich mit der Beschränkung auf die Kathedralen und sonstige hervorragende Kirchen ${ }^{3}$. Doch dürfte er auch vorher wohl kaum in kleineren Kirchen allgemein in Übung gestanden haben.

1 Explication p. 309, note b.

2 S. oben S. 163, Anm. 2. Als die Subdiakone eine besondere, der Dalmatik ähnliche Amtstunika bekamen, behielten sie den Gebrauch der Planeta natürlich an den Tagen bei, an welchen auch die Diakone sich ihrer za bedienen pflegten, und zwar aus dem gleichen Grund, aus dem diese sie dann trugen.

3 Rubr. general. XIX, n, 6 7. Caerem. episc. I. 2 , c. 13, n. $9 ; 18$, n. 3 . 


\section{ANLEGUNGSWEISE DER KASEL BEI DEN DIAKONEN, SUB- DIAKONEN UND AKOLYTHEN. DIE PLANETA PLICATA.}

Nach dem römischen Missale tragen Diakon und Subdiakon, wie früher ausgeführt wurde, die Kasel an den Tagen, an welchen sie sich ihrer abweichend ron der gewöhnlichen Ordnung statt der Dalmatik und Tunicella bedienen, nicht wie der Priester, sondern in Form der planeta plicata. Dieser Brauch stammt nicht erst aus neuerer Zeit, sondern ist ein Erbe aus alten Tagen. Im 14. Jahrhundert erwähnt ihn der 14. römische Ordo, in der zweiten Hälfte des 13. Durandus, welch letzterer zugleich nach seiner Weise weitläufig erörtert, was es bedeute, wenn Diakon und Subdiakon die Kasel vorn über die Arme hinaufhöben, anstatt sie nach Weise der Priester rechts und links auf ihnen zusammenzufalten, warum der Subdiakon die Epistel ohne Kasel singe, der Diakon aber die seinige vor dem Evangelium nach Art der Stola umlege und erst gegen Ende der Messe sich wieder in der anfänglichen Form mit dem Gewand bekleide. Im 12. Jahrhundert reden Honorius und Robert Paululus von ihm, im 11. Johannes von Avranches ${ }^{1}$, um den Beginn des 11. die Consuetudines Farfenses ${ }^{2}$, in der zweiten Hälfte des 10. die Concordia regularis St Dunstans. Hic autem mos casularii tantummodo quadragesimali et quattuor temporibus usu praecedentium patrum observetur: subdiaconus quoties casula induitur, exuat eam dum legit epistolam, qua lecta rursus ea induatur. Diaconus vero ad evangelium legendum exuat casulam et duplicans eam circumponat sibi in sinistra scapula, annectens alteram summitatem eius cingulo albae. Peracto communionis sacramento induat eam antequam collecta finiatur ${ }^{3}$, sagt beispielsweise St Dunstans Concordia. Es ist im wesentlichen die gleiche Praxis, wie sie uns später bei Durandus, im 14. Ordo und im römischen Missale begegnet, nur daf nicht angegeben wird, wie der Diakon vor dem Evangelium und nach der Kommunion und der Subdiakon vor und nach der Epistel ihre Kasel zu tragen pflegten. Bemerkenswert ist, daf die Concordia den Brauch als aus der Väter, d. i. früherer Zeit, stammend bezeichnet. Wirklich läßst er sich bis in die Frühe des 9. Jahrhunderts nachweisen. Diaconus, qui non est indutus dalmatica, casula legit circumcinctus, ut expedite possit ministrare..., ipsa habet pertusas subtus alas, quoniam Christum vult imitari, qui lancea perfossus est in latere et vult, ut nos sequamur eius vestigia, quod significat pertusus in latere, sagt Amalar ${ }^{4}$. Was er mit der letzten Bemerkung meint, ist nicht ganz klar. Wahrscheinlich

1 M. $147,34,38$.

${ }^{2} \mathrm{Albers,}$ Consuet. Farf. 27.

3 M. 137, 488.

4 L. 4, c. 21 (M. 105, 1097): Schon PseudoAlkuin scheint mit den Worten: Ipsa pertusas habet subtus alas etc. nicht viel haben anfangen können; denn er hat nur den ersten Teil der Stelle aus Amalar aufgenommen. Pseudo-Beda hat auch den zweiten ausgeschrieben, dabei jedoch die Worte Amalars zu verdeutlichen gesucht. Er schreibt: „Bisweilen liest dex Diakon, umgeben (cireumdatus) mit einer Kasel, auf daf er frei zur Verkündigung des Evangeliums hinzutreten oder den Tisch des Herm bereiten könne. Die Kasel ist aber an der rechten Seite offen, wo der Arm herausgesteckt werden soll, weil der Urheber des Evangeliums, den der Diakon nachahmen soll, an der rechten Seite mit der Lanze durchbohrt wurde." Amalar hat vielleicht sagen wollen, daf die Kasel im Gegensatz zur Dalmatik wie ein Gewand aussehe, das an den Seiten aufgeschlitzt sei, Pseudo-Beda aber, daß sie den rechten $\Lambda \mathrm{r} m$ des Diakons völlig frei lasse, wenn dieser sie zusammengefaltet auf der linken Schulter trage. Es liegt kein Grund vor, die Worte beider auf wirkliche, zum Zwecke des Durchsteckens der Arme im Gewand angebrachte Schlitze zu deuten, zumal der römische Brauch, den Amalar wie Pseudo-Beda wiedergeben, allem Anschein nach solche nie gekannt hat. 
denkt er daran, dafs die Kasel, wenn sie auf den Armen aufgerollt war, im Gegensatz zu der mit Ärmeln versehenen Dalmatik, an den seiten gleichsam offen war. Aber anch der Sinn des circumcinctus, "umgürtet", liegt keineswegs allzu offen am Tage. Indessen gibt Amalar selbst in seiner zweiten Vorrede zur Schrift De ecclesiasticis officiis einen Kommentar zu der eben angeführten Stelle, der an Deutlichkeit kaum etwas zu wünschen übrig lälit 1. Hiernach geschah das circumcingere in der Weise, dafs sich der Diakon heim Alleluja (nach dem Graduale) seiner Planeta entledigte, dann die Stola und mit ihr zugleich die Planeta hinter dem Rücken her unter den rechten Arm zog und so beide bis gegen Ende der Messe belief. Nach dem ersten Ordo legte der Diakon die Kasel schon etwas vorher in dieser Weise an, nämlich nach Schluf der Oration: Igitur diaconus, quando dixerit (sc. pontifex): Per omnia saecula saeculorum post Gloria in excelsis Deo, levant (sic) planetas in scapulas ${ }^{2}$. Von dem Subdiakon heibt es im Anschluf an diese Worte: Similiter et subdiaconi levant, sed cum sinu; subdiaconus vero de schola statim ubi imposuerit antiphonam ad introitum levat planetam cum sinu. Ähnlich der 2. Ordo ${ }^{3}$. Es zogen also auch die Subdiakone die Kaseln auf die Schulter hinauf, jedoch so, daks sich bei ihnen (vorn) ein tief herabhängender Faltenbausch (sinus) bildete. Seinen Grund hatte das wohl in dem Umstand, daf die Subdiakone die heiligen Geräte und Bücher, wie die Patene, das Evangeliar u. ä., eben mittelst der Planeta anfassen mufaten. Über die Weise, in welcher die Lektoren und übrigen niedern Kleriker die Kasel trugen, lassen uns Ordines wie Liturgiker völlig im dunkeln. Das einzige, was wir von ihnen vernehmen ${ }^{4}$, ist, dab wie die Subdiakone vor Absingung der Epistel, so sie vor Vornahme der Lesung die Kasel ausziehen musten. Auch die Bildwerke geben uns keinen befriedigenden Aufschlus. Denn der mantelartige Umwurf, den wir auf der schon früher erwähnten Miniatur des Sakramentars von Autun mit der Darstellung der verschiedenen Weihestufen (vgl. Bild 24, S.62)

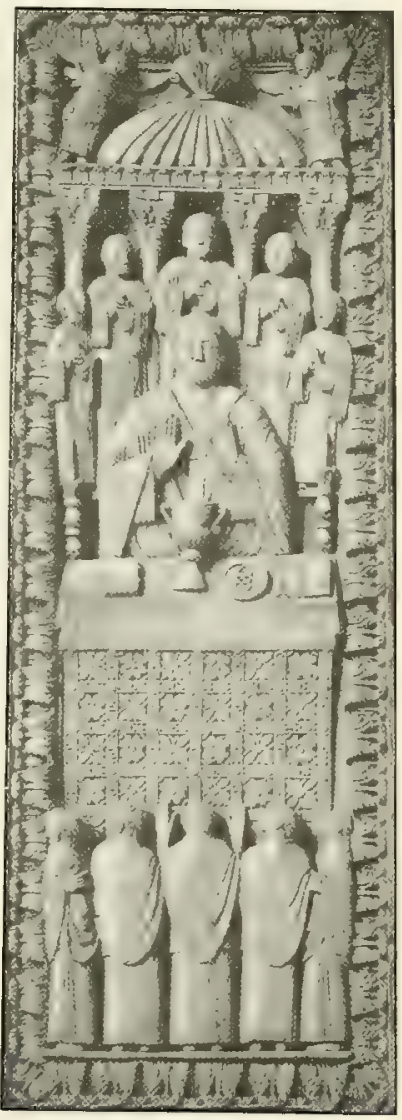

Bild 65. Elfenbeintafel Franklurt, Startbibliothek. bei dem Lektor, Exorzist, Akolyth und Ostiarius über deren Albe gewahren, ist wohl nicht eine Kasel in der Form, in der sie die Diakone vom Evangelium an anzulegen pflegten, sondern die Sindon, mit der jene Kleriker die Opferkelche, die Patene, die Wasserkrüge und das sonstige Opfergerät zu halten hatten ${ }^{5}$.

\footnotetext{
I A mala 1., Praefatio altera (M. 105, 992): Quando versus de Alleluia canitur, exuit se planeta diaconus stolamque post tergum ducit subtus alam dexteram una cum planeta et parat se ad ministrandum ac in eo habitu perseverat usque dum Apostolicus recesserit de altari.
}

2 N. 51 (M. 78, 960).
3 N. 3 (ebd. 969).

4 Ordo 1, n. 40 (ebd. 955); Ordo 5, n. 8 $=\mathrm{S} \cdot \mathrm{G} \cdot \mathrm{K} \cdot(\mathrm{ebd} .985)$; A ma l., De off. eccl. 1. 3, c. 15 (M. 105, 1122).

5 Man hat geglaubt, in dem Lmwurf das (Mantel-)Pallium sehen zu sollen, welches auf altchristlichen Bildwerken so oft auftritt. Indessen kann von einem solchen bel ihm 
Auf der Frankfurter Elfenbeintafel sind die Cantores nach Weise der Priester mit der Kasel bekleidet (Bild 65, S. 167), doch mag dieselbe hier nicht eine eigentliche Kasel, sondern, wenngleich mit Auslassung der Kapuze, die dieser damals noch sehr ähnliche Cappa darstellen sollen. Denn auf dem Gegenstück des Elfenbeins, der ehemaligen Spitzerschen, jetzt in englischem Privatbesitz befindlichen Tafel, ist das fragliche Gewand in aller Deutlichkeit mit einer Kapuze versehen (Bild 66). Freilich ist wie in andern Fällen, so auch im vorliegenden unsicher, was zuletzt auf Rechnung der Wirklichkeit

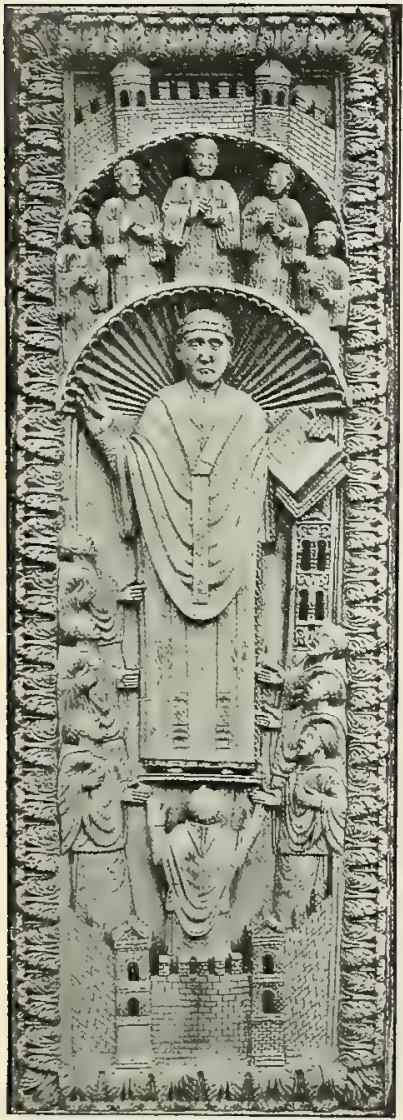

Bild 66. Elfenbeintafel. Rusthall House, Tunbridge (Wells), England. und was auf die des Künstlers fällt. Halten wir übrigens vor Augen, daf die Tätigkeit der Akolythen beim Gottesdienst im 9. Jahrhundert sehr verwandt war mit derjenigen der Subdiakone, welche damals ebenfalls noch $\mathrm{zu}$ den Minoristen zählten, so liegt der Schluk nahe, daß sie die Kasel in ähnlicher Weise wie diese getragen haben. Muften sie doch auch, wie wir vorhin hörten, wenn sie lasen, gerade wie diese bei der Epistel das Gewand ablegen.

Man hat gesagt, es sei die Kasel der Lektoren usw. kleiner gewesen als die der Priester ${ }^{1 .}$ Wirklich mag sie hie und da geringere MaßverhäItnisse gehabt haben als diese. So führt, um von den Darstellungen des Frankfurter und Spitzerschen Elfenbein abzusehen, auf welchen die Kasel bzw. Cappa der Cantores merklich kürzer als die Kasel des Bischofs ist, das Inventar von St-Riquier vom Jahre 831 im Verzeichnis der Paramente einer Nebenkirche casulae parvae sericiae 2 an $^{2}$. Ob es aber allgemein und namentlich zu Rom so gehalten worden sei, ist mehr als fraglich. Man hat sich freilich auf die Worte des 1. römischen Ordo berufen: Parat evangelium, qui lecturus est, reserato sigillo ex praecepto archidiaconi super planetam acolythi et, si necesse fuerit propter maiora evangelia, duobus acolythis super planetas tenentibus ${ }^{3}$. Allein der richtige Sinn dieser Rubrik dürfte wohl nur sein: Ist das Evangelium zu grof, als dafs ein Akolyth es bequem halten könnte, so sollen das zwei tun, natürlich auf ihren Planeten. Wie dem indessen sein mag, ein ganz kleines Gewand, eine Art von blosem Schultermäntelchen, waren die Kaseln der Lektoren und Akolythen jedenfalls nicht; denn die früher angeführten Stellen des 1. Ordo setzen notwendig voraus, daß sie eine ziemliche Größe hatten.

unmöglich die Rede sein. Denn im 9. Jahrhundert gab es unter den liturgischen Gewändern, die doch auf der fraglichen Miniatur zur Darstellung kommen, kein derartiges Pallium. Was unter dem in Frage stehenden Tuch $z u$ verstehen ist, erhellt aus $D u c h$. , Orig. 461: Et veniunt acolythi ... involuti cum sindonibus et unus ex jllis... tenens patenam ... et alii tenentes sciffos cum fontes, alii saccula (zur Aufnahme der sacrae species).

1 Hef., Beitr. II 201; Thalh of er I 883 u. a.

2 Chron. Cent. 1. 3, c. 3 (M. 174, 1261).

${ }^{3}$ Ordo 1, n. 5 (M. 78, 940). 
Die Gründe, welche den Brauch, mit dem wir uns bisher beschäftigten, veranlaßsten, hat schon Durandus richtig erkannt, wenn er - freilich neben andern Erklärungsversuchen - meint, die Ministri trügen die Kasel in einer von derjenigen beim Priester abweichenden Form, sowohl um sich von diesem besser zu unterscheiden, als auch um ungehinderter ihren Dienst versehen zu können. Den letzten führt schon Amalar an. Er war indessen nicht der Hauptgrund, das war vielmehr derjenige, den Durandus an erster Stelle nennt. Denn wenn beim Mangel von Diakonen ein Priester als Diakon fungierte, so behielt er, wie der 1. Ordo ausdrücklich anmerkt ', die ganze Zeit des Gottestienstes seine Kasel in der gewöhnlichen Weise an, wiewohl es doch auch für ihn bequemer gewesen wäre, das Gewand schärpenartig umzulegen. Der Hauptgrund kann also nicht die Notwendigkeit gewesen sein, Unzuträglichkeiten, die aus dem Crebrauch der Kasel für die Ministri entstehen konnten, durch eine andere Anlegungsweise der letzteren vorzubeugen - ein Punkt, der ja auch zuletzt nur beim Diakon zutraf -, sondern die Absicht, an den Tagen, an welchen alle beim Gottesdienst Beschäftigten in der Planeta amtierten, die Priester von den Nichtpriestern äuferlich zu unterscheiden und die Diakone, Subdiakone, Lektoren usw. durch die Art, wie sie die Kasel trugen, als solche zu kennzeichnen. Daneben mögen dann freilich auch Rücksichten auf größere Bequemlichkeit auf die Bildung des Brauchs von Einfluf gewesen sein.

Interessant ist die mystische Deutung, welche Amalar dem fraglichen Brauch gibt, soweit dieser den Lektor oder Cantor betrifft. Das Amt des Lektors oder Cantors, meint er, ist eine Art Kriegsdienst, und zwar treten diese Kleriker bei der Lesung oder dem Absingen (des Responsorium nach der Lesung und des Tractus) in einen Einzelkampf; sie gehen aber, um ihres Dienstes zu walten, aus dem Chor heraus, machen also gleichsam einen Marsch. Wer jedoch einen Marsch antritt, kann all die frommen Werke nicht üben, welche durch die Kasel versinnbildet werden, und so also ist es nach Amalar zu verstehen, weshalb Lektor und Cantor die Kasel ausziehen, wenn sie die Lectio verlesen oder das Responsorium singen wollen. Es liegt auf der Hand, daf diese Erklärung nur eine der vielen mehr oder minder gesuchten Deutungen ist, die frommes Grübeln nachträglich zur eigenen oder fremden Erbauung erfunden hat. Der geschichtliche Grund der fraglichen Gepflogenheit ist in ihr nicht gegeben.

\section{DIE KASEL IM LITURGISCHEN GEBRAUCH.}

Wie die Kasel zur Karolingerzeit noch nicht ausschließlich priesterliches, ja noch nicht einmal ausschlieflich liturgisches Gewand war, so war sie noch viel weniger schon ausschlieflich Mefgewand. Sie wurde das erst seit der Wende des Jahrtausends, als sich das Pluviale als liturgisches Gewand einbürgerte und die Kasel, ausgenommen bei der Messe und den damit in Verbindung stehenden Akten, zu ersetzen begann. Bis dahin erscheinen darum auch die Priester und Bischöfe auf den Bildwerken stets in der Planeta, gleichviel, bei welcher liturgischen Handlung sie dargestellt sind. Sehr instruktiv sind in dieser Hinsicht z. B. die Miniaturen des Sakramentars Drogos von Metz $(\dagger 855)^{2}$ und die mit liturgischen Szenen geschmückten Elfenbeinplatten vom Deckel des Sakramentars. Da sehen wir den Bischof bei der Messe, bei der Erteilung der heiligen Weihen, der Konsekration der heiligen Öle, der Segnung des Taufwassers und der Vornahme der Taufe, bei der Kirchweihe, bei der Erteilung der heiligen Ölung und bei Exorzismen; überall trägt

N. 51 (ebd. 960). Etwas anders im Ordo Duchesnes (Orig. 464), nach dem der Priester, welcher die Stelle des Diakons vertritt, wie dieser das Evangelium procinctus de planita singt. Beim weiteren Ministrieren trägt er aber auch hier die Planeta in gewöhnlicher Weise, wie aus den Worten: descendens de ambone induit se planita, erhellt.

2 Die Miniaturen bei $\mathrm{C}$ al $\mathrm{l}$ er, Ivoires $116 \mathrm{ff}$. 
er die Liasel (Bild 67 u. 68). Belehrend sind auch die Miniaturen des Göttinger Sakramentars, welche den Bischof bei der Spendung der heiligen Ölung, der Terkündigung der Skrutinien und der Rekonziliation der Büliser darstellen 1. Auch hier tritt derselbe überall in der Kasel auf. Nur bei ein paar Darstellungen des Drogosakramentars ist er mit der Cappa bekleidet. Es sind die Spendung der Firmung (vielleicht besser die Salbung des Täuflings mit dem Katechumenenöl), eine Totenerweckung und eine Teufelsaustreibung.

An schriftlichen Angaben über den Gebrauch der Kasel liegt nur sehr wenig vor. Was wir indessen davon besitzen, bestätigt, was die Bildwerke

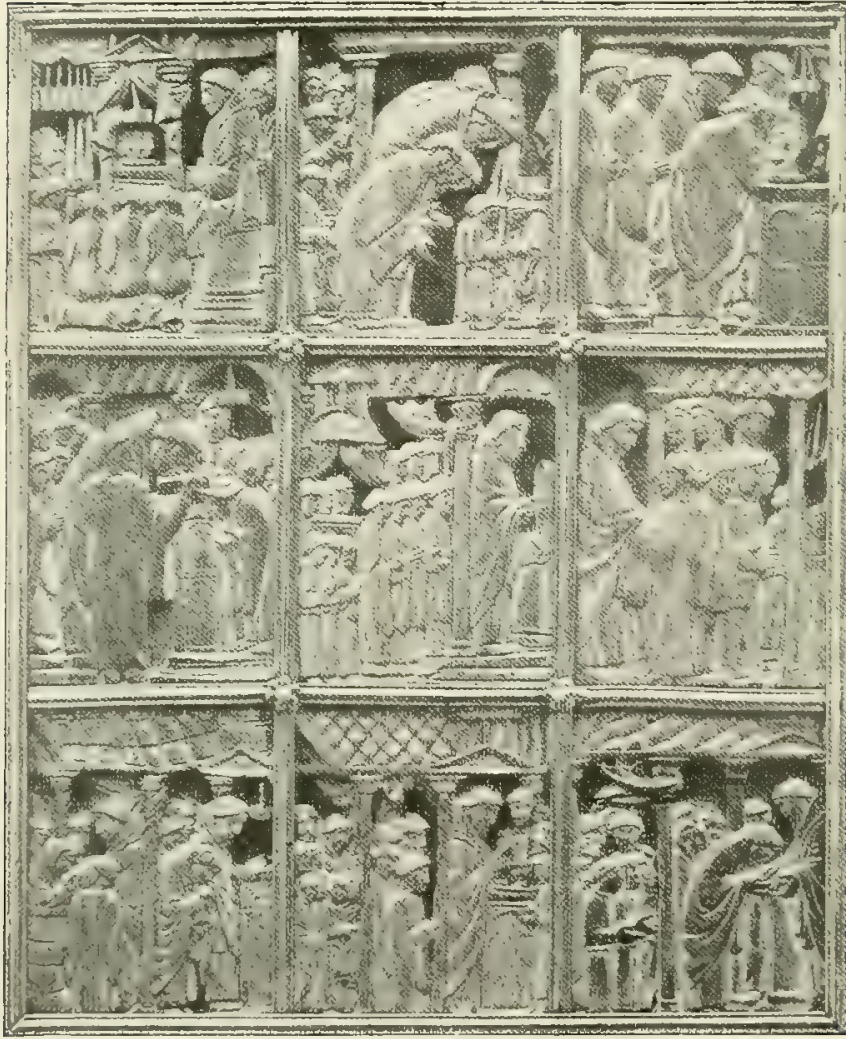

Bild 67. Elfenbeinplatte vom Sakramentar des Drogo. (Nach Kra us, Kunst und Aitertum in Elsafs-Lothringen.) erzählen. So vernehmen wir aus dem sog. Egbertpontifikale, dem Pontifikale von Aletis (St Malo) und dem Pontifikale Dunstans, daf Bisch of wie Ministri bei der Kirchweihe mit den Gewändern bekleidet sein mufsten, cum quibus divinum mysterium (ministerium) adimplere debent, also mit der Kasel und den übrigen Meßsgewändern ${ }^{2}$. Hinsichtlich der Krankenversehgänge schreibt das Pontifikale von Aletis vor: Sacerdos... induat se superhumerali, alba et stola cum phanone atque planeta, si affuerit, si alias, casula non induatur ${ }^{3}$.

Natürlich trug man bei der Spendung der Sterbsakramente, der Taufe u. ä. die Kasel nur, wenn diese Funktionen in feierlicher Weise vollzogen wurden, wie man ja auch später nur in solchen Fällen sich des Pluviale bediente.

Einen deutlichen Hinweis auf den Wechsel, der sich im 11. Jahrhundert hinsichtlich der Verwendung der Kasel vollzog, finden wir in einem Brief Lanfranks an Erzhischof Johannes von Rouen. Letzterer, der uns bereits bekannte Johannes von Avranches, hatte in einem Schreiben an Lanfrank die Meinung ausgesprochen, es müsse der Bischof bei der Kirchweihe auker den

Beissel, Ein Sakramentar aus Fulda, in Zeitschrift IX (1894) 65 ff. Vgl. fernel ein Elfenbein im Museum zu Amiens aus dem 9. Jahrh. bei Roh. VII, pl. DLxvir.
2 M art. 1. 2,c. 13 , ordo 234 ; Il 247 250 255. Das Pontif. von Aletis heift hier Pontif. Gemmeticense (Jumièges).

3 Ebd. 1. 1, c. 7, art. 4, ordo 1; I 301. 
andern pontifikalen Gewändern auch die Kasel tragen. Darob ist dieser jedoch erstaunt und bemerkt in seiner Antwort, er könne sich nicht erinnern, es irgendwo bemerkt zu haben, daf man die Konsekration der Kirche in der Kasel vollzogen habe. Man habe sich vielmehr stets bei der Weihe der Cappa, der Kasel aber erst bei der Messe bedient. So habe es auch Papst Leo gehalten, als er die Kirche von Rémiremont konsekrierte ${ }^{1}$. Man merkt deutlich, dak man in einer Zeit steht, da man anfängt, darüber Erörterungen anzustellen, wann die Kasel zu gebrauchen sei und wann nicht, und man die Kasel schon vielfach als eigentliches Mefgewand betrachtet.

Solange die Kasel noch die weite Form hatte, mufte sie an den Seiten aufgehoben und auf den Armen zusammengelegt werden, damit der Celebrans seine Hände frei gebrauchen konnte. Es geschah dies nicht erst am Altar nach dem Confiteor, wie man gesagt hat, sondern schon in der Sakristei. So war es, wie aus dem 1. und 3. Ordo klar hervorgeht, in Rom bereits im 8 . und 9. Jahrhundert üblich, so hielt man es dort auch noch, wie aus den Ausführungen Innozenz' III. erhellt 2 , im 13. und, wie der 14. Ordo beweist, im 14. Jahrhundert: Subsequenter diaconus a dextris et subdiaconus a sinistris

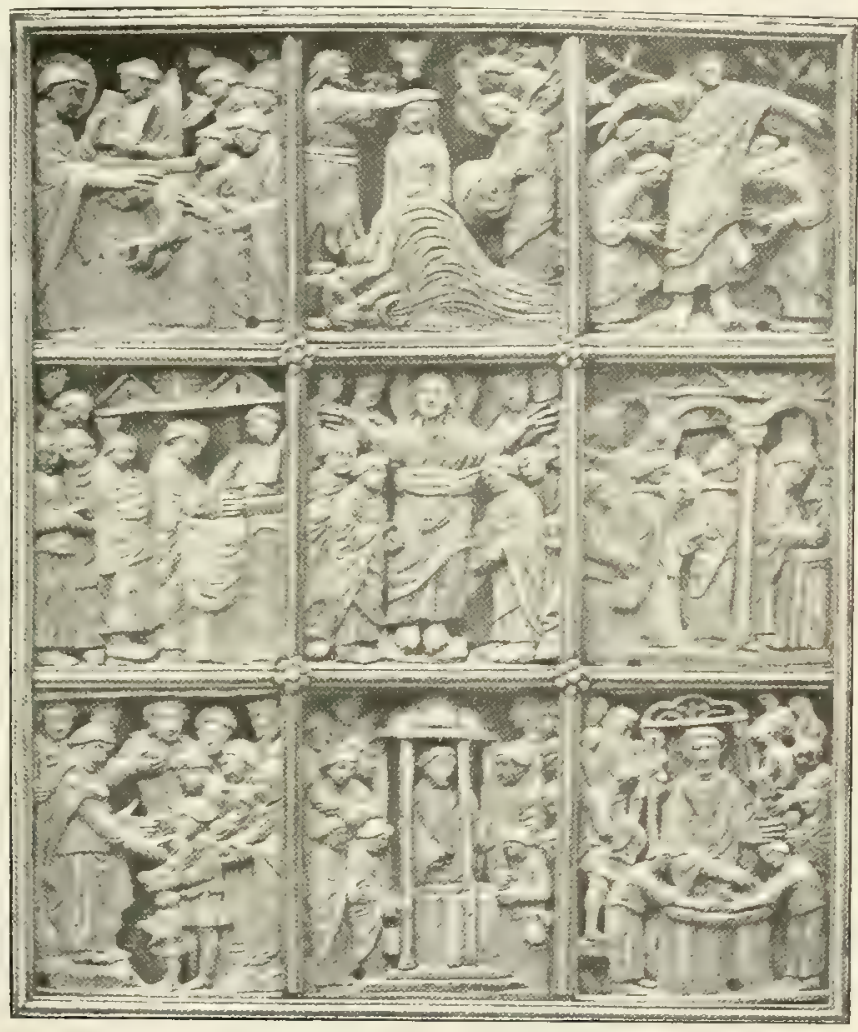

Bild 68. Elfenbeinplatte vom Sakramentar des Drogo. (Nach Kraus, Kunst und Altertum in Elsak-Lothringen) planetam super brachia pontificis apte complicent ${ }^{3}$, ja solange die Kasel an den Seiten ein Aufrollen erheischte, d. i. bis in die Neuzeit hinein *. Dak es auch aufier Rom so Brauch war, ergibt sich aus Sicards Mitralis ${ }^{5}$, aus des Durandus Rationale ${ }^{6}$ und seinem kaum weniger einflufreichen Pontifikale?

1 Ep. 13 (M. 150, 520).

2 De sacrif. missae 1. 1, c. $78 \mathrm{vgl}$ mit 1.2 , c. 113 (M. 217, 795801806 ).

${ }^{3}$ C. 53 (M. 78, 1158).

- Caerem. episc. 1. 2, c. 8, n. 19.

5 L. 2, c. 8 vgl. mit dem Prologus zu 1. 3, und 1. 3ै, c. 2 (M. 213, 8994 ).

G L. 4 , c. 7 ; f. 103 .
7 Mart. 1. 1, c. 4, art. 12, ordo 23; I 221. Das Pontifikale ist nicht von Durandus d. J. wie Ehrensberger, H. (Libri liturgici, Freiburg 1897,548 ) meint, sondern von Durandus d. $\ddot{A}$. Denn im Pontifikale beruft sich Durandus auf sein Rationale, z. B. De praemissis singulis rationes in nost $\mathrm{x}$ o Rationali posuimus (ebd. 222). 
Die Kasel erst am Altar nach dem Confiteor zu ordnen, dürfte nur vereinzelt üblich gewesen sein. Es lag ja dafür auch kein Grund vor. Eine solche Gepflogenheit bestand nach einem alten Ordinarium des 13. Jahrhunderts zu Laon ${ }^{1}$. Auch Johannes Beleth wird zum Zeugen für dieselbe angerufen, doch ist hier die Sache zum mindesten sehr unklar ${ }^{2}$. Er gibt offenbar keine historische Reihenfolge, sonst würde aus seinen Angaben folgen, der Bischof habe die Kasel sogar erst, nachdem er die Orationen gesungen und das übrige gebetet, auf den Schultern zusammengefaltet.

\section{DIE KASEL IM WEIHERITUS.}

Bei der Priesterweihe legt der Bischof, wie wir früher hörten, dem Ordinanden, nachdem er dessen Stola über die rechte Schulter gezogen, eine Kasel an, deren Vorderteil herabhängt, während die hintere Hälfte bis nach der Kommunion zusammengefaltet bleibt.

Es ist ein sehr alter Brauch, den Neopresbytern bei ihrer Ordination die Planeta (Kasel) zu übergeben. In Spanien war er schon wenigstens im Anfang des 7. Jahrhunderts bekannt. Als Teil des römischen Weiheritus wird er zuerst im 8. Ordo erwähnt ${ }^{3}$, der bezüglich des Zeremoniells der Priesterweihe bemerkt: „Der Archidiakon zieht ihm (dem Ordinanden) die Dalmatik aus und legt ihm dann die Planeta an." Sogar der Akolyth wurde bei seiner Weihe diesem Ordo zufolge mit dem Gewand bekleidet, was allerdings nicht wundernehmen kann. Denn diese Zeremonie steht ganz im Einklang mit der schon besprochenen römischen Gewohnheit, wonach auch die niedern Kleriker sich der Kasel bedienten. Beim Subdiakon wird im 8. Ordo vorausgesetzt, daß er bereits die Planeta trage, da der Archidiakon oder der Bischof ihm bei seiner Weihe den Kelch in ulnas foras planeta legen soll.

In das gregorianische Sakramentar erhielt unser Ritus seit dem 9. Jahrhundert, vielleicht aber auch schon etwas früher, Aufnahme. Übergibt aber nach dem 8. Ordo noch der Archidiakon dem Neopresbyter die Kasel, so tut solches nach den Pontifikalien und Sakramentaren des 10. Jahrhunderts und der Folgezeit regelmäßig der Bischof selbst. Ein besonderer Begleitspruch scheint hierbei nicht überall und allzeit Brauch gewesen zu sein. Verschiedene Sakramentare begnügen sich bloß mit der Bemerkung: "Hier bekleidest du ihn mit der Kasel"; andere haben für die Anlegung der Stola und Kasel nur einen Begleitspruch.

In den älteren Pontifikalien und Sakramentaren, besonders angelsächsischen, lauten die Begleitworte meist: "Der Segen des Vaters und des Sohnes und des Heiligen Geistes steige über dich herab, auf daf du im Priesterstand gesegnet seiest und sühnkräftige Opfergaben für des Volkes Sünden und Übertretungen dem allmächtigen Cott darbringest, dem Ehre und Ruhm ist in alle Ewigkeit." Häufig ist aber auch das Gebet: "Nit dem Gewande der Unschuld bekleide dich der Herr." Es erhielt sich in manchen Pontifikalien bis ins 14. Jahrhundert. Die Worte, welche der Bischof jetzt nach dem römischen Pontifikale zu sprechen hat, kommen schon im 12. Jahrhundert vor ${ }^{4}$. Gewöhnlicher werden sie indessen erst im 13. und 14. Jahrhundert; doch haben sie noch im 15. keineswegs allgemein in die Pontifikalien Aufnahme gefunden.

\footnotetext{
1 Mart. 1. 1, c. 4, art. 12, ordo 20; I 218. Irrig steht hiex in der Überschrift: ecclesiae Lugdunensis. Es muf heifen: Laudunensis.
}

2 Rationale c. 33 (M. 202, 43).

${ }^{3}$ N. 124 (M. 78, 1000 1001).

4 M art. 1. 1, c. 8, art. 12 , ordo 8; II 53. 
Scharf tritt der Charakter der Kasel im Gebete eines Pontifikale von Séez aus dem Jahre 1045 hervor: Recipe planetam, ut possis legaliter celebrare missam „Nimm hin die Planeta, damit du ordnungsgemäf die Messe feiern könnest." 1

Die Liturgiker reden bis zum 13. Jahrhundert kaum von der uns beschäftigenden Weihezeremonie, vermutlich, weil sie diese nur als einen Ritus von untergeordneter Bedeutung, der lediglich zur Solemnität gehöre, betrachteten. Im 13. Jahrhundert aber erwähnt Durandus sie nicht nur, sondern rechnet sie sogar zum Wesen der Priesterweihe ${ }^{2}$. Vermutlich hat das seit dem 12. Jahrhundert in Aufnahme gekommene Gebet: "Nimm hin das priesterliche Kleid usw." zu dieser seiner Meinung beigetragen, sofern in ihm ausdrücklich die Kasel als das Priestergewand bezeichnet wird.

Die Anlegung der Kasel bei der Weihe der Priester war in der Form, wie sie nunmehr das römische Pontifikale als Weihezeremonie vorschreibt, dem 13. Ordo zufolge ${ }^{3}$ sicher bereits um die Mitte des 13. Jahrhunderts in Rom gebräuchlich. Wie weit dieselbe in die Vergangenheit zurückreicht, läßst sich nicht sagen, doch scheint sie verhältnismäfig jungen Ursprungs zu sein. Außserhalb der römischen Kirche hielt man mehr oder minder lang an dem älteren und einfacheren Weihezeremoniell fest, welches ein anfängliches Zusammengefaltetsein und folglich auch die nachherige Entfaltung des Gewandes nicht kannte.

Über die Art und Weise, wie die Kasel bei der Weihe gefaltet wurde, sagt ein dem 14. Jahrhundert angehörendes Pontifikale der Vaticana: "Die Planeta soll blof im Nacken zusammengelegt werden, so daß sie lediglich im Nacken nicht herunterfällt, an der Vorderseite aber sich zwischen Hand und Arm befindet (d. i. hier lang herabhängt)." 4

\section{FORM DER KASEL IM MITTELALTER BIS ZUM XIII. JAHRHUNDERT.}

Nach den bildlichen Monumenten zu urteilen, war die Planeta der vorkarolingischen Zeit ein weiter, glockenförmiger Überwurf, der nur eine Öffnung zum Durchlassen des Kopfes hatte, im übrigen aber ganz geschlossen war. Das letzte hebt, wie wir bereits hörten, auch die gallikanische Meferklärung ausdrücklich hervor. Lieb man das Gewand herunterhangen, so waren die Arme und selbst die Hände völlig unter demselben geborgen. Denn nach den römischen und ravennatischen Mosaiken des 6. und 7. Jahrhunderts reichte die Planeta damals wenigstens bis zu den Ḱnieen, vielfach sogar über dieselben. Wollte man die Hand frei benutzen, so war man genötigt, die Planeta über den Arm zurückzuschlagen. In der Tat ist, um auf einige Beispiele hinzuweisen, bei Maximian auf dem Mosaik in S. Vitale, der in der Rechten das Kreuz trägt, das Gewand auf den rechten Arm hinaufgezogen (Bild 63, S. 159). In gleicher Weise tragen ihre Planeta Ecclesius, Ursus, Severus und Ursicinus auf den Mosaiken in S. Apollinare in Classe, welche die Rechte zum Segen oder Redegestus erhoben haben. Der hl. Vinzentius auf dem Fresko in der

1 Le Brun I, traité prélim. art. $4, \S 1$, chasuble; I 47, note e.

${ }^{2}$ Rationale 1.2 , c. 10 ; f. 61 .

${ }^{3}$ N. 6 (M. 78, 1107).

4 Cod. Vat. lat. 1153, f. 5\%: Planeta plicata super collum tantum, ita quod non descendat solum super collum et a latere anteriore stet inter manum et brachium. Andere Pontifikalien des 14. und 15. Jahrhunderts, welche den Gebrauch, die Kasel bei der Weihe auf den Rücken zu falten, im Ordinationsritus erwähnen, sind z. B. Cod. Vat. lat. 5791 und Ottob. 27330501574. Vgl. auch Ma rot. 1. 1 , c. 8 , art. 11 , ordo 17 ; II 85 . 
Katakombe des Pontian heht beide Arme zum Gebet empor. Hier ist daher die Kasel auf beiden Armen emporgerafft.

Planeten aus rotkarolingischer Zeit haben sich unseres Wissens leider nicht erhalten. Eine ehemals zu Vreden aufbewahrte und nummehr im bischöflichen Museum zu Münster befindliche Kasel des hl. Sixtus II. († 258) ${ }^{1}$ stammt aus der Mende unseres Jahrtausends, Aus derselben Zeit datiert das Mésewand des lll. Ebbo $(\uparrow 750)$ in der Kathedrale zu Sens, ein byzantinisches Gewebe ron der Art der Adlerkasel zu Brixen, dem Löwenstoff zu Siegburg 11. ¿. Die Kasel des hl. Johannes "des Engelschauers" im Dom zu Ravenna ist. wie Stoff, Ausstattung und Besatz mit aller Bestimmtheit beweisen, eine Arbeit des 11. bis 12. Jahrhunderts. Dasselbe gilt von einem Mefigewand, welches zu Dokkum (Friesland) aufbewahrt wird, und dem hl. Bonifatius zugehört luaben soll?. Die Kasel des hl. Regnobert († ca 668) zu Bayeux mag dem 12. Jahrhundert entstammen ${ }^{3}$.

Es ist zu bedauern, daf sich aus vorkarolingischer Zeit keine Kaseln erhalten haben. Es ist kaum möglich, b]of an der Hand der Monumente den genauen Schnitt des Gewandes festzustellen. Nur auf Grund von noch vorhandenen Gewandstücken lälst er sich mit Sicherheit bestimmen. Mit Hilfe der Monumente kommt man über eine gewisse allgemeine Gestalt nicht hinaus. Die Skizzen, welche Rohault de Fleury von den Kaseln auf ravennatischen und römischen Mosaiken in seiner chronologischen Übersicht über die Kaselform gibt, sind denn auch nur Produkte der Phantasie*.

Auch im 9. und im Beginn des 10. Jahrhunderts sind wir, was die Form des Mefsgewandes anlangt, noch allein auf die Monumente angewiesen. Es sind besonders einige späte Mosaiken in Rom, wie die musivischen Darstellungen in den Apsiden von S. Prassede, S. Marco, S. Cecilia, sowie die karolingischen Miniaturen und Elfenbeine, aus denen wir unsere Kenntnis der Kasel zu schöpfen haben. Unter den Miniaturen verdient besondere Erwähnung die Darstellung der Bibel Karls des Kahlen, auf der die Mönche von St Martin zu Tours ${ }^{j}$ dem Fürsten die Bibel überreichen, unter den Elfenbeinen die Deckelskulpturen des Drogosakramentars. Die Liturgiker des 9. Jahrhunderts lassen uns iiber die Form der Planeta ganz im unklaren. Genaueren Aufschlubi über Schnitt und Form des Meḱgewandes erhalten wir erst seit Ausgang des 10. Jahrhunderts. Die Liturgiker wissen uns freilich auch jetzt nur wenig davon zu berichten. Alles, was sie erzählen, läuft auf einige allgemeine Bemerkungen hinaus. Sie schildern die Kasel als ein Fiewand, das ringsum geschlossen, ohne Schlitz (undique clausa, una est et integra; Rupert) und so lang und weit war, dafs es auf den Armen, vor der Brust und auf dem Rücken in Falten gelegt werden mußste (duplicatur in pectore et inter humeros; triplicatur in dextro brachio ... in sinistro; Honorius). Hatte der Priester sie angelegt, so schien sie gleichsam aus zwei Hälften zu

' liaun, Die sog. Sixtus-Kasel von Vreden in Zeitschrift XII (1899) 23.

2 Uther die Form des Gewandes erhielten wir freundiche Mitteilung durch Herrn Dechanten van Hrukelum zu Jutfaas bei Utrecht. Ein Stäck des Stoffes sahen wix im rabischiotlichen Muscum zu Lrecht.

De Farey in Mémoires de la Société des antiquaires de la Normandie 1881; Rob. VII 141 und pl. DISXXVil.
4 La messe VII 179. Das Gesagte gilt überhaupt von den Rekonstruktionen, welche dort Robault de Fleury auf Grund der Monumente versucht hat. Die chronologische Folge der Kaselformen, welche er bietet, gibt darum ein ganz unzutreffendes Bild von der Entwicklung des Nefigewandes.

5 Nicht zu Metz, wie es infolge Übersehens bei der Korrektur oben S. 27 heißst. Abbildung der Miniatur siehe T'itelbild. 
bestehen (in anteriorem et posteriorem partem quodammodo dividitur; Rupert), welche so ziemlich gleich waren (suppar est post tergum et ante pectus; Pseudo-Beda).

Das ist alles. Um so wichtiger sind darum für die Geschichte der Form der Kasel die Monumente des 11., 12, 13., 14. und 15. Jahrhunderts, deren es eine unabsehbare Menge gibt; nur muf man sich sehr hüten, alles und jedes, was uns auf ihnen entgegentritt, unbesehen als gute Münze und als unverfälschtes Abbild der Wirklichkeit hinzunehmen. Das gilt namentlich von den Bildwerken des 11., 12. und selbst teilweise noch denen des 13. Jahrhunderts.

Die Phantasie hat bei den Künstlern zu allen Zeiten eine grobe Rolle gespielt; im besondern Maf3 ist das aber bei nicht wenigen Darstellungen aus der Frühe unseres Jahrtansends der Fall, die obendrein nur zu oft grobe Infähigkeit verraten, die Wirklichkeit korrekt wiederzugeben. Es ist deshalb einige Vorsicht in der Benutzung der Monumente aus dieser Zeit durchaus von nöten, wenn man nicht zu irrigen Schlüssen gelangen will.

Wenn z. B. auf einzelnen Bildwerken die Vorderseite der Kasel wie spitz zugeschnitten erscheint, so dalis sie bisweilen unten einen Winkel von etwa 45 Grad zu bilden scheint, so tun wir nicht gut, darum schon, wie solches in der 'Tat geschehen ist, von einer barocken Kasel zu reden. Delartige Eigentümlichkeiten fallen nicht auf Rechnung des Gewandes, sondern der Künstler. Um Einzelheiten gar nicht ängstlich besorgt, haben diese die Kasel so wiedergegeben, wie sie aussah, wenn der Priester sie trug, also scheinbar unten spitz zulaufend. Dabei haben sie aber, was man ihnen allerdings verzeihen darf, den Falten wurf darzustellen vergessen, der sich vorn bildete, wenn man das Gewand auf den Armen zusammenlegte.

Ein treffliches Beispiel, wie wenig man aus derartigen Bildwerken auf eine Verstümmelung der Kasel schliefien darf, bieten die Fresken der Unterkirche von S. Clemente zu Rom. Wollte man die Figur des die Messe lesenden Papstes Klemens für mafgebend halten, so sollte man freilich glauben, es habe das Mefsgewand bereits im 11. Jahrhundert eine gar sonderbare, voru merkwürdig zugespitzte Form angenommen. Vergleicht man aher das Bild mit den zahlreichen andern Fresken der Unterkirche aus derselben Zeit, den Darstellungen der Päpste und des Priesters Calepodius auf dem Apsismosaik in S. Maria in Trastevere u. a, auf denen das Gewand ganz normal erscheint, so wird man bald inne, dafs das Aussehen der Kasel des hl. Klemens lediglich auf Künstlerlaune und Künstlerfreiheit zurückzuführen ist.

Sehr gewöhnlich ist ferner auf den Monumenten die Kasel an der Vorderseite kiirzer wie an der Rückseite. Man hat daraus schliefen wollen, es sui das Gewand bereits vorn mehr oder weniger verkürzt worden. Auch diese Folgerung ist indessen unrichtig. Da\& das Gewand vor der Brust kürzer erscheint, ist durchaus natürlich, weil durch die Form des Körpers, durch den Schnitt des Gewandes und durch die Art, in der die Kasel auf den Armen zurückgerollt wurde, begründet. Man mache nur einmal mit einer Glockenkasel die Probe. Man wird alsbald finden, dabs sie trotz gleicher Länge der Vorder- und Rückseite hinten tiefer herabsteigt als vorn. Die Wahrnehmung lälit sich selbst bei Kaseln gewöhnlicher Form machen. In diesem Punkte entsprechen also die Bildwerke genau der Wirklichkeit. Unrichtig ist nur, was man aus Unkenntnis des tatsächlichen Verhältnisses aus denselben hat folgern wollen. 
Wir müssen noch auf einen Punkt aufmerksam machen, der gleichfalls zu Mißsverständnissen Anlaf gegeben hat. Wir finden auf einigen älteren Bildwerken Kaseln. die scheinbar mit einer Kapuze ausgestattet sind. Sollen wir daraus folgern, dafs es wirklich Kiaseln gab, die mit einer solchen versehen waren? Der Schluł wäre nicht berechtigt. Die Möglichkeit freilich, dals hie und da gelegentlich derartige Kaseln gebraucht worden sind, läfst sich nicht bestreiten; denn was ist nicht schon alles vorgekommen. Jedenfalls war aber solches, wo es geschah, nicht die Regel, sondern eine der gewöhnlichen Praxis zuwiderlaufende Ausnahme. Keiner der alten Liturgiker erwähnt die Kapuze, nicht einmal der sonst bis ins kleinliche gehende Amalar. Namentlich ist aber für den Stand der Dinge das Verhalten Hrabans bezeichnend, der in seiner den Etymologien Isidors entnommenen Definition der Kasel gerade den die Kapuze betreffenden Passus ausläßst. In der Tat, welchen Zweck hätte diese auch an dem Mefgewand gehabt, da ja die Messe unbedeckten Hauptes gefeiert werden mußte? Wirklich handelt es sich auf den Darstellungen, die eine Kapuze an der Kasel aufweisen oder aufzuweisen scheinen, entweder nicht um die Meßkasel, sondern um ein zwar kaselförmiges, im Gebrauch aber unserem Pluviale analoges Gewand, oder es erklärt sich die scheinbare Kapuze aus der eigentümlichen Machweise der Kasel. Ihr Schnitt war nämlich, wie wir später sehen werden, derart, daß sie, angezogen, im Nacken einen kapuzenähnlichen Bausch bildete. Man suchte das freilich häufig dadurch zu beseitigen, daß man den Kopfdurchlaß erweiterte, doch geschah das nicht immer oder doch nicht allzeit in ausreichendem Maß, wie die noch vorhandenen zahlreichen Glockenkaseln aus dem 11., 12. und 13. Jahrhundert beweisen. Es kann deshalb keineswegs wundernehmen, wenn der fragliche Bausch sich hie und da auch auf den Bildwerken zeigt.

Eines der besten Beispiele bilden die Miniaturen des Weiherotels Landulfs II. von Benevent $(1108-1119)^{1}$ in der Casanatense zu Rom aus dem Anfang des 12. Jahrhunderts. Hier ist der Bausch in auffälliger Weise sichtbar. Aber es handelt sich, wenn man das Original genau betrachtet, auch nur um einen Bausch. So sieht eine Kapuze nicht aus. Klar wird die Sache aber ganz besonders aus der Miniatur, welche die Übergabe der Kasel an die Neopresbyter darstellt. Denn das Mefgewand, welches einer der Ordinanden in der Hand hält, ist zweifelsohne kapuzenlos. Auch ist bemerkenswert, daß dasjenige, was wie eine Kapuze aussieht, nur auf dem Weiherotel Landulfs, nicht aber auf seinem ebenfalls in der Casanatense befindlichen Taufrotel, noch auch den übrigen verwandten beneventanisch-kapuanischen Miniaturen auftritt. Bei der Annahme, es handle sich um eine wirkliche, in Brauch stehende Kapuze, wäre das schwer zu erklären. Anders, weun man sich die Sache als den gewöhnlichen Kaselbausch denkt, den der eine andeutete, der andere unangedeutet lief3, ein dritter mit künstlerischer Lizenz etwas kapuzenähnlich gestaltete. Ein anderes treffliches Beispiel bietet eine Elfenbeinplatte in der königlichen Bibliothek zu Berlin mit der Darstellung Bischof Sigeberts von Ninden (Bild 69), einer Arbeit des frühen 11. Jahrhunderts. Neben Sigebert stehen zwei Priester wie der Bischof in liturgischer Gewandung. Wer die Figuren ohne nähere l'rüfung hetrachtet, könnte glauben, Kaseln mit Kapuzen bei denselben zu finden. Dem Kenner entgeht es indessen nicht, daßs die scheinbare Kapuze nur ein Kaselhesatz ist, den der Künstler allerdings in der Absicht. ihn mehr zur freltung zu bringen, etwas stark herausgearbeitet hat, Eine Bestitigung erhält das durch eine zu dem Elfenbein durchaus parallele und mit ihm gleichzeitige Hiniatur, welche ebenfalls Jischof Sigebert inmitten seiner Kleriker darstellt ${ }^{2}$. Hier tritt die scheinbare Kapuze klar als das auf, was sie wirklich ist, als Besatz.

Nicht Landulfs I. (957-983), wie Wilpert sagt (fiew. 52. Cap. 99). Abrildungen bei Wilp., Gew. und Cap. Ag., Mal. Tfl $37 \mathrm{f}$.

2 Berlin, kgl. Bibl.; Theol. quart. 3, f. $1^{v}$. 
Schon auf einigen karolingischen Monumenten scheint die Kasel mit einer Kapuze ausgestattet zu sein, so z. B. auf dem Tidmungsbild der Bibel Karls des Kahlen und den Elfenbeinplatten auf dem Deckel des Drogosakramentars. Doch gilt auch hier, was von den im ganzen wenig zahlreichen gleichartigen Miniaturen des 11. und 12. Jahrhunderts gesagt wurde. Tamentlich macht auf dem Elfenbein des Deckels des Drogosakramentars für den oberflächlichen Blick das Pallium im Nacken des Bischofs die Täuschung vollkommen, doch auch nur für den oberflächlichen Blick. Denn untersucht man die Sache etwas näher, so wird man bald gewahr, daf es sich um den Kaselbausch, nicht um eine Kapuze handelt.

Es gibt nur vier Bildwerke, auf denen uns eine mit einer wirklichen Kapuze versehene Kasel entgegentritt: ein Elfenbeinrelief auf dem Deckel des Drogosakramentars (Salbung mit dem Katechumenenöl oder Firmung), zwei Miniaturen desselben Sakramentars (die gleiche Szene und Begebenheiten aus dem Leben des hl. Arnold, Bischofs von Metz, darunter namentlich eine Teufelsaustreibung und eine Totenerweckung durch Salbung mit dem heiligen Öl) und die ehemalig Spitzersche, jetzt in englischem Besitz ${ }^{1}$ befindliche Elfenbeintafe] (Erteilung des feierlichen bischöflichen Segens). Es handelt sich in diesen Fällen jedoch nicht um das Melsgewand, sondern um die Cappa, von der in einem späteren Kapitel ausführlicher die Rede sein wird. In den drei ersten Fällen begegnen wir ihr bei einem Bischof, in dem letzten bei den Cantores?

Fragt man, warum der vorhin erwähnte Bausch im Nacken des Kaselträgers sich nicht regelmäßig auf den Monumenten bemerklich mache, so ist die Antwort schon gelegentlich andeutungsweise gegeben worden. Weil der Bausch keineswegs eine Annehmlichkeit war, zumal bei schweren Stoffen, pflegte man ihn durch Erweiterung des Kopfdurchschlupfs zu beseitigen. Er war also auch in der Wirklichkeit bei weitem nicht immer an der

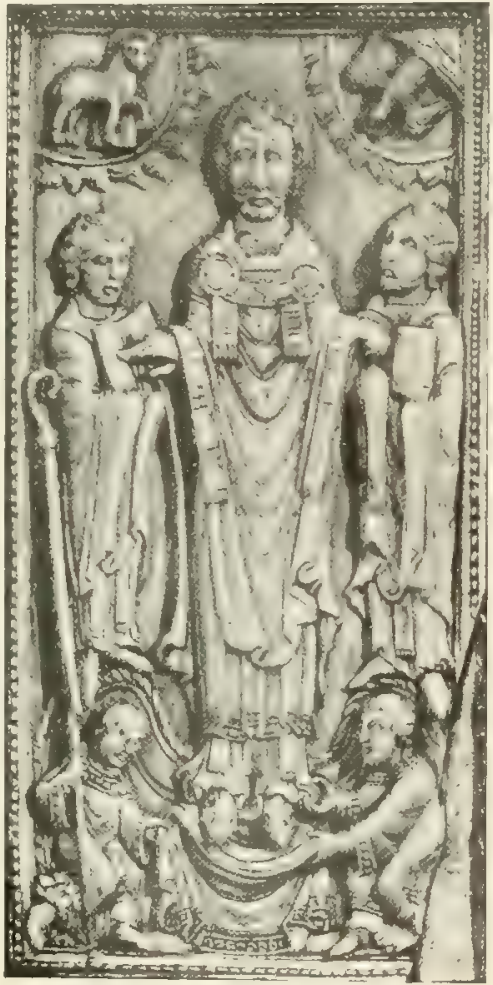

Bild 69. Elfenbeintafel. Berlin, Kgl. Bibliothek.

Kasel vorhanden. Auferdem aber war es den alten Künstlern um nichts weniger als eine photographisch genaue Wiedergabe des Gegenstandes zu tun.

Die beste Quelle für die Kenntnis der Form, welche das Mefagewand gegen Ende des 10., im 11., 12. und noch im Beginn des 13. Jahrhunderts besaf, bilden die aus jener Zeit noch erhaltenen Kaseln. Ihre Zahl ist so groß, daß sie uns einen völlig befriedigenden Aufschluls über Machweise und Schnitt des Gewandes in damaliger Zeit geben. Einige davon sind freilich in

1 Der jetzige Besitzer ist Esq. Frank Maclean, Rusthall House, Tunbridge, Wells.

Näheres über die Darstellungen im Abschnitt, welcher sich mit dem Pluviale beschaftigt, woselbst auch eine Abbildung des licliefs vou Deckel des Drogosakramentars gegeben ist. Die Kapuze, welche sich auf leu Widmungsbild des St Bernwardsevan-

Braun, Die liturgische fiewandung. geliars in Dom zu Hildesheim an der Kasel des hl. Bernward (Abbildung bei Beissel, Das St Bernmardsevangeliar TI 4) zu finden scheint, ist, wie sich bej genauerem Zusehen ergibt, nichts als eine schildförmige Dekoration des Gewandes, wie sie die Glockenkasel in St Godehard zu Hildesheim aufweist. Die Darstellung ist übrigens sehr verzejchnet. 
späterer Zeit mehr oder weniger zugestutzt worden und haben darum für das Studium der Form des Mefogerandes nur dann Wert, wenn sie bei und trotz aller Yerstümmelung den ursprünglichen Schnitt genügend erkennen lassen. Die Mehrzahl ist indessen der Form nach völlig intakt.

Besonders reich ist an Kaseln aus der Wende des ersten und der Frühzeit des zweiten Jahrtausends Deutschland. Zu Augsburg befinden sich ihrer drei, eine in St Ulrich und zwei im Dommuseum; alle drei werden dem hl. Ulrich zugeschrieben (Bild 70).

Die Schloßkkirche zu Aschaffenburg ${ }^{1}$ und St Stephan zu Mainz ${ }^{2}$ besitzen je eine Kasel des hl. Willegis, die ehemalige Abtei zu Branweiler ${ }^{3}$ und der Dom zu Xanten je eine, der Überlieferung nach vom hl. Bernhard benutzte, jedenfalls aber dem 12. Jahrhundert entstammende Kasel. Die frühere Benediktinerkirche zu Niederaltaich (Bayern) bewahrt ein Meßsgewand des hl. Godehard, Bischofs von Hildesheim ( $\uparrow 1038)$, auf. Eine zweite, demselben Heiligen zugeschriebene Kasel, die jedoch in Wirklich-

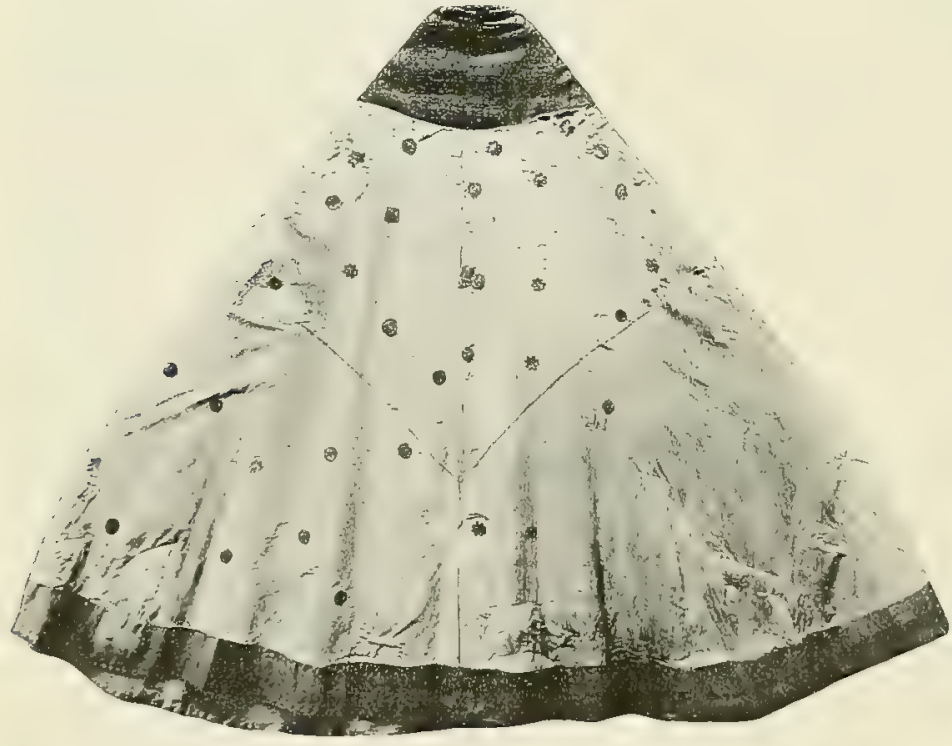

Fild 70. Glockenkasel. Augsl)urg, Dommusemm. keit erst aus dem 12. Jahrhundert stammt, findet sich in St Godehard zu Hildesheim. St Emmeram zu Regensburg darf sich eines Meßgewandes des hl. Wolfoang (Bild 71), die Pfarrkirche zu Iburg einer Kasel Bennos von Osnabriick ( $†$ 1088), der Dom zu Hildeshein der Kasel des hl. Bernward († 1022), die Pfarrkirche zu Deutz derjenigen des hl. Heribert von Köln († 1029) rühmen. Die sog. Sixtuskasel im bischöf-

lichen MLseum zu Münste: wurde schon erwähnt. Auch in dem kgl. bayrischen Tationalmuseum zu München gibt es eine Kasel aus der Frühe des Jahrtausends. Fine weitere befindet sich im Dom zu Würzburg; sie mag dazu gedient haben, die Gebeine des hl. Bruno bei deren Erhebung zu bekleiden (Bild 72, S. 180). Besonders reich aber ist der Dom zu Bamberg an Kaseln dieser Art, bewahrt er doch deren nicht weniger als vier auf, die alle in den Beginn des 11. Jahrhunderts hinaufreichen.

Von mehr oder weniger stark beschädigten Meßsgewändern müssen erwähnt werden die dem hl. Bruno zugeschriebene Kasel im Dom zu Würzburg von der Art der Bamberger Paramente, ehedem ein ungemein prächtiges Stück, das außser dem Futter lajder nur heste les ursprünglichen Oherstoffes aufweint, das Mefogewand des Bischofs Meinwerk in der Bufidorfkirche zu Paderborn, von dem nur mehr das Futter vorhanden, dessen Oberstoff aber samt den Besätzen bis auf winzige Spuren ver-

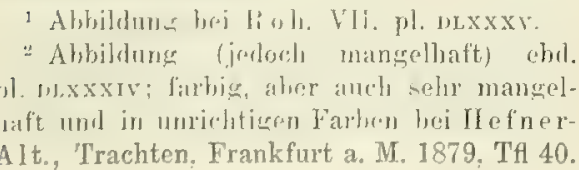

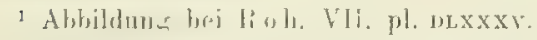
pl. Juxxxiv; firbig, alier amch selu mangelA It. Trachten. Frankfurt a. M. 1879, Tf 40.
Abbildung bei Bock H. TH:32 Sie ist nicht nur in derFarbe ungenau, sondern auch hinsichtlich der Richtung, in welcher sich die Mustelung des itolfes howegt. Statt nimlich horizontal zu verlaufen, geht sio von unteu mach ohen. 
schwunden ist, die im Privatbesitz des Herrn Domkapitular Schnütgen zu Kïln hetinlliche, an den Seiten stark beschnittene Kasel des hl. Anno, ein sehr entstelltes, angeblich vom hl. Benno von Meifen herrührendes Meßgewand in der Liebfrauenkirche zu München, sowie die St Wolfgangskasel im Dom zu Regenshurg, von der im trund nur noch die in Cioldstickerci hergestellten Besätze vorhanden sind; denn alles andere an ihr ist aus späterer Zeit.

Auch in 0 sterreich - Ungarn erfrent man sich noch einer hemerkenswerten Zahl von Kaseln aus dem 11.--13. Jahrhundert. Je zwei gibt es deren in St Peter zu Salzburg, zu St Paul in Kärnten und im Dom zu Brixen (Bild 73, S. 181), je eine im Kloster Martinsberg (Ungarn), im Stilt Melk, zu Gö. (Steiermark) und Marienberg (Tirol). Die beiden herrlichen, ganz mit Bildwerk bestickten Kaseln zu St Paul stammen aus St Blasien in Schwarzwald; einige der angeführten Kaseh hahen im Lauf der Zeit die verwüstende Wirkung der Schere an sich erfahren müssen, so eine der Brixener Kaseln, dann das Gößer und das Narienberger Mefagewand. Eine von Gisela, der Gemahlin Stephans d. Hl., gestiftete Kasel war ursprüglich auch der erst bei der

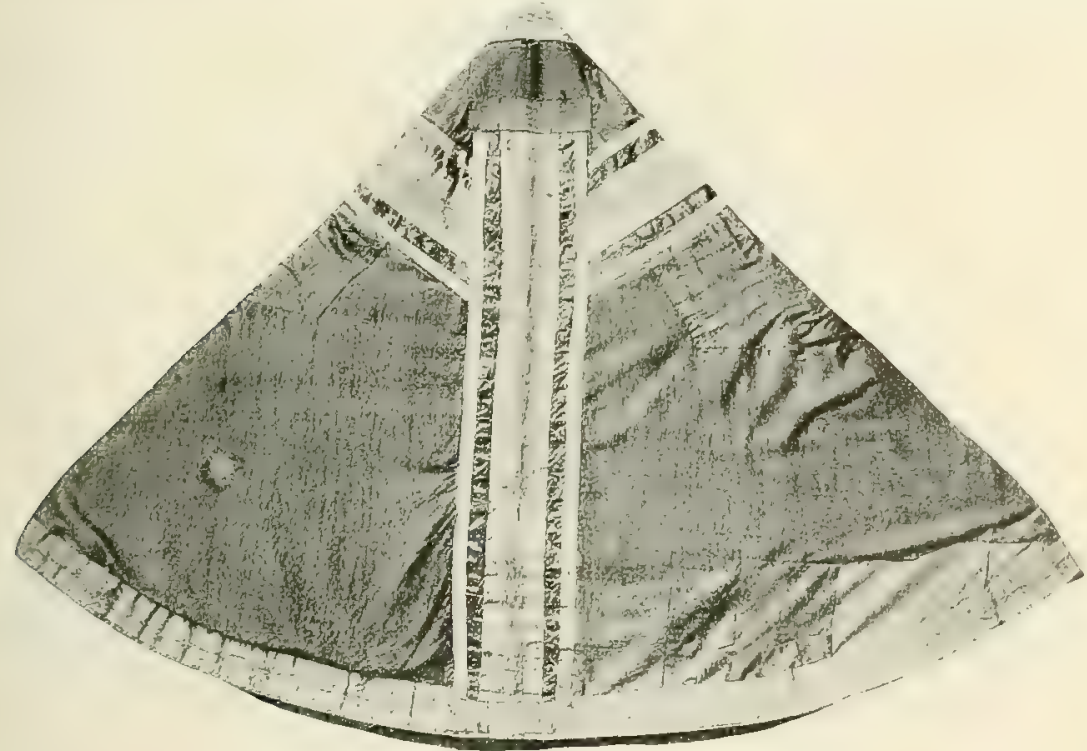

Bild 71. Glockenkasel. Reyensburc, S. Fmmeram.

Krönung Maria Theresias aufgeschlitzte ungarische Krönungsmantel im Kronschatz zu Ofen.

In Belgien besitzt man aus der Frühe des Jahrtausends nur noch eine völlig unversehrte Kasel. Sie befindet sich in der Kathedrale zu Tournai und wird dem hl. Thomas Becket zugeschrieben. Ein Mefigewand in St-Donat zu Arlon, das vom hl. Bernard gelegentlich gebraucht worden sein soll, ist schon an den Seiten merklich zurückgeschnitten und dürfte, wenn solches nicht erst in spüterer Zeit geschah, wohl kaum über die Mitte des 13. Jahrhunderts hinaus anzusetzen sein. Eine Kasel in St-Michel zu Courtrai, die wie die Tournaier dem hl. Thomas Becket angehört haben soll, hat, wenn wirklich von dem Heiligen herstammend, ehenfalls ihre ursprüngliche Form nicht bewahrt. Für $\mathrm{Holl}$ and verzeichnen wir die schon früher erwähnte Kasel zu Dokkum.

Frankreich war noch im 18. Jahrhundert sehr reich an Kaseln aus dem 10., 11., 12. und 13. Jahrhundert, darunter solchen von auferordentlichem Wert ${ }^{1}$. Von den wenigen, welche dem Wüten der Revolution glucklich entronnen und üherhanpt:

: Enige derselben sind nach alten Skizzen abgebildet hei Roh. TIII, pl. ncv ı Ix I«s. 
in der Form intakt auf die Gegenwart gekommen sind, seien hier etwa erwähnt die beiden unter dem Namen des hl. Ebbo, bzw. des hl. Thomas Becket gehenden Meßgewänder im Schatz der Kathedrale von Sens', die Kasel des hil. Edmund von Canterbury († 1240) zu Provins ${ }^{2}$ und ein dem hl. Ivo ( $\dagger 1303$ ) zugeschriebenes, doch wohl älteres Mefagewand zu Louannec ${ }^{3}$ (Diözese St-Brieuc). Nicht mehr vollständig sind die Kaseln zu St-Rambert-sur-Loire ", Biville und Maubeuge, wenn sie überhaupt vor 1250 fallen. Zwei in St-Sernin zu Toulouse aufbewahrte Mefigewänder ${ }^{5}$, von denen eines dem hl. Petrus Martyr († 1252), das andere dem hl. Dominikus zugeschrieben wird, dürften ihrer Form und sonstigen Beschaffenheit nach kaum vor Ende des 13. Jahrhunderts entstanden sein.

Italien ist an Mebgewändern aus der Frühe unseres Jahrtausends sehr arm. Es gehören zu ihnen aufer einer Kasel in S. Trinità zu Florenz, welche von dem hl. Bernardo degli Uberti $(\dagger 1153)$ herstammen soll ${ }^{6}$. die sehr heschädigte, reich bestickte

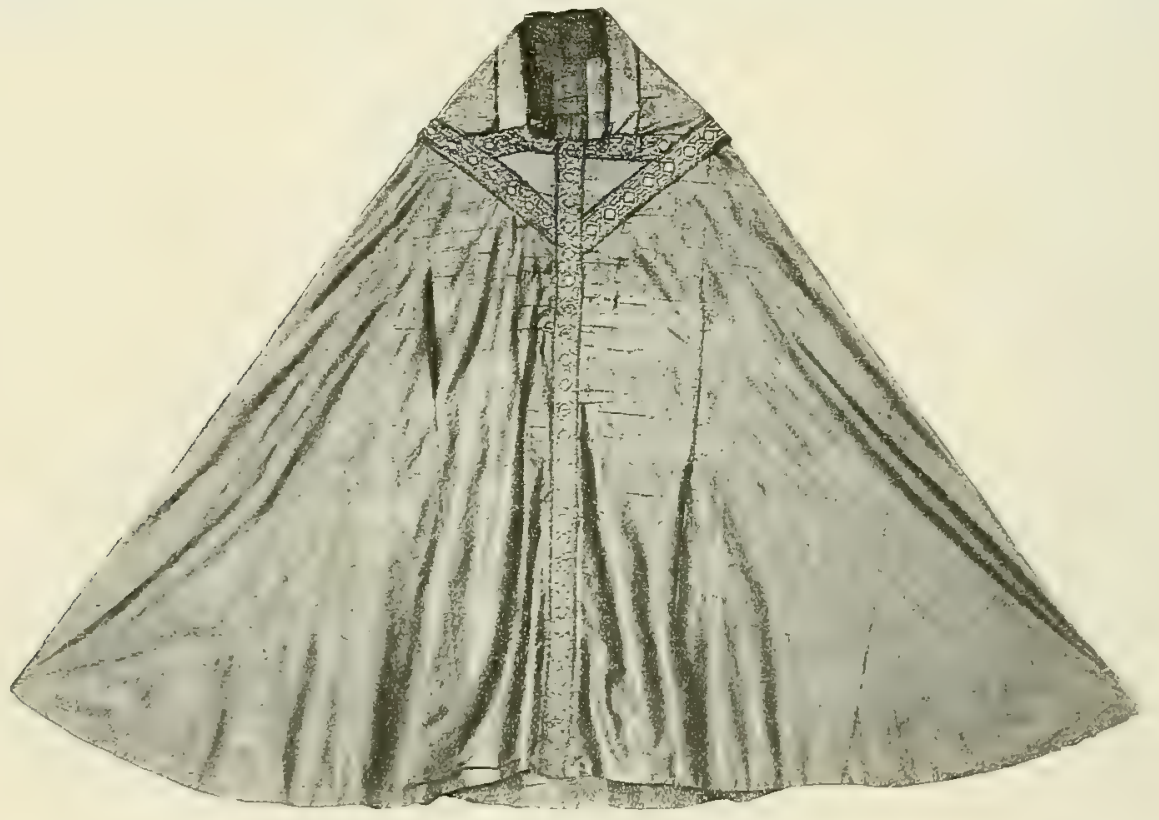

Bild 72. Glockenkasel. Würzburg, Dom.

Kasel des hl. Johannes des "Engelschauers" in S. Urso zu Ravenna, eine kostbare Arbeit des 12. Jahrhunderts, und zwei Linnenkaseln zu Castel S. Elia bei Nepi T.

Es ist eine stattliche Anzahl von Kaseln, die wir aufzählen konnten. Sie sind zweifellos hinreichend, um uns von der Form und dem Schnitt der Kaseln des 10., 11., 12. und beginnenden 13. Jahrhunderts ein anschauliches und genügend vollständiges Bild zu geben, zumal es ja nicht bloß Meligewänder aus nur einem, sondern aus ganz verschiedenen Ländern sind.

Alle angeführten Kaseln haben oder hatten doch ein und dieselbe Gestalt. Es sind bzw. waren Glockenkaseln im vollen Sinne, so genannt wegen der grofen $̈$ hnlichkeit mit einer Glocke. Alle weisen das Charakteristikum der (tockenkaseln auf; sie hahen alle wesentlich die gleiche Länge

1 Oft ahgebildet, am besten bei hoh. VII, Ill. Lx: und de Farcy pl. 11.

2 Abbildung bei Roh. VIII, pl. vevir.

3 Ebd. pl. Dcvir.

4 Ebd. VII, pl. DLxxx; VIII, pl. Devi DeviII.
5 Vgl. die Skizzen and Details ebd. VIII, pl. nexI.

6 Abbildung ebd. VII, pl. DLxxxix.

"Zeitschrift, Jahrg. XII (1899) 343 ff. Abbildungen in Bild 86-88, S. 195 u. 202. 
an der Vorderseite, an der Ruickseite und iber den Armen. Hie und da mag: eine kleine Differenz bestehen, doch ist dieselbe mehr zufälig als beahsichtigt. Nicht selten ist sie nur scheinbar und die Folge mrichtigen Messens. Legt man die beiden Gewandhälften so übereinander, wie es der Schnitt erfordert. so wird man kaum je eine auch nur etwas nennenswertere Verschiedenheit hinsichtlich der Länge entdecken. Übrigens weils, wer sich eingehend mit der mittelalterlichen Kunst befaßst hat, sehr wohl. wie wenig es mnsern Vorfahren um strenge Symmetrie und Regelmäligkeit zu tun war und wie wenig skrupulös sie sich in Einhalten der gleichen Walie zu heweisen pflegten.

Am stärksten tritt der Unterschied in den Mafverhältnissen bei der St Willegiskasel zu Mainz auf, welche an der Vorderseite um ca $0,30 \mathrm{~m}$ kürzer ist als an der Rückseite, wiewohl sie daselbst immer noch die bedeutende Länge von $1,20 \mathrm{~m}$ aufweist. Eine andere Ausnahme bildet die dem

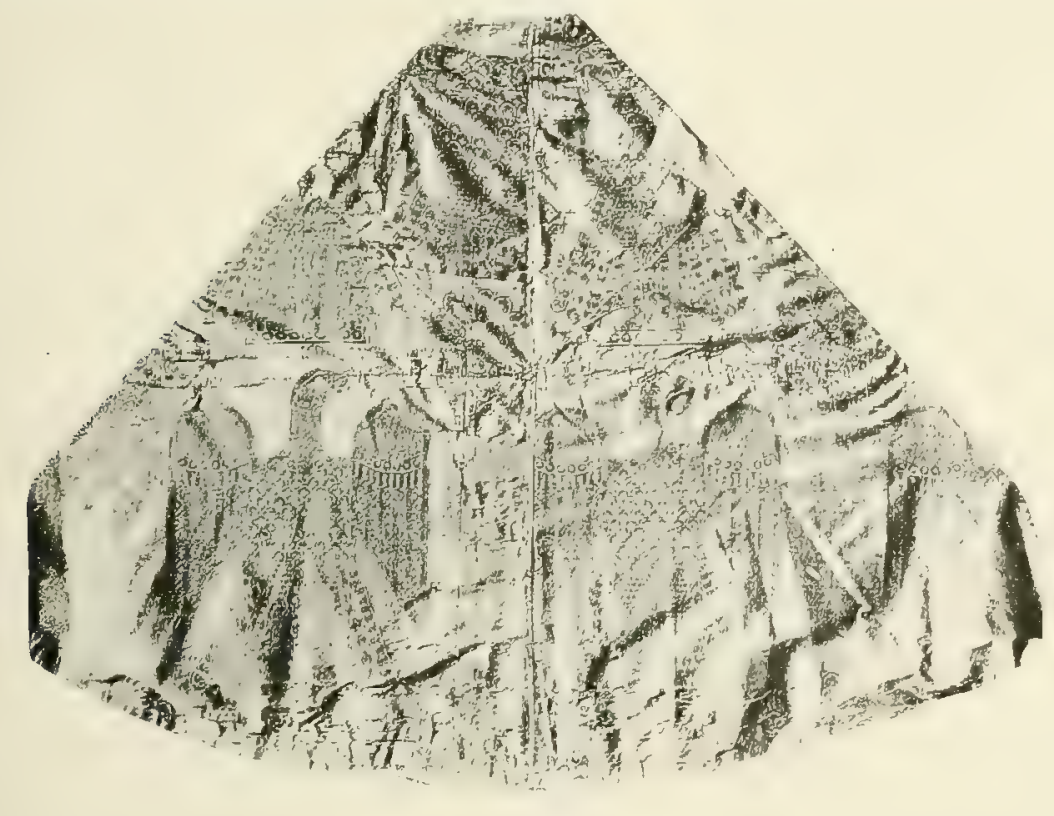

Bild 73. Glockenkasel. Brixen, In,

hl. Thomas Becket zugeschriebene Kasel in der Kathedrale zu Sens. Sie mist an der Vorderseite ca $0,10 \mathrm{~m}$ und über den Armen ca $0,20 \mathrm{~m}$ weniger als im Rücken.

Jedenfalls beweisen die zahlreichen noch vorhandenen Mefogewänder aus den 11., 12. und 13. Jahrhundert mit aller Bestimmtheit, dafs ein systematisches, aus Bequemlichkeitsrücksichten hervorgehendes Beschneiden der Kasel bis tief in das 13. Jahrhundert noch nicht Brauch war. Wo die Kasel von der vollen Glockenform etwas abweichende Malie aufweist, liegt das, falls diese noch die ursprünglichen sind, und das Gewand nicht in späterer Zeit eine Veränderung erlitten hat, an zufälligen Ursachen, wie Mangel an ausreichendem Stoff und ähnlichem. Insbesondere aber war es so wenig Sitte, die Vorderseite der Kasel zu verkürzen, daf man selbst noch im späteren Mittelalter sich lediglich darauf beschränkte, die Seitenlänge und die Gesamtlänge iiherhaupt zn vermindern. Ein besonderes Zustutzen der Vorderseite ist nicht einmal im 14. und 15. Jahrhundert Brauch geworden. 
Legt man eine der Glockenkaseln aus der Frühe unseres Jahrtausends so aufemandel, daf ihre beiden Hälften sich decken, so erhält man einen Ireisteil, dessen beide Geradseiten, falls nicht etwa die Spitze behufs Erweiterung des Kopfdurchlasses abgeschnitten wurde, unter einem rechten Winkel aneinanderstolien, also ein Kreisviertel.

Spreitet man aber das Gewand auseinander, nachdem man es vorn in der Mitte von oben nach unten aufgeschlitzt hat, so gleicht es genau einem Pluviale. Es stellt dann nämlich einen Kreisteil dar, der bisweilen ein wenig über einen Halbkreis hinausgeht. bisweilen auch ein wenig hinter demselben zurückbleibt, gewöhnlich aber einen rollen Halbkreis bildet. Hierbei verlaufen die in der Regel sehr breiten Stoffstreifen ihrer Länge nach von der Peripherie senkrecht zum Durchmesser, gerade wie es auch heute noch bei der Chorkappe der Fall ist, nicht aber parallel zu diesem.

Die Anfertigung der Glockenkasel war hiernach sehr einfach. Man brauchte nur ein Pluviale zu machen bzw, ein halbkreisförmiges Gewand herzustellen, dann dieses an der Vorderseite von unten an bis nahe zum oberen Ende zu vernähen, und die Kasel war im wesentlichen fertig ${ }^{1}$ (Bild 74 a u. b).

So einfach diese Art von Herstellung des Mefigewandes war, so hatte sie doch zwei üble Folgen. Da sie ohne Rücksicht auf die Höhe und Breite der Schultern geschah, so hildete sie im Nacken einen unschönen, eimer Kapuze nicht unähnlichen

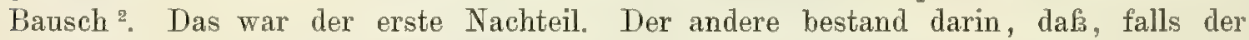
Gewandstoff gemustert war, die Muster auf der Rückseite senkrecht aufwärfs stiegen, während sie sich auf der Torderseite wagerecht hinzogen und in der Mitte kopfüber aneinanderstießen. Zur Hehung des zweiten Nachteils empfahl es sich, die Naht an der Torderseite mit einem Zierstreifen zu verdecken, der gleichsam einen Übergang zwischen den einander entgegenlaufenden Mustern herstellte. Diese Borte war somit, solange man das Mefogewand in der angegebenen Weise herstellte, nicht blok ein Ornament, sondern hatte auch eine aus der Natur der Sache sich ergebende praktische und ästhetische Bedeutung (Bild $74 \mathrm{a} \mathrm{u.} \mathrm{b).}$

Um dem erstgenannten ebenso unschönen wie lästigen Übelstand wenigstens einigermaßsen zu begegnen, schnitt man häufig die obere Ecke des Nefsgewandes ab, indem man gleichzeitig den Schlitz, der als Kopfdurchlaf diente, in der Teise entsprechend erweiterte, daf man durch Beseitigung der voln noch übrig bleibenden Einsprünge einen trapezförmigen oder, jedoch seltener, oralen Ausschnitt herstellte (Bild 7ta). Beide Arten von Durchlässen für den Kopf erhielten sich im ganzen Mittelalter, ja mit einiger Modifizierung bis in die Gegenwart. Noch jetzt erinnert die Form der Halsöffnung römischer Kaseln an den Schlitz der Glockenkaseln.

Aulier dem Durchschlupf für den Kopf gab es an dem Melsgewand für gewöhnlich keine weitere Öfinung. Schlitze zum Durchlassen der Arme dürften sehr selten und lediglich Ausnahmen gewesen sein. Ein Beispiel eines mit Armlöchern versehenen Kaselgewandes bietet die Kasel des Stiftes Melk; sie ist aher auch das einzige. Obendrein kann man fragen, ob die (1,50 m langen und in Schulterhöhe beginnenden Schlitze ${ }^{3}$ bei ihr ursprüng-

1 Die heschrichene Anfertigungsweise der Kasel war die gewöhnliche, doch nicht die ausschliekliche. Bei Herstellung des Mefsgewandes kam auch die Form der zu Gebote stehenden Stoffstücke in Betracht. Waren diese unregelmäfig geformt, so hat man sich geholfon, so gut wie es sing. In einem solchen Fall konute natiulich von einem regelrechten Verlauf der Nähte und Stoffmuster nicht die fiede sein. Das Beispiel einer liasel, hei der sich beide ungewirhm. licherweise schräg über das Gewand hinziehen, bildet z. B. das MeßkkJeid des hl. Bernward zu Hildesheim.

2 S. oben S. 176. Man kann den Bausch noch heute am Pluviale beobachten.

" Nach giitiger Mitteilung des hochw. P. Dr Fd. Katschthaler zu Stift Melk. Die Kreuze auf der Kasel sind zweifelsohne erst in spaiter'r zeit aufgesetzt worden. 
lich sind oder ob sie nicht vielmehr in später Zeit angebracht wurden. Die einzige uns bekannte Darstellung einer mit Öffnungen für die Arme ausgestatteten Kasel befindet sich auf einem Bischofsgrabmal aus dem 13. Jahrhundert im Dom zu Freising ${ }^{1}$; doch scheint es fast, als hätten wir es hier bloß mit einem Erzeugnis künstlerischer Phantasie zu tun.

Von einer Kapuze findet sich bei keiner der noch erhaltenen Glockenkaseln eine Spur. Allerdings redet ein Tredener Kanonikus Nïnning im Anfang des 18. Jahrhunderts ron einem capucciolum der Sixtuskasel: ad cervicem in dorso capucciolum defluit, capiti forte, dum convenit, imponendum. Doch haben wir an ihr von einem solchen nichts finden können. Die eigentliche Sixtuskasel, der jetzige Innenstoff des Gewandes, war sicher mit einer Kapuze nicht ausgestattet. Das Gewand wurde in späterer Zeit umgedreht und mit einem andern Oberstoff versehen. Vielleicht, dafis Nïnning den breiten, kapuzenartigen Besatz, mit dem es bei dieser Gelegenheit um die Halsöfinung herum ausgestattet worden sein muls, für eine Kapuze gehalten hat. Angesichts des defekten Zustandes, in dem sich das Mebgewand zur' Leit des Kanonikus befand, wäre ein solcher Irrtum wohl begreiflich².

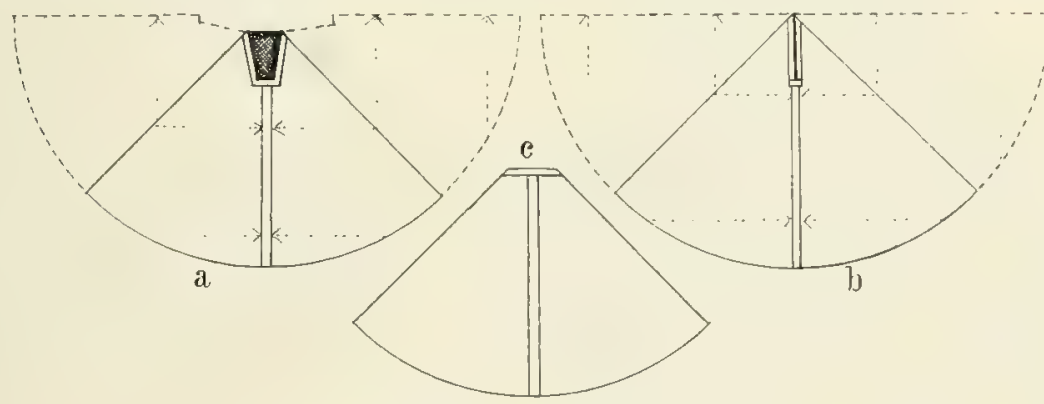

Bild 74. Schnitt der Glockenkasel.

Die gestriehelten Linien bezeichnen die Form des Gewandes, wenn es vorn aufgeschnitten und auseinandergespreitet gedacht wrd; die junktierten gehen dio Yehenuabte und zuuleich den Lauf des Stofimusters an.

Ähnlich wie mit der Kaselkapuze steht es mit den Schnüren, welche man nach Bock seitlich an den Glockenkaseln angebracht haben soll, um diese in gleichmäß̊igem Faltenwurf heraufziehen und in der Gegend des Oberarms in beliebiger Höhe befestigen zu können und so zu verhindern, dals die aufgehäufte Masse der schweren Seidenstoffe bei Verrichtung der heiligen ()pferhandlung lästig und hinderlich werde ${ }^{3}$. Den einzigen Beweis bilden die Schnüre an der Willegiskasel in St Stephan zu Mainz; allein dieselben sind, wie ihre Beschaffenheit beweist, erst in späterer Zeit und wohl ïherhaupt nicht einmal mehr im Mittelalter hinzugefügt worden. An allen andern Kaseln aus dem Mittelalter fehlt die Einrichtung*. Insbesondere aber wird

1 Abbildung bei v. Hefner-Alt. III 149. Zwei Kaseln in S. Marco zuVenedig, die indessen erst dem 15. Jahrhundert entstammen, hat man der Bequemlichkeit halber an den Seiten vom Saum an etwa eine Spanne weit aufgeschnitten. Ähnlich ist es bei der Kasel Kalixts III. (1455-1458) zu Valencia geschehen. Wahrscheinlich wurden indessen diese Schlitze, die wir sonst bei keiner mittelalterlichen Kasel gefunden haben, nachträglich angebracht.

${ }^{2}$ Braun, Die sog. Sixtus-Kasel von Vreden, in Zeitschrift XII (1899) $26 \mathrm{ff}$.

3 Bock, Gescl. I 433.

4 Die Kasel Kalixts III. zu Valencia ist zux Erleichterung des Aufraffens auf den Seiten in Schulterhöhe mit einem Lnopi und etwa $0,20 \mathrm{~m}$ vom Saum mit einer schleite 
man bei den vielen sonstigen noch vorhandenen Glockenkaseln des 11.-13. Jahrhunderts rergeblich nach Spuren von Schniuren zum seitlichen Aufraften des Gewandes fahnden. Nicht ander's verhält es sich mit den vielın Hunderten von mitteJalterlichen Bildwerken, auf denen eine Kasel vorkommt. Nirgends auch nur ein Anzeichen der fraglichen Vorrichtung. Es ist in der Tat auffällig, wie man die Behauptung Bocks so unbesehen hat hinnehmen und immer wieder von neuem hat wiederholen können.

\section{ANDERUNGEN IN DER FORM DES GEWANDES SEIT DEM XIII. JAHRHUNDERT.}

Im Verlauf des 13. Jahrhunderts - der Zeitpunkt ist nicht näher bestimmbar - beginnt ein neues Stadium in der Entwicklung der Planeta. Es hebt die 7eit der systematischen und fortgesetzten Zustutzung des Mefogewandes an, deren letzte Frucht die moderne Kasel ist. Das Beschneiden betrifft sowohl die Gesamtlänge als auch, und zwar ganz besonders, die Seitenlänge. In erster Beziehung ist noch gegen Ende des 15. Jahrhunderts die Verkürzung gering; erst um das 17. Jahrhundert kommt es zu einem entschiedeneren Zustutzen. Anders verhält es sich mit der Seitenlänge der Kasel, die schon gegen Ausgang des Mittelalters vielenorts eine beträchtliche Verminderung erfahren hatte.

Fragen wir nach den Gründen, welche die Umgestaltung der Kaselform herbeiführten, so muf vor allem der Wechsel im Kunstgeschmack genannt werden. Leichte, flotte, aber zugleich eben- und gesetzmäßige Linienführung ist für die Gotik charakteristisch, ein grof angelegter, lang gezogener, weich fliefsender, lebensvoller Faltenwurf, eine Eigentïmlichkeit des Bildwerkes des gotischen Stiles bis ins 15. Jahrhundert hinein. Dabei waren an die Stelle der vollen Rundung einander schneidende Bogen getreten. Es war aber damals eine Zeit, wo die Kunst eine wirkliche Volkskunst war, wo sie noch das ganze Leben beherrschte und alles in den Kreis ihres Wirkens zog, wo Kirche und Haus, Hausrat und Kleidung den Einfluf der Zeitkunst an sich verspürten und nach deren Grundprinzipien ungeschaffen wurden. Unmöglich konnte unter solchen Umständen die kirchliche Gewandung und namentlich das priesterliche Obergewand von dem Einflufs der neuen Kunstrichtung umberïhrt bleiben.

Man hat die Kaseln des 13., 14. und 15. Jahrhunderts gotische Kaseln genannt. Der Name hat an sich ebensowenig Sinn wie der Name Gotik überhaupt. Und doch, nimmt man einmal die Benennung Gotik hin, dann ist auch die andere, "gotische Kasel", immerhin bezeichnend. Wir verstehen rlarunter eine Kasel, bei der die Grundanschauungen der Gotik in der Form wie in Faltenwurf, soweit das möglich ist, ihren Ausdruck gefunden haben. Es ist ganz sicher, dalis Kaseln, die auf den Armen mäßig zurückgeschnitten sind und infolgedessen einen leichteren Faltenwurf ermöglichen, und aufierrlem unten, vorn wie rïckwärts, statt in eine volle Rundung in cine leichte Spitze ausgelien, entschieden ein "gotischeres" Gepräge an sich tragen als eine allenthalben glcich lange, unten runde und auf den Armen einen mächtigen Bausch bildende Glockenkasel.

Es ist sicher nicht ohne Grund, dafs das seitliche Beschmeiden des Mel:gewandes, das notwendig auch eine mehr oder weniger starke Zuspitzung

versehen. Ancls liver ist indessen die Finrichtung wol] etonsowenie ursprïnglich wie die ca $0,20 \mathrm{~m}$ langen Schlitze, die man vom Rand aus bher den Seiten angebracht hat. 
der unteren Enden desselben im Gefolge hatte, in Frankreich wie überhaupt im Norden nicht nur zuerst begann, sondern auch am raschesten und energischsten fortschritt. Gewif konnte sich auch der Süden dem mit der Gotik herrschend gewordenen Zustutzungstrieb ebensowenig wie der Aufnahme dieser selbst völlig entzichen. Allein wie hier die Gotik nur in beschränktem Mabe und in einer durch die überlieferten Baugepflogenheiten und antiken Reminiszenzen nicht wenig veränderten Auffassung und Formengabe Boden fand, so vollzog sich auch der Umbildungsprozels des Melágewandes daselbst unter dem Einflus uralter, tief eingewurzelter Sitte im ganzen in weit langsamerem Tempo und minder durchgreifend.

Indessen dürfte es nicht ausreichen, die Änderung in der Form und dem Schnitt des Mefigewandes lediglich auf einen Wechsel in den Kunstprinzipien und dem künstlerischen Geschmack zurückzufülıren. Das Bestreben, dem Mesigewande eine bequemere Form zu geben, hat sicherlich zu dessen allmählicher Umgestaltung auch seinen guten, wenn nicht gar den größten Teil beigetragen.

In der Tat läft sich nicht verkennen, dafs die alten Glockenkaseln nicht gerade immer für den Träger eine Annehmlichkeit waren, dafs vielmehr die durch die Länge und Weite dieses Gewandes bedingte und auf den Armen lastende Faltenmasse unter Umständen für den Zelebranten sehr lästig werden konnte. Das muste besonders dann der Fall werden, wenn, wie das im späten Mittelalter sehr gewöhnlich geschah, das Mekgewand aus schwerem, steifem Brokat, aus Goldstoff oder kräftigem Samt angefertigt wurde.

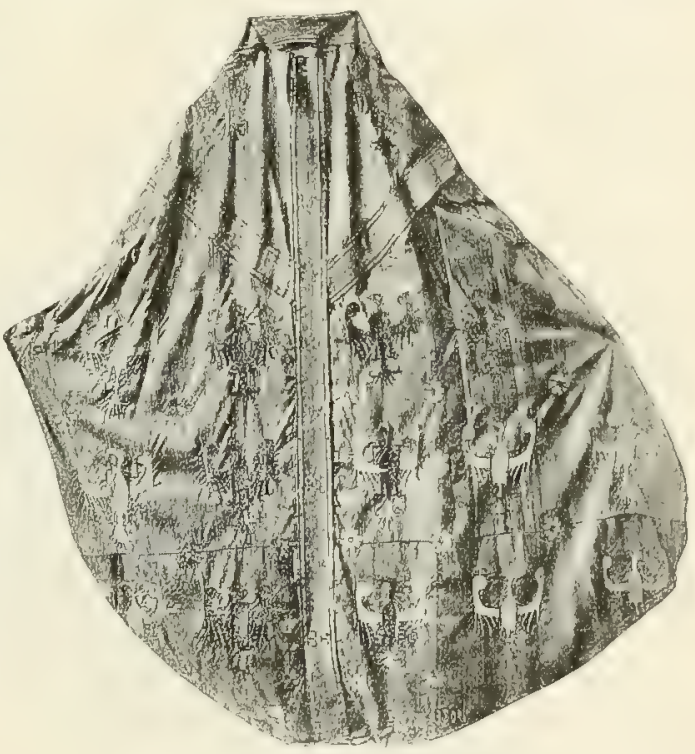

Bild 7.). Kiasel. Halberstalt, Dom.

Bezeichnend für das Gewicht, das schon im 13. Jahrhundert die Kaseln infolge der Stoffmenge und der Ausstattung wohl hatten, ist eine Mitteilung der Mainzer Chronik ${ }^{1}$, worin von einem Mebgewand erzählt wird, das wegen des dabei verwendeten Goldes so steif war, daf es nicht in Falten gelegt werden konnte, und so schwer, daf ein sehr kräftiger Mann dazu gehörte, um in ihm die heilige Messe zu feiern. Die Bischöfe und Prälaten hätten sich seiner an Festtagen bedient, aber nach dem Evangelium und Offertorium es mit einem biegsameren vertauscht und in diesem dann das heilige Opfer vollendet. Daf aber ähnliche Kaseln damals durchaus keine Seltenheiten waren. sondern oft genug vorkamen, beweisen zur Genüge die Inventare aus jener Zeit. Eine Idee solcher schwer mit Gold bestickten Mefgewänder gibt eine Kasel im Dom zu Halberstadt (Bild 75)².

Unter solchen Umständen ist es wohl begreiflich, wenn man dazu überging, die manchmal allzu ungefïgen Kaseln handlicher und bequemer zu ge- 
stalten, indem man sie an den seiten zurückschnitt und dadurch die Last und die Faltemmenge, welche auf den Armen sich aufzuhäufen pflegte, verminderte. Was so auf der einen Seite dem Mefigewand zum Vorteil gereichte, der kostbare Stoff und die prächtige Ausstattung, wurde auf der andern der alten majestätischen Form der Planeta zum Verderben.

Wir werden übrigens mit der Annahme schwerlich fehlgehen, daf hie und da auch Ersparnisrücksichten für die Einführung des Zustutzungssystems mafgebend gewesen sind, und es ist wohl nicht blof Zufall, dals die Terkürzung der Kaseln beginnt, nachdem sich bestimmte liturgische Farben ausgebildet hatten. Riculf von Soissons konnte sich noch damit bescheiden, dafis er seinen Priestern vorschrieb, sie sollten eine Mebakasel besitzen. Seit dem 13. Jahrhundert war das nicht mehr tunlich, da wenigstens in größ̉eren Kirchen entsprechend den $4-6$ ja 7 Kirchenfarben auch ebensoviele Kaseln vorhanden sein musten.

Der Umbildungsprozels, der sich mit dem Mefigewand im 14. und 15. Jahrhundert vollzog, betraf, wie schon vorhin bemerkt wurde, vor allem die Seitenlänge desselben. Alle andern Veränderungen, die bezüglich der Form der Kasel vor sich gingen, sind sekundärer Natur, namentlich die Verkuirzung der Vorder- und Rückseite und die beim Ausgang des Mittelalters auftauchende Änderung im Schnitt. Bis gegen Ende des 15. Jahrhunderts bildeten die Schrägseiten der Kasel, wenn man diese mit ihren beiden Hälften übereinanderlegte, regelmäfig vor wie nach einen rechten Winkel. Dann aber führte die inzwischen mächtig vorangeschrittene seitliche Zustutzung des Mersgewandes dazu, dieses, bei dem von einem ergiebigen Faltenwurf und einem Anschmiegen an den Körper schon seit einer Weile nicht mehr wohl die Rede sein konnte, besser den Schultern anzupassen. Man lief zu dem Ende die Schrägseiten statt unter einem rechten unter einem stumpfen Winkel aneinanderstofen, indem man dadurch dem Schulterteil des Gewandes den steilen Anstieg benahm und eine flachere Form gab.

Die Unwandlung der Kasel von der Glockenform zur heutigen Skapulierform vollzog sich übrigens weder plötzlich noch an allen Orten zu gleicher Zeit. Hier hielt man zäher an der alten Form fest, während man anderswo munter mit dem Strom der Keit schwamm. Auch scheint die weite, faltige Kasel am ehesten aus dem Alltagsgottesdienst verschwunden zu sein, während sie bei feierlichen Gelegenheiten sowie bei den Bischöfen und sonstigen Dignitaren noch längere Zeit im Gebrauch blieb.

Am konservativsten war man in Italien; der Norden war demselben in der Zustutzung der Kasel um wenigstens ein halbes Jahrhundert voraus. Über die Kasel in Deutschland zu Ende des 15. Jahrhunderts finden wir eine interessante Notiz in der gedruckten "Auslegung des Amts der heyligen Messe" (Augsburg 1486). Dort heibt es bei Deutung der Kasel: „Die casula. das ist das obergewandt oder oberkleid das wir nennen und heyssen das melgewandt. das solt gewönlich rott seyn und glocken weytte. und nicht ausgespitzt und geschnitten seyn. als man sie denn in disen teutschen landen pfligt ze machen."

Um die Mitte des 13. Jahrhunderts hatte die Kasel selbst in Deutschland noch keine namhafte Veränderung hinsichtlich der Form erlitten. Denn damals beschreilst sie uns Bertold von Regensburg in seiner treuherzigen, ansprechenden Weise noch mit den Worten: "Der melachel ist gar michel und allumbe ganz und geschaffen als ein glog und als der himel, und so ihn der 
prister uf die arme leget, so ist er geschaffen als ein schilt rorn und hinten und bezeichnet die grofe minne, die got $\mathrm{zu}$ dem menschen hät." 1 Zu Bertolds Zeit war also das Mefagewand ersichtlich noch eine Glockenkasel, jedenfalls kann es an den Seiten noch nicht in merklicher Weise zugestutzt gewesen sein.

Im allgemeinen stellt noch im 14. und selbst bis ins 15. Jahrhundert hinein die Kasel auî den Bildwerken eine solche Stofffülle und eine so reiche Faltenmasse auf den Armen dar, daß an eine ibermäfige Zustutzung für diese Zeit noch nicht zu denken ist. Dasselhe heweisen auch die Mefigewänder dieser Periode, soweit sie unverändert und unbeschnitten sich in die Gegenwart gerettet haben.

Die Kasel des hl. Petrus Martyr zu St-Sernin in Toulouse hat anf den Amen eine Länge von ca $1,10 \mathrm{~m}$, das ebendort aufbewahrte, dem hl. Dominikus zugewiesene, der Beschaffenheit des Stoffes und der Stickerei nach aber vielleicht erst im 14. Jahrhundert entstandene Meßgewand eine Seitenlänge von nahe $1 \mathrm{~m}$. Die Kasel, welche Grimaldi im Grab Bonifaz' VIII. fand, als man 1605 dasselbe öfnete, ging nach dem Protokoll über den Leichenbefund noch um eine kleine Strecke über die Hände hinaus, hatte also über den Armen jedenfalls noch eine Länge von ca $1,10 \mathrm{~m}$. Die vom hl. Bernardin gebrauchte Kasel in der Opera del Duomo zu Siena mifst an den Seiten ca $1,10 \mathrm{~m}$. Sie scheint im frühen 15 . Jahrhundert aus einem älteren Stoff hergestellt worden zu sein, wenigstens stammen aus dieser Zeit die Besätze des Gewandes. Zwei ebenfalls dem 15. Jahrhundert angehörige, aus schlichtem, violettem Wollstoff gemachte Kaseln in S. Marco

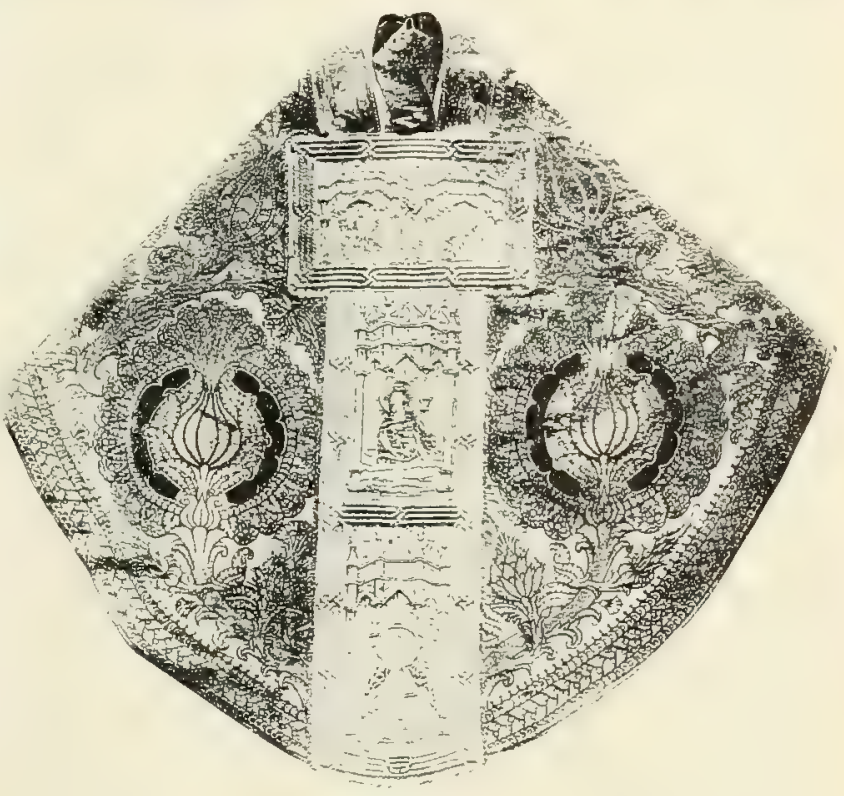

Bild 76. Kasel Kalixtus III. Valencia. zu Venedig haben vorn und rückwärts eine Länge von $1,37 \mathrm{~m}$, an den Seiten aber eine solche von $1,20 \mathrm{~m}$. Eine von Blanka, der zweiten Genahlin Philipps von Valois, in der zweiten Hälfte des 14. Jahrhunderts gestiftete Kasel zu Briennon (Yomne) milist $1,55 \mathrm{~m}$ im Rücken, gegen $1 \mathrm{~m}$ auf den Seiten ${ }^{2}$.

Die dem seligen 'Thomas von Biville $(\uparrow 1257)$ der Tradition nach einst angehörige, zu Biville befindliche Kasel hat über den Armen nur eine Länge von ca $0,95 \mathrm{~m}$, ein Anzeichen, dafs das Gewand, wenn unbeschnitten, wohl aus etwas späterer Zeit stammt.

Von zwei Mefgewändern im historischen Museum zu Bern hat eines bei einer Gesamtlänge von $1,50 \mathrm{~m}$ auf den Armen ca $0,95 \mathrm{~m}$. Es gehört dem 14. Jahrhundert an, ist italienischer Herkunft und wahrscheinlich an den Seiten etwas zurückgeschnitten. Das andere stammt von Bischof Aimo von Lausanne († 1517); es weist auf den Armen nur noch $0,67 \mathrm{~m}$ auf $^{3}$.

I W a c ke r n a g e 1, Altdeutsche Predigten, Basel $1876, \mathrm{Nr} 41$, S. 70.

Ahbildung bei Roli. VIII, pl. vexvil.
3 Abbildung der Kasel Aimos bei de Farcy, Suppl. pl. 163; eine Skizze der ersten bei Roh. VIII, pl. Dcxiv, der sie aher zu huch laticut. 
Die Kasel, die von Kalixtus III. (1455-1458) bei der Kanonisation des h1. Vinzenz Ferrerius getragen wurde und nun zu Valencia aufbewahrt wird, hat eine Seitenlänge von ca $0,90 \mathrm{~m}$ (Bild 76, S. 187). Nan hat das Gewand an den Seiten vom Rand an so weit eingeschlitzt, daß es nur mehr bis über den Ellenbogen reicht, die anfgeschlitzten Teile aber flügelartig rechts und links vom Arm herabhangen, eine Einrichtung, welche auch die beiden Wollkaseln in S. Marco, deren schon Erwähnung geschah, aufweisen.

Ton den zwei Meßsgewändern zu Eichstädt ist die sog. Liutigerskasel in St Walburga eine vortreffliche Arbeit aus dem Beginn des 15. Jahrhunderts. Das interessante Dessin des Stoffes besteht aus Quadraten, denen Rosetten eingefügt sind. Das Kreuz auf dem Rücken des Gewandes weist bereits horizontale Arme auf; es enthält eine gut gestickte Darstellung des Gekreuzigten. Im Rücken 1,36 m lang, hat es auf den Schultern im Einklang mit der Zeit seiner Entstehung eine Länge von $0,60 \mathrm{~m}$. Das andere Mefogewand, die St Willibaldskasel im Dom, ist älteren Datums, aber später an den Seiten beschnitten worden. Es ist aus ungemusterter gelber Seide gemacht, wie die Form der Besätze bekunden, italienischen Ursprungs und allem Anschein nach in der zweiten Hälfte des 13. Jahrhunderts entstanden. Besonders bemerkenswert sind die interessanten griechischen oder doch gräzisierenden Figurenstickereien anf dem Besatz der Rückseite. Das Gewand hat eine Länge von 1,51 m; auf den Schultern mikt es $0,75 \mathrm{~m}$ !

Zwei Kaseln in der Alten Kapelle zu Regensburg haben eine Länge von 1,40 bzw. $1,38 \mathrm{~m}$; über den Seiten messen sie 0,50 bzw. $0,56 \mathrm{~m}$; sie gehören dem 15. Jahrhundert an, falls sie nicht etwa wegen Schadhaftigkeit um diese Zeit an den Seiten auf ihre jetzige Breite zugestutzt wurden. Jedenfalls reichen sie nicht weit über das 15 . Jahrhundert hinaus?

Die größte Zahl spätmittelalterlicher Meßgewänder befindet sich in dem Herzoglichen Museum zu Braunschweig, dem Dom zu Brandenburg, der Marienkirche zu Danzig, dem Dom zu Halberstadt und zu Castel S. Elia bei Nepi. Das Herzogliche Inseum zu Braunschweig besitzt 30 Kaseln, welche zum Teil aus dem 14,, zum Teil aus dem 15. Jahrhundert herstammen. Die größste Länge derselben beträgt $1,45 \mathrm{~m}$, die geringste $1,31 \mathrm{~m}$; bei den meisten schwankt sie zwischen 1,40 und $1,35 \mathrm{~m}$. Die Seitenlänge fällt von $1,17 \mathrm{~m}$ bis auf $0,67 \mathrm{~m}$, bei der Mehrzahl der Kaseln hält sie sich zwischen 1,00 und $0,85 \mathrm{~m}$. Von einer Zustutzung kann wohl nur bei einem der Mefgewänder die Rede sein; alle übrigen geben sich, abgesehen von den Besätzen, die bei einzelnen in neuerer Zeit hinzukamen, in dem Zustande, in welchem die sog. Reformation sie fand, Ein Teil der Kaseln ist aus einem ungemusterten grünen, violetten, roten und blatuen Wollstoff' gearbeitet, die meisten bestehen jedoch ans Seide. Brokatellen und Brokaten.

Der Schatz von St Marien zu Danzig darf sich rühmen, die höchst bedeutende Zahl von 79 mittelalterlichen Kaseln zu bergen. Sie gehören zum Teil noch dem 14., meist aber dem 15., einige dem frühen 16. Jahrhundert an. Ihre Länge schwankt zwischen 1,45 und $1,30 \mathrm{~m}$; über den Armen messen sie, soweit sie aus dem 14. und

1 Abhildung der Gewänder in Fichstäts Kunst", München 1901, 2 f u. 78. Über eine sehr schadhafte Kasel zu Altenburg (Süidtirol) vgl. Mitt. 1895, 259.

2 Fischbach Fr., Ornamente der Gewebe vi und Tfl 144 145. Nach Fischbach (ebd.) xiahrt der Stoff del Gewauder aus der zweiten Hälfte des 12. Jahrhunderts her. Denn eine arabische Inschrift auf einer Dalmatik und einer Tuncella, welche zu einer der Kaseln gehüren, soll nach Karabacek lauten: "Verfertigt hat dieses Feierkleid der Meister Abdul Aziz in seiner Fabrik fiir Wilhrolm II. (von Sizilien)*.
Indessen ist die Übersetzung nach einer freundlichen Mitteilung des P. L. Cheikbo S. J. zu Beirut (St Josephs-Universitait) unrichtig. Il faut être devin pour lire le nom de Guillanme II, roi de Sicile; en tout cas les lettres quion voit ne le montrent pas. Der Stoff stammt wie die durchaus gleichartigen Zeuge bei einer Kasel in Herzoglichen Museum zu Braunschweig, einer Kasel zu Kulm und einem Pluviale in St Marien zu Danzig frühestens ans den 14. Jahrhundert. Es sind Brokatgewebe, bei welchen die Goldfuiden aus vergoldeten Lederriemchen bestehen. 
15. Jahrhundert stammen und nicht im 16. Jahrhundert seitlich zugestutzt wurden, ca $0,75-0,60 \mathrm{~m}$. Einige im 16. Jahrhundert entstandene Mefgewänder haben nur mehr eine Seitenlänge von ca $0,40 \mathrm{~m}$.

Im Dom zu Halberstadt finden sich, abgesehen von den Kaselresten und verschiedenen späteren Kaseln, noch mehr denn 30 vollständige Kaseln aus dem Mittelalter. Einige reichen noch ins 13 . Jahrhundert hinauf, so namentlich das prächtige, aus kräftigem blauem Seidenköper bestehende, mit goldgestickten Adlern geschmückte Wefsewand, das indessen allem Anschein nach in späterer Zeit an der Seite beschuitten wurde. Die übrigen fallen zumeist in das 14. und 15. Jahrhundert?. Bei einigen der Halberstadter Kaseln belänft sich die Länge auf mehr denn $1,50 \mathrm{~m}$, im allgemeinen schwankt dieselbe bei ihnen jedoch zwischen 1,45-1,35 m. Die Seiten. länge beträgt bei den älteren Gewändern ca $1,10-0,95 \mathrm{~m}$, um dann allmählich bis zum Beginn des 16. Jahrhunderts auf ca $0,50 \mathrm{~m}$ herabzusinken.

Auch das bayrische Nationalmuseum besitzt unter seinen zahlreichen, meist freilich später beschnittenen Nefgewändern noch eine Anzahl solcher, die, aus dem 15. Jahrhundert stammend, ihre ursprüngliche Form ganz oder doch nur mit geringer Veränderung beibehalten haben.

Von den Kaseln zu Castel S. Elia wird weiter unten ausführlicher die Rede sein.

Das 16. Jahrhundert, das für die Neubelebung des kirchlichen Lebens und kirchlichen Geistes so bedeutungsvoll wurde und ganz hesonders durch seine segensreichen Reformen auf dem Gebiete der Liturgik eine neue Periode eröffnete, hat der Kasel nichts Gutes gebracht. Wäre man nur auf dem Standpunkt stehen geblieben, auf dem man beim Beginn der neuen \%eit angelangt war! Das 16. Jahrhundert hat zwar nicht die wenig schüne Mel:gewandform geschaffen, die noch jetzt trotz aller dagegen aufgewandten Bemühungen den Markt beherrscht, allein es hat denn doch mit dem überlieferten Schnitt endgültig gebrochen. Wohl war das Melsgewand, wie es am Schlusse des 16. Jahrhunderts in Brauch war, im ganzen noch ein erträglicher, ja im Vergleich mit der späteren Kasel sogar noch ein würdiger Ornat. Allein das mittelalterliche Mefgewand war es nicht mehr, und der Name Kasel war bei ihm in jeder Beziehung nur mehr eine blofe Reminiszenz, ein Wort ohne Bedeutung. Schon die Kasel des 15 . Jahrhunderts hatte blof noch mit teilweiser Berechtigung ihren Namen wahr gemacht. Das Mefigewand des beginnenden 17. Jahrhunderts war in keinem Sinne ein "Hüttchen " mehr.

"Nostra aetate ac superioribus aliquot saeculis casula ab utraque parte concisa ante et retro sine errore ullo producitur usque ad talos adeoque accisa atque in aliam speciem deformata, ut si cum antiqua casula, unde defluxit, componatur, vix suum nomen tueatur, sagt mit Recht Stephan Durant im Anschluti an Wilhelm Lindanus ( $\dagger$ 1588) in seiner 1592 erschienenen Schrift De ritibus ecclesiae catholicae?

Selbst in Rom, wie überhaupt in Italien, wo die Kasel am längsten der alten Form treu geblieben war, hatte das Mefagewand, abgesehen ron etwas gröberer Breite, schon am Ende des 16. Jahrhunderts wesentlich die jetzige Form.

1 Verschiedene sind mit alteren, kostharen Besätzen verziert, so z. B. $\mathrm{Nr} 209$, welche wohl ehenfalls noch aus dem 13. Jahrhundert datiert, und $\mathrm{Nr}$ 20?. Ein merkwirdiges Gewand ist Nr 206. Es bestelit aus plïscllartigem, grünem Samt und stellt eine Glockenkasel dar. Das mit Heiligen in Reliefstickerei verzierte, geradbalkige Kaselkreuz ist eine
Arheit des 15. Jahrhunderts. Das Metigewand selbst diufte jedoch kaum dieser Zeit angehören, sonderu weit älter sein. Es ist schmer anzunehmen, dal 3 man in 15. Jahlhundert im Norden noch eine Glockenkase] a e u hergestellt habe.

2 L. 2, c. 9, n. 8; (ed. Colon, 15), p. 326. 
Es ist interessant, die der Wende des 15. Jahrhunderts entstammenden Grabfiguren in den Basiliken Roms in Bezug auf die Kasel mit römischen Bildwerken aus dem Beginn des 17. Jahrhunderts zu vergleichen. Dort ist sie noch ein langes, weites Gewand mit mächtigem Faltenbausch auf den Armen, hier legt sie sich fast völlig glatt, falten- und runzellos dem Körper an und schliefst im besten Fall etwas über der Mitte des Oberarmes ab. Man halte nur einmal die Kardinäle auf den Grabmonumenten in S. Maria del Popolo, einen Christoforo della Rovere $(\dagger 1480)$, einen di Castro $(\dagger 1506)$, einen Costa $(\dagger 1508)$ und einen Podocatharos $(\dagger 1500)$ und die Statuen an der Fassade von S. Susanna aus dem Anfang des 17. Jahrhunderts gegeneinander.

Eines der frühesten Beispiele einer schon ziemlich stark beschnittenen Kasel bietet zu Rom das Grabmal des Kanonikus von St Peter, Bernardo Capella († 1524), in S. Stefano Rotondo, welches dem Verstorbenen nach seinem Tode von zwei Freunden gesetzt wurde. Das Gewand reicht unter sehr mäfigem Faltenwurf nur noch eben

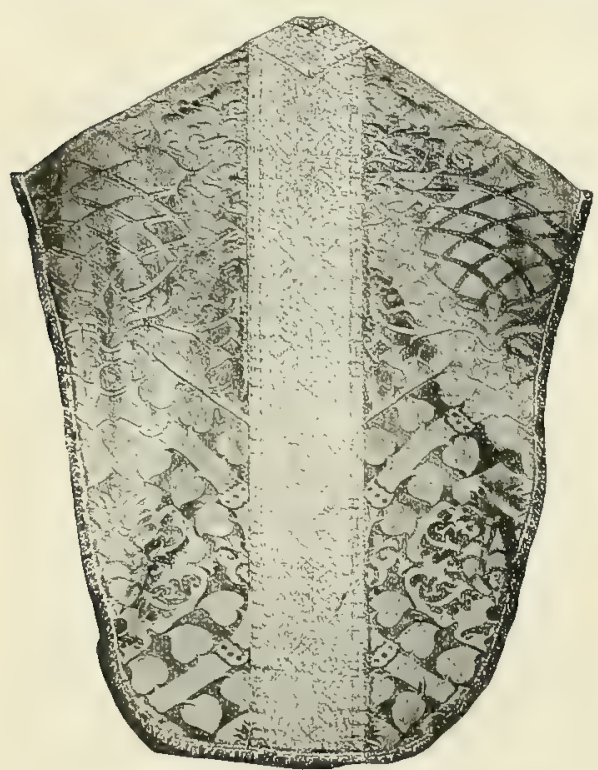

Bild 77. Kasel des hl. Karl Borromäus. Rom, S. Miaria Maggiore.

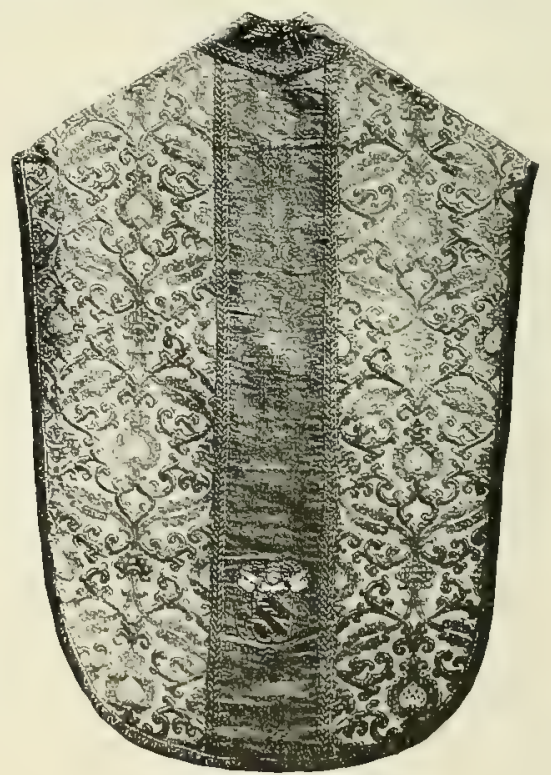

Bild 78. Kasel Pins' V. Rom, S. Marja Magrione.

ïber den Oberarm hinaus. Recht bezeichnend tritt der Wechsel in den Maßen der Kasel an zwei Mefsgewändern hervor, die in S. Maria Maggiore aufbewahrt werden. Das eine stammt vom hl. Karl Borromäus, der bekanntlich Erzpriester der Basilika war (Bild 77), das andere vom hl. Pius V. (Bild 78). Jenes ist ca 1,45 m lang, $1,10 \mathrm{~m}$ im Rücken, $0,90 \mathrm{~m}$ vor der Brust weit und auf den Armen $0,60 \mathrm{~m}$ lang. Dieses hat ebenfalls eine Länge von $1,45 \mathrm{~m}$, dagegen beträgt die Rückenbreite nur mehr $0,95 \mathrm{~m}$, die vordere Breite $0,73 \mathrm{~m}$ und die Seitenlänge über den Armen $0,50 \mathrm{~m}{ }^{2}$.

Bemerkenswert ist, dafi Paul IV. (1555-1560) den Versuch machte, die Kasel auf ihre fruhere Form zurückzubringen. Oldoinus berichtet darüber in seinen Zusätzen zu Chacons Vitae Rom. Pontificum: Pontificum indumenta, quae a naiestate formaque desciverant, suo splendori ac figurae

1 Die Kasal hes lıl. Karl Borromäus im Jom zu Mailand weist auf dom Armen eine liange von ca $0, i, 4$ m anf, im Riucken mifst sie in die Breite ca $\mathbf{1 , 0 6} \mathrm{m}$. Die Iuänge des Ge- wandes bolatuft sich auf $1,27 \mathrm{~m}$. Es sint, wie man sieht, so ziemlich dieselben Mafie, welche dre Kascl des hl. Karl in Maria Maguiore zu hom eignun. 


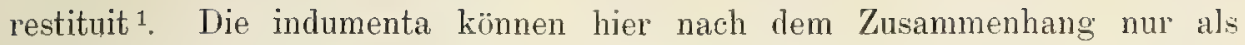
liturgische Gewänder gefafit werden, und zwar wird man bei ihnen in Anbetracht der damaligen Verhältnisse, wenn nicht allein, so doch vorzugsweise an die Kiasel zu denken haben. Der gutgemeinte Versuch hatte leider keine nachhaltige Wirkung.

Um die Wende des Jahrtausends war die Rückenbreite der römischen Kasel schon auf $0,85 \mathrm{~m}$ und ihre Länge über den Schultern auf ca $0,45 \mathrm{~m}$ herabgesunken, Mase, welche genau den Angaben Gavantis in dessen 1628 erschienenem Thesaurus entsprechen ${ }^{2}$.

Zur Charakterisierung der römischen Kaselform des ausgehenden 16. Jahrhunderts kann ein Mefigewand dienen, dessen sich der sel. Petrus Canisius zu Freiburg in der Schweiz während seiner letzten Lebenstage bediente $O b$ es römischen Ursprungs ist, läft sich nicht feststellen, jedenfalls gibt es aher nach Schnitt und Mabverhiciltnissen treu die damalige römische Kasel wieder (Bild 79).

Es ist aus einfarbig grüner, leichter Taffetseide angefertigt und höchst einfach; die Stäbe sind durch Börtchen imitiert. Seine hintere Hälfte ist $a$ $85 \mathrm{~cm}$ breit; die nur sehr mälsig ausgeschnittene Vorderseite ist blok um ein weniges schmaler. Auf den Schultern hat es eine Länge von $0,45 \mathrm{~m}$. Das Gewand besteht aus zwei Stoffstücken, einem gröferen und einem kleineren. Jenes bildet den Rückteil und zugleich die obere Partie des Vorderteils, dieses das untere Stück des letzteren. Die Weise der Anfertigung der Kasel ist aus der beistehenden Skizze ersichtlich. An dem größeren Stück wurden die Abschnitte o und o' um ab bzw. cd nach vorn geschlagen und das kleine Stück an die nunmehr vorn in gerader Linie liegenden Seiten ef und gh angenäht. Dann wurde dem Ganzen ein leichter Piquéstoff als Futter untergelegt und schließlich dureh Börtchen der Besatz nachgebildet. Das 1,32 $\mathrm{m}$ lange Gewand hat infolge seiner eigentümlichen Anfertigung eine Öffnung zum Durchlassen des Kopfes, wie sio in ähnlicher Weise bei der früher geschilderten Herstellung der Planeton des 11. Jahrhunderts entstand.

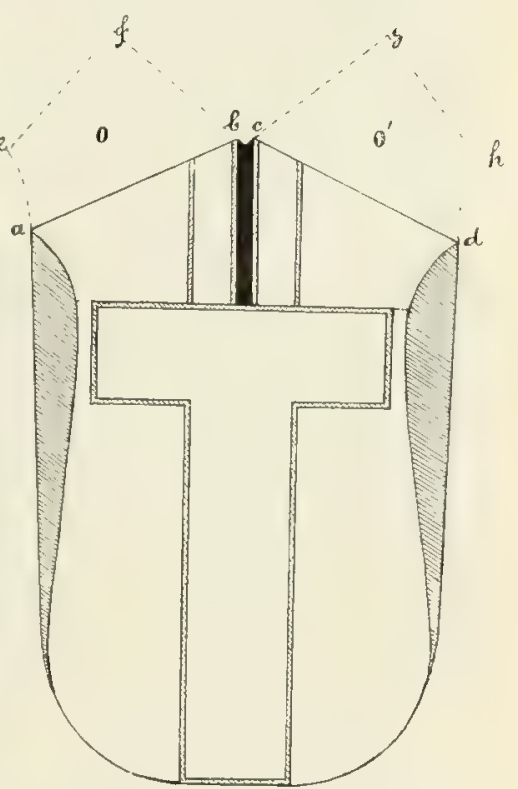

Bild 79. Kasel des sel. Petrus Canisius. Exaten, Cinnisius-Krnleu.

Im übrigen Italien vollzog sich die Umbildung der Kasel in derselben Weise und denselben Tempo wie zu Rom. Man braucht, um sich davon zu ïberzeugen, nur die Bildwerke in Neapel. Florenz, Pisa, Siena, Ravenna, Bologna, Venedig, Verona, Mailand usw. zu studieren. Es ist nicht nötig. auf Einzelheiten einzugehen. Nicht darf jedoch das Bestreben des hl. Karl, ler Vergewaltigung der Kasel in seinem Machtbereiche ein Ende zu machen, unerwähnt bleiben. ITm dem Gewand eine würdige Form zu erhalten, bestimmte der Heilige, es solle die líasel etwas mehr als 3 Cubiti = ca 1,30 m breit und ebenso lang oder noch etwas länger sein, so dabs sie fast bis zu den Kinöcheln reiche ${ }^{3}$. Freilich konnten auch die Bemühungen des hl. Karl

1 Ciaconii-Oldoini Vitae Rom. Pontif.JIl, Romae 1677, 832.

- Gav. I[ 273.

3 A. E. Med. 627. Es wird dort ausdrück- lich noch bemerkt, es müsse die Kasel so breit sein, dals sie unterhalb der schultur woch eine Faltung von dex breite ciner Spanne zulasse. 
die unwiderstehlich dahinrauschende /eitströmung nicht aufhalten. Es ging in Mailand wie anderswo. Um die Wende des 16. Jahrhunderts war die Kasel auch dort hei denselben Mafen angelangt. die um diese Zeit in Rom und dem übrigen Italien bei dem Mel̈gewand üblich geworden waren. Sellost die zu Rom und Mailand aufbewahrten Kaseln des großen Mailänder Erzbischofs entsprechen nicht einmal mehr ganz jenen Mafien.

Eine treffliche Planeta aus der zweiten Hälfte des 16. Jahrhunderts befindet sich in der Opera del Duomo zu Florenz (Bild 80). Sie ist $1,41 \mathrm{~m}$ lang, im Rücken $0,98 \mathrm{~m}$ breit und auf den Schultern $0,50 \mathrm{~m}$ lang. Das Mefsewand, welches St Gemi-

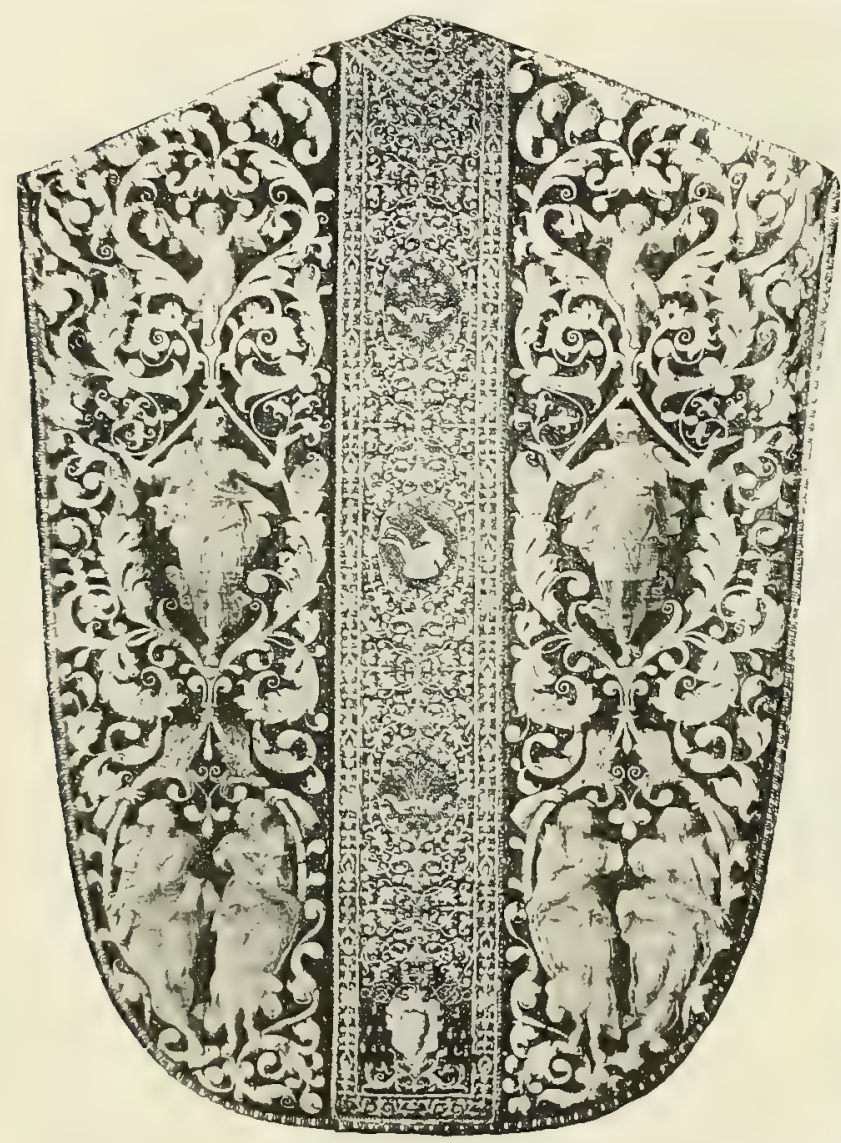

Bild so. Kasel. Floren\%, Opera del Luomo. nianus nud St Markus zu Venedig auf den Mosaiken im Portikus von S. Marco aus den Jahren 1535 und 1545 tragen, ist von etwas gröfreren Maßsverhältnissen als die Florentiner Kasel, die man Kardinal Alexander Farnese zuschreibt. Aus dem Anfang des 17. Jahrhunderts mag die prächtige Kasel stammen, welche in der Kapelle der Familie Chigi des Domes zu Siena aufbewahrt wird. Man eignet die Entwürfe zu den Stickereien, mit denen sie in reichstem Maßse bedeckt ist, fälschlich Raffael zu (Bild 81). Das Gewand hat bei einer Länge von ca $1,30 \mathrm{~m}$ eine Rúckenbreite von ca $0,90 \mathrm{~m}$ und eine Schulterlänge von ca $0,45 \mathrm{~m}$.

Eine bemerkenswerte $\mathrm{Ka}$ sel italienischen Ursprungs aus der ersten Hälfte des 16. Jahrhunderts besitzt das Stift Einsiedeln. Thre Länge beträgt $1,12 \mathrm{~m}$, ihre Rückenbreite von Schulter zu Schulter $0,93 \mathrm{~m}$. Der Stoff des Gewandes besteht aus derber Leinwand, der mittelst kräf-

tiger, dunkelblauer Seidenfäden Hirsche. Vögel und Lilien eingewoben sind. Das Kreuz mit dem Kruzifixus ist nachträglich der Kasel aufoesetzt worden ${ }^{1}$.

Im Norden machte auch im 16. Jahrhundert die Kasel den Verbildungsprozef rascher durch als im Süden. Hier finden wir bereits in der ersten Hälfte desselben Melggewänder von ciner Form, wie sie uns in Italien erst gegen 1600 begegnen. So hat beispielsweise die 1528 von Bischof Carandolet rer Katherleale von Besançon geschenkte Kasel 2 bei eincr Länge von ca $1,30 \mathrm{~m}$

Nach nen gitisen Mitteilungen des hochw. Herru J'. Orlilo lingholz. Cinte Abbildung des Gewandes in P. Odilo Ringholz, Geschichte des Stifts Einsiedeln I, Einsiedeln 1904, 256.
2De liarcy pl. Fo. Bisehof Carandolet von l'alermo war Dechant vou Besancon. I)je Kascl ist eine Arheit ans Bruges und datiert. 
eine Rückenbreite von nur $0,94 \mathrm{~m}$ und eine Schulterlänge von ca $0,48 \mathrm{~m}$. Die Kasel Friedrichs von Brandenburg im Dom von Halberstarlt milit hei $0,90 \mathrm{~m}$ im Rücken auf den Schultern nur $0,45 \mathrm{~m}$. Ebenso weist das durch seinen Stoff und namentlich seine glänzenden Stickereien in Goldlasurtechnik berühmte Melägewand des Kanonikus sibert von Ryswick († 1540) im Schatz des Xantener Domes bei einer Gesamtlänge ron 1,45 m eine Riickenbreite von nur $0,95 \mathrm{~m}$ und über den Schultern eine Länge von blok $0,45 \mathrm{~m}$ auf.

Sehr lehrreich sind für die Kenntnis der Kasel des 16. Jahrhunderts und ihrer Umbildung die Grabmäler der Erzbischöfe im Dome zu Mainz. Das Mergewand, init dem Kurfürst von Henneberg $(\uparrow 1504)$ bekleidet erscheint, ist noch weit und faltenreich; dasselbe gilt von demjenigen seiner nächsten Nachfolger. In der zweiten Hälfte des Jahrhunderts aber verliert es auf den genannten Monumenten seinen reichen Faltenwurf und schrumpft bis zum Beginn des 17. Jahrhunderts immer mehr zusammen. Dann aber verschwindet die nunmehr allzu bedeutungslos gewordene Kasel von den Denkmälern, um durch das mächtigere und wirkungsvollere Pluviale ersetzt zu werden.

Auch die Grabmäler der Trierer Erzbischöfe Johann von Metzenhausen $(†$ 1540) und Johann von Schönenberg († 1599) im Dom zu Trier sind für den Entwicklungsprozeß; , den die Kasel bei uns nahm,

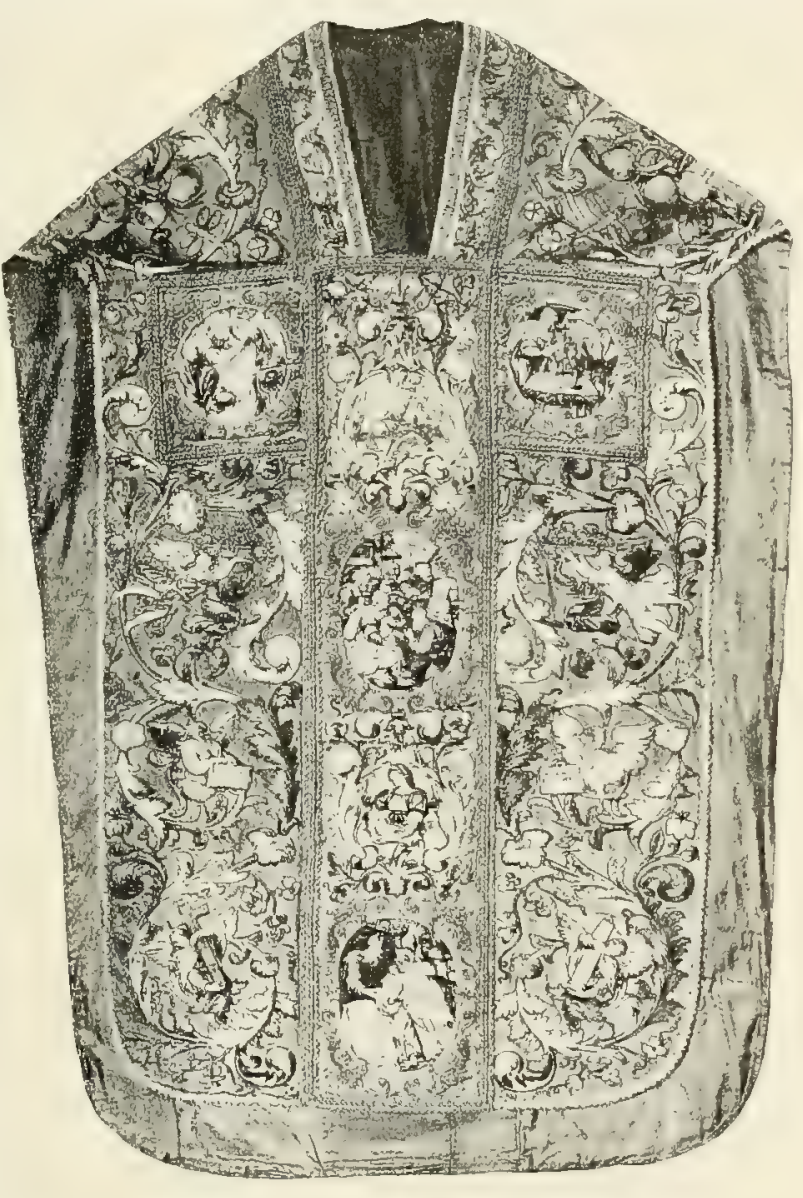

Bild 81. Kasel. Siena, Dom, Kapelle Chici. recht bezeichnend. Bei ersterem reicht das Mebgewand noch bis zur Mitte des Unterarmes, bei letzterem nur noch ein wenig auf den Oberarm.

Eine vorzügliche Übersicht üher Form, Schnitt und Größenverhältnisse des Mebgewandes im 12., 13., 14., 15. und 16. Jahrhundert liefern eine Anzahl Kaseln, welche sich zu Castel S. Elia bei Nepi in der römischen Campagna erhalten haben. Sie bieten eine förmliche Entwicklungsreihe des Gewandes durch das spätere Mittelalter hindurch his in die Frühe der neueren Zeit hinein, und zwar besteht dieselbe nicht, wic etwa in einem Museum, aus Kaseln, die aus den verschiedensten Orten und regenden zusammengetragen wurden, es sind Mefgewänder -.- und das gibt ihnen eine besondere. Bedeutung - aus einer und derselben Kirche. Das Bild, welches sie uns von der Umgestaltung der Planeta vermitteln, ist darum ein durchaus treues und lebenswahre. Spiegelbild der Wirklichkeit. 
Sie zeigen uns aber nicht nur, wie es sich mit der allmählichen Umwandlung des Mefogewandes im mittleren Italien verhalten hat. Da nämlich die Verbildung des Gewandes allenthalben im Abendland wesentlich den gleichen Gang nahm, wenn sie

\begin{tabular}{|c|c|c|c|c|}
\hline \multirow[b]{2}{*}{$\mathrm{Nr}$} & \multicolumn{3}{|c|}{ Lünge der Kasel } & \multirow[b]{2}{*}{ Entstehmugszeit 1} \\
\hline & $\begin{array}{l}\text { auf den } \\
\text { A.rmen }\end{array}$ & rom & $\begin{array}{l}\text { riick- } \\
\text { wïrts }\end{array}$ & \\
\hline 1 & 0,45 & 1,30 & 1,30 & 16. Jahrh., \\
\hline 2 & 0,50 & 1,54 & 1,41 & 2. Hälfte \\
\hline 3 & 0,59 & 1,39 & 1,39 & \\
\hline 4 & 0,66 & 1,50 & 1,50 & 16. Jahrh., \\
\hline 5 & 0,69 & 1,48 & 1,60 & 1. Hälfte \\
\hline 6 & 0,80 & 1,33 & 1,33 & 15. Jahrh. \\
\hline 7 & 1,20 & 1,58 & 1,58 & \\
\hline 8 & 1,22 & 1,55 & 1,55 & 14. Jahrh. \\
\hline 9 & 1,45 & 1,50 & 1,84 & 13.-14. Jahrh \\
\hline 10 & 1,60 & 1,60 & 1,60 & 12. - 13. Jahrh \\
\hline 11 & 1,62 & 1,60 & 1,62 & \\
\hline
\end{tabular}
sich auch in dem einen Lande rascher vollzog als in dem andern, so kann das Bild, welches wir durch die Kaseln von Castel S. Elia von der Entwicklungsgeschichte des Mefogewandes erhalten, mit allem Fug als Reflex der allmählichen Umgestaltung der mittelalterlichen Kasel überhaupt betrachtet werden.

Es sind im ganzen 11 Meß̋gewänder, welche die schlichte Landkirche birgt. Ihre Mafiverhältnisse erhellen aus nebenstehender Tabelle.

Bei nur zwei Kaseln ist der Vorderteil teil; die Mehrzahl weist vorn und rückwärts dieselbe Länge auf; bei einer ist sogar die vordere Hälfte um $0,13 \mathrm{~m}$ länger als die hintere. Es sei hierauf besonders aufmerksam gemacht; denn es zeigt, wie wenig bis in die Neuzeit hinein das Bestreben herrschte, die Kasel vorn zu verkürzen, und wie verkehrt es ist, aus künstlerischen Lizenzen oder scheinbaren Ungenauigkeiten der Monumente den Schluß zu ziehen, man habe schon im 11. Jahrhundert die Kasel der Bequemlichkeit halber vorn zugestutzt. Die Kaseln von Castel S. Elia beweisen aufs schlagendste, daß für Bildwerke, auf denen das Meßggewand vorn kürzer aussieht als auf dem Rücken, eine andere Erklärung gesucht werden muß?

Beachtenswert ist ferner, wie bei den Kaseln im ganzen die Tendenz sich äufert, um so mehr an Länge abzunehmen, je näher sie der Neuzeit kommen. Am interessantesten ist aber die Tabelle mit Rücksicht auf die Seitenlänge der Mefsgewänder. Dieselbe fällt von $1,62 \mathrm{~m}$ auf $0,50 \mathrm{~m}$, mit andern Worten: bei Kasel 11 und 10 gleich der Gesamtlänge des Gewandes beträgt sie bei Kasel 2 und 1 nur noch ca ein Drittel derselben.

Wie schon früher bemerkt wurde, bestand die Umgestaltung des Melígewandes vor allem und wesentlich in der seitlichen Zustutzung.

Die sonstigen Veränderungen, welche mit ihm vor sich gingen, die Verkürzung nach unten und die Einführung eines neuen Schnittes zum Zwecke, das Gewand der Schulter besser anzupassen, stehen in ursächlichem Zusammenhang mit der seitlichen Beschneidung ter Kasel. Je mehr diese an den Seiten zusammenschrumpfte, um so mehr mufste sie auch unten verkürzt werden, sollte ihr nicht alles Ehenmafs genommen werden. Je mehr man ferner durch die Zurückschneidung an den Seiten die Bildung eines Faltenwurfes auf dem Oberarm erschwerte, um so mehr mufte man daran denken, dem Mefogewand eine Form zu geben, bei der es sich möglichst glatt den Schultem anlegte. Klar tritt dieser Gang der Dinge bei den Skizzen 82-87 zu Tage, welche die Kaseln $\mathrm{Nr} 1,5,6,7,9$ und 11 der Tabelle wiedergeben. Sie bieten eine Darstellung der Umbillung des Mefigewandes in den verschiedenen Phasen seiner Entwicklung vom 12. his zum 17. Jahrhundert, wie man sie sich besser und vollstïndiger kaum wünschen könnte. Zugleich zeigen sie aber auch den tiefgreifenden Unterschied zwischen der ursprünglichen rlockenform des Gewandes und der skapulierform, auf welche dieses durch das anhaltende Zustutzen bis zum Schluf des 16. Jahrhunderts gebracht worden war.

Ührigens muls betont werden, dalis tiotz aller Beschneidung die Kasel bis in das 17. Jahrhundert im Norlen wie im Südlen immer noch ein wïrdiges

Kasel $\mathrm{Nr} 3$ ist aus einem Meligewand des 14. Jahrbunderts durch seitliche Beschneidung hergestrollt worden. Auch die
Kiseln Nr 2 und 4 wurden aller Wahrscheinlichkeit nach in gleicher Weise aus älteren Meligewändern gemacht. 2 S. obens. 175. 
Erstes Kapitel. Die Kasel.

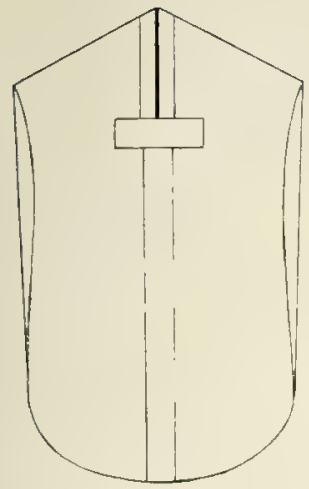

Bile 82
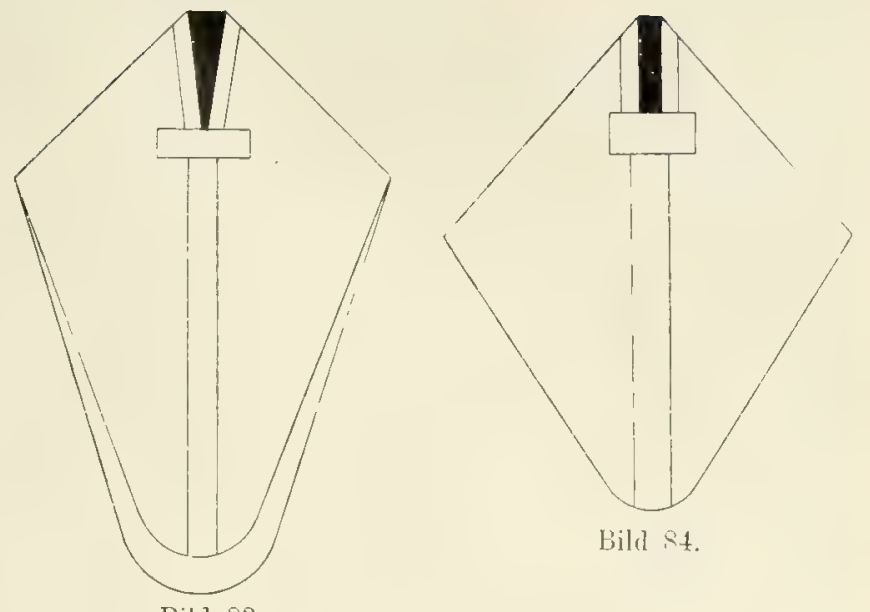

Bild \&4.

Bild 83.

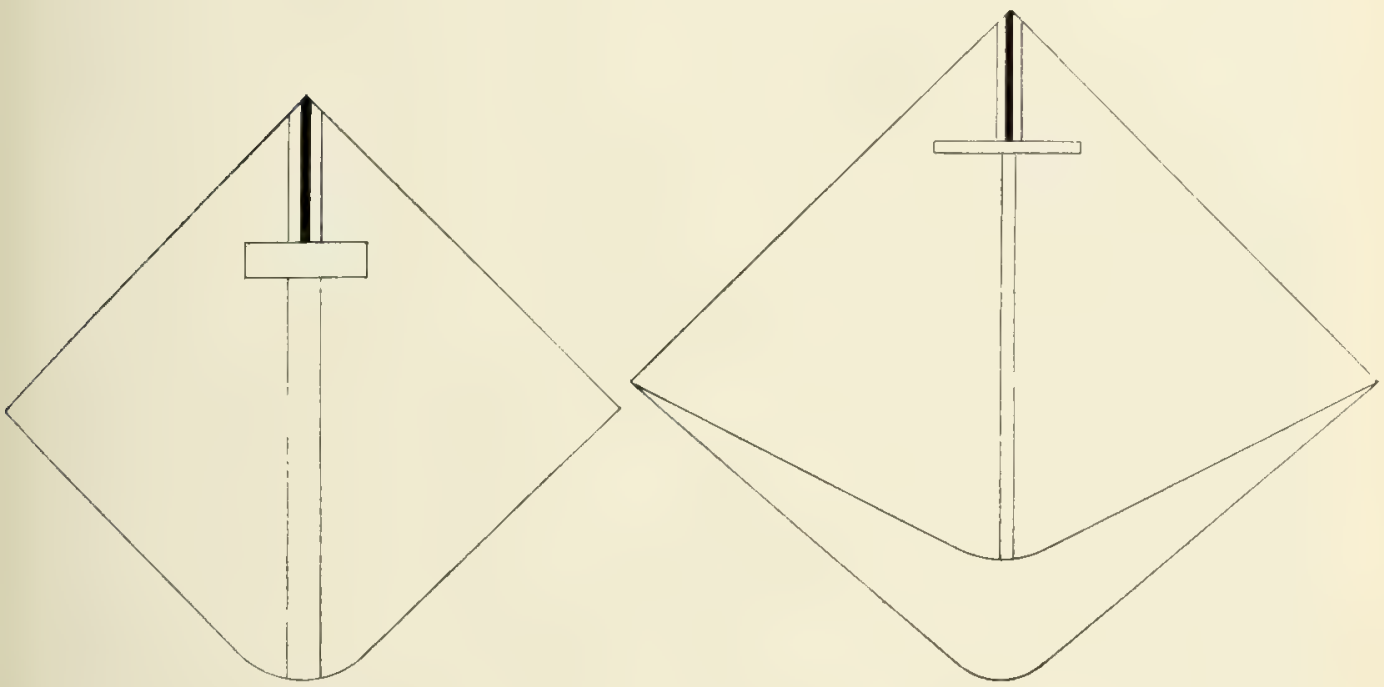

Bild 85 .

Pild $\times 6$.

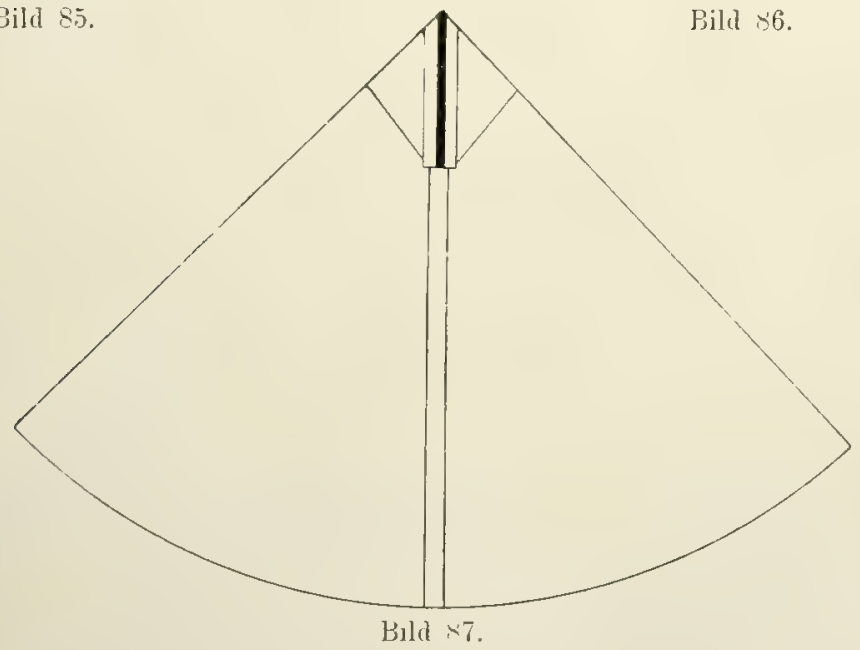

Bild 82- 87. Kaseln, die Entricklung der Kasel vom 12, Jahrl. an bietend. Castel S. Elia. 
Mefscewand bliel, wenngleich es natürlich schon lange nicht meln das Iteal eines solchen war. Die eigentliche Verbildung der Tasel hebt erst in der zweiten Hälfte des 1\%. Jahrhunderts an. Bis dahin hatte das Gewand ilurchgängig noch überall die angemessene Rückenbreite ron $0,80 \mathrm{~m}$. Nun siukt diese zunächst auf $0,75 \mathrm{~m}$, dann im Verlauf des 18 . Jahrhunderts auf $0,70 \mathrm{~m}$ und zuletzt gar auf $0,65-0,60 \mathrm{~m}$ herab, hier etwas früher, dort etwas später.

Damit aber nicht blok auf den Armen, sondern auch vor der Brust keine lästigen Falten entständen, blieb man dabei nicht stehen, nur die Breite des Gerrandes zu verringern, sondern ging auch dazu über, die vordere Hälfte der Kiasel recht gründlich vor den Schultern auszuschneiden. Es war ein Radikalmittel, durch welches indessen der Zweck, den man verfolgte, rollkommen erreicht wurde; denn nunmehr gestattete auch das schwerste und steifste Mebigewand den unbehinderten Gebrauch der Arme. Dal’s dadurch die Vorderseite der Kasel die häfliche Gestalt einer Geige oder eines Schurzes erhielt, machte keinen Eindruck. War doch das Gewand nun walnhaft bequem geworden. Und dann gewährte ja eine solche gründliche Zustutzung des altehrwïrdigen Kleides volle Möglichkeit, die schwersten und strotzendsten Goldstickereien auf ihm anzubringen und so der Prunksucht die weiteste Rechnung zu tragen ${ }^{1}$.

Die Führerschaft in der Vergewaltigung des Mefgewandes hatte Frankreich übernommen. Zwar schrieb noch im Jahre 1651 das Rituale von Rouen vor, es sollte die Form der heiligen Gewänder eingehalten werden, welche die von den Vätern getroffene Anordnung und das elıwürdige Alter der Kathedralkirche vorschreibe, und darum mülsten die Kaseln oder Planeten nach beiden Seiten hin eine solche Auselelnung haben, daf sie wenigstens den ganzen Arm bedeckten ${ }^{2}$. Ja es waren, wie Lebrun-Desmarettes (de Moléon) in seinen Voyages liturgiques de France berichtet, noch 1718 an bestimmten Tagen in einzelnen Kirchen Kaseln von mittelalterlicher Form in Gebrauch und es hatte damals überhaupt das Mefsgewand an verschiedenen Orten noch eine solche Breite, daf es bis auf den Arm des Priesters herabging. Allein das waren Ausnahmen und keinesweg's der Ausdruck für den Geist und Geschmack der Zeit. Besser pafte zu demselben die Anschauung, die nach de Vert ein Pariser Caeremoniale zum Ausdruck bringt, wenn es bestimmt: revolutae illae partes ut superfluae amputandae sunt ${ }^{3}$. Die Falten auf den Armen waren überflïssig und mufisten darum beseitigt werden. Aber auch in Deutschland, Spanien, Portugal und den Niedlerlanden brach man gründlich mit der überlieferten Kaselform. Die zahlreichen Meligewänder des 18. Jahrhunderts, die sich in den Sakristeien noch erhalten haben, legen vollwichtiges Zeugnis dafür ab. Man hatte sich zu sehr in den Bann des französischen Beispiels begeben. Wie auf dem Gebiet der Kunst, des Wissens, der Etikette, der profanen Tracht usw., so war dieses auch auf dem der Paramentik tonangebend geworden. Lyon und Paris beherrschten den Paramentenmarkt samt den Sakristeien und beglückten alle Welt nicht blof mit ihren "reizenden", den kirchlichen Farbenregeln freilich wenig entsprechenten Stoffen, sondern auch mit ilıren von "wahrhaft modernem und ausgesucht geläutertem Geschmack zengenden " fertigen liturgischen Gewändern.

Am konservativsten war man in Italien, namentlich zu Rom, wo das Mefigewand stets eine erträgliche Form heibehielt und kaum je zu ilen kläg-

1 Eine Piejlıe derarticer hiochst liostharer Kaseln sind abgethildet hei de F a r c y pl. 88 $913610 ? 12813011$ a
2 Ioan, I'revotii Observat. ad lihr. Inan. Abrinc. de off. eccl. n. 122 (M. 147, 8x). De Vert 318 note. 
lichen Nafsverhältnissen herabgewürdigt wurle, die aufer Italien allenthalben gang und gäbe waren.

Das 17. und namentlich das 18. Jahrhundert sind denn auch vornehmlich die Zeit, la man die Schere an ältere Mebgewänder legte. WVelche Barbarei und welche unbeschreibliche Geschmacklosigkeiten man dabei bewies, bezeugen laut die verstümmelten Stickereien. die Heiligen, denen die Füise amputiert wurden oder die man geradezu halbierte. Unsere Sakristeien und Museen weisen Hunderte ron Beispielen dafür auf. Falls eine Kasel nicht als Reliquie eines Heiligen galt, fand sie keine Barmherzigkeit. Daher die eigentïmliche Tatsache, dab sich aus der Fühe unseres Jahrtausends so viele unversehrte Mefagewänder crhalten haben, aus dem ausgehenten Wittelalter und selbst dem 16. Jahrhundert jedoch in katholischen Firchen nur äuberst wenige. Wenn man intakte Kaseln aus dieser Zeit sehen will, muf man vor allem nach Danzig (St. Marien), Halberstadt (Dom) und Brandenburg (Dom) gehen. Aus protestantischen Kirchen stammt in den meisten Fällen wohl auch, was wir an unbeschnittenen spätmittelalterlichen Kaseln in den Iuseen finden.

Etwas spezifisch Tatholisches war freilich das Zustutzen des Gewandes nicht. Wo, wie in Dänemark und Schwerlen, die Kasel sich his in die fiegenwart beim protestantischen Gottesdienst in Gebrauch erhielt ${ }^{1}$, lat sie denselben Prozel.; durchgemacht, der sich mit dem Mebgewand im katholischen Ritus vollzog. Es gibt in Schweden noch eine grofe Zahl Kaseh aus dem ausgehenden Mittelalter. Sie bieten indessen dasselbe Bild, welches uns so manches Meligewand aus jener Zeit in katholischen Sakristeien gewährt. Das Beschneiden des altehrwürdigen Gewandes lag in dem Geschmack der Zeit und der herrschenden Mole. Es wurde daher iiberall geibt, wo dieses sich in Gebrauch befand, bei den Katholiken wie bei den Protestanten.

\section{DIE KASEL IN DER NEUESTEN ZEIT.}

Auch in der neuesten Zeit hat das Mefrgewand seine Geschichte. Die Bestrebungen, den liturgischen Gewändern statt der bisherigen entarteten Formen eine würdigere, der Heiligkeit der liturgischen Feier und dem religiösen Anstand entsprechendere Gestalt zu geben, kam vor allem der Kasel zu gut. Das Beriürnis nach einer Lmgestaltung der Kasel war in der Tat zu schreiend, um ungehört zu verhallen. Wenn irgendwo, dann galt es hier, nach mancherlei Seiten hin, nach Stoff, Anfertigungsweise, Ausschmückung und Form hin Wandel zu schaffen. So erhoben sich denn, unterstützt durch manche Bischöfe, in England, Frankreich, den Niederlanden und Deutschland eine Reihe von Männern, welche, voll Begeisterung für die gute Sache, unermüdlich alle Kräfte für eine gründliche Reform der Kíasel einsetzten. Als anzustrebendes Ziel galt möglichste Einführung eines Meligewandes, wie es im späteren Mittelalter in Gebrauch war.

Aucl in Deutschland blieb die Kasel bei den Protestanten manchenorts bis tief in das 17. $j a$ bis ins 18. Jahrhundert neben der Alhe als liturgisches Gewand in Gehrauch (vgl. Stimmen aus Maria-Laach LV [1898] 104). Zu Rostock wurde sie im Beginn des 18. Jahrbunderts aus der Liturgie verbannt, zu Nüruberg wurde sie erst 1810 abgeschafft
(Kirchenlex. IX 573). Zu Hamnover, Grimm: und Libeck erhielt sie sich bis in den Anfang des vorigen Jahrhunderts (ebd. VII 175). Ehenso trug die sächsische Hof- und Pfarr geistlichkeit bis ins 19. Jahrhundert Kaseln, und $\mathrm{zwar}$ recht farbjge und mit Goldstickerei geschmückte (C. Gurlitt, Kirchen, Stuttgart 1906, 75). 
Die Prager Synode vom Jahre 1860 sagt bezüglich der Kasel: Dolemus autem impraesentiarum casulas esse adeo decisas contra debitam maiestatem et in aliam prope speciem deformatas, ut si cum prisca et propria huius indumenti forma componantur, vix sum tueantur nomen. . . . Longe pateant ad minimum ulnas duas et ab utroque latere infra humeros aliquatenus dependeant; fasciam porro habeant decentis latitudinis assutam ab anteriori et posteriori parte usque ad extremum dependentem, cui altera fascia transversalis crucis quandam speciem exprimant 1 . Sie verlangte also für das Gewand eine Breite ron ca $1,20 \mathrm{~m}$, d. i. das gleiche Maß3, welches das Prager Ḱonzil vom Jahre 1605 in Anlehnung an die Bestimmungen des hI. Karl vorgeschrieben hatte? Die Dekrete der Prager Synode wurden von Rom bestätigt, ein ITmstand, der für die Frage nach der Erlaubtheit der sog. gotischen Kaseln nicht ohne Bedeutung ist. Denn diese sind es ja, welche das Konzil im Sinne hatte, wenn es auch nicht ausdrücklich von gotischen Kaseln redet.

In Deutschland haben sich namentlich Dr Bock und der von Pfarrer Laib und Dr. Schwarz herausgegebene Kirchenschmuck wie um die Regeneration des Paramentenwesens überhaupt, so besonders um die der Kasel grokies und dauerndes Verdienst erworben.

Man nannte die mittelalterliche Kasel, deren Einführ'ung man wieder anstrebte, gotische, altdeutsche und Bernarduskasel, eine kleinere Form aber, die sich an die Verordnungen des hl. Karl anschlob, Borromäuskasel. Auch wurde der Vorschlag gemacht, sie altrömisches Meßsgewand zu heißen. Die Namen waren allesamt nicht besonder's glücklich, die Bezeichnungen „altdeutsche", „altrömische" und "Bernarduskasel" sind sogar schlechthin falsch ${ }^{3}$. Die in Frage stehende Form des Mefagewandes war nie etwas spezifisch Deutsches oder Römisches, zur Zeit des hl. Bernard aber hatte dieses, wie die zahlreichen Kaseln des 12. Jahrhunderts und namentlich die beiden Kaseln zu Xanten und Brauweiler beweisen, noch die volle Glockenform. Am entsprechendsten wäre wohl die Bezeichnung "spätmittelalterliche" Kaselform gewesen; denn es war ja das Mefrgewand des ausgehenden Mittelaltels, das man wieder in Gebrauch zu bringen suchte. Vielleicht, dafs in diesem Falle die Wiedereinfuhrung der alten Form auf etwas weniger Schwierigkeit gestoßen wäre. Man darf nicht vergessen, daf das Wort "Gotik" in den fünfziger und sechziger Jahren des vorigen Jahrhunderts noch für viele, namentlich aber in Italien, einen übeln Beigeschmack hatte. Die Schwierigkeiten waren so grok, dak es sogar eine Weile den Auschein hatte, als sollte eine völlige Verurteilung der Rückkehr zur spätmittelalterlichen oder "gotischen" Kaselform - denn nur diese, nicht die Glockenkasel kam in Frage - seitens del Ritenkongregation erfolgen.

Die Veranlassung gab der Umstand, daßs sich Dr Bock zu Rom in der Anima einer gotischen Káasel bei der Messe bedient hatte. Die Sache war aufgefallen und kam vor die Kongregation der Riten, vor der sich Dr Bock zur Rechtfertigung auf Bischof Johann Georg von Münster bericf. Dieser

1 Tit. 5 , c. 7 (Coll. Lac. $V$ 538).

2 C. 13 (Hartzh. VIII 691).

"Die Bezeichnung "Bernarduskasel" rührt von Ir Bock her und knipft an eine Kasel im Münster zu Aachen an, in welehex der 11. Hernard bei seinem Aufenthalt zu Aachen das heilige Opfer dargebracht haben soll. Allein es ist wenig wahrscheinlich, daf dieses
Gewand aus den Tagen des Heiligen stammt; jedenfalls ist seine heutige Form nicht aus jener Zeit. Dagegen ist wohl nicht zweifelhaft, dafi der hl. Bernard zu A achen zelehrierte und der betreffende Text der Miracula S. Berm. 1. 6 , c. 4 lauten muf wie M. G. SS. XXVI 132; denn dak er in einem Tage von Jülich nach Maastricht $\mathrm{zog}$, ist unannehmbar, 
wurde zu einem Bericht aufgefordert, den er denn auch unter dem 10. Juni 1859 der Kiongregation eimreichte. Die Denkschrift wurde dem apostolischen Zeremonienmeister Msgr Johannes Corazza übergeben, welcher darüber 'xin sehr ausführliches Votum in 131 Nummern abfafste. Die üblichen Fragen am Schlusse desselben lauteten, 1. ob der Bischof die Vollmacht habe, in seiner Diözese ohne Anfrage beim Heiligen Stuhl und ohne Riocksicht auf die Fol'm, wie sie in der römischen Kirche gebräuchlich sei, eine längst in Abgang gekommene Form des Mefagewandes wieder einzuführen; 2. ob die sog. gotische Form zu tolerieren oder zu verbieten sei; 3 . ob die sog. Bafigeigenform geduldet oder untersagt werden solle und 4. was in Betreff der" Angaben des Gavantus und der römischen Form zu sagen sej, die dem Bischof von Münster zufolge durch kein positives Gesetz oder Dekret angeordnet sei. Der Referent schlug vor, auf $\mathrm{Nr} 1$ mit Nein, auf den ersten 'Teil von Nr 2 und 3 gleichfalls mit Nein, den zweiten mit Ja zu antworten. Bezuiglich $\mathrm{Nr}_{\mathrm{r}} 4$ ging sein Antrag dahim, die römische Form solle nach Beratung mit ılem Papst füı maligebend erklärt werden. Die Bischöfe aber sollten angewiesen werden, zu verordnen, es dürften neve Gewänder nur gemäls den Mafen und der Form der römischen angefertigt werden, die vorhandenen aber könnten, wenn clie Abweichungen gering seien, aufgebraucht werden, andernfalls seien sie umzuändern ${ }^{1}$.

Indessen kam es zur wirklichen Verurteilung nicht, wie der päpstliche Zeremonienmeister im Eifer für den römischen Usus gewollt, noch wurde eben dieser Usus für einzig mafigebend erklärt. Das Zirkular vom 21. August 1863 enthielt sich einer allgemeinen und definitiven Entscheidung, wihlirend es in einer andern Frage, der Aufbewahrung des Allerheiligsten in einem sog. Sakramentshäuschen zur Seite des Altars, ein kategorisches Verbot erliefs, und begnügte sich mit der Bemerkung: eadem perdurante disciplina - es meint den durch Gewohnheit eingeführten Gebrauch der seitlich zugestutzten Kasel - necnon sancta Sede inconsulta nihil innovari posse. Als Grund gilit es nicht die verpflichtende Kraft des Brauches der römischen Kirche, sondern den Umstand an, daß Änderungen dieser Art, weil der erprobten Sitte der Kirche zuwider, Verwirrung stiften und bei den Gläubigen Aufsehen erregen könnten. So wenig beabsichtigte das Dekret ein Verbot, dal es clie Bischöfe verbis amantissimis einlud, falls etwa in ihrer Diözese tatsächlich der Wechsel in der Form der Kasel stattgehabt, über Grund und Veranlassung davon $\mathrm{zu}$ berichten ${ }^{2}$.

Die Utrechter Provinzialsynode vom Jahre 1865 nahm das Dekret zum Anlaf, für den Bereich der Utrechter Kirchenprovinz jede andere als die römische Kaselform ausdrücklich zu untersagen ${ }^{3}$. Das Rottenburger Ordinariat verordnete unter dem 24. November 1863, daf vorerst und bis zur weiteren Entscheidung des Heiligen Stuhles bei Anschaffungen never Paramente nur auf den hergebrachten römischen Stil das Absehen genommen werden dürfe 4 Das Limburger Ordinariat will in seinem Erlaf rom 20. November 1863 zwar nicht den Gebrauch der gotischen Mefgewänder verbieten, aber doch deren weiteres Anschaffen widerraten, weil ein positives Verbot seitens des Heiligen Stuhles über kurz oder lang erfolgen könne ${ }^{5}$. Die Prager Synode

${ }^{1}$ Analecta iuris Pontif. 1888 fasc. 239240 und die Besprechung des Votums in "Archiv für christl. Kunst" 1891, $21 \mathrm{ff} \mathrm{u,} 44 \mathrm{ff}$ durch den gegenwärtigen hochw. Herrn Bischof Dr P.W. Keppler.
-Analecta imris Pontif. fasc. 61; M ïh Ib a $u \in \mathbf{r}$, Decreta auth. II, München 1865, 628.

3 C. 2 (Coll. Lac. V 850 ).

4 Vogt, Verordnungen 318.

5 Eichstätter Pastoralblatt 1864, 27. 
von 1860 war, während noch die Sache in Rom verhandelt wurde, in ihren ron Rom approbierten Statuten, wemn auch nicht formell unter dem Namen gotische Kasel, so doch tatsächlich zur spätmittelalterlichen Kasel zurückgekehrt.

Es war ein Fehler gewesen, daf man beim Bestreben, die Kaselform les späteren Mittelalters wieder einzuführen, mehr als zweckmäßig den für manche abschreckenden Namen "gotische Kasel" betont und zugleich sich zu sehr den Anschein gegeben hatte, als gäbe es aufer der Gotik keine wahrhaft kirchliche Kunst. Auch wäre ein ruhigeres und vorsichtigeres Eintreten für die frỉhere Form des Mefogewandes der Sache unzweifelhaft weit förderlicher gewesen als der gewiß bestgemeinte, aber nicht immer genug überlegende Eifer, den man im Kampfe um die Reform der Kasel entwickelte.

Eine endgültige formelle Entscheidung und eine Verwerfung der sog. gotischen Kasel ist bisher nicht erfolgt und dürfte auch wohl noch nicht so bald in Zukunft erfolgen, nachdem in jüngster Zeit durch die Jubiläen Leos XIII. unbeanstandet Mefsgewänder spätmittelalterlicher Form als Gaben ihren Weg nach Rom gefunden haben und auch die neueste editio typica des Caeremoniale episcoporum die Rubrik beibehalten hat, wonach die Ministri die Kasel auf (lem Arm des Bischofs zurückfalten sollen, damit sie ihn nicht behindere ${ }^{1}$. Im Gegenteil dürfen solche Kaseln, und zwar auch dann, wem sie mit Gabelkreuz ausgestattet sind, nummehr als zweifellos zulässig gelten, seitdem der päpstliche Visitator bei der jüngsten Visitatio apostolica zu Rom gelegentlich seiner Tätigkeit im Campo Santo keinen Anstand gegen die dort befindlichen Mefgewänder dieser Art erhoben, sondern ihre Verwendung beim heiligen Opfer gestattet hat.

\section{STOFF DES MESSGEWANDES.}

Über den Stoff, aus dem in vorkaroling ischer Zeit das Mefgewand gemacht zu werden pflegte, fehlt es an Nachrichten. Für gewöhnlich mag es damals noch aus wollenen Zeugen, Leinwand oder Baumwollstoffen hergestellt worden sein. Doch hat es sicher schon früh auch seidene Meligewänder vegeben, zumal in hervorragenderen. Kirchen, in denen man alle Mittel daran setzte, den Gottesdienst mit möglichster Pracht zu feiern. Allerdings waren im 4. und 5. Jahrhundert die Seidenzeuge noch immer sehr kostbar, indessen war ihr Preis doch keineswegs mehr so enorm, dal’3 man unmöglich an die Anfertigung seidener Kaseln lıätte denken können. Wenn man die Mittel besalu, die Kirchen nicht blof mit limnenen, sondern auch mit halbseidenen und ganzseidenen Wandbehången auszustatten — und solches geschah, nach Ausweis der Charta Cornutiana, der 471 abgefalsten Stiftungsurkunde einer bei Tivoli gelegenen Dorfkirche, sellsst in kleineren Kirchen --, so konnte erst recht die Beschaffung seidener Gewänder an dem Kostenpunkt kein Hindernis finden.

Im 9. Jahrhundert waren seidene Kaseln nicht einmal im Frankenlanrl mehr etwas Ungewöhnliches. Die Stoffe zu denselben kamen aus Byzanz, sylien, Pelsien, Arabien, Ägypten, Indien und selbst dem äufersten Osten Asiens. Es ist zum Erstaunen, welch eine Fülle der kostbarsten Melagewänder sich schon im Begimn des 9. Jahrhunderts in den Sakristeien bevolzugter Kirchen angehäuft hatte. Unter den Paramenten, welche Angilbert dem Kloster St-Riquier schenkte, befanden sich z. B. casulae de pallio (Seiden-

${ }^{1}$ L. 2, c. ×, ग. 19. Surgit episcopus et induitur planeta, quae hinc inde super brachia aptatur et revolvitur diligenter, ne illum impediat. 
stoff) 30 , de purpura 10, de storace (gelber Seidenstofi) 6, de blatta (eine Purpurart) 15, de cendato (leichterer Seidenstoff) 5. Aus dem 831 aufgestellten Inventar von St-Piquier heben wir hervor: casulae sericae nigrae 10, persae (pfirsichblitenfarbige) sericae 3 , ex blatta 1, ex pallio 20, galbae (gelb) sericae 5, melnae (gelblich) sericae 3, ex cendato 4. Ansegisus gab dem Kiloster Fontanelle um dieselbe Zeit casulas ex cindato indici coloris (blauseidene) 3 , viridis coloris ex cindato item 3, item rubei sive sanguinei coloris ex cindato 1, blatteam item casulam 1. In den Gesta abbatum Trudonensium wird uns zum Jahre 870 von casulae 12 preciosae de pallio berichtet ${ }^{\text {. Gegen }}$ Ausgang des 9. Jahrhunderts waren die Seidenstoffe im Frankenland hereits so wenig selten mehr, dali Riculf von Soissons seinen Priestern vorschreiben konnte, es solle ein jeder eine seidene Kasel für die Messe vorrätig halten.

Im 11. und 12. Jahrhundert mußs die Verwendung von Seide zur Anfertigung der Kaseln schon etwas recht Gewöhnliches gewesen sein, da sonst Aht Stephan von Citeaux um 1110 sich wohl nicht veranlalst gesehen hätte, zum Ausdruck der strengen Armut, die er in den Klöstern seines Ordens gepflegt wissen wollte, den Seinen den Gebrauch seidener Hefrewandel zu verbieten. Die Statuten des Heiligen erlauben nur solche aus Bammolle oder Leinwand". Wirklich lassen die Inventare dieser Zeit keinen Zweifel an dem ausgedehnten Gebrauch seidener Kaseln. Besonders lehrreich sind die diesbezilglichen Angaben der Chronik yon Monte Cassino und des liegister's von Rochester. Nicht ohne wesentlichen Einfluf auf die bedeutende Vermehrung solcher Meßsgewänder war die Einführung der Seidenfahrikation in Sizilien und die hohe Blüte, zu der gerade damals die Seidenindustrie in Spanien gelangte. Doch hatte auch wohl die durch die Kreuzzỉge veranlafate Frhöhung des Verkehrs mit dem Orient und die damit im Zusammenhang stehende häufigere Importierung orientalischer Seidenstoffe keinen geringen Anteil daran.

Im 13., 14. und 15. Jahrhundert strotzen die Inventare geradezu von Kaseln aus Brokaten, Brokatellen, Damasten, Samten, Köper, C'endel (Taft) und andern Seidenzeugen von oft kaum mehr zu deutenden Namen. Der Grund für diese Steigerung des Verbrauchs der Seide im Dienste des Kultus lag einerseits in dem mächtigen Aufschwung, den das ganze gesellschaftliche und wirtschaftliche Leben, die Kunst und namentlich auch die Äulierungen des religiösen Sinnes im 13. Jahrhundert genommen hatten, anderseits in der erhöhten Produktion und dem vermehrten Angebot der mannigfachen Arten von Seidenzeugen. Die Seidenfabrikation hatte sich aus sizilien zuerst nach dem südlichen und dann auch nach dem mittleren und nördlichen Italien verpflanzt und namentlich zu Lucca, Genua und Venedig rasch zu herrlichster Bliite entfaltet. Die Stoffe, welche hier erzeugt wurden, waren zum grofen Teil mehr oder weniger freie Nachbildungen orientalischer Gewebe, da noch immer die prächtigen byzantinischen, syrischen, mamelukischen, sarazenischen und maurischen Muster den Markt beherrschten. So aber entstand bald ein lehhafter Konkurrenzkampf zwischen Orient und Okzident, der zur Folge hatte, daßs sich eine wahre Flut von Erzeugnissen der Seidenfabrikation uiber"

M, G. SS. X 230. Wenn Leo IV. ea 850 den Judex Leo in Sardinien beauftragt, lana marina für jeden Preis zu kaufen, weil er sie fïr seiue und seiner Palastgeistlichen Festtagkleidung nütig habe (Britische Sammlung der
Papstbriefe in "Neues Archip" V [1879] 383), so scheint es sich hier nicht um liturgische Kleider, sondern um die auferliturgische Festgewandung zu handeln.

2 Exordium Cisterc. c. 17 (M. 166, 1509). 
das Abendland ergoß. Das byzantinische Kaiserreich entsandte seine panni de Romania, Syrien sein diasprum de Antiochia; aus Ägypten und Persien kamen die panni tartarici, aus Bagdad der baldequinus, von Cypern die panni Cyprenses. Die Mauren boten ihre glänzenden panni hispanici zum Kauf an, Lucca das bald hochberïhmte opus lucanum, Venedig seine herrlichen panni de Tenetiis, Genua seine kaum geringer geschätzten pauni ianuenses. Kein Wunder, dafs bei dem Eifer, der alle Welt für die Förderung der Ehre Cottes erfüllte, dem tiefgläubigen Frommsinn des Volkes, das mehr auf den Glanz des Gotteshauses und des Gottesdienstes wie auf den Schmuck und die Behaglichkeit des eigenen Heims bedacht war, und jener wahrhaft fürstlichen Freigebigkeit gegenüber den Kirchen, welche hoch und niedrig im 13., 14. und 15. Jahrhundert beseelte, die Schränke und Truhen der Sakristeien sich immer mehr mit kostbaren seidenen Mefrgewändern füllten.

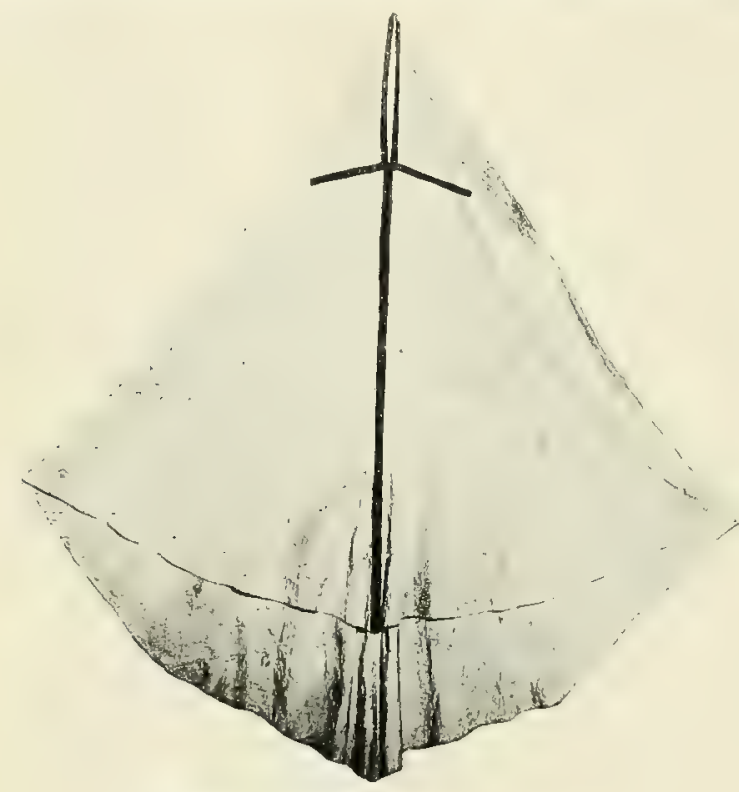

Bild 88. Leinwandkasel. Castel s. Elia.

Allerdings gab es auch jetzt noch vor wie nach Meßgewänder aus Wollzeugen, aus Leinwand und Baumwolle. Befinden sich doch unter den 30 mittelalterlichen Kaseln im Herzoglichen Museum zu Braunschweig nicht weniger als zwölf, die aus feinem einfarbigem rotem, grünem oder violettem Wollstoff gemacht sind. Indessen waren nach Ausweis der Inventare derartige Mefigewånder bei weitem nicht mehr das Gewöhnliche, namentlich nicht in hervorragenderen Kirchen. Insbesondere begegnet man im späteren Mittelalter in den Inventaren nur selten mehr Kaseln aus Linnen oder Baumwolle. Ganz ausgestorben waren solche

freilich noch nicht. Erwähnt doch sugar das Schatzverzeichnis des Apostolischen Stuhles aus dem Jahre 1329 noch unam planetam albam de tela bombacina seu fustamica, tamen modici valoris. Desgleichen sind in den Inventaren von St Peter aus dem 14. und 15. Jahrhundert noch eine Anzahl von Kaseln dieser Art verzeichnet ${ }^{1}$. So heist es zum Jahre 1361: 9 planetar de panno lineo albo cum aliquibus crucibus de sindone rubeo sine signo et sine fodere (Futter); zum Jahre 1436: planetae albae de panno lineo numero 6, zum Jahre 1454/1455: planetae lineae inter bonas et malas numero 15. Beispiele solcher Kaseln aus Leinwand befinden sich noch jetzt zu ('astel S. Elia, in St-Donat zu Arlon, im Dom zu Halberstadt. Zu Castel S. Elia gibt es ihrer nicht weniger denn fünf (Bild 88), während der Dom zu Hallerstarlt ihrer zwei besitzt. Die Busätze dieser Moßsgewänder bestehen meist in schmalen Streifen von roter Seide oder blauer Leinwand. Statt einfachen Linnens benutzte man anch wohl mit dem Moclel berlruckte

1 Müntze Fyothingham. Il tesoro di S. Pietro 398197. 
Leinwand. Ein derartiges Mefogewand besitzt z. B. noch die Kirche zu Husaby in S'chweden ', ein anderes veröffentlichte der Straf̧burger Antiquar Forrer unter der romanhaften Bezeichnung "Pestkasel" 2. Eine solche bedruckte Kasel ist auch wohl in einem Inventar der Kathedrale von Chalons aus dem Jahre 1410 gemeint, wenn es darin heift: casula de tela nigra, duplex de tela alba, depicta de diversis operibus factis ad colores et supra partem nigram loco aurifrisii est una banda stricta ad crucem de pari opere 3 .

Die einzigen Bestimmungen über den Stoff des Mefsgewandes, welche aus dem Mittelalter vorliegen, wurden bereits erwähnt; es sind die rerordnung Riculfs von Soissons aus dem Ende des 9. und das Statut des hI. Stephan Harding aus dem Beginn des 11. Jahrhunderts. Möglich, daf auch sonst noch gelegentlich ähnliche partikuläre Bestimmungen über das Matcrial der Kaseln erlassen wurden, doch ist das jedenfalls schwerlich häufig vorgekommen. Ein allgemein verbindliches Gebot ist niemals in Mittelalter in Botroff dieses Punktes ergangen.

Die Stoffe, welche man im Mittelalter zur Kasel verwendete, scheinen bis ins 12. Jahrhundert hinein meist einfarbig gewesen zu sein. Darauf läfst schon der Tmstand schliefien, dafo diese auf den Monumenten, angefangen von den Mosaiken des 5., 6. und 7. Jahrhunderts bis zu den Miniaturen des 12., regelmäfig als einfarbiges Gewand auftritt, obschon es loch sonst an buntgemusterten Kleidern auf ihnen nicht fehlt. Es ist fast eine Ausnahme, wemm sie auf dem Widmungsbild der Bibel Karls des Kahlen und einigen wenigen verwandten Darstellungen mit Gruppen von je drei Goldpunkten verziert ist. Noch bemerkenswerter und wichtiger ist jedoch, dafs die noch vorhandenen Kaseln aus dem 10. und 11. Jahrhundert heinahe alle einfarbig gelb, purpurn, blau, braun usw. sind. Etwaige Muster sind auf ihnen nicht durch Wechsel in der Farbe, sondern, wie es bei den Damastgeweben geschieht, durch Wechsel in der Bindung erzielt worden. Sie sehen aus, als ob sie dem Grund blof eingeritzt wären, und sind in ihren Einzelheiten oft nur mit Mühe erkennbar. Sie sind die Vorläuferinnen ausgebildeter Damaste und als solche für die Geschichte der Textilkunst von grolier Bedeutung. Die einzigen Beispiele, welche eine andersfarbige Musterung aufweisen, sind die Adlerkasel zu Brixen mit ihren mächtigen dunkeln Adlern auf rotpurpurnem Grund und die sog. Ehbokasel im Schatz der Kathedrale zu Sens mit ihren grołen gelben Weinblättern und Rosetten auf weisem mit Adlern damaszierten Fond.

1 Revue 1867, 211. Eine Kasel aus bedrucktem Limmen, welche wir in einer Privatsammluug zu Robecco bei Cremona sahen, dürte, wie es scheint, nur das Futter einer Kasel getwesen sein.

2 Die Kunst des Zeugdrucks, Straß̧burg: 1898, Tfl xxvr, 87. Forrer hat die Bezeichnung ${ }_{\text {Pestkasel }}$ Bock entlehnt. Pestkaseln nannte dieser die Linnenkaseln, weil er meinte, man habe sie getragen, wenn man zur Pestzeit den vom schwarzen Tod Befallenen das Viatikum gebracht. Linnenkaseln habe man aber, statt, wie Vorschrift, Kaseln aus Seide, zu diesem Zwecke genommen, um sie nach dem Gebrauch waschen zu können und so weitere Ansteckung zu verhüten (Bock II $2+9$ und Die Anfänge der Druckerkunst in Bild und Schrift, Leipzig 1866, 14). Bock hat aufer acht gelassen, dafs es im 13., 14, und 15. Jahrhundert nicht Sitte war, bei Versehgängen das Meßsgewand zu tragen, sondern Albe oder Superpelliceum (vgi. oben S. 138) und Stola, daf überhaupt eine Kasel bei dieser Funktion und zumal bei Pestkranken sehr unbequem und unangebracht gewesen wäre, und daßs Bestimmungen über den Stoff des Mefagewandes erst mehrere Jahrhunderte später erlassen wurden, nicht aber, wie Bock annimmt, schon im Vittelalter bestanden. Ausführlicheres über die angeblichen Pestkaseln in einem Aufsatz des Verfassers in Stimmen aus Maria-Laach" LIX (1900) $361 \mathrm{ff}$.

s De Farey 67. Sonst sind uns bedruckte Linnenkaseln in Inventaren nicht begegnet. 
Eine erhöhte Verwendung von zwei- und mehrfarbigen Seidenzengen scheint erst das 12. Jahrhundert gebracht zu haben. Im 13. werden solche Stoffe damn unter dem Einfluß der allgemein steigenden Prachtliebe mit immer gröberer Vorliebe gebraucht, im 14. und 15, aber ist ihre Verwertung zur Herstellung der Meligewänder etwas yanz Gewöhnliches, wie nicht nur die noch vorhandenen, manches Tausend betragenden Kaselreste aus jener Zeit, sondern auch die Inventare mit ihren oft ins einzelne gehenden Beschreibungen der Kaselstoffe bekunden.

Die Dessins, welche sich auf den mittelalterlichen Paramentenstoffen finden, sind äuferst mannigfaltig, doch haben die einzelnen Perioden ihre besondern, die betreffende Zeit kennzeichnenden Typen ${ }^{1}$. Für die gemusterten Stoffe der Frühe des 2. Jahrtausends kommen deren namentlich zwei in Betracht. Für den einen ist eine Einteilung in Felder charakteristisch. Sie

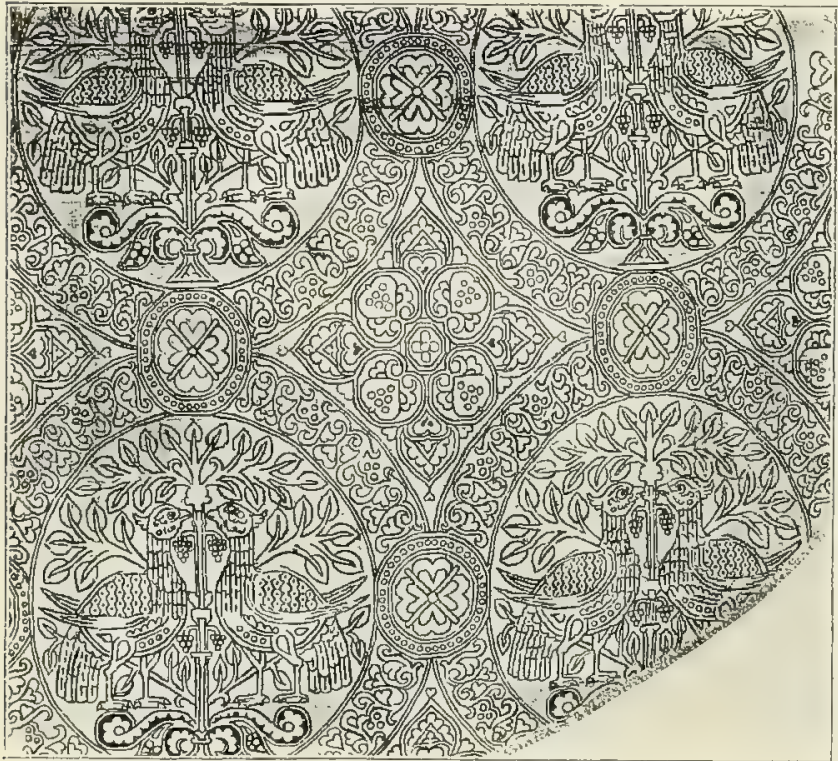

Bild 89. Musterung der Bernwardskasel. Hildesheim, Dom. sind bald größer bald kleiner und bestehen meist aus Kreisen, die sich in wagerechter und senkrechter oder in schräger Richtung aneinander reihen, oder aus spitz-ovalen, von wellenförmigen Streifen eingeschlossenen Kompartimenten, doch auch wohl aus Polygonen, vierpafäähnlichen Gebilden u. ä. Gefüllt sind die Felder bald mit Tierunholden (Löwen, Drachen, Greife, Adler usw.), die hier einzeln, dort paarweise angebracht sind (Bild 89), bald mit leichten phantastischen, halb geometrischen und halb vegetabilischen Gebilden. Ein zweiter häufiger Typus der Dessins auf den Geweben des 10,11. und 12. Jahrhunderts besteht in größeren oder kleineren sitzenden, schreitenden oder aufspringenden Tiergestalten, welche ohne alle Umrahmung einzeln orler zu zweien in regelmäßrigen horizontalen Reihen ühereinander angeordnet sind. Ein Beispiel desselben bietet die Brixener Adlorkasel mit ihren gewaltigen Adlerm, cines der hervorragendsten Specimina dieses Typus (Bild 73, S. 181).

Im 13. Jahrhundert verschwinden die bisherigen Typen allmählich. Sie werten iluch einen neuen verdrängt, der bald zu gröiter Beliebtheit gelangt, las ganze 14. Jahrhundert tonangebend ist und sich bis tief in das 15 . hinein zu behaupten weils. Reichen doch some letzten Vertreter bis zur Wende des 15. Jahrhunterts. Die starre Anordnumg und Teilmo ist verschwunden. In lehenrliger Komposition überspinnt ein Gemisch von Tiergebilden, Ranken-

i Selbstverständlich kann hier nur auf die charakteristischsten aufmerksam gemacht werien, ta kein Abrif der Geschichte der Weberei geboten werden kann und soll. 
und Laubwerk, Monden, Somnen, Somnenstrahlen, Wolken mi Inschriften in immer neuen und wechselnden Verbindungen die Stoffe. Man weik nicht, was man an diesen Mustern mehr bewundern soll, die schier endlose Erfindungsgabe der Zeichner oder ihren feinen Sinn für hamonische Gruppierung, ebenmäfige Verteilung von Grund und Musterung und wohltuende, hei aller Frische zart abgestimmte Farbenzusammensetzung. Ein besonderer Vorzug dieser Stoffe vor den früheren besteht in del reichlichen Verwendung von Gold, wie sie freilich erst durch Benutzung des sog. Cyperngoldes an Stelle echter Goldfäden ermöglicht wurde. Waren vordem nur einzelne kleinere Partien der Dessins, wie z. B. Köpfe, Klanen, Krallen, obere Flügelteile, in Gold broschiert worden, so wurde jetzt mit Hilfe des billigeren, mittels vergoldeten Häutchen hergestellten Goldfadens, der ohne grolse Kosten durch den ganzen Stoff hindurchgeführt werden konnte, das ganz. Huster in Gold ausgeführt.

Sehr interessant und nicht minder belehrend ist, was die Schatzverzeichnisse des 14. und 15. Jahrhunderts über die Muster der Paramentenstoffe erzählen. Wer sich mit den mittelalterlichen Textilien vertraut gemacht hat, glaubt manchmal die Gewebe selbst vor sich $\mathrm{zu}$ sehen, so eingehend sind nicht selten die Beschreibungen, welche von den Stoffmustern nach Gegenstand und Farbe geboten werden. Zu den rorzïglichsten Inventaren dieser Art gehört das Inventar von St Veit zu Prag aus dem Jahre 1387.

Es ist eine bunte Folge von Dessins, die es zu verzeichnen weif, und kaum minder bunt ist die Reihe der Motive, die bei den Mustern zur Verwendung gekommen sind. Da begegnen uns Greife, Adler, Hasen, grofe und kleine Togelgestalten, Löwen, Leoparden, Elefanten, Hirsche, ein- und mehrschwänzige Drachen, Hunde, Fische, geflügelte Rosse, Schwäne, Pfauen, Pelikane und andere mehr oder weniger phantastische oder naturalistische Tiergestalten; dann Rosen, Lilien, Glockenblumen, großes und kleines Blattwerk und sonstige meist nur als flores bezeichnete vegetabilische Gebilde; ferner Kreuze, Sterne, Pfauenfedern, sarazenische (litterae gentiles) und lateinische Inschriften, Kronen, Kreise, schachbrettartige, gewürfelte und gestreifte Nusterungen, Punkte, kleine goldene Scheihen nach Art von Goldmünzen, Türme: weiterhin Franengestalten, geflügelte Frauenköpfe, Mädchen mit einem Körbchen und kleinen Tögeln, Häinde, die Hunde festhalten, mit Ketten am Fuf3 gefesselte Tiere, wasserschüpfende Mirlchen, strahlende Sonnen $u$. a. im mannigfaltigsten Wechsel und immer neuen, von geradezu unerschöpflicher Phantasie zeugenden Verbindungen. Aus den vielen hier nur einige Beispiele. Da gab es ein schwarzes Pluviale, auf dem in Gold gewebt Hunde in Unfriedigungen dargestellt waren, über ihnen die Sonne, welche ihre Strahlen auf sie herabsandte. Auf einem andern sah man auf rotem Fond in Gold grofe Vögel, zwischen deren Krallen ein Menschenhaupt angebracht war, im Wechsel mit kleinen Vögeln dargestellt, welche im Schnabel einen Zweig und in den Krallen ein Tuch hielten; wieder ein anderes wies auf rotem Grund goldene Hirschkälber und grüne Bäume auf. Zahlreich sind die Muster, in die goldenes oder farbiges Blumen- und Rankenwerk mit Drachen, Löwen, Adlern oder sonstigem mehr oder weniger phantastisch behandeltem Getier eingewoben waren. Auf einem Seidenstoff, den Herzog Johannes von Görlitz bei den Exequien eines Paulus von Wlassym geschenkt, gewahrte man auf. grünem Fond in Gold Löwen, Bäume, pelikanartige Vögel, die auf den Bäumen ihre Jungen atzten, und Drachen, die mit den Löwen kämpften. Ein anderes Zeug enthielt auf rotem Grund inmitten von Ranken und Blumen in Gold und farbiger Seide goldene Vögel, die mit den Klauen kleine Tiere gepackt hatten, sowie goldene Hunte. die aus einem von Strahlen umglänzten Dorngebuisch hervortraten. Ein Pluviale aus rotem Brokat war mit goldenen Vügeln, Vierfüßlern und Bnchstaben gemustert. einem gelb und weifs gestreiften Altarbehang waren Reiter in gelben Kreisen zur Darstellung gekommen. 
Das herrorstechendste Gewebemuster des 15. Jahrhunderts ist der Granatapfel. Eine Schöpfung des ausgehenden 14. Jahrhunderts, wußste es hald mit den immer neuen reizenden Variationen, in denen es auftrat, allen andern Dessins den Rang abzulaufen. Seine höchste Blüte fällt etwa in die Mitte des 15. Jahrhunderts. Es sind wahrhaft köstliche Formen, in die es sich um diest Zeit kleidet. Dann beginnt es allmählich zu entarten, ohne jedoch an Beliebtheit zu verlieren. Nachklänge des GranatapfeImusters erhalten sich im ganzen 16. Jahrhundert; ja selbst im 17. treten noch häufig genug Spuren desselben auf.

Es war eine Zeit, da man in den Mustern der mittelalterlichen Stoffe viel symbolik finden wollte. Kaum ein Dessin, für das man nicht eine mystische Deutung versucht hätte, und zwar wufste der eine für die Tierunholde oder den Granatapfel noch eine tiefsinnigere Erklärung als der andere. Kein Wunder, daßs man die mittelalterlichen Stoffe mit Vorzug als kirchlich pries. Man war indessen auf einem Irrweg, wie hente jeder gesteht, der sich näher mit den mittelalterlichen Textilien beschäftigt hat. Die religiöse Symbolik, welche man in diesen zu finden vermeinte, ist den Künstlern, welche die Muster entwarfen, in den allermeisten Fällen durchaus fremd gewesen. Ein beträchtlicher Teil der Paramentenstoffe war bis zum Ausging des Mittelalters sarazenischen oder maurischen Ursprungs; die Seidenzeuge aber, welche Lucca, Venedig und Genua schufen, erweisen sich zum sehr großen Teil als mehr oder minder freie Kopien orientalischer Dessins, bei denen selbst die arabischen Inschriften, Lobpreisungen Allahs oder irgend eines Sultans, ein Koranspruch u. ä. nachgebildet wurden. Es hat allerdings auch Stoffe mit spezifisch christlich-religiösen Mustern gegeben, sie waren aber keineswegs häufig. Unter den vielen Tausenden von Resten mittelalterlicher Gewebe, die in unsern Sakristeien und Museen aufbewahrt werden, findet sich nur ein äuferst kleiner Bruchteil, dessen Musterung eine christlich-religiöse Symbolik zu Grunde liegt. Jan war im Mittelalter ungemein frei in der Verwendnng gemusterter Stoffe. Würde man auf den Gegenstand der Muster gesehen haben, hätte man sicherlich bei Auswahl der Paramentenstoffe mit mehr Unterscheidung verfahren. Denn Löwen, die Gazellen würgen, Falken, die auf Hasen stofien, zähnefletschende Hunde, die an der Kette liegen, Halbmonde um Halbmonde, Mädchen, die Wasser schöpfen, um Hunde damit zu tränken, Frauengestalten, die aus einer Tritonsmuschel hervorragen und Netze auswerfen, Schwäne, die über das Wasser rudern, Affen im Spiel mit einem Hund, der auf einem vierräderigen Karren sitzt, ein Hund im Kampf mit einem ergrimmten Schwan, Anrufungen Allahs u. ä. sind nicht gerade passende Darstellungen für Meßsgewänder und sonstige Paramente. Allein der Gegenstand des Musters war es nicht, der anzog und gefiel, sondern dessen Wirkung. Die Löwen, Hunde, Drachen, Adler, Wolken, Strahlen und was sich sonst noch an Dessins dem Blick immer wieder auf den mittelalterlichen Stoffen darbietet, waren für ihre Zeit dasselbe, was die Tulpen, Blumenhouquets u. a. auf den Seidenzeugen des 17. und 18. Jahrhunderts darstellten, hloßes Ornament. Man verband mit ihnen nicht mehr Sinn wie mit den arabischen Inschriften, welche uns hald als sarazenische Originale bald als mehr oder weniger gute Kopien auf so zahlreichen mittelalterlichen Stoffen begegnen und so sehr als blofies Ornament angesehen wurden, das die lucchesischen Seidenweber sie schlechthin kopierten, obwohl es ihnen ein leichtes gewesen wäre, sie durch religiöse Sprüche in lateinischer oder italienischer Sprache zu ersetzen. Was bei den Stoffen Eindruck machte und gefiel, ist chenclasselbe, was sie allzeit für Paramentenstoffe als vorbildlich erscheinen lafft, die reiche Pracht. die elle Komposition, die feste Stilisierung, die geschmackvolle Farkengelung, die Vermeidung aller plastischen Behandlung des Dessins, die Ursprünglichkeit fler Darstellung und der schier unerschöpliche Reichtum der Erfindung in Verbindung mit weisestem Maßhalten.

Auch der Umstand, daßs man die gleichen gemusterten Gewebe sowohl im Alltagsleben und zu profanen Zwecken, als auch im Dienste des Kultus und zu kirchlichen '/wecken zu verwenden pflegte, bekundet, wie wenig man mit den Dessins eine 
religiöse Symbolik verband. Dieselben Muster, welche wir auf mittelalterlichen Kiseln und sonstigen Paramenten antreffen, kamen bei profanen Festtagskleidern, bei Dekorationsstücken weltlicher Prachträume, ja selbst bei Pferdeschabracken vor.

Erst die allerneueste Zeit sollte über den Stoff der Kasel feste Bestimmungen bringen. Nicht einmal die eingehenden Vorschriften des hl. Karl bezüglich des Mefagewandes und die diesbezüglichen Verordnungen der Prager synode vom Jahre 1605 hatten über ihn ein Wort verlauten lassen. Es gab darum auch bis ins vorige Jahrhundert hinein in den Sakristeien neben seidenen und halbseidenen vor wie nach wollene und, wenngleich nur vereinzelt, aus Leinwand gemachte Mebigewänder. Aus demselben Grunde hegreift es sich, wie es möglich war, daf man im 18. Jahrhundert sogar dazu übergehen komte, Kaseln aus Leder anzufertigen.

Es war keineswegs wertloses Zeug, was man zur Herstellung dieser ledernen Mefsgewänder verwertete. Das Leder war nach Art der Ledertapeten vergoldet, mit Blumen bemalt und mit Pressungen versehen, aber es war doch zuletzt nur ein Stoff, der sich allenfalls für einen Koller, nicht aber für ein Mésgewand eignete.

Es hat sich noch eine ziemliche Anzahl von Lederkaseln erhalten. Ein aus schwarzem, teilweise vergoldetem und versilbertem Leder hergestelltes Meßgewand befindet sich zu Kendenich in der Nähe von Köln. Ein weiteres besitzt die Kirche zu Billerbeck. Das bischöfliche IInseum zu Münster bewahrt noch zwei lederne Meßsgewänder samt den dazu gehörigen Stolen und Manipeln auf. Das eine hat einen silbernen, buntgemusterten Grund und ein rotes, mit Goldund Silbermusterung versehenes aufgemaltes Kreuz; bei dem andern ist der vergoldete Grund mit Blumen ausgestattet, während die Stäbe Goldmuster auf Silbergrund aufweisen. Das Landesmuseum zu Zürich besitzt drei Lederkaseln. Zu allen dreien ist noch die Stola, zu einer auch der Manipel vorhanden. Sie gleichen vollständig den Kaseln im bischöflichen Museum zu Münster.

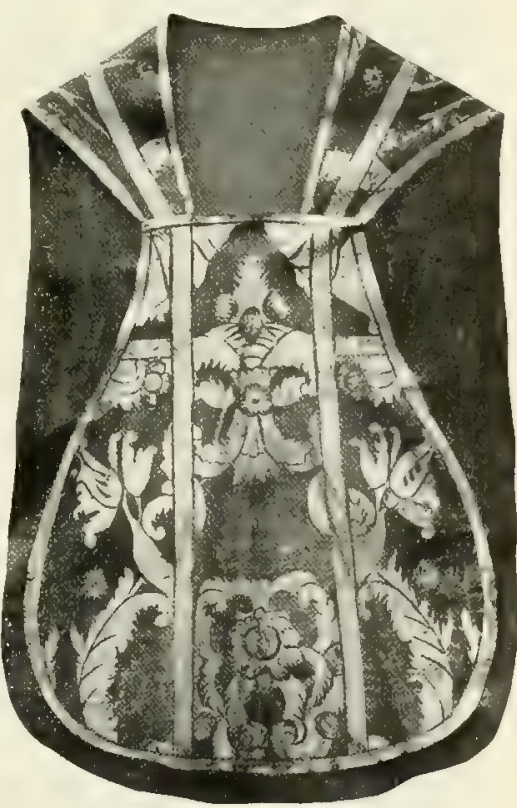

Bild 90. Lederkasel. Eichstät, Bischöfliches I'alain. Auch im kgl. Kunstgewerbemuseum zu Berlin gibt es drei Lederkaseln, von denen die eine einen Goldfond mit silbernen Ranken und blaue, silbergemusterte Stäbe, die zweite einen mit Goldblumen geschmückten roten Fond und silberne, goldgemusterte Stäbe, die dritte einen blau lasierten Silbergrund mit silbernen und farhigen Dessins und goldene, mit silberner und farbiger Musterung versehene Stähe aufweist.

In Württemberg befinden sich noch Lederkaseln zu Delkhofen (0.-A. Spaichingen), zu Mochenwangen (0.-A. Ravensburg), in der Schlofkapelle zu Oppenweiler (0.-A. Backnang) und in der Altertumssammlung zu Stuttgart ${ }^{1}$. Auch das Germanische Museum zu Nürnberg und das bischöfliche Museum zu Eichstätt besitzen je ein Exemplar dieser ledernen Meßgewänder (Bild 90). Eine Lederkasel mit zugehörigen ledernen Levitengewändern birgt die Stiftskirche zu Oberwesel.

Die Lederkaseln, welche recht häufig gewesen sein müssen ${ }^{2}$, stellen in jeder Beziehung den Höhrpunkt der Verbildung der einst so majestätisch

1 P. W. K e p p L e r, Württembergs kirchl. Kunstaltertümer, Rottenburg 1888, Lxxvi.
2 Vgl. auch Swoboda, Das Parament l'm? seine Geschichte, in "Mitt, des K. K. Musenms" 
Glockenkasel dar. Sie sind überkurz und überschmal und gleichen an der Torderseite rollständig amem Kinderschürzchen. Es mufste in der Tat das faltenreiche Mrofgewand crst zum leblosen, steifen, platten Küraßs werden, ehe Misgrohurten wie die Lederkaseln das Tageslicht begrülien durften. Dauerhaft waren dieselben freilich; sie waren, wo sie nicht etwa von Mäusen gefressen worden, wiklich unverschleibbar, höchstens, daf man sie hie und da einmal mit etwas Lack, Farbe und Blattgold aufzuputzen hatte. Die Leder-

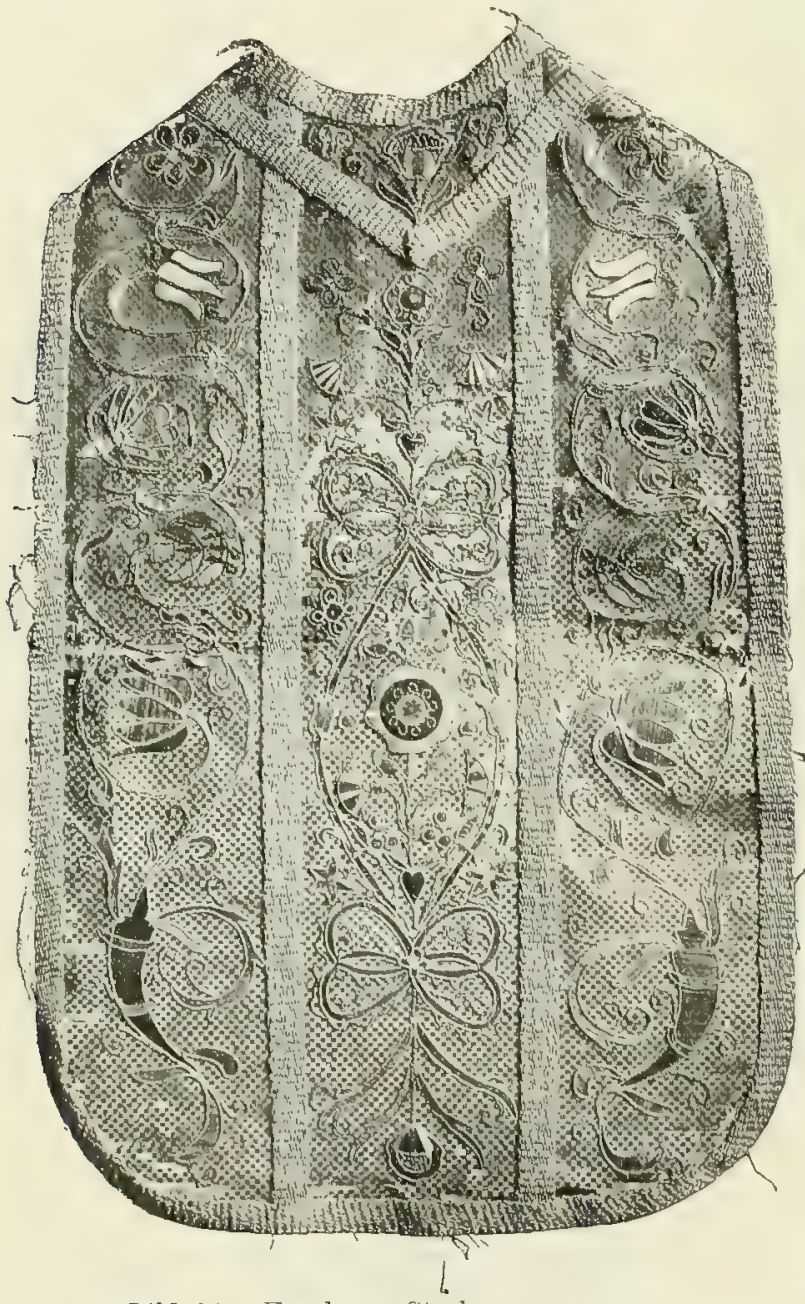

Bild 91. Kasel aus Stroh. Pra, Domschatz.

(Aus Podlaha u. Sittler, Der Domschatz zu Praw, kaseln blieben noch teilweise bis in das 19. Jahrhundert hinein im Gebrauch, wenngleich neue in demselben wohl kaum mehr angefertigt worden sein dürften.

Die Lederkaseln waren eine arge ästhetisch-liturgische Verirrrung und doch noch nicht die schlimmste. Eine ärgere war die Kasel aus Stroh, von der im "Kïchenschmuck" erzählt wird. Von moderner Form natürlich und mit Verzierungen und Besätzen versehen, die gleichfalls aus Stroh gemacht waren, wurde sie als Mefigewand bei der ersten Weihnachtsmesse--der Hirtenmessegebraucht 1 . Die Meinung dessen, der die Kasel anfertigen lief, war gewils gut, das Gewand aber, wenn man es so überhaupt nemnen kann, der ärgste Frevel am guten Geschmack und an der liturgischen Sitte, ein ästhetisch-liturgischer Unsinn. Eine Kasel dieser Art befindet sich im Dom zu Prag (Bild 91).

Seit ctwa dem Beginn des 18. Jahrhunderts entsprachen die gemusterten Stolfe wenig mehr dem Ernst und der. Würde des Gottesdienstes. Die Dessins waren zu unruhig, zu bunt, zu schwulstig, später zu naturalistisch, zu nüchtern. Dazu kam seit dem Ende des 18. Jahrhunderts unter dem Einflulis der Revolution der qualitative Niedergang der Seidenstoffe. Es mufte sich daher

Neue Folge, 10. Jahrg., Hft 7, Wien 1895; ferner die Kataloge der Ausstellungen zu Hiinster von 1879 (5) I, derkaseln), Brïssel von 1888 (1 Lederkasel), Augshurg von 1886
(1 Lederkasel), Paderborn von 1899 (2 Lederkaseln, und zu TI ien von 1887 ( 10 Lederkaseln). I Jahrg. 1857, I 60. Gemeint ist wohl die Strohkasel im Dom zu Prag. 
das Bestreben derjenigen, welche in den fünfziger Jahren des letzten Jahrhunderts alle Hebel zu einer Reform des Paramentenwesens in Bewegung setzten, auch, und zwar nicht zum wenigsten, auf die Herstellung von Geweben nach dem Muster der mittelalterlichen Seidenstoffe richten. Die Bemiihungen sind bekanntlich nicht fruchtlos geblieben. Man hat in Anlehnung und teilweise unter Kopierung alter Stoffe Brokate, Brokatelle, gemusterten Samt und Samtbrokate geschaffen, die sich kïhn neben die mittelalterlichen Seidengewebe stellen dürfen, ohne fürchten zu müssen, von denselben in den Schatten gestellt zu werden.

\section{VERZIERUNG DES MESSGEWANDES.}

Schon auf den Mosaiken des 6. und 7. Jahrhunderts finden wir die Kasel mit einem Besatz versehen. In S. Venanzo zu Rom besteht derselbe in einer Einfassung des Halsdurchschlupfes und einem über die Brust sich hinabziehenden Zierstreifen. Auf ravennatischen Mosaiken, wie den Figuren. des hl. Ecclesius und des Bischofs Maximian in S. Vitale und den Bischofsbildern der Apsis von S. Apollinare in Classe, hat er die Form eines Gabelkreuzes ${ }^{1}$. Die ungemein geringe Breite, den hier die Besätze besitzen, könnte allerdings bei oberflächlichem Zuschauen dazu verleiten, in ihnen lexliglich die Gewandnähte zu erkennen. Indessen unterliegt es bei genauerem Studium keinem Zweifel, dab es sich nicht um eine Darstellung der Kaselnähte, sondern um die eines Zierbesatzes handelt. Denn erstens pflegen sonst nie die Nähte der Gewänder auf den Mosaiken angedeutet zu werden; zweitens ist nicht ersichtlich, weshalb sie hier ausnahmsweise wiedergegeben wurden; drittens dürften an den Stellen, wo die Schrägstreifen sich finden, Nähte ïberhaupt keinen Sinn haben; viertens endlich gibt es verschiedene Bildwerke aus der Zeit, aus welchen die Mosaiken entstammen, auf welchen dlas, was auf diesen zuletzt bei oberflächlicher Betrachtung als Nähte gelten könnte, sich mit aller wünschenswerten Klarheit und Bestimmtheit als gabelförmiger Zierbesatz kundtut. Was dabei besonders interessiert, ist der Umstand, daf die auf diesen Monumenten abgebildeten Personen, welche eine mit einem Gabelkreuz geschmückte Kasel tragen, Laien, und zwar vornehmlich Juden, darstellen. Diese Bildwerke sind eine. Elfenbeintafel mit der Szene der Blindenheilung im Museo archeologico zu Mailand (Bild 92, S. 210), eine Elfenbeinpyxis im Britischen Museum, auf welcher die Hinrichtung und Verehrung des hl. Mennas zur Darstellung gebracht ist ${ }^{2}$, eine Miniatur der Wiener Genesis ${ }^{3}$ und zwei Miniaturen des Evangeliars von Rossano (Unteritalien) ${ }^{4}$. Die Elfenbeintafel entstammt der Kathedra des hl. Maximian (546-556) im Dom zu Ravenna. Die Person, welche darauf eine mit einem Gabelkreuz versehene Kasel (Pänula, Planeta) trägt, ist der Blinde, welcher vom Heiland das Augenlicht zurückerhielt. Auf der Pyxis findet sich der gabelkreuzförmige Besatz bei einer der Personen, welche den hl. Mennas verehren, der Stellung und Tracht nach

1 Auf den Abbildungen, die von den Mosaiken bei Garrucei und sonst vorliegen, kommen die Besätze vielfach nicht genug zur Geltung. Die gabelkreuzförmigen Besatzstreifen der Planeta auf den ravennatischen Mosaiken weisen unseres Erachtens bestimmt anf eine Beeinflussung derselben durch die Kunst des Ostens hin.

Braun, Die liturgische Gewandung.
2 Gråve n, Frühchristliche und mittelalterliche Elfenbeinwerke Ser. 1, Nr 17.

3 Wickhoff, Fr., Die Wiener Genesis, Wien 1895, Tfl xvI.

4 Ha s l off, Codex purpureus Rossa. nensis Tfl III. Abbildung auch bei Beissel, S't., Geschichte der Evangelienbiicher, Freiburg: $1906,33$. 


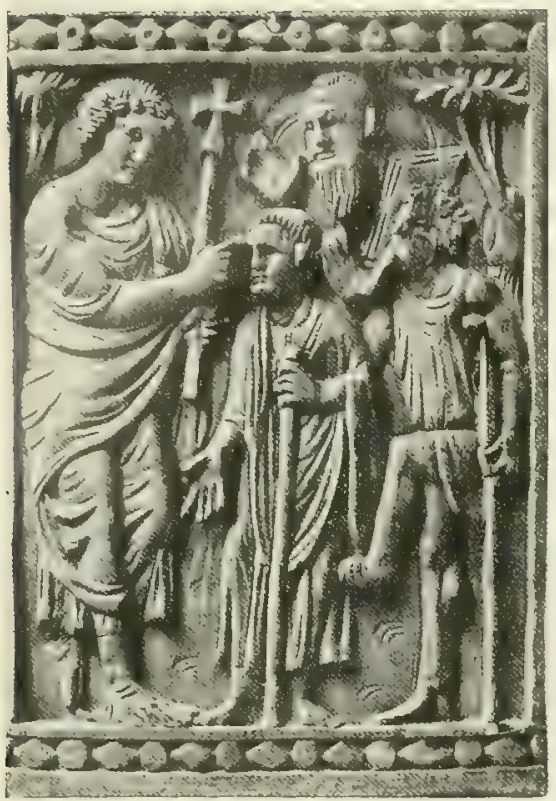

Bild 92. Elfenbeinrelief von der Kathedra Maximians zu Ravenna. Mailand, Mus. arch.

einem Mann aus gewöhnlichem Stande. Die Miniaturen des Codex von Rossano, welche das Gabelkreuz aufweisen, sind die Auferweckung des Lazarus und der Einzug Jesu. Auf beiden sind es Juden, bei welchen sich die mit dem gabelkreuzartigen Besatz geschmückte Kasel findet. Auf der Miniatur der Wiener Genesis, ,Isaak bei Abimelech", treffen wir das Gabelkreuz gleichfalls bei Juden, Isaak und seinen Begleitern, an. Hervorgehoben mú werden, daf die das Kreuz bildenden Besatzstreifen auch auf diesen Bildwerken fast überall sehr schmal sind.

Selbst beim Ausgang des 10. Jahrhunderts finden sich auf Kaseln noch Gabelkreuze von äuferst geringer Breite. Bei der Adlerkasel zu Brixen (Bild 73, S. 181) sind die Besätze z. B. nur etwa $5 \mathrm{~mm}$ breit; kaum breiter war der gabelkreuzförmige Besatz, mit dem eine in den Stürmen der Revolution zu Grunde gegangene, gleichfalls mit mächtigen Adlern gemusterte Kasel in St Arnold zu Metz ausgestattet war. Bei einer der St Ulrichskaseln im Dommuseum zu Augsburg wird das Gabelkreuz von einem Kördelchen gebildet (Bild 70, S. 178). Auch das Gabelkreuz, mit dem die Kasel Gregors des Großen auf der Miniatur eines dem 10. Jahrhundert entstammenden Registrum S. Gregorii in der Stadtbibliothek zu Trier geschmückt ist (Bild 93), besitzt nur eine sehr geringe Breite.

Sehr reich ist die Kasel der Mönche des Klosters zum hl. Martin zu Tours auf dem Widmungsbild der Bibel Karls des Kahlen mit Besätzen verziert (Titelbild). Es umgibt hier sowohl den Saum wie den Kopfdurchschlupf des Gewandes eine Borte; außerdem zieht sich ein vertikaler Zierstreifen in der Mitte der Vorderseite von oben bis unten herab. Dazu kommt bei drei Mönchen ein Besatz, der von dem Streifen auf der Brust aus über die beiden Schultern läuft und auf dem Rücken unter einem spitzen Winkel zusammenstöbit. Es scheint fast, als habe man eine Kapuze imitieren wollen; eine wirkliche Kapuze findet sich jedoch bei keinem der Mönche.

Übrigens sind mit Borten (Aurifrisien, auriphrygium, aurifrisium) verzierte Kaseln auf den Bildwerken des 1. Jahrtausends keineswegs das Gewöhnliche. Es ist bezeichnend, daf bis ins 10. Jahrhundert hinein das Mefgewand in der Regel als ein ganz einfaches, jedes Zierbesatzes entbehrendes Gewand auftritt, höchstens, dab es etwa um den Hals eine schmale Bordüre aufweist.

Erst gegen die Wende des Jahrtausends werden auf den Monumenten mit Zierstreifen versehene Kaseln häufiger. Bald umgibt ein Besatz bloß3 den Kopfdurchlaf, hald umrandet er auch den Saum oder zieht sich senkrecht über die Vorlerseite des Gewandes herab. Hier mangelt jeder Zierbesatz, dort gesellt sich zu dem Vorderstah und der Einfassung des Kopfdurchschlupfs und des Saums ein Vertikalstreifen in der Mitte der Rückseite, während 
andierswo die Besätze ein förmliches Gabelkreuz bilden. Auch kommt es vor, dafs die Umbordung des Kopfdurchlasses wie zu einem breiten Kragen ausgestaltet erscheint. Kurz, es herrscht auf den bildlichen Darstellungen des 10., 11. und 12. Jahrhunderts ein völliger Wirrwarr in der Anbringung der Besätze.

Daf indessen dieses Durcheinander nicht lediglich auf die Phantasie der Künstler zurückzuführen ist, sondern ein Spiegelbild der Wirklichkeit darstellt, beweisen die zahlreichen Mefsgewänder, die wir aus dieser Zeit besitzen. Bald fehlt bei ihnen jeder Besatz, wie z. B. bei der St Heribertsund der Bennokasel (lburg), bald beschränkt derselbe sich auf eine Einfassung des Halsdurchlasses, wie bei der St Bernwards- und der Sixtuskasel, bald besteht er aufer in der Umbordung des Kopfdurchschlupfes noch in einem Vertikalstab, sei es blok an der Vorderseite oder zugleich an der Vorder- und Riückseite des Gewandes, wie bei der St Bermardskasel zu Brauweiler und Xanten u. a. Ein Gabelkreuz finden wir bei der Adlerkasel zu Brixen, den beiden Kaseln im Dommuseum zu Augsburg, der St Meinwerkskasel zu Paderborn, den beiden St Wolfgangskaseln in St Emmeram und dem Dom zu Regensburg, der st Regnobertskasel zu Bayeux, dem jetzigen ungarischen Krönungsmantel (ursprïnglich ein von Stephan dem Heiligen und seiner Gemahlin gestiftetes Meforewand) u. a. Bei einer der St Tirichskaseln im Dom zu Augsburg scheint indessen das aus zwei parallelen Börtchen bestehende Gabelkreuz eine Zugabe aus späterer Zeit zu sein. Die St Willegiskasel zu Aschaffenburg, welche jetzt ebenfalls ein Gabelkreuz aufweist, war ursprünglich nur mit Vertikalstreifen geschmückt. Bei der St Willegiskasel in St Stephan zu Mainz zieht sich ein schmales, in eine Spitze auslaufendes, $0,20 \mathrm{~m}$ langes Goldbörtchen von der Finfassung des Kopfdurchlasses an eine Spanne weit über den Rücken herab.

Um den Saum ist ein Besatz angebracht bei der Kasel im Dom zu Ravenna, bei einer der St Ulrichskaseln im Dom zu Augsburg, bei der St Wolfgangskasel zu St Emmeram in Regensburg, bei einer der Salzburger Kaseln, bei dem Mefogewand des hl. Thomas von Canterbury zu Sens, der Kasel des hl. Edmund zu Provins u. a. Er ist bei keiner übermäßig breit, da seine Breite nie $0,10 \mathrm{~m}$ weit übersteigt, und besteht meistens aus einer Goldborte.

Auch an der Innenseite ist bei einigen Kaseln den Saum entlang ein Besatz aufgenäht, so bei der St Meinwerkskasel, der Kasel im kgl. bayrischen Nationalmuseum zu München u. a. El hatte den Zweck, den beim Aufraffen des Gewandes zum Vorschein kommenden Partien der Unterseite ein gefälligeres Aussehen zu verleihen. Als Futter der Kaseln wurde nämlich für gewöhnlich nur geringwertiger Stoff, grauliche, gelbliche, rötliche oder blaue Lein-

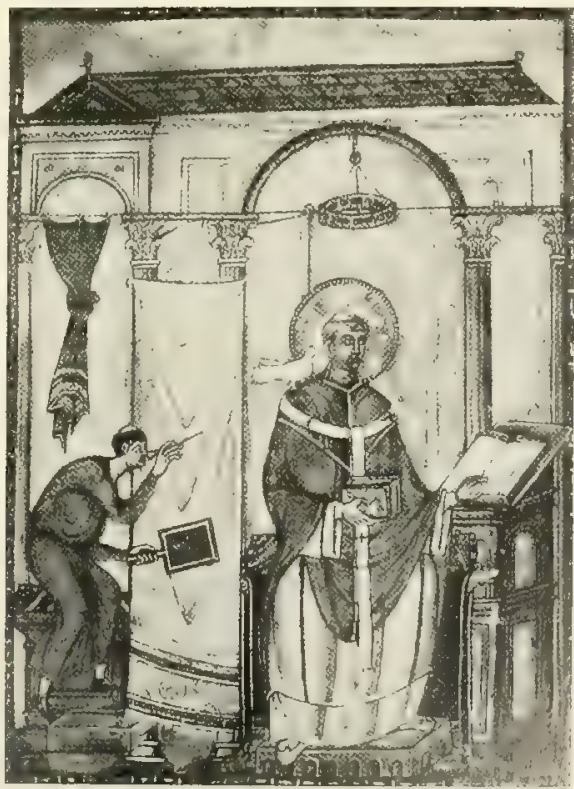

Bild 93. Miniatur des Registers Cregors des Grofien. Trier, Stadtbibliothek, 
wand verwendet; nicht selten lief man es sogar ganz beiseite, weil es bei den schweren, kräftigen Seidenstoffen, wie sie zur Anfertigung der Kaseln gebraucht wurden, nicht nur kein Bedürfnis war, sondern unter U'mständen sogar sehr lästig werden konnte ${ }^{1}$. Der Besatz war in solchen Fällen eine Art Ersatz für einen besseren Futterstoff. In Fällen, in denen die Kasel des Futters ganz entbehrte, mochte er aufier dieser ästhetischen auch noch die praktische Aufgabe haben, den Saum, der am ehesten Schaden leiden konnte, zu stärken.

Eine merkwürdige Verzierung weist die in St Godehard zu Hildesheim aufbewahrte Kasel auf. Eine Skizze derselben, welche die Hälfte der Vorder- wie der Rückseite darstellt, überhebt uns einer näheren Beschreibung (Bild 94). Das Gewand ist nicht das einzige seiner Art. Ähnlicher Ausstattung ist nämlich auch das MeßBgewand des hl. Thomas Becket in der Kathedrale zu Sens. Von einer dritten Kasel des gleichen Typus haben wir nur noch aus der Abbildung und Beschreibung, die Montfaucon von ihr hinterlief, Kenntnis ". Sie befand sich in der Kathedrale zu Angers

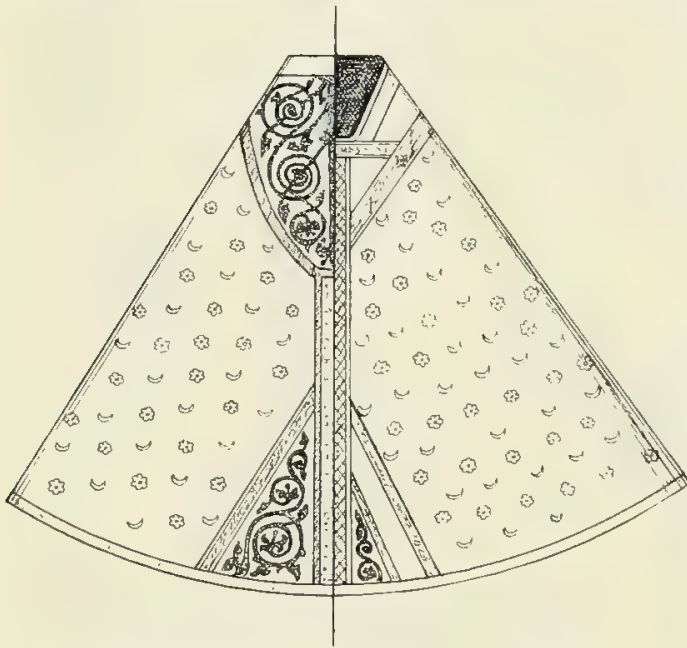

Bild 94. Tíasel. Hildesleim, St Godehard. und galt, indessen mit Unrecht, als Mefagewand des hl. Bischofs Lupus († ca 680). Leider wurde sie, wie so vieles andere, von den Stürmen, die am Ende des 18. Jahrhunderts über Frankreich dahinbrausten, unwiederbringlich weggerafft.

Ebenfalls ein Opfer der Revolution wurde eine sehr interessante Kasel in der Kathedrale zu Angers, bei welcher der Besatz auf dem Rücken durch eine oben und unten von Rankenwerk des Übergangsstiles umspielte Reihe von fünf über einander stehenden Medaillons ersetzt war $^{3}$. Montfaucon hat auch von ihr glücklicherweise eine Skizze hinterlassen. Noch eigenartiger ist die Verzierung zweier um 1200 entstandener Meßgewänder im Schatz der Kathedrale zu Reims. Eines davon ist in Bild 95 wiedergegeben 4. Wie man sieht, hat sich hier der Zierbesatz der Rückseite zu einem förmlich baumartigen Gebilde entwickelt.

$\mathrm{Zu}$ bestimmten Typen des Kaselbesatzes kommt es erst seit etwa dem Beginn des 13. Jahrhunderts. Es sind deren zwei, von denen man den einen den nordischen, den andern den italienischen oder römischen nennen kann,

\footnotetext{
1 Selbst von den kostbaren Kaseln, die im Inventar von St Peter (1361) verzeichnet werden, entbehrten viele, wie ausdrícklich bei ihnen angemerkt ist, des Futters (sine fodere). Wenn man heute klagt, daf Meßgewänder von mittelalterlicher Form sehr lästig, weil zu schwer seien, so kommt das daher, daf man sie gerade wie moderne Kaseln behandelt, $d$. $h$. sie nicht nur mit einem kräftigen Futter, sondern obendrein noch mit einem besondern $Z$ wischenstoff versieht. Wiurde man sich mit einem leichten Futter hegnügen oder, wo dex Oberstoff das zuläist, lediglich mit einem Randbesatz an
}

der Innenseite des Gewandes, so würden die Klagen bald verstummen.

${ }^{2} \mathrm{R}$ oh. VII 144, pl. DLXXix. Vgl. auch die Angaben de Farcys in Revue 1886, 184. $\mathrm{Zu}$ Angers befanden sich vor der Revolution noch eine größsere Anzahl von mittelalterlichen Kaseln (ebd. 1885, 183 und Roh. VII 144 171; VIII, pl. DCIx DCx). Eines dev Mefigewänder wurde irrtümlich dem hl. Licinius ( + ca 605 ) zugeschrieben.

3 Ebd. VIII, pl, Dcix.

4 Nur die Verzierung ist ursprünglich, das Gewand selbst ist erneut. Gute Wiedergabe bei de Fa r cy pl. 25, farbig bei Bock II, 'Tfl xir. 
nicht als ob diese ausschlieflich im Norden bzw. ausschließlich in Italien zur Verwendung gelangt seien, sondern weil der eine im Norden, in Deutschland, Frankreich, England, der andere in Italien vorherrschte.

Beim nordischen Typus war auf jerler der beiden Hälften des Mefogewandes ein sog. Gabelkreuz angebracht. Die beiden Kreuze hatten entweder, wenngleich nur selten, ähnlich wie das Pallium die Form eines oder - und das war die Regel - die eines und stiefen auf den Schultern oder dem Oberarm mit ihren Schrägbalken zusammen.

Wir haben diese Verzierungsweise der Kasel schon anf den ravematischen Mosaiken angetroffen. Aber auch im Norken kanute man sie bereits eine gute Weile vor dem 13. Jahrhundert. Sie findet sich hier schon auf Bildwerken des 10. und 11. Jahrhunderts, wie z. B. einer Miniatur der aus Fulda stammenden Laudes S. Crucis Hrabans in del' Vatikanischen Bibliothek (Bild 96, S. 214) ${ }^{1}$, der früher erwähnten Darstellung Gregors des Groken in dem Trierer Fragment des Registrum S. Gregorii M. (Bild 93, S. 211) und ein wenig später bei Bischof Bernward auf dem Widmungsbild des Bernwardevangeliars im Dom zu Hildesheim ${ }^{2}$. Auch bei den Kaseln, die sich aus dem Ende des 10. und der Frühe des 11. Jahrhunderts erhalten haben, kommt bereits der gabelförmige Besatz vor, so z. B., wie wir früher hörten, bei der Adler-

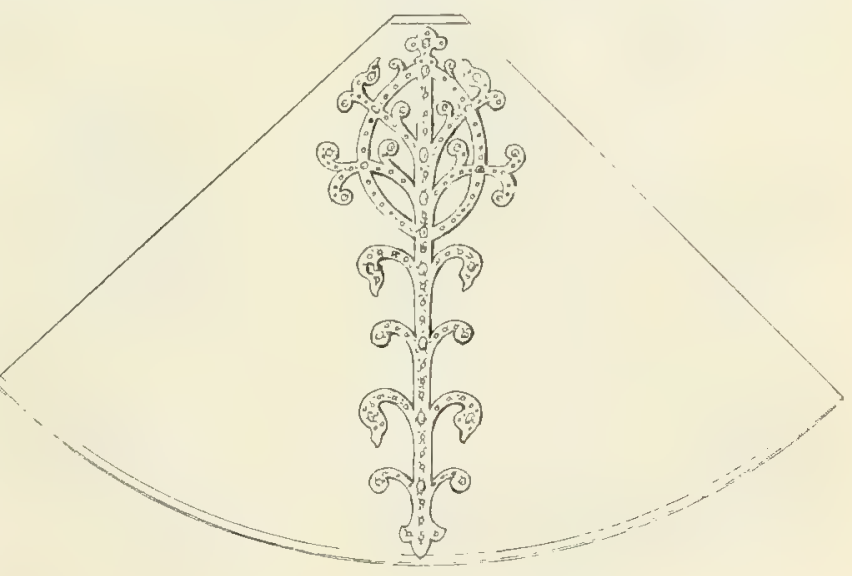

Bild 95. Kasel. Reims, Kathedrale.

kasel zu Brixen und einer der St Ulrichskaseln im Dommuseum zu Augsburg, dann bei den Kaseln des hl. Wolfgang zu Regensburg und des hl. Meinwerk zu Paderborn sowie dem später als Krönungsmantel verwendeten Mefgewand, welches 1031 König Stephan der Heilige und Königin Gisela der Marienkirche zu Stuhlweifanburg zum Geschenk machten. Ebenso muf die Kasel, von welcher die Geschichte der Bischöfe von Auxerre in der Biographie Hugos von Chàlon (1000-1039) erzählt, mit einem gabelförmigen Besatz versehen gewesen sein. Denn wenn dort berichtet wird, ihre handbreiten Besätze hätten ein Bild des Schulterkleides und Richtschmuckes (des Alten Testamentes) nach Art des erzbischöflichen Palliums geboten, so kann das offenbar nur von einem Gabelkreuz verstanden werden ${ }^{3}$.

Der gabelförmige Kaselbesatz ist also keineswegs eine Erfindung des 13. Jahrhunderts. Während er aber vordem nur vereinzelt zur Anwendung kam, war er seit Ausgang des 12. Jahrhunterts ein sehr gewöhnlicher Schmuck des Meligewandes, besonders aber in Deutschland, Frankreich und England, so dak er hier zum förmlichen Typus wurde.

1 Vat. Reg. Lat. Cod. 124. a Be is se l, St., Des hl. Bernward Evangelienbuch, Hillesheim 1891, Tfl IV.

s Hist. episc. Autiss. c. 49 (M. 138, 278). 
Die Frage, wie es zur Entstehung des Gabelkreuzes gekommen, hat eine verschiedene Beantwortung erfahren. Die einen, wie z. B. Thalhofer, führen sie auf mystische Erwägungen zurück. "Galt einmal", so sagt dieser, ,das Mefagewand als ingum Domini, dann lag es gewif nahe, auf demselben (zunächst auf der Rückseite) das Kreuz des Erlösers, das eigentliche iugum Domini, abzubilden." 1 Andere, wie Bock, hahen im Gabelkreuz eine Nachahmung des erzbischölichen Palliums sehen wollen. "Es lag nahe", meint derselbe, „durch eine reiche Stickerei in Gold- und Seidenfäden auf beiden T'eilen des Mefsgewandes die Form des griechischen Tau als ornamentales Beiwerk unbeweglich aufzunähen und zu befestigen, die als auszeichnendes Ornatstück nur die Erzbischöfe und Metropoliten in ähnlicher Form und Anlegungsweise beweglich auf der Planeta zu tragen das Vorrecht besafen." Bock beruft sich dann zur Stütze seiner Ansicht auf die bereits angeführte Notiz aus der "Geschichte der Bischöfe von Auxerre" und schließst: „Durch eine kunstreiche Stickerei, die in ihrem Äufern die Gestalt des erzbischöflichen Palliums nachahmte, wurde also bereits im 12. Jahrhundert auf der Dorsal- und Pektoralseite der bischöflichen Kasel der Mangel des ebengedachten, nur Erzbischöfen zustehen-

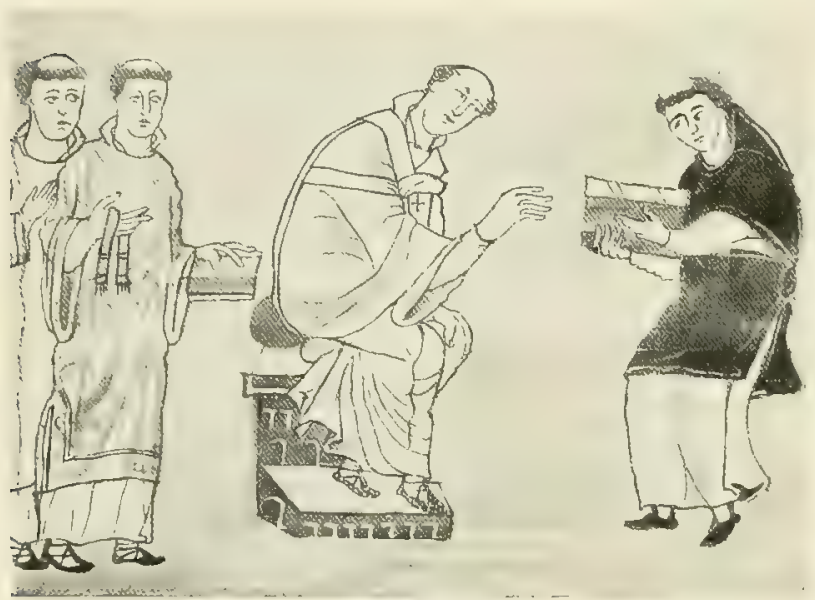

Bild 96. Miniatur in Hrabans Laudes S. Crucis (10. Jahrh.). Rom, Vatikan. den Ornates weniger sichtbar." 2

Die eine wie die andere Erklärung ist jedoch unzutreffend. Es gab einen gabelförmigen Besatz bei der Kasel, wie die früher erwähnten Bildwerke bekunden, schon im 6. Jahrhundert, ja noch früher, und zwar war er nicht eine Eigentümlichkeit einzig der lit u rgischen Planeta, sondern Schmuck der Planeta (Kasel) überhaupt, da er sich ja auf den Monumenten nicht blof bei Bischöfen, sondern auch bei Laien, ja selbst bei Juden findet. Er kann also ursprünglich weder als Dar-

stellung des Kreuzes noch als Nachahmung des Palliums, sondern nur als bloßes Ornament gedacht worden sein.

Kreuz wird der Besatz auch erst in dem späteren Mittelalter genannt und selbst dann keineswegs allgemein. Vor dem Ende oder frühestens der Mitte des 18. Jahrhunderts ist diese Bezeichnung ganz ungebräuchlich. Das frủheste Beispiel, das uns bisher vorkam, findet sich in dem Register von Rochester und stammt aus der Zeit zwischen 1258-1279. Dazu kommt die sehr bemerkenswerte Tatsache, daf bei allen sonstigen Deutungen, welche die alten Liturgiker der Kasel zu teil werden lassen, keiner, nicht einmal Durandus, von einem Kreuze redet, womit man dieselbe als Sinnbild des iugum Domini zu verzieren pflege. Und doch sollte man das bestinmt erwarten, falls der gabelförmige Besatz in der Tat jener mystischen Anschauung seinen Ursprung zu verdanken gehabt oder damals auch nur als Kreuz gegolten hätte ${ }^{3}$. Er hat offenbar in den Augen eines Bruno von Segni, Iro von Chartres, Honorius, Sicard, Innozenz usw. nur dekorativen Zweck gehaht. Es dürfte

1 Liturgik I $880 . \quad 2$ B ock II 107.

Auch in dem angeführten Passus der Ciesta epp. Autiss. wird der Kaselbesatz, der darin mit ïherschwenglichen Worten ge- schildert wird, mit keiner Silbe Kreuz genannt; es wird nur seine Ähnlichkeit mit dem alttestamentlichen Rationale und dem erzbischöflichen Pallium hervorgehoben. 
übrigens auch schwer fallen, für das erste Jahrtausend in der christlichen Kunst überhaupt Kreuze in Gabelform nachzuweisen. Im späten Mittelalter erscheint das Kreuz allerdings nicht selten in der Form eines schrägarmigen oder gegabelten Kreuzes, weil man es liebte, das Kreuz des Herrn in naturalistischer Weise als Lebensbaum mit schräg aufsteigenden Ästen erscheinen zu lassen, im ersten Jahrtausend tritt es dagegen stets als horizontalarmiges Kreuz auf. Eine wirkliche Kreuzesdarstellung in Gestalt eines Gabelkreuzes dürfte selbst noch für das 12. Jahrhundert ein Anachronismus sein.

Gegen die Ansicht Bocks, wonach das Gabelkreuz auf das Pallium zurückzuführen ist, wäre im besondern zu bemerken: erstens. der fragliche Kaselbesatz hat

abweichend vom Pallium in der ältesten Zeit regelmäßig nicht

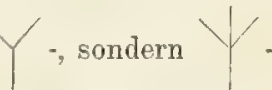

form; zweitens haben die Besätze bisweilen eine so minimale Breite - man denke nur an die Brixener Adlerkasel, an das früher erwähnte Meßgewand des hl. Ulrich im Dom zu Augsburg und an die Miniatur des Registers Gregors des Grofen in der Stadtbibliothek zu Trier -, dak schon ein ziemlich guter Wille dazu gehört, in ihnen Verwandte des erzbischöflichen Palliums zu sehen; drittens erscheinen die gabelförmigen Besätze auf den Bildwerken so wenig als Kopien des Palliums, dafs sie sich nicht bloßs auf den ravennatischen $\mathrm{Mo}_{0}$ saiken, sondern anch auf den angeführien Viniaturen der Laudes S. Crucis des Hraban und des Registers Gregors des Grofen in Verbindung mit diesem dargestellt finden. Wenn aber der Schreiber der Vita Hugos von Châlon den Kaselbesatz, von dem er erzählt, als dem Pallium ähnlich bezeichnet, so folgt daraus eben nur eine gewisse formelle Übereinstimmung beider, nicht aber auch, daf der Besatz eine beabsichtigte Nachahmung des Palliums war, und noch viel weniger, daß das Gabelkreuz überhaupt dem Bestreben, das Pallium zu kopieren, sein Dasein verdankt.

Die Blüte des Gabelkreuzes fällt in das 13. und 14. Jahrhundert. Im Verlauf des 15. kommt es allmählich in Abgang, Bild 97. Kaselkrenz. Danzig, Marienkirche. doch währt es lange, bis es ganz von dem

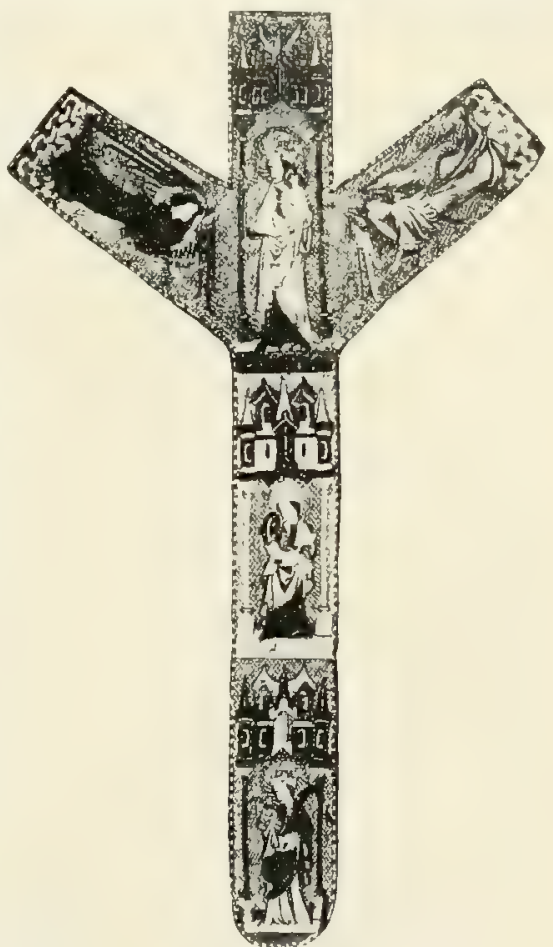
Mebigewand verschwunden ist. An einzelnen Orten erhält es sich bis tief ins 17. Jahrhundert hinein in Gebrauch. So findet es sich z. B. in Lüttich noch auf Grabsteinen aus den Jahren 1605 (Hof des alten bischöflichen Palastes) und 1641 (Kreuzgang von St Paul). In St-Maurice zu Angers aber gab man das Gabelkreuz erst Ende des 17. oder Anfang des 18. Jahrhunderts auf ${ }^{1}$. Immerhin waren das nur vereinzelte Erscheinungen; schon in der zweiten Hälfte des 15. Jahrhunderts war nicht mehr das Gabelkreuz das Gewöhnliche, sondern das horizontalarmige.

Eine Abart des Gabelkreuzes und zugleich wohl die Mittelform zwischen dem gabelförmigen und dem horizontalarmigen war ein Kreuz, dessen Querbalken zwar schräg anstiegen, sich aber nicht bis auf die Schultern hinaufzogen. Es wurde meist nur auf der Rückseite des Mebgewandes angehracht

\footnotetext{
${ }^{1}$ Revue 1885, 184.
} 
und scheint im Verlauf des 1t. Jahrhunderts aufgekommen zu sein. Im 15. war es nach Ausweis der Monumente, die häufig Darstellungen von ihm bringen, recht beliebt. Vorzügliche Beispiele dieser Kaselkreuzart, der wir noch auf dem Grabmal des Trierer Erzbischofs Johannes von Schönenberg († 1599) im Dom zu Trier begegnen, birgt die Schatzkammer von St Marien zu Danzig. Sie gehören zum Teil zu den hervorragendsten Werken spätmittelalterlicher Figurenstickerei (Bild 97, S. 215).

Eine andere, doch sehr seltene Umbildung des Gabelkreuzes, die aber erst aus der Wende des 15 . Jahrhunderts zu datieren scheint, bestand darin, daf man in der Absicht, eine gröfsere Fläche zur Anbringung von Stickereien zu schaffen, die Schrägbalken fast bis zum Kopfdurchschlupf erbreiterte. Trotz aller reichen Nadelarbeiten, mit denen man diese Abart des Gabelkreuzes versah, war dieselbe doch nur eine wenig schöne Verzierung des Mefogewandes.

Horizontalarmige Kreuze kamen vereinzelt schon um die Mitte des 13. und in der Frïhe des 14. Jahrhunderts vor. So treffen wir ein solches in Verbindung mit einem Gabelkreuz bereits auf der dem hl. Petrus Martyr († 1252) zugeschriebenen Kasel in St-Sernin zu Toulouse und für sich allein zu Castel S. Elia auf einem Mefagewand aus der ersten Hälfte des 14. Jahrhunderts an (Bild 88, S. 202).

Es handelt sich indessen bei derartigen Beispielen bis zum Ende des 14. Jahrhunderts nur um Ausnahmen, nicht um die Regel. Erst dann gewinnt das horizontalarmige Kreuz größrere Verbreitung. In Deutschland und Frankreich drängt es im Laufe des 15. Jahrhunderts das Gabelkreuz nach und nach ganz in den Hintergrund und wird hier an dessen Stelle zum vorherrschenden Kaselbesatztypus. In Frankreich erhält sich dabei die breite Einfassung des Kopfdurchschlupfs, der wir bei den Kaseln des 12. und 13. Jahrhunderts nicht selten begegnen, während diese in Deutschland entweder ganz aufer Anwendung kommt oder zu einem schmalen Börtchen zusammenschrumpft.

In der Regel wurde das geradbalkige Kreuz nur auf der Rückseite der Kasel angebracht. Indessen kam es auch wohl vor, dab man beide Seiten mit einem solchen bedachte. Ein frïhes Beispiel eines derartigen Meßagewandes ist die Bild 88 wiedergegebene Kasel zu Castel S. Elia (14. Jahrhundert), ein spätes eine Kasel in der Kathedrale von Bergamo ${ }^{1}$; ein anderes aus der Wende des Mittelalters sahen wir in einer Privatsammlung zu Robecco bei Cremona, in die es aus einer Kirche des Aostatales gelangt war. Auch die Melker Kasel ist mit zwei Kreuzen versehen, die indessen jünger als das Gewand selbst sind. Auf den Bildwerken begegnen uns ebenfalls seit dem 14. Jahrhundert hie und da Kaseln mit horizontalarmigem Kreuz auf der Vorder- wie der Rückseite. Ein gutes Beispiel aus dem Beginn des 16. Jahrhunderts liefert eine aus der "Groote Kerk" zu Goudla stammende Skulptur im Rijksmuseum zu Amsterdam.

Am meisten scheinen Kaseln mit zwei horizontalarmigen Kreuzen in Italien vorgekommen zu sein, wo allerdings der Umstand, daf die Vorderseite hier regelmäig mit einem kreuzartigen Besatz versehen wurde, das häufigere Auftreten eines doppelten horizontalbalkigen Kreuzes auf dem Meßsgewand leicht erklärt. Kum Typus ist diese Verzierungsweise der Kasel indessen auch in Italien nicht geworden, obschon der hl. Kall Borromäus ausdrücklich bestimmte,

1 Abbildung bei Beltra mi, L'arte negli arredi sacri della Lombardia, Milano 1897, tav. xIx. 
es solle auf beiden Gewandhälften ein durch mindestens 8 unciae (= ca $0,14 \mathrm{~m}$ ) breite Streifen gebildetes Kreuz aufgenäht werden ${ }^{1}$. Es ist interessant, zu beobachten, wie selbst die vom hl. Karl stammenden Kaseln in S. Maria Maggiore zu Rom und im Dom zu Mailand nur den gewöhnlichen Besatz der italienischen Mefigewänder, einen Stah auf der Rückseite und ein Kreuz auf der Vorderseite, aufweisen. In Deutschland müssen Kaseln mit geradbalkigem Kreuz auf Brust und Rücken stets nur Ausnahmen gewesen sein. Unter den zahlreichen Mefagewändern aus dem Mittelalter, die sich hier bis zur Stunde erhalten haben, ist uns nur ein Beispiel bekannt, welches auf cler Vorderwie Rückseite ein solches aufweist, die Kasel zu Stift Melk, Wenn es in der "Nachfolge Christi" heifst: "(Sacerdos) habet ante se et retro dominicae crucis signum" 2, so ist hier unter dem doppelten Krevz das eigentliche Gabelkreuz zu verstehen, mit welchem sowohl die Vorder- wie die Rückseite des Mefigewandes versehen wurde.

Es war sogar in Deutschland im 15. Jahrhundert sehr gewöhnlich, die Vorderseite der Kasel bei Anwendung des horizontalarmigen Kreuzes ohne allen Besatz zu lassen. So weisen von den zahlreichen mit einem derartigen Kreuz auf dem Rücken geschmückten Mekgewändern in dem Museum zı Braunschweig, dem Dom zu Halberstadt, dem Dom zu Brandenburg und St Marien zu Danzig nur sehr wenige vorn den jetzt allgemein gebräuchlichen Vertikalstreifen auf.

Welche Einflüsse die Imwandlung des Gabelkreuzes in das horizontalbalkige herbeigeführt haben, ist mit Sicherheit nicht zu sagen. Es waren wohl mehrere Faktoren, die den Wechsel bewirkten, so die seitliche Verkỉizung der Kasel, die im Norden schon um das Ende des 14. Jahrhunderts einen bedeutenden Grad erreicht hatte, ferner die seit dem 14. Jahrhundert mächtig gestiegene Vorliebe für Kaselbesätze mit reicher Figurenstickerei und darum auch für breitere Besätze, als Gabelkreuze es sein können, ohne schwer, plump und unschön zu werden, endlich und wohl am meisten das Bestreben, durch ein eigentliches Kieuz das Geheimnis sinnfällig anzudenten, bei dessen Feier sich der Priester der Kasel bedient, die unblutige Emeuerung von Christi Kreuzestod. Es ist wohl nicht ohne Grund, dafi zur Zeit, da das horizontalarmige Kreuz an Verbreitung gewinnt, auch die Darstellung des Gekreuzigten auf der Kasel häufiger wird. Um die Wende des 15. Jahrhunderts gab man sogar dem Kreuz häufig die Gestalt eines förmlichen, mit knorrigen Ästen besetzten Baumes (Bild 98, S. 218).

Der zweite Besatztypus, den wir oben den italienischen nannten, weil er in Italien vorherrschte, wie im Norden das Gabelkreuz, l,estand. aus einem Stab auf der Vorder- und der Rückseite des Mebgewandes, einer Einfassung der Halsöffnung von wenigstens der halben Breite der Vertikalbesätze und einem kurzen Querstuick zwischen der Bordüre des Kopfdurchlasses und dem oberen Ende des vorderen Stabes, der vornehmsten Eigentümlichkeit des Typus. Querbalken eines Kreuzes zu sein, war nicht der' ursprüngliche Zweck dieses Querbesatzes. Er wurde vielmehr aus praktischen und ästhetischen Rücksichten angebracht. Aus praktischen; denn er sollte das Einreißzen des Kopfdurchlasses verhüten; aus ästhetischen, weil er den um die Halsöffnung angebrachten Borten an ihrem unteren Ende einen passenten Abschluls geben und eine Überleitung zu dem vorderen Vertikalstab bilden sollt

\footnotetext{
'A. E. Med. 627.

2 L. 4 , c. 5, n. 3.
} 
Er ging deshalb auch urspringlich nicht oder nur wenig über die Bordüre des Kopfdurchschlupfes seitlich hinaus. Selbst im 15. und 16. Jahrhundert springt der Querbesatz noch häufig blok um ein geringes über die Einfassung des Kopfdurchschlupfes vor, wie das aufer den zahlreichen bildlichen Darstellungen z. B. die Kaseln zı Castel S. Elia, die Kaseln von S. Marco zu Venedig, die Kasel des Papstes Kalixt II. und die Kaseln des hl. Karl zu Rom (S. Maria Maggiore) und Mailand (Dom) beweisen.

Es ging überhaupt keine wesentliche Wandlung mit dem Besatz seit dem 13. Jahrhundert vor sich. Die hauptsächlichste Veränderung betraf seine Breite. Im 13. Jahrhundert erscheint er meistens noch recht schmal, dann aber erwacht auch in Italien die Vorliebe für breite, die Anbringung reicher

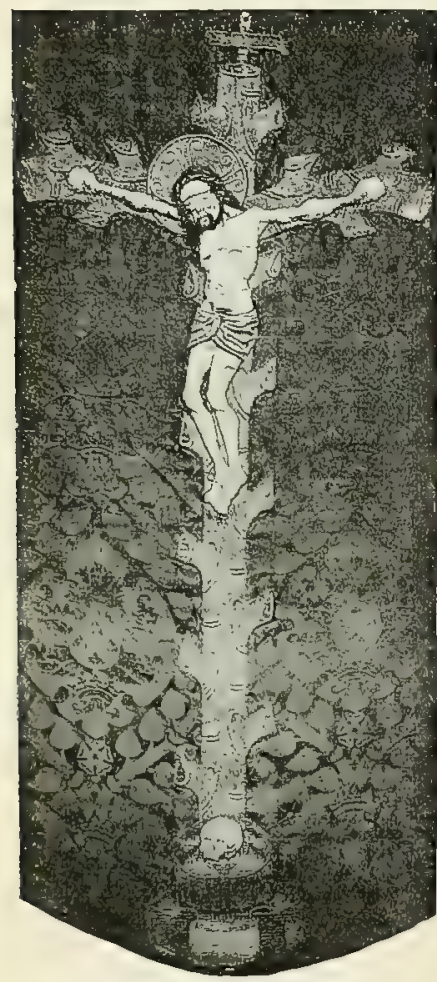

Bild 98. Kaselkreuz. BerIin, Kunstgewerbemuseum, Figurenstickerei ermöglichende Besätze. Im übrigen gewährt in Bezug auf die Verzierungsart die italienische Kasel des 14. und 15. Jahrhunderts dasselbe Bild, welches das Mefsgewand im 13. bot. Der Besatztypus kommt schon auf den unter Innozenz II. $(1130-1143)$ angefertigten Apsismosaiken in S. Maria in Trastevere beim Presbyter Calepodius vor. Seit dem 14. Jahrhundert gewahrt man auf den italienischen Bildwerken kaum eine andere Besatzart auf der Kasel mehr.

Gute Beispiele finden sich auf dem Meßsgewand des hl. Bernardo degli Uberti in S. Trinità zu Florenz, der Kasel des hl. Bernardin von Siena in der dortigen Opera del Duomo, den beiden Meßggewändern in S. Marco zu Venedig sowie den andern vorhin genannten Kaseln.

Die Neuzeit bietet wenig Bemerkenswertes in Bezug auf die Form des Kaselbesatzes. Die Typen, welche das ausgehende Mittelalter als Erbe hinterlief, erhielten sich ohne weitere Umbildung bis in die Gegenwart. Nur bekamen nunmehr alle Kaseln Besätze, während sie im Mittelalter, ja noch teilweise bis in das 16 . Jahrhundert nicht selten ganz ohne solche geblieben waren, doch wurden bei gewöhnlichen Mes̉gewändern Kreuz und Stäbe gern durch schmale Börtchen nachgebildet, namentlich in Italien.

Im allgemeinen waren die Besätze jetzt stets von ziemlicher Breite. Die Neuzeit hatte aus dem späten Mittelalter auch die Vorliebe für breite Besätze als Vermächtnis herübergenommen. Ja je mehr das Gewand an Breite abnahm, um so mehr schien das Kaselkreuz an Ausdehnung gewinnen zu sollen, gleich als ob ein mächtiges Kreuz einen Ersatz für die unbedeutende Wirkung des zusammengeschrumpften Gewandes liätte bieten sollen. Allerdings dürfte auf die Erbreiterung des Kaselbesatzes auch noch eine andere, praktische Er*wägung Einfluf gehabt haben.

War nämlich das Kaselkreuz recht breit, so reichte bei der geringen Ausdehnung des Mefkleides selbst zur Anfertigung des Rückteiles eine Stoffbreite aus. Man konnte in diesem Fall sogar bei etwas Nachlenken und L̈bung durch kluges Zuschneiden das Material für die Stola und den Manipel 
aussparen, so daf man bei Kasel und Zubehör fast mit $21 / 2-3 \mathrm{~m}$ Stoff, die Breite zu $54 \mathrm{~cm}$ gerechnet, auskam. Allerdings ein gewaltiger Unterschied im Vergleich mit den Glockenkaseln früherer Zeit, zu denen bei sleicher Breite das Dreifache erforderlich gewesen war!

Was die Beschaffenheit der Kaselbesätze anlangt, so bestanden sie bis in das 13. Jahrhundert hinein gewöhnlich aus gewebten Borten. Dieselben hatten durchweg eine Breite von $3-8 \mathrm{~cm}$. Breitere Borten scheinen nur selten verwendet worden zu sein, häufiger dagegen schmälere, doch wurden auch wohl zwei oder drei schmälere Besätze nebeneinander angebracht, wie z. B. bei der Glockenkasel in St Emmeram zu Regensburg und einer der Kaseln im Dommuseum zu Augsburg.

Es haben sich noch manche dieser Borten erhalten. Sie stellen ein vorzügliches, äufierst dauerhaftes, fast lederartig festes Gewebe dar. $\mathrm{Zu}$ ihrer Herstellung wurde eine Doppelkette gebraucht und die beiden Kettenfäden nach der jedesmaligen Einführung des Einschlages umeinander gedreht. Bei der Mehrzahl dieser Borten ist reichlich Gold zur Anwendung gebracht worden. Dasselbe besteht bis in das 12. Jahrhundert hinein aus einem massiv goldenen Metallriemchen, welches um einen Seidenfaden gesponnen ist, dann aus einem silbervergoldeten, gleichfalls um einen Seidenfaden gesponnenen Metallstreifchen. Der irrig sog. cyprische Goldfaden, ein Surrogat echter Goldfäden, bei dem ein vergoldetes Häutchen um einen Linnenfaden gedreht ist, gehört erst dem späteren Mittelalter an. Die zu den Borten im 11. und 12. Jahrhundert gebrauchten Goldfäden sind

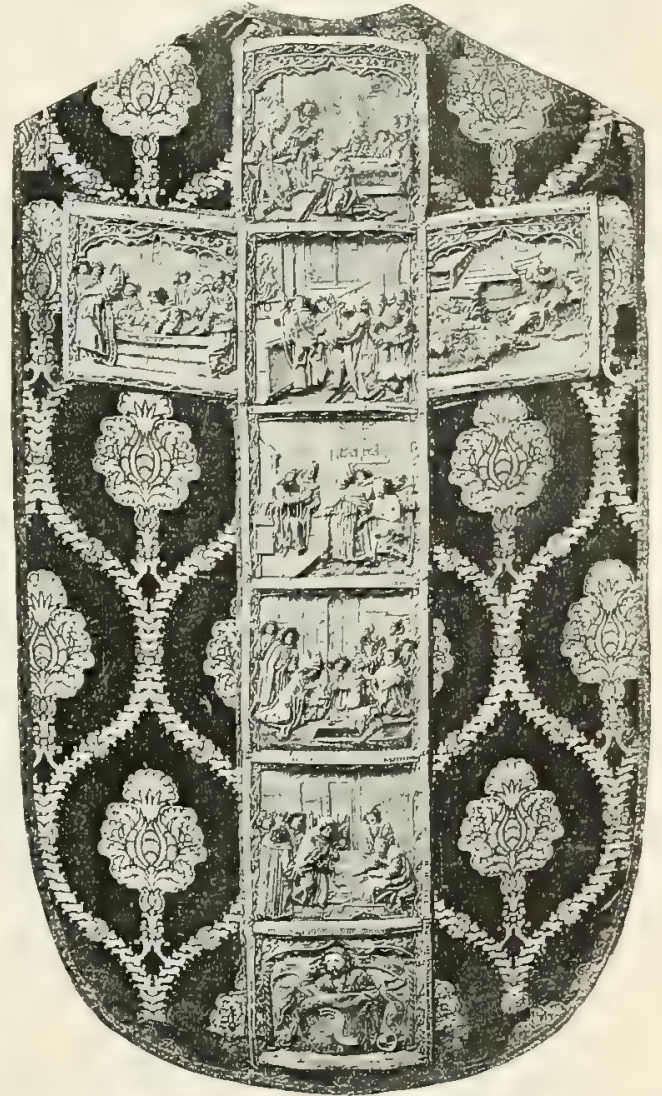

Bild 99. Kasel. Krakau. Dom. (I'hot. J. Krieger,) von äuferster Feinheit. Um ihre Wirkung zu erhöhen, pflegte man die fertig gewebte Borte zu walzen. Es ist erstaunlich, wie vortrefflich sich diese durch ihr Material ungemein kostbaren Borten durch alle die Jahrhunderte hindurch erhalten haben. Vorzügliche Beispiele derselben bieten die sog. Sixtuskasel im bischöflichen Museum zu Münster, die beiden Willegiskaseln zu Mainz und Aschaffenburg, die Brixener Adlerkasel, die Kaselı im Schatz des Bamberger Domes und namentlich die St Wolfgangskasel in St Emmeram zu Regensburg.

Die Borten des späteren 12. und des 13 . Jahrhunderts, bei denen das rein goldene Metallstreifehen durch ein silbervergoldetes ersetzt und obendrein mu hi farbige Seide verwendet ist, haben weniger gut der Zeit zu trotzen verstanden. obschon auch sie sich immer noch als sehr haltbar erwiesen haben. 
Die Musterung der Besätze bestand bis ins 13. Jahrhundert hinein fast nur aus geometrischen Gebilden, aus stilisierten Ranken und phantastischen Tieren. Figurale Darstellungen bürgern sich auf ihnen erst ein, als die Stickkunst beginnt, mit ihren Schöpfungen die Stäbe zu beleben. Schon das 13. Tahrhundert bringt manche herrliche, mit Bildwerk reich geschmückte Kaselbesätze hervor; die eigentliche Blütezeit derselben fällt aber in das 14 . und 15. Jahrhundert.

Die Darstellungen, denen wir auf ihnen begegnen, sind sehr mannigfaltig. Sie nehmen vor allem natïrlich Bezug auf den Heiland und sein Leben, doch auch, und zwar ganz besonders, auf die allerseligste Jungfrau und die Geheimnisse ihrer irdischen Pilgerschaft bis zu ihrer Aufnahme in den Himmel und

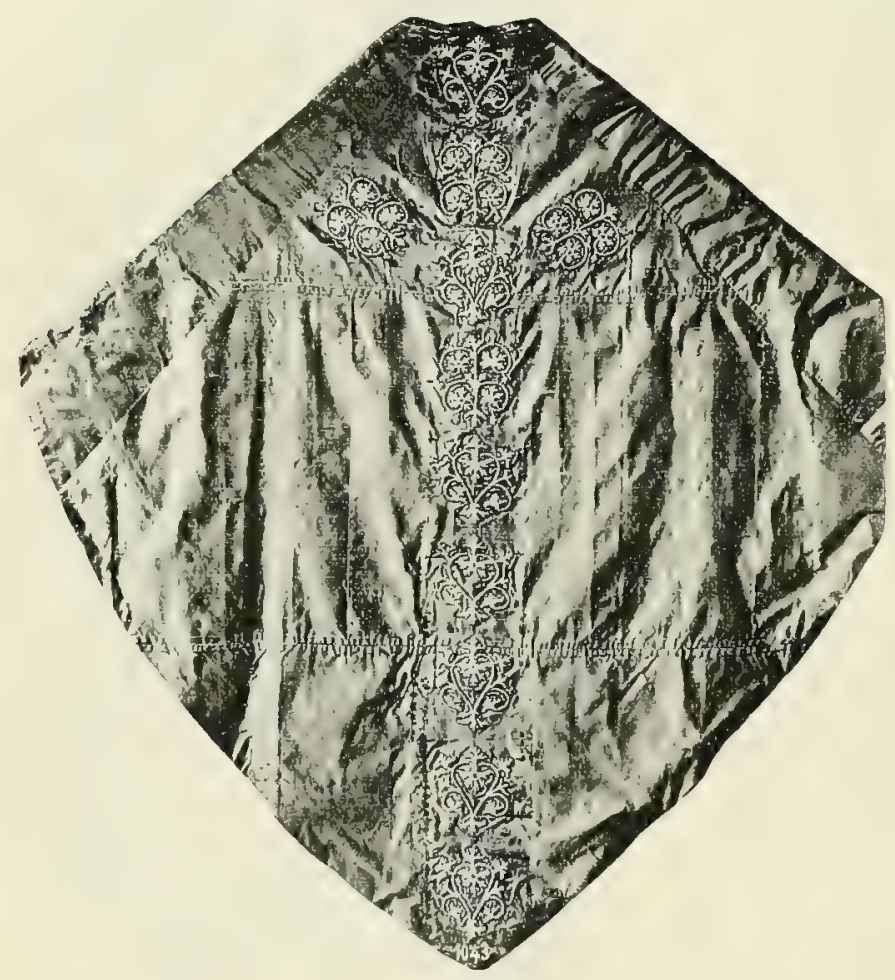

Bild 100. Kasel mit Kreuz in Perlen. Aachen, Münster. ihrer Krönung, auf die Engel, die Apostel und die Heiligen, namentlich auf die vom Volk verehrten $\mathrm{Pa}-$ trone und die Titelheiligen der Kirchen und Altäre. Es ist ein äußerst wechselvolles Bild, was sich bei der Durchmusterung der Kaselreste aus alter Zeit oder beim Durchlesen der Inventare des späteren Mittelalters dem Auge oder der Phantasie darbietet. Es waren diese Stickereien keineswegs ausnahmslos Kunstwerke; sie waren zum Teil handwerksmäkige, kunstlose, ja rohe Arbeiten. Aber es gab unter ihnen auch zahllose Perlen wahrer Kleinkunst, Nadelmalereien, die in ihrer erleln Ausführung den Vergleich mit den besten Schöpfungen des Pinsels nicht zu scheuen brauchten. Die vielen Reste mittelalterlicher Kaselbesätze in den Kirchen, Museen und Privatsammlungen legen dafür beredtes Zeugnis ab.

Das ausgehende 15. und das beginnende 16. Jahrhundert sehen auf den Kaselstähen Stickereien in Hochrelief entstehen. Es sind meistens Einzelfiguren wie der Gekreuzigte (Bild 98, S. 218), Maria und Heilige, die in Reliefstickerei auf dem Kaselkreur angebracht werden, doch kommen in dieser Stickweise auch ganze Szenen auf demselben zur Ausführung. Das hervorragendste Beispiel hildet wohl eine Kasel im.Dom zu Krakau mit Darstellungen aus dem Leben des heiligen Bischofs Stanislaus (Bild 99, S. 219).

Technisch hetrachtet, waren diese üher Werg modellierten Reliefstickereien vielfach sehr kunstreich, vom ästhetischen Standpunkt aus und als Ornamente 
eines Gewandes müssen sie indessen entschieden verurteilt werden. Sie bekunden, das der Sinn für das wahrhaft Schöne schon im Weichen begriffen und die Vorliebe zum Bizarren und Sonderbaren erwacht war, und dab man das Verständnis für die wahre Bedeutung der Besätze bereits in hohem Mafe verloren hatte und das zur Hauptsache zu machen begann, was als Ornament doch nur Nebensache war.

Håufig werden seit dem 13. Jahrhundert auch Perlen, seltener Edelsteine zur Verzierung der Kaselbesätze verwendet. Die Inventare führen sehr oft Aurifrisien dieser Art an. Eine interessante Kasel, deren Stab in eigentümlicher Weise aus Perlen gebildet wird, ist die sog. St Beruardskasel im Münster zu Aachen. Eine Abbildung des Gewandes (Bild 100) überhebt uns einer näheren Beschreibung. Ein anderes interessantes, ganz mit feinen Perlen besticktes Kreuz findet sich im Berliner Kunstgewerbemuseum (Bild 101). Öfters wurden ferner im späteren Mittelalter gestanzte vergoldete Metallplättchen zur Ausschmückung der Kaselstäbe gebraucht (Bild 102, S. 222). Sie hatten die Form von Rosetten, Vierpässen, Rauten u. ä. und waren in der Mitte mit Ornamenten, ja selbst mit religiösen Darstellungen, z. B. Szenen aus dem Leben Christi, versehen. Statt gestanzter kamen auch wohl, wie die Inventare bezeugen, mit Emailbildchen geschmückte Zierplättchen zur Verwendung.

Übrigens wurden auch im späteren Mittelalter neben bestickten immer noch häufig gewebte Besätze gebraucht. Hauptbezugsquellen derselben waren im 14. Jahrhundert den Inventaren zufolge Lucca (opus lucanum), Venedig (opus venetum), Siena (opus senense), Romania, d. i. Griechenland (opus romanum), Cypern (opus cyprense oder

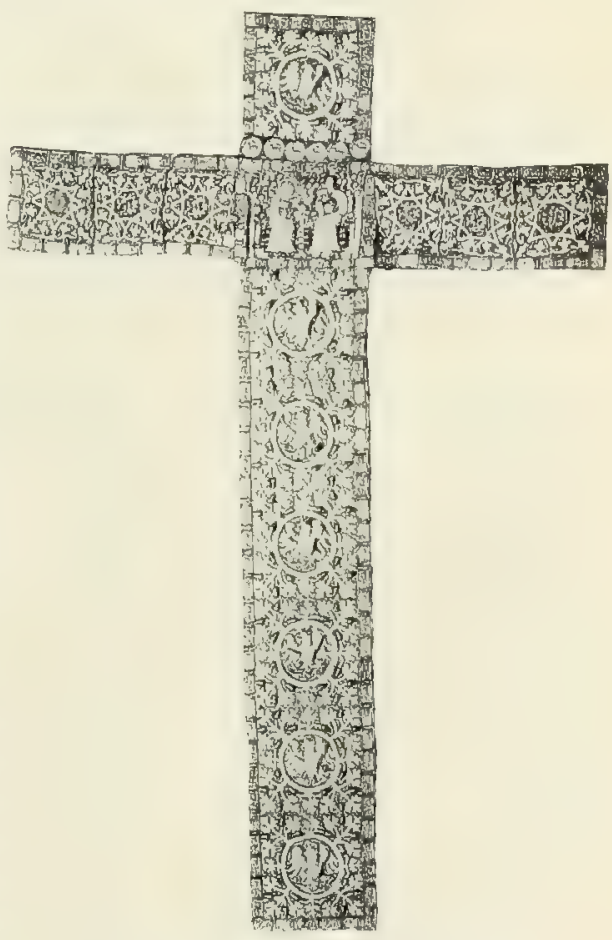

Bild 101. Kaselkreuz in Perlenstickerei. Berlin, Kunstgewerhemuseum. cyprianum) und der sarazenische Osten (opus tartaricum). Im 15. kommen dazu Florenz mit seinen schon den Einflufs der Renaissance atmenden Florentiner und der Niederthein (Köln) mit den ebenso wirkungsvollen wie charakteristischen sog. Kölner Borten, die hier eine besondere Erwähnung verdienen. Sie gehören zu den vorzüglichsten Borten, welche im Mittelalter von der Hand des Webers geschaffen wurden. Der Grund war bei ihnen entweder in dem fälschlich sog. Cyperngold oder in farbiger Seide hergestellt. Im letzten Falle liebte man es, in bestimmten Abständen und in regelmäfiger Wiederkehr mit der Farbe zu wechseln. Das Ornament, für welches satte, kräftige Farben, namentlich ein tiefes Blau und ein leuchtendes Rot bevorzugt wurden, bestand bald in fortlaufenden Ranken, bald in reizend stilisierten Bäumchen, Blumen, Rosetten, kurzen, in die Quere gestellten Inschriften, Wappenschildchen und ähnlichen Motiven, die in mannigfachen Zusammen- 
stellungen miteinander kombiniert wurden, bald endlich in freistehendem oder unter Baldachinen angebrachtem Figurenwerk (dem Gekreuzigten, der allerseligsten Jungfran, Heiligen usw.). Bei Borten mit figürlichen Darstellungen, welche den Höhepunkt der Fabrikation bildeten, wurden nur die Hauptteile der Figur auf dem Webstuhl fertiggestellt, nicht aber auch die Einzelheiten, wie die Gesichter, das Haar, Köpfe, Hände und Füße, die Faiten und die Musterung des Gerrancles. Alles das wurde nachträglich durch die Hände des Stickers

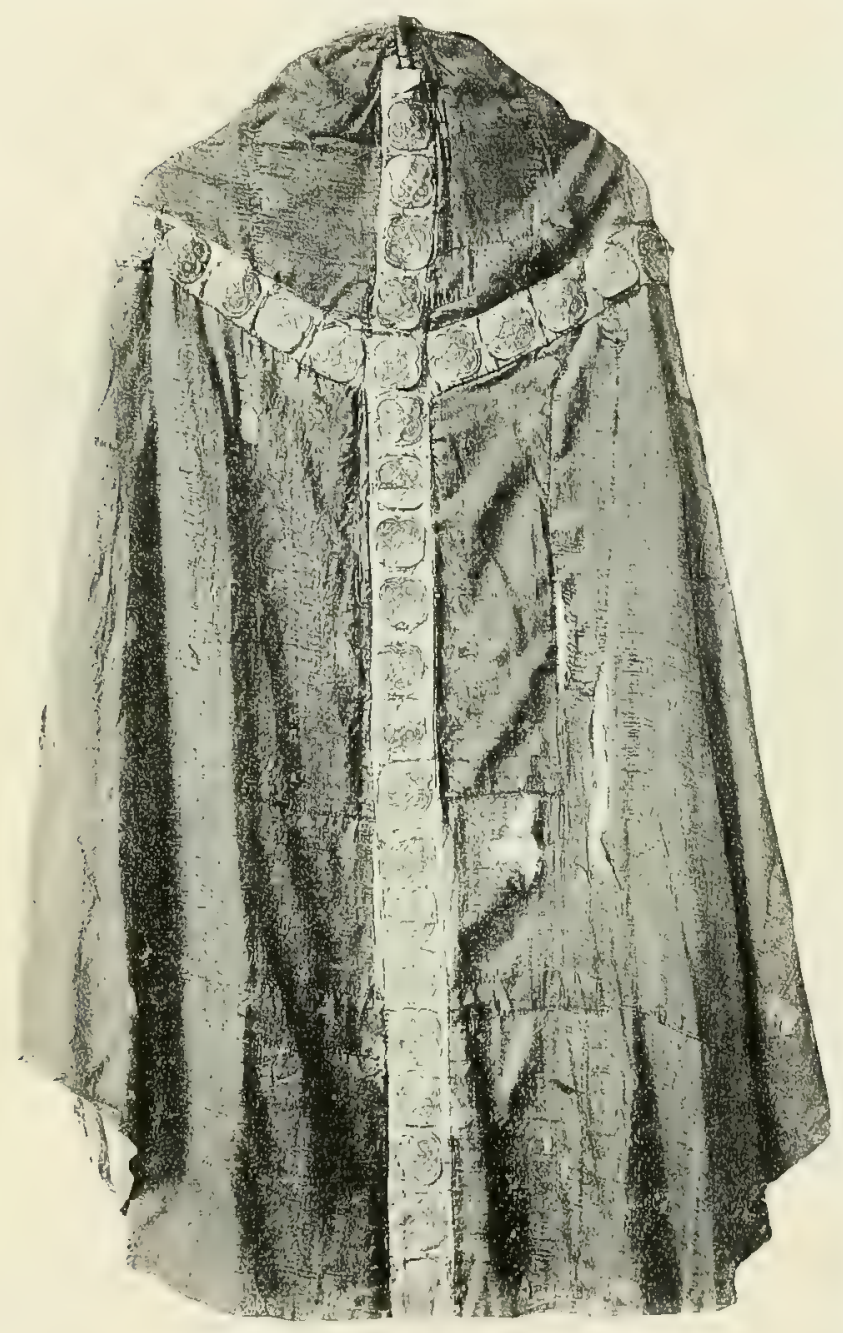

Bild 102. Kasel. Halluerstadt, Dom. oder der Stickerin ergänzt (gemischte Technik). Wie bekannt, hat man in jüngster Zeit zu Krefeld die Herstellung der alten Kölner Borten, von denen sich noch manche Überbleibsel erhalten haben, mit Gluick von neuem ins Leben gerufen.

Die Bildstickerei stellt um das Ende des 16. Jahrhunderts auf den Kaselstäben fast ganz ihre Tätigkeit ein. Ganz mit figürlichen Darstellungen ausgestattete Besätze sind im 17. Jahrhundert Ausnahmen. Vorzügliche Beispiele finden sich auf der Kasel Oliers, des Stifters der Sulpicianer in St-Sulpice zu Paris 1, und namentlich einem $\mathrm{Mes}$ gewand in der ehemaligen Jesuitenkirche zu Köln, einer Arbeit des Laienbruders Johannes Lütgen, der von 1643 bis 1673 im Kölner Kolleg als acupictor, wie die Kataloge sagen, tätig war. Bild 103 gibt die Rückseite wieder. Auf der Vorderseite sind übereinander Christus als Feldherr, unter seinem Mantel heilige Kreuzesträger, zwei weibliche Heilige (Cäcilia? und Lucia) und die Apostel Petrus und Paulus dargestellt. Kreuz und Stab, die beide in sog. Lasurstickerei über Goldfäden hergetellt sind, dürfen sich in ihrer äußerst delikaten Ausführung kühn den besseren Werken des Mittelalters anreihen ${ }^{2}$. Den Grund der Kasel bedecken in Gold ausgeführte, technisch vollendete, aber allzu schwere und massige Hochstickereien (Ranken, Früchte, Vögel), die 
zu den flachen Stickereien des Kreuzes und des Stabes in auffallendem Kontrast stehen.

Wollte man den Kaselbesatz mit Bildwerk verzieren, so begnügte man sich für gewöhnlich damit, in der Kreuzung der Balken ein Medaillon mit eingesticktem Bilde anzubringen. Indessen geschah nicht einmal das allzu oft. In der Regel lieb man es in der Mitte des Ḱreuzes bei irgend einem Symbol bewenden; für die Balken und Stäbe selbst aber wollte die Mode Arabesken, klassizierende Ranken, Riemen- und Kartuschenwerk 1 . ̈.. Bei besseren Mefagewändern wurden die Stickereien mit Vorliebe in steifem, schwerem Goldoder Silberguipé (der bekannten Hochstickerei, bei welcher die Gold- bzw. Silberfäden über dick aufgelegte Fäden oder kräftigen Karton gespannt und so auf dem Grund aufgenäht werden) ausgeführt. Es ist das die Reliefstickerei, die wir schon um 1500 in Blïte fanden. Technisch betrachtet, sind die Stickereien auf den Kaselbesätzen im 17. Jahrhundert durchweg gute, ja vielfach ausgezeichnete Arbeiten von ungemeiner Sauberkeit und Glätte und reich entwickelter, mannigfaltiger Technik. Leider entsprach der Sorgsamkeit in der Ausführung und der Ausbildung der Technik nicht im gleichen Maß̌e der gute Geschmack. Es war denn doch das immer wiederkehrende, an die Antike sich anlehnende, monotone Rankengewirr ein schlechter Ersatz für das herrliche Bildwerk, welches die früheren Künstler mit der Nadel auf die Kaselbesätze zu zaubern verstanden hatten.

Im 18. Jahrhundert gewähren die bestickten Kaselstäbe im großen und ganzen dasselbe Bild wie im 17., nur dab auch aus dem Medaillon in der Mitte des Kreuzes das Bild verschwindet, und dafs das Ornament sein antiki-

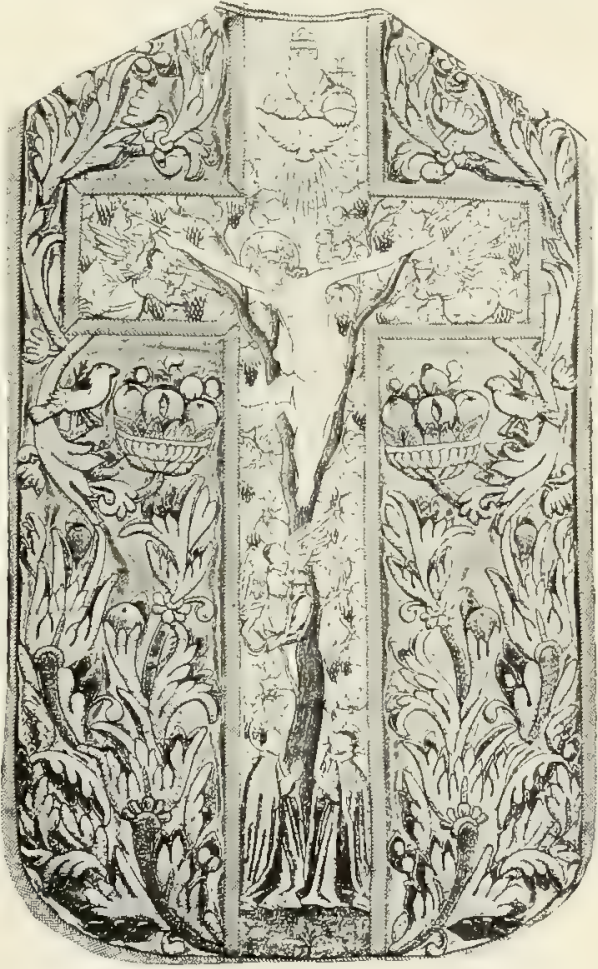

Bild 103. Kasel. Kähn, ehem. Tesuitenlibehe. Arbeit des Laienbruders Joh. Liitgens. sierendes Gepräge verliert und einen naturalistischen Charakter erhält oder zu willkürlichem Schnörkelwerk wird. Die technische Ausführung der Stickereien stand auch jetzt noch auf einer hohen Stufe, dagegen nahm der gute Geschmack immer mehr ab, wie das namentlich in der üppigen Anwendung überladener Goldstickereien zu Tage trat.

Das 19. Jahrhundert sah bei seinem Anbruch die kirchliche Stickkunst wie die Kunst überhaupt auf einer tiefen Stufe, bis auch ihr in den fünfziger Jahren des vorigen Jahrhunderts die Reformbewegung in Deutschland, Frankreich, Belgien und Holland neues Aufblïhen brachte. Es entstanden in Anlehnung an die mittelalterliche Technik wie die mittelalterliche Darstellungsweise Kaselbesätze, die sich kühn neben den alten Meisterwerken sehen lassen durften. Namentlich gingen aus stillen Klosterräumen, in denen frommer Eifu für die Zierde des Heiligtums im Verein mit hoher Kunstfertigkeit, feinen! 
Verständnis für Stil und edlem Geschmack waltete, manche herrliche Stickereien zur Ehre Gottes und zum Schmuck der Kaselbesätze hervor. Besondere Erwähnung verdienen die zahlreichen vollendeten Schöpfungen der technisch ebenso geschulten wie feinsinnigen und kunsterfahrenen Schwestern vom Armen Kinde Jesı zu Aachen und Simpelveld (holländisch Limburg).

Es war kein Vorteil für die Kasel, daß sich in dem letzten Viertel des vorigen Jahrhunderts die aufstrebende Industrie mit ihrer Stickmaschine und ihrer künstlerisch wertlosen Dutzendware und die sog: Anstalten für christliche Kúunst. mit ihren Spekulationen der Paramentenstickerei bemächtigten. Was von ihnen in den letzten zwanzig Jahren auf den Markt gebracht wurde, ist vielfach so stil- und charakterlos und künstlerisch so minderwertig, dals man oft, trotz aller ihrer Gebrechen, die Zeit des Rokoko wieder herbeiwünschen möchte.

Spanien und Italien blieben mit ihren Kaselstickereien stilistisch auf dem Standpunkt des 18. Jahrhunderts. Eine Rückkehr zur mittelalterlichen Stickweise wurde in Spanien nur in bescheidenstem Maße, in Italien kaum versucht.

Die Verwendung von eigens zu diesem Zweck gewebten Kaselbesätzen nahm seit dem 17. Jahrhundert allenthalben ab. Die Besätze wurden, was allerdings auch schon früher vielfach geschehen war, nun gern durch schmale Parallelbörtchen imitiert oder, was gleichfalls schon im Mittelalter Brauch gewesen war, aus Streifen andersfarbigen, gemusterten oder ungemusterten Stoffes hergestellt. Eigens als solche gewebte Kaselbesätze kamen erst im 19. Jahrbundert wieder mehr in Aufnahme. Es war indessen bis über die Mitte des Jahrhunderts hinaus technisch und namentlich stilistisch betrachtet nur sehr geringwertiges Zeug, was an Kreuzen und Stäben zu Lyon fabriziert und von dort überallhin vertrieben wurde. Es mag genügen, an die Urnen, die Genien mit Fackeln und die Monumente mit Zypressen zu exinnern, die auf den Stäben schwarzer Kaseln mit Vorliebe dargestellt wurden. Erst der Anschluf an mittelalterliche Motive führte eine teilweise Wandlung zum Besseren herbei.

\section{BESTICKTE MESSGEW ÄNDER.}

Außer zur Verzierung der Besätze wurde die Stickkunst auch zur Ausschmückung des Melagewandes selbst herangezogen. Das geschah namentlich, seitdem die Kasel zu einem skapulierförmigen Gewand geworden war, das die Arme nicht weiter bedeckte und darum auch nicht weiter belastete. So lange sie bis tief auf die Arme herabreichte und beim Gebrauch über denselben in Falten zusammengelegt werden mufte, empfahl es sich wenig, das ganze Gewand mit Stickereien zu verzieren, weil solches sie sehr unbequem gemacht haben würde. Wirklich treffen wir in den mittelalterlichen Inventaren nicht allzu häufig ganz mit Stickereien versehene Kaseln an. Selbst das Schatzverzeichnis des Apostolischen Stuhles aus dem Jahre 1295 und die Inventare von St Peter aus dem Jahre 1361 wissen nur wenig von solchen zu berichten. Es verhält sich eben mit dem Mé̉gewand anders wie mit dem Pluviale. Pluvialien, die vollständig bestickt waren, kamen im Mittelalter häufiger vor. Begreiflich, weil hier der Grund wegfiel, welcher verbot, die Kaseln in dieser Weise zu verzieren. Da nämlich das Pluviale vorn geöffnet war, brauchte es nicht, wie es beim Mefgewand zu geschehen hatte, auf die Arme emporgehoben und dort in Falten gelegt zu werden. 
Die Ausführung der Stickereien erfolgte bei bestickten Kaseln entweder in Gold oder in farbiger Seide. Im ersten Fall diente als Stickgrund weifer oder farbiger Seidenstoff, im zweiten Leinwand. Bei Linnengrund wurde aufer dem Muster auch der Fond ausgestickt. Die Stickereien selbst bestanden für gewöhnlich nur in ornamentalen Motiven von der Art, wie sie sich auf den gewebten Stoffen fanden, also in bald größeren, bald kleineren animalischen, vegetabilischen oder geometrischen Gebilden, welche in regelmäßrigen Reihen übereinander angebracht wurden, hier dicht aneinander, da wie verstreut.

Beispiele von Kaseln, die in dieser Weise bestickt erscheinen, sind die Mefsgewänder in S. Urso zu Ravenna und in S. Godehard zu Hildesheim, eine Kasel im Dom zu Halberstadt, sowie eine leider um das Ende des 16. Jahrhunderts stark verstümmelte Kasel in der Kathedrale zu Anagni. Das erstgenannte Gewand ist auf dunkelblauem Fond, dem eine leichte Musterung wie eingeritzt ist, mit Miniaturadlern und Möndchen, das zweite auf bräunlichem Seidengrund mit kleinen Rosetten und Möndchen bestickt. Die Kasel in der Katherlrale zu Anagni stammt aus der Schenkung Bonifaz' VIII. und mufs ursprünglich ein ungemein prächtiges Stück gewesen sein. Sie besteht aus einem schweren seidenküper von leuchtend roter Farhe und ist mit groß̉en, kreisförmigen Feldern verziert, in denen doppelköpfige Adler, Löwen, Greife und anderes phantastisches Getier angebracht sind. Auch hier ist die Stickerei ganz in Gold ausgeführt. Das Gewand wird im Verzeichnis der Paramente, welche Bonifaz VIII. der Kathedrale von Anagni verehrte, mit den Worten aufgeführt: una planeta de samito laborato de auro cum acu ad leones, papagallos, grifos et aquilas cum geminis capitibus et aurifrisio de samito laborato de auro ad ymagines generalogiae Salvatoris cum perlis et lapidibus pretiosis '. A uf dem Halberstädter Mefagewand (Bild 75, S. 185) sieht man in Reihen geordnet goldene Adler mit dazwischen eingestreuten goldenen Rosetten auf dunkelblauem seidenem Grund. Ein ferneres vorzügliches Exemplar war die zweite der früher erwähnten, durch die Revolution leider vernichteten Kaseln in der Kathedrale zu Angers, welche mit Möndchen, Sternen und kleinen Löwen bestickt war². Auch die Kaselfragmente, die man im Grabe Theodorichs II. von Trier fand, geben ein gutes Bild der in Frage stehenden Verzierung des Mef3gewandes, bei welcher den Künstlern ersichtlich die prïchtigen Goldhrokate als Vorbilder vorschwebten. Das Gewand war mit einem förmlichen Netz goldgestickter Spitzwecken, wie sie beim Überschneiden von Kreisen entstehen, überzogen. Da, wo dieselben aneinanderstiefen, war ein Krnöpfchen angebracht, in den von den Spitzwecken eingeschlossenen Feldern aber befand sich eine Rosette. Das glinzendste und großartigste Beispiel bildet aber eine der Bamberger Kaseln. Sie ist mit mächtigen Rundmedaillons bedeckt, in welchen ein Reiter hoch zu Rof dargestellt ist, in der Linken ein Zepter, in der Rechten einen Falken, auf clem Haupt eine Krone, während am Boden Krieger liegen und ein Löwe sich mächtig gegen Rols und Reiter aufbäumt ${ }^{3}$. Die Umrahmung der Medaillons und die Zwickel zwischen denselben haben eine Füllung von Rankenwerk, dem Tiergestalten eingegliedert sind, erhalten. Verbunden sind die Reitermedaillons untereinander durch Scheiben, in welchen zwei Vögel symmetrisch auf einem Baum angebracht sind. Über die Mitte der Vorderseite zieht sich gegenwärtig ein breiter Vertikalstreifen aus gelbem Brokat, eine Zutat aus nenerer Zeit. Er dürfte Ersatz für eine ehedem hier befindliche Goldborte sein. Übrigens sind von der ursprünglichen Kasel nur noch die Stickereien übrig; der dunkelblaue Seidenstoff, auf dem

1 Tnter samitum ist hier, wie auch sonst häufig, nicht Samt, sondern Seidenköper zu verstehen. Unseres Erachtens wurde ursprüglich mit dem Namen examitum, catexamitum, xamitum, samitum nicht ein sechsftidiger, besonders starker Stoff, also eine Art sog. Gros, bezeichnet, wie man gewöhnlich sagt, sondern ein Stoff, bei dem die Braun, Die liturgische Gewandung.
Bindung allemal erst beim sechsten Faden statthatte, d. i. ein sog. sechsschäftiger Köper.

${ }^{2}$ Ein getreues Gegenstinck zur Stickerei bildet die Musterung des Mantels Ottos IV. im Herzogl. Museum zu Braunschweig. Farbige Abbildung bei Bock, Reichskl. Tfi $\mathrm{X}$.

${ }^{3}$ Abbildung bei Bock II, Tft xxxiI und in Farben bei Bock, Reichskl. Tfl xLIr. 
dieselben in ungemein geschickter Weise aufgenäht sind, ist nicht mehr der alte, sondern stammt aus dem Ausgang des Mittelalters. Er ist bereits der dritte Grundstoff. Bock läßast das Gewand, das unseres Erachtens stets als Kasel gedient hat, frühestens im 12. Jahrhundert entstanden sein; man wird es indessen richtiger wohl dem 11., und zwar dessén Frühzeit zuweisen.

Die Inventare wissen, wie schon bemerkt wurde, im ganzen nur wenige mit Stickereien versehene Kaseln zu verzeichnen, doch ist zu beachten, daf ihre Angaben mehrfach unvollständig oder unklar sind, so daf nicht sicher erhellt, ob eine Kasel aus Brokat oder eine goldgestickte Kasel gemeint ist. Es mag daher in Wirklichkeit mehr der Mebgewänder der letzteren Art gegeben haben, als es nach den Inventaren scheinen könnte.

Schatzverzeichnisse, die bestimmt von goldbestickten Kaseln reden, sind z. B. das Inventar des päpstlichen Schatzes von 1295, das Verzeichnis der Gaben, welche Bonifaz VIII. der Kathedrale von Anagni spendete, das Inventar von St Paul zu London von 1295, das Schatzverzeichnis von Cluny von 1382, das Inventar von S. Francesco zu Assisi von 1320 u. a. So heibt es im Inventar von St. Paul : Item casula de radice Iesse, quam dedit rex Henricus, breudata cum stellis et lunis et dorsali (Besatz anf der Rückseite) cum ymagine crucis, 16 lapidibus insertis, et deficiunt 2 lapides, im Inventar von Cluny (in Übersetzung): item une chasuble noire travaillée à l'aiguille avec des figures et des lettres d'or, item une chasuble couleur indienne travaillée à l'aiguille avec des cercles d'or et des figures; und im Schatzverzeichnis von Assisi: una planeta de diaspro laborato ad acum de auro ad figuras cum perlis cum fregio (- frisio) aureo a pede (am Saum); item alia planeta in campo albo laborata de auro ad acum ad figuras avium et arborum et perlis; item alia planeta cum campo rubeo laborata ad acum cum griffonibus et catenis et aliis figuris de auro. Auch die Chronik von Mainz berichtet uns von einem mit goldenen Wöndchen und Sternen bestickten purpurnen Melgewand. Es war jene früher erwähnte Kasel, die wegen der Menge der Goldstickereien nach dem Bericht des Chronikschreibers kaum in Falten gelegt werden konnte und wegen ihrer Schwere nur bis nach der Opferung getragen zu werden pflegte, um dann mit einer leichteren vertauscht zu werden ${ }^{3}$.

Die meisten dieser goldbestickten Mefgewänder entstanden im 11., 12. und 13. Jahrhundert, d. i. zu einer Zeit, in welcher der aus vergoldeten Häutchen hergestellte Goldfaden noch nicht oder nur erst wenig zur Verwendung kam. Damals mochte es allerdings bei dem geringen Preis der Arbeit empfehlenswerter sein, um an Gold zu sparen, das Gewand mit Mustern in Gold zu besticken, statt es mit solchen zu durchweben. Anders verhielt sich jedoch die Sache, als jenes Surrogat echter Goldfäden an die Stelle rein goldener oder silbervergoldeter zu treten begann. Nun konnte man ohne Schwierigkeit den Goldfaden als Schuf durch die ganze Breite des Stoffes gehen lassen, ohne diesen allzusehr zu verteuern und allzu schwer zu machen. Es war daher auch nicht mehr nötig, die Kasel in mühsamer und langwieriger Arbeit mit Goldornamenten zu besticken, und so begreift es sich unschwer, weshalb die Inventare des 14. und 15. Jahrhunderts fast nur Mefagewänder aus Brokat verzeichnen. Was noch in dieser Zeit an goldgestickten Kaseln erwähnt wird, dürften aus früheren Tagen stammende Gewänder sein.

Aufer Kaseln, welche mit ornamentalen Goldstickereien nach Art der Goldbrokate geschmückt waren, gab es im Mittelalter aber auch solche, die ganz mit figürlichen Darstellungen bestickt waren. Une chasuble rouge, ouvragé avec des cercles et des figures de saints en or heikt es z. B. in dem Inventar von Cluny: item una planeta de samito albo ad ymagines sanctorum 
et angelorum et aliarum figurarum de auro in dem Inventar von S. Francesco zu Assisi; item una planeta contexta ad aurum de serico de historia Salvatoris ab annuntiatione beatae virginis im Anagneser Gabenverzeichnis ${ }^{\text {. }}$

Es hat sich noch eine verhältnismäbig beträchtliche Anzahl solcher: bildbestickter Mefigewänder erhalten. Die älteren sind in Gold auf farbigem Seidengrund, die jüngeren in Seide oder Seide und Gold auf Linnengrund ausgeführt. Einige sind leider stark beschnitten oder sonst stark beschädigt. Im wesentlichen unversehrt sind drei derartige Kaseln im Dom zu Bamberg, zwei zu St Paul in Kärnten, eine im Schatz der Kathedrale zu Anagni, ferner das später zum ungarischen Krönungsmantel gemachte Meß̉gewand im Kronschatz zu Preliburg und die zum Mefornat des Ordens vom goldenen Vlies gehörige Kasel in der k. k. Schatzkammer zu IVien. Nur Torsos sind die Kaseln zu Marienberg (Tirol), Göß (Steiermark) und eine Kasel im Dom zu Würzburg.

Von den drei Bamberger Kaseln stellt eine, das Werk eines gewissen Ismael, in ihrem Bildwerk den Sternenhimmel dar: DESCRIPTIO TOCIVS ORBIS $\downarrow$ PAX ISMAHELI QVI HOC ORDINAVIT, sagt eine diesbezügliche Inschrift ?. Indessen kommen zu den Sternbildern auch einige religiöse Bilder, wie der thronende Heiland, die allerseligste Jungfrau, Johannes der Täufer, Maria mit den Kinde usw. Die Darstellungen sind durch entsprechende Inschriften erläutert, die für die Sternhilder auf einer um 700 im Frankenreich entstandenen und etwas später bearbeiteten lateinischen Übersetzung der griechischen Scholien zu Arats Sterngedicht fußen. Das Gewand stammt, laut der in mächtigen Unzialen den saum entlang angebrachten Inschrift: 0 DECVS EVROPAE CESAR HENRICE BEARE ANGEAT (augeat) IMPERIVII IBTI (tibi) REX Q (qui) REN (regnat) WINE (in evum), aus den Tagen Heinrichs des Heiligen, also aus dem Beginn des 11. Jahrhunderts ${ }^{3}$. Daf es von Anfang an zum Gebrauch beim Gottesdienst bestimmt war, also stets als Kasel gedient hat, daran läßt die unter dem Bilde des Erlosers angebrachte Weiheinschrift: SVPERNE VSYE SIT GRATV(M) HOC CESARIS DONVM keinen Zweifel. Die Meinung Bocks, es sei ursprünglich ein Mantel Heinrichs gewesen und ein Geschenk Ismaels, des Herzogs von Apulien, später aber von dem Kaiser seiner Lieblingsstiftung, dem Dom zu Bamberg, übergeben worden, ist nicht blob leere Vermutung, sondern tut auch deu Inschriften des Gewandes fiewalt an. Übrigens ist auch bei diesem nur die Stickerei alt; der dunkelblaue, mit dem Granatapfel gemusterte Seidenstoff, der als Fond dient, gehört dem späten 15. Jahrhundert an. Den ursprünglichen Grund der Stickerei bildete ein tiefblauer, schwerer Seidenköper.

1 Vgl. auch das Inventar von Lincoln (1539): Inprimis a chasuble of white cloth broidered with images and angels of gold with costly orphreys of gold, having The Trinity in the back, the holy Ghoost beeing of pearls... gift of John Welburne sometime treasurer (1351-1381).

? Adelheid, die Mutter König Roberts von Frankreich ( $†$ 1031), schenkte der Abtei St-Denis ein kostbares nornamentum quod vocatur orbis terrarum" (Helga a di, Vita Roberti regis [M. 141, 918]). Bock hat dasselbe für eine Kasel und für ein Gegenstiick der Bamberger Kasel angesehen, doch dürfte es sich nach dem Zusammenhang bei Helgaud schwerlich um ein Meßggewand handeln. Dem Kloster des hl. Martin stiftete Adelheid eine Kasel, auf der im Nacken die Maiestas Domini zwischen anbetenden Cherubim und
Seraphim, auf der Brust aber das Lamm Gottes zwischen den Evangelistensymbolen in Goldstickerei angebracht war (ebd. 918).

3 Abbildung in Buntdruck bei Bock, Reichskl. Tfl $\mathbf{X I 1}$, in Zinkätzung in Zeitschrift XII (1899), Sp. 327 ff. Die beste Besprechung des Bildwerkes bietet der vortreffliche Aufsatz von Prof. Ernst Ma as, Inschriften und Bilder des Mantels Kaiser Heinrichs II., ebd. $321 \mathrm{ff}$. Díe Ansführungen Bocks im 'T'ext zu den "Kleinodien" S. $192 \mathrm{ff}$ und der "Geschichte" I $167 \mathrm{ff}$ werden hier in manchen Punkten korrigiert und die Inschriften als aufs Arats Sterngedicht sich gründend nachgewiesen und richtig erklärt. Irrig scheint es uns indessen, wenn das Bildwerk des Mantels mit Sternengewändern des altheidnischen Kultus oder römischer Kaiser in Verbindung gebracht wird. 
Die Kasel mit dem Sternenhimmel ist unzweifelhaft ein ungemein hervorragendes Stück, und doch ist ein zweites der drei mit Bildwerk verzierten Mesgewänder des Bamberger Domschatzes noch weit ausgezeichneter, allerdings nicht hinsichtlich des Materials und der Technik, welche bei beiden Gewändern die gleichen sind, wohl aber durch größeren Reichtum und tieferen Gehalt des Bilderschnuckes ${ }^{1}$. Die Anordnung des Bildwerks erhellt aus Bild 104. Der Gedanke, welcher in ihm versinnlicht wird, ist die Verheißsung des Heilandes, die Erwartung und Geburt desselben und die Spendung des in Christus gegebenen Heiles an die Juden und Heiden dureh die Stiftung und Wirksamkeit der Kirche. Thre segensreiche Tätigkeit bei den Juden wird durch die Wunder Petri bei den Juden (links), die zum Frommen der Heiden durch seine Taten zu Rom (rechts) dargestellt. Dort schauen wir Petris den Lahmen heilen, Tabitha zum Leben erwecken usw., hier gewahren wir ihn zusammen mit Paulus den Simon Magus bekïmpfen und für den Glauben sterben. Wenn dabei auch das Ende Neros zur Darstellung kommt, so will das wohl auf den schließlichen Sieg der Kirche und das Ende ihrer Widersacher hinweisen. Alle Bilder sind dureh Um-

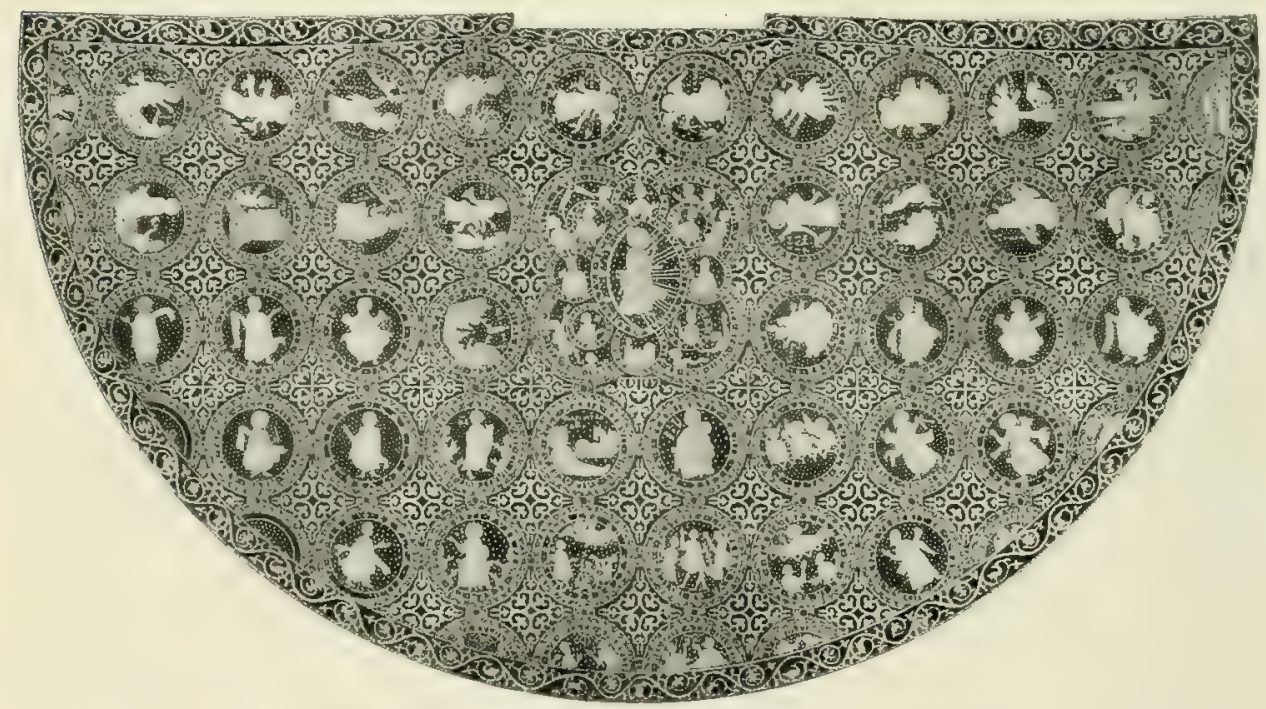

Bild 104. Kasel (11. Jahrh.). Bamberg, Dom. (Nach Bock.)

schriften erläutert. Am großartigsten gedacht ist die Bildergruppe in der Mitte der Kasel; in ier Mandorla tritt der Heiland aus seiner Himmelsherrlichkeit hervor. Von den acht Kreisen, die sich um die Mandorla lagern, stellen sechs ebensoviele der grofen O-Antiphonen symbolisch dar, während der siebte durch die Wiedergabe von Bethlehem auf die bekannte Weissagung des Propheten Nichäas und der achte auf die Prophetie Balaams hindeutet. Die vier Kreisausschnitte endlich, welche die Gruppe oben und unten zur Rechten und Linken abschließsen, enthalten Personen, welche unter lebendig bewegten Gesten dem Kommen des Heilandes entgegenharren. In der Tat, nur wenige Yeßggewänder dürften jenals mit einem gleich bedeutungsvollen und inhaltreichen Bilderschmuck versehen worden sein. Schade, daf das künstlerische Können des Stickers nicht auf gleicher Stufe mit dem technischen stand und die śtickerei darum manche zeichnerische Mängel aufweist. Allerdings hahen dieselben zum T'eil in der 'Technik ihren Grund, die hier zur Anwendung kam. Goldstickerei, bei der nach Art eines Brokates alles in Gold ausgeführt wird, ist für figürliche Stickereien die allerundankbarste Stickweise, zumal wenn es sich wie hier um Darstellungen von geringer Gröfe handelt. Ein Mangel ist auch die Einteilung des Grundes 
in kreisförmige Medaillons, deren Folge am Rảnd des Gewandes unschöne Kreissegmente mit halben Figuren und verstümmelten Inschriften sind ${ }^{\text {. }}$

Ungleich besser ist in dieser Beziehung die Weise, in welcher das Bildwerk auf rem jetzigen ungarischen Krönungsmantel angeordnet ist (Bild 105). Hier hat der Künstler von einer regelmäfigen Flächeneinteilung abgesehen und es vorgezogen, die Darstellungen in vier Zonen ühereinander anzubringen. Der Bilderschnuck dieses ehemaligen Meßggervandes stellt die Verherrlichung Christi dar und darf als eine grofsartige Illustration des Tedeum bezeichnet werden ${ }^{2}$. Die obere Zone weist in der Mitte in einer Mandorla Christus als Sieger üher die höllischen Mächte auf; rechts davon ist Christi Auffahrt, links der Gottesgebärerin Aufnahme dargestellt. Die Trenuung zwischen der oberen und der zweiten Zone wird durch die Schrägstreifen des Gabelkreuzes gebildet, mit dem, wie schon früher gesagt wurde, die Kasel verziert ist. Dieselben enthalten in Rundmedaillons Brusthilder von Engeln. Die zweite Zone ist durch die VertikaI-

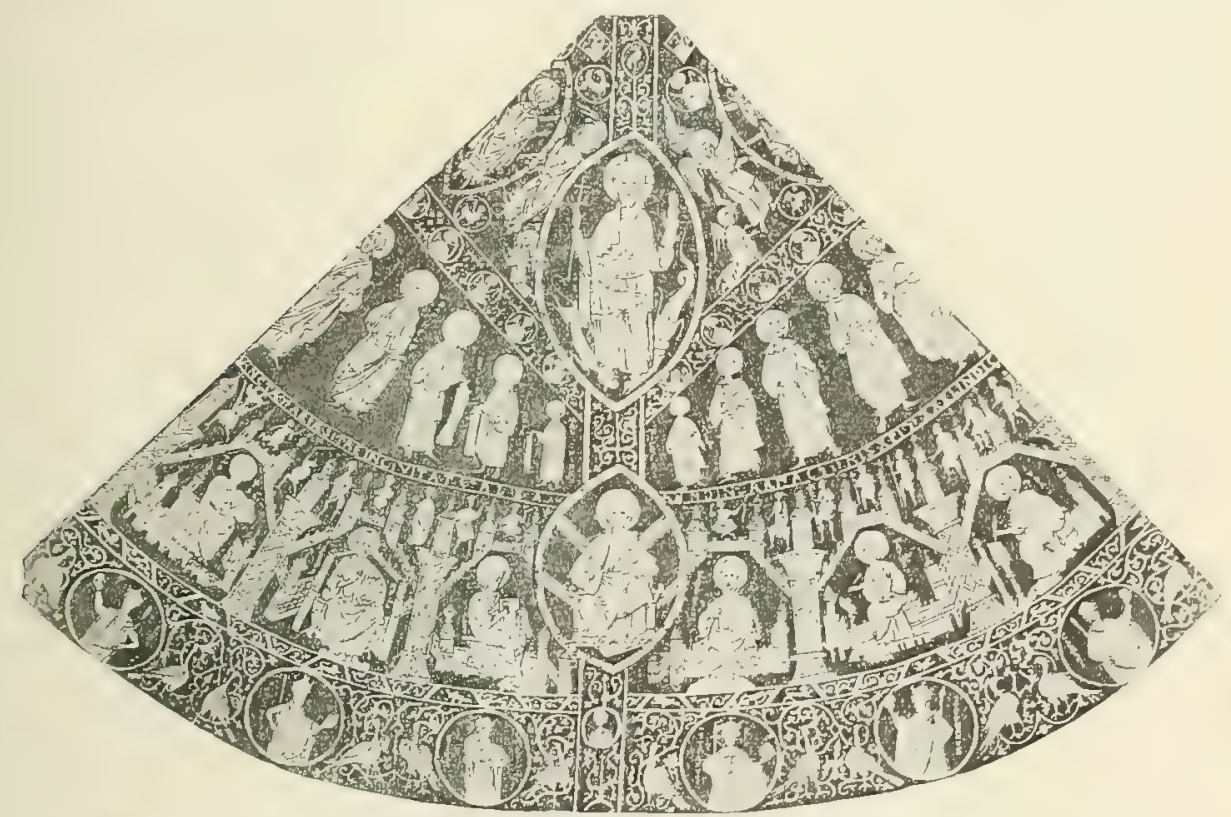

Bild 105. Kasel, gestiftet von König Stephan d. H. und seiner Gemahlin (Gisela, jetzt ungarischer Krïnngsmantel. Wach Bork.)

besätze des Gewandes, von denen jetzt freilich nur mehr der rückseitige vorhanden ist, in zwei Hälften geschieden. Beide enthalten Christus, der das eine Mal durch die beigefügten 1 und !!. das andere Wal durch die Worte principimm und finis gekennzeichnet ist, umgeben von je zwei der großen und je sechs der kleinen Propheten. Lin Band scheidet die zweite Zone von der dritten. Die Inschrift, die auf ihm an gebracht ist, enthält die Widmung: CASULA HEC OPERATA ET DAT(A) ECULESIAE SANCTAE MARIAE SITAE IN CIVITATE ALBA ANYO INCARNACIONIS TRT UAXXI INDICCIONE XIII A STEPHANO REGE ET GISLA R. ${ }^{3}$ Die dritte Zone zeigt in der

1 Die dritte Kasel im Schatz des Bamberger Domes können wir hier übergehen, weil wir doch bei Besprechung des Rationale näher auf sie eingehen müssen.

2 Farbige Abbildung bei Bock, Reichskl. TH XVII.

${ }^{3}$ Nach Bock I 157 wïre das Gewand von der kunstsinnigen Königin Gisela mit eigenen
Händen angefertigt worden. Wenn er das ans der Inschrift erschlielit, hätte er auch wohl den hl. Stephan als eigenhändigen Verfertiger bezeichnen müssen. Ein Irrtum ist es, wenn Bock im Text zur Tafel (Reichskl. 88) die Halbbilder der unteren Zone unter den sonderbarsten Konjekturen als Könige deutet und den an der Vorderseite angelrachuen, 
Mitte in spitzovalem Medaillon Christus als Herscher, rechts und links unter Arkaturen je sechs Apostel. Der Raum oberhalb dieser Arkaturen ist mit kleinen, leblaft bewregten menschlichen Figuren gefüllt, vielleicht eine Darstellung der Ecclesia militans oder der Welt der vorchristlichen Zeit, der die Propheten das Heil in Christus verkündeten. Die unterste, vierte Zone ist von der darüberliegenden dritten durch einen mit vegetabilischen und animalen Motiven ornamentierten Streifen geschieden und weist in Rundmedaillons zwischen Rankenwerk, dem Pfauen eingefügt sind, in der Mitte die Halbbilder Stephans und Giselas, zur Rechten und Linken aber diejenigen von je fün heiligen Martyrern als Vertretern des chorus martyrum auf. Mahrscheinlich schlof sich an diese vierte Zone noch ein Streifen mit Brustbildern heiliger Bekenner und Jungfrauen an, von dem sich noch ein kurzes, jetzt an der Vorderseite des Gewandes angebrachtes Stück erhalten hat. Das einst vorn geschlossene Gewand wurde gelegentlich der Krönung Maria Theresias ${ }^{1}$ gröfserer Bequemlichkeit halber aufgeschlitzt, wobei ein Teil der dort befindlichen Stickereien verloren ging, darunter namentlich der gröfste Teil eines Medaillons und eines darüber befindlichen rechteckigen Feldes?. Die Kasel ist wie die Bamberger ganz in Goldstickerei auf blaupurpurnem, kräftigem Seidenstoff ausgeführt.

Auch die sehr schadhafte und fast nur aus Fetzen bestehende Kasel im Dom zu Würzburg gehört nach Material, Technik, Stil und Charakter des Bildwerkes zur Gruppe der Kaseln im Bamberger Domschatz ${ }^{3}$. Es kann darum wohl nicht zweifelhaft sein, dafs auch sie wie diese der Frühe des 11. Jahrhunderts entstammt. Die Überlieferung: will, dafs sich Bischof Bruno († 1045) ihrer bedient habe. Zur Zeit, da das Gewand noch intakt war und in seinem ursprünglichen Glanz strahlte, muf es ein wahres Prachtstück gewesen sein, das den Vergleich mit dem jetzigen ungarischen Krönungsmantel und den Kaseln im Kaiserdom zu Bamberg kaum zu scheuen brauchte. Es war mit grofen Medaillons geschmückt, welche, nach den spärlichen Resten zu urteilen, Christus und Heilige enthielten.

Sehr verschieden von den bisher beschriebenen Kaseln sind die beiden Meßgewänder zu St Paul. Während bei jenen nur der Bilderschmuck in Stickerei hergestellt ist und sie darum den Anschein erwecken, als seien sie aus goldbroschiertem blauem Purpur hergestellt, ist bei diesen sowohl das Bildwerk wie der Fond auf grober, kanevasähnlicher Leinwand mit der Nadel angefertigt. Während ferner dort, abgesehen von den zum Abheften nötigen roten Seidenfäden, ausschließlich Gold zur Verwendung kam, diente hier entweder lediglich farbige Seide oder Seide in Verbindung mit Gold als Stickmaterial.

Die eine der beiden Kaseln zu St Paul entstammt etwa der Mitte des 12. Jahrhunderts; die Form, welche die Mitra auf verschiedenen Darstellungen hat, macht das zweifellos. - Als Stiche sind bei der Kasel nur der Zopfstich und der Kettenstich verwendet worden. Im Zoplstich sind Grund und Ornamente ausgeführt; der Kettenstich diente zur Markierung der Konturen, der Falten und des sonstigen Details, wie z. B. der Gesichtszüge.

mit Brustbildern von Heiligen verzierten Streifenrest als Überbleibsel des vorderen Vertikalstabes ausgibt. Die Stellung dieser Brustbilder läßt keinen Zweifel übrig, daßs sie von einem horizontal verlaufenden Zierstreifen herruhren, wie es ein Saumstreifen war.

1 Erasmus Froelichs S. J. Casmlae S. Stephani Reg. Hung. vera imago et ex positio, Viennae $1754,54$.

2 Die Kasel zu Martinsberg (vgl. oben S. 179) entheilt dieselben Darstellungen wie der jetrige ungarische Krönungsmantel, jedoch nicht in Stickrei, soudern in Nalerci auf einem feinen, jetzt stark gedunkelten (sei- denen?) Stoff. Die Figuren und Ornamente sind farbig, die Konturen derselben schwarzbraun (Jahrb. der k. k. Zentralkommission I, Wien 1857, 105). Ob sie die Vorlage zur Giselakasel ist oder eine Kopie, wagen wir nicht zu entscheiden, da wir sie nicht von Augenschein kennen.

3 Zu dieser Gruppe gehören auch die schon crwähnte Kasel mit den Reitern im Dom zu Bamberg, der sog. St Kunigundenmantel daselbst, der Besatz der St Wolfangskasel im Dom zu Regenshurer und die sog. 'l'unika Jeinrichs II im kgl. bayr. Nationalmusenu zu Miulclien. 
Die Anordnung des Bilderschmuckes ist aus Bild 106 ersichtlich. Der quadratischen Felder, in welche die Fläche des Gewandes eingeteilt ist, gibt es im ganzen 38. von denen indessen 12 unvollständig sind. Sie werden durch geometrisch gemusterte Streifen voneinander getrennt und sind bis auf die vier kleinsten Quadrattragmente allesamt mit figuralen Darstellungen gefuillt. Das Bildwerk gliedert sich in vier Gruppen. Die erste umfaßist auf acht Feldern Begebenheiten aus dem Leben des Erlösers (Verkündigung, Geburt, Anbetung durch die Weisen, Taufe, Gefangennehnung, Geifselung, Krenzigung, Christus als Weltrichter); die zweite auf vier Feldern acht Bilder von Propheten (David und Salomon, Isaias und Jeremias, Ezechiel und Daniel, Job und Balaam); die dritte auf 12 Feldern vorbildliche Szenen aus dem Alten Bunde (Evas Erschaffung, Kain und Abel, Nelchisedech und Aaron, Isaaks Verheifung, Isaaks Opferung, Joseph in die Zisterne versenkt, Moses und Elisäus, Aarons Stab, Josue und Judas, Verkündigung der Geburt Samsons, Samuel erschlät Agag, Naamans Heilung im Jordan); die vierte endlich auf zehn Feldern Heiligenfiguren (Gregor

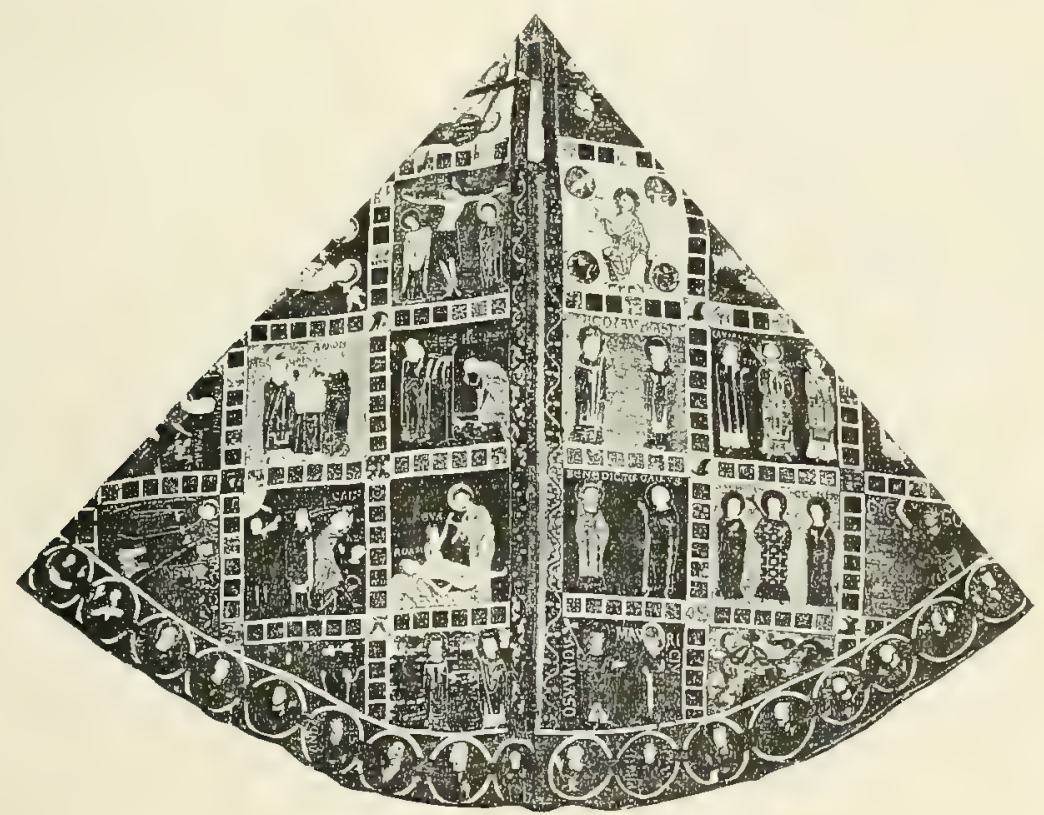

Bild 106. Kasel. St Paul (Kürnten).

d. Gr., Nikolaus und Blasius, Laurentius, Stephanus und Vinzentius, Sebastianus und Georg, Regula und Felix, Benediktus und Gallus, Verena, Agnes und Cäcilia, Oswald und Mauritius, Ulrich und Konrad, Erasmus und Pantaleon). Zur Füllnng der von figürlichen Darstellungen freien Felder wurden romanisch stilisierte Drachen und Ranken benutzt. Den Saum umgibt als Abschluf eine breite Borte, welche in kreisförmigen Medaillons die Brustbilder von Persönlichkeiten aus dem Alten und Neuen Testament enthält. Jenem wurden die kleinen Propheten, die Könige Ezechias und Josias, Esther und die EItern Johannes' des 'Täufers entnommen; diesem die Evangelisten und Apostel, Kaiser Konstantin, St Helena und Kaiser Otto (I.).

Die zweite Kasel datiert aus dem Beginn des 13. Jahrhunderts; sie steht zeichnerisch wie technisch um ein bedeutendes höher als ihre ältere Schwester. Der Fond ist wie bei dieser uber straminartigem Linnen im Zopfstich hergestellt. Ebenso wurden auch bei ihr die Umrisse, die Faltenlinien und ähnliches im Kettenstich gestickt, dagegen ist das Figurenwerk teils im Köperstich, teils in Goldabheftarbei. ausgeführt.

Die Kasel ist oder besser war einst in 36 quadratische Felder eingeteilt, von denen 26 vollständig, 10 unvollständig waren. Über die Mitte der Rückseite verläuft von olıen 
nach unten ein mit neun Scheibenmedaillons verzierter Streifen. Das Bildwerk, welches diese umschliefen, besteht aus dem Lamm Gottes, den Evangelisten und den vier großen Propheten. Die dem Tertikalstreifen rechts und links zunächstliegende Reihe ron je fünf Feldern enthält Szenen aus dem Neuen Testament (die Verkündigung und Heimsuchung, die Geburt Christi und ihre Offenbarung an die Hirten, die Anbetung durch die Weisen, die Taufe, Geißelung und Dornenkrönung, Christus am Kreuz, die Grablegung, Anferstehung und Vorhöle). Alle übrigen Felder weisen Darstellungen aus dem Leben des hl. Nikolaus auf. Geschieden werden die Felder durch Bänder, die zum Teil mit vegetabilischem oder geometrischem Ornament, zum Teil mit erlïuternden Inschriften versehen sind. Zur Füllung der Felder, welche sich für figürliche Darstellungen als zu klein erwiesen, wurden auch hier Pflanzen- und Tiermotive benutzt ${ }^{1}$.

Auch bei den gegenwärtig verstümmelten Kaseln zu Marienberg und Göß sind Inster und Grund in Seidenstickerei hergestellt. Auf dem Narienberger Mefsgowand sind oben auf dem Rücken in Rundmedaillons das Lamm Gottes und die vier Evangelistensymbole angebracht. Das Lamm Gottes befindet sich in der Mitte eines aus romanischen Ranken bestehenden Kreuzes; die Evangelistensymbole haben in dem Raum zwischen dessen Armen eine Stelle erhalten. Über der Brust ist, begleitet von zwei Engeln, in ovalem Medaillon der Weltrichter dem Gewand aufgestickt. Im übrigen überziehen den Fond mächtige, mit Blättern reichbesetzte Bäume, eine ganz eigenartige Dekoration. Die Kasel mag der ersten Hälfte des 13. Jahrhunderts entstammen ?.

Die anțs äuferste zugestutzte und schrecklich entstellte Gösser Kasel weist auf dem oberen Teil der Rückseite in einem grofen Kreise den Heiland auf dem Throne, auf dem unteren Engel unter rundbogigen Arkaturen auf. Die Vorderseite schmückt oben eine Kreuzigungsgruppe, gleichfalls in großem Kreise, unten gewahrt man Apostel unter Rundbogen. Die Kasel ist mitsamt einem Pluviale, einer Dalmatik, einer Tunicella und einem Antependium die Stiftung einer Äbtissin Kunigunde ans der zweiten Hälfte des 13. Jahrhunderts ${ }^{3}$.

Aus dem späten Mittelalter giht es nur noch eine ganz mit figürlichen Darstellungen bestickte Kasel, das zum Mefornat des Ordens vom Goldenen Vlies gehörende Mefogewand in der k. k. Schatzkammer zu Wien, künstlerisch betrachtet nnstreitig das Vollendetste, was mittelalterliche Sticker an Bilderkaseln horvorgebracht haben. Es ist keine Glockenkasel mehr, denn seine Länge beträgt über den Schultern nur noch ca $0,60 \mathrm{~m}$. Ebenso ist der Schnitt, wie der stumpfe Winkel beweist, welchen die Schrägseiten bilden, schon ein anderer geworden. Allein es wäre eine Glockenkasel bei der hier beliebten Stickweise auch schlechthin unbrauchbar gewesen.

Auf der Rückseite der Kasel (Bild 107) ist, und zwar teils auf dem Gabelkreuz teils auf dem Gewand selbst, in grofen Figuren die Verklärung, auf der Vorderseite die Taufe Christi dargestellt. Die noch übrige Fläche beleben anbetende Engel in

1 Ausführlich werden die beiden Kaseln besprochen in $\mathrm{He}$ ider, Liturgische Gewånder aus dem Stifte St Blasien in Schwarzwald (Jahrbuch der k. k. Zentralkommission zur Erforschung und Erhaltung der Baudenkmäler IV 111 fí) nebst guten Teilillustrationen. Abbildung dor ganzen Vorderseite beider Kascin bei $\mathrm{Kr}$ a ns, Der Kirchenschatz von St Blasien (Freiburg, Akademische Verlagshandlung), Atlas Tft I Ir, wo indessen die Unterschriften vertauscht sind. Dazu Kraus, Die Kunstdenkmäler der Grofherzogtums Baden, Kreis Waldshut, 103. Die Kaseln wurden zuerst beschrieben und abgebildet won Abt frobort von St Jjasien (Jiturgia allem. I 247267 , tah. vi vij). Ilic Abbildungen sind fur ihre Zeit überraschend getreu.
2 Über die Marienberger Kasel vgl. Mitt. 1895, $189 \mathrm{ff}$, nebst Skizzen.

3 Über das Gösser Meßgewand vgl. namentlich ebd. 1858, $57 \mathrm{ff}$. Eine mangelhafte farbige Abbildung der Vorderseite des Gewandes findet sich Beilage If des "Kirchenschmucks" Jahrg. 1874. Skizzen der Vorder- und Ritickseite ebendort Beilage I. Eine gute phototypische Abbildung beider bei De F a r c y 77. Die Darstellungen auf der Marienberger Kasel decken sich vollständig mit dem bildlichen Schmuck des von Adelheid, der Mutter Roberts von Frankieich, dem Kloster des hl. Martin verehrten Mefsgewandes (s. oben S. 227, Anm. 2), nur dafs, was bei diesem die Brustseite schmückte, bei jener auf der Ruckseite angehracht ist und umgekehrt. 
langgezogenen, sechseckigen Feldern. Die figürlichen Darstellungen sind mit Ausnahme der Fleischteile, des Haares und ähnlicher Einzelheiten in vollendetster Lasurstickerei, die Goldborten, welche die Umrahmung der Sechsecke bilden, im Korbstich, die Rosetten an den Ecken der Felder, die Ränder der Spruchbänder und Nimben und ähnliches in Perlstickerei hergestellt. Der einzige Mangel ist die hier schlecht angebrachte Einteilung der Gewandfäche in Sechsecke. Was bei den zur Kasel gehörigen drei Pluvialien vortrefflich wirkt, weil sich dort die Felder radienförmig und ohne Verstümmelung un einen Vittelpunkt gruppieren können, wirkt hier unschön, da werler die strahlenförmige Anorknung zur Geltung kommt, noch ein Zerschneiden einzelner Felder bei der Form des Gewandes sich vermeiden lief. Die Kasel steht mit ihrem Zubehör, drei Pluvialien, DaImatik und Tunicella, im späten Wittelalter vereinzelt da. Sie dürfte schwerlich zu ihrer Zeit ein Gegenstück gefunden haben.

Ein namhaftes Hindernis für die Bestickung des ganzen Melogewandes bildeten im Mittelalter seine große Länge und Weite und die damit im Zusammenhang stehenden Unzuträglichkeiten beim Gebrauch derartig bestickter Kaseln. Selbst in der Spätzeit hatte es im Vergleich mit den Kaselmafien im 17. und 18. Jahrhundert immer noch sehr beträchtliche Gröfenverhältnisse. In dem Grade, wie das Mebgewand seit dem 16. Jahrhundert an Ausdehnung abnahm, muste daher, wie leicht begreiflich, bei der Prachtliebe der Renaissance die $\mathrm{Vor}$ liebe für bestickte Kaseln zunehmen.

Wirklich entstanden schon im 16. und in der Frühe des 17. Jahrhunderts zahl-

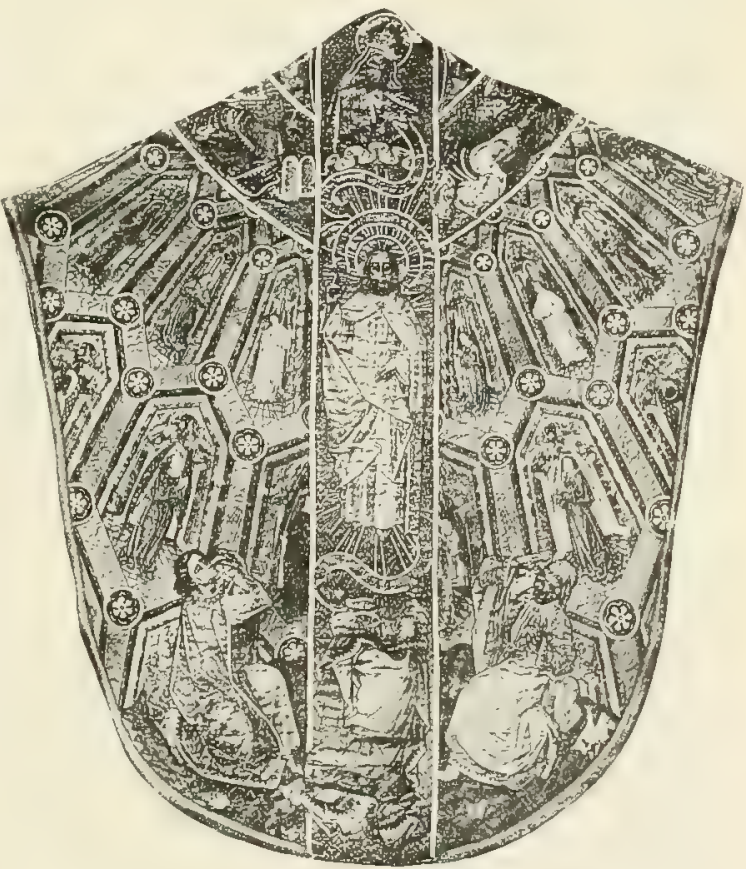

Bild 107. Kisel des Ornats des Ordens vom Goldenen Vlies. Wien, k. k. Schatzkammer. reiche ganz mit Stickereien überzogene Kaseln. Die Regel war, den Fond entweder mit grölieren Ranken in klassischem Geschmack oder kleinerem, dicht zusammengerücktem Ornament auszufüllen, wobei gern den liand des Gewandes entlang eine breite Borte gestickt wurde. Als Arbeitsmaterial wurde zu den Stickereien mit grolier Vorliebe Gold und Silber gebraucht. Figuirliche Darstellungen waren durchaus Ausnahmen. Die vorziiglichsten, mit Bildwerk verzierten Kaseln aus dieser Zeit sind die bereits gelegentlich erwähnten Kaseln in der Kapelle der Chigi im Dom zu siena und in der Opera del Duomo zu Florenz (Bild 80, S. 192 und 81, S. 193); aber selbst diese weisen auf den neben dem Besatz liegenden Flächen zuletzt nur mäbigen figürlichen Schmuck auf, der überdies bei dem Florentiner Meligewand stark antikisiert, jeder tieferen Bedeutung bar ist und statt in Stickerei mit dem Pinsel hergestellt wurlt: Besonders beliebt wurden bestickte Kaseln seit der zweiten Hälfte de: 17. Jahrhunderts, d. i. zur Zeit, da das Mefgewand in das letzte Stallium srind 
Verbildung getreten und ein weiteres Zustutzen desselben kaum mehr möglich war. Mit Vorzug wurden jetzt möglichst schwere und in die Augen fallende Gold- und Silberguipés unter reichlicher Verwendung von glitzerndem Bouillon und glänzendem Platt zum Besticken des Gewandes gebraucht, das nur zu häufig infolgedessen zu zwei steifen Brettern oder zu einem Küraf wurde. Es war. wie wir schon früher bemerkten, als ob man die Wirkung, welche die Kasel hinsichtlich ihrer Form eingebüßst hatte, durch Entfaltung gröften Prunkes hätte wettmachen wollen. Welches Gewicht das Meßzgewand infolge dieser Gold- und Silberstickereien bisweilen erhielt, beweist z. B. das zum Klementinenornat im Dom zu Köln ${ }^{1}$ gehörende Mesgewand, welches nicht weniger denn 13 Kilo wiegt. Und doch kann man es noch nicht als das prunkrollste und schwerste bezeichnen. Wird doch von de Farcy eine Kasel aus dem Jahre 1690 erwähnt, welche ein Gewicht von 18 Kilo erreichte?

Es kann kein 7 weifel sein, dafs derartige Meßsgewänder, so glänzend sie auch sein mochten und so vollendet auch die Technik der auf ihnen angebrachten Stickereien war, bei ihrer Steifheit, ihrer Schwere und dem aufdringlichen Charakter der Verzierungen, mit denen sie förmlich beladen waren, als Geschmacksverirrung zu bezeichnen sind. Es verdient hervorgehoben zu werden, daf man am längsten noch in Italien guten Geschmack bei Anfertigung bestickter Kaseln bewahrte. Statt mit unbeholfenen Bossagestickereien verzierte man hier bis ins 18 . Jahrhundert hinein das Mefogewand gern mit leichten, biegsamen Anlegearbeiten, bei welchen dieses mehr als anderswo Weichheit und Schmiegsamkeit behielt.

\section{DAS MESSGEWAND IN DEN RITEN DES OSTENS.}

In den Riten des Ostens tritt das priesterliche Obergewand in zweierlei Formen auf. Bei den verschiedenen Zweigen des griechischen Ritus ist es im wesentlichen der mittelalterlichen Glockenkasel gleich, nur dafs sich

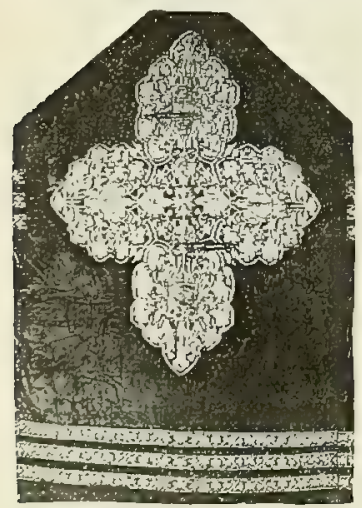

Bild 10s. Giechische Kaselverzierung. Danzig, Jarienkirche. bei ihm im Rücken statt des ganz ungebräuchlichen Vertikalbesatzes regelmäfig ein durch aufgenähte Borten gebildetes, ein gesticktes oder ein gewebtes Kreuz angebracht (Bild 108) findet. Auf der Vorderseite kommt auch beim griechischen Mefigewand häufig ein schmaler, die Naht in der Mitte bedeckender Zierstreifen vor.

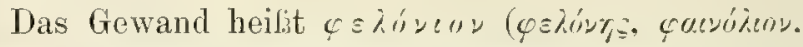

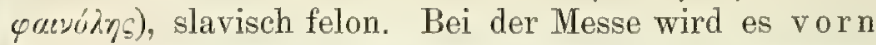
bis zur Brusthöhe aufgehoben, damit es den Priester bei Ausübung seiner Funktionen nicht belästige, ähnlich wie im Mittelalter die abendländische Kasel aus gleichem Grunde rechts und links a den Armen zusammengerafft wurde. Um den Faltenbausch, der dabei vor der Brust entsteht, zu verringern, ist es vielfach Brauch, die Vordèrseite des Gewandes zu verkürzen, gerade wie die mittelalterliche lateinische Kasel aus demselben Motive an den Seiten zugestutzt wurde. Indessen ist das Beschneiden nie so bedeutend. dafs die Wirkung des Phelonion dadurch irgendwie merklich litte.

1 - Klemrontinr.nornat" heifst dieser von E1zbischof Klenens August, der ihn 1740 um den Preis von 6200 Taler zu Lyon für die
Feicr der Kaiserkrönung seines Bruders Karls VII. anfertigen lict.

2 De Farey 77. 
Bei den übrigen Riten des Orients, den Armeniern, Syrern, Chaldäern und Kopten, hat das priesterliche Obergewand (arm. schurtschar, syr. phain $\bar{a}$, chald. maaphra, phaina, kopt. burnos, felonion, kuklion) die Form des lateinischen Pluviale (Bild 109); doch fehlen die Besätze, welche dieses rorn hesäumen, und der im Rïcken angebrachte Schild. Dafür ist hinten wie hei dem Phelonion ein gleichbalkiges, mäfig grobies Kreuz angebracht.

Bezüglich des Stoffes des priesterlichen Obergewandes gibt es in den orientalischen Riten keine bestimmten Vorschriften. Wenn möglich, pflegt man es aus Seide żu machen, doch kann es auch aus Woll- und andern Zeugen hergestellt werden.

Bei den Armeniern, Syrern, Chaldäern und Kopten kommt das Gewand nur dem Priester zu; bei den Griechen eignet das Phelonion aufer dem Priester auch dem Lektor, nur daf es bei diesem kürzer ist als bei jenem. Außerdem kommt es den Lektoren mehr in der Theorie denn in der Praxis $z u$, da diese für gewöhnlich bei ihren Funktionen das Sticharion, die Tunika ${ }^{1}$, tragen.

Die Verwendung, welche das Phelonion und das ihm entsprechende Obergewand der übrigen Riten bei den liturgischen Verrichtungen finden, ist etwas umfassender als die der lateinischen Kasel. Denn sie werden nicht blof beim heiligen Opfer, sondern überhaupt gebraucht, so oft eine liturgische Funktion sollemniter vollzogen wird, z. B. bei feierlichen Traungen, bei der feierlichen Abhaltung des Officium divinum, bei Prozessionen $u$. ä., bei den unierten Orientalen anstatt des Pluviale auch bei feierlichen, aus dem lateinischen Ritus herüibergenommenen Andachten. Wie im lateinischen, so wird auch in den orientalischen Riten der Priester bei seiner Weihe mit dem Mefsgewand bekleidet.

Bei den Russen, den Ruthenen, Bulgaren und Italo-Griechen wird von den Bischöfen statt

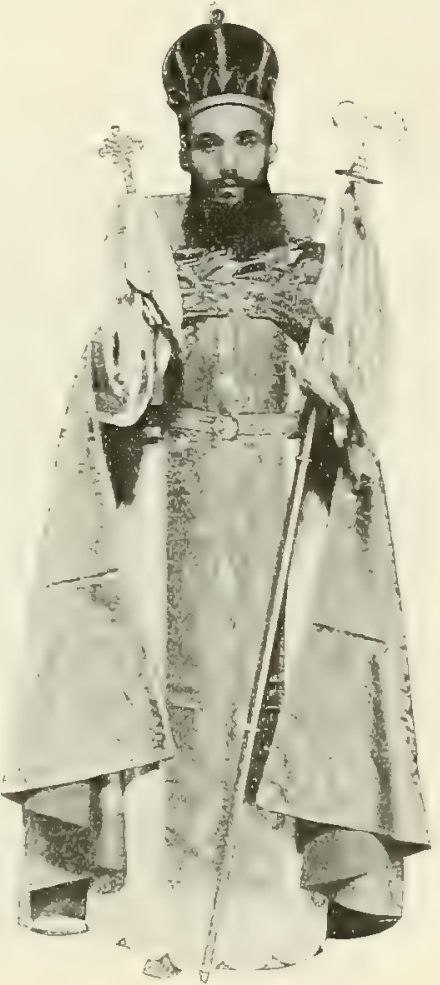

Bild 109. Armenischer Priester. des Phelonion der Sakkos (griech. aízzos, slav. sakkos) getragen; bei den Griechen und den Gräco-Melchiten bildet derselbe eine Auszeichnung der Metropoliten. In den übrigen orientalischen Riten ist der Sakkos nicht in Gebrauch ?

Die Geschichte des priesterlichen Obergewandes der orientalischen Riten bietet nicht viel des Bemerkenswerten. Obendrein hebt sie hier erst verhältnismäfig spät an, nicht als ob vorher ein solches in den Riten des Ostens noch nicht in Brauch gewesen wäre, sondern weil es an genügenden Nachrichten über dasselbe mangelt. Es ist nur äuferst wenig an Bildwerk aus der Zeit vor dem 9. Jahrhundert hekannt, auf welchem das liturgische Phelonion zur Darstellung käme. Wohl sind z. B. auf den Mosaiken der St Georgskirche der Presbyter Romanus und der Bischof Philippus in eines: Planeta abgebildet, allein ein gleiches Oherklcid tragen auf ihnen ebens, 
die hll. Kosmas und Damianus. Überdies findet sich in der Kleidung der beiden kein sonstiger Anhaltspunkt, der uns berechtigte, ihre Planeta als etwas über die gewöhnliche Tracht Hinausgehendes anzusehen. Nicht besser verhält es sich nut del Darstellung des Bischofs Eusebius von Cäsarea in dem syrischen Evangeliar der Laurentiana aus dem Jahre 586. Eusebius trägt auf dersellen eine hellbraune Tunika und eine dunkelbraune (kastanienfarbige) Glockenkasel. Irgend etwas, was darauf hinwiese, daf wir ihn uns in liturgischer Gewandung zu denken haben, ist auch hier nicht vorhanden. Ein Monmment, welches ein zweifellos liturgisches Phelonion aufweist, ist die hekannte Trierer Elfenbeintafel mit der Darstellung einer Reliquientranslation, vorausgesetzt, dab dieselbe wirklich dem 6. Jahrhundert und nicht einer späteren Zeit angehört. Was man nämlich zu Gunsten jenes älteren Datums

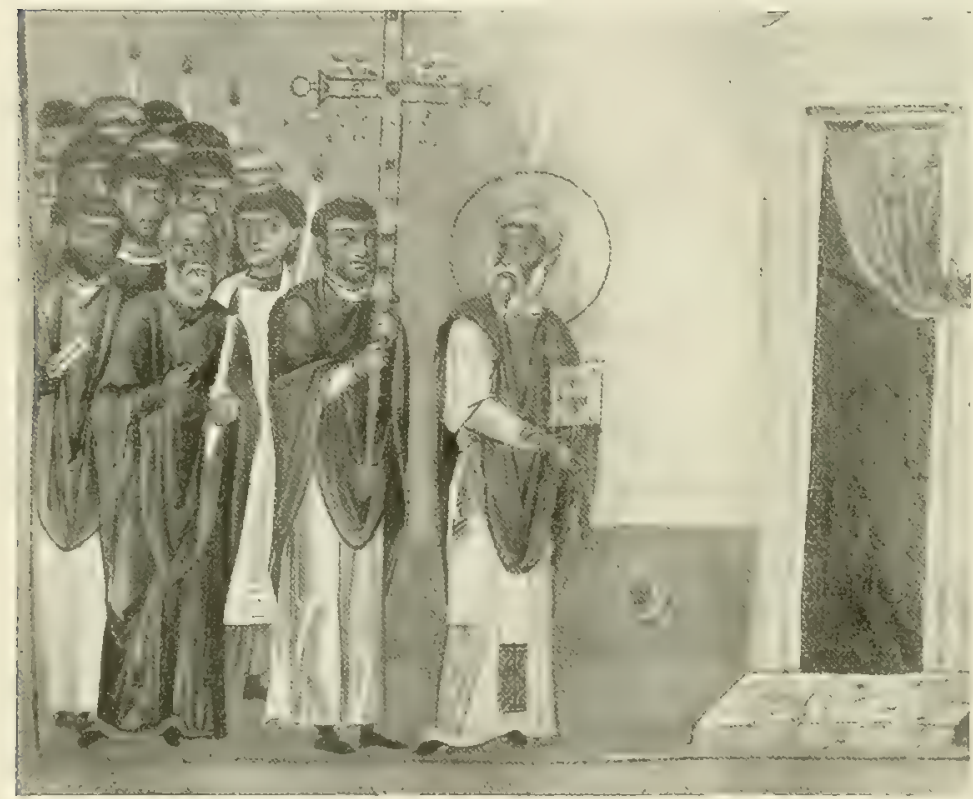

Bild 110. Prozession Miniatur im Menologium Basılius' II. Rom, Vatikan. vorgebracht

hat ${ }^{1}$, erscheint keineswegs so ausschlaggebend, daf jeder Zweifel daran schlechthin als unberechtigt bezeichnet werden könnte. Ein anderes frühes Beispiel des liturgischen Phelonion scheinen zwei Miniaturen mit den Bildern des Patriarchen Theophilus von

Alexandrien $(\uparrow 412)$ zu bieten, welche sich in einem wahrscheinlich noch

im 5. Jahrhundert geschriebenen, eine Weltchronik enthaltenden Papyrus finden. Theophilus ist in beiden Fällen in gelher Tunika, rotbraunem hzw. hlauriolettem Mantel und kurzem Omophorion, in der Linken ein mit einem Kreuz geschmücktes Buch haltend abgebildet?

Auch was an schriftlichen Nachrichten über den liturgischen Gebrauch des Gewandes aus der Zeit vor dem 9. Jahrhundert vorliegt, ist höchst unliedeutend. Es beschränkt sich fast einzig auf die Angabe des Panegyrikus auf den hl. Rabulas, Bischof von Edessa, wonach dieser außer seiner gewöhnlichen ärmlichen Fileidung zwei Mäntel zur Verwendung bei dem Gottesdienst hatte, einen für den Sommer, den zweiten für den Winter ${ }^{3}$. Die Ioropía

$1 \mathrm{Vgl}$. besonders J. Strzy gowski, Orient oder Rom, Leipzig 1901, 85 ff.

A. Pa u u r und J strzygowski, Eine alexandrinische Weltchronik, Wien 1905, 'Tft $f^{3}{ }^{3}$ und fov. [yas Gerwarl jist nicht ganz klar dargestellt, duch kam wohl kein Zweifel sein, daf es ein auf die rechte Schulter aufgerafftes Phelonion wiedergeben soll.

${ }^{3}$ Bibliothek der Kirchenväter: Bicke 11, Syrische Kirchenväter 188. 
redet nur andeutungsweise von dem Phelonion; denn es ist nicht ganz klar, ob auch unter der oturiy des Bischofs, von der sie spricht, dasselhe zu ver-

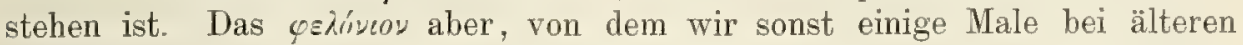
griechischen Schriftstellern hören, bezeichnet entweder ein auferliturgisches klerikales Gewand oder eine laikale Kleidung 1.

Seit dem 9. Jahrhundert begegnet uns das Phelonion des griechischen Ritus häufig auf den Bildwerken. Es hat genau das Aussehen der ahendländischen Glockenkasel und ist auch im Gegensatz zur späteren Praxis wie diese an den Seiten, nicht vorn aufgehoben und a uf den Armen statt vor der Brust in Falten gelegt (Bild 110).

Bis in das 11. Jahrhundert hinein erscheint das Phelonion auf dem Bild stets als einfarbiges, gänzlich schmuckloses Gewand, gleichriel ob es sich bei Priestern, Bischöfen, Metropoliten oder Patriarchen findet. Dann ändert sich die Sache und es wird Brauch, das patriarchale Phelonion zum Unterschied von dem der übrigen hierarchischen Rangstufen durch eingewebte Kreuze auszuzeichnen. Man nannte ein solches Phelonion von den vielen Kreuzen, mit denen es ver-

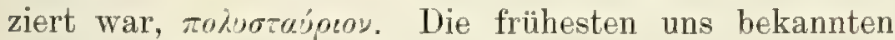

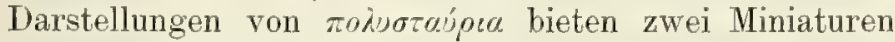
der Vatikanischen Bibliothek. Die eine (Bild 111) gehört einer dem 11. Jahrhundert entstammenden Sammlung von Marienpredigten, die andere der um 1100 entstandenen und Kaiser Alexios Komnenos (1081-1118) gewidmeten Panoplia des Euthymios ${ }^{2}$ an. Ihre erste

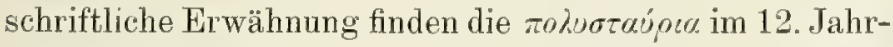
hundert bei Balsamon, der sie ausdrücklich als patriarchales Vorrecht bezeichnet. Auf die Anfrage des Patriarchen Markus von Alexandrien, ob es den Hegumenen und Protopapen erlaubt sei, die Epimanikien und das Epigonation zu tragen, antwortet dieser nämlich, es sei das ebensowenig statthaft, wie dafi die Bischöfe sich des den Patriarchen zustehenden Sakkos und des diesen gleichfalls vorbehaltenen Polystaurion bedienten ${ }^{3}$.

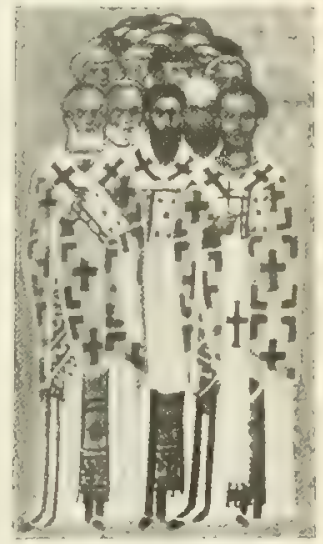

Bild 111. Chor der Bischöfe. Miniatur einer Sammlung griechischer Marienpredigten. Rom, Vatikan.

Später kamen die mit Kreuzen geschmückten Phelonien auch bei den Metropoliten in Aufnahme. Es mufs das spätestens im Laufe des 14. Jahrhunderts geschehen sein, da diese zur Zeit Simeons von Saloniki, d. i. um 1400, das roìazúpoco bereits zu tragen pflegten 4 . Den gewöhnlichen Bischöfen war es jedoch damals noch nicht gestattet, ein mit Kreuzen geschmücktes Phelonion zu tragen ${ }^{5}$. Übrigens wurden nur die weiben (bzw. die als weifs geltenden), nicht aber die violetten Phelonien mit Kreuzen geschmückt. Die purpurnen mubten, wie uns der bulgarische Erzbischof Demetrius Chomatenus

1. Vgl. z. B. Theophyl. simocattes, Hist. 1. 7 , n. 6 , Bonnae 1834,280 . Menander Prot., Fragm. hist., Bonnae 1829, 439. Chron. Pasch. ad an. 419, Bonnae 1832, 574. Iohannis Jaurenti Lydi De magistrat. 1. 1 , n. 7 ; 1. 3, n. 8, Bonnae 1837, 126201. Auf die sog. Liturgie des hl. Johannes Chrysostomus und das Typicum Sabbae c. 45 hinzuweisen, halten wir für überflüssig, da die Stellen, in welchen des Phelonion in ihnen
Erwälnnung geschieht, späte Einschiebsel sind.

2 Cod. Vat. gr. 666. Eine Abbildung bei Seroux d A gincourt, Valerei Tfl Lvir.

3 Resp. ad Marcum Alex. resp. 37 (Mg. 138, 989. Vgl. auch $\mathrm{Balsamon}$, Meditata

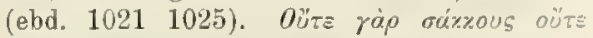

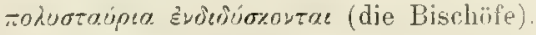

4 Resp. ad Gabriel. Pentapol. qu. 19 (Mg. 155, 872). 5 Ebd. 
(ca 1200) in seinem Schreiben an den Metropoliten von Dyrrhachium, Konstantin Cabasilas, belehrt, weil Ausdruck der Trauer, nach herrschendem Brauch stets einfarbig und ohne Verzierung sein ${ }^{1}$.

Wann es Gewohnheit wurde, das Phelonion vorn statt seitlich aufzuheben und zusammenzurollen, läfit sich nicht bestimmen. Wäre das in den Antiquités de l'empire de Russe abgebildete, angeblich von Bischof Niketas (12. Jahrhundert) herrührende Phelonion echt, und wären die Ösen, welche zum Aufraffen des Gewandes an dessen Vorderseite angebracht sind, ursprünglich, so hätte schon sehr früh die Sitte bestanden, dasselbe vorn aufzurollen. Indessen läfst die ebendort wiedergegebene Musterung des Phelonion keinen Zweifel daran, dakis wir es bei demselben mit einem Gewand nicht aus dem 12., sondern etwa dem 16. Jahrhundert zu tun haben ${ }^{2}$. Insicher ist auch, seit wann die jetzt

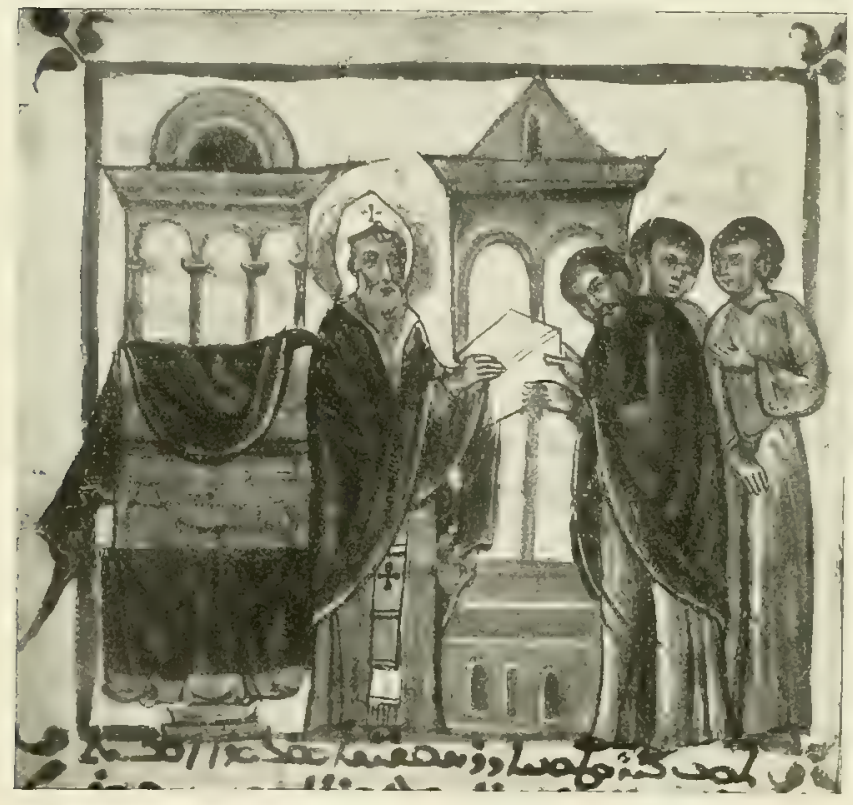

Bild 112. Einsegnung des Archipresbyter. Miniatur eines syrischen Pontifikale (1239). Paris, Bibl. Nat. vielfach beliebte Verkürzung der Vorderseite des Gewandes datiert. Noch auf den Bildern des ausgehenden Mittelalters hängt dieses vorn regelmäfig weit herab. $\mathrm{Ob}$ das ein Reflex der Wirklichkeit oder eine Folge der künstlerischen Tradition ist, welche bekanntlich in der griechischen religiösen Kunst stets eine so bedeutende Rolle spielte und noch spielt, ist nicht festzustellen; pflegt doch selbst noch auf den bildlichen Darstellungen aus der Neuzeit das Gewand nach alter Weise an der Vorderseite weit herabzusteigen.

Wie die Kasel des lateinischen Ritus, so war übrigens auch das Phelonion lange Zeit kein ausschließlich priesterliches Gewand ${ }^{3}$. Denn als die Legaten Hadrians II. $(867-872)$ in Konstantinopel ihren Einzug hielten, wurden sie, wie das Papstbuch berichtet ${ }^{ \pm}$, von Geistlichen jedes Ordo, die alle im Phelonion erschienen waren, in Empfang genommen. Die einzigen, welche sich des Gewandes, wie es scheint, für gewöhnlich nicht bedienten, waren die Diakone, welche im Sticharion und dem Orarium zu antieren pflegten. Bei den Subdiakonen muf das Phelonion bis um das 12. Jahrhundert noch in Gebrauch gewesen sein. Im späteren Mittelalter war es dagegen bei ihnen ganz ab-

I $\mathrm{Mg} .119,949$.

2 Tfl 99 u. 100. Auf Th 101 ist das PheIonion eines Bischofs Sergius vom Dreifaltigkeitskloster ahgebildet, welches gleichfalls auf der Brust mit einer Vorrichtung zum Aufheben des Vorderteils versehen ist, indessen ebensowenig wie das angebliche Phelonion des Bischofs Niketas ïber das 16. Jahrhundert zurückreichen dürfte.

${ }^{3}$ Siehe oben S. 237 die Zitate aus älteren griechischen Schriftstellern.

\& Duch., L. P. II 180. 
gekommen, indem sie sich nunmehr bei ihren liturgischen Funktionen des Sticharion bedienten ${ }^{1}$.

Bei den Lektoren erhielt sich das Phelonion in einem gewissen Mafe bis auf die Gegenwart, doch war es schon im späteren Mittelalter nicht melrr deren einziges liturgisches Gewand, da sie sich bereits um 1400 statt seiner auch wohl des Sticharion zu bedienen pflegten?. Aufierdem war schon wenigstens damals das Lektorenphelonion oder xusiou,, wie es auch genannt wurde, kleiner als das priesterliche, offenbar, damit es sich von diesem unterscheide?

Über das Gegenstuick des Phelonion in den übrigen Kirchen des Ostens können wir kurzerhand weggehen. Die wenigen Notizen, die wir darïber zusammenstellen konnten, bieten nichts von Belang. Bemerkenswert ist nur, daf nach Ausweis der Miniaturen des dem Beginn des 13. Jahrhunderts angehörenden syrischen Pontifikale in der Nationalbibliothek zu Paris die Phaina damals noch ein ringsum geschlossener Mantel ganz von der Art des griechischen Phelonion war (Bild 112). Die Pluvialeform hätte demnach das priesterliche Obergewand bei den Syrern und demgemäk auch wohl bei den andern Riten erst im späteren Mittelalter erhalten. Bei den Armeniern trugen wenigstens schon in der zweiten Hälfte des 12. Jahrhunderts nach Nerses von Lampron nur die Bischöfe und Priester den Schurtschar, nicht die ïbrigen Kleriker, insbesondere nicht die Subdiakone und Lektoren. Derselbe war beim Katholikos, aber auch nur bei diesem, mit Kreuzen geschmückt, wohl in Nach-

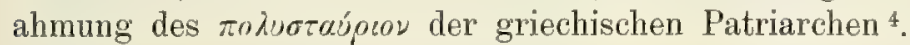

\section{URSPRUNG DES MESSGEWANDES.}

Wo wir den Ursprung des Meligewandes zu suchen haben, kann keinem auch nur einen Augenblick zweifelhaft sein, der an der Hand der schriftlichen Zeugnisse wie namentlich der Monumente die profane Tracht der sechs ersten christlichen Jahrhunderte studiert. Beide beweisen mit aller Bestimmtheit, daf die Kasel, welche der Liturge am Altare trägt, auf ein Obergewand der gewöhnlichen Volkskleidung der römisch-griechischen Welt nachchristlicher Zeit zurückgeführt werden muf.

Die schriftlichen Zeugnisse wurden schon früher angeführt. Planeta und casula erscheinen in denselben nicht nur als ein Bestandteil der Altarkleidung, sondern als Stück der gewöhnlichen klerikalen Tracht, der Mönchsgewandung und der Kleidung der Laien, der Vornehmen wie der Leute geringen Standes ${ }^{5}$.

Fast noch erdrückender ist das Zeugnis der Monumente, auf welchen uns bei Leuten jeder Art und jeden Geschlechtes sehr häufig ein mit der Planeta in ihrer ursprünglichen Gestalt unverkennbar verwandtes Obergewand begegnet.

Dasselbe tritt in zwei Hauptformen auf. Bei der eimen ist es, gerade wie es die Glockenkasel war, ringsum völlig geschlossen und nur mit einer

I Ass. C. 1. VIII, pars 4, 114 137; vgl. indessen die Rubrik am Schluf des Ordo subdiaconatus (142), wonach dem Subdiakon uach der Weihe das Phenolion ausgezogen und der Gürtel gelöst werden soll.

2 Vgl. oben S. 98.

s Simeon Thess., De ordinat. c. 186

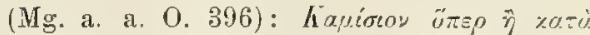

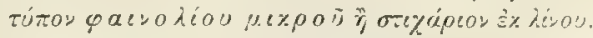
Vgl. auch c. 156 (ebd. 365).

4 Erklärung der göttl. Liturgie c.5 (ed. Vent 80 ff). Auch der Katholikos Isaak erwähnt Gewand (Adv.Arm.orat. 1, c.8[Mg.132, I179]) 5 S. oben S. 153157. 
Öffnung zum Durchlassen des Kopfes versehen (Bild 113). Bei der andern ist es vorn in der Mitte rom Saum bis etwa unterhalb der Brust aufgeschlitzt (Bild 114 und Bild 13, S. 46), offenbar, um bequemer die Arme gebrauchen und das Gewand leichter über die Schultern und Arme zurückschlagen zu können.

Bei beiden Formen sehen wir das Gewand auf den Monumenten gerade wie die mittelalterliche Glockenkasel bald auf beiden Schultern, bald nur auf einer, bald endlich auf den Armen zusammengerollt. Bisweilen hat es infolgedessen das Aussehen, als ob es an den Seiten stark beschnitten wäre. Es bieten die Monumente in solchen Fällen ein Bild desselben, wie es uns auch die Miniaturen aus der Frühe des 2. Jahrtausends von der Kasel bisweilen gewähren. Man hat daraus geschlossen, es habe schon in altchristlicher Zeit ein Gegenstiick zur Kasel des Barock gegeben. Allein man wird wohl richtiger die scheinbare seitliche Verkürzung des Gewandes den Künstlern oder besser Handwerkern zur Last legen, aus deren Hand das Bildwerk hervorging. Sie

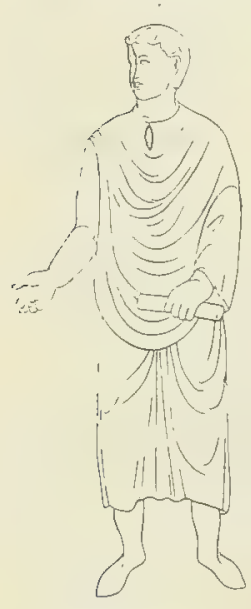

Bild 113.

Sarkophagskulptur (altchristlich).

Mantua, Dom. haben wie ihre mittelalterlichen Kollegen den Mantel in der Form dargestellt, wie er gewöhnlich getragen wurde, dabei aber infolge Unachtsamkeit oder künstlerischer Unfähigkeit die Falten entweder ganz oder nahezu ganz vergessen.

Daß es sich wirklich bei derartigen Bildern nur um eine Ungenauigkeit in der Darstellung handelt, liegt bei einzelnen Monumenten ganz klar zu Tage, so z. B. auf einer Grabstele eines Centurio in der vatikanischen Sammlung, auf der unser Mantel fast nur mehr einem Skapulier gleicht, das auf den Schultern leicht umgeschlagen ist (Bild 115). Ein Ding wie dieses Obergewand konnte doch einem Soldaten wahrlich keinen Schutz bieten. Es kann sich darum auf der Stele unmöglich um eine korrekte Wiedergabe der Wirklichkeit handeln.

Die zweite Hauptform, bei welcher das Gewand vorn bis zur Brust aufgeschlitzt ist, kommt namentlich bei Soldaten vor, begreiflich, weil diesen besonders daran gelegen sein musste, auch dann noch, wenn sie mit demselben bekleidet waren, im Gebrauch der Hände möglichst unbehindert zu sein.

Die Länge des Mantels ist auf den Monumenten verschieden. Bald reicht er bis über die Kniee, bald bis in die Mitte des Oberschenkels; hie und da ist er selbst noch kürzer. Im Nacken ist er sehr häufig, zumal bei Militärs, mit einer Kapuze versehen.

Vortreffliche Beispiele für das Gesagte liefern aus dem Beginn des 2. Jahrhunderts verschiedene Reliefs der Trajanssäule zu Rom, auf denen nicht nur die Soldaten das in Rede stehende Gewand tragen, dessen Beschaffenheit auf einzelnen der Darstellungen (Bild 19, S. 46) in besonders vorzüglicher Weise erkennbar ist, sondern auch Trajan selbst zu wiederholten Malen damit bekleidet ist, so bei seiner Einschiffung zum zweiten Feldzug gegen die Dacier und sogar bei der Vornahme eines Opfers (Bild 114). Ein römischer Bürger ist mit unserem Oberkleid dargestellt auf einem wohl noch dem 2. Jahrhundert angehörigen Grabcippus in der vatikanischen Inschriftengalerie ${ }^{1}$. Bildwerke aus der Zeit des Septimius Severus mit der Darstellung unseres Gewandes finden sich am Triumphbogen des Severus auf dem römischen Forum, am Bogen der Wechsler hei S. Giorgio in Velabro zu Rom, auf der Grabstele eines Infanteristen im lateranensischen Museum² und auf der Stele eines Kavalleristen

I Wilp., Gew. Fig. 14.

${ }^{2}$ Wilp., Cap. Fig. 28. 
in der Inschriftengalerie des Vatikans". Sind es hier überall Soldaten, bei welchen wir dasselbe gewahren, so sind es auf den Schranken der Rednerbühne des Forums Zivilisten, welche mit ihm bekleidet sind.

Auch die auferitalischen römischen Monumente aus der Kaiserzeit liefern viele treffliche Beispiele, so verschiedene Cippen im Römischen Museum zu Regensburg, die Grabsteine des Sklaven Peregrinus im Museum zu Speier ${ }^{2}$ und des Schiffers Blussus im Germanisch-römischen Zentralmuseum zu Mainz (Bild 116, S. 242), das Fragment eines mächtigen Grabmonumentes am ehemaligen Mansfeldschen Schlosse zu Klausen hei Luxemburg usw. Andere finden sich auf Abbildungen römischer Skulpturen in den noch grofenteils unedierten Manıskripten des Jesuiten Alexander Wiltheim († 1684), eines hervorragenilen Kenners und Sammlers römischer Altertümer, welche um so mehr von Wert sind, als sie manche inzwischen zu Grunde gegangene Monumente wiedergeben ${ }^{3}$. Bemerkenswert ist, dafs das Gewand in den Provinzen häufiger als zu Rom bei Zivilisten vorkommt. Zu Rom herrschte eben noch $\mathrm{zu}$ sehr die Toga, wenn auch

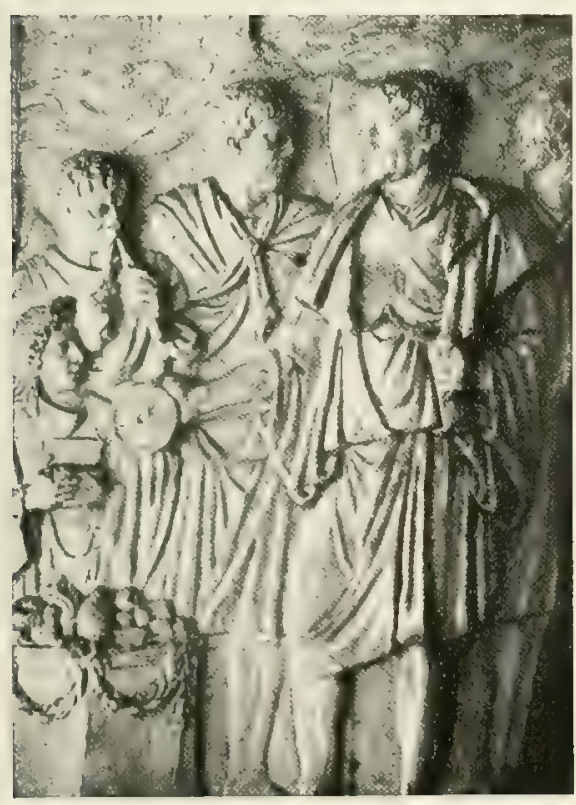

Bild 114. Relief von der Trajanssäule zu Rom.

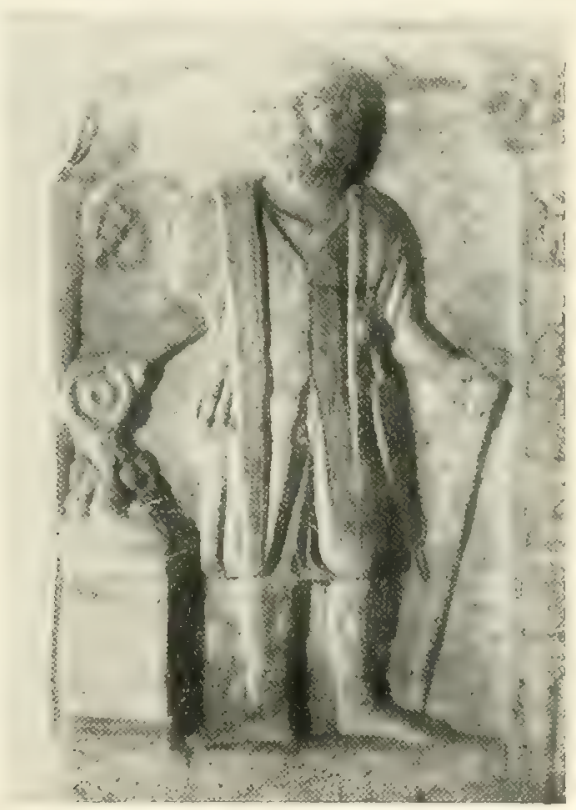

Bild 115. Grabstele eines Centurio. Rom, Vatikan (Galerie der Inschriften).

nicht als Alltagskleid, so doch als Oberkleid bei feierlichen Gelegenheiten, weshalb denn auch dort die Künstler für ihre Darstellungen die T'oga bevorzugten. In den Provinzen war diese zwar auch das offizielle Staatskleid, doch stand sie hier weit weniger im Vordergrund, teils weil die Verhältnisse auf ein praktischeres Gewand hinwiesen, als es gerade die Toga der Kaiserzeit war, teils weil die überkommene Sitte in der Fremde naturgemäß weniger Einfluf auszuüben vermochte.

Aus dem 3. Jahrhundert stammt das bekannte Fresko in S. Priscilla, welches einen Bischof auf seiner Kathedra in unserem Mantel darstellt; dem Beginn des 4. angehörende Bildwerke, auf denen dieser uns begegnet, sind ein Fresko in S. Callisto (der hl. Nemesius), Malereien in S. Pietro e Marcellino (Oranten) ${ }^{\text {s }}$ und ein Relief des Triumphbogens Konstantins d. Gr. (römische Bürger).

1 Wil p., Gew. Fig. 12.

2 Jahrbuch des Vereins von Altertumsfr. im Rheinland Hft 108 109, Bonn 1902, TH 5, 11. 34 . Wegen der Abbildung des Grabsteines des Blussus vgl. oben S. 46 Anm. 1.

Bran, Die liturgische Gewandung.
Im Besitz der historischen Sektion des Institut Grand-ducal zu Luxemburg.

${ }^{4}$ Wilp., Kat. TH 110160185223 . Die Darstellungen in $\mathrm{S}$. Pietro e Marcellino scheinen von einer Hand herzurühren. 
Monumente des ausgehenden 4., des 5. und 6. Jahrhunderts, die eine besondere Erwähnung verdienen, sind das Diptychon des Probian (Berlin, Kl. Bibliothek), auf dem die Notare unser Gewand tragen ${ }^{1}$, dann die in jeder Beziehung so wichtige Holztüre von S. Sabina auf dem Aventin, auf der wir es bei römischen Bürgern, bei Soldaten und bei Juden gewahren ${ }^{2}$, die Mosaiken in S. Maria Maggiore zu Rom und S. Apollinare Nuovo zu Ravenna ${ }^{3}$, wo es die Juden charakterisiert, ein prächtiger altchistlicher Sarkophag im Dom zu Mantua ${ }^{\ddagger}$, verschiedene altchristliche Sarkophage mit der Darstellung des Durchgangs durch das Rote Meer ${ }^{5}$ und der zur letzten Ruhestatte des Dogen Domenico Morosini ( $†$ 1262) benutzte altchristliche Sarkophag im Portikus von S. Marco zu Venedig mit seinen zwei Reihen von abwechselnd männlichen und weiblichen, durch ein Rauchfaf getrennten Oranten. Alle Mänmer tragen gleichmäfig über einer langen, engärmeligen Tunika einen der Glockenkasel ähnlichen, auf den Schultern zusammengelegten Überwurf. Auf dem Sarkophag von Mantua sehen wir den mit gegürteter Tunika und einer Kasel bekleideten Verblichenen von seiner Gattin Abschied nehmen. Interessant ist hier der unter der Halsöffnung des Mantels befindliche kleine, oben geschlossene Schlitz, welcher offenbar des leichteren

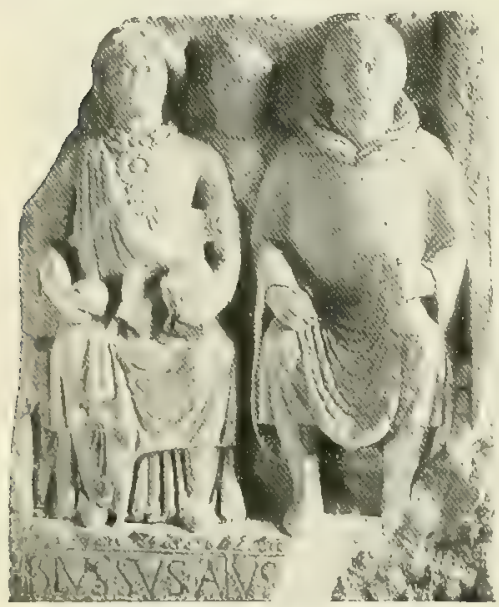

Bild 116. Grabstele des Schiffers Blussus.

Mainz, Germ.-römisches Zentralmuseum. Anziehens halber angebracht wurde (Bild 113, S. 240). Auf den Sarkophagen mit der Szene des Durchgangs durch das Rote Meer dient das Gewand ähnlich wie auf den obengenannten Mosaiken zur Kennzeichnung der Juden.

Auch die Frauen trugen den unserer Kasel ähnlichen Mantel. Interessante Beispiele aus der Frühe des 1. Jahrhunderts liefern einige Tonfiguren und sechs Wandgemälde aus Pompeji im Museum von Neapel. Letztere stellen Frauen, die einen Totentanz aufführen ${ }^{6}$, die Tonfiguren ${ }^{7}$, von denen sich auch im Musée Guimet zu Paris drei vorzügliche Exemplare finden, Klageweiber dar. Im ersten christlichen Jahrhundert mag hiernach das Gewand bei den Frauen besonders zu Trauerzwecken gedient haben. Später finden wir es jedoch selbst bei hochstehenden Persönlichkeiten; so tragen es z. B. auf den Mosaiken in S. Vitale die Damen, welche den Hofstaat der Kaiserin Theodora bilden".

Griechische Monumente aus frühchristlicher Zeit mit Darstellungen des Gewandes sind selten; rloch ist $\mathrm{zu}$ beachten, daf überhaupt griechische Bildwerke aus dieser Epoche nicht gerade häufig sind. Es gehören zu ihnen verschiedene Miniaturen im Kodex von Rossano und der Wiener Genesis, die Menaspyxis im Britischen Nuseum ${ }^{9}$, eine ägyptische Arbeit, wie es scheint, und eine Elfenbeintafel im Museo archeologico zu Mailand, die unter ägyptischem oder griechischem Einflufs entstanden sein dürfte und einst zur Kathedra Maximians im Dom zu Ravenna gehörte (vgl. Bild 92, S. 210).

1. Wilp., Cap. Fig. 5 ; besser bei E. M 0 Iin ier, Les ivoires pl. IV.

2 Wiegand, Das altchristliche Hauptportal an der Kirche der hl. Sabina, Trier 1900, Tf 581221.

${ }^{3}$ Garr. tav. 219, 3; 220, 3; 248, 6; 249 , $34 ; 250,456 ; 252,2$. Die ravennatischen Abbildungen sind besser bei R i c c i, Ravenna, Bergamo 1903, 27.

${ }^{4}$ Die Abbildung bei Garr. (tav. 320, 1), welche die Figur in einer Art von Toga zeigt, ist unrichtig.
5 Beispiele derselben finden sich zu Arles, Nimes, Spalato. Vergleiche die freilich mangelhaften Abbildungen bei Garr. tav. 308, 2 und 309, 124 . P e yre, Nîmes, Arles, Orange (Paris 1903) 93.

6 Abteilung der Pompejanischen Fresken $\mathrm{N}_{1} \cdot 9352-9357$.

Museo Naz. mezzanino n. 43264425 63026621 .

4 Abbildung bei Garr. tav. 264. Kraus, F. X., Geschichte der christl. Kunst I, Freiburg 1896, 443. $\quad 9$ Vgl. oben S. 209. 
Aber nicht blob in Rom. Gallien, Germanien und Griechenland, sondern auch im Orient muf das Gewand in Gebrauch gewesen sein. Es ist sehr bemerkenswert, daßs es ebensowohl auf den angeführten griechischen Bildwerken wie auf den Mosaiken Roms und Ravennas und einer Anzahl altchristlicher Sarkophage vorwiegend bei Darstellungen von Juden vorkommt. Auf den griechischen Monumenten bleibt das so bis in das zweite Jahrtausend hinein. In späterer Zeit, als die Tradition und Schablone die Kunst des Ostens beherrschten, mag diese Gepflogenheit bei ihnen allerdings blob ein Erbstück aus früheren Tagen gewesen sein. In der altchristlichen griechischen Kunst, welcher ein stark realistisches Gepräge eigen ist, war sie jedoch ebenso wie auf den durchaus gleichartigen römischen Monumenten wohl nur ein Abbild der wirklichen Verhältnisse.

Wir haben indessen auch einen direkten Beweis, daf wenigstens schon im zweiten nachchristlichen Jahrhundert das Gewand im Orient ein sehr gebräuchliches und dabei angesehenes Kleidungsstiick gewesen sein muf: die damals unter dem syro-römischen Einflufs entstandenen buddhistischen Gandharaskulpturen. Es sind keine geringeren als Buddha und seine Schüler, die auf diesen Bildwerken mit ihm bekleidet erscheinen, und zwar so regelmäßig, dak das Gewand eine Art von Charakteristikum derselben bildet. Es sind merkwürdige Darstellungen, die nicht selten wie ein getreues Bild eines christlichen Priesters aus altchristlicher Zeit in seiner liturgischen Gewandung aussehen. Fehlt doch selbst das Sudarium vorn auf dem linken Arm bei manchen nicht (Bild 117) ${ }^{1}$.

Der römische Name des Gewandes war paenula. Es gab bei den Römern verschiedene Arten von mantelartigen Obergewändern. Man unterschied, um von einigen selten vorkommenden Namen abzusehen, bei den Männern toga, pallium, lacerna, birrus, chlamys (sagum, paludamentum) und paenula ${ }^{2}$. Vergleichen wir, was wir über diese Gewänder wissen,

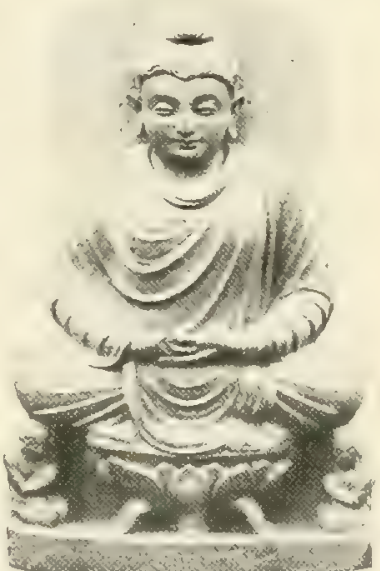

Bild 117. Buddha mit Tunika, Kasel und Sudarium. Kalkutta India Museum. mit den Monumenten, so ergibt sich, dab der kaselartige Mantel, der uns so oft auf denselben begegnet, nur paenula geheifen haben kann.

Eine Schwierigkeit scheinen freilich die Definitionen zu bilden, welche Isidor von Sevilla im Anschluf an den Kommentator des Persius ${ }^{3}$ und Eucherius von Lyon $(† \text { ea } 450)^{4}$ von der Pänula geben. Nach Isidor bzw. dem Scholiasten des Persius war dieselbe ein mit langen Fransen versehener Mantel: paenula est pallium cum fimbriis longis. Eucherius bezeichnet sie als verwandt mit der lacerna (einem auf der Brust mit einer fibula befestigten Um- oder Überwurf), aber mit clavi, $d$. i. von oben nach unten herablaufenden Zierstreifen, versehen: est quasi lacerna descendentibus clavis. Wer indessen die höchst ungenaue Definitionsweise der alten Scholiasten kennt, wird weder den Worten Isidors bzw. des Kommentators des Persius noch denen des Eucherius eine Bedeutung beimessen. Zudem lassen sie sich genügend mit den Bildwerken und sonstigen Angaben in Einklang bringen. Isidor bzw. sein Gewährs-

1 Abbildung in The ancient monuments, temples and sculptures of India. Part I. The earliest monuments, London 1897, und The Journal of Indian art vol. VIII, n. 6369. Auf die Gandhara-Skulpturen wurde ich durch meinen Ordensgenossen $P$. Jos. Dahlmann freundlichst aufmerksam gemacht.

${ }^{2} \mathrm{Vgl}$. dariuber namentlich Wilp., Gew. 7 ff.

${ }^{3}$ Etymol. 1. 19, c. 14 (M. 82, 691).

4 Instr. ad Salon. 1. 2, c. 10 (M. 50, 820). 
mann mag die zottige Regen- und Winterpänula der älteren Zeit, Eucherius aber jene Pänulaform, welche vorn bis auf die Brust aufgeschlitzt war und darum ohne große Ungenauigkeit als quasi lacerna bezeichnet werden konnte, im Sinne haben. Wenn letzterer aber auch von clavi descendentes, Vertikalbesätzen, redet, so liegt kein ernstlicher Grund vor, deren wirkliches Vorkommen bei der Pänula zu bezweifeln.

Ton der Pänula — zusammenhängend mit pannus, Tucl,, Gewebe - ist bei den lateinischen Schriftstellern sowohl aus der Zeit der Republik wie der Kaiserzeit wiederholt die Rede. Sie begegnet uns bei Plautus, bei Cicero und Tarro, bei Horaz, Martial, Lampridius u. a. ${ }^{1}$ Bei Plautus ist sie ein Sklavenkleid 2, bei Cicero erscheint sie als Reisemantel und als Obergewand eines Maultiertreibers ${ }^{3}$. Bei Varro hat die Pänula den Charakter eines Regenmantels ${ }^{4}$, während Horaz sie nicht undeutlich als Überwurf für den Winter bezeichnet ${ }^{5}$. Nach Martial scheint sie für gewöhnlich nur von Leuten niederer Klasse getragen worden zu sein ${ }^{6}$. Doch hören wir von Sueton, dafa auch der freilich zu Extravaganzen geneigte Caligula sich der Pänula bedient habe. Fs waren allerdings bestickte und mit Edelsteinen verzierte paenulae ${ }^{7}$. Ebenso bedienten sich bereits nach dem Dialogus de oratoribus, der gewöhnlich dem Tacitus zugeschrieben wird, die Advokaten bei Gericht der Pänula ${ }^{8}$. Der Verfasser des Dialogus sieht darin eine der Ursachen des Niederganges der Gerichtsreden, da das Gewand die freie Bewegung und die Entfaltung eines grofartigen Gestus hindere und den Redner zu einer bloken Unterhaltung mit dem Richter zwinge.

Eigentlich römische Tracht war aber selbst gegen Ende des 2. Jahrhunderts die Pänula noch nicht geworden. Es war vielmehr gegen alle Sitte und Gewohnheit, dafi Commodus zu Leichenfeierlichkeiten, denen er selbst präsidierte, die Senatoren — diese Lesart ist wohl vorzuziehen - nicht in der Toga, sondern in der Pänula entbot ${ }^{9}$. Beim Volk muk diese indessen schon im Beginn des 3. Jahrhunderts sehr verbreitet gewesen sein, da von Kaiser Makrinus berichtet wird, er habe zu Ehren seines Sohnes Diadumenianus, den er zum Cäsar hatte ausrufen lassen, dem Volk rosenfarbene paenulae zu spenden beabsichtigt 10, und um etwa dieselbe Zeit Ulpian die Pänula neben dem Pallium zu den vestimenta communia, d. i. zu den Kleidungsstücken, welche Männer und Frauen ohne Unterschied gebrauchten, rechnet ${ }^{11}$. Alexander Severus gestattete den Senatoren (senes), sich der Kälte halber innerhalb der Stadt der Pänula zu bedienen; den römischen Matronen erlaubte er jedoch blok, auf Reisen dieselbe anzulegen ${ }^{12}$. Lampridius, der uns das berichtet, weist zur Erklärung dieser Verordnung darauf hin, daf die Pänula stets als ein Reise- oder Regenmantel gegolten habe (cum id vestimenti genus semper itinerarium aut pluviale fuisset). Bei Tertullian ist die Pänula einmal ein bürgerliches Obergewand, dessen sich Christen wie Heiden bedienten, ein anderes Mal ein Soldatenmantel ${ }^{1 \%}$. Im Maximaltarif Diokletians gehört die Pänula noch nicht gerade zu den kostbarsten Gewändern. Sie ist auf 4000 bis 5006 Denare (den Denar zu 14/5 Pfennig) gewertet, während z. B. ein gallisches

1 Die Stellen sind gut zusammengestellt hei Marriott 192 ff; vgl, auch Forcell. II, 276 and Marqu a $\mathrm{dt}$, Das Privatleben der Römer, Leipzig 1886, 564.

2 Most. IV, 11, 74.

${ }^{3}$ Mil. 20; P. Sest. 38; Att. 13, 33.

4 Apud Nonn. 14, 3.

5 Epist. 1, 1118.
6 Epig. 5, 27.

8 N. 39. ¿ Cal. 52.

$10 \mathrm{Id}$. in Anton. Diadum. 2.

11 Dig. 34, 2, 23.

12 L a mprid. in Alex. Sev. 27.

1s De orat. c. 15 (M. 1, 1171); De corona milit. c. 1 (M. 2, 95). Unklar ist Apolog. adv. gent. c. 6 (M. 1, 301). 
Sagum auf 8000 Denare angesetzt ist ${ }^{1}$. Im Kleidergesetz vom Jahre 382 wird bestimmt, es solle kein Senatol ein militärisches Kleid für sich in Anspruch nehmen und darum nicht die militïrische Chlamys, sondern Kolobium (Talartunika) und Pänula tragen; die Offizialen, deren Aufgabe es war, die Beschlïisse zum Vollzug zu bringen und das Notwendige durchzuführen, also die Exekutivbeamten, sollten sich einer gegürteten Tunika und der Pänula bedienen. Es handelt sich in diesem Erlab übrigens nicht um die offizielle Tracht der Senatoren, das „Staatskleid“, sondern, wie wir sagen würden, um die „Interimskleidung". Bezüglich des "Staatskleides" der Senatoren sollte es beim alten bleiben, und vor wie nach die Toga als solches gelten: Cum autem vel conventus ordinis candidati coeperit agitari vel negotium eius sub publica iudicis sessione cognosci togatum eundem interesse mandamus ${ }^{2}$.

Die Monumente geben im Verein mit diesen Angaben der römischen Schriftsteller ein treffliches Bild von dem Wechsel der römischen Node, bei welchem die Pänula, anfangs nur ein Kleid der Sklaven, geringer Leute und der Soldaten, bei besseren Ständen höchstens Reise- und Regenmantel, der Toga immer mehr Terrain abgewinnt und sich zuletzt als Alltagsgewand selbst in den höchsten Kreisen einbürgert.

Die Bezeichnung paenula verlor sich im Lauf der Zeit; an ihre Stelle trat der uns schon bekannte Name planeta, der seitdem nie mehr aus dem Gebrauch verschwinden sollte. Der 7eitpunkt dieses Wechsels in der Benennung des Gewandes läfit sich nicht bestimmt feststellen. Von vestes planeticae redet, wie früher gesagt wurde, bereits Cassian (Anfang des 5. Jahrhunderts), von planetae die Vita S. Fulgentii (erste Hälfte des 6. Jahrhunderts).

In Gallien und Afrika wurde die paenula von ihrer Gestalt casula, in Gallien nach ihrer Anlegungsweise auch amphibalus genannt.

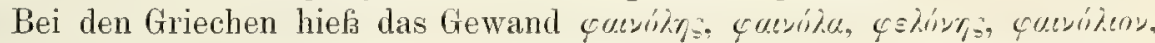

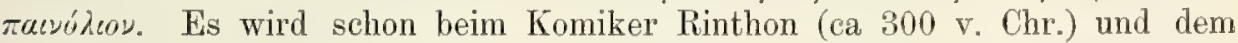
Mechaniker Athenäus (ca 150 v. Chr.) erwähnt. Später wird es im zweiten Brief des hl. Paulus an Timotheus $(4,13)^{3}$, bei Epiktet (2. Jahrhundert n. Chr.), bei Artemidor (ca 150 n. Chr.), bei Julius Pollux (Ende des 2. Jahrhunderts n. Chr.), bei Johannes Laurentius Lydus ( $\uparrow$ ca 565), bei Menander Protector (Ende des 6. Jahrhunderts), bei Theophylakt Simokattes (Anfang des 7. Jahrhunderts) und in dem um die Mitte des 7. Jahrhunderts entstandenen Chronicon paschale genannt ${ }^{4}$. Bei Simokattes handelt es sich um ein klerikales Gewand, wie es scheint ${ }^{5}$, bei allen übrigen aber um ein laikales Kleidungsstück. Bei Lydus finden wir es bei den Advokaten ${ }^{6}$; im Chronicon paschale erscheint es als Bestandteil der 'Tracht des Stadtpräfekten von Konstantinopel ' Bezeichnend für die Bedeutung, welche der cskóvns allmählich erlangt hatte,

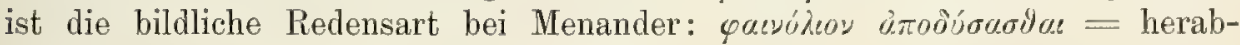
kommen, unter seinen Stand herabsteigen ${ }^{8}$.

1 M ommsen-B 1 ümner, Der Maximaltarif des Diokletian $154 \mathrm{ff}$.

2 Cod. Theod. 1. 14, tit. 10 de habitu (ed. Ha ene 1, Lipsiae 1837, 1400*).

${ }^{3}$ So wenigstens nach der gewöhnlicheren Auffassung; man hat nämlich den $\varphi$ skirns im 2. Timotheusbrief auch als Buchhiulle ausgelegt. An der fraglichen Stelle bittet der Apostel den Adressaten, er möge ihm bei seinem Herkommen die paenula ( $\varphi$ shóns), die er bei Karpus in Troas zurückgelassen habe, sowie die Bücher und zumal die Pergamente mitbringen.

4 Sophokles, Griechisches Lexikon (Leipzig und New York 1893) unter yaivókrs

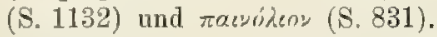

5 Hist. 1. 7, n. 6 (Bonnae 1834, 280).

6 De magistrat. 1. 3, n. 8 (Bonnae 1837, 201).

7 Ad an. 419 (Bonnae 18:2, 574).

8 Fragm. hist. (Bonnae 18:9, 439). 
Es kann nach dem Gesagten keinem Zweifel unterliegen, dak die liturgische Planeta oder Kasel von dem Gewand herkommt, welches die Römer paenula,

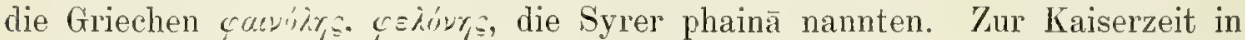
der ganzen griechisch-römischen Welt bekannt, war es ein wirklicher Allerweltsmantel. Denn wir finden es zu Rom und überhaupt in Italien wie in Germanien, in Gallien wie im Norden Afrikas, in Griechenland wie in Syrien, ja im äufersten Nordwesten Indiens in Gebrauch, und zwar galt es damals sogar zu Fom nicht mehr als ein gering gewertetes Kleidungsstück der Sklaven, Maultiertreiber, Soldaten und Leute ähnlichen Schlages, oder als bloßer Regenmantel, dessen man sich nur bei Wind und Wetter bediente. Selbst hier war es allmählich zu Ansehen gekommen und ein beliebtes, weil praktisches Obergewand geworden, in dem man mit allen Ehren in der Öffentlichkeit auftreten konnte. Wohl hatte die Toga offiziell noch immer, und zwar noch für lange Zeit das Vorrecht, das eigentliche römische Staatskleid zu sein. In Wirklichkeit aber war ihre Verwendung bereits eine sehr beschränkte geworden. Hatte sich doch die Pänula nicht blof auf dem Forum, sondern selbst schon bei den Gerichtshöfen heimisch gemacht. Sogar bei den Senatoren war sie austatt der Toga im Lauf der Zeit nicht zwar zur amtlichen, aber doch zur auferamtlichen Tracht emporgestiegen.

Unter solchen Umständen ist es leicht erklärlich, daß das Gewand auch bei den christlichen Liturgen sich einbürgerte, und zwar nicht blof zu Rom und überhaupt im Abendland, sondern auch im Osten.

Welche Ursachen darauf eingewirkt haben, das die Pänula eine so weite Verbreitung in der ganzen römisch-griechischen Welt fand, läbt sich nicht feststellen. Möglich, dafa die Soldatenpänula, die mit den römischen Soldaten überall hinkam, darauf von Einfluß gewesen ist. Indessen ist es ja auch von wenig Belang, klarzulegen, wie das zuging. Nicht die Gründe der allgemeinen Verbreitung des Gewandes sind es, was uns hier zuletzt interessiert, sondern die Tatsache dieser seiner allgemeinen Verbreitung. Denn diese gibt uns den Schlüssel zur Lösung der Frage, wie es kam, dał jenes später ebensowohl im Osten wie im Westen einen Bestandteil der liturgischen Kleidung bildet. Das priesterliche Obergewand ist nicht etwa im Orient aus dem profanen $\varphi$ kiúrs entstanden und dann vom Abendland adoptiert worden, noch haben umgekehrt die Riten des Ostens es dem lateinischen Ritus entlehnt, nachdem in diesem aus der Pänula die sakrale Planeta geworden war. Es ist vielmehr hier wie dort autochthon, d. h. es hat sich hier wie dort gleichmäbig aus dem gewöhnlichen Mantel des Alltagslebens herausgebildet, der im Abendland freilich schon lange völlig außer Gebrauch gekommen ist, im Orient aber sich noch jetzt, wenngleich mit Veränderungen, in Gestalt des Burnus der Araber erhalten hat.

Den Zeitpunkt zu bestimmen, zu dem die Pänula bzw. der profane çíny = bei den Liturgen in Gebrauch kam, ist unmöglich. Es geschah schwerlich überall zu gleicher Zeit. Immerhin darf angenommen werden, dal.; solches nicht erst erfolgte, als die Fesseln für die Kirche gefallen waren und diese frei ihre Wirksamkeit entfalten konnte. Wirklich ist sehon der Bischof auf dem Fresko der "Einkleidung einer gottgeweihten Jungfrau " in der Katakombe der hl. Priscilla zu Rom, einem Werk des 3. Jahrhunderts, mit der Pänula bekleidet. Natürlich hatte das Gewand damals noch keinen spezifisch liturgischen Charakter. Diesen erhielt es crst in weit späterer Zeit, als die Mode (ine rückläufige Bewegung hegann, und es zunächst bei den Laien, dann 
aber auch als Alltagsgewand bei den Geistlichen wieder aufer Brauch kam. Erst von da ab kann man von einer spezifisch liturgischen Planeta, einem eigentlich liturgischen Phelonion reden.

Man hat aufälligerweise mehrfach geglaubt, die paenula (çkivrs), von welcher der Apostel Paulus im 2. Timotheusbrief 4, 13 redet, als liturgische Kasel auffassen zu sollen. Eine solche Annahme heist indessen die Entwicklung. der sakralen Gewandung völlig verkennen. Sie entbehrt aber auch allen Grundes. Haben doch schon zur Zeit des hl. Hieronymus einzelne Exegeten unter jener paenula sogar eine Bücherumhüllung verstanden ${ }^{1}$. Bedeutet sie, was allerdings das wahrscheinlichste ist, ein Gewand, so ist sie lediglich der cekirurs des Alltagslebens. So und nicht anders fassen denn auch Tertullian ${ }^{2}$. Pelagius ${ }^{3}$, Johannes Chrysostomus ${ }^{4}$ und Eucherius ${ }^{5}$ sie auf. Ton einer Andeutung, daks sie vielleicht ein Sakralgewand gewesen, findet sich bei keinem von diesen auch nur eine Spur; ein Zeichen, wie fern noch eine liturgische Pänula im späteren Sinn ihrem Ideenkreis lag. Besonders bezeichnend ist wie für die Bedeutung der paenula beim lıl. Paulus, so überhaupt für die Frage nach der Existenz einer sakialen Pänula in vorkonstantinischer /eit das Verhalten Tertullians in seiner Schrift De oratione. Es gab damals Christen, welche in Nachahmung der Heiden beim Beten die Pänula ablegten. Tertullian will das als abergläubisch und töricht tadeln, und er bemerkt deshalb mit dem ihm eigenen Salze, wenn man die Pänula beim Gebet abzulegen habe, so hätten das denn doch wohl vor allem die Apostel, die uns üher das Verhalten beim Gebet belehrten, begriffen; man mübte denn annehmen, Paulus habe seine Pänula bei Karpus vergessen, als er betete. Ob wohl Gott, welcher die drei Jünglinge im Feuerofen in ihren Pluderhosen und Mützen erhörte, nicht auch die höre, welche mit einer Pänula bekleidet seien? Es liegt auf der Hand, daf Tertullian weder die Pănula des Timotheusbriefes für ein Mefagewand gehalten noch iiberhaupt eine liturgische Pänula gekannt hat.

\section{ZWEITES KAPITEL.}

\section{DALMATIK UND TUNICELLA.}

\section{DALMATIK UND TUNICELLA NACH GEGENWÄRTIGEM BRAUCH.}

Das liturgische Obergewand der Diakone ist die Dalmatik, das der Subdiakone die Tunicella. Gemär dem jetzigen Brauch sind beide der Form und Verzierung nach nicht mehr voneinander verschieden. Dalmatik und Tunicella sind nur noch zwei Namen für ein und dasselbe Gewand. Nach dem bischöflichen Caeremoniale soll sich allerdings die subdiakonale Tunika von der Dalmatik dadurch unterscheiden, daßs sie etwas engere und längere Ärmel als diese hat ${ }^{6}$, weshalb denn auch die Provinzialsynode von Prag aus dem Jahre 1860 verordnete, es solle die Tunicella mit engeren und kürzeren Ärmeln als die Dalmatik versehen werden und überhaupt etwas kleiner als diese sein ? Allein praktisch wird der Unterschied nicht einmal zu Rom mehr festgehalten.

1 Chrysost. in $2 \operatorname{Tim} 4,13$ (Mg. 62, 656). Hieron., Ep. 36, n. 13 ad Damas. (M. 22, 458).

2 De orat. c. 15 (M. 1, 1171).

${ }^{3}$ In 2 Tim 4, 13 (M. 30, 895).
4 A. a. 0.

5 Instruct. ad Salon. 1. 2, c. 10 (M. 50, 820).

¿ $\mathrm{L} .1$, c. 10, n. 1 ; von einem Unterschied in der Länge der Gewänder ist keine Rede.

7 Tit. 5 , c. 7 (Coll. Lac. V 539). 
In Frankreich, England, Spanien, Deutschland usw. stellen die Dalmatik und Tunicella in ihrer gegenwärtigen Gestalt einen skapulierähnlichen İberwurf mit einem Durchlaf für den Kopf und viereckigen, von der Schulter ỉber den Oberarm herabfallenden Zeuglappen, den Überbleibseln der ehemaligen Ärmel, dar. Eine wirkliche Tunika sind sie noch in Italien. Zwar sind sie auch hier an den Seiten bis unter die Achseln aufgeschlitzt, doch haben sie noch förmliche Ärmel.

Die Verzierung der Dalmatik (Tunicella) besteht vor allem in zwei ron der Schulter bis zum Saum hinabgehenden Streifen, welche bei der italienischen Dalmatik schmal, bei der deutschen und französischen aber ron ziemlicher Breite sind und durch einen Querbesatz verbunden zu werden pflegen. Bei der Dalmatik, wie sie in Frankreich üblich ist, befindet sich dieses Querstück in der Regel hart oben am Kopfdurchlaf, bei der deutschen vor der Brust bzw. mitten auf dem Rücken, bei der italienischen tief unten nahe am Saum des Gewandes, und zwar stellt es bei den beiden ersten einen einfachen, breiten Streifen dar, während es bei der letzten aus zwei schmalen Borten besteht, die so weit voneinander entfernt sind, daf sie mit den Vertikalstreifen nahezu ein Quadrat bilden. Dalmatiken, die, ähnlich dem Mefagewand, blob mit einem Stab versehen sind, kommen nur in Deutschland und Frankreich vor, aber auch hier nicht als das Gewöhnliche. Der Besatz ist bei solchen in der Mitte der Vorder- und Rückseite angebracht und meist von bedeutender Breite.

Die Vertikalstreifen bilden eine für die Dalmatik (Tunicella) charakteristische Verzierung. Ein Schmuck mehr nebensächlicher Art sind die Besätze, welche am Saum der Ärmel bzw. deren Surrogats, der Ärmellappen, aufgesetzt werden, sowie die Fransen, mit denen man gern die seitlichen Schlitze und den unteren Rand versieht. Die früher so beliebten, von der Schulter auf den Rücken herabfallenden Quasten sind, wenigstens in Deutschland, in jüngerer Zeit stark in Abgang gekommen.

Über den St off der Dalmatik und Tunicella gibt es weder in den Rubriken eine Vorschrift, noch bestehen darüber sonst ausdrückliche Bestimmungen; indessen liegt auf der Hand, daßs es nicht passend ist, sie aus minderwertigen Zeugen herzustellen. Es sollte nur Seide zu ihnen genommen werden. Nicht nötig ist, daf sie genau aus dem gleichen Stoff gemacht oder gleich kosthar sind wie das Melsgewand, zu dem sie gehören, wofern sie nur die gleiche Farbe haben 1.

Die Gelegenheiten, bei denen die beiden Gewänder zur Verwendung kommen, sind nach dem römischen Missale die missa solemnis sowie die feicrlichen Prozessionen und Benediktionen. Nicht gebraucht werden sie jedoch an den Tagen, welche den Charakter der Bufse haben ", desgleichen nicht bei der Aschenweihe sowie ebenfalls nicht bei der Kerzen- und Palmenweihe und der an diese sich anschliebenden Prozession ${ }^{3}$, weil Dalmatik und Tunicella von alters her die Bedeutung eines Festgewandes besitzen. Tunicella und Dalmatik sind das spezifische (Obergewand der Subdiakone und Diakone; darum werden denn auch diese bei ihrer Weihe mit ihnen feierlich durch den Bischof bekleidet. "Die Tunika der Freude und das Gewand des Jubels ziehe dir an der Herr. Im Namen usw.", spricht der Bischof, wenn er dem neuen Subdiakon die Tunicella anlegt. "Es bekleide dich der Herr mit dem Gewand

1 C. PR. 4. Juli 1817 (Decret. auth. 2578). ${ }^{2}$ Siehe S. 148. ' B Rubricae generales tit. 19, n. 56 . 
des Heiles und dem Kleid der Freude, und mit der Dalmatik der Gerechtigkeit umgebe er dich auf immerdar. Im Namen usw." sind die Worte, mit welchen er die Übergabe der Dalmatik an den eben geweihten Diakon am Ende der heiligen Handlung begleitet.

Auker den Diakonen und Subdiakonen bedienen sich beider Gewänder aber auch die Bischöfe, wodurch, wie gewöhnlich gesagt wird, angedentet werden soll, dafi in diesen alle Ordines vereinigt sind, sowie diejenigen Prälaten, welchen kraft eines allgemeinen oder persönlichen Privilegs der Gebrauch der Pontifikalgewänder zusteht. Während indessen Diakon und Subdiakon die Dalmatik und Tunicella auch bei andern Funktionen als dem heiligen Opfer tragen, dürfen die Bischöfe und die genannten Prälaten sie lediglich bei der Messe und bei Funktionen, welche innerhalh der Messe statthaben, also nur in Verbindung mit der Kasel benutzen, nie zugleich mit dem Pluviale. Die Nichtbischöfe, welche sich des Vorrechtes erfreuen, die beiden Gewandstiicke zu gebrauchen, dürfen solches obendrein nur an den Tagen, bei den Gelegenheiten und an den Orten, für welche ihnen, sei es gemäls den allgemeinen Regeln ${ }^{1}$, sei es kraft ihres besondern Privilegs, die Benutzung der Pontifikalkleidung zugestanden wurde.

\section{ALTER DES GEBRAUCHES DER DALMATIK.}

Die Dalmatik war zu Rom sicher schon in der zweiten Hälfte des 4. Jahrhunderts bei dem Papst und den Diakonen in Gebrauch. Die allem Anschein nach zu Rom geschriebenen, jedenfalls aber die römischen kirchlichen Verhältnisse anffallend berücksichtigenden Quaestiones Veteris et Novi Testamenti stellen das aufer Zweifel. Man hatte behauptet, David sei Priester gewesen, und zum Beweise dessen angeführt, daf er nach Angabe der Heiligen Schrift den priesterlichen Ephod getragen habe. Der Verfasser der Schrift widerlegt nun dieses Argument, indem er darauf hinweist, daf ja doch auch die Diakone wie die Bischöfe eine Dalmatik trügen, ohne deshalb ebenfalls Bischöfe zu sein: Quasi non hodie diaconi dalmaticis utantur sicut et episcopi ${ }^{2}$. Es müssen also zu Rom zur Zeit der Entstehung der Quaestiones, d. i. zur Zeit Damasus' I. (366-384), sowohl der Papst wie die Diakone sich bereits der Dalmatik bedient haben. Übrigens gesetzt auch, ihr Verfasser habe bei jener Bemerkung nicht lediglich den Stand der Dinge im Auge gehabt, wie er damals zu Rom lag, so behält trotzdem sein Zeugnis seinen vollen Wert. Denn wenn es auch dann nicht ausschlieflich auf Rom und die römischen Verhältnisse bezogen werden kann, so gilt es doch jedenfalls wenigstens in erster Linie bezüglich des römischen Brauches, da die Dalmatik bis zur Karolingerzeit hin gerade für den dortigen Ritus ein charakteristischer Ornat war.

Wollen wir dem Papstbuche glauben, so geschah zu Rom die Einführung der Dalmatik im Kultus durch Silvester I. (314-335). Hic constituit, ut

1 Decret. Alexandri VII. circa usum pontificalium rom 27. September 1659 und die Konstitution Pius' VII, "Decet Romanos pontifices" vom 4. Juli 1823 in Decret. auth. n. 1131 und 2624.

2 Quaest. 46 (M. 35, 2246). Über den ungenannten Verfasser ist man nicht einig ( $\mathrm{vgl}$. Bardenhewer, Patrologie, Freiburg 1901, 387). Das Alter der Schrift ergibt sich ans
Quaest. 44 (M. 35, 2243), wo es heißt, es seien seit der Erfüllung der Weissagung Daniels von den Jahrwochen durch die Geburt und das Leiden Christi sowie dem Untergang Jerusalems etwa 300 Jahre verflossen: Et quis ambigat de hoc numero, cum trecenti circiter anni nunc super hunc numertm inveniantur. Sie entstand also wohl unter Damasus I. (367-385). 
diaconi dalmaticis in ecclesia uterentur, berichtet dieses ${ }^{1}$, und so klingt es wie ein Echo ohne Ende von da an durch alle folgenden Zeiten nach. Dagegen soll nach der Vita S. Silvestri erst unter Liberius (352-366) die Dalmatik liturgisches Gewand geworden sein ${ }^{2}$.

Leider sind nicht blof die Angaben des mit Fabeln angefüllten Silvesterlebens, sondern auch die Notizen in den älteren Papstbiographien des Papstbuches wenig zuverlässig. Wie die Dinge liegen, ist es daher unmöglich, auch nur mit einiger Sicherheit zu bestimmen, ob wirklich die Dalmatik unter Silvester I. im römischen Ritus Aufnahme fand oder erst unter Liberius oder sonst einem Papste; ob das Gewand, wie die Vita anzudeuten scheint, beim Papst und den Diakonen zu gleicher Zeit in Gebrauch kam, oder ob es sich zunächst blof bei jenem und dann erst bei diesen einbürgerte; endlich ob die Dalmatik eingeführt wurde, um die Diakone vor den übrigen Klerikern auszuzeichnen, wie das dem Papstbuch am meisten entspricht, oder lediglich auf Grund praktischer und ästhetischer Erwägungen. Immerhin sind die Angaben des Silvesterlebens und der Silvesterbiographie im Papstbuch insofern wenigstens für die Geschichte der Dalmatik nicht ohne Belang, als auch sie beweisen, dafs diese nicht erst gegen Anfang des 6. Jahrhunderts, sonderm schon eine geraume Zeit vor der Abfassung der beiden Schriften zu Rom Verwendung gefunden haben muf.

Es ist sogar nicht unwahrscheinlich, daf die Dalmatik bereits im 3. Jahrhundert im römischen Kultus Eingang fand. Wenn damals nämlich der hl. Cyprian († 258) zu Karthago sich ihrer bei der Liturgie bediente, so geschah ähnliches, wenigstens seitens des Papstes, zu gleicher Zeit auch wohl schon zu Rom, wo ja das Gewand als profanes Kleidungsstück bereits recht gebräuchlich geworden war. Daß aber jener sie tatsächlich bei den gottesdienstlichen Verrichtungen getragen habe, dürfen wir mit allem Fug aus den Akten seines Martertodes schlieben. Denn wenn er diesen Akten zufolge selbst im Alltagsleben aufer der Tunika und dem Mantel eine Dalmatik anzog ${ }^{3}$, wird er es sicher erst recht in gleicher Weise bei der Feier der heiligen Geheimnisse gehalten haben, bei der er doch zweifelsohne nicht weniger reich gekleidet war als auf der Straße. Es war aber auch die Lage der Christen im 3. Jahrhundert zu Rom keineswegs so armselig und so ungünstig mehr, daß3 nicht wenigstens der Papst hätte daran denken können, bei der Liturgie die im

1 Duch., L. P. I 171.

2 S. oben S. 68 . Die Vita S. Silvestri stammt aus dem Beginn des 6. Jahrhunderts. Der erste Teil des L. P. entstand nach Duchesne (L. P.Introd. p. xxx.IIff) unter Hormisdas $(514-523)$. P. Grisar setzt ihn (Zeitschrift für kath. Theologie, Innsbruck 1887, $426 \mathrm{ff}$ ) in die Zeit des Pontifikats Bonifaz' II. (530-532). Dagegen verweist Mommsen in der Vorrede zu der in den Monumenta Germaniae von ihm besorgten neuen Ausgabe des Papstbuches selbst die $\mathrm{Ab}$ fassung der ersten Redaktion in die erste Hälfte des 7. Jahrhunderts (Proleg. c. 1, p. Xvili), doch halten Duchesne (Mélanges d'archéologie et d'histoire XVIII $381 \mathrm{ff}$ ) wie P. Grisar (Analecta Romana, Romae $1899660 \mathrm{ff}$ ) an ihrer Datierung fest. Mit Recht. Wenn Mommsen (Proleg. p. xvi ) unter anderem darum will, dafi der älteste Teil des I. P. erst nach
Gregor d. Gr. entstanden sei, weil der L. P. den Papst Telesphorus sieben Fastenwochen anordnen läfst, Gregor aber erst sechs kennt, so ist zu erwidern, dak es bekanntlich auch nach Gregor bis jetzt in der römischen Kirche nie sieben Fastenwochen gegeben hat. Noch schwerer begreiflich ist aber, wie er (ebd.p. xvI) die ordinationes im Brief Gregors d. Gr. an Secundinus (1. 9, c. 147 [M. G. Epp. II 147]) als Weihen verstehen und daraus dann einen weiteren Beweis für seine Aufstellung herleiten konnte, da doch der richtige Sinn von ordinatio an jener Stelle evident ist. Ordinatio heißt dort nicht Weihe, sondern Verordnung, wie auch sonst in den Briefen Gregors (vgl. den Index ebd. II 570).

${ }^{3}$ Acta proconsularia c. 5 (Corp. SS. eccl. III, app. cxIII). 
gewöhnlichen Verkehr schon weit verbreitete, der Erhabenheit der gottesdienstlichen Verrichtungen so ganz entsprechende Dalmatik in Verwendung zu nehmen. Im Gegenteil mußsten die verhältnismäbig langen damaligen Friedensperioden, in denen es sogar nicht an Begünstigungen seitens einzelner Kaiser fehlte und das Christentum in den höheren Irreisen manche Anhänger gewann, notwendig darauf hinwirken, dafi, sich der Gottesdienst nach Möglichkeit mit der ihm gebührenden äuberen Würde und Zier vollzog. Gab es doch zu Rom im 3. Jahrhundert auch schon eine grofe Anzahl eigentliche öffentlich bekannte, wenn auch noch nicht staatlich als solche anerkannte Kirchen ${ }^{1}$. Dazu kommt, dafs wir wirklich bereits auf einem Katakombenfresko des 3. Jahrhunderts bei einem Bischof unter der Pänula (Kasel) eine dalmatikartige Tunika, um nicht zu sagen eine richtige Dalmatik antreffen. Es ist die Szene der Einkleidung einer gottgeweihten Jungfrau in S. Priscilla? Demnach ist es keineswegs so ganz unwahrscheinlich, dafie die Dalmatik schon im Laufe des 3. Jahrhunderts zu Rom beim Gottesdienst in Gebrauch kam, wenigstens beim Papste. Wenn daher Silvester I. wirklich die ihm im L. P. zugeschriebene Verordnung erlassen haben sollte, was in sich durchaus nichts Unmögliches enthält, so ist dieselbe wohl dahin zu deuten, dafs er durch sie den Gebrauch der Dalmatik auf die Diakone ausdehnte, um diese dadurch als die nächsten Ministri des Papstes vor den ührigen Klerikern auszuzeichnen. Ob freilich die Dalmatik schon in vorkonstantinischer Zeit ein eigentlich liturgisches Gewand war, falls sie damals wirklich heim Gottesdienst Verwendung fand, mub dahingestellt bleiben. Um das Ende des 4. Jahrhunderts dürfte sie aber wohl schon einen eigentlich sakralen Charakter hesessen haben. Die Art und Weise, wie der Verfasser der Quaestiones Novi et Veteris Testamenti von ihr spricht, scheint darauf hinzuweisen.

Träger der Dalmatik waren, wenn vielleicht nicht ursprünglich, so doch schon im 4. Jahrhundert zu Rom der Papst und die römischen Diakone, und zwar hatten nach römischer Auffassung nur sie das Recht, sich des Gewandes zu bedienen. Andere Bischöfe und andere Diakone bedurften dazu einer ausdrücklichen oder stillschweigenden Genehmigung des Papstes. Eine solche gab z. B. Papst Symmachus (498-514) den Diakonen des hl. Cäsarius von Arles ${ }^{3}$ und nahezu ein Jahrhundert später Gregor d. Gr. unter Beifügung von zwei römischen Originaldalmatiken dem Bischof Aregius von Gap, der ihn bei seiner Anwesenheit zu Rom darum gebeten hatte, für diesen selbst und seinen Archidiakont. Wir begegnen selbst noch um die Mitte des 8. Jahrhunderts einer Verleihung des Rechtes an auswärtige Diakone. In der Bulle nämlich, in welcher Abt Fulrad von St Denis 757 von Papst Stephan II. (752-757) die Erlaubnis empfängt, sechs Diakone beim Gottesdienst verwenden zu dürfen, erhalten diese Diakone zugleich die Ermächtigung, , allzeit bei Ausübung ihres Ministeriums das Ehrengewand der Dalmatik anzuziehen" 5.

1 Die Beweisstellen sind sehr gut zusammengestellt in Kirsch, J. P., Die christlichen Kultusgebåude in vorkonstantinischer Zeit, in "Festschrift zum elfhundertjährigen Jubiläum des deutschen Campo Santo", Freiburg 1897, 6 ff.

2 Abbildung in Wilp., Die gottgeweihten Jungfrauen Tft 1 und Wilp., Kat. Tfl 79. Warum man das Gewand des Bischofs nux als Ärmeltunika bezeichnet, die obere Tunika der Orans des Fresko und anderer Oranten aber als Dalmatik, will nicht recht einleuchten. Ich sehe dafür keinen genügenden Grund.

3 Vita S. Caesarii Arel. 1. 1, c. 4 (M. 67, 1016): Diaconos ipsius ad romanae instar ecclesiae dalmaticarum fecit habitu praeminere.

* Epist. 1. 9, ep. 107 (М. 77, 1034).

5 J. 276; M. 89, 1018: Congruum prospeximus... sex constituere diaconos, qui 
Es sind im ganzen nur einige wenige Fälle bekannt, in welchen auswärtigen Bischöfen und Diakonen die Erlaubnis gewährt wurde, sich der Dalmatik zu bedienen; sie sind ohne Zweifel nicht die einzigen, welche erfolgten, doch hat sich von den meisten alle Kunde verloren. Indessen hat man es auch zu Rom mit der Notwendigkeit einer ausdrücklichen Genehmigung zum Gebrauch der Dalmatik wohl schwerlich allzu streng genommen und manchmal als Tatsache hingenommen, was man ohnehin kaum hätte ändern können.

Welche Verbreitung der Gebrauch der Dalmatik bis etwa zum Ende des 6. Jahrhunderts bei auswärtigen Bischöfen und Diakonen gewonnen hatte, sei es unter stillschweigender Anerkennung der tatsächlich erfolgten Herübermahme des Gewandes, sei es mit ausdrücklicher Genehmigung seitens des Papstes, läst sich nicht bestimmen. Schon zu Ende des 4. Jahrhunderts mag sie manchenorts bei den einen wie den andern eingebürgert gewesen sein, wie vielleicht die früher angeführte Stelle aus den Quaestiones Veteris et Novi Testamenti andeutet. Fanden wir sie doch selbst bereits im 3. Jahrhundert beim lıl. Cyprian. Zu Mailand begegnet sie uns schon auf den dem 5. Jahrhundert entstammenden Mosaiken in der Kapelle des hl. Satyrus bei den Bildern der hll. Ambrosius (Bild 62, S. 158) und Maternus, zu Ravenna aber erst auf den kurz vor 550 entstandenen Mosaiken in S. Vitale bei dem Etsbischof Maximin und seinen Diakonen, woraus natürlich keineswegs folgt, dak sie daselbst erst im 6. Jahrhundert in Gebrauch genommen worden sei.

Man hat aus der Definition, welche Isidor von Sevilla in seinen Etymologien von der Dalmatik gibt: Dalmatica vestis primum in Dalmatia provincia Graeciae texta est, tunica sacerdotalis candida cum clavis ex purpura ${ }^{1}$, geschlossen, daf das Gewand schon damals eine so große Verbreitung bei den Bischöfen gefunden habe, daf der Heilige sie geradezu die „priesterliche Tunika" nenne ${ }^{2}$. Indessen läfst sich das aus den Worten des großsen Bischofs von Sevilla doch wohl keineswegs folgern. Noch weniger aber berechtigen sie zu dem Schluf, daf damals vielleicht auch schon Priester sich nach Weise der Bischöfe der Dalmatik bedient hätten.

In Spanien und Gallien entsprach der diakonalen Dalmatik im 6., 7. und 8. Jahrhundert eine Tunika, welche Alba genannt wurde. Sie

stolam dalmaticae decoris induantur, ut sic sacrum peragant omni tempore ministerium. Eine Bulle, in welcher Gregor III. (731-741) den Bischöfen Englands mitteilt, er habe Tatwin, dem Erzbischof von Canterbury, den Gebrauch der Dalmatik und des Palliums verliehen und zum Primas von Britannien bestellt, ist verdächtig; die Bulle des Papstes Zacharias $(741-752)$, in welcher dem Erzbischof Austrobert von Vienne das Recht gewäht wird, dils Gewand zu tragen, ist gefälscht.

1 Etymol. 1. 19, c. 22 (M. 82, 684).

2 Wilp., Gew. 39. Ob iiberhaupt Isidor von der diakonalen und bischöflichen Dalmatik spricht? ob er nicht vielmehr an ein Gewand des heidnischen Kultus bei seiner Erklärung des Wortes denkt? Es ist auffällig, daf er in seinen Etymologien sonst nirgends auch mü das feringste über die christliche Kultkleidung des Neuen Bundes verlauten läkt. Nan vergleiche tunica (1. 19, c. 22 ; ebd. 685), casula, planeta (c. 24 ; ebd. 691), stola, anaboladium (c. 25 ; ebd. $692 \mathrm{f}$ ), cingulum (c. 33; ebd. 702) und namentlich auch p a 11 i u m (c. 24; ebd. 689). Ganz fehlen sudarium, mappula, campagus, udo und, was besonders auffallend ist, a l b a und orarium. Unter solchen Umständen ist es offenbar sehr fraglich, ob Isidor bei sacerdotalis an ein Gewand des christlichen Kultus denkt. Um mit Sicherheit den Sinn der Stelle feststellen zu können, müliste man die Quelle kennen, aus der Isidor geschöpft hat. Im Itinerarium Hierosolymitanum n, 38 wird von einem sarazenischen Priester auf dem Berg Horeb erzählt, der mit einer Dalmatik and einem linnenen Pallium bekleidet war (Corp. SS. eccl. XXXIX 184) : Sacerdos ipsorum indutus dalmatica et pallium lineum (sic). 
findet in den Quellen aus dieser Zeit wiederholte Erwähnung. So ist bei Gregor von Tours († 594) in der Historia Francorum von einem Archidiakon die Rede, der am Weihnachtstage mit der Alba bekleidet den zur Kirche kommenden Bischof in Empfang nimmt und einladet, zum Altar zu gehen ${ }^{1}$ In der Vita S. Aridii begegnen uns Diakone, die in albis eine Bittprozession um Abwendung übermäbigen Regens abhalten. Die Synode von Narbonne vom Jahre 589 verordnet, es solle sich weder der Diakon noch der Lektor unterfangen, vor Ende der Messe die Alba auszuziehen ${ }^{3}$; der 41. Kanon der Statuta ecclesiae antiqua aber verbietet den Diakonen, die Alba anders als zur Zeit der Messe und Lesung, also aufierhalb der liturgischen Funktionen zu tragen ${ }^{4}$. Nach dem 28. Kanon der vierten Synode von Toledo war es in Spanien Brauch, den Diakonen bei ihrer Weihe aufier dem Orarium auch die Alba zu überreichen ${ }^{5}$. Demgemäls bestimmt die Synode in dem gleichen Kanon, es solle die Restitution eines etwa unschuldig abgesetzten Diakons durch die Zurückgabe beider Gewandstücke erfolgen. Auch Isidor von Sevilla erwähnt in seiner für die Folge so einflubreichen Schrift De ecclesiasticis? officiis im Kapitel, das von den Diakonen handelt, die diakonale Alba: Levitae altari albis induti assistunt ${ }^{6}$. Eine freilich sehr mangelhafte Beschreibung der Diakonalalba des gallikanischen Ritus gibt die unter dem Namen des hl. Germanus gehende Mefzerklärung. Wir erfahren daraus, dafs sie ron weilser Farbe sein mufste, aus Seide oder Wollstoff bestand und ungegürtet getragen wurde.

Die Alba war zweifelsohne ein eigentlich liturgisches Gewand. Der 12. Kanon der Synode von Narbonne und noch mehr der 41. Kanon der Statuta und der 28. Kanon der vierten Synode von Toledo bekunden das mit aller Bestimmtheit. Seit wann sie jedoch ihren sakralen Charakter besal, und seit wann sie überhaupt im Gebrauch war, läßst sich nicht feststellen.

Ein privilegiertes Gewand der Diakone, wie die römische Dalmatik, war diese Alba nicht. Sie kam auch den Lektoren zu, wie sich ans dem 12. Kanon der Narbonner Synode ergibt, und wich in Bezug auf ihre Farbe, Form und sonstige äufere Erscheinung von der subdiakonalen Tunika so wenig ab, dafo der 9. Kanon des zweiten Konzils ron Braga es den Diakonen einschärfen zu sollen glaubt, das Orarium über der Tunika zu tragen, weil man sie sonst nicht von den Subdiakonen unterscheiden könne ${ }^{\top}$. Wenn es eine Verschiedenheit zwischen der Alba der Diakone und derjenigen des niederen Kilerus gab,

1 L. 4 , c. 44 (M. 71, 306).

2 C. 8 (ebd. 1124).

${ }^{3}$ Can. 12 (H a rd. III 493).

4 Ebd. I 981. Über Alter und Herkunft der Statuta ecclesiae antiqua, bekannter unter dem Namen der Kanones des sog. 4. Konzils von Karthago, liegen manche Untersuchungen vor. Die Hauptarbeit ist die der Gebrider Ballerini im Appendix zu den Opera Leonis Mag. II, c. 3, $\$ 4$ (M. 56, 104 ff), welche sie als eine private Arbeit aus der zweiten Hälfte des 5. Jahrhunderts bezeichnen. Vgl. auch Hef., Concilien II 68. A. M a In ory nimmt dagegen die Statuta für Cåsarius von Arles in Anspruch und setzt ihre Entstehung in die Zeit von 502 bis 506 (Congrès scientif. internat. II, Paris 1888,428 ff), während J. Peters sie nach Spanien versetzt, wo sie in der ersten Hålfte des 5. Jahrhunderts zusammengestellt sein sollen (Congrès scientif. internat. II , Brüssel 1894, $220 \mathrm{ff}$; vgl. anch TübingerQuartalschrift $1896,693 \mathrm{ff})$. M a a ssen glaubt sich (Geschichte der Quellen und der Literatur des kanonischen Rechts, Graz 1870, 382 ff) für Arles als Ursprungsort und die zweite Hälfte des 5. Jahrhunderts als Entstehungszeit entscheiden zu sollen, P. H. Brewer aber weist die Statuta auf Grund neuerer, demnächst $\mathbf{z u}$ veröffentlichendex Forschungen Hilarius von Arles ( $†$ 449) zu und läßst sie um 441 geschrieben sein.

5 Hard. III 586.

${ }^{6}$ C. 8 (M. 83, 789).

7 Hard. III 351. 
so kann derselbe höchstens darin bestanden haben, daf man zur diakonalen Alba besseres Material, namentlich auch Seide nahm.

Auf den Monumenten tritt vor dem 9. Jahrhundert im ganzen nur selten die liturgische Dalmatik auf, weil Darstellungen von Bischöfen und Diakonen auf denselben bis dahin nicht häufig sind. Das früheste Bildwerk, auf dem sie uns begegnet, ist das schon genannte Mosaik in der Satyruskapelle bei S. Ambrogio zu Mailand mit den hll. Ambrosius und Maternus. Dann folgen die Mosaiken in S. Vitale zu Ravenna (Bild 63, S. 159) und S. Apollinare in Classe, Werke aus der Mitte und der zweiten Hälfte des 6. Jahrhunderts. In Rom lassen sich nach dem jetzigen Bestand der Denkmäler mit Sicherheit Darstellungen mit der liturgischen Dalmatik erst im 7. Jahrhundert nachweisen ". Die frühesten Beispiele bieten daselbst die Mosaiken in S. Agnese fuori le Mura und in der Kapelle des hl. Venantius bei der lateranensischen Taufkirche. Dort erscheinen Honorius I. (Bild 64, S. 160) and Symmachus, hier Johannes IV., sein Nachfolger Theodorus, die heiligen Bischöfe Venantius, Maurus, Domnio und der heilige Diakon Septimins im Schmuck der Dalmatik. Häufiger werden Darstellungen, auf denen sie auftritt, auch zu Rom erst im 9. Jahrhundert.

Von einem eigenartigen Brauch, der im 6. Jahrhundert zu Rom bestand, erfahren wir durch eine Bestimmung einer unter Gregor d. Gr. (ca 595) gehaltenen römischen Synode. Es hatte sich daselbst ex amore fidelium die Sitte eingebürgert, den Leichnam der verstorbenen Päpste auf dem Wege zur Begräbnisstätte mit Dalmatiken zu bedecken. Nach erfolgter Beisetzung zerriß das Volk dieselben, und die Stücke wurden dann als Reliquien pro sanctitatis reverentia unter die Gläubigen verteilt. Der Papst verbietet diesen Brauch als durchaus umpassend und verordnet aufs strengste, daf in Zukunft ïberhaupt keinerlei Decke auf die Bahre eines Papstes gelegt werden dürfe? Man wird wohl nicht fehlgehen, wenn man es der Bedeutung, welche die Dalmatik in Rom hatte, zuschreibt, daf man gerade zu dem genannten Zwecke die Dalmatik verwendete ${ }^{3}$. Auch bei der Bestattung von Diakonen kam es zu Rom vor, daf3 man üher die Bahre eine Dalmatik ausbreitete, wie aus einer Notiz im vierten Buche der Dialoge Gregors des Großen erhellt. Es wird dort nämlich berichtet, ein Besessener

1 Über die Fresken in S. Callisto, auf denen die hll. Kornelius, Cyprian, Sixius und Optatus unter der Planeta die Dalmatik tragen, vgl, oben S. 159.

${ }^{2}$ Hard. III 497: Praesenti decreto constituo, ut feretrum quo romani pontificis corpus ad sepeliendum ducitur, nullo tegmine veletur. Suam decreti mei curam gerere sedis huius presbyteros et diaconos censeo. Si quis vero ex eorum ordine haec curare neglexerit, anathema sit.

C. 40 (M. 77, 397). Wenn Li ell (Die Kirche des hl. Quiriakus zu T'ảben, Trier 1895, 46) die Sitte mit dem angeblichen Dekret des Papstes Eutychian (275-283): Ut quicumque fidelium martyrem sepeliret, sine dalmatica aut colobio purpurato nulla ratione sepeliret (D uch., L. P. I 159), in Zusammenhang bringt, so geschieht das ohne Grund, da ihr Zweck ein ganz anderer war. Bei jener Verordnung erscheint die mit Purpurstreifen besetzte Dalmatik als Erkennungszeichen der Märtyrereigenschaft des Toten, während auf die Bahre des Papstes Dalmatiken nur gelegrt wurden, um nachher in Stücke gerissen zu werden, die dann als Andenken aufbewahrt wurden. Aber auch
Liells Behauptung, nach Anfhebung der blutigen Verfolgung sei der Gebrauch, von dem das Dekret Eutychians redet, bei Bischöfen und Diakonen, die im Rufe der Heiligkeit gestorben waren, beibehalten worden, entbehrt einer genügenden Unterlage. Oder ist die römische Sitte, welche Gregor sich abzuschaffen veranlafit sah, und das vereinzelte Faktum, von dem derselbe in den Dialogen berichtet, wirklich schon ein Beweis? Erst recht unberechtigt ist es jedoch, wenn Liell den fraglichen Gebrauch als einen nicht bloß zu Rom, sondern auch anderswo herrschenden hinstellt (a. a. O. 19). Unzutreffend ist es endlich, wenn er meint, Papst Gregor habe den Gebrauch, über die Leichen von Bischöfen und Diakonen eine Dalmatik zu spreiten, wieder auf die Märtyrer beschränkt. Das Statut der römischen Synode sagt davon nicht das Geringste. Wohl spricht es von velamina a sacris corporibus apostolorum martyrumque, allein sind denn etwa diese Hülleu, welche man über die Gräber der Apostelfürsten - denn nur diese könmen gemeint sein - und der heiligen Märtyrer ausbreitete, mit den dalmaticae Eutychians ein und dasselbe? 
habe die Dalmatik berührt, welche auf der Bahre des zur Zeit des Papstes Symmachus (498-514) verstorbenen Diakons Paschasius gelegen habe, und sei alsbald geheilt worden.

\section{DER GEBRAUCH DER DALMATIK SEIT DEM IX. JAHRHUNDERT.}

Um das 9. Jahrhundert gehörte die Dalmatik ziemlich allgemein zum Bestand der liturgischen Gewandung, und es bedurften weder die Bischöfe noch die Diakone weiterhin einer besondern Ermächtigung, sie zu tragen, die einen als Obertunika unter der Kasel, die andern als das ihnen eigentümliche liturgische Obergewand. Dak sie sich bei den Diakonen allenthalben eingebürgert hatte, mag teilweise darauf zurïckzuführen sein, daf man das angebliche Dekret Silvesters I. als allgemein geltende liturgische Vorschrift auffafte, ein Standpunkt, auf dem natürlich von der Notwendigkeit einer speziellen Erlaubnis zum Gebrauch des Gewandes nicht die Rede sein konnte. In Gallien aber war die karolingische Reform auf die Verbreitung. welche die Verwendung der Dalmatik daselbst bei den Bischöfen und Diakonen gewonnen hatte, sicher nicht ohne Einfluf.

Um das zweite Viertel des 9. Jahrhunderts war der Gebrauch des Gewandes bereits so allgemein geworden, daf nach der Versicherung Walafried Strabos hie und da selbst Priester dasselbe unter der Kasel tragen zu diirfen glaubten ${ }^{1}$. Wirklich sind auf dem Widmungsbild der Bibel Karls des Kahlen alle Mönche von St Martin zu Tours mit einer einzigen Ausnahme - einer ist nämlich als Diakon gekleidet -- in Dalmatik und Kasel dargestellt, obschon doch keiner von ihnen Bischof war (Titelbild).

Zu Rom war es jedoch noch keineswegs Brauch, daf Priester sich der Dalmatik bedienten. Hatten ja, wie aus dem S. G. K. hervorgeht, dasellost nicht einmal die sieben Hebdomadar- oder Kardinalhischöfe, d. i. die Bischöfe der sieben suburbikarischen Diözesen, welche an den Wochentagen in Vertretung des Papstes in der Laterankirche abwechselnd den Dienst versahen und bei den feierlichen päpstlichen Messen assistierten, bis ins 9. Jahrhundert hinein das Recht, sie zu tragen. Der Grund hierfür lag ohne Zweifel im Bestreben, diese bei ihren Funktionen von dem Papst durch die Kileidung hesser zu unterscheiden. An Stelle der Dalmatik waren sie deshalb blof mit einer tunica alba, wie der S. G. K. sagt, bekleidet, d. i. mit einer Tunicella. Indessen trugen sie die Dalmatik wohl nur zu Rom nicht, während sie in ihren eigenen Diözesen sich derselben sicher bedienen durften, da ja hier der Grund wegfiel, um dessentwillen sie zu Rom ohne das Gewand zu amtieren hatten. Sie waren also keineswegs vollständig von dem Gebrauch der Dalmatik ausgeschlossen. Ebendarum aber wurden auch sie wie alle andern Bischöfe bei ihrer Konsekration mit dieser bekleidet?. Übrigens mag sich

1 De rerum eccl. exordio et increm. c. 24 (M. 114, 952): Ubi intelligitur, non omnibus tune fuisse concessum, quod nunc pene omnes episcopi et nonnulli presbyterorum sibi licere existimant, id est, ut sub casula dalmatica vestiantur.

2 Ordo 9, n. 4 (M. 78, 1005). Der Weiheordo, wie er sich hier findet, ist ganz allgemeinen Charakters und galt daher zweifelsohne auch bezüglich der suburbikarischen Bischöfe. Es liegt kein Grund vor, seine
Geltung einzig auf die übrigen Bischöfe der römischen Kirchenprovinz und auf Bischöfe anderer Provinzen, deren Weihe zu Rom statthatte, zu beschränken. Wenn der Ordo die Anweisung gibt, den Consecrandus vor der heiligen Handlung unter anderem auch mit der Dalmatik zu bekleiden, und zwar nicht blof mit der dalmatica ninor, der tunica alba des S. G. K, sondern auch der dalmatic. maior, der eigentlichen Dalmatik, so stand dem auch bei den Kardinalbischöfen niclits 
schon zeitig im 9. Jahrhundert die Sache dahin geändert haben, daf die Suburbikarbischöfe auch zu Rom die Dalmatik trugen.

Seit welcher Zeit die römischen Kardinalpriester von der Dalmatik Gebrauch machen durften, ist nicht genau festzustellen. Um den Beginn des 11. Jahrhunderts waren sie sicher schon im Besitz dieses Privilegs. Denn in dem Schreiben Klemens' II. an den Abt von Fulda aus dem Jahre 1046 sagt der Papst ausdrücklich: Dalmaticas nostri cardinales presbyteri ferunt ${ }^{1}$, und als Viktor II. 1057 den Kardinalpriester Friedrich von Lothringen zum Abt von Monte Cassino machte, verlieh er ihm zwar nochmals das Recht, die Sandalen und die Dalmatik zu gebrauchen, bemerkte jedoch dabei, dafo der Neuernannte dasselbe eigentlich bereits vom Apostolischen Stuhl iure cardinalatus empfangen habe2. Wie es scheint, datiert die Ingebrauchnahme des Gewandes seitens der Kardinalpriester etwa aus der ersten Hälfte des 10. Jahrhunderts. Denn bald nach 950 beginnen die Verleihungen des Privilegs an Äbte und an auswärtige Kardinalpriester.

Das früheste bekannte Beispiel einer Erteilung des Privilegs an Äbte fällt in die Zeit Johannes' XIII. (965-972), welcher 970 dem Abt des Klosters vom hl. Vinzenz zu Metz auf Ansuchen des Bischofs Theodorich Dalmatik und Sandalen ver-

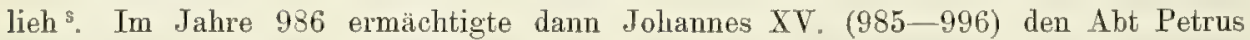
des Klosters S. Pietro in Celo d'oro zu Pavia, 994 aber den Abt Hatto von Fulda, sich der Dalmatik zu bedienen *. Gregor V. (996-999) gewährte 998 das Privileg dem Abt Alarich von Reichenau und seinen Nachfolgern auf Bitten Kaiser Ottos ${ }^{5}$, Leo IX. (1049-1054) 1050 dem Abt Fulco von Corbie, 1054 dem Abt Albuvinus von Nienburg anf Fürsprache des Abtes Richerius von Monte Cassino ․ Viktor II. (1055-1057) 1057 dem Abt Friedrich von Monte Cassino ${ }^{7}$, Nikolaus II. (1058-1061) dem Abt Desiderius daselbst ${ }^{8}$. Alexander II. (1061-1073) begabte mit dem Recht, die Dalmatik zu gebrauchen, 1063 den Abt Egelsinus vom St Augustinuskloster zu Canterbury und 1069 den Abt Reinbert von Echternach ${ }^{9}$, Urban II. (1088-1099) 1088 den Abt Hugo von Cluny ${ }^{10}$, Paschalis II. (1099-1118) 1102 den Abt Anselm von S. Pietro in Celo d'oro zu Pavia ${ }^{11}, 1109$ den Abt Pontius von Cluny, 1113 den Abt Johannes von Nonantula und 1114 den Abt von S. Michele della Chiusa ${ }^{12}$. Weitere Verleihungen begegnen uns bis zum letzten Viertel des 12. Jahrhunderts unter Honorius II. (1124 bis 1130), Eugen III. (1145-1153), Alexander III. (1159-1181) und den Gègenpäpsten Anaklet II. (1130-1138), Viktor II. (1159-1164), Paschalis III. (1164 bis 1168) und Calixt III. (1168-1178). Bei allen diesen Privilegien handelt es sich übrigens nie um die Dalmatik allein, sondern stets zugleich um andere Teile des Pontifikalornates. Bis ca 1050 sind es Dalmatik und Sandalen, deren Gebrauch den

im Weg, denen es ja nach dem oben Gesagten nur verwehrt war, zu Rom in Vertretung des Papstes oder als dessen Assistenten die Dalmatik zu tragen, nicht aber, sich threr in der eigenen Kathedrale zu bedienen. Wegen des 9. Ordo vgl. neuerdings J. Kösters, Studien zu Mabillons römischen Ordines, Münster 1905, 25 ff, dessen Ausführungen jedoch sowohl in Einzelheiten wie in ihren Ergebnissen meines Erachtens teils nicht genug begrundet teils unzutreffend sind. Von großem Nachteil für die Untersuchung war, dak der Verfasser sich nicht über das Alter der Handschriften in der Stiftsbibliothek zu St Gallen, welche den 9. Ordo enthalten, vergewisserte. Es mufte das den unumgänglich notwendigen Ausgangspunkt dexselben bilden.
1 J. n. 4134 .

2 Ebd.4368. Ähnlich in der Bulle Nikolaus'II. für den Abt Desiderius von Monte Cassino (ebd. 4397). Daf in den angeführten Stellen nur von den Kardinalpriestern die Rede ist, nicht von den Kardinalbischöfen, liegt daran. daf es sich in den fraglichen Verleihungen nur um eine Erteilung des Privilegs, die Dalmatik zu gebrauchen, an Priester handelte.

3 Ebd. n. 3741.

4 Ebd. n. $38263853 . \quad 5$ Ehd. n. 3880.

${ }^{6}$ Ebd. n. $42124335 . \quad 7$ Ebd. n. 4368.

8 Ebd. n. 4397; M. 143, 1306.

3 J. n. $45414667 . \quad 10$ Ebd. n. 5372.

11 Ebd, n. 5891; vgl, auch die Erneuerung des Privilegs im Jahre 1105 (ebd. n. 6011).

12 Ebd. n. 624263546385. 
Äbten gestattet wird; dann gesellen sich zu denselhen Mitra und Handschuhe odler die Mitra bzw. die Handschuhe allein. Einige Bullen enthalten eine genaue Angabe der Tage und der Gelegenheiten, für welche den Adressaten die Erlaubnis gegeben wird, die Dalmatik zu tragen, die meisten schweigen jedoch darüher, wahrscheinlich, weil die Regeln für den Gebranch des Gewandes als bekannt vorausgesetzt wurden. Als Anlaf für die Erteilung des Privilegs wird in den Bullen bald das Verdienst des Empfängers, bald die von diesem gestellte Bitte um Gewährung jenes Vorrechtes, bald die ihm von einflufreichen Persönlichkeiten zu teil gewordene Empfehlung oder ähnliches bezeichnet.

Die erstbekannte Erteilung des Rechts, die Dalmatik zu tragen, an Kardinalpriester auswärtiger Kathedralen fällt in das Pontifikat Benedikts VII., welcher 975 den Kardinalpriestern von Trier für den Fall, dafs sie dem Erzbischof beim Pontifikalamt Assistenz leisteten oder in seiner Vertretung als Hebdomadare im Dom zelebrierten, gestattet, sich dabei der Dalmatik und der Sandalen zu bedienen '. Eine Bulle, in welcher Benedikt VIII. (1012 - 1024) 1012 den zwölf Kardinalpriestern von Magdeburg den Gebrauch der Dalmatik erlaubt, unterliegt hinsichtich ihrer Echtheit einigen Bedenken ${ }^{2}$. Leo IX. (1049-1054) erneuerte 1049 dem Erzbischof Eberhard von Trier das Privileg, welches Benedikt VII. dessen Vorgainger Theodorich für seine Kathedrale gegeben hatte ${ }^{3}$; den Kardinalpriestern von Besançon aber erlaubte er nicht nur, sondern gebot er 1051 sogar, die Dalmatik zu tragen, wenn sie an den Festen des Herm, der Mutter Gottes, des Erzengels Michael, der Apostel, des Erzmärtyrers Stephanus und einiger anderer Heiligen, sowie am Allerheiligen- und Kirchweihtage an dem von ihm selbst am 3. Oktober 1050 geweihten Hochaltar der dortigen Kathedrale zelebrierten ${ }^{4}$. Eine Bulle, in welcher Leo IX. für die Kölner Kathedrale sieben Kardinalpriester verordnet und denselben zugleich gestattet, Festtags an den beiden Hauptaltären der Kirche mit der Dalmatik bekleidet

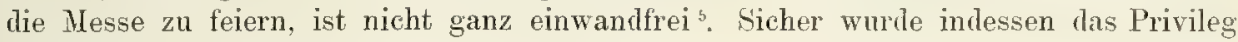
100 Jahre später dem Erzbischof Arnold durch Eugen III. (1145-1153) für seine Kathedrale gegeben ${ }^{6}$.

Fassen wir das Gesagte kurz zusammen, so ergibt sich als Praxis im 11. Jahrhundert: die Dalmatik ist das liturgische Obergewand der Diakone; ebenso bildet sie allgemein einen Bestandteil der Pontifikalkleidung der Bischöfe. Von den Priestern haben nur die römischen Kardinalpriester de iure ein Recht, nach Weise der Bischöfe unter der Kasel die Dalmatik zu tragen. Andere Priester dürfen solches nur kraft besonderer Ermächtigung seitens des Apostolischen Stuhles. Es ist das die Praxis, welche von da an für alle Folgezeit bis in die Gegenwart hinein in Geltung bleiben sollte. Sie ist der Abschluf einer langsamen, durch manches Jahrhundert sich hindurchziehenden Entwicklung.

Eine Insignie, d. i. das Abzeichen des Ordo, war die Dalmatik nie. Sie hätte das ja auch nur bei den Diakonen sein können. Nun aber erscheint sie niemals als diakonales Abzeichen. Das ist vielmehr schon zur Karolinger-

1 Ebd. n. 3783.

${ }^{3}$ Ebd. n. 4161.

4 Ebd. n. 4249; M. 143, 668.

J. n. 4271. J. hält den die Kaiserkrönung betreffenden Passus für eingeschoben, das übrige für echt, andere (vgl. J. a. a. O.) bezeichnen die ganze Bulle als unecht. J.s Ansicht dürfte den Vorzug verdienen. Wäre die Bulle Leos IX. nur eine Bearbeitung der Bulle Eugens III., so versteht man nicht, warum die Fälscher unterlieken, auch die Mitra aufzunehmen, die in letzterer den sieben Braun, Die liturgische Gewandung.
Kardinalpriestern verliehen wird. In einer Bulle Leos IX. aber paft das Fehlen der Nitra sehr gut. Auferdem ist es schwer begreiflich, daf Eugen noch 1152 sieben Kölner Diakonen und Subdiakonen das Recht gewährt, die Sandalen zu tragen, wenn diese sich nicht bereits infolge eines älteren Privilegs jenes Vorrechts erfreuten und sonach Eugens Bulle nur Bestätigung eines älteren Privilegs war. Eine erstmalige derartige Verleihung ist für $1152 \mathrm{zu}$ ungewöhnlich

${ }^{6}$ Ebd. n. 9515; M. 180, 1487. 
zeit die Stola. Die Dalmatik war lediglich ein liturgisches Gewand, wie z. B. die Kasel der Priester und die Pontifikalschuhe der Bischöfe und die Tunicella der Subdiakone. Wohl war und ist es mit Ausnahme der Bischöfe und Kardinäle de iure keinem andern als den Diakonen gestattet, sich der Dalmatik zu bedienen ${ }^{1}$, indessen ist nicht jedes privilegierte Gewand auch schon eine Insignie. Aber auch in der vorkarolingischen Zeit war die Dalmatik kein Abzeichen des diakonalen Ordo. Wohl betrachtete man sie anfänglich zu Rom als Vorrecht der römischen Diakone, doch nur in dem Sinne, wie überhaupt ein auszeichnendes Gewand ein Vorrecht bildet. Es verhielt sich mit der Dalmatik ähnlich wie mit gewissen modernen auferliturgischen Gewandstücken, z. B. dem Rochett, der Mozetta und der Cappa. Sie sind privilegierte Gewänder bestimmter hervorragender Geistlichen, aber nicht auch Insignien derselben. Auferdem aber war die Dalmatik zu keiner Zeit ein den Diakonen allein und ausschlieflich zukommender Ornat, den niemand sonst besessen hätte. Wenn man daher auf die Bahre des Diakons Paschasius dessen Dalmatik legte 2 , so beweist das noch keineswegs, daf diese als Abzeichen des diakonalen Ordo betrachtet wurde. Bildete sich ja im 6. Jahrhundert auch der Brauch, auf die Bahre der Päpste eine Dalmatik auszuspreiten, und doch war diese zu keiner Zeit päpstliche Insignie.

\section{BESCHAFFENHEIT DER DALMATIK IN VORKAROLINGISCHER ZEIT.}

Die Dalmatik erscheint auf den Monumenten der vorkarolingischen Zeit stets als eine lange, mit weiten Ärmeln ausgestattete Tunika. So schon auf

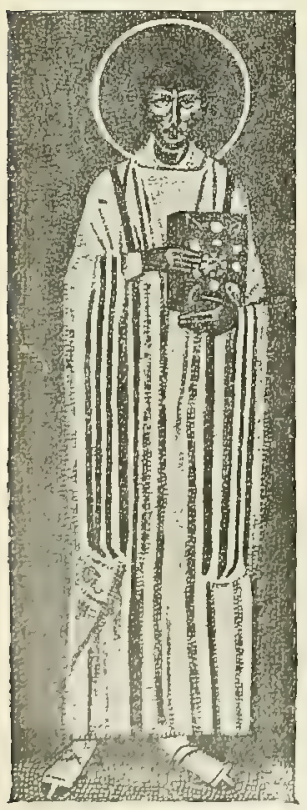

Bild118. HL. Septimius. Mosaik.

Rom, S. Venunzo. dem früher erwähnten Fresko in S. Priscilla, so später auf dem Mosaik in S. Satiro zu Mailand, so auf den ravennatischen Mosaiken des 6. und den römischen Mosaiken des 7. Jahrhunderts (Bild 118). Ein Unterschied zwischen der Dalmatik der Diakone und Bischöfe ist nicht $\mathrm{zu}$ bemerken. Sie ist bei beiden ganz dasselbe Gewand.

Die Weite der Ärmel muß sehr bedeutend gewesen sein. Auf den musivischen Darstellungen in S. Venanzo zu Rom kommt ihre vordere Breite nahezu der halben Länge des Gewandes, ihr Gesamtumfang also beinahe dessen ganzer Länge gleich. Ebenso verhält es sich auf dem Mosaik in S. Satiro zu Mailand (Bild 62, S. 158). Dagegen sind auf den ravennatischen Mosaiken die Ärmel der Dalmatik etwas enger, wenngleich auch hier ihre Weite sich noch wenigstens auf ein Drittel der Gewandlänge beläuft.

Was die Farbe betrifft, so ist die Dalmatik auf den Bildwerken der vorkarolingischen Zeit stets weif. Eine Ausnahme bildet nur die Darstellung des hl. Ecclesius auf dem Apsismosaik in S. Vitale zu Ravenna, auf welcher das Gewand mit farbiger, aus Kreisen bestehender Musterung versehen ist. Indessen ist dieses hier in seiner jetzigen Gestalt nicht mehr ursprünglich, sondern das Ergebnis einer im

1 Priester tragen natürlich die Dalmatik, wenn sie an Stelle von Diakonen fungieren, aber dann auch nur die Dalmatik.

2 S, oben S. 254. 
12. Jahrhundert vorgenommenen Restauration. Seine ganze Beschaffenheit läßst daran keinen Zweifel. Die Dalmatik ist nämlich auch noch in anderer Beziehung sehr auffällig und befremdend. Sie ist sehr kurz, kaum daf sie unter der Planeta hervorkommt, am Saum ungewöhnlicherweise mit breiter Borte versehen und an der rechten Seite der Vertikalbesätze mit roten Fransen geschmi̊ckt, alles Dinge, die mit Sicherheit auf eine spätere Restauration hinweisen ${ }^{1}$. Wie die Dalmatik zu Ravenna im 6. Jahrhundert aussah, zeigt die Darstellung des Bischofs Maximian und seiner Diakone auf der Seitenwand des Chores von S. Vitale (Bild 63, S. 159).

Über den Stoff, aus dem die Dalmatik gemacht zu werden pflegte, können die Monumente natürlich keine Auskunft geben. Es fehlt aber darïber für die uns beschäftigende Periode auch an genügenden sonstigen Angaben. Im gewöhnlichen Leben waren um die Wende des 4. Jahrhunderts die Dalmatiken, wie der Maximaltarif Diokletians zeigt, aus Leinwand, Wolle oder Halbseide gemacht. Später, als die Seide häutiger und billiger geworden war, hat es jedenfalls auch ganzseidene profane Dalmatiken gegeben. Auch bei der liturgischen Dalmatik wird ursprünglich Leinwand oder feiner Wollstoff die Regel gewesen sein, später wurde indessen sicher auch Seide zu ihrer Anfertigung verwendet. In demselben Maßse, in welchem die Kirche über größere Mittel verfügte und das Ansehen und die Stellung des Klerus nach aufen sich hob, mußste ja auch der Glanz, mit dem man die Feier des Gottesdienstes umgab, und der Reichtum der liturgischen Gewandung zunehmen. Es ist bemerkenswert, dafi im 8. Jahrhundert zu Rom die untere Dalmatik den Namen dalmatica linea führte? Die obere Dalmatik, d. i, die Dalmatik im eigent-

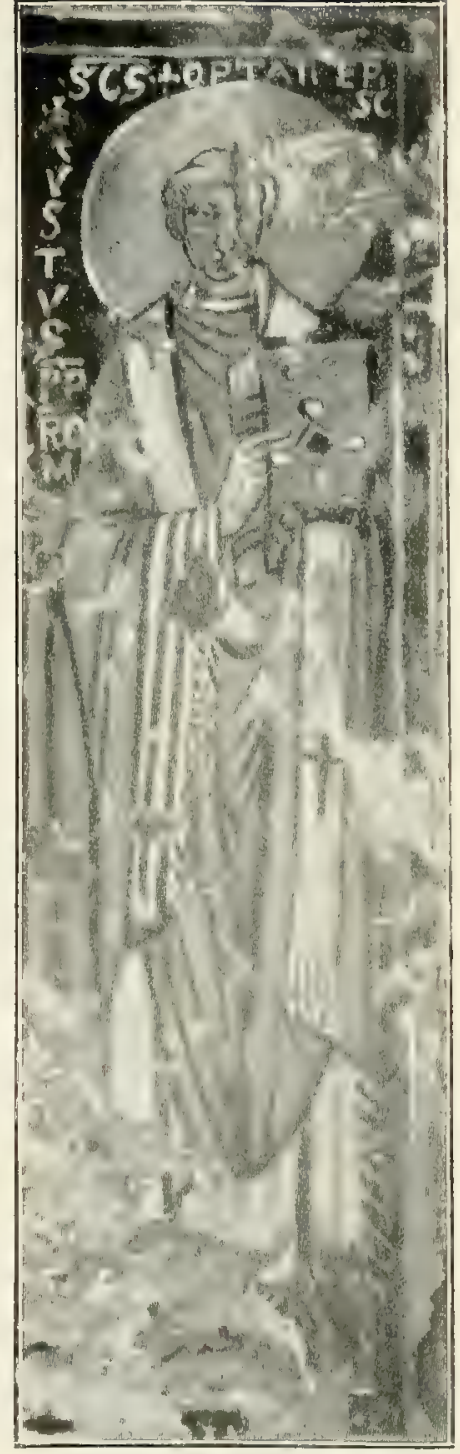

Bi]d 119. Der hl. Optatus. Rom, Callistuskatakombe, lichen Sinne, wird daher schon damals für gewöhnlich nicht aus Linnen, sondern entweder aus Wolle oder aus Seide angefertigt worden sein.

Die Verzierung der Dalmatik bestand, wie es scheint, ursprünglich nur in den sog. Clavi und in Besätzen am Saum der Ärmel, später aber auch in Fransen, welche teils am Ärmelrand teils unten an der Seite des Gewandes angebracht wurden. Die Clavi waren zwei schmale, über die Vorder- und Rückseite der Dalmatik von den Schultern bis zum Saume verlaufende Vertikalstreifen. Sie sind auf den ältesten Monumenten von dunkler, an tiefes Violett erinnernder Farbe, auf späteren Darstellungen dagegen rot. Rote

1 S. unten im Kapitel Stola, Abschn. 3.

2 Ordo 1, n. 6 (M. 78, 940); vgl. ordo 3 , n. 6 (ebd. 978). Wegen der muteren [h]. matik, gewöhnlicher Tunica, vgl. S. $2: 4$. 
Clavi begegnen uns zuerst auf den Mosaiken in S. Venanzo, jedoch nur auf der Dalmatik der hll. Tenantius und Domnio. Bei den übrigen sind sie von schwärzlichblauer oder braungrauer Farbe.

Die Zierstreifen, welche den Ärmelsaum umziehen, setzen sich in der Regel aus zwei schmalen, nahe nebeneinander stehenden Streifen zusammen. Fransen hegegnen uns schon auf dem Mosaik in S. Venanzo bei den Figuren Johannes IV. und des hl. Domnio. Sie sind hier unten links an der Dalmatik angebracht und dienten, wie in späterer Zeit, zweifelsohne als Abschluk der Ränder eines Schlitzes, mit dem man dort behufs Erleichterung des Anziehens das Gewand zu versehen pflegte. Eine ausgiebigere Verwendung mögen die Fransen erst gegen Ende des 9. Jahrhunderts gefunden haben. Eine bestimmte Regel scheint für ihre Anbringung nicht bestanden zu haben, wenigstens

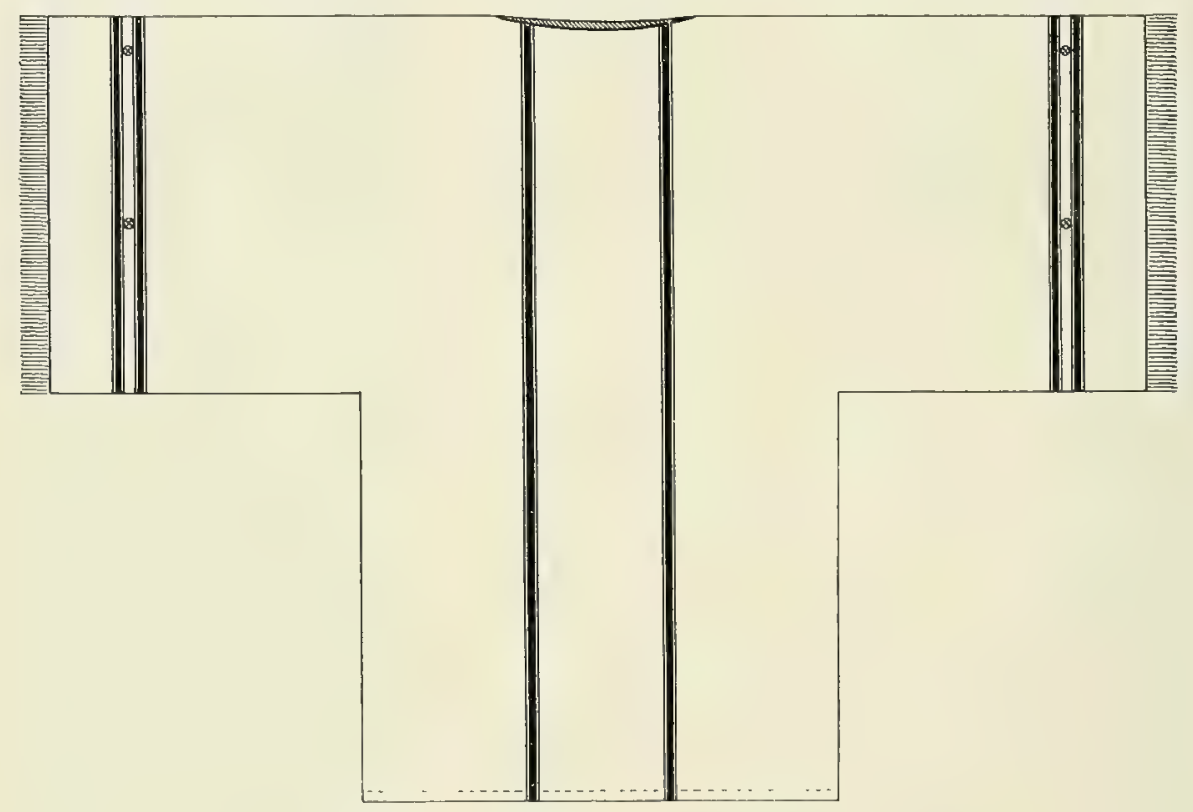

Bild 120. Dalmatik. Moyen-Moutier.

finden sie sich auf den bildlichen Darstellungen bald an der rechten, bald an der linken Seite des Gewandes. Fransen am Ärmelsaum kommen bei dem Bild des hl. Optatus auf dem Wandgemälde der vier heiligen Bischöfe in S. Callisto vor (Bild 119, S. 259); auf den römischen Mosaiken begegnen wir ihnen erst im 9. Jahrhundert. Die Ärmelfransen auf dem Fresko in S. Callisto dürften ein Anzeichen sein, dab dieses später als im 6. Jahrhundert entstanden ist.

Eine treffliche Mllustration zum Gesagten liefert eine zu Moyen-Moutier aufbewahrte Dalmatik, welche von den einen dem hl. Hildulf $(\dagger 707)$, von andern dem hl. Leodegar $(\dagger$ 678) zugeschrieben wird, jedenfalls aber spätestens aus dem 8. oder 9. Jahroundert stammt. Das Bild, welches das Gewand bietet, ist im wesentlichen dasselbe, welches uns die Mosaiken von S. Venanzo und S. Vitale von der Dalmatik gewähren (Bild 120).

Das Gewand ist 1,40 m lang, oben bei ausgestreckten Ärmeln 1,95 m, unten $0,92 \mathrm{~m}$ breit. Die Länge der Ärmel beträgt $0,515 \mathrm{~m}$, ihre Weite $0,67 \mathrm{~m}$. An den Ärmelsaiumen sind Fransen angehracht; auferdem umziehen dieselben ca $10 \mathrm{~cm}$ vom 
Rand entfernt zwei rote, $0,014 \mathrm{~m}$ breite, zu beiden Seiten von einer roten Linie begleitete Streifen, zwischen denen vereinzelte, mit einer kreuzartigen Verzierung im Innern versehene Kreise angebracht sind. Die clavi werden durch einen roten Mittelstreifen von $0,014 \mathrm{~m}$ Breite, der rechts und links von einem ganz schmalen roten Streifchen eingefafst ist, gebildet. Clavi und Ärmelbesätze sind von Seide 1.

Die Dalmatik von Moyen-Moutier ist für die Geschichte der Dalmatik um so wichtiger, als sie in ihrer Art einzig dasteht.

Möglich allerdings, daß auch noch die 1833 im Schrein des hl. Quiriakus zu Taben an der Saar aufgefundene Dalmatik bis ins 8. Jahrhundert hinaufreicht. Sie besteht aus weifer, durch Alter vergilbter Seide mit einer technisch wie zeichnerisch gleich interessanten Vusterung. Ihre Länge betrïgt $1,42 \mathrm{~m}$, die Breite anf den Schultern $0,73 \mathrm{~m}$, am Saum $0,92 \mathrm{~m}$. Über Vorder- und Rückseite ziehen sich zwei schmale, aus roter Seide geschnittene und dem Gewandstoff anfgenähte Vertikalbesätze. Die Ärmel fehlen gegenwärtig. Vielleicht, daßs sie abgetrennt wurden, als man das Gewand als Decke der Reliquien des Heiligen in dessen Schrein legte. Dafs sie ursprünglich vorhanden waren, dentet der Schnitt des nach oben zu sich verjüngenden Gewandes genugsam an ${ }^{2}$.

\section{BESCHAFFENHEIT DER DALMATIK VOM IX. JAHRHUNDERT BIS ZUM SPÄTEN MITTELALTER.}

Im 9. Jahrhundert macht sich in Bezug auf die Form des Gewandes zu Rom noch keine Veränderung bemerkbar, gleichviel ob es sich um die diakonale oder pontifikale Dalmatik handelt. Wie die Mosaiken in S. Marco zu Rom, S. Prassede und S. Cecilia zeigen, hat es überall noch dieselbe Weite, dieselhe Länge und dieselbe Breite der Ärmel wie vordem. Auch in der Folge erweist man sich zu Rom und überhaupt in Italien noch lange Zeit sehr konservativ. Die Miniaturen, zumal ile der Exsultetroteh des 11. mnd 12, Jahrhunderts, die Fresken der Unterkirche von S. Clemente und andere Monumente legen hierfür reichlich Zeugnis ah. Erst im 12. Jahrhundert treten vereinzelte leise Spuren einer beginnenden systematischen Verkïrzung des Gewandes auf.

Etwas anders als im Süden vollzieht sich die Entwicklung des Gewandes im Norden. Hier erfährt es schon im 9. Jahrhundert eine deutlich

1 Journal de la Société darchéologie lorraine Jahrg. 1854, $101 \mathrm{ff}$. Über Gewandfragmente aus rotem, taffetartigem, dïnnem Seidenstoff in S. Ambrogio zu Miiland, welche als Reste einer Dalmatik des hl. Ambrosius bezeichnet werden, vgl. Revue 1899, 307. Ein friherer, mehrach abweichender Bericht ebendort 1860,652 . Schon im 11. Jahr hundert glaubte man in S. Ambrogio die Dalmatik des hl. Ambrosius zu besitzen. Ob die Fragmente, welche Form und Schnitt des Gewandes nicht mehr erkennen lassen, wirklich von dem Heiligen herrühren, mußs auf sich beruhen bleiben. Von einer beim Gottesdienst von ihm gebrauchten Dalmatik stammen sie indessen nicht, da die liturgische Dalmatik bis ins 10. Jahrhundert hinein stets vou weifser Farbe war.

${ }^{2}$ Liell, Die Kirche des hl. Quiriakus zu Taben, Trier 1895, 38 ff mit Skizze der Dalmatik und vortrefflicher Abbildung des Stoffmusters.
Der Verfasser sieht in dem Gewand ein altchristliches Kolobion (ärmellose Tunika) aus dem 4. Jahrhundert. Was er jedoch an Beweisen für seine Ansicht vorbringt, hält einer ruhigen Prüfung keinen Stand. Eine angebliche Dalmatik des hl. Lambertus in der Liebfrauenkirche zu Mastricht ist erst in jüngster Zeit in eine Dalmatik umgetauft worden. Vordem hief3 sie Superpelliceum des hl. Lambertus. Die ältesten Nachrichten über das Gewand reichen nicht über die Neuzeit hinaus. Clavi und Zierbesätze fehlen. Der Stoff, eine Art gemusterter Gaze, ist nach Musterung wie Technik ein Unikum; eine sichere Datierung des Gewandes ist nicht nöglich, es scheint indessen verhältnismäfig jungen Ursprungs zu sein. Wir wïrden nicht wagen, es dem hl. Lambertus wirklich zuzuschreiben. Abbildung und genawe Beschreibung bei $\mathrm{B}$ ra un, Die Dalmatiz des hl. Lambertus (Zeitschrift 1899, 375ff). 


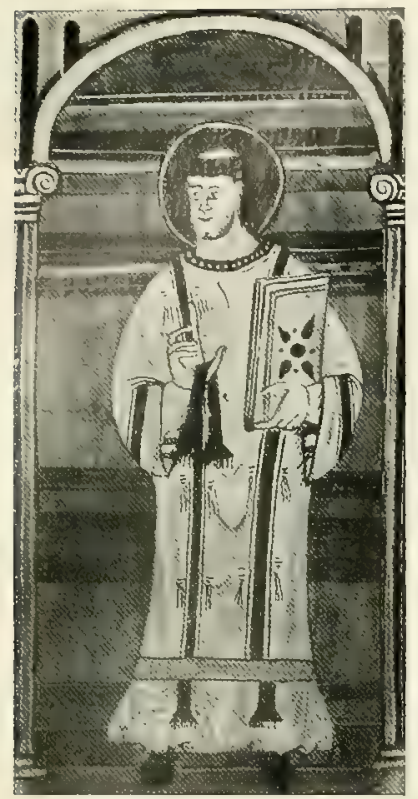

Bild 121. St Laurentius. Miniatur eines Tropars von Prủm. Paris, Bibl. Nat.

wahrnehmbare Verringerung seiner Länge. Man vergleiche z. B. das Widmungsbild in der Bibel Karls des Kahlen (Titelbild), die Miniaturen des Sakramentars von Autun (Weihestufen und der hl. Gregor der Große), die Bischofsbilder im Metzer Kanon ${ }^{1}$ u. a. Am frühesten begann man bei der bischöflichen Dalmatik mit der Verkürzung. Bei der diakon alen hielt man, wie es scheint, an der alten Form etwas zäher fest, doch betrat man auch bei ihr nur zu bald den gleichen Weg. So ist z. B. bereits auf dem unter Erzbischof Angilbert (824-860) angefertigten Mailänder Palliotto, der Arbeit des fränkischen Mönches Wolvinius, bei dem Diakon die Dalmatik merklich verkürzt. Im 10. Jahrhundert muf nicht bloß bei der Dalmatik der Bischöfe, sondern auch bei der Diakonendalmatik im Norden das Zustutzen bereits sehr um sich gegriffen haben, um nicht zu sagen, allgemein üblich gewesen sein. Die Darstellungen auf dem im Grab des hl. Kuthbert zu Durham gefundenen Manipel, einer Arbeit aus der Frühe des 10. Jahrhunderts ${ }^{2}$, Miniaturen des Tropars von Prüm in der Pariser Nationalbibliothek (Bild 121) und andere Bildwerke bekunden das zur Genüge. Überall kommt auf ihnen unter der Dalmatik mehr oder weniger die Albe zum Vorschein. Auch sind schon die Ärmel von geringerer Weite, als es noch auf den Monumenten des 9. Jahrhunderts der Fall zu sein pflegt.

Übrigens war die Veränderung, welche die Dalmatik im Norden erfuhr, nach Ausweis der Bildwerke noch im 11., ja 12. Jahrhundert im ganzen wenig bedeutend und blof ein Anfang. Erst gegen Ausgang des letzteren wurde sie erheblicher.

Eine auf Bildwerken des 12. Jahrhunderts häufige Eigentümlichkeit der Dalmatik besteht in Ausschnitten, welche seitlich unten an Stelle bloßer Schlitze bei ihr angebracht erscheinen. Sie schliefsen oben bald geradlinig, bald mit einer Rundung $a b$ und sind regelmäfrig mit breiten Borten eingefafst. Diese Einrichtung findet sich fast ausschlieblich auf deutschen, französischen und englischen Monumenten. Eines der ältesten Bildwerke, auf denen die Dalmatik mit jenen Ausschnitten ausgestattet erscheint, ist eine Miniatur des etwa um die Mitte des

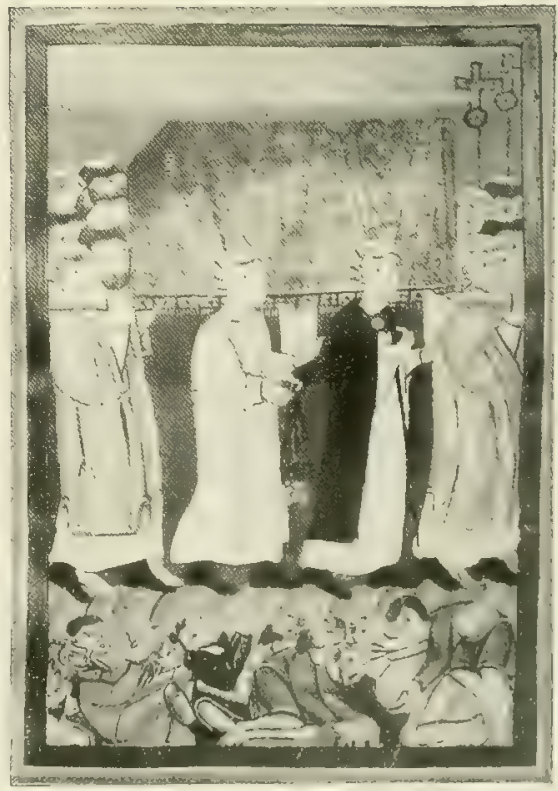

Bild 122. Translation der Reliquien des hl. Stephanus. Miniatur eines Evangeliars. Brüssel, kgl. Billiothel.

1 Abbildung in Farben hei Louandre pl. $x$ v.
2 Abbildung bei Roh. Vll, pl. Dxxxi, wo der Manipel irrig als Stola bezeichnet ist. 
11. Jahrhunderts entstandenen Echternachter Evangeliars in der kgl. Bibliothek zu Brüssel. Sie stellt die Übertragung der Reliquien des hl. Stephanus dar. Die Ausschnitte der Dalmatik sind hier noch gering (Bild 122).

Monumente aus der Wende des Jahrhunderts, auf denen sie bei dem Gewand vorkommen, sind ein Tragaltar im Dom zu Paderborn ", eine Emailplatte in St Severin zu Köln ${ }^{2}$ und eine Miniatur in einem Pontifikale des Britischen Huseums mit der Darstellung des hl. Gregor des Großen ${ }^{3}$. Ein wenig spätere Beispiele liefern verschiedene Miniaturen des Salzburger Antiphonars '. Bildwerke aus der zweiten Hälfte des 12. Jahrhunderts, welche die Ausschnitte aufweisen, sind unter andern mehrere Illustrationen des Hortus deliciarum der Herrad von Landsherg ${ }^{5}$, die Miniaturen eines Evangeliars der kgl. Bibliothek zn Stuttgart ${ }^{6}$, das Bild des hl. Heribert in einem aus Deutz stammenden Codex der fürstl. Bibliothek zu Donaueschingen?. Lm 1200 bietet gute Beispiele der Einrichtung die zweite Reihe der Eichstätter Bischöfe im Gundekarpontifikales.

Auf Siegeln ist die Einrichtung auffallenderweise bei der Dalmatik weit seltener, wenngleich sie auch auf ihnen bei dieser nicht völlig fehlt. So treffen wir sie auf den Siegeln der Bischöfe Alexander $(\dagger 1147)$ und Robert $(\dagger 1166)$ von Lincoln, Robert III. von Chartres $(\dagger 1164)^{9}$, Hermann $(\dagger 1254)$ und Berthold $(\dagger 1267)$ von Würzburg ${ }^{10}$ an. Auch das Siegel des Mainzer Domstiftes weist die Ausschnitte auf (Bild 123).

Daßs dem Befund auf den Bildwerken ein wirklicher Tatbestand entsprochen haben mus, steht bei der großen Zahl der aus den verschiedensten Gegenden stammenden und sich durch das ganze 12. Jahrhundert, ja vereinzelt selbst noch bis in die zweite Hälfte des 13. hinziehenden Beispiele außer Frage. Die barocke Form, welche die Ausschnitte auf den Miniaturen hie und da haben, wird indessen nur ein Produkt der Phantasie der Künstler sein.

\section{Die Ausschnitte der Dalmatik} verlieren sich auf den Bildwerken seit

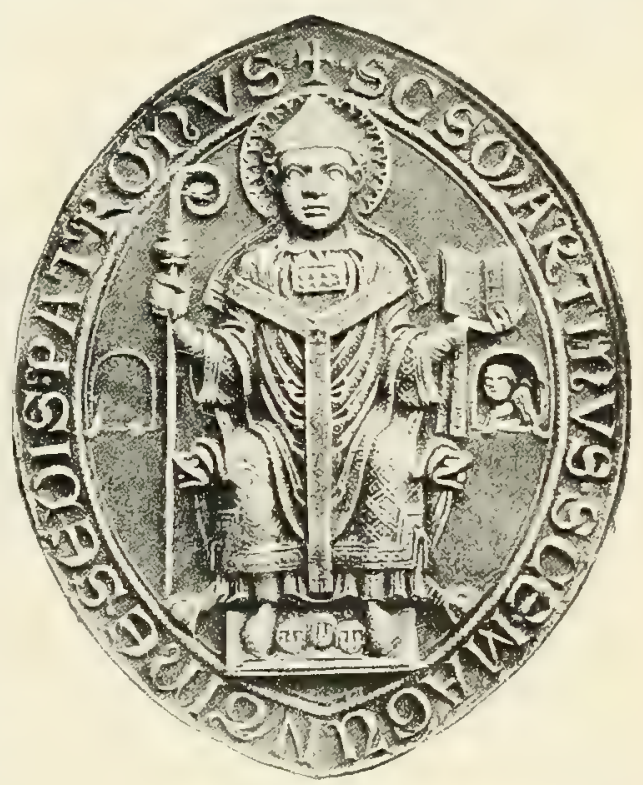

Bild 123. Siegel des Mainzer Domstifts (13. Jahrl.). etwa 1200 mehr und mehr, doch kommen sie vereinzelt noch bis gegen Ende des 13. Jahrhunderts vor.

Über den Stoff, welcher zur Herstellung der Dalmatik verwendet zu werden pflegte, erhalten wir auch in dieser zweiten Periode kaum je nähere Nachrichten. Die Liturgiker schweigen sich darüber vollständig aus, und auch

1 Abbildung bei B ock, Die byzantinische Zellenschmelze, Aachen 1890, Tfl 6. O.v.Falke, Deutsche Schmelzarbeiten des Mittelalters, Frankfurt 1904, Tfl 10.

" Bock, Das heilige Köln, St Severin. O. v. Falke a. a. O. Tfl 2 .

${ }^{3}$ Cotton. Claudius A. IlI. Farbige Abbildung bei Westwood, Facsimiles of the miniatures of the anglo-sax on manuscr. pl. I und A. Fäh, Geschichte der bildenden Künste, Freiburg 1903, THl 19. Bei Croyau-Pératé, Der Vatikan, Ein- siedeln 1898, 37 irrig dem 10. Jahrhundert zugeschrieben.

4 Lind, Fin Antiphonar mit Bilderschmuck, Wien 1870, Tfl 421263445.

${ }^{5}$ Herrade de Landsberg, Hortus deliciarum, Straßhurg 1901, pl. XIII LIII LIX LXI.

6 Abbildung bei Roh. VII, pl. DLrI.

"Roh.VII,pl. DLv. ${ }^{*}$ Eichstätts Kunst" 36.

Rol. VII, pl. DLIII DCLIV.

$10 \mathrm{H}$ effner, Die Würzburger Siegel im Archiv des Historischen Vereins für Aschaffenburg and Unterfranken Tfl 6, n. 2. 
die Inventare, von denen man doch am ehesten Aufschluf zu erwarten berechtigt wäre, reden fast nie von dem Material des Gewandes. Immerhin darf angenommen werden, daf wenigstens die Dalmatiken, welche man an den höheren Festen gebrauchte, bereits im 11. und namentlich im 12. Jahrhundert regelmäbig aus Seide bestanden. Das läbt sowohl die reiche Ausstattung, welche man nach den Inventaren und den Bildwerken der Dalmatik damals geru zu geben pflegte, als namentlich auch die Musterung, welche das Gewand auf den Miniaturen aus jener Zeit häufig aufweist, vermuten. Denn diese Musterung ist von ähnlicher Art wie die, welche uns auf den aus jenen Tagen noch erhaltenen Seidenzeugen begegnet. Außerdem aber waren damals nicht einmal seidene Subdiakonaltuniken etwas Aukerordentliches mehr, und dann bot ja auch im 11. und 12. Jahrhundert die Beschaffung der nötigen Seidenstoffe weiter keine erheblichen Schwierigkeiten.

Im Beginn des 13. Jahrhunderts waren seidene Dalmatiken unzweifelhaft schon so wenig selten, daf sie fast als das Gewöhnliche bezeichnet werden dürfen. Man vergleiche z. B. die durch ihre genauen Angaben ausgezeichneten Inventare von Salisbury (1222) und Mainz (erste Hälfte des 12. Jahrhunderts) ${ }^{1}$. Sie geben ein treffliches Bild des Bestandes der Sakristeien in den größeren Kirchen damaliger Zeit. Nahezu alle in ihnen aufgefülırten Dalmatiken erscheinen als aus Seide gemacht.

Was die Farbe anlangt, so wird die Dalmatik bis zur Wende des Jahrtausends nach wie vor der Regel gemäb weib gewesen sein. Jerlenfalls war sie es noch im 9. Jahrhundert. „Weiß soll die Dalmatik erglänzen, frei von entstellenden Falten", singt Theodulf in seiner Paränese an die Bischöfe. Bei Amalar ist der candor der Dalmatik Sinnbild eines unbefleckten Lebens. Hraban spricht von del Farbe des Gewandes nicht ausdrücklich; daf er indessen bei seinen Ausführungen an die weife, mit Purpurstreifen verzierte römische Dalmatik denkt, zeigt der Umstand, daß̊ er deren purpureos tramites, die purpurnen Besätze, erwähnt. Auch das Verhalten der karolingischen Miniatoren ist bemerkenswert. Bei aller Vorliebe, welche sie für färbige Gewandung hegen, und bei all ihren Sonderlichkeiten in der Anwendung der Farbe verwenden sie für die Dalmatik regelmälỉig entweder Weif oder eine ersichtlich Weifs vertretende helle Farbe. Dak zu Rom im 9. Jahrhundert das Gewand von weifer Farbe war, bekunden die Mosaiken in S. Marco, S. Prassede u. a.

Seit dem Beginn des zweiten Jahrtausends werden aber farbige Dalmatiken allmählich häufiger, namentlich a uberhalb Italiens, wo die alte Tradition, die in Rom so tief wurzelte, fehite und die Neigung zur Weiterbildung der liturgischen Gewandung sich stets stärker geltend machte als im konservativeren Süden. Indessen blieb wohl noch bis gegen Ausgang des 12. Jahrhunderts bei dem Gewand allenthalben Weif vorherrschend. Sowohl Johamnes von Avranches wie Honorius nennen die Dalmatik schlechthin candida, und noch Sicard von Cremona sagt von ihr: est saepius candida... propter munditiam. Auch auf den Bildwerken ist im 11. und 12. Jahrhundert das Gewand noch in den meisten Fällen von weifaer oder doch heller Farbe. Am frühesten scheinen bei den Bischöfen farbige Dalmatiken in Aufnahme gekommen zu sein. Das Speculum de mysteriis ecclesiae bezeichnet sogar - wenngleich zweifelsohne in übertriebener Weise - die Pontifikaldalmatik einfachhin als hyazinthfarbig (purpurn).

1 Sehr instruktiv ist auch das Register von Rochestor. 
In den Inventaren dieser Zeit wird wie des Stoffes, so auch der Farbe nur ausnahmsweise gedacht. So verzeichnet das Register von Rochester eine Dalmatik aus weifem Damast, welche Erzbischof Lanfrane († 1089) geschenkt hatte, zwei Dalmatiken aus weiker, gemusterter Seide, welche Bischof Emulf $(\dagger 1124)$ gestiftet, eine, wie es scheint, rotseidene Dalmatik, die von Bischof Gwalerannus († 1184) gegeben worden war, und eine Dalmatik aus weibem Damast, welche Bischof Gilbert $(\dagger 1214)$ der Kathedrale verehrt hatte.

Farbige Dalmatiken wurden erst das Gewöhnliche, seitdem sich ein liturgischer Farbenkanon herausgebildet hatte, d. i. seit der Spätzeit des 12. Jahrhunderts, und zwar offenbar gerade infolge der Fixierung bestimmter liturgischer Farben. Gab es einmal eine liturgische Farbenregel für das Obergewand des zelebrierenden Priesters, so muste es in der Tat passend erscheinen, dati ihr auch das Obergewand der Diakone, die Dalmatik, und die pontifikale Dalmatik folgten. Es entspricht ganz diesen Verhältnissen, wenn Christian von Mainz in seiner Chronik gelegentlich der Beschreibung des vormaligen Domschatzes bei Aufzählung der Kaseln alsbald auch der zu ihnen gehörenden gleichfarbigen Dalmatiken und Tunicellen gedenkt.

Die Verzierung der Dalmatik bestand noch bis gegen das 13. Jahrhundert nach altem Brauch in den für das Gewand charakteristischen clavi. Noch der großse Innozenz III. betont. um von den diesbeziiglichen Äuferungen der früheren Liturgiker abzusehen, es müsse die Dalmatik vorn und rickwärts mit zwei von oben bis zum Saum laufenden roten Streifen versehen sein. Wir finden dem auch die roten clavi auf den bildlichen Darstellungen bis wenigstens zur Wende des 12. Jahrhunderts, d. i. bis sich die liturgische Farbenregel ausbildete. Dann verschwanden sie entweder ganz von dem Gewand oder es traten je nach der Beschaffenheit der Kasel andersfarbige an ihre Stelle.

Freilich können auch schon vorher die clavi nicht mehr ausnahmslos und in jedem Fall zur Anwendung gekommen sein. Denn es finden sich bereits vor dem 13. Jahrhundert mehrfach Darstellungen der Dalmatik, auf denen diese der roten Vertikalstreifen völlig entbehrt. Zum Teil mag das allerdings seinen Grund in einer Vergeflichkeit des Künstlers haben. Indessen kommen Dalmatiken ohne die clavi denn doch zu häufig vor, als dal; das Fehlen der letzteren stets auf Rechnung des Malers zu setzen wäre. Man darf nicht vergessen, daf das Gewand sich schon lange in einem Stadium der Entwicklung befand, bei welcher es zwar langsam, aber in stetigem Fortschritt immer mehr ron seiner ursprünglichen Eigenart einbüfte, zumal fern von Rom, wo keine Tradition einen hemmenden Einfluß ausübte.

Auch die schmalen Zierstreifen, die einige Zentimeter entfernt um den Rand der Ärmel herum angebracht wurden, bleiben bis ins 1\%. Jahrhundert hinein sehr beliebt, zumal zu Rom, wo z. B. noch das unter Innozenz II. (1139-1143) entstandene Apsismosaik von S. Maria in Trastevere gute Beispiele dieser Verzierung der Dalmatikärmel aufweist (vgl. Bild 21, S. 50). Dann gehen sie in einen mehr oder minder breiten, dicht am Ärmelrand sich himziehenden Besatz über. Auf deutschen Miniaturen findet sich dieser schon in der Frühe des 11. Jahrhunderts, wie beispielsweise auf einer den Bischof Sigebert von Minden immitten von Geistlichen darstellenden Miniatur in de' kgl. Bibliothek zu Berlin (Bild 124, S. 266) beim Diakon zur Linken des Bischof4.

Am Saum des Gewandes einen Besatz aufzunähen, war in vorkarolingischer Zeit nicht üblich; seit dem 9. Jahrhundert fängt man jedoch an, 
auch hier einen solchen anzubringen. Er findet sich bereits bei den Diakonendarstellungen auf dem im Grab des hl. Kuthbert zu Durham gefundenen Manipel und etwas später auf Miniaturen des Prümer Tropars in der Pariser Nationalbibliothek (vgl. Bild 121, S. 262). Im 11. Jahrhundert sind Besätze am Saum der Dalmatik auf den Bildwerken schon sehr häufig; noch mehr ist das in 12. der Fall. Auch hier scheint der Norden vorangegangen zu sein, doch liefern selbst zu Rom bereits im 11. Jahrhundert die Fresken in der Tnterkirche von S. Clemente und nicht lange nachher die Mosaiken ron S. Maria in Trastevere gute Beipiele des Saumbesatzes der Dalmatik.

Von eigentümlicher Art war die Fransenverzierung, welche man vom 9. bis 13. Jahrhundert gern der Dalmatik zu teil werden lief. Wie früher gesagt wurde, hatte man schon wenigstens im 7. Jahrhundert an-

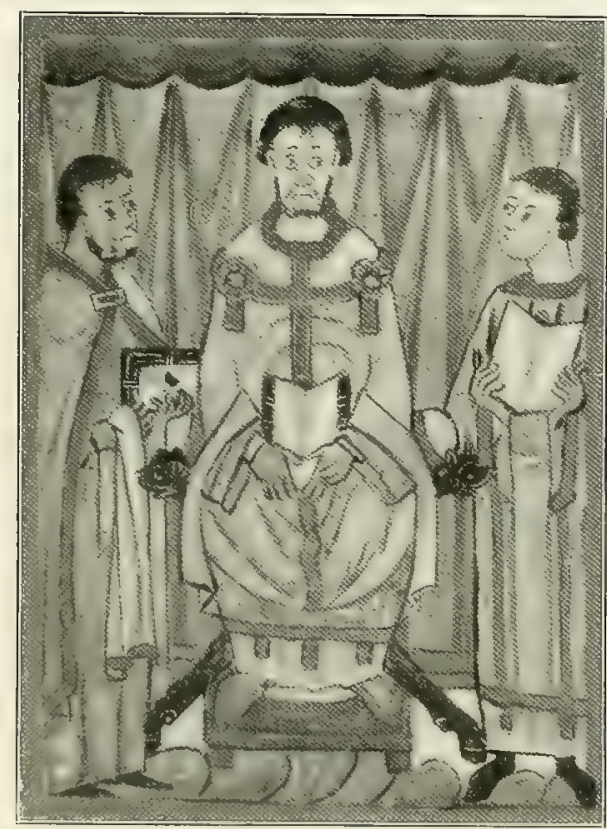

Bild 124. Sigebert von Minden mit seinen Klerikern. Miniatur eines Mindener Codex (ca 1030) Berlin, Jigl. Bibliothek. gefangen, das Gewand unten an den Seiten, den dort angebrachten Schlitz entlang, mit Fransen zu besetzen. Etwas später, wie es scheint, hatte man dann auch solche am Ärmelsaum hinzugefügt. Gegen das 9. Jahrhundert nun kommen zu diesen Fransen an der Seite und an den Ärmeln noch kleine Fransenbüschel an den clavi. Die seitlichen Fransen wurden nach Amalar, welcher uns die erste Beschreibung dieses Fransensystems gibt, nur an der linken Seite angebracht, die Ärmelfransen nur am linken Ärmel. Wie die Fransenflocken an den clavi angesetzt wurden, ob nur von einer oder von beiden Seiten derselben her, geht aus Amalars Worten nicht bestimmt hervor. Die Fransen an der Seite und dem Ärmel waren wie das Gewand von weiker, die an den clavi angenähten Fransenbüschel wie die clavi von roter Farbe. Die Zahl dieser Büschel betrug im ganzen bald 56 , bald 60 , so daf auf den einzelnen clavus entweder 14 oder 15 fimbriae kamen. Im letzten Falle sollten sie nach Amalar die „fünfzehn Äste der Gottesliebe" versinnbilden, von denen der Apostel Paulus im ersten Brief an die Korinther $(13,4-7)$ spricht, wenn er sagt: Caritas patiens est, benigna est, non aemulatur, non agit perperam, non inflatur, non est ambitiosa, non quaerit quae sua sunt, non iritatur, non cogitat malum, non gaudet super iniquitate, congaudet autem veritati, omnia suffert, omnia credit, omnia sperat, omnia sustinet.

Eine vorzügliche Illustration zur Schilderung, welche Amalar vom Fransenschmuck der Dalmatik gibt, bilden die Skulpturen auf der Frankfurter Elfenbeintafel und deren Gegenstück, dem ehemaligen Spitzerschen Elfenbein (Bild 65, S. 167 und Bild 66, S. 168). Es ist fast, als ob er bei seiner Beschreibung diese Tafeln vor sich gehabt hätte. Sowohl beim Bischof wie hei den Diakonen finden sich Fransen nur am linken $\ddot{A}$ :mel, an der linken 
Seite und an den clavi; bei letzteren sind sie paarweise rechts und links vom Streifen, dem stipes caritatis, wie Amalar sagt, angebracht. Am Ärmel und an der Seite des Gewandes bilden die fimbriae eine fortlaufende Reihe, an den Vertikalbesätzen vereinzelte Büschel.

Andere Bildwerke weichen mehr oder minder von den Angaben Amalars ab, so z. B. das Widmungsbild der Bibel Karls des Kahlen (vgl. Titelbild) und die Bischofsdarstellungen im Metzer Kanon. Bei beiden fehlen an der Seite die Fransen; bei den clavi sehen wir sie nur an deren linker Seite. Ärmelfransen finden sich nur auf der Miniatur der Bibel, und zwar teils am rechten, teils am linken $\ddot{A} r$ mel, überall aber in Gestalt vereinzelter roter Flocken. Auf den rö$\mathrm{m}$ is $\mathrm{ch}$ en Mosaiken des 9. Jahrhunderts kommen Fransen nur an den Ärmeln und der Seite des Gewandes vor. Im einzelnen herrscht aber auch hier keine Übereinstimmung. So gewahrt man z. B. in S. Marco bei der Dalmatik des heiligen Diakon Agapitus Fransen blok an beiden Ärmeln, beim heiligen Diakon Felicissimus auferdem unten links, und bei dem Titelheiligen der

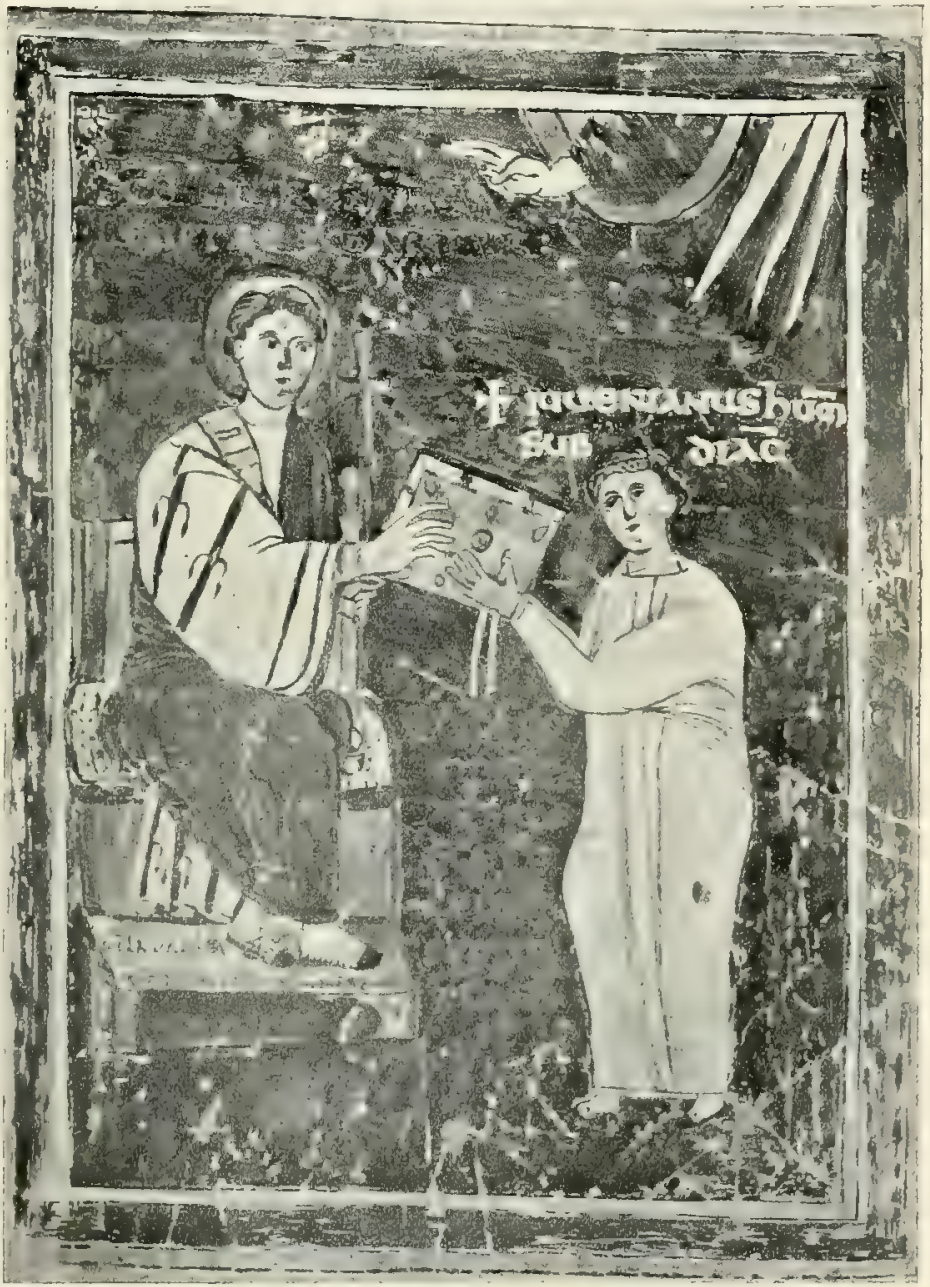

Bild 125. Der Subdiakon Juvenianus. Miniatur eines Codex (9. Jahrh.). Rom, Bill. Vallicelliana.

Kirche, dem Papste St Markus, außer an beiden Ärmeln auch unten rechts. Ganz fehlen die Fransen auf den Mosaiken in S. Cecilia; nur an der Seite der Dalmatik sind sie angebracht auf den Mosaiken in S. Prasserle bei Papst Paschalis (unten links) und einem heiligen Diakon (unten rechts). Eine Miniatur in einem Codex der Vallicelliana (Rom), den man dem 9. Jahrhundert zuschreiht, zeigt uns die Fransen in merkwürdiger Anordnung. Aufer den mit Fransenbüscheln besetzten clavi und den Besaitzen, welche den Ämelsaum der Dalmatik umgeben, laufen noch zwei breite rotfarbige, nit vereinzelten Fransenflocken zu beiden Seiten geschmückte Zierstreifen quer oben über den Ärmel. Der Miniator hat hier seiner Phantasie offenbar allzusehr die Zitgel schiefaen lassen (Bild 125). 
Angesichts der großen Mannigfaltigkeit, welche hinsichtlich der Fransen auf den Bildwerken zu Tage tritt, ist es zweifellos, da/s in Bezug auf die Anbringung derselben eine einheitliche, feste Praxis nicht bestanden haben kann, Ind dalis, was Amalar darüber sagt, nur eine der vielen Weisen, die Dalmatik mit fimbriae zu schmücken, darstellt. Es hing offenbar von örtlichen Gewohnheiten, vom Geschmack des einzelnen, von mystischen Erwägungen, die man mit den Fransen verband, und ähnlichem ab, in welchem Umfang und in welcher Weise diese zur Verwendung kommen sollten. Auch kann die fragliche Verzierungsweise des Gewandes bei aller Verbreitung, die sie im 9. und 10. Jahrhundert im Norden gehabt haben mag, in jener Zeit dort keineswegs allgemein üblich gewesen sein; denn es fehlt nicht an Bildwerken aus den Tagen der Karolinger, auf denen das Gewand vollständig der Fransen entbehrt. Dahin gehören z. B. die Darstellungen der Messe auf einem der Deckelelfenbeine (Bild 67, S. 170) und den Miniaturen des Drogosakramentars, die Miniaturen des Sakramentars von Autun und die von Frankenhand geschaffenen Reliefs des Palliotto von S. Ambrogio zu Mailand. Auch Hraban spricht nicht von den fimbriae der Dalmatik, obwohl er ihrer purpurnen Vertikalstreifen und der Ärmelbesätze Erwähnung tut.

Wann und wo die Sitte aufkam, nicht blof an dem seitlichen Schlitz und dem Ärmelrand Fransen anzubringen, sondern obendrein die clavi mit roten Flöckchen zu verzieren, ist nicht mit Bestimmtheit zu sagen. Da sie bereits im Beginn des 9. Jahrhunderts bestand, muf sie sich spätestens in Lauf des 8. Jahrhunderts gebildet haben, und zwar geschah das allem Anschein nach im Frankenland. Hier findet sie ja zuerst bei Amalar Erwähnung, hier tritt sie auch zuerst auf den Bildwerken auf.

In Italien mag der Brauch ïberhaupt niemals grofe Verbreitung gefunden haben. Bruno von Segni scheint nur von den Fransen an der Seite des Gewandes zu sprechen. Auch ist die Zahl der italienischen Monumente, auf welchen die fraglichen Fransen an den clavi der Dalmatik angehracht sind, im ganzen nur gering. Um so beliebter wurde die Gepflogenheit im Norden. Es ist keine blofie Wiederholung der Ausführungen Amalars, wenn das Speculum de mysteriis ecclesiae, Robert Paululus und Honorius von den an den Zierstreifen der Dalmatik angebrachten fimbriae reden. Es gibt bis tief ins 12. Jahrhundert hinein zahlreiche Bildwerke, welche für diesen Brauch Zeugnis ablegen. Begegnen uns die fimbriae an den clavi doch noch auf der gegen Ende des 12. Jahrhunderts entstandenen zweiten Serie der Bischofsbilder im Pontifikale Gundekars von Eichstätt. Erst mit dem Ausgang des Jahrhunderts kommt die Sitte im Norden endgültig in Abgang.

Allgemein war hier der Brauch indessen auch im 11. und 12. Jahrhundert nicht geworden. Man kann sogar fragen, ob er überhaupt das Gewöhnlichere gewesen sei. Denn neben den freilich zahlreichen Darstellungen, auf welchen die Dalmatikbesätze mit Fransenflöckchen geschmückt erscheinen, gibt es aus dieser Zeit fast noch mehr, auf welchen sie derselben gänzlich entbehren. [yer Umstand aher, daf Honorius, Robert Paululus und das Speculum der Gepilogenheit gedenken, beweist besten Falls blob, dal man noch immer die Vertikalhesätze und Ärmelborden der Dalnatik gern mit fimbriae versehen habe, nicht ahcr auch, daßs solches damals regelmälig geschehen oder gar: Vorschrift gewesen sei, wie man aus Unkenntnis des wirklichen Tatbestandes behauptet hat. 
Sowohl die Form der Fransen wie die Weise, in der sie den clavi angesetzt erscheinen, sind auch im 11. und 12. Jahrhundert anf den Bildwerken noch immer sehr verschieden. Wie im 9. und 10. Jahrhundert, so kann deshalb auch jetzt weder in der einen noch in der andern Übereinstimmung geherrscht haben. Selbst wenn man manches der dichtenden Phantasie oder besser der Willkür der Künstler zuschreibt, bleiht noch immer zu viel Mannigfaltigkeit, als daß man an eine mit dem Geist des Mittelalters ohnehin wenig harmonierende einheitliche Praxis bezüglich der Fransen und ihrer Verwendung glauben könnte. In Frankreich muf es nach Johannes von Avranches ${ }^{1}$ und dem Speculum de mysteriis ecclesiae Sitte gewesen sein, aufier den üblichen Flöckchen der Vertikalbesätze auch auf Brust und Riucken einem dort angebrachten Querbesatz je drei Fransenbüschel anzunähen. Sie sollten die heiligste Dreifaltigkeit symbolisieren.

Dalmatiken des 9., 10., 11. oder 12. Jahrhunderts, deren $\mathrm{Be}$ sätze mit fimbriae geschmückt wären, haben sich leider nicht erhalten. Es fehlt überhaupt, um von der Dalmatik zu Taben, die vielleicht noch in die vorkarolingi-

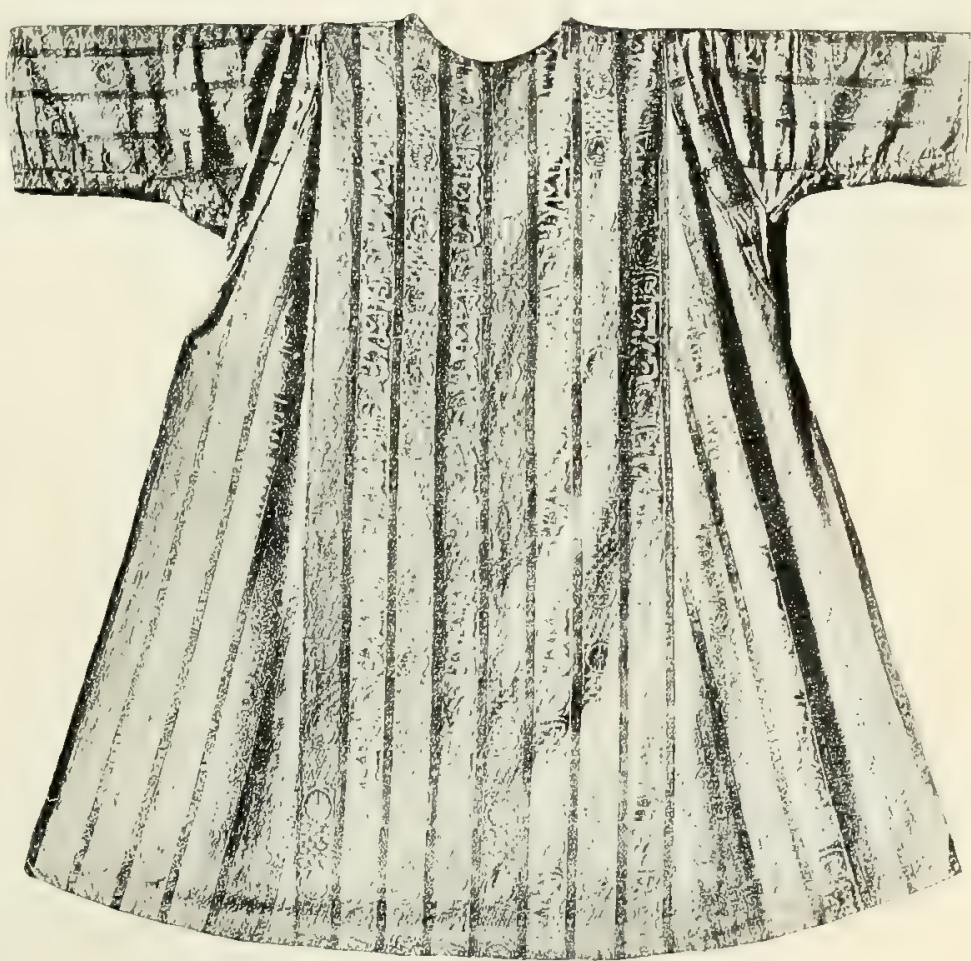

Bild 126. Dalmatik. Regensburg, Alte Kapelle.

sche Zeit hinaufreicht, abzusehen, ganz an Dalmatiken, welche mit einiger Sicherheit der uns hier beschäftigenden Periode zugewiesen werden könniten.

Ein als Dalmatik des hl. Ulrich bezeichnetes, aus purpurfarbigem, gelb und grün gemustertem (Vögel in Kreisen) Brokatell gemachtes Gewand in St Ulrich zu Augsburg, dürfte den ungemein engen Ärmeln zufolge eher eine Tunika gewesen sein, wenn es überhaupt, was aber schwerlich der Fall ist, von dem Heiligen herrührt. Eine zu Ambazac befindliche, dem hl. Stephan von Muret (†1124) zugeschriebene Dalmatik wird erst dem 13. Jahrhundert entstammen ${ }^{2}$. Zwei Dalmatiken in der Alten Kapelle zu Regensburg, welche zu den früher erwähnten Kaseln ${ }^{3}$ daselbst gehören, lürften wie diese frühestens aus dem Ende des 14. Jahrhunderts datieren. Eine derselben (Bild 126) scheint keine besondern Veränderungen in späterer Zeit erfahren zu haben, bei der andern werden dagegen später die seitlichen Schlitze vergröfsert und Saum, Schlitze und Ärmel mit Fransen besetzt worden sein. Auch muf der

\footnotetext{
1 De offic. eccles. in fine (M. 147,62); vollständig ebd. 210.

2 Abbildung bei Rol. VII, pl, DxLvi

3 S. oben S. 188.
} 
Kopfdurchschlupf eine Erweiterung erlitten haben. Die vordere Ärmelweite beträgt bei dem zweiten der beiden Gewänder $0,35 \mathrm{~m}$, die Länge $1,20 \mathrm{~m}$, die Weite am unteren Saum 1,20 m. Die entsprechenden Mare des ersten sind 0,25, 1,35 und $1,28 \mathrm{~m}$. Ein Besatz fehIt an beiden Dalmatiken.

\section{BESCHAFFENHEIT DER DALMATIK SEIT DEM SPÄTEN MITTELALTER.}

Als Stoff gebrauchte man zur Dalmatik in den letzten Jahrhunderten des Mittelalters mit Vorzug Seide. Ein Blick in die vielfach sehr ins einzelne gehenden Inventare dieser Zeit läßt daran keinen Zweifel. Es wurden sogar mit Vorliebe zu ihrer Herstellung bessere Seidenstoffe verwendet. Unter den zahlreichen Dalmatiken, welche sich aus dem späten Mittelalter erhalten haben, ist dementsprechend denn auch kaum die eine oder andere, die nicht aus Seide bestände. Das ist namentlich da besonders bemerkenswert, wo sie

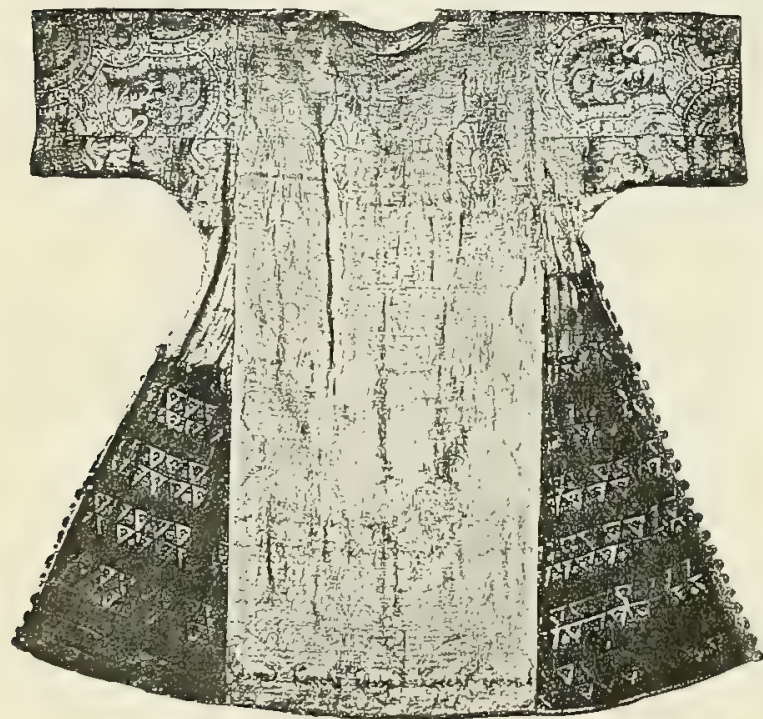

Bild 127. Dalmatik. Danzig, Marienkirehe. sich, wie zu Danzig, in grofer Anzahl in unsere Zeit hinein gerettet haben, nicht weil man bestrebt gewesen wäre, sie wegen ihres kostbaren Stoffes vor dem Untergang zu bewahren, sondern weil sie ihrer Zeit lediglich beiseite gelegt wurden und dann bis in unsere Tage völliger Vergessenheit anheimfielen. In den Inventaren werden die Dalmatiken in der Regel in Verbindung mit der Kasel, zu welcher sie gehörten, aufgeführt.

In Deutschland begegnet uns etwa seit dem Ausgang des 14. Jahrhunderts die eigentümliche Sitte, die Dalmatik aus Stoffen von verschiedener

Farbe und Musterung zusammenzusetzen. Eine bestimmte Regel gab es dafür nicht. Bald hestanden bloß Giren und Rumpf, bald blof Ärmel und Rumpf, bald Giren, Ärmel und Rumpf aus ebenso vielen verschiedenen Stoffen. Hie und da ging die Laune und Geschmacklosigkeit selbst so weit, die Vorderseite des Gewandes aus ganz andern Zeugen zu machen als die Rückseite. Treffliche Belege des Gesagten liefern die Dalmatiken im Dom zu Halberstadt und in St Marien zu Danzig. Bei einzelnen sind nicht weniger denn vier verschiedene Stoffe zur Verwendung gekommen, einer für den Gewandkörper, ein zweiter für die Ärmel, ein dritter für den unteren Teil der Giren, ein vicrter für den oberen Teil derselhen (Bild 127). Das abschreckendste Beispiel einer derartigen Dalmatik findet sich im herzoglichen Museum zu Braunschweig, eine wirkliche Musterkarte von Stoffen, bei der auf einer Seite sich selbst der liumpf aus zwei verschieden gemusterten Seidenzeugen zusammensetyt. Zum Teil mag die Entstehung solcher Gewänder sich durch das Bestreben erklären, vorhandene Stoffreste zu verwerten. Doch trug sicherlich auch ein Stück Vode die Schuld daran. Die Periode, in der wir mehrstoffige 
Dalmatiken antreffen, ist dieselbe Zeit, in der auch im profanen Leben die buntscheckige Tracht blïhte.

Bestickte Dalmatiken werden nur selten in den Inventaren erwähnt und wohl auch in Wirklichkeit nicht häufig gewesen sein. Finden sich deren doch selbst im Verzeichnis der Schätze Bonifaz' VIII. nur etwa drei verzeichnet, während in dem sehr detaillierten Inventar von St Peter aus dem Jahre 1361 auch nicht eine einzige, wie es scheint, aufgeführt wird.

Zwei schöne Beispiele derartiger Dalmatiken, Arbeiten des 13. Jahrhunderts, besitzt der Dom zu Halberstadt. Bei der einen besteht der Rumpf aus rotem Seidenköper, während die Ärmel aus gelber Seide gemacht sind; die andere ist ganz aus einem schweren, hochroten Seidenstoff angefertigt. Bei beiden Gewändern ziehen sich

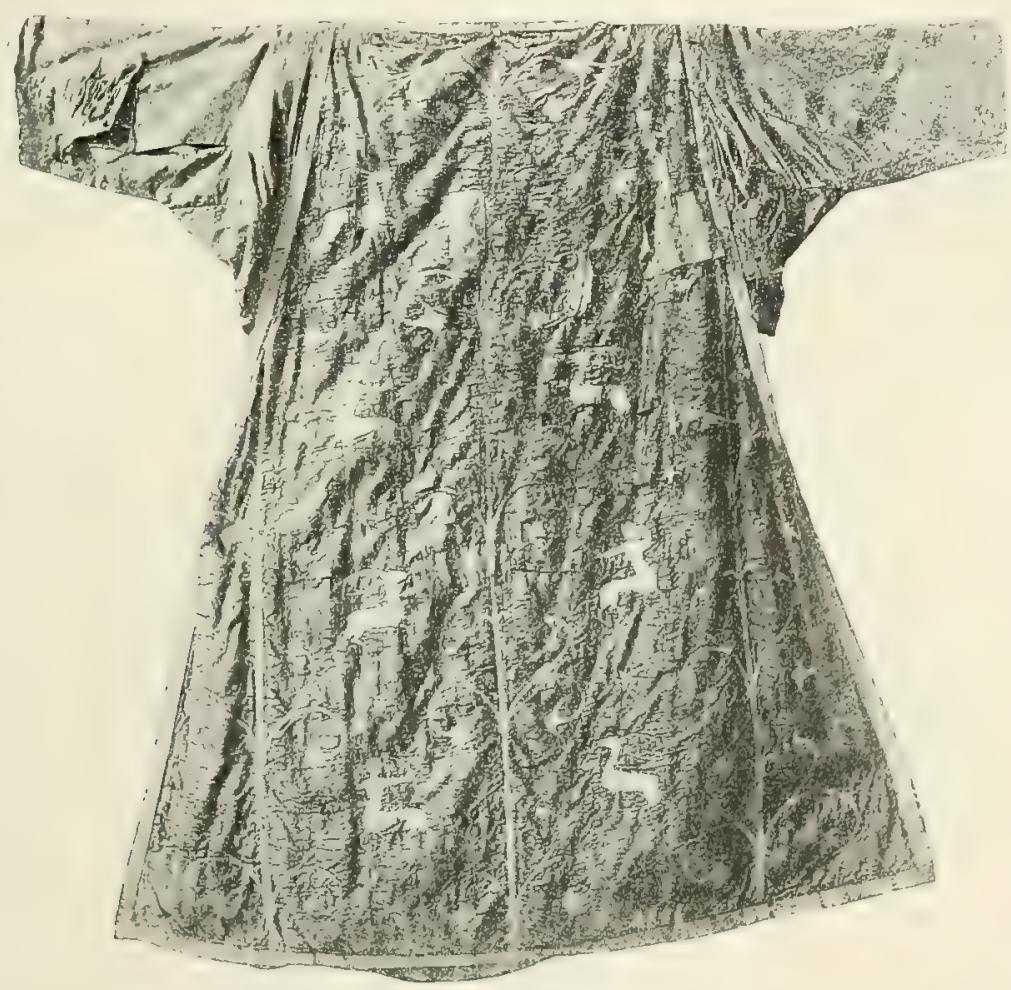

Bild 128. Dalmatik. Halberstaut, Dow.

über die Vorder- wie Rückseite in einer Entfernung von beiläufig 0,35 bzw. $0,30 \mathrm{~m}$ voneinander drei schmale Streifen von oben bis unten, von welchen in bestimmten Abständen nach rechts und links Ranken ausgeben wie eine Reminiszenz an die ehemaligen fimbriae. Den Raum zwischen diesen Vertikalstreifen füllen bei der einen Dalmatik aufier kleinen über den Grund zerstrenten Ornamenten Centauren, die einen Hirsch jagen (Bild 128), auf der andern Löwen ${ }^{1}$, die von einem Doppelkreis umahmt sind. Alle Stickereien sind in Gold, und zwar in ungemein zarter Abhefttechnik, ausgeführt. Die Ärmel wurden ohne Verzierung belassen.

Eine andere reich in Gold bestickte Dalmatik birgt die Kathedrale zu Anagni. Das Gewand entstammt ebenfalls dem 13. Jahrhundert, hat aber leider zu Ende des 16. Jahrhunderts durch eine Restanration scine ursprüngliche Form eingebüfst. Si wurde von Bonifaz VIII. der Kathedrale geschenkt und ist wie die früher erwähnte

1 Abbildung bei Bock II, TA 5 . 
Kasel ', der sie entspricht, ein sehr kostbares Stück. Der ganze Fond des Gewandes ist auch hier mit mächtigen Kreisen bedeckt, in denen doppelköpfige Adler, zu Paaren gestellte Papageien und Greife angebracht sind. Den freien Raum zwischen den Kreisen füllt wie bei ähnlich gemusterten Brokaten ein kreuzförmig gestaltetes Blattornament. Im Inventar der Gaben, welche Bonifaz VIII. der Kathedrale von Anagni zukommen liefs. ist die Dalmatik verzeichnet als: Item una dalmatica rubea cum grifis et aliis avibus, aquilis cum duobus capitibus et paraturis in manicis et fimbriis ad ymagines et pernas (= perlis) ${ }^{2}$.

Sehr selten müssen Dalmatiken gewesen sein, welche mit figürlichen Darstellungen bestickt waren. Zwei ungemein kostbare Gewänder dieser Art sind in dem Verzeichnis der Geschenke, die Bonifaz VIII. der Kathedrale von Anagni machte, mit den Worten vermerkt: Item una dalmatica contexta de

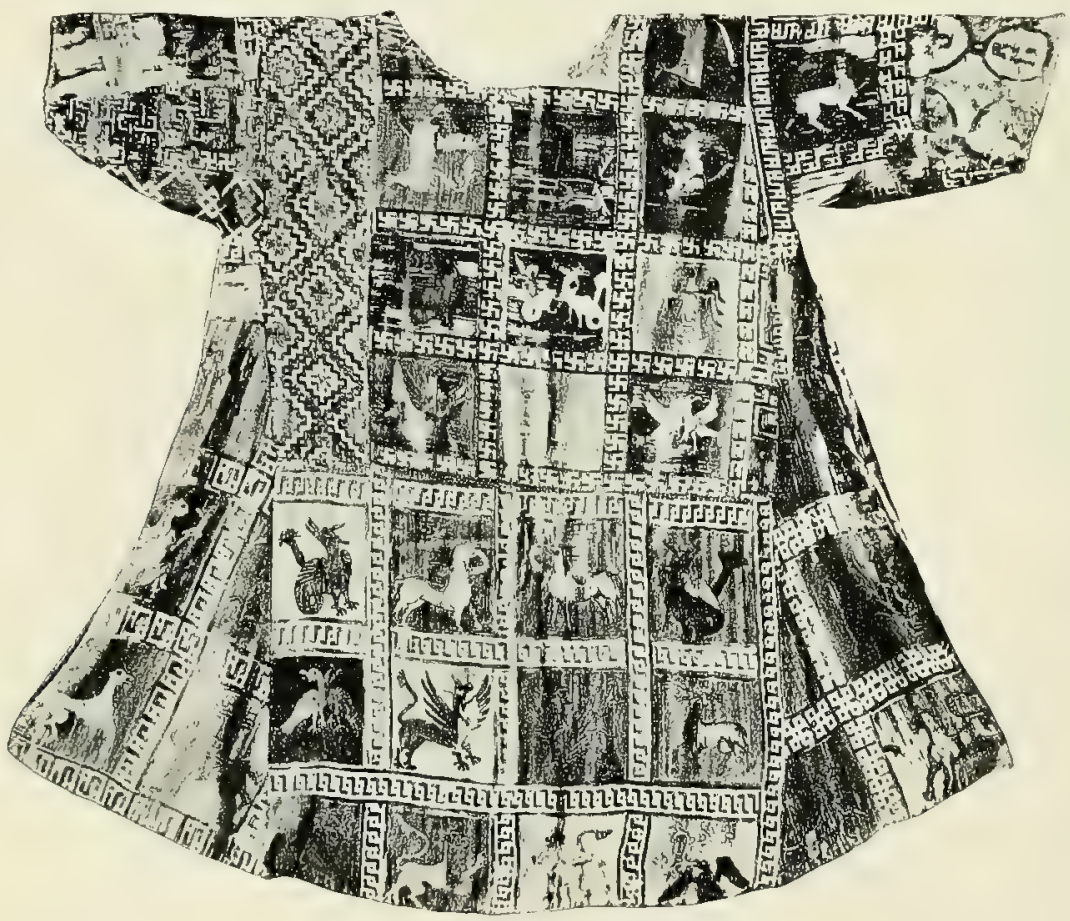

Bild 129. Dalmatik. Güß (Steiermark).

auro, argento et serico cum 82 plactis de auro et perlis ad ystoriam beati Nicolai; item una daImatica de samito rubeo cum diversis passionibus sanctorum ad ymagines salvatoris et virginis in pectorale et foderata sennato (= cendato) viridi. Die zweite dieser Dalmatiken ist ganz verschwunden. Die erste dagegen ist zwar noch vorhanden, jedoch inzwischen in eine Kasel umgewandelt

1 S. oben S. 222.

2 Bei der Restauration hat die Dalmatik leider ihre kostharen gestickten Besätze verloren. Die jetzt auf ihr angebrachten schmalen Bïrtchen stammen aus dem Ende des 16. Jahrhunderts. Eine Tunicella im Schatz del Kathedrale von Anagni von derselben Art wie die Dalmatik ist nicht ursprünglich, sondern wurde um das Ende des 16. Jahr- hunderts aus einem Pluviale angefertigt, das im Verzeichnis Bonifaz' VIII, beschrieben wird: Item unum pluviale de samito rubeo laborato ad acum de auro battuto ad grifos, pappagallos et aquilas cum duobus capitibus et aurifirisio cum pernis. Von diesem Pluviale wurde auch genommen, was seiner Zeit zur Restauration der schadhaft gewordenen Dalmatik nötig war. 
und zu dem Ende aufs bedanerlichste verstïmmelt worden. Nur die Ärmel dienen noch ihrem alten Zweck; sie sind jetzt an einer Bilderdalmatik des Schatzes, welche um das Ende des 16. Jahrhunderts aus einem mit Figurenwerk auf das glänzendste bestickten Pluviale hergestellt wurde, angebracht .

Die einzige mit Bildwerk bestickte Dalmatik aus dem 13. Jahrhundert, welche im wesentlichen wohlerhalten auf die Gegenwart gekommen ist, befindet sich zu Göl in Steiermark. Sie bildet mit der früher erwähnten Kasel, einem Pluviale, einer Tunicella und einem Antependium einen vollständigen Ornat. Die Veränderungen, die mit ihr vorgegangen sind, bestehen in der Hauptsache blof in einer Verkürzung ihrer Länge und in einer Vergröferung des Halsausschnittes. An figuralen Darstellungen findet sich nur eine auf dem Gewand, die Verkündigung, im übrigen besteht alles Ornament aus geometrischen Gebilden und phantastischen, quadratischen Feldern eingefügten Tiergestalten.

Ein Kunstwerk und schön kann die Dalmatik nicht gerade genannt werden, dafür ist die Arbeit zu derb, das Arrangement zu unruhig und die

Farbengebung' zu bunt, aber sie ist interessant und kunstgeschichtlich unzweifelhaft aller Beachtung wert (Bild 129).

Aus dem

14. Jahrhundert gibt es keine

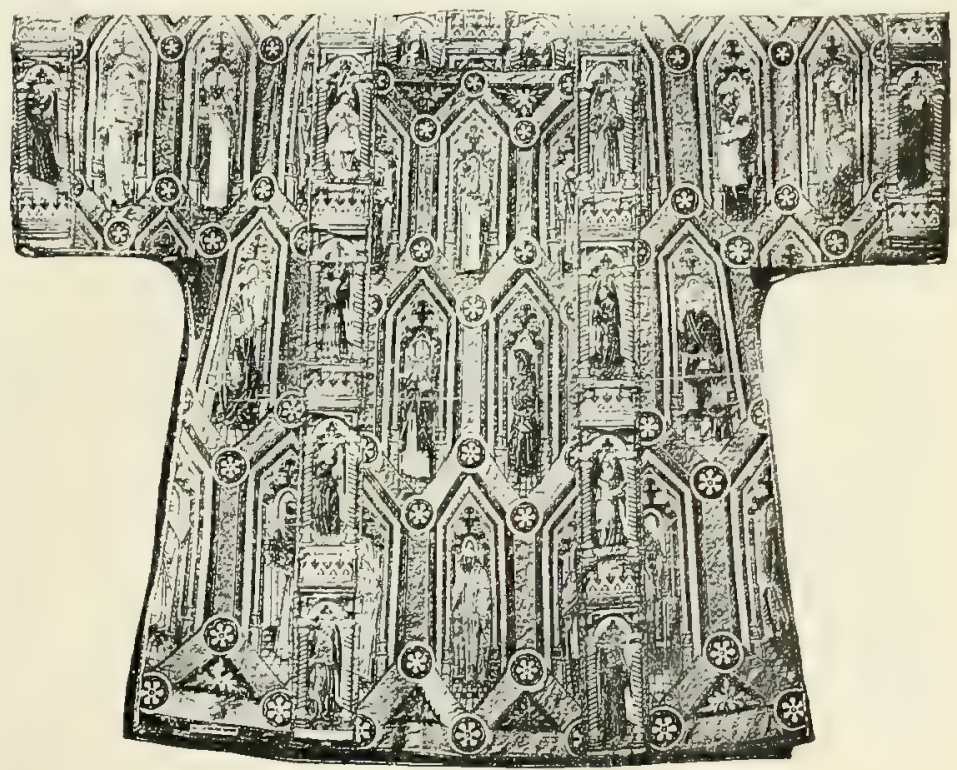

Bild 130. Dalmatik. Wien, k, k. Selatzkammer.

Bilderdalmatik;

dem 15. gehört die mit Bildwerk auf das grofartigste bestickte Dalmatik des burgundischen Mefsornats in der k. k. Schatzkammer zu Wien an (Bild 130). Den Fond des Gewandes bedecken die Darstellungen männlicher Heiligen, auf den Besätzen haben lobpreisende Engel Platz gefunden. Anorduung des Bilderschmucks, Technik und Material sind bei der Dalmatik (wie die übrigen Bestandteile des Ornats eines der hervorragendsten Erzeugnisse der Stickkunst aller Zeiten) die gleichen wie bei der schon beschriebenen Kasel.

Manches Bemerkenswerte bieten in dem uns beschäftigenden Zeitraum Form und Austattung der Dalmatik.

Im 13. Jahrhundert beträgt die Länge des Gewandes etwa 1,40-1,30 m. In Italien und insbesondere in Rom bleibt es so auch noch im 14. Jahrhundert, während im Norden, wo sich die auf Verkürzung des Gewandes hinzielende

' Das Pluviale war ebenfalls ein Geschenk Bonifaz' VIII. und wird im Gabenregister beschrieben als: Item unum pluviale laboratum

Braun, Die liturgische Gewandung. ad aurum de auro battuto et serico de diversis ystoriis et passionibus sanctorum, foderatum de purpura ad aves croceas. 
Tendenz nach wie vor stärker als im Süden geltend machte, die Länge damals nur selten mehr $1,30 \mathrm{~m}$ überschritten haben dürfte. Im 15. Jahrhundert erscheint auch in Italien die Dalmatik schon merklich zugestutzt, in Deutschland aber war ihre Länge um diese Zeit bereits auf 1.25-1,20 $\mathrm{m}$ herabgesunken. Im 16. Jahrhundert war das Gewand auch in Italien nur mehr ca 1,20 $\mathrm{m}$ lang.

Die Armelweite bleibt in dieser Periode sich ziemlich gleich. In der Regel bewegt sie sich zwischen 0,30 bis $0,35 \mathrm{~m}$. Unter $0,25 \mathrm{~m}$ scheint sie nach Ausweis der Monumente und der noch erhaltenen Dalmatiken nur selten herabgestiegen zu sein. Ebenso dürfte sie aber auch kaum je $0,40 \mathrm{~m}$ überschritten haben.

An den Seiten des Gewandes war regelmäßjig zur Erleichterung des Anziehens ein Schlitz angebracht. Nur bei Dalmatiken, welche durch Anfügung von Giren unten eine Breite erhalten hatten, daß Schlitze überflüssig

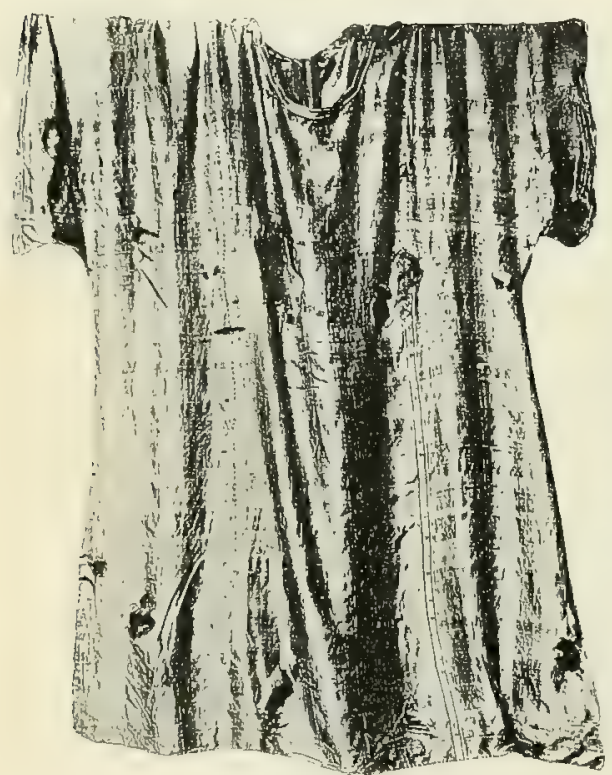

Bild 131. Dalmatik. Sens, Kathedrale. erscheinen mochten, fehlten allenfalls solche. Was die Länge der Schlitze anlangt, so reichten dieselben im 13. und teilweise noch im 14. Jahrhundert durchweg nur bis etwa zur Mitte der Seiten. Dann werden sie immer gröferer, bis sie zuletzt vom Saum bis zu den Ärmeln gehen. Die Ärmel selbst blieben noch im 15 . Jahrhundert fast ausnahmslos geschlossen. Wenn Dalmatiken, die aus der Wende des Mittelalters stammen, auch unter dem Ärmel aufgeschlitzt sind, so ist der Schlitz regelmäßßig erst in späterer Zeit angebracht worden, als es Brauch geworden war, die Ärmel durch Ärmellappen zu ersetzen. Das einzige Beispiel einer Dalmatik aus dem 15. Jahrhundert, deren Ärmel an der Unterseite von Anfang an geöffnet waren, bildet die zum Mefornat des Ordens vom Goldenen

Vlies gehörende Dalmatik (Bild 130, S. 273). Sie werden hier mit Hilfe von Knnöpfen und Schleifen geschlossen. Allein es begreift sich angesichts der schweren Stickereien, mit denen die Ärmel bedeckt sind, unschwer, daßis man hier dazu ïberging, diese aufzuschlitzen. Andernfalls wäre es kaum möglich gewesen, das Gewand anzuziehen.

Auch der Kopfdurchschlupf wurde bisweilen mit seitlichen Schlitzen, welche nach Anlegung des Gewandes mit Schnüren geschlossen wurden, versehen. Im 15. Jahrhundert wurde es Brauch, an den Enden dieser letzteren eine Quaste anzubringen, welche man von den Schultern ïber Brust und Rücken oder auch blol, üher den Rücken herabhangen lief. Frühe Beispiele dieser Einrichtung, welche in Italien aufgekommen zu sein scheint, bieten die Fresken Fra Angelicos in der Ḱapelle Nikolaus' V. im Vatikan (vgl. Bild 58, S. 144). Später wurden aus der einen Quaste oft zwei, drei oder gar ein ganzes Quastenbündel; außerdem wendete man nun häufig Schnüre mit Quasten als blofien Zierat auch bei solchen Dalmatiken an, bei denen sich keine Schlitze neben dem Kopfdurchschlupf befanden und die Schnüre daher nicht zum Zubinden dienen konnten. 
Was das Gesamtbild der Dalmatik anlangt, so muk seit dem 13. Jahrhundert jene Form vorgeherrscht haben, bei welcher sich das Gewand von den Ärmeln an nach unten zu mehr oder weniger erweiterte. Es gibt unter den zahlreichen noch vorhandenen Dalmatiken aus dem 13, 14. und 15. Jahrhundert nur sehr wenige, bei welchen der Gewandrumpf überall die gleiche Breite hat. $7 u$ ihnen gehören z. B. die Dalmatiken im Hospiz zu Lisieux (Frankreich) und eine Dalmatik samt Tunicella im Historischen Museum zu Bern. Die meisten nehmen nach unten an Weite zu, die einen nur mäfig, wie z. B. die sog. Ebbo-Dalmatik in der Kathedrale zu Sens, eine aus äußserst dünnem, violettem Taft gemachte, mit einfachen Zierstreifen versehene bischöfliche Dalmatik (Bild 131), andere dagegen in bedeutendem Mafi (vgl. Bild 127, S. 270).

Eine großie Mannigfaltigkeit herrschte im 13., 14. und 15. Jahrhundert hinsichtlich der Ausstattung der Dalmatik. Fransenbüschel an den clavi waren nicht mehr üblich. Wenn Durandus ihrer noch gedenkt, so sind seine Worte kein Spiegelbild des damaligen Brauches, sondern ohne Rücksicht auf die bestehenden Verhältnisse wörtlich aus älteren Liturgikern herübergenommen. Sogar die clavi waren stark in Abgang gekommen, und das nicht blofs auferhalb Roms, sondern selbst bei den römischen Dalmatiken. Man durchlese nur das Inventar Bonifaz' VIII.; das Verzeichnis der Paramente, welche derselbe Papst der Kathedrale von Anagni schenkte, und die Inventare von St Peter, zumal das detaillierte Inventar vom Jahr 1361. Nur sehr selten werden

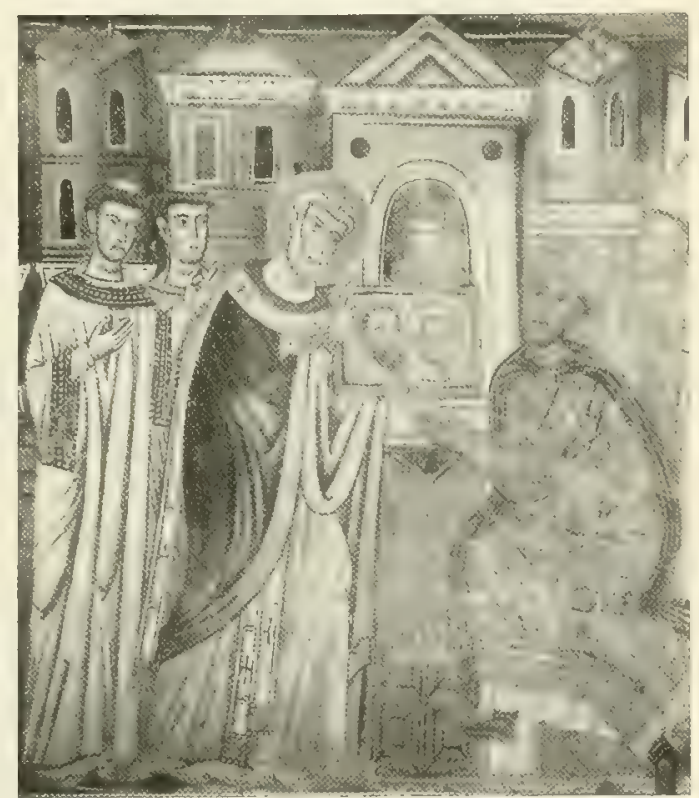

Bild 132. Papst Silvester zeigt Kaiser Konstantin die Bilder der Apostelfürsten. Fresko. Rom, S. Quattro Coronati (Kapelle des hI. Siivester).

darin Dalmatiken verzeichnet, welche von der Schulter bis zum Saum sich hinziehende Vertikalbesätze aufiesen. Auch die römischen Monumente des 13. Jahrhunderts lassen diese Zierstreifen durchweg vermissen (Bild 132). Erst gegen das 15. Jahrhundert kommen die Vertikalbesätze wieder mehr in Gebrauch, in Rom und überhaupt in Italien sowie in Spanien in Form schmaler, etwa $2-3 \mathrm{~cm}$ breiter Streifen, in Deutschland und Frankreich dagegen in Gestalt breiterer Borten, die bald eigens zu diesem Zweck gewebt oder gestickt, bald aus einem zum Gewandstoff kontrastierenden Stoff geschnitten waren. Man begnügte sich sogar hie und da nicht einmal mit zwei Vertikalstreifen, sondern brachte, wie Dalmatiken in den Domen zu Halberstadt und Brandenburg bekunden, ihrer auch wohl drei auf den beiden Gewandseiten an. Anderseits lief man freilich, wie die zahlreichen Dalmatiken in St Marien zu Danzig zeigen, auch noch im 15. Jahrhundert häufig alle Besätze fort. 
Nach römischem Brauch bestand die Ausstattung der Dalmatik im 13., 14. und 15. Jahrhundert aus Besätzen (paraturae) die den Rand der Ärmel rings umgaben und, wenn breit, in den Inventaren auch wohl schlechthin manicae, Irmel, genannt zu werden pflegten, aus den fimbriae (grammata, listae. aurifrisia, fasciae), d. i. parurenartigen Zierstücken am Saum der Torder- und Rückseite des Gewandes, und dem aurifrisium ad collum, einer schmalen, den Kopfdurchschlupf umziehenden Borte. Dazu kamen vielfach noch amifrisia ad spatulas, Borten, welche vom Hals der Länge nach über die Schulter bis zum Ärmelansatz liefen, ferner aurifrisia ad brachia, Borten, welche die Stelle verdeckten, wo die Ärmel dem Rumpf angesetzt waren, dam Zierbesätze auf Brust und Rücken nach Art der fimbriae des Saumes

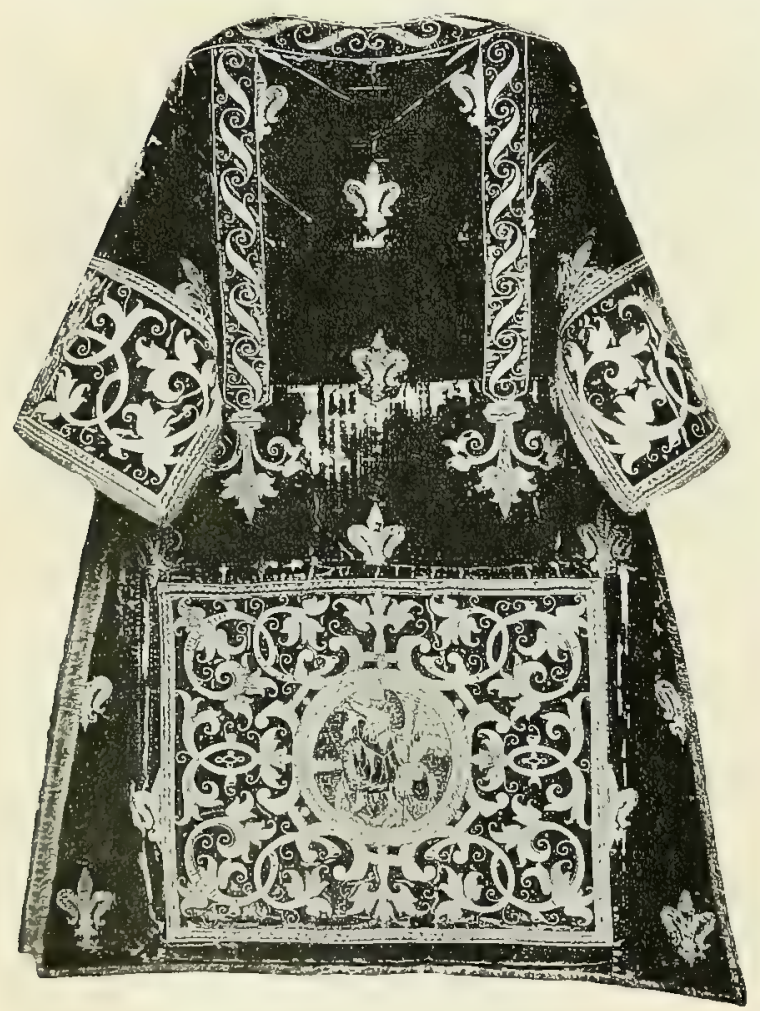

Bild 193. Spanische Dalmatik Berlin, Kunstgew erbemuseum. und endlich, jedoch häufiger erst seit dem 15. Jahrhundert, zwei aus einer Borte gebildete Vertikalbesätze von der Art der ehemaligen clavi, aurifrisia genannt. Auffallend ist die geringe Übereinstimmung, welche den Inventaren zufolgezwischen den verschiedenen Besätzen in Bezug auf Stoff, Farbe, Musterung, Stil und Technik geherrscht haben mus. Allein das Mittelalter liebte eine bunte Mannigfaltigkeit und war dabei keineswegs engherzig und feinfühlig, eine Wahrnehmung, die man auf allen Gebieten des damaligen Kunstschaffens machen kann.

Besondere Beachtung verdient der Wechsel, welcher mit den Maß̧verhältnissen der fimbriae (Saumbesätze) allmählich vor sich ging. Im 13. und 14. Jahrhundert haben sie die Form eines langgezogenen, verhältnismäßig niedern Rechtecks, im 15. aber nähern sie sich einem Quadrat oder nehmen selbst völlig Quartratsgestalt an. Die fimbriae, welche man bei der Dalmatik der Leiche Bonifaz' VIII, antraf, besaksen nach dem Protokoll über den Leichenbefund eine Länge von ca $0,7 \mathrm{~m}$ und eine Höhe von ca $0,35 \mathrm{~m}$. Die Saumbesätze einer dem 14. Jahrhundert entstammenden Dalmatik (richtiger wohl Tunicella) in dor I'farmirche zu Castel S. Elia haben bei einer Länge von $0,73 \mathrm{~m}$ eine Höhe von nur $0,24 \mathrm{~m}$.

Die Besätze auf den Schultern und über den Ärmelnähten verschwinden gegen Ausgang des Mittelalters; ein gleiches gilt von den Zierstücken auf Brust und Riucken lles Gewandes, so dab um den Beginn des 16. Jahrhunderts die Ausstattung der Dalmatik zu Rom und überhaupt in Italien bereits wesentlich dieselbe ist, wie sie ihr gegenwärtig daselbst gegeben zu werden pflegt. 
In Frankreich und Deutschland scheint bis zum Ausgang des Mittelalters eine auch nur einigermafien einheitliche Verzierungsweise der Dalmatik nicht bestanden zu haben. Häufig blieb diese ohne allen und jeden Besatz, ausgenommen etwa eine Einfassung des Kopfdurchlasses; in andern Fällen versah man sie nur am Saum und den Ärmeln mit einer schmäleren oder breiteren Borte. Auch wurden wohl auf den Schultern Zierstreifen (aurifrisia ad spatulas) angebracht oder, wenngleich bis ins 15. Jahrhundert im ganzen nur seltener, die Vorderund Rückseiten des Gewandes mit parallelen Vertikalbesätzen verziert. Saumparuren, wie sie in Italien an der Tagesordnung waren, sind in Frankreich und Deutschland nur vereinzelte Erscheinungen. Beispiele bieten dit Dalmatik von Ambazac, zwei Dalmatiken des Historischen Museums zu Bern und die angebliche Dalmatik des hl. Ludwig von Anjou zu Brignoles ${ }^{1}$.

Eine gröfere Übereinstimmung in der Verzierungsweise tritt erst im Verlauf des 15. Jahrhunderts ein. Die Ärmel erhalten am Saum einen mittelbreiten Besatz, vorn und rückwärts werden zwei breite Vertikalstreifen angebracht und zwischen diesen auf Brust und Rücken (Deutschland) oder nahe am Kopfdurchlaf (Frankreich) ein Querbesatz eingefügt. Es ist die Besatzweise, die dann seit dem 16. Jahrhundert allmählich typisch wird.

In Spanien mag man im Mittelalter, den Monumenten nach zu urteilen, hinsichtlich der Ausstattung der Dalmatik mit Vorliebe römischem Brauch gefolgt sein. Noch im 16. und 17. Jahrhundert erinnert dort das Gewand, was seine Besätze anlangt, einigermafen an die Weise, wie man im 13., 14. und 15. Jahrhundert dasselbe in Italien zu schmücken pflegte (Bild 138).

Inwieweit Fransen nach römischem und außerrömischem Gebrauch im späteren Mittelalter als Schmuck der Säume der Dalmatik Verwendung fanden, läßst sich schwer bestimmen. Allzuhäufig scheinen sie indessen keineswegs benutzt worden zu sein. Jedenfalls bildeten sie keine ständige Verzierung des Gewandes. Die noch erhaltenen Dalmatiken aus jener Zeit lassen daran

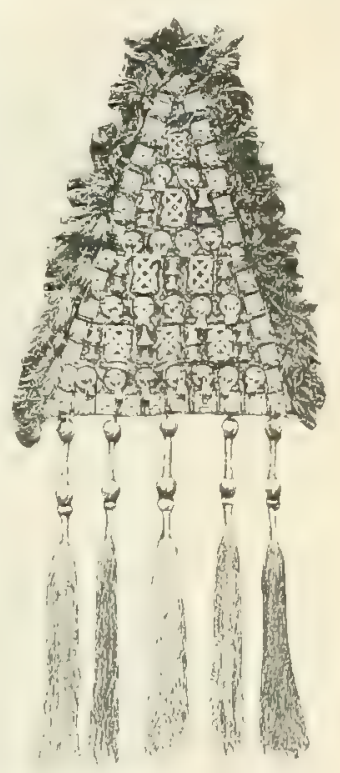

Bild 134. Dalmatikfliigel. Danzig, Marienkirelie. keinen Zweifel. Es sind nur wenige, welche an dem Saum und den seitlichen Schlitzen oder gar an den Ärmeln mit Fransen besetzt sind; die meisten entbehren ihrer. Auch in den Inventaren ist, selbst wo eingehendere Beschreibungen der Dalmatiken gegeben werden, nur selten von ihnen die Rede. Häufiger werden sie an dem Gewand erst gegen Ausgang des Mittelalters. Die einzige auf uns gekommene Dalmatik, welche, wie es scheint, noch nach früherem Brauch nur am linken Ärmel und am Schlitz der linken Seite mit Fransen umsäumt war, ist die Dalmatik Theobalds von Nanteuil, Bischofs von Beauvais $(1283-1300)^{2}$.

Eine eigentümliche, übrigens seltene Verzierung haben zwei im Dom zu Brandenburg befindliche Dalmatiken. Auf ihrer Rückseite ist oben nahe dem

I Abbildung bei Roh. VII, pl. DxLIx, besser Revue IV 561. Das Gewand scheint, wie seine Mafe vermuten lassen, eine Dalmatik zu sein, die im 15. Jahrhundert für eine Statue des Heiligen angefertigt wurde. Es hat einen
Gesamtbrustumfang von nur $0,90 \mathrm{~m}$ und ist dazu nicht einmal bis zur halben Seitenhöhe offen.

2 Revue $1860,653 \mathrm{ff}$ mit Ablilduns ter Dalmatik. 
Rande ein Paar silbelvergoldeter Löwenköpfe aufgenäht, aus deren Maul einst eine Quaste herabhing. Die Dalmatiken stammen aus der Wende des 15 . Jahrhunderts ${ }^{1}$.

Noch merkwürdiger ist ein Schmuck, welchen wir bis tief in das 16. Jahrhnudert hinein im Norden und Nordosten Deutschlands wiederholt bei dem Gewand antreffen. Er bestand in dreieckigen, von Fransen eingefafitell und mit vergoldeten Silberplättchen reich besetzten Seidenstücken, welche von den Schultern auf den Riücken herabhingen. Sie waren urspritinglich wohl nicht blok als Verzierung gedacht, sondern sollten auch, wie es scheint, gleich den vorhin erwähnten Quasten zum Verschlielỉen eines an dem Kopfdurchschlupf angebrachten Schlitzes dienen. Die St Marienkirche zu

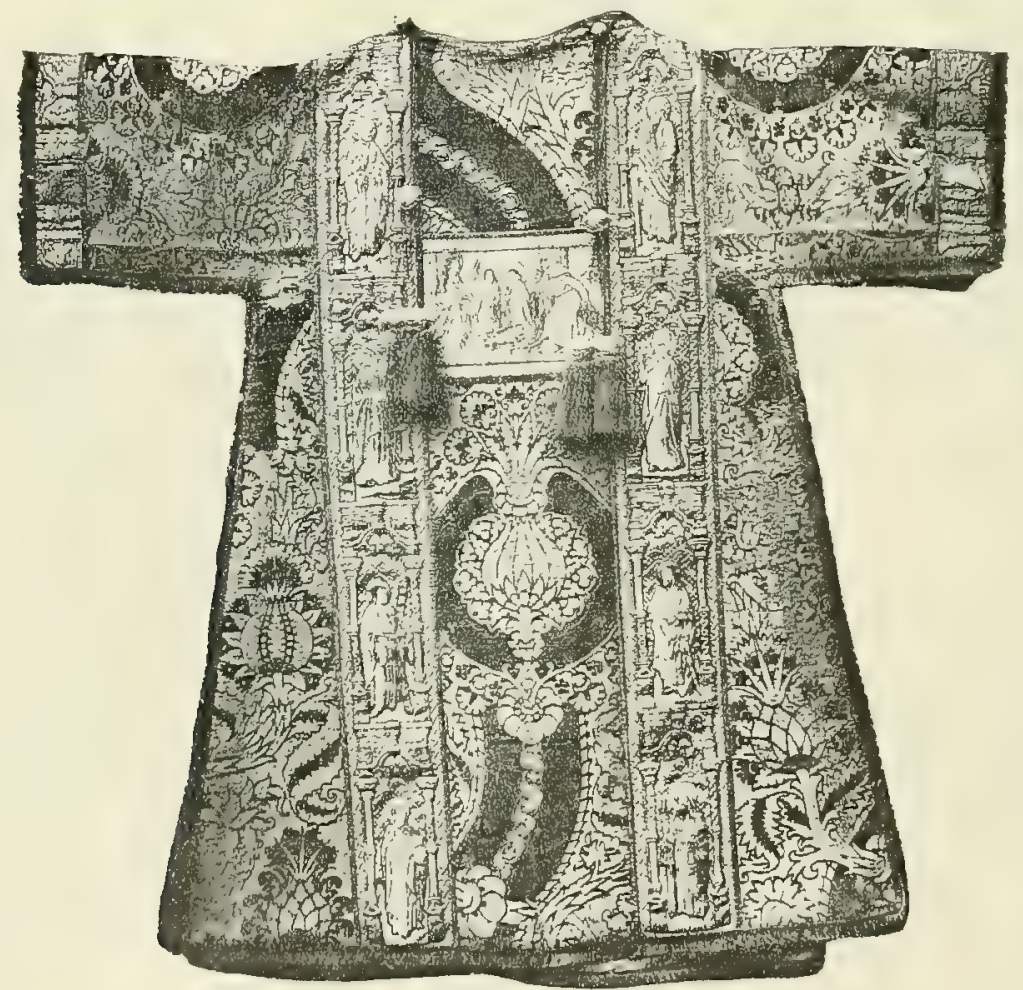

Bild 135. Dalmatik. Xanten, Dom.

Danzig bewaht noch zwei dieser Zierstücke auf (Bild 134, S. 277). Daf diese wirklich in dor angegebenen Weise verwendet wurden, bekundet ein Gemälde des St Barluaraaltars in derselben Kirche, welches die Bestattung der Heiligen durch Engel darstellt. Die Dalmatik, welche einer der Engel trägt, weist auf dor Rü̈ckscite zwei Behänge von derselben Art wie jene Zierstücke im Schatz von St Marien auf. Man nannte diese dreieckigen, reich verzierten Zeugstücke "Flügel, scapularia". So heift es z. B. in einem Elbinger Inventar aus dem Jahr 1544: 1 Kestlein, darin 4 flügcl zu Dalmatiken mit 4 silbern ülorgulten bildern und vergulten spangen . . 8 paar Hügel zu Dal-

1 Fin Inventar von St Elisitheth zu Breslan

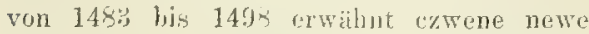
diene Kïcke von Jiottrun Sannath m it c zween
Silluern Knewffenn. Diese Knäufe waren wohl auf dem Rïcken angehracht und Gegenstïcke der Löwenköpfe. 
matiken mit übergulten spangen und knöpfeln ... schwartze flügel mit leberchen; und in einem Allensteiner Schatzverzeichnis von 1581: Dalmaticae 2 danascenae rubrae cum scapularibus 3 plene fibulatis et 4 to in extremitatibus tantummodo. Ebenso verzeichnet das Inventar der Dominikanerkirche zu Stolp von 1523: item 58 Rosetten Spangenn unde 4 Bordtspangenn up den twe flögeln tho den Dyakenn Röcken und mit 10 Knöpenn ${ }^{1}$.

Die Besätze der Dalmatiken mit Bildstickereien zu versehen, scheint nicht einmal im späteren Mittelalter sonderlich Branch gewesen zu sein. Es gibt unter den noch vorhandenen Dalmatiken aus dieser Zeit nur wenige, welche auf den Stäben figurale Darstellungen aufweisen; aber auch die Inventare erwähnen nur selten solche. Kommt doch in dem an kostbaren Dalmatiken so reichen Inventar von St Peter aus dem Jahre 1361 nur eine vor, bei der vermerkt ist, daf auf ihren fimbriae (Saumbesätzen) je drei Heiligenbilder in Rundmedaillons angebracht seien. Nicht besser verhält es sich im Inventar der Schätze des Apostolischen Stuhles aus dem Jahre 1295. Ein wenig günstiger steht es um bestickte Dalmatikbesätze im Verzeichnis der Paramente, welche Bonifaz VIII. der Kathedrale voll Anagni schenkte, da sich unter den vielen hier genannten Dalmatiken doch

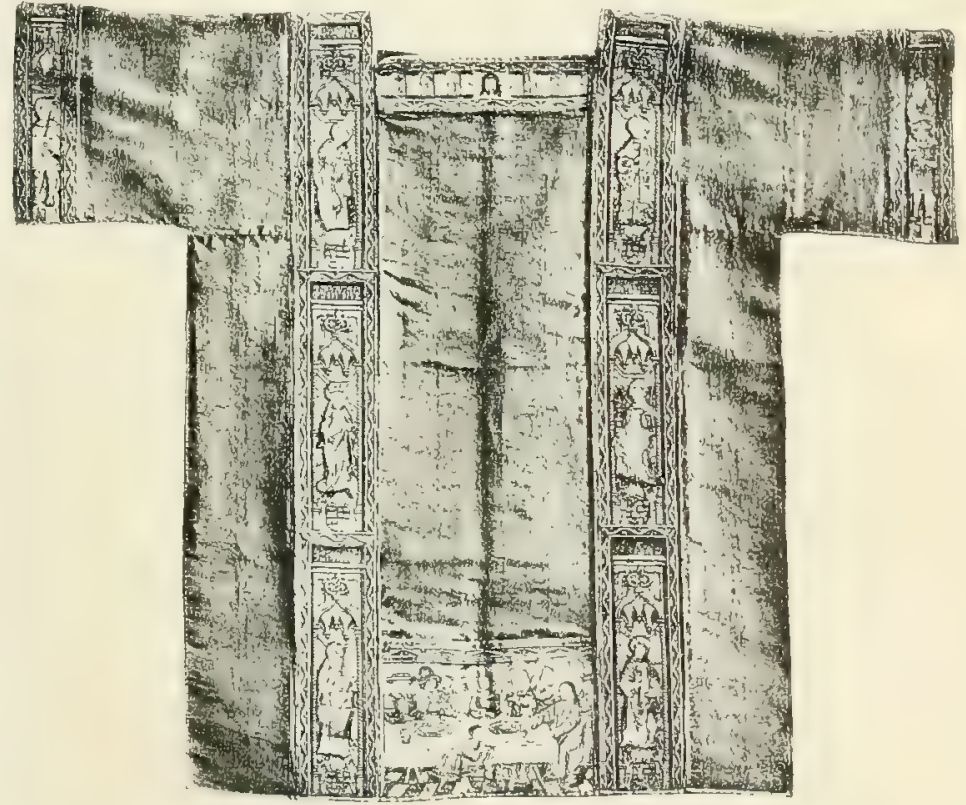

Bild 136. Dalmatik. Bern, Hist, Musenm. (Phot, de Fares.)

wenigstens drei befinden, welche auf den Stäben Figurenwerk aufwiesen: Item una dalmatica... cum ymaginibus Salvatoris et apostolorum Petri et Pauli ex parte ante et beatae Virginis, sci Toannis et sci Nicolai a tergo in fimbreis de auro et in manicis cum 10 ymaginibus... item una dalmatica... cum fimbriis ad ystoriam sci Eustacii ... et manicas ad minutas ymagines et aves. Die dritte wurde schon erwähnt?

In der Tat boten die Besätze der Dalmatik mit etwaiger Ausnahme der Querstücke am Saum oder auf Brust und Rücken wegen ihrer geringen Breite zu wenig Raum für figurale Darstellungen. Es ging, falls das Bildwerk nicht

1 Im Inventar von St Veit zu Prag aus dem Jahre 1387 werden als Verzierung der Dalmatik und des Subtile trica e erwähnt, so $\mathrm{Nr}_{1} 226$ : Integer ornatus de nachone (eine Art von Brokatell) blavo... et subtile ac dyalmatica habent tricas de rubeo serico, and $\mathrm{Nr} 233$ :
Integer ornatus albus... dyalmatica et subtile habent tricas dependentes de rubeo serico. Unter tricae werden sonst Flechten verstanden; was sie hier bedeuten, ist unklar, am wahrscheinlichsten Vertikalbesätze.

2 S. oben S. 272 . 
miniaturartig klein oder die Besätze zu breit und schwer werden sollten, kaum anders, als Einzelfiguren auf ihnen anzubringen. Die sind es denn auch fast allein, welche man auf ihnen antrifft. Vorzügliche in dieser Weise mit Heiligenfiguren geschmückte Dalmatikbesätze finden sich zu Greven und Vreden (beide in Westfalen), zu Xanten (Bild 135, S. 278) sowie im Historischen Museum zu Bern (Bild 136, S. 279). Bei der Dalmatik im Berner Museum sind auf den entsprechend hohen, nach italienischer Weise am Saum angebrachten Querbesätzen Szenen aus dem Leben Christi (der Jesusknabe im Tempel, die Hochzeit zu Kana) zur Darstellung gekommen.

Die Zahl der Dalmatiken, welche sich aus dem späteren Mittelalter erhalten haben, ist, wie früher schon gelegentlich bemerkt wurde, eine beträchtliche. Die Mehrzahl derselben findet sich in Deutschland; namentlich sei, um von einzelnen Exemplaren abzusehen, auf die Dalmatiken im Dom zuXanten, in der St Marienkirchezu Danzig, in den Domen zu Halberstadt und Brandenburg und in der Alten Kapelle zu Regensburg hingewiesen. Von den zahlreichen Halberstädter Dalmatiken gehören zwei noch dem 13., die übrigen zum Teil dem 14., zum Teil dem 15. Jahrhundert an. Die Mehrzahl der Danziger entstammt dem 15, einige dem 14. und 16. Jahrhundert'. Von spätmittelalterlichen Dalmatiken in Österreich sind besonders bemerkenswert die Dalmatiken zu Göf und zu Wien, von denen schon ausführlicher die Rede war. In der Schweiz haben sich unseres Wissens keine andern erhalten als die drei, welche sich samt den zu ihnen gehörenden Tunicellen im Historischen Museum zu Bern befinden (vgl. Bild 136, S. 279) ${ }^{3}$.

Auch Italien ist sehr arm an Dalmatiken aus dem Mittelalter. Was sich an solchen noch zu Anagni befindet, ist leider nicht mehr in dem ursprünglichen Zustand. Einige Dalmatiken in der Opera del Duomo zu Orvieto und im Museo degli Arrazzi zu Florenz scheinen gleichfalls nicht mehr intakt zu sein. Zwei dalmatikartige Gewänder in der Pfarrkirche zu Castel S. Elia bei Nepi sind angesichts der ungewöhnlich schmalen Ärmel wohl keine Dalmatiken, sondern Tunicellen.

Auch Frankreich kann sich nur mehr einer recht beschränkten Zahl mittelalterlicher Dalmatiken rühmen. Sie sind fast alle schon gelegentlich erwähnt worden. Wir reihen daher hier noch an die unten leider um etwa $15-20 \mathrm{~cm}$ verkürzte Dalmatik des sel. Peter von Luxemburg in St-Pierre zu Avignon ${ }^{3}$. Die Dalmatiken im Hospiz zu Lisieux, die bis vor kurzem als Reliquien des hl. Thomas Becket galten, wurden seitdem als solche des hl. Thomas von Cantilupe nachgewiesen "

\section{DIE DALMATIK IN DER NEUZEIT.}

Die Geschichte der Dalmatik in der Neuzeit läßst sich mit wenig Strichen zeichnen. Zu Rom ist um die Mitte des 16. Jahrhunderts der Typus fertig, der dort von nun an für alle Folgezeit maligebend bleibt. Die fimbriae der Inventare, d. i. die Paruren am Saum, sind bei dem Gewand verschwunden oder werden, richtiger gesagt, durch zwei parallele Horizontalborten angedeutet. Die Länge des Gewandes, dessen Ärmel stets geschlossen sind, beträgt ca 1,20 $\mathrm{m}$. Fruhe treffliche Beispiele bieten zwei Dalmatiken in S. Maria Maggiore

1 Im Dom zu Halberstadt beläuft sich die Zahl der Dalmatiken und der ibnen nach Stoff, Form und Ausstattung gleichartigen Tunicellen anf' 24, zul St Marien in Danzig auf 18, im Dom zu Brandenburg auf 19, zu Xanten auf 10.

" Abbildungen der beiden andern bei de Farcy, Suprol. pl. 164, wo sie jedoch irrtümlich als Heroldsröcke (tabars) bezeichnet sind. Vgl. wegen der Dalmatiken auch J. Stammler, Der Domschatz von Lausame und seine Überreste, in "Katholische SchweizerBlaitter X (1894) $38 \mathrm{ff} 85 \mathrm{ff} 91 \mathrm{ff}$.

s Abbildung und Beschreibungbei de Linas, Anciens vetements sacerdotaux I $57 \mathrm{ff}$.

4 Bullet. mon. 1849, $262 \mathrm{ff}$ mit Abbildung und Revue 1891, $91 \mathrm{f}$. Vgl. wegen der Zuweisung auch oben S. 74, Anm. 1. 
zu Rom, von denen die eine vom hl. Pius V., die andere vom hl. Karl Borromäus stammt. Es sind Dalmatiken, wie sie noch jetzt in Italien allenthalben gebräuchlich sind (Bild 137).

Auferhalb Roms dauert die Entwicklung über das 16. Jahrhundert hinaus fort. Bezüglich des Besatzes hatte sich auch hier bereits zu Ende des Mittelalters ein Typus gebildet, der seitdem eine wesentliche Veränderung nicht mehr erlitt. Dagegen hatte die Weiterbildnng, besser Verbildung des Gewandes in Bezug auf die Makverhältnisse und die Form noch kemeswegs ihren Abschluf gefunden.

Schon im 15. Jahrhundert war es, wie wir hörten, wenngleich nur vereinzelt, vorgekommen, daßs man anch die Ärmel des Gewandes aufschlitzte. Im 16. Jahrhundert wurde diese Gepflogenheit immer häufiger und im 17. dann allgemein gebräuchlich. Schon um 1650 dïrften im ganzen Norden Dalmatiken mit geschlossenen Ärmeln kaum mehr gemacht worden sein. Anfang's wurden die Ärmel mittels Haften oder Bändern, die man an den Schlitzen angebracht hatte, nach Weise eines geschlossenen Ärmels zusammengebunden, doch kam auch das bald aufer Gebrauch, und schon im 17. Jahrhundert waren bei der diakonalen Dalmatik die Ärmelallenthalben zu Flügeln geworden, welche lose über den Oberarm herabhingen. Bei der bischöflichen Dalmatik erhielten sich die Bänder aus

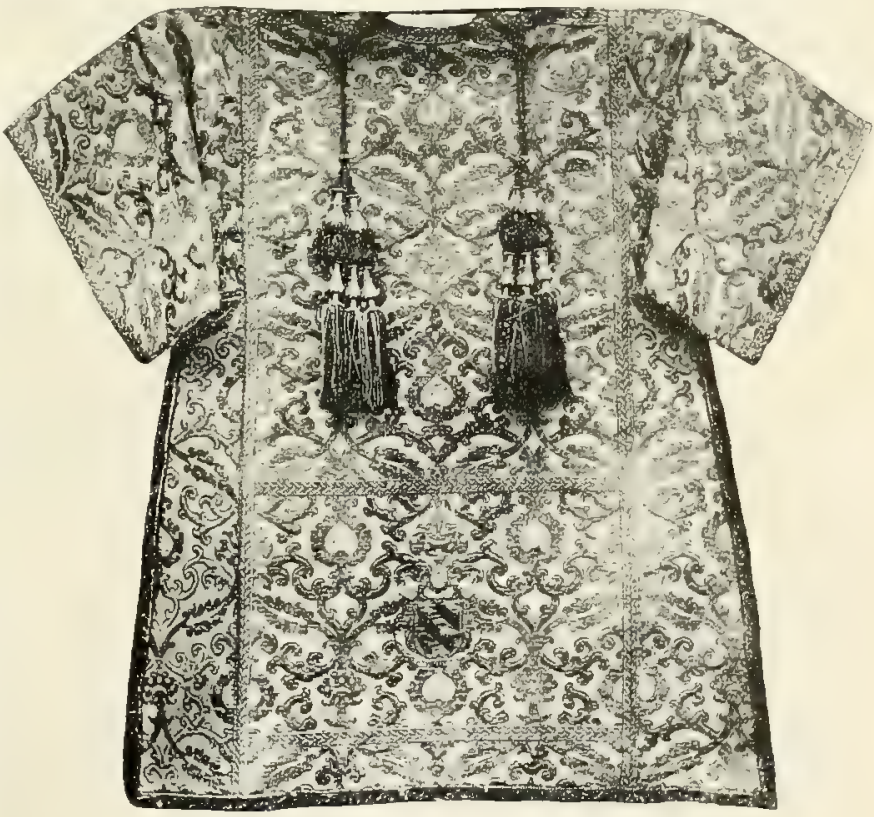

Bild 137. Dalmatik. Rom, S. Maria Maggiore.

7weckmäligkeitsrücksichten; in der Tat waren sie ja hier anch kaum zu entbehren. Den Grund zur Änderung der Form der Ärmel haben wir in dem leidigen Bestreben zu suchen, das Gewand möglichst bequem zu gestalten. Es war das aber auch die Triebfeder, dieses immer mehr nach Länge und Weite zuzustutzen.

Im 16. Jahrhundert betrug die Länge der Dalmatik durchweg noch $1,20-1,15 \mathrm{~m}$. Im 17. Jahrhundert sehen wir sie dann auf $1,15-1,10 \mathrm{~m}$ und im 18. sogar auf nur $1,00 \mathrm{~m}$ herabsinken. Weiter konnte man allerdings nicht gehen. Man latte die äulierste Grenze in der Zustutzung des Gewandes erreicht. Die stets zunehmende Verkürzung der Länge bedingte aber auch eine entsprechende Verringerung der Weite, sollte nicht alles Verhältnis gestört werden. Wirklich fiel denn auch die untere Breite der Dalmatik ron etwa $1,00 \mathrm{~m}$ im 16. Jahrhundert allmählich auf blok $0,75 \mathrm{~m}$ im 18., die Brustweite aber in gleichem Mafe von ca $0,75 \mathrm{~m}$ auf ca $0,50 \mathrm{~m}$. Zuletzt ging 
man sogar nicht selten dazu über, der größseren Bequemlichkeit halber die Vorderseite der Dalmatik, ähnlich wie man es bei der Kasel zu machen pflegte, vor den Armen auszuschneiden. Je mehr dabei der Sinn für die Wirkung der Form schwand, um so mehr legte man auf glänzende Ausstattung Wert. Auch in diesem Punkt verhielt es sich mit der Dalmatik wie mit dem Mefogewand. Noch jetzt gibt es zahlreiche Dalmatiken aus dem 17. und 18. Jahrhundert, welche über und über mit schweren Gold- und Silberstickereien bedeckt sind. Es sind zum Teil wirkliche Prunkstücke, darauf berechnet, möglichst grofen Effekt zu machen, aber gleich den Prachtkaseln aus jener Zeit auch nur Prunkstücke. Religiöse Motive treten bei ihren Stickereien sogar noch mehr zurück wie bei diesen. Für gewöhnlich geht das Ornament bei ihnen ganz in Arabesken, pseudo-klassischem Rankenwerk und allerlei Schnörkelwesen auf. Am wenigsten war auf den Dalmatiken ein Plätzchen für figürliche Darstellungen mehr übrig, und wäre es selbst nur ein bescheidenes Brustbild gewesen, namentlich im 18. Jahrhundert.

Nur in Spanien erhielt sich die Figurenstickerei auf den Dalmatiken noch eine Weile über das 16 . Jahrhundert hinaus. Die breiten, rechteckigen Besätze, welche man hier vor wie nach bei besseren Dalmatiken am Saum anzubringen pflegte, waren, weil für Bildstickerei besonder's geeignet, ohne Zweifel darauf von Einfluk. Die bildlichen Darstellungen sind vornehmlich in der sog. Lasurtechnik ausgeführt (Bild 133, S. 276). Im 17. Jahrhundert verschwinden indessen auch auf der spanischen Dalmatik allmählich die figürlichen Stickereien ${ }^{1}$.

Es ist ein gewaltiger Unterschied zwischen der alten Glockenkasel, wie sie uns auf den frühchristlichen Bildwerken entgegentritt und sich bis ins 13. Jahrhundert in Gebrauch erhielt, und dem überkurzen und iiberschmalen Miniaturmefogewand, wie es allmählich infolge einer durch Jahrhunderte sich hinziehenden Verkümmerung im 18. Jahrhundert Mode geworden war. Indessen fast noch gewaltiger ist der Kontrast zwischen der weihevollen, bis auf die Fübe herabwallenden Dalmatik des ersten Jahrtausends mit ihren mächtigen, bauschigen Ärmeln, ihren Purpurstreifen und dem edlen, vollen Faltenfluf, mit welchem sie den Körper umhüllte, und dem armseligen, pygmäenlaften, geflügelten Skapulier, womit das altehrwürdige Gewand die lange Reihe seiner verschiedenen Entwicklungsphasen in der Zeit des Pokoko endlich beschlieken sollte. Der Grund aber für die Verkümmerung beider Gewänder war hier wie dort neben dem Verlangen nach gröberem Glanz in der Ausstattung vor allem die stets wachsende Sucht nach immer gröberer Bequemlichkeit. Die schlimmste Entartung waren wie die Lederkaseln die Lederdalmatiken, gleich geschmacklos in Bezug auf Form, Material and Verzierung, aber würdig der 'Keit der' Aufklärung, deren Errungenschaft sie waren. Beispiele solcher Dalmatiken finclen sich noch in der Stiftskirche zu Oberwesel am Rhein und zu Kremsbrücken in Kärnten.

Bei der Emeuerung des Paramentenwesens im Beginn der zweiten Hälfte des 19. Jahrhunderts wandte man auch der Verbesserung der Dalmatik sein Augenmerk $z 1$ und erzielte in Deutschland wirklich eine bemerkenswerte Reform. Inslyesondere erhielt die Dalmatik bessere Malaverhältnisse. Zu völlig geschlossenen ïrmeln kehrte man leider nicht zurück, roch wurde es vielfach Brauch, an den $̈$ rmeln wieder Haften ouler Schnüre zum Schliefon an- 
zubringen. Weniger Glück hatte das Bestreben in Frankreich und Belgien. Die römische Dalmatik bedurfte kaum einer verbessernden Hand, da sie his in die Gegenwart alles in allem eine genïgend wiirdige Form bewahrt hatte.

\section{ALTER DER VERWENDUNG DER TUNIKA BEI DEN SUBDIAKONEN UND BISCHÖFEN.}

Eine subdiakonale Obertunika war zu Rom, wie aus dem Schreiben Gregors des Grofien an den Bischof Johannes von Syrakus erhellt, schon im 6. Jahrhundert vorühergehend in Gebrauch; sie wurcle aher gegen Ende desselben durch Gregor „im Einklang mit der alten Sitte der Kirche", wie es in dem Briefe heift, wieder abgeschafft ${ }^{1}$. Seitdem bedienten sich die Subdiakone von neuem wie vorher der Planeta, und zwar wohl bis in den Anfang des 9. Jahrhunderts. Jedenfalls geschah das noch um die Mitte des 8. Jahrhunderts, d. i, zur Zeit, da der 1. Ordo entstand. Denn trotzdem dieser den Ritus der feierlichen Papstmesse am ()stertag beschreibt, treten in ihm die Subdiakone doch überall nur in Planeten, nirgends in einer der diakonalen Dalmatik verwandten Tunika auf. Allein es scheint zu Rom selbst um das Ende des 8. Jahrhunderts bei den Subdiakonen eine solche noch nicht zur Verwendung gekommen zu sein, da auch der 2. und 3. römische Ordo, die aus jener Zeit stammen mögen, die Subdiakone noch immer in der Planeta ihres Amtes walten lassen 2.

Amalar kennt schon die subdiakonale Dalmatik, wie er das Gewand nennt ${ }^{3}$. Das gleiche gilt vom Ordo Duchesnes und vom S. G. K. Auch in den Inventaren des 9. Jahrhunderts ist bereits von der Tunika der Subdiakone die Rede. So verzeichnet das Inventar ron St-Riquier vom Jahre 8.31 neben 31 Dalmatiken hrocci serici 15 , lanei 11 , sericus albus 1, persi (pfirsichblütarbige) serici 2. In eimer Tebenkirche befanden sich zusammen mit Kaseln und Dalmatiken hrocci de pallio 3. Ein Schatzvelzeichnis ron St Bertin aus dem Jahre 867 erwähnt unter den liturgischen Gewändern eine dalmatica subdiaconalis, ein Inventar von St Trond aus dem Jahre 870 dalmaticae 9 cum tunicis subdiaconalibus. In der Kirche zu Staffelsee befand sich laut der um 810 gemachten Aufnahme des Bestandes auber 2 planetae castaneac, 1 planeta de lana facta et tincta, 7 albae und 1 dalmatica auch 1 linea, worunter nach dem Zusammenhang nur die subdiakonale Tunika verstanden werden kann.

Bildwerke aus dem 9. Jahrhundert, welche einen Subdiakon in seiner Tunika wiedergeben, sind ein Relief des Mailänder Palliotto ${ }^{*}$, die Miniatur des

Ep. 1. 9, n. 26 (M. G. Epp. II 59): Subdiaconos autem ut $\mathrm{spoli}$ atos procedere facerem, antiqua consuetudo ecclesiae fuit. Sed placuit cuidam nostro pontifici, nescio cui, qui eos vestitos procedere praecepit. Nam vestrae ecclesiae (in Sizilien) numquid traditionem a Graecis acceperunt? Unde habent ergo lodie ut subdiaconi in eis in tunicis procedant, nisi quia hoc a matre sua romana ecclesia perceperunt. Spoliati kann hier nach dem Zusanmonhang nur heifen ,ohne besondere Obertunika", wie die Diakone sie trugen, vestiti "mit einer solchen". Aus dem Brief geht hervor, daf der Brauch vou Rom sich auch schon nach Sizilien ver- pflanzt hatte. Die gedruckten Ausgaben haben auf Grund eines Codex lineis statt in eis, doch ist in eis wohl das Richtige.

\section{S. oben S. 161 .}

3 De offic. eccles. 1. 2, c, 26 (M. 105, 1102) : Dalmatica diaconi et sui ministri (d. i. des Subdiakons), quae est itineri habilis, cura proximorum est. $\mathrm{Ob}$ indessen vielleicht nicht besser zu lesen ist: Dalmatica episcopi et sui ministri, d. i. des Diakons (vgl. c. 22 ; ebd. 1098).

$\$$ Das Relief stellt St Amlrosius am Altar in Schlaf versunken dar. Ein Diakon, des hinter ihm steht, zupft ihn an der Schulter, wie um ihn $z u$ wecken, während cin sub- 
Sakramentars von Autun mit der Darstellung der Weihegrade (vgl. Bild 24, S. 62) und eine Niniatur in Codex B 252 der Vallicelliana zu Rom mit der Figur des Subdiakons Juvenianus (Bild 125, S. 267).

Wir werden, alles in allem genommen, wohl nicht fehlgehen, wenn wir die Einführung einer Obertunika bei den Subdiakonen an Stelle der bis dahin ausschlielalich gebräuchlichen Planeta für Rom etwa in die erste Hälfte des 9. Jahrhunderts setzen. Außerhalb Roms mag der Wechsel etwas früher vor sich gegangen sein. Wenigstens würde es sich so am leichtesten erklären, daf schon im Inventar von Staffelsee die linea aufgeführt wird und bereits um 850 das Relief des Palliotto eine Darstellung des Gewandes aufweist. War man ja doch auferhalb Roms ungleich fortschrittlicher wie zu Rom, wo man konservativen Sinnes möglichst am Alten festzuhalten liebte.

Welche Verbreitung die subdiakonale Tunika im Lauf des 9. Jahrhunderts fand, läßst sich bei dem Mangel an diesbezüglichen Nachrichten nicht feststellen. Zur Zeit Drogos von Metz $(826-855) \mathrm{kam}$ sie jedenfalls noch nicht allgemein zur Verwendung, da auf den durch Treue der Darstellung so wichtigen Elfenbeinreliefs der Deckel des Drogosakramentars die Subdiakone lediglich in gegürteter Albe wiedergegeben sind.

Wie es in vorkarolingischer Zeit auferhalb Roms im Abendland hinsichtlich einer Obertunika der Subdiakone gehalten wurde, ist unklar. Aus Gallien fehlt jegliche Nachricht über eine solche wie überhaupt über die Kleidung, in welcher diese ministrierten. Die Lektoren trugen wie die Diakone die Alba ${ }^{1}$. In Spanien hatten die Subdiakone zufolge dem 9. Kanon der Synode von Braga aus dem Jahre 561 bei ihren Amtsverrichtungen eine ungegürtete Tunika. Dieselbe kann, wie schon früher gesagt wurde, von der diakonalen Albe nicht merklich verschieden gewesen sein, weil die Synode vorschreibt, es sollten die Diakone das Orarium über der Tunika tragen, damit sie sich so von den Subdiakonen genügend unterschieden ${ }^{2}$.

Ungleich früher als bei den Subdiakonen finden wir die Tunika zu Rom bei dem Papste. Sie erscheint schon im 1. Ordo als Bestandteil der päpstlichen Pontifikalkleidung und hieb dalmatica minor, dalmatica linea oder schlechthin tunica. Die römischen Kardinalpriester und Hebdomadarbischöfe durften sich nach dem S. G. K. nur dieser Tunika bedienen ${ }^{3}$. Bei den übrigen Bischöfen war die Verwendung des Gewandes allem Anschein nach im 9. Jahrhundert nur erst wenig verbreitet, zumal im Norden. Denn weder Hraban noch Walafried tut seiner bei Aufzählung der bischöflichen Sakralgewänder irgendwelche Erwähnung. Amalar widmet zwar der 'Tunika einige Worte ${ }^{4}$, deutet aber durch die Art und Weise, wie er von ihr spricht, genugsam an, dafi es damals noch keineswegs bei den Bischöfen die Regel war, aufer der Dalmatik auch die Tunika zu tragen. Es hat überhaupt lange gedauert, bis sich diese neben der Dalmatik als fester Bestandteil der Pontifikalkleidung allenthalben eingebürgert hatte; war sie doch erst gegen

diakon (Lector?) die Epistel singt. Als St Mar tin von Tours gestorben war, so erzählt Gregor von Tours (Le nirac. S. Mart. 1. 1, c. 5 [M. 71, 918]), stand zur Zeit, da er bestattet werden sollte, St Ambrosius am Altar, um das heilige Opfer darzubringen. Allein plötzlich fiel er in einen tiefen Schlaf, während dessen er wunderbarerweise nach 'Tours entrickt wurde und dort die Beisetzung seines Freundes rornahm. 1 S. oben S. 253.

\& Hard. JII 351 und oben S. 253.

3 S. oben S. $255 \mathrm{f}$.

4 De offic eccles. 1. 2, c. 22 (M. 105, 1098): Si quis voluerit uti duabus tunicis (gemeint sind Dalmatik and Tunicella), ostendet se esse diaconum et sacerdotem. 
Ende des 12. Jahrhunderts bei den Bischöfen allgemein in Gebrauch. Bis dahin lieken es sich diese noch immer vielfach mit der Dalmatik genug sein, die dann häufig schlechthin statt dalmatica tunica genannt wurde. So kennen z. B. nur eine Tunika, d. i. die Dalmatik, das Sakramentar von Corbie aus dem Ende des 10. Jahrhunderts ${ }^{1}$, der Weiheordo bei Hittorp ${ }^{2}$, die Gemma animae des Honorius, Gilbert von Limerick, Rupert von Deutz und ein interessanter anonymer Traktat über die bischöflichen Gewänder in einer dem 12. Jahrhundert entstammenden Handschrift der St Gallener Stiftsbibliothek ${ }^{3}$; der Tractatus de sacramento altaris aber macht die Bemerkung, der Bischof ziehe über der Albe eine oder, wie andere wollten, zwei Tuniken an. Bei Ivo von Chartres ist die Sache nicht ganz klar. Wie es indessen scheint, spricht auch er nur von einer Tunika, d. i. der Dalmatik; denn von den beiden Tuniken, die er dem Bischof zuschreibt, bedeutet eine unzweifelhaft die Albe*.

Zwei Tuniken im Sinne von Dalmatik und Tunicella zählen zur Pontifikalgewandung Hugo von St Viktor, Robertus Paululus, Sicard von Cremona und Innozenz III. Im Sacramentarium gedenkt anch Honorius der Tunika. Sie heifst hier subucula ${ }^{5}$.

Bei den Subdiakonen war die Tunika schon um die Wende des Jahrtansends so gebräuchlich, dafs man Tunika und Manipel kurzerhand als vestes subdiaconales zu bezeichnen pflegte, ähnlich wie Stola und Dalmatik vestes diaconales genannt wurden. Der Subdiakonat hatte allmählich eine höhere Bedleutung gewonnen, und schon war die Zeit nicht ferm, da er den ordines maiores zugesellt werden sollte. Es ist daher leicht verständlich, dafo bei den Subdiakonen die Tunika schmell allgemeine Aufnahme fand. Das höhere Ansehen, welches dem Subdiakonat nach und nach zu teil geworden wal und seine Inhaber fast den Diakonen gleichstellte, mulite in der Tat gebieterisch dazu drängen, dals ihnen ein Gegenstïck zur diakonalen Dalmatik in Gestalt einer besondern Obertunika beigelegt und der Gebrauch der Planeta, wo ein solcher stattgehabt, auf jene Tage beschränkt wurde, für welche die festtägliche Tunika nicht passend erschien. Schon um die Wende des Jahrtausends ist die Zahl der subdiakonalen Tuniken in den Schatzverzeichnissen bisweilen eine sehr bedeutende. So führt z. B. ein Inventar von Prüm aus dem Jahre 1003 neben 28 dalmaticae diaconales nicht weniger als 24 dalmaticae subdiaconales auf.

Übrigens bedienten sich nicht an allen Orten alle Subdiakone ohne Ausnahme der Tunika. In Mailand, wo das Gewand Alba hießs, durften es heispielsweise lediglich die Subdiakone der Kathedrale - die sog. ordinarii und solche Subdiakone, welche Äbte waren, tragen ${ }^{6}$, allen übrigen war der Gebrauch der Alba verboten. So war es dort noch gegen Ende des 13. Jahrhunderts Brauch. Immerhin werden Gepflogenheiten dieser Art doch mehr den Charakter von Ausnahmen besessen haben. Es war sogar manchenorts üblich, daßs auch die Akolythen nach Weise der Subdiakone über der Albe eine Tunika trugen. Ceroferarii et thuriferarii, sagt z. B. das Ordinarium von Bayeux aus dem 13. Jahrhundert, in omni festo cum quattuor cappis

\footnotetext{
1 Mart. 1. 1, c. 4, art. 12, ordo 11 ; I 203.

2 Hitt. 109.

s Cod. 777, f. 89 ff. Der Verfasser rechnet zu den bischöflichen Gewändern auch das Rationale, ein Schultergewand.
}

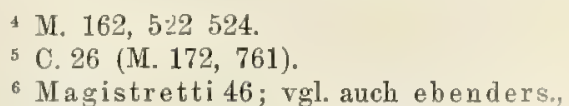
Pontificale in usum ecclesiae Mediolanensis, Mediolani $1897,40$. 
de stallo altiore induuntur super albam et amictum tunicis sericis ${ }^{1}$. Das Inventar des Domes zu Mainz weils von einer grofen Zahl derartiger Tuniken zu erzählen: item multae tunicae diversorum colorum, videlicet rubei, viridis et violacei coloris, virgulatae, croceae, albae, quibus utebantur ministri altaris et acolythi et chrismatis portatores. Ein Inventar von Soignies aus dem Jahre 1382 erwähnt 4 tournikials denfans. Die Sitte muf namentlich in England, Spanien und Frankreich häufig gewesen sein. In Spanien hat sie sich vereinzelt bis in die Gegenwart erhalten; in England ging sie mit dem Umsturz der alten kirchlichen Ordnung zu Grunde; in Frankreich dauerte sie nach Ausweis der Inventare hie und da noch bis wenigstens ins 17. Jahrhundert? Man nannte die Akolythentunika auch wohl dalmatica, so in den Inventaren von Angers von 1297 bis 1643 und noch jetzt in Spanien, sowie alba, so besonders in England; 7 albes called ferial black, 40 blue albs of divers sorts, red albs for Passion week 27, sagt beispielsweise ein Inventar von Peterborough von $1539^{3}$.

7u Rom mïssen Akolythentuniken nach den Angaben des S. G. K. schon im Lauf des 9. Jahrhunderts in Gebrauch gekommen sein. Un die Wende des ersten Jahrtausends begegnen uns solche zu Farfa, wo den Consuetudines Farfenses zufolge an bestimmten hohen Festen sämtliche pueri in tunicis erschienen, an andern dagegen wenigstens die Akolythen, welche die Evangeliare zu tragen oder die Prophetie bzw. die Epistel zu singen hatten *. Sie mögen zu Farfa in Nachahmung römischer Sitte eingeführt worden sein. Auch in Frankreich dürften bereits im 10. Jahrhundert hie und da Akolythentuniken ïblich gewesen sein. Denn unter den corcibals 8 et alios vetulos 5 samt den camsili (sic) serici 3 und den rocci serici 3 im Inventar von ClermontFerrand können wohl nur Akolythengewänder verstanden werden.

Äbten scheint das Recht, die Tunika zu tragen, in älterer Zeit nur selı selten verliehen worden zu sein; wenigstens hören wir nur ausnahmsweise von der Erteilung dieses Privilegs. Johannes XV. gewährte es 990 dem Abt Folcuin von Lobbes, Alexander III, 1169 dem Abt von La Cava, 1176 dem Abt von Monreale und 1177 dem Abt von St-Vaast zu Arras ${ }^{5}$. Möglich, dab̧ das Vorrecht, sich der Dalmatik zu bedienen, wie es manchen Äbten zu teil wurde, das andere, auch die Tunika zu gebrauchen, ohne weiteres einschlok; indessen ist das keineswegs sicher, da ja im 11. und 12. Jahrhundert nicht einmal bei den Bischöfen der Gebrauch von Tunika und Dalmatik allgemein war. Im Gegenteil macht der Umstand, daf in den Bullen für Lobbes, La Cava, Monreale und St Vaast die Tunika ausnahmsweise ausdrücklich erwähnt wird, es wahrscheinlicher, daf den Äbten wirklich für gewöhnlich nur der usus dalmaticae bewilligt wurde. Erst als um das 13̈. Jahrhundert die Tunika zum selbstverständlichen Bestandteil der Pontifikalkleidung und zu einer Art von Zubehör der bischöflichen Dalmatik geworden war, hedurfte sie in den Bullen, wodurch den Äbten der Gebrauch der Pontifikalien gestattet wurde, keiner besondern Nennung mehr.

1 Chevalier, Ordinaire et coutumier de Bayeux 36 et passim.

2 Vergleiche z. B. (Revue 1886, 176) die Inventare von Angers, in denen noch zum Jahre 1643 Akolythentuniken aufgeführt werden. Ein Inventar von St-Omer aus dem Jahr 1557 (ebd. 464, note 4) verzeichnet 36 tuniques pour les enfants de chour, ein
Inventar von St Johann zu Köln von 1406 neben 8 leisröcke (Levitentuniken) auch 2 scholarenröcke.

$8 \mathrm{M}$ a calister, Ecclesiast. vestments, London 1896, 65. Vgl. auch oben S. 60.

4 Albers, Consuet. Farfens. 10142343 5783 (pueri toti tunicas habeant).

5 J. 3837115911268312770 . 


\section{NAMEN DER LEVITENGEWÄNDER.}

Die Dalmatik hat ihren Namen nie gewechselt. Sie hief so zur Zeit, da sie zu Rom in Gebrauch kam und dann von dort aus sich im übrigen Abendland einzubürgern begann, und sie heibt noch jetzt so nach kirchlichem Sprachgebrauch. Nur hier und dort wurde im Mittelalter das Gewand mit dem allgemeinen Namen tunica bezeichnet ${ }^{1}$. Dio Namen der subdiakonalen Obertunika waren ehedem sehr mannigfaltig. Die hauptsächlichsten Bezeichnungen waren subtile und tunica (tunicella). In Italien, England und Frankreich wurde sie vornehmlich tunica genannt. In Deutschland herrschte etwa seit der Wende des Jahrtausends die Benennung subtile vor.

Wir begegnen dem Namen subtile schon in einem unter Abt Hesso im Beginn des 10. Jahrhunderts entstandenen Inventar der Klosters Pfäffers in der Schweiz und einem Inventar der königlichen Basilika zu Monza von ca $910^{2}$. Im 11. und 12. Jahrhundert bildet er in den Schatzverzeichnissen deutscher Kirchen die ständige Bezeichnung für die subdiakonale Obertunika. Man vergleiche die Inventare von Pfäffers aus dem 11. und 12. Jahrhundert, das Inventar von Wörthsee in Kärnten (ca 1000) und Lamspringe (?) (10. bis 11. Jahrhundert), das Verzeichnis der Paramente, welche Bischof Meinwerk von Paderborn dem Kloster Abdinghof gab, die Angaben Adams von Bremen betreffs der liturgischen Gewänder, welche Kaiser Heinrich IV. dem Dom zu Hamburg schenkte ${ }^{3}$, die Notiz Ekkehards des Jüngeren über die Paramente, welche Hedwig von Schwaben dem Kloster St Gallen verehrtes, die Inventare von St Gallen (11. Jahrhundert), Enger (11. Jahrhundert), Benediktbeuren (1032), Speier (1156), St Georg zu Köln (ca 1100), Krakau (1101), Bamberg (1127), Martinsberg in Ungarn (12: Jahrhundert), Prüfening bei Regensburg (1165), Altmünster zu Mainz (12. Jahrhundert), Gandersheim (12. Jahrhundert), Neumünster zu Würzburg (1230), Trier (1238) u. a. ${ }^{5}$ Nur sehr selten führt die subdiakonale Obertunika in den älteren deutschen Schatzverzeichnissen einen andern Namen, wie z. B. im Inventar von Prüm von 1003, wo sie dalmatica subdiaconalis heißt. Auch Honorius nennt in seiner Gemma animae das Obergewand des Subdiakons subtile? Er ist der einzige von allen Liturgikern, bei dem es diesen Namen trägt, ein Umstand, der unzweifelhaft nicht wenig zu Gunsten der Annahme spricht, daf Honorius ein Deutscher war oder doch in Deutschland seine Schrift verfaßte ${ }^{7}$.

Der Name subtile erhielt sich in Deutschland bis ins späte Mittelalter hinein. Wir finden ihn z. B. noch in den Inventaren von Freising (1352), Prag $(1354,1387,1396,1413)$ und Olmütz (1435). Wie es gekommen, dafi

1 Ein älterer französischer Name der Dal matik ist wardecor; sie heift so z. B. im Inventar der Kapelle Roberts von Flandern von 1319 (Dehaisnes, L'art en Flandre, Documents 225); ältere deutsche Benennungen siehe unten am Schluf des Abschnittes.

Der Verfasser des Inventars, ein gewisser Subdiakon Adalbertus, muf, wie die Schreibweise Perengarius statt Berengarius, talmatica statt dalmatica, ein Süddeutscher gewesen sein.

${ }^{3}$ Gesta Pontif. Hammaburg. eccl. 1. 3, n. 44

(M. G. SS. VII 352).

${ }^{4}$ Ekkeh. IV, Casus S. Galli c. 10 (M. G. SS. II 123).

5 Auch in der sog. Missa lllyrica heißt die Tunika subtile (M art. 1. 1, c. 4, art. 12, ordo 4; I 177). In Frankreich scheint der
Name nur sehr wenig gebräuchlich gewesen zu sein. Ein Beispiel findet sich in einem Obituarium der Sorbonne ad an. 1324: Idem dominus (Gilbertus de Sancta Aldeghonde) dedit ornamenta bona, videlicet casulam ... et subtile subdiaconi (Recueil des Histoires de la France, Obituaires I 739).

${ }^{6}$ Gemma 1. 1, c. 229 (M. 172, 613) : Subdiacono... subtile et sudarium adduntur.

7 Wenn auch Sicald (Mitralis I. 2, c. 8 [M. 213, 85]) das Gewand subtile nennt, so kommt das daher, daf seine Worte einfachhin der Gemma des Honorius entlehnt sind. Ähnlich verhält es sich später bei Durandus (1. 3 , c. 10 ; f. 73), der zudem genügend andeutet, dak subtile für ihn nicht die gewöhnliche Bezeichnung war: tunica quae alibi subtile. 
man das Gewand subtile genannt, ist unklar. Bei Ezechiel $(16,10)$ und Isaias $(19,9)$ bedenten subtilia feine Gewebe oder Gewänder aus feinem Stoff. Möglich, daf. man der subdiakonalen Obertunika im Anschlufs an rliese Stellen der Heiligen Schrift darum den Namen subtile gab, weil sie aus besserem und feinerem Stoff als die untere Tunika, die Albe, gemacht wurde.

Als spezifisches Obergewand der Subdiakone hief die Tunika restis subdiaconalis oder auch wohl, wie z. B. im Verzeichnis der liturgischen Geräte und Paramente, welche Bischof Reginard von Lüttich dem Kloster St Laurentius 1034 bei Gelegenheit der Konsekration der Klosterkirche schenkte, schlechthin subdiaconale.

Auch dalmatica subdiaconalis wird die Tunika der Subdiakone wiederholt genannt, wohl im Anschluk an die römischen Ordines, welche von einer dalmatica maior und minor sprechen. Als sich im späten Mittelalter der Unterschied in Bezug auf die Form der Dalmatik und Tunicella rerwischt hatte, verlor sich vielfach auch der Unterschied in der Bezeichnung, so daß beide Gewänder gleichmäßig Dalmatik genannt wurden.

Die, wie es scheint, nur ganz vereinzelt gebräuchliche Benennung linea ${ }^{1}$ duirfte sich an den Ausdruck dalmatica linea des 1. römischen Ordo anlehnen und sich auf den Tmstand gründen, daß̉ die subdiakonale Tunika ursprünglich nur aus Linnen gemacht zu werden pflegte.

Der Name alba, welchen sowohl die Tunika der Subdiakone wie der Bischöfe in Mittelalter nicht selten führte, wird teils von der Ähnlichkeit, welche diese wegen ihrer engen Ärmel mit der gewöhnlichen Albe hatte, teils ron der weifen Farbe, welche die Tunika ursprünglich besaf, lierkommen. Dieses letztere Moment geriet freilich im Lauf der Zeit so gründlich in Vergessenheit, dafs man ohne alles Bedenken von albae rubrae, virides, nigrae usw. redete $^{2}$. Übrigens mag sich in dem Namen alba auch eine Erinnerung an die liturgische Tunika der Diakone und Lektoren des gallikanischen Ritus erhalten haben.

Stricta tunica oder kurz stricta wurde das subdiakonale Obergewand an einigen Orten genannt, weil sie von geringerer Weite als die Dalmatik war und namentlich engere Ärmel als diese besaß3. ${ }^{3}$. Der Name blieb auch, als sich der Formunterschied zwischen Dalmatik und Tunicella verloren hatte, doch erlangte er nie weitere Verbreitung ${ }^{4}$. Er begegnet uns noch im 16. Jahrhundert in der italienischen Umbildung stretta in einem Caeremoniale von S. Marco zu Venedig als gemeinsame Bezeichnung der Dalmatik und Tunicella ${ }^{5}$.

Der Name roceus gehört der älteren Zeit an. Wir treffen ihn z. B. im Inventar von St-Riquier, im Testament Riculfs von Elne ${ }^{6}$ und noch im 11. Jahrhundert, wenngleich in angelsächsischer Umformung im Testament Leofrics von Exeter $(\dagger 1072)^{7}$ an. Leofric vermacht darin unter andern liturgischen Gegenständen seiner Kathedrale 3 pistel roccas, Tuniken für diejenigen, welche die Epistel sangen, die Subdiakone.

1 Vgl. z. B. das Inventar von Staffelsee.

2 S. oben S. $1: 0$.

3 Gemma 1. 1, c. 229 (M. 172, 613).

s Er findet sich z. B. im Inventar von St Johann im Lateran von 145 s, im Inventar des Santo zu Padua vom Jahre 1396 und dem des Domes zu Aquileja von 1358 bis 1378.
5 Civiltà cattolica 1899, ser. 17, vol.8, S. 460. Vgl. auch das Schatzverzeichnis vou S. Marco aus dem Jahre 1519.

$6 \mathrm{Vgl}$. auch die Inventare von Fontanelle und St Bavo zu Gent.

`Warren, Leofric Missal p. xxı. Im Registrum Roffense heifst das Gewand ähnlich tunica epistolaria. 
Die Benennung tunicella, Diminutiv von tunica, kam allem Anschein nach erst im Verlauf des 13. Jahrhunderts in Gebrauch. Allerdings treffen wir schon in einem Inventar von Marchiennes aus dem 9. Jahrhundert den ganz verwandten Namen tunichellus an: tunichelli 5 ; jedoch bleibt dieser bis in das 13 . Jahrhundert eine durchaus vereinzelte Erscheinung. Die Bezeichnung tunicella findet sich bereits in dem auf Befehl Gregors X. herausgegebenen Caeremoniale romanum ${ }^{2}$ sowie im Rationale und Pontifikale des Durandus², doch kann sie noch um das Ende des Jahrhunderts nicht sehr verbreitet gewesen sein. Denn das Verzeichnis der Paramente, welche Bonifaz VIII. der Kathedrale von Anagni schenkte, kennt sie noch gar nicht, im Inventar des päpstlichen Schatzes vom Jahre 1295 aber logegnet sie uns blof einmal. Dagegen ist im Inventar desselben vom Jahre $1327^{3}$ und im Schatzverzeichnis von St Peter aus dem Jahre 1361 tunicella bereits die ständige Bezeichnung für die subdiakonale Tunika. In nordischen Inventaren kommt der Name erst wieder im Anfang des 14. Jahrhunderts vor, so $1385 \mathrm{im}$ Schatzverzeichnis der Kathedrale von Tournai und bereits 1319 in der französischen Umformung tournikel im Inventar der Kapelle Roberts von Flandern*. Übrigens gelangte er bis zum Ende des Mittelalters im Norden nirgends zu gröberer Verbreitung. Besonders zäh hielt man in Frankreich nach Ausweis der Inventare an der Benennung tunica fest. Ähnlich geschah es auch in England, wo indessen in der Volkssprache sich die Diminutivform tunacle (von tunicula) herausbildete.

Mittelalterliche deutsche Bezeichnungen für Dalmatik und Tunicella waren korerock, lessrock, leisrock und namentlich dienrock, dienstrock, dienerock

\section{BESCHAFFENHEIT DER TUNIKA IM MITTELALTER UND IN DER NEUZEIT.}

Über die Form und Beschaffenheit der subdiakonalen Obertunika erfahren wir Näheres erst im 9. Jahrhundert. Wie dieselbe damals zu Rom aussah, zeigt die Figur des Subdiakons Juvenianus auf der schon erwähnten Miniatur des Codex B 252 der Vallicelliana. Juvenianus, welcher dem hl. Laurentius ein Buch überreicht, trägt eine his auf die Fülie reichende, dem Ǩ̈rper sich ziemlich dicht anschließ̋ende Tunika von weifser Farbe (vgl. Bild 125, S. 267). Die Ärmel sind eng; Schlitze an den Seiten fehlen; die Ausstattung des Gewandes besteht in einem schmalen, die Ärmelsäume umgebenden Zierstreifen. Daf es sich bei ihm nicht um die gewöhnliche untere Tunika oder Albe handelt, ergibt sich aus dem Umstand, dafi es der Gürtung entbehrt.

Ein etwas anderes Bild der subdiakonalen Tunika gewährt die Darstellung des Subdiakons im Sakramentar von Autum (vgl. Bild 24, S.62). Wir haben hier das Gewand in der Umbildung, wie es im Frankenland in Gebrauch war, vor uns. Es reicht nur bis zur Mitte des Schienbeins, dagegen sind die Ärmel weiter, als es auf der Miniatur des Codex der Vallicelliana der Fall ist. Von Zierstreifen ist an ihm nichts zu bemerken.

N. 6 (M. 78, 1107).

= L. 5 , c. 2. n. 6 , f. 256 ; M a rt. 1. 1, c. 4 , art. 12, ordo 23 ; I 221.

s Denifle-Ehrle, Archiv für Literatur und Kirchengeschichte des Mittelalters I, Berlin 1885, 319.

Bran, Die liturgisehe Gewanduno.
4 Dehaisnes, L'art dans la Flandre, Documents 225 .

$5 \mathrm{Vgl}$. z. B. die Inventare von Breslan, St Quintin zu Mainz, Odesloe, Schweidnitz, St Stephan zu Wien (St Moranduskapelle), Zeitz u. a. 
Die Entwicklung, welche die subdiakonale Obertunika in der Folge nimmt, vollzielıt sich analog der Umbildung der Dalmatik; die Länge verringert sich langsam, aber stetig; an den Seiten werden Schlitze angebracht, die immer länger werden und zuletzt die ganze Seite bis zum Ansatz der Ärmel einnehmen. Die Ärmel, welche anfänglich nur eine sehr mäsige Weite hatten, gewinnen im Gegensatz zu den Ärmeln der Dalmatik an Umfang, bis zuletzt zwischen der diakonalen und subdiakonalen Obertunika kaum mehr ein Unterschied wahrnehmbar ist. Um das Ende des Mittelalters sind Dalmatik und Tunika vielfach gar nicht mehr voneinander zu unterscheiden. Man studiere z. B. nur die Dalmatiken und Tunicellen im Dom zu Halberstadt, in St Marien zu Danzig, im Dom zu Brandenburg, im Historischen Museum zu Bern und in der Alten Kapelle zu Regensburg. Es ist in den meisten Fällen schlechterdings unmöglich, zu bestimmen, welches Gewand die Dalmatik und welches die Tunicella darstellen soll.

Den Entwicklungsgang der Tunicella vom 9. bis zum 16. Jahrhundert näher ins einzelne zu verfolgen, ist unmöglich, weil die Liturgiker zu wenig Aufschluf über die Form des Gewandes geben, und auf den Monumenten die subdiakonale Tunika verhältnismäßig nur selten auftritt.

In Rom und überhaupt in Italien kam die Verbildung der Tunicella wie die der Dalmatik im 16. Jahrhundert zum Abschlus. In Frankreich, Deutschland, Spanien, kurz außerhalb Italiens dauert sie gerade wie bei dieser bis in das 18 . Jahrhundert hinein fort, d. i. bis aus der einstigen Talartunika ein bis kaum zu den Knieen reichendes, mit Ärmellappen statt Ärmeln versehenes Skapulier geworden war. Der Unterschied zwischen der Tunicella und Dalmatik war aber auch in Italien schon im 16. Jahrhundert verwischt. Wohl bestimmte noch die dritte Mailänder Synode, es sollte die Tunika der Subdiakone engere Ärmel haben als die Dalmatik ${ }^{1}$. Allein einen nachhaltigen praktischen Erfolg hatte diese Verordnung ebensowenig wie die Anweisung des 1600 auf Befehl Klemens' VIII. herausgegebenen römischen Caeremoniale: (Tunicella) eiusdem forma est, cuius est dalmatica diaconi nisi quod strictiores longioresque aliquantulum manicas habere debet ${ }^{2}$.

Nur bezüglich der pontifikalen Tunicella und Dalmatik erhielt sich ein Unterschied hinsichtlich der Weite der Ärmel, begreiflich, da ja die Dalmatik über die Tunicella angezogen werden muf.

Als Stoff, aus dem die Tunika hergestellt wurde, diente anfänglich Leinwand ${ }^{3}$. Doch gab es nach dem Ordo, den Duchesne herausgegeben hat, schon im 9. Jahrhundert neben leinenen auch seidene Subdiakonaltuniken: Et induunt se (subdiaconi) tonicas albas, quales habent, sericas aut lineas. Das Inventar von St-Riquier aus dem Jahre 831 bestätigt das, da es neben 31 Dalmatiken im ganzen nicht weniger denn 18 seidene Tuniken vermerkt; bei 1; fehlt eine Angabe der Farbe, eine wird als weib hezeichnet, zwei als pfirsichblütenfarhig. Im späteren Mittelalter war bei der Tunicella gleichwie bei der Malmatik Seide das Gewöhnliche; andere Stoffe waren mehr Ausnahme, und zwar nicht bloßs bei der pontifikalen, sondern auch bei der subdiakonalen Tunicella. Dio Inventare lassen daran keinen Zweifel. Das Material, ans dem in denselben die Tuniken gemacht erscheinen, sind immer wieder dieselhen prächtigen Cendelzeuge, Köper, Damaste, Brokate, Samte usw., aus 
denen auch die in ihnen aufgeführten Kaseln hergestellt sind. Bemerkenswert und auffällig ist, dafi es nach Ausweis des Inventars von St-Riquier schon in der Frühe des 9. Jahrhunderts farbige Tuniken gab. Eine purpurne Tunika wird 915 im Testament Riculfs von Elne erwähnt. Indessen mag die Verwendung von Tuniken dieser Art eine der Neuerungen sein, welche das Frankenreich bei der liturgischen Gewandung hervorbrachte. In Rom dürfte es um diese Zeit wohl noch kaum farbige Tuniken gegeben haben. Der Grund, weshalb bei der Tunika früher als bei der Dalmatik sich die Farbe einbürgerte, liegt vielleicht darin, daß es bei ihr keine alte Tradition gab wie bei der Dalmatik; sie war ja ein jüngeres Gewand.

Man hat behauptet, die bischöfliche Tunicella sei bis ins 13. Jahrhundert vorherrschend hyazinthfarbig; d. i. blaurot, gewesen. Allein die Liturgiker sagen nichts davon. Amalar redet, wenn er von einer hyazinthfarbenen Tunika spricht, von dem alttestamentlichen Heil. Auch die Angahen Ivos von Chartres beziehen sich aul dieses aaronitische Kultgewand. Auf keinen Fall besagen seine Worte, daß die Pontifikaltunika stets oder doch der Regel nach hyazinthfarbig zu sein pflegte. Was Johannes von Avranches bei Besprechung der Tunika bezüglich der Farbe bemerkt, ist nur eine Exegese der Worte des Pentateuchs: Facies tibi tunicam hyacinthinam (Ex 28, 31). Nach dem Speculum de mysteriis ecclesiae war die dritte Tunika des Bischofs, wie es darin heißst, also die pontifikale Dalmatik, hyazinthfarbig. Sicard meint, wenn er die Tunika als hyazinthfarben bezeichnet, das eine Mal die Obertunika des alttestamentlichen Hohenpriesters, das andere Mal folgt aus seinen Worten lediglich, dafo die bischöfliche Tunika auch wohl hyazinthfarbig war, nicht aber, dafs sie stets diese Farbe hatte. Wie es um die Farbe der Pontifikaltunika im frühen 12. Jahrhundert in Wirklichkeit stand, hören wir von Bruno von Segni, dessen Worte es außer Zweifel stellen, daß es für dieselhe damals im Gegensatz zum hyazinthfarbigen Meil des Alten Bundes keine bestimmte Farbe gegeben hat'.

In den Inventaren ist bis zum 13. Jahrhundert von der Farbe der Tunika kaum jemals die Rede. Für gewöhnlich führen sie nur die Zahl der vorhandenen Tuniken an, höchstens, daf sie noch über die Ausstattung eine besondere kurze Notiz anfügen. Wo sie aber von deren Farbe reden, bestätigen sie, was uns Bruno von Segni hinsichtlich der Farbe des Gewandes sagt.

Tunicae coccineae 5 werden in einem Inventar des Klosters Abdinghof zu Paderborn aus der Zeit des Abtes Gumbert erwähnt. Eine grüne Tunika erwarb für das Kloster Monte Cassino Abt Desiderius, der spätere Papst Viktor III. $\left(†\right.$ 1087) ${ }^{2}$, eine pfirsichblütenfarbene schenkte ihm Robert Guiscard ${ }^{3}$. Das Register von Rochester führt als Gabe des Erzbischofs Lanfrank eine tunica epistolaris aus schwarzem Purpur, als Gabe Bischof Ernulfs (1114-1123) drei violette und zwei rote Tuniken und als Geschenk Bischof Gilberts (1185-1215) eine Tunika aus weifem Damast an!. Rote Tuniken begegnen uns auch schon in des Beroldus Caeremoniale von S. Ambrogio.

Als sich ein liturgischer Farbenkanon gegen Ende des 12. Jahrhunderts bildete, wurde derselbe natürlich auch für die Tunicella maßgebend. In den Inventaren kommt das seitdem wie bei der Dalmatik gewöhnlich in der Weise zum Ausdruck, dafs die Tunicellen nicht mehr gesondert für sich aufgezählt, sondern in Verbindung mit Kasel und Dalmatik unter dem Gesamtnamen ornatus integer verzeichnet werden.

1 Tract. de sacr. eccl, c. de tunica ( $M$. 165,1104 ): Tunica in veteri testamento hyacinthina solummodo erat et alterius coloris non erat... Et tali quidem tunica apostolus indutus dicebat: ${ }_{\pi}$ Nostra conversatio in coelis est (Phil 3, 20). Ad hanc igitur tunicam respiciat episcopus. Si enim candida fuerit, significat, quod candidi esse debent et immaculati, si autem alterius coloris tunica fuerit, est et alterius significationis.

2 Chron. Cassin. ]. 3, n. 18 (M. G. SS.

VII 711),

Ebd. 1. 3, n. 58 (ebd. 743).

- Revue 1887, 335. 
Tas die Verzierung der Tunika anlangt, so wurden, soweit wenigstens die Monumente ein Trteil darüber zulassen, nie die Purpurclavi, das für die Dalmatik charakteristische Ornament, dazu verwendet. Ebenso finden wir niemals bei dem Gewand die eigenartigen fimbriae, Fransenflöckchen, mit der man, wie wir sahen, die Dalmatik bis tief ins 12. Jahrhundert hinein gern zu bedenken pflegte. Wohl aber scheint man im 11. und 12. Jahrhundert nicht selten die Tunika mit kostbaren Borten oder Goldstickereien geschmückt zu haben. Wiederholt begegnen uns derartige Tuniken in den Inventaren aus jener Zeit. Es werden darin sogar eigentümlicherweise häutiger reich verzierte Tuniken als reich verzierte Dalmatiken aufgeführt. In manchen Fällen dürfte es sich freilich bei solchen goldverzierten Tuniken um bischöfliche Tuniken handeln, sicher aber nicht immer. Ihren Grund mag diese ungleiche Be-

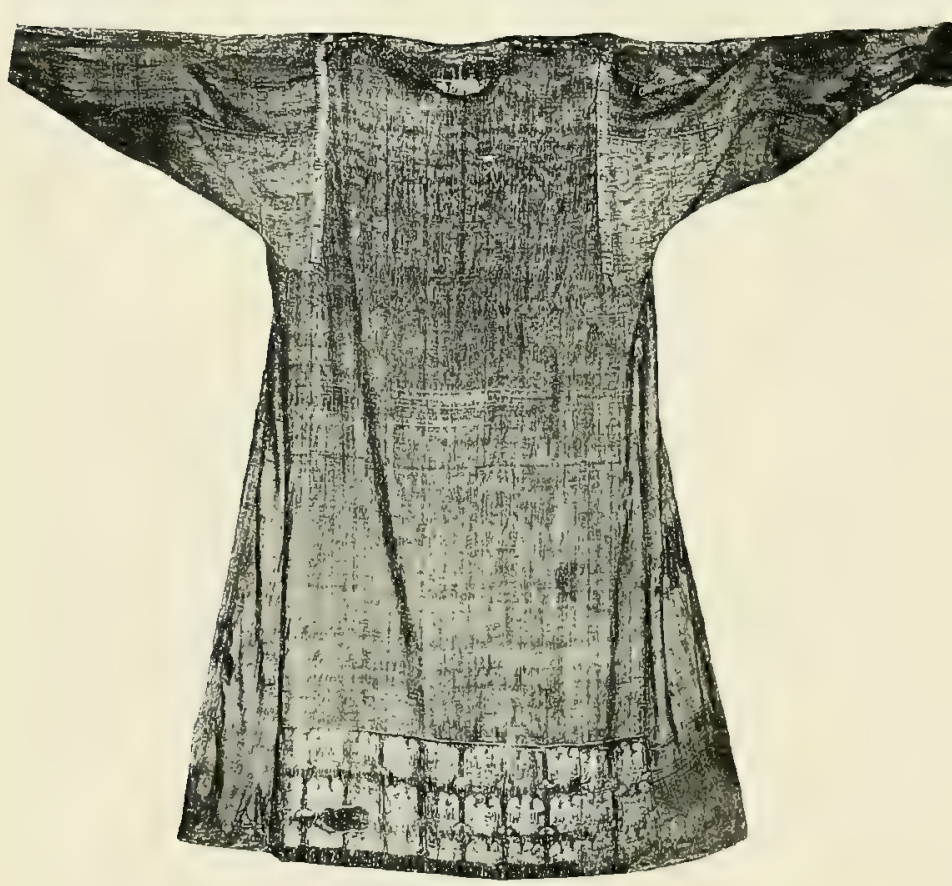

Bild 138. Tunicella. Castel S. Elia. handlung der beiden Gewänder darin haben, dafs für die Dalmatik damals noch eine bestimmte traditionelle Verzierungsweise mittels der Purpurstreifen bestand, nicht aber für die Tunika, und man somit in der Ausstattung der letzteren weniger durch alten Brauch gebunden und beschränkt war.

Schon das TestamentRiculfs von Elne erwähnt roccum purpureum cum auro, und nur

wenig später das dem 10. Jahrhundert angehörende Inventar von Clermont-Ferrand tunicas duas cum auro. Abt Desiderius erwarb für Monte Cassino eine grüne Tunika (tunica diapistin) cum urna (Borte) amplissima a pedibus et manibus ace scapulis; Kaiser Heinrich II. schenkte dem Kloster eine Tunika aus Damast, aureis operibus ornatam, Viktor III. aber hinterlief ihm anßer 19 einfachen fünf tunicae paratae, d. h. mit Zierbesätzen geschmückte 'Tuniken ${ }^{1}$. Das Inventar von St Gallen verzeichnet neben 18 andern drei aurata, d. i. mit Goldborten oder Goldstickereien versehene sultilia. Im Domschatz zu Bamberg befanden sich im Anfang des 12. Jahrhunderts unter den 14 darin vorhandenen subtiliae (sic) nicht weniger denn neun, welche mit kostbaren Goldborten ausgestattet waren. Die Kathedrale von Ely (England) hesaf.3 1079 tunicae tres cum aurifriso (sic); im Schatzverzeichnis des Klosters Prüfening bei Regenshurg aus dem 12. Jahrhundert aber werden duo subtilia argentofregiata (= frisiata), zwei mit Silherborten verzierte Subtilien, notiert. Ein sehr kosthares fiewand muf auch das subtile pene aureum gewesen sein, welches Hadawiga,

1 Chron. Cassin. 1. 2, n. $43 ; 1.2$, n. 74 (M. G. SS. VII 656753 ). 
Tochter des Herzogs Heinrich von Schwaben, mitsamt einer gleichen Dalmatik dem Kloster St Gallen schenkte, später aber, da ihr der Abt ein von ihr gewünschtes Antiphonarium verweigerte, mit echt weibischer Verschlagenheit zurïckzubekommen wuste !

Als das Charakteristikum der Dalmatik, die roten clavi, gegen Ausgang des 12. Jahrhunderts aufer Brauch kam, verschwindet in Bezug auf die Verzierungsweise jeder Unterschied zwischen beiden Gewändern. Es ist daher überflüssig, auf die Ausstattung, welche die Tunicella im späteren Mittelalter und in der Neuzeit fand, näher einzugehen. Was in dieser Beziehung des weiteren betreffs der Dalmatik ausgeführt wurde, gilt alles auch hinsichtlich der Tunicella.

Von den noch vorhandenen mittelalterlichen Tunicellen geht keine über das 13. Jahrhundert hinaus; sie entstammen alle der Zeit, in der sowohl bezüglich der Form als namentlich bezüglich der Verzierung ein Unterschied zwischen Dalmatik und Tunicella sich kaum mehr bemerklich machte. Hinsichtlich des Stoffes sind am bemerkenswertesten die Tunicellen in der Alten Kapelle zu Regensburg, durch ihre mit vorzüglichen Bildstickereien geschmůckten Besätze eine Tunicella im Historischen Museum zu Bern und einige Tunicellen im Dom zu Xanten. Ganz in Stickerei hergestellt sind die Tunicella zu Göß, doch ohne figürliche Darstellungen, und die großartige, zum Meßornat des Ordens vom Goldenen Vlies gehörende Tunicella in der k. k. Schatzkammer zu Wien, das vollkommene Gegenstück der früher besprochenen und abgebildeten Dalmatik (vgl. Bild 130, S. 273). Die Tunicellen in St Marien zu Danzig weisen keine Besätze auf, sind aber wie zum Ersatz dafür aus zwei oder mehreren verschiedenen Seidenstoffen hergestellt. Zwei leider sehr schadhafte Tunicellen zu Castel S. Elia (Bild 138), Arbeiten aus dem 14. Jahrhundert, bestehen aus blauer repsartiger Seide und sind unten wie die damaligen italienischen Dalmatiken mit einem paruraartigen Zierstück, auf den Schultern aber und über der Ansatznaht der Ärmel mit einem schmalen Börtchen geschmückt. Sie gewähren ein gutes Bild der charakteristischen Verzierung, welche man damals in Italien dem Gewand zu geben pflegte.

\section{LITURGISCHE VERWENDUNG DER DALMATIK UND TUNICELLA.}

Über die Verwendung, welche Dalmatik und Tunicella im Mittelalter beim Gottesdienst fanden, erfahren wir, abgesehen von gelegentlichen Äuberungen einzelner noch erhaltener Ordinare und Consuetudinare, im ganzen nur wenig. Sie bildeten das liturgische Obergewand der Diakone und Subdiakone, vornehmlich dann, wenn diese als Ministri beim feierlichen Amt tätig waren, und waren sonach vor allem das Gegenstück des priesterlichen Mefgewandes. Indessen wurden sie auch bei sonstigen gottesdienstlichen Feierlichkeiten gebraucht, wie z. B. bei Reliquientranslationen, bei feierlichen Empfängen, bei Prozessionen und ähnlichem und entsprachen dann nach Ingebrauchnahme des Pluviale dem Pluviale des fungierenden Priesters (vgl. Bild 122, S. 262).

Die Bischöfe, Äbte und sonstige Prälaten, welchen der Gebrauch von Dalmatik und Tunicella zugestanden war, bedienten sich derselben nur bei feierlichen liturgischen Funktionen. Bei der Privatmesse hatten sie wie alle andern Priester die Kasel unmittelbar über der Stola und Albe. Der Papst trug dagegen nach dem S. G. K. bei derselben über der Albe zwar nicht die Dal-

1 Ekkeh. IV, Casus S. Galli c. 10 (M. G. SS. II 123). 
matik, aber eine seidene Tunika ${ }^{1}$. Später freilich verwendete auch er bei ihr nur noch die gewöhnliche Priesterkleidung ${ }^{2}$.

Zum Pluviale scheint man sich nach $\mathrm{r}$ ömischem Brauch niemals der Dalmatik und Tunicella bedient zu haben. Jedenfalls war es so schon im späteren Mittelalter zu Rom Sitte. Auferhalb Roms war dagegen die Praxis bei den Bischöfen eme verschiedene. Meistens wird man freilich auch hier die Gewänder nur in Verbindung mit der Kasel getragen haben ${ }^{3}$; jedoch geschah das keineswegs überall, namentlich nicht in der Spätzeit des Mittelalters. Die spätmittelalterlichen Monumente mit ihren zahlreichen Bischofsfiguren, bei denen Dalmatik und Tunicella zusammen mit dem Pluviale vorkommen, lassen daran keinen Zweifel t. Es sind ihrer zu viele und zu verschiedenartige, als das man für das gleichzeitige Vorkommen der drei Gewänder lediglich die Phantasie des Künstlers verantwortlich machen dürite. Angesichts der liturgischen Eigenarten, welche um jene Zeit allenthalben eingerissen waren, und des Mangels an klaren, bestimmten Vorschriften kann ja auch ein solches Abweichen vom römischen Ritus nicht im geringsten befremden. Wirklich beweist z. B. ein Mainzer Pontifikale aus dem Beginn des 14. Jahrhunderts, daf man sich damals zu Mainz der Dalmatik und Tunicella auch wohl zum Pluviale bediente ${ }^{5}$.

Die Gepflogenheit, wonach zu jenen Zeiten des Kirchenjahres, welche einen Bufcharakter besitzen, Diakon und Subdiakon ohne Dalmatik und Tunicella zu amtieren haben, indem sie diese entweder ganz weglassen oder durch die planeta plicata ersetzen, stammt aus Rom und verbreitete sich von dort im übrigen Abendlande. Die lichte Dalmatik entsprach, wie früher schon gesagt wurde, nach römischer Anschauung zu wenig der liturgischen Eigenart gewisser Abschnitte und Tage des Kirchenjahres. Für die Bufe und Trauer, welche dieselben beherrschten, erschien ein dunkles Obergewand anstatt der Freude und Festesstimmung kündenden Dalmatik und Tunicella angemessener. Daher denn die Dalmatik und entsprechend später auch die subdiakonale Tunika zu diesen Zeiten durch eine braune oder schwarze Planeta ersetzt wurde ${ }^{6}$. Die Anschauung, welche diesem Brauche zu Grunde lag, ist dieselbe, welche den Ordo officiorum vulgatus sagen heift: Quam litaniam (die litania maior am St Markustag) observare debent omnes christiani... non pretiosis vestibus induti, und: Nullus autem his diebus (den Rogationstagen) vestimenta pretiosa induetur, quia in sacco et cinere lugere debemus ${ }^{\top}$.

1 Cotidianis diebus, sagt der S. G. K., d. i. bei der Privatmesse.

So wohl schon im 13. Jahrhundert, wie wiv aus dem im 13. Ordo, n. 6 (M. 78, 1108) mitgeteilten Ritus der Priesterweihe eines zum Papst erwáhlten Diakons mit Fug folgern zu diirfen glauben.

Vgl. z. B. Maxt. 1. 1, c. 6, art. 7, ordo 1319 (Auszitge aus Pontifikalien von Besaneon und [syoll); I 289 294, und 1. 4, c. 22 (Auszuige ans einem Pontifikale von Aix, einem Ordinarium von Rouen und einem Pontifikale von Arles); III 8485 116. Ebenso Cluevalier, Ordinarium Bayocense (13. Jahrh.) 61118135.

\footnotetext{
4 Bei den Darstellungen aus der früheren Zeit des Jahrtausends erscheint das Pluviale in der Regel bei den Bischöfen allein ohne Dalmatik und Tunicella, und zwar nicht bloß zu Rom, sondern selbst im Norden. Beispiele bei Roh. VIII, pl. DcxxIff. Andere im Salzburger Antiphonar, jm Echternachter Evangeliar der $\mathrm{kgl}$. Bibliothek zu Brüssel, in einem Liber officialis der Einsiedler Bibliothek ( $\mathrm{Nr}$ 112) usw.

${ }^{5}$ M a r t. 1. 4, c. 22 (Auszug aus einem Mainzer Pontifikale); III 119: Episcopus indutus dalmatica et subtili vel tantum alba, si volet, et desuper pluviali.

${ }^{6}$ S. oben S. 165.7 Hitt. c. 89.
} 
Die Tage, an welchen zu Rom von den Diakonen und Subdiakonen anstatt der Dalmatik und Tunika die Kasel getragen wurde, waren, wie früher ebenfalls schon ausgeführt wurde ${ }^{1}$, die Sonntage und Ferien des Advents und der Zeit von Septuagesima bis Ostern, sowie die Quatembertage. Auch bei der Prozession am Lichtmelatage und den Bitttagen trat die Kasel an Stelle des gewöhnlichen diakonalen und subdiakonalen Obergewandes ${ }^{2}$.

Auserhalb Roms herrschte in Bezug auf die Beiseitelassung der Dalmatik und 'Tunicella an den Buftagen im Mittelalter lange eine sehr verschiedene Praxis. Am ehesten wurde die Nichtverwendung jener Gewänder seitens der Diakone und Subdiakone in der Zeit von Septuagesima bis Ostern allgemein; länger dauerte es hiermit dagegen bezüglich des Advents und der Zeit zwischen Septuagesima und Aschermittwoch. War doch selbst im 12. Jahrhundert hinsichtlich dieser Zeiten der Brauch noch keineswegs einheitlich?. Dabei beließ man es häufig, wie es scheint, lediglich bei Nichtbenutzung der Dalmatik und der Tunicella, ohne an deren Stelle die planeta plicata treten zu lassen. Ganz unklar ist, inwieweit der römische Brauch, an den Quatembertagen, an den Bitttagen und bei der Prozession am Lichtmelstage das diakonale und subdiakonale Obergewand durch die Kasel zu ersetzen, aufierhalb Roms Verbreitung fand. Es fehlen darüber so gut wie ganz alle Nachrichten.

Eine Ausnahme von der Regel, welche den Diakonen und Subdiakonen in der Fastenzeit den Gebrauch der Dalmatik und Tunicella verbot, bildete der Gründonnerstag, und zwar war der Grund hierfür die feierliche (i)weihe, welche an diesem Tage statthatte: Diaconi (induunt) dalmaticas pro reverentia chrismatis, heifst es im 10. Ordo Mabillons ${ }^{4}$. So war es von alters her Brauch. Hora autem tertia ingressi sacrarium induantur dalmaticis tam pontifex quam omnes diaconi vel omni ornamento, sagt schon der 1. römische Ordo Mabillons ${ }^{5}$. Ähnlich lautet die Angabe des von Duchesne herausgegebenen Ordo: Diaconi cum dalmaticis et subdiaconi non induunt planitas (sic) ${ }^{6}$. Auffallend ist, dafi der Ordo die subdiakonale Tunika nicht erwähnt, da diese ihm doch keineswegs mehr etwas Unbekanntes war. Indessen galt auch wohl vom Gründonnerstag die eingangs des Ordo gemachte Bemerkung: Quando dalmaticas induit (scil. pontifex), et diaconi similiter induunt se et subdiaconi ... induunt se tonicas albas quas habent, sericas aut lineas ${ }^{7}$. Ausdrücklich nennt die Tunika ein von de Rossi veröffentlichter Ordo der Funktionen an den drei Kartagen, worin es zur feria $V$ heibst: Posteaquam de secretario exeunt, subdiaconi cum albis vestibus procedunt et diaconi cum dalmaticis ${ }^{8}$, und noch deutlicher der etwas jüngere Ordo officiorum bei Hittorp: Presbyteri vero et ceteri clerici hora tertia induant se vestimentis sollemnibus et diaconi dalmaticis atque subdiaconi albis sericis induantur 9 .

S. oben S. 163.

2 $\mathrm{Duch}$, , Orig. 474479.

$3 \mathrm{Um}$ schon Gesagtes hier nicht noch einmal zu wiederholen, verweisen wir für Näheres auf unsere diesbezüglichen früheren Ausführungen (S. 163 ff).

+ N. 3 (M. 78, 1010). Nach Honorius wäre auch die Rekonziliation der Biißer, welche an diesem Tag statthatte, Grund für den Gebrauch der Dalmatik und Tunika gewesen: Vestes sollemues i. e. dalmatica et subtile hodie portantur, quia poenitentes ad missas sanctitatis vestes reparantur et chrisma atque oleum baptizandis quasi coelestes vestes hodie praeparantur (Gemma I. 3, c. 85 [M. 172, 665]).

${ }_{5}$ N. 30 (M. 78, 951). Vgl. auch PseudoAlkuin, De offic. div, c. 16 (M, 101, 1206).

6 D u ch., Orig. 466. 7 Ebd. 456.

Inscript. christ. II, Romae 1888, 34.

9 Hitt. 62. Vgl, auch M art. 1. 4, c. 22 (Auszïge aus Pontifikalien von Besançon, Beauvais und St-Germain-des-Prés); III 109 110114 u. a. 
Bezüglich der Terwendung der Levitengewänder bei Totenmessen herrschte im Mittelalter eine verschiedene Praxis. In der ältesten Zeit mag es am gebräuchlichsten gewesen sein, daß die Diakone und Subdiakone bei denselben entweder ohne jedes liturgische Obergewand blok in der Albe oder wie in der Fasten- und Adventszeit in Albe und Kasel fungierten. Kaseln statt Dalmatik und Tunicella schreiben für die Exequien z. B. die Consuetudines von Farfa (10.-11. Jahrhundert) ${ }^{1}$ und das Ordinarium des Bischofs Johamnes von Avranches vor ${ }^{2}$, während ein Ordinarium von Bayeux ${ }^{3}$ (13. Jahrhundert) will, daßs die Leviten bei Messen für Verstorbene lediglich in Alben amtierten. Als sich jedoch ein liturgischer Farbenkanon herausgebildet hatte und Schwarz die charakteristische Farbe für den Totengottesdienst geworden war, änderte sich die Sache, und der Gebrauch von Dalmatiken und Tunicellen wurde bei demselben bald sehr gewöhnlich. Die Inventare des späteren Mittelalters mit den darin immer wieder vorkommenden schwarzen Levitengewändern stellen das aufer Zweifel.

Schon die Mainzer Chronik (ca 1250) vermerkt neben zwei roten, grünen usw. auch zwei schwarze Kapellen mit je einer Dalmatik und einem Subtile. Seit dem Ende des 13. Jahrhunderts aber entbehrt wohl kaum ein Inventar schwarzer Levitengewänder. Hie und da werden sie in den Verzeichnissen mit der ausdrücklichen Bemerkung aufgeführt, daß sie pro missis defunctorum bestimmt seien ${ }^{*}$.

$\mathrm{Zu}$ Rom müssen schwarze Dalmatiken und Tunicellen schon wenigstens um das Ende des 13. Jahrluunderts bei den Exequien in Gebrauch gewesen sein. Denn wenn nach römischem Brauch schwarze Paramente nur, wie Innozenz III. schreibt, in die abstinentiae et afflictionis, pro peceatis et pro defunctis gebraucht wurden, an Buktagen aber die Levitengewänder nicht zur Verwendung kamen, so können die schwarzen Dalmatiken und Tunicellen, welche im Inventar der Schätze des Apostolischen Stuhles vom Jahre 1295 aufgeführt werden, nur bei den Totenmessen gebraucht worden sein. Um 1400 schreibt der 15. römische Ordo für Allerseelen ausdrücklich schwarze Levitengewänder für die Ministri vor ${ }^{5}$.

Ob auch der Papst bzw. die Bischöfe an Buftagen ursprünglich ohne Dalmatik fungierten, ist nicht ganz klar. Nach dem Ordo Duchesnes galt im 9. Jahrhundert als Regel, daß die Diakone die Dalmatik und die Subdiakone die Tunika trugen, so oft der Papst sich der Dalmatik bediente, daß sie aber, falls der Papst eine solche nicht anzog, in Albe und Planeta fungierten ${ }^{6}$. Es entsprachen somit Dalmatik und Tunika bei den Ministri der Dalmatik beim Pontifex. Wenn daher erstere in der Fastenzeit, an den Bitttagen und bei ähnlichen Gelegenheiten statt ihres sonstigen liturgischen Obergewandes die Planeta trugen, so benutzte also wohl auch der Papst dann die Dalmatik nicht. Eine Bestätigung scheint diese Schluffolgerung in der Rubrik des 1. Ordo Mabillons zu finden ${ }^{7}$ : Hora autem tertia (scil. feriae $\mathrm{V}$ in Coena Domini) ingressi sacrarium induuntur dalmaticis tam pontifex quam omnes diaconi. Wenn hier nämlich hervorgehoben wird, daßs am Gründonnerstag

Consuet. Farfens. (ed. Albers) 124195200.

2 M. 147, 38.

${ }^{3} \mathrm{Chevalier}$, Ordinaire et coutumier de l'église cath. de Bayeux 41. Das etwa aus derselben Zeit entstammende Ordinarium von St-Lo zu Pouen schreibt für die Totenmessen Dalmatik und Tunicella vor (M. 147, 191). Das gleiche tut ein Rituale von Corbie bei Mart., Mon. 1. 5, c. 10 , n. 45 ; IV 261 ; dasselbe wurde zufolge der
Praefatio Martènes im Jahre 1411 zusammengestellt.

4 Vgl, z. B. die Inventare von Angers in Pievue 1885, $172 \mathrm{ff}$.

5 C. 132 (M. 78, 1346). ${ }^{6}$ Orig. 456.

7 N. 30 (M. 78, 951). Vgl. auch die inhaltlich gleiche Angabe im Ordo Duchesnes: In eadom die hora $V$ procedunt ad ecclesiam et mutant se vestimentis suis tam pontifex quam et diaconi cum dalmaticis (a. a. 0.466). 
Pontifex und Diakone die Dalmatik zu gebrauchen hätten, so werden an den andern Tagen der Fastenzeit wohl entsprechend Pontifex und Diakone sie nicht getragen haben. Wie den indessen gewesen sein mag', später galt die Unterscheidung zwischen vestes quadragesimales und non quadragesimales nur für die liturgische Tracht der Ministri. Wenn in der Folgezeit in den liturgischen Büchern, Sakramentaren, Pontifikalien, Ordinaren u. a. oder bei den Liturgikern davon die Rede ist, daf in der Fastenzeit Dalmatik und Tunicella nicht angezogen würden, so wird das immer nur bezüglich der Diakone und Subdiakone, nicht aber beziiglich der Bischöfe oder des Papstes gesagt. Als daher das Caeremoniale der Bischöfe in Beschreibung der Karfreitagszeremonien bestimmte, es solle der Bischof bei denselben mit allen pontifikalen Gewändern, ausgenommen die Handschuhe und die Pontifikalsandalen, angetan sein, also auch mit Dalmatik und Tunicella ${ }^{1}$, verordnete es nur, was schon seit Jahrhunderten Brauch gewesen war.

Der Ritus, wonach der Bischof den Diakonanden bei der Weihe die Dalmatik anlegt, ist in seinen Anfängen sehr alt. In S panien war es schon zur Zeit der vierten Synode von Toledo Brauch, dats die Diakone bei ihrer Weihe auker mit dem Orarium auch mit der Alba, der in den spanischen Kirchen ïblichen diakonalen Tunika, bekleidet wurden 2 . Es lag in der Tat zu nahe, den eben geweihten Diakon mit seinem Amtsgewande auszustatten, als daf solches nicht im Weiheritus einen Platz hätte erhalten sollen.

Für Rom wird uns die Zeremonie zuerst in dem 8. und 9. römischen Ordo Mabillons bezeugt. Nach dem 8. Ordo trug der zum Diakon zu Weihende, weil noch Subdiakon, beim Beginn seiner Weihe eine tunica alba und darüber die planeta, also Albe und Kasel. Letztere wurde ihm dann im Verlauf der heiligen Handlung ausgezogen, dafür aber ihm am schlub derselben die diakonale Obertunika, die Dalmatik, angelegt ${ }^{3}$. Etwas genauer beschreibt den Hergang der 9. Ordo. Hiernach befand sich das indumentum der Ordinanden, d. i. die Dalmatik, anfangs in der Hut eines ihnen beigegebenen Klerikers. Beim Beginn der Weihe überreichte derselbe das Gewand dem Archidiakon, der es alsbald dem zu weihenden Diakon übergab. Dann folgte der Weiheakt, worauf der Archidiakon den Neugeweihten die Stola umlegte und zuletzt der Bischof ihnen die Dalmatik anzog. Und nun standen sie da induti diaconilia indumenta, wie der Ordo sagt 4 .

Von Pom aus verbreitete sich der Brauch allmählich auch im übrigen Abendlande, doch dauerte es bis ins späte Mittelalter, ehe er sich allgemein cingebürgert hatte. Der Grund hierfür mag gewesen sein, daf die Ministri die Dalmatik und Tunika nicht ausnahmslos bei allen Funktionen trugen, und dafs deshalb diese Gewänder nur als ornamentum, wie Bruno von Segni sagt, nicht aber als Insignien, als Abzeichen des Ordo galten.

I L. 2 , c. 25, n. 6 .

2 Can. 28 (Hard. III 586). S. oben S. 253.

3 N. 3 (M. 78, 1001).

- N. 2 (ebd. 1005). Im Text heißt es allerdings, und zwar in allen mir bisher zu Gesicht gekommenen Handschriften wie Drucken, von denen derjenige Migne-Mabillons der ungenaueste ist: Et pontifex induit eos planetis, doch ist planetis offenbar ein Schreibfehler anstatt dalmaticis, da es unmittelbar darauf heilst: et stant induti diaconilia indumenta, d. i. mit der den Diakonen eigenen Dalmatik. Aber auch, was in n. 8 (ebd. 1008) bezüglich der Gewänder gesagt wird, mit denen der Diakon bei der Weihe bekleidet wurde, beweist, daf statt planetis dalmaticis zu lesen ist: Et revestit eos; si enim diaconi ordinandi sunt, orarios et dalmaticas, si vero presbyteri. orarios et planetas. Die Zeremonie wird übrigens in n. 8. etwas anders dargestellt wie in n. 2, doch sind die Angaben hier ersichtlich durcheinander geworfen. 
Vor dem 12. Jahrhundert ist in den liturgischen Büchern im Weiheritus des Diakonats nu äukerst selten von der Bekleidung mit der Dalmatik die Rede, im Ritus der Subdiakonatsweihe aber von der Anlegung der Tunika nie. Selhst im 12. und 13. Jahrhundert werden diese Zeremonien noch keineswegs häufig erwähnt. Erst seit dem 14. Jahrhundert finden sie allgemeinere Aufnahme in den Ritus der Diakonats- und Subdiakonatsweihe. Recht bezeichnend für die geringe Wertschätzung, die man ihnen entgegenbrachte, ist, was ein um 1214 für Apamea in Syrien ${ }^{1}$ geschriebenes lateinisches Pontifikale und ein in der vatikanischen Bibliothek befindliches Pontifikale von Cagliari aus dem 14. bis 15. Jahrhundert hinsichtlich der Überreichung der Tunicella sagen: Tradat eis tunicam, si paratam habuerit?. Nach einem dem 12. Jahrhundert entstammenden Pontifikale von Besançon sollen bei ihrer Weihe nur diejenigen Diakone und Subdiakone mit Dalmatik und Tunika bekleidet werden, qui in monasteriis morantur ${ }^{3}$, d. i. welche Kathedral-, Stifts- oder Klosterkirchen angehörten; denn monasteria ist hier wohl in diesem weiteren Sinne zu fassen, also im Gegensatz zu kleineren Kirchen und gewöhnlichen Pfarrkirchen, nicht aber blof im engeren Sinne von Klosterkirchen ${ }^{4}$. Sollte indessen monasteria wirklich in dieser letzten Bedeutung zu nehmen sein, so dürte die Rubrik etwa dahin sich erklären, daf die diaconi und subdiaconi saeculares von selbst und ohne weiteres das Recht hatten, Dalmatik und Tunicella zu tragen, daß̧ aber die dem Mönchsstand angehörenden Diakone und Subdiakone dasselbe erst erhielten durch die besondere Übergabe der Gewänder bei der Weihe. Ein Pontifikale von Magalone in der vatikanischen Bibliothek will eigentümlicherweise, daf̧ die Tunika allen Neosubdiakonen überreicht, von den Neodiakonen jedoch nur einer mit der Dalmatik bekleidet werde ${ }^{5}$. Der Codex gehört dem 15. Jahrhundert an und beweist, wie wenig Bedeutung man selbst damals noch der Zeremonie hie und da beilegte.

Der erste Liturgiker, welcher der Überreichung der Dalmatik gedenkt, ist Sicard von Cremona; doch geht aus seinen Worten klar hervor, dafo die Zeremonie damals noch keineswegs allgemein gebräuchlich war: Dalmatica, si cui datur, sollemnitatis est et non substantiae ${ }^{6}$. Die Übergabe der Tunicella an den neugeweihten Subdiakon erwähnt zuerst von den alten Liturgikern der Verfasser des Tractatus de sacramento altaris ${ }^{7}$.

Seit wann es üblich wurde, mit der Zeremonie einen Begleitspruch zu verbinden, wie es jetzt geschieht, läßst sich nicht feststellen. Der 8. und 9. römische Ordo Mabillons und der Ordo Duchesnes enthalten keinerlei Andeutung: eines solchen. Auch im Weiheordo bei Hittorp findet sich noch kein derartiges Gebet, wie man überhaupt in den liturgischen Büchern bis zum 12. Jahrhundert niemals ein solches antrifft. Selbst in den Pontifikalien des 12. Jahrhunderts ist ein die Zeremonie begleitendes Gebet noch eine durchaus vereinzelte Erscheinung:

Am frühesten scheint ein Gebet bei Übergabe der Tunika an den Neosubdiakon aufgekommen zu sein. Es läbt sich bis ins 12. Jahrhundert naclı-

1 M a r t. 1. 1, c. 8, art. 11, ordo 14; II 70 .

2 Cod. Vat. Lat. 4747, f, 13v. Ebenso 5791 $(13-14$ f) f. $38 \%$.

3 Mart. 1. 1, c. 8, art. 11 , ordo 10 ; II 62 .

- Man erimere sich, daf zu Mailand bis ins spätere Mittelalter nur die Subdiakone der Kathedrale und die Äbte, welche Subdiakone waren, die alba, d. i. die Tunika, tragen durften (s. oben S. 285).

"Cod. Vat. Ottob. 330, f', 52 ".

6 Mitralis 1. 2, c. 2 (M. 213, 64).

7 C. 5 (M. 172, 1277). 
weisen; denn wir begegnen einem solchen schon in dem vorhin erwähnten Pontifikale von Besançon, im Tractatus de sacramento altaris und bei sicard von Cremona. Im Tractatus lautet es: Induat te vestimento salutis et indumento iustitiae circumdet te semper. Im Pontifikale von Besançon und bei Sicard lautet es etwas abweichend: Tunica iucunditatis et indumento laetitiae induat te Dominus. Es ist dies dasselbe Gebet, welches später ins römische Pontifikale Eingang fand. Bemerkenswert ist, dal von den Pontifikalien, welche bereits die Übergabe der Tunika in den Ritus der Subdiakonatsweihe aufgenommen haben, manche selbst noch im 14. Jahrhundert eines die Zeremonie begleitenden Gebetes entbehren. Erst in 15. wird ein solches in den Weiheordines allgemein.

Im Ritus der Diakonatsweihe konnten wir ein Gebet für die Übergabe der Dalmatik erst im 14. Jahrhundert nachweisen. Eines der frühesten Beispiele bietet der 14. Ordo Mabillons ${ }^{1}$. Die Pontifikalien begnügen sich bis dahin regelmälaig mit der kurzen Rubrik: Hic traditur dalmatica, cum consecrati fuerint, induantur dalmatica, oder ähnlichem. Noch im 15. Jahrhundert fehlt das Gebet mehrfach. Die Sache ist auffallend. Ob vielleicht die Erklärung darin zu suchen ist, dafs es, nachdem sich der Unterschied zwischen Dalmatik und Tunicella bezüglich der Form verwischt hatte, als üherflïssig betrachtet wurde, auch noch die Anlegung der Dalmatik mit einem besonderm Gebet zu begleiten? Das Gebet, welches die Pontifikalien des 14. und 15. Jahrhunderts für die Zeremonie angeben, hat einen verschiedenen Wortlaut. Am häufigsten kommen vor: Induat te Dominus novum hominem, qui secundum Deum creatus est in iustitia et sanctitate veritatis, und: Induat te Dominus vestimento salutis et indumento laetitiae circumdet te. In nomine etc. Aus dem letzteren, welches sich auch im 14. Ordo Mabillons findet und also schon wenigstens im 14. Jahrhundert zu Rom gebräuchlich war, hat sich das Gebet entwickelt, welches das römische Pontifikale jetzt den Bischof sprechen läbt, wenn dieser den Neodiakon mit der Dalmatik bekleidet.

\section{URSPRUNG DER DALMATIK UND TUNICELLA.}

Ihren Ursprung hat die Dalmatik von einem gleichnamigen Gewande genommen, das zur Zeit der Antonine, also etwa im Verlauf des 2. Jahrliunderts, zu Rom in Gebrauch kam. Diese profane Dalmatik war kein einheimisches Kleidungsstück, sondern wurde wie so manches andere zur Kaiserzeit von aufen nach Rom importiert. Schon Kommodus und Heliogabal bedienten sich ihrer, wenn sie in der Öffentlichkeit anftraten, wie deren Biograpl berichtet, ein Vorgehen, das natïrlich der weiteren Verbreitung des Gewandes nur förderlich sein konnte 2 .

Die Dalmatik war eine Tunika, und zwar im Gegensatz zu der bei den Römern von alters her gebräuchlichen Tunikaart, die zur VervolIständigung einen Um- oder İberwurf erheischte, eine Obertunika, etwa im Sinne unseres Überrockes. Natïrlich hindert nichts, auch zu ilır einen Mantel zu tragen, was denn auch tatsächlich oft geschah. So berichten, wie wir schon hörten, die Akten der Hinrichtung des hl. Cyprian, der Heilige sei, da er auf dem Richtplatz erschien, mit der Untertunika, der Dalmatik und der Lacerna, einer vorn aufgeschlitzten Mantelart, bekleidet gewesen ${ }^{3}$. Eine Toga findet sich

1 N. 103 (M. 78, 1234).

${ }^{2}$ Hist. Aug. Comm. 8, 8; Heliog. 26, 2. Vgl. auch Pert. 8, 2.

3 S. oben S. 65. 
über der unteren Tunika und Dalmatik bei den Statuen zweier Adile im Kapitolinischen Nuseum zu Rom (Bild 139). Ebenso gewahren wir bei Darstellungen der Konsuln auf den Konsulardiptychen über der nicht selten reich gemusterten Dalmatik eine Toga, und zwar meist eine solche von der Art der zwar prächtigen, aber in Bezug auf die Form bereits stark verbildeten toga picta des 4. und 5. Jahrhunderts (Bild 140) ${ }^{1}$.

Die Dalmatik wurde sowohl nach Ausweis der Monumente wie des Maximaltarifs Diokletians nicht nur von Männern, sondern auch von Frauen getragen. Die Männerdalmatik war ursprünglich etwas kürzer als die Frauendalmatik. Wo auf den äIteren Malereien der Katakomben bei Männern eine Dalmatik

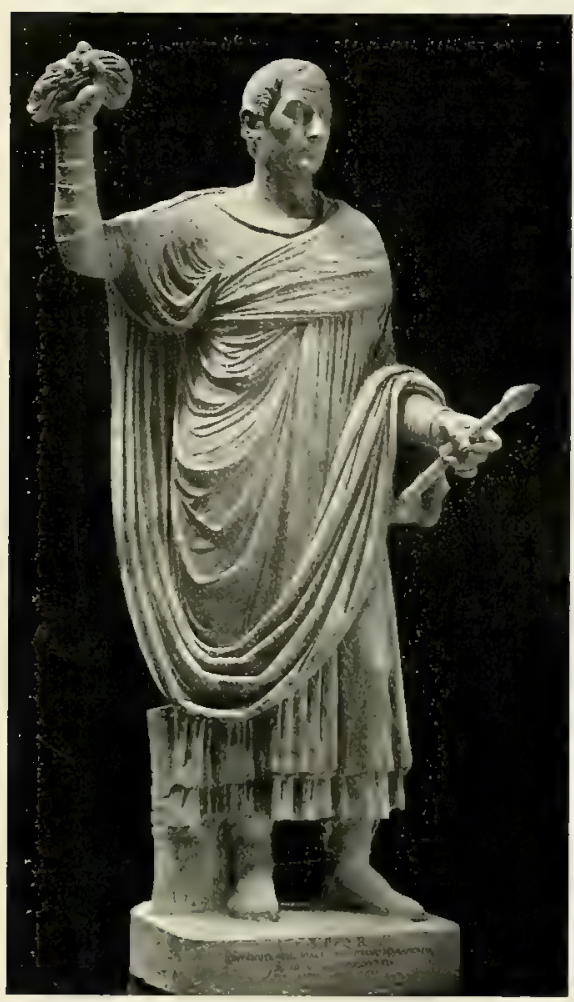

Bild 139. Adıl, das Zeichen gebend. Rom, Kapitol. vorkommt, was übrigens nur selten der Fall ist, geht sie nur bis etwa zur Mitte des Schienbeins. Allmählich nahm jedoch die Männerdalmatik an Länge $\mathrm{zu}$, bis sich zuletzt in Bezug auf diese zwischen der Dalmatik der Männer und Frauen kaum mehr ein Unterschied bemerklich machte.

Gegürtet wurde die Dalmatik nicht oder doch nur ausnahmsweise. Die Ärmel waren weit, aber anfänglich nur mäfrig lang, indem sie gewöhnlich nur bis zum Ellenbogen oder bis zur Mitte des Unterarms reichten und so den von der unteren Tunika bedeckten Vorderarm zum Vorschein kommen liefen. Dann gewannen die Ärmel an Länge, und zwar, wie es scheint, rascher bei der Frauen- als bei der Männerdalmatik, doch müssen sie auch bei dieser schon eine gute Weile vor Beginn des 6. Jahrhunderts den ganzen Arm bedeckt haben; denn sonst hätte sich wohl schwerlich die um diese Zeit entstandene Erzählung der Silvesterlegende, von der früher die Rede war, bilden können.

Als Material zur Anfertigung der Dalmatik dienten für gewöhnlich Leinwand und Wollzeug", doch gab es auch halbseidene und seidene Dalmatiken. Dafi es nicht immer feine Stoffe waren, die zur Herstellung des Gewandes gebraucht wurden, bekundet der Maximaltarif, wenn er neben andern auch rauhhaarige Männerdalmatiken aufführt ${ }^{3}$.

Wollte man der Dalmatik eine Verzierung geben, so versah man sie auf der Vorder- und Rückseite mit je einem oder gewöhnlicher mit je zwei Vertikalstreifen. Außerdem pflegte man in diesem Fall gern um den Rand der $̈$ rmel herum einen oder zwei Besätze anzubringen. Beliebt waren namentlich purpurne Zierstreifen. Notwendig waren diese Verzierungen, clavi ge-

\footnotetext{
1 Andere Abbildungen bei Wilp., Cap. $3 \mathrm{ff}$.
}

2 Edict. Dioclet. ed. XIommsen-13liimner

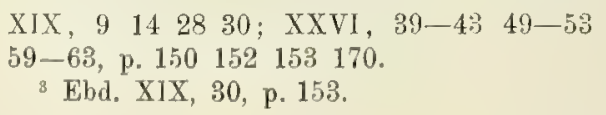


nannt, nicht; denn der Maximaltarif verzeichnet sowohl Dalmatiken mit Streifen

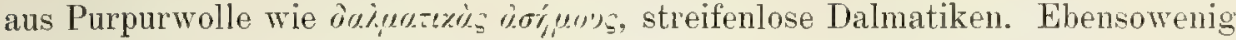
bildeten sie einen der Dalmatik ausschlieflich zukommenden schmuck. Nur das Gewand, nicht dessen Ornament, war aus der Fremde nach Rom gekommen; die clavi, Streifen, ein altrömischer Schmuck der Tunika, waren echt römisch; man denke nur an den latus clavus der Senatoren und den angustus clavus der Ritter. Die Streifen waren, wie die Monumente bekunden, durchweg schmal, indessen kamen auch wohl breitere clavi vor.

Ein spezifisches Gewand bestimmter Personen von Stand scheint die Dalmatik nie gewesen zu sein, es mïliten denn die Senatoren sie an Stelle ihrer ungegürteten, mit breiten Purpurstreifen rerzierten Standestunika, der sog. tunica laticlavia, angenommen haben. Immerhin wurle sie als L̈berrock nur von Leuten aus besseren Klassen getragen, und so kann es natürlich nicht auffallen, wenn wir sie auch beim Gottesdienst in Gebrauch kommen und zum liturgischen Gewande werden sehen.

Bezüglich der Heimat der Dalmatik sagt Isidor von Sevilla in seinen Etymologien: Dalmatica vestis primum in Dalmatia, provincia Graeciae, texta est. In der Tat weist der Name des Gewandes auf Dalmatien als seinen Herkunftsort hin ${ }^{1}$. Woher Isidor seine Angabe hat, ob er sie, wie so viele andere Erklärungen, einem älteren Schriftsteller oder dem Namen dalmatica entnahm, ist unbekannt. Sie ist eine stereotype Redensart geworden, mit der später die Liturgiker immer wieder ihre Ausführungen über die Dalmatik einzuführen pflegten.

Neben ihren gewöhnlichen Namen soll die Dalmatik bisweilen die Benennung colobium, colobus geführt haben. Auffallend wäre das in keiner Weise; pflegt man ja doch auch sonst im praktischen Leben, dem die exakte Sprache der Wissenschaft fern liegt, gern die Benennungen verwandter Gegenstände miteinander zu vertauschen. Man denke nur an die modernen Namen mancher Kleidungsstücke. Auch ist aus der täglichen Erfahrung bekannt, wie sehr die Ausdrücke nicht blofs nach Zeiten, sondern auch nach Orten wechseln.

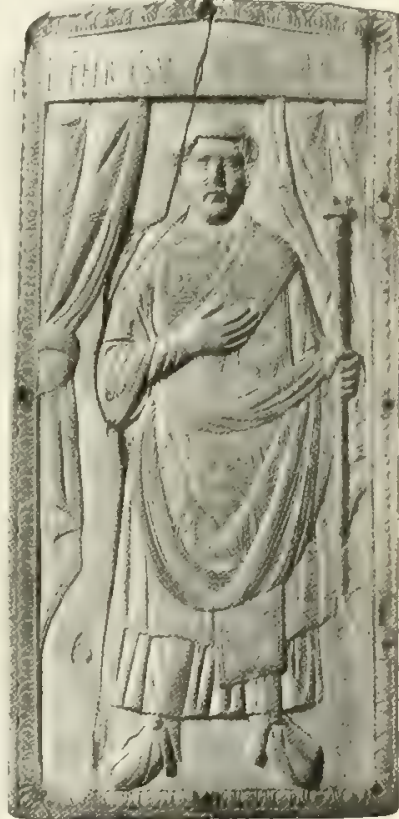

Bild 140.

Diptychon des Konsuls Felix. Paris, Nationalluibliothek.

So ist es jetzt, so war es früher. Im vorliegenden Fall aber war eine Vertauschung der Namen um so leichter möglich, als man mit colobium (von xíkoßjos, verstümmelt, beschnitten, zugestutzt) an sich und zunächst zwar eine ärmellose Tunika bezeichnete $^{2}$, bisweilen jedoch auch eine kurzärmelige ${ }^{3}$. Wirklich scheint im Maximaltarif Diokletians ${ }^{4}$ colobium nur ein anderer Name für die Nännerdalmatik zu sein. Ebenso dürfte im Theodosianischen Kleideredikt vom Jahre 382, in welchem den Senatoren gestattet wird ${ }^{5}$, sich auferamtlich des Colobium zu bedienen, dieses Colobium die Männerdalmatik bedeuten. Dagegen sind, wie es scheint, im angeblichen Dekret des Papstes Eutychian, wonach die Martyrer non sine dalmatica aut colobio purpurato

1 Isid., Etymol. 1. 19, c. 22 (M. 82, 684).

2 Doroth., De doctrina c. 12 (M g. 88, 1632). Rufin., Hist. monach. c. 3 (M. 21, 407). Nach Dorotheus war das Colobium der Mönche mit Purpurstreifen versehen. Bei
Rufinus wird es mit einem linnenen Sack verglichen.

3 Cassian, De coenob. inst. 1. 1, c. 5 (M. 49, 69).

4 Edict. XXVI 39. 5 S. oben S. 24\%. 
bestattet werden sollten 1, und ebenso bei Eusebius ${ }^{2}$ Colobium und Dalmatik zwei verschiedene, wenngleich der Art nach verwandte Kleidungsstücke. Auf keinen Fall aber bezeichnet die tunica pectoralis sine manicis, von der hei Ammianus Marcellinus die Rede ist ${ }^{3}$, eine Dalmatik, wie man gesagt hat. Sowohl der Zusammenhang, in dem sie als regale indumentum erscheint, wie die nähere Bestimmung pectoralis schliefaen durchaus eine solche Bedeutung aus.

Der Ursprung der Tunika bedarf keiner Darlegung. Das Gewand ist nichts als eine Nachbildung der liturgischen Dalmatik, wobei blof die clavi weggelassen wurden.

\section{DIE TUNIKA DER DIAKONE UND SUBDIAKONE IN DEN RITEN DES OSTENS. DER SAKKOS.}

In den Riten des Ostens ist bei den Diakonen und Subdiakonen nie eine Obertunika im Sinne der Dalmatik und Tunicella gebräuchlich gewesen. Allerdings hat wenigstens gegenwärtig die Tunika, welche dieselben bei der Liturgie über der Alltagskleidung tragen, insofern mit der Dalmatik und Tunicella, wie diese im Mittelalter beschaffen waren, einige $̈$ hnlichkeit, als auch sie nicht gegürtet wird, Ärmel von mittlerer Weite besitzt und häufig nicht mehr weif, sondern farbig ist. Nichtsdestoweniger ist die diakonale und subdiakonale Tunika in den Krirchen des Ostens nach ihrer ganzen geschichtlichen Erscheinung im wesentlichen nicht ein Gegenstück der Dalmatik und Tunicella, sondern der lateinischen Albe. Nur insofern, als sie über der Alltagskleidung getragen wurde und wird, kann man sie in gewissem Sinn als Obertunika bezeichnen; also nicht mit Rücksicht auf eine liturgische untere Tunika, wie sie im Abendland in Gestalt der Albe in Gebrauch war und ist, sondern mit Bezug auf die Tunika des gewöhlichen Lebens *

Eine wirkliche Obertunika ist aber der pontifikale Sakkos, der freilich nur im griechischen Ritus gebräuchlich ist. Bei den Italo-Griechen, den Russen Ruthenen und Bulgaren wird dieses Gewand von allen Bischöfen getragen, bei den Graeco-Melchiten und den Griechen bildet es dagegen eine Auszeichnung des Patriarchen und der Metropoliten.

Der Sakkos ist der lateinischen Dalmatik durchaus verwandt. Wie das Phelonion folgt er jetzt der liturgischen Tagesfarbe, soweit es eine solche im griechischen Ritus gibt. Seine Ärmel sind weit und wie bei der römischen Form der Dalmatik gewöhnlich geschlossen. An den Seiten des Gewandes aber pflegen behufs bequemeren Anziehens Schlitze angebracht zu werden. Der Sakkos ist, wie es scheint, im Laufe des 11. Jahrhunderts in Gebrauch gekommen. Seine früheste Erwähnung findet er bei Balsamon ${ }^{5}$. Auf Bildwerken kommt das Gewand erst im 14. Jahrhundert vor, wenigstens sind uns bis jetzt ältere nicht bekannt geworden. Allerdings hat Rohault de Fleury zwei Miniaturen mit Darstellungen des Sakkos abgebildet, welche er dem 11. Jahrhundert zuschreibt ${ }^{\circ}$. Eine von ihnen gehört einer Homiliensammlung: $-$

L Duch., L. P'. I 159.

2 Haeres. 1. 1, c. $15(\mathrm{Mg}, 41,245): 2 \lambda \lambda \lambda^{\prime}$

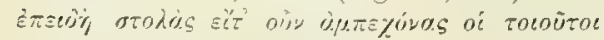

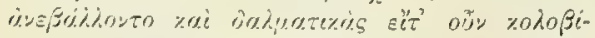

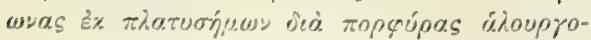

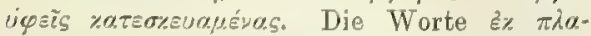

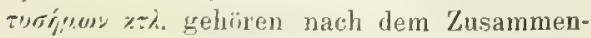

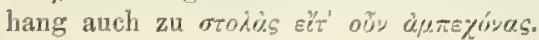

${ }^{3}$ Her. gest. 14, 9. Vel. dazu Realenc.
II 208 and Wilp., Gew. 37 sowie Wilp., Kat. 88, wo das Gewand als Dalmatik auf. gefafit wird.

- Näheres ïber die 'Tunika der Diakone und Subdiakone in den Piten des Ostens s. oben S. 92 ff.

SMeditata (M g. 138, 1021 1025). Resp. ad Marc. Alex, n. 37 (ebd. 990).

i) Roh. VII, pl. DxLir. 
Gregors von Nazianz in der Nationalbibliothek zu Paris, die zweite einem Rotel mit der Liturgie des hl. Johannes Chrysostomus in der Bibliothek zu Genf an. Allein er hat das Alter beider Miniaturen um ein bedeutendes zu hoch angesetzt; denn anstatt dem 11. entstammt die Pariser Handschrift dem 14., die Genfer aber sogar erst dem 15. Jahrhundert ${ }^{1}$.

Anfangs war der Sakkos, wie ans den Angaben Balsamons hervorgeht, ein ausschlieflich patriarchales Ornatstück; er blieb ein solches jedoch nicht lange: denn schon im Beginn des 13. Jahrhunderts hatten einzelne Metropoliten das Recht, ihn zu tragen. Eine Korrespondenz zwischen dem Metropoliten Cabasilas von Dyrrhachium und dem Metropoliten von Bulgarien, Demetrius Chomatenus, bekundet das ${ }^{2}$. Indessen war, wie sich gleichfalls aus diesem Briefwechsel ergibt, den Metropoliten der Gebrauch des Sakkos nur in sehr beschränktem Umfang, weil blof an den drei hohen Festen, Weihnachten, Ostern und Pfingsten, gestattet. Auf die Anfrage des Cabasilas, ob das Gewand auch purpurn sein dürfe, antwortet nämlich Chomatenus verneinend, weil die Purpurfarbe Ausdruck und Zeichen der Trauer sei, der Sakkos aber blok an den angeführten drei Festtagen getragen werden dürfe. Übrigens stand das Gewand noch im Beginn des 15. Jahrhunderts keineswegs schlechthin allen Metropoliten zu. Wie Simeon von Saloniki sagt, kam es damals vielmehr lediglich den „Е้xxoเto

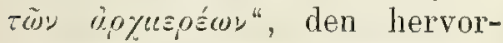
ragendsten unter den Erzbischö-

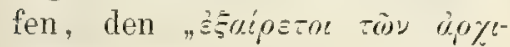

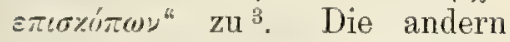
Metropoliten bedienten sich statt

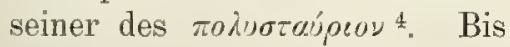

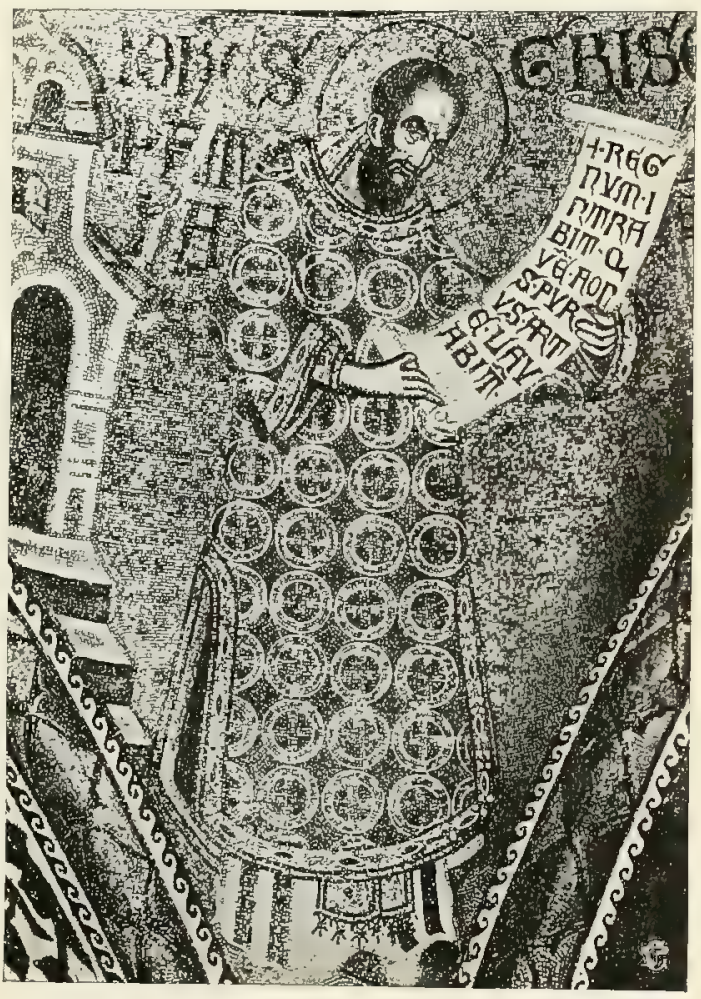

Bild 141. St Johannes Chrysostomus. Mosaik. Venedig, S Mureo. gegen Ende des Mittelalters erscheint der Sakkos nur seIten anf den Monumenten. Der Grund ist in dem Gesagten angedeutet. Solange er noch ein Sondergewand weniger Personen war, hatte er für die darstellende Kunst zu wenig Bedeutung, als daf man eine häufigere Wiedergabe desselben für diese Zeit erwarten könnte. Zwei Bildwerke mit Abbildungen des Gewandes aus dem 14. bzw. 15. Jahrhundert wurden schon erwähnt. Bei beiden ist der Sakkos

1 Genauen Aufschluß über die Genfer Handschrift verdanke ich der Gite des Herrn Professor E. A. Stückelberg zu Basel. Die Pariser habe ich selbst eingesehen; sie wird iibrigens auch in dem neuen, von Omont angefertigten Katalog der griechischen Manu- skripte der Nationalbibliothek als dem 14. Jahrhundert angehörend bezeichnet.

$2 \mathrm{Mg} .119,949$.

"s De div. templo c, 43 und Resp. ad Gabr. Pentapol. q. 19 (Mg. 155, 716 872).

* S. oben S. 237 . 
mit Kreuzen geschmïckt, die im Unterschied von den Kŕreuzen, wie sie bei den Polystaurien vorkoumen, von einem Kreis umrahmt sind, eine Eigentümlichkeit, welche wir bei ilım übrigens auch sonst nicht selten auf den Monumenten antreffen. Eine andere, auch historisch sehr interessante Darstellung des Gewandes aus dem 15. Jahrhundert findet sich auf einem Fresko in S. Maria Novella zu Florenz, dem Grabmonument des Patriarchen Joseph von Konstantinopel, der am Unionskonzil zu Florenz teilgenommen hatte, aber ror der Rückkehr in die Heimat am 10. Juni 1439 starb und in S. Maria bestattet wurde. Das Gemälde gibt den Patriarchen in Lebensgröfe in seiner patriarchalen Gewandung wieder. Von sonstigen Monumenten des späten Mittelalters mit Abbildungen des Sakkos seien nur noch die Mosaiken in der Cappella Zeno von S. Marco mit der Darstellung des hl. Johannes Chrysostomus erwälnt (Bild 141, S. 303). Bemerkenswert ist, dafs gerade dieser Heilige vornehmlich im Sakkos ab-

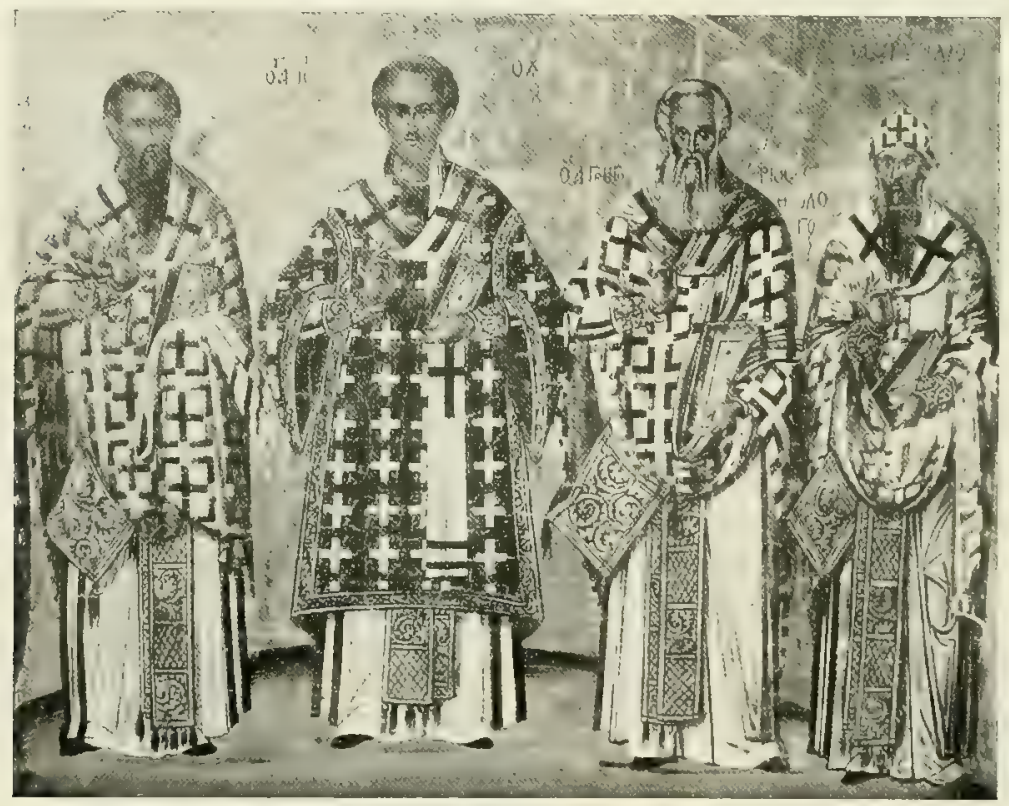

Bild 142. Griechische Tafelmalerei. Rom, Vatikan (Museo eristiano).

gebildet wird. Ein griechisches Tafelgemälde im Museo cristiano des Vatikans, worauf wir ihn ebenfalls in diesem Gewand erblicken, bringen wir zur Wiedergabe (Bild 142), weil hier die Kreuze des Sakkos gegen die Gewolnnheit der kreisförmigen Einfassung entbehren. Von Bock irrig dem 13. Jahrhundert zugeschrieben ${ }^{1}$, gehört es in Wirklichkeit frühestens dem Ausgang des Mittelalters, richtiger aber wohl erst dem 16. Jahrhundert an.

Ein wirklicher Sakkos aus dem Mittelalter hat sich in St Peter zu Rom erhalten. Fr wurde seinerzeit von Bock unter dem falschen Namen "Kaiserdalmatik" in dem Prachtwerk "Die Kleinodien des heiligen römischen Reiches deutscher Nation" in guten Abbildungen veroffentlicht?. Das Gewand

1 Reichskl. 109.

2 Tft 18 19, dazu im Texthand S. 95 bis 110. Die ganze, für ein Stück wie dieses rewand sclon recht bedeutende Literatur jst gut zusammengestellt bei A. Colasanti, Nuovi riscontri sulla Dalmatica Vaticana, in Nuovo Bollettino di archeologia christiana VJII, Roma 1902, 155. 
kam im dritten Viertel des 15. Jahrhunderts in den Schatz von St Peter und entstammt etwa dem Ende des 14. oder dem Beginn des 15. Jahrhunderts ${ }^{1}$. Aus schwerem blauen Seidenstoff gearbeitet, ist es über und über mit vorzüglichen Bildstickereien geschmückt. Auf den Schulterstïcken ist die Ausspendung des heiligen Sakramentes durch Christus an die Apostel unter den Gestalten von Brot und Wein dargestellt, auf der Vorderseite die Verklärung auf Tabor, auf der Rückseite Christus, umgeben von Engeln und von Heiligen aus allen Ständen in der himmlischen Glorie. In den Zwickeln unter dem letzten Bild befinden sich links Abraham als Seelenvater, rechts der gute Schächer mit dem Kreuz auf der Schulter. Bemerkenswert ist, dals das Gewand, ähnlich wie die deutsche Dalmatik, nicht nur an den Seiten, sondern auch unter den Armen offen ist. Wie es den Anschein hat, war dem von Anfang so, und sind die Ärmel nicht erst in späterer Zeit aufgeschlitzt worden. Ferner ist die blaue Farbe des Sakkos beachtenswert. Zur Zeit, da das Gewand entstand, war der Brauch bezüglich seiner Farbe ersichtlich schon minder streng geworden.

Ein anderer mittelalterlicher, reich bestickter Sakkos hat sich zu Moskau erhalten; er stammt aus dem Beginn des 15. Jahrhunderts (ca 1417) 2.

Wie es zur Einführung des Sakkos gekommen ist, darüber liegen Nachrichten nicht vor. Sicher ist solches jedoch nicht ohne Mitwirkung des Kaisers geschehen. Der Sakkos, der Abkömmling der reich bestickten Dalmatik der Konsuln, von der uns die Konsulardiptychen ein Bild hinterlassen haben, war ein den Kaisern eigenes Prachtgewand ${ }^{3}$. Wir finden diese häufig auf den byzantinischen Bildwerken in demselben dargestellt ${ }^{4}$. Es liegt darum auf der Hand, das die Patriarchen ibn nicht ohne Erlaubnis der Kaiser in Gebrauch nelimen konnten, am wenigsten aber der Hofpatriarch zu Konstantinopel. Wenn wir daher den Sakkos im 12. Jahrhundert auch bei den Patriarchen antreffen, so läßt sich das nur unter Annahme der Verleihung eines diesbezüglichen Privileg's seitens des Kaisers erklären, durch welches die Patriarchen vor allen andern besonders ausgezeichnet und als gewissermafsen neben den Kaisern stehend hingestellt werden sollten. Es verdient hervorgehoben zu werden, daks das Gewand zu einer Zeit auf dem Plan erscheint, da der Alfall der griechischen Welt von Rom vollkommen geworden war, und es den Kaisern darum zu tun sein mubte, nunmehr ihre Patriarchen auch in deren äußierer Erscheinung irgendwie als die Päpste des Ostens zu charakterisieren.

1 Näheres über das Auftreten des Sakkos im Schatz von St Peter, sein Alter und seine ursprïngliche Bestimmung in des Verfassers Aufsätzen: Das Alter der sog. Kaiserdalmatik im Schatz von St Peter, in ,Stimmen aus Maria-Laach" LVII (1899) $575 \mathrm{ff}$, und La dalmatique du trésor de St-Pierre, in Revue $1901,52 \mathrm{ff}$. Colasanti hat in jüngster Zeit versucht, nachzuwejsen, daß der Sakkos jm 11. Jahrhundert entstanden sei. Sein Versuch kann nicht als geglückt bezeichnet werden. Der ganze Beweis Colasantis gründet sich auf eine Auswahl von Miniaturen, einige völlig ungenügende Ausführungen über die byzantinischen Seidenwebereien und ein einziges, hier bedeutungsloses palermitanisches Inventar. Ungleich belangreichere sind Braun, Die liturgische Gewandung. unberücksichtigt geblieben, die späteren griechischen Stickereien, Tafelgemãlde, Wandmalereien und Mosaiken in keiner Weise herangezogen.

2 Mitteilungen der Gesellschaft für altrussische Kunst 1874, 45 und Repertorium für Kunstgeschichte XV 376.

${ }^{3}$ Codin., De offic. palat, constant. c. 617 ( $\mathrm{Mg} .157,69$ 104).

4 Vgl. z. B. G. Schlumberger, L'épopée byzantine à la fin du $\mathrm{X}^{\circ}$ siècle I, Paris 1896 , 4581 141; Wilp., Cap. 91 93; N. Kondak off, Geschichte des byzantinischen Emails, Frankfurt 1892, 146 245; H. V. Sau erland und A. Hasel off, Der Psalter Erzbischof Egberts von Trier 'Tfl $45 ;$ D. C. X, Tfl 56 ; Grïven I, Nr 5773. 
DRITTES KAPITEL.

\section{DAS PLUVIALE.}

\section{DAS PLUVIALE NACH GEGENWÄRTIGEM BRAUCH.}

Das Pluviale (pluviale, cappa) ist ein bis zu den Füfen reichender, vorn geöffneter, mit Schlielien vor der Brust befestigter liturgischer Mantel. Es heibt auch wohl Chorkappe, Vespermantel, Rauchmantel, Benennungen, welche sich aus den Funktionen erklären, bei denen es gebraucht wird.

Die Länge des Gewandes beträgt etwa 1,40 m. Ausgebreitet stellt es so ziemlich einen Halbkreis dar. Die Geradseite entlang, an welcher nach der Mitte hin die Schlieken zur Befestigung des Gewandes angenäht werden, zieht sich ein breiter Besatzstreifen. Im Nacken ist das Pluviale mit dem sog. Schild, d. i. einem schildförmigen, über den Rücken herabhängenden Stoffstiuck, verselıen, welcher bald an dem Rande des Gewandes selbst, bald unterhalb des die Geradseite begleitenden Besatzes beginnt, mit Börtchen sowie häufig auch mit Fransen eingefast und am unteren Ende nicht selten mit einer Quaste verziert ist. Am Saum wird es gern mit einem schmalen Börtchen oder einer kurzen Franse besetzt. An französischen Pluvialen ist häufig in der Mitte der Gerarlseite ein Ausschnitt für den Hals angebracht, damit sich das Gewand nicht allzusehr im Nacken aufbausche.

Die Farbe des Pluviale hat dem liturgischen Farbenkanon zu entsprechen. Von dem Stoff des Gewandes gilt, was in dieser Beziehung hinsichtlich der Dalmatik und Tunicella gesagt wurde. Auch für den Chormantel ist kein bestimmtes Material ausdrücklich vorgeschrieben, indessen ist es jedenfalls das angemessenste, ihn aus seidenem oder wenigstens halbseidenem Stoff herzustellen.

Das Pluviale kommt nicht einem bestimmten Ordo ausschließlich zu. Denn es darf, wie aus dem römischen Caeremoniale erhellt, auch von bloken Klerikern getragen werden. So kömmen bzw. sollen die clerici ad baculum et mitram im Pontifikalamt und den Pontifikalvespern und die cantores bei $\mathrm{Ab}$ singung des Tedeum in der feierlichen Matutin mit dem Pluviale bekleidet sein ${ }^{1}$. Immerhin zählt dieses vornehmlich zu den priesterlichen Gewändern, und zwar ist es das liturgische Obergewand des Priesters und Bischofs bei allen jenen feierlichen Funktionen, bei welchen die Kasel nicht gebraucht werden darf. Akte dieser Art sind die Prozessionen, die feierlichen Segnungen, z. B. die Einweihung von Kirchen, die Aschen-, Kerzen-, Palmen- und Taufwasserweihe $\mathbf{u}$. a., die feierlichen Vespern und Laudes, die Begräbnisse und die Absolutio am Katafalk nach der Totenmesse, der Segen mit der Monstranz, die Austeilung des Weihwassers vor dem Hochamt? Auch der beim Pontifikalamt assistierende Priester soll mit dem Pluviale bekleidet sein. Bei Bittprozessionen darf nur der Officiator es anziehen; bei feierlichen theophorischen Prozessionen können dagegen auch die Dignitare es tragen. Bei den feierlichen Vesjuern und Laudes bedienen sich aufier dem Celebrans auch die vier

\footnotetext{
1 Caerem. 1. 1, c. 11. n. $56 ; 1.2$, c. 6 , 1. 1 \%.

2 Rubricae generales tit. 19, n. 3. Die verschiedenen Fảlle, in denen das Pluviale
}

gebraucht wird, sind mit Nachweis der betreffenden kirchlichen Entscheidungen gut zusammengestellt bei $V$ ictor ab Ap pelteru, Manuale liturgicum I 79. 
oder sechs Priester, die Assistenz leisten, des Pluviale ${ }^{1}$. Wie man sieht, findet das Gewand eine sehr weitgehende Verwendung bei den liturgischen Funktionen.

Stehen die Akte, bei denen es gebraucht wird, in Verbindung mit der Messe, so trägt man das Pluviale über der Albe, andernfalls über dem Superpelliceum.

\section{NAME DES GEWANDES.}

Während heute das Gewand im kirchlichen Sprachgebrauch am häufigsten Pluviale genannt wird, war im Mittelalter der Name Cappa vorherrschend. Das Wort kommt als Bezeichnung eines Gewandstïckes erst im nachklassischen Latein vor.

Eine Art von Kapuze ist mit ihm gemeint, wenn Gregor von Tours in der Vita des hl. Nicetius von einer capsa (cappa) spricht, die an einer von diesem Heiligen herrührenden Kasel angebracht war ${ }^{2}$. Ebenso versteht [sidor von Sevilla unter cappa eine Kopfbedeckung ${ }^{3}$. Auch die cappa des hl. Martinus, die von den fränkischen Königen als Palladium mit in den Krieg geführt wurde und Anlaß zu mancherlei Legendenbildung wurde, mag eine Kapuze gewesen sein.

Als Name eines mantelartigen Kleidungsstückes kommt das Wort cappa schon in den gegen das Ende des 7. Jahrhunderts geschriebenen Virtutes S. Frusei abbatis vor ${ }^{4}$. Häufiger begegnet es uns in dieser Bedeutung jedoch erst zur Karolingerzeit, so in der Regel Chrodegangs ${ }^{5}$, in den Briefen Alkuins ${ }^{6}$, in c. 61 der Aachener Synode von $817^{7}$, im Schreiben Theodemars von Monte Cassino an König Karl $^{8}$, in der wohl im 9. Jahrhundert entstandenen Vita S. Goari ${ }^{9}$, in c. 6 der Synode von Metz von $88^{10}$, den Inventaren von St-Riquier aus der Frühe des 9. Jahrhunderts u. a.

Zu Monte Cassino bezeichnete man mit cappa jenes Oberkleid der Mönche, welches man in Gallien cuculla zu nennen pflegte, d. i. ein sackartiges, ärmelloses, an den Seiten bis oben aufgeschlitztes, mit einer Kapuze versehenes Gewand, das, übergeworfen, seitlich an einer oder zwei Stellen zugenestelt wurde. Bei den Mönchen in Italien war es schmaler und kürzer als bei den Mönchen in Gallien, wie Theodemar ausdrücklich hervorhebt. In Gallien verstand man unter cappa bald einen klerikalen Mantel, bald einen Mönchsmantel, denselben, welchen man zu Monte Cassino casula oder mantus nannte. Der Unterschied zwischen der klerikalen und mönchischen cappa scheint darin bestanden zu haben, daf die erstere vorn aufgeschlitzt, die letztere aber nach Art einer Glockenkasel ringsum geschlossen war. Die Aachener Synode vom Jahre 817 verbietet nämlich den Mönchen, cappas disconsutas zu tragen ${ }^{11}$; nur aus zottigem, schwerem Stoff gemachte durften offen sein, begreiflich, da sie sonst kaum zu brauchen gewesen wären. Zu Rom war die klerikale Cappa ein ringsum geschlossenes Gewand, wie die cappa more romano consuta beweist, welche Bischof Arno von Salzburg Alkuin zum Geschenk sandte ${ }^{12}$.

1 Caerem. 1. 2, c. 3 , n. 1.

2 M. G. SS. M. I 696.

3 Etymol. 1. 19, c. 31, n. 3 (M. 82, 699).

M. G. SS. M. IV 442.

5 C. 29 (M. 89, 1113).

6 Ep. 8 (M. G. Epp. Carol. aevi II 33 ) : Alkuin beauftragt den Flaccus Albinus, ihm schwarze und rote cappae aus Ziegenhaar nach England zu schicken; ep. 84 (ebd. 127): er dankt seiner Schwester Gisla für die ihm gesandte cappa; ep. 184 (ebd, 309) : er teilt dem Erzbischof Amo von Salzburg mit, dalis er die ilum von diesem geschenkte cappa romano more cousuta empfangen habe.
${ }^{7}$ H ard. IV 1232; vgl. c. 22 (ebd. 1230).

\& M. G. Epp. Carol. aevi II 512.

${ }^{9}$ M. G. SS. M. IV 416.

$10 \mathrm{H}$ ard. VI 411.

11. C. 61 (H ard. IV 1232); disconsutus hat denselben Sinn wie inconsutus bei $R$ up prt von Deutz, De div. offic. 1. 2, c. 24 (M. 170, 54): Cappae ab anteriore parte patulae sunt et omnino praeter solam necessariam fibulam incousutae.

12 Ep. 184 (M. G. Epp. Carol, aevi II 309). Die Kardinalscappa blieb zu Rom das ganze Mittelalter hindurch an der Vorderseite geschlossen; höchstens, dafs sie zum leichteren 
Als Name eines liturgischen Gewandes ist das Wort cappa erst seit dem Ende des 8. Jahrhunderts nachweisbar ${ }^{1}$.

Im späteren Mittelalter bedeutete cappa erstens den gewöhnlichen klerikalen oder mönchischen Mantel, zweitens die sog. Cappa choralis, ein beim Chorgehet gebrinchliches, meist bis auf einen Schlitz in der Mitte der Vorderseite ganz geschlossenes, also kaselartiges Gewand aus schwarzem Stoff, und drittens das liturgische Pluviale. Die gewöhnliche klerikale und mönchische Cappa wurde seit etwa dem Ende des 12. Jahrhunderts vielfach mit weiten Ärmeln versehen. Sie hief dann cappa manicata. Ein solches Vorgehen, bei dem das Gewand seines Mantelcharakters verlustig ging und sich zu einer Art von Tunika umbildete, wurde indessen von verschiedenen Synoden mit allem Ernst untersagt ${ }^{2}$, freilich nur mit teilweisem Erfolg.

Als Name des Pluviale war das Wort cappa während des Mittelalters im ganzen Abendland gebräuchlich, am verbreitetsten war er in dieser Bedeutung jedoch a berhalb Italiens. Nur selten, dafs uns hier in den alten Inventaren, welche ja besonders in Betracht kommen, der Name pluviale begegnet. Dementsprechend ging das Wort denn auch allenthalben aufiserhalb Italiens als Benennung des Pluviale in die Volkssprache über: Chorkappe, kap (holländisch), chape (französisch), cope (englisch), capa (spanisch).

In Italien herrschte schon im Mittelalter der Name pluviale, italienisch piviale, vor. Das Wort erscheint bereits in dem um $830-840$ entstandenen Pontifikalbuch des Agnellus. Es werden nämlich hier in der Vita Mauri († ca 642) unter den Gegenständen, welche das der Kirche von Ravenna zugehörige Patrimonium in Sizilien jährlich als Abgabe zu entrichten hatte, neben iacintae casulae, laenae et cetera indumenta auch pluviales syriae exornatae aufgeführt ${ }^{3}$. Leider erhalten wir weder über den Zweck dieser seidenen, verzierten pluviales, noch über ihre Form von Agnellus nähere Auskunft. Ein Jahrhundert später wird in dem Verzeichnis der durch Hildebrand von Castello Matenano 947 der Abtei Farfa genommenen Kostbarkeiten ein pluviale aufgeführt ${ }^{4}$. Da es inmitten anderer gottesdienstlicher Paramente erscheint, war es ohne Zweifel selbst gleichfalls ein solches. Die um das Ende des 10. Jahrhunderts aus Cluny übernommenen Consuetudines von Farfa gebrauchen statt pluviale die Bezeichnung cappa. Liturgische Gewandstücke waren ferner die pluvialia octo, welche in einem Inventar des Kloster's S. Liberatore zu Chieti aus dem Jahre 1019 zugleich mit planetae sericae quattuor et castaneae tres cum tunicis et amictis et stolis et mappulis suis unter den indumenta sacerdotalia erwähnt werden 5. Auch das pluviale de purpura und das pluviale de pallio valde bonum, von welchen der Bericht des Abtes Bonus über die Einrichtung von S. Michele zu Pisa um das Jahr 1048 spricht, hatten nach dem Zusammenhang unzweifelhaft liturgischen Charakter ${ }^{6}$.

Im Norden kommt das Wort pluviale bereits in einer Schenkung des Chorbischofs Madalwin von Passau aus dem Jahre 903 vor, und zwar bezeichnet es hier ohne Zweifel ein zu liturgischen Zwecken dienendes, von der

Gebrauch der Hände in der Mitte des Körpers mit einem Schlitz versehen wurde.

1 Vgl. die Nachweise im folgenden Paragraphen.

${ }^{2}$ Vgl. z. B. Syn. Eborac. a. 1195 , n. 6 ; Constit. Gallon. Card. a. 1208, c. 3; Syn. Avenion. a. 1209, c. 18; Conc. Montispes. a. 1215 , c. 3 ; Conc. Lat. IV, c. 16 ; Conc. Salisber. a. 1217, c. 10 (H ard. VI 19311976 1991 2046; VII 34 91); sonstige Belege bei D. C. sub cappa.

3 M. G. SS. Langob. 350.

\& M. G. SS. XI 536.

s. Mr., Ant. IV 769 .

6 Ebd. 789. 
Kasel verschiedenes Gewandstück ${ }^{1}$. Von einem pallium pluviale ist um das dritte Viertel des 10. Jahrhunderts in der Biographie des hI. Odo von Cluny die Rede. Es wird dort erzälllt, es sei dem Heiligen in einem Traumgesicht St Martin erschienen stola splendida inclutus, super quam pallio pluviali utebatur et episcoporum more ferulam gerebat?. Eine vestis pluvialis begegnet uns in der um 1060 von Wibert, Archidiakon zu Toul, geschriebeneu Vita Leos IX. ${ }^{3}$ Sie wird ausdrücklich mit der cappa identifiziert: quae cappa vocitatur, und scheint den päpstlichen Mantel zu bedeuten. In den römischen Ordines heilist das Gewand stets pluviale. Die ersten, welche seiner unter diesem Namen gedenken, sind der 10. und 11. Ordo; beide entstammen der Frühe des 12. Jahrhunderts*. Die Cappa, welche in den römischen Ordines hie und da erwähnt wird, bedeutet bald, wie auch sonst im Mittelalter häufig, die Cappa choralis oder den klerikalen Mantel, bald das mantum des Papstes, d. i. den Papstmantel.

Wie sehr in Italien schon im Mittelalter die Bezeichnung pluviale vorherrschte, zeigen am besten die Inventare, welche das Gewand fast nur unter dem Namen pluviale, piviale, aufführen. Durch die Aufnahme in das römische Missale, Caeremoniale und Pontifikale erhielt das Wort offizielle Bedeutung.

Was die Etymologie des Wortes pluviale anlangt, so muf dasselbe ursprünglich ein Gewand bezeichnet haben, welches zum Schutze gegen den Regen diente, also wohl einen Mantel, der mit einer Kapuze versehen war. Im Lanfe der Zeit stumpfte sich indessen, wie es auch in andern Fällen nicht selten geschieht, diese Bedeutung dahin $a b$, daf man überhaupt einen mit einer Kapuze ansgestatteten Mantel pluviale nannte, auch wenn er nicht gegen den Regen getragen wurde. Zur Zeit, als das Pluviale unter die liturgischen Gewänder Aufnahme fand, dürfte der anfïngliche Sinn des Wortes schon ganz verdunkelt gewesen sein; denn die Funktionen, bei denen der Mantel zur Anwendung kam, vollzogen sich ja vornehmlich in der Kirche oder sonstigen bedeckten Räumen, in denen ein „Regenmantel“ offenbar keinen Sinn hatte.

Der Ursprung des Wortes cappa, statt dessen auch wohl capa geschrieben wird, ist unsicher. Isidor von Sevilla, nach welchem es eine Kopfbedeckung bedeutet, meint, es komme entweder von dem Buchstaben Kappa her, mit dem die Kopfbedeckung: wegen ihrer beiden Spitzen Ähnlichkeit habe, orler es sei auf caput zurückzuführen 5 . Es bedarf kaum der Bemerkung, daf diese rein äuferlichen Ableitungsversuche wie so manche andere in den "Etymologien“ unmöglich ernst genommen werden können. Eine andere Erklärung bringt cappa mit capere in Verbindung: capa sic dicta, quia quasi totum capiat hominem. Sie soll sich nach Du Cange ${ }^{5}$ ebenfalls in den Etyno-

1 Monum. Boica XXVIII, pars 2, p. 201 : Tradidit namque suum apparatum i. e. sicut ipse paratus ad missam solitus fuerat stare: pluviale purpureum auro paratum, casulam purpuream siricam de sirico precioso, stolas 2 cum anfanone auro et gemmis paratum (sic). Unter dem pluviale mag hier vielleicht eine mit Kapuze versehene Kasel zu verstehen sein, wenn nicht etwa, was wohl das richtige ist, ad missam solitus fuerat stare als minder genaue Angabe zu betrachten ist.

2 I. 2, n. 2 (M. 133, 61); vgl. Nagoldj, Vita S. Odonis n. 29 (ebd. 97).

3 L. 2 , c. 8 (M. 143, 496).

4 In den früheren römischen Ordines ist weder von einer Cappa, noch einem Pluviale die Rede, mit Ausnahme des 6., welcher die dem Priester assistierenden Priester mit Cappae ausgestattet sehen will. Dieser aber ist nicht sowohl ein eigentlich römischer Ordo als vielmehr eine Darstellung der Pontifikalmesse, wie sie sich auf der Grundlage des römischen Ritus außerhalb Roms vollzog, daher denn auch durchsetzt mit nichtrömischen Elementen, wozu unter anderem die Cappa der Assistenten samt deren Namen gehören mag.

5 Etymol. 1. 19, c. 31 (M. 82, 699).

6 A. a. O. s. v. cappa II, 110. Aus Du Cange ist die Erklärung vielfach von andern, selbst von Grimm, Deutsches Wörterbuch V 188 , unbesehen und ohne weiteres als Äuferung Isidors herübergenommen worden. 
logien finden, in Tirklichkeit kommt sie jedoch darin nirgends vor. Ob die Ableitung an sich zutreffend ist oder ob nicht cappa vielleicht besser mit capsa in Terbindung gebracht wird, möge dahingestellt bleiben.

In älteren spanischen Inventaren wird das Pluviale auch wohl mantus genamnt, so z. B. in einem Verzeichnis der Paramente, welche König Ferdinand 106.3 der Kathedrale von Leon bei der. Translation der Reliquien des hl. Isidor ron Sevilla schenkte: mantos 2 aurifrissos (sic). Ebenso in einem Inventar der Tiathedrale von Leon aus dem Jahre 1073: tres mantos, unum ciquilatonem et duos morgones. Eine Bedeutung hat dieser Name nie gewonnen. In spätmittelalterlichen deutschen Inventaren heist das Pluviale gewöhnlich kore kappe (korkappe), doch auch wohl rauchkasel ${ }^{1}$.

\section{ALTER DES GEWANDES.}

Die früheste Erwähnung findet das Gewand in der Stiftungsurkunde des Klosters Obona in Spanien aus dem Ende des 8. Jahrhunderts, in dem Inventar von St-Riquier ${ }^{2}$ und im Verzeichnis der gottesdienstlichen Gegenstände, welche der hl. Ansegisus zufolge seiner von einem Zeitgenossen verfasten Biographie dem Kloster Fontanelle schenkte. Wenn nämlich die Stiftungsurkunde von Obona neben drei Kaseln unam cappam sericam, das Inventar von St-Riquier neben 40 Kaseln cappam castaneam (kastanienfarbig) auro paratam unam, sericam unam und die Vita S. Ansegisi neben zwölf Kaseln cappas romanas duas, unam videlicet ex rubeo cendato (rotes, ungemustertes Seidenzeug) et fimbriis viridibus ornatam, alteram ex cane pontico, quem vulgo beuvrum nuncupant, similiter fimbriis sui coloris decoratam verzeichnet, so können unter diesen von den Kaseln offenbar irgendwie verschiedenen cappae nur liturgische Gewandstïcke verstanden werden. Das beweist ebensowohl ihre Kostbarkeit wie der Umstand, daf sie mitten unter sonstigen gottesdienstlichen Paramenten aufgeführt werden. Insbesondere gilt solches von den cappae, von welchen in der Vita S. Ansegisi die Rede ist, da diese ausdricklich als vestimenta ecclesiastica bezeichnet werden. De vestimentis ecclesiasticis, heift es hier, largitus est ... dalmaticas ... roccum subdiaconalem ... planetas ... cappas romanas. Es liegt um so weniger ein Grund vor, an der liturgischen Bestimmung der fraglichen cappae zu zweifeln, weil bereits in Inventaren aus der zweiten Hälfte des 9. Jahrhunderts die cappae in einer Anzahl auftreten, die sich nur bei Annahme einer gottesdienstlichen Verwendung des Gewandes erklären läßt ${ }^{3}$. So gab es in St Bavo zu Gent

I So z. B. im Inventar von St Michael zu Zeitz aus dem Jahr 1514.

2 Chron. Centul. 1. 3, c. 3 (M. 174, 1258). Das Inventar erwähnt auch cappae 377 , wie schon das Schatzverzeichnis aus dem Beginn des Jabrhunderts cappae 200 aufgefüht hatte. Diese cappae waren indessen keine liturgischen Gew andstücke, sondern cappae, welche von den Mönchen an den höchsten Feiertagen beim Gottesdienst angezogen wurden, also Foiertagsmätel, die man in der Sakristei aufbewahrte, weil sie niemand besonders zugewiesen waren, sondern an den Festtagen in der Sakristei zum Gebrauch in der Kirche unter die Jïnclis vertoilt wurden.
3 E. B ishop hat in seinem vorzïglichen Aufsatz: The origin of the cope as a church vestement (Dublin Review CXX 31 ) Bedenken gegen die liturgische Bestimmung der cappae der Inventare von St-Riquier und Fontanelle. Dieselben sind jndessen um so weniger begrïndet, als der Verfasser selbst die nur zwei Jahrzehnte späteren cappae von St Bavo zu Gent als kirchliche Gewänder ansieht. Daf die eine Cappa, welche in der Vita des hl. Ansegisus erwähnt wird, aus Biberpelz bestand, kann nichts verschlagen. Biberpelz war ein kostbares Material. Auch darf wohl an die zahlreichen Lederkaseln des 18. Jahrhunderts erinnert werden. 
schon 851 nicht weniger als 24 kostbare cappae de pallio, die etwas später freilich bei dem Einfall der Normannen zum größten Teil abhanden kamen. Denn ein nach dem Abzug der Feinde und nach Wiederherstellung der Ordnung aufgestelltes Inventar vermerkt neben casulae 7 nur noch cappae 3. Zu St Trond besaf man um 870 neben 12 casulae pretiosae de pallio 33 cappae pretiosae de pallio. Im Jahre 877 schenkte Abt Hilduin der Abtei St-Bertin cappam nivei coloris, rubeis intersectam volucrum figuris ${ }^{1}$. Ein Inventar von Marchiennes aus dem Ende des 9. Jahrhunderts verzeichnet 18 cappae gegenüber nur 8 Kaseln, ein Inventar von Pfäffers gleichfalls aus der Wende desselben 6 Cappae neben 6 casuculae.

Die erste Hälfte des 9. Jahrhunderts ist ersichtlich die Zeit, in der die cappa Aufnahme unter den liturgischen Gewändern fand und die Kasel aus einer Reihe von Funktionen, bei welchen diese bis dahin zur Anwendung. kam, zu verdrängen begann. Im 10. Jahrhundert war ihr Gebrauch bereits weit verbreitet. Die Inventare und Gabenverzeichnisse ans dieser Zeit lassen daran keinen Zweifel.

Man vergleiche beispielsweise die Schenkung Madalwins von Passau von 903 (pluviale purpureum, auro paratum), das Testament Riculfs von Elne von 915 (capas duas, una purpura et alia bition [blattion]), die Dotationsurkunde des Klosters S. Salvador von Lerez aus dem Jahre 916: 12 vestimenta sacra sacerdotalia (Kaseln) et 4 cappas sericas, ein Inventar von Lamspringe (?): casulae 4, cappae 5; ferner die Schenkung des Bischofs Abraham von Freising (957--994): cappae cum aureis fibulis paratae $6^{2}$, aliae cappae de probatissimis palliis 16 , planetae auro paratae 6 , das Inventar von Clermont-Ferrand: casulas optimas 5 , cotidianas $2 \ldots$ capas 27 , die Schenkung des Bischofs Ethelwold für Peterborough: 6 masse hacelan (Kaseln) and 4 caeppan; weiter das Inventar von Würthsee (Kärnten): cappae 2, planetae 6, das Testament Brunos von Köln: Monasterio Sosacio fundando ... cappa et casula ex nostris ${ }^{3}$, das Verzeichnis der durch Hildebrand von Castello Matenano ahhanden gekommenen Kostbarkeiten des Klosters Farfa: pluviale unum; dann das Inventar der von Bischof Odalrich erworbenen und der Kathedrale von Cremona geschenkten Paramente aus dem Jahre 984: pluviales dedimus 4 cum frisis aureis et 1 iterum sine auro, 3 quoque alia de manibus raptorum eruimus, die Schatzverzeichnisse von Pfäffers aus dem 10. Jahrhundert u. a. Dazu kommen noch gelegentlich vereinzelte Nachrichten. So erzählt Helgaud, es habe Adelheid, die Mutter des Königs Robert, zu Ehren des hl. Martin cappam unam intextam auro, duas vero de argento gestiftet 4 . Abt Immo von St Gallen bereicherte 675 sein Kloster mit stolas deauratas, cappas, dalmaticas, subtilia ${ }^{5}$, um die Mitte des 10. Jahrhunderts aber gab es zu St Gallen eine cappa aquilifera, eine mit Adlern verzierte cappa ${ }^{6}$.

Im 11. Jahrhundert muß die liturgische Cappa oder, was dasselbe ist, das liturgische Pluviale sich bereits allgemein Eingang verschafft haben. Es gibt wohl kaum ein Inventar gröferer Kirchen aus dieser Zeit, in dem sich nicht auch eine Anzahl mehr oder minder kostbarer Pluvialien verzeichnet fände. Beispiele bieten die Schatzverzeichnisse von Speier (1051) mit cappae 12, quarum 8 auro texto ornatae, von Kremsmünster (1011) mit cappae coccineae 26, von Kloster Abdinghof zu Paderborn (1031) mit cappae 25, von Prüm (1003) mit cappae 29 neben casulae 30, von Benediktbeuren (1032) mit casulae 9, aber cappae 12, von Enger (ca 1000) mit 6 cappae, 2 auro ornatae, von Ely in England (1079) mit 34 cappae, 4 earum cum aurifriso, von St-Laurent zu Lütich (1034) mit cappae 9 ex palliis optimis, von St Gallen

1 Folcuini Gesta abb. S. Bertini Sithiens. n. 85 (M. G. SS. XIII 622).

(M. G. SS. XXIV 321. 3 Ebd, IV 275.
M. 141, 917.
5 Cas. S. Galli cont. II, c. 1 (M. G. SS. II 150).

6 Ekkehardi IV. Casus S. Galli c. 3 (ehd. II 108). 
(11. Jahrhundert) mit cappae 32, davon 8 cappae auro paratae, von Pfäffers unter Abt Hartmann (1012-1026) mit 6 cappae und unter Abt Ulrich (1067-1080) mit 8 cappae.

Die ältesten bildlichen Wiedergaben der Cappa entstammen der Mitte des 9. Jahrhunderts; sie finden sich auf zwei Miniaturen, den Initialen O und D, und auf einer der Deckelskulpturen des Drogosakramentars. Das Relief (Bild 143) und die Initiale O stellen die Spendung des Sakramentes der Firmung dar, während die Initiale D Begebenheiten aus dem Leben des hl. Arnold, Bischofs von Metz, insbesondere eine Teufelaustreibung und eine durch Salbung mit dem heiligen Öl bewirkte Totenerweckung erzählt. Die Cappa erscheint auf allen drei Bildwerken mit einer Kapuze ausgestattet, im übrigen aber sieht sie einer Kasel völlig gleich. Das Relief und die Initiale 0 lassen es allerdings ein wenig fraglich, ob wir uns das Gewand vorn als offen oder als geschlossen zu denken haben. Indessen wird jeder diesbezügliche

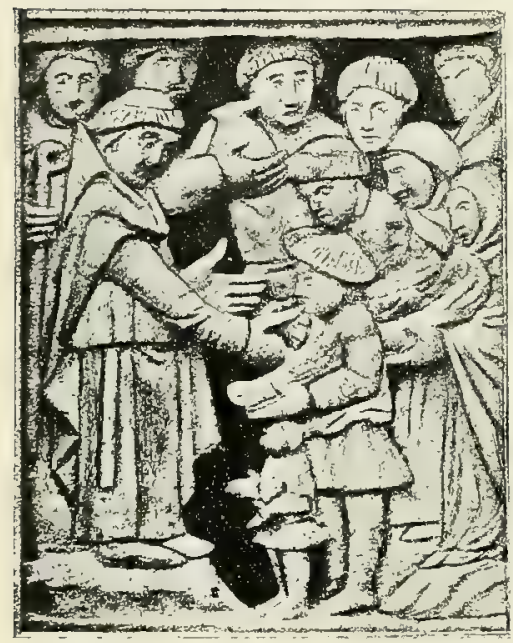

Bild 143. Relief vom Deckel des Drogosakramentars. Paris, Natinnalbibliothek. Zweifel durch die Initiale $\mathrm{D}$ beseitigt, bei welcher die Cappa in aller wünschenswerten Deutlichkeit als vorn geschlossen dargestellt ist.

Ein anderes frühes Beispiel der Cappa liefert die vielleicht noch dem 9. Jahrhundert angehörende Elfenbeintafel der Macleanschen Sammlung (Bild 66, S. 168). Sie stellt die Erteilung des bischöflichen Segens dar. In der Mitte steht der Bischof neben dem Lectorium, die Rechte zum Segen erhoben; über ihm sind fünf Diakone in der Dalmatik angebracht, zu seinen Füßen aber gruppieren sich um ihn sieben Cantores in gegürteter Albe und Cappa. Auch hier ist das Gewand vorn geschlossen ${ }^{1}$.

Vor der Brust aufgeschlitzte Cappae, also Cappae nach Art unseres heutigen Pluviale, kommen auf den Monumenten vor dem 11. Jahrhundert nicht vor. Die beiden ältesten Beispiele dürften eine Miniatur eines aus Minden herrührenden Codex der kgl. Bibliothek zu Berlin ${ }^{2}$ und eine Federzeichnung in dem Pontifikale von Aletis (St-Malo) in der Stadtbibliothek zu Rouen ${ }^{3}$ bieten. Die Berliner Miniatur stellt den Bischof Sigibert von Minden auf seinem Thronsessel dar, zur Linken einen Diakon, zur Rechten einen Priester. Alle sind in ihre liturgischen Gewänder gekleidet, der Bischof in Pontifikaltracht, um die Schultern das Rationale, der Diakon in Albe, Stola und Dalmatik, der Priester in Albe und vorn offener, auf der Brust mit einer Schliefie befestigter Cappa. Eine Kapuze fehlt bei dem Gewand. Die Miniatur muli zwischen 1022 und 1036 entstanden sein. Die Federzeichnung im Pontifikale von Aletis gibt die Einweihung einer Kirche wieder. Der konsekrierende Bischof ist in vollem Ornat abgebildet, nur trägt er statt der Kasel ein Pluviale, das mit grofer rechteckiger Fibel über der Brust zusammengehalten

$\iota$ Vgl. wegen des Gewandes auf den vier angeführten Bildwerken auch oben S. 177.

¿ Theol. 4", n. 3, p. 1.
${ }_{3}^{3}$ Eineallerdings sehr mangellatte Abbildung bei M ïller und Mothes, Archäologisches Wörterbuch I 55 . 
wird. Die Federzeichnung scheint ebenfalls noch der Frühe des 11. Jahrhunderts anzugehören. Eine um etwa ein halbes Jahrhundert jüngere Darstellung einer vorn offenen Cappa findet sich auf einer früher schon erwähnten Miniatur eines Evangeliars der kgl. Bibliothek zu Brüssel. Wir erblicken das Gewand hier bei einem Bischof, der die Reliquien des hl. Stephanus überführt (Bild 122, S. 262).

Nachrichten iiber die A r t der Verwendung der Cappa beim Gottesdienst erhalten wir erst in der zweiten Hälfte des 10. Jahrhunderts. Sie finden sich in der englischen Concordia regularis ${ }^{1}$, den Consuetudines Farfenses, die, weil aus Cluny herübergenommen, zugleich die Praxis von Cluny enthalten?, den Consuetudines von St-Vanne (Viton) zu Verdun ${ }^{3}$ und den aus Einsiedeln stammenden Consuetudines von St Emmeram zu Regensburg ${ }^{4}$, also ausschliefilich in Dokumenten, welche den Brauch in Benediktinerklistern wiedergeben. Über die Verwertung einer liturgischen Cappa in andern Kirchen kommen uns die frühesten Nachrichten erst im 11. Jahrhundert zu.

Den römischen Ordines der Karolingerzeit, d. i. dem 1., 2. und 3. Ordo Mabillons und dem Ordo Duchesnes, sowie dem St Gallener Kleiderverzeichnis ist die Verwendung der Cappa noch völlig fremd. Der einzige liturgische Mantel, welchen sie kennen, ist die Kasel ${ }^{5}$.

Aber auch die Liturgiker des 9. Jahrhunderts wissen noch nichts von ihrem Gebrauch beim Gottesdienst. Bei Hraban und Walafried ist das freilich von keiner Bedeutung, da sie nur von der pontifikalen Mekkleidung handeln. Auch bei Pseudo-Alkuin kann es nicht auffallen, da seine Ausführungen über die liturgischen Gewänder, einige fragmentarische Bemerkungen ausgenommen, lediglich Auszüge aus Amalar sind. Bemerkenswert ist das Schweigen rlagegen bei Amalar. Er behandelt die gesamte liturgische Gewandung. Nichtsdestoweniger tut er der Cappa und ihres Gebrauches mit keinem Worte Erwähnung. Er übergeht sie selbst da, wo er, seine Erörterungen über die liturgischen Gewänder kurz zusammenfassend, omnem clericorum ornatum aufzähIt. Mehr noch, er versichert uns mit aller Bestimmtheit, dafs die Kasel das allen Geistlichen gemeinsame Gewand sei, gerade wie später Honorius vom Pluviale sagt: a singulis ordinibus portatur, und zwar bedienten sich ihrer nach Amalar insbesondere auch die Cantores, die beim Gottesdienst heteiligten offiziellen Sänger ${ }^{6}$.

Unter solchen Umständen liegt es auf der Hand, dab zur Zeit, da Amalar zu Metz seine Schrift De officiis ecclesiasticis verfafte, d. i. um 820, die liturgische Verwendung der Cappa statt der Kasel noch eine ganz vereinzelte Erscheinung gewesen sein mufs. In der Tat wird vor Abfassung der Schrift nur einmal der liturgischen Cappa gedacht, in der Schenkungsurkunde Adelgasters für Obona. Denn das Inventar von St-Riquier datiert erst von 831, die Schenkung der beiden cappae an das Kloster Fontanelle aber, von welcher die Vita S. Ansegisi erzählt, fällt in die Zeit, da der Heilige Abt dieses Klosters war, d. i. zwischen 823 und 833.

1 M. $137,475 \mathrm{ff}$.

2 Albers, Consuetud. Farfen. Index sub cappa xxxvin. $\quad{ }^{3}$ Mart., Mon. IV $297 \mathrm{ff}$.

+ P. Odilo Ring hol z: Des Benediktinerstifts Einsiedeln Tätigkeit für die Reform deutscher Klöster, in Studien und Mitteilungen aus dem Benediktiner- und Cistercienserorden VII, Würzburg 1886, 269 ff.
${ }^{5}$ S. oben S. 169. Die Bezeichnung cappa romana in der Vita $S$. Ansegisi dirfte daher nur auf die Form der fraglichen Gewänder gehen, nicht aber zum Schlub berechtigen, daf damals auch zu Rom schon die Kappe beim Gottesdienst in Gebrauch gewesen sei.

${ }_{6}^{6}$ S. oben S. $161 \mathrm{f}$. 


\section{GEBRAUCH DES GEWANDES.}

Wenn im vorhergehenden der Gebrauch der Cappa bis in das 9. Jahrhundert hinaufgeführt wurde, so soll damit nicht gesagt werden, daf er damals bereits der gleiche war wie gegenwärtig und im späteren Mittelalter. Es danerte vielmehr eine gute Weile, bis die Kasel ausschließlich Meßgewand geworten ${ }^{1}$ und bei den übrigen liturgischen Funktionen die Cappa an ihre Stelle getreten war. Noch auf den Miniaturen des Göttinger Sakramentars gewahren wir beim Bischof überall die Kasel, selbst bei Spendung der heiligen Ölung und der Entgegennahme der Beichte. Ähnlich schreibt noch das Pontifikale von Aletis für die Versehgänge nicht etwa die Cappa, sondern die Planeta vor ${ }^{2}$. Ja es konnte sich selbst noch in der zweiten Hälfte des 11. Jahrhunderts zwischen Lanfrank und Exzbischof Johannes von Rouen eine Meinungsverschiedenheit darüber erheben, ob der Bischof bei der Konsekration der Kirchen die Kasel, wie letzterer wollte, oder die Cappa, wie Lanfrank meinte, zu tragen habe ${ }^{3}$. Zu Rom war es damals, wie sich aus dem Briefe Lanfranks ergibt, bereits Brauch geworden, dafs sich der Konsekrator bei dieser Funktion der Cappa bediente. Wie man sieht, herrschte noch im 11. Jahrhundert im Gebrauch von Kasel und Cappa Schwanken. Leider ist es nicht möglich, dem Prozeß, bei dem die Kasel mehr und mehr der Cappa. weichen mufte, in seinen einzelnen Phasen nachzugehen, da die Angaben darüber allzu spärlich sind.

Über die Praxis, welche im 10. Jahrhundert hinsichtlich der Verwendung der Cappa herrschte, geben die vorhin erwähnten monastischen Consuetudines mancherlei Aufschlüsse. Für das 11. Jahrhundert bieten die Consuetudines von Eynsham*, eine Bearbeitung der Concordia regularis St Dunstans, die Consuetudines von Cluny ${ }^{5}$ und Hirsau ${ }^{6}$, die Decreta Lanfranks ${ }^{7}$ und der Ordo des Erzbischofs Johannes von Rouen's manche Belehrung. Der Brauch war weder überall noch zu den verschiedenen Zeiten derselbe. Im einzelnen finden sich bezüglich der Verwertung der Cappa beim Gottesdienst vielfache Abweichungen. Das Bild, welches wir in den angeführten Schriften von dem Gebrauch des Gewandes erhalten, ist nur in seinen Grundzügen das gleiche. Sieht man von der in manchen Klöstern und Stiftskirchen herrschenden Sitte ab, wonach an bestimmten Tagen alle Mönche, die Laienbrüider und Oblaten eingeschlossen bzw. alle Stiftsgeistliche in der Cappa dem Amt und der ihm vorhergehenden Prozession beiwohnten ${ }^{9}$ - eine Sitte, bei der es sich

1 S. oben S. 169.

2 Mart. 1. 1, c. 7, art. 4, ordo 1: I 301: Induat se... planeta, si affuerit; sin alias, casula non induatur. Das Pontifikale wird bei Martène als Pontifikale von Jumièges bezejchnet.

3 Lanfranci ep. 13 (M. 150, 520). Wenn nach dem Liber de offic. eccl. des Erzbischofs Johannes von Rouen (M. 147, 42) am Feste des hl. Johannes Ev. die bei der Messe ministrierenden Priester Kaseln tragen sollten, so geschah das, weil dieses Fest das Fest der Priester war, wie das Fest des hl. Stephanus das der Leviten und der Tag der unscluuldigen Kinder las der Chorknaben. Wie darum am St Stephanstag Diakone in
Dalmatik den Chor dirigierten, so waren am St Johannistag die assistierenden Priester in Kaseln gekleidet.

4. Winchester Obedientiaries' Rolls $179 \mathrm{ff}$ (Dublin Review CXX 27).

5 Uldalrici Cluniac. monachi Consuet. Cluniac. 1.3 (M. $149,635 \mathrm{ff}$ ).

${ }^{6}$ S. Guilielmi abb. Hirsaug. Constitut. Hirsaug. 1. 2 (M. 150, 927 ff).

Lanfranci Decreta pro ordine S. Benedicti (ebd. 443).

${ }^{8}$ Liber de offic. eccl. (M. 147, $27 \mathrm{ff}$ ).

" Die Sitte mala schon zu St-Riquier im Beginu des 9 . Jahrhunderts geherrscht haben, wie die ungemein große Zahl der cappae (200 bzw. 377) in den damaligen Inventaren 
offenbar nicht um eine eigentlich liturgische Verwendung des Gewandes handelte -, so sind es namentlich fünf Gelegenheiten, bei denen dieses gebraucht zu werden pflegte.

Vor allem bedienten sich die Cantores, der Chordirigent und die Sänger, welche im Chor am Ambo das Invitatorium, die Responsorien, das Graduale, das Alleluja usw. absangen, der Cappa, und zwar galt diese im besondern Sinn als das den Cantores eigentümliche liturgische Gewand. Cappa vestis propria cantorum est, sagt Honorius, obschon er zugleich bemerkt: a singulis ordinibus portatur ${ }^{1}$. Doch trugen die Cantores nicht an allen Tagen das Gewand, sondern nur an durch den Ortsgebrauch bestimmten Festen. Nach dem Ordinarium des Erzbischofs Johannes von Rouen war beispielsweise an den gewöhnlichen Sonntagen nur der Cantor, welcher das Alleluja sang, mit der Cappa bekleidet; an Festen schwankte die Zahl der im Pluviale amtierenden Sänger je nach dem Rang des Festtages zwischen zwei und sechs.

Zu Farfa sangen beim Officium das Invitatorium bald zwei, bald vier in der Cappa, doch nur an Festtagen; an den andern Tagen trugen die Sänger beim Invitatorium lediglich die Albe. Bei der Messe war an gewöhnlichen Tagen, wie z. B. der Vigil vor Weihnachten, an den Sonntagen Septuagesima, Sexagesima, Quinquagesima, den Sonntagen der Fastenzeit u. ä., nur einer der Cantores mit der Cappa bekleidet, an Festtagen dagegen je nach deren Qualität drei, vier, sechs, acht oder zwölf.

Zweitens bediente sich der Cappa der Priester, welcher beim Magnificat der Vespern und bei der Matutin die Altäre zu inzensieren hatte; doch nur an Festtagen. An hohen Festen waren es in einzelnen Klöstern zwei Priester, welche in Cappa die Beräucherung der Altäre vornahmen.

Eine dritte Gelegenheit, bei welcher das Gewand Verwendung fand, bildeten die Prozessionen. Sie waren entweder mit der Abhaltung des Officiums innig verbunden, wie z. B. Sonntags, am Lichtmefstage, am Palmsonntag usw., so daf sie regelmäßig im Verlauf des Kirchenjahres wiederkehrten, oder sie hatten nur bei besondern Anlässen statt, wie bei Reliquientranslationen und Empfängen hoher geistlicher oder weltlicher" Würdenträger. Bald trugen bei den Prozessionen nur die Offiziatoren, Priester und Cantores, bald der ganze Konvent die Cappa. Es hing das teils vom lokalen Brauche, teils von dem liturgischen Rang der Prozession und der Würde der Person $a b$, welcher der Empfang galt.

Die vierte Gelegenheit, bei welcher die Cappa getragen wurde, waren die feierlichen Segnungen. Zu Farfa kam diese schon im 10. Jahrhundert bei der Einsegnung des Abtes zur Verwendung, und zwar war sowohl der amtierende Bischof wie der Electus mit ihr bekleidet?. Bei der Vornahme der Kirchweihe mag sie sich auch bereits in 10. Jahrhundert eingebürgert haben; jedenfalls war sie bei ihr in der zweiten Hälfte des 12. schon sehr gebräuchlich. Bei der Kerzensegnung wurde es verschieden gehalten. Während z. B. die Concordia regularis Dunstans will, daf der Abt in Cappa die Zeremonie vornehme $^{3}$, schreiben die fast hundert Jahre jüngeren Decreta Lanfranks

des Klosters beweist (s. oben S. 310). Nur jene Gewänder sind als liturgische zu betrachten, welche von den beim Gottesdienst amtlich tätigen Personen als Amtskleidung getragen werden.

1 In der Schenkung Leofrics von Exeter $(\dagger$ 1072) werden unter den Paramenten, welche der Bischof seiner Kathedrale gab, auch os catercaeppa genannt.

2 Albers, Consuet. Farfen. 142; vol. auch Udalrici monachi Consuet. Cluniac. I. 3 , c. 1 (M. 149, 733). ${ }^{3}$ M. 137, 488 . 
vor, sie solle nur in Albe und Stola vollzogen werden ${ }^{1}$. Bei der Weihe der Asche war das Gewand nirgends üblich, nicht einmal zu Farfa?, wo man doch sonst mit seiner Verwertung keineswegs sparsam war.

Den ausgedehntesten Gebrauch scheint man von der Cappa in dem prachtliebenden Cluny und in den Klöstern gemacht zu haben, welche die Consuetudines ron Cluny übernommen hatten. Anderswo, wie zu Einsieleln, Canterbury und Rouen, war er weit seltener. Bei Begräbnissen dürfte die Cappa im 10. und 11. Jahrhundert nirgends benutzt worden sein; der amtierende Priester erschien bei ihnen bloß in Albe und Stola. Wenn wir auf zwei Miniaturen eines Antiphonars zu Salzburg, von denen die eine das Begräbnis des hi. Johannes Ev., die andere das des hl. Rupert darstellt, einen Priester im Pluviale die Einsegnung der Leiche vornehmen sehen, so ist hier das Gewand wahrscheinlich eine Zutat des Miniators. Das Antiphonar entstammt nach Ausweis der Form, welche die Mitra auf den Miniaturen hat, etwa der Mitte des 12. Jahrhunderts ${ }^{3}$. Bei Absingung des Evangeliums am Schluf der dritten Nokturn des Officiums nach dem Tedeum war der Hebdomadarpriester mit Albe, Manipel, Stola und Kasel bekleidet, welche er während des Hymnus in der Sakristei anlegte ${ }^{4}$.

Die fünfte Gelegenheit endlich bildeten die Synoden. Schon um das Ende des 11. Jahrhunderts war es Brauch, daf3 die Bischöfe auf ihnen die Cappa trugen ${ }^{5}$. Im 12. Jahrhundert wird uns diese Sitte durch das Ordinarium von Limoges ${ }^{6}$ bezeugt.

Wenn also auch von einer Einheit in der Verwendung des Gewandes bis zum Beginn des 12. Jahrhunderts keine Rede sein kann, so war immerhin die spätere Praxis damals bereits in den Hauptzïgen fertig, und es bedurfte nur eines Ausbaues, einer Befestigung und einer Verallgemeinerung des bestehenden Brauches. Sie erfolgten im Verlauf des 12. Jahrhunderts ${ }^{7}$. Im Beginn des 13. hatte die Entwicklung im grofen und ganzen ihren $\mathrm{Ab}$ schluß erreicht, und das Pluviale unter den liturgischen Gewändern die Stellung sich erobert, welche es seitdem bis auf die Gegenwart ununterbrochen behauptet hat. Was das römische Missale und etwas später das Caeremoniale bezïglich der Verwendung des Gewandes bestimmten, war nichts anderes, als was schon das ganze spätere Mittelalter hindurch gang und gäbe gewesen war. Die liturgischen Bücher aus dieser Zeit, die Missalien, Pontifikalien, Ordines, Ritualien, Konsuetudinare, Ordinare und wie sie immer. heiken mögen, beweisen das zur Genüge. Von den Liturgikern des 12. Jahrhunderts ist Honorius der erste, welcher von der Cappa redet, leider ohne über ihre Verwendung nähere Angaben zu machen. Er begnügt sich mit der schon friuher angefïhrten Bemerkung, dab die Cappa das den Cantores im besondern zustehende Gewand sei, daf sie im übrigen aber von allen Geistlichen getragen werden dürfe". Die Cappae, deren Rupert von Deutz Erwähnung tut, wenn $\mathrm{H}^{\circ}$ in der Schrift De officis divinis schreibt: cappam in

Sect. 2 (M. 150, 452).

2 Albers, Consuet. Farfen. 31.

3 Lind, Ein Antiphonar mit Bilderschmuck, Wien 1870, 'Tfl 4 und 34.

+ Lanfiranc. Decret. sect. 710 (M. 150, 473 479). S. Guilielmi abb. Hirsaug. Constitut. Hirsaug. e. 82 (ebd. 1007).

5 Eadmeri Historia novorum in Anglia 1. 2 (M. G. SS. XIII 143).
6 Mart. 1. 3, c. 1, ordo 3; II. 311.

7 Lin Pontifikale von Besançon (12. Jahrh.) läst den Bischof in purpurner Cappa an Aschermittwoch die Ausweisung der Büfaer vornehmen (Mart. 1. 1, e. 8, art. 7, ordo 13; I 289); ein Rituale von Narbonne (12. Jahrh.) schreibt für die Aschenweihe die Cappa pluvialis vor (ebd. 1. 4, c. 15, ordo 1 ; III 50.)

${ }^{8}$ Gemma 1. 1, c. 227 (M. 172, 612). 
maioribus festis superinduimus, sind, wie es scheint, nicht das eigentlich liturgische Pluviale, sondem die Festtagscappa, welche man in den Benediktinerklöstern an hohen Festen im Chor beim feierlichen Gottesdienst zu tragen ptlegte ${ }^{1}$.

Von den römischen Ordines Mabillons ist der 6. Ordo der erste, der von der Existenz und Verwendung der Cappa Mitteilung macht. Er giht indessen blof an, dalis die dem Bischof assistierenden Priester mit ihr ausgestattet seien ${ }^{2}$. Aber auch die dem 12. Jahrhundert entstammenden Ordines erzählen nur wenig von dem Pluviale, wie die Cappa in ihnen stets genannt wird, teils weil sie überhaupt von der liturgischen Kleidung, welche sie offenbar als bekannt voraussetzen, kaum etwas Belangleiches sagen, teils weil sie blok eine bestimmte Summe von Funktionen besprechen. Es sind nur ganz vereinzelte Angaben, welche sie über den Gebrauch des Gewandes machen. So lesen wir im 10. Ordo Mabillons, dafs am Gründonnerstag bei der Ölweihe und den Karfreitagszeremonien die Bischöfe dem Papste im Pluviale zu assistieren und beim Begräbnis eines römischen Kilerikers vier Bischöfe, Kardinalpriester oder Erzpriester im Pluviale die Inzensation des Altares vorzunehmen hatten ${ }^{3}$. Im 11. Ordo wird uns berichtet, dafs die iudices und praefecti navales, welche den Papst bei seiner feierlichen Heimkehr von der Stationskirche begleiteten, und die notarii, die im Chore der Stationskirche der Stationsmesse anwohnten, das Pluviale trugen 4 . Der 12. Ordo endlich lälit das Gewand gebrauchen den Kardinaldiakon, welcher beim Mahl am Weihnachtstag die Tischlesung hatte, die Kardinäle bei der Prozession nach S. Croce am Karfreitag und den Papst beim Zug nach S. Lorenzo beim Lateran am Osterfest ${ }^{5}$. Eine sehr interessante Notiz findet sich in n. 46 des 12. Ordo. Wir erfahren dort, daf die mappularii und cubicularii, welche bei der Weihe eines Bischofs beschäftigt gewesen waren, das Recht auf das Pluviale des Neukonsekrierten hatten. Wollte letzterer dieses behalten, so mulite er es mit einer nach seinem Rang und Vermögen vom camerarius bemessenen Geldsumme auslösen ${ }^{6}$.

\section{FORM UND BESCHAFFENHEIT DES GEWANDES.}

Zur Karolingerzeit war die liturgische Cappa, nach den Bildwerken zu urteilen, ein nach Weise der Kasel vorn von unten bis oben geschlossener, mit einer Kapuze versehener Mantel. Ob es damals auch schon an der Vorderseite aufgeschlitzte und auf der Brust mit einer Schliefse befestigte gegeben hat, muls dahingestellt bleiben. Unwahrscheinlich ist das allerdings nicht, da ja in jener Zeit nach gallischer Sitte auch die klerikale Cappa, wie vorhin gesagt wurde, an der Vorderseite offen gewesen sein dürfte ${ }^{7}$. Die cappae romanae, von welchen in der Vita S. Ansegisi die Rede ist, waren

L. 2, c. 24 (M. 170,54 ).

2 N. 1 (M. 78,989). Vgl. oben S.309, Anm. 4.

${ }^{3}$ N. $313 \quad 37$ (ebd. 10091013 1023).

4 N. 1921 (ebd. 1033).

${ }^{5}$ N. 52832 (ebd. 10661075 1077).

- Ebd. 1088. Die mappularii und cubicularii waren Bedienstete, deren Aufgabe es war, bei den Stationen die Teppiche, Behänge, den Betschemel, die Kissen u. ä. zu tragen, auszubreiten bzw. aufzustellen und wieder mitzunehmen. So beschreibt Ordo 12 n. 45 ihr Amt. Auch hatten sie für heißes Wasser zu sorgen, so oft der Papst an einer Bittprozession teilnahm, damit derselbe, der in solchen Fällen stets barfuß zu gehen hatte. nach Beendigung der Feier seine Füße waschen könne. Desgleichen hatten sie die mappula (eine Art von Baldachin) zu tragen, unter welcher der Papst von der Türe der Stationskirche zum Altar derselben schritt. Von dieser mappula hatten sie ihren Namen.

7 S. oben S. 307. 
aller Wahrscheinlichkeit nach rings geschlossene Gewänder. Darauf lälit die cappa more romano consuta, welche Bischof Arno von Salzburg Alkuin zum Geschenk machte, schliefen ${ }^{\mathbf{1}}$; dem wenn diese auch wohl nur eine gewöhnliche klerikale Cappa war, so zeigt sie doch, welche Form das Gewand damals nach römischem Brauch zu haben pflegte.

Im 11. Jahrhundert war die liturgische Cappa nach Ausweis der friiler erwähnten Miniaturen schon vorn aufgeschlitzt, und so blieb es dann für die ganze Folgezeit Regel. Die früheste Beschreibung der Cappa geben Timpert von Deutz und Honorius. Beide bezeichnen sie im Einklang mit den bildichen Darstellungen als ein vorn offenes Gewand, das nur "mittelst einer Fibel geschlossen wurde.

Ein Schild, wie er jetzt am Pluviale angebracht ist, war diesem ursprünglich fremd. Statt seiner war ihm oben im Nacken eine Kapuze angenäht. Sie ist uns schon auf Bildwerken der Karolingerzeit begegnet ${ }^{2}$. Auffällig ist, daß auf den Darstellungen des Gewandes, welche dem 11. Jahrhundert entstammen, eine Kapuze nicht vorgesehen ist ${ }^{3}$. Ob diese wirklich häufig weggelassen wurde, seitdem das Pluviale vorn offen war und sich infolgedessen auch ohne sie von der Kasel deutlich unterschied? Klar kommt sie auf den beiden eben angeführten Miniaturen des Salzburger Antiphonars zum Vorschein*. Ein wirkliches mittelalterliches Pluviale mit Kapuze hat sich zu St Paul in Kärnten erhalten; die Kapuze ist jedoch bei ihm bereits so klein, daf sie niemals praktischen Zwecken gedient haben kann (Bild 144). Beträgt doch ihre Länge nur $0,45 \mathrm{~m}$ und ihre Höhe nur $0,22 \mathrm{~m}$. Sie beweist, dafs die als Kopfbedeckung gebrauchte Kapuze nicht unmittelbar durch den Schild ersetzt wurde, sondern dafs sich zwischen beide als Übergangsform eine Zierkapuze einschob, indem jene zunächst zur Miniaturkapuze und als solche zum blofen ornamentalen Anhängsel wurde und erst dann zu einem einfachen Zeugstück verkümmerte.

Wann die eigentliche Kapuze in Abgang kam und durch die Zierkapuze ersetzt wurde, läß sich nicht näher bestimmen. Wie so manche andere Änderung in Bezug auf die Form und Beschaffenheit der liturgischen Gewandung wird auch diese an den verschiedenen Orten zu verschiedenen Zeiten vor sich gegangen sein. In der ersten Hälfte des 13. Jahrhunderts war die Umbildung schon vollzogen, wie das aus dieser Zeit stammende Pluviale von St Paul mit seiner Miniaturkapuze beweist.

Der Hauptgrund der Änderung dürfte in der stofflichen Beschaffenheit des Pluviale zu suchen sein. An einem Prachtgewande, wie es die liturgische Cappa schon im 10. Jahrhundert so häufig war, hatte eine wirkliche Kapuze nur wenig praktische Bedeutung mehr. Oder wie hätte man eine Kapuze länger als Kopfhedeckung verwenden sollen, die aus so kostbaren Zeugen angefertigt war, wie sie damals zur Herstellung des Chornantels germ ge-

1. S. oben S. 307. Tm 1020 kommt die Bezeichnum capla romana in der Historia Ademars von Chavannes gelegentlich der Beschreibung der Weihe und Inthromisation des Bischof's Giraldus von Limoges (1. 3, n. 49 [M. G. SS. IV 138]), im 12. Jahrhundert aber in einem Ordinarium von St-Martial zu Limoges vor ( $\mathrm{M}$ a $\mathrm{rt} .1 .3$, c. 1 , ordo 34 ; IL 311). Auch in einem Tabularium von St-Cyhar zu Angouline (J). C. sub cappa
Il 112), das ebenfalls wohl noch der Frühe des Jahrtausends angehören dürfte, findet sich der Ausdruck. In allen drei Faillen ist ohne Zweifel das Pluviale gemeint, d. i. die liturgische Cappa in der damals allgemein gebräuchlichen Form. Hinzugefügt sei, daß Limoges wie Angouleme im Niidwesten Frankreichs liegen.
2 S. oben S. 312
1 S. oben S. 316 . 
braucht wurden:' Wäre sie doch in diesem Falle nur zu bald sclmutzig geworden und verdorben. Um so eher aber konnte die Kapuze zı einem blofien Ornament verkümmern, weil die meisten Gelegenheiten, bei denen man sich des Gewandes bediente, wie z. B. die Inzensierung des Altares, die Vornahme der feierlichen Segnungen, die Prozessionen in der Kirche und dem Claustrum und ähnliches, eine Berleckung des Kopfes als überflüssig erscheinen lielien, für die Fälle aber, wo der Gebrauch einer solchen zweckmäbig war, sich allmählich eine besondere Kopfbedeckung eingebürgert hatte.

Am frühesten begegnet uns diese bei den Cantores. Schon Honorius erwähnt sie bei ihnen: Cantores caput pileis ornant. Ja es reichen die ersten Spuren dieser Kopfbedeckung der Cantores bis in das Ende des ersten Jahrtausends hinauf. Eine Urkunde des Erzbischofs Villegis von Mainz aus dem Jahre 976 bringt uns, wie es scheint, bereits von ihr Kunde. Der Cantor und Prior

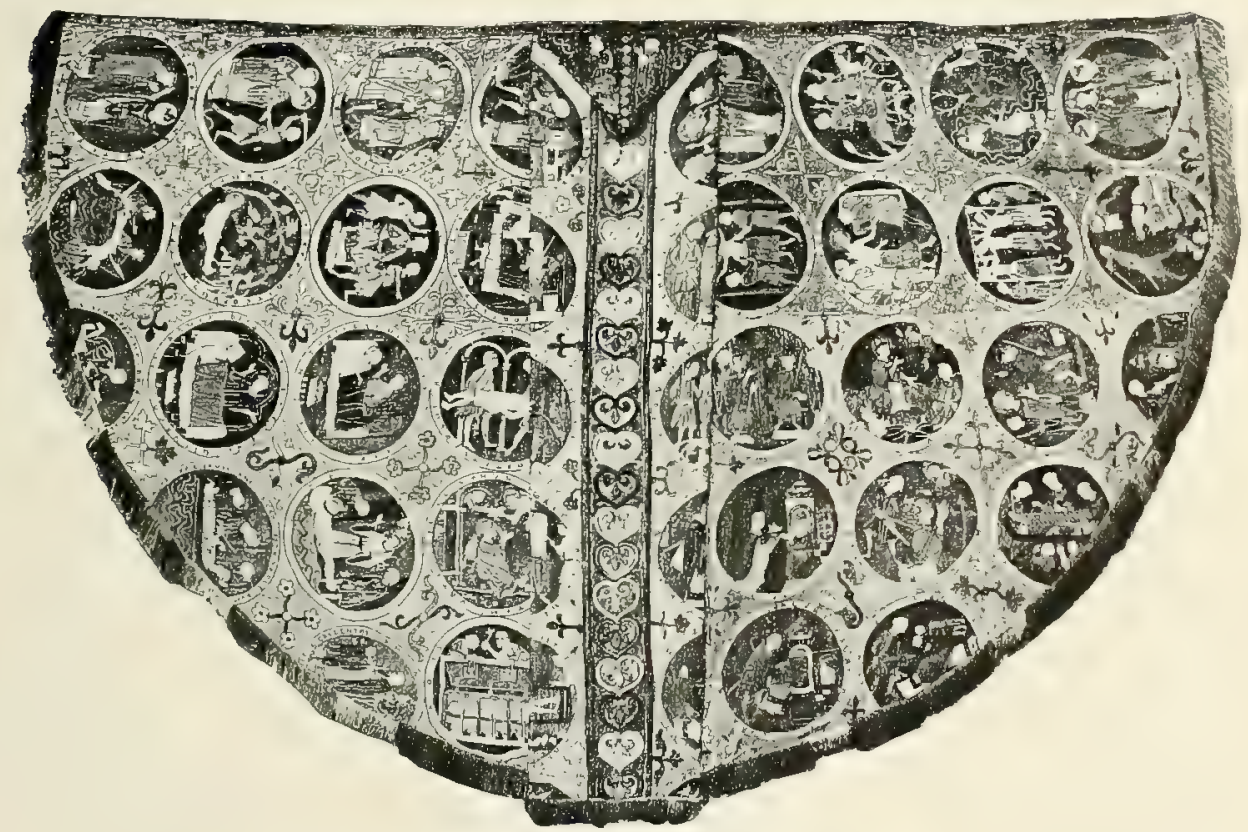

Bild 144. Pluviale. St Paul (Kärnten).

Gozmarus des Stifts Aschaffenburg hatte durch grobe Unvorsichtigkeit einen Sichüler mit der Schreibtafel erschlagen. Willegis verurteilte ihn deshalb zur Absetzung von Amt und Einkommen, trennte die Kantorie und das Priorat voneinander und entzog dem Inhaber der Kantorie das Recht, die Abzeichen des Chorregenten, Stab und Infula, hier wohl der pileus cantorum des Honorius, die Cantormütze, zu tragen ${ }^{1}$. Der Grund für die Einführung der Mütze bei den Cantores mag die Absicht gewesen sein, ihnen eine Art von Abzeichen zu geben. Aber auch bei den andern Geistlichen gab es zur Zeit, da die Kapuze zum Zierstück wurde, beim Chorgebet schon eine besondere Kopfbedeckung, die bald mützen- bald kapuzenartige Almucia ${ }^{2}$. Es ist wohl

\footnotetext{
1 Gudenus, Codex diplom. I 354. Bei der vielfachen Bedeutung, welche infula im Mittelalter hatte, könnte man freilich an sich auch an die Cappa des Cantors denken; in-
}

dessen wird denn doch wegen der Bemerkung des Honorius über den pileus der Sänger die infula am besten als pileus aufgefa, $B_{t}$

2 Näheres am Ende dieses Kapitels. 
kaum zweifelhaft, daß ihr Auftreten mit der Umbildung der Kapuze ebenfalls in einem inneren Zusammenhang steht.

Bei einer Kapuze, die bloßer Zierat war, blieb es nicht lange. Sie wurde schon im Verlauf des 13 . Jahrhunderts zu einem blolien schildförmigen Zeugstick, das freilich noch lange caputium orler capulum hief und anch noch durch seine dreieckige Form an die ursprüngliche Kapuze erinnerte. Anfangs war das capulum klein, nicht größer als die Miniaturkapuze, an deren Stelle es getreten war, eher sogar kleiner als diese und meist ein regelrechtes, gleichseitiges Dreieck. Im 14. Jahrhundert wurde es jedoch langsam, aber stetig gröfier, während seine Seiten zu gleicher Keit sich bogenförmig zu kriummen begannen. In der ersten Hälfte des 15. Jahrhunderts hatten seine Make und die Krümmung der Seiten bereits so sehr zugenommen, daf es wirklich war, was der Name, den es nun erhielt, besagte, ein clipeus, Schild.

Eine weitere Veränderung hob dann um die Mitte des 15. Jahrliunderts an. Der Spitzbogen, in dem der Schild unten endigte, erhielt eine stark gedriickte Form, bei der vielfach kaum mehr die Spitze wahrnehmbar war. Auch artete er wohl in einen völligen Eselsrücken aus. Im 16. Jahrhundert verschwand der spitzbogige Abschlußs ganz, um zunächst von einem halbrunden und hierauf von einem halbovalen abgelöst zu werden. Damit war eine Form des Schildes gefunden, welche für lange Zeit nicht mehr vom Plan verschwinden sollte und sich selbst gegenüber den Reformversuchen beim Wiederaufblühen der Paramentik im 19. Jahrhundert im grofien und ganzen als sieghaft erwies (Bild 145).

Die einzige Weiterentwicklung, die seitdem mit dem Schilde vor sich ging, bestand in der Zunahme seiner Małsverhältnisse. War er um 1500 noch immer blok mäfäig grok, so war er bis zum 18. Jahrhundert ein den Rücken in seiner ganzen Breite bedeckendes, bis über die Körpermitte herabhangendes Zeugstück geworden. Das bei der Wiederbelebung des Sinnes für edlere Formen der Paramente sich geltend machende Bestreben, den Schild auf ein bescheideneres Maßs zurückzuführen, hatte nur teilweisen Erfolg.

Man kann die Frage aufwerfen, ob das Pluviale oder die liturgische Cappa im Mittelalter stets mit einer Kapuze bzw. einem Schild ausgestattet worden sei. Eine diesbezügliche Vorschrift hat nie bestanden, wenigstens findet sich keine Spur einer solchen. Doch war es jedenfalls das gewöhnliche, weshalb denn auch Honorius schlechthin bemerkt: In supremo caputium habet. Auffällig ist, wie schon bemerkt wurde, daf auf den Miniaturen, zumal den früheren, das caputium oder der clipeus häufig fehlen. Indessen könnte das zuletzt auf einer dem Künstler zur Last fallenden Vergeblichkeit oder auf der zeichnerischen Unfähigkeit des Miniators beruhen. Wichtiger ist, dafs an verschiedenen der noch vorhandenen mittelalterlichen Pluvialien ein Schild nicht blok gegenwärtig fehlt, sondern auch nie angebracht gewesen zu sein scheint. Immerhin dïrften das nur Ausnahmen gewesen sein, die sich zum Teil aus der besondern Beschaffenheit der betreffenden Gewänder - meist handelt es sich bei ihnen um ganz bestickte Pluvialien - genügend erklären. In der Tat wird beispielsweise im Inventar des apostolischen Schatzes von 1295 nur bei einem von 26 Pluvialien das Fehlen des caputium vermerkt. Im Schatzverzeichnis von st Peter aus dem Jahre 1.361 ist bei keinem von 83 Pluvialien das Nichtvorhandensein eines Schildes notiert, wohl aber wird dieser bei 66 aus irgend einem Girund, wie der Stickereicn oder des Stoffes wegen, ausdrücklich erwähnt. 
Damit die Cappa von den Schultern nicht hinabgleite, mubte sie, seitdem sie vorn aufgeschlitzt war, vor der Brust mittels Haken und Ösen zusammengehalten werden. Diese waren entweder unmittelbar am Saum des Gewandes befestigt oder an rechteckigen, vorn in der Brustgegend angebrachten Laschen angenäht. Bei reicheren Pluvialien wurden diese Laschen gern mit Stickereien oder aufgesetzten Perlen und Edelsteinen verziert. Item cappa una quae fuit Warneri de Sandford cum morsu de aurifrisio cum lapillulis multis in morsu. ... Item cappa una quae fuit magistri Ioannis de Brideport cum morsu de aurifrisio continente lapides 18, heibt es z. B. in dem Inventar von Salisbury aus dem Jahre 1212. Item pluviale . . cum firmali cum duobus buttonibus (Zierknöpfchen) de perlis et tertio de auro, in quo uno, scilicet medius, est unus balassus (Rubin) in castone (Einfassung) de auro, merkt das Inventar des päpstlichen Schatzes von 1295 an. Man nannte die Befestigungsvorrichtung allgemein fibula, morsus, firmale, firmarium. Im besondern aber bezeichnete man mit diesen Worten eine Spange oder Agraffe, die vielfach an dem Pluviale an Stelle blofer Haken oder Laschen angebracht
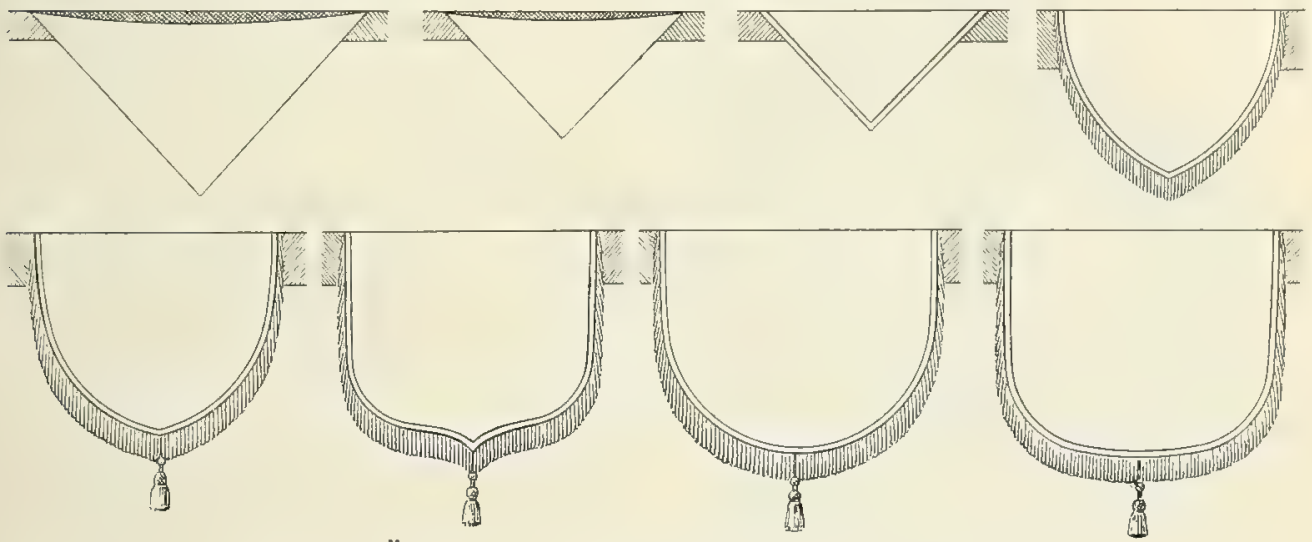

Bild 145. Übersicht über die Entwicklung des Plavialschildes.

zu werden pflegte, um das Gewand über der Brust zusammenzuhalten. Sie führte auch die Namen monile oder pectorale.

Schon früh wurden solche Agraffen zum Schliefen des Pluviale angewendet, wie nicht nur die vorhin erwähnten Miniaturen des 11. Jahrhunderts beweisen, sondern auch die Inventare von Wörthsee (ca 1000): cappae cum fibulis aureis, und von Ely (1079): 4 tasselli ad usus earum capparum. Sie waren häufig sehr kostbar und kunstreich mit Filigran, Schmelzen, Perlen und Edelsteinen ausgestattet. So verzeichnet schon ein Inventar von Martinsberg in Ungarn, das ins 12. Jahrhundert hinaufreichen mag, eine cappa, quae habet super se pectorale aureum smaldo paratum.

Derartige Agraffen müssen namentlich in England sehr beliebt gewesen sein, da die englischen Inventare sie in großer Zahl anführen. Bereits das Schatzverzeichnis von Salisbury aus dem Jahre 1212 erwähnt ihrer 5 : cappa una... cum morsu argenteo, in quo continetur lapis unus cameu et alii 13 et lapilluli 9 a latere; item cappa una ... cum morsu argenteo continente lapides 35 et a latere lapides 19 cum magna multitudine margaritarum usw. Ungemein reich an solchen Agraffen war dem Inventar von 1245 zufolge St Paul zu London. Es besaf deren 17 aus vergoldetem Silber, 4 aus vergoldetem Kupfer und 7 aus Holz, das mit Silberblech überzogen war. Alle waren mit Steinen, Perlen oder Schmelzen mehr oder weniger kostbar verziert; 
12 wiesen obendrein bildliche Darstellungen auf, wie die Maiestas Domini, Szenen aus dem Leben Christi, die Krönung Mariä, die Apostel Petrus und Paulus und andere Heilige. Ein Inventar der Kathedrale von York aus dem Jahre 1548 vermerkt im ganzen 11 morsus, darunter einen von 2, einen andern von 1 Pfund 8\% Unzen.

Aber auch in nichtenglischen Schatzverzeichnissen werden die Agraffen oft in großzer Zahl erwälnt. So führt das Inventar von Cluny aus dem Jahre 1382 ihrer volle 19 unter dem Namen pectorale auf, darunter 8 aus massivem, vergoldetem Silber. Eine der Agraffen war mit einer Kamee geschmückt, um die sich je 6 von Rubinen umgehene, dicke Perlen und grofe Saphire gruppierten, eine andere mit den Bildern des hl. Petrus und zweier Engel, die von 3 Saphiren, 2 Rubinen, 1 Kristall und 12 sonstigen Edelsteinen umrahmt waren. Die übrigen wiesen, mit Ausnahme einer einzigen, figürliche Darstellungen als Verzierungen auf. Das Inventar der Kathedrale zu Cambrai von 1859 kennt 32 tassiaux (Sing, tassiel), wie in Flandern die Agraffen genannt wurden, das von 1401 sogar 55, große und kleinere, die einen quadratisch, andere rund, wieder andere vierpaßförmig, einige in Form des Buchstabens $D_{\text {; }}$; alle aber mehr oder weniger reich ausgestattet mit Perlen, Edelsteinen, Heiligenstatuetten, Niellos, Emailbildchen usw. In St-Amé zu Douai besaf man 1377 und 138619 tas-

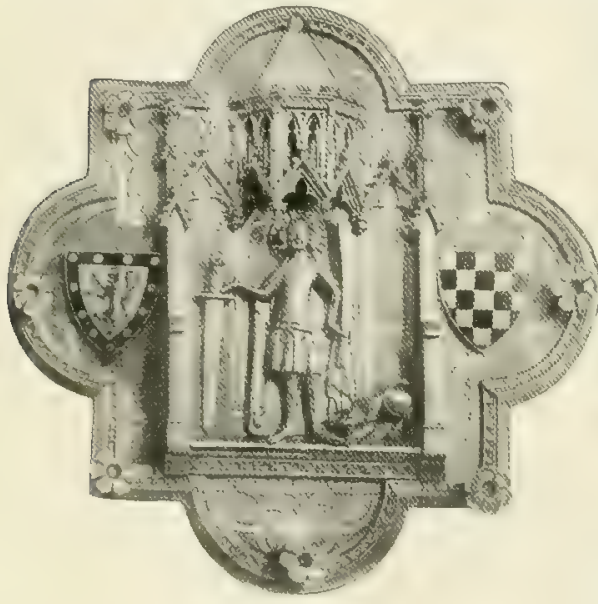

Bild 146. Pluvialschliefse. Elten, Pfarkirche. siaux von ähnlicher Art wie die in den Schatzverzeichnissen von Cambrai aufgeführten, ungerechnet eine Anzahl kostbarer, mit figürlichen Darstellungen bestickter und mit Perlen und Edelsteinen besetzter Schließen aus Stoff.

Wenn in den Inventaren die Pluvialschlieken nicht immer ausdrücklich genannt werden, so kommt das wohl daher, daf sie vielfach als selbstverständlicher Teil des Pluviale, an welchem sie befestigt waren, betrachtet wurden.

Der Pluvialfibel erging es übrigens ähnlich wie der Kapuze. Auch sie wurde allmählich ihrem praktischen Zweck entfremdet und zum bloßen Schmuck, nur war hier der Grund für den Wandel ein anderer. War es dort der Umstand, daf die Kapuze keine praktische Bedeutung mehr besaf, dann hier das Bestreben, die Schliebe möglichst prächtig auszugestalten. Zum bloßen Zierstuck geworden, war die Fibel in der Regel nicht mehr dauernd am Pluviale angebracht, sondern so eingerichtet, daf man sie mittels Haken oder Ösen beim Gebrauch an den Laschen, welche das Gewand über der Brust zusammenhielten, aufhängen und nach der Benutzung wieder von diesen loslösen und für sich aufbewahren konnte. So hiclt man es namentlich dann, wenn das Gewicht der Schlieke ein bedeutenderes war. In der Tat war es auch kaum tunlich, solche Agraffen an ihrem zugehörigen Pluviale aufzubewahren. Dementsprechend werden rlem auch häufig die morsus, oder wie die Schliefien immer heilicn, in den Inventaren getremnt für sich als ein besonderes Schmuckstiuck anferführt. So beispielsweise schon in den Schatzverzeichnissen der Kathedrale von salisbury (1212) und von St Paul zu London (1245) und dem Inventar der Schätze des Apostolischen Stuhles vom Jahre 1295. Item, heifst es hier z. B., unum firmale pro pluviali de auro cum $V$ zaffiris grossis et IV perlis et VIII granatellis cum acu argentea; pond. I m. et dimid. unc. . . . item quorldam aliurl firmale pro pluviali do ligno guarnitum de auro et XI vitris 
zaffirini coloris; pond. I $\mathrm{m}$. et II unc. ...; item quoddam firmale de argento deaurato cum $V$ imaginibus in tabernaculis; pond. II $\mathrm{m}$. et III unc. et dimid. 1

Noch haben sich manche mittelalterliche Pluvialagraffen erhalten, zumal in Deutschland, wenngleich was davon vorhanden ist, zuletzt nur einen verschwindenden Teil des ehemaligen Bestandes ausmacht.

Eine schöne, silhervergoldete Fihel im Śchatz der Münsterkirche zu Essen (ca 1500) hat die Form eines Vierpasses, den ein achtseitiger Stern durchquert. Unter spätgotischen Baldachinen thronen in der Mitte Maria mit dem Kinde und derselben zur Seite die beiden Stiftspatrone Kosmas und Damian?. Ein morsus von ebenso edeln Formen als guter Ausführung aus dem Beginn des 14. Jahrhunderts befindet sich in der ehemaligen Stiftskirche zu Elten am Niederrhein (Bild 146). Er besteht ans vergoldetem Silber, stellt einen Vierpafs von $14 \mathrm{~cm}$ Durchmesser dar, den ein Quadrat durchschneidet, und weist auf dem Rande aufgestiftete silberne Rosetten, in der Mitte aber unter vorspringendem Baldachin die Standfigur des hl. Vitus auf, rechts und links vom Wappen derStifter begleitet. Ein zweiter morsus im Schatz derselben Kirche ist kreisrund und hat $15 \mathrm{~cm} \mathrm{im}$ Durchmesser. Die Mitte nimmt Christus ein, der zwisehen Maria und $J_{0}$ hannes auf grün emailliertem Berge steht. Die auf der Agraffe angebrachten Wappen bekunden, dae dieselbe um das Ende des 14. Jahrhunderts entstand. Von eigenartigem, ganz profanem Charakter ist eine dritte Pluvialschliefe in dem Schatz zu Elten. Sie stellt einen Vierpak mit stark geschwungenem

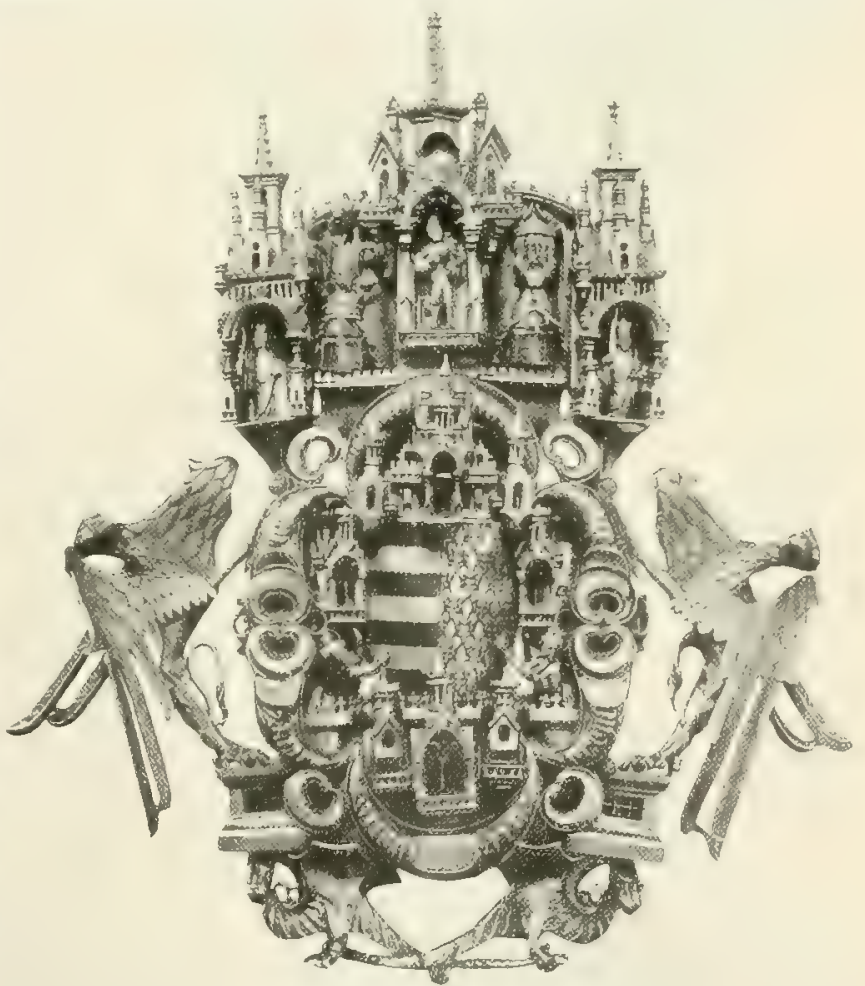

Bild 147. Pluvialschliefe. Aachen, Münster. Rahmen dar, dessen Inne-

res durch eine in mächtigem Relief gearbeitete turmreiche Burg ausgefüllt wird. Im geöffneten Tor steht ein Knappe, auf den von der Brüstung des Oberbanes des Tores ein Mann herabschaut. Das Stück ist sehr interessant, aber ursprünglich schwerlich für gottesdienstliche Zwecke bestimmt gewesen. Der Durchmesser der Agraffe (15. Jahrhundert) beträgt ca $14 \mathrm{~cm}^{3}$.

1 Biblioth. de l'École des Chartes XLIII (1882) 637. Weon der Herausgeber meint, auch die XLV (1884) 46 genannten nuscae seien wahrscheinlich Agraffen für Pluvialien, so ist das irrig. Es sind sog. Phylakterien, an Bändern oder Kottchen aufgehängte Medaillons, in welchen sich Reliquien befanden.
2 Abbildung bei G. H u mann, Die Kunstwerke der Münsterkirche zu Essen, Düsseldorf 1904, TH 58.

3 Abbildung in Kunstdenkmäler des Kreises Rees, Dïsseldorf 1892, Tfl 4. Eine schöne Fibel in der Pfarrkirche zu Kempen (E, 16. Jahrh.) s. Kunstd. des $\mathrm{Kr}$. Kenpen, ebd. 1891, 76. 


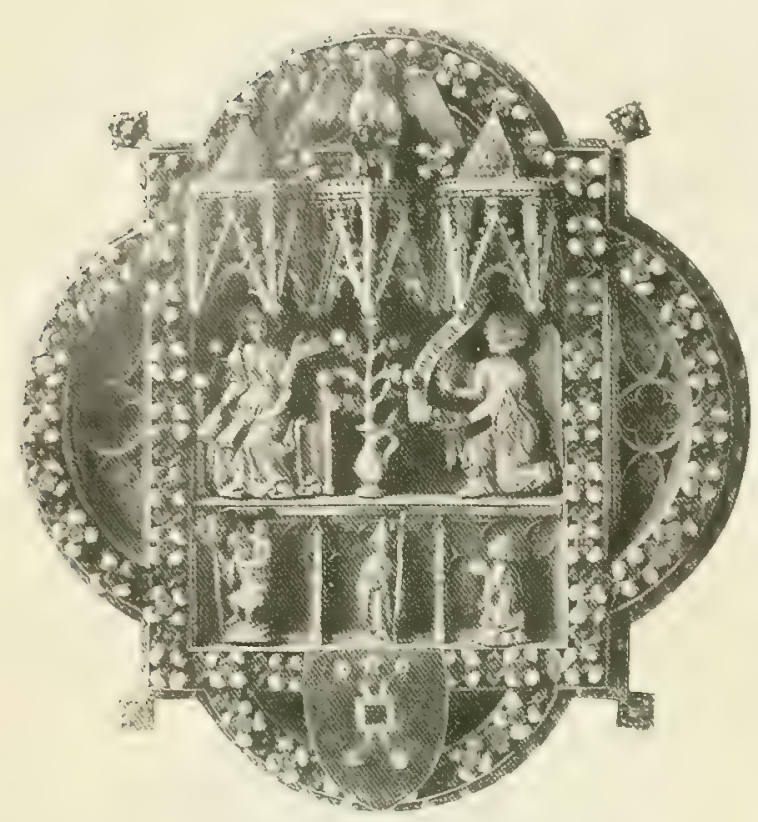

Bild 148. Pluvialschlief̧e. Aachen, Münster.

Eine große Zahl mittelalterlicher Pluvialfibeln enthält der Aachener Münsterschatz. Eine derselben, eine Arbeit aus dem Beginn des 16. Jahrhunderts, ist in späterer Zeit in ein Paxtäfelchen umgewandelt worden. Sie stellt eine sechsblätterige Rose dar, in welche ein Dreipaß gelegt ist. Derselbe enthält in der Mitte unter luftigem Baldachin den vor der Gottesmutter mit dem Jesuskind knienden Donator, rechts und links dessen Patrone. Zwei andere, in ihrem Entwurf ebenso originelle wie in der Ausführung reiche Agraffen sind ein Geschenk Ludwigs von Ungarn (Bild 147, S. 323). Sie sind $22 \mathrm{~cm}$ hoch bei $19 \mathrm{~cm}$ Breite und wurden zwischen 1340 und 1367, wie es scheint, zu Klausenburg angefertigt. Die Abbildung uiberhebt uns einer näheren Beschrei-

bung. Viel edler als die beiden letztgenannten ist eine vierte Fibel des Aachener Schatzes. Ein rechteckiger, mit Perlen und Rosettchen dicht besetzter Rahmen ist durch einen Querstab in eine größere obere und eine kleinere untere Abteilung. geschieden. Die obere enthält unter zierlichen Baldachinen in vortrefflichster Arbeit eine Gruppe der Verkündigung: Maria auf dem Throne zur Linken, den Engel mit dem Spruchband zur Rechten, eine Blumenvase in der Mitte. Den mit Rauten gemusterten Hintergrund bedeckt durchsichtiges blanes Email. Die untere Abteilung ist durch Pilaster in drei Kammern geteilt, von denen die mittlere die Statuette eines heiligen Papstes, die beiden seitlichen den hl. Christophorus bzw. den knienden Donator anfweisen. Von den vier Kreisabschnitten, welche sich an die Seiten des Rechtecks anlehnen, enthält der obere einen Engel, der untere das Wappen des Stifters; die seitlichen füllt Maßwerk. Die Umrahmung der Abschnitte ist in Über-

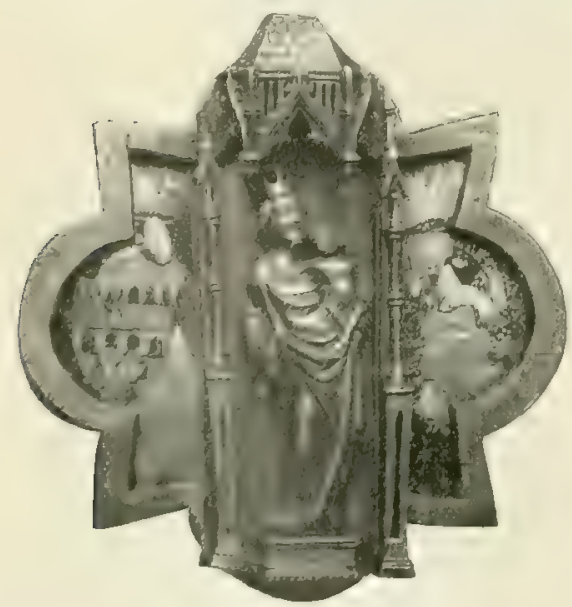

Bild 149. Pluvialschliefse. Tongern, Pfarrkirche. einstimmung mit derjenigen des Rechtecks gleichfalls mit kleinen Rosetten und Perlen besetzt. Die $20 \mathrm{~cm}$ hohe und $18,5 \mathrm{~cm}$ breite Agraffe entstammt der zweiten Hälfte des 14. Jahrhunderts und ist eine der schönsten ihrer Art (Bild 148).

Ungemein reich an alten Pluvialschliefen ist der Schatz der Stiftskirche zu Tongern (Belgien). Zählt er deren doch nicht weniger als ein volles Dutzend, von denen die Mehrzahl entweder ganz oder doch in ihren Hauptbestandteilen noch dem 15 . Jahrhundert angehören. Zwei derselben stellen einen Vierpaf dar, in dessen Mitte unter einem reichen Baldachin Maria mit dem Kinde angebracht ist, während auf den seitlichen Pässen in durchsichtigem Email der Geschenkgeber und sein Wappen dargestellt erscheint. Eine dieser beiden Schliefen ist laut Inschrift eine Stiftung 
des Kanonikus Johannes Cleinjas (Bild 149). Zwei andere Agraffen des Schatzes, durchaus genaue Gegenstücke, haben die Form einer sechsblätterigen Rose (Bild 150) von $0,15 \mathrm{~m}$ Durchmesser. In ihrer Mitte gewahren wir innerhalb eines Kreises auf ehemals blau emailliertem Fond in Relief die allerseligste Jungfrau mit dem Kind, umgeben und getragen von Engeln, während wir in den acht Pässen die in durchsichtigem Email ausgeführten Brustbilder von Christus und sieben Aposteln bemerken. Zwei weitere Schliefen, ebenfalls Gegenstücke, weisen als Schmuck in getriebener Arbeit den Verrat des Judas und die Kreuztragung auf. Nur das Mittelstück entstammt jedoch bei ihnen dem Mittelalter; die sehr unbedeutende Umrahmung ist das

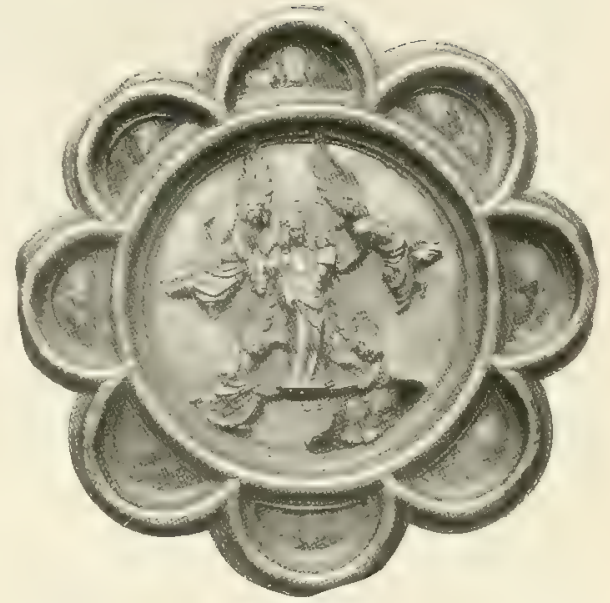

Bild 150. Pluvialschließ3e. Tongeru, Pfarrkircho. Werk einer im 17. Jahrhundert erfolgten Restauration (Bild 151). Von den übrigen Pluvialagraffen des Schatzes verdient noch Erwähnung ein Paar, das sich ebensowohl durch seine wirkungsvolle, originelle Unirahmung wie die auffallende Größe von $0.195 \mathrm{~m}$ Durchmesser anszeichnet. Das Bildwerk des Mittelfeldes ist bei ihnen alter als der Rahmen, indessen durch Restaurationen in späterem Geschmack verändert (Bild 152, S. 326).

Eine Fibel aus dem 16. Jahrhundert in der Kirche zu Hamont (belgisch Limburg) ist im Lauf der Zeit wie ihre oben besprochene Aachener Schwester zum Paxtäfelchen umgestaltet worden. Sie hat im Durchmesser $16 \mathrm{~cm}$, ist vierpafförmig und enthält in der Witte auf einem mit zierlichen Ranken gemusterten Untergrund in Relief eine Kreuzigungsgruppe, flankiert von den Aposteln Petrus und Paulus. Eine gute Agraffe aus dem 17. Jahrhundert besitzt die Kirche des Beginenhofes zu Tongern. Inuerhalb eines Kranzes steht unter einem Bogen Maria mit dem Kind. Rechts und links ist je ein Herold mit einem Wappenschilde angebracht. Die allerseligste Jungfrau wächst aus einem Lilienkelche hervor. Die Inschrift auf der $14 \mathrm{~cm}$ im Durchmesser haltenden Agraffe lautet im flämischen Dialekt: HOOCHSTE - VE (R)HEVE- KEYSERINE - 'TER . NOOT - MA(RIA) - WEEST - O(NS) - VRI(N)DTNNE - REYN - LILYE - ONBESMET.

Eine im Besitz der St Ursulakirche zu Köln befindliche Fibel stellt einen Vierpaß dar, aus dessen Ecken Blattwerk hervorwäehst. Das Bildwerk, welches sie schmückt, besteht in Statuettchen der Gottesmutter, eines heiligen Apostels und des hl. Franziskus. Das Schmuckstïck mag dem Ende des 15. Jahrhunderts angehören und hat $0,165 \mathrm{~cm}$ im Durchmesser ${ }^{1}$.

Eine interessante Agraffe von ausgesprochenen Renaissanceformen, die bezüglich des Grundschemas, eines Vierpasses, und der Anordnung des Bildwerkes im Mittelfeld aber noch ganz auf dem Boden des Mittelalters steht, besitzt der Dom zu Paderborn 2. Sie ist $16 \mathrm{~cm}$ breit. In den Pässen sind beflügelte Engelköpfchen dar-

1 Abbildaug bei Back, Das heilige Küln, Leipzig 1858, Tfl 8.

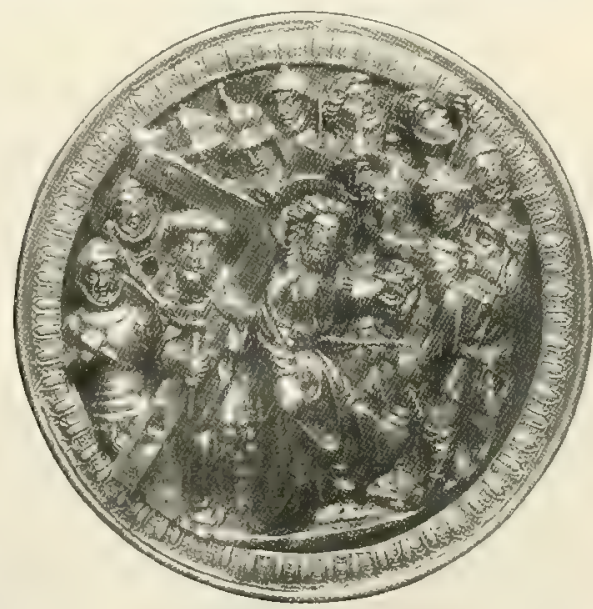

Bild 151. Pluvialschlief3e. T'ongern, Pfarrkireho.

3 Abbildung in Bau- und Kunstdenkmäler des Kreises Paderborn, Münstex 1899, Tf 56. 
gestellt; unter den Bogen in der Mitte der Fibel gewahren wir Maria, St Liborius und St Kilian.

Von sonstigen Pluvialagraffen seien noch kurz erwähnt eine herrliche Fibel im Kunstgewerbemuseum zu Berlin, welche 1484 für den Dom zu Minden von Goldschmied Reinecke vam Dressche verfertigt wurde (Bild 153), eine überaus zarte und edle Arheit, eine Fibel in ungarischen Nationalmuseum zu Pest aus dem Beginn des 16. Tahrhunderts "; eine einfache, aber schöne Schlief3e mit der Darstellung der hl. Anna - selbdritt" in der Johanneskirche zu Herford; eine kupfervergoldete, mit einer Statuette der hl. Agatha verzierte Agraffe im großßherzoglichen Museum zu Darmstadt 2 ; eine mit Silberstatuetten der hll. Bartholomäus, Johannes Baptista und Margareta geschmückte Agraffe im St Bartholomäusdom zu Frankfurt a. M.; zwei aus der letzten Hälfte des 15. Jahrhunderts stammende Fibeln im fürstlich hohenzollernschen IIuseum zu Sigmaringen; zwei Pluvialschließen im Rothschildmuseum zu Frankfurt, von denen eine die Verkündigung, die andere eine Bischofsfigur aufweist ${ }^{3}$; eine prächtige, mit Statuettchen der Mutter Gottes, der Apostel Petrus und Paulus und der hll. Kosmas und Damian gefüllte Agraffe im königlich bayrischen Nationalmuseum zu Iünchen; drei Pluvialschliefsen der ehemaligen Sammlung Felix zu Leipzig, von tenen eine in

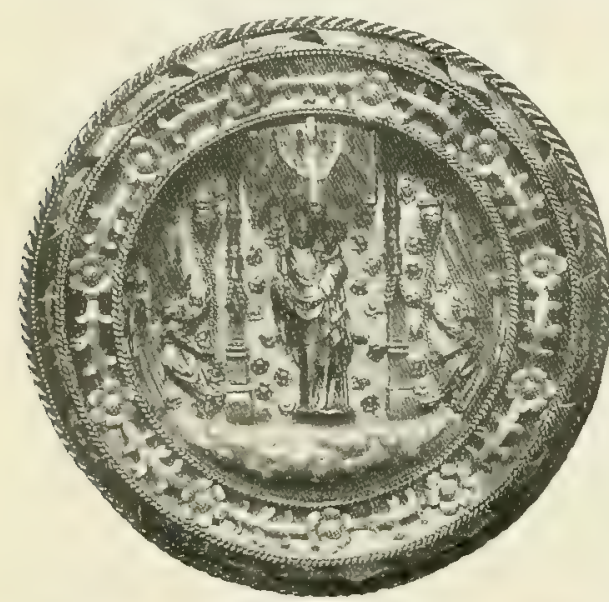

Bild 152. Pluvialschliefe. Tongern, Pfarrkirche. Niello Szenen aus dem Leben des Erlösers (Verkündigung, Geburt, Kreuzigung, Auferstehung und Gericht) enthält, während auf den zwei andern eine Anbetung der heiligen drei Könige in Niello bzw. Relief die Mitte einnimmt *, endlich die glänzende Agraffe in der kaiserlichen Zeichenschule zu Petersburg in Form einer zehmblätterigen Rose ${ }^{5}$.

Von dem gewöhnlichen Typus weicht ganz $a b$ eine Fibel in der Pfarrkirche $z u$ Villingen (Baden). Sie besteht aus einem grökeren mittleren und zwei kleineren seitlichen Schilden. Diese enthalten je einen knienden Engel mit Kerze in der Hand, jener Maria mit dem hl. Johannes dem Täufer und St Katharina. Die seitlichen Schildchen sind bestimmt, an den beiden Säumen des Pluviale angenäht zu werden. Das eine jst an dem Mittelschild durch eine Scharnier befestigt, das andere wird mit ihm durch einen Stachel verbunden (Bild 154, S. 328).

Was den Stoff des Gewandes anlangt, so kommen bereits früh Pluvialien aus besseren Zeugen vor. Schon die Stiftungsurkunde von Obona (Ende des 8. Jahrhunderts) erwähnt eine cappa serica. Erinnert sei ferner an die aus rotem Cendel (Seidentaft) gemachte Cappa, welche St Ansegisus Fontanelle schenkte, an die cappa serica des Inventars von St-Riquier, die cappae :3:3 preciosae de pallio und 24 de pallio der Inventare ron St Trond und Gent, die drei reich mit Gold- und Silberverzierungen geschmuickten Cappae, welche Adelheid zu Ehren des hl. Martin stiftete, die kostbaren Cappar des Inventars von Clermont-Ferrand usw., von welchen ebenfalls bereits die liede war. Mit dem 11. Jahrhundert nimmt die Zahl der kostbaren

1 Abbildung in Mitt. XII (1867) 110.

Abbildung hei J

Abbildung hej I, ut hmer, Grold nud Silber, Leipzig I $8 \times 8$, 'I'H $2 x, 57$.

${ }^{4}$ Katalog dror Sanmulume Felix Nr sij7
868 506. Durch die Versteigerung 1886 in verschiedene Sammlungen zerstreut.

"Sie stammt aus der Sammlung Leven zu Köln; Abbildung bei He ide loff, Die Ornamente des Mittelalters IX, 'I'H 3. 
Pluvialien um ein namhaftes zu. Je mehr sich der liturgische Charakter der Cappa und die Stellung, welche sie unter den liturgischen Gewändern erhalten hatte, befestigte, und je mehr die Gelegenheiten zunahmen, bei welchen sie zur Verwendung kam, um so mehr muste in der Tat das Bestreben dahin gehen, bessere Gewebe zu ihr zu verwenden; war doch kein anderes Gewand wie gerade sie geeignet, an Festtagen dem Gottesdienste besondern Glanz zu verleihen. Man denke nur an die zwölf Cantores, welche manchenorts dann mitten im Chor mit Prachtpluvialien bekleidet das Alleluja sangen. Es ist nicht nötig, aus den Inventaren des 11. Jahrhunderts Einzelheiten anzufïhren, es mag genügen, auf das S. 311 Gesagte hinzuweisen. Sehr bezeichnend für den Stand der Dinge in damaliger Zeit ist es, wenn das Register ron Rochester anmerkt, Erzbischof Lanfrank von Canterbury († 1080) habe auf einmal 25 seidene, mit reichem Besatz geschmïckte Cappae nach Rochester gesandt ${ }^{1}$; noch bezeichnender aber ist, wenn Leo von Ostia in der Chronik von Monte Cassino erzählt, Abt Desiclerius habe auf das Gerücht hin, dafi der Kaiser nach 1talien komme, 20 Stück kostbaren Seidenstoffes gekauft, um diesem damit, wenn nötig, ein Geschenk zu machen, dann aber, als die Rede ging, der Kaiser habe sein Vorhaben aufgegeben, sofort aus ihnen Pluvialien anfertigen lassen 2 . Das Inventar des Domes zu Bamberg aus dem Jahre 1127 führt 84 Cappae auf, von denen 26 mit kostbaren Besätzen versehen waren. Sie müssen ebenfalls noch aus dem 11. Jahrhundert stammen, da nach dem großen Brandunglück rom Jahre 1081 wegen des dadurch notwendig gewordenen Neubaues des Domes in den nächsten Jahrzehnten schwerlich eine Anschaffung derselben möglich war.

Dem Bestreben, das Pluviale aus

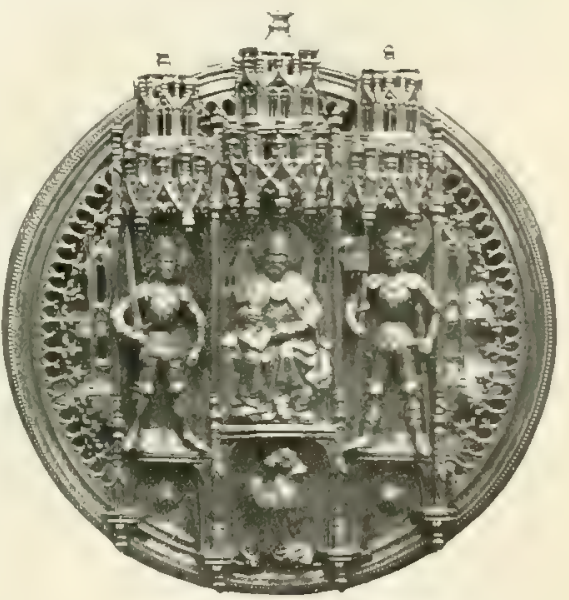

Bild 153. Pluvialschliefe. Berlin, Kunstgewerbemuseum.

besseren Stoffen herzustellen, kam der Umstand sehr entgegen, daf im 12. Jahrhundert infolge des gesteigerten Verkehrs mit dem Orient die sarazenischen, persischen und byzantinischen Stoffe in immer wachsenden Mengen ins Abendland importiert wurden, und dab bald auch in diesem selbst die Seidenindustrie zur höchsten Blüte gelangte. Schon um die zweite Hälfte des 13. Jahrhunderts hatten manche Sakristeien einen wahren Überfluk an Pluvialien aus Goldbrokat und den verschiedenartigsten gemusterten und ungemusterten Seidenstoffen. Noch mehr war das aber im 14. und 15. Jahrhundert der Fall. Man durchgehe nur die Schatzverzeichnisse der Kathedrale von Rouen (ca 1200), der Kathedrale von Salisbury (1212), des Domes zu Monza (1275), die Inventare von St Paul zu London (1245, 1295 und 1402), das Verzeichnis des Schatzes

1 Das Register gibt anch über die Schenkungen von kostbaren Cappae während des 12. und 13. Jahrhunderts manche Auskunft. So stiftete Mönch Clemens (ca 1100) eine rote und eine schwarze, Mönch Hugo von Totesclive (ca 1115) zwei grüne und eine weike
Cappa, Bischof Gilbert $(\dagger 1215)$ cappam bonam de rubeo samit. Eine cappa principalis für die höchsten Festtage, welche Bischof Ernulf († 1124) seiner Kathedrale verehrte, war mit silbernen Schellchen ausgestattet usw.

2 L. 3, n. 18 (M. G. SS. VII 711 ). 
des Apostolischen Stuhles aus dem Jahre 1295 und der Paramente, welche Bonifaz VIII. der Kathedrale von Anagni schenkte, das Inventar von s'. Antonio zu Padua (1396) und von S. Francesco zu Assisi (1320), die Schatzverzeichnisse ron St Peter zu Rom (1361, 1436, 1455, 1489), der Kathedrale von Anger's (1297, 1418 und 1421), der Kathedrale von Cambrai (1359 und 1401), der Stiftskirche St-Amé zu Douai (1377 und 1386), der Stiftskirche St-Pierre zu Lille (1397) und des St Veitsdomes zu Prag (135t und 1387), das Inventar des Domes zu Olmütz (1435), der Kathedralen von Peterborough (1539) und Lincoln (1536) u. a. Es sind Berge von brokatenen, seidenen und in den späteren auch samtenen Pluvialien, die wir in manchen dieser Listen antreffen.

So vermerkt das Inventar von Salisbury beispielsweise 58 Cappae, nach der Beschreibung, die von ihnen gegeben wird, größtenteils von der kostbarsten Art; das Inventar von St Paul aus dem Jahre 1245 führt 34 cappae magis preciosae neben 40 minus preciosae auf, dasjenige aus dem Jahre 1402108 Cappae, die man fast alle als sehr wertvoll bezeichnen darf. Unter den Paramenten, welche Bonifaz VIII. der Kathedrale von Anagni schenkte, waren nicht weniger als 16 der hervorragendsten Pluvialien,

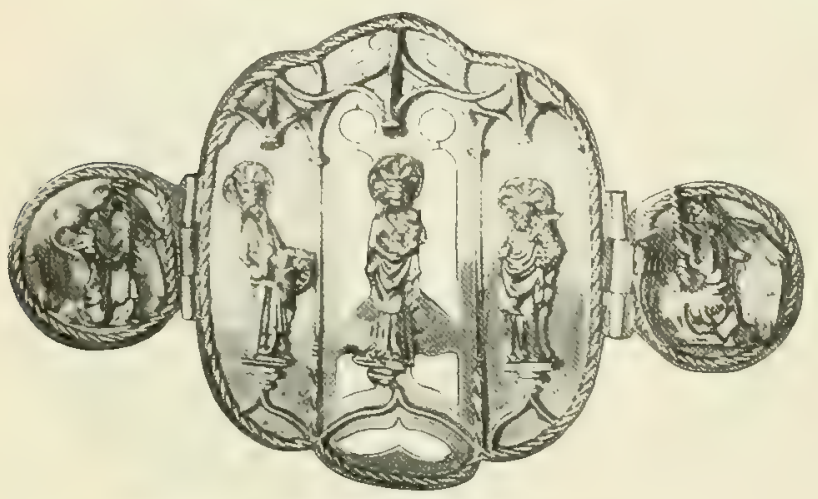

Bild 154. Pluvialschliese. Villingen, Münster. von denen manche Prachtstücke ersten Ranges gewesen sein můssen. Das Inventar von St Veit zu Prag aus dem Jahre 1387 weif von mehr als 150 Cappae zu berichten, ein wahres Lager der interessantesten und glänzenden Seidenzeuge; das der Kathedrale zu Peterborough von 1539 verzeichnet ca 115 , das der Kathedrale von Lincoln aus dem Jahre 1536 gar 253 Cappae, davon 121 rote, 59 weifse, 7 purpurfarbige, 37 blaue, 20 grüne und 9 schwarze. Nicht gerade soviel Pluvialien besab der Dom zu Olmütz, doch zâhlt das Schatzverzeichnis von 1435 deren immerhin ca 70 auf, die sich stofflich auf jeden Fall mit den Cappae zu Prag und Lincoln messen durften.

Das Inventar der Kathedrale zu Cambrai von 1359 notiert 34, das von 1401 114 Pluvialien; das Schatzverzeichnis von Cluny aus dem Jahre 1382 verzeichnet ihrer 67. In St-Amé zu Douai hatte man, um auch einige minder bedentende Kirchen anzuführen, 1377 und 1386 wenigstens $38^{1}$, in St-Pierre zu Lille 1397 54, in der Pfarrkirche U. L. Frau zu Hermannstadt in Siebenbürgen 144012 Pluvialien. Noch jetzt gibt es im Dom zu Brandenburg aus vorreformatorischer Zeit 16, im Dom zu Halberstadt 28 und in St Marien zu Danzig 26 fast ausnahmslos kostbare Chorkappen.

Der Grund, warum in manchen Kirchen sich eine so grofe Zahl von Pluvialien aufspeicherte, lag zum Teil in dem Frommsinn fürstlicher und nichtfürstlicher Wohltäter, zum Teil, und wohl nicht zum wenigsten, in der vielenorts bestehenden Gewohnheit, wonach jeder neue Canonikus entweder bei Antritt seiner. Pfründe oder innerhalh einer bestimmten Frist nach deren Besitzergreifung ein Pluviale zu beschaffen hatte, das er, solange el lehte

1 In dem Abdruck des Inventars bei Dehaisnes, L'art dans la Flaudre, Documents
546 sind nur die 38 besseren Pluvialien aufgenommen worden. 
oder an der betreffenden Kirche als Canonikus tätig war, selbst benutzte, bei seinem Tode oder seinem Abgang aber der Sakristei als Eigentum hinterlief. Man nannte solche Pluvialien Cappae professionis. Die Sitte reicht bis ins 12. Jahrhundert hinauf. So wurde für die Stiftskirche zu Aschaffenburg schon 1193 die Bestimmung getroffen, es sollten die Stiftsherren statt sonstiger unnützer Ausgaben bei Besitznahme ihrer Pfründe der Kirche zu Ehren Gottes und des hl. Petrus eine purpurne Cappa im Wert von 11/2 Mark zum Geschenk machen ${ }^{1}$. In der Kathedrale von Angers führte Bischof Nikolans (1260-1290) den Brauch ein ². Das Pluviale, das hier die Domherren innerhalb der nächsten drei Jahre nach Antritt ihrer Prähende zu beschaffen hatten, mubte aus Seide bestehen und 12 Livres kosten. In St-Amé zu Douai hatten die Stiftsherren nach den dortigen Statuten für die Chorkappe, welche sie bei Besitzergreifung ihres Benefiziums der Kirche zu schenken verpflichtet waren, wenigstens 10 Florins auszulegen ${ }^{3}$.

Natürlich mußsten unter solchen Umständen sich nach und nach viele Pluvialien in den Sakristeien mancher Stifts- und Domkirchen ansammeln. Die Praxis hatte unzweifelhaft ihre guten Seiten; sie hatte aber auch ihre Nachteile, da sie notwendig zu Luxus und Rivalität führen mufste.

\section{VERZIERUNG DES PLUVIALE.}

Schon früh wurden Fransen als Verzierung am Saum des Pluviale angebracht. Fimbriae quoque subter ornatae sunt (sc. cappae), sagt Rupert von Deutz; sicut illa (se. tunica hyacinthina legis) tintinnabulis, ita ista (sc. cappa) insignitur fimbriis. Auch Honorius gerlenkt ler fimbriae. Später, als die Kapuze zum Schild geworden war, wurde es sehr gebräuchlich, auch den Rand des clipeus mit Fransen zu besetzen.

Auch in den Inventaren kommen bereits früh mit Fransen besetzte Cappae vor. Man erinnere sich nur an die Cappae, von denen in der Vita Ansegisi die Rede war. Handelte es sich bei diesen mit grünen bzw. graubraunen Fransen verzierten Cappae auch noch nicht um liturgische Pluvialien im vollen Sinne der späteren Zeit, so haben wir in ihnen doch jedenfalls die Anfänge der nachmaligen liturgischen Cappa zu sehen und dürfen darum immerhin auf sie verweisen. Ein kostbares Pluviale, das Abt Desiderius für Monte Cassino erwarb, war mit Goldfransen ausgestattet 4 . Ubrigens ist in den mittelalterlichen Inventaren von den Fransen nur ausnahmsweise die Rede. Ob man die fimbriae für einen selbstverständlichen Schmuck der Cappa hielt, den man keiner Erwähnung für wert erachtete, oder ob sie nicht so häufig angewandt wurden, wie das nach den Äubierungen eines Rupert und Honorius scheinen könnte? Das letztere dürte das wahrscheinlichere sein; denn auch auf den Monumenten kommen im 12., 13. und selbst 14. Jahrhundert Fransen nicht allzuoft an den Pluvialien vor. Sie

G u denus, Codex diplom. I 321.

2 Revue 1884, 271. Die Sitte bestand auch zu Barcelona (M art., Thes. IV 611). Das Pluviale, das die neu aufgenommenen Stiftsherren zu Neuchâtel binnen Jahresfrist $z u$ geben hatten, mufte einen Wert von 50 Pfund liaben ( $\mathrm{Hurter}$, Inuozenz III., Hamburg 1838, III 376). Andere Beispiele bei D. C. sub cappam solvere II 112.
3 Dehaisnes, L'art dans la Flandre, Documents 546, note 4. Auch die Chormäntel in den Inventaren von Salisbury, St Paul zu London, Prag, St Peter u. a. rührten zum großen Teil von den Canonici her, wie die Inventare bei manchen ausdrücklich angeben.

4 Chron. Casin. 1. 3, n. 18 (M. G. SS. VII 711). 
werden auf den bildlichen Darstellungen erst im 15. Jahrhundert an denselben gewöhnlicher.

Mit den Monumenten stimmen die noch vorhandenen, im ganzen recht zahlreichen mittelalterlichen Pluvialien überein. Auch hier treten fimbriae fast nur an den Cappae aus späterer Zeit auf. Wo sie sich bei älteren Pluvialien finden, sind sie, wie sich unschwer erkennen läßt, in den meisten Fällen eine Zutat der Folgezeit.

Anstatt Fransen gebrauchte man übrigens auch Quästchen, Glöckchen, kurz, was immer als ein mit Fransen verwandtes Ornament galt, zur Verzierung des Saumes. So geschah es ja auch bei der Stola, dem Manipel und den Behängen der Mitra. Eine solche mit langen Schellchen am unteren Saume versehene Cappa aus der zweiten Hälfte des 14. Jahrhunderts hat sich im Aachener Münster erhalten. Dieselben sind an einer stark gedrehten Seidenkordel über dem reich gestickten Besatz angebracht, welcher den unteren Rand des Gewandes umzieht. Schon in der Frühzeit unseres Jahrtausends waren Pluvialien, die statt mit Fransen mit Glöckchen geschmückt waren, nichts Unbekanntes. Von dieser Art war z. B. die Cappa, welche Bischof Emulf von Rochester (1114-1124) seiner Kathedralkirche schenkte. Ein Pluviale, das Abt Kionrad von Christ Church zu Canterbury 1108 hinterliefi, war unten mit nicht weniger als 140 silbernen Glöckchen besetzt ${ }^{1}$. Auch in späterer Zeit kommen in den Inventaren noch mit Schellchen ausgestattete Chorkappen ror. So heifst es z. B. in einem Inventar von St Georg zu Köhn aus dem 14. Jahrhundert: Item cappa cum tyntinabulis (sic).

Zur Einfassung und Verzierung des unteren Saumes wurde auch wohl ein Börtchen gebraucht, und zwar bald anstatt der Fransen, bald zugleich mit solchen. Es hatte der Regel nach nur eine geringe Breite und erlangte nie eine größrere Bedeutung. Mit Stickereien scheint es den Inventaren zufolge nur sehr selten bedacht worden zu sein.

Im Rücken des Pluviale wurde nur ganz vereinzelt ein Zierstreifen angebracht. Ein Beispiel bietet das bestickte Pluviale zu St Paul in Kärnten. Um so beliebter waren Besätze oder Aurifrisien an den Vordersäumen des Gewandes. Sie finden sich schon auf der früher erwähnten Miniatur mit der Darstellung Sigeberts von Minden². Ebenso sind ohne Zweifel die Besïtze an der Vorderseite des Pluviale gemeint, wenn in den Inventaren des 10. und 11. Jahrhunderts von cappae auro paratae die Rede ist.

Wie die Kaselbesätze bestanden auch diese Aurifrisien bis ins 13. Jahrhundert hinein vornehmlich aus gewebten Borten von geringer Breite; bei besseren Pluvialien wurden mit Vorliebe Goldborten verwendet. Die Ära besticktel Besätze beginnt auch für die liturgische Cappa erst im 13. Jahrhundert. Anfangs waren es, gerade wie bei der Kasel, vornehmlich statuarische Darstellungen oder Brustbilder von Heiligen, mit welchen man die Aurifrisien schmückte. Bald aber ging man dazu über, ihneu ganze Szenen mit del Narlel aufzumalen. Natiolich sctzte das voraus, dab die Besätze einc entsprechenrle Breite erhielten. Schon das Anbringen von Einzelfiguren hatte dahin geführt, sie zum Zweck der Aufnahmo solcher zu verbreitern. Erst recht wurde das aber nötig, seitdem man den Aurifrisien förmliche Gruppen aufstickte. Es ist dieselhe Erscheinung, welche wir bercits bei der Kasel wahrunehmen Gelegenheit hatten.

\footnotetext{
I Chambers $39 . \quad 2$ Vgl. Bild 124, S. 266.
} 
Die Darstellungen trugen auch auf den Aurifrisien der Pluvialien bis gegen Ende des 14. Jahrhunderts den Charakter von Flachornament an sich. Selbst die Baldachine und Lauben, unter denen das Bildwerk seinen Platz hatte, waren von blofs geometrischer Bildung; eine Perspektive gab es bei ihnen entweder noch gar nicht oder doch nur in sehr geringem Mafie. Das 15. Jahrhundert sieht die Perspektive unter dem Einflus der Tafelnalerei, wo sie bereits zur Herrschaft gelangt war, auch auf den Aurifrisien der Pluvialien ihren Einzug halten. Figuren und Szenen werden nun mit Vorliebe unter perspektivisch nach innen sich vertiefenden Baldachinen dargestellt und dementsprechend dann natürlich auch selbst perspektivisch behandelt.

Technisch betrachtet hielten sich die Stickereien zunächst noch immer im Bereich des Flachornaments. Indessen ging man auch in dieser Beziehung allmählich vom alten Brauche ab. Aus der Flachstickerei wurde die Hochstickerei, die dann um die Wende des Jahrhunderts auch auf den Chorkappen manche Probe hohen Könnens, aber auch des Terfalles des guten Geschmackes liefern sollte.

Rein ornamentale Stickereien scheinen im Mittelalter auf den Aurifrisien weniger zur Anwendung gekommen zu sein. Wo man nicht in der Lage war, Bildwerke auf denselben anzubringen, pflegte man sich mit gewebten Borden zu behelfen.

Seit dem Ende des 16. Jahrhunderts kommen figürliche Darstellungen auf den Besätzen des Pluviale immer mehr in Ahgang. Wite anf den Kaselstäben, so tritt auch auf den Aurifrisien der Cappa an deren Stelle bloßes Ornament. Tur dal, noch bestenfalls ein verschämtes Symbol, der Name Jesu, das Auge Gottes, ein Pelikan, das Lamm oder ein Kreuz daran erimnerte, daf die Stickerei gottesdienstlichen Zwecken zu dienen bestimmt war.

Auf der Kapuze dürften Stickereien erst angebracht worden sein, als sie zum blofen Zierat geworden war. Das caputium des prächtigen Pluviale von St Paul enthält auf der Oberseite zwei Figuren, den hl. Blasius und einen vor diesem knienden Abt, ohne Zweifel den Donator, auf der Unterseite zwei Drachen (Bild 144, S. 319). Häufiger wurden die Stickereien anf dem caputium, als es sich zum Schild umgebildet hatte. Natürlich bot dieser, solange er (wie es im 13. und 14. Jahrhundert der Fall war) nux eine mäßige Gröfe hatte, keinen Platz für Darstellungen von bedeutenderem Unfang. Es waren darum entweder nur Einzelfiguren, wie der Heiland, die Ciottesmutter oder Heilige, oder doch nur kleinere Gruppen, was man auf dem Schild anbrachte. Nicht selten begnügte man sich sogar mit dem Wappen des Besitzers oder Stifters oder mit irgend welchen symbolischen Darstellungen. Sehr instruktiv sind in dieser Beziehung durch ihre eingehenden Angaben die Inventare von St Peter zu Rom vom Jahre 1361 und von St Veit zu Prag aus dem Jahre 1387. Da heifst es z. B. im Schatzverzeichnis von St Peter: In cuius caputio est ymago Salvatoris et beate Virginis .... in cuius caputio est figura beate virginis Marie ..., in cuius caputio est imago beati Petri ..., in cuius caputio est ymago cuiusdam pontificis cum mitra in capite ...., in cuius caputio est ymago cuiusdam episcopi benedicentis etc. Nur cin einziges Mal heift es: in cuius caputio sunt quatuor ymagines episcoporum, vier Bischofsbilder, die wir uns indessen wohl als Halbbilder zu clenken haben. In dem Prager Inventar von 1387 aber lesen wir z. B.: in capulo arma Domini archiepiscopi Pragensis...., in capulo clipeus cum flammis argenteis et rubeis sericis . in capulo habens arma ecclesiae et arma Arnesti (des Prager Erzbischofs) 
et aquila cum duobus capitibus ..., in capulo unius est imago sancti IVenceslai et in alterius imago, sancti Sigismundi ... in capulo imago duorum angelorum .... in capulo habens imaginem (sancti Sigismundi) et armis ex utraque parte imaginis.

Bestanden die Aurifrisien an der Vorderseite des Gewandes nur aus gewebten Borten oder wurden sie (was nicht selten der Fall war) blof aus irgend einem rom Grundstoff des Pluviale sich abhebenden Zeug gemacht, so lief man auch am Schild die Stickereien meistens fehlen. Man gebrauchte dann zu ihm entweder den Stoff, aus dem man den Besatz an-

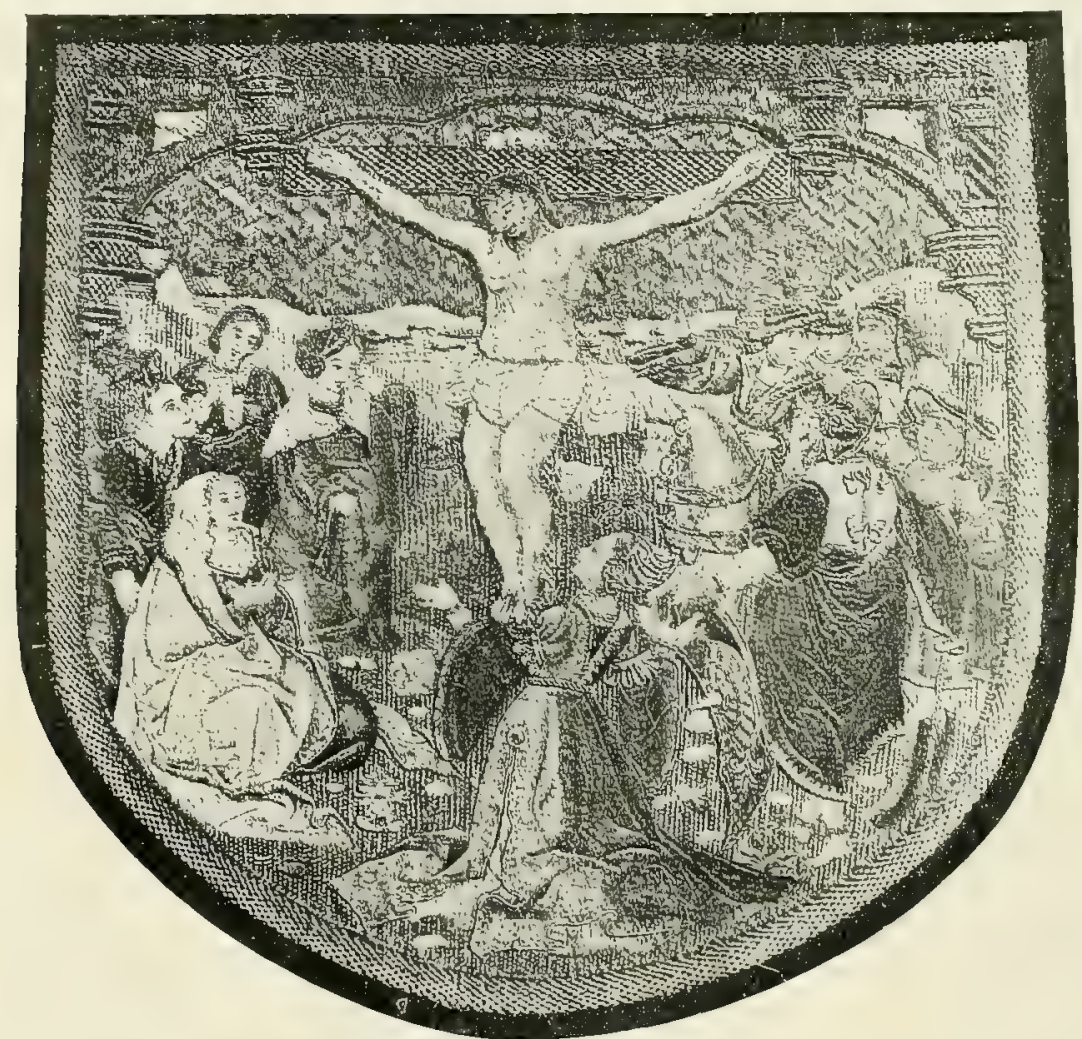

Bild 155. Pluvialschild (Ende des 15, Jahrh.). Paris, Sammlung M. Hochon. (Phot, de Farcy.)

gefertigt, oder gewöhnlicher denjenigen, welchen man zum Pluviale selbst verwendet hatte. Auch in dieser Beziehung ist das Inventar von St Peter von 1:361 ungemein lehrreich. Unter den vierzig dort anfgezählten Pluvialien der Benefiziaten finden sich nur einige wenige, auf deren caputium Bildwerk angebracht war. Bei den übrigen heibt es: cum caputio de eodem panno (nämlich wie das Pluviale selbst) ..., cum caputio de eodem panno et frisio ..., cum caputio le ryaspero giallo cum aliquali frisio..., cum caputio de eodem aurifrisio und ähnlich.

Fs ist zwcckmägig, ausrlüucklich darauf hinzuweisen, daß es selbst noch im späten Nittelalter neben sehr reichen auch manches einfache Pluviale gegeben hat, weil die Sache hie und la in übertriebener Weise so dargestellt wirl, rlat man fast anf ien Glauben kommen sollte, man habe damals kaum 
andere als mit Stickereien auf den Stäben und dem Schild versehene Pluvialien gekannt. Gewif waren reich bestickte Cappae in jener Zeit nicht selten, zumal in den beleutenderen Stifts- und Klosterkirchen sowie den hervorragenderen Pfarrkirchen; sie waren sogar infolge der Verhältnisse häufiger als jetzt, aber derartige Pluvialien waren zuletzt nur Gewänder für die hohen Feste und dem Vorrat an einfacheren Pluvialien gegenüber durchweg die Minderzahl. Die Inventare beweisen das zur Genïge.

Je mehr der Schild der Cappa an Ausdehnung gewann, um so mehr bot er natürlich Raum für Bildwerk. Man kann denn auch an zahlreichen Pluvialien des 15. Jahrhunderts die Beobachtung machen, mit welchem Eifer die Sticker diesen Umstand ausgenutzt laben, um statt blofer Einzelbilder figurenreiche Gruppen auf dem clipeus anzubringen; indessen ist es sicher der Wirklichkeit nicht minder entsprechend, wenn man annimmt, dals umgekehrt gerade das Verlangen, Platz für reichen bildnerischen Schmuck zu erhalten, nicht wenig zur Vergröferung des Schildes beigetragen habe (Bild 155).

Es würde selbstredend zu weit führen, wollten wir auf alle oder auch nur einen größeren Teil der vielen Pluvialien näher eingehen, die sich aus dem Mittelalter erhalten haben, ja selbst sie auch nur einzeln aufzählen. Immerhin dürfte es am Platze sein, auf einige durch die Stickereien ihrer Besätze und des Schildes hervorragende Beispiele aufmerksam zu machen.

Eines der vorzüglichsten ist unstreitig eine aus dem Domschatze von Lausanne stammende Cappa im Historischen Museum zu Bern. Auf Schild und Besätzen sind die sieben Sakramente dargestellt. Der Schild weist die heilige Encharistie als Opfer (Messe) und speise (Kommunion) auf, das linksseitige Aurifrisium die T'aufe, die letzte Ölung und die Firmung, das rechtsseitige die Priesterweihe. Ehe und Beichte. Die anf den Besätzen sich findenden Szenen sind unter Nischen angebracht, welche sich in flach geschweiftem Bogen dem Beschauer zu öffnen. Die Darstellungen sind ebenso trefflich komponiert und edel, wie die technische Ausführung in jeder Beziehung vorzüglich ist.

Aus der großen Zahl der Halberstädter Plnvialien, unter denen mehrere auch hinsichtlich der Stickerei Beachtung verdienen, sei die Cappa des Dompropstes von Gharwen (1506) hervorgehoben. Ihre Besaitze sind Beispiele spätel Reliefstickereien. Auf dem. Schild ist die Krönung Mariä dargestellt, auf den Stäben gewahren wir unter Baldachinen die hll. Stephanus, Laurentius, Liborius, Wolfgang, Petrus, Paulus, Johannes Baptista und Andreas.

Von den vielen Pluvialien der Danziger Marienkirche sind zwei besonderer Berücksichtigung wert. Das eine ist eine italienische Arbeit aus dem Beginn des 15. Jahrhunderts. Auf dem Schild erblicken wir in der Mitte Maria mit dem Jesuskind in offener Landschaft, in den Ecken herniederschwebende Engel, in der Hand eine Blume, wie um sie dem Kind zu überreichen. Die Besätze sind mit Heiligenfiguren und charakteristischen Baldachinen gefüllt. Die Darstellungen sind ebensowohl stilistisch bemerkenswert wie technisch hervorragend durch die meisterhatte Anwendung des sog. Modellierstiches ' (Bild 156, S. 334).

Noch vorzüglicher ist ein zweites Pluviale, auf dessen Aurifrisien in einer Folge von zehn Szenen das Leben der hl. Maria Magdalena, wie es durch die Legende gestaltet wurde, zur Darstellung gelangt ist (Bild 157. S. 385 ). Die erste zeigt uns die Heilige als Weltkind inmitten von sechs Tieren, den Symbolen ihrer Laster. Es folgt. der Besuch am Grabe usw. Den Beschluf macht die letzte Kommunion der Heiligen. Die einzelnen Bilder werden überragt von einem architektonischen Überbau. Eine lebendige, edle Darstellung und eine vortreffliche technische Ausführung lassen die Stähe der Cappa als wirkliche Meisterwerke der Stickkunst erscheinen. Ein Schild fehlt dem Gewande, das der Frühe des 15. Jahrhunderts angehören dürfte.

1 Über den sog. Modellierstich vg]. Braun, Winke 123. 


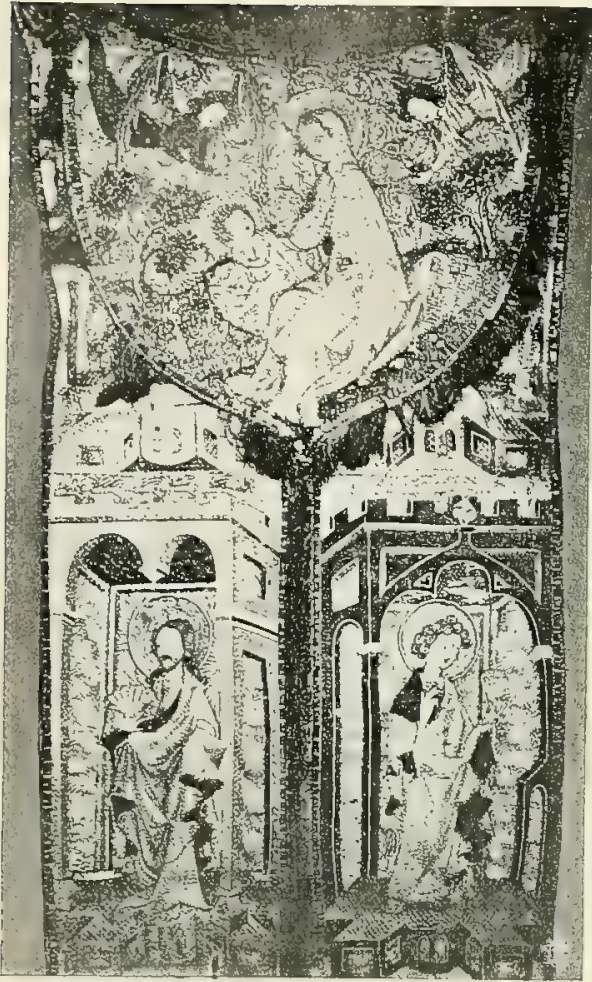

Bild 156. Schild und Teile des Besatzes eines Pluviale. Danzig, Marienkirche.

Gute, teilweise sogar vorzûgliche Beispiele von Pluvialbesätzen und Pluvialschilden, die in der sog. Lasurmanier ausgeführt sind, finden sich in dem an alten Paramenten reichen Dom zu Xanten. Sie entstammen dem 16. Jahrhundert. Die Stickereien haben leider stark gelitten. Den ersten Platz unter ihnen dürte die Chorkappe einnehmen, welche samt zugehöriger Kasel, Dalmatik und Tunicella dem Dom von dem 1540 verstorbenen Canonikus Sibert geschenkt wurde. Die Stickereien dieser Paramente stellen, wie "Die Kunstdenkmäler der Rheinprovinz" mit Recht sagen, „den Höhepunkt der niederrheinischen Nadelmalerei um 1540" dar. Die Kompositionen sind ebenso meisterhaft in Ausdruck, Gewandung und Raumausfüllung, wie die technische Durchführung vollendet und von einer fast raffinierten Virtuosität zeugend. Der Künstler arbeitet mit wenig Farben; Blau, Grün, Purpur, Orange und Braun durchziehen in vertikalen feinen Seidenfäden den Grund und umspinnen die Goldfäden; Köpfe und Hände sind in feinem Plattstich ausgeführt. Die gleichzeitigen niederrheinischen Denkmale des Lasurstiches in Kalkar, Wissen, im erzbischöflichen Museum zu Utrecht stehen der Xantener Kapelle weit nach" 1 .

Ins 14. Jahrhundert führt uns das Pluviale von Harlebeke im Musée Cinquanténaire zu Brüssel. Die Stickereien der Saumbesätze, welche bereits die ansehnliche Breite von $20 \mathrm{~cm}$ haben, stellen das Martyrium der zwölf Apostel dar. An den Pfeilern, auf denen sich der die einzelnen Szenen oben abschließende Giebel aufbaut, sind allerliehste musizierende Engel angebracht. Der Schild ist in seinem jetzigen Zustand ein Konglomerat verschiedener Stücke, unter denen sich indessen auch die mit zwei Vögeln geschmückten Reste des kleinen ursprünglichen clipeus befinden. Der Charakter der Stickereien läßt dieselben deutlich als opus anglicanum, als englische Arbeit des 14. Jahrhunderts erkennen.

Von älteren italienischen Pluvialien sei hier -- von andern wird weiter unten die Rede sein - nur eines Pluviale gedacht, das sich im Besitze der Universität zu Perugia hefindet. Dasselbe enthält auf seinen Besätzen und dem Sichild Darstellungen aus dem Leben der Gottesmutter, welche mit vorziiglicher technischer Ausführung: all den Reiz der umbrischen Malereien des ausgehenden 15. Jahrhunderts verbinden. Die Stickereien gehören zu dem Vortrefflichsten, was die um jene Zeit vielgepflegte Lasurmanier in Italien geschaffen hat.

Als Kuriosa seien endlich noch zwei Pluvialgarnituren erwähnt, auf denen uns Totentanzszenen entgegentreten. Die eine gehört dem I)om zu Osnabrick (Bild 158, S. 337), die andere der Kirche St-Nicolas-en-Havré zu Mons an ${ }^{2}$. Ein Totentanz auf Paramenten ist nicht gerade geschmackvoll, noch auch der Idee eines liturgischen Gewandes entsprechend. Immerhin ist eine solche Verirrung nicht so grof wie die, welche man im 1\%. unl im Joreim des 19. Jahrhunderts heging, als man 'Totenküpfe, T'otengebeine,

1 C L $\Leftrightarrow$ man. Dic Kunstrakmiler des Kreises Mörs, Duisseldort 1892, 139.
2 Nähere Beschreibung in "Stimmen aus Naria-Laach" LX 118 ff. 
Aschenkrüge, Genien mit umgestürzter Fackel und ähnliches auf die Besätze der beim Totengottesdienst gebrauchten Gewänder zauberte.

Bisher war nur von Pluvialien mit bestickten Aurifrisien und besticktem Schild die Rede. Es hat deren aber auch gegeben, die ganz in Stickerei hergestellt waren, und zwar meinen wir nicht blok solche, die man nach Art eines Gewebes mit bestickten Ornamenten, Möndchen, Rosetten, Seraphim, Blumen, Wappenbildern und ähnlichen Dingen überstreut hatte - Pluvialien dieser Art kamen noch in der Zeit des Rokoko vor -, sondern solche, welche ganz und gar mit Bildwerk überdeckt waren. Die Neuzeit hat keine Cappae dieser Art hervorgebracht, das Mittelalter dagegen manche. Es ist nicht zu viel behauptet, wenn man sagt, daf gerade diese Pluvialien den Höchststand der mittelalterlichen Paramentik bezeichnen.

Wohl hat es auch reich bestickte Kaseln gegeben. An keinem der liturgischen Gewänder aber haben Sticker und Stickerinnen so ihren Kunstsinn und ihre Kunstfertigkeit erprobt, wie an dem Pluviale. Der Grund, warum sie eben dieses vor der Kasel bevorzugten, lag zum Teil in dem Umstand, dak es durch den ganzen Verlauf seiner geschichtlichen Entwicklung den Charakter eines Prachtgewandes erhalten hatte, zum Teil in der ihm eigentümlichen Beschaffenheit, welche es ungleich geeigneter zur Aubringung reichster figülicher Stickereien erscheinen lief als das Mefsgewank. Denn während dieses in dichtem Gefältel sich dem Körper anlegte - eine Folge der Notwendigkeit, das Gewand auf den Armen zusammenzuraffen -, flo: das Pluviale in wenigen langen Falten glatt zum Boden herab.

Es waren durchaus keine vereinzelten Erscheinungen, diese ganz und gar mit Heiligenfiguren oder Szenen aus der heiligen Geschichte überstickten Pluvialien; es hat ihrer im 13., 14. und 15. Jahrhundert eine grofe Zahl gegeben. Item unum pluviale laboratum ad acum de auro battuto et serico de diversis ystoriis et passionibus sanctorum, foderatum de purpura rubea ad aves croceas, lesen wir im Verzeichnis der Paramente, welche Bonifaz VIII. der Kathedrale zu Anagni schenkte. Item una magna cappa deaurata ad imagines, heist es in einem Inventar von Chartres von 1327. Item cappa GodofredideWesenham derubeo sameto, brodata eum ymaginibus regum et episcoporum ${ }^{2}$...; item cappa, quam dedit Edwardus tilius regis Henrici, breudata

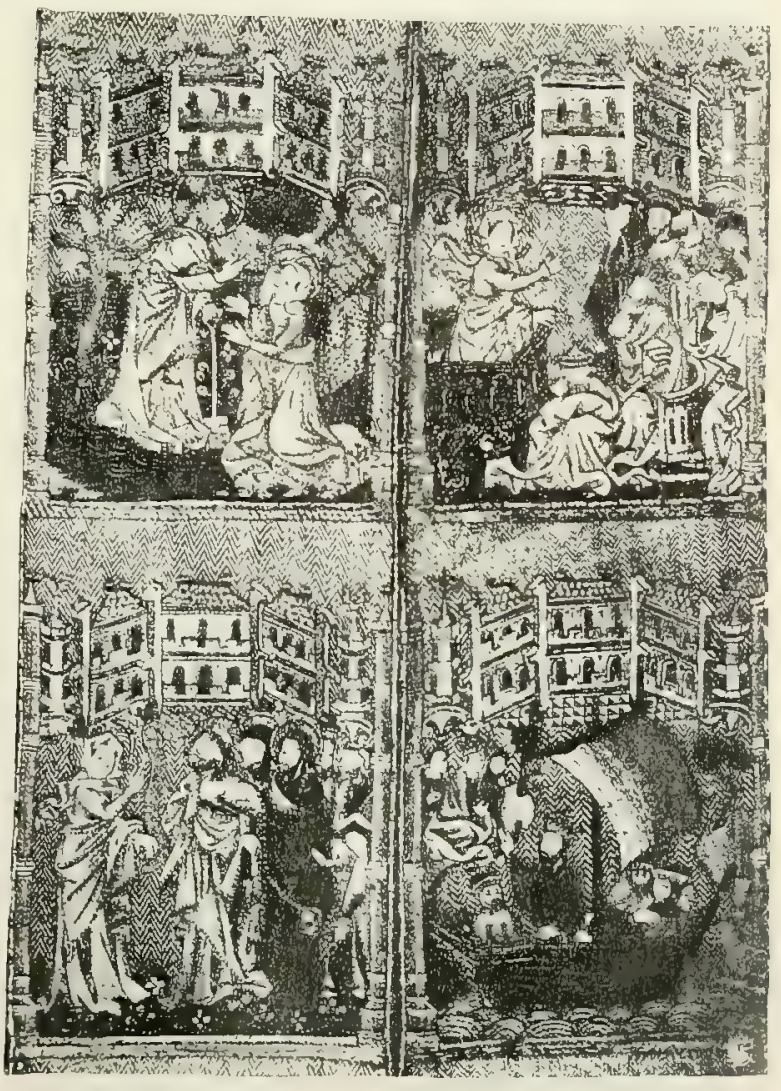

Bild 157. Szenen aus dem Leben der hl. Magdalena. Pluvialbesatz. Danzig, Marienkirche. 
cum regibus, angelis, episcopis et rosis ...; item cappa pretiosa quae fuit Thomae de Cantilupe de rubeo sameto breudata ymaginibus episcoporum, regum et apostolorum, schreilt das Inventar von St Paul zu London von 1295 bei Aufzählung der zahlreichen Cappae.

In primis, vermerkt das Inventar von St Peter aus dem Jahre 1361, unum pluviale, quod dedit Basilicae bonae memoriae papa Ioannes XXII, de auro cum multis et diversis historiis novi et veteris testamenti et aliis compassibus ad perlas cum uno pulchro aurifrisio de auro, ornatas ad figuras diversorum animalium et avium de perlis et vitreolis in cuius caputio ornato de perlis sunt duo angeli incensantes et in pede ipsius est unum monile rotundum de perlis plenum; a pede vero ipsius pluvialis est unum aurifrisium rubei et viridis coloris mirae pulchritudinis ...; item nnum pluviale de auro cum infinitis imaginibus diversarum ystoriarum sanctorum de opere anglicano, scilicet cum ystoria passionis Christi et beati Petri cum anrifrisio mirae pulchritudinis ad figuras diversorum animalium et avium de perlis et vitriolis et in caputio ornato de perlis sunt duo angeli incensantes et a pede (am Saum) ipsius est una vitis de perlis cum avibus et animalibus infra ipsam vitem, quod transivit (sic) Basilicae sanctissimus pater Clemens papa VI ... ; item unum pluviale de auro de opere anglicano quod fuit Bonifatii papae VIII cum imagine in modum pontificis cum corona, amicto pallio pontificali, et libro de perlis et a medietate infra in circuitu imagines apostolorum cum frisio ornato de perlis minutis et crucibus nigris de serico et in caputio est annuntiatio dominae nostrae, a pede vero est aurifrisium ornatum de perlis...; item unum aliud pluviale de (opere) anglicano, quod fuit Nicolai III cum diversis figuris et in campo aureo ..., in medio eius praecipue est imago salvatoris cum luna et sole ab utraque parte et duobus angelis uno a dextris et alio a sinistris ...; item unum pluviale de cassamito viridi cum diversis compaxibus aureis et diversis imaginibus salvatoris et apostolorum Petri et Pauli ... in euius caputio est imago salvatoris et beatae virginis (wohl die Krönung Mariä) ${ }^{2}$. Bemerkenswert ist, daf unter den zahlreichen Kaseln des Inventars sich keine findet, die wie die angeführten Pluvialien ganz mit Figuren bestickt war.

Auch das Inventar Bonifaz' VIIL. vom Jahre 1295 gedenkt eines mit Bildern geschmückten Chormantels: Item unum pluviale anglicanum cum campo toto de auro filato cum multis imaginibus sanctorum et figuris avium et bestiarum cum frisio ad perlas.

Das Inventar Karls V, von Frankreich vom Jahre 1379 schreibt: Une chappe à ymages sur champ d'or d'ouvraige d'Angleterre, l'orfroi et la broderie à perles ...; une autre chappe à prélat, brodée sur or à ymages de point; im Inventar von Poitiers von 1406 aber lesen wir: Une autre fort belle chappe, ... en laquelle est comprise toute la Bible en ymages et enrichie d'un magnifique orfroi In einem Inventar der Kathedrale zu Lyon von 1448 sind verzeichnet eine cappa preciosa... contexta cum acu de auro, seminata in campo de virga Jesse..., und eine cappa, iam antiqua, aurea brodata cum acu ... seminata de Passione. Ungemein reich an figurierten Pluvialien war ehedem die Kathedrale von Bourges, so reich, daf sie in dieser Beziehung selbst St Peter zu Rom übertraf. Verzeichnet doch das Inventar von 1537 ihrer nicht weniger denn sechs. Drei wiesen Bilder aus dem Leben des Heilandes und Liariä, eine vierte Marterszenen, eine fünfte den Jessebaum auf. Die sechste hief La chappe du Te Deum von den auf ihr dargestellten Ordnungen heiliger Nänner und Frauen ${ }^{2}$. Andere mit Bildern bestickte Chorkappen werden in dem Inventar von Cluny (1382) und den Verzeichnissen der Schätze Philipps des Kühnen (1404), I'hilipps des Guten (1+20) und Karls des Kühnen (1467) aufgeführt. In der Kapelle Philipps des Kühnen gah es ihrer ganze fün, von denen zwei Florentiner Herkunft waren.

In der Ste-Chapelle zu Bourges besak man noch 1757 zwei mit figürlichen Darstellungen bestickte Pluvialien, von denen die eine Szenen aus dem Leben des

1 i'ber cassamitum $=$ catexanitum $\mathrm{vgl}$. oben S. 225, Anm. 1 ; compaxus (compassus) hodentet ein rundes, viereckiges oder vjerpafformiges Feld. 2 hevue 1888, 176. 
hl. Ludwig von Marseille, die andere Begebenheiten aus dem des heiligen Königs Ludwig aufwies ?. Drei fernere fanden sich bis zur Revolution in der Abtei La-Chaise-Dieu (Auvergne). Man schrieb sie irrtümlich dem Stifter der Abtei, dem hl. Robert, zu; die Abbildung, welche wir durch Montfaucon von einer derselben besitzen, wie die Beschreibung, die wir von ihnen erhalten, lassen in ihnen unschwer Schöpfungen des 14. Jahrhunderts erkennen. Eines der Pluvialien hiefs La caille (Wachtel), weil swischen den Heiligendarstellungen auker andern Tieren besonders häufig eine Wachtel angebracht war. Die Besätze an der Vorderseite wiesen Heilige unter Baldachinen auf, der Schild das Lamm Gottes, das Gewand selbst die Krenzigung und die zwölf Apostel. Von den beiden andern Chorkappen nannte man die eine La Pentecôte, die andere La Toussaint", Namen, die zur Genüge verraten. was auf denselben dargestellt war. Sehr eigenartig war der Bilderschmuck auf einem Pluviale in der Kathedrale zu Chartres. Über das ganze Gewand zogen sich mit Fischen belebte Flüsse hin, die einander kreuzten und so Medaillons bildeten. An den Kreuzungspunkten sah man groGe Krebse. Der Bilderschmuck des Pluviale bestand in einer Kreuzigungsgruppe, die unterhalb des Schildes angebracht war, einer Darstellung der thronenden Gottesmutter, die nach dem Saum der Rückseite zu ihren Platz gefunden hatte, und den

1 Girardot, Trésor de la cathédrale de Bourges 2646 . Revue 1888, 176.

${ }^{2}$ Roh. VIII 5 und pl. Dexxv.

Braun, Die liturgische Gewandung.
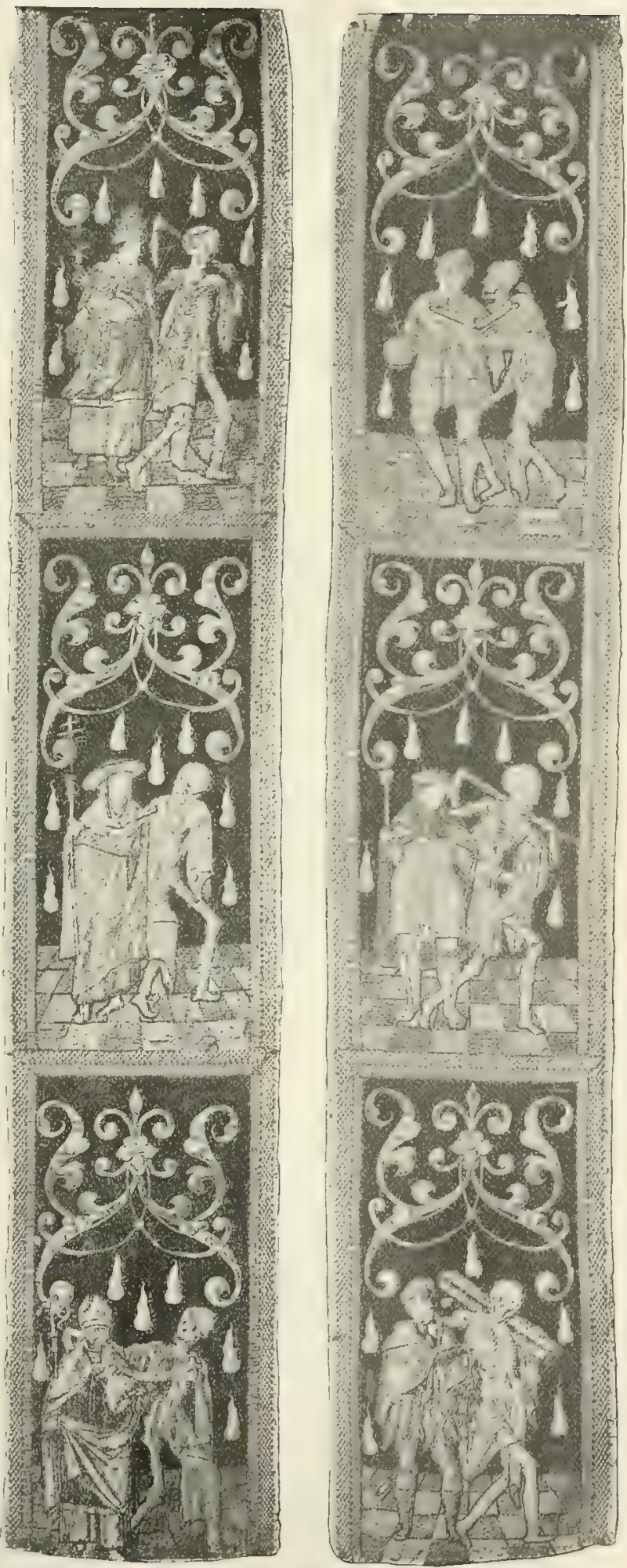

Bild 158. Pluvialstäbe mit Totentanzszenen. Osnabräck, Dom. 22 
von VogeIgestalten begleiteten Figuren der Apostel, welche sich rechts uns links an Maria anreihten. Das Pluviale befand sich noch 1620 im Besitz der Kathedrale ${ }^{1}$.

Doch wozu die Inventare erzählen lassen, da es doch noch jetzt eine verhäItnismäßsig stattliche Anzahl dieser Prachtpluvialien des 13., 14. und 15. Jahrhunderts gibt.

Wohl das älteste derselben, es mag in die erste Hälfte des 13. Jahrhunderts hinaufreichen, ist das früher bereits erwähnte Pluviale von St Paul in Kärnten (Bild 14t, S. 319). Der ganze Grund des Gewandes ist mit Kreisen von nahezu $30 \mathrm{~cm}$ Durchmesser ausgefüllt, die auf der einen Hälfte des Pluviale Szenen ans dem Leben des hl. Blasius, auf der andern Szenen aus dem des hl. Vincentius enthalten. Die Bedeutung der jedesmaligen Darstellung erhellt aus der in der Umrahmung angebrachten Umschrift. Die Zwickel zwischen den Kreisen werden durch romanische Ranken und sonstiges dem Raum entsprechendes Ornament, namentlich romanisch stiilisierte Kreuze, belebt. Über die Mitte der Rïckseite zieht sich von oben nach unten ein $11 \mathrm{~cm}$ breiter Zierstreifen, der das Gewand in zwei Halften teilt, eine Einrichtung, die, wie schon gesagt wurde, bei Chormänteln eine große Seltenheit ist. Die Stickerei

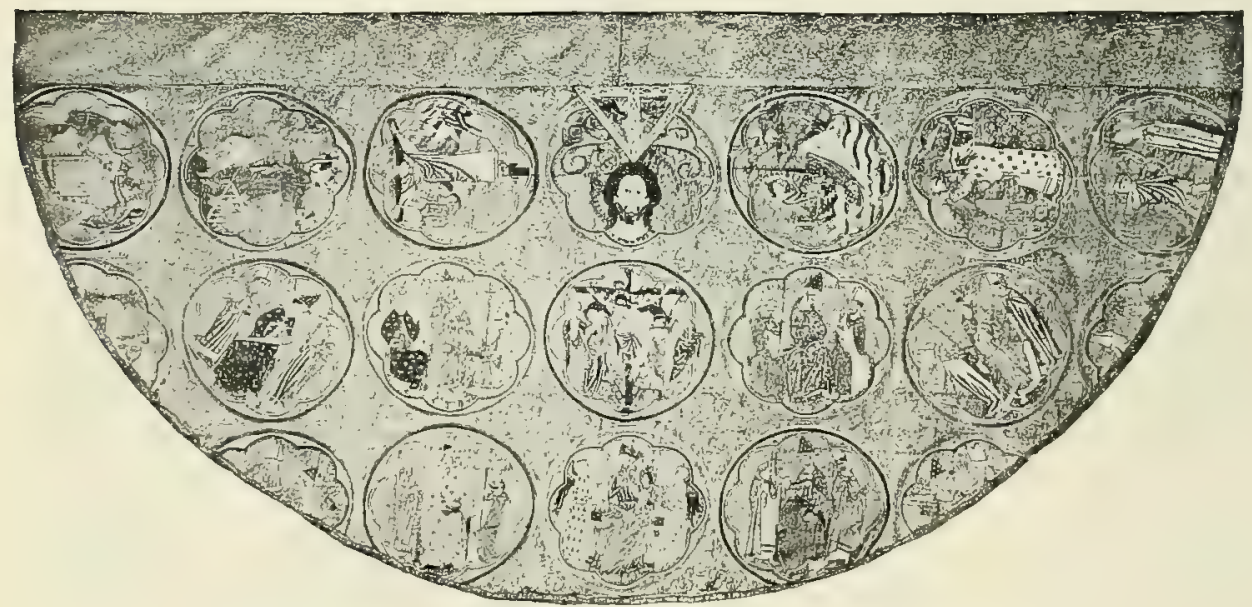

Bild 159. Pluviale Nikolaus' IV. Ascoli Piceno. (Phot. Alinari.)

ist in Seide auf derbem Linnen aufgeführt. Die Zeuglasche, welche vorn am Saume behufs Schließens des Gewandes angebracht ist, weist die Brustbilder Christi und der hll. Blasius und Nikolaus auf ${ }^{2}$.

Etwas jünger als das Pluviale von St Paul ist die Chorkappe in der ehemaligen Klosterkirche zu Göf in Steiermark, eine Arbeit aus der zweiten Hälfte des 13. Jahrhunderts $^{3}$. Wie die zugehörige Kasel, Dalmatik und Tunicella eine Stiftung der Äbtissin Kunigundis II., ist sie auch in Bezug anf den Charakter der Darstellungen und der angewendeten Technik diesen Gewändern durchaus gleichartig. Ihre Verzierung besteht teils aus Hakenmustern untermischt und wechselnd mit Flechtwerk, geometrischem Bandornament und treppenartigen Gebilden, teils aus quadratischen Feldern, in denen phantastisches Getier, Adler, Elefanten, Löwen, Greife und ähnliches angebracht sind.

$1 \mathrm{Gay}$ 1 322. Vergleiche auch das Invental von Tork $(1,50)$ ): Item 3 capae ruheae opere acus operatae cum historiis Bibliae; ferner $\mathrm{L}$ u r h a m, Wills and Inventories 21 27, das Inventar von Fécamp (1375), das Schatzverzeichnis von Lincoln (1536), das Inventar von Amiens (1419) u. a.
2 Heider, Liturgische Gewänder aus Stift St Blasien im Schwarzwald, in Jahrbuch der k. k. Zentralkommission IV, Wien 1860, $135 \mathrm{ff}$ und Kraus, Kunstdenkmäler des Groß̧berzogtums Baden, Kreis Waldshut III 104, wo auch die Literatur über das Pluviale.

${ }^{3}$ Abbildung bei de Farcy $77^{3}$. 
Figurales Bildwerk findet sich nur auf der Rückseite des Pluviale. Es beschrïnkt sich auf das Bild der Gottesmutter, die das Jesuskind an ihrer jungfräulichen Brust nährt, die vier Evangelistensymbole und eine Darstellung der Donatrix Kunigundis. Maria und die Evangelistensymbole sind in Scheihen angebracht, die Stifterin unter einem Rundbogen. Die Kapuze bzw. der Schild fehlt gegenwärtig, vielleicht, daf solches von Anfang an der Fall war. Schön ist das Gewand nicht, noch auch technisch eine Musterleistung, jedoch sehr interessant.

Ungleich vorzüglicher, ja wixklich vortrefflich ist ein aus derselben Zeit stammendes Pluviale in der Kathedrale zu Ascoli (Bild 159). Es wurde dieser von Nikolaus IV. († 1292) zum Geschenk gemacht und soll auf Bestellung Nikolaus' III. $(\dagger$ 1280) durch einen französischen Meister angefertigt worden sein. Das Gewand ist ein Papstpluviale im vollsten Sinne des Wortes. Der Fond des Bildwerks ist in Gold- und Silberstickerei hergestellt. Neunzehn zum Teil allerdings unvollständige Rundmedaillons mit eingeschriebenem Achtpafs verteilen sich in drei Reihen über die ganze Fläche. Die drei mittleren enthalten ein Brustbild Christi, Christi Kreuzigung und Maria mit dem Kind zwischen zwei Engeln thronend, die 16 übrigen

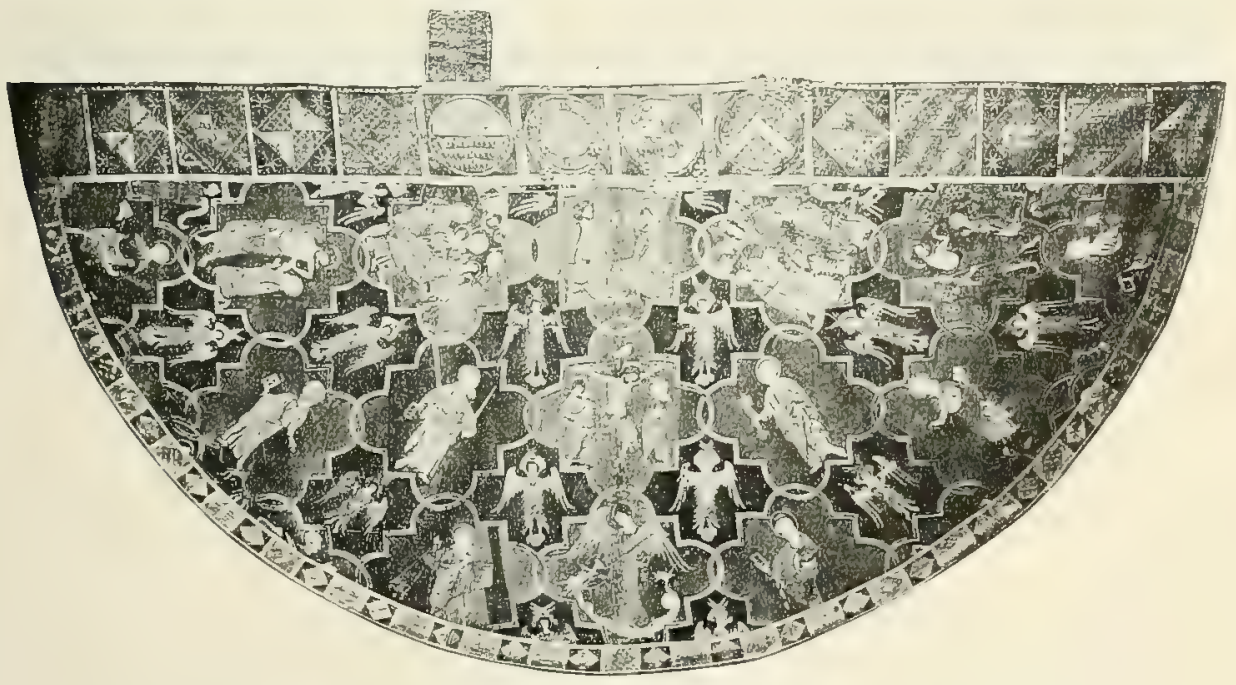

Bild 160. Pliviale aus Syon. London, Kensington-Mrnseum, (Phot. de Farcy.)

Darstellumgen von Päpsten. Sechs derselben schildern das Martyrium der hll. Petrus, Varcellus, Alexander, Klemens, Kornelius und Fabianus, sechs zeigen uns die heiligen Bekennerpäpste Silvester, Hilarius, Leo, Gregor I., Lucius und Anastasius inmitten von je zwei heiligen Bischöfen, die übrigen vier weisen die Brustbilder Innocenz' IV. (1243-1254), Alexanders IV. (1254-1261), Urbans IV. (1261 bis 1264) und Klemens' IV. (1265-1268) aut, jedes begleitet von dem Brustbilde eines Bischofs. Der winzige Schild enthält zwei inzensierende Engel, ein hier beliehtes Motiv. Aurifrisien ziehen sich sowohl am Vordersaum hinab wie rings um den unteren Rand. Sie waren einst mit Perlen reich besetzt. Es ging diesen indessen wie so vielen andern Kostbarkeiten: man mußte sie herabnehmen, um sie zur Bezahlung einer von Napoleon I. auferlegten Kriegskontribution zu verwenden.

Sonstige Prachtpluvialien aus der zweiten Hälfte des 13. Jahrhunderts sind das Pluviale des hl. Ludwig von Anjou zu St-Maximin (Var), der unter dem Namen Syon cope bekannte Chormantel im Kensington-Museum, ein aus Daroca stammendes Pluviale im Museum zu Madrid und ein dem Bischof Wedekind von Hildesheim einst angehöriger, nach dessen Tode aber vom Kensington-Museum erworbener Chormantel. Reste einer Cappa aus dieser Zeit finden sich an einer Dalmatik im Schatz der Kathedrale von Anagni. 
Das Pluviale von St-Maximin ist leider am unteren Rand stark heschnitten ${ }^{1}$. Auferden fehlen die Aurifrisien, der clipeus und ein breiter Streifen in der Hitte des Gewandes, den man rermutlich herausgeschnitten hat, um daraus einen Kaselbesatz oder ähnliches zu machen. Dreißig auf vier Reihen verteilte Rundmedaillons mit Szenen ans dem Leben des Heilandes und seiner heiligen Mutter, ein völliges Marienleben bildend, füllen, besser füllten den in Goldstickerei hergestellten Grund. In den Zwickeln zwischen den Scheiben haben vierflügelige Engel Platz gefunden, die sich in ausgezeichneter Weise dem Raum anpassen.

Die sog. Syon-Cappa im Kensington-Museum (Bild 160, S. 339) ist mit 19 in drei Reihen angeordneten Medaillons bedeckt?. Sie haben die Form eines Vierpasses durch den ein Quadrat geschoben ist, und sind nach Art eines aus Ringen bestehenden Netzes ineinander gekettet. Die Darstellungen, welche sie enthalten, sind: Christus am Krenze, Christus und Magdalena, Christus und Thomas, Mariä Tod, Mariä Begräłnnis und Krönung, St Michael und die zwölf Apostel, von welchen letzteren indessen vier nur noch in winzigen Resten vorhanden sind. Der Raum zwischen den Vierpässen ist

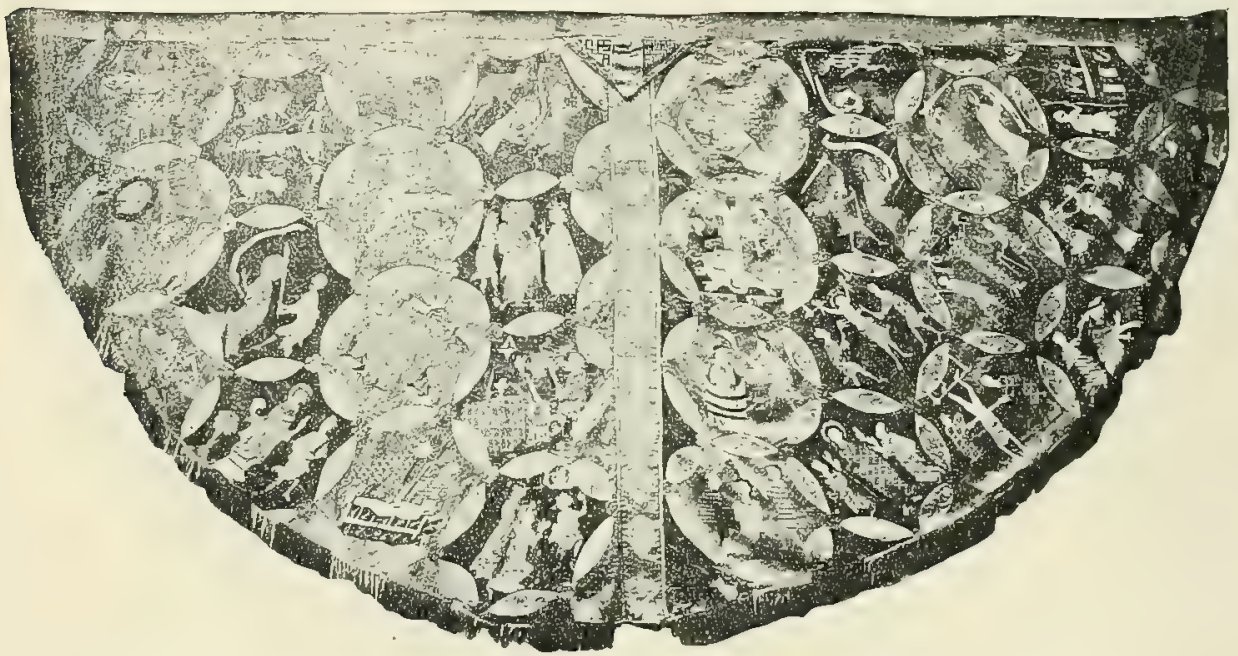

Bild 161. Pluviale aus Hildesheim. London, Kensington-Museum. (Phot, de Farey.)

mit sechsflügeligen Seraphim ansgefüllt. Der Fond des Pluviale ist in grüner, derjenige der Medaillons in roter Seide ausgestickt; die Figuren sind in Gold, Silber und farbiger Seide gearbeitet. Die Besätze unten und am vorderen Saume sind um etwa ein Jahrhundert jünger als das Gewand selbst.

Das Pluviale von Daroca ist gleichfalls mit drei Reihen von Vierpässen geschmückt, aus deren Ecken rechte Winkel hervorwachsen; doch sind die Medaillons nicht ineinandergeschlungen, sondern durch eine vierköpfige Schlange miteinander verknüpft. Die drei übereinander stehenden Medaillons in der Mitte des Gewandes geben oben den Engeldienst nach der Versuchung Christi, darunter Christus am Kreuze und unten die Verkündigung wieder, die übrigen Szenen der Schöpfung und des Sündenfalls. In den Zwickeln zwischen den Pässen gewahren wir auch hier sechsflügelige Engelsgestalten. Der ursprüngliche clipeus ist verloren gegangen. Die Besätze am Vordersaum weisen Bilder von Bischöfen und Königen unter steil ansteigenden, auf Löwenküpfen

1 Abliblung bei de Far c y $40^{2}$.

2 Das Pluviale rihnt ans dem Kloster Syon hei Isleworth (Engrand) her. Zur. Zeit der sog. Reformation nach Portugal gabracht, kam es mit den Nonnen, die es besaßen, in
Beginn des 19. Jahrhunderts nach England zurück. Von den Eigentiimerinmen dem Earl of Shrewsbury zum Dank für die ihnen geWührte Gastfreundschaft geschenkt, gelangte es 1864 durch Kauf an das Kensington-Museum. 
ruhenden Baldachinen anf. Der Grund des Pluviale und der Medaillons ist ganz in Gold gestickt; die Figuren sind in Seide ausgeführt, die Umrahmung der Medaillons in Gold. Das Gewand, welches leider durch die Ungunst der Zeit stark gelitten hat, ist eines der interessantesten seiner Art ${ }^{1}$.

Die vorhin erwähnten Chormantelreste an einer Dalmatik im Schatz der Ka* thedrale zu Anagni sind die letzten Úberbleibsel eines glanzvollen Pluviale, das Bonifaz VIII, dieser seiner Lieblingskirche verehrte. Seltener, vielleicht niemals, sind Stickereien in so brutaler Weise zersehnitten und in so widersinniger Weise zu einem Gewande verarbeitet worden, wie das hier in der Zeit der Renaissance mit einem Meisterwerk der Stickkunst aus der zweiten Hälfte des 1:. Jahrhunderts geschehen ist. Die Ärmel der Dalmatik sind einer gleichfalls von Bonifaz VIII. herrührenclen, ganz mit Bildern aus dem Leben des hl. Nikolaus bestickten Dalmatik entnommen, als diese das Geschick ereilte, in eine Kasel verunstaltet zu werden. Das Bilderpluviale, welches der Papst der Katherlrale gab, war mit Marterszenen bestickt. Wirklich finden wir solche auf der Dalmatik des Schatzes von Anagni. Die Umrahmung der Darstellungen ist von ähnlicher Art wie bei den Medaillons auf dem Pluviale im Kensington-

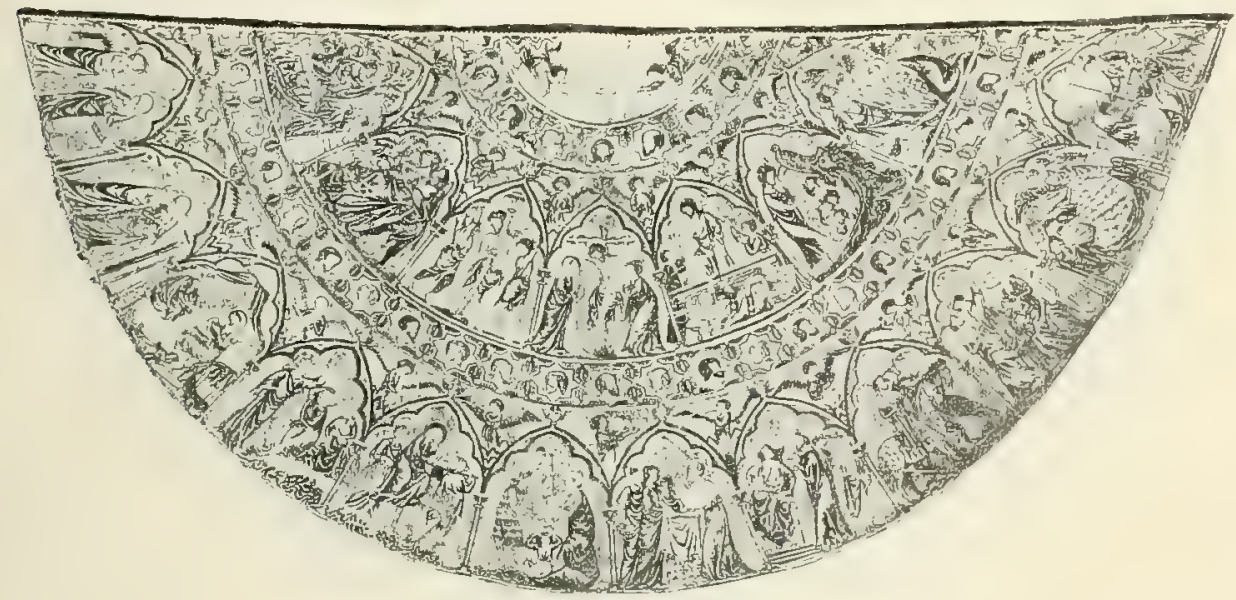

Bild 162. Pluviale. Bologna, Museo civico. (Phot. Alinari.)

Museum und der Cappa von Daroca, nur daf die einzelnen Pässe Dreiblattform haben. Dex Raum zwischen den Vierpässen nehmen Engel ein. die auf Thronen sitzen ?

Bei dem Hildesheimer Pluviale, einem auch durch seine charakteristische Sticktechnik bedeutsamen Stïck, das leider seinen Weg in die Fremde genommen hat, bilden

1 Abbildung des ganzen Gewandes nebst Detail bei de Farcy pl. $212 \%$.

2 Abbildung ebd. pl. 36. De Farcy (126) irrt, wenn er meint, die Ärmel der Dalmatik und die im Text erwähnte Kasel seien Reste eines Pluviale; sie stammen von der im Inventar der Geschenke Bonifaz' VIII. verzeichneten Dalmatik: Item una dalmatica, contexta de auro, argento et serico cum octoginta duobus plactis (sic) de auro et pernis ad historiam beati Nicolai. Ebenso ist die Meinung Barbiers de Montault (Annales archéolog. XVII 273), die Dalmatik sei identisch mit der im Inventar erwähnten una dalmatica de samito rubeo cum diversis passionibus sanctorum ad imagines salvatoris et virginis in pectorali, unzutreffend, wie die Angabe de samito rubeo beweist. Im Schatz der Kathedrale gibt es gegenwärtig auch ein mit Bildern ganz besticktes Pluviale, das als völliges Gegenstück des Chormantels des hl. Ludwig von Anjou gelten könnte. Wenn wir das prächtige Stïck im Text nicht anfiubren, so hat das seinen Grund in dem Umstand, dafs selbiges ursprünglich eine Kasel war und erst später seine jetzige Form und Verwendung erbielt: Item una planeta contexta ad aurum et de serico de historia salvatoris ab anuntiatione beatae virginis et nativitate Christi usque ad resurrectionem et de assumptione beatae virginis, heifst es im Inventar der Gaben Bonifaz' VIII. Die beste Reproduktion des Gewandes bei de F a c y 53. 
die Rundmedaillons keine horizontalen, sondern vertikale Reihen (Bild 161, S. 340). Außerdem hat man dadurch, daß man sie ineinander hat übergreifen lassen, alle Zwickel vermieden. Bemerkenswert ist der gewebte Besatz, der sich über die Nitte des Rückens von oben nach unten zieht. Der kleine, geradseitige clipeus ist mit geometrischen Figuren bestickt. Die Medaillons sind mit Darstellungen von Marterszenen (im ganzen 29), die Segmente mit Drachen gefüllt. Die Behandlung der Gewandungen mit ihren geometrischen Musterungen erinnert an die Stickereien von Göß3, nur ist die Arbeit beim Hildesheimer Pluviale ungleich sauberer und zarter. Gold ist nur an den Rosetten zur Verwendung gekommen, welche an den Verbindungspunkten der Tireissegmente angebracht sind. Was die Komposition der Szenen, den Ausdruck und die Haltung der dargestellten Figuren, die Drappierung und ähnliches anlangt, kann sich das Gewand mit seinen Genossen in Ascoli usw. unzweifelhaft nicht im entferntesten messen. Dagegen ist es als Beispiel deutscher Stickerei und um seiner Technik willen zum mindesten ebenso interessant wie diese.

Der Wende des 13. Jahrhunderts oder dem Beginn des 14. gehören außer einem grofartigen Pluviale im Museo civico zu Bologna zwei im ganzen noch ziemlich gut erhaltene Chormäntel in St-Bertrand zu Comminges sowie die Reste einer Cappa im

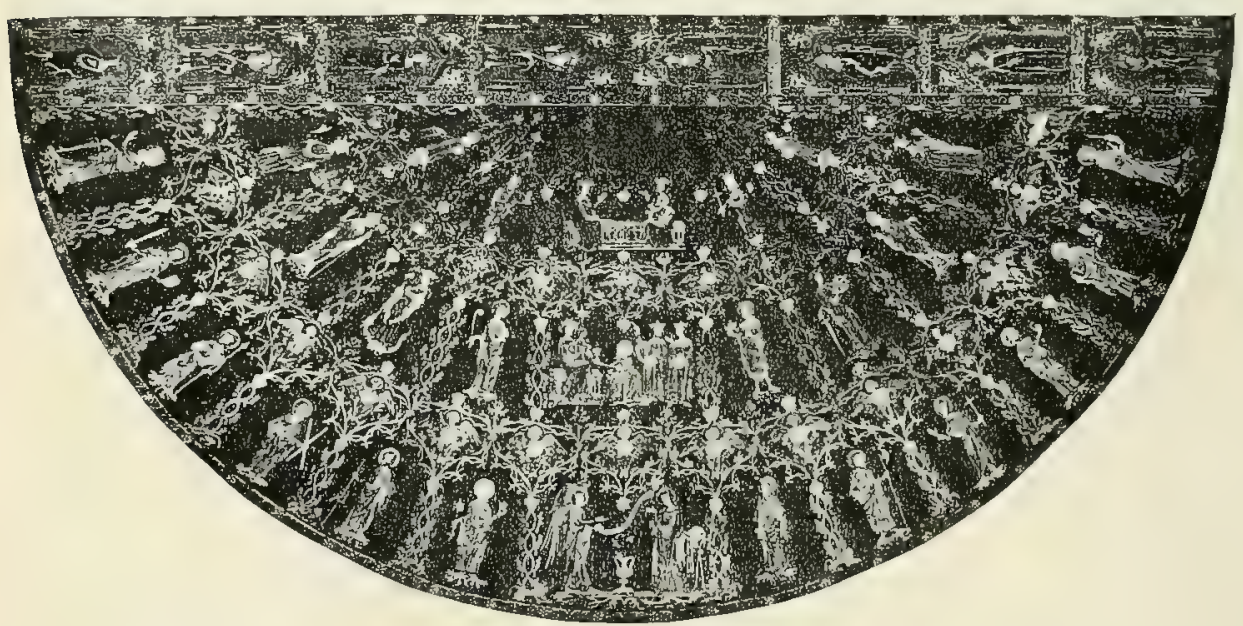

Bild 163. Pluviale. (Relkonstruktion.) Plensington, Lanenshire. (Phot. de Farey.)

Corpus Christ House zu London an. Etwas späteren Datums, doch immer noch aus der Frühe des 14. Jahrhunderts wird ein Pluviale sein, das von Papst Gelasius II. $(\dagger 1119)$ dem Dom zu Pisa geschenkt worden sein soll und gegenwärtig im Museo civico daselbst ausgestellt ist. Seit etwa dem zweiten Viertel des 14. Jahrhunderts entstanden das Prachtpluviale von S. Giovanni im Lateran zu Rom, der Chormantel im Dom zu Pienza, ein Pluviale in der Kathedrale von Toledo, die Reste einer im englischen Privathesitz (Familie Bowden zu Pleasington, Lancashire) befindlichen Cappa sowie die Überbleibsel eines Chormantels im bischöflichen Nuseum zu Vich (Spanien). Auch die bedentenden Fragmente eines mit Bildern bestickten Pluviale zu Steeple Aston (Oxforlshire) in England werden dieser Zeit zugeschriehen; wir möchten sie indessen lieber dem Anfang des 14. Jahrhunderts zuweisen.

Von den beiden Pluvialien in St-Bertrand zu Comminges schliefit sich das eine hinsichtlich der Ausstattung im wesentlichen noch an den Typus an, welcher für die Pluvialien des 13. Jahrhunderts charakteristisch ist ${ }^{1}$. Inmerhin bietet es manches Neue. Die Kreise sind zu beiden Seiten nach Art eines Kranzes mit Blättern besetzt und durch mittelgrofie, gleichfalls kranzartige Ovale miteinander verbunden. Da, wo

1 Abbildung thd. ri, 31. 
Kreise und Ovale sich berühren, sind Vierfüfler der mannigfachsten Art angebracht. Die Ovale enthalten allerlei Vögel, eine wahre Menagerie, die Rundmedaillons Prophetengestalten, der Raum zwischen den Medaillons Szenen aus der Leidensgeschichte samt der Darstellung der Himmelfahrt des Herrn, der Sendung des Heiligen Geistes und der Krönung Mariä. Man könnte das Pluviale in Anhetracht all des Getiers, das auf demselben, und zwar zum Teil in ungemeiner Lebenstreue, seinen Platz gefunden, "Arche ${ }^{1}$ nennen.

Auch die Chormantelfragmente zu Steeple Aston haben die Erinnerung an die im 13. Jahrhundert beliebte Ausstattungsweise des Pluviale noch keineswegs verloren ${ }^{1}$. Nur dak die Vierpässe, die in drei Reihen übereinander den in Gold gestickten Fond überziehen und außer der Kreuztragung, der Kreuzigung und Maria Krönung Yarterszenen wiedergeben, bereits eine freiere Form bekommen haben, und dafs sie, ähnlich wie die Kreise auf dem Chormantel von Comminges, mit Blättern versehen sind. Die Zwickel zwischen den Medaillons beherbergen den englisehen Löwen, auf denA urifrisien am Vordersaume gewahrt man musizierende Engel - hoch zu Rok, eine eigen-

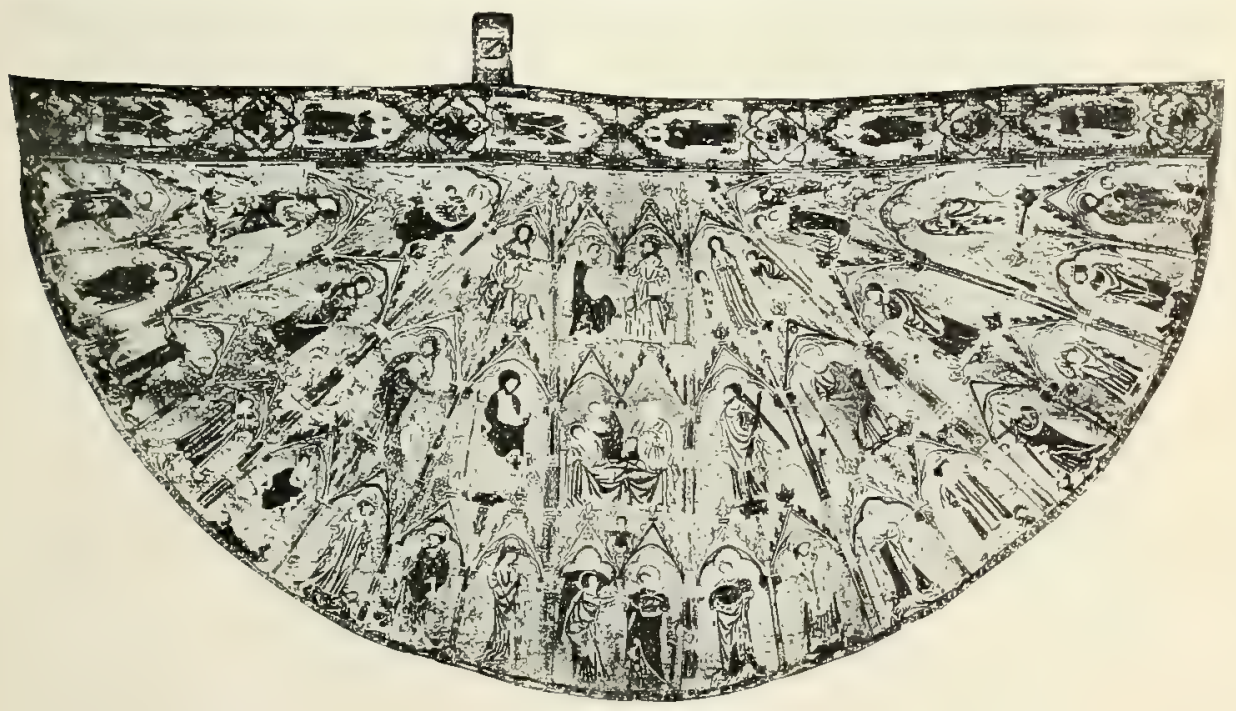

Bild 164. Pluviale des Kardinals Albornoz. Toledo, Museum.

artige Darstellung. Sie werden durch Vierpässe voneinander geschieden, welche in der Mitte die englische Rose, in den einzelnen Pässen aber die auf englischen Stickereien traditionellen Vögel und Vierfüßler aufweisen.

Eine sehr bemerkenswerte Arbeit ist das leider nur unvollständig vorhandene Pluviale in Corpus Christ House ${ }^{2}$. Es ist auf seidenem Fond mit dem Jessebaum geschmïckt, hier ein Weinstock, der in der Hitte des unteren Saumes aus der Seite des schlafenden Jesse ausgeht und sich aufsteigend nach rechts und links über das ganze Gewand verzweigt. Die Stammväter des Herrn und Maria mit dem Jesuskind befinden sich in kreisförmigen Feldern, in welche die einzelnen Reben auslanfen. Außer den Ahnen des Erlösers haben auch Propheten, die von diesem weissagten, in Medaillons solcher Art auf dem Gewand einen Platz gefunden. Der übrige Teil des Fonds wird in ungemein gefälliger und harmonischer Weise durch kleinere Ranken, durch Blattwerk und Trauben belebt.

Ein Pluviale ganz verwandter Art begegnet uns schon 1245 im Inventar von St Paul zu. London ${ }^{3}$. Der Jessebaum scheint bei den englischen Pluvialstickern

1 Abb. ebd. pl. $150 . \quad 2$ Abb. ebd. pl. 42.

3 Cappa G. de Wesenham de rubeo samito, bene breudata Iesse et stirpe per totum et apostolis in anteriore parte et crucifixo. Die Apostel in anteriore parte haben wir uns wohl auf dem Aurifrisium zu denken, welches den 
recht beliebt gewesen zu sein. Ex findet sich unter anderem auch auf einer Stickerei, welche von de Farcy veröffentlicht wurde und die mittlere Partie eines englischen Chormantels oder wohl besser den Besatz einer Kasel gebildet haben dürfte ".

Der Chormantel zu Pisa besteht aus rotem Wollstoff ${ }^{2}$. Seine Musterung setzt sich aus vier Reihen Medaillons von der bekannten Vierpakform zusammen. Die Zwickel zwischen den Medaillons sind mit einer Rosette angefüllt, von der vier Ranken ausgehen, die Medaillons aber enthalten Brustbilder von Heiligen. Die Stickerei ist teils in farbiger Seide, teils in Gold gearbeitet. Den Besatz an der Vorderseite des Gewandes schmückt in der Mitte das Brustbild des hl. Petrus; seine übrigen Darstellungen geben Szenen aus dem Leben Christi wieder. Den unteren Saum umzieht eine mit einer Ranke bestickte Borte. Der Schild fehlt.

Das Pluviale im Museo civico zu Bologna nennt de Farcy das Nonplusultra aller Pluvialien. Das Lob ist wohl etwas übertrieben. Wer indessen Gelegenheit hatte. dasselbe an Ort und Stelle näher zu studieren, wird immerhin gestelıen müssen, daf es einer der vorzüglichsten Chormäntel ist, die wir aus dem Mittelalter noch besitzen. Eine Abbildung überhebt uns der Beschreibung (Bild 162, S. 311). Kann sie auch von der allseitigen Vorzüglichkeit der Nadelmalereien, mit denen das Gewand ansgestattet

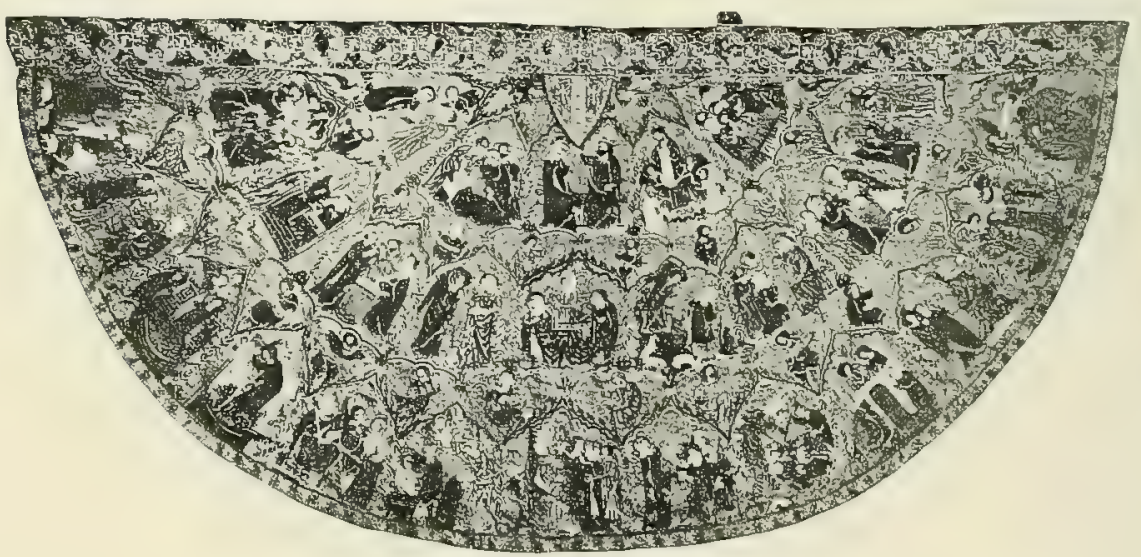

Bild 16.5. Pluviale. Pienza, Dom. (Phot. Lombardi.)

ist, keinen Begriff geben, so ermöglicht sie doch wenigstens eine Idee von der Weise, wie der Künstler das Bildwerk angeordnet hat.

Im 18. Jahrhundert liebten es die Sticker, in Nachahmung der mit eingewebten Yedaillons gemusterten Stoffe den Fond des Pluviale mit aneinandergereihten Kreisen oder Vierpässen zu besticken und in diese dann das Bildwerk einzufügen. Es hatte dies jedoch einen grofen Ühelstand im Gefolge. Da die Cappa ausgebreitet nicht ein Rechteck, sondern ein Halbrund darstellt, konnten nämlich verschiedene der Jedaillons nur unvollständig auf dem Gewand Platz finden. Die zerschnittenen Kreise und verstummelten Figuren sind also keineswegs üherall das häßliche Ergebnis einer unverständigen Zustutzung aus späteren Tagen. Wir finden sie auch bei Pluvialien, an welche sich eine Schere nie nachträglich herangemacht hat.

Das Pluviale im Museo civico zeigt nun einen neuen Typus. Der Sticker hat auf dem Gewand in der Richtung der Radien eine doppelte Reihe von Arkaturen

vorderen Saum entlang angebracht war. Wo die Kreuzigungsgruppe sich befand, ob in der Mitte des genannten Saumbesatzes oder auf dem clipeus, mufs dahingestellt bleiben.

Ablibling etbl. pl. 41. Auch de Farcy möchte sie für einen Kaselhesatz halten. Sio ist eine aufrerst feine Arbeit. Die Figuren und der Jessebaum sind in Seide gestickt. Der Fond wurde mittels Abheften vou Goldfaden gebildet, und zwal wurde er dabei in kunstreicher Weise durch den Wechsel im Lauf der Fäden mit Vierpässen gemustert, welche mit einem Leoparden gefüllt sind.

2 Abbildung bei Rolı. VIII, pl. DCxxv. 


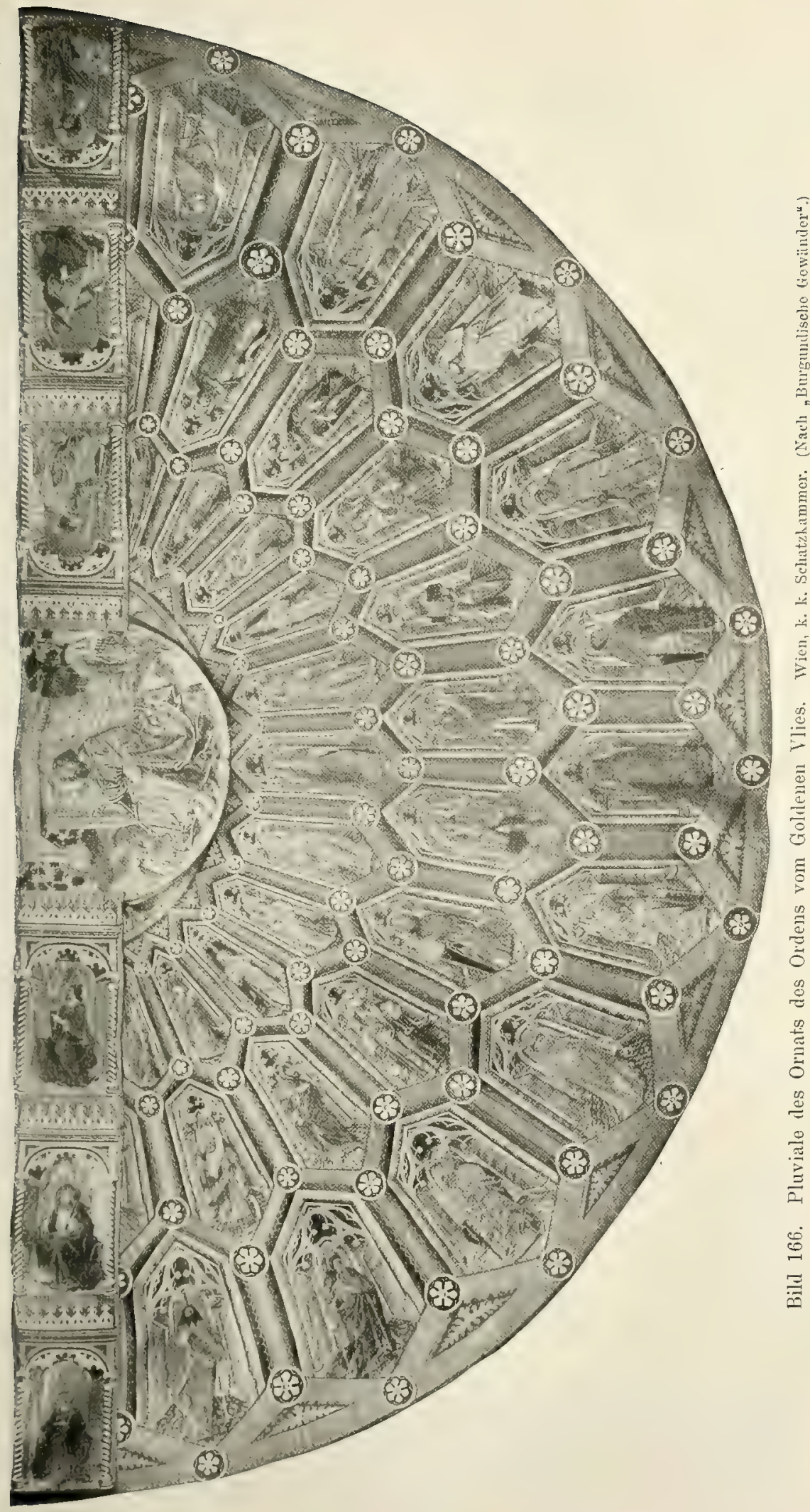


angebracht, von denen sich die untere auf der Peripherie, die obere auf einem zur Peripherie parallelen. die beiden Bogenzonen trennenden Fries erhebt; dann hat er unter diesen zwei Folgen von Bogen die Szenen aus dem Leben des Heilandes, die er sich zum Yorwurf wällte, angeordnet; unzweifelhaft ein ebenso glücklicher wie geistreicher Gedanke, Der Typus erscheint übrigens auf dem Bologneser Chormantel erst in seinem Anfang. Die beiden Arkadenreihen stehen noch zu los und zu unvermittelt übereinander, Vollständiger durchgebildet ist er bei dem zweiten Pluviale von St-Bertrand zu Comminges ${ }^{1}$. Die trennenden Friese sind hier fortgefallen und die Bogen durch Doppelranken ersetzt, die einander umwinden und eine doppelte Reihe von Arkaturen, eine obere kürzere und eine untere längere, initieren. In seiner ganzen Tollendung tritt der Typus seit etwa dem zweiten Viertel des 14. Jahrhunderts bei den Prachtpluvialien von Toledo, von Pienza, von S. Giovanni im Lateran, den im Privatbesitz der Familie Bowden zu Pleasington befindlichen Chormantelresten (Bild 163, S. 342) und den Pluvialfragmenten zu Vich auf ". Wir haben hier überall drei Bogenzonen. Die Architektur ist bald strenger bald freier, immer aber als Flachornament behandelt. Die in der Mitte des Gewandes senkrecht übereinander sich erhebenden Bogen, welche regelmäfig Doppelbogen sind, enthalten stets Gruppen, wozu mit Vorliebe die Verkündigung, die Geburt Christi, die Anbetung durch die Weisen, die Kreuzigung und die Krönung Mariä verwendet werden. Unter den übrigen Bogen sind bald Einzelfiguren bald gleichfalls Gruppen angeordnet. Nur Gruppen besitzen unter den Bogen das Pluviale von S. Giovanni im Lateran und das von Pienza. In den Zwickeln zwischen den einzelnen Zonen haben meistens musizierende Engel Platz gefunden. Bei dem Pluviale von Toledo (Bild 164, S. 343), welches sich durch eine sehr strenge, zugleich aber ungemein edle Behandlung der Architektur auszeichnet, sind die Zwickel ganz weggefallen, dafür aber oberhalb der die Bogen bekrönenden Wimperge zur Ausfüllung des Raumes die für die englische Stickerei des Mittelalters charakteristischen Vögel dargestellt. Bei dem Pluviale von Pienza (Bild 165, S. 344) sind statt der Engel in der unteren Zwickelreihe die Apostel in sitzender Stellung, in der oberen die Brustbilder von acht Ahnen des Heilandes angebracht. Eine eingehende Beschreibung der angeführten Pluvialien, die unstreitig einer Monographie würdig wären, gestattet der Raum nicht. Die Abbildungen der Pluvialien von Bologna, Pleasington (Rekonstruktion), Toledo und S. Giovanni im Lateran mögen einen teilweisen, allerdings sehr geringen Ersatz bieten. Immerhin werden sie das Gesagte besser verstehen helfen und eine allgemeine Idee dieser Prachtpluvialien geben.

Aus dem 15. Jahrhundert verzeichnen wir die drei zum Ornat des Goldenen Flieses gehörigen Cappae (Bild 166, S. 345 ) in der k. k. Schatzkammer zu Wien. Die Errungenschaft des 14. Jahrhunderts, die drei konzentrischen Zonen sind auch hier zur Anwendnng gekommen, weggefallen ist dagegen eine zusammenhängende Architektur. Der Meister, der die Zeichnung für die Pluvialien entwarf, ist wieder auf die frühere Musterungsweise mittels Medaillons zurückgegangen. Indessen hat er sich doch den Fortschritt zu nutze gemacht, den das 14. Jahrhundert zu verzeichnen hatte. Er hat die Medaillons, die er als langgezogene, nach oben zu sich verjüngende Sechsecke bildete, parallel zur Peripherie in Form eines Halbkreises nebeneinandergelagert und überdies die obere und untere Reihe in Weise der Bienenzellen in die mittlere hineingreifen lassen. Die Lösung ist genial, doch läbt sich nicht verkennen, daf die Einrichtung der Frische, des Wechsels und des Lebens entbehrt, welche der Dekoration der Prachtpluvialien des 14. Jahrhunderts in so hohem Maß̉e eigen ist. Viel trägt allerdings dazu bei, daßs die Umrahmung der Felder zu schwer und zu breit ist, ein Fehler, der sich um so fühlbarer macht, je luftiger und lebendiger innerhalb der Iedaillons die Architektur behandelt ist, unter welcher das Bildwerk seinen Platz gefunden.

Im übrigen dürfte man kaum ein Parament finden, welches sich hinsichtlich der T'echnik und der kïnstlerischen Ausfïhrung wie des Adels und des Liehreizes

1 Abhildung bei de Fitrey pl. 31.

2 Abribrungen der I'luv. von S. Giovanni und Vich chd. 11. 43 153; vgl. fïl jenes und die C. zu Pienza anch Revue $1-88,179440$. 
des Bildwerkes mit den Pluvialien des Ordens vom Goldenen Vlies messen könnte. Es sind geradezu herrliche Figuren, diese Engel in der ersten und die Heiligen in der zweiten und dritten Felderreihe, wahre Meisterwerke, korrekt in der Zeichnung, edel in der Haltung, voll Andacht und Innigkeit. Kaum das sich etwas Vollendeteres mit der Nadel schaffen liefe.

Die Aurifrisien der drei Pluvialien enthalten sitzende Heiligengestalten unter spätgotischer, stark gedrückter, mit Perlen reich hesetzter Architektur. Die Schilde, in deren Form schon die eindringende Renaissance merkbar zum Worte kommt, weisen den Heiland als Weltenrichter bzw. die Gottesmutter und den hl. Johannes den Täufer auf.

Die Wiener Pluvialien sind die jüngsten der noch vorhandenen mittelalterlichen Bilderpluvialien. Sie sind das Erzengnis flandrischen Kunstfleibes, um die Mitte des 15. Jahrhunderts entstanden und in Lasurstickerei ausgeführt. Die Fleischteile und die Haare ausgenommen, ist alles andere über Goldfäden mittels feinster Überfangstiche hergestellt.

Flandern war im 15. Jahrhundert ein Hauptfabrikationsplatz grofartiger und kunstvoller Stickereien, im 13. und 14. waren es Frankreich und namentlich England. Immer und immer wieder stöft man in den Inventaren des 13. und 14. Jahrhunderts auf das opus anglicanum, d. i. auf englische Arbeiten, englische Stickereien. So bezeichnet z. B., wie wir hörten, das Schatzverzeichnis von St Peter 1361 drei der darin erwähnten Prachtpluvialien ausdrücklich als opus anglicanum ${ }^{1}$. Es ist denn anch der grölite Teil der vorhin beschriebenen Chormäntel des 13. und 14. Jahrhunderts in der Tat englischen Ursprunges. Drei sind deutscher Provenienz, die Cappae von St Paul, Göfs und Hildesheim; italienischer Herkunft dürfte das Pluviale im Museo civico zu Pisa sein. Bei einigen, wie dem Chormantel von St-Maximin, mag es zweifelhaft sein, ob sie in Frankreich oder England entstanden sincl. Dagegen sind englisches Fabrikat die Pluvialien von Toledo, S. Giovanni im Lateran, Pienza, Steeple Aston, Vich, Comminges, das im Privatbesitz befindliche Pluviale zu Pleasington und die Chormantelreste in Corpus Christ House zu London, die Syon-Cappa und wohl auch die Cappa von Daroca. Der Stil, die Behandlung der Architektur und der Charakter der ornamentalen Motive lassen darüber keinen begründeten Zweifel. Wahrlich, ein glänzenderes Monument hätten sich die englischen Stickel nicht setzen können, als sie es in Gestalt all dieser Prachtpluvialien getan haben. Aber auch in Italien entstanden herrliche, mit Figurenwerk bestickte Pluvialien. In den Inventaren Philipps des Kühnen und Philipps des Guten wird ein derartiger Chormantel ausdrücklich "ouvraige de Fleurence" genannt. Er muf eine Arbeit des ausgehenden 13. oder beginnenden 14. Jahrhunderts gewesen sein, denn die Darstellungen befanden sich in Feldern "de quatre demi compas", d. h. in Vierpässen. Ein solches opus Florentinum mögen die Pluvialreste an der Dalmatik zu Anagni sein. Ebenso ist wohl die Chorkappe im Museo civico zu Bologna italienische und zwar Florentiner Arbeit.

Die Neuzeit hat keine mit Bildwerk verzierten Pluvialien mehr geschaffen. Verschwanden doch seit dem Ende des 16. Jahrhunderts selbst von den Besätzen und dem Schilde rasch die figürlichen Darstellungen. Wohl entstanden kostbare Chormäntel, allein bestenfalls überzog man dieselben in Gold- oder Seidenstickerei mit allerhand Ranken, Blumen und Schnörkeln, oder sogar, wie im 18. Jahrhundert, mit chinesischen Landschaften. Was man aber auch

1 Vgl. auch die Inventare Karls V. von Frankreich, Philipps des Guten u. a. 
so schuf, mit den Prachtpluvialien des 13., 14. und 15. Jahrhunderts kann es nicht in Tergleich kommen, am wenigsten aber, was den geistigen Gehalt der Stickereien betrifft.

\section{URSPRUNG DES GEWANDES. DAS PÄPSTLICHE MANTUM. DIE CAPPA MAGNA UND ALMUTIA.}

Ilan hat die liturgische Cappa auf die römische lacerna zurückgeführt. In der Tat war diese ein dem Pluviale gleichartiges Gewand, weil auch sie ein vorn ganz geöffneter Mantel war, der über dex Brust mit einer Bindvorrichtung oder einer Spange geschlossen wurde. Auch darin ähnelt die lacerna der Cappa, dafs sie gern mit einer Kapuze versehen wurde. Abbildungen eines Mantels von der Art der lacerna finden sich mehrfach auf den römischen und ravennatischen Mosaiken. Auffallenderweise erscheint er hier stets als das die alttestamentlichen Priester charakterisierende Obergewand. So tragen ihn auf den Mosaiken in S. Maria Maggiore zu Rom z. B. Melchisedech, Jethro, die Priester, welche die Bundeslade begleiten usw. ${ }^{1}$; auf den Mosaiken in S. Vitale zu Ravenna und S. Apollinare in Classe Melchisedech ${ }^{2}$; auf dem musivischen Wandschmuck in S. Apollinare nuovo zu Ravenna die Hohenpriester und Priester in den Szenen: Jesus vor dem Hohen Rat, Judas vor den Hohenpriestern, Jesus vor Pilatus und Jesus zum Tode geführt ${ }^{3}$.

Nichtsdestoweniger liegt kein Grund vor, das Pluviale auf die lacerna der Kaiserzeit zurïckzuführen. Abgesehen davon, dab es liturgisches Gewand erst wird, als der Name lacerna schon längst aufer Gebrauch gekommen war, ist ja die liturgische Cappa in ihrem Ursprung nachweislich eins mit dem gleichnamigen Mantel, den die Geistlichen, die Mönche und auch die Laien im Frankenland zu tragen pflegten. Von einer ummittelbaren Ableitung aus der lacerna kann also auf keinen Fall die Rede sein.

Aber auch eine mittelbare scheint fraglich. Denn unter der zur Alltagstracht der Geistlichen und Mönche gehörenden Cappa verstand man zur Zeit, da sich aus ihr das liturgische Pluviale entwickelte -- und so blieb es das ganze übrige Mittelalter - , nicht bloß einen vorn geöffneten, sondern auch einen vorn ganz oder teilweise geschlossenen Mantel von der Art der alten paenula, welche auf den Monumenten vorn bald ganz vernäht, bald bis zur Brust, vereinzelt sogar bis oben aufgeschlitzt erscheint". Was hindert also, die Cappa statt auf die lacerna auf die paenula oder casula zurückzuführen, zumal sie auf den ältesten Darstellungen wirklich als vorn geschlossenes Gewand erscheint?

Übrigens kommt es zuletzt wenig darauf an, ob man in letzter Linie die liturgische Cappa ron der lacerna oder der paenula (casula) herleitet, zumal diese durchaus verwandte Mäntel waren. Die Hauptsache ist - und das steht aufer Frage -, daf sie keine künstliche Schöpfung ist, dalis sie sich vielmehr gerade wie die übrigen gottesdienstlichen Gewänder allmählich

1 Garr. tav. $215^{\prime} 218^{2} 220^{3}$.

2 Ebd. $262^{1} 266^{5}$.

${ }^{3}$ Ebd. $250^{6} 251^{315}$. In der griechischen Kunst erhielt sich das Gewand als Charakteristikum der jüdischen Priester die ganze Folgezeit, in der abendländischen verlor es schon früh diese Eigenschaft. Es kann wohl kein Zweifel sein, dalis es jene Bedeutung nicht im Okzident, sondern in der Kunst des Ostens erhalten hat.

* Ein treffliches Beispiel einer vorn ganz aufgeschlitzten paenula, die mit einer Schnur über der Brust zusammengebunden ist, bildet die Stele eines römischen Soldaten Largennius im Museum zu Strabburg (Abbildung im Bonner Jalıbuch LXVI, T'f 3). 
aus der Alltagstracht herausgestaltet hat. Wir haben aber, wie es scheint, die Entstehung der liturgischen Cappa in den spanischen und fränkischen Klöstern zu suchen. Von hier verbreitete sich dann ihre liturgische Verwendung allmählich im übrigen Abendland. Von grofem Einfluf hierauf war ohne Zweifel der Umstand, daß die Gebräuche hervorragender Abteien gern ron andern Ǩlöstern derselben Ordensfamilie, zumal Tochterklöstern, adoptiert wurden. Insbesondere mögen die manchenorts herühergenommenen Gewolınheiten von Cluny, in denen der Gebrauch der Cappa bei gottesdienstlichen Verrichtungen bereits sehx entwickelt erscheint, nicht wenig zur Befestigung des liturgischen Charakters des Gewandes und zur weiteren Ausbildung der Verwendungsweise beigetragen haben. Waun die liturgische Cappa zu Rom in Brauch kam, lälst sich leider nicht näher bestimmen. Eine klerikale Cappa gab es dort schon wenigstens um den Beginm des 9. Jahrhunderts. wie die cappa more romano consuta beweist, welche Arno von Salzburg Alkuin schickte.

Der Prozes, durch den die klerikale Cappa zum liturgischen Gewand wurde, vollzog sich allem Anschein nach in drei Phasen. In der ersten ist sie lediglich festtägliches Obergewand der Mönche bei der Teilnahme am Gottesdienst und den Prozessionen anstatt der gewöhnlichen schwarzen Cappa. In der zweiten erscheint sie als das eigentümliche gottesdienstliche Obcrgewand der bei der Messe und dem Offizium tätigen Cantores; in der dritten wird sie bei einer Reihe von Funktionen das liturgische Obergewand des Priesters an Stelle der bis dahin bei diesen üblichen Kasel.

In dem ersten Entwicklungsstadium war die Cappa noch kein liturgisches Gewand, sondern nur ein besserer Festtagsmantel, der in der Sakristei aufbewahrt und durch den Prior, den Sakristan oder wer sonst immer damit beauftragt war, den Mönchen beim jedesmaligen Gebrauch übergeben wurde. In dieser Bildungsphase finden wir sie in dem um das Jahr 800 entstandenen Inventar von St-Riquier. Denn die darin erwähnten 200 cappae bedeuten offenbar nichts anderes als feiertägliche Mönchscappae. An die Alltagscappae kann bei ihnen nicht gedacht werden, da diese nicht zum Bestand der Sakristei gehörten; für liturgische Cappae im späteren Sinne ist ihre Zahl zu grof.

Nicht überall mochten aber genug Festtagscappae vorhanden sein, noch auch die Mittel ausreichen, solche in hinreichender Zahl zu beschaffen. In diesem Falle konnte es angebracht erscheinen, zum wenigsten die Cantores an Festtagen mit einer besondern Cappa zu versehen. Wo jedoch die andern Mönche eine solche an bestimmten vorzüglichen Festen allesamt trugen, mochte es als passend gelten, daf die Sänger in Anbetracht ihrer hervortretenden Stellung: beim Gottesdienst sich auch an minderen Festen der Cappa bedienten. Nach römischem Brauch sollten sie freilich die Kasel tragen. Allein es ist mehr als fraglich, ob das auch außerhalb Roms bei Aufnahme des römischen Ritus überall Brauch geworden sei. Jedenfalls verschwand die Kasel bei den Cantores hier schon bald und trat die Cappa an deren Stelle. Diese hatte vor der Kasel den Vorzug, daf die Sänger sie nicht abzulegen brauchten, wenn sie zum Ambo gingen, um dort das Invitatorium usw. zu singen. Denn die Cappa wich in ihrer Erscheinung genügend von der Kasel ab, um die Cantores von dem am Altar fungierenden Priester äulierlich zu unterscheiden. Der Grund, weshalb die Sänger nach römischem Brauch die Kasel für ihre Funktionen auszuziehen hatten, fiel also weg. Namentlich war das der Fall, wenn die Cantores sich einer vorn aufgeschlitzten Cappa bedienten, welche zudem den 
Trorteil mit sich brachte, daf die Sänger freier und ungehinderter ihre Arme gebrauchen konnten.

Dem ersten Schritt folgten bald fernere. Der nächste mag darin bestanden haben, daf man die Cappa bei der Inzensation des Altars während der Matutin und den Vespern zu gebrauchen begann. Weitere Funktionen waren die feierlichen Segnungen, an welche sich Prozessionen anschlossen, wie die Kerzen- und Palmenweihe.

Damit war die Cappa im Prinzip ein liturgisches Gewand geworden, und es konnte sich nur noch darum handeln, das sie als solches allgemein anerkannt wurde, und daf die Gelegenheiten sich endgültig fixierten, bei denen sie anstatt der Kasel zur Verwendung zu kommen hatte.

Die einzelnen Stadien in der Entwicklung der liturgischen Cappa lassen sich zeitlich nicht genau bestimmen. Sie ging nicht überall in gleichem Schritt voran. Hier blieb man länger beim alten, dort war man fortschrittlicher. In manchen Kilöstern und Kirchen scheint man noch eine gute Weile seit dem ersten Auftauchen des Gewandes selbst an Festtagen keine Cappa gebraucht zu haben, indem die Cantores an ihnen lediglich in der Albe fungierten. Zu Rom, wo man von jeher sehr konservativ war, kann die Cappa kaum lange vor der Wende des Jahrtausends unter die liturgische Kleidung Aufnahme erhalten haben. Im 9. Jahrhundert war sie nach Ausweis des S. G. K. dort wohl noch nicht in Gebrauch.

Man hat dem Pluviale ein sehr ehrwürdiges Alter zugeschrieben ${ }^{1}$. Seinen Grund hat das zum Teil darin, dab man den Fragepunkt verkannte. Um nicht in die Irre zu gehen, muls man die Frage so formulieren: Seit wann hat es neben und anstatt, d. i. als Ersatz der Kasel für bestimmte Funktionen ein besonderes liturgisches Obergewand in Sinne eines Mantels gegeben? Aber auch eine sehr ungenügende Ausnützung der monumentalen und schriftlichen Quellen hat nicht wenig zu den Schiefheiten beigetragen, welche betreffs des Alter's und der Entstehung unseres Pluviale geäufiert wurden.

In den orientalischen Riten kennt man kein dem Pluviale analoges liturgisches Gewand. Hier gibt es für alle feierlichen Funktionen nur eine Mantelart2, welche allerdings bei den Armeniern, Syrern, Nestorianern und Kopten der Form nach mit unserem Chormantel verwandt ist. Der Mandyas (urstís der griechischen Bischöfe, ein vorn offener Mantel, hat keinen sakralen Charakter, sondern ist nur ein aulierliturgisches Ehrenkleid, ähnlich wie die lateinische Cappa magna. Er ist gegenwärtig gewöhnlich von violetter Farbe und mit schrägen, meist weib und roten Zierstreifen versehen, den sog.

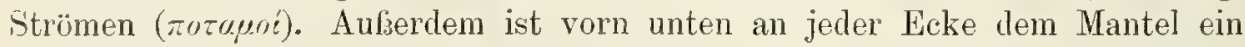
viereckiges Zierstück aufgesetzt, die sog. Gesetzestafeln, welche die heiligen Schriften des Alten und Neuen Testamentes versinnbilden sollen. Die Streifen gelten als Symbole der Ströme der göttlichen Wahrheiten, welche gleichsam vom Bischof aus sich unter das gläubige Volk ergielien sollen. Die viereckigen Besätze unten am Gewand sind mit den zúsjur eins, mit denen man nach Ausweis der Monumente schon im 4. Jahrhundert die chlamys zu verzieren pflegte. Sie waren bald unten an den Ecken, bald höher hinauf in

${ }^{1}$ Nach Gay (Annal, arch. II 154) würde z. B. die Cappa nicht bloß bis ins 6. Jahrbundert hinaufreichen, sondern selbst seit Beginn desselben obligatorisch gewesen sein. Das angebliche Testament Leodebods von Aniane aus dem Jahr 667 (M. 88, 1188), in dem schon Cappae erwïhnt werden, ist unecht.

${ }^{2} \mathrm{Vgl}$, oben S. $234 \mathrm{ff}$. 
der Gegend der Brust angebracht. Das älteste bekannte Beispiel bietet der zu Almendralejo (Estremadura) gefundene Silberdiskus mit der Darstellung des Kaisers Theodosius und seiner Söhne ${ }^{1}$. Um ein und ein halbes Jahrhundert jüngere liefern die Mosaiken in S. Vitale zu Ravenna (Bild 63, S. 159).

Im Anschlub an das liturgische Pluviale sei kurz einiger mit demselben verwandten Gewandstücke gedacht, die zwar keinen eigentlichen sakralen Charakter haben bzw. hatten, jedoch immer noch im weiteren Sinne den liturgischen Gewändern beigezählt werden können. Es sind das päpstliche Mantum, die Cappa magna, die Cappa choralis und die Almucia.

Das Mantum, welches seit dem 11. Jahrhundert bis in die Spätzeit des Mittelalters eine so hervorragende Bedeutung hatte, wird auch wohl cappa, chlamys und pluviale genannt. Den Namen pluviale führt es namentlich in den römischen ()rdines, welche das Gewand bald mit mantum, bald mit pluviale, bald mit beiden Namen zugleich bezeichnen: mantum sive pluviale?

Das Mantum war von roter Farbe und galt wie die Tiara als Abzeichen der päpstlichen Würde. Habes nunc forsitan, schreilt Petrus Damiani an Cadalous von Parma, der sich unter dem Namen Honorius 1I. als Gegenpapst gegen Alexander II. aufgeworfen hatte, mitram (= Tiara), habes iuxta morem romani pontificis rubeam cappam ${ }^{3}$. Die Immantatio, d. i. die Bekleidung mit der cappa rubea nach erfolgter Papstwahl, wal der änliere Ausdruck der Übergabe der päpstlichen Regierungsgewalt, also eine Art symbolischer, von den dazu befugten Wählern nach der Wahl vorgenommener Investitur. Sie bildete gleichsam die tatsächliche Einweisung in die durch den Wahlakt dem Gewählten zugefallenen Rechte, wie sie seitens des letzteren die wirkliche Übernahme dieser Rechte samt allen damit verbundenen Vollmachten bedentete.

Von den römischen Ordines erwähnt zuerst der 12. Ordo Mabillons die Zeremonie 4 Ausführlicher beschrieben wird sie im Ordo Gregors X. (1272 bis 1276). Danach ging sie in der Weise vor sich, dab der Kardinalarchidiakon dem Electus zunächst seine gewöhnliche Cappa auszog, dann ihm Rochet (alba romana), Albe (camisia) und Stola (orarium) anlegte und nun ihm unter den Worten: Investio te de papatu romano, ut praesis urbi et orbi, das Mantum umhing ${ }^{5}$. Wie man sieht, kommt die Bedeutung der Zeremonie in diesen Begleitworten klar und bestimmt zum Ausdruck.

Eine eigenartige Rolle spielte das Mantum infolge dieser mit der Immantatio verbundenen Symbolik bei der Papstwahl des Jahres 1159. Während Kardinal Roland (Alexander III.) aus löblicher Bescheidenheit, wie Arnulf von Luxeuil sagt, das Pluviale, das ihm fast aller Hände nach getätigter

1 Jetzt zu Madrid. Abbildung bei Ca h i er: Curiosités pl, viı.

2 Ordo 18 , п. 23 ; ordo 15 , c. 24 (M. 78 , 110511061287 ).

${ }^{3}$ Epp. 1. 1, n. 20 (M. 144, 242). Andere Stellen, in denen die Bedeutung des Mantum zum Ausdruck kommt, bei Z ü p f f el, Papstwahlen 168 und Grauert, Das Dekret Nikolaus' II. von 1059, in Historisches Jahrbuch 1880,556 .

4 C. 48 (M. 78, 1097): De pluviali rubeo ipsum ammantat.

5 N. 2 (ebd. 1105). Die Angabe des Ordo hinsichtlich der Immantatio stammt un- zweifelhaft aus friiherer Zeit und nicht erst aus dem Ende des 13. Jahrhunderts. Das beweisen die Namen der liturgischen Gewänder: camisia und orarium. Zu Gregors X. Zeit gebrauchte man dafür, wie die übrigen Abschnitte des Ordo beweisen, alba und stola Wenn Petrus Diakonus in der Chronik von Monte Cassino 1.4, c. 2 (M. G. SS. VII 761) beziiglich der Immantatio Urbans II. erzählt: Mox eum cappam lanean exuentes purpuream induunt et in pontificali solio ponunt, so ist das ersichtlich ganz dasselbe wie das, was wir aus der Angabe des Ordo Gregors $\mathbf{X}$. über den Akt erfahren. 
Tahl anboten, zurïckwies, warf sich sein Mitbewerber, der Kardinal Octarian und Gegenpapst Tiktor IV., ein Pluviale, das ihm einige wenige darreichten, mit solcher Ilast um die Schultern, dak er es völlig verkehrt anzog und die Fransen den Hals umgaben, während das obere Ende des Gewandes den Boden berührte ${ }^{1}$. Wirklich entschied das Afterkonzil von Paria auf Grund der frïheren Immantatio zu Gunsten Viktors IV. gegen den rechtmäfỉg erwählten Alexander III.: A saeculo non est exauditum, quod post unius immantationem die transacta alius postea fuerit immantatus ${ }^{2}$. Demgemäß schrieb dem auch Bischof Eberhard von Bamberg an Erzbischof Eberhard von Salzburg: Praevaluit tandem pars domni Victoris ... quia domni Victoris immantatio prior, illa posterior, quo solo Innocentius Anacleto (nämlich bei der Doppelwahl im Jahre 1130) praevaluit ${ }^{3}$.

Die Bedeutung des Mantum verlor sich infolge des Aufenthaltes der Päpste zu Avignon und des daran sich anschließsenden groben Schismas. Der Ordo des Petrus Amelii scheint die Immantatio nicht mehr zu kennen. El* begnügt sich mit der Bemerkung, der Electus wechsele die Kleider.

Die älteste Nachricht über das Mantum findet sich in dem sog. Constitutum Konstantins ${ }^{4}$. Denn wenn darin dem Papst unter andern Gnadenerweisen auch das Vorrecht gewährt wird, eine chlamys purpurea nach Weise der Kaiser zu tragen, so dürfen wir wohl mit Grund anneimen, daf zur Zeit, da das Dokument entstand, heim Papst eine solche schon gebräuchlich gewesen sei.

Was die Form des Mantum anlangt, so war es im 12. Jahrhundert jedenfalls ein vorn ganz offener Mantel. Das beweist die vorhin erwähnte Erzählung Arnulfs von Luxeuil. Ein Gewand von der Art der Kasel hätte sich unmöglich so anziehen lassen, wie es durch Kardinal Octavian mit dem ihm in Eile dargereichten Pluviale geschah. Auch der Name pluviale, den der päpstliche Mantel bereits im 12. Jahrhundert neben mantum fülnte ${ }^{5}$, bekundet, daf dieser schon damals ein dem liturgischen Pluviale gleichartiges Gewandstiuck war. Welche Gestalt es vor dem 12. Jahrhundert besaf, ob es damals vorn offen oder geschlossen war, läfit sich nicht sagen.

Von dem päpstlichen Mantum ist die päpstliche Cappa rubea zu unterscheiden, von der in den späteren römischen Ordines hie und da die Rede ist. Sie war aus Wollstoff oder Samt gemacht, voln bis zur Brust offen und hatte eine mit Hermelin gefütterte Kapuze. Der Papst bediente sich ihrer bei der Totenvesper an Allerheiligen. in den Weihnachtsmetten und bei ähnlichen Gelegenheiten, doch nur in der Zeit zwischen Allerheiligen und Ostern ${ }^{6}$. Sie blieb bis zum Pontifikat Pius' VI. in Gebrauch, seit dessen Tode sie nach Moroni nicht mehr zur Anwendung kam ${ }^{\top}$. Einen eigentlichen liturgischen Charakter hatte die Cappa rubea nicht, sie war vielmehr ein Gewand von der Art der heutigen Cappa magna.

Diese Cappa magna ist das Vorrecht der Kardinäle, Patriarchen, Erzbischöfe, Bischöfe und bestimmter sonstiger Prälaten. Die Cappa der Kardinäle ist in der Regel rot und nur zu gewissen Zeiten, wie in der Fastenzeit,

Arnulfi Lexov. ep. 232 24 (M. 201, 3742 ); Gerhch Reichersb., De investigat. antichristi I. 1 (W atterich, Vitae Pontif. II 505); Duch., L. P. II $397 \mathrm{f}$.

2 M. G. LL. (ed. Pertz) II 126.

M. G. SS. XX 487.
${ }^{4}$ Hinschins, Decret. Pseudo-Isidor. 253.

5 Auch in Rom, wie aus dem ordo 12, c. 48 (M. 78, 1097) hervorgeht.

6 Vgl z. B. ordo 15, n. 775131138 (ebd. 1276131513451347 ).

7 Mor. 8, 83. 
und bei sonstigen bestimmten Gelegenheiten von violetter Farbe; bei den übrigen Prälaten ist sie stets violett. Kardinäle und Prälaten, die einem Orden angehören, welcher eine eigene Tracht hat, bedienen sich einer Cappa von der Farbe der Ordensgewandung ${ }^{1}$.

Durch besonderes Privileg wird auch Kapiteln als Auszeichnung das Recht verliehen, die violette Cappa magna zu tragen, wenngleich mit gewissen Einschränkungen. Sie darf nur in der betreffenden Kirche benutzt werden, auß3erhalb derselben aber bloß dam, wenn das liapitel kollegialiter. d. i. als Korporation, auftritt. Auferdem müssen die Canonici die Cappa zusammengefaltet über den linken Arm legen oder zusammengebunden unter dem linken Arm befestigen. Sie zu entfalten ist nur gestattet, wenn eine diesbezügliche besondere Erlaubnis vorliegt.

Die Cappa magna ist mit grofer Kapuze versehen, die im Winter je nach dem Rang des Trägers mit Hermelin oder grauem Pelzwerk, im Sommer aber mit roter Seide gefüttert ist. Bei den Kardinälen, Bischöfen und Prälaten ist sie obendrein mit langer Schleppe (cauda) versehen, welche von einem Kleriker, dem sog. caudatarius, nachgetragen wird.

Die rote Kardinalscappa (Bild 167) wird schon im Ordo des Petrus Amelii erwähnt, doch ist dort auch die Rede von grünen Cappae der Kardinäle 2. Zur Zeit, da c. 118 des 14 . Ordo entstand, war die Cappa rubea bei diesen noch nicht in Gebrauch. Nur den päpstlichen Legaten war es, solange sie als Legaten fungierten, gestattet, eine cappa rubei coloris an-

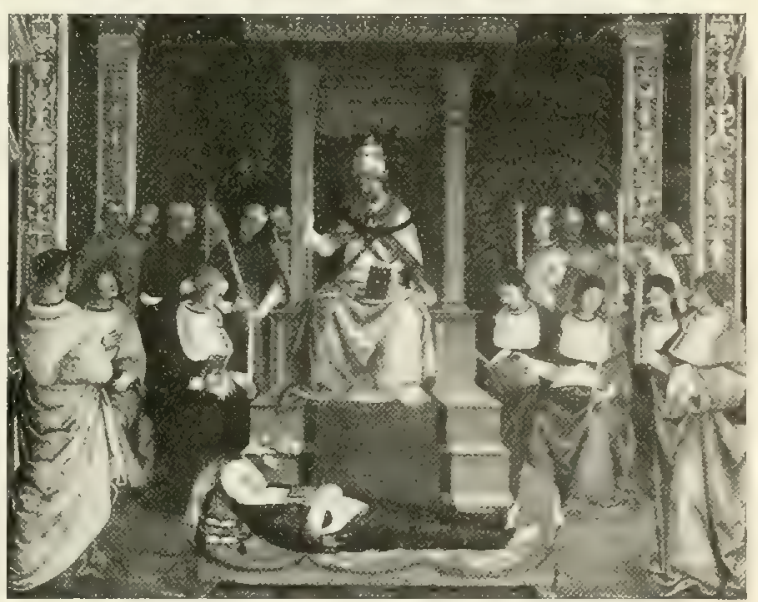

Bild 167. Kanonisation der hI. Katharina.

Fresko Pinturicchios. Siena, Dombibliothek. zulegen ${ }^{3}$. Wenn die Kardinäle auf Giottos Fresko "St Franziskus von Assisi" (Bild 168, S. 354) zum Teil eine rote Cappa tragen, so wird man das wohl auf Rechnung des Künstlers zu setzen haben. Auch der cauda gedenkt schon der Ordo des Petrus Amelii ${ }^{4}$.

Entstanden ist die Cappa magna aus der mittelalterlichen Cappa choralis, weshalb sie noch immer in den Entscheidungen der Ritenkongregation diesen Namen führt.

Die Cappa choralis war ein mit einer Kapuze versehener, bis $z u$ den Füßß㇒en reichender, bald ganz geschlossener, bald halb offener, bald vorn mit einem Schlitz zum Durchstecken der Hände versehener Mantel aus schwarzem Wollstoff. In den mittelalterlichen Ordinaren, Consuetudinaren und Statuten ist oft von ihr die Rede. Sie wurde beim Chorgebet, bei Bittprozessionen sowie den gewöhnlichen Prozessionen benutzt, welche in der Fastenzeit und an Bußtagen mit dem Offizium verbunden waren. Im einzelnen war indessen der Brauch

\footnotetext{
1 Ausführlicheres über die Cappa magna der Kardinäle und Prälaten ebd. $85 \mathrm{ff}$.

2 Ordo 15, n. 145 (M. 78, 1353).

Braun, Die liturgische Gewandung.
}

${ }^{3}$ Ordo 14, n. 118 (ebd. 1273).

4 Ordo 15, n. 145 (ebd. 1353): Tune (camerario) cauda (cappae) non portatur. 
in den verschiedenen Kathedral- und Stiftskirchen nicht der gleiche. Übrigens bediente man sich beim Chorgebet der Cappa nicht das ganze Jahr hindurch, sondern nur im Winter; im Sommer begnügte man sich mit dem Superpelliceum oder Rochett und der Almucia. Als Winter galt nach römischem Brauch die Zeit ron Allerheiligen bis Ostern, genauer von der Totenvesper am Allerheiligentage bis zum Karsamstag ${ }^{1}$. Zu Bayeux begann man die Winterordnung mit den Metten am Fest des hI. Hieronymus (30. September) ${ }^{2}$; in der Kathedrale zu Paris nach Beendigung der Oktav des hl. Dionysius ${ }^{3}$, also am 17. Oktober; zu Vienne mit dem Feste des hl. Martin von Tours (11. November) ${ }^{ \pm}$.

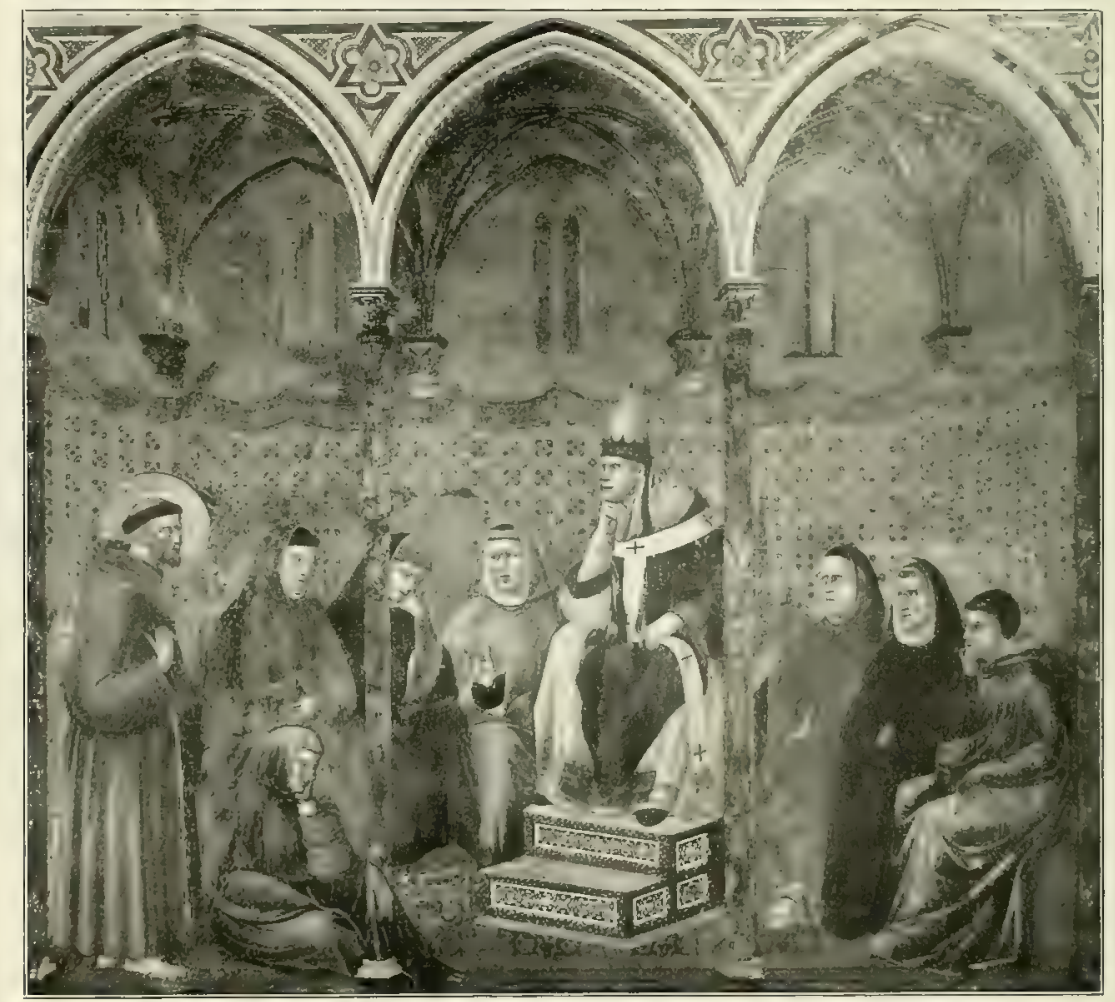

Bild 168. Der hl. Franziskus vor Honorius III. Fresko Giottos. Assisi, Oberkirche von S. Francesco. (Phot. Alinari.)

Wann sich aus der Cappa choralis die im Grunde nichts anderes ist als die gewöhnliche Cappa clericalis, der Alltagsmantel der Geistlichen, die Cappa magna entwickelt hat, läßst sich nicht mit Bestimmtheit angeben. Da der Ordo des Petrus Amelii bereits das Gewand, wenn auch nicht dem Namen, so doch der Sache nach kennt, mufa solches spätestens im Lauf des 14. Jahrhunderts geschehen sein. Im 15. hegegnet uns die Cappa magna auch schon bei französischen Bischöfen; denn die Domherren von Notre-Dame beklagen sich, daks sich der Bischof von Meaux unter Verletzung des Vorrechtes des Bischof's und der Kirche von Paris hier in einer Cappa cum cauda gezeigt und die cauda hinter sich habe nachtragen lassen ${ }^{5}$. Als die Heimat

1 Constitut. Lateran. (iregor. XI. n. 14 (M. 78, 1396).

2 Chevalier, Ordinaixe de Bayeux 252.
3 M art. 1. 1, c. 5, ordo 1; II 182.

4 D. C. sub cappa II 191.

De Vert II 278, note a. 
der Cappa magna wird man die päpstliche Kurie, als ihr Vorbild die Cappa rubea des Papstes anzusehen haben.

Die Almucia (almutia, almucium, armucia, armucium), deren vorhin Erwähnung geschah, war ursprünglich eine bloße Kopfbedeckung. Die Statuta Massiliensia identifizieren sie mit der Kapuze 1, dagegen erscheint sie in den Statuten von St Viktor zu Paris (12. Jahrhundert) im Gegensatz zur Kapuze als eine Art von Mütze ${ }^{2}$. Auch in den Statuta Viennensis ecclesiae ${ }^{3}$, den Synodaldekreten der Synoden von Ravenna aus den Jahren 1314 und 13174, den Konstitutionen Benedikts XII. für den Augustinerorden vom Jahre $1339^{5}$ und den Bestimmungen des Kionzils von Sens des Jabres $1485^{6}$ ist unter almucia eine mützenartige Kopfbedeckung verstanden.

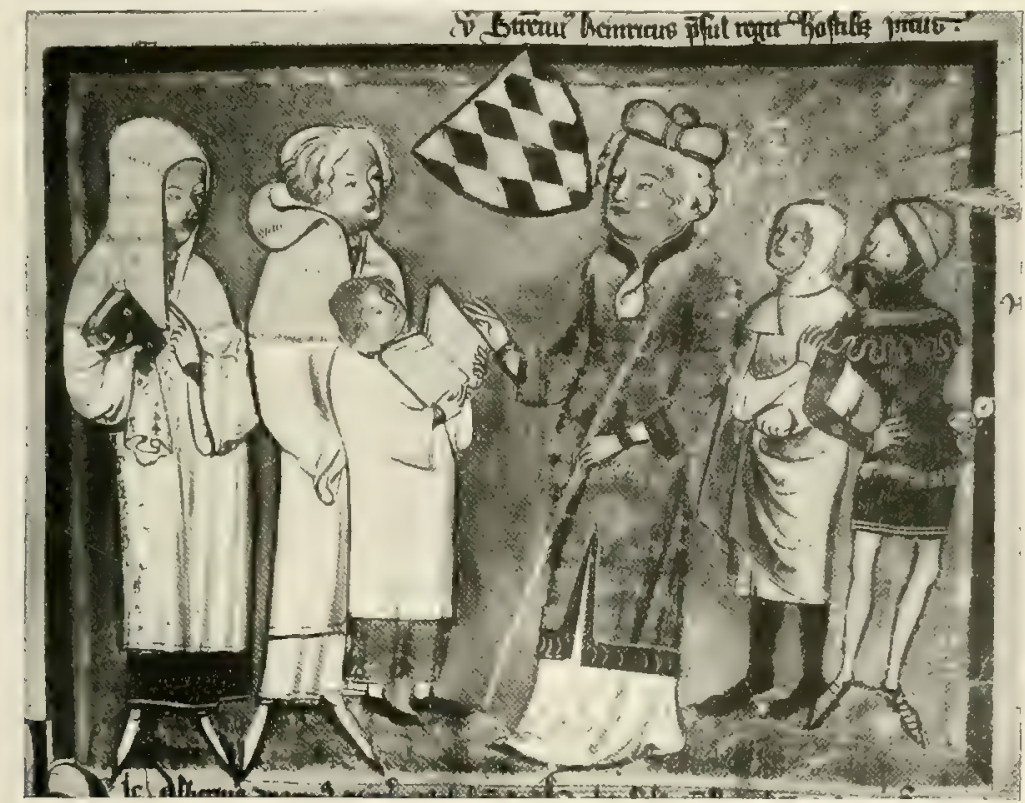

Bild 169. Bischof Albert von Hohenfels ( $†$ 1355) und seine Canonici. Miniatur des Gundekarpontifikale. Eichstätt, Ordinariat.

Radulfs Statuten von Bayeux (ca 1270) unterscheiden zwei Formen der Almucia ${ }^{7}$. Die eine stellte eine förmliche, etwas über die Ohren reichende Mütze dar; die zweite lief im Nacken nach Art einer Kapuze in eine Spitze aus und verlängerte sich nach unten in dem Mafse, dafs sie über Brust und Rücken kragenartig herabhing (Bild 169). Sie wird an einer andern Stelle geradezu caputium genannt. Die erste Art der Almucia sollten jene Canonici der zweiten Stallumreihe tragen, welche Priester oder bei Jahren waren; die übrigen dieser Reihe mufiten unbedeckten. Hauptes am Chorgebet teilnehmen. Die einer Kapuze ähnliche Almucia war dagegen den Canonici der oberen Stalla vorbehalten. So war es wenigstens früher, wie Radulf sagt, gewesen.

I D. C. sub almucia II 191.

2 N. 16 (M a r. t. 1. 4 app.; III 292).

D. C. a. a. $\mathrm{O}$.

- Rubr. 10 (Hard. VII 1387) : capita cooperiant pileo vel bireto vel armutia oblonga ad aures.
5 N. 40 (Bull. rom. IV 446): Infra ecclesias, claustrum, capitulum, refectorium ... non caputiis, sed almuciis honestis utantur.

${ }^{6}$ C. 1 (H a rd. IX 1522): non caputia, sed almucia vel bireta tenentes in capite.

${ }^{7}$ Chevalier, Ordinaire de Bayeux 353. 
Dekan Heribert (1238-1258) hatte seinerzeit solchen Canonici der unteren Stalla, welche sich zu langer Almucien bedienten, erbarmungslos den Befehl gegeben, diese auf das gehörige Maß zurïckzuschneiden. Zur Zeit, da die Statuten abgefast wurden, hatte sich aber, wic ihr Verfasser klagt, der Tnterschied in dem Mafe wieder verwischt, dab sellost die jüngeren Canonici der unteren Stalla im Chor, ja sogar draufen almucias cornutas ante et retro super humeros pendentes trugen.

Im 15. Jahrhundert erscheint die Almucia zwar auch wohl noch in Form einer Kopfbedeckung, meist aber ist sie zu einem förmlichen Kragen geworden, bei dem ihre ursprüngliche Bestimmung ganz oder fast ganz in den Hintergrund getreten war. Dieser Kragen hatte am häufigsten die Form eines Schultermäntelchens, das gegen Ausgang des 15. Jahrhunderts gewöhnlich bis über die Ellbogen reichte, also den Oberarm völlig verhüllte (Bild 170). Bei einer zweiten Form stieg er hinten zwar bis zur Mitte des Rückens hinab, dagegen bedeckte er die Schultern nur bis zu den Armen, während er vorn in zwei lange, schmale Streifen auslief, die nach Art einer Stola über die Brust hinabhingen (vgl. Bild 59, S, 145) ${ }^{1}$. Zwar war an dem Kragen vor wie nach gewöhnlich noch eine kleine Kapuze angebracht, doch war sie ihm mehr als blobe Reminiszenz an die frühere Bestimmung der Almucia, denn zu praktischem Gebrauch angefügt. Als Kopfbedeckung diente vielmehr das Birett, dessen Verwendung seit der ersten Hälfte des 15. Jahrhunderts in erhöhtem Maßie zugenommen hatte. Die Bildwerke des 15. und beginnenden 16. Jahrhunderts bieten zahlreiche Beispiele beider Formen der Almucia, deren Umwandlung in ein kragenartiges Gewandstuck zum nicht geringen Teil eben die Folge der immer größeren Verbreitung war, welche das Birett damals als Kopfbedeckung beim Chorgebet fand.

Was das Material anlangt, aus dem die Almucia bestand, so wurde sie schon im 13. Jahrhundert, wie die Statuten von Bayeux beweisen, gern aus Pelzwerk angefertigt. Zu gewöhnlichen Almucien bediente man sich der Lamm- oder Kalbfelle, zu besseren nahm man die Pelze von Eichhörnchen, Mardern u. ä. Im Innern fütterte man sie entweder mit Pelz oder mit Wollzeug oder Seide. Indessen gab es auch Almucien, die ganz aus Seide oder Wollstoff ${ }^{2}$ gemacht waren. Es waren das besonders jene, welche die Form eines schmalen Schulterkragens hatten.

Bei den Almucien, die aus Pelz hergestellt waren, brachte man gern am Saum. Pelztroddeln an (Bild 170).

Auch die Almucia war nie ein eigentliches liturgisches Gewand, sondern nur ein Bestandteil der Chorkleidung. Wann sie Aufnahme unter diese erhielt, ist nicht festzustellen ${ }^{3}$. Zu Bayeux gehörte sie schon in der ersten Hälfte des 13. Jahrhunderts zu ihr. Die Almucia wurde auch im Sommer beim Chorgebet getragen. Diese ausgiebige Verwendung wurde Anlaf, daf sie zuletzt so eine Art von Insignie der Canonici wurde. Daher kommt es, dals man bei den Grabfiguren von Stiftsherren aus dem Ausgang des 15. und dem Peginn des 16. Jahrhunderts regelmäßrig die Almucia antrifft, es sei denn, daf der Verstorbene in der Melßgewandung dargestellt wird. Zahlreiche

1 Vgl. auch die diesbezüglichen Angaben bei D. C. sub almucia I 191.

${ }^{2}$ Constit. Benedicti XIV. Ordinis canonicorum S. Augustini n. 40 (Bull. rom. IV 446): Almutiac autem, si de pannofuerint, illius coloris, cuius cappae esse debent, existant.

${ }^{3}$ Wegen des noch nicht genügend erklärten Namens almucia vgl. W i e g a n d, Jeutsches Würterbuch II 224. 
Belege hierfür liefern z. B. die Grabplatten im Dom zu Würzburg, im Kreuzgang des Domes zu Regensburg, in der Heiligen Nagel-Kapelle des Bamberger Domes, zu Freising, Halberstadt u. a. Das 5. Mailänder Provinzialkonzil vom Jahre 1579 bezeichnet das Gewandstück ausdrücklich als insigne canonicorum ${ }^{1}$.

Wenn das Provinzialkonzil dabei vorschreibt, die Canonici sollten, je nachdem es Brauch sei, die Almucia entweder auf den Schultern oder auf den Armen tragen, so bekunden diese Worte, daf das Gewand nicht nur nicht aufgehört hatte, Kopfbedeckung zu sein, sondern daß es überhaupt schon vielfach jede praktische Bedeutung verloren hatte. In der Folge geschah das in noch höherem Grade. Wo es sich überhaupt in Gebrauch erhielt, war es zuletzt lediglich Abzeichen, Distinktivum der Canonici oder der sonst zum Tragen der Almucia Berechtigten. Es wurde deshalb auch fast nur mehr auf dem linken Arm getragen und während des Chorgebetes auf das Pult des Chorstuhles gelegt? ${ }^{2}$ Gegenwärtig ist die Almucia nicht viel mehr im Gebrauch, so zu Amiens, Arras, Bayeux, Chartres; an ihre Stelle trat manchenorts durch päpstliches Privileg die sog. Mozzetta.

Die Mozzetta (Mozetta) ist ein mit einer Miniaturkapuze versehener Schulterkragen, welcher vorn mittelst einer Reihe von Knöpfchen geschlossen wird. Sie ist ein Privileg der Kardinäle und Bischöfe, doch wird auch den Canonici hervorragender Kathedralund Stiftskirchen vom Papst das Vorrecht erteilt, sich der Mozzetta zu bedienen. Die Mozzetta besteht aus Seide oder feinem Wollzeug und ist bei den Kardinälen bald rot, bald violett, bei den übrigen Prälaten aber violett, sofern die Kardinäle und Prälaten nicht einem Orden mit eigener Ordenskleidung angehören. Denn dann hat sie, wie die Cappa magna, die Farbe der Ordenstracht ${ }^{3}$.

Über das Alter der Mozzetta sind die fabelhaftesten Ansichten ausgesprochen worden; hat man sie doch bis in die altchristliche Zeit hinaufführen wollen ${ }^{4}$. Es ist das um so auffälliger, als sie in Wirklichkeit ein verhältnismäfig sehr junges Gewandstück ist. Unwahrscheinlich ist, daf bereits das man-

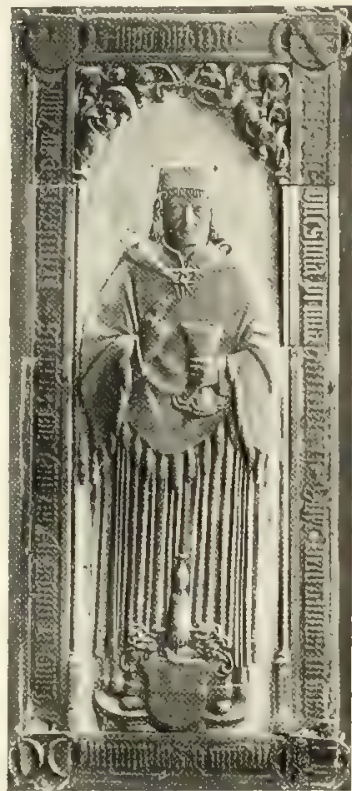

Bild 170. Grabplatte des Georg von Schaumburg († 1514). Bamberg, Dom. tellum, welches im Ordo Gregors X. bei Beschreibung des Festmahls nach der Papstweihe erwähnt wird: cardinales omnes habebunt superpelliceum cum camisia et mantello, mit der späteren Mozzetta identisch ist ``. Immerhin war diese jedoch schon in der zweiten Hälfte des 15. Jahrhunderts in Gebrauch. Das beweist das Fresko Melozzos da Forli "Die Ửbergabe der vatikanischen Bibliothek an den Bibliothekar Platina", auf dem Papst Sixtus IV. in Rochett und Mozzetta dargestellt ist (Bild 58, S. 144). Das Bild wurde 1477 gemalt.

1 Conc. V. Mediol. c. de div. offic. (A. E. Med. 271). Vgl. C. R, 20. Juli 1765 (Decret. auth. 2478).

2 Bei den Pfarrern der Stadt Köln hat sich die Almucia in Gestalt eines weifen Pelzkragens erhalten. In einer Entscheidung der Ritenkongregation vom 29. März 1851
(Decret. auth. 2986) heift die almucia zanfarda. Die Anfrage kam aus der Diözese Adria. 3 Năheres in Kirchenlexikon VIII 1968. Genaue Angaben über die Verwendung im Caerem, episc. 1. 1, c. 3.

4 Mor. XLVII 27.

5. 9 (M. 78, 1111). 
Unsicher ist, seit wann die Mozzetta als spezifisch bischöfliches Gewand gilt. Im 16. Jahrhundert hatte sie schon diesen Charakter ${ }^{1}$. Vielleicht, oder wohl besser wahrscheinlich, daf es von Anfang an so war.

Was den Ursprung der Mozzetta anlangt, so wird sie meist von der Cappa abgeleitet; sie wird nämlich als verkürzte Cappa ausgegeben und demgemäfs ihr Name mozzetta auf das italienische mozzo, verstümmelt (von mozzare, abschneiden), zurückgeführt. So bereits von Pallavicino in seiner Geschichte des Konzils zu Trient, auf dem es bekanntlich wegen der Mozzetta zu vielen Erörterungen kam, weil die spanischen Bischöfe durchaus bei den Sitzungen in ihr erscheinen wollten?. Andere möchten es rorziehen, das Gewandstiick auf die Almucia zurückzuführen. In der Tat besteht zwischen der zum Schulterkragen gewordenen Almucia und der Mozzetta in der Form eine sehr große Ähnlichkeit. Auch bietet zuletzt die Ableitung des Namens mozzetta von almucia nicht melr Schwierigkeiten wie die des Wortes "Mütze", das sich im ausgehenden Mittelalter aus almucia entwickelte ${ }^{3}$. Wir müssen es dahingestellt sein lassen, welche Ableitung die richtige ist. Es ist interessant, zu sehen, wie wenig klar der Ursprung eines Gewandes ist, dessen erstes Auftreten doch gar nicht einmal so fern liegt. Da kann man sich wirklich nicht wundern, wenn Meinungsverschiedenheiten und Unsicherheit hinsichtlich der Ableitung solcher liturgischer Gewänder bestehen, deren Gebrauch in die altchristliche Kirche zurückreicht.

\footnotetext{
1 Conc. IV. Mediol., Const. pars III, c. de Episc. (A. E. Med. 168).

2 Storia del Concilio di Trento 1. 15, c. 13, n. 5 (Roma 1833); II 359 : cappa breve o
}

mozza, che perciò volgarmente è chiamata mozzetta.

3 Wiegand, Deutsches Wörterbuch II 224; Grimm, Deutsches Wörterbuch VI 2839. 
DRITTER ABSCHNITT.

\section{DIE LITURGISCHEN BEKLEIDUNGSSTÜCKE DER HÄNDE, DER FÜSSE UND DES KOPFES.}

ERSTES KAPITEL.

\section{DIE PONTIFIKALHANDSCHUHE.}

\section{NAME DER LITURGISCHEN HANDSCHUHE. DIE PONTIFIKAL- HANDSCHUHE IN DER GEGENWART.}

Die Pontifikalhandschuhe können gleich der Kasel als ein liturgisches Ornatstück in besonderem Sinne bezeichnet werden. Der Bischof, oder wer immer die Erlaubnis hat, sie zu tragen, bedient sich ihrer nämlich blof bei der Feier des heiligen Opfers. Es ist durch Dekret der Ritenkongregation vom 21. Juli 1855 selbst als unstatthaft bezeichnet worden, bei Erteilung des sakramentalen Segens die Handschuhe zu gebrauchen, sei es mit, sei es ohne Schultervelum ${ }^{1}$.

Die offizielle Benennung der Pontifikalhandschuhe ist chirothecae. Ehedem wurde das Ornatstück in den liturgischen Büchern auch wohl manicae und wanti (vuanti, wanta, guanti und ähnlich) genannt. Manicae heifen die Handschuhe beispielsweise im Sakramentar von Corbie ${ }^{2}$, in einem um 1100 entstandenen Pontifikale von Salzhurg ${ }^{3}$ und in dem Weiheordo bei Hittorp ${ }^{4}$. Mit dem zumeist in Frankreich, Deutschland und dem Norden überhaupt gebräuchlichen wantus, woraus später das französische gant, das spanische und portugiesische guante und das italienische guanto sich gebildet hat, bezeichnete man vornehmlich den Handschuh des gewöhnlichen Lebens; als Name des pontifikalen Ornatstückes kommt das Wort weniger häufig vor ${ }^{5}$. Schon im 12. Jahrhundert war chirotheca die vorherrschende Bezeichnung des Pontifikalhandschuhs. Insbesondere heift dieser ausschlieflich so in den päpstlichen Bullen und bei den Liturgikern des 12. und 13. Jahrhunderts.

Nach dem gegenwärtigen Brauch werden die Pontifikalhandschuhe aus Seide angefertigt. Dort, wo sie den Rücken der Hand bedecken, sind sie

1 Decret, auth. 3031 .

2 M art. 1. 1, c. 4, art. 12, ordo 11 ; I 203.

3 Ebd. 1. 1, c. 8, art. 11, ordo 8; II 53.

1 De div, offic. 109. Manica hat als Bezeichnung eines liturgischen Ornatstïckes oinen mehrfachen Sinn. Bald bedentet das Wort den Pontifikalhandschuh, bald den Manipel, bald endlich liturgische Stauchen, diese jedoch nur im altgallikanischen Ritus. In den einzelnen Fảllen mußs der Zusammenhang über den jeweiligen Sinu von manica entscheiden.
So in einem Pontifikale von Besançon (ca 1100 ) bei Mart. 1. 2, c. 1, ordo 3 ; II 153 und in einem Pontifikale von St Remigius zu Reims, ebd. ordo 6; II 156. Auch in Inventaren und Gabenverzeichnissen findet sich die Bezeichnung wantus, so im Testament Riculfs von Elne (915), den Inventaren von Clermont-Ferrand (10. Jahrhundert), dem von Cremona (984) und noch im Schatzverzeichnis von Oberaltaich (ca 1150). Über wantus vgl. D. C. sub wantus VIII 401 und B a rraud in Bullet. mon. 1867, $249 \mathrm{ff}$. 
mit einem Kreuze verziert; auch pflegt das untere Ende, wo der Einschlupf sich befindet, mit einem Zierstreifen oder sonst einem Ornament versehen zu sein. Tie für Kasel, Stola und Manipel, so gelten auch für die Handschuhe die Bestimmungen ïber die liturgischen Farben; nur gibt es keine schwarzen, weil bei Totenmessen und bei der Karfreitagsfeier, bei welchen allein schwarze Paramente zur Verwendung gelangen, das Ornatstück nicht benutzt werden darf.

Der usus chirothecarum steht von Rechts wegen nur dem Papst, den Kardinälen und Bischöfen zu. Wie indessen der Gebrauch der Mitra, der bischöflichen Fußbekleidung, der Dalmatik und Tunicella kraft eines Privilegs Äbten, Dignitaren von Kathedral- und Stiftskirchen und sonstigen Prälaten gestattet wird, so auch derjenige der Pontifikalhandschuhe, natiirlich mit denselben gröberen oder geringeren Beschränkungen, welche für das Tragen der andern Pontifikalien, sei es nach den allgemeinen kirchlichen Bestimmungen ${ }^{1}$, sei es nach dem jeweiligen Indult, gelten.

Nach dem römischen Caeremoniale soll der Bischof, wenn er sich zur Messe rüstet, mit den chirothecae ausgestattet werden, sobald er mit der Dalmatik bekleidet worden ist. Das Anziehen des rechten Handschuhs hat der Diakon, das des linken der Subdiakon zu besorgen. Der Bischof behält das Ornatstück nur bis zur Händewaschung vor der Opferung ${ }^{2}$. Von da an amtiert er bis zum Schluf der Messe ohne die Handschuhe. Für die Dauer des Kanons ist das leicht begreiflich; daf der Bischof sie aber auch nach der Kommunion nicht wieder anlegen dürfe, besagt eine ausdrückliche Entscheidung der Ritenkongregation vom 5. März $1870^{3}$. Die Verwendung, welche die chirothecae bei der Liturgie finden, ist demnach von sehr beschränktem Umfang.

Bei der Bisch ofsw eihe werden die Handschuhe dem Neukonsekrierten von dem Konsekrator selbst unter Beihilfe der assistierenden Bischöfe angezogen. Die Zeremonie vollzieht sich am Schluf der Messe nach dem Segen, sobald das Haupt des Neugeweihten mit der Mitra geschmückt worden ist. Das Gebet , unter welchem die Bekleidung der Hände stattfindet, lautet: „Umgib, - Herr, dieses deines Dieners Hände mit der Reinheit des neuen Menschen, der vom Himmel herabstieg, auf dafs er durch die heilsame Gabe, welche er mit seinen Händen dir aufopfert, so sich deinen Gnadensegen verdienen möge, wie einst Jakob, dein Liebling, sich den väterlichen Segen erwarb, weil er, an den Händen mit der Böcklein Fellchen bedeckt, dem Vater gar willkommene Speise samt Trank darbrachte, durch Christus, unsern Herrn, der sich dir für uns in der Weise des sündigen Menschen selbst hingab. Amen." Christus belud sich mit unsern Sünden. Mit ihm, der für unsere Sünden genugtat, d. i. mit der durch ihn den Menschen zuteil gewordenen Gerechtigkeit, müssen die Hände des Bischofs bekleidet sein, wenn er Gottes Gnadensegen durch das heilige Opfer herabfleht, so wie einst Jakobs Hände mit den Fellchen der Böcklein verhüllt waren, als er dem Vater das gewünschte Mahl darreichte und sich den Erstgeburtssegen erhat. Daran sollen die Handschuhe den Bischof allzeit erinnern.

1 Allgemeine Form für den usus pontificalium seitens der Nichtbischöfe sind die Dekrete Alexanders VII, vom 27. September 1659 (Decret. auth. 1181) und die Kon- stitution Pius' VII. "Decet Romanos Pontifices" vom 4. Juli 1823 (ebd. 2624).

2 Caerem. episc. 1. 2, c. 8, n. 1957.

3 Decret. auth. 3213. 


\section{ALTER DES GEBRAUCHES DER PONTIFIKALHANDSCHUHE.}

In den frühesten $\mathrm{römischen} \mathrm{Ordines} \mathrm{herrscht} \mathrm{betreffs} \mathrm{der} \mathrm{liturgischen}$ Handschuhe völliges Schweigen. Wir hören im 1. und 3. Ordo Mabillons, mit welchen Gewändern die Regionarsubdiakone den Papst bekleiden sollen, sehen gleichsam, wie diese den Pontifex mit Albe, Cingulum und Schultertuch, mit der Tunicella, der Dalmatik und Planeta, mit Pallium und Mappula ausstatten; von chirothecae erfahren wir nichts. Fs wird hier und im Ordo Duchesnes beschrieben, wie der Papst die Oblationen entgegenzunelimen und dann die Hände zu waschen habe, ohne daf der Handschuhe anch nur im geringsten Erwähnung geschieht ${ }^{1}$. Ebensowenig ist endlich von dem Ornatstiick im S. G. K. die Rede, das uns doch mit der gesamten liturgischen Festund Alltagsgewandung des Papstes sowie der Sakralkleidung der sonstigen römischen Geistlichen bis zu den Akolythen herab bekannt macht.

Dieses völlige Schweigen der ältesten römischen Ordines unter Umständen, unter denen Reden sozusagen Pflicht gewesen wäre, kann unbedenklich als Beweis betrachtet werden, dab es zur Zeit ihrer Entstehung, also im 8. und 9. Jahrhundert, zu Rom noch keine Sakralhandschuhe gab. Wären dort solche schon damals in Gebrauch gewesen, so hätten sie doch zweifellos an irgend einer Stelle der Ordines Erwähnung finden müssen, zumal aber in dem S. G. K. und in der Angabe des 1. oder 3. Ordo, mit welchen Gewändern der Papst fuir die Messe versehen werden mufste. Nach Barraud und Rohault de Fleury wären im römischen Ritus freilich schon im 6. oder 7. Jalırhundert die liturgischen Handschuhe zur Verwendung gelangt ${ }^{2}$. Allein beide ïbersehen, dafs der Weiheordo bei Hittorp, auf welchen sie sich stiutzen, nicht den Tagen Pipins, wie sie annehmen, sondern erst dem 11. Jahrhundert angehört. Es ist allerdings richtig, dafi im Ordo vulgatus sich Stücke befinden, welche in das 8. Jahrhundert hinaufreichen, ja noch älter sind; allein das gilt bei weitem nicht von allen seinen Teilen und am wenigsten von dem fraglichen Weiheordo.

Sehr früh sollen schon in Gallien liturgische Handschuhe gebräuchlich gewesen sein. IVenn man indessen die Beweise hierfür etwas näher anschaut, erkennt man bald, dafs es um dieselben herzlich schlecht steht. Was in der Vita der hll. Maria Magdalena und Martha von den Pontifikalhandschuhen des hl. Fronto ${ }^{3}$ und in den Acta S. Hildeverti von denjenigen des hl. Hildevert

1 Ordo 1 , n. 14 ; ordo 2 , n. 9 ; ordo $3,12.12$ (M. 78, 944973 980). Vgl. desgleichen den von Duchesne herausgegebenen römischen Ordo (Orig. 459).

2 Bullet. mon, 1867, 207: L'Ordre romain, que le pape Étienne envoya aux églises de France à la demande de Pépin et qu'Hittorp a publié dans son recueil, contient les rites, que l'on doit suivre pour l'ordination des évêques. Il est prescrit de mettre après l'Évangile les sandales aux pieds du nouveau prélat et de lui donner aussitôt les gants. Cet ordre, fait on remarquer, n'a pas été composé exprès pour être envoyé aux églises des Gaules. Celle de Rome s'en servait auparavant et peut-être depuis assez longtemps. On peut donc en conclure que l'usage des gants remonte au moins au VIe ou au VII siecle. So auch Roh. VIII 192. Hittorp gibt zwei Ordimes für die Bischofsweihe, einon älteren (De div. offic. 106) und einen jüngeren (ebd. 109). Nur der letzte erwähnt die Handschuhe; ỉnn kann darum Barraud blok im Auge gehabt haben.

s C. 49 (M. 112, 1506). Es wird dort berichtet, an dem Sonntagmorgen, an welchem die hl. Martha zu Tarascon habe begraben werden sollen, habe sich St Fronto in der Kirche zu Périgueux befunden, um das heilige Opfer zu feiern. Indem er aber auf das herbeikommende Volk gewartet, sei er auf dem Bischofsstuhl eingeschlafen. Da sei nun plötzlich der Heiland dem Bischof er- 
von Meaux († ca 680) 1 . erzählt wird, sind späte, kaum vor 1000 entstandene Legenden. Die Handschuhe, von denen in den Biographien des hl. Betharius, Bischofs von Chartres $(\dagger \text { ca 600 })^{2}$, und des hl. Philibert, Abtes von Jumièges $(\dagger 684)^{3}$, die Rede ist, bedeuten nach dem Zusammenhange lediglich Handschuhe des gewöhnlichen Lebens, wie sie im Norden allgemein gebräuchlich waren. Ein in St-Sernin zu Toulouse aufbewahrtes Handschuhpaar. welches der hl. Remigius dem hl. Germerius von Toulouse ( $\dagger$ ca 560) zum Geschenk gemacht haben soll, entstammt statt dem 6. erst dem 13. Jahrhundert. Selbst Rohault de Fleury, welcher doch die liturgischen Handschuhe bereits im 6. Jahrhundert in Gebrauch sein läbt, bemerkt bezüglich desselben: Le caractère romain de cet objet ne semble pas le reporter au delà du $\mathrm{XII}^{e}$ siècle .

Die manualia oder manicae endlich, welche in der dem hl. Germanus von Paris $(\dagger 576)$ zugeschriebenen Meßserklärung unter den übrigen dort angeführten liturgischen Gewändern genannt werden ${ }^{5}$, sind nicht Handschuhe, sondern eine Art von Stauchen.

„Bei den sacerdotes (Bischöfe oder wohl besser Bischöfe und Priester)“, so heibt es dort, "ist es Sitte, manualia, d. i. manicae, nach Art der Armbänder (armillae) anzuziehen, welche der Könige oder (heidnischen?) Priester Arme umgeben. Sie bestehen aber aus irgend einem kostbaren Wollzeuge (vellere) ${ }^{6}$, nicht aus hartem Metall, wohl damit alle sacerdotes insgemein,

schienen und habe ihn mit hinïber nach Tarascon genommen, damit er, wie er es der hl. Martha versprochen, an deren Begräbnis teilnehme. Inzwischen habe zu Périgueux das Volk sich in der Kirche versammelt und eine Weile auf den Beginn des Gottesdienstes gewartet. Da es dann jedoch über die Verzögerung ungeduldig geworden, sei man zu St Fronto, dex scheinbar noch immer geschlafen habe, hingetreten, um ihn zu wecken. Erwacht, habe dieser erzählt, was geschehen sei, und hiozugefügt, man möge nach Tarascon schicken und den Ping und die grauen Handschuhe (chirothecas criseas) holen, die er allda der Hand des Sakristans übergeben, während ex den Leib der Heiligen im Grab beigesetzt. Solches habe man dann auch getan und es hätten die Boten richtig dje bezeichneten Gegenstände zu Tarascon vorgefunden. Den Ring und einen der Handschuhe habe man nach Périgueux mitgebracht, der andere sei zu Tarascon als Beweis des stattgefundenen Wunders verblieben. Die Vita B. Mariae Magdalenae et sororis eius Marthae wurde von Faillon (Monuments inédits sur l'apostolat de Sainte Marie-Madeleine en Provence) fälschlich Hraban zugeschrieben (A. SS. 17. Oct., VIII $29 \mathrm{ff}$ et 25. Oct. XI 394). Sie ist nur die Erweiterung einer älteren Legende, über deren Alter und Wert Näheres bei Duchesnes, Fastes épiscopaux I $326 \mathrm{ff}$. Diesclbe findet sich unter anderem in der Legenda aurea Jakobs de Voragine, wo der Vorfall, der sich beim Begräbnis der hl. Martha ereignete, wörtlich wie in der Vita des Pseudo-Hraban erzählt wird.

1 A. SS. 27. Maii, VI 705. Es wird daselbst berichtet, die Handschuhe des Bischofs, welche dieser vor der Konselration ausgezogen habe, hätten drei Stunden lang an einem Sonnenstrahl in der Luft geschwebt. Ähnliche Legenden wiederholen sich auch in den Leben anderer Heiligen.

2 A. SS. 2. Aug., I 170. In der Rezension der M. G. (SS. M. III 617) steht statt chirothecae richtig manicae. Manicae ist unzweifelhaft das Ursprüngliche, da zur Zeit der Abfassung der Vita S. Betharii chirotheca noch nicht gebräuchlich war. Chirotheca ist erst im 10. Jahrhundert nachweisbar.

${ }^{3}$ C. 2 A. SS. 20 . Aug, IV 77.

^ Ebd. VIII 194. Im Schatz des Aachener Münsters wird ein Handschuhpaar aufbewahrt, das irrtümlich dem hl. Germanus von Paris zugeschrieben wird. Seine riesenhaften Mafsverhältnisse beweisen, daf es sich bei ihm entweder nul um Hüllen für Armreliquiare oder um Handschuhe, die über Eisenhandschuhe angezogen wurden, handeln kann.

s. M. 72, 97.

' Daf vellus hier nicht, wie es wohl geschehen ist (Barrand in Bullet. mon. 1867, 229), als Leder zu nehmen ist, ergibt sich aus der Angabe der Meferklürung, daf die Diakonalalbe sirico aut vellere gemacht werde; da diese offenbar nicht aus Leder angefertigt wurde, mußs vellus Wollstoff bezeichnen. 
auch die, welche in der Welt eine mindere Stellung einnehmen, sie leichter haben können. Das kleine Gewandstück, welches lediglich bei der Feier des heiligen Opfers gebraucht wird, bezeichnet etwa, daf unsere Hände nicht mit weltlichen Ehren belastet, sondern mit der erhabenen Ausübung der Gebote Gottes umgeben werden sollen. Prohibet autem manica tonica, ne appareat vile vestimentum aut quocumque indignum tactum sordium super divina sacrificia, quo manus immolantis discurrunt." 1

Man hat unter den manualia bzw. manicae Handschuhe verstanden, wohl, weil manica anderswo wiederholt in dieser Bedeutung vorkommt ${ }^{2}$; doch dürfte eine solche Auffassung kaum zur Beschreibung passen, welche die Meferklärung von ihnen gibt. Sie erscheinen vielmelır als ein armbandartiges, bis zu den Händen reichendes und zur Tunika (manica tonica $[=$ tonicae, tunicae]) gehörendes Schmuckstück, das nicht wie sonst aus Metall, sondern aus Zeug gemacht war, also als Gegenstiuck der Stauchen oder Manchetten, welche in den Riten des Ostens wenigstens schon im 10.-11. Jahrhundert bei der Feier der Liturgie gebraucht wurden und unter dem Namen îruruvike bekannt sind ${ }^{3}$. Es ist um so weniger zweifelhaft, daf dies der Sinn des Wortes ist, weil unmittelbar vorher bei Besprechung der Kasel manica den Sinn ron Ärmel hat.

Es kann selbst in der ersten Hälfte des 9. Jahrhunderts in Gallien noch keine liturgischen Handschule gegeben haben. Bei den Liturgikern der Karolingerzeit, bei Hraban, Amalar und Walafried Strabo, findet sich ebensowenig eine Bemerkung bezüglich einer sakralen Handbekleidung wie beziiglich der Mitra, obschon es nach der Weise, wie sie die liturgischen Gewänder besprechen, offenbar ist, dafi sie den ganzen zu ihrer Zeit gebräuchlichen pontifikalen Ornat behandeIn wollen. Besonders klar tritt dieses Fehlen der chirothecae an zwei bezeichnenden Stellen bei Amalar zu Tage.

An der ersten zählt dieser den liturgischen Ornat des summus pontifex (hier wohl im Sinne von Erzbischof) auf. Danach hatte derselbe, im Einklange mit der Anzahl der Gewänder, welche dem levitischen Hohenpriester eigneten, vom Kopf bis zu den Füken acht Ornatstücke: den Amikt, die Albe, das Cingulum, die Stola, die

1 Das barbarische Latein und vielleicht auch Schreibfehler bieten für Verständnis und Übersetzung des letzten Satzes große Schwierigkeiten. Der Sinn desselben scheint zu sein: Die manica der Tunika hindert, daf das vile vestimentum, wohl die Alltagstunika, zum Vorschein kommt; zugleich sorgt sie dafür, daßs selbiges bei den Handbewegungen des Opfernden die Opfergaben nicht in unpassender Weise berührt. So unseres Erachtens salva meliore interpretatione.

2 So in den Aachener Kapitularien vom Jahre 817 c. 22 (M. G. LL. Capit. I, 345) : Manicas, quas vulgo wantos appellamus, und in der ca 730 geschriebenen Vita S. Guthlaci († 714) n. 26 (A. SS. 11. April., II 44). Im ersten Fall handelt es sich un Mönchshandschuhe, im zweiten um die eines vornehmen Lajen. Auch in c. 12 der Mönchsregeln des hl. Isidor (M. 83, 882) hat manica den Sinn von Handschuh. Andere Beispiele s. oben S. 359. ${ }^{3}$ S: oben S. 99. Auch in der Schenkungs- urkunde der Äbtissin Emhilda des Klosters Milz aus dem Jahr 800 werden manicae erwähnt: manicae 6 ... manicae purpureae 10 . Sie sind nach dem Zusammenhang liturgische Ornatstücke und allem Anschein nach mit den manicae der gallikanischen Meferklärung eins. Handschuhe sind sie auf keinen Fall. Aber auch Manipel können nicht unter ihnen verstanden werden, da diese in der Urkunde fanones heiken: oraria purpurea 4, fanones auro argentoque parati 7 , cetera purpurata (mit Purpurbesatz versehen) 3. Die manicae, welche in einem Inventar von Staffelsee (Bayern) aus dem ersten Dezennium des 9. Jahrhunderts erwähnt werden: manicas sericas auro et argento paratas et alias sericas 4, sind gemäß dem Zusammenhang allem Anschein nach Manipel. An Pontifikalhandschuhe zu denken, verbietet auch hier durchaus der Umstand, daß es sich um ein Inventar einer gewöhnlichen Klosterkirche handelt. 
beiden Tuniken (Tunicella und Dalmatik) und das Pallium. Über die Zahl der jüdischen Pontifikalkleider hinaus $\mathrm{kam} \mathrm{ihm}$ auferdem noch ein vestimentum pedum, die bischöfliche Fufbekleidung, und das sudarium in manu, die Mappula oder der Manipel zu. Von einem vestimentum manuum, d. i. von liturgischen Handschuhen, schweigt Amalarius rollständig: eine Sache, die um so auffäliger ist, als derselbe das Schweifituch in manu der Erwähnung für wert hält ${ }^{2}$. An der zweiten Stelle wiederholt der Liturgiker kurz den ganzen Ornat (omnem ornatum) der Geistlichen, d. i., wie aus der Aufzählung erhellt, der Bischöfe, Priester und Ministri. Aber auch hier spricht er mit keiner Silbe von der liturgischen Handbekleidung ${ }^{2}$. Ob Amalar wohl, so darf man mit allem Recht fragen, an beiden Stellen die chirothecae übergangen hätte, wenn sie zu seiner Zeit im römischen Ritus des Frankenreiches zum liturgischen Ornat des Bischofs gehört hätten? Will man dagegen geltend machen, daf er doch auch Stab und Ring nicht erwähne, obschon diese bereits seit langem Insignien der Bischöfe waren, so ist $\mathrm{zu}$ bemerken, daßs er nicht von den bischöflichen Insignien, sondern von der liturgischen Gewandung handeln will und tatsächlich handelt. Er hatte daher keine Veranlassung, von Ring und Stab zu sprechen, die ja auch niemand als ,vestimenta" betrachten wird".

Erst das 10. Jahrhundert bringt uns von der Verwendung liturgischer Handschuhe Kunde. Schon um 900 werden in zwei Inventaren der Basilika zu Monza manicae, wie es scheint, im Sinne von Pontifikalhandschuhen aufgefühtt. 915 vermacht Riculf von Elne seiner Kathedrale aufier andern liturgischen Gewändern wie caligae, sandalia, amictus, albae, stolae, zonae, manipuli und casulae episcopales auch vuanti paria unum (sic). Etwas später

1 De offic. eccl. 1. 2, c. 22 (M. 105, 1098).

2 Ebd. c. 26 (ebd. 1102).

3 Es können daher die zwei kastanienfarbigen, mit Gold verzierten wanti des 831 aufgestellten Inventars von St.Riquier samt den beiden dort erwähnten linnenen wanti keine liturgischen Handschuhe im späteren Sinne sein. Die Äbte hatten ja auch im Beginn des 9. Jahrhunderts noch nicht das Recht, sich der Pontifikalhandschuhe zu bedienen. Die wanti castanei auro parati 2 , linei 2 mögen angelegt und getragen worden sein, wenn man mit heiligen Gegenständen, z. B. mit Reliquien, umzugehen hatte. Wenn man aher nach dem Bericht des von Johannes Longus ( $\uparrow$ 1383) verfafiten Chron. monast. S. Bertini c. 13 (Mart., Thes. III 516) im 14. Jahrhundert zu St-Bertin bei St-Omer aufer andern Gewändern des hl. Folcuin, Bischofs von Térouanne ( $†$ 855), auch dessen Mitra und Handschuhe zu besitzen sich rühmte, so dürfen wir heute ohne Bedenken, wie die zweifellos falsche Mitra, ebenso diese Handschuhe als unecht bezeichnen. Wahrscheinlich übrigens, daf es sich bei diesen Handschuhen, der Mitra und den andern Gewandstücken um Gegenstände handelte, mit denen in späterer Zeit bei einer Rekognition der Leichnam des Heiligén neu bekleidet worden war, und die ntan dann bei einer neuen Erhebung irrtimlich für ursprünglich ansah, ein Vorgang, der sich im Mittelalter wiederholt abspielte.
* Manicas 1 paratas heift es im ersten, manicas $2 \mathrm{im}$ zweiten der beiden Inventare. Manipel können nicht gemeint sein, da sie unter dem Namen mappula besonders aufgeführt werden; zudem weist die Ausdrucksweise des ersten Inventars auf einen als Paal vorhandenen Gegenstand hin. Handschuhe blof zum Anfassen von Reliquiaren u. ä. scheinen durch den Zusammenhang ausgeschlossen. Es kann also blof an liturgische Stauchen oder an liturgische Handschuhe gedacht werden. Die meiste Wahrscheinlichkeit hat die letzte Auffassung für sich, da um den Beginn des 10. Jahrhunderts wohl kaum mehr liturgische Stanchen zur Verwendung kamen, und es obendrein fraglich ist, ob man je in der Mailänder Kirchenprovinz solche gebraucht habe. Auffallen könnte nux, daf in dem Inventar einer nichthischöflichen Kirche Pontifikalhandschuhe erwähnt werden. Jedoch läibt sich das hier genügend erklären. Das zweite Inventar ist uberschrieben: De capella domni Perengarii (sic) regis, quando ego Adalbertus magistro meo Egilolfo praesentavi. Dieser Egilolf, dem der Kustos der Schätzo, der Subdiakon Adalbert, bei einer Visitation die ihm anvertrauten Geräte und Paramente vorwies, ist aber kein anderer als Bischof Egilolf von Mantua, der in einem Dokument Berengars von 902 zugleich als sacri palacii nostri archicapellanus erscheint. Es ist also leicht zu verstehen, wenu im Inventar Pontifikalhandschuhe exwähnt werden. 
verzeichnet ein Inventar von Clermont-Ferrand neben galeas (caligas) paria tria gantos paria quattuor. Im letzten Viertel des 10. Jahrhunderts begegnen uns liturgische Handschuhe im Sinne der nachherigen Pontifikalhandschuhe im Inventar von Cremona und im Sakramentar Ratolds von Corbie, hier unter dem Namen manicae ${ }^{1}$. Das letztere weist den Bischof, der sich zur Feier des heiligen Opfers rüsten will, an, zunächst sich mit den pontifikalen Strümpfen, den Sandalen, dem Amikt, Cingulum und Balteus, der Stola und Tumika zu bekleiden, dann die Hände zu waschen und sich das Haar ordnen zu lassen. Hierauf soll der Minister ihm die manicae anziehen und an die rechte Hand über die manica, die hier offenbar einen Handschuh, und zwar einen sog: Fingerhandschuh, bedeutet, den bischöflichen Ring legen. Der Bischof hat die manicae zu behalten, bis er nach Entgegennalıme der Opfergaben dic Hände wäscht. Dann soll er sich ihrer entledigen und des weiteren ohne Handschuhe fungieren. Auch der um 1080 zusammengestellte, unter dem Namen Missa Illyrica bekannte Ordo kennt die Pontifikalhandschuhe bereits, wie aus der Rubrik ad induendas manus erhellt?

Welche Verbreitung die liturgischen Handschuhe während des 10. Jahrhunderts hatten, lälit sich nicht feststellen. Grob wird dieselbe aber damals noch nicht gewesen sein, da des Ornatstïckes nur in dem Sakramentar von Corbie Erwähnung geschieht. Alle übrigen schweigen von demselben. Freilich ist nicht zu übersehen, dak die Pontifikalien und Sakramentare damaliger Zeit überhaupt über die Pontifikalkleidung nur wenig Angaben machen, wie sie selbst mit Rubriken erst spärlich versehen erscheinen. Indessen sind ja auch sonstige Nachrichten über die Existenz der Pontifikalhandschuhe im 10. Jahr'hundert noch selten. Denn es sind im ganzen doch nur vier Inventare, welche solche erwähnen.

Zu Rom muß die Velwendung liturgischer Handschuhe sicher schon in der ersten Hälfte des 11. Jahrhunderts heimisch gewesen sein, da seit 11175 der Apostolische Stuhl wiederholt einzelnen $\ddot{\Lambda}$ bten das Privileg erteilt, wie die bischöfliche Dalmatik, die Sandalen und Mitra, so auch die chirothecae zu gebrauchen.

Allerdings folgt aus einer solchen Gewährung der Befugnis, die Handschuhe zu tragen, an sich noch nicht, daf man sich auch zu Rom ihrer beim Gottesdienst bedient habe. So gestattete der Papst im 11. und 12. Jahrhundert mehrfach Bischöfen den Gebrauch des Rationale ${ }^{3}$, ohne daß dieses jemals ein Bestandteil der römischen Pontifikalkleidung gewesen wäre. In unserem Falle liegt die Sache indessen anders, da ja die Pontifikalhandschuhe nicht lange nachher tatsächlich auch als Ornatstïck des römischen Ritus sich nachweisen lassen ".

Ob aber die römische Kirche auch schon im 10. Jahrhundert die sakrale Handbekleidung gekannt habe, ist unsicher. Wohl gibt es zwei Bullen Iohannes' XV. aus den Jahren 986 und $993^{5}$, in welchen der Papst den Äbten der Klöster Cielo d'Oro zu Pavia und Braunau die Erlaubnis erteilt, sich der. Pontifikalhandschuhe zu bedienen. Doch gestatten dieselben nicht einmal

${ }^{1}$ M a r t. 1. 1, c. 4, art. 12, ordo 11; I 203.

2 Ebd. ordo 4; I 177.

3 Über das Rationale, einen liturgischen Schulterschmuck, s. unten Abschnitt 4.

4 Als im Jahr 1606 gelegentlich des Neubaues der Peterskirche das Grab Hadrians IV. († 1159) eröffnet wurde, fand man die Hände der Leiche mit den Pontifikalhandschuhen bekleidet (Grimaldi, Instrum. authent. translat. ss. corporum et ss. reliqua rum e veteri in moram principis apostolorum basilicam (Bibl. Vatic., Barber. XXXIV, n. 49, f, $\left.184^{r}\right)$.

5 J. n. 38263849 . 
einen sichern Schluls auf die Verwendung liturgischer Handschuhe auferhalb Roms, weil beide Schriftstizcke nicht zuverlässig sind.

Interessant ist es, dafis schon in der ersten Hälfte des 12. Jahrhunderts Honorius in seiner Gemma animae den Gebrauch der Pontifikalhandschuhe auf die Apostel zurïckführt ${ }^{1}$, freilich ohne auch nur im geringsten einen Beweis dafür zu versuchen. Und doch waren erst 200 Jahre verflossen, seitdem die Handschuhe unter den liturgischen Gewändern einen Platz erhalten hatten. So rasch geraten Dinge oft in Vergessenheit.

\section{DIE PONTIFIKALHANDSCHUHE IM XII. UND XIII. JAHRHUNDERT.}

Von den Liturgikern, welche um die Wende des 11. und in der ersten Hälfte des 12. Jahrhunderts schrieben, schweigen Ivo von Chartres und Rupert

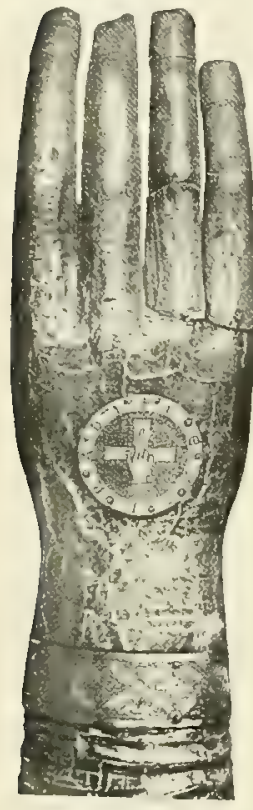

Bild 171.

Armreliquiar.

Essen, Münsterschatz. (Nach Humann.) von Deutz bezüglich der Pontifikalhandschuhe. Bei Ivo mag das einigermafen auffallen, bei Rupert kaum, da dessen Behandlung der Sakralkleidung auch sonst lückenhaft ist. Von Belang: ist aber nicht einmal das Schweigen des Bischofs von Chartres, da ja seine Zeitgenossen Bruno von Segni, Honorius und Gilbert von Limerick die. Handschuhe ausdrücklich zu dem bischöflichen Sakralornat rechnen.

In der zweiten Hälfte des 12. Jahrhunderts zählen der Verfasser des Speculum mysteriorum ecclesiae sowie Robert Paululus die chirothecae zu den specifisch bischöflichen Gewảndern, um 1200 tun solches Sicard und Innozenz III. Novem autem sunt ornamenta pontificum specialia, videlicet caligae, sandalia, succinctorium, tunica, dalmatica, mitra et chirothecae, anulus et baculus, sagt letzterer.

Unter den römischen Ordines Mabillons spricht erst der 13. von den chirothecae? Sie erscheinen in ihm als Bestandteil der Pontifikalkleidung des Papstes. Der 14. Ordo erwähnt aufer den Sakralhandschuhen des Papstes auch diejenigen der Kardinalbischöfe ${ }^{3}$. Daf im 10, 11. und 12. Ordo Mabillons, welche allesamt dem 12. Jahrhundert entstammen, die Pontifikalhandschuhe nicht vorkommen, erklärt sich durch den Umstand, daf dieselben überhaupt von der liturgischen Kleidung nirgends eingehender handeln und nur das eine oder andere Gewand gelegentlich und fast wie durch Zufall nennen.

In den Weihe-Ordines begegnen uns die Handschuhe schon gegen das 12. Jahrhundert, wenngleich erst sehr vereinzelt". Doch werden sie bald auch schon in dem Ritus der Benedictio abbatum erwähnt ${ }^{5}$.

Auf den Monumenten treten die Pontifikalhandschuhe auffälligerweise in ziemlich später Stunde auf. Im 12. Jahrhundert sind die Bildwerke, auf wolchen sie uns begegnen, noch äufierst selten. Genannt sei das prächtige

1 L. 1, c. 215 (M. 172, 609). Chirothecarum usus ab apostolis - nicht epistolis, wie bei Hittorp und Migne steht - traditus est. Honorius folgen oder besser sehreiben ab: Pobert Paululus, De caerimoniis, sacramentis et offic. eccl. 1. 1, c. 56 (M. 177, 406), Sicard, Mitralis 1. 2, c. 5 (M. 213, 79) und Durandus, Rationale 1. 3, c. 12 (a. a. O. f. 75). Bei
Durandus heift es: Pontifex iuxta ritum apostolorum manus operit chirothecis.

${ }_{2}$ N. 6 (M. 78, 1108).

${ }^{3}$ C. 4853 (ebd. 1153 1157).

${ }^{4}$ Mart. l. 1, c. 8, art. 11, ordo 8 (Pontifikale von Salzburg); II 53. Hitt. 109.

5 Ebd. 157. Mart. 1. 2, c. 1, ordo 3 (Pontifikale von Iiesançon); II 153. 
Armreliquiar mit Reliquien des hl. Basilius im Schatz der Münsterkirche zu Essen (Bild 171). Horizontale Reihen kleiner schräger Linien, die sich in der einen nach rechts und in der folgenden nach links neigen, deuten die Technik an, in welcher sich der Künstler den Handschuh hergestellt dachte ${ }^{1}$. Zahlreicher werden bildliche Darstellungen mit Wiedergabe der Pontifikalhandschuhe erst nach 1200 , besonders seit $1250^{2}$. Um diese Zeit finden sie sich auch zuerst auf den Siegeln, so z. B. auf dem Siegel Roherts von Beauvais (1237-1248), Thomas' von Reims (1251-1263), Wilhelms von Sens (1258-1267), Erhards von Auxerre (1271-1279), Guidos von Bourges (1276-1281)3, Johannes' von Langres (1295-1305), Siegfrieds von Augsburg (1208-1227), Hermanns von Halberstadt (1296-1304), Siegfrieds von Köln (1275-1297), Heinrichs II. von Mainz $(1286-1288)^{4}$ u. a. Auch auf den Bischofsbildern des Gundekar-Pontifikale zu Eichstätt zeigen sich die Handschuhe erst bei Reimboto von Meilenhard ( $\uparrow 1297)$, also erst um das Ende des 13. Jahrhunderts ${ }^{5}$. Der Grund, warum die Handschuhe bis ins 13. Jahrhundert hinein nur selten auf den Bildwerken auftreten, mag teils in der Schwierigkeit liegen, welche ihre bildliche Wiedergabe den Kiinstlern bot, teils vielleicht in dem Umstand, daf sie bis dahin als ein wenig bedeutsames Ornatstiick galten. In der Tat konnte die geringe Verwendung, die sie in der Liturgie fanden, ihneu nur einen sehr untergeordneten Wert verleihen. Es mag selbst einigermafen fraglich sein, ob die Handschuhe schon vor der Mitte des 12. Jahrhunderts allgemein bei den Bischöfen in Gebrauch gewesen sind. Wenigstens ist es auffallend, dab in den Inventaren bis dahin fast nur ausnahmsweise von Pontifikalhandschuhen die Rede ist. Auf den Siegeln kommen die Handschuhe erst vor, oder vielleicht besser, sind sie erst erkennbar, als sich ihr unteres Ende zu einer Art von weiten Stulpen entwickelt hatte.

\section{VERLEIHUNG DES USUS CHIROTHECARUM AN NICHTBISCHÖFE.}

Die Sakralhandschuhe erscheinen niemals als ein spezifisch römisches Ornatstück wie die Dalmatik, die Sandalen, die Caligae und die Mitra. Nirgends findet sich insbesondere eine Andeutung, dab jemals der Apostolische Stuhl einen Bischof mit dem Recht, sich ihrer zu bedienen, begabt hätte. Dagegen hatten die liturgischen Handschuhe nach römischem Brauch und Recht stets den Charakter eines bischöflichen Sondergewandstückes, welches Nichtbischöfen nur kraft einer päpstlichen Ermächtigung zustand. Die elsten Beispiele einer solchen bringt das Pontifikat Johannes' XV., welcher, wie schon erwähnt wurde, die chirothecae dem Abte der Klöster S. Pietro in Cielo d'Oro ${ }^{6}$

${ }^{1}$ G. Humann, Die Kunstwerke der Münsterkirche zu Essen, Düsseldorf 1904, TA 39 , S. 291. Der Verfasser hat nicht beachtet, daf die Hand des Armreliquiars einen Handschuh aufweist.

${ }^{2}$ Hervorragende Beispiele liefert das Bildwerk der Portale französischer Kathedralen, wie Chartres, Amiens und Reims.

3 Roh. VIII 195.

4 Würdtwein, Nova subsidia IV, tab. 21.

Sonstige Beispiele aus derselben Zeit siehe bei Roh. VIII 196, pl. DcLxxIx, sowie bei Barraud, Des gants dans les cérémonies religieuses (Bullet. mon. 1867, 22 f). Wegen der französischen Bischofssiegel vgl, auch G. Demay, Le costume au moyen âge d'après les sceaux, Paris 1880, 293: Ils ne paraissent sur les sceaux d'un façon distincte, mais sans détails que vers le milieu đu $13^{\circ}$ siècle.

${ }^{6}$ J.n. 3826. Die Bulle scheint zum mindesten interpoliert zu sein. Es existiext eine ganze Reihe von Bullen, in welchen dem Abte von S. Pietro in Cielo d'Oro neben andern bedeutsamen Privilegien das Vorrecht verliehen wird, sich bischöflicher Ornatstücke, wie der Dalmatik, der Sandalen, der Handschuhe und später auch der Mitra, zu bedienen. Eines dieser Dokumente, eine Bulle Kalixts II. 
und Braunau verlieh ${ }^{1}$, wofern es mit den betreffenden Bullen seine Richtigkeit hat. Jedoch ist das sehr fraglich, da die darin gewährten Privilegien im Vergleich mit denjenigen, welche in unzweifelhaft echten Bullen noch in der ersten Hälfte des 11. Jahrhunderts verliehen werden, ungewöhnlich weit gehen. Namentlich gilt das von dem Braunauer Dokument. Überhaupt lassen sich sichere Verleihungen des Privilegs erst um das letzte Viertel des 11. Jahrhunderts nachweisen. Wohl liegen zwei Bullen vor, in denen Leos IX. dem Abt Balduin von S. Pietro in Cielo d'Oro ${ }^{2}$ und dem Abt Johannes von S. Giustina zu Padua ${ }^{3}$ den usus chirothecarum gewährt. Allein das erste dieser Dokumente ist nicht über alle Zweifel erhaben, das zweite sicher eine Fälschung. Wenn aber die Chronik von Monte Cassino berichtet, Leo habe dem Abt Richerius daselbst gestattet, sich der Pontifikalhandschuhe zu bedienen ${ }^{4}$, so beruht diese Angabe auf einem Irrtum des Chronisten.

Allerdings mag Leo dem Abte die Erlaubnis erteilt haben, sich gewisser Pontifikalien zu bedienen; doch mufs diese sich auf die Sandalen und die Dalmatik beschränkt haben. Das beweisen die noch vorhandenen Bullen Viktors II. (1057) ${ }^{5}$ und Nikolaus' II. $(1059)^{6}$, welche des Richerius Nachfolgern, den Äbten Friedrich und Desiderius, nur das Privileg zu teil werden lassen, Sandalen und Dalmatik zu tragen. Hätte Leo IX. ihrem Vorgänger schon den usus chirothecarum gestattet, so wäre die Nichterwähnung der Handschuhe in den Bullen Viktors und Nikolaus' kaum erklärlich.

Die erste Urkunde, an deren Zuverlässigkeit ein ernster Zweifel wohl nicht mehr erhoben werden kann, ist die Bulle, in welcher Alexander IV. 1070 dem Alot von S. Pietro in Cielo d'Oro den usus chirothecae zugesteht ${ }^{7}$.

Urban II. verleiht dann die chirothecae 1088 dem Abte Hugo von Cluny Paschalis II. 1105 Anselm von S. Pietro in Cielo d'Oro ${ }^{9}$, dann 1109 Pontius von Cluny ${ }^{10}$ und 1113 Johannes von Nonantula ${ }^{11}$. Der Afterpapst Anaklet II. erfreut 1130 mit ihnen Simon von Rastede in Oldenburg. ${ }^{12}$ und zwischen 1131 und 1136 Franco von S. Sophia zu Benevent ${ }^{13}$. Honorius II. gewährt den Gebrauch der Pontifikalhandschuhe 1125 dem Abt Tribunus von S. Giorgio Maggiore zu Venedig "*, Alexander III. aber 1159 Rainald von Monte Cassino ${ }^{15}$, 1169 Marin von La Cava ${ }^{16}$ und 1176 dem Abte des von Wilhelm II. gegründeten Klosters Monreale auf Sizilien ${ }^{17}$. Die Echtheit aller dieser Privilegien steht außer Frage; es kamen somit die Handschuhe schon sicher seit etwa dem letzten Viertel des 11. Jahrhunderts bei einzelnen Äbten kraft einer besondern päpstlichen Ermächtigung zur Verwendung.

Es muf übrigens auffallen, daß3 der usus chirothecarum verhältnismäßig nicht gerade häufig den Äbten zu teil wird. Selbst das Recht, die Mitra zu tragen, wird

vom 11. April 1120 für Abt Balduin, ist sicher unecht (J, n, 6841). Folgt daraus zwar nicht, dafs auch die ïbrigen Fälschungen sind, so ist doch die Unechtheit der Bulle Kalixts dem Vertrauen auf die Zuverlässigkeit der andern nicht gerade förderlich (Pflugk-Haxttung II 74). Die Pontifikalstrümpfe, welche in den späteren Bullen. nicht mehr genannt werden, heifen in der Bulle Johannes' $X V$. auffälliger- und ungewöhnlicherweise pedules.

1 J. n. 3849. Die Bulle ist unzweifelhaft interpoliert. Fraglich ist nur, was Einschiebsel ist. Die mitra gehört jedenfalls nicht dem. ursprüinglichen Text an; sie findet sich in der Tat nicht in der Rezension bei Ludewig, Reliquiae manuscr. dipl. VI 54. Unverständ- lich ist, was die mapilla (M. 137, 847) bzw. die manipularii bei Ludewig bedenten sollen. $\mathrm{Ob}$ Baldachin bzw. Baldachinträger?

2 J. n. 4233. Hier heifsen die Pontifikal. strümpfe richtig nach römischem Brauch udones, sie werden jedoch merkwürdigerweise doppelt erläutert: i. e. licinis sive pedulibus.

${ }^{3}$ Ebd. n. 4300.

4 Chron. Cassin. 1. 2, c. 79 (M. G. SS. VII 683).
5 J. n. 4368 .
6 Ebd. n. 4397.
7 Ebd. n. 4679.
9 Ebd. n. 6011.
11 Ebd. n. 6354.
13 Ehd. n. 8428.
15 Ebd. n. 10594.
8 Ebd. n. 5372.
10 Ebd. n. 6242.
12 Ebd. n. 8372.
14 Ebd. 13. 7211.
16 Ebd. n. 11591.

17 Ebd. n. 12683. 
ihnen weit öfter gewährt als der Gebrauch der Pontifikalhandschuhe. So wurde schon 1063 Egelsinus, Abt vom Augustinuskloster zu Canterbury, und 1078 Manasses, Abt von Bergues, mit der pontifikalen Kopfbedeckung, nicht aber mit den Handschuhen ausgezeichnet. Noch zur Zeit des hl. Bernhard kann der usus chirothecarum bei den Ähten nur wenig verbreitet gewesen sein. Wenn der Heilige nämlich in seinem Brief an Bischof Heinrich von Soissons einige Äbte wegen ihrer übermäßigen Sucht nach pontifikalen Ornatstücken bitter tadelt, so versteht er darunter blof Dalmatik, Mitra und Sandalen. Immerhin ist es beachtenswert, daf schon im 12. Jahrhundert die chirothecae, wenngleich nur vereinzelt, im Ritus der Abtsbenediktion erwähnt werden ${ }^{1}$, und noch mehr, daß sich 1100 die Synode von Poitiers veranlaft sah, den Äbten das Tragen der Pontifikalhandschuhe ausdrücklich zu verbieten, falls ihnen solches nicht durch ein Privileg von dem Apostolischen Stuhle gestattet worden sei².

\section{FORM UND HERSTELLUNGSWEISE DER PONTIFIKAL- HANDSCHUHE.}

Die pontifikalen Handschuhe des 10. und 11. Jahrhunderts waren, wie sich aus dem Sakramentar von Corbie ergibt, sog. Fingerhandschuhe. Das ist aber auch das einzige, was wir über dieselben wissen, da über ihre sonstige Beschaffenheit keinerlei Nachrichten vorliegen. Die Inventare, welche Handschuhe erwähnen, begnügen sich damit, die Zahl der Paare zu nennen. Über Stoff, Farbe und Ausstattung schweigen sie.

Im 12. und 13. Jahrhundert werden die bischöflichen Handschuhe mehrfach als inconsutiles bezeichnet, so in der ersten Hälfte des 12. Jahrhunderts von Honorius und einem Pontifikale von Besançon "3, um 1200 von Sicard und einem Pontifikale von Reims ${ }^{*}$ und im letzten Viertel des 13. Jahrhunderts von Durandus. Da aus Stoffstücken (Seide, Wollzeug, Leinen) zusammengenähte Gewänder offenbar nicht inconsutiles, ungenäht, heißen können, müssen also die Pontifikalhandschuhe im 11. und 12. Jahrhunclert vielfach aus einem nahtlosen Gewebe bestanden haben. In der Tat stellen die bischöflichen Handschuhe, welche in St-Sernin zu Toulouse aufbewahrt und dem 13. Jahrhundert zugeschrieben werden, sowie diejenigen des hl. Ludwig von Anjou († 1297) zu Brignoles eine Art von Trikot dar. Auch die Handschuhe in S. Trinità zu Florenz, welche dem hl. Bernardo degli Uberti zugeeignet werden (Bild 172, S. 370), jedenfalls aber dem 12. oder doch dem frühen 13. Jahrhundert angehören, sind mit der Nadel gearbeitet. Sie sind nicht gestrickt, sondem stellen eine eigenartige Maschenarbeit dar, wie sie uns auch bei einem Par Pontifikalstrümpfen in der Kirche zu Delsberg (Schweizer Jura) begegnet. In derselben Technik waren auch die Handschuhreste gearbeitet, die man in einem Bischofsgrab im Speierer Dom fand, als man die Gräber im Königschor daselbst öffnete. Sie ist ferner angedeutet auf dem Handschuh des schon erwähnten Armreliquiars der Münsterkirche zu Essen aus dem 12. Jahrhundert. Ébenso machen die Handschuhe bei einzelnen der Bischofsstatuen, welche den südlichen und nördlichen Portalbau der Kathedrale von Chartres schmücken, den bestimmten Eindruck, als sollten sie ein durch Nadelarbeit hergestelltes

1 Das Benediktionsformular wird irrig Theodor von Canterbury ( $\dagger 690)$ zugeschrieben, so von B on a (Rerum liturg. 1. 1, c. 24, $\$ 12$; II 247) und noch von de Linas (Revue 1861, 639). Nur der kurze einleitende Kanon ist aus c. 3 des fälschlich sog. Pönitentiale Theo-

Braun, Die liturgische Gewandung. dors (H. J. Schnitz, Die Bußbücher, Mainz 1883, 540; über Theodors Autorschaft 510 ff).

2 C. 5 M. S dralek, Wolfenbittler Fragmente, Münster 1891, 137.

3 M a t. 1. 2, c. 1, ordo 3; II 153.

4 Ebd. ordo 6; II 156. 
Gewebe wiedergeben ${ }^{1}$. Auch im 14. und 15. Jahrhundert waren chirothecae inconsutiles in Gebrauch.

So waren die Handschuhe, welche man 1605 an den Händen der Leiche Bonifatius TIII. fand 2, gemäl乃 dem über die Eröffnung des Grabes aufgenommenen Protokoll ex serico albo ad acum, also durch Nadelarbeit und nicht aus zusammengenähten Seidenstücken hergestellt. Auf der Nadel angefertigt sind auch die Handschuhe Peters von Courpalay im Cluny-Mruseum zu Paris (Bild 173) und in der Stadtbibliothek zu Amiens ${ }^{3}$; ferner ein aus dem Ende des 14. Jahrhunderts stammender Handschuh in St Veit zu Prag (Bild 174), zwei aus dem 15. datierende Handschuhpaare im Dom zu Brixen (Bild 175-177, S. 372), vier um den Ausgang des 15. und den Beginn des 16. Jahrhunderts entstandene Handschuhe im Dom zu Halberstadt (Pild 178-79, S. 373) und ein der Frühe des 16. Jahrhunderts, wie es scheint, angehörendes Handschuhpaar in St-Bertrand zu Comminges ${ }^{4}$.

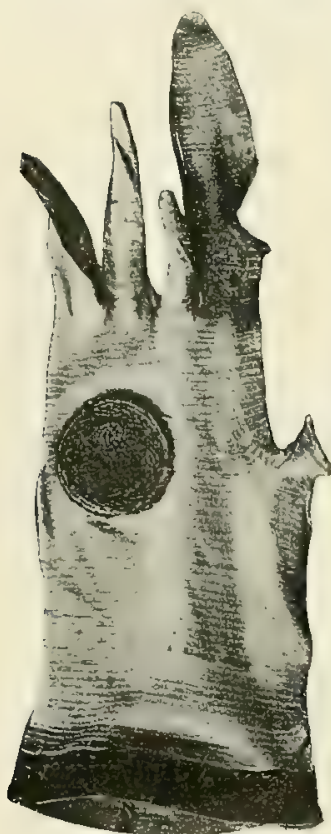

Bild 172.

Pontifikalhandschuh. Florenz, S. Trinità.

Der Handschuh im Cluny-Nuseum ist mittels eines ungemein feinen Seidenfadens im Schlingenstich hergestellt; alle andern stellen ein trikotartiges oder gestricktes Gewebe dar.

Neben den auf der Nadel entstandenen Pontifikalhandschuhen gab es aber vom 12. bis 16. Jahrhundert auch solche, die aus Stoffstücken zusammengenäht waren. Von dieser Art sind beispielsweise die Handschuhe, welche in Conflens (Savoyen) aufbewahrt werden und vielleicht noch ins 13. Jahrhundert hineinreichen (Bild 180, S. 373). Sie bestehen aus einem weiken, auf der Oberfläche wolligen Stoff und wurden hergestellt, indem man ein Stück Zeug von der doppelten Breite der Handschuhe und einer Länge von $27 \mathrm{~cm}$ nahm, es in der Mitte faltete, die

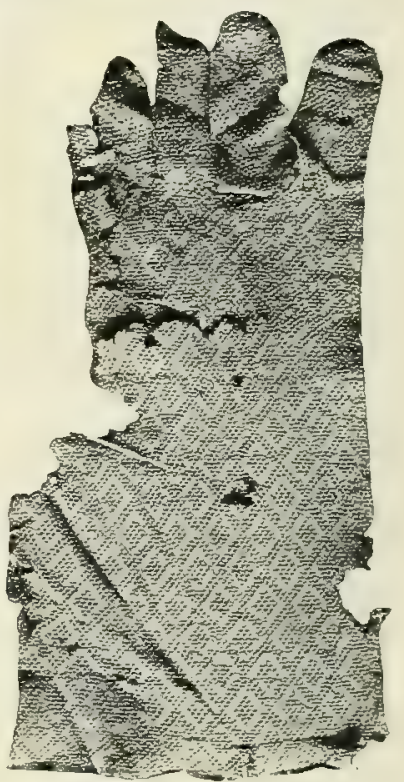

Bild 173. Pontifikalhandschuh Peters von Courpalay. Paris, Musée Cluny.

Langseiten zusammennähte, oben drei Finger hineinschnitt, dieselben vernähte und dann an den Seiten in schräger Richtung Daumen und kleinen Finger ansetzte ${ }^{5}$.

1 Abbildung bei Bock II, Tfl 14 und in Monographie de la Cathédrale de Chartres, Paris 1867, pl. xx.

2 Bzovius, Annal. ad 1303, XIV 52.

3 Jie Handschuhe stammen aus einem Grab der Kirche St-Germain-des-Prés zu Paris. Der Pariser Handschuh (rechte Hand) wird in seiner Aufschrift und von Rohault de Fleury (La messe VIII 193) dem Abt Morard von St-Germain-des-Prés (990-1014), von de Linas aber (Revue 1861, 634) dessen Nachfolger Ingon (1014 bis ca 1025) zugeschrieben. In Wirklichkeit barg das Grab den Leichnam des 1334 gestorbenen Abtes Peter von Courpalay. Vgl. Näheres Bullet. mon. 1867, 226. Der Handschuh der linken Hand in der Stadtbibliothek zu Amiens scheint Rohault de Fleury und de Linas nicht bekannt gewesen zu sein. Über die Technik, in welcher die Handschuhe hergestellt sind, vgl. Braun, Winke 111 und Bild 44 .

* Abbildang und Beschreibung in Revue 1861, 617 636. Vgl. auch B o ck II, Tfl 194.

5 Barbier de Montault, Les gants pontificaux, in Bullet. mon. 1876, 673. Die Handschube sollen dem hl. Thomas von 
In der Neuzeit kamen die aus Stoffstücken verfertigten Pontifikalhandschuhe aufier Gebrauch. Derhl. Karl Borromäus bestimmte ausdrücklich: Chirothecae episcopales contextae esse debent ${ }^{1}$.

Von der Größe der Pontifikalhandschuhe schweigen die Liturgiker des 12. und 13. Jahrhunderts. Die Handschuhe, welche sich zu Conflens erhalten haben, besitzen eine Länge von $27 \mathrm{~cm}$, reichen also über dasHandgelenk hinaus. Noch etwas länger sind diejenigen, welche sich in St-Sernin zu Toulouse befinden; sie kommen bis auf $28 \mathrm{~cm}$. Bei beiden Handschuhpaaren sind die Finger im Verhältnis zu ihrer Länge unverhältnismäßjig breit. Die Brixener Handschuhe sind $25 \mathrm{~cm}$, die Handschuhe von St-Bertrand zu Comminges $29 \mathrm{~cm}$ lang. Auf den Bildwerken des 12 . und 13. Jahrhunderts gehen die Handschuhe regelmäbig über das Handgelenk.

Bis ca 1250 scheint der untere

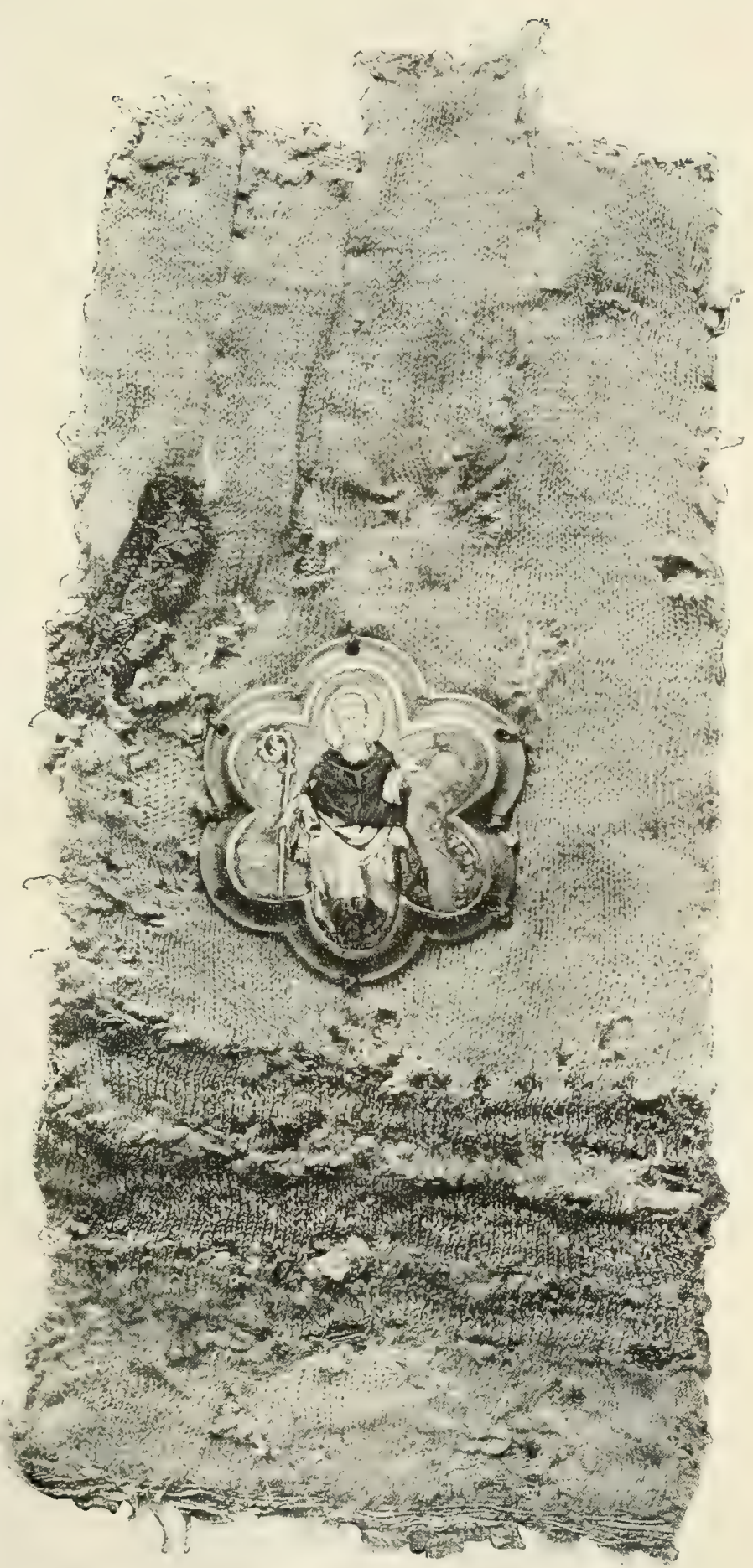

Bild 174. Pontifikalhandschuh im Domschatz zu Prag.

(Aus Podlaha und šittler, Der Domschatz zu Prags)
Canterbury angehört haben. Doch stimmt damit nicht die Beschaffenheit des Börtchens, welches den Einschlupf umrandet und auf eine spätere Zeit hinweist. ${ }^{1}$ A. E. Med. 627. 
Teil der chirothecae kaum breiter gewesen zu sein als der obere. Seit etwa der zweiten Hälfte des 13. Jahrhunderts trifft man dagegen auf den Monumenten häufig Handschuhe, welche sich nach dem Einschlupfe zu stauchenartig erweitern oder besser, mit einem stauchen- oder stulpenartigen Ansatz versehen sind, der gern mit Stickereien oder sonstigem Schmuck verziert wurde. Diese Stulpen hiefs man manicalia oder pugnalia. Sie waren vielfach so eiugerichtet, dafs sie leicht rom Handschuh losgetrennt werden konnten, und sie werden demgemäf in den Inventaren auch wohl für sich aufgeführt. Ein vorzügliches Beispiel solcher Handschuhstulpen wurde in einem Bischofsgrabe im Dom zu Spalato gefunden ${ }^{1}$. Sie zeichnen sich, wie Bild 181, S. 374 bekundet, durch reiche figürliche Stickereien aus.

Nicht selten erweiterten sich die Handschuhe am Einschlupf so sehr, daf sie zipfelartig vom Handgelenk herunterhingen (Bild 182, S. 375). An dem Ende
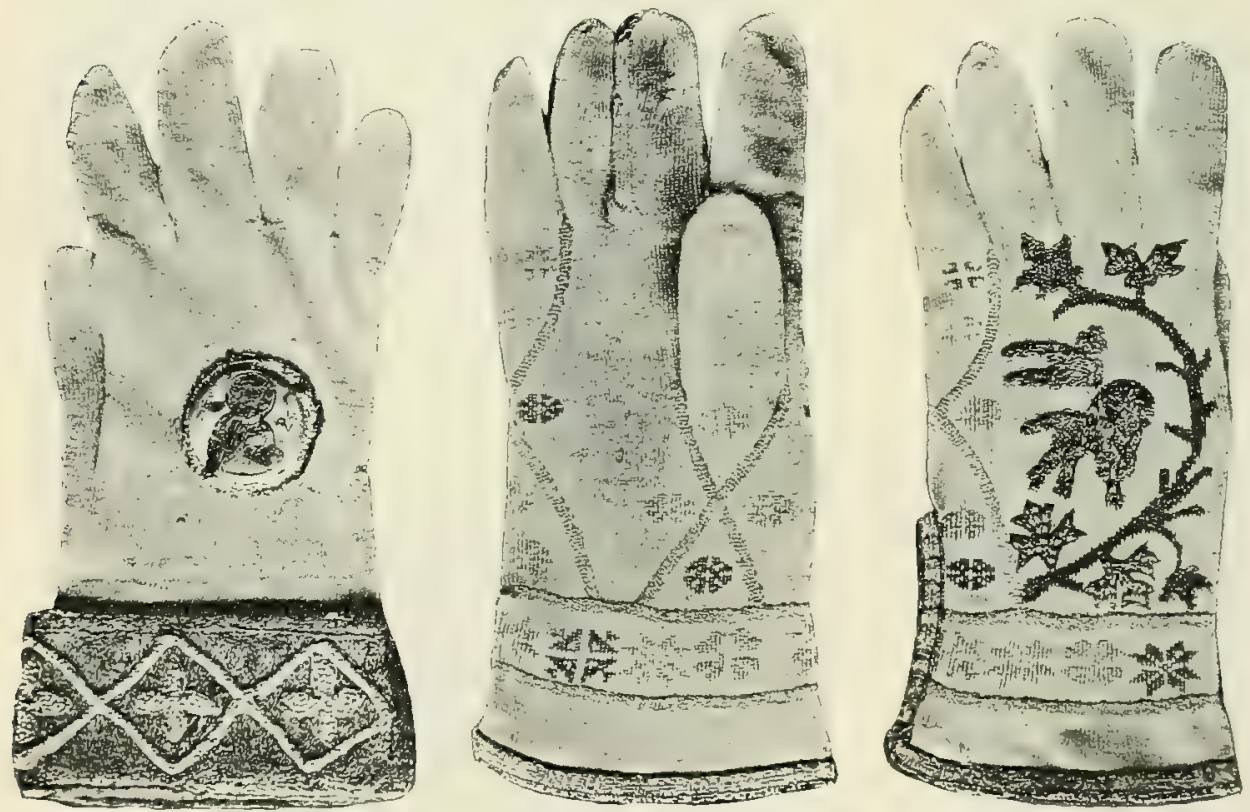

Bild 175-177. Pontifikalhandschuhe. Brixen, Dom.

des Zipfels wurde als Abschluf gern ein Glöckchen oder Quästchen angebracht. Solche Handschuhe müssen im 14. und 15. Jahrhundert, wenn anders wir den zahlreichen bildlichen Darstellungen (Gemälden wie Skulpturen) Glauben schenken dürfen, namentlich in Deutschland, Fngland und Frankreich beliebt gewesen sein. Allgemein, wie man wohl gesagt hat, waren sie jedoch damals nicht im Gebrauch. Das beweisen zur Genüge die aus dem 14. und 15. Jahrhundert noch erhaltenen Beispiele von Pontifikalhandschuhen, welche fast alle der stauchenartigen Erweiterung am Einschlupf entbehren.

Auch in der Neuzeit wurden die Pontifikalhandschuhe trotz allem Wechsel in Mode und Geschmack vor wie nach gern mit stauchenartigen Ansützen versehen. So blieb es selbst noch im 18. Jahrhundert, wie unter andern eine Anzahl aus dieser Zeit stammender Beispiele im Dom zu Würzburg, im Münster zu Freiburg im Breisgau (Bild 183, S. 375), zu Kamp am Niederrhein (Bild 184, S. 376) und im bayrischen Nationalmuseum zu

1 Mitt. 1887, LXXXVIII. 
München bekunden. Wenn Bock klagt ${ }^{1}$, Im 18. und vollends in den ersten Jahrzehnten des 19. Jahrhunderts erlitten die bischölichen Handschuhe eine solche verflachende und modernisierende Umformung, daf sie in neuester Zeit hinsichtlich des Schnittes und der stofflichen Ausdehnung in manchen Diözesen so ziemlich mit fein gewirkten Salonhandschuhen übereinstimmen; die alte Dauerhaftigkeit und Gediegenheit, desgleichen die althergebrachte Verzierungsweise, die Erweiterung des untern ornamentalen Saumes in Weise von breiten Stulpen, die den bischöflichen Handschuhen ein kirchliches Äukere geben, sind heute gänzlich verschwunden", so ist das ihm zwar wiederholt nachgeschrieben worden, aber nichtsdestoweniger zum mindesten stark übertrieben. Pontifikalhandschuhe ohne Stulpen und ohne jede Erweiterung hat es selbst in den besten Zeiten des Mittelalters übergenug

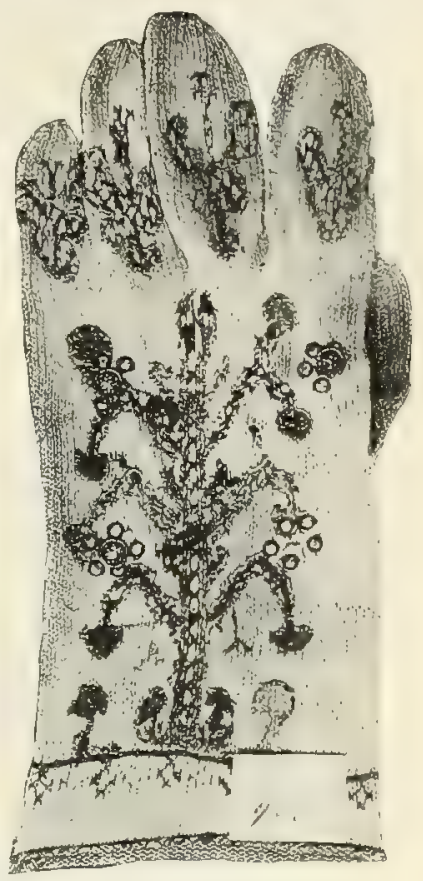

Bild 178-179. Pontifikalhandschuhe. Halberstadt, Dom. gegeben, während es umgekehrt die ganze Neuzeit hindurch bis ins 19. Jahrhundert hinein nicht an Handschuhen gefehlt hat, welche mit Ansätzen, die sich erbreiterten, versehen waren. So namentlich zu Rom, wo mit solchen stauchenartigen Endstücken ausgestattete Pontifikalhandschuhe bis jetzt in Gebrauch blieben. Die liturgischen Handschuhe haben überhaupt bis in die Gegenwart durchweg eine durchaus würdige Form bewahrt, falls man nicht mit Bock ganz unzutreffenderweise meint, weite, lang herabhangende Stulpen seien das, was den Pontifikalhandschuhen ein kirchliches Aussehen gebe. Denn in diesem Falle müfte man ja nicht nur allen Handschuhen des 11. und 12. Jahrhunderts, sondern auch sehr vielen des 13., 14. und 15. wie der Folgezeit den Charakter der Unkirchlichkeit zuerkennen. Auferdem erfreute sich zur selben Zeit, als die trichterförmigen, unten in eine Spitze endigenden Stauchen an den pontifikalen chirothecae üblich waren, nicht minder die profane Handbekleidung dieser Ansätze; ja es dürfte wohl kaum einem Zweifel unterliegen, daf sie bei den Pontifikalhandschuhen aufkamen, weil sie bei den profanen Mode geworden waren. Immerhin kann durchans empfohlen werden, bei Herstellung von Pontifikalhandschuhen denselben unten eine entsprechende stauchenartige Erweiterung zu teil werden zu lassen, da ihnen eine solche nur zur Zier gereicht.

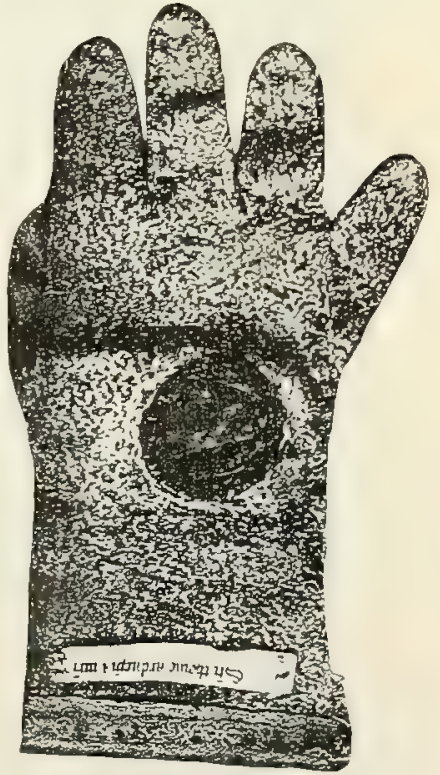

Bild 180. Pontifikalhandschui. Conflens, Savoyen. 


\section{AUSSTATTUNG DER LITURGISCHEN HANDSCHUHE.}

Bezüglich der Ausstattung unseres Ornatstückes sagt Innozenz III.: Chirotheca circulum aureum desuper habet. Er versteht unter dem circulus ein auf dem Handschuh in der Mitte des Handrückens angebrachtes goldenes oder vergoldetes, mehr oder wenig verziertes Plättchen (Bild 185, S. 376). Es hiels anch wohl tassellus, fibula, monile, paratura und ähnlich und war meist von runder Gestalt; doch gab es auch vierpaß- und rosettenförmige, rautenförmige u, a. Zu seiner Verzierung dienten Edelsteine, Perlen und namentlich figürliche oder symbolische Darstellungen, die bald blok graviert, bald reich in Email ausgeführt waren. So waren von den Zierplättchen der Handschuhe im Schatz des Apostolischen Stuhles, worin sie esmalti genannt werden, nach dem
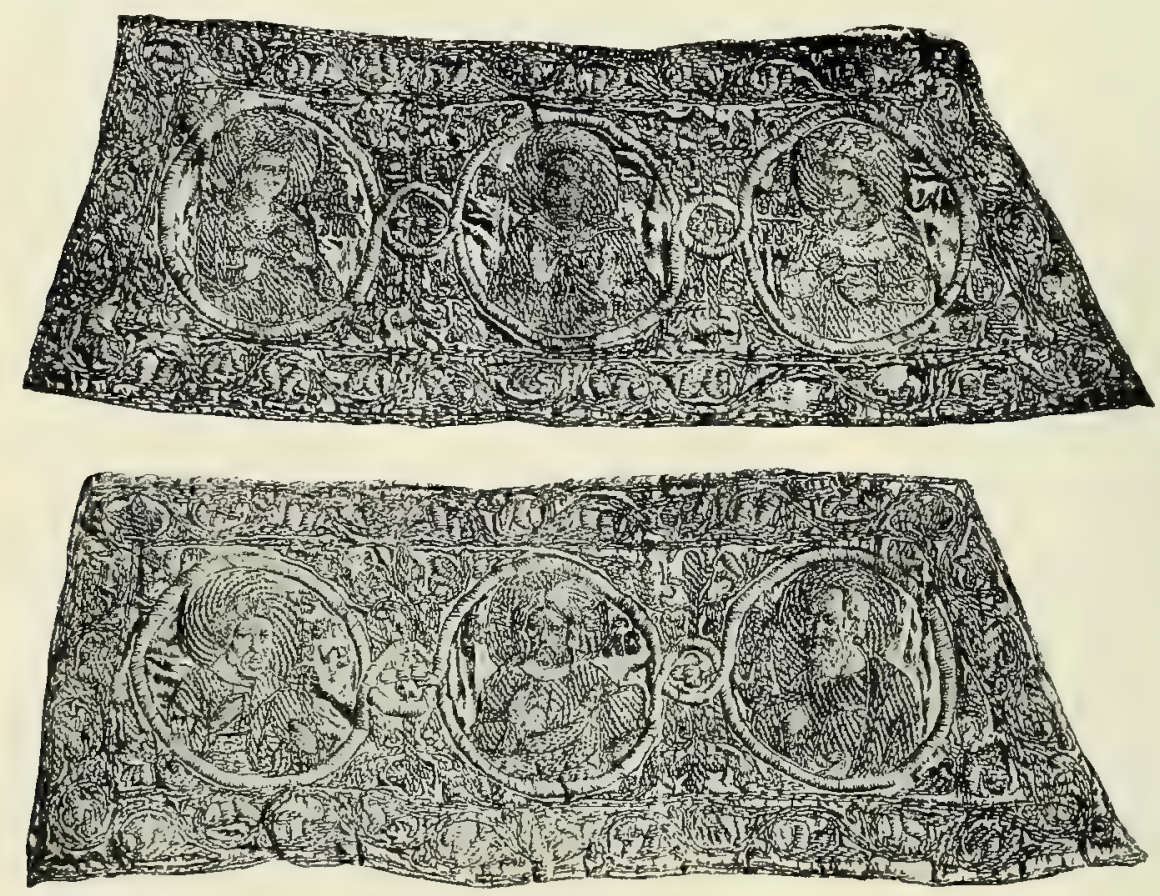

Bild 181. Stulpen eines Handschuhpaares aus einem Bischofsgrab. Spalato, Dom.

Inventar von 1295 zwei aus Gold gemacht und in Email mit Bildchen der Auferstehung und Darstellung im Tempel geschmiickt. Zwei andere bestanden aus Silber; das Emailbildchen, mit dem sie versehen waren, umgaben kleine Granaten, Saphire und Rubine. Ein drittes Paar trug einen orientalischen Saphir, den ein Kranz kleinerer Elelsteine umstand. Von losen esmaltj, die sich gerade nicht auf Handschuhen befanden, wies ein Paar Maria bzw. das Lamm Gottes auf; auf einem zweiten sah man die sog. Majestas und Maria, auf einem dritten den Erlöser und Maria, auf einem vierten (es wird als aus Paris stammend bezeichnet) die Verkündigung und Maria mit dem Jesuskind. Als Darstellungen, welche auf den circuli angebracht zu werden pflegten, waren neben dem Bilde des Heilands und der Gottesmutter besonders beliebt das Lamm Gottes, die segnende Rechte Gottes und das Kreuz. Man bevorzugte sie vor andern olne Zweifel im Hinblick auf das heilige Mebopfer, bei dem sich der Bischof der chirothecae bediente. Das 


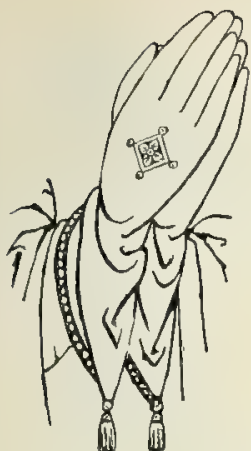

Bild 182.

Pontifikalhandschuh mit Zipfeln.

Kreuz wies darauf hin, dafs sich unter den Händen des Pontifex das Kreuzopfer von Golgatha zwar unblutig, aber wirklich erneuere; das Lamm Gottes erinnerte an die Opfergabe, welche der Bischof mystisch auf dem Altare schlachtet; die segnende Hand Gottes aber symbolisierte die Allmacht Gottes, in deren Kraft der Stellvertreter Christi Brot und Wein in den Leib und das Blut des Heilandes wandelt.

Zierplättchen finden sich noch an den Pontifikalhandschuhen in St-Sernin zu Toulouse, einem Handschuhpaar im Dom zu Brixen (Bild 175, S. 372) und dem Handschuh in St Veit zu Prag (Bild 174, S. 371). Die Plättchen der Toulouser Handschuhe sind aus vergoldetem Kupfer gemacht und mögen etwa dem 13. Jahrhundert angehören, während die aus kräftigem weifsem Seidengarn gestrickten Handschuhe selbst wohl einer späteren Zeit entstammen. Die Darstellungen, mit denen sie geschmückt sind, bestehen in dem Lamm Gottes mit dem Siegeskrenz. begleitet von Sonne und Mond und einem einfachen Kreuz mit ausladenden Balkenenden. Ursprünglich müssen die Plättchen emailliert gewesen sein '. Die Fibeln des Brixener Paars sind eine schöne Arbeit des 12. bis 13. Jahrhunderts. Eine von ihnen ist mit dem Brustbilde der Gottesmutter, die andere mit dem des hl. Paulus versehen. Ausgeführt sind diese Bildehen in byzantinisierendem, durchsichtigem Zellenschmelz von vortrefflicher 'Technik. Die Art der Befestigung läßst vermuten, daf sie ursprünglich nicht für Handschuhe bestimmt waren, sondern einem Reliquiar oder einem ähnlichen Gegenstand entnommen wurden. Die Handschuhe selbst rühren mitsamt der stauchenartigen Verzierung des Einschlupfs erst aus dem späten Mittelalter her. Auf dem Medaillon des Prager Handschuhs ist in durchsichtigem Email St Benedikt in Priestertracht dargestellt. Zwei interessante Zierplättchen, welche 1872 in einem Bischofsgrab der Kathedrale von Cahors gefunden wurden und in der ersten Hälfte des 18. Jahrhunderts entstanden sein werden, sind in Limoger Schmelz mit dem Lamm und der Rechten Gottes geschmückt ${ }^{2}$. An ihrem Rand hat man eine Anzahl kleiner Löchlein angebracht, um sie mittels dieser den Handschuhen aufnähen zu können (Bild 186 bis 187, S. 377). Die in den Gräbern der Trierer Erzbischöfe Hillin († 1169) und Arnold $(†$ 1183) seinerzeit entdeckten cireuli waren statt aus Metall in Goldstickerei hergestellt ${ }^{3}$.

Statt mit metallenen circuli versah man nämlich die Pontifikalhandschuhe häufig mit Medaillons, die aus Zeug ge-

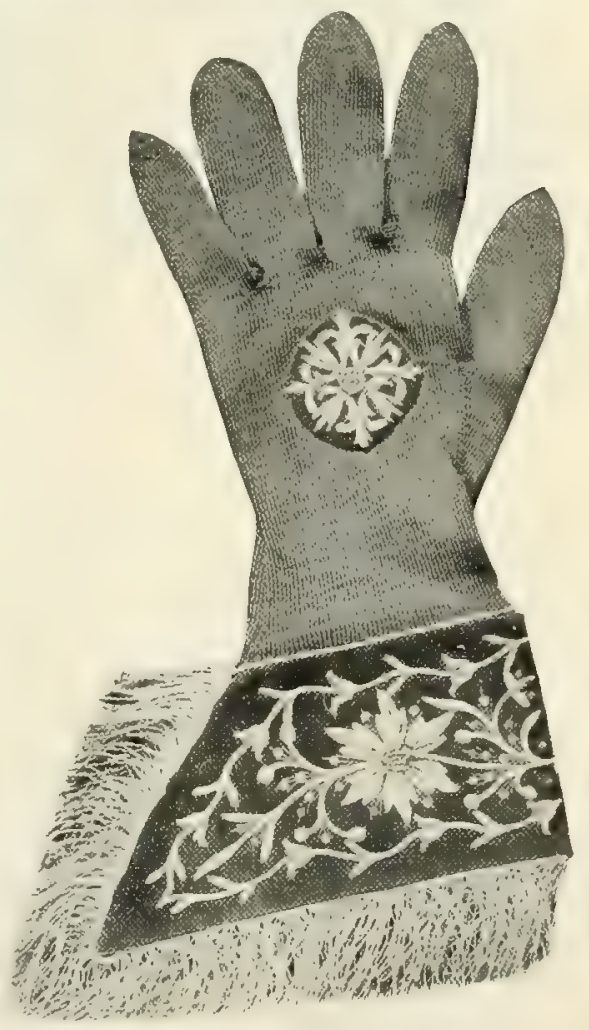

Bild 183. Pontifikalhandschuh. Freiburg, Münster.

2 Abbildung in Bullet. mon. a. a. 0.; Text S. $785 \mathrm{ff}$.

${ }^{3}$ v. Wilmowsky, Die historisch-denkwhirdigen Grabstätten im Dom zu Trier 618 u. Tfl 5 . 
macht waren. Sie wurden entweder mit Stickereien geschmückt oder mit Perlen und Edelsteinen besetzt und scheinen meist scheibenförmig gewesen zu sein.

Ein gutes Beispiel bietet der Handschuh in S. Trinità zu Florenz (Bild 172, S. 370). Zwei andere traf man vor einigen Jahren bei Aufdeckung der Kaisergräber in einem etwa dem Ende des 12. Jahrhunderts angehörenden Bischofsgrabe des Speierer Domes an. Sie waren in kostbarer Goldstickerei hergestellt und enthielten das Lamm Gottes und die Rechte Gottes. Auch in dem Grabe des 1223 gestorbenen Bischofs Herväus von Troyes entdeckte man auf den Handschuhen goldgestickte Zierscheibchen dieser Art ${ }^{1}$. Das eine trug das Lamm Gottes mit der Umschrift Agnus Dei, das andere die segnende Rechte Gottes nebst Sonne und Mond mit der Legende In nomine Patri(s)

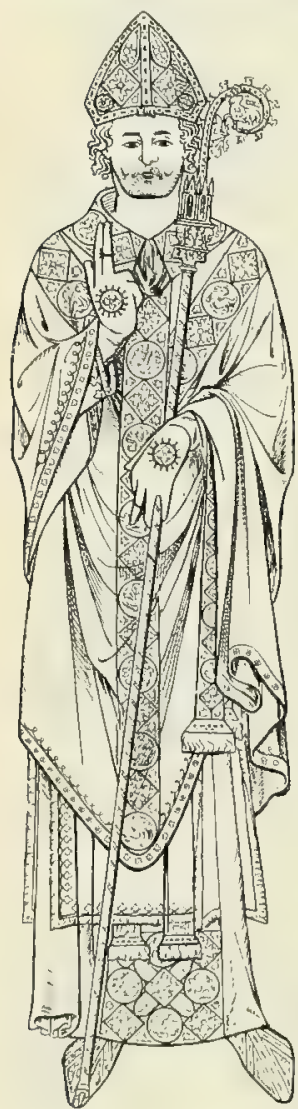

Bild 185. Grabfigur des Bischofs Johannes von Lüblieck († 1.250). Lüberk, rom. et Filii et Spiritu(s) (Bild 188). Hand und Lamm waren in weiflicher Seide, die Inschriften samt den sie einfassenden Kreisen in Gold gestickt. Drei ähnliche Medaillons finden sich im Dommuseum zu Trier. Sie stammen aus Gräbern Trierer Erzbischöfe. Zwei weisen die Dextera Dei, eines das Agnus Dei auf. Ihres Schmuckes beraubt sind die Zierscheibchen auf den Handschuhen zu Conflens ${ }^{2}$. Von welcher Beschaffenheit die Medaillons waren, denen man bei den Handschuhen der Leiche Hadrians IV. ( $†$ 1159) gelegentlich des Umbaues von St Peter begegnete, ist aus dem Bericht, der darüber vorliegt, nicht ganz klar ersichtlich ${ }^{3}$.

Im späten Mittelalter kam die Sitte auf, den Rücken der Handschuhe vollständig mit Ornamenten zu übersticken, statt ihn nur mit einem metallenen oder stofflichen circulus zu versehen. Ja man ging so weit, auch die Finger und die Innenseite in ähnlicher Weise zu verzieren. Gute Beispiele derartiger Pontifikalhandschuhe sind die Handschuhe im Dom zu Halberstadt (Bild 178, 179, S. 373) und von St-Bertrand zu Comminges, sowie eines der Handschuhpaare zu Brixen.

Von einer Saumverzierung spricht Innozenz III. nicht. Sie kam in der Tat nicht immer zur Anwendung, wiewohl sie für gewöhnlich nicht leicht gefehlt haben wird. Wie die Bildwerke und die noch vorhandenen mittelalterlichen Handschuhe bekunden, bestand sie entweder in einer förmlichen Bordüre oder in einem den Rand des Einschlupfes entlang laufenden gestickten Ornament.

Die Ausstattung, welche das 12. und 13. Jahrhundert den Pontifikalhandschuhen zu teil werden liek, wurde für dieselben bis auf unsere Tage typisch. Wie im 12. und 13., so wurden sie im wesentlichen auch im 14. und 15.
1 Bullet mon 1876, $781 \mathrm{ff}$.

2 Vgl. oben Bild 180, S. 373.

3 Ph. Jaur. Dionysius, Sacr. Vat, Bas. cryptae monumenta, Roma 1773, 124: Agni formam cum cruce et litteris Agnus Dei, quae chirothecis intexta apparebant. Vgl. auch den handschriftlichen Bericht ïber den Befund in der Barberinischen Bibliothek (s. oben S. 365); am ehesten wird man an bestickte Scheibchen zu denken baben. 
16. und 17, 18. und 19. Jahrhundert verziert. Etwaige Unterschiede sind nur nebensächlicher Art und betreffen kaum etwas anderes als den jeweiligen Stil des Ornamentes. Nur in den Motiven, welche bei dem Medaillon auf dem Handrücken verwendet wurden, ging seit dem Ausgang des Mittelalters insofern ein Wechsel vor sich, als sich dieselben vereinfachten und auf den Namen Jesus oder ein Kreuz beschränkten. Es ist ein ähnlicher Vorgang, wie er sich seit derselben Keit auch in der Verzierung der übrigen Paramente vollzog.

Die Zahl der Pontifikalhandschuhe aus mittelalterlicher Zeit, die auf uns gekommen sind, ist nicht grof. Die Pontifikalhandschuhe waren ein Ornatstück, das nicht blok wenigen zustand, sondern obendrein nur bei sehr wenigen Gelegenheiten Verwendung fand. Es war daher nie eine namhaftere Menge derselben vorhanden. Auch hatte man kaum je Veranlassung, alte, schadhaft gewordene Handschuhe aufzubewahren, da, was an ihnen Wert besaß, leicht abgetrennt werden konnte. Es ist deshalb leicht erklärlich, dafs wir nur noch eine sehr beschränkte Zahl mittelalterlicher Pontifikalhandschuhe besitzen. In Italien finden sich noch liturgische Handschuhe aus dem Mittelalter in S. Trinità zu Florenz und in der Kathedrale zu Narni, welch letztere irrtümlich dem hl. Cassius zugeschrieben werden. In Deutschland und Österreich
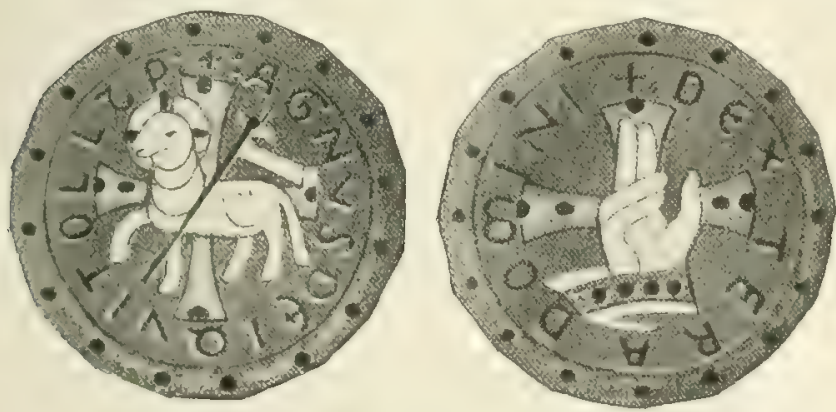

Bild 186-187. Handschuhfibeln aus einem Bischofsgrabe. Limoger Emailplättchen. Cahors, Kathedrale.

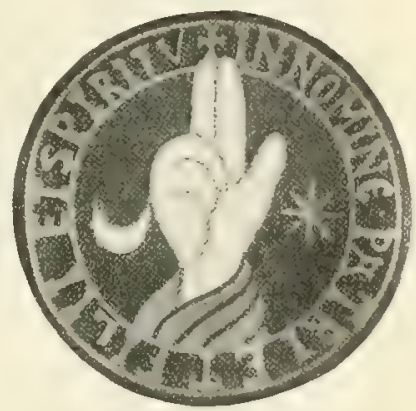

Bild 188. Zierscheibchen in Stickerei. Troyes, hithedrale.

gibt es solche in den Domen zu Brixen, Prag und Halberstadt, in England zn Oxford (New College), in Frankreich zu Conflens (Pfarrkirche), Toulouse (St-Semin), Paris (Cluny-Museum) und Amiens (Stadtbibliothek). Nur die Pontifikalhandschuhe in S. Trinità zu Florenz mögen noch dem 12. Jahrhundert angehören, dagegen können die angeblichen Handschuhe des hl Thomas von Canterbury zu Conflens diesem wohl nicht mehr zugewiesen werden. Alle übrigen, die Handschuhe in St-Sernin zu Toulouse nicht ausgeschlossen, datieren aus dem 14., 15. oder dem Beginn des 16. Jahrhunderts ${ }^{1}$. Keiner der angeführten Handschuhe kann besonders kostbar genannt werden. Um Handschuhe mit kostbarer Ausstattung kennen zu lernen, muf man zu den Inventaren greifen. Besonders zahlreich sind Pontifikalhandschuhe dieser Art im Inventar des Apostolisehen Stuhles vom Jahre 1295 vertreten.

Im ganzen werden in ihm aufer sechs einfachen 22 mehr oder weniger reich ausgestattete Handschuhpaare samt drei Paaren prächtiger, in Gold- und Perlen- bzw.

1 Ein Handschuhpaar in der Kathedrale zu Moutiers (Savoyen), das vom hl. Petrus von Tarantaise ( $†$ 1171) herrúhren soll, wird von $\mathrm{B}$ a rbier de Monta $\mathrm{lt}$ (Bullet. mon. 1877, 10 ff) dem 15. Jahrhundert zugeschrieben. In Wirklichkeit aber reicht es wohl kaum weit über das Ende des 16. hinaus. Darin aher lot Barbier olne $Z$ weifel recht, dab die Handschuhe früher die Reliquien des Heiligen schmückten und infolgedessen nachher schlechthin als Handschuhe angesehen wurden, die dieser im Leben getragen habe. Übrigens beweisen aufer der Beschaffenheit auch die geringen Mafe der Handschuhe, daß sie vom hl. Petrus bei seinen Lebzeiten nicht haben gebraucht werden könuen. 
Bildstickerei hergestellter und mit Schmelzplättchen und Edelsteinen reich besetzter pugnalia verzeichnet. Aber auch in andern Inventaren finden sich kostbare Handschuhe. Duo paria cirothecarum ornata laminis argenteis deauratis et lapidibus insertis; item duo cirothecae similis operis - nämlich wie eine vorherbeschriebene, mit Perlen und Edelsteinen besetzte Mitra -, in quibus deficiunt multi lapilli, heißst es beispielsweise in einem Schatzverzeichnis von St Paul zu London aus dem Jahre 1295. Das Inventar von St Paul von 1402 erwähnt tria paria chirothecarum episcopalinm aurifrisiata cum margaritis et monilibus argenteis deauratis. Das Schatzrerzeichnis von Prag aus den Jahre 1387 vermerkt: Cyrotecae argenteae cum limbo (Bordure), videlicet circa manicam argentum deauratum habentes et in parte superiori agnus in fibula et in secunda episcopus in cathedra. Aliae cyrothecae cum fibulis, quarum in una est Christus et in alia Virgo gloriosa. Das Inventar von 1397 fügt diesen Handschuhen noch bei: Item duo manicalia pulcra cum crucibus de perlis albis in examito rubeo; quaelibet habet unum monile aureum; in uno deficit unus lapis et habet in circuitu zaphyros. Von den Pontifikalhandschuhen, welche in einem Inventar der Kathedrale von Canterbury aus dem Beginn des 14. Jahrhunderts aufgeführt werden, war ein Paar mit einem rautenförmigen Zierplättchen, das mit Perlen und Edelsteinen besetzt war, geschmückt; ein zweites war mit silbernen Plättchen und kleinen Edelsteinen verziert; bei vier Handschuhpaaren werden nur tasselli argentei notiert. Ein Paar, das aus Linnen gemacht war, wies aufer den tasselli auch Perlstickereien auf ${ }^{1}$. Das Inventar von Cluny (1382) verzeichnet 22 Paar verzierter Handschuhe, leider ohne diese im einzelnen näher zu beschreiben.

Handschuhe, welche Erzbischof Dietrich von Köln (1414-1463) dem Herzog von Cleve verpfändete, werden folgendermaßen geschildert ${ }^{2}$ : "Zum irsten ein Paar Henschen mjt Perlen, der ejne mjt den drjn Konynegen, der andere mjt ejne Crucefix. Item ein ander Paar Henschen yechlichen mit ejnre Broidschen (das Medaillon) up der Handt mjt Gestejntz. Item in dem Myddel ejn Sofir wigende II. Mr. XIIII. Loit Goultz geacht vur... CXXXI Guld."

\section{STOFF UND FARBE DER PONTIFIKALHANDSCHUHE.}

Als Stoff gebrauchte man im Mittelalter für die liturgischen Handschuhe gewöhnlich Linnen (Baumwolle) oder Seide, doch werden auch Pontifikalhandschuhe aus Wolle erwähnt. So verzeichnet z. B. ein Inventar der Kathedrale von Angers zum Jahre 1467: unum par cyrothecarum de lana alba. Ein Handschuh dieser Art ist der aus derber Wolle gestrickte Pontifikalhandschuh in St Veit zu Prag (Bild 174, S. 371) ${ }^{3}$. In der Frühzeit des Jahrtausends scheint vornehmlich Linnen bei Anfertigung liturgischer Handschuhe zur Verwendung gekommen zu sein ${ }^{4}$, im späteren Mittelalter wurde indessen wohl vorwiegend Seide gebraucht. Es ist bezeichnend, daf das Schatzverzeichnis der Kathedrale von Canterbury vom Jahre 1321 bei einem Handschuhpare besonders anmerkt, dafi es aus Linnen bestehe: item unum par de lino cum tasselis et perlis. Immerhin bekunden die Handschuhe im Dom zu Halberstadt, daf noch um die Wende des Mittelalters linnene Handschuhe vorkamen.

\footnotetext{
1 Schon Erzhisch of Hubert ( $† 1205)$ schenkte der Katledrale chirothecarum paria tria omnia gemmis et auro parata (Revue 1861, 636). Er gab der Kathedrale auch chirothecas sine auro. Manche andere gute Beispiele sind zusammengestellt bei $\mathrm{G}$ ay 760 .

${ }^{2}$ Bock II 14\%.

${ }^{3}$ Nach güiger Mitteilung des hochw. Herrn Kanonikus Dr A. Podlaha.
}

\footnotetext{
4 Bock (II 135) läfat Bruno von Segni sagen, es sollten die Pontifikalhandschuhe aus Linnen angefertigt sein. Ähnlich de Linas (Revue 1861, 633) und Moroni (Dizionario XXXIII 95). Allein der Heilige redet mit keinem Worte an der fraglichen Stelle des Tractatus de sacramentis ecclesiae vom Stoff derselben (M. 165, 1108). Moroni scheint die Quelle des Irrtums zu sein.
} 
In der Neuzeit verloren sich linnene Pontifikalhandschuhe ganz aus dem Gebrauch und wurde es Regel, die liturgischen Handschuhe nur noch aus Seide anzufertigen, ohne daf jedoch solches je ausdrücklich vorgeschrieben worden wäre. Selbst die Mailänder Synodalstatuten des hl. Karl enthalten sich hinsichtlich des Stoffes der Handschuhe jeglicher Bestimmung.

Von der Farbe der liturgischen Handschuhe redet unter den Liturgikern des 12. und 13. Jahrhunderts nur Durandus. Es scheint, daf der Verfasser des Rationale blof weje gekannt hat. Wirklich sind die Pontifikalhandschuhe zu Florenz, Conflens, Toulouse und Prag, um von den dem späteren Mittelalter angehörenden abzusehen, alle von weifer Farbe. Ebenso waren die Handschuhe, welche man 1606 bei der Leiche Bonifaz' VIII. fand, aus weiser Seide gemacht. Es mag sogar fraglich sein, ob schon im 14. und 15. Jahrhundert der Jiturgische Farbenkanon für die Pontifikalhandschuhe gegolten habe.

Man hat freilich gemeint, der auf Befehl Gregors X. herausgegebene römische Orilo deute an. daf es bereits damals zu Rom Handschuhe in der Tagesfarbe gegehen habe. Mit Unrecht. Wenn es darin heifst: (electus in papam) lotis manibus induetur omni ornamento sno, scilicet primo alba, cingulo cum subcinctorio, postea pectorali, demum fanone (das päpstliche Schultertuch), postea stola, deinde tunicella et postea dalmatica; subsequenter recipit chirothecas et demum casulam et mitram in capite suo sine pallio et annulo pastorali, quae postea recipiet in suo loco et vestimenta erunt coloris tempori convenientis ${ }^{1}$, so will die letzte Bemerkung offenbar nur im allgemeinen sagen, es habe die Pontifikalkleidung des Papstes der jeweiligen Tagesfarbe zu entsprechen. Wollte man aus derselben schliefen, auch die Handschuhe seien damals schon den Vorschriften über die liturgischen Farben' unterworfen gewesen, so müfte man, was jedoch durchaus unzulässig ist, ein gleiches für die Mitra und das Schultertuch annehmen.

Als ferneren Beweis, daßs schon im 13. Jahrhundert für die Handschuhe die liturgische Tagesfarbe mafgebend gewesen sei, hat man eine Vergabung Gottfrieds von Loudon (1234-1255) angeführt, durch welche dieser der Kathedrale von Le Mans quinque paria cirothecarum et duas paraturas argenteas deauratas ad opus earumdem cirothecarum übermachte ${ }^{2}$. Ces plaques, meint de Linass, s'adaptaient donc tour à tour aux cinq paires de gants, transport inutile, si ces dernières avaient toutes affecté la même couleur. Indessen heift das doch zu viel aus den Worten der Schenkung herauslesen. Oder wo sagt diese, daf die paraturae abwechselnd bald bei dem einen, bald bei dem andern Paar zu gebrauchen seien? Man kann die Sache doch auch dahin verstehen, daf die Besätze bestimmt waren, nacheinander zur Ausschmückung der fünf Paare zu dienen, so daf3 sie also, ähnlich wie die Parura am Amikt, so lange an den einzelnen Handschuhen blieben, bis letztere durch Verschleiß oder Schmutz zum ferneren Gebrauch ungeeignet geworden waren. Es lürfte das sogar die einzig richtige Anffassung sein. Oder ist es wahrscheinlich, dafs man jedesmal nach der Verwendung der Handschuhe die paraturae wieder lostrennte und Handschuhe und Zierbesätze bis zur demnächstigen Verwertung gesondert aufbewahrte?

Es bleibt also noch der Beweis zu führen, dafs schon das 13. Jahrhundert Pontifikalhandschuhe in der jedesmaligen Tagesfarbe gekannt habe. Wohl mögeu damals schon farbige Handschuhe vorgekommen sein. So sollen die Handschuhreste, welche man im Grabe des Bischofs Herväus von Troyes († 1223) fand, einen violettbräunlichen Ton aufgewiesen haben; doch kann dieser freilich auch die Wirkung der Zersetzung und Vermoderung gewesen sein. Sicher gab es im 14. und 15. Jahr-

I Ordo 13, n. 6 (M. 78, 1108).

2 Mabillon, Vet. analecta III 390.
${ }^{3}$ Revue 1861,637 , note 4 . Vgl. B o c k II 143 
hundert neben weilsen anch wohl farbige Handschuhe, wie die rotseidenen Handschuhe Wilhelms von Wykeham $(\dagger 1404)$ in New College zu Oxford beweisen. Aus Handschuhen dieser Art indessen folgern, daßs bereits im 13., 14. und 15. Jahrhundert für die pontitikale Handbekleidung die liturgische Tagesfarbe mafogebend gewesen sei, ist ebensowenig zulässig, wie aus roten und blauen Mitren des 15. Jahrhunderts den völlig falschen Schlufs ziehen, daf damals für die Mitra der kirchliche Farbenkanon gegolten habe.

Es dürfte kaum möglich sein, den Zeitpunkt auch nur annähernd zu bestimmen, zu dem die liturgische Farbenregel auch auf die Pontifikalhandschuhe ausgedehnt wurde. In Rom bestand im 14. Jahrhundert ein Unterschied zwischen chirothecae pretiosae und chirothecae sine perlis, von denen die ersten der mitra pretiosa, die letzten der mitra alba simplex entsprachen ${ }^{1}$. Von der Farbe der Handschuhe ist dagegen in keinem römischen Ordo die Rede. Die Unterscheidung zwischen chirotheca pretiosa und chirotheca sine perlis sowie ihre Zusammenstellung mit mitra pretiosa und mitra simplex scheint sogar bestimmt darauf hinzudeuten, daf der liturgische Farbenkanon damals auf die Handschuhe noch keine Anwendung fand.

Auch das römische Pontifikale und das Caeremoniale der Bischöfe enthalten keine Bestimmung über die Farbe der Pontifikalhandschuhe. Dagegen schrieb der hl. Karl Borromäus ausdrücklich vor, dals die liturgischen Farben, mit Ausnahme von Schwarz, auch für die sakrale Handbekleidung Geltung haben sollten und demmach weifse, rote, grüne und violette Handschuhe vorrätig zu halten seien ${ }^{2}$. Es ist die erste ausdrückliche Bestimmung über die Farbe der Pontifikalhandschuhe, welche uns begegnet ist.

\section{DIE LITURGISCHE VERWENDUNG DER HANDSCHUHE.}

Ihre Hauptverwendung fanden die liturgischen Handschuhe von Anfang an beim Pontifikalamte. Sehr bezeichnend für ihren Charakter als Bestandteil des bischöflichen Mefornates ist namentlich eine Rubrik des Ritus der Benedictio abbatum in einem Pontifikale von Besançon (12. Jahrhundert) und von Reims (ca 1200): De manu episcopi accipiat baltheum et wantos inconsutiles ad cantandam missam ${ }^{3}$. Allein ihr Gebrauch beschränkte sich im Mittelalter noch keineswegs überall lediglich auf die Mekfeier, wie in der Gegenwart. So bediente sich beispielsweise im 13. Jahrhundert zu Bayeux der Bischof der Pontifikalhandschuhe auch, wenn er an bestimmten hohen Festtagen das Offizium abhielt oder an den Prozessionen teilnahm ${ }^{4}$, und schon Alexander III. hatte den Äbten von Monte Cassino und La Cava den Gebrauch der Handschuhe bei Konzilien gestattet ${ }^{5}$. Eine derartige ausgedehntere Verwendung der liturgischen Handschuhe mag namentlich im späteren Mittelalter nicht

1 Ordo 14 , c. 82 ; ordo 15 , c. 65 (M. 78 , 1204 1301). Eine Angabe in c. 144 des ordo 15, wo von der Weise die Rede ist, wie der Papst zum Begräbnis zu bekleiden sei, lautet zu unbestimnt, um daraus einen Schluf ziehen zu können (ebd. 1351).

2 A. E. Med. 627.

${ }^{3} \mathrm{M}$ a r t. 1. 2, c. 1, ordo 36 ; II 153156.

$\$$ Chevalier, Ordinaire et coutumier de l'église cath. de Bayeux (XIlI $\left.{ }^{\mathrm{e}} \mathrm{s}.\right) 61166$ et passim. '/u bayeux trug auch der Cantor' nach altrom firauch an höheren Festen Hand- schuhe (ebd. 4316 : cantor ob honorem dignitatis... cyrothecis adornatur).

5 Bullar. Roman. (ed. Taux.) II 663 : Usum chirothecae... ad missas seu in consessu concilii habendum concedimus; P f J ugk-Harttung, Acta III 221: In conciliis Romanorum Pontificum seu exequiis magnarum ecclesiasticarum personarum et nobilium defunctorum. In der letztgenannten Bulle wird dem Abt von La Cava also auch der usus chirothecarum f'ü Exequien hoher geistlicher und weltlicher Standespersonen gewährt. 
selten gewesen sein. Wenigstens lassen darauf die zahlreichen Bildwerke schliefen, auf denen sich die Pontifikalhandschuhe in Verbindung mit dem Pluviale finden. Was die ältere römische Praxis hinsichtlich des Gebrauches der Pontifikalhandschuhe betrifft, so fehlt es darüber leider an ausreichenden Nachrichten; indessen spricht der konservative Sinn, der zu Rom hinsichtlich des liturgischen Brauches herrschte, für die Annahme, es seien die Handschuhe dort stets nur bei der Messe verwendet worden. So geschah es daselbst sicher im späteren Mittelalter. Wenn nach dem 13. und 14. Ordo der Papst die Handschuhe auch bei dem feierlichen Zuge trug ${ }^{1}$, der nach seiner Krönung und am Gründonnerstag statthatte, so war das lediglich eine Ausnahme; vielleicht die einzige, wenn man überhaupt hier von einer Ausnahme reden kann. Trat doch der Papst dann nicht blob in Pontifikalhandschuhen, sondern in voller Mefkleidung auf, nur daf die Tiara an Stelle der Mitra getreten war; denn er sollte bei dieser Gelegenheit als der Priesterkönig erscheinen. Wie die übrigen Gewänder, hatten auch die Handschuhe bei jener Feier lediglich symbolische Bedeutung. Nur insofern wich im späten Mittelalter zu Rom der Brauch vom jetzigen ab, als noch bis ins 15. Jahrhundert hinein die Pontifikalhandschuhe auch bei der Liturgie des Karfreitags zur Verwendung kamen 2. Bei Totenmessen war aber ihr Gebrauch daselbst bereits gegen Ende des 14. Jahrhunderts unzulässig ${ }^{3}$

Nach dem Sakramentar von Corbie trug der Bischof die Handschuhe nur von Beginn der Messe bis zur Händewaschung, welche nach Entgegennahme der Opfergaben vor der Opferung stattfand. Damit stimmt überein, was im 14. Ordo Mabillons und im Pontifikale des Durandus ${ }^{4}$ betreffs der Verwendung der chirothecae vermerkt ist. Denn auch nach diesen bediente sich der Pontifex der Handschuhe nur bis zur Händewaschung vor der Opferung. Daßs es jedoch nicht gerade überall so gehalten wurde, zeigen ein Mainzer Pontifikale des ausgehenden 13. Jahrhunderts ${ }^{5}$ und ein um 1400 entstandenes Missale eines Klosters der Diözese Basel ${ }^{6}$. Nach letzterem behielt der Abt die chirothecae bis nach der Opferung und der Inzensierung der Oblata, nach ersterem sogar bis zum Beginne des Kanons; auferdem trug er sie beiden zufolge wieder nach der Kommunion. Auch zu Evesham zog der Abt nach der Kommunion die Handschuhe wieder an. Auferdem war es dort Brauch, daf derselbe sich ihrer bei feierlichen Prozessionen sowie bei den Karfreitagszeremonien bediente ${ }^{7}$.

1 Ordo 13, n. 8 ; ordo 14 , c. 19 (M. 78,1110 1130). Wenn es an der ersten der beiden Stellen heifst, der Papst sei im Pluviale aufgezogen, so beruht das auf einer Verderbtheit des Textes, der, wie er bei Migne sich findet, überhaupt keinen Sinn gibt. Den richtigen Text gibt ordo 14, c. 19. Aber auch aus ordo $13, \mathbf{n}, 9$ erhellt klar, daf der Papst bei dem Zug nicht das Pluviale, sondern die Kasel trug. Deponit (nämlich am Schlußs desselben) pallium et casulam tantum ac chirothecas et resumit pluviale (ebd. 1111). Die Sitte, wonach der neu konsekrierte Bisch of nach seiner. Weihe in seinen liturgischen Gewändern feierlich heimzog, wird auch in andern Pontifikalien erwähnt, doch war er dabei statt mit der Kasel mit dem Pluviale bekleidet. Vgl. z. B. M a r t. 1. 1, c. 8, art. 11, ordo 17; II 88; Vat. Cod. lat. 4748, f. 17 и. а. Der Brauch war offenbar eine Nachahmung der römischen Praxis.

2 Ordo 14 , c. 93 ; ordo 15 , c. 7677 (M. 78 , 121612171318 1319). Der Pontifex behielt die Handschuhe nur bis zur missa praesanctificatorum.

${ }^{3}$ Ordo 15, c. 132 (ebd. 1347).

$4 \mathrm{M}$ a r t. 1. 1, c. 4, art. 12, ordo 23; I 221 .

5 Ebd. ordo 18; I 217.

6 Ebd. ordo 32; 1235.

7 Offic, eccl, abbat, in Evesham monast. (Bradshaw Society), London 1893, c. 121588. 
Hinsichtlich des Zeitpunktes, da der Bischof die Handschuhe anlegte, herrschte im Mittelalter keine einheitliche Praxis. An dem einen Ort zog er sie an, sobald er sich mit der Dalmatik, anderswo erst, wenn er sich mit der Kasel versehen hatte. In Rom war es schon um die Wende des 12. Jahrhunderts Sitte, sie unmittelbar nach der Dalmatik anzulegen, und so blieb es daselbst durch das ganze Mittelalter bis in die Neuzeit ${ }^{1}$.

Über die Rolle, welche den chirothecae im Weiheritus während des Nittelalters zukam, liegen nur vereinzelte Nachrichten vor. Nach einem Mainzer Pontifikale aus dem Ausgange des 13. Jahrhunderts hatte die Zeremonie, mit den Handschuhen die Hände des Electus zu bekleiden, gleich nach der Salbung derselben innerhalb der Messe statt 2, nach einem Lyoner Pontifikale von ca 1400 aber gerade wie jetzt am Schlusse des heiligen Opfers ${ }^{3}$. Dagegen werden nach einigen Weiheordines aus dem Beginne des 12. Jahrhunderts dem Konsekranden schon gleich bei Beginn der Feier manicae angezogen *. Natiurlich muften in diesem Falle die Handschuhe vor der Salbung der Hände wieder ausgezogen werden. Angelegt wurde dem Electus das Ornatstück bald durch den Konsekrator selbst, bald durch die demselben assistierenden Bischöfe, bald durch den Archidiakon. Es herrschte auch hierin im Mittelalter keine Übereinstimmung.

Im Ritus der Benedictio abbatum wird, wie schon gelegentlich bemerkt wurde, die Überreichung des Ornatstückes bereits im 12. Jahrhundert erwähnt. Doch konnte hier natürlich die Zeremonie nur dann statthaben, wenn der Abt sich kraft eines Privilegs des usus chirothecarum erfreute.

Das Gebet, welches gemäßs den älteren Pontifikalien gesprochen wurde, während der Archidiakon unter Beihilfe von Subdiakonen in Gegenwart zweier Bischöfe dem Konsekranden die Handschuhe anzog, lautete: "Allmächtiger, mildreichster Gott, wir bitten deine unermefliche Güte, du wollest die Hände dieses deines Dieners, unseres Mitbruders, sowie sie äußerlich mit diesen Handschuhen umhüllt werden, auch innerlich mit deines Segens Tau besprengen, dak, was immer sie zu segnen oder zu weihen haben, durch dich gesegnet und geweiht werde." Nach den Pontifikalien des späten Mittelalters verrichtete der Konsekrator selbst bei Anlegung der Pontifikalhandschuhe das Gebet. Das heutzutage bei dieser Zeremonie gebräuchliche findet sich schon im Pontifikale des Durandus ${ }^{5}$.

\section{URSPRUNG DER PONTIFIKALEN HANDBEKLEIDUNG.}

Über den Ursprung der liturgischen Handschuhe läfst sich nur weniges sagen. Dieselben sind ein dem Abendlande durchaus eigentiimliches Ornatstück. In der Kirche des Ostens haben chirothecae niemals bei der Liturgie Verwendung gefunden. Es können darum die Pontifikalhandschuhe nicht aus der griechischen Kirche entlehnt worden sein; sie sind vielmehr zweifellos im Abendlande selbst aufgekommen.

I In acent. III., De sacrif. missae 1. 1, c. 104157 (M. 217, 780789795 ). Ordo 13, n. 6 ; ordo 14 , c. 4853 (ebd. 78,1108 1153 1157). Vgl, auch Sicard., Mitralis 1. 2 , c. 8 (M. 213,88 ).

2 M a $x$ t. 1. 1, c. 8, art. 11 , ordo 16 ; II 82 .
3 Ebd. ordo 18; II 94. Vgl. auch Vat. Cod. Borgh. 72 (s. XIV) und Vat. Cod. lat. 1152 (s. XIV).

4 So der Ordo vulg. bei Hitt. 109 und ein Salzburger Pontifikale (M a rt. a. a. 0. ordo 8; II 53).

b Vat. Cod. lat. 1145, f. 35. 
In der römischen Kirche müssen die Handschuhe sich im Verlaufe des 10. Jahrhunderts eingebürgert haben. Sie treten also dort etwa gleichzeitig mit der Mitra auf. Zwischen der pontifikalen Kopfbedeckung und den Pontifikalhandschuhen ist jedoch insofern ein grober Unterschied, als jene sich bei ihrem ersten Auftreten als spezifisch römisches Ornatstủck kundgibt, während bei diesen ein solch ausschliefilicher Charakter niemals wahrzunehmen ist. Da nun die frühesten Pontifikalhandschuhe im Frankenreiche auftauchen, so scheint die Annahme nicht unbegründet, dak sie eben hier zuerst unter die liturgischen Gewänder Aufnahme erhielten, daf3 sie von dort sich dann allmählich über das Abendland verbreiteten und dabei gegen die Wende des Jahrtausends auch zu Rom Eingang fanden.

Wie ist es aber zur Entstehung der liturgischen Handschuhe gekommen? Daf dieselben zuletzt auf die Handschuhe des Alltagslebens zurückzuführen sind, welche namentlich im Norden weitverbreitet und bei allen Ständen ${ }^{\text {, }}$ zumal aber den vornehmen, gebräuchlich waren, liegt zu Tage. Fraglich ist nur, was ihre Aufnahme unter die Sakralkleider veranlast hat.

Es ist gesagt worden, die Handschuhe seien eingeführt worden, um die Hände des Bischofs gegen die zur Winterszeit gewis oft sehr empfindliche Kälte zu schützen. Ebenso hat man gemeint, es sei geschehen, um den häufig sehr kostbaren Hirtenstab gegen die Ausdiinstungen der Hände und damit zugleich gegen Verderben zu sichern. Beides ist jedoch mehr als unwahrscheinlich. Dagegen spricht sowohl die beschränkte Verwendung, welche die Handschuhe bei den pontifikalen Funktionen fanden, als im besondern der Tmstand, dals sie nicht blok im Winter, sondern auch im Sommer getragen wurden, und nicht blof zugleich mit dem Stab, sondern, wie schon aus dem Sakramentar von Corbie erhellt, auch ohne denselben.

Der Hauptgrund dürfte vielmehr die Absicht gewesen sein, nach Art der bereits lange üblichen liturgischen Fufbekleidung anch die geweihten Hände des Bischofs mit einem entsprechenden Schmuck zu versehen. Wer die Entwicklung der Pontifikalgewandung verfolgt, dem kann nicht entgehen, daf. die hervorragende Stellung, welche die Bischöfe seit der Karolingerzeit einnahmen, ihren Einfluf auch auf die Ausgestaltung der bischöflichen liturgischen Tracht ausübte. Mehr denn je gingen diese darauf aus, sich beim Gottesdienst mit möglichster Pracht zu umgeben. Was immer der Osten an kostharen Zeugen und Borten schuf, wurde ohne Rücksicht auf Kosten und Mïhen ins Abendland gebracht, um hier den Bischof bei seinen heiligen Funktionen zu zieren. Unter solchen Umständen muste man es begreiflicherweise nachgerade vermissen, daß es zwar für die Füße des Bischofs eine eigentliche liturgische Kleidung gab, nicht aber für die Hände, die doch weit unmittelbarer am heiligen Dienst beteiligt waren. Und so erklärt es sich leicht, wenn die Bischöfe seit dem Ende des 9. Jahrhunderts dazu übergingen, ihre Hände mit einem entsprechenden Schmuck auszustatten, und wie im gewöhnlichen Leben, so auch beim Gottesdienst mit Handschuhen zu bekleiden.

Auch in den Klöstern waren Handschuhe, und $\mathrm{zw}$ ar sow ohI Finger- wie Fausthandschuhe, keineswegs unbekannt. Das 22. der Aachener Kapitel me monachis" vom Jahre 817 bestimmt, es solle jeder Mönch im Sommer wantos und im Winter muffulas verveciaas (Fausthandschuhe aus Schöpsenfell) erhalten (M. G. LL. c. 1, 345). Die Statuten Adalhards von Corbie aus dem Jahre 822 gewaihren den Klosterinsassen wantos duos (1. 1, c. 3 [M. 105, 538]). Die Constitutio Ansegisi abbat. Fontanellensis wirft für Anschaffiung der Handschuhe ein Pfund jährlich aus: ad wantos 1. 1 (ebd. 750); vgl, auch die manicae ( $=$ wanti) des c. 12 der Regeln des hl. Isidor (M. 83,882 ). 
Wir sagten, der Hauptgrund; denn es mag auf die Einführung der Pontifikalhandschuhe auch das praktische Bestreben von Einfluls gewesen sein, die Hände des Bischofs bis zur Vornahme der Opferung möglichst gegen Verunreinigung zu sichern. Dafür spricht zunächst die eigenartige, auf den Beginn der Messe beschränkte Verwendung, welche die Pontifikalhandschuhe, wie das Sakramentar von Corbie beweist, schon im 10. Jahrhundert fanden. Damn ist es wohl nicht ohne Grund, wenn bereits die älteste bekannte mystische Deutung in den bischöflichen chirothecae das Symbol der Reinheit sieht ${ }^{1}$. Endlich ist auch die Antwort bemerkenswert, welche Bruno von Segni auf die Frage gibt, warum die Hände des Bischofs mit Handschuhen bekleidet würden. "Ich antworte", sagt er, „kurz und bündig: damit sie rein, sauber, von allem Schmutze frei und lauter seien."

ZWEITES KAPITEI.

\section{DIE PONTIFIKALE FUSSBEKLEIDUNG.}

\section{DIE PONTIFIKALE FUSSBEKLEIDUNG IN DER GEGENWART. IHRE BESTANDTEILE: SANDALEN UND CALIGAE.}

Im Gegensatze zu dem Hohenpriester des Alten Bundes, der barfuf seinen Dienst verrichtete, trägt der Bischof bei Darbringung des heiligen Opfers eine besondere Fubbekleidung, die Sandalen und die CaIigae, d. i. liturgische Schuhe und Strümpfe. Sie bilden wie die Pontifikalhandschuhe einen spezifischen Mefornat, da sie nur bei der Mefifeier, nicht aber auch bei andern pontifikalen Amtshandlungen zur Verwendung kommen. Sie werden dem Bischof angezogen, während er die Vorbereitungsgebete zur Messe verrichtet 2. Das Anlegen der Sandalen und der Caligae, welches beim rechten Fub beginnt, hat der Subdiakon, welcher die Epistel singt, unter Beihilfe der Akolythen und der bischöflichen Diener zu besorgen. Sache des Subdiakons ist es auch, die durch ein Velum verhüllten Sandalen und Caligae mit verdeckten Händen vom Kredenztisch herbeizuholen und nach Schluls der Messe dem Bischof die pontifikalen Schuhe und Strümpfe auszuziehen ${ }^{3}$.

Die Sandalen und Caligae tragen zu dürfen ist ein bischöfliches Vorrecht4. Äbten und sonstigen Prälaten steht ihr Gebrauch nur kraft eines besondern Privilegiums zu. In dieser Beziehung gilt bezïglich der liturgischen Fußbekleidung dasselbe, was hinsichtlich der Pontifikalhandschuhe bemerkt wurde. Sandalen und Caligae folgen nach gegenwärtigem Gebrauch der Tagesfarbe. Schwarze gibt es nicht, da der Bischof sich weder in Totenmessen noch am Karfreitag der pontifikalen Schuhe und Strümpfe bedient ${ }^{\circ}$. Über ihre Beschaffenheit und Form bestehen keine ausdrücklichen Vorschriften. Die Gewohnheit will jedoch, dafs der Oberteil der Schuhe und die Strümpfe, welch letztere sowohl durch Wirkerei als auch durch Zusammennähen von Stoffstücken hergestellt werden können, aus Seide gemacht seien. Behufs Befestigung werden die Caligae am oberen Ende zweckmäßsig mit Bändern versehen. Die Schuhe, die von den alten Sandalen nur mehr den Namen halıen, hinsichtlich der Form aber von ihnen vollständig verschieden

\footnotetext{
I Sie findet sich im Sakramentar von Corbie.

Caerem. epise. 1.2, c. 8, n. 7 .

3 C. H. vom 27. März 1824 (Decret. auth. 26.34).
}

\footnotetext{
Von den Kardinälen bedienen sich nur die Kardinalbischöfe und die Kardinalpriester der liturgischen Fußbekleidung.

${ }^{5}$ Cacrem. episc. 1.2 , c 11, n. 2 et c. 25, n. f.
} 
sind, haben meist Pantoffelform und können oben und an den Seiten mit Stickereien verziert werden. Ein Krenz auf der Mitte des Oberteiles anzubringen, ist nicht notwendig und zu Rom sogar nur bei den Sandalen des Papstes, nicht aber bei denen der Kardinäle oder Bischöfe gebräuchlich ${ }^{1}$.

Bei der Bischofsweihe sind Sandalen und Caligae nicht der Gegenstand einer besondern Zeremonie. Das Gehet, welches der Bischof nach dem römischen Missale bei Anlegung der liturgischen Fubbckleidung spricht, lautet: „Beschuhe, o Herr, meine Fiibe zur Verkündigung des Evangeliums des Friedens und beschütze mich unter dem Schirme deiner Fittiche." Der Bischof ist vor allen der Herold des Friedensevangeliums. Er hat daher stets gerïstet zu sein, dahin zu cilen, wo das Brot der göttlichen Lehre den christlichen Volke gebrochen werden muf. Das Simubild dieses Bereitseins ist die pontifikale Fubbekleidung, bei deren Anlegung deshalb der Bischof un die Gnade einer rechten Bereitwilligkeit zur Predigt des Evangeliums fleht. Der zweite Teil des Gebetes bezieht sich auf die Caligae, das Symbol des göttlichen Schutzes, dessen der Verkündiger der Heilshotschaft hei der Ausiubung seiness hohen Amtes bedarf.

\section{DIE LITURGISCHE FUSSBEKLEIDUNG IN DER RÖMISCHEN KIRCHE BIS ZUR WENDE DES ERSTEN JAHRTAUSENDS.}

Eine liturgische Fublekleidung ist, anders wie die pontifikale Mitra und die sakrale Handbekleidung, nicht erst die schöpfung des ausgehenden ersten Jahrtausends. Sie tritt uns vielmehr im römischen Ritus schon recht früh entgegen. Indessen wurde die Zeit, welche die Mitra und die Handschuhe in den Kinltus einführte, doch auch für die liturgische Fulbekleilung insofern sehr bedeutungsvoll, als sie aus dieser ein ausschlielilich pontifikales Ornatstïck machte.

Die sakrale Beschuhung kam vor allem stets dem Papste zu. Als Stephan III. (752-757) dem Abte Fulrad von St-Denis 757 das Recht verlieh, sich des udonis ac subtalaris calciamentum zu betienen, bezeichnete $\mathrm{el}^{\circ}$ diese Fulibekleidung als ornatum apostolici vestimenti, als Bestandteil der päpstlichen Gewandung? ${ }^{2}$. Dieselbe war dem Papste sogar in einem solchen Mafe eigen, daßs sie als eine Art von Abzeichen desselben galt.

Als darum Kaiser Konstans den Papst Martin I. (649-655) zu Konstantinopel widerrechtlich seiner Würde beraubte, liels er ilm nicht nur, wie ein \%eitgenosse des Heiligen und Augenzenge der von diesem erlittenen Mibhandlungen berichtet, das psachnion (Pallium) ahreicien, sondern auch die Liemen seiner campagi zerschneiden 3. Ähnlich berichtet der Liber Pontificalis in der Vita Stephani IV. (768-772), es habe der Diakon Maurianus dem

' Die Pontifikalstrümpfe sind nicht mehr iiberall in Brauch, so nicht in vielen Diözesen Deutschlands. Man begnüigt sich mit den gewöhulichen violetten bischöflichen Strümpfen.

2 J.n. 2330. Wegen der Echtheit des Dokumentes, welche Pflugk-Harttung leugnet, vgl. Hist. Jahrb. 1883, 587, worin Grauert füx dieselbe eintritt. Dafür auch Oelsner, Jahrbìcher des fränkischen Reiches, Leipzig 1871, 287. Aus dem Inbalt der Bulle dürfte

Braun, Die liturgisehe Gewandung. sich schwerlich ein Grund für die Unechtheit hernehmen lassen; aber auch sonst liegt unseres Erachtens kein genïgender Anlak vor, ihre Echtheit in Frage zu ziehen. Fulrad war nur Priester, weshalb der liturgische Schuh, dessen Gebrauch ihm gestattet wird, in der Bulle ganz richtig subtalaris genannt wird (vgl. die Angaben des S. G. K.).

${ }^{3}$ Commemoratio eorum, quae saeviter acta sunt in sanctum... martyrem Martinum papam (M. 129, 595). 
Afterpapst und Eindringling Konstantin zum Zeichen seiner Absetzung das Orarium (hier Pallium) rom Halse genommen und die campagi von den Füfren geschnitten ${ }^{1}$.

Nichtsdestoweniger ist es unzutreffend und eine Übertreibung, wenn die beiden Yönche Theodosius und Theodorus in ihrem um 670 geschriebenen Hypomnestikon die Bemerkung machen, es trage diese Beschuhung kein anderer unter den Menschen als der rönische Papst ${ }^{2}$. Denn wir treffen genau dieselbe Fufbekleidung, wie sie die Päpste Honorius I. (625-638) und Symmachus (498-514) auf dem um 630 entstandenen Mosaik der Apsis von St Agnese fuori le Mura haben (Bild 64, S, 160), bereits um die Mitte des 6. Jahrhunderts auf den musivischen Darstellungen in S. Vitale zu Ravenna (Bild 63, S. 159) bei Erzbischof Maximian von Ravenna und seinen Ministri, ja sogar schon gegen das Ende des 5. Jahrhunderts bei den hll. Ambrosius und Maternus auf dem Mosaik der Kapelle des hl. Satyrus bei S. Ambrogio zu Ma iland (Bild 62, S. 158) an. Ebenso finden wir sie beim Presbyter Vincentius auf einem dem 6.-7. Jahrhundert entstammenden Fresko in S. Callisto zu Rom ${ }^{3}$. Dafs ferner die Diakone von Messina bereits um die Mitte des 6. Jahrhunderts die campagi trugen, erhellt ans dem Schreiben Gregors d. Gr. an den Bischof Johannes von Syrakus. "Wir haben gehört", so schreibt der Papst, ,es hätten sich die Diakone von Catania minterfangen, mit campagi beschuht (zur Messe) aufzuziehen. Bisher ist so etwas in ganz Sizilien nur den Diakonen von Messina erlaubt gewesen, welche dazu von unsern Vorgängern unzweifelhaft ermächtigt wurden. Da man nun ein so verwegenes Beginnen nicht leicht nehmen darf, so wolle Eure Fraternität mit aller Gründlichkeit den Sachverhalt untersuchen. Sollte die Nachricht, die wir erhielten, der Wirklichkeit entsprechen, so möge Eure Fraternität uns auch genau mitteilen, ob die Diakone von Catania aus sich oder auf Anstiften von irgend einem andern hin der Sache sich unterfangen haben, damit wir das Nötige anordnen." 3 Es war also schon unter den Vorgängern Gregors d. Gr. den Diakonen von Messina gestattet worden, sich des campagus bei ihren Amtsverrichtungen zu bedienen.

Daf auch die römischen Diakone zu Gregors Zeit den campagus trugen, wird in dem Schreiben an Johannes nicht ausdrücklich ausgesplochen. Indessen kann das Vorrecht, welches des Papstes Amtsvorgånger den Diakonen von Messina verliehen hatte, wohl nur als Zuwendung einer den Diakonen von Rom zustehenden Fußbekleidung aufgefast werden. So war ja auch vor Gregor in Sizilien nach dem Vorbild der römischen Kirche eine Amtstunika für die Subdiakone eingeführt worden. Es ist sogar nicht unwahrscheinlich, dab zu Gregors d. Gr. Lebzeit zu Rom eine liturgische Beschuhung nicht blof bei den Diakonen, sondern auch bei den Subdiakonen und Akolythen im Gebrauche war. Jedenfalls verhielt es sich so um den Beginn des 8. Jahrhunderts.

1 Duch., L. P. I 472; vgl. dazu nota 21 , 1. 482. Was hier und in der Commemoratio berichtet wird. wirft ein helles Licht auf eine bisher ungedeutete Stelle in des A gnellus Liber pontificalis (M. G. SS. Langob. 352), von der noch der Herausgeher desselhen in den M. G., Holder-Igger, gestand (ebd. nota 4): Hoc quid sibi velit, non intelligo. F.s mird dort erzihlt, Papst Vitalian loabe den schismatischen Erzbischof Maurus vou Riavenna exkommuniziert, worauf dieser das gleiche mit Bezug auf den Papst getan. Dariber seien beire gestorbon. Wie num berichtet werlo, sei die Sache nach längerer
Zeit zu Rom auf einem Konzil beraten worden und hätten dann die Bischöfe zum Zeichen der Absetzung beider summitatem cunpadis pedis dexteri zerschnitten. Liest man statt des verderbten cunpadis das richtige campagi, so erklärt sich die - freilich fabelhafte - Angabe des romfeindlichen Agnellus auf die einfachste Weise. Der campagus galt damals als Symbol des Amtes, sein feierliches Zerschneiden war also Ausdruck der Amtsentsetzung.

2 M. 129, 685. Sie tun das mit Bezug auf einen als Reliquie des hl. Martin I. aufbewalirten campagus.

Ep. 1.8, n. 27 (M. G. Epp. II 28). 
Unter den Vorrechten nämlich, welche der Verfasser des Constitutum Constantini den Kaiser Konstantin clericis diversis ordinibus eidem romanae ecclesiae servientibus verleihen läbt, befindet sich auch dieses, daß sie sich der Auszeichnung erfreuen sollten, sicut noster senatus calceamenta uti cum udonibus, i. e. candido linteamine ${ }^{1}$. Es wurde demnach zur Zeit, da die pseudo-konstantinische Schenkung entstand, sonder Zweifel schon lange das auszeichmende Schuhwerk von den verschiedenen Ordines des römischen Klerus getragen.

Selbst im 9. Jahrhundert fand eine liturgische Fußsbekleidung in Rom noch bei Geistlichen aller Ordines Verwendung. Denn Amalar berichtet in seiner Erklärung des römischen Mefritus und der römischen Sakralkleidung ausdrücklich von den sandalia des Bischofs, des Priesters, des Diakons und des Subdiakons. Ebenso weist noch das St Gallener Kleiderrelzeichnis den Presbytern, Diakonen und Subdiakonen, ja selbst den Akolythen eine liturgische Beschuhung $\mathrm{zu}^{2}$.

Der 1. und der 3. römische Ordo reden weder von den campagi noch ron den udones, obschon sie doch genau angeben, mit welchen Gewänderu der Papst vor dem Amte zu bekleiden war. Dem olverflächlichen Blick mag das auffällig erscheinen. Die Sache erklärt sich indessen sehr leicht. Mit der Fulibekleidung versahen sich Papst und Ministri bereits vor dem feierlichen Aufritt zur Kirche, in welcher Station zu halten war. Ein Wechsel der Beschuhung in der Sakristei war infolgedessen natiulich nicht notwendig. Wenn jemand die Bischofsweihe empfangen sollte, wurde er nach dem 8. Ordo Mabillons, welcher noch ins 8. Jahrhundert hinaufreichen wird, im Sekretarium während der Absingung des Graduale mit den campobi verterbte Lesart für campagi) versehen ${ }^{3}$.

Ob campagi und udones von Anfang an ein ausschliebilicher Mefornat wie die jetzigen Sandalen und Caligae waren, muk dahingestellt bleiben. Es ist bemerkenswert, daf noch auf den Bildwerken des 6. und 7. Jahrhunderts selbst Laien mit derselben Fulbekleilung versehen sind, welche wir auf ihnen bei den Päpsten, bei Bischöfen und sonstigen Geistlichen gewahren. Beispiele liefern die Mosaiken in S. Cosma e Damiano (die Titelheiligen) ${ }^{4}$ und S. Teodoro (der hl. Theodor und ein zweiter ungenannter Heiliger) ${ }^{j}$ zu Rom und der musivische Wandschmuck in S. Vitale (das Gefolge Justinians und Theodoras) zu Ravenna.

1 Hinschius, Decret. Pseudoisidor. 253. Ol, man unter den römischen Klerikern rer śchenkung nur die Kardinalkleriker versteht, wie Grauert (Histor. Jahrbuch IV [1883] 48) will (vgl. auch Scheffex-Boichorst in Mitteilungen des Institutes für österreichische Geschichtsforschung X [1889] $305 \mathrm{f}$ und $\mathrm{S}$ ä g $\mathrm{m}$ ü ll le r, Tätigkeit und Stellung der Kardinäle, Freiburg 1896, 159, Anm. 3), oder den ganzen Weltklerus Roms, ist hier von keinem Belang.

2 Die Interpunktion, wie sie in $\operatorname{dem} \mathrm{Ab}$ druck des S. G. K. bei Mabillon (M. 78, 985) im Anfang von $\mathrm{n}$. 3 sich findet, ist sinnlos. Statt presbyter romanus similiter, praeter tantum subtalares, quos mittit presbyter et diaconus. In primis cam. etc. ist zu lesen: quos mittit presbyter, et diaconus in primis cam. Nach der jetzigen Interpunktion werden auch dem Diakon die subtalares zugeschrieben, obschon sich aus dem Folgenden ergibt, daf er wie der Bischof die campagus genante Schuhart trug.

${ }^{3}$ N. 8 (ebd. 1004).

${ }_{4}$ Eutstanden unter Felix IV. (526-550). G a r r. tav. 253.

${ }^{5}$ 6.-7. Jallrhundert. G arr. tav. 252. Auch auf dem Mosaik in S. Venanzo zu Rom tragen die Laien Paulinianus, Telius, Antiochianus und Gajanus jetzt dieselbe Fuf̧̧bekleidung wie die Bischöfe Domnio usw. Es ist wahrscheinlich, daß solches schon im wesentlichen vor der in diesem Jahrhundert erfolgten Erneuerung der Fall war. 
Die offiziellen $\mathrm{Namen}$ für den liturgischen Schuh waren bis ins 10. Jahrhundert hinein zu Rom campagus und subtalaris. Gegen die Wende des Jahrtausends kommen damn beide allmählich auker Gebrauch, indem sie der Bezeichnung sandalia Platz machen. Im 12. Jahrhundert ist cie neue Benennung fast ansschliefalich üblich. Sehon die Bullen des 11. Jahrhunderts, in welchen Äbten das Recht verliehen wird, die liturgischen Schuhe zu tragen, reden mit verschwindenden Ausnahmen nur noch ron sandalia. Dieses Wort begegnet uns als same der sakralen Fufbekleidumg zuerst im Norden. Sandalia heifst dieselbe z. B. schon bei Hraban, bei Amalar, bei Walafried Strabo a. a., während der S. G. K. den liturgischen Schuh noch campagus bzw. subtalaris nennt. Der Name Sandalia dürfte sich, wie sich aus den Ausführungen Hrabans ergibt, an Mk 6, 9 anlehnen. Immerhin mag auch die sandalenartige Form des Schuhes, von der später die Rede sein wird, zum Aufkommen der Bezeichnung beigetragen haben.

Der älteste Name für den sakralen Strumpf bzw. die unmittelbar über den Füßen getragene, bis zu den Knieen reichende innere Fußbekleidung ist udo (odho, odo). Das Wort kommt im klassischen Latein nur selten vor. Bei Martial (Epigr. 14, 140) bedeutet es wohl einen Filzschuh. Diokletians Maximaltarif zählt die udones zu den Gewandstïcken, welche der hraccarius, der Hosenmacher, Schneider, anfertigte ${ }^{1}$. Ulpian rechnet sie nicht $\mathrm{zu}$ den vestes, sondern zu den calceamenta ${ }^{2}$. Als terminus technicus der inneren Fußghekleidung erhielt sich das Tort bis gegen das zweite Jahrtausend; dann verschwindet es, um der Bezeichnung caliga Platz zu machen. Caliga bezeichnete bei den Römern den Soldatenschuh und noch in den Regeln des lil. Benedikt und des Magisters einen schweren Winterschuh ${ }^{3}$. Später verknüpfte man aber mit ihm die Bedeutung Strumpf, und es wurde dann caliga der Sondername für den pontifikalen Strumpf. Wie es scheint, geschah letzteres gleichfalls zuerst im Norden. So wiederholt sich auch bei der liturgischen Fußsbekleidung, was sich schon bei andern zum Kultus gehörenden Gewandstücken wahrnehmen ließ, daß eine dem Ursprung nach auferrömische Benennung zu Rom Eingang findet und die dort gebräuchliche Bezeichnung allmählich ganz verdrüngt. Die Caligae hicfsen übrigens im späteren Hittelalter auch wohl sotulares (soculares), verderbt aus subtalares; so in einem Inventar von Angers: Duo paria sandaliorum cum socularibus; ferner in einem Schatzverzeichnis von Amiens (1347): sandalia pontificalia de dyaspreto rubeo cum sotularibus - et sunt sotulares ipsi operati de auro cum nodulis et armis Franciae et Navarrae und in den Gesta der Bischöfe von Le Mans ", wo berichtet wird, Gottfried von Loudon habe der Kathedrale sandalia et sotulares rubei serici, auri preciosorumque lapidum varietate distincta geschenkt.

\section{DIE LITURGISCHE FUSSBEKLEIDUNG AUSSERHALB ROMS BIS ZUM XI. JAHRHUNDERT.}

Am frïhesten begegnen uns campagi und udones in der Mailänder Kirche, früher noch als selhst in Rom. Denn es ist gewif nicht Zufall, wenn auf dem Mosaik in der Kapelle des hl. Satyrus (5. Jahrhundert) nur Ambrosius und Maternus, nicht aber die neben ihnen stehenden hll. Gervasius, Protasius, Nabor und Felix mit solchen ansgestattet sind, letztere vielmehr bloge Füfe und die gewöhnlichen Sandalen aufweisen. Die Fubhekleilung soll ersichtlich den Stand der beiden heiligen Bischöfe andeuten.

In Sizilien bedienten sich die Diakone von Messina des campagus seit etwa der Mitte des 6. Jahrhunderts; zu Gregors d. Gr. Zeit aher hatten

Ehenso weist Rufinianus auf den Fresko in dem Cömeterium der Generosa, das nach de Rossi vor 682 entstanden sein muk, die gleiche Beschuhung auf (Abbildung bei de Rossi, Roma sott. III, tav. LI, besser bei Wilp., Kat, Tft 262).
I Vommsen-Blümner, Des Naximaltarif des Diokletian 113.

2 Dig. 34, 2, 25, \$ 4.

3 Benedict. Anian, Concordia regul. c. 62 , \$ 1 2) (H. 10\%, 1229 f 1252).

${ }^{4}$ C. 44 ( $\mathrm{Iabillon}$, Vet. Anal. III 390). 
auch die Cantanenser Diakone angefangen, ihn zu tragen. Daf auch sizilianische Bischöfe damals von ihm Gebrauch machten, wird zwar nicht berichtet, ist aber sehr wahrscheinlich. Denn wenn sich Diakone auf Sizilien des campagus rühmen konnten, so werden sich seiner erst recht die Bischöfe erfreut haben. Wir hören überhaupt niemals davon, daf Rom Bischöfen die Erlaubnis verlieh, sich seiner zu bedienen. Es scheint, dak diese dazu nie einer Ermächtigung bedurften.

Zu Ravenna müssen campagi und udones schon vor der Mitte des 6. Jahrhunderts sowohl beim Bischof wie auch bei den Diakonen in Benutzung gewesen sein. Auf den Mosaiken in S. Vitale zu Ravenna und S. Apollinare in Classe, welche ca 547 und 567 entstanden, finden sie sich nämlich nicht blof bei den Bischören Maximian, Ecclesius, Trsicinus, es sind vielmehr ebenso die Diakone Maximians in S. Vitale mit ihnen ausgestattet.

Wie weit sie sonst noch in Italien im 6. und 7. Jahrhundert verbreitet waren, läft sich nicht sagen ${ }^{1}$. Nach England mögen sie zugleich mit dem römischen Ritus durch den hl. Augustinus gekommen sein "2: doch fehlt es an Nachrichten über ihre Verwendung daselbst.

Freilich soll im 3. Kapitel des Pönitentiale Theodors von Canterbury († 690), das seit dem 12. Jahrhundert in den Pontifikalien mehrfach dem Ritus der Abtsweihe vorausgeschickt wurde, von der liturgischen Fußbekleidung die Rede sein ${ }^{3}$. Es heifst darin: In ordinatione abbatis episcopus debet missam cantare et eum benedicere.. et dat ei baculum et pedules. Indessen ist erstens die Autorschaft Theodors mehr als fraglich. Dann aber scheint pedules ein Schreibfehler für regulas zu sein ". Ein um 1200 entstandenes Pontifikale von Sens schreibt richtig: dat ei baculum et regulam ${ }^{5}$. Tatsächlich wird auch in keinem Formular für die Einsegnung der Äbte der Übergabe einer besondern Fufbekleidung weiter gedacht; wohl aber werden nach allen dem Abte aufer dem Stab, wie das auch sehr bezeichnend ist, die Ordensregeln übergeben ${ }^{6}$. Drittens endlich, was sollen überhaupt die pedules im Kapitel Theodors bedeuten: Unter den pedules wurde keine Schuhart, sondern die innere Fufibekleidung, also eine Art von Strumpf verstanden. In diesem Sinne begegnet uns das Wort wiederholt in den MIönchsregeln. Auch waren die pedules kein dem Abte ausschliefilich zustehendes Gewandstück. Vielmehr trugen alle Mönche dieselben, zumal zur Winterszeit ${ }^{7}$. Allerdings kommen in späterer Zeit pedules hie und da, wenngleich nur sehr

1 In der Vita S. Fulgentii († ca 529), die von einem Schüler des Heiligen verfaßt wurde, werden calceamenta clericorum erwihnt. Es ist darinter aber allem Anschein nach Keine sakrale, sondern eine außBerliturgische Beschuhung der Geistlichen zu verstehen. Es folgt das aus dem Gegensatz, in welchem dieselben zur mönchischen winterlichen caliga und sommerlichen caligula gesetzt werden. Der Biograph will nur sagen, der hl. Fulgentius habe sich, seitdem er aus einem Mönch Bischof geworden, aus Demut weiterhin der den Mönchen eigenen Fufbekleidung bedient. Sic studio humilitatis ambitionem vestium fugit, ut nec ipsa calceamenta suscipiens clericorum ant ultimis (vilissimis) caligis in tempore hiemis, aut caligulis in tempore aestatis nteretur. Intra monasterium sane interdum soleas accipiebat, frequenter nudis pedibus ambulabat (c. 18 [M. 65, 136]).
2 Nach Beda sandte Gregor d. Gr. dem hl. Augustinus durch Mellitus, Justus, Paulinus und Rufinianus, die er dem Apostel Englands zu Hilfe schickte, quae ad cultum erant ac ministerium necessaria, darunter auch sacerdotalia vel clericalia indumenta. Auch übersandte er ihm das erzbischöfliche Pallium, indem er gleichzeitig selbiges für die demnächst zu kreierenden Metropoliten von York und London (Canterbury) in Aussicht stellte (Hist. eccl. 1. 1, c. 29 [M. 95, 69]).

${ }^{3}$ Roh. VIII 179 a. a.

4 Vielleicht veranlaft durch ein Mifverständnis der angelsächsischen $\mathrm{p}, \mathrm{g}$ und $\mathrm{e}$.

${ }_{5}$ Mart. 1. 2, c. 1, ordo 5; II 155. Vgl. auch ebd. ordo 1; II 147: dat ei regulam.

${ }^{6} \mathrm{Hitt}$. 155. M art. 1. 2, c. 1; II 146.

7 Cf. Benedict. Anian., Concordia regul. c. 62 (M. $103,1229 \mathrm{ff}$ ). Vgl. auch D. C. sub pedules VI 246. Bei Ulpian (Dig. 34, 2, $25, \$ 4)$ werden die pedules gleich den 
vereinzelt, im Sinne der Pontifikalstrümpfe vor ${ }^{1}$. Indessen welchen Sinn hat eine Übergabe der Pontifikalstrümpfe ohne die der Sandalen? Und dann kamen ja die Pontifikalstrümpfe erst in weit späterer Zeit bei den Äbten in Gebrauch.

Ein unbegreifliches Mißverständnis ist es, wenn de Linas den ehrwürdigen Beda von der liturgischen Fufbekleidung sprechen lifist. Bede (De tabernaculo), sagt derselbe $^{2}$, énumérant les habits de lin, qui doivent envelopper le corps du prêtre, dit au sujet des fasciae crurales et pedules: Genua, ne ab orationis instantia torpeant, tibias et pedes, ne ad malum currant. Beda redet an der fraglichen Stelle ${ }^{3}$ von der Tunika, nicht von fasciae crurales et pedules. Auch spricht er nicht von der Gewandung der christlichen, sondern der jüdischen Priester, bei denen es bekanntlich eine derartige Fußbekleidung nicht gab.

Die früheste Nachricht, die wir aus Gallien über eine liturgische Fußbekleidung erhalten, findet sich in dem bereits erwähnten Dokument Stephans III. vom Jahre 757, in welchem der Papst dem Abt Fulrad von St-Denis den Gebrauch der udones und der subtalares gestattet.

Allerdings geschieht der subtalares schon in Urkunden der Bischöfe Innocentius († 541), Domnolus $(\dagger 552)$, Hadoindus $(\dagger 652)$ und Berarius $\left(†\right.$ 678) von Le Mans Erwähnung ${ }^{\dagger}$. Allein diese Schriftstücke sind nichts als spätere Fälschungen zum Zwecke der Wahrung vermeintlicher Rechte $ّ$. Unecht ist auch die von 667 datierte Schenkung Leodebods von Aniane mit ihren sandalia duo ad missam ${ }^{6}$.

Im gallikanischen Ritus scheint es eine besondere Beschuhung nicht gegeben zu haben, wenngleich es den Klerikern durch den 20. Kianon des Konzils von Agde aus dem Jahre $506^{7}$ und durch den 5. Kanon des Konzils von Mâcon vom Jahre $583^{\mathrm{s}}$ untersagt worden war, calciamenta saecularia, nisi quae religionem decent, anzuziehen.

Für die Aufnahme der liturgischen Fußbekleidung im Frankenreich war die Reformtätigkeit Karls d. Gr. von höchster Bedeutung. Ein Kapitular des Kaisers aus dem Jahre 789 beschäftigte sich unter anderem auch mit den calciamentis secundum usum romanum ${ }^{9}$. Leider ist vou dem betreffenden Kapitel nur mehr der Titel vorhanden, so dalis es nicht hinlänglich klar ist, ob es sich darin um eine sakrale oder eine profane Fufbekleidung handelte; doch ist nach der Überschrift wie dem Zusammenhang: kaum daran zu zweifeln, daf an die erstere gedacht ist.

fasciae crurales und den impilia (Filzsocken) zu den vestes gerechnet, quia partem cor'poris vestiunt.

1 So in zwei, allerdings wenig zuverlässigen Bullen für S. Pietro in Cielo d'Oro zu Pavia (J. n. 3826 4283) und in einer Handschrift des 12. (nicht 11.) Jahrhunderts bei Gerbert, Ironum. liturg. alem. II 52.

2 Pievue 1863,241 . So auch aus de Linas Roh. VIII 179 .

${ }^{3}$ De tabernac. L. 3, c. 8 (M. 91, 480).

1 Es lejfit darin, das Kloster des hl. Carilef zu Anisola ('st-Calais-ru-Desert, Mayeune) solle jährilich an die Mutterkirche von Le Mans aufser anderu Abgaben ad opus episcopi... subtalares 2 entrichten (Mabillon, Vet. Analect. III 85105163181 233). Nicht die bischife hintroliefien lie subtalares den
Äbten des Klosters des hl. Carilef, wie de Livas (Revue 1862,620) sagt. Es hatten diese vielmehr die subtalares zum Gebrauch des Bischofs von Le Mans jährlich zu liefern. In der Bestätigungsurkunde Chilperichs, welche derjenigen des Bischofs Domnolus beigefitgt ist, wird sogar ausdrücklich bemerkt: et 2 subtalares ad missam cantandam optimos (ebd. 107; cf. 184: duo subtalares ad officium sum peragendum).

5 Paul Poth, Benefizialwesen, Erlangen 1850, 451. Havet, Les chartes de St-Calais, in Biblioth. de l'École des Chartes XLVIII (1887) $5 \mathrm{f}$.

6 M. $88,1188$.

$7 \mathrm{H}$ ard. II 1000.

8 M. G. IJL. sect. III, Conc. I 156.

9 Ebd. sect. II, Cap. I 64. 
Seit dem Ende des 8. Jahrhunderts ist in der Tat wiederholt von einer liturgischen Beschuhung die Rede, zuelst bei Theodulf von Orléans ${ }^{1}$, dann bei Hraban, Amalar, Walafried Strabo, Pseudo-Alkuin u. a. Von keinem wird sie als spezifisch bischöflicher Ornat bezeichnet. Amalar redlet sogar ausdrücklich von den Sandalen des Bischofs, des Priesters, des Diakons und des Subdiakons 2. Ein gleiches tut Pseudo-Alkuin, dessen Ausführungen indessen zum größten Teil fast wörtlich von Amalar entlehnt sind.

Daf3 sich wirklich im 9. Jahrhundert im Frankenreiche nicht die Bischöfe allein einer besondern Beschuhung beim heiligen Opfer hedienten, erhellt aus Kapitel 371 des ersten Buches der Kapitularensammlung des Benedikt Levita: "Ein jeder Priester soll das Meß3opfer nach dem römischen Ordo in Saudalen darbringen." 3 Ein gleiches ergibt sich ans c. 105 der Kapitel Herards von Tours aus dem Jahre 858, welches bestimmt, es sollten die Priester in Sandalen die Messe feiern". Tnklar ist, wohin die Tendenz dieser Bestimmungen wie auch des Kapitulars Karls d. Gr. aus dem Jahre 789 ging. Wollte man durch Einführung der römischen Fubbekleidung eine minder passende in Gallien gebräuchliche beseitigen, oder hat man ilre Aufnahme vorgeschrieben, weil man sie als Bestandteil des römischen Ritus ansah, oder sollte endlich die Herübernahme der auszeichnenden römischen Beschuhung eine Ehrung für den gallischen Klerus darstellen?

Übrigens kann die Verwendung einer sakralen Fulihekleidung seitens der Priester und des übrigen Ḱlerus im Frankenlande während des 9. Jahrhunderts nicht allgemein gewesen sein; denn die sandalia werden weder in der sog. Admonitio synodalis noch in den Capitula Riculfs von Soissons unter die Ornatstücke gerechnet, deren sich der Priester bei der Messe zu bedienen und die er darum für die Feier des heiligen Opfers vorrätig zu halten hatte. Zudem muf die sakrale Beschuhung spätestens im Verlauf des 10. Jahrhunderts bei dem niedern Klerus dort wieder anfier Gebrauch gekommen sein. wo sie etwa im 9. von ihm getragen zu werden pflegte. Denn die Sandalen waren bereits un die Tende des Jahrtausends im Norden allgemein ein durchaus pontifikales Ornatstück geworden.

\section{DIE BESTANDTEILE DER LITURGISCHEN FUSSBEKLEIDUNG.}

Wie die sakrale Fufbekleirlung gegenwärtig aus zwei Stucken besteht. so setzte sie sich auch schon im ersten Jahrtausend aus zwei Bestandteilen zusammen, dem Schuh und der inneren Umhüllung des Fukes.

Man hat freilich gesagt, von den Pontifikalstrümpfen sei erst bei Ivo von Chartres († ca 1117) die Rede, und es habe die liturgische Fußbekleidung im 9. Jahrhundert nur in Sandalen bestanden 5 . Beides ist jedoch durchaus unzutreffend.

Von den Caligae redet nicht erst Ivo, sondern schon 1046 Klemens II. in seinem Schreiben an den Abt von Fulda und das Sakramentar von Corbie gegen das Ende des 10. Jahrhunderts. Usum sandaliorum, caligarum ac dalmaticarum ... cunctis ... abbatibus ... abradentum omnino iubemus, sagt

${ }^{1}$ Carm. 1. 5, n. 3 (H. 105, 355): Linea crusque pedesque tegant talaria ut apte, qui super, addatur campagus ipse decens. $110)$.
3 Baluzius, Capit. reg. Franc. I 903

M. 97,750 .

* Ebd. I 1293; M. 121, 771.

5 Realenc. II 215. Vgl. auch Hef., Beitr II 221 und Thalh ofer 893. 
Klemens ${ }^{1}$; das Sakramentar aber bemerkt: Prius quidem minister deferat caligas usque ad genua tendentes ... deinde minister det sandalia ${ }^{2}$. Es werden die Caligae sogar bereits im Testament Riculfs von EIne († 915) (caligae et sandalia paria duo) und dreiviertel Jahrhundert früher in einem Inventar ron St-Riquier erwähnt (sandalia cum caltionibus $[=$ caligis $]$ ).

Ebenso rechnet schon Amalarius mit ausdrücklichen Worten ein Linnen (limm calceamenti), womit die Füßre bekleidet wiinrden (quo pedes vestiuntur) ${ }^{3}$, zur sakralen Beschuhung. Noch etwas früher unterscheidet Theodulf von Orléans in seiner Ermahnungsrede an die Bischöfe klar und bestimmt zwischen dem eigentlichen Schuh und der inneren Umhüllung des Fulses und des Schienbeins (linea crusque perlesque tegant talaria) und dem dariber befindlichen campagus (ut apte, qui super, addatur campagus ipse decens). Beide Bestandteile der sakralen Fufbekleidung werden ferner bereits in Konstantins Constitutum, im Privileg Stephans für den Abt Fulrad und im St Gallener Kleiderkatalog erwähnt.

Auch auf den Mosaiken zu Rom, Ravenna und Mailand sind beide auf das deutlichste erkennbar. Man betrachte nur Papst Paschalis I. auf den musivischen Darstellungen in S. Cecilia, S. Maria in Domnica und S. Prassede, und die Päpste Gregor IV. und Markus samt den Diakonen Felicissimus und Agapitus auf denjenigen in S. Marco zu Rom; dann die Bilder Honorius' I. und Symmachus' in S. Agnese fuori le Mura, des Erzbischofs Maximian und seiner Ministri in S. Vitale zu Ravenna und der hll. Ambrosius und Maternus in S. Satiro zu Vailand. Das gleiche gilt von den Cömeterialfresken, wie z. B. der Darstellung des hl. Vincentius in der Katakombe des Pontian und des hl. Kornelius in s. Callisto. Nirgends ist der Fub bloß und lediglich mit einer Sandale versehen, wie das bei den Darstellungen Christi und der Apostel die Regel ist. Überall besteht die Fufbekleidung vielmehr aus einer weiben Bedeckung, die sich fest um den Fuf, das Gelenk und das Schienbein legt — den udones und dem Schuh - dem eigentlichen calceamentum oder campagus.

Unter diesen Umständen hat es offenbar nichts zu bedeuten, wenn Gregor der Grofe im Schreihen an Johannes von Syrakus nur vom campagus, oder Hraban, Pseudo-Alkuin, Walafried und Pseudo-Beda nur von den sandalia rerlen. Die uclones waren ein selbstrerständliches und zugleich minder bedeutsames Zubehör des Schuhes. Daher gehen Hraban, Pseudo-Alkuin und Walafried in ihren sehr kurzen Ausführungen über die liturgische Beschuhung nur auf die Sandalen ein. Gregor aber wird unter dem campagus als dem vorzüglicheren Teile die ganze Fußbbekleidung verstehen. Wie wenig sein und der andern b'chweigen ein Beweis gegen den Gebrauch der udones ist, folgt aus dem Umstande, daf noch in den päpstlichen Bullen des 11., 12. und 13. Jahrhunderts fast niemals die caligae, sondern nur die sandalia erwähnt werden.

Allein sagt man nicht, dak "Hraban und Pseudo-Alkuin die Existenz der bischöflichen Strümpfe geradezu in Abrede stellen" *? Allerdings, doch mit Unrecht.

Denn wenn Pseudo-Alkuin schreibt: Est autem genus calceamenti, quo induuntur ministri ecclesiae, subterius quidem solea muniens pedes a terra, superius vero nil operimenti habens patet ${ }^{5}$, so ist darnit nur gesagt, daf die Sandalen eine Art von

1 M. 142, 580.

2 M a t. 1. I, $\therefore$, art. 12, ordo 11; I 203.

${ }^{3}$ De eccles. off. 1. 2, c. 18: Sicut per linum, quo pedes vestiuntur, castigatio pedum significatur, ita per sandalia profectus ad praedicandum; c. 26: Calceamenti linea prohibitio pedum ad malum festinandos, sandalia ornatus iter praedicatoris (M. 105, 1095 1102).

4 Hef., Beitr. II 221.

5 De divin. offic. c. 39 (M. 101, 1242). 
Beschuhung seien, welcher das Oberleder fehle (nil operimenti habens). Wenn aber Hraban bemerkt: Sicut ergo sandalia partem pedis tegunt, partem inopertam relinquunt, so bedeutet das ersichtlich blof, die Sandalen bedeckten den Fufs nur zum Teil (nämlich unten), nicht aber, sie würden über den nackten Fuf angezogen und liefsen diesen demgemäß oben entblößst zum Vorschein kommen. Aber heifst es nicht bei Hraban mit klaren Worten unmittelbar vorher: Hoc calceamentum mysticam significationem habet, ut neque pes sit tectus, neque $\mathrm{nudus}$ ad terram, i. e. ut nee occultetur evangelium, nec terrenis commodis innitatur ${ }^{1}$ ? Gewib; allein auch Analarius bemerkt: Sandalia subtus cooperiunt pedem, desuper nudum relinquunt, während er doch zu gleicher Zeit und fast in demselben Atemzuge von einem Linnen redet, womit die Füfse bekleidet würden (linum, quo pedes vestiuntur). Hraban und Amalar wollen nur sagen, dafs der sakrale Schuh so beschaffen sei, daf er nicht den ganzen Fußs, sondern die Fußssohle allein vollständig bedecke.

\section{BESCHAFFENHEIT DER BEIDEN BESTANDTEILE DER LITUR- GISCHEN FUSSBEKLEIDUNG BIS ZUM XI. JAHRHUNDERT.}

Die udones haben auf den Monumenten stets eine weilse Farbe? Wie das Constitutum, Theorulf von Orléans und Amalar angeben, bestanden sie aus Linnen. Wie lange sie ein blofes Tuch blieben, das um das Bein geschlagen wurde, und wann sie die Gestalt eines Strumpfes erhielten, läßst sich nicht bestimmen. Im 10. Jahrhundert, d. i. zur Zeit, in welcher die Bezeichnung caliga in Gebrauch kommt, hatten sie jedenfalls Strumpfform, aber auch im 8. und 9. war das, dem Namen udo nach zu urteilen, wohl schon der Fall.

Der Schuh, welcher bis ins 10. Jahrhundert im wesentlichen auf den Bildwerken dieselbe Form aufweist, ist weder eine Sandale, wie sie auf den altchristlichen Monumenten auftritt, noch allseitig geschlossen (Bild 189). Er besteht aus einer Sohle, aus niedrigen, vielfach kaum bemerkbaren Seitenstücken, einer Kappe, welche die Ferse umschlieft, and einem Oberleder, das nur eben die Spitze des Fußes bedeckt. Behufs Befestigung sind an dem Schuh verschiedene Riemen angebracht. Kreuze sind auf den Vorderstücken nicht vorhanden ${ }^{3}$, doch findet sich auf ihnen wohl ein $T$-, ein lanzett- oder ein lilienförmiges Ornament, in welches entweder das Oberleder ausläuft oder welches wie in dieses hineingeschnitten ist. Die Farbe der Schuhe ist auf den Monumenten überall die schwarze, selbst bei den Bildern der Päpste. Rote Sakralschuhe sind also im ersten Jahrtausend noch nicht in Gebrauch gewesen.

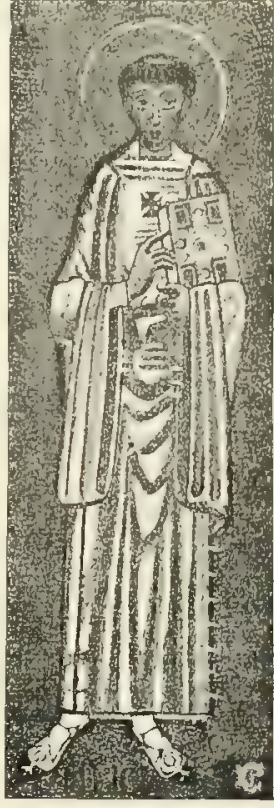

Bild 189.

S. Felicissimus.

Mosaik.

Rom, S. Marco.
' Die Worte Hrahans sind der Erk]arung des ehrw. Beda zu Mk 6, 9 entnommen (M. 92, 187). Es ist dort von den Sandalen der Apostel die Rede. Aus Beda haben überhanpt die mittelalterlichen Liturgiker manches geholt; doch haben sie nicht immer darauf geachtet, ob das, was sie ihm entnahmen, genau passe.

2 Vgl. aufier den S. 392 angefuihten Bildwerken auch die früher wiedergegebenen
Miniaturen einer Handschrift der Vallicelliana zu Rom und des Codex Reg. 124, f. $3^{\text {th }}$ der Vaticana (Bild 125, S. 267 und Bild 96, S. 214)

${ }^{3}$ Die Kreuze, welche jetzt die Schuhe der Päpste Honorius und Symmachus auf dem Mosaik in S. Agnese schmücken, sind ganz neuen Datums (de Rossi, Mus. fasc III IV. 
Hraban sagt ron der Beschaffenheit der liturgischen Schuhe nur sehr wenig. Wir entnehmen ihm blok, daf diese oben offen waren und infolgedessen den Rücken des Fußses unbedeckt ließsen. Walafried schweigt ganz von ihr. Ausführlich beschäftigt sich dagegen Amalar mit den Einzelheiten der Sandalen, so dafs wir durch ihn ein ziemlich vollständiges Bild der sakralen Beschuhung des 9. Jahrhunderts erhalten ${ }^{1}$.

Hiernach waren damals die liturgischen Sandalen im Äufern schwarz, im Innern aber mit weifem Leder gefüttert. Oben, wo der Fub in den Schuh eintrat, war das schwarze äufere und das innere weiße Leder mit vielen Fäden vernäht, damit sie sich beide beim Gebrauch nicht voneinander lostrennen könnten. Im einzelnen unterscheidet Amalar bei der sakralen Beschuhung drei Hauptteile: die Sohle, die von der Sohle rückwärts aufsteigende Kappe und das den Fuß vorn deckende Oberleder. Dazu kamen ein Stïck weißen Leders, das zwischen Sohle und Fuf lag, und das weißlederne Futter. Auf dem Oberleder befanden sich drei vom Schuster angebrachte Streifen, von denen einer über die Mitte des vorderen Teiles des Fußjes bis zu ressen Spitze lief, die andern beiden aber an den Seiten aufstiegen und sich bis zum Besatz in der Mitte erstreckten.

Die Zeichnung, welche Amalar von der sakralen Beschuhung entwirft, entspricht im wesentlichen dem Bild, welches die Mosaiken und Fresken zu Rom, Ravenna und Mailand gewähren (Bild 62, S. 158; 63, S. 159; 64, S. 160; 189, S. 393). Es ist fast, als ob der Metzer Chorbischof diese bei seiner Beschreibung vor Augen gehabt hätte. Die Sandalen Amalars sind offenbar nichts anderes als die zu Ron übliche liturgische Fufsbekleidung der Geistlichen, die mit dem römischen Ritus auch ins Frankenreich kam.

Auffallend ist, daf auf den allerdings nicht zahlreichen fränkischen Bildwerken des 9. Jahrhunderts bei den Geistlichen eine Fufbekleidung, wie sie von Amalar beschrieben wird, kaum je vorkommt, selbst da nicht, wo dieselben mit liturgischen Handlungen beschäftigt sind. Sollten damals Sakralschuhe von der Form der römischen campagi diesseits der Alpen nur erst wenig verbreitet gewesen sein, oder haben wir den Mangel auf Rechnung der Schöpfer der fraglichen Darstellungen $\mathrm{zu}$ setzen? Daßs dieselben sich Freiheiten gestattet, ist unverkennbar, da die Schuhe nicht einmal immer oben offen sind, was doch nicht blof nach Amalar, sondern auch nach Hraban und Pseudo-Alkuin der Fall gewesen sein muf.

Amalar unterscheidet zwischen den sandalia des Bischofs und Diakons einerseits und denen des Priesters und Subdiakons anderseits. Wirklich machte man im 9. Jahrhundert zu Rom einen derartigen Unterschied. Denn nach den Angaben des St Gallener Kleiderverzeichnisses trugen der Papst, die Bischöfe und die Diakone campagi, die Priester und Subdiakone subtalares. Die odhones, die innere Fubbekleidung, war bei allen gleich.

Worin die Verschiedenheit der campagi und subtalares bestanden, sagt uns Amalar in seiner Beschreibung der liturgischen Fufabekleidung. Hiernach

1 De eccles. off. 1. 2, c. 25 (M. 105, 1100): Solea... subtus est... Lingua de corio albo, quae subtus calcaneum est. .. Lingua, quae inde surgit et est separata a corio sandaliorum. ... Lingua superior. ... Intrínsecus de corio albo circundata sunt sandalia... extrinsecus nigrum apparet. ... Superior pars sandaliorum, per quam pes intrat, multis filis consuta est, ut non separentur duo coria... Linea opere sutoris facta procedens a liugua sandalii nämlich der lingua sandaliorum quae super pedem est) usque ad finem eius.... Lineae procedentes ex utraque parte... ipsae recapitu- latae sunt ad medianam lineam, quae usque ad finem currit... Corrigias supererogatas sandaliis, quae manibus huc illucque ducuntur, ut ligentur. Zum Verständnis der an sich nicht gerade klaren Ausfïhrungen Amalars trägt viel die mystische Deutung bei, welche dieser mit den einzelnen Angaben verbindet. Bock (a. a. O. II 5) versteht unter der linea opere sutoris facta die innere linnene Fußbekleidung. Dem widerspricht indessen die Beschreibung, welche Amalar von den lineae gibt. Dieselhen bedeuten au der friglichen Stelle wohl einen vom Schuster vorn auf den Oberleder angebrachten Streifen. 
unterschied sich der Schuh des Bischofs und des Diakons von demjenigen des Priesters und des Subdiakons durch das Vorhandensein bzw. den Mangel einer ligatura, also eines besondern Bund- oder Riemenwerkes 1. Wir haben uns demnach die subtalares wohl als mehr niedrige Schuhart nach Teise unserer Pantoffel zu denken. Dazu paßst auch, was wir sonst von den subtalares hören ${ }^{2}$. In der Tat trägt del Subdiakon .Jurenianus auf der schon erwähnten Miniatur einer Handschrift der Vallicelliana eine pantoffelartige Beschuhung, während der hl. Laurentius als Diakon Schuhe mit Riemen von der Art der campagi an den Füßen hat (Bìld 125, S. 267).

Pontifikale Fufbekleidungen, die auch nur mit einiger Sicherheit dem ersten Jahrtausend zugeschrieben werden könnten, fehlen.

Die Sandale des hl. Silvester I., welche in S. Martino ai Monti zu Rom aufbewahrt wird, dürfte erst dem 13. Jahrhundert entstammen. Älter mag der Rest eines Pontifikalschuhes des heiligen Papstes Martin sein, welcher ebendort gezeigt wird ${ }^{3}$. Doch wird auch er seiner Beschaffenheit zufolge schwerlich dem ersten Jahrtausend angehören. Die Überbleibsel eines Schuhes, welche als Reliquie des hl. Amon, zweiten Touler Bischofs (Ende des 4. Jahrhunderts), in St-Gengoul zu Toul aufbewahrt werden, bieten wenig Anhaltspunkte für eine Datierung. Die Durchbrüche des Oberleders scheinen auf das 11. und 12. Jahrhundert hinzuweisen :

Drei Sandalen und zwei Paar Caligae, welche sich zu Delsberg bei Basel finden, sollen von dem heiligen Abt Germanus von Moutier-Granval († ca 677) herrühren; sie würden demnach ins 7 . Jahrhundert hinaufreichen ${ }^{5}$. Die Zueignung ist jedoch ein Anachronismus, da zu Lebzeiten des Heiligen die Äbte sich noch nicht der Pontificalia erfreuten. Die Strümpfe sind nach Ausweis ihrer Beschaffenheit frühestens im 12, ein Paar vielleicht erst im 13. Jahrhundert entstanden. Von den Sandalen mag eine noch dem 11. Jahrhundert entstammen; die beiden andern aber, welche ein Paar bilden und in der Form durchaus verwandt mit den Pontifikalschuhen sind, die man im Grabe des Bischof's Konrad II. von Worms († 1192) antraf, werden etwa in die zweite Hälfte des 1:2. zu setzen sein. Daf die Sandalen und Caligae dem hl. Germanus zugeschrieben werden, mag vielleicht daher kommen, dafú die Reliquien des Heiligen ehedem mit ihnen bekleidet waren.

$\mathrm{Zu}$ Niederzell auf der Reichenau endlich gab es vordem ein Paar Sandalen, welche Abt Gerbert von St Blasien († 1793) seinerzeit als Pontifikalschuhe des heiligen Bischofs Egino von Verona ( $\dagger$ 802), des Gründers von Niederzell, bezeichnen zu dürfen glaubte. Er fand sie dureh Zufall im Pfarrhause daselbst ${ }^{6}$; eine Tradition kann es also zu seiner Zeit in Betreff des Sandalenpaares nicht gegeben haben. Gerbert meint, es sei unzweifelhaft dem Grabe des hl. Egino in der Mitte der Apsis der Kirche entnommen worden, wie solches ja auch in andern Fällen geschehen sei. Allein irrtümlicherweise; denn die campagi (sandalia) waren im 9. Jahrhundert von schwarzer Farbe, wie sowohl die Monumente als die ausdruicklichen Angaben Amalars bezeugen, während die Sandalen zu Niederzoll aus rotem Leder bestanden. Was ihre

'De eccles. off. c. 25 (M. 105, 1100): Episcopus habet ligaturam in suis sandaliis, quam non labet presbyter. . diaconus ipse ligaturam habet (sc. in sandaliis) ... subdiaconus ... necesse est, ut habeat dissimilia sandalia, ne forte aestimetur diaconus.

${ }^{2}$ D. C. sub subtalares VII 639. I sidor von Sevilla sagt in seinen Etymologien (1. 20 , c. 34 [M. 82, 705]): subtulares (sc. vocantur) quod sub talo sunt, quasi subtalares.
Skizzen der beiden Sandalen bei Roh. VIII, pl. DCLXXiII.

4 Ebd. pl. DcLxxvi und 182.

5 skizzen der schuhe ebd. pl. Dchxxvi und DCLXXVII.

G Gerbeit, Vetus Liturg. alemam. I 252 (mit Abbildung): Casu in aedibus parochialibus cellae inferioris in insula Augiae divitis reperimus.... Sandalia a nobis reperta aerique incidi curata, componuntur uno ex corio absque elevatiori solea... coriumque molle est, ubique sibi simili colore, uti videtur, puniceo. 
Form anlangt, so waren sie mit dem Sandalenpaar von Delsberg sehr nahe rerwandt. Sie werden deshalb wohl derselben Zeit wie dieses, d. i. der Spätzeit des 12. Jahrhunderts, zuzuweisen sein ?

\section{DIE TRÄGER DER SANDALEN UND CALIGAE SEIT DEM ENDE DES ERSTEN JAHRTAUSENDS.}

Bei den Liturgikern des 12. Jahrhunderts hat die liturgische Fußbekleidung durchaus den Charakter eines bischöflichen Gewandstickes; so um den Beginn des Jahrhunderts bei Ivo von Chartres, Bruno von Segni, Rupert von Deutz und Honorius, in weiteren Verlaufe desselben bei Robert Paululus, sowie den Verfassem des Speculum de mysteriis ecclesiae und des Tractatus de sacramento altaris, gegen 1200 endlich hei Sicard von Cremona ind Innozenz III.

Die sakrale Beschuhung war allzeit vornehmlich ein bischöfliches Ornatstück; zu einem den Bischöfen vorbehaltenen wurde sie indessen erst, wie es scheint, im Verlauf des 10. Jahrhunderts. Die Bullen, in welchen seit etwa der zweiten Hälfte desselben Äbten und andern hervorragenden Geistlichen die Ermächtigung zu teil wird, sich der Sandalen zu bedienen, beweisen mit aller Bestimmtheit, daf die liturgische Fulbekleidung damals bereits den Charakter eines privilegierten bischöflichen Ornatstückes erlangt hatte. Auch ein ebenso interessantes wie lehreiches Vorkommnis, von welchem Hermannus Contractus berichtet ${ }^{2}$, bezengt das.

Berno, Abt von Reichenau, so erzählt dieser, habe 1032 von Johannes XIX. die Bestätigung der Privilegien seines Klosters erhalten. Dabei sei inm denn auch inshesondere wieder gestattet worden, sich bei der Mefsfeier der Sandalen zu bedienen. Darüher sei aber Warmann, Bischof von Konstanz, in dessen Ḧprengel Reichenau lag, sehr zornig geworden und habe den Abt bei Kaiser Konrad als sui pervasor officii et honoris verklagt. Zuletzt sei Berno wirklich gezwungen worden, Privileg und Sandalen an Warmann auszuliefern, damit sie auf der nächstfolgenden Gründonnerstagssynode öffentlich verbrannt würden.

In Rom waren um dieselbe Zeit die Sandalen und Caligae nur mehr bei den. Kardinalbischöfen, Kardinalpriestern und Kardinaldiakonen im Gebrauch. Wir erfahren das aus einem Schreiben Klemens' II. an den Abt von Fulda ${ }^{3}$.

Der Abt von Fulda hatte sich an Papst Klemens II. mit der Bitte um Bestätigung der Privilegien seines Klosters gewandt. Auf dieses Ansuchen antwortet nun der Papst 1046 mit den bezeichnenden Worten: „Den Gebrauch der Sandalen, der Caligae und dei Dalmatik, welcher durch die heiligen Kanones Deinem Ordo untersagt ist, wollen Wir kraft apostolischer Autorität nicht blof bei Dir und Deinen Nachfolgern, sondern ïberhaupt bei allen lebenden und zukünftigen Äbten der Klöster auf dem ganzen Erdenrund durchaus ahgeschafft wissen, wenngleich es einige Päpste auf diesem Stuhle gegeben hat, welche, durch die Tyrannei der Schlechten gezwungen, unziemlicherweise das Eurer und verschiedenen andern Kirchen gewährt haben, was der heiligen Väter Satzungen ersiehtlich zuwider ist.... Fast die ganze IV elt weib, daf3 unsere Bischöfe, Kardinalpriester und Kardinaldiakone besonderer

1 F. X. Kraus bezeichnet in seinen Kunst. denkmälem des Groliherzogtums Baden, Kreis Kunstanz I 360, denen man allerdings gröfere Genauigkeit zutrauen sollte, mit ausdrücklichen Wrorten rie Sandalen als noch vorhanden, tatsächlich aber sind diese bereits seit ca 140 Jahren nicht mehr auf der Reichenau. Sie wurden nämlich seinerzeit von Abt Gerbert nach St Blasien gebracht, um dort ahgezeichnet und dann in der Liturgia alemannica wiedergegehen zu werden. Wie dem Verfasser auf der Reichenau mitgeteilt wurde, sind sie seitdem nicht mehr nach Niederzell zurickgekommen.

2 Chron, ad anm. 1032 (M. 143, 235).

s M. 142, 580. 
Auszeichnungen sich erfreuen, welche derartigen Rangstufen anderer Kirchen nicht zustehen. ... Wenn es Unsere Vorgänger für angebracht erachtet hätten, so würde gewifs die Abtei St Paul, welche dem römischen Stuhle weit näher steht und befreundeter ist als alle andern, das Vorrecht der Dalmatik und Sandalen geniefen. Was also St Paulus nicht von St Petrus erbittet, sollen erst recht die übrigen jüngeren Heiligen von Uns nicht zu erlangen trachten."

Fragt man, wie es geschehen sei, daf, die liturgische Fufbekleidung zu Rom ein Vorrecht der Kardinäle wurde und bei den andern Klerikern aufer Gebranch geriet, so wird man wohl den Grund für diesen Wandel in der gegen die Neige des Jahrtausends mächtig steigenten Bedeutung der römischen Kardinäle zu sehen haben. In der Tat, je mehr diese aus der Schar der Geistlichen hervortraten, je mehr sie an Finflul, und Anselien vol dem übrigen Kierus zunahmen, um so mehr mufste es für sie zu Auszeichnungen und Privilegien kommen. Die hervorragende Stellung, welche die Kardinäle allmählich gewonnen latten, konnte unmöglich ohne mancherlei Ehrenrechte bleiben, und das nicht blof im gewöhnlichen Leben, sonclem mehr noch bei den kirchlichen Funktionen, bei welchen ja die Kardinäle als die eigentlichen Gehilfen des Papstes erschienen.

Außerhalb Roms kann, wie schon bemerkt wurde, eine besondere liturgische Beschuluung bei der niedern Geistlichkeit nicht allgemein, ja kaum weit verbreitet gewesen sein ${ }^{1}$. Hier hatte es somit keine Schwierigkeit, dal: sie nach und nach ein Vorrecht der Bischöfe wurde. Dafs solches aber tatsächlich geschah, darauf mag neben andern L'rsachen inshesondere der Wancle] von Einfluf gewesen sein, der sich zu Rom hinsichtlich der Träger der liturgischen Fußsbekleidung vollzog.

Übrigens verblieb nicht einmal den Kardinaldiakonen auf die Dauer der usus sandaliorum et caligarum. Sie scheinen diesen sogar schon im Beginne des 12. Jahrhunderts nicht mehr besessen zu haben, da Ivo von Chartres die Sandalen nur den Bischöfen und den Kardinalpriestern zuweist . Sicher war das bereits in der zweiten Hälfte des 13. Jahrhunderts der Fall. Denn nach dem auf Befehl Gregors X. herausgegebenen (hdo durfte sellost ein zum Papst el'wählter Diakon beim Empfang der Priesterweihe noch nicht die liturgischen Schuhe und Strümpfe tragen". Es hat sich also die jetzige Praxis, wonach von den Kardinälen nur die Kardinalbischöfe und Kardinalpriester sich der Sandalen und Caligae bedienen dïrfen, nicht erst beim Ansgange des Mittelalters oder gar in der Neuzeit gebildet.

Eine interessante Notiz über die bei der Messe zu tragenden gewöhnlichen klerikalen Kleidungsstïcke findet sich bei $\mathrm{G}$ il b e $\mathrm{rt}$ von Limerick, De statu ecclesiae (M. 159, 1001): Quotidiana ad missam ut paucissima quattuor, camisia, tunica, femoralia, calceamenta. Addunt tamen Romani caljgas. In Irland bestand also die klerikale Tracht, die der Priester bei der Messe unter und außer der liturgischen Gewandung zu tragen hatte, aus einer klerikalen Albe, dem Rock, Beinkleidern und Schuhen. Nach römischen Brauch kamen Striumpfe hinzu.

2 Sermo 3 (M. 162, 525): Utuntur episcopi et cardinales presbyteri sandaliis.

${ }^{3}$ N. 6 (M. 78, 1107); vgl. auch ordo 14 , c. 103: De ordinatione diaconi cardinalis, wo zwar der Mitra, nicht aber der Sandalen gedacht wird (ebd. 1233). Auffallen könnte allerdings, daf noch Eugen III. dem Erzbischof Arnold von Köln 1151 das Privileg erteilt, ut septem presbyteri cardinales in praedicta ecclesia (sc. Coloniensi) ordinentur, qui induti dalmaticis et mitra ornati ad principalia duo altaria eiusdem ecclesiae cum totidem diaconis, quibus sandaliorum usum concedimus, missarum sollemnia in festivis diebus tantummodo administrent (J.n. 9515). Indessen handelt es sich hier nur um Bestätigung eines bereits durch Leo IX. 1052 verliehenen Privilegs, (Wegen der Echtheit der Bulle Leos IX. s. oben S. 257 Anm. 5.) 


\section{VERLEIHUNG DER PONTIFIKALEN FUSSBEKLEIDUNG AN NICHTBISCHÖFE.}

Wenn Stephan III. 757 dem Presbyter Fulrad, Abt von St-Denis, die udones nnd subtalares gewährte, so bedeutete das für diesen nur eine durchaus persünliche Auszeichnung. Der Papst hebt ausdrücklich hervor, es solle das Vorrecht in keiner Weise auch für die Nachfolger Fulrads gelten, vielmehr solle die ihm zu teil gewordene Beschuhung nach seinem Ableben zugleich mit seiner Leiche dem Grabe übergeben werden. Das Privileg blieb auch, wie es scheint, für die nächsten zweihundert Jahre eine ganz vereinzelte Erscheinung, vielleicht weil seit Karls Reformtätigkeit im Frankenreiche die Priester glaubten, sich ohne besondere Ermächtigung der liturgischen Fubbekleidung bedienen zu können.

Erst um das dritte Viertel des 10. Jahrhunderts begegnet uns eine neue Verleihung des usus sandaliorum an Äbte, also mm die Zeit, da die liturgische Beschuhung einen ausschliefilich pontifikalen Charakter erhalten hatte. Eben damais stoben wir auch wieder nach langem Zwischenraum auf einen Fall, in dem Diakone das Recht erhalten, sich der sakralen Fubbekleidung zu bedienen.

Die Verleihungen sind vor dem Beginn des neuen Jahrtausends nicht zahlreich. Johannes XIII. gestattet 970 dem Abte des St Vinzenzklosters zu Metz ${ }^{1}$, Benedikt VII. 975 den KardinaIpriestern und Kardinaldiakonen von Trier ${ }^{2}$, Johannes XV. 990 dem Abt Folcuin von Lobbes ${ }^{3}$ und 994 Hatto von Fulda ${ }^{4}$, Gregor V. 998 Alavicus von Reichenau und dessen Nachfolgern ${ }^{5}$, Silvester II. 999 Erkanbald von Fulda ${ }^{6}$ den usus sandaliorum.

Häufiger werden die Privilegien im 11. Jahrhundert. 1012 erlaubt Benedikt VIII. das Tragen der Sandalen zwölf Kardinalpriestern und sieben Kardinaldiakonen der Kirche von Magdeburg ${ }^{7}$. Johannes XIX. gewähntt dann 1031 Berno von Reichenau's daś Vorrecht, während Leo IX. es 1049 den Kardinalpriestern und Kardinaldiakonen von Trier ${ }^{9}$, 1050 Fulco von Corbie ${ }^{10}$, 1052 den Kardinalpriestern, Kardinaldiakonen und Kardinalsubdiakonen der Kölner Metropolitankirche ${ }^{11}$, 1054 Albuvinus von Nienburg an der Saale ${ }^{12}$ zugesteht. Viktor II. erlaubt den usus sandaliorum 1057 Friedrich von Monte Cassino ${ }^{13}$, Alexander II. 1063 Egelsinus vom St Augustinuskloster zu Canterbury ${ }^{1 \pm}, 1069$ Reinbert von Echternach ${ }^{15}$, 1070 Benediktus von S. Pietro in Cielo d'Oro zu Pavia ${ }^{16}$, Gregor VII. 1078 Manasses von Bergues ${ }^{17}$ und Urban II. 1088 Hugo von Cluny ${ }^{18}$. Sehr zahlreich sind die Zuwendungen im 12. Jahrhundert ${ }^{19}$.

Wenn die Bullen des 11. und 12. Jahrhunderts, in welchen Nichtbischöfen der usus sandaliorum gewährt wird, der Caligae fast gar nicht gedenken ${ }^{20}$, so wird das

1 J. n. 3741.

3 Ebd. n. 3837.

Ebd. n. 3880 .

2 Eld. n. 3783.

4 Ebd. n. 3853.

6 Ebd. n. 3907.

‘ Ebd. n. 3989. Vgl. wegen der Echtheit der Bulle oben S. 257.

Ebd. n. 4093.

9 Ebd, n. 4161.

20 Ebd. n. 4212.

11 Ebd. n. 4271 (doch nur die Sandalen, nicht auch schon die Mitra).

12 Ebd. n. 4885. Nach dem Chron. Cass. 1.2, c. 79 (M. G. SS. VII 683) verlieh Leo IX. die Sandalen auch Abt Richerius von Monte Cassino. S. oben S. 368.
13 J. n. 4368.

15 Ebd. n. 4667.

14 Ebr, n. 4541.

17 Ebd. n. 5090. Die Verleihung wird hier indessen als $z$ weifelhaft bezeichnet.

18 Ebd. n. 5372.

19 Vgl. z. B. ebd. ᄁ. 5891638572119280 $9439 \quad 95159749 \quad 1059412861 \quad 1446914492$ 1450317418.

20 Sie werden mur in den Bullen Jolnannes' $X V$. und Leos IX. für S. Pietro in Cielo d'Oro zu Pavia moter der auffälligen Bezeichnung pedules $b z w$. udones i. e. licini sive pedules erwahnt, während sie in den späteren Bullen 
seinen Grund in dem Umstand haben, daf sie unter den sandalia als dem vornehmsten und hauptsächlichsten Bestandteil die ganze pontifikale Fulabekleidung verstehen. Die Caligae bildeten ja nach römischem Gebrauch kein für sich bestehendes Ornatstück, sondern nur eine Ergänzung des pontifikalen Schuhes. Wer von den sandalia redete, dachte ohne weiteres auch an die innere Bedeckung des Fufes, und wer die Ermächtigung erhielt, sich der Sandalia zu bedienen, hatte danit zugleich das Recht auf deren Zuthehör, die Caligae, bekommen. In den Verleihungsurkunden diese ausdrücklich zu erwähnen, mochte daher, weil es sich bei ihnen um etwas Selbstverständliches handelte, üherflüssig erscheinen. Dafs unter den sandalia der päpstlichen Bullen aber wirklich beides, die Pontifikalschuhe wie die Pontifikalstrumpfe, zu verstehen sind, ergibt sich beispielsweise aus einer Bulle Innozenz' III. für Abt Hamelin von Vendome aus dem Jahre $1205{ }^{1}$. Denn wenn es darin heifst: Sandaliorum usum, tunicae et dalmaticae, mitrae et annuli, sicut eis presbyteri cardinales utuntur, vobis in perpetuum auctoritate apostolica confirmamus, so ist hier mit den Sandalen offenbar die ganze auszeichnende Fuß̧̧bekleidnug der römischen Kardinalpriester einschlief̧lich der Caligae gemeint. Es wäre auch höchst sonderbar, wenn Innozenz III. Hamelin die Schuhe, die Tunika, die Dalmatik, den Ring und selbst die Mitra, nicht aber die liturgischen Strümpfe der Kardinalpresbyter gewahrt hätte. Ührigens spricht schon vor der Witte des 11. Jahrhunderts das Schreiben Klemens' II. an den Abt von Fulda nicht nur von Sandalen, sondern auch von Caliga., welche durch seine Vorgänger Äbten zugestanden worden seien.

Den nicht von Rechts wegen zum Gebrauch der pontifikalen Fucbekleidung: befugten Prälaten wurde der usus sandaliorum gerade wie der der andern Pontifikalien bisweilen nur unter bestimmten Einschränkungen verliehen. So durfte der Abt von S. Michele della Chiusa (Diözese Turin) sich der Iiturgischen Beschubung nur an Ostern, Christi Himmelfahrt, Pfingsten, Weihnachten, Epiphanie und den Festen der Mutter Gottes, des hl. Michael und des hl. Benedikt bedienen².

Gegenüber der im 11. Jahrhundert stark zunehmenden Sucht mancher Äbte, wie die Bischöfe die liturgische Beschuhung zu gebrauchen, und der damit im Zusammenhang stehenden eigenmächtigen Anmafiung dieses Rechtes sah sich eine Synode von Poitiers aus dem Jahre 1100 zu dem ausdrücklichen Verbot veranlafest: Ut nullus abbatum utatur cirotecis, sandaliis, anulo, nisi quibus fuerit per privilegium a romana ecclesia concessum ${ }^{3}$.

\section{BESCHAFFENHEIT DER SANDALEN UND CALIGAE VOM XI. BIS XIV. JAHRHUNDERT.}

Was wir ïber die Beschaffenheit der pontifikalen Fubibekleidung bei den Liturgikern des 12. und 13. Jahrhunderts vernehmen, gewährt nur ein fragmentarisches Bild derselben. Selbst die weitläufigen Ausführungen des Bischofs von Mende deuten mehr die Veränderungen an, welche im Laufe der Zeit mit derselben vorgegangen waren, als dafí sie darïber klaren Aufschluf gewähren. Zudem offenbart sich bei kaum einem andern Ornatstïck in den Ausführungen eines Honorius, Sicard, Durandus und Genossen so sehr der Einfluf Amalars, als gerade bej den Sandalen. Was sie uns über diese erzählen, ist zum grołen Teil fast nur eine wörtliche Wiedergabe dessen, was der Metzer Diakon g'eschrieben hatte. Das Bild, welches sie von der pontifikalen Fukbekleidung

für S. Pietro nach gewöhnlichem Brauch nicht genannt werden, ein Punkt. Telcher nicht gerade zu Gunsten der Zuverlässigkeit jener beiden Bullen spricht.

1 M. 225, 749. Innozenz III, iibergibt in der Bulle dem Abt Hamelin die Titelkirche von S. Prisca zu Rom und in Zusammenhang damit das Recht, sich der Gewandung der Kardinalpresbyter zu bedienen. Vgl. auch Sägmüller, Tätigkeit und Stellung der Kardinäle 163, Anm. 2.

Pflugk-Harttung, Acta II 207

C. 5 (S dralek, Wolfenbiittler Fras'mente 137). 
zeichnen. ist daher hie und da eher dasjenige der sakralen Beschuhung des 9. als derjenigen des 12. und 13. Jahrhunderts.

Fassen wir es kurz zusammen, was die Liturgiker über die pontifikale Fußbekleidung sagen.

Die Caliga e reichten nach Ivo ${ }^{1}$, Innozenz III. und Durandus bis in die Gegend des Kinies, woselbst sie sorglich festgebunden wurden. Zu Ivos Zeit bestanden sie noch aus Byssus oder Linnen; Sicard herichtet dagegen schon, sie seien aus Seide angefertigt ". Da die Pontifikalstrümpfe im "Mitralis" als Simnbild der Reinheit der Füße hingestellt werden, so mögen sie noch um die Wende des 12. Jahrhunderts von weifer Farbe gewesen sein. Zu Durandus' Zeit war das aber jedenfalls schon anders geworden, da er die Caligae ausdrücklich als hyacinthinae i. e. aerei seu coelestis coloris, also als blauviolett bezeichnet ${ }^{3}$.

Die Sandalen waren nach Ivo oben an verschiedenen Stellen durchbrochen, nach Robert Paululus hatten sie oben Öfnungen; nach Sicard und nach dem Speculum war das Oberleder teilweise mit Schlitzen ausgestattet: Innozenz III. und Durandus nennen dasselbe fenestratum, mit Fenster'n versehen. Liner Bindevorrichtung gedenken Rupert von Deutz, Honorius, Sicard, Innozenz und Durandus, ohne indessen zu vermelden, wie sie beschaffen gew esen sei. Nach Sicard sollen die Sandalen vier oder doch wenigstens zwei lingulas ligandas (Laschen), unum super pedem, aliam a calcaneo surgentem, haben 4.

Von Zierstreifen auf dem Oberleder der Sandalen sprechen Honorius, Sicard und Durandus; der Verfasser des Mitralis gibt auljerdem an, es würden die Pontifikalschuhe auch wohl mit Gemmen geschmückt. Von der Farbe reden Sicard und Durandus; wir erfahren von ihnen, dab schwarze und rote Sandalen in Gebrauch waren.

Als Stoff, aus dem die pontifikalen Schuhe hergestellt wurden, nennen die Liturgiker, soweit sie seiner Erwähnung tun, lediglich Leder. Diese Angabe schliebt indessen nicht aus, dalà der lederne Oberstoff, wie es tatsächlich häufig geschehen sein mag, einen Überzug von Seide erhielt. Es war ja in diesem Falle nicht eigentlich die Seide, aus der die Sandalen gemacht waren; vielmehr diente diese blol; zur Ausstattung der aus Leder angefertigten Schulie. Später rerhielt sich die Sache freilich umgekehrt, als Seide und Samt den eigentlichen Oberstoff bildeten, dümmes, weiches Leder aber nur das Futter.

Die bildlichen Darstellungen aus dem 11., 12. und teilweise selbst noch dem 13. Jahrhundert gewähren sehr wenig Aufschlul ïber die pontifikale Fufsbekleidung der damaligen Zeit. Ton den Caligae ist auf ihnen kaum etras wahrzunelımen: die Schulle aber treten, wo immer sie hinreichend zum Torschein kommen, in so mannigfaltiger Gestaltung und Ausstattung auf, daf: es unnöglich ist. aus ihnen einen sichern Schluf auf die tatsächliche Form und Beschaffenheit der damaligen bischöflichen Sandalen zu machen.

\footnotetext{
1 Sermo 3 (H. 162, 525).

2 L. 2, c. 5 (M. 213, 72): Igitur holosericae caligae illam pedum significat munditiem, de qua Dominus ait: Qui lotus est totus, non indiget, nisi ut pedes lavet.

3 In ordo 13, n. 3 (M. 78, 1106) wird von caligae de rubeo panno des Papstes gesprochen. Es handelt sich dort allerdings nur um anßerliturgische Strümpfe, doch dürfte die Annahme nahe liegen, er habe sich roter Caligae
}

auch bei der Messfejer bedient, gerade wie die Bischöfe nach Durandus dabei lyyazinthfarbige (violette) trugen.

* Unter den lingulae werden bei Sicard die Laschen zu verstehen sein, die an den Pontifikalschuhen des 11. und 12. Jahrhunderts angebracht $z u$ werden pflegten und mit einer Schnur oben am Fuße angebunden wurden. Nihleres siche unten in der Beschreibung der noch vorhandenen Sandalen aus jener Zeit. 
Bald sind sie, wenngleich nicht allzu häufig, noch ganz niedrig und denjenigen des 9. Jahrhunderts ähnlich, bald gleichen sie Pantoffeln, bald förmlichen Schuhen, wie sie uns auch bei Laien begegnen. Die einen Darstellungen weisen im Oberleder der Schuhe Schlitze oder sonstige Öffnungen auf, bei andern fehlen solche. Hier endet das Oberleder auf der Mitte des Spanns in einem lanzettförmigen Ausläufer, dort schließt es mit einer Spitze oder mit einer Rundung ab. Bald finden sich an den Schuhen Riemen, bald mangeln diese. In manchen Fällen entbehren die Sandalen jeden Schmuckes, in andern zieht sich ein Streifen vom Fufsgelenk oben über den Schuh bis zur Fufsspitze; wieder in andern zieren aufer dem Besatz in der Mitte noch zwei von der Seite zum mittleren Streifen schräg verlaufende und mit demselben eine Art von Gabel bildende Börtchen das Oberleder. Auch erscheint dieses wohl mit Ranken und Blumen gemustert oder mit Steinen geschmückt. Hinsiclitlich der Farbe der Schuhe herrscht auf den bildlichen Darstellungen ebenfalls der gröste Wechsel; hier sind die Schuhe golden, da grün, dort rot, blau, schwarz usw.

Offenbar hat die Phantasie der Kï̈nstler bei der Wiedergabe der Fufbekleidung keine geringe Rolle gespielt. Die Sache ändert sich erst im Verlauf des 13. Jahrhunderts. Seit dieser Zeit nehmen die Sandalen auf den Bildwerken eine gleichmäGigere Form an. Insbesondere erscheint nun auf den Monumenten häufig eine vorn ziemlich spitz auslaufende und den ganzen Fuf deckende Schuhart, welche auf dem Vorderstïck eine gabelartige Verzierung trägt ${ }^{1}$ (Bild 190).

Angesichts des Wirrwarrs, welcher auf den Monumenten aus

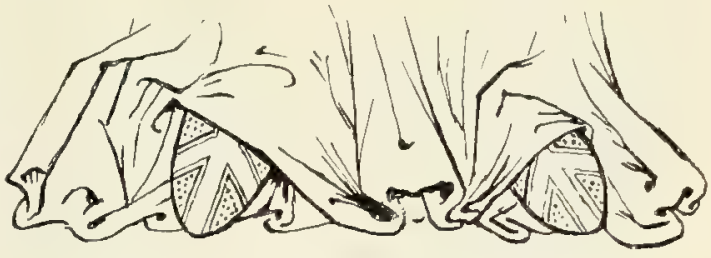

Bild 190. Pontifikalschuhe der Grabfigur des Bischofs Otto von Braunschweig ( $† 1279)$. Hildesheim, Dom.

dem 11., 12. und 13. Jahrhundert hinsichtlich der Form und Beschaffenheit der liturgischen Beschuhung herrscht, sind natürlich von besonderer Wichtigkeit die Sandalen und Caligae, welche sich aus dieser Zeit erhalten haben. Sie bilden zu der Beschreibung, welche die Liturgiker des 12. und 13. Jahrhunderts von der pontifikalen Fub́bekleidung geben, eine ungleich bedeutungsvollere Ergänzung als die Bildwerke. Dasselbe gilt von den Pontifikalstrümpfen und Pontifikalschuhen, die man gelegentlich der Eröffnung von Bischofsgräbern zu beobachten in der Lage war.

Pontifikaler Caligae gibt es aus dem 12. und 13. Jahrhundert zwei Paar zu Delsberg (Schweiz); es sind die früher erwähnten, dem hl. Germanus von MoutierGranval irrig zugeschriebenen Pontifikalstrümpfe. Als weiteres Beispiel kann das zum ehemaligen Krönungsornat der deutschen Könige gehörende Caligapaar im kaiserlichen Schatze zu Wien angeführt werden. Denn wenn dieser Omat auch nie einen eigentlich liturgischen Charakter besessen hat, so waren doch die zu ihm gehörenden Gewandstücke Nachbildungen der entsprechenden Teile der Pontifikaltracht?

Von den beiden Paar Caligae zu Delsberg ist das eine (Bild 191, S. 403) mittels eines halbstarken Linnenfadens in einer Art von Maschenarbeit, welche einigermafen an Schlingenwerk erinnert, hergestellt. Es ist die gleiche Technik, welche auch der

1 Eine gabelfürmige Verzierung ist wohl gemeint, wenn Grimaldi die Schuhe Bonifaz' VIII. mit den Worten beschreibt: Sandalia nigri coloris acuta et cuspidata more Braun, Die liturgiselie Gewandung. gothico sine cruce ex serico nigro ad flores parvos auro intextos longitudinis $1 \frac{1}{2} \mathrm{palm}$. (Bzovius, Annales ad 1303, XIV 51).

2 Vgl. unten Kap. 3 (Mitra), V. 
Pontifikalhandschuh in S. Trinità zu Florenz aufweist. Die Caligae dürften nach Ausweis des Börtchens, welches den Einschlupf umsäumt, dem 12. Jahrhundert entstammen. Sie sind $70 \mathrm{~cm}$ lang und mit Bändern zum Anbinden versehen. Von den beiden andern Pontifikalstrümpfen (Bild 192) ist nur einer vollständig erhalten. Er ist ca $67 \mathrm{~cm}$ lang und besteht aus einem weiGen Seidendamast arabischen oder sizilianischen Ursprungs; oben ist er mit einem Randbesatz, zwischen Saum und Ferse aber mit zwei Querstreifen geschmückt. Die Sohle ist aus Linnen gemacht. Auch hier sind am Einschlupf zum Zweck der Befestigung des Strumpfes Bänder angebracht. Von dem zweiten Strumpf sind nur noch Bruchstücke vorhanden. Nach dem Muster des Damastes zu urteilen, dürfte das Caligapaar dem Ende des 12. oder besser dem beginnenden 13 . Jahrhundert zuzuweisen sein.

Die zum einstigen Krönungsornat der deutschen Könige gehörenden Caligae sind sizilianische Arbeit und gemäßs der Inschrift des Randbesatzes ursprünglich für Wilhelm II. von Sizilien angefertigt. Sie bestehen aus schwerem hochroten Seidendamast und sind aus zwei Teilen, dem Fuß- und dem Schienbeinstück, zusammengenäht. Ersteres ist völlig schmucklos; letzteres ist mit Goldstickereien verziert, ineinandergreifenden Vierpässen, in deren Mitte sich ein vierblätteriges Rosettchen befindet. Die jetzigen der Befestigung der Strümpfe dienenden Bänder gehören erst einem der letzten Jahrhunderte an. Den oberen Rand umgibt eine gewirkte Bordüre mit arabischer Inschrift in kufischen Schriftzeichen. Die Caligae haben von der Ferse bis zum oberen Rande eine Höhe von $60 \mathrm{~cm}$ und reichen somit über das Knie!

Es sind nur einige wenige Beispiele von Pontifikalstrümpfen des 12 . und 13. Jahrhunderts, von denen wir berichten können. Immerhin geben sie ein genügendes Bild des inneren Bestandteiles der damaligen bischöflichen Fufbekleidung. Von besonderem Interesse ist dabei, daf aus ihnen unwiderleglich das Vorhandensein und die Verwendung von Caligae, die auf der Nadel gearbeitet waren, hervorgeht. Es ist nämlich gesagt worden, die Pontifikalstrümpfe des 12. und 13. Jahrhunderts seien stets aus Stoffstiucken hergestellt worden. Die Delsberger Caligae beweisen das Gegenteil.

Von den Entdeckungen bei Gelegenheit der Eröfnung von Bischofsgräbern interessieren hier am meisten die Caligae, welche man in den achtziger Jahren des vorigen Jahrhunderts im Dom zu Worms bei der Leiche des Bischofs Konrad von Sternberg $(† 1192)$ antraf. Der Tote war nach Brauch in pontifikaler Tracht. Unterschenkel und Füfse waren in offenen, unvernähten Seidenstoff eingeschlagen und darüber mit Strümpfen von feiner Maschenarbeit bedeckt, welche mit ganz schmalen, lineär gemusterten Borten rings umschnürt waren ${ }^{2}$. Leider hat man von den Strümpfen damals keine Skizze aufgenommen. Es kann indessen wohl kaum zweifelhaft sein, daß sie in derselben Technik hergestellt waren wie das erstbeschriebene Delsberger Caligapaar. Jedenfalls beweist auch die Wahrnehnung, die man bei der Leiche Konrads von Sternberg machte, das Unrichtige der Behauptung, es habe im 12. Jahrhundert keine auf der Nadel gearbeiteten Pontifikalstrümpfe gegeben.

Die Strümpfe, welche man im Grabe Bonifaz' VIII. fand, bestanden nach Grimaldi aus Taftseide und waren, wenn der Borichterstatter nicht etwa irrig Dunkelviolett für Schwarz gehalten hat, von schwarzer Farbe ${ }^{3}$.

Von bischöflichen Sandalen hat sich aus dem 12. und 13. Jahrhundert noch eine gute Anzahl erhalten. Es gibt deren, aufer den bereits erwähnten zu Delsberg und Rom, weitere zu Hildesheim (Dom), Trier (Domschatz), Niederaltaich (Bayern), Castel S. Elia bei Nepi, Worms (Paulusmuseum),

1 Bock, Reichskl. 56 und Tfl 12.

2 Schneider, Ein Bischofsgrab des 12. Jahrhunderts 9. A. $\mathrm{S}$ c h n üt $\mathrm{g}$ e $\mathrm{n}$ in
"Westdeutsehe Zeitschrift", KorrespondenzBlatt VI (1887), Nr 1, Sp.8.

${ }^{3}$ Bzovius a. a. O. 
Châlons-sur-Marne (Kathedrale) ${ }^{1}$, Pontigny ${ }^{2}$, Chelles (Diözese Meaux ${ }^{3}$ ) und Rivadeo in Spanien". Dazu kommen Fragmente von Sandalen zu Toul (St-Gengoul) ${ }^{5}$, im Museum von Lausanne ${ }^{6}$, im Musée Cinquanténaire zu Brüssel ${ }^{7}$ und im Cluny-Museum zu Paris. Zu Castel S. Elia finden sich drei Paare; Chelles besitzt wie Delsberg eineinhalb Paar. Auch die aus der Altarmensa der Kapuzinerkirche zu Stavelot stammenden Fragmente im Brüsseler Museum lassen deutlich eineinhalb Paar unterscheiden.

Nicht mehr vorhanden, aber durch Beschreibung und Abbildung genügend bekannt sind aufer dem schon genannten Niederzeller Sandalenpaar einige Pontifikalschuhe, die jetzt wieder mit den Leichen, bei welchen man sie antraf, in der Erde ruhen. Es sind die Schuhe der Trierer Erzbischöfe Bruno († 1124), Albero († 1152) und Hillin $(† 1169)^{8}$.

Ein Teil dieser Pontifikalschuhe ist bestimmt datiert. Die Hildesheimer Sandalen stammen aus dem Grabe Bernhards II. († 1153), die Trierer aus dem des Erzbischofs Arnold I. († 1183), die Sandalen zu Pontigny aus dem Schrein des hl. Edmund von Canterbury († 1240). Die bischôflichen Schuhe zu Rivadeo rühren aller Wahrscheinlichkeit nach von Bischof Pelagius II. $(\dagger$ 1218) her, dem einzigen Bischof von Rivadeo, das nur kurze Zeit als Bistum bestand. Der Pontifikalschuh im Paulusmuseum zu Worms wurde dem Grabe des Bischofs Konrad von Sternberg († 1192) entnommen ${ }^{9}$, die Reste der Pontifikalsandalen, welche im Museum von Lausanne aufbewahrt werden, fanden sich im Grabe des Bischofs Roger († 1212). Das genaue Datum macht diese Pontifikal-

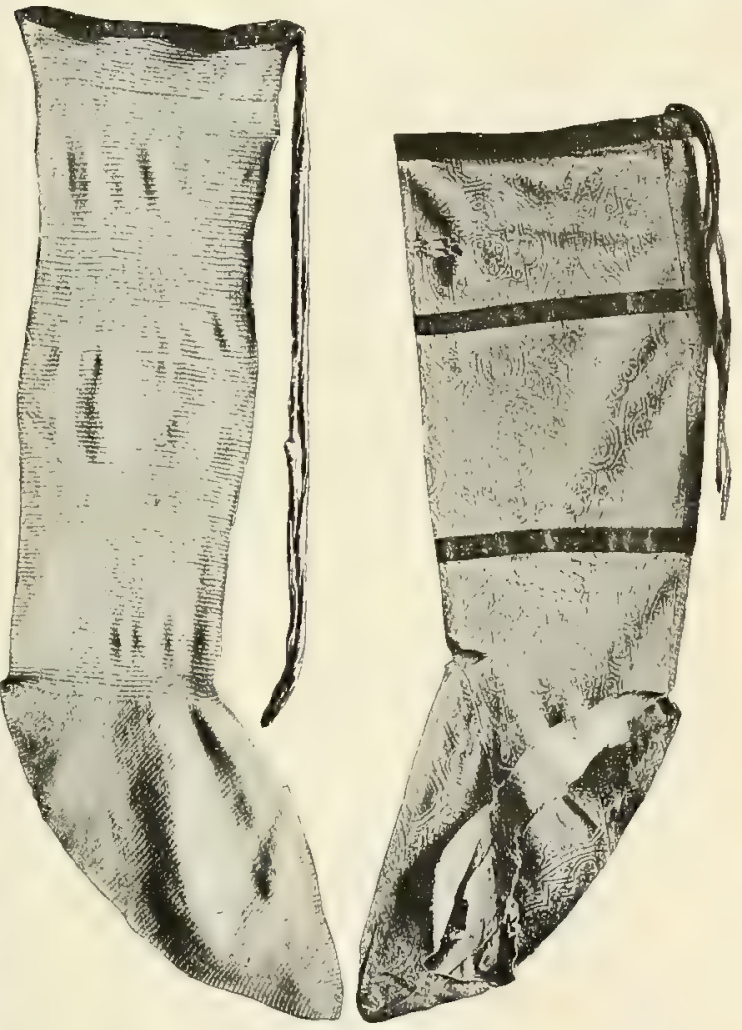

Bild 191-192. Pontifikalstrümpfe. Delsberg.
1 Abbildung bei de Far cy 122 und pl. 10. Die Schuhe des hl. Malachias kamen durch den letzten Abt Louis-Maria Rocourt nach Châlons. Einer von ihnen wurde 1838 durch Bischof de Prilly dem Prior von Valbonne geschenkt. $\mathrm{Ob}$ er noch existiert, ist ungewif. (Nach den giitigen Mitteilungen des P. L. Carrez S. J.) Übrigens scheinen die Schuhe erst ans der Zeit zu stammen, da die Erhebung des Leibes des Heiligen statthatte, d. i. aus dem Ende des 12. Jahrhunderts. Eine Mitra des hl. Malachias, die auf dem gleichen Wege von Citeaux in die Kathedrale zu Châlons gelangte, entstammt nach Ausweis ihrer Form, Mafe und Beschaffenheit erst dem 15. Jahrhundert.

${ }^{2}$ Abbildung ebd. pl. 14.

${ }^{3}$ Abbildung bei de Linas, Anciens vêtements sacerdotaux III, Paris 1863, 3.

* Abbildung in Museo Español de Antigüedades II 399.

${ }^{5}$ Abbildung bei Roh. VIII, pl. DcLxxvi.

6 Abbildung ebd. pl. Docxxvir.

7 Abbildung in Bullet. mon. 1872, 397.

s Abbildung und Beschreibung bei v. Wilm ow sky, Die Grabstätten der Erzbischöfe im Dom zu Trier 6915 und Tfl 45.

9 Abbildung und Bericht bei Schueider a. a. 0 . 
schuhe natürlich sehr ledeutungsvoll für die Geschichte der Entwicklung der pontifikalen Beschuhung im 11., 12. und 13. Jahrhundert. Sie sind aber auch darum von grofsem Wert, weil sie eine sichere Norm zur Datierung anderer Sandalen bieten, über deren Alter entweder keine oder nur legendenhafte Angaben vorliegen.

Alle diese Schuhe haben eine von derjenigen der Pontifikalsandalen vorkarolingischer und karolingischer Zeit merklich abweichende Form. Sie ähneln wenig oder gar nicht mehr Sandalen im eigentlichen Sinne, sondern sind entweder schon vollständige Schuhe geworden oder stehen doch der Schuhform nicht mehr fern.

Im einzelnen lassen sich drei Typen unterscheiden. Beim ersten läuft das Oberleder vorn und an den Seiten in zusammen fünf oder drei lange, zungenförmige Laschen aus, welche bis zum Fuggelenk reichen. Die mittlere derselben befindet sich auf dem Rücken des Fußes, die andern steigen seitwärts auf. Alle sind am Ende mit einem Haken oder einer Öse versehen, durch welche man eine von den Ecken der Kappe ausgehende Schnur hindurchzog, um mit ihr die Laschen rings um den Fuß festzubinden. Die Kappe war durchweg ebenso biegsam wie der übrige Oberteil. Über der mittleren Zunge pflegte vom oberen Ende bis zur Fufspitze eine schmälere oder breitere Borte oder ein dieselbe ersetzendes Ornament, z. B. sich umeinander windende Schlangen (Brüssel), angebracht zu werden.

Zu diesem Typus gehören die Pontifikalsandalen zu Hildesheim, Trier, Lausanne, Niederaltaich, Brüssel, dann einer der Delsberger Schuhe und zwei Paare der Sandalen zu Castel S. Elia. Auch die Schuhe, die man in den Gräbern der Trierer Erzbischöfe Bruno und Albero fand, wiesen ihn auf. Ob auch diejenigen Hillins, ist aus der Skizze, welche v. Wilmowsky davon anfertigte, nicht genügend ersichtlich, doch wahrscheinlich, da ihn noch die Sandalen seines Nachfolgers Arnold I. zeigen ${ }^{1}$.

Beim zweiten Typus, der etwas jünger ist, sind die Laschen in der Verkümmerung begriffen. Die mittlere hat sich zu einem lanzett- oder herzförmigen Zierstück umgebildet. Die andern dienen noch zum Zweck der Befestigung; sie sind aber kürzer und schmäler geworden, während gleichzeitig das Oberleder an den Seiten an Höhe gewonnen hat.

Klar tritt dieser zweite Typus bei den Pontifikalsandalen auf, die man bei der Leiche Konrads II. von Worms antraf 2. Aufierdem gehören ihm die früher zu Niederzell befindlichen Schuhe, ein Paar Sandalen zu Delsberg und die drei Pontifikalschuhe zu Chelles ${ }^{3}$ an.

Beim dritten Typus endlich, dem jüngsten, haben wir einen förmlichen, bis zu den Knöcheln reichenden und den Fuf völlig einschließsenden Schuh vor uns. Laschen und Riemen sind verschwunden, dagegen sind die Sandalen vorn am oberen Ende mit einem kurzen Schlitz, einem kleinen Ausschnitt oder einer Ausbauchung versehen, die das Anziehen erleichtern sollten.

\& Auch bei den zum Krönungsornat der deutschen Könige gehörenden Schuhen findet sich der Typus, doch erscheinen hier die Laschen schon merklich verkürzt. Ehenso war er einem zweiten Sandalenpaar der Reichskleinodien eigen, das aber seit 1794 verschwunden und nur mehr aus der Beschreibung v. Murrs und der Abbildung bei Delsenbach bekannt ist (vgl. Bock, Reichskl. 21 nebst Tfl 4 sowie Anhang $\mathrm{Nr} 3, \mathrm{~S} .4$ ).
2 Auch die Sandalen, die man 1606 bei der Leiche Hadrians IV. († 1159) sah, gehörten nach einer freilich mangelhaften Skizze Gri$\mathrm{m}$ aldis, Instrum. auth. translat. ss. corporum et ss, reliquiarum e veteri in novam Principis apostolorum basilicam pars 2, f. 184' (Vat. Barb. XXXIV), wohl dem zweiten Typus an.

${ }^{3}$ Nach de Linas (Revuo 1862, 347) vielleicht Frauenschuhe; mit Unrecht (etwas anders ders. übrigens in Anciens vêtem. III 201). 
Zu diesem Typus, der den Übergang zu den Pontifikalschuhen des späteren Mittelalters bildet, zählen die Sandalen zu Pontigny, Rivadeo, eines der drei Schuhpaare zu Castel S. Elia, sowie auch wohl die angebliche Pontifikalsandale Silvesters I. in S. Martino ai Monti zu Rom. Bei den Pontifikalschuhen zu Châlons wird der Schlitz durch einen Überschlag verdeckt, der an der Seite mittelst eines Knopfes geschlossen wird.

Verschiedenen der noch vorhandenen Pontifikalschuhe aus dem 12. und 13. Jahrhundert fehlt eine Sohle im gewöhnlichen Sinne, so den Sandalen im Dom zu Hildesheim und zu Chelles. Auch bei den Pontifikalschuhen zu Niederzell mangelte sie. Andere besitzen eine dicke, mit Leder überzogene Kork- bzw. Holzsohle, wie die Sandalen zu Châlons, Castel S. Elia und Rivadeo.

Was das Material anlangt, aus dem der Oberteil der Sandalen angefertigt ist, so besteht dieser bei fast allen aus Leder. Bei einigen, z. B. einem Paar Sandalen in Castel S. Elia und den Pontifikalschuhen Arnolds I. von Trier, ist das Oberleder mit dünner Seide überzogen; die andern haben es beim blofen Leder belassen. Aus Zeug ist blofi bei zweien der angeführten Sandalen der Oberteil angefertigt, bei den Pontifikalschuhen zu Pontigny und der sog. Silvestersandale zu Rom, beide Schöpfungen des 13. Jahrhunderts. Den Oberteil der Pontifikalschuhe aus Zeug, Seide oder Samt zu machen, dürfte kaum vor dem 13. Jahrhundert, der Zeit, da die Sandalen sich zum förmlichen Schuh ausbildeten, aufgekommen sein. Jedenfalls wurde solches erst damals gewöhnlicher. Wiederholt hören wir darum auch seit dieser Zeit von Sandalen aus Seidenstoffen. So berichten die Gesta der Bischöfe von Le Mans, Gottfried von Loudon († 1255) habe der Kathedrale von Le Mans Pontifikalschuhe aus roter Seide geschenkt, während uns das Inventar von Salisbury aus dem Jahre 1212 von duo paria sandaliorum, unum de serico indico,... et aliud de viridi cendali brusdato, und das Schatzverzeichnis von St Paul zu London aus dem Jahre 1245 von Sandalen aus rotem und blauem samitum (Seidenköper, nicht Samt in unserem Sinne) zu erzählen weif. Gegen Ende des 13. Jahrhunderts mufs es schon sehr gebräuchlich gewesen sein, die Pontifikalschuhe aus Seide herzustellen. Von den zehn Sandalenpaaren z. B., die 1295 im Schatzverzeichnis Bonifaz' VIII. vorkommen, werden nicht weniger denn vier ausdrücklich als aus roter oder violetter Seide gemacht notiert; eines bestand aus weißem sarazenischem Seidenstoff, bei den andern fünf aber schliest der Wortlaut eine Anfertigung aus Zeug zum mindesten nicht aus.

Die meisten der aus dem 12. und 13. Jahrhundert noch vorhandenen Sandalen sind reich ornamentiert. Die Verzierungen, welche vornehmlich in Rankenwerk bestehen, sind teils in Stickerei, teils in Aufnäharbeit gearbeitet. Im letzten Falle ist das aufgesetzte Ornament mit Vorzug aus vergoldetem Leder gemacht. Beispiele einer solchen Verzierungsweise liefern unter andern die Sandalen zu Brüsse], Delsberg und Castel S. Elia (Bild 198, S. 409). Ganz vergoldet ist der Pontifikalschuh Konrads von Sternberg im Paulusmuseum zu Worms; ferner war ursprünglich vergoldet eines der drei Sandalenpaare zu Castel S. Elia. Die Pontifikalsandale des hl. Malachias in der Kathedrale zu Châlons-sur-Marne und die Sandalen von Pontigny sind von roter F a rbe; rot waren auch die nunmehr verschwundenen Niederzeller Pontifikalschuhe. Von blaugrüner bzw. blaner Färbung sind die angeblichen Schuhe des hl. Silvester in S. Martino ai Monti, die St Godehardssandalen zu Niederaltaich und die beiden andern Sandalenpaare zu Castel S. Elia. Die übrigen vorhin erwähnten Pontifikalschuhe sind entweder schwarz (z. B. Delsberg, 
Brüssel, Chelles) oder lassen infolge des Alters oder der Grabesfeuchtigkeit die Farbe nicht mehr hinreichend erkennen.

Eine Eigentümlichkeit von verschiedenen der auf uns gekommenen Pontifikalschuhe (Châlons, Trier, Castel S. Elia u. a.) bilden die zahlreichen kleinen Löchlein, die allenthalben im Oberleder, im Vorderstück, an den Seiten

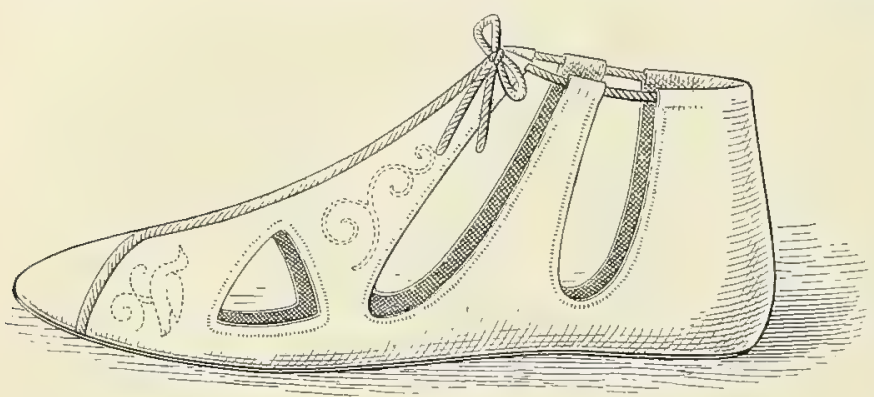

Bild 193. Pontifikalschuh St Godehards. Niederaltaich. und an der Kappe angebracht sind. Von diesen Löchlein redet auch Reginald von Durham, wenn er in der Beschreibung der bischöflichen Schuhe, mit denen nach seiner Angabe der Leichnam des hl. Cuthbert ausgestattet war, sagt: In pedibus calceamenta pontificalia gerit, quae vulgus sandalia vocare consuevit. Quae ex regione superiori multis foraminibus minimis patere videntur, quorum operamina artificiosa ex industria taliter confecta comprobantur ${ }^{1}$.

Die Löchlein haben manche Erörterungen veranlaft. Man hat geglaubt, ihr Zweck sei gewesen, die Ausdünstungen des Fufes austreten zu lassen. Doch ist das sicher unzutreffend; denn die zahlreichen kleinen Durchbrechungen des Stoffes befinden sich nicht nur an Schuhen, die oben völlig geschlossen sind, sondern auch, und zwar vornehmlich, an denjenigen Sandalen, welche mit Zungen bzw. mit tief herabgehenden Ausschnitten versehen sind und darum etwaigen Ausdünstungen des Fufes mehr als hinreichenden Austritt gewährten. Andere haben den Grund für die Anbringung der

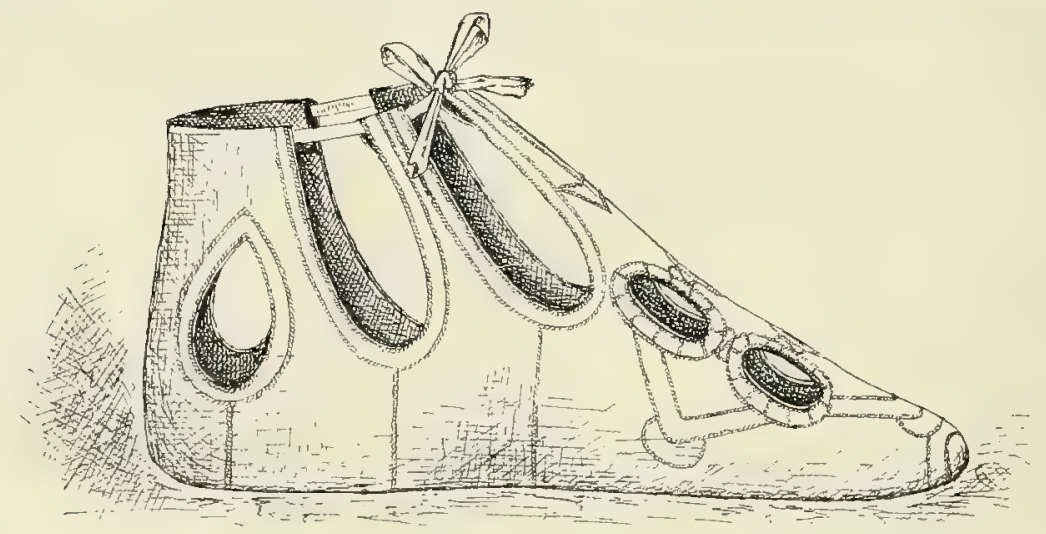

Bild 194. Pontifikalschuh des Bischofs Bernhard von Hildesheim ( $†$ 1153). Hildesheim, Dom.

zahlreichen Löchlein darin gesucht, daf nach einer mystischen Anschauung die Sandalen unten geschlossen, oben aber offen sein solten. Sie beachten aber nicht, daf

1 De admix. B. Cuthb, virt. c. 42 (ed. Surtees Society, Newcastle $1 \times 35,88$ ). Die Pontifikalsandalen, welche Rieginald mit diesen Worten beschreibt, siud nicht diejenigen des 8. Jahrhunderts, sondern die seiner eigenen Zeit, d. i. des 12. Jahrhunderts. Damals trug der Leichnam die ursprünglichen Sandalen nicht mehr, da diese nach der von einem Zeitgenossen des Heiligen verfaften Vita S. Cuthberti n. 14 bei der ersten Erôffnung aus dem Sarge genommen worden waren (A. SS. 20. Mart., III 123). 
die Löchlein fast winzig klein sind, und daf sie nicht nur auf dem Fuf, sondern auch an dessen Seiten bis zu den Sohlen und selbst an der Kappe sich finden. Freilich wissen die alten Liturgiker allerlei mystische Erklärungen, warum die Sandalen oben aperturas hätten, warum sie daselbst pertusa, forata, perforata, quibusdam locis aperta, quibusdam clausa seien und warum ihr Oberleder fenestratum sei. Indessen ist es erstens am wahrscheinlichsten, daßs sie dabei nicht an die kleinen Öffnungen, sondern an die grofen und tief hinabsteigenden Einschnitte des Oberstoffes denken. Dann aber dürften ihre Ausführungen kaum etwas mehr als eine symbolische Deutung sein, welche sie nachträglich mit einer vorhandenen Gepflogenheit verknüpften. Man darf nicht vergessen, dafi die alten Liturgiker bei all ihren langen Erörterungen kaum je über den wirklichen Grund einer Sache Aul'schluf geben, sondern sich damit begnügen, allerlei mystische Beziehungen in die sich ihnen darbietenden Erscheinungen hineinzulegen bzw. aus denselben herauszulesen. Der wahre Zweck der Löchlein war rein ornamentaler Art. Sie sollten die Einförmigkeit des Grundes in einfacher, aber gefälliger Weise brechen, in Verbindung mit Rankenwerk aber angebracht, die Ranken wirkungsvoller hervortreten lassen. Dann aber dienten sie, wie aus zwei der San-

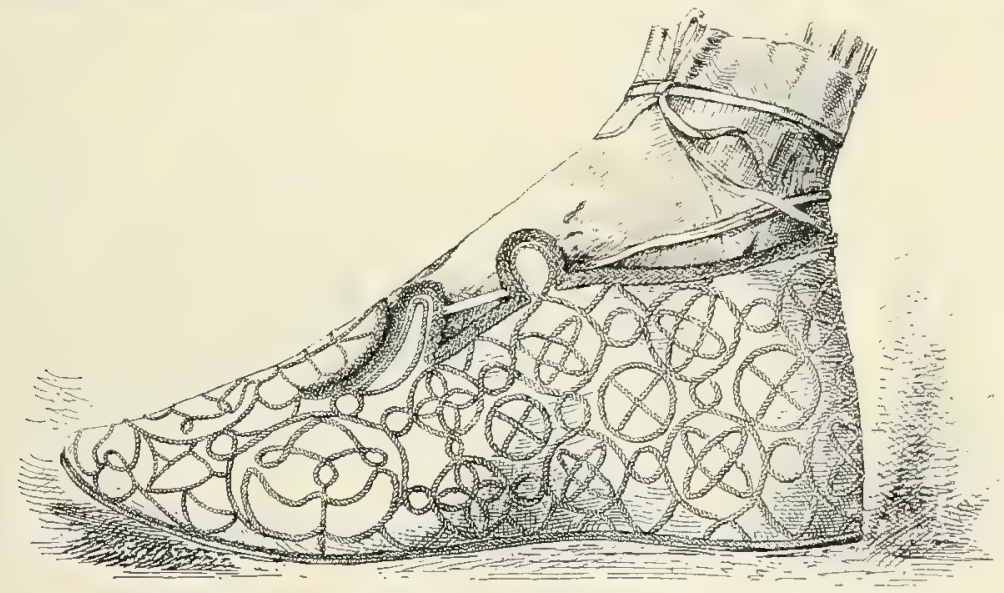

Bild 195. Pontifikalschuh des Bischofs Konrad II. von Worms.

Worms, Paulusmusenm. (Nach Schneider.)

dalenpaare von Castel S. Elia hervorgeht, auch zur Aufnahme kleiner Silbernieten. Bei einem dieser Paare hat sich noch der grökere Teil dieser Nieten erhalten, bei dem andern finden sich wenigstens noch so viele vor, daßs sich der Zweek der Löchlein, die hier eine netzförmige Musterung bilden, mit aller Bestimmtheit feststellen läßst.

Zum besseren Verständnis und zur Vervollständigung der vorstehenden Ausführungen über die Pontifikalschuhe des 11. bis 13. Jahrhunderts dürfte es sich empfehlen, ihnen eine etwas ausführlichere Beschreibung einiger besonders typischer Sandalen anzureihen. Es sind: der Pontifikalschuh des hl. Godehard zu Niederaltaich, die Schuhe des Bischofs Bernhard von Hildesheim und des Bischofs Konrad von Worms, die drei Sandalenpaare zu Castel S. Elia und die Pontifikalschuhe zu Rivadeo.

Über die Form der St Godehardssandale gibt die nebenstehende Skizze (Bild 193) Aufschluf ${ }^{1}$. Von den Laschen, die auf der Abbildung vollständig erscheinen, sind

1 Leider war es nicht müglich, von dem Schuh eine photographische Aufnahme herzustellen, da er hoch oben im Altar hinter festem Glasverschluf aufbewahrt wird. Es war selbst nicht wenig schwierig, auch nur eine Skizze vou ihm zu machen. $\mathrm{Ob}$ der Schuh wirklich vom hl. Godehard herrührt, mufs dahingestellt bleiben. Zur Zeit, da der Heilige Abt des eben nach hundertjähriger Auflösung neu wieder eingerichteten Bene- 
zum Teil nur noch Reste vorhanden. Der Oberstoff des Schuhes besteht aus dunkelfarbigem, blaugrünem Leder, das Futter aus weißem Leder. Zwischen Oberstoff und Futter scheint eine Einlage von Linnen eingeschaltet zu sein. Über den Spann zieht sich ein schmaler Zierbesatz, der sich nahe an der Spitze des Fußses gabelförmig teilt. Auch den Rand und die Ausschnitte des Oberleders umzieht eine schmale Borte. Die Ranken und Tögel, mit denen dieses verziert ist, sind mittels Seide in Konturstickerei ausgeführt. Die Sohle ist eigens eingesetzt, aber weich. Fast eine Kopie des Schuhes ist eine der Delsberger Sandalen. Auch der Pontifikalschuh, den man im Grab Alberos von Trier fand, weist den gleichen Typus auf.

Die Pontifikalschuhe Bernhards von Hildesheim (Bild 194, S. 406) haben eine Länge von $28 \mathrm{~cm}$ und eine Höhe von $12 \mathrm{~cm}$. Sie sind aus einem weichen braunen Leder gemacht und innen mit feinem weißen Leder gefüttert. $O b$ das jetzige Braun der Aufenseite den Schuhen immer eigen war oder ob es sich erst durch Zersetzung der Farbe in Grabe bildete, läßt sich nicht erkennen. Da das Futterleder indessen sein Weißs beibehielt, dürfte auch mit der Farbe des Aukenleders keine Veränderung vor sich gegangen sein. Sohlen und Oberleder bestehen aus demselben weichen Stoff. Im Gegensatze zu andern Sandalen haben die Pontifikalschuhe Bernhards am Einschlupf nur vier Ausschnitte und darum nur drei Laschen. Zwei weitere Ausschnitte sind zu eiförmigen, mit der Spitze aufwärts gerichteten Durchbrechungen der Kappe verkümmert. Die drei Laschen sind oben durch Umschlagen des Leder's mit Osen zur Aufnahme des Bandes versehen, mit welchem der Schuh oberhalb des Fubgelenkes befestigt wurde. Vorn befinden sich im Oberleder vier große, fast kreisrunde Öffnungen. Sowohl die vier Ausschnitte als die sechs Löcher in dem Vorderleder und der Kappe waren ehedem mit zwei ca $5-6 \mathrm{~nm}$ voneinander entfernten Metallgoldfäden umsäumt. Hie und da haben sich noch Spuren dieser Fäden erhalten. Im übrigen war die Verzierung der Schuhe einfach; sie beschränkte sich auf einen Pfeil über der mittlern Lasche, auf ein rhombenförmiges Gebilde, welches die vier Kreise auf dem Vorderstück einschlof, und drei senkrechte Linien zu beiden Seiten der Sandalen. Alle diese Ornamente sind leicht in das Leder eingeritzt. Ehedem waren diese Ritzen mit einem Goldfaden ausgelegt. Leider haben die Sandalen eine üble Restauration durchmachen müssen; derselben gehören nicht nur die nit Bronzepulver hergestellten Goldtupfen und Striche, sondern auch die aufgesetzten Goldkördelchen an. Die Schuhe Bernhards sind ein vorzügliches Beispiel des älteren Sandalentypus.

Bei dem Schuh Konrads von Worms (Bild 195, S. 407) besteht der Oberteil aus prächtig vergoldetem Leder mit einem Unterstoff aus starkem Gewebe. Die Laschen sind ersichtlich in der Rückbildung begriffen, immerhin jedoch gut zu erkennen. Auch dienten sie noch zur Aufnahme der Schnur, mit dem der Schuh am Fuß angebunden wurde. Eigenartig ist die Verzierung des Oberstoffes. Sie besteht in sehr sorgsam und geschickt aufgenähten Seidenkordeln, die, größere und kleinere Kreise bildend, ein geometrisches Zeugmuster nachahmen. Ein einfaches Kreuz füllt die kleineren, ein vierpafartiges die gröferen Kreise. Die Verzierung verbreitet sich über die ganze Oberfläche. Die Abheftstiche sind durch die Unterlage des Leders durchgeführt. Die Länge der Sandale beträgt ea $28 \mathrm{~cm}$, ihre Höhe ca $10 \mathrm{~cm}$. Die Sohle ist dünn und weich, umgewandt angenäht und absatzlos. Die Pontifikalschuhe Bischof Konrads stellen ein instruktives Specimen des mittleren Sandalentypus dar.

Von den drei Paaren Pontifikalsandalen zu Castel S. Elia ist dasjenige am äItesten, von welchem in Bild 196 ein Schuh wiedergegehen ist. Die Sohle besteht bei ihm aus einer kräftigen Korkplatte, welche unten mit schwarzem, seitlich aber mit weifsem Leder überzogen ist. Auch im Innem sind die Sandalen mit weisem Leder

diktinerklosters Niederaltaich war, hatten dessen Åbte, wie kaum zu bezweifeln ist, noch nicht das Pecht, Pontifikalsandalen zu tragen. Den Gebrauch der Mitra und des Ringes erhielten sie sogar erst 1240 durch
Gregor IX. (Mon. Boica XI 211). Wenn der Schuh vom hI. Godehard stammt, wird er also wohl als Reliquie des Heiligen von Hildesheim nach dem früheren Wirkungskreis desselben gekommen sein. 
ausgestattet. Das Oberleder ist mit blauer Seide bekleidet. Das Schlingenornament auf dem Vorderstück besteht aus nebeneinander gelegten, mit Seidenfäden aufgehefteten vergoldeten Lederriemchen, denen man im 12. Jahrhundert auch sonst mehrfach begegnet, so z. B. bei einem der Delsberger Pontifikalschuhe. Dort, wo die durch die Goldriemchen hergestell-

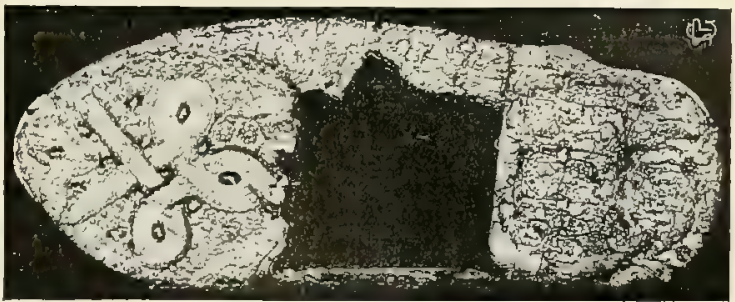

Bild 196. Pontifikalschuh. Castel S. Elia.

ten Bänder einander schneiden, sind sie mit silhernen Nieten am Oberleder befestigt, zu beiden Seiten aber werden sie von Kettenstichen in gelber Seide begleitet. Auf der Kappe und den Seitenteilen der Schuhe steht eine arabische Inschrift in grofien Kufen, welche durch ein vergoldetes Lederstreifchen gebildet und gleichfalls von Kettenstichen eingefafist werden. Der Grund, welchen Inschriften urd Ornament ührig lassen, ist teils mit kleinen Rosettchen aus vergoldetem Leder verziert, in deren Mitte sich eine silberne Niete befindet, teils von feinen Löchlein durchbrochen, in welche ebenfalls

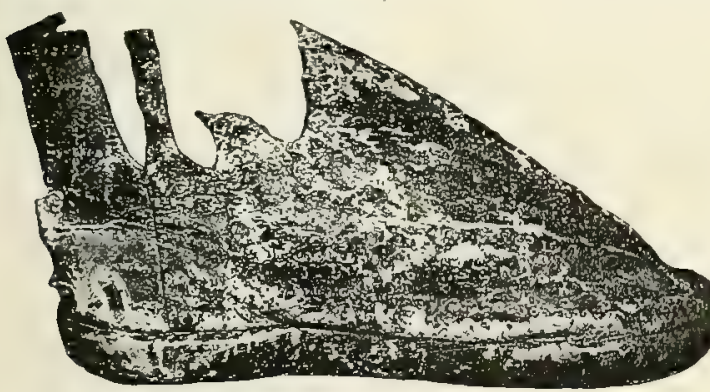

Bild 197. Pontifikalschut. Castel s. Elia. ein Silberknöpfchen von der Gröfse eines kräftigen Stecknadelkopfes befestigt ist.

Die Länge der Sandalen beträgt $30 \mathrm{~cm}$, die Sohlenhöhe $1 \frac{1}{2} \mathrm{~cm}$, die Kappenhöhe $10 \mathrm{~cm}$. Schade, dak ihr Oberteil nicht mehr intakt ist. Es sind nämlich die Laschen im Laufe der Zeit abgerissen worden; nur ihre Ansätze sind noch vorhanden, jedoch als solche deutlich erkennbar. Die ganze Technik der Sandalen, ihre Form und ihre Ausstattungsweise lassen sie als eine Arbeit aus dem 12. Jahrhundert erscheinen.

Das zweite Sandalenpaar (Bild 197) gehört ebenfalls noch dem 12. Jahrhundert an. $30 \mathrm{~cm}$ lang, hat es eine Kappenhöhe von $13 \mathrm{~cm}$. Die Korksohlen, welche eine Dicke von $2 \mathrm{~cm}$ besitzen, sind an den Seiten und unten mit rotem Leder überzogen. Das Oberleder besteht aus ursprünglich weißsem, aber rot gefärbtem und dann vergoldetem Eselsleder. Im Innern sind die Schuhe mit rotem Leder gefüttert.

Eine besondere Verzierung haben die Sandalen weder auf dem Vorderteil, noch an der Kappe, doch ist das ganze Oberleder mit zahllosen Löchlein versehen, welche eine regelmäßige, netzartige Quadrierung bilden und einst mit Silberstift-

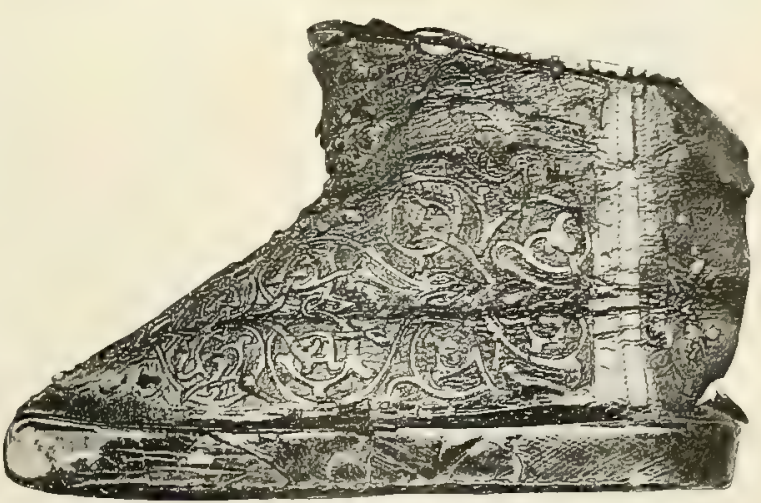

Bild 198. Pontitikalschuh. Castel S. Elia. chen gefüllt waren. Noch jetzt finden sich solche, wie schon vorhin bemerkt wurde, in einzelnen Löchlein eingenietet vor.

Die Laschen zum Anbinden des Schuhes sind noch ziemlich gut erhalten, doch schon verhältnismäfig klein. Die Form bezeichnet das Übergangsstadium vom ersten zum zweiten Typus. 
Das dritte Paar (Bild 198, S. 409), welches wir unter den mittelalterlichen Paramenten in Castel S. Elia antreffen, vertritt den dritten, jüngsten Typus. Die Länge des Schuhes beträgt $30 \mathrm{~cm}$, die Kappenhöhe $16 \mathrm{~cm}$. Die Korksohlen sind hier $2^{1 / 2} \mathrm{~cm}$ dick. Invendig sind die Sandalen mit rotem Leder ausgefüttert, während die Sohlen unten mit dunkelbraunem, seitlich mit vergoldetem Leder bedeckt sind. Das Oberleder lıat gegenwärtig eine tiefbraune Färbung, ursprünglich war es jedoch mit grüner Farbe bemalt, von der sich noch verschiedene Reste erhalten haben. Über den Spann zog sich einst der Länge nach ein vergoldeter Lederstreifen. Ein ähnlicher Streifen an den Seiten ist noch vorhanden. Die übrigen Teile des Oberleders sind mit Ranken romanischer Bildung, wie sie auch an den Pontifikalschuhen Arnolds I. von Trier, des hl. Edmund von Canterbury zu Pontigny und andern vorkommen, gänzlich übersponnen.

Die Pontifikalsandalen zu Rivadeo bestehen aus Leder. Die Sohle ist aus Fichtenholz gemacht und unten sowie an den Seiten mit Kalbleder überzogen. Über das Vorderleder laufen in der Längsrichtung der Schuhe abwechselnd vergoldete und versilberte Streifen, die durch ein rotes Bändchen voneinander getrennt sind. Die drei vergoldeten sind mit einer Prägung versehen, die bei dem mittleren ein netzförmiges Muster, bei den beiden andern blofe Querlinien darstellt. Die beiden versilberten weisen eine grüne Zickzacklinie auf. Die Streifen enden an einem versilberten Band, das sich etwas hinter der Vitte des Fußes quer über den Spann zieht. An der Ferse und den beiden Knöcheln steigt je ein versilberter, von einer roten Linie eingefaßster und mit eingeprägten Querlinien belebter Streifen senkrecht von der Sohle zum Fußsgelenk herauf, wo er durch ein versilbertes Band begrenzt wird, das horizontal den Fufs umgibt. Die Seiten der breiten Sohle sind mit einer Ranke geschmückt, welche sich aus zwei roten und einer mittleren grünen Linie zusammensetzt. An der Spitze ragt das Oberleder schnabelförmig ein wenig hervor. In der Form zeigen die Schuhe das gewöhnliche Bild der Sandalen des dritten Typus. Die Verzierung ist dagegen sehr eigenartig ${ }^{1}$.

\section{BESCHAFFENHEIT DER SANDALEN UND CALIGAE IM SPÄTEN MITTELALTER UND DER NEUZEIT.}

Es bleibt noch übrig, auf die Beschaffenheit der pontifikalen Fußbekleidung im späten Mittelalter und in der Neuzeit etwas näher einzugehen.

Von den Caligae des 14. und 15. Jahrhunderts geben uns einige noch vorhandene Pontifikalstrümpfe des ausgehenden Mittelalters ein gutes Bild. Es scheinen auf der Nadel gearbeitete Caligae allmählich außser Mode gekommen und die pontifikalen Strümpfe nur oder doch fast nur noch aus den kostbaren sarazenischen, maurischen und italienischen Seidenstoffen gemacht worden zu sein, mit denen Europa vom Orient, von Italien und Spanien in damaliger Zeit wie überschwemmt wurde.

1 Museo Español de Antigüedades II 399. Wir fïgen noch ein paar Worte über zwei an sich zwar unwichtige, immerhin aber der Erwähnung würdige Reste bischöflicher Pontifikalsandalen des 13. Jahrhunderts an. Fragmente von Sandalen, die dem hl. Ludwig von Anjou zugeschrieben werden und demgemäß dem Ende des 13. Jahrhunderts entstammen würden, befinden sich zu St-Maximin (Var). Soweit sich aus den noch vorhandenen Teilen die ehemalige Form erkennen läst, scheinen sie die Form eines niederen Schuhes gehabt zu haben. (Näheres Revue 1862, 352.) Der Oberstoff war aus einem reichen Brokat gemacht und mit einer Einlage von Linnen und gelbseidenem Futter versehen. Andere Reste von Sandalen, deren Oberstoff anscheinend aus Seide bestand und mit einem aus Goldborten hergestellten Gabelkreuz verziert war, entdeckte man in einem ins 13. Jahrhundert hinaufreichenden Bischofsgrab der Kathedrale von Châlons-sur-Marne (Abbildung in Bullet. de la Soc. Nat. des Antiq. de France 1895, 193). 
Die Caligae, welche man bei der Leiche Peters von Courpalay, Abtes von St-Germain-des-Prés († 1334), gelegentlich der 1799 vorgenommenen Eröffnung seines Sarges antraf, waren aus einem dunkelvioletten Seidendamast angefertigt, der mit goldenen Vögeln in Sechsecken, goldenen Lilien und ähnlichem gemustert war ${ }^{1}$.

Aus grünem sarazenischen Seidendamast besteht ein Pontifikalstrumpf des Kardinals Arnold de la Vie († 1335), welcher im Cluny-Museum zu Paris (Bild 199) aufbewahrt wird. Er ist $63 \mathrm{~cm}$ lang. Die Köpfe, Füße, Krallen und Hufe der dem Stoff eingewebten Adler und Antilopen sind in Gold broschiert.

Die Caligae Wilhelms von Wainfleet, Bischofs von Winchester († 1486), welche sich im Besitze des Maria Magdalena-Kollegs zu Oxford, der Stiftung Wilhelms, be-

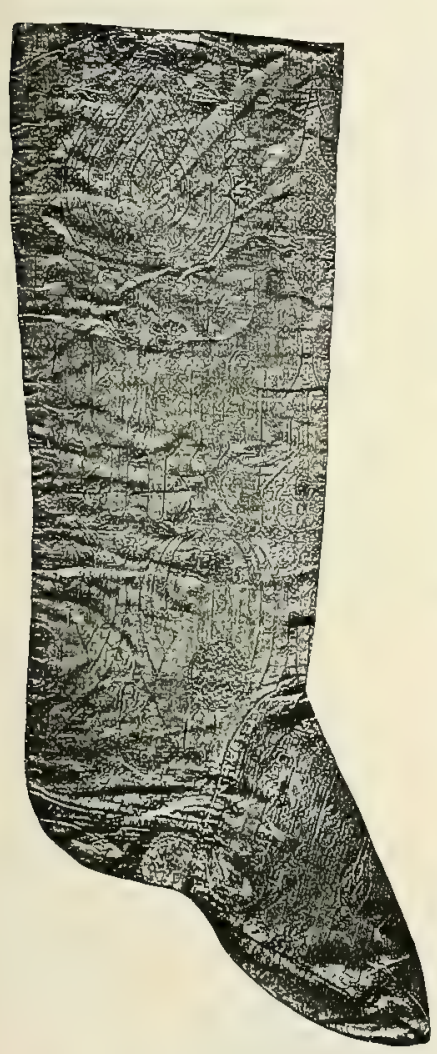

Bild 199. Pontifikalstrumpf des Arnold de la Vie.

Paris, Musée Cluny. finden, sind aus einem mit Vögeln, Blumen, Strahlen verzierten Brokat gemacht. Sie sind $50 \mathrm{~cm}$ lang und zum Zweck des Anbindens oben in einer Entfernung von $14 \mathrm{~cm}$ vom Rand seitlich mit einem Knopf versehen, dem auf der andern Seite eine Schnur entspricht. Inwendig sind sie mit Linnen gefüttert.

Ein Pontifikalstrumpf des späten Mittelalters im Dom zu Halberstadt (Bild 200) ist aus einem leichten Seidentaft von bräunlichvioletter Farbe hergestellt, welcher von gelblichen, in schräger Richtung das Bein umziehenden Streifen durchquert ist. Die Länge des Strumpfes beträgt vom oberen Rande bis zur Zehe $78 \mathrm{~cm}$.

Die Gepflogenheit, die pontifikalen Strümpfe aus Seidenstücken zusammenzunähen, erhielt sich, wo überhaupt Caligae in Brauch blieben, wie z. B. in Italien, bis in die Gegenwart. Es kann das angesichts des Aufschwunges, den die

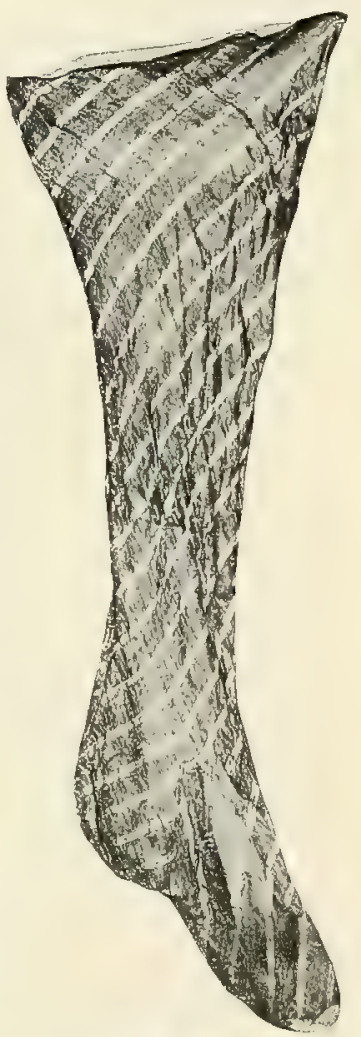

Bild 200.

Pontifikalstrumpf.

Halberstadt, Dom.

Strumpfwirkerei seit dem 16. Jahrhundert nahm, auffällig erscheinen. Allein es erklärt sich ohne Schwierigkeit, wenn man bedenkt, daß die Caligae nach der seit Jahrhunderten herrschenden Praxis nicht eigentlich Bekleidung der bloken Füßse sind, sondern einen Alltagsstrumpf voraussetzen, und daf sie darum im Grunde nur eine Art von Überzug über letzteren darstellen. Als Beispiel der Caligae der Neuzeit können die Pontifikalstrümpfe des hl. Pius V. dienen, welche in der Kathedrale zu Mondovi aufbewahrt werden und 1898 zu Turin ausgestellt waren. Sie sind, ihrem Zwecke entsprechend, sehr weit und in ihrem oberen Teile aus einem reich gemusterten Brokat gemacht. Der

1 Revue 1863, 245. Reste der Caligae finden sich im Cluny-Museum zu Paris. 


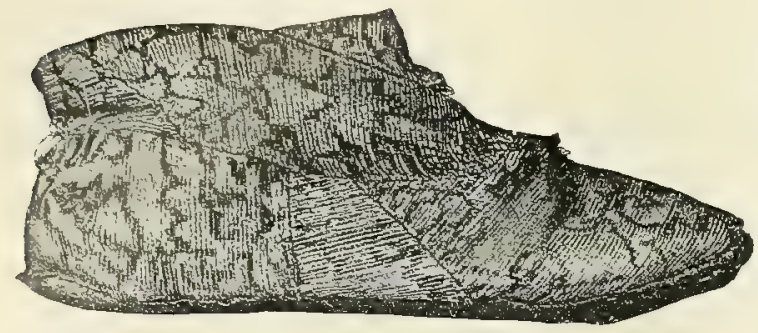

Bild 201. Pontifikalschul., Kopenhagen, Nationalmuseun.

Fusteil besteht aus einem einfacher gemusterten Brokat. Den Einschlupf umsäumt eine dreifache Goldkordel.

Von Pontifikalschuhen haben sich aus dem späteren Mittelalter nur wenige Exemplare erhalten.

Zu ihnen gehören die leider stark restaurierten Pontifikalsandalen in der Kathedrale von Comminges. Sie werden dem hl. Bertrand $(\dagger 1123)$ zugeschrieben. Form und Beschaffenheit lassen jedoch keinen Zweifel, daß diese Zuweisung irrig ist. Die Schuhe stammen aus dem späten Mittelalter, frühestens aber aus dem Ende des 13. Jahrhunderts. Als Oberstoff ist eine auf grobem Linnen im Kreuzstich ausgeführte Seidenstickerei benutzt, welche sich schachbrettartig aus Quadraten zusammensetzt. Die Quadrate selbst sind abwechselnd mit einem Löwen, einem Stern oder einem Kreuz gefült. An der Innenseite der Schuhe ist ein langer Schlitz angebracht, der mittels Knöpfe geschlossen ,wurde ${ }^{1}$.

Ein zweites Beispiel spätmittelalterlicher Pontifikalschuhe liefern die im Maria Magdalena-Kolleg aufbewahrten Sandalen des Bischofs Wilhelm von Wainfleet. Der Oberteil wird durch einen roten Samt gebildet, welcher mit Blumen in Gold und Blättern in gelber und grüner Seide gemustert ist. Der Schlitz befindet sich bei ihnen statt seitlich auf dem Fure.

Ein weiteres Paar zeigt man zu Strengnäs in Schweden (Södermanland). Die Schuhe sollen dem Bischof Konrad Rogge († 1501) zugehört haben. Ihr Oberstück besteht aus gelber Seide und ist mit einem gabelförmigen Besatz ausgestattet. Der Schlitz liegt wie bei den ersterwähnten Sandalen an der Innenseite des Schuhes; die Sohlen sind $0,015 \mathrm{~m}$ dick ${ }^{2}$.

Ein viertes Paar sahen wir im Schatz des Domes von Halberstadt. Es ist in seinem oberen Teil aus rotem Samt gemacht und ohne alle Verzierung. Der Schlitz ist auch hier an der Seite angebracht. Die Schuhe mögen aus dem 15. Jahrhundert herrühren und sind $0,29 \mathrm{~m}$ lang, $0,15 \mathrm{~m}$ hoch ${ }^{3}$.

Ein fünftes Sandalenpaar besitzt der Dom zu Brixen. Der Oberstoff ist hier ein Brokatell, der auf violettem Grund Greife, Blattwerk und die Inschrift grifone aufweist. Den Schlitz gewahrt man wiederum an der Innenseite. Je fünf Löcher, die rechts und links von ihm vorgesehen sind, dienten zur Aufnahme einer Schnur, mittels deren der Schuh festgebunden wurde. Die Länge der Sandalen beträgt $0,27 \mathrm{~m}$, die Höhe ca $0,10 \mathrm{~m}$.

Auch das Nationalmuseum zu Kopenhagen hat noch ein Paar interessanter Pontifikalsandalen, welche einer freilich wenig verbürgten Überlieferung zufolge aus Kloster

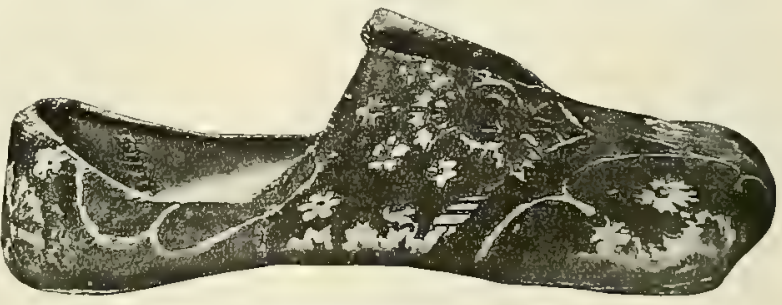

Bild 202. Pontifikalschuh. Hallerstadt, Dom. Sorö (Dänemark) stammen sollen und etwa der Zeit um 1500 angehören (Bild 201). Thre Länge beträgt $0,25 \mathrm{~m}$, ihre Höhe $0,08 \mathrm{~m}$; sie nähern sich also schon wieder ein wenig der Pantuffelform. Im übrigen weisen sie noch den bei den Pontifikalschuhen im späteren Mittelalter herrschend gewordenen Typus auf. Der Schlitz, an dessen

1 Pevue 1xt:2, 349. Abbildung 336.

2 Pievue 1867, 21\%. De Linas liält die Schuhe fïr Arbeiten des 13. Jabrhunderts, besser wird man sie indessen wohl dem 14. Jahrhundert zuschreiber.

3 Eine Kopie im Kestner-Mus. zu Hannover. 
Seiten oben Löchlein zum Durchziehen eines Riemens angebracht sind, befindet sich oben auf dem Fuf 3 und ist $0,09 \mathrm{~m}$ lang. Die Sohlen der Schuhe sind dünn und weich; den Oberstoff bildet ein dunkelroter Brokat ${ }^{1}$.

Alle angeführten Pontifikalschuhe stellen einen förmlichen Schuh dar, wie wir ihn

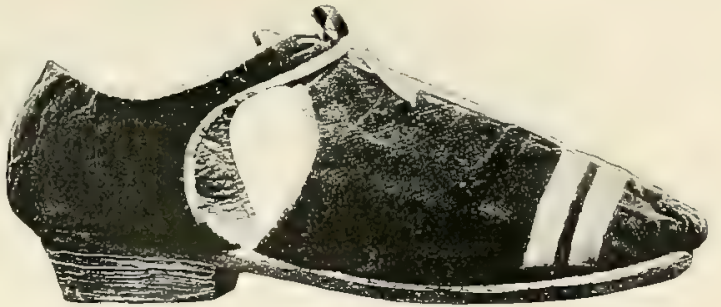

Bild 203. Pontifikalsandale. Hildesheim, St Godehard. im 13. Jahrhundert gebräuchlich werden sahen. Der Umstand, dafs die fünf Schuhe sich auf Frankreich, Deutschland, England und Schweden verteilen, dürfte beweisen, dafi diese Sandalenform im 14. und 15. Jahrhundert, wenn nicht allgemein gebräuchlich, so doch sehr weit verbreitet war. Auch zu Rom wird sie, soweit die Monumente einen Schlub erlauben, damals in Gebrauch gewesen sein.

Wie die Pontifikalschuhe im 16. Jahrhundert gemäßs römischer Gepflogenheit beschaffen waren, lehrt eine Sandale Pius' V. in der Kathedrale von Mondovi. Sie ist aus rotem Samt angefertigt, mit dicker Sohle versehen und auf dem Vorderblatt mit zwei Goldbörtchen besetzt, von denen sich eines von der Schuhspitze bis zum Gelenk, das andere von der Sohle bis zur Sohle quer über die Mitte des Spanns hinzieht. Der Form nach stellt die Sandale einen wirklichen Schuh dar. Ein Schlitz fehlt sowohl an der Seite wie oben auf dem Spann, statt dessen läuft die Kappe in zwei zungenförmige Laschen aus, die sich vor dem Fufe treffen und durch eine Schnur zusammengebunden wurden.

In Deutschland treffen wir im 16. Jahrhundert eine ganz eigenartige bischöfliche Fulbbekleidung. Sie ist mehr pantoffel- als schuhartig, ohne Bindevorrichtung und an der Spitze von außerordentlicher, geradezu häficher Breite. Ein Sandalenpaar, das sich im Schatz des Halberstäiter Domes befindet (Bild 202), ist ein Beispiel dieser Art von Pontifikalschuhen. Es ist aus rotem, mit dem sog. Granatapfelmuster versehenem Samt angefertigt, auf dem Spann mit einem Einschnitt versehen und bei einer Kappenhöhe von nur $7 \mathrm{~cm} 30 \mathrm{~cm}$ lang. Man sollte fast meinen, es handle sich hier eher um

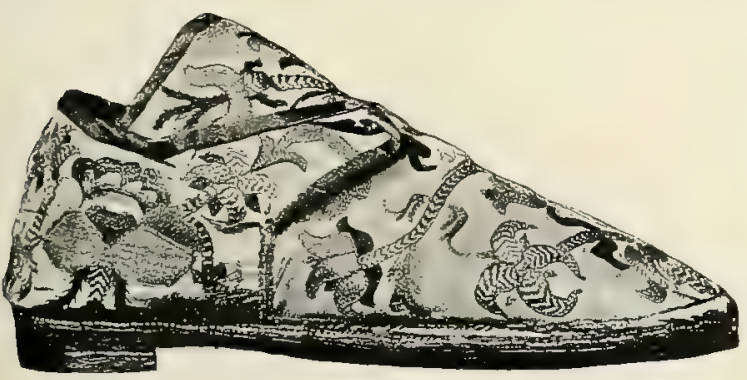

Bild 204. Pontifikalschuh. Berlin, Kunstgewerbemuseum. einen Überschuh, als einen eigentlichen Schuh. Wie der schon ziemlich entartete Granatapfel beweist, stammen die Sandalen aus der Frühe des 16. Jahrhunderts.

Schuhe dieser Art finden sich im 16. Jahrhundert sehr häufig auf deutschen Bischofs. monumenten. So gewahren wir sie z. B. bei den Grabstatuen der Mainzer Erzbischöfe Albrecht von Brandenburg $(\dagger 1545)$, Sebastian von Heufenstamm $(\dagger 1555)$ und Wolfgang von Dalberg († 1601). Selbst im fernen Osten treffen wir sie an, so auf dem Grabdenkmal des Bischofs Petrus Kostka $(\dagger 1595)$ in der ehemaligen Domkirche zu Kulmsee. Sie

1 Auskunft ïber die Schuhe verdanke ich der Liebenswïrdigkeit des Herrn Museums- direktors Mollerup, die Photographie derselben der Güte des Herrn Inspektors Dr Mackeprang. 
scheinen sich vereinzelt bis tief ins 17 . Jahrhundert in Gebrauch erhalten zu haben, da sie uns noch auf dem Nonument des Bischofs Adolf von der Recke $(\dagger 1661)$ im Dom zu Paderborn begegnen.

Diese Schuhform war dem profanen Leben entnommen. Zahlreiche Bildwerke des 16. Jahrhunderts weisen sie auf. Als sie hier aus der Mode kam, verschwand sie auch wieder aus dem Kultus. Die Sandale, welche dann an ihre Stelle trat, war der römischen nachgebildet. Beispiele von Pontifikalschuhen dieser letzten Art sind nicht selten. Ein treffliches Exemplar besitzt z. B. die St Godehardskirche zu Hildesheim (Bild 203, S. 413). Es stammt aus dem 17. Jahrhundert, vielleicht sogar aus der Frühzeit desselben, und besteht aus rotem Samt. Auf dem Vorderblatt sind die Schuhe nach Weise der Sandalen Pius' V. mit zwei gelbseidenen Besatzstreifen in Kreuzesform verziert, dagegen fehlt ihnen die jenen eigene dicke Sohle. Sie haben eine solche von nur mäbiger Stärke, jedoch mit hohem Absatz. Auch ist die Kappe des Schuhes, im Unterschied von den Sandalen Pius' V., vom Vorder-

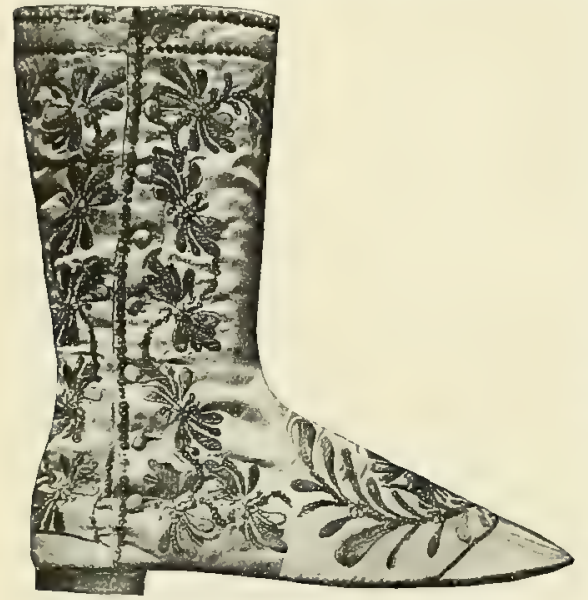

Bild 205. Stiefelartiger Pontifikalschuh. Münster, Bischöfl. Museum. teil durch einen tiefen Einschnitt getrennt und selbständig behandelt; indessen endet sie auch hier in zwei auf dem Spann zusammenstofende Laschen, welche die Verwandtschaft mit der römischen Schuhform deutlich erkennen lassen.

Ein anderes Paar von Sandalen dieser Art begegnet uns im Schatz des Freiburger Münsters. Es ist kostbarer als die Hildesheimer Sandalen ausgestattet, da bei ihm auf dem Spann statt einfacher Besätze, wie bei diesen, schwere Goldstickereien, in deren Nitte sich ein Kreuz befindet, angebracht sind. Allein es dürfte auch etwas jünger sein und wohl erst dem 18. Jahrhundert angehören. Das Schuhpaar mag aus Konstanz herrühren. Ein drittes Paar von Pontifikalschuhen von der Form, wie sie den Sandalen Pius' V. eigen ist, besitzt das königliche Kunstgewerbemuseum zu Berlin (Bild 204, S. 413). Den Oberstoff bildet ein weifer Reps, welcher mit barocken, in Gold und Seide ausgeführten Ranken und Blumen bestickt ist. Die Schuhe gehören etwa dem Anfang des 18. Jahrhunderts an. Auch sonst haben sich noch manche Pontifikalschuhe dieser Art erhalten. So gibt es ihrer im historischen Museum zu Frankfurt zwei Paare, in der Sammlung des historischen Vereins für Unterfranken zu Würzburg ein Paar, im Dom daselbst fünf Paare, im Cluny-Museum zu Paris siehen Paare usw. Es sind das alles Schöpfungen des 17., meist aber des 18. Jahrhunderts.

Ein in neuerer Zeit unternommener Versuch, die Pontifikalstrümpfe und die Pontifikalschuhe miteinander zu verbinden, hatte als Ergebnis eine Art von Stiefel. Das bischöfliche Museum zu Münster besitzt einjge Exemplare dieses ebenso unschönen wie aller kirchlichen Überlieferung widerstreitenden Surrogates (Bild 205).

Ein recht anschauliches Bild von der Entwicklung, welche die bischöflichen Sandalen vom 12. bis ins 18. Jahrhundert hinein genommen laben. bieten die Beobachtungen, welche bei der Eröffnung der Trierer Bischofsgräber gemacht wurden. Leider sind die Mitteilungen, welche v. Wilmowsky über den Befund der pontifikalen Fubbekleidung gibt, bei weitem nicht so vollständig, wie man wünschen möchte; doch finden sie eine teilweise Er- 
gänzung in den Abbildungen, welche derselbe nach den von ihm gemachten Aufnahmen seinen Ausführungen beigefügt hat ${ }^{1}$ (Bild 206-208).

v. Wilmowsky bespricht die Pontifikalschune von acht Trierer Erzbischöfen. Die Sandalen Brunos $(† 1124)$ bestanden nach seinen Wahrnehmungen aus einfachem Leder (Bild 206). Der Oberteil war durchbrochen. Bezüglich der MaEverhältnisse sagt v. Wilmowsky: "Die Sandale ist $4 \frac{1}{2}$ Zoll $(=12 \mathrm{~cm})$ am Ballen breit, von der Fufspitze bis zum Ballen $3 \%$ Zoll $(=10 \mathrm{~cm}$ ) lang; der dreieckige Ausschnitt ist $1 \frac{1}{4}$ Zoll $(=3,4 \mathrm{~cm})$ groß und von der Spitze des Fufes bis zu seinem Gelenke $53 / 4$ Zoll (= $15 \mathrm{~cm}$ ) erhalten." Die Beschuhung des Erzbischofs Albero ( $\uparrow 1152)$ war gleichfalls aus Leder gemacht, doch war sie mit Seide überzogen und auf dem Spann mit einer breiten, an den Rändern der Laschen und der Ausschnitte des Vorterstückes aber mit einer schmalen Goldborte verziert (Bild 207). Bei den Sandalen Hillins ( $\dagger$ 1169) bestand die Sohle aus Korkholz; das Leder des Oberteils und der Kappe war auch hier mt Seide bekleidet. Die Sandalen waren reich mit Gold bestickt und mit farbigen Edelsteinen geschmückt. Der Grund zwischen den Vustern war mit den feinen Löchlein belebt, von denen vorher die Rede war (Bild 208). Reicher noch
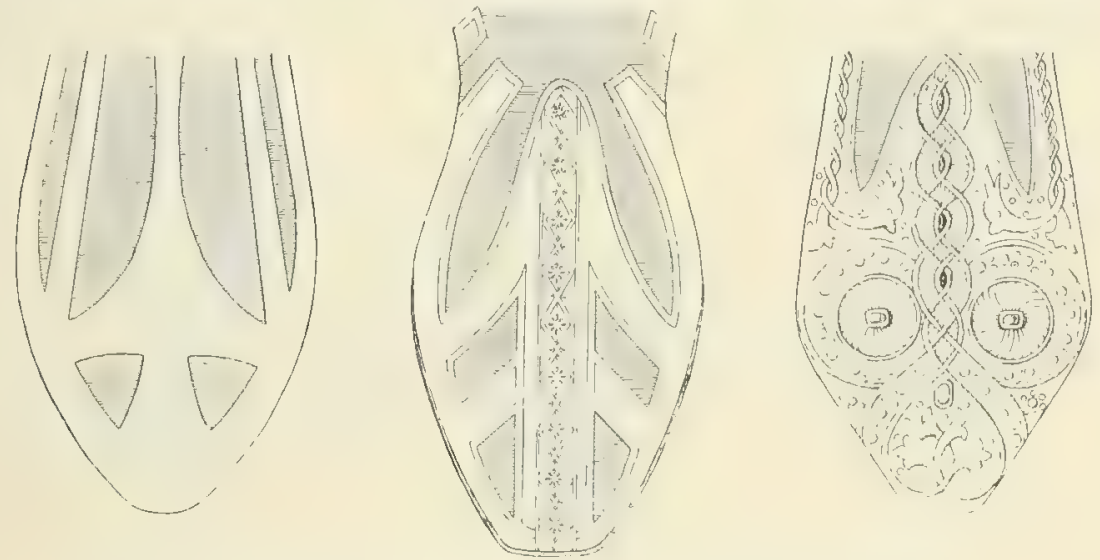

Bild 206-208. Pontifikalschuhe aus den Trierer Bischofsgräbern.

(Nach $\vee$. Wilmowsky.)

als die Pontifikalschuhe Hillins waren diejenigen Arnolds I. († 1183), wahre Prachtstücke ihrer Art (Bild 209, S. 416). Ihre Sohle war von dichtem, festem Leder; das obere Stuick wurde durch ein feines, rot gefärbtes Leder gebildet, das mit Seide von gleicher Farbe bedeckt und mit kunstreich verschlungenem romanischem Rankenwerk in Gold bestickt war. Die Stickereien waren im Stepp-, Kreuz- und Kettenstich ausgeführt. Die kleinen Löchlein, die sich auch hier über den Fond ausgestreut fanden, waren mit einem Goldfaden zierlich eingefast. Außserdem waren die Schuhe mit wasserhellen Bergkristallen, leichtgelben T'opasen, violetten Amethysten und bläulichen Saphiren besetzt. Von dem oberen Ende der mittleren Lasche lief ein Zierstreifen bis zur Fufsspitze. Haken, in welche die Laschen ausliefen, dienten zur Aufnahme der goldenen Litze, mittels deren der Schuh am Fersengelenk festgebunden war. Die Sandalen Boemunds II. († 1:367) hatten die Gestalt eines hoch ansteigenden Schuhes; sie bestanden aus gemustertem Goldstoff und waren oben auf dem Fußse mit einem Einschnitt versehen (Bild 210, S. 417). Bei den Pontifikalschuhen Ottos von Ziegenhain $(† 1430)$ (Bild 211, S. 417) diente als Oberstoff ein schachbrettartig gemustertes Zeug. Die Vierecke wechselten in Gold und Schwarz und waren von kleinen weifen und grofen grünen Perlen besetzt. Auch diese Sandalen hatten die Form eines hohen

1 v. Wilmowsky, Der Dom zu Trier 57 und TAl 8; Die Grabstätten der Erzbischöfe in Dom zu Trier 6915 und Tfl 45 . 
Schuhes; sie waren mit einem goldenen Schnällchen geschlossen '. Die Beschuhung der Erzbischöfe Jakob von Elz $(† 1581)$ und Johann Philipp von Walderdorf († 1768) bot wenig Bemerkenswertes mehr. Sie war nach v. Wilmowsky nicht mehr schuhartig, also wohl, wie auch die Abbildung anzudeuten scheint, pantoffelartig und entbehrte jeder Verzierung (Bild 212). Bei der Beschuhung Jakobs von Elz war das Oberstuck ans Wollstoff hergestellt, bei derjenigen Philipps von Walderdorf aus Croldtuch. Ein Kreuz fand sich auf keinem der Pontifikalschuhe der Trierer Bischofsgräber.

Die Entdeckungen in den Grabstätten der Erzbischöfe von Trier geben an sich und zunächst nur ein Bild der Entwicklung, welche die bischöflichen Sandalen in der Trierer Kirche im Terlaufe unseres Jahrtausends genommen haben. Doch dürfen wir sie nach allem, was wir sonst von der Geschichte der Pontifikalschuhe gehört haben, im wesentlichen als Spiegelbild des Wechsels überhaupt betrachten, welcher mit der sakralen Beschuhung seit dem 12. Jahrhundert vor sich ging. Wie sollte es auch anders sein können? Hat doch auch die Umbildung der sonstigen liturgischen Paramente in dieser Zeit allenthalben im Abendlande in der Hauptsache denselben Gang eingehalten.

Fassen wir das über die Entwicklnng des Pontifikalschuhes Gesagte kurz zusammen, so ergibt sich folgendes Bild. Ursprünglich als campagus weder eine eigentliche Sandale noch ein wirklicher Schuh, stellte er ein Mittelding zwischen beiden dar,

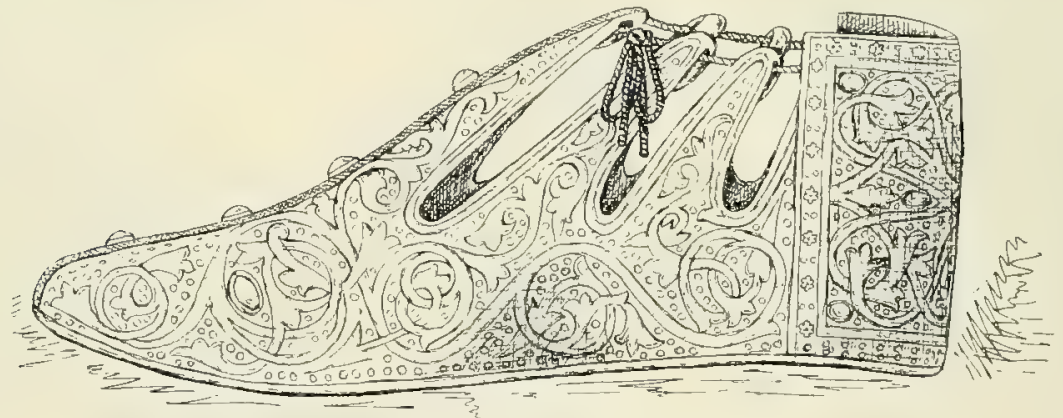

Bild 209. Pontifikalschuh des Erzbischofs Arnold I. von Trier. Trier, Dom. (Nach v. Wilmowsky.)

bei welchem Ferse und Fußspitze durch eine Kappe bedeckt waren, wälrend er im übrigen durch Riemen am Fuf festgehalten wurde. Um die Wende des Jahrtausends wurden die Riemen sowie die Vorderkappe zu langen zungenförmigen Laschen, welche oben durch eine von der hintern Kappe ausgehende Schnur vor dem Fufgelenk zusammengebunden wurden. Im 12. Jahrhundert begannen diese Laschen langsam, aber stetig zu verkümmern, bis sich schließlich die Sandale im 13. Jahrhundert zum völligen Schuh umgebildet hatte. Diese Form behauptete sich von da an im wesentlichen unverändert das ganze späte Mittelalter hindurch. In der Neuzeit fing dann eine Art von rückläufiger Bewegnng an, bei welcher der Pontifikalschuh zu einem Pantoffel wurde, der gern, namentlich aber nach römischem Brauch mit Hilfe von zwei von der Kappe ausgehenden Laschen am Fufs festgehalten wurde.

Die Frage, seit wann ein Kreuz auf dem Vorderstück der Pontifikalschuhe angebracht worden sei, ist sehr verschieden beantwortet worden. Hat man es doch schon auf den alten Mosaiken entdecken wollen. Die Sucht, alles in möglichst ferne Zeiten hinaufzuführen, mag dabei nicht wenig im Spiel gewesen sein.

1 Man beachte, wie die Schuhe Boemunds und Ottos, was die Form betrifft, genau dem Bild entsprechen, welches uns die noch vorhandenen Pontifikalschulie des 14. und
15. Jahrhunderts (s. oben S. 412) vermitteln. Bei v. Wilmowsky ist das Grab Ottos von Ziegenhain irrtümlich als das Theodorichs († 1242) bezeichnet. 
Wenn wir ins Auge fassen, was wir von den Liturgikern des Mittelalters von Hraban bis auf Durandus, zumal aber von Amalar über die Pontifikalschuhe hören, und was die Bildwerke und besser noch die erhaltenen Sandalen früherer Tage uns erzählen, dann kann es uns nicht zweifelhaft sein, dak das Kreuz auf den bischöflichen Schuhen erst sehr spät einen Platz erhielt.

Allerdings tritt schon auf dem leider nicht mehr vorhandenen Sandalenpaar von Niederzell ein gabelartiger Besatz auf. Im 13. Jahrhundert war ein solcher auf den Pontifikalschuhen sogar recht häufig. Es wäre indessen verkehrt, wollte man annehmen, es hätten diese als Dreizack aufgenähten Börtchen ein Kreuz darstellen sollen. Sie waren nur als Zierbesatz gedacht. Immerhin werden sie als Keim anzusehen sein, aus dem sich später das Kreuz entwickelte; doch dauerte es damit noch bis etwa zum Ende des 14. Jahrhunderts.

Selbst auf den Sandalen der Päpste kommt ein Kreuz erst im 14. Jahrhundert auf 1 . Bei den zehn Sandalenpaaren Bonifaz' VIII., die im Inventar von 1295 eine so eingehende Beschreibung erfahren, ist von einem solchen noch mit keinem Worte die Rede
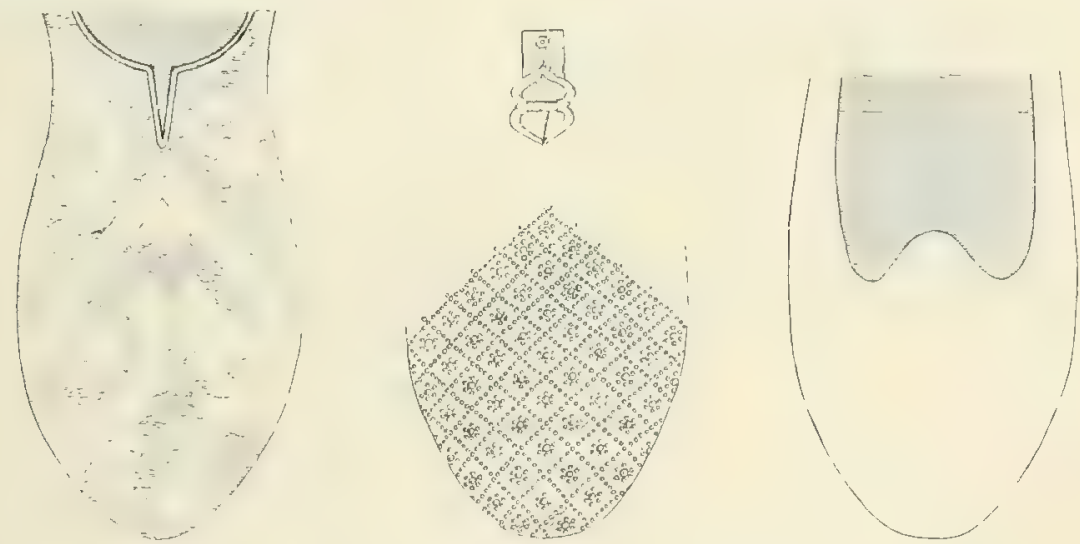

Bild 210-212. Pontifikalschuhe aus den Trierer Bischofsgrähern.

(Nach v. Wilmowsky.)

Eines der frühesten Beispiele eines geradbalkigen Kreuzes auf Pontifikalsandalen findet sich bei der Grabfigur Bonifaz’ IX. (1389-1404)². Dabei läuft aber hier, wie auch anf den Grabmälern Martins V. (Bild 213, S. 418), Nikolaus' V., Pauls II., Sixtus' IV., Alexanders VI., Julius' II., Pius' V. und selbst Benedikts XIV., der Querstreifen noch von der Sohle auf der einen Seite des Schuhes über die ganze Breite des Oberstoffes bis zur Sohle auf der andern Seite, während sich gleichzeitig der Längsstreifen von der Fubspitze bis zum oberen Ende des Vorderstückes erstreckt.

In Deutschland treffen wir derartige Besätze schon bei den Pontifikalschuhen der Grabfigur des Kölner Erzbischofs Friedrich von Saarwerden († 1414) im Dom zu Köln an ${ }^{3}$. Im 16. Jahrhundert begegnen wir ihnen auf der Grabplatte des Bischofs Johannes von Hoya ( $†$ 1574) im Dom zu Münster und ihrem Pendant, der Grabplatte des Bischofs Rembert von Kerssenbroich († 1568) im Dom zu Paderborn, ferner bei mehreren Statuen heiliger Bischöfe im Chorumgang des Münsterischen Domes. Auch die Sandalen, die man an den Füßsen der Leiche des Mainzer Erzbischofs Adam von Bicken

1 Wegen der Kreuze, welche sich jetzt auf den Schuhen der Päpste Honorius I. und Symmachus auf dem Apsismosaik in S. Agnese fuori le Mura finden, vgl. oben S. 393, Anm. 3.

2 Abbildung des beim Neubau der PetersBraun, Die liturgische Gewandung. kirche zerstörten Grabmals in Ciaconii-Oldoini Vitae et res gestae Pontif. Rom. II, Romae 1677,695 .

${ }^{3} \mathrm{Vgl}$. auch die Sandalen der Grabstatue Ruperts von der Pfalz ( $† 1480)$ im Bonner Münster. 
(† 1604) fand, waren vorn oben mit sich kreuzenden Bändern besetzt ${ }^{1}$. Der Hildesheimer Sandalen aus St Gorlehard (Bild 203, S. 413) ist schon früher gedacht worden.

Immerhin war ein solches Kreuz keineswegs allgemein oder auch nur das Gewöhnliche. Häufig fehlen alle Besätze, in andern Fällen zieht sich nur ein Längsstreifen vom Rist zur Fufspitze hin, noch in andern ist der Schull iiber und über mit Stickereien bedeckt. Das kleine quadratische Kreuz findet sich als Verzierung der Pontifikalschuhe auf den Papstdenkmälern erst bei Klemens XIV. († 1774). Es ist also sehr späten Urspruugs. Auf deutschen Grabmonumenten erscheint es, wenngleich ganz vereinzelt, schon aufergewöhnlich früh, so z. B. bei der Grabfigur Konrads von Hochstaden $(† 1261)$ im Dom zu Köln. Im 16. Jahrhundert ist es auf der Grabplatte des Bischofs Johannes Nasus († 1590) in der Franziskanerkirche zu Innsbruck zur Darstellung gekommen. Doch dürfte es allem Anschein nach in diesen und den ähnlichen seltenen Fällen lediglich eine Zutat des Künstlers sein, der die fraglichen Bildwerke schuf.

Zu Rom galt der kreuzförmige Besatz der Pontifikalschuhe schon im 15. Jahphundert als Vorrecht des Papstes. Daher verbot Nikolaus V. dem Gegenpapst Felix V. bei dessen Abdankung, einen solchen auf den Sandalen zu tragen, trotzdem er ihm manche andere Privilegien und die bischöflichen Abzeichen belief. Noch jetzt sind in

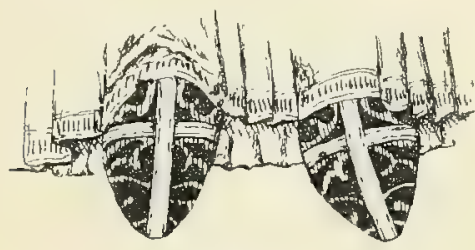

Bild 213.

Pontifikalschuhe der Grabfigur Martins V. Rom, Lateran.

Rom nur die Pontifikalschuhe des Papstes mit dem Zeichen der Erlösung geschmückt. Ess dürfte das wohl mit der Sitte des Fußkkusses zusammenhängen, wenngleich diese schon lang bestand, ehe man noch daran dachte, die päpstlichen Sandalen mit einem Kreuz zu zieren 2 .

Seit welcher Zeit Caligae und Sandalen dem liturgischen Farbenkanon unterliegen, ist nicht näher zu bestimmen. Schon im 12. Jahrhundert gab es, wie wir bereits hörten, neben schwarzen auch farbige Pontifikalschuhe, im 13. aber treffen wir nicht selten in den Inventaren rote, blaue, violette oder grüne Strümpfe und Schuhe an. Noch häufiger werden solche dann im 14. Jahrhundert. Indessen folgt daraus noch nicht, dafs auch für die pontifikale Fubibekleidung schon damals die liturgische Farbenregel gegolten habe. In der zweiten Hälfte des 13. Jahrhunderts bestand der Farbenkanon für sie jedenfalls noch nicht, wie sich zur Genüge aus des Durandus Äuferungen hinsichtlich der Farbe der Sandalen und Caligae ergeben dürfte. Dagegen scheint er um 1400 bereits für sie Geltung besessen zu haben; denn der 15. Ordo schreibt für Karsamstag ausdrücklich weife Pontifikalschuhe vor?.

Um eine Idee zu geben, wie kostbar man im Mittelalter die Pontifikalschuhe auszustatten pflegte, lassen wir die auf sie bezüglichen Angaben des Inventars von St Paul von 1295 folgen. Sandalia, heißt es dort, de indico sameto cum caligis breudatis cum scalopis (Jakobsmuscheln) et leonibus, item duo sandalia de nigro serico, breudata vineis et lunulis sine scaligine (caligis) parvi pretii, item sandalia de rubeo sameto cum caligis breudatis aquilis, leonibus et rosis et in summitate vinea breudata, sotulares sunt breudatae ad modum erucis, item sandalia bona et nova breu-

1 Schneider, Fr., Die Gräberfunde im Ostchor des Domes zu Mainz 17. Joh. Schweikards Leiche trug eine Art Stiefel (ebd. 10).

2 C̈ber den Fiffkulis, der schon in den äItesten römischen Ordines erwähnt wird, z. B. ordo 1, n. 11 ; ordo 2, n. 8 ; ordo 3 , n. 10 (M. 78, 942971 979), vgl. Stimmen aus Maria-IAach" XLVIL $486 \mathrm{f}$ und Kirchenlex. IV 2143.

s C. 83 (M. 78, 1328). 
data cum aquilis et griffonibus..., item sandalia Fulconis episcopi cum caligis breudatis opere pectineo, item sandalia cum caligis de $\mathrm{r} u b \in 0$ sameto diasperato (Damast), breudata cum imaginibus regum in rotellis simplicibus... Item sandalia Henrici de Wengham episcopj cum flosculis de perlis indici coloris et leopardis de perlis albis cum caligis breudatis et frectatis de armis palatis et undatis, item sandalia cum caligis de $\mathrm{rubeo}$ sameto breudatis cum ymaginibus regum in vineis circulatis, item sandalia cum caligis breudatis cum circulis cerici (coloris) purpurei, rubei et albi cum rosulis et crucibus quae fuerunt Ioannis de Chishulle Episc. Londin. Sehr lehrreich ist auch, was die Ausstattung der Pontifikalschuhe anlangt, das Inventar des apostolischen Schatzes von 1295 wegen seiner dieshezuiglichen eingehenden Witteilungen.

\section{VERWENDUNG DER SAKRALEN FUSSBEKLEIDUNG IM LITUR- GISCHEN DIENST.}

Über den Umfang, in welchem die pontifikale Fubbekleidung bein Gottesdienst Verwendung fand, fehlen genauere Nachrichten. Sie war unzweifelhaft von Anfang an ein Bestandteil des Mefornates. In dieser Eigenschaft begegnet sie uns schon bei Gregor d. Gr. in seinem Brief an Bischof Johannes von Syrakus; denn das procedere, von welchem darin die Rede ist, besagt: zur Meffeier aufziehen. Fraglich ist, ob sie auch bei andern Funktionen gebraucht worden sei oder ob sie ausschlieflich im Dienst des heiligen Opfers gestanden habe. Für das erste dürfte die Bulle Alexanders III. sprechen, in welcher Heinrich von Fécamp die Ermächtigung erteilt wird, sich wie anderer Pontifikalien, so auch der Sandalen bei Prozessionen, auf Konzilien der römischen Päpste und auf Synoden, denen päpstliche Legaten präsidierten, zu bedienen ${ }^{1}$. Die Gewohnheit, am Karfreitag bei den liturgischen Zeremonien die sakrale Fubbekleidung nicht zu tragen, muf zu Rom schon früh in Kraft gewesen sein, da bereits der zwischen 1192 und 1198 von dem Kardinal Cencius de Sabellis verfafte römische Ordo unter der Rubrik: Quid dominus papa facere debeat feria VI. in Parasceve, unter anderem sagt, es sollten die Ministri dem Papst nicht die Sandalen, sondern die Alltagsschuhe anziehen ${ }^{2}$. Dalä nach römischem Ritus die liturgische Fulibekleidung auch bei Totenmessen schon in Mittelalter keine Verwendung fand, erfahren wir sowohl aus dem Pontifikale des Durandus ${ }^{3}$ als aus dem 15. Ordo ${ }^{4}$. Im Ritus der Bisch ofsweihe kamen die Sandalen und Strumpfe nur in untergeordneter Weise zur Geltung. Der Electus wurde mit ihnen bald erst nach dem Graduale, bald bereits nach dem Examen, bald schon bei Beginn der Feier ausgestattet ${ }^{\circ}$. Die Anlegung der liturgischen Fubhekleidung vollzogen gewöhnlich die zwei assistierenden Bischöfe und der Archidiakon unter Beihilfe von Subdiakonen und Akolythen. Dabei beteten die Bischöfe nach dem Ordo vulgatus: „All-

1 Pf I ugk-H a r t tung. Acta I, 263; vgl. auch I, 336 .

2 C. 13 (M. 78, 1075); vgl. auch ordo 10, n. 13 ; ordo 14 , c. 93 ; ordo 15 , c. 75 (ebd. 101312141315 ).

${ }^{3}$ M art. 1. 1, c. 4, art. 12, ordo 23; I 225: Sandaliis uti non debet, quia tunc (in missa pro defunctis) omnis sollemnitas cessare debet.

${ }^{+}$C. 133 (M. 78, 1347).

5 Mart. 1. 1, c. 8 , art. 11, ordo 81012 $1416 ;$ II 5357667281 und der ordo vulg. bei Hitt. 109. In mehreren der angeführten Weiheordines führen die caligae auffallenderweise den Namen cambagi. Vermutlich stand in dem msprünglichen Text nur cambagi (= campagi); als Glosse scheint dann sandalia eingeschaltet, cambagi aber infolgeressen nachgerade als ein von den Sandalen verschiedenes Ornatstïck und als Bezeichnung der caligae angesehen worden zu sein; daher denn nun auch wohl zwischen cambagi und sandalia ein et trat, z. B. (Hitt. a. a. O.): Quando induitur cambagis et sandaliis. 
mächtiger, ewiger Gott, der du Anfang und Ende bist, laf diesen deinen Diener, unsern Bruder, durch deinen Segen mit dieser Fußbekleidung zur Verkündigung des Friedensevangeliums ausgerüstet werden."

Die jetzige römische Praxis, wonach die Ministri den Bischof vor dem Pontifikalamt mit den Caligae und Sandalen ausrüsten, während die fünf Vorbereitungspsalmen rezitiert werden, reicht wenigstens bis ins 12 . Jahrhundert hinauf. Denn sie begegnet uns nicht blok im 14. Ordo Mabillons ${ }^{1}$, sondern auch schon bei Innozenz III. ${ }^{2}$ Auch das Pontifikale des Durandus kennt sie ${ }^{3}$. Die Praxis war jedoch im Mittelalter keineswegs allgemein, wie denn überhaupt in Bezug auf den Ritus der Vorbereitung auf die Feier des heiligen Opfers damals eine große Verschiedenheit und eine bunte Mannigfaltigkeit herrschte.

Die Anlegung der pontifikalen Fufibekleidung fand nach mittelalterlichem Brauch gerade wie heute stets vor Annahme der übrigen liturgischen Gewänder, nicht aber auch überall vor der Händewaschung statt. Meistens freilich scheint der Bischof diese erst vorgenommen zu haben, nachdem er Caligae und Sandalen angezogen hatte. So wollte es, wie aus den Angaben Innozenz' III. sowie des $13 .{ }^{4}$ und 14. Ordo erhellt, namentlich die römische Praxis, das Pontifikale des Durandus und schon um das Ende des ersten Jahrtausends das Sakramentar von Corbie ${ }^{5}$; ja schon Theodulf von Orléans ${ }^{6}$ läßst um 800 den Diakon zunächst den Bischof mit der liturgischen Fußbekleidung versehen und erst dann ihm das Wasser zur Waschung reichen. Indessen stoßen wir doch auch auf die entgegengesetzte Sitte: so in einem Pontifikale von Cambrai ${ }^{\top}$ aus dem Ende des 12. Jahrhunderts, bei Sicard von Cremona ${ }^{8}$ und in einem im 12. Jahrhundert geschriebenen Salzburger Pontifikale ${ }^{9}$.

Bei Anlegung der Caligae ein Gebet zu sprechen, scheint nur sehr vereinzelt üblich gewesen zu sein. Es sind uns nur äuferst wenige Pontifikalien oder Missalien bekannt geworden, welche ein solches enthalten. Nach dem Sakramentar von Corbie soll der Bischof flehen: "Allmächtiger Gott, Urheber aller Ziemlichkeit, mach des alten Feindes Ränke zu Schanden, indem du voll Gnaden diese Caligae durch unseres Dienstes Geheimnis segnest, auf daf sowohl im Wandel des Evangeliums Wahrheit hervorleuchte, als auch im Sinn unversehrter Glaube sich betätige." Ein Pontifikale der Vaticana heist ihn beten: "Bekleide mich, Herr, mit den Caligae der Geradheit, auf dafs ich voll Treue den Weg deiner Gebote wandle." In zwei andern, ebenfalls der vatikanischen Bibliothek angehörenden Codices lautet das Gebet: „Beschuhe mich, Herr, mit den Caligae der Freude und kräftige meine schwachen Kniee, daf ich ohne zu ermüden auf dem Wege deiner Gebote zu dir gelangen kann." 10 Der Grund, warum bei Anlegung der Pontifikalstrümpfe nur sehr selten ein besonderes Gebet üblich war, ist unschwer zu erkennen. Caligae und Sandalen

1 C. 53 (M. 78, 1156).

2 De sacro altaris mysterio 1. 1, c. 4748 (M. $217,791 \mathrm{f})$.

3 M art. 1. 1, e. 4, art. 12, ordo 23; I 221. Cf. Dur andus, Rationale 1.3, c. 8 ; f. 71 : Celebraturi pontifices pedes interea, dum dicuntur quinque Psalmi in praeparatione evangelii pacis, caligis et sandaliis calciantur.
4 N. 6 (M. 78, 1108).
5 So auch Vat. Ottob. 27, f. $8^{\mathrm{a}} ; 547$, f. $133^{\mathrm{n}}$; 576 , f. $217^{\mathrm{b}}$. Vat. lat. 4730 , f. $14^{\mathrm{n}} ; 4743$, f. $6^{\text {l }} ; 9340$, f. $4^{\text {b }}$.

6 Carm. I. 5, n. 3 (M. 105, 355).

7 Mart. 1. 1, c. 4, art. 1; I 127.

8 Mitralis II, c. 8 (M. 213, 87).

9 Mart. 1. 1, c. 4, art. 12, ordo 13; I 207.

10 Vat. lat. 1145 , f. $151^{1} ; 4730$, f. $14^{\mathrm{a}}$ und Ottob. 27, f. $8^{n}$. 
galten und gelten als ein Ganzes, daher denn auch jetzt noch beim Anziehen der ersteren kein Gebet gesprochen wird.

Übrigens war es im Mittelalter nicht einmal allgemein gebräuchlich, beim Anschuhen der Sandalen ein Gebet zu verrichten. Wo aber diese Sitte bestand, finden wir meistens dasselbe, welches der Bischof noch heute nach der Anweisung des römischen Missale zu verrichten hat ${ }^{1}$.

Ein Pontifikale der Vaticana läbt den Bischof flehen: "Allmächtiger, barmherziger Gott, beschuhe meine Neigungen und Wünsche, damit ich nicht durch den Erdenstaub befleckt werde und würdig sei, im Verein mit den Jüngern Christi, die mit Sandalen bekleidet waren, zur Verkündigung des Evangeliums vom Frieden auszuziehen."

Ein anderes heilst ihn sprechen: "Mit den Sandalen deines Schutzes beschirme, o Herr, meine Füfe, damit ich nach dem Beispiel der Heiligen würdig: deine Geheimnisse feiere." 2

\section{ABLEITUNG DER LITURGISCHEN FUSSBEKLEIDUNG.}

Bei der liturgischen Fußbekleidung ist an eine Ableitung von einem entsprechenden Ornatstïck des Alten Bundes nicht zu denken, wie auch schon Pseudo-Alkuin bemerkt hat ${ }^{3}$, weil sie unter den Sakralkleidern der Synagoge kein Gegenstück findet. Dagegen führen mehrere der alten Liturgiker die bischöflichen Sandalen auf die Beschuhung zurïck, mit welcher der Herr nach Markus die Apostel sich versehen hiel, als er sie zum Predigen aussandte. Bildeten einerseits die Sandalen einen Teil der Ausrüstung der Apostel, als sie auszogen, um die Botschaft des Heiles zu verkiindigen, und gab es anderseits auch für den Bischof, dessen heilige Amtspflicht es ist, den Gläubigen das Brot des Lebens in Gestalt des Wortes Gottes zu brechen, eine besondere liturgische Fubbekleidung, so lag es in der Tat nahe, diese zu jenen in Beziehung zu setzen. Von einer wirklichen Ableitung der Pontifikalschuhe von den Apostelsandalen kann aber keine Rede sein; denn die Reisesandalen der Apostel waren weder ein auszeichnender Schmuck, noch hatten sie liturgischen Charaktert. Ebensowenig können endlich Sandalen und Caligae aus den Piten des Ostens herïbergenommen sein; denn diese kennen werler jetzt eine sakrale Fußbekleidung, noch haben sie je eine solche gekannt.

Wir werden daher das Abendland als die Heimat unserer liturgischen Beschuhung zu betrachten haben, und zwar kann diese angesichts des Umstandes, daf sie sich in der Geschichte stets als spezifisch römischer Ornat gibt, nur in Rom aufgekommen sein. Darauf weist denn auch das Constitutum Konstantins hin, wenn es den römischen Klerikern das Vorrecht erteilt, sich des calceamentum und der udones der Senatoren zu bedienen. Welches war aber die Beschuhung, auf welche die liturgische Fußsbekleidung zurückgeführt werden muf? War es etwa der altrömische Senatorenschuh?

L Mart. 1. 1, c. 4, art. 12, ordo 1213 ; I 204 207, und die Messe eines Sakramentars des 11. Jahrhunderts im Appendix zu Menards Gregor M. Liber sacrament. (M. 78 , 245). Vgl. auch Vat. Ottob. 547, f. $133^{\mathrm{a}}$ und 576 , f. $217^{\mathrm{b}}$.

2 Vat. lat. 4743 , f. $4^{\text {b }} ; 1145$, f. $151^{b}$.

3 De div. offic. c. 38 (M. 101, 1240).

4 Es ist merkwürdig, wie Rinaldi-Bucei
(De insignibus episcoporum commentaria, Ratisb. 1891, 2) schreiben kann : Sandaliorum itaque origo ab apostolicis temporibus esse repetenda scriptores omnes rerum ecclesiasticarum unan imiter affirmant, eo quod ipsis Apostolis I. Ch. D. N. praecepit, ut sandalia gestarent. Und wo sind denn alle Archäologen, die das einhellig sagen? 
Es ist bekannt, daf in Rom die patrizischen Senatoren von alters her eine besondere Schuhart trugen. Von den plebejischen Senatoren bedienten sich ihrer ursprünglich nur die curules; später stand sie allen ohne Ausnahme zu. In der ersten Zeit scheint zwischen dem patrizischen und dem plebejischen Senatorenschuh eine Verschiedenheit in der: Form oder Ausstattung geherrscht zu haben; doch ist es nicht hinlänglich sicher, worin dieselbe bestand. In der Kaiserzeit dürften die Unterschiede sich aher ausgeglichen und alle Senatoren ein und denselben Schuh getragen haben. Diesen calceus senatorius will man bei einer Anzahl von Monumenten, und zwar sowohl bei Togastatuen wie bei Bildwerken in militärischer Gewandung, vorgefunden haben. Der Schuh deckt hier den Fufs vollständig und steigt bis zur Wade hinauf. Von dort, wo die Zehen beginnen, ziehen sich zwei Riemen im Kreuz über den Fuf́, welche das Fußgelenk umschnüren und vorn zusammengebunden sind. Etwas höher hinauf umgibt den oberen Teil des Schuhes ein zweites, gleichfalls vorn in einen Knoten geschlungenes Riemenwerk ${ }^{1}$.

$\mathrm{Ob}$ die Annahme, welche in dieser Schuhform den calceus senatorius sieht, richtig ist, bleibe dahingestellt. Jedenfalls kamn die fragliche Beschuhung nicht die unmittelbare Ahnherrin der campagi und udones gewesen sein, die wir im 6. Jahrhundert im Gebrauche der Kleriker antreffen. Dafür ist die Verschiedenheit beider zu groß. Hier ein der Sandale nahestehender Schuh und eine innere weilse Umhüllung des Fufes, dort ein hoher, den Fuf völlig einschliekender Schuh ohne eine darunter sichtbare Bekleidung des Fußes.

Das Constitutum Konstantins muf also eine andere Beschuhung im Sinne haben. In der Tat gab es in nachkonstantinischer Zeit eine auszeichnende Fufbekleidung, welche mit den liturgischen campagi und udones unzweifelhaft innigst verwandt ist. Wir kennen sie sowohl aus der Beschreibung, die Johannes Lydus im 6. Jahrhundert von ihr gibt, als aus ihrer Wiedergabe auf einer Reihe von Monumenten.

Nach Johannes Lydus bestand sie aus zwei Stücken, den $\pi \varepsilon \rho \iota \sigma x \varepsilon \lambda \iota \delta \varepsilon \varsigma$

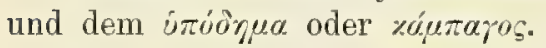

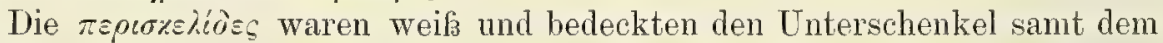
Fufe; die xóstarot waren von schwarzer Farbe und unten mit einer Sohle versehen, aber ohne ein den Fuf einhüllendes Oberleder. Ferse und Zehen umschlob ein kleiner Aufsatz. An den Fufs wurde der Schuh mit Riemen befestigt, die von Streifen unter dem Fufs ausgingen und sich oben auf demselben trafen. Infolge dieser Beschaffenheit der xupururo war von ihnen blof ein wenig vorn an den Zehen und hinten an der Ferse sichtbar, während der von den $\pi$ sporshiòs umgebene Fuf fast so gut wie ganz zum Vorschein kam 2. Das Bild, welches Johannes Lydus in dieser Weise von der Patrizierbeschuhung entwirft, entspricht, wie man sieht, in der Hauptsache durchaus demjenigen, welches man aus den Bildwerken des 6 . Jahrhunderts von der damaligen liturgischen Fußbekleidung gewinnt. Nicht minder stimmt seine

1 P a u Iy, Real-Encyklopädie III $^{2} 1342$. Marquardt, Römische Altertümer VII $591 \mathrm{ff}$. Wil p., Cap. 13.

2 De mag. I 17 (Bonnae 1837, 134) : ПE-

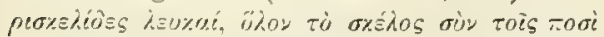

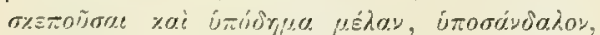

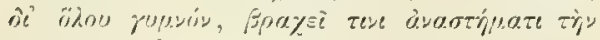

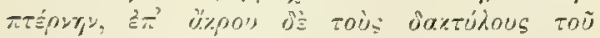

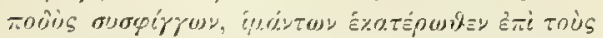

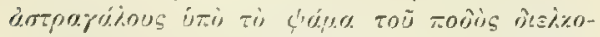

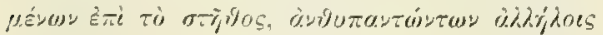
zai derì̃

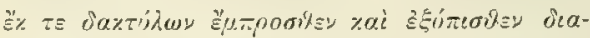

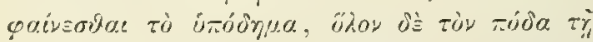

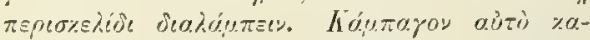
hoẽov. Lydus redet allerdings an dieser Stelle von der Fußbekleidung der alten Patrizier, doch hat er hier, wie vielfach anderswo, Gegenwärtiges auf die Vergangenheit übertragen. Sein Mangel an historischem Sinn ist bekannt. Was Lydus beschreibt, ist die Standesbeschubung nicht des alten Rom. sondern seiner eigenen Zeit. Für diese aber sind seine Angaben zutreffend. 
Beschreibung mit der Schilderung überein, die zwei Jahrhunderte später Amalar von den sakralen campobi (= campagi, sandalia) und dem linum, quo pedes vestiuntur, gibt.

Abbildungen der fraglichen Standesbeschuhung begegnen uns beim Gefolge Justinians und Theodoras in S. Titale zu Ravenna, bei den Titelheiligen auf den Apsismosaiken in S. Cosma e Damiano und S. Teodoro zu Rom, beim hl. Rufinianus auf dem Fresko im Cömeterium der Generosa ${ }^{1}$, auf den Mosaiken in S. Venanzo bei der lateranensischen Taufkapelle, auf einem Elfenheindiptychon zu Monza ${ }^{2}$, auf dem Schild von Almendralejo (Estremadura) im Nuseum zu Madrid ${ }^{3}$ und einem Privatdiptychon in der Kathedrale zu Novara ${ }^{4}$, einer Arbeit des 5. bis 6. Jahrhunderts. Auf dem Mailänder Elfenbein und dem Madrider Schild macht sich die innere Umhullung: des Fufes kaum bemerklich. Auf dem Diptychon zu Novara ist sie dagegen durch ihre Faltenbildung deutlich zu erkennen. Klar und bestimmt treten beide Bestandteile der Fußbekleidung auf den angeführten Mosaiken und dem Fresko des Cömeteriums der Generosa hervor, die schwarzen, noch an Sandalen erinnernden campagi, welche nur Fersen und Zehen bedecken, und die weifen udones. Es ist eine Fufbekleidung wesentlich derselben Art, wie wir sie bei den hll. Ambrosius und Maternus in der Kapelle des hl. Satyrus zu Maíland, bei Maximian und seinen Ministri in S. Vitale, bei Papst Pelagius II. in S. Lorenzo fuori le Mura und einer Reihe ähnlicher Bildwerke gewahren.

Die Übereinstimmung ist unverkennbar und unleugbar, welche zwischen der

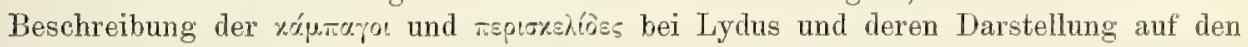
Monumenten" einerseits und dem Namen, den die liturgische Fußbekleidung hatte. der Schilderung, den die Liturgiker des 9. Jahrhunderts von ihr machen, und der Art ihrer WViedergabe auf zahlreichen Bildwerken anderseits herrscht. Es kann darum nicht zweifelhaft sein, dafs die liturgischen campagi und udones in der Tat auf den auszeichnenden profanen Standesschuh nachkonstantinischer Zeit zurückzuführen sind, von dem wir eben durch Lydus und die angeführten Monumente Kunde haben.

Da campagus und udo uns schon im 6. Jahrhundert zu Rom und Ravenna, im 5. bereits zu Mailand auf den Bischofsdarstellungen begegnen, und Gregor d. Gr. von dem campagus als einer schon seit geraumer Zeit in Gebrauch stehenden klerikalen Ehrenbeschuhung spricht, so muf die den Senatoren und sonstigen hochstehenden Personen, wie den Palastbeamten u. a., eigentümliche Fußbekleidung spätestens im Verlauf des 5. Jahrhunderts in kirchliche Dienste übergegangen sein. Von grofem Einfluf hierauf ist unzweifelhaft die bedeutsame Stellung gewesen, welche der lilerus im öffentlichen Leben erlangt hatte, seitdem der Kirche durch Konstantin die Freiheit geworden war. Im übrigen ist über den Vorgang nichts bekannt. Was sich über die Veranlassung zur Herübernahme des weltlichen Standesschuhes und die näheren Umstände dieses Ereignisses sagen lielse, geht daher über bloßse Möglichkeiten nicht heraus. Wenn die Konstantinische Schenkung den Ge-

1 Siehe oben S. 387, Anm. 5.

2 Abbildung in Ann. XXI 222225.

${ }^{3}$ Cahier", Curiosités pl. vir.

* Abbildung bei Gori, Thesaur. vet, diptych. II, Tfl 4 und Westwood, A descriptive catalogue of the fictile ivories in the South Kensington Museum Nr 7475.

${ }^{5}$ Selbstverständlich kann es sich bei der Übereinstimmung zwischen den Angaben des Lydus und den Wiedergaben der fraglichen Beschuhung auf den Monmmenten nur um eine solche in den wesentlichen Punkten handeln. Daf in Nebensächlichem, wie Zahl der Riemen, Anordnung derselben, Größe des die Zehen bedeckenden Vorderstuickes, kleinere Abweichungen sich geltend machen, ist offenbar von keiner Bedeutung. Sie liegen teilweise daran, daf 3 auch die Beschuhung selbst nach Zeit, Ort und Mode darin von Wechsel sich keineswegs frei erhielt; teilweise aber werden sie den Künstlern zur Last fallen, die ja weit davon entfernt waren, ein photographisch genaues Bild der Fukbekleidung geben zu wollen. 
brauch der Senatorenschuhe seitens der römischen Kleriker auf Kaiser Konstantin zurückführt, so heift das nur, das Ergebnis einer geschichtlichen Entwicklung an eine bestimmte Persönlichkeit knüpfen ${ }^{1}$.

Den Ursprung der profanen campagi und udones können wir auf sich beruhen lassen, da es sich hier ja nicht um eine Geschichte der profanen Tracht handelt. Es mub genügen, die Ableitung der liturgischen Fufbekleidung ron einer auszeichnenden profanen Beschuhung nachgewiesen zu haben.

\section{DRITTES KAPITEL.}

\section{DIE MITRA.}

\section{NAME DES ORNATSTÜCKES.}

Nach den Anordnungen, welche Moses auf Befehl Gottes bezïglich der Kultkleidung des hebräischen Opferdienstes getroffen hatte, mußsten bei ihren Amtsverrichtungen der Hohepriester wie die Priester in gloriam et decorem einen besondern Kopfschmuck tragen ${ }^{2}$. Bei diesen bestand derselbe in der Migba'ah, bei jenem in der Miznephet und dem Ziz. Welche Gestalt die Migba'ah und die Miznephet gehabt, ob sie eine Art Mütze oder Turban gewesen und wie sie sich voneinander unterschieden, erhellt aus der Heiligen Schrift nicht. Nach Josephus Flavius, dem Hieronymus im wesentlichen bei seiner Beschreibung der priesterlichen Kopfbedeckung folgt, bestand die Priestermütze aus einer linnenen Binde, die turbanartig zusammengenäht und von einem an ihr befestigten feinen Linnentuch verhüllt wurde. Sie hatte die Form eines stumpfen Hutes oder, wie Hieronymus sagt, einer Halbkugel und bedeckte nur zwei Drittel des Kopfes, also etwa den Scheitel. Die Kopfbedeckung des Hohenpriester's setzte sich nach Josephus zusammen aus einer Mütze, wie die Priester sie trugen, einer zweiten Mütze von blauem Zeug und einem dreireihigen Goldreifen, an welchem über der Stirn der Ziz, die goldene Platte mit dem Namen Gottes, hinten aber von Schläfe zu Schläfe nach Art der Zacken einer Krone kelchförmige Blumen angebracht waren. Die Beschreibung, welche uns Josephus Flavius und Hieronymus von der Migba'ah und Miznephet geben, past für die letzte Zeit des Tempeldienstes. $\mathrm{Ob}$ und inwieweit sie für eine frühere Epoche des jüdischen Kultus zutrifft, lälst sich nicht bestimmen. Mit den Vorschriften, welche Moses über die Herstellung des hohenpriesterlichen Kopfschmuckes erliek, stimmen die Angaben des Josephus jedenfalls nicht ganz überein. Nach des Moses Anordnung sollte nämlich der Ziz mit der Inschrift "Heilig dem Herrn" versehen und mit hyazinthfarbigem (blaupurpurnem) Band vorn ïber der Miznephet angebunden sein. Von einer zweiten blauen Mütze und einem Goldreifen, die Josephus erwähnt, ist bei ihm keine Rede.

1 De Linas glaubt (Revue 1862, 617) mit aller Wahrscheinlichleit den Ursprung einer ausschlieblich dem Kultus vorbehaltenen Fufbekleidung auf das Dekret Stephans I. zurückführen zu künnen, worlurch den Geistlichen der Gebrauch der vestes sacratae auferhalb der Kirche untersagt wird. Allein es ist erstens unsicher, ob die Verordnung wirklich von Stephan I. herriihrt. Zweitens gehört aber, wie die Praxis unseres ganzen Jahrtausends beweist, ejne besondere Beschuhung nicht notwendig zur liturgischen Tracht. Sollte daher auch das Dekret wirklich von Papst Stephan stammen, so läfit sich doch keineswegs aus ihm folgern, daf dieser Papst schon eine sakrale Fufbekleidung vorgeschrieben habe.

2 Ex 28, 4; 29, 9. 
Auch der christliche Kultus kennt eine liturgische Kopfbedeckung. Sie findet sich nicht nur im römischen, sondern auch in den meisten Riten des Orients, und zwar kommt sie, abgesehen von den Armeniern, bei denen auch die Priester sich ihrer bedienen, überall an sich nur dem Bischof zu. Der verbreitetste Name dieser Kopfbedeckung ist Mitra, lat. mitra, griech. píp slav. mitra. Bei den Armeniern heift sie saghavart, bei den Nestorianern biruna, bei den schismatischen Kopten ballin.

Mitra ist das latinisierte uíro, welches bei den griechischen Schriftstellern bald in der Bedeutung von Leibgurt, Brustbinde und überhaupt Binde, bald in dem besondern Sinne von Kopfbinde, Kopfschleier und Mütze gebraucht wird ${ }^{1}$. Als Name einer bischöflichen liturgischen Kopfbedeckung kommt uípo gerade wie das Ornatstïck selbst erst in sehr später Zeit vor.

Die römischen Profanschriftsteller verstehen unter dem Worte mitra ebenfalls entweder eine Binde oder gewöhnlicher eine orientalische, binden-, schleier- oder haubenartige Kopfhedeckung, welche bei den Lydern, Phrygiern, Syrem, Arabern, Ägyptern und Persern allgemein von Personen beiderlei Geschlechts, in Rom aber fast nur von Dirnen und Weichlingen getragen wurde. Doch nennen sie auch die Kopfhïlle alter Frauen mitra ${ }^{2}$.

In der Vulgata besagt mitra bald den priesterlichen bzw. hohenpriesterlichen Kopfschmuck, bald eine Frauenkopfbedeckung ${ }^{3}$. Bei Optatus von Mileve bedeutet das Wort (in Diminutivform auch mitella) den Kopfschleier der gottgeweihten Jungfrauen *. Hieronymus redet von gekräuselten Mitren (crispantes mitrae) als einem Putzstück ïppiger Frauen ${ }^{5}$. Isidor von Sevilla ${ }^{6}$ beschreibt mitra als pileum phrygium caput protegens, quale est ornamentum devotarum; sed pileum virorum est, nitra feminarum, also als eine Hauptbedeckung weiblicher Personen, namentlich solcher, die sich dem Dienste Gottes gewidmet hatten.

In der späteren Zeit verstand man unter mitra nur noch eine mützenartige Kopfbedeckung. Bei Honorius ${ }^{7}$, bei Johannes Beleth ${ }^{8}$ und Sicard ${ }^{9}$ und im Manuale von Roeskilde ${ }^{10}$ bezeichnet das Wort beispielsweise das Mützchen der Täuflinge, in den Statuten des Pariser St Viktorstiftes ${ }^{11}$ den Hut der Laienbrüder bzw. einen Reisehut. Eine Schlafmütze bedeutet mitra in der Regel des Klosters Melk vom Jahre $1451^{12}$, eine Kopfbedeckung der Geistlichen in den Statuten der Tournaier Synode des Jahres $1366^{13}$ und der Halberstädter vom Jahre $1408^{14}$, eine laikale Vännermütze in denjenigen der T'rierer Synode des Jahres $1310^{15}$ und in der Chronik des Löbener Anonymus ${ }^{16}$ und sonst ${ }^{17}$. Mitra hiefa auch die der liturgischen Mitra nachgebildete Mütze, welche der Kaiser und die Kaiserin unter der Krone trugen ${ }^{18}$; vor allem aber bezeichnete man mit dem Worte die bischöfliche sakrale Kopfbedeckung.

1 Stephani, Thesaurus graecae linguae V, Paris, 1835, 1101.

2 Forcell. sub mitra II 8889.

3 Ex 39, 26 30. Lv 8, 13. Eccli 45, 14.

Jdt 10, 3. Is 3, 19. Bar 5, 2.

+ De schism. Donat. 1. 2, c. $19 ; 1$. 6, c. 4

(M. 11, 973 1072).

5 Ep. 54 ad Furiam n. 7 (M. 22, 553).

6 Etymol. 1. 19, c. 31 (M. 82, 699).

7 Gemma 1. 3, c. 111 (M. 172, 673).

$s$ Rationale c. 110 (M. 202, 114).

9 Mitralis 1. 6, c. 14 (M. 213, 335).
10 Vanuale Cuat. sec. usum eccl. Rosckild. (ed. Freisen), Paderborn 1898, 14.

11 C. 20 (M a t. III 261).

12 D. C. sub mitra V 427.

${ }^{13}$ D. C. a. a. O

14 C. 4 (Hartzh. V 14).

15 C. 14 (Haxtzh. IV 131).

16 Boehmer, Fontes I, Stuttgart 1843, 425.

17 D. C. a. a. O.

is Ordo 14, c. 105 (M. 78, 1241). D. C. $\mathrm{V} 427$ f. Vat. lat. 4747, f. $60^{\mathrm{v}} 70^{\mathrm{v}}$. Näheres unten am Schluß von $\mathrm{Nr} \mathrm{V}$ dieses Kapitels. 
Außser dem Namen Mitra trägt der pontifikale Kopfschmuck des römischen Ritus anch die Bezeichnung infula, Inful. Wir treffen sie schon im 12. Jahrhundert bei Honorius ${ }^{1}$, Robert Paululus ${ }^{2}$ und Sicard von Cremona ${ }^{3}$ an, doch hat diese Benennung nie eine allgemeine Verbreitung gefunden. Die liturgischen Bücher wie überhaupt der offizielle kirchliche Sprachgebrauch kennen das Wort nicht, sondern reden nur von der Mitra.

Weil heute die bischöfliche Mitra auch wohl Inful genannt wird, hat man irrigerweise bis in die neueste Zeit hinein vielfach unter dem im Mittelalter nicht selten vorkommenden Wort infula überall den pontifikalen Kopfschmuck verstanden. Die Folge war, daf man der Mitra ein Alter zuschrieb, welches sie keineswegs besitzt, indem man sie zu einer Zeit in Gebrauch zu finden glaubte, zu der es in Wirklichkeit eine solche noch nicht gegeben hat.

Allerdings ist es richtig, daßs infula bei den Klassikern und spätlateinischen Schriftstellern wiederholt eine Kopfbinde heidnischer Priester bezeichnet. Als solche erscheint sie z. B. bei Virgil, wenn der Dichter vom Priester Hämonides singt: Infula cui sacra, redimibat tempora vitta (Aen. $X, 538$ ), und es bemerkt zutreffend Servius Honoratus (Ende des 4. Jahrhunderts) zu dieser Stelle: Infula fascia in modum diadematis, a qua vittae ab utraque parte dependent, quae plerumque lata est, plerumque tortilis de albo et cocco. Eine solche infula trugen insbesondere auch die Vestalinnen : Allein es wäre verkehrt, unter infula ausschließzlich einen priesterlichen Kopfschmuck zu verstehen, oder zu glauben, daf3 alle Priester die Kopfbinde getragen hätten. Auf der Trajanssäule sind z. B. eine Reihe von Opfern dargestellt, ohne daßs einer der Priester mit einer solchen ausgestattet wäre. Alle tragen vielmehr Kränze ${ }^{\overline{5}}$, und nur der opfernde Feldherr hat den über den Rücken sich sonst hinziehenden Teil der Toga leicht über den Kopf hinaufgezogen. Festus aber erklärt infula ganz allgemein als filamenta lanea, quibus sacerdotes et hostiae templaque velabantur. Es wurden also auch die Bänder, mit denen die Tempel und Opfertiere geschmückt wurden, infulae genannt. Bezüglich der ersten bestätigt das Lukan 2, 355: Infula in geminos discurrit candida postes, bezüglich der letzten Virgils Georg. III, 487: Saepe in honore deum medio stans hostia ad aram, lanea dum nivea circumdatur infula vitta. Gute Beispiele von Opfertieren, die mit der Infula geschmückt zum Opfer geführt werden, bieten die Reliefs der Trajanssäule und die Skulpturen der Rednerbühne auf dem römischen Forum. Als Abzeichen von Bittflehenden erscheint die infula in Cäsars B. C. 2, 12: Inermes cum infulis sese porta foras universi proripiunt, ad exercitum supplices manus tendunt, bei Livius 30, 36 aber begegnet uns ein karthagisches Schiff zum Ausdruck friedfertiger Absichten velata infulis ramisque oleae. Von duumviratus aliorumque honorum infulis spricht ein Dekret Konstantins ${ }^{6}$. Sie sind in diesem wohl bildlich von der Amtswürde zu verstehen gerade wie bei Ambrosius in ter Schrift De officio ministrorum ", wo der Heilige sagt, man habe ihn weggerissen de tribunalibus atque administrationis infulis. Auf keinen Fall können sie einen Kopfsehmuck, den es bei den Duumvirn nicht gab, bedeuten. In Ciceros Agr. 1, 2 werden die Provinzen die Insignien und Infulae des Reiches genanut, sofern dieselben gleichsam die Ehrenzeichen des römischen Staates und der römischen Tapferkeit waren. Rein metaphorisch im Sinne eines Abzeichens, das andere mit heiliger

1 Gemma 1. 1, c. 214 (M. 172, 609). Vgl. auch Rupert. Tuit. Vita S. Heriberti c. 2, n. 8 (A. SS. 16. Mart. II 473).

2 De off. ecel. 1. 1, c. 55 (M. 177, 405).

3 Mitralis 1. 2, c. 5 (M. 213, 78). Auch in der im 12. Jahrhundert entstandenen Vita B. Petri Cavens. (c. 3, n. 25) ist unter der infula pontificalis die Mitra verstanden (A. SS. 4. Mart., I 332).
4 Ambrosius, Ep. 18, n. 11 (M. 16, $975)$.

5 Vgl. auch Tertull., De corona militis (M. 2, 93), wo von den Kränzen, mit denen sich die Opfernden schmückten, weitläufig gesprochen wird.

${ }^{6}$ Corp. Lar. Civ. 1. 7, tit. 68, n. 1: (ed. Herrman $n$, Lipsiae 1844) II 502.

7 L. 1, c. 1 (M. 16, 25). 
Scheu erfüllt, und vor dem selbst noch die mittelmäfig Schlechten Achtung haben, nennt Seneca in Ep. 14 die Philosophie eine Art von infulae: Hae litterae infularum loco sunt, während er in ähnlicher Weise in der Schrift De consol. ad Helv. 13 sagt, derjenige, der gegen die schlimmsten Unglücksfälle sich erhebe, und über die Übel, von denen andere bedrückt würden, triumphiere, habe das Leiden selbst loco infularum, d. h. dessen Leiden flöfe Achtung ein. In Ciceros Or. 3, $21^{11}$ scheint infula ein Tuch oder sonst einen Gegenstand zu bedeuten, auf den man zu malen pflegte.

Unter den infulae in dem Rundschreiben des Papstes Gelasius (492-496) an die Bischöfe Lukaniens, in welchem dieser gewisse Personen als clericalibus infulis unwürdig hinstellt ${ }^{2}$, ist die klerikale Kleidung oder wohl besser die geistliche Würde zu verstehen. Einen ähnlichen Sinn hat die Bemerkung Gregors von Tours, wenn dieser den Märtyrer Eugenius als sacerdotalis infulae maximum decus bezeichnet ${ }^{3}$. Innozenz I. redet in seinem Schreiben an die Bischöfe von Makedonien von den infulae summi sacerdotii: eos, qui viduas accepisse suggeruntur, non solum clericos effectos cognovi, verum etiam usque ad summi sacerdotii infulas pervenisse ${ }^{4}$. Hier bezeichnen die infulae die Bischofswürde.

Prudentius Klemens rühmt in seinem Hymnus auf die achtzehn Märtyrer von Saragossa die Stadt wegen der domus infulata sacerdotum Valeriorum ${ }^{5}$, wo die domus infulata metaphorisch besagen will, dafo in der Familie der Valerier Priester oder Bischöfe waren. Anderswo erscheint bei ihm die infula als Abzeichen heidnischen Opferdienstes ${ }^{6}$. Im Cathemerinon ${ }^{7}$ heißst es vom König David: rex sacerdos infulatus, wozu Mönch Iso um 860 die Glosse macht: infulatus — veste sacerdotali indutus, während der Cod. Vat. 5821 (10. Jahrhundert) anmerkt: Sacerdos David, qui fuit sacerdos, qui ephod vestitus saltavit coram arca.

Für die Bedeutung, welche man im 8. Jahrhundert mit dem Wort infula verband, sind bezeichnend ein Schreiben Johannes' VII. (705-707) an den englischen Klerus, in dem er die klerikale Kleilung, zumal aber die römische Talartunika, infulae clericales nennt ${ }^{8}$, und der Brief des hl. Bonifatius an den Erzbischof Cuthbert von Canterbury, worin das erzbischöfliche Pallium inifula archiepiscopatus heibt?

Interessante Belegstellen für die Bedeutung von infula im 9. und den nächstfolgenden Jahrhunderten bieten: Vita Hadriani II. ${ }^{10}$ apostolicis infulis missas celebrare; Flodoard. († 966) Hist. eccl. Rhem. 1. 4, c. $48^{11}$ : conspiciensque videt corpus integrum sacerdotalibus infulis redimitum; Vita Ludov. Pii ${ }^{12}$ : Ludwig der Fromme lief dem zu ihm kommenden Papst Stephan seinen Erzkaplan Hildebald, die Bischöfe Theodulf von Orléans und Johannes von Arles aliorumque ministrorum ecclesiae copiam infulis indutos sacerdotalibus entgegengehen; Odjlon is De translat. S. Sebast. et Gregor. c. $23^{13}$ : religiosa monachorum concio, ecclesiasticis infulis redimita ...; Vita S. Fridolini abb. (aus dem Ende des 9. Jahrhunderts) 1. 2, c. 2, n. $10^{14}$ : Sanctus Fridolinus... cum sacerdotali infula venisse visus est; Hist. translat. S. Cuthberti c. $1^{15}$ : Cuthbertus pontificaliter infulatus, verglichen mit c. $6^{16}$ : Cuthbertus episcopalibus vestimentis sollemniter indutus; Vita B. Wolphelmi abb. Brunwiller. n. $18^{17}$ : episcopalibus infulis decenter ornatum; Petri Dam. Epist. 1. 1, n. 8 ad Nicol. II. ${ }^{18}$ : Si ergo summi illi pontifices, Aaron videlicet et Cyrillus, post amissionem vestium perdiderunt etiam consequenter sacerdotalium infulas dignitatum, quid mihi parvulo et indigno datur intellegi, nisi quia dum ornamentis sacerdotalibus exuor, sacerdotali procul dubio dignitate deponor.

1 Bezüglich dieses und der voraufgehenden Zitate vgl. For ce 1l. sub Infula I 522.

2 Ep. 14, c. 9 ('Thiel, Epp. R. P, Brunsbergae 1868,368 ).

$\$$ De gloria martyr. c. 57 (M. G. SS. M. I 527).

${ }^{4}$ Ep. 17, c. 1 (M. 20, 528).

${ }^{3}$ Peristeph. h. 4, v. 79 (M. 60, 366).

${ }^{6}$ Contra Symmach. 1. 2, v. 1085 (M. 60, 269).
7 Cathem. 9, 5 (M. 59. 862).

8 M. 89,63 .

9 Ep. 78 (M. G. Epp. III 350).

$10 \mathrm{Duch}$., L. P. II 174.

11 M. $135,322$.

13 M. 132, 598.

14. A. SS. 6. Mart., I 439.

15 Ebd. 20. Mart., III 127.

16 Ebd. 134. 17 M. 154, 419.

18 M. $144,212$. 
Sehr beachtenswert ist auch das Benediktionsgebet: Et qui me infula pontificali dignatus est sublimare ..., aus der bischöflichen Konsekrationsmesse eines Salzburger Pontifikale (c. 1100$)^{1}$, weil der vorhergehende Weiheordo wohl Sandalen, Dalmatik, Stab, Ring und die sonstigen pontifikalen Ornatstücke, selbst die Handschuhe erwähnt, aber von einer Mitra oder sonst einem Kopfschmuck nicht das geringste weif. Bezeichnend ist ferner eine Stelle in der ca 900 geschriebenen Vita S. Eucharii ${ }^{2}$, wo erzählt wird, wie Eucharius und Valerius dem Maternus erschienen sacerdotalibus infulis coruscantes, coronas singulas rosis et liliis ac ceteris odoriferis floribus mirabili arte intextas in capite gestantes, in der Hand für Maternus consimile sertum.

In allen diesen Stellen, welche sich leicht um manche weitere Beispiele vermehren lassen ${ }^{3}$, bezeichnet infula entweder metaphorisch die bischöfliche Würde oder die liturgische Gewandung im allgemeinen. Für den Gebrauch des Wortes im Sinne eines liturgischen Kopfschmuckes läfst sich vor dem 12. Jahrhundert kein Beleg beibringen.

Einmal, nämlich in einer Urkunde des Erzbischofs Willegis von Mainz aus dem Jahre 976, erscheint infula in der Bedeutung des pileus cantoris, des Hutes, welchen der Cantor zu tragen pflegte $\$$. Daß hier unter infula nicht eine Kopfberleckung im Sinne der pontifikalen Mitra verstanden werden kann, ergibt sich aus dem Umstand, daf selbst die Mainzer Erzbischöfe erst 1052 von Leo IX. das Recht erhielten, die Mitra zu tragen.

In einem Inventar der Kapelle Berengars zu Monza aus dem Beginn des 10. Jahrhunderts bedeutet infula, wie ein Vergleich mit einem kurz nachher entstandenen zweiten Schatzverzeichnis zeigt, entweder das Humerale oder die Albe ${ }^{5}$. Daf mit dem Worte seit dem 11. Jahrhundert sehr häufig die Kasel, das priesterliche Mefakleid im besondern Sinne, bezeichnet zu werden pflegte, wurde früher, als von den Namen des Mefigewandes die Rede war, des weiteren ausgeführt und nachgewiesen". Es ist interessant, wahrzunehmen, wie ein und derselbe Terminus zu zwei so ganz verschiedenen Bedeutungen kommt wie Mitra und Kasel, ein Beweis, wie wenig man mit infula den überlieferten Begriff einer sakralen Kopfbinde verknüpfte. Bei der Annahme des Gegenteils wäre der Vorgang schwer zu erklären. Blof weil das Wort infula nach dem Sprachgebrauch der kirchlichen Schriftsteller nur noch entweder die liturgische Kleidung überhanpt oder metaphorisch das geistliche Amt, sei es die Bischofs- oder Priesterwürde, bedeutete, konnte es zur Benennung zweier äuferlich so ungleicher Dinge werden, wie es die pontitikale Koptbedeckung und der priesterliche Mantel sind, von denen allerdings die eine den Bischof, der andere den Priester in seiner Würde kennzeichnete.

Blof mittelalterliche Namen des pontifikalen Kopfputzes sind cuphia, cidaris, tiara und pileum (pileus). Cidaris und tiara hies er wohl im Himblick auf die Kopfbedeckung des alttestamentlichen Kultus, welche in der Vulgata nicht nur mit mitra, sondern auch mit cidaris und tiara bezeichnet wird . Alle vier Ausdrücke waren übrigens wenig gebräuchlich; im späten Mittelalter kommen sie gar nicht mehr vor.

Unter dem Namen cuphia, welcher häufig bei mittelalterlichen Schriftstellem als Benennung einer laikalen Kopfbedeckung, besonders des Helmes, gebraucht wird 8 , erscheint die Mitra z. B. in einer an Liuthbald von Mainz gerichteten Bulle Leos IX. ${ }^{9}$ Die Bezeichnungen cidaris und tiara finden sich

1 Mart. 1. 1, c. 8, art. 11, ordo 8; II 54.

C. 6, n. 23 (A. SS. 29. Ian., III 537).

3 Vgl. z. P. Aldhelmi De laud. virg. c. 26 (M. 89, 124); Petxi Dam. Op. 31 contra philarguriam c. 6 ( M. 145, 538); Leonis IX ep. 100, n. 12 ad Michaelem patriarch. (M. 143, 752).
4 Gudenus, Cod. diplom. I 354. S. oben S. 319.

Bullet. mon. 1880, 314: das zweite Inventar ebd. 465 .

6. S. oben S. 153. $\quad 7 \operatorname{Ex~28,440.~}$

${ }^{8}$ D. C. sub cuphia Il 658 .

M. 143,695 . 
bei Honorius und Sicard, das Wort pileum bei Honorius, Sicard und Robert Paululus. Der auferliturgische päpstliche Kopfschmuck, ein kegelartig ansteigender, ursprünglich kronenloser, dann mit einer, zuletzt mit drei Kíronen ausgestatteter Hut, welcher nunmehr den Namen Tiara führt, hief im Mittelalter regnum oder corona', später triregnum.

\section{DIE MITRA IN DER GEGENWART.}

Die gegenwärtig üblichen Mitren stellen im wesentlichen eine Art von Klappmütze dar, deren zwei durch eine Einlage gesteiften Hälften vorn über der Stirn und auf dem Hinterkopf nach Weise von Hörnern - daher cornua (Hörner) mitrae - ansteigen und oben in eine Spitze endigen. Das Caeremoniale der Bischöfe ${ }^{2}$ unterscheidet dreierlei Mitren, die pretiosa, die auriphrygiata und die simplex.

Unter der ersten versteht es eine Mitra, welche mit Juwelen, mit Plättchen von Gold oder mit Silberblechen verziert ist. An der mitra auriphrygiata sollen nach dem Caeremoniale Edelsteine und Perlen nicht angebracht werden, wohl aber darf der weifsseidene Grund mit etlichen kleineren Perlen oder mit einem (durch Weberei oder Stickerei hergestellten) Goldmuster verziert sein. Auch kann die auriphrygiata aus ungemustertem Goldstoff angefertigt werden, jedoch olıne Zierplättchen und Perlen. Der Unterschied zwischen der mitra pretiosa und der mitra auriphrygiata liegt also lediglich in der gröferen bzw. geringeren Kostbarkeit. Die mitra simplex soll unter Beiseitelassung aller Goldverzierung aus einfachem weifen Seidendamast oder sonstiger weifer Seide oder aus weifem Linnenstoff bestehen; die an ihrer Ruickseite herabhangenden Streifen müssen an den Enden mit roten Fransen versehen sein. Bei der pretiosa werden keine Besatzstreifen erwähnt; bei der auriphrygiata scheint der Name auf solche hinzuweisen; doch mag mit demselben auch nur eine etwaige Ausstattung mittels Stickerei angedeutet werden sollen

Über die Verwendung der drei Mitraarten gibt das Caeremoniale eingehende Anweisungen ${ }^{3}$.

Hiernach hat der Bischof an höheren Festen und überhaupt, so oft im Offizium der Hymnus Te Deum und in der Messe das Gloria gebetet wird, die "kostbare" Mitra zu tragen; doch kann er sich auch an diesen Tagen aus Bequemlichkeitsrücksichten ne scilicet nimis gravetur - bei den Vespern wie der Messe abwechselnd der pretiosa und der auriphrygiata bedienen. In diesem Falle gebraucht er die pretiosa bei Beginn und am Ende der Vesper bzw. des Amtes, beim Hingang zur Kirche und bei der Rückkehr von derselben, bei Annahme und Ablegung der Paramente, beim Händewaschen und bei dem feierlichen Schlufsegen; die auriphrygiata dagegen in den Vespern von Beginn des ersten Psalmes bis zum Magnificat ${ }^{4}$ und in der Messe nach $\mathrm{Ab}$ betung des Kyrie bis zur Opferung ${ }^{5}$.

${ }^{1}$ Bruno Sign., De sacr. eccl. (M. 165, 1107). Durandus, Rationale 1. 3, c. 13 , f. 76 ; ordo $9, n .6$; ordo 11 , n. 1646 ; ordo 12 , n. 6 (M. 78, 100710321043 1067). D. C. sub regnum VII 96.

${ }^{2}$ L. 1, c. $17 . \quad 3$ Ebd. n. 234.

4 Caerem. episc. 1. 2, c. 1, n. 712.

5 Ebd. 1. 2, c. 8, n. 3657 . Wo man keine mitra pretiosa im Sinne des Caeremoniale, d. h. keine mit Edelsteinen, Gold und Silber bedeckte, sondern nur eine mit schön gestickten Aurifrisien in circulo und titulo besitzt, wird füglich diese als pretiosa gelten und bei feierlichen Gottesdiensten abwechselnd mit einer minder reich ausgestatteten oder auch mit der mitra simplex gebraucht werden können; wo überhaupt nur zweierlei Mitren vorhanden sind, wird man sich an allen Tagen, für welche das Caeremoniale die mitra auriphrygiata vorschreibt, der einfachen Mitra zu bedienen haben" (Thalhofer I 903). Nach dem 
Die auriphrygiata hat der Pontifex während des Advents sowie in der Zeit von Septnagesima bis Gründonnerstag mit Ausnahme des dritten Adventssonntags Gaudete, des vierten Fastensonntags Laetare und der einfallenden Feste zu benutzen. Auferdem soll sie an allen Vigilien, die mit Fasten verbunden sind, an den Quatember- und Bitttagen. bei den Litaneien und sonstigen Bufprozessionen, am Feste der unschuldigen Kinder. wofern es auf einen Wochentag fällt, und bei nicht feierlichen Benediktionen und Konsekrationen zur Verwendung kommen. Bei der Messe und den Vespern kann der Bischof an allen diesen Tagen nach der Regel, welche oben für die pretiosa angegeben wurde, die auriphrygiata durch die simplex ersetzen. Die mitra simplex trägt der Pontifex am Karfreitag, beim Totenoffizium und bei den Seelenmessen. Auferdem mußs sie nach dem Caeremoniale bei der Kerzenweihe an Lichtmefatage ${ }^{1}$, der feierlichen Übergabe des Palliums ${ }^{2}$ und der Absolutio am Katafalk ${ }^{3}$ benutzt werden.

Bei den Feierlichkeiten der Provinzialkonzilien bedienen sich nach dem römischen Caeremoniale der Erzbischof der mitra pretiosa, die Bischöfe der auriphrygiata. und etwa teilnehmende infulierte $̈$ ïte der simplex ${ }^{4}$. Auf einem allgemeinen Konzil hahen die Bischöfe eine weife, linnene, die Kardinäle eine weife, damastseidene Mitra. Dasselbe ist der Fall, wenn Bischöfe oder Kardinäle in Pontifikalkleidung feierlichen Pontifikalhandlungen des Papstes beiwohnen.

Träger der Mitra sind von Rechts wegen die Bischöfe, die Kardinäle und vor allem natürlich der Papst. Andere dürfen sich des Ornatstückes nur kraft eines vom Apostolischen Stuhle ihnen besonders erteilten Privilegs bedienen. Ein solches Vorrecht besitzen häufig die Äbte, dann die Dignitare der Domkapitel und vorzüglicherer Stiftskirchen, sowie auch wohl ganze Kapitel; doch bestehen für solche privilegierte Geistliche zum Unterschied von den Bischöfen bezüglich des Gebrauches der Vitra gröfere oder geringere Einschränkungen, welche teils die Beschaffenheit des Ornatstïckes, teils den Ort und die Gelegenheit seiner Benutzung betreffen.

Nach der allgemeinen liegel sollen sie sich keiner mitra pretiosa, sondern nur einer mitra simplex ex tela alba cum sericis laciniis rubri coloris bedienen. Als Ort, an welchen den infulierten Prälaten das Tragen der Mitra zusteht, gilt nur der Bereich ihrer Kirche, als Gelegenheiten gelten lediglich höhere Feste ${ }^{\overline{5}}$. Im einzelnen Falle kommt es aber auf den Wortlaut und die Bestimmungen des jeweiligen Privilegs an, durch welches dessen Empfängern nicht selten weitergehende Vollmachten erteilt werden, als die gewöhnliche Norm enthält.

Die Mitra ist ein liturgisches Ornatstück. Denn ihre Träger bedienen sich ihrer nicht nur vor oder nach liturgischen Akten, sondern vollziehen solche auch mit der Mitra auf dem Haupte. Ganz besonders gilt das vom Bischof, der sie nicht nur bei verschiedenen Segnungen, Salbungen und Inzensationen, sondern auch bei sakramentalen Handlungen trägt, z. B. beim Taufakt, bei spendung der Firmung und bei der Handauflegung, durch welche die Weihe des Diakons, Priesters und Bischofs geschieht. Nichtsdestoweniger unterscheidet sich die Mitra bezüglich des sakralen Charakters bis zu einem gewissen Grade von den ührigen Kultgewändern. So oft nämlich ihr Träger in vorzüglichem sinne als Mann des Gebetes auftritt, wie z. B. bei den Ora-

bischöflichen Caeremoniale (1, 2, c. 8, n. 39 5.) darf der Jischof hei der Messe an Stello der auriphrygiata auch die simplex im Wechsel mit der pretiosa verwenden.

L. 2 , c. 16, n. 4.
L. 1 , c. 16, n. 1.
3 L. 2 , c. 12, n. 6.

4 L. 1, c. 31, 1. 11 .

5 Decret. Alexandri VII. circa usum pontificalium 27. Sept. 1659 und die Konstitution Pius' VII. "Decet Romanos Pontifices" 4. Iul. 1823 (Decret. auth. 1311 2624). 
tionen der Messe und des Offiziums, dem Kanon der Messe und den Orationen im Ritus der heiligen Weihen und der andern Sakramente, hat er sich der Kopfbedeckung zu entledigen. Der Grund hierfür liegt wohl in der Vorschrift des Apostels, es solle der Mann mit entblöstem Haupte beten ${ }^{1}$.

Bildet die Mitra ein hervorragendes pontifikales Ornatstück, so kann es nicht wundernehmeu, daf sie Gegenstand einer hesondern Zeremonie bei der Bischofsweihe ist 2 .

Hat der Konsekrator nämlich nach der Messe, in welcher die Bischofsweihe vollzogen wurde, den feierlichen Schlufsegen erteilt, so läft er sich die Mitra des Neugeweihten reichen und segnet sie mit den Worten: "Herr, Gott, allmächtiger Vater, von dessen hell leuchtender Giite und unermeflicher Kraft alle gute Gabe, alles vollkommene Geschenk und alle schmückende Zier kommt, segne und heilige gnädigst die Mitra, welche dem Haupte dieses deines bischöflichen Dieners aufgesetzt werden soll. Durch Christum, unsern Herm." Hieranf hesprengt er sie mit Weihwasser und schmückt dann unter Beihilfe seiner Mitkonsekratoren mit ihr den neuen Bischof unter dem Gebet: "Wir setzen, o Herr, auf das Haupt dieses deines Bischofs und Kämpen den Helm des Schutzes und des Heiles, auf daf er den Feinden der Wahrheit durch des Angesichtes Schmuck und die Rïstung des Hauptes, die Hörner beider Testamente. schrecklich erscheine und unter deinem Gnadenbeistande machtvoll gegen sie streite, der du deines Dieners Moses Angesicht dadurch, dalis du zu ihm geredet, mit Zier übergossen und durch die licht strahlenden Hörner deiner Klarheit und Wahrheit ausgezeichnet, sowie auch das Haupt deines Hohenpriesters Aaron mit der Tiara auszustatten geboten hast. Durch Christum, unsern Herm." Die IVorte, mit denen der Konsekratol die Übergabe der Mitra begleitet, nehmen, wie man sieht, auf die Gestalt derselben, nämlich die üher Stirn und Hinterkopf sich erhelenden Hörner ${ }^{3}$, Bezug.

Wie im Ritus der Bischofsweihe, so findet sich die Zeremonie auch in dem der Abtsweihe; doch kommt sie hier natïrlich nur dann zur Anwendung, wenn der zu benedizierende Abt das Vorrecht genielst, die Inful zu tragen.

Das Gesagte mag bezüglich der Mitra nach heutigem römischen Brauch genügen. Das Bild ist zwar nicht völlig erschöpfend, doch nach Maligabe des Raumes und als Grundlage für die nachfolgende geschichtliche U'ntersuchung ausreichend. Wenden wir uns daher del Geschichte des bischöflichen Kopfschmuckes zu.

Die Frage, welche uns zunächst zu beschäftigen hat, ist: Seit wann gab es in der abendländischen Kirche eine Mitra, oder, da es nicht sowohl auf den Namen als vielmehr auf die Sache ankommt, seit wann ist im Abendland bei den Bischöfen ein liturgischer Kopfschmuck in Gebrauch?

\section{ERSTES AUFTRETEN DER PONTIFIKALEN MITRA.}

Über das Alter der Mitra ist seit dem 17. Jahrhundert bis in die Gegenwart sehr viel geschrieben und gestritten worden. Nach den einen soll sie in die Zeit der Apostel zurückreichen, andere wollen, dafo man wenigstens im 8. und 9. Jahrhundert einen liturgischen Kopfschmuck gekannt habe. Eine dritte Meinung läft die Mitra erst um den Beginn des zweiten Jahrtausends

1 Kor 11, 4. Dazu can. Nullus episcopus. De consecrat. dist. 1, n. 57 (ed. Richter I, Lipsiae 1879, 1310).
2 Pontif. rom., De consecrat. electi in episc. circa fin.

3 Ebd., De benedict. abb. circa fin. 
in Gebrauch kommen, eine vierte unterscheidet zwischen Form und Form. Ihr zufolge gehört nämlich der pontifikale Hauptschmuck, wie ihn die jetzige Mitra darstellt, zwar erst der Wende des 10. Jahrhunderts an, doch soll es schon vorher eine mehr band-, kranz- oder kronenartige bischöfliche Kopfzier gegeben haben. Einen andern Mittelweg schlägt eine fünfte Ansicht ein, indem sie behauptet, es sei die Mitra erst um den Anfang des zweiten Jahrtausends zu allgemeiner Verwendung gekommen, vordem aber nur von einzelnen oder doch nur auf Grund einer besondern Erlaubnis des Papstes getragen worden. Indessen ist die Sache denn doch nicht so dunkel, wie es nach diesem Wirrwarr von Ansichten scheinen könnte. Hätte man sich nicht vom Bestreben leiten lassen, der Mitra ein möglichst hohes Alter zu sichern, und hätte man die Quellen etwas vorurteilsloser durchforscht, würde man unschwer zur Überzeugung gekommen sein, da s in Rom erst um die Mitte des 10. Jahrhunderts, aukerhalb Roms aber, im übrigen Abendland, erst um 1000 von einem pontifikalen Kopfschmuck die Rede sein kann.

Keiner der dem 8. und 9. Jahrhundert entstammenden römischen Ordines erwähnt auch nur mit einem Wort eine pontifikale Kopfbedeckung, obwohl die weitläufigen und bis ins einzelne gehenden Angaben über den Mefritus dazu mehr als einmal hätten führen müssen, falls eine solche bereits in Gebrauch gewesen wäre. Es ist nicht einmal von ihr die Rede, wo die Gewänder aufgezählt werden, mit welchen die Regionarsubdiakone den Papst vor der Messe zu bekleiden hatten ${ }^{1}$. Wir hören, wie die Ministri ihm die Albe, das Cingulum usw., das Pallium nicht ausgenommen, anlegen, betreffs eines sakralen Kopfschmuckes herrscht dagegen tiefes Schweigen. Ebensowenig findet sich im S. G. K. irgend eine Spur der Mitra, obwohl darin mit aller Ausführlichkeit die festtäglichen und alltäglichen Sakralkleider des Papstes nebst den liturgischen Gewändern der Hebdomadarbischöfe, der Presbyter, der Diakone, Subdiakone und Akolythen aufgezählt werden.

Es ist wahr, ein aus dem Schweigen hergenommener Beweis ist nur dann von Kraft und Wert, wenn er durch die Umstände einer bestimmten Verneinung gleichkommt. Indessen trifft das ohne Zweifel in unserem Falle zu. Hätte es zur Zeit der Entstehung des 1., 2. und 3. Ordo Mabillons, des von Duchesne herausgegebenen Ordo und des St Gallener Kleiderverzeichnisses im römischen Ritus eine liturgische Kopfbedeckung gegeben, so hätte ein solch bedeutungsvolles Ornatstück doch irgendwo, zumal aber im St Gallener Verzeichnis der zu Rom gebräuchlichen Pontifikalkleider erwähnt werden müssen. Oder soll man in allen diesen Fällen seine Nichtnennung auf ein Versehen und Vergessen des Schreibers oder auf etwas ähnliches zurückführen?

Einen ferneren Beweis liefern Hraban, Theodulf von Orléans, Amalar, Walafried Strabo und Pseudo-Alkuin. Hraban, welcher die liturgische Kleidung seiner Zeit, d. i. die römische, unter Vergleichung mit der Kultkleidung des Alten Bundes behandeln will, schweigt vollständig von einer liturgischen Kopfbedeckung, obwohl er die Sandalen und selbst das erzbischöfliche Pallium eingehend behandelt. Ebenso fehlt bei Theodulf von Orléans ${ }^{2}$, der doch in seiner "Ermahnung an die Bischöfe" eingehend schildert, wie der Diakon den Pontifex mit scinen bischöflichen Gewändern beklcidet, jede Erwähnung eines

1 Ordo 1, n. 67 ; ordo 3, n. 67 (M. 78, 940 978).
2 Carm. 1. 3, n. 3, Paraen. ad episc. (M. 105, 355). 
pontifikalen Kopfschmuckes. Wohl ist bei ihm von einer goldenen lamina (Stirnplatte) und einer mitra die Rede. Allein es ist auffallend, dafo in denselben nicht blof ältere Gelehrte, wie du Saussay, Mabillon, Martène und Sala in seinem Kommentar zu Bonas Liturgik, sondern selbst solche aus neuester Zeit einen liturgischen Kopfschmuck des Bischofs haben sehen können ${ }^{1}$. Ein auch nur oberflächlicher Blick auf die betreffende Stelle der "Paränese" beweist klar, das Theodulf unter der lamina und mitra nicht eine Kopfzier des christlichen Pontifex, sondern den Ziz und die Miznephet des aaronitischen Hohenpriesters versteht. Man lese nur ${ }^{2}$ :
Aurea pontificis cingebat lamina frontem,
Qua bis binus apex nomen herile dabat.
At tibi frons mentis cingatur sensibus almis
Christum evangelico vox et ab ore sonet...
lllins ergo caput splendescens mitra tegebat,
Contegat et mentem ius pietasque tuam.

Wie wenig Theodulf von einer bischöflichen Mitra weik, erhellt klar aus dem Umstand, daf er der lamina und der mitra nicht ein entsprechendes Ornatstück des christlichen Kultus gegenüberstellt, sondern bemerkt, wie des alttestamentlichen Pontifex Haupt jene Schmuckstücke geziert, so müsse beim Bischof erhabenes Sinnen des Geistes Stirn umgeben und Recht und Frömmigkeit die Seele bedecken.

Auch Amalar ist eine sakrale Kopfbedeckung des Bischofs noch völlig unbekannt. Zweimal zählt er in seinen weitläufigen Erörterungen ủber die liturgische Gewandung im einzelnen alle Gewänder des Bischofs auf. Das eine Mal im Kapitel über die Tunika ${ }^{3}$, das andere Mal am Schlusse seiner Ausführungen über die liturgischen Gewänder" Dort nennt er uns die Ornatstücke, welche, wie er sagt, den Bischof rom Kopf bis zu den Füßen bedecken, hier will er noch einmal kurz den ganzen geistlichen Ornat wiederholen (breviter desideramus recapitulare omnem ornatum clericorum). Über eine sakrale Hauptbedeckung läfat aber Amalar nirgends das geringste Wort fallen, obschon er doch an der letztgenannten Stelle zum geistlichen Ornat neben Amikt, Albe, der liturgischen Fubbekleidung, Tunika, Stola, Dalmatik, Sudarium und Pallium sogar die Tonsur rechnet. Nicht minder bezeichnend für den Stand der Dinge ist, daf Amalar beim christlichen Pontifex als Ersatz für die goldene Stirnplatte des jüdischen Hohenpriesters das Pallium ${ }^{5}$ betrachtet.

Walafried Strabo hat ein Bild der Entwicklung der liturgischen Kleidung, soweit es ihm möglich war, zu zeichnen versucht und stellt nun die einzelnen Teile der heiligen Gewandung des Alten Bundes denjenigen des christlichen Kultus gegenüber: die jüdische Obertunika der Dalmatik, die linnene Untertunika der Albe usw. Als Gegenstück der lamina führt er

I So Hefele (Beitr. II 233), de L inas (Revue 1861, 294), B a r a u d (Bullet. mon. 1866, 140), B ock (Gesch. II 152) und mit einigem Zweifel Roh. (VIII 115) Selbst Kra us sagt noch (Geschichte der christl. Kunst II 498): „Die Mitra (infula) ist mit Sicherheit erst im 9. Jahrhundert nachzuweisen, wo sie von Theodulf von Orléans... genannt wird." Und doch hatte bereits M arriott (Vestiarium christ. 191) auf Braun, Die Jiturgische Gewandung. den rechten Sinn der Worte der Paränese aufmerksam gemacht und $\mathrm{Krieg}$ in der von Kraus berausgegebenen Realencyklopädie (II 213) schon bemerkt: "Selbst Theodulf ... redet nur bildich, wenn ev sagt, illius ergo caput mitra resplendens tegebat."

2 M. 105, 357360.

${ }^{3}$ De eccl. offic. 1. 2, c. 22 (ebd. 1098).

4 Ebd. c. 26 (ebd, 1102).

5 Ebd. c. 23 (ebd. 1098). 
hierbei, ähnlich wie der Metzer Diakon, das Pallium, als das der Tiara aber sonderbarerweise - die Kasel an. Ob wohl Walafried je zu einer solchen Gegenüberstellung gekommen wäre, wenn es zu seiner Zeit eine Mitra oder überhaupt einen pontifikalen Kopfschmuck gegeben hätte? 1

Pseudo-AIkuin hat den Kopfschmuck des aronitischen Priestertums beschrieben und sowohl ein Bild der Tiara der jüdischen Priester als der mit einer' Krone versehenen Hauptbedeckung des Hohempriesters entworfen. Dann fährt er fort: „Ein Gewandstück dieser Art gibt es in der römischen Kirche und überhaupt in unsern Gegenden nicht. Denn es ist nicht Brauch, daß3 man mit einer Kopfbedeckung versehen (pileati) die göttlichen Geheimnisse feiere. Bei den Griechen soll das aber geschehen und sollen dieselben pilei (Mützen), d. i. cuphiae, auf dem Kopfe tragen, wenn sie am Altare stehen." Auferdem bemerkt Pseudo-Alkuin, nachdem er die goldene Stirnplatte des mosaischen Kultus besprochell, mit kurzen aber bestimmten Worten: "Auch diese Art von Ornament nahm die Kirche Christi nicht herüber." 2 Der Verfasser der Schrift De divinis officiis sagt es somit klar und ausdrücklich, daf zu seiner Zeit, d. i. also etwa um 900, keinerlei liturgische Kopfbedeckung in der römischen Kirche wie überhaupt im Abendlande Verwendung fand.

Auch in den Sakramentaren und Pontifikalien des 9. und 10. Jahrhunderts wird einer Mitra und überhaupt einer liturgischen Hauptbedeckung nirgends gedacht. In manchen dieser liturgischen Bücher kann das freilich nicht auffallen, da sie überhaupt der Sakralkleider keine Erwähnung tun. Anders verhält es sich dagegen z. B. mit dem der zweiten Hälfte des 10. Jahrhunderts angehörigen Sakramentar von Corbie ${ }^{3}$, welches aufs eingehendste beschreibt, wie der Bischof sich auf die Messe vorzubereiten und welche liturgische Gewandstücke er anzuziehen habe, dabei aber von der Mitra oder sonst einem pontifikalen Kopfschmuck völlig schweigt. Es ist das um so bemerkenswerter, als es das stets nur vereinzelt gebräuchliche Rationale keineswegs vergessen hat und auch schon die Pontifikalhandschuhe kennt.

Auch auf den Monumenten findet sich trotz zahlreicher Darstellungen von Bischöfen vor dem zweiten Jahrtausend keine Spur einer pontifikalen Hauptbedeckung, gleichviel in welcher Weise uns die Bischöfe auf ihnen entgegentreten. Nirgends eine Mitra, nirgends ein Ornatstück, was man als sakralen Kopfschmuck des christlichen Pontifex aufzufassen hätte.

Man vergleiche z. B. die Bischofsgestalten auf den römischen, mailändischen und ravennatischen Mosaiken und die Bilder der hll. Cornelius, Sixtus II., Cyprianus

\footnotetext{
$1 \mathrm{Vgl}$. auch Walafrieds Zeitgenossen Ratramnus (Contra Graec. oppos. 1. 4, c. 5 [M. 121, 323]): Si radant barbam (sc. Romani vel Latini), comam tamen nec nutriunt, nec caput vel prophetantes $\nabla$ el orantes velant. ...

${ }_{2}$ De div, offic. c. 38 (M. 101, 1239). Ob os mit dem, was Pseudo-Alkuin über eine liturgische Kopfbedeckung der griechischen Kirche berichtet, seine Richtigkeit hat, ist in unserer Frage ohne Bedeutung. Er sagt ja auch nur: „es soll". Jedenfalls kannte der Verfasser der Schrift De div. offic. den Gebrauch der römischen Kirche wie des Abendlandes überbaupt.
}

\begin{abstract}
3 Wenn das Sakramentar, nachdem es beschrieben, mit welchen Gewândern und wie der Bischof zu bekleiden sei, bemerkt: Cum omni quoque diligentia episcopus veneretur a suis. Eo autem rationabiliter flamineato, accedat ordinatim omnis processio, so will das flamineari nach dem ganzen Zusammenhang und nach den später folgenden Rubriken nur sagen: mit den pontifikalen Gewändern bekleidet, nicht aber, mit einer sakralen Kopfbedeckung geschmückt werden. Ganz denselben Sinn hat in der Missa Illyrica (Mart. 1. 1, c. 4, art. 12, ordo 4; I 177) die Notiz: postquam infulatus fuerit.
\end{abstract}


und Optatus in S. Callisto; dann die Elfenbeinschnitzereien, welche den Deckel des Sakramentars Drogos von Metz schmücken - sie stellen die Meffeier und sonstige liturgische Funktionen dar -., die Miniaturen desselben Sakramentars, die Elfenbeintafel in der Stadtbibliothek zu Frankfurt und das ehemalig Spitzersche, jetzt in englischem Besitz befindliche Gegenstück der Frankfurter Tafel ${ }^{1}$; weiterhin die Darstellungen auf dem Palliotto (der Hochaltarbekleidung) in S. Ambrogio zu Mailand, die Abbildung einer Kirchweihe in dem der Stadtbibliothek von Rouen zugehörigen Pontifikale von Aletis, die Elfenbeinplatte des Museums von Amiens mit Szenen aus dem Leben des hI. Remigius 2, die Miniaturen des Benediktionale Äthelwolds", sowie die Darstellungen auf dem im Grabe des hl. Cuthbert gefundenen, aus dem Beginn des 10. Jahrhunderts stammenden Manipel '; fernel die mit Bischofsfiguren bestickten, ursprünglich von einem Altarbehang stammenden Besatzstreifen im Museum zu Ravenna, die Miniaturen des Sakramentars Warmunds von Ivrea ${ }^{5}$ und des Göttinger Sakramentars ${ }^{6}$, beide reich an liturgischen Darstellungen, die Miniaturen des Vigilanuskodex in der Bibliothek des Escorial ${ }^{7}$ und zahlreiche andere.

Indessen werden ja doch eine Anzahl von Monumenten aus dem ersten Jahrtausend genannt, auf welchen sich schon die Mitra oder doch sonst ein pontifikaler Kopfschmuck vorfinden soll.

So weist Rohault de Fleury auf Abbildungen von Mitren hin, welche sich auf zwei silbernen, dem Schatze des Cav. Giancarlo Rossi zu Rom angehörenden und angeblich dem 8. Jahrhundert entstammenden Buchdeckelplatten befinden. Dann führt er ein Siegel Roricos von Laon aus dem Jahre 968 an, auf welchem dieser Bischof eine Mitra trägt. Ebenso glaubt er auf dem Mosaik der Kapelle der hl. Fausta (des hl. Satyrus) in S. Ambrogio zu Mailand, auf welchem der hl. Viktor im Brustbild dargestellt ist, ein Beispiel für den sakralen Kopfschmuck entdeckt zu haben: Saint Victor est en costume ecclésiastique et pourvu d'un diadème gemmé sur le front. Er nennt die Darstellung sogar monument important des anciemnes coiffures sacerdotales ${ }^{8}$.

Barraud ${ }^{9}$ beruft sich auf die Papstbilder Chacons und die Miniatur eines Manuskripts der Bibliothek von Valenciennes, den hl. Amandus und den hl. Vindicianus darstellend, welche or um des viereckigen Nimbus willen, mit welchem der erste der beiden versehen ist, dem 7 . Jahrhundert zuweisen möchte.

De Linas will die Mitra auf drei englischen Miniaturen gefunden haben, von denen er zwei dem 8, und die dritte dem 10. Jahrhundert zuschreibt ${ }^{10}$. Die erste soll sich in dem Manuskript des Britischen Museums, Cotton. Claud. B. IV, dem angelsächsischen Heptateuch Älfriks, befinden und einen König in der Mitte von Prälaten wiedergeben, welche auf ihrem Haupte einen kegelförmigen Hut tragen: maintenu par un bandeau frontal et recouvrant un voile, qui descend sur la nuque. Die zweite soll einer Paraphrase der Genesis des Pseudo-Caedmon in der Bodleian Library zu Oxford (Iunius n. 11) angehören; sie stellt eine Kirchweihe dar. Der amtierende Bischof trägt angeblich ein head-linen, eine linnene Kopfhülle, auf dem Haupte. In einer Anzahl von Personen, welche im Hintergrund stehen und mit einer Spitzmütze versehen sind, möchte de Linas, wie es scheint, Bischöfe vermuten, die nicht unmittelbar bei der Weihe beteiligt sind und darum ihren pileus auf dem Kopfe haben. Die dritte Miniatur soll den hl. Dunstan darstellen. Der Kodex, der sie enthält, ein englisches Pontifikale, befindet sich im Britischen Museum, Cotton. Claudius A. III.

1 Vgl, oben Bild 62-68, S. 158159160

$167 \quad 168 \quad 170171$.

2 Abbildung bei Roh. VII, pl. DLxvirr.

3 Abbildung bei Ga $g \theta$, Archaeologia $\mathrm{XXIV,} \mathrm{pl.} \mathrm{xxxiI.}$

* Abbildung bei Roh. VII, pl. DxxxI.

5 Carta-Cipolla-Frati, Atlante paleografico-artistico, Torino 1899, Tfl 23.

${ }^{6}$ Abbildungen in Zeitschrift VII (1894) $74 \mathrm{f}$.

7 Museo Español de Antigüedades III 510 ff. s Roh. VIII 114115 et pl. DCLII Dchiv. Vgl. auch Barraud in Bullet. mon. 1866, 318. Das Siegel Roricos ist nur mehr in einer Abbildung bei Mabillon (De re diplomat, Paris. 1709, 451) erhalten. Der Wiedergabe desselben bei Rohault de Fleury und bei Barraud liegt diejenige bei Mabillon zu Grunde.

${ }^{9}$ Bullet. mon. 121134313.

10 Revue 1861, 297 453. Bock II 156. 
Rock glaubte eine bischöfliche Krone im Benediktionale Äthelwolds ( $†$ 984) entdeckt zu haben '. Wüscher-Becchi endlich beruft sich auf die bekannte Tafel mit den Bildern der Apostelfürsten in St Peter, die aus dem 9. Jahrhundert stammen und in ihrem unteren Teil außer einem Papst mit einem Camelaucum auf dem Haupte die hll. Cyrillus und Methodius in pontitikaler Kleidung, auf dem Kopfe die Mitra, aufweisen soll ${ }^{2}$.

Allein die Buchdeckelplatten Rossis sind bekanntlich berüchtigte moderne Fälschungen ${ }^{3}$. Ebenso ist das Siegel Roricos unecht; es ist eines der nicht gerade seltenen gefälschten mittelalterlichen Siegel. Es hat noch mehrere Jahrhunderte gedauert, bis eine Mitra, wie sie der Bischof auf dem Siegel trägt, in Gebrauch kam ${ }^{4}$, eine Sache, die dem Fälscher offenbar nicht bekannt war. Was aber die Kopf bedeckung des hl. Viktor auf dem Mosaik in der Kapelle des hl. Satyrus anlangt, so läßt ein einziger Blick auf die Abbildung bei Garrucei ${ }^{5}$ zur Genüge erkennen, daf die angebliche ancienne coiffure sacerdotale mit einem liturgischen Kopfschmuck ebensowenig zu tun hat wie die Gewandung des heiligen Märtyrers Viktor mit einem costume ecclésiastique. Sonderbarerweise weist Rohault de Fleury gleichzeitig auf das Mosaik von S. Prisco zu Capua hin ${ }^{\circ}$, wo ähnliche Kronen zu finden seien, obschon er doch aus ihm erst recht hätte ersehen müssen, daß seine Auffassung von der Krone des hI. Viktor irrig sei.

Die Papstbilder in Chacons "Geschichte der Päpste" sind Phantasien kühnster Art. Sind doch selbst Päpste des 6 . Jahrhunderts auf denselben mit den zugestutzten Kaseln der Renaissance bekleidet. Es ist wirklich wunderlich, daf man ihnen einen Beweis entnehmen zu können geglaubt hat. Die Miracula S. Amandi der Bibliothek von Valenciennes gehören frühestens dem letzten Viertel des 11. Jahrhunderts an " Rohault de Fleury schreibt sie, und zwar wohl mit Recht, sogar dem 12. Jahrhundert zu.

Die beiden angelsächsischen Darstellungen, welche de Lin as dem 8. Jahrhundert zuweist, sind um ca 250 Jahre zu früh datiert. Die zweite derselben befindet sich obendrein nicht in der Genesis-Paraphrase des Pseudo-Caedmon, sondern im Pontifikale von Aletis der Stadtbibliothek zu Rouen, wo wir sie selbst eingesehen und kopiert haben. Auch ist es unrichtig, daß der auf ihr abgebildete Bischof, welcher die Kirchweihe vornimmt, eine Inful trage; er ist vielmehr ohne Kopfbedeckung oder sonst irgend einen Kopfschmuck. Vielleicht hat die kräftig ausgehildete Haarkrone des Bischofs oder eine ungenaue Wiedergabe des Originals den Irrtum veranlaßst. Die im Hintergrunde stehenden Personen mit der spitz ansteigenden Kopfbedeckung sind Mönche in ihren Kapuzen. Auf der ersten der von de Linas angezogenen Darstellungen sehen wir nicht einen König inmitten von Prälaten, sondern Pharão, der eben den Bäcker hat hängen lassen (Gn 40, 20), umgeben von seinem Gefolge ${ }^{8}$. Die Spitzmützen der vermeintlichen Prälaten kehren auch noch auf mehreren andern Miniaturen des Kodex wieder, so fol. 80 a bei zwei Ägyptern, die einen Israeliten (Ex 5, 14) prügeln. Die dritte Miniatur ${ }^{y}$ entstammt.nicht dem 10 ,

\footnotetext{
1 'lhe Church of our Fathers II 93. Bock II 154.

2 Ursprung der päpstlichen Tiara und der bischöflichen Mitra, in „Röm. Quartalschrift" XIII 104.

${ }^{3} \mathrm{Vgl}$, uber den Schatz Grisar in der Zeitschrift für krth. Theologie, Innsbruck $1895,30 f$ ff und frisar, Ancora del preteso Tesoro, Roma 1896.

4 Bischof Waltex von Laon (1152-1174) trägt auf Siegel und Münze noch die seitlich gehörnte Mitra (Abbildung bei Roh. VII, pl. oxci et VIIJ, pl. ocLX).

5 Storia tav. 235.

Ebd. tav. 254.
}

7 Vgl, auch M. G. SS. XI 413.

${ }^{8}$ Richtig sagt Westw o od, Facsimiles of Miniatures, London 1868, in der Note (p. 126) zu dem sog Pontifikale St Dunstans (Claud. A. 3): In earlier drawings bishops are represented withont any head-covering.

${ }^{9}$ Abbildung ebd. pl. L. Andere bei Mar$x$ iott, Vestiar. christ. pl. xLIV und GoyauPératé, Der Vatikan 37, sowie Fäh. Geschichte der bildenden Künste Tff 19. Die Datierungen sind hier teils ungenau teils geradezu unrichtig. Die Miniatur stellt auch nicht St Dunstan, sondern Gregox d. Gr. in der beliebten typischen Weise mit der Taube am Ohr dar. Zur Meinung, das Bild gebe 
sondern gemäß der Form des Palliums und der Dalmatik sowie den Ornamenten der Umrahmung frühestens dem Ende des 11. Jahrhunderts.

Das Diadem, welches sich auf einer Miniatur im Benediktionale Äthelwolds findet', hat mit einem bischöflichen Kiopfschmucke durchaus nichts gemein. Anf derselben ist St Benedikt abgebildet, welcher in seiner Hand eine Zackenkrone und um sein Haupt einen goldenen Reifen trïgt. Der Winiator, ein geistlicher Sohn des Heiligen, hat offenbar den grofien Ordensstifter auszeichnen wollen und ihm darum eine Krone in die Hand und das Diadem um die Stirne gelegt. Daf der Maler dies Bestreben hatte, erhellt aufs deutlichste ans einer andern Darstellung des Benediktionale, dem chorus confessorum ${ }^{2}$. St Benedikt steht hier in der Mitte des Bildes zwischen Gregor d. Gr. und St Cuthbert, angetan mit bischöflichen Gewändern, ja selbst mit dem Pallium. Er hat eine Zackenkrone wie die andern ihn umringenden Bekenner; doch ist sie bei ihm ungleich reicher wie bei Gregor d. Gr., St Cuthbert und den übrigen. Wie wenig der eben erwähnte Stirnreifen des Patriarchen des abendländischen Mönchtums als sakraler Kopfschmuck aufgefalat werden kann, ergibt sich klar aus dem Bilde des heiligen Bischofs Swithun und einer Miniatur, welche einen Bischof (Äthelwold selbst?) den Segen erteilend darstellt ${ }^{3}$. In beiden Fällen fehlt jede Art von Hauptzier. Aber auch die Zackenkronen, welche wir bei Papst Gregor, St Benedikt, St Cuthbert und den andern Bekennern auf dem Bilde des chorus confessorum gewahren, berleuten kein bischofliches Ornatstïck, sondern die Himmelskrone. Denn genau derselbe Kopfsehmuck erscheint auch bei den Jungfrauen auf den beiden prächtigen Darstellungen des chorus virginum.

Was endlich die Tafel in St Peter anlangt, so ist es durchans unzutreffend, wenn sie von Wüscher-Becchi dem 9. Jahrhundert zugeschrieben wird. Derselbe beruft sich zwar auf einen Aufsatz L. Jelićs: L'icone vaticana di S. Pietro e Paolo ", allein trotz der "absoluten Sicherheit", mit welcher dieser das Bild nicht blof ins 9. Jahrhundert versetzt, sondern sogar für eine Arbeit der hll. Cyrillus und Methodius selbst ausgibt, kann es frühestens erst um den Beginn des 12. Jahrhunderts entstanden sein. Die Form des Palliums, welches der Papst trägt, stellt das aufer Zweifel. Sie ist nicht die des 9. Jahrhunderts, sondern die, welehe erst gegen das 12. auf den Monumenten auftritt. Obendrein ist es keineswegs so sicher, daß die beiden als Cyrillus und Methodius gedeuteten Personen wirklich Bischöfe und nicht vielmehr fürstliche Persönlichkeiten darstellen. Denn der griechische Ritus kannte selbst noch um den Ausgang des Mittelalters keine liturgische Kopfbedeckung.

Wir wiederholen, man wird auf den Bildwerken, die den ersten Jahrtausend entstammen, rergebens nach einer Mitra oder üherhaupt einem liturgischen pontifikalen Kopfschmuck fahnden.

Man hat dieses vollständige Fehlen auf den Monumenten des ersten Jahrtausends mit der Annahme begründen wollen, es sei damals bei den Künstlem nicht Sitte gewesen, die Bischöfe mit ihrer sakralen Kopfzier darzustellen. Allein eine solche Erklärung kann keineswegs befriedigen. Sie ist mehr eine blotie Umschreibung, als eine wirkliche Erklärung des so eigentümlichen Tatbestandes. Ebenso wie nach 1000 wurden doch die Bischöfe auch schon vor 1000 regelmäßig in ihren liturgischen Gewändern dargestellt. WVarum also nicht auch in dem liturgischen Kopfschmuck, worin dieser immer bestanden haben mag, wenn es einen solchen damals bereits gegeben haben sollte? Mufi man nicht erwarten, dats die Künstler ein so bedeutungsvolles Ornatstück, wie es die pontifikale Kopfbedeckung ist, irgendwo einmal zur Darstellung

St Dunstan wieder, scheint die ersichtlich von späterer Hand lierrihrende Anfschrift Dunstani Archiepiscopi Veranlassung gegeben zu haben.

1 Archaeologia XXIV (1852), pl. xxx.
2 Ebil. pl. III.

3 Ehd. pl. xxix xxxir. Auf pl. xxiv hat auch Christus einen Stimreifen, wie ihn St Benedikt (pl. xxx) trägt.

+ Röm. Quartalschirift Vl $83 \mathrm{ff}$. 
gebracht hätten, wenn es tatsächlich schon im Gebrauch war? Es ist sicher nicht ohne Grund, daß die Mitra um die Zeit, da die ersten schriftlichen Nachrichten über sie auftauchen, auch auf den Bildwerken aufzutreten beginnt, und dals sie, als sie in den schriftlichen Quellen als all gemein eingebiargert erscheint, uns regelmäßig auch auf den Kunstdenkmälern begegnet. Wenn vor 1000 nirgends, und zwar auch nicht bei Darstellung kirchlicher Funktionen, eine sakrale Hauptbedeckung bei den Bischöfen zur Abbildung kommt, dann darf das unbedingt als Beweis gelten, dafs damals eine solche in der Westkirche noch nicht gebräuchlich war, zumal die schriftlichen Denkmale gleichfalls schweigen.

Allein gibt es nicht verschiedene Mitren, die noch dem ersten Jahrtausend angehören sollen? Zeigt man nicht zu Rom in S. Martino ai Monti eine Mitra Silvesters I. (genauer die vordere Hälfte einer solchen), zu Capua die Mitra des hl. Paulinus ( $†$ 843), zu Cividale diejenige des hl. Paulinus von Aquileja († 802), eine Mitra des hl. Exsuperius († ea 414) in St-Sernin zu Toulouse, die pontifikale Kopfbedeckung des hl. Zeno († 380) in St Zeno zu Verona, zu Prag die Mitra des hl. Eligius († 659), zu Regensburg die des hl. Wolfgang († 994) und zu St-Gildas-de-Rnis die des hl. Gildas? Und befand sich nicht zu Valencia zur Zeit Salas, des Kommentators ron Bonas Liturgik, eine Mitra des hl. Augustinus, und zu Bologna die des hl. Isidor, eines sizilianischen Bischofs ans den Tagen Gregors d. Gr.? ${ }^{1}$ Und hören wir nicht von Johannes Longus von Ypern († 1383), dafs man damals im Kloster Sithiu bei St-Omer eine Mitra des hl. Foleuin von Térouanne († 855) besaf?? ${ }^{2}$ Birgt endlich nicht noch jetzt, wie Bock angibt ${ }^{3}$, das Grab des hl. Augustinus zu Pavia unter andern Reliquien auch eine Mitra des Heiligen? Allerdings, schade nur, daß keine dieser Mitren authentisch ist.

Die Mitra Silvesters entstammt ihrer Beschaffenheit nach dem 14. Jahrhundert. Obendrein geht aus ihren Maßen - sie würde vollständig erhalten nur eine Weite von 40-42 cm haben - hervor, daß sie überhaupt niemals von einem erwachsenen Manne hat getragen werden können ${ }^{4}$. Die Mitren zu Capua, Verona, Toulouse und Regensburg datieren aus dem 13., die Infuln von Cividale und St-Gildas-de-Ruis aus dem 14. bzw. 15. Jahrhundert. Der pontifikalen Kopfbedeckung des hl. Isidor haben wir in Bologna vergeblich nachgeforscht. Nach der Schilderung Salas zu urteilen, dürfte sie eine der zwei in der Kathedrale aufbewahrten Mitren des 15. Jahrhunderts sein, die jetzt beide dem seligen Nikolaus Albergati $(\dagger$ 1443) zugeschrieben werden. Die Mitra des hl. Augustinus zu Valencia kann nach der Beschreibung, welche der Kommentator Bonas von ihr gibt, wohl nicht vor dem 14. Jahrhundert entstanden sein. Bemerkenswert ist, daß selbst Sala, der doch das hohe Alter des pontifikalen Kopfschmuckes so warm verteidigt, den Ursprung der beiden Mitren als fragwürdig betrachtet. Die Mitra des hl. Folcuin, die leider verloren gegangen ist, kann darum nicht als echt gelten, weil es nach den klaren Zeugnissen der Liturgiker des 9. Jahrhunderts in Gallien eine liturgische Kopfbedeckung der Bischöfe noch nicht gegeben hat. Selbst Rohault de Fleury nimmt keinen Anstand, seine Zweifel an der Echtheit der angeblichen Mitra Folcuins auszusprechen. Was endlich die Mitra des hl. Augustinus zu Pavia anlangt, so ist zu bemerken, dafs der Schrein des Heiligen nicht dessen Mitra, sondern nur die Reste eines seidenen Velums enthält, mit dem ehedem die bleierne Lade bedeckt war, welche dia Gebeine des grocien

1 Bona 1. 1, c 24, \$14, nota 5 ; II 254 : vgl. Moroni XLV 262.

2 C. 13 (Mart., Thes. 11 II 516).

s Gesch. II 158.

4 Die Mitra hat ohne Zweifel ehedem eine Statue des hI. Silvester geschmückt. Es ist unbegreiflich, dab bisher keiner von allen, welche die Mitra gesehen und beschrieben haben, auf ihre äuferst geringe Weite aufmerksam geworden ist, und noch unbegreiflicher, wie sie überhaupt als wirkliche Mitra Silvesters hat angesehen werden können. 
Bischofs barg. Es ergibt sich das mit aller Klarheit aus den Berichten über die Auffindung der Reliquien im Jahre 1695 und über die späteren Rekognitionen ".

Mit den angeblichen Mitren aus dem ersten Jahrtausend ist es also nichts. Aber auch in den Schatzverzeichnis sen geschieht vor 1000 nirgends des pontifikalen Kopfschmuckes Erwähnung. Besonders auffallend ist das im Testament des Bischofs Riculf von Elne $(\uparrow 915)$. Es finden sich darin caligae und sandalia, amictus, albae, zonae, stolae, manipuli, casulae episcopales, vanti, dalmaticae, ein anulus, kurz alle Bestandteile des Pontifikalornates vertreten, aber keine Mitra. Hinsichtlich einer liturgischen Kopfbedeckung herrscht im Testament tiefes Schweigen. Ähnlich verhält es sich mit den höchst interessanten Inventaren von Cremona und von Clermont-Ferrand aus dem 10. Jahrhundert. Wenn das Inventar von St-Riquier aus dem Jahre 831 von einem capellum auro paratum und einem capellum de pallio redet, so ist darunter eine Kapuze zu verstehen, welche auch capellum genannt wurde ${ }^{2}$; die Mitra, d. i. eine bischöfliche liturgische Kopfbedeckung, ist sicher nicht gemeint, da ja St-Riquier nur eine Klosterkirche war. Zudem wurde die Mitra nie capellum (capellus) genannt.

Wir könnten hier mit unsern Erörterungen über das erste Auftreten der bischöflichen Mitra abschließsen. Allein man bringt zahlreiche schriftliche Zeugnisse vor, welche dartun sollen, daf eine Mitra oder eine sonstige sakrale Kopfbedeckung schon lange vor dem 2. Jahrhundert in Gebrauch gestanden habe. Wir dürfen an denselben nicht vorbeigehen, ohne sie auf ihren Wert geprüft zu haben.

Ammianus Marcellinus erzählt, so sagt man, es habe der Häuptling Firmus, um mit dem römisehen General Theodosius zum Frieden zu kommen, so wie ihm befohlen worden, die Stadt Icosium, die militärischen Zeichen und eine corona sacerdotalis samt allem andern, was er erbeutet hatte, ohne Zögern zurückgegeben ${ }^{3}$. Unter dieser corona sacerdotalis hat man den pontifikalen Kopfschmuck verstehen wollen; Hefele bemerkt sogar: „Unter dieser Priesterkrone ist offenbar die Inful jenes Bischofs gemeint, welchen die heidnischen Afrikaner (nach A mmian. lib. 28, 6) in der Gegend von Leptis und Ona vor kurzem getötet hatten." Allein daf die corona sacerdotalis hier einen bischöflichen Kopfschmuck und erst gar ein liturgisches Ornatstück bedeutet, ist gar nicht sicher. Es ist zwar nicht sonderlich wahrscheinlich, daf sie als Schmuckgegenstand eines heidnischen Priesters aufzufassen sei ${ }^{+}$; weshalb soll man sie aber nicht für eine der kostbaren Kronen halten, welche man als Zierat oder als Kronleuchter in der Kirche bei dem Altar aufzuhängen pflegte? Man darf nicht auferer acht lassen, daf3 Ammianus ein Heide und darum in christlichen Dingen wenig bewandert war. Daf aber jene corona sacerdotalis dem Bischof Rusticianus angehört habe, ist nicht nur nicht offenbar, sondern eine blofe Vermutung. Es ist sogar höchst

1 A. SS. 28. Aug., VI 372 et 374. In Notre-Dame zu Puy-en-Velay wurde ehedem nach Barraud (Bullet. mon. 1866, 130) eine Mitra aufbewahrt, die man als diejenige Aarons bezeichnete. Angesichts solcher Reliquien begreift man leicht, daß man bei aller Ehrfurcht gegen etwaige Überlieferungen einer sachgemäßen Kritik Raum gewähren muk, wenn man Gewandstücke, die von Heiligen aus früherer Zeit herstammen sollen, als Material in einer Geschichte der liturgischen Gewandung zu verwerten hat.

${ }^{2}$ D. C. sub capellum II 123 . Vgl. auch Constit. Ansegisi (M. G. SS. II 299) : capellos nigros 8 , alios 4, unumquemque solidis 3. Auch in den Consuet. Farfen. (ed. Albers) 142 hat capellum den Sinn von Kapuze. Vgl. ferner Udalrici Consuet. Cluniac. 1. 3, c. 29 (M. 149, 773).

3 Ammiani Marcellini Rerum gest. 1. 29, c. 5 .

4 So Marriott 190; Ménard in Note 947 zuna Gregorianischen Sakramentar (M. 78, 544) u. a. Da Firmus die antistites ritus christiani als Unterhändler zu Theodosius schickt, scheint es näher zu liegen, unter der corona sacerdotalis einen den Christen geraubten Gegenstand zu verstehen. 
unsicher, ob der Rusticianus sacerdotalis, der zu den Dekurionen zählte, überhaupt Bischof oder auch nur christlicher Priester gewesen ist.

Ennodius besingt Mailänder Bischöfe. Dabei sagt or von dem hl. Ambrosius:

Serta redimitus gestabat lucida fronte.

Also, schliefat man, trug der Heilige schon einen bischöflichen Kopfschmuck. Gewißs, wenn nur die Worte im buchstäblichen Sinne aufzufassen wären. Allein ein Blick auf den Zusammenhang zeigt alsbald, dafo der Vers wie alle übrigen bildlich zu nehmen, und unter den serta der Ruhmeskranz zu verstehen ist, welchen die Beredsamkeit dem grofen Bischof um die Stirn gewunden hat ${ }^{\text {. }}$

Vincentius von Lerin soll aber doch in seinem Kommonitorium bestimmt von wirklichen Kronen der Priester reden?. Allerdings, antworten wir, spricht er von sacerdotum coronae; doch beweist die ganze Fassung der Stelle, dafs auch die Worte des Leriner Mönches nur als Metapher gelten können, und daß sie bloß "priesterliches Ansehen, priesterliche Würde" bedeuten sollen.

Hieronymus, Augustinus, Sidonius, Paulinus, Ennodius ${ }^{3}$ u. a. bedienen sich, so heist es ferner, bei der Anrede an die Bischöfe wiederholt des Ausdruckes corona vestra. Within müssen, so folgert man, die Bischöfe in jener Zeit wirkliche Kronen getragen haben und "haben diese meistens goldenen Kronen, wie Bock meint, schon damals als hervorragendes und wesentliches Abzeichen der bischöf lichen Würde gegolten "

Darauf ist jedoch erstens zu bemerken, daf es, wenn die Sache sich wirklich so verhalten haben sollte, schlechterdings unbegreiflich ist, warum sich auf den zahlreichen Bildwerken aus dem ersten Jahrtausend nirgends eine Spur der angeblichen, und zwar sogar meist ,goldenen Krone“ zeigt. Dann aber beweist eine nähere Betrachtung der einschlägigen Stellen, daß corona eine blofe Titulatur ist im Sinne von „Eure Erhabenheit, Eure Hochwürden, Eure Herrlichkeit". Vestra corona steht auf einer Stufe mit vestra beatitudo, sanctitas, veneratio, reverentia, vester apostolatus und ähnlichen Anreden, die in dem schwulstigen Briefstil des 5. und 6. Jahrhunderts immer wiederkehren. Ein treffliches Beispiel bietet das Schreiben der Bischöfe Galliens an Papst Leo I, in dessen Unterschriften sich in buntem Wechsel folgen: Ego N. N. beatitudinem vestram, sanctitatem vestram, coronam vestram oder apostolatum vestrum venerans saluto ${ }^{5}$. Recht deutlich erhellt jene Bedeutung von corona vestra auch aus den Ausdrücken humilitas, exiguitas, mediocritas, parvitas nostra, mit welchen die Brief-

1 Carm. 1. 2, n. 77 (M. 63, 348):

Roscida regifico cui (Ambrosio) fulsit murice lingua

Vere suo pingens germina quae voluit.

Serta redimitus gestabat lucida fronte

Distinctum gemmis ore parabat opus....

Succinctus gladiis, clypei de pondere tutus Pectore claudebat textilibus chalybis.

Ensis habet vires vitiorum sector et hostis Vipera non tangit squamea terga viri.

Will man die serta wörtlich fassen, wird man auch wohl das übrige so verstehen und den Heiligen in Schwert, Schild und Panzer aufziehen lassen muissen.

${ }^{2}$ Commonit, I, n. 5 (M. 50, 644) : Nam quis ille tam demens est, qui eos non adsequi evaleat ... quos a defensione fidei maiorum nulla vis depulit,... quos Dominus tanto munere dignos iudicavit, ut per eos prostratas restauraret ecclesias, exstinctos spiritales populos vivificaret, deiectas sacerdotum coronas reponeret et nefarias illas novellas impietatis non litteras, sed lituras infuso coelitus episcopis fidelium lacrymarum fonte deleret.

${ }^{3}$ Hieron. ep. 142 ad Aug. (M. 22, 1180). Aug. ep. 33, n. 5 ad Proculeian. (N. 33, 131). Episc. Gall. ep. ad Leon. I. c. 14 (M. 54, 880 883). Eorundem ep. altera (ebd. 968). Sidonius Apoll., Ep. 1. 6, ep. 3; 1. 7, ep. 8 (M. 58, 554 574). Ennodins, Ep. 1. 4, ep. $2229 ; 1.5$, ер. $10 ; 1.8$, ер. 32 38; 1. 9, ep. 27 (M. 63, 808392144147 161). Marculfi form. 1. 1, n. $26 ; 1.2$, n. 46 (M. 87, 715 754). Relatio Andreae Praevalitani (Skutari) episc. ad Hormisdam P. (M. 63, 443). Paulini Nol. ep. 3 ad Alyp. (M. 61, 163); Floriani ep. ad S. Nicetium ep. Trevir. (M. 72, 918); Paschasii episc. Lilybet. (Marsala) ep. ad Leon. I. (M. 54, 606); Fortunat. epise. praef. ad vitam S. Martini (M. 88, 363); Bedae presb. praef. ad vitam S. Cuthberti episc. prosaic. (M. 94, 734); Braulionis episc. ep. 3 ad Isidor. Hispal. (M. 80, 651),

${ }^{2}$ Bock, Gesch. II $151 \mathrm{f}$.

${ }^{5}$ Episc. Gall. altera epist. ad Leon. I. (M. 54, 968). 
schreiber im Gegensatz zu der dem Adressaten beigelegten Titulatur corona vestra sich selber zu bezeichnen pflegen '. Die Anrede corona vestra schliefist sich unzweifelhaft an den Sprachgebrauch der Heiligen Schrift an, in welcher das Wort corona häufig metaphorisch den Sinn von Zier, Ehre, Schmuck hat ${ }^{2}$. In der Tat, ist die Bischofswürde die Fülle und Krone des Priestertums, wird ferner der Bischof bei der Weihe durch die Handauflegung mit der Bischofswürde gleichsam gekrönt, ist die Bischofswürde für ihn eine Art danernder geistiger Krone und ist er durch die Bischofswürde die Spitze und Krone des Klerus, so erklärt es sich ohne Schwierigkeit, wie man dazu kam, in einer die Titulaturen liebenden Zeit die Bischöfe mit corona vestra anzureden ${ }^{3}$. Es ist darum nicht nötig, zur Erklärung des Terminus auf die kranzförmige Tonsur und noch weniger auf eine fabelhafte Krone hinzuweisen, welche die Bischöfe getragen haben sollen.

Im übertragenen Sinne von "bischöflicher Würde" wiird corona sacerdotalis auch von dem Zeitgenossen Amalars und Walafrieds, Jonas von Orléans ( $\dagger$ 843), gebraucht, wenn er Claudius von Turin mit dem betrunkenen Silen vergleicht ${ }^{4}$, dessen Krug in Scherben ging und dessen Kranz zu Boden fiel. Der Bischof von Orléans will mit seinem Vergleich nicht sagen, daf Claudius durch seine unkirchlichen Predigten und Schriften eine wirkliche Krone vom Haupte geworfen - eine solche gab es nach den früher gegebenen Belegen im 9. Jahrhundert in Gallien nicht - sondern nur, dafs ex sich seines bischöflichen Ranges und seiner hohen Stellung unwürdig betragen und gehandelt habe, als ob er seine bischöfliche Würde weit von sich geworfen hätte.

Von einer wirklichen bischörlichen Sakralkrone ist aber, so sagt man weiter, zweifellos wenigstens im 2. rönischen Ordo Mabillons ${ }^{5}$ und in den Eklogen die Rede ${ }^{6}$. "Wenn der Diakon“, so führen ja beide aus, „Sequentia sancti Evangelii secundum Lucam (Mareum etc.) gesungen, so macht er das Kreuzzeichen auf Stine und Brust. Dasselbe tut der Bischof und das ganze Volk; dann wendet man sich zum Evangelium hin. Es legen aber auch alle die Stöcke aus den Händen; desgleichen haben sie zur selben Zeit weder eine Krone noch eine andere Bedeckung auf ihrem Kopfe." In der Tat handelt es sich hier mn eine wirkliche Krone. Nur ist es ein Irrtum, wenn man glaubt, der 2. Ordo und Amalar sprächen von einem heiligen Kopfschmuck, den der Bischof beim Gottesdienst getragen habe. Es gilt dio Bemerkung bezunglich der corona und dem operimentum capitis vielmehr von den dem heiligen Opfer beiwohnenden Gläubigen. Dieselben sollen bein Evangelium aus Ehrfurcht gegen das Wort Gottes nicht bloß̧ die Stäbe, auf die man sich, um weniger zu ermüden, zu stützen pflegte ${ }^{7}$, aus den Händen legen, d. i. eine aufrechte Stellıng einnehmen, sondern anch ihr Haupt entblofen, selbst weun die Kopfbedeckung in einer Krone bestinde. Das und nichts anderes meinen der zweite Ordo und die Eklogen.

Dafs in England im 6., 7. und 8. Jahrhundert ein pontifikaler Kopfsehmuck gebräuchlich gewesen, dafür werden die Vita S. Samsonis, der Bericht Reginalds von Durham über den Befund bei Eröffnung des Grabes des hl. Cuthbert, die Vita S. Birini und Bedas des Ehrwürdigen Schrift De tabernaculo als Beweis herangezogen. Allein mit Unrecht.

1 Vgl. z. B. die vorhin angeführten Schreiben des Sidonius Apollinaris, den Brief der Bischöfe der Kirchenprovinz Tarragona an Papst Hilarius, des Bischofs Paschasius von Lilybäum an Leo I., des hl. Paulinus von Nola an Bischof Victricius von Ronen (ep. 18 [M. 61, 237]) und aus späterer Zeit das Schreiben des Bischofs Ebroin von Bourges (Beginn des 9. Jahrhunderts) an Bischof Magnus von Sens (M. 87, 763). Die Anrede corona vestra wird nach dem 6 . Jahrhundert immer seltener. Im Brief Ebroins steht statt ihrer in gleichem Sinne magnitudo vestra.
2 Spr 12, 4; 14, 24; 16, 31; 17,6. Eccli 1,$11 ; 1,22 ; 25,8$. Is 28,$5 ; 62,3$. 1 Thess 2, 19. 2 Tim 4, 8. Phil 4, 1. Jak 1, 12. 1 Petr 5, 4. Offb 3, 11. Hebr 2, 79.

3 Braulio schreibt in ep. 5 ad Isid. (M. $80,651)$ : peto a culmine vestri apostolatus.

4 De cuitu imag. 1. 2 in fine (M. 106, 364).

s Ordo 2, n. 8 (M. 78, 972).

6 M. $105,1822$.

7 Amalar., De offic. eecl. 1. 3, c. 18 (ebd. 1126). Hildeberti Cenom. De myst. missae (M. 171, 1178). Vgl, Realonc. I 106. 
In der Schrift De tabernaculo ${ }^{1}$ spricht Beda nur von der Hauptbedeckung der jüdischen Priester, nicht aber von einem bischöflichen Kopfschmuck. Es kann sogar nach der ganzen Art und Weise, wie der Heilige sich über die Mitra des aaronitischen Kultus auslïfist, keinem vernünftigen $Z$ weifel unterliegen, daßs ihm eine pontifikale Nitra oder ein sonstiger liturgischer Kopfschmuck im christlichen Kultus noch etwas durchaus Unbekanntes war.

Die Krone, welche die Apostel Petrus, Johannes und Jakobus auf dem Haupte trugen, als sie der legendenhaften Biographie des hl. Samson zufolge dem Heiligen in Traume erschienen ${ }^{2}$, kann nur als Zeichen der Heiligkeit und als Himmelskrone gedentet werden ${ }^{3}$. Es liegt durchaus kein Anhalt vor, in ihr eine liturgische Kopfzier zu sehen. Nicht einmal, daß die Apostel in Gestalt von Bischöfen erschienen, bietet für eine solche Auffassung eine genügende Unterlage. Obendrein darf man nicht vergessen, daß es sich an der fraglichen Stelle der Vita um keinen realen Vorgang, sondern um ein blofes Traumgesicht handelt.

Die Angabe Reginalds von Durham (ca 1170), es habe sich bei der 1104 vorgenommenen Erhebung des Leibes des hl. Cuthbert auf dem Haupte des Heiligen unter einem purpurnen Schweißtuch eine Mitra von unbekanntem, damals nicht mehr vorkommendem Stoff und über der Stirn eine mit kleinen Edelsteinen allenthalben wie besäte vergoldete Platte gefunden, ist durchaus unzuverlässig, um nicht zu sagen, eine fromme Fabel.

Die von einem Lindisfarner Mönch, einem Zeitgenossen St Cuthberts, herrührende Vita spricht wohl von einem Schweißtuch, mit dem man des heiligen Bischofs Haupt bei der elf Jahre nach seinem Tode erfolgten ersten Öffnung des Grabes verhüllt angetroffen habe, sagt jedoch von dem Stirnschmuck und der Mitra nicht das geringste 4 Ebensowenig weiß der gegen die Mitte des 12. Jahrhunderts entstandene Bericht über die 1104 vorgenommene Translation etwas von der goldenen Platte oder der Mitra, obgleich er einlässig die Wahrnehmungen erzählt, welche man bei Eröffnung des Sarges machte ${ }^{5}$. Die Pontifikalkleidung des hl. Cuthbert, von welcher Reginald ein anschauliches Bild entwirft, ist die bischöfliche Sakralkleidung des 12. Jahrhunderts. Das zeigt sich insbesondere bei der Beschreibung, die er von der Dalmatik und den Pontifikalschuhen gibt. Es sind die Sandalen und die Dalmatik seiner Zeit, nicht die des 7. Jahrhunderts, was Reginald zeichnet. Wie wenig zuverlässig die Schilderung des Durhamer Mönchs ist, geht unter anderem namentlich auch daraus hervor, daßs sie den Heiligen mit den Pontifikalsandalen bekleidet sein läfrt, während doch die zeitgenössische Vita desselben ausdrücklich mitteilt, man habe die Schuhe bei der ersten Erhebung des Leibes aus dem Sarge genommen ${ }^{6}$.

1 L. 3 , c. 8 (M. 91, 482): Verum sive byssinae, seu fuerint aureae coronulae, cum constet, eas factas esse cum mitris, dicamus breviter de figuris (die mystische Bedentung). Mitras cum coronulis habent sacerdotes ex bysso, qui sic visum. ... in venustate castimoniae custodiunt, ut pro eadem custodia se coronam vitae... accipere sperent. . . Nam qui sic continentiae vel bonis operibus studet, ut pro his aeterna praemia retributionis quaerere negligit, mitram quidem byssinam hahere videtur in capite, sed coronam non habet.

2 C. 5 (A. SS. 28. Inl., VI 583). Es gibt eine Reihe von Lebensheschreibungen des hl. Samson, in denen sich viel Legendenhaftes findet. Die Bollandisten halten diejenige, welche sie in ihren Acta zum Ausdruck bringen, für die beste von allen, bemerken aber zu- gleich (a. a. O. 572 D) : Fateor dolendum maxime, in tam foecunda et abundanti rerum praeclarissimarum messe aptam falcem non suppetiisse, quae omnia accurate demessa colligeret, disponeret et ordinaret. Bezüglich der Weihe sagen sie (ebd. 569 A): Quam miranda stupendaque in ea ordinatione acciderint... exactis hoc loco praeter modum prodigiosis facile intelleges.

3 Vgl. die oben S. 428 angeführte Stelle aus der Vita S. Eucharii; der hier geschilderte Vorgang ist ein vorzügliches Gegenstitck zur Erzählung der Vita S. Samsonis.

4 L. 4, n. 1314 (A. SS. 20. Mart., III 123).

${ }^{5}$ C. I, n. 8 (ebd. 139). Auch in sonstigen Pnukten wejcht der Bericht von den Angaben Reginalds ab, wobei die letzteren als Erweiterungen erscheinen.

A A. SS. a. a. 0. 123. 
Reginald war kein Augenzeuge der 1104 erfolgten Rekognition des heiligen Leibes; was er berichtet, bezeichnet er als aus zweiter Hand kommend. Er erzählt in bestem Glauben und voll heiliger Begeisterung für St Cuthbert, was er gehört hat. Seine Schilderung gibt indessen nicht den einfachen Leichenbefund wieder, sondern stellt eine legendenhafte Erweiterung und Ausschmïckung desselben dar, deren natürliche Erklärung die im Verlaufe der drei ersten Viertel des 12. Jahrhunderts mächtig gestiegene Verehrung des großen Heiligen bildet?

Übrigens auch einmal angenommen, der Bericht Reginalds entspreche im wesentlichen dem tatsächlichen Befunde, und es habe der hl. Cuthbert wirklich getragen, was der Erzähler als Mitra bezeichnet, so folgt selbst dann nicht, daß es wirklich schon in England im 7. Jahrhundert eine liturgische Kopfbedeckung gegeben habe. Denn es müfte zuvor nachgewiesen werlen, daf die angebliche Yitra ursprünglich war und nicht nachträglich in den Schrein hinein kam; das um so mehr, als die Beschreibung Reginalds, wenn zutreffend, keinen Zweifel läfst, dafs der Leib des Heiligen in späteren Tagen mit neuen Gewandstücken bekleidet wurde?

Wie wenig ängstlich man noch im Beginn des 11. Jahrhunderts in der Behandlung des heiligen Leibes war, ergibt sich aus dem, was Reginald von dem Hönch Elfredus berichtet, der 1022 in den Rollen von Durham als feretrarius genannt wird und als solcher die Sorge um den Schrein des hl. Cuthbert hatte. Elfrerl, so lesen wir in c. 26, habe den Verschluf des Grabes offnen und ungestraft, so oft er gewollt, circa eum, quae voluit, componere dürfen. Eines Tages habe er sogar Haare vom Haupt des Heiligen abgeschnitten.

Daf aber wirklich in späterer Zeit Gewandstucke in den Schrein des Heiligen gebracht worden sind, beweist der Umstand, daß man 1827 bei der jüngsten Eröffnung des aus Anlaf der Protestantisierung Durhams in den Fufboden versenkten Schreines den heiligen Leib mit einer Stola und einem Manipel geschmückt fand, welche laut eingestickter Inschrift aus dem Beginn des 9. Jahrhunderts stammten ${ }^{3}$.

Trug St Cuthbert wirklich 1104 eine Mitra, so wird diese in ähnlicher Weise in den Sarg gekommen sein wie jener Manipel und jene Stola, und zwar dürfte sie dann identisch mit dem pileus regius auro textus, dem aus kostbarem Goldgewebe angefertigten Königshut sein, welchen König Athelstan 934 außer zwei Kaseln, einer Albe, einem Manipel, einer Stola, einem Cingulum und zahlreichen sonstigen Kostbarkeiten dem hl. Cuthbert als Weihegabe stiftete ${ }^{ \pm}$Da dieser pileus damals wohl kaum zu einem andern Zwecke verwendet werden konnte, lag es nahe, ihn dem Haupt des Heiligen im Schreine aufzusetzen - und das mag auch die Absicht des Gebers gewesen sein.

1 De admir. B. Cuthb virt. c. 40 (p. 84). Er will die Erhebung des heiligen Leibes erzählen, wie er sie a maturioribus ecclesiae in Erfahrung gebracht. Hi (seine Gewährsmänner) illos ... viderant, audierant, qui Beati Cuthberti corpus manibus contrectabant. .. Qui suis auditoribus magnalia retulere et quaedam etiam eis secreta planius detexere, quae omnia tamen noluere scriptis inserere. Nos vero ea describere duximus dulce habentes, nosse perfectius ea, quae non vidimus, ac posteris nota facere ea, quae quibusdam incerta fore cognoscimus.

${ }^{2}$ Der Leib des Heiligen hat mancherlei Irrfahrten machen müssen. $\mathrm{Zu}$ Lindisfarne begraben und elf Jahre nach seinem Tode zum erstenmal erhoben, wohei Kasel und Schuhe aus dem Sarge herausgenommen wurden, blieb ex noch etwa ein Jahrhundert im Frieden auf der Insel. Als aber dann
Lindisfarne zerstört wurde und die Mönche flüchten mufsten, nahmen sie den Sarg an die verschiedenen Orte mit, wo sie eine Zufluchtsstätte suchten, bis er zuletzt bleibend in Durham ein Heim fand. Daf der Schrein auf den Wanderungen geöffnet worden sej, geht aus den Reliquien hervor, die man bei seiner Eroffuung 1104 in ilum fand (Historica narrat. c. 1, n. 6 [A. SS. a. a. O. 138]). Es ist aber auch ausdrücklich bezeugt, dafs man jene heiligen Gebeine zum Leibe des hl. Cuthbert gelegt hat und also den Sarg geöffnet haben muf (Hist transl. c. 4, n. 23 [A. SS. a. a. 0.132$])$.

${ }^{3}$ Raine, St Cuthbert, Durham 1828, 202 ff. Vgl. oben S. 110.

* Monasticon anglic. I (ed. 1635) 40: Ego Athelstanus rex do S. Cuthberto . . . 2 casulas et 1 albam et 1 stolam cum manipulo et 1 cingulum et 1 regium pillenm auro textum. 
Die Vita des hl. Birinus $(\dagger 650$ ) erzählt, bei der Erhebung des Leibes des Heiligen, welche gegen das Ende des 12. oder im Beginne des 13. Jahrhunderts zu Dorchester statthatte, habe man im Sarge den vollständigen Leichnam des Bischof's cum duplici stola et infula rubra e panno serico atque cum cruce e metallo confecta, pectori eius imposita gesehen ${ }^{1}$. Demnach mufs es also, so hat man geschlossen, in England bereits im 7. Jahrhundert eine bischöfliche Mitra (Inful) gegeben haben. Allerdings, wenn nur, um von anderem abzusehen, unter der infula der Vita wirklich eine Mitra zu verstehen und überhaupt der fragliche Leichnam in der Tat derjenige des hl. Birinus gewesen wäre Allein infula bedeutet hier dem englischen Sprachgebrauch des 13. Jahrhunderts entsprechend wohl die Kasel, falls nicht etwa die Tasche gemeint sein sollte, von der im Bericht über die zweite Eröffnung des Sarges im Jahre 1224 die Rede ist. Man habe, so heibt es darin, im Sarge außer den Gebeinen einen Ring, ein bleiernes Kreuz auf der Brust, einen kleinen Kelch, particulae vestimentorum eius and duae stolae, sed non integrae, angetroffen. Inventa est, sagt der Bericht dann weiter, etiam crumena quaedam serica super pectus eius itemque pera ex una parte auro contexta. Was aber den Leichnam anlangt, den man in Dorchester erhoben hatte, so kann derselbe unmöglich der des hl. Birinus gewesen sein, da dieser bereits gegen das Ende des 7. Jahrhunderts nach Winchester übertragen worden war $^{2}$.

Ein weiterer Beweis für den Gebrauch eines bischöflichen Kopfschmuckes im ersten Jahrtausend soll in verschiedenen Stellen gegeben sein, welche von einer infula pontificalis oder sacerdotalis sprechen. So heifst es im Hodoeporicum des hl. Willibald von dem Heiligen: summae sacerdotalisque infulae praelatus, und vom hl. Wunibald: sacerdotali praelatus infula ${ }^{3}$. In der Vita des hl. Burchard wird Papst Zacharias als summus pontifex, summi pontificatus infulae non incongruus genannt und erzählt, wie der hl. Bonifatius erklärt habe, er halte Burchard pontificali infula dignum *. Das Papstbuch verzeichnet in der Vita Valentini den Ausruf des Volkes: Valentinum sancti pontificatus infula decorandum ${ }^{5}$; im Weihezeugnis aber, welches Herard von Tours 866 über die Konsekration Elektrans von Rennes ausstellte, wird gesagt: Haec ergo aliaque ad institutionem et informationem fidelis viri.... Electranni die praefixo verbo pariter et stylo promulgantes, pontificali eum infula adornantes, sacra quoque benedictione more sanctae ecclesiae ditantes, anulo quoque et baculo decorantes, sanctae Redonensis (Rennes) ecclesiae pontificali eum ordine praefecimus ${ }^{6}$.

1 Surius, Vitae prob. 3. Dec. XII 122.

${ }^{2}$ Nach Bedas Kirchengeschichte 1. 3, c. 7 (M. 95, 126) wurde der hl. Birinus allerdings zu Dorchestex begraben, doch übertrug dessen Nachfolger Hedda (Headda) später den Leib nach Winchester, wo er ihn in der Kirche der Apostel Petrus und Paulus beisetzte. Die Ĺbertragung erfolgte ca $678-683$ (Gams, Series episcop. 198), als Hedda seinen Sitz von Dorchester nach Wintonia (Winchester) verlegte, d. i. also ca 25 Jahre nach Birinus' Tode mod ca 50 Jahre vor dem Hinscheiden Bedas. Auch Wilhelm von Nlalmeshury erwähut die Translation des Leichnams des Bischot's Birinus durch Hedda und fügt hinzu: patronus civitatis post Deum habetur (Grest. Pont. angl. 1. 1; de episc. occid. [M. 179, 1523]). Um den Beginn des 13. Jahrhunderts entspann sich zwischen den Kanonikerr von Darchester und den Mönchen von Winchester über den Leib des Heiligen ein erregter Streit, der seine Wellen bis nach
Rom schlug. Die ersteren behaupteten, nicht die Reliquien des hl. Birinus, sondern eines Bischofs namens Bertinus, des Heiligen zehnten Nachfolgers, seien nach Winchester gebracht worden. Allein Hedda wufste obne Zweifel, wo der Leichnam seines vor 25 Jahren verstorbenen Vorgängers ruhte, als er denselben mit sich nach seinem neten Bischofssitz nahm. Aufierdem ist unter den Nachfolgern des hl. Birinus ein zehnter mit Namen Bertinus nicht bekannt. Auch hätte Hedda, der vierte Bischof nach Birinus (Gams a. a. O.), schwerlich den Leib des zehnten Amtsnachfolgers desselben nach Winchester übertragen können.

${ }^{3}$ N. 3 (A. SS. 7. Tulii, II 501).

4 N. 34 (ebd. 14. Oct, VI 574). Die Vita ist vor 984 geschrieben, während das Hodoeporicum ca 800 verfafit wurde.

Dueh., L. P. II 72.

- Baluzius, Capit. reg. Franc. II, Paris. 1677,621 . 
Allein ist denn wirklich in diesen Stellen unter infula ein pontifikaler Kopfschmuck zu verstehen? Wird das Wort nicht, wie früher des weiteren ausgeführt wurde, bei den christlichen Schriftstellern in mannigfacher Bedeutung gebraucht? Bezeichnet es bei ihnen nicht bald metaphorisch das pontifikale Amt, die Würde des Bischofs oder des Priesters, bald die pontifikale oder priesterliche Gewandung im allgemeinen, ja selhst das klerikale Kleid, bald endlich einzelne bestimmte Gewandstücke, wie das Pallium und, namentlich in späterer Zeit, die Kasel? ' Welchen Anhalt hat man, in den oben angeführten Stellen infula im andern Sinn zu nehmen? In der Tat ist infula in den vier ersten Stellen nur metaphorisch für „Papst- oder Bischofswürde" gebraucht, während das Wort im Weihezeugnis Herards allgemein "Pontifikalgewandung" besagt. Die Zeremonie, dem Bischof bei der Weihe die Mitra aufzusetzen, fand erst im 12. Jahrhundert in den Weiheritus Aufnahme; den alten Weiheordines war sie durchaus fremd. Der richtige Sinn von infula im Weihezeugnis Herards ergibt sich aus einem Vergleich dieses Schriftstückes mit der Beschreibung, welche Hinkmar von Reims $(\dagger 882)$, der Zeitgenosse des Bischofs von Tours, von der Bischofsweihe gibt. Was dieser pontificali infula adornare nennt, heift bei Hinkmar pontificalibus vestibus induere ${ }^{2}$.

Im Sinne eines liturgischen bischöflichen Kopfschmuckes läßst sich überhaupt infula, wie früher gesagt wurde, vor 1100 nicht belegen, weder mit Zengnissen aus älterer noch solchen aus karolingischer Zeit ${ }^{3}$. Wenn Tertullian in der Schrift De monogamia schreibt: "Wenn wir uns gegen den Klerus erheben und aufblähen, so sind wir alle dasselbe, sind wir alle Priester; wenn es sich aber darum handelt, uns derselben Disziplin (nämlich nur einmaliger Heirat) wie jener zu unterwerfen, dann legen wir die infula ab, und alle Gleichheit hat aufgehört (infulas deponimus et impares sumus") ${ }^{4}$, so ist die Wendung infulas deponere offenbar bloke Metapher. Höchstens könnten die infulae hier von einem liturgischen Abzeichen von der Art der späteren Stola verstanden werden. Auf keinen Fall bezeichnen sie eine sakrale Kopfbinde, wie sie von bestimmten heidnischen Priesterklassen getragen wurde. Mag auch die Kirche den einen oder andern Brauch aus dem Heidentum herübergenommen und christlich umgebildet haben, so ist es doch völlig unwahrscheinlich, daf die christlichen Priester als Charakteristikum ihres Standes und ihrer Würde eine Insignie heidnischer Priester adoptierten; dafür war denn doch der innerste Gegensatz zwischen dem christlichen und heidnischen Priestertum, dem lautern christlichen und dem orgienvollen heidnischen Kultus allzu grof. Wie wenig in der Tat bei den infulae Tertullians an Kopfbinden zu denken jst, beweist des Afrikaners Schrift De corona, in welcher dieser jeden kranzartigen Kopfsehmuck, bestehe er aus Laub, Gold oder Binden, als heidnischen Grevel brandmarkt und bei Christen ganz allgemein mit aller Entschiedenheit verwirft ${ }^{5}$.

Auch in den beim ersten Anblick so frappierenden Worten des hl. Paulin von Nola im vierten Natalitium auf den hl. Felix:

\begin{abstract}
Quod quia perspicna meriti virtute gerebat Iure sacerdotis veneranda insignia nanctus Mente loco digna meritum decorat honore. Sed ne sola sacrum caput infula comeret illi, Exstitit et potior geminandae causa coronae ${ }^{6}$.
\end{abstract}

1 S. oben S. $426 \mathrm{ff}$.

2 Ep. 29 ad Advent. ep. Metens. (M. 126, 187).

3 Wenn Bock (II 155) angibt, in Älfriks, Erzbischofs von Canterbury ( $†$ 1005), Glossar werde infula als bischöfliches Kopftuch, infula $=$ biscop heafod lin, erklärt, so ist das unzutreffend. Älfriks angelsächsisches Glossar (ed. Zupitza, Berlin 1880) kennt das Wort infula nicht.
4 C. 12 (M. 2, 997).

${ }_{5}^{5}$ C. $91012 \quad 13 \quad 1415$ (ebd. $108 \quad 110 \quad 114$ 115118 121). Vgl, namentlich c. 9: Quis ... episcopus videtur coronatus. Unter corona versteht aber Tertullian nicht blok die aus Blumen oder Laub gemachten Kränze, sondern Kopfbinden aller Art (c. 715 [ebd. 104 121]).

${ }_{6}^{6}$ Poema 15, v. $111 \mathrm{ff}$ (M. 61, 471). 
sind insignia wie infulae lediglich metaphorisch von der Würde und der Auszeichnung, welche das Priestertum verleiht, zu verstehen. Deutlicher tritt der bildliche Charakter der Ausdrucksweise im 13. Natalitium auf den hl. Felix zu Tage, wenn es darin heift:

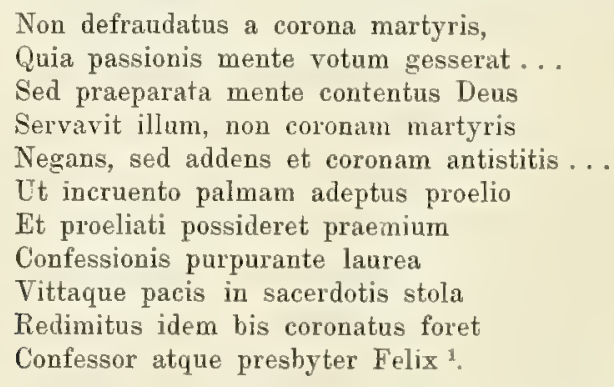

Felix erscheint hier mit doppelter Krone ausgezeichnet, mit der Friedensbinde in Gestalt der Priestergewandung und dem purpurstrahlenden Lorbeerkranz des Martyriums.

Um die Sprech- und Darstellungsweise Paulins richtig würdigen und verstehen zu können, mufs man die Zeit, in welcher er schrieb, und die literarischen Gepflogenheiten derselben vor Augen halten.

In beiden Natalitien handelt es sich nicht um eine blof dichterisch gehobene Darstellung, sondern geradezu um Wendungen, welche dem klassisch-heidnischen Sprachschatz entnommen sind. Paulin hat christliche Gedanken in klassische Formen gegossen, christliche Ideen in die landläufige, auf heidnischer Grundlage aufgebaute Bildersprache der absterbenden Latinität seiner Zeit eingekleidet. Das Gegenstück zu den angeführten Stellen aus den Hymnen auf den hI. Felix bildet der Schluk eines Briefes, den Paulin an den Bischof Victricius von Rouen schrieb ${ }^{2}$. Jeder vielleicht noch bestehende Zweifel an dem metaphorischen Charakter der Ausdrucksweise in den Hymnen mufs sofort verschwinden, wenn man den Schlufpassus dieses Schreibens durchliest. Wie die Worte der Hymnen in schlichte Prosa wiedergegeben lauten, zeigt die von Marcellus von Nola angefertigte und dem Bischof Leo von Nola gewidmete Prosaübertragung derselben: Et ut sacratissimum caput eius duplex gratiae coronae praecingeret ${ }^{3}$.

Wie kann man übrigens auch unter der infula im Hymnus auf den hl. Felix eine die priesterliche Würde des Heiligen kundtnende sakrale Kopfbinde - Felix war nur Presbyter - verstehen, da doch auf den Monumenten des ganzen ersten Jahrtausends keine Spur von einer solchen wahrzunehmen ist, trotzdem uns auf ihnen genug Priester, Bischöfe und Päpste in ihrer gottesdienstlichen Tracht begegnen? Wie kommt das, wenn ein infula wirklich Verwendung fand? Oder war vielleicht zur Zeit, da die fraglichen Bildwerke entstanden, die fragliche Kopfbinde schon wieder außer Gebranch gekommen? Allein auf welche Gründe stützt sich eine solche Annahme? Ist es überhaupt denkbar, daf ein so hochbedeutsames Ornatstück wie die infula, das angebliche Symbol und Abzeichen der bischöflichen und priesterlichen Würde, in so kurzer Frist - denn die hier in Betracht kommenden Wonumente reichen bis ins 6., ja 5. Jahrhundert zurück - und in so gründlicher Weise aus dem Kult aus= zuscheiden vermochte? Was konnte Ursache und Veranlassung sein, ein so bezeichnendes Ornatstück wieder abzuschaffen? Heift eine solche Annahme zudem nicht vollständig die Entwicklung verkennen, welche die liturgische Gewandung bis zur Wende des

1 Poema 21, v. $152 \mathrm{ff}$ (ebd. 578).

2 Ep. 18, n. 10 (M. 61, 242): Memineris quaeso te nostri in illa die, qua ad te innumera meritorum tuorum cohorte comitatum ornamentisque felicibus comtum et infulis pariter et adoreis coronatum et niveas sacratorum antistitum vittas et floridas confessorum purpuras occurrentium manus afferrent angelorum.
${ }^{3}$ C. 1, n. 4 (A. SS. Ian. 14; II 229). Welchem Bischof Leo Marcellus die Schrift widmete, ist unklar, da es mehrere Nolaner Bischöfe dieses Namens gegeben hat. Gregor von Tours übersetzt in seiner Vita des hl. Felix n. 1 (ebd. 2ะ3) die Worte Paulins mit: presbyteri honore praeditus. 
Jahrtausends nahm? Wo und wann findet sich in dieser Periode eine Spur von der völligen Darangabe irgend eines Bestandteiles der sakralen Tracht? Geht nicht vielmehr in ihr alle Tendenz nachhaltig auf weitere Ausbildung und Vermehrung der liturgischen Gewandung hinaus?

Als letzten Beweis hat man verschiedene Bullen aus dem ersten Jahrtausend angeführt, in welchen gewissen Prälaten das Recht verliehen wird, sich der Mitra zu bedienen. In einer gewährt Johannes XV. (993) dem Abt von Braunau ${ }^{1}$, in einer zweiten Johannes XIII. (966) dem Abt von S. Bartolomeo (Diözese Ferrara) ${ }^{2}$, in einer dritten Sergius II. (846) dem Erzbischof Ansgar von Hamburg. ${ }^{3}$, in zwei andern Gregor II. (729) dem Abt Basinus von St Maximin zu Trier ${ }^{*}$ und Theodor I. (643) dem Abt von Bobbio dieses Privileg ${ }^{5}$. Wir können über alle diese Dokumente kurzerhand hinweggehen. Die Bulle Johannes' XV. ist interpoliert, alle andern sind zweifellos Fälschungen ${ }^{6}$.

Wir haben uns mit Absicht auf die Frage nach dem Alter der bischöflichen Kopfbedeckung aufs eingehendste eingelassen. Wir glaubten zur Klarstellung der Sache keiner Schwierigkeit aus dem Wege gehen, keinen irgendwie belangreicheren Einwand unbeachtet und unbeleuchtet lassen zu sollen. Es kann ja unmöglich die einfache Versicherung befriedigen, dafs es in älterer Zeit noch keinerlei liturgischenKopfschmuck gegeben habe. Es muk, wenn eine solche Behauptung wissenschaftlichen Wert haben soll, anch der Nachweis für sie geliefert werden. Einegründliche Untersuchung sehien aber um so

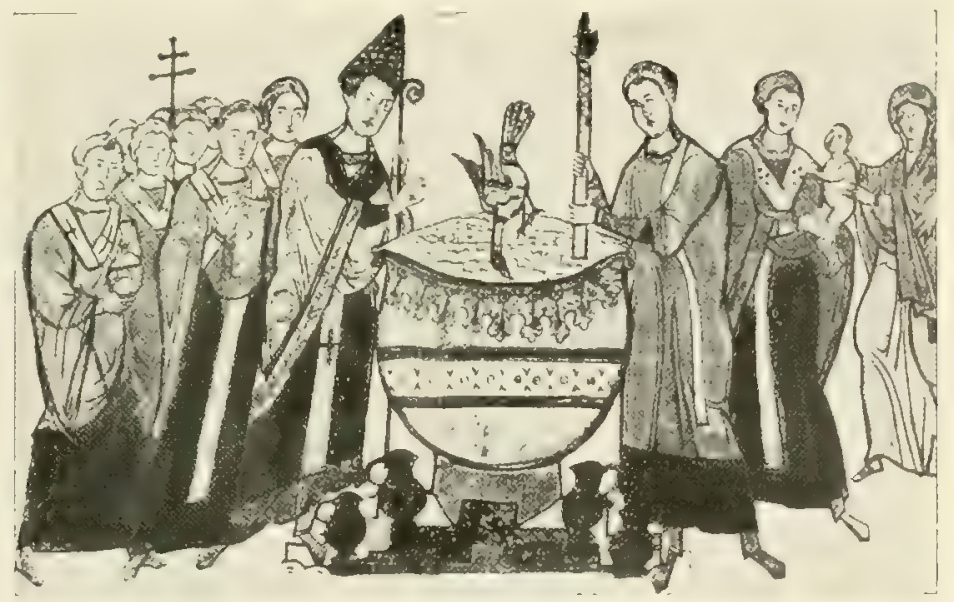

Bild 214. Segnung des Taufwassers. Miniatur eines Taufrotels. Bari, Dom. mehr angebracht, als die Fabel von einer altchristlichen liturgischen Kopf'binde hie und da noch immer ihre Vertreter findet?

Die erste zuverlässige Nachricht über die Mitra bringt das Pontitikat Leos IX. (1049-1054). Eberhard von Trier hatte letzteren nach Rom begleitet. Dort bestätigte der Papst am Passionssonntag 1049 in der Peterskirche den Primat der Trierischen Kirche, deren Suffragan Leo als Bischof von Toul gewesen war. Zugleich setzte er Eberhard pro investitura ipsius primatus die mitra romana mit der Bemerkung auf das Haupt, er und seine Nachfolger sollten sich ihrer bei den kirchlichen Verrichtungen (in ecclesiastico

I J. n. 3849 .

2 Ebd. n. 3711.

3 Ebd. n. 2588.

4 Ebd. n. 2179

5 Ebd. n. 2053.

'Über die Bulle Johannes' XV. s. oben S. 368. Bezüglich der übrigen Urkunden vgl. Pflugk - H arttung, Acta II, n. 83 ; J. n. 20532179 und Bullar. rom. I 186.

$7 \mathrm{Vgl}$. Röm. Quartalschrift XIV $46 \mathrm{ff}$ (H. Swoboda, Zwei Infula aus altchrist- licher Zeit). Wir ziehen es vor, statt den Weg luftiger Hypothesen zu ziehen, uns an die Strafse der nüchternen Tatsachen zu halten; denn nur auf ihr ist für die archäologische Wissenschaft wirklich Förderung zu erhoffen. Vgl. ferner ebd. XIII 77 ff (W üscherBecchi, Ursprung der päpstl. Tiara und der bischöfl, Mitra, und noch J.Kösters, Studien zu Mabillons Ordines, Münster 1905, 35). 
ofticio) nach römischer Sitte bedienen und sich dabei allzeit erinnern, dak sie Schüler des Apostolischen Stuhles seien. Eine auf der Ostersynode desselben Jahres ausgestellte Bulle bekräftigte das Geschehene ${ }^{1}$.

Die Bulle ist nach einer dreifachen Richtung von großer Bedeutung. Sie berreist zunächst, dafs es zu Leos IX. Zeit bereits eine liturgische Mitra gab, dam, daf die Verleihung derselben noch eine durchaus auberordentliche Auszeichmung bildete, und drittens, daß das Ornatstück um die Mitte des 11. Jahrhunderts schon eine Weile zu Rom in Gebrauch gewesen sein mub;, da sonst Leo IX. schwerlich Erzbischof Eberhard mit der Mitra begnadet hätte. Die äIteste bildliche Darstellung der Mitra findet sich auf einem im Beginn des 13. Jahrhunderts entstandenen Exultetrotel und einem gleichzeitigen Taufrotel der Kathedrale von Bari² (Bild 214, S. 447). Auf den Monumenten kommt sonach das Ornatstück einige Jahrzehnte eher vor als in den schriftlichen Quellen. Die Miniatur, welche übrigens für längere Zeit durchaus vereinzelt bleibt, bekundet, dafs in Süditalien die Mitra bei einzelnen Bischöfen schon in der Frühe des 11. Jahrhunderts Verwendung fand. Daßs sie hier indessen damals noch nicht allgemein getragen wurde, darauf läfst der Umstand schliefen, dab sie nur auf dem Rotel von Bari auftritt, nicht aber auf andern Roteln des 11. Jahrhunderts.

\section{WEITERE VERLEIHUNGEN UNTER LEO IX. DIE MITRA WIRD BISCHÖFLICHER ORNAT.}

Der Verleihung der pontifikalen Kopfbedeckung an Eberhard von Trier folgen noch unter Leo IX. einige weitere. Im Jahre 1051 gestattet der Papst in einem Schreiben an den Erzbischof Hugo von Besançon den sieben Kardinälen der dortigen Kathedrale, die Mitra zu tragen, wenn sie an den Festen des Herrn, der Mutter Gottes, des Erzengels Michael, der Apostel, des Erzmärtyrers Stephanus und einiger sonstigen Heiligen sowie am Allerheiligenund Kirchweihtag an dem von ihm selbst am \$. Oktober 1050 geweihten Hochaltar als Celebrans, Diakon und Subdiakon amtierten ${ }^{3}$. Im folgenden Jahre gewährt er den Gebrauch der pontifikalen Kopfbedeckung, die hier cuphia genannt wird, dem Erzbischof Liuthbald von Mainz . Um dieselbe Zeit verlieh er dem Bischof Hartwig von Bamberg für dessen Domkirche, in welcher der Leichnam seines Vorgängers Klemens III. (1046-1047) seine letzte Ruhestätte gefunden, ein ähnliches Privileg, wie es Hugo von Besançon von ihm für seine Kathedrale erhalten hatte ${ }^{5}$. Im Jahre 1053 endlich gestand Leo dem Erzbischof Adalbert von Hamburg das Recht zu, sein Haupt mit der mitra, quod est insigne Romanorum, zu schmücken ${ }^{6}$.

Auch in der Folge ist noch häufig von einer Erteilung des Privilegs, sich der Mitra bedienen zu dürfen, die Rede. Der Fälle, in welchen es Bischöfen

\footnotetext{
1. J. n. 4158. Alexander II. verlieh (ebd. n. 4667) 1069 dem Abt Reinbert von Echternach auf die Fübitte des Trierer Erzbischofs Udo auker andern Pontifikalien auch die Mitra. Hätte letzterer selbst noch nicht den usus mitrae besessen, so würde er sich für Reinbert wohl nicht wegen desselben beim Papst verwendet haben. Es muk also wirklich damals schon der Erzbischof von Trier das Recht erhalten haben, sich der Mitra zu bedienen.
}

2 Abbildung der Miniatur des Exultetrotels bei Berteaux, L'art dans l'Italie méridionale I, Paris 1904. Ebendort auch Wiedergabe der Miniatur der Taufrotels, beide als Einschalttafeln.

3 J. n. 4249.

5 Ebd. n. 4283.

${ }^{6}$ Ebd. n. 4290. Die Bulle, welche früher als echt galt, wird übrigens newerdings angezweifelt. Vgl. ebd. und $\mathrm{D}$ ie $\mathrm{k}$ a $\mathrm{mp}$ in Historisches Jahrbuch IV 364, Anm. 1. 
gegeben wurde, sind allerdings nur einige wenige bekannt. So gewährte Viktor II. 1055 dem Erzbischof Adalbert von Hamburg ${ }^{1}$, Alexander II. 1063 dem Bischof Burchard von Halberstadt ${ }^{2}$ und 1064 dem Bischof Helisäus von Mantua ${ }^{3}$, Kalixtus II. 1119 den Bischöfen Godebald von Utrecht ${ }^{*}$ und Dietrich von Naumburg ${ }^{\circ}$ den usus mitrae. Indessen kann wohl nicht bezweifelt werden, daf3 auch noch andere Fälle von Verleihungen des Ornatstückes an Bischöfe vorgekommen sind. Denn wenn Erzbischof Anno von Köln bei Alexander II. als Fürsprecher für Bischof Helisäus von Mantua in Sachen der Mitra auftritt, muß er doch selbst bereits im Besitz des Privilegs gewesen sein. Und wenn Alexander II. 1063 dem Abt Egelsinus vom Kloster des hl. Augustinus zu Canterbury den Gebrauch der pontifikalen Kopfbedeckung gestattet ${ }^{6}$, so hatte der dortige Erzbischof sicher schon früher dazu die Berechtigung erhalten. Übrigens kann die grolise Verbreitung, welche die Mitra bereits in der ersten Hälfte des 12. Jahrhunderts bei den Bischöfen gefunden hatte, nicht lediglich in Gnadenerweisen des Apostolischen Stuhles ihren Grund haben. Als eine Anzahl von Privilegien, die Mitra zu tragen, an Bischöfe erfolgt waren, scheint das Ornatstück bald schlechthin den Charakter eines bischöflichen Schmuckes erhalten zu haben und von den Bischöfen weiterhin ohne besondere Ermächtigung seitens des Papstes, wenngleich nicht ohne dessen stillschweigende Billigung, angenommen worden zu sein.

Daf3 Rom jemals gegen ein solches Vorgehen der Bischöfe eingeschritten sei oder selbiges auch nur getadelt habe, davon hören wir nie etwas. Die Päpste hatten ja auch um so weniger Ursache dazu, weil sie nicht bloß durch ihre Verleihungen selbst die Veranlassung gegeben hatten, dafs die Mitra bischöfliche Auszeichnung geworden war, sondern auch fortfuhren, selbst zahlreichen Nichtbischöfen, wenngleich mit bestimmten Beschränkungen, den usus mitrae zu gewähren. Den Päpsten konnte sogar die Annäherung der Bischöfe an den römischen Brauch nur willkommen sein, da die schweren Kämpfe, welche sie in jenen Tagen für die Freiheit der Kirche, die Hebung der Kirchenzucht sowie die Besserung des sittlichen und religiösen Verhaltens der Kirchendiener wie der Gläubigen führten, eine möglichst innige Verhindung der Oberhirten der einzelnen Dïzzesen mit Rom sehr wünschenswert, ja notwendig machte. Von einer Erteilung des Vorrechts, die Mitra zu tragen, an die Bischöfe im allgemeinen ist nichts bekannt.

Bis zur Mitte des 12. Jahrhunderts hatte die Mitra als sakrale Kopfbedeckung bei den Bischöfen bereits allgemeine Aufnahme gefunden.

In Italien rechnet Bruno von Segni $(\dagger 1123)^{7}$, in Irland Gilbert von Limerick († 1139) sie zu den bischöflichen Kultgewändern; in Frankreich tun das gleiche die Verfasser des Tractatus de sacramento altaris und des Speculum de mysteriis ecclesiae sowie Ivo von Chartres, in Deutschland Honorius († ca 1150). Ebenso zählt der hl. Bernhard die Mitra schlechthin zur bischöflichen Tracht, wenn er in seinem Schreiben an den Erzbischof Heinrich von Sens ca 1126 diejenigen Äbte ernst tadelt, welche sich unter vieler Mühe und hohem Preis das Privilegium verschafften, die insignia pontificalia zu

I J, n, 4339. Auch die Echtheit dieser Bulle wurde jüngst in Zweifel gezogen, wohl mit Unrecht.

2 Ebd. n. 4498.

3 Ebd. n. 4553.

4 Ebd. n. 6762. Godebald war Bischof, nicht blof Priester, wie es Realenc. II 214 heifst.

Braun, Die liturgische Gewandung.
5 Ebd. n. 6766. Lepsius, Geschichte der Bischöfe des Hochstiftes Naumburg I 241.

${ }^{6}$ J. n. 4541.

7 Dafs zu Mailand die Mitra im Beginn des 12. Jahrhunderts zur Pontifikalkleidung gehörte, erfahren wir von Beroldus (Muratori, Antiq. ital. IV, Mediol. 1741, 864 ; vgl. M a g istretti 69 , nota 6 ). 
tragen, und more pontificum Mitra, Ring und Sandalen gebrauchten ${ }^{1}$. Daf aber auch zu Rom schon die Mitra als allgemein bischöfliches Ornatstück galt, beweist beispielsweise die Bulle, in welcher Innozenz II. (ca 1139) dem Propst ron Masio verbietet, sich in Zukunft der Mitra, des Ringes und anderer bischölicher Abzeichen, welche sich derselbe angemabt hatte, zu bedienen?

Wenn Rupert von Deutz in seinem um 1100 zu Lüttich verfasten Werke De divinis officiis der bischöflichen Kopfbedeckung noch keine Erwähnung tut, so mag das daran liegen, daf diese damals bei dem Bischof von Lüttich noch nicht in Gebrauch war. Erhielt doch erst 1119 der Bischof von Utrecht das Recht, die Mitra zu tragen. Zu Köln finden wir die Mitra auf einer Miniatur mit dem Bilde des Kölner Erzbischofs Friedrich (1100-1131) in der für diesen im Anfang des 12. Jahrhunderts angefertigten Abschrift der Briefe des hl. Hieronymus (Bild 215) ${ }^{3}$.

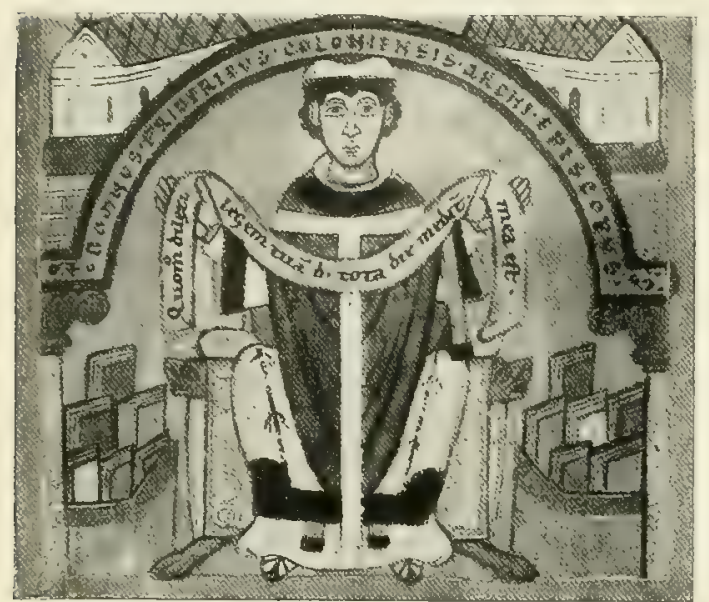

Bild 215. Erzbischof Friedrich von Köln.

Miniatur einer Sammlung der Hieronymusbriefe. Köln, Dombibliothek.

Die Bildwerke aus dem 11. Jahrhundert, auf welchen die Mitra auftritt, sind sehr gering an Zahl. Es sind aufier den schon erwähnten Miniaturen des Exsultet- und des Taufrotels von Bari die Fresken in der Unterkirche von S. Clemente zu Rom ${ }^{4}$, eine Miniatur einer süditalischen Kanonessammlung der Vaticana ${ }^{5}$ (Bild 216), sowie die Darstellung des hl. Gregor in dem Pontifikale Cotton. Claudius A. III der Bibliothek des Britischen Museums ${ }^{6}$.

Echte Siegel aus der zweiten Hälfte des 11. Jahrhunderts, auf denen uns bereits die Mitra begegnet, sind uns bislang nicht zu Gesicht gekommen ${ }^{7}$. Bis 1100 sind die Bischöfe auf ihren Siegeln regelmäßig entblößten Hauptes dargestellt, begreiflich, weil die Mitra erst im Begriff stand, sich als Bestandteil der Pontifikalkleidung einzubürgern.

1 C. 9, n. 36 (M. 182, 832). 2 J. n. 8068.

3 Bibliothek des Domkapitels LIX.

4 Die Fresken sind entstanden vor 1084, da in diesem Jahr die jetzige Unterkirche, damals Oberkirche, bei der Verwüstung Roms durch die Normannen zerstört wurde.

5 Cod. lat. 1339.

6 Ob im Gundekarpontifikale die Kopfbedeckung Gebhards I. von Eichstätt, des späteren Papstes Viktor II. († 1057), das regnum (Tiara) oder die Mitra darstellen soll, ist unsicher.

${ }^{7}$ Rohault de Fleury gibt ein Siegel Herimanns von Metz (1073-1090) wieder, auf welchem schon eine Mitra auftritt. Die Abbildung ist nach einem alten Abdruck angefertigt, welchen die Mönche von St Felix, verstehen wir Robault de Fleury recht, nach dem Original fuir eine Abschrift der Originalurkunde hergestellt haben sollen (VIII, pl. Dourv und p. 117). Das Siegel ist unecht. Schon die Form, welche die Mitra auf dem angeblichen Siegel Herimanns besitzt, beweist das, Es ist die Form, welche erst gegen die Mitte des 12. Jahrhunderts in Gebrauch kommt. Auch die Angabe Rohaults (p. 118), das Siegel Lamberts von Arras vom Jahr 1097 und dessen Nachfolgers Robert weise bereits die Mitra auf, ist irrig. Vgl. Demay, Inventaire de sceaux de la Flandre, Paris 1873, II 108. Auf den älteren Siegeln täuscht leicht die ungeschickte Darstellung der Tonsur und der Haakrone. 
Seit Beginn des 12. Jahrhunderts, zumal aber seit der Mitte desselben, ist die Mitra auf den Bildwerken nicht mehr selten. Insbesondere erscheinen nunmehr auch die Bischöfe auf ihren Siegeln immer häufiger mit der Mitra; um die Mitte des Jahrhunderts sind sie auf diesen schon sehr gewöhnlich mit dem pontifikalen Kopfschmuck ausgestattet dargestellt.

Auf den französischen Bischofssiegeln kommt die Mitra schon in der ersten Hälfte des 12. Jahrhunderts des öfteren vor". Auch die englischen Siegel jener Zeit kennen sie bereits ${ }^{2}$. In Deutschland tritt sie auf den Bischofssiegeln im allgemeinen etwas später auf, als es in Frankreich und England der Fall ist. Von den Mainzer Erzbischöfen hat auf seinem Siegel zuerst Arnold (1153-1160) das Ornatstück ${ }^{3}$. Auf Münsterischen Bischofssiegeln finden wir die Mitra bereits bei Ludwig (1169 bis 1173) ${ }^{4}$, auf den Paderborner dagegen erst bei Bernhard II. (1186-1203); auf den Osnabrücker scheint zuerst Gerhard (1192-1216) sie zu tragen. In Hildesheim weist schon das Siegel des Abtes Friedrich von St Godehard, welcher 1136 sein Amt antrat, den bischöflichen Kopfschmuck bei St Godehard, der Friedrich den Stab überreicht, auf. Auf den Kölner Siegeln begegnet uns die Mitra zuerst bei Erzbischof Arnold II. (1151-1156), auf Hildesheimer Bischofssiegeln schon wenigstens bei Bruno (1153 bis 1162). Auf den Salzburger Bischofssiegeln ist Eberhard (1147-1164) der erste,

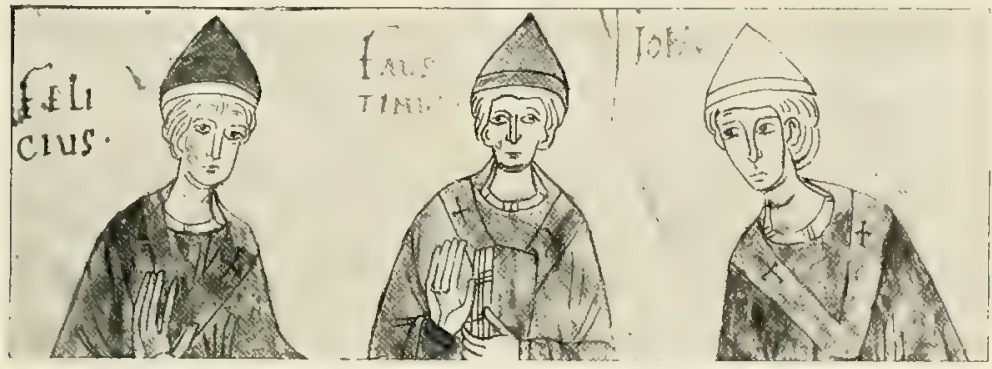

Bild 216. Die Bischöfe Felicins, Faustinus und Johannes.

Miniatur einer Kanonessammlung. Rom, Vatikan.

bei welchem sie vorkommt, auf den Würzburger Siegfried von Quernfurt (1146-1151), auf den Bamberger Egilbert (1139-1146). Auf den Regensburger Siegeln scheint sie erst bei Hartwich (1155-1164) oder doch frühestens bei dessen Vorgänger aufzutreten ${ }^{5}$.

In der zweiten Hälfte des 12. Jahrhunderts war die Mitra bei den Bischöfen allgemein in Gebrauch und ein fester Bestandteil der Pontifikal-

1 Vgl. die Siegel bei Roh. auf den Tafeln des VII. und VIII. Bandes, besonders VIII, pl DoLIv ff und die freilich nicht ganz korrekte Tabelle p. 123; ferner Louis Blancard, Iconographie des sceaux et bulles conservées dans la partie antérieure à 1790 des Archives Départementales des Bouches-du-Rhône, Marseille $1860,122 \mathrm{ff}$ und pl. $38 \mathrm{ff}$ und Demay a. a. O. II $108 \mathrm{ff}$.

2 Roh. VII, pl. Dxcrin Dxcix.

3 W ürdtwein, Nova subsid. dipl. II, tab. 13.

4 Ob auch schon das Siegel Werners (1132 bis 1151) und Friedrichs I. (1152-1168) die Mitra aufweist, ist nicht klar. Die Angaben bezinglich der Minnsterischen, Paderbornischen usw. Siegel beruhen teils auf Abbildungen in "Die Westfäl. Siegel des Mittelalters" Hft 1, Abt. 1, Miinster 1882, Tfl $2 \mathrm{ff} 17$; Hft 2, Abt. 1, Münster 1885, 'Tfl $42 \mathrm{ff}$, teils auf Aburücken in der dem Scriptorenhaus der deutschen Ordensprovinz S. J. gehörigen Siegelsammlung.

${ }^{5}$ Für die Salzburger, Bamberger und Regensburger Siegel sind vornehmlich die Siegelsammlungen des historischen Vereins für Niederbayern zu Regensburg und des $\mathrm{kgl}$. bayrischen Reichsarchivs zu vergleichen, für die Würzburger die vorzügliche Sammlung des historischen Vereins für Unterfranken zu Würzburg and $H$ effner, Würzburgisch-Fränkische Siegel in Archiv des bistorischen Vereins von Unterfranken" XXI, Hft 3, S. $73 \mathrm{ff}$. 
kleidung. Sie erscheint darum auch in dieser Zeit bei den Liturgikern schlechthin als bischöfliches Ornatstück. Im 13. Jahrhundert wird sie sogar in dem Mafe als ein den Bischöfen von Rechts wegen zustehender Kopfschmuck angesehen, daß Siegfried, Erzbischof von Mainz (1230-1249), kein Bedenken trägt. ans eigener Macht verschiedenen Äbten den usus mitrae zu gestatten. Er erteilte dies Privileg 1238 dem Abt von Oldisleben, 1240 dem Abt von St Johames zu Bischofsberg (jetzt Johannisberg) und 1241 dem Abt von Narienmünster ${ }^{1}$. Schon Erzbischof Konrad hatte 1194 dem Abt Dietmar von St Peter zu Erfurt den Gebranch der Mitra für den Gottesdienst an den Hauptfesttagen und für den Empfang des Kaisers und sonstiger hohen Persönlichkeiten gewährt, jedoch, wie es in dem betreffenden Dokument ausdrücklich heift, ex auctoritate Domni apostolici, cuius legatione fungimur?

\section{DIE MITRA BEI KANONIKERN, BEI ÄBTEN UND BEI DEN KARDINÄLEN.}

Es wurde schon erwähnt, daß Leo IX. bestimmten Kanonikern der Kathedralen von Bamberg und Besançon die Erlaubnis erteilt habe, an gewissen Tagen beim Gottesdienst die Mitra zu tragen. In der Folge wird dieses Vorrecht noch für manch andere Dom- und Stiftskirchen gewährt. Hier genüge es, auf einige Verleihungen hinzuweisen, welche noch dem 11., 12. und 13. Jahrhundert angehören.

Im Jahre 1063 gestand Alexander II. die Mitra den hervorragenderen Canonici von Halberstadt, Priestern, Diakonen und Subdiakonen zu. Doch war der Gebrauch des Ornatstückes örtlich auf die Kathedrale und zeitlich auf die Festtage des Herrn, der allerseligsten Jungfrau, des hl. Johannes des Täufers, der hll. Johannes und Paulus, des heiligen Erzengels Michael, des hl. Stephanus, der heiligen Apostel Petrus, Paulus und Andreas, den Gründonnerstag, Karsamstag, Allerheiligen und das Kirchweihfest beschränkt. Außerdem durften die Subdiakone den liturgischen Kopfschmuck nur dann tragen, wenn sie in dem feierlichen Amt ministrierten ${ }^{3}$. Im folgenden Jahre erhielten von Alexander II. den usus mitrae der Archidiakon und der Subarchidiakon von Mantua: Den Dignitaren des Domkapitels zu Compostella erlaubte 1105 Paschalis II. den Gebrauch der pontifikalen Kopflbedeckung ${ }^{5}$. Dem Kölner Domkapitel wurde das Privileg 1152 unter Erzbischof Arnold durch Eugen III. zu teil, jedoch wurde hier die Vergünstigung auf die sieben Kardinalpriester beschränkt, welche obendrein die Mitra nur an Festtagen beim Hochamte an einem der beiden Hauptaltäre des alten Domes tragen durften ${ }^{6}$. A lexander III. (1159-1181) soll den liturgischen Kopfschmuck dem Primicerius der St Markusbasilika in Venedig verliehen haben? Honorius III. erlaubte 1217 den usus mitrae dem Dechanten, dem Archidiakon und andern Dignitaren des Kapitels von Toledo, im Falle der Erzbischof feierlich mit dem Pallium zelebriertes, Innozenz IV. (1244) dem Dekan des Domes zu Mainz und seinen Nachfolgern ${ }^{9}$.

Wie sich aus den angeführten Beispielen ergibt, pflegte, gerade wie später, so schon gleich von Anfang an die Erteilung des usus mitrae an

\footnotetext{
1 Wür atwe in, Nova subsid. dipl. III, pl. $\mathrm{xxx} x \mathrm{x}$.

2 Gudenus, Codex diplomat. I 324.

3 J. n. 4498. Ein ähnliches Privileg wie den Canonici von Halberstadt soll Alexander II. (1062-1073) auch den sieben Kardinälen und andern Würdenträgern des Prager Domkapitels gewährt haben, doch
}

ist die fragliche Bulle eine Fälschung (J. n. 4753$)$.

4 J. n. 4553. 5 Ebd, n. 6042.

6 Ebd. n. 9515.

7 Bullet. mon. 1866, 166.

s Mor. XLV 279.

9 G. Chr. I o ann is, Rerum Moguntiac. 1. 5 de Sigefrido 11I., Frankfurt 1722, p. 600 . 
Canonici unter verschiedenen größeren oder geringeren Einschränkungen zu erfolgen. Sie sollten diejenigen, welchen jenes Vorrecht gegeben wurde, daran erinnern, daßs sie das Ornatstïck nicht trügen kraft eines Rechtes, sondern kraft eines blofen aus Gnade ihnen gewährten Privilegs.

Äbten soll die Mitra schon vor dem zweiten Jahrtausend verliehen worden sein; doch wurde bereits bemerkt, daf die diesbezüglichen Bullen unecht oder interpoliert sind. Die ersten zuverlässigen Nachrichten über die

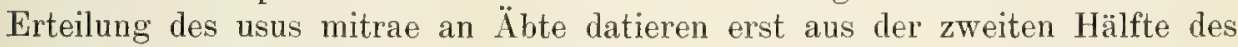
11. Jahrhunderts. Den Reigen eröffnete die Bulle, wodurch Alexander II. 1063 dem Abt Egelsinus vom Kloster des hl. Augustinus zu Canterbury die Mitra zu teil werden läft. Sechs Jahre später gewährt derselbe Papst sie dem Abt Reinbert von Echternach ${ }^{1}$. Dann reiht sich unter den folgenden Päpsten eine Mitraverleihung für Äbte an díe andere.

Von Gregor VII, empfängt das Privileg, sich der bischöflichen Hauptbedeckung. zu bedienen, 1078 Manasses, Abt von Bergues ${ }^{2}$; von Urban II. 1088 Hugo von Cluny $^{3}$ und 1097 Oderisius von Monte Cassino ${ }^{4}$; von Paschalis II. 1105 Anselm von S. Pietro. in Cielo d'Oro zu Pavia ${ }^{5}, 1109$ Pontius von Cluny ${ }^{6}, 1114$ der Abt von Chiusa S. Michele (Diözese Turin) ${ }^{7}, 1113$ Johannes von Nonantola (bei Modena) ${ }^{8}$; von Honorius II. 1125 Tribunus von S. Giorgio Maggiore zu Venedig ${ }^{9}$; von dem Gegenpapste Anakletus II. 1130 Simon von Rastede (Oldenburg) ${ }^{10}$ und ca 1133 Franco von S. Sophia zu Benevent ${ }^{11}$; von Eugen IlI. 1151 Marcuardus von Fulda ${ }^{12}$; von Anastasius IV. 1153 der Abt von S. Salvatore zu Montamiata

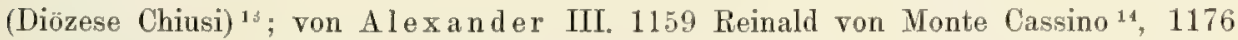
der Abt des von Wilhelm II. gegründeten Klosters Monreale auf Sizilien ${ }^{15}, 1160$ bis 1178 der Abt von St-Gilles (Departement Gard) ${ }^{16}$; 1168-1170 der Prior Vivianus von S. Salvatore zu Venedig ${ }^{17}, 1171-1181$ Peter von S. Severino e Sosio (Neapel) ${ }^{18}$; von Klemens III. 1188 der Abt Herold von St Stephan zu Würzburg ${ }^{19}$ und 1189 Abt Joel von S. Clemente zu Pescara (Diözese Penne) ${ }^{20}$; von Cölestin III. 1192 der Abt von S. Siro (Genua) ${ }^{21}, 1193$ Abt Dietrich von St Michael zu Hildesheim ${ }^{22}, 1194$ Abt Johannes von S. Pietro zu Casamagna (Diözese Anagni) ${ }^{23}, 1196$ Rudolf von Fécamp 21, 1197 Burchard von Ebersberg (Diozese Freising, anf Bitten des Erzbischofs Konrad von Mainz) ${ }^{25}$ und Heinrich von Kempten (Diözese Konstanz) ${ }^{26}$.

Die Zahl der Mitraverleihungen, welche von der Mitte des 11. bis gegen Ende des 12. Jahrhunderts an Äbte erfolgten, ist, wie man sieht, nicht gering, und doch werden die angeführten Beispiele nur einen Bruchteil aller in jener Zeit wirklich erfolgten derartigen Zuwendungen darstellen.

Vielfach hatte das Privileg seinen Grund in den Verdiensten, welche sich ein Abt oder ein Kloster durch seine Ergebenheit, seinen Eifer und seine Treue um die Kirche und den Apostolischen Stuhl erworben hatte ${ }^{27}$. Doch entsprang es auch wohl dem Verlangen der Päpste, die vielfach sehr einfluf-

1 J. и. 4667.

2 Ebd. n. 5090 .

3 Ebd. n. 5372.

4 Ebd. n. 5681. Von Urban II. erhielt auch Petrus, Abt von La Cava, die Mitra. Vgl. Vita S. Petri Cavens. c. 3, n. 25 (A. SS.4. Mart., I 332).

5 J. n. 6011.

7 Ebd. n. 6385.

9 Ebd. n. 7211.

6 Ebd. n. 6242.

8 Ebd. n. 6354.

11 Ebd. n. 8428.

13 Ebd. n. 9748.

10 Ebd. n. 8372.

12 Ebd. n. 9439.

14 Ebd. ก. 10594.

15 Ebd. n. 12683.

16 Ebd. n. 12969.

17 Ebd. n. 11 693. Zur selben Zeit verlieh Alexander auch Marin von La
Cava (Diözese Salerno) die Mitra (ebd. n. 11591).

18 Ebd, n. 14292.

20 Ebd. n. 16417.

22 Ebd. n. 16948.

24 Ebd, n. 17418 . die Mitra dem Abt Walter von S. Bartolomeo zu Carpineto, Diözese Penne (ebd. 17147 ).

${ }^{27} \mathrm{Vgl}$. besonders die Bulle Paschalis' II. für Chiusa S. Michele (Pflugk-Harttung, Acta II 207). 
reichen Äbte im Interesse der kirchlichen Wohlfahrt sich enger zu verbinden. Eximierten, d. i. unmittelbar unter dem Apostolischen Stuhl stehenden und der Gewalt der Bischöfe entzogenen Äbten, welche für den Bereich des Kloster's quasi-bischöflichen Charakter hatten, wurde die Mitra auch wohl mit Rücksicht auf diese Exemtion zu teil. Das ist in einzelnen Bullen ausdrücklich ausgesprochen. So sagt z. B. Cölestin III., als er 1194 dem Abt Walter von S. Bartolomeo zu Carpineto das Recht zugestand, wie seine Vorgänger Krummstab, Ring und Mitra bei der Messe und den Prozessionen zu tragen, die römische Kirche sei gewohnt, die Prälaten derjenigen Orte, welche unmittelbar dem Apostolischen Stuhle unterständen, mit vorzüglicheren Insignien zu ehren, und darum wolle er nach Weise früherer Päpste Walter die genannten bischöflichen Abzeichen gewähren ${ }^{1}$.

Indessen hätten die Mitraverleihungen an Äbte schwerlich einen so großen Umfang gewonnen, wenn letztere weniger larauf ausgegangen wären, sich mit bischöflichem Glanze zu umgeben. Die Initiative zur Erteilung des Privilegs dürfte weit mehr von den Äbten, als von dem Apostolischen Stuhle ausgegangen sein. Im Hinblick auf die macht- und bedeutungsvolle Stellung, welche viele Klöster einnahmen, und namentlich im Hinblick auf die Exemtion von der bischöflichen Gewalt, wodurch manche Äbte zu Quasibischöfen wurden, ist solches allerdings sehr begreiflich, doch fand jenes Streben darum nicht auch schon den ungeteilten Beifall der Zeitgenossen. $\mathrm{Zu}$ seinen Gegnern gehörte namentlich der hl. Bernhard, mit dessen ideàlen Anschauungen vom Ordensleben es freilich wenig im Einklang stand. Der Heilige scheut sich nicht, in seinem Schreiben an Bischof Heinrich von Sens über die Äbte, deren Trachten auf die Erlangung der Mitra und sonstiger bischöflicher Insignien hinausging, in heiligem Eifer den herbsten Tadel auszusprechen ${ }^{2}$. Dafs auch andere ähnlich dachten, beweist z. B. der Brief Peters von Blois an Abt Wilhelm von Blois, der vom Papst eximiert und mit der Mitra begabt worden war ${ }^{3}$ : Petrus Cantor versteigt sich sogar zur Bemerkung: Mitra abbatis inanis est et superflua et puerilis sicut mitra pueri in recitatione miraculi facta ex schedula 4. Die von Innozenz III. 1198 bestätigte Konstitution der Prämonstratenser untersagte, um dem Ehrgeiz ein für allemal Tür und Tor zu schließen, den Prämonstratenseräbten einfachhin den Gebrauch der Mitra und der Pontifikalhandschuhe ${ }^{5}$. Gegen die Übergriffe eines Propstes, der sich Mitra, Ring und andere Insignien angemaßst, hatte sich schon Innozenz II. einzuschreiten veranlafat gesehen. Gegen Mißßbräuche bezüglich des usus mitrae seitens infulierter Äbte wandte sich auch die Konstitution Klemens ${ }^{3}$ IV. vom Jahre 1266, welche noch jetzt mafgebend ist ${ }^{6}$, und eine Verordnung der Provinzialsynode von Salzburg aus dem Jahre $1274{ }^{7}$.

Ein von Rechts wegen den Äbten zustehendes Gewand ist die Mitra niemals gewesen. Sie erscheint in den Bullen vielmehr stets als ein besonderer

1 Vgl. auch die Bulle Cölestins III. für Rudolf von Fécamp: Cum monasterium tibi commissum eo privilegio gaudeat libertatis, ut non nisi romano pontifici sit subiectum, dignum est et conveniens, ut te speciali curemus gratia decorare... Eapropter... tibi et successoribus tuis usum mitrae... duximus indulgendum.

2 Ep. ad Henr. Archiep. Senon. c. 9, n. 36 (M. 182, 832): Ite resistite nunc Christi vicario (sc. episcopo).... Verum aperte indicant quidam horum, quid cogitent, dum multo labore ac pretio apostolicis adeptis privilegiis per ipsa sibi vindicant insignia pontificalia, utentes et ipsi more pontificum mitra, anulo atque sandaliis.... Profecto esse desiderant, quod videri gestiunt (sc. episcopi); meritoque nequeunt esse subiecti, quibus iam ipso se comparant desiderio. Quid si et nomen eis conferre privilegiorum posset auctoritas? Quanto putas auro redimerent, ut appellarentur pontifices? Quo ista, o monachi? Ubi timor mentis, ubi rubor frontis? Vgl. n. 37 (ebd. 833).

${ }^{3}$ Petri Bless. Ep. 90 (M. 207, 283 284). Vgl, auch Thom. Cantiprat. De apibus mysticis 1. 1, e. 6, n. 2 (Mart. 1. 2, c. 1, n. 4; II 146).

4. Verbum abbreviatum c. 44 (M. 205, 159).

5 Regest. 1. 1, n. 197 (M. 214, 173).

6 Bull. Rom. III 764.

7 C. 4 (Hard. VII 723). 
Gnadenerweis des Apostolischen Stuhles an dieselben. Zum Ausdruck dessen wird denn auch den Äbten meist keine unbeschränkte Benutzung der Mitra zugestanden. In der Regel wird ihnen nur gestattet, sie an den vorzüglicheren Festen, die auch wohl genau angegeben werden, bei dem Hochamt und allenfalls noch bei den Prozessionen zu tragen. Von der Erlaubnis, sich ihrer auch bei Synoden zu bedienen, ist seltener in den Bullen die Rede. Sie bei Exequien zu verwenden, wird in den Verleihungen des 12. Jahrhunderts nur sehr vereinzelt zugestanden, und zwar wiederum gewöhnlich mit der ansdrücklichen Beschränkung auf die Leichenfeiern hochstehender geistlicher oder weltlicher Personen. Eine örtliche Beschränkung der Befugnis, die Mitra zu gebrauchen, findet sich in den älteren Bullen nur vereinzelt; von einer Unterscheidung in Bezug auf die Beschaffenheit der Mitra haben wir in den uns zur Kenntnis gekommenen Verleihungsurkunden des 11. und 12. Jahrhunderts nichts gefunden. Eine solche macht unseres Wissens erst Klemens IV. in seiner schon erwähnten Konstitution; doch bezieht sich auch diese nur auf den Fall, daf Äbte auf Provinzial- oder Diözesansynoden erscheinen.

Damit. nämlich die einzelnen nach ihrer Würde kenntlich seien, sollen die exemten Äbte auf denselben lediglich Mitren mit Besätzen (mitrae auriphrygiatae), nicht aber mit Gold- und Silberblechen oder Edelsteinen geschmückte, die nicht exemten Äbte dagegen blof einfache weifse Mitren tragen. Des übrigen sollen sich die einen wie die andern nach dem Wortlaute der Bulle richten können, durch welche ihnen der usus mitrae gestattet wird.

Daßs die Mitra der Äbte von jeher den Charakter eines liturgischen Gewandstückes hatte, daran kann kein Zweifel sein. Nicht nur, daß sie in den Bullen sehr häufig mit Dalmatik, Sandalen und Handschuhen auf eine Stufe gesetzt wird, ihre Verwendung wird auch gewöhnlich ausdrücklich auf Gelegenheiten heschränkt, die entweder wie die feierliche Messe und die Prozessionen im besondern Sinne oder doch wie Synoden im weiteren Sinne einen liturgischen Charakter an sich haben. Selbst in dem weitgehenden Privileg, durch welches die Afterpäpste Viktor IV. 1162 und Kalixtus III. 1172 Erlebold von Stablo die Befugnis gewährten, die Mitra nicht nur an vorzüglichen Festen in seiner Kirche, sondern anch congruis temporibus am Königshofe zu benutzen ${ }^{1}$, dürften unter diesen passenden Gelegenheiten nur kirchliche Feiern zu verstehen sein.

Die römischen Kardinäle hatten schon früh das Recht, die Mitra zu gebrauchen. Bereits in der Bulle, durch welche Paschalis II. 1105 den Dignitaren von Compostella auf Grund der Bitten des Bischofs Didakus die Erlaubnis erteilte, an hohen Festen innerhalb der Kirche mit Gemmen verzierte Mitren zu tragen, heifst es ausdrücklich: ut in sollemnibus diebus... mitris gemmatis capita contegant in speciem videlicet presbyterorum seu diaconorum sedis apostolicae cardinalium ${ }^{2}$. Die Kardinäle müssen sich ihrer sogar schon zur Zeit Gregors VII. bedient haben. Wie nämlich Bonizo von Sutri († ca 1090) berichtet, befanden sich damals an der Peterskirche 60 und mehr mansionarii, denen die Bewachung des Gotteshauses oblag. Alle waren Laien und entweder verheiratet oder Konkubinarier. Statt ihrer Pflicht nachzukommen, trieben sie in der Kirche mancherlei schändlichen Unfug. Unter anderem gaben sie sich, indem sie zu diesem Behuf den Bart schoren und Mitren aufsetzten, bei den frommen Betern als Priester und Kardinäle

1 J. n. 1446914503 .

2 Ebd, 6042. Vgl. auch das Schreiben Innozenz' III. an Abt Hamelin von Vendôme, wolin er S. Prisca zu Rom von neuem dem
Kloster inkorporiert: Sandaliorum usum, tunicae et dalmaticae, mitrae et anuli, sicut eis presbyteri cardjnales utuntur, vobis ... confirmamus (M. 225, 749). 
aus. Gregor machte wie so manchem andern Unwesen auch dem gottlosen Vorgehen dieser Bande ein Ende. Offenbar war es nach dieser Erzählung im dritten Viertel des 11. Jahrhunderts zu Rom Brauch, daf die Kardinäle sich mit der Mitra schmückten. Denn die mansionarii setzten ja eine solche auf, um vor den Leuten als die zu erscheinen, für welche sie sich ausgaben ${ }^{1}$.

Es hatten sogar sonder Zweifel bereits zu den Zeiten Leos IX. die römischen Kardinäle das Recht, die Mitra zu tragen. Denn wenn der Papst den Kardinälen von Besançon sowie bestimmten Priestern und Diakonen der Bamberger Kathedrale erlaubt, sich ihrer zu bedienen, so wird man mit der Annahme nicht fehlgehen, daf damals erst recht die cardinales presbyteri et diaconi zu Rom sich der gleichen Befugnis erfreut haben. Was Leo IX. für Bamberg und Besançon gestattete, war sicher nur eine Kopie des römischen Brauches.

Von den hier in Betracht kommenden römischen Ordines Mabillons gedenkt der, wie es scheint, erst gegen Ende des 12. Jahrhunderts abgefaßste kurze 10. Ordo, in welchem sich bezüglich der liturgischen Kleidung überhaupt nur kärgliche Angaben finden, weder der Mitra des Papstes noch derjenigen der Kardinäle. Der 11., zwischen 1140 und 1143 entstandene Ordo, welcher ebenfalls die Sakralgewandung nur gelegentlich streift, spricht außer von der Mitra des Papstes nur noch von der des Primicerius der Sänger, des Chordirigenten, welcher im Range den Kardinaldiakonen folgte ${ }^{2}$. Der 12., zu Lebzeiten Cölestins III. (1191-1198) entstandene Ordo erwähnt die Mitra der Kardinäle einigemal, ohne jedoch anzugeben, wie sie beschaffen sein mufste ${ }^{3}$. Aus dem auf Befehl Gregors X. (1271-1276) herausgegebenen (13.) Ordo erfahren wir, daß die Kardinäle beim Krönungsmahle eine einfache weiße Mitra trugen *. Ausdrücklich unterscheidet zwischen der mitra pretiosa und simplex alba der Kardinäle der 14. Ordo. Vom Kardinalbischof von Ostia, dem Konsekrator des Papstes, heißst es z. B. darin, er habe sich bei der Papstweihe je nach Erfordernis der Zeit der kostbaren oder der einfachen Mitra zu bedienen ${ }^{5}$. Eine allgemeine Regel für den Gebrauch der beiden Mitren bei den Kardinälen findet sich weder im 14. noch im 15. Ordo. Wie es aber scheint, war die diesbezügliche Praxis schon im späten Mittelalter wesentlich dieselbe wie gegenwärtig. In Gegenwart des Papstes muften die Kardinäle die einfache Mitra anfsetzen. Selbst der Kardinalbischof, welcher ihm bei der Messe diente, durfte sich nur mit der mitra simplex schmücken *.

Auker Bischöfen, Äbten und sonstigen Prälaten wurde seit der Mitte des 11. Jahrhunderts die Mitra vom Papste auch wohl weltlichen Fürsten verliehen. Das früheste bekannte Beispiel eines solchen Privilegs fällt in die Zeit Nikolaus' II. (1058-1061), welcher dasselbe dem Herzog Speciocneus (Spitineus) von Böhmen gewährte ${ }^{7}$. Etwas später schmückte A lex ander II. Wratislaus von Böhmen mit der Mitra, eine Vergünstigung, welche dann Gregor VII. 1073 dem Herzog bestätigte ${ }^{8}$. Roger von Sizilien soll von

1 Liber ad amicum 1. 7 (M. 150, 838). Vgl. für das Ende des 12. Jahrhunderts die Vita des hl. Albert von Lüttich n. 10 (M. G. SS. XXV 146); sie meldet: Albert, der zum Bischof von Lüttich erwählt worden, sei nach Pom gegangen, um gegenüher dem Findringling Lothar von Hochstaden, dem Schützling des Kaisers, Bestätigung der Wahl von Cölestin III. zu erlangen. Der Papst habe nach Untersuchung der Sachlage nicht blok dem Verlangen Alberts entsprochen, sondern ihn auch unter Überreichung der Mitra ins
Kardinalskollegium aufgenommen. Der Bericht der Vita ist darum besonders interessant, weil aus ihm hervorgeht, daf wie jetzt die Übergabe des roten Hutes, so am Ende des 12. Jahrhunderts die der Mitra eine Zeremonie bei der Kardinalskreierung war.

2 N. 4547 (M. 78, 1043 1044).

${ }^{3}$ N. 232732 (ebd. 10721074 1077).

4 N. 9 (ebd. 1111).

5 Ordo 14, c. 45 (ebd. 1140).

6 Ordo 14, c. 18 (ebd. 1130).

7 J. n. 4452 \& Ebd. n. 4812. 
Lucius II. (1144-1145) wie Stab, Ring, Dalmatik und Sandalen so auch die Mitra erhalten haben ${ }^{1}$. Innozenz III. begabte mit ihr 1204 Peter von Aragonien ${ }^{2}$.

Daf auch dem Kaiser die Mitra zugestanden habe, erhellt aus dem Ritus der Salbung und Krönung der deutschen Kaiser. Es heißst darin, wenn Epistel und Graduale gesungen worden seien, ziehe der Kaiser in Prozession zum Altare, woselbst der Papst ihm zuerst die mitra clericalis aufs Haupt setze und dann auf die Mitra das kaiserliche Diadem $^{3}$. Auch auf den späteren Kaisersiegeln kommt die Mitra vor (Bild 217); Der erste Kaiser, von dem wir bestimmt wissen, daf er bei der Krönung die Mitra trug, ist Heinrich VI. ${ }^{*}$ Wie es sich bei seinen Vorgängern bezüglich des Ornatstückes verhielt, läßt sich nicht sagen.

Die Verleihung des pontifikalen Kopfschmuckes und sonstiger geistlichen Gewandstücke und Vorrechte an weltliche Fürsten, wie das im Verlaufe des Mittelalters mehrfach vorkam, war der plastische

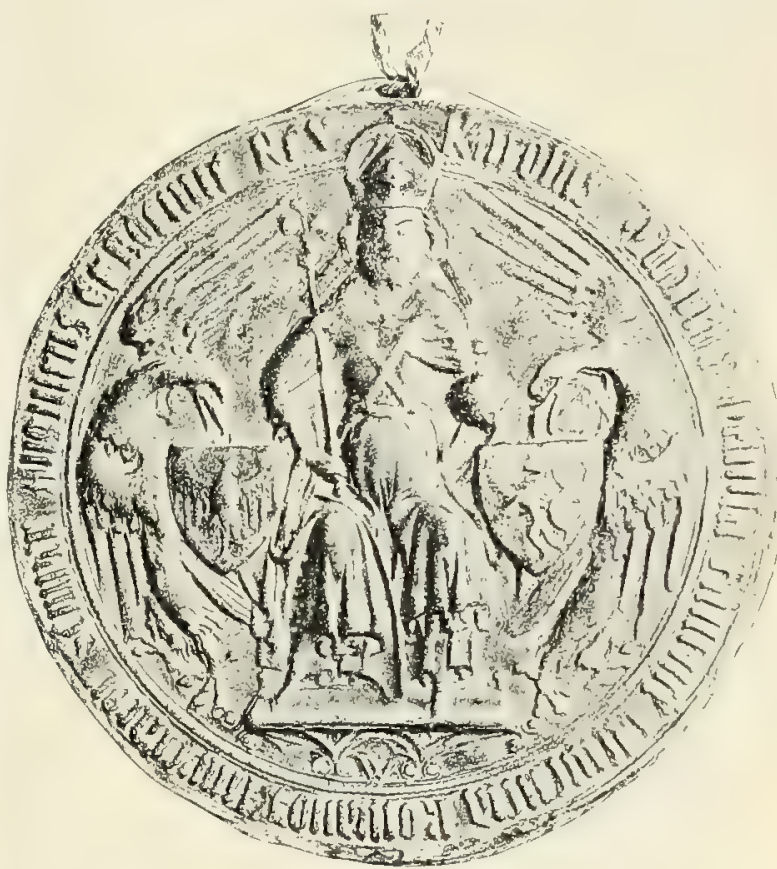

Bild 217. Majestätssiegel Kaiser Karls IV. Luxemburg, sammlung des skriptorenhauses.

Ausdruck der innigen Beziehung, in welcher nach damaliger Anschauung Staat und Kirche, weltliche und geistliche Gewalt, der Kaiser und die Fürsten als Träger der zeitlichen, und der Papst, der Stellvertreter Christi, als Verkörperung aller geistlichen Macht zueinander standen.

1 Otto Frising., De gest. Friderici 1. 1, c. 28 (M. G. SS. XX 367).

2 Innocent. III. Epist. 1. 7, n. 229 (M. 215, 550). Vgl. Bullar. rom. III 197.

${ }^{3}$ Ordo 14 , c. 15 (M. 78, 1241).

* Vgl. den wohl für die Krönung Heinrichs VI. am 15. April 1191 verfafsten Ordo in M. G. Leg. II (ed. P ertz) $187 \mathrm{ff}$ und neuestens bei $\mathrm{Paul} \mathrm{Fabre}$, Le Liber censuum, Paris. 1905, 1* ff. Die Annahne Schwarzers (Forschnngen zur deutschen Geschichte XXII 172) und eimiger anderer, wonach der Ordo für die Krönung Heinrichs III. am 25. Dezember 1046 zusammengestellt worden sei, eine Vermutung, welche auch Duchesne in der Vorrede zu Fabres Ausgabe des Liber censuum wahrscheinlich erscheint, ist, von anderem abgesehen, unseres
Erachtens schon wegen Erwähnung der Mitra unhaltbar. Über Otto IV. siehe die Annales Ceccan. ad 1209 (M. G. SS. XIX 298): Oddo ... vestitus vestimentis imperialibus sacratis, mitratus et coronatus. Vgl. anch Diemand, Das Zeremoniell der Kaiserkrönungen $84 \mathrm{f}$. Über dio Mitra der Kaiserin s. ordo 14, c. 106 (M. 78,1244 ). Sie wird in dem bei der Krönung Heinrichs VI. gebrauchten Ordo noch nicht exwähnt. Die Mitra wurde übrigens der Kaiserin so aufgesetzt, daf die cornua nach den Seiten gerichtet waren: Cornua mitrae sint a dextris et a sinistris. Auf den Kaisersiegeln aus der zweiten Hälfte des 15. Jahrhunderts trägt auch der Kaiser sie in dieser Weise, während er sie auf den frïheren Siegeln so auf dem Kopf hat, daf die Hörner sich über Stirn and Hinterhaupt erheben. 


\section{VI. ÄLTESTE FORM DER MITRA.}

Die Mitra hat nach Gestalt und Beschaffenheit eine wechselvolle Geschichte. Zwischen dem pontifikalen Kopfschmuck des 11. und dem des 19. Jahrhunderts ist ein so grofer Unterschied, daf fast kaum eine Verwandtschaft zwischen beiden erkennbar ist.

Bei den Wandlungen, welche die Mitra durchgemacht hat, lassen sich bestimmt abgegrenzte Stadien nicht unterscheiden. Während man hier an einer älteren Form mit Zähigkeit festhielt, war man anderswo bereits zu einer weiteren Bildungsstufe vorgeschritten. Die interessanteste Periode der Ausgestaltung der Mitra umfafit das 11., 12. und teilweise noch das 13. Jahrhundert. Leider geben die Litw'giker dieser Zeit über die Beschaffenheit, Gestalt und Entwicklung des pontifikalen Kopfschmuckes nur sehr spärlichen Aufschluf.

Bruno von Segni sagt, die Mitra sei aus Linnen gemacht; das Speculum mysteriorum ecclesiae nennt sie corniculata. Honorius benerkt, sie bestehe aus weifsem Byssus. Sicard von Cremona gibt an, sie werde mit Gold und Edelsteinen verziert und rückwärts

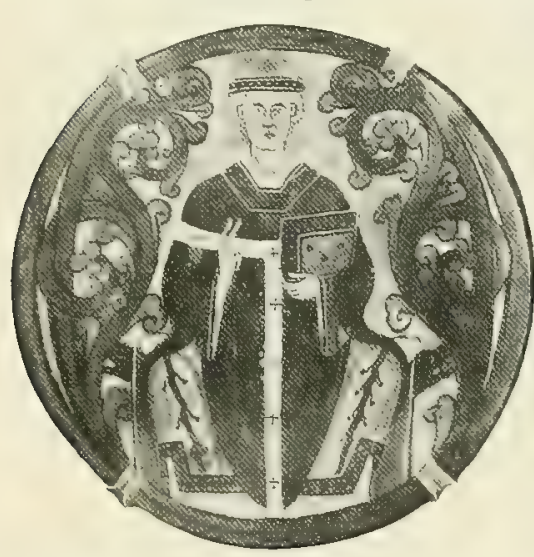

Bild 218. Miniatur in der Vita

S. Willibrordi. Gotha, Herzogl. Bibliothek. mit zwei Bandstreifen (linguae) ausgestattet, an denen sich unten Fransen befänden. Innozenz III. redet von den beiden Hörnern, den ron der Hinterseite der Mitra herabhangenden Bändern (fimbriae) und einem circulus aureus, qui anteriorem et posteriorem partem complectitur, d. i. von einer Goldborte, die rings das Ornatstück umzog. Da er von einem vorderen und hinteren Teil der Mitra spricht, so mub sich eines der beiden Hörner, deren er Erwähnung tut, über der Stirne, das andere auf dem Hinterkopfe erhoben haben. Durandus endlich fügt den Angaben seiner Vorgänger nur noch hinzu, daß die Fransen an den über die Schultern herabhangenden Bändern von roter Farbe seien, und dafs man bald eine einfache, aus weifem Linnenstoff verfertigte, bald eine aurifrisiata, d. i. eine mit Besätzen aus Goldstoff bzw. mit Stickereien versehene Mitra trage.

Hervorgehoben zu werden verdient, daf erst Robert Paululus, das Speculum und der Tractatus de sacramento altaris der cornua der Mitra gedenken. In der Tat konnte von Hörneru noch keine Rede sein, solange jene kegel- oder kalottenförmig war oder solange sie nur niedrige Bausche an den Seiten aufwies. Anders lag die Sache, als die Bausche sich zu spitz ansteigenden, über den Schläfen sich erhebenden Schilden umgebildet hatten. Nun durfte man mit einigem Recht von cornua sprechen; denn jetzt lag wirklich eine gewisse $\ddot{\Lambda}$ nnlichkeit mit Hörnern vor. So dürftig also auch die Angaben der Liturgiker des 12. Jahrhunderts sind, so spiegelt sich doch immerhin in ihnen, wenngleich nur schwach, die Entwicklung wieder, welche sich damals in Bezug auf die Form der Mitra vollzog. Ungleich klarer offenbart sich allerdings der Wechsel in der Gestalt des pontifikalen Kopfschmuckes auf den Bildwerken des 11. und 12. Jahrhunderts. Aus ihnen lernen wir den bei den Liturgikern nur eben angedeuteten Gang der Dinge mit aller Deutlichkeit in seinen einzelnen Hauptphasen kennen.

Die Mitra war hiernach in ihrer ältesten Form eine einfache, oben spitz zulaufende, also kegelartige Mütze aus weichem Stoff. Um den unteren Rand zog sich, wenngleich keineswegs allzeit und regelmäßig, nach Art eines Diadems 
ein ringförmiger Besatz, der circulus. Beispiele bieten die schon erwähnten Darstellungen in dem Exultetrotel und dem Taufrotel von Bari (Bild 214, S. 447), dem Kodex 1339 der Vaticana (Bild 216, S. 451) und der Unterkirche von S. Clemente. Andere, auf denen das Ornatstïck zwar noch kegelförmig ist, aber doch schon an Höhe abgenommen hat, finden sich in Thiofrids Willibrordileben aus der Zeit zwischen 1102 und 1106 (herzogl. Bibliothek $\mathrm{zu}$ Gotha) und auf einem dem Kloster Abdinghof entstammenden Tragaltar aus der Frühe des 12. Jahrhunderts (jetzt im Besitz der Franziskaner zu Paderborn). Dort ist Bischof Bruno von Trier (Bild 218), hier der hl. Blasius dargestellt ${ }^{1}$.

Gegen 1100 beginnt die Mitra ihre liegelgestalt zu verlieren; sie wölbt sich oben ab und wird zur Rundmütze. Ein gutes Beispiel dieser Form begegnet uns auf der früher besprochenen Darstellung des hl. Gregor im sog. Dunstanpontifikale, auf welcher sowohl Gregor wie der vor diesem knieende Bischof sie aufweist ${ }^{2}$. Der obere Teil der Mitra erhielt dann, seitdem man angefangen hatte, ihm eine ibgerundete Gestalt zu geben, im weiteren Verlauf der Entwicklung bald sehr gewöhnlich eine von der Stirn zum Hinterhaupt verlaufende Vertiefung, ähnlich, wie sie entsteht, wenn man mit der Schmalseite der Hand einen weichen Filzhut oben in die Länge eindrückt. Durch diese Einsenkung bildete sich zu beiden Seiten ein stumpf abschliefaender Bausch (Bild 215, S. 450). Bei reicheren Mitren zog sich zugleich mitten über den Kopf, vom Randbesatz über der Stirn bis zu dem der Rückseite ein Zierstreifen, welcher die Einbuchtung schärfer betonte und die Bausche rechts und links klarer und ausgeprägter hervortreten liek, aber auch den Zweck gehabt haben mag, eine unschöne Naht zu verdecken (Bild 219). Wie der circulus muf er, den Bildwerken nach zu urteilen, häufig aus kostbarem Stoff bestanden haben und selbst mit Edelsteinen geschmïckt worden sein. Die Miniatorén malen beide Besätze fast durchweg in Gold.

Von dem unteren Rand der Hinterseite der Mitra fielen zwei Bänder (fasciae, fimbriae, vittae, penduli, fanones, linguae, ligulae, später auch infulae) auf die Schultern herab. Bei den frühesten Abbildungen kommen sie noch keineswegs regelmäßig vor. In der zweiten Hälfte des 12. Jahrhunderts ist dia Mitra jedoch fast immer mit ihnen versehen. Sie erscheinen bald in der Mitte, bald nach den Seiten zu angebracht. Auf manchen Bildwerken befinden sie sich sogar fast geradezu an den Schläfen. Insbesondere treten sie uns in dieser Weise ungemein oft auf den Bischofssiegeln entgegen. Daf solche Darstellungen nicht das blobe Produkt einer Künstlerphantasie sind, sondern der Wirklichkeit entsprachen, beweist der höchst interessante Bericht, den v. Wilmowsky über den Befund der Leiche des Erzbischofs Albero von Trier $(\dagger 1152)$ gibt, sowie die Skizze, die er von der Mitra des Toten aufnahm (Bild 220, S. 460) ${ }^{3}$. Threr Form nach sind die fasciae meist ein überall gleich breites Band. An den Enden pflegen sie

1 Abbildung bei v. Falke und Frauberger, Deutsche Schmelzarbeiten des Mittelalters, Frankfurt 1904, Tfl 14.
2 Vgl. oben S. 436, Anm. 9.

$s$ v. Wilmowsky, Die Grabstätten der Erzbischöfe im Dom zu Trier 5 und Tfl 28. 
nach Teise der Stola oder des Manipels mit Fransen oder mit sonst einem Abschluf verziert zu sein.

Was die Entstehung der fasciae anlangt, so sagt man gewöhnlich, sie seien ursprünglich die rückwärts herabfallenden Enden des Bandes gervesen, das man unten $u m$ den Rand der Mitra herumgeschlungen und hinten zusammengebunden habe. Für diese Ansicht könnte sprechen, daßs sich auf einigen Miniaturen der Randbesatz an der Rückseite des Ornatstückes wirklich zu einem Knoten zusammenzuschürzen scheint ${ }^{1}$. Es bleibt bei ihr indessen zu erklären, warum die fasciae auch bei solchen Witren vorkommen, die des circulus entbehren; dann, warum Streifen und Bordüre sehr häufig aus verschiedenen Stoffen bestehen oder verschieden gemustert sind; endlich, warum die Bänder so häufig nach den Seiten des Kopfes zu oder gar fast bei den Schläfen an der Mitra angesetzt sind. $O b$ es daher nicht zutreffender ist, anzunehmen, es seien die fasciae von Anfang an lediglich als Zierbehänge gedacht ge-

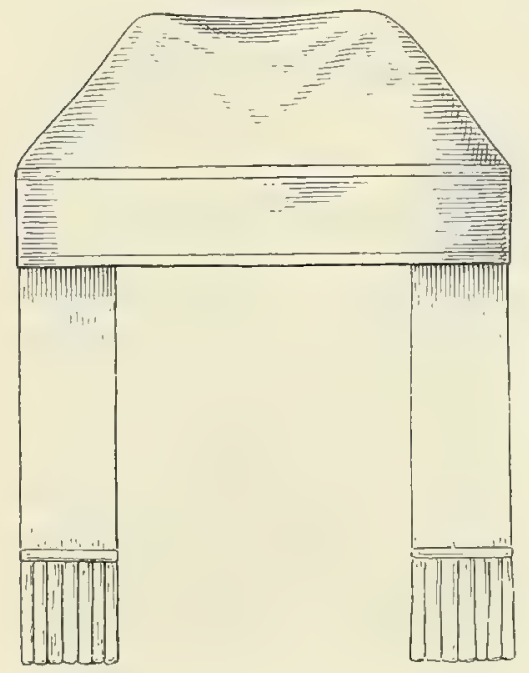

Bild 220. Mitra aus dem Grab des Trierer Erzbischofs Albero ( $†$ 1152). (Nach v. Wilmowsky.) wesen, wie man deren auch wohl im profanen Leben an vorzüglicheren Kopfbedeckungen anzubringen pflegte? ${ }^{2}$

Irrig ist jedenfalls die Auffassung, welche in neuester Zeit Wüscher-Becchi von der Bedeutung des um den Rand der Mitra angebrachten Besatzes vorgetragen hat ${ }^{3}$. "Was diese halbkugelförmige Kopfbedeckung, die vom Papst und den Bischöfen zugleich getragen wird, besonders auszeichnet", meint dieser, "das ist bei beiden die Mitra, jenes Band, das im ganzen Altertum den ,Geweihten, Geheiligten' bezeichnet. Der bischöflichen Mütze gab sie geradezu den Namen." Er übersieht, daß es, wie noch jetzt und im späteren Mittelalter, so von Anfang an Mitren gegeben hat, welche des Randbesatzes gänzlich entbehrten. Darum sagt auch Ernold $(\dagger 1156)$ in seiner Abhandlung De septem verbis Domini in cruce nur: Tiara (des jüdischen Kultus) erat byssina, circumdata coronula aurea, opere textili facta, sicut hodie phrygium mitris nostrorum pontificum plerumque (nicht semper) consuitur 4 . Dann beachtet er nicht, daf der fragliche Besatz niemals als etwas anderes denn als blofe Verzierung gaît. Keiner der Liturgiker redet vor Innozenz III. von dem angeblich heiligen Band, aber auch Innozenz III., welcher zuerst des circulus Erwähnung tut, weif nichts von der Bedeutung, welche Wüscher-Becchi mit ihm verbinden möchte. So wenig hatte der Randbesatz einen sakralen oder auch nur auszeichnenden Charakter, dak wir ihn nicht hos an der Mitra, sondern ebensogut an profaneu Mützen antreffen. Welchen Anhalt hat man überhaupt, irgend einen Zusammenhang zwischen dem circulus der Mitra und der Koptbinde persischer Könige, dem angeblichen Abzeichen aller Priesterkönige des Altertums, zu behaupten? Was hat man denn im 10. und 11. Jahrhundert noch von dieser ehemaligen heiligen Binde gewuft? Es ist darum auch

' Roh. VII, pl. duvr: VIII, pl. douv. Die Miniaturen, denen die Abbildungen entnommen sind, stammen fast alle aus demselben Stuttgarter Kodex; der Knoten wird wohl auf Rechnung des Malers zu setzen sein.

${ }^{2}$ Vgl. z. B. die Bebänge der Kronen auf den Siegeln der deutschen Kaiser aus dem 11. und 12. Jahrbundert.
3 Ursprung der päpstlichen Tiara und der bischöflichen Mitra (Römische Quartalschrift XIII 105). Der Wert der Arbeit liegt in den lesenswerten Erörterungen über die Kopfbedeckung der Orientalen; was über die Entstehung dex Nitra gesagt wird, entbehrt der Kritik.

4 M. $189,1723$. 
ganz unzutreffend, daß̧ das Band am Rand der Nitra, wie Wüscher-Becchi glauht, dieser geradezu den Namen gegeben habe. Er belehrt uns doch selbst in ausführlicher Weise über die verschiedenen Bedeutungen, welche mitra im klassischen und nachklassischen Latein und Griechisch besak. Wenn man im 10. bzw. 11. Jahrhundert die neu aufgekommene pontifikale Kopfbedeckung mitra nannte, so geschah es entweder, weil das Wort im Laufe der Zeit den Sinn von Haube, Mütze bekommen hatte oder - und das ist wohl das wahrscheinlichste - weil in der Vulgata die sakrale Kopfbedeckung der jüdischen Priester mitra genannt wird; nicht aber mit Rücksicht auf den Randbesatz als auf eine Reminiszenz heiliger Kopfbänder vorchristlicher orientalischer Priesterkönige, von der man damals nicht die geringste Ahnung hatte.

Die kegel-, kalotten- oder haubenartige Mitra blieb teilweise bis weit ins 12. Jahrhundert hinein im Gebrauch. Monumente des 11. Jahrhunderts, auf denen sie auftritt, wurden schon früher erwähnt: Im Anfang des 12. Jahrhunderts begegnet sie uns auf dem Bild des Erzbischofs Bruno von Trier in der Gothaer Vita S. Willibrordi, auf dem Bilderschmuck der Chronik von Volturno ", der Darstellung des Erzbischofs Friedrich vou Köln in der Sammlung der Hieronymusbriefe der Kölner Dombibliothek und auf manchen sonstigen Bildwerken. Gegen die Mitte desselben treffen wir sie unter anderem noch auf den Miniaturen eines Salzburger Antiphonars ${ }^{2}$ sowie auf den Siegeln des Abtes Friedrich von St Godehard zu Hildesheim (nach 1136) und des Bischofs Alexander von Lincoln in England (1123-1148) an. Sie kommt selbst noch nach 1150 auf den Monumenten vor. Zum Belege dafür sei hier nur hingewiesen auf die Siegel Roberts von Lincoln (1148-1168), Arnulfs von Lisieux (1141-1181), Hugos von Rouen (1130-1164) ${ }^{3}$, Rotrocus'von Rouen (1165-1183) 4, Alberts von S. Malo (1163-1184) u. a., sowie auf die Darstellung des hl. Heribert in der ca 1164 abgefaßsten Deutzer Chronik (Bild 219, S. 459) ${ }^{5}$.

Die Wahrnehmungen, welche v. Wilmowsky bei Öffnung der Gräber der Trierer Erzbischöfe machte, beweisen sogar, daß die mützenartige Mitra, wenigstens hie und da, noch bis in das letzte Viertel des 12. Jahrhunderts hinein Verwendung gefunden haben mufa. Es waren nämlich nicht nur Albero $(†$ 1152) und Hillin $(\dagger$ 1169) mit einer solchen ausgestattet, es deckte noch selbst das Haupt Arnolds I. († 1183) eine ,zylinderförmige, fast halbkugelrunde Mitra von Seide" 6.

Vielleicht stellte auch die unter dem Namen eines Biretts des hl. Proculus gehende Kalotte, welche bis wenigstens 1861 in S. Zeno zu Verona aufbewahrt wurde, eine Mitra des 11. oder des frühen 12. Jahrhunderts dar ${ }^{7}$.

1. Ag. Malerei Tfl 69. Vgl. ebd. TA 66, $\mathrm{Nr} 4$ (aus Donjzos Vita Mathildis comitissae); Tfl $67, \mathrm{Nx} 1$ (aus einer Bullensammlung); Tfl 68, $\mathrm{Nr} 142145147153$.

2 Lind, Ein Antiphonar mit Bilderschmuck, Wien 1870, TAl 182021344345.

3 Vgl. die Tafeln bei Roh. VII VIII, besonders VIII, pl. DCLV DCLVI DCLXIY.

4 Ebd. VII, pl. DLIII DLI; VIII, pl. DCLIV DcLxiv. In einzelnen Fällen ist es auf den Siegeln unklar, ob noch die älteste Mitrenform gemeint ist. Es liegt das teils an dem unvollkommenen Schnitt des Stempels, teils an mangelhafter Ausprägung oder nachträglicher Abstumpfung des Siegels.
${ }^{5}$ Fürstl. Hohenzoll. Biblioth. zu Sigmaringen. Vgl.auch A us m Werth, Kunstdenkmäler 'I'f1 17 (T'ragaltar aus Xanten) und 48 (Tragaltar aus Siegburg), und Destrée, Les Musées Royaux livr. 4, pl. In (Reliquiarvon Stabloca 1145).

${ }^{6} \mathrm{v}, \mathrm{W}$ il m o w s ky, Die Grabstätten etc. 6.

7 In Zeitschrift XV (1902), 6 machte der Verfasser auf eine Mitra zu Vallombrosa aufmerksam, die, ihm zugekommenen Mitteilungen gemäfi, noch die primitive Mützenform haben sollte. Nähere Auskunft, die P. Tacchi Venturi S. J. mir zu verschaffen die Güte hatte, bewies jedoch, daf es sich bei ihr um eine Mitra von gewöhnlicher Form aus dem 13. Jahrhundert handelt. 
De Linas sagt darüiber: J'ai vu dans la sacristie de l'église de St-Zénon à Vérone une espèce de calotte en grosse toile damassée (grand oeil-de-perdrix) avec cette légende inscrite sur parchemin en caractères italiens du XIV siècle: Birretum sancti Proculi epi. quarti Veronensis. Cette calotte a-t-elle réellement appartenu à Saint-Procule, qui vivait sous Dioclétien? Je n'ose me prononcer, mais je la crois de la même famille que la coiffure de Saint-Dunstan ${ }^{1}$. Das Birett des hl. Proculus ist gegenwärtig leider spurlos verschwunden.

Man hat die Ansicht ausgesprochen, es sei die Mitra anfänglich bloß ein Tuch getresen, das man um den Kopf des Bischofs gelegt und dann mittels einer Binde befestigt habe. Dabei habe man die Zipfel hinten auf den Nacken herabfallen lassen. Diese Annahme ist indessen unseres Erachtens ganz unzutreffend. Die Mitra erscheint bereits auf den frühesten Abbildungen als eine Art Mütze. Eine Mützenform war auch bei ihr durch die Verwendung, welche sie beim Gottesdienste fand, geboten. Dieselbe brachte es ja mit sich, das der Bischof die Mitra bald aufzusetzen bald wieder abzunehmen hatte. Schriftliche Zeugnisse fehlen zudem für die Hypothese vollständig. Die wenigen Bildwerke aber, auf die man sich beruft, Skulpturen eines nunmehr verschwundenen Grabmals in St-Remi zu Reims ${ }^{2}$, die früher schon erwähnten Miniaturen der Niracula S. Amandi zu Valenciennes mit den Bildern der hll. Amandus und Vindicianus ${ }^{3}$ und eine segnende Bischofsfigur in St-Bertrand zu Comminges ${ }^{4}$ beweisen nichts. Sie gehören alle einer Zeit an, in welcher die Mitra allgemein eine förmliche Mütze war. Sollten sie also wirklich etwas anderes als eine solche dargestellt haben bzw. darstellen, so kann das, wie so manches bei den mittelalterlichen Darstellungen, nur als künstlerische Freiheit aufgefaft werden. Allein tatsächlich hatten oder haben die pontifikalen Kopfbedeckungen auf den fraglichen Monumenten die Gestalt einer Mütze ${ }^{5}$. Eigentümlich ist bloß, daß bei ihnen die fasciae nach Art eines gefältelten Tuches gebildet sind. Dabei ist es, was die beiden Skulpturen anlangt, durchaus zweifelhaft, ob die Abbildungen, die davon vorliegen, das Original korrekt wiedergeben ${ }^{6}$.

1 Revue 1861, 297. Unter der coiffure de Saint-Dunstan versteht er die Kopfbedeckung, welche St Gregor auf der Miniatur des Kodex Cotton, Claudius A, III trägt. Vgl. S. 459. Über das „birretum S. Proculi" siehe auch B o ck II 347.

2 De Vert II, pl. virI, 9; daraus auch bei B o ck II, Tfl 22, 4. Eine kleine Skizze des ganzen Monumentes in Mart. und Durand, Voyage littéraire II 81.

3 Oben S. 436. Abbildungen bei $R$ oh. VIII, pl. Dcxxxrin Delxiy; Bock a. a. O. II, Tf 2:, 23.

4 Cahier, Décorations d'églises 4.

5 Da das Grabmal in St-Remi nicht mehr vorhanden ist, lassen sich die Skizzen bei de Vert und Martène nicht mehr am Original kontrollieren. Und doch weif jeder, der die damalige Reproduktionsweise kennt, wie notwendig das wåre. Übrigens sagt de Vert selbst bezüglich der fraglichen Kopf bedeckung mit aller Klarheit: On voit à Rheims dans l'église de Saint-Remy un tombeau, où sont représentés des moines d'un côté et de l'autre des prêtres et des évêques avec des mitres en forme de vrais bonnets, d'où pendent par derrière des bandes de même étoffe, ce semble, que le bonnet (II $: 341$ note c).
' Der Vollständigkeit halber sei hier noch auf zwei Beispiele von Bischofsdarstellungen mit ungewöhnlichem Kopfschmuck aufmerksam gemacht. Die erste, ein Steinrelief, befindet sich zu Moissac (Tarn-et-Garonne). Sie gibt den hl. Durandus von Toulouse $(†$ 1072) wieder und ist sonach keinenfalls vor dem 12. Jahrhundert entstanden. Der Kopfschmuck besteht hier in einem schmalen Band, das sich um die breite Haarkrone schlingt, hinter dem Kopf gebunden zu sein scheint und mit seinen Enden auf die Schultern herabfällt (Abbildung bei $\mathrm{C}$ a h i e r, Caractéristique des Saints I 296, doch ungenau, und Revue 1892, 456). Der Heilige ist obendrein mit dem Nimbus geziert. Ein pontifikaler Kopfsehmuck ist hier angesichts der Entstehungszeit des Reliefs offenbar nicht gemeint, sondern, ähnlich wie auf Miniaturen im Benedictionale Aethelwolds, die Himmelskrone. Die andere, noch eigentümlichere Art von Kopfzier begegnet uns auf einer Miniatur des Evangeliars von Niedermünster, des sog. Utakodex (München, Kgl. Bibl. Cim. 54). Sie stellt St Erhard, Bischof von Regensburg (ca 700), dar. Um das Haupt des Heiligen ist turbanartig ein Tuch gewunden, auf der Stirn aber ein kleines 


\section{VII. ÄNDERUNGEN IN DER FORM DER MITRA.}

Ein etwas anderes Aussehen als die bisher besprochene Mitraform hat eine zweite, der wir seit etwa 1125 häufig begegnen. Bei ihr haben sich die beiden seitlichen, mehr oder weniger stark ausgeprägten Bausche zu senkrecht aufsteigenden und in eine Spitze endenden Hörnern entwickelt, welche durch eine feste Einlage von Pergament oder steifem Linnenzeug ihre Form erhielten.

Daf diese Form auch in Italien bekannt gewesen ist, ergibt sich z. B. aus einem Gemälde der Platonia bei S. Sebastiano zu Rom ${ }^{1}$, aus Darstellungen des Regestum von S. Angelo in Formis ${ }^{2}$, der seitlichen Erztüre der Kathedrale zu Troja von 1127, der Chronik von S. Sophia zu Benevent ${ }^{3}$, des. Exultetrotels von Fondi ${ }^{4}$ und andern Bildwerken.

Sehr häufig trifft man die an beiden Seiten zu Spitzen sich ausgestaltende Mitra bis zum letzten Viertel des 12. Jahrhunderts auf franzo̊sischen Bischofssiegeln an ${ }^{5}$ (Bild 221). Sie findet sich auf verschiedenen Siegeln sogar bis in das 13. Jahrhundert hinein, so auf Bischofssiegeln von Béziers, Arles, Agde, Maguelone, St-Paul-des-Trois-Châteaux u. a.

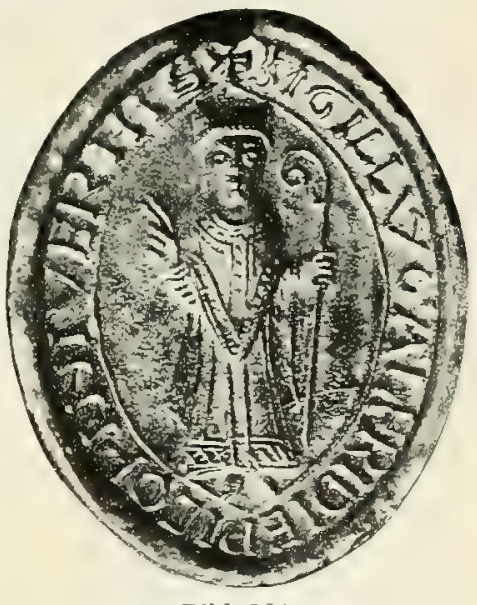

Bild 221.

Siegel Gottfrieds von Nevers († 1159). Luxemburg, tammlumg des ikriptorenhauses. Auf den Arler Bischofssiegeln sehen wir sie noch 1222, auf den Siegeln der Bischöfe von St-Paul-des-Trois-Châteaux noch bei Bischof Godefredus († 1230). In Deutschland begegnet sie uns noch auf dem Siegel des Erzbischofs Arnold von Mainz $(1153-1160)^{6}$ und einem Siegel Hartwichs von Regensburg von

goldenes Plättchen von dreieckiger Form angebracht (Abbildung bei Cahier pl. II und Sw arzenski, Regensburger Buchmalerei, Leipzig 1901, Tfl 13). Auch hier handelt es sich nicht um eine pontifikale Kopf bedeckung. Wie das Stirnplättchen beweist, haben dem Viniator vielmehr der Kopfbund und die lamina, das goldene Stirnblech des jüdischen Hohenpriesters vorgeschwebt, wie denn auch im übrigen sich in der Gewandung Anklänge an die Tracht des letzteren bemerklich machen. Das Evangeliar wird jetzt meist der Uta von Kirchberg (1002-1025) zugeschrieben. Eine dritte bemerkenswerte Art von Kopfschmuck erscheint auf einer Miniatur des Prümer Kartulars in k. Staatsarchiv zu Koblenz bei Abt Friedrich. In Albe, Dalmatik und Plaviale gekleidet, trägt dieser um den Scheitel einen goldenen Reifen. Derselbe Schmuck findet sich auf der gleichen Miniatur beim hl. Benedikt und soll offenbar die Abtswürde symbolisieren. Das Kartular entstand unter Abt Friedrich, also in der ersten Hälfte des 13. Jahrhunderts (Abbildung der Miniatur in Zeitschrift XIX [1906] 47).

1 Bock II 157 und Tfl 22, 7.
2 Le miniature dei Cod. Cassin. (Monte Cassino 1887) saec. XII, tav. 1.

3 Vat. lat. 4939.

${ }^{\star}$ Les miniatures des rouleaux d'Exultet, Monte Cassino 1899, pl. 614.

Roh. VIII, pl. oclvil delxi Delxiv; ferner Blancard, Iconographie des seeaux et bulles des Archives des Bouches-du-Rhône pl. 38 ff und Demay, Inventaire des sceaux II $108 \mathrm{ff}$.

${ }^{6}$ W ü r d t we in, Nova subsidia dipl. II 13. Wenn die zweite Mitraform noch auf einzelnen Münzen des Erzbischofs Konrad von Köln (1237 bis 1261) auftritt (K a p pe, Kölnische Münzen TA 11, 176179180 181), so ist sie hier unzweifelhaft auf die Rechnung des Stempelschneiders zu setzen, da in Köln die dritte Mitraart schon lange vor dem 13. Jahrhundert in Gebrauch war. Eine zu beiden Seiten spitz ansteigende Mitla erscheint schon auf Münzen Hildebolds von Köln (1076-1079). Vgl. K ap pe a. a. O. Tfl 7, 110113114115. Dieselben sind jedoch spätere Fälschungen (ebd. S. 65). Auf den echten Münzen der Kölner Erzbischöfe kommt die Mitra überhaupt erst unter Philipp (1167-1191) vor: 
1161, in England, wo sie ebenfalls sehr gebräuchlich gewesen sein muf, auf einem Siegel des hl. Thomas von Canterbury (1162-1170) ${ }^{1}$.

Es ist die Meinung geäufert worden, es habe eine seitlich in spitzen Hörnern aufsteigende Witra in Wirklichkeit nicht gegeben. Es handle sich auf den Darstellungen, welche eine solche aufweisen, nur um eine ungenaue Wiedergabe der über der Stirn und dem Hinterhaupt mit Hörnern versehenen Mitra. Darauf ist zu erwidern, daß die Bildwerke es allerdings hie und da, wenngleich im allgemeinen sehr selten, unentschieden lassen, welche Mitrenart gemeint ist. Im übrigen tritt die an den Seiten gehörnte Vitra auf den Monumenten so oft und in solcher Deutlichkeit auf, und zwar auch auf Bildwerken von vortrefflichster Arbeit, daf es durchaus unbegründet ist, lediglich an eine unrichtige Zeichnung zu denken. Man wird angesichts der überaus zahlreichen Beispiele dieser Mitraform nur dann den Monumenten gerecht, wenn man

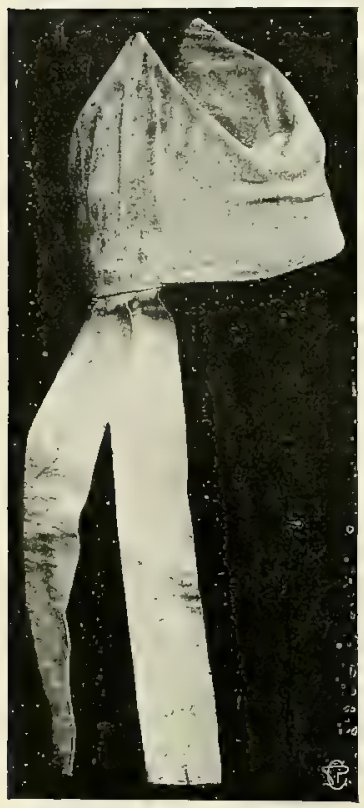

Bild 222. Mitra. Florenz, S. Trinità. festhält, daf die seitlich mit spitzen Hörnern versehene Mitra, welche uns so häufig auf denselben entgegentritt, die Wirklichkeit wiedergebe.

Übrigens bildete diese Mitraform nur den Übergang zu einer dritten Art der Mitra, die sich jedoch von ihrer Vorläuferin im Grunde nicht sowohl durch die ihr eigene Gestalt und Machweise, als vielmehr blof durch die Stellung unterschied, welche sie auf dem Haupte einnahm. Statt nämlich die Mitra so aufzusetzen, daf die cornua sich über den Schläfen erhoben, wendete man sie so, daß̧ eines der Hörner über der Stirn, das andere über dem Hinterkopf aufstieg. Die einzige Veränderung, die hierbei an der Mitra vorgenommen werden mufte, bestand darin, daf die fasciae statt am hinteren Ende der Einbuchtung nunmehr am unteren Rande des hinteren Hornes befestigt wurden.

Sie ist im wesentlichen die noch jetzt gebräuchliche Mitraform. Wo sie zuerst aufkam, ist nicht zu sagen, da sie sich fast zur seiben Zeit in Frankreich, Italien und Deutschland zeigt. Die ersten zuverlässigen Beispiele treten gegen die Mitte des 12. Jahrhunderts auf.

Für die Feststellung der Zeit, da es zu dieser dritten Mitraart kam, sind namentlich die Siegel von gröfter Bedeutung. St Godehard trägt auf dem Siegel des Abtes Friedrich (1136) noch eine Mitra mit stumpfen seitlichen Hörnern, dagegen weist das Siegel des Bischofs Bruno von Hildesheim (1153-1162) schon die neve Form der pontifikalen Kopfbedeckung auf. Die Kölner Bischofssiegel bringen die Änderung unter Rainald von Dassel (1159-1167). Wie Arnold II. (1151-1156), so trägt auch noch Friedrich von Altena ( $\dagger$ 1158) auf seinem Siegel eine Mitra in Form einer Spitzmütze. Dagegen schmückt Rainalds Haupt eine Mitra, deren Hörner ausgesprochenermafen sich uiber der Stirn und dem Hinterkopf erheben. Die Form, bei welcher die cornua über den Schläfen aufsteigen, ist auf den Kölner Siegeln nicht verireten. Auf den Regensburger Bischofssiegeln erscheint die dritte Form unter Bischof Kuno (1167-1185), auf den Würzburger tritt sie unter Herold von Hochheim (1165-1171) auf. Auf einem Siegel von 1165 hat die Mitra bei ihm noch die Kalottenform, auf einem Siegel von 1170 ist sie dagegen schon vorn und hinten mit Hörnern versehen. Auch hier fehlt die Mittelform?

\footnotetext{
1 Thurston, The Pallium, London $1892,17$.

2 Von den bei Lepsius, Geschichte der Bischöfe des Hochstifts Naumburg, abge-
} 
In Dentschland kann die jüngste Art des bischöflichen Kopfschmuckes schon im dritten Viertel des 12. Jahrhunderts nicht mehr selten gewesen sein. Sie begegnet uns um diese Zeit beispielsweise auf der Grabplatte des Erzbischofs Friedrich $\left(\dagger\right.$ 1152) im Dom zu Magdeburg ${ }^{1}$, auf einer Miniatur des Missale Rattmanns im Dome zu Hildesheim und der Vita $\mathrm{S}$. Bernwardi in der königlichen Staatsbibliothek zu Hannover ${ }^{2}$, bei den Figuren des hl. Godehard und des Bischofs Bernhard $(\uparrow 1154)$ am St Godehardsschrein im Dome zu Hildesheim und auf dem Bilderschmuck des 1175 vollendeten Hortus deliciarum der Herrad von Landsberg ?.

Zur selben Zeit wie Rainald von Dassel trägt auch schon Radulf von Ripen (1156-1170) in Dänemark auf seinem Siegel die Mitra, deren cornua über Stirn und Hinterhaupt ansteigen. Auf den Lincolner Bischof'ssiegeln findet der Wechsel um 1170 statt, auf den französischen Siegeln vollzieht er sich meist im letzten Viertel des 12., teilweise sogar erst im Beginn des 13. Jahrhunderts ${ }^{4}$. So hat Godofredus von Angers (1162-1177) auf seinem Siegel noch die Mitra mit seitlichen cornua ${ }^{5}$, während dasjenige seines Nachfolgers Raoul (1178-1197) die vorn und rückwärts ansteigende Kopfbedeckung auf-

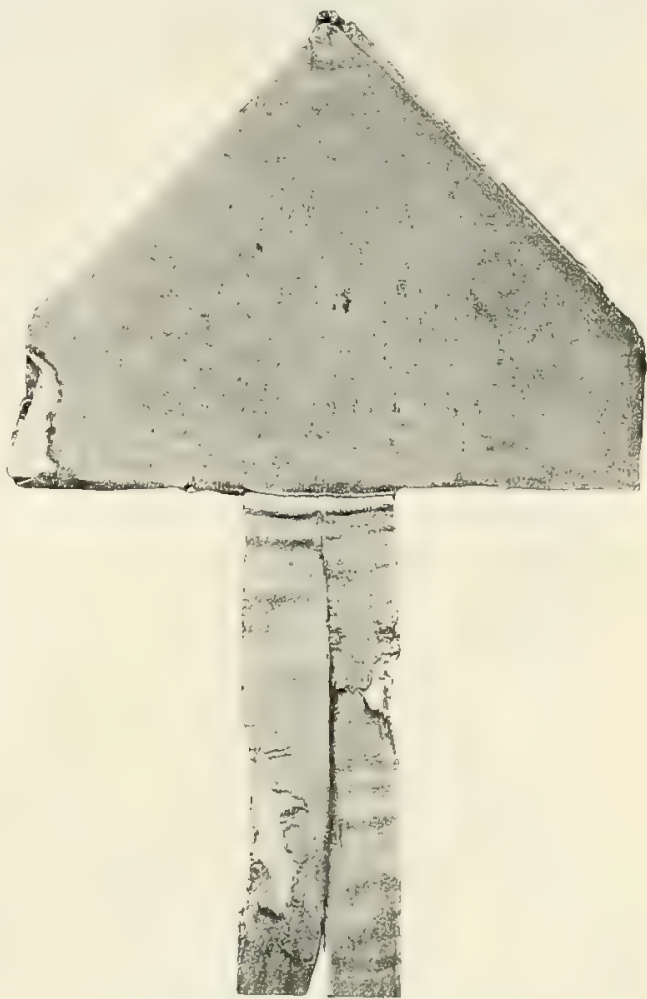

Bild 223. Mitra. Anagni, Kathodrale. weist ${ }^{6}$. Auf den Pariser Siegeln besitzt das Ornatstück bei Petrus Lombardus (1158-1160) und Moritz von Sully (1160-1196) die Gestalt, welche ihm im zweiten Bildungsstadium eignete ${ }^{7}$, bei Odo von Sully (1196-1208) erscheint dagegen die

bildeten Naumburger Bischofssiegeln sind nach Ausweis des Details $\mathrm{Nr} 1-345$ Fălschungen. Echt ist das Siegel Utos I. (1140) Nr 2, Utos II. (1166) Nr 6 und Bertholds II. (1195) Nr 7. Uto I. erscheint ohne Mitra, Uto II. in seitlich, Berthold II. in vorn gehörnter Mitra.

1 Fürster, Denkmale deutscher Bildnerei und Malerei III. Die Grabplatte wird dort S. 17 des Textes als diejenige des Erzbischofs Gisler bezeichnet und unter Hinweis auf die Türen in Hildesheim als Entstehungszeit derselben die Fríluzeit des 11. Jahrhunderts angenommen. Aus ihrer Inschrift: Octava decima februi redeunte calenda, quem deus ascivit, presul venerandus obivit, geht jedoch klar hervor, daf die Grabfigur nicht Gisler, sondern den am 15. Januar 1152 gestorbenen Erzbisch of Friedrich wiedergibt.

2 Beide Miniaturen stellen St Bernward dar. Das Manuskript der Vita S. Bernwardi wird M. G. SS. IV 755 und Archiv VII 428

\footnotetext{
Braun, Die liturgische Gewandung.
}

ins 11. Jahrhundert versetzt. Mit Unrecht. Dex Hannoversche Codex, eine Kopie von Thankmars Leben Bernwards, entstand erst nach der 1150 erfolgten Kanonisation des großen Hildesheimer Bischofs, und zwar frühestens im dritten Viertel des 12. Jahrhunderts. Das heweist nicht nur der Heiligenschein, der St Bernwards Haupt umgibt, sondern ebensosehr und mit aller Bestimmtheit die Mitra, welche dasselbe schmückt.

3 Herrade de Landsberg, Hortus deliciarum, Straß̧burg 1901, pl. LXVIII.

4 Die Mitra, welche die Bischofsfigur an dem angeblichen Stab des hl. Ivo - jetzt im Bargello zu Florenz - trăgt (Abbildung bei Martin et Cahier IV, pl, xvir), beweist, daf derselbe nicht im Anfang, sondern erst in der Spätzeit des 12. Jahrhunderts entstanden ist.

5 Roh. VIII, pl, noIx.

6 Ebd. pl. Dcxxxix.

7 Ebd. pl. DCLX DeLvir. 
dritte Entwicklungsstufe ${ }^{1}$. Auf den Siegeln von Avranches bildet dasjenige Achards (1161-1171) die Grenzmarke der zweiten Mitraform ${ }^{2}$; mit Bischof Richard (1171-1182) beginnt auf den Siegeln die dritte ${ }^{3}$. Auf den Arler Siegeln ändert sich die Mitra unter Hugo II. Ein Siegel von 1222 hat noch die seitlich, das von 1230 aber die vorn und hinten gehörnte Mitra. Zu Arras tritt der Wechsel auf den Bischofssiegeln um 1175, zu Cambrai um 1190, zu Avignon zwischen 1190 und 1200, zu Marseille um 1220, zu Toulon um 1200, zu Aix um 1180", zи Beauvais um 1175 anf. Zu Mende hält sich die zweite Mitraform bis nach 1215 auf den Siegeln.

Nach Rohault de Fleury soll der dritte Mitratypus in Châlons-sur-Marne schon 1142, in Senlis 1151, in Beauvais 1140 und Arras 1143 vorkommen. Die beiden ersten Angaben haben wir nicht kontrollieren können ${ }^{5}$. Die beiden letzten dürften auf einem Irrtum beruhen. Wie es scheint, hat Rohault oder sein Gewährsmann die kegelförmige Mitra des ersten Typus für die dritte Mitraform angesehen. Denn zu Arras weist noch das Siegel des Bischofs Andreas (1170), zu Beauvais aber dasjenige des Bischofs Heinrich 1160 die seitlich gehörnte Mitra auf' ${ }^{6}$.

Daßs auch in Italien bereits in der zweiten Hälfte des 12. Jahrhunderts die vorn und hinten gehörnte pontifikale Kopfbedeckung in Gebrauch war, beweisen beispielsweise eine Bischofsbïste an einem Weihwasserbecken in Borgo

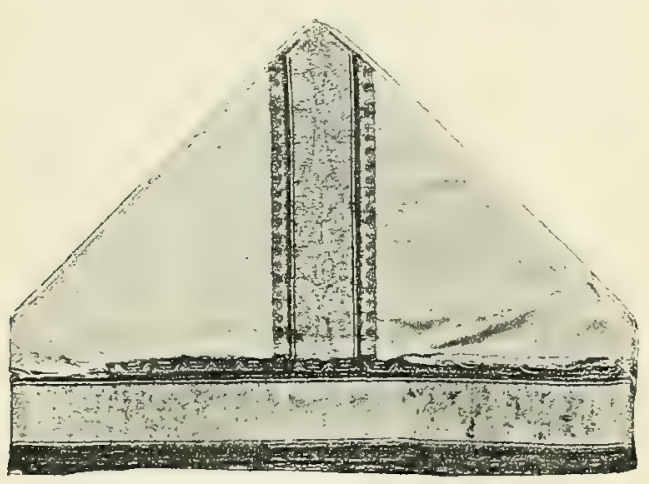

Bild 224. Mitra. Brixen, Dom.

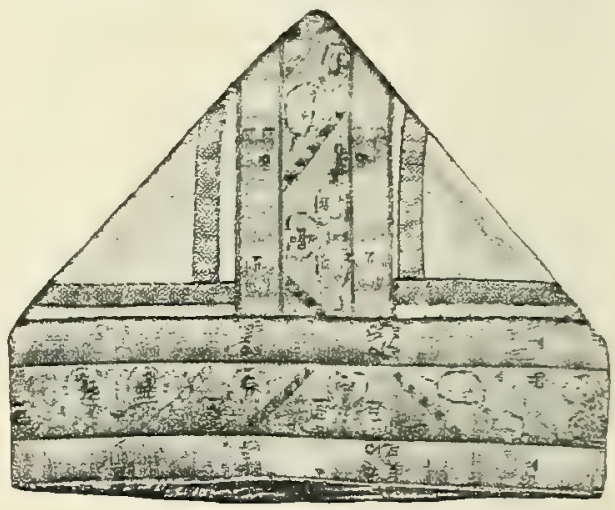

Bild 225. Mitra. Brixen, Dom.

S. Donnino (bei Parma), Reliefs der Erztüren und Skulpturen am Portalbau von S. Zeno zu Verona, die Darstellung des Erzbischofs Bonifatius in der ca 1189 entstandenen zweiten Fortsetzung der Annalen von Genua (ad 1188) ${ }^{7}$, Reliefs der Erztüren des Domes zu Benevent u. a.

Das Auftreten der Mitra und die Form, welche sie im einzelnen Falle bei Bischofsdarstellungen hat, sind für die Datierung von Monumenten und

1 Roh. VIII, pl, DCLVIr.

2 Ebd. VII, pl. Dxx.

3 Elod. VIII, pI. DCxxxviIt.

4 Vgl. wegen der Siegel D emay, Inventaire de sceaux de la Flandre $108 \mathrm{ff}$, und Blancard, Iconographie des sceaux pl. 38 ff.

5 Roh. VIII 123. Wir geben darum diese Angaben nur mit Vorbehalt wieder. Die Tatsache, daf die vorn sich erhebende Mitra durchweg erst spät in Frankreich auftritt, und mehr noch die so häufige fehlerhafte Datierung bei Rohault de Fleury bieten dazu hinlänglich Grund. Von den VII, pl. DXcvi abgebildeten drei Grabfiguren aus Sens, Chartres und Poitiers (Bischöfe mit über der Stirn aufsteigender Mitra), welche, wie es scheint, dort und p. 158 den Jahren 1144, 1122 und 1115 zugeschrieben werden, sind die beiden letzten kaum vor dem 13. Jahrhundert entstanden. Aber auch die erste, welche Bischof Heinrich den Eber (le Sanglier) darstellen soll († 1142), dürfte nicht viel fruher angefertigt sein.

6 Über das Siegel des Bischofs Andreas von Arras vgl. Demay a. a. O. II 109, des Bischofs Heinrich von Bequvais Roh. VIII 122.

7 M. G. SS. XVIII, tab. 3. Erzbischof Hugo (ad 1169) trägt in der ca 1172 vollendeten ersten Fortsetzung der Annalen eine Mitra mit seitlichen Hörnern. 
illustrierten Codices von großer Wichtigkeit. Bildwerke, auf denen irgend eine der verschiedenen Formen der pontifikalen Kopfbedeckung auftritt, sind auf alle Fälle nach 1000, meist aber erst in den Ausgang des 11. oder den Beginn des 12. Jahrhunderts zu setzen. Hat die Mitra Kegel- oder Kalottenform, so sind die Darstellungen in der Regel der Zeit vor 1050 zuzuweisen; ist sie dagegen mit seitlichen, spitz ansteigenden Hörnern versehen, so werden die betreffenden Monumente nicht vor 1100, für gewöhnlich aber auch nicht nach 1175 entstanden sein, es sei denn, daßj es sich um französische Bildwerke handelt, auf denen, sich diese Mitraform länger erhielt. Darstellungen mit Mitren, deren Hörner sich über Stirn und Hinterhaüpt erheben, können im allgemeinen frühestens dem dritten Viertel des 12. Jahrhunderts zugeschrieben werden; jedenfalls gehen sie nicht über das zweite Viertel zurück.

Es gibt nicht viele Mitren des dritten Typus mehr, welche noch in das 12 . Jahrhundert gesetzt werden können. Eine davon befindet sich in S. Tri-

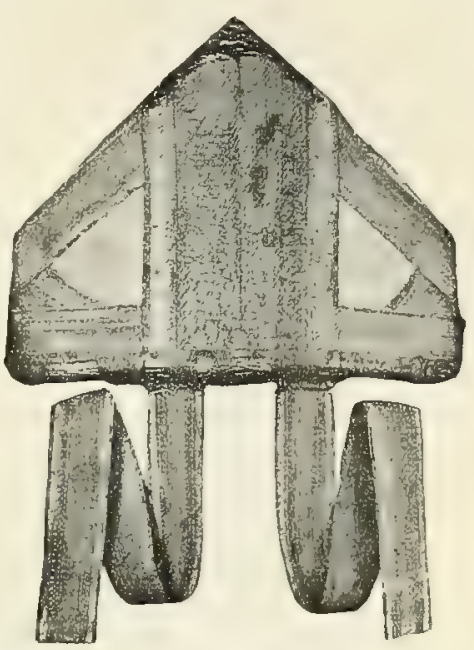

Bild 226. Mitra. Bamberg, St Michael. nità zu Florenz, eine andere im Domschatz von Anagni. Beide sind aus weifsem Linnen gemacht, ohne alle Besätze und mit schlichten weiflinnenen Behängen versehen. Die Mitra zu Florenz ist nur $19 \mathrm{~cm}$ (Bild 222, S. 464), die zu Anagni $21 \mathrm{~cm}$ (Bild 223, S. 465) hoch. Auch die beiden Mitren im Schatz von St Johann zu Monza mögen vielleicht noch dem 12. Jahrhundert angehören. Sie sind in titulo und circulo mit breiten Goldborten verziert und haben eine Höhe von 21 bzw. $22 \mathrm{~cm}{ }^{1}$.

Aus dem 13. Jahrhundert hat sich noch eine verhältnismäsig beträchtliche Anzahl von Mitren erhalten. In Frankreieh gibt es deren aus dieser Zeit noch
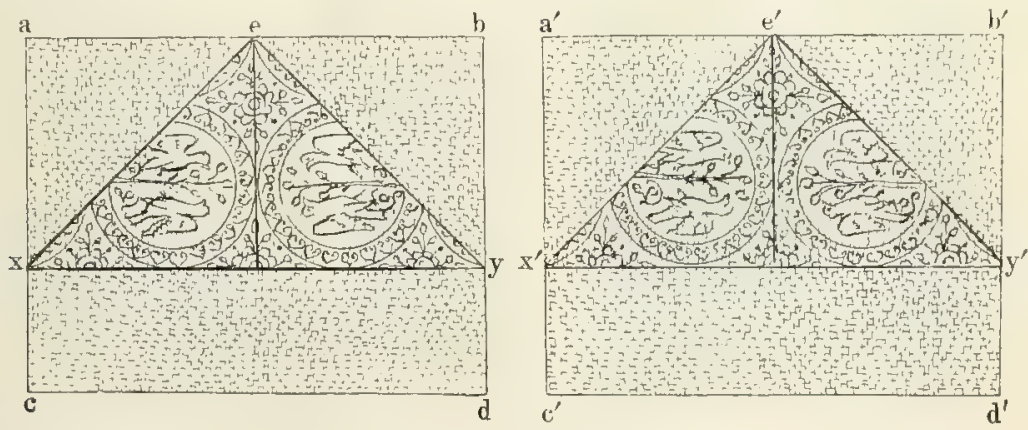

Bild 227. Herstellungsweise der Mitra im 12, und 13. Jahrhundert.

zwei zu Sens (Kathedrale), sowie je eine zu Comminges (St-Bertrand), Beauvais (Museum), Pontigny, Toulouse (St-Sernin) und St-Lizier-de-Consérans ${ }^{2}$, in Italien aufer den beiden bereits erwähten Mitren in St Johann zu Nonza, die vielleicht noch dem

1 Eine genauere Untersuchung der Mitren, welche deutliche Zeichen späterer Restaurationen aufweisen, hinderte leider der Umstand, dak sie sich hinter Glas und Rahmen befanden.

${ }^{2}$ Von zwei Mitren in der Kathedrale zu Lyon gehört eine trotz ihrer geringen Höho nach Ausweis ihrer Beschaffenheit erst dem 15. Jahrhundert an; sie besteht aus rotem Samt. Die andere, welche auf den Schilden mit Stickereien verziert ist, dürfte zwar noch dem 13. Jahrhundert entstammen, sie mußs aber später eine Restauration erfahren haben. (Abbildungen der Mitren bei de Farcy pl. 10). $30 *$ 
12. Jahrhundert entstammen, drei zu Anagni (Kathedrale), zwei zu Castel S. Elia und je eine zn Capua (Kathedrale), Verona (S. Zeno) und Ferentino (Katheirale). Die letztgenannte rührt von dem heiligen Papst Cölestin V. her. Auch eine aus der Spätzeit des 13. Jahıhunderts stammende Mitra im Germanischen Museum zu Nürnberg ist nach dem Stil der aufgestickten figürlichen Darstellungen italienischen Ursprungs; sie scheint im Venetianischen entstanden zu sein (Bild 232, S. 472).

Belgien besitzt noch zwei Mitren aus dem 13. Jahrhundert, welche sich beide im Besitz der Schwestern Unserer Lieben Frau zu Namur befinden. Eine derselben, welche auf den Schilden mit Darstellungen des Martyriums der hll. Laurentius und Stephanus bedeckt ist. soll dem Kardinal Jakob von Vitry ( +1244$)$ angehört haben. In Spanien bewahrt man gleichfalls noch zwei Mitren des 13. Jahrhunderts auf; die eine zeigt man im erzbischöflichen Museum zu Vich, die andere, welche irrig dem hl. Oldegarius zugeschrieben wird, in der Kathedrale zu Barcelona.

Am zahlreichsten sind die Mitren aus dem 18. Jahrhundert in Deutschland, Österreich eingeschlossen. Man hat deren noch vier zu Salzburg (Dom und St Peter), je zwei zu Bamberg (Dom und St Michael), Brixen (Dom) (Bild 224 und 225, S. 466), München (Frauenkirche und Nationalmuseum) und Halberstadt (Dom), sowie eine zu Regenshurg

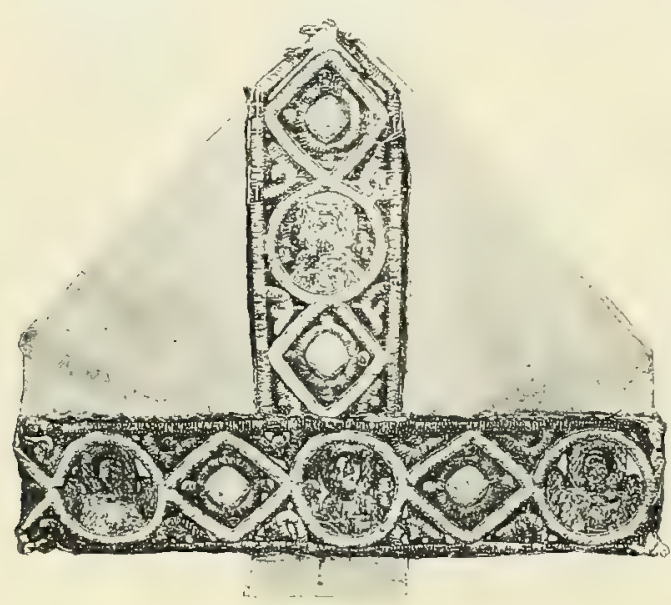

Bild 228. Mitra. Anagni, Kathedrale.

(St Emmeram) ${ }^{1}$. Die Mitra in St Michael zu Bamberg soll dem hl. Otto $(†$ 1139)(Bild226, S.467), diejenige in der Frauenkirche zu München dem hl. Benno von Meifen († 1106) zugehört haben, in Wirklichkeit entstammen jedoch beide erst dem 13 . Jahrhundert. Wahrscheinlich handelt es sich bei ihnen um Mitren, mit denen man zu dieser Zeit bei einer Erhebung oder einer ähnlichen Gelegenheit die Reliquien jener Heiligen schmückte?

Alle diese Mitren aus dem 12. und 13. Jahrhundert weisen drei Eigentümlichkeiten auf. Ihre erste besteht in der geringen Höhe. Im 12. Jahrhundert betrug diese nur etwa $19-22 \mathrm{~cm}$, also nur etwa zwei Drittel der Breite. Im 13. nahm sie dann zwar allmählich zu, jedoch blieb sie bis zum Ende desselben immer noch merklich unter der Breite. Bei keiner der vorhin genannten Mitren aus dem 13. Jahrhundert übersteigt die Höhe $26 \mathrm{~cm}$, bei den meisten beträgt sie ca $24 \mathrm{~cm}$; bei der Mitra des Bischofs

1 Abbildungen eines Teiles der angeführten Mitren bei Roh. VIIl, pl. DcLviII (Florenz), DClix (Rom, Monza), deux (Lyon, Comminges), DClxi (Beauvais, Sens), DClxiI (Namur), DClxiI (Pontigny), Dchxr (Anagni); bei Bock II, TAl 16 (Salzburg, St Peter), 23 (Sens, Bamberg), 24 (Verona); in Revue 1861, 225 (Toulouse); in Mitt. 12. Jahrg., TA 2, 2 (Salzburg, St Peter), 3 und 4 (Salzburg, Dom), S. 73 (Brixen) - die hier Tfl 2, 1 wiedergegebene Mitra aus dem Dom zu Krakau dürfte frühestens in das Ende des 13. Jahrbunderts zu setzen sein -; bei Cahier, Décorations d'églises 9 (Bamberg), 10 (St-Lizier-de-Consérans), 1617 (Namur)
- die allda 14 mitgeteilte Mitra von St-Gildasde-Ruis (Bretagne) wird wohl ehestens dem 14. Jahrhundert angehören - ; bei d e F a r c y pl. 10 (Lyon), 11 (Sens), Suppl. pl. 154 (Vich) und Zeitschrift 1890, 130 (Nürnberg) und 1902, 11 f (Anagni, Capua). Über die Mitren von Anagni vgl. auch Didron, Annales archéolog. XVII 231; daselbst auch p. 227 die Mitra von Beauvais.

2 Die Kasel, welche man als einst dem hl. Otto zugehörig in St Michael zugleich mit der Mitra aufbewahrt, entstammt erst dem Beginn des 16. Jahrhunderts. Ihr Stoff, ein gemusterter Samtbrokat, und ihre Form lassen keinen Zweifel daran. 
Bruno (1250-1288) im Dom zu Brixen (Bild 224, S. 466) beläuft sie sich sogar noch wie bei den Mitren des 12. Jahrhunderts auf nur ca $21 \mathrm{~cm}$. Erst im 14. Jahrhundert beginnt die Mitra stärker zu wachsen. Die zweite Eigentümlichkeit liegt darin, dafo die Mitra von unten bis zum Anfang der Schrägungen dieselbe Weite beibehält. Daher stehen, wenn man eine der vorhin genannten Mitren zusammenklappt, die Seiten allemal senkrecht zum Rand. Erst eine spätere Zeit schafft Mitren, die sich von unten nach oben zu erweitern.

Drittens stofen die Schrägseiten der Hörner, die stets eine gerade Linie darstellen, an der Spitze der Mitra regelmäfig unter einem rechten Winkel zusammen.

Ihren Grund haben diese drei Eigentümlichkeiten in der von der späteren Herstellungsart ganz abweichenden Machweise, welche bei den Mitren des 12. und 13. Jahrhunderts zur Anwendung kam. Man nahm zwei rechteckige Stoffstücke von der für das Ornatstück gewünschten Höhe und entsprechender Breite (a bed und $\left.a^{\prime} b^{\prime} c^{\prime} d^{\prime}\right)$, versah sie mit Futterstoff, schlug die Ecken a, b, $a^{\prime}, b^{\prime}$ so nach innen um, daf bei e und $e^{\prime}$ ein rechter Winkel entstand, nähte e a und e b, e $e^{\prime} a^{\prime}$ mit $e^{\prime} b^{\prime}$, x y mit $x^{\prime} y^{\prime}$, $\mathrm{xe}$ mit $\mathrm{x}^{\prime} \mathrm{c}^{\prime}$ und $\mathrm{yd}$ mit $\mathrm{y}^{\prime} \mathrm{d}^{\prime} \mathrm{zu}-$ sammen, fügte dem Ganzen die fasciae und den Besatz hinzu, wenn ein solcher angebracht werden sollte, und die Mitra war fertig (Bild 227, S. 467). Damit die Mitra größsere Steifheit erhielt, wurde zwischen Ober- und Unterstoff ein kräftiges Zeug- oder ein Pergamentstück von der Form der Hörner eingeschoben. Einfache Mitren fertigte man auch wohl in der Weise an, daß3 man aus zwei kleineren oder einem größeren gefütterten Stoffstück eine taschenähnliche, im zusammengelegten Zustande viereckige Mütze herstellte, welche man mit dem nötigen Besatz

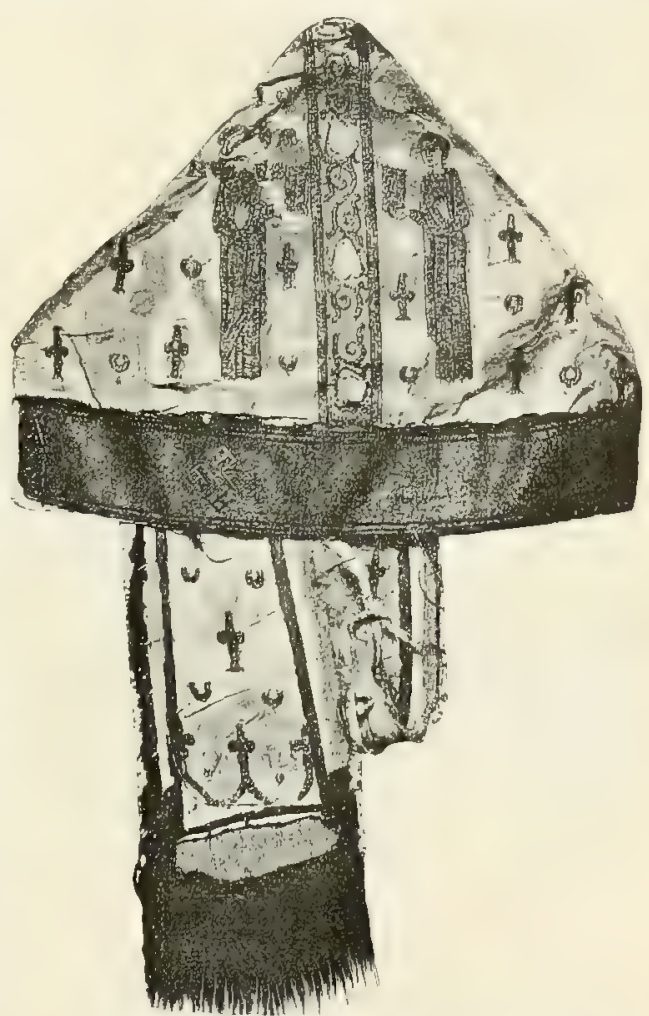

Bild 229. Mitra, Anagni, Kathedrale. versah und dann auf dem Kopf so eindrückte, daf über Stiru und Hinterkopf sich eine Spitze bildete.

Kostbar ist kaum eine der eben genannten Mitren. Die meisten sind aus weifier Seide gemacht. Drei bestehen aus rautenförmig gemustertem Limnenköper und entbehren, von den Behängen abgesehen, aller Verzierung. Es sind die vorhin erwälnten Mitren zu Florenz und Anagni und eine der beiden Mitren zu Castel S. Elia. Aber auch die übrigen weisen im Vergleich mit so manchen Prachtmitren aus dem späten Mittelalter durchweg nur mäfigen Schmuck auf. Bei keiner fehlt der circulus, d. i. der ringförmige Randbesatz. Bei den meisten kommt zu ihm ein Vertikalbesatz in titulo, der Zierstreifen, der in der Mitte der Hörner vom circulus zur Spitze aufsteigt. Er hatte nicht blof den Zweck, den Schilden der cornua eine gefällige 
Teilung zu geben und die aufstrebende Richtung der letzteren sinnfälliger und ausdrucksvoller zur Geltung zu bringen, sondern diente auch dazu, und zwar ganz besonders, die Naht zu verdecken, welche sich über die Mitte eines der tituli oder auch beider zu ziehen pflegte. Man konnte diese freilich an die Seiten legen. Es war jedoch praktischer, sie über den Schilden anzubringen und hier durch einen Vertikalbesatz zu verdecken, da sich in diesem Falle nirgends ringsum eine Naht bemerklich machte. An den Seiten findet sich nur bei einzelnen Mitren (Regensburg, St Michael zu Bamberg) ein Besatz; an den Schrägungen kommt ein solcher häufiger vor. Auch zieht sich wohl ein Börtchen oben über die Mitra von Hornspitze zu Hornspitze.

Diese Besätze, gewöhnlich Aurifrisien genannt, bestehen bei den meisten der oben erwähnten Mitren aus Goldborten; in Stickerei hergestellte Zierstreifen finden sich, zum Teil neben gewebten, auf zwei Mitren zu Anagni (Bild 228 und 229, S. 468 und 469), auf den Mitren im Dom zu Bamberg, in S. Zeno zu Verona (Bild 230), im Dom zu Capua, in der Kathedrale zu Barcelona und im erzbischöflichen Museum zu Vich sowie auf einer der Mitren zu Castel S. Elia und im

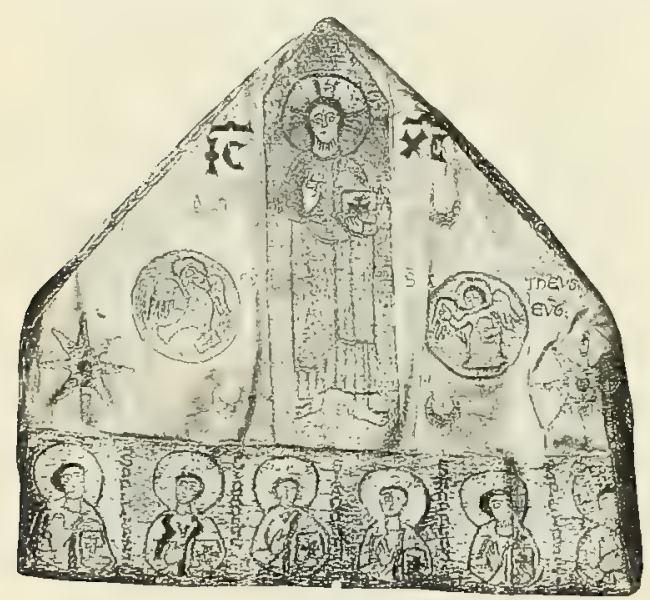

Bild 230. Nitra, Verona, S. Zeno. Dom zu Halberstadt (Bild 231). Figürliche Stickereien, vornehmlich Brustbilder in Medaillons, weisen blof die Mitren zu Verona, Capua, Barcelona, Nürnberg und eine der Mitren zu Anagni auf (Bild 228, S. 468); bei den übrigen sind den Besätzen nur ornamentale Motive aufgestickt. Steine sind nur bei wenigen der Mitren zur Verzierung der Aurifrisien zur Verwendung gekommen (Monza, Regensburg). Durch ihren kostbaren Perlenschmuck zeichnen sich die Besätze der Mitra im Dom zu Bamberg aus. Auf einer der Halberstädter Mitren bestehen die Zierstreifen aus Schmelzperlen und Korallen (Bild 231).

Die dreieckigen neben dem Vertikalbesatz liegenden Zwickel der tituli sind bei der Mehrzahl der genannten Mitren entweder ganz schmucklos oder doch blof mit einem leichten Ornament versehen. Dasselbe besteht meistens nur in einem Rundmedaillon oder einem Stern, welche den Zwickeln in der Mitte aufgesetzt sind, bei der dem hl. Thomas Becket irrig zugeeigneten Mitra im Schatz der Kathedrale zu Sens in Goldranken, bei einer der Mitren zu Anagni und der Mitra zu Verona (Bild 230), in Möndchen, kleinen Sternen oder Lilien, die über den Grund verstreut sind.

Figürliche Darstellungen sind nur bej wenigen der angeführten Mitren den Schilden aufgestickt; es sind die Mitren im Dom zu Anagni, die Mitra im kgl. bayrischen Nationalmuseum zu München, eine der beiden Mitren zu Namur, eine der Mitren zu Sens und die Mitra im Germanischen Museum zu Nürmberg (Bild 232, S. 472). Bemerkenswert ist, dab bei dreien dieser Mitren (Namur, München, Sens) auf einem der Schilde dieselbe Szene, und zwar in gleicher Technik — Goldstickerei mit tief eingezogenen Abheftfäden -, wiederkehrt, während uns auf dem andern, ebenfalls in der gleichen Technik, bei zweien das Martyrium des hl. Stephanus (Sens, München), bei der dritten aber 
das des hl. Laurentius begegnet. Die drei Mitren stammen zweifellos aus einer und derselben Werkstatt.

Mit Malereien geschmückt sind die Besätze und tituli der zweiten der beiden Mitren zu Namur (Bild 233, S 473). Auf dem circulus sind auf Goldgrund unter Arkaden die Apostel dargestellt, auf den Vertikalbesätzen in Medaillons vorn Christus, Maria und ein heiliger Bischof, rückwärts phantastische Tiergestalten. Die Zwickel der Schilde enthalten Engel und Evangelistensymbole bzw. Sonne und Mond. Die Mitra beweist, dak man schon früh auch die Malerei zur Verzierung des pontifikalen Kopfschmuckes zu Hilfe nahm.

Die fasciae, Behänge, sind bei vielen der erwähnten Mitren nicht mehr vorhanden. Bei den unverzierten, weiflinnenen Mitren zu Florenz, Anagni und Castel S. Elia sind sie ebenfalls aus weifen, geköpertem Linnen gemacht. Bei andern bestehen sie entweder aus gewebten Borten von ähnlicher Art, wie sie zum circulus und den Vertikalbesätzen gebraucht zu werden pflegten, oder aus dem Stoff der Mitra; letzteres namentlich da, wo die Aurifrisien in Stickerei hergestellt sind. So hat z, B. eine mit gestickten Besätzen verzierte linnene Mitra in der Kathedrale zu Anagni Behänge aus Linnen, während eine weiß̊seidene daselbst fasciae aus weifer Seide besitzt. Immer bestehen sie aus dem Stoff der Mitra, wenn auch sie, wie z. B. bei der Mitra Jakobs von Vitry zu Namur, der Mitra im Dom zu Salzburg und der sog. Mitra des hl. Thomas Becket zu Sens, mit Stickereien verziert sind. Den Behängen der beiden letztgenannten Mitren sind Goldranken aufgestickt, denjenigen der Mitra Jakobs

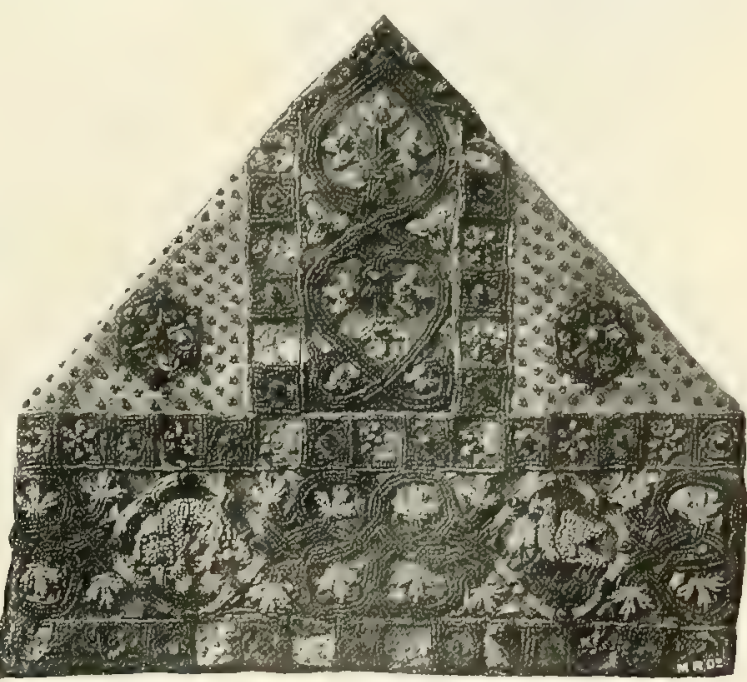

Bild 231. Mitra. Halberstadt, Dom. von Vitry figürliche Darstellungen. Die fasciae der Mitra im Germanischen Museum zu Nürnberg sind ungewöhnlicherweise auf beiden Seiten mit reichen Figurenstickereien geschmückt, Heiligen unter Baldachinen im Wechsel mit Kreisen, die mit phantastischem Getier gefüllt sind (Bild 232, S. 472). Es verdient hervorgehoben zu werden, das die fasciae ebenso oft aus dem Stoff der Mitra gemacht sind wie aus Borten von dem Charakter des circulus. Es zeigt das, wie wenig sie, wie man wohl gewollt hat, als bloke Verlängerung des Randbesatzes zu betrachten sind.

Behänge aus Goldborten besitzen zwei der Mitren in St Peter zu Salzburg, die beiden Mitren zu Monza, eine der beiden Mitren zu Brixen, die Mitra in St Michael zu Bamberg und die Mitra in St Emmeram zu Regensburg.

Die Behänge sind bei allen Mitren entweder ganz in der Mitte der Rückseite oder doch nahe der Mitte zu angebracht. Bei keiner finden sie sich nach den Seiten hin. Ihrer Form nach stellen sie in den meisten Fällen einen überall gleichbreiten Streifen dar; Behänge, die sich nach unten zu erweitern, 
finden sich an der Mitra Jakobs von Vitry, der sog. Mitra des hl. Thomas Becket zu Sens, einer der Mitren zu Anagni und der Mitra zu Pontigny.

An den Enden sind die fasciae bei einzelnen Mitren mit Fransen geschmủckt; bei andern, bei welchen solche gegenwärtig an den Behängen fehlen, mögen sie im Lauf der Zeit abhanden gekommen sein.

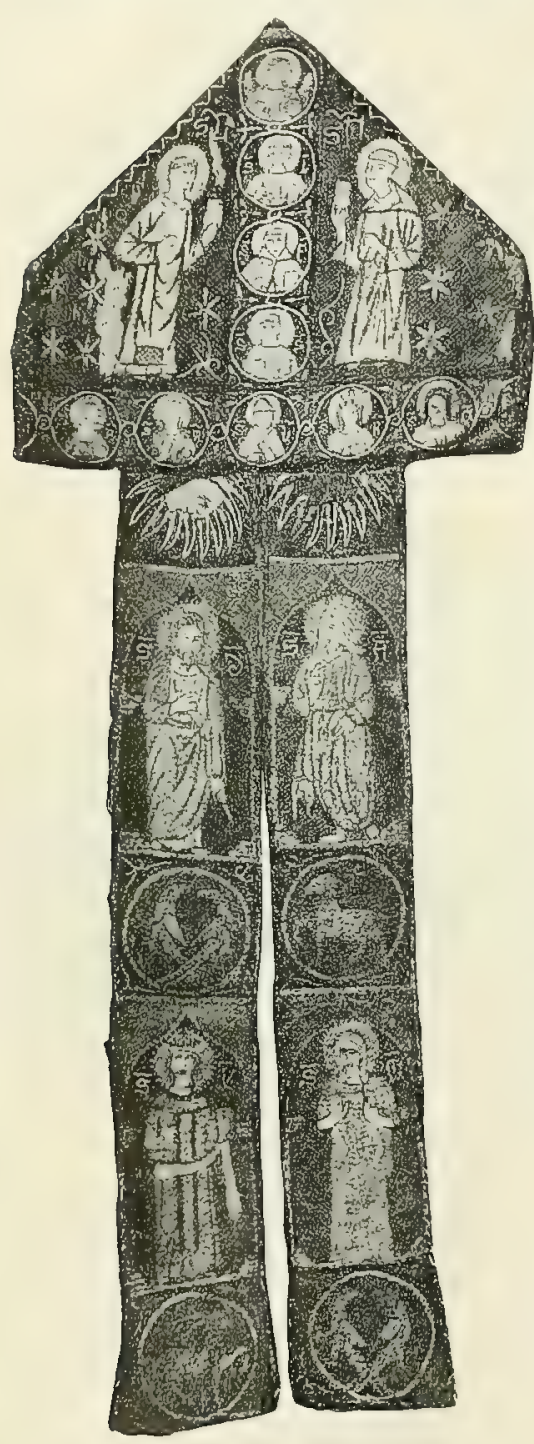

Bild 232. Mitra. Nürnberg, Germ. Museum.

Das Futter besteht bei den Mitren bald aus kräftigem weißen Linnen, bald aus roter oder grüner Seide.

Der 13. Ordo unterscheidet drei Mitren des Papstes; die erste war ganz weif, die zweite nur mit einem Besatz versehen, welcher in der Mitte der cornua sich von oben nach unten zog (cum aurifrisio in titulo - titulus ist die über Stirn und Hinterkopf aufsteigende Fläche - sine circulo), bei der dritten endlich zog sich auferdem ein Streifen um den unteren Rand hin (aurifrisiata in circulo et titulo) ${ }^{1}$. Die simplex alba trug der Papst bei Totenmessen sowie an den Sonn- und Ferial-(Werk-)tagen der Zeit von Septuagesima bis Ostern und des Advents mit Ausnahme der Sonntage Lätare und Gaudete. An diesen wie an den sonstigen Tagen des Jahres bediente er sich der aurifrisiata in circulo et titulo. Die zweite Mitrenart setzte der Papst nur im Konsistorium auf ${ }^{2}$. Dafs auch schon zu Ende des 12. Jahrhunderts irgend ein Unterschied zwischen Mitra und Mitra in Rom bestanden, ergibt sich aus dem 12. Ordo Mabillons, wonach der Papst am Ostertag eine mitra sollemnis gebrauchen soll ${ }^{3}$. Durandus unterscheidet nur zwei Sorten von Mitren, die simplex alba und die aurifrisiata 4 . Unter der letzteren wird er die aurifrisiata in circulo et titulo oder die aurifrisiata in circulo verstehen, da die aurifrisiata in titulo sine circulo auferhalb Roms nicht gebräuchlich gewesen sein dürfte.

Seit welcher Zeit die Unterscheidung zwischen der mitra simplex, der mitra cum aurifrisio in titulo sine circulo und der mitra cum aurifrisio in circulo et titulo datiert, ist nicht festzustellen. Sie mag aber in ihren Anfängen recht hoch hinaufgehen. Denn wenn Paschalis II. den Dignitaren von Compostella gestattet, ut mitris gemmatis capita contegant, in speciem videlicet presbyterorum seu diaconorum sedis apostolicae,

1 Cireulus heißst bald der untere Teil der Mitra, bald der um diesen sich herumziehende Besatz.

${ }^{2}$ Ordo 13, n. 12 (M. 78, 1114).
3 Ordo 12, n. 33 (ebd. 1078).

4 Rationale 1. 3, c. 13 ; f. 76 . D urandi Ep. Mimat. Pontificale (Mart. 1. 1, c. 4, art. 12, ordo 23; I 225). 
so scheint in diesen Worten der Bulle eine Andeutung zu liegen, dafs man bereits zwischen Mitra und Mitra zu unterscheiden angefangen hatte. Die genauere Fixierung des Unterschiedes nnd die Bestimmungen über den Gebrauch der verschiedenen Mitraklassen mögen freilich erst im 13. Jahrhundert erfolgt sein, da sich vorher davon keine Spur findet.

Beispiele von mitrae simplices bilden die schmucklosen weißinnenen Mitren zu Florenz, Anagni, Castel S. Elia. Eine Illustration der mitra cum aurifrisio in titulo et circulo bieten die übrigen noch vorhandenen Mitren aus dem 12. und 13. Jahrhundert. Eine mitra aurifrisiata in titulo sine circulo hat sich nicht erhalten.

Es fehlt der Raum, aus Inventaren des 13. Jahrhunderts längere Auszüge zu bringen, um das Bild, das uns die aus dieser Zeit stammenden Mitren gewähren, zu ergänzen. Immerhin können wir es uns nicht versagen, wenigstens dem Schatzverzeichnis des Apostolischen Stuhles aus dem Jahre 1295 und dem gleichzeitigen Inventar von St Paul zu London einige die Mitren betreffende Angaben zu entnehmen. Sie zeigen, welche Pracht schon um den Ausgang des 13. Jahrhunderts bei der Mitra entfaltet wurde. Ganz besonders gilt das von den zahlreichen Vlitren des päpstlichen Schatzes. Es sind unter ihnen namentlich neun, die unsere besondere Aufmerksamkeit erregen. Nehmen wir nur eine der einfachsten. Sie war ganz mit Perlen bestickt und wies auf der Vorderseite 7 Emails in Rosettenform, 6 durchsichtige grüne Emails, wie wir sie so oft bei den alten Schmelzen zu bewundern haben, 24 Smaragde und 35 kleine Rubine, an der Rückseite außjer Emails derselben Zahl und Art wie auf der Stirnseite 35 kleine Smaragde und 25 kleine Rubine auf. Die Behänge, caudae genannt, waren gleichfalls ganz mit Perlen besetzt und mit Schmelzen, Smaragden und Rubinen verziert. Der Schmelze gab es auf ihnen 20,

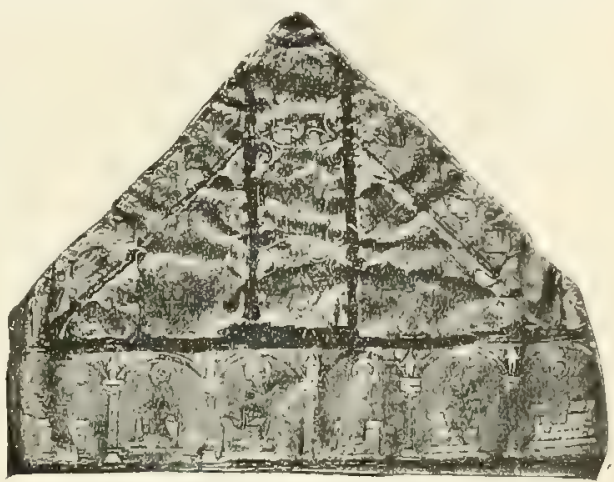

Bild 233. Mitra.

Namur, Kloster der schwestern U. L. Frau. der Smaragde 25 und der Rubine 26. Die Mitra wog 5 me 4 une, also $2^{3 / 4}$ Pfund. Eine andere Mitra, es ist der Kostbarkeit nach erst die sechste, war auf jedem der beiden Schilde mit 7 in Schmelz ansgeführten Medaillons, die mit Brustbildern von Heiligen gefüllt waren, geschmückt. Dazu kamen auf der Vorderseite 16 Saphire, 4 Smaragde, 12 große Türkise, 5 Karfunkel und 17 Granate, auf der Rückseite 24 kleine Saphire, 17 kleine Granate, 12 Turkise und eine Anzahl anderer kleiner Edelsteine. Die Spitze des vorderen Schildes krönte ein grofer dunkler Rubin, die des hinteren Schildes ein großer Chrysopras. Die caudae waren hesetzt mit Schmelzen von verschiedener Form, mit vielen kleinen Saphiren, mit Granaten, Perlen und Glöckchen. Das Gesamtgewicht der Mitra betrug $6 \mathrm{me} 1$ une $=3^{1 / 16}$ Pfund.

Der Aufwand an Email, Edelsteinen und Perlen bei den im Inventar unter n. 5, 4, 3 und 2 aufgeführten Mitren läßt sich zur Genüge aus dem Gewicht erraten, welches diese hatten. Nr 5 wog $6 \mathrm{mc}=3$ Pfund, Nr $48 \mathrm{mc}=4$ Pfund, Nr $37 \mathrm{me}$ 1 unc $-3^{9} / 16$ Pfund, $\mathrm{Nr} 29 \mathrm{mc}=4 \frac{1}{2}$ Pfund.

Am kostbarsten war die in Inventar an erster Stelle genannte Mitra. Hier zählen wir auf der Vorderseite außer drei antiken Kameen auf dem circulus und zwei Kameen auf den Schildzwickeln 20 grofe und 5 kleine Karfunkel, 11 Smaragde, 2 große und 6 kleinere Saphire, 6 Granate, 31 große und 10 kleinere Perlen. Die Rückseite war kaum minder reich behandelt. Da gab es außer 5 Kameen auf dem circulus und den Schildflächen 26 Saphire, 18 Karfunkel, einen großsen Smaragd und 10 kleinere, 6 Granate und 27 Perlen. Von den Behängen aber war einer mit 
6 Karfunkeln, 6 grofen Saphiren, 9 kleinen Granaten, 9 kleinen Saphiren, 27 Perlen, der andere mit 6 Saphiren, 6 grofsen Karfunkeln, 10 kleineren Saphiren, 9 kleinen Granaten und 37 Perlen geschmückt. Dazu endeten beide caudae in je 5 Glöckchen. Das Gesamtgewicht des Ornatstückes entsprach der Ausstattung; es belief sich auf 12 me 1 une $=61 / 16$ Pfund.

Natürlich handelt es sich bei den Mitren, die uns im Inventar Bonifaz' VIII. geschildert werden, um päpstliche Mitren. Indessen würde man fehlgehen, wollte man annehmeu, es habe auferhalb Roms bei den Bischöfen nicht wenigstens ähnliche gegeben. Man durchgehe nur die Angaben des Inventars von St Paul. Da heist es z. B.: Una mitra breudata cum stellis anterius et posterius, insertis lapidibus in laminis argenteis deauratis et deficit 1 lapis in altero pendulorum et in parte anteriori 7 lapides et multae perlae et in parte posteriori 4 lapides et multae perlae; . . . item mitra de Sandvico episcopo (Heinrich von Sandwich, 1263-1273), breudata 2 stellis anterius et 2 stellis posterius et ornata 2 rotellis argenteis insertis lapidibus et perlis multis, et deficiunt in anteriori parte 1 lapis et 2 in pendulis ${ }^{1}$; item una mitra alba breudata cum stellis et frecturis (= aurifrisiis) et 8 limbis (Rundmedaillons) in circulo de purpura ornata lapidibus et floseulis; item una mitra de dono Ricardi episcopi (Richard von Gravesend, 1280-1303) ornata perlis albis per campum (gemeint sind die Schildfächen) et flosculis argenteis deauratis lapidibus insertis ordine spisso (in dichten Reihen) et deficit 1 campanula in 1 pendulorum. Schon fast ein Jahrhundert früher erzählt das Register von Rochester von einer Mitra, welche mit 175 Edelsteinen und 4 Schmelzen geschmückt war. Sie war ein Geschenk des Erzbischofs Hubert von Canterbury $(† 1205)^{2}$.

Die interessanteste Zeit in der Entwicklungsgeschichte der Mitra ist das 12. und 13. Jahrhundert. Um die Mitte des letzteren steht das Ornatstïck unzweifelhaft auf seinem Höhepunkte. Reich, ohne übermäßßigen Prunk, nach Umständen prächtig und kostbar, aber keineswegs protzenhaft, ron mäßiger Höhe und dabei allerwegen von den besten Verhältnissen, nach keiner Richtung hin vordringlich und doch voll Würde, darf die Mitra jener Zeit als das Ideal einer pontifikalen Kopfbedeckung bezeichnet werden.

\section{DIE MITRA IM SPÄTEN MITTELALTER UND IN DER NEUZEIT.}

Die Verbildung des Ornatstückes begann etwa im Verlauf des 14. Jahrhunderts. Sie vollzog sich, wenngleich nur allmählich, doch unaufhaltsam so lange, bis die Mitra im 17. Jahrhundert zu einem himmelanstrebenden, trotz aller Pracht der Ausstattung wenig geschmackvollen Turmbau geworden war. Es ist eigentümlich, dak man um dieselbe Zeit, da man begann, das liturgische Obergewand, die Kasel, zu beschneiden und zu verkürzen, anfing, die Mitra in die Höhe und Breite wachsen zu lassen, gerade als ob beim Bischof das eine ein Ersatz für das andere hätte sein sollen.

Schon die Mitren des 14. Jahrhunderts nahmen an Höhe merklich zu. Noch zu Ende des 13. übertraf die Breite des zusammengeklappten Ornatstückes die Höhe um mehrere Zentimeter, im 14. aber wurden Höhe und Breite bald einander gleich. Im 15. Jahrhundert änderte sich dann das Verhältnis noch mehr zu Gunsten der Höhe. Nicht lange und sie überragte

1 Zu den hier geschilderten Mitren mit aufgesticktem Stern auf den Schilden biklen die Mitren von St-Bertrand zu Comminges und Pontigny sowie eine der vier Mitren in St Peter za Salzhurg (Mitt. XVIII [1873] 201) vortreffliche Illustrationen. Die An- gaben des Inventars von St Paul sind daher sehr wichtig für die Datierung der genannten Mitren. Vgl. auch die nach einer noch vorhandenen Skizze Montfaucons bei Roh. VIII, pl. DCLXIJI abgebildete Mitra.

${ }^{2}$ Revue 1887, 335. 
die Breite fast ebenso, wie sie derselben ursprünglich nachstand. Verhielten sich beide anfänglich wie etwa $1:{ }^{2 / 3}$, wobei 1 als Breite angenommen ist, so jetzt beinahe wie $1:{ }^{t / 3}$. Wie sich dann die Sache im weiteren Verlauf der Dinge gestaltete, erhellt aus den zahlreichen Bildwerken, welche sich aus der Zeit der absterbenden Gotik und der aufblühenden Renaissance allenthalben erhalten haben. Barock und Zopf konnten der Höhe der Mitra kaum noch etwas hinzufügen, so hoch war das Ornatstück schon im Beginne des 17. Jahrhunderts geworden.

Eine andere Umwandlung, welche mit der Mitra vor sich ging, bestand darin, dafs man diese sich vom unteren Rande an bis zu den Schrägungen allmählich erweitern lief, indem man den Seiten eine Neigung nach aufen gab. Vereinzelt mag solches schon im 14. Jahrhundert vorgekommen sein, doch hatte eine derartige Praxis noch in der ersten Hälfte des 15. Jahrhunderts sehr wenig Verbreitung erlangt. Erst gegen Ausgang desselben wurde sie, wie es scheint, häufiger, um dann freilich rasch sehr gewöhnlich und im 17. Jahrhundert sogar zur Regel zu werden.
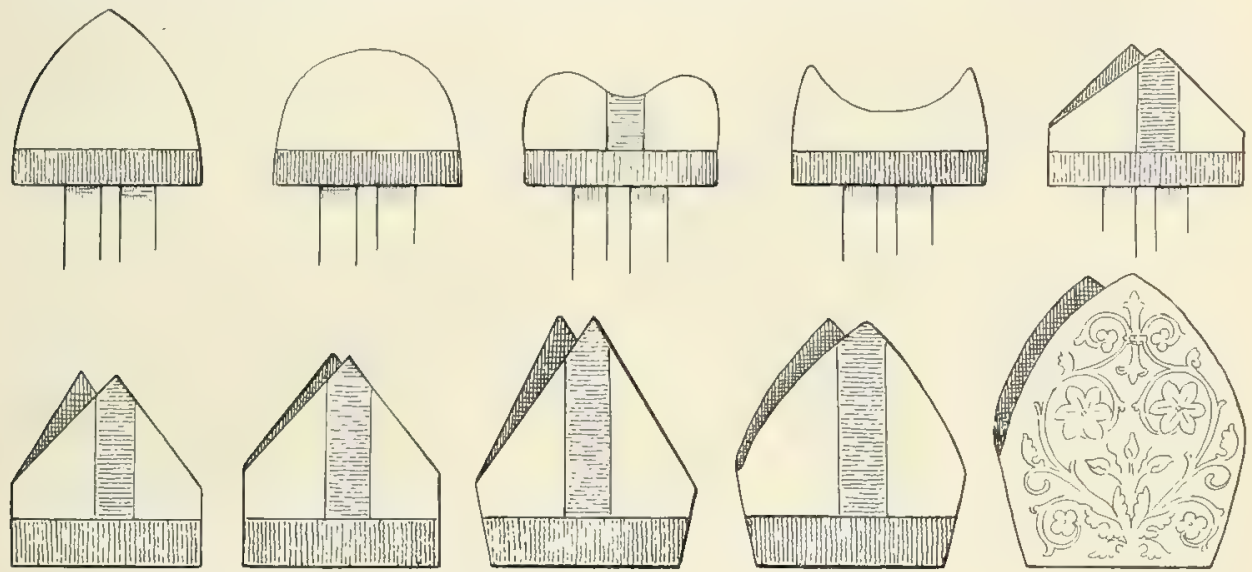

Bild 234. Entwicklung der Mitra vom 11. Jahrhundert bis hente.

Den Veränderungen hinsichtlich der Höhe und Weite gesellten sich um den Ausgang des Mittelalters, namentlich aber seit dem 16. Jahrhundert noch zwei weitere hinzu. Die erste war, daß man nicht nur die Mitra überhaupt, sondern auch, und zwar ganz besonders, die cornua selbst mehr als vordem aufsteigen lief, so dafi an die Stelle des rechten Winkels, mit dem dieselben früher abschlossen, ein spitzer trat; die zweite darin, dak man die ehemals eine gerade Linie darstellenden Schrägungen der Hörner bald mehr bald weniger bogenförmig gestaltete und sie auferdem auch wohl ohne jeden Winkel durch eine bloße Krümmung in den unteren Teil der Mitra überleitete (Bild 234).

Was seit dem 13. Jahrhundert die verschiedenen Veränderungen an der pontifikalen Kopfbedeckung veranlabte, war die steigende Prunkliebe und im Zusammenhang damit die immer mehr zunehmende Lust, die Mitra möglichst reich zu dekorieren. Man bedurfte dazu natürlicl größerer Flächen und erzielte diese durch Erhöhung und Erweiterung des Ornatstückes. So hatte man den nötigen Platz, auf dem Sticker und Goldarbeiter um die Wette ihre Tätigkeit entfalten konnten.

Was den Reichtum und den Glanz der Ausstattung anlangt, können denn auch die Mitren aus dem 13. Jahrhundert, so kostbar sie auch in ein- 
zelnen Fällen seim mochten, mit denen der Folgezeit durchweg keinen Vergleich aushalten. Alles geht nun im Ornament auf. Perlen, Steine in kostbaren Fassumgen, Gold- und Silberbleche, Emailplättchen, aufgestickte geometrische Gebilke, Blumen, Ranken und figürliche Darstellungen (bald Einzelbilder, bald Gruppen) u. a. schmücken oder imitieren die Besätze und füllen die tituli sowie die Behänge. Man holt zur Ornamentierung der Mitra selbst aus der Architektur Motive herbei, indem man nicht nur die Flächen der Schilde mit Bogenstellungen, Ziergiebeln, Fialen, Konsolen und Baldachinen bestickt, sondern auch auf den Schrägseiten nach Art der Ziergiebel Krabben aufplianzt und die Spitze der Hörner in eine Kreuzblume endigen läßst. Man betrachte nur die Gemälde, auf welchen die Meister des ausgehenden Mittelalters mit kunstgeübter Hand und in aller Sorgfalt gar manche damalige Mitra in der ganzen Pracht ihrer Ausstattung wiedergegeben haben; lese die Schatzverzeichnisse, die uns von dem Reichtum an kostbaren Mitren Kunde tun, welchen in jener Zeit die Truhen der Dom-, Kloster- und Stiftskirchen bargen; beschaue die Mitren, welche sich aus jenen Tagen in unsere hineingerettet und nun in irgend einem Museum oder dem Schatze einer Kirche ein schützendes Plätzchen gefunden haben, oder werfe auf die prächtigen Grabfiguren des 14. und 15. Jahrhunderts einen Blick, und man wird das Gesagte hundertmal bestätigt finden. Es kann nicht geleugnet werden, dafs jene Zeit gar manche überaus glanzvolle Mitra hervorgebracht hat, und daf nicht wenige dieser Mitren wahrhafte Meisterwerke der Kleinkunst gewesen sind; indessen lälit sich ebensowenig verkennen, dafs das Übermaf, von Prunk, welches man schon damals auf dem Ornatstücke zu entfalten liebte, nicht nur die Abkehr von wïrdevoller, einfacher Größe und schlichter Hoheit bedeutete, sondern, was noch schlimmer' war, auch den Weg zu immer größerer Entartung des pontifikalen Kopfschmuckes bildete. Wie kostbar die Nitren im 15. Jahrhundert bisweilen waren, ergibt sich aus einer Vitteilung Vasaris im Leben Lorenzo Ghibertis. Danach lieb Eugen IV. 1439 durch diesen Florentiner Künstler eine Mitra anfertigen, welche 15 Pfund wog und einen Wert von 30000 Golddukaten hatte. Von dem Gesamtgewicht entfielen allein auf die Perlen, mit welchen das Ornatstück geschmückt war, 51/2 Pfund 1 . Eine Mitra, welche Heinrich VIII. von England bei Aufhebung der Abtei Fountain beschlagnehmen liek, wog vor lauter Perlen und Edelsteinen 70 Unzen $=4^{1 / 4}$ Pfund $^{2}$.

Es kann nicht unsere Absicht sein, alle aus dem 14. und 15. Jahrhundert noch vorhandenen Mitren einer Besprechung zu unterziehen. Die 7ahl derselben ist dafür zu groß. Immerhin dürfte es sich empfehlen, wenigstens auf einzelne derselben, die eines besondern Interesses wert sind, etwas näher einzugehen. Wir werden aber gut tun, dabei wieder den verschiedenen Ländern zu folgen. Aus Italien verzeichnen wir die Mitra Johannes' XXII. im Museo cristiano des Vatikans, eine dem hl. Ubaldus von Gubbio zugeschriebene, nach Ausweis ihrer Form und des Stiles ihrer Stickereien aber dem 15. Jahrhundert angehörende, teils in S. Pietro in Vincoli teils in S. Maria della Pace zu Rom hefindliche Mitra, dann zwei als Reliquien des seligen Nikolaus Albergato († 1443) geltende Mitren im Dom zu Bologna, eine irrigerweise als Mitra des hl. Bonaventura bezeichnete Mitra im Collegio delle Missioni zu Bagnorea, eine Mitra im Dom zu Cividale, welche fälschlich dem hl. Paulinus von Aquileja († 802) zugeeignet wird, und endlich eine Nitra im Museum zu Ravenna.

1 Vasari, Le vite II, Firenze 1878, 236. Möglich übrigens, daf unter der Mitra, von der hier Vasari erzihlt, eine Tiara zu verstehen ist, da auch djese wohl Mitra genannt wurde, obsehon nicht gerade häufig.

${ }^{2}$ Dugdale, Monast. anglican. V 290. 
Abgesehen von der Mitra Johannes' XXII. gehören alle dem 15. Jahrhundert an. Die Mitra von Bagnorea, die jüngste von ihnen, erscheint schon zum förmlichen Tur'm entwickelt, ist aber im übrigen ein schönes Stück. Ausgezeichnete Arbeiten sind die mit Halbfiguren gefüllten Vierpässe auf den Zwickeln der Schilde. Die beiden Mitren im Dom zu Bologua sind nicht nur die kostbarsten mittelalterlichen Uitren, welche Italien aufzuweisen hat, sie gehören unzweifelhaft zu den prächtigsten, welche überhaupt sich aus dem Mittelalter erhalten haben. Beide sind charakteristisch für ihre Zeit. Hat doch die eine eine Höhe von $0,38 \mathrm{~m}$ bei einer Breite von $0,32 \mathrm{~m}$, während die andere $0,38 \mathrm{~m}$ hoch und $0,31 \mathrm{~m}$ breit ist ${ }^{1}$.

Bei der ersten ist der Fond durch im Korbstich applizierte Silberfäden gebildet. Die Zierstreifen weisen Goldgrund auf und sind mit Ranken in Perlstickerei und Medaillons prächtig verziert. Auch auf den Schilden ist zu beiden Seiten des Vertikalbesatzes ein Medaillon angebracht, Die Figuren in den Medaillons - Christus, Maria und Heilige -, vortreffliche Arbeiten, sind vornehmlich im sog. gespaltenen Stich hergestellt. Die Umrahmung der Schrägseiten hildet eine mit Ranken verzierte Goldborte. Die Hörner sind durch eine Klappe von rotem Samt miteinander verbunden und enden an der Spitze mit einem dunkelblauen Stein. Von den Edelsteinen, mit denen einst die Zierstreifen in titulo und circulo besetzt waren, sind nur noch einzelne vörhanden.

Die Behänge, welche an ihrem unteren Ende eine Breite von $0,08 \mathrm{~m}$ haben ihre Länge liek sich nicht genau feststellen, weil sie im Reliquiar teilweise zusammengefaltet sind - - sind in derselben Weise wie der Fond der Mitra gearbeitet und unten mit zwei vorzüglich gestickten, unter einem Baldachin angebrachten Heiligenfiguren geschmückt. Jm Inneren ist die Mitra mit weißlinnenem Futter ausgestattet.

Die zweite Mitra entbehrt der figürlichen Stickerei vollständig. Dafür ist sie aber in anderer Beziehung um so kostbarer. Die Stelle der in Bildstickerei hergestellten Medaillons vertreten bei ihr sowohl auf den Besätzen als auch auf den beiden Zwickeln der Schilde schwere silhervergoldete, mit je fünf Edelsteinen besetzte Plättchen. Außerdem ist die Mitra samt ihren Besätzen und Behängen noch mit einer Anzahl alleinstehender Edelsteine verziert.

Der Grund der Besätze besteht aus abgehefteten Goldfäden, derjenige der Mitra und der Behänge, welcher von Goldfäden in Form von Ranken durchzogen ist, aus dicht aneinander gefügten kleinen Perlen. Der Vertikalstreifen des titulus schlieft oben mit einem dreieckigen Emailplättchen ab, auf dem das Lamm Gottes dargestellt ist. Die Behänge endigen gleichfalls mit einem Emailplattchen. Dasselbe hat die ganze Breite der Behänge, ist mit zwei Büsten, wie es scheint, der Apostel Petrus und Paulus, geschrnückt und oben mit einem Kamm, unten aber mit drei langen, silbervergoldeten Glöckchen versehen. Hart oberbalb der Plättchen sieht man zwei in Email ausgeführte Wappen, welche ein rotes Kreuz in weifem Felde enthalten.

Die Schrägseiten der Mitra sind mit den in der Spätgotik bei den Mitren nicht seltenen, den Giebelkrabben nachgebildeten Blättern geschmückt.

Beide Mitren sind in vorzüglichem Zustande. Die Mitra Johannes' XXII. († 1334) wurde 1759 zu Avignon in dessen Grab gefunden. Aus weifem Damast gearbeitet, entbehrt sie jeden Besatzes. Thre mit roter Seide gefütterten caudae haben an den Enden rote Fransen ${ }^{2}$. Ihre sichere Datierung ist für die Geschichte der Entwicklung der Mitra von Wichtigkeit.

In Spanien gibt es nur sehr wenige Mitren aus dem späten Mittelalter. Die vorzüglichste von allen befindet sich in dem auch in sonstiger Beziehung reichhaltigen bischöflichen Museum zu Vich ${ }^{3}$. Sie entstammt dem Ende des 14. Jahrhunderts, ist

1 Abbildung der Mitren zu. Bagnorea und Bologna in Zeitschrift XV (1902) 13, der Mitra zu Cividale in J. P. K i $\mathrm{rsch}$ und V. Luksch, Gesch. der. kath. Kirche 231. 2 Wegen der übrigen Mitren vgl. Braun,
Italien. Mitren aus dem Mittelalter, ebd. 5 ff. Wenn wir oben die Mitra in S. Martino ai Monti (vgl. S. 438) nicht erwähnten, so geschah das, weil sie ohne Bedeutung ist.

${ }^{3}$ Abbildung bei de Farcy pl. 154. 
aus weißer Seide angefertigt, mit reichen, in Gold- und Seidenstickerei hergestellten Borten besetzt und reist in Vierpässen, die von einem Quadrat durchschnitten sind, auf der Torderseite die Verkündigung, auf der Hinterseite die Krönung ILariä auf. Andere Nitren haben sich zu Saragossa und Toledo erhalten. Beide sind auf dem vorderen Achilde mit einer Darstellung der Kreuzigung versehen. Die Mitra zu Saragossa mag noch dem 14. Jahrhundert angehören; dagegen stammt die zu T'oledo unzweifelhaft erst aus dem 15. Jahrhundert ".

Anch in Frankreich ist die Zahl spätmittelalterlicher Mitren nicht grof. Sie gehören der Mehrzahl nach dem 15. Jahrhundert an.

Eine Mitra in der Kathedrale zu Lyon, die sich durch ihre auffallend geringe Höhe auszeichnet, besteht aus rotem Samt. Ihre Besätze, breite Goldborten, sind mit ornamentierten, silbervergoldeten Zierplättchen, die zum Teil mit kleinen, losen Behängseln versehen sind, geschmückt ${ }^{2}$.

Eine Mitra in der Kathedrale zu Besançon kommt von Bischof Karl von Neufchâtel, der sie 1481 zu Caen anfertigen lief. Sie ist ein ebenso kostbares wie prunkvolles Stück. Die aus abgehefteten Goldfäden gebildeten Besätze und Behänge sind

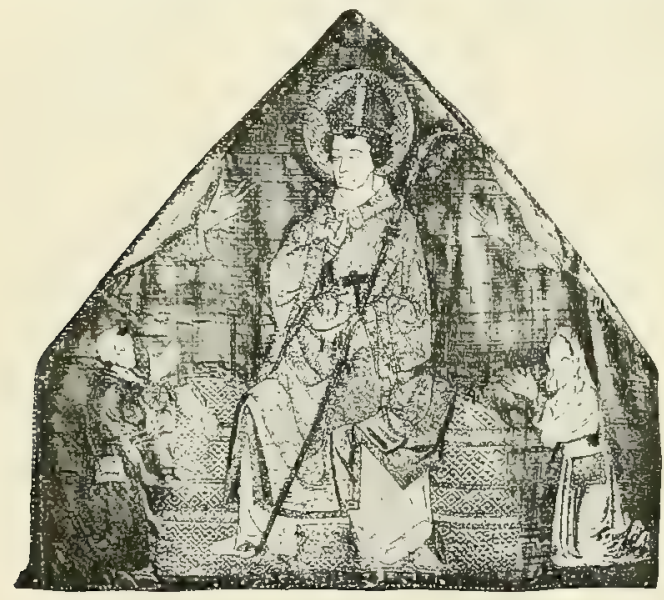

Bild 235. Mitra des Jean de Marigny. Evreux, Museum, (Phot. de Farcy.) reich mit Edelsteinen und perlen. gestickten Rosetten besetzt. Von den Schilden, deren Fond aus Silberfäden gebildet wird, weist der vordere in Reliefstickerei die Verkündigung, der hintere die Geburt Christi auf. Über die Schrägseiten ziehen sich silbervergoldete Krabben hinauf zur Spitze, die von einem zierlich gearbeiteten Kreuz bekrönt wird ${ }^{3}$.

Eine dem Cluny-Museum zu Paris angehörige, um 1400 entstandene Mitra, welche ehedem gleichfalls eine vorzügliche Arbeit gewesen sein muß, jetzt aber in sehr schlechtem Zustand ist, hat auf den goldgestickten Zwickeln der Schilde die Verkündigung bzw. die Krönung Mariä und auf den goldgestickten Besätzen Halbbilder von Heiligen unter gedrückten Arkaturen *

Eine Mitra im Museum zu Evreux stammt nachweislich aus der ersten Hälfte des 14. Jahrhunderts (Bild 235). Die Höhe ist bei ihr der Breite nahezu gleich. Ausgezeichnet sind die Stickereien der beiden Schilde, von denen einer St Petrus zwischen Cornelius und Dorkas, der andere aber St Eligius zwischen den Stiftern, Enguerrand von Marigny und seiner Gemahlin, enthält. Besätze fehlen der Mitra gänzlich.

Drei Mitren des Nationalarchivs zu Paris, jetzt ebenfalls im Cluny-Museum, stammen aus dem Temple. Sie sind schon zu bedeutender Höhe herangewachsen. Zwei von ihnen sind besonders bemerkenswert. Die eine ist mit Stickereien geziert. Üher einer den Randbesatz vertretenden Folge von Arkaden mit Heiligen, die in Halbfigur dargestellt sind, erhebt sich eine förmliche Architektur, ähnlich dem Querschnitt einer gotischen dreischiffigen Kirche mit überhöhtem Mittelschiff. Heilige stehen in den Seitenteilen, während der mittlere Teil unten die Geburt bzw. die Anbetung des Jesuskindes und oben die Kreuzigung bzw. die Verkünaigung aufweist. Die Behänge sind mit dem Bilde der Gottesmutter, die das Jesuskind im Arm hält, und dem eines betenden Bischofs bestickt ${ }^{5}$. Die Mitra mag um 1450 angefertigt sein.

\footnotetext{
1 Abbildung bei C'alsier', Décorations

${ }^{3}$ Abbildung ebd. pl. 59. d'églises 1441.

2 Abbildung bei de Farey pl. 10.

5 Abbildung ebd. pl. 51.
} 
Die zweite Mitra (Bild 236) besteht aus weißer Seide und ist in Schwarz auf dem circulus mit den Halbbildern der Apostel unter gotischen Bogen, auf den tituli aber mit den Darstellungen des Begräbnisses und der Auferstehung Jesu bemalt. Ihrem ganzen Charakter nach scheint sie gemacht worden zu sein, um bei Tranerfeiern gebraucht zu werden. Sie entstammt dem Encie des 14. oder Anfang des 15. Jahrhunderts. Ein Gegenstück zu ihr bildet eine aus der St-Chapelle zu Paris herrührende. jetzt in der Stadtbibliothek zu Amiens befindliche Trauermitra, wie wir sie wohl nennen dürfen. Sie ist einfacher und gegen Ende des 15. Jahrhunderts entstanden. Die Schilde enthalten eine Kreuzigungsgruppe bzw. das jüngste Gericht, der circulus ist mit Rosetten geschmückt ?

Eine Mitra zu Brignoles (Var), welche dem hl. Ludwig von Toulouse zugeschrieben wird, bildet ein Gegenstück zur sog. Mitra des hl. Silvester zu Rom. Wir haben es anch bei ihr zweifelsohne mit einer Mitra zu tun, die für eine Statue oder eine Reliquienbiiste des Heiligen gemacht wurde. Das beweist mit aller Bestimmtheit ihre minimale Breite von nur $0,218 \mathrm{~m}$. Die Mitra stammt, wie Form und Höhe beweisen - sie ist bei ihrer geringen Breite $0,28 \mathrm{~m}$ hoch aus dem 15. Jahrhundert?

Eine Mitra in der Kathedrale zu Châlons-sur-Marne besteht aus grauer, gestreifter Seide. Sie hat bei einer Breite von $0,27 \mathrm{~m}$ die bedeutende Höhe von $0,37 \mathrm{~m}$, während sie an den Seiten nicht weniger denn $0,20 \mathrm{~m}$ hoch ist. Die rotseidenen, $0,05 \mathrm{~m}$ breiten Besätze ziehen sich auch die Schrägungen entlang und sind mit Kreisen geschmückt, in denen doppelköpfige Adler und Leoparden angebracht sind. Die Dessins sind in Gold ausgeführt ${ }^{3}$.

Was Schweden anlangt, so wäre neben einer Mitra in der Kathedrale zu Westerås, Provinz Westmanland, welche dem 15. Jahrhundert angehört und auf den Schilden mit einem Weinstock als Krenzesbaum, einem Pelikan darüber und je einem Einhorn zu beiden Seiten geschmückt ist, vor allem der Mitra im Nationalmuseum zu Stockholm zu gedenken. Auch sie entstammt dem

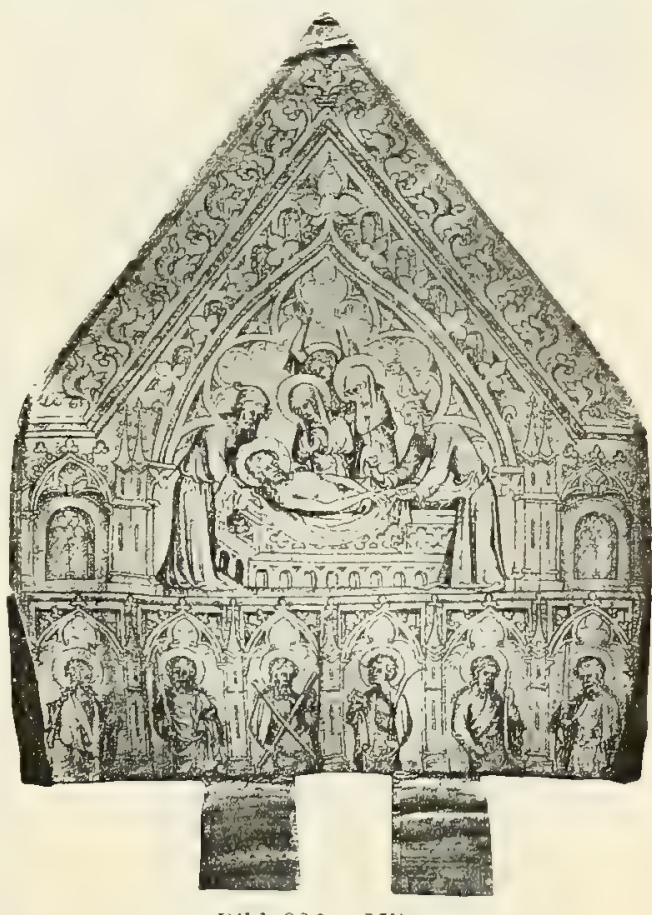

Bild 236. Mitra.

Paris, Muscée Cluny. (Phot. de Farey.।

15. Jahrhundert, doch sind die Emails, mit denen die Besätze und Behänge versehen sind, jedenfalls älteren Datums. Neben einer Anzahl trapezförmiger Plättchen gibt es auf denselben achtzehn Rundmedaillons von $0,05 \mathrm{~m}$ und zehn von $0,03 \mathrm{~m}$ im Durchmesser. Dazu kamen ehedem auf den Zierstreifen und den caudae noch eine gröfsere

1 Abbildung ebd. pl. 158.

2 Es ist unverståndlich, wie selbst ein so gewiegter Forscher wie de Linas (Revue 1861, $225 \mathrm{ff}$ mit Abbildung) die Mitra als authentisch hat ansehen konnen. Der Stoff der Mitra ist allerdings aus früherer Zeit als die Mitra selbst, da diese aus einem älteren Stoff hergestellt wurde.

${ }^{3}$ Nach gütiger Mitteilung des P. L. Carrez S. J. Die Mitra soll vom hl. Malachias herrühren. Eigentümlich ist, daßs einer der Kreise auf den Besåtzen mit einem Kreuz gefüllt ist, und daß die Löwen und Adler in den übrigen zu beiden Seiten so gestellt sind, dak sie dem Kreise mit dem Kreuz den Kopf zuwenden. Es läfst sich das kaum anders als durch die Annahme erklären, als daf3 der Besatz ursprünglich eine Stola war. Vielleicht, daf diese aus dem Schrein des hl. Malachias herriihrt. In diesem Fall wïrde es sich leicht begreifen, wie die Mitra dazu kam, als diejenige des hl. Malachias zu gelten. 
Zahl nummehr bis auf die Fassung verschwundener Edelsteine. Die Schildzwickel sind mit figürlichen Perlstickereien, die Verkündigung usw. darstellend, gefüllt ${ }^{1}$.

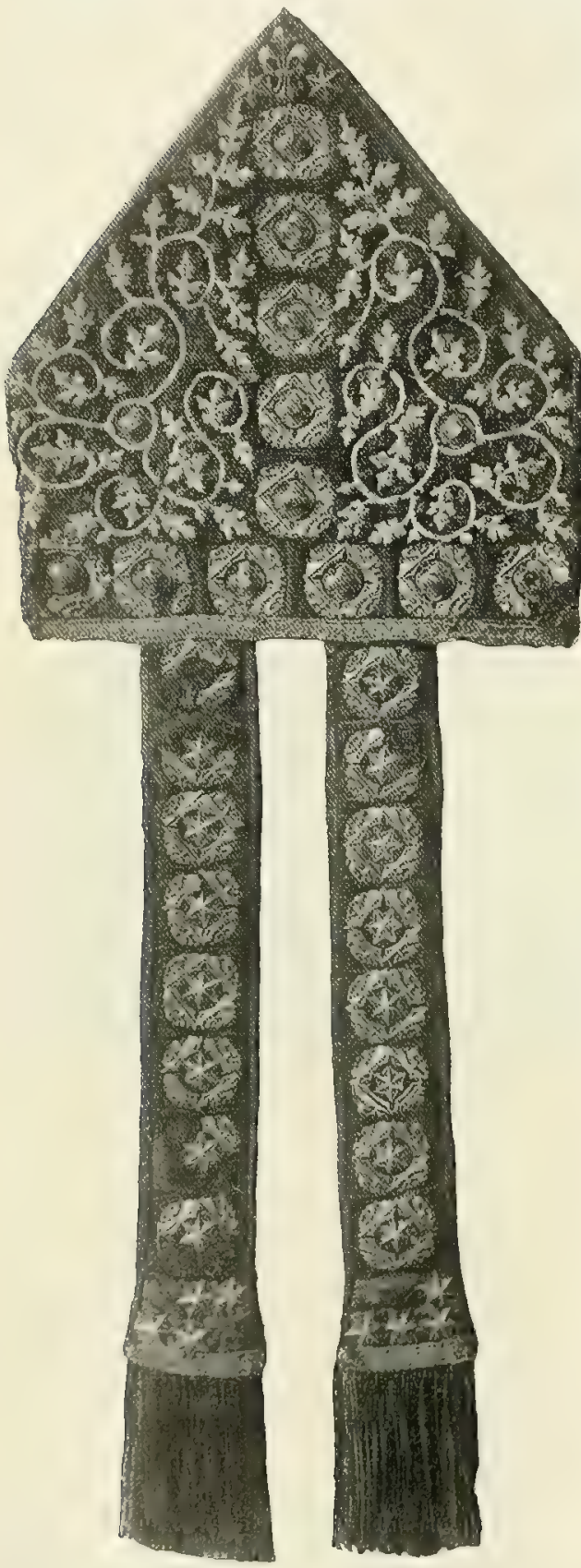

Bild 237. Mitra. Halberstaßt, Dom,

Drei Mitren im Nationalmuseum zu Kopenhagen gehören dem Beginn des 16. Jahrhunderts an; eine stammt von Skalholt in Island, eine zweite von Sorö, die dritte aus Ripen. Am bemerkenswertesten ist bei ihnen die Höhe, die sich bei den beiden ersten auf ca $0,38 \mathrm{~m}$ beläuft; im übrigen sind sie unbedeutend.

In Irland findet sich zu Limerick eine ungemein kostbare, mit Edelsteinen und Perlen aufs reichste geschmückte Mitra ${ }^{2}$; in England besitzt man zu Oxford im New College noch eine leider sehr schadhafte Mitra des Bischofs von Winchester Wilhelm von Wykeham $(\dagger 1404)^{3}$.

Die meisten spätmittelalterlichen Mitren haben sich in Deutschland und Österreich erhalten. Im Dom zu Halberstadt allein gibt es deren sechs, vier andere besitzt das historische Museum zu Dresden, zwei das königliche Gewerbemuseum zu Berlin, je eine der Dom zu Prag, die Benediktinerabtei Admont in Steiermark, der Dom zu Brixen, das St Peterstift zu Salzburg, der Dom zu Krakau und das Museum für Kunst und Industrie zu Wien.

Von den Mitren des Halberstädter Domes sind besonders erwähnenswert die beiden reich mit Perlen und silbervergoldeten Plättchen besetzten rotsamtnen Mitren (Bild 237, 238), Eigenartig ist eine Mitra, welche auf dem Vorderschild mit einer Kampfesszene geschmückt ist. Bock hat, weil er einen der beiden Kämpfer irrtümlich für einen Juden hielt, die Darstellung auf den Kampf zwischen Christentum und Judentum gedeutet ${ }^{4}$. Indessen gibt dieselbe lediglich einen Kampf zwischen zwei Rittern wieder. Die Mitra ist ein Beispiel, wie unbefangen man im Mittelalter bei Anfertigung kirchlicher Gewänder zu Werke ging. Wie man in aller Naivität für die Kaseln Stoffe mit arabischen Inschriften brauchte und nicht im mindesten danach fragte, ob auf den Zeugen, aus denen man die Paramente anfertigte, Hunde, Löwen, Hasen und sonstiges Getier, Ritter, Frauengestalten

${ }^{3}$ Dieselbe ist ebenfalls mit zahlreichen Edelsteinen besetzt.

4 Abbjldung bei Bock II, Tfl 24, dazu S. 178; in Farben: Mitt. XII (1867) XLV. byzantinischen Emails, Frankfurt 1892, 257.

2 Abbildung bei Macalister, Ecclesiastical vestments 120 . 
und Ungeheuer, Jagdszenen, Fischfang, Brunnenszenen und ähnliche Dinge dargestellt waren, so hat man hier eine Stickerei mit einem Ritterkampf, die man gerade besaf, benutzt, um daraus mit Hilfe eines andern Zeugrestes, der für die Rückseite verwendet wurde, eine Mitra zu machen. Nichts ist verkehrter, als im Nittelalter überall Symbolik zu wittern. Von den beiden Mitren im Berliner Gewerbemuseum besteht die eine aus blauem Samt; ihre Besätze weisen in farbiger Seide gestickte Ranken auf. Die andere ist auf den Schilden, den Besätzen und Behängen mit Perlen reich geschmückt. Eine Abbildung dieser aus dem Dom zu Minden stammenden Mitra, die noch jetzt trotz ihres defekten Zustandes sehr bemerkenswert ist, überhebt uns einer näheren Beschreibung (Bild 239, S. 482).

Durch vortreffliche Figurenstickereien zeichnen sich aus die Mitra des Stiftes Admont, die aus Arnoldstein herrührende Mitra des Wiener Museums für Kunst und Industrie sowie zwei der Dresdener Mitren. Bei einer der letzteren sind die Darstellungen (Verkündigung usw.) in Perlstickerei ausgeführt ${ }^{1}$. Die Arnoldsteiner Inful stammt aus dem 14. Jahrhundert ${ }^{2}$. Bemerkenswert ist, daf zur Einfassung der Medaillons, mit denen ihre Aurifrisien und Behänge verziert sind, wie auch zu den Börtchen der Aurifrisien statt wirklicher Perlen Silberperlen zur Verwendung gekommen sind. Die Mitra des Stiftes Admont ist eine Arbeit aus dem Beginn des 15. Jahrhunderts ${ }^{3}$. Sie ist von sehr gefälliger Form. Die Zwickel der Schilde enthalten auf Goldgrund die Ganzfiguren der Gottesmutter mit dem Kind und dreier Bischöfe. Auf den Behängen gewahrt man die Brustbilder der Apostel in perlenumrahmten Medaillons. Von glücklichster Wirkung ist, dafs die Aurifrisien nur mit eleganten spätgotischen Ranken und Blumen, nicht aber mit Heiligendarstellungen gefüllt sind. Wo alles, auch die Besätze mit Heiligendarstellungen geschmückt sind, müssen, was in der Tat durch manche der spätmittelalterlichen Mitren bestätigt wird, die Besätze mehr oder weniger im Ganzen aufgehen und ihre Bedeutung verlieren.

Die Mitra im Dom zu Krakau bekundet, obwohl unter Bischof Thomas Strzempinski (1455-1460) angefertigt, bereits

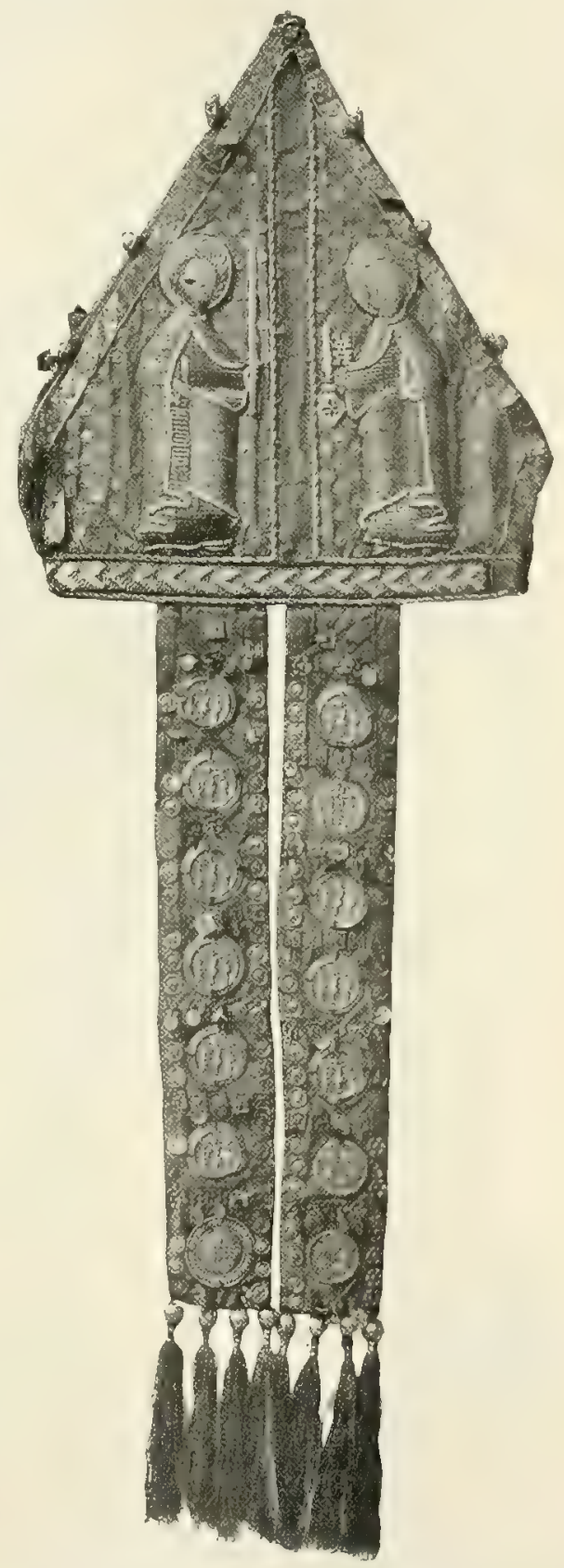

Bild 238. Mitra. Halberstadt, Dom.

der freundlichen Auskunft, welche die Direktion mir bereitwilligst erteilte.

2 Abbildung Mitt. N. F. VIII (1882) 27.

3 Abbildung Mitt. XII (1867), 75. 
deutlich den Einfuß der Renaissance. Die Form ist freilich noch die im 15. Jahrhundert gewöhnliche: hoch ansteigende Schilder mit geraden Schrägseiten, auf denen sich Metallkrabben hinziehen; auch sind noch die Aurifrisien gebührend betont. Dagegen hat das Ornament der Schildzwickel und Behänge einen ausgesprochenen Renaissancecharakter.

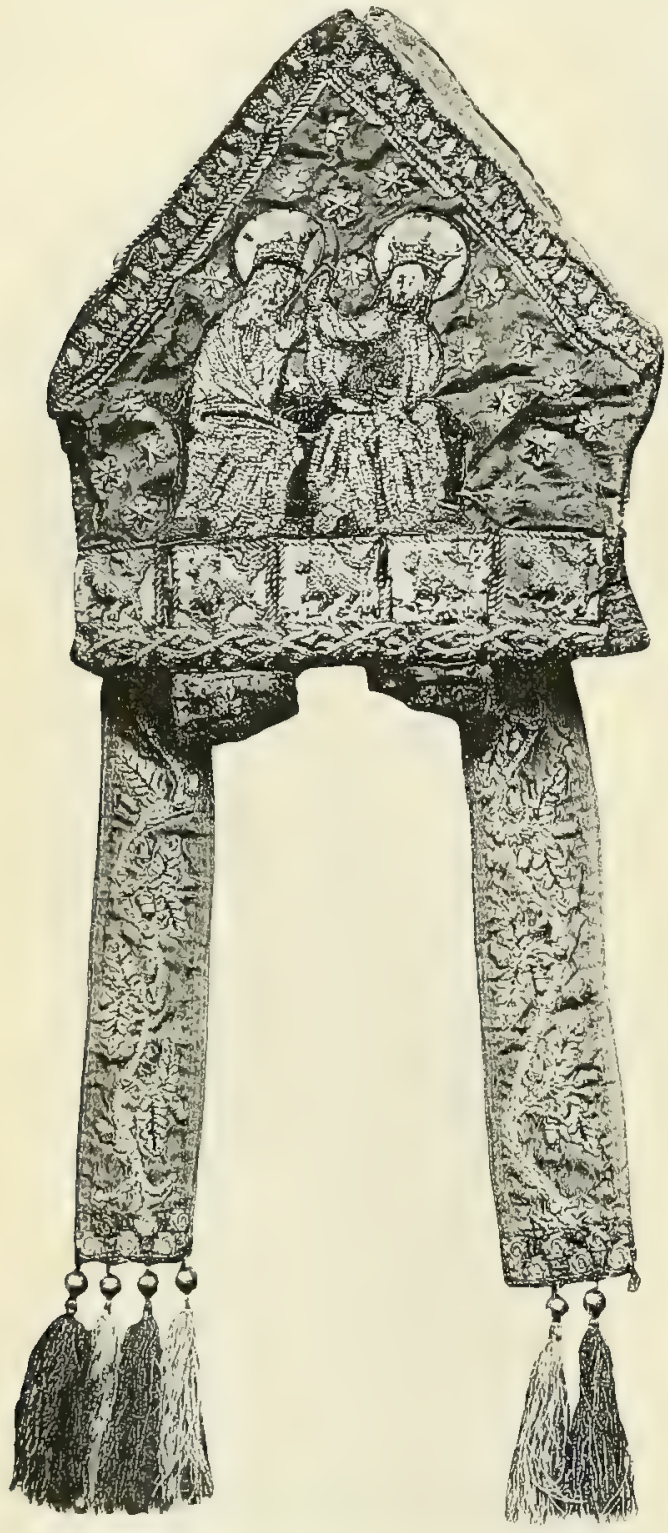

Bild 239. Mitra. Berlin, Kunstgewerbemuseum.

Ungemein kostbar ist die Mitra des Salzburger St Peterstiftes; sie ist die prunkvollste Inful, die wir überhaupt aus dem Mittelalter noch besitzen. Es genüge zu bemerken, dak auf ihr auker manchen Hunderten von großen und kleinen Perlen über 500 mehr oder weniger kostbare Steine angebracht sind, und daßs sie etwas über fünf Pfund wiegt. Die Schrägseiten sind mit den so beliebten Giebelblumen versehen. Die Spitze der Hörner endet in einer Kreuzblume, deren Abschluß ein großer blaner Stein bildet. Wie der Mitra selbst, sind auch den Behängen Perlen und Edelsteine in überreichstem Mafe aufgesetzt. Die Salzburger Mitra kann als Illustration jener Mitra dienen; welche Eugen IV. dureh Ghiberti anfertigen lief'.

Mit dem 16. Jahrhundert beginnen allgemach die figürlichen Darstellungen von dem pontifikalen Kopfschmuck zu verschwinden, doch kamen noch bis zum Ende desselben Mitren vor, die mit Heiligenfiguren geschmückt waren. Zwei interessante Beispiele sind die Mitra Friedrichs von Wirsberg († 1573) im Dom zu Würzburg und eine jetzt im Kensington-Museum zu London befindliche Mitra aus dem Jahre 1592. Die gotische Architektur, welche bei der letzteren die Schilde in zwei Felder teilt, verrät wenig Verständnis der gotischen Formen und Stilgesetze mehr. Eine um so vorzüglichere Leistung sind dafür die Heiligenfiguren in den Schildzwickeln und auf den Behängen, zumal die ersteren. Die Würzburger Mitra trägt (Bild 240) schon ganz Renaissancecharakter. Nur die plastisch ausgeführten Halbfiguren der vier lateinischen Kirchenväter verraten noch etwas die spätmittelalterliche Formensprache. Ungemein reizend ist das in Sprengarbeit und Bouillonstickerei

1 Abbildungen der Mitren von Krakau Mitt. XII (1867) 77; der Salzburger Mitra ebd. XVIII (1873) 201311. 
hergestellte Ornament, welches die schon stark gerundeten Schrägseiten einfaßst und den circulus samt den Vertikalbesätzen imitiert 1.

Das 17. Jahrhundert gibt den mit Bildwerk versehenen Mitren endgültig den Abschied. Die Mode ist eine andere geworden. Beladet man die Mitra nicht mit Steinen und Perlen, so überzieht man sie in Goldstickerei mit Arabesken, Grotesken und sonstigen Ornamenten, wie dieselhen gerade der zur Zeit herrschenden Kunst- und Geschmacksrichtung entsprechen (Bild 2 41 , S. 484). Von religiösen Symbolen brachte man allenfalls noch ein Kreuz, den Pelikan, die Taube, $̈$ hren und Trauben, das Auge Gottes und ähnliches auf der Mitra an. Doch war selbst das keineswegs allgemein gebräuchlich. Eine Reihe der kostbarsten Mitren des 17. und 18. Jahrhunderts entbehren jedes religiösen Abzeichens. Es läft sich nicht leugnen, dak das 16., 17. und 18. Jahrhundert manche dem Material nach kostbare, der technischen Ausführung nach vorzügliche und der ganzen Ausstattung nach prachtvolle Mitren geschaffen haben. Es sei zum Belege dafür nur auf eine Mitra des Graner Domes vom Jahre 1549 und die des Bischofs Paul Bornemsiza im Raaber Domschatz vom Jahre 1550 hingewiesen, von welchen jede wegen des Übermakes der zur Verwendung gekommenen Perlen und Edelsteine auf etwa

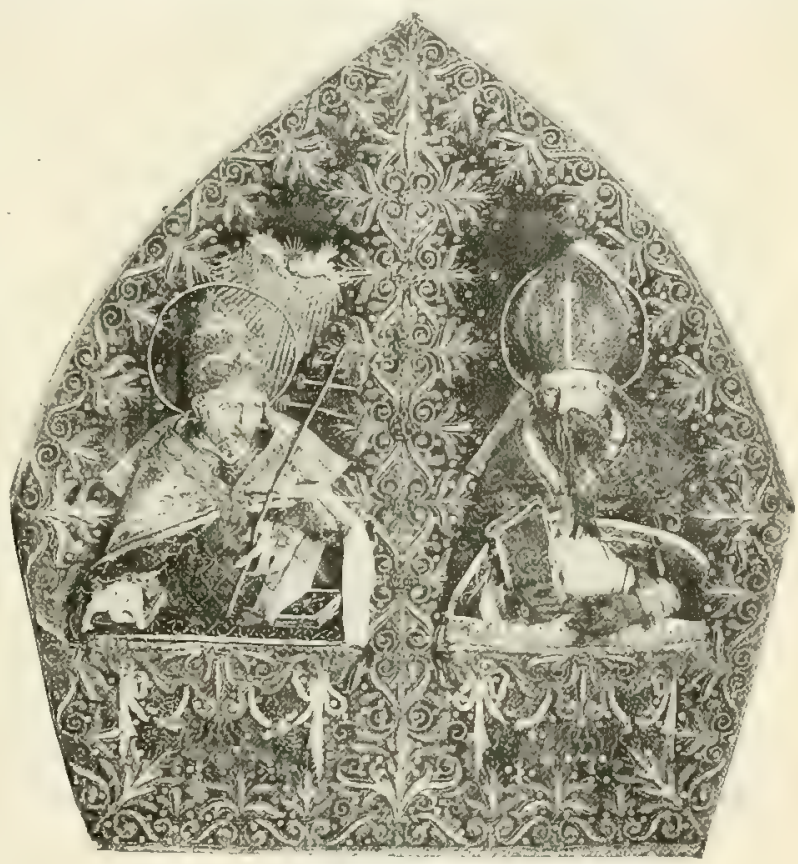

Bild 240. Mitra. Würzburg, Dom. 30000 Gulden gewertet wurde ${ }^{2}$, sowie namentlich auch anf die aus Trier stammende Mitra im Dom zu Limburg. Fine andere Frage ist indessen, ob

1 Abbilchung der Mitra im KensingtonMuseum bei de Farcy pl. Lxxx.

2 Mitt. XII (1867) 78 80. Von der Mitra des Raaber Domschatzes heifst es dort: "Der Grund der ganzen Mitra besteht, den Stoff völlig deckend, aus aneinandergereihten Zahlperlen. Linien von größeren Perlen bezeichnen den Rand der damit nur angedenteten Aurifrisia; in ähnlicher Weise wurden die Einfassungen der Dependenzen sowie die auf den Schilden deutlich hervortretenden Ornamente gebildet. Reicher Edelsteinbesatz schmückt die einzelnen Teile. Die äufersten Ränder, aus stark vergoldeten Silberbeschlägen bestehend, sind mit einer Reihe von zierlichen Knorren und einer Kreuzblume an der Spitze geziert; aus jedem dieser Knorren sproft ab- wechselnd eine Blüte von blanem und grỉinem Email. Ein Medaillon, in dem sich ein goldener Schwan mit einem Sträuschen im Schnabel auf rotem Emailgrund befindet, schmückt die Mitte... Bemerkenswert ist auch, daf jede der Dependenzen, die gleichfalls mit reichem Perlenornament und ziemlich großen Edelsteinen besetzt sind, in drei Zwischenrätmen mit je zwei kleinen goldenen Glöckchen, zusammen zwölf, geziert ist" (ebd. 78). Angesichts des Gewichtes, welches die mitra pretiosa seit dem ausgehenden Mittelalter häufig hatte, begreift man, warum das Caeremoniale den Bischöfen gestattet, im Pontifikalamt die "kostbare" Mitra mit der leichteren Auriphrygiata zu vertauschen, nne nimis gravetur". 
man die Mitren, wie sie seit dem 16. Jahrhundert in Gebrauch waren, als Ideal einer pontifikalen Kopfbedeckung betrachten kann, und ob man die Entwicklnng. welche die pontifikale Kopfbedeckung seit jener Zeit genommen

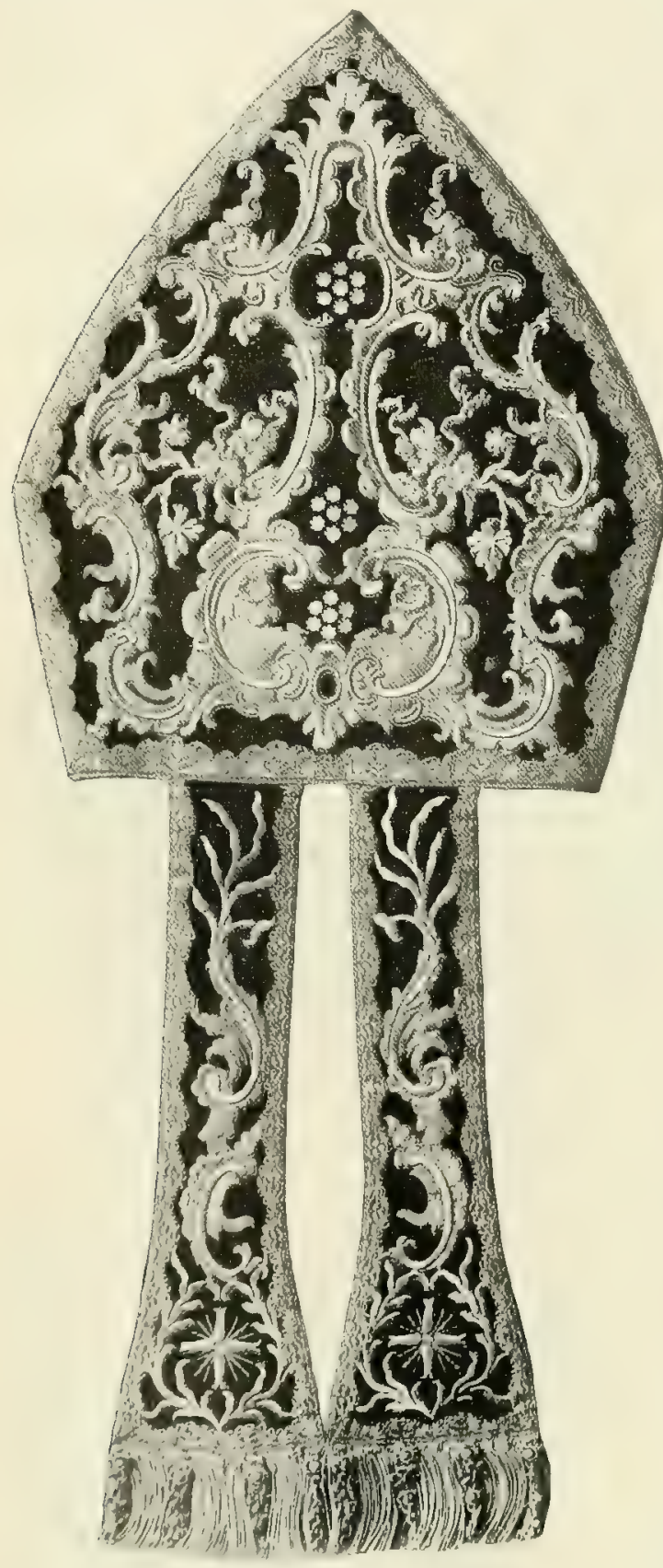

Bild 241. Mitra. Kamp a, Niederrbein. hat, für einen Fortschritt oder für eine Abkehr vom guten Geschmack zu halten hat. Es ist eine Frage ähnlicher Art, wie man sie bezüglich der modernen Kasel und ihrer Ausstattung stellen kann.

$\mathrm{Ob}$ es nicht besser gewesen wäre, wenn man sich in Bezug auf die Mitra etwas konservativer verhalten hätte? Denn es läbt sich weder in Abrede stellen, daf man zuletzt denn doch nach Höhe und Breite das rechte Maßs entschieden überschritt, noch auch, daf die Ausstattung, welche man der Mitra zu geben beliebte, nur allzuoft auf leeren Prunk hinauslief. So wenig konnten die Edelsteine, Perlen oder Goldstickereien, mit denen man den pontifikalen Kopfschmuck seit dem 16. Jahrhundert in überschwenglichster Weise zu bedecken pflegte, ihm sein anspruchsvolles Wesen nehmen und das Übermak an Höhe und Weite ausgleichen, dafs sie ihm vielmehr erst recht ein weltliches und vordringliches Aussehen gaben. Es wäre besser gewesen, wenn man in Beziehung auf die Abmessungen wie auch bezüglich der Ausschmückung an der goldenen Mitte festgehalten hätte.

Am wenigsten gelang es den letzten Ausläufern der Renaissance, dem Rokoko mit seinen willkürlichen, sinnlosen Schnörkeleien (Bild 241) und dem Zopf mit seinem nüchternen Ornament eine pontifikale Kopfbedeckung zu schaffen, die auch nur halbwegs befriedigen kanu. Man betrachte nur einmal die noch in grofer Zahl vorhandenen Mitren aus der Rokoko- und der Kopfperiode, beispielsweise die Mitren 
des KöIner Domschatzes, welche Erzbischof Kklemens August († 1761) zur Feier der Krönung seines Bruders, des Kaisers Karl VII., um vieles Geld zu Lyon anfertigen liek, die zahlreichen Mitren im St Veitsdom zu Prag, die Mitren im Münster zu Freiburg (Bild 242) u. a. Gewifs, reich und prunkhaft mochten solche Mitren oft genug sein; allein es gehörte denn doch ein ganz eigenartiger Geschmack dazu, sie auch schön und würdevoll zu finden.

Als in neuester Zeit der Sinn für angemessenere Formen der heiligen Gewänder wieder erwachte und die christliche Paramentik sich vom Schlafe erhob, in dem sie nur allzulang befangen gewesen, knïpfte man in Frankreich, England, Holland, Belgien und Deutschland wie bei Anfertigung der andern kirchlichen Gewänder, so auch bei derjenigen der Mitra mit Glïck an mittelalterliche Vorbilder an. Freilich stief ein solches Unternehmen anfangs auf erhebliche Schwierigkeiten. Wie es eine Zeitlang nahe daran war, daf eine Rückkehr. zur mittelalterlichen Kaselform ausdrücklich untersagt wurde, so ging es ähnlich hinsichtlich der Mitra. Doch ist es auch hier am Ende zu einem wirklichen Verbot nicht gekommen. Ob indessen je wieder für die Mitra allgemein die mittelalterliche Form, Machweise und Ausstattung aufgenommen werden, scheint uns mehr als fraglich. Wenigstens ist zur Zeit dafür wenig Aussicht vorhanden.

\section{LITURGISCHE VERWENDUNG DER MITRA.}

In welchem Maßs die Mitra während des Mittelalters $\mathrm{z} u$ R om beim Gottesdienste Verwendung gefunden, läßt sich im einzelnen nicht mit Bestimmtheit feststellen. Nach den römischen Ordines des 14. und 15. Jahrhunderts zu urteilen, dürfte der Unterschied zwischen

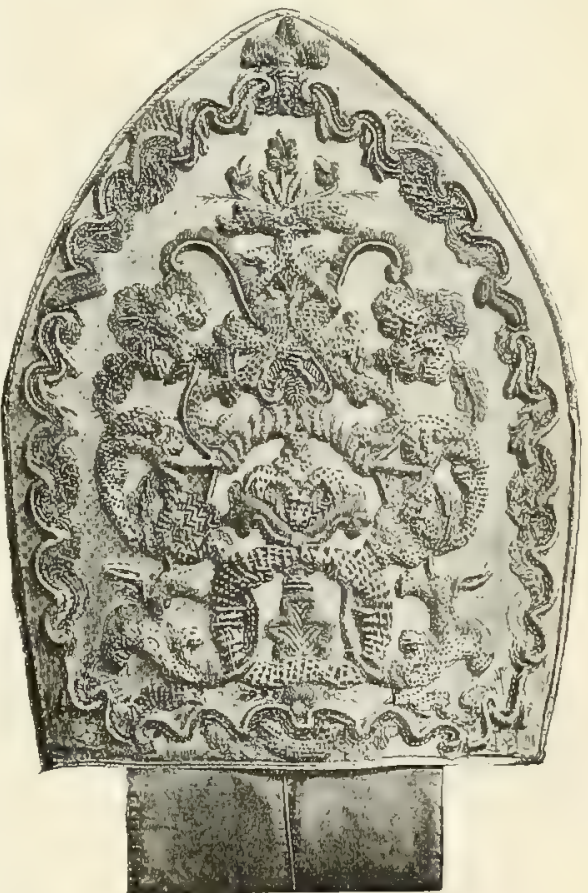

Bild 242. Mitra. Freilurg i. Br., Münster. damals und jetzt nicht bedeutend gewesen sein. Immerhin fehlt es an einzelnen Abweichungen nicht. So trugen Papst und Kardinäle die Mitra nach dem 13., 14. und 15. Ordo auch bei verschiedenen Gelegenheiten, die an sich keinen liturgischen Charakter hatten, aber sich an Kulthandlungen gleichsam als Voroder Nachspiel anschlossen, z. B. bei dem feierlichen Mahle am Krönungstage und dem Gründonnerstage, bei der Entgegennahme des Presbyterium (Geldspende) и. ä. Bei der sich an die Papstweihe anschliekenden Prozession zum Lateran, dem sog. possesso, und der Heimkehr von der lateranensischen Basilika, Aufzügen, die zu Pferde abgehalten wurden, bedienten sich nur die Kardinäle, Bischöfe und sonstigen dazu berechtigten Prälaten der Mitra; der Papst selbst war bei ihnen mit der Tiara (corona, regnum, triregnum), dem Sinnbild seiner königlichen Würde, geschmückt.

Auferhalb Roms war im Mittelalter in Bezug auf den Gebrauch der Mitra im großen und ganzen die römische Sitte makgebend. Angesichts 
des Umstandes, daf diese von Rom gekommen war, konnte es auch kaum anders sein. Im allgemeinen galt hier wie dort der Grundsatz: der Bischof legt die Mitra ab, wenn er zum Altare tritt, um daselbst zu beten; er trägt sie, so oft el sich zum Volke wendet. Verschiedenheit herrschte namentlich hinsichtlich der Verwendung des Ornatstückes bei der Erteilung des feierlichen Segens und der Inzensierung des Altars. Zu Rom wurden diese Akte ohne Mitra vorgenommen, anderswo dagegen, wie aus den Angaben des Durandus hervorgeht, bald mit ihr, bald ohne sie ${ }^{1}$. Umgekehrt verhielt es sich mit den Exequien. Während sich nämlich nach römischem Brauch bei diesen der Bischof der Mitra bediente, fungierte er auferhalb Roms bei ihnen hie und da ohne eine solche.

Die Zeremonie der Übergabe der Mitra an den neu konsekrierten Bischof muf sich spätestens im Verlauf des 12. Jahrhunderts ausgebildet haben. Jedenfalls wal sie schon im dritten Viertel desselben, wie aus des Nikolaus von Clairvaux ( $\dagger$ 1175), des Notars des hl. Bernhard, Predigt über die zwölf Sakramente erhellt, nichts Unbekanntes mehr. Ungitur caput, liniuntur et manus, ponitur et evangelica pagina super caput . . imponitur cidaris capiti consecrato et aurea lamina frontis gloria praesignitur, in qua contexitur nomen divinitatis (gemeint ist wohl der aus Goldstoff gewebte circulus der Mitra), traditur anulus ${ }^{2}$. Seit etwa 1200 wird der Pitus auch in den Pontifikalien wiederholt erwähnt ${ }^{3}$. Die Überreichung des Ornatstückes fand stets erst nach vorausgegangener Salbung des Hauptes statt. Bald erfolgte sie bei der Weihe selbst während der Messe, bald, wie noch jetzt, am Schluf der letzteren, je nachdem das heilige Salböl auf dem Haupt des Geweihten sogleich oder erst am Ende der ganzen Feier abgetrocknet wurde. Das Gewöhnlichere scheint gewesen zu sein, das die Mitra dem neugeweihten Bischof er'st am Schlusse der ganzen heiligen Handlung unmittelbar vor der Heimkehr aufgesetzt wurde.

Ein Gebet pflegte die Zeremonie nicht allzeit zu begleiten. Ein Mainzer Pontifikale aus dem Ende des 13. Jahrhunderts läfst den Konsekrator bei der Übergabe der Mitra die zwar kurzen, aber bedeutungsvollen Worte sprechen: „Ein Zeichen setze ich auf dein Haupt, auf daf du außer deinem Schöpfer selbst keinen andern Liebhaber zulassest im Namen des Herrn. Amen." In einem um 1400 geschriebenen Lyoner Pontifikale lautet das Gebet gerade wie jetzt im Pontificale Romanum *.

Daf auch bei der Segnung der Äbte schon um das ausgehende 13. Jahrlundert die Zeremonie der Überreichung der Mitra vorkam, beweist ein handschriftliches Mainzer Pontifikale jener Zeit ${ }^{5}$.

Dasselbe enthält nämlich im Ordo ad benedicendum abbatem die Rubrik, es solle der Bischof, wenn er die Einsegnung eines Abtes vornehme, der die Mitra zu tragen gewohnt sei, selbigem das Ornatstück unter den Worten überreichen: „Nimm

1 Rationale 1. 3, c. 8; f. 77. Pontificale Durandi Mimat. bei Mart. 1. 1, c. 4, art. 12 , ordo 23; I 225. Über die Mitra bei Totenmessen vgl. ebenfalls das Pontifikale des Durandus a. a. $\mathrm{O}$.

2 M. 144, 899. Der Sermo über die zwälf Sakramente - das Wort ist hier im weiteren Sinne einer heiligen und heiligenden Einrichtung zu nehmen - wird mehrfich (so auch von de Linas [Revue 1861, 455] und Hefele [Beitr. II 5.52]) irrtümlich dem hl. Petrus Damiani zugeschrieben. Es konnte jedoch zu dessen Lebzeiten im Ritus der Weihe noch nicht wohl von der Zeremonie der Überreichung der Mitra die Rede sein. Anders lag natürlich die Sache, als diese im 12. Jahrhundert allgemein zum bischöflichen Kopfschmuck geworden war.

${ }_{3} \mathrm{~V}$ gl. z. B. außser den Auszügen bei $\mathrm{M}$ a 1 t. I. 1, c. 8 , art. 11 , ordo 14161718 ; II 73 828894 den Ritus der Bischofsweihe in Vat. lat. 1152115957917114.

${ }_{4}$ Mart. 1. 1, e. 8, art. 11, ordo 18; II 94.

5 Ebd. 1. 2, c. 1, ordo 9; II 160. 
hin, liebster Bruder, des Alten und des Neuen Bundes sinnbildliches Zeichen. Mögest du kraft der Wissenschaft beider Testamente die dir anvertrante Herde unbefleckt bewahren, auf daf du mit ihr froh zu den Pforten des Paradieses einziehest im Namen usw."

\section{DIE LITURGISCHE KOPFBEDECKUNG IN DEN ORIENTALISCHEN RITEN.}

Nicht blof im römischen, auch in den orientalischen Riten gibt es eine liturgische Kopfbedeckung. Sie findet sich bei allen Riten des Ostens.

Im verbreitetsten dieser Riten, dem griechischen, steht sie wie im Abendland nur den Bischöfen zu. Sie wird auch

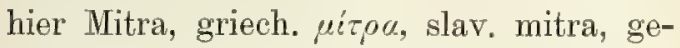
nannt, ist aber von dem gleichnamigen lateinischen Ornatstück der Form nach durchaus verschieden. Etwas mehr Ähnlichkeit hat sie mit der päpstlichen Tiara. Sie besteht aus einem Reifen, welcher von zwei unter einem rechten Winkel in ihrem Scheitelpunkt sich kreuzenden Bügeln überspannt ist (Bild 243). Reifen und Bügel, welche mit getriebenen Ornamenten, Steinen, Perlen und ähnlichem reich verziert zu sein pflegen, bergen im Innern eine Mütze aus gesteiftem Stoff, vielfach rotem Samt, welche in den zwischen den Reifen liegenden Zwischenräumen wulstartig hervorquillt. Die Wulste sind mit Stickereien

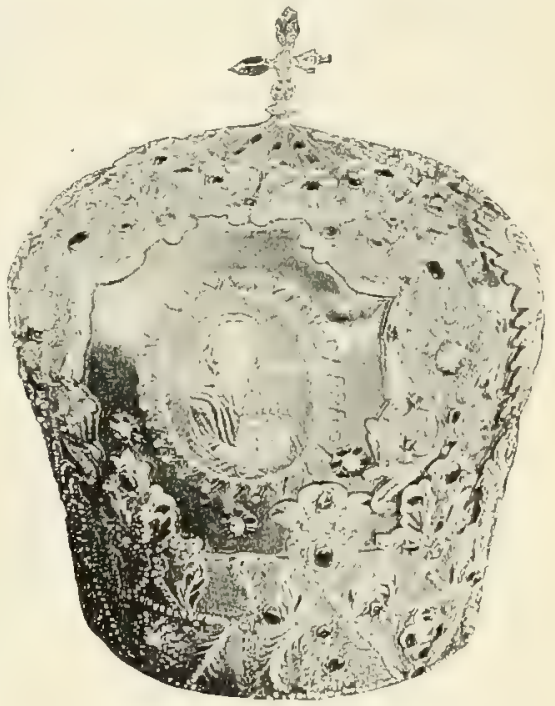

Bild 243. Griechische Mitra. oder Zierstücken aus Metall besetzt. Auf dem S'chnittpunkt der Bügel befindet sich ein Kreuz, welches nach russischem Brauch eine horizontale Lage haben muf. Ein aufrecht stehendes Kreuz auf der Mitra tragen zu dïrfen, ist in Rufland eine besondere Auszeichnung, welche nur einzelnen Metropoliten zu teil wird. Kraft eines alten Privilegs erfrenen sich dieses Vorrechtes die Bischöfe und der Metropolit der Kiewschen Eparchie.

Bei den Armeniern tragen aufer den Bischöfen auch die Priester und selbst die Archidiakone eine liturgische Kopfbedeckung. Die Bischöfe bedienen sich der zweigehörnten lateinischen Mitra, die Priester und Archidiakone dagegen eines Saghavart genannten Hutes (Bild 244). Derselbe erinnert an die Mitra der griechischen Bischöfe, entbehrt jedoch der vier Wulste, welche dieser eigentümlich sind. Auferdem wird er statt nur von zwei von vier Bügeln überspannt, ohne daß

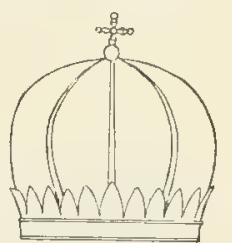

Bild 244.

Liturgische Kopfbedeckung der armenischen Priester. dieselben jedoch seine Form beeinfluften und etwas mehr als bloße Zierreifen wären. Charakteristisch für ihn ist die Zackenkrone, welche unten den Rand umgibt. Eine liturgische Kopfbedeckung bei Diakonen begegnet uns einzig im armenischen Ritus (vgl. Bild 40, S. 93).

Von den Syrern haben sich die Maroniten und die unierten Jakobiten, die sog. reinen Syrer, hinsichtlich der liturgischen Kopfbedeckung ganz dem römischen Brauch angeschlossen. Es erscheinen daher die Bischöfe bei den- 
selben in einer modemen abendländischen Mitra, und zwar von möglichst bedeutenden Abmessungen. Auch die unierten Chaldäer und Kopten haben die römische Mitra herübergenommen. Bei den schismatischen Syrern erfreut sich nur der Patriarch einer liturgischen Kopfbedeckung, bei den nestorianischen Chaldäern tragen dagegen eine solche auch die Bischöfe, und zwar behalten sie dieselbe während der ganzen Messe auf dem Kopfe. Sie heift biruna und ist ein kapuzenartig über das Haupt gelegtes Tuch, während der Kopfschmuck des syrischen Patriarchen mit der griechischen Mitra Ähnlichkeit hat. Im Ritus der nichtunierten Kopten endlich gibt es eine sakrale Kopfloedeckung. sowohl bei dem Patriarchen und den Bischöfen, wie bei den Priestern, allerdings mit einem. Unterschied in der Beschaffenheit.

Bei den Priestern und Bischöfen besteht sie aus einem ca $40 \mathrm{~cm}$ breiten und 5,50 m langen, mit Kreuzen oder auch wohl Inschriften gezierten Bande, ballin genannt, das nach Art eines Turbans um den Kopf geschlungen wird und bei den Priestern aus Linnen, bei den Bischöfen aber aus farbiger Seide angefertigt ist. Der Patriarch hat einen mehr helmförmigen Kopfschmuck.

Für die Geschichte der liturgischen Kopfbedeckung in den orientalischen Riten liegt nur sehr wenig Material vor, zumal bezüglich des sakralen Kopfschmucks im armenischen, syrischen, chaldäischen und koptischen Ritus.

Am meisten interessiert die Frage, seit wann es in den Riten des Orients eine liturgische Kopfbedeckung gegeben hat.

Man hat gemeint, es sei im Orient schon in frühester Zeit eine solche in Gebrauch gewesen, und sich hierfür auf die lamina, die goldene Stimplatte (Ziz), berufen, deren sich nach des Epiphanius und Polykrates Angaben die Apostel Jakobus und Tohannes bedient haben sollen ". Ebenso hat man auf das Schreiben des Patriarchen Theodosius von Jerusalem hingewiesen, worin derselbe dem Patriarchen Ignatius von Konstantinopel mitteilt, er habe ihm aufer der Talartunika und dem Schulterkleid des

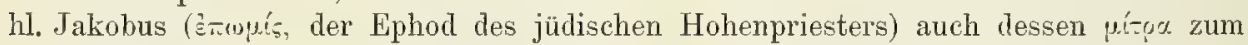
Geschenk gesandt, und die Bemerkung anfügt, es hätten sowohl seine Amtsvorgänger im Patriarchat wie er selbst sich dieser Gewänder bedient, so oft sie zur Ausübung ihres Priesteramtes ins Allerheiligste eingetreten seien 2. Jedenfalls sollen schon im 4. Jahrhundert die Bischöfe im Orient eine liturgische Kopfbedeckung getragen haben. Als Beweis führt man eine Rede Gregors von Nazianz ${ }^{3}$ und die Ansprache an, welche Eusebius bei der Einweihung der Basilika von Tyrus an die anwesenden Bischöfe hielt:

Allein die Worte des Polykrates lassen sich sehr wohl bildlich von der Bischofswürde des hl. Johannes verstehen. Sollten sie aber wörtlich aufzufassen sein, so haben sie zweifellos, gerade wie die Angabe des Epiphanius betreffs des Stimschmuckes des hl. Jakobus, nur legendenhaften Charakter. Bei der Erzählung des Epiphanius liegt das klar zu Tage, da die Hohenpriester es sicher nicht geduldet haben würden, wenn der hl. Jakobus sich mit dem spezifisch hohenpriesterlichen $\mathrm{Ziz}$ geschmückt hätte. Übrigens würde auch aus den Worten des Polykrates und Epiphanius - deren Bericht einmal als der Wirklichkeit entsprechend angenommen - offenbar zuletzt nur das eine folgen, daß die hll. Johannes und Jakobus sich der goldenen Stirnplatte des aaronitischen Hohenpriesters zu bedienen pflegten, keineswegs aber, dal3 zu deren Lebzeiten üherhaupt ein liturgischer Kopfschmuck beim Gottesdienst in Gebrauch war. Beim hl. Jakobus wird das Tragen der lamina von Epiphanius sogar ausdrücklich als dessen besonderes Vorrecht hingestellt.

1 Epiph., Adv. haer. 1. 3, t. 27814 (Mg. 42, 721); ebd. 1. 1, t. 2294 (Mg. 41, 396). Euseb., Hist. eccl. 1. 3, c. 31 (Mg. 20, 280 ).
$2 \mathrm{H}$ ard. V 1029.

${ }^{3}$ Orat. 10, n. 4 (Mg. 35, 829).

4 Euseb., Hist. eccl. 1. 10, c. 4 (Mg. 20, 849). 
Was die $\mu i t p \%$ des hl. Jakobus anlangt, welche Theodosius von Jerusalem dem Patriarchen Ignatius von Konstantinopel mitsamt dem poderes und der epomis des Apostels sandte, so tragen wir kein Bedenken, alle drei Gewandstücke als unecht zu bezeichnen, da, wie schon vorhin bemerkt wurde, die über ihre Stellung und Würde so eifersüchtig wachenden Hohenpriester es ohne Zweifel nicht zugelassen hahen würden, daf ein anderer als sie selbst diese hohempriesterlichen Ornatstücke trug. Sehr auffallend ist zudem die geringe Wertschätzung, welche Theodosius den drei Gewandstücken gegenüber an den Tag legt. Sie waren ihm zufolge Reliquien des hl. Jakobus, des ersten Bischofs von Jerusalem, Reliquien, die nach des Patriarchen eigener Aussage alle Nachfolger des Apostels und anch er selbst bei den liturgischen Funktionen anzulegen pflegten, und trotzdem verschenkt Theodosius alle drei, ohne dazu einen Grund von irgend einer erkennbaren Bedeutung zu haben. Es wäre doch wahrlich übergenug gewesen, wenn Theodosius nur ein einziges jener Ornatstücke dem Patriarchen Ignatius zum Geschenk gemacht hätte. Er hat ersichtlich von der Mitra, der Talartunika und dem Schultergewand des hl. Jakobus nicht viel gehalten, daf er sich ihrer so leicht entäufern konnte. Aber auch die Bemerkung des Patriarchen, er wie seine Amtsvorgänger hätten sich bei ihren heiligen Funktionen stets der fraglichen Gewänder bedient, dürfte mit einem Fragezeichen zu versehen sein. Gewiß gibt es auch heutzutage noch liturgische Kleider, welche ihre 800 Jahre zählen, allein sie sind schon seit vielen Jahrhunderten entweder ganz oder doch so gut wie ganz aufer Verwendung gesetzt. Dafs aber Gewandstücke, die man fortwährend bei der Feier der Liturgie zu tragen pflegte, 800 Jahre alt werden konnten, ohne durchaus unbrauchbar geworden zu sein, ist, die Sache nüchtern betrachtet, schlechthin unglaubhaft, zumal angesichts der entsetzlichen Stürme, welche in dieser langen Zeit über Jerusalem hinwegbrausten, Stürme, unter denen doch auch der ganze Kultus schwer leiden mufte. Und wie hielt es Theodosius mit einem Kopfsehmuck, seit er die Mitra des hl. Jakobus verschenkt hatte?

Eusebius drückt sich in der Ansprache, die er an die zu 'Tyrus versammelten Bischöfe hielt, nur bildlich aus, wenn er sie in rhetorischem Schwung mit den Worten anredet: "Thr Freunde Gottes, ihr Bischöfe, bekleidet mit dem heiligen poderes, der himmlischen Krone der Ehre, der von Gott kommenden Salbung und dem priesterlichen Gewand des Heiligen Geistes!" Es ist uns geradezu unverständlich, wie man

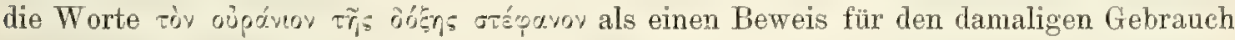
eines pontifikalen Kopfschmuckes hat ausgeben können.

Gregor von Nazianz schildert in der fraglichen Rede seine eigene Weihe unter dem Bilde der Weihe, wie sie nach Moses' Anordnung an Aaron und den jüdischen Priestern vollzogen wurde. Mit der cidaris, von welcher er redet, ist darum nicht eine damals etwa im Gebrauch befindliche liturgische Kopfbedeckung, sondern die Mitra des jüdischen Hohenpriesters gemeint.

Im griechischen Ritus ist erst in sehr später Zeit eine liturgische Mitra in Gebrauch gekommen. Allerdings sagt schon Pseudo-Alkuin, es trügen die Griechen pilei, i. e. cuphiae, auf den Kopfe, wenn sie am Altare die heiligen Geheimnisse feierten. Doch fügt er dieser Notiz, was wohl zu bemerken ist, ein "soll“ hinzu: apud Graecos autem hoc dicitur. Daß sie in der Tat nur ein unbestimmtes Gerücht ohne wirklichen Untergrund darstellt, ergibt sich alsbald, wenn wir die griechischen Bildwerke einem Studium unterzichen oder bei den griechischen Schriftstellern uns umsehen ${ }^{2}$.

1 Trug der Bischof von Jerusalem wirklich im 9. Jahrhundert bei der Liturgie die Mitra des hl. Jakobus, so geschah das sicher nur wegen ihres vermeintlichen Reliquiencharakters, nicht weil es dort schon einen pontifikalen Kopfschmuck gab. War doch ein solcher noch nicht einmal im 12. Jahrhundert daselbst im Gebrauch (vgl. S. 490). Oder ist es glaubhaft, daß Theodosins mit des hl. Jakobus Mitra überhaupt anf eine sakrale Mitra verzichtet hätte, wenn es damals zu Jerusalem eine solche gegeben?

${ }^{2}$ Vielleicht, daf sich die Angabe PseudoAlkuins an eine Bemerkung des Ratramnus anlehnt (Contra Graec. opposit. 1. 4, c. 5 [M. 121, 322 323]), wo es sich aber bei der Kopfhïlle der griechischen Geistlichen, von der dort die Rede ist, offenbar nur um die gewöhnliche Bedeckung des Hauptes, nicht um einen liturgischen Kopfschmuck bandelt. 
Keine griechische bildliche Darstellung weist vor Ende des Mittelalters eine sakrale Kopfbedeckung auf, und zwar bezeichnenderweise auch dann nicht, wenn liturgische Funktionen dargestellt werden. Klassisch sind in dieser Beziehung namentlich eine Reihe von Miniaturen im Menologium Basilius' II. Mit einer Kopfbedeckung treffen wir in ihm nur an den hl. Cyrillus ron Alexandrien, den hl. Athanasius und den heiligen Bischof Spiridion von Cypern (Bild 245 und 246). Es bleiben das aber auch die einzigen, welche bis zur Neuzeit auf den Bildwerken mit einer Kopfbedeckung erscheinen (vgl. Bild 142, S. 304). Von der Mitra des hl. Cyrillus wird nachher die Rede sein. Die Mütze, welche St Spiridion auf dem Haupte hat, stellt keinen liturgischen Kopfschmuck dar, sondern eine Hirtenmütze. Sie soll daran

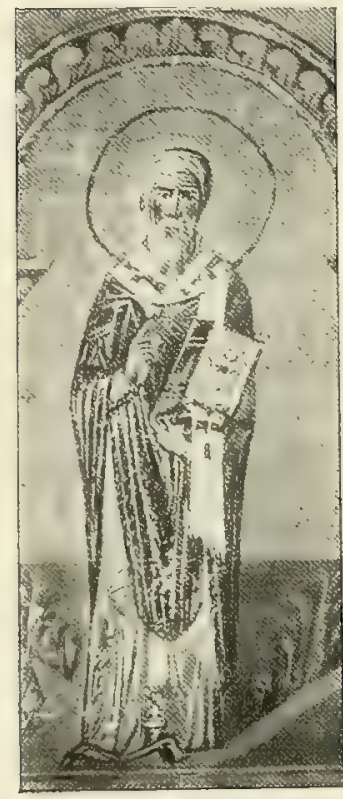

Bild 245. Athanasius. Miniatur im Menologium Basilius' II. Rom, Vatikan. erinnern, was der Heilige war, ehe er Bischof ward.

Auch die griechischen Schriftsteller wissen ausnahmslos vor dem Ende des Mittelalters nichts von einer liturgischen Kopfbedeckung im griechischen Ritus. Insbesondere findet sie weder in der Ioropía noch den unter den Namen der hll. Germanus und Sophronius gehenden Mefserklärungen Erwähnung. Ebenso schweigt Balsamon, Chartophylax des Patriarchen von Konstantinopel, seit 1193 Patriarch von Antiochien († 1214), von einer liturgischen Kopfbedeckung, wo er die Privilegien der Patriarchen behandelt und dabei im einzelnen die Bestandteile ihrer Sakralkleidung aufzählt ${ }^{1}$. Ja er versichert sogar an einer andern Stelle ausdrücklich, daf nur der Patriarch von Alexandrien sich einer solchen

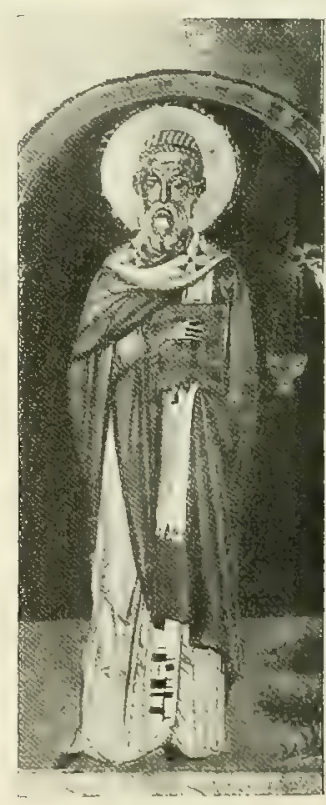

Bild 246. Spiridion.

Miniatur im Menologium Basilius' II. Rom, Vatikan.

bediene, während alle übrigen mit unbedecktem Haupte die heiligen Geheim-

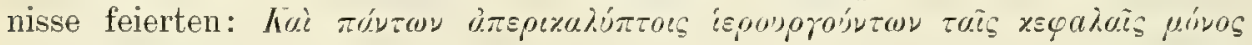

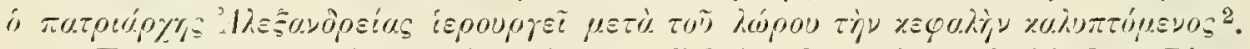

Es gab selbst im Beginn des 15. Jahrhunderts im griechischen Ritus noch keine liturgische Kopfbedeckung. Das beweisen die diesbezüglichen bestimmten Auslassungen des Erzhischofs Simeon von Saloniki ( $\dagger$ 1429), der gerade wie Balsamon sowohl in seiner Schrift De divino templo ${ }^{3}$ wie in seinen Antworten auf die Anfragen des Bischofs Gabriel von Pentapolis ${ }^{4}$ mit aus-

\footnotetext{
1 Meditata c. 1 (Mg. 138, 1021).

2 Ehd. c. 2 (ehd. 1048).

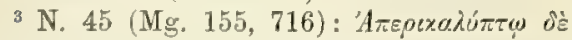

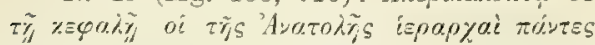

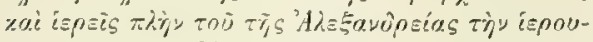

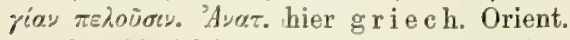

4 Qu. 20 (ebd. 872). Nach Kondak off (Histoire de l'art byzantin, Paris 1891, 64)
}

wäre eine Cidaris (bischöfliche Mitra) schon auf einer bald nach 880 gemalten Miniatur der Homilien Gregors von Nazianz in der Pariser Nationalbibliothek (f. gr. 501, fl. 64) zur Darstellung gekommen. Es ist das jedoch ein grober Irrtum. Was Kondakoff für eine $\mathrm{C}$ id a $\mathrm{r}$ is angesehen hat, ist ein Evangelienbuch. Die Miniatur stellt die Weihe 
drücklichen Worten erklärt, nirgends sei bei den Bischöfen und Priestern des Orients mit Ausnahme des Patriarchen von Alexandrien eine liturgische Liopfbedeckung bei den gottesdienstlichen Funktionen im Gebrauch.

Hierzu stimmt, daf der Patriarch Joseph von Konstantinopel, der 1439 gelegentlich des Unionskonzils zu Florenz starb und in S. Maria Novella beerdigt wurde, auf dem ihm daselbst errichteten Grabmal zwar in seiner liturgischen Kleidung, jedoch ohne Mitra dargestellt ist. Hätte es eine solche damals bereits gegeben, würde sie gewißs auf der Abbildung des Verstorbenen nicht fehlen. Denn man vergesse nicht, als man zu Florenz das Monument errichtete und den Patriarchen in Fresko auf demselben anbrachte, war es in Italien allenthalben Sitte, die Bischöfe auf den Grabdenkmälern mit der Mitra geschmückt darzustellen.

Es ist nicht möglich, den Zeitpunkt zu bestimmen, da die Mitra im griechischen Ritus in Gebrauch kam. Vielleicht geschah es unter dem Einfluf der veränderten Verhältnisse schon bald nach dem Untergang des oströmischen Reiches und der Eroberung Konstantinopels durch die Türken, jedenfalls aber spätestens im Laufe des 16. Jahrhunderts. Denn im Jahre 1589 hatte bereits die Einführung der Mitra in Rubiland statt. Immerhin fand die Mitra, wie aus den Kommentaren Gretsers und Goars zu des Kodinus Liber de officialibus hervorgeht ${ }^{1}$, selbst noch in dem Anfange des 17. Jahrhunderts erst bei wenigen griechischen Bischöfen Verwendung.

Die Einführung der Mitra in dem russischen Ritus erfolgte anlälich der Errichtung des russischen Patriarchats, bei welcher Gelegenheit der Zar Theodor dem neugeschaffenen Patriarchen Job unter anderem das Recht verlieh, den Sakkos, den Mandyas und die Mitra zu tragen?. Offenbar waren diese bis dahin in Rubland nicht verwendet worden, sonst hätte ja der Zar den Patriarchen nicht mit dem Vorrecht, sich dieser Ormatstücke bedienen zu dürfen, zu beglücken brauchen.

Woher Zar Theodor die Mitra genommen, sagt der Bericht, den ein Augenzeuge des Vorganges hinterlassen hat, nicht; doch kann es wohl kaum zweifelhaft sein, daß er sie aus dem griechischen Ritus herüberholte. Denn von dort stammten ja auch der Sakkos und die magna cappa, d. i. der yovósos, die er dem neukreierten Patriarchen als Auszeichnung verlieh. Zudem war es ja das Bestreben des Zaren, diesen in allem dem Patriarchen von Kionstantinopel gleichzustellen. Daf aber bei letzterem bereits eine Mitra in Gebrauch war, beweist der Umstand, dafs sich unter den Geschenken, welche Patriarch Jeremias II. für seine Gefügigkeit bei Errichtung des russischen Patriarchats erhielt, sich auch eine kostbare, mit Perlen, Steinen und Bildwerk reichgeschmückte Mitra befand. Ja es bekamen für die Feier der Proklamation des Patriarchen Job selbst die Bischöfe, welche die Begleitung des Patriarchen von Konstantinopel bildeten, kostbare Mitren ${ }^{3}$.

Gregors dar. Eine Abbildung bei Roh. VI, pl. colxvir.

1 Gretseri et GoariNotae ad Codinilibrum de officialibus c. 16: Mitra non utuntur episcopi graeci in sacrificis, sed aperto capite totam liturgiam perficiunt. ... Diximus, Graecos non celebrare operto capite excepto patriarcha Alexandrino et $p$ a u culis a 1 i is (Mg. 157, 184 186).

2 Arsenii Elas. episc. descriptio itineris in
Moscoviam habiti a Ieremia II. patr. Constant. (Wichmann, Kleinere Schriften zur Kenntnis des russischen Reiches I, Berlin 1820, 83): Primatum super'ceteros episcopos ad te spectare declarat maiestas mea edicitque ut in posterum a d mirandum saccum gestes mitramque ac magnam capp a $m$ atgue per omnia imperii regna patrialcha renuntieris.

3 Ebd. I 79116. 
Über die Form, welche die Mitra zur Zeit ihrer Einführung im russischen Ritus hatte, gibt eine noch erhaltene Mitra des Patriarchen Job Aufschluf. Sie stellt eine runde, oben abgeflachte Mütze dar, die am Rand ringsum mit einem weifsen Pelzbesatz, darüber mit einer Inschrift in Perlen und noch höher mit einem aus Halbfiguren sich zusammensetzenden Fries geschmückt ist. Die Mitte nimmt der Heiland ein; rechts und links schließen sich Maria und St Johannes der Täufer an; dann folgen Heilige (Apostel). Die Umrisse der Bilder sind in Perlen, die Gewänder und Fleischteile in Seidenstickerei hergestellt. Auf dem Deckel der Mitra ist in einem von Perlen gebildeten Medaillon Maria mit dem Jesuskind in gleicher Technik wie die Halbfiguren an den Seiten zur Darstellung gekommen. Das Medaillon ist von einer in Perlen auf blauem Grund gestickten Inschrift umrahmt. Das Ganze ist eine ebenso interessante wie kostbare Arbeit.

Die Mitra des Patriarchen Job hat noch nicht ganz die Form, welche der griechischen Mitra gegenwärtig eigen ist. Noch fehlt ihr der untere Reifen samt den Bügeln und dem Kreuz auf der Spitze. Dagegen weisen eine Anzahl überaus kostbarer und prunkvoller, mit Gold, Edelsteinen, Perlen und Emails förmlich überladener Mitren des Patriarchen Nikon (seit 1652), des anfangs so mächtigen, bald aher elend gestürzten Günstlings des Zaren Alexis, zumeist Geschenke eben dieses Zaren, bereits in allem die jetzt gebräuchliche Form auf?

Ursprünglich im russisch-griechischen Ritus nur dem Patriarchen eigen, blieb die Mitra nicht lange dessen ausschließliches Vorrecht. Schon eine Verordnung über den liturgischen Ornat vom Jahre $1675^{3}$ rechnet sie auch zur Ausstattung der russischen Erzbischöfe und Bischöfe. Sie muß also zwischen den Jahren 1589 und 1675 bei diesen in Gebrauch gekommen, spätestens aber ihnen 1675 durch den angeführten Erlas zuerkannt worden sein. Weit früher als im griechischen tritt in einigen andern orientalischen Riten eine liturgische Kopfbedeckung auf.

Daf im syrischen Ritus bereits im 13. Jahrhundert eine solche Verwendung fand, bekunden die Miniaturen eines aus dem Jahre 1239 stammenden syrischen Pontifikale der Pariser Nationalbibliothek (Bild 216, S. 51; 112, S. 238). Sie stellen die Vornahme der Weihen dar und zeigen uns die Bischöfe bei ihren Funktionen mit bedecktem Haupte. Die Kopfbedeckung besteht indessen nicht in einer Mitra oder in einer der Mitra ähnlichen Mütze. Sie hat vielmehr die Form einer über den Kopf gezogenen Kapuze und ist über der Stirn mit einem Kreuze geschmückt. Es ist dieselbe Kopfbedeckung, die uns wiederholt bei abendländischen Mönchen auf süditalischen, der Frühe unseres Jahrtausends angehörigen Miniaturen begegnet. Der Umstand, daf; sie auf den Darstellungen des Pontifikale nur bei Bischöfen auftritt, läßst keinen Zweifel, daßs sie nur ihnen zustand.

Die Kopfbedeckung, von der uns die Miniaturen des syrischen Pontifikale ein so anschauliches Bild gewähren, besteht noch jetzt, wenn auch ihrem

1 Abbildung in Antiquités de l'empire de Russie pl. Lxxxv. Eine ähnliche Mitra ebd. pl. cxviII. Sie wird samt einer Stola, einer Kasel, einem Omophorion und liturgischen Stauchen einem Bischof Nicetas (12. Jahrh) zugeschrieben, dürfte aber wie diese dem Beginn des 17. Jahrliunderts angehören. Wenn die Gewïnder in das 12 . Jahrhundert yersetzt wer- den, so ist das ganz bestimmt irrig. Das pl. c abgebildete Muster des Kaselstoffes allein schon genügt, um daran keinen Zweifel zu lassen.

2 Abbildung ebd. pl. Lxxxvi LxxxviI LXXXVIII LXXXIX XU XCI.

${ }^{3}$ Philaret, Geschichte der Kirche Ruf3lands (deutsch von Blumenthal, 1872) II 109. 
früheren Zwecke entfremdet. Es ist die Maçnafta, von der bei Besprechung des Amikts die Rede war. Es ist nicht schwer, in ihr die ursprüngliche kapuzenartige Kopfbedeckung wiederzuerkennen. Man braucht sie nur üher den Kopf zu ziehen, statt auf dem Nacken ruhen zu lassen, um eine Kopfhiille zu erhalten, wie sie uns auf den Miniaturen des erwähnten syrischen Pontifikale entgegentritt.

Was seinen Ursprung anlangt, scheint das Ornatstück von der Mönchskapuze herzukommen. Die Bischöfe wurden aus dem Kreise der Mönche genommen. Es mochte sich daher der Gedanke nahe legen, denselben als Bischöfen, und zwar insbesondere für die liturgischen Funktionen, ein Gewandstück zu belassen, durch welches sie äuferlich als das gekennzeichnet wurden, was sie auch noch als Bischöfe waren, als Mönche.

Noch fast ein Jahrhundert früher als für den syrischen Ritus läst sich für den armenischen der Gebrauch einer Kopfbedeckung beim Gottesdienst nachweisen. Unter den Vorwürfen nämlich, welche der vom Schisma zur katholischen Kirche zurückgekehrte armenische Katholikos Isaak seinen Landsleuten macht, befindet sich auch der, raf die Bischöfe und Hegumenen (Klostervorsteher) nicht nur bedeckten Hauptes, sondern selbst mit doppelter Kopfbedeckung die heiligen Geheimnisse feierten ${ }^{1}$. Sie setzen, sagt Isaak, iiber dem gewöhnlichen noch ein zweites Kamelaukion auf oder ziehen, wie es in einer kürzeren Rezension heift, über ihre Kopfbedeckung noch eine Kapuze.

Wie aus Isaaks Schrift ebenfalls hervorgeht, wurde bei den Armeniern vielfach eine besondere liturgische Kleidung ganz vernachlässigt ${ }^{2}$. Die Bischöfe und Klostervorsteher hielten die Liturgie sehr gewöhnlich in ihrer Alltags-. d. i. der Mönchstracht. Denn auch die Bischöfe pflegten wie die Vartapeds (Lehrer), aus denen sie meist genommen wurden, obwohl nicht eigentlich Mönche, doch häufig in den Klöstern zu wohnen. Die beiden Kopfbedeckungen, deren man sich nach Isaak bei der Messe bediente, dürften also wohl ein Stück der Mönchsgewandung gewesen sein.

Es ist nicht schwer, in der jetzigen liturgischen Kleidung des armenischen Ritus die beiden Kopfbedeckungen wiederzufinden, deren Verwendung Isaak tadelt. Die eine ist die Saghavart genannte Mitra der Priester und Archidiakone, die andere das Vakas heifende Schultertuch, jetzt eine Art Amikts, einst aber sonder Zweifel nichts als die Kapuze oder der Kopfschleier, von welcher der armenische Katholikos spricht. Die moderne römische Form der Mitra, wie sie jetzt bei den armenischen Bischöfen ïblich ist, mag sich um das Ende des 16. oder den Beginn des 17. Jahrhunderts infolge des lebhaften Verkehrs, welcher damals zwischen Rom und den Armeniern bestand, eingebürgert haben. Dagegen ist die abendländische Form der armenischen bischöflichen Mitra überhaupt weit älter. Sie kam schon im Beginu des 13. Jahrhunderts bei den Armeniern in Gebrauch. 1203 schickte nämlich Innozenz III. durch seinen Kardinallegaten Petrus von Capua dem armenischen Katholikos und 24 Bischöfen Mitra und Hirtenstab, wobei er von ihnen das Versprechen der Treue gegen den römischen Stuhl entgegennahm ${ }^{3}$. Die nächste Veranlassung zur Übersendung der Mitra war ein Schreiben des Erzbischofs von Sisum, in welchem derselbe den Papst um Mitra, Ring und Pallium bat ${ }^{4}$.

1 Oratio II adversus Armenos c. 29 ( $\mathrm{Mg} .132$, 1235). Eine kürzere Rezension ebd. I 657.

2 S. oben S. 98, Anm. 4.

\$ Sicardi Crem. episc. chron. (M. 213, 535): Eodem anno magister Petrus cardinalis apo- stolicae sedis legatus... Armeno catholico et XXIV episcopis mitras et baculum .. tribuit pastoralem, recipiens ab eo debitam S. Romae ecclesiae fidelitatem.

* Innocent. III. Epp. 1. 5. n. 47 (M. 214, 1013). 
Von einer sakralen Kopfbedeckung des chaldäischen (nestorianischen) Ritus redet schon im 12. Jahrhundert das "Buch der Väter" und bereits im 10., wie es scheint, Georg von Arbela. Dieselbe wird hier wie dort maaphra genannt, während sie bei späteren Schriftstellern biruna heifit ${ }^{1}$. Über ihre Verwendung sagt das "Buch der Väter", daß sie nicht getragen wurde während des Opferaktes und der Verlesung des Evangeliums. Wie die syrische Maçnafta und der armenische Vakas mag auch die Maaphra (Biruna) von dem Mönchsschleier herzuleiten sein.

Sehr frïh läfst sich eine liturgische Kopfbedeckung beim Patriarchen von Alexandrien nachweisen. Die älteste schriftliche Nachricht über dieselbe entstamnt allerdings erst der zweiten Hälfte des 12. Jahrhunderts. Es ist Balsamon, der uns von ihr berichtet? Daf sie indessen schon eine geraume Weile früher beim Patriarchen in Gebrauch war, beweist eine Miniatur des Menologiums Basilius' II., auf welcher die hll. Athanasius und Cyrillus aufer mit der gewöhnlichen liturgischen Gewandung auch mit einer mützenartigen Kopfbedeckung ausgezeichnet sind. Sie muß also schon um das Ende des 10. Jahrhunderts eine bekannte und anerkannte Eigentülichkeit des alexandrinischen Patriarchen gewesen sein.

Nach Balsamon soll Papst Cölestin dem hl. Cyrillus von Alexandrien die Mitra verliehen haben, als er ihn an seiner Stelle mit der Leitung des Konzils zu Ephesus betraute. Das ist jedoch nur eine Fabel. Zu Cölestins Zeit gab es zu Rom noch keine Mitra, und darum konnte der Papst unmöglich Cyrillus mit dem Vorrecht auszeichnen, als sein Vertreter sich ihrer zu bedienen. Balsamon glaubt freilich, es habe der Papst damals wirklich schon die Mitra getragen. Denn die falsche Konstantinische Schenkung, kraft deren Konstantin Silvester I. auch den pileus phrygius gewährt, ist für ihn noch eine wirkliche Tatsache.

Die Ansicht Balsamons scheint vielfach im Orient geteilt worden zu sein. Es erwähnen dieselbe z. B. auch Nicephorus Callistus ${ }^{3}$ und Simeen von Saloniki. Andern aber mochte es bedenklich vorkommen, die Mitra der alexandrinischen Patriarchen auf eine Verleihung durch den römischen Papst zurückzuführen. Sie zogen es daher vor, das Vorrecht des alexandrinischen Patriarchen in einer andern, freilich recht sonderbaren Weise zu erklären. Sie sagten, es habe sich Cyrillus von einer Synode wegen Schwächlichkeit die Erlaubnis erteilen lassen, die Mitra zu tragen. Simeon von Saloniki, der beider Ansichten gedenkt, hält es seinerseits für wahrscheinlicher, dafs der Hinblick auf den jüdischen Hohenpriester für die Patriarchen Alexandriens Anlab gewesen sei, die Mitra in Gebrauch zu nehmen* ${ }^{4}$.

Wie es sich aber auch mit dem Ursprung der Mitra des alexandrinischen Patriarchen verhalten mag, jedenfalls hat sie bei diesem bereits eine gute Zeit vor dem Ende des 1. Jahrtausends Verwendung gefunden. Es ist demnach eine liturgische Mitra zu Alexandrien früher als zu Rom zur Verwendung gekommen; ob jedoch auch eher als die schon im Beginn des 8. Jahrhunderts nachweisbare auferliturgische Kopfbedeckung des Papstes, aus der um die Wende des Jahrtausends die liturgische Mitra des Abendlandes hervor-

1 La Science catholique 1890, 450. Vgl. ferner oben $\mathrm{S} .50$.

2 Meditata c. 2 (Mg. 138, 1048). Vgl. auch die Scholien Balsamons zum Nomokanon des Photius (Mg. 104, 1083).
${ }^{3}$ Hist. eccl. 1. 14, c. 34 (Mg. 146, 1169).

4 Resp. ad Gabr. Pentapol. qu. 20 (Mg. 155, 871). Wer anders denke, möge wenigstens, sagt er, in der Mitra das Symbol der Dornenkrone und des heiligen Schweißtuches sehen. 
ging, muf dahingestellt bleiben. Es fehlt zur Beantwortung dieser Frage alles Material. Die Mitra blieb auch in der Folge im koptischen Ritus stets ein privilegiertes Ornatstiick des Patriarchen.

\section{URSPRUNG DER MITRA.}

Die Zeit, zu der in Rom die Mitra in Gebrauch kam, läkt sich zwar nicht genau, doch immerhin annähernd bestimmen. Da dieselbe bis ins 10. Jahrhundert hinein noch nicht zum Sakralornat der römischen Kirche gehörte und es anderseits bereits vor der Vitte des 11. Jahrhunderts bei Papst und Kardinälen Sitte war, sich des Ornatstücks beim Gottesdienst zu bedienen, wird dessen Einführung wohl zwischen ca 900 und 1000 liegen. Dafs sich von dem Ereignis keine Kunde erhalten hat, kann nicht auffallen. Die Zeit war damals gar stïrmisch; ein folgenschweres Ereignis drängte das andere; Rom selbst war der Schauplatz zahlreicher Parteikämpfe und blutiger Fehden; die Griechen machten Schwierigkeiten ïber Schwierigkeiten, die Mibstände im Klerus und die Ausschreitungen der weltlichen Groken waren schreiend: Tage wiederholten sich, wie sie kaum schlimmer eine frühere Zeit gesehen; was war gegenüber solchen Verhältnissen die Ingebrauchnahme einer liturgischen Kopfbedeckung, zumal wenn dieselbe nicht mit einem Schlag, sondern allmählich erfolgte? Der Ereignisse, denen gegenüber ein solches Vorkommnis verschwinden muste, waren zu viele und zu wichtige.

Wie ist es aber zur Einführung des pontifikalen Kopfschmuckes gekommen? Hat etwa der Hinblick auf die sakrale Kopfbedeckung der alttestamentlichen Priester den Anstof dazu gegeben?

Selbstverständlich ist diese Frage nicht von einer unmittelbaren Herübernahme der Mitra des mosaischen Kultus zu verstehen, da ja die pontifikale Mitra erst um die Wende des ersten Jahrtausends aufkam. Sie kann nur den Sinn haben, die Erinnerung an den hohenpriesterlichen Kopfbund des aaronitischen Opferdienstes habe damals die Ingebrauchnahme der Mitra veranlaßit. Allein auch so dürfte die Frage zu verneinen sein.

Es liegt nichts vor, woraus sich eine solche späte Ableitung unseres Ornatstückes von dem entsprechenden Gewandstück des mosaischen Kultus erschlielien liefe. Insbesondere findet sich in den Bullen, in denen die Päpste Bischöfen oder Äbten das Recht verleihen, die Mitra zu tragen, absolut keine Spur, welche zu Gunsten einer solchen Auffassung spräche. Sehr zu beachten ist auch, daf die römische Mitra im Gegensatz zur Sitte des Alten Bundes, wonach alle Priester eine sakrale Kopfbedeckung trugen, stets nur der hohen und höchsten Geistlichkeit zukam.

Allerdings behaupten einige Liturgiker des 12. Jahrhunderts, Honorius von Autun, Robertus Paululus und Sicardus, es sei die Mitra dem mosaischen Gesetze entnommen. Est assumpta a lege, so Honorius bzw. Sicardus; ex usu legis, so Robertus. Doch erhellt aus ihren Worten weder, wie sie sich deren Ableitung von der Miznephet denken, ob mittelbar oder unmittelbar, noch führen sie einen Grund für ihre Behauptung an. Bekannt ist auch, wie es um die historische Kritik der Liturgiker des 12. und 13. Jahrhunderts bestellt gewesen ist. Was sie sagen, ist daher ohne allen Belang. Man ist leicht geneigt, aus aprioristischen Gründen an eine Beeinflussung der christlichen Sakralkleidung durch diejenige des Gesetzes zu denken. Wer sich aber eingehender mit der Geschichte unserer liturgischen Gewänder beschäftigt, 
dem kann es nicht entgehen, daß selbst eine bloß mittelbare Einwirkung auf die Entwicklung der neutestamentlichen Kultgewandung nur in selır geringem Mafe und fast nur in Nebensächlichkeiten stattfand.

Aber auch aus den Riten des Ostens kann die Mitra nicht herübergenommen worden sein. Es bedarf das nach dem, was früher über das Auftreten der Mitra daselbst gesagt wurde, keines weiteren Beweises. Höchstens könnte eine Ableitung der römischen Mitra von derjenigen des alexandrinischen Patriarchen in Frage kommen, allein die völlige Bedeutungslosigkeit, in welche das Patriarchat von Alexandria gegen Ende des ersten Jahrtausends versunken war, und der Mangel aller näheren Beziehung zwischen Rom und ihm in jener Zeit schliefen den Gedanken an solche Herübernahme völlig aus. Wie sollte auch die römische Kirche noch um die Wende des Jahrtausends einem orientalischen Ritus die Mitra entlehnt haben? Für ein solches Vorgehen war es nicht mehr die Zeit. Schon gingen der Osten und der Westen in liturgischen Dingen ganz und gar getrennte Wege.

Die richtige Erklärung des Ursprunges der römischen Mitra wird durch die Erwägung nahegelegt, daßs nachweislich alle übrigen Kultgewänder auf die auferliturgische Tracht zurückzuführen sind ', so die Albe, das Cingulum, der Manipel, die Stola, die Kasel usw. Es wird sich also ohne Zweifel ebenso mit der Mitra verhalten. Wirklich glauben wir unsere Finger auf das Ornatstück legen zu können, von welchem dieselbe herstammen dürfte. Es ist das camelaucum, auch frigium (phrygium) und regnum genannt, d. i. eine auszeichnende Kopfbedeckung, deren sich der Papst auferhalb der Kirche bei feierlichen Aufzügen zu bedienen pflegte.

Dieselbe muf wenigstens schon im 8. Jahrhundert bei ihm in Gebrauch gewesen sein. Es erhellt das klar aus dem Constitutum Constantini, der sog. Konstantinischen Schenkung ${ }^{2}$.

Der Kaiser habe, so lesen wir darin, Silvester I. aufer andern kaiserlichen Insignien und Vorrechten auch die Krone und das frigium verliehen. Die erstere habe sich der Papst Silvester anzunehmen geweigert, da er über seiner Tonsur, die er zu Ehren des hl. Petrus trage, eine goldene Krone nicht habe tragen mögen; das frigium habe Konstantin jedoch mit eigenen Händen ihm auf das Haupt gesetzt und dabei bestimmt, es sollten sich sowohl Silvester wie alle seine Nachfolger desselben bei den Aufzügen (in processionibus) in Nachahmung der kaiserlichen Würde bedienen.

Hätte der Papst zur Zeit, da die Fälschung entstand, das frigium entweder noch gar nicht oder doch nur erst seit kurzem getragen, so hätte ihr Verfasser unmöglich den Kiaiser dasselbe Silvester I. zum Gebrauch für ihn selbst wie für seine Nachfolger schenken lassen können.

In der Tat erzählt das Papstbuch in der Vita Konstantins (708-715), es habe derselbe bei seinem feierlichen Einzuge in Konstantinopel das camelaucum getragen, womit er in Rom aufzuzienen gewohnt sei (cum camelauco, ut solitus est Roma procedere) ${ }^{3}$, d. i. eine kegel- oder mützenartige Kopf-

1 Über die Beziehungen der alttestamentlichen Sakralkleidung zu der liturgischen Gewandung des christlichen Kultus vgl. die diesbezüglichen Ausführungen in $\mathrm{Nr}$ I des Schlukkapitels.

2 Hinschius, Decret. Pseudoisid. 253. Über das frigium, das hier eine mützenartige
Kopfbedeckung bedeutet, vgl. D. C. sub phrygium VI 306. Wenn in der Rezension des Constitutum bei Hinschius einmal pallium frigium statt frigium (phrygium) steht, so ist entweder blofs frigium oder richtiger pileum frigium zu lesen.

${ }^{3} \mathrm{Duch}$., L. P. I 390. 
bedeckung; denn das verstand man unter dem camelaucum, auch camelaucium und mit Vertauschung der Konsonanten calamaucum, calamacum und ähnlich genannt. Super caput gestat pileum (der jüdische Priester) in modum parvuli calamaci aut cassidis, sagt Rufin in seiner Übersetzung der Altertiumer des Josephus Flavius ${ }^{1}$.

Der 9. Ordo Mabillons bezeugt den Gebrauch des Ornatstückes, hier regnum genannt, für den Zug, der nach der Papstweihe stattfand. Es setze, so gibt er an, der Marschall dem Papst nach seiner Konsekration das regnum auf das Haupt, bevor dieser das Roß besteige, um von St Peter heimzuziehen?

Auf den päpstlichen Münzen erscheint das camelaucum (frigium, regnum) zuerst bei Sergius III. (904-911) und dann wieder bei Benedikt VII. (974-983) ${ }^{3}$.

Das Ornatstück war, wie der Name camelaucum besagt ${ }^{4}$, eine Art von Mütze. Der 9. Ordo bemerkt bezüglich seiner Form und Beschaffenheit, das päpstliche regnum sehe einem Helme ähnlich und werde aus weifsem Zeug angefertigt. Auch aus der sog. Konstantinischen Schenkung vernehmen wir, dafa es von weiker Farbe war. Auf den Münzen der Päpste Benedikt und Sergius hat es die Gestalt eines kegelförmigen, mit Besatzstreifen gezierten Hutes. Alles in allem gewährt es ein Bild, wie es uns ähnlich in der ältesten Form der Mitra entgegentritt.

Wie wird sich aber die Mitra aus der auszeichnenden Kopfbedeckung, mit welcher der Papst bei seinen Aufzügen geschmückt war, gebildet haben? Nun, dadurch, dafi dieser im Verlauf des 10. Jahrtausends dazu überging, das Ornatstück nicht mehr blok in processionibus, sondern auch bei dem an diese sich anschiefienden Gottesdienste zu tragen. Ob dabei schon sofort irgend ein äuferer Unterschied zwischen der liturgischen und aufierliturgischen Kopfbedeckung eingeführt wurde, ist zweifelhaft. Jedenfalls kann derselbe anfangs nicht bedeutend gewesen sein. Die ältesten Abbildungen der Mitra, wie sie sich z. B. auf Miniaturen des Exultetrotels von Bari, des Taufrotels daselbst und einer Kanonessammlung der vatikanischen Bibliothek finden ${ }^{\circ}$, lassen noch keine formelle Verschiedenheit der Mitra und des päpstlichen außserliturgischen Kopfschmuckes erkennen.

Ein entschieden wahrnehmbarer Unterschied zwischen beiden Ornatstücken trat auf, als die Mitra im Laufe des 12. Jahrhunderts ihre ursprüngliche

1 L. 3 , c. 11 (ed. Colon. 1524) ; f. 29 ; aus Rufinus bei Beda, De tabernaculo 1. 3 , c. 8 (M. 91, 481). Über camelancum vgl, auch D. C. sub camelaucum II 44 und Dissert. sur l'histoire de St-Louis (ebd. IX 82). Im sermo Theodors von Trimithus auf den hl. Johannes Chrysostomus erscheint saundaúzor als eine Art von Bauernmütze (n. 11 [Mg. 47, 63]). Vgl. auch Theophan., Chronogr. ad 472544761 (ed. Bonn. 1839) I 198354 687. Noch jetrt heift die mützenartige klerikale Kopfbedeckung im griechischen Ritus xasnhauxov. In der Form camaurum (ital. camauro) hat sich der Name camelaucum erhalten als Bezeichnung einer rotsamtenen, mit weifem Pelz umrandeten, auferliturgischen Kopf bedeckung des Papstes, die bis ins 19. Jahrhundert gebräuchlich blieb, dann aber dem weifen päpstlichen Pileolus weichen mufite.

Braun, Die liturgische Gewandung.
${ }^{2}$ N. 6 (M. 78, 1007). Kösters (Studien zu Mabillons Ordines 36 ff) schreibt den Abschnitt des 9. Ordo, worin von dem Regnum die Rede ist, dem 11. Jahrhundert zu. Unter dem Leo nämlich, welcher in den in jenem Passus angeführten Laudes genannt wird: Dominus Leo papa, quem S. Petrus elegit, in sua sede multis annis sedere, versteht er Leo IX, nicht wie andere Leo III. oder Leo IV. Kösters' Auffassung ist jedoch schon darum allein unhaltbar, weil der fragliche Abschnitt bereits in Handschriften aus der Zeit vor Leo IX, vorkommt. $\mathrm{Ob}$ uberhaupt der Name Leo in jenen Laudes auf einen bestimuten Papst zu beziehen und ob er nicht vielmehr blok typisch ist?

3 Promis, Monete dei Rom. Pont., Torino 1858, tav. 7, 12 ; tav. 9, 12.

4 Vgl. vorhin Anm. 1.

s S. oben S. 448 und 450 . 
Kegelform allmählich verlor und zunächst mit Bauschen, dann aber mit. Hörnern versehen wurde, während das regnum seine Kegelgestalt beibehielt. Trefflich tritt die formelle Verschiedenheit beider auf den Miniaturen des Hortus deliciarum der Herrad von Landsberg († 1195) zu Tage. Die Mitra der Bischöfe hat bereits cornua erhalten, welche über Stirn und Hinterkopf aufsteigen, dagegen besteht die Kopfbedeckung des Papstes aus einem hohen, kegelförmigen Hut. Nur zu Benevent behielt die Mitra die ursprüngliche Form bis ins 16. Jahrhundert bei, d. i. bis Paul II. den ferneren Gebrauch den Erzbischöfen von Benevent untersagte ${ }^{1 .}$

VIERTES KAPITEL.

\section{TIARA, PILEOLUS, BIRETT.}

\section{DIE TIARA.}

Im Anschlufs an die Mitra empfiehlt es sich, die Geschichte von noch drei weiteren Kopfbedeckungen kurz zu behandeln, der Tiara, des Biretts und des Pileolus. Die Tiara ist kein liturgischer Ornat. Sie steht indessen zur Mitra in so inniger Beziehung, daß diese es zur Genüge rechtfertigt, wenn wir mit einigen Zügen den Entwicklungsgang des so hochbedeutsamen Ornatstückes zeichnen. Dazu kommt, dals ursprünglich, wie es scheint, in Bezug auf die Form von Mitra und Tiara entweder gar kein oder doch kein erheblicher Unterschied bestand.

Birett und Pileolus können, ja müssen zu den liturgischen Gewändern im weiteren Sinne gezählt werden. Denn wenn sie auch außerhalb der liturgischen Funktionen zur Verwendung kommen, so wird doch anderseits, und zwar auf Grund kirchlicher Bestimmungen, nicht minder bei gottesdienstlichen Verrichtungen von ihnen Gebrauch gemacht?

Die Tiara. In der Entwicklung der Tiara lassen sich drei Hauptphasen unterscheiden. Die erste geht bis zu dem Zeitpunkte, da sie mit einem Kronreifen verbunden wird, die zweite reicht bis zur Einführung dreier Kronen, die letzte von da bis zur Gegenwart. Über die erste Periode wurde schon bei der Besprechung des Ursprungs der Mitra das Nötige gesagt. Es war die Tiara, wie aus der Konstantinischen Schenkung hervorgeht, in dieser Zeit lediglich eine helmartige, aus weißem Stoff gemachte Mütze.

Wann die zweite Periode angehoben hat, d. h. wann zu dieser Mütze ein Kronreifen hinzukam, läst sich nicht genau bestimmen. Man hat behauptet, es habe der Papst bereits zur Zeit des Hormisdas eine Krone getragen und

1 Sarnelli, Memorie cron, dei vescovi ed arcivescovi di Benevento, Napoli 1690, 141. Die Mitra hiek zu Benevent camaurum. So schreiht Hugo, Erzhischof von Benevent, im Jahr 1374: Nos pro nostra ecclesia Beneventana prae ceteris ecclesis metropolitanis maiori, digniori et praecellenti regno sive thiara ad modum summi pontificis utimur, quod hic camaurum vocatur ( $\mathrm{B}$ arbier de Hontault, Deuvres compl. IIL 265).

2 Die ziemlich, veichhaltige ältere Literatur utber die Tiara ist zum großen Teil ohne Bedeutung. Wil verzeichnen von ihr nur:
Vettori, Il fiorino d'oro antico illustrato, Florenz 1738, 28 ff; M ar ang oni, Chronologia Romanorum pontificum, Rom 1751, $72 \mathrm{ff}$; Gar ampi, Illustrazione di un antico sigillo della Garfagnana, Rom 1759, $89 \mathrm{ff}$. Dazu in neverer Zeit M o r. LXXXI $29 \mathrm{ff}$; Bock Jl $158 \mathrm{ff}$; Hef., Beitr. II $236 \mathrm{ff}$; Roh. VIII 137 und $\mathrm{Müntz}$, La tiare pontificale ơu $\mathrm{VIII}^{e}$ au XVI ${ }^{\circ}$ siècle, in Mémoires de l'Académie des Inscriptions et Belles-Lettres XXXVI (1898) 235 ff, die beste, auf eingehendem Studium der Monumente und schriftlichen Quellen beruhende Arbeit. 
sich dafür auf das regnum berufen, das Chlodwig damals dem hl. Petrus als Weihegabe sandte ${ }^{1}$. Allein es handelt sich um ein Mißverständnis. Das fragliche regnum war nicht eine Papstkrone oder auch nur, wie Hefele meint, eine Fürstenkrone, sondern eine jener Weihekronen, die man in den Kirchen um den Altar aufzuhängen pflegte.

Es ist selbst unsicher, ob schon im 9. Jahrhundert die Papstmütze mit einem Kronreifen versehen war. Eine Stelle in der Biographie Nikolaus' I. (856-861), auf die man sich zum Beweise dafür berufen hat, spricht nicht von einer Krönung des Papstes, sondern von einer Bekränzung der Stadt. Aber auch der 9. Ordo, der, wie es scheint, aus der Zeit Leos IV., jedenfalls aber aus dem 9. Jahrhundert stammt, läßt die Sache unentschieden, trotzdem er die Kopfbedeckung, welche ihm zufolge dem Papst nach seiner Konsekration vor dem feierlichen Heimritt vom Marschall aufgesetzt wurde, regnum nennt ${ }^{3}$. Denn wenn auch die Bezeichnung regnum an sich den Gedanken an einen Kronreifen nahe legt, so ist es doch merkwürdig, dafs die Beschreibung, welche der Ordo von dem Kopfschmuck gibt, diesen lediglich als eine aus weißem Zeug gemachte helmartige Mütze hinstellt. Nicht die geringste Andeutung eines Kronreifens.

Im Beginn des 12. Jahrhunderts war zur Papstmütze die Krone unzweifelhaft schon hinzugekommen. Denn um diese Zeit unterscheidet nicht nur Bruno von Segni bestimmt zwischen der Mitra und dem Regnum und noch klarer der 12. römische Ordo zwischen der Mitra und der Corona des Papstes ${ }^{4}$, sondern es beschreibt auch Suger von St-Denis das Phrygium, welches Innozenz II. $1130 \mathrm{am}$ Osterfest beim Zug zur Abteikirche getragen hatte, als phrygium imperiale instar galeae circulo anreo circumdatum, d. i. als eine helmförmige, von einem goldenen Reifen umgebene Kopfbedeckung ${ }^{5}$. Es muf also der Kronreifen spätestens im Verlauf des 11. Jahrhunderts zum päpstlichen Camelaucum hinzugekommen sein.

Die Bildwerke lassen uns in Bezug auf die Bestimmung des Zeitpunktes, zu dem sich der Kronreifen einbürgerte, vollständig im Stich. Es gibt nicht nur äuferst wenige Monumente aus dem 10. und 11. Jahrhundert, auf denen die Tiara zur Abbildung gekommen ist, es bleibt obendrein auf allen diesen Darstellungen unentschieden, ob der Zierstreifen, der sich um den unteren Rand der auf ihnen sich findenden Tiara zieht, ein Band oder ein Kronreifen sein soll, ja ob es sich bei der Kopfbedeckung, die uns auf einigen von ihnen begegnet, überhaupt um eine Tiara und nicht vielmehr um die Mitra handelt.

Die Bildwerke, welche hier in Betracht kommen, wurden schon anderswo gelegentlich erwähnt. Es sind für das 10. Jahrhundert Münzen Sergius' III. (904-911) und Benedikts VII. (974-983). Auf beiden ist es der hl. Petrus, nicht der Papst, welcher mit einer Spitzmütze dargestellt erscheint. Die Monumente des 11. Jahrhunderts beschränken sich auf eine Miniatur des Exultetrotels von Bari (Bild 247, S. 500) und eine Federzeichnung in der schon früher erwähnten Konziliensammlung der Vaticana ${ }^{6}$.

I Duch., L. P. I 271.

2 Ebd. II 152. 3 N. 6 (M. 78, 1007).

+ N. 4546 (ebd. 1045).

5 Vita Ludov. Grossi c. 21 (M. 186, 1331). $\mathrm{Vgl}$. auch die von Zeitgenossen geschriebene Vita Paschalis II. bei D u ch., L. P. II 296. Hier wird das regnum thyara genannt, vielleicht das früheste bekannte Beispiel für den Gebrauch des Wortes zur Bezeichnung der
Papstkrone. Daß aber diese und nicht die Mitra gemeint ist, erhellt aus dem coronatus auf S. 297.

6 Vat. lat. 1339. Die Miniatur stellt einen Papst inmitten von Bischöfen dar. Vielleicht, daf 3 auch auf den Fresken in der Unterkirche von S. Clemente zu Rom (Abbildungen bei Roh. VII, DLxxv und Wil p., Cap. p. 80) die Kopfbedeckung des Papstes die Tiara und nicht die Mitra (s. oben S. 450) darstellt. 
Auf keinen Fall kann der Kronreifen vor dem 9. Jahrhundert zum päpstlichen Camelancum hinzugefügt worden sein. Denn so hoch auch das Ansehen sein mochte, in dem die Päpste damals standen, und so bedeutend auch ihr Einflufs in Rom und Italien, ja im ganzen Abendland bereits war, noch waren sie keine Fürsten, noch keine eigentlichen Landesherren. Aber auch nachdem für den Kirchenstaat durch die Krönung Karls und die Ereignisse der nachfolgenden Jahre die Geburtsstunde geschlagen hatte, war für die Päpste noch nicht sofort die Zeit gekommen, sich mit allen Zeichen der Souveränität zu umgeben. Erst muste sich der neue Stand der Dinge klären und befestigen. Vielleicht, daß es unter den Wirren, welche das 9. und 10. Jahrhundert Rom brachten, und unter den damaligen entsetzlichen Parteikämpfen, bei welchen die weltliche Herrschaft des Papstes eine Zeitlang wieder zu Grunde ging, noch bis gegen das 11. Jahrhundert dauerte, ehe die

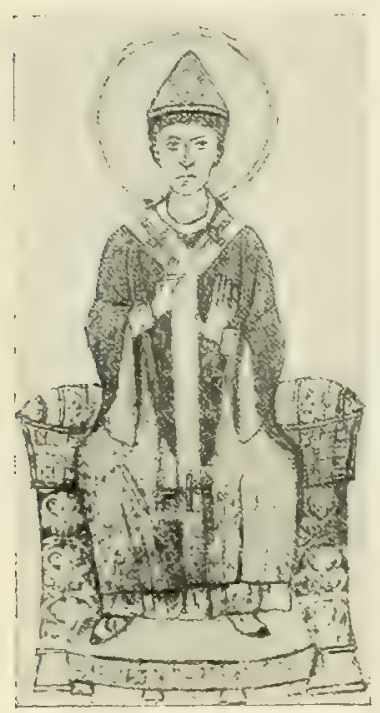

Bild 247. Papst. Miniatur eines Exultetrotels. Bari. Päpste ihrem Phrygium die Krone hinzufügten. Es ist darum auch wohl nicht ohne Grund, wenn der 9. Ordo noch nicht von einer Krönung des Papstes redet, wie die späteren Ordines es tun. Nur insofern kommt die neue Ordnung der Dinge bei ihm zum Ausdruck, als er der landesherrlichen Stellung des Papstes entsprechend die weife, helmartige Mütze, die der Marschall vor den Stufen von St Peter diesem nach dessen Konsekration aufsetzte, regnum nennt. Ob übrigens das Aufkommen der liturgischen Mitra so ganz ohne Einfluf auf die Einführung der Kronreifens geblieben sein sollte? Seitdem das Camelaucum auch als liturgischer Kopfschmuck des Papstes zu dienen begann und dann bald in gleicher Eigenschaft sich bei den Kardinälen einbürgerte, lag es doch sicher sehr nahe, dasselbe, soweit es als Abzeichen der weltlichen Machtstellung des Papstes gebraucht wurde, mit dem Symbol zeitlicher Herrschaft, einem Kronreifen, zu versehen, um so das Camelaucum im Sinne des Regnum von dem Camelaucum im Sinne der Mitra äuferlich zu unterscheiden.

Die Tiara blieb eine hohe, zuckerhutförmige, um den unteren Rand herum mit einem edelsteingeschmückten Goldreifen verzierte Mütze bis zum Beginn des 14. Jahrhunderts. Es gibt eine namhafte Anzahl von Bildwerken des 12. und 13. Jahrhunderts, auf denen sie zur Darstellung gekommen ist. Auf einzelnen Monumenten ist an Stelle des Reifens eine Zackenkrone angebracht, so z. B. bei der Grabfigur Honorius' IV. in S. Maria in Araceli zu Rom, der Grabstatue Benedikts XI. in S. Domenico zu Perugia, der Figur Nikolaus' IV. auf dem Apsismosaik der Laterankirche, dem Bilde Innozenz' III., auf dem Fresko Giottos "St Francisci Predigt vor Innozenz III.“ in der Oberkirche von S. Francesco zu Assisi, der Figur Bonifatius' VIII, auf dem Giottoschen Freskenfragment "Die Verkündigung des Jubiläums“ in der Laterankirche u. a. Diese Zackenkrone tritt jedoch erst gegen Ende des 13. Jahrhunderts auf den Bildwerken auf. Die Figur Innozenz' IV. auf dem Fresko am Grabmale des 1256 gestorbenen Kardinals Wilhelm Fieschi in S. Lorenzo fuori le Mura trägt noch eine Tiara mit blokem Reifen. Dasselbe ist mit den Darstellungen Silvesters I. auf dem um dieselbe Zeit entstandenen 
Zyklus von Bildern aus der Silvesterlegende in der Kapelle des Heiligen bei der Kirche der SS. Quattro Coronati der Fall.

Auch auferhalb Italiens wird man vor Ende des 13. Jahrhunderts keine Zackenkrone an der päpstlichen Tiara finden. Wie im Hortus deliciarum der Herrad von Landsberg, so erscheint diese z. B. auch bei den Papstfiguren an den Portalen der Kathedralen von Reims und Chartres lediglich mit einem schlichten Reifen ausgestattet.

Beispiele eines früheren Auftretens der Zackenkrone an der Tiara sind uns weder in Italien noch außerhalb Italiens bekannt geworden. Die Grabplatte Lucius' III. (1181-1185) im Dom zu Verona, auf der sie uns begegnet, entstammt der Zeit des Neubaues des Domes, d. i. dem 14. Jahrhundert. Ein Relief in den vatikanischen Grotten, auf dem Nikolaus III. (1277-1280) mit einer Tiara dargestellt ist, welche unten ein mit Blumen statt blofer Zacken versehener Reifen umgibt, ist eine Schöpfung des 14. Jahrhunderts, eine Stiftung des Kardinals Rainald Orsini († 1374). Die bei Ciampini sich findende Abbildung des Apsismosaiks der früheren St Peterskirche, auf der. Innozenz III. (1198-1216) eine Tiara mit Zackenkrone trägt, ist, wie alles Detail bei Ciampini, absolut unzuverlässig. Ein Fresko in Subiaco, welches ihn mit einer derartigen Tiara darstellt, ist erst im 14. Jahrhundert entstanden ${ }^{1}$.

Merkwürdigerweise erhielt sich die einfache Zackenkrone auf den Bildwerken noch lange, nachdem die dreikronige Tiara in Gebrauch gekommen war, und zwar nicht blok auferhalb Italiens, sondern auch in Italien, ja nicht allzufern von Rom. So findet sie sich z. B. noch bei Papst Gregor auf einer der Bronzetüren im Dom zu Florenz, einer Schöpfung des Luca della Robbia aus der Mitte

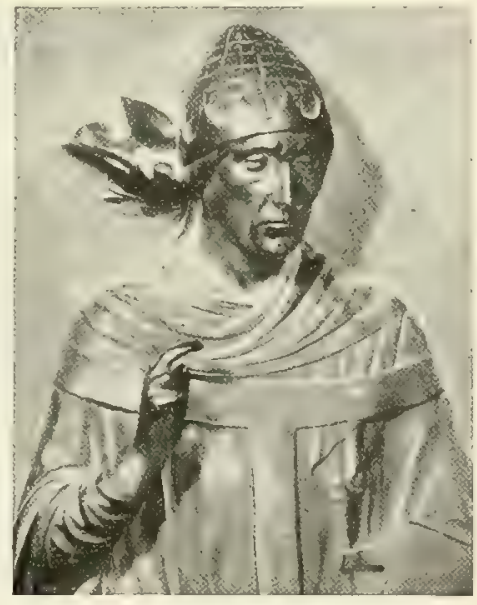

Bild 248. St Gregor d. Gr'. Von der Bronzetüre des Luca della Robbia. Florenz, Dom. des 15. Jahrhunderts (Bild 248), von Bildwerken aus dem 14. Jahrhundert ganz zu schweigen.

Wann das Regnum mit Behängen (caudae, lemnisci, infulae) versehen worden ist, ob schon in der ersten Phase seiner Entwicklung oder erst im zweiten Stadium derselben, läbt sich nicht feststellen. Jedenfalls war es im 13. Jahrhundert Brauch, solche an dem Regnum anzubringen. Wir gewahren sie deutlich auf einem Fresko der Silvesterkapelle an der Tiara Silvesters, auf dem Apsismosaik in der Laterankirche an der Tiara Nikolaus' IV. (1288

1 Eine Initiale der Register Innozenz' III. stellt den Papst mit einer Tiara dar, an deren Reifen in der Mitte und an den Seiten eine Art von aufrecht stehendem Blatt angebracht ist. Das Register stammt aus dem Beginn des 13. Jahrhunderts. Abbildung der Miniatur bei Pitra, Nova analecta I. Es ist bei Miniaturen nicht immer möglich, sicher festzustellen, was der Phantasie des Künstlers zuzuschreiben ist und was der Wirk- lichkeit entspricht. Im vorliegenden Fall kann es aber nicht zweifelhaft sein, dafs die Verzierung lediglich auf Rechnung des Künstlers zu setzen jst. Wenn Johannes XXI. (1276-1277) auf seinem Grabmal im Dom zu Viterbo eine Tiara mit drei Kronen auf dem Kopfe lat, so ist zu bemerken, daf die Figur des Papstes nicht aus dem 13. Jahrhundert, sondern erst aus weit späterer Zeit stammt. 
bis 1292), auf dem Fassadenmosaik von S. Maria Maggiore bei Papst Liberius und den Apsismosaik derselben Kirche bei Papst Nikolaus IV. Auf den drei letzten Nonumenten sind die Behänge auffallenderweise von schwarzer Farbe. Daß solches jedoch wirklichen Brauch wiedergibt, beweist das Inventar Bonifaz TIII. vom Jahre 1295, wo sich in der Tat caudae nigrae cum VIII esmaltis pro qualibet verzeichnet finden. Die Behänge weisen noch selbst auf dem Fresko Fra Angelicos in der Kapelle Nikolaus' IV., welches die Weihe des hl. Laurentius darstellt, eine schwarze Farbe auf. Wirklich bekundet die Beschreibung einer von Pius II. stammenden Tiara in einem Inventar des Domes zu Siena von 1467, dafs sie noch im 15. Jahrhundert schwarz waren.

Auffällig ist, daßs bei einer großen Zahl von Bildwerken die Tiara ein Flechtwerk darstellt. Es ist das wohl kaum anders als durch die Annahme zu erkläı'en, dał die Tiara in der Tat im 13. Jahrlhundert aus Bändern geflochten worden sei. Treffliche Beispiele liefern ein Fresko in der St Silvester-

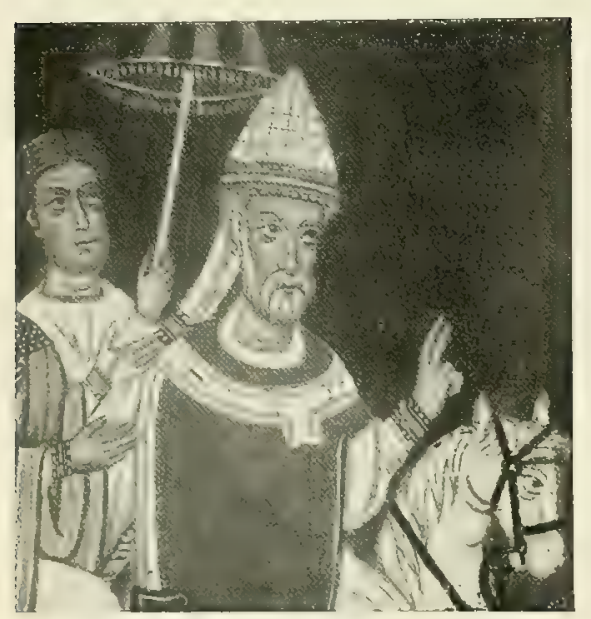

Bild 249. St Silvester. Fresko. Rom, sS. Quattro Coronati (Kapelle des hl. Silvester). kapelle bei der Kirche der SS. Quattro Coronati zu Rom, die Grabfiguren Honorius' IV. (1285-1287) in der Kirche Araceli, Benedikts XI. in S. Domenico zu Perugia, Gregors $X$. im Dom zu Arezzo, die Statuette Gregors d. Gr. am Prachtsarkophag des hl. Petrus Martyr in S. Eustorgio zu Mailand, einer Arbeit des Giovanni Balduccio aus Pisa (1339), der hl. Gregor d. Gr. auf einem Gemälde Simone Martinis ( $†$ 1344) im Museo Civico zu Pisa und einem Glasgemälde in der Unterkirche von S. Francesco zu Assisi, Bonifaz VIII. auf dem Fresko Giottos in S. Giovanni im Lateran und manche andere. Das Flechtwerk stellt bald eine schachbrettartige (Bild 249), bald eine ähren- oder grätenförmige Musterung (Bild 250) dar. Selbst im 15. Jahrhundert kommen noch Bildwerke vor, auf denen die Tiara den Anschein hat, als bestehe sie aus Flechtwerk. Es sei nur auf das bereits erwähnte Relief der Bronzetür Robbias im Dom zu Florenz (Bild 248, S. 501) sowie auf eine ähnliche Darstellung an einer der Bronzetüren des Baptisteriums daselbst hingewiesen. Auch bei letzterer ist es Gregor d. Gr., der eine Tiara jener Art trägt. Es scheint fast, als seien geflochtene Tiaren für Abbildungen dieses Papstes typisch geworden.

Eine neue Phase in der Geschichte der Tiara beginnt unter Bonifaz VIII. (1294-1303). Aus einem Inventar des päpstlichen Schatzes vom Jahre 1295, der bezeichnenderweise nur e in Regnum neben einer grofen Anzahl der kostbarsten Mitren erwähnt, ergibt sich, dał damals die Tiara nur erst mit einem circulus versehen war. Es dauerte aber nicht lange, bis es anders wurde, und zwar lassen die Statuen Bonifaz' VIII. in der Laterankirche und der Krypta von St Peter keinen Zweifel, dals schon unter ilım die Tiara mit zwei Kronen versehen wurde.

Es gibt eine auffallend große Zahl von Statuen Bonifaz' VIII. Alle sind zu Lebzeiten des Papstes angefertigt worden. Eine Ausnahme macht nicht einmal die Grabfigur desselben anf seinem Sarkophag in den Grotten der Peterskirche, da selbst 
diese aller Wahrscheinlichkeit nach noch vor dem Tode Bonifaz' ausgeführt worden ist. Von jenen Statuen betindet sich je eine im Dom zu Florenz, im Museum zu Bologna, an der Seitenfront der Kathedrale von Anagni und in der Laterankirche zu Rom, je zwei zu Orvieto und in den vatikanischen Grotten. Zu diesen plastischen Darstellungen kommt noch das von Giotto gemalte Bild des Papstes auf dem früher erwähnten Fresko in S. Giovanni im Lateran.

Von besonderer Wichtigkeit sind die drei aus den letzten Lebenstagen des Papstes stammenden Statuen in der Krypta von St Peter und in der Laterankirche. Während nämlich das Fresko Giottos, die von Manno 1301 aus getriebenem und vergoldetem Kupfer angefertigte Statue zu Bologna, die beiden Statuen zu Orvieto und die imposante sitzende Figur Bonifaz VIII. im Dom zu Florenz uns diesen mit einkroniger Tiara geschmückt zeigen, ist seine Tiara bei den drei Statuen in St Peter und St Johann mit zwei Kronen ausgestattet?

Die drei Bilder stammen unzweifelhaft aus einer Werkstätte, wenn nicht von ein und derselben Hand. Die beiden Figuren in der Krypta von St Peter hatten ihren Platz ehedem an dem Altarbau, den Bonifaz VIII. kurz vor seinem Tode dureh Arnulf von Cambio ${ }^{2}$ zu Ehren seines Vorgängers, des hl. Bonifaz IV., hatte aufführen lassen. Derselbe bestand aus einem auf Säulen ruhenden, an der Eingangswand von St Peter sich erhebenden Baldachin, unter dem ein Altar zu Ehren des Titelheiligen errichtet war. Die Grabfigur Bonifaz' VIII. befand sich oberhalb der Altarmensa auf einem aus der Wand hervortretenden Sarkophag. Ein darüber angebrachtes Mosaik, das leider verloren gegangen ist, zeigte den Papst kniend vor dem hl. Petrus, der Mutter Gottes mit dem Kinde vorgestellt ${ }^{3}$. Ist der Abbildung der Darstellung bei Ciampini zu trauen, so trug Bonifaz auch auf diesem Mosaik eine zweikronige Tiara nach Art derjenigen der Grabstatue. Die segnende Halbfigur des Papstes mufs oberhalb der Verdachung unter dem dort angebrachten Baldachin gestanden haben. Die Statue im Lateran stellt den Papst kniend dar (Bild 18, S. 54).

Man hat freilich in dem oberen Reifen, mit dem bei den drei Statuen die Tiara Bonifaz' VIII. geschmuickt ist, ein blokes Ornament sehen wollen. Indessen darf eine solche Auffassung ohne Bedenken als nicht zutreffend bezeichnet werden. An sich könnte der zweite Reifen aller-

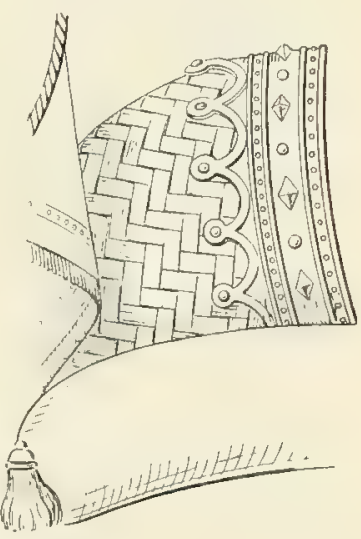

Bild 250. Tiara der (irabstatue Benedikts XI. Perugia, S. Domenico. dings vom Künstler lediglich als Dekoration gedacht sein. Betrachtet man aber -und das ist doch das allein Richtige - die Form der Tiara, wie sie bei den fraglichen Statuen auftritt, im Zusammenhang mit der zeitlich unmittelbar folgenden Entwicklung des päpstlichen Regnum und insbesondere mit einer zehn Jahre später datierenden Notiz des Inventars des päpstlichen Schatzes, wonach damals die Tiara bereits drei circuli aufwies, dann läfst sich kaum verkennen, daßs jener obere gleichfalls mit Blättern geschmückte Reifen ebenfalls eine wirkliche Krone und nicht eine bloße, von der Phantasie des Künstlers eingegebene Verzierung darstellen sollte.

1 Man gibt die Statue Bonifaz' VIII. in der Laterankirche gewöhnlich als die Nikolaus'IV. aus, und so bezeichnen sie denn auch $\mathrm{Roh}$. (VIII 139), M ü $\mathrm{n} \mathrm{z}$ (La tiare pontificale du VIII ${ }^{e}$ au $X V I^{e}$ siecle, in Mémoires de l'Académie des Inscriptions et Belles-Lettres XXXVI [1898] 264) und Goyau, Pératé und Fabre, Der Vatikan (Einsiedeln 1898) 450 น. а. Diese Zuweisung ist indessen unzutreffend. Ein Vergleich der Statue mit derjenigen Bonifaz' VIII. in Florenz und den beiden Statuen in den vatikanischen Grotten bekundet deutlich, daks wir in ihr gleichfalls Bonifaz VIII, vor uns haben. Tatsächlich galt anch noch im 17. Jahrhundert die Figur als die Bonifaz' VIII. Vgl, Ci acon., Vitae Pontif. II, Romae 1677, 315, wo sich Abbildungen fast aller Statuen des Papstes finden.

2 Ci a m pini, De sacris aedif., Romae 1747 , c. 4 , sect. 5, n. 47 . Vgl. auch $\mathrm{V}$ as ari (Le vite II, Florenz 1878, 278).

${ }^{3} \mathrm{C}$ iampini a. a. O. und tab. 1920. 
Die drei Statuen, welche - was wohl zu beachten ist - unter den Augen des Papstes entstanden, und von denen wenigstens zwei in dessen Auftrage ${ }^{1}$ angefertigt wurden, lassen demnach keinen vernünftigen Zweifel daran, dak die 1295 erst mit e in em , circulus " geschmückte Tiara des päpstlichen Schatzes noch unter Bonifaz VIII. um einen zweiten Reifen bereichert wurde ${ }^{2}$.

Was hat Bonifaz VIII, zu dieser Neuerung veranlaft? War es der Wechsel des Stiles? wie Müntz meint. Wohl nicht, denn was hatte der Stilwechsel in der Kunst mit den Reifen der Tiara zu tun? War es vielleicht Prunkliebe, welche den Papst dazu führte? Möglich, denn Bonifaz VIII. war ein prachtliebender Fürst. Man sehe nur das Inventar seines Schatzes von 1295 ein mit der darin verzeichneten Unmenge der kostbarsten Geräte und herrlichsten Paramente ${ }^{3}$. Immerhin mögen aber anch noch Erwägungen anderer Art ihn zur Einführung der doppelgekrönten Tiara gebracht haben. Man hat in der Doppelkrone, mit welcher Bonifaz dieselbe schmückte, eimen Ausdruck der Anschauungen des Papstes über die Doppelgewalt des Papsttums erblicken wollen. Läßst sich auch eine solche Annahme nicht mit Sicherheit beweisen, so kann man ihr doch eine gewisse Wahrscheinlichkeit wohl kaum absprechen.

Die erste Nachricht von drei Kronreifen bringt ein aus dem Jahre 1315 oder 1316 datierendes Inventar des päpstlichen Schatzes. Es heißt darin von dem Regnum, das Benedikt XI. mit sich nach Perugia genommen hatte und das von hier nach Lyon gebracht und dort bei der Krönung Klemens' V. gebraucht worden war: Item unam coronam, quae vocatur regnum, cum tribus circulis aureis, und: Item corona, quae dicitur regnum sive thyara, cum tribus circulis aureis ${ }^{4}$. Zu den beiden Reifen, mit welchen die Tiara am Ende des Pontifikates Bonifaz' VIII. versehen war, hatte sich also entweder schon unter Benedikt XI. oder doch wenigstens unter Klemens $V$. ein dritter gesellt. $O b$ freilich damals bereits alle drei circuli wie später mit Blättern verziert waren, muf dahingestellt bleiben; denn die Angaben des Inventars lassen das nicht erkennen. Indessen ist solches ja auch von keinem wesentlichen Belang.

Auf den Grabmonumenten der Päpste scheint die dreikronige Tiara erst bei Benedikt XII. (1334-1342) zur Darstellung gekommen zu sein. Benedikt XI. (1303-1304) trägt auf seinem Grabmal in S. Domenico in Perugia ein mit nur einer Zackenkrone versehenes Regnum alten Stiles. Die Grabstatue Klemens' V. zu Uzeste (Gironde) wurde von den Calvinisten zu sehr verstümmelt, als daf sie über die Form der Tiara des Papstes Aufschluf geben könnte ${ }^{5}$. Johannes XXII. war auf seinem

1 Eine der Anschuldigungen du Plessis gegen Bonifaz VIII. war: Fecit imagines suas argenteas erigi in ecclesia per hoc homines ad jdolatriam inducens. Bulla eus, Hist. univers. IV $42 \mathrm{ff}$; H e f., Concilien VI 356.

2 Man hat gemeint, es habe die Tiara bereits im 11. Jahrhundert zwei Kronen besessen. Man bezog sich dabei auf die Notiz bei Benzo von Alba (M. G. SS. XI 672) : Prandellus (Hildebrand) habe Nikolaus III. eine corona regalis aufgesetzt, auf deren unterem Ping man die Worte gelesen: Corona regni de manu Dei, auf dem oberen aber: Diadema eiusdem imperii de manu Petri. Es ist kein Zweifel, daß diese Angabe nichts ist als eine der vielen von Schmähsucht und Parteigeist eingegebenen Lügen, von denen die Schrift selbst nach dem Urteil sonst dem Papsttum und der Kirche nicht gerade wohlgesinnter Histo- riker wimmelt (vgl. z. B. W a t te a b a c h, Geschichtsquellen II 202). Wie unbegründet sie ist, ergibt sich klar aus dem Zeugnis der Monumente, nach denen erst unter Bonifaz VIII. zwei Kronen an der Tiara vorkommen. Es ist auffallend, dak man je den Worten Benzos irgendwelchen Wert hat beimessen können.

3 Es ist uns kein Inventar aus dem Mittelalter bekannt, welches sich an Menge und Kostbarkeit der darin verzeichneten Gegenstände mit demjenigen des päpstlichen Stuhles unter Bonifaz VIII. im entferntesten messen könnte.

4 E h le, Der konstantinische Schatz, in „Archiv für Literatur und Kirchengeschichte" IV 195, Anm. 4.

5 Eine Statue Klemens' V. am Nordportal der Kathedrale zu Bordeaux, bei welcher die Tiara drei Kronen hat, ist zwar keine Arbeit 
Grabmal mit einem doppelkronigen Regnum geschmückt. Das Monument ist leider nicht mehr erhalten, doch gibt es glücklicherweise noch eine Abbildung des Kopfes der Grabstatue des Papstes aus der Zeit vor der Zerstörung '.

Von Benedikt XII. sind zwei Statuen vorhanden. Die eine, ein Kniestück, befindet sich in der Krypta von St Peter. Sie war ehedem in der alten Kirche an der Eingangswand über dem Armenseelenaltar angebracht und - vielleicht noch zu Lebzeiten des Papstes - von den Kanonikern zum Dank für die vom Papste dem Kapitel erwiesenen Wohltaten errichtet worden ${ }^{2}$. Die Tiara, welche hier nur zwei Kronreifen aufweist, hat grofe Ähnlichkeit mit der 'Tiara der Grabstatuen Bonifaz' VIII. Sie scheint fast deren Nachbildung zu sein. Die zweite Statue befand sich anf dem Grabmal des Papstes in der Kathedrale zu Avignon. Die Reste derselben birgt jetzt das Museum daselbst. Die Tiara ist hier in aller wünschenswerten Klarheit mit drei Kronreifen versehen (Bild 251) .

Von Benedikt XII. an tritt das Regnum regelmäßig auf den Grabmonumenten der Päpste in der Form des Triregnum auf', so bei den Grabfiguren Klemens' VI. (1342-1352) zu La Chaise-Dieu ", Innozenz' VI. (1352 bis 1362) zu Villeneuve-lès-Avignon ${ }^{5}$ usw. Die Bildung der an den Reifen angebrachten Blätter, die bald kreuzförmig, bald lilienartig, bald weinblattähnlich sind, und sonstiges nebensächliche Detail wechselt, in der Hauptsache aber herrseht von Benedikt XII. an volle Übereinstimmung in Bezug auf Gestalt der Tiara.

Eine Ausnahme macht nur die Grabfigur Urbans VI. in den vatikanischen Grotten, welche eine einkronige Tiara trägt. Es scheint indessen, daß die Grabplatte einem älteren Papstsarkophage entnommen wurde. Denn

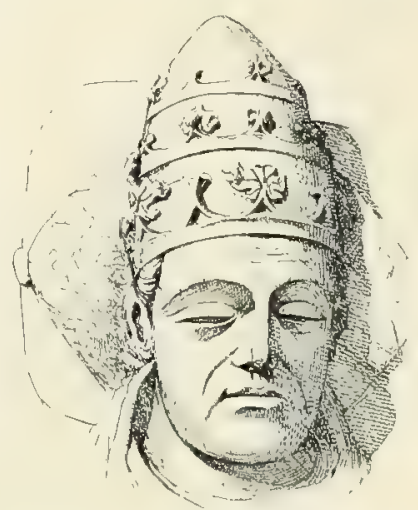

Bild 251. Fragment der Grabstatue Benedikts XII. Arignon, Museum. iNach Rohault de Fleny. auf den Reliefs der Vorderseite ist der Papst der Zeit durchaus entsprechend mit dem Triregnum ausgestattet. Auch die Tiara, welche rechts und links vom Mittelrelief über dem Wappen Urbans VI. angebracht ist, weist die gewöhnliche Form auf.

aus jüngerer Zeit, wie man gemeint hat - ihr Stil und ihre Beschaffenheit gestatten eine solche Annahme nicht - , sie stamnt aber ebensowenig aus der Zeit Klemens' V. Vgl. über die Statue namentlich Revue 1896, $453 \mathrm{ff}$ - und $\mathrm{M}$ üntz, La tiare pontificale du $\mathrm{VIII}^{\circ}$ au $\mathrm{XVI}^{\mathrm{e}}$ siècle, in Mémoires de l'Académie des Inscriptions et Belles-Lettres XXXVI $275 \mathrm{ff}$.

1 Garampi, Illustrazione di un antico sigillo della Garfagnana, Roma 1759, tav. III, 1.

${ }^{2}$ Ciampini, De sacris aedif. c. 4 , sect. 5 , n. 48 und tav. $18 \mathrm{~A}$.

${ }^{3}$ Abbildung bei Roh. VIII, pl. Dchxrx, wonach die Abbildung im Text; das Fragment wird von Rohault als vom Grabmal Urbans $V$. herrïhrend bezeichnet; so auch Müntz, La tiare pontificale du VIII au XVI ${ }^{\circ}$ siècle a. a. O. XXXVI 282; jedoch mit Unrecht. Der Kopf stammt vom Grabmal Benedikts XII. Urban V. wurde nur für wenige Monate provisorisch in der Kathedrale $\mathrm{zu}$ Avignon beigesetzt, um daun nach StVictor zu Marseille übergeführt zu. werden, wo ihm ein prächtiges Grabmonument errichtet wurde. Wio aber die Abbildung des- selben bei den Bollandisten (A. SS. Propyl. Maii 93**) beweist, war der Papst darauf gegen die Gewohnheit statt mit der Tiara mit der Mitra dargestellt. Vgl, auch $\mathrm{K}$ o th e $n$, Notice sur la crypte de l'abbaye St-Victorlez-Marseille, Marseille 1864, pl. $\nabla$, p. 80 . Die Papstfigur, die sich bei Rohault de Fleury findet, kann also nicht Urban $V$., sondern nur Benedikt XH. wiedergeben. Eine ältere Abbildung bei Garampi a. a. O. tav. IV 2.

4 Abbildung unten Bild 253, S. 509. Der größte Teil des Kopfes ist zwar eine spätere Restauration, veranlafst durch die Schäden, welche die Figur bei der Schändung des Grabes durch die Calvinisten erlitt; doch ist von dem ursprünglichen Triregnum noch genug erhalten, um dentlich die drei Kronen erkennen zu können (Roh. VIII 142).

5 Abbildung in Revue 1892, 281 und Garampi a. a. O. tav. IV, 3 (hier unkorrekt ohne Bart). Urban V. trug, wie vorhin bemerkt wurde, auf seinem Grabmonument statt der Tiara die Mitra. Die silberne Büste des hl. Petrus in S. Giovanni im Lateran, welche Urban V. 1369 anfertigen lief, ist mit einem dreikronigen Regnum ausgestattet. 
Dafs die Grabstatuen der Päpste nicht sofort, nachdem die Inventare ausdrücklich drei circuli verzeichnen, ebenfalls deren drei an der Tiara aufweisen, mag ron verschiedenen Ursachen herkommen. Der Hauptgrund aber war wohl, dafs die drei Kronreifen, welche rasch, wie über Nacht, und dazu ganz geräuschlos gekommen waren, noch nicht die Bedeutung hatten, welche sie später besaben, und in den Ideen der Zeit und der Künstler noch nicht heimisch geworden waren. Erst mukte sich zeigen, dab sie nicht eine vorübergehende Mode waren, erst mukten sie für die Papstkrone typisch werden, ehe sie gleichsam Anspruch darauf erheben konnten, bei den Papststatuen dargestellt zu werden. Es hieße den Gang der Entwicklung völlig verkennen, wollte man die drei Kronreifen um dieselbe Zeit, da in den Inventaren von ihnen zum erstenmal die Rede ist, auch schon auf den Grabmälern der Päpste erwarten.

Von dem oberen Abschlusse der Tiara läßt sich aus den Papststatuen kein sicheres Bild gewinnen, da manche derselben an ihren oberen Enden stark verletzt sind. Nach dem Inventar von 1295 war das damalige Regnum an der Spitze von einem mächtigen Rubin bekrönt. Der Stein ging bei Gelegenheit der Krönung Klemens' V. zu Lyon verłoren. Als nämlich nach der Feier der Papst in prächtigem Reiterzug durch die Strafien zog, stürzte eine Mauer ein, die in ihrem Falle das Rof des Papstes und diesen selbst samt seiner Tiara mit sich zu Boden ris. Dabei brach der Rubin, der auf 6000 Goldgulden geschätzt wurde, Ios und verschwand auf Nimmerwiedersehen ${ }^{1}$. Die Grabfigur Bonifaz VIII. trägt einen dicken, büschelartigen Abschluf. Auf den Grabstatuen der Päpste des 15. Jahrhunderts endet das Triregnum in einem Knauf von recht mäßigen Verhältnissen ${ }^{2}$. Ein Kreuz als Abschluls der Tiara findet sich niemals auf den mittelalterlichen Papstmonumenten.

Die Geschichte der Tiara bietet seit dem Mittelalter nichts Bemerkenswertes. Die hauptsächlichste Veränderung, welche mit ihr seit dieser Zeit vor sich geht, besteht in ihrer immer mehr zunehmenden Ausbauchung. Ein Kreuzchen finden wir schon auf dem Triregnum Julius' II.

Die Bedeutung, welche das Regnum hatte, mufte naturgemäl乃 dazu führen, demselben eine entsprechende Ausstattung zu teil werden zu lassen. Es hat damit nicht gedauert, bis die Tiara die Form des Triregnum erhalten hatte. Man lese nur die Beschreibung, welche das Inventar des päpstlichen Schatzes vom Jahre 1295 von der Tiara macht. Befanden sich doch

${ }^{1}$ Duch., I.P. II 473; Mur., SS. III 673 und Regesta Avenjon. Ioannis XXIL. tav. 43, f. $258^{\text {a }}$, bei Elhrle, Archiv IV 195.

2 Wir haben bei unserer Darstellung der Entstehung des Triregnum nur auf die Grabmäler der Päpste Bezug genommen, nicht auf Miniaturen und sonstige Darstellungen. Wenn hier Monumente von Wert sind, so sind es unstreitig die Grabfiguren der Päpste. Geben die Tiaren darauf auch keine absoluten Kopien der Papsttiara wieder, so darf man sie doch, wo nicht die Umstände das Gegenteil beweisen, als im wesentlichen treue Wiedergaben ansehen. Es herrscht im 14. und 15. Jahrhundert auf den Monumenten (Miniaturen, Fresken, Skulpturen) in Bezug auf die Form der Tiara ein äufselster
Wirrwarr, wie es bei keinem andern Ornatstick der Fall ist. Bald ist sie hoch, bald niedrig, bald ein spitzer Kegel mit geraden Seiten, bald ausgebaucht, bald fingerhutförmig, jetzt mit einer, dann mit zwei, ein anderes Mal mit drei Kronen versehen. Nicht die Wirklichkeit, sondern die Phantasie hat exsichtlich meistens den Pinsel und den Meißel des Künstlers geleitet. Allerdings leicht begreiflich, da es im ganzen unter den Künstlern nur sehr wenige gegeben haben wird, welche je eine 'Tiara persönlich in Angenschein zu nehmen Gelegenheit hatten. Die meisten waren auf Beschreibungen oder Abbildungen angewiesen, bei denen wiederum nur zu oft die Einbildungskraft eine Rolle gespielt hatte. 
an derselben aufer einer Anzahl kleiner Smaragde und Karfunkel sowie vielen Schmelzen nicht weniger als 66 große Perlen und 165 große Edelsteine, nämlich 48 Karfunkel und Rubine, 72 Saphire sowie 45 Chrysoprase und Smaragde. So kostbar indessen auch dieses Regnum war, gegen manche Tiaren der Folgezeit erscheint es nur wie ein Schatten.

Es würde zu weit führen, auf die verschiedenen prunkvollen Triregna näher einzugehen, welche das 15. und das 16. Jahrhundert hervorgebracht hat. Paul II. lieb, um flüchtig ein paar Beispiele anzuführen, zwei Tiaren anfertigen, von denen die eine 180000 , die andere 200000 Scudi kostete ". Ein von Sixtus IV. dem venetianischen Goldschmied Bartolomeo di Tommaso in Arbeit gegebenes Triregnum wurde auf 110000 Dukaten geschätzt ${ }^{2}$. Das kostbarste schuf aber der Mailänder Juwelier Caradossa im Auftrage Julins' II. Es hatte einen Wert von 200000 Dukaten = ca 800000 Mk (Bild 252) ${ }^{3}$. Die Inschrift am unteren Rande, welche Julius II. als den Schöpfer und das 7. Jahr seiner Regierung als die Entstehungszeit des Ornatstückes bezeichnete, war aus lauter Diamanten hergestelit. Unter solchen Umständen begreift man, warum die Päpste wiederholt gerade die Tiara bei Geldanleihen als Pfand gaben. Hatten dieselben ja nicht blok einen ideellen, sondern auch einen enormen materiellen Wert.

Von allen diesen mehr prunkhaften als wahrhaft schönen, mehr kostbaren als eigentlich kunstvollen Tiaren ist keine mehr vorhanden. Die von Paul II. und Sixtus IV. geschaffenen Triregna gingen bei dem berichtigten Sacco Roms 1527 zu Grunde. Damit sie nicht in die Gewalt der mit einer Barbarei sondergleichen plündernden Horden gerieten, liek Klemens VII. die Perlen und Edelsteine derselben durch Cellini ausbrechen und das Gold einschmelzen ${ }^{4}$. Die Tiara Julius' II. ent-

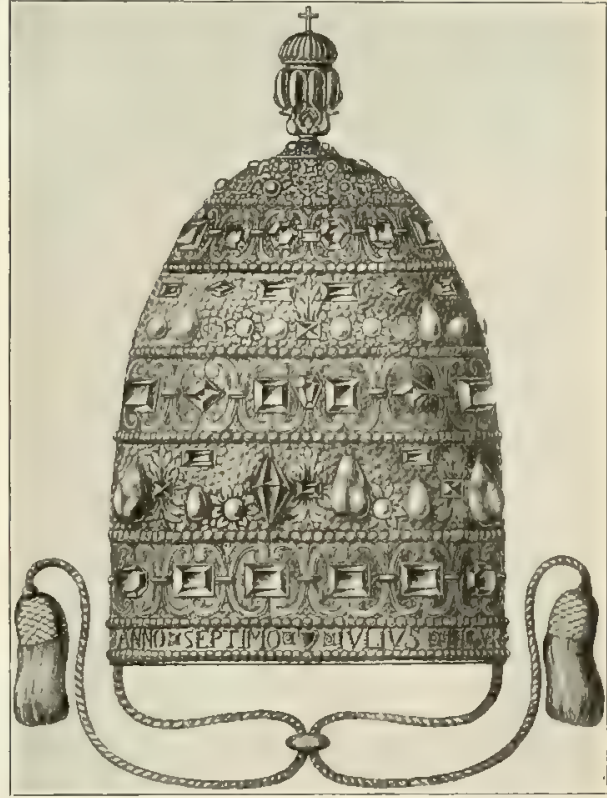

Bild 252. 'Tiara Julius' II. Nach dem Stich von Bartoli, Paris, École des Beaux-Arts. ging damals der Zerstörung, vielleicht, weil sie gerade in Pfand gegeben war. Im Jahre 1789 wurde sie auf Befehl Pius' VI. einer kostspieligen, durchgreifenden Restauration unterzogen. Allein schon nach wenigen Jahren verfiel sie einem ähnlichen Geschick wie einst die Tiaren Pauls II. und Sixtus' IV. Um die gewaltigen Kriegskosten bezahlen zu kömnen, welche im Frieden von Tolentino Napoleon im Namen der Pepublik dem Papst aufgezwungen, sah sich dieser genötigt, das Triregnum Julius' II. zerlegen zu lassen und die Edelsteine, die Perlen und das Gold zur Bezahlung der Schuld zu verwenden, ein tragisches Ende der Tiara, das gewif Julius II. nicht vorausgesehen hatte. Übrigens war die Tiara des Mediceers es nicht allein, die damals einem so traurigen Untergang geweiht wurde; dieselbe teilte ihr Los mit den kaum

1 Mor. LXXXI 52. Müntz, Les arts à la cour des Papes II 148; Vita Pauli II. : M u 1., SS. III 2, 1009.

${ }^{2}$ Müntz, La tiare pontificale du $\operatorname{VIII}^{\ominus}$ au
XVIe siècle, a. a. O. 296, und Les arts à la cour des Papes III 30243259260.

${ }^{3}$ M ủntz, La tiare pontif,, a. a. $0.303 \mathrm{ff}$.

4 Cellini, Benv., Vite I 38; Flor. 1866, 84. 
weniger kostbaren Triregna, welche Paul III., Klemens VIII. und Urban VIII. hatten anfertigen lassen und die durch Pius VI. gleichfalls unter gewaltigen Kosten waren erneuert worden ${ }^{1}$. Von all der Herrlichkeit ist nur ein Smaragd von $440^{1} .2$ Karat übrig geblieben, den Gregor XIII. der 'Tiara Julius' II. hinzugefügt hatte. Derselbe kam 1798 durch die Kommissionäre der französischen Regierung nach Paris, wo er bis 1805 im naturgeschichtlichen Museum blieb. Damn nahm ihn Napoleon aus diesem heraus und lief ihn an der Tiara anbringen, die er Pius VII. schenkte. 1809 entrif General Rodet dem Papst Tiara und Smaragd wieder, doch wurden 1814 beide zurückgestellt.

Über den Ursprung der Tiara hat man mancherlei Vermutungen aufgestellt. Die einen haben sie als Nachbildung der Cidaris des alttestamentlichen Hohenpriesters ausgegeben, nach andern soll sie ein Gegenstück des pileus libertatis der römischen Freigelassenen darstellen und vom Papste als Zeichen, daf die Kirche durch Konstantin die Freiheit erlangt habe, in Gebrauch genommen worden sein. Eine dritte Hypothese bringt sie mit dem Albogalerus der römischen Flamines, Pontifices und Salier in Verbindung, eine vierte möchte in der Tiara der persischen Könige und Vornehmen das Vorbild der päpstlichen Tiara suchen und so letztere als eine Art von Import aus dem Orient ansehen. Und damit auch die Komik zu ihrem Rechte komme, hat man unter die Ahnen des päpstlichen Kopfschmuckes sogar den Pileolus aufgenommen, welcher dem hl. Hieronymus zur Elwärmung seines alten Kopfes von einem Freunde übersandt wurde und dessen Empfang der Heilige diesem im 85. seiner Briefe dankbarst bescheinigt ${ }^{2}$ : Pileolum textura breve caritate latissimum senili capiti confovendo libenter accepi et muneris auctoris laetatus.

Es hat keinen Zweck, auf diese Hypothesen, von denen die eine ebenso grundlos ist wie die andere, sich des Näheren einzulassen. Sie sind Luftgebilde, weiter nichts. Die Einführung des Camelaucum, des Vorgängers der späteren Tiara, erklärt sich zur Genüge und ohne Schwierigkeit durch die bedeutsame Stellung, welche die Päpste im 7. Jahrhundert in Italien und zumal in Rom eimnahmen. Waren diese rechtlich und formell auch noch keine souveräne Herrscher, so standen sie doch tatsächlich und dem Einflusse nach, zumal im römischen Dukat, kaum anders, denn als wirkliche Fürsten da. Es war daher ganz natürlich, dafis sie diese ihre Stellung auch äuferlich in ihrer Tracht und in ihrem Auftreten zum Ausdruck brachten und darum unter andern Auszeichnungen anch eine ihren Rang kündende Kopfbedeckung annahmen. Eine Krone oder Diadem konnte das natürlich nicht sein, weil sie nicht souverän waren; sie mußsten sich vielmehr, wie andere Leute in ähnlicher hervorragender Stellung, mit einer Mütze, dem weiben Camelaucum, begnügen.

Das Vorbild der Kopfbedeckung, deren frühester Name camelaucum deutlich auf den byzantinischen Orient hinweist, haben wir wohl in dem damals tonangebenden Byzanz zu suchen. Müntz hat die Vermutung ausgesprochen, dafs sich die Ingebrauchnahme des Camelaucum unter einem der griechischen und syrischen Päpste aus dem Ende des 7. und dem Beginn des 8. Jahrhunderts vollzogen habe. Seine Annahme entbehrt in der Tat nicht aller Wahrscheinlichkeit; vielleicht sogar, daf es durch denselben Papst zur Einführung gelangte, bei dem es uns zuerst begegnet, den Syrer Konstantin, von dem das Papsthuch berichtet, er sei zu Konstantinopel mit dem Camelaucum auf dem Haupt aufgezogen, wie er es zu Rom zu tun gewohnt sei. 


\section{DER PILEOLUS.}

Unter dem Pileolus versteht man ein klerikales Scheitelkäppchen. Es heist auch wohl Calotte, Subbiretum, Submitrale, Soli-Deo und ist bei dem Papst von weiGer, den Kardinälen von roter, den Bischöfen von violetter und den übrigen Geistlichen, falls nicht ein besonderes Privileg besteht, von schwarzer Farbe. Der Pileolus gehört nicht zur liturgischen Kleidung.

Wenn wir ihn nichtsdestoweniger hier einer kurzen Erwähnung würdigen, so geschieht das deshalb, weil er bei denen, die zum Gebrauch der Mitra berechtigt sind, eine Art von Zubehör der Mitra ist und in dieser Eigenschaft im bischöflichen Caeremoniale Erwähnung findet. Indessen kann er natürlich auch nur unter diesem Gesichtspunkt hier in Betracht kommen.

Wann der Pileolus als Zubehör der Mitra (Tiara) zur Verwendung ge-

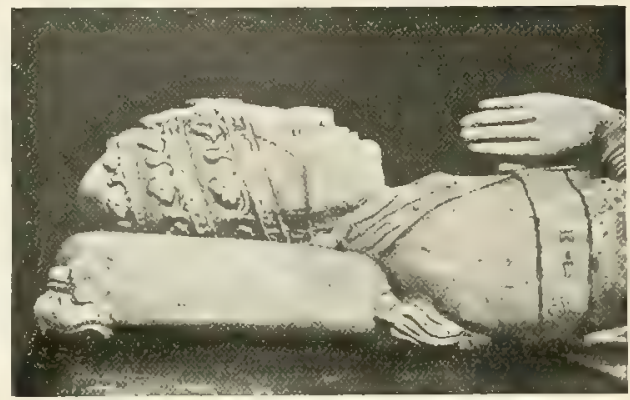

Bild 253. Vom Grabmal Klemens VI. La Chaise-Dieu. langte, läfst sich nicht genau angeben. Im 13. Jahrhundert scheint das, soweit wenigstens die Monumente entscheidend sind, noch nicht der Fall gewesen zu sein. Überall blof die Mitra, nirgends eine Mitra in Verbindung mit dem Scheitelmützchen. Zugleich mit der Kapuze der Cappa begegnet dieses uns schon auf dem bekannten Fresko Giottos "St Franziskus von Honorius III." (Bild 168, S. 354).

Eines der ersten Monumente, wenn nicht das früheste, auf dem der Pileolus unter der Tiara dentlich erkennbar ist, bildet die Grabfigur Klemens VI.

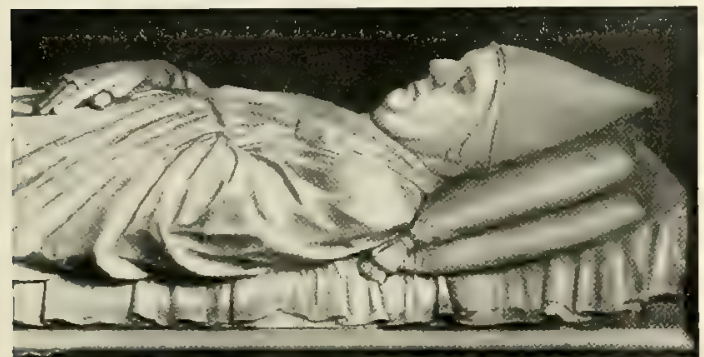

Bild 254. Vom Grabmal des Kardinals Alanus († 1474). Rom, S. Prassede. († 1352) zu La Chaise-Dieu (Bild 253) 1. Im 15. Jahrhundert weisen schon genug Skulpturen und Malereien bei Bischofsclarstellungen unter der Mitra die Scheitelkappe auf, namentlich solche, die der zweiten Hälfte desselben entstammen. Manche Beispiele bieten z. B. die Bischofsmonumente aus jener Zeit, die uns in den römischen Kirchen begegnen (Bild 254). Aber auch auferhalb Roms kommt bereits der Pileolus im 15. Jahrhundert auf Bischofsdarstellungen vor.

In den römischen Ordines hören wir zum erstenmal gegen Ende des 14. Jahrhunderts von dem Scheitelmützchen als einem Zubehör der Mitra. Der Ordo des Kardinals Jakobus Cajetanus kennt es in dieser Eigenschaft noch nicht? ${ }^{2}$. Wir treffen es darin unter dem Namen biretum nur in Ver-

1 Das Scheitelkäppchen war auch bei der Grabstatue des Gegenpapstes Klemens' VII. dargestellt. Abbildung bei Garampi a. a. 0 . tav. IV 4, nach dem Fragment des Kopfes im Museum zu Avignon in Revue 1896, 454.

2 Vgl. namentlich c. 48 und 53 (M. 78, $11531156 \mathrm{ff})$. 
bindung mit dem Hut der Kardinäle an ${ }^{1}$. Zusammen mit der Mitra gebraucht, erscheint es erst in dem um 1400 entstandenen Ordo des Petrus Amelii ${ }^{2}$.

Der Pileolus ist auf den Monumenten des 15. und 16. Jahrhunderts noch nicht das kleine Scheitelkäppchen der Jetztzeit. Es deckt noch den ganzen Hinterkopf und zieht sich seitlich in Form von mehr oder weniger breiten Laschen über die Schläfen hinab (Bild 254, S. 509).

Was seine Einführung veranlaßte, ist unbekannt. Wie es scheint, geschah sie, um zu verhindern, daf die Mitra durch etwaigen Schweif leide. Man darf nämlich nicht vergessen, das sich die pontifikale Kopfbedeckung bereits gegen Ende des 14. Jahrhunderts zu einem recht ungefügen und schweren Ding entwickelt hatte, das, zumal im warmen Süden, wohl geeignet war, dem Kopfe reichliche Schweistropfen zu entlocken. Vielleicht jedoch, daf auch noch andere Gründe dahin gewirkt haben; so etwa die Absicht, die drückende Last der Mitra dem Kopfe weniger fühlbar zu machen oder ein festeres Sitzen des mittlerweile mächtig emporgestiegenen und dabei gründlich versteiften pontifikalen Kopfschmuckes zu ermöglichen.

Welche Verbreitung der Gebrauch des Submitrale, wie der Pileolus in den Mailänder Statuten heist, im 15. Jahrhundert hatte, läbt sich nicht bestimmen. Allgemein war er jedenfalls noch nicht, er wurde das erst im Verlauf des 16. und 17. Jahrhunderts. Nach den Statuten des hl. Karl Borromäus sollten in der Kathedrale zum Gebrauch für den Bischof vier subbireta mitralia vorrätig gehalten werden. Dieselben mulsten aus Wolle gemacht und von runder, nicht viereckiger Form sein ${ }^{3}$.

\section{DAS BIRETT.}

Mit mehr Recht als der Pileolus kann das Birett der liturgischen Gewandung (diese im weiteren Sinne genommen) zugezählt werden. Ist dasselbe nämlich an sich auch ohne jeden sakralen Charakter und nur klerikale Kopfbedeckung, so findet es doch nach der gegenwärtigen Praxis bei den gottesdienstlichen Funktionen eine so ausgiebige Verwendung ${ }^{4}$, daf man es füglich als Appendix zur liturgischen Kleidung betrachten kann.

Das Birett läßst sich unter dem Namen pileus bis in die Frühe des 12. Jahrhunderts, unter der Bezeichnung infula aber bis zum Ende des 10 . zurückverfolgen ${ }^{5}$. Im Beginn des 12. ist es Honorius, der uns von ihm Kunde gibt, um die Wende des 9. eine Urkunde des Erzbischofs Willegis von Mainz für Aschaffenburg. ${ }^{6}$. Es erscheint bei Honorius als Kopfbedeckung der Cantores, d. i. der offiziellen liturgischen Sänger beim feierlichen Amt und Offi-

1 C. 118 (ebd. 1272).

2 C. 144 (ebd. 1351): Et ponent in capite eins biretam albam cum mitra alba.

3 A. E. Med. 627.

4 Am ausgiebigsten erörtert in Linzer Quartalschrift 1885, $591 \mathrm{ff}$.

5 Wenn es im Kirchenlexilson II 854 bezüglich des Alters des Biretts heift: „Die erste Erwähnung des Biretts findet sich im 10. Jahrhundert bei dem Bericht von der Degradation eines Bischofs von Cahors durch Johannes XII. im Jahre 956, wobei demselben auch das Birett abgenommen wurde", so liegt hier eine Verwechslung von Johannes XII. und Jo- hannes XXII. vor. Obendrein handelte es sich bei dem fraglichen Vorfall nicht um das klerikale, sondern, wie der Berichterstatter Amalrich ausdricklich hervorhebt, um das Doktorenbirett : bireto suo doctorali, quum esset legum doctor. Wenn ferner bei B on a-Sala 1. 1, c. 24, \$20, app.; II, 290 zum Beweis, daf das Birett schon im 10. Jahrhundert in Gebrauch war, auf das Chronicon Leodiense (genauer St Laurentii Leodiensis) verwiesen wird, so ist zu bemerken, daf an der betreffenden Stelle von einem biretum nicht im geringsten die Rede ist, sondern nur von der Cappa.

6 S. oben S. 319. 
zium, in der Urkunde für Aschaffenburg aber als eine Art von Auszeichnung des Präcentor. Derartige Cantorespilei sind auch wohl unter den 6 pileoli officiariorum zu verstehen, welche ein englisches Inventar aus dem Jahre 1218 neben acht Mitren aufführt.

Häufiger wird des Biretts erst seit dem 13. Jahrhundert gedacht. Außer pileus und pileolus fïhrt es jetzt auch den Namen biretum. Was seinen Charakter aber anlangt, so erscheint es bald blof als ein Hut bzw. eine Mütze der Geistlichen im Alltagsleben, bald als eine Kopfbedeckung, deren man sich statt der Kapuze beim Chorgebet bediente. In ersterer Eigenschaft erscheint das Birett z. B. in Rubr. 10 der Synode zu Ravenna von 1314: Capita cooperiunt pileo vel bireto vel armutia oblonga ad aures?. Als Kopfbedeckung: beim Chorgebet begeguet es uns in den Statuten der Stiftskirche zu Stoke (England): Utantur omnes in choro nigris pileis ancehuris et nullo modo capuciis sive capis monstruosis ${ }^{3}$; in den Statuten des Bischofs Grandisson von Exeter aus dem Jahre 1337 c. 21 : Debent omnes indui exterius cappis nigris ... et in capite pileolis nigris ${ }^{4}$; in den Bestimmungen der Synode von Sens von 1485: Horas canonicas dicturi cum tunica talari et superpelliceis mundis ultra medias tibias longis, non caputia sed almutia vel bireta tenentes in capite ${ }^{\circ}$, und in einer Verordnung der Synode zu Bergamo von 1311: Intersint (sc. officiis divinis) aut discooperto capite aut cum biretis in capite ad modum laicorum, capucia non habentes ${ }^{6}$. Den Benediktinern von St Augustin zu Canterbury, welche ihren Regeln zufolge unbedeckten Kopfes am Gottesdienst teilnehmen mußsten, gestattete Innozenz IV. 1243, mit Rücksicht auf die Kälte und die dadurch verursachte Gefahr für die Gesundheit, sich beim Offizium und der Messe einen pileus aufzusetzen, nur sollten sie ihn beim Absingen des Evangeliums, bei der Elevation und ähnlichen Gelegenheiten mit Rücksicht auf die bei diesen Akten an den Tag zu legende Ehrfurcht abnehmen. Die gleiche Erlaubnis gab der Papst noch in demselben Jahre deı Benediktinern von Winchester ${ }^{7}$. Mit der Sitte, beim Chorgebet das Birett zu gebrauchen, mag es zusammenhängen, daßs es Brauch wurde, die Übertragung eines kirchlichen Benefiziums durch Überreichung des Biretts zu symbolisieren. Schon um 1300 war diese Art der Investitur mit einer kirchlichen Pfründe bekannt ${ }^{8}$.

Der Unterschied, der zwischen dem Pileolus und dem Birett bestand, scheint darin gelegen zu haben, daf jener lediglich Nützlichkeitszwecken

1 Buck II 345.

2 Hard. VII 1387.

${ }^{3}$ Bock II 345. Ancehura - Scheitelmütze aus dem mittell. anca = occipitium, Hinterkopf ( $G$ raf, Althochdeutscher Sprachschatz, Berlin 1834, I 345) und hura = Hut, Muitze (vgl. Gesta Abb. S. Albani ad 1156-1166: Episcopus assurgens in manu regis per capitis sui galerum, qui hura dicitur, resignavit id iuris quod dicebat se habere [ed. London 1867, I 156]). S. 344 meint Bock, es scheine gegen Mitte des 12. Jahrhunderts bei gewissen Teilen der heiligen Messe in einigen englischen Diözesen wenigstens von den Bischöfen eine kleine Kopfbedeckung in Form eines Pileolus getragen worden zu sein. Er verweist zum Beleg dafür auf zwei Vitae des hl. Johannes Becket, wonach dieser bei seiner Ermordung einen pileus (pileolus) auf dem Kopfe getragen habe. Bock hat übersehen, daf die Untat nicht am Morgen, sondern nachmittags zur Zeit der Vesper geschah. Die betreffende Notiz der beiden Vitae bekundet nur, daf der pileus beim Chorgebet im 12. Jahrhundert gebraucht wurde.

4 Ebd. ${ }^{5}$ C. 1 (Hard IX 1522).

${ }^{6} \mathrm{Mag}$ istretti 35 .

7 Berger, Les Régistres d'Innocent IV n. 80135 (I 19 26). Eine gleiche Erlaubnis gab lunozenz IV. auch dem Abt und den Mönchen des Benediktinerklosters zu Compiègne (D. C. VI 322).

8 D. C. I 663. 
diente und darum auch unter der Mitra und zur Kapuze getragen wurde, während dieses aufer der praktischen Bedeutung den besondern Charakter einer klerikalen Kopfbedeckung hatte. Übrigens sind Pileolus und Birett zwei durchaus verwandte Dinge; kein Wunder also, daf man, solange letzteres noch eine weiche Mütze und ersterer etwas mehr als ein blobes Scheitelkäppchen war, zwischen beiden nicht streng schied und biretum nannte, was wir heute pileolus nennen würden, und umgekehrt 1 .

Eine sehr frühe Darstellung des Biretts findet sich auf der Grabplatte Peters von Thure im Dom zu Brandenburg († 1281). Es stellt hier eine mittelhohe, runde, seitlich sich etwas ausbauchende, oben aber abgeflachte Mütze dar, die in der Mitte des Deckels mit einem Knöpfchen versehen ist

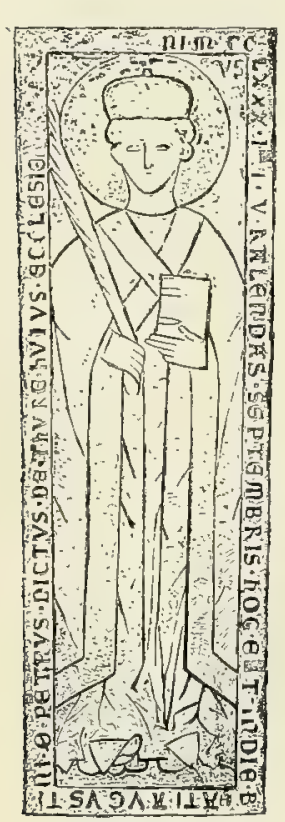

Bild 255.

Grabstein Peters von Thure († 1281). Brandenburg, Dom. (Nach Bergau.) (Bild 255). Aus dem 14. Jahrhundert gibt es manche Abbildungen des Biretts. Treffliche Beispiele liefern aus dieser Zeit das Grabmal des Speierer Dechanten Hartmann von Landisberg $(†$ 1339) in der Stiftskirche zu Oberwesel, dann die Grabplatten eines Kanonikus Jakob († 13..), des Dechanten Joh. Lang $(†$ 1394) und des Kanonikus Leonardus Zinginger $(† 1380)$ im Kreuzgang des Domes zu Brixen, ferner die Grabfiguren des Protonotars Bernard Stenbringh († 1383), des Propstes John Thoutendorp († 1380) und des Propstes Nikolaus Holsten $(\dagger$ 1353) in Heiligkreuz zu Rostock ${ }^{2}$ sowie des Propstes Rutger zu Kloster Rühn $(\dagger 1367)^{3}$. Bei den letztgenannten Darstellungen ist auf der Mitte des Deckels statt eines kleinen Knöpfchens eine kräftige Quaste angebracht, die besonders auf dem Grabstein Bernard Stenbringhs auffällt.

Um die Mitte des 15. Jahrhunderts beginnt das Birett, das bis dahin ziemlich niedrig war, in die Höhe zu wachsen, wobei zugleich die oben auf ihm angebrachte Quaste entweder verkümmert oder sich sogar ganz verliert. So bleibt es bis gegen Ende des Jahrhunderts. Dann hebt jener Umbildungsprozes an, welcher in langsamer, aber steter Entwicklung in seinem letzten Stadium zum modernen Birett führte. Aus der weichen Rundmütze ist am Ende desselben eine steife, vierkantige, mit drei oder vier Aufsätzen, die an Hörner erinnern, versehene Kopfbedeckung geworden, von der man eigentlich nicht weik, ob man sie den Mützen oder den Hüten zuzählen soll.

Die Hauptperiode des Prozesses fällt in das 16. Jahrhundert, das 15. sieht nur seinen Beginn, das 17. aber braucht blo6 der um den Ausgang des 16. im wesentlichen schon fertigen neuen Form ihre letzte Vollendung zu geben. Schon in der Frühe des 16. Jahrhunderts zeigen sich deutliche Ansätze zu vier Kanten; um die Mitte desselben scheinen diese schon ziemlich ent-

1 Vgl. z. B. das Statut Grandissons, wo pileolus im Sinn von Birett, und ordo 14, c. 118 ; ordo 15 , c. 7 (M. 78,1272 1276), wo biretum im Sinne von pileolus gebraucht ist. Auch in den Statuten von Aix von 1260 (D. C. sub biretum I 664) hat biretum die Bedeutung einer Untermütze.
2 Abbildung bei Schlie, Die Kunst- und Geschichtsdenkmäler des Groß3herzogtums Mecklenburg-Schwerin I, Schwerin 1898, 194 197 205. Vgl, auch S. 215 die Grabplatte des Propstes Ludolf Nygendorp (1406).

3 Ebd. IV 90. Beisp. von 1342, 1345, 1349, $1362 \mathrm{im}$ Kreuzgang des Augsburger Domes. 
wickelt, in letzten Viertel aber treten sie in voller Klarheit und Bestimmtheit zu Tage.

Um diese Zeit begegnen wir denn auch verschiedenen Synodalbeschlüssen, welche darauf dringen, dafs die Geistlichen sich des quadratförmigen Biretts als Kopfbedeckung innerhalb wie außerhalb der Kirche bedienen sollten. Biretum semper gerant in modum crucis consutum, ut ecclesiasticos homines decet, bestimmt die Synode von Aix (1585) ${ }^{1}$. Pileum quadratum seu biretum semper gerant in ecclesia et extra ecclesiam, heift es in den Synodalbeschlüssen der Synode von Bourges (1584)². Clericale biretum, quod est ecclesiasticorum hominum proprium, ad crucis formam confectam semper gerant, schreibt 1607 die Synode von Mecheln vor ${ }^{3}$. Was die Umgestaltung des Biretts veranlafite, ist nicht näher anzugeben. Wenn man in den angeführten und in andern ähnlichen Verordnungen die Vierkantform mit der Kreuzesgestalt in Verbindung gebracht findet, könnte sich leicht der Gedanke aufdrängen, es sei eben diese Symbolik es gewesen, welche den Wandel herbeigeführt habe. Allein eine solche Vermutung wird durch die Wahrnehmung widerlegt, dafs die Vierkantform anfangs nur sehr unmerklich und wie in ihren ersten Keimen auftritt, und daf es eine geraume Zeit dauert,
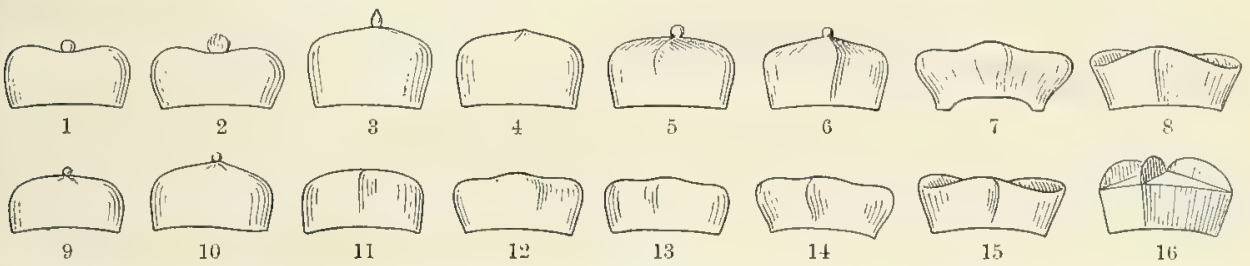

Bild 256. Übersicht über die Entwicklung des Biretts an Hand der Grabplatten in den Domen zu Augsburg (A), Bamberg (B), Regensburg (R) und Würzburg (W).

1. A 1342; 2. R 1426; 3. R 1460; 4. R 1471; 5. R 1505; 6. R 1550; 7. R 1564; 8. R 160(5?); 9. W 144 (?); 10. B. 1483; 11. W $1493 ; 12$. W $1521 ; 13$. W ... 14. W $1565 ; 15$. W $1610 ; 16$. B 1626.

bis sich aus der Rundmütze ein ausgesprochen vierkantiges Birett herausgebildet hat. Immerhin mag die fragliche Symbolik auf die endgültige Fixierung der Vierkantform, namentlich aber auf ihre Verbreitung nicht ohne Einfluf geblieben sein.

Da durch die Umgestaltung des Biretts das Aufsetzen und Abnehmen desselben erschwert worden war, begann man, um dem abzuhelfen, oben an den Nahtstellen drei oder vier niedrige Erhöhungen anzubringen. Ganz vereinzelt begegnen uns solche schon beim Ausgang der 16. Jahrhunderts, doch werden sie erst seit der Frühe des 17. gewöhnlich. Nur in Spanien bleibt das Birett ohne diese Hörner. Um das Ende des 16. oder den Beginn des 17. Jahrhunderts kommt es ferner auf, das Birett statt mit einer Einlage aus steifem Stoff mit einer solchen aus Pappdeckel zu versehen. Das moderne Birett war damit fertig; seitdem ist es das straff mit Zeug überzogene Pappdeckelgestell, aus welchem oben drei oder vier bretterartige, schwibbogenförmige Aufsätze hervorwachsen, die in der Mitte bei einer Quaste oder einem kleinen Zipfelchen zusammentreffen. Das 18. Jahrhundert hrachte dem Birett keine weitere Veränderung, als dalis es dieses vielenorts zu einem mächtigen Bau aufwachsen ließ, der an Höhe mit den turmartigen Mitren derselben Zeit fast die Konkurrenz aufnehmen konnte.

\footnotetext{
1 C. De vita et honest. cleric. ( $\mathrm{H}$ a rd.

2 Tit. 25, c. 5 (ebd. 1486).

$\mathrm{X}$ 1542).

3 Tit. 8 , c. 4 (ebd. 1958).

Braun, Die liturgische Gewandung.
} 
Eine Illustration zu der ganzen Entwicklung, welche die klerikale Kopfbedeckung von der Mitte des 15. Jahrhunderts bis zum Ende des 16. durchgemacht hat, bieten die Grabplatten im Kreuzgang des Domes von Hildesheim. Bei Dompropst Ekhard von Hanensee $(\dagger 1460)$ und dem gleichnamigen Kanonikus ( $\uparrow$ 1494) ist das Birett noch eine hohe, weiche Mütze, beim Kanonikus Dietrich von Alten $(†$ 1502) und dem Domvikar Hermann Berkenvelt $(\uparrow 1519)$ macht sich schon die Vierkantform in ihren Anfängen bemerkbar, beim Domkantor Kaspar von Dechau († 1588) ist dieselbe klar ausgeprägt.

Noch instruktiver bezüglich der Umbildung des Biretts sind die Grabplatten in den Domen zu Würzburg, Augsburg und Bamberg, sowie im Dom und in der Alten Kapelle zu Regensburg. Hier treten uns nicht einzelne Erscheinungen aus dem Verlauf des Prozesses vor die Augen, es läßst sich dieser hier vielmehr gleichsam Schritt um Schritt verfolgen; je mehr die Jahre vorrücken, um so schärfer tritt auch der Umwandlungsprozefi zu Tage, so daf man in manchen Fällen lediglich aus der Form des Biretts bis auf das Jahrzehnt die Entstehungszeit der Grabplatten bestimmen kann (Bild 256, S. 513).

Der Umbildungsprozef, welcher sich mit dem Birett im 16. Jahrhundert vollzog, hat große Ähnlichkeit mit dem Wandel, welcher vier Jahrhunderte zuvor bei der Mitra vor sich ging. Hier wie dort bildete den Ausgangspunkt eine weiche Rundmütze, hier wie dort ist das Resultat eine steife, konventionelle Kopfbedeckung von eigenartiger Formgestaltung. Wenn es dem Birett nicht beschieden war, sich so glanzvoll zu entwickeln, wie es die Mitra getan hatte, so lag das eben daran, daj es weder einen eigentlich liturgischen Charakter noch die Bedeutung eines auszeichnenden Ornatstückes besaf, sondern lediglich eine gewöhnliche klerikale Kopfbedeckung war. 


\title{
DIE INSIGNIEN.
}

\author{
ERSTES KAPITEL.
}

\section{DER MANIPEL.}

\section{DER MANIPEL IN DER GEGENWART.}

Hat der Priester die Albe gegürtet, so legt er den Manipel an. Der Manipel ist ein streifenförmiges Ornatstück, welches, von Ende zu Ende gemessen, ca $1 \mathrm{~m}$ lang ist und gedoppelt so auf dem linken Arm getragen wird, daß zu beiden Seiten eines der Enden herabhängt.

Die Breite des Manipels schwankt zwischen 5 und $10 \mathrm{~cm}$. Am breitesten pflegt er in Italien zu sein, während auferhalb Italiens eine Vorliebe für schmale Manipel herrscht. Es ist vielfach üblich, den Manipel nach unten $\mathrm{zu}$ breiter werden zu lassen. Solange sich die Zunahme an Breite innerhalb gewisser Grenzen hält, läfst sich gegen einen solchen Brauch nichts einwenden, anders jedoch, wenn die Enden zu häßfichen Schaufeln ausgebildet werden.

Das Ornatstück wird meist auf der Mitte des Unterarmes getragen, seltener in der Armbeuge oder am Oberarm. Die erste Tragweise ist die richtigere und bessere. Denn sie entspricht nicht nur den alten Traditionen, wie die Bildwerke des Mittelalters und der Renaissance zu hunderten Malen beweisen, sie ist auch die schönste. Es ist kein lieblicher Anblick, vom Ellenbogen oder dem Oberarm des Priesters einen Stoffstreifen in die Luft starren oder krumm herabhangen zu sehen. Freilich sagt man zur Verteidigung dieser Tragweise, sie sei die bequemste, da so der Manipel am wenigsten dem Priester bei seinen Funktionen hinderlich sei. Namentlich werde aber durch sie die Gefahr vermieden, dafis das Ornatstück mit dem hhl. Sakrament in Berührung komme. Allein, ist denn wirklich der Manipel auf dem Vorderarm so lästig;, falls er gut befestigt ist - und die Befestigung macht doch keine Schwierigkeit? Was aber die erwähnte Gefahr anlangt, so kann man derselben sehr leicht dadurch begegnen, dafs man dem Manipel die gehörige Länge gibt. Ist dieser nur etwa $2 \% 30 \mathrm{~cm}$ lang, so ist allerdings bei Mangel an Vorsicht eine Berührung der heiligen Spezies nicht ganz ausgeschlossen; allein ein solcher Manipel ist auch entschieden zu kurz.

Um den Manipel am Arm zu befestigen und sein Herabfallen zu verhindern, bindet man ihn entweder mit zwei Bändern fest, die an der Innenseite angenäht sind, oder bildet durch Vernähen des gedoppelten Streifens im oberen Teile einen Durchschlupf, mittels dessen man ihn an den Arm streift. Das Anbinden des Manipels ist in Italien sehr gebräuchlich. Man wendet es sogar auch dann noch gern an, wenn man den Manipel in der angegebenen Weise mit einem Durchlaß versehen hat. Eine in Frankreich häufige Befestigungsweise des Manipels besteht darin, daß man in der Mitte desselben ein Bändchen 
annäht und dieses mit einer Nadel an der Albe festlıeftet. Sie kann nicht als sehr praktisch bezeichnet werden, da das Einstecken der Nadel der Aibe Schaden bringt.

Das römische Caeremoniale läßst den Diakon dem Bischof den Manipel anbinden ${ }^{1}$. Das Missale begnügt sich mit der Bemerkung: imponit brachio sinistro. Bei uns in Deutschland ist es wohl allgemein Brauch, den Manipel nur mittels eines Durchschlupfes an dem Arme zu befestigen. Es ist die einfachste Weise, nur mufs dafür gesorgt werden, dafs der Durchlafs nicht weiter sei, als eben nötig ist, um das Ornatstück ohne Mühe über den Ärmel der Albe schieben zu kö́nnen?2

Zum Manipel sollten stets nur seidene oder halbseidene Stoffe verwendet werden. Was die Farbe anlangt, muf er sich wie Stola und Kasel nach der Tagesfarbe richten, da auch für ihn der liturgische Farbenkanon gilt.

Der Manipel ist nach dem Brauch der letzten Jahrhunderte regelmäßig mit drei Kreuzen versehen, davon eines in der Mitte, die beiden andern an den Enden. Notwendig sind drei Kreuze nicht. Eines, das Kreuz in der Mitte, darf aber nicht fehlen. Denn wenn das römische Missale den Priester anweist: Sacerdos accipit manipulum, osculetur crucem in medio et imponit brachio sinistro, so setzt das offenbar voraus, daf wenigstens ein $\mathrm{Kreuz}$, und zwar mitten auf dem Manipel, angebracht sei. Außer mit den genannten Krreuzen kann das Ornatstück übrigens auch noch mit Stickereien verziert werden, nur muß, wie übrigens selbstverständlich, dabei sein Farbencharakter und darum seine Grundfarbe genügend gewahrt bleiben. An den Fnden pflegt der Manipel mit Fransen geschmückt zu werden.

Der Manipel kommt vom Subdiakon an aufwärts allen Weihestufen zu. Er wird dem Subdiakon vom Bischof bei der Subdiakonatsweihe unter den Worten: „Nimm hin den Manipel, das Simnbild der Frucht guter Werke, im Namen des Vaters" usw., an den linken Arm gelegt und bildet das spezifische Amtsabzeichen desselben. Mag es daher auch dem Minoristen, welcher gelegentlich bei der feierlichen Messe die Dienste eines Subdiakons zu versehen hat, erlaubt sein, sich dabei der subdiakonalen Tunicella zu bedienen, den Manipel zu tragen, ist ihm durchaus nicht gestattet 3 .

Zum Pluviale darf der Manipel nach der ausdrücklichen Bestimmung des römischen Missale nicht gebraucht werden *. Er ist wie die Kasel Meß3parament im eigentlichen Sinne. Der Priester, der Diakon und Subdiakon bedienen sich seiner fast nie anders als bei der Opferfeier. Eine nur scheinbare Ausnahme bilden die Karfreitagszeremonien. Auch kann es kaum als wirkliche Ausnahme betrachtet werden, wenn die bei der Ölweihe assistierenden zwölf Priester, sieben Diakone und sieben Subdiakone den Manipel tragen ${ }^{\overline{5}}$; denn das geschieht wohl mit Rücksicht auf die Messe, in welcher die Weihe der heiligen Öle statthat, und jene Priester, Diakone und Subdiakone als Assistenten des Bischofs auftreten. Wenn aber der Diakon und Subdiakon das Ornatstück auch bei einigen Gelegenheiten auferhalb der Messe gebrauchen, bei denen sie die Epistel bzw. das Evangelium zu singen haben (wie z. B. bei der Palmenweihe am Palmsonntag), so hat das seinen Grund in dem Umstand, dafs die Absingung von Epistel und Evangelium eine spezifisch

\footnotetext{
1 L. 2, c. 8, n. 32 .

2 Näheres über die Beschaffenheit des Manipels und die Befestigungsvorrichtung in Braun, Winke $37 \mathrm{f}$.

${ }^{3}$ C. R. 17. Juli 1894 (Decret. auth. 3832);

10. März 1906 (Anal. ecel. 1906, IV 166).

4 Rubricae generales tit. 19, n. 4 .

${ }^{5}$ Pontificale rom. p. III, De off. in fer, V C. D.
} 
subdiakonale bzw. diakonale Funktion und deshalb die Verwendung der vollen Antstracht bei ihr durchaus am Platze ist. Ähnlich verhält es sich am Kíarsamstag mit der Absingung des Osterpräkonium durch den Diakon. Bei Prozessionen, der Spendung der heiligen Sakramente und den Benediktionen wird der Manipel nie getragen, ausgenommen die Erteilung der heiligen Weihen und die Ölsegnung, weil diese vom Bischof in Verbindung mit der Messe vollzogen werden. Bei der Verehrung des heiligen Kreuzes am Karfreitag und bei der Vornahme der Absolutio am Katafalk miissen Priester und Ministri ebenfalls ohne Manipel sein, weshalb sie ihn vor diesen Akten abzulegen haben ${ }^{1}$.

Diakon und Subdiakon ziehen den Manipel an letzter Stelle, also nach der Dalmatik bzw. Tunicella an, und zwar erst, nachdem sie dem Celebrans beim Ankleiden geholfen haben. Ausdrücklich vorgeschrieben ist das, wie aus dem Caeremoniale für die Bischöfe hervorgeht 2 , bei der Vorbereitung für das Pontifikalamt. Nach dem Amt entledigen sich die Ministri zunächst des Manipels, der übrigen Gewänder aber erst, nachdem sie dem Celebrans beim Auskleiden behilflich waren.

Dem Bischof legt der Subdiakon am Altare den Manipel an, welchen er im Evangelienbuch dorthin gebracht hat, und zwar nach dem auf das Sündenbekenntnis folgenden Indulgentiam.

\section{NAMEN DES ORNATSTÜCKES.}

Das liturgische Gewandstück, welches wir jetzt mit dem Namen Manipel bezeichnen, wurde ehedem auch mappula, sudarium, mantile, fano, manuale und sestace genannt.

Bis zum Beginn des zweiten Jahrtausends führte es vorherrschend den Namen mappula. Mappula ist das Diminutiv von mappa. Mit mappa bezeichnete man im klassischen Latein ein Tuch, dessen man sich bei Tisch zum Abputzen des Mundes und der Hände bediente, also, wie wir sagen würden, eine Serviette. Außerdem verstand man unter mappa das Tuch, womit seitens des Kaisers, des Konsuls oder Prätors bzw. ihrer Vertreter das Zeichen zum Beginn der öffentlichen Spiele gegeben wurde (vgl. Bild 139, S. 300); namentlich sehen wir die Mappa in diesem Sinne fast regelmäfigig auf den Konsulardiptychen in der Rechten des Konsuls (Bild 257, S. 518) ${ }^{3}$.

Mappula kommt nur im nachklassischen Latein vor. Eine ausschliefliche Bedeutung hat darin das Wort nicht. Es bezeichnet bald ein Hals- bzw. Schultertuch, bald ein Schweistuch, bald ein Tuch, das zur Umhüllung eines Gegenstandes dient, bald eine Art von Baldachin, bald endlich den liturgischen Manipel. Immer liegt ilım der generelle Begriff "Tuch" zu Grunde *. Als Name des Manipels erscheint mappula z. B. im 1. und 3. römischen Ordo, bei Hraban, Walafried Strabo, Pseudo-Alkuin, Riculf von Soissons und sonst. Auch in den Sakramentaren, Pontifikalien, Missalien und Schatzverzeichnissen ${ }^{5}$ kommt das Wort in diesem Sinne häufig vor. Mappula wav die eigentlich römische Bezeichnung des Ornatstückes. Seit der Wende des ersten Jahrtausends verliert sich der Name mappula in der Bedeutung von Manipel allmählich; im späteren Mittelalter ist er in diesem Sinne eine seltene Erscheinung.

1 C. R. 15. Sept. 1736 (Decret. auth. 2326).

2 L. 2 , c. 8, n. 32.

3 Vgl. über mappa und mappula For cell. III 29 und D. C. sub mappa V 255.
4 D. C. sub mappula $V 255 \mathrm{f}$.

$5 \mathrm{Vgl}$ z. B. die Inventare von Monza (ca 900), St Gallen (11. Jahrh.), Paderborn (1031), Speier (1051), Trier (1238) u. a. 
Das Wort fano (phano, fanon, fanum, favo, wie wir es auch geschrieben finden), zusammenhängend mit unserem "Fahne", dem althochdeutschen fano, dem mittelhochdeutschen van, dem angelsächsischen und

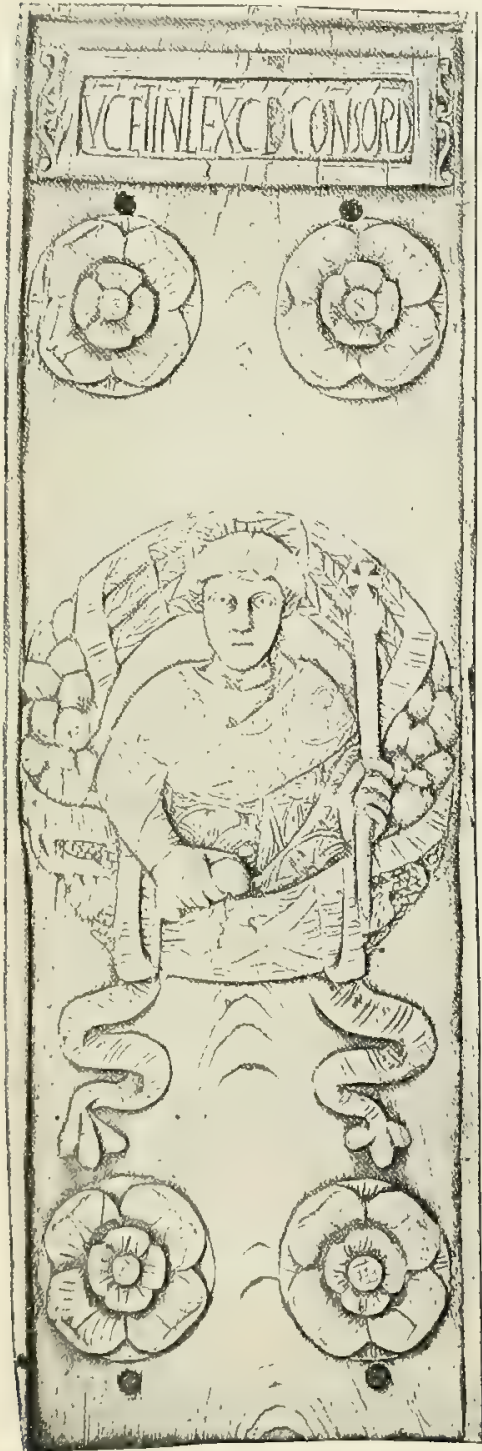

Bild 257. Anonymes Konsulardiptychon. Rom, Museo Barberini. gotischen fana, dem lateinischen pannus (Tuch, Gewebe) und dem griechischen $\pi$ ĩ $\nu$ os (Faden des Einschlags, Gewebe, Gewand), kommt bei den Liturgikern und in liturgischen Schriften in mehrfachem Sinne vor. Es bezeichnet das Oblationsvelum, mittels dessen man die Opfergaben darbrachte, das Korporale, den päpstlichen Amikt (Orale) und besonders den Manipel, mittelhochdeutsch ha $\mathrm{ntf}$ ane, hantfan, hantfano ${ }^{1}$. Als Name des Manipels begegnet uns fano zum erstenmal bei Hraban. Etwas später finden wir das Wort in gleichem Sinne in der "Synodalermahnung": Nemo cantet missam . . . sine fanone, sowie auch bei Regino von Prïm ${ }^{2}$. Im 12. Jahrhundert treffen wir fano in der Bedeutung von "Manipel" bei Honorius, bei Robert Paululus und Sicard von Cremona an. In den Sakramentaren und Pontifikalien kommt der Name nur selten vor, so z. B. in Vat. lat. 7231 und einem Missale von Stablo ${ }^{3}$; um so häufiger ist er bis in das späte Mittelalter in den Schatzverzeichnissen, besonders in Inventaren aus Deutschland. Man vergleiche z. B. die Schenkung Emhildas von Milz (800), Madalwins von Passau (903), die Inventare von Lamspringe (10. Jahrh.), Pfäffers (10. Jahrh.), Prüm (1003), St Georg zu Köln (ca 1100), Bamberg (1127) u. a. In Spanien scheint der Name wenig verbreitet gewesen zu sein; er kommt hier in den Inventaren nur sehr selten vor *. In England finden wir ihn noch im Inventar der Kathedrale von York von 1500 . In Frankreich ging fano als fanon in die Volkssprache über. Der Manipel führt diesen Namen in den französisch abgefaßten Schatzverzeichnissen schon wenigstens seit der Mitte des 14. Jahrhunderts, wie z. B. die Inventare von Cambrai (1359) und Fécamp (1362-1375) bekunden, und behält ihn in denselben bis um die Mitte des 17. Jahrhunderts. Treffen wir ihn beispielsweise doch noch im Inventar von Angers von 1643 an.

Sudarium, Schweifstuch, heifst der Manipel bei Amalar, Honorius u. a. Mantile, manuale und sestace sind nur vereinzelt vorkommende Benennungen des Manipels.

1 Grimm III 1241; IV 2 386. Graf, Althochdeutscher Sprachsehatz III 522.

2 De discipl. eccl. 1. 1, can. 80 (M. 132, 207). s Mart. 1. 1, c. 4, art. 12, ordo 15 ; I 210.

${ }^{4} \mathrm{Vgl}$ z. B. das Inventar von S. Benito zu Baga (Diözese Vich) von 972. 
Mantile bezeichnete im klassischen Latein ein Tischtuch, aber auch, wie mappa, die Serviette. Als Name des Manipels treffen wir das Wort bei Hraban und im Inventar von Enger (11. Jahrh.). Die Bezeichnung manuale, „etwas zur Hand Gehöriges", begegnet uns in Aelfrics angelsächsischem Glossar ${ }^{1}$, den Gesta der Bischöfe von Auxerre ${ }^{2}$ und den Schatzverzeichnissen von St Peter ${ }^{3}$.

Eine höchst eigenartige Benennung des Manipels ist sestace. Sie findet sich nur im St Gallener Kleiderverzeichnis. Das unter der in ihm genannten sestace blof der Manipel und kein anderes Ornatstück verstanden werden kann, bedarf keines Nachweises. Fs ist uns gelungen, den Ursprung des Wortes nachzuweisen, welches bislang eine Deutung nicht hatte finden können. Sestace ist ein ins Vulgårarabische eingedrungenes persisches Lehnwort und mit dem arabo-persischen schuschtudsche, schustadsche eins. Schuschtudsche bedeutet nach Wahrmunds neuarabischem Lexikon: Handtuch, schustadsche nach Vullers Lexicon persico-latinum: linteum quo abstergitur (Abputztuch), mantile (Serviette), sudarium (Schweibtuch) ${ }^{4}$. Schwer erklärlich ist, wie das persische sestace im 10. Jahrhundert zum Namen des Manipels hat werden können. Ob es auf dem Wege des Kaufhandels mit persischen Stoffen ins Abendland kam, oder ob der Schreiber des Ordo ein Orientale von Geburt war? Für das letzte dürfte namentlich der Umstand sprechen, dafi es um das Ende des 9. Jahrhunderts tatsächlich zu St Gallen Mönche gab, die aus dem Osten stammten. Es ergibt sich das aus Notkers ( $†$ 912) Brief an Lambert, worin er diesem einen Grufs von den Ellinici fratres übermittelt: Salutant te Ellinici fratres ${ }^{5}$. Überhaupt fehlte es zur Karolingerzeit im Westen keineswegs an orientalischen Mönchen. Berichtet doch Thegan in der Vita Ludwigs d. Fr. ausdrïcklich, Karl habe die Evangelien mit Hilfe von Griechen und Syrern verbessert ${ }^{6}$.

Das älteste Dokument, in dem uns der Name manipulus begegnet, ist die Schenkungsurkunde, in welcher Adelgaster, Sohn des Königs Silo von Asturien, um 790 aufer andern Paramenten auch 6 stolas und 5 manipulos dem Kloster Obona übermacht ${ }^{7}$. Im 10. Jahrhundert treffen wir ihn in der Dotation des Salvatorklosters zu Lerez (ca 916), im Testament Riculfs von EIne († 986), einem Sakramentar von Tours ${ }^{8}$, dem Sakramentar Ratolds von Corbie († 986), dem sog. Pontifikale Egberts von York sowie dem Sakramentar von Moyssac, falls die beiden letzteren nicht etwa nach 1000 anzusetzen sind ${ }^{9}$, dem Inventar von Cremona (984) u. a. Dann wird der Name

1 Zupitza, Aelfrics Grammatik und Glossar, Berlin 1880, 314, wo manualis handlin, Handlinnen, Handtuch bedentet.

2 Gesta episc. Autiss. c. 49 (M. 138, 277).

3 So im Inventar von St Peter ( $M$ üntz e Frothingham, Il tesoro 12 48). Vgl. auch D. C. sub manuale 2; V 237.

4 Nach gütigen Mitteilungen des P. Franz Zorell S. J.

5 M. 131, 1172.

6 C. 7 (M. G. SS. II 592). Vgl, auch B e is s e1, Gesch. der Evangelienbücher $163 \mathrm{f}$.

7 Ann. O. S. B. 1. 25, §53, ad a. 785; II 255.

8 Mart. 1. 1, c. 4, art. 12, ordo 7; I 193. Das ebd. unter ordo 5 angeführte Sakramentar von St-Denis gehört nach $\mathrm{De} /$ is $1 \mathrm{e}$, Mém. 289, dem 11. Jahrhuudert an.
9 Die drei letztgenannten Codices befinden sich in der Pariser Nationalbibliothek f lat. 229312052 10575. Der unter dem Namen Egbert-Pontifikale bekannte Kodex stammt nicht aus dem 8. Jahrhundert, sondern ist die erst im 10., wenn nicht noch später entstandene, teilweise interpolierte Kopie einer älteren Vorlage. Die Rubrik: et tradat ei . . manipulum, ist ein Zusatz des Kopisten. Dasselbe gilt von der spätelen, durch verschiedene Benediktionsformulare, die nicht an die betreffende Stelle gehören, von den Weihegebeten der Subdiakonatsweihe getrennte Notiz: Deinde donet ei manipulum. Ein Abdruck des Weiheordo aus dem sog. EgbertPontifikale findet sich bei $\mathrm{M}$ a r t. 1.1 , c. 8 , art. 11, ordo 2 ; II 34 . 
manipulus rasch allgemeiner. Im 12. Jahrhundert herrscht er bereits bei weitem vor, namentlich aber in den liturgischen Büchern. Insbesondere adoptierte man ihn statt der alten Bezeichnung mappula auch zu Rom, wie z. B. aus Innozenz III. und dem 13. Ordo erhellt. Im 14. Jahrhundert kommen die sonstigen Benennungen unseres Gewandstückes nur noch vereinzelt vor. Namentlich aber wird man sie um diese Zeit in den Missalien und Pontifikalien nur mehr selten antreffen. Im 15. Jahrhundert heift unser Gewand fast allgemein manipulus, selbst - nur Frankreich ausgenommen - in der Tolkssprache, welche doch sonst mit aller Zähigkeit die alteinheimischen Namen festzuhalten pflegt. Die Aufnahme des Wortes ins römische Missale war daher nur die Besiegelung des offiziellen Charakters, den es sich schon eine geraume Weile vorher errungen hatte.

Das Wort manipulus bezeichnet im klassischen Latein ursprünglich wohl eine "Handvoll", dann einen Bund von Heu, Gras, Getreide und weiterhin eine Abteilung von Fufssoldaten, eine Kompanie ${ }^{1}$. Da der liturgische Manipel anfänglich, wie aus dem Folgenden hervorgeht, ein Tuch war, das man zusammengefaltet in der Hand trug, erklärt es sich leicht, wie er zu seinem Namen kam.

Auch die Namen der liturgischen Gewänder haben ihre Geschichte, wie man auch hier wieder sieht. Es ist aber nicht blofi interessant, den Umwandlungsprozef zu verfolgen, sondern auch nützlich, da die Benennung ja oft auf den Charakter und die Beschaffenheit eines Gewandstuickes einen Lichtstrahl wirft. Aufserdem machen wir auch beim Manipel die bemerkenswerte Wahrnehmung, dafs sich Rom zwar in Bezug auf die liturgische Gewandung, nicht aber in gleichem Mase hinsichtlich deren Benennung gebend verhielt. Die römische Bezeichnung mappula hat sich nicht einbürgern können. Im Gegenteil hat der auferrömische Name manipulus zuletzt selbst in Rom Eingang gefunden und die althergebrachte Benennung mappula völlig aus dem Gebrauch verdrängt.

\section{DER MANIPEL SEIT DER KAROLINGERZEIT.}

Im 9. Jahrhundert erscheint die Mappula in aller Klarheit als fester Bestandteil der priesterlichen (pontifikalen), der diakonalen und subdiakonalen Sakralgewandung.

Als priesterliches Ornatstück begegnet sie uns in dem 1. und 3. Ordo, im S. G. K., bei Hraban, Amalar, Walafried Strabo, Pseudo-Alkuin und Regino von Prüm, in der Synodalermahnung und den Statuten Riculfs von Soissons. Nullus cantet missam ... sine fanone, hörten wir z. B. bereits die „Synodalermahnung" sagen.

Von der Mappula der Diakone ist seltener die Rede. Ausdrücklich spricht von ihr Amalar. Hrabanus erwähnt sie, wie es scheint, nicht. Zwar bemerkt er: Oportet ergo sacerdotes et ministros altaris mappulas manibus tenere, quorum officium est, divina sacramenta conficere, ut cum devotione mentis opus spontaneum concordet (et) digne exerceatur officium, quod pie divino est munere collatum ${ }^{2}$, allein er scheint nach dem Zusammenhang unter jenen ministros altaris die Bischöfe zu verstehen, die ja als sacerdotes auch die ministri altaris sind. Denn seine ganzen übrigen Ausführungen über die liturgischen Gewänder gelten nur der bischöflichen Kleidung. In dem 1., 2.

\footnotetext{
"Forcell. III 24. ${ }^{2}$ De instit. cleric. 1. 1, c. 18 (M. 107, 307).
} 
und 3. römischen Ordo heift die diakonale Mappula offertorium ${ }^{1}$. Der Diakon benutzte das offertorium nach den genannten Ordines, um mittels desselben den Kelch anzufassen, wenn er ihn zur Konsekration zubereitet hatte und auf den Altar stellte, sowie auch, wenn er ihn nach der Wandlung erhol und dem Volke zeigte. Diese Angabe ist von der gröften Wichtigkeit, da sie bestimmt beweist, daf das offertorium nichts anderes ist als die diakonale Mappula. Bei Amalar, der in Rom eigene Studien über den römischen Ritus gemacht hatte und, wie aus der zweiten Vorrede zu seiner Schrift De ecclesiasticis officiis hervorgeht, gerade in dem uns hier beschäftigenden Punkte den römischen Brauch genau wiedergibt, hält nämlich der Diakon bei jenen Gelegenheiten den Kelch mit seinem Sudarium. Unter diesem Sudarium versteht der Metzer Diakon aber unsere Mappula ${ }^{3}$. Wegen der Identität von offertorium und sudarium bzw. mappula sagt darum auch der 2. Ordo Mabillons ganz zutreffend, es solle der Diakon die Henkel des Kelches einhüllen offertorio suo, mit sein em offertorium. Im St Gallener Kleiderverzeichnis scheint der Diakon der Mappula zu entbehren. Denn während nach derselben alle andern Kleriker mit der sestace ausgerůstet sind, fehlt diese dem Diakon. Statt dessen wird ihm ein brachiale zugelegt: brachiale in manu dextra. Es liegt jedoch nahe, unter diesem brachiale die subdiakonale Mappula zu verstehen. Daf diese Angabe in der Tat richtig ist, ergibt sich aus dem 9. Ordo Mabillons, wo auch die Mappula des Bischofs brachiale heifst ${ }^{4}$. Wir müssen im Auge halten, dak wir uns im 9. Jahrhundert in einer Zeit befinden, in welcher sich noch kein einheitlicher terminus technicus für den liturgischen Manipel herausgestaltet hatte.

Bestätigt wird die Tatsache, daß auch den Diakonen die Mappula zustand, durch Bildwerke des 9. Jahrhunderts. Wir weisen hier besonders hin auf die Darstellungen von Diakonen auf einer der Schmalseiten des herrlichen Palliotto in S. Ambrogio zu Mailand (Bild 258). Treffliche Beispiele aus dem 10. Jahrhundert liefert der $1827 \mathrm{jm}$ Grabe des hl. Cuthbert in der Kathedrale zu Durham aufgefundene Manipel, welchen Königin Elflaed, Gemahlin Eduards d. ̈̈. († vor 916), für Bischof Frithestan von Winchester laut der eingestickten Inschrift anfertigen liej ${ }^{5}$, sowie eine Miniatur des noch dem 10. Jahrhundert entstammenden Tropars von Prüm in der Pariser Nationalbibliothek (vgl. Bild 121, S. 262).

1 Ordo 1, n. 1516 ; ordo 2, n. 910 ; ordo 3 , n. 1415 (M. 78, 944945973974981 ).

2 Praef. altera (M. 105, 992); De eccl. offic. 1. 3, c. 1926 (ebd. 1131 1144).
${ }^{3}$ De eccl. offic. 1. 2, c. 24 (ebd. 1099).

* N. 4 (M. 78, 1006).

5 Abbildung bei Roh. pl. Dxxxr. Vgl. jedoch unten S. 532, Anm. 1. 
Auffallend ist, daßs nicht nur Johannes von Avranches ${ }^{1}$, sondern auch Gilbert von Limerick ${ }^{2}$ bei Aufzählung der liturgischen Gewänder der Diakone die Mappula ganz unerwähnt lälit. Von einem Versehen kann bei beiden wohl kaum die Rede sein. Es scheint demnach, als ob der Manipel zu ihrer Zeit bei den Diakonen nicht überall zur Verwendung gekommen wäre.

Die erste Nachricht über den Manipel der Subdiakone gibt der St Gallener Katalog. Um dieselbe Zeit, d. i. im 9. Jahrhundert, kommt das Ornatstück aber auch schon auf einer Miniatur im Cod. B 252 der Vallicelliana zu Rom bei dem Subdiakon Juvenianus vor (vgl. Bild 125, S. 267). Juvenianus trägt in der linken Hand einen Manipel in Form eines ganz kurzen, schmalen Streifens.

Wie es die Subdiakone im 9. Jahrhundert auferhalb Roms mit dem Gebrauch des Manipels hielten, läfst sich nicht feststellen. Jedenfalls mufis sich dieser dort, wenn solches nicht schon vorher geschehen war, spätestens gegen das Ende des Jahrtausends bei denselben eingebürgert haben, d. i. also um die Zeit, da man anfing, dem Subdiakonat eine höhere Bedeutung beizumessen und sich dessen Aufnahme unter die höheren Ordines vorbereitete. Wenn Johannes von Avranches und Gilbert von Limerick den Manipel nicht zur Gewandung der Diakone, sondern nur zu derjenigen der Subdiakone zählen, so mag der Grund hierfür darin zu suchen sein, dak sie, wie sie die Stola als diakonales Abzeichen betrachten, so den Manipel als Charakteristikum des subdiakonalen Ordo auffassen.

Eigentümlicherweise waren um den Ausgang des 9. bzw. den Beginn des 10. Jahrhunderts zu Rom auch die Akolythen mit der Mappula ausgestattet. Denn das St Gallener Kleiderverzeichnis nennt unter ihren liturgischen Gewändern ausdrücklich die sestace. Im Unterschied von den Subdiakonen trugen sie indessen das Tuch nicht in der Hand, sondern am Gürtel: sestace in sinistra latera (sic) ad cingulum. Wie lange sich der Manipel zu Rom bei den Akolythen erhielt, läßst sich nicht näher nachweisen. Desgleichen ist unsicher, ob er sich hie und da auch auferhalb Roms bei denselben einbürgerte; doch scheint es fast, als ob dem so gewesen sei. Denn im 11. Jahrhundert wurde mehrfach behauptet, es sei der Manipel ein Ornatstïck, das wie Amikt und Albe allen gemeinsam sei ${ }^{3}$.

Diese Ansicht scheint insbesondere von den Mönchen gepflegt worden zu sein. "In den Klöstern der Mönche“, sagt Lanfrank, „tragen sogar die laici (Laienbrüder, nicht Laien im gewöhnlichen Sinne), wenn sie Alben anziehen, nach alter Einrichtung der Väter den Manipel."

In der Tat hören wir von Rupert von Deutz, daß bei ihnen an Festtagen alle, die im Chor psallierten, alt und jung, in Alben und Manipeln erschienen 4. Auch ein Ordinarium des 12. Jahrhunderts bei Gerbert ${ }^{5}$ liefert eine Bestätigung der Worte Lanfranks. Denn wenn darin für Mariä Lichtmef die Weisung erteilt wird: In hac die neque fanones neque cappae alicui dantur, exceptis is, qui in presbyterio (Altarraum, im Gegensatz zum Raum, wo der Chor gehalten wurde) famulantur, qui tantum infra missam fanonibus utuntur, und betreffs der Messe des Palmsonntags gesagt wird: Infra hane missam fratres communiter albis induuntur, sed absque fanonibus, so setzt das voraus, daß an andern Festtagen alle fratres mit einem Manipel aus-

1 De eccl. offic. (M. 147, 32).

2 De statu eccl. (M. 159, 999). Vgl, auch den gegen 1000 entstandenen 6. Ordo Mabillons n. 1 (M. 78, 989) und Rupert., De offic. div. I. 1, c. 33 (M. 170,29 ).
3 Lanfranci Ep. 13 ad Ioan. Rotomag. (M. 150, 520).

1 De offic. div. 1. 2, c. 23 (М. 170, 54).

5 Liturgia alemannica I 238. M a r t., Mon. 1. 4, c. 1, n. 38 ; II 199). 
gerüstet am Gottesdienste teilnahmen. Daß zu Cluny diese Sitte herrschte, ergibt sich aus einem Dialog zwischen einem Cluniacenser und einem Cistercienser, in welchem letzterer es einen Raub an den Armen nennt, daßs die Mönche von Cluny für unnötige und überflüssige Dinge Ausgaben machten, sicut sunt albae et manipuli, quibus a minimo usque ad supremum tam conversi quam monachi in diebus festis induuntur ${ }^{1}$.

Aber auch sonst blieb der Brauch nicht ohne Widerspruch. So verordnete das Konzil von Poitiers vom Jahre 1100 in seinem 5. Kanon: Ut nemo monachorum deinceps manipulis utatır, nisi fuerit subdiaconus ordinatus". Allein noch zu de Verts Zeiten war es zu Cluny üblich, daß3 die Chorknaben Albe und Manipel trugen s, kraft eines Privilegiums, wie man glaubte. Ein eigenartiger Brauch war es, wenn den Kartäuserinnen bei ihrer Benediktion der Manipel an den linken Arm gelegt wurde*. Es ist das bekanntlich eine Zeremonie, welche bei der Weihe des Subdiakons statthat.

Die Liturgiker des 12. und 13. Jahrhunderts besprechen in der Regel nur die liturgische Gewandung der Priester und Bischöfe; höchstens daß sie gelegentlich des einen oder andern Gewandstückes der übrigen Ordines gedenken. Eingehender handeln von deren Sakraltracht blof Honorius, Sicard von Cremona und Durandus. Honorius erwähnt ausdrücklich und bestimmt nur den Manipel der Subdiakone; über die Verwendung desselben seitens der Diakone spricht er sich nicht direkt aus. Dagegen lassen Sicard ${ }^{\tilde{y}}$ und Durandus ${ }^{6}$ keinen Zweifel daran, daf der Manipel zu ihrer Zeit sowohl subdiakonales wie diakonales Ornatstïck war.

Wie es sich zu Rom im 13. Jahrhundert verhielt, ersehen wir aus dem 13. Ordo ${ }^{7}$. Der Manipel kam dort zu jener Zeit allen Geistlichen der höheren Ordines, aber freilich auch nur ảiesen zu, also den Bischöfen, Priestern, Diakonen und Subdiakonen, und so ist es im römischen Ritus bis jetzt geblieben.

\section{DIE ÄLTESTEN NACHRICHTEN ÜBER DIE VERWENDUNG DES MANIPELS.}

In der vorkonstantinischen Zeit, aus der wir überhaupt über die bei der Liturgie gebräuchliche Gewandung nichts Näheres hören, herrscht natürlich auch hinsichtlich der Verwendung der Mappula völliges Schweigen. Allein es steht auch in den beiden nächstfolgenden Jahrhunderten nicht besser. Erst das 6. Jahrhundert bringt über ihre Existenz, ihre Beschaffenheit, ihren Charakter und ihren Gebrauch einige Nachrichten. Es sind zwei Stellen im Papstbuch und ein Briefwechsel zwischen Gregor d. Gr. und dem Erzbischof Johannes von Ravenna, worin sich diese finden. Sie sind allerdings keineswegs erschöpfend, aber das, was sie uns mitteilen, ist von größter Bedeutung für die Geschichte des Manipels. Es ist darum durchaus notwendig, daf wir sie einlässig würdigen.

Von den beiden Stellen des Liber Pontificalis findet sich die eine in der Vita Silvestri. Fs wird hier mitgeteilt, Papst Silvester I. (314-326) habe die Verordnung erlassen, es sollten die Diakone sich in der Kirche der Dal-

1 Mart., Thes. V 1610. Vgl. auch Sicard, Mitralis 1. 2, c. 5 (M. 213, 78): In quibusdam monasteriis, quoties in festis albis utuntur, manipulos portant.

${ }^{2}$ Hard. VI 2, 1859. Sdralek, Wolfenbüttler Fragmente 137.

${ }^{3}$ De Vert II 291.

4 M art. 1. 2, c. 6, ordo 13; II 197. Der
Brauch besteht noch jetzt, und zwar handelt es sich bei dem fraglichen Manipel nicht um eine Art von Schweiß- oder Ziertuch oder ähnliches, wie vermutet wurde, sondern um einen wirklichen Manipel.

5 Mitralis 1. 2, c. 8 (M. 213,85 ).

6 Rationale 1. 2, c. 8 ; 1. 3 , c. 6 , f. 5670.

7 N. 56 (M. 78, 1106 1107). 
matik bedienen und mit pallia linostima ihre Linke bedecken: Et pallia (pallis, palleis, pallia) linostima leva eorum tegerentur (levam eorum tegerent, leva eorum tegeretur). Die andere begegnet uns in der Vita Zosimi. Dort heißst es nach dem gegenwärtigen Texte des Liber Pontificalis: Hic fecit constitutum, ut diacones leva (leba, levam) tecta (tectam) haberent de palleis linostimis. Nach der ersten Redaktion lautete dagegen die fragliche Stelle: Ut diacones leva tecta haberent de palleis linostimis per parroecias ${ }^{1}$. In dem einen Falle hätte Zosimus (417-418) nur die Bestimmung seines Vorgängers von neuem eingeschärft, in dem andern aber die Verordnung Silvesters hinsichtlich der pallia linostima auf die suburbikarischen Bistümer ausgedehnt. Hier kann natürlich für uns nur die Form maßsgebend sein, in welcher die Notiz in der ersten Redaktion auftritt.

Ob die Verordnungen wirklich von Silvester und Zosimus herrühren oder ob es sich bei den fraglichen Angaben blok um eine mehr oder weniger zuverlässige lokale Tradition handelt, läbt sich nicht feststellen. Wir kemnen sie eben nur durch das Papstbuch, welches für die vier ersten Jahrhunderte eine Quelle von recht zweifelhaftem Wert ist. Jedenfalls spiegeln sie die Praxis wider, welche zur Zeit der Abfassung des L. P. bereits geraume Zeit zu Rom und in den suburbikarischen Diözesen in Kraft war. Außerdem dürften sie auch insofern den tatsächlichen Verhältnissen entsprechen, als der Gebrauch des pallium linostimum ursprünglich auf Rom beschränkt gewesen sein wird und erst im Lauf der Zeit auf die suburbikarischen Diözesen ausgedehnt wurde.

Ihrer Beschaffenheit nach bestanden die pallia linostima, wie der Name besagt, aus einem Zeug, dessen Kette durch Linnen und dessen Einschuß durch Wolle oder Seide gebildet wurden. Sie waren also Tücher von besserer Qualität. Die Art, wie sie von den Diakonen getragen wurden, ist bei dem jetzigen Stand des Textes nicht genau festzustellen. Sollten sie den linken Arm oder nur die linke Hand bedecken? Der so sehr verderbte Text läst das unentschieden. Nach Hraban und Walafried Strabo hätten sie der linken Hand aufgelegen; denn diese geben die Silvestrinische Verordnung in der Fassung: ut pallio linostimo leva eorum tegeretur. Wie dem jedoch sein mag, jedenfalls befand sich das pallium an der linken Seite, und zwar wenn wir den Wortlaut der Verordnung Silvesters recht verstehen - über der Dalmatik, ein Punkt, der für die Bestimmung seines Charakters nicht ohne Wichtigkeit ist.

Was diesen Charakter anlangt, so läbt der Liber Pontificalis keinen Zweifel, dafs das pallium linostimum ein Tuch war, welches bei der Liturgie verwendet wurde, und zwar kann es, wenn wir den römischen Brauch zur Karolingerzeit, das Ergebnis der seit Konstantin datierenden Entwicklung der liturgischen Gewandung des römischen Ritus, in Betracht ziehen, nur entweder die diakonale Stola oder die Mappula sein. Leider gibt uns der Text des Pontifikalbuches keinen direkten Aufschlus, mit wem von beiden wir es zu identifizieren haben. Hält man indessen vor Augen, dafo das pallium linostimum der linken Hand oder dem linken Arm auflag, gerade wie die Mappula des 8. und 9. Jahrhunderts, und daßs anderseits die Stola nach römischer Sitte im 9. Jahrhundert unter der Dalmatik getragen wurde, wälırend das pallium linostimum sich nach der Notiz der Vita Silvestri über derselben befunden

1 D u ch., L.P.I 87171225. Die eingeklammerten Worte bezeichnen die verschiedenen Lesarten. 
zu haben scheint, so kann unter diesem wohl nur die spätere Mappula verstanden werden ${ }^{1}$.

Als Träger des pallium linostimum erscheinen im Liber Pontificalis die Diakone. Haben wir das im ausschließlichen Sinne zu verstehen, so daf nur sie sich seiner bedient hätten, kein anderer, oder bedeutet die angebliche Verordnung Silvesters nur die Verleihung eines bis dahin päpstlichen oder bischöflichen Vorrechtes an die römischen Diakone? Man kann darüber verschiedener Meinung sein; wer indessen unbefangen die Verordnung Silvesters betrachtet und dabei vor Augen hält, daf im 6. Jahrhundert die Dalmatik allerdings eine Auszeichnung der römischen Diakone war, dafs diese sich aber ihrer nicht allein erfreuten, sondern daf das Recht, die Dalmatik zu tragen, für sie nur die Teilnahme an einem Vorrecht des Papstes bedeutete, wird kein Bedenken tragen, etwas Ähnliches bezüglich des pallium linostimum anzunehmen. In der Folge finden wir ja auch beim Papst die Mappula. Wie kam dieser zu ihr, wenn sie ihm nicht bereits vor den Diakonen eignete? Ist es denn auch nur im geringsten wahrscheinlich, daf er sie von den Diakonen ibernommen habe? Welcher Anhalt liegt dafür vor, und welche Parallele gibt es dazu? Wenn wir im 9. Jahrhundert auch die römischen Subdiakone und selbst die Akolythen im Besitz der Mappula finden, so erklärt es sich angesichts der hervorragenden Stellung, welche diese nach und nach erlangt hatten, ohne Schwierigkeit, wie auch sie dazu kamen, die Mappula tragen zu dürfen. Daßs aber der Papst diese von den Diakonen herübernalım, können wir nur dann annehmen, wenn dafür triftige Beweise vorgebracht werden.

Über den Zweck des pallium linostimum läßst das Papstbuch nichts verlauten. Immerhin scheint es nicht wahrscheinlich, dab es sich bei ihm um ein zu praktischen Zwecken, wie sie der diakonale Dienst etwa mit sich brachte, bestimmtes Tuch handelte. Es war vielmehr, seinem Namen nach zu urteilen, wohl etwas Besseres als ein blokes Handtuch oder eine Serviette. Dafür spricht auch die Verordnung des Papstes Zosimus, welche den Gebrauch des pallium linostimum auf die Diakone der suburbikarischen Diözesen ausdehnte. Wäre dieses ein Tuch gewesen, welches durch den Dienst der Diakone gefordert wurde, so ist nicht einzusehen, warum es nicht von Anfang an wie für Rom so auch für die um Rom liegenden und $\mathrm{zu}$ Rom gehörenden Diözesen vorgeschrieben wurde. Der Sinn des Dekretes kann daher wohl nur sein, daf durch dasselbe die Diakone dieser Kirchen nach Art der römischen das Vorrecht erhielten, das pallium linostimum zu tragen. Das unsere Auffassung der Sache salvo iudicio meliore.

Was den Briefwechsel zwischen Gregor d. Gr. und Johannes von Ravenna anlangt, so kommt alles bei ihm darauf an, was unter der Mappula, um welche es sich darin handelt, zu verstehen ist.

1 Wenn irgendwo, so ist es gerade für das richtige Verständnis des pallium linostimum wichtig, den Stand der Dinge in der Folgezeit im Auge zu halten. Denn dieser ist ja nichts Willkürliches, sondern in lebendigem Prozef aus dem Brauch früherer Tage herausgewachsen. Eine Betrachtungsweise, die von ihm absieht, kommt, wie die Erfahrung beweist, leicht in Gefahr, sich in bloße Hypothesen uber die Bedeutung des pallium linostimum zu verlieren. Jedenfalls wirft der liturgische Brauch zu Beginn des 9. Jahrhunderts ein helleres und zuverlässigeres Licht auf das pallium linostimum des Papstbuches als die Darstellungen von sog. camilli und delicati, heidnischen Opferdienern und Aufwärtern bei profanen Mahlzeiten, deren mantile, wenn man die Sache genau betrachtet, doch nur eine scheinbare Analogie zu dem pallium linostimum der römischen und suburbikarischen Diakone und der diakonalen Mappula bildet (vgl. unten $\mathrm{Nr}$ XII). 
Gregor hatte sich beklagt, daf die ravennatischen Priester und Diakone sich der mappulae bedienten; es sei das eine Anmafung. Darauf antwortete Johannes 1: , Tas die mappulae anlangt, welche sich dem Schreiben Eurer apostolischen Herrlichkeit zufolge meine Priester und Diakone angenaßst haben sollen, so mag ich darüber nichts anführen, da die Wahrheit, die bei meinem Herrn allein etwas gilt, genügt. Denn da die kleineren Kirchen in der Umgebung der Stadt (Rom) dazu die Erlaubnis haben, so wird mein apostolischer Herr, falls er den ehrwürdigen Klerus des ersten apostolischen Sitzes zu fragen geruht, allerwegen finden, daßs, so oft wegen einer Bischofsweihe oder in Botschaftsangelegenheiten die Priester und Leviten der ravennatischen Kirche nach Rom kamen, alle unter den Augen Eurer allerheiligsten Vorgänger cum mappulis procedebant, ohme irgend einen Tadel zu erfahren. Daher haben auch damals, als ich Sünder dort von Eurem Vorgänger geweiht wurde, alle meine Priester und Diakone, in obsequium domni papae mecum procedentes, sich derselben bedient."

Gregor aber antwortet auf dieses Schreiben ${ }^{2}$ : „Gegen das, was Ihr über den Gebrauch der mappulae seitens Enres Klerus geschrieben, hat unser Klerus heftigen Widerspruch erhoben; niemals, sagten sie, sei ein solches irgend einer andern Kirche gestattet worden. Ebensowenig hätten die Kleriker von Ravenna dort oder in Rom ihres Wissens sich dessen unterfangen. Aber wenn selbige das auch wirklich versucht hätten, so folge aus einer solchen heimlichen Anmaßsung nichts für sie. Man müsse, sagen sie, falls man sich in irgend einer Kirche solches angemafat, bessern, wessen man sich nicht kraft Erlaubnis des römischen Papstes, sondern widerrechtlich allein durch Erschleichung unterfange. Wir indessen gestatten, indem wir die Ehre Deiner Fraternität wahren (servantes honorem fraternitatis tuae), gegen den Willen unseres vorgenaunten Klerus den ersten Diakonen Ravennas, die ja den Zeugen gemäfs auch schon vorher sich der mappulae bedient haben, den Gebrauch derselben, doch nur in Deinem Dienst (in obsequio tuo). Für eine andere Gelegenheit und andere Personen verbieten wir solches aufs entschiedenste."

Man hat geglaubt, unter den mappulae tragbare Baldachine verstehen zu sollen ${ }^{3}$, allein mit Unrecht. Denn diese gehören einer viel späteren Zeit an. Den älteren römischen Ordines sind sie völlig unbekannt. Obendrein waren sie nie bei gewöhnlichen Priestern und Diakonen, von denen doch im Brief Gregors d. Gr. die Rede ist, üblich.

Auch die Stola können sie nicht bedeuten. Denn diese wurde, falls sie damals überhaupt bei den römischen Klerikern in Gebrauch war, wie schon gesagt, auf keinen Fall sichtbar über der Dalmatik getragen. Bei den Mappulis handelt es sich aber offenbar um ein Ding, das in die Augen fällt. Zudem findet sich das Wort mappula nirgends als Bezeichnung der Stola gebraucht.

Es kann sonach nur die Frage sein, ob in den mappulae, die den Gegenstand des Briefwechsels Gregors und Johannes' bilden, die liturgischen Mappulae oder die gewöhnlich mappuli genannten weißen Schabracken zu erblicken sind. Diese weißsen Schabracken lassen sich schon zu Beginn des 8. und um die Wende des 7. Jahrhunderts zu Rom mit aller Bestimmtheit nachweisen. So vermeldet das Papstbuch in der Vita Constantini, als Papst Konstantin (707-708) seinen Einzug in Konstantinopel gehalten habe, seien seine und der Vornehmsten aus seinem Gefolge Rosse mit vergoldeten Sätteln, goldgeschmückten Zügeln und mappulis versehen gewesen 4 . In der Vita Cononis (686-687) aher wird berichtet, daf dieser Papst den Syrakusaner Diakon Konstantin zum Rektor des Patrimonium von Sizilien gemacht und ihm die Erlaubnis gegehen habe, sich der Schabracke beim Aufritt zu bedienen: Sed et mappulum ad caballicandum, uti licentiam ei concessit ${ }^{5}$. Auch die sog. Konstantinische Schenkung kennt bereits die Schabracke. Denn zu den Privilegien, welche in ihr dem römischen Klerus erteilt werden, gehört auch das Recht: Ut mappulis et linteaminibus, i. e.

1 Gregor. M., Epist. 1. 3, n. 66 (M. G. Epp. I 229).

2 Ebd. 1. 3, n. 54 (ebd. 214).
3 Hefele, Beitr. II, 180 in Anschluk an A. J. Binterim, Denkwürdigkeiten VII3, 359. 4 D u ch., L. P. I 390. 5 Ebd. 369. 
candidissimo colore decorari equos et ita equitari ${ }^{1}$. Es müssen also die römischen Geistlichen schon eine gute Weile vor der Abfassung des Constitutum im Besitz des Vorrechts gewesen sein, beim Reiten sich weiker linnener Pferdedecken zu bedienen; andernfalls wäre ja die Fälschung allzu plump und geradezu offenkundig gewesen.

Die römischen Kleriker erhielten das Recht, sich der weifen Schabracke zu bedienen, wie aus dem 9. Ordo Mabillons erhellt, beim Empfang der Tonsur. Ex hac (d. h. wenn die cantores cubicularii geworden) accipiunt primam benedictionem ab archidiacono, ut liceat eis super linteum vellosum sedere, quod mos est ponere super sellam equi". Aber auch auswärtigen Geistlichen wurde zur Auszeichnung die Erlaubnis zu teil, bei feierlichen Aufzügen von der weifen Pferdedecke Gebrauch zu machen. Das früheste bekannte Beispiel wurde bereits angeführt. Von einem andern, nur wenig späteren wird aus dem Pontitikat Stephans II. (752-757) berichtet; es war Abt Fulrad von St-Denis, welchem dieser das Privileg gewährte: Praevidimus tuam nobis dilectam adornare religionem .. . et super sellam equitanti mappulum ${ }^{3}$. Johannes VIII. verlieh 1877 das Vorrecht dem Bischof Johannes von Pavia ${ }^{4}$, Benedikt VII. 975 dem Erzbisch of Theoderich von Trier ${ }^{5}$. Klemens II. gibt es 1047 dem Erzbischof Idalbert von Hamburg ${ }^{6}$, Leo IX. 1052 den Erzbischöfen Hermann von Köln ${ }^{7}$ und Liuthbald von Mainz ${ }^{8}$; 1049 bestätigt Leo das Privileg dem Erzbischof Eberhard von Trier ${ }^{9}$. Die Schabracke führt jetzt den Namen naceus (nattus) statt mappula oder mappulus.

Es ist leicht begreiflich, dak man unter den mappulae im Briefwechsel zwischen Gregor und Johannes von Ravenna die weifen Schabracken verstanden hat. Ein auszeichnender Schmuck des römischen Klerus und dessen ausschliefiches Vorrecht, das andern nur kraft eines besondern Privilegs zustand, passen diese in der Tat trefflich auf den Gegenstand, dessen angebliche Usurpation seitens der ravennatischen Priester und Diakone beim römischen Klerus so viel böses Blut machte. Allerdings werden jene Decken erst gegen das Ende des 7. Jahrhunderts erwähnt, jedoch waren sie damals sicher schon eine gute Weile im Gebrauch, und so hindert nichts, anzunehmen, daf sie auch bereits zu Gregors d. Gr. Lebzeiten ein Privileg des römischen Klerus bildeten. Demgemäß glaubte denn auch der Verfasser seinerzeit sich dahin aussprechen zu sollen, daß aller Wahrscheinlichkeit nach mit den fraglichen mappulae eben die weißen Schabracken gemeint seien ${ }^{10}$. Indessen können wir diese Auffassung nicht länger mehr vertreten. Es scheint uns vielmehr im Gegenteil nahezu als zweifellos, daf es sich bei ihnen um die liturgische Mappula oder das pallium linostimum des Papstbuches handelt.

1 Hins chius, Decret. Pseudo-Isidor. 253.

2 N. 1 (M. 78, 1003). Wenn Johannes Diakonus im 9. Jahrhundert in der Vita S. Gregorii M. 1. 2, n. 43 (M. 75, 104) von planetatorum mappulatorumque processionibus erzäblt, die im Gefolge des Papstes aufritten, so sind das römische Kleriker in der Planeta auf Pferden, die mit der mappula, der weízen Schabracke, geschmückt waren, nicht Kleriker in der Planeta mit der liturgischen Mappula in der Hand. Nahm doch der Papst selbst diese nach dem 1. Ordo erst im Sekretarium, nachdem er alle übrigen Gewänder angezogen hatte. Bekanutlich begab sich der Papst mit seinem Gefolge bis ins späte Mittelalter stets zu Roß zur Kirche, wo er feierlichen Gottesdienst halten wollte.

3 J. n. 2330. Über die Echtheit des Dokuments s. oben S. 385 , Anm. 2.

4 Ebd. n. 3111, wo die Bulle aber als verdächtig bezeichnet wird. Auch unter der mapilla oder den manipularii der Bulle Johannes' XV. (ebd. n. 3849), worin 993 der Abt von Braunau das Privileg erhält, sich der Mitra, der Handschuhe, der Sandalen, der Mapilla (manipularii) und des Balteus zu bedienen, ist vielleicht die Schabracke zu verstehen, falls nicht etwa eine Art Baldachin damit gemeint sein sollte. Obendrein mufs dahingestellt bleiben, ob die Mapilla dem ursprünglichen Text angehört oder interpoliert ist. Über die Bulle s. oben S. 368, Anm. 1.

5 Ebd. n. 3783.

6 Ebd. n. 4146.

7 Ebd. n. 4271 ; über die Echtheit der Bulle s. oben S. 257, Anm. 5.

8 Ebd. n. 4281.

9 Ebd. n. 4161. Andere Beispiele ebd. n. 3566 (Lüttich), n. 4074 (Salzburg), n. 4498 (Halberstadt), n. 6013 (Pavia), n. 7576 (Aquileja), n. 7620 (Genua), n. 7890 (Pisa).

10 Priester]iche Gewänder S. 61. 
Entscheidend ist hierbei für uns der Terminus procedere. Das Wort kommt in den Briefen Gregors d. Gr. häufig vor, immer aber ist es der technische Ausdruck für ,am Altar tătig sein, dem Altardienst obliegen, zum Altar treten". Beispiele bieten die Briefe 1. 3, n. 66: Ingredientibus diaconibus (sc. in secretarium) ut mox procedatur ${ }^{1}$; 1. 5, n. 61: Procedens a salutatorio ad sacrarum missarum celebranda $^{2}$; 1. 8, n. 27 : Diaconos calciatos campagis procedere ${ }^{3} ; 1.9$, n. 26 : Subdiaconos spoliatos - vestitos (sc. ohne bzw. mit einer besondern Amtstunika nach Art der Dalmatik) procedere ${ }^{4} ; 1.9$, n. 69 : Petrus clericus... si insons fuerit declaratus ... vobiscum procedendi habeat licentiam ${ }^{5}$. Namentlich aber lassen an der Bedeutung des procedere in den Briefen Gregors keinen Zweifel die Briefe 1. 14, n. 2, 1. 5, n. 45 und 1. 9, n. 156. Das erste dieser drei Schreiben ist an den Vitalis, den Densensor (Vogt) von Sardinien, gerichtet. Dieser hat Gregor berichtet, der Bischof Johannes von Cagliari habe zur Zeit, quo sacrificium eelebrat, häufig mit so grofer Beklemmung zu tun, daf er erst nach langer Weile den unterbrochenen Kanon wieder aufnehmen könne. Infolgedessen sei bei vielen Unruhe darüber entstanden, $\mathrm{ob}$ in solchen Fällen die Kousekration gültig und das Kommunizieren zulässig sei. Gregor beschwichtigt die Bedenken, fügt aber hinzu: secretius tamen omnino isdem frater noster hortandus est, ut quotiens sibi aliquam molestiam senserit, non procedat ${ }^{6}$. Das procedere ist hier offenbar identisch mit dem vorhergehenden sacrificium celebrare. In Brief 1. 5, n. 45 verbietet Gregor dem Diakon Sabinian, seinem Vertreter zu Konstantinopel, sich zu unterfangen, mit Bischof Johannes, der sich den Titel, ökumenischer Patriarch" beigelegt hatte, jemals procedere ${ }^{7}$, d. i., wie der Papst in seinem Schreiben an Johannes selbst mit ausdrücklichen Worten sagt, mit diesem die Messe zu feiern: eum (sc. Sabinianum) missarum sollemnia cum fraternitate vestra celebrare prohibui ${ }^{8}$. Brief l. 9, n. 156 endlich ist ein Rundschreiben an verschielene Bischöfe Griechenlands, in welchem Gregor diese ermahnt, Cyriakus, dem Nachfolger Johannes, den Titel ,okumenischer Patriarch" um keinen Preis zuzugestehen. Schon Pelagius sei gegen Johannes, den Vorgänger des Cyriakus, wegen der gleichen Anmaßsung mit aller Entschiedenheit vorgegangen; er habe sogar seinem Diakon, der ihn zu Konstantinopel vertrat, untersagt, bis der Bischof sich gebessert habe, illi proceder e ${ }^{9}$, oder wie es im eben erwähnten Briefe Gregors an Johannes, in welchem auf diesen Befehl des Papstes Pelagius gleichfalls Bezug genommen wird, heift, mit ihm missarum sollemnia celebrare.

Unter solchen Umständen müssen wir natürlich auch die Ausdrücke cum mappulis procedebant und in obsequio domni papae (im Dienst des Herrn Papstes) mecum procedentes gleichfalls vom Hinzutreten zum Altar und den liturgischen Funktionen verstehen. Allerdings besagt procedere auch wohl auferliturgisch aufziehen, in feierlichem Zug zu Fuf oder zu Rok sich bewegen. Allein in unserem Falle ist für die Bedeutung des Wortes offenbar nicht entscheidend, was es überhaupt bedeuten kann oder irgendwo bedeutet, sondern welcher Sinn ihm in den Parallelstellen in Gregors Briefen zukommt. Es hiefe offenbar dem Ausdruck Gewalt antun, wollten wir ihn hier von einem feierlichen Aufritt zur Kirche verstehen, statt vom Altardienst. Ebendarum aber können auch die mappulae keine weifen Schabracken, sondern nur die liturgische Mappula sein.

1 M. G. Epp. I 229.

2 Ebd. I 375.

3 Ebd. II 28.

5 Ehd. 89.

4 Ebd. 59.

7 Ebd. I 344.

8 L. 5, n. 44 (elod. I 339).

" Ehd. II 157. Was das Verbot des "procedere" bedeutet, erhellt auch aus 1. 7, n. 30 (ebd. I 477), in dem Gregor dem Kaiser
Mauritius schreibt: Mecum feci eos (die Gesandten des Cyriakus von Konstantinopel) sacra missarum solemnia celebrare, quia sicut meus diaconus ad exhibenda sancta mysteria illi non debet ministrare, ita minjstri illius in celebratione $\mathrm{m}$ issarum mihi adesse debuerunt, quia custodiente Deo in superbiae errorem non cecidi. 
Die einzige Schwierigkeit, welche etwa erhoben werden könnte, ist, daßs nach dem Papstbuch nicht blof zu Rom, sondern auch in den umliegenden Kirchen die mappula im Gebrauch war, während die römischen Kleriker nach dem Briefe Gregors es verneinen, dafs diese je einer andern Kirche bewilligt worden sei. Allein wirklich erheblich ist dieser Einwand nicht. Man wird die Behauptung der römischen Kleriker. daf der Gebrauch der mappula nie einer sonstigen Kirche gestattet worden sei, nicht anf die Goldwage legen dürfen. Sie sprechen zu sehr im Eifer des Streites, im Eifer aber pflegt man nicht gerade die Worte abzuwägen. Ihre Behauptung hinsichtlich der ravennatischen Kleriker war jedenfalls irrig. Denn wenn Gregor trotz des heftigen Widerstrebens der römischen Kleriker den ersten Diakonen Ravennas gestattet, sich der mappula zu bedienen, so tut er das, wie er sagt, weil durch Zeugen festgestellt worden war, dak diese solches wirklich schon zu tun gewohnt gewesen waren. Zudem betrifft die Differenz zwischen der Angabe des Papstbuches und der Behauptung der römischen Kleriker nicht sowohl die Tatsächlichkeit des Gebrauches der mappula in den kleineren Kirchen um Rom, als vielmehr die Frage, ob diese die Erlaubnis dazu erhalten hatten oder nicht. Die römischen Kleriker leugnen, wie es scheint, jede ausdrückliche Verleihung dieses Rechtes, das Papstbuch führt sie auf Zosimus zurück. Wer von beiden recht hat, muf dahingestellt bleiben. Das von Johannes behauptete Faktum wird von den römisshen Klerikern nicht in Abrede gestellt, was doch das Allernächste gewesen wäre. Sie begnügen sich dem Erzbischof gegenüber mit der allgemeinen Bemerkung, dak die Verwendung der mappula nie einer andern Kirche gestattet worden sei. Wäre diese in den Kirchen um Rom wirklich nicht in Gebrauch gewesen, so hätten sie es hierbei ohne Zweifel nicht bewenden lassen, sondern das von Johannes behauptete Beispiel sicher schlechthin in Abrede gestellt. Denn mit Bezug auf die Angabe des Erzbischofs, dafs die Priester und Diakone von Ravenna zu Rom sich der mappula bedient hätten, bleiben sie bei jener Bemerkung nicht stehen, sondern sagen ausdrücklich, daf diese ihres Wissens niemals, nicht zu Rom, nicht zu Ravenna die mappula gebraucht hätten. Der Briefwechsel bildet also hinsichtlich der Verwendung der mappula in den suburbikarischen Kirchen so wenig einen Widerspruch gegen die Angabe des Papstbuches, daf er diese in der Hauptsache, d. i. in der Tatsächlichkeit ihrer dortigen Benutzung, eher bestätigt. Es liegt aber auch auf der Hand, das Johannes, bevor er in seinem Brief darauf aufmerksam machte, dak man in jenen Kirchen die Erlaubnis habe, die mappula zu verwenden, sich genau über den Stand der Dinge unterrichtet hatte. Wie hätte er es sonst wagen dürfen, dem Papst gegenüber sich mit solcher Bestimmtheit auf die um Rom liegenden Kirehen als Präzedenzfall zu beziehen? Er hätte gewärtig sein müssen, daß3 man ihn alsbald der Unwahrheit überführe.

Der Briefwechsel zwischen Johannes von Ravenna und Gregor d. Gr. ist eine wichtige Ergänzung zu der Mitteilung des Papstbuches über das pallium linostimum. Erstens beweist er, daf das pallium linostimum und die Mappula ein und dasselbe sind. Zweitens bekundet er, daf es zu Gregors Zeiten zu Rom nicht blof die Diakone waren, welche sich der Mappula bedienten, sondern auch die Priester, und daf die Mappula darum nichts spezifisch Diakonales war, wenngleich die Diakone kraft ihrer hervorragenden Stellung sich ihrer vor allem erfreut haben werden. Drittens geht aus dem Briefwechsel hervor, daß die Mappula kein für dienstliche Verrichtungen, z. B. das Händewaschen und Ähnliches, bestimmtes Tuch gewesen sein kann, sondern eine Auszeichnung darstellte und der Auszeichnung halber getragen wurde. Viertens belehrt er uns, daf trotz dieses Charakters die Mappula noch keine Insignie, d. h. noch kein Abzeichen eines Ordo war wie später. Sie erscheint vielmehr nur als Eigentümlichkeit des römischen Klerus, welche dieser mit Eifersucht sich zu reservieren trachtete. Es läst darum auch fünftens der Briefwechsel keinen Zweifel übrig, dafis die Mappula ihren Ursprung in Rom hat, und daf sie 
sich von hier aus allmählich in andere Kirchen verbreitete, wobei sie natürlich ihren ausschlieflich römischen Ckarakter immer mehr einbübte. Ob auch der Erzbischof Johannes sich ihrer bediente, ist aus dem Briefwechsel nicht direkt ersichtlich. Wenn indessen die ravennatischen Priester und Diakone nach seiner Angabe die Mappula trugen, als sie bei Gelegenheit seiner Weihe mit ihm am Pontifikalamt des Papstes teilnahmen, dann dürfte auch er wohl kaum olne sie geblieben sein, zumal wir ja später in der Tat die Bischöfe gleich den Priestern und Diakonen von derselben Gebrauch machen sehen.

Auf den Monumenten der vorkarolingischen Zeit begegnet uns die Mappula nie. Bei den Mosaiken zu Ravenna mag solches daher kommen, daf sie dort noch nicht in Gebrauch war, als diese geschaffen wurden. Auf den sehr wenigen römischen Bildwerken dürfte ihr Fehlen vielleicht seinen Grund darin haben, das sie zu deren Entstehungszeit keine besondere Bedeutung mehr besaßs; denn die frühesten der hier in Betracht kommenden Monumente gehören dem zweiten Viertel des 7. Jahrhunderts an. Überhaupt hat die Mappula, so sehr sie ein auszeichnendes Ormatstück des römischen Klerus war, schwerlich je eine derartige Wichtigkeit besessen, wie es nach dem Briefwechsel zwischen Gregor und Johannes von Ravenna scheinen könnte. Wenn die Kleriker zu Rom damals so viel Aufhebens davon machten, dab die ravennatischen Priester und Diakone ebenfalls sich der Mappula bedienten, so lag das, wie es scheint, weniger an der Bedeutung des Ornatstückes, als weil es galt, den ravennatischen Klerus, dessen Gelüste, es dem römischen gleich zu tun, nur zu bekannt waren, in den gebührenden Schranken zu halten. Übrigens kann das Fehlen der Mappula auf den römischen Monumenten auch aus rein zufälligen Ursachen herrühren; mangelt sie doch noch fast auf allen Bildwerken aus dem 9. Jahrhundert zu Rom, namentlich auf allen Mosaiken.

Im Kloster vom heiligen Kreuz zu Poitiers wurde im 15. Jahrhundert nach einem von Barbier de Montault veröffentlichten Inventar aus dem Jahre 1476 aufer der Stola auch der Manipel des hl. Medardus ( $†$ 545) aufbewahrt ${ }^{1}$ Im 12. Jahrhundert zeigte man, wie der Mönch Thomas von Ely erzählt, zu Durham einen herrlichen, mit Gold und kostbaren Steinen geschmückten Manipel, den die hl. Etheldreda von EJy, der Goldweberei kundig, dem hl. Cuthbert († 681) mit eigenen Händen angefertigt haben sollte ${ }^{2}$. Einen angeblichen Manipel des hl. Licinius († 605) besak man vor der französischen Revolution in St-Julien zu Angers ${ }^{3}$. Wir brauchen kaum zu bemerken, daf diesen Manipeln, deren spätere Entstehung die Beschreibung, die wir von ihnen haben, mit aller Bestimmtheit verbürgt und deren Zahl sich leicht noch um andere ähnliche vermehren liebe, eine Bedeutung für die Geschichte des Manipels in vorkarolingischer Zeit nicht zukommt.

\section{BESCHAFFENHEIT DES MANIPELS ZUR KAROLINGERZEIT. SEINE UMWANDLUNG IN EINEN ZIERSTREIFEN.}

Der moderne Manipel ist ein Band oder Streifen. Die Mappula des 8. und des beginnenden 9. Jahrhunderts war das noch nicht; sie war vielmehr ein streifenförmig zusammengefaltetes Tuch. Denn wenn im 1. Ordo das Tuch, mit dem die Akolythen die Ampulla, worin sich das Chrisma befand, zu halten hatten, mappula genannt wird ${ }^{4}$, dann haben wir die im nämlichen Ordo bald

\footnotetext{
1 Roh. VII $3 s$.

2 Acta S. Etheldredae Reg. I. 1, n. 31 (A. SS. 23. Iun., V 430).

3 Roh. VII 52 .

4 N. 2 (M. 78, 938).
} 
nachher erwähnte Mappula des Pontifex ebenfalls wohl als ein gröferes Tuch anzusehen und nicht als einen blofen Zierstreifen. Auch was Hraban, Amalar und noch Pseudo-Alkuin über die Mappula, das Sudarium oder den Fano sagen, stellt, wie man auch immer die von ihnen gegebenen Deutungen beurteilen mag, das unseres Erachtens aufer Zweifel. Namentlich gilt solches von der Bemerkung Pseudo-Alkuins: Im Alten Bunde fehlten (den Priestern) Stola, Sandalen und Sudarium, quod ad tergendum sudorem in manu gestari mos est, quod usitato nomine fanonem vocamus ${ }^{1}$, und den Worten Amalars: Sudarium (sc. diaconi) est habile ad hoc, ut quidquid accesserit sordidi, illo tergatur et sacerdotis mundissimum maneat ${ }^{2}$. Ebenso beweist das goldverzierte Enchirion, welches vom Patriarchen Nicepholus von Konstantinopel Papst Leo III. zum Geschenk gesandt wurde ${ }^{3}$ und nach dem Zusammenhang nur die Mappula bedeuten kann, daf diese damals noch ein förmliches Tuch war. War doch das Enchirion ein solches selbst noch im 11. Jahrhundert.

Wann die Mappula aus einem streifenförmig zusammengefalteten Tuch zu einem bloben Zierstreifen wurde, läfst sich nicht genau bestimmen. Die Umbildung erfolgte nicht mit einem Schlag, nicht wie über Nacht. Kein Dekret hat ihr die primitive Form genommen und eine andere gegeben. Der Wandel hat sich auf dem Wege einer allmählichen Entwicklung vollzogen, bei der man hier ein schnelleres, dort ein langsameres Tempo einhielt. Jedenfalls war der Manipel im Beginn des 2. Jahrtausends allenthalben schon zum Zierstreifen geworden, der seitdem höchstens durch die mystische Berleutung, die man mit ihm verband, an die frühere Gestalt erinnerte. Ad extremum sacerdos fanonem in sinistrum brachium ponit, quem et manipulum veteres et sudarium appellaverunt, per quem olim sudor et narium sordes extergebantur. So oder ähnlich reden Honorius, Robert Paululus, sicard, Innozenz III. und Durandus *. Eine Ausnahme machte vielleicht hie und da bis zu einem gewissen Grade der subdiakonale Manipel. Denn Honorius schreibt noch um 1120: Subdiacono ... subtile et sudarium adduntur. ... Sudarium, quo sordes a vasis deterguntur, portat, ut transacta mala sordium a se per poenitentiam tergat. Notandum vero, quod subdiacono maius aliis formatur, quia ubi nunc fano, olim mappula portabatur. Es scheinen hiernach die Subdiakone noch im Beginn des 12. Jahrhunderts hier und dort im Gegensatz zu den Priestern und Diakonen einen durch seine Maße an ein Tuch erimnernden Manipel getragen zu haben, eine Erscheinung, die Honorius mit dem Hinweis auf die Tatsache erklärt, daßs früher ïberhaupt statt des Fano (hier Zierstreifen) eine Mappula, ein Tuch, gebraucht worden sei.

Es ist allerdings richtig, daf man bei Honorius zusehen muf, ob nicht etwa irgend eine Angabe über die liturgische Gewandung das blofe Echo der Äuberung eines älteren Schriftstellers ist. Allein im vorliegenden Fall liegt, wie es scheint, zu einer solchen Annahme kein Grund vor; namentlich gilt das bezüglich des letzten Satzes, der sich nicht nur in früherer Zeit kaum nachweisen lassen dürfte, sondern auch ersichtlich das Gepräge einer persönlichen Bemerkung des Honorius an sich trägt. Wenn aber um 1200 Sicard von Cremona und um 1275 selbst noch Durandus die Ausführungen

1 De offic, div. c. 38 (M. 101, 1240).

\& De eccl. offic. 1. 3, c. 19 (M. 105, 1131).

3 M. 102, 1068. Patr. Nicephorus übersendet dem Papst aufer dem Enchirion ein goldenes Enkolpion (Reliquiar nach Art eines Pekto- rale), ein Sticharion (Tunika, Dalmatik), ein goldverziertes Epitrachelion (Stola), ein kastanienfarbiges Phelonion (Kasel), alles Gegenstände für den gottesdienstlichen Gebrauch.

${ }^{4}$ Vgl. auch Bruno von Segni (M. 165, 1108). 
der Gemma wortwörtlich wiederholen, obschon damals der Manipel der Subdiakone sicher ïberall ein Zierstreifen war, so folgt daraus selbstverständlich nicht, daß Honorius gleichfalls nur gedankenlos geechoet habe, was einmal jemand vor ihm über den subdiakonalen Manipel sclrieb. Vielleicht ist es auch nicht ohne Grund, dal; in den Inventaren des 11. und des beginnenden 12. Jahrhunderts die subdiakonalen Manipel verschiedentlich gesondert aufgeführt und ausdrücklich als solche bezeichnet werden; so im Gabenverzeichnis Leofrics von Exeter († 1072): 4 subdiakons handlin (Handlinnen, Manipel), und im Bamberger Inventar von 1127: 8 fanones subdyaconorum, ex his 4 cum aurifrigio.

Der älteste noch erhaltene Manipel in der jetzigen Streifenform stammt aus dem Beginn des 10. Jahrhunderts. Er wurde schon gelegentlich erwähnt. Es ist der Manipel, welcher 1827 im Grabe des hl. Cuthbert aufgefunden wurde, und welchen laut Inschrift Königin Elflead für Bischof Frithestan anfertigen ließ. Er ist eine ausgezeichnete Arbeit, die den Beschauer unwillkürlich zur Bewunderung zwingt. Der Manipel hat eine Länge von $86^{\circ} \mathrm{cm}$ bei einer Breite von $6 \mathrm{~cm}$ und ist auf beiden Hälften mit Heiligenfiguren, die auf Wolken stehen und zu deren Häupten Blattwerk angebracht ist, geschmückt. Die dargestellten Heiligen sind Gregor d. Gr., Petrus Diakonus, Sixtus II. und Laurentius. Der Fond des Figurenwerks besteht aus äuferst feinen, mit tief eingezogenen Abheftstichen befestigten Goldfäden. An den Seiten ist der Manipel mit einem schmalen, goldgemusterten Rändchen eingefafst, an den Enden aber mit quadratischen Abschlubstücken, die Halbbilder aufweisen, versehen ${ }^{1}$. In der Mitte enthält er in einem Vierpaf die Rechte Gottes. Der Manipel bildet einen unzweifelhaften Beweis, daßs es bereits im Beginn des 10. Jahrhunderts Manipel in der später allgemein üblichen Streifenform gegeben hat.

Er bekundet aber auch, daßs die Umbildung der Mappula zum Zierstreifen nicht erst damals ihren Anfang genommen haben kann; denn ein so reich verziertes Stück, bei dem sich jede Erinnerung an ein Tuch verloren hat, ist offenbar nicht die erste Phase, sondern das Endresultat eines längeren Prozesses. Wirklich treffen wir bereits im 9. Jahrhundert Bildwerke an, auf denen der Manipel allem Anschein nach Streifenform besitzt. Das erste Beispiel findet sich auf einer der Kopfseiten des Palliotto in S. Ambrogio zu Mailand (vgl. Bild 258, S. 521); ein zweites bietet eine Miniatur in dem Fragment eines aus der zweiten Hälfte des 9. Jahrhunderts stammenden Sakramentars der Pariser Nationalbibliothek ${ }^{2}$, ein drittes die früher schon erwähnte Miniatur in dem Cod. B. 252 der Vallicelliana zu Rom (vgl. Bild 125, S. 267). Auf dem Palliotto gewahren wir den streifenförmigen Manipel bei Diakonen, auf der Pariser Miniatur bei zwei Bischöfen und auf dem Bild der römischen Handschrift beim Subdiakon Juvenianus. Was uns in allen diesen drei Fällen in dem abgebildeten Manipel nicht ein streifenförmig zusammengefaltetes Tuch, sondern einen bloben Streifen sehen heibt, ist nicht die Verzierung der Enden als solche, sondern die Art der Verzierung. Freilich darf man nicht aufer acht lassen, daf den alten Künstlern, namentlich aber den Miniatoren wenig zu trauen ist, sobald es sich um das Detail handelt, bei welchem nur zu oft, um nicht zu sagen in der Regel, die Phantasie die Hand geführt hat. Am wenigsten kann die Miniatur im Kodex der Valli-

\footnotetext{
I Abbildang bei Roh. VII, pl. Dxxxi, wo er aber im Gegenteil zum Text (p. 39) irrig als Stola bezeichnet ist. Vgl, auch
}

Ra ine, Life of St. Cuthbert, Durham 1828, 209.

Ahhildung in Arts sompt. pl. xxirr. 
celliana als zuverlässig gelten. Der Manipel, den die Mönche des Kilosters vom hl. Martin zu Tours auf dem Widmungsbild der Bibel Karls des Kahlen tragen, scheint eher ein zusammengefaltetes Tuch als einen blofen Streifen darzustellen. Die Verzierung an den Enden gibt sich hier wie ein fortlaufender Besatz, nicht wie das Endstück eines Streifens. Außerdem sind auf dem Manipel selbst Falten angedeutet (vgl. Titelbild).

Auf den Bildwerken des 10. und 11. Jahrhunderts erscheint der Manipel regelmäfig als ausgesprochener Zierstreifen. Namentlich gibt er sich als solchen durch die eigenartige Bildung der beiden Enden kund. Statt von oben bis unten die gleiche Breite aufzuweisen, wie das bei einem zu einem Streifen gefalteten Tuche zu erwarten wäre, haben diese nämlich sehr häufig Trapezoder Schaufelform (Bild 259). Thre Verbreiterung: ist bisweilen so beträchtlich, daß sie stark an die Schaufeln der Manipel des späten Barock und des Rokoko erinnern. Hat die Endverzierung aber eine rechteckige oder quadratische Gestalt, so ragt sie sehr gewöhnlich in auffälliger, ja oft geradezu häßlicher Weise seitlich über den Manipelstreifen hinaus. Es unterliegt keinem Zweifel, daf eine derartige Bildung der Endstücke zum Teil auf die Rechnung der Künstlerphantasie und künstlerischer Lizenzen zu setzen ist. Doch ist sie, weil allgemein und konstant, wohl nicht bloß Ausgeburt einer Künstlerlaune. Das eine zeigt sie jedenfalls klar, dafi mit dem Ornatstück ein Wechsel vor sich gegangen war, bei dem die Mappula ihren Tuchcharakter verloren hatte und zu einem Zierstreifen geworden war.

In den Inventaren des 9. und 10. Jahrhunderts spiegelt sich der Umbildungsprozef nur sehr mangelhaft wider. Zwar werden in ihnen nicht selten goldverzierte Mappulae aufgeführt - Beispiele finden sich in der Schenkung Embildas von Milz (ca 800): Fanones auro argentoque parati; dem Inventar von St Bavo zu Gent (860): Manipulos cum auro; dem Verzeichnis der Gaben Madalwins von Passau (903): Cum fanone auro et gemmis parato; dem Testament Riculfs von Elne: manipulos sex cum auro, unum ex is cum tintinnabulis; dem Inventar von Clermont-Ferrand: Fanones

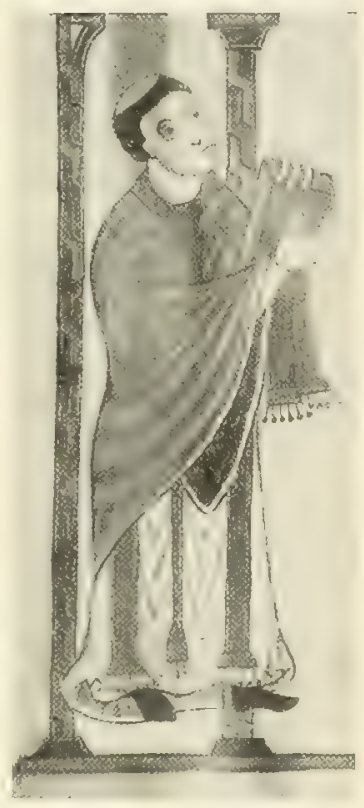

Bild 259. Ausschnitt aus einer Miniatur des Geroevangeliars.

Darmstadt, Giroliherzoslich $\theta$ Bibliothek.

cum auro; dem Inventar von Cremona (984): Stolas aureas egregio opere compertas (sic) integras cum dependentiis suis aureis et manipulis suis u. a. -, allein nirgends ein sicherer Anhalt, ob wir es bei solchen manipuli oder fanones mit einem bloßen Zierstreifen oder mit einem Tuch zu tun haben. Am ehesten könnte in den Angaben des Testaments Riculfs von Elne und dem Inventar von Cremona eine Andeutung gefunden werden, daf sie von einem blofen Streifen reden.

Aber auch im 11. Jahrhundert lassen die Inventare vielfach noch nicht erkennen, ob der Manipel ein Tuch oder einen Streifen darstellte; so das Inventar von Prüm (1003): Manipuli, quos nos phanones vocamus, 20, quorum 12 anro et 6 argento sunt praeparata; das St Gallener Inventar: mappulae 18 cum auro, u. a. Immerhin gibt es einige Schatzverzeichnisse, in denen die darin angeführten goldverzierten Manipel kaum anders mehr als blofe Zierstreifen aufgefaft werden können. Als Beispiele seien genannt das Inventar von Speier (1051): mappulae $V$ ex pallio, quarum una auro texta; das Inventar des Klosters Abdinghof zu Parlerborn (1031): stolae auro textae adiunctis mappularum pertinentiis u. a. Auch die Manipel, 
welche Heinrich II. (stola, manipulus atque cingulum, singula intexta auro) und Benedikt TIII. (1012-1024) dem Kloster Monte Cassino schenkten: stolam unam optimam, auro brustam (goldbestickt) cum manipulo suo, sowie die Manipel, welche von Viktor II. (1054-1057) verpfändet, von Abt Desiderins aber eingelöst worden waren: 9 stolae auro textae cum manipulis suis, waren ohne Zweifel blofe Streifen ?

Über die Verbreitung, welche der streifenförmige Manipel im 9. Jahrhundert besafs, Vermutungen anzustellen, wäre eine müßßgige Sache. Weder die Bildwerke noch die Inventare bieten für solche eine genügende Unterlage. Was den Weg anlangt, auf dem sich die Umbildung des Mappula vollzog, so konnte solches an sich auf doppelte Weise geschehen. Entweder wurde aus der streifenartig zusammengefalteten Mappula direkt ein einfacher Streifen, oder dieser entstand, indem sich ein Zierbesatz, der die zusammengelegte Mappula oben bedeckte, ablöste und nun als Surrogat der letzteren diente. Der erste Weg ist der natürlichste und wahrscheinlichste, zumal es für den zweiten an jedem Analogon in der Geschichte der liturgischen Gewandung fehlt.

Auffallend ist, dafs in einzelnen Inventaren des 9. und 10. Jahrhunderts die Mappula vollständig mangelt. Dürfen wir daraus schlieben, dabi sie sich noch nicht überall eingebürgert hatte? Vielleicht; doch ist es wohl richtiger, in den facitergia (facitercula), welche in solchen Inventaren aufgeführt zu werden pflegen, Mappulae oder Sudarien zu sehen. Namentlich scheint das in dem Inventar von Marchiennes geboten, wo die facitercula in einem Atem mit den stolae, casulae und dalmaticae genannt werden.

Über den Stoff der Manipel liegen aus dem 9. und 10., ja selbst noch dem 11. Jahrhundert so gut wie keine Nachrichten vor. Was wir darüber hören, beschränkt sich fast ganz auf eine Andeutung Amalars, wonach zu seiner Zeit das Sudarium gewöhnlich aus Linnen angefertigt worden zu sein scheint, sowie auf den Vermerk des Inventars von St-Riquier aus dem Beginn des 9. Jahrhunderts: fanones de pallio 10, woraus wir ersehen, daf auch kostbarere Stoffe zu den Mappulae verwendet wurden ${ }^{2}$ (vorausgesetzt, dafs unter den fraglichen fanones wirklich Mappulae zu verstehen sind). Die Verzierung, mit der man bessere Mappulae bedachte, bestand in Fransen und obendrein auch wohl noch in einem schmalen, an den Enden angebrachten Besatz; so wenigstens auf den Bildwerken, die in diesem Punkt im großen und ganzen die Wirklichkeit wiedergeben dürften. Einer der Manipel, welche Riculf von Elne seiner Kathedrale hinterließ, war an Stelle von Fransen mit Glöckchen geschmückt. Die Besätze scheinen, wo sie als Endverzierung zur Anwendung kamen, mit Vorzug aus einer Goldborte gemacht worden zu sein.

Als die Mappula zum bloken Streifen geworden war, entstanden bald Manipel, die ganz in kostbarster Stickerei hergestellt waren. Ein glänzendes Beispiel aus dem beginnenden 10. Jahrhundert ist der bereits erwähnte Manipel im Museum der Kathedrale zu Durham. Ein gutes Beispiel der golddurchwirkten Ziermanipel, von denen die Inventare des 11. Jahrhunderts

1 Chron. Cass, 1. 2, c. 43 ; 1. 3, c. 18 (M. G. SS. VII 656657 711). In der Hinterlassenschaft Viktors JII. befand sich ein fauo imperalis totus aureus (ebd. 1. 3, c. 74 [ebd. 751]).

2 Auch die 10 fanones de pallio auro parati unter den von Angilbert stammenden
Paramenten im ersten Inventar von St-Riquier mögen Mappulae bedeuten. Dagegen sind die fanones de pallio usw. in Inventar von Fontanelle keine solche, da dieses die Mappulae cigens aufführt. Wie es mit den fanones im Inventar von St-Riquier ans dem Jahr 831 sich verhält, ist unklar. 
sprechen, ist ein Manipel, der im Archiv des (jansenistischen) bischöflichen Ordinariats zu Utrecht aufbewahrt und wie die Albe daselbst, deren früher Erwähnung geschah, dem hl. Bernulf zugeschrieben wird. Er hat eine Breite von $0,075 \mathrm{~m}$ und die bedeutende Gesamtlänge - die $0,11 \mathrm{~m}$ langen Fransen an den Enden eingerechnet - von 1,57 m. Eine sich wiederholende Folge von acht verschiedenen Bildern aus dem Leben des Erlösers ziert ihn (Bild 260). Die Szenen, welche zur Darstellung gebracht wurden, sind die Verkündigung, die Geburt, die Anbetung durch die drei Weisen, Christus am Kreuz, die Frauen am Grabe, die Auferstehung, die Himmelfahrt und Christus in der Glorie. Jedes der naiven und kindlich unbeholfenen Bilder ist durch eine Überschrift gekennzeichnet, durch welche es zugleich von dem nächstfolgenden geschieden wird. Der Grund der Szenen ist ein prächtiger, leuchtend roter Purpur; das Bildwerk ist durch eingewebte Goldfäden hergestellt. An den beiden Langseiten des Ornatstückes zieht sich nach Art eines Börtchens eine Einfassung hin, die auf Goldgrund ein doppeltes, in regelmäfigen
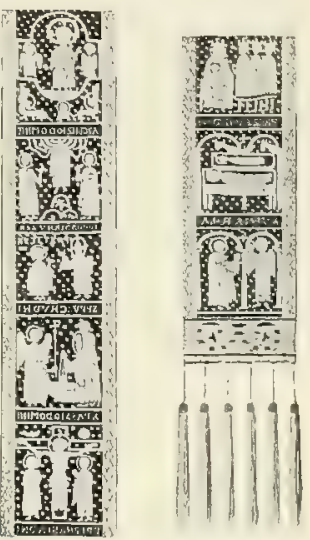

Bild 260. Manipel des hl. Bernulf. Utrecht. Intervallen gebrochenes Zickzackmuster von grüner Farbe aufweist. Die Endstücke sind auf Goldgrund mit einer abwechselnd weifen und grünen Doppelranke geschmückt, die in einem roten Blatt endigt.

\section{DER MANIPEL SEIT DEM XII.JAHRHUNDERT BIS ZUR NEUZEIT.}

Über die Beschaffenheit, Gestalt, Ausstattung und Größenverhältnisse des Manipels machen die Liturgiker des 11. und 12. Jahrhunderts leider keine Angaben. Nur Rupert von Deutz berichtet uns, daß er mit Fransen geschmückt werde. Indessen gibt uns bezüglich des Stoffes, den man im Beginn des 12. Jahrhunderts mit Vorliebe zur Anfertigung des Manipels gebrauchte, eine sehr interessante Notiz im achten Briefe Abälards an Heloise Aufschluf 1. Abälard gibt darin Anweisung, wie das Oratorium im Kloster zum Paraklet einzurichten sei. Es soll darin die äuferste Einfachheit herrschen. Eine Ausnahme dürfen indessen Stola und Fanon machen. Im Gegensatz zu den übrigen Paramenten können sie aus Seide bestehen. Es mufis also damals offenbar der Manipel mit Vorzug aus Seide gemacht worden sein. Ihre Bestätigung erhält diese Folgerung durch das 10. Kapitel der Cistercienserstatuten vom Jahre 1134, wodurch die Verwendung von Seide ebenfalls nur für Stola und Manipel gestattet wird 2 .

Auch Durandus weif uns im folgenden Jahrhundert von der Form usw. des Manipels nichts zu erzählen. Es war ihm genug, das zusammenzuschreiben, was man je über die mystische Bedeutung des Ornatstückes ausgeklügelt hatte.

Über die Gröbenverhältnisse des Manipels in der Zeit des Durandus findet sich eine bemerkenswerte Angabe in den Statuten der Lütticher Synode vom Jahre 1287. Dieselbe bestimmte, es solle das Ornatstiuck so lang sein, dafs es zwei Fuß unter den Arm herunterhange ${ }^{3}$.

Die Bildwerke lassen den Manipel seit dem 12. Jahrhundert stets als einen verhältnismäfig langen, aber gewöhnlich ziemlich schmalen Streifen

M. 178, 281. 2 M. 181, 1727.

${ }^{3}$ C. 5, n. 1 (Hartzh. III 690). Eine gleiche Bestimmung traf noch 1550 eine Synode von Cambrai tit. 8 (ebd. VI 698). 
erscheinen, welcher meist mit geometrischen Gebilden, Ranken- und Laubwerk, seltener, und zwar erst in späterer Zeit, mit figuralen Darstellungen ausgestattet ist. Bis gegen das 14. Jahrhundert ist den beiden Streifen vor wie nach sehr häufig ein besonderes Endstück als Abschluf angefügt. Es hat bis in das 13. Jahrhundert hinein noch immer sehr gewöhnlich die Trapezform, welche uns schon um die Wende des Jahrtausends bei ihm begegnete. Damn aber verliert es dieselbe rasch mehr und mehr, bis sie zuletzt so gut wie rollständig verschwindet. Auf den Bildwerken des 14. und 15. Jahrhunderts gibt sich der Manipel in der Regel als einen überall gleich breiten Streifen. Weniger oft, das er sich auf ihnen von unten nach oben zu verschmälert, aber auch in diesem Falle mangelt fast immer ein besonderer Abschluf. Bei diesem Wechsel, den wir mit der Form des Manipels vor sich gehen sehen, blieb es nach Ausweis der Bildwerke jedoch stets Gewohnheit, den unteren Rand mit Fransen und Quasten oder gar Glöckchen, Äpfelchen, Eichelchen und ähnlichem Zierat aus Silber, vergoldetem Kupfer u. dgl. zu besetzen.

Über die Befestigungswe ise des Manipels erhalten wir aus dem Bildwerk keinen vollen Aufschlulis. Dafs man irgendwie dafür sorgen mukste, dafs

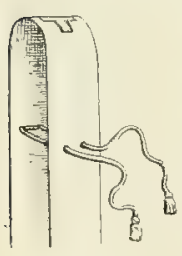

Bild 261.

Ehemalige

Bindevorrich-

tung am

Manipel. er nicht vom Arm heruntergleite, ist begreiflich. Wie verschiedene Darstellungen vermuten lassen, scheint man das bald dadurch erreicht zu haben, daf man ihn mittels eines an der Innenseite angebrachten Bandes am Arm festband, bald dadurch, daf man die beiden Streifen unterhalb des Armes teilweise zusammennähte oder mittels eines Knopfes miteinander verband.

Eine eigenartige Befestigungsvorrichtung erblickt man am Manipel bei der Grabfigur des Domscholasters Konrad Barscher († 1493) im Kreuzgang des Domes zu Augsburg. Es sind in einem Abstand von etwa $0,15 \mathrm{~m}$ von der Mitte an der Innenseite einer der beiden Hälften zwei Schnüre angenäht, welche durch zwei in der andern Hälfte angebrachte Löchlein gezogen und dann zusammengebunden erscheinen (Bild 261). Diese Eimrichtung gewahrt man auch an dem Manipel des Erzbischofs Johann von Metzenhausen († 1540) auf dessen Grabmonument im Dom zu Trier. Ein wirklicher Manipel dieser Art findet sich im Trierer Dommuseum; er gehört zu der sog. Balduinskasel und stammt wie diese aus der zweiten Hälfte des 16 . Jahrhunderts.

Mit Kreuzchen sieht man auf den mittelalterlichen Bildwerken im ganzen nur selten den Manipel ausgestattet. Auf Monumenten des 10. oder gar 9. Jahrhunderts sind uns mit Kreuzen versehene Manipel bisher nicht vorgekommen!. Zu den ältesten Darstellungen, auf denen man solche auf ihm antrifft, gehört ein Fresko der Unterkirche von S. Clemente zu Rom und die Miniatur eines Evangeliars der Kölner Dombibliothek. Dort ist ein Kreuz in der Mitte einer jeden Hälfte des Ornatstückes angebracht, hier ist dieses

1 Der Weiherotnlus der Casanatense zu Rom, auf dessen Miniaturen der Bischof hie und da einen Manipel tragen soll, der mit einem Kreuz versehen ist, stammt nicht aus dem 10. Jahrhundert, wie Langlois, Le rouleau d'Exultet de la Bibliothèque Casanatense, in Mélanges d'archéologie et d'histoire VI, Jahrg. 1886 behauptet, sondern aus dem Beginn des 12. Jil riuht nicht von Jandulf I. von Benevent her, wie Langlois will, sondern, wie aus einer Folge von Hexametern in dem Taufrotulus der Casanatense sich ergibt, von Landulfus alter, Landulf II., her. Auch handelt es sich bei dem angeblichen Manipel allem Anschein nach nur um das Ende des Palliums, das der Bischof hier in der linken Hand hält. Denn auf den Bildern, wo das Pallium fehlt, mangelt auch der Manipel. 
mit einer Reihe von Kreuzen verziert. Im letzteren Fall sind indessen die Kreuze sicher nur ein Werk der Phantasie, weshalb ein Schlufs von ihnen auf die Praxis nicht zulässig ist. Freilich soll keineswegs geleugnet werden, daf man auf dem Manipel auch wohl schon im Mittelalter Kreuze angebracht habe. Einzelne noch erhaltene mittelalterliche Exemplare, von denen noch die Rede sein wird, beweisen das mit aller Bestimmtheit. Nur läfit sich nicht jedes Bildwerk, auf dem ein Manipel mit Kreuzen dargestellt ist, zum Beleg dafür verwenden. Bemerkenswert ist, daf der Manipel selbst auf den römischen Grabmälern gewöhnlich ohne Kreuz ist. Wenigstens fehlen die Kreuze an den unteren Enden. In Mainz erscheinen Kreuze auf dem Manipel der Grabfiguren der Erzbischöfe im Dom erst gegen Ende des 16. Jahrhunderts.

Die Schatzverzeichnisse des späteren Mittelalters pflegen meistens die Manipel nicht näher zu beschreiben. Sie führen nicht einmal immer die Manipel ausdrücklich an. Sehr gewöhnlich begnügt man sich mit der Bemerkung: "Eine Kasel (Dalmatik usw.) mit ihrem Zubehör." Nur die vereinzelt vorhandenen oder kostbaren Manipel werden besonders genannt. Wir erfahren darum aus manchen Inventaren nur äußerst wenig über die Beschaffenheit des Ornatstückes. Immerhin ist jene summarische Erwähnung der Manipel in den Schatzverzeichnissen insofern von Belang, als wir daraus ersehen, dabs sie dem Stoff und der Farbe nach meist von derselben Beschaffenheit wie die Kasel bzw. Dalmatik oder Tunicella gewesen sein werden, wozu sie gehörten. Unumstö6liche Regel war das freilich nicht, wie man überhaupt die mittelalterliche Praxis keineswegs nach dem liturgischen Brauch der Gegenwart bemessen darf. Wie bemerkt, sind es durchweg nur die wertvolleren oder ohne eine Kasel bzw. Dalmatik und Tunicella vorhandenen Manipel, die einzeln aufgeführt und näher beschrieben werden. Aus solchen Notizen erfahren wir dann aber, daf es wie im 10. und 11. Jahrhundert, so auch noch in der Folge manche reich verzierte Manipel gegeben hat, bei welchen man an Perlen, Edelsteinen, Gold oder vergoldetem Silberbleche und kunstvollen Stickereien keineswegs gespart hatte.
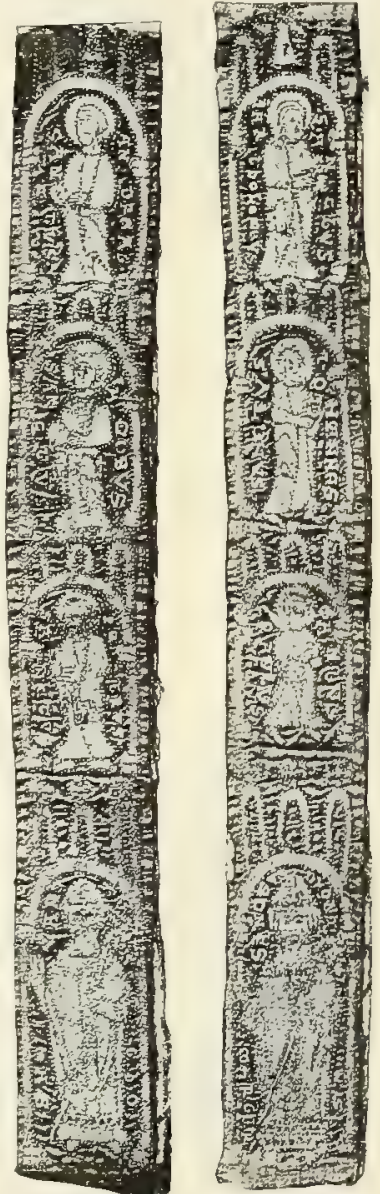

Bild 262. Manipel.

Namur, Convent des Relig. de N.-D.

So vermerkt das Schatzverzeichnis von Salisbury aus dem Jahre 1212 unter andern einen mit Perlen besetzten und vier bestickte Manipel. Das Inventar des Schatzes des Apostolischen Stuhles führt 1295 im ganzen 26 Manipel auf, die zum Teil ungemein kostbar gewesen sein müssen. So heift es z. B. darin: Item stolam et manipulum de opere venetico cum imaginibus habentibus coronam de perlis...; item stolam et manipulum de opere anglicano cum imaginibus de serico diversorum colorum ... ; item stolam et manipulum de serico diversorum colorum ad historiam Passionis...; item stolam et manipulum laboratos ad aurum et sericum rubrum et nigrum cum perlis grossis et minutis et 23 campanulis argenteis deauratis clausis...; item unum manipulum laboratum super cendato indico eum rosetis ad 4 angulos de argento deaurato, in quibus sunt granatelli et turchisii u. a. Einige der Manipel waren, 
wie das auch sonst im Mittelalter nicht selten geschah, aus Borten gemacht; so lesen wir: item unum manipulum de frixio anglicano cum fimbriis sericis...; item unum manipulum de frixio albo de Alamania ad aurum antiquum. Im Schatze von St Peter aber befand sich 1861 neben andern Manipeln mit und ohne Figuren in englischer und venetianischer Arbeit einer cum Salvatore in medio, cum sancto Petro ab una parte et cum sancto Paulo ab alio(a) et cum uno pistillione de argento deaurato (Knöpfchell wohl als Befestigungsvorrichtung). Unter den Paramenten, welche Gottfried ron Loudon, Bischof von Le Mans († 1255), seiner Kathedrale schenkte, begegnen uns ein manipulus rubei coloris cum imaginibus deauratis, ein Hanipel aus weifer Seide von wunderbarer Arbeit, ein manipulus auro intextus cum imaginibus bestiarum et arborum subtiliter intextarum ${ }^{1}$.

Viele andere Beispiele reich verzierter Manipel bieten auch die Inventare von Angers und Cluny, namentlich aber das von St Paul zu London aus dem Jahre 1245.

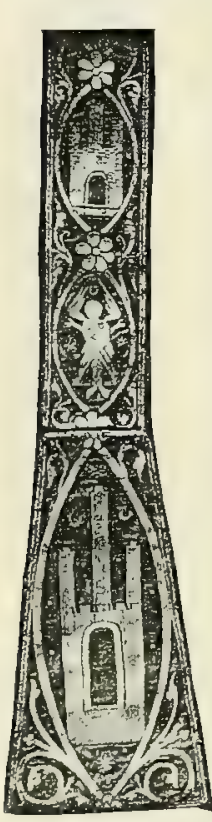

Bild 263. Manipel des hl. Edmund.

Pontigny. (Phot. de Farey.1 Da gab es, um aus der großen Zahl der in ihm aufgeführten Manipel den einen oder andern herauszugreifen, einen, der aus blauem Köper bestand und mit den Bildern der Apostel und der hll. Erkenwald und Edmund bestickt war. Ein anderer wies auf schwarzseidenem Grund Apostel, Propheten und die hll. Nikolaus und Edmund auf. Ein weiterer - er war aus rotem Seidenköper angefertigt - war mit aufgestickten, kreuzförmigen vegetabilischen Gebilden, auf den Endstücken aber mit Engeln geschmückt. Ein Manipel, den ein verstorbener Pönitentiar hinterlassen hatte, war mit Löwen bestickt und mit Edelsteinen besetzt usw.

Die Zahl der Manipel, die sich aus dem 12. und 13. Jahrhundert erhalten haben, ist nicht grof. Dem 12. Jahrhundert gehört vielleicht noch ein Manipel im Schatz der Kathedrale zu Sens und ein anderer in der Kartause Valsainte bei Bulle (Schweiz) an. Jedenfalls stammen beide erst aus dem späten 12. Jahrhundert. Mehr Manipel sind aus dem 13. Jahrhundert auf uns gekommen. $\mathrm{Zu}$ ihnen gehören namentlich die Manipel im Besitz der Schwestern U. L. Frau zu Namur, in St-Donat zu Arlon, zu Provins, zu Pontigny, in den Kathedralen zu Troyes und Bayeux und in dem kgl. Kunstgewerbemuseum zu Berlin. Auch ein Manipel im Schatz der Kathedrale zu Anagni mag noch dem 13. Jahrhundert angehören. Jedenfalls gilt solches von einem der ehemaligen Sammlung Bocks angehörigen Exemplare, das dieser in seiner schichte der liturgischen Gewänder" abgebildet und beschrieben hat. Von zwei wertvollen Manipeln im Schatz des Benediktinerpriorats Andechs dürfte einer, als manipulus S. Gregorii bezeichnet, dem 13. entstammen, der andere, ein manipulus S. Udalrici, aber zum wenigsten ins 12. hinaufreichen.

Der Manipel in der Kathedrale zu Sens ist ein schönes Stück. Er hat eine Gesamtlänge von $1,60 \mathrm{~m}$. Seine trapezartigen Endstücke sind $0,22 \mathrm{~m}$ lang und bestehen aus gemustertem Goldstoff, während die Streifen selbst mit Goldmustern auf farbigem (grünem, violettem oder braunem) Grund verziert sind. Unten schlieken sie mit einem Eisenblechstreifen $a b$, der mit einem ornamentierten Silberplättchen bedeckt und mit einem Behang von silbervergoldeten Glöckchen in Birnenform versehen ist.

Wohl nicht mehr ganz vollständig ist der höchst interessante Nanipel im Schatz der Schwestern U. L. Frau zu Namur. Es fehlen, wie es scheint, die Endstücke. Der Manipel ist aus gelbbrauner, einst wohl roter Seide gemacht und stammt aus der Frühe des 13. Jahrhunderts. Bei einer Breite von $0,08 \mathrm{~m}$ ist or im ganzen $1,19 \mathrm{~m}$ lang und auf jeder Hälfte mit vier Heiligenfiguren (Apostel und der hl. Dionysius), die unter Baldachinen stehen, ausgestattet. Die Heiligen und die Arkaturen sind mittels 
Goldstickerei hergestellt. In der Mitte des Ornatstückes, da, wo es dem Arm auflag: ist ein gleicharmiges Kreuz eingestickt (Bild 262, S. 537).

Aus nur wenig späterer Zeit stammt der Manipel des hl. Edmund, Erzbischofs von Canterbury, zu Pontigny. Selbiger hat eine Länge von 1,32 m und eine Breite von $0,065 \mathrm{~m}$, erweitert sich aber unten bis zu $0,11 \mathrm{~m}$. Der rote Grund ist mit Goldstickereien geziert, welche Cherubim und Schlösser, eingefaft von Laubwerk und geschieden durch Rosetten, darstellen ${ }^{1}$ (Bild 263).

Auch der Manipel zu Provins soll vom hl. Edmund herrühren. Statt mit figürlichen und vegetabilischen Gebilden ist er nur mit geometrischen Mustern in Gold, Gelb und Braun bestickt. Seine Gesamtlänge beträgt $1,66 \mathrm{~m}$. Die Enden sind mit Fransen besetzt ${ }^{1}$.

Der Manipel in der Kathedrale zu Troyes stammt aus der zweiten Hälfte des 13. Jahrhunderts und weist noch immer den trapezförmigen Abschluf auf. Was die Ausstattung, und die stoffliche Beschaffenheit anlangt, bietet er nichts Bemerkenswertes?

Ein kostbares Stück ist der Manipel, den die Kathedrale zu Bayeux besitzt. Er geht unter dem Namen des hl. Regnobert ( $\dagger$ ca 668), ist aber in Wirklichkeit erst im 13. Jahrhundert entstanden. Die Ornamentierung besteht bei ihm in geometrischen Gebilden, Zickzack, Rauten, verkümmerten Mäandern usw. Auf den Streifen wechselt Gold mit Violett, die Endstücke weisen nur Goldgrund auf. Das Ornatstück war und ist zum Teil noch reich mit kleinen Perlen verziert ${ }^{3}$.

Der Manipel im kgl. Kunstgewerbemuseum zu Berlin zeichnet sich durch die vorzüglichen figürlichen Stickereien aus, mit denen er geschmückt ist. Auf den Endstücken, die sich trapezartig erweitern, sind zwei heilige Diakone, auf dem Manipel selbst aber vier heilige Bischöfe dargestellt. Alle befinden sich unter Kleeblattbogen. Getrennt werden die Figuren voneinander durch romanisierendes Rankenwerk, dem ein Kreis mit je einem Evangelistensymbol eingeschaltet ist. Die Mitte nimmt ein Bild des Gotteslammes ein. Der Fond des Manipels besteht aus grüner Taftseide; die ungemein zarten und edeln Stickereien, welche eine wirkliche Künstlerhand verraten, sind mit Ausnahme von Gesicht, Händen, Haar und Blumen in Gold ausgeführt, wobei die Abheftfäden so tief in den Stoff eingezogen sind, dafs sie für das Auge verschwinden. An den Enden waren seidene Kordonnetfransen angebracht, die sich indessen nur mehr an einem derselben erhalten haben. Der Manipel stammt aus Brauweiler und

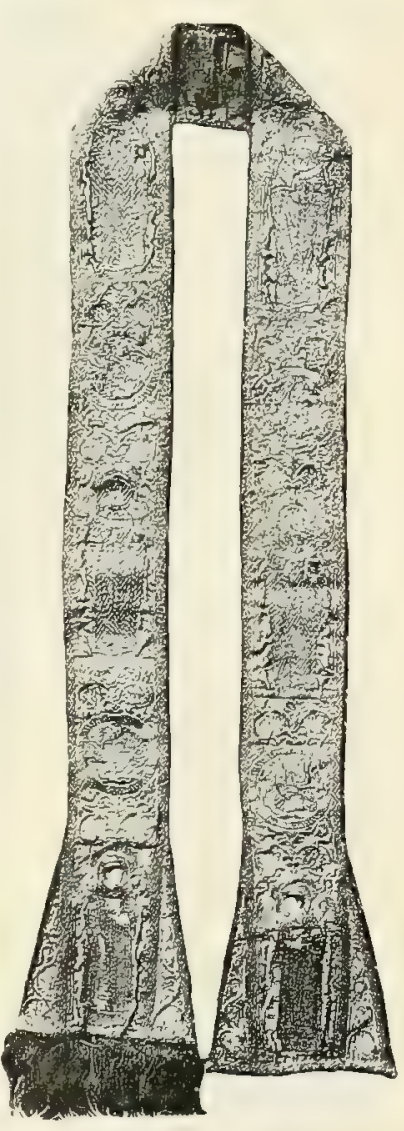

Bild 264. Manipel.

13erlin, Kunstgewerbemusetm. ist, wie die Art der Besätze auf der Dalmatik der Diakone beweist, italienischen Ursprunges. Er ist $1,36 \mathrm{~m}$ lang, $0,07 \mathrm{~m}$ breit und erweitert sich an den Enden auf $0,13 \mathrm{~m}$. Künstlerisch ist er unzweifelhaft der bedeutendste Manipel, der sich aus dem 13. Jahrhundert erhalten hat (Bild 264).

Der Manipel in St-Donat zu Arlon ist aus einer kräftigen, aus starkem Linnengarn in Köperbindung gewebten Borte gemacht, die auf blau und braunrot gestreiftem Grund allerlei weißlichgelbe Tiergestalten (zum Teil von bizarrster Bildung) untermischt mit stilisierten Lilien und geometrischen Motiven aufweist. In der Hitte ist

Roh. VII 43.

2 Abbildung beiViollet-le-Duc, Dictionn. raison. du mobilier franç. IV, pl. XIV.
${ }^{3}$ De Farcy, La chasuble de St Regnobert, Caen 1881, und Roh. VII 43. Eine Abbildung der gleichartigen Stola pl. Dxxxv. 
das Lamm Gottes angebracht. Die Endstücke sind ursprünglich, aber später neu mit Seide üherzogen worden (Bild 265). Der Manipel hat bei einer Breite von nur $0,04 \mathrm{~m}$ eine Gesamtlänge von $1,28 \mathrm{~m}$; die Enden sind $0,125 \mathrm{~m}$ lang und oben $0,04 \mathrm{~m}$, unten aber $0,09 \mathrm{~m}$ breit.

Der Manipel der Bockschen Sammlung, jetzt im Kensington-Museum, wird von seinem einstigen Besitzer folgendermaßen beschrieben: „Der Manipel hat eine gröste Länge von $1,68 \mathrm{~m}$ bei einer Breite von nur $0,075 \mathrm{~m}$. Seine Fußsteile sind $0,105 \mathrm{~m}$ lang und aus reinem roten Seidenstoff mit einer kleinen Erweiterung auf

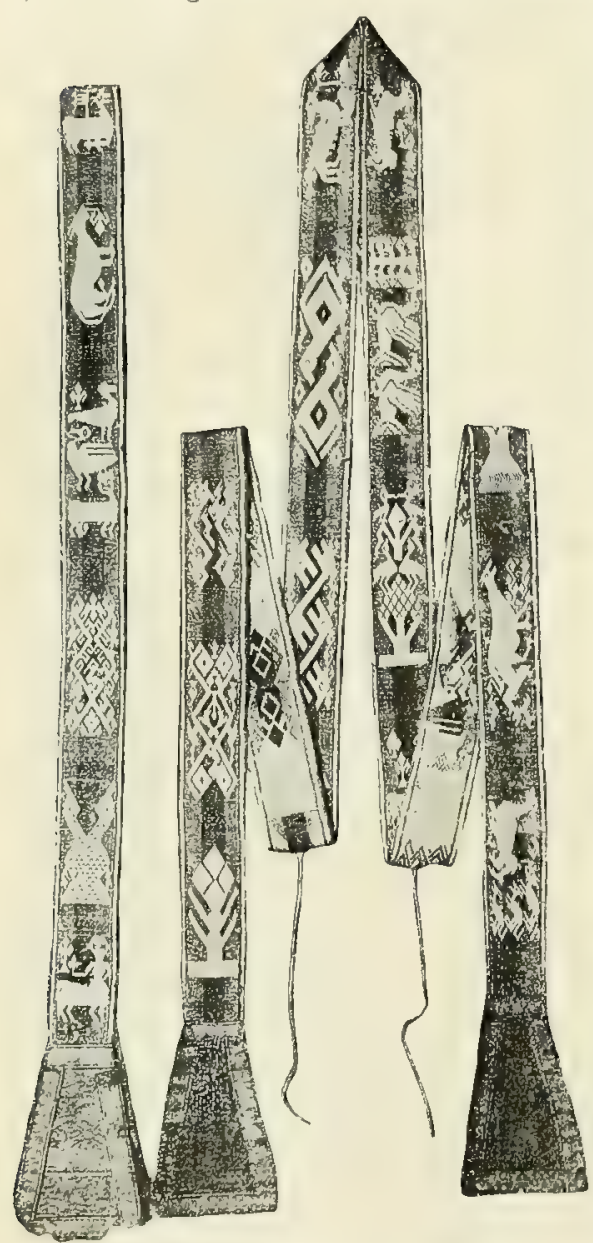

Bild 265. Manipel und Stola. Arlon, st-Donat. beiden Seiten so angesetzt, daß auf der Unterlage von gemustertem Seidenstoff eine quadratisch in Kreuzform gehaltene Perlstickerei einen reichen Abschluß gewährt. Außerdem sind als fimbriae fünf längere Seidenquasten angenäht, welche oben eine zierliche Knotenverschlingung erkennen lassen.... In der mittleren Füllung des Manipels sind kleine Tierunholde und Pflanzenornamente mit der fleur de lis eingewebt. ... In den beiden Rändern des in Gold gewirkten Manipels sind in grüner und violetter Farbe romanische Versalien angebracht, die folgende Lesung ergeben: 0 spes divina, via tuta, potens medicina, porrige subsidium miseris, o sancta Maria. Protege, salva, benedic, sanctifica famulum tuum Alebertum crucis per signaculum. Corr(ige) consortem sanctae sortis patrone (?) ministrum, effice Corneli meritis prece regna mereri. Morbos averte corporis et animae, hoc contra signum nullum stet periculum. 0 coeli porta, nova spes mor(talium). 0 clemens domina, spes desperantibus una." 1

Der manipulus S. Udalrici zu Andechs ist $1,15 \mathrm{~m}$ lang und fast $0.05 \mathrm{~m}$ breit. An den Enden ist er mit $0,05 \mathrm{~m}$ langen seidenen Fransen versehen. Die in weiker Seide auf gelblichem Grund hergestellte Musterung besteht aus paarweise nebeneinandergestellten kleinen Kreisen, welche Tiergestalten umschließen. Die Zwickel zwischen den Kreisen werden durch vegetabilische Motive ausgefüllt. Den seitlichen Abschluf bildet ein schmaler Längsstreifen von grüner Farbe. Der andere Manipel ist $1,11 \mathrm{~m}$ lang und $0,05 \mathrm{~m}$ breit. Auch er trägt an den Enden Fransen von $0,05 \mathrm{~m}$ Länge. Das ihm eingewehte Dessin setzt sich aus über Eck gestellten Quadraten zusammen, welche Hakenmuster enthalten und in ihren Farben nach Zonen wechseln?

Der Manipel im Kartäuserkloster Valsainte stellt eine schwere Seidenborte von weiker Farbe dar und ist an den Enden mit einem rechteckigen. aus einer Goldborte genachten Endstück geschmückt, das mit weilien Fransen abschliefit. Er ist $0,05 t$ m

\footnotetext{
1 Bock JI 80 und TH xviri.

2 Aucl die stola st Nicolai zu Andeclss dürfte wohl nur einen Manipel darstellen, da ihre Gesantlänge blof $1,31 \mathrm{~m}$ beträgt. Sie setat sich aus einem illteren Stiuck, einer mit
}

kleinen Quadraten gemusterten Borte von $0,805 \mathrm{~m}$ Länge, und einem isabellenbraunen, ungemusterten Seidenstreifen von $0,505 \mathrm{~m}$ luainge zusammen und ist an den Enden mit $5 \mathrm{~cm}$ langen Fransen verziert. 
breit und 1,56 m lang. Als Muster, mit dem er verziert ist, weist er kleine Rauten auf, deren Umfassung und Kern mit perlförmigen Punkten gefüllt sind ${ }^{1}$.

Der Manipel im Schatz der Kathedrale von Anagni aus dem Ende des 13. Jahrhunderts besteht aus einer mit geometrischen Gebilden (Rauten) belebten Goldtresse, welche überall die gleiche Breite von ca $0,06 \mathrm{~m}$ hat.

Von Manipeln ans dem 14. Jahrhundert verzeichnen wir nur zwei. Der eine befindet sich im Dom zu Xanten, der andere in St Andreas zu Köln. Der letztgenannte ist aus blanem Samt hergestellt und ist mit einer Folge von sechs ca 0,10 bis $0,11 \mathrm{~m}$ hohen freistehenden Heiligenfigürchen bestickt, welche die hl. Ursula, die hl. Katharina und andere weibliche Heilige wiedergeben. Getrennt sind die einzelnen Bildchen durch fünf Kleeblätter. Die Länge des Manipels beträgt ca $1,00 \mathrm{~m}$, seine Breite $0,065 \mathrm{~m}$. Er ist überall gleichbreit und an den Enden mit rotseidenen Fransen besetzt?

Der Xantener Manipel ist aus roter Seide angefertigt und in Stickerei mit acht miniaturartig feinen Passionsgrüppehen von vorzüglicher Ausführung und trefflicher Zeichnung geschmückt. Es sind der Verrat, die Verspottung, die Geifelung, die Kreuztragung, die Kreuzigung, die Abnahme, das Begräbnis und die Auferstehung. Jede Szene ist von einer luftigen Arkatur überdacht. Der Manipel, bei dem gegenwärtig in der Mitte ein Stückchen fehlt, ist $1,02 \mathrm{~m}$ lang und 0,075 breit und stellt ebenfalls ein 'Band von gleichbleibender Breite dar.

Aus dem 15. Jahrhundert haben sich manche Vanipel erhalten, doch ist uns keiner von hervorragenderem Wert bekannt geworden. Sie sind allesamt sehr einfach und haben meist keine andere Verzierung als die Fransen, mit denen ihre Enden besetzi sind. Einzelne sind aus gewebten Borten gemacht, gewöhnlich aber bestehen sie aus dem Stoff der Kasel, zu der sie gehörten. Thre Breite geht selten unter 0,06 bis $0,07 \mathrm{~m}$ herab, ihre Länge beträgt durchweg ca $1 \mathrm{~m}$. Dabei haben sie regelmäßig von oben bis unten gleiche Breite ${ }^{3}$ (Bild 266). Die meisten Manipel aus dem 15. Jahrhundert finden sich in dem Dom zu Halberstadt und in St Marien zu Danzig. Zu Halberstadt gibt es ihrer an die zwanzig Stück, zu Danzig aber wenigstens doppelt so viel. Wer die Manipel des ausgehenden Mittelalters studieren will, darf darum

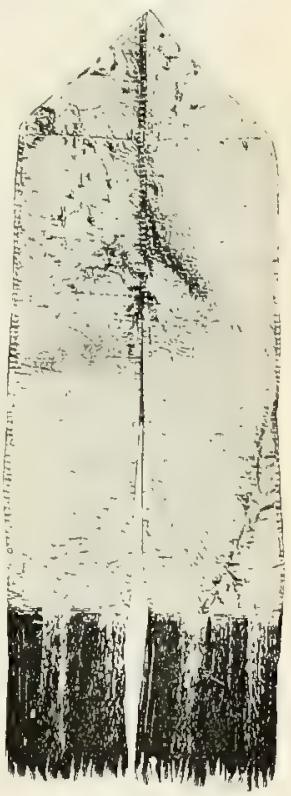

Bild 266. Manipel. Danzig, Marienkirche. nicht unterlassen, den Dom zu Halberstadt und die Narienkirche zu Danzig aufzusuchen. Dafs aber Form und Beschaffenheit, welche die Manipel hier aufweisen, nicht etwas rein Nordisches waren, sondern dem allgemeinen Brauch der Zeit entsprachen, beweisen nicht nur die anderswo vorkommenden spätmittelalterlichen Manipel, von denen einer in der Opera del Duomo zu Siena hier ausdrücklich erwähnt werden soll, weil er vom hl. Bernardin von Siena gebraucht wurde", sondern auch ein Vergleich mit den Darstellungen des Manipels auf den Monumenten des 15. Jahrhunderts.

\section{DER MANIPEL IN DER NEUZEIT.}

Um das Ende des Mittelalters begann in gewissem Sinne eine Rückwärtsbewegung in der Entwicklung des Manipels. Studiert man die römischen

1 Eine allerdings mangelhafte Abbildung in Revue 1905, 409.

2 Abbildung bei Bock II, Tfl 34.

3 Es muf darauf aufmerksam gemacht werden, daß nicht alle Manipel, die aus einem Stoff des 14. oder des 15. Jahrhunderts bestehen, wie man deren hie und da gelegentlich antrifft, auch wirklich dem 14. oder 15. Jahrhundert entstammen. Bisweilen sind sie in späterer Zeit aus älteren, von Kaseln oder Chorkappen herrührenden Zeugen gemacht. In solchen Fällen ist die Form in der Regel entscheidend. Verbreitern sich derartige Manipel am Ende schaufelartig, so darf unbedenklich trotz des älteren Stoffes anf spätere Entstehung geschlossen werden.

4 Der Manipel ist an den Enden mit einem Kreuzchen bestickt und mit Eransen besetzt; eine sonstige Verzierung fehlt. 
Grabmäler aus dem Ende des 15. Jahrhunderts, so gewahrt man, wie er auf denselben fast ausnahmslos die Form eines überall gleichweiten Streifens von mäbiger Breite hat. Wo man auf ihnen beim Manipel eine Erweiterung des

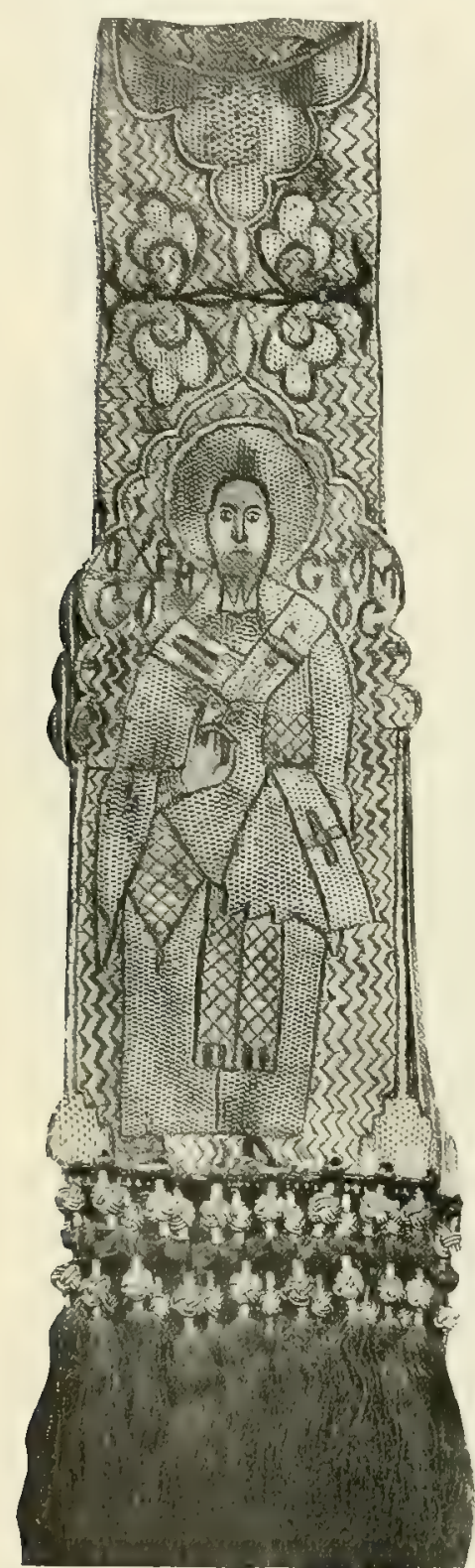

Bild 267. Manipel in Goldstickerei. (Slavische Arbeit des 16.-17. Jahrh.) Aachen, Münster. unteren Endes antrifft, ist diese noch so geringfügig, das sie sich kaum bemerkbar macht. Betrachtet man dagegen die Manipel, welche zu den vom hl. Karl Borromäus und vom hl. Pius V. herrührenden Ornaten in S. Maria Maggiore gehören, so fällt alsbald die Änderung in der Form auf, die seit dem Beginn des 16. Jahrhunderts mit dem Ornatstück vor sich gegangen war. Der Manipel ist nicht blok breiter geworden, er hat sich insbesondere auch an den Enden beträchtlich erweitert.

Dieser Wechsel in der Form des Manipels blieb aber nicht einzig auf Rom beschränkt; wir sehen ihn zur gleichen Zeit sich allenthalben vollziehen (Bild 267). Wer sich die Mühe gibt, die Bildwerke aus dem 16. Jahrhundert auf die Umbildung des Manipels hin zu untersuchen, oder einen Vergleich anstellt zwischen den Manipeln, die sich aus der Wende des 15. erhalten haben, und jenen, die dem späten 16 . entstammen, wird sich wundern, wie rasch und wie allgemein der Wandel in der Form des Ornatstückes damals vor sich ging. Schon um das letzte Viertel des 16. Jahrhunderts war es nahezu allgemeine Sitte, den Manipel an den Enden weiter werden zu lassen. Es war daher nur der Ausdruck einer bereits bestehenden Gepflogenheit, wenn der hl. Karl und im Anschlufs an ihn 1605 die Synode von Prag ${ }^{1}$ solches ausdrücklich vorschrieben.

Das ausgehende 17. und das im Bann des Rokoko stehende 18. Jahrhundert schufen die häflichen sog. Schaufel- oder Taschenmanipel. Dieselben entstanden dadurch, daf man die Enden des Ornatstückes bis auf $0,20 \mathrm{~m}$ und selbst mehr erbreiterte, seinen mittleren Teil dagegen, soweit es nur eben anging, verkürzte und verschmälerte. Die Taschenmanipel waren die äußerste Entartung der alten Mappula. Von einem eigentlichen Streifen konnte bei ihnen kaum mehr die Rede sein; sie stellten vielmehr zwei Lappen dar, welche durch ein kurzes, schmales Zeugstück miteinander verbunden waren. Was die Ausstattung anlangt, waren diese Manipel allerdings bisweilen sehr reich und kostbar; nur war ihre in breiten Goldhorten und schweren Gold- 
stickereien bestehende Verzierung gewöhnlich kaum minder geschmacklos als ihre Gestalt. Es muf jedoch betont werden, dafs es vor allem Frankreich und im Gefolge Frankreichs Deutschland und Spanien waren, wo die unschönen Schaufelmanipel zur Herrschaft kamen. In Italien hat das Ornatstück stets eine würdige Form bewahrt. Wohl wurden auch hier die Enden breit genug, allein man verbreiterte den Manipel nicht blof an den Enden, sondern überhaupt, so dał wenigstens ein erträgliches Verhältnis zwischen den Endstücken und dem mittleren Teil gewahrt blieb (vgl. Bild 11, S. 43). Die neueste Zeit hat wenigstens in Deutschland die Schaufelform der Manipel beseitigt, indem sie zur Form des 13., 14. und 15. Jahrhunderts zurïckkehrte oder doch das Endstuick auf ein besseres, weil geringeres Maßs beschränkte.

Im übrigen bietet die Geschichte des Manipels in der Neuzeit kaum etwas Bemerkenswertes. Das einzige, was etwa noch angemerkt zu werden verdient, ist, dafi es seit dem 16. Jahrhundert Regel wurde, das Ornatstück mit den gegenwärtig allgemein üblichen drei Kreuzen zu versehen. Wie schon früher bemerkt wurde, genügt ein Kreuz den Rubriken des römischen Missale. Daher beschränkt sich z. B. auch die Synode von Brixen vom Jahre 160.3 , vorzuschreiben, es solle e in Kreuz auf dem Manipel angebracht werden ${ }^{1}$. Drei Kreuze fordert dagegen der hl. Karl und nach seinem Vorgang die eben erwähnte Synode von Prag: Habent tres cruces annexas, unam scilicet in medio et alias duas in partibus extremis. Behufs Befestigung des Manipels will die Prager Synode Bänder mit Quästchen inwendig an demselben angebracht sehen.

\section{TRAGWEISE DES MANIPELS.}

Der 1. Ordo gibt nicht an, wie der Papst die Mappula zu tragen pflegte, sondern begnügt sich blof mit der Bemerkung: Subdiaconus porrigit ei mappulam. Der etwas spätere 3. Ordo weist den Subdiakon an, die Mappula auf den linken Arm des Papstes über die Kasel zu legen; dagegen hatten nach dem St Gallener Kleiderverzeichnis der Papst, die Bischöfe, die Priester und Subdiakone die sestace in manu sinistra. Ebenso heift es im 6. Ordo, der um den Ausgang des ersten Jahrtausends entstand, aber noch im 11. Jahrhundert in Gebrauch war, bezüglich der Mappula der Subdiakone ausdrücklich: Mappulae in manu ferendae. Auch nach Hraban und Amalar wurde die Mappula in der Hand getragen. Manibus eorum (sc. sacerdotum) mappula tenetur, sagt Hraban; Amalar aber schreibt genauer: In manu sinistra portatur.

Die Bildwerke des 9. Jahrhunderts zeigen uns die Mappula meist in der Hand ihres Trägers. Auf dem Arm gewahren wir sie bei einem der Kanoniker von St Martin zu Tours auf dem Widmungsbild der Bibel Karls des Kahlen (vgl. Titelbild) und bei den Diakonen auf einer der Kopfseiten des Palliotto in S. Ambrogio (vgl. Bild 258, S. 251). Offenbar gab es im 9. Jahrhundert noch keine völlig einheitliche und konstante Praxis in der Art, wie man die Mappula trug, auch wenn man den Bildwerken in dieser Sache keine besondere Bedeutung beimessen will. Der Regel nach scheint man sie allerdings in der Hand gehalten zu haben; doch lief man sie ohne Zweifel, wenn das durch die Umstände als zweckmälíg gefordert wurde oder gerade am bequemsten war, auch auf dem Arm ruhen.

1 Cap. de Eccl. n. 16 (ebd. 565). 
Wie lange der Brauch in Kraft blieb, die Mappula in der Hand zu tragen, lälist sich nicht mit Genauigkeit feststellen. Der 6. Ordo Mabillons kennt ihn noch, wie wir eben sahen; er wird sich also verschiedenenorts bis in das 11. Jahrhundert erhalten haben. Aber auch auf bildlichen Darstellungen haben noch im 11. Jahrhundert wiederholt Bischöfe (Priester) und Diakone den Manipel in der Hand; so auf zwei Federzeichnungen des Pontifikale von Aletis in der Stadtbibliothek von Rouen, von denen die eine eine Kirchweihe, die andere einen Bischof mit seinem Diakon wiedergibt, auf einer Miniatur der Enzyklopädie des Hraban in der Bibliothek ron Monte Cassino (Bischof inmitten seiner Kleriker), anf dem Bild des hl. Willibald im Gundekar-Pontifikale und sonst. Auf andern Bildwerken findet sich der Manipel zugleich das eine Mal in der Hand, das andere Mal auf dem Arm; so auf einem Fresko der Unterkirche von S. Clemente, auf dem St Klemens den Manipel in der Hand hält, während die Diakone ihn am Arm tragen. Im ganzen sind übrigens Darstellungen aus dem 11. Jahrhundert, auf denen wir den Manipel noch in der Hand der Geistlichen sehen, schon selten, im 12. kommen solche kaum mehr vor. Insbesondere erscheint auf den infolge ihrer sorgfältigen Ausführung so wichtigen Bischofssiegeln dieser Zeit der Manipel fast ausnahmslos auf dem Arm seines Trägers, und zwar bald über oder doch nahe dem Handgelenk, bald mitten auf dem Unterarm. Unter den Liturgikern des 12. Jahrhunderts sind es nur Bruno von Segni $(\dagger 1123)$ und Ivo von Chartres $(\dagger 1117)^{1}$, welche angeben, es werde das Ornatstück in der Hand gehalten. Bei Ivo ist das von wenig Bedeutung, da seine Worte eine blobe Wiederholung der gleichartigen Äuferung Amalars zu sein scheinen. Anders verhält es sich jedoch mit dem nüchternen und selbständigen Bruno von Segni. Wenn dieser zweimal versichert, der Manipel werde in der Hand getragen, so darf das immerhin als Beweis gelten, daf sich zu seiner Zeit, d. i. im Beginn des 12. Jahrhunderts, wirklich noch keine allgemein gültige und einheitliche Praxis herausgebildet hatte. Auffallend ist, dab auch noch Innozenz III. ausdrücklich sagt, es werde der Manipel in der Hand gehalten, einmal weil von Rupert von Deutz an alle andern Liturgiker des 12. Jahrhunderts uns versichern, der Manipel werde auf den linken Arm gelegt, dann weil wir auch zu Rom den Manipel auf den Bildwerken bereits in der ersten Hälfte des 12. Jahrhunderts auf dem linken Arm erblicken. Man vergleiche z. B. Papst Julius I. auf dem Apsismosaik in S. Maria in 'Trastevere, einem Werk Innozenz' II. (1130-1143). Indessen sind die Worte Innozenz' III.: In sinistra manu quaedam apponitur mappula, quae manipulus vel sudarium appellatur ${ }^{2}$, unzweifelhaft nichts als eine bloße Anleihe aus Amalar und Ivo. Auf keinen Fall darf man aus der Bemerkung des Durandus: In sinistra manu ponitur quaedam mappula, quae fanon vel manipulus vel sudarium appellatur, schliefien, es sei der Brauch, den Manipel in der Hand zu halten, selbst noch in der letzten Hälfte des 13. Tahrhunderts in Kraft gewesen. Des Durandus Frörterungen über den Manipel geben kein Bild von der damaligen Gepflogenheit, sie sind nur systemund gedankenlos zusammengestellte Exzerpte aus den Schriften früherer Liturgiker und als solche von hohem Wert, aber kein Spicgel ihrer Zeit. Bald hören wir darum auch von ihm, man habe den Manjpel in der linken Hand, bald, er befinde sich auf dem linken Arm.

1 Es ist wohl ein Versehen, wenn im
${ }_{n}$ Katholik ${ }^{*} 1900,257$ Bruno und Ivo als
Zeugen dafür angefuhit werden, daß der

Manipel am Arm getragen wurde. Das Gegenteil ist richtig.

2 De sacro alt. myst. 1. 1, c. 59 (M. 217, 796). 
Nach dem St Gallener Katalog wurde der Manipel in der linken Hand getragen. Nur der Diakon hielt sein Brachiale in der rechten. Auch bei Amalar heifit es, wie wir hörten: In sinistra manu portatur, während PseudoAlkuin allgemeiner sagt: Mappula sinistra parte gestatur. Das Gewöhnliche wird also gewesen sein, dafi man die Mappula, wie auch am bequemsten, in der linken Hand bzw. auf dem linken Arm hatte. Wirklich erscheint sie auf den Bildwerken des 9., 10. und 11. Jahrhunderts fast immer entweder in der linken Hand oder auf dem linken Arm. Auf dem rechten Arm gewahren wir sie z. B. bei einem der Kanoniker von St Martin auf dem Widmungsbild der Bibel Karls des Kahlen und den Diakonen auf dem eben erwähnten Fresko in der Unterkirche von S. Clemente zu Rom, in der rechten Hand auf einer Miniatur des Tropars von Prüm in der Pariser Nationalbibliothek (vgl. Bild 121, S. 262). Möglich, daf diese und ähnliche Bildwerke, die jedoch keineswegs häufig sind, wirklich die bestehende Praxis widerspiegeln; wahrscheinlicher ist indessen, daf es sich in den Fällen, in welchen wir die Mappula in der rechten Hand bzw. auf dem rechten Arm antreffen, nur um eine auf die Rechnung des Künstlers zu setzende Erscheinung handelt. Das kann z. B. kaum einem /wweifel unterliegen bei dem Widmungsbild der Bibel Karls des Kahlen, auf dem in bunter Mannigfaltigkeit der Manipel sich bei drei Kanonikern in der rechten Hand, bei vier in der linken Hand und bei einem am rechten Arm befindet. Noch klarer aber liegt es wo möglich auf einem Elfonbeindiptychon im Schatz der Kathedrale von Tournai zu 'Tage, das allem Anschein nach aus der Frühe des 11. Jahrhunderts herrührt ${ }^{1}$. Wenn wir hier nämlich von zwei einander gegenüberstehenden Diakonen den einen mit dem Manipel in der Linken, sein Gegenüber aber mit dem Manipel in der Rechten schauen, so hat das offenbar nur in der symmetrischen Behandlungsweise der Darstellung seinen Grund.

Die römischen Akolythen, welche sich der sectace bedienten, hatten dieselbe nach dem St Gallener Katalog am Gürtel befestigt.

Die Gewohnheit, den Manipel am Arm zu tragen, wie sie im 12. Jahrhundert allgemein geworden, blieb auch für alle Folgezeit in Kraft. Nur erhob sich in der Neuzeit die Streitfrage, wo derselbe am Arm zu tragen sei, ob am (Ober- oder am Unterarm². Nach dem 1t. Ordo soll der Subdiakon ihn in ipsa plicatura sinistri brachii (pontificis) legen und gleichsam verbergen ${ }^{3}$. Eine maßgebende Entscheidung ist in dieser Frage nicht erfolgt: das römische Missale und Caeremoniale der Bischöfe begnügen sich damit, zu sagen, er solle dem linken Arm aufgelegt werden.

\section{VERWENDUNG DES MANIPELS.}

Im römischen Brauch erscheint der Manipel als ein Ornatstück, dessen man sich nur bei der Feier der heiligen Messe bediente, auferhalb Roms trug man ihn jedoch hie und da, zumal in älterer Zeit, auch bei sonstigen Funktionen. So schreiben z. B. die Statuten von Citeaux den Gebrauch des Manipels bei Erteilung der heiligen Ölung vor ${ }^{ \pm}$. Übrigens finden sich be-

1 Eine vorzügliche Wiedergabe des Diptychon bei Molinier, Les ivoires pl, xiv.

2 Gav. zu Ritus celebr, tit. 1, n. 3; I, ed. Venet. 1823, 173.

${ }^{3}$ C. 53 (M. 78, 1158).

${ }^{4}$ C. 94 (M. 166, 1471). Vgl. auch M art. Braun, Die liturgische Gewandung.
1. 1 , c. 7 , art. 4 , ordo 1 ; I, 301 (Auszug aus dem Pontifikale von Aletis): (Ad iniungendum infirmum) induat se superhumerali, alba et stola cum phanone atque planeta, si affuerit; ferner La fran i Decreta pro ordine S. Benedicti c. 23 (M. 150, 508). 
züglich seiner Verwendung bei andern liturgischen Handlungen als dem heiligen Opfer, abgesehen ron dem, was Lanfrank, Rupert u. a. über die Benutzung des Manipels beim Chordienste der Festtage sagen, nur wenige Angaben. Auf den Monumenten fehlt er noch selbst in späterer Zeit nicht selten bei der Darstellung der Messe, also da, wo man ihn vor allem erwarten sollte; dagegen begegnet er uns auf ihmen sehr häufig mit den übrigen liturgischen Gewändern lediglich zum Ausdruck des sakralen Charakters der Person, die ihn trägt. Auch gewahrt man ihn wohl bei der bildlichen Wiedergabe von liturgischen Handlungen, bei denen man ihn jetzt nicht trägt, z. B. bei der einer Kirchweihe1. Nach der heutigen Praxis wird, wie früher ausgeführt wurde, der Manipel nur bei der heiligen Messe oder bei Funktionen, die mit dem heiligen Opfer in Verbindung stehen, getragen. Zum Pluviale bedient man sich nie des Manipels, wie gleichfalls schon gesagt wurde. Man hat diese seine ausschliekliche Verwendung beim heiligen Opfer mit mystischen Gründen, namentlich mit einem Hinweis auf die symbolische Bedeutung des Manipels, $\mathrm{zu}$ erklären gesucht. Der wahre Grund liegt aber wohl darin, dalis nach dem ursprünglichen römischen Gebrauch die alte Mappula nur da gebraucht wurde, wo die Geistlichen in ihrer ganzen liturgischen Amtstracht erschienen, d. i. bei der Mesfeier, ähnlich wie die Pontifikalschuhe und später die Pontifikalhandschuhe. Die Erinnerung hieran hat sich in der Folgezeit, auch als das Ornatstück zum Zierstreifen geworden war, dadurch erhalten, daß seine Verwendung vor wie nach auf die Messe beschränkt blieb.

Nach der jetzigen Gewohnheit legen die Priester den Manipel an, nachdem sie die Albe mit dem Cingulum gegürtet haben. Diakon und Subdiakon nehmen ihn, wenigstens bei Pontitikalämtern, nachdem sie sich mit der Dalmatik bzw. der Tunicella bekleidet haben. Der Bisch of versieht sich mit ihm erst, wenn er am Altare das Confiteor gebetet hat; nur in Totenmessen legt auch er, wie die Priester, den Manipel vor der Stola an. Auch diese Praxis hat ihre Geschichte.

Nach dem 1., 2. und 3. Ordo gab der Regionarsubdiakon dem Pontifex die Mappula, wenn dieser die übrigen liturgischen Kleider bereits angezogen hatte und die für die Feier des Gottesdienstes nötigen Anordnungen und Maßnahmen getroffen waren. Die Überreichung der Mappula, des letzten Gewandstückes, wurde so für den Celebrans das Zeichen. daß er den Wink zum Anfang der Liturgie geben könne.

Die in den genannten Ordines mitgeteilte Gepflogenheit erhielt sich in Rom bis zum 13. Jahrhundert; dann aber bildete sich dort die Sitte aus, den Manipel nicht in der Sakristei, sondern erst am Altar nach dem Confiteor anzulegen. Sicard und Innozenz III. kennen sie noch nicht; aus ihren Erörterungen geht viehmehr mit Bestimmtheit hervor, daß der Bischof das Ornatstück damals noch annahm, ehe er in die Kirche zog ${ }^{2}$. Zu den Zeiten des Durandus bestand aber schon die Sitte. Wir werden demnach ihre Entstehung in die erste Hälfte des 13. Jahrhunderts zu setzen haben. Eingehend beschreibt den Gebrauch der 14. Ordo, demzufolge übrigens der Manipel nur dann erst nach dem Confiteor angelegt wurcle, wenn der Celebrans sich nicht in der Nähe des Altars angekleidet hatte. Tat dieser das beim Altar, so nahm er ihn gleich nach der Kasel bzw. dem Pallium ${ }^{3}$.

Auch anferhalb Roms war es zu Durandus' "Zeiten schon an verschiedenen Orten Gebrauch, daf der Bisch of sich mit dem Vanipel erst nach dem Confiteor ver-

\footnotetext{
1 So im I'ontifikale von Aletis in der Stadtbibliothek zu Pouen.

2 Mitralis 1. 2, c. 8 (M. 213, 89); De sacrif. missae 1.2, c. 1 (M. 217, 801).

3 Ordo 14, c. 53 (M. 78, 1158 1159).
}

\footnotetext{
4 Rationale 1. 4, c. 7, f. 103 . Vgl. anch den Auszug aus dem Pontifikale des Bischofs von Mende bei M a rt. 1. 1, c. 4, art. 12 , ordo 23; I 221: Quidam tamen cum confessio coram altari fit, manipulum imponunt.
} 
sah. Indessen scheint, manchen handschriftlichen Pontifikalien nach zu urteilen, die Sitte, ihn mit den übrigen Gewändern bereits vor dem Hingang zum Altar anzulegen, sich vielenorts noch bis gegen das Ende des Mittelalters in Kraft erhalten zu haben.

Einen eigentümlichen Mittelweg fanden wir in einem Pontifikale der Vaticana aus dem 15. Jahrhundert vermerkt ". Es soll der Bischof den Manipel nach dem Cingulum annehmen, vor dem Hintritt zum Altar aber wieder ausziehen und dann nach dem Confiteor von neuem anlegen. Durch das römische Nissale und Caeremoniale der Bischofe wurde die römische Praxis allmählich allgemein zur Geltung gebracht. Der Grund ihrer Entstehung ist uns unbekannt. Wahrscheinlich waren es mystische Erwägungen, welche dazu führten "; wenigstens ist ein praktischer Grund nicht ersichtlich.

Die Priester nahmen bis gegen das 13. Jahrhundert den Manipel bald vor bald nach der Kasel an. Eine einheitliche Praxis bestand in diesem Punkte nicht. Am gewöhnlichsten scheinen sie bis ins 12. Jahrhundert hinein ihn erst angelegt zu haben, wenn sie sich mit allen andern Gewandstücken bekleidet hatten und sich anschickten, zum Altare zu gehen. Es erhellt das namentlich aus den Sakramentaren des 9., 10., 11. und 12. Jahrhunderts, welche ihm fast inmer die letzte Stelle anweisen, wenn sie die liturgischen Gewänder mit ihren Gebeten in der Vorbereitung zur Messe aufführen, und zwar auch da, wo es sich ersichtlich um die priesterliche liturgische Kleidung handelt. Das gleiche geht aber auch aus dem dritten Kapitel der Synode von Coyaca (1050) hervor. Im 12. Jahrhundert bezeugen den Brauch mit aller Bestimmtheit Ivo von Chartres, Honorius, Robert Paululus und das Speculum de mysteriis ecclesiae. Solange der Manipel in der Hand getragen wurde, war es in der Tat das zweckmäbigste, mit der Annahne desselben bis nach Anlegung der Kasel zu warten. Denn hierbei war es ja nötig, die Hände frei zu haben, zumal das Gewand auf die Arme aufgerollt und dort zurechtgelegt werden mufte. Als man dagegen anfing, ihn am Arm zu befestigen, mochte es gleichgutitig sein, ob man ihn vor oder nach der Planeta annahm.

Aber auch da, wo die Priester den Manipel erst nach der Kasel anlegten, taten sie das, ehe sie zum Altar gingen, in der Sakristei und nicht erst am Altar nach dem Confiteor. Es ist durchaus unzutreffend, wenn Thalhofer bemerkt: „Bis tief ins Mittelalter herein nahmen (wenigstens vielfach) auch die Priester - zu Durandus' Zeit nur noch der Papst und die Bischöfe, wie jetzt - den Manipel erst am Altar nach dem Sündenbekenntnis an." Es war das, wie vorhin ausgeführt, vor dem 13. Jahrhundert nicht einmal bei den Bischöfen Brauch. Keiner der Liturgiker weif auch etwas davon, daf die Priester sich mit dem Manipel erst an Altar nach dem Confiteor versehen hätten, wiewohl sie den Eingang des Priesters und das Sindenbekenntnis wiederholt beschreiben. Im Gegenteil sagt Honorius da, wo er die liturgische Kleidung des Priesters bespricht, unmittelbar, nachdem er zuletzt vom Manipel gehandelt: His vestibus sacerdos ornatus procedit, confessionem facit. ... Auch die Sakramentare und Missalien kennen den fraglichen Brauch beim Priester nicht, gleichviel, ob sie der späteren oder früheren Zeit angehören. Nach allen nimmt er den Manipel mit den übrigen Gewandstücken in der Sakristei an. Es genüge, auf die ron Martène gegebenen Auszüge aus alten handschriftlichen Missalien hinzuweisen ${ }^{3}$. Die Wahrnehmungen, die wir

1 Vatic. Ottob. lat. 27.

${ }^{2}$ Durandus (Rationale 1. 4, c. 7) führt drei mystische Gründe für jenen Gebrauch an, die indessen wenig Bedeutung haben und äbergangen werden können.

3 M art. 1. 1, c. 4, art. 12, ordo 4 ff; I 176 ff. $35 *$ 
hier in Bezug auf den uns beschäftigenden Punkt gemacht haben, fanden wir in allen Sakramentaren und Missalien des Mittelalters, die uns bislang zu Gesicht kamen, ausnahmslos bestätigt. Es war so wenig bei den Priestern vor des Durandus Zeit üblich, erst am Altar nach dem Confiteor den Manipel anzuzielien, dafs eine solche Gepflogenheit sich selbst bei den Bischöfen erst seit dem Beginn des 13. Jahrhunderts einzubürgern begonnen hatte.

Die Sitte, wonach die Priester den Manipel eher als die Kasel anlegen, wurde erst im 12. Jahrhundert allgemeiner ${ }^{1}$, danm aber allgemach die Regel. Demgemäßs nennen denn auch die späteren Missalien ihn in der "Vorbereitung zur Messe" stets vor dem Mefgewand 2. Schon Durandus sagt ohne Einschränkung: Sacerdos vero econtra ante indutam casulam manipulum sumit ${ }^{3}$.

Wie die Diakone und Subdiakone es im früheren Mittelalter zu halten pflegten, ist nicht ganz klar. Doch scheint es, dafs sie den Manipel erst nach allen andern Gewandstücken annahmen. Solange sie noch Dalmatiken bzw. Tunicellen mit wirklichen Ärmeln trugen, war das übrigens auch ron selbst geboten. Ganz bestimmt schreibt der 14. Ordo vor, es sollten Diakon und Subdiakon erst dann den Manipel anlegen, wenn sie dem Bischof beim Ankleiden behilflich gewesen seien ${ }^{4}$. Ähnlich sollten sie nach dem Amte den Manipel alsbald rom Arm ziehen, die Dalmatik und Tunicella aber behalten, bis sie den Bischof seiner liturgischen Gewänder entkleidet hätten. Diese letzte Rubrik mag ein Überbleibsel aus der Zeit sein, da man den Manipel noch in der Hand hatte; doch mag sie auch mit der Auffassung zusammenhangen, wonach der Manipel nur innerhalb der Messe getragen werden sollte. Die Bestimmung des römischen Caeremoniale deckt sich mit derjenigen des 14 . Ordo.

\section{DIE ÜBERREICHUNG DES MANIPELS IM RITUS DER SUBDIAKONATSWEIHE.}

Nach der Vorschrift des römischen Pontifikale zieht der Bischof dem Ordinanden den Manipel an den linken Arm an, indem er dabei spricht: „Nimm hin den Manipel (manipulus $=$ Garbe), durch den die Frucht der guten Werke bezeichnet wird, im Namen des Vaters" usw.

Will man mittelalterlichen Liturgikern ${ }^{5}$ glauben, so gehörte diese Weihezeremonie samt den sie begleitenden Worten zum Wesen der Subdiakonatsweihe. Allein diese Ansicht ist mit Recht schon längst allgemein verlassen. Die Überreichung des Manipels erfolgte weder stets unter irgend welchen Begleitworten, noch ist sie überhaupt von hohem Alter ${ }^{6}$. Nur ein einziges Pontifikale des ersten Jahrtausends kennt unseres Wissens diesen Ritus, das

1 Gilb. L unic., De statu eccl. (M. 159, 1001); Tract. de sacr. alt. c. 10 (M. 17\%, 1282); Sermo 14 (M. 177, 928). Beleth., Rationale c. 32 (M. 202, 43). Innocenti i III. De sacro altaris myst. 1. 1 , c. 10 (M. 217, 780).

2 Vgl. z. B. die Auszüge aus späteren Missalien bei Mart. a. a. O.

3 Rationale 1. 4, c. 7; f. 103.

4 C. 53 (M. 78, 1156 1170).

5 S i cardi Mitralis 1. 2, c. 2 (M. 213,63).

- Schon Hraban soll die UUberreichung des
Manipels an den Diakon kennen. Allein es handelt sich an der Stelle, anf die man sich zum Beweise beruft, in der Ausgabe Mignes (De eleric. instit. 1. 1, c. 8 [M. 107, 304]) lediglich um einen verderbten Text. Statt: Suscipiunt (sc. subdiaconi) ab archidiacono scyphum aquae cum aqua, mantile et manutergium, mufs es heifen: cum aquamanili et manutergium. Schon Hittoxp (De div, off. 570) hat den richtigen Wortlaut; so auch nach den Handschriften Knöpflers neueste Ausgabe der Schuift, München 1901, 25. 
sog. Pontifikale Egberts, Erzbischofs von York, in der Nationalbibliothek zu Paris ${ }^{1}$, wenn dieses überhaupt noch aus dem 10. und nicht erst dem 11. Jahrhundert stammt. Er scheint demgemäf frühestens im 10. Jahrhundert aufgekommen zu sein. Diese Annahme wird bestätigt durch ein Schreiben Lanfranks, Erzbischofs von Canterbury (1070-1089), an Johannes von Avranches. Aus ihm geht hervor, dafi in der zweiten Hälfte des 11. Jahrhunderts allerdings in der Normandie jener Gebrauch sich vorfand, daf er aber durchaus nicht allgemein und insbesondere in England noch nicht in Übung war. Lanfrank, nach welchem der Manipel in der Anschauung mancher ein allen Klerikern gemeinsames Ornatstück war, weifs keine Autorität, auf die man sich für den fraglichen Weiheritus berufen köune 2 . Es ist gewifa nicht Zufall, daf die Einführung der Zeremonie in die Zeit fällt, in welcher sich das Subdiakonat im letzten Stadium seiner Entwicklung zu einem ordo maior hefand. Die höhere Bedeutung, welche die Subdiakone nachgerade gewonnen hatten, führte dazu, daf ihr Manipel sich für sie zu einem der diakonalen Stola entsprechenden Amtsabzeichen ausbildete. Nachdem aber dieser so die Eigenschaft einer Insignie des Subdiakonats erlangt hatte, lag es natürlich nicht allzufern, ihn den Subdiakonen ebenso bei der Weihe zu überreichen, wie man den Diakonen die Insignie des Diakonats, die Stola, schon seit langer Zeit und allgemein bei der Ordination zu übergeben pflegte. Als sich auf diese Weise der fragliche Weiheritus gebildet hatte, hat man, wie es nach Andentungen Lanfranks scheint, ihn nachträglich durch eine Korrektur der auf lem fiinften Kanon des sog. vierten Konzils von Karthago heruhenden Weiherubrik: Postea accipiat ab archidiacono urceolum cum aquamanili ac manutergium, zu begründen versucht, indem man las cum aqua, mantile ac manutergium.

Es dauerte ïbrigens eine geraume Weile, his der Ritus allgemein wurde. Spät entstanden, konnte er sich nur langsam einbürgern. Von den liturgischen Schriften des 12. Jahrhunderts erwähnen ihn nur der Tractatus de sacramento altaris und der Mitralis des Sicardus. Auch in den Pontifikalien findet er sich im 12. Jahrhundert nur erst vereinzelt verzeichnet.

Es hat den Ritus z. B. der Weiheordo bei Hittorp ${ }^{3}$, der in der Form, wie ihn dieser gibt, nicht vor dem 12. Jahrhundert entstanden ist, dann ein Pontifikale von Soissons und ein anderes von Besançon ${ }^{4}$. Dem Ordo Hittorps und dem Pontifikale von Soissons zufolge soll der Bischof die Übergabe des Ornatstückes mit den Worten begleiten: „Bei der Bekleidung mit diesen Manipeln bitten wir dich, o Gott, flehentlich, es mögen diese deine Diener so in ihrem Wandel in der Zeit wirken, dafs sie nach dem Beispiel der früheren

1 Wir glauben nochmals wiederholen zu sollen, was wir schon früher gelegentlich sagten, daf das sog. Eghert-Pontifikale nicht, wie so oft angenommen wird, das Original des 8. Jahrhunderts, sondern eine spätere, teilweise interpolierte Kopie aus dem 10. oder besser 11. Jahrhundert ist. Zu den Interpolationen gehört insbesondere die Rubrik: et tradat ei .... manipulum. Dasselbe gilt von der durch verschiedene, nicht an die betreffende Stelle gehörende Benediktionsformulare von den Weihegebeten der Subdiakonatsweihe getrennten Notiz: Donet ei manipulum. In den durchaus gleichartigen englischen Weiheordines bei Mart. 1. 1, c. 8 , art. 11, ordo 311 ; II 3763 fehlt die Rubrik betreffs des Manipels.

${ }^{2}$ Ep. 13 (M. 150, 520). Beachtenswert sind die Worte Lanfranks: In nostris episcopalis ordinis codicibus, quos ex diversis regionihus multos habenus, et de ordinando subdiacono inter cetera sic habetur: Postea vero ete. ... In qua scriptura sive saeculari sive divina sic vocatum manipulum reperitis, posco sanctam paternitatem vestram, ut indicare mihi competenti diligentia studeatis.

3 Col. 100.

${ }_{4}^{4}$ Mart. I. 1, c. 8, art. 11, ordo 7 10; II 5062. 
Täter in Zukunft ewig sich zu freuen verdienen." Nach dem Pontifikale von Besançon aber hat der Bischof bei der Vornahme der Zeremonie zu sprechen: "Nimm hin die Mappula; erfülle deinen Dienst; Gott ist ja mächtig genug, die Gnade dir zu mehren." Diese Worte, deren auch Sicardus Erwähnung tut, nehmen ersichtlich auf die Bedeutung des Manipels als Insignie des Ordo Bezug. In andern Pontifikalien des 12. Jahrhunderts findet sich der Brauch nicht im Text, sondern in einer Randglosse aus späterer Zeit vermerkt.

Erst die liturgischen Bücher des 13. und namentlich des 14. Jahrhunderts gedenken häufiger der Übergabe des Manipels an die Subdiakone, wenngleich auch jetzt noch keineswegs alle ihrer Erwähnung tun.

Interessant ist die Mannigfaltigkeit der Gebete, mit denen der Bischof nach den späteren Pontifikalien die Zeremonie zu begleiten hat. Wir haben deren wenigstens sechs verschiedene gefunden. Am häufigsten kommt das Gebet vor, welches der Bischof jetzt nach dem römischen Pontifikale betet, wenm er dem Ordinanden den Manipel überreicht. Das eigentümlichste begegnete uns in zwei der Vaticana angehörigen Pontifikalien des 13. Jahrhunderts ${ }^{1}$. Es lautet: „Nimm hin den Fano, das Zeichen der Verkündigung des Wortes Gottes, im Namen unseres Herrn Jesu Christi."

Auf die Frage, wo es zuerst zur Einführung des Ritus gekommen sei, läft sich eine sichere Antwort nicht geben. Der Umstand jedoch, daf dieser zuerst in nordfranzösischen Pontifikalien erwälnht ist und uns überhaupt aus dem nördlichen Frankreich die erste Kunde über denselben wird, macht es nicht so ganz unwahrscheinlich, daks wir eben hier seine Heimat zu suchen haben, und dak er sich von hier aus nach und nach überallhin verbreitete.

\section{DAS GEGENSTÜCK DES MANIPELS IN DEN RITEN DES OSTENS.}

In den Riten des Ostens gibt es keinen Manipel 2, ausgenommen den armenischen, in welchem er jedoch nur den Subdiakonen zukommt. Er wird diesen bei ihrer Weihe vom Bischof an den linken Arm gelegt ${ }^{3}$. Der ManipeI der Armenier stammt nicht aus dem römischen Ritus, sondern ist ein altarmenisches Stück; nur war er, wie aus Nerses von Lampron erhellt, ehedem eine Stola, welche die Subdiakone in der linken Hand trugen.

Man pflegt gewöhnlich als Gegenstück des abendländischen Manipels die Epimanikien der orientalischen Riten, die liturgischen Stauchen, hinzustellen. Das ist indessen irrig. Nicht sie, sondern das sog. Epigonation ist das Pendant desselben. Die Epimanikien sind, wie wir hörten, lediglich die von den Ärmeln losgelösten und zu selbständigen Ornatstücken gewordenen Besätze des Sticharion.

Das Epigonation hat seinen Namen von dem Umstand, dak es auf das Knie herabhängt. Es befindet sich an der rechten Seite und darf nur von den Bischöfen und der höheren Geistlichkeit getragen werden. Aulierdem ist es blof im griechischen und armenischen Ritus, nicht aber in den sonstigen orientalischen Riten in Gebrauch und in seinem Ursprung ein spezifisch

1 Vat. Barb. lat. 1868; Vat. Borgh. lat. 49 .

2 Ein in den Gräberfeldern von Achmîm gefundener, mit Seidenappliquen (Scheibchen, Kreuze, Peclitecke) besetzter und in Fransen endigender Linnenstreifen von ca $0,60 \mathrm{~m}$ Länge und $0,075 \mathrm{~m}$ Breite, der von dem Strakburger Antiquar F or r er als altkoptiseher Manipel (bzw. altkoptische Stola) veröffent- licht wurde (Die frühchristlichen Altertiumer aus dem Gräberfeld von Achmim-Panopolis TH VIII 1), einem "Diakon gedient haben und unsere Kenntnis des Priesterornats um ein Wesentliches ergänzen soll", hat mit einem Manipel (bzw. Stola) nicht das geringste $\mathrm{zu}$ schaffen (vgl. auch oben S. 13).

${ }^{3}$ Denzinger, Ritus Orientalium II, Würzburg 1864, 284. 
griechisches Ornatstück. Die Armenier entlehnten es zweifellos den Griechen; schon des Nerses Kommentar kenut es als Ornat der armenischen Bischöfe.

Man trägt das Ornatstück unter dem liturgischen Obergewande; nur die Metropoliten bzw. Bischöfe, welche sich des Sakkos statt des Phelonion bedienen, haben es über demselben. Das Epigonation wird mittels Schnüren am Gürtel oder der Schulter aufgehängt. Wer den Sakkos trägt, befestigt es an einem an diesem angebrachten Knöpfchen.

Seiner Gestalt nach stellt das Ornatstiuck ein übereck stehendes Quadrat dar. Es besteht aus einem mit Seide überzogenen Karton und ist ringsum von einer Borte eingefafst. In der Mitte ist gewöhnlich nur ein Kreuz oder ein Schwert angebracht, letzteres, weil das Epigonation als Symbol des Geistesschwertes gilt, mit dem der Bischof ausgerüstet sein soll. Doch gibt es auch solche, die mit Bildwerk verziert sind (Bild 268). An einer der vier Ecken befinden sich die zum Aufhängen dienenden Schnüre, die drei andern sind gewöhn- lich mit Quästchen verziert. Etwas anders ist im russisch-griechischen Ritus das Epigonation einge- richtet, welches als Auszeichnung den niederen fy Prälaten und sonstigen verdienten Geist- $\% 9$ wird. Es ist zwar

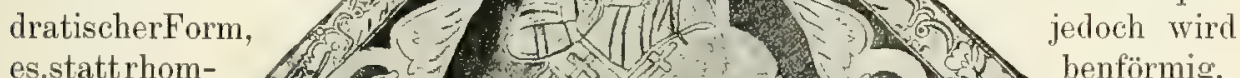
es,stattrhom-

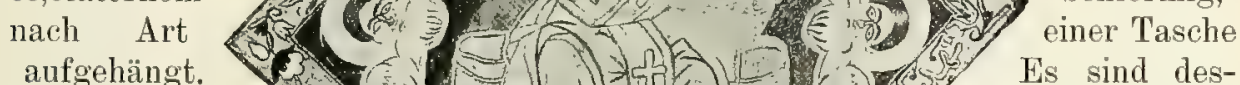
aufgehängt.
halb bei ihm an

der zum Zweck gebracht und demEcken mit Quästchen

Das Epigonation hief (Erretocov). Das Schreiben Antiochien an Michael Cärulanen Zweifel. Denn wenn es hier

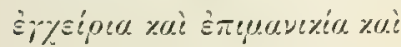

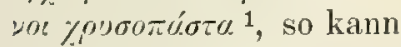
bar nur das Epigonation

Bild 268. Epigonation.

Dủsseldorf, Kunstgewerbemuseum. der Befestigung angemäf auch nur zwei versehen.

ursprünglich Enchirion des Patriarchen Petrus von rius (ca 1054) läßt daran kei-

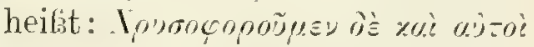

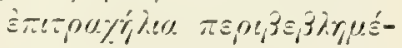
unter diesen Érycip a offenverstanden werden. Ein anderes liturgisches Ornatstück, das mit ihnen gemeint sein könnte, gibt es nicht 2. Der Name Epigonation begegnet uns zuerst in einem Siclireiben Balsamons an den Patriarchen Markus von Alexandrien, also um das dritte Viertel des 12. Jahrhunderts ${ }^{3}$.

Die früheste Nachricht von dem Enchirion erhalten wir bei PseudoGermanus und, wie es scheint, in dem Briefe des Patriarchen Nicephorus an Leo III. (795-816) $)^{ \pm}$Denn wenn auch das goldverzierte Enchirion, von dem

$1 \mathrm{Mg} .120,799$.

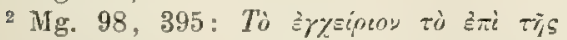

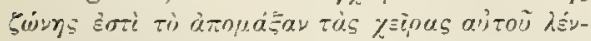

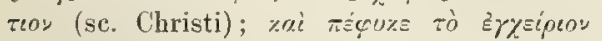

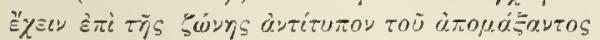

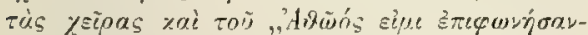
tos (sc. Pilati). Es handelt sich nicht, wie es beim ersten Blick scheinen könnte, an dieser Stelle um die Diakone - dean diese trugen keinen Gürtel -, sondern um den Bischof. Vgl. auch den aus Pseudo-German us kompilierten Pseudosophronius n. 7

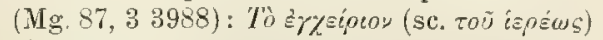

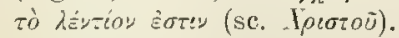

${ }^{3} \mathrm{Mg} .138,988$.

4 M. 102, 1067 . 


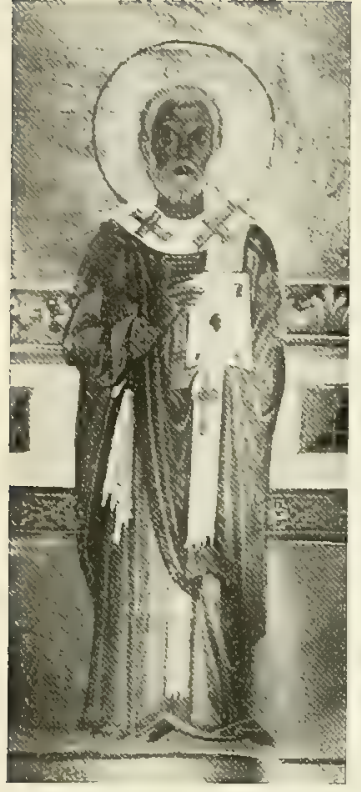

Bild 269. St Gregor der Wundertäter. Miniatur des Menologium Basilius' II.

Rom, Vatikan.

hier die Rede ist, wohl die Mappula des römischen Ritus bedeutet, so dürfte doch der Name darauf hinweisen, daf damals auch schon im griechischen Ritus das Enchirion in Gebrauch war.

Auf den Bildwerken treffen wir das Enchirion erst im Beginne des zweiten Jahrtausends an. Die älteste uns bekannte Darstellung desselben findet sich im Menologium Basilius' II. in der Vatikanischen Bibliothek (Bild 269). Von da an kommt das Enchirion häufig auf den Monumenten vor.

So begegnet es uns z. B. bei den hll. Gregor von Nyssa und Gregor dem Wundertäter auf den Mosaiken der Kathedrale von Kiew (11. Jahrhundert)', ferner auf einer Miniatur einer griechischen Handschrift der Vaticana aus dem Ende des 11. Jahrhunderts (vgl. Bild 111, S. 237) ${ }^{2}$, auf den Mosaiken der Apsis des rechten Seitenschiffes in der so interessanten Basilika von Torcello bei Venedig, dann auf dem grofartigen Mosaikenschmuck des Domes von Monreale aus dem Ende des 12. Jahrhunderts ${ }^{3}$, auf den Mosaiken der Kuppel des südlichen Querarmes und des Chores von S. Marco zu Venedig, auf den aus dem Beginn des 12. Jahrhunderts stammenden Teilen der Pala d'oro, den in Silbertauschierung ausgeführten Bronzetürflügeln des Hauptportals von S. Harco ท. a. (Bild 270).

Auf allen diesen Darstellungen erscheint das Enchirion noch keineswegs als steifes, rautenförmiges Ornatstück von der Art des jetzigen Epigonation, sondern seinem Namen entsprechend als viereckiges Tuch, welches an der rechten Seite mit einem seiner vier Zipfel unter dem Gürtel durchgesteckt ist, während der übrige Teil mit den drei andern Zipfeln rhombenähnlich bis zum Knie herabhängt. Indessen ist auch so die Verwandtschaft mit dem heutigen Epigonation unverkennbar. Es brauchte das Enchirion, um sich zu diesem umzubilden, nur versteift und oben mit einer Vorrichtung zum Aufhängen versehen zu werden.

Wann dieses geschah, läft sich nicht mit Sicherheit feststellen, doch mit einiger Wahrscheinlichkeit vermuten. Es ist nämlich wohl nicht ohne Grund, daf in der zweiten Hälfte des 12. Jahrhunderts an Stelle des Namens "Enchirion" die seitdem ausschlieflich gebräuchliche Bezeichnung „Epigonation" auftaucht. Dieser Wechsel in der Benennung war, wie es scheint, nur die Folge eben des Wechsels der Form. Sobald das Ornatstück seinen Tuchcharakter verloren hatte, war auch die Bezeichnung "Enchirion" bedeutungslos geworden. Es war daher ganz natürlich, daf man diese nun aufgab und eine andere einführte, die von seiner Form und Beschaffenheit absah und nur noch seine ornamentale Bedeutung hetonte. Wir hätten also den Umbildungsprozef, wie es den Anschein hat, in das 12. Jahrhundert zu verlegen. Allerdings kommen auch noch im 13. Jahrhundert hie und da Bildwerke vor, auf denen das Epi-

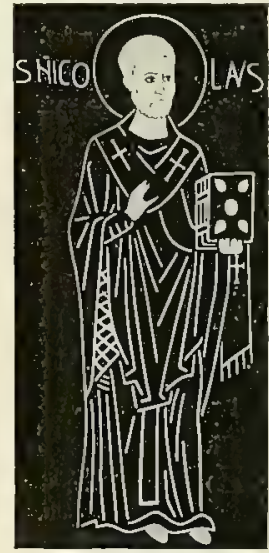

Bild 270.

St Nikolaus.

(Tauschierarbeit.)

Venedis, S. Marco Bronzetüre).

\footnotetext{
1 I'Epopce byzantine i la fin du $\mathrm{X}^{\mathrm{e}}$ siecle, Paris 1896, I 537. 2 Cod. gr. 1162.
}

${ }^{3}$ Don Gravina, Il duomo di Monreale, Palermo 1859, tav. 10 A 14 D 17 D. 
gonation die alte Tuchform hat. Indessen erklärt sich das ohne Schwierigkeit durch die Schablone, welche in die griechische Ikonographie damals bereits Eingang gefunden. Auch mochte im 13. Jahrhundert infolge des großen Konservativismus des Ostens die neue Form noch nicht allgemein geworden sein. Und dann ist es ja, wie in der Einleitung hervorgehoben wurde, eine bekannte Sache, daß die Kunst nicht selten eine Strecke hinter der Wirklichkeit herhinkt, und dak Erscheinungen, die bereits der Vergangenheit angehören, in den künstlerischen Gebilden noch lange nachleben. Sahen wir z. B. doch, wie die Tiara noch auf Bildwerken aus der Mitte des 15. Jahrhunderts mit einem Kronreifen geschmückt ist, obwohl doch schon seit hundert Jahren deren drei an ihr gebräuchlich waren. Wie kann man in der Tat erwarten, daßs die Künstler von jedem Wechsel, der mit der Beschaffenheit der ihnen oft fernliegenden pontifikalen Gewänder vor sich ging, alsbald Kenntnis hatten?

Die ältesten uns bekannten Bildwerke, auf denen das Ornatstück seine jetzige Form hat, gehören dem 14. Jahrhundert an. Es sind eine Miniatur einer Sammlung der Homilien Gregors von Nazianz in der Nationalbibliothek zu Paris ${ }^{1}$ und die Darstellungen der vier griechischen Kirchenlehrer in der Zenokapelle von S. Marco zu Venedig (Bild 271). Das Epigonation hat hier schon vollständig seine gegenwärtige Gestalt und Beschaffenheit. Im 15. Jahrhundert sind Bildwerke, auf denen es dargestellt ist, häufig.

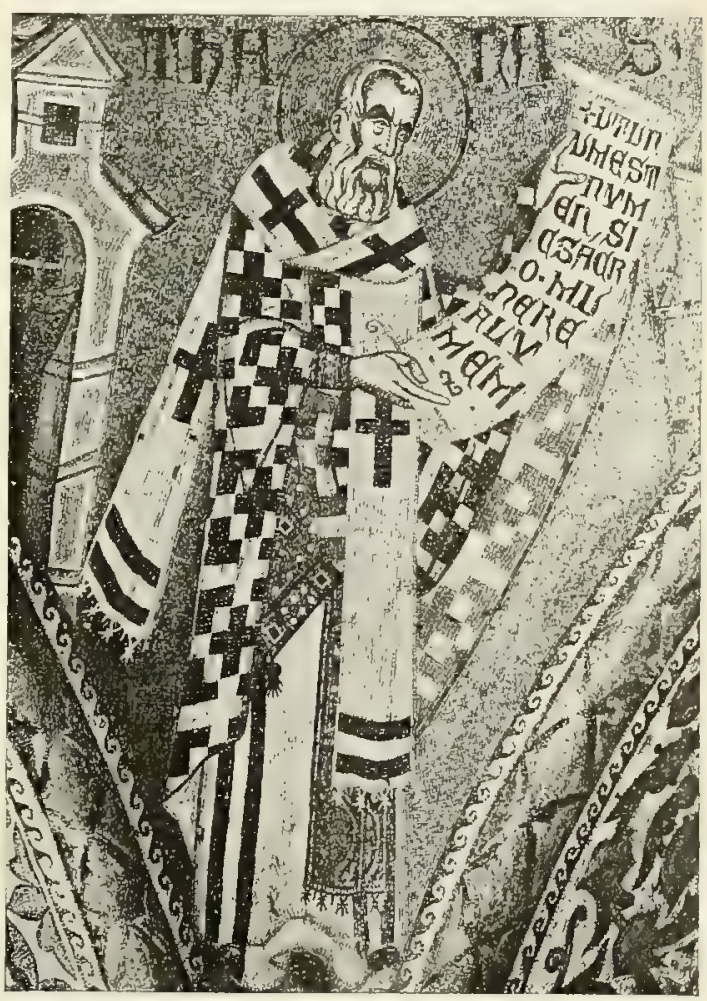

Bild 271. St Athanasius. Mosaik. Venedig, s. Marco.

Das Recht, das Epigonation zu tragen, stand im 12. Jahrhundert ausschließlich den Bischöfen zu. Nicht einmal die Hegumenen (Äbte) und Protopapen (Erzpriester) durften sich seiner bedienen. Auf eine diesbezïgliche Anfrage des Patriarchen Markus von Alexandrien antwortet Balsamon durchaus verneinend. Es ist dies das gleiche Schreiben, in dem uns zum erstenmal der Name Epigonation begegnet. Die Anfrage des Patriarchen deutet darauf hin, dafs sich damals im alexandrinischen Patriarchat in den Kreisen der Hegumenen und Erzpriester dlas Streben geltend machte, das Recht zu erhalten, wie die Bischöfe das Epigonation zu tragen.

1 Abhildung bei Roh. VII, pl. DxLIII; hier jedoch irrig dem 11. Jahrhundert zugeschrieben (s. oben S. 303). Auch Nerses von Lampron kannte anscheinend schon seine jetzige Form. Er nennt es rationale iudicii und sagt, es trage den Namen Christi. 
Zweihundert Jahre später hatte sich die Sache einigermaßen geändert. Zwar galt noch immer das Ornatstück an sich als dem Bischof vorbehalten, doch hatten inzwischen auch hervorragendere Priester, wie Staurophore und Archimandrite, das Privileg erlangt, von ihm Gebrauch machen zu dürfen ${ }^{1}$.

Unklar ist, ob das Enchirion schon von Anfang an ein privilegiertes Gewandstück war oder ob es das erst wurde, seitdem es sich zum Epigonation umbildete. Den Monumenten zufolge ist jedoch das erste das wahrscheinlichste; denn in allen Fällen, in denen es uns auf ihnen begegnet, handelt es sich um Darstellungen von Bischöfen.

Eigentümlicherweise schreibt Pseudo-Sophronius Ėrysotóca auch den Diakonen zu. Es ist das erste und einzige Mal, dafs wir von solchen bei diesen hören.

\section{ABLEITUNG DES MANIPELS.}

Von einer Beziehung des liturgischen Manipels zu einem Kultgewande des Alten Bundes kann in keiner Weise die Rede sein. Er ist weder unmittelbar aus dem jüdischen Opferdienst herübergenommen, noch in späterer Zeit im Hinblick auf eines der aaronitischen Priesterkleider als Ornatstück der christlichen Liturgen eingeführt worden.

Unter den mosaischen Opfergewändern gibt es keines, welches das Gegenstück unseres Manipels sein könnte. Darum haben auch nicht einmal die Liturgiker des Mittelalters es versucht, denselben von einem Kultgewande des Gesetzes abzuleiten. Wenn Walafried ihn dem Schulterkleid des jüdischen Hohenpriesters gegenüberstellt, so tut er das lediglich, weil er den acht Kultgewändern des Alten Bundes ebencoviele des Neuen Bundes entgegensetzen wollte. Pseudo-Alkuin erklärt dagegen ausdrücklich, daf bei den jüdischen Priestern das Sudarium nicht in Brauch gewesen sei. Die Entstehung des Manipels muf also anders erklärt werden.

Das ist denn auch geschehen, und zwar sind in Bezug auf den Ursprung des Manipels drei Theorien geltend gemacht worden. Die eine will ihn auf ein Handvelum, die zweite auf ein diakonales Diensttuch, die dritte auf ein Schweiftuch zurückführen.

Die Vertreter der ersten Ansicht meinen, es habe im christlichen Altertum als feststehende Regel gegolten, alles Heilige nur mit bedeckten und verhüllten Händen anzufassen, wie aus eincr Reihe von Monumenten seit dem 4. Jahrhundert hervorgehe. Man müsse daraus mit Recht schließsen, daf auch der Diakon bei Entgegennahme der Opfergahen, namentlich aber bei Beschäftigung mit dem Heiligen selbst, zumal bei Austeilung der heiligen Kommunion seine Hände bedeckt hatte. Fs sei demnach der Manipel ursprïnglich nichts anderes als jenes Handvelum, mit dem z. B. Petrus auf den altchristlichen Bildwerken von Christus die Schlüssel oder eine Buchrolle und Moses vom Herrn das Gesetz entgegennimmt, Elisäus den Mantel des Elias auffängt, Päpste und Bischöfe ein Kirchenmodell oder das Evangelienbuch, Heilige eine Krone halten usw.

\footnotetext{
1. De sacra liturgia c. 83 ( $\mathrm{Mg}, 155,261$ ). Staurophore hieken gewisse Priester an Hauptkirchen, denen es der Auszeichnung
}

halber erlaubt war, eine mit Kreuzen versehene Kasel sowje ein Kreuz auf der Kapuze zu tragen. 
Allein ist es denn wirklich zutreffend, daf jenes Prinzip, das Heilige nur mit bedeckten Händen zu berühren, so ausnahmslos und konstant zu Recht bestand Es ist doch bekannt, daß den Männern ehedem bei der Kommunion das allerheiligste Sakrament auf die blofe Hand gelegt wurde. Aber auch auf den Bildwerken ist es keineswegs überall durchgeführt. Beispiele bieten die Mosaiken in S. Vitale zu Ravenna, S. Lorenzo fuori le mura und S. Venanzo beim Lateran zu Rom, und zwar sind es bezeichnenderweise hier immer Diakone, welche das Evangelienbuch in bloken Händen halten. Dann aber geht es auch unmöglich an, aus Bildwerken wie denjenigen, auf die man sich beruft, einen Schlub auf die Praxis bei der Feier der Liturgie zu machen. Es wäre geradezu untunlich gewesen, wenn der Diakon nur mit bedeckten Händen die Opfergaben, heilige Geräte und die heiligen Geheimnisse hätte anfassen dürfen. Man denke sich nur einmal den Diakon, wie er den Gläubigen mit verhüllten Händen etwa die fistula, das Pöhrchen, reicht, damit sie mit dessen Hilfe aus dem Kelch, den der Subdiakon trug, das heilige Blut genössen. Und wie war es praktisch ausführbar, die Opfergaben der Gläubigen nur mit verhüllten Händen entgegenzunehmen oder nur mit verhüllten Händen den Kelch zur Opferung zu bereiten, $u$. ä.? Außerdem aber sehen wir ja auch Päpste und Bischöfe auf den Bildwerken mit verdeckter Hand das Evangeliar oder eine Kirche tragen. Bestand also anch für sie bei der Liturgie das fragliche Prinzip? Doch wohl nicht; denn wie konnten sie mit verhüllten Händen z. B. die konsekrierten Spezies brechen und die Gläubigen damit kommunizieren? Welche Gefahr der Verunehrung hätte das nicht mit sich gebracht?

Gewißs gab es bei der Feier der Liturgie Velen gerade wie noch jetzt. So hielt z. B. der Akolyth, der vom Beginn des Kanons an bis nach dem Paternoster die Patene aufzubewahren hatte, diese mit einer Art von Schultervelum. Allein in solchen Fällen handelte es sich offenbar in erster Linie um Beobachtung der Reinlichkeit; darum legte denn auch der Subdiakon, der die Patene beim Paternoster vom Akolyth empfing, diese auf seine Kasel, bis er sie dem Regionarsubdiakon zur Übermittlung an den Diakon übergab, der sie seinerseits aber wie der Regionarsubdiakon ohne Benutzung eines Velum oder der Kasel in Empfang nahm ${ }^{1}$. Jedenfalls folgt aus solchen Velen nicht, dafs auch die Mappula ursprïnglich ein ähnliches Velum war. Denn es ist gar nicht einzusehen, warum die für den Dienst des Altars geweihten höheren Ordines, die Diakone, Priester und Bischöfe, noch eimes Handvelum berlurften, um mittels desselben die Opfergaben, heiligen Geräte usw. anzufassen. Bei den Akolythen und Subdiakonen der älteren Zeit licß3e sich das zuletzt noch begreifen, bei den Diakonen, den Priestern und Bischöfen ist es jedoch schlechthin unverständlich.

Wie konnte überhaupt die Mappula, falls sie ursprünglich ein durch die Ehrfurcht vor dem Heiligen notwendig gefordertes Handvelum war, je diesem Zweck entfremdet und, was doch schon im 9. Jahrhundert mit ihr geschah, $\mathrm{zu}$ einem Zierstreifen werden? Was hat man denn bei dieser Umwandlung für sie substituiert? Wie will man ferner bei der in Frage stehenden Theorie vom Ursprung des Manipels es erklären, dals die Mappula bei ihrem ersten Auftreten als spezitisch römisches Ornatstück erscheint? Galt etwa jenes angebliche Prinzip, wonach das Heilige nur mit verdeckter Hand berïhrt werden

${ }^{1}$ A mal., De eccl. off. 1. 3, c. 27 (M. 105, 1146); dazu ordo 2, n. 11 (M. 78, 975). 
durfte, ausschließzlich zu Rom? Und wie konnte Gregor gegen den Gebrauch der Mappula gegenüber den ravennatischen Diakonen so grofie Schwierigkeiten erheben, wenn diese nur ein liturgisches Handvelum war?

Die zweite Meinung hinsichtlich des Ursprungs des Manipels geht von der Erwägung aus, daf die Diakone als nächste Diener des Altars für die Opfergaben zu sorgen, die Spenden der Gläubigen an Brot und Wein entgegenzunehmen, die für das Opfer notwendige und geeignete Materie auszuwählen, die Opfergeräte herbeizuschaffen und nach dem Gebrauch zu reinigen hatten u. ä. und deshalb eines Tuches bedurften, ohne welches sie die nötige Reinlichkeit nicht wahren konnten. Dasselbe soll eben die Mappula sein. Anfangs also lediglich ein zu praktischen Zwecken, wie der Dienst sie mit sich brachte, verwendetes Tuch, blieb diese ein solches, sagt man, bis die Diakone einen Teil ihrer Dienste an die Subdiakone abgaben. Dann wurde sie Abzeichen des diakonalen Ordo, indem die Diakone ihre Mappula, die sie nun nicht mehr zu Reinlichkeitszwecken benutzten, schön und reich ausstatteten und zu einem schmalen Streifen zusammenfalteten oder auch. wohl durch ein einfaches Band ersetzten. Auf diese Weise Insignie der Diakone geworden, wurde sie dann auch von den höheren Gliedern der Hierarchie, insbesondere auch vom Papst angenommen.

Analogien des diakonalen Diensttuches soll aber das Tuch bilden, welches nach den antiken Monumenten die Opferdiener, die sog. camilli, und die Aufwärter bei profanen Gelagen, die sog. delicati, bald schlicht zusammengelegt, bald in einen Streifen zusammengefaltet auf dem Arm, der linken Schulter oder auch nach Art der Priesterstola um den Hals zu tragen pflegten.

Dieser Versuch, den Ursprung des Manipels zu erklären, hat unzweifelhaft etwas Bestechendes. Alles klingt ungemein natürlich, ja fast selbstverständlich; um so mehr bedauern wir, ihm nicht zustimmen zu können.

Vor allem kann nämlich doch wohl kaum behauptet werden, dafi die Diakone eines Diensttuches bedurft hätten. Durchgehen wir ihre Tätigkeit bei der Liturgie, so ergibt sich, daf3 die Verrichtungen, bei denen sie überhaupt irgend ein Tuch nötig hatten, sich auf einige wenige Fälle beschränken, auf die Händewaschung nach đem Einsammeln der Opfergaben, das Auftrocknen des bei Entgegennahme der Weinfläschchen oder der Herrichtung des Kelches etwa verschütteten Weines und die Reinigung der Opfergefäße am Schluf der Liturgie. Denn zum Herbeiholen der Opfergeräte, das zu Rom schon gegen Ausgang des 4. Jahrhunderts keine Sache der Diakone mehr war ${ }^{1}$, bedurfte es keines Tuches; bei der Entgegennahme der Opfergabe aber wäre es sogar sehr unpraktisch gewesen, die Hände mit einem solchen zu bedecken. Von den genannten Funktionen müssen nun aber abgerechnet werden die Händewaschung, für die manutergia vorhanden waren, das Auswaschen der gebrauchten Kelche, das übrigens nicht am Altare, sondern erst nach dem Gottesdienst in der Sakristei statthatte und für welches es ohne Zweifel erst recht besondere Tücher gab, und das Aufputzen des etwa beim Einsammeln der Gaben auf den Fußsboden geflossenen Weines, wofür jedes gewöhnliche Aufputztuch gut genug, ein feines diakonales Diensttuch aher sicher zu schade war. Es bleibt sonach lediglich die Herrichtung des Kelches übrig. $O b$ es nun aber nötig, ja auch nur zweckmäligig war, daf die Liakone lediglich dieser Funktion halber die ganze Liturgie hindurch

\footnotetext{
1 Quaest. utriusque test. n. 101 (M. 35, 2301).
} 
ein Tuch mit sich auf dem Arm herumtrugen? Ja wenn dieses noch Insignie des diakonalen Ordo gewesen wäre. Aber das war es ja noch nicht. Demn zum Standesabzeichen der Diakone soll es ja erst geworden sein, nachdem die Subdiakone einen Teil der diakonalen Ohliegenheiten übernommen hatten.

Zweitens ist es schwer begreiflich, wie die Mappula sich bei den römischen Subdiakonen und Akolythen, bei denen wir sie doch im 9. Jahrhundert antreffen, noch einbürgern konnte, nachdem sie einmal zur diakonalen Insignie geworden war ${ }^{1}$. Und erst die Mappula des Papstes, welche schon im 1. Ordo ausdrücklich erwähnt wird, und der Bischöfe! Ist es wirklich glaulhaft, dafs die höchsten kirchlichen Würdenträger den Diakonen deren Amtsinsignie entliehen? Beweist die Geschichte der liturgischen Gewandung nicht im Gegenteil, daf die liturgische Kleidung der unteren Ordines nur eine Vereinfachung derjenigen der oberen ist, und dafs alle Gewandstïcke der Priester, Diakone usw. der bischöflichen Tracht entlehnt sind. Ganz unverständlich aber ist, daf, sich das diakonale Diensttuch zur Insignie der Diakone umgebildet haben soll, weil die Subdiakone einen Teil der diakonalen Funktion übernahmen. Denn entweder blieben den Diakonen noch Verrichtungen, bei denen sie des fraglichen Tuches bedurften, oder es gingen diese allesamt an die Subdiakone über. Im ersten Fall ist es offenbar unerklärlich, wie das Tuch seiner praktischen Bedeutung verlustig gehen und zur bloben Insignie werden konnte, im zweiten aber, warum nicht auch das Tuch zugleich mit den diakonalen Funktionen von den Subdiakonen übernommen wurde, sondern bei den Diakonen blieb und bei diesen sogar den Charakter einer Insignie erhielt, obschon es zu den ihnen noch bleibenden Amtshandlungen durchaus keine Beziehung mehr hatte. Was waren das überhaupt für Funktionen, welche auf die Subdiakone übergingen, und zu welcher Zeit vollzog sich dieses Ereignis? - zwei Punkte, die für die ganze Frage ersichtlich von gröfter Bedeutung sind und vor allem klargestellt werden müsten.

Drittens darf man wohl fragen, warum die Mappula bei ihrem ersten Auftreten in der Geschichte als spezifisch römisches und nicht viel mehr als allgemein gebräuchliches Ornatstïck erscheint. Warum finden wir sie, wenn sie ein durch die Funktion der Diakone gefordertes Diensttuch war, nicht im ganzen Abendland? Oder war z. B. in Gallien und Spanien im 6. Jahrhundert die Feier der Liturgie vielleicht der Art, daß in jener Zeit dort bei den diakonalen Verrichtungen kein Bedürfnis für ein solches Tuch vorlag?

Viertens muß betont werden, daßs der Erklärungsversuch weder zu den Mitteilungen past, die wir im 9. Jahrhundert von der liturgischen Mappula erhalten, noch zu den Angaben, die uns das Papstbuch und der Briefwechsel zwischen Gregor d. Gr. und Johannes von Ravenna direkt oder indirekt über die Beschaffenheit, die Träger, den Charakter usw. des pallium linostimum bzw. der Mappula machen².

Was endlich die Darstellungen der camilli und delicati anlangt, so können wir ihnen leider eine Bedeutung nicht beimessen. Sollen sie blof

\footnotetext{
1 Nach Wilpert (Gew. 56) wäre das Diensttuch der Diakone allmählich zu einem Taschen- oder Schweiftuch geworden und als solches dann anch von den übrigen Ordines angenommen worden. Allein auch so bleibt die auffallende, durch nichts begründete Erscheinung, daf3 der Papst und die Bischöfe von den Diakonen ein Ornat-
}

stïck entliehen. Auferdem ist völlig unbegreiflich, daf ein Tuch, welches, wie doch Wilpert selbst sagt, „für den liturgischen Dienst der Diakone absolut notwendig war", allmählich zu einer Art von Taschen- oder Schweißtuch werden konnte.

2 S. oben S. 523 f. 
illustrieren, wie wir uns die Diakone mit dem pallium linostimum auf dem Arm zu denken haben, dann sind sie offenbar von geringem Wert, um nicht zu sagen, ziemlich überflüssig. Denn wie man das Ornatstück zu tragen pflegte, ersehen wir besser aus den Darstellungen des 9. Jahrhunderts, welche uns liturgische Personen mit der Mappula vorführen, als aus antiken Darstellungen heidnischer camilli und delicati. Einen wirklichen Aufschluf über den Charakter und Zweck des pallium linostimum aber können sie nicht geben. Das wäre nur unter der Voraussetzung möglich, daß man die volle Analogie zwischen dem Dienst der Diakone einerseits und dem der camilli und delicati anderseits erwiesen hätte. Die allgemeine Bemerkung, dafi die einen Diener am Tisch des Herrn, die andern Diener am Götzenaltar oder beim profanen Tisch waren, reicht dazu offenbar nicht aus. In der Tat war das mantile der camilli lediglich ein Handtuch, an welchem der Opfernde nach Auflegung des Weihrauchs seine Hände abputzte, kein Diensttuch, wie man es dem Diakon vindizieren will. Sein Gegenstück war bestenfalls das manutergium, welches einer der Subdiakone dem Bischof oder Priester zum Abtrocknen der Hände darreichte, wenn diese nach Empfang der Opfergaben und nach Austeilung der heiligen Kommunion ihre Hände wuschen ${ }^{1}$. Was aber das Abputztuch der Aufwärter anlangt, so war denn doch die Aufgabe der Diakone eine wesentlich andere als die eines delicatus. Oder ging etwa die diakonale Tätigkeit im Auftragen, Abräumen und dem, wenn irgendwo, dann namentlich bei antiken Gelagen unvermeidlichen Aufwischen und Händewaschen auf? Wie viele Funktionen gab es überhaupt, bei welchen der Diakon irgend eines Tuches, von einem Diensttuch ganz zu schweigen, nötig hatte?

Die dritte Ansicht führt den Manipel auf ein Sudarium (Schweistuch) zurück. Es ist die gewöhnliche Auffassung. Sie gründet sich darauf, daß bei Amalar und Pseudo-Alkuin das Ornatstück mit aller Bestimmtheit als Schweißtuch bezeichnet wird. Wir tragen kein Bedenken, an ihr festzuhalten.

Man hat freilich Amalar wie Pseudo-Alkuin als durchaus unglaubwürdig hinzustellen versucht. Was Amalar sagt, soll nur die Ausgeburt einer übertriebenen Vorliebe für allegorische Erklärung und übel angebrachte Pietät gegen einen lieben Heiligen, nämlich den Vater Arsenius, sein und demgemäß ins Gebiet der Fabel gehören. Pseudo-Alkuin aber, sagt man, habe lediglich die Phantasien Amalars nachgeschrieben. Indessen heibt das doch unseres Erachtens weder Amalar noch Pseudo-Alkuin genügend gerecht werden. Es klingt allerdings recht drastisch, wem Amalar schreibt: Sudario solemus tergere pituitam oculorum et narium atque superfluam salivam decurrentem per labia... sive propter effusionem lacrimarum sudarium fertur; allein wovon redet derselhe denn eigentlich in diesen Worten, von dem liturgischen Sudarium oder vom Sudarium überhaupt? Jedenfalls ist seine Schilderung kein genügender Grund, zu behaupten, lediglich Amalars Phantasie habe das Ornatstiick zu einem Sudarium gemacht; in Wirklichkeit habe es mit einem solchen nichts zu tun. Wer Amalar näher kennt, weik, wie er ihn zu verstehen hat. Man muß bei ihm Spreu und Weizen sondern, statt mit der Spreu zugleich den Weizen wegzuwerfen. Auch in seinen Ausführungen über das Sudarium steckt unzweifelhaft ein richtiger Kern. Amalar war ein zu tüchtiger Kenner und ein zu

1 Schon im 4. Jahrhundert lag es zu Rom nachweislich den Subdiakonen ob, dem Bischof
(Priester) beim Händewaschen zu ministrieren. Vgl. Quaest. ex utroque test. n. 101 (M.35, 2301). 
aufrichtiger Freund des römischen Ritus, um das Ornatstück fälschlich als sudarium hinzustellen, wenn es nach römischer Auffassung mit einem solchen in keiner Weise etwas zu schaffen gehabt hätte, sondern ein zur Insignie gewordenes diakonales Diensttuch oder sogar nur mehr ein blokes Band gewesen wäre.

Was aber Pseudo-Alkuin anlangt, so ist es durchaus unrichtig, daf er lediglich Ausschreiber Amalars ist. In dem Kapitel, das er der liturgischen Gewandung des Neuen Bundes gewidmet hat, hat er freilich Hraban und Amalar kopiert. Jedoch gilt das keineswegs von einer Anzahl wichtiger Bemerkungen, die er seinen Eröterungen über die alttestamentliche Kultkleidung eingestreut hat. Vielmehr verraten diese ein ebenso selbständiges wie nüchternes Urteil. Gerade hier nun ist es aber, wo Pseudo-Alkuin sagt: Sunt tamen alia, quae apud illos non habebantur, ut stola, sandalia et sudarium, quodad tergendum sudorem in manu gestari mos est, quod usitato nomine fanonem vocamus ${ }^{1}$. Die Worte sind klar und schlieben jeden Zweifel aus. Pseudo-Alkuin redet von einem sudarium, das zur liturgischen Tracht des Neuen Bundes gehörte. Dieses sudarium ist, wie die von ihm gegebene Beschreibung beweist, das sudarium des Amalar und, wie der Name fano bekundet, der fano Hrabans und sonach auch die mappula der römischen Ordines. Als Zweck des sudarium aber gibt Pseudo-Alkuin an, es pflege in der Hand getragen zu werden ad tergendum sudorem.

Es kann demnach nicht wohl zweifelhaft sein, dabs die Mappula wirklich den Charakter eines Sudarium hatte, nur darf man sich unter ihr kein gewöhnliches Taschen- oder Schweiftuch vorstellen. Sie war vielmehr ein von der Etikette gefordertes feines Tuch, das zur Verrollständigumg der liturgischen Tracht gehörte und mehr der Zierde als des praktischen Gebrauches wegen in der Hand oder auf dem Arm getragen wurde, ähnlich wie das bekannte, mit Spitzen besetzte Battisttüchlein, das noch jetzt nicht ganz ausgestorben ist, eine mappa da etichetta, wie P. Grisar treffend sagt? ${ }^{2}$. Solche Etiketteoder Ziertücher waren auch der alten Zeit nicht unbekannt ${ }^{3}$.

1 De div. off. c. 38 (M. 101, 1240).

2 Analecta rom. $683 ; \mathrm{vgl} .551$.

3 Beispiele bieten das bekannte Mosaik in S. Vitale zu Ravenna, Theodora im Kreise ihrer Hofdamen; das von de Rossi veröffentlichte Fresko einer syrakusanischen Katakombe, eine gewisse Marcia vor Christus darstellend (Bullet, archeol. III [1877], tav. 11); ein Fresko jm Cömeterium der Comodilla zu Rom (Abbildung in Nuovo Bullet. di arch. christ. X [1905], tav. 6) ; ein Diptychon im Dom zu Monza (Abbildung in Ann. XXI 222); ein ehedem zur Maximianskathedra im Dom zu Ravenna gehörendes Elfenbein in der Sammlung Stroganoff zu Rom (Abbildung bei Gräv. II, n. 62); eine Miniatur in dem Kosmas Indikopleustes der Vaticana (f. 134); das Apsismosaik in der erzbischöflichen Palastkapelle zu Ravenna (Abbildung in Revue 1896, 282); die Darstellung der Verkündigung in dem Etschraiadzin-Evangeliar (Abbildung bei Strzygowski, Byzantinische Denkmäler I, Wien 1891, 'Tfl 5); zwei Miniaturen des Gregor von Nazianz in der Nationalbibliothek zu Paris (Msc. grecs 510 , f. $247^{\mathrm{v}}$, wo der König der Philister, und f. $226^{\mathrm{v}}$, wo Moses ein Sudarium in der Linken trägt; Abbildung bei $\mathrm{H}$. $\mathrm{O}$ m o $\mathrm{nt}$, Fac-similés des miniatures des plus anciens manuscrits grees de la Bibl. nat, Paris 1902, pl. 2L XLIX); die Panagia auf dem Apsismosaik der Kathedrale zu Kiew (Abbildung bei Sch 1 u m b erger, L'Epopée byzantine I 197) u. a. Auch das 'Tuch, welches die Konsuln auf den Konsulardiptychen in der Hand halten, ist unseres Erachtens ein Etikette- oder Staatstuch, was natürlich nicht ausschliefst, dak es auch gebraucht wurde, um das Zeichen zum Anfang der Spiele zu geben. Es ist schwer begreiflich, warum sie so oft, um nicht zu sagen meist, mit diesem Tuch dargestellt werden, wenn dasselbe nichts anderes war als die Mappa, nit der sie die Spiele eröffneten, zumal dieser Akt nicht einzig durch die Konsuln vollzogen wurde. 
Bei dieser Auffassung des Sudarium fällt denn auch von selbst der Einwand, unter dem sudarium des Amalar, das offenbar ein sakrales Orratstück darstelle, da es mit der Stola, der Kasel usw. auf einer Stufe stehe, könne unmöglich ein Schweistuch verstanden werden, weil es unamnehmbar erscheine, dak ein durchaus profanes und praktischen Zwecken dienendes Tuch wie ein Taschen- oder Schweistuch jemals irgend weIchen liturgischen Charakter gehabt habe. Das Sudarium war eben kein "gemeines Schweik- oder Schnupftuch", wie man irrtümlich voraussetzt, sondern ein Staatstuch, ein Etikettetuch, ein Anstandstuch, ein Ziertuch. Schweistuch war es nur in der Theorie, nicht in der Praxis. Als wirklicher Schweistücher bediente man sich der facistergia, die schon in Inventaren des 9. und 10. Jahrhunderts in größerer oder geringerer Anzahl aufgeführt werden ${ }^{1}$.

Weiterhin begreift man, das Sudarium so verstanden, ohne Schwierigkeit, wie dasselbe den Diakonen als offertorium dienen konnte, als was diese es ja nach den römischen Ordines verwendeten, d. i. als das Tuch, womit sie ihre Opfergabe darbrachten; ebenso dał die Diakone mit ihrèm Sudarium die Henkel des Kelches umwickelten, wenn sie diesen hergerichtet hatten und zum Altar trugen bzw. nach der Konsekration emporhielten und dem Volke zeigten. Ein gewöhnliches Taschentuch hätten sie zu solchen Zwecken natürlich nicht verwenden können; nichts aber hinderte, daf sie dazu ihr Etikettetuch benutzten.

Aber auch die Geschichte des Ornatstücks in vorkarolingischer Zeit liegt klar vor uns, sobald wir die Mappula als Sudarium im Sinne eines Etikettetuches auffassen, und es bedarf zu ihrer Aufhellung und ihrem Verständnis weiterhin weder luftiger Hypothesen noch der Darstellungen heidnischer Opferknaben und antiker Aufwärter. Die Angaben des Papstbuches und der Briefwechsel zwischen Gregor d. Gr. und Johannes von Ravenna reichen dann vollständig aus, um in genuigender Bestimmtheit die Grundzüge der Entwicklung der Mappula in vorkarolingischer Zeit festzustellen. Namentlich aber ist es bei jener Ansicht von der Entstehung des Ornatstückes nicht mehr rätselhaft, daf dieses ursprünglich nur zu Rom als ein dem dortigen Klerus eigentümlicher, auszeichnender Ornat in Gebrauch war, der allem Anschein nach anfänglich nur dem Papst zustand, dam aber mitsamt der Dalmatik den als papabili so hervorragenden römischen Diakonen bewilligt wurde, hierauf, sei es durch besondere Verordnung (Zosimus) oder durch Gewohnheit, bei den Diakonen der suburbikarischen Diözesen Aufnahme fand und zuletzt sich bei der ganzen römischen Geistlichkeit einbürgerte. Das alles sowie auch der Streit zwischen dem römischen und ravennatischen Klerus wegen der Mappula, die diese sich angeblich angemafst haben sollten, ist alsbald verständlich, sobald man das Ornatstiick als Sudarium im Sinne eines Anstands-, Staats-, Etikettetuchs auffafit.

Dieser Ursprung des Manipels findet ferner seine genaue Parallele in dem Ursprung des griechischen bischöflichen Epigonation. Denn auch dieses war, wie wir früher sahen ${ }^{2}$, ursprünglich ein Tuch, und zwar, wie der Name

$1 \mathrm{Vgl}$. z. B. die Inventare von St-Riquier (831), Fontanelle (ca 830), St Bavo zu Gent (860), St Trond (870), Pfüffers (ca 900), Marchiennes (9. Jahrh.) u. a.; desgleichen die Consuetudines S. Vitonis zu Verdun (Mart., Mon. IV 297): Ponet super altare ... facistergium.

2 Vgl, oben S. 551 f. 
Enchirion, den letzteres führte, bekundet, eine Art von Schweilistuch, aher kein Schweibtuch im gewöhnlichen Sinne des Wortes, sondern als auszeichnendes Ornatstück der Bischöfe und als Bestandteil des Pontifikalornats wie die römische Mappula ein Staats- oder Etikettetuch. Es braucht kaum bemerkt zu werden, daf dieser Ursprung des Epigonation eine nicht unwichtige Bestätigung der Ansicht bildet, welche den Manipel auf ein Sudarium im Sinne eines Anstands- oder Etikettetuches zurückführt.

Neben der Mappula gab es natürlich auch zu allen Zeiten wirkliche Schweiftücher, und zwar müssen solche schon im 9. und 10. Jahrhundert zum förmlichen Bestand der Sakristeien gehört haben. Denn es finden sich bereits in den Inventaren aus diesex Zeit nicht selten neben den fanones oder mappulae auch facistergia (facistercula) verzeichnet. Ausdrïckliche Bestimmungen über den Gebrauch derartiger Schweistücher begegnen uns freilich erst um das 13. Jahriundert. Eine der friihesten treffen wir in den Synodalstatuten Odos von Paris aus dem Jahre 1200 an. Districte praecipitur, heist es darin, ut quilibet sacerdos habeat in celebratione missae propter munditiam vestimentorum servandam circa altare (es sind wohl die Altarvelen gemeint) unum manutergium pendens circa missale ad tergendum os et nares, si fuerit necesse ${ }^{1}$. Ähnliche Bestimmungen trafen die Kölner Synode des Jahres $1281^{2}$, die Konstanzer Synodalstatuten aus dem Anfang des 13. Jahrhunderts ${ }^{3}$, eine Lütticher Synode von $1287^{4}$, die Synode von Bayeux von $1300^{5}$, Synodalstatuten von Meaux u. a. ${ }^{6}$ In den Synodalstatuten von Lüttich lesen wir beispielsweise: Missale semper involutum camisia linea et munda altari imponatur et habeat sudariolum seu manutergium dependens, quo presbyteri nares, os et faciem detergeant. Bischof Grandisson von Exeter (1327-1369) traf in seinen Statuten die eigenartige Bestimmung, dak bei der Messe sowohl der Priester wie der

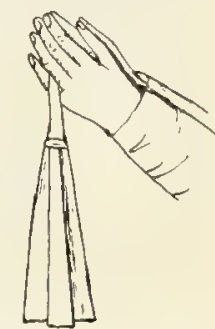

Bild 272. Doigtier. (Nach de Vert.)

Diakon und Subdiakon ein kleines Tuch in ihren Händen halten sollten, um die Gewänder vor Schmutz zu bewahren und den Schweís abtrocknen zu können 7 .

In eigentümlicher Weise trugen die Kanoniker von Reims das Sudarium ${ }^{8}$. Nach de Vert war es nämlich am kleinen Finger der linken Hand befestigt und führte davon den Namen doigtier (Bild 272). Man legte es an, wenn man zum Altar ging, und behielt es bis zur Opferung an der Hand. Dann wurde es abgelegt, aber nach der Kommunion wieder genommen. Der doigtier war auch in Antwerpen gebräuchlich, wie ein Bild Pieter Neffs des Älteren im Rijks-Museum zu Amsterdam beweist. Es stellt das Innere der Antwerpener Dominikanerkirche dar. Die Staffage bildet ein Umzug, bei dem Diakon und Subdiakon den doigtier tragen.

1 L e Brun, 'Traité prélim. art. 4, § 1, p. 44.

${ }^{2}$ C. 7 (Hartzh. HII 662).

s C. 35 (Mart., Thes. IV 811).

4. 5 , n. 8 (Hartzh. III 690).

${ }^{5}$ C. 2 I (H ard. VII 1229).

${ }^{6}$ C. 47 (Mart. a. a. 0.900).

7 Vgl. über das Schweifstuch auch Braun, Die priesterlichen Gewänder 69 f. Nach dem Braun, Die liturgische Gewandung.
12. römischen Ordo (n. 7; M. 78, 1067) ritt vor dem Papst beim Zug nach S. Stefano am Feste des hl. Stephanus prior subdiaconus regionarius cum toalea, ut cum dominus papa voluerit spuere, possit illo gausape os suum mundare.

${ }^{8} \mathrm{De}$ Vert II 295, note. Der doigtier war nicht der Manipel, wie man irrig geglaubt hat. 


\section{I E S T O L A.}

\section{DIE STOLA NACH DER GEGENWÄRTIGEN PRAXIS.}

Dem Manipel ist hinsichtlich der Beschaffenheit durchaus verwandt die Stola. Sie ist wie er ein streifenförmiges Ornatstück und unterscheidet sich von ihm fast nur durch ihre größseren Maßsverhältnisse. Während nämlich der Manipel im ganzen blof etwa $1,00 \mathrm{~m}$ lang ist, hat die Stola eine Gesamtlänge von ca $2,50 \mathrm{~m}$. Hinsichtlich des Stoffes, der Farbe, der Form, der Machweise und der Verzierung (namentlich auch der drei Kreuze und der Fransen an den Enden) besteht zwischen beiden Paramenten kein Unterschied. Es kann daher wegen alles dessen auf die diesbezüglichen Ausführungen in der Besprechung des modernen Manipels hingewiesen werden.

Die Stola kommt nur den Diakonen, Priestern und Bischöfen zu, deren charakteristisches Abzeichen sie bildet. Die Erstgenannten tragen sie in Form einer Schärpe, welche auf der linken Schulter ruht und von dort schräg über Brust und Rücken zur rechten Seite läuft, wo ihre Enden unter dem Arm miteinander verbunden werden. Bei den Priestern und Bischöfen liegt die Stola dem Nacken auf und zieht sich von da über die Brust bis etwa zu den Krnieen hinab. Während indessen die bischöfliche Stola stets gerade herabfällt, mag nun der Bischof die Albe oder das Superpelliceum tragen, muf die priesterliche Stola, so oft sie in Verbindung mit der Albe gebraucht wird, allemal über der Brust gekreuzt werden. Nur wenn der Priester sich des Superpelliceum bedient, läit auch er die Stola gerade herabsteigen. Nach römischem Brauch wird die priesterliche und bischöfliche Stola in der Weise über den Nacken geworfen, daf sie etwa eine Spanne weit nach hinten herabhängt. Allerdings setzt das voraus, dals sie entweder, wie das zu Rom wirklich zutrifft, sehr weich und faltsam ist und daf sie sich auf dem Rücken zusammenlegen läkt, oder dafs die beiden Stolahälften in der Mitte unter einem Winkel zusammenstoben, statt einen gerade fortlaufenden Streifen zu bilden: zwei Eigenschaften, welche übrigens auch da dem Ornatstück nicht fehlen sollten, wo es nicht üblich ist, dasselbe weit nach rückwärts herabhangen zu lassen.

Wie der Subdiakon den Manipel, so erhält der Diakon bei seiner W eihe aus der Hand des Bischofs die Stola. "Nimm hin", sagt dieser, während er das Ornatstuick auf die linke Schulter des Ordinanden legt, „aus Gottes Hand das weiße Gewand und erfülle deinen Dienst; denn Gott ist mächtig genug, um dir seine Gnade in reichem Maßje zu spenden, er, der da lebt usw."

Wird der Diakon zum Priester geweiht, so führt der Bischof denjenigen Teil der Stola, welcher sich hinter dem Rücken herzieht, über die rechte Schulter zur Brust, wo er die beiden Hälften in Form eines schrägen Kreuzes übereinander legt. Als priesterliche Amtsinsignie ist die Stola das Symbol des Priesteramtes. Darum begleitet der Bischof die $\ddot{A}$ derung in der Tragweise der Stola mit den Worten: "Nimm hin des Herrn Joch; denn sein Joch ist süb̆ und seine Bürde leicht."

Bei der Bischofsweihe ist die Stola nicht der Gegenstand einer besondern Zeremonie. Sie wird dem Konsekranden schon gleich, wenn er nach dem sog. Examen mit den bischöflichen Gewändern (Mitra und Handschuhe aus- 
genommen) bekleidet wird, in der Weise umgehängt, wie die Bischöfe sie zu tragen haben.

Über den Gebrauch der Stola gibt es eine ungemein grobe Anzahl von Entscheidungen der Ritenkongregation ${ }^{1}$, welche freilich zum großen Teil immer wieder dieselbe Sache betreffen. Wie schon bemerkt, ist die Stola Amtsabzeichen, Insignie des empfangenen Weiheordo. Dieser Anschauung gemäb lassen sich die Antworten der Kongregation in die allgemeine Regel zusammenfassen: die Stola darf „nur beim Vollzug eines spezifisch im Ordo gelegenen Offizium oder Ministerium getragen werden". Sie kann bzw. muls also gebraucht werden bei der Opferfeier, bei der Spendung der Sakramente und Sakramentalien sowie bei jeder mittellaren und unmittelbaren Berührung des Allerheiligsten. Bei Verwaltung des Predigtamtes darf man sich ihrer bedienen, wo solches Sitte ist 2 . Nicht als Ausühung des Ordo gilt das kirchliche Stundengebet, weshalb nicht einmal der Offiziator die Stola tragen darf, selbst dann nicht, wenn das Offizium feierlich gehalten wird ${ }^{3}$. Nur beim Totenoffizium kann, wenn dasselbe in Verbindung mit den Exsequien, d. i. unmittelbar vor der Messe, statthat, die Stola gebraucht werden*. Nicht als exercitium ordinis im engeren Sinne wird ferner die Assistenz bei der Messe ${ }^{5}$ oder bei Prozessionen betrachtet, die theophorischen nicht ausgenommen. Ein eigentliches signum iurisdictionis ist die Stola niemals ${ }^{6}$. Der Fälle, in denen ihr Gebrauch nicht zwar zum Zeichen der Jurisdiktion, aber doch eines gewissen Vorranges auch ohne Ausübung des Ordo ausnahmsweise gestattet wurde, sind nur sehr wenige. So wurde es den Pfarrern wohl erlaubt, bei Prozessionen die Stola zu tragen, falls sie collegialiter an denselben teilnähmen. Nach einer neueren Entscheidung scheinen sogar, wo das Gewohnheit ist, die Pfarrer auch dann bei Prozessionen sich mit ihr versehen zu dürfen, wenn sie nicht in corpore auftreten ${ }^{7}$. Der Bischof trägt nach dem römischen Caeremoniale $^{8}$ die Stola auch bei der feierlichen $V^{\top}$ esper, weil er, wie Thalhofer meint ${ }^{9}$, spezieller Repräsentant des im Himmel nicht blolis opfernden, sondern auch betenden Hohenpriesters ist.

\section{NAMEN DES ORNATSTÜCKES.}

Untel den Gewandstücken, welche die alten Liturgiker als zum heiligen Dienst gehörend bezeichnen, befindet sich eines, welches den Namen orarium führt. Es ist die Stola. Das geht nicht nur aus der Beschreibung hervor, welche sie von dem Orarium geben, sondern mehr noch daraus, daf manche ausdrücklich Stola und Orarium als eine Sache hinstellen; so schon Hraban, danı Pseudo-Beda und Pseudo-Alkuin, später Ivo von Chartres, der Verfasser des Speculum de mysteriis ecclesiae, Robertus Paululus u. a.

Abzuleiten ist das Wort Orarium von os, Mund, Gesicht. Demnach war das Orarium ursprünglich ein Tuch, das zum Abputzen des Mundes oder des

1 Sie sind ausfíhrlich zusammengestellt bei P. Victor ab Appeltern, Manuale liturg., Mechl. 1901, 76 f 553 und in der neuesten offiziellen Sammlung der Dekrete der C. R., Index gea. V $469 \mathrm{f}$.

2 C. R. 26. Sept. 1868; 11. Mär'z 1871 (Decret. auth. 3185 3237).

3 C. R. 4. Aug. 1663; 7. April 1832; 11. Sept. 1847 (ebd. 12752689 2956).
${ }^{4}$ Caerem. episc. 1. 2, c. 10 , n. 10 ; C. R. 12. Aug. 1854 (Decret. auth. 3029).

5 C. R. 12. Mariz 1836; 4. Sept. 1875 (ebd. 27413367 ).

${ }^{6}$ C. R. 11. Sept. 1847 (ebd. 2956).

7 C. R. 30. Mårz 1824; 11. März 1837; 22. Juli 1848; 9. Mai 1857 (ebd. 26352763 2973 3051). $\quad 8$ L. 2, c. 1, n. 4.

9 Liturgik 879, Anm. 3. 
Gesichtes bestimmt war, also eine Art von Schweirtuch. So definiert es wirklich Ammonius von Alexandrien (ca 458) in seinem fragmentarisch erhaltenen Kommentar zur Apostelgeschichte. "Oraria nennt man", so sagt er, "die 'Tücher, welche dazu dienen, Schweis, Speichel, Tränen und ähnliches vom Gesicht wegzuputzen." 1 Indessen hatte schon vor der Zeit des Ammonius das Wort eine weitere Bedeutung erlangt.

Bei den profanen lateinischen Schriftstellern werden Orarien nur selten und erst im 3. nachchristlichen Jahrhundert erwähnt. Nach Trebellius Pollio ${ }^{2}$ schenkte Kaiser Gallienus (259-268) dem Claudius (Kaiser von 268 bis 270) 4 oraria sarabdena (?); Aurelianus (270-275) aber, so berichtet Flavius Vopiscus ${ }^{3}$, spendete zuerst dem römischen Volke oraria, quibus uteretur ad favorem, d.i. oraria, mittels deren es (bei den Zirkusspielen) seinen Beifall äufsern, applaudieren sollte. Häufiger ist von dem Orarium bei den Kirchenschriftstellern die Rede. Bei Hieronymus erscheint es als eine Art von linnenem Umwurf oder Halstuch, wenn er an Nepotian schreibt: Non absque amictu lineo incedere ... laudabile est; alioqui ridiculum est, referto marsupio quod sudarium orariumque non habeas gloriari ${ }^{\ddagger}$. Ambrosius spricht in seiner Schrift über das Hinscheiden seines Bruders Satyrus von einem Orarium, welches das Haupt des toten Lazarus verhüllte ${ }^{5}$. Ebendort ${ }^{6}$ erzählt er, bei einem Schiffbruch habe Satyrus die heilige Eucharistie in ein Orarium gebunden, selbiges dann um den Hals gewickelt und sich so im Vertrauen auf Gottes Hilfe ins Meer gestürzt. Von Orarien, die man auf die Reliquien der Heiligen legte, damit sie so selbst im gewissen Sinne Reliquien würden, redet der Heilige im Briefe über die Wunder der hll. Gervasius und Protasius ${ }^{\top}$. Augustinus ${ }^{5}$ berichtet, man habe mit einem Orarium das Auge eines Jünglings verbunden, das aus der Höhlung getreten, aber dann in dieselbe zurückgelegt worden war. Prudentius Clemens ${ }^{9}$ und nach ihm Gregorius von Tours ${ }^{10}$ aber erzählen uns, als Hesychius und Chelidonius ans Calahorra in Spanien für ihren Glauben nach mancherlei Peinen getötet worden seien, habe sich ein großes Wunder ereignet; denn des einen Ring und des andern Orarium seien von einer Wolke aufgenommen und zum Himmel emporgetragen worden, während die Menge bestürzten Blickes den Glanz des Goldes und die Weife des Linnentuches verfolgt habe. Prudentius nennt in einem Wortspiel jenes Orarium das pignus oris, d. i. das Pfand seines treuen Bekenntnisses. Gregor der Große ${ }^{11}$ schickte einem gewissen Marinus und Christodorus, wie es scheint, Höflingen, zwei Tuniken und vier Orarien als Geschenk nach Konstantinopel; offenbar Orarien besserer Sorte. Isidor von Sevilla verbietet den Mönchen in seiner Regel, ein Orarium zu gebrauchen ${ }^{12}$. Fügen wir noch hinzu, daß nach Gregor von Tours Sigiric, Sigismunds Sohn, mit einem Orarium erdrosselt wurde, welches er im Schlaf um den Hals trug und das unter dem Kinn gebunden war ${ }^{13}$, dak Chram, der sich gegen seinen Vater empört hatte, auf dessen Befehl orario suggilatus est ${ }^{14}$, und daf nach den Akten der hll. Narcion und Nikander der Henker mit Orarien deren Augen verband, ehe er zum Todesstreich ausholte ${ }^{15}$.

1 C. 9 , v. 12 (Mg. 85, 1576).

2 In Claudio c. 1417.

3 In Aureliano c. 48. Vgl. dazu Euse b., Hist. ecel. 1. 7, c. $30(\mathrm{Mg}, 20,713)$, wo erzählt wird, Paulus von Samosata habe sich in der Kirche dixúvars (mit linnenen Tüchern) Beifall zuwinken lassen, wie es in den Theatern geschehe.

4 Ep. 52 ad Nepot. n. 9 (M. 22, 535).

5 De excessu fratr. Satyr. 1. 2, n. 78 (M. 16, 1837).

B L. 1, n. 43 (ebd. 1304).

7 Fp. 22 de mir. SS. Gervasii et Protasii n. 9 (ebd, 1022).

${ }^{8}$ De civ. Dei 1. 22, c. 8, n. 7 (M. 41, 765).
9 Peristephan. 1. 1, v. 86 (M. 60, 289).

10 De gloria mart. c. 93 (M. 71, 787).

11 Epist. 1. 7, n. 27 (M. G. Epp. I, 474).

12 C. 12 , n. 2 (M. 83, 882).

13 Hist. franc. 1. 3, c. 5 (M. 71, 245).

14 Ebd. 1. 4, c. 20 (ebd. 286). Vielleicht bedeutet orarium 1. 6, c. 17 (ebd. 389) den Talith, den jüdischen Gebetsmantel. Cumque die Sabbati Priscus (ein Jude, der sich taufen lassen sollte, aber nicht wollte), praecinctus orario nullum in manu ferens ferramentum, Mosaicas leges quasi impleturus secretiora competeret, subito Phatir (sein Feind) adveniens ipsum gladio iugulavit.

15 A. SS. 17. Iun., IV 219. 
In allen diesen Fällen handelt es sich bei dem Orarium um ein profanes Tuch. Hier ist es ein Schweilituch, da ein Kopftuch, dort ein Halstuch, wieder anderswo ein Tuch ohne bestimmten Charakter. Als Name eines Bestandteiles der liturgischen Kleidung begegnet uns orarium im Abendlande erst im 6 . Jahrhundert.

Im Osten kommt das Wort in diesem Sinne schon im 22. Kanon des Konzils von Laodicea, also um die Mitte des 4. Jahrhunderts, vor. Wie so manches andere lateinische Wort hatte nämlich auch orarium von Rom als wrópocov aus seinen Weg ins Griechische gefunden ${ }^{1}$. Später schrieb man den Namen des liturgischen Orarium gewöhnlich ióríntoy, wobei zugleich der lateinische Ursprung des Wortes so sehr der Vergessenheit anheimfiel, dab: Balsamon ${ }^{2}$ und Blastares ${ }^{3}$ es von hoù (zusehen, auf etwas achten) und Simeon von Salonikit von curcíse (schmücken) ableiten konnten. Denn der Diakon habe, so belehren uns die beiden ersten, obacht zu geben, wie weit der Priester in der heiligen Handlung sei, um dem Diakon auf dem Ambo zur rechten Zeit mit dem Ornatstück das Zeichen zum Anfang der Fürbitten fiir die Katechumenen und Gläubigen zu geben. Simeon aber meint, dasselbe werde copromy genannt, weil es die Diakonen mit Anmut ziele und mit göttlicher Schönheit schmücke.

Ging das lateinische orarium in das Griechische über, so entlelnte diesem umgekehrt der abendländische Sprachgebrauch den Namen stola.

Das Wort oroky hat in Griechischen die allgemeine Berleutung "Kleid" und diente demgemälí zur Bezeichnung aller Arten von Bekleidung; jedoch hat es auch wohl die nähere Bedeutung eines schmückenden, auszeichnenden Gewandes. Im Lateinischen entspricht ihm vestis, das indessen nicht blot ein Gewand im engeren Sinne bedeutete, sondern überhaupt ein Ausdruck für alle Arten von Überzügen und Bedeckungen war. Der griechische Text

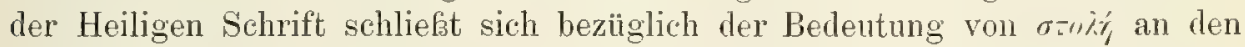
griechischen Sprachgebrauch an. Aus ihm ging dann, wie manche andere Benennung, $\sigma \tau$ orir, als stola im gleichen Sinn in die lateinische Bibelübersetzung und infolgedessen auch in die Kirchensprache iuber. Weit früher war das Wort schon in das klassische Latein eingedrungen und hier zum technischen Ausdruck eines weiten, bis auf die Fübe herabwallenden Frauenkleides, der auszeichnenden Tracht ehrbarer römischer Matronen, geworden. Als Benennung von Mannskleidern kommt stola bei den klassischen Profanschriftstellern seltener und fast nur in bestimmten Fällen vor ${ }^{5}$.

Im kirchlichen Sprachgebrauch gewann das Wort neben seiner allgemeinen Bedeutung im Lauf der Zeit noch eine besondere, indem es Name des orarium genannten liturgischen Gewandstückes wurde. In Gallien war stola in diesem Sinne schon zu guter Zeit in Brauch; denn die gallikanische Meferklärung spricht bereits ausdrücklich von einer stola des Diakons, und es kann nach der Beschreibung, welche sie von dieser gibt, nicht zweifelhaft sein, daf wir in ihr das Orarium zu sehen haben.

Man beruft sich für den frühen Gebrauch des Wortes stola als Benennung unseres liturgischen Gewandstückes auch auf die Vita S. Mauri, die von seinem Zeit-

1 Sehr lehrreich für die Aufnahme lateinischer Bezeichnungen in das Griechische ist Diokletians Maximaltarif. Die Zusammenstellung solcher Worte bei Blümner-Mommsen, Der Maximaltarif Diokletians, Berlin 1893, $57 \mathrm{f}$.
2 In can. 22. Conc. Laodic. (Mg. 137, 1369).

3 Syntagma litt. E, c. 9 ( Mg. 144, 1276).

$4 \mathrm{D}_{\theta}$ sacris ordinationibus c. $174 \quad(\mathrm{Mg}$. 155, 381).

5 For cell. sub stola IV 186. 
genossen und Schüler Faustus herrühren soll. Dort wird erzühlt, eines Tages hätten Eltern ihr stummes und lahmes Kind zum Heiligen gebracht, damit selbiger es durch seine Wunderkraft heile. Dieser aber habe die Stola, mit der er in demselben Jahre auf Befehl seines heiligen Lehrers für den Dienst eines Leviten (Diakons) geweiht worden sei, und die er nach Sitte und Brauch im ersten Jahre sanctitatis gratia beständig getragen habe, vom Hals genommen, über das Haupt des kranken Kindes gelegt md letzteres so wunderbarerweise gesund gemacht'. Wirklich kann kein Zweifel obwalten, daf die Stola, von der hier die Rede ist, mit unserem jetzigen gleichnamigen Ornatstück eins ist. Allein es ist zu beachten, dafs die Vita S. Mauri nicht von Faustus, sondern von Odo von Glanfeuil und somit erst aus dem 9. Jahrhundert herrührt ${ }^{2}$.

Gegen Ende des 8. Jahrhunderts begegnet uns das Wort stola im Sinne von orarium in der Schenkung Adelgasters von Asturien. Nicht lange nachher treffen wir es in der gleichen Bedeutung bei Hrabanus Maurus, dann in den Inventaren von St-Riquier, bei Amalar und in der Synodalermahnung an. Gegen Ende des Jahrhunderts wird das Ornatstück stola genannt im 26. Kapitel des Konzils von Tribur, in den Statuten Riculfs von Soissons und einer spanischen Schenkungsurkunde vom Jahre $888^{3}$. Auch führt es in Sakramentaren des 9. Jahrhunderts schon diesen Namen; so beispielsweise in einem Sakramentar von Tours und einem Sakramentar von Amiens.

Es ist bemerkenswert, daf alle diese Dokumente dem Norden angehören. Immerhin war daselbst die Bezeichnung stola im 9. Jahrhundert noch keineswegs die allein gebräuchliche; denn wir finden neben stola auch den Ausdruck orarium. Orarium, quod quidam stolam vocant, sagt z. B. Hraban, doch mögen diese quidam gerade die Franken gewesen sein. Wie dem indessen auch sei, um die Mitte des Jahrhunderts überwog der Name stola im Norden jedenfalls. Amalar und die "Synodalermahnung " führen das Ornatstück nur unter der Benennung stola an. Im 26. Kapitel der Synode von Tribur heift es: stola vel orarium ", und wenn Riculf von Soissons vorschreibt, es sollten die Priester für die Meffeier aufer den andern liturgischen Gewändern anch zwei Orarien vorrätig halten, so erklärt er selbst, ähnlich wie etwas später Pseudo-Alkuin, diesen offenbar minder gebräuchlichen Ausdruck durch den bekannteren stola: cum duobus orariis, i. e. stolis. Sehr beachtenswert ist, daß in den Inventaren aus dem 9. Jahrhundert das Ornatstück fast immer den Namen stola führt; so in den Schatzverzeichnissen von St-Riquier, Fontanelle, St-Bavo zu Gent, St-Bertin zu St-Omer, Marchiennes, Pfäfers, denen wir auch wohl noch das von Tankirchen (903) anfügen dürfen. Die Bezeichnung orarium kommt nur in den Inventaren von Staffelsee und Milz vor.

Im 10. und 11. Jahrhundert findet der Name stola sich sehr häufig in den Pontifikalien und Sakramentaren; so in dem angelsächsischen Pontifikale Egberts, dem Pontifikale des hl. Dunstan, den Pontifikalien von Aletis und Cahors, den Sakramentaren von Moyssac und Corbie. Die Synode von Coyaca redet 1050. von der Stola des Priesters und Diakons in einer Weise, daf man annehmen mufi, es sei das Wort stola damals schon die landläufige Benennung unseres Ornatstückes gewesen. Daß es sich um die Mitte des 11. Jahrhunderts in der That damit so verhielt, sagt Wipert in der Biographie Leos IX, ausdrücklich, wenn er schreibt: orarium, quod vulgo stola dicitur ${ }^{5}$. Selbst in Italien war der Name stola inzwischen bereits recht gebräuchlich geworden.

IN. 15 (A. SS. 15. Ian. ; II 324).

2 Ebd. 15. Febr.; II 842 D. Potthast, Bibl. hist. II 1470 . a Ann. O. S. B. III 251.

$4 \mathrm{Hartzh}$. II 410 .

5 L. 1, c. 1 (A. SS. 11. Apr.; II 648). 
Die römischen Ordines des 8. und 9. Jahrhunderts reden nur vom Orarium ${ }^{1 .}$ Auch außerhalb Roms mag damals in Italien diese Bezeichnung noch dio vorherrschende gewesen sein; allein schon im 10. Jahrhundert begegnet uns im mittleren wie namentlich im nördlichen Italien daneben wiederholt der Name stola, so in einem Mailänder Pontifikale², in der Synodica ad presbyteros des Bischofs Ratherius von Verona $(\dagger 974)^{3}$, dem Consuetudinarium von Farfa, dem Inventar der Kathedrale von Cremona, ja sogar dem Schatzverzeichnisse von Monza, wo freilich sich der Gebrauch des Wortes aus der Nationalität des Schreibers Adalbertus, wie es scheint, eines Deutschen, erklären lälit. Dieselbe Bezeichnung führt das Ornatstück in einem im Beginn des 2. Jahrtausends geschriebenen Benediktinermissale der Vaticana ${ }^{4}$ und einem nicht gar lange nachher entstandenen Sakramentar von Arezzo 5, in der Chronik von Monte Cassino ${ }^{6}$ u. a. Unter den Liturgikern des 11. und 12. Jahrhunderts nennt Bruno von Segni das uns beschäftigende Ornatstück noch immer mit dem alleinigen Namen orarium; alle andern, Sicard und Innozenz III. nicht ausgenommen, brauchen dagegen entweder gar nicht mehr diesen Ausdruck oder behandeln ihn nur als eine Nebenbezeichnung, die sie anführen, teils etwa, weil der Name sich in älteren Akten fand, teils weil sie sich bei ihren Ausführungen über die Stola an die frïheren Liturgiker anlehnen, teils, und vielleicht vornelmmlich, weil ihnen das Wort orarium einen Hinweis auf die Funktionen zu enthalten schien, bei denen die Stola angelegt wurde.

Schon das Konzil von Toledo bezieht im 40. Kanon das Orarium auf das Predigtamt und bringt es mit orare im Sinne von praedicare (predigen) in Verbindung. „Dex Levit“, heift es dort, „muf ein Orarium, und zwar auf der linken Schulter, tragen, propter quod orat, i. e. praedicat." " Die Liturgiker des 9. und 10. Jahrhunderts haben die Erklärung jenes Konzils aufgegriffen, weil sie ihnen bei der Deutung des Gewandes gute Dienste leistete; so Hraban, Walafried und Pseudo-Alkuin. "Trefflich", sagt der erstere, „paßt es sich für die oratores Christi, ein Orarium zu haben, weil sie dadurch, daf ihr Gewand mit ihrem Amt übereinstimmt, zum Eifer im Dienste des Wortes ermahnt werden, und zugleich das ihnen anvertraute Volk durch den Anblick des heilbringenden Abzeichens ermuntert wird, feuriger zur Erwägung des Gesetzes hinzueilen." Walafried aber bemerkt: „Die ersten Ordnungen (der Kleriker, d. i. Bischof, Priester und Diakon) in der Kirche tragen das Orarium, weil ihnen das Lehramt zukommt." 8

Spätere, Bruno von Segni, Sicardus, Durandus, bezogen orarium auf orare im Sinne von beten; unter orare aber verstanden sie die Verrichtung der liturgischen Gebetsfunktionen, bei denen der Priester das Orarium zu tragen hatte. Es heiße Orarium, so belehrt uns Bruno, weil die Priester zwar ohne die sonstigen Gewänder taufen, firmen und manches andere betend (orando) tun könnten, ohne Orarium jedoch nichts von allem dem vornehmen dürften, es sei denn, dafs groke Not solches erheische ${ }^{9}$.

1 Ausgenommen eine von Grisar aus einer Handschrift des 11.-12. Jahrhunderts veröffentlichte Rezension des 1. Ordo (Analecta Romana, Rom 1899, 221), in der aber das Wort stola vielleicht nicht ursprünglich, sondern eine spatere Interpolation ist. Die andern Rezensionen des Ordo haben nämlich weder orarium noch stola. Sollte sich indessen stola schon in der Vorlage der Handschrift gefunden haben, welcher Grisar jene Rezension ontnahm, so diirfte es sich bei dieser Vorlage wohl um eine von einem Nichtrömer herrührende Kopie des 1. Ordo handeln.
2 Magistretti, Pontificale in usum eccl. Mediol., Mediol. 1897, 43.

${ }^{3}$ N. 611 (M. 136,559562 ).

4 Vat. lat. 4770.

5 Ebd. 4772.

${ }^{6}$ L. 3, n. 1874 (M. G. SS. VII 711 $753)$.

${ }^{7} \mathrm{H}$ ard. III 588.

${ }^{8}$ De exordiis et incrementis c. 10 . Hitt. 670. Bei M. 114, 931 steht fehlerhait oratoriis statt orariis. Der Mignesche Text gibt keinen Sinn.

9 Tract. de sacr. eccl. (M. 165, 1104). 
Seit dem 13. Jahrhundert wird die Bezeichnung orarium nur noch vereinzelt gebraucht. Der regelmäkige Name für das uns beschäftigende Gewandstïck ist, wie namentlich aus den Schatzverzeichnissen und den liturgischen Büchern erhellt, stola. In den Inventaren wird man seit 1200 kaum je auf die Bezeichnung orarium stoßen; selbst römische Verzeichnisse reden nur mehr von stolae. Kaum anders verhält es sich in den späteren römischen Ordines, den Pontifikalien, Missalien und sonstigen liturgischen Büchern des 13., 14. und 15. Jahrhunderts. Wir haben eine ungemein grofe Zahl derselben aus Frankreich, Deutschland und Italien durchforscht. Fast überall heifst das Ornatstiuck stola. Zwar kommt in ihnen bis zum Ende des Mittelalters noch immer hie und da der Name orarium vor. Aber solche Fälle sind nur verschwindend geringe Ausnahmen und mehr Folgen gedankenlosen Kopierens alter Vorlagen als Zeugen des derzeitigen Brauches ${ }^{1}$.

In das römische Missale und das Caeremoniale der Bischöfe hat bloß der Name stola Aufnalme erhalten. Nur im römischen Pontifikale hat sich die Bezeichnung orarium, wenngleich auch hier blof an einer einzigen Stelle, in die Gegenwart hineingerettet. In dem Ritus der Priesterweihe lesen wir nämlich: Pontifex reflectit orarium sive stolam humero cuiuslibet, d. i. der Ordinanden. In Ritus der Diakonenweihe heifst das Ornatstïck blof stola.

Das Kind des Hauses hat einer Fremden, der Name orarium der Bezeichnung stola Platz und Recht abtreten müssen. Es ist derselbe interessante Vorgang, den wir auch hinsichtlich der Bezeichnung des Manipels, der Albe und des Amikts sich vollziehen sahen.

Wie aber kam es, daß gerade das Orarium den Namen stola, d. i. "Gewand im engeren Sinne", erhielt? Man hat noch in jüngerer Zeit gesagt, "es sei schwierig, das zu erklären, und eine nur einigermaßen stichhaltige Erklärung sei noch nicht gefunden worden". Ausführlich ist die Frage in der "Realenzyklopädie für christliche Altertümer" unter "Kleidung “ behandelt, woselbst auch interessante neue, doch ungenügende Lösungsversuche gemacht werden ${ }^{2}$. Eine bessere Deutung gibt Thalhofer ${ }^{3}$. Die durch die Ordination empfangene Predigtgewalt, meint er, habe im Anschluf an Sir 15, 5 als die stolae gloriae gegolten; als das sinnfällige Zeichen dieses erhabenen Ministerium sei aber das Orarium (orare $=$ predigen) angesehen worden, und darum sei denn die Bezeichnung stola vom Amt auf das Amtsabzeichen übertragen worden.

Indessen, so ansprechend diese Lösung ist, sie ist unseres Erachtens etwas zu gesucht. Man braucht nicht so weit in die mystischen Tiefen hinabzusteigen, wie das Thalhofer tut. Die Sache erklärt sich einfacher. Man beachte drei Punkte: 1. daf das Orarium schon sehr früh als Abzeichen des Amtes galt; 2. dak die Bezeichnung stola nicht da aufkommt, wo das Wort eine enger begrenzte Bedentung hatte, zu Rom, sondern fern vom klassischen Boden im Norden, wo der Sprachgebrauch nicht so festgelegt war und man darum mit einem Ausdruck leichter eine Sonderbedeutung verbinden konnte; 3. dal, in der Heiligen Schrift das Wort stola öfters ein ausgezeichnetes Gewand bedeutet, man denke z. B. an die stola gloriae bei Sir 6, 32, die stola prima bei Lk 15, 22, die stola alba in Offb 6, 11 und 7, 9. Die Erklärung, wie das Orarium den Namen stola erhielt, ist hiernach diese: Man hat da, wo das Wort stola in einem minder eingeengten Sinn gebraucht wurde,

1 Vgl, z. B. die Synode von Eichstät von 1447, c. De custodia Euch. (H artzh, V 367).
2 II $200 \mathrm{f}$.

${ }^{3}$ Liturgik I 877. 
d. i. im Norden, und zwar wohl im Anschlufs an den Sprachgebrauch der Heiligen Schrift, in welcher stola mehrfach ein hervorragendes Kleid bedeutet, eben das Stïck der liturgischen Gewandung stola genannt, welches als Abzeichen des Amtes und darum als das liturgische Gewand im besondern Sinne galt. Orales (= oraria) 10, quod Scripturas (sic) dicunt stolas, heist es sehr bezeichnend in einem Verzeichnis der Gaben des Bischofs Ovico von Leon für S. Juan de Vaga (ca 950) ${ }^{1}$.

\section{DIE ÄLTESTEN NACHRICHTEN ÜBER DIE STOLA IM ABENDLAND.}

In der Ostkirche treffen wir, wie wir später sehen werden, schon in der zweiten Hälfte des 4. Jahrhunderts den Gebrauch eines liturgischen Orarium an. Im Abendlande erhalten wir erst eine geraume Weile später von ihm Kunde.

Den ausgiebigsten Aufschluß empfangen wir über das Orarium und seine Verwendung im Kultus aus Spanien, und zwar ist es der 9. Kanon der Synode von Braga aus dem Jahre 563, dem wir die erste Nachricht darüber verdanken?

Während nach Kanon 22 und 23 des Konzils von Laodicea in der Ostkirche die niedern Kleriker danach gestrebt zu haben scheinen, gleich dem höheren Klerus das Orarium zu tragen, oder gar selbiges sich widerrechtlich angemaft haben mögen, legten die spanischen Diakone an verschiedenen Orten, der Bestimmung des Konzils von Braga nach zu urteilen, allzu wenig Gewicht auí ihr Amtsabzeichen. Der angezogene Kanon rügt nämlich, daf in einzelnen Kirchen die Diakone das Orarium unter der Tunika trügen und infolgedessen sich ein Unterschied zwischen ihnen und den Subdiakonen nicht bemerklich mache, und dringt auf Abschaffung einer solchen verkehrten Gewohnheit. Es erhellt aus ihm, daf in der zweiten Hälfte des 6. Jahrhunderts in Spanien das Orarium über der Obertunika getragen wurde; daf die Obertunika der Diakone und Subdiakone nicht merklich voneinander verschieden war; daf das Orarium, das der Diakon über der Tunika hatte, ihn als solchen zum Unterschied von den Subdiakonen kennzeichnete und somit für ihn das Amtsabzeichen war, und dak das Orarium entweder ein blofer Streifen oder doch ein streifenartig zusammengelegtes Tuch gewesen sein muf, da die Diakone es andernfalls wohl nicht unter der Tunika hätten anlegen können. Desgleichen ergibt sich aus dem Kanon, dafs das Orarium der spanischen Diakone weder ein liturgischen Zwecken dienendes Tuch, noch eine Art von Sudarium gewesen sein kann, da dieselben es weder in dem einen noch dem andern Falle vernünftigerweise unter der Tunika hätten verborgen tragen können. Auch hätte die Synode gewifs darauf hingewiesen, wenn das Orarium eine solche praktische Bestimmung gehabt hätte, statt lediglich auf dessen Charakter als den eines liturgischen Distinktivum aufmerksam zu machen.

Weitere Nachrichten über das Orarium in der spanischen Kirche und seinen Gebrauch erhalten wir 70 Jahre später. Es liefern uns dieselben der 28. und 40. Kanon des unter dem Vorsitze des hl. Isidor von Sevilla abgehaltenen, schon wiederholt angeführten 4 . Konzils von Toledo vom Jahre 633. Aus dem ersten der beiden ersehen wir, dab nicht blof der Diakon das Orarium trug, sondern daf dieses auch einen Teil der Amtstracht des Priesters und

\footnotetext{
1 Florez, España sagrada XXXIV $454 \mathrm{f.} \quad 2$ Hard. III 351.
} 
des Bischofs ausmachte. Weiterhin belehrt uns der Kanon, daf schon im Anfang des 7. Jahrhunderts in der spanischen Kirche die Sitte bestand, dasselbe dem Diakon, dem Priester und dem Bischof bei deren Ordination als Symbol der empfangenen Weihe zu übergeben. Endlich erhellt aus ihm, dafí die Piestitution eines ungerechterweise abgesetzten Diakons, Priester's und Bischofs unter anderem auch durch die Wiederübergabe des Orarium zu erfolgen hatte.

Von nicht geringerem Interesse als der 28. ist der 40. Kanon des Toletaner Konzils. Hatte die Synode von Braga die allzu grobe Bescheidenheit und einen gewissen Mangel an Standesbewuftsein bei den Diakonen einzelner spanischen Kirchen getadelt, so sehen sich die zu Toledo versammelten Bischöfe genötigt, wider den entgegengesetzten Mißzbrauch einzuschreiten. Es war nämlich vorgekommen, daf Diakone sich statt eines zwei Orarien zugelegt hatten, für jede Schulter eines. Auferdem hatten sie statt schlichter, weißer, unverzierter Orarien buntfarbige und mit Goldornamenten ausgestattete angenommen. Darum bestimmt die Synode: "Zwei Orarien dürfen nicht einmal der Bischof und der Priester haben, geschweige also der Diakon, welcher deren Diener ist. Der Levit soll daher ein einziges Orarium auf seiner linken Schulter trager, quia orat, i. e. praedicat. Die rechte Seite aber soll er frei haben, damit er unbehindert für den Altardienst hin und her eile. Der Levit hüte sich also, ein doppeltes Orarium zu gebrauchen, sondern bediene sich nur eines einzigen, und zwar unverzierten und mit keinen Farben und mit keinem Gold geschmückten." 1 Zu Anfang des 7. Jahrhunderts war mithin das liturgische Orarium der spanischen Diakone - denn dafs es sich bei demselben um ein wirkliches Kultkleid handelt, kann nach dem ganzen Wortlaut der beiden Kanones nicht zweifelhaft sein - entweder ein förmlicher Streifen oder doch ein streifenförmig umgelegtes Tuch aus einfachem, weifem Stoff. Wäre es ein breites, nach Art eines Umwurfes über den Schultern getragenes Tuch gewesen, so hätte es den Diakonen wohl nicht einfallen können, auf beiden Schultern ein solches zu tragen. Ebenso kann es nur ein Abzeichen, nicht aber ein Halstuch, ein Schweistuch oder ein bei den liturgischen Verrichtungen zu gebrachendes Tuch gewesen sein. Denn so allein verstehen wir, wie die Diakone dazu kommen konnten, es zu verdoppeln und auf jeder Schulter ein Orarium zu tragen. Kanon 40 der 4. Synode von Toledo bildet sonach eine ebenso interessante und lehrreiche wie wichtige Bestätigung des 9. Kanons des Braccarense.

Etwa 40 Jahre nach Abhaltung des Konzils von Toledo versammelte sich eine andere Synode zu Braga (675). Auch sie ist für die Kenntnis des

1 Hard. III 586588 . Es kann auffällig erscheinen, dâs die Diakone in Spanien dem Konzil von Braga zufolge angefangen hatten, das Orarium unter der Albe zu tragen, und daßs sie wiederum zwei Menschenalter später begannen, selbiges zu verdoppeln, d. i. auf beide Schultern ein nach vorn und nach rückwärts herabfallendes Orarium zu legen, und noch dazu ein farbiges und goldverziertes. Sollte nicht die Lösung des Rätsels in dem Bestreben der spanischen Diakone zu suchen sein, die Tracht der römischen Diakone nachzuahmen? Trugen diese ein Orarium, so befand dasselbe sich jedenfalls unter der Dalmatik; bei den Beziehungen der spanischen zur römischen Kirche mochten es daher den Diakonen in Spanien sich nahelegen, ebenso wie die römischen das Orarium verborgen unter der Tunika zu tragen. Da indessen die Bestimmung der Synode von Braga ihnen einen Strich durch die Rechnung machte, scheint es später den spanischen Diakonen in den Sinn gekommen zu sein, ihre Tracht der der römischen Diakonen dadurch ähnlich zu gestalten, dak sie statt des bisherigen einen weifen Orariums zwei farbige anwandten. Sie mochten hoffen, in dieser Weise ein Sur rogat für die römische, mit roten oder purpurfarbigen Streifen geschmückte Dalmatik zu schaffen. 
liturgischen Orarium in der spanischen Kirche jener Zeit von Bedeutung gew orden.

Im 4. Kanon ${ }^{1}$ bestimmt sie nämlich: "Wenn der Priester zur Meffeier sich anschickt, um das Opfer darzubringen und das Sakrament des Leihes und Blutes unseres Herrn Jesu Christi zu empfangen, so soll el das nicht tun, ohne das Orarium auf beide Schultern gelegt zu haben, wie es ja auch bei seiner Weihe geschah, und zwar in der Weise, dafo er, mit einem und demselben Orarium Nacken und Schultern belastend, auf seiner Brust das Zeichen des Kreuzes trägt." Als Grund dieser Verordnung gibt die Synode an: „Da nach alter kirchlicher Bestimmung angeordnet ist, daf jedem Priester bei seiner Weihe das Orarium über beide Schultern gelegt werde..., wie soll er da nicht zur Zeit des Opfers tragen, was er im Sakrament (der Weihe) empfangen zu haben nicht bezweifelt?"

Aus diesem Kanon folgt wiederum ein Mehrfaches. Vor allem beweist er mit aller Klarheit, daf das Orarium in der zweiten Hälfte des 7. Jahrhunderts in Spanien als liturgisches Gewand angesehen wurde. Dann bekundet er die hohe Bedeutung, die man diesem Ornatstück zuschrieb. Dasselbe war offenbar weder ein Hals- noch Schweis- noch Opfertuch, sondern priesterliches Abzeichen. Weiterhin lernen wir aus ihm, dab schon zur Zeit des Konzils von Braga für den Priester die Sitte bestand, das Orarium bei der heiligen Messe vor der Brust gekreuzt zu tragen, und daf darum das priesterliche Orarium, wenn nicht schon ein förmlicher Streifen, so doch wenigstens ein streifenartiges Tuch gewesen sein muf. Endlich erfahren wir, daf damals bei der Weihe des Priesters, ähnlich wie es noch jetzt geschieht, das Orarium über Nacken und Schultern des Ordinanden gelegt wurde und daf dieser Weiheritus schon seit alter Zeit in Gebrauch war.

Die ausführlichen Nachrichten, welche wir über den Gebrauch des liturgischen Orarium im 6. und 7. Jahrhundert aus der spanischen Kirche besitzen, sind für uns um so wichtiger und wertvoller, als wir über seine damalige Verwendung in den andern Teilen des Abendlandes nur sehr mangelhaft unterrichtet sind. Ebendarum war es durchaus notwendig, die hier in Betracht kommenden Kanones der beiden Synoden von Braga und des 4. Konzils von Toledo eingehend zu würdigen.

In der gallischen Kirche war, wenn wir der "Geschichte der Metzer Bischöfe" glauben wollen, die Stola schon in apostolischer Zeit in Gebrauch. Dieselbe erzählt nämlich ${ }^{2}$, K'lemens, der Oheim des Papstes Klemens I., sei vom Apostelfürsten nach Metz geschickt worden und habe daselbst eine furchtbare Schlange, welche die Stadt bedrohte, mittels seiner Stola, quam sanctissimo gerebat in collo, gebunden, unter den Augen des Volkes zum nahen Fluf gebracht und ihr dort geboten, zu entweichen. Die Geschichte ist indessen, wie kaum gesagt zu werden braucht, nichts als eine sehr späte Legende und ohne jede Bedeutung für die Geschichte unseres Ornatstückes.

Die einzigen Angaben über den Gebrauch der Stola im vorkarolingischen Gallien, welche überhaupt von Wert sind ${ }^{3}$, bieten die gallikanische Mef-

1 Ebd. 1034.

2 Gesta episc. Met. (M. 95, 712).

3 Ohne Wert ist es $z$. B., wenn in der von Flodoard im 10. Jahrhundert geschriebenen Historia eccl. Remensis (1. 1, c. 14 [M. G. SS. XIII 425]) erzählt wird, Genebald, Bisehof von Laon, habe sich wiederholt Unenthaltsarnkeit zu Schulden kommen lassen, zuletzt sich aber voll Reue zum hl. Remigius begeben, bei diesem als Zeichen seiner Unwürdigkeit alsbald die Stola abgelegt und dann dem Heiligen seine Vergehen bekannt. 
erklärung. ${ }^{1}$ und der 6. Kanon der Synode von Màcon aus dem Jahre 581. In der Melierklärung wird die diakonale Stola ausdrücklich mit dem Namen stola bezeichnet. Sie wurde über der aus Seide oder Wolle angefertigten Diakonenalba getragen und bestand allem Anschein nach aus weibem Stoff. In der Fastenzeit wurde sie, weil sie den Charakter eines Festgewandes hatte, pro humiliatione nicht gebraucht. Das priesterliche Orarium führt in der Melierklärung den Namen pallium. Denn unter dem pallium, von dem diese spricht, kann wohl nur die priesterliche bzw. bischöfliche Stola verstanden werden. Als diakonale Amtskleider verzeichnet die Meferklärung Alba und Stola, als priesterliche auser den manicae (Stauchen) Kasel und Pallium. Die Alba des Diakons entspricht der Kasel des Priesters, das Pallium mufa also demnach wohl das Gegenstiick der diakonalen Stola sein. Eine Bestätigung erhält das durch den 28. Kanon der Synode von Toledo vom Jahre $633^{2}$, in welchem als liturgische Gewänder der Diakone ebenfalls alba und orarium, als solche der Priester aber planeta und orarium genannt werden, wobei zu beachten ist, daf die Sakralkleidung in Spanien auch in anderer Beziehung: der gallikanischen verwandt erscheint. Denn wie die gallikanischen Diakone trugen auch die spanischen die Stola über der Alba.

Welches Ornatstück sollte übrigens jenes pallium auch anders sein, als die priesterliche Stola? Die einzigen Gewandstücke, die sonst etwa in Frage kommen könnten, sind das angebliche gallikanische Pallium, ein spezitisch bischöfliches Ornatstück, und das gewöhnliche Schultertuch. Allein ein bischöfliches Gewandstück kann nicht gemeint sein, weil die Mefierklärung nur von Kleidern handelt, welche Priestern wie Bischöfen gemeinsam waren. Denn unter den sacerdotes, deren Gewänder sie beschreibt und mystisch deutet, versteht sie offenbar ebendieselben Geistlichen, welche sie an den andern Stellen damit meint, die pontifices und presbyteri ${ }^{3}$. Aber auch das Humerale kann die Meberklärung nicht im Sinne haben. Denn abgesehen davon, daf

Eine Stola des hl. Martin von Tours zu Aschaffenburg entstammt erst der Frühe unseres Jahrtausends. Eine dem hl. Cäsarius von Arles zugeschriebene, aus Linnen gemachte nud mit Kreuzen, Rauten und ähnlichem bestickte Stola, von deren Enden eines mit einer Tasche versehen ist ( $\mathrm{R}$ oh. VII 51 ff), dürfte dem 11.-13. Jahrhundert zuzuweisen sein und die Tasche nur das damals vielfach gebräuchliche, schaufelförmige Endstück darstellen. Bei einer Stola des hl. Licinius ( $\dagger$ 605), die vor der Revolution zu Angers aufbewahrt wurde (ebd. 52), kann es sich zufolge den Stickereien auf den Enden (Eva mit der Beischrift: Per Evam perditio, und die Verkündigung mit der Beischrift: Per Mariam reparatio) nur um ein Stück gehandelt haben, das frühestens aus dem 12-13. Jahriundert herrührte.

I M. 72, 95. Palleum, quod circa collo usque ad pectus venit, rationale vocabitur in vetere testamento; scilicet signum sanctitatis super memoriam pectoris.... Quod autem collo cingit, antiquae consuetudinis est, quia reges et sacerdotes circumdati erant palleo veste fulgente, quod gratia praesignabat. Quod autem fimbriis vestimenta sacerdotalia adnectuntur, Dominus Moysi praecepit in Numeris, ut per quattuor angulos palleorum filii Israel fimbrias facerent.

2 S. oben S. 569.

3 Das erhellt klar aus dem Passus, wo sie von der Erteilung der benedictio spricht (M. 72, 94). Desgleichen aus dem Abschnitt, der von den manicae handelt: manicae ex quolibet pretioso vellere extant, ut omnes communiter sacerdotes, etiam minoris digni tatis in saeculo facilius inveniant. Wenn die Meferklärung sagt, das pallium sei im Alten Bunde rationale genannt worden, so erklärt sich das aus dem Umstand, daf 3 die Stola nicht blof den Priestern, sondern auch den Bischöfen zukam. Aufzerdem muß darauf hingewiesen werden, dak die Ideen, welche ihr Verfasser von der alttestamentlichen Sakralkleidung hat, sehr unklar sind, da er die Kasel ausdrúcklich als von Moses angeordnet bezeichnet, und daf somit anch aus diesem Grunde die fragliche Bemerkung betreftis des pallium ohne Belang ist. 
die Fransen, mit denen das pallium anscheinend am Saum besetzt wurde. nicht zum gewöhnlichen Schultertuch passen, so wäre doch vor allem erst darzutun, daß überhaupt ein Humerale im gallikanischen Ritus zur liturgischen Kleidung gehört habe; wurde ja doch nach dem von Duchesne herausgegebenen Ordo noch im 9. Jahrhundert nicht einmal zu Rom ein solches regelmäßig gebraucht. Auferdem aber ist ein Schultertuch ersichtlich ein zu unbedeutendes Ding, als daf die Meferklärung, welche selbst der priesterlichen Tunika kein einziges Wort widmet, mit ihm sich zu beschäftigen Veranlassung gehabt hätte.

Was den 6. Kanon der Synode von Mâcon anlangt, so bestimmt diese, es dürften die Bischöfe sich nie unterfangen, ohne pallium die Messe zu feiern ${ }^{1}$. Auch hier ist das pallium, dessen Gebrauch den Bischöfen hier so ernst eingeschärft wird, allem Anschein nach das Orarium, von welchem der 28. Kanon des vierten Konzils von Toledo spricht, d. i. die priesterlich-bischöfliche Stola. An ein gewöhnliches Schultertuch bei ihm zu denken, verbietet der ganze Tenor des Kanons; ein spezifisch bischöflicher Ornat nach Art des römischen Pallium kann aber unter ihm nicht verstanden werden, weil es unseres Erachtens ganz unglaubhaft ist, daf die Bischöfe einen solchen beiseite gelassen hạben würden². Zudem mufs der Kanon der Synode von Màcon doch auch wohl im Einklang mit der gallikanischen Meferklärung gedeutet werden.

Für England liegen in Betreff des Orarium der vorkarolingischen Zeit nur zwei Angaben vor, die zudem erst aus dem 12. bzw. 11. Jahrhundert herrühren. Nach der ersten hätte Etheldreda, Äbtissin von Ely, für den hl. Cuthbert außer dem Manipel, dessen wir schon früher gedachten, mit eigener Hand eine mit Gold und edeln Steinen verzierte Stola verfertigt ${ }^{\text {. }}$. Das andere Zeugnis findet sich in der Lebensbeschreibung des hl. Livinus, welche berichtet, es habe der hl. Augustinus denselben während mehrerer Jahre erzogen und unterrichtet und ihm, als er ihn dann zum Priester geweiht habe, eine purpurne, mit Gold und Edelsteinen verzierte Kasel und eine stola mit einem von kostbarsten Gemmen und Gold leuchtenden orarium geschenkt ${ }^{4}$. Beide Angaben sind leider durchans unzuverlässig, so daf sie keinen Glauben verdienen. Bei der Notiz der Vita S. Livini kommt obendrein hinzu, daf ganz unklar ist, was in ihr unter stola und orarium $\mathrm{zu}$ verstehen ist.

Dafs in Nordafrika im 6. Jahrhundert das Orarium in Gebrauch war, hat man aus der Lebensbeschreibung des hl. Fulgentius schliefen wollen. Diese berichtet nämlich, es habe sich der Heilige niemals wie alle sonstigen Bischöfe eines Orarium bedient ${ }^{5}$. Allein nach dem Zusammenhang kann es nicht zweifelhaft sein, dafs an der fraglichen Stelle nicht von einem liturgischen Ornatstück, sondern einem profanen Orarium die Rede ist. Es wird dort nämlich die gewöhnliche Tracht des Heiligen beschrieben und ausgeführt, wie er auch als Bischof die Mönchskleidung in ihrer ganzen Einfachheit beibehalten habe. Das Orarium, das in der Vita erwähnt wird, ist also nichts anderes als das Orarium, dessen in dem 20. Kanon des Konzils von Orléans vom Jahre $511^{6}$ und dem 12. Kapitel der Regel des hl. Isidor von Sevilla ${ }^{7}$ ge-

1 M. G. Conc. I 157: Ut episcopus sine palleo missas dicere non praesumat. Die frühere Leseweise archiepiscopus statt episcopus machte den Kanon unverständlich. Aber auch die besten Handschriften haben richtig episcopus.
2 Vgl. auch unter Pallium Abschnitt 10.

${ }^{3}$ Acta S. Etheldredae Reg. 1. 1, n. 31

(A. SS. 23. Iun., V 430).

4 N. 14 (M. 87, 335).

5 C. 18 (M. 65, 136).

6 Hard. II 1011.
7. M. $83,882$. 
dacht wird. In ersterem wird den Mönchen verboten, im Ǩloster ein Orarium und eine bestimmte Schuhart, zangae genannt, zu tragen. In dem angeführten Kapitel der Regel des hl. Isidor aber heißst es ähnlich, es dürften die Mönche sich keines Linnenzeuges, noch des Orarium, des Birrus (einer Mantelart) und der Planeta (Kasel) bedienen.

Überhaupt haben wir kein direktes Zeugnis für den Gebrauch der Stola in der altchristlichen Kirche Nordafrikas. Ein indirektes dürfte jedoch darin liegen, daf der Diakon Ferrandus im 6. Jahrhundert seiner Kanonessammlung ${ }^{1}$ den 22. Kanon des Konzils von Loadicea einverleibte, worin den Subdiakonen untersagt wird, das Orarium zu tragen. Denn die Aufnahme auch dieses Kanons hatte ja doch nur dann Sinn, wenn das Orarium damals in der Kirche Nordafrikas Verwendung fand.

Aus Rom hören wir rom Gebrauch des liturgischen Orarium erst seit der Mitte des 8. Jahrhunderts. Wohl ist im Papstbuch schon in der Biographie Agathos (678-681) wie in der Vita Stephans III. $(768--772)^{2}$ von einem Orarium die Rede; jedoch ist damit nach dem Zusammenhang. in unkorrekter Ausdrucksweise das Omophorion bzw. Pallium gemeint. Man hat auch die Angabe des Liber Pontificalis in der Vita Silvesters: Hic constituit, ut ... pallia linostima levae eorum (der Diakon) tegerentur, und die Verordnung des Papstes Zosimus: ut diacones leva tecta haberent de palleis linostimis, vom Orarium der Diakone verstanden. Allein es ist, wie schon früher bemerkt wurde, kaum zweifelhaft, daf die pallia linostima die Mappula bedeuten.

Die römischen Bildwerke der vorkarolingischen Zeit lassen keine Spur des Orarium erkennen. Daraus indessen schlechthin zu schliefien, die Stola habe damals zu Rom noch nicht existiert, scheint verfehlt. Denn wenn sie sich nach römischem Brauch unter der Dalmatik befand, konnte sie auf jenen Bildern, auf welchen Bischöfe wie Diakone bis auf die Fülie gehende Dalmatiken haben, selbstverständlich nicht zum Vorschein kommen. Die Stola des Papstes und der Diakone bleibt sogar noch im 12. und 13. Jahrhundert auf den römischen Monumenten infolge der langen Dalmatik, in der jene dargestellt sind, unsichtbar, obschon doch das Ornatstück damals zu Rom nicht nur getragen wurde, sondern sogar àls Insignie des diakonalen und priesterlichen Ordo galt. Ludem konnte es, wie Wilpert mit Recht meint ${ }^{3}$, den Künstlern genug erscheinen, einen Papst bzw. Erzbischof bloß durch das Pallium zu kennzeichnen.

Die frühesten Nachrichten über ein liturgisches Orarium zu Rom erhalten wir durch den dritten und achten Ordo ${ }^{*}$ sowie durch Hraban ${ }^{5}$ und

1 Breviat, canon. c. 124141 (M. 67,956 957).

2 D u ch., L. P. I 354472.

3 Cap. 80 .

${ }_{4}$ Ordo 8, n. 1; ordo 3, n. 6 (M. 78, 1000 978) ; vgl. auch den St Gallener Kleiderkatalog.

${ }^{5}$ De cleric. instit. 1. 1, c. 19 (M. 107, 307). Die liturgische Kleidung, welche Hraban behandelt, ist die römische Sakralgewandung seiner Zeit, was schon aus Zahl und Art der Gewänder klar erhellt. Vgl. aber auch 1. 1, c. 14 und die Worte der praefatio: (Liber) primus continetur ... de officio missae secundum morem romana e eclesiae (ebd. 295 306). Daß der Papst um 800 die Stola trug, bekundet auch das kosthare Epitrachelion, welches Patriarch Nicephorus mit einem En- chirion und andern liturgischen Gewändern Leo III. zum Geschenk machte. Von den drei Texten des 1. Ordo bei Hittorp (c. $10 \mathrm{ff}$ ), Mabillon (M. 78, $937 \mathrm{ff}$ ) und Grisar (Analecta romana $217 \mathrm{ff}$ ) erwähnt nur letzterer die Stola; doch muf es hingestellt bleiben, ob auch die Vorlage der Handschrift, welche diesen Text bietet, derselben bereits gedachte (vgl. oben S. 567, Anm. 1). Wie dem aber auch sein mag, einen Beweis gegen die Existenz der Stola im römischen Ritus bildet die Nichtnennung des Orarium im 1. römischen Ordo auf keinen Fall, da diese ja sehr wohl auf einer Vergeflichkeit und einem Übersehen beruhen kann, und auferdem der nur wenig jüngere 3. Ordo das Ornatstück 
Amalar ${ }^{1}$, d. i. also erst in der zweiten Hälfte des 8. und in Beginn des 9. Jahrhunderts. Es fand dort, abweichend vom spanischen und gallikanischen Brauch, um diese Zeit nicht bloß bei den höheren Ordines, sondern auch bei den Subdiakonen und den übrigen niederen Klerikern Verwendung. Den Minoristen, die Subdiakone eingeschlossen, wurde es bei der Weihe zugleich mit der Planeta übergeben, den Diakonen zugleich mit der Dalmatik, den Priestern wiederum zugleich mit der Planeta.

Seit wann das Orarium zu Rom in Gebrauch gewesen ist, läkt sich nicht bestimmen. Schwerlich dürfte es indessen erst um den Ausgang des 8. Jahrhunderts in den römischen Ritus aufgenommen worden sein. Nirgends tritt es als eine neue Erscheinung auf. Auch liegt sonst kein Anhalt zur Annahme vor, als habe das Orarium erst damals zu Rom Eingang gefunden. Eine solche Auffassung der Dinge scheint daher unhaltbar. Es wäre in der Tat mehr als auffallend, wenn man sich zu Rom inmitten der allgemeinen Verwendung, welche das Ornatstück schon seit Jahrhunderten im übrigen Abendland wie auch in der mit der römischen in vielfache Berührung kommenden griechischen Kirche fand, bis zur Karolingerzeit hermetisch gegen ein liturgisches Orarium abgesperrt hätte, um dieses dann über Nacht nicht nur bei den Diakonen und Priestern, sondern im Gegensatz zu den übrigen Riten selbst bei allen Klerikern einzuführen.

Eben wurde erwähnt, daf im Papstbuch in der Vita Agathos das Omophorion (Pallium) unkorrekt orarium genannt wurde. Allein gerade dieser ungenaue Gebrauch des Wortes orarium scheint vorauszusetzen, daf es zur Zeit der Abfassung der Vita, d. i. im 7. Jahrhundert, wirklich zu Rom schon ein liturgisches Orarium gab, da die Verwechslung sich sonst nicht wohl crklären läft. Oder würde es wohl jemand eingefallen sein, jenes so hochbedeutsame pontifikale Ornatstiuck orarium zu nennen, wenn man zu Rom unter diesem Worte lediglich ein ganz gewöhnliches, profanes Halstuch verstanden hätte?? Aber auch die eben erwähnte, alle Ordines umfassende, von der Weise im übrigen Abendland und im Orient abweichende, ganz eigenartige Verwendung, deren sich das Orarium in der zweiten Hälfte des 8. Jahrhunderts im römischen Ritus erfreute, dürfte bekunden, daf das Ornatstück damals zu liom keine junge Erscheinung mehr war. Vielmehr läßt eine solche ausgiebige Benutzung des Orarium nach dem gewöhnlichen Gang der Dinge mit ziemlicher Sicherheit darauf schliefen, daf es dort schon längere Zeit in Gebrauch war.

Auch im übrigen Italien ist es um die Bezeugung des Gebrauchs eines liturgischen Orarium in der vorkarolingischen Zeit sehr schlecht bestellt.

Allerdings liefert für seine Verwendung zu Ravenna im 6. Jahrhundert anscheinend das um 547 entstandene Apsismosaik in S. Vitale ein hochberdeut-

ausdrücklich aufführt. Immerhin ist es bemerkenswert, daf wenigstens einer der Texte des 1. Ordo die Stola erwähnt.

1 De offic. eccl. praef. alt. und 1.2, c. 20 2226 (M. 105, 99210961098 1102). Besonders wichtig ist der Passus der praefatio, welcher ausgesprochenermafen und in aller Klarheit von dem $\mathrm{x}$ ö $\mathrm{m}$ is chen Brauch handelt.

2 Duchesne bemerkt noch zur Notiz der Vita Steph. III. (L. P. I 481, nota 20): Si le clergé romain eut alors fait usage de l'insigne liturgique désigné maintenant par ce nom et qui apparaît de bonne heure en dehor's de Rome sous le nom orarium, on n'aurait pu employer ce dernier terme pour désigner Je pallium pontificale. Und doch kann nach dem 8. und 3. Ordo und den bestimmten Angaben Amalars kein Zweifel sein, daf jedenfalls zu Stephans III. Zeit das Orarium zu Rom schon in Gebrauch war. Die Bemerkung Duchesnes ist demnach verfehlt. Trotzdem es damals bereits zu Rom das Orarium gab, nenut der L. P. doch das päpstliche Pallium ungenau orarium. 
sames Zeugnis. Dasselbe stellt den Bischof Ecclesius bekleidet mit Tunika, Stola, Dalmatik und Kasel dar (Bild 273). Die Dalmatik ist aus reich gemustertem Stoff gemacht und mit breiter Bordüre versehen. Die Albe fällt in dichten Falten bis zum Boden, wo ihr Saum sich teilweise über den Füßen umschlägt. Die Stola befindet sich zwischen beiden Gewändern und schaut mit ihren reichgeschmückten Enden unter dem Besatz der Dalmatik hervor.

Bisher hat man allgemein das Mosaik, so wie es vorliegt, als Original betrachtet. Es war zuerst Grisar ${ }^{1}$, der, von der Anschauung geleitet, es habe im 6. Jahrhundert in Italien keine Stola gegeben, auf die Möglichkeit einer Umgestaltung des Bildes bei einer späteren Restauration hinwies; doch behandelt noch Wilpert unter ausdrück-

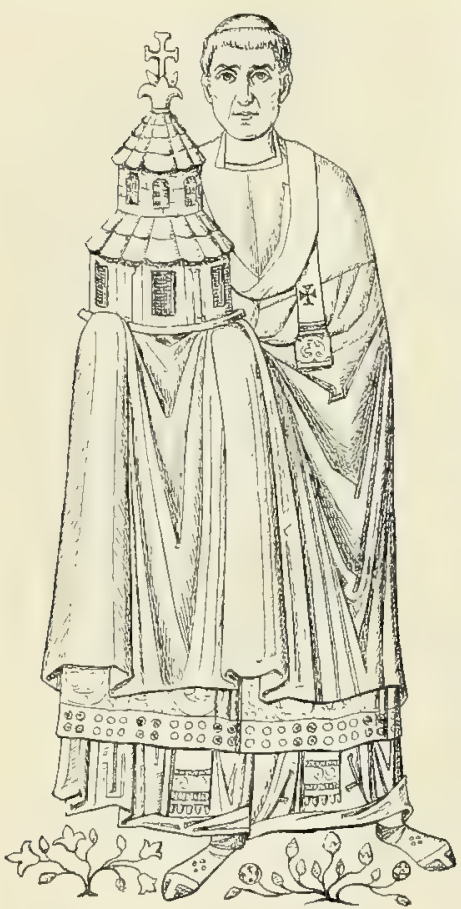

Bild 273. Bischof Ecclesius.

Mosaik. Ravema, S. Vitale. licher Ablehnung einer solchen das Mosaik schlechthin als ursprünglich ?. Indessen ist dieses wirklich in seinem jetzigen Zustand die Frucht einer Restauration des 12. Jahrhunderts. Nur der obere Teil des Körpers gehört noch dem ursprünglichen Werk an. Dagegen können, wie ein Vergleich der Figur des Bischofs Ecclesius mit den sonstigen musivischen Darstellungen zu Ravenna, zumal den andern Bischofsbildern in S. Vitale und S. Apollinare in Classe, aufser Zweifel stellt, die in einer Reihe von Punkter so eigenartigen unteren Partien unmöglich Original sein. Sie entstammen vielmehr der gleichen Zeit, welche die Bischofsfiguren in der Apsis des rechten Seitenschiffes im Dom zu Torcello bei Venedig, sowie in der Kuppel und den Zwickeln des Querbaues von S. Marco schuf, d. i. dem 12. Jahrhundert.

Dieselben Eigentümlichkeiten, welche uns beim Bilde des Ecclesius entgegentreten und hier inmitten der andern ravennatischen Mosaiken so ganz aus dem Rahmen fallen und wie ein fremdartiger Anachronismus anmuten, finden wir bei den Bischofsdarstellungen in S. Narco und auf Torcello wieder.

In der Tat wurden im Beginn des 12. Jahrhunderts zu Ravenna größsere Mosaikarbeiten ausgeführt; damals wurde nämlich der St Ursusdom mit musivischen Bildwerken geschmückt, welche leider beim Umbau von S. Urso im 16. Jahrhundert bis auf einen sehr geringen Rest - jetzt teils in der erzbischöflichen

Palastkapelle, teils in Museum - zu Grunde gingen. Bei dieser Gelegenheit wird man auch das Mosaik in S. Vitale, das stark beschädigt gewesen sein mag, im Stil und in der Auffassung des 12. Jahrhunderts restauriert haben.

Es ist bemerkenswert, wie auch auf andern ravennatischen Mosaiken die unteren Partien verschiedener Figuren sehr gelitten haben. Besonders auffallend ist das in S. Apollinare in Classe, wo St Apollinaris in der Koncha und die vier Bischöfe an den Wänden der Apsis in ähnlicher Weise verdorben sind, wie es einst die Figur des Ecclesius gewesen sein muf. In unserer "Geschichte der priesterlichen Gewänder" haben wir seinerzeit, wenngleich mit Vorbehalt, das Mosaik in S. Vitale als ursprünglich behandelt. Seitdem wir in der Lage waren, es an Ort und Stelle zu studieren und mit andern zu vergleichen, müssen wir dem Gesagten zufolge leider darauf verzichten, es weiterhin als Beweis zu benutzen, daf man zu Ravenna bereits im 6. Jahrhundert die Stola gekannt habe.

1 Das römische Pallium (Festschrift zur 1100jährigen Jubelfeier des Campo Santo) 85.

2 Cap. p. 79 . 
Auch eine Notiz in des Agnellus Geschichte der Bischöfe von Ravenna, die von dem diakonalen Orarium handelt, ist ohne Belang. Sie berichtet von einem Vorkommnis, das sich dort um die Mitte des 8. Jahrhunderts unter Erzbischof Sergius abspielte ${ }^{1}$. Dieser hatte, weil sich sein Klerus von ihm getrennt hatte, nach vergeblichen Vereinigungsversuchen andere Priester und Diakone geweiht. Als es aber dann infolge dieser Weihen nach neuen Unterhandlungen zum Frieden zwischen dem Erzbischof und den alten Klerikern kam, wurde vereinbart, es sollten die neu ordinierten Diakone - offenbar zum Unterschied von ihren älteren Amtsgenossen unter Weglassung der Dalmatik das Superhumerale nach Weise der Griechen anlegen ${ }^{2}$. Das Superhumerale kann hier nur das Epitrachelion, d. i. die Stola oder das Orarium bedeuten. Ferner ist sicher, dafs die Diakone erster Weihe nach römischravennatischem Brauch in der Dalmatik, diejenigen zweiter Weihe in der Tracht der griechischen Diakone dem Gottesdienst assistieren sollten. Dagegen läßt der Bericht bedauerlicherweise unklar, ob die letzteren das fragliche Superhumerale erst neu von den Griechen herüberzunehmen hatten, oder ob sie unter der Dalmatik bis

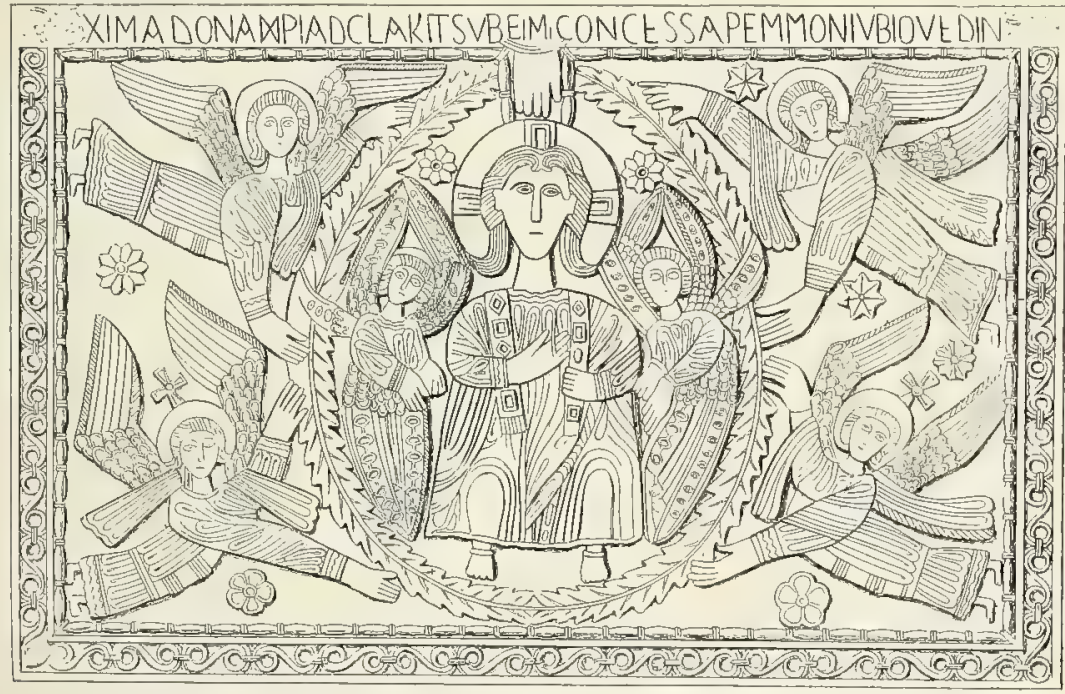

Bild 274. Altar des Ratchis. Ciridale, S. Martino. (Nach Garrucei.)

dahin schon eine Stola anzulegen pflegten, so dafs sie jene blof auszulassen brauchten, um gemäf der Übereinkunft das Orarium nach griechischer Weise zu tragen.

Ein Monument aus dem zweiten Viertel des 8. Jahrhunderts, auf dem anscheinend eine Priesterstola sich dargestellt findet, ist der von König Ratchis (744-749) gestiftete Altar in St Martin zu Cividale (Bild 274). Es ist freilich nicht ein Priester, der sie trägt, sondern Christus. Allein Christus ist ja der Priester der Priester, und das Ornatstück, welches in Form eines reichverzierten, an den Enden mit Fransen geschmückten Streifens vom Nacken her über die beiden Schultern nach vorn herabsteigt, gleicht so sehr einer Stola, daf man schwerlich den Gedanken abweisen kann, es solle hier eine solche dargestellt werden. Es wäre die früheste Abbildung einer Priesterstola, die uns bekannt ist, da wir, wie schon bemerkt, die Stola des Ecclesius durchaus für eine Restauration aus späterer Zeit halten.

1 Liber Pontif. Ravenn. P. II, Vita Sergii c. 1 (M. 106, 725). Der Text ist nicht genau. Besser findet er sich in den M. G. SS. Langob. 378.

Braun, Die liturgische Gewandung.
2 Liber Pontif. eccl. Ravenn.n. 154 (M G.SS. Langob. 378) : Statuerunt de novella consecratione, ut diacones relicta dalmatica superhumeralem imponerent more Graecorum. 
Das Ergebnis der bisherigen Untersuchungen ist im ganzen recht bescheiden. Klare, unzweideutige und sichere Zeugnisse für den Gebrauch eines liturgischen Orarium in der Westkirche vorkarolingischer Zeit besitzen wir nur für Spanien und Gallien, und selbst diese führen uns nicht über das 6. Jahrhundert hinaus. Als ein Ornatstück, das im ganzen Abendland bei der Liturgie Verwendung findet, läbt sich die Stola erst in der zweiten Hälfte des 8. Jahrhunderts mit Bestimmtheit nachweisen. Seitdem erscheint sie damn freilich ununterbrochen durch alle fernere Zeit hindurch bis in die Gegenwart als ein Teil der liturgischen Kleidung.

\section{DIE STOLA ALS LITURGISCHES ORNATSTÜCK ZUR KAROLINGERZEIT.}

Im 9. Jahrhundert war das Orarium zu Rom bei allen Klerikern in Gebrauch. Auch der Papst bediente sich seiner. Es ist das freilich bezweifelt worden, weil, wie man sagt, neben dem Pallium eine Stola überflüssig war. Allein mit Unrecht. Denn wenn der Patriarch Nicephorus von Konstantinopel Leo III. aufer einer liturgischen Tunika, Kasel und Mappula auch ein Epitrachelion, eine Stola, zum Geschenk übersendet, so folgt daraus offenbar, dafis sich der Papst damals einer Stola bediente. Wenn ferner nach Hraban, der in seiner Vorrede zu der Institutio clericorum ausdrücklich bemerkt, er wolle die Messe secundum morem Romanae ecclesiae behandeln ${ }^{1}$, und der darum unter der vestis sacerdotalis moderna ${ }^{2}$, die er in der genannten Schrift beschreibt, die römische Sakralgewandung versteht, die Erzbischöfe zugleich Stola und Pallium trugen ${ }^{3}$, wird dann nicht auch der Papst sich beider bedient haben? Ein Nichtgebrauch der Stola hätte nur dann einen Sinn gehabt, wenn dem Pallium und der Stola ein und derselbe Charakter eigen gewesen wäre. Wenn man aber meint, darum habe das Pallium die Stola ausgeschlossen, weil es den Inbegriff aller priesterlichen und hohenpriesterlichen Gewalt bedeutet habe, dann darf man wohl fragen, wie es überhaupt je dazu kommen konnte, daf der Papst anfing, zugleich sich des Pallium und der Stola zu bedienen. Allerdings ist es richtig, daf der 1. Ordo Mabillons das Orarium unter den päpstlichen Gewändern nicht erwähnt ${ }^{4}$ Ob das indessen nicht ein Versehen des Kopisten ist? Denn der 3. Ordo - der 2. spricht nicht von der liturgischen Gewandung des Papstes - rechnet das Orarium ganz bestimmt und ausdrücklich zur Sakralkleidung des Papstes.

Auch der Umstand, daf3 im 9. Jahrhundert auf den Darstellungen von Päpsten die Stola nicht auftritt, ist von keinem Belang. Denn sie erscheint auf den Monumenten selbst noch im 11. und 12. Jahrhundert bei diesen nur in vereinzelten Fällen, obschon die Päpste sich damals sowohl der Stola wie des Pallium bedienten. Nie kommt die Stola zum Vorschein, wenn die Päpste mit der Dalmatik bekleidet dargestellt sind. Es war den Künstlern ersichtlich nur darum zu tun, die Päpste als solche zu charakterisieren, und das erreichten sie genügend dadurch, daß sie dieselben mit dem Pallium versahen.

1 Y. $107,295$.

2 L. 1, c. 14 (ebd. 306).

3 L. 1, c. 23 (ebd. 309): Super haec autem omnia (sc. superhumerale, tunicam, cingulum, mappulam, stolam etc.) summo pontifici, qui archiepiscopus vocatur, propter apostolicam vicem pallii honor decernitur. Vgl. auch A mal., De eccl. offic. 1. 2, c. 22 (M. 105 , 1098).

4 So wenigstens nach dem Text Mabillons und Hittorps. Wegen der von Grisar veröffentlichten Rezension vgl. oben S. 574, Anm. 5. 
Daf die Bischöfe sich des Orarium bedienten, erhellt aus Hraban, Amalar, dem St Gallener Katalog sowie dem 9. Ordo. Von der Stola der Priester reden der S. G. K., der 9. Ordo und der Ordo Duchesnes. Amalar spricht nicht ausdrücklich von der Priesterstola, doch stellt er ebensowenig die Stola als ausschließliches Ornatstück der Diakone und Bischöfe hin.

Das Orarium der Diakone ist im St Gallener Kleiderverzeichnis unerwähnt geblieben. Dagegen gedenken seiner der 9. Ordo wie auch Amalar, der sich sogar ganz speziell und eingehend mit der Diakonalstola befaft.

Auffallend ist es, daf zu Rom auch die Subdiakone und Akolythen ein Orarium trugen. Indessen kann an diesem Brauch kein Zweifel bestehen, da sowohl der 8. Ordo wie das St Gallener Verzeichnis des Orarium der Subdiakone und Akolythen gedenken ${ }^{1}$. Wir dïrfen nicht vergessen, daß wir in einer Zeit stehen, da die liturgische Kleidung noch auf dem Wege zur endgültigen Fixierung war. Ein Gegenstück zum Gebrauch des Orarium seitens der Subdiakone und Akolythen ist es, wenn ebendieselben auch mit der Planeta (Kasel) ausgestattet erscheinen.

Übrigens ist die Notiz des St Gallener Katalogs nicht zu übersehen: Acolythus ... quando in gradu psallitur ... orarium portat in manu. Wenn also der Akolyth zum Ambo trat, um daselbst das Responsorium zu singen, mufite er das Orarium, das er sonst am Halse hatte, abnehmen und in der Hand halten.

Auch die Subdiakone scheinen das Orarium nur mit einer ähnlichen Einschränkung getragen zu haben. Denn wir lesen im 8. Ordo: Et si ad diaconatus ordinem voluerit episcopus eum (sc. subdiaconum) provocare, dum introitus missae inchoatur, ipse subdiaconus indutus tunicam albam et tenens orarium suum in manu stat ante rugas altaris ${ }^{2}$. Wenn sich also der Subdiakon in seiner Amtstracht zur Diakonatsweihe einstellte, hatte er sein Orarium in der Hand zu halten.

Das Orarium, welches wir beim Ausgang des 8. und im Beginn des 9. Jahrhunderts zu Rom im Georauch antreffen, war ein wirkliches liturgisches Ornatstück. Was immer wir in den römischen Ordines, bei Hraban, Walafried und Amalar oder sonst über dasselbe hören, bekundet solches auf das bestimmteste. Allenthalben erscheint das Orarium als förmlicher Bestandteil der Sakraltracht. Es ist verboten, ohne Stola die heilige Messe zu feiern. Das Orarium steht auf gleicher Linie mit dem liturgischen Schultertuch, der liturgischen Albe, dem Cingulum usw. Es war demnach ein Irrtum, wenn man sagte, in Rom erscheine die Stola oder das Orarium in liturgischem Sinne erst nach dem 10. Jahrhundert.

Welches war aber der besondere Charakter des römischen Orarium? War es ein Tuch, das Priester und Ministri eines praktischen Zweckes halber bei den liturgischen Funktionen bei sich haben muiten, also etwa ein liturgisches Diensttuch, ein Halstuch oder Schweibtuch, war es ein blofes Ornament ohne weitere Berleutung und ohne einen speziellen Zweck, oder war es etwa eine Art von, wil sagen nicht förmlicher Insignie, sondern liturgischem Unterscheidungszeichen im weiteren Sinne, etwa wie die klerikale Kleidung Abzeichen der Geistlichen gegenüber den Laien, die Dalmatik Abzeichen der Diakone, die Kasel das der Priester ist? Es handelt sich hier wohlgemerkt um den Charakter, den das Ornatstück im 9. Jahrhundert hatte, nicht um die Frage, was es vielleicht ursprünglich war. 
Ein Schweifstuch oder Halstuch war es zweifellos nicht. Kein Schweifstuch, da es unter dem Obergewand getragen wurde; man hätte ja die Planeta oder Dalmatik aufheben müssen, um zum Orarium zu gelangen, falls es nötig wurde, dasselbe zum Abputzen des Schweifes zu gebrauchen. Aber auch als Halstuch kann das Orarium nicht gedient haben. Denn für die Zwecke eines Halstuches war das liturgische Schultertuch, das anabolagium, der Amikt da, dessen sich nach dem St Gallener Katalog alle Ordines, die Akolythen allein ausgenommen, zu bedienen pflegten. Allein auch ein blobes Ornament kann das Orarium nicht gewesen sein. Demn welchen Sinn hatte es in diesem Falle bei den Diakonen und Bischöfen? Weil von der Dalmatik völlig bedeckt, war es als blofer Schmuck bei diesen offenbar völlig zwecklos.

Es bleibt also wohl nichts übrig, als in dem Orarium eine Art von Distinktivum des römischen Klerus überhaupt im Gegensatze zu den Laien und weiterhin der höheren Ordines im Unterschied von den niedern Klerikern in dem eben angegebenen Sinne zu sehen. In der Tat lassen die Angaben, welche wir über das Orarium erhalten, wohl kaum einen ernsten Zweifel, daßs eine solche Auffassung die richtige ist. Oder warum der Brauch, alle Ordines, auch die Akolythen, bei ihrer Weihe mit dem Orarium zu bekleiden? ${ }^{1}$ Weshalb ferner die vom 9. Ordo für das Orarium der Diakone ausdrücklich bezengte Gepflogenheit, das Ornatstück am Abend vor der Weihe auf die Confessio des hl. Petrus zu legen und hier bis zum Weiheakt am folgenden Tage zu belassen?2 Warum die Rubrik des 8. Ordo, daf die Subdiakonen in Tunika und Planeta, ihr Orarium aber in der Hand, zum Empfang der Diakonatsweihe an die Altarschranken zu treten hatten? 3 Warum die Anordnung, dak die Akolythen, wenn sie am Ambo als Cantores oder Lectores fungierten, nicht blok die Planeta auszuziehen, sondern auch das Orarium abzulegen und in der Hand zu halten hatten? Endlich woher die römische Sitte, der zufolge der Diakon an den Tagen, an welchen er sich statt der Dalmatik der Planeta bediente, vor dem Evangelium nicht nur diese letztere, sondern zugleich mit der Planeta auch die Stola, die er bis dahin nach Weise der Priester am Halse getragen hatte ${ }^{4}$, sich schärpenartig umschlang, um nun so bis zum Ende der Messe zu ministrieren? War das Orarium lediglich ein blofies Schweiftuch, Halstuch oder Ornament, so ist alles das unverständlich. Nur wenn man es als eine Art von Unterscheidungszeichen auffast, dürften diese Gepflogenheiten ihr Licht erhalten. Ganz besonders gilt das von den beiden an letzter Stelle genannten Bräuchen. Es hätte doch zum Zweck, die Akolythen von dem amtierenden Priester zu unterscheiden, völlig ausgereicht, wenn sie die Planeta abgelegt bzw. schärpenartig umgelegt hätten. Warum also solches auch noch mit dem Orarium tun, wenn es nur ein Ornament oder ein Hals- bzw. Schweistuch war?

1 Gegenwärtig wird freilich auch der Subdiakon mit dem Humerale bei seiner Weihe bekleidet; allein diese Zeremonie ist sehr jungen Datums. Sie kam erst im Laufe des 14. Jahrhunderts auf und war noch im 15. keineswegs allgemein (vgl, oben S. 30).

2 N. 28 (ehd. 10115 1018).

${ }^{3}$ N. 3 (ebd. 1001): indutus tunicam albam et tenens orarium sum in manu.... Exuitur planeta a diacono.

1 Siehe unten S. 586

${ }_{5}$ Amal., De eccl. offic. praef. altera (M.
105, 992): Quando versus Alleluia canitur, exuit se planeta diaconus stolamque post tergum ducit subtus dextram alam una cum planeta et parat se ad ministrandum ac in eo habitu perseverat usque dum apostolicus recesserit de altari. Die Worte una cum planeta sind keine Interpolation, wie Wilpert für wahrscheinlich hält (Cap. 83), und stehen keineswegs im Widerspruch mit exuit se planeta. Der Diakon legte die Kasel, nachdem er sie ausgezogen hatte, mit der Stola schärpenartig $\operatorname{um}$ (s, oben S. $166 \mathrm{f}$ ). 
Der Gründe, um derentwillen Duchesne dem römischen Orarium den Charakter eines Distinktivum absprechen zu sollen glaubt, sind zwei '. Erstens meint er, sei das Orarium nicht offen über dem Obergewande getragen worden. Das ist allerdings richtig. Allein wenn dieser Umstand maßsgebend ist, dann hätte ja die Stola im römischen Ritus auch später noch des Charakters eines Distinktivum entbehrt. Und doch war die Stola zu Rom schon eine förmliche Insignie des diakonalen und priesterlichen Ordo, als noch die Dalmatik bis zu den Füßen reichte und die glockenförmige Kasel fast den ganzen Körper einhüllte. Ferner ist dann nicht verständlich, wie überhaupt die Stola dort jemals das diakonale und priesterliche Abzeichen hat werden können, da der Priester diese immer unter der Kasel, der Diakon unter der Dalmatik trug.

Zweitens weist Duchesne darauf hin, daf er kein römisches Bildwerk aus der Zeit vor dem 12. Jahrhundert kenne, auf dem die Stola dargestellt sei. Auch dieser Einwand ist ohne Belang. Einmal kommt nämlich bereits auf den vor 10 - 4 entstandenen Fresken in der Unterkirche von S. Clemente die priesterliche und bischöliche Stola vor. Dann ist überhaupt die Zahl der noch vorhandenen römischen Bildwerke des 9., 10. und 11. Jahrhunderts, die hier in Betracht zu ziehen wären, im ganzen äuferst gering. Endlich aber sind die Päpste und Diakone auf den Darstellungen aus dieser Zeit stets mit der bis auf die Füfe reichenden Dalmatik versehen. Es liegt also zn Tage, warum die Künstler wenigstens bei den Diakonen die Stola nicht abgebildet haben ${ }^{2}$. Aus dem gleichen Grunde gewahren wir ja auch selhst noch auf den römischen Monumenten des 12. und 13. Jahrhunderts bei den Diakonen, Päpsten und Bischöfen, wofern nur letztere mit der Dalmatik versehen sind, keine Stola.

Zutreffend ist allerdings, daf die Stola zu Rom im 9. Jahrhundert noch nicht so ausgesprochenermaßen als Insignie des Ordo galt, wie das etwa um die gleiche Zeit im Frankenland und früher noch in Spanien und wohl ebenfalls in Gallien unter der Herrschaft des gallikanischen Ritus der Fall war ${ }^{3}$. Sie konnte im römischen Ritus ja auch erst dann etwas mehr als ein blobes Unterscheidungszeichen, eine wirkliche Insignie der höheren Ordines werden, nachdem sie darin bei den Subdiakonen und Akolythen aufier Brauch gekommen war. Wie lange sie bei denselben verbliel, ist nicht festzustellen. Es ist darum gleichfalls nicht möglich, genau zu hestimmen, wann die Stola zu Rom den Charakter einer förmlichen Insignie erhielt, den sie daselbst in der Folge hatte und noch jetzt hat. Wie es scheint, fand das Orarium schon um die Wende des Jahrtausends bei den römischen Subdiakonen und Akolythen keine Verwendung mehr. Um dieselbe Zeit wird es daher zu Rom auch bereits Amtsabzeichen des Diakonats und Presbyterats gewesen sein.

Auferhalb Roms stand, soweit sich darüber ein Urteil fällen läßst, im 9. Jahrhundert die Stola nur im Dienste der Priester (Bischöfe) und Diakone. Bemerkenswert ist die scharf ausgeprägte symbolische Bedeutung, welche unzweifelhaft in Verbindung damit dem Orarium im Frankenland eignete. Es war daselbst im 9. Jahrhundert in einem solchen Grade Abzeichen des Presbyterats, daß es den Priestem zur Pflicht gemacht wurde, die Stola beständig zu tragen. So verordnet das 20. Kapitel des Konzils von Mainz aus dem Jahre 813, es sollten die Priester sonder Unterbrechung das Orarium anlegen propter differentiam sacerdotii dignitatis, d. i. also, um als dem Priesterstande angehörig kenntlich zu sein ${ }^{4}$. Ähnlich sagt ein Kapitular der Sammlung des Benedikt Levita: es sollten die Priester die Stola tragen propter signum castitatis, also als Zeichen ihrer priesterlichen Ehelosigkeit ${ }^{5}$. Das Konzil von Tribur er-

1 Duch., Orig. 391.

2 Vgl. auch das oben S. 574 Gesagte.

${ }^{3}$ S. oben S. 567 und die dort angeführten Stellen aus Hraban, Walafried und Pseudo-Alkuin.
- Conc. Mogunt. c. 28 (Hartzh. I 411; V. (․ LL. Cap. II 248).

5 L. 2, c. 172 (Bal u zi i Capit. Reg. Franc. I 952; M. 97, 768). 
neuert 895 die Bestimmung der Mainzer Synode und fügt ergänzend hinzu: wenn Priester auf Reisen beraubt, verwundet oder getötet würden, ohne mit der Stola bekleidet zu sein, so sollten die Täter mit einfacher, andernfalls - nämlich falls jene die Stola getragen hatten und darum nach ihrem Stand hatten erkannt werden können - mit dreifacher Strafe ihr Verbrechen büfen ${ }^{1}$. Entsprechend heist es in einer Rezension der Admonitio synodalis unter n. 38: Nullus presbyter in itinere sine stola incedat, während nach der Anweisung Reginos von Prüm der Visitator sich zu erkundigen hat (n.62): si sine stola vel orario in itinere incedat ${ }^{2}$. Als Charakteristikum der Kanoniker erscheint die Stola in einem Briefe Alkuins an einen kranken Kanoniker, der ihm seine Absicht mitgeteilt hatte, in ein Kloster einzutreten, um sich dort auf das Gericht vorzubereiten: Si sub orario plus laborasti quam sub cuculla in servitio Dei, quid causae est in articulo mortis tui laboris insignia abicere?:"

Seit etwa 1000 herrscht allenthalben im Abendland in Bezug auf die liturgischen Personen, denen der Gebrauch der Stola zusteht, wie auch hinsichtlich des Charakters des Ornatstückes volle Übereinstimmung. Es erhellt das in gleicher Weise aus den zahlreichen liturgischen Büchern wie den Schriften der Liturgiker des 11., 12. und 13. Jahrhunderts. Die Stola kommt nur den Diakonen, Priestern und Bischöfen zu, letzteren wegen des ihnen eigenen Priestercharakters. Sie ist das Symbol des diakonalen Ministerium und des 1)iesterlichen iugum Domini. Den Subdiakonen bleibt das Ornatstïck versagt, auch als der Subdiakonat im 11. Jahrhundert förmlich zum höheren Ordo wird. Ihr Amtsabzeichen ward der Manipel.

\section{GEBRAUCH DER STOLA.}

Hinsichtlich der liturgischen Funktionen, bei denen die Stola im Mittelalter Verwendung fand, erhalten wir, zumal in der früheren Zeit desselben, nur vereinzelte Angaben. Im großen und ganzen wird sie bei denselben Akten gebraucht worden sein wie heutzutage. Vor allem war sie zu Rom wie auferhalb Roms Mefornatstück. Sie wurde aber auch bei der Spendung der heiligen Sakramente, bei der Predigt und bei der Vornahme von Segnungen verwendet, und zwar bis wenigstens zum Beginn unseres Jahrtausends bald mit bald ohne Kasel. Die Kasel war nicht erforderlich; man hatte sie, ähnlich wie jetzt das Pluviale, nur bei einer feierlichen Ausübung der genannten Akte. Dagegen wurde die Stola stets getragen. Aus Hraban ersehen wir, dab man sich ihrer bei der Predigt bediente. Auf einer Miniatur der Wessobrunner Handschrift in der kgl. Bibliothek zu München ${ }^{4}$ aus dem Jahre 814 bzw. 815 (Bild 275) finden wir sie bei einem Priester, welcher die Taufe spendet. Auf einer Federzeichnung des Pontifikale von Aletis in der Stadtbibliothek von Rouen ist ein Bischof, welcher eine Kirchweihe vornimmt, mit ihr ausgerüstet. Nach demselben Pontifikale soll der Priester, der einem Kranken die letzten Sakramente spendet, mit Amikt, Albe, Fano und Stola ausgestattet sein, mit einer Kasel nur, wenn gerade eine solche zur Hand ist. Ein Missale von Rennes aus dem 11. Jahrhundert schreibt vor, es solle der Priester die

1 Conc. Trib. c. 26 (apud Burcardum) (Hartzh. II 410).

2 M. $132,190$.
${ }^{3}$ Ep. 55 (M. G. Epp. Carol. Aevi II 99). Del Brief ist geschrieben um 790.

Cod. lat. 22053, Cim. 20. 
Brautleute an der Kirchtïre in Albe und Stola erwarten ${ }^{1}$. Auch bei Prozessionen wurde das Ornatstück gebraucht (vgl. Bild 122, S. 262).

Daf Bruno von Segni und Sicard von Cremona im 12. Jahrhundert die Anschauung ihrer Zeit hinsichtlich des Gebrauches der Stola dahin aussprechen, der Priester könne zwar ohne sonstige Gewänder taufen, firmen und manche andere Gebetsakte vornehmen, ohne das Orarium aber dürfe er nichts von allem dem tun, es sei denn, daß3 großse Not solches erheische, wurde schon früher bemerkt.

Seit dem 13. Jahrhundert wird wiederholt durch die Synoden den Priestern eingeschärft, bei den Kírankenversehgängen die Stola zu tragen. Auch bei den Provinzial- und Diözesansynoden hatten die Teilnehmer sich mit ihr zu bekleiden.

Der im 9. Jahrhundert verschiedenerorts, namentlich aber im Frankenreiche, für die Priester geltenden Vorschrift, stets das Orarium zu tragen, ist

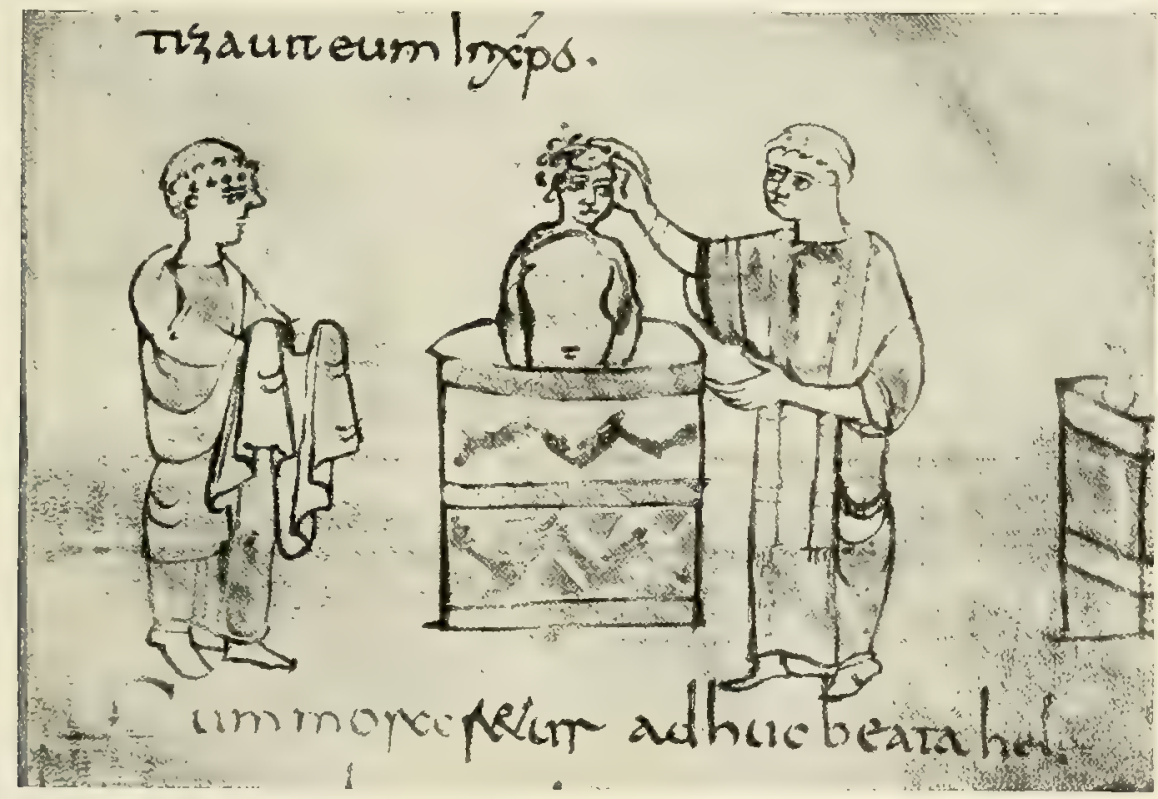

Bild 275. Taufszene. Miniatur in einer Wessobrunner Handschrift. München, Kgl. Bibliothek.

bereits Erwähnung geschehen. Wie lange sie in Traft blieb, ist nicht zu bestimmen. Noch die Synodica ad presbyteros des eifrigen Bischofs Ratherius von Verona ( $†$ 974) enthält die Bestimmung, es solle kein Priester ohne die Stola umhergehen ${ }^{2}$. Der Zweck, den eine solche Verordnung hatte, ging ohne Zweifel dahin, bei den Priestern das Bewustsein ihrer hohen Würde zu heben und sie von sittlichen Verirrungen abzuhalten. Seit der Synodica des Ratherius hören wir von der Sache nichts mehr.

Eine andere eigenartige Gepflogenheit begegnete uns schon in der Vita S. Mauri († 584). Danach war es Brauch, im ersten Jahre nach der Weihe als Zeichen der erlangten Würde beständig die Stola zu tragen ${ }^{3}$. Für das 6 . Jahrhundert, wie überhaupt für Italien, gilt das freilich nicht. Die Sitte entspricht aber ganz der Anschauung, welche

1 Mart. 1. 1, c. 9, ordo 2; II 127. Manche Angaben über den Gebrauch der Stola enthalten namentlich die Consuetudines von
Farfa (ed. Albers, $\begin{array}{llllll}35 & 51 & 52 & 56 & 71 & 73\end{array}$ 122 142).

N. 11 (M. 136, 562). $\quad$ Siehe S. 566 
in 9. Jahrhundert im fränkischen Norden bestand, und stimmt darum vortrefflich zu der Zeit, da die Tita, wenigstens in ihrer jetzigen Redaktion, aus den Händen Odos von Glanfeuil hervorging.

Der Brauch mufs, wie wir aus der Biographie des hl. Odo von Cluny († ca 970) ersehen, noch im 10. Jahrhundert in Kraft gewesen sein ${ }^{1}$. Es wird uns darin nämlich erzählt, es sei der Heilige in der Nacht, die seiner Weihe folgte, aufgewacht und dann, als er um seinen Hals nach Sitte und Brauch die ihm vom Bischof übergebene Stola bemerkt habe, gleich als wenn ihm ein großes Übel begegnet wäre, sofort in Tränen ausgebrochen, und er habe lange Zeit nicht gewußst, wie er es wagen dürfe, aus dem Kloster zu gehen. Auch vom hl. Thomas von Canterbury wird noch berichtet, er habe die Stola, Christi Joch, alle Tage um seine Schultern gehabt ${ }^{2}$.

Was die Trag weise der Stola anlangt, so haben wir zuzusehen erstens, welche Stelle das Ornatstück in der Reihenfolge der liturgischen Gewänder einnahm, und zweitens, wie man sie anzulegen pflegte.

Was den ersten Punkt anlangt, so ist es zweifellos, daf sich das Orarium, so oft es in Verbindung mit der Planeta gebraucht wurde, stets gerade wie noch jetzt unter derselben, nie über derselben befand. Es erhellt das sowohl aus den Angaben der Liturgiker und der liturgischen Bücher, als auch aus den Monumenten. Es ist uns nur eine Miniatur bekannt, auf welcher die Stola sich über der Kasel befindet. Sie gehört dem karolingischen Psalterium der St Gallener Stiftsbibliothek an. Es ist offenbar nichts als Naivität oder Willkür des Miniators, wenn er auf derselben den hl. Gregor oder wer immer der Heilige sein soll, mit der Stola über der Planeta dargestellt hat ${ }^{3}$.

Eine auffallende Verschiedenheit herrscht im 9. und 10. Jahrhundert hinsichtlich der Angaben über die Weise, wie Papst und Bischöfe die Stola trugen. Hier hatte sich offenbar eine bestimmte, dauernde Praxis noch nicht gebildet. Der Papst hatte das Orarium dem 3. Ordo wie dem St Gallener Katalog zufolge zwar unter der Planeta, aber über den beiden Dalmatiken, während er nach späterem Brauche dasselbe unmittelbar nach dem päpstlichen Fano anlegte, also ehe er sich mit Tunicella und Dalmatik bekleidete.

Bei den Bischöfen finden wir die Stola im St Gallener Verzeichnis über der Obertunika, im 9. Ordo zwischen der dalmatica minor (Tunicella) und dalmatica maior, bei Hraban, der nur einer Dalmatik der Bischöfe gedenkt, unter dieser Dalmatik, bei Amalar, der dieselben mit Tunicella und Dalmatik ausgestattet sein läßst, unter der Tunicella.

Auch auf den bildlichen Darstellungen gewahren wir eine ähnliche Verschiedenheit. So bemerken wir z. B. auf dem Widmungsbild der Bibel Karls des Kahlen (vgl. Titelbild) und auf zwei Miniaturen des Sakramentars von Autun (Gregor d. Gr. und die "sieben Weihegrade") das Orarium unter der Dalmatik, während wir es bei den hll. Sixtus und Gregor auf dem Manipel Frithestans von Winchester im Museum zu Durham, bei der Abbildung eines den Segen spendenden Bischofs im Benediktionale Ethelwolds u. a. über der Dalmatik finden.

1 Io ann. Cluniac., Vita S. Odonis 1. 1, n. 37 (M. 133, 60), Nagold., Vita eiusd. c. 26 (ebd. 96).

${ }^{2}$ H e r ib e r.t. Vita S. Thomae Cantuar. 1. 3, c. 6 (M. 190, 1095): Thoras quodam sacri ordinis insigni, quod stola seu orarium dicitur, mox ut sacerdos utrumque, quod sacerdotum est humerum, ambiebat et hoc quotidie et in omnium visu gestabat. Wenn man auch Johannes von Salisbury erzählen läist, es habe der Heilige Tag und Nacht das stifie Joch Christi um seinen Hals gehabt, so ist zu bemerken, daf sich in dessen Vita S. Thomae kein Wort darüber findet.

3 Gute Abbildung bei R. R a h n, Das Psalterium aureum von St Gallen, St Gallen 1878, Tfl VII. Das Pallium ist wohl nicht gemeint. 
Auch hier bringt erst das zweite Jahrtausend eine einheitliche Praxis. Die Ordnung der Pontifikalgewänder ist nun regelmäfig: Amikt, Albe, Cingulum, Stola, Tunicella, Dalmatik, Kasel, Manipel usw.

Die Diakone trugen, wo der römische Brauch galt, das Orarium unter der Dalmatik; auch im Frankenlande, wo sie unter der Herrschaft des gallikanischen Ritus die Stola über der Alba, ihrer liturgischen Tunika gehabt hatten. Über der Obertunika finden wir bei den Diakonen das Orarium nach dem 9. Jahrhundert nur im ambrosianischen Ritus und in Süditalien.

Im südlichen Italien, wo die Gewohnheit, die diakonale Stola sichtbar über dem Obergewand zu tragen, wohl dem dort mächtigen griechischen Einflub ihre Entstehung verdankte, ging man in späterer Zeit zum römischen Brauch über. Doch erhielt sich die alte Sitte wenigstens bis zum 13. Jahrhundert. Es ergibt sich das aus einer großen Anzahl beneventanischer und capuanischer Miniaturen des 11. und 12. Jahrhunderts, so z. B. aus einer Darstellung in der Enzyklopädie des Hrabanus Maurus zu Monte Cassino (11. Jahrhundert) ${ }^{1}$, dem Weiheordo Landulfs II. von Benevent in der Casanatense zu Rom (Beginn des 12. Jahrhunderts) ${ }^{2}$ und den teils dem 11., teils dem 12. Jahrhundert angehörenden Exultetroteln der Vaticana, der Casanatense und Barberiniana zu Rom, des Domes zu Bari, der Klosterbibliothek zu Monte Cassino, des Domes zu Capua ${ }^{3}$ u. a. (Bild 276). Ü̉berall haben hier die Diakone die Stola über ihrem Obergewande. Auch auf der Exultetrolle von Salerno aus dem frühen 13. Jahrhundert ist das noch der Fall. Andere bemerkenswerte Beispiele liefern die herrlichen Mosaiken

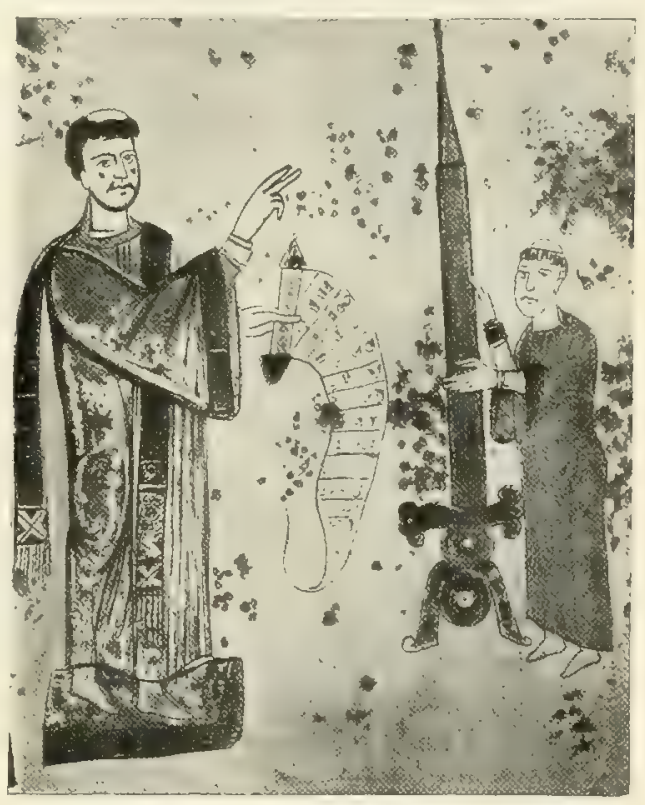

Bild 276. Segnung der Osterkerze. Miniatur eines Exultetrotels. Gaeta.

des Domes von Monreale mit den heiligen Diakonen Laurentius, Stephanus, Genesius, Euplius und Vinzentius *

In Mailand ist es bis auf die Gegenwart Sitte geblieben, daf der Diakon die Stola über der Dalmatik trägt. Wer die mittelalterlichen Kunstdenkmäler in Mailand und dem Mailänder Gebiet durchforscht, wird häufig auf Bildwerke stoben, die von dem Brauche Zeugnis ablegen; allen voran der Palliotto von S. Ambrogio ${ }^{5}$, dieses Meisterwerk der Goldschmiede- und Emaillierkunst aus der Mitte des 9. Jahrhunderts, dann das Apsismosaik in S. Ambrogio, das ebenfalls vielleicht noch dem ersten Jahrtausend an-

1 Abbildung in Miniature sacre e profane dell' anno 1023, Monte Cassino 1896, tav. 14

a Vl. die Abbildung bei $\mathrm{W}$ il p., Cap. 67 73 und Gew. Fig. 2833.

${ }^{3}$ Vorzügliche Abbildungen einer Anzahl dieser Exultetroteln in Les miniatures des rouleaux d'Exultet, Monte Cassino 1899. Andere bei Wilp., Cap. 85 89. Vgl. auch A g. Malerei Tfl 5354.

4 Gravina, Il Duomo di Monreale, Palermo 1859, tav. $14 \mathrm{D} 17 \mathrm{E} 24 \mathrm{~A}$.

s Roh. I, pl. virr. 
gehört. Ein Monument aus der Frühe des 13. Jahrhunderts, auf das zu verweisen wäre, ist das Basrelief an S. Maria Beltrada zu Mailand 1, welches eine Prozession zu Ehren der Gottesmutter darstellt. Aus der letzten Hälfte des 13. Jahrhunderts sei ein prächtiges Marmorrelief in dem Dom zu Monza (Bild 27\%) genannt. Ein vortreffliches Beispiel aus dem Beginne des 14. Jahrhunderts liefern die Reliefs des Sarkophags des Bischofs Berardus in der Rotonda zu Brescia. Seit dem Ende des 14. Jahrhunderts häufen sich die Darstellungen, auf denen Diakone nach ambrosianischem Brauche mit der Stola über der Dalmatik erscheinen, so sehr, daß es unnötig, ja unmöglich ist, dieselben im einzelnen namhaft zu machen.

Die Diakone tragen im Mailändischen die Stola unter der Dalmatik blof, wenn sie an den drei ersten Tagen der Karwoche nach der Terz die Lektionen aus dem Buch Job singen. Es ist das unzweifelhaft eine sehr alte Sitte. Indessen mag füglich bezweifelt werden, ob das ca $5,00 \mathrm{~m}$ lange und $0,08 \mathrm{~m}$ breite Teife Linnenband, mit dem sie dann ausgestattet sind und welches sie kreuzweise über Brust und Rücken geschlungen haben, wirklich eine Stola ist. Alter und Ursprung des Brauches ist unbekannt ${ }^{2}$.

Bezüglich der Gewandung der Subdiakone heifst es im St Gallener Katalog: Subdiaconi camisia, cingulum, deinde anagolagium et tunica alba, orarium et sestace in manu sinistra. Die Subdiakone hatten sonach das Orarium über der Obertunika, wahrscheinlich um es gegebenen Falles leichter abnehmen zu können. Hinsichtlich der Akolythen lesen wir ebendort: Tunica alba et orarium ad collum et planeta. Auch sie hatten also ihr Orarium wie die Subdiakone über der Tunika.

Was die Anlegungsweise des Ornatstückes anlangt, so erinnern wir daran, dak nach der jetzigen Praxis der Diakon die Stola als Schärpe so auf der linken Schulter trägt, dafs die beiden Streifen, quer über Brust und Rücken verlaufend, unter dem rechten Arm zusammenkommen; der Priester legt sie auf Hals und Schultern und läft dann die beiden Bänder entweder vorn herabhangen, oder er kreuzt dieselben über der Brust, je nachdem er mit einem Superpelliceum oder mit Albe und Cingulum versehen ist. Bei dem Bischof fallen stets die beiden Stolenstreifen vorn gerade herab. So war es indessen in allem dem nicht immer. Auch in Bezug auf die Tragweise der Stola hat es eine Entwicklung gegeben, obwohl wir dieselbe nur in ihren Hauptzügen verfolgen können.

Dak wenigstens bereits im 13. Jahrhundert der Diakon die Stola in der jetzigen Weise trug, erhellt aus Durandus, welcher bemerkt, der Levit lege an Fasttagen beim Amte die Kasel zusammengefaltet nach Art der Stola um, indem er sie nämlich auf die linke Schulter werfe, dann nach der rechten Seite herüberziehe und dort unter dem Arm befestige. Ja es kennt schon mehr als 100 Jahre früher Honorius diese Anlegungsweise der Diakonalstola. Zu Amalars Zeiten war selbige aber noch nicht Brauch, denn dieser bemerkt ausdrücklich, erstens dak die Stola des Diakons, von welcher er an dem betreffenden Orte allein redet, zu den Knieen sich herabziehe (ad genua tendit) $^{3}$, zweitens daf dieselbe dem $\mathrm{Halse}$ aufgelegen habe: Sciat diaconus in stola superposita collo se ministrum evangelii esse, non praepositum. Auch der y. Ordo sagt unterschiedslos bezüglich der Priester und Diakone: A pontifice (sc. oraria) super eorum colla ponantur ${ }^{4}$. Aus dem St Gallener

\footnotetext{
1 Abbildung bei Magistretti 5 .

2 Vgl. ubber dio Sitte auch Magistretti 63.

${ }^{3}$ C. 20 (M. 105, 1096).

${ }_{4}$ N. 8 (M. 78, 1008).
} 
Verzeichnis erhellt, dafs selbst die Akolythen ihr Orarium am Halse trugen: orarium ad collum.

Nur wenn der Diakon, wie schon früher gelegentlich bemerkt wurde, sich statt der Dalmatik der Planeta bediente, trug er vom Evangelium an das Ornatstück in Form einer von der linken Schulter über Brust und Rücken unter den rechten Arm sich hinziehenden Schärpe. In der Folge wurde dann, was im 9. Jahrhundert noch Ausnahme war und nur gelegentlich geschah, feststehende allgemeine Regel.

Wie lange der römische Brauch sich erhielt, wonach auch die Diakone für gewöhnlich die Stola um den Hals trugen, ist nicht zu bestimmen. Die liturgischen Bücher wie die Liturgiker bieten zu wenig darüber. Sollen wir den mittelalterlichen Bildwerken Glauben schenken, so wäre er hie und da sogar noch im 13., ja 14. Jahrhundert in Kraft gewesen. Denn bis zu dieser Zeit treffen wir Darstellungen von Diakonen an, bei denen die beiden Enden der Stola vorn unter der Dalmatik zum Vorschein kommen. Beispiele bieten das Tropar von Prüm in der Pariser Nationalbibliothek aus dem Ende des 10. Jahrhunderts (vgl. Bild 121, S. 262), eine Miniatur der $\mathrm{kgl}$. Bibliothek zu Berlin mit einer Darstellung Sigeberts von Minden aus dem Beginn des 11. Jahrhunderts (vgl. Bild 124, S. 266), der leider im Original bei der Belagerung von Straßburg verbrannte Hortus deliciarum der Herrad von Landsberg (12. Jahrhundert) ${ }^{1}$, die Statuen des hl. Laurentius am Portal von St-Germain-l'Auxerrois zu Paris und des hl. Stephanus am Portal der Kathedrale von Chartres (13. bzw. 14. Jahrhundert) u. a. ${ }^{2}$ Haben wir es der Phantasie des Künstlers zuzuschreiben und es als eine unkorrekte Darstellungsweise anzusehen, wenn auf den genannten Bildwerken die diakonale Stola nach Weise der Priesterstola abgebildet ist, oder entsprechen dieselben dem tatsächlichen Verhältnis? Man wird vielleicht am besten zwischen den Bildwerken aus dem ersten Jahrtausend und den späteren

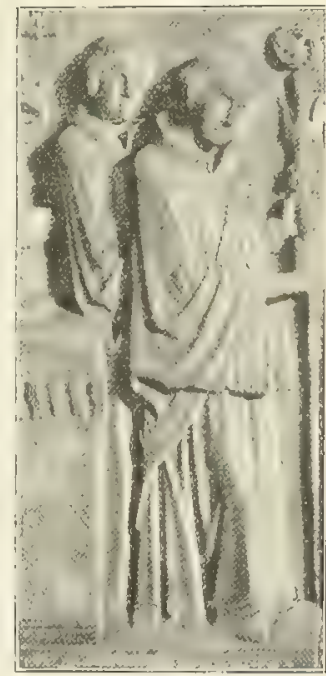

Bild 277. Diakon. Marmorrelief.

M̄onza, Dom. (Phot. Alinari.) Darstellungen unterscheiden. Die ersten mögen wirklich einen noch bestehenden Brauch wiedergeben, die letzteren jedoch sicher nicht mehr. Wenigstens darf das mit Bestimmtheit von den Monumenten des 12., 13. und 14. Jahrhunderts behauptet werden, da es um das 12. Jahrhundert unzweifelhaft schon überall Brauch war, daß die Diakone die Stola auf der linken Schulter hatten. Es erhellt das zur Genüge aus den Angaben der Liturgiker des 12. Jahrhunderts wie auch aus den damaligen liturgischen Büchern. Aus dem zweiten Jahrtausend ist uns kein Pontifikale bekannt, demzufolge der Bischof bei der Diakonatsweihe die Stola noch auf den Nacken des Ordinanden zu legen hatte. Es mag aber eine Reminiszenz an früheren Brauch sein, wenn wir noch in späterer Zeit auf Bildwerken gewisse heilige Diakone - es sind namentlich die hll. Stephanus und Laurentius - als ikonographische Eigenheit die Stola nach Art der Priester tragen sehen.

1 Herradede Landsberg, Hortus deliciarum, Straß̧burg 1901, Tfl LxviI.

2 Vgl. z. B. M a calis ter, Eccl. vest. 80
(Bildwerke der Kath. von St David's in Wales), Lind, Ein Antiphonar mit Bilderschmuck, Wien 1870, TAl 43 und Roh. VII, pl. DxLII. 
In Südtalien und in Mailand scheinen die Diakone gerade wie in Spanien und in der Ostkirche das Orarium stets auf die linke Schulter gelegt zu haben. Wie die Bildwerke zeigen, fielen die beiden Enden des Ornatstiuckes lose von der Schulter nach vorn und rückwärts herab. So gewahren wir es z. B. auf den Reliefs des Palliotto in S. Ambrogio.

Wie weit die Bestimmung des Konzils von Braga, wonach der Celebrans (Bischof und Priester) bei der Messe das Orarium über der Brust gekreuzt tragen sollte, im ibbrigen Abendland zur Geltung gelangte, läfst sich nicht feststellen. Jedenfalls war im 12. Jahrhundert diese Anlegungsweise nicht allgemein üblich. Denn wenn auch Bruno von Segni und Honorius bemerken, die Stola werde kreuzweise über die Brust gelegt, so ersehen wir doch aus den Ausführungen Ivos von Chartres ${ }^{1}$, dafs zu seiner Zeit auch die Gewohnheit bestand, die Stolenstreifen über die Brust gerade herabhangen zu lassen. Zu Rom war um das Ende des 12. Jahrhunderts die Vorschrift, von welcher der 4. Kanon des Konzils von Braga redet, nicht in Kraft?. Wenigstens gilt das bezüglich der Bischöfe. Aber auch auferhalb Roms wurde sie, wie wir von Durandus erfahren, nicht überall beobachtet. Nam non ubique partes stolae reducuntur ante pectus in modum crucis. Und zwar gilt diese Bemerkung nicht blof von den Bischöfen, sondern auch von den Priestern. In episcopo vero vel sacerdote ab utraque parte aequaliter dependent ${ }^{3}$.

In England trug der Priester am Ende des 14. Jahrhunderts die Stola kreuzweise vorn über der Albe ${ }^{4}$. Mit einer auf der Brust gekreuzten Stola ist auf einem dem 13. Jahrhundert entstammenden Wandgemälde in St Cäcilien zu Köln ein taufender Papst abgebildet. Gute Beispiele der über der Brust gekreuzten priesterlichen Stola liefert im 12. Jahrhundert namentlich das Rituale von Lambach ${ }^{5}$. Im 14. und 15. Jahrhundert sind Darstellungen dieser Art häufig. Auf den Bildwerken aus der Spätzeit des ersten und dem Beginn des zweiten Jahrtausends hängt die Stola in der Regel gerade herab ${ }^{6}$. Der gegenwärtigen Praxis, welche zwischen Bischof und Priester unterscheidet und durch die Aufnahme in das römische Missale und in das Caeremoniale der Bischöfe ihre allgemeine Verbindlichkeit erhielt, begegnen wir bereits im Pontifikale des Durandus 7. "Die gewöhnlichen Priester", heißt es dort, „sollen das Orarium in Kreuzesform über ihre Brust legen; dagegen ziemt es sich für die Bischöfe, dessen Enden vorn gerade herabhangen zu lassen." Indessen wurde der hier gemachte Unterschied zu des Durandus Zeit noch keineswegs allgemein beobachtet, wie das aus den vorhin angeführten Worten des Rationale hervorgeht. Nach den Mefierklärungen des ausgehenden Mittelalters ordneten die Priester damals regelmäßsig die Stola kreuzweise über der Brust.

Beim umgegürteten Superpelliceum, welches bereits vor 1200 bei einzelnen Funktionen die Albe zu ersetzen begann, lief man natürlich stets die Stolastreifen vorn gerade herabfallen.

Des Brauches, die Stola vor dem Anlegen derselben zu küssen, wie solchen das römische Missale vorschreibt, gedenkt bereits Durandus in seinem

\footnotetext{
1 Sermo 3 (X. 162, 525).

2 Innocent. III., De sacrif. missae 1. 1 , c. 51 (M. 217, 794). Über den gleichen römischen Gebrauch in späterer Zeit vgl. ordo 14, c. 53 ( (M. 78, 1157).

${ }^{3}$ L. 3 , c. 5 ; f. 69 .

4 B r o m y ar d., Summa praedicantium, bei Chambers 49 .
}

5 Abbildungen bei Franz, Das Rituale von St Florian, Freiburg 1904, TH $2 \mathrm{ff}$.

${ }^{6}$ Die Stola fällt bei dem taufenden Priester gerade herab z. B. auf der Miniatur der Wessobrunner Handschrift (Bild 275, S. 583), ferner auf einer Taufdarstellung in einem Sakramentar der Bamberger Bibliothek (A II, 52) u. a.

7 Mart. 1. 1, c. 4, art. 12, ordo 23; I 221. 
Rationale 1. Er deutet denselben auf die Bereitwilligkeit des Priesters, sich den Geboten des Herrn zu unterwerfen. Auch der 14. Ordo Mabillons kennt bereits die Sitte ${ }^{2}$.

\section{DIE ÜBERREICHUNG DER STOLA IM WEIHERITUS.}

Schon im 7. Jahrhundert bestand, wie wir sahen, in Spanien die Gewohnheit, dem Diakon, dem Priester und selbst dem Bischof bei der Weihe das Orarium zu überreichen. Ob diese Weihezeremonie vor dem 9. Jahrhundert im Abendland weit verbreitet war, läbt sich nicht feststellen. Nach 800 scheint aber dieselbe in den meisten Teilen der abendländischen Kirche einheimisch gewesen zu sein. Daf der Diakon zur Zeit Amalars bei der Weihe die Stola empfing, sagt dieser Liturgiker mit ausdrücklichen Worten. Wenn noch nicht in allen Sakramentaren und Pontifikalien des 9. und 10. Jahrhunderts im Weiheritus von der Überreichung und Anlegung der Stola die Rede ist, so kann das nicht befremden. Dieselben waren damals ja noch erst in ihrer Entwicklung und Ausgestaltung begriffen, und es dauerte noch einige Zeit, bis sie Missalien und Pontifikalien in unserem Sinne, d. i. Missalien und Pontifikalien mit allen Gebeten und Rubriken, wurden. Immerhin findet sich die Zeremonie schon in manchen Pontifikalien und Sakramentaren des 9. und 10. Jahrhunderts verzeichnet ${ }^{3}$; auferdem gedenken auch der 8., der 9. Ordo Mabillons sowie der von Duchesne herausgegebene römische Ordo der Übergabe des Orarium an den zu ordinierenden römischen Kleriker bzw. Diakon und Priester. Seit dem Beginn des zweiten Jahrtausends begegnet uns die Rubrik, welche von der Anlegung der Stola handelt, im Weiheritus des Diakons und des Priesters fast regelmäßig. Ältere Pontifikalien und Sakramentarien, die ursprünglich diese Zeremonie nicht erwähnten, werden nunmehr wohl mit darauf bezïglichen Einschiebseln versehen, so das Sakramentar Leofrics von Exeter 4.

In zahlreichen Pontifikalien des 11. und der nächstfolgenden Jahrhunderte findet sich im Weiheritus des Diakons die Übergabe der Stola unter der Rubrik: Ad consummandum diaconatus officium. Martène glaubt zwar nicht, daf durch diese Bemerkung jene Zeremonie als wesentlicher und zur Gültigkeit der Weihe erforderlicher Bestandteil der Weihe bezeichnet werde. Wie dem jedoch sein mag, tatsächlich herrschte seit Ende des 12. Jahrhunderts mehrfach die Ansicht, es gehöre die Anlegung der Stola zur Substanz der Diakonatsweihe. Vielleicht, dafs gerade die angeführte Rubrik in Verbindung mit dem Umstand, daß die Stola als die diakonale Insignie betrachtet wurde, diese Meinung veranlakte. Dieselbe ist indessen schon lange mit Recht aufgegeben.

Nach der jetzigen Vorschrift des römischen Pontifikale spricht, wie früher schon bemerkt wurde, der Bischof, wenn er dem Diakon die Stola auf die linke Schulter legt: "Nimm hin die weife Stola (das weife Gewand) aus Gottes Hand und vollziehe deinen Dienst; denn Gott ist mächtig genug, dir seine Gnade zu vermehren." Führt er hingegen bei der Priesterweihe den über den Rücken des Ordinanden sich hinziehenden Streifen des Gewandstückes über dessen rechte Schulter nach vorn, so sagt er: „Nimm hin des Herrn Joch, denn sein Joch ist süf und seine Bürde leicht."

1 L. 3, c. 5 ; I 68 .

2 C 53 (M. 78, 1157).

${ }^{3}$ Beispielsweise in einem Mailänder Pontifikale (M a istretti, Monumenta 43), in den Pontifikalien Egberts und Dunstans, dem
Pontifikale von Aletis, den Sakramentaren von Moyssac und Tours u. a. Vgl. die Auszinge bei $\mathrm{M}$ a r.t. I. 1, e. 8 , art. 11 , ordo $2 \mathrm{ff}$; II $31 \mathrm{ff}$.

* Warren, The Leofric missal, Oxford $1883,215$. 
Beide Formeln nehmen ersichtlich auf das Amt des Diakons bzw. Priesters Bezug. Sie treten, allerdings neben andern, bereits seit dem 12. Jahrhundert in den Pontifikalien des Mittelalters auf. Doch auch in den übrigen Weihegebeten erscheint die Stola häufig als Sinnbild des Amtes. Ganz besonders tritt diese ihre Bedeutung in den höchst interessanten Worten zu Tage, mit denen in angelsächsischen und verwandten Pontifikalien der Bischof die Übergabe der Stola an den Diakon begleitet. Da dieselben für die Anschauungen der damaligen Zeit sehr bedeutsam sind, seien sie hier nach dem sog. Pontifikale Egberts wiedergegeben: Accipe stolam, quam tibi Dominus per humilitatis nostrae famulatum seu per manus nostras accipiendam praeparavit, per quam scias sarcinam Domini Dei tui cervicibus tuis impositam esse et ad humilitatem atque ministrationem te esse conexum et per quam te cognoscant fratres tui ministrum Dei esse ordinatum, ut qui in diaconatus ministerio es constitutus, leviticae benedictionis ordine clarescas et spiritali conversatione praefulgens gratia sanctificationis eluceas. Sed et in Christo Iesu firmus et stabilis perseveres, quatenus hoc, quod per hanc stolam significatur, in die districti iudicii ante tribunal Domini sine macula repraesentare valeas, ipso auxiliante, cui est honor et gloria in saecula saeculorum. Amen.

In dem Ritus der Überreichung der Stola herrschte im frïheren Mittelalter eine nicht geringe Mannigfaltigkeit. Nach einigen Pontifikalien legte der Bischof noch vor der Handauflegung dem Diakon die Stola an; nach andern geschah das erst am Schluf der Weihe. Im 9. römischen Ordo übergibt nicht der Bischof, sondern der Archidiakon dem Ordinanden das Orarium, während in andern gleichzeitigen Ordinationsriten der Bischof selber solches tut. Nach dem Weiherotel Landulfs erhielt der Diakon zuerst die Dalmatik und dann die Stola, weil es in Süditalien gebräuchlich war, die Stola über der Dalmatik zu tragen; nach römischem Ritus wurden dagegen die Diakone umgekehrt erst mit dem Orarium und dann mit der Dalmatik bekleidet. Bezüglich des Wechsels der Stola bei der Priesterweihe finden sich ähnliche Verschiedenheiten. Wann eine größere Einheit in diesen Riten eingetreten ist, läbt sich kaum annähernd feststellen. Doch scheint eine solche schon um das 12. Jahrhundert sich gebildet zu haben. Freilich eine volle Übereinstimmung herrscht selbst in den Pontifikalien des 14. und 15. Jahrhunderts noch nicht.

Die Sitte, dem Diakon bei der Weihe die Stola auf die linke Schulter zu legen, bei der Ordination des Priesters aber den rückwärts herabfallenden Streifen über die rechte Schulter nach vorn herüberzuziehen, erwähnen schon Pontifikalien des 10 . Jahrhunderts ${ }^{1}$. Seit dem 12 . ist sie, wie aus den Weiheformularen erhellt, allgemein üblich.

\section{BESCHAFFENHEIT DER STOLA IM MITTELALTER.}

Über die Beschaffenheit des spanischen Orarium in der vorkarolingischen Zeit wurde schon bei Besprechung der Bestimmungen der Synoden von Braga und Toledo das Nötige gesagt. Es war ein streifenförmig gefaltetes Tuch, wenn nicht gar ein wirklicher Streifen. Das Diakonalorarium muste schlicht weib und schmucklos sein. Das Orarium der Priester und Bischöfe werden wir uns aber wohl als mit farbigen und goldenen Verzierungen versehen zu denken haben. Wenigstens scheint das den Diakonen gegebene Verbot, andere

Mart. 1. 1, c. 8, art. 10, ordo 5; II 46; ordo 3 ; Il 39 , wo statt mittas zu lesen ist mutas; ordo 2; II 35 hat dem Sinne nach das- selbe: Circumdentur humeri eius stola ab episcopo; bei der Diakonatsweihe heift es nämlich: Circumdetur eius humerus sinister. 


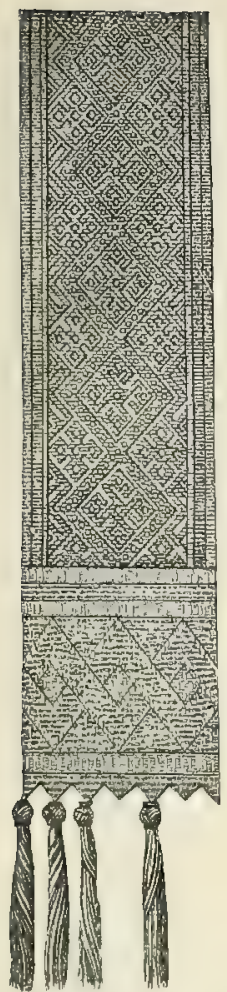

Bild 278. Stola. St-Hubert (Ard.)

als einfach weife Orarien zu tragen, auf eine reichere Ausstattung des priesterlichen und bischöflichen Orarium hinzudeuten.

Über die Beschaffenheit der Stola im gallikanischen Ritus wissen wir nichts Näheres. Die gallikanische Mefarklärung macht uns darüber leider keine Angaben. Wohl werden verschiedene Stolen aufbewahrt, die aus einer Zeit stammen sollen, da noch der gallikanische Ritus in Kraft war; so die schon erwähnte Stola des hl. Cåsarius von Arles zu Arles, die des hl. Martin von Tours zu Aschaffenburg, die des hl. Hubertus $(†$ 727) zu St-Hubert u. a. (Bild 278). Doch müssen wir darauf verzichten, uns bei ihnen Aufschluß über die Beschaffenheit der gallikanischen Stola zu holen. Dieselben stammen alle aus späterer Zeit. Wie es mit dem Orarium in Italien in vorkarolingischer Zeit aussah, wissen wir gleichfalls nicht.

Eine bessere Kenntnis der Stola gewinnen wir erst seit dem 9. Jahrhundert. Die Liturgiker lassen uns freilich hinsichtlich ihrer Beschaffenheit so viel wie ganz im Stich, und zwar gilt das nicht bloß bezüglich eines Hraban und Amalar, sondern auch noch bezüglich eines Honorius, Sicard, Innozenz und selbst Durandus. Alle schweigen einhellig von der Farbe, der Ausstattung und dem Stoff des Ornatstïckes und geben uns höchstens $\mathrm{zu}$ verstehen, daß es einen langen, bis fast zum Boden reichenden Streifen darstellte.

Indessen ersetzen diesen Mangel zur Genüge sonstige gelegentliche Notizen, die Angaben der Schatzverzeichnisse, die Bildwerke und eine Reihe von noch vorhandenen Stolen.

Über den Stoff, aus dem die Stola gemacht werden mufte, bestanden keine Bestimmungen. Riculf von Soissons will, daf jeder Priester zur Messe eine seidene Kasel habe; bezüglich der Stola gibt er dagegen keine solche Vorschrift, sondern verlangt nur stolas duas nitidas, "zwei reine Stolen".

Noch beim Ausgang des Mittelalters gab es ebensowohl Stolen von Linnen und Wollstoff wie Stolen von Seide. Zu Fest- oder bischöflichen Stolen verwendete man natürlich besseres Material. Doch waren, wie aus den Inventaren hervorgeht, schon im 12. Jahrhundert auch die Alltagsstolen sehr gewöhnlich aus Seide.

Nicht immer wurden übrigens die Stolen aus streifenförmig zugeschnittenen Stoffen angefertigt; man stellte sie auch unmittelbar als Band auf dem Webstuhl her. Solche Stolen sind z. B. die sog. Bernulfusstola zu Utrecht, die
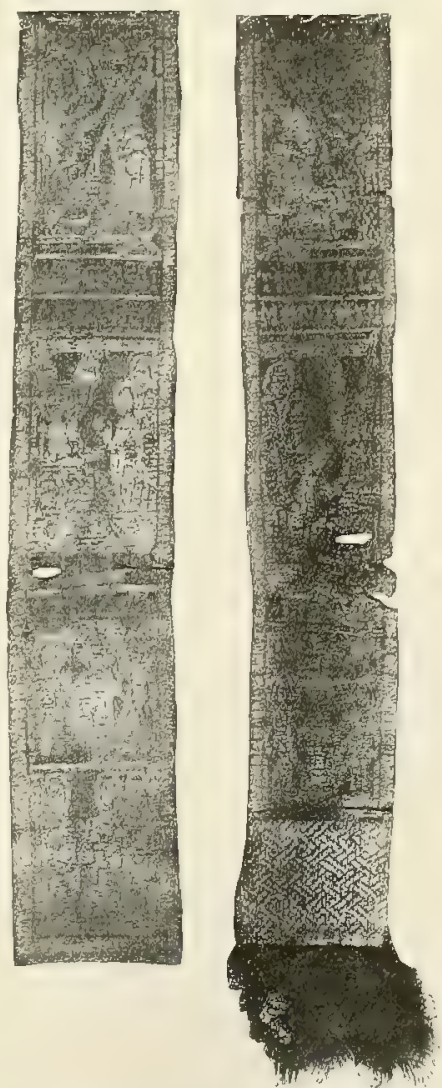

Bild 279. Stola aus dem Grabe Theodorichs II. von Trier. Trier, Dommuselum. 
St Martinsstola zu Aschaffenburg und die Stola zu St-Hubert. Andere lehrreiche Beispiele sind eine dem hl. Bernhard zugeschriebene Stola in St-Donat zu Arlon, eine von demselben Heiligen der Überlieferung nach herrührende Stola in der Liebfrauenkirche zu Trier und die im Grabe des Trierer Erzbischofs Theodorich II. († 1242) aufgefundenen Stolareste im Dommuseum zu Trier (Bild 279, S. 591). Alle diese Stolen sind nach Art breiter Tressen oder Borten gewebt und teilweise den Besätzen ähnlich, mit denen man die Kaseln und die sonstigen Paramente zu verzieren pflegte. Übrigens waren bandartig gewirkte Stolen nicht blok im 11., 12. und 13., sondern auch noch im 14. und 15. Jahrhundert gebräuchlich. Besondere Erwähnung verdienen die nach Weise der sog. Kölner Borten gewebten Stolen mit ihrer kräftigen, nach Farbe und Dessin gleich wirkungsvollen Musterung. Ein gutes Beispiel derselben findet sich im Schatz von St Marien zu Danzig, ein anderes im Schatz des Domes zu Halberstadt.

Schon früh werden mit Gold verzierte Stolen genannt. Sie begegnen uns schon im 9. Jahrhundert. Eine solche Stola sandte z. B. Patriarch Nicephorus dem Papst Leo III. zum Geschenk. Auch in den Inventaren des 9. Jahrhunderts werden Stolen dieser Art aufgeführt; so im Verzeichnis der Gaben Ansegisus' von Fontanelle: stolae auro paratae 5, im Inventar von St Bavo zu Gent: stolam 1 auream et 2 cum auro, im Inventar von Marchiennes. Bei solchen Stolen bestand entweder blok das Endstück aus einem Goldgewebe, oder es war das ganze Ornatstück mit Gold durchwirkt bzw. sein Fond, wie bei den Resten der prächtigen Stola Frithestans von Winchester im Museum zu Durham (Anfang des 10. Jahrhunderts), in Gold ausgestickt.

Im 10., 11. und 12. Jahrhundert ist häufig von kostbaren, mit Goldverzierungen versehenen Stolen in den Inventaren die Rede. Man vergleiche beispielsweise das Testament Riculfs von Elne: stolae 4 cum auro, die Inventare von Cremona: 3 stolae aureae egregio opere comptae, und ClermontFerrand: stolae ab auro 3, die Schenkung Madalwins von Passau: stolae 2 . . auro et gemmis paratae, die Inventare von Lamspringe: 5 stolae deauratae, Speier: stolae 3 auro textae, Abdinghof zu Paderborn: stolae 6 auro textae, Ely: 15 stolae cum aurifriso (sic), Enger: 4 stolae ... auro lapidibusque ornatae, die Schenkung des Bischofs Pelagius von Leon (1073): 2 stolae argenteae et alia auro fressa (sic) u. a. Zu Prüfening besab man acht mit Gold und Silber geschmückte Stolen; zu St Gallen hatte man ihrer nach einem dem 11. Jahrhundert angehörenden Inventar sogar achtzehn, nicht eingerechnet die acht goldverzierten Stolen, die zu ebensovielen vollständigen Mefornaten gehörten. Das Inventar des Domes zu Bamberg aus dem Jahre 1128 erwähnt 17 Goldstolen 1. Natürlich war man nicht überall in so glücklicher Lage wie zu St Gallen und zu Bamberg.

Seit dem 13., namentlich aber im 14. und 15. Jahrhundert wurden die Stolen nicht selten mit Gold oder vergoldeten Blechen in der Form von Rosetten, Vierpässen, Rauten usw. besetzt. Auch verwandte man wohl Emailplättchen, Perlen und Edelsteine zu ihrer Verzierung, wenngleich solche Prachtstolen, wie leicht begreiflich, nicht allzu häufig gewesen sein werden. Mit besonderer Vorliebe aber wurden die Stolen mit Stickereien versehen, und zwar waren es nicht blok geometrische oder vegetabilische Muster, mit denen man sie bestickte, sondern auch wohl figürliche Darstellungen.

' Vgl. auch Chron. Cassin. 1. 3, c. 1874 (M. G. SS. VII 711758 ). 
Schon die Stola Frithestans im Museum zu Durham, die vorzüglichste und zugleich eine der ältesten unter den noch erhaltenen mittelalterlichen Stolen, ist mit Heiligenfiguren bestickt. Auch von den Stolen aus dem späteren Mittelalter sind verschiedene mit Nadelmalereien dieser Art versehen; so z. B. die Stola des hl. Edmund zu Pontigny, die zum Mefgewand des sel. Albertus Magnus gehörende Stola in St Andreas zu Köln und die interessante in der "Zeitschrift für christliche Kunst" von A. Schnütgen veröffentlichte Stola in dem Xantener Dom. Auch die Inventare gedenken solcher mit Bildwerk geschmückter Stolen, so die Inventare von St Paul zu London, von Cluny und St Peter zu Rom (1361), das Schatzverzeichnis des Apostolischen Stuhles von 1295 u. a.

Fransen und Quasten hat man schon wenigstens im 9. Jahrhundert zur Ausstattung unseres Ornatstückes verwendet. Auf den Miniaturen der karolingischen Zeit ist die Stola regelmälıig unten mit Fransen geschmückt. Auch auf den Bildwerken des 10., 11. und der folgenden Jahrhunderte fehlen die fimbriae selten, und so bleibt es das ganze Mittelalter hindurch. Bei reicheren Stolen wurden die Fransen oder Quasten gern durch Glöckchen oder birnund eichelförmige Behänge aus vergoldetem Silber ersetzt. Bereits in der Nachlassenschaft Riculfs von Elne $(\dagger 915)$ wird unter den vier mit Gold verzierten Stolen una cum tintinnabulis genannt. Von den sieben Stolen, welche Meinwerk der von ihm gestifteten Abtei Abdinghof zu Paderborn schenkte, war eine mit 27, eine andere mit 21 Schellchen geschmückt. Fin Beispiel solcher mit metallenen Behängen versehenen Stolen wird noch im Schatz der Kathedrale zu Sens aufbewahrt. Sie wird gewöhnlich als Stola des hl. Thomas Becket bezeichnet. Wie kostbar diese Behänge bisweilen waren, erhellt aus einer Notiz des Inventars der Kathedrale zu Cremona von 984, wonach die 88 dependentiae von zwei Stolen, zwei Manipeln und zwei Cingula zusammen nicht weniger denn $31 / 2$ Pfund reines Gold ausmachten. Auch auf den Miniaturen sind die Stolen vielfach mit Glöckchen und ähnlichen Zieraten verziert (vgl. Bild 259, S. 533). Ihren Ursprung verdankt diese Ausschmückung unseres Ornatstückes vielleicht der Erinnerung an die Glöckchen, mit denen die hyazinthfarbige Obertunika des juidischen Hohenpriesters am unteren Rand besetzt sein mufte.

Kreuze begegnen uns, wenngleich nur vereinzelt, schon im 11. und 12. Jahrhundert auf den Stolen. Diejenige des hl. Thomas von Canterbury zu Sens ist schon in der jetzt üblichen Weise mit solchen ausgestattet; denn es findet sich von den drei Kreuzen, mit denen sie versehen ist, eines in der Mitte und je ein anderes an den beiden Enden, wo die Streifen sich zu erweitern beginnen. Wie indessen die Bildwerke, die Inventare und namentlich die noch vorhandenen Exemplare mittelalterlicher Stolen beweisen, sind Kreuze auf unserem Gewandstück erst um den Ausgang des Mittelalters häufiger geworden. Zwar sollte der Priester schon zu Durandus' Zeiten, also in der zweiten Hälfte des 13. Jahrhunderts, die Stola beim An- und Ablegen küssen, und der 14. Ordo gibt sogar genauer die Stelle an, wo dies zu geschehen habe, nämlich etwa um die Mitte ${ }^{1}$; allein dak zu dem Fnde ein Kreuz daselbst anzubringen sei, davon vernehmen wir nichts; ja die nicht sonderlich bestimmte Ausdrucksweise des 14. Ordo, es solle der Bischof die

1 C. 53 (M. 78, 1157): Deinde accipiat stolam et deosculatam circa medium ponat circa collum suum. 
Stola „um die Mitte" küssen, läst vermuten, daf es damals noch nicht Regel gewesen sei, jene mit einem Kreuz in der Mitte auszustatten. Für den Stand der Dinge im 14. und 15., ja noch im begimnenden 16. Jahrhundert ist bezeichnend, daf von den zahlreichen aus jener Zeit stammenden Stolen in St Marien zu Danzig nur eine ein Kreuz aufweist.

Allgemein wurde die Sitte erst im Lauf des 16. Jahrhunderts, so zwar, daf es sogar bald üblich wurde, nicht blok ein Kireuz auf der Stola anzubringen, sondern drei. Die Veranlassung, sie in der Mitte mit einem solchen zu versehen, bildete wahrscheinlich eben die Gewohnheit, die Stola vor dem Aulegen zu küssen. Das römische Missale spricht nicht ausdrücklich von einem Kreuz auf der Stola; wenn es aber bemerkt: accipiens stolam simili modo deosculatur, nämlich wie den Manipel, so ist darin wohl angedeutet, daf es auch bei der Stola in der Mitte ein solches voraussetzt.

Über die Farbe der Stolen gab es natürlich noch keine Bestimmung, solange sich überhaupt keine liturgische Farbenregel herausgebildet hatte. Man verwandte sie daher in jeglicher Färbung zu der jeweiligen Kasel, wie es gerade passend erschien. Doch wurde schon im 11. und 12. Jahrhundert die Stola häufig der Farbe und dem Stoff nach der Kiasel angepafit, indem sie als Zubehör zu derselben aufgefafit wurde. Beispiele hierfür enthält das Register von Rochester. So schenkte nach demselben Erzbischof Lanfrank ( $†$ 1089) eine Kasel samt Stola und Manipel aus dunklem Purpur, Bischof Walter $(†$ 1182) eine Kasel nebst Stola und Manipel aus grünem Seidenstoff, Bischof Gwalerannus $(† 1184)$ eine Kasel, Dalmatik, Stola und einen Fano aus rotem Zeug. Von Frau Alicia de Lillingstune heift es: Dedit casulam et albam paratam et stolam et phanum unius panni ${ }^{1}$. Die Regel war das aber noch nicht. Denn gerade das Register von Rochester bietet auch zahlreiche Beispiele für das Gegenteil. Erst als sich ein liturgischer Farbenkanon herausgebildet hatte, wurde es allmählich ständiger Brauch, die Stola hinsichtlich der Farbe sich nach der Kasel richten zu lassen. Da jedoch die Farbenregeln im Mittelalter keineswegs so strikte durchgeführt wurden, wie das heute geschieht, so wurden auch noch nach Entstehung bestimmter Farbenvorschriften kostbarere Stolen ohne Rïcksicht auf ihre Farbe zu allen Sorten von Kaseln gebraucht.

Gröfere Übereinstimmung hinsichtlich der Farbe wie überhaupt bezüglich der Ausstattung und sonstigen Beschaffenheit herrschte wohl schon früh zwischen Stola und Manipel. Der Manipel galt nicht nur als ein Seitenstück zur Stola, sondern auch als Zubehör zu derselben. In den Inventaren werden deshalb die Manipel nicht nur sehr gewöhnlich mit den Stolen zusammengestellt, sondern anch geradezu als Zubehör zu derselben bezeichnet: stolae cum manipulis suis oder ähnlich. So heibt es z. B. im Inventar von St Georg zu Köln (11. Jahrh.): 12 stolae cum totidem fanonibus, in einem Schatzverzeichnis der Abtei Martinsherg (12. Jahrh.): 6 stolae cum earum manipulis, in der Clronik von Monte Cassino: stola optima una auro brusta (goldbestickt) cum manipulo suo. Sonstige lehrreiche Beispiele der Übereinstimmung zwischen Stola und Manipel liefern das Register von Rochester: stola et phanum de albo filo lineo, stola et phanum de alba purpura, die Inventare von Cremona, Speier, Muri, Georgenberg bei Goslar, Abdinghof zu Paderborn, Ely u. a.

Was die Gestalt der Stola anlangt, so war diese unzweifelhaft im 9. Jahrhundert allenthalben ein blokes Band wie später. Denn die Stola erscheint selbst auf den Darstellungen, auf welchen der Manipel sich hin- 
reichend klar als streifenförmig gefaltetes Tuch zu erkennen gibt, wie auf dem Widmungsbild der Bibel Karls des Kahlen, deutlich als ein förmlicher Streifen.

Bemerkenswert ist, dafo die Stolen in der Frühe unseres Jahrtausends durchweg die bedeutende Länge von $2,50 \mathrm{~m}$ und mehr hatten. Ihre Breite war jedoch sehr gering. So gibt es jetzt noch Stolen aus dieser Zeit von nur $0,04-0,05 \mathrm{~m}$ Breite. Es waren die Stolen also damals nicht selten lediglich lange, aber schmale, an den Enden mit Fransen verzierte Bänder. Im späteren Mittelalter begannen die Stolen an Länge zu verlieren, dagegen an Breite etwas zu gewinnen. Noch die Statuten von Lüttich aus dem Jahre 1287 schreiben vor, es solle die Stola ad minus usque ad paramentum oder besser bis zum Saum der Albe herabhangen ${ }^{1}$. Die Synode von Cambrai von 1300 begnügte sich schon damit, zu verordnen, sie solle bis zum Albenbesatz reichen?

Im übrigen entwickelt sich die Stola hinsichtlich ihrer Gestalt ganz analog dem Manipel, was allerdings angesichts der nahen Beziehungen beider Ornatstücke zueinander auch durchaus natürlich ist.

Auch bei der Stola fehlen bis gegen das 11. Jahrhundert vielfach besondere Endansätze; wo solche aber vorkommen, sind sie in der Regel rechteckig oder quadratisch. Dann beginnt sich bei ihnen, wie die Monumente bekunden, die Trapezform immer mehr einzubürgern (vgl. Bild 259, S. 533), aus welcher sich im Verlauf des 12. Jahrhunderts durch Zunahme an Länge und Breite die noch im 13. sehr beliebte Schaufelform entwickelt. Gerade diese schaufelförmigen Enden waren es, welche man, wie die Inventare dartun, gern mit reicherem Schmuck versah und namentlich zur Anbringung figürlicher Darstellungen benutzte. Kann man diese schaufelartigen Ansätze auch nicht besonders schön nennen, so waren sie doch anderseits noch lange nicht jene häs-

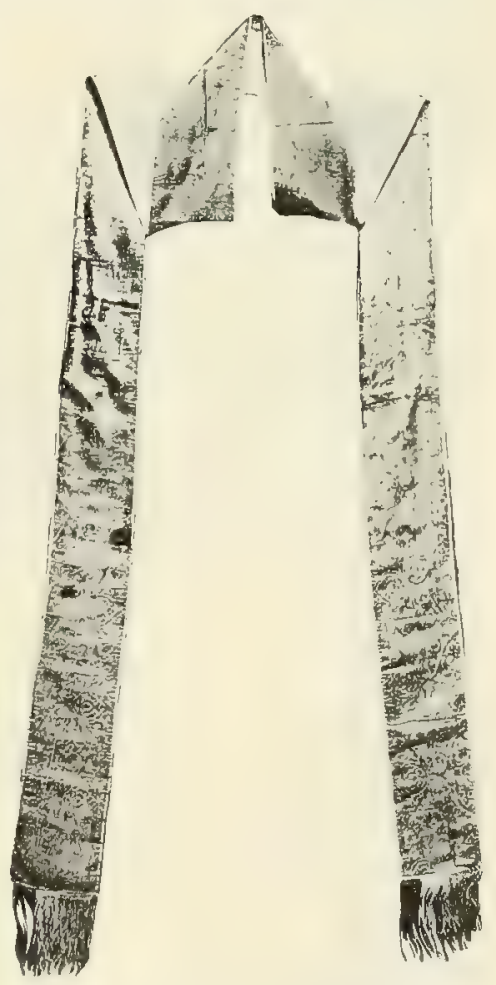

Bild 280. Stola. Danzig, Marienkirche. lichen Schaufeln und Taschen, welche der späte Barock und das Rokoko hervorbrachten; denn ihre Maßsverhältnisse blieben stets innerhalb bescheidener Grenzen. Um den Ausgang des 13. Jahrhunderts verschwand die Schaufelform wieder. Die Endstïcke kehrten entweder zur Gestalt eines Rechtecks bzw. Quadrates zurück oder verschmolzen, was ebenso häufig war, mit der Stola zu einem Ganzen, so daf diese dann einen einförmigen, allenthalben gleichbreiten Streifen darstellte. Gegen Ende des Mittelalters kam aber hie und da wiederum die Sitte auf, die Stola an dem unteren Ende etwas zu verbreitern, ohne daf dabei jedoch die Endteile nach Weise des 12. Jahrhunderts als vom Streifen gesonderte Stücke behandelt wurden. Doch herrschten noch bis in den Beginn des 16. Jahrhunderts stolen von der Form eines überall gleichbreiten Streifens so sehr vor, daf man auf den Bildwerken dieser 
Zeit nur selten solche zu Gesicht bekommt, die an den Enden breiter werden. Auch die zahlreichen, dem Ausgang des Mittelalters entstammenden Stolen in St Marien zu Danzig und im Dom zu Halberstadt bekunden, dafs das

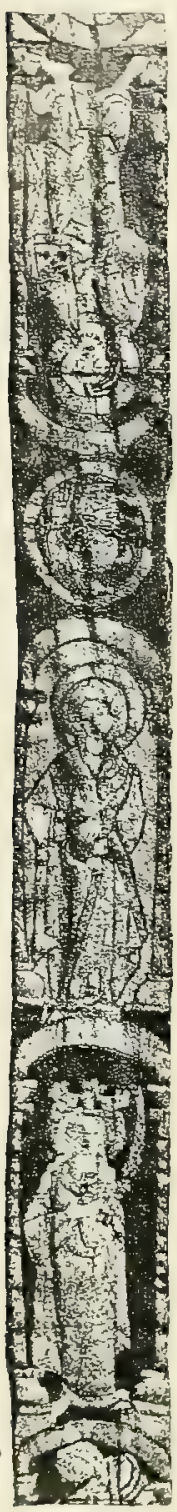

Bild 281

Stola.

(Mittelstück.) Halberstadt, Jyom.

Ornatstück damals für gewöhnlich ein Streifen war, der von oben bis unten die gleiche Breite aufwies (Bild 280, S. 595).

Zur Vervollständigung des Bildes, das wir von der Stola des Mittelalters entworfen haben, fügen wir eine kurze Beschreibung der bemerkenswertesten unter den noch vorhandenen mittelalterlichen Stolen an.

Eine der ältesten und zugleich eine der vorzüglichsten ist ohne Zweifel die schon gelegentlich erwähnte Stola Frithestans von Winchester $(†$ 933), die zugleich mit dessen früher besprochenem Manipel 1827 im Grabe des hl. Cuthbert in der Abteikirche zu Durham aufgefunden wurde. Material und Kunst, Gold, Seide und Stickerei haben sich auch bei ihr vereinigt, um ein überaus glänzendes Ornatstück zu schaffen. Die Heiligen, die auf ihr dargestellt sind, bestehen aus den alttestamentlichen Propheten, Isaias, Jeremias, Daniel, Amos, Abdias usw. Leider sind nicht mehr alle Figuren erhalten. In der Mitte der Stola ist in einem Vierpaßs das Lamm Gottes angebracht, auf der Vorderseite des einen ihrer Endstücke der hl. Jakobus, auf derjenigen des andern der hl. Thomas. Auf der Kehrseite tragen die Abschlufansätze die Inschrift: Alfflaed fieri precepit... Pio episcopo Frithestano ".

Die berühmteste der mittelalterlichen Stolen ist ohne Zweifel die dem hl. Hubertus ( $†$ 727) zugeschriebene Stola zu St-Hubert in den Ardennen. Der Ritus, Partikel derselben der Stirn derjenigen einzufügen, welche von einem wütenden Hunde gebissen waren, ist bereits in dem gegen Ende des 11. Jahrhunderts geschriebenen Liber miraculorum bezeugt und war ohne Zweifel schon um die Wende des Jahrtausends im Brauch ${ }^{2}$. Die Stola muf demnach ebenfalls bereits um diese Zeit vorhanden gewesen sein, da kein Grund vorliegt, anzunehmen, sie sei später durch eine andere ersetzt worden. Dagegen ist es unseres Erachtens wenig wahrscheinlich, daß sie vom hl. Hubertus selbst herstammt. Sie mag bei einer der zahlreichen Translationen des heiligen Leibes - wie solches auch sonst geschah - in den Sarg des Heiligen gelegt, später dort gefunden worden und so in den Ruf gekommen sein, einst dem hl. Hubertus wirklich angehört zu haben. Natürlich kann sie auch so nach altem kirchlichem Brauch als Reliquie betrachtet und behandelt werden.

Die Stola besteht jetzt nur mehr aus zwei Stücken, von denen eines $0,684 \mathrm{~m}$, das andere $0,264 \mathrm{~m}$ lang ist. Sie ist merkwürdig schmal; denn ihre Breite beläuft sich nur auf $0,042 \mathrm{~m}$. Die Fransen haben sich bloß an einem Ende erhalten; sie haben eine Länge von $0,093 \mathrm{~m}$. Die Stola ist mit einer geometrischen Musterung versehen, wie sie uns auf den Borten des 10., 11., 12. und 13. Jahrhunderts immer wieder begegnet und für diese Zeit charakteristisch ist. Abschnittsweise ist das Muster in Gold ausgeführt (Bild 278, S. 591).

Eine wertvolle Arbeit des 11. Jahrhunderts ist die dem hl. Bernulf zugeschriebene Stola zu Utrecht. Ohne die Fransen, die 0,11 m lang sind, beträgt ihre Länge $2,74 \mathrm{~m}$ bei einer Breite von ca $0,08 \mathrm{~m}$. Die in Gold auf Purpurgrund gewebten Darstellungen sind ganz dieselben wie freim Mranipel des Heiligen. Auch im übrigen ist die Stola diesem völlig gleich (vgl. Bild 260, S. 535).

1 'Teilweise Abbildung bei Roh. VII, Dxxxr.

2 A. SS. 3. Nov, I 873. Ausführlicheres über die Stola, ihre heutige Beschaffenheit und den erwähnten Ritus ebd. 1 868, wo zugleich eine gute farbige Ahbildung des Ornatstïckes geboten wird. 
Dem 11. bis 12. Jahrhundert mag die Stola des hl. Martin in der Stiftskirche zu Aschaffenburg angehören. Sie ist aus feinem Linnengarn gewebt, $3,08 \mathrm{~m}$ lang und $0,07 \mathrm{~m}$ breit und von dunkelblauer Farbe. Das Ornament, womit sie versehen ist, setzt sich aus fortlaufenden geometrischen Gebilden zusammen, in welchen als Leitmotiv der Zickzack erscheint. In bestimmten Abschnitten sind Querstreifen angebracht, welche in Kapitalen die doppelreihige Inschrift tragen: In nomine Domini ora pro me. Die Musterung ist von roter, die Inschrift von weifer Farbe. An den Enden sind die Kettenfüden zu einer Art von Quastentransen zusammengeflochten ${ }^{1}$.

Von den noch vorhandenen Stolen des 12. und 13. Jahrhunderts nennen wir vor allem die Stola des hl. Thomas Becket zu Sens. Thre Länge beträgt einschlieflich der Endstücke 2,90 m, ihre Breite 0,095 m. Die Endstücke erreichen am unteren Rand die bedeutende Breite von $0,17 \mathrm{~m}$. Thre Ausstattung ist derjenigen des früher beschriebenen Manipels gleich.

Mit figürlichen Darstellungen bestickt ist eine kostbare Stola im Dom zu Halberstadt. Sie ist $2,86 \mathrm{~m}$ lang und $0,075 \mathrm{~m}$ breit. In der Mitte ist in einem Kreise das Lamm Gottes angebracht, rechts davon sehen wir unter rundbogigen Arkaturen eine Folge männlicher, links eine solche weib. licher Heiligen. Arkaturen wie Figuren - die Fleischteile und das Haar allein ausgenommen - sind ganz in abgehefteten Goldfäden ausgeführt. Der Fond innerhalb der Bogenstellungen ist abwechselnd mit grüner, blauer und roter Seide ausgestickt (Bild 281).

Eine Stola verwandter Art findet sich zu Marienberg in Tirol. Sie hat bei einer Breite von $0,06 \mathrm{~m}$ zur Zeit nur noch eine Länge von $2 \mathrm{~m}$. Die Mitte nimmt hier ein aus rankenartigen Motiven sich zusammensetzendes romanisierendes Ornament ein, an welches sich rechts unter Rundbogen die Standfigur Christi, links diejenige Marias anschliebt. Dann folgen zu beiden Seiten weitere Heilige. Alle

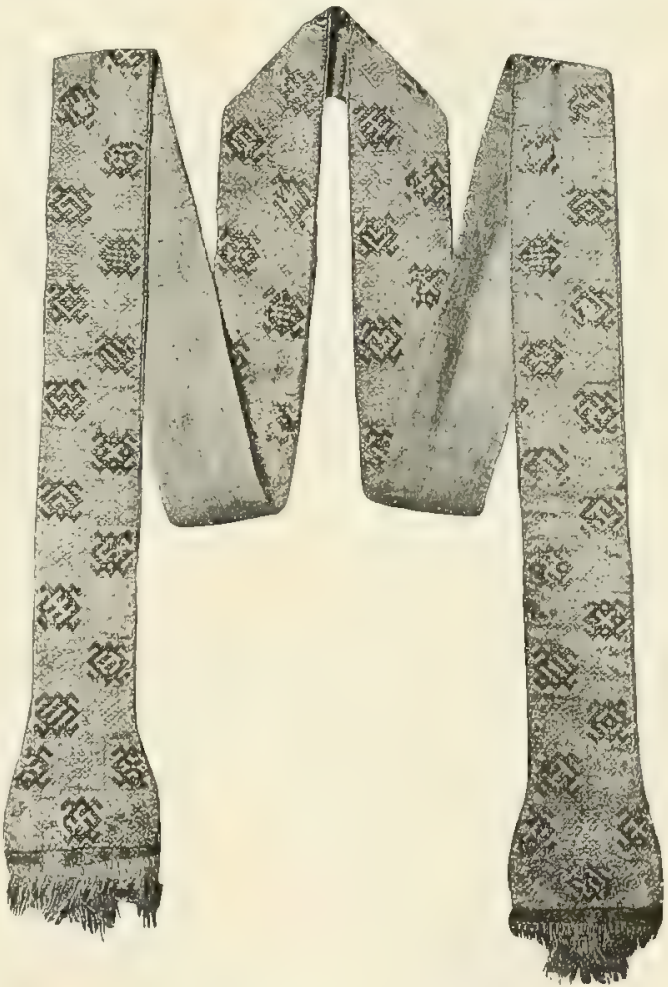

Bild 282. Stola. Sens, Kathedrale.

Darstellungen sind durch Inschriften gekennzeichnet, der Heiland durch Maiestas. Die Stola ist wie die Halberstiddter auf linnenem Fond ausgeführt, Gold ist bei ihr jerloch nur in verschwindend geringem Umfang zur Verwendung gekommen. Der Fond ist gleichmäßig in dunkler rotvioletter Seide ausgestickt, die Konturen der Darstellungen sind in blaner Seide hergestellt. Die Stola mag wie die Halberstädter um die Mitte des 13. Jahrhunderts entstanden sein ${ }^{2}$.

Dem hl. Edmund von Canterbury $(\dagger 1240)$ werden drei Stolen zugeschrieben. Die eine wird zu Provins aufbewahrt. Sie ist 2,66 $\mathrm{m}$ lang und mit geometrischen Mustern in Blau, Gelb, Gold, Rot, Grün bestickt, bietet aber sonst nichts Bemerkenswertes ${ }^{3}$. Die andere befindet sich zu Pontigny. Sie hat bei einer Breite von $0,066 \mathrm{~m}$

1 Abbildung bei Roh. VII, pl. vxxxrir.

2 Skizze und nähere Beschreibung der Stola in Mitt. 1895, $190 \mathrm{f}$, wo dieselbe indessen ohne hinreichenden Grund dem 12. Jahrhundert zugewiesen und als das Werk Utas, der. Gemahlin des Stifters von Marienberg, bezeichnet wird.

3 Roh. VII 66. 
eine Länge von $2,96 \mathrm{~m}$. An den Enden erweitert sie sich in der Art der Stola des hl. Thomas. Nach einer Skizze, welche Rohault de Fleury von ihr gibt, hat sie als Schnuck figürliche Darstellungen, die in mandorlaförmigen, durch Ranken gebildeten Medaillons angebracht sind'. Die dritte Stola hefindet sich in Besitz der Kathedrale von Sens. Auch sie erweitert sich an den Enden ein wenig, doch bleibt die Erweiterung in sehr mäßigen Grenzen (Bild 282, S. 597). Wie die Stola von Provins ist sie mit geometrischen Dessins bestickt. Aus kleinen Goldrauten gebildete Linien teilen die eigentliche Stola in Reihen von je zwei, die Enden in solche von je drei Quadraten, die abwechselnd mit einer blauen und grünen Hakenfigur ausgestickt sind. Dieselbe ist gelb konturiert und mit goldenem Kern gefüllt.

Eine Stola im Domschatz zu Anagni besteht aus einer der bekannten geometrisch gemusterten Goldborten des 13. Jahrhunderts. Es genüge, hier auf sie aufmerksam gemacht zu haben.

Die sog. Stola des hl. Regnobert zu Bayeux scheint nicht mehr ihre ursprüng. lichen Maße zu besitzen. Denn sie hat bei einer Breite von $0,04 \mathrm{~m}$ eine Gesamtlänge von nur $1,57 \mathrm{~m}$, von der zudem noch auf jedes der beiden nach unten sich auf $0,09 \mathrm{~m}$ erweiternden Endstücke $0,15 \mathrm{~m}$ entfallen. Sie ist in Gold und Violett nach Tressenart gewebt und war ehedem mit Perlen aufs reichste besetzt. Wie die vorgenannten entstammt auch sie dem 13. Jahrhundert 2 .

Zu Trier werden im Dommuseum die Reste einer Stola aufbewahrt, welche man 1898 bei Restauration des Lettners im Grabe Theodorichs II. († 1242) entdeckte. Sie stellen ein schweres rotseidenes Band dar, dem in Gold Szenen aus dem Leben des Erlösers eingewebt sind. An den Enden schlof die Stola mit einem kurzen, ein wenig sich verbreiterndem Ansatzstück, das ebenfalls in Gold mit dem im 13. Jahrhundert so häufigen Flechtwerk gemustert war. Von den verschiedenen Szenen, die auf ihr zur Darstellung gekommen waren, sind noch gut erkennbar die Kreuzigung, der Abstieg zur Vorhölle, der Besuch der Franen am Grabe und die Himmelfahrt (vgl. Bild 279, S. 591) ${ }^{3}$.

Eine im Besitz der Liebfrauenkirche zu Trier befindliche Stola besteht aus einem $0,047 \mathrm{~m}$ breiten Seidenbande, das mit einer romanischen Rankenmusterung, der phantastische Vögel- und Vierfüßlergestalten eingefügt sind, verziert ist. Der Grund der Stola ist von violetter, die Zeichnung von weifer Farbe. Die Stola wird von der Überlieferung mit dem hI. Bernhard in Verbindung gebracht. Auch eine Stola in St-Donat zu Arlon soll von dem hl. Bernhard herrühren (vgl. Bild 265, S. 540). Sie ist $0,045 \mathrm{~m}$ breit und hat einschließlich der beiden $0,13 \mathrm{~m}$ langen Abschlußsstücke eine Gesamtlänge von $2,75 \mathrm{~m}$. Von ihrer Beschaffenheit gilt, was früher über den zur Stola gehörenden Manipel gesagt wurde.

Eine Stola zu Valsainte (Schweiz) ist genau von der gleichen Art wie der seines Orts beschriebene, ebendort befindliche Tianipel und unterscheidet sich von diesem nur durch die größsere Länge, $3,22 \mathrm{~m}$, sowie durch die Farbe der Fransen an den Enden, die hier rot sind.

\footnotetext{
${ }^{1}$ Roh. VII 65. Text und Abbildung widersprechen einander; wir glauben dieser den Vorzug geben zu sollen.

2 Abbildung bei Roh. VII, pl. oxxxv; dazu p. 66, wo auch eine Stola des hl. Thomas von Biville erwähnt wird (Abbildung ebd. VIII, pl. DCVI). Dieselbe scheint aus einer mit Hakenmustern verzierten Goldborte $\mathbf{z u}$ bestehen.

${ }^{3}$ Vgl. des Verfassers Aufsatz ${ }_{n}$ Die Stola des Erzbischofs Theodorich II. von Trier" in Zeitschrift 1901, $27 \mathrm{f}$. Die Stola wurde schon von $\mathrm{Wilmows}$ in in Die historisch denkwürdigen Grabstätten der Erzbischöfe im Dom zu Trier " Tfl 6 auf Grund einer frïheren
}

Eröffnung des Grabes beschrieben und veroffentlicht. Sie wird hier und S. 17 irrig als Stola Boemunds II. († 1367) bezeichnet. Die Abbildung, welche $\nabla$. Wilmowsky von der Stola gibt, ist nicht blok stilistisch, sondern auch, was die Darstellungen selbst anlangt, sehr fehlerhaft. Reste einer der Trierer qualitativ und technisch gleichartigen Stola fand man bei Aufdeckung der Kaisergräber in einem Bischofsgrabe zu Speier. Die Musterung besteht hier jedoch nicht aus einer Folye von Szenen aus dem Leben Christi, sondern aus einer sich stets wiederholenden Einzelfigur, dem thronenden Christus. Die Reste befinden sich jetzt im Speierer Dom. 
Eine interessante Stola zu Andechs ist leider nicht mehr vollständig, sondern in späterer Zeit durch andere Stïcke ergänzt worden. Der ursprüngliche Teil ist eine mit vegetabilischen und animalen Motiven gemusterte Borte von $0,63 \mathrm{~m}$ Länge.

Von den Stolen, welche sich aus dem 14. Jahrhundert erhalten haben, seien erwähnt die Stola im Dom zu Xanten und die zur sog. Kasel des sel. Albertus Magnus gehörende Stola in St Andreas zu Köln. Die Xantener hat eine Länge von 2,97 m und eine Breite von $0,085 \mathrm{~m}$. Sie ist aus roter, mit Leinwand unterlegter Seide angefertigt und mit figürlichen Darstellungen bestickt. In der Mitte befindet sich eine Krönung Mariens begleitet von zwei in Wolken schwebenden inzensierenden Engeln, an welche sich dann rechts und links je sechs Apostel, einer der Stiftspatrone und einer der Stifter anschließen. Alle diese Figuren sind unter zierlichen, etwas gedrückten gotischen Arkaturen angebracht, die knieenden Stifter nicht ausgenommen. Die Enden sind mit Rauten gemustert, denen der Buchstabe A bzw. eine Rosette eingestickt ist, und schliefen mit einem schmalen Goldbörtchen und Kordonnetfransen von abwechselnd blauer, weiker, grüner und roter Farbe ab. Die Stola besitzt überall die gleiche Breite und scheint der zweiten Hälfte des 14. Jahrhunderts anzugehören.

Die Stola in St Andreas zu Köln besteht aus blanem Samt, ist von oben bis unten gleichbreit und mit zierlichen Heiligenfiguren nach Weise des früher erwähnten, ebendort befindlichen Manipels geschmückt. Auch bei ihr werden die einzelnen Heiligen, welche ohne Baldachine übereinander angeordnet sind, durch fünf, zusammen ein Andreaskreuz bildende, kleeblattartige Blümchen geschieden.

Für die Kenntnis der Stolen des 15. Jahrhunderts sind die zahlreichen Stolen im Dom zu Halberstadt und in St Marien zu Danzig (Bild 280, S. 595) sehr wichtig. Es sind einfache, meist aus dem gleichen Stoff wie die zugehörige Kasel gemachte, allenthalben gleichbreite Streifen, welche als einzige Ausstattung an den Enden Fransen aufweisen und bei einer Breite von' ca $0,08-0,09 \mathrm{~m}$ eine Länge von ca $2,40 \mathrm{~m}$ besitzen. Eine aus Goldstoff gemachte Stola im Historischen Museum zu Bern ist durch ihre eigenartige Verzierung, schwarzsamtene Kreuze, bemerkenswert. Sie ist 2,70 m lang, $0,06 \mathrm{~m}$ breit und stammt aus dem Ende des 15. Jahrhunderts'.

Schon der neueren Zeit gehört eine Stola im Münster zu Aachen an, welche Bock irrig dem 12. Jahrhundert zuschrieb ${ }^{2}$. Sie ist ein ebenso interessantes wie kostbares Stück. Der Mitte zunächst sind ihr zwei Engel aufgestickt; dann folgen rechts die Brustbilder der Evangelisten Markus und Johannes, getrennt durch die Ganzfigur der Gottesmutter, die Ganzfigur des hl. Nikolaus und die Brustbilder der Apostel

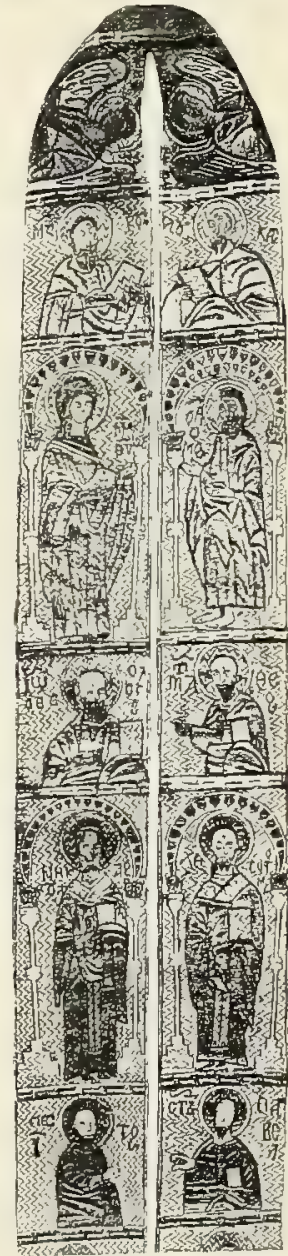

Bild 283. Stola (oberes Stück). Aachen, Münster. Petrus und Bartholomäus, links die Ganzfigur der Vorläufer des Herrn zwischen den Brustbildern der Evangelisten Lukas und Matthäus, die Ganzfigur des hl. Johannes Chrysostomus und die Brustbilder der Apostel Paulus und Simeon. Mit Ausnahme der Gesichter, Hände und Füße ist sonst fast alles in Goldstickerei ausgeführt. Die

1 J. Stammler, Der Domschatz von Lausanne, in "Katholische Schweizer Blätter" X (1894) 179. Velschiedene beachtenswerte Stolen aus dem 13., 14. und 15. Jahrhundert besitzt auch das Kensington-Museum zu London. Die hervolragendsten derselben stammen aus dex ehemaligen Bockschen Sammlung, darunter die bei B o ck II, Tfl 18 , n. 14 abgebildeten Stolen.

2 Bock, Gesch. II 70. Die Stola hat bei einer Breite von $0,12 \mathrm{~m}$ die Länge von ca $3,10 \mathrm{~m}$, die Fransen nicht eingerechnet. 
Darstellungen sind zeichnerisch mangelhaft, um so vollendeter ist die zur Anwendung gekommene Technik. Die Stola, zu der ein ähnlicher Nanipel gehört (vgl. Bild 267, S. 542), ist eine südslavische Arbeit und wohl durch ungarische Pilger nach Aachen gelangt (Bild 283, S. 599).

Seit dem Beginn des 16. Jahrhunderts nimmt die Stola an den Enden rasch an Breite zu. Auffallend ist dies namentlich zu Rom wie in Italien iiberhaupt. Eine vom hl. Karl Borromäus herrührende Stola in S. Maria Maggiore zu Rom ladet an ihren Enden bereits in bemerkenswerter Weise aus.

Nach der Verordnung, welche der hl. Karl Borromäus über die Form und Beschaffenheit der liturgischen Gewänder erließ, soll die Stola bei einer Länge von etwa $2,60 \mathrm{~m}$ eine Breite von $11 \mathrm{~cm}$ haben. An den Enden soll sich das Ornatstück nach und nach erweitern und am unteren Rand mit ca $5 \frac{1}{2} \mathrm{~cm}$ langen Fransen oder Quasten versehen sein. In der Farbe muf es samt seinem Futter, das aus dünnem Seidenstoff zu bestehen hat, mit dem Mefsgewand übereinstimmen. Weiterhin ist es mit drei Kreuzen auszustatten, einem in der Mitte und je einem an den Enden. Die Kreuze sollen klein und quadratisch und ihre Balken etwa 3 unciae $\left(=5^{1 / 2} \mathrm{~cm}\right)$ lang sein. An die Priesterstola soll nichts angehängt werden, an die Episkopal- und Diakonalstolen mag man zum Zweck der Befestigung derselben in der Mitte gleichfarbige, seidene, mit Quästchen geschmückte Schnüre anbringen ${ }^{1}$.

Ein getreues Echo der Verordnung des hl. Karl bildet die Bestimmung, welche die Prager Synode vom Jahre 1605 hinsichtlich der Beschaffenheit der Stola traf. Auch diese betont, es müsse die Stola von derselben Farbe wie die Kasel sein; ein dünnes seidenes Futter von der gleichen Farbe haben, sich an den Enden etwas erweitern, mit Fransen geschmückt sowie mit drei Kreuzen versehen werden und endlich beiläufig $2,70 \mathrm{~m}$ lang und 0,12 breit sein ${ }^{2}$.

Im allgemeinen bewahrte das Ornatstück bis in das 17. Jahrhundert hinein noch eine angemessene Form, obgleich es an den Enden schon in erheblicherem Maße an Breite zugenommen hatte, als gerade nötig;, wünschenswert und schön war. So steigt eine im Besitze des Collegium Canisianum zu Exaeten befindliche Mefsstola, deren sich der sel. Petrus Canisius in seinen letzten Lebenstagen bedient hat, bei einer Streifenbreite von $9 \mathrm{~cm}$ und einer Gesamtlänge von $2,50 \mathrm{~m}$ an den Enden auf $22 \mathrm{~cm}$.

Die eigentliche Entartung der Stola begann um die Mitte des 17. Jahrhunderts. Wie man den Manipel dadurch zu verschönern glaubte, daßs man seine Streifen verschmälerte, seine Enden aber ins Ungemessene verbreiterte, so vermeinte man auch den Stolen einen Dienst zu erweisen, wenn man sie oben zu einem schmalen Bande werden, uncen dagegen zu Taschen oder Schaufeln sich auswachsen liek. Daher denn die Stolen mit den sinnlos breiten Endstücken, welche bis ins 19. Jahrhundert in Mode waren und auch jetzt noch nicht allerwegen ausgestorben sind.

Mit Recht gingen daher die Bemühungen zur Neubelebung und Hebung des Paramentenwesens auch darauf hinaus, unter Anknüpfung an die bessere Gepflogenheit einer vergangenen Zeit jene hälliche Stolaform zu beseitigen und durch eine würdigere zu ersetzen. Es ist auch manches erreicht worden, namentlich in Deutschland.

Ein neucres Provinzialkonzil, das von Prag aus dem Jahre 1860, welches auf das Wiedererwachen des rechten Sinnes für edle Formen der liturgischen

\footnotetext{
1 A. E. Med. 626.

${ }^{2}$ C. 13 (Hartzh. VIII 691).
} 
Gewänder großen Einfluß ausgeübt und dadurch sich wahres Verdienst erworben hat, bestimmt betreffs der Stola: „Die Länge der Stola betrage wenigstens 4 Ellen (ea $2^{1 / 2} \mathrm{~m}$ ), so daf sie bis unter die Kniee reiche; breit sei sie etwa eine halbe Hand (ca $8 \mathrm{~cm}$ ), an den Enden aber soll sie nach und nach ein wenig breiter werden und mit Fransen verziert sein." 1

\section{DIE STOLA IN DEN RITEN DES OSTENS.}

Die Stola ist in allen Riten der Ostkirche in Gebrauch, und zwar kommt sie in den meisten Riten, wie im Abendland, blob den Diakonen, Priestern und Bischöfen zu. Bei den Maroniten, Syrern (Bild 284) und Chaldäern bedienen sich ihrer auch die Subdiakone, bei den Maroniten aufserdem die Lektoren ${ }^{2}$.

Nur im griechischen Ritus führt die Stola der Diakone einen von demjenigen der priesterlichen und bischöflichen Stola verschiedenen Namen. Die Diakonalstola heißst hier úoúoєov (slav. orar), die Priester-

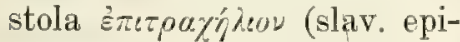
trachil). Die armenische Bezeichnung urar, die syrische uroro, die koptische batraschil werden ohne Unterschied für beide Stolaarten gebraucht, wenngleich diese ihrer Gestalt nach voneinander verschieden sind.

Die priesterliche (bischöfliche) Stola tritt vornehmlich in zwei übrigens ganz verwandten Formen auf. Nach der einen ist sie ein ca $1,20 \mathrm{~m}$ langes und ca 0,18 bis $0,20 \mathrm{~m}$ breites seidenes

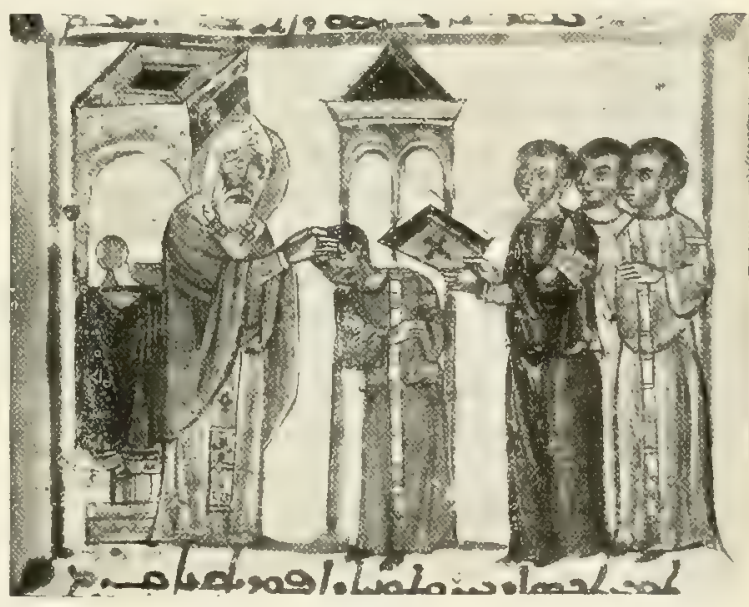

Bild 284. Weihe der Subdiakone. Miniatur eines syrischen Pontifikale (1239). Paris, Bibl. Nat.

Zeugstïck, welches nahe einer der beiden Schmalseiten mit einem Ausschnitt zum Durchstecken des Kopfes versehen ist. Dasselbe ist mit Futterstoff unterlegt, von Borten ringsum eingefafit und mit Kreuzen besetzt, von denen eines sich oberhalb des Kopfdurchschlupfes befinden mub. Die andere nähert sich mehr der abendländischen Priesterstola. Bei ihr ist das geschilderte Zeugstuick vom Kopfdurchlaf an der ganzen Länge nach, also bis zum andern Ende, in zwei gleichbreite Streifen zerschnitten, von welchen jeder von einer Borte umrahmt und mit den obligaten Krreuzen verziert ist. Die beiden Streifen sind aber stets an mehreren Stellen aneinander genäht, so dafs sie zuletzt doch als ein Ganzes erscheinen (Bild 285, S. 602).

Bei den Armeniern, Syrern und Kopten ist blof die erste Art der Priesterstola im Gebrauch. Im griechischen Ritus ist die zweite bevorzugt, doch kommt darin auch die andere zur Verwendung. Eine bestimmte Farbe ist

1 Tit. 5, c. 7, n. 2 (Coll. Lac. V 539).

2 Auch der chaldäische Ritus kennt ein Orarium der Lektoren. Es wird denselben bei ihrer Weihe von dem Bischof auf die ausgestreckten Arme gelegt. (D e n z inger Ritus orient. II 228; Ass., Bibl. III 2, 796.) In der Praxis kommt es bei ihnen jedoch nie zur Verwendung. 
für das Ornatstïck in keinem der verschiedenen Riten vorgeschrieben. In der Regel folgt es indessen in Beziehung auf die Farbe dem liturgischen Mantel, dem Phelonion.

Die Priesterstola wird gerade wie im lateinischen Ritus unter dem Obergewand getragen. Sie wird mittels des Gürtels am Körper befestigt und liängt bei den Bischöfen wie bei den Priestern vom Hals gerade herab. Nur bei den Chaldäern machen letztere eine Ausnahme, da sie das Ornatstiick, wie es im Abendlande Vorschrift ist, über der Brust kreuzen müssen. Es gleicht daher auch die Priesterstola des chaldäischen Ritus der Form nach abweichend von dem sonstigen Brauch des Ostens der lateinischen Stola.

Die Stola der Diakone ist ein ca $0,08-0,10 \mathrm{~m}$ breites und $2,50-4 \mathrm{~m}$ langer, meist seidener Zeugstreifen, der bei den Griechen in der Regel von weißer Farbe ist. Der große Unterschied in der Länge des diakonalen Orarium hängt mit der Weise zusammen, in welcher es angelegt wird. In dieser Be-

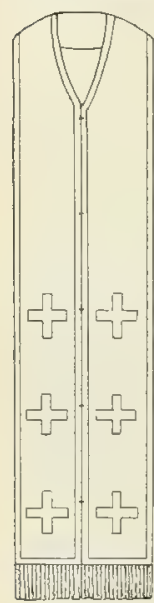

a

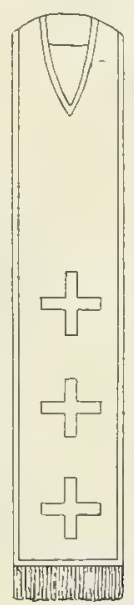

b ziehung herrscht nämlich in den einzelnen Riten der Ostkirche eine verschiedene Praxis.

Im griechischen Ritus läßst man das Orarium entweder sofort von der linken Schulter nach vorn und rückwärts herabfallen oder schlingt es von dort zuvor schärpenartig um Rücken und Brust. Die erstere Weise ist die gewöhnliche und verbreitetste, die letztere ist bei den Ruthenen und Bulgaren üblich. Vor der Kommunion legen übrigens überall im griechischen Ritus die Diakone das Ornatstück in derselben Form um, wie die griechischen Subdiakone ihr Cingulum ${ }^{1}$.

Bei den Armeniern (Bild 286) tragen die Diakone die Stola entweder nach Art der abendländischen oder der bulgarischen Diakone (vgl. Bild 40, S. 93). Bei den maronitischen Lektoren hängt das Orarium von der rechten Schulter herab; die maronitischen, syrischen und chaldäischen Subdiakone schlingen es um den Hals, indem sie dabei die Enden von der linken Schulter nach vorn und nach rückwärts herabwerfen. Die Diakone der Maroniten, Syrer und Chaldåer lassen das Orarium

Bild 285. Priesterstola des griechischen (a b), syrischen, armenischen und koptischen (b) Ritus.

von der linken Schulter über Brust und Rücken gerade herunterfallen. Bei den Kopten endlich legen die Diakone die Stola nach bulgarischem Brauch um.

Die Verwendung, welche die Stola in der Ostkirche findet, ist im ganzen die nämliche wie im lateinischen Ritus. Sie ist auch dort das liturgische Universalgewand. Desgleichen gehört die Bekleidung mit der Stola überall in der Ostkirche zum Ritus der Ordination der Diakone und Priester. Bei den Syrern ( $\nabla$ gl. Bild 284, S. 601), Chaldäern und Maroniten bildet sie auferdem einen Bestandteil der Subdiakonen- und Lektorenweihe (diese jedoch bei den Syrern ausgenommen). Ein besonderes Gebet während der Zeremonie zu verrichten, ist nicht in allen Riten üblich. Bei den Maroniten spricht der Bischof, wenn er dem Lektor das Ornatstück anlegt: „Bekleide, o Herr, diesen deinen Diener mit dem Orarium des Lektorats zum Preise Gottes und zur Erbauung der heiligen Kirche und aller ihrer Kinder, im Namen des Vaters" usw. Ähnlich lautet das Gebet, mit dem der Bischof die Zere-

1 S. oben S. 116 und Bild 53, S. 115. 
monie bei der Weihe des Subdiakons, Diakons und Priesters begleitet. Bei den Griechen begnügt er sich dagegen während der Übergabe der Stola an die

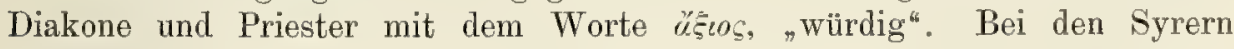
betet der Bischof, wenn er den Ordinanden mittels der Stola bekleidet, ähnlich wie bei den Maroniten: „Zum Lob, zur Ehre, zur Zierde und zur Erhöhung der hochheiligen und wesenseinen Dreifaltigkeit und zum Frieden wie zur Erbauung der heiligen Kirche Gottes." Im koptischen Ritus spricht er bei Vollziehung der Zeremonie: "Ruhm und Ehre sei der heiligen, wesenseinen Dreifaltigkeit, dem Vater, Sohne und Heiligen Geiste; Friede und Wachstum Gottes heiliger Kirche. Amen." 1

Bei der Geschichte der Stola in der Ostkirche müssen wir uns in Anbetracht der Spärlichkeit des vorhandenen Materials auf die Hauptpunkte beschränken ${ }^{2}$. Die Priesterstola wird zuerst in der Iozop'́ erwähnt, also immerhin noch vor dem 9. Jahrhundert. Einen andern frühen Hinweis auf dieselbe bildet der Brief des Patriarchen Nicephorus an Papst Leo III. Denn

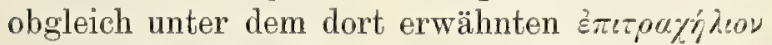
die abendländische Stola zu verstehen sein wird, so beweist doch die dafür gebrauchte Bezeichnung, daf auch im griechischen Ritus schon damals eine Priesterstola in Gebrauch gewesen sein mußs.

Bei Pseudo-Germanus heist das Ornatstück

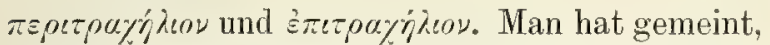
mit den beiden Worten würden wegen der verschiedenen mystischen Erklärungen, welche an der fraglichen Stelle von denselben gegeben werden, zwei verschiedene Gewandstücke bezeichnet.

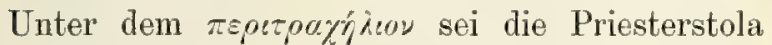

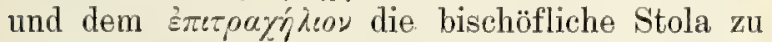
verstehen. Das ist indessen unrichtig. Die Bischöfe und Priester trugen das Gewand stets auf ein und dieselbe Weise. Zudem wird sonst nicht bloß die Bischofsstola, sondern auch die

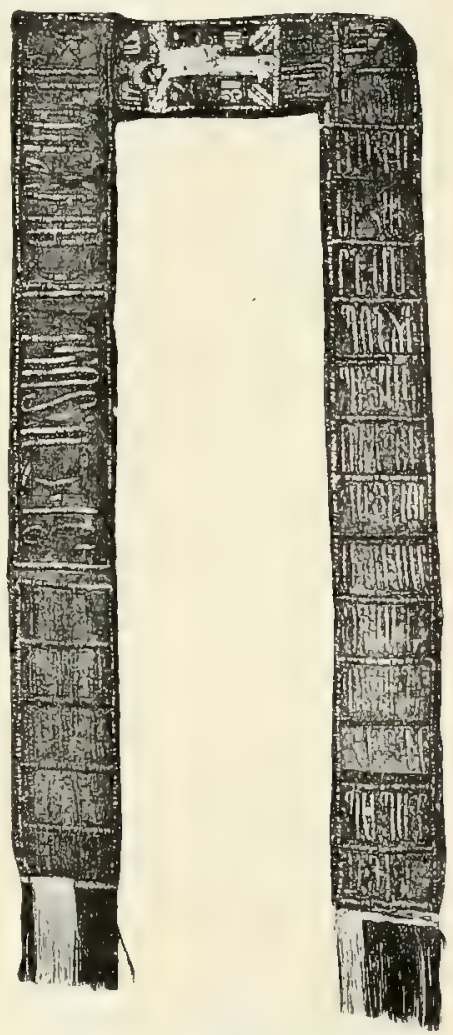

Bild 286. Armenische Diakonstola. Düsseldorf, Kunstgewerbemuseum.

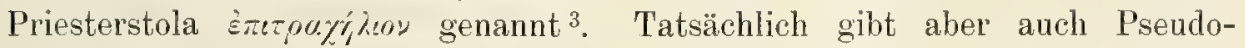
Germanus keine Deutung von zwei Gewändern, er erklärt vielmehr zunächst

1 Ass., C. 1. 1. 8, pars 2, 284780143. Ebd. pars 4, 208 214. (In den älteren griechischen Weiheordines fehlt das begleitende ü เos.) Mart.1.1, c. 8, art. 9, ordo 192223 ; II $96 \mathrm{f} 115119$.

2 In der Revue de l'Orient chrétien (1905, $309 \mathrm{f} 350 \mathrm{f}$ ) hat S. Pétrides die von Anastasius Bibliothecarius $869-870$ zu Konstantinopel angefertigte und Karl dem Kahlen (p. 297) gewidmete lateinische Übersetzung der' 'Iotopia veröffentlicht. In dem Schreiben an Karl heißst es, die Schrift werde von den Griechen dem hl. Germanus von Konstanti- nopel zugeschrieben. Ob dieser wirklich der Verfasser ist, muf dahingestellt bleiben, doch dürfte die Schrift allem Anschein nach immerbin in das 8. Jahrhundert hinaufreichen (vgl. oben S. 10).

S imeon. Thess., De sacra liturgia c. 83 (M. 155, 262); Philoth. Patr., In ordine sacri ministerii (M. 154, 748). Andere Stellen bei D. C., Gloss. graec. I, Breslau 1891, 348. In den Handschriften der '/otopia, welcher Pseudo-Germanus den ersten Teil seiner Erklä-

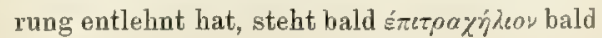
$\pi \equiv \rho \iota \tau \rho \chi \eta ் \lambda ı$ für ein und dasselbe Gewand. 


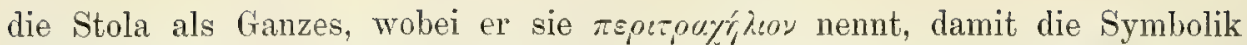
besser passe. El sieht nämlich in der Stola ein Abbild der Halsfesseln des Heilandes. Dam gibt er an, was die beiden Streifen sinnbilden. Der rechte ist Abbild des Rohres, das die Schergen dem Heiland in die Rechte gaben, der linke Simbild des Kreuzes, das der Herr auf seinen Schultern trug ${ }^{1}$.

Aus den andern Riten liegen Nachrichten über die priesterliche Stola aus dem ersten Jahrtausend unseres Wissens nicht vor. Denn die unter dem Namen des Severus von Antiochien von Boderianus herausgegebene syrische Liturgie, das Rituale des koptischen Patriarchen Gabriel 2, das „Buch der Väter", die syrischen, chaldäischen und armenischen Weiheordines u. a., die ihrer Erwähnung tun, gehören erst späterer Zeit an.

Sehr früh vernehmen wir von dem diakonalen Orarium. Dasselbe begegnet uns schon kurz nach der Mitte des 4. Jahrhunderts, und zwar als ein in der ganzen Ostkirche gebräuchliches Gewandstück. Am ersten redet die

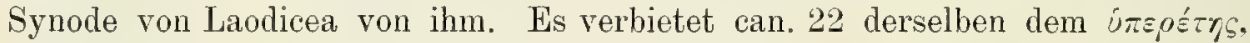
dem Subdiakon, sich des Orarium zu bedienen und von der Türe sich zu entfernen, wo er Aufsicht zu führen hatte. In gleicher Weise bestimmt can. 23: "Die Lektoren und Cantores dürfen das Orarium nicht tragen und so lesen oder psallieren." 3

Das Orarium ist hier offenbar ein liturgisches Ornatstück und kein profanes Tuch. Es folgt das namentlich aus can. 23. Es wird nicht ausdrücklich als spezifisches Gewand der Diakone bezeichnet; allein aus der Natur des Verbotes folgt, dab das Orarium, wenn nicht überhaupt den höheren Ordines, so doch wenigstens den Diakonen zustand.

Was seinen Charakter anlangt, so liegt auf der Hand, dafs es kein Tuch gewesen sein kann, das bestimmten liturgischen Verrichtungen des diakonalen Ministerium diente; denn in diesem Fall hätte es offenbar keinen Sinn gehabt, dafs auch die Subdiakone und Lektoren sich vermaßsen, es zu tragen. Ebenso kann es kein 'Tuch gewesen sein, das lediglich persönlicher' Zwecke halber da war, etwa zum Abtrocknen des Schweiles, zum Schutz des Halses oder der Kleidung usw, da ja auch in diesem Falle die Synode sicher nicht das Verbot erlassen haben würde. Das Orarium, von dem die Kanones des Laodicenum sprechen, kann also nur als ein auszeichnendes Gewandstück der Diakone und als deren Distinktivum gegenüber den niederen Klerikern, also nur als eine Art von Abzeichen des Ordo verstanden werden.

Als ein solches Amtsabzeichen müssen wir auch das Orarium auffassen, von dem wir im jüngst entdeckten Testamentum Domini N. I. Christi hören. "Wer unter den Diakonen“, so lesen wir dort, "durch Fleik und Verwaltungstüchtigkeit hervorragt, soll mit der Aufnahme der Fremden beauftragt werden und in dem in der Kirche befindlichen Hospiz weilen, wobei er mit weifem Gewande bekleidet zu sein und auf der Schulter nur das Orarium zu tragen hat." * Eines Handtuches bedurfte der Diakon, dem die Sorge für die Fremden anvertraut war, doch nur bei gewissen Gelegenheiten; wozu ihm also vorschreiben, in seinem Dienst ein solches beständig bei sich auf der Schulter zu haben? Dagegen war es durchaus zweckmäfig, daf er stets in seiner Amtstracht war, der weiben Tunika und dem of fen (nicht verdeckt durch ein Obergewand) auf der Schulter getragenen Orarium, damit die Fremden ihn

\footnotetext{
i Mg. 98, 394.

z Renaudot Euseb., Liturgiarum orient. collectio I, Frankfurt 1847, 160.
}

3 H a d. I 786. Über die Zeit, da das Konzil abgehalten ward, vgl. Hef, Conciliengeschichte I $746 \mathrm{ff}$.
4 L. 1 , c. 24, p. 83. 
in jedem Augenblick als den erkennen konnten, an welchen sie sich zu wenden hatten.

Bei Isidor von Pelusium († ca 440) heift das Orarium bióv linteum, Linnentuch. "Das Linnentuch", so schreibt derselbe, „mit dem ausgestattet die Diakone ihre gottesdienstlichen Verrichtungen im Gotteshause vollziehen, erinnert an die Verdemütigung, welcher der Herr sich unterzog, als er seiner Jïnger Füfe wusch und abtrocknete. Das nicht aus Linnen, sondern aus Wolle gemachte Omophorion des Bischofs symbolisiert hingegen das Schäflein, das der Herr in der Irre suchte und auf seinen Schultern heimwärts trug." 1 Das Linnentuch der Diakone, das hier als diakonales Charakteristikum erscheint, wie das Omophorion, dem es gegenübergestellt wird, bischöfliches Abzeichen war, ist zweifelsohne dasselbe Gewandstiuck, welches das Laodicenum und das Testamentum orarium nennen. Man hat aus den Worten des Heiligen schliefen wollen, es sei die dyínn eine Art von Abputztuch oder liturgischer Serviette gewesen. Allein das geht zu weit und liegt nicht in dem Vergleich, den Isidor anwendet. Isidor will bloß sagen: das Abzeichen des diakonalen Dienstes solle den Diakon an die Demut Christi erinnern, die dieser an den Tag legte, als er sich zum Diener seiner Jünger machte, und ihn zu g]eicher Demut ermuntern, wie ja das bischöfliche Abzeichen, das Omophorion, dem Bischof den Eifer zur Nachahmung ins Gedächtnis rufen solle, mit dem der Heiland dem verlorenen Schäflein nachging. Die inirn erscheint also lediglich als Abzeichen des diakonalen Ministerium.

Vielleicht noch etwas früher als bei Isidor begegnet uns das Orarium der Diakone unter dem Namen bilivy in der wohl von Severian von Gabala († nach 408) verfafiten Predigt vom "verlorenen Sohne" 2. Denn wenn darin die Diakone geschildert werden als ausgerüstet bei Verrichtung ihres heiligen Amtes in Nachahmung der beschwingten Engel mit feinem Linnentuch auf der linken Schulter, so ist auch hier die bifón ersichtlich das sonst Orarium genannte diakonale Ornatstück. Wir machen auf den Vergleich aufmerksam, den Severian anwendet, da er wenig zur Annahme pafst, es sei die ilyivry ein Tuch gewesen, das der Diakon zu dienstlichen Zwecken bei sich getragen. Später vergleichen auch Pseudo-Germanus und Pseudo-Sophronius im Anschluf an die Predigt vom "verlorenen Sohne" die Diakone mit Engeln und ihr Orarium mit den Flügeln der Engel.

Seit wann bei den Syrern, Chaldäern und Maroniten auch die Subdiakone bzw. die Lektoren des Orarium sich bedienten, ist nicht festzustellen. Jedenfalls ist der Brauch nicht erst jüngeren Datums, da schon in dem "Buch der Väter" 3 und im arabischen Kommentar zum Laodicenum seiner gedacht wird *. Das "Buch der Väter" gibt einen sonderbaren, nicht gerade geschmackvollen Grund an, warum die Diakone und Subdiakone sich mit dem Orarium schmückten. Das Ornatstück soll eine Erinnerung an die Tiereingeweide sein, mit denen die Juden zum Spotte der Apostel Hals umgeben hätten. Da es sich nämlich nicht zieme, daf auch wir dergleichen um den Hals hingen, so trügen die Diakone und Subdiakone das Orarium, um so den Aposteln wenigstens einigermafien zu gleichen. Daf auch bei den Armeniern die Subdiakone sich frihher der Stola bedienten, erhellt aus den diesbezüglichen aus-

1 Epp. 1. 1, n. 136 (Mg. 78, 272).

$2 \mathrm{Mg} .59$, 520. Die Deutung, welche Severian vom Orarium gab, hat gefallen; denn sie wurde selbst noch von Simeon von
Saloniki (De sacr. ordinat. c. 174 [Mg. 155, 381]) wiederholt.

3 La science catholique $1890,450$.

4 As s., Bibl. IlI 2, 805. 


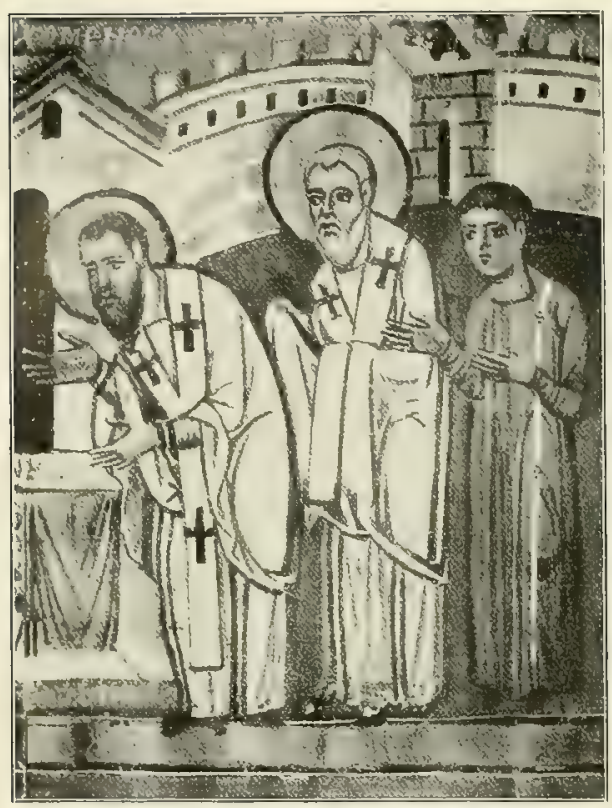

Bild 287. Bittgottesdienst. Miniatur ans einer Homiliensammlung Gregors v. Nazianz. Paris, Bibl. Nat. drücklichen Angaben des Nerses von Lampron ${ }^{1}$. Sie hatten dieselbe in der linken Hand. Es braucht kaum wiederholt zu werden, daf die subdiakonale Stola, von der Nerses erzählt, mit dem heutigen Manipel der armenischen Subdiakone eins ist.

Der arabische Kommentator des Laodicenum will can. 22 desselben mit der bestehenden syrischen Praxis ausgleichen. Er gibt ihm daher den Sinn, es sei in ihm den Subdiakonen nur verboten, das Orarium wie die Diakone von der linken Schulter herabhangen zu lassen, nicht aber, es um den Hals zu schlingen, wie das die Diener der Könige täten.

Hinsichtlich der Beschaffenheit der Stola in der Ostkirche fehlen die Nachrichten fast ganz. Der Name ¿ývin und der Vergleich mit den Engelsflügeln dürfte darauf hinweisen, daß das diakonale Orarium um den Beginn des 5. Jahrhunderts noch ein förmliches (wenngleich wohl zu einer Art von Streifen zusammengelegtes), aus Linnen angefertigtes Tuch war. Von dem Epitrachelion hören wir blof, daf man es wohl mit reichen Verzierungen zu versehen pflegte $^{2}$. $O b$ es je ein eigentliches Tuch war, wie lange es das blieb und wann es zu einem Bande wurde, davon wird uns nichts berichtet; wir erhalten darüber auch nicht einmal eine Andeutung.

Leider geben auch die Bildwerke über die Beschaffenheit des Orarium und des Epitrachelion in älterer Zeit keinen Aufschluk. Monumente, auf denen das diakonale Orarium zum Vorschein kommt, sind uns keine bekannt geworden, welche über die letzte Hälfte des 9. Jahrhunderts hinausreichten. Das Epitrachelion begegnet uns aber auf den bildlichen Darstellungen erst ein ganzes Jahrhundert später.

Die früheste Abbildung des Orarium der Diakone, die zu unserer Kenntnis gekommen ist, findet sich auf einigen Miniaturen der für Basilius I. (867-886) geschriebenen Sammlung der Homilien Gregors von

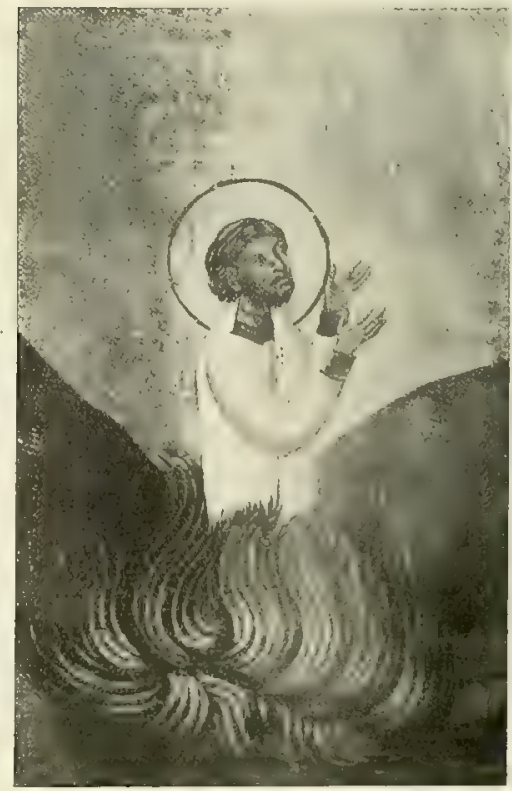

Bild 288. St Abibus. Miniatur im Menologium Basilius' II. Rom, Vatikan.
, Kommentar zur heil. u. göttl. Liturgie c, 5 (ed. Venet. 80 f). Vgl. auch oben S. 550.

2 Vgl. das Schreitien des Patriarchen Nice. phorus an Leo III. (M. 102, 1068) und das des Patriarchen Petrus von Antiochien an deu Patriarchen Michael Cärularius (Mg, 120,800). 
Nazianz in der Pariser Nationalbibliothek (Bild 287). Gute Beispiele aus der Wende des ersten Jahrtausends bieten verschiedene Darstellungen (Bild 288) im Menologium Basilius' II. (976-1025). Das Ornatstück ist dort und hier, gerade wie in der ganzen Folgezeit auf den Bildwerken, ein langes, schmales,

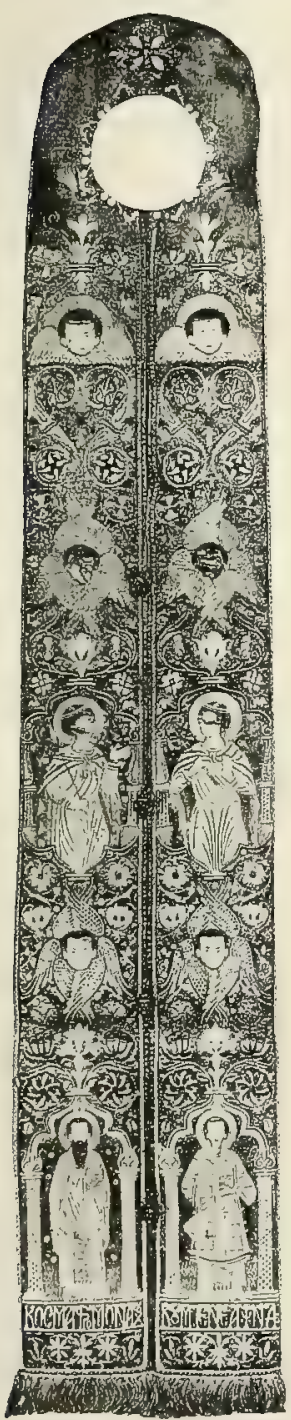

Bild 289. Griechische Priesterstola.

Düsseldorf, Kunstgewerbemuseum. von der linken Schulter über Brust und Rücken herabfallendes Band. Dasselbe ist nur mit kleinen Kreuzen versehen, sonst aber noch ohne alle Verzierung, während es später auf den Monumenten auch wohl mit Schlufstücken und Fransen an den Enden und ähnlichem ausgestattet ist. Das dreimalige "Arros, das doch schon zur Zeit Simeons von Saloniki auf dem diakonalen Orarium angebracht wurde ${ }^{1}$, findet sich niemals auf den Bildwerken. Es scheint demnach erst im späteren Mittelalter Brauch geworden $\mathrm{zu}$ sein, das Ornatstück mit ihm zu schmücken.

Es verdient angemerkt zu werden, dafs auf einzelnen Darstellungen heilige Diakone auf der linken Schulter einen Umwurf tragen. Eine verwandte Erscheinung finden wir auf abendländischen Monumenten wiederholt beim hl. Laurentius und beim hl. Stephanus. Man darf das Tuch nicht mit dem Orarium verwechseln. Weil, wie übrigens auch natürlich, ganz durch den Umwurf verdeckt, ist letzteres in den meisten Fällen unsichtbar. Es wäre indessen verkehrt, daraus zu schliefen, eben jenes Tuch solle das Orarium sein. Denn es gibt Bildwerke, auf denen der Künstler beide zugleich darzustellen verstanden hat. Der Umwurf ist bald das antike Mantelpallium, mit dem in der altchristlichen Kunst die heiligen Diakone Stephanus und Laurentius regelmäßig ausgestattet sind, bald, wie es scheint, eine Art von Velum, mit dem die Heiligen eine Pyxis halten.

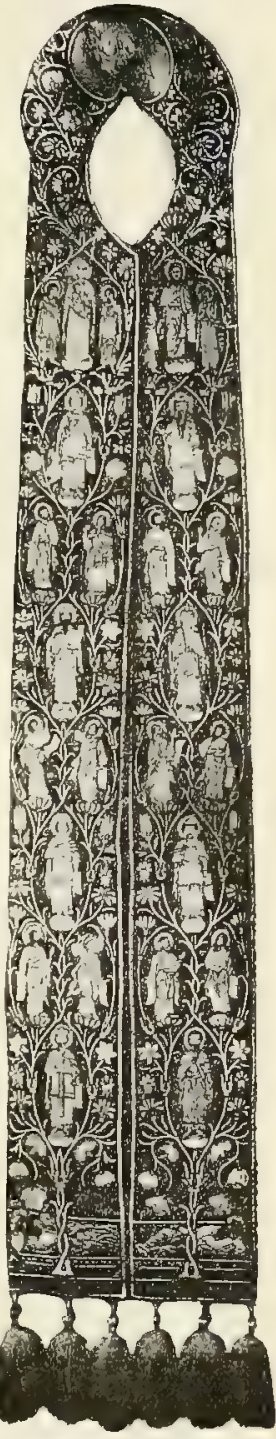

Bild 290.

Reichgestickte griechische Priesterstola von 1617.

Das Epitrachelion tritt auf den Monumenten auffallenderweise erst um die Wende des Jahrtausends auf. Wir sehen es häufig auf den Miniaturen im Menologium des Basilius II. (Bild 245 und 246, S. 490; 269. S. 552). Es hat hier die Form eines schmalen, an seinen Enden reich ver-

${ }^{1}$ De sacris ordinat. c. 173 (Mg. 155, 381). 
zierten Streifens und ist in der Regel von weifer Farbe. Die Enden hangen bald mehr oder weniger übereinander, bald nebeneinander, ein Beweis, dafs man im Beginn dieses Jahrtausends die jetzige Form des Epitrachelion noch nicht kannte. Kreuze finden sich noch nicht regelmäßig auf dem Ornatstück angebracht.

Gegen Ende des Mittelalters hat das Epitrachelion auf den Bildwerken schon an Breite gewonnen und sich insofern der modernen griechischen Stola genähert. Doch besteht es noch immer aus zwei frei vom Halse herabfallenden Streifen. $\mathrm{Ob}$ es auch schon im Mittelalter mit ornamentalem und bildlichem Schmuck versehen wurde, muf dahingestellt bleiben, da weder die Bildwerke darüber Auskunft geben, noch mittelalterliche Stolen dieser Art vorliegen. In der Neuzeit war solches Brauch, wie verschiedene aus dem 16. und 17. Jahrhundert stammende, ungemein kunstvoll in Gold, Silber und Seide bestickte Stolen beweisen (Bild 289 u. 290, S. 607) ${ }^{1}$.

Über die Verwendung der Stola in der Vergangenheit hören wir kaum etwas. Im späteren Mittelalter durfte nach griechischem Brauch der Priester ohne das Epitrachelion keine Amtshandlung vornehmen. Wenn derselbe darum irgend eine Funktion dieser Art zu vollziehen, etwa die Taufe zu spenden hatte, eine Stola aber nicht zur Hand war, so mubte er den Gürtel, ein Band oder irgend ein Tuch segnen und nach Weise des Epitrachelion umlegen?

Der Diakon benutzt nach gegenwärtigem Brauch sein Orarium beim Gottesdienst, um mittels desselben bei bestimmten Gelegenheiten ein Zeichen zu geben. Er hält zu dem Zwecke in den meisten Zweigen des griechischen Ritus das nach vorn herabfallende Ende des Ornatstückes beständig in der Hand. Schon Balsamon kennt den Brauch ${ }^{3}$. Derselbe muf also bereits im 12. Jahrhundert bestanden haben. Eingehendere Mitteilung erhalten wir über ihn in der unter dem Namen des hl. Johannes Chrysostomus gehenden Liturgie ${ }^{4}$. Die Sitte, mit dem Orarium bei dem heiligen Opfer Zeichen zu geben, ist übrigens unseres Wissens nur dem griechischen Ritus eigen.

\section{URSPRUNG DER STOLA.}

Es bleibt noch die Frage nach dem Ursprunge der Stola bzw. des Orarium. Von einem der jüdischen Kultgewänder des Alten Bundes kann dieses Ornatstück auf keinen Fall herstammen. Wie für den Manipel, so gibt es auch für die Stola so wenig ein Vorbild unter den aaronitischen Priesterkleidern, dab es nicht einmal die alten Liturgiker unternommen haben, dieselbe von einem der Opfergewänder des mosaischen Kultus abzuleiten. PseudoAlkuin sagt sogar, wie bezüglich des Manipels, so auch hinsichtlich der Stola, ausdrücklich: Sunt tamen alia, quae apud illos non habebantur, ut stola,

1 Vgl, auch das kostbare Epitrachelion vom Jahr 1651 in Die katholische Kirche* II, Mïnchen 1900 , 374. Die Abbildungen beweisen, wie falsch es ist, weun man die griechische Kunst des späten Mittelalters und der Neuzeit als schlechthin dem Stadium äukerster Dekadenz verfallen hinstellt, wie das doch sehr gewöhnlich geschieht. Namentlich ist die in Bild 290, S. 607 wiedergegebene Stola mit ihren bis ins kleinste fein ausgeführten, zahlreichen, nur ca $0,10-0,12$ hohen Figürchen voll Ausdzuck and Adel ein
Meisterwerk der Nadelmalerei, zu dem man im Abendland nicht viele Gegenstücke aus gleicher Zeit finden dürfte. Die Photographie zu Bild 290 wie zu Bild 243, S. 487 verdanke ich der Freundlichkeit des Direktors des Kunstgewerbemuseums zu Düsseldorf, Herrn H. Frauberger.

${ }^{2}$ Simeon. Thess., Responsa ad Gabr. Pentap. qu. 17 (Mg. 155, 868).

3 In can. 22 Syn. Laodic. (Mg. 137, 1369).

${ }_{1} \mathrm{Mg} .63,901 \mathrm{ff} . \mathrm{Vgl}$. auch Philoth. Patr., In ordine sacri ministerii (Mg. 154, 752). 
sandalia et sudarium ${ }^{1}$. Der Ursprung der Stola mus also in anderer Weise erklärt werden. Sehen wir zu, wie man solches versucht hat und was von den verschiedenen Erklärungsversuchen zu halten ist.

Eine ehedem weit verbreitete, aber auch noch in jüngerer Zeit wiederholt ausgesprochene Ansicht fafst die Stola auf als den allein übrig gebliebenen Besatz eines "Stola" genannten Gewandes. Sie gründet sich also auf den Namen "Stola".

Die Ansicht tritt in drei verschiedenen Schattierungen auf. Nach der ersten wäre die Stola herzuleiten von den Längsstreifen, den clavi, der Tunika der römischen Matronen, die „Stola“ genannt wurde und in kirchlichen Gebrauch übergegangen sein soll. Lassen wir uns die Sache näher erklären.

Wie die paenula, sagt man, in den ersten christlichen Jahrhunderten zum gottesdienstlichen Gebrauch erhoben und der Name derselben unverändert beibehalten wurde, so sei auch ein anderes Ehrengewand, die Stola der römischen Matronen, als gottesdienstlicher Ornat bei der Feier der heiligen Geheimnisse der Christen in Brauch genommen worden, ohne daf man sich veranlaft sah, den Namen desselben zu ändern, indem seine bisher gebräuchliche Form unverändert belassen wurde. Das einzige verzierende Ornament, womit das faltenreiche Gewand der Stola des klassischen Altertums gehoben wurde, habe in einem, kaum eine Hand breiten Streifen (fascia) bestanden, der als Verzierung in Gold- oder Purpurstoffen so auf die Stola aufgenäht war, daf er als fascia, limbus die Stola an zwei Stellen parallel laufend verzierte und auf beiden Seiten über die Schulter als langer Streifen bis zu den Füßen herunterstieg. Wie Durandus (Rat. III, 5) ganz richtig bemerke, sei dieser schmale verzierende Streifen, ähnlich einer Schlinge, als auszeichnendes Ornament von der alten Stola heute nur allein übrig geblieben und der faltenreiche Unterstoff, das eigentliche primitive Stolagewand des Altertums, fortgefallen, so daf heute auf einen kleineren ornamentalen Teil der Name des ehemaligen weiten Gewandes stola übergegangen sei. Die Stola soll von Konstantin an bis zum 6. Jahrhundert noch als faltenreiches Gewand mit aufgenähten Bandstreifen ohne Veränderung bestanden und auf den Nosaiken in S. Vitale zu Ravenna sich in der Tunika des Erzbischofs Maximianus und seiner Diakone in ihrer ursprünglichen Gestalt erhalten haben. Dafs aber die von dem Gewande übrig gebliebenen Streifen orarium genannt wurden, soll seinen Grund in der Ähnlichkeit dieser fasciae mit dem im profanen Leben gebräuchlichen orarium (Halstuch) haben.

Andere lassen, um den Namen orarium besser erklären zu können, die Stola in einem im übrigen analogen Prozebs statt aus den senkrechten Parallelstreifen aus dem Besatz entstehen, welcher den unteren Saum (ora) des alten Matronen- und angeblich späteren Priestergewandes verzierte und allein von diesem übrig geblieben sein soll. Die dritte Modifikation endlich geht dahin, es sei die „Stola" ein vorn offenes Kleid und die jetzige liturgische Stola bzw. das Orarium die Einfassung der Halsöffnung und des vorn vom Halse nach. unten verlaufenden Schlitzes gewesen. Sie glaubt, durch diese Annahme am leichtesten die Namen Stola und Orarium wie auch die Tragweise der priesterlichen Stola erklären zu können.

In welcher Form indessen auch die Hypothese auftritt, sie ist in jeder unzutreffend und unannehmbar.

Es ist allerdings richtig, dak schon sehr früh im christlichen Kultus eine lange Tunika in Gebrauch war; allein es ist doch wohl nicht zutreffend, daf dieselbe von der römischen Matronentunika abstammt, am wenigsten aber, daß sie von dieser den Namen angenommen hat. Verkehrt ist es auch, in den mit Streifen versehenen

${ }^{1}$ Pseudo-Alkuin, De div. offic. c. 38 (M. 101, 1240).

Braun, Die liturgisehe Gewandung. 
Tuniken des Erzbischofs Maximianus und seiner Diakone die Stola wiedererkennen zu wollen; das fragliche Gewand ist die Dalmatik. Neiterhin ist nirgends eine Spur von der Tmwandlung der angeblichen Stola als Gewand in die Stola als Streifen zu entdecken, und doch sollte man meinen, das völlige Verschwinden eines so faltenreichen und weiten Kleides, wie die Stola es war, unter blofser Erhaltung ihrer Streifen bzw. der Saumeinfassung, habe sich nicht vollziehen können, ohne irgend eine Erinnerung daran zurückzulassen, zumal noch im 6. Jahrhundert dieses Gewand in Brauch gewesen sein soll. Im Gegenteil finden wir, daß die Besätze der stola genannten Tunika selbst, nachdem sie angeblich zur jetzigen Stola geworden waren, mitsamt der ganzen Tunika vor wie nach auf den Bildwerken erscheinen. Dazu kommt, daß die Zierstreifen, die zum Orarium geworden sein sollen, aus Purpurstoffen angefertigt waren, während doch die griechischen und sparischen Orarien aus weifrem Zeug bestanden.

Warum, so fragen wir ferner, erscheint, wenn das Orarium von der alten Matronenstola abstammen soll, der Name stola nicht da zuerst, wo jenes Gewand zu Hause war, und wie kommt es, dak er im Norden am frühesten auftritt, ja allem Anschein nach dort zur Benennung des Ornatstückes wurde? Und wie ging es zu, daß 3 aus den Doppelstreifen bzw. dem Randbesatz der stola genannten Talartunika die Diakonal- und Priesterstola hat werden können? Wie entstand aus den zwei Streifen, die sich vorn und rückwärts von der Schulter bis zu den Füfsen hinzogen, das nur auf der linken Schulter aufliegende Orarium des Diakons und die um den Hals sich hinziehende und in zwei Streifen über die Brust herabfallende bischöfliche oder die vor derselben sich kreuzende priesterliche Stola? Wie kam es, daf, wenn man das Orarium rom unteren Saumbesatz ableitet, dieser auf die linke Schulter oder den Hals heraufstieg, und wie geschah es, daf dasselbe, falls man es als die ehemalige Einfassung der vordern Öffnung betrachtet, zur Diakonalstola wurde? Und dann gab es ja doch im griechischen Ritus eine Stola bereits um die Mitte des 4., in Spanien aber schon wenigstens in der ersten Hälfte des 6. Jahrhunderts, also eine Weile vor der angeblichen Umbildung der "Gewand"-Stola in die "Streifen "Stola.

Man beruft sich auf Durandus ". "Man beachte", so führt derselbe aus ${ }^{4}$, „dak vor alters die Stola ein weißglänzendes Kleid war, das bis zu den Füf́nen reichte und dessen sich die Patriarchen vor dem Gesetze bedienten, das die Erstgebornen, wenn sie den Segen des Vaters erhielten, anzogen und in dem sie dem Herrn als Priester opferten; allein nachdem man anfing, die Albe zu tragen, wurde sie in einen torques (Kette, Schmuckkette, Halsjoch, Ringel, Guirlande, hier wohl Streifen) umgewandelt." Allein wo ist in diesen Worten von der stola matronalis, die zum christlichen Kultkleide geworden, und überhaupt von einer Stola im Sinne eines langen tunikaartigen Sakralgewandes des Neuen Bundes die Rede? Wo spricht Durandus von den fasciae und den andern Besätzen, und wo führt unser Liturgiker aus, daß von der alten Matronenstola nur die Verzierungen in Gestalt der jetzigen Stola übrig geblieben seien? Der Verfasser des Rationale will nur sagen: Im Alten Bunde war die stola ein bis zu den Füfen herabwallendes priesterliches Kleid der Erstgebornen zur Patriarchenzeit. Nun aber hat, da man im christlichen Kultus die Albe trägt, das Gewand, welches man stola nennt, ein anderes Aussehen, als jenes patriarchale Priestergewand es besafs, indem es jetzt einen torques darstellt. Auf eine Entstehung der Stola geht Durandus nicht ein. Es ist in der Tat schwer verständlich, wie man den Worten des Durandus, dessen Mangel an historischem Sinn zudem doch männiglich bekannt ist, je irgend eine Bedeutung hat beilegen können.

1 Ebd. 1.3 , c. 5 , n. 6 ; f. 69 . Ähnlich wie Durandus sprechen auch Honorius (Gemma 1. 1, c. 205 [M. 172, 606]) und Sicard (Mitralis 1. 2, c. 5. [M. 213, 74]), von denen der Verfasser des Rationale seine Änfierung entlehnt zu haben scheint. Auch sie wollen nur sagen, als man angefangen habe, die
Albe zu tragen, habe man die Stola, die vestis candida, pertingens ad vestigia ersetzt durch die "Streifenstola". Daß letztere der allein beibehaltene Besatz der "Gewandstola" sei, findet sich in ihren Worten nicht nur nicht ausgesprochen, sondern nicht einmal angedeutet. 
Eine zweite Meinung möchte das Wort orarium mit orare (beten) in Verbindung bringen und den Ursprung unseres Gewandstückes in einer Art Gebetsmantel suchen. Die Juden, heibt es ihr zufolge, hätten die Gewohnheit gehabt, beim öffentlichen Gebete sich eines besondern Umhangstuches, einer Art von Ephod, zu bedienen, das von dem gleichnamigen hohenpriesterlichen Gewande zwar verschieden, aber demjenigen ähnlich gewesen sei, mit dem David (2 Kg 6, 14) vor der Arche bekleidet war. Da nun das Christentum zunächst unter den Juden seine Anhänger gefunden habe, und zumal in den Städten die ersten Gläubigen zum großen Teil Judenchristen gewesen seien, habe sich auch bei den Christen die Gewohnheit herausgebildet, beim Gottesdienst sich jenes Gebetsmantels zu bedienen. Auf ein solches Gewand, meint man, spiele wahrscheinlich die Apokalypse an, wenn sie die Ältesten mit vestimentis albis vor dem Thron des Lammes angetan sein läßt; auch glaubt man in den weifen Mänteln, welche die 24 Ältesten auf alten Mosaiken so umhüllen, dafs sie nicht blok deren Schulter, sondern anch deren Hände bedecken ${ }^{1}$ - wie man sagt, im Altertum das besondere Zeichen der Flehenden --, den fraglichen Gebetsschleier zu erkennen. Derselbe soll überhaupt auf verschiedenen Monumenten der altchristlichen Zeit auftreten, zumal aber auf Goldgläsern, auf welchen wir z. B. die Apostelfürsten, die hl. Agnes u. a., darunter auch Personen in der Haltung von Oranten, mit einem um die Schultern geworfenen und mittels einer Spange auf der Brust festgehaltenen Umhangstuch dargestellt sehen ${ }^{2}$. Dieser Gebetsmantel, so erklärt man weiter, sei anfangs Klerikern und Laien gemeinsam gewesen, später aber sei er bei den letzteren abgekommen, wie das auch mit andern liturgischen Ornatstïcken geschehen sei; seitdem habe er sich blok im Gebrauch der Kleriker erhalten ${ }^{3}$.

Indessen erheben sich auch gegen diese Ansicht ernste Bedenken. Die Ableitung des Wortes orarium von orare im Sinne von beten findet sich erst im 12. Jahrhundert. Den Gebetsmantel der Juden, den sog. grolsen Tallith ', haben zudem, soweit darüber ein Urteil möglich ist, die Tage Christi und der Apostel noch nicht gekannt.

I Garr. IV, tav. 253 (Cosma e Damiano), tav. 286 (S. Prassede), tav. 292 (S. Cecilia).

Ebd.III, tav. 179181182 (Petrus und Paulus), tav. 187 (Christus), tav. 188 (Marcellus und Callistus), tav. 191 (Agnes), tav. 193 (Xystus und Timotheus), tav. 185 (Ursus und Dion), tav. 194 (Simon, Philippus, Damas und Thomas) u. a.

${ }^{3}$ Martigny, Dictionnaire des antiquités chrétiennes unter Orarium 545 und unter Vêtements 783 .

* Man unterscheidet zwei Arten des Tallith (Talles), den grofen und den kleinen. Letzterer, ein mä́ỉg breiter, längerer Tuchstreifen, der in der Mitte mit einem Loch zum Durchstecken des Kopfes und an den Enden mit den sog. Schaufäden versehen ist, wird in Form eines Skapuliers unter den oberen Kleidern getragen. Der erste, ein grokes 'Tuch, das an seinen Ecken - es sind deren gewöhnlich vier - ebenfalls die Schaufäden haben muf, wird beim Gebet, besonders in der Synagoge, tiber den Kopf und die Schultern geworfen. Wie es scheint, ist der Tallith nichts anderes als ein Rest des altjüdischen Ober- kleides, welches bekanntlich mit den Zizith (Quasten) ausgestattet sein mußte ( $\mathrm{Nm} \mathrm{15,}$ 38. Dt 22, 12). Auch der Heiland trug diesen mantelartigen Überwurf (Yt 9, 20; 14, 36. Mk 6, 56). Die Quasten sollten den Juden daran erinnern, daf er gehalten sei, das Gesetz zu beobachten. Eine besondere liturgische Bedeutung hatte dieser Mantel zur Zeit Christi nicht. Den Charakter eines Gebetsmantels scheint dieses Kleidungsstück infolge der Zerstreuung des auserwählten Volkes erlangt zu haben. Unter den Heiden konnten nänlich die Juden den mit Zizith versehenen Überwurf nicht mehr öffentlich wie einstmals tragen. Darum lag es nahe, seinen Gebrauch auf die Zeit des Gebetes und namentlich der religiösen Zusammenkünfte in den Synagogen zu beschränken, für das gewöhnliche Leben aber in dem unter den äußeren Kleidern verborgenen kleinen Talles einen Ersatz desselben zu schaffen. So aber dürfte dann unter dem Einfluß der rabbinischen Doktrinen aus jenem Unwurf sich allgemach ein Gebetsmantel, der große Talles, herausgebildet haben. 
Iit dem Ephod, einem Schulterkleid, hat dieses den Kopf und die Schultern bedeckende Tuch nichts zu tun. Der Tallith ist, wie es scheint, rabbinischen Ursprunges. Zur Zeit seiner Einführung war das jüdische Element in den christlichen Gemeinden so gering, daß die Annahme, es hätten die Christen überhaupt um ihrer judenchristlichen Glaubensgenossen willen einem talmudischen Gebrauch sich anbequemt, durchaus unwahrscheinlich ist. Wohl haben auf den alten Monumenten die weiblichen Oranten eine Kopfverhüllung; allein dieser Gebetsschleier ist uichts als das gewöhnliche Frauenkopftuch und hat mit dem jüdischen Gebetsmantel, den die männlichen Juden tragen, nichts zu schaffen. Ebenso unbegründet ist es in den weízen Gewändern der vierundzwanzig Ältesten der Apokalypse eine Andeutung des Gebetsmantels sehen zu wollen. Der liberwurf aber, den die apokalyptischen Greise auf den Mosaiken tragen, ist dasselbe Gewand, mit dem auch Christus, die Apostel, die Engel und sonstige Personen angetan erscheinen, das gewöhnliche Mantelpallium. Dasselbe verhüllt allerdings die Hände der Ältesten, welche Kronen halten; jedoch ist es unrichtig, diese Verschleierung der Hände als ein Zeichen des Betens zu betrachten. Wie immer es die Heiden damit gehalten haben mögen, die Oranten bekunden, dafs die Christen beim Gebet die Hände nicht zu verdecken pflegten. Wenn die Ältesten mit den vom Pallium verhüllten Händen ihre Kronen dem Lamm darbringen, dann ist das freilich der Austruck der Ehrfurcht sowohl vor dem Gegenstand selbst, den sie in denselben halten, als auch vor demjenigen, dem sie ihre Weihegabe darbieten. Wie wenig aber deshalb ihr Pallium als Gebetsmantel anfgefaft werden kann, bekunden jene häufigen Darstellungen, auf denen in ähnlichen Fällen die Planeta, ja selbst die Chlamys, zur Verschleierung der Hände dient ${ }^{1}$.

Das Tuch, mit dem die hll. Petrus und Paulus, Agnes, Calixtus und andere auf den Bildwerken bekleidet erscheinen, ist ein gewönnlicher, auf der Brust fibulierter Mantel oder Überwurf, der uns auch auf sonstigen Darstellungen mehrfach begegnet und bald auf der Brust, bald auf der rechten Schulter mit einer Spange festgehalten erscheint, also die lacerna. Derselbe könnte eher der Ahnherr unseres Pluviale als der Stola sein. Ihn als eine Art von Gebetsschleier aufzufassen, dazu dürfte nicht einmal dann ein Anlaßs vorliegen, wenn die Oranten regelmäßig mit demselben angetan wären, was jedoch nicht der Fall ist. Der fragliche Mantel findet sich fast nur auf einer AnzahI von Goldgläsern, die dem Stil und dem Charakter der Bilder nach zu urteilen aus einer Werkstätte stammen dürften. Daß der Künstler für seine Darstellungen (Brustbilder) die lacerna mit der Fjbula auf der Brust wählte, erklärt sich unschwer aus dem Umstande, daßs gerade dieses Gewand ihm vom künstlerischen Standpunkt aus für seine Darstellungen (Medaillons) am zweckmäßigsten erscheinen mochte. Auf Mosaiken des 5. und 6. Jahrhunderts tragen allerdings, wie schon früher gelegentlich gesagt wurde 2, auch die jüdischen Priester sowie Melchisedech und Jethro einen auf der Brust mit einer Spange festgehaltenen Umwurf. So in Maria Maggiore ${ }^{3}$, in S. Vitale zu Ravenna ${ }^{4}$, in S. Apollinare in Classe ${ }^{5}$ und in S. Apollinare Nuovo ${ }^{6}$. Allein es ist wohl zu beachten, dak sie jenen Mantel nicht nur bei den wenigen liturgischen Funktionen (Melchisedech, Jethro), sondern auch bei Handlungen des Alltagslebens haben. Ein Gebetsmantel ist derselbe nicht, sondern nur ikonographische Eigentümlichkeit der alttestamentlichen Priester auf den altchristlichen Bildwerken, zumal auf solchen, die unter dem Einfluf der Kunst des Ostens entstanden.

Eine blofe Behauptung und nichts mehr ist es, wenn man weiterhin sagt, es hätten anfangs alle den Gebetsmantel getragen, dann aber hätten die Laien dem Klerus denselben überlassen. Die geschichtlichen Quellen bieten weder direkt noch indirekt für eine solche Hypothese einen Anhaltspunkt. Es ist freilich wahr, dak gewisse nunmehr liturgische Gewandstücke ehedem auch im Gebrauch der Laien sich befanden, z. B. die Tunika und die Kasel; allein hier wissen wir auf Grund historischer

${ }^{1}$ Garr. IV, tav. $252256264^{2} 267^{1} 272$ u. a.

${ }^{2}$ S. ohen S. 584 .
${ }^{3}$ Garr. IV, tav. $212^{2} 214215^{1} 218^{2} 220^{3}$.

4 Ebd. tav. 262 ! 5 Ebd. tav. 266.

"Ebd. tav. 2506 $251^{345}$. 
Zeugnisse, dak dieselben sich nach und nach aus der gewönlichen und allgemeinen Tracht ausschieden und zuletzt nur den fungierenden Klerikern verblieben.

$\mathrm{Zu}$ sonderbaren Resultaten aber kommen wir, wenn wir der Zeit nachforsehen, in welcher der Gebetsschleier zum Orarium wurde. Die Mosaiken von S. Prassede, welche unter Papst Paschalis I. (817-824) entstanden, zeigen die Ältesten noch mit dem angeblichen Gebetsmantel bekleidet; derselbe wäre also höchst merkwürdigerweise noch im 9. Jahrhundert in Rom in Brauch gewesen. Will man aber jene Darstellungen als unverstandene Kopien der Mosaiken in S. Cosma e Damiano erklären. so wird man wohl annehmen müssen, daf der Gebetsmantel zu Rom immerhin noch im zweiten Viertel des 6 . Jahrhunderts, der Zeit, in welcher diese letzteren angefertigt wurden, bekannt war. Oder sind vielleicht auch sie nur unbegriffene Nachbildungen älterer Bildwerke?

Unerklärlich bleiht endlich bei der Gebetsschleierhypothese, wie dieses anfangs allgemein gebräuchliche, dann spezifisch liturgische Gewand sich sowohl zur diakonalen als zur priesterlichen Stola ausbildete.

Eine dritte Ansicht führt die Stola teils auf ein Halstuch, teils auf ein liturgisches Handtuch bzw. eine liturgische Serviette zurück. Aus einem Halstuch, das den Zweck hatte, im Winter gegen die Kälte zu schülzen, im Sommer aber die Kleider vor dem Eindringen des Schweifies zu bewahren. soll die römische Stola sowie die priesterliche und bischöfliche Stola der Kirchen des Ostens, Galliens und Spaniens entstanden sein, aus einer liturgischen Serviette das diakonale Orarium der orientalischen Riten, des altspanischen Brauches und des gallikanischen Ritus.

Das Halstuch wurde dadurch zur Insignie, dafs man zunächst anfing, es streifenartig zu falten, und dann dazu überging, es durch einen bloßsen Streifen zu ersetzen, der natürlich praktischen Zwecken zu dienen nicht weiter im stande war. Das Handtuch der Diakone aber soll sich dadurch zur diakonalen Insignie umgebildet haben, daf die Subdiakone einen Teil der diakonalen obliegenheiten überuahmen, weshalb sie denn auch nummehr bei ihrer Weihe als Symbol ihres Amtes ein Kännchen mit Wasser, eine Schüssel und ein Handtuch erhielten. Infolge dieser Verschiebung der diakonalen und subdiakonalen Funktionen wurde nämlich, so sagt man, die diakonale Serviette ihrer anfänglichen praktischen Bestimmung entfremdet und zu einem bloßen Band, das nur noch als Amtsabzeichen der Diakone getragen wurde.

Die Gründe, auf die hin man das römische Orarium und die priesterliche und bischöfliche Stola im Orient, in Spanien und Gallien von einem Halstuch ableiten zu sollen glaubt, sind der Name orarium und der Umstand, daf in der Vita des hl. Fulgentius ( $\dagger$ ca 530) ein orarium im Sinne eines von den afrikanischen Bischöfen im Alltagsleben benutzten Halstuches erwähnt wird. Als Beweise aber, dafí das diakonale Orarium in der orientalischen, spanischen und gallischen Kirche auf eine liturgische Serviette zurïckgehe, bringt man vor:

1. Der Dienst der Diakone machte ein Handtuch oder liturgische Serviette notwendig.

2. Auf antiken und altchristlichen Monumenten begegnen wir zwei Klassen von Dienern, welche ein Tuch zusammengefaltet auf der linken Schulter tragen, den camilli und delicati, den Opferknaben und Tafeldienern. Nun waren aber die Diakone die ministri des Tisches des Herrn, also werden auch sie ein Abputztuch, ein Handtuch oder eine Serviette bei ihrem Dienst über der linken Schulter getragen haben.

3. Die dyóvn, welche den Diakonen bei Ausübung ihrer Funktionen eignete, sollte nach Isidor von Pelusium denselben die Demut ins Gedächtuis 
rufen, die Christus dadurch bewies, daf er seiner Jünger Füße wusch und abtrocknete. Sie muls also, schlieft man, ein Abputztuch bzw. Handtuch gewesen sein.

Diese dritte Hypothese steht wissenschaftlich ohne Zweifel ungleich höher als die beiden vorhin besprochenen und verdient sicher alle Beachtung. Indessen lassen sich denn doch auch gegen sie mancherlei Bedenken geltend machen, namentlich was die gewollte Ableitung der diakonalen Stola aufierhalb Roms betrifft.

Wenn das Orarium der griechischen, spanischen und gallikanischen Diakone, um mit diesem Punkte zu beginnen, ursprünglich ein von den diakonalen Funktionen gefordertes liturgisches Handtuch im Sinne einer liturgischen Serviette war, wie konnte dieses dann sehon im Orient in der zweiten Hälfte des 4. Jahrhunderts und in Spanien zum wenigsten bereits im Beginn des 6. Jahrhunderts zum bloken Abzeichen werden? Hatte sich denn der Dienst der Diakone bis dahin schon so wesentlich verändert, dak es als Handtuch weiterhin überflüssig geworden war? Wenn nicht, so ist nicht einzusehen, wie es zur blofen Insignie werden konnte. Aber man sagt uns, daf allerdings ihr Dienst teilweise ein anderer geworden sei, da die Subdiakone ihnen gewisse Funktionen abgenommen hätten, darunter namentlich auch die, dem Priester das Wasser zur Händewaschung samt Handtuch zu reichen. Für das 6. Jahrhundert mag das zutreffen, nicht aber für das ausgehende 4. Jahrhundert. Zwar erfahren wir schon aus dem achten Buch der Apostolischen Konstitutionen, daß der Subdiakon dem Priester das Wasser zum Händewaschen darreichte. Allein der fragliche Passus ist unzweifelhaft aus späterer Zeit. Denn dafs in der zweiten Hälfte des 4. Jahrhunderts es noch die Diakone waren, die das zu besorgen hatten, und dak die Subdiakone damals noch vom Altare fern gehalten wurden, ergibt sich aus Cyrills von Jerusalem 23. Katechese ${ }^{1}$, dem 22. Kanon des Laodicenum, dem Testamentum Domini nostri Iesu Christi, worin die Subdiakone ganz und gar zurücktreten, und der Schrift Quaestiones ex utroque testamento $\%$ Besonders interessant ist, was die letztgenannte Schrift sagt. Sie bezeichnet es als einen Gebrauch aller Kirchen, daf die Diakone den Priestern das Wasser reichten, und tadelt es, daf die Diakone es zu Rom anders hielten. Doch einmal angenommen, es hätten bereits die Subdiakone in der zweiten Hälfte des 4. Jahrhunderts das Amt erhalten, dem Priester beim Gottesdienst das Wasser zur Händewaschung darzubieten: was folgt daraus für die Umbildung der Serviette zur Insignie? Unseres Erachtens nichts. Oder hatten die Diakone die ijośn während der ganzen Zeit des Gottesdienstes blok getragen, um sie bei höchstens zwei GeIegenheiten dem Priester zum Abtrocknen der Hände darzureichen? Wenn ja, warum hielten sie dann überhaupt ein Tuch bei, das für sie sowohl praktisch wie als Abzeichen keinen Sinn mehr hatte, nachdem es samt dem Dienst des Wasserreichens an die Subdiakone übergegangen war? Wenn nein, wie konnte es dann, solange nicht eine wesentlichere und einschneidendere Änderung eintrat als die angefürte, zu einem bloßen Distinktivum werden?

Das manutergium, das Handtuch. das doch den Subdiakonen nach den Statuta ecclesiae antiqua oder dem sog. vierten Konzil von Karthago, schon in 5. Jahrhundert, in Gallien bei der Weihe übergeben wurde, hat sich nie zur Insignie ausgebildet, trotzdem die erwähnte Weihezeremonie sich allmählich im ganzen Abendland wie im Orient verbreitete. Und da soll das die Diakone auszeichnende Tuch, welches wir bereits in der Mitte des 4. Jahrhunderts im griechischen Ritus antreffen, ein Handtuch gewesen sein? Welchen Zwecken diente überhaupt das Orarium im Sinne der in Frage stehenden Hypothese? War es blokes Handtuch? Aber wozu es dann während der ganzen Messe auf der Schulter bei sich tragen? Haben etwa später auch die Subdialione es so mit dem manuterginm gehalten, das sie gelegentlich dem Priester anzubieten hatten? Und wenn es ein Handtuch zum Abputzen der Hände war,

${ }^{1}$ Cat. 23, n. 2 (Mg. 33, 1109). ${ }^{2}$ N. 101 (M. 35, 2301). 
wie konnte es dann passenderweise noch zu sonstigen liturgischen Verrichtungen gebraucht werden?

Man weist auf die camilli hin. Allein stehen dann diese mit den Diakonen wirklich a pari? ${ }^{1}$ Beschränkte sich etwa der letzteren Aufgabe ebenfalls darauf, dem Bischof das Wasser über die Hände zu gieß̊en und ihm dann das Handtuch zum Abtrocknen der Hände darzureichen? Doch gewifs nicht. Es war das sogar der kleinste und geringfügigste Teil ihrer dienstlichen Verrichtungen.

Aber auch die delicati beweisen nichts. Sie könnten doch höchstens dann als eine Art wirkliches Gegenstück der Diakone bezeichnet werden, wenn das Orarium der letzteren in der Tat ein für Abputzzwecke bestimmtes Tuch gewesen sein sollte; allein das ist ja in Frage. Obendrein darf man, wie wir ebenfalls schon früher zu bemerken uns veranlafst sahen, nicht aufer acht lassen, dafo der Dienst der delicati nach der Natur und den Gepflogenheiten des antiken Gastmahles ein wesentlich anderer war als der Dienst der Diakone am Altare Gottes. Auch dürfte es vielleicht am Platze sein, darauf hinzuweisen, daf nicht alle delicati auf den Monumenten mit einer Serviette versehen sind. Auf der Miniatur des vatikanischen Virgil, dem Gastmahl bei Dido trägt das mantile auffälligerweise nicht der Diener, welcher mit Wasserkrug und Schüssel ausgerüstet ist, sondern der Mundschenk.

Über die Worte Isidors von Pelusium ist schon früher gesprochen worden?. Sie beweisen, dafs die iflom Dienstabzeichen der Diakone war, aber auch nur dieses.

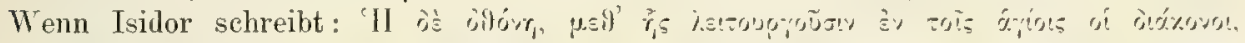
so heift das blok: "Das Linnentuch, das die Diakone bei ihrem heiligen Dienst tragen." Der Umstand, dafs das Tuch im Gegensatz zum wollenen Omophorion des Bischofs aus Linnen bestand, erklärt sich leicht durch die Tatsache, daf3 Linnen im alten Ägypten das Gewönliche, Wolle das Seltenere und Kostbarere war. Wer sich etwas näher mit den altkoptischen Grabfunden beschäftigt hat, weik, dafs das Linnen selbst bei den Obergewändern die Hauptrolle spielt. Außerdem wurden ja doch auch nicht bloß die Handtücher und Servietten, sondern auch die Orarien, Sudarien u. dgl. aus Linnen gemacht. Wenn aber Isidor die zilsw, auf den Heiland auslegt, der sich zum Diener seiner Jünger machte, indem er ihre Füße wusch und abtrocknete, so will er nur sagen, daßs das Tuch, welches den Diakon als solchen bei seinen Funktionen kennzeichne, ihn zugleich zur. Demut mahne, indem es ihn an die Demut des Erlösers erinnere, der es ja nicht verschmäht habe, Diener zu werden. Man darf aus den Deutungen, welche man mit den liturgischen Gewändern verbunden hat, nicht zu viel herauslesen; andernfalls wird man oft zu sonderbaren Resultaten kommen. Im vorliegenden Fall wird man sich davor um so mehr hüten müssen, als das Orarium schon ein halbes Jahrhundert vor Isidors Zeit als ein die Diakone kennzeichnendes Gewandstück erscheint.

Es lassen sich also in der Tat gegen die Theorie, welche das diakonale Orarium auferhalb Roms auf eine liturgische Serviette zurückführt, nicht unerhebliche Bedenken geltend machen. Und doch sind die bisher vorgebrachten noch nicht einmal die einzigen. Wie erklärt es sich, so fragen wir, daf das Ornatstück schon gleich bei seinem ersten Auftreten den Namen ipripegr führt? Erscheint denn das Wort sonst jemals im Sinne von Handtuch oder Serviette? Die Stellen, in denen uns dieses begegnet, sind doch recht zahlreich. Und warum das ipápoov des Laodicenum und das diakonale Orarium der Synoden von Braga und Toledo als Handtuch auffassen, während man das Orarium der Priester eben wegen seines Namens als Halstuch nimmt? Gibt der Umstand, daf die Diakone es statt um den Hals auf der Schulter trugen, dazu genügenden Grund? Endlich wie konnten die Subdiakone, Lektoren und Cantores auf die Idee kommen, bei ihren Verrichtungen ebenfalls das épápıv zu tragen, wenn dieses seinem Charakter nach eine liturgische Serviette war, und zwar selbst dann, wenn es praktisch als solche nicht mehr gebraucht worden sein sollte?

1 S. oben S. 557, wo der Ursprung der Mappula behandelt wurde.

2 S. oben S. 557. 
Was hatten denn die Lektoren an dem Ambo mit einer Serviette zu tun, was die Subdiakone an der Türe, was die Cantores beim Absingen der liturgischen Gesänge?

Man wirl es dem Gesagten gemäß begreiflich finden, daf wir uns nicht entschließsen können, die Theorie, welche die Stola der Diakone auf eine liturgische Serviette zurückführen will, zur unsrigen zu machen. Weniger Bedenken hätten wir gegeniiber der Hypothese, welche die bischöfliche und priesterliche Stola von einem Halstuch ableitet. Wenn wir indessen auch dieser unsere Zustimmung nicht zu geben vermögen, so liegt das vornehmlich daran, dab sie uns die Sache nicht ausreichend zu erklären scheint.

Zunächst verstehen wir nicht recht, wie das Orarium der spanischen Priester und Bischöfe als Halstuch habe dienen können. Ein Halstuch bietet Schutz gegen den Frost und bewahrt die Kleider vor dem Eindringen des Schweifes denn doch nur dann, wenn es rings um den Hals geschlungen wird nach Art unseres Amikts. So dem Nacken aufgelegt, daf die Streifen sich über der Brust kreuzen oder gerade herabfallen, kann es doch wohl kaum nach der einen wie der andern Richtung hin von Wirkung sein. Und wenn es den angegebenen Zweck hatte, wie konnte es in diesem Falle zu einem bloßen Streifen werden? Ist denn jemals etwas Ähnliches mit dem Humerale vor sich gegangen? Und doch wurde dieses im Mittelalter eine Reihe von Jahrhunderten hindurch mit einem kragenartigen Besatz versehen, der sich sogar zuletzt hie und da von ihm ablöste und zum selbständigen Schmuck wurde (Spanien, Lyon, Mailand). Aber das Humerale ist geblieben, was es war. Selbst der päpstliche Fano erhielt sich bei aller Veränderung, die im Lauf der Zeit mit ihm vorging, als wirkliches Tuch, das zwar, seitdem der Papst auker ihm auch noch den gewöhnlichen Amikt trägt, nur noch Schmuck ist, aber an sich noch sehr wohl seinen ursprünglichen praktischen Zwecken dienen könnte. Auch hat man das Halstuch, als es zum bloken Abzeichen wurde, nicht durch ein anderes Tuch ersetzt, jedenfalls nicht im griechischen Ritus. Und doch hätte man das, wie es scheinen will, sicher getan, wenn es wirklich der eben angegebenen Zwecke halber eingeführt worden wäre. Weist man uns aber darauf hin, daf ja die römische Mappula im Lauf der Zeit zu einem bloßen Zierstreifen geworden sei, so vergißst man, daß diese von Anfang an nicht sowohl bestimmten praktischen Bedürfnissen diente, als vielmehr ein Etiketteoder Ziertuch war.

Zweitens ist es schwer begreiflich, daf gerade ein so gewöhnliches Tuch wie ein blokes Halstuch, das doch von aller Welt getragen wurde, zum auszeichnenden Ornat und liturgischen Abzeichen werden konnte. Und doch erscheint es schon früh als solches. Denn um von dem Osten abzusehen - wiewohl kein Grund vorliegt, das diakonale ápápcov hier als aus einer Serviette entstanden zu betrachten — so war ja in Spanien das Orarium schon im 6. Jahrhundert liturgisches Distinktivum aller höheren Ordines vom Diakon angefangen bis zum Bischof; und ähnlich dürfte es sich damals auch bereits im gallikanischen Ritus verhalten haben.

Drittens ist es beachtenswert, daf die Stola in allen Riten liturgisches Abzeichen ist, und zwar selbst bei den monophysitischen Syrem und Kopten und den nestorianischen Chaldaiern. Ob das sich wohl genügend erklärt bei der Annahme, daf sie ursprünglich ein gewöhnliches Halstuch gewesen sei?

Endlich konnte, wie es scheint, die Umwandlung des Halstuches in ein liturgisches Distinktivum wohl kaum geschehen ohne irgend welche positive Bestimmungen der makgebenden kirchlichen Autoritit. Warum also dann noch die Stola von einen Halstuch ableiten und nicht vielmehr annehmen, sie sei nnmittelbar als liturgisches Distinktivum eingeführt worden? 1

1 Vielleicht darf auch darauf hingewiesen werden, dak sich die gewöhnlichere Bezeich-

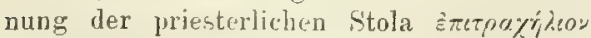
nje im Sinne von Halstuch gebrauclit findet oder sonst als Name eines profanen Gewand- stückes vorkommt. Nur einmal begegnen wir beim Grammatiker Suidas (10.-11. Jahrh.) der

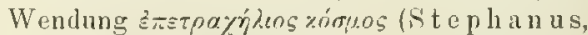

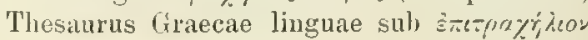
III, Paris. 1835, 1855). 
Am ehesten liefe sich noch das Orarium der römischen Kleriker als Halstuch auffassen. Allein warum in diesem Fall der Brauch, dafs man dasselbe vor der Weihe auf die Confessio legte, wie es doch für die Orarien der Diakone und Priester ausdrücklich bezeugt ist? " Und warum außer dem Orarium zu Rom noch ein besonderes Schultertuch, das anabolagium, der Amikt? Hat man denn das Halstuch zu einem Zierstück gemacht, um es alsbald durch ein neues Halstuch zu ersetzen? Wenn das Orarium so wenig praktische Bedeutung hatte, dafs es zum blofen Schmuck werden konnte, warum dann, nachdem es sich zu einem solchen umgebildet hatte, von nenem ein anderes Halstuch in Gestalt des Amikts einführen? Wie konnte sich überhaupt zu Rom das Orarium der Diakone, falls es seinem Charakter nach lediglich ein Halstuch war und keinerlei andere Bedeutung hatte, zum Zierorarium und zur Insignie des Ordo umbilden, da es doch vollständig unter der bis zu den Füfen reichenden Dalmatik verschwand? Man sagt freilich, es sei das unter dem Einflusse des Brauches im übrigen Abendland geschehen. In der Tat mag es einer Einwirkung von aufen her zuzuschreiben sein, daf das Orarium zu Rom zuletzt aus der liturgischen Tracht der Subdiakone und der übrigen niederen Kleriker ausschied und nur den Diakonen und Priestern (Bischöfen) als Ahzeichen ihres Ordo verblieb. Ob indessen ein solcher Vorgang praktisch genommen denkbar ist, wenn das Ornatstück nach römischem Brauch lediglich ein Halstuch war, wie es alle Welt gebrauchte? Ob er nicht vielmehr voraussetzt, daf das römische Orarium schon vorher irgend einen über ein gewöhnliches Halstuch hinausgehenden Charakter besaf? Endlich mufs betont werden, lak alle Angaben, welche wir seit dem Ende des 8. Jahrhunderts über das Orarium der römischen Kleriker erhalten, dieses, wie früher des weiteren ausgeführt wurde, unzweifelhaft als etwas mehr denn ein blokes Halstuch erscheinen lassen, wie es zuletzt jedermann tragen konnte und zum Schutz gegen Kälte usw. zu tragen pflegte. Warum also annehmen, das Ornatstïck sei in früherer Zeit Halstuch gewesen? Es ist gewif richtig, daf die liturgische Tracht sich aus der profanen Tracht herausgebildet hat, und dafo ihre einzelnen Bestandteile an Bestaniteile der letzteren anknüpfen. Allein das will denn doch nieht heifen, dak jedes liturgische Ornatstücknun auch wirklich einmal ein profanes Gewand gewesen sei und rein praktischen Bekleidungszwecken gedient habe. Auch das liturgische Orarium knüpft nach Name, Beschaffenheit und Form an das profane Orarium an; folgt aber darans, daf es je ein wirkliches Halstuch gewesen, das man zum Schutz gegen den Frost und gegen die übeln Wirkungen des Schweifres getragen? Welcher Grund liegt für eine solche Annahme vor? Ist es der Name orarium? Allein hatte das Wort orarium nicht eine Reihe von Bedeutungen? Wurde mit ihm doch sogar das Tuch bezeichnet, mit dem man bei den Spielen seinen Beifali kundgab?. Sind es Form und Tragweise des liturgischen Orarium? Doch auch wohl nicht. Sie beweisen höchstens, daf das Orarium des profanen Lebens, das übrigens keineswegs immer um den Hals getragen wurde, für die Form und Tragweise des liturgischen Orarium Vorbild gewesen sei, nicht aber, daf dieses ursprünglich demselben Zwecke wie jenes gedient habe; das um so mehr, als das profane Orarium, wie aus dem früher Gesagten erhellt ${ }^{3}$, zu sehr verschiedenen Zwecken gebraucht wurde.

Sind die vorgebrachten Bedenken auch nicht derart, dafs sie die Ableitung dex Stola von einem zur liturgischen Tracht gehörenden Halstuch als schlechthin undenkbar und unzulässig erscheinen lassen, so sind sie anderseits doch zu gewichtig, als dak eine solche Theorie auch nur als wahrscheinlich, geschweige denn als sicher bezeichnet werden könnte.

Eine fünfte Hypothese unterscheidet zwischen dem römischen und dem aufierrömischen (abendländischen wie orientalischen) Brauch. Aukerhalb Roms war ihr zufolge das Orarium von Anfang an liturgisches Abzeichen der höheren

1 Ordo 9, n. 8 (M. 78, 1008). 2 Flav. Vopisc., In Aurel. c. $48 .{ }^{3}$ S. oben S. 564. 
Ordines, weshalb es auch von den Diakonen und Priestern in verschiedener Weise getragen wurde, zu Rom abel bildete es ursprünglich, wie auch die vorhin besprochene Theorie will, ein Halstuch, das freilich zuletzt insofern eine Art ron heiligem Charakter erhielt, als es im Lauf der Zeit Brauch wurde, die Orarien vor der Weihe auf die Confessio des hl. Petrus niederzulegen.

Die fundamentale Unterscheidung, welche diese Hypothese gemacht wissen will, scheint uns durchaus zutreffend. Die Entstehung der Stola kann zu Rom und aufierhalb Roms unmöglich ganz die gleiche gewesen sein. Denn während das Orarium im Osten schon im 4. Jahrhundert als ausgesprochenes Prärogativ der höheren Ordines gilt und auch in Spanien bereits bei seinem ersten Auftreten im 6. Jahrhundert sich als liturgisches Distinktivum gibt, ist es zu Rom noch im 9. Jahrhundert ein Gewandstück, das allen Klerikern eignete und bei den Diakonen, weil von ihnen unter der Dalmatik getragen, auf keinen Fall zum Vorschein kam.

Aber auch die Weise, wie die Theorie den Ursprung der Stola auferhalb Roms erklärt, hat unseres Erachtens alle Wahrscheinlichkeit für sich. Es ist sehr auffällig und für die Frage nach der Entstehung des Ornatstücks sicher von hoher Bedeutüng, daß das Orarium hier schon so frïh als ein die Diakone, Priester und Bischöfe als solche kemneichnendes Ornatstück erscheint.

Bereits im 22. und 23. Kanon des Konzils von Laodicea begegnete uns, wie man sich erinnern wird, das Orarium als Ornatstück, das dem niedern Klerus zu tragen durchaus verwehrt war. Isidor von Pelusium stellt das linnene Orarium des Diakons, das Sinnbild des demütigen Dienstes Christi, der den Jüngern die Füße wusch, neben das wollene Omophorion, die Insignie des Bischofs, welche diesen als Abbild des guten Hirten kennzeichnet, der das verlorene Schäflein auf seiner Schulter heimbringt. Als Abzeichen der Diakone fanden wir ferner das Orarium im Testamentum Domini nostri Iesu Christi. In Spanien kommt in einzelnen Kirchen bei den Diakonen der Mißbrauch auf, das Orarium unter der Alba zu tragen; allein alsbald rügt solches Gebaren die Synode von Braga 563 und schärft den Diakonen die Pflicht ein, das Ornatstück sichtbar über der Tunika zu haben, damit sie sich so von den Subdiakonen unterschieden. Im 27. Kanon des 4. Toletanum erscheint die Überreichung des Orarium beim Diakonen, Priester und Bischof als ein Teil des Weihe- bzw. Restitutionsaktes. Bei der Priesterweihe war dieser Ritus schon zur Zeit der Synode von Braga aus dem Jahre 675 seit alters vorgeschrieben.

Der so bemerkenswerte Umstand, daf das Orarium schon so bald, und zwar bereits sofort bei seinem ersten Auftreten im 4. Jahrhundert als fertiges Abzeichen dasteht, weist unserer Auffassung nach durchaus darauf hin, daf es nicht das Produkt einer allmählichen Entwicklung ist. Wir werden vielmehr in Anbetracht jener Erscheinung schwerlich mit der Annahme fehlgehen, daf es seine Einführung in der Tat einem diesbezüglichen direkten Akt der maß̈gebenden kirchlichen Autorität verdankt 1 .

Diese Theorie ist aber unseres Erachtens um so wahrscheinlicher, als es wohl kaum ein Zweifel sein kann, daf das Pallium und das Omophorion der griechischen Bischöfe von Anfang an den Charakter eines Distinktivum hatten. Zudem waren ja auch im profanen Leben Abzeichen keineswegs un-

1 Wir freuen uns, daßs auch P. Grisar, dessen Auffassung wir wohl mit Recht großen Wert beilegen diirfen, der von uns vertretenen Ansicht ist: Non sara dunque un errore ascrivere la sua origine (der Stola) come una insegna, non ad un lento e spontaneo sviluppo, ma col Braun ad una ordinazione precisa dell' autorità ecclesiastica, la quale stabilì una consi fatta sciarpa. Essa si servi nella scelta della sua forma di quel antico tipo proprio degli inservienti (Analecta Romana 682 ). 
bekannt 1 . Es genüge, an das zu erinnern, was früher bezüglich der Bedeutung des Wortes infula gesagt wurde, sowie auf die Theodosianische Verordnung hinzuweisen, wonach die officiales palliis discoloribus pectus contegentes (über der paenula) condicionis suae necessitatem ex huiusmodi agnitione testentur.

Die verschiedene Tragweise des Orarium erklärt sich bei dieser letzten Theorie leicht durch den Zweck, den es hatte. Möglich, dak bei Festsetzung der Art, wie der Diakon es anlegen sollte, die Weise, auf welche im profanen Leben die Aufwärter ihre Serviette trugen und auf antiken Bildwerken Diener mit einem streifenartig zusammengefalteten Tuch ausgerüstet erscheinen (Bild 291), von vorbildlichem Einfiuf gewesen ist; doch läfist sich darüber nichts Sicheres feststellen. Die einzige Schwierigkeit bietet nur der Name orarium. Indessen ist diese nur eine scheinbare. Hält man einerseits vor Augen, daf sich die ursprüngliche Bedeutung des Wortes „Mundtuch oder Gesichtstuch" schon früh abgestumpft hatte, und daß auferdem das liturgische Distinktivum nach Form und Tragweise an das profane Orarium erinnerte, so erklärt sich leicht, daf jenes Distinktivum den $\mathrm{Na}$ men orarium erhielt. Ja es konnte in Anbetracht der Weise, wie Benennungen zu entstehen pflegen, kaum anders als orarium genannt werden.

Was den zweiten Teil der Theorie anlangt, so wurde bereits vorhin ${ }^{2}$ darüber das Nötige gesagt. Es liegt unseres Erachtens kein Grund vor, das Orarium der römischen Kleriker auf ein gewöhnliches Halstuch zurückzuführen. Was es um den Ausgang des 8. und im 9. Jahrhundert war ${ }^{3}$, kann es sehr wohl von Anfang an gewesen sein. Warum also zur Theorie vom Halstuchorarium seine Zuflucht nehmen?

Es ist bemerkenswert, dafs man zu Rom das Orarium vor der Weihe auf die

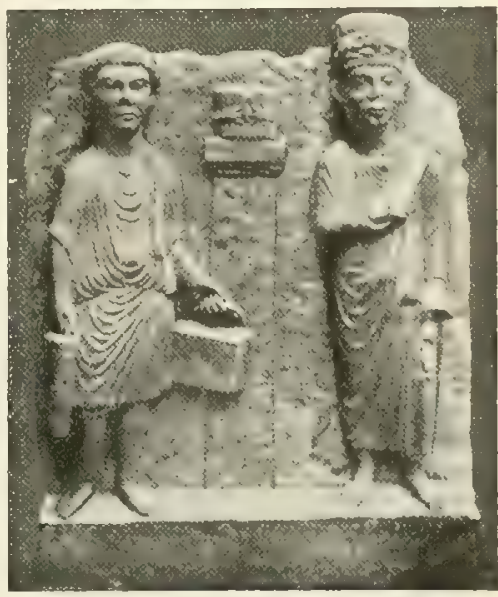

Bild 291. Koptische Grabstele. (Nach Strzygowski.)

Kopenhagen, Ny Carlsherg-Gisptothek.

Confessio des hl. Petrus niederlegte. Sollte das nicht ein Licht auf die Frage nach dem anfänglichen Charakter des römischen Orarium werfen? Duchesne meint allerdings: "On finit par lui (dem Orarium) donner une sorte de consécration qui le transformait en relique." 4 Allein warum soll die fragliche Sitte das Endresultat einer längeren Entwicklung sein? Tücher auf die Confessio zu legen, war doch ein uralter Brauch. Warum nicht lieber annehmen, daf jene Gepflogenheit ursprüglich war und das das Orarium zu Rom ein Weihetuch, wenn wir so sagen sollen, darstellte, welches durch Hinterlegung auf die Confessio geheiligt wurde und dessen Übergabe bei der Weile ein Doppeltes zum Ausdruck brachte, einmal daf die Erhebung zu Klerikern der römischen Kirche komme de benedictione S. Petri, dann, dafs die Ordinanden durch ihre Weihe den Dienst des hl. Petrus, d. i. den Dienst

\footnotetext{
1 Unter den Funden, die in den Gräbern zu Antinoe gemacht wurden, befand sich auch die kostbar bekleidete Leiche eines "byzantinischen E Edelmannes, der zahlreiche Schärpen, eine davon mit dem Bilde eines
}

heiligen Drachentöters, trug ( $\mathrm{K}$ a $\mathrm{n}$ f $\mathrm{m}$ an $\mathrm{n}$, Handbuch der christlichen Archäologie, Paderborn 1905, 548).

2 S. oben S. $616 \mathrm{f}$. $3 \mathrm{Vgl}$. oben S. $579 \mathrm{f}$.

4 Orig. 391, note 1. 
in eben jener römischen Kirche, auf sich nähmen? Es wäre dann das römische

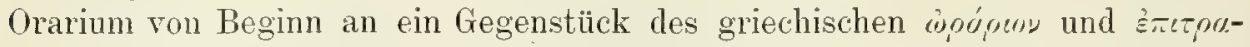
yrjkov, des gallikanischen pallium, der gallikanischen stola und des spanischen orarium, nul dals es anfänglich nicht wie diese ein Distinktivum der höheren Ordines und eigentliche Insignie war, sondern das erst später, und zwar wohl nicht ohne Einwirkung der auferrömischen Anschauung und Praxis wurde. Wann das Orarium zu Rom in Gebrauch gekommen ist, mub dahingestellt bleiben. Zur Zeit des Papstes Cölestin I. (422-432) soll es noch auf keinen Fall Verwendung gefunden haben. Man schliest das aus dem Briefe desselben an die Bischöfe Galliens, in welchem er will, daßs Kleriker und Laien in der Tracht sich nicht unterschieden ${ }^{1}$. Wirklich mag es damals zu Rom noch kein liturgisches Orarium gegeben haben; aus dem Briefe Cölestins folgt solches jedoch keineswegs. Denn 1. ist in dem Schreiben, wie es scheint, nicht von der liturgischen, sondern von der auferliturgischen Tracht der Kleriker die Rede; 2. will der Papst in demselben nur die aufergewöhnliche, fremdartige und sonderbare Kleidung abgeschafft wissen, welche sich einige Bischöfe Galliens zugelegt hatten, um sich dadurch von den Laien abzuheben; 3. war selbst im profanen Leben ein Amtsabzeichen im 4. Jahrhundert nichts Unerhörtes und Auffälliges.

\section{DRITTES KAPITEL.}

\section{DAS PALLIUM.}

\section{DAS ABENDLÄNDISCHE PALLIUM IN DER GEGENWART.}

Das Pallium stellt in seiner jetzigen Gestalt ein ringförmiges, Brust, Nacken und Schultern umziehendes Ornatstück dar, von welchem vorn und rückwärts je ein etwa anderthalb Spannen langer Streifen herabhängt. Ring und Streifen sind etwa drei Finger breit und aus weifser Wolle verfertigt. Dem Ring sind vier schwarzseidene Kreuze aufgenäht; die Streifen, an welchen der Beschwerung halber am untern Ende ein mit schwarzer Seide überzogenes, abgerundetes Bleiplättchen befestigt ist, sind nur mit je einem versehen (Bild 292).

Die Wolle, aus welcher die Pallien verfertigt werden, stammt zum Teil von den zwei weißen Lämmern her, welche von den lateramensischen Regularkanonikern am Feste der hl. Agnes in Sant' Agnese fuori le Mura dem Kapitel von St Johann im Lateran als Abgabe entrichtet, nach dem Pontifikalamt feierlich auf dem Hochaltar der Kirche gesegnet und dann dem Papste dargebracht werden ${ }^{2}$. Die Schur der Tierlein findet in der Karwoche durch die Nonnen statt, deren Obsorge dieselben bis dahin anvertraut waren. Die von den Nonnen des Klosters am Torre dei Specchi gewebten neuen Pallien werden am Frühmorgen der Vigil von Peter und Paul in die Gruft der Peterskirche getragen, in welcher der Leib des Apostelfürsten ruht. Thre Weihe, welche, wenn möglich, vom Papst selber vorgenommen werden soll, findet nach der Vesper desselben Tages statt. Die geweihten Pallien werden nach der Anordnung Benedikts XIV. vom 12. August $1748^{3}$, welcher die Weihe des Ornatstückes neu regelte, alsbald in ein besonderes, aus vergoldetem Silber angefertigtes Kästchen

\footnotetext{
1 C. 1 (M. 50, 430). Wenn die Überschrift des Briefes in der Sammlung des Dionysius Exiguus die Worte dahin deutet, es habe der Papst verboten, in der Kirche amicti pallio et lumbos Dienst zu tun, so ist das eine
}

Interpretation, welche im Schreiben kein Fundament hat.

2 Ausführlicheres über die Zeremonie bei Mor. XI 275.

${ }^{3}$ Bullar. Bened. XIV. VI, Mechl. 1827, 233 f. 
gelegt und in demselben in der nächsten Nähe des Apostelgrabes (Confessio) aufbewahrt, bis sie zur Verwendung kommen.

Von den vier Kreuzen, welche den Ring des Palliums schmücken, ist je eines auf der Brust, dem Rücken und den beiden Schultern angebracht. An den beiden ersten sowie auch an dem Kreuze, welches sich auf der linken Schulter befindet, gewahrt man Ösen aus schwarzer Seide. Sie dienen zur Aufnahme kostbarer Nadeln.

Der Diakon, welcher letztere am Pallium anzuheften hat, muf nach der ausdrücklichen Angabe des römischen Caeremoniale darauf achten, dał sie weder das Kreuz noch das Pallium durchbohren, noch auch die Kiasel berühren, desgleichen, daf der mit Edelsteinen verzierte Nadelkopf nach rechts liege. Die Annahme des Palliums hat nach Anlegung der Kasel statt. Sie soll durch den Diakon unter Beihilfe des Subdiakons geschehen ${ }^{1}$.

Das römische Pallium ist ein durchaus sakrales Gewandstïck. Denn nicht einmal der Papst trägt es bei andern als bei eigentlich liturgischen Funktionen. Die Erzbischöfe und Bischöfe, welche sich des usus pallii erfreuen, dürfen sich mit dem Ornatstück blok bei der Feier des Pontifikalamtes schmücken. Es ist ihnen nicht nur jede Verwertung des Palliums außerhalb des Gotteshauses, z. B. bei Prozessionen, sondern auch jede Verwendung bei andern Kultakten als der Missa sollemnis, z. B. den feierlichen Vespern, untersagt?

Was das Gebiet anlangt, in welchem der Inhaber des Palliums sich des Gewandstückes bedienen darf, gibt es für den Papst natürlich keine Beschränkung. Als oberster Hirt der Kirche kann er es überall tragen. Dagegen darf ohne besondere Ermächtigung seitens des Apostolischsn Stuhles der Metropolit sich des Palliums nur in seiner

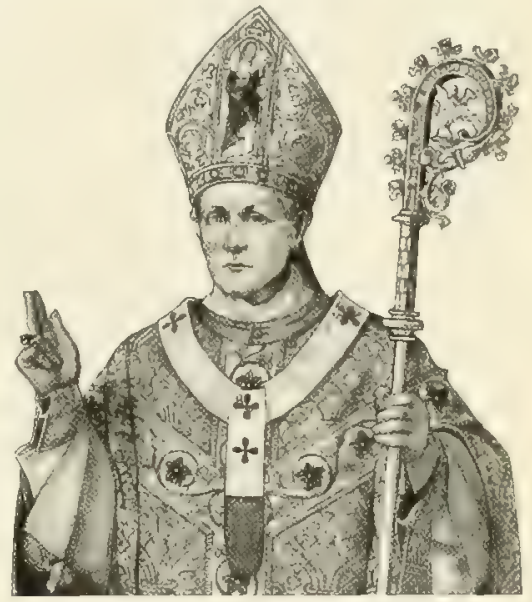

Bild 292. Vodernes Pallium. Provinz, der Bischof aber, welchem der usus pallii gewährt wurde, sich seiner nur innerhalb seines Sprengels bedienen ${ }^{3}$.

Auch hinsichtlich der Zeit sind die zum Gebrauch des Palliums Berechtigten mit Ausnahme des Papstes bestimmten Beschränkungen unterworfen.

Als Tage, an welchen es gestattet ist, das Ornatstück zu tragen, nennt das römische Pontifikale Weihnachten, Beschneidung, Epiphanie, die drei Ostertage, Christi Himmelfahrt, Pfingstsonntag, Fronleichnam, die Feste der Reinigung, Verkündigung, Aufnahme, Geburt und unbefleckten Empfängnis Marias, das Fest der Geburt des hl. Johannes des Täufers, des hl. Joseph (19. März) und des hl. Erzmärtyrers Stephanus, die Aposteltage und Allerheiligen, den Palmsonntag, den Gründonnerstag, den Karsamstag, den Weißen Sonntag, die vornehmsten Feste der Metropolitan- bzw. Kathedralkirche, das Kirchweihfest und den Jahrestag der Konsekration des be-

1 Caerem. episc. 1. 2, c. 8, n. 20.

2 Vgl. über dieses und das Folgende die Angaben des Pontificale Romanum über den Gebrauch des Palliums, p. I de pallio, dann das Caerem episc. 1. 1, c. 16 und im Corp. iur. can. Decret. 1. 1, tit. 8 , c. $1 \mathrm{ff}$ und tit. 6 , c. 428 (Lipsiae 1839, II 96 ff 48 70). Eine vortreffliche Zusammenstellung aller das Pallium betreffenden Bestimmungen bei $\mathrm{M} u ̈ \mathrm{~h} l \mathrm{~b}$. II $594 \mathrm{ff}$ und suppl. III 15.

${ }^{3}$ Daher wird ein Titularerzbischof, weil auferhalb der Diözese befindlich, auf deren Titel er konsekriert ist, nicht mit dem Pallium geschmückt. 
treffenden Erzbischofs (Bischofs). Auch erlaubt es den Gebrauch des Palliums bei Erteilung der heiligen Teihen, der Konsekration eines Bischofs und der Einsegnung von Äbten und Nonnen. Übrigens sind für die Verwendung des Ornatstückes zunächst die jeweiligen Privilegien mafgebend. Sind in ihnen bestimmte Tage nicht genannt, so gelten die gemeinrechtlichen Anweisungen des römischen Pontifikale.

Zum Tragen des Palliums ist an sich nur der Papst berechtigt. Denn das Pallium ist das Symbol der Oberhirtengewalt des Statthalters Christi, dessen Aufgabe es ist, Lämmer wie Schafe, Gläubige wie Hirten zu weiden. Es ist das Sinnbild der Fülle des pontifikalen Amtes, welche ohne alle Beschränkung und nach ihrem ganzen Umfang im Nachfolger Petri ruht ${ }^{1}$.

Gewöhnlichen Bischöfen wird das Pallium nur in Ausnahmefällen gewährt. Die Verleihung dieser päpstlichen Insignie bedeutet für einen Bischof eine besondere Auszeichnung; Vorrechte bringt sie ihm nach der gegenwärtigen Praxis nicht. Sie gewährt ihm nicht einmal den andern Bischöfen seiner Kirchenprovinz gegenüber das Recht der Präzedenz. Am wenigsten entzieht sie ihn der Obergewalt seines Metropoliten. Auch darf der Bischof, welchem der usus pallii zu teil wurde, sich des Ornatstückes in Gegenwart von Kardinälen, Nuntien sowie seines Erzbischofs selbst in der eigenen Diözese nur mit deren Genehmigung bedienen ?

Den Erzbischöfen wird das Pallium nicht als Ausnahme, sondern regelmäßrig, nicht kraft eines besondern Privilegs, sondern allgemein zu teil. Sie müssen innerhalb einer Frist von drei Monaten nach dem Tage ihrer Konsekration bzw. ihrer Konfirmation — weun sie nämlich schon Bischöfe sind sich in Rom persönlich oder durch einen Prokurator das Ornatstück instanter, instantius, instantissime, wie die Formel lautet, erbitten und erhalten erst durch die Gewährung und Übergabe des Palliums wie den Titel so auch das Recht, die Metropolitanfunktionen auszuüben, selbst wenn sie schon vorher von ihrem Stuhl Besitz ergriffen oder einen andern erzbischöflichen Thron innegehabt haben sollten. Vor Empfang des Ornatstiuckes darf der Erwählte sich weder Erzbischof nennen noch sich das erzbischöfliche Kreuz vorantragen lassen. Ebensowenig kann er eine Provinzialsynode berufen, seine Provinz visitieren oder sonst eine seiner Metropolitanbefugnisse ausüben. Er kann selbst, auch wenn er bereits Bischof sein sollte, nicht einmal erlaubterweise bischöfliche Amtshandlungen verrichten, wie das Chrisma weihen, die Ordines erteilen, Kirchen konsekrieren ${ }^{3}$. Werden derartige Funktionen nötig, so muf er einen andern damit betrauen. Das Pallium darf daher mit allem Fug auch als erzbischöfliche Insignie bezeichnet werden.

Immerhin ist das Ornatstück nicht im gleichen Sinne ein Abzeichen bei dem Papste und den Metropoliten. Jenem kommt die Insignie von Rechts wegen und unabhängig von irgend eines Menschen Genehmigung zu. Diese diirfen sie nur auf Grund der Bevollmächtigung tragen, welche sie auf ihr Ansuchen hin vom Apostolischen Stuhle empfingen. Beim Papste ist ferner das Pallium der Ausdruck der ihm kraft göttlicher Anordnung eigenen höchsten

$1 \mathrm{Vgl}$. das herrliche Gebet, welches bei der Weihe der Pallien gesprochen wird (M ühIb. II 596).

2 Benedict. XIV. ad episc. Herbipol, et Quinqueecles. (ebd. $603 \mathrm{ff}$ ). Noch in neuerer Zeit hatten mehrere Verleihungen des Palliums an Suffragane statt. So schmückte z. B. Pius IX. 1851 mit ihm den Bischof von Marseille und
1875 den Fürstbischof Förster von Breslau, Leo XIII. aber die Bischöfe Faict von Brügge und Senestrey von Regensburg.

3 Ũber den Umfang der einem Metropoliten vor Empfang des Palliums untersagten Funktionen vgl. auch Phillips, Kirchenrecht $\S 352 ; \mathrm{VI} 840 \mathrm{f}$ und Wernz, Ius decretalium II $862 \mathrm{ff}$. 
Hirtengewalt, bei den Metropoliten ist es dagegen das Symbol der ihnen vom Nachfolger Petri für eine bestimmte Kirchenprovinz gewährten und lediglich auf kirchlichem Recht beruhenden Teilnahme an dessen oberster Regierungsgewalt

So berechtigt es also auch ist, das Pallium eine erzbischöfliche Insignie zu nennen, in erster Linie und vor allem ist es päpstliches Abzeichen, welches den Metropoliten nur darum verliehen wird, weil sie in einem gewissen Umfang Stellvertreter des Apostolischen Stuhles in der obersten Leitung eines bestimmten Bereiches der Kirche sind. Die Gewährung dieses päpstlichen Schmuckes soll die Übertragung der geistlichen Obergewalt zum Ausdruck bringen, welche den Erzbischöfen als den Repräsentanten des Papstes für ihre Kirchenprovinz zu teil wird.

Aus der Bedeutung des Palliums erklärt es sich denn auch leicht, warum das Ornatstück vor der Weihe auf die Confessio des Apostelfürsten gelegt, warum es nach derselben in der allernächsten Nähe des Grabes aufbewahrt und warum sowohl das Pallium des Papstes als dasjenige der Metropoliten gleichsam vom Leibe des hl. Petrus genommen wird (pallium de corpore b. Petri sumptum). Es soll dadurch ausgedrückt werden, daf die geistliche Gewalt, welche durch das Ornatstück versinnbildet wird, unmittelbar oder mittelbar auf Petrus zurückgeht. Unmittelbar beim Papste, dem persönlichen Amtsnachfolger des Apostelfürsten, mittelbar bei den Metropoliten, da ja ihre Metropolitanvollmachten eine ihnen vom Papste gewährte Teilnahme an dessen von Petrus stammender Oberhirtengewalt darstellen.

Das Pallium ist ein durchaus persönlicher Schmuck, weil Symbol der besondern persönlichen Beziehung des Metropoliten (Bischofs) zum Apostolischen Stuhle. Auf der andern Seite hat es indessen auch einen gewissen örtlichen Charakter, weil die spezielle Stellvertretung des Papstes, welche in der Verleihung des Ornatstückes zum Ausdruck kommt, auf eine bestimmte Kirchenprovinz beschränkt ist. Aus dieser doppelten Eigentümlichkeit des Palliums erklärt sich eine Reihe eigenartiger Bestimmungen.

Wird z. B. ein Erzbischof von einem Metropolitansitz auf einen andern versetzt, so bedarf er eines neuen Palliums. Würde er später zu seinem früheren Stuhl zurückkehren, so müfte er für diesen wieder um das Ornatstück nachsuchen. Ein gleiches gilt von einem Metropoliten, der auf seine Würde verzichtete, sie aber später wieder zurückerhält. Ferner mufs ein etwaiger Inhaber zweier Sitze, die den usus pallii haben, für beide gesondert das Pallium erbitten, ein Erzbischof aber, der auf seinen Sitz Verzicht leistet, darf weiterhin vom Pallium keinen Gebrauch machen, selbst wenn er ein Bistum übernehmen sollte. Ein Metropolit kann sein Pallium keinem andern zum Gebrauch überlassen. Dem zum Tragen des Ornatstückes Befugten wird dasselbe beim Tode mit in das Grab gegeben. Verseheidet er in der eigenen Kirchenprovinz (Diözese), so legt man es um seinen Hals, wie er es im Leben trug, andernfalls unter den Kopf. Alle diese und ähnliche Gepflogenheiten finden ihre Begründung in dem Doppelcharakter des Palliums, wonach es eine dem Metropoliten für seine Person, aber mit Rücksicht auf einen bestimmten Bezirk verliehene Insignie ist.

Die Übergabe des Palliums an den Metropoliten (Bischof) findet entweder in Rom oder außerhalb Roms statt. Im ersten Falle erfolgt sie durch den ersten der Kardinaldiakone, im letzten durch einen mit derselben beauftragten Bischof. Sie vollzieht sich nach vorausgegangener Feier der heiligen Messe und nach Ablegung des Treueides. Im übrigen ist der Ritus, wie ihn das römische Pontifikale für die Übergabe des Palliums vorschreibt, sehr einfach.

Die Worte, unter denen das Pallium dem erwählten Erzbischof über die Schultern gelegt wird, lauten: „Zu Ehren des allmächtigen Gottes, der seligen, allzeit reinen Jungfrau Maria, der hll. Apostel Petrus und Paulus, unseres Herrn, des Papstes $\mathrm{N}$., der heiligen römischen und der dir anvertrauten Kirche übergebe ich dir das vom Leib des hl. Petrus genommene Pallium, in welchem die Fülle des pontifikalen 
Amtes liegt, zugleich mit dem Titel Patriarch (Erzbischof), auf dak du es innerhalb deiner Kirche an den in den Privilegien des Apostolischen Stuhles bestimmiten Tagen gebranchen mögest. Im Namen des Vaters und des Sohnes und des Heiligen Geistes. Amen." Wie man sieht, kommt in dem Gebet die Bedeutung des Ornatstückes klar zum Ausảruck.

\section{ALTER DES RÖMISCHEN PALLIUMS.}

Nach dem sog. Constitutum Constantini reicht das römische Pallium bis in die erste Hälfte des 4. Jahrhunderts hinauf. Konstantin soll nämlich rem Constitutum zufolge dem Papst Silvester I. aufer andern Auszeichnungen auch das Recht verliehen haben, das lorum, d. h. das Pallium ${ }^{1}$, zu tragen. Indessen ist die Konstantinische Schenkung bekanntlich unecht und ihre Angabe über die Verleihung des Palliums durch Konstantin durchaus unglaubwürdig. Wenn der Fälscher, der das Constitutum schmiedete, dieses auf den ersten christlichen Kaiser zurïckführt, so tut er das nicht, weil sich noch eine Erimnerung an ein solches Ereignis erhalten hätte, sondern weil er darauf ausgeht, für die bestehenden Vorrechte des Papstes statt der wirklichen geschichtlichen und rechtlichen Grundlage ein an den Namen des ersten christlichen Kaisers anknüpfendes und darum gewichtigeres und bedeutungsvolleres Fundament zu schaffen. Sehr gut sagt Grisar: "Die Idee, das Pallium von Konstantin herzuleiten, entstammt nur dem ebenso irrigen wie in der Erfindung kindlichen Bemühen, den bestehenden päpstlichen Gebräuchen eine imponierende kaiserliche Grundlage zu verleihen. Die Idee ist kein Echo von damals noch gekannten, wirklich historischen Vorgängen, ebensowenig wie die in der Urkunde gemachte Schenkung Italiens und der Inseln des ganzen Westens." 2

Auch nach dem Liber Pontificalis war das Pallium schon in der Frühe des 4. Jahrhunderts im Gebrauch. Er berichtet nämlich in der Vita des Papstes Markus, derselbe habe dem Bischof von Ostia das Pallium verliehen, weil diesem die Weihe des Papstes obliege ${ }^{3}$. Vielleicht, daf der Angabe irgend eine örtliche Überlieferung zu Grunde liegt. Da sie indessen keine anderweitige

\footnotetext{
1 Pallinm bezeichnet im klassischen Latein jede Art von Bedeckung, zumal einen mit der Toga verwandten Überwurf. Die Belege bei Force11. III, 283. Im späteren Latein hat pallium eine noch mannigfaltigere Bedeutung. Es heift hier Mantel, Schleier (Nonnen-, Hochzeitsschleier), Decke (z. B. Altardecke), Behang usw. Häufig erscheint es auch als Name eines Gewebes, zumeist von besserer Art, ähnlich wie unser "Tuch" (vgl. D. C. VI $113 \mathrm{ff}$ ). Is id or sagt (Orig. 1. 19, c. 24 [M. 82, 689]) bezüglich der Ableitung des Wortes: Dictum autem pallium a pellibus, quia prius super indumenta pellicea veteres utebantur, quasi pellea, sive a palla per derivationem. Die letzte Erklärung wird die richtige und pallium aus palla gebildet sein. Palla selbst, womit vorzüglich das mantelartige Obergewand römischer Frauen bezeichnet wurde, läßt $\nabla$ arro (Ling. lat. 4, 39) aus palam entstehen, weil das Gewand sichtbar (palam) über den andern Kleidern getragen werde, ähnlich wie indusium von intus herkomme. Eine andere Etymologie findet sich
}

bei Servius (ad Aen. I 652): Rectius

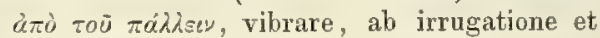
mobilitate, quae est in fine huiusmodi vestium et pedibus in incedendo vibrari et iactari solet. Beide Ableitungen gehören in die Kategorie der mehr spitzfindigen als wahren und oft genug recht sonderbaren etymologischen Versuche, denen wir bei den alten Grammatikern und Scholiasten begegnen. Palla wird mit pannus, $\pi \tilde{y}$ vos (Faden, Gewebe) zusammenbängen ( $\mathrm{V}$ a $\mathrm{n}$ i č e k, Etymolog. Wörterbuch ${ }^{2}$ 332).

2 Grisar, Das römisehe Pallium, in „Festschrift zum 1100 jährigen Jubiläum des deutschen Campo Santo" 101. Der Text des Constitutum lautet: Beato Silvestro .... contradimus ... necnon et superhumerale, videlicet lorum, qui imperiale circumdare assolet collum ( $\mathrm{H}$ in s chius, Decret. Pseudo-Isidor. 253).

${ }^{3}$ So in der ersten Edition (D u ch., L.P. I 81). In der zweiten (ebd. 202) ist der Text etwas verschieden, doch der sinn im wesentlichen der gleiche. 
Bestätigung findet und das Papstbuch für die ersten fünf Jahrhunderte keine zuverlässige Quelle ist, muf3 es dahingestellt bleiben, ob und inwieweit an der Sache etwas Wahres ist. Immerhin ist die Nachricht des Papstbuches auch so zweifellos von grofer Bedeutung, nicht nur, weil sie das Vorhandensein des römischen Palliums für die erste Hälfte des 6. Jahrhunderts außer allen Zweifel setzt, sondern mehr noch, weil wir aus ihr mit allem Fug schließsen dürfen, daf das Pallium zu Rom schon eine geraume Weile vor dem 6. Jahrhundert in Brauch war. Denn wenn um 530 der Verfasser des Papstbuches den Papst Markus dem Bischof von Ostia das Pallium verleihen läft, so muf dieses damals offenbar schon seit Menschengedenken sowohl bei dem Papst als bei dem Bischof von Ostia Verwendung gefunden haben ${ }^{1}$.

Eine Bestätigung erhält dieser Schlufs durch die sonstigen Nachrichten, die wir aus dem 6. Jahrhundert über das Pallium erhalten. Im Jahre 513 zeichnet Papst Symmachus den hl. Cäsarius von Arles, den er zu seinem Vikar für Gallien bestellt hatte, mit dem Pallium aus ${ }^{2}$. Ein wenig mehr als zwei Jahrzehnte später versuchte Felix IV. (526-530) sich selbst einen Nachfolger zu geben, indem er dem Auserkorenen in Gegenwart der Priester. Diakone, Senatoren und anderer Zeugen sein Pallium übergab ${ }^{3}$. Bald nachher ließs umgekehrt Belisar dem Papst Silverius (5:36 bis 538) das Pallium abnehmen, als er sich anmafte, diesen gegen alles Recht freventlich seiner Würde zu entsetzen ". 545 bzw. 546 verlieh Papst Vigilius den Nachfolgern des hl. Cäsarius, den Bischöfen Auxanius und Aurelian, das Pallium ${ }^{5}$. Unter Pelagius I. (555-560) begegnen wir diesem bei Secundus von Taurominium (Taormina) auf Sizilien ${ }^{6}$ und unter Johannes III. $(560-573)$ bei dem Erzbischof Petrus von Ravenna ${ }^{7}$. Gregor d. Gr. verleiht das Pallium den Metropoliten von Mailand und Ravenna, Salona, Korinth, Nikopolis und Iustiniana prima (Ochrida in Albanien), Sevilla, Arles und Canterbury, sowie den Bischöfen von Messina, Palermo, Syrakus und Autun.

In allen diesen Nachrichten erscheint das Pallium als eine allbekannte, längst gebräuchliche Sache, nirgends als ein erst in jüngster Zeit, also im 6. Jahrhundert, eingeführtes Ornatstück. Insbesondere lassen die Pallienverleihungen, denen wir mit Sicherheit schon seit 513 begegnen, keinen Zweifel, dal das Pallium bereits eine gute Weile vor dem Beginn des 6. Jahrhunderts in Gebrauch gekommen sein muf.

1 Nach Grimaldi wurden wirklich im Sarkophag Leos I. (440-461) gelegentlich des Umbaues von St Peter Spuren eines Palliums entdeckt. Man fand auf der rechten Schulter ein kleines rotes und auf der Brust nach rechts zu ein etwas gröseres schwarzes Kreuz, Mitten vor der Brust sah man eine goldene, in die Kasel hineingesteckte Nadel (Instrum. auth. translat. ss. corporum e veteri in novam Principis apost, basilicam f. 6075 [Vat. Barb. XXXIV 49]). Kreuze und Nadel lassen jedoch kaum einen Zweifel daran, daß es sich um Reste eines Palliums handelte, welches erst in späterer Keit in den Sarg kam, wie P. Grisal meint. In St Maximin zu Trier wurde vor der Aufhebung des Klosters das Fragment eines Palliums des hl. Maximin († ca 349) gezeigt. Nach der Erzählung des Mönches Sigehard (ca 962) wurde letzteres mitsamt einer Stola 898 bei Wiederauffindung des angeblich seit dem Einfall der Nor-

Braun, Die liturgische Gewandung. mannen (882) völlig verschollenen Grabes aus dem Sarg des Heiligen genommen (AA. SS. 29. Mai; VII 32). Allein es kann wohl kaum zweifelhaft sein, dafs es sich auch hier um ein Pallium handelt, mit dem bei einer früheren Translation der heilige Leib geschmäckt worden war. Oder sollen wir vielleicht auch die Stola für ein Original aus der ersten Hälfte des 4. Jahrhunderts halten?

2 Epist. arelat. n. 2741 (M. G. Epp. III 40 62). Vita S. Caesarii 1. 1, c. 4 (M. 67, 1016). Ein Schreiben, in welchem Papst Symmachus dem Erzbischof Theodor von Lorch das Pallium verleiht, ist unecht (J. n. 767).

Duch., L. P. I 282 in nota 4 ad Vitam Bonifacii II. $\quad$ Ebd. 293.

${ }^{5}$ Epist. arelat. n. 4144 (M. G. Epp. III $6266)$.

6 L ö w e n f e ld, Epistolae Rom. Pont., Lipsiae 1885, n. 30, p. 16.
J. д. 1041 


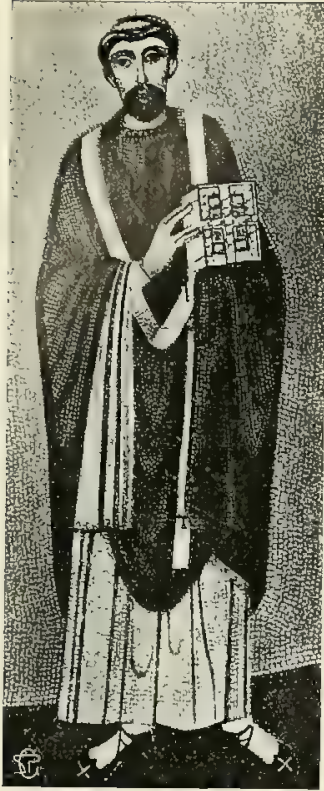

Bild 293. Papst Symmachus. Mosaik. Rom, S. Agnese. (Nach de Rossi.)

Auf den Bildwerken findet sich das römische Pallium nirgends vor dem 6 . Jahrhundert. Wie die dem 5, Jahrhundert entstammende Darstellung der hll. Ambrosius und Maternus in der Kapelle des hl. Satyrus zu Mailand, so lassen auch die gleichzeitigen Brustbilder der Päpste aus S. Paolo zu Rom das Ornatstück noch vermissen ${ }^{1}$.

Die ältesten Monumente, welche das Pallium aufweisen, sind die Mosaiken in S. Vitale zu Ravenna (vgl. Bild 63, S. 159) und in S. Apollinare in Classe, auf welchen die ravennatischen Bischöfe St Apollinaris, St Severus, St Ursus, Ecclesius, Ursicinus und St Maximian mit demselben geschmückt sind ${ }^{2}$. Sie entstammen der Mitte des 6. Jahrhunderts. Die ältesten römischen Bildwerke, welche das Pallium zur Abbildung bringen, sind gegenwärtig das Mosaik in S. Agnese fuori le Mura mit den Abbildungen der Päpste Honorius (vgl. Bild 64, S. 160) und Symmachus (Bild 293) und das Mosaik im Oratorium des hl. Venantius mit den Bildern Johannes' IV., seines Nachfolgers Theodorus und der Bischöfe Venantius und Maurus ${ }^{3}$. Die erste der beiden musivischen Darstellungen ist das Werk Honorius' I. (625-638), die zweite das Johannes' IV. (640-642). Auf den aus dem 6. Jahrhundert herrührenden Mosaiken in S. Cosma e Damiano und S. Lorenzo fuori le Mura haben die Darstellungen Felix' III. und Pelagius' eine so durehgreifende Veränderung erfahren, dab sie in keiner Hinsicht mehr als Originale gelten können ". Immerhin lassen es die gleichzeitigen Mosaiken Ravennas nicht zweifelhaft, dafs beide Figuren auch ursprünglich mit dem Pallium ausgestattet waren.

\section{DIE VERLEIHUNG DES PALLIUMS.}

Die Palliumverleihungen, deren wir vorhin gedachten, sind nicht die einzigen im 6. Jahrhundert gewesen. Es müssen noch eine Anzahl anderer vorgekommen sein. Das erhellt aus verschiedenen Schreiben Gregors d. Gr. Denn wenn derselbe einem Bischof den usus pallii gewährte, so pflegte er dabei zu bemerken, er tue das ex more, iuxta antiquum morem, sicut prisca consuetudo habet, antiquae consuetudinis ordine provocatus und ähnlich ${ }^{5}$. Auch wies er wohl den mit dem Pallium Begnadigten an, die Insignie in der Weise zu tragen, wie das sein Vorgänger getan ${ }^{6}$. Es muf also schon vor Gregor die Verleihung des Palliums in Flor gestanden haben.

Selbst die Sitte, bestimmten Sitzen regelmäßig den Gebrauch des Ornatstückes zu gewähren, entstand nicht erst zu Gregors Lebzeiten; sie hatte sich schon vor den

\footnotetext{
1 Gar r. tav. $108 \mathrm{ff}$. Garrucci glaubte bei Linus das Pallium wahrnehmen zu können. Allein das Bild des Papstes Linus ist wie die Darstellungen aller Päpste von Petrus bis auf Urban so sehr durch spätere Restauration verunstaltet, daf von dem Original nur wenig mehr da ist. Die auf Urban folgenden Papsthilder haben sich besser erhalten; keines von diesen aber weist das Pallium auf, wie wir uns an Ort und Stelle selbst überzeugten. Vgl, auch Wilp., Cap. 30 , nota 2.

2 Garr. tav. 258264265267.
}

De Rossi, Mus. fasc. III-IV XIII bis XIV. Garr. tav. 272274

- De Rossi, Mus. fasc. III-VI, Garr. tav. 253 271. Über die Papst- und Bischofsbilder in S. Callisto siehe oben S. 159. Der Elfenbeintafel des Trierer Domschatzes wird später bei Besprechung des griechischen Palliums gedacht werden.

${ }^{5}$ Gregor. M. Epist. 1. 4, n. 1; 1. 5, n. 58 $606162 ; 1.6$. n. 8 ; 1. 9, n. 176228 (M. G. Epp. I 232368373375376387 ; II 171221 ).

6 Ebd. 1. 5, n. $62 ; 1.6$, n. 818 ; 1. 13, .. 40 (I $376 \quad 387$ 397; II 403). 
Tagen des grofen Papstes herausgebildet. Wie Symmachus das Pallium dem hl. Cäsarius von Arles verlieh, so erteilte Vigilius es dessen Nachfolgern Auxanius und Aurelian und Pelagius dem Erzbischof Sapaudus. Auch die Erzbischöfe von Ravenna wurden, wie sich aus den Mosaiken in S. Vitale und in S. Apollinare in Classe ergibt, nicht erst durch Johannes III. und Gregor d. Gr. der Ehre des Palliums gewürdigt. Ebenso kann das, was der Liber Pontificalis in Betreff der Verleihung des Ornatstiuckes an den Bischof von Ostia sagt, nur von einer gewohnheitsmäfigen Erteilung dieses Privilegs verstanden werden. Ausdrücklich aber bezeugt den Brauch bereits das Schreiben Johannes" III. an den Erzbischof Petrus von Ravenna. "Wir wissen", so heibt es darin, „daf es der Vernunft entspricht, diejenigen mit dem Pallium zu schmücken, welche die Bischofswürde durch Gottes Barmherzigkeit in jenen Stälten ziert, in denen es auch den früheren Bischöfen vom Apostolischen Stuhle nachweislich verliehen wurde. " 1

Empfänger des Palliums waren von Anfang an vornehmlich päpstliche Vikare und Metropoliten. Schon in den Briefen Gregors d. Gr. begegnet uns eine nennenswerte Anzahl von Würdenträgern dieser Art, deren Vorgänger bereits den usus pallii besaken. Neu verleiht der Papst das Privileg dem hl. Augustinus für die von demselben gegründete englische Kirche? Auch stellt er in seinem Schreiben an den Heiligen die Insignie den beiden demnächst zu gründenden Metropolitansitzen London (später Canterbury) und York in Aussicht. Indessen wurde das Pallium um die Neige des 6. Jahrhunderts noch keineswegs von allen Metropoliten des Abendlandes getragen, wie man vielleicht aus dem Verhalten Gregors gegenüber Augustinus und den beiden zukünftigen englischen Metropolen schließen möchte. Denn als der Erzbischof Desiderius von Vienne unter Hinweis auf die alte Gewohnheit in Rom um das Pallium bat, weigerte sich Gregor, dem Ansuchen zu willfahren, bis der Bittsteller aus dem Archiv seiner Kirche nachgewiesen, dafi schon seine Vorgänger den usus pallii gehabt ${ }^{3}$.

Ebendarum aber kann damals auch noch nicht den Erzbischöfen die Pflicht obgelegen haben, das Pallium vom Apostolischen Stuhle zu erbitten und sich vor Empfang der Insignie der Metropolitanfunktionen zu enthalten. Wann diese Pflicht sich herausgebildet hat, läst sich nicht mit Genauigkeit bestimmen. Um die Mitte des 8. Jahrhunderts war sie, nach dem Briefwechsel zwischen Papst Zacharias und dem hl. Bonifatius zu urteilen, jedenfalls noch nicht in Kraft.

Bonifatius hatte für die von ihm eingesetzten Metropoliten Grimo von Rouen, Abel von Reims und Hartbercht von Sens von Zacharias die Bestätigung und das Pallium erbeten. Der Papst antwortete, er sende die Pallien und habe über die Bedeutung und den Gebrauch der Insignie usw. den Bischöfen Weisung zugehen lassen. Noch ehe dieser Brief jedoch in die Hände des Heiligen kam, mufs derselbe ein nenes Schreiben an Zacharias gerichtet haben, in dem er nur für Grimo das Pallium nachsuchte. Wie es scheint, veranlaste die Furcht, Sporteln zahlen zu müssen, Abel und Hartbercht, auf das Ornatstück zu verzichten. Zacharias antwortete voll des Erstaunens über die Wendung der Dinge und wünschte Aufklärung. Von der Pflicht der Metropoliten, das Pallium in Rom zu erbitten, hören wir aber nicht das geringste 4

Drei Jahre später hatte der Heilige auf einer fränkischen Synode den Beschluf erwirkt, es sollten die Metropoliten das Pallium beim Apostolischen Stuhle nachsuchen. 751 aber muß er bei Zacharias sich entschuldigen, dak derselbe noch

1 M. 77, 655, nota h.

2 Gregor. M. Epist. I. 11, n. 39 (M. G. Epp. II 311).
3 Ebd. 1. 9, n. 220 (II 212).

4 S. B o n if a cii Epist. n. 5758 (M. G. Epp. III 313 315). 
nicht zur Ausführung gebracht sei. „Was man versprochen, hat man bisher zu verwirklichen gezögert. Man schiebt auf, überlegt hin und her und weifs darum nicht, was man tun will. Wäre es nach meinem Willen gegangen, so wäre das Versprechlen längst erfüllt." Die Ursache der Verzögerung scheint auch hier die Furcht vor etwaigen Abgaben gewesen zu sein. In der Antwort erkennt Zacharias den guten Willen des hl. Bonifatius an; betreffs der Sache aber bemerkt er blofs: "Wenn die Metropoliten gemäfs dem Beschluß vorangehen, wird ihnen das zum Lobe gereichen; wenn nicht, lafs sie (sin vero aliter egerint, ipsi videbunt). Wir geben durch Gottes Gnade umsonst, was wir selbst umsonst empfangen haben." ${ }^{1}$ Ob sich der Papst mit diesem Entscheide begnügt hätte, wenn die Metropoliten schon damals vorschriftsmäßig um die Erteilung des Palliums einkommen nufsten und vor Empfang der Insignie keine erzbischöflichen Amtshandlungen vornehmen durften? Zweifelsohne nicht.

Sicher bestand die kanonische Bestimmung, wonach die Metropoliten nach ihrer Wahl beim Apostolischen Stuhle um das Pallium zu bitten hatten und vor Verleihung desselben ihres Amtes nicht walten durften, in der Hauptsache bereits um die Mitte des 9. Jahrhunderts. Es ergibt sich das aus einer Verordnung Nikolaus' I., aus dem 1. Kapitel des 877 unter Johannes VIII. gehaltenen Konzils von Ravenna und aus einem Schreiben Johannes VIII. an den Erzbischof Rostagnus von Arles.

Auf eine Anfrage, welche die Bulgaren hinsichtlich des demnächst zu erwählenden Erzbischofes an Nikolaus I. gerichtet hatten, antwortet dieser nämlich, es solle der zukünftige Metropolit gerade so, wie das bei allen Erzbischöfen Deutschlands, Galliens und anderer Länder bekanntermaken geschehe, vor dem Empfang des Palliums nicht seinen Thron benutzen ${ }^{2}$. Desgleichen solle er keine Konsekration mit Ausnahme derjenigen des Leibes und Blutes Christi vornehmen. Das erste Kapitel der Synode von Ravenna bestimmt in ähnlicher Weise, es hätten die Metropoliten innerhalb dreier Monate ihr Glaubensbekenntnis dem Apostolischen Stuhle vorzulegen und um das Pallium zu bitten. Solange jemand in Bezug auf diese Punkte die alte Sitte verachte, solle er weder seinen Sitz einnehmen noch Konsekrationen vollziehen dürfen ${ }^{3}$. Johannes VJII. endlich beauftragt 878 in seinem Briefe Rostagnus, den er zu seinem Vikar gemacht hatte, darüber zu wachen, dafo kein Erzbischof eine Weihe vornehme, wofern er nicht vom Papste das Pallium erhalten habe, die Zuwiderhandelnden aber in seinem Namen zu tadeln*. Er habe nämlich die Wahrnehmung gemacht, dafs gallische Bischöfe schon vor Erlangung des Palliums Konsekrationen auszuüben gewagt hätten, obschon doch sowohl von seinen Vorgängern (antecessores nostri) als von ihm selbst solches untersagt worden sei ${ }^{5}$.

Allem Anschein nach fällt die Einführung der Verordnung, durch welche die Metropoliten verpflichtet wurden, das Pallium vom Apostolischen StuhI zu erbitten, in die erste Hälfte des 9. oder noch in das Ende des 8. Jahrhunderts ${ }^{6}$. Ihr Ziel war nicht die Schädigung oder gar die Vernichtung der Metropolitangewalt. Sie sollte vielmehr die Metropoliten zu innigerer und festerer Einheit mit dem einzigen Grund aller Metropolitanvollmachten, dem Stuhle Petri, verknüpfen, sollte den dem innersten Wesen der Kirche widerstrebenden zentrifugalen und selbstherrlichen Bestrebungen mancher Metropoliten mitsamt den daraus hervorgehenden Mißständen in wirksamer Weise begegnen und zugleich das in Auflösung und Verfall geratene Metropolitan-

1 S. B on if a ci i Epist. n. 788687 (M. G. Epp. III 351368 370).

2 Resp. ad Bulg. consultan.73 (M.119, 1007).

${ }^{3} \mathrm{Hard}$. VI 185.

1 Ad univers. ep. Gall. (M. 126, 778).

5 Ad Rostagnum archiep. (M, 126, 777).
${ }^{6}$ Das Gratiansehe c. Quoniam quidem (Decr. I, D. 100 , c. 1; Corp. iur. can. I, Lipsiae 1879, 352), eine Erweiterung des c. 1 der Synode von Ravenna, wird bei Gratian irrig Papst Pelagius (II.) zugeschrieben. J. n. 1064 . 
system von neuem kräftigen, festigen und $\mathrm{zu}$ frischem Leben führen. Sie bildete so wenig einen Eingriff in die Befugnisse der Metropoliten und den Tod der Metropolitanautorität, daf sie vielmehr nur die Äußerung eines dem Papste ureigensten und unverlierbaren Rechtes und zugleich eine entschiedene Hebung und einen nachhaltigen Schirm der Metropolitangewalt bedeutete ${ }^{1}$. Wie groß die Notwendigkeit war, die Erzbischöfe enger mit Rom zu verknüpfen, hat niemand besser als der grofe Apostel Deutschlands erkannt; daher denn auch Bonifatius als der eifrigste Förderer des römischen Palliums auftrat ${ }^{2}$.

Das früheste Beispiel eines mit dem Pallium geschmückten abendländischen $\mathrm{Suffragans}$ bietet der Bischof von Ostia. In der zweiten Hälfte des 6. Jahrhunderts begegnet uns dann die Insignie bei verschiedenen zum römischen Metropolitanverbande gehörenden Bischöfen Siziliens. Der Grund, warum sie diesen zugestanden wurde, mag in dem Umstande liegen, daf die Bischöfe des Patrimonium Petri auf Sizilien mehr als die sonstigen Suffragane des römischen Metropolitanstuhles als Stellvertreter des Papstes erschienen ${ }^{3}$. Es ist wohl nicht umsonst, daf Gregor in seinen Briefen an Donus von Messina und Johamnes von Syrakus, in welchen er denselben das Ornatstück verleiht, zugleich ausdrücklich alle Privilegien bestätigt, welche beiden Kirchen von seinen Vorgängern verliehen worden seien *

Der Bischof von Ostia und die Bischöfe von Sizilien bleiben innerhalb des römischen Metropolitanbereiches die einzigen, bei denen wir den usus pallii antreffen. "Im weiten Unkreis von Rom", sagt Grisar, "absorbierte gleichsam alles Ansehen der in der Hauptstadt regierende Apostel Petrus, vertreten durch seine Nachfolger. Die andern Bischöfe waren auch zu zahlreich und hatten zu kleine Diözesen, um besondere Wichtigkeit zu erlangen." 5

Das erste bekannte Beispiel, daf im Abendland ein nicht zum römischen Metropolitanverband gehörender Suffraganbischof mit dem Pallium geschmückt wurde, bildet Syagrius von Autun. Der Grund, warum Gregor diesem das Ornatstück gewährte, waren teils die Verdienste, welche sich Syagrius um Augustinus, den Apostel Englands, erworben hatte, teils die Bitten des fränkischen Hofes ${ }^{6}$. Bemerkenswert ist, daf der Papst dem Bischof um des Palliums willen - ne indumenti munificentiam nudam videamur quodammodo contulisse - das Recht der Präzedenz vor den Komprovinzialen gewährte und ihn zugleich mit der Sorge für die Zusammenberufung einer Synode der gallischen Bischöfe beauftragte ${ }^{7}$.

${ }^{1}$ Phillips, Kirchenrecht $\$ 73$; II 87, und $\S 348$; VI 813.

2 Vgl. den Briefwechsel zwischen Papst Zacharias und dem Heiligen und des letzteren Brief an Erzbischof Cuthbert von Canterbury (S. Bonifacii Epist. n. 78 [M. G. Epp. III 351]).

${ }^{3} \mathrm{Grisar}$ (Das römische Pallium: Festschrift" ${ }^{4}$ etc. 110$)$ vermutet: ${ }_{\text {Die Berührung }}$ mit griechischen Gebräuchen mag auf Sizilien, obwohl diese Insel von jeher zur Kirchenprovinz des römischen Bischofs gehörte, es mit sich gebracht haben, dafs das Pallium von manchen besonders hervorragenden Bischofssitzen gebraucht wurde."
4 Gregor. M. Epist. I. 6, n. 818 (M. G. Epp. I 387 397). Ein ständiger Vikar wax in Sizilien nicht. Etwaige Vikariatsgeschäfte besorgten entweder der Defensor oder ein Bischof im Auftrage des Papstes (1.2, n. 8 [I 107]).

5 Grisar a. a. 0. 110.

Gregor. M. Epist. 1. 8, n. 4 ; 1. 9, n. 222 (M. G. Epp. II 5 213).

7 Ebd. Bezeichnend ist. der Schluf des Briefes, worin er den Bischof ermahnt, mit allem Eifer zu Werk zu gehen: ut nos utiliter providisse, qui vestram ad hoc prae ceteris personam eligimus, videamur; $\nabla g l$. auch Epist. 1. 9, n. 219 (II 210). 
Wie unter Gregor d. Gr. so kamen auch noch in der Folgezeit neben den Palliumverleihungen an Metropoliten solche an gewöhnliche Bischöfe vor. Sie waren indessen nie häufig. Hier einige Beispiele aus älterer Zeit.

Chrodegang von Metz soll das Pallium durch Stephan II. 754 erhalten haben, als dieser zur Salbung Pipins ins Frankenland kam ', Drogo von Metz $84 t$ durch Sergius II. " Actardus von Nantes wurde 868 durch Hadrian II. ${ }^{3}$, Wala von Metz 878 durch Johannes VIIL. der Ehre des Palliums gewürdigt ${ }^{4}$, Argrinus von Langres 900 durch Benedikt IV. ${ }^{5}$, Ragembert von Vercelli 912 durch Anastasius III. ${ }^{6}$, Richarius von Lüttich 922 durch Johannes X. ${ }^{7}$, Atto von Vich (Spanien) 971 durch Johannes XIII. ${ }^{8}$ Leo IX, verlieh es 1051 Stephan von Le Puy ${ }^{9}, 1053$ Hartwig von Bamberg ${ }^{10}$, Alexander II. 1063 Burchard von Halberstadt ${ }^{11}$, Gregor VII. 1076 Ivo von Dol ${ }^{12}$ sowie Hermann von Metz ${ }^{13}$, Paschalis II. 1105 Guido von Pavia ${ }^{14}, 1111$ Otto von Bamberg ${ }^{15}$, Calixt II. (1119-1124) Benedikt von Lucea ${ }^{16}$, Innozenz II. 1139 Egilbert von Bamberg ${ }^{17}$, Eugen III. 1146 Eberhard II. von Bamberg ${ }^{18}$. Von neueren Beispielen erwähnen wir die Palliumverleihung an die Bischöfe von Ermeland und Würzburg durch Benedikt XIV. Die Gewährung des Ornatstückes erfolgte je nach den Verhältnissen unter ausdrücklicher Befragung und Zustimmung des jeweiligen Metropoliten und unter Wahrung der metropolitanen Rechte desselben ${ }^{19}$.

Bis zum 11. Jahrhundert pflegte das Pallium denjenigen, welchen der Gebrauch desselben zugestanden worden war, durch einen Boten übersandt zu werden. Ein persönliches Erscheinen beim Apostolischen Stuhle zum Zwecke der Entgegennahme des Ornatstückes war nicht gefordert. Im Laufe des 11. Jahrhunderts drängten die Päpste indessen mit aller Entschiedenheit darauf, es sollten die Bewerber nach Rom kommen, um in eigener Person das Pallium daselbst in Empfang zu nehmen ${ }^{20}$. Das Unwesen der Simonie, die papstfeindliche Stellung und die Verweltlichung mancher Erzbischöfe, der gewaltige Kampf gegenüber den Übergriffen der Macht der Fürsten und die sonstigen Schäden der Zeit mufsten diese Mafregel damals als zweckmäßig, ja geradezu als nötig erscheinen lassen ${ }^{21}$. Mit dem Aufhören der Gründe verlor dieselbe ihre Bedeutung, weshalb denn auch in späterer Zeit ein persönliches Erscheinen zu Rom nicht weiter verlangt wurde.

Bei der Verleihung des Palliums war vor der Zeit Gregors d. Gr. eine Abgabe zu entrichten. Da der Papst diese Sportel durchaus míbilligte, schaffte er sie auf der römischen Synode des Jahres 595 ab, wobei er indessen

\footnotetext{
1 M. G. SS. X 568 .

3 J. n. 2904.

Ebd. n. 3527.

7 Ebd. n. 3566. Die Bulle wird übrigens

bei Jaffé als zweifelhaft bezeichnet.

8 Ebd. и. 3747. 9 Ebd. п. 4265.

10 Ebd. n. 4287. 1 Ebd. n. 4498.

12 Ebd, n. 5004.

${ }^{13}$ Kraus, Kunst und Altertümer in ElsafLothringen III, Strakburg 1889, 717.

$14 \mathrm{~J}, \mathrm{n} .6013$.

15 Ebd. n. 6291.

16 Ebd. n. 7091.

17 Ebd. n. 8048.

18 Ebd. n. 8975. Zugleich mit dem Pallium wurde den betreffenden Bischöfen auch wohl der Titel, Erzbischof* zu teil, wie z. B. dem Bischof Ivo von Dol.
}

19 Vgl. Z. B. das Schreiben Hadrians II. vom Jahr 866 an Actardus von Nantes und Leos IX. an Hartwig von Bamberg.

20 Gregor. VII. Epist. I. 1, n. 24 (J. n. 4795). Alexandri II. Epist. ad Ravengerum electum Aquileien. (J. n. 4504), ad Annonem archiep. Colon. und ad Hugon. abb. Clun. (ebd, n. 45074529 ). Vgl. auch Phillips, Kirchenrecht $\$ 241 ; \mathrm{V} 2,645$.

21 Bezeichnend sind die Worte Alexanders II. in seinem Brief an Ravengerus: Licet antiquis temporibus pallia absentibus metropolitanis aliquando concessa fuerint, ... tamen antecessores nostri, ... ad cautelam maxime simoniacae haereseos, quam in quibusdam nunc regionibus praevalere cognoscimus, ipsa solummodo praesentibus dari salubri consilio statuerunt. 
erklärte, freiwillige Gaben sollten nicht verboten sein, da in ihnen nichts Verkehrtes und Schuldbares liege ${ }^{1}$.

Wie lange diese Bestimmung in Kraft blieb, läft sich nicht sagen. Der Vertrag Leos II. (681-683) mit dem Erzbischof von Ravenna, kraft dessen der ravennatische Metropolitansitz in Zukunft von aller und jeder Palliumsportel frei sein sollte?, dürfte fast vermuten lassen, es sei damals wieder eine solche erhoben worden. Indessen stellt noch Papst Zacharias 744 einer Bemerkung des hl. Bonifatius gegenüber mit Entschiedenheit und voll Unwillen in Abrede, daf der Apostolische Stuhl für die Verleihung des Palliums eine Belohnung fordere und Geld verlange. 805 klagen aber die englischen Bischöfe bei Leo III., daf das Pallium gekauft werden müsse, während es früher umsonst verliehen worden sei ${ }^{3}$. Aus einem Briefe des hl. Anselm († 1109) ergibt sich, daßs man damals bei Empfang der Insignie einen Geldbetrag entrichtete ${ }^{4}$. Es erhellt indessen nicht, ob derselbe schon den Charakter der späteren sog. Palliumgelder hatte.

Daf man zu Rom infolge der Verhältnisse im Laufe der Zeit von der gregorianischen Praxis abging und eine Taxe bei der Palliumverleihung zu erheben begann, bedarf keiner Rechtfertigung. Man tat nur, was die Not der Lage erheischte. Die Palliumgelder sind seit dem ausgehenden Mittelalter Gegenstand mancher Anfeindung und Klage geworden, allerdings häufig mit Unrecht und in übertriebener Weise.

Der Treueid, welchen der Empfänger des Palliums abzulegen hat, scheint im 11. Jahrhundert aufgekommen $\mathrm{zu}$ sein. Er begegnet uns schon unter Paschalis II. $(1099-1118)^{5}$. In früherer Zeit war statt dessen die Ablegung der professio fidei üblich ${ }^{6}$. Johannes VIII. verweigerte dem Erzbischof Wilibert von Köln 873 das Pallium, bis derselbe statt der ungenügenden professio eine andere eingesandt habe?. Der Grund für die Einführung der Ablegung des Treueides lag in den Verhältnissen des 11. Jahrhunderts.

\section{LITURGISCHER CHARAKTER DES RÖMISCHEN PALLIUMS. SEINE VERWENDUNG BEIM GOTTESDIENST.}

Über den sakralen Charakter und die gottesdienstliche Verwendung des römischen Palliums schweigen sowohl Symmachus wie Vigilius, Pelagius I. wie Johannes III. Erst Gregor d. Gr. gibt uns in seinen Briefen darüber näheren Aufschlub. Das Pallium war, wie aus manchen seiner Schreiben mit aller Bestimmtheit hervorgeht, schon damals ein durchaus liturgisches Ornatstück, das nur innerhalb der Kirche, und zwar, falls nicht ein ganz besonderes Privileg einen weitergehenden Gebrauch gestattete, lediglich bei der Feier des heiligen Opfers getragen werden durfte ${ }^{8}$. Das erhellt namentlich aus dem Briefwechsel, welcher bezüglich der Verwendung der Insignie zwischen Gregor und Johannes von Ravenna geführt wurde ${ }^{9}$.

1 C. 5 (M. 77, 1337). Cf. Epist. 1. 5, n. 57

(M. G. Epp. I 364).

2 Vita Leonis II. (Dueh., L. P. I 360).

${ }^{3}$ M. 102, 1033.

4 Epist. n. 88 (M. 159, 244).

6 Epist. ad archiep. Spalat. (J, n. 6570).

${ }^{6}$ Liber diurnus n. 46 (Sickel 37); Conc. Ravenn. a. 877, c. 1; Z a c h a r i a P. Epist. ad Bonif. (M. G. Epp. IIJ 313).

7 J. n. 2986. Vgl. auch n. 2982, worin Bertulf von Trier zur Ablegung der professio fidei aufgefordert wird.
${ }^{8}$ Gregor. M. Epist. I. 4, n. 1; 1. 5, n. $61 ; 1.9$, n. $222227 ; 1.11$, n. 39 (M. G. Epp. I 232 375; II 213218311 ).

9 Ebd. 1. 3, n. 6654 ; 1. 5, n. 111561 ; I. 6, n. $31 ;$ I. 9, n. 167 (I 228211291295 375409 ; II 165). Es ist unzutreffend, wenn M. G. Epp. III 211, nota 2 das Schreiben 1. 3, n. 54 als das frühere, n. 66 als das spätere bezeichnet wind. Der Inhalt beider Briefe, namentlich aber der Abschnitt, welcher von der Mappula handelt, beweist klar, dafs umgekehrt n. 54 erst nach n. 66 zu setzen ist. 
Gregor hatte erfahren, daf sich Johannes eine zu ausgiebige Verwertung des Palliums gestattet habe. Er sollte es nicht blof bei der Messe, sondern auch bei den Litanien (Prozessionen), sowie bei der Entgegennahme der üblichen Begrüßüungen, die vor der Messe im Sekretarium (Sakristei) statthatten, verwendet haben. Die Sache führte zu einem längeren, lebhaften brieflichen Meinungsaustausch. Gregor tadelt das Verhalten des Erzbischofs mit ernsten Worten. Er betont, man habe, und solches sei Johannes nicht unbekannt, kaum je gehört, dafs sich irgend ein Metropolit in irgend einem Weltteil den Gebrauch des Palliums auferhalb der Meffeier angemafit habe. Der Erzbischof habe sich daher entweder der Gewohnheit aller Metropoliten anzuschliefen, oder nachzuweisen, daf3 der Kirche von Ravenna von Gregors Vorgängern ausgedehntere Privilegien verliehen worden seien. Könne er das letztere nicht, so solle er sich nicht weiter unterfangen, des Palliums sich auf der Strafe oder bei den Audienzen im Sekretarium zu bedienen.

In einem zweiten Schreiben gestattet dann Gregor auf Grund der Fürsprache hochstehender Personen dem Erzbischof, an vier Tagen, nämlich den Festen des hl. Johannes Baptist, der Apostelfürsten Petrus und Paulus und des hl. Apollinaris sowie am Jahrestage seiner Konsekration die Insignie bei dem feierlichen Zuge zur Kirche zu tragen. Aufserdem erlaubt er ihm, dieselbe bereits im Sekretarium nach dem Ende der Begrüfung, statt erst am Altar, anzulegen.

Das Zugeständnis des Papstes 'scheint den Erzbischof noch nicht befriedigt zu haben. Denn bald mufs sich Gregor in einem dritten Briefe wiederum darüber beklagen, daß3 Johannes das Pallium bei den Litanien zu häufig benutze. Zugleich bemerkt er diesem, er habe seinen Geschäftsträger in Konstantinopel beauftragt, bei allen Metropoliten, auch wenn sie 30 oder 40 Suffragane hätten, über den Gebrauch des Ornatstïckes Erkundigungen einzuziehen. Falls es sich finde, daf irgendwo die Gewohnheit bestehe, bei den Litanien mit dem Pallium zu gehen, so sei es fern von ihm, die Kirche von Ravenna in ihrer Ehre beeinträchtigen zu wollen.

Inzwischen starb Johannes, ohne dafs Gregor eine endgültige Entscheidung getroffen hatte. Dem neuen Erzbischof Marianus gestattete der Papst vielmehr nur, was er auch schon dessen Vorgänger erlaubt hatte. Als derselbe ihn jedoch durch seinen Diakon Florentius um weitere Vollmachten anging und ein gewisser Andreas, ein Mann von hohem Stande, ihn drängte, den angeblich alten Brauch der ravennatischen Kirche wiederherzustellen, befahl er seinem Notar Castorius wiederholt, eine genaue Untersuchung anzustellen, ob es wirklich in Ravenna Sitte gewesen sei, daß der Erzbischof bei allen feierlichen Litanien das Pallium trug, und welche Litanien als feierliche gegolten hätten. Wie die Sache auslief, ist nicht bekannt.

In welchem Umfang der Papst selbst vom Pallium bei kirchlichen Funktionen Gebrauch machte, ist aus den Briefen Gregors nicht zu ersehen. Es scheint jedoch, dafi derselbe es nicht blof bei der Messe, sondern auch bei sonstigen Gelegenheiten, insbesondere bei den feierlichen Prozessionen, anzulegen pflegte. Denn es muß auffallen, sowohl daf Gregor dem Erzbischof von Ravenna die Verwendung der Insignie bei einzelnen Litanien gestattet, als auch, daßs er gegenüber Johannes nie hervorhebt, wie sogar er selbst sich des Palliums nur bei dem heiligen Opfer bediene ${ }^{1}$.

Auch in der Folge bleibt das Pallium ein durchaus liturgisches Ornatstück. Es genüge, auf die Ausführungen der mittelalterlichen Liturgiker von Hraban an bis zu Innozenz III. und Durandus, auf die römischen Ordines,

\footnotetext{
1 Dak Gregor sich des Palliums je auch bei andern als kirchlichen Funktionen, also auch auferliturgisch bedient habe, ist mit den Anschauungen, die er namentlich Johannes von Ravenna gegenüber entwickelt, durchaus unvereinbar. Man vergleiche z. B. unter anderem die Worte: Et
}

quid dicturi sumus futuro iudici, frater dilectissime, se illud grave iugum atque vinculum cervicis nostrae, non dico pro ecclesiastica, sed pro quadam saeculari nobis dignitate defendimus (Epist. 1. 3, n. 54 [M. G. Epp. I 211]; vgl. auch I. 9, n. 213 [II 198]). 
auf die einschlägigen Bestimmungen des Corpus iuris canonici und besonders auf die Verleihungsbullen hinzuweisen. Es erscheint darin überall nur als liturgisches Gewandstück, und zwar als Sakralornat im ganz besondern Sinne, als Mebornat. Namentlich betonen die Bullen immer wieder, das Pallium werde ad missarum sollemnia tantum celebranda verliehen 1.

Allerdings fehlte es noch im 9. Jahrhundert nicht an weiter gehender, misbräuchlicher Benutzung des Ornatstuickes, so daf3 sich die unter Johannes VIII. 877 abgehaltene Synode von Ravenna veranlaft sah, im dritten Kapitel ihrer Dekrete denjenigen Metropoliten mit dem Verlust des Palliums zu bedrohen, welcher sich seiner auf der Strafse, bei den Litanien und an andern Tagen als den Hauptfesten und den sonstigen vom Apostolischen Stuhle festgesetzten Zeiten bei der Melfeier bediene?

Wie es sich ursprünglich mit dem liturgischen Charakter des Palliums verhalten habe, läßst sich mit Sicherheit nicht feststellen. Da dieses jedoch seit wenigstens dem Ende des 6. Jahrhunderts beständig als Sakralornat auftritt, da ferner kein Anhaltspunkt vorliegt, es sei das Pallium jemals ein auferliturgisches Abzeichen gewesen und erst später sakrale Insignie geworden, und da endlich das griechische Pallium schon im 4. Jahrhundert als im Dienste der Liturgie stehend erscheint, so kann es kaum zweifelhaft sein, daf das römische Pallium stets ein liturgisches Gewandstück war.

Eine ausdrückliche Angabe über die Tage, an welchen den Metropoliten bzw. den mit dem Pallium geschmückten Bischöfen das Tragen des Ornatstückes gestattet war, begegnet uns erst im 9. Jahrhundert; indessen müssen bereits früh darüber irgend welche Bestimmungen bestanden haben.

Bereits Gregor d. Gr. schreibt an Johannes von Palermo, er erlaube ihm das Pallium zu den Zeiten und in der Ordnung zu benutzen wie seine Vorgänger und die andern Bischöfe Siziliens. Ähnlich spricht der Papst in seinen Briefen an Donus von Messina und Johannes von Syrakus. Welcher Art diese Beschränkungen waren, und auf welche Tage sie sich bezogen, wird nicht näher angegeben. Bemerkenswert ist übrigens, dafs nur in den Schreiben an die drei sizilianischen Bischöfe, nicht aber in den sonstigen Briefen Gregors von solchen die Rede ist.

Einen sehr ausgedehnten Gebrauch des Palliums gestattete Leo IV. 851 dem Erzbischof Hinkmar von Reims auf Bitten Lothars, indem er ihm die tägliche Verwendung des Ornatstückes (cotidianum usum pallii, i. e. in diebus festis sive in consecratione episcoporum aut alio quoque tempore) erlaubte ${ }^{3}$. Es war das indessen gegen die gewöhnliche Praxis. Die Tage, für welche Nikolaus I. 860 dem Erzbischof Adalwinus von Salzburg das Tragen der

1 Vgl. die Bullen bei Mühlb. II $600 \mathrm{ff}$.

2 Hard. VI 186. Bei Ivo ist der Kanon als Dekret Honorius' I. (J. n. 2030) bezeichnet. In den römischen Ordines erscheint das Pallium auch beim Papst fast ausschlieflich als Meßornatstiuck. Als sonstige kirchliche Gelegenheiten, bei welchen derselbe es benutzte, werden darin nur bestimmte feierliche Prozessionen genannt, bei welchen der Papst die ganze Meßkleidung trug, ausgenommen die Mitra, an deren Stelle ex mit der Tiara geschmückt war. Vgl z. B. ordo 12, n. 33 und ordo 14 , c. 19 (M. 78, 1078 1130). Auch auf Synoden bediente sich der Papst des Palliums ( $E$ admeri Hist. novorum in. Anglia 1. 2 [M. G. SS.
XIII 143] : Papa non in cappa, sed in casula et pallio desuper redimitus concilio praesidebat).

${ }^{3}$ Die Verleihung, von der, Flodoard in seiner Hist, Rem. eccl. 1. 3, n. 10 (M. G. SS. XIII 482) erzählt, ist von Bona (1. 1, c. $24, \S 16$; II 272) und Pagi (Breviar. II 67) angezweifelt worden. Vgl. jedoch die neuerdings bekannt gewordenen Schreiben Leos an Lothar und Hinkmar (Ewald, Die Papstbriefe der britischen Sammlung, Epist. Leon. 12 13, in "Nenes Archiv" V 382) und neben dem Briefe Hinkmars an Nikolaus I. (Ep. 11, bei M. 126, 88 f) das Schreiben des letzteren an den Erzbischof (Ep. 108, bei M. 119,1110 ). 
Insignie zugestand, waren nur Ostern, die Apostelfeste, Mariä Himmelfahrt, Weihnachten und das Fest des hl. Johannes Baptist ${ }^{1}$. Einige Tage mehr enthielt die Bulle, in welcher Hadrian II. 868 Actardus von Nantes mit dem Pallium schmückte, doch ist die Zahl der Gelegenheiten auch hier noch sehr beschränkt 2. Als Herimann von Köln Johannes X. (914-928) um die Erlaubnis bat, die Insignie an allen Festtagen anlegen zu dürfen, gab ihm der Papst eine abschlägige Antwort ${ }^{3}$. Dagegen bekam Bruno von Köln 954 die aulierordentlich weitgehende Vollmacht, das Ornatstïck, so oft er es wolle, zu benutzen ${ }^{4}$. Im übrigen waren nach Ausweis der Verleihungsbullen schon im 10. und erst recht im 11. Jahrhundert die Tage, für welche der usus pallii erlaubt $\mathrm{zu}$ werden pflegte, fast die nämlichen wie heute ${ }^{5}$. Eine sehr beschränkte Ermächtigung wurde indessen noch 1052 dem Bischof Hartwig von Bamberg zu teil, da ihm von Leo IX. der Gebrauch der Insignie nur für drei Festtage zugestanden wurde ${ }^{6}$.

\section{DIE PALLIUMVERLEIHUNGEN IM VI. JAHRHUNDERT UND DER KAISER.}

In einigen Fällen von Palliumverleihungen vernehmen wir von einer Beteiligung des Kaisers bzw. seines Vertreters in Italien. Man hat der Sache eine zu große Bedeutung beigelegt und geglaubt, es sei der Papst bei der Erteilung des Palliums an die Mitwirkung des byzantinischen Hofes gebunden gewesen. Das ist jedoch durchaus unrichtig. Um jemand mit der Insignie zu schmücken, dazu bedurfte es für den Apostolischen Stuhl keinerlei Mitwirkung des Kaisers, dem weder das Recht des Vorschlags, noch der Verleihung, noch der Bestätigung, noch irgend eines Einspruches zustand. Doch sehen wir die Fälle etwas näher an, mit denen man beweisen hat wollen, es sei der Papst verpflichtet gewesen, zu einer Erteilung des Palliums die kaiserliche Genehmigung einzuholen. Es sind deren vier.

Zwei ereigneten sich unter Vigilius. Auxanius von Arles hatte den Papst um das Vikariat und das Pallium gebeten. Darauf antwortete dieser, er habe dem Verlangen mit bereitwilligem Herzen noch im gegenwärtigen Schreiben ohne Verzug entsprechen können. Jedoch habe er es für vernünftig gefunden, das mit Kenntnis des Kaisers zu tun, sowohl damit dem Bischof das Gewährte doppelt lieb komme, weil es ihm ja mit kaiserlicher Zustimmung zu teil werde, als auch damit man ihm selhst das Zeugnis gebe, er habe die Ehre des Glaubens des Kaisers in geziemender Achtung gewahrt, d. i. er habe auf den ,allerchristlichsten" Kaiser gemäßs dessen Interesse für den Glauben entsprechende Rücksicht genommen?. Anderthalb Jahre

1 M. 119,772 .

2 M. $122,1271$.

3 J. n. 3568 .

4 Ruotger, Vita Brunonis n. 27 (M. G. SS. IV 265).

$5 \mathrm{Vgl}$ z. B. L e o $\mathrm{n}$ is VII. Epist. ad Gerhard. arch. Laureac. (M. 132, 1071); I o a n n. XIII. Epist. ad Landulf. arch. Sipont. (M. 135, 977) und Mühlb. II 600 ff 608 ff.

6 M. 143, 700.

7 Vigil. Epist. ad Auxan. arch. Arelat. (M. G. Epp. III 59): De his vero, quae caritas vestra tam de usu pallei quam de aliis sibi a nobis petiit debere concedi, libenti hoc animo etiam in praesenti facere et sine dilatione potuimus, nisi cum christianissimi domni ..., sicat ratio postulat, voluissemus perficere notitia, ut et vobis gratior praestitorum causa reddatur, dum, quae postulastis, cum consensu christianissimi principis conferuntur, et nos honorem fidei eius servasse cum competenti reverentia indicemur. Es ist sonderbar, daf Lön ing, welcher (Geschichte des deutschen Kirchenrechts II, Straßburg 1878, 92 ff) für eine Abhängigkeit des Papstes vom Kaiser in Bezug auf die Verleihung des Palliums eine Lanze bricht, mit keinem Wort erwähnt, daf Vigilius ausdrücklich betont, er könne sofort und ohne Verzug den Bitten des Auxanius willfahren, und daf der Papst Auxanius und Aurelian 
später erteilt dann Vigilius in einem zweiten Briefe wirklich Auxanius das Vikariat. Dabei ermahnt er ihn, für Justinian und Theodora zu beten, welche zur Übertragung. desselben pia devotione ihre Zustimmung gegeben hätten. Er solle desgleichen Belisars im Gebet gedenken, auf dessen Anraten die Majestiten das getan. Zugleich fordert er ihn auf, auf Wahrung des Friedens zwischen Childebert und Justinian hinzuwirken. Schließlich fügt er noch hinzu: „Und weil wir es für angemessen erachten, dafs demjenigen, der unsere Stelle vertritt, der Schmuck des Palliums nicht fehle, so gewähren wir Dir den Gebrauch desselben, so wie ihn unser Vorgänger heiligen Gedenkens, Symmachus, Deinem Vorgänger verlieh, kraft der Autorität des hl. Petrus." Das ist der eine Fall ${ }^{1}$. Der andere begegnet uns kaum mehr als ein Jahr später.

Auxanius war gestorben. Sein Nachfolger hatte sich ebenfalls an Vigilius mit der Bitte um das Vikariat und das Pallium gewendet. Die Sache erledigt sich diesmal ungehend. In einem Briefe von 23. August 546 uiberträgt Vigilius Aurelian die päpstliche Stellvertretung. Zugleich schreibt er ihm: „Damit aber unser Vikar in keinem Punkte hinter seinen Vorgängern zurückzustehen scheine, halten wir es für nötig, ihm, wie wir es schon Eurem Vorgänger getan, kraft dieses Schreibens (praesenti auctoritate) den usus pallii zu gestatten." Der Brief des Papstes endet mit der Mahnung, es möge Aurelian mit allem Eifer dafür sorgen, daß die friedlichen Beziehungen zwischen dem Frankenkönig Childebert und Ost-Rom erhalten blieben. Dann aber möge er auch Belisar dafür danken, daß derselbe den Boten Aurelians der Mühe überhoben habe, an den kaiserlichen Hof zu gehen, indem er die Sache selbst rasch erledigt habe".

Die beiden andern Fälle ereigneten sich unter Gregor d. Gr. Der eine spielt im Osten. Kaiser Justin II. hatte den Patriarchen Anastasius von Antiochien von seinem Sitze verjagt. Gregor, der den Verbannten hochschätzte, wollte demselben eine Genugtuung gewähren. Er ging deshalb die kaiserlichen Herrschaften an, Ana-

das Pallium gewährt beati Petri sancta auctoritate, praesenti auctoritate. Warum das? Löning bringt doch die Stelle aus dera Brief an Aurelian von nisi cum, d. i. von da an, wo sie ihm paft, zum Abdruck. Freilich läßst sich so leichter von einer Verpflichtung des Papstes zur Einholung der kaiserlichen Genehmigung sprechen. Wenn Graf v. Hacke (Die Palliumverleihungen bis 1143 , Marburg 1898 , 106) zum ersten Brief des Papstes bemerkt: "Vigilius schreibt 543 Okt. 18 an Auxanius von Arles, er könne ihm das erbetene Pallium erst nach erhaltener Einwilligung des Kaisers ïbersenden, und wartet tatsächlich auch ab, ehe el es ihm $1 \frac{1}{2}$ Jahre später verleiht", so ist das letzte natürlich richtig, das erste aber schlechthin faisch. Gregor sagt ja ausdrücklich das Gegenteil. Durchaus ungenau ist es, wenn es ebendort heift: „Aus einer freilich verdächtigen Erzählung des. Agnellus (M. G. SS. Langob. 326) hören wir, daf Vigilius eine Konsekrierung und Palliumverleihung einmal direkt auf Befehl des Kaisers vorgenommen habe, die an Maximianus von Ravenna." Hier ist nur zutreffend, dak nach Agnellus Vigilius auf Befehl des Kaisers die Weihe vornahm; das Pallium verlieh dem Maximian nicht Vigilius, sondern der Kaiser, von dem die Ravennaten es angeblich erbeten hatten. Wozu übrigens mit einer
Angabe operieren, die rom Verfasser selbst als verdächtig bezeichnet wind und nach dem Zusammenhang nur eine Erdichtung des genugsam als romfeindlich bekannten Agnellus ist. Daf aber v. Hacke des weiteren meint: Wenn Vigilius die Intervention des Königs Childebert einmal ein mandatum, das andere Mal voluntas nennt, so ist in alledem wohl eine Einwirkung des byzantinischen Staatsrechtes zu erblicken, dessen Geschöpf Vigilius, der ehemalige Apokrisiar und Vertraute der "Theodora, selbst war", hat seinen Grund in einem Mifiverständnis der betreffenden Ausdrücke. Mandatum heißt an der fraglichen Stelle nur "Empfehlung*, voluntas aber "Geneigtheit": Childeberti ... in perhibeado vobis testimonio voluntas. Unverständlich ist, daß Graf v. Hacke noch an dem Phantasiegebilde einer fränkischen Nationalkirche festhält and behauptet (S. 107), der Papst sei bei Eingriffen in ihr Gebiet an das Einverständnis des Landesherrn gebunden gewesen, da er doch S. 128 bezinglich der Interventionen seitens fürstlicher Persönlichkeiten durchaus zutreffend bemerkt, es dürfe aus ihnen nicht gefolgert werden, der Papst habe das Pallium nur an die vom Herrscher vorgeschlagene Person verleihen können.

1 Ebd. III 62.

${ }^{2}$ Vigil. Epist. ad Aurel. archiep. Arelat. (VI. G. Epp. III 66). 
stasius nach Rom zu schicken und zuzulassen, daf derselbe sich dórt bei der Meffeier des Palliums bediene, damit er, wenn er nicht zu seinem Sitze zurückkehren dürfe, doch wenigstens bei Gregor in seiner Würde leben könne. Wir erfahren von diesen Bemühungen des Papstes in dessen Brief an Bischof Sebastian von Risano ${ }^{1}$

Der aweite betrifft den Bischof Syagrius von Autun. Brunhilde hatte Gregor gebeten, denselben mit dem Pallium zu schmücken. Der Papst spricht darob in seinem Schreiben an die Königin seine Freude und zugleich seine Bereitwilligkeit aus, ihrem Ansuchen zu willfahren, zumal auch der Kaiser, wie er das von seinem Geschäftsträger. vernommen, der fraglichen Verleihung geneigt gegenüberstehe, ja dieselbe durchaus wünsche ${ }^{2}$.

Das sind die vier Fälle. Handelt es sich nun bei irgend einem derselben um ein pflichtmäfiges Nachsuchen der kaiserlichen Zustimmung? Offenbar nein. Nehmen wir den letzten Fall. Einer Sache geneigt sein, etwas durchaus wünschen, heift noch lange nicht eine Art von Genehmigungs- oder Einspruchsrecht in Bezug auf dieselbe haben. Vieles kann uns sehr genehm sein; wir können vieles durchaus wünschen, ohne daf es uns darum zustände, irgend einen entscheidenden Einfluf darauf auszuüben. Ebenso sind es zwei durchaus verschiedene Dinge, eine Verpflichtung zur Einholung der kaiserlichen Genehmigung haben und sondieren, wie man sich in Byzanz zu irgend einem Projekt stelle, welche Stimmung demselben gegenüber am Hofe herrsche, und sich versichern, dafs dasselbe nicht nur keinen Schwierigkeiten seitens der Majestäten begegnen werde, sondern sogar deren Beifall habe. Das bedentet kein Abhängigkeitsverhältnis, sondern nur ein von berechtigter Staatsklugheit geleitetes Vorgehen, weiter nichts. Es gehört in der Tat eine eigenartige Auffassung dazu, um aus den Worten Gregors herauszulesen, es sei der Papst bei Verleihung des Palliums pflichtmäßig an die Zustimmung des Kaisers gebunden gewesen.

Noch klarer liegt die Sache im ersten und zweiten Fall. Vigilius sagt ja doch ausdrücklich, daßs er sofort, ohne Aufschub, also ohne den Kaiser in Kenntnis gesetzt zu haben, dem Auxanius Vikariat wie Pallium gewähren könne. Und wenn er Auxanius und Aurelian mit dem Pallium schmückt, so tut er es, wie er das ausdrücklich bemerkt, beati Petri sancta auctoritate, praesenti auctoritate. Klarer kann man wohl nicht sprechen. Und dann sagt ja auch Vigilius keineswegs, daf es seine Pflicht sei, dem Kaiser von seinem Vorhaben Mitteilung zu machen, und dafs er es bloß in Abhängigkeit von demselben ausführen könne. Er hält es nur aus Zweckmäßigkeitsrücksichten für vernunftentsprechend und angebracht, der kaiserlichen Majestät von der beabsichtigten Verleihung Kenntnis zu geben.

Obendrein handelt es sich in Sachen der Bischöfe Auxanius und Aurelian nicht sowohl um das Pallium, als vielmehr um das päpstliche Vikariat. Denn es ist sehr auffallend, daf3 Vigilius in seinem Briefe vom 22. Mai 545, in welchem er Auxanius beides verleiht, nur bezüglich der Stellvertretung die Zustimmung Justinians und Theodoras erwähnt, während er die Gewährung des Palliums schlechthin als sein eigenes Werk hinstellt. Was konnte dem Kaiser auch an dem Pallium viel liegen, welches Vigilius selbst nur als ornatus bezeichnet? Was ihn interessierte, war höchstens die Übertragung des Vikariats. Indessen kann bei unbefangener Würdigung. der Schreiben des Papstes nicht einmal von einer pflichtmäfigen Einholung der kaiserlichen Genehmigung für die Verleihung der päpstlichen Stellvertretung die Rede sein.

Was endlich den dritten Fall anlangt, so hat derselbe es überhaupt mit keiner Verleihung des Palliums an den Patriarchen zu tun; es handelt sich in demselben nur um die Ermöglichung einer ungestörten Benutzung des Ornatstückes seitens des Verbannten.

Allein man sagt, es lasse sich das Verhalten Vigilius' und Gregors ohne die Annahme, der Papst sei verpflichtet gewesen, zur Palliumverleihung die kaiserliche Genehmigung einzuholen, nicht genügend erklären ${ }^{5}$. Nun, es scheint denn doch nicht

1 Epist. 1. 1, n. 27 (M. G. Epp. I 41).

2 Ebd, 1. 8, n. 4 (ebd. II 5).
So Löning (a. a. O.) bezüglich des 1 , 2. und 4. Falles. 
schwer, für das Vorgehen beider eine völlig ausreichende und ungezwungene Erklärung: zu geben. Es sind Erwägungen politischer Klugheit, welche sie zu ihrem Handeln bestimmten ".

Vigilius kannte aus den Erfahrungen, die er gemacht, Byzanz sehr wohl. Er hatte Grund genug, zu fürchten, es werde die Verleihung des Palliums oder besser des Vikariats an Auxanius und Aurelian am Hofe übel gedeutet, ja vielleicht gar als Konspiration mit den Franken angesehen werden und darum nicht blok für ihn selbst allerlei Mißhelligkeiten, sondern auch eine Spannung zwischen Ost-Rom und dem Frankenreiche zur Folge haben ${ }^{2}$. Vigilius wollte dem vorbeugen und beschlofs deshalb, schwankend, zaghaft und überrücksichtsvoll gegen Byzanz, wie er nun einmal war, dem Kaiser seine ehrfurchtsvolle Gesinnung und seine Ergebenheit dadurch zu bekunden, daf er ihm von der Angelegenheit Mitteilung machte.

Gregor will in Sachen des Patriarchen Anastasius zweierlei. Er suchte einerseits dem hochverdienten und unschuldig verfolgten Manne, soweit es ihm möglich war, eine ehrenvolle Genugtuung zu teil werden zu lassen und doch anderseits Verwicklungen und Schwierigkeiten mit Ost-Rom in der Angelegenheit zu vermeiden. In der weiteren Verwendung des Omophorion durch Anastasius lag ja ausgedrückt, daf dieser sich vor wie nach als rechtmäßigen Patriarchen betrachtete und seine $A b$ setzung für ungültig ansah.

Rücksichtnahme auf die Umstände und Erwägungen der Klugheit sind es endlich auch, welche Gregors Verhalten in der Angelegenheit des Bischofs Syagrius bestimmten. Dem Papste lag es am Herzen, den Frieden zwischen dem Kaiser und der Königin zu befördern, sowie Brunhilde dem Beherrscher des römischen Reiches näher zu bringen und zu verpflichten. Eine weitere Bedeutung hat es nicht, wenn der Papst sich bei seinem Vertreter in Konstantinopel danach erkundigt, welche Stellung Byzanz dem Projekt gegenüber einnehme, und wenn er dann seine diesbezüglichen Wahrnehmungen gelegentlich dem Schreiben an die Königin einflicht.

Es ist wirklich nicht zu verwundern, daß nachgerade nicht mehr blof katholische Kanonisten die Theorie von einer Verpflichtung des Papstes, zur Verleihung des Palliums die kaiserliche Autorisation nachzusuchen, abweisen, sondern daß selbst Hinschius erklärt: "An den Konsens des römischen Kaisers ist der Papst bei Gewährung (des Palliums) nicht gebunden gewesen. Mehrfache derartige, vor derselben vom Römischen Stuhle gemachten Anfragen erklären sich wohl aus speziellen, nicht mehr festzustellenden Gründen, da in andern Fällen die Päpste jene Auszeichnung olne Berïcksichtigung des Kaisers erteilt haben." 3

In der Tat, wer vorurteilslos die Schreiben eines Vigilius, eines Gregor und der andern Päpste prüft, dem kann es nicht verborgen bleiben, dab es die Päpste und nur die Päpste waren, welche das Pallium verliehen, wie sie es auch allein waren, von denen es abhing, zu bestimmen, in welchem Umfang sich ein Metropolit des Palliums bedienen durfte, und wie sie es ferner allein waren, welche gegen eine unzeitige und der bestehenden Gewohnheit widersprechende Verwendung der Insignie einschritten.

Das Pallium kommt vom Sitze des hl. Petrus ${ }^{4}$, es ist ein Segensgeschenk ${ }^{5}$, eine Tröstung des Apostelfürsten ${ }^{6}$. Seine Gewährung erfolgte beati Petri sancta auctoritate, praesenti auctoritate 7 , also kraft der dem Papste inne-

1 Vgl, auch die trefflichen Ausfïhrungen Grisars (Rom und die fränkische Kirche VI) in Zeitschrift für katholische Theologie XIV, Innsbruck 1890, $488 \mathrm{ff}$.

2 Wie sehr es Vigilius um den Frieden zwischen den beiden Reichen zu tun war, beweisen die Briefe an Auxanius und Aurelian.
${ }^{3} \mathrm{Hins} \mathrm{chius}$, System des katholischen Kirchenrechtes, Berlin 1878, II 26.

4 Gregor. M. Epist. 1. 9, n. 228 (M. G. Epp. II 221).

5 Ebd. n. 227 (ebd. 218).

6 Ebd. n. 213 (ebd. 198).

7 Vgl. oben S. 635 . 
wohnenden und von Petrus stammenden apostolischen Machtvollkommenheit, gleichviel, ob die Empfänger Untertanen des Kaisers waren oder nicht. Wenn dabei aber in ein paar Fällen die Verleihung der Insignie erst nach einer Verständigung mit dem byzantinischen Hofe bzw. nach einer Sondierung von dessen IIünschen erfolgt, so gibt es eine weit größere Zahl anderer, in welchen von einem derartigen Vorgehen nicht das geringste verlautet. Und dann wird ja doch in den zwei bemerkenswertesten jener wenigen Fälle ausdrïcklich betont, daf der Papst das Pallium ohne weiteres geben könne, daf er es gebe beati Petri sancta auctoritate, praesenti auctoritate.

Man hat freilich gemeint, der Papst habe dann wenigstens zu einer Verleihung des Palliums der Zustimmung des Kaisers bedurft, wenn es sich bei der Person des Empfängers um einen Nichtumtertanen desselben gehandelt habe. Aber es sagt doch Vigilius gerade bezïglich eines solchen, nämlich bezügIich des Auxanius, dafs er alsbald und olne Verzug und ohne den Kaiser von der Sache zu benachrichtigen, seiner Bitte um Vikariat und Pallium entsprechen könne. Obendrein beweist auch das tatsächliche Verhalten der Päpste das Willkürliche und die Haltlosigkeit jener Theorie. Wie Sapaudus von Arles von Pelagius I., so erhalten Leander von Sevilla und Augustinus von Canterbury von Gregor I. das Ornatstück, ohne daf dabei irgendwie des Kaisers gedacht wurde. Ebenso stellt Gregor die Insignie den zukünftigen Metropoliten von York und London in sichere Aussicht, ohne die Notwendigkeit irgend einer Genehmigung seitens des byzantinischen Hofes auch nur im geringsten anzudeuten.

Es ist selbst grundlos und zu viel behauptet, wenn man mit Duchesne ${ }^{x}$ auch nur sagt, es hätten die Päpste im 6. Jahrhundert die Gew ohnheit gehabt, bei einer Terleihung des Palliums an Bischöfe, welche keine Untertanen des griechischen Reiches waren, zuvor die Autorisation des Kaisers nachzusuchen. Ganz abgesehen tavon, daf sie in derartigen Fällen sich niemals eine Ermächtigung erbeten haben - sie bedurften einer solchen weder, noch hatten ihre Schritte den Charakter einer Bitte um Autorisation -, die Päpste des 6. Jahrhunderts haben bei Ausübung der ihnen durchaus eigenen Gewalt, einem Bischof das Pallium zu verleihen, nur dann dem byzantinischen Hofe von ihrem Vorhaben Mitteilung gemacht oder auf die Wünsche des Kaisers Rücksicht genommen, wenn ihnen das in Anbetracht der besondern Verhältnisse zweckdienlich oder durch die Umstände geraten schien. Wie kann man zudem bei nur drei Fällen (Auxanius, Aurelian und Syagrius) von einer Gewohnheit reden, zumal, da in andern von einer Verständigung mit dem Hofe von Byzanz absolut keine Rede ist?

Was von der Stellung des Kaisers zur Verieihung des Palliums gesagt wurde, gilt in erhöhtem Maße in Bezug auf die Intervention anderer Fürsten. Irgend ein Recht, an dessen Erteilung mitzuwirken, sei es auch nur durch Genehmigung derselben, hat diesen noch viel weniger als den Beherrschern Ost-Roms jemals zugestanden. Nicht einmal die fränkischen Herrscher haben sich trotz ihrer angeblichen Nationalkirche eine solche Befugnis beigelegt. Die erste, welche von ihnen überhaupt bei einer Palliumverleihung interveniert, ist Brunhilde im Falle des Bischofs Syagrius von Autun ${ }^{2}$. Wenn Childebert I. bei Vigilius für Auxanius, Aurelian und Sapaudus von Arles ${ }^{3}$ und Childebert II. bei Gregor für Virgilius von Arles ${ }^{4}$ sich verwendeten, so handelte es sich in allen diesen Fällen nicht um das Pallium, sondern um das Vikariat.

Die Intervention der Fürsten erfolgte lediglich durch Wunsch, Bitte und Empfehlung. Es liegt aber auf der Hand, daß die Päpste, wo nur immer

1 Orig. 385.

2 Gregor. M. Epist. 1. 8, n. 4 (M. G. Epp. II 5).

3 Epist. Arelat. n. 51 (M. (1. Epp. III 75).
${ }^{4}$ Gregor. M. Epist. 1. 5, n. 60 (M. G. Epp. I 373). Die Intervention exfolgte aber auch in diesen Fällen nur mittels Wunsch und Empfehlung. 
die Umstände es gestatteten, den Herrschern bereitwilligst entgegenkamen. Lag es doch im Interesse ihres Wirkens zum Heile der Kirche, das sie mit den weltlichen Machthabern, soweit nur möglich, in gutem Einvernehmen lebten.

Interventionen von Fürsten bei Palliumverleihungen kamen namentlich in der früheren Zeit häufiger vor. Hier einige Beispiele: König Edwin interveniert 634 bei Honorius I. für die Erzbischöfe Honorius von Canterbury und Paulin von York (quae sperastis) ${ }^{1}$, Karl d. Gr. ea 775 bei Hadrian I. für Tilpin von Reims (ad petitionem) ${ }^{2}$ und ca 790 für Erminbert von Bourges (affatibus vestris) ${ }^{3}$, Lothar bei Leo IV. ca 850 für Alteus von Autun (mandastis, ut concederemus) *, Salomo, König der Bretonen, 865 bei Nikolaus I. für Festinian von Dol (deprecamini) ${ }^{5}$, Ludwig II. bei Johannes VIII. 873 für Bertulf von Trier (cotidianis precibus) ${ }^{6}$ und 874 für Willibert von Köln (interveniente domno Ludovico) ${ }^{7}$, Karlmann bei Johannes VIII. 877 für Theotmar von Salzburg (imperatoris petitione) ${ }^{2}$, Otto I. bei Johannes XIII. 968 für Adalbert von Magdeburg (petitione)", Heinrich III. bei Klemens II. 1047 für Eberhard von Trier (supplicatio imperatoris) ${ }^{10}$, die Gräfin Mathilde bei Urban II. 1092 für Daimbert von Pisa (precibus) ${ }^{11}$, Alfons von Kastilien bei Paschalis II. 1104 für Didacus von Compostela (precibus) ${ }^{12}$ u. a. Die Interventionen hatten in späterer Zeit besonders dann statt, wenn sich der Palliumverleihung an einen Erzhischof persönliche oder sonstige Schwierigkeiten entgegenstellten, oder wenn es sich um eine Auszeichnung für einen Bischof handelte.

\section{BEDEUTUNG DES PALLIUMS.}

In der Kirche des Ostens erscheint das Pallium (Omophorion) schon um den Beginn des 5. Jahrhunderts als Symbol des bischöflichen Hirtenamtes. Es sollte das Bild des verlorenen Schäfleins darstellen, welches zur Herde zurückzutragen der Bischof als der Nachfolger des guten Hirten die Aufgabe hat. Nicht so in der römischen Kirche, wo das Pallium ausschlieflich dem Inhaber des Apostolischen Stuhles vorbehalten war. Hier wird es in der älteren Zeit nie als Symbol des bischöflichen Hirtenamtes bezeichnet, obschon doch Gregor d. Gr. diejenigen, welchen er das Pallium sendet, melirfach zur sorgfältigen Erfüllung ihrer bischöflichen Amtspflichten auffordert und die Formulare des Liber diurnus teilweise sogar weitläufig dazu ermahnen. Vielleicht bietet der Brief Kilemens' II. an den Bischof Johannes von Salerno eines der ersten Beispiele für das Vorkommen dieser Symbolik im Abendlande 13. In Rom hat das Pallium, sobald es uns daselbst entgegentritt, den Charakter einer den römischen Bischof als solchen kennzeichnenden Insignie und eines Abzeichens seiner papalen oder doch wenigstens patriarchalen Gewalt ${ }^{14}$.

1 J. n. 2019.

3 Ebd. n. 2475.

5 Ebd. n. 2789.

7 Ebd. n. 2988.

9 Ebd. n. 3728.

11 Ebd. n. 5464.

12 Ebd. n. 5986. Andere Beispiele sind mit großem Fleiß zusammengestellt bei v. Hacke, Die Palliumverleihungen $127 \mathrm{f}$.

13 J. n. 4143; vgl, auch ebd. $415 \mathrm{1}$ (Palliumverleihung an Eberhard von Trier).

14 Ob der Inhaber des Apostolischen Stubles das Pallium zu allen Zeiten als Primas der ganzen Kirche oder anfünglich nur als Patriarch des Abendlandes getragen habe, dürfte kaum zu entscheiden sein. Nach Liutprand von Cremona (Legat. Constant. c. 62 [M, G. SS. III 361]) hätte der Patriarch von Konstantinopel bis zu Johannes XII. zum Gebrauch des Palliums der Erlaubnis des Apostolischen Stuhles bedurft; doch kann diese Angabe auf Richtigkeit keinen Anspruch erheben, da Liutprand zu wenig glaubwürdig ist und fuir seine Mitteilung eine sonstige Bestätigung fehlt. Im Gegenteil ist es kaum zu bezweifein, dafs die Patriarchen des Ostens weder das Pallium vom Papst empfingen, noch dafs sie dessen Genehmigung zum Tragen der Insignie einholten (Ljherat. Breviar. Hist. Nest. c. 20 [M. 68, 1036]). 
Als Papst Felix seinen Archidiakon Bonifatius zu seinem Nachfolger bestimmt, übergibt er ihm zum Zeichen dessen sein Pallium. Ferner war es, wie aus dem Liber diminus hervorgeht, schon wenigstens im 8. Jahrhundert Brauch, den Papst bei seiner Konsekration mit dem Pallium zu bekleiden ". Umgekehrt berauben Belisar und Kaiser Konstantius die Päpste Silverius ${ }^{2}$ und Martin ${ }^{3}$ gewaltsam des Ornatstückes, als sie dieselben eigenmächtig und widerrechtlich absetzen. Ebenso nimmt die römische Synode des Jahres 769 dem Usurpator Konstantin die angemaßste Würde, indem sie unter anderem ihm das Pallium abreißen läßst *

Unter solchen Umständen könnte es scheinen, es seien die Palliumverleihungen seitens des Apostolischen Stuhles stets der Ausdruck der Übertragung besonderer geistlichen Vollmachten und der Gewährung irgend einer Anteilnahme an der papalen oder patriarchalen Obergewalt gewesen. Dem ist indessen nicht so. Die Erteilung des Palliums hatte vielmehr ursprünglich nur den Charakter einer Auszeichnung, gerade wie noch jetzt bei Suffraganen, und das nicht blof bei einfachen Bischöfen, sondern auch bei den Metropoliten und päpstlichen Vikaren.

Daf das Pallium bei einem Suffragan an sich keinerlei Vorrechte und Vollmachten einbrachte, erfahren wir aus Gregors d. Gr. Schreiben an Syagrius von Autun 5. Der Papst bezeichnet ja darin die Verleihung des Ornatstückes an den Bischof als nuda munificentia; darum, sagt er, gewähre er Syagrius aufer dem Pallium das Recht der Präzedenz, ne indumenti munificentiam nudam videamur quodammodo contulisse.

Indessen lag auch bei den Metropoliten und päpstlichen Vikaren die Sache nicht anders. Allerdings hatte bei ihnen das Privileg vornehmlich in ihrer hervorragenden Stellung seinen Grund. Trotzdem bestand ursprủnglich zwischen der Verleihung des Palliums und der Übertragung der Metropolitanund Vikariatsbefugnisse nur ein sehr loser und blok äuferlicher Zusammenhang. Wie die Ausübung der Metropolitan- und Vikariatsvollmachten noch nicht an den Empfang des Palliums geknüpft war, so erfolgte auch deren Mitteilung noch nicht durch die Gewährung des Ornatstückes. Das Pallium war lediglich eine Ehrenzugabe, welche der Würde eines Metropoliten oder päpstlichen Vikars je nach dem Ermessen des Apostolischen Stuhles beigefügt wurde. Man konnte Metropolit sein, ohne das Pallium zu besitzen, und anderseits des usus pallii verlustig gehen, ohne zugleich der Stellung entsetzt zu werden. Ebendarum war denn auch das Pallium noch keine Insignie der Metropoliten, welche diese von den einfachen Bischöfen unterschieden hätte.

Es galt das den Vikaren und Metropoliten verliehene Pallium nicht einmal ursprünglich als Sinnbild der denselben verliehenen besondern Gewalt.

Eine solche Symbolik ist nicht nur den Schreiben der vorgregorianischen Päpste, sondern auch noch denen Gregors, ja selbst noch den offiziellen Formularen des Liber diurnus so gut wie völlig fremd ${ }^{6}$. Das Pallium wird darin überall nur als Ehrenschmuck (ornatus, decus, habitus praeclarus, exterioris cultus ornatus, honoris beneficium) bezeichnet. Insbesondere ist das in den Briefen Gregors der Fall, welcher die Verleihung des Palliums fast

1 N. 57 (Sickel, T. D. 46).

2 Vita Silverii (Duch., L. P. I 293).

3 Commemoratio (M. 129, 595).

4 Vita Stephani III. (Duch., L. P. I 472).

Das Pallium heist hier orarium; ebenso in der Vita Agath. (ebd. 354).

5 Epist. 1. 9, n. 222 (M. G. Epp. II 213 ).
${ }^{6}$ Nur einmal erscheint das Pallium bei Gregor d. Gr. als Symbol der Metropolitenwürde, nämlich in einem Briefe an den Apostel Englands (Epist. 1. 11, n. 39 [M. G. Epp. II 312]): Usum pallii tibi concedimus, ita ut per loca singula duodecim episcopos ordines, qui tuae subiaceant dicioni. 
regelmä6ig mit der Mahnung begleitet, es solle der Empfänger dafür sorgen, daf dem äuferen Schmuck die innere Tugendzier entspreche, und zugleich vor Überhebung zu warnen pflegt.

Dagegen dürfte schon früh die Verleihung bzw. das Nachsuchen und die Entgegennahme des Ornatstückes Ausdruck der Einheit und Eintracht zwischen dem Apostolischen Stuhl und den Metropoliten gewesen sein.

Mit Bestimmtheit läfst sich diese Auffassung allerdings erst für das 8. Jahrhundert in einem Formular des Liber diumus ${ }^{1}$ und in einem Briefe des Papstes Zacharias an den hl. Bonifatius nachweisen?2. Dafs sie sich aber nicht erst damals gebildet, geht aus dem Verhalten des Erzbischofs Maurus von Ravenna ( $†$ 671) hervor, welcher zum Zeichen der Autokephalie Ravennas (Unabhängigkeit vom römischen Patriarchalsitz) vom Kaiser statt vom Apostolischen Stuhle sich das Pallium erbat ${ }^{3}$.

Eine bestimmtere, immer schärfer sich ausprägende Bedeutung erhielt das Pallium, als in der karolingischen Zeit sich in der Praxis der Palliumverleihungen ein bedeutungsvoller Wechsel zu vollziehen begann.

Das römische Pallium kam bei allen Metropoliten in Brauch. Es wurde sogar die Ausübung nicht nur der erzbischöflichen, sondern selbst pontifikaler Funktionen von dem Fmpfang desselben abhängig. Den Metropoliten brachte erst die Verleihung des Palliums die vollen Metropolitan- und bischöflichen Rechte samt dem Titel. Sie und nur sie machte jene zu rechtmäßigen Vertretern des Papstes im Bereich ihrer Provinz. Infolgedessen lag es denn auch nicht länger mehr in ihrem Belieben, um das Pallium zu bitten oder auf dasselbe zu verzichten. Sie hatten es vielmehr innerhalb einer bestimmten Frist nach ihrer Wahl bzw. ihrer Konsekration beim Apostolischen Stuhle nachzusuchen. Die Verleihungsbullen des 10. Jahrhunderts bieten für alles das reiche Belege.

Unter solchen Umständen kann es natïrlich nicht wundernehmen, dak das Pallium immer bestimmter als Symbol der Metropolitangewalt und als erzbischöfliche Insignie erscheint und zuletzt schlechthin Ausdruck und Inbegriff der pontifikalen Gewalt ist und die plenitudo pontificalis officii darstellt.

Das Pallium, sagt Hraban, ziert den Erzbischof, weil er Stellvertreter des Papstes ist. Amalar, Pseudo-Alkuin und später Robert Paululus nennen es das Unterscheidungsmerkmal zwischen den Metropoliten und den gewöhnlichen Bischöfen. Rupert von Deutz und Honorius sehen in seiner Verleihung die Übertragung der Metropolitanvollnachten. Fülle des pontifikalen Amtes heifst das Pallium bei Innozenz III. "Das Pallium heifst die plenitudo pontificalis officii", sagt dieser, "weil in ihm und mit ihm die Vollgewalt des pontifikalen Amtes verliehen wird. Denn bevor der Metropolit mit dem Pallium geschmückt wird, darf er weder Kleriker ordinieren noch Bischöfe konsekrieren, noch Kirchen weihen, noch überhaupt Erzbischof tituliert werden."

In den Verleihungsbullen wird das Pallium erst im 11. Jahrhundert ausdrücklich als erzbischöfliche Insignie bezeichnet. Anfangs sind die diesbezüglichen Formeln noch schwankend und unbestimmt: tuae dignitatis insigne ${ }^{4}$, supplementum totius sacerdotalis ordinis ${ }^{5}$, bis sich gegen Ende des Jahrhunderts unter Urban II. der Ausdruck schärfer präzisiert: plenitudo omnis sacerlotalis dignitatis ${ }^{6}$, pontificatus plenitudo ${ }^{7}$ und zuletzt in plenitudo pontificalis officii ${ }^{\text {s }}$ verdichtet. Damit ist die Formel

1 N. 47 (Sickel, L. D. 38).

2 N. 58 (M. G. Epp. III 315).

3 A g elli, Liber pontif., Vita Mauri n. 110112 (M. G. SS. Langob. 349 ff). Pallium ab imperatore petite, quacumque enim die Romae subiugati fueritis, non eritis inBraun, Die ]iturgische Gewandung. tegri (n. 113 [ebd. 352]), mahnte Maurus die Ravennaten noch vor dem Tode.

4 J. n. 40985204.

s Ebd. n. 52585412.

6 Ebd. n. 53665450.

7 Ebd. n. 5386. 8 Ebd. n. 5464. 
gemünzt, welche von da ab dauernde Geltung haben sollte und darum konstant wiederkehrt. „Im Pallium ", heifst es z. B. bei Pelagius II., wird die Fülle der pontifikalen Gewalt gewährt, da es gemäfs der Gewohnheit des Apostolischen Stuhles und des ganzen Europa den Metropoliten vor Empfang des Palliums durchaus nicht gestattet ist, Bischöfe zu weihen oder Synoden zu halten." "

Seitdem das Pallium eine gesteigertere Bedeutung gewonnen hatte, begann man auch, mit der Sitte, dasselbe vor seiner Weihe oder seiner Versendung auf das Grab des Apostelfürsten niederzulegen, eine besondere Symbolik zu verbinden. Das Pallium war die verkörperte Fülle des bischöflichen Amtes geworden. Diese plenitudo pontificalis officii hinwiederum stammt von Petrus her, welchem der Heiland die Binde- und Lösemacht für die ganze Kirche übertragen hatte. Das war es denn, was man nunmehr in jener Hinterlegung des Palliums sinnfällig ausgedrückt fand. Wie dem Erzbischof das Pallium kam de corpore beati Petri, so die erzbischöfliche Vollgewalt von dem in den Päpsten fortlebenden Apostelfürsten. Angedeutet findet sich diese Symbolik bereits im Schreiben Paschalis' II. an den Erzbischof von Spalato ${ }^{2}$.

Wie alt der Brauch ist, das Pallium auf dem Grabe des Apostels zu deponieren, läßst sich nicht feststellen. Bestimmte Zeugnisse haben wir für ihn erst aus dem 12. Jahrhundert ${ }^{3}$. Da indessen selbst die Orarien im 9. Jahrhundert vor der Ordination der Diakone und Priester auf die Confessio Petri gelegt zu werden pflegten ", so dürfte ähnliches damals auch wohl schon mit dem Pallium geschehen sein. Sehr fraglich erscheint, ob bereits in den Worten Gregors d. Gr.: Reverendissimo autem fratri et coepiscopo nostro Leandro pallium a beati Petri apostoli sede transmisimus, ein Hinweis auf jene Gewohnheit enthalten ist ${ }^{5}$.

\section{GESTALT UND BESCHAFFENHEIT DES PALLIUMS.}

Zwischen dem Pallium der frühchristlichen Zeit und demjenigen der Gegenwart besteht nach Anlegeweise wie Beschaffenheit eine grofie Verschiedenheit. Wie mit den übrigen liturgischen Gewändern, so sind auch mit dem Pallium im Laufe der Zeit manche Veränderungen vor sich gegangen. Dabei hat sich auch bei ihm dieselbe Erscheinung wiederholt, welche wir bei der Entwicklung der andern Kultgewänder gewahren: die Umbildung, welche sich allmählich mit dem Ornatstück vollzog, ist nicht zu seinem Vorteil gewesen; sie war nicht sowohl eine Weiterbildung als eine Verbildung. Aus dem in leichtem, lebendigem und malerischem Flusse die Brust, die Schultern und den Nacken umschlingenden Bande ist ein schmächtiger Ring geworden, von welchem vorn und rückwärts ein kurzer Streifen steif herabhängt. Welch ein Gegensatz, wenn wir ein modernes Pallium neben eines

1 J. n. 6570 . Vgl. auch ebd. n. 59045914 5948608868317039709971367231 usw. sowie ordo 12, n. 81, wonach der Archidiakon, wenn er dem Papst nach dessen Konsekration das Pallium überreichte, sprach: Accipe pallium, plenitudinem pontificalis officii etc.

2 M. 168, 428: Quum igitur a sede apostolica vestrae insignia dignitatis exigitis, quae a beati Petri tantum corpore assumuntur, iustum est, ut vos quoque sedi apostolicae subiectionis debitae signa solvatis.

${ }^{3}$ Petri II 11 i i Hist. Vatic. Conf. ad Alex. III. (A. SS. Iun. VII, app. 35*). Addit. ad
Petr. Ma 11. Hist. (ebd. 104*). Vgl. auch die vorgenannte Bulle Paschalis' II.

4 Vgl. oben S. 580.

5 Epist. 1. 9, n. 228 (M. G. Epp. II 221). Unmittelbar vorher sagt Gregor: Clavem parvulam a sacratissimo beati Petri apostoli corpore vobis (nämlich König Reccared) pro eius benedictione transmisimus. Würe das Leander gesandte Pallium vom Grab des Apostels genommen worden, so hätte, scheint es, der Papst statt a beati Petri apostoli sede auch wohl a beati Petri apostoli corpore geschrieben. 
der alten Papstbilder auf den römischen Mosaiken, etwa neben dasjenige der Päpste Symmachus und Honorius in S. Agnese, halten (vgl. Bild 293, S. 626 und Bild 64, S. 160)!

Für die Geschichte der Umbildung des Palliums sind wir hauptsächlich auf die zum Glück zahlreichen Monumente angewiesen. An schriftlichen Angaben, die uns über die Entwicklung der Insignie Aufschluß geben, ist nur sehr wenig vorhanden, von Originalpallien aber ist beinahe so viel wie nichts auf uns gekommen, weil schon früh der Brauch bestand, das Ornatstiick dem Toten ins Grab mitzugeben.

Im ganzen haben sich unseres Wissens aus dem Mittelalter nur vier Pallien erhalten. Zwei befinden sich zu St-Trophime in Arles. Eines von ihnen ist 2,40 $\mathrm{m}$ lang und $0,09 \mathrm{~m}$ breit. Es besteht aus sehr feiner, weifer Wolle und ist statt mit Kreuzen mit dem Monogramm Christi und den griechischen Buchstaben II im Kettenstich mittels roter Seide bestickt. Das zweite Pallium ist etwas kiirzer; denn es ist nur 1,75 m lang. Zweifelsohne ist es etwas verkürzt. Seine Breite ist die gleiche wie die des ersten Palliums; ebenso ist es wie dieses aus weifier Wolle gemacht. Als Verzierung sind ihm drei Kreuze aufgenäht, die aus rotem, damastartigem Seidenstoff hergestellt sind ${ }^{1}$.

Die beiden andern Pallien werden in del Pfarrkirche zu Siegburg aufbewahrt. Sie stammen von den hll. Heribert und Anno. Wir werden später auf sie zurückkommen. Spärliche Fragmente eines Palliums, das man bei den jüngsten Restaurationsarbeiten des Domes zu Trier im Grabe des Erzbischofs Otto von Ziegenhain $(\dagger 1430)$ antraf, sind im Trierer Dommuseum niedergelegt. Von den Pallien, welche gelegentlich früherer Herstellungsarbeiten bei den Tueichen der Trierer Erzbischöfe gefunden wurden, hat v. Wilmowsky zwei in seiner Schrift über die Grabbefunde im Dom zu Trier wiedergegeben. Leider hat er unterlassen, von ihnen wie von den andern Pallien, die damals entdeckt wurden, eine nähere Beschreibung zu geben?

Die ältesten Darstellungen des römischen Palliums erscheinen, wie schon bemerkt wurde, auf den Mosaiken vou S. Apollinare in Classe und von S. Vitale zu Ravenna (vgl. Bild 63, S. 159). Zu Rom besitzen wir Abbildungen des Ornatstückes erst auf Bildwerken, die der Frühe des 7. Jahrhunderts entstammen, nämlich den Mosaiken in S. Agnese fuori le Mura (vgl.

1 De Linas, Rap. sur les vêtements sacerdot. 47. Roh. VIII 48. Die Pallien werden dem hl. Cäsarius von Arles zugeschrieben, doch rührt das kleinere wohl sicher nicht von ihm her; die drei roten Damastkreuze bekunden das. Beim größeren ruft der Umstand, dak es statt mit Kreuzen mit dem Monogramm Christi bestickt ist, sogar Bedenken wach, ob es überhaupt ein Pallium ist.

${ }^{2}$ v. Wilmowsky, Die historisch denkwürdigen Grabstätten der Erzbischöfe im Dom zu Trier THl 2. Wenn Forrer (Römische und byzantinische Seidentextilien $19 \mathrm{ff}$; dazu TH 916 17) von einer in Achmîm-Panopolis gefundenen 2,17 crn langen, mit aufgesetzten Seidenstückchen und eingesticktem Bildwerk geschmückten Leinwandbiode sagt: „Dje kleinen Seidenfragmente dirften vielleicht als Reliquien zu deuten sein.... Dies allein gibt eine befriedigende Deutung der kleinen, unscheinbaren Gewebeappliquen.... Dieses (Pallium) wurde wiederum durch jene Reliquienappliquen geweiht, und auch nur ein Geweihter, d. h. (!) ein Priester hohen Ranges, Bischof oder Erzbischof, kann der Träger dieses Ornatstückes gewesen sein... Wir dürften kaum fehlgehen, wenn wir diese Seidenstickerei als ein vom Papst einem ägyptischen Erzbischof verliehenes päpstliches Insignum, direkt als italisch-römisches Kunstwerk bezeichnen " so haben wir diese Auslassungen zwar schon früher (Pontifikale Gewänder, Freiburg 1898, 161) als blofe Produkte der Phantasie charakterisiert, glauben aber, auch hier solches noch einmal tun zu sollen. Vgl. auch S. 13, Anm. 1. 
Bild 64, S. 160 und Bild 293, S. 626) und im Oratorium des hl. Venantius beim lateranensischen Baptisterium 1. Dem Beginn des 8. Jahrhunderts gehört das Bild des mit dem Pallium geschmückten Johannes VII. aus dem ehemaligen Marienoratorium der vatikanischen Basilika an, das sich nunmehr in der Unterkirche von St Peter befindet. Es ist zwar vielfach überarbeitet, weist aber in den Hauptlinien noch die ursprünglichen Formen auf?

Auf allen diesen Bildwerken stellt das Pallium ein langes, mittelbreites Band von weiker Farbe dar, das seinem unteren Ende zu mit einem schwarzen oder roten Kreuze verziert ist und mit Fransen abschliebt. Es ist in der Weise um Brust, Schultern und Nacken geführt, daf es vorn eine Wendung bildet, und daf von der linken Schulter das eine der beiden Enden nach vorn, das andere nach hinten herabsteigt.

Über den St off, aus welchem das Pallium bestand, erfahren wir natürlich durch die Bildwerke nichts. Die beiden Pallien zu Arles sind aus Wolle gemacht. Dagegen war dasjenige, welches man unter Gregor IV. im Sarge Gregors d. Gr. fand, nach Johannes Diakonus aus Byssus; also aus feinem Linnen bzw. aus Baumwolle angefertigt ${ }^{3}$, vorausgesetzt, daf der Berichterstatter unter byssus einen Linnen- oder Baumwollstoff und nicht vielmehr überhaupt ein feines weißes Gewebe ohne Rücksicht auf das Material versteht 4. Noch um die Wende des ersten Jahrtausends brauchte das Pallium keineswegs unter allen Umständen aus Wolle zu sein. Mochte dasselbe damals auch für gewöhnlich und der Regel nach aus solcher angefertigt sein, so waren andere Stoffe jedoch noch nicht schlechthin unzulässig. Das beweist die Bulle, in welcher Johannes XV. 989 dem Erzbischof Liavizo von Hamburg das Pallium verleiht. In einer Nachschrift nämlich teilt der Papst dem Erzbischof mit, er überschicke ihm zugleich mit der Bulle ein Pallium, und erlaube ihm obendrein, dieses oder ein anderes, von welcher Art es sein möge, zu gebrauchen, vorausgesetzt, daf es von weifer Farbe sei ${ }^{5}$.

$\mathrm{Nadeln}$ wurden zur Befestigung des Palliums ursprünglich nicht angewandt. Denn Johannes Diakonus verzeichnet ausdrücklich, man habe bei Erhebung des Leibes Gregors d. Gr. die Wahrnehmung gemacht, dafs das Pallium um die Schultern bloß herumgeschlungen, nicht aber mit Nadeln (acubus) befestigt gewesen sei, gerade wie man das auch an den ältesten Mosaiken und Malereien bemerke ${ }^{6}$. Die drei noch jetzt gebräuchlichen acus oder spinulae mögen im Verlauf des 8. Jahrhunderts in Gebrauch gekommen sein. Jedenfalls müssen sie vor der Mitte desselben schon Verwendung gefunden haben, da der Diakon oder Subdiakon, welcher dem Papste das Pallium anlegte, bereits nach Anweisung des ersten römischen Ordo das Ornatstück

1 Vgl. wegen der Fresken in S. Callisto oben S. 159.

2 Grisar, Das römische Pallium, in Festschrift zum 1100jährigen Jubiläum des Campo Santo" 89. Das allerdings stark restaurierte Mosaik aus S. Apollinare in Classe, den Bischof Reparatus darstellend, wäre wohl auch noch hier zu erwähnen ( ( a r r tav. $275^{2}$ ).

${ }^{3}$ Vita Gregor. 1. 4, n. 80 (M. 75, 228).

4 Úber die Bedeutung von byssus sind viele Erörterungen angestellt worden. Eine Zusammenstellung derselben bei $\mathrm{Pauly}$, Realencyklopädie $\mathrm{III}^{2}$ 1108. Im Mittelalter scheint byssus nicht immer ein Zeug aus be- stimmtem Material, sondern auch wohl allgemein ein feines weifses Gewebe bezeichnet zu haben; im späten Mittelalter verstand man unter byssus gewöhnlich ein feines weifes Seidenzeug.

5 J. n. 3835 . M. 137, 839. Pallium vobis mittimus et insuper concedimus, isto vel alio, cuiuscumque generis nitidi candoris vobis placuerit, vos indui.

6ita Gregor, 1. 4, n. 84 (M. 75, 231). Rohault de Fleury irrt, wenn er aus der Stelle herausliest, es habe Johannes schon auf den alten Bildwerken die Nadeln gefunden (VIII 51). 
mit Nadeln im Nacken, vorn und auf der linken Schulter an der Planeta festzumachen hat 1 .

Es scheint, daf die Ingebrauchnahme der drei Nadeln mit einem Wechsel in der Anlegung der Insignie zusammenhing, welcher zwar zunächst nur geringfügig war, jedoch in der Folge zu einer gänzlichen Umgestaltung des Palliums führen sollte. Er bestand darin, daf man die Bandenden, welche man bis dahin von der linken Schulter nach vorn und hinten lotrecht herabgeworfen hatte, nunmehr zunächst vor die Mitte der Brust und des Rückens führte und erst dann niederfliefsen lief. Es liegt auf der Hand, daßs solches untunlich war, wenn man dabei nicht Nadein zu Hilfe nahm.

Daß diese Veränderung schon in der zweiten Hälfte des 9. Jahrhunderts eingetreten war, ergibt sich aus der Beschreibung, welche Johannes Diakonus von einem Bilde Gregors I. gibt, das noch zu Lebzeiten des Papstes angefertigt worden war. Es wird darin nämlich hervorgehoben, der von der linken Schulter nach vorn herabfallende Streifen sei seitlich, nicht in der Mitte des Körpers herabgestiegen? Angesichts der Rubrik des ersten Ordo über die drei Nadeln wird man aber mit der Annahme schwerlich fehlgehen, es habe sich der Wechsel bereits vor der Mitte des 8. Jahrhunderts vollzogen. Was die Monumente anlangt, so scheint die neue Anlegungsweise des Palliums schon auf dem ursprünglichen Mosaik des lateranensischen Triclinium zur Darstellung gekommen zu sein, wie sich aus einem Vergleich der verschiedenen von demselben erhaltenen Abbildungen ergibt. Es war das Werk Leos III. $(795-816)^{3}$. Andere gleichzeitige oder nur um ein weniges jüngere Monumente wie die Apsismosaiken in S. Cecilia, S. Prassede und S. Maria in Navicella mit dem Bilde des Papstes Paschalis I. (817-824) gestatten kein sicheres Urteil, weil der Gang des Palliums vor der Brust durch ein Buch oder sonst einen Gegenstand verdeckt ist, wenngleich auch hier die ganze Führung des Bandes eher auf die neue Weise der Anlegung hinzudeuten scheint. Hinreichend klar kommt der Wechsel bei der Figur des Papstes Markus auf dem Apsismosaik Gregors IV. (827-844) (Bild 294) in S. Marco zu Rom zum Vorschein. Hier fällt ersichtlich der vordere Streifen nicht mehr seitlich, sondern in der Mitte herab, ohne dás, wie die Paralleldarstellungen in S. Agnese und S. Venanzo zeigen, die Haltung der Figur eine derartige Anordnung verlangt hätte. Ein um einige Dezennien

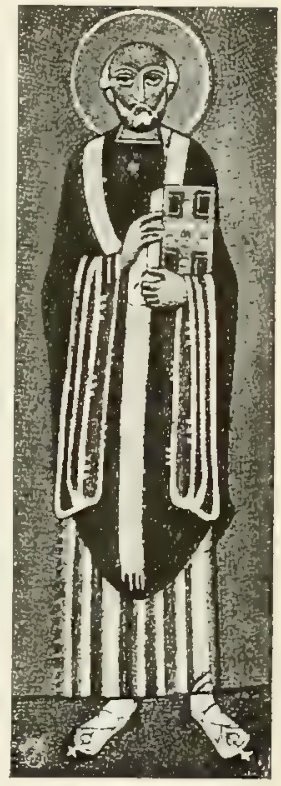

Bild 294. Papst Markus. Mosaik. Rom, S. Marco. jüngeres Beispiel bietet die Darstellung des hl. Klemens auf dem von den hll. Cyrillus und Methodius ea 868 gestifteten Votivbild in der Unterkirche von S. Clemente: Man hat auf diese Anfangsstufe in der Umbildung des Palliums bislang nicht genügend geachtet. Und doch darf man sie nicht unberücksichtigt lassen; denn sie erklärt, warum das Pallium gerade die Gestalt eines $Y$ erhielt, als es eine feste Form bekam. Jene Anfangsstufe ist das naturgemäfe Mittel- und Bindeglied zwischen der ersten Anlegungsweise, bei welcher die Enden an der linken Seite herabflossen, und der festen Y -Form mit ihren mitten vor der Brust und im Rücken herabfallenden Streifen.

Dem ersten Schritt, der Überführung der Streifenenden zur Mitte der Brust und des Rückens, folgte bald ein zweiter von ungleich einschneidenderer Bedeutung. Bei jener ersten, an sich nur geringfügigen Veränderung war das Pallium ein förmliches, lose umgeschlungenes Band geblieben. Wir sehen

1 N. 6 (M. 78, 940).

2 Vita Gregor, 1. 4, n. 84 (ebd. 231).
3 G a r r. tav. 283.

4 Abbildung in Mitt. 1869, 3. 
das deutlich an der Figur der Päpste Markus und Gregor IV, auf dem von letzterem gestifteten Mosaik in S. Marco und der Figur Leos IV. (847-855) auf einem Fresko der Unterkirche von S. Clemente. Nun ging man dazu über, durch entsprechendes Zusammennähen des Streifens dem Ornatstück dauernd die Form zu geben, welche es sonst erst beim Anlegen empfing. Am frühesten dürfte sich diese Umwandlung außerhalb Roms vollzogen haben. Wir schlieben das aus einer Miniatur des Sakramentars von Autun ${ }^{1}$, aus den Miniaturen eines Meßkanons der Pariser Nationalbibliothek ${ }^{2}$, aus den Elfenbeinskulpturen auf dem Deckel des Drogosakramentars und dem Elfenbein der Frankfurter Stadtbibliothek samt seinem Gegenstuick, dem ehemaligen Spitzerschen Elfenbein (Bild 65-68, S. 167-171), aus Reliefs des unter Erzbischof Angilbert (824-860) entstandenen Palliotto in S. Ambrogio zu Mai-

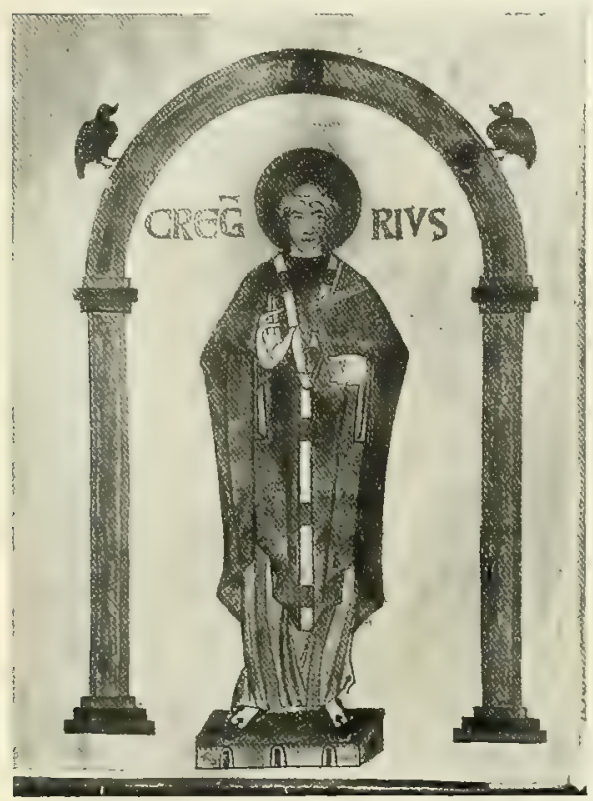

Bild 295. Hl. Gregor. Miniatur eines Evangeliars aus St Gereon zu Köln. Stuttgart, kgl. Bibliothek. land ${ }^{3}$ u. a. Das Pallium hat auf allen diesen Monumenten bereits die ausgebildete Y-Form und ist ersichtlich kein loses, nur $Y$ artig mit Nadeln angestecktes Band mehr.

Zu Rom, wo man konservativer war als auferhalb Roms und zäher wie hier auch in der liturgischen Kleidung am Alten festhielt, mag es erst im 10. Jahrhundert zum fertigen $Y$ förmigen Pallium gekommen sein. Beispiele eines solchen bieten Fresken mit Darstellungen aus dem Leben der hll. Klemens, Alexius und Cyrillus in der Unterkirche von S. Clemente aus dem 11. Jahrhundert ${ }^{4}$, und etwas später die Mosaiken im ehemaligen Oratorium des hl. Nikolaus beim alten Lateran ${ }^{5}$ und in der Apsis von S. Maria in Trastevere ${ }^{6}$.

Wir möchten übrigens keineswegs behaupten, dafs das Pallium auferhalb Roms bereits im 9. und 10. Jahrhundert allenthalben die feste $Y$-Form gehabt habe. Man scheint, nach den Bildwerken zu urteilen, hie und da länger an der ursprünglichen Weise festgehalten, dem Pallium seine lose Bandform belassen und sich begnügt zu haben, die Streifen zur Mitte des Körpers zu führen und dort dann zu befestigen. So sehen wir z. B. auf zwei Miniaturen in der Vatikanischen Handschrift von Hrabans Laudes s. Grucis den vorn herabfallenden Streifen mit dem vor der Brust sich hinziehenden auffallenderweise einen formlichen Knoten bilden ?. Offenbar hat der Miniator beim Pallium noch an ein loses Band, das erst beim Gebrauch umgeschlungen wurde, gedacht. Der Korlex entstamnt dem 10. Jahrhundert. Freilich mögen derartige Erscheinungen lediglich ikonographische Reminiszenzen alten Brauches sein. Finden wir doch z. B. noch bei einer Figur Gregors d. Gr. in einem aus St Gereon zu Köln stammenden Evangeliar (11. Jahrhundert) der

1 Abbildung bei Wil p., Cap. 77.

2 Abbilaung in Arts sompt. pl. xxirr.

${ }_{3}$ Abbildung bei Roh. I, pl, viIr; VIII, pl. I) XXXII.

4 Abbildung in Mitt. 1863, Tfl 11 12; 1869, 1. Wil p., Cap. 3379.
A. SS. Prop. Maii 210*.

${ }^{6}$ De Rossi, Mus. fasc. VII-VIII. Vgl. auch die zahlreichen Abbildungen von Darstellungen des Palliums bei $\mathrm{R} \circ \mathrm{h}$. VIII, pl. DCXXx-DCXXXvır.

${ }^{7}$ Vgl. oben Bild 96, S. 214. 
Landesbibliothek zu Stuttgart ein dem Anschein nach ein loses Band darstellendes Pallium (Bild 295), während doch in Wirklichkeit das Ornatstück damals zu Köln nach Ausweis des Palliums des hl. Heribert bereits feste Gestalt hatte, ja sogar schon statt der $Y$-Form die T-Form aufwies.

Nicht näher bestimmbar ist, wie lange den Erzbischöfen das Pallium als loses Band geschickt wurde. Immerhin ist es nicht so unwahrscheinlich, daf selbst, nachdem man angefangen hatte, das Ornatstück in fester Form zu tragen, dieses noch längere Zeit den Metropoliten in Gestalt eines Streifens zuging, und daf es erst an Ort und Stelle seine feste Form bekam, nicht wie nachher bereits zu Rom. Wenigstens erklärt sich bei dieser Annahme am leichtesten der Umstand, daf es auf den Bildwerken hier früher, dort aber erst später in fester Form auftritt.

Wir kommen zum letzten Stadium im Umbildungsproze: des Palliums. Aus der Y-Form wird die T-Form. Der die Schultern, den Rücken und die Brust umziehende Teil des Palliums wird zu einem wagerecht den Oberkörper umgebenden Ring, dessen linksseitige Hälfte sich meist aus einer doppelten Stofflage zusammensetzte. Deshalb merken einzelne mittelalterliche Liturgiker ausdrücklich an, es sei das Pallium in sinistra duplex, während es rechts nicht gedoppelt sei. So Bruno von Segni, Sicard, Innozenz III. und später Durandus. Die Vertikalstreifen mögen anfangs mit dem Ring noch ein Ganzes ausgemacht haben, dann aber waren sie wie jetzt besondere vorn und hinten in der Mitte des Ringes angenähte Bånder.

Die beste Illustration der neuen Form des Palliums bilden die beiden Pallien der hll. Heribert ( $†$ 1021) und Anno ( $\dagger$ 1075) in der Pfarrkirche zu Siegburg (Bild 296), zwei für die Geschichte der Entwicklung des Palliums äuferst wichtige Errb-

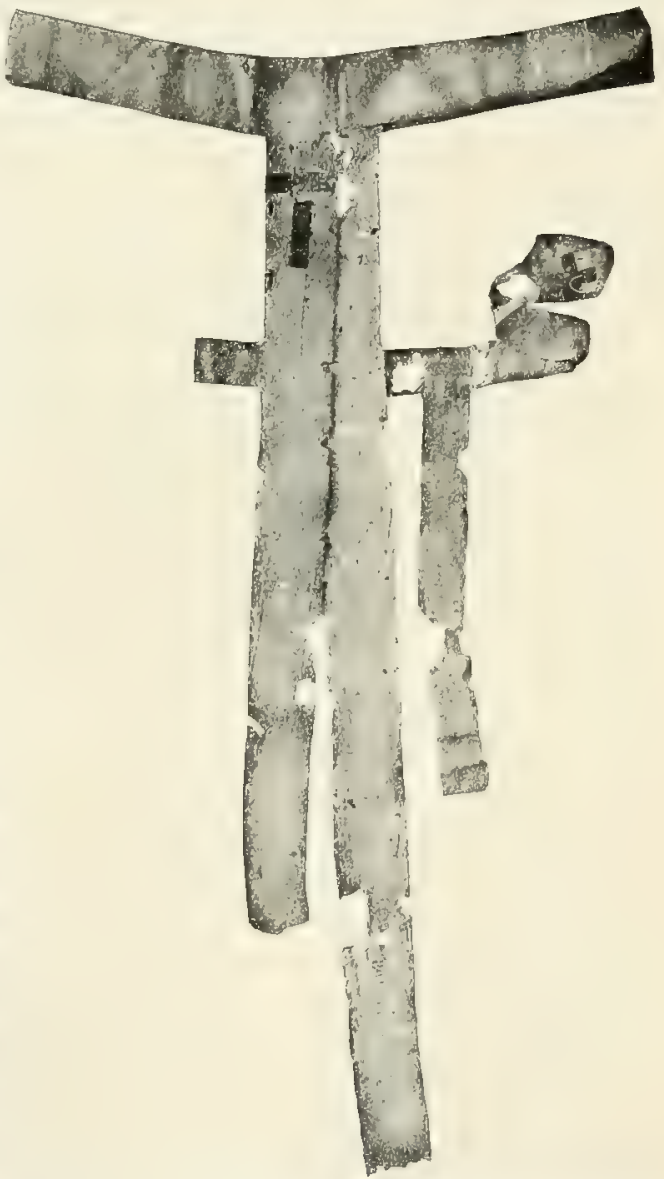

Bild 296. Pallien der hll. Heribert und Anno. Sieghurg, Pfarrkirehe.

stücke des 11. Jahrhunderts. Beide stellen einen vollständigen Ring dar, dem vorn und rückwärts die Behänge angesetzt sind. Beim Heribertspallium ist dessen linksseitige Hälfte gedoppelt, während er beim Annopallium ringsum nur aus einer Bandlage besteht. Beide Pallien sind aus feinster Wolle in Köperbindung gewebt, wobei jenes eine Rauten-, dieses eine Zickzackmusterung erhielt. Der Ring hat (bzw. hatte) bei beiden Pallien einen Umfang von $1,21 \mathrm{~m}$; die Behänge sind weder bei dem einen noch dem andern mehr völlig intakt. Immerhin hat der Behang an der Vorderseite des Heribertspalliums noch jetzt eine Länge von $1,13 \mathrm{~m}$. Auffallend ist bei den beiden Pallien der Unterschied in der Breite des Bandes. Während 
diese sich beim Heribertspallium auf $0,075 \mathrm{~m}$ beläuft, beträgt sie beim Annopallium nur $0,05 \mathrm{~m}$.

Auf den Bildwerken kommen ausgesprochen T förmige Pallien erst gegen 1100 vor. Frühe Beispiele bieten die Darstellung des Kölner Erzbischof's Friedrich (1100 bis 1131) in den für ihn kopierten Hieronymusbriefen der Kölner Dombibliothek (Bild 215, S. 450), das Bild Brunos von Trier $(\dagger 1124)$ in der Gothaer Vita S. Willibrordi (Bild 218, S. 458), die Figur Gregors d. Gr. in dem mehrerwähnten St Dunstanpontifikale in der Bibliothek des britischen Museums u. a. Auf den Siegeln der Kölner Erzbischöfe tritt die T-Form erst unter Hermann von Nordheim († 1099) auf; bis dahin kommen auf ihnen nur $Y$ förmige vor. Es könnte auffallend erscheinen, daf die Monumente die Form erst zur Wiedergabe bringen, nachdem sie schon eine geraume Weile in Brauch gekommen war. Indessen steht diese Erscheinung nicht vereinzelt da. Kommt doch etwas Ähnliches z. B. auch bei der Mitra und den Pontifikalhandschuhen vor. Namentlich darf man aber nicht vergessen, daf es nur wenige Miniatoren gewesen sein mögen, welchen es je vergönnt war, ein Pallium mit eigenen Augen zu sehen. Es begreift sich daher leicht, wenn in Bezug auf dieses die Tradition besonders lang nachklang. Übrigens findet sich schon eine Weile vor dem Ausgang des 11. Jahrhunderts auf den Bildwerken eine Mittel- und Übergangsform vom $Y$ förmigen zum $T$ förmigen Pallium, bei welchem die $Y$-Form sich der $T$-Form so weit genähert hat, daß es sich nicht immer leicht entscheiden läßt, ob noch die $Y$-Form oder schon die T-Form auf den betreffenden Darstellungen gemeint ist.

Es dauerte eine geraume Zeit nach dem ersten Auftreten der ausgesprochenen T-Form, bis diese auf den Bildwerken allgemein herrschend geworden und die Y-Form ganz verschwunden war. Zum Teil mag das eine Widerspiegelung des tatsächlichen Brauches sein; mehr noch aber hat es ohne Zweifel seinen Grund in den gleichen Umständen, welche die T-Form erst so spät auf den bildlichen Darstellungen erscheinen ließsen, der künstlerischen Überlieferung, den benutzten Vorbildern und dem Mangel an eigener Kenntnis des so seltenen und obendrein so selten gebrauchten Ornatstückes. Noch im 13. Jahrhundert kommen Monumente vor, auf denen die Y - Form erscheint ${ }^{\text {. }}$.

Was den Wechsel in der Form des Palliums herbeiführte, ist unbekannt. Vielleicht war es bloß die Mode, die ja auch in Bezug auf die liturgische Kleidung nicht ohnmächtig gewesen ist. Vielleicht aber auch, daß er mit der zunehmenden Verbreitung des Gabelkreuzes als Verzierung der Kasel zusammenhängt. Seit dem 11. Jahrhundert kommt der gabelförmige Besatz auf derselben immer mehr zur Verwendung. Es mochte darum zweckmäfig erscheinen, von ihm das Pallium dadurch deutlicher zu unterscheiden, daf man diesem statt der $Y$ - die T-Form gab.

Was die Tragweise des Tförmigen Palliums anlangt, so ruhte es anfangs hoch oben auf dem Oberarm nahe an den Achseln. Später aber finden wir es auf den Bildwerken sehr gewöhnlich etwa in der Mitte des Oberarmes. Es könnte das als Caprice der Künstler gedeutet werden; indessen gibt der 14. Ordo ausdriicklich an, der Diakon, welcher dem Bischof beim Ankleiden zu helfen habe, solle das Pallium so tief auf den Arm herabziehen, daßs es mitten zwischen Schultergelenk und Ellenbogen zu liegen komme?2.

Der vom Ring vorn und hinten herabfallende Streifen behält bis ins 15. Jahrhundert hinein eine ansehnliche Länge. Man vergleiche z. B. die Grabfigur Martins $V$. in der lateranensischen Basilika. Gegen das Ende

1 Das Tförmige Pallium auf der bekannten Tafel mit den Bildern der Apostelfürsten in St Peter zu Rom beweist mit aller Bestimmtheit, dafs dieselbe nicht aus dem 9. Jahr- hundert stammt und also auch nicht von der Hand des hl. Methodius herrühren kann (vgl. oben S. 437).

C. 53 (M. 78, 1158). 
des Jahrhunderts ist er jedoch schon merklich verkürzt, wie beispielsweise das prächtige Grabmonument Sixtus' IV. in St Peter (Bild 19, S. 54), die Papstbilder in der Sistina (Bild 20, S. 55), die Grabplatte des Erzbischofs Gabriel Sforza in S. Maria Incoronata zu Mailand ${ }^{1}$ und die Figur des Mainzer Kurfürsten Diether von Isenburg ( $\uparrow$ 1482) im Dom zu Mainz beweisen. Immerhin scheinen die Behänge noch bis ins 16. Jahrhundert eine angemessene Länge besessen zu haben, wie die in mehrfacher Hinsicht für das Studium der liturgischen Kleidung sehr beachtenswerten Grabmäler der damaligen Mainzer Erzbischöfe bekunden. Im 17. Jahrhundert verschwindet mit der Kasel auch das Pallium von den Denkmälern; leicht erklärlich, da beide, weil allzusehr zugestutzt, sich nicht mehr zur bildlichen Darstellung empfehlen mochten. Im Beginn des 18. Jahrhunderts betrug die Länge der Streifen nur noch ca $0,33 \mathrm{~m}^{2}$.

Eine Übersicht über die Entwicklung des Palliums gewährt auf Grund der zuverlässigsten Monumente Bild 297. Es zeigt uns das Ornatstiuck in allen Hauptstadien seiner Umbildung vom 6. Jahrhundert an bis zu unsern Tagen.

Als Verzierung des Palliums dienten, wie aus den ravennatischen und römischen Mosaiken erhellt, bereits im 6. und 7. Jahrhundert zwei Kreuze.
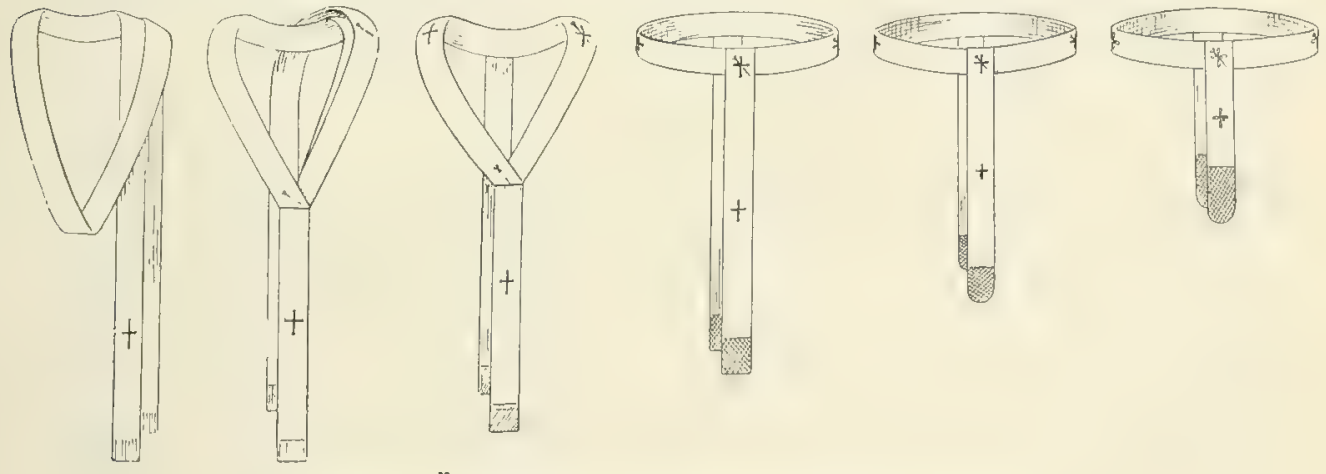

Bild 297. Übersicht über die Entwicklung des Palliums.

Eines derselben befand sich auf dem vorn, das andere auf dem rückwärts herabsteigenden Streifen. Eine gröfere Anzahl von Kreuzen auf dem Pallium anzubringen, scheint erst in der letzten Hälfte des 9. Jahrhunderts Sitte geworden zu sein ${ }^{3}$. Noch Hraban redet, wie es scheint, blof von zwei Kreuzen, von denen sich das eine auf dem vorderen, das andere auf dem hinteren Streifen befand. Als frühe Beispiele römischer Monumente, auf denen das Pallium mit mehr als zwei Kreuzen verziert ist, führen wir an das Votivfresko der hll. Cyrillus und Methodius in der Unterkirche von S. Clemente mit der Darstellung des hl. Klemens und das Bild des Papstes Urbanus vom ehemaligen Grabe der hl. Cäcilia in S. Callisto - von de Rossi dem 10.-11. Jahrhundert zugeschrieben ${ }^{4}$. Beide Bildwerke verraten übrigens deutlich griechischen Einfluf. Die beiden

1 Abbildung bei Braun, Pontifikale Gewänder 165.

2 Catalani, Caerem. eccl, rom. I 341.

${ }^{3}$ Ob die Zunahme der Kreuze auf dem Pallium auf griechischen Einflufs zurückgeht oder ob sie unabhängig von solchem erfolgte, mufs dahingestellt bleiben. Inmerhin verdient Beachtung, dấ bereits auf den unter Johannes VII. († 707) und Paul I. († 767) entstandenen Bildern griechischer Bischöfe in S. Maria Antiqua zu Rom das Omophorion mit mehr als zwei Kreuzen versehen ist. Eine Einwirkung griechischen Brauches auf die Zunahme der Kreuze des lateinischen Palliums liegt also keineswegs außer dem Bereiche der Möglichkeit.

4 Abbildung bei de Rossi, R. sott. II, tav. 6, und Wilp., Kat. Tfl 260. 
Bischöfe auf dem Triumphbogenmosaik in S. Prassede, welche abweichend von der Figur des Papstes Paschalis I. in der Apsis derselben Kirche ebenfalls ein mit mehreren Kreuzen besetztes Pallium tragen, sind wohl das Werk einer späteren Restauration ${ }^{1}$.

Eine bestimmte Regel scheint im späteren Mittelalter bezüglich der Zahl der Kreuze nicht bestanden zu haben. Zwar geben Innozenz III. und Durandus an, es werde das Pallium mit vier Kreuzen geschmückt, von denen sich je eines auf der Brust, dem Rücken und den beiden Schultern befinde. Allein die ungemeine Mannigfaltigkeit, welche in diesem Punkte auf den mittelalterlichen Bildwerken herrscht, läßjt den Gedanken an eine feste Norm nicht aufkommen. Bald fehlen die Kreuze ganz, bald sind ihrer zwei, bald drei, vier, fünf oder mehr auf der wahrnehmbaren Vorderseite angebracht. Hier finden sie sich nur auf dem Ring, dort blok auf dem Längsstreifen; anderswo sind sie gar durch eine das ganze Pallium überziehende Musterung ersetzt. Und diese Verschiedenheit offenbart sich nicht bloß auf den auferrömischen Bildwerken, sondern auch auf den römischen Monumenten, die Grabmäler der Päpste nicht ausgenommen. Dak vieles von diesem bunten Vielerlei der Phantasie und Laune der Künstler zugeschrieben werden mußs, ist nun freilich klar. Schwerlich würde indessen hinsichtlich der Anzahl der Palliumkreuze auf den mittelalterlichen Bildwerken ein solches Durcheinander herrschen, wie es uns tatsächlich darauf begegnet, wenn in diesem Punkte eine bestimmte Vorschrift oder eine konstante Gewohnheit in Kraft gewesen wäre. Der Verschiedenheit auf den Monumenten hat gewißs auch eine Verschiedenheit in der Praxis entsprochen. In der Tat beweisen die Beobachtungen, welche v. Wilmowsky bei Öffnung der Gräber der Trierer Erzbischöfe machte, daß die Zahl der Palliumkreuze nicht überall gleich war. Während nämlich das Pallium Alberos $(† 1152)$ auf dem Ring keine, auf dem vordern Streifen aber fünf Kreuze anfwies, war dasjenige Boemunds ( $\dagger$ 1367) auf dem Ring mit vier und auf den Behängen mit je zwei Kreuzen geschmückt. Ein ehedem zu St-Denis befindliches Pallium hatte auf dem Ring vier Kreuze, auf den Behängen aber keines 2. Umgekehrt weist das Heribertspallium nur auf den Streifen ein Kreuz auf, das hart am obern Ende angebracht ist; auf dem Ring hat es bei ihm nie solche gegeben. Das Annopallium ist auf dem Ring mit vier Kreuzen geziert; wie es sich ehedem mit den Behängen verhielt, ist jetzt nicht mehr zu bestimmen. Die Verschiedenheit in der Zahl der Kreuze, wie sie uns auf den Bildwerken beim Pallium begegnet, ist also evident nur ein Widerschein des wirklichen Tatbestandes.

Auch bezüglich der Farbe der Palliumkreuze hat es im Mittelalter keine sich gleich bleibende Regel gegeben. Auf den Mosaiken des 6., 7., 8. und 9. Jahrhunderts sind die Kreuze teils schwärzlich, teils rot. Ebenso verhält es sich auf den späteren Bildwerken. Von den Liturgikern des Mittelalters, welche auf ihre Farbe zu sprechen kommen, bezeichnen Hraban, Robert Paululus, Innozenz III. und Durandus die Kreuze als rot, Sicardus dagegen als schwarz. Das Pallium, welches man 1605 bei der Leiche Bonifaz' VIII. fand, war nach Grimaldis Protokoll mit schwarzseidenen Kreuzen besetzt $^{3}$. Von gleicher Farbe waren die Kreuze des ehedem zu St-Denis aufbewahrten Palliums. Dagegen war dasjenige des Kölner Erzbischofs Klemens August († 1761), des letzten Wittelsbachers auf dem Stuhl des hl. Maternus,

I Abbildung bei de Rossi, Mus. fasc. IX bis $X$, und hei Garr. tav. 285. Die größere Anzahl von Kreuzen bei den Figuren des hl. Apollinaris in der Apsisconcha und des Erzbischofs Reparatus an der Chorwand von S. Apollinare in Classe sind das Werk späterer Restaurationen.
${ }^{2}$ Millet, Trésor de Saint-Denis, Paris 1645, 113. Roh. VIII 53. Das Pallium wurde Stephan II. (752-757) zugeschrieben, doch läst die Beschreibung, welche wir von ihm erhalten, keinen Zweifel, daß es ans weit späterer Zeit stammte.

${ }^{9}$ B z ovius, Annal. ad 1303; XIV $51 \mathrm{ff}$. 
aufer mit zwei schwarzen auch mit sechs roten Kreuzen verziert ${ }^{1}$. Die Kreuze auf den Palliumfragmenten im Trierer Dommuseum bestehen aus rotem Taft, diejenigen des Heriberts- und Annopalliums aus tiefblauem, fast schwarzblauem Brokatell, die des kleineren der beiden Pallien zu Arles aus rotseidenem Damast.

Dafi man, wie später, so auch schon wenigstens um die Wende des 13. Jahrhunderts die herabfallenden Palliumstreifen an den Enden mit Blei beschwerte, beweist der Bericht Grimaldis über die Untersuchung des Grabes Bonifaz' VIII. Es wird darin mitgeteilt, daf an den beiden Behängen des Palliums, welches man bei der Leiche fand, unten ein mit schwarzer Seide überzogenes Bleistückchen angebracht gewesen sei. Auch unter den Fragmenten des Palliums, das man bei den jüngsten Restaurationsarbeiten im Trierer Dom auf der Leiche des Erzbischofs Otto von Ziegenheim $(\uparrow 1430)$ entdeckte, befand sich ein ca $0,08 \mathrm{~m}$ langes, mit schwarzer Seide überzogenes Bleiplättchen, das als Fndstuick des vorn herabfallenden Bandes gedient hatte. Es war von rechteckiger Gestalt. Von Fransen, wie wir sie wohl an den Enden des Palliums auf den Bildwerken antreffen, war keine Spur an seiner Bekleidung zu entdecken.

Ein unten sich abrundendes Schlufistück, also ein Schlufstück ron der Form, wie sie heute demselben eigen ist, treffen wir bereits beim Grabmal Sixtus' IV. in St Peter und einige Dezennien früher beim Grabmonument des Erzbischofs Gabriel Sforza $(\uparrow 1457)$ im Baptisterium von S. Maria Incoronata zu Mailand an. Es wären demnach die Fransen, welche sich noch das ganze 16. Jahrhundert hindurch auf den Denkmälern der Mainzer Erzbischöfe an dem Pallium finden, wohl nur eine künstlerische Freiheit.

Die Nadeln, mit denen man das Pallium an der Planeta festheftete, blieben, auch als das Ornatstück aufgehört hatte, ein loser Bandstreifen zu sein. Vielleicht, dafs sie noch bis zum 12. Jahrhundert zur Befestigung der Insignie gedient haben ${ }^{2}$. Kaum hundert Jahre später scheinen sie jedoch bereits alle praktische Bedeutung eingebübt zu haben ${ }^{3}$. Jedenfalls waren sie um den Beginn des 14. Jahrhunderts bereits zu einem bloken Schmuckstiuck geworden. Denn der 14. Ordo gehietet ausdrücklich, dafür zu sorgen, daf3 die Spitze der Nadel in keiner Weise die Planeta berïhre 4

Nach Bruno von Segni sollen vor alters an der Kasel Ösen (ansulae) zur Aufnahme der Nadeln angebracht gewesen sein. Umgekehrt versah man in der Neuzeit, seitdem das Ornatstück nicht mehr an der Kasel befestigt wurde, die Insignie selbst mit einer besondern Vorrichtung zum Durchstecken der spinulae. Verstehen wir die Angaben des 14. Ordo recht, so befand sich eine solche auch schon zur Zeit der Abfassung desselben am Pallium. Auffallend ist, dab auf den Bildwerken des Mittelalters die Nadeln im ganzen nur selten vorkommen. Sollen wir daraus schlielien, daf sie tatsächlich mehr der Theorie wie der Praxis angehörten?

1 Pertsch, De origine, nsu et auctoritate pallii 21.

${ }^{2}$ Bruno Sign., 'Tract, de sacr, eccl. (M. 165,1107 ): Acus ad planetam palliumque iungendum inventae sunt.

${ }^{3}$ Ordo 12 , e. 48 (M. 78, 1098) und Innozenz III. scheinen das anzudeuten. Nach beiden waren die Nadeln ans Gold verfertigt und mit einem runden Kopf und einem kostbaren Stein versehen. Der ordo 12 spricht von einem Hyazinthe; die Nadeln, welche man im Grab Bonifaz' VIII. fand, waren mit einem Saphir geschmückt. Das Inventar des påpstlichen Schatzes von 1295 erwähnt Nadeln mit Granaten, Rubinen, Saphiren, Perlen u. a.

${ }^{4}$ C. 53 (M. 78, 1157). 


\section{URSPRUNG DES PALLIUMS.}

Eine schon von de Marca, Thomassin u. a. und neuerdings wieder von Duchesne ${ }^{1}$ vertretene Ansicht sieht in dem Pallium eine von Konstantin bzw. einem seiner Nachfolger dem Bischof von Romverliehene Insignie. Fis soll eine Art von Nachahmung des durch Verbildung der alten Toga entstandenen Umwurfes sein, der mehr als ornamentale Zutat und Insignie denn als eigentliches Gewand im 4., 5. und 6. Jahrhundert den obersten Bestandteil der konsularen Tracht bildete?. Die Konsulardiptychen aus jener Zeit weisen genug Beispiele desselben auf. Hier der alten Toga noch sehr ähnlich, wurde er später, seitdem man ihn im Übermaß̊ mit Stickereien und Steinen belud, zu einem breiten Streifen, der kaum mehr an das klassische Römergewand erinnerte, von dem er ausgegangen war. Er erhielt in dieser Form den bezeichnenden Namen lorum. Die Bildwerke des 7. und der folgenden Jahrhunderte liefern zahlreiche Beispiele des Gewandes in diesem seinem Jetzten Verbildungsstadium. Insbesondere pflegen die beiden Himmelsfürsten Michael und Gabriel regelmäßig mit dem Lorum dargestellt zu werden, und zwar nicht blow in der byzantinischen Kunst, sondern in Nachahmung byzantinischer auch auf abendländischen Darstellungen.

Man begründet die Theorie durch den Hinweis auf eine angebliche Ähnlichkeit zwischén dem genannten konsularen Umwurf und dem Pallium und durch die Berufung auf das Constitutum Konstantins und die angebliche Verpflichtung der Päpste, bei Palliumverleihungen die Genehmigung des Kaisers einzuholen.

Allein bezüglich der Berufung auf das Constitutum Konstantins bemerkt Grisar mit Recht: „Nur infolge einer grofen Überschätzung der sog. Konstantinischen Schenkung kann man in diesem Dokumente eine Bestätigung der Ansicht sehen wollen." 3 In der Tat, eine Fiktion, wie sie der Urheber der Fälschung ersann, entspricht allerdings der auch in weltlicher Beziehung hochbedeutenden Stellung, welche die Päpste zu seinen Lebzeiten in der christlichen Völkerfamilie einnahmen. In den Beginn des 4. Jahrhunderts paft dagegen die angebliche Begabung des Papstes mit Krone, Phrygium, Lorum und sonstigen kaiserlichen Gewandstücken in keiner Weise.

Über die Pflicht des römischen Stuhles, den kaiserlichen Konsens zu einer Verleihnng des Palliums nachzusuchen, ist früher mehr als genug gesagt worden. Was aber die Ähnlichkeit zwischen dem Pallium einerseits und dem in Frage kommenden Umwurf auf den Monumenten anderseits in Bezug auf Form und Beschaffenheit anlangt, so ist dieselbe denn doch zu gering, um daraus den Schluf ziehen zu können, das Pallium stamme von kaiserlicher Bewilligung her. Man vergleiche nur einmal letzteres, wie es uns auf den ältesten Darstellungen begegnet - und wir haben keinen Grund, für die frühere Zeit einen wesentlichen oder auch nur größeren Wechsel in Bezug auf das Aussehen anzunehmen -, etwa mit der Toga des Felix (Bild 140, S. 301) oder des Anonymus (Bild 257, S. 518) usw. auf deren Diptychen. Indessen eine wirkliche Ähnlichkeit einmal zugegeben, so könnte daraus doch höchstens folgen, es sei die

1 Orig. 385: Cet insigne paraît remonter à une concession impériale.

${ }^{2}$ Das Verdienst, das Ornatstück als eine Umbildung der Toga nachgewiesen zu haben, gebührt Wilpert, der fukend auf den Untersuchungen des Baron Kanzler über die Entwicklung der Toga die Konsulardiptychen einer eingehenden Exforschung bezüglich der Tracht der Konsuln unterzog. Er hat die Ergebnisse in der ersten Studie seiner Schrift
Un capitolo di storia del vestiario niedergelegt. Ein eigentliches Gewand im Sinn der alten römischen Toga kann der Überwurf wobl nicht mehr genannt werden. Als Oberkleid war an Stelle der letzteren vielmehr die Dalmatik getreten. Wilpert bezeichnet den Umwurf mit Recht als quasi un accessorio ornamentale (Cap. 8).

3 Das römische Pallium n. 4 (Festschrift zum 1100jährigen Jubiläum des Campo Santo 101). 
Einführung des Palliums nach dem Vorbilde des eine Art von konsularischer Insignie darstellenden profanen Ornatstücks erfolgt, auf keinen Fall aber, sie sei auf eine Bewilligung durch den Kaiser zurückzuführen.

Die Theorie, welche den Kaiser als den Urheber des päpstlichen Palliums betrachtet, ist indessen nicht nur ganz unhegründet, sie entspricht auch keineswegs den tatsächlichen Verhältnissen.

Das Pallium tritt stets als durchaus liturgisches Gewandstück auf, und das gleichmäßrig in Rom wie in der Ostkirche. Was hat aber der Kaiser mit der Einführung eines Kultuszwecken vorbehaltenen Ornates zu tun? Wäre das Pallium ursprünglich eine außerkirchliche, weltliche Insignie des Papstes gewesen, ließe es sich eher auf eine kaiserliche Verleihung zurückführen. Aher das war es nach allem, was wir von ihm wissen, niemals. „Es handelt sich um das Heiligtum des Altars, um die Liturgie, und hier sind weltliche Anordnungen und Verleihungen nicht ohne zwingende Gründe anzunehmen." 1

Dann aber findet sich ein Pallium nicht nur beim Papste, es begegnet uns unter dem Namen omophorion auch bei den Bischöfen des Ostens, und zwar hier schon bei Isidor von Pelusium. Rührt etwa das Omophorion der griechischen Liturgie auch von kaiserlicher Bewilligung her? Und woher das liturgische Abzeichen der Diakone, das uns unter dem Namen orarium bereits im 22. Kanon des Konzils von Laodicea entgegentritt?

Endlich darf nicht übersehen werden, daß die Päpste, welche Metropoliten das Pallium gewähren, das aus eigenster Nachtvollkommenheit und kraft der Autorität des hl. Petrus tun, und dafs das Pallium ex benedictione S. Petri kommt. Ja, wenn noch die Päpste vom Kaiser in der Verleihung des Palliums ahhängig gewesen wären! Aber so verhielt sich die Sache nicht. Wie daher die Zuwendung der Insignie des Apostolischen Stuhles eigenstes Recht war, so kann auch das Ornatstück selbst nur dem Boden der Kirche erwachsen und nur durch die maßzgebenden kirch. ljchen Faktoren ins Dasein gerufen worden sein.

Indessen berichtet ja Agnellus im ravennatischen Pontifikalbuch, es habe Valentinian III. den Erzbischof Johannes von Ravenna und später Justinian den Erzbischof Maximian mit dem Pallium begabt?. Freilich; jedoch ist weder das eine noch das andere richtig, wie, von allem andern abgesehen, klar aus dem früher besprochenen Briefwechsel zwischen Gregor d. Gr. und Johannes und Marianus von Ravenna hervorgeht. Allein es verlieh doch Konstantius II. dem schismatischen Erzbischof Maurus das Pallium ". "Also", so folgert Duchesne, "sprach sich der Kaiser das Recht zu, dasselbe direkt zu gewähren. " Allerdings, aber was haben die Kaiser nicht alles für sich in Anspruch genommen! Wenn sie sich das Recht nahmen, Bischöfe einzusetzen oder zu verjagen, so konnte sich Konstantius noch viel mehr die Verleihung des Palliums anmaken. Folgt daraus aber, dak die Insignie in kaiserlicher Bewilligung ihren Ursprung habe? Doch wohl ebensowenig, wie Ring und Stab der Bischöfe auf Heinrich IV. zurückzuführen sind, weil derselbe den Anspruch erhob, mit Ring und Stab zu investieren.

Es geht denn auch gegenwärtig die herrschende Stimmung mit Recht durchaus dahin, dem Pallium einen kirchlichen Ursprung zuzuschreiben, wenngleich über die Zeit sowie über das Warum und das Wie seiner Einführung die Ansichten auseinandergehen.

Eine Beziehung des Palliums zum Ephod des Alten Bundes (und dem damit verbundenen Brustschmuck, hígev, rationale) betonen schon mittelalterliche Liturgiker ${ }^{5}$, ohne es indessen förmlich von ihm ab-

${ }^{1}$ Grisar, Das röm. Pallium (a. a. 0. 100).

2 Lib. pont. ravennat. n. 4070 (M. G. SS. Langob. 305 326).
3 Ebd. n. 110112 (349 350).

4 Orig. 385

5 Ex. 28, 9 ff; 39,2ff. Flav.Ios., Antiq. III, 7. 
zuleiten. Sie sehen in ihm vielmehr lediglich ein Gegenstück des hohenpriesterlichen Schulterschmuckes.

Es ist in der Tat an eine wirkliche Herübernahme des alttestamentlichen Ephod nicht zu denken. Dem widerspricht alles, was wir in Bezug auf seine Form und Beschaffenheit wissen. Und warum hat man blof den Ephod, nicht aber auch die Brustplatte dem jüdischen Kultus entlehnt? Warum fehlt ferner jeder Hinweis auf das Pallium, wenn z. B. Hieronymus oder Gregor d. Gr. weitlüufig die Bedeutung des alttestamentlichen Superhumerale erörtern? ${ }^{1}$ Es könnte das jüdische Sakralschulterkleid höchstens insofern der Anstok zur Einführung der Insignie gewesen sein, als es den Gedanken an die Schaffung eines liturgischen Schulterschmuckes des christlichen Hohenpriesters, des Papstes, angeregt hätte. Indessen mangelt selbst dafür jeglicher Anhaltspunkt.

Andere haben das römische Pallium von einem Mantel des hl. Petrus abzuleiten gesucht, der das Oberhirtenamt desselben symbolisierte? Derselbe soll von dem hl. Petrus seinem Nachfolger Linus hinterlassen und dann von diesem und den folgenden Päpsten benutzt worden sein. Vielleicht auch, daf man Stücke von ihm abschnitt und andern gab. So oder durch Verschleifs oder sonst in einer Weise, sagt man, ging jedoch das Gewandstück im Lauf der Zeit verloren. Inzwischen aber hatte sich die Sitte, das Pallium des Apostelfürsten zu tragen und andern davon mitzuteilen, so eingewurzelt, dafo man sie nicht mehr darangeben konnte; man soll darum als Ersatz für das pallium Petri ein anderes in Gebrauch gezogen bzw. versendet haben. Will man dem Verfasser des Artikels „Pallium" im Kirchenlexikon glauben, so wäre diese Meinung jetzt ziemlich allgemein angenommen; indessen ist sie in Wirklichkeit ebensowenig allgemein wie begründet.

Zwar bringt Vespasiani, ihr Hauptvertreter, eine lange Reihe von Beweisen für sie vor, allein unter allen ist keiner, der sie auch nur halbwegs wahrscheinlich machte. Was soll es z. B., wenn Vespasiani sich auf Elias beruft, der Elisäus seinen Hantel hinterlief ${ }^{3}$ ? Was seine Bezugnahme auf zwei Zeugnisse für die Kirchen von Jerusalem und Alexandrien, die noch zudem von sehr zweifelhaftem Werte sind, auf die Acta S. Materni und eine auf legendarischen Quellen beruhende Notiz bei Rupert von Deutz? Und nun erst die Beweise aus gewissen Äuferungen päpstlicher Schreiben, in welchen gesagt wird, das Pallium werde verliehen apostolorum principis solatio, ex benedictione S. Petri apostoli, oder es komme de corpore beati Petri; aus der Segnung des Ornatstückes; ans der Weise, wie der Papst die Insignie nach seiner Weihe annimmt; aus der Farbe, dem Stoff und den Kreuzen des Palliums; aus dem Torgehen des Apostolischen Stuhles bei Palliumverleihungen; aus der Praxis der Orientalen und gar aus dem Ursprung der Kasel, welche nach Vespasiani ebenfalls von dem Pallium Petri herzuleiten ist. Noch am bedeutungsvollsten sind scheinbar zwei-Belege, die aus einem dem Eusebius von Cäsarea zugeschriebenen Sermo über Epiphanie und einer angeblichen Rede des hl. Maximus De veste sacerdotali herrühren sollen. Wir sagen scheinbar; denn erstens spricht in Wirklichkeit keine derselben von einem Mantel des hl. Petrus; das pallium, von dem sie reden, ist vielmehr das pontifikale Pallium. Zweitens aber sind beide Stellen hörhst zweifelhafter Herkunft und darum wertlos 4 .

1 Ep. 64 ad Fabiol. n. 15 (M. 22, 615). Gregor M., In Iob 1. 28, c.5 (M. 76, 455); eiusd. Regulae past. pars 2, c. 234 (M. 77, $27 \mathrm{ff}$ ); Epist. 1. 1, n. 24 (M. G. Epp. I 28).

2 Vespasiani, De sacri pallii origine $34 \mathrm{ff}$ 66. Es genügt zur Charakterisierung dieser 'Theorie und ihler Bedeutung fast, dieselbe wiederzugeben.
3 Kg 19, 19.

4 Vespasiani hat die beiden Stellen Catalan is Kommentar zum römischenCaeremoniale (edit. Rom. 1750) 342, entlehnt, während dieser sie aus $\mathrm{Chr}$ ist. Marcelli, Sacr. caerem. 1. 1, sect. 5, c. 10 (bei Hoffma $n$, Nova scriptorum ac monument, collectio II 423) genommen hat. Bei Marcellus werden 
Weder das christliche Altertum noch das Mittelalter weif etwas von dem sagenhaften Mantel des Apostelfürsten. "Zu Rom hatte man", soviel bekannt ist, „als Erbe Petri nur dessen Kathedra, und die Übertragung der Vollmachten des Apostels an den neuen Papst wurde unter anderem durch die Besitzergreifung von diesem Stuhle ausgedrückt." 1 Der Mantel Petri gehört erst dem 19. Jahrhundert an. Die Theorie, welche von ihm das päpstliche Pallium herleitet, mag geistreich sein; doch ist sie darum nicht auch schon begründet und wahr.

Eine dritte Ansicht leitet das Pallium von einem'sakralen Mantelpallium ab, dessen sich ursprünglich die Päpste bedient haben sollen. Garrucci, der dieselbe vertritt ${ }^{2}$, will dieses angebliche pallium sacrum auf einigen Goldgläsern gefunden haben. Die Umbildung des Mantels zum späteren Pallium hätten wir uns ihm zufolge etwa in folgender Weise vorzustellen. Zunächst ging man dazu über, das Gewand zu einer Art von Streifen zusammenzufalten. Dann änderte man die Anlegeweise dahin, dafs man, anstatt beide Enden ïber die Brust herabfallen zu lassen, das rechte zur linken Schulter führte und über diese zum Rïcken warf. Endlich ersetzte man den durch Zusammenfaltung des Mantels gebildeten Streifen durch ein einfaches Band. Die Theorie hört sich gut an, leider ruht sie auf mehr denn unsichern Fundamenten.

Von dem angeblichen sakralen Mantelpallium des Papstes findet sich keine Spur vor. Es ist nichts als eine Fiktion. Das Gewandstïck auf einigen Goldgläsern, in dem Garrucci es wiederzuerkennen meinte, ist kein sakraler Ornat, sondern die lacerna des gewöhnlichen Lebens. Es sind nicht blof Päpste auf den vetri mit ihm dargestellt, sondern auch Christus, Apostel, zumal Petrus und Paulus, ein Timotheus, Damas, Dion, Ursus, Demetrius und die hl. Agnes ${ }^{3}$.

Auch die Behauptung, es sei das Mantelpallium im Verlauf der Entwicklung zu einem Streifen zusammengefaltet worden, entbehrt jeder Begründung und ist blofe Hypothese.

Allerdings weist Garrucci unter Verweis auf Tertullian auf den Brauch hin, die Läna (wie er sagt, richtig die Toga) streifenartig zusammenzufalten. Allein er beachtet nicht, daf, wie die Bildwerke beweisen, hierbei nur ein Teil des Gewandes zu einem Streifen zusammengelegt wurde, während der andere in losen Falten den Körper umschlang. Ist ja noch auf den Konsulardiptychen des 6. Jahrhunderts, also zu einer Zeit, da doch das Pallium sich als ganz und gar streifenartiges Ornatstück gibt, lie Toga trotz aller mit ihr vorgegangenen Veränderungen ein wirkliches Tuch von nicht geringer Breite, das nur etwa in seiner ersten Hälfte zu einer Art von Band zusammengeschlagen ist, im übrigen aber frei den Körper umzieht und in natürlichem Faltenwurf dem rechten Arm aufliegt.

Dann aber liegt auf der Hand, daf aus einer Veränderung, welche mit der Toga vor sich ging, keineswegs ohne weiteres geschlossen werden kann, dieselbe sei auch bei dem Mantelpallium in Brauch gekommen. Das wäre vielmehr offenbar nur dann zulässig, wenn die gleichen oder doch verwandte Gründe für einen solchen Wechsel vorlagen. Die Sitte, das eigentliche Staatskleid des römischen Bürgers in bestimmte Falten zu legen, ging aus dem Bestreben hervor, dasselhe prunkvoller zu gestalten. Man war mit der alten, einfacheren Togaform nicht mehr zufrielen. Daher die neue, verzwickte Weise, das Gewand anzulegen, welche Tertullian mit so beißendem spott.

sie leider nur so zitiert: Maximus ep. in homilia de veste sacerdotali und Eusebii Caesareensis in sermone de Epiphania. Wir haben weder die eine noch die andere dieser Stellen irgendwo entdecken können. Bei beiden haben wir es zweifellos mit unechten, späten Stücken zu tun, die kaum in die
Frïhe unseres Jahrtausends hinaufreichen dürften.

1 Grisar, Das römische Pallium (a. a. 0. 109). 2 Garr. I 96106.

${ }^{3}$ Ebd. tav. $179 \mathrm{ff}$. Vgl. femer oben S. 611. Hänfig tragen auch die drei Magier auf den altchristlichen Bildwerken den Mantel (I 94). 
und köstlichem Humor geißelt. Bestanden die gleichen oder ähnliche Tendenzen auch bezüglich des sakralen Mantelpalliums? Wenn nicht, und es dürfte das wohl niemand behaupten können, so läbt sich offenbar von der Toga kein Schluf auf das Pallium ziehen.

Vielleicht hat aber die Rücksicht auf Bequemlichkeit oder die Einführung der Pänula als Obergewand bei ihm dasselbe veranlaft, was bei der Toga Prunkliebe zuwege brachte. Vielleicht, aber was beweisen blofe Möglichkeiten? Man kann doch nicht Hypothesen mit Hypothesen glaubhaft machen; am allerwenigsten, wenn letztere, wie es hier der Fall ist, aller Wahrscheinlichkeit entbehren. Oder ist es wahrscheinlich, daf man zu einer Zeit, in welcher man die lange Ärmeltunika in Gebrauch nahm und die Toga zu einer Bürde machte, aus Bequemlichkeit einen Wechsel in der Anlegungsweise des heiligen Mantelpalliums vorgenommen habe? Bequemlichkeitsrücksichten fingen erst in weit späterer Zeit an, sich in Bezug auf Schnitt und Beschaffenheit der geistlichen Gewandung geltend zu machen.

Auch die Einführung der Pänula (Planeta) als Obergewand konnte kein Grund für die Veränderung sein, da ein Mantel, wie er uns auf den Goldgläsern begegnet, sehr wohl über der Planeta getragen werden konnte. Ja es ist nicht einmal abzusehen, wie die Pänula beim Papst als Oberkleid in Brauch kommen konnte, falls es bei ihm das angebliche heilige Mantelpallium gab; zumal dann, wenn beide Gewänder miteinander nur schwer verträglich waren. Es liegt doch auf der Hand, dafs der Papst eher auf die so ganz bedeutungslose Pänula verzichtet haben würde, als dafo er das altehrwürdige Pallium einer so gründlichen Änderung unterzogen hätte.

Endlich aber erklärt die Hypothese nicht, wa rum es zu einer Anlegungsweise kam, bei der von den beiden Enden des Palliums eines vor der Brust. das andere auf den Rücken herabfiel, während das heilige Mantelpallium der Theorie Garruccis nach Art des Pluviale der Schulter auflag und vorn auf der Brust mit einer Spange geschlossen wurde. Hätte es, wenn die Hypothese richtig wäre, nicht zu einer Tragweise kommen müssen, wie sie bei der Priesterstola üblich ist?

Das einzige, was scheinbar für die Theorie spricht, ist der Name pallium. Indessen schwindet auch diese Stütze, sobald man sich einmal etwas näher nach dem Sinne des Wortes pallium umsieht. Allerdings verstand man unter pallium anch einen Umwurf, einen Mantel, indessen hatte das Wort noch verschiedene sonstige Bedeutungen. Es diente zur Bezeichnung eines kleineren Schultertuches, eines Kopftuches, des Handtuches, der Bettdecke, eines Vorhanges; ja es war selbst Stoffname, gerade wie unser "Tuch", das überhaupt in allen genannten Bedeutungen ein vorzügliches Gegenstück zu pallium darstellt. Wie wenig ausschließlich das Mantelpallium unter dem Wort pallium zu verstehen ist, beweisen namentlich die pallia discolora, mit denen nach des Theodosius Kleideredikt die Exekutivbeamten ihre Brust bedecken sollten, ut conditionis suae necessitatem ex huiusmodi agnitione testentur ${ }^{\text {. }}$ Denn diese über der paenula auf der Brust angebrachten, in ihrer Farbe von derjenigen des Obergewandes abstehenden pallia können doch wohl nur als Abzeichen

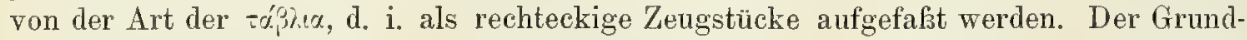
bedeutung nach bezeichnete pallium, wie Wilpert mit Recht bemerkt ${ }^{2}$, allgemein

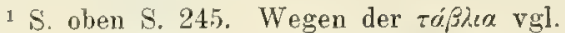
S. 250. Auch Wilpert, der früher (Cap. $13 \mathrm{ff}$; Gew. 48) in den pallia discolora ein zu einem Streifen zusammengefaltetes, um Brust, Schulter und Rücken geschlungenes Zeugstück sah, also ein Gegenstück des päpstlichen Palliums nach dessen ursprünglicher Form, hat sich neuerdings für die obige, von uns schon in "Die pontifikalen Gewänder des Abendlandes" (Freiburg 1898) S. 173 vertretene Auffassung entschieden (Bessarione $X$ 215). Doch geht es nicht an, unter der paenula der Exelutivbeamten, von welchen das Dekret spricht, die chlamys zu verstehen. Denn nur wenige Zeilen vorher wird in der gleichen Verordnung ausdrücklich die paenula von der chlamys unterschieden: Nullus senatorum habitum sibi vindicet militarem, sed chlamydis terrore deposito quieta coloborum ac paenularum induat vestimenta. Wenn hier chlamys und paenula mit aller Bestimmtheit einander entgegengesetat werden, dann können beide unmittelbar nachher unmöglich identisch sein. $\quad 2$ Cap. p. 47. 
ein Stück Stoff; aus ihr entwickelten sich alle übrigen. Angesichts dieses Tatbestandes liegt es aber auf der Hand, dak aus dem Worte pallium nicht geschlossen werden kann, das Pallium sei ursprünglich ein Mantel gewesen. Nur das eine lälat sich allenfalls aus ihm folgern, dafis es ursprünglich ein Stück Zeug und nicht ein blofes Band darstellte. Zur Stütze der Theorie Garruccis ließe sich das Wort pallium nur dann verwerten, wenn es einzig die ganz konkrete Bedeutung „Mantel“ gehabt hätte.

Eine vierte Theorie hat Wilpert aufgestellt. Sie schliebt sich insofern an diejenige Garruccis an, als auch sie das heilige Pallium aus einem Mantel sich entwickeln läßst, weicht aber von jener darin ab, daf sie das heilige Mantelpallium, welches nach Garrucei die Päpste ursprünglich getragen haben sollen, aufgibt und statt seiner das gewöhnliche Mantelpallium zum Ausgangspunkt nimmt. Im vierten Jahrhundert soll es Mode geworden sein, dieses Pallium, „das in der Kirche stets als ein Gewand der Auszeichnung und Würde (un abito di sommo onore e dignita) gegolten habe" 1, zu einem Streifen zusammenzufalten, ähnlich wie es bei der Toga und der Palla der Frauen allmählich Brauch geworden. Ihren Grund soll diese Änderung darin gehabt haben, daß damals an Stelle des Palliums ein anderer ebenso würdiger als zweckmäfiger Mantel in Gestalt der Pänula in Aufnahme kam. Durch dieses neue Gewand wurde das Pallium, wie Wilpert sagt, als wirkliches Kleidungsstïck überflïssig; man habe es aber nicht ganz beiseite legen können, da es bis dahin in der Kirche als das ehrenvollste Gewand gegolten. So habe man es denn zu einem Streifen zusammengefaltet und in einer durch die Form der Pänula bedingten etwas reränderten Weise um die Schultern geschlagen. In dieser Gestalt vorzugsweise auf den Schultern ruhend, sei es treffend von den Griechen wuopópoov genannt worden. Die Umbildung des Mantelpalliums, wie sie Wilpert schildert, soll sich in der zweiten Hälfte des 4. Jahrhunderts vollzogen haben ${ }^{2}$. Die Theorie ist scharfsimnig und klingt, wie wir gern gestehen, ungemein ansprechend und überzeugend. Nichtsdestoweniger sehen wir uns aufer stande, die Ansicht des so ausgezeichneten und hochverdienten Gelehrten zu teilen.

Zunächst kann man nämlich doch wohl keineswegs behaupten, es sei das Pallium in der Kirche schon seit dem 2. Jahrhundert als abito di sommo onore e dignità betrachtet worden. Welchen Anhaltspunkt gibt es hierfür hinsichtlich der Anschauung: der Kirche des Ostens? Keinen. Oder will man etwa als Beweis anführen, daß sich das Omophorion ${ }^{3}$ der griechischen Bischöfe aus dem Pallium entwickelt habe? Aber das wäre ja ein Zirkel; denn das ist es doch gerade, was nachgewiesen werden soll.

In Afrika war das Mantelpallium jedenfalls kein Gewand der höchsten Ehre und Auszeichnung bei den Christen. Es ergibt sich das mit aller Deutlichkeit aus der um 193 abgefaften Schrift Tertullians De pallio ${ }^{4}$, in welcher dieser seinen Landsleuten mit feinem Witz und übertriebenen Hymnen das Pallium anstatt der Toga als Obergewand anpreist. Zwar war selbiges damals den Christen keineswegs mehr fremd, vielmehr stand es auch bei ihnen schon in Gebrauch. Indessen war es so wenig ein spezifisch christliches oder auch nur bei den Christen in besonderem Ansehen stehendes Gewand, daf vielmehr, wie Tertullian zum Preise des Palliums mit

1 Wilp. a. a. O. $30 ;$ vgl. Gew. $47:{ }_{n}$ Von dem Pallium wissen wir, daßs es in der Kirche schon seit dem 2. Jahrhundert als ein Gewand der A uszeichnung und Würde in Gebrauch war."

2 Wil p., Cap. 24 ff; Gew. 47 ff; Kat, 74.

s Über dessen Ursprung vgl. S. $672 \mathrm{f}$.

4 Die Schrift entstand wohl bald, nachdem

Braun, Die liturgische Gewandung.
Tertullian das Christentum angenommen hatte. Die Veranlassung zu ihrer Abfassung war der Spott, den er sich dadurch zugezogen hatte, daf er die Toga mit dem bei den Philosophen beliebten Pallium vertauscht hatte. Es geschah das wahrscheinlich gelegentlich seines Übertrittes zum Christentum (Kirchenlex. XI² 1397 f). 
großem Wortschwall hervorhebt, seiner sich alle zu bedienen pflegten, welche irgendwie den freien Künsten oblagen, die Philosophen, Grammatiker, Rhetoren, Sophisten, Ärzte, Dichter, Musiker, ja selbst die Astrologen und A u gurn ${ }^{1}$.

Aber auch für $\mathrm{R}$ om ist der Beweis noch nicht geliefert worden, daf das Pallium dasellust bei den Christen als Gewand der höchsten Ehre und Würde gegolten habe. Wilpert weist freilich auf die Katakombenmalereien hin. Allein richtig ist unseres Erachtens nur, daf auf ihnen das Mantelpallium als ein Gewand besserer Klassen und höher stehender Personen erscheint. Daf auf ihnen die Fossores und andere gewöhnliche Leute ohne dasselbe dargestellt werden, ist ebenso natürlich, wie dafs der gute Hirt ohne Pallium auftritt. Pflegt man doch auch heute noch in den nicdern Ständen keinen Paletot zu tragen. Wem wird es darum aber einfallen, diesen als abito di sommo onore e dignità zu bezeichnen?

Und dann sehen wir ja auch Personen, wie die nichtswürdigen Ältesten in den Susannaszenen, mit dem Pallium bekleidet, während der Bischof bei der ,Einkleidung einer gottgeweihten Jungfrau " kein Pallium, sondern eine Pänula trägt. Namentlich diese letzte Darstellung dürfte denn doch deutlich beweisen, wie wenig zur Zeit ihrer Entstehung, d. i. im 3. Jahrhundert, das Pallium als abito di sommo onore e dignità galt. Übrigens gesetzt einmal, es sei wirklich das Pallium zu Rom und darum wohl überhaupt in Italien als ein Gewand der höchsten Ehre und Auszeichnung angesehen worden, wie hat es denn kommen können, daf man es der Mode zulieb oder aus Bequemlichkeit mit der gewöhnlichen Pänula vertauschte, und daf nur der Papst es in Form eines unbedeutenden Streifens beibehielt, die Bischöfe und Priester aber es vollig aufgaben? Es spricht das denn doch offenbar nicht gerade für eine sonderliche Wertschätzung des Gewandes.

Zweitens: wer hat das Mantelpallium in der Kirche getragen? War es blok der Papst oder haben sich seiner auch die Bischöfe und Priester bedient? Wohl nicht der Papst allein; denn es trägt ja auch ein taufender Priester in einer der sog. Sakramentskapellen von S. Callisto das Gewand. Zudem würde im andern Falle die Theorie im wesentlichen so ziemlich mit derjenigen Garruccis identisch sein. Und dann kommt ja auch das Pallium auf den Cömeterialmalereien bei den verschiedensten Personen vor.

Wenn aber nicht blok der Papst, sondern auch die Bischöfe und Priester das Nantelpallium getragen haben, wie ist es denn zugegangen, daß es zu einem ausschlieflich päpstlichen Schmucke ward, als es sich zu einem zusammengefalteten Streifen umbildete? Konnte es, die Sache praktisch genommen, ohne eine positive Bestimmung geschehen, dak die Priester und Bischöfe insgesamt den abito di sommo onore e dignita preisgaben und in der Kirche des Westens nur mehr der Papst sich desselben als eines einzig ihm zustehenden Ehrengewandes zu berienen das Recht hatte? I'enn aber das ohne eine solche Verordnung nicht wohl denkbar ist, warum dann nicht, statt

I De pallio c. 6 (M. II 1104) : Viderit nune philosophia, quid prosit, non enim sola mecum est: De meo (das Pallium spricht) et primus informator litterarum et primus edomitor vocis et primus numerorum arenarius et grammaticus et rhetor et sophista et medicus et proeta et qui musicam pulsat atque stellarem coniectat et qui volaticam spectat. Omnis liberalitas studiorum quattuor meis angulis tegitur... At ego iam illi etiam divinae sectae ac disciplina commercium confero. Gaude pallium et exsulta, melior iam te philosophia dignata est, ex quo christianum vestire coep isti (seitum du anf ängs $\dot{c}$, Christen zu hekleiden). Niclit recht verstindlich ist, wenn Wilpert (Cap. 29) sagt: Lifatti in questi due manti (Toga und Pallium) venne espresso il contrasto fra lo spirito nazionale romano e il cosmopolitismo cristiano. War denn das Pallium ein Charakteristikum der Christen und trugen nur sie es, nicht die Heiden? Freilich war auch noch im 3. und 4. nachchristlichen Jahrhundert die Toga das offizielle Staatskleid, weshalb natürlich auch christliche Beamte und Senatoren sie anlegten, so oft sie in offizieller Tracht auftraten; im gewöhnlichen Leben aber bedienten sich die Heiden wie die Christen der Obergewänder, welche die gerade herrschende Mode wollte, ohne sich - vongewissen Philosophen abgesehen durch philosophische und nationalistische Litwägungen leiten zu lassen. 
durch so viele in der Luft schwebende Hypothesen die Entstehung des Palliums zu erklären, lieber einfach annehmen, es sei das Gewandstuick direkt als liturgisches päpstliches Distinktivum in Form eines streifenförmig zusammengefalteten Tuehes durch eine diesbezügliche Bestimmung des Papstes eingeführt worden?

Drittens: die Umbildung des Mantelpalliums soll durch die Einführung der Pänula als Obergewand veranlafist worden sein? Es wurde schon darauf hingewiesen, wie wenig das angesichts des Charakters, den das Mantelpallium gehabt haben soll, verständlich ist. Jedenfalls läfit sich ein derartiges Auferbrauchkommen bzw. eine derartige Umgestaltung eines Gewandes „der höchsten Ehre und Würde" nicht ohne hinreichende Anhaltspunkte glaubhaft und annehmbar machen. Gibt es nun aber deren? Nein. Es läßst sich, wie bei Besprechung der Theorie Garruccis ausgeführt wurde, weder durch den Namen eine Umbildung des Mantelpalliums zum Streifenpallium begründen, noch gibt es irgend ein Mon ument oder irgend eine schriftliche Nachricht, die uns von dem Vorgang Zeugnis ablegten.

Aber haben wir zu diesem nicht wenigstens eine Parallele in der Umgestaltung der Toga? Auch das nicht einmal. Solange die Toga nämlich zu Rom Staatskleid und offizielles Gewand war, ist sie weder durch die Pänula ersetzt worden, noch anch zu einem schmalen Band entartet, wie das heilige Pallium es ist. Noch auf den Konsulardiptychen des 6 . Jahrhunderts tritt sie trotz aller Verändermngen und wiewohl teilweise zu einem Streifen zusammengefaltet, als ein Umwuri auf, welchem eine recht erhebliche Breite eigen ist. Im Alltagsleben und als Tracht des gewöhnlichen römischen Bürgers ist allerdings die Toga ziemlich früh aus dem Gebrauch verschwunden und der Painula geoptert worden. Bezeichnenderweise aber hat man es nicht der Yühe für wert gehalten, sie streifenförmig zusammenzufalten und in dieser Form als Erinnerung an die frühere Sitte über dem neuen Oborgewand zu tragen. Und doch war die Toga ein so hochbedeutsames und charakteristisches Gewand des echten Römers. Wozu also unter solchen Umständen eine Berufung auf die Toga? Ja, wenn noch das Mantelpallium einen ähnlichen Charakter besessen hätte wie die Toga. Aber das ist bislang weder im geringsten bewiesen noch auch nur wahrscheinlich gemacht worden. Jedenfalls könnte, wenn die Berufung auf die Toga konsequent durchgeführt werden soll, der Analogieschlub nur lauten: Im gewöhnlichen Leben ist das Pallium durch Aufnahme der Pänula völlig aúber Brauch gekommen; im offiziellen kirchlichen Leben hat man auf Einführung der Pänula verzichtet, aber zur Entfaltung gröferen Prunkes dem Mantel eine kostbarere Beschaffenheit gegeben und ihn in etwas komplizierterer Weise zu tragen angefangen.

Auch der Hinweis auf die angeblich durch Umbildung der Mantelpalla (des mantelartigen Obergewandes der Franen) entstandene Schärpe, mit welcher die Isispriesterinnen auf den Billwerken verschiedentlich dargestellt werden, ist zur Stützung der Theorie von der Umgestaltung des Mantelpalliums zum sakralen Pallium von keinem Belang. Denn zunächst und vor allem scheint es doch wohl kaum zutreffend, daf die Schärpe der Isispriesterinmen eine zum blofen Bande verbildete Mantelpalla ist. Wilpert hat selbst eine Statue, sei es der Isis, sei es einer Isispriesterin aus der ersten Hälfte des 2. Jahrhunderts, zur Abbildung gebracht, welche über der Mantelpalla auch noch die in Frage stehende Schärpe und somit Palla und Schärpe zugleich aufweist ${ }^{1}$. Es kann also die letztere unmöglich die zum Streifen gewordene oler streifenartig gefaltete Mantelpalla sein?. A ufserdem aber folgt, die Umwand-

1 Cap. p. 16, fig. 19.

2 Wenn Wilpert sich für seine Theorie von dem Ursprung der Schärpe der Isispriesterinnen auf die palla multiplici contabulatione dependula beruft, mit der Apulejus (Metamorph. 11, 24) die Isis im Traum bekleidet schante, so will uns bedünken, daß der Dichter diese contabulatio multiplex nur gewaluen konnte, wenn mit ihr eine Reihe nebeneinanderliegender Falten gemeint ist. Überhaupt spricht der ganze Tenor der Stelle durchaus für ein weites mantelförmiges Gewand, nicht für eine zu einem bloßen Streifen zusammengefaltete Palla. Jedenfalls ist die erste Auffassung der cont. mult. mindestens ebenso berechtigt wie die letzte 
lung der Palla zur. Schärpe einmal als wirklich angenommen, auch dann aus einem solchen Torgang doch nur, dafa wie in der ersten Hälfte des 2. Jahrhunderts die Mantelpalla zum Streifen verkümmerte, so in der zweiten Hälfte des 4. Jahrhunderts das Mantelpallium zu einem blofen Streifen werden konnte, nicht jedoch auch, dak es tatsächlich oder auch nur wahrscheinlich ein solcher wurde. Das aber und nicht die absolute Möglichkeit ist es, worauf es ankommt.

Besonderes Gewicht legt Wilpert zur Glaubhaftmachung der Umbildung des Mantelpalliums auf ein um 356 oder etwas später entstandenes Fresko im Cömeterium der hl. Domitilla. Es stellt die hl. Petronilla dar, wie sie eine Verstorbene, namens Veneranda, in das Paradies einführt. St Petronilla trägt eine lange Untertunika, eine kürzere Obertunika und darüber die Palla (Bild 298). Man betrachte indessen einmal aufmerksam das Bild; handelt es sich denn bei dem Mantel der Heiligen um ein künstlich zu einem Streifen zusammengefaltetes Gewand? Zieht er sich nicht vielmehr von der rechten Seite in langen, losen Falten schräg vor dem Körper zur linken Schulter hinauf? ${ }^{1}$ Nur das Ende des Umwurfes erscheint zusammengefaltet, vorausgesetzt, dak die Form, welche dasselbe hat, eine getreue Darstellung der Wirklichkeit und nicht blof eine der hundert Zufälligkeiten oder Freiheiten ist, die wir auf den bildlichen Darstellungen so oft antreffen, namentlich aber auf Bildwerken von so handwerksmäßigem, skizzenhaftem Charakter, wie das die Cömeterialfresken sind?

Überhaupt ist es nicht einzusehen, welche Bedeutung das Fresko für die hier uns beschäftigende Frage besitzt, wie es sich nun immer mit der Form der Palla der hl. Petronilla verhalten mag. Denn was hat, so fragen wir, diese Palla, das gewöhnliche Obergewand römischer Frauen ${ }^{2}$, mit dem Mantelpallium der Priester und Bischöfe zu tun, dem abito di sommo onore e dignità, und wie kann man von der Faltung der einen auf die des andern schließen? Selbst wenn Christen und Heiden sich im profanen Leben hinsichtlich des Mantelpalliums einer etwaigen diesbezüglichen Mode anbequemt haben sollten, so folgt daraus offenbar noch lange nicht, daf auch der Papst, die Bischöfe und Priester bezüglich der bei der Liturgie üblichen Gewandung sich derselben unterwarfen. Zudem genügte ein nur teilweises Zusammenfalten noch keineswegs, um aus dem Mantelpallium ein förmliches Streifenpallium werden zu lassen, von der Änderung in der Umlegeweise ganz abzusehen. Allein nicht einmal einen Schluf auf eine Faltung des Mantelpalliums der Laien gestattet das Fresko. Oder kann man wirklich aus einer einzigen Darstellung einer an dem einen Ende zusammengefalteten Fra uenpalla eine entsprechende Gewohnheit auch für das Mantelpallium der Männer herleiten? Die Folgerung: "In jedem Falle beweist das Fresko, daf die Gewohnheit, die Palla - und infolgedessen auch das Pallium - zu talten, bei den Christen bereits wenige Jahre nach der Mitte des 4. Jahrhunderts in Übung war", geht offenbar entschieden zu weit ${ }^{3}$.

(vgl. auch Forcell. I 580). Hieran kann auch die von Wilpert veröffentlichte Isispriesterin der vatikanischen Sammlung (Cap. fig. 18) nichts ändern. Sie beweist nur, daßs man auch auf der Schärpe der Isispriesterinnen die Symbole des Kultus, Mond und Sterne, anzubringen pflegte, nicht aber, daß diese Binde ursprünglich ein förmlicher Mantel war.

1 Wilpert sagt von der fraglichen Palla (Kat. 76) selbst: "Die Palla bildet nicht in ihrer ganzen Länge einen Streifen, sondern ist in der zweiten Hälfte entfaltet." Welche Bedeutung hat aber dann noch die Darstellung?

2 Es ist doch nur eine Vermutung, wenn Wilpert (Gew. 48; Kat. 76) sagt: „Der Maler gab der Heiligen offenbar einen solchen Mantel, um sie besonders auszuzeichnen; vielleicht wollte er dadurch ihre hohe $\mathrm{Ab}$ - kunft andeuten." Und dann war denn doch die Palla keineswegs ein auszeichne $\mathrm{n}$ des Frauengewand.

${ }^{3}$ Ebd. Nach dem im Text angeführten Litat Wilperts muf das Pallium noch nach der Mitte des 4. Jahrhunderts bei den Christen überhaupt in Gebrauch gewesen sein. Wann ist es also ein Sondergewand des Papstes geworden? Ein solcher Wechsel vollzieht sich doch nicht iber Nacht. Um $400 \mathrm{muk}$ derselbe nach Wilpert schon vollendet gewesen sein. Also um 356 noch ein wirklicher, nur am Ende zusammengefalteter, bei den Christen überhaupt gebräuchlicher Umwurf und um 400 eine liturgische Spezialinsignie des Papstes von völliger Streifenform. Wie es scheint, eine sehr rapide Fntwicklung. 
Wilpert ${ }^{1}$ verweist auch auf das Elfenbein aus der Sammlung Harbaville im Louvre (Bild 299, S. 663), auf das ich selbst ihn seinerzeit aufmerksam machte, und auf eine Miniatur des Cod. Vat. gr. 752, f. $42^{2}$ als auf zwei Monumente des 10. bzw. 12. Jahrhunderts, auf denen sich eine letzte Reminiszenz an das alte Wantelpallium finde. Er meint, der Künstler, der hier das heilige Pallium gefaltet darstellte, müsse eine Vorlage aus einer Zeit vor sich gehabt haben, welche der Epoche nahestand, in der das heilige Pallium noch ein zusammengefaltetes Mantelpallium gewesen. Ob jedoch nicht auch hier das Wort gilt: Non saprei dare grande autorità a questi casi eccezionali, essendo pitture del $X$ e XII secolo ${ }^{3}$. Kann man denn wirklich die genannten beiden Bildwerke als Kopien einer Vorlage etwa aus dem 4. oder 5. Jahrhundert ansehen? Werden wir nicht vielmehr die sonderbare zickzackartige Faltung des Endes des Palliums, wie so manches andere auf den alten Monumenten, als die Frucht der Phantasie oder der Laune des Künstlers zu betrachtenhaben? Auf keinen Fall können die Bildwerke zum Beweise dienen, dafs das heilige Pallium ursprünglich ein Mantel war. Höchstens liefe sich, was keineswegs geleugnet werden soll, aus ihnen folgern, es sei dieses anfänglich noch kein schmales Band gewesen wie später, sondern ein zu einer Binde zusammengefalteter Zeugstreifen !

Doch genug der Kritik. Das Angeführte dürfte ja zur Wertung der Aufstellungen Wilperts über den Ursprung des Palliums vollkommen ausreichen. Der Schwierigkeiten, an denen seine Theorie krankt, sind nach dem Gesagten zu viele und zu erhebliche. Wir ziehen daher eine andere Erklärung der

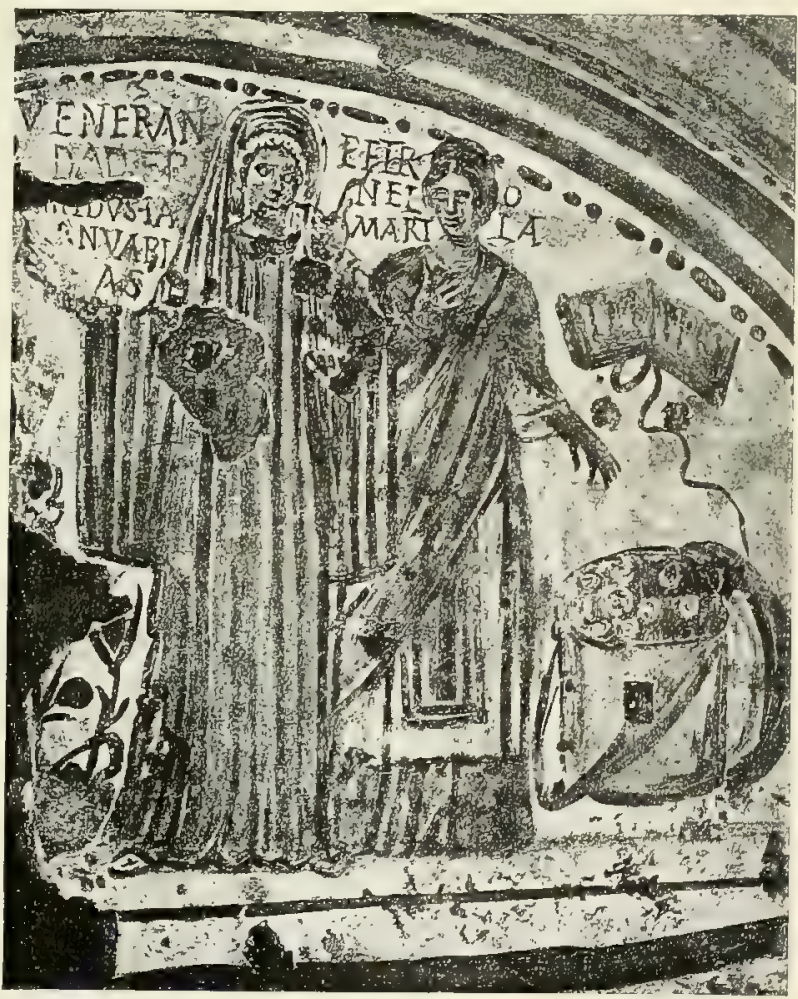

Bild 298. Veneranda mit der hl. Petronilla. Fresko in der Katakombe S. Donitilla zu Rom. (Nach Wilpert,)

Entstehung des Ornatstückes vor, die wir zwar keineswegs als schlechthin sicher bezeichnen möchten, die aber, alle Umstände in Rechnung gezogen, immerhin die größste Wahrscheinlichkeit für sich haben dürfte. Das

1 Cap. 97 ; Gew. 48.

2 Abbildung Cap. 83.

3 Ebd. 75, nota 5.

4 Auch durch interessante Rekonstruktionsversuche hat Wilpert seine Theorie zu bekräftigen sich bemüht. Was dieselben beweisen, ist aber zuletzt blof dies, daf das Mantelpallium absolut genommen zu einem freilich recht breiten Streifen zusammengefaltet werden konnte, wofern nur der Stoff nicht allzu dick war. Für die Feststellung der tatsächlichen Umbildung des Mantelpalliums zum sakralen Streifenpallium sind solche Rekonstruktionen jedoch ohne Bedeutung, so bestechend sie für den Nichtfachmann sein mögen. Nicht durch Rekonstruktionen kann die Frage nach dern Ursprung des sakralen Palliums gelöst werden, sondern nur auf dem Weg der historischen Forschung. 
Pallium ist ihr zufolge nicht das Produkt einer langsamen Entwicklung, nicht ein durch die Lmstände verkümmertes Obergewand; es wurde vielmehr zu Rom von Anfang an als das eingeführt, als was es uns stets in der Geschichte begegnet, als auszeichnender Schmuck und als Abzeichen des obersten Hirten der Kirche und des Patriarchen des Abendlandes, des römischen Bischofs. Eine bloke Binde war es allerdings ursprünglich nicht; das wurde es erst allmählich. Wie der Name pallium andeutet, war es vielmehr anfänglich ein Tuch, das um Schultern, Brust und Rücken geschlungen wurde. Ob es hierbei schon gleich in der ersten Zeit streifenförmig zusammengefaltet wurde oder ob man erst allmählich dazu überging, es streifenförmig zusammenzulegen, muf dahingestellt bleiben. Jedenfalls dürfte es, bevor es zum bloßen Bande wurde, bereits zu einem Streifen gefaltet getragen worden sein ${ }^{1}$.

Es besteht heutzutage die Tendenz, nach Möglichkeit überall in der Geschichte einen Entwicklungsgang nachzuweisen. Es ist das gewif nicht blok zu billigen, sondern selbst freudig zu begrüßen; denn erst das führt zu einem tieferen Verständnis der einzelnen Erscheinungen. Man darf indessen nicht aufer acht lassen, daß̧ eine naturgemäß3e Entwicklung sich da, wo kein positives Eingreifen statthat, nur langsam zu vollziehen pflegt. Wie lange hat es z. B. gedauert, bis sich eine liturgische Kleidung im besondern Sinne ausgebildet hatte, wie lange, bis Fano und Subcinctorium Sondergewänder des Papstes geworden waren. Man wird diese Tatsache auch bei der Frage nach dem Ursprung des Palliums vor Augen halten müssen. Ohne irgend eine positive Bestimmung oder Tat hat es unseres Erachtens zur Bildung desselben nicht kommen können. Selbst wenn man mit Wilpert annehmen wollte, daf sich das Streifenpallium aus dem Mantelpallium entwickelt habe, wird man einer solchen nicht entbehren können. Denn wie hat ein Gewand, das Priestern wie Bischöfen, ja selbst Laien eigen war, in der kurzen Zeit, die Wilpert dafür ansetzt, ohne irgend eine diesbezügliche Verordnung im Abendland ein ausschliefiches päpstliches Ornatstück und die Insignie des römischen Bischofs zu werden vermocht?

Warum also unter solchen Umständen nicht lieber annehmen, es sei das römische Pallium von Anfang an als das eingeführt worden und das gewesen, als was es uns allzeit begegnet, als liturgisches Abzeichen des

Der Verfasser hat diese seine Auffassung von dem Ursprung des römischen Palliums schon in seiner Schrift Die pontifikalen Gewänder des Abendlandes" S. $172 \mathrm{ff}$ zum Ausdruck gebracht. Eine verwandte Anschaung hatte bereits $P$. G $\mathrm{r}$ is a $r$ ausgesprochen in "Das römische Pallium" $\mathrm{Nr} 3$ (Festschrift zur 1100 jährigen Jubelfeier des Campo Santo, Freiburg 1897, 101). Vgl. auch P. Grisar (Analecta Romana, Rom. 1899, 677), wo er die Theorie Wilperts sowie die des Verfassers ausführlich bespricht und letzterer ausdrücklich die größere Wahrscheinlichkeit zuerkennt: Ammettendo pure un simile sviloppo (Umbildung des Mantelpalliums durch Zusammenfalten), il quale per altro ha assai oscuro, si può sempre e con maggiore probabilità assegnare al pallio sacro una origine immediata per mezzo di qualche ordinazione ecclesiastica, la quale avrebbe introdotto il pallio sacro direttamente come insegna gerarchica ed in forma simile a quel pallio-manto accorciato dalla contabulatio imitandone la forma di modesta fascia. Bei dem Vermittlungsvorschlag, den Grisar in den letzten Worten macht, läßst er das Pallium sich nicht aus dem Mantelpallium entwickeln, sondern nur das gefaltete Mantelpallium, wie er S. 678 sagt, das Vorbild sein, dem jenes nachgebildet wurde: Prendendo per modello il palliomanto, diminuito e accorciato. So jedoch unterscheidet sich sein Versuch, beide Theorien in Einklang miteinander zu bringen, im Grunde in keiner Weise von unsern Aufstellungen, nach welchen wix uns ja, wie aus den Ausführungen oben in Text erhellt, das sakrale Pallium keineswegs von Anfang an als bloßses schmales Band, sondern als einen breiten, aber zusammengefalteten Zeugstreifen zu denken haben. 
Papstes: Das ist, wie es scheint, die einfachste, nächstliegende und den tatsächlichen Verhältnissen entsprechendste Erklärung.

Dabei braucht man natürlich, wie eben schon gesagt wurde, keineswegs anzunehmen, es sei das Pallium auch schon von Anfang an das schmale, nur ca $0,08-0,09 \mathrm{~m}$ breite Band gewesen, als welches es bereits im Laufe des 6. und 7. Jahrhunderts auf den Bildwerken auftritt. Im Gegenteil wird man es auf Grund des Namens pallium in seiner ursprünglichen Gestalt wohl als ein wirkliches, wenngleich zusammengefaltetes Tuch von vielleicht $0,40-0,50 \mathrm{~m}$ Breite aufzufassen und seine Umbildung zu einem blofien Bande erst der weiteren Entwicklung zuzuschreiben haben.

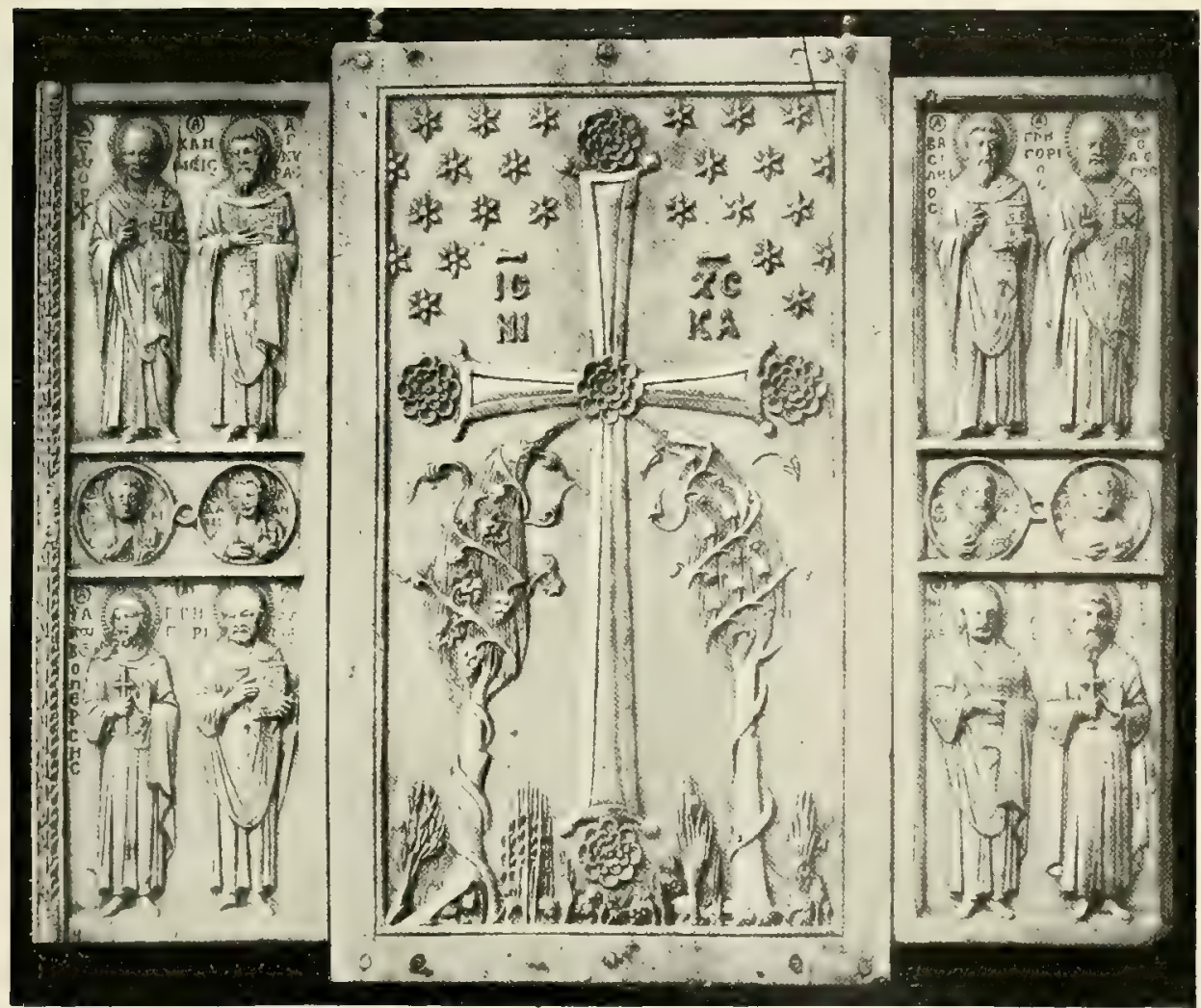

Bild 299. Triptychon der Sammlung Harbaville. (Rüickseite.) Paris, Lonvro.

Eine colche Erklärung der Entstehung des römischen Palliums wird nicht nur dem Namen pallium vollständig gerecht, der als ganz begründet und als durchaus zutreffend erscheint, sie lälst auch der formellen Ausgestaltung des Ornatstückes alles Recht und allen Spielraum.

Es hat aber auch ein solcher Ursprung durchaus nichts Befremdendes. Tücher als Abzeichen haben auch schon die Römer gekannt. Oder waren derartige Abzeichen nicht die infulae? ' Und war die Schärpe oder wie wir den Streifen nennen wollen, welche die Isispriesterinnen über der Tunika oder auch über Tunika und Palla trugen, nicht auch eine Art

1 S. oben S. 426619. 
Insignie? 1 Sellost die Toga war in der Form, welche sie im 4. Jahrhundert erhielt, mehr eine Insignie als ein praktischen Zwecken dienendes Gewand. Auch auf die pallia discolora des Theodosianischen Kleideredikts darf hier wohl hingewiesen werden. Denn wenn es sich auch bei ihnen nicht um Abzeichen in Form einer Schärpe oder eines Umwurfes handelt, so bekunden sie doch, daf die Tendenz, Distinktiva zu schaffen, jenen Tagen keineswegs fremd war 2.

Auf der andern Seite lag es einer Zeit, in welcher die beim Gottesdienste gebräuchliche Kleidung sich dem Schnitte nach noch nicht von der auferliturgischen und der Laienkleidung unterschied, sicher nicht allzufern, ein liturgisches Distinktivum einzuführen. Insbesondere aber muste das beim Bischof von Rom, dem Papst, passend erscheinen, seitdem dieser nach dem Aufhören der Verfolgungen und nach Anerkennung des Existenzrechtes der Kirche seitens der staatlichen Macht ungehindert in der Öffentlichkeit seines hohenpriesterlichen Amtes walten und nach allen Richtungen hin frei die Fülle seiner pontifikalen Gewalt entfalten durfte.

In der Kirche des Ostens muf das dem Pallium analoge Omophorion, von dem im folgenden näher die Rede sein wird, schon vor 400 in Gebrauch gekommen sein. Das römische Pallium läfat sich, wie wir hörten, schon für das 5. Jahrhundert mit genügender Sicherheit nachweisen; ob es auch schon im 4. zur Verwendung kam, muß dahingestellt bleiben. Man kann die Frage aufwerfen, ob das römische Pallium nach dem Vorbilde des Omophorion bzw. letzteres nach demjenigen des päpstlichen Palliums eingeführt wurde oder ob beide selbständige, voneinander unabhängige Bildungen sind. Eine sichere Antwort läßt sich auf dieselbe leider nicht geben, da wir nicht einmal genau wissen, zu welcher Zeit das römische Pallium aufkam. Immerhin darf es als nicht so unwahrscheinlich gelten, daß zwischen dem Pallium und dem Omophorion irgend ein Zusammenhang bestanden haben wird. Denn die Punkte, in Bezug auf welche Unterschiede zwischen beiden Ornatstücken herrschen, sind nur nebensächlicher Art; im wesentlichen waren und sind diese nach Form, Charakter und Bestimmung dasselbe liturgische Gewand ${ }^{3}$. Vielleicht wird man sogar nicht fehlgehen, wenn man zu der Ansicht hinneigt, das päpstliche Pallium sei eingeführt worden nach dem Vorbild des bereits in Gebrauch befindlichen Omophorion. Der Einflus des Ostens auf den Westen war in altchristlicher Zeit in liturgischen Dingen größer, als man gemeiniglich denkt; auch Rom ist von ihm keineswegs frei geblieben ${ }^{4}$.

\section{DAS BISCHÖFLICHE SCHULTERGEWAND IN DEN RITEN DES OSTENS.}

Dem lateinischen Pallium entspricht im griechischen, armenischen und syrischen Ritus das Omophorion. Während jenes jedoch ein liturgisches Sondergewand des Papstes und der Erzbischöfe ist und Bischöfen nur ganz

1 W il p., Cap. 2125 27. Bezúglich des Charakters des Streifens sagt derselbe zutreffend: Questa palla, secondo ogni apparenza, non serviva di vero abito, ma per scopo ornamentale o piutosto come insegna del grado delle sacerdotesse (ebd. p. 15; vgl. 23).

2 Vgl, auch den oben S. 619, Anm. 1 erwähnten Grabfund aus Antinoe, der keinen Zweifel am Gebrauch von Schärpen als $\mathrm{Ab}$ zeichen lassen dürfte.
${ }^{3} \mathrm{Vgl}$. wegen der Identität von Omophorion und Pallium Gre gor. M., Ep. 1. 1, n.27 (M. G. Epp. I 41) und Liberat, Brev. c. 202123 (M. 68, 1036 1039 1046), wo mit dem Worte pallium das Omophorion bezeichnet wird.

4 L̈ber den Einflula, den der Osten in Italien und namentlich auch zu Rom ausübte, vgl. St. Beissel, Geschichte der Evangelienbuicher in der ersten Hälfte des Mittelalters, Freiburg 1906, 72 ff. 
ausnahmsweise als Auszeichnung verliehen wird, kommt dieses allen Bischöfen als spezifisch bischöfliche Amtsinsignie zu. Es besteht zwischen beiden Ornatstücken aber auch ein Unterschied bezüglich der Form, der stofflichen Beschaffenheit und der Anlegungsweise.

Das griechische Omophorion ist ein ca $3,50 \mathrm{~m}$ langes und ca $0,25 \mathrm{~m}$ breites Band, welches frei um Brust und Schulter geschlungen wird. Soll es angelegt werden, dann befestigt der Diakon es zunächst in der Weise an einem auf des Bischofs linker Schulter am Obergewande angebrachten Knöpfchen, das eines der beiden Enden in einer Länge von etwa einem Meter nach vorn hinabhängt. Dann leitet er den übrigen Teil des Bandes iiber den Nacken zur rechten Schulter und von da nach vorn bis unterhalb der Brust. Dort wendet er den Streifen, führt ihn wieder zur linken Schulter hinauf, wo er ihn ein zweites Mal anknüpft, und schlägt zuletzt den Rest so nach rückwärts, daf sich das andere Ende des Omophorion dort ehenfalls etwa einen Meter lang hinabzieht (Bild 300).

Über die Farbe des Omophorion scheint gegenwärtig eine allgemein gültige Vorschrift nicht mehr zu bestehen; wenigstens bekommt man aufer weifen anch wohl blaue, gelbe, rote usw. zu Gesicht. Immerhin darf Weifs bzw. als Weif geltender Gold- oder Silberstoff als das Gewöhnliche, eine andere Farbe dagegen als das Seltenere und mehr als Ausnahme bezeichnet werden. Das Omophorion wird stets aus Seide gemacht. Sein Hauptschmuck sind mächtige $\mathrm{Kreuze}$, welche entweder durch aufgenähte Borten gebildet oder in Goldbzw. Silberstickerei hergestellt werden. Es sind ihrer zum mindesten fünf, je eines an den beiden Enden und auf den beiden Schultern und eines im Nacken, falls nicht etwa ein Lamm an Stelle des letzten zum Ausdruck der Symbolik des Omophorion angebracht ist. Wie schon gelegentlich bemerkt wurde, gilt dieses ja als Simnbild des verlorenen Schäfleins, das der Bischof

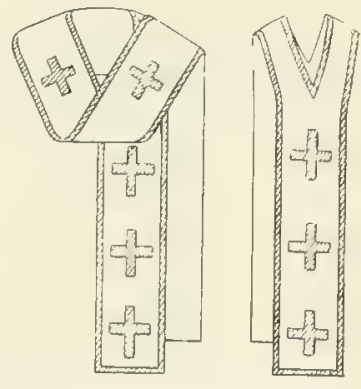

Bild 300. Omophorion in den orientalischen Riten.

als guter Hirt seiner Herde zur Hürde zurückbringen soll. Übrigens trifft man aufer Kreuzen und dem Lamme auch wohl andere Verzierungen, bildliche Darstellungen nicht ausgeschlossen, auf dem Ornatstück an, wie auch, wo die Mittel reichen, selbst Edelsteine und Perlen zu seiner Ausschmückung verwendet werden.

Das Omophorion des armenischen Ritus, emiforon genannt, unterscheidet sich in keiner Weise von dem gleichnamigen griechischen Sakralgewand. Es hat die gleiche Form und die gleiche Beschaffenheit und wird auch in derselben Weise angelegt.

Von ganz anderer Form ist dagegen das syrische Omophorion (omophorion, bitraschil). Denn es besteht aus einem ca 2,50 $\mathrm{m}$ langen und ca $30 \mathrm{~cm}$ breiten, mit Kreuzen besetzten Streifen, welcher in der Mitte mit einem Ausschnitt zum Durchlassen des Kopfes versehen ist und so übergeworfen wird, daf die eine Hälfte über die Brust, die andere über den Rücken herabhängt. Es hat also mit einem doppelten griechischen Epitrachelion oder einem Skapulier großse Ähnlichkeit (Bild 300).

Entstanden ist die jetzige Form des syrischen Omophorion offenbar durch Verkümmerung seiner ursprünglichen Gestalt und Anlegeart. Noch immer erinnert das Ornatstück in seinen Hauptlinien an die Weise, wie man es einst, da es noch ein Streifen war, um die Schultern schlang. 
Die Nestorianer (nichtunierte Chaldäer) kennen weder beim Patriarchen noch bei den Bischöfen ein Omophorion oder sonst ein Gegenstück zum lateinischen Pallium. Ein gleiches gilt bezüglich der Bischöfe der zur kirchlichen Einheit zurückgekehrten Chaldäer. Der Patriarch der unierten Chaldäer bedient sich des lateinischen Palliums, das ihm von Rom als Zeichen seiner Verbindung mit dem Apostolischen Stuhl und der ihm übertragenen Patriarchalgewalt verliehen wird.

Auch bei den schismatischen Kopten gibt es kein dem römischen Pallium entsprechendes Ornatstück. Bei den mit Rom wiedervereinigten Kopten treffen wir als Abzeichen des Patriarchen und der Bischöfe das griechische Omophorion, hier apostolicon genannt, an.

Das über das Omophorion, wie es gegenwärtig in den Riten des Ostens gebräuchlich ist. Nun zur Geschichte desselben.

Die erste sichere Nachricht erhalten wir über das Ornatstück erst um das Jahr 400. Zwar hören wir in den Akten der konstantinopolitanischen Bischöfe Metrophanes und Alexander bereits von einem Omophorion des Metrophanes, der zur Zeit Konstantins den bischöflichen Stuhl von Konstantinopel inne liatte. Ja nach Liberatus von Karthago besaf man zu Alexandrien sogar ein angebliches Pallium des hl. Markus, das nach dem Tode eines Patriarchen sein Nachfolger zum Zeichen der Übernahme der patriarchalen Gewalt um den Hals zu legen pflegte?. Allein die Akten des Metrophanes sind durchaus unzuverlässig; das pallium beati Marci aber, von dem Liberatus erzählt, war entweder ein vermeintliches Omophorion des Heiligen oder wir haben mit Rücksicht auf die Gründung der alexandrinischen Kirche durch Markus darunter lediglich in übertragenem Sinne das Omophorion der dortigen Patriarchen zu verstehen. Es als wirkliches Pallium (Omophorion) des Evangelisten aufzufassen, geht unmöglich an. Für die Tage des hl. Markus wäre ein solches ein Anachronismus.

Seit dem Beginn des 5. Jahrhunderts ist mehrfach von dem Omophorion die Rede, zuerst bei Isidor von Pelusium ${ }^{3}$, dann bei Theodorus Lektor ${ }^{4}$, bei Eustratius ${ }^{5}$, bei Liberatus von Karthago ${ }^{6}$, bei Johannes Moschus ${ }^{7}$, von Späteren ganz zu schweigen.

Als Träger des Omophorion erscheinen bei Isidor von Pelusium die Bischöfe schlechthin. Es war dasselbe also schon um 400 ein allgemein bischöfliches Ornatstïck und nicht ein Sondergewand der Inhaber bestimmter hervorragender Sitze. Es ist eine Fabel, wenn Luitprand von Cremona das Omophorion erst seit etwa 950 auch bei den griechischen Bischöfen in Brauch kommen läbt ${ }^{8}$. Es genüge, dem entgegen auf den 14. Kanon des vierten allgemeinen Konzils von Konstantinopel ${ }^{9}$ und den Brief Johannes' VIII. an

1 Photii, Bibl. cod. 256 (Mg. 104, 114).

2 Breviar. c. 20 (M. 68, 1036). Daf hier unter Pallium kein Mantel, sondern das Omophorion zu verstehen ist, folgt aus andern parallelen Stellen derselben Schrift, wo unter pallium nur das Omophorion verstanden werden kann, so c. 21 (1039) und c. 23 (1046).

3 Epist. 1. 1, n. 136 (Mg. 78, 272).

4 Hist. eccl. 1. 2, c. 15 ( $\mathrm{Mg} .86^{1}, 189$ ).

5 Vita Eutychii Patr. c. 5 ( $\mathrm{Mg} .86^{2}, 2317$ ).

- Breviar. c. 21 und 23.

7 Pratum spirit. c. 36 ( $\left.\mathrm{Mg} .87^{3}, 2885\right)$.
${ }^{8}$ Legat. Constant, c. 62 (M. G. SS. III $361)$.

9 Hard. V 1103. Daß3 der Kanon dahin zu verstehen ist, daf alle Bischöfe bereits das Omophorion trugen, nicht aber, dak dieses nur ein Vorrecht einzelner Bischöfe war, folgt aus der Strafandrohung am Schlusse des Kanons. Es wird dort Absetzung den Bischöfen in Aussicht gestellt, welche das Ornatstück anders als bei bestimmten Gelegenheiten tragen sollten. Wäre das Omophorion damals noch kein allgemein den 
Photius ${ }^{1}$ hinzuweisen. - Immerhin mag in Bezug auf den Gebrauch des Omophorion ein Unterschied zwischen den Patriarchen, den Metropoliten und den gewöhnlichen Bischöfen bestanden haben. Von den Patriarchen scheint es in früherer Zeit auch wohl auferhalb der eigentlichen gottesdienstlichen Funktionen getragen worden zu sein ${ }^{2}$, während es bei den gewöhnlichen Bischöfen lediglich liturgisches Ornatstück war, das zudem nur an bestimmten Tagen und bei bestimmten Gelegenheiten zur Verwendung kommen durfte. Dem Bestreben mancher Bischöfe, ihre Befugnisse hinsichtlich der Benutzung des Omophorion zu erweitern, trat der eben erwähnte Kanon des vierten Konzils von Konstantinopel mit Entschiedenheit entgegen. Es sollten die Bischöfe, so verordnet er, sich des Ornatstückes nur bei den Gelegenheiten bedienen, für die ihnen das schriftlich oder sonstwie erlaubt worden sei, nicht aber das Gewand aus Prunksucht und Hoffart gebrauchen, noch zu jeder Zeit während des beiligen Opfers oder bei jeder beliebigen kirchlichen Funktion. Den Zuwiderhandelnden wird für den Fall, dafs sie sich nicht bessern, Absetzung angedroht ${ }^{3}$. In späterer Zeit war das Omophorion bei allen, auch den Patriarchen, ein ausschließich liturgisches Ornatstück. Seine Verwendung beschränkte sich auf die Feier des heiligen Opfers und die Vornalıme von Weihehandlungen ${ }^{4}$. Beim Evangelium wurde es abgelegt und erst vor der Elevation nach der Konsekration wieder angenommen. Bei dem groken Einzug wurde es von den Diakonen dem Bischof vorausgetragen . Der Brauch, das Omophorion beim Evangelium abzulegen, ist uralt. Schon Isidor von Pelusium kennt ihn. Er reicht also sicher bis ins 4. Jahrhundert hinauf.

Die symbolische Deutung des Omophorion, wonach dasselbe Simnbild des verlorenen Schäfleins ist, welches der Heiland suchte, auf seine Schultern nahm und zur Herde heimtrug, stammt von Isidor von Pelusium ${ }^{6}$. Sie wurde in der Folge auch wohl dahin erweitert, daf man in dem Ornatstück ein Bild der durch den Sündenfall der Stammeltern in die Irre gegangenen menschlichen Natur sah, die der Heiland in der Menschwerdung zum Heile des verlorenen Menschengeschlechtes angenommen und so gleichsam auf sich geladen hatte?

Aber auch als Insignie des Bischofs und als Sinnbild seiner Würde und seines Amtes erscheint das Omophorion schon sehr früh, und zwar mufs es nach dem Schreiben Isidors von Pelusium an Herminus, worin es dem Orarium, dem Abzeichen der Diakone, gegenübergestellt ist, diesen Charakter schon im Beginn des 5. Jahrhunderts besessen haben. Auch der in dem Briefe

Bischöfen zustehendes Gewand, sondern blof ein privilegiertes Ornatstïck einzelner Bischöfe gewesen, hätte das Konzil gewifs nicht auf Absetzung, sondern auf Entziehung des Omophorion erkannt.

' H ard. VI 75. Wenn der Papst Photius untersagt, den bulgarischen Bischöfen das Pallium zu verleihen, so will er demselben selbstredend nicht verbioten, überhaupt Bischöfen das Omophorion zu geben. Die Bulgaren unterstanden nicht dem Patriarchen von Konstantinopel, sondern dem römischen Stuhl. Es war also rechtswidrig und eine Anmakung, wenn Photius Bischöfen, die ihm nicht untergeben waren, das Pallium sandte. 2.Vgl. die angeführten Stellen aus Theo- dorus Lektor, Eustratius und Johannes Moschus.

3 Hard. V 1103.

* Simeon. Thessal., De sacra liturgia c. 98 ; De ordin. c. 209; De divino templo c. $6976 \quad$ yo $\quad(\mathbf{M g} .155,293 \mathrm{f} \quad 421 \quad 724$ $728739)$.

5 so schon im Pseudo-Sophronius ( $M g$. $\left.87^{3}, 4002\right)$. Vyl auch Simeou Thessal., De sacra liturgia c. 110 und De divino templo c. 76 (Mg. 155, 296 728).

6 Es kann nach dem einleitenden Satz des Briefes kein Zweifel sein, daß die Symbolik eine eúprots Isidors ist.

7 Simeon. Thessal, De sacra liturgia c. $82($ ebd. 260$)$ u. a. 
erwähnte Brauch, wonach der Bischof bei Verlesung des Evangeliums aus Ehrfurcht vor dem Worte Gottes das Gewand abzulegen hatte, weist auf jenen Charakter hin. War das Omophorion lediglich ein Kleidungsstick wie die andern, welche der Bischof sonst noch trug, so lag kein Grund vor, sich desselben bei dieser Gelegenheit zu entledigen. Hatte es dagegen den Charakter einer Insignie, welche die bischöfliche Würde nach aulien hin kund tat, so versteht man die Sitte ohne Schwierigkeit. Wenn das Evangelium gelesen wurde, d. i. wenn Christus selbst sprach, war nämlich auch der Bischof nur Hörer, nicht Lehrer, Untergebener, wie Simeon von Saloniki sagt, nicht Herr, bei der Konsekration aber erschien er nicht in seiner bischöflichen Hirtengewalt, sondern blof als Diener Christi. Es war mit dieser Auffassung durchaus im Einklang, wenn er sich bei jenen Akten des spezifischen Abzeichens seiner Würde entkleidete. Umgekehrt war er von neuem der Hirt der Herde, wenn er die heiligen Gestalten dem Volke zeigte und den Gläubigen die Kommunion austeilte, und darum nahm er alsbald nach der Wandlung die Insignie wieder an ${ }^{1}$. "Wenn sich der wahre Hirt beim Entrollen der verehrungswïrdigen Evangelien naht, so erhebt sich der Bischof und legt das Gewand ab, durch das er als dessen Abbild dasteht, um anzudenten, dab zugegen sei der Herr selbst, der Oberhirt", sagt in gleichem Sinne schon Isidor von Pelusium.

Thren praktischen Ausdruck fand diese Bedeutung des Omophorion in der Rolle, welche dasselbe ehedem, und zwar schon wenigstens seit dem 6. Jahrhundert bei der Ernennung und Absetzung der Bischöfe, Metropoliten und Patriarchen spielte. Rückgabe des Gewandes bedeutete Verzichtleistung auf das Amt ${ }^{2}$; einem Bischof, Metropoliten oder Patriarchen das Omophorion abnehmen, war dasselbe, wie ihn seines Amtes entsetzen ${ }^{3}$. Mit dem sog. Omophorion des hl. Markus sich bekleiden, wurde zu Alexandrien als rechtskräftige Besitzergreifung des dortigen Patriarchalstuhles angesehen ${ }^{ \pm}$. Das Pallium jemanden übergebell, hief ihn zum Nachfolger im Patriarchat machen ${ }^{5}$. Von einem Patriarchen das Omophorion annehmen, besagte, sich dessen Patriarchalgewalt unterwerfen ${ }^{6}$. Bischöfen das Gewand schicken galt soviel wie die Jurisdiktion über dieselben beanspruchen bzw. sich anmaken ${ }^{7}$. Die genannte Bedeutung des Omophorion war auch wohl der Grund, weshalb die Patriarchen von Konstantinopel im 6. Jahrhundert, wie es scheint, selbst außerhalb der liturgischen Funktionen das Ornatstück trugen ${ }^{8}$.

Über die Beschaffenheit des Omophorion besitzen wir aus dem Mittelalter nur äufierst wenige Angaben. Der Name, den es gleich bei seinem ersten Erscheinen in der Literatur führt, weist darauf hin, daf es schon damals ein von dem ipúzıџ, dem Mantelpallium, ganz verschiedenes Schultergewand war ${ }^{9}$.

1 De div. templo c. 7090 (ebd. 723739 ).

2 Liberati Breviar. c. 21 (M. 68, 1039).

s Ebd. c. 23 (1046); Nicet. Paphlag. Vita S. Ignatii Patr. (Mg, 105, 520). Vgl. auch die Verhandlungen betreffs des Bischofs Bassianus von Ephesus auf dem Konzil von Chalcedon 451 ( $\mathrm{Hard}$. II 548), wo unter

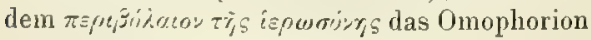
zu verstehen ist (ebd. III 1181).

* Liberati Breviar. c. 20 (M. 68, 1036).

${ }^{5}$ Photii Bibl. cod. 256 (Mg. 104, 115).

${ }^{6}$ Constant. IV. can. 17 (lat.) (Hard. V 906).
7 I a nn. VIII. Epist. ad Phot. (ebd. VI 75 ).

8 Theodori L ect. Hist. eccl. 1. 2, c. 15 (Mg. 861, 189); Eustratii Vita S. Eutychii Patr. c. 58 (Mg. 86², 2317 2359). Vgl. Theophan., Chronographia ad 489 (I, ed. Bonnae 1839,217 ).

9 Unter dem isuopipooy verstand man, wie aus Pallad., De vita S. Ioannis Chrysost. c. $6(\mathrm{Mg}, 47,23)$ hervorgeht, eine Art von Schal. Die Vita wurde c. 408 geschrieben, ist also gleichzeitig mit dem Brief Isidors an Herminus. In der aus derselben Zeit 
Es wurde ans Wolle angefertigt, wie uns Isidor von Pelusium und noch Simeon von Saloniki ${ }^{1}$ sagt, und nach Pseudo-Germanus ${ }^{2}$ und dem Metropoliten von Saloniki mit Kreuzen geschmückt. Nach letzterem gab es deren vier auf ihm. Aus dem von Krasnojeljcev herausgegebenen Fragments und aus Pseudo-Sophronius ${ }^{*}$ endlich vernehmen wir, daß es im Gegensatz zum diakonalen Orarium, das in einem Zug angelegt wurde, in drei Zügen umgeschlungen wurde. Das ist alles, was uns vom Omophorion erzählt wird, und dieses wenige verteilt sich obendrein auf die Zeit von nahezu einem Jahrtausend. Wir werden also diese spärlichen Daten durch die Beobachtungen zu ergänzen haben, die uns die Bildwerke gestatten.

Die ältesten Darstellungen des Omophorion finden sich auf den zwei schon früher erwähnten Miniaturen einer wahrscheinlich noch im 5. Jahrhundert geschriebenen Weltchronik ${ }^{5}$. Das nächstfolgende Monument, auf dem es uns begegnet, ist wohl die Trierer Elfenbeintafel (Bild 301), wenn anders diese wirklich dem 6. Jahrhundert angehört ${ }^{6}$. Bildwerke aus dem 7. und

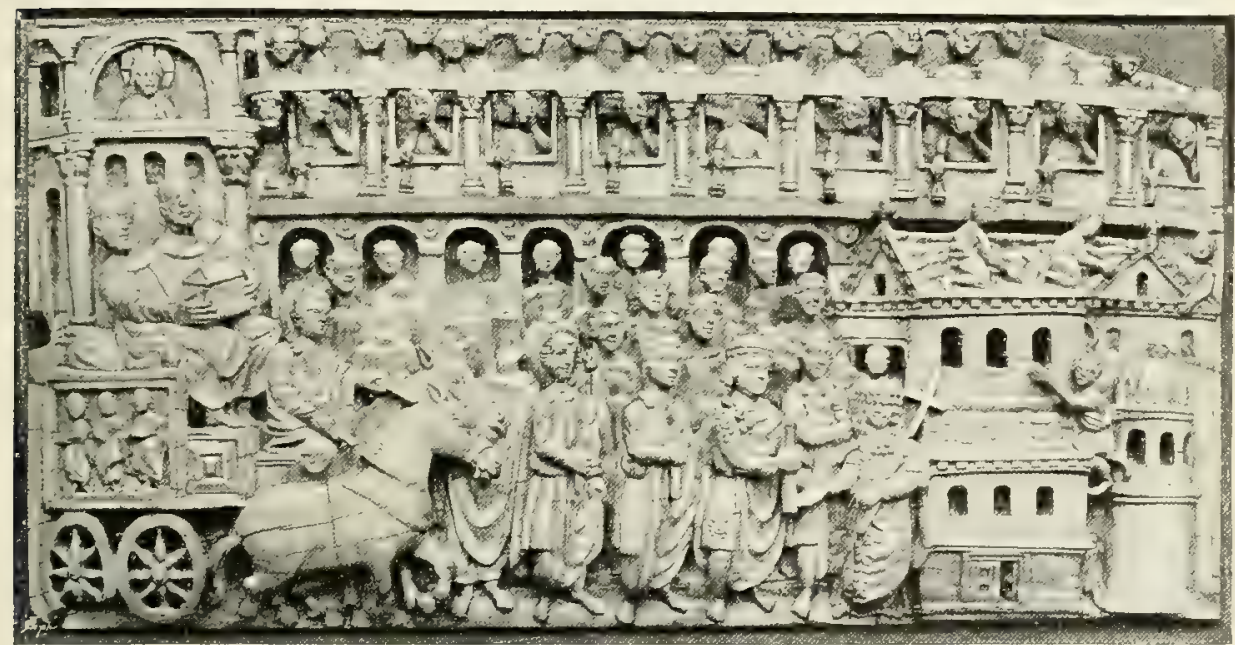

Bild 301. Reliquientranslation. Elfenbeinplatte. Trier, Dom.

8. Jahrhundert, welche das Omophorion aufweisen, sind die in jüngster Zeit entdeckten Fresken in S. Maria Antiqua am römischen Forum mit den Bildern griechischer Bischöfe. Sie werden in die Zeit Martins I. ( $\uparrow 655)$, Johannes' VII. $(\dagger 707)$ und Pauls I. († 767) gesetzt ${ }^{7}$. Aus dem 9. Jahrhundert verzeichnen

stammenden Historia Lausiaca wird c, 38 (Mg. 34, 1236) bestimmt $\mathrm{zwischen} \mathrm{iuáreov}$

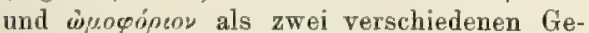

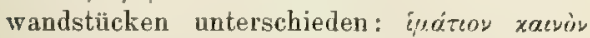

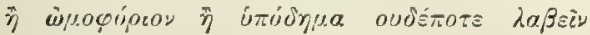

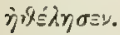

1 De sacra liturgia c. 82 (Mg. 155, 260).

2 Mg. 98, 396.

${ }^{3}$ N. Krasnojeljcer, Addenda ad Anecdota graeco-byzantina n. 13.

${ }^{4} \mathrm{Mg} .87^{3}, 3985$.

5 Vgl. über dieselbe oben S. 236.

6 Über das Alter der Tafel vgl. ebd.
Da die Fresken erst nach unserem Aufenthalt zu Rom aufgedeckt wurden und Photographien derselben nicht erhältlich sind, haben wir uns über die Bilder ein eigenes Urteil nicht bilden können. Doch erhielten wir Auskunft über sie durch die gütigen Mitteilungen von Msgr Dr Wilpert, der gerade eine Veröffentlichung aller in S. Maria Antiqua gefundenen Fresken mit der ihm eigenen, bei der Herausgabe der Katakombenmalereien so glänzend exprobten Fāhigkeit leitet. Genaueres über die Bischofsbilder wird eben diese Publikation bringen. 
wir Miniaturen mit Darstellungen des Ornatstückes im Chludolfpsalter zu Moskau ${ }^{1}$ und in einer Sammlung der Homilien Gregors von Nazianz in der Pariser Nationalbibliothek². Seit dem 10. werden die Monumente, auf denen uns das Omophorion begegnet, bald sehr zahlreich.

Das Omophorion, welches der Patriarch Theophilus auf den Miniaturen der Weltchronik trägt, ist ein streifenartiges Tuch, welches in der Weise den Hals umgibt, daf eines semer Enden von der linken, das andere von der rechten Schulter eine kurze Strecke über die Brust herabhängt. Auf dem Trierer Elfenbein (Bild 301) gleicht es dem Pallium der ravennatischen Mosaiken, nur dafs es etwas weniger tief und zugleich etwas loser als dieses um Brust

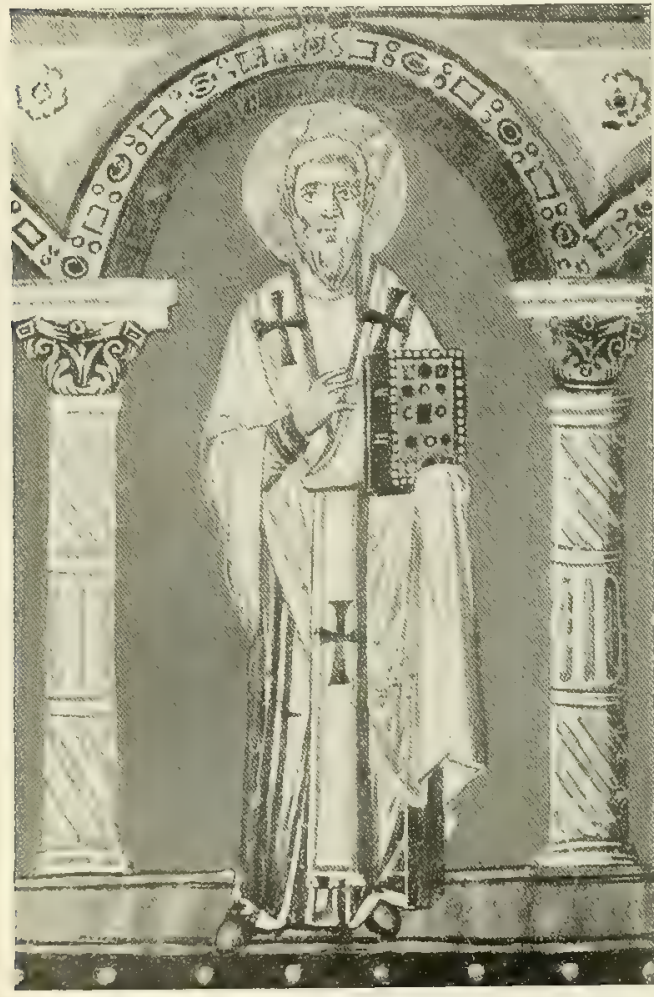

Bild 302. Der hl. Gregor von Nyssa. Miniatur einer Sammlung der Homilien Gregors von Nazianz. Paris, Bill. Nat. und Nacken geschlungen ist. Wesentlich das gleiche Bild gewährt auch das Omophorion auf den Darstellungen aus dem 7.-9. Jahrhundert, doch ist es hier bereits von merklich gröberer Breite als auf der Tafel zu Trier; bisweilen erscheint es sogar fast doppelt so breit wie das Omophorion auf dem Trierer Elfenbein. Aufserdem zeigtes sich schon auf einzelnen Bildwerken in Y-Form umgelegt (Bild 302).

Seit dem 9. Jahrhundert ist keine weitere Entwicklung in der Form und Anlegungsweise des Omophorion auf den Monumenten wahrzunehmen. Das Bild, welches diese uns seit jener Zeit von dem Ornatstück gewähren, ist regelmäßig das eines breiten Bandes, welches bald nach Weise des Palliums auf den ravennatischen und den älteren römischen Mosaiken lose um Schultern, Brust und Rücken geschlungen ist, bald auf der Brust des Trägers ein $Y$ (Bild 42, S. 97; 111, S. 237; 142, S. 304) bildet. Meist sind es Bildwerke aus dem Ende des 1. und der Frühe des 2. Jahrtausends, auf denen diese letzte Aulegungsart auftritt; in späterer Zeit kommt sie auf den Monumenten seltener vor oder erscheint doch wenigstens auf ihnen minder scharf ausgesprochen.

Von einer besondern Ausstattung des Omophorion ist auf den Miniaturen der alexandrinischen Weltchronik und dem Trierer Elfenbein nichts wahrzunehmen. Auf den Bildwerken der Folgezeit ist es regelmäßig mit groken schwarzen Kreuzen verziert, von denen sich zwei vor den Schultern, zwei andere nahe den unteren Enden des Omophorion zu befinden pflegen.

\footnotetext{
1 Abbildung hei Tlk kanen, Psalterillustrationen I 82.

${ }^{2}$ F. gr. 510; Wieldergabe der Winiaturen
}

in H. O mont, Facsimilés des miniatures des plus anciens manuscrits grees de la Bibliothèque nationale, Paris 1902, pl. xxvi ff. 
Die Farbe des Omophorion ist auf den Monumenten - die Skulpturen kommen natürlich bezüglich dieses Punktes nicht in Betracht -- stets weik. $\mathrm{Ob}$ es ursprünglich aus mehreren Stofflagen bestand und nicht ein einfaches Band, sondern ein streifenartig zusammengefaltetes Tuch war, lassen die Bildwerke nicht erkennen. Nur auf einem dem 10,-11. Jahrhundert angehörenden Elfenbeintriptychon der ehemaligen Sammlung Harbaville zu Arras, jetzt im Louvre (Bild 299, S. 663), und auf einer Miniatur einer griechischen Handschrift der Vaticana aus dem 12. Jahrhundert scheint die eigenartige Form, welche hier das Omophorion einiger Bischofsfigurenunten hat, auf eine mehrfache Faltung hinzuweisen, vorausgesetzt; daf es sich bei ihr nicht um eine künstlerische Willkürlichkeit handelt, was allerdings, wie früher gesagt wurde, nicht gerade unwahrscheinlich ist 1.

Ein interessantes älteres Omophorion befindet sich zu Grottaferrata bei Frascati (Bild 303). Laut einer Inschrift, die nahe an dem einen der beiden Enden dem Gewand aufgestickt ist, gehörte es ehedem dem Metropoliten Theophanes von Patrasso. Es ist aus weißem, mit ganz entartetem Granatapfel gemusterten Damast gemacht und aufer mit vier großen, die ganze Breite des Streifens einnehmenden Kreuzen in der Mitte mit dem Bilde des Erlösers, nach den Enden zu aber mit je zwei parallelen

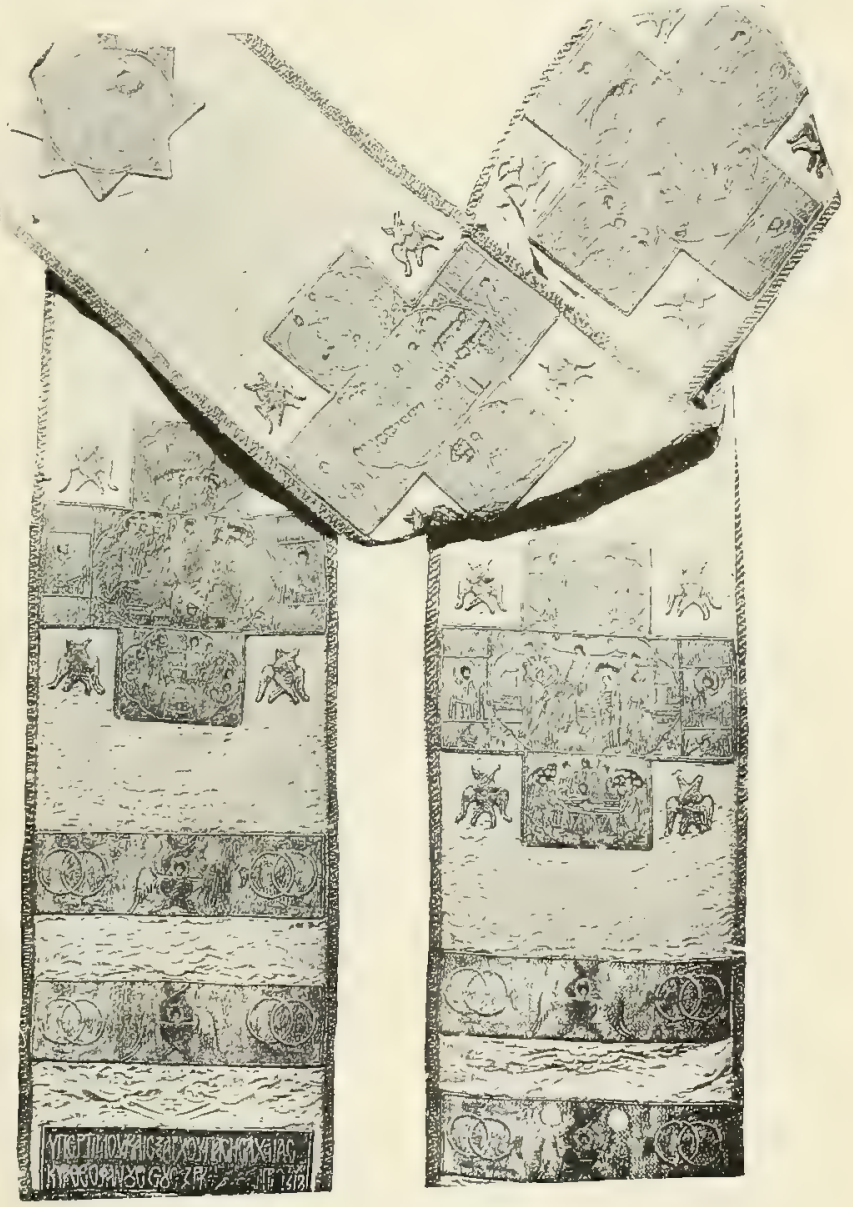

Bild 303. Reichbesticktes griechisches Omophorion. Grottaferrata, Kloster.

Querstreifen verziert. Dazu kommen noch in den Winkeln zwischen den Kreuzesbalken sechsflügelige Seraphim. Die Kreuze weisen je drei Szenen aus dem Leben des Heilandes und der Gottesmutter auf, von denen die mittlere zur Rechten und zur Linken von einem Propheten flankiert ist. Die beiden Parallelstreifen an den Enden des Omophorion enthalten Cherubim. Alle diese Verziernngen sind in Goldstickerei ausgeführt; nur zur Herstellung der Fleischpartien und des Haares ist farbige Seide verwendet.

Das Omophorion trägt das Datum 1618, doch soll das nur vom Stoff, nicht von den. Stickereien gelten. Mit Unrecht. Ein Vergleich der letzteren mit andern

I S. oben S. 661 . 
griechischen Stickereien dieser Zeit beweist, daf sie diesen nach Stil und Technik durchaus gleichartig sind. Wenn man sich für die Zuweisung der Stickereien an das 13. Jahrhundert auf den Charakter der Inschriften beruft, so ist zu beachten, daf gerade die Goldstickerei infolge ihrer eigenartigen schwerfälligen Technik länger als die gewöhnliche Schrift an altertümelnden Formen festgehalten hat 1 .

Zwei andere ältere Omophorien sind in den Antiquités de l'empire de Russe abgebildet ${ }^{2}$. Sie sind mit einfachen Kreuzen besetzt und an den Enden mit Quästchen verziert. Das eine soll angeblich vom Metropoliten Nicetas $(\dagger 1126)$, das andere vom Metropoliten Moses († 1359) herrühren, doch dürften beide, ihrer Beschaffenheit nach zu urteilen, aus weit späterer Zeit stammen.

Wann es im syrischen Ritus zu der jetzigen Form des Omophorion gekommen, läßt sich nicht bestimmen. Dürfen wix den Miniaturen des syrischen Pontifikale in der Pariser Nationalbibliothek trauen, einer Arbeit aus dem Jahre 1239, so war sie zur Zeit der Entstehung desselben schon in Brauch. Jedenfalls war das Omophorion damals bereits entschieden im Stadium der Verbildung begriffen (Bild 16, S. 51; 112, S. 238).

Wie aber steht es um den Ursprung der bischöflichen Insignie in den Riten des Ostens? Ist diese h i e r vielleicht auf eine kaiserliche Bewilligung zurủckzuführen oder hat auch in ihnen die Kirche sie geschaffen? Es ist dieselbe Frage, die wir hinsichtlich des römischen Palliums aufwerfen muß̧ten; dieselbe Antwort, die wir dort gaben, gilt auch im vorliegenden Fall. An sich und absolut genommen liefe sich ja freilich denken, es habe eines Tages irgend ein Kaiser im 4. Jahrhundert, etwa Konstantin, den Bischöfen oder doch wenigstens den Inhabern hervorragender Sitze die Erlaubnis gegeben, als Auszeichnung sich des Omophorion zu bedienen. In Wirklichkeit begegnet uns jedoch niemals auch nur die geringste Spur eines derartigen Ursprungs. $\mathrm{Zu}$ Alexandrien führte man vielmehr — und zwar schon im Beginn des 6. Jahrhunderts - das Omophorion auf den hl. Markus zurück. Zudem erscheint das Ornatstück stets als ein ausgesprochen kirchlicher Schmuck, als die sakrale Insignie der Bischöfe. Und dann gab es ja aufer dem Omophorion noch ein anderes liturgisches Abzeichen, das diakonale Orarium, dessen Ingebrauchnahme sicher nicht auf eine kaiserliche Vergünstigung zurückgeht.

Allerdings berichtet uns Liberatus ${ }^{3}$, dafs Anthimus, den Theodora auf den Stuhl von Konstantinopel erhoben hatte, dem Kaiser und der Kaiserin das Pallium zurückgegeben, als er erkannt habe, daß er gegen den Einspruch des Papstes Agapet sich nicht halten könne. Indessen liegt auf der Hand, daf aus dem Verhalten des Eindringlings nur folgt, das Omophorion sei damals ausgesprochene bischöfliche Insignie gewesen, nicht aber auch, es sei auf Grund einer Bewilligung durch irgend einen Kaiser in Brauch gekommen. Als Anthimus dem Kaiserpaar das Omophorion zurückstellte, bedeutete das lediglich die Verzichtleistung auf die Würde, die er durch die Protektion und die Machinationen der Kaiserin Theodora erhalten hatte, weiter nichts. Ähnlich verhält es sich, wenn uns Liberatus berichtet, es habe Kaiser Pelagius dem päpstlichen Apokrisiar Pelagius, den Patriarchen von Jerusalem und Antiochien und dem Bischof von Ephesus befohlen, den Patriarchen Paulus von Alexandrien, der sein Mißfallen erregt hatte, des

1 C̈her das Omophorion von Grottaferrata vgl. Farabulini, Archeologia ed arte rispetto a un raro monumento greco, conservato nella badia di Grottaferrata, Roma 1883, und Gri- sar, Liomoforio o pallio sacro di Grottaferrata (1897) ser. XVI, vol. IX, p. 220 ff.

2 Antiquités J, pl. 97100.

s Breviar, c. 21 (M. 68, 1039). 
Palliums zu entkleiden und so abzusetzen, was denn auch in der Tat geschehen sei ${ }^{1}$. Der Vorgang beweist wiederum blok, daf das Omophorion Abzeichen der bischöflichen, hier der patriarchalen Würde war; einen Schlulis auf den Ursprung des Gewandes gestattet er ebensowenig, wie der Befehl des Kaisers, Paulus seines Amtes zu entsetzen, einen Schluf auf den Ursprung der bischöflichen Würde überhaupt oder doch wenigstens der Patriarchalwürde von Alexandrien erlaubt.

Die Theorie, wonach der Ursprung des Omophorion auf eine kaiserliche Verleihung zurückgehen soll, hat darum auch noch viel weniger Beifall gefunden als die Hypothese, welche das päpstliche Pallium auf eine Bewilligung durch den Kiaiser zurückführen wollte. Was in Bezug auf dieses für manche den mangelnden Beweis ersetzte, der Wunsch, eine Abhängigkeit des Papstes vom Kaiser zu konstruieren, fiel ja beim Omophorion nicht ins Gewicht.

Wie ist es nun aber, wenn das Omophorion auf kirchlichem Boden entstanden ist, zur Einführung desselben gekommen? Hat es sich vielleicht infolge des angeblich in Mode gekommenen Brauches, das Mantelpallium ('uŕżov) zusammengefaltet zu tragen, aus dem Mantelpallium entwickelt, so dafs es also nur eine Verbildung und Verkümmerung eben dieses Mantelpalliums wäre? So will es Wilpert im Einklang mit seiner Hypothese iiber den Ursprung des römischen Palliums ${ }^{2}$.

Wir müssen eine solche Theorie auch hier ablehnen. Es fehlt jeder Anhaltspunkt, daf das Mantelpallium im Osten bei den Christen und mehr noch bei den Priestern und Bischöfen je die hohe Bedeutung hatte, die Wilpert ihm zuschreibt. Ebenso mangelt dort alle Spur von der angeblichen

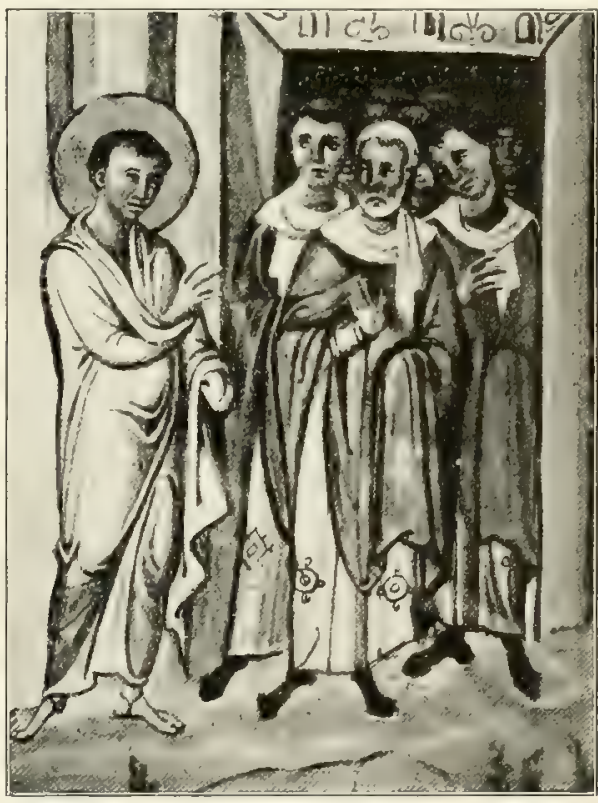

Bild 304. Profanes Omophorion. Miniatur eines Psalterium (10. Jahrh.). Paris, Bibl. Nat.

Mode, das Himation zusammengefaltet umzulegen. Nichts weist ferner darauf hin, daf dieses jemals ein den Bischöfen vorbehaltenes Gewand gewesen oder geworden sei. Ja wenn das Omophorion noch wenigstens ifúzov hiebe oder doch früher einmal so genannt worden wäre. Allein es trägt weder jetzt diesen Namen, noch findet sich der leiseste Anhalt, daß es ihn zu irgend einer Zeit geführt habe. Wohl aber steht es fest, dak es schon um 400 aufer dem bischöflichen Omophorion auch bei andern Leuten, Männem wie Frauen, ein Schultertuch des Namens culıocrírov gab ${ }^{3}$ (Bild 304), und ebenso ergibt sich

I Ebd. c. 23 (1046). 2 Cap. 56.

${ }^{3}$ Pallad., Devita S. Ioannis Chrys. c. 6 (Mg. 47, 23) : Éva $\iota$ si (sc. Theophilus, Patriareh

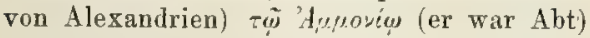

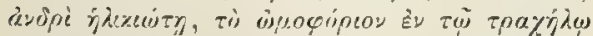

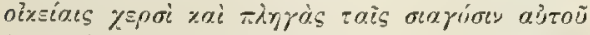

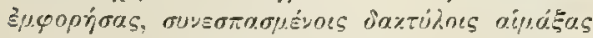
tàs pìnos. Histor. Lausiaca c. 38 (M. 34, Braun, Die liturgisehe Gewandung.

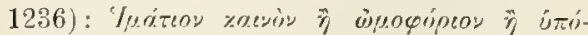

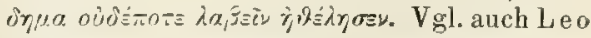
Grammat., Chronographia, ed. Bonnae 1842, 241311 ( $\mathrm{Mg}, 108,1073$ 1145), wo ein in der Blachernenkirche zu Konstantinopel aufbewahrtes Omophorion der Mutter Gottes erwähnt wird, und Codinus, De aedif, ed. Bonnae 1843, 98 ( $\mathrm{Mg} .157,177$ ), wo von einem 43 
aus der Historia Lausiaca mit aller Klarheit, daf dieses Omophorion ein durchaus selbständiges, neben dem Himation bestehendes und von diesem ganz verschiedenes Gewandstück war, ähnlich wie heutzutage Mantel und Shawl zwei besondere, voneinander unabhängige Dinge sind ${ }^{1}$. Wozu also, dürfen wir wohl mit Recht fragen, das Omophorion auf den zwar behaupteten, aber nicht bewiesenen Brauch, das Himation zusammengefaltet zu tragen, zuriickführen, wenn uns um 400 ein Gewand begegnet, dessen ganz und gar konkrete Benennung seine Verwandtschaft mit dem gleichnamigen bischöflichen Ornatstück zur Genüge andeutet? Ist es nicht das natürlichste, die bischöfliche Insignie mit eben diesem Schultertuch in Zusammenhang zu bringen?

Wie aber haben wir uns diesen Zusammenhang vorzustellen? Nun, entweder haben die Bischöfe ein dem gewöhnlichen Omophorion gleichartiges und daher ebenfalls Omophorion genanntes Schultertuch direkt durch eine positive Bestimmung als sakrales bischöfliches Abzeichen eingefülırt, und das scheint uns das wahrscheinlichere, oder es hat das gewöhnliche Omophorion zunächst als bloßer Schmuck und ohne eine besondere Bedeutung zu besitzen, einen Bestandteil der bischöflichen Altarkleidung gebildet, dann sich nach und nach zu einem auszeichnenden Ornat der Bischöfe entwickelt und in dieser Eigenschaft schliefilich den Charakter einer Insignie erhalten ${ }^{2}$. Wann das Omophorion als bischöfliches Abzeichen aufkam, läbt sich nicht feststellen. Immerhin legt der Umstand, daf bereits der 22. Kanon des Konzils von Laodicea ein Orarium als Insignie der Diakone kennt, die Vermutung nahe, dafs um dieselbe Zeit, d. i. um das dritte Viertel des 4. Jahrhunderts, ebenfalls schon ein bischöfliches Abzeichen in Gestalt des Omophorion in Brauch gewesen sei. Auch auf die Frage, wo die Heimat des letzteren zu suchen sei, läst sich keine bestimmte Antwort geben. Am ehesten dürfte es jedoch eine Schöpfung der Kirche von Alexandrien sein; denn es begegnet uns nicht nur zuerst im Bereich der alexandrinischen Kirchenprovinz, es war auch der Bischof von Alexandrien bekanntlich zur Zeit der Entstehung des Omophorion der erste Hierarch des Orients und überhaupt der nächste im Rang nach dem römischen Bischof, die Kirche zu Alexandrien aber rechtlich und tatsächlich die hervorragendste unter allen andern des Ostens.

\section{DIE BISCHÖFLICHE INSIGNIE IN DEN KIRCHEN GALLIENS, SPANIENS UND NORDAFRIKAS.}

Im bisherigen war nur die Rede von dem römischen Pallium und dem bischöflichen Omophorion in den Riten des Ostens. Es erubrigt daher, zu

Omophorion der hl. Anna die Rede ist, das in der von Justinian erbauten Kirche der Heiligen gezeigt wurde. Solche Omophorien waren auch noch in späterer Zeit gebränchlich. Beispiele derselben finden sich u. a. auf den griechischen Fresken, die in S. Saba zu Rom aufgedeckt wurden, in einem Pariser Psalterium (Msc. gr. 139, f. 431 ${ }^{\text {y }}$ ) Bild 304, S. 673 und einem Pariser Gregor von Nazianz (Jsce. gr. 510, f. $143^{*} 196^{\circ} 310^{\circ}$ ).

1 Wenn Wilpert, wie es den Anschein hat, meint, das iscizco: habe seinen Namen gewechselt, seitdem man es zusammengefaltet auf der Schulter getragen habe, und von

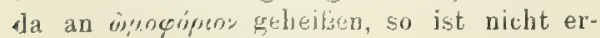

sichtlich, welcher Anhalt für eine solche Annahme vorliegt.

$2 \mathrm{Zu}$ Rom dürfte unseres Erachtens das Pallium direkt als lnsignie eingeführt worden sein. Der Umstand, daß3 es hier ursprünglich ein spezifisch päpstliches Ornatstück war, scheint durchaus darauf hinzuweisen. Beim Omophorion, welches schon nach Isidor von Pelusium die Bischöfe überhaupt trugen, möchten wit dagegen eine allmähliche Ausbildung zur Insignie nicht schlechthin ausschlielien, wiewohl wir auch hier für unsere Person am meisten zu der ersten im Text dargelegten Auffassung von dem Ursprung des Ornatstückes neigen 
untersuchen, ob es auch in den Kirchen Galliens, Spaniens und Nordafrikas eine jenen analoge bischöfliche Insignie gegeben habe. Ist die Frage auch von keiner besondern Bedeutung, so darf sie doch nicht ganz unberührt bleiben. Natürlich kann es sich bei ihr nur um die ältere Zeit handeln, für Nordafrika insbesondere blok um die Zeit vor der Vernichtung der dortigen Kirche durch die Sarazenen im 7. Jahrhundert.

Die Stellen, in welchen man einen Hinweis auf eine im gallikanischen Ritus gebräuchliche bischöfliche Insignie zu finden glaubte, sind der 6. Kanon der Synode von Macon (583) ${ }^{1}$ und die auf ein liturgisches pallium sich beziehenden Ausführungen der gallikanischen Meferklärung. Dafi eine solche in Spanien Verwendung fand, soll der 28. Kanon des vierten Konzils von Toledo $(633)^{2}$ bekunden. Für ihre Existenz in den Kirchen Afrikas beruft man sich auf einen Passus in der Vita des hl. Fulgentius ( $\dagger$ ca 530) ${ }^{3}$ und auf den Brief ${ }^{4}$, in welchem Viktor von Karthago dem Papst Theodor (642-649) unter anderem auch seine Erhebuug auf den bischöflichen Stuhl von Karthago mit den Worten anzeigt, er habe in sancta Carthaginiensis civitatis ecclesia pontificalis honoris consecrationem et stolam empfangen.

Bieten nun diese Stellen wirklich eine genügende Unterlage für die Annahme, daks es in den Kirchen Nordafrikas, Spaniens und Galliens eine dem römischen Pallium oder dem griechischen Omophorion analoge bischöfliche Insignie gegeben habe? Unseres Erachtens nein. Denn das orarium in dem angeführten Passus der Vita Fulgentii kam, wie schon früher dargelegt wurde, nach dem Zusammenhang nur ein gewöhnliches Halstuch besserer Qualität oder (vielleicht richtiger) ein Schweistuch, wie es bei den Bischöfen, nicht aber bei den Mönchen in Gebrauch war ${ }^{\bar{*}}$, bedeuten. Der Biograph will nur sagen, obwohl der Heilige sich wie die andern Bischöfe seinem Stande gemäls einen gewissen Luxus in der Kleidung habe gestatten kömen, so habe er es doch vorgezogen, auch als Bischof weiterhin mönchische Einfachheit zu beobachten. Es ist also unter dem fraglichen Orarium so wenig ein bischöfliches Pallium zu verstehen, dab mit ihm nicht einmal ein liturgisches Ornatstück gemeint ist ${ }^{6}$. Was die stola im Schreiben Viktors von Karthago betrifft, so besagt das Wort hier allem Anschein nach nicht sowohl ein bestimmtes sakrales Gewand, als vielmehr entweder allgemein die Pontifikalkleidung oder wohl zutreffender metaphorisch die bischöfliche Würde ${ }^{7}$. Das orarium im 28. Kanon der Synode von Toledo erscheint zwar als liturgisches Ornatstiuck, ja als liturgisches Abzeichen ${ }^{8}$; bei ihm an eine spezifisch bischöfliche Insignie von der Art des Palliums oder des Omophorion zu denken, verbietet jedoch der Umstand, daf im gleichen Kanon von einem diakonalen und priesterlichen Orarium die Rede ist. Auch beim pallium des 6. Kanons der Synode von Macon und der gallikanischen Meferklärung handelt es sich wohl nicht um ein spezifisch bischöfliches Abzeichen von der Art des römischen Palliums oder des griechischen Omophorion. Denn in diesem Falle wäre es ja kaum verständlich, daf sich die Synode von Mâcon veranlabt sah, den Bischöfen seinen Gebrauch

1 M. G. Conc. I 157.

2 Hard. III 586 .

s C. 18 (M. 65, 136).

$+\mathrm{H}$ a r d. III 755 .

$5 \mathrm{Vgl}$. z. B. Is idori Reg. monach. c. 12 (M. 83, 88\%) : Orarium non est fas uti (sc. monacho) und Conc. Araus. a. 511 , c. 20
(M. G. Conc. I 7): Monacho uti orario in monasterio ... non licet.

6 S. auch oben S. 573 .

${ }^{7}$ Im griechischen Text des Schreibens fehlt $\sigma \tau o \lambda j$ und ist auf die Gewandung kein Bezug genommen.

\& S. oben S. $569 \mathrm{f}$. 
bei der Messe einzuschärfen. Oder haben wir etwa in der Geschichte des Palliums und des Omophorion irgend ein Gegenstück zu einer solchen Verordnung? Ging' hier nicht im Gegenteil die 'Tendenz stets statt auf Verminderung der Verwendung auf ibermäßigen Gebrauch der Insignie hinaus? Es ist nicht ganz sicher, welchen Bestandteil der liturgischen Gewandung wir in dem fraglichen pallium zu sehen haben. Doch scheint es kaum zweifelhaft, daf wir darunter die priesterliche Stola zu verstehen haben ${ }^{1}$.

Die Theorie von einem afrikanischen, spanischen und gallischen Pallium steht sonach auf einer so unzuverlåssigen Unterlage, daf wir kein Bedenken tragen, sie abzulehnen. Gab es in den Kirchen Nordafrikas, Spaniens und Galliens wirklich ein Pendant des römischen Palliums und des Omophorion, so ist es schwer begreiflich, dafis wir nicht irgend eine auch nur halbwegs sichere Nachricht von ihm erhalten. Femer ist es unverständlich, warum nicht nur die Metropoliten in Gallien und Spanien, sondern auch Bischöfe um das römische Pallium baten, falls sie eine eigene pontifikale Insignie hatten. Oder hören wir jemals dergleichen von griechischen Bischöfen? ${ }^{2}$ Und warum weist Gregor d. Gr., der doch bei den Palliumverleihungen die Sache sehr genau nahm, in seinen Verhandlungen mit Syagrius und Brunhilde wegen der Erteilung des Palliums an Syagrius nicht mit irgend einem Wort auf das gallikanische bischöfliche Pallium hin? Endlich wie konnte es zugehen, daf ein so hochbedeutsames Ornatstück bei den Bischöfen Spaniens und Galliens vollständig aus dem Gebrauch kam, ohne dafß es durch etwas anderes ersetzt wurde? Solange nicht andere Beweise für ein bischöfliches Pallium in Nordafrika, Spanien und Gallien gebracht werden, darf man also ein solches wohl als unhistorisch betrachten.

VIERTES KAPITEL.

\section{DAS RATIONALE.}

\section{DAS RATIONALE IN DER GEGENWART.}

Unter dem Rationale versteht man einen liturgischen pontifikalen Schulterschmuck, ein Gegenstück des erzbischöflichen Palliums ${ }^{3}$. Es ist gegenwärtig nur noch bei den Bischöfen von Eichstätt, Krakau, Paderborn und Toul gebräuchlich, während es sich im Mittelalter bei einer größeren Anzahl dentscher

1 S. oben S. $572 \mathrm{f}$.

2 Wenn die Bischöfe von Korinth, Justiniana prima und Nikopolis von Gr. d. Gr. das Pallium erbaten und erhielten (s. oben S. 625), so geschah das, weil sie damals noch zum römischen Patriarchat gebörten und demnach das Omophorion nicht trugen.

3 Die jüngere Zeit hat eine Anzahl mehr oder weniger eingehende Untersuchungen über das Rationale zu Tage gefördert, von deven wir hier die bemerkenswerteren verzeichnen: Barbier de Montault, Particularité du costume des évêques de Poitiers, in Bullet. mon. XIIII (1877) 6:39; Le buste de saint Adelphe, in Mémoires de la Société d'archéologie lorraine 1885; Le Surhuméral des évêques de Toul, ebd. 1887; Compte rendu critique de la dissertation de l'abbé Cerf sur le Rational, in Revue 1890. Corf, Dissertation sur le Rational en usage dans l'église romaine et dans l'église de Reims, in Travaux de l'Académie de Reims 1889. Bra un, Das Rationale, in Zeitschrift 1903. P. Beda Kleinschmidt, Das Rationale der Bischöfe zu 'I'oul, ebd.; Das Rationale im Domschatz zu Regensburg, in Kirchensehmuck, Graz 1904; Das Rationale in der abendländischen Kirche, in Archiv für christliche Kunst 1904. Eugen Martin, Le Rational et Surhuméral, in Revue 1904. L. Eis e nhofer. Das bischöfliche Rationale, seine Entstehung und Entwicklung, München 1904. 
Bischöfe nachweisen läft. Bei den Eichstätter, Krakauer und Paderborner Bischöfen ist es nie völlig auker Gebrauch gekommen. Die Verwendung des Schulterschmuckes wurde für Paderborn auf Bitten Ferdinands von Fïirstenberg 1666 durch Alexander VII. ${ }^{1}$, für Eichstätt bei Gelegenheit der 1000jährigen Jubelfeier der Diözese 1745 durch Benedikt XIV. von neuem bestätigt ${ }^{2}$. Zu Toul hörte die Benutzung des Ornatstückes im Laufe des 17. Jahrhunderts auf, und zwar, wie es scheint, infolge des Übergangs des Bistums an Frankreich durch den Westfälischen Frieden und der damit in Verbindung stehenden Okkupierung des Bischofsstuhles durch Bischöfe französischer Nationalität ${ }^{3}$. Es wurde jedoch 1852 durch Bischof Menjaud wieder in Gebrauch genommen, was dann 1865 auf Bitten des damaligen Touler Oberhirten, des späteren Kardinal Lavigerie, durch ein päpstliches Breve ausdrücklich gutgeheifien wurde ${ }^{ \pm}$. Das Ornatstïck heißt zu Toul surhuméral, und zwar passender, weil das alttestamentliche Rationale kein Schultergewand, sondern ein Brustschmuck war; nur der Ephod, die Folie, von der sich das Rationale auf der Brust abhob, war ein Schultergewand.

Das Rationale, wie es zu Paderborn (Bild 305), Eichstätt und Toul gebräuchlich ist, hat die Form eines Schulterkragens, der sowohl an der Vorder- wie der Rückseite mit zwei Behängen versehen ist. Das Krakauer besteht aus zwei stolaartigen Streifen, die an den beiden Enden durch ein scheibenförmiges, mit zwei kurzen, schmalen Behängen versehenes $\mathrm{Me}$ daillon verbunden sind.

Das Rationale ist keine Insignie, sondern nur ein auszeichnender Schmuck. Es wird wie das Pallium nur über der Kasel angelegt. Bezüglich der Tage, an welchen es ge-

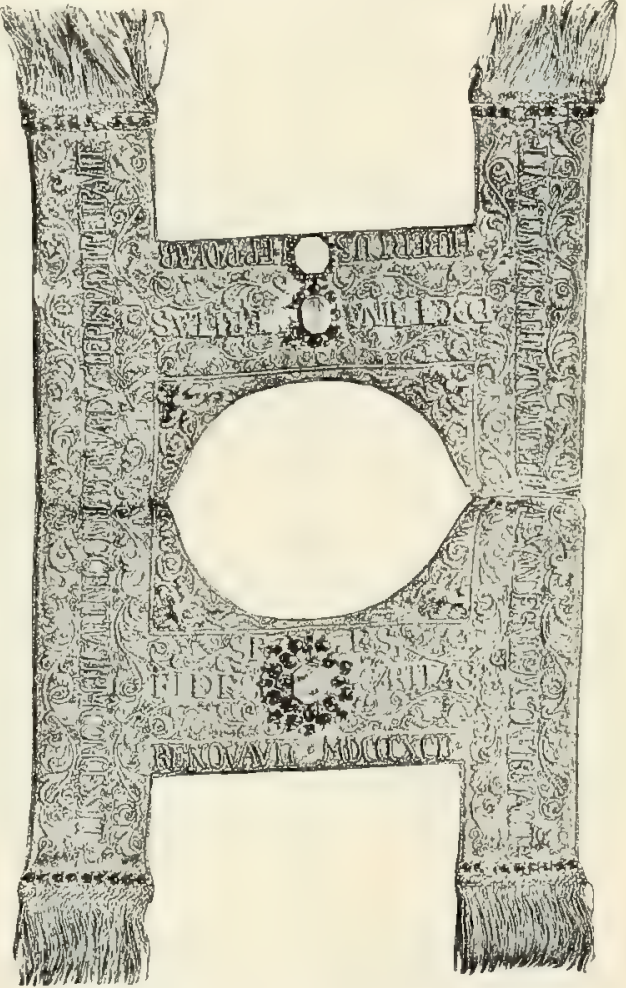

Bild 305. Rationale des Bischofs von Paderborn. Paderborn, Bischöfi. Palais.

tragen werden darf, bestehen für Eichstätt keine Einschränkungen; ebenso wurde in dem Breve für Toul dem Bischof gestattet, sich seiner zu bedienen, so oft er pontificaliter zelebriere. Für Paderborn dagegen ist die Benutzung des Rationale an bestimmte Tage gebunden, ähnlich wie es beim Pallium der Metropoliten der Fall ist. Sie finden sich in der Bulle aufgeführt, durch welche Innozenz II. 1133 dem Bischof Bernhard I. den Gebrauch des Ornatstückes gestattete; doch kamen zu ihnen einige weitere hinzu, als Alexander VII. den Paderborner Bischöfen diesen neu bestätigte: das Fron-

1 Laut Inschrift des zu Paderborn noch gebräuchlichen Rationale.

2 Bullar. Benedict. XIV. III, Mechlin 1826,
3 Revue 1904, 38.

4 Martin, Histoire des diocèses de Toul, de Nancy et de Saint-Dié, Nancy 1903, 395 435 . 
leichnamsfest, das Fest der Beschneidung des Herrn, sowie die Feste TrreuzErfindung und Kreuz-Erhöhung.

Was das Territorium anlangt, in welchem das Rationale benutzt werden darf, so ist für Paderborn sein Gebrauch auf den Bereich der Diözese beschränkt, für Eichstätt besteht in dieser Beziehung keine Bestimmung.

\section{DAS ERSTE NACHWEISBARE AUFTRETEN DES RATIONALE.}

Die früheste Nachricht erhalten wir über das Rationale durch einen Briefwechsel zwischen Adalbero von Metz (984-1105) und Hildward von Halberstadt (968-995) ${ }^{1}$. Adalbero bittet darin den Bischof von Halberstadt, dieser möge ihn an der Frlaubnis teilnehmen lassen, das Rationale oder logion, das Abzeichen der Lehre und Wahrheit, zu tragen, welche ja Papst Agapet II. (946-955) den Halberstädter Bischöfen verliehen habe. Hildward gibt dem Ansuchen Folge und sendet eine Kopie des Ornatstückes; jedoch multe sich Adalbero verpflichten, das Recht, sich des Rationale zu bedienen, nicht noch andern weiter zu übertragen. Allerdings gibt der Briefwechsel keinen direkten Aufschluf über die Art und Beschaffenheit des in Frage stehenden Rationale; halten wir jedoch im Auge, daß bei den Bischöfen von Metz bis dahin durch päpstliche Verleihung schon wiederholt das Pallium in Gebrauch gewesen war'2, daf Burchard von Halberstadt 1063 von Alexander II. das Pallium erhielt ${ }^{3}$, daf das Rationale, um das es sich in den Schreiben Adalberos und Hildwards handelt, den Bischöfen von Halberstadt ebenfalls seitens des Apostolischen Stuhles bewilligt worden war, und namentlich endlich, dafs bereits im Beginn des 11. Jahrhunderts ein Rationale im Sinne eines das Gegenstïck des Palliums bildenden Schulterschmuckes mit aller Bestimmtheit nachweisbar ist, so kann es kaum zweifelhaft sein, daf auch unter dem Rationale des Briefwechsels eben dieses Schultergewand verstanden werden mußs.

Ein anderes sehr frühes Zeugnis bringt die Bulle Johannes' XIX. vom Jahre 1027, in welcher der Papst dem Patriarchen Poppo von Aquileja aufier dem Pallium auch das Rationale gewährt, so zwar, daß der Patriarch das Pallium dem bestehenden Fiecht gemäßs nur an den höchsten Feiertagen sowie bei der Konsekration von Bischöfen tragen durfte, während ihm das Rationale für die übrigen Feste zugestanden wurde ${ }^{4}$. Das Rationale, von dem in der Bulle die Rede ist, haben wir uns demnach nicht als einen Schmuck zu denken, der zugleich mit dem Pallium gebraucht wurde, sondern als Gegenstück des letzteren, weil Ersatz desselben an den gewöhnlichen Festen, an denen die Benutzung des Palliums unstatthaft war. Es kann darum auch kein blofer Brustschmuck gewesen sein, sondern muf als ein dem Pallium analoges Schulterkleid aufgefast werden.

Die Liturgiker des Mittelalters tun des Rationale keine Erwähnung. Wohl reden Ivo von Chartres, Honorius und im Anschlufs an letzteren auch Sicard von einem rationale, sie verstehen aber darunter kein bischöfliches

I Sigeberti Vita Deodorici I. ep. Metens. c. 9 (M. G. SS. IV 468). Vgl, auch den Brief Hildwards bei Labbe, Novae biblioth. I 682. J. 113361.

2 S. oben \$. 690

3 Ehd.

1 J. n. 4085; M. 141, 1137: Insuper pallium vobis concerlimus, quo vos ad missarum sollemnia celebranda uti volumus in Natali Domini ... et in ceteris praecipuis festivitatibus et in consecratione episcoporum. De rationali autem idipsum praecipinus, ut in ceteris festivitatibus utamini quemadmodum et de pallio (sc, praecepimus). 
Schultergewand, sondern einen pontifikalen Brustschmuck, auf den wir später zurückkommen werden. Nur ein kurzer anonymer Traktat über die liturgische Gewandung in einer dem 12. Jahrhundert entstammenden Handschrift der St Gallener Stiftsbibliothek gedenkt des uns hier beschäftigenden Ornatstückes mit den wenigen Worten: Rationale, quod circumdat humeros et pectus, doctrinam et veritatem ostendit, quod tintinnabulis resonans exemplum vitae ad praedicationem insinuat.

In Sakramentaren ist uns nur zweimal ein rationale im Sinne eines pontifikalen Schmuckes begegnet: in dem Sakramentar Ratolds von Corbie ${ }^{1}$ und in dem für Sigebert von Minden um 1030 geschriebenen, als Missa Illyrica ${ }^{2}$ bekannten Ordo. In ersterem ist unter ihm entweder ein über der Kasel am Superhumerale (Amikt) befestigter Brustschmuck oder (vielleicht richtiger) eine paruraartige Verzierung des Amiktes, die nach Anlegung der Kasel kragenförmig um den Hals gelegt wurde, zu verstehen. An ein Schultergewand

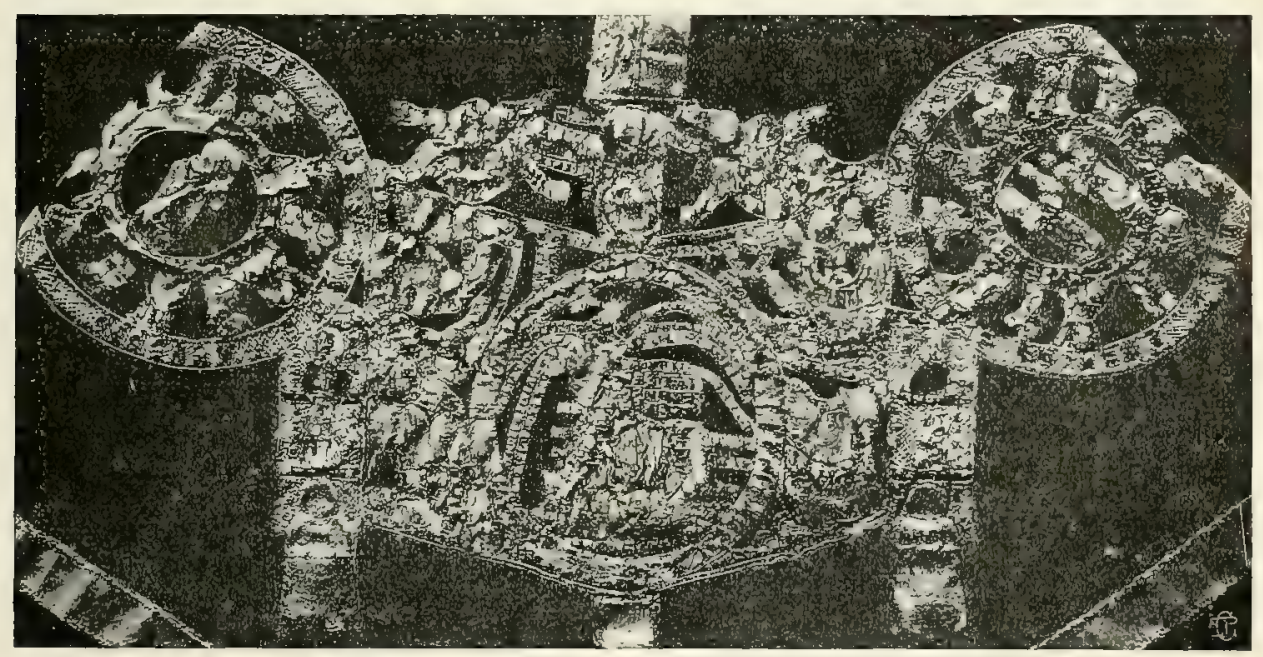

Bild 306. Rationale (Riuckseite). Bamberg, Dom.

ist bei ihm nicht zu denken. Der Ordo Sigeberts gibt keinerlei Andeutung über den Charakter des Gewandes, das er mit rationale bezeichnet, sondern vermerkt lediglich das Gebet, das bei Annahme des Ornatstückes zu sprechen war. Doch erhellt aus zwei Bildwerken, einer Elfenbeinskulptur und einer Miniatur, die ursprünglich dem den Ordo enthaltenden Kodex zum Schmuck dienten, wie wir uns das fragliche Rationale zu denken haben. Es sind die zwei Darstellungen Sigeberts von Vinden $(1022-1036)$, von welchen bereits gelegentlich die Rede war. Sigebert erscheint auf beiden in gleicher Weise mit einem dem Pallium verwandten Schulterschmuck, der die Gestalt eines die

1 M art. 1. 1, c. 4, art. 12, ordo 11; I 203 : Postea ministretur ei casula; tandem vero rationale cohaerens iunctim (die Handschrift [Paris, Bibl. nat. f. lat. n. 1205-] hat vinctim, wohl ein Fehler des Kopisten) superhumerali. Da kurz vorher der Amikt superhumerale heift, müssen wir auch hier wohl das Wort in der gleichen Bedeutung nehmen, zumal kein zwingender Grund vorliegt, hier in dem superhumerale einen auszeichnenden pontifikalen Schulterschmuck zu sehen. Es scheint sogar eine solche Auffassung dem Wortlaut der Rubrik wenig entsprechend. Wäre unter dem superhumerale ein pontifikales Schultergewand zu verstehen, so hätte diese wohl lauten müssen: tandem vero superhumerale unacum rationali oder ähnlich.

2 Ebd. ordo 4; I 177. 
Schultern, die Brust und den Rücken umziehenden, mit Zierscheiben und Doppelbehängen besetzten Ringes hat, bekleidet (vgl. Bild 69, S. 177 und Bild 124, S. 266).

Es hat sich sogar noch ein wirkliches Rationale aus dem Beginn des 11. Jahrhunderts erhalten. Dasselbe befindet sich im Besitz des Domes zu Bamberg und stammt aus den Tagen Heinrichs II., wie ein Vergleich mit der ron diesem herrührenden Kasel des Domschatzes bekundet (Bild 306, S. 679). Die Verwandtschaft mit dem Pallium tritt bei ihm minder deutlich hervor; denn statt aus einem mit Scheiben und Behängen verzierten Ringe besteht es aus einem Vorder- und Rückteil, die unten, zum Ersatz der Behänge, in $z_{\text {wei }}$ Streifen auslaufen und über den Schultern durch eine Scheibe verbunden sind. Wir müssen später auf dies Rationale näher eingehen, weshalb wir hier von einer eingehenderen Beschrejbung desselben absehen können.

Das Rationale ist demnach mit aller Sicherheit bereits um die Wende des Jahrtausends im Sinne eines dem Pallium bis zu einem gewissen Grade entsprechenden, auszeichnenden pontifikalen Schulterschmuckes nachweisbar. Sehen wir daher zu, welche Verbreitung sein Gebrauch im Mittelalter gehabt hat.

\section{VERBREITUNG DES GEBRAUCHES DES RATIONALE.}

Der Gebrauch des Rationale läfst sich im Mittelalter bei einer gröberen Anzahl von deutschen Bischöfen feststellen. Wir finden es bei den Bischöfen von Würzburg, Regensburg, Eichstätt, Naumburg, Halberstadt, Paderborn, Minden, Speier, Metz, Prag, Olmïtz, sowie den ehemals ebenfalls zum deutschen Reich und zu deutschen Metropolitanverbänden gehörenden Bischöfen von Toul und Lüttich; bei verschiedenen allerdings nur vorübergehend, wie zu Speier, Metz, Halberstadt und Olmütz ${ }^{1}$.

Bei den Bischöfen von Wü r z burg kam es schon um 1100 zur Verwendung, wie die Würzburger Bischofssiegel beweisen. Das Rationale erscheint auf denselben zuerst bei Emehard von Rothenburg (1088-1104) und erhält sich auf ihnen bis auf Gottfried von Hohenlohe (1314-1322). Von da ab wird es in fast ununterbrochener Folge durch die Grabmäler der Bischöfe im Dom zu Würzburg bezengt. Die Reihe derselben beginnt mit Mangold von Neuenburg ( $\dagger$ 1303); mit Johann Gottfried von Aschhausen (1617-1622) tritt das Pallium an Stelle des Rationale. Bei der Grabfigur Mangolds von Neuenburg ist das Ornatstück in Nalorei, bei den folgenden Bischöfen in Skulptur dargestellt (Bild 307).

Auf den Regensburger Siegeln begegnet uns das Rationale zuerst, wie es scheint, bei Hartwig I. (1106-1126). Es erhält sich auf denselben bis über die Vitte des 14. Jahrhunderts, da es sich noch auf einem aus dem Jahre 1353 stammenden Siegel Friedrichs von Nürnberg vorfindet (1341-1368). Auf den Grabmälern der Regensburger Bischöfe kommt es erst spät vor; der erste, bei dessen Grabfigur es sich nachweisen läßst, ist Bischof Heinrich von Absberg (1465-1492). Freilich ist die Zahl älterer Grabmonumente sehr gering. Seit dem Ende des 15. Jahrhunderts tritt es dann aber bis zu Bischof David Kölderer von Burgstall (1567

\footnotetext{
1 Fül einen Gebrauch des Rationale seitens der Bischöfe von Münster und Osnabrïick liegen keine Zeugnisse vor. Vielleicht, daß St Ludgerus auf dem alten Siegel des Ludgeristiftes (13. Jahrh.) mit ihm ausgestattei ist. Ehenso mag der Schulterschnuck auf dem Siegel des Osnabrücker Bischof's Ger-
}

hard von Oldenburg ( $†$ 1216) ein Rationale darstellen sollen. Man wird indessen gut tun, auf derartige ganz vereinzelte Beispiele, die zudem nicht einmal zweifellos sind, kein Gewicht zu legen, zumal die Siegel oft genug von auswärtigen Meistern oder nach auswärtigen Vorlagen angefertigt wurden. 
bis 1579) auf einer ununterbrochenen Reihe prächtigster Grabplatten Regensburger Bischöfe auf. Aus dem Ende des 13. Jahrhunderts stammt eine mit dem Rationale geschmückte Bischofsbüste im Tympanon einer zum südlichen Seitenchor des Domes zu Regensburg führenden Türe, aus der ersten Hälfte des 14. Jahrhunderts verschiedene mit dem Rationale ausgezeichnete Bischofsfiguren in den Fenstern des südlichen Seitenschiffes und des südlichen Querschiffes.

Über den Beginn des 12. Jahrhunderts hinaus läßt sich der Gebrauch des Rationale zu Regensburg nicht feststellen. Man beruft sich freilich auf eine Miniatur in dem aus Niedermünster stammenden Utakodex aus dem Anfang des 11. Jahrhunderts. Allein mit Unrecht. Die Miniatur stellt den hl. Erhard in merkwürdiger Verquickung der pontifikalen und jüdisch-hohenpriesterlichen Tracht dar ${ }^{1}$. So wenig aus dem Kopfbund und der dreieckigen, goldenen Stirnplatte gefolgert werden kann, daf sich da mals die Regensburger Bischöfe eines solchen Kopfschmuckes bedienten, ebensowenig gestattet das geradezu phantastische Schultergewand St Erhards einen Schluf auf den Gebrauch des Rationale. Mit mehr Recht könnte man auf die Darstellung St Emmerams in einem dem Ende des 10. Jahrhunderts entstammenden Kodex der kgl. Hof- und Staatsbibliothek zu München hinweisen . Doch scheint uns die Sache auch hier zum mindesten zweifelhaft. Man darf nicht vergessen, daf die Miniatoren in der Verleihung des Palliums ungleich freigebiger waren als Rom, dafs sie es aber dafür auch gern nach Lust und Laune ausstatteten und umgestalteten.

Zu Bamberg fand das Rationale, wie das im dortigen Domschatz befindliche, noch aus der Zeit Heinrichs II. stammende Exemplar beweist, schon um 1020 Verwendung. Es blieb daselbst bis in den Beginn des 17. Jahrhunderts in Gebrauch. Denn die Kustodierechnungen erwähnen bis 1626 wiederholt das Rationale, so für die Jahre 1476, 1485, 1512, 1539,1544 und 1616; 1544 lieferte ein Goldschmied 32 Schellchen für das Rationale, 1626 reparierten und erneuerten die Jungfrauen ,zum heiligen Grab" das Ornatstück; auch reinigten

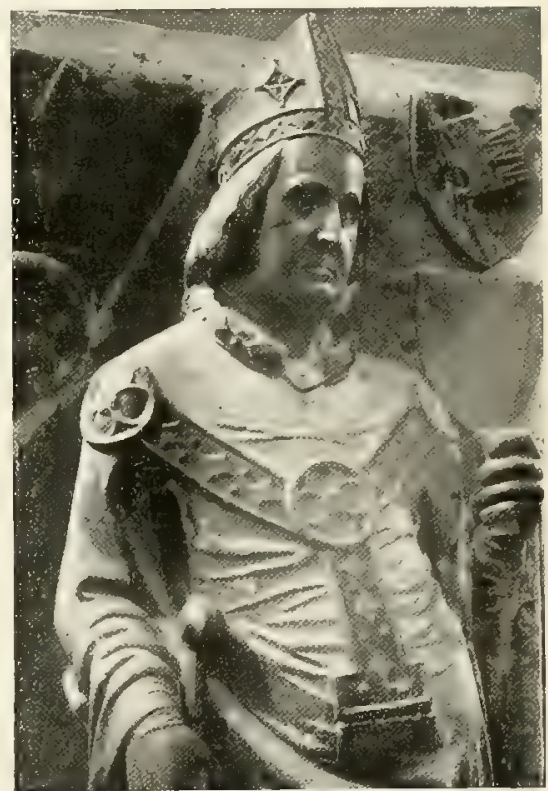

Bild 307. Grabmal des Bischofs Albert von Hohenlohe († 1372). Wuirzburg, Dom. sie damals die Perlen und Edelsteine, womit es besetzt war ${ }^{3}$. Die Angaben zu den Jahren 1476 und 1485 mögen sich auf das Rationale aus der Zeit Heinrichs U. beziehen. Die späteren, namentlich die Vermerke zu den Jahren 1544 und 1626, setzen indes ein zweites voraus, das mit Perlen, Edelsteinen und Perlen geschmuickt gewesen sein muß.

Scheinbar auffallend ist, daf bei der langen Reihe der Grabfiguren der Bamberger Bischöfe im Dom zu Bamberg nirgends das Rationale auftritt, die Bischöfe

1 S. oben S. 462 , Anm. 6.

2 Cim. 14 272. Abb. in G. Swarzenski, Die Regensburger Buchmalerei Tfl III, Bild 9 und L. E isenh of er, Das bischöfl. Rationale, Abb. 4 Man hat auch auf einer Darstellung des hl. Wolfgang in dem Evangeliar Heinrichs IV. (jetzt im Dom zu Krakau) das Rationale finden wollen; doch handelt es sich hier lediglich um ein Pallium. Schon der Umstand, daf3 der Miniator den gleichen
Schmuck auch dem hI. Dionysius gegeben hat, muf davon abhalten, in jhm das Rationale zu sehen. Wie frejgebig die alten Künstler in der Verleihung des Palliums waren, erhellt z. B. aus dem Unstande, daß sie selbst den hl. Benedikt damit schmücken (so in dem bekannten Benedictionale Ethelwolds und in einem Prümer Kartular des Staatsarchivs zu Koblenz).

${ }^{3}$ Pfister, Der Dom zu Bamberg 74. 
tragen vielmehr regelmäfig das Pallium. Die Sache erklärt sich indessen sehr leicht durch den Umstand, das die Inhaber des Bamberger Bischofsstuhles seit 1053, d. i. seitdem Leo IX. Hartwig den usus pallii verlieh, das Privileg besåen, sich des Palliums zu bedienen ${ }^{5}$. Wenn sie trotzdem vor wie nach auch das Rationale gebranchten - - die eben erwähnten Kustodierechnungen lassen keinen Zweifel daran-, so hat das seinen Grund wohl darin, dak sie sich mit dem Pallium nur an wenigen bestimmten Tagen schmücken durften, deren anfangs bloß drei waren. Die Bamberger Bischöfe werden es wie Patriarch Poppo von Aquileja gemacht haben, der, wie wir hörten, an denjenigen Tagen, an welchen ihm untersagt war, das Pallium zu tragen. zum Ersatz dafür das Rationale anlegte. Auf den Monumenten, auf welchen Pallium und Rationale nicht zugleich dargestellt werden konnten, hatte natürlich ersteres als das vorzüglichere den Vorzug.

Vom Eichstäter Rationale berichtet zuerst Bischof Philipp ( $†$ 1322) in seiner Lebensbeschreibung des hl. Willibald. Er führt das Ornatstück auf den hl. Bonifatius zurück. Dieser habe, so erzählt er nämlich, dem hl. Willibald und seinen Nachfolgern die Stellvertreterschaft des Errbischofs von Mainz samt dem Vorrang vor allen andern Suffraganen des Mainzer Metropolitanverbandes verliehen und zum Ausdruck dieses Rechtes ihn sowie die späteren Eichstätter Bischöfe mit dem Rationale begabt 2 . Die Angabe Bischof Philipps ist, wie kaum gesagt zu werden loraucht, nur eine Legende, die blok beweist, dafs das Rationale im Beginn des 14. Jahrhunderts schon eine gute Zeit zu Eichstätt gebräuchlich gewesen sein mußs. Wirklich bezeugt die zweite Serie der Bischofsbilder im Pontitikale Gundekars, dak es schon wenigstens im 12. Jahrhundert bei den Eichstätter Bischöfen Verwendung fand. $O b$ auch bereits im 11. Jahrhundert, ist zweifelhaft, da der gabelförmige Schmuck, welcher bei verschiedenen Bischofsbildern der ersten, zu Gundekars Zeit entstandenen Serie und auch noch auf einigen der zweiten vorkommt, ein sog. Gabelkreuz darzustellen scheint, nicht das Rationale ${ }^{3}$. Die wenigen Eichstätter Bischofssiegel, welche uns zu Gesicht gekommen sind, lassen es unentschieden, wann das Ornatstück zu Eichstätt in Gebrauch kam.

$\mathrm{Zu}$ Minden begegnen wir dem Rationale nach Ausweis des für Bischof Sigebert geschriebenen Ordo und der früher erwähnten Darstellungen Sigeberts schon im Beginn des 11. Jahrhunderts. Auf den Mindener Bischofssiegeln kommt es blof einigemal vor, und zwar nur in 13. Jahrhundert. Die Siegel, auf denen es sich findet, sind die Siegel der Bischöfe Widekind I. von Hoya $(\dagger 1261)$ und Volkwin von Schwalenberg († 1293) ${ }^{4}$. Das Chronicon Mindense (15. Jahrhundert) nennt das Ornatstück pallium und rationale und führt es auf Leo III. zurück, der, wie die Chronik berichtet, es den Bischöfen von Minden verlieh, als er bei seiner Anwesenheit in Deutschland im Jahre 799 den Dom zu Yinden einweihte ${ }^{5}$. Ist diese ganze

1 Historisches Jahrbuch XX $618 \mathrm{ff}$. Vgl. auch oben S. 630. Znr Zeit Innozenz' IHI. waren der Tage, an denen der Gebrauch des Palliums den Bischöfen von Bamberg erlaubt war, dreizehn aufer den Ordinationstagen.

2 Vita S. Willibaldi c. 23 (ed. Gretser, Ingolstadii 1617, 89).

Vgl. die Wiedergabe der Miniaturen des Gundekarpontifikale in "Eichstäts Kunst", München 1901. Die Bilder der zweiten Serie entstanden um das Ende des 12. Jahrhunderts. Der Umstand, dafs die Mehrzahl der Bischofsbilder der zweiten Serie das Rationale aufweist, dürfte schwerlich berechtigen, in der gabelförmigen Verzierung, mit der bei einigen Darstellungen die Kasel geschmückt ist, ebenfalls ein Rationale zu sehen. Dem Künstler hat es beliebt, zu wechseln. Den einen Bischöfen gab er das durch seine eigenartige Bildung als selbständiger Schmuck sofort auffallende Rationale, den andern ein mehr oder weniger reich verziertes Gabelkreuz: Zufälligkeiten, wie sie sich auf manchen mittelalterlichen Bildern finden.

4 Die westfälischen Siegel des Mittelalter's. Siegel der Bischöfe Tfl 54, 45.

$5 \mathrm{M}$ e ibom, Rer. german. I 552: Et hoc templum consecratur - a Iseone et ditatur multis privilegiis - nam hic praesul honoratur - Mindensis qui vocitatur - dignitate pallii - quod bene rationale - vocamus et hoc non male - nam trini episcopi - tantum isto decorantur - per quen recte venerantur locus, gens et clerici. In Prologus wird die- 
Erzählung auch Fabel, so erhellt doch aus ihr, daß das Rationale noch in 15. Jahrhundert bei den Mindener Bischöfen in Gebranch war. Um so auffälliger ist es, dafs sich auf deren Siegeln in jener Zeit keine Spur von ihm bemerklich macht.

Die Bischöfe von Paderborn erhielten das Recht, das Ornatstück zu gebrauchen, 1133 durch Innozenz II. ' Auf den Siegeln der Paderborner Bischöfe gewahren wir das Rationale nur bei Wilbrand von Wildeshausen ( $\dagger$ 1227) und Bernhard IV. $(\dagger 1247)^{2}$; anch auf den sonstigen Paderborner Monumenten findet es sich kaum jemals. Fast das einzige Beispiel bietet die Statue des hl. Liborius (?) am Portal der Domkirche (13. Jahrh.), falls es sich bei dem gabelkreuzartigen Schmuck, den der Heilige über der Kasel trägt, wirklich um das Rationale handelt.

Den Bischöfen von Naumburg wurde 1119 durch Calixt IV. (1119-1124) in einer Bulle für Dietrich von Naumburg die Erlaubnis verliehen, sich des Rationale zu bedienen ${ }^{3}$. Wie lange sein Gebrauch bei ihnen gedauert hat, lälat sich nicht bestinmen, da weder schriftliche noch monumentale Nachrichten, soweit uns bekannt, darüber vorliegen. Von den Naumburger Bischofssiegeln bei Lepsins weisen nur zwei eine Art von Rationale auf. Es sind die mit Ausnahme der Inschrift völlig identischen Siegel Utos $(\dagger 1148)$ und Wichmanns $(\dagger 1152)$, nach Charakter und Stil der Darstellungen evidente Fälschungen aus dem 13. Jahrhundert.

Zu Metz und Halberstadt fanden wir das Rationale bereits in der zweiten Hälfte des 10. Jahrhunderts. Das einzige Metzer Siegel, auf dem das Rationale auftritt, ist das des Bischofs Bertram $(\dagger$ 1212). Im übrigen lafst sich weder zu Metz noch zu Halberstadt weiter die Spur des Rationale verfolgen".

Für Speier, Prag und Olmütz bieten nur die Inventare Belege für die Verwendung des Rationale. Zu Speier begegnet uns schon 1151 ein rationale auro et gemmis ornatum; zu Olmütz wird das Ornatstück erst im Inventar von 1435 erwïhnt: Item rationale pulchrum margaritis et imaginibus ornatum, quorl dedit dominus Wenceslaus Patriarcha Antiocenus ecclesiae Olomucensi.

$\mathrm{Zu}$ Prag treffen wir das Rationale in den Inventaren von 1854, 1355, 1387 und 1396 an. Das Schatzverzeichnis von 1354 vermerkt: Rationalia duo cum perlis, unum episcopale, aliud diaconale; im Inventar von 1387 werden drei Rationalien beschrieben: Rationale de perlis preciosis, quod ex antiquo reparavit dominus Arnestus archiepiscopus Pragensis. Aliud rationale cum perlis plenum (sic) et crucibus nigris, donatum per imperatorem, in quo deficiunt multae perlae. Aliud rationale diaconale cum perlis parvis et capitibus draconum. In den Inventaren von 1396 und 1397 ist ein viertes hinzugefügt: Aliud rationale, quod donavit Iohannes archiepiscopus Pragensis de perlis, gemmis, auro et argento, habens a parte anteriori Virginem gloriosam cum puero; a parte posteriore continens crucifixum. Dieses letzte Rationale war allerdings auch schon 1387 vorhanden; es wird jedoch im damaligen Inventar nicht als Rationale, sondern als crux de perlis super ornatum, quem fecit dominus Iohannes archiepiscopus modernus ${ }^{3}$ etc, aufgeführt, ein Umstand, der für Feststellung des Charakters und der formellen Beschaffenheit der Prager Rationalien

selbe Begebenheit erzählt, nur daf hier das von Leo III. angeblich verliehene Ornatstück blof pallium genannt wird. "Hunc pastorem cum ornavit - usu sacri pallii."

I J. n. 7630 .

2 Westfälische Siegel Tfl 49, 24.

9 J. n. 6766. Luepsius, Geschichte der Bischöfe des Hochstifts Naumburg I 241.

4 Eine jetzt nicht mehr vorhandene, jedoch noch durch Abbildung bekannte Silberbüiste des hl. Adelf, Bischofs von Metz, wies allerdings auch das Rationale auf (B a r bier de Montault, Le buste de St-Adelphe, in Mémoires de la Soc. d'archéol. lorraine 1885); allein dieselbe war, wie ein Vergleich mit der noch vorhandenen Büste des hl. Lambert zu Lüttich beweist, eine bis ins kleinste genaue Kopie eben dieser letzteren und ist darum für die Geschichte des Rationale zu Metz ohne Belang.

5 Podlah a und šittler, Chrámový poklad, XXXIX (vgl. LVIII). Ob das fragliche Rationale urspringlich als Gabelkreuz oder als Rationale gedacht war, ist von keiner Bedeutung. Tatsächlich galt es $1390^{\circ}$ und 1397 als Rationale. Fs muf also offenbar die Form und Beschaffenheit besessen haben, welche diesem nach Prager Brauch eigen waren. 
von großer Bedeutung ist. Könnte nämlich noch ein Zweifel daran bestehen, daß wir es bei diesen nicht mit einem Brust-, sondern mit einem Schulterschmuck und einem Gegenstück des Palliums zu tun haben, so wird er durch jene Angabe des Inventars von 1387 durchaus zu Gunsten eines Schultergewandes behoben. Auffallend und ungewöhlich, aber darum um so bemerkenswerter ist das rationale diaconale, welches sich unter den Rationalien des Schatzes befand. Was man darunter zu verstehen hat. ist unklar; an das Rationale eines gewöhnlichen Diakons ist dabei wohl kaum zu denken. Ob ein Rationale des Suffragans oder des Archidiakons gemeint ist?

Wichtig ist die Notiz des Inventars von 1355, da.3 Erzbischof Ernst (1343 bis 1364), mit dem Prag zum Erzbistum erhoben wurde, eines der Rationalien, die in jenem Verzeichnis beschrieben werden, ex antiquo reparieren liek. Sie beweist, daf das Ornatstück zu Prag nicht erst um die Mitte des 14. Jahrhunderts gebräuchlich wurde, sondern schon eine längere Weile vorher daselbst zur Verwendung gekommen sein muf. Zugleich bekundet sie, dą auch dann noch, als die Prager Bischöfe Erzbischöfe geworden waren und das Pallium erhalten hatten, das Rationale vor wie nach in Benutzung blieb, eine Folgerung, die sowohl durch das von Karl IV. $\left(1346^{\circ}-1378\right)$ als das von Erzbischof Johannes VI. (1379-1396) geschenkte Rationale bestätigt wird ${ }^{1}$.

Den Lütticher Bischöfen soll nach Ägidius von Orval, dem Verfasser des Chronicon Leodiense, das Rationale von Papst Stephan X., einst Domherr zu Lüttich, verliehen worden sein ${ }^{\circ} . \mathrm{Ob}$ dem wirklich so ist, muß dahingestellt bleiben; wahrscheinlich handelt es sich bei jener Angabe nur um eine Lütticher Tradition. Denn die Bulle, durch welche Innozenz II. 1135 dem Bischof Adalbero II. den Gebrauch des Rationale gestattet - das älteste sichere Zeugnis für die Verwendung desselben seitens der Lütticher Bischöfe -, nimmt nicht nur keinen Bezug auf eine frühere Gewährung desselben, sondern beschränkt auch im Widerspruch mit dem angeblichen Privileg Stephans X, die Erlaubnis, es zu tragen, ausdrücklich auf die Person Adalberos ${ }^{3}$. Auf den Lütticher Bischofssiegeln kommt das Gewand zum ersten- und zugleich für länger zum letztenmal bei Rudolf von Zähringen $(\dagger 1191)$ vor. Um dieselbe Zeit finden wir es aber auch bei dem Lütticher Bischof auf einer der Emailscheiben des St Heribertsschreines zu Deutz, welche das Examen und die Bischofsweihe des Heiligen wiedergibt. Denn der Bischof, welcher beide Akte vornimmt, scheint den Bischof von Lüttich, den nächsten Suffragan der Kölner Kirchenprovinz, darstellen zu sollen ". Im späten Vittelalter sehen wir das Rationale regelmäßig auf den Lütticher Siegeln (vgl. Bild 313, S. 693) ${ }^{5}$. Häufig begegnet es uns auch seit dem 15. Jahrhundert als Charakteristikum des hl. Lambert, bei dessen Darstellungen es seitdem bis tief in die Neuzeit hinein fast immer wiederkehrt (Bild 308) ${ }^{6}$.

1 Das Rationale fand zu Prag wohl eine ähnliche Verwendung wie zu Aquileja, wo ja auch Pallium and Rationale nebeneinander in Gebrauch waren.

2 M. G. SS, XXV 88. Hic superhumerale et eius usum Theoduino episeopo suisque successoribus misit.

${ }^{3} \mathrm{~J}, \mathrm{n} .7333$. Vgl. übrigens $\mathrm{G}$ or i, Thesaurus veterum diptych. I, Elorentiae 1759, 11.

4 Der Schrein entstand in der zweiten Hälfte des 12. Jahrhunderts, Als Meister wird neuestens Codfrojd de Claire bezeichnet, ein Künstler von der Maas. Der Umstand, daf der Examinator und Konsekrator des hl. Heribert auf dem Email mit dem Rationale geschmückt ist, scheint diese Zuweisung zu bestätigen. Wenigstens begreift sich so am leichtesten, wie der Künstler dazu kam, den fraglichen Bischof aufälligerweise mit jenem Schultergewand auszustatten. Utber den St Heribertsschrein und Godfroid de Claire vgl. ₹. Falke und Fraberger, Deutsche Schmelzarbeiten des Mittelalters, Frankfurt 1904, 84 ff; das im Text erwähnte Email auf Tfl 88.

${ }^{5}$ Gute Beispiele bieten die Siegel Johannes' von Arkel († 1378), Johannes' von Heinsberg $(† 1455)$, Johannes' von Horn († 1505), Eberhards von der Mark ( $\dagger$ 1538) u. a.

${ }^{6}$ Ob der Schulterschmuck, den die Figur des hl. Lambert auf dem ältesten Kapitelsiegel von St-Lambert (ca 1200) aufweist, schon das Rationale oder nur eimen Kaselbesatz darstellt, ist nicht klar. Abbildung bei Helbig, Ia sculpture au pays de Liège, Bruges 1890, 132. 
Für Toul fehlt jede Nachricht über eine Verleihung des Rationale an die dortigen Bischöfe. Denn es ist eine unbegründete Tradition, wenn man diese mit der Person Leos IX, in Verbindung bringt, der bekanntlich vor seiner Erhebung auf den päpstlichen Stuhl als Bruno von Dachsburg die Diözese Toul regierte ${ }^{1}$. Immerhin müssen die Touler Bischöfe schon früh das Rationale getragen haben, da es schon auf den Siegeln Peters von Brizey († 1192) und Odos von Sorey († 1228) vorkommt $^{2}$. Seit dem 14. Jahrhundert erscheint es häufig auf den Touler Bischofssiegeln. Auch die Grabfiguren Heinrichs von Ville-sur-Illon († 1436) in der Kathedrale zu Toul und Hugos von Hazards i† 1517) zu Blénod-lès-Touls, sowie andere Touler Bildwerke des späteren Mittelalters weisen das Rationale auf . Wie früher gesagt wurde, erhielt es sich im Gebrauch, bis das Bistum Toul Frankreich einverleibt wurde und Franzosen den Bischofsstuhl bestiegen. Dann verschwand es allmählich von der Bildfläche. 1700 wird seiner zwar noch in dem damals gedruckten Caeremoniale gedacht, doch fand es in Wirklichkeit wohl kaum mehr Verwendung: denn schon Dom Calmet konnte 1726 an Montfaucon schreiben, daf sich die Bischöfe von Toul seiner ehedem bedient hätten ${ }^{\text {. }}$

Von nichtdeutschen Bischöfen sind nur zwei bekannt, bei denen das Rationale im Gebrauch war, der Patriarch von A quileja und der Bischof von Kraka u. Bei ersterem fand es noch 1132 Verwendung; denn 1132 bestätigte Innozenz II. dem Patriarchen Peregrinus die Erlaubnis, sich des Palliums und des Rationale zu bedienen, wie sie einst Poppo von Johannes XIX, erhalten hatte ${ }^{6}$. Wann zu Krakau das Ornatstück heimisch wurde, ist nicht zu ermitteln. Jedenfalls kam es dort schon um das Ende des 14. Jahrhunderts zur Verwendung, da das noch jetzt benutzte Rationale, ein Geschenk der Königin Hedwig, der Gemahlin Ladislaus' (1371-1399) und Tochter Ludwigs von Ungarn, aus dem Jahre 1384 stammt ? Nach dem Bericht über die Erhebung der Leiche des seligen Bischofs Vinzenz Kadlubeck († 1233) im Jahre 1634 dürfte es sogar schon im Beginn des 13. Jahrhun-

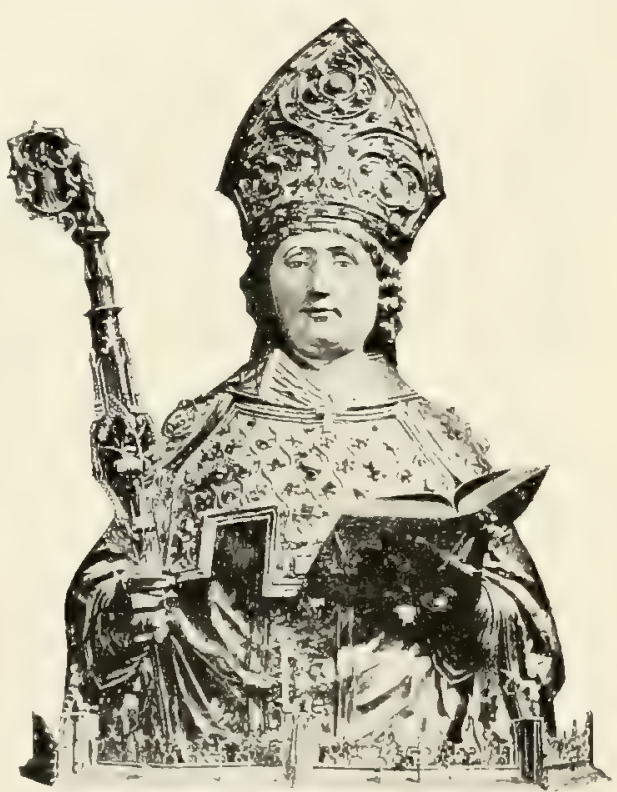

Bild 308. Büste des hl. Lambertus. Lüttich, Kathedrale.

derts von den Krakauer Bischöfen getragen worden sein; denn es heift darin, man habe die Reste an dem pallium episcopale erkannt, quo episcopi Cracovienses in diem hodiernum utuntur, d. i. wohl an dem Rationale. Bischof Johannes Grot († 1347) soll bei Benedikt XII. (1334-1842) die Bestätigung des Gebrauches des Rationale nachgesucht und diese dann auch erhalten haben ${ }^{8}$.

Sehr bemerkenswert ist, daf aus Frankreich kein Beispiel von der Verwendung eines Rationale im Sinne eines dem Pallium analogen bischöflichen Schulterschmuckes bekannt ist. Keine Bulle, in der es einem franzüsischen Bischof bewilligt

${ }^{1}$ Martin, Histoire des diocèses de Toul, de Nancy et de St-Dié I, Nancy 1899, 465.

${ }^{2}$ Ro be rt, Sigillographie de Toul, Paris 1868, pl. II, n. 3: pl. IV, n. 19.

${ }^{3}$ Abbildung bei Martin a. a. 0.469470.

* Vgl. z. B. Revue 1904, 41 (Grabmal des hl. Mansuetus [Anfang 16. Jahrh.] in der Krypta der Kapelle des Faubourg St-Mansuy zu Toul). s Roh. VIII 73: Les évêques de Toul se servaient autrefois d'une espèce d'éphod ou de superhuméral.

6 J. n. 7576.

7 Alex. Przezdziecki und Édouard Rastawiecki, Monuments du moyen-âge dans l'ancienne Pologne n. 17.

${ }^{8}$ Encycklopedja kościelna XI 371. 
wurde; kein französisches Inventar, in dem ein solches verzeichnet wäre, kein französischer Schriftsteller des Mittelalters, der seiner gedächte ${ }^{1}$; keine liturgische Schrift, kein Sakramentar, kein Caeremoniale, die Zeugnis dafür ablegten, daßs es je von französischen Bischöen getragen worden sei. Ist alles das erklärlich, wenn das Rationale, wie man will, noch im 12. Jahrhundert in Frankreich in Branch war? Allerdings hat man zum Beweise, daf3 auch dort das Ornatstück Verwendung gefunden habe, auf verschiedene Miniaturen und sonstige Bildwerke hingewiesen. Mit Unrecht jedoch. Was man für ein Rationale angesehen hat, ist in Wirklichkeit bald ein kragenförmiger Besatz der Kasel, bald ein mehr oder weniger phantastisches Gabelkreuz, bald ein in freier Weise behandeltes Pallium. Wer die Weise der alten Meister näher kennt, wird sich über derartige Erscheinungen ebensowenig wundern, wie ihnen eine Bedeutung beilegen, die sie weder besitzen, noch nach der Absicht der Künstler besitzen sollten. Übrigens müßste im vorliegenden Falle allein schon das völlige Versagen aller schriftlichen Nachrichten abhalten, auf den fraglichen Bildwerken das Rationale zu finden. Soweit die vorhandenen Quellen ein Urteil gestatten, war dieses ein spezifisch deutsches bischöfliches Ornatstück. Wenn es sich zu Krakau einbürgerte, kann das wohl nur nach deutschem Nuster geschehen sein. Aber auch für Aquileja ist unseres Erachtens in Deutschland das Vorbild zu suchen. War doch Poppo von Aquileja, der zuerst die Erlaubnis erhielt, das Rationale zu tragen, aus bayrischem Geschlecht und ein Verwandter Meinwerks von Paderborn?. Wahrscheinlich hatte er das Gewand kennen gelernt, als er 1019 mit Benedikt VIII. nach Dentschland kam und sich mit dem Papst längere Zeit zu Bamberg aufhielt, wo letzterer bekanntlich 1020 in Gegenwart des Patriarchen und einer großen Zahl von Bischöfen die St Stephanskirche konsekrierte ${ }^{3}$.

Betont muf werden, daßs das Rationale niemals als eigentlich bischöfliche Insignie erscheint. Allerdings brachte man es zu Eichstätt und zu Toul schon im späten Mittelalter mit dem Umstand in Verbindung, dafis die dortigen Bischöfe angeblich das Amt eines Dekans in den Kirchenprovinzen von Mainz und Trier, sowie das Recht, ihren Erzbischof in dessen Abwesenheit zu vertreten, besafen. Allein die Tatsache, daf das Rationale auch bei andern Bischöfen vorkam, beweist denn doch mit Bestimmtheit, dafo dieses mit dem beanspruchten Dekanat nichts zu tun hatte.

Das Rationale war nur ein $\mathrm{Schmuck}$, wenngleich ein auszeichnender Schmuck, also ein Ornatstück von der Art, wie es etwa das Pallium war, ehe es zur Insignie der Metropoliten und zum Ausdruck der diesen vom Papst mitgeteilten erzbischöflichen Machtvollkommenheiten wurde. Es brachte dem Inhaber weder irgend eine Jurisdiktion, noch die Exemption von der Metropolitangewalt, noch auch das bloßse Vorrecht der Präzedenz. Es begreift sich daher auch ohne Schwierigkeit, wie es im Verlauf des 17. Jahrhunderts zu Toul, Regensburg, Lüttich, zumal aber zu Bamberg, wo man das Recht besaf, das Pallium zu tragen, aufer Gebrauch kommen konnte. In-

1 Das Rationale, welches uns in der Historia episc. Autiss c. 49 (M. 138, 277) begegnet, bedeutet lediglich den Brustbesatz einer Prachtalbe, die hier in etwas überschwenglichen Worten gefeiert wird. Mit dem uns beschäftigenden Ornatstück hat es nichts zu tun. Wenn es ebendort (ebd. 278) heift, das handhreite Auriphrygium einer Kasel habe das Bild des Superhumerale und Rationale nach Weise des erzbischöflichen Pal. liums dargestellt, so sind unter diesem Superhumerale und Pationale die betreffenden
Ornatstücke des levitischen Hohenpriesters zu verstehen, nicht ein pontifikaler Schmuck des christlichen Kultus. Das Rationale, on welchem in der Bulle Lucius' III. für Erzbischof Wilhelm von Monreale vom Jahre 1183 die Rede ist, hat nur metaphorische Bedeutung (J. n. 14834).

2 Vita S. Meinwerci c. 199 (M. G. SS XI 153). Jahrbücher des deutschen Reichs unter Heinrich II. III 14\%.

${ }^{3}$ Adelbert., Vita Henrici II. n. 25 (M. (G. SS. IV 807). Jahrbủcher etc. 111 lisy. 
dessen waren jedenfalls auch die schlimmen äuferen Verhältnisse des 17. Jahıhunderts, die Wirren und das Kriegselend, die Anhäufung von Bistümern in der Hand eines Bischofs, der dann seine Nebendiözesen durch Weihbischöfe und Generalvikare verwalten lief, und ähnliches von nicht geringerem Einflufs darauf. Nicht mehr benutzt, mufte das Rationale von selbst der Vergessenheit anheimfallen. Zu Prag kam das Ornatstück ohne \%weifel durch die infolge der hussitischen Unruhen eingetretene, mehr denn ein Jahrhundert dauernde Verwaisung der Prager Erzdiözese in Abgang. Als diese 1561 wieder einen Hirten erhielt, war mitsamt den perlenbesetzten Rationalien der Inventare von 1354, 1387 und 1396 auch die Erinnerung an das Rationale selbst verschwunden.

\section{FORM UND AUSSTATTUNG DES RATIONALE.}

Die Form des Gewandes war weder überall noch zu allen Zeiten dieselbe. Wie die übrigen Ornatstücke hat auch das Rationale seine Entwicklung gehabt.

Zu Paderborn erscheint es, soweit die Monumente ein Urteil gestatten, in seiner ältesten Gestalt als ein dem Yartigen Pallium formverwandter Schmuck. Man vergleiche z. B. die Siegel Wilbrands und Bernhards IV. In späterer Zeit wurde es dort eine Art von Schulterkragen, der vorn und hinten mit je zwei Behängen versehen war. Von dieser Art ist das Rationale, das noch jetzt in Paderborn gebraucht wird (vgl. Bild 305, S. 677). Es stammt aus der Zeit Ferdinands II. († 1683) und wurde unter Bischof Hubertus einer Restauration unterzogen. Vorder- und Rückseite bestehen bei ihm aus einem Mittelstück und zwei seitlichen Vertikalstreifen. Schulterschilde fehlen, es stoken vielmehr die den mittleren Teil rechts und links begleitenden Streifen unmittelbar über der Schulter aneinander. Durch eine reich mit Edelsteinen besetzte Agraffe getrenut sind auf dem vorderen Mittelstück die Worte doctrina. veritas, auf dem hinteren fides - spes · caritas eingestickt. Auf die Vertikalstreifen verteilt sich eine Inschrift, welche einen kurzen Abris der Geschichte des Paderborner Rationale gibt: Bernardus I. epis pad. impetravit - Innocentius II. P. M. concessit - Alexander VII. P. M. confirmavit - Ferdinandus II. epus pad. ampliavit. An die jüngste Restauration, bei der die Vorder- und Hinterseite ein wenig verlängert wurden, erinnern die Worte: Hubertus I. ep. paderb. renovavit MDCCCXCII, sowie das am Rand der Vorderseite aufgenähte, von Perlen umrahmte Wappen des Bischofs Hubertus. Die Inschriften auf dem Mittelfeld wie den Streifen werden von zierlichen Bouillonstickereien umrahmt. Die um den Kopfdurchlaf liegenden vier 'Zwickel sind mit Perlenstickereien verziert, die Vertikalstreifen enden in Goldfransen.

Sehr lehrreich ist in Bezug auf die Entwicklung des Rationale zu Eichstätt das Pontifikale Gundekars II. mit seinen Abbildungen der Eichstätter Bischöfe. Es wurde unter Gundekar II. begonnen und reicht bis zum Jahre 1540. Die Serie der Eichstätter Bischöfe bis Gundekar II. († 1076) einschlieblich entstand noch unter dem Pontifikat Gundekars, die Bilder der Bischöfe des 12. Jahrhunderts wurden um 1200 gemalt, die übrigen nach und nach hinzugefïgt. Es läfst sich nun freilich nicht verkennen, dafs bei diesen Darstellungen die Phantasie des Künstlers ein gutes Stück mitgearbeitet hat. Eine so bunte Mannigfaltigkeit, wie sie uns hier in Bezug auf die Gestalt und Ausstattung des Rationale entgegentritt, ist zweifelsohne nicht vorhan- 
den gewesen. Sieht man indessen von den Einzelheiten ab und achtet man blok auf den Typus, so dürfen die Miniaturen als ein genügend treues Spiegelbild der Entwicklung des Ornatstückes zu Eichstätt gelten. Bei den Bischöfen des 12. Jahrhunderts, bei welchen dasselbe zuerst vorkommt, steht es, was die Form anlangt, dem Pallium noch recht nahe, nur daf der Behang kürzer ist wie bei diesem, und daf auf den Schultern bei der Mehrzahl der Darstellungen scheibenförmige Zierstücke angebracht sind. Im 13. Jahrhundert entfernt sich dann das Rationale immer mehr vom Pallium, indem es sich in demselben Mafie der. Kragenform nähert, bis im Beginn des 14. Jahrhunderts die doppelten Behänge auf Brust und Rücken auftreten.

Wie das Ornatstiick im 15. Jahrhundert zu Eichstätt beschaffen war, zeigt das noch erhaltene, in Gold- und Perlenstickerei ausgeführte prächtige Rationale des Bischofs Johannes von Eich (1445-1464) ${ }^{1}$. Es besteht aus einem Vorder- und einem Rückteil, welche durch scheibenförmige Schulterstücke miteinander verbunden sind. Auf der einen von diesen Scheiben ist der hl. Bonifatius mit dem Mainzer, auf der andern der hl. Willibald mit dem Eichstätter Wappen dargestellt. Vorn und im Rücken ist das Rationale in Perlen mit einer von Eichenranken eingerahmten Inschrift geschmückt. die sich teils auf das Mittelstück, teils auf die Behänge verteilt. Sie lautet auf der Vorderseite: Fides, spes, caritas (Mitte), iustitia (linker), fortitudo (rechter Behang), auf der Rückseite veritas, disciplina (Mitte), temperantia (linker), prudentia (rechter Behang). Das die Inschriften umziehende Eichenlaub weist nach Art eines redenden Wappens auf den Namen des Bischofs hin.

Das Rationale auf den Darstellungen Sigeberts von Minden besteht aus einem Ring, dem vor der Brust zwei kurze Behänge angefügt und außserdem als Verzierung noch zwei Rundscheiben aufgesetzt sind (Bild 69, S. 177 und Bild 124, S. 266). Von ganz gleicher Art war der Schulterschmuck, mit dem Bischof Bruno († 1055) auf seiner ehedem in der Mauritiuskirche zu Minden befindlichen Grabplatte ausgestattet war. Auch hier bildete das Rationale ein die Brust, die Schultern und den Rücken umziehendes, palliumartiges Band mit zwei kurzen Behängen, die von zwei auf dem Ring befindlichen Zierscheiben ausgingen ${ }^{2}$. Auf den Siegeln Widekinds und Volkwins erscheint es dagegen als Ring, an welchem - die Siegel sind nicht sehr scharf - kleine kreuz- oder quastenartige Anhängsel angebracht sind.

Form und Beschaffenheit des Bamberger Rationale kennen wir nur aus dem früher schon erwähnten Exemplar im Domschatz zu Bamberg (Bild 300, S. 679). Es besteht wie das des Bischofs Johannes von Eich aus einem vorderen und hinteren Teil, welche durch Scheiben miteinander verbunden sind, und ist ganz in Goldstickerei ausgeführt, bei der als Stickmaterial ein mit purem Gold hergestellter Faden verwendet ist. Leider ist das kostbare Ornatstück in sehr schlechtem Zustande. Stark beschädigt wurde es gegen Ende des 15. Jahrhunderts auf die Glockenkasel aufgeheftet, auf der es sich zur Zeit befindet, dabei aber vorn mitten durchgeschnitten. Von der Technik

1 Abbildung bei Bock II, Tfl 27 und in „Eichstätts Kunst" 5.

3 Abbildung in Sch rö de $\mathbf{r}$, Chronik des Bistums und der Stalt Minden, Minden 1886 , 80. Das Grabmal kaun erst im 12. Jahrhundert entstanden sein. Außer der Archi- tektur beweist das auch die Form der Dalmatik. Es soll sich jetzt nach der Angabe des P. Beda Kleinschmidt in der Simeonskirche zu Minden umgekehrt in den Fufboden eingelassen befinden (Das Rationale in der abendländischen Kunst 22). 
der Stickerei gilt das gleiche, was früher von den bestickten Kaseln des Bamberger Domschatzes bemerkt wurde. Tiefsinnig ist der Bilderschmuck des Ornatstuickes. Auf den Schulterscheiben sind in der Mitte zwei einander begegnende bzw. zwei einander sich küssende Frauengestalten dargestellt, deren Bedentung durch die Umschrift: Misericordia et veritas obviaverunt sibi und: Iustitia et pax osculatae sunt ( $\left.P_{s} 84,11\right)$ gekennzeichnet ist, die Symbole des Alten und des Neuen Bundes. Trm sie herum sind, durch ein Blattornament voneinander getrennt, je sechs Brustbilder angebracht, laut Beischrift die zwölf Stämme Israels darstellend. Die vor der Brust und im Rücken herabfallenden Teile des Ornatstücks setzen sich aus zwei schmalen seitlichen Vertikalstreifen und einem etwas kürzeren Mittelfelde zusammen. Die Vertikalstreifen enthalten je drei Halbbilder der zwölf Apostel. Im mittleren Felde ist auf der Rückseite das Lamm der Apokalypse abgebildet, umgeben von Engeln und von den Evangelistensymbolen. Von den Engeln reicht einer dem hl. Johannes eine Rolle zum Schreiben, ein anderer bläst in eine Posaune. Über dem Mittelfelde gewahrt man den Weltenrichter, rechts und links von einem Engel begleitet. Auf der Vorderseite füllt eine großartig gedachte Allegorie der Kirche die Mitte. Unter fünftürmigem Überbau, der mit Behängen drappiert ist, steht Christus, der neue Salomon, der rex pacificus, wie es auf dem Rationale heifst, auf einer Estrade, dem ferculum Salomonis und reclinatorium aureum, zu der rechts und links ein Aufstieg führt. Der Überbau ruht auf zwei Säulen, den columnae argenteae, neben denen Petrus und Paulus, die Säulen der Kirche, stehen. In dem Aufstieg zur Linken sehen wir Märtyrer, von denen einer als Stephanus bezeichnet ist, in dem Aufstieg zur Rechten den Herold der Liebe, Johannes Ev. Zwei Wege führen zum Friedenskönig, das

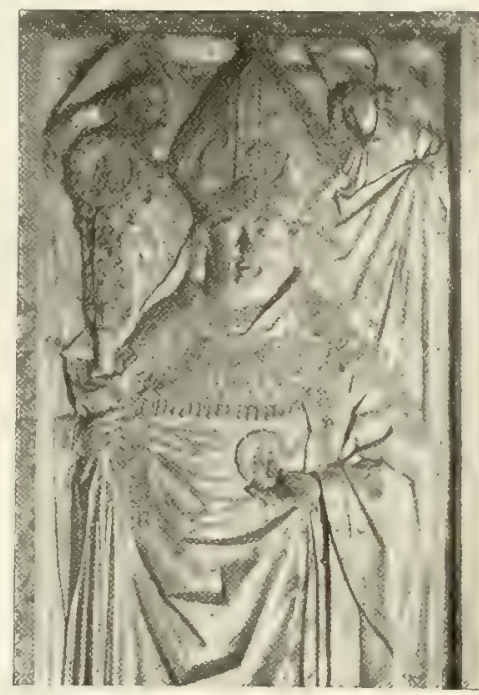

Bild 309. Vom Grabmal ies Bischofs Heinrich von Absberg ( $†$ 1492). Regensburg; Dom. Martertum, der ascensus purpureus, und die Liebe. Vor der Estrade erhebt sich in der Mitte eine Frauengestalt, die Kirche, zu deren Füßen die Halbbilder zweier anderer Frauen angebracht sind, die ausdrücklich als Maria und Martha bezeichnet sind, das beschauliche und das tätige Leben. Zahlreiche Beischriften erläutern auf der Vorderseite wie auf der Rückseite das Bildwerk. Die Darstellungen der Vorderseite beruhen ganz auf der Apokalypse, die der Rückseite im wesentlichen auf dem Hohenlied und seinen mystischen Deutungen bei den alten Exegeten ${ }^{1}$.

1 Es sei übrigens bemerkt, daß das Bamberger Rationale wohl nie ein selbständiges Ornatstück darstellte, sondern von Anfang an einer Kasel aufgestickt war. Es beweist das der Umstand, daß auf der Rückseite der Heiland mit den beiden Engeln zu seinen Seiten nicht innerhalb des Mittelfeldes, sondern ï b e r demselben angebracht ist. Er kann auch nie innerhalb desselben gestanden haben, wie Braun, Die liturgische Gewandung. die Makverhältnisse der Vorder- und Rückseite des Rationale bekunden. Es muf dieses daher von Beginn an auf einer Kasel seinen Platz gehabt und der Kaselstoff für dasselbe als Stickgrund gedient haben. Auf dem Regensburger Rationale, das unzweifelhaft als selbständiges Ornatstìck gedacht und ausgeführt wurde, hat der Heiland mit den Engeln auf dem Mittelfeld der Rückseite eine Stelle gefunden. 


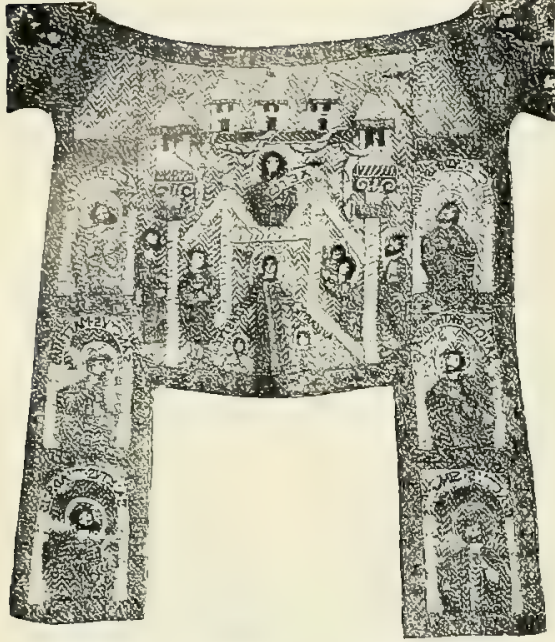

Bild 310. Rationale (Vorderseite). Münchev, Nationalmuseum.
Selnr gut läst sich die Entwicklung des Rationale zu Regensburg verfolgen, wo Siegel, Glasgemälde, Grabmäler und sonstige Monumente samt zwei wirklichen Rationalien reiches Material zum Studium des Ornatstückes bieten. Für die ältere Zeit sind es die Siegel, welche uns über die Form des Ornatstiuckes Aufschluf geben, in der späteren namentlich die Grabmonumente. Die Siegel beginnen bei Hartwig I. (1106-1126). Bis zu Konrad V. von Luppurg (1296-1313) hat das Rationale auf ihnen eine dem Pallium durchaus verwandte Gestalt. Fast der einzige Punkt, durch welchen es sich von diesem unterscheidet, ist die merklich größere Kürze seines Behanges. Scheiben auf den Schultern kommen erst seit der Mitte des 13. Jahrhunderts vor. Doppelbehänge treten zuerst bei Nikolaus von Stachowitz (1313-1340) und Friedrich von Nürnberg (1342-1368) auf. Auf den Grabmälern erscheint dann das Gewand als förmlicher mit Doppelbehängen ausgestatteter Kragen (Bild 309, S. 689). Von den beiden noch erhaltenen Regensburger Rationalien befindet sich eines im Dom zu Regensburg, das andere in dem kgl. bayr. Nationalmuseum zu München, wohin es von Schloł Tießßling bei Mühldorf kam. Nach Tiefling scheint es im Nachlaß des Bischofs Franz Wilhelm von Wartenberg $(1649-1661)$ gelangt $\mathrm{zu}$ sein.

Das Rationale im Dom zu Regensburg ${ }^{1}$ ist eine Kopie des Bamberger Rationale, das es nicht blok was die Form, sondern auch was das Bildwerk betrifft, von unwesentlichen Veränderungen abgesehen, getreu wiedergibt. $\mathrm{Be}-$ züglich der Form weicht es darin von seiner Vorlage ab, dafi die Darstellung des Weltenrichters bei ihm auf dem Mittelfeld der Rückseite einen Platz erhielt, während sie beim Bamberger Rationale über diesem angebracht ist. Die Folge war, daf dem

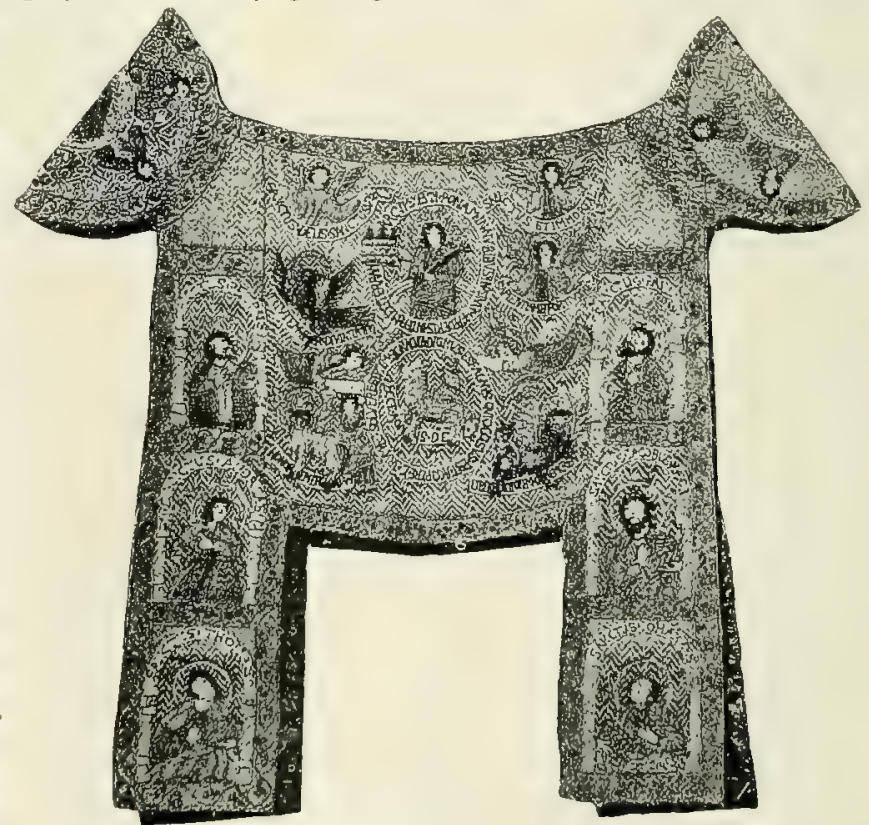

Bild 311. Rationale (Pückseite). München, Nationalmuseun.
1 Abbildung bei $C$ a h i e r, Ivoires 196 199. De Farcy pl. 6 und P. Beda Klein- sc h m idt in Kirchenschmuck, Graz 1904, $\mathrm{Nr} 48$. 
mittleren Teil eine größere Länge gegeben werden mußste. Was die Bilder anlangt, so unterscheidet sich das Regensburger Rationale von seinem Bamberger Vorbild nur durch Vereinfachung der Inschriften. Der Hauptunterschied zwischen beiden Gewändern betrifft den Stil des Bildschmuckes und die Technik. In dem einen wie in der andern steht das Regensburger ungleich höher als das Bamberger Rationale. Während bei diesem nur das Bildwerk gestickt wurde, ist bei jenem alles, auch der Fond, in Stickerei ausgeführt. In seide sind hergestellt die Fleischpartien, das Haar, die Konturen und einiges sonstige kleinere Detail. Alles übrige ist in entwickeltster Ablefttechnik in Gold gestickt. Die Hand, welche das Rationale schuf, hat es meisterlich verstanden, durch Wechsel im Abheften und in der Lagerung der Goldfäden die verschiedensten Effekte zu erzielen. Sie hat überall nach Makgabe des Gegenstandes gearbeitet. Auch zeichnerisch betrachtet sind die Darstellungen vorzüglich ; sie sind ebenso ausdrucksvoll wie edel in der Form.

Wann diese Kopie nach Regensburg gekommen ist, läßt sich nicht feststellen. Für Regensburg angefertigt ist sie jedoch wohl kaum, da den Bildwerken zufolge das Rationale daselbst erst um das zweite Viertel des 14. Jahrhunderts eine dem Bamberger verwandte Form annahm.

Das Rationale im kgl. bayr. Nationalmuseum (Bild 310 und 311) ist eine getreue Kopie des Regensburger. Es entstand, wie es scheint, in der ersten Hälfte des 16 . Jahrhunderts und ist für die da-

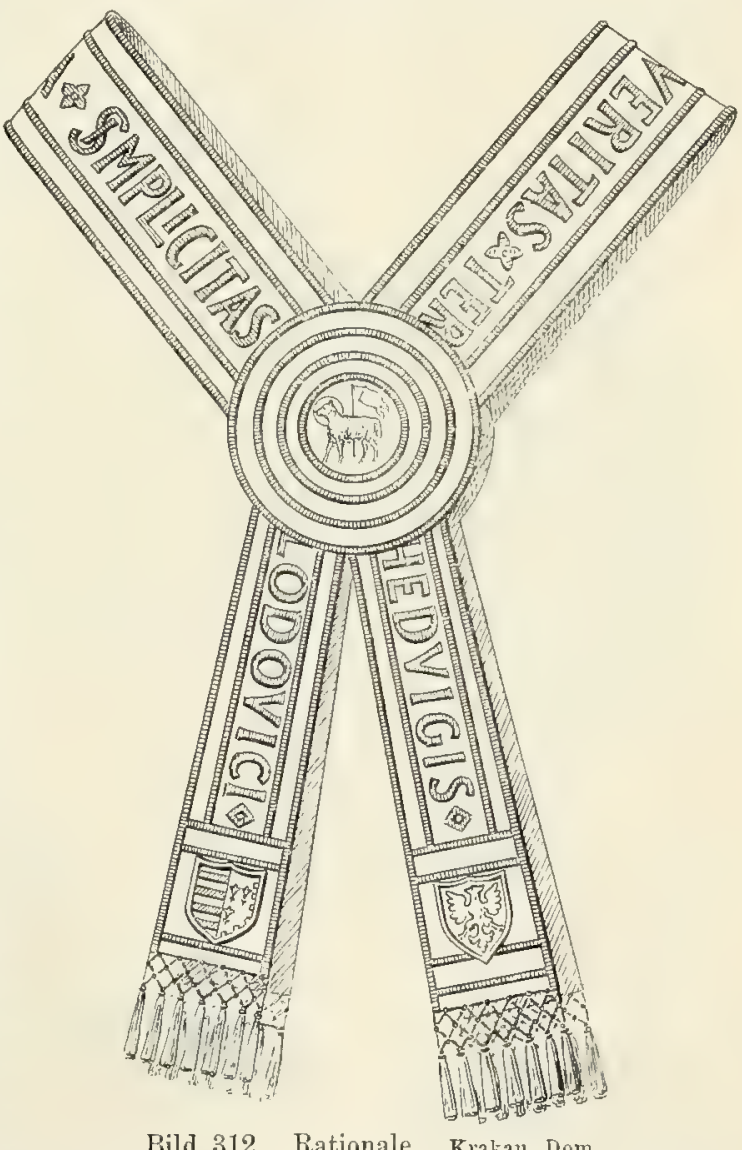
malige Zeit nicht ungeschickt gearbeitet. Am wenigsten gelang es der Hand des Stickers oder der Stickerin, den Stil der Vorlage wiederzugeben. Bezeichnend ist, daf die Inschriften entweder ganz weggelassen oder durch neue ersetzt wurden, bei denen die reiche Allegorie, welche den Bilderschmuck beherrscht, kaum mehr zur Geltung kommt. Die mystischen Auffassungen waren eben andere geworden.

Keine besondere Entwicklung hat das Rationale zu Würzburg erfahren; es erscheint hier von seinem ersten Auftreten unter Emehard bis zum Augenblick, da es durch das Pallium ersetzt wird, auf den Monumenten, Siegeln wie Grabmälern, als palliumartiges Ornatstück. Fs sind im ganzen vielleicht etwa drei Siegel, auf welchen es eine etwas abweichende Form zeigt, zwei Siegel Embrichos von Leiningen $(\dagger$ 1146) und ein Siegel Herolds 
von Höchhein († 1172). Sie sind jedoch um so weniger von Bedeutung, als es auf andern Siegeln derselben Bischöfe die normale Bildung hat.

Von eigentiumlicher Art ist das Krakauer Rationale. Es besteht aus zwei den Schultern aufliegenden Streifen, welche vor der Brust und im Rücken unter einem rechten Winkel zusammenstoßen. Über diesen Kreuzungsstellen ist eine in Gold gestickte Rundscheibe mit dem Bild des Gotteslammes angehracht, an welche zwei mit Fransen besetzte, schmälere Behänge angesetzt sind. Die den Schulterstreifen in Gold aufgestickten Inschriften sind zurzeit verderbt. Nach einem Inventar von 1563 lauteten sie: DOCTRINA VERITAS ET PRVDENS SIMPLICITAS ${ }^{1}$. Auf den Behängen ist der Name der Stifterin verewigt: Hedwigis regina filia regis Lodovici (Bild 312, S. 691). Die mit Fransen verzierten Endstücke weisen die Wappen von Polen, Ungarn und Anjou auf.

Die Rationalien, welche in den Prager Inventaren erwähnt werden, besaßen nach dem früher Gesagten wohl eine dem Pallium verwandte Form.

Zu Lüttich zeigte das Rationale, wie das Siegel Johannes' von Heinsberg (Bild 313 ) bekundet, schon wenigstens im frühen 15. Jahrhundert den Typus, welchen das Bamberger und dessen Abkömmlinge aufweisen. Doch waren Vorder- und Rückteil kürzer; auch liefen beide nicht in zwei, sondern in drei Streifen aus. Auferdem haben die Schulterstücke auf den späteren Bildwerken nicht Scheiben-, sondern Halbkreisform wie beim Touler. Vielleicht dafo schon im 12. Jahrhundert das Gewand zu Lüttich eine ähnliche Form wie das Bamberger hatte. Das Rationale, welches auf dem früher erwähnten Email des St Heribertsschreines sich findet, hat allerdings das Aussehen eines Schulterbandes, dem drei kurze Streifen angesetzt sind, einer in der Vitte der Brust und je einer vor den Schultern; dagegen scheint es auf dem Siegel Rudolfs von Zähringen aus zwei Mittelteilen und zwei verbindenden Schulterstücken zu bestehen ${ }^{2}$.

Sehr mannigfach ist das Rationale auf den Darstellungen der Touler Bischöfe. Auf dem Siegel Peters von Brizey ( $†$ 1192) hat es die Form eines die Schultern, die Brust und den Rücken umziehenden Bandes, an dem kleine, durch bogenförmige Zacken getrennte Kreuzchen hangen. Bei Odo von Sorcy $(\dagger 1228)$ befindet sich in der Mitte der Brust über dem Ring ein mächtiges Rundmedaillon, von dem zwei kurze Streifen herabfallen. Beim oberflächlichen Zuschauen könnte man auf den Glauben kommen, es bestehe aus zwei Bändern, die sich vor der Brust kreuzen. Als Schulterband, dem zwei getrennte Behänge angebracht sind, erscheint das Rationale zuerst auf dem Siegel Thomas' von

\footnotetext{
1 Inventar 1563 , f. 39. Nach gütiger Mitteilung meines Ordensbruders P. Overmans.

2 Nach Gori (Thesaurus veterum diptych. 1. Florentiae 1759,11 ) besaf man gegen die Vitte des 18. Jahrhunderts in der Kathedrale zu Liittich noch ein Rationale in Form eines Palliums, das 6 Zoll $(=0,16 \mathrm{~m})$ breit und zur Zeit, als Gori es sah, einer Kasel als Kaselkreuz aufgenäht war. Am unteren Ende der Rückseite bemerkte der Berichterstatter eine Bischofisfigur in Pluviale und Mitra. Er hielt sie für eine Darstellung Stephans IX., der angeblich nach der Lütticher Chronik (8. oben S. 684) dem Bischof Theodwin fuir ihn und seine Nachfolger die Erlaubnis gab, das Rationale (Superhumerale) zu tragen, und
}

vermutete, es sei das fragliche Rationale eben jenes Superhumerale, welches Stephan IX. dem Bischof damals zum Geschenk übersandt haben sollte. Indessen wird diese Annahme widerlegt durch die Beschreibung, welche Gori von der Bischofsfigur gibt. Überhaupt kann es wohl nicht zweifelhaft sein, daf es sich bei dem angeblichen Rationale nur um ein Gabelkreuz gehandelt hat. Die Breite und die auf das späte Mittelalter, in dem das Lütticher Rationale nach Ausweis der Siegel ein Schulterkragen war, hinweisende Bischofsfigur bekunden das. Gori hatte, das zeigen seine Ausführungen, von dem Gabelkrenz der mittelalterlichen Kaseln keine Abnung. 
Bourlemont († 1353). Bei der Grabfigur Heinrichs von Ville († 1436) ist der Ring am unteren Rand auberdem mit Fransen eingefafst, bei derjenigen des Bischofs Hugo († 1517) haben sich zu den Behängen halbkreisförmige Ansätze über den Schultern gesellt. Es ist das die Form, welche die Statuta von Toul aus dem Jahre 1497 mit den Worten beschreiben: Est stola larga, fimbriata, circuiens desuper humeros cum duobus manipulis dimissis ante et retro et circa spatulas ex utraque parte in modum scuti rotundi lapidibus pretiosis cooperti. Bei einem Bilde des hl. Mansuetus in der Krypta der Kapelle des Faubourg St-Mansuy zu Toul (Beginn des 16. Jahrhunderts) ist das Ornatstück ein förmlicher Líragen, der mit zwei halbkreisförmigen Schulterstücken geschmückt ist und unten die üblichen streifenartigen Behänge aufweist.

Fassen wir das Gesagte kurz zusammen, so lassen sich im ganzen drei Haupttypen des Rationale unterscheiden. Typus I gibt ein Yförmiges Pallium wieder, nur daf der Behang weniger lang und die Ornamentation ungleich reicher und freier ist. Typus II gleicht einem Tförmigen Pallium, bei welchem der eine Streifen in der Mitte durch zwei kurze, nach den Seiten zu angebrachte ersetzt ist. Bei Typus III, der schon im Bamberger Rationale gegeben erscheint, tritt eine Verwandtschaft mit der erzbischöflichen Insignie kaum zu Tage, um so mehr aber die Reminiszenz an den alttestamentlichen hohenpriesterlichen Schulterschmuck. Dem Typus. I kann als Nebentypus die Form hinzugezählt werden, welche im Krakauer Rationale und auf dem Siegel des Touler Bischofs Odo von Sorcy vertreten ist.

Typus I erhielt sich bis in die Neuzeit zu Würzburg. Zu Eichstätt und Regensburg zeigt das Rationale zunächst Typus I, hierauf Typus II, um

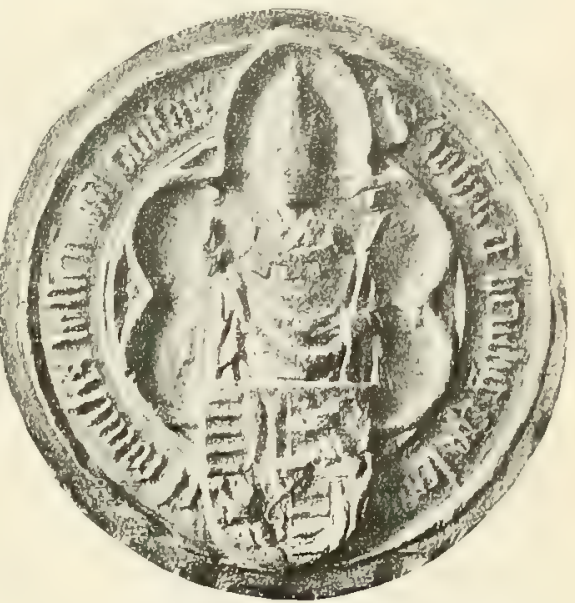

Bild 313. Siegel des Lütticher Bischofs Johannes vou Heinsherg $(1419-1455)$. dann gegen Ende des Mittelalters langsam in den im Bamberger Rationale verkörperten Typus III überzugehen. Ob auch zu Paderborn zwischen den ursprünglichen Typus I und den späteren Typus III (der freilich nicht ganz rein ist, da die Scheiben fehlen) Typus II sich als verbindendes Mittelglied einschob, läst sich beim Mangel an Monumenten nicht bestimmen. Zu Toul, wo sich Typus I nur in der Form des Nebentypus nachweisen läkt, wie er durch das Krrakauer Rationale dargestellt wird, dauert Typus II im wesentlichen unverändert bis zur Zeit fort, zu der das Rationale dort aus dem Gebrauch verschwindet. Denn wenn sich auch um 1500 an dem Schulterband halbkreisförmige Scheiben einbürgern, so bilden diese doch nicht eigentlich die Verbindung zwischen dem Brust- und Rückenteil, wie bei dem Bamberger Rationale und dessen Regensburger Kopien, sowje bei dem Eichstätter Rationale. Auch zu Lüttich ist Typus I nicht nachweisbar. Das Rationale auf der früher' erwähnten Emailplatte des Heribertsschreines gehört dem Typus II an, das Rationale auf dem Siegel Rudolfs von Zähringen dagegen, wenn anders es sich hier um das Rationale handelt, dem Typus III, wie es scheint. Die Lüitticher Bischofssiegel des 14. und 15. Jahrhunderts gestatten zum Teil kein genaues 
Urteil über den Typus, den das Rationale auf ihnen vertritt. Klar erscheint Typus III auf dem Siegel Johannes' von Heinsberg.

Für die Ornamentation des Gewandes gab es keine Regeln. Das bekundet zur Gentige der bunte Wirrwarr, den die Rationalien auf den Monumentell hinsichtlich ihrer Verzierung bieten. Man betrachte nur die Miniaturen des Gundekarpontifikale oder die Siegel und Grabmäler der Würzburger und Regensburger Bischöfe. Hätte es irgend welche Normen für die Terzierming des Rationale gegeben, so hätten die Künstler, deren Hand die Bildwerke schuf, unmöglich ihrer Phantasie so freien Lauf lassen können, wie sie es wirklich getan haben.

An dem Saum des Rationale brachte man, wie die Bildwerke bekunden, gern Glöckchen an. Auch der St Gallener Kodex bezeugt das: Tintinnabulis resonans. Das gleiche tun die Kustodierechnungen des Bamberger Domes zum Jahre 1544. Erhalten haben sich noch einzelne Schellchen an den Rationalien zu Regensburg und Eichstätt.

\section{URSPRUNG DES RATIONALE.}

Über den Ursprung des Rationale im Sinne eines pontifikalen Schulterschmuckes hat man die verschiedensten Hypothesen aufgestellt.

Nach einer derselben kommt es von einem Tunikabesatz her, der uns im Bilde auf altchristlichen und mittelalterlichen Monumenten, in Wirklichkeit bei den koptischen Grabfunden begegnet und aus zwei auf den Achseln angebrachten Scheiben und zwei von den Schultern bis über die Brust sich herabziehenden Streifen besteht. Es soll sich diese Verzierung, zu der oft noch eine den Kopfdurchlaß verzierende Borte kam, im Mittelalter losgclöst haben und als selbständiger Schulterschmuck zu einem Distinktivum kirchlicher Dignitare geworden sein. Dieser Meinung widerspricht indessen, dace wir den Besatz nur bei der Tunika, nicht aber auch bei der Planeta (Kasel) antreffen. Wie soll also, fragen wir wohl nicht mit Unrecht, das von der Tunika losgelöste Ornament den Charakter eines über der Kasel angelegten selbständigen Gewandes erlangt haben? Auferdem ist das Rationale nur in Deutschland und den angrenzenden Teilen von Deutschland in Gebrauch gewesen, hier aber hat man den fraglichen Besatz der Tunika nicht gekannt. Endlich stimmt die Hypothese durchaus nicht mit dem überein, was die Monumente uns von der anfünglichen Form des Ornatstückes und seiner Entwicklung zu erzählen wissen.

A ndere glauben, das Rationale bzw. Superhumerale habe sich aus der breiten, kragenartigen Verzierung gebildet, welche wir nicht selten auf Bildwerken des 12. und 13. Jahrhunderts um den Kopfdurchschlupf der Kasel herum angebracht sehen. Allein wir treffen eine solche Verzierung nicht blof bei der Kasel, sondern auch bei der Dalmatik und Tunicella an; ja nicht blof bei Geistlichen, sondern auch bei Laien, Männern und Frauen. Außerdem erscheint dieser nicht selten geradezu bizarre und phantastische Besatz des Meßggewandes niemals als Besonderheit eines bestimmten Bischofs, noch auch als irgend einem Land eigentümlich; denn wir begegnen ihm ebensowohl auf französischen und italienischen wie englischen und deutschen Bildwerken, und zwar auch noch dann, als das Rationale schon lïngst als Auszeichnung hestimmter Bischöfe in Gebrauch war. Wie kam es, daß wir trotzdem das Ornatstück nur bei deutschen Bischöfen und bei ein paar Deutschland benachbarten Prälaten finden? Wie, daß jener Kaselhesatz ein Gewandstück wurde, zu dessen Benutzung man eines Privilegs des Apostolischen Stuhles bedurfte, weil es als eine Art von Gegenstück des Palliums galt? Wie, daf, das Rationale von Anfang an in ganz bestimmten Typen auftritt, die mit jenem Kaselbesatz bei genauem Zusehen formell wenig oder keine Verwandtschaft rekunden? Wie endlich, daf, wir diesen, nachdem er angeblich zum bischöflichen Rationale geworden war, vor wie nach immer wieder auf den Monu- 
menten dargestellt sehen? Nimmt man die Sache freilich blof als Möglichkeit, so ist es gewif denkbar, dafs sich das Rationale in der Weise bilden konnte, wie es die Hypothese will; allein es kommt nicht darauf an, was absolut genommen geschehen konnte, sondern was nach Mafggabe der tatsächlichen Verhältnisse wirklich geschehen sein wird.

Eine dritte Hypothese leitet das Rationale vom päpstlichen Fano ab, mit dem es identisch sein soll. Sie übersieht jedoch, daf der Fano im Grunde nichts anderes ist als der gewöhnliche Amikt; dafs er noch im 12. und 13., ja 14. Jahrhundert ein wirklicher Amikt war, der freilich statt unter der Albe über derselben getragen wurde; endlich dafs er noch gegen Ende des Mittelalters ein förmliches Tuch darstellte und erst zu einer Art von Schulterkragen wurde, als das gewöhnliche Humerale in die Pontifikalkleidung des Papstes Aufnahme fand. Ebenso läßt sie ganz aufier acht, dak das Rationale zu keiner Zeit mit dem Fano irgend welche Ähnlichkeit hatte, sondern stets als ein ganz eigenartiger Schmuck auftritt, mag es nun als ein dem Pallium formverwandtes Ornatstück, oder, wie zu Bamberg, als eine Art Schultergewand erscheinen.

Eine vierte Theorie führt das Rationale auf ein gallikanisches bischöfliches Pallium zurỉck, indem sie im Anschluf an Ruinart auf Grund des Konzils von Màcon in der altgallischen Kirche ein bischöfliches Pallium in Sinne eines spezifisch bischöflichen Abzeichens und Ehrenschmuckes annimmt. Allein, hat es denn wirklich ein gallikanisches bischöfliches Pallium gegeben? Unseres Erachtens ist das zum mindesten sehr unwahrscheinlich. Das Pallium, von dem die gallikanische Meferklärung und die Synode von Mâcon reden, kann allem Anschein nach nur im Sinne der bischöflich-priesterlichen Stola verstanden werden 1. Jedenfalls ist bisher in keiner Weise bewiesen worden, daß noch im 9. und 10. Jahrhundert das angebliche gallikanische Pallium in Gebrauch war. Im Gegenteil kann es wohl kaum zweifelhaft sein, daß ein solches damals nicht zur Verwendung kam, gleichviel, wie es sich früher verhalten haben mag. Keiner der Liturgiker weib etwas von ihm, nicht einmal Hraban, der doch den deutschen Brauch gewiß kannte; kein Monument bringt uns von ihm Kunde: diese wie jene kennen nur ein Pallium, das römische. Und wenn das Rationale nichts anderes als das gallikanische Pallium ist, wie kommt es denn, daß es bei seinem ersten Auftreten alsbald drei verschiedene Typen aufweist, von denen einer in aller Klarheit als Nachbildung des hohenpriesterlichen Schulterschnuckes erscheint? Wie, daßs das Rationale gerade im Heimatlande des gallikanischen Palliums nirgends naehweisbar ist, sondern nur auf deutschem Boden und bei ein paar den deutschen Grenzen benachbarten Bischöfen?

Eine fünfte Meinung will das Rationale von dem Schulterschmuck des alttestamentlichen Hohenpriesters herleiten. In der Tat kann es wohl nicht bezweifelt werden, dafs die Erinnerung an jenen auszeichnenden Ornat Aarons und seiner Nachfolger auf die Entstehung des Rationale von irgend welchem Einfluf war. Das beweist nicht blof der Name, den das Ornatstück von jeher geführt hat, das zeigen auch die Erinnerungen an den jüdischen pontifikalen Schulterschmuck, die beim Bamberger Rationale unverkennbar in der Form wie in dem Bilderschmuck zu Tage treten. An die am Ephod, dem Schultergewand, angebrachten Schulterstücke, auf denen je sechs Namen der Stämme Israels angebracht waren, gemahnen hier deutlich die Scheiben mit den Darstellungen von je sechs Söhnen Jakobs, an die Brustplatte mit den Namen der zwölf Stämme, die auf den beiden Blättern des Bamberger Ornats sich findenden Apostelbilder. Eine Kopie des alttestamentlichen hohenpriesterlichen Schulter- und Brustornats ist das Rationale zu Bamberg freilich nicht. Allein abgesehen davon, daf es bei der Dunkelheit der Berichte, welche die Heilige Schrift und Flavius Josephus über den Schmuck geben, unmöglich war, diesen schlechthin nachzubilden, verboten auch die veränderten Verhältnisse, ihn herüberzunehmen, ohne ihn mit christlichem Gehalt erfüllt zu haben.

\footnotetext{
1 S. oben S. $674 \mathrm{f}$.
} 
Indessen ist die Erimmerung an das Schultergewand und das Rationale des alttestamentlichen Kultus nicht der einzige Faktor, den der uns hier beschäftigende pontifikale Schulterschmuck sein Dasein verdankt. Sie kann nicht cinmal als der Hauptfaktor betrachtet werden. Die verschiedenen Typen, welche das Rationale bereits bei seinem ersten Auftreten aufweist, lassen Feinen Zweifel, daß noch ein anderer auf seine Entstehung eine Einwirkung ausgeübt hat, ja, wie es scheint, sogar eine gröfere als. der Hinblick auf den hohenpriesterlichen Ornat des mosaischen Kultus: das Bestreben, einen dem Pallium analogen bischöflichen Schmuck zu schaffen, der den Bischöfen eine Art von Ersatz der ihnen nicht zustehenden erzbischöflichen Insignie bieten sollte. Wie bei dem Bamberger Rationale die Beziehung zum Ornat des Hohenpriesters unverkennbar ist, so liegt bei der Form, welche das Ornatstück ursprünglich zu Regensburg und Eichstätt hatte und zu Würzburg bis zum 17. Jahrhundert behielt, der Anklang an das Pallium offen zu Tage. Selbst Typus II, der schon auf den Bildern Sigeberts von Minden vertreten ist, erimnert, weil ein Schulterband darstellend, klar an die erzbischöfliche Insignie.

Aber auch aus den Bullen, in welchen Innozenz II. den Bischöfen Adalbero II. von Lüttich und Bernhard I. von Paderborn das Recht verleiht, das Rationale zu tragen, erhellt, daf wirklich beide Faktoren bei Entstehung des Ornatstïckes mitgewirkt haben.

"Billig ist es, daß Du", so heißst es in der zweiten, "für die Willfährigkeit, welche Du gezeigt, vom Apostolischen Stuhl einer besondern Ehrung teilhaft werdest und . . . zeitlich wie geistlich willkommenen Vorteil empfangest. Und weil Du wie ein anderer Aaron zum Gipfel der bischöflichen Würde durch Gottes Walten berufen und an Stelle Moses' zum Herrscher und Leiter des christlichen Volkes hingestellt wardst, so machen wir Dich auch ihrer Auszeichnung teilhaft und verleihen Dir und Deinen Nachfolgern aus des Apostolischen Stuhles Gnade den Gebrauch des Rationale." In der für Adalbero bestimmten Bulle aber sagt der Papst: "Und wie sie (die römische Kirche) als gute Mutter ihre Kinder zu Hohem erhebt und andere zu Patriarchen, andere zu Erzbischöfen, andere zu Bischöfen macht, so ziert sie aus der reichen Fülle der ihr von Gott verliehenen Gaben dieselben auch voll Milde mit dem Schmuck verschiedener Abzeichen."

In der zweiten Bulle erscheint das Rationale in aller Bestimmtheit als Gegenstück des erzbischöflichen Palliums. Daher denn auch seine Verwendung ähnlichen Beschränkungen unterlag. Es durfte gerade wie das Pallium nur im Bereich der eigenen Diözese, und zwar bloß bei wenigen ausdrücklich festgesetzten Gelegenheiten und Festen, getragen werden. Dazu war sein Gebrauch nur in der Kirche, also z. B. nicht bei Prozessionen, gestattet.

"Wir verordnen", sagt die für Bernhard von Paderborn erlassene Bulle, "dafs Du Dich des Rationale nur in Deiner Diözese innerhalb der Kirche am Gründonnerstag, an Ostern, Christi Himmelfahrt, Pfingsten, am Geburtsfest Johannes' d. T., an den Festen der Apostelfürsten und der Gottesmutter, am Allerheiligenfeste, an Epiphanie, am Feste des hl. Liborius, bei der Einweihung von Kirchen und der Ordination der Kleriker und am Jahrestag der Konsekration der Kathedralkirche bedienest." $̈$ hnlich lauten die Bestimmungen der Bulle, in welcher Innozenz II. Adalbero den Gebrauch des Rationale gestattet.

Noch lezeichmender für den Ursprung des Rationale übrigens als die Bullen Innozenz' II. ist die Bulle Johannes' XIX. für Poppo von Aquileja. Denn 
wenn irgendwo, so erscheint gerade in ihr das Rationale in aller Bestimmtheit als Gegenstück und als Ersatz des Palliums für den Patriarchen bei der Feier der Messe an den niederen Festen, an welchen ihm der Gebranch des Palliums selbst untersagt war. Wenn man aber das Ornatstück Rationale nannte und ihm eine von dem Pallium mehr oder weniger abweichende, von Erinnerungen an den alttestamentlichen hohenpriesterlichen Schulter- und Brustschmuck beeinfluste Form gab, so geschah das zweifelsohne, um es von dem Pallium zu unterscheiden und einer Verwechslung beider Ornatsticke vorzubeugen ${ }^{1}$.

Wie aber kam es, daf das Rationale erst um den Ausgang des zehnten Jahrhunderts auftauchte, und zwar gerade in Deutschland? Eine bestimmte Antwort läfst sich auf diese Fragen leider nicht geben. Immerhin mufs auf zwei Punkte aufmerksam gemacht werden, welche einiges Licht auf sie zu werfen geeignet sind. Dak es ülerhaupt zu einer Einführung des Rationale kan, dürfte mit dem gleichzeitigen lebhaften Streben zusammenhangen, die Pontifikalgewandung möglichst glänzend und reich auszugestalten. Die Zeit, in der uns das Rationale zum erstenmal begegnet, sah nicht blob die Gewandschränke der Dome sich mit den kostharsten Ornaten füllen wie kaum zıvor - man denke nur an die goldgestickten Prachtkaseln im Schatz des Bamberger Domes --, sondern bereicherte die Pontifikaltracht auch um die pontifikalen Handschuhe, das Subcinctorium und die Mitra. Dab aber das Rationale gerade auf deutschem Boden entstand und Verbreitung fand, mag mit der hervorragenden Stellung zusammenhangen, welche hier der Episkopat vor den übrigen Ländern einnahm, zumal aber seit den Tagen der Ottonen.

\section{DAS RATIONALE ALS BISCHÖFLICHER BRUSTSCHMUCK.}

Außer einem Rationale im Sinne eines Schulterschmuckes begegnet uns im Mittelalter hie und da auch ein Rationale in der Bedeutung eines Brustschmuckes. Ton Rationalien dieser Art reden, wie wir früher schon hörten,

1 Wenu Eisenhofer in seiner trefflichen Schrift über das bischöfliche Rationale (S. 31) meint: "Will man... nicht zu der in der liturgischen Tradition nicht begrüindeten und historisch sehr anfechtbaren Hypothese seine Zufucht nehmen, daf das Rationale seine Entstehung einer gewissen Konkurrenz gegen das erzbischöfliche römische Pallium verdankt, so sieht man sich zur Annahme genötigt, daß das Pallium-Rationale nach Deutschland kam aus einem Lande, wo dasselbe schon längst bekannt und in Gebrauch war"; dazu die Fuknote: Es ist ganz undenkbar, daßs die Metropoliten oder der römische Stuhl ein solches Unterfangen geduldet haben würden", so gibt es erstens doch auch andere Erscheinungen in der Sakralkleidung, die nicht in der liturgischen Tradition begründet waren; man denke nur an die Handschuhe und die Mitra, an die Paruren der Albe und des Amikts u. a. Ebenso darf wohl an das Bestreben so mancher Äbte, den Bischöfen gleich das Recht zum Gebrauch der Pontifikalgewänder zu erlangen, erinuert werden. Dann aber geht es auch angesichts der tatsächlichen Verhältnisse, namentlich aber angesichts des Wortlautes der päpstlichen Bullen, wohl nicht gut an, von einer historisch sehr anfechtbaren Hypothese zu reden. Wäre die Einführung des Rationale der Ausdruck des Bestrebens gewesen, mit diesem Ornat zugleich eine Art von Exemtion von der Metropolitangewalt und gewisse jurisdiktionelle Rechte zu erlangen, so hätte Eisenhofer gewiß recht, daß weder die Metropoliten noch der Papst ein solches Unterfangen geduldet haben würden. Allein den Simn hatte sie in keiner Weise. Das Rationale war nur Schmuck, der keinerlei Rechte, nicht einmal die Präzedenz brachte, ähnlich wie die Mitra oder, wenn man will, das Bischöfen verliehene Pallium. Darum hat sich denn auch nie eine Opposition gegen die Ingebranchnahme des Rationale geregt, noch haben die Päpste je Bedenken gefunden, Bischöfen als Auszeichnung den Gebrauch des Rationale zu gestatten. 
Ivo, Honorius und Sicard. Bei dem Rationale, von dem Ivo spricht, hat man allerdings an das erzbischöfliche Pallium gedacht; jedoch macht es der Zusammenhang meln als wahrscheinlich, dak auch er bei seinen Worten einen bischöflichen Brustschmuck im Sinne hat. Hic ornatus solius erat pontificis, sicut et numc est apud eos, quibus eo uti concessum est propter distantiam maiorum et minorum sacerdotum, schreibt er, nachdem er den Brustschild des alttestamentlichen Hohenpriesters mystisch gedeutet hatte. Auch in dem Sakramentar Ratolds, das ursprünglich für die Kathedrale zu Arras bestimmt war, ist unter dem Rationale wohl ein Brustschild zu verstehen, falls nicht etwa, wie frủher gesagt wurde, damit eine Amiktverzierung gemeint ist.

Von einem Rationale dieser Art berichtet um 1200 ein Mönch des Klosters Admont. Bischof Gebhard von Salzburg († 1088), so erzählt er, hatte es, als er zu Gesandtschaftszwecken am byzantinischen Hofe weilte, vom Kaiser zum Andenken erhalten, weil er dessen Sohn getauft hatte. Es war aus Gold und Edelsteinen verfertigt, hing an goldenen Ketten und wurde auf 1000 Mark gewertet. Das Kleinod ging, wie der Admonter Mönch klagt,

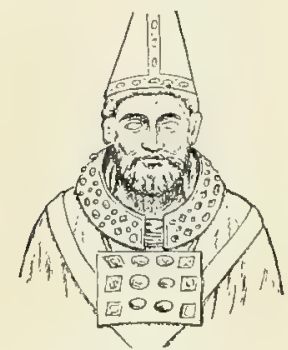

Bild 314. Statue des hl. Klemens. Reims, Kathedrale. leider schon 1085 in den Wirren, welche der Eindringling Berthold anstiftete, schmählich zu Grunde 1.

Rationalien im Sinne eines auf der Brust über der Kasel befestigten bischöflichen Brustschildes haben sich aus dem Mittelalter nicht erhalten. Dagegen gibt es eine Anzahl von Bischofsdarstellungen aus dem 12. und 13. Jahrhundert, welche das Rationale aufweisen und treffliche Illustrationen zu den Ausführungen eines Ivo und Honorius bilden. So findet sich der Brustschmuck beipielsweise auf den Siegeln der Münsterischen Bischöfe Werner († 1151), Ludolf $(\dagger$ 1248), Wilhelm $(\dagger 1260)$, der Paderborner Bischöfe Bernhard III. († 1223), Bernhard IV. († 1247), Simon I. († 1277), der Mindener Bischöfe Johann $(†$ 1253), Wilhelm I. $(† 1242)$ und Widekind I. $(† \text { 1261 })^{2}$, der Mainzer Erzbischöfe Christian († 1251), Gerhard I. († 1259), Werner $(† 1284)^{3}$, sowie auf dem Siegel des Mainzer Domstiftes (Bild 123, S. 263). Auch auf sonstigen Monumenten begegnet es uns nicht selten. Wir erwähnen hier nur die drei aus Maastricht stammenden Reliquiare des Musée Cinquantenaire zu Brüssel mit den Darstellungen der hll. Monulphus, Gondulphus und Valentin ${ }^{4}$, die Statuette des hl. Servatius am Kopfende des Schreines des Heiligen in der St Servatiuskirche zu Maastricht5, die Statue des hl. Gregor d. Gr. am Südportal der Kathedrale von Chartres und ganz besonders die Figur des heiligen Papstes Klemens (Bild 314) ${ }^{6}$ und die Bilder der Reimser Erzbischöfe am Nordportal und an der Fassade der Kathedrale von Reims, sowie die nach deren Vorbild gearbeitete Statue Klemens' II. im Dom zu Bamberg (Bild 315) ?.

1 Nonachi Adrnont. Vita Gebehardi n. 8 (M. G. SS. XI 39). Eine Reliquienkapsel oder ein Brustkreuz war das Rationale, nach dem Bericht zu urteilen, wohl nicht.

2 Abhildungen in Die westfälischen Siegel des Mittelalters ${ }^{4}$ Tet $1^{3} 43^{2} 44^{3} 4912354356$.

${ }^{3}$ Abbildungen bei $W$ ür d twe in, Nova subsid. dipl. III, tah. 18; IV, tab. 20.

4 Abbildung bei J. Destrée, les musées royaux du Parc du Cinquantenaire, livr. 5.
${ }^{5}$ Abbildung bei Bock und M. Willemsen, Die mittelalterlichen Kunst- und Reliquienschätze zu Maastricht, Köln 1872, 47.

${ }^{6}$ Abbildung der Statue des hl. Klemens bei Bock I 3 , Tft 6 .

7 Neueste Abbildungen bei A. W e ese, Die Bamberger Domskulpturen, Strałb. 1897, Abb. 32 33. Die Bamberger Statue, auch bei Hasak, Geschichte der deutschen Bildhauerkunst des 13. Jahrh., Berlin 1899, 64. 
Der Brustschmuck, den wir auf den genannten Bildwerken antreffen, ist meist von rechteckiger Form, doch auch wohl rund. Er ist bald gröfer, bald kleiner, immer aber reich verziert, zumal mit Steinen. Angebracht ist er oben über der Kasel hart unter dem Kopfdurchlaf. Er scheint im Einklang mit den Angaben des Honorius fast immer an der Kasel befestigt zu sein. Bei der Klemensstatue und den andern Bischofsdarstellungen am Portal des Querbaues und an der Fassade der Kathedrale von Reims hängt das Rationale an Kettchen, die unter der Parura des Amikts verschwinden.

Das Rationale im Sinne eines pontifikalen Brustschmuckes dürfte nie sehr verbreitet gewesen sein, vielleicht weniger verbreitet, als es nach den Bildwerken scheinen könnte. Denn es kann wohl kaum einem Zweifel unterliegen, dafs es sich bei der Agraffe oder dem agraffenartigen Schmuck, welche man auf diesen bei Bischöfen vorn oben über der Kasel bemerkt, nicht selten statt um das Rationale um eine dem Künstler zur Last fallende Verzierung handelt. Wenn irgendwo bei Verwertung der Monumente, dann ist bezüglich des in Frage stehenden pontifikalen Brustschmuckes Vorsicht und nüchterne Zurückhaltung nötig.

In der zweiten Hälfte des 13. Jahrhunderts verschwindet der Schmuck von den Bildwerken. Wenn er sich zu Reims länger auf ihnen erhielt, so hatte das seinen Grund in dem Umstand, daß er hier tatsächlich fortdauernd Verwendung fand. War doch das Rationale im Sinne eines Brustschildes nach Ausweis der Inventare der Kathedrale von 1470 und 1518 daselbst noch um den Beginn der Neuzeit im Gebrauch ${ }^{1}$. Es gab damals im Schatz zwei Rationalien, ein größeres und ein kleineres. Das größsere bestand aus lauterem Gold und war mit zwölf verschiedenfarbigen Edelsteinen besetzt, auf denen die Namen der zwölf Kinder Israels eingegraben waren. An seinen vier Ecken waren Ringe und Agraffen angebracht. Die goldene Kette, mit der es am Hals aufgehängt wurde, wies auf den Schultern einen in Gold gefaften Sardonix, im Nacken aber einen grofien Kristall

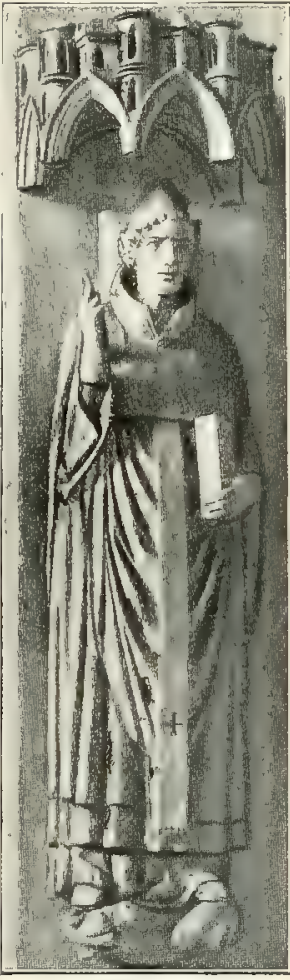

Bild 315.

Papst Klemens II. Bamberg, Dom. auf. Das kleinere Rationale war ebenfalls aus Gold gemacht und mit goldener Kette versehen, im übrigen aber ungleich einfacher; denn seine Verzierung bestand nur aus einem freilich aufergewöhnlich großen Sardonix, den vier Smaragde und vier Rubine umgaben. Zu beiden Rationalien gehörten drei silbervergoldete Nadeln, ad tenendum dicta rationalia cum casula, deren Zweck also war, die Rationalien an der Kasel anzuheften, offenbar, um ein ebenso unschönes wie lästiges Hin- und Herbaumeln des Schmuckes zu verhüten ${ }^{2}$.

1 Cerf, Dissertation sur le rational. Travaux de l'Académie de Reims 1889, 251.

2 Vielleicht spielt schon um 1180 Petrus Cellensis, damals Abt von St-Remi, in seinem Brief an Erzbischof Wilhelm von Reims († 1202) auf den fraglichen Brustschmuck an. Certe, schreibt er, hoc in rationali (das Rationale) et superhumerali (Pallium) tuo, pater amantissime, stylo ferreo . . scribetur, quod in vicariis Christi eligendis nulla te movet humana gratia (Ep. 1. 2, ep. 17 [M. 202, 567]). 
Nach Ivo von Chartres war der Brustschmuck ein privilegiertes Ornatstück entweder der Bischöfe überhaupt oder doch solcher Bischöfe, denen das besondere Vorrecht zu teil geworden war, sich seiner zu bedienen. Das erste ist das wahrscheinlichere, um nicht zu sagen das richtige; denn in einer späteren Äuferung weist Ivo das Rationale den Bischöfen schlechthin in tregensatz zu den Priestern zu ${ }^{1}$. Wirklich ist keine Bulle bekannt, in welcher einem Bischof vom Apostolischen Stuhle eine Erlaubnis gegeben worden wäre, den fraglichen Brustschmuck zu tragen. Wenn Johannes XIX. dem Patriarchen Poppo von Aquileja gestattet, aufer dem Pallium sich auch des Pationale zu bedienen, so ist hier, wie aus dem Zusammenhang erhellt und früher schon näher ausgeführt wurde, nicht ein Brustschmuck, sondern ein dem Pallium analoges Schulterkleid zu verstehen. Auf den Bildwerken findet sich der Brustschmuck auch wohl zugleich mit dem Pallium oder mit dem Rationale im Sinne eines Schultergewandes vor.

Was den Ursprung des Brustschmuckes anlangt, so werden wir wohl nicht fehlgehen, wenn wir auch ihn vor allem auf die im 11. Jahrhundert zunehmende Prachtliebe in der Ausstattung der pontifikalen Gewandung zurückführen, also auf denselben Grund, dem das Rationale in der Bedeutung eines Gegenstücks des Palliums vorzüglich sein Dasein schuldete. Der Gedanke an einen solchen Schmuck mochte sich aber um so eher nahe legen, als es vielfach gebräuchlich war, am unteren Ende des Kopfdurchschlupfes der Kasel aus praktisclien und ästhetischen Gründen einen Zierbesatz anzubringen. Vielleicht auch, daf die manchmal sehr kostbare Agraffe, mit der man die zum Schliefsen des Pluviale bestimmten Laschen schmïckte, die Idee weckte, mit einer ähnlichen Zierat die Kasel zu versehen. Indessen war auch wohl die Erinnerung an die Brustplatte des jüdischen Hohenpriesters auf die Entstehung des uns beschäftigenden Brustschmuckes von Einfluk; das Reimser Rationale mit seiner dem hohenpriesterlichen Rationale durchaus nachgebildeten Ausstattung bekundet das. Jedenfalls erhielt der Schmuck von letzterem scinen Namen. Der Ursprung des Rationale im Sinne eines pontifikalen Brustschmuckes erklärt sich sonach in ähnlicher Weise wie derjenige des Rationale im Sinne eines Gegenstückes des erzbischöflichen Palliums.

1 M. 162, 521: Novi testamenti sacerdotes nec duabus tunicis utuntur, nec rationali praeter solos pontifices. 


\title{
SYMBOLIK, FARBE UND SEGNUNG DER LITURGISCHEN GEW ÄNDER.
}

\author{
ERSTES KAPITEL.
}

\section{DIE MYSTISCHE DEUTUNG DER LITURGISCHEN GEW ÄNDER.}

\section{DIE MYSTISCHE DEUTUNG IM ABENDLAND.}

Fine Geschichte der liturgischen Gewandung muf sich notwendig auch mit der mystischen Deutung beschäftigen, welche den einzelnen Ornatstïcken im Laufe der Zeit zu teil geworden ist. Wir verstehen darunter aber nicht jene Symbolik, kraft deren einzelne der Sakralgewänder, wie Pallium, Stola und Manipel, den Charakter eines Abzeichens haben; vielmehr meinen wir jene symbolischen Erklärungen, wonach die verschiedenen Bestandteile der liturgischen Kleidung entweder moralisch auf die dem Priester nötigen Eigenschaften und Tugenden hinweisen, oder typisch auf Christus, den grolien Opferpriester, dessen Abbild und Vertreter der zelebrierende Priester ist. Man kann diese letztere Symbolik passend die dogmatische nennen, weil sie an das erinnern soll, was der Glaube von Christus lehrt. Die mystische Bedeutung der heiligen Gewänder, wie sie gegenwärtig namentlich in den Gebeten der Kirche, dann aber auch in den Handbüchern der Liturgik vorgetragen wird, ist nicht eine Frucht des Zufalls oder der Willkür, sondern wie der Ritus und die Gewandung das Ergebnis einer langen Entwicklung.

Man hat geglaubt und behauptet, die liturgischen Gewänder verdankten ihr Dasein eben diesen mystischen Anschauungen. Das ist indessen unzutreffend. Es gibt keinen Bestandteil des liturgischen Ornates, dessen Einführung auch nur mit einigem Schein von Berechtigung solchen Auffassungen zugeschrieben werden könnte. Die Wahrheit ist, dals sich derartige Deutungen durchaus an die bereits im Gebrauch befindlichen liturgischen Kleider anschlossen. Sie gingen denselben nicht voraus, sondern kamen erst auf, seitdem jene im Laufe der Zeit einen liturgischen Charakter erhalten hatten. Selbst die mitunter eigenartige Verzierungsweise der Sakralgewänder ist kaum je die Frucht solcher tiefsinnigen Spekulationen gewesen. Am frühesten wird dem Pallium bzw. Omophorion und dem diakonalen Orarium eine mystische Deutung zu teil, begreiflich, weil gerade diese Gewandstücke als sakrale Abzeichen am ehesten einen liturgischen Charakter erhielten.

Im Orient sah schon der hl. Isidor von Pelusium im Omophorion die Aufforderung, dafs der Bischof ein guter Hirt sein solle, der nach dem Vorbild des göttlichen Hirten das verirrte Schäflein liebreich aufsucht und auf seinen Schultern zur Herde zurückträgt. Im A bendland ảber galt bereits zu Gregors d. Gr. Zeit das Pallium als Symbol der Tugenden, mit denen die 
Seele der zum Tragen des Ornatstückes berechtigten Prälaten ausgestattet sein mủsse. Das diakonale Orarium gemahnte schon nach Isidor die Diakone, nach dem Beispiele Christi, der wie ein niedriger Diener vor dem letzten Abendmahl semer Jünger Füß̊ gewaschen und abgetrocknet hatte, demütig zu sein.

Auch die Albe und der Gürtel erfuhren zu guter Stunde eine symbolische Deutung; denn sie erscheinen bereits in dem sog. Stowe-Missale als Simmbild der Keuschheit und der Liebe.

Die älteste, umfassendere Deutung der liturgischen Gewandung, von der wir aus dem Abendland wissen, gehört noch der vorkarolingischen Zeit an; es ist die sog. gallikanische Meßerklärung. Sie behandelt die Kasel, ein "pallium", die "manicalia oder manicae" sowie die diakonale Alba und Stola. Die mystischen Erörterungen, welche an diese Gewänder angeknüpft werden, sind moralischen Charakters, dabei aber sehr willkürlich, unklar und verworren. Am ausführlichsten beschäftigt sich der Verfasser der Schrift mit der Alba der Diakone. Weil diese von weifer Farbe sei, versinnbilde sie die Reinheit, welche die Seele des Trägers zieren müsse. Sei sie aus Seide gemacht, so erinnere sie im besondern an die zukünftige Auferstehung, da ja der Seidenwurm, von dem die Seide stamme, zuerst gleichsam absterbe, um dann herrlich aus seinem Grab zu erstehen. Daß3 sie lose den Körper umwalle und der Gürtung entbehre, mahne den Leviten, dak er in seinem Sehnen nach dem himmlischen Vaterland sich von dem Erdenwerke ledig halten müsse und mit dem Gürtel der Sünde nicht umgeben sein dürfe.

Im ganzen scheint man sich vor der karolingischen Zeit im Abendland noch wenig mit der Deutung der liturgischen Gewandung befast zu haben. Gedenkt doch der ehrwürdige Beda in seiner Abhandlung De tabernaculo, in welcher er im Anschluf an des hl. Hieronymus Brief an Fabiola die Bedeutung der alttestamentlichen Kultkleidung aufs eingehendste erörtert, in keiner Weise der liturgischen Gewandung des Neuen Bundes, obschon es an manchen Stellen sehr nahe gelegen hätte, einige Worte auch über deren Symbolik zu sagen.

Erst die Karolingerzeit ist es, welche uns mit reichlicheren Erörterungen über den mystischen Sinn der neutestamentlichen Sakralgewänder beschenkt. Den Reigen in der Ausdeutung der liturgischen Kleidung erüffnete Hraban. Seine Auslegungen sind schlicht. Für den Amikt, die Albe und das Cingulum lehnt er sich an Bedas Schrift De tabernaculo an, indem er auf jene überträgt, was diese von dem Ephod des Hohenpriesters und von der Linnentunika sowie dem Gürtel der Priester sagt. Den Ausführungen über das Orarium liegt die Bemerkung des 40. Kapitels des 4. Konzils von Toledo zu Grunde: Orarium oportet levitam gestare in sinistro humero, quod orat, i. e. praedicat. Bei der Kasel geht Hraban von der Erklärung aus, welche Isidor von dem Wort casula gibt, bei den Sandalen von Mk 6, 8. Eigenartig ist die Deutung der mappula oder des mantile, d. i. des Fano oder des Manipels. Hraban findet in den Etymologien Isidors die Definitionen: Mappae convivii et epularum appositarum sunt..., cuius diminutivum mapella est, und: Mantilia nunc pro operiendis mensis sunt, quae ut nomen ipsum indicat, olim tergendis manibus praebebantur ${ }^{1}$. Auf der andern Seite erinnert er sich, dak, die Messe nicht blob, oin Opfer, sondern auch ein Mahl ist. Er falit darum die mappula als eine Art von Serviette auf, welche der Bischof in

1 Etymol. 1. 19, c. 26 (M. 82, 694). 
der Hand halte zum Zeichen, dafi er zum Dienst des Tisches des Herrn bereit sei, und deutet sie dann im Einklang hiermit auf die innere Bereitschaft des Bischofs, der sich zur Feier der heiligen Geheimnisse anschickt.

Dem Abt von Fulda folgt hart auf dem FuB Amalar. Auch dieser entnimmt den einen oder andern Gedanken den Schriften Bedas, im iibrigen aber ist er nicht nur ungleich ausführlicher, sondern auch wesentlich origineller als Hraban. Amalar legt alles bis auf die geringsten Kleinigkeiten symbolisch aus; überall unterscheidet er Buchstaben und Geist, die äufere Erscheinung und den inneren Sinn. Besonders eingehend behandelt er die Dalmatik und die Sandalen.

Die Deutungsweise Amalars fand indessen bald in Florus von Lyon einen ebenso erbitterten wie voreingenommenen und zugleich unehrlichen Gegner, der durch seine einseitige Darstellung der Sachlage es zuletzt dahin brachte, daf die Synode ron Quiercy 8:38 über das Vorgehen Amalars das Verwerfungsurteil aussprach. Sein ganzes System sei verdammungswürdig und von Grund aus von allen Katholiken abzuweisen. Seine Lehre sei von der Reinheit des wahren Glaubens und dem Geist der Kirche sehr weit entfernt. Im AIten Bunde habe es Vorbilder und Typen gegehen. Im Neuen Bunde sei es nie jemand erlaubt gewesen, neve Arten von Typen und mystischen Deutungen aufzustellen. Man solle bezüglich der kirchlichen Gewandung und beim mannigfaltigen Gebrauch der heiligen Geräte demiitig den Anordnungen der Kirche folgen, ohne sich in allerlei nebelhaften Phantasien und eiteln Deutereien zu ergehen. So berichtet uns wenigstens Florus über den Ausgang des Streites ${ }^{1}$, doch mag man mit Mönchemeier zweifeln, ob das Urteil der Synode wirklich gerade so gelautet, wie es der Diakon von Lyon mitteilt ${ }^{2}$. Denn unter den zu Quiercy versammelten Prälaten befand sich auch Hraban; hätte die Synode gesprochen, wie Florus zu erzählen weif, so hätte sich ja der Abt von Fulda damit selbst gerichtet ${ }^{3}$.

Es läfst sich nicht leugnen, daf manches in den Deutungen Amalars gesucht, gekünstelt, kleinlich, verworren und Spielerei ist; aber es ist ebenso sicher, dal; es wenige Männer im 9. Jahrhundert gegeben hat, welche an Geist und Scharfsinn Amalar überlegen oder auch nur gleich gewesen sind. Eine Reihe von Vorwïren, die Florus gegen Amalar erhob, sind nichts als perfide Verdrehungen. Der Lyoner Diakon rißs Sätze aus ihrem Zusammenhang heraus, legte ihnen einen fremden Sinn unter und bekämpfte sie dann als unkirchlich und verwerflich. Von andern Anschuldigungen waren lediglich Haf und Tadelsucht die Eltern. Es fehlt für sie jeder auch nur scheinbare Untergrund *. Bei allen Sonderbarkeiten enthalten die Deutungen Amalars so viel des Schönen, des Groliartigen und Erbaulichen, daf man darüber etwaige Spreu schon gern mit in den Kauf nimmt. Darum hat denn auch die Folgezeit das Urteil der Synode von Quiercy keineswegs bestätigt. Es hat so wenig die Verbreitung der Schriften Amalars hindern können, dafó der Verfasser des Liber de tribus epistolis bereits im Jahre 853 sich bitter darüber beklagt, dab dieselben in fast allen Kirchen des Frankenlandes und selbst über dessen Grenzen hinaus Aufnahme gefunden hätten und ihre unheilvolle Wirksamkeit ausäbten ${ }^{5}$.

Hraban und namentlich Amalar sind für die ganze spätere Zeit tonangebend geworden. Auf sie grüden sich Pseudo-Alkuin und Pseudo-Beda,

1 Opusculum de causa fidei (M. 119, 82 f).

2 Mönchemeier, Amalar von Metz 53. Anm. 3. 3 Epist. Flori (M. 119, 71).
4 Sehr gut ist die ganze Frage bei M önchem e i e r a. a. $0.44 \mathrm{ff}$ behandelt.

М. $121,1054$. 
auf sie die Liturgiker des 11. und 12. Jahrhunderts, Innozenz III. nicht ausgenommen; aus ihnen schöpfte Durandus für sein Rationale. Ja wenn jemand die Deutungen liest, welche am Ausgang des Mittelalters ein Gabriel Biel in seiner Sacri canonis missae expositio litteralis et mystica und ein halbes Jahrhundert später ein Berthold von Chiemsee in seinem Tewtsch Rational den liturgischen Gewändern angedeihen läßt, so wird er auch hier noch überall Anklänge an Hrabans und Amalars Auslassungen wiederfinden. Das bezeichnet mehr als alles andere, welchen Wert man den mystischen Eirörterungen des groben Fuldaer Abtes und namentlich des in diesem Punkte bei seinen Lebzeiten so heftig angefeindeten Metzer Diakons beigelegt hat.

Übrigens hat man den Einflus, den Hrabans und Amalars Schriften auf die Ausdeutung des liturgischen Ornats bei der Nachwelt ausübten, nicht dahin zu verstehen, daßs alles, was man später darüber schrieb, nur eine gedankenlose Wiederholung dessen war, was einst die beiden Liturgiker gesagt hatten. Einige Schriften von untergeordneter Bedeutung sind allerdings lediglich Exzerpte aus Hraban und Amalar. Bei andern Liturgikern aber haben wir, so sehr sie auf diesen beiden fußen mögen, durchaus selbständige Gedanken und eigene Verarbeitung vor uns. Das gilt z. B. von Bruno von Segni, Ivo von Chartres, Rupert von Deutz, von den Verfassern der "Predigt ïber die priesterlichen Gewänder" und des Speculum de mysteriis ecclesiae, von Innozenz III. und zum Teil selbst von Honorius und Sicard.

Nicht viel mehr als bloßse Kompilation sind die Erörterungen des Durandus über die symbolik der liturgischen Gewänder. Wir haben in seinem Rationale so ziemlich alles zusammen, was die Liturgiker bis auf ihn über die heilige Gewandung an Naivem, Fremdartigem und Kleinlichem, aber auch an Schönem, Erhabenem, Tiefsinnigem und Erbaulichem ersonnen hatten. Von besonderem Werte war das natürlich für die damalige Zeit. Denn nun war es nicht mehr nötig, so und so viele, oft schwer bekömmliche Bücher zur Hand zu nehmen, um sich über die Symbolik der liturgischen Gewänder zu unterrichten. Durandus hatte die Arbeit ein und für allemal getan, und zwar recht gründlich und ausführlich. Um alles in vollstem Make zu finden, wonach man verlangte, brauchte man nur nach seinem Rationale zu greifen. Aus diesem hat man denn auch seitdem bis ins 16 . Jahrhundert hinein vornehmlich statt aus den Originalschriften geschöpft, was man über die mystische Bedeutung der liturgischen Gewänder zu sagen pflegte. Von neuer Symbolik ist seitdem im ganzen nicht viel mehr vorgebracht worden. Dahin gehört z. B., dafs man in den Zierbesätzen an den Säumen und auf den Ärmeln ter Albe und am Humerale ein Sinnbild der heiligen fünf Wunden sah oder das man die Paruren unten an der Albe auf Kugeln auslegte, mit denen des Heilandes Füßse nach der Gefangennahme belastet worden seien ${ }^{1}$. Denn auch die Deutung der liturgischen Gewänder auf das Leiden des Herrn ist schon dem Durandus bekannt gewesen.

Bei Hraban und Amalar sind die mystischen Deutungen ausschlieflich moralischer Art. Kaum, daf sich bei ihnen anch nur ein leiser Anklang an eine typische Auslegung findet. Die liturgischen Gewänder sind für beide Symbole der diakonalen, priesterlichen und bischöflichen Amts- und Standestugenden.

1 Christian Petersen, Danske Skriften II 475. Über die Deutung dex liturgischen Kleidung im 14. und 15. Jahrhundert finden. sich manche interessante Notizen bei Franz, Die Messe im dentschen Mittelalter, Abschn. $8-14$. 
Erst im 12. Jahrhundert tritt neben die bis dahin gepflegte moralische Auslegung die typisch-dogmatische. Ist der Priester bei der Opferfeier Stellvertreter Christi, dann lag es in der Tat nicht fern, die liturgischen Gewänder auch auf Christus zu deuten. Bruno von Segni, Ivo von Chartres und Honorius ziehen noch die alten Wege. Der erste, welcher die sakralen Kleider auf Christus auslegt, ist Rupert von Deutz. Die typische Deutung steht aber bei ihm ersichtlich noch in den Anfängen, bestimmter ausgeprägt und entschiedener durchgeführt erscheint sie erst bei Sicard und Innozenz III. Die liturgischen Gewänder versinnbilden bei ihr bald die Menschwerdung Christi, seine beiden Naturen, ihre Einheit und ihr Verhältnis zueinander, bald Tugenden des Erlösers, bald seine Lehre, bald endlich seine Beziehungen zur Kirche. Das Leiden und der Opfertod wird eigentümlicherweise, so sehr das auch zu erwarten gewesen wäre, von keinem berücksichtigt und noch viel weniger zum Ausgangspunkt der Symbolik genommen, nicht einmal von Innozenz III., der doch die typische Deutung am vollständigsten und konsequentesten pflegt. Zu jener im späten Mittelalter so beliebten Auslegung der Mefsgewänder, bei welchen der mit ihnen bekleidete Priester als Abbild des leidenden Eriösers und sie selbst als Symbole seiner Ketten, Banden und Fesseln, des Spottkleides, des Purpurmantels und des Kreuzes erscheinen, kommt es erst im 13. Jahrhundert.

Eine um 1200 enstandene gereimte deutsche Meßerklärung erwähnt diese Symbolik noch nicht; sie deutet die Gewänder meist moralisch; den Manipel bezieht sie auf die Siegesbeute, mit welcher der Heiland aus der Vorhölle heimkehrte, die Stola eigentümlicherweise auf das Kreuz Petri 1. In der Predigt Bertholds von Regensburg ( $†$ 1272) werden die Merkkleider zwar auf Christus ausgelegt, doch versinnbilden sie hier lediglich die Menschwerdung des Herrn, seine Tugenden, seine Mühen (Manipel) und seine lange Marter im allgemeinen (Stola). Indessen kennt denn doch bereits Durandus jene Deutung auf den leidenden Heiland; ein Zeichen, dals sie, wie eben bemerkt, schon vor dem letzten Dezennium des 13. Jahrhunderts ziemlich bekannt gewesen sein muf.

Das Aufkommen dieser Art von typischer Dentungsweise, die man die dogmatisch-repräsentative nennen kann, weil die Gewänder bei ihr an die einzelnen Phasen des Leidens Christi erinnern und den leidenden Heiland in der Person des Priesters vorführen, dürfte mit dem im 13. Jahrhundert so entschieden auftretenden Bestreben zusammenhängen, das christliche Volk tiefer in die Bedeutung der Messe einzuführen. Für diesen Zweck war es ja unzweifelhaft sehr praktisch, den Priester am Altar dadurch, dafs man seine Gewänder auf die Fesseln usw. des leidenden Erlösers deutete, gewissermałen sinnfällig als das hinzustellen, was er nach der Lehre der Kirche wirklich ist, d. i. als Stellvertreter Christi, welcher an des Gottmenschen Statt unblutigerweise das Kreuzesopfer erneuert. Zudem war das die einfachste und für das Volk verständlichste Symbolik der liturgischen Kleidung.

Außer den genannten begegnet uns übrigens im 12. Jahrhundert noch eine Deutung der Sakralgewandung, die man wohl am besten als die allegor is che bezeichnet. Sie scheint nur wenig verbreitet gewesen zu sein ; nichts-

' Ke 11 e, Speculum ecclesiae, München 1858, $149 \mathrm{ff}$. Unter den "lappen", die der Geistliche tragen soll und die vom Verfasser der Meferklärung als Sinnbild der Keusch-

Braun, Die liturgische frewandung. heit bezeichnet werden, sind wohl nicht Bäffchen $\mathrm{zu}$ verstehen, wie $\mathrm{Franz}$ (a. a. 0.680, Anm. 1) meint, sondern ein skapulierartiges Surrogat der klerikalen Camisia. 
destoweniger rerdient sie hier, und wäre es auch nur der Vollständigkeit halber, eine kurze ErTähnung: der Bischof (Priester) ist ihr zufolge am Altar ein Kämpe. der in hartem Streit mit dem Feinde des Volkes Gottes ringt. Daran erinnern die Gewänder, in denen er beim heiligen Opfer erscheint. Die Sandalen sind gleichsam die Beinschienen, das Humerale der Helm, die Albe der Panzer, die Stola die Lanze, das Cingulum der Bogen, das Subcingulum der Köcher, die Kasel der Schild, der Manipel die Keule.

Diese Symbolik dürfte ihren Grund in der biblischen Anschauung haben, wonach Christi Leiden und Kreuzestod ein Kampf gegen den höllischen Feind des Menschengeschlechtes war. Stand der Erlöser in seinem Opfertod als Streiter da, so konnten in der Tat auch die Priester und Bischöfe bei Erneverung dieses Opfers als Kämpen gedeutet werden.

Schon bei Amalar findet sich ein Ansatz zu dieser Symbolik. Ebenso erscheinen bereits in Ankleidegebeten des 9. und 10. Jahrhunderts Spuren derselben, so in dem Gebete eines Sakramentars von Tours: Pone, Domine, galeam salutis in capite meo ad expugnandas diabolicas fraudes et omnium inimicorum meorum persequentium me saevitiam superandam, und in dem eines Pontifikale von Troyes: "Indue me, Domine, lorica fidei et galea salutis et gladio Spiritus Sancti. Ausgewirkt tritt sie uns jedoch erst bei Honorius entgegen. Von späteren Liturgikern erwähnen sie nur Johannes Beleth und Durandus, deren Ausführungen wörtlich aus der Gemma animae herübergenommen sind. Dann verschwindet sie ganz vom Schauplatz. Es ist auffallend, daf die fragliche Symbolik so wenig Beachtung gefunden hat, zumal sie sich leicht mit der moralischen Deutung hätte vereinigen lassen.

Neben der mystischen Auslegung der liturgischen Gewänder, die uns bei den Liturgikern entgegentritt, gab es aber schon früh eine andere, die vielfach unbekümmert um das, was die Liturgiker erdacht hatten, ihre eigenen Wege geht. Sie kommt in den Gebeten zum Ausdruck, welche der Priester bzw. Bischof bei Anlegung der heiligen Gewänder zu beten hatte, und kann darum im Gegensatz zur rein privaten Symbolik, welche ein Hraban, ein Amalar, ein Bruno u. a. mit der Sakralkleidung verbanden, die offiziell kirchliche genannt werden; allerdings nicht in dem Sinne, in welchem heutzutage der römische Ritus der offiziell kirchliche heist. Die rituelle Einheit, welche gegenwärtig in der abendländischen Kirche herrscht, war dem Mittelalter fremd. Selbst wo man römischen Brauch angenommen hatte, gab es noch eine Menge partikulärer Gewohnheiten und liturgischer Sondergebräuche. Es war erst dem Konzil von Trient vorbehaIten, eine gröfere Einheit im Ritus anzubahnen. Wenn wir also von einer in den Ankleidegebeten sich aussprechenden offiziell kirchlichen Symbolik der heiligen Gewänder reden, so will das nur sagen, es handle sich dabei um die Symbolik, welche in die offiziellen liturgischen Bücher Aufnahme gefunden hatte; nicht aber, es sei die in jenen Gebeten sich findende Deutung der sakralen Kleider infolge rechtsgültiger Praxis oder ausdrücklicher Bestimmungen als die kirchlich allein mafigebende anerkannt gewesen; ja nicht einmal, sie sei allenthalben in den Ankleidegebeten in gleicher Weise zum Ausdruck gekommen. So verschieden vielmehr die Missalien waren, fast ebenso wechselnd waren auch die Ankleidegehete und die in diesen niedergelegte Symbolik. Quot missalia, tot sensus. Kaum, dab man von bestimmten Typen reden kann. Erst gegen Ende des Mittelalters bildete sich eine gröbere Übereinstimmung aus, doch blieb auch jetzt noch die Verschiedenheit bis zur allgemeinen Annahme des 
römischen Missale bzw. der Anpassung nichtrömischer Missalien an den römischen Ritus recht grof.

Bemerkenswert ist, daf, wie eben schon angedeutet wurde, die den mittelalterlichen Ankleidegebeten zu Grunde liegende Symbolik sich keineswegs ïberall mit derjenigen deckt, welche die alten Liturgiker vortrugen. Die Abweichungen sind nicht selten geradezu auffallend. Die Symbolik, welche in den Ankleidegebeten sich ausspricht, hat vorherrschend eine moralisierende Tendenz. Es erscheinen die heiligen Gewänder in ihnen mit Vorliebe als Sinnbilder der priesterlichen Tugenden. Die namentlich im späten Mittelalter so beliebte typische Auslegung auf Christus, als dessen Stellvertreter der Priester am Altar steht, ist ihnen völlig fremd. Dagegen findet sich in ihnen nicht selten die vorhin besprochene allegorische Deutung auf die geistliche Rüstung des Priesters, des Streiters Christi. Auch sehen die Ankleidegebete bisweilen von einer eigentlichen Symbolisierung der Gewänder ganz ab und begnügen sich mit der Bitte um Heil, Gnade oder Gottes Schutz, ohne dabei auf den Charakter und die Beschaffenheit des betreffenden Ornatstückes nähere Rücksicht zu nehmen. Das ist z. B. der Fall, wenn ein Sakramentar von St-Denis den Priester beim Anziehen der Albe beten heibt: ,Zerreif, o Herr, meinen Sack und umgib mich mit der Freude deines Heiles" 1 , oder wenn ein Missale von Chalons für den Manipel das Gebet vorsieht: "Gib, Herr, mir rechten Sinn und reine Rede, daßs ich dein Lob künden kann." 2

\section{DIE MYSTISCHE DEUTUNG DER LITURGISCHEN GEWÄNDER IN DEN RITEN DES OSTENS.}

Den frühesten bekannten Versuch einer umfassenden Deutung der liturgischen Gewandung des griechischen Ritus bietet die laropio. Sie behandelt aber nur die bischöflichen Gewänder, die atokin, hier wohl das Phelonion, das Sticharion, das Epitrachelion und das Omophorion. Die Symbolik, die uns in ihr entgegentritt, ist die typische. Der Bischof erscheint als Abbild Christi. Sein Obergewand simnbildet das heilige Fleisch Christi, den Purpurmantel, den er beim Leiden trug, aber auch das Kreuz, das er zum Kalvarienberg schleppte. Die rote Farbe der ozuly erinnert an die Worte der Heiligen Schrift: Qui

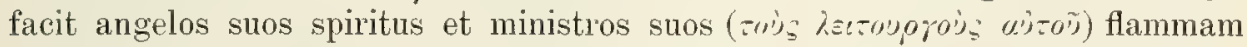
ignis ${ }^{3}$; ferner: Quis est iste, qui venit de Edom, tinetis vestibus de Bosra? ${ }^{4}$; endlich: Quare rubrum est indumentum tuum et vestimenta tua sicut calcantium in torculari? ${ }^{5}$; Stellen, von denen die erste auf den Altardienst, die Liturgie, die beiden andern auf Christus bezogen sind. Aber auch daran gemahnt sie, dafs des Erlösers heiliges Fleisch am Kreuz mit seinem Blut gerötet wurde. Ungegürtet ist das Phelonion, weil ja auch Christus ungegürtet, d. i. freiwillig, zum Kalvarienberg das Kreuz trug. Die Besätze an den Ärmeln des Sticharion stellen nach der Ioropí die Fesseln dar, mit denen der Heiland gebunden war, als er von Kaiphas zu Pilatus geführt wurde, die clavi des Gewandes aber die Ströme des heiligen Blutes, das aus der Seite Christi am Kreuze flof. In dem Epitrachelion sieht sie das Tuch, mit dem dieser am Nacken gebunden war, als man ihn zur Kreuzigung hinausbrachte. Das

1 Vart. 1. 1, c. 4, art. 12, ordo $5 ;$ I 187.

2 Ebd. 1. 1, c. 4, art. 1, n. 13; I 127.

3 Ps 103, 4. Die Stelle ist nach dem griechischen Text zitiert; im lateinischen ist statt der dritten die zweite Person gebraucht. 4 Is $63,1 . \quad 5$ Is $63,2$. 
Omophorion endlich erinnert an das große Sudarium (Schweistuch), welches der alttestamentliche Hohepriester einst nach der Tozopí auf der linken Schulter zu tragen pflegte ${ }^{\text {. }}$

Die Yozopic blieb mit ihren Deutungen für lange Zeit tonangebend. Was Pseudo-Germanus, Pseudo-Sophronius und das von Krasnojeljcev in jüngster Zeit herausgegebene Fragment über den mystischen Sinn der liturgischen Genänder sagen, ist zum größten Teil nur eine mehr oder weniger wörtliche

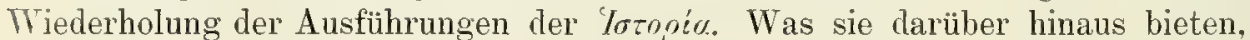
ist umbedeutend; obendrein bestehen selbst diese Zusätze meist gleichfalls wieder nur aus Entlehnungen. Wenn in ihnen z. B. die Diakone als Abbilder der himmlischen Geister dargestellt werden, deren Orarium an die Flügel der Engel erinnere, so treffen wir diese Symbolik schon in der früher dem hl. Johannes Chrysostomus zugeschriebenen, in der Tat aber wohl von Severian von Gabala († nach 408) verfabten Predigt über den verlornen Sohn an. Die Deutung des Omophorion auf den guten Hirten und des Orarium auf die von Christus bei der Fußwaschung geübte Demut ist Isidor von Pelusium entnommen.

Was aber auch immer zu den Ausführungen der 'Jatopía hinzukommt, die Auslegung bleibt immer im Rahmen der typischen Symbolik. Selbst da, wo auf Tugenden Bezug genommen wird, sind es nicht die Tugenden des Trägers der Gewänder, welche zunächst gemeint sind, sondern die Tugenden Christi. Eine ausgesprochenere moralische Ausdeutung der liturgischen Kleidung findet sich erst bei Simeon von Saloniki, vielleicht im Zusammenhang mit der Symbolik, welche jene mittlerweile in den offiziellen liturgischen Büchern bekommen hatten. Denn auch in dem griechischen Ritus kamen im Laufe der Zeit bestimmte Ankleidegebete auf; wann und unter welchen Umständen, ist allerdings unbekannt. Simeon von Saloniki erwähnt sie bereits ${ }^{2}$ und knüpft bei seinen Deutungen an sie an. Sie waren also jedenfalls schon im 14. Jahrhundert in Gebrauch. In diesen Gebeten, in denen ähnlich wie in der abendländischen Kirche die Symbolik enthalten ist, die man offiziell mit der liturgischen Kleidung verband, kommt ausschlieflich die moralische Auslegung zur Geltung. Entnommen sind sie der Heiligen Schrift, namentlich den Psalmen; eine Ausnahme bildet nur das Gebet, welches der Bischof nach Simeon von Saloniki zu sprechen hatte, wenn er sich mit dem Omophorion bekleidete. Denn dieses nimmt Bezug auf die bereits früher von uns gelegentlich erwähnte Deutung, welche in dem Gewande die in die Irre gegangene Menschennatur sah, und lautet mach Simeon: "Die verlorene Menschennatur hast du, Christe, auf deine Schultern genommen und, in den Himmel erhöht, Grott und dem Vater dargebracht." 3

Die Gebete, welche der Priester bei Anlegung der Tunika, des Gürtels und des Phelonion beten muf, erinnern an Gebete verwandten Inhaltes, welche ehedem vielenorts in der abendländischen Kirche bei Bekleidung mit den genannten Gewändern in Gebrauch waren. Doch dürfte diese Ähnlichkeit nur

1 Woher die Irtopio es hat, dab die Hohenpriester auf der linken Schulter ein großes Sudarium trugen, ist uns unbekannt. Die Heilige Schrift spricht nicht davon, aber auch bei Josephus Flavius ist von dem angeblichen Sudarium nichts zu finden.

${ }^{2}$ De div, liturg, c. 81 (Mg. 155, 257 f); De div. templo n. $33 \mathrm{ff}$ (ebd. $712 \mathrm{ff}$ ). Die Handschrift 2509 der Pariser Nationalbibliothek f. gr. (ca 1430) hat ebenfalls schon die Gebete. Die Gebete, welche jetzt gesprochen werden, sind ganz die gleichen wie die, welche bereits Simeon von Saloniki erwähnt.

s De div. templo n. 44 (ebd. 716). 
eine zufällige oder, besser gesagt, nur eine durch den Charakter der betreffenden Gewänder veranlakte sein 1 .

Auch bei andern Riten des Orients treffen wir schon im Mittelalter Deutungen der liturgischen Kleidung an. Eine kurze, aber eigenartige und interessante Erörterung der Symbolik der Sakralgewänder des nestorian ischen Ritus findet sich in dem "Buch der Väter.". Der Gürtel, so heift es hier, versinnbildet die Losschälung von den irdischen Dingen und die Unterdrückung der sinnlichen Begierden. Die Stola der Diakone und Subdiakone solle an die Eingeweide erinnern, mit denen die Juden zum Spott der Apostel Hals umschlangen, da es ja doch nicht passend sei, dafs sie, um den Aposteln ähnlich zu werden, wirkliche Eingeweide um den Hals legten. Die Priesterstola bedeute die Engelsflïgel, weil Bischöfe und Priester die Engel auf Erden seien. Der Mantel kennzeichnet den Bischof als Hirten, die Kopfhülle (maaphra) versinnbilde den Schleier, mit dem Moses sein Angesicht verhüllt habe, wenm er zum Volk geredet?. Wie man sieht, wechselt hier die moralische und typische Auslegung.

Die Symbolik, welche man bei den Syro-Jakobiten mit den heiligen Gewändern verknüpfte, erhellt aus den Ankleidegebeten der syrischen Mefliturgie, welche zuerst Guido Fabricius Boderianus zugleich mit dem Taufritus des Patriarchen Severus von Antiochien herausgab ${ }^{3}$. Die Gewänder sind in ihmen teils moralisch, teils allegorisch auf den geistlichen Streit gerleutet. Die Tunika erscheint als Sinnbild der heiligmachenden Gnade und der übernatürlichen Gnadenkraft des Heiligen Geistes, die Stola als das geistliche Schwert, das zu ruhmreichem Siege führt. Beim Angürten des Cingulum fleht der Priester, Gott möge ihm Stärke zum Kampfe verleihen und alle Feinde und Widersacher vor ihm vernichten; beim Anziehen des Mefagewandes betet er: „Deine Priester mögen gekleidet sein in Gerechtigkeit und mit dem Ruhm deines Gerechten; um deines Knechtes David willen weise nicht ab das Angesicht deines Gesalbten" (Ps 131, 10). Unverkennbar klingt auch in den Ankleidegebeten des syrischen Ritus die Symbolik an diejenige in den mittelalterlichen abendländischen an, doch ist das ebenso hier wohl nur Zufall und begrïndet in dem Charakter der Gewänder und in der gleichen Auffassung von der Tätigkeit des Priesters. Dagegen ist es sehr wahrscheinlich, daf die Gebete, welche im armenischen Ritus der Priester beim Anziehen der liturgischen Gewänder sprechen mufs, und damit auch die in ihnen ausgesprochene Symbolik aus dem Abendlande stammt. Die Übereinstimmung derselben mit den entsprechenden Gebeten mittelalterlicher la-

\footnotetext{
1 Um eine Idee der griechischen Ankleidegebete zu gehen, und auch, um einen Vergleich derselben mit den abendländischen zu erwöglichen, geben wir hier einige von innen wieder. Bei Anlegung des Sticharion betet der Priester: .Meine Seele jubelt im Herm ; denn ex hat mir angezogen das Gewand des Heiles und mich umgeben mit dem Kleid der Freude und wie einem Bräutigam mir den Kopfbund aufgesetzt und einer Braut gleich mit Geschmeide mich geziert" (Is 61, 10). Bei Angürtung des Cingulum lautet das Gebet: „Gepriesen sei der Herr, der mich mit Kraft umgürtet und seine Gnade immerdar über mir ausgiefst jetzt und in alle
}

Ewigkeit." Bei Annahme des Epigonation: "Schirre dir an das Schwert uber deinem Schenkel, Hochmächtiger usw." (Ps 44, 4 fi). Das Anziehen des Phelonion begleitet der Priester mit den Worten: ,Deine Priester sollen sich mit Gerechtigkeit bekleiden, o Herr, und deine Heiligen allzeit jubeln jetzt und in alle Ewigkeit" (Ps 131, 9). Beim Anstreifen der Epimanikien und beim Umlegen der Stola endlich soll derselbe Ex 15, $6 \mathrm{f}$ und Ps 118, 73, bzw. Ps 132, $2 \mathrm{ff}$ sprechen.

2 Dom Jean Parisot, Livre des Pères, in La science catholique 1890, 450 .

3 Ed. Antverp. 1572, 105 f. 
teinischer Missalien ist überraschend. Beim Aufsetzen der Mitra betet z. B. der Bischof (Priester): "Setze, o Herr, den Helm des Heiles auf mein Haupt zum Kampf gegen die Macht des Feindes durch die Gnade unseres Herrn Jesu Christi, dem Ruhm, Macht und Ehre sei in alle Ewigkeit." Beim Anziehen der Tunika lautet das Gebet: "Bekleide mich, o Herr, mit dem Gewand des Heiles und mit der Tunika der Gerechtigkeit und umgib mich mit dem Kleid der Freude“; bei der Gürtung: „Binde das Cingulum des Glaubens um mein Herz und meinen Sinn und ersticke darin alle unreinen Gedanken und lafs wohnen darin deine Gnade für immer"; beim Anlegen der Stauchen: "Gib, Herr, Kraft meiner Hand und wasche ab alle meine Unreinigkeit, auf daf ich mit reiner Seele und reinem Leib dir zu dienen vermöge."

Es sind das alles Gebete, welche auch in den abendländischen mittelalterlichen Missalien, und zwar bei den gleichen oder doch bei ähnlichen Gewändern rorkommen ${ }^{1}$. Die Worte, welche nach dem armenischen Ritus beim Anlegen der liturgischen Stauchen gesprochen werden, sind noch jetzt im römischen Ritus gebräuchlich, wenngleich nicht mehr, wie es im Mittelalter hie und da der Fall war, bei Anlegung des Manipels, sondern beim Händewaschen. Ähnlich verhält es sich mit dem Gebet, das der armenische Priester beim Anziehen der Tunika verrichtet; es wird mit unbedeutender Veränderung im Abendland rom Bischof gesprochen, wenn er mit der Dalmatik bekleidet wird, während es einst häufig bei Anlegung der Albe gebetet wurde.

Die Übereinstimmung läßt sich kaum anders als durch die Annahme erklären, es seien die fraglichen Gebete infolge der lebhaften Unionsbestrebungen des 14. Jahrhunderts und des dadurch angebahnten freundschaftlichen Verkehrs zwischen Rom und den Armeniern im armenischen Ritus in Aufnahme gekommen. Sicher ist, daf auf diesem Wege Elemente des römischen Ritus in den armenischen hineingebracht wurden.

\section{DIE SYMBOLISCHE BEDEUTUNG DER PRIESTERLICHEN GEW ÄNDER IM ABENDLAND.}

Es ist nicht nötig, näher auf die Symbolik einzugehen, welche man in den Riten des Ostens im einzelnen mit der Sakralgewandung verknüpfte. Das Gesagte reicht zu ihrer Charakterisierung vollständig aus. Dagegen empfiehlt es sich dringend, die mystische Bedeutung genauer ins Auge zu fassen, welche im Abendland den verschiedenen Gewändern während des Mittelalter's in den Schriften der Liturgiker und den liturgischen Büchern beigelegt wurde. Wer verstehen will, warum heute mit jedem der sakralen Kleider eine bestimmte Symbolik verbunden wird, muf wissen, was man von ihm in der Vorzeit ersonnen und gesagt hat. Natürlich ist es weder möglich, alle Deutungen zu berühren, welche irgend eimmal jemand vorgebracht hat, zumal soweit sie nur nebensächliche Punkte betreffen, noch auch alle Ankleidegebete hier zusammenzustellen, die sich in den mittelalterlichen Sakramentaren usw. finden. Der zur Verfügung stehende Raum reicht dazu bei weitem nicht hin. Es muf genügen, das Charakteristischste hervorzuheben.

Das Schultertuch gilt Hraban als Sinnbild der guten Werke, der Zeichen eines makellosen Herzens und aufrichtigen Glaubens; Amalar deutet es auf die Bewachung

$1 \mathrm{Vgl}$, die Auszirge aus mittelalterlichen Missalien bei Mart. I. 1, c. 4, art. 1, n. 13 und art. 12, ordo $3 \mathrm{ff}$; I $126176 \mathrm{ff}$, Eben- so Vat. lat. 4730 , f. $19^{a}$ und Ottob. 27, f. $10^{\text {a }}$ (Mitra) ; ebd. 4770 , f. 114; 9340, f. 78

(Tunika und Cingulum) u, a. 
der Zunge, Pseudo-Alkuin auf die Reinheit des Leibes von aller Sünde. Hraban und Pseudo-Alkuin gehen bei ihrer Deutung aus von der Farbe und Beschaffenheit des Stoffes, aus welchem das Humerale bestehen mujte; Amalar denkt an die Weise, wie es getragen wurde (collum undique cingimus). Von den späteren Liturgikern schliefst sich Ivo von Chartres an Hraban, Bruno von Segni aber, für welchen der Amikt sowohl die Reinheit des inneren Menschen als auch die Wahrhaftigkeit in der Rede bedeutet, an Pseudo-Alkuin und Amalar an. Der Sermo ,über die priesterlichen Gewänder" legt das Schultertuch auf das dem Priester so notwendige geduldige Ertragen der Erdenmühen aus; Rupert von Deutz sieht in ihm ein Sinnbild der heiligen Menschheit, mit welcher Christus in der Menschwerdung sein Haupt, d. i. seine Gotheit, gleichsam verschleiert habe. Er hat dabei ersichtlich den Brauch in Auge, wonach man den Amikt beim Anlegen zunächst um den Kopf schlug. Nach Honorius gemahnt das Humerale an die Hoffnung auf den Himmel. In dem Umstand, dafs man mit ihm den Kopf bedeckte, findet er angedeutet, daf man um des Himmels willen frott dienen müsse; darin, dafs es den Hals umgebe und die Schultern verhülle, sieht er die Aufforderung, im Hinblick auf den Himmel nur Gottes Lob zu künden und des Lebens Last in Geduld zu tragen. Die beiden Enden des Schultertuches, die auf der Brust miteinander verknüpft werden, sinnbilden nach Honorius Glauben und Wirken. Vor der Brust wird der Amikt gebunden, um anzudeuten, daß um des himmlischen Vaterlandes willen aller böse Gedanke von der Seele ferngehalten werden müsse. Das Speculum de mysteriis ecclesiae legt das Gewand auf die Weisheit ans, die dem Priester eigen sein soll. Damit hatte die Symbolik des Amikts vorläufig ihren Abschluf gefunden. Was Sicardus, Innozenz III. und die andern Liturgiker vorbringen, ist nichts wesentlich Neues, und so bleiht es in Bezug auf die Ausdentung des Gewandes, his man anfing, den Amikt auf die Binden, mit denen die Schergen das Haupt des Heilandes umbanden, und seine Parura auf die Seitenwunde oder die Wunden des heiligen Hauptes Christi anszulegen. In der früher erwähnten, um 1200 entstandenen gereimten dentsehen Mef3. erklärung wird das Humerale als "Schatten des Heiligen Gieistes" hingestellt ?. Die Deutung erinnert an ein Ankleidegebet, welches wiederholt in mittelalterlichen Missalien vorkommt und lautet: „Beschatte, o Herr, mein Haupt mit dem Schirm des heiligen Glaubens und vertreibe aus mir aller Unwissenheit Gewölk." Sowohl dies Gebet wie die Auslegung jenes Gedichtes über die Messe beruhen ersichtlich auf der Sitte, den Amikt bis nach Annahme der Kasel auf dem Haupt zu behalten.

Mannigfaltig wie bei den Liturgikern ist auch in den Gebeten, welche der Priester bei Anlegung des Schultertuches zu sprechen hatte, die Symbolik. In einem Gebet des Sakramentars von Corbie schliekt sie sich an die Deutung Hrabans an. Es lautet:

Allgewaltiger Gott, des Weltalls herrlicher Lenker,

Segne doch unsern Amikt, mit dem wir nunmehr uns rüsten,

Daß3 die Macht uns sei, dir züchtigen Herzens zu dienen?.

In andern geht sie von dem Umstand aus, daf der Amikt Schultern und Nacken bedeckt. Er ist in diesem Falle bald Bild des Joches Christi, bald des göttlichen Gnadenschutzes. So läst ein Sakramentar von Tours den Priester beten: "Lege, o Herr Jesu Christe, auf meinen Hals dein Joch - denn es ist süe — und deine Bürde - denn sie ist leicht" "s, während wir in dem Ordo Sigeberts von Minden lesen: „Decke, o Herr, meine Schultern mit der Gnade des Heiligen Geistes und umgürte meine Nieren nach Austreibung aller Laster, damit ich dir opfern möge, der da lebt und regiert in Ewigkeit." ${ }^{4}$ Ein Sakramentar von Amiens hat (für Amikt

1 S. oben S. 705. Vgl. auch die in deutschen Inventaren des späten Mittelalters geläufige Bezeichnung des Schultertuches als umbrale, vielleicht unter dem Einflus der Symbolik vom ${ }_{n}$ Schatten des Heiligen Geistes" aus humerale verderbt.

2 Mart. 1. 1, c. 4, art. 12, ordo 11; I 203.
${ }^{3}$ Ebd. I. 1, c. 4, art. 1; I 126. Vgl. auch Vat. lat. 4770 (saec. $\mathrm{X}-\mathrm{XI}$ ) und 4772 (saec. XI).

4 Ebd. 1. 1, c. 4, art. 12, ordo 4; I 177. Vgl. ferner Vat. Iat. 5742 (saec. XIV-XV) und Missale Colon. a. 1487; Missale August. (Augsburg) a, 1555 u. a. 
und Albe zugleich): "Bekleide mich, o Herr, mit dem Gewande des Heiles und umgib mich mit dem Kleide der Gerechtigkeit immerdar" ${ }^{1}$; nach einem Sakramentar von St-Denis aber soll der Priester beim Anlegen des Amiktes sprechen: "Umgil, mich, o Herr, mit den Waffen der Freude und des Glaubens, auf daß ich, gegen die Pfeile der Bosheit geschuitzt, Billigkeit und Gerechtigkeit zu bewahren vermöge." a

Eigenartig ist das in verschiedenen mittelalterlichen Missalien wiederholt vorkommende Gebet: „Zerreis, o Herr, meinen Sack und umgib mich mit der Freude des Heiles. " 3 Unter dem Sack, im Alten Testament das Gewand der Trauer, ist hier die sünde verstanden, weshalb er in einem Augsburger Missale deutlicher saccus peccati mei heifst; der Amikt bedeutet also in jenem Gebet die heiligmachende Gnade.

Die Gebete, in welchen der Amikt als geistlicher Helm oder als Schirm des Hauptes bezeichnet wird, lehnen an die Sitte an, ihn zunächst auf den Kopf zu legen und erst nach dem Anziehen der Kasel auf die Schultern herabzulassen. Es sind ihrer vornehmlich zwei. Das eine wurde schon vorhin erwähnt: „Beschatte, o Herr, mein Haupt mit dem Schirm des heiligen Glanbens und vertreibe von mir der Unwissenheit Nebel." Das andere ist das bekannte Gebet, welches noch jetzt der Priester und mit einer kleinen Erweiterung auch der Bischof betet: "Setze, o Herr, des Heiles Helm auf mein Haupt, daf ich die teuflischen Ränke abwehren möge." Es kommt, wenngleich nur vereinzelt, schon vor Beginn des zweiten Jahrtausends vor ", also noch ehe die Liturgiker jener Sitte gedenken. Nach 1000 wird es bald häufig und in den letzten Jahrhunderten des Mittelalters vorherrschend ${ }^{5}$.

Hinsichtlich der mystischen Deutungen der Albe herrscht bei den mittelalterlichen Liturgikern wenig Verschiedenheit und Entwicklung. Da Durandus die Auslegungen seiner Vorgänger allesamt mit großer Emsigkeit und vieler Sorgfalt gesammelt hat, genügt es, ihn zu hören, um zu erfahren, was das Mittelalter vor ihm über die Bedeutung unseres Gewandes schrieb.

Threr Farbe wegen, so belehrt uns das Rationale, ist die Albe das Sinnbild der Reinheit. Aus Linnen wird sie angefertigt, um anzudeuten, daf die Reinheit cler Seele die Frucht angestrengten, von der Gnade unterstützten Strebens, vieler Abtötung und eifriger Ausübung guter Werke ist. Denn das Linnen hat nicht von Natur aus seine blendende Weiße, sondern erhält sie erst durch die Bearbeitung, wobei es Stöfe und Schläge aushalten muf. Demnach liegt in der Albe für den Priester die Mahnung, den Worten des Apostels gemäßs seinen Leib zu kasteien und in die Knechtschaft zu bringen, damit er nicht selbst verloren gehe, während er andern predigt (1 Kor 9, 27). Die Halseinfassung bedeutet, daß der Priester die Verpflichtung zur Keuschheit übernommen hat; die Schliefse an derselben, die ligula, aber sinnbildet die Zunge des Priesters, welche bindet oder losspricht, je nachdem der Sünder hartnäckig bei der Sünde beharrt oder sie bereut. Weit ist die Albe in Elinnerung an die Freiheit der Gotteskinder; ihre kosthare Ausstattung läßst den Priester als königliche Braut Christi erscheinen; gegürtet wird sie, damit sich der Priester erinnere, alle fleischlichen Gelüste zu bezähmen; als ein Gewand, das bis zu den Füßen reicht, ermahnt sie zur Beharrlichkeit. So weit die Symbolik der Albe im Lichte der moralischen Deutung. Typisch auf Christus bezogen, weist das Gewand, wie Durandus sagt, weil weif und makellos, auf Christi Sündenlosigkeit hin; aus demselben Grund erinnert es an die

1 Bibl. Nat. f. lat, 9432. Vgl. ebenfalls Vat. lat. 4772.

2 Mart. 1. 1; c. 4, art. 12, ordo 5; I 187.

3 Vat. lat. 3808; Bibl. Angelica zu Rom 477; Trierer Missale des 13. Jahrhunderts (Dombibliothek zu Trier n, 155); Missale des Stiftes Pfalzel bei Trier 1429-1449 (Stadtbibliothek daselbst $n$. 358); Trierer Missale, Erstdruck von 1498 (Seminarbibliothek daselbst); Pontifikale von Troyes (Mart. 1. 1, c. 4 , art. 12, ordo 6 ; I 190).
4 So in einem Sakramentar von Tours, St-Gatien (M art. 1. 1, c. 4, art. 12, ordo 7; I 192), und einem Pontifikale von Troyes (ebd. ordo 6; I 190). Vgl. über das letztere indessen oben S. 29, Anm. 1.

5 Vgl. die Auszüge ebd.; ferner Vat. Ottob. 27221574576 ; Vat. lat. 114547304743 608272319340 ; Vat. Barber. B X 1; Rom, Bibl. Angel. 1092; Paris, Bibl. Nat. f. lat. 2293; Florenz, Bibl. Riccard. 300; Mailand, Bibl. Ambros. 84 u, a. 
strahlende Weiße, welche die Gewänder des Herrn bei der Verklärung annahmen. Es ist aber auch ein Abbild des weißen Spottkleides, mit dem Herodes den Heiland verhöhnte. Einzig neu, d. i. nicht bei den früheren Liturgikern vorkommend, ist die Deutung auf das spottgewand.

Es ist interessant, mit den Deutungen der Liturgiker die Symbolik der Albe zu vergleichen, welche in den Ankleidegebeten zum Ausdruck kommt.

Das Gebet, welches der Priester heute spricht, ist bekannt: „Läutere mich, o Herr", so lautet es, "und reinige mein Herz, auf daf ich, im Blute des Lammes gereinigt, verdienen möge, die ewigen Freuden zu geniefen." Es betrachtet die Albe als Sinnbild der Reinheit und findet sich schon, wenngleich nicht allzuhäufig, in mittelalterlichen Missalien ". Andere Ankleidegebete des Mittelalters sehen in ihr das Gewand des Heiles und den Panzer der Stärke, wieder andere, mit Rücksicht auf ihre weißse Farbe, ein Symbol der heiligen Freude oder der Gerechtigkeit. Am gewöhnlichsten, und zwar vom 10. Jahrhundert an bis zum Ausgang des Mittelalters, ja selbst bis in die Neuzeit hinein, ist das Gebet: „Bekleide mich, o Herr, mit dem Gewand des Heiles und umgib mich mit dem Kleid der Gerechtigkeit immerdar" 2. Das Gebet des Stowe-Missale fafat die Albe als Bild der Keuschheit auf. Mehr auf die Reinheit im allgemeinen weist dasjenige der Missa Illyrica hin. Ganz kriegerisch ${ }^{3}$ lautet es im Pontifikale von Troyes: „Bekleide mich, o Herr, mit dem Panzer des Glaubens, mit dem Helm des Heiles und dem Schwert des Heiligen Geistes." Sehr schön aber läfít im Anschlufs an die allgemeinere Auffassung das Sakramentar von Corbie den Bischof flehen:

Dak im Engelsgewande wir Spende heiligen Duftes

Dir zu reichen vermögen, gewähr es, o König der Milde;

Tilge voll Güte darum des schlimmen Sinnes Befleckung:

Und nimm eilig hinweg, was meine Seele beschmutzet.

Das Cingulum erscheint bei Hraban als Symbol der custodia mentis. Die Gürtung der Albe soll dem Priester ins Gedächtnis rufen; daf er in Bewahrung der Keuschheit nicht nachlässig und träge sein dürfe, dafs ex die Überhebung und den Stolz fliehen müsse und daf er nicht im Übermaßs nach T'ugend strebe, damit nicht diese selbst durch den Schmutz der irdischen Begierlichkeit befleckt werde. PseudoAlkuin sieht in dem Cingulum in Anlehnung an den letzten Gedanken der Symbolik Hrabans die discretio virtutum, das Einhalten der goldenen Mitte; die Tugenden seien ohne diese discretio nicht Tugenden, sondern Laster; die Tugend beruhe vielmehr im rechten Mittelmaß. Die übrigen Liturgiker, von Amalar bis Durandus, beschränken sich fast alle darauf, das Gürten der Albe mittels des Cingulums als Sinnbild der Enthaltsamkeit und der Bezähmung der sinnlichen Begierden hinzustellen. Es lag das in der Tat am nächsten. Galt die Albe als Symbol der Reinheit und Keuschheit, so war es das natürlichste, ihre Gürtung auf die Bändigung der ungeordneten niederen Triebe zu denten. Debet alba ... praecingi ..., sagt Durandus, ut castitas, per albam significata, nullis incentivorum stimulis solvatur; cingulum namque continentiam significat. Auch in den Ankleidegebeten wird das Cingulum fast nur als Symbol der Enthaltsamkeit und der Abtötung aller fleischlichen Begierlichkeit hingestellt. So heift es sehr schön im Sakramentar von Corbie:

Der du die Herzen erforschest, du Freund des züchtigen Sinnes,

Göttlicher Richter des Innern, o giurte mir gnädig dje Lenden,

Jegliches sündige Regen im keuschen Leibe ertötend ${ }^{4}$.

1 Z. B. in einem Pontifikale von Cambrai (Mart. 1. 1, c. 4, art. 1; I 127); ferner Vat. lat. 4730 und Ottob. 27221 .

2 V.gl. die Auszüge aus französischen und deutschen Missalien bei M a rt. 1. 1, c. 4 , art. 12; die oben S. 712, Anm. 3 erwähnten Trierer Missalien; ferner Vat. lat. 11454770
9340 ; Vat. Barber. B X 1; Rom, Bibl. Angel. 1092; Florenz, Bibl. Riccard. 299 300, beide aus dem 11. Jahrhundert; Mailand, Bibl. Ambros. 84 u. a.

3 M a r t. ebd, ordo 6; I 190.

4 Die gleichen Gebete im Sakr. Leofrics von Exeter (ed, Oxford 1883, 59). 
Kurz, aber krïftig lautet das Gebet in den Sakramentaren von St-Denis, Tours und andern: "Umgürte, o Herr, meine Lenden und beschneide die Laster meines Herzens." Das Gebet im Missaie des hl. Karl Borromäus " und in den Pontifikalien von Narbonne, Chalons. Cambrai, Troyes ${ }^{3}$ und Amiens ${ }^{4}$ deckt sich fast wörtlich mit demjenigen, welches der Bischof nach dem römischen Missale bei der Gürtung spricht: "Umgürte mich, o Herr, mit dem Gürtel des Glaubens und meine Lenden mit der 'Tugend der Kenschheit und tilge in ihnen aus alle fleischlichen Triebe, auf daf in mir immerdar die Lebensfrische aller Keuschheit verbleibe." s

Das Gebet, welches der Priester gegenwärtig nach dem römischen Missale bei Anlegung des Gürtels zu beten hat, ist uns in mittelalterlichen Missalien nicht aufgestoßen. Es ist allem Anschein nach lediglich eine Vereinfachung des Gebetes: "Umgürte mich, o Herr, mit dem Gürtel des Glaubens usw."

Es gibt nur wenige Ankleidegebete, welche von der gewöhnlicheren Anschauung abweichen; so heilst es im Gedankengang Hrabans in verschiedenen mittelalterlichen Missalien: "Herr, gürte mir an die Bewachung des Geistes und lafs diesen nicht durch den Geist der Überhebung abgelenkt werden." "

Ungewöhnlich, aber schön, entschieden und mutig, und des Mannes, der sich zum geistlichen Streite rüstet, würdig, klingt das Gebet eines Missale von Stablo ${ }^{\top}$ : "Gürte mir dein Schwert über meinen Schenkel, Allmächtiger, auf daf ich mannhaft und in der festen Zuversicht auf deine Wahrheit gegen meine Feinde zu kämpfen vermöge." Es ist die uns schon bekannte Symbolik, wonach der Priester beim heiligen Opfer gleichsam als Kämpfer gegen den Teufel auftritt. Auf Christus bezogen, wird der Gürtel bei Durandus im Anschluf an das Wort des Propheten Isaias: Et erit iustitia cingulum lumborum eius, auf Christi Gerechtigkeit gedeutet. Doch kennt der Verfasser des Rationale auch schon die Symbolik, derzufolge das Cingulum als Sinnbild der Geifeln galt, mit denen Pilatus den Herrn geißeln liefs.

Manche mystischen Deutungen hat der Manipel gefunden. Für Hraban, der seine Ausführungen auf Isidors Definition von mappa und mantile aufbaut, ist er das Simnild, daß der Priester, der nach Anlegung desselben äußerlich zum heiligen Opfer vorbereitet erscheint, anch innerlich in der Verfassung sein muf, die eine solch heilige Handlung erfordert. Nach Amalar bedeutet das Sutarium fromme und heilige Gedanken und Erwägungen, doch auch den Hinblick auf die heiligen Väter, wodurch wir alle natürlichen und gleichsam angeborenen verkehrten Ergötzlichkeiten aus uns entfernen und die aus der Gebrechlichkeit des Körpers hervorgehenden Belästigungen der Seele wegschaffen sollen. Begierlichkeit und Überdruf kennt nur das Erdenwallen, das durch die linke Seite bezeichnet wird, nicht der Himmel, dessen Sinnbild die rechte ist; daher trägt man das Sudarium nicht in der rechten, sondern in der linken Hand. Nach Ivo von Chartres mahnt der Manipel den Priester, mit Fleiß und Wachsamkeit der einschleichenden Sorglosigkeit zu begegnen; nach dem Sermo XIV aber fordert er ihn auf, alle Nachlässigkeit zu meiden, wenn er seinen heiligen Dienst verrichtet; denn er legt ihn ja an den Arm der Vorsicht halber, pro cautela.

1 Ebd. ordo 5; I 187. Etwas erweitert findet sich das Gebet in einem Pontifikale von Troyes, einem Sakramentar von Tours (ebd. ordo 67 ; I $190 \mathrm{f}$ ) sowie in manchen sonstigen Missalien, z. B. in Vat. lat. 5742 und Vat. Ottob. 221, den früher erwähnten drei Trierer Missalien, einem St Gallener Sakramentar (Stiftsbibl. 354), dem Kölner Missale von 1487 u. a.

2 M a t. 1. 1, c. 4, art. 12, ordo 3; I 173.

"Ehd. art. 1, n. 13; J 127.

4 Bibl. Nat. f. lat. n. 9432.

5 Das Gebet kommt auch sonst nicht selten vor, wie Vat. lat. 4748 und 9340 ; Vat. Ottob.
27 und 221; Vat. Barber. XII 2 und B X 1 ; Florenz, Bibl. Riccard. 300 u. a.

${ }_{6}$ M a rt. 1. 1, c. 4, art. 12, ordo 12; I 204. So auch in Vat. lat. 47726082 7231; Vat. Ottob. 574; Florenz, Bibl. Riccard. 299 und 300 (hier neben einem andern Gebet) sowje Stiftsbibliothek von St Gallen 339. Vgl. den Auszug aus einem Sakramentar des 11. Jahrhunderts in M. 78, 245.

- Nach cod. 354 der St Gallener Stiftsbihliothek bei Anlegung des Subcinctorium zu sprechen; ebenso in einem Sakramentar von Arezzo (Vat. lat. 4772), beide aus dem Beginn des 11. Jahrhunderts. 
Honorius und andere sehen im Manipel ein Simnbild der Bufe, durch welche die Makel der täglichen Ausschreitungen getilgt werde. Wie man sieht, klingen diese Auslegungen meist in irgend einer Weise an den ursprünglichen Charakter des Ornatstückes an.

Einige wenige Deutungen Iehnen sich an die Psalmworte an: Euntes ibant et flebant, mittentes semina sua, venientes autem venient cum exsultatione, portantes manipulos suos; sie betrachten das Gewandstück als Sinnbild der Garben der Gerechtigkeit und des himmlischen Lohnes ${ }^{1}$. Veranlassung hierzu bildete ersichtlich der Name manipulus. In den Gebeten, mit welchen der Priester gemärs der Anweisung der mittelalterlichen Missalien die Anlegung des Manipels begleiten soll, wird nur wenig auf dessen anfänglichen Charakter angespielt. Begreiflich, da sie meistens aus einer Zeit stammen, in welcher das Ornatstück desselben schon längst ganz entkleidet und zum bloßen Zierstreifen geworden war.

Einen, wenn auch nur entfernten Hinweis auf ihn bietet z. B. das Gebet, welches zwei Sakramentare des 11. Jahrhunderts den Priester sprechen lassen: "Gib, o Herr, den Manipel in meine Hände zur Entfernung des Schmutzes meines Herzens und Leibes, auf dafi ich, frei von Makel, dir, o Herr, zu dienen würdig sei." 2 Ähnlich verhält es sich mit dem andern Gehete: „Gib, o Herr, meinen Händen die Kraft, alle Nakel abzuwaschen, damit ich ohne Befleckung von Leib und Seele dir zu dienen vermöge", Worte, die der Priester nach gegenwärtigem Brauch bei der Händewaschung spricht, die ehedem aber häufig bei Annahme des Manipels gebetet wurden ${ }^{3}$. Das Gebet, welches der Priester nach der Anweisung des römischen Wissale zu verrichten hat: „Möge ich, o Herr, es verdienen, den Manipel des Weinens und des Schmerzes zu tragen, auf daf ich voller Freude den Lohn für meine Mühen erlange", schliefat sich wie die obengenannte gleichartige Dentung einiger Liturgiker rein änßerlich in Anknüpfung an den Ausdruck manipulu an den Psalmvers: Euntes ibant usw. an. Es war schon sehr früh in Gebrauch,-da es sich bereits mit geringen Abweichungen im Pontifikale von Troyes ${ }^{4}$ vorfindet. Häufiger treffen wir es in den Missalien aber erst in den letzten Zeicen des Mittelalters an ${ }^{5}$.

In verschiedenen Gebeten ist ein Grund der in ihnen zum Ausdruck kommenden Symbolik nicht oder doch kaum erkennbar, so z. B. in dem Spruch eines Missale von Châlons: „Gib mir, o Herr, rechten Sinn und reine Stimme, damit ich dein Lob wirken könne ${ }^{67}$, und in der Bitte einer St Gallener Handschrift: „Zerreiße, o Herr, alle Schlingen des Satans und bekräftige in uns den Anteil deiner Exhschaft." 7 Im letzten Fall scheint der Nanipel als Sinnbild der Gotteskindschaft, des funiculus haererlitatis, gedacht zu sein. Auf die Keuschheit bezogen wird er in einem Augustinermissale der Vaticana: ,Lege den Manipel der Unschuld, o Herr. an meine Hand, daf ich, von deiner Vaterliebe geschützt, reinen Sinnes und Herzens alle unerlaubten Berührungen vermeiden und unter Frohlocken die Garben wahrer Seligkeit unter deinen Heiligen auf immer besitzen möge." 8 Einige Gebete deuten ihn, weil Schmuck der Hand, auf die Werke der Hände. So heißst es in einem Missale von Beauvais nit den Worten des 17. Verses des 89. Psalmes: ,Sit splendor Domini Dei nostri super nos, et opera manuum nostrarum dirige super nos, et opus manuum nostrarum dirige. " 9 Auch in dem hie und da vorkommenden Gebete: „Durch die Anlegung dieses Hanipels bitte ich dich flehentlich, o Herr, du wollest mir in meiner Lehenszeit ein

1 So z. B. Bruno von Segni (M. 165, 1107).

2 Florenz, Bibl. Riccard 299300.

3 Rom, Bibl. Angel. 477; Kölner Missale von 1487; Missale von Augsburg von 1555 u. a. Vgl, auch die Auszitge bei M a r t. a. a. $\mathrm{O}$.

+ Ebd. 1. 1, c. 4, art. 12, ordo 6; I 190.

5 Vat. lat. 47305742 und 9430 ; Vat. Ottob. 27; Vat. Barber. XII 2 und B X 1.
M a t. 1. 1, c. 4, art. 1, n. 13; I 127. Vgl. auch ebd. art. 12, ordo 16 ; I 214; dann den Auszug aus einem Sakramentar des 11. Jahrhunderts bei M. 78, 246, sowie der St Gallener Bibliothek 339; Vat. lat. 6082 und 7231; Vat. Ottob. 574 und 576 u. a. 7 Cod. 354.

8 Vat. Ottob. 221. Auch im Gebet des Sakramentars von Corbie erscheint der Manipel als Sinnbild der Keuschheit.

${ }_{9}^{9}$ Mart. 1. 1, c. 4, art. 1, n. 13; I 127. 
solches Wirken verleihen, daß ich nach dem Beispiel der alten Väter in Zukunft die ewige Freude verdiene" 1 , spricht sich diese Auffassung aus.

Die Symbolik, welche in den Worten zum Ausdruck kommt, mit welchen der Bischof hei der Weihe die Übergabe des Manipels begleitete, bietet wenig Neues. Die betreffenden Gebete sind recht zahlreich. Eines der gebräuchlichsten war: „Nimm hin den Manipel, durch den die Frucht der guten Werke bezeichnet wird." " In einem andern, das uns ebenfalls in den alten Pontifikalien nicht selten begegnet, erscheint das Ornatstück als Insignie des subdiakonalen Ordo, ohne daf eine weitere Symbolik mit ihm verbunden wäre: „Nimm hin den Manipel und warte deines Amtes ${ }^{3}$. Gott ist mächtig genug, dir seine Gnade zu mehren." Sinnbild der Reinheit ist das Ornatstück in dem Spruch: ,Nimm den Manipel in deine Hände zur Tilgung der Makel an Seele und Leib, auf dafs du ohne Befleckung dem allmächtigen Gott zu dienen vermögest." " An den geistigen Streit gegen die Höllenmächte erinnern die Worte eines Pontifikale von Riga: "Nimm hin diesen Fano zum Kampf gegen die Nachstellungen des Seelenfeindes." ${ }_{5}$ Was sonst noch an Gebeten bei der fraglichen Zeremonie üblich war, kann hier übergangen werden.

Auf Christus bezogen, wird der Manipel von Innozenz III. auf den himmlischen Lohn ausgelegt, den der Heiland durch sein Leiden für seine beilige Menschheit verdiente. Spätere sahen in ihm die Stricke und Banden, mit welchen die Judenrotte den Gottessohn fesselte.

Die Stola gilt bei den mittelalterlichen Liturgikern vorzugsweise als Symbol des Amtes. Indem Diakon und Priester sich dem besondern Dienste Gottes weihen, der ihnen heilige Pflichten und schwere Obliegenheiten auferlegt, treten sie unter das Joch des Herrn und laden dessen Büde auf Schulter und Nacken. Das Sinnbild dieses Joches und dieser Bürde ist die auf der Schulter bzw. dem Nacken ruhende Stola; beider Übernahme wird durch die Anlegung der Stola bei der Weihe dargestellt.

Aus dieser ersten und grundlegenden Symbolik der Stola ergaben sich alsbald und wie von selbst für die Liturgiker verschiedene andere Bedeutungen. Nach Hraban, welcher das Gewand (orarium) zu dem Predigtamt in besondere Beziehung bringt, mahnt es den Träger, wohl zu überdenken, was er mit dem Munde vorbringe, damit er nicht unvorbereitet und sinnlos rede und Schaden leide. Amalar findet in der Stola die Aufforderung zur Demut. Ivo von Chartres legt sie auf die Waffe der Gerechtigkeit, d. i. die Tugend des Starkmuts, aus, mit welcher der Priester in Glück and Unglück - er trägt ja auf beiden Seiten, der rechten wie der linken, einen Streifen der Stola - versehen sein soll. Rupert von Deutz deutet das Ornatstück auf den Gehorsam, Honorius auf die Reinheit, Innozenz III. auf die Weisheit und Geduld. Der Umstand, daß die Stola mit dem Cingulum verknüpft wird, soll nach den Liturgikern sinnbilden, daf die durch die Stola symbolisierten Tugenden mit Selbstbezähmung verbunden sein müssen, wenn anders sie beim Audrang der Versuchung nicht Gefahr laufen wollen.

In den Gebeten, welche der Priester beim Umlegen der Stola zu sprechen hatte, tritt die Grundsymbolik des Ornatstückes weit weniger deutlich hervor als in den Auslegungen der Liturgiker.

1 Vat. lat. 3808. Vgl. auch das Ankleidegebet in der Missa Illyrica bei Mart. 1. 1, c. 4, art. 12 , ordo 4; I 177.

2 Ebd. 1. 1, c. 8, art. 11, ordo 16; II 79. Vat. lat. 11596748 7114; Vat. Ottob. 27 330501.

3 M art. ebd. ordo 10; II 62. Vat. Borgh. 99: Cod. Vat. Iat. 3748 u. a. Es ist eines der ältesten der Gebete seiner Art, ja wahrscheinlich das ïlteste; denn es reicht bis hoch ins 12. Jahrhundert hinauf. Doch stammt es jedenfalls erst aus einer Zeit, da der Subdiakonat höherer Ordo geworden war. Eigenartig ist das Gebet in Vat. Barber. 1868: „Nimm hin den Fano, das Symbol dex Verkündigung des Wortes Gottes." Es findet sich auch in Vat. Borgh. 49. Beide Codices stammen aus dem 13. Jahrhundert. Unter der Verkủndjgung des Wortes Gottes ist in dem Gebet wohl die Absingung der Epistel verstanden. Jedenfalls erscheint auch in ihm der Manipel als Insignie des subdiakonalen Ordo.

4 Vat. lat. 4746.

5 Vat, Borgh. 14. 
Zwar fehlt auch in ihnen der Hinweis auf die Amtsbürde nicht, doch knüpft die in ihnen zum Ausdruck gelangende Symbolik mindestens ebensohäufig an den Namen Stola an. Das Ornatstück war das liturgische Gewand im vorzüglichen Sinne. die eigentliche liturgische Insignie, das Gewand schlechthin, ohne das der Priester keinerlei Funktionen vornehmen durfte. Es begreift sich daher, daf man in ihr ein Abbild des Kleides der Gerechtigkeit und Unsterblichkeit, d. i. das Symbol der heiligmachenden Gnade sah, und dak sie in dieser Eigenschaft dann weiterhin anch als das Gewand der Freude und des Frohlockens bezeichnet wurde.

Die Gehete, welche bei Anlegung der Stola gesprochen zu werden pflegten, sind im Gregensatz zu denjenigen, welche bei den übrigen Gewändern gebetet wurden, ausnahmsweise wenig mannigfaltig. Auf den ersten Blick mag das bei einem so bedeutungsvollen Gewande auffällig erscheinen. Man versteht es aber unschwer, sobald man die hohe Bedentung der Stola als des Sinnbildes des Amtes und als des liturgischen Gewandes schlechthin ins Auge faßst.

Die Gebete lassen sich anf vier Grundtypen zurückführen. Der eine lautet: "Zerbrich, o Herr, meiner Sünden Banden, auf daß ich, angeschirrt an das Joch deines Dienstes, mit Furcht und Ehrerbietung dir zu dienen vermöge; denn th hast gesagt: Mein Joch ist süßs und meine Bürde ist leicht"; der zweite: "Umgib meinen Nacken mit dem Gewand der Gerechtigkeit und reinige meinen Sinn von allem Sündenverderben." Den dritten Typus stellt das heute noch beim Bischof gebräuchliche Gebet dar: „Gib mir wieder, o Herr, ich flehe, das Gewand der Unsterblichkeit, das ich durch die Sünde des Stammvaters verloren, und weil ich nun mit diesem Schmuck, wenngleich unwürdig, deinem Dienste mich nahe, gewähre mir, auf ewig mit ihm mich zu erfreuen." Beim seltener vorkommenden vierten heifst das Gebet: „Es bekleide mich der Herr Jesus Christus mit dem Gewande der Freude und des Frohlockens, der da zu seinen Jüngern gesagt: Mein Joch ist süfs und meine Bürde ist leicht."

Typus II und III begegnen uns schon in einem aus der zweiten Hälfte des 9. Jahrhunderts stammenden Sakramentar von Amiens?. Der vierte ist der jüngste; er tritt erst in späteren Missalien auf. Typus I und II erscheinen meist getrennt, doch sind sie auch wohl miteinander verbunden.

Was an sonstigen Gebeten noch bei Anlegung der Stola in den mittelalterlichen Missalien vermerkt wird, ist keiner besondern Beachtung wert. Erwähnung finden möge von ihnen nur das Gebet einer Handschrift der Vaticana aus dem 11. Jahrhundert: „Bekleide mich, o Herr, mit dem Schmuck der Demut, der Liebe und des Friedens, auf daf ich, von Tugenden allseitig beschirmt, den Feinden der Seele und des Leibes zu widerstehen vermöge ${ }^{3}$; die Stola wird als liturgisches Gewand im besondern Sinne darin auf den Tugendschmuck der Seele gedeutet.

In dem Gebete, unter welchem der Bischof bei der Priesterweihe das rechte Stolaende über die Schulter des Ordinanden zur Brust führte, erscheint die Stola fast immer als Symbol des presbyteralen Amtes. "Nimm hin", so pflegte jener nach fast allen Pontifikalien zu sagen, „das Joch des Herrn; denn sein Joch ist süf und seine Bürde ist leicht." Bei der Diakonatsweihe lautete das Gebet, unter welchem der Bischot dem Ordinanden die Stola anlegte, in der Regel entweder: "Nimm hin deine Stola und erfülle deinen Dienst; Gott ist ja mächtig, dir seine Gnade zu vermehren, der da lebt usw.", oder: "Nimm hin, in den Augen der göttlichen Majestät von allem Sündenschmutz rein, von des Herrn Hand die weife Stola, auf daks dein Lebenswandel allen ein Vorbild sei und das in Christi Namen geheiligte Volk dir nachfolge und in der Gerechtigkeit dir ähnlich werde." 4 In dem letzten dieser beiden

1 Es mag genügen, auf die Auszüge bei M art. 1, 1, c. 4, art. 1 und 12; I $126 \mathrm{f} 171 \mathrm{ff}$ zu verweisen, wo sich genug Belege finden. Eine Verbindung von Typus I und II $z$. B. in Vat. lat. 5742 und Ottob. 576; eine. Verbindung von I und III in Ottob. 221.

2 Paris, Bibl. Nat. f. lat. 9432.
3 Vat. lat. 4772. Vgl. auch das Sakramentar von Stablo bei M a r. 1. 1, c. 4, art. 12, ordo $15 ;$ I 210.

* Vgl. die Auszïge aus dem. Weiheritus bei Mart. 1. 1, c. 8, art. 11, ordo $3 \mathrm{ff}$; II $37 \mathrm{ff}$, sowie Vat. lat. 11531159474557917114 ; Vat. Ottob. 27 270; Vat. Borgh. 99 u. a. 
Gebete ist die Stola das Sinnbild der Heiligkeit, welche den Diakon zieren muf, im ersten aber das Symbol des diakonalen Amtes. Daß in diesen Weihegebeten noch geringere Mannigfaltigkeit herrscht als in den Ankleidegebeten, liegt hauptsächlich wohl an dem. Charakter der Zeremonie, bei der sie gesprochen wurden. Weil nämlich die Stola als Insignie des priesterlichen und diakonalen Amtes galt, so lag es offenbar am nächsten, bei den Gebeten, unter denen der fragliche Ritus statthatte, vor allem auf eben diese Symbolik Rücksicht zu nehmen.

Typisch wurde die Stola auf den Gehorsam gedeutet, in dem Christus Knechtsgestalt annahm und bis zum Tode unterwürfig ward; auf den leidenden Gottmenschen bezogen, war sie bald Simnbild des Strickes, den man ihm am Ölberg um den Hals schlang, bald des Kreuzes, das er tragen mubte, bald, und zwar schon bei Durandus, der Fesseln, womit man ihn an die Geifelsäule band.

In dem Gebete, mit welchem der Bischof jetzt bei der Weihe die Anlegung des II fígewandes begleitet, wird dasselbe als ein Sinnbild der Liebe bezeichnet. Das ist auch die Bedeutung, welche die Liturgiker des Mittelalters von Hraban an bis auf Durandus in einer überraschenden Einmütigkeit mit der Kasel verknüpfen, „Dieses Kleid " welches als das oberste aller Gewänder alle andern deckt und schützt „können wir", sagt Hraban, „als die Liebe auffassen, welche alle Tugenden überragt und ihnen Schönheit, Schutz und Glanz verleiht." Die übrigen Liturgiker haben diese Deutung entweder bloß wiederholt oder mit Beziehung auf die beiden Hälften des Gewandes und die hei dessen Anlegung entstehenden Falten im Geiste der Zeit weiter ausgesponnen ${ }^{1}$. Nur Amalar und Rupert gehen ihre eigenen Wege; jener deutet die Kasel auf die guten Werke, dieser auf die Kirche.

Auch in dem Gebete, welches der Priester nach den mittelalterlichen Sakramentaren und Missalien bei Anlegung der Kasel sprechen sollte, findet sich oft unser Gewand als Sinnbild der Liebe aufgefaßst. "Bekleide mich, o Herr", so lautet ein häufig vorkommendes Gebet, „mit der Zier der Demut, der Liebe und des Friedens, auf daf ich, allseitig mit Tugenden ausgerüstet, den Lastern und den Feinden zu widerstehen vermöge." 2 Liebe setzt wahre Demut voraus; ihre Frucht aber ist der Friede. Allein die Kasel erscheint in den Ankleidegebeten keineswegs ausschlieklich als Sinnbild der Liebe wie bei den Liturgikern, sondern auch als Symbol der priesterlichen Gerechtigkeit und Heiligkeit ${ }^{3}$, als Abbild der Gnade des Heiligen Geistes, welche der Priester beim Anlegen des Meßggewandes auf sich herabflehte ", ja sogar vereinzelt als Panzer des Glaubens und als Helm der Hoffnung ${ }^{5}$. Besonders häufig aber kam das Gebet zur Verwendung, welches gegenwärtig allgemein beim Anziehen der Kasel gesprochen wird und das Gewand auf das sübe und leichte Joch Christi deutet $^{6}$. Es findet sich schon in ảen Sakramentaren des 9. und 10. Jahrhunderts.

Ähnlich wie mit den Ankleidegebeten verhält es sich mit den Worten, unter welchen der Bischof dem Ordinanden bei der Priesterweihe die Kasel anzulegen pflegte. Auch hier herrscht keine Einheit. Am häufigsten versinnbildet darin das Mefogewand allerdings die Liebe, jedoch erscheint es in ihnen oft auch als Symbol der Unschuld: Stola innocentiae induat te Dominus. Vielleicht bei keinem Gewand zeigt sich in so auffallender Weise, wie wenig Einflußs die mystischen Auslegungen der Liturgiker auf die Deutung in der Praxis hatten, als gerade bei der Kasel.

1 So bei Honorius, Sicard, Innozenz III.

2 Vat. lat. 57426082 7231; Vat. Ottob. 221 576. Vgl. ferner die drei Trierer Missalien (S. 712, Anm. 3) : die beiden Sakramentare von St Gallen (339 und 354), das Kölner Missale von 1487; die beiden Sakramentare der Bibl. Riccard. zu Florenz 299 und 300; desgleichen verschiedene der bei Mart. I. 1 , c. 4, art, 1 und 12 sich findenden Auszüge aus mittelalterlichen Missalien, sowie M. 78,246 .
3 Vat. lat. 3808 und 4743; Rom, Bibl. Angel. 477 u. a. So auch in der Missa Illyrica. 4 Cod. Vat. lat. 4770 und 4772; das Missale von Augsburg (1555) u. a.

${ }^{5}$ Mart. 1. 1, c. 4, art. 1; I $126 \mathrm{f}$ (Sakramentar von Tours und Missale von Auxerre)

6 Vat, lat. 4730 und 9340; Rom, Bibl. Angel. 1092. Vgl. ferner die Auszüge bei M a r t. a. a. O. u. a. Das Gebet kommt am fruhesten in französischen Sakramentaren yor. 
Im typischen Sinne wurde das Mefigewand auf die Kirche als das Gewand Christi gedeutet, und zwar sah man in seiner vorderen Hälite die Kirche des Alten Bundes, in seiner hinteren aber die des Neuen Bundes. In dem Umstand, daf die Kasel ringsum geschlossen und nirgends aufgeschlitzt war, erkannte man ein Bild der Einheit der Kirche. Im späten Mittelalter galt das Gewand allgemein als Abbild des Purpurmantels, den die Soldaten nach der Dornenkrönung dem Heiland umwarfen. Schon Durandus gedenkt dieser Deutung, die demnach im 13. Jahrhundert aufgekommen sein muf. Berthold von Regensburg exklärt die Kasel als Sinnbild der ,grofen und ganzen minne, die unser herre zuo de menschen hat" ${ }^{\text {. }}$

\section{DIE SYMBOLIK DER BISCHÖFLICHEN ORNATSTÜCKE.}

Auch die spezifischen Pontifikalgewänder, die Mitra, die Handschuhe, die pontifikale Fubbekleidung, das Subcinctorium und das Pallium, haben mannigfaltige Ausdeutungen erfahren, wenngleich nicht in dem Mafie wie die Bestandteile der priesterlichen Kleidung. Obendrein beschäftigen sich die Liturgiker seit Durandus kaum mehr mit der Darlegung ihrer Symbolik. Die liturgischen Schriften des 14. und 15. Jahrhunderts behandeln in der Regel nur die Symbolik der priesterlichen Gewandung:

Der erste unter den Liturgikern, welcher die Mitra mystisch dentet, ist Bruno von Segni. Weil aus Linnen gemacht, ist sie für ihn sinnbild der Keuschheit; weil das Haupt des Bischofs deckend, wird sie von ihm als Mahnung betrachtet, die Sinne zu bewachen. Honorius fügt der Auslegung Brunos die Deutung auf Christus und die Kirche hinzu. Christus ist das Haupt, der Bischof der Stellvertreter Christi, die Kirche die Mitra. Eine Mitra, sagt Honorius, umgibt das Haupt des Bischofs, wenn die in der Taufe gereinigte und durch gute Werke strahlende Kirche Christus in seinen mannigfaltigen Leiden im Hinblick auf die Krone der Herrlichkeit nachahmt, wenn die Gläubigen, durch des Bischofs Unterweisung erleuchtet, der bischöflichen Würde den Tribut ihrer Verehrung zollen, wenn Klerus und Volk sich um ihn als ihren Hirten scharen. Von Hörnem der Mitra gibt weder Bruno noch Honorius eine mystische Erklärung. Begreiflich, da beide solche noch nicht kennen konnten.

Die früheste Symbolik der Hörner findet sich in Übereinstimmung mit der Entwicklung der Mitra bei Robert Paululus, im Speculum de mysteriis ecclesiae und im Tractatus de sacramento altaris. Sie werden hier auf die beiden Testamente ausgelegt, eine Deutung, die in der Folge auch in die liturgischen Gebete überging, „Des Bischofs gehörnte Mitra“, sagt das Speculum, ,stellt die beiden Testamente dar, mittels deren er der Kirche Feinde besiegen muß." Ähnlich drücken sich Robert Paululus, der irrig Stephan von Bangé zugeschriebene Tractatus de sacramento altaris ${ }^{2}$, Sicard von Cremona und Innozenz III. aus.

Sehr weitläufig erörtert Durandus die Bedeutung der Mitra. Die cornua betrachtet er als Sinnbilder der beiden Hauptgebote der Gottes- und Nächstenliebe, aber auch als Symbole des Alten und Neuen Bundes, mit welchen ja der Bischof durchans vertraut sein müsse. Den circulus des Ornatstückes, welcher dessen beide Hälften umschliefst, deutet er auf den scriba doctus in regno coelorum, qui profert de thesauro suo nova et vetera, $d$. $i$. auf den Bischof selbst, der aus den Schätzen beider Testamente zu Nutz und Frommen seiner Herde hervorlangen soll. In den Streifen, die von der pontifikalen Kopfbedeckung herabhangen, sieht Durandus, indem er an seiner Auslegung weiterspinnt, Geist und Buchstaben, d. i. das mystische und das historische Verständnis der Heiligen Schrift. Die fasciae sind mit roten Fransen an den Enden versehen, um die Bereitwilligkeit des Bischofs anzudenten, Glauben und

1 W akernage l, Altdentsche Predigten, Basel 1876, 70.

${ }^{2}$ Der Tractatus wird mit dem gleichen Unrecht Stephan von Baugé $(† 1136)$ zugeschrie- ben, wie das Speculum Hugo von St Victor $\dagger$ ca 1141). Weder der eine noch der andere konnte von Hörnern der Mitra reden, wie es doch in beiden Schriften gesehieht. 
Schrift selbst mit seinem Blut zu verteidigen. Sie hangen über die Schultern herab. mit denen man die Lasten trägt, weil sie den Pontifex darauf hinweisen sollen, das in die Tat umzusetzen, was er mit dem Munde predigt ${ }^{1}$. Auf Christus gedeutet, bezeichnet die Jitra nach dem Rationale die Verherrlichung und Glorie der heiligen Menschheit Christi, eine Symbolik, die Sicard und Innozenz III. entlehnt ist; doch wurde der pontifikale Kopfschmuck, wie Durandus mitteilt, von einigen auch wohl als Sinnbild der Dornenkrone Christi hingestellt.

Ein Gebet scheint nur sehr selten beim Aufsetzen der Mitra gesprochen worden zu sein. Wir haben ein solches bisher nur in zwei mittelalterlichen Handschriften gefunden 2. Es lautet beide Male: „Setze auf, o Herr, die Mitra als Helm des Heiles auf mein Haupt, damit ich gegen des alten Feindes und aller Gegner Nachstellungen geschirmt sei." Es ist das gleiche Gebet, welches der Bischof heute beim Aufsetzen der Mitra zu sprechen pflegt. In dem erst im 14. bis 15. Jahrhundert entstandenen Gebete, unter welchem dem neugeweihten Bischof die Mitra aufgesetzt wird, erscheint diese gleichfalls als Helm des Heiles; doch ist darin auch die Symbolik aufgenommen, welche die liturgischen Schriften seit Ausgang des 12. Jahrhunderts mit den beiden cornua der Mitra verbanden.

Von den Deutungen, welche die Liturgiker seit dem Beginn des 12. Jahrhunderts den Pontifikalhandschuhen angedeihen lassen, ist diejenige am einfachsten, natürlichsten und ansprechendsten, welche sich bei Bruno von Segni findet: „Du fragst, warum die Hände (des Bischofs) mit Handschuhen bekleidet werden? Nun, ich antworte kurz und bündig: auf daß sie rein, sauber, von allem Schmutze frei und lauter seien." Schön ist indessen auch eine andere mehrfach wiederkehrende Auslegung. Sie knüpft an die Auffassung an, wonach die Hände das Sinnbild der guten Werke sind. Die chirothecae mahnen ihr zufolge den Bischof, er möge, wie er bald die Hände mit den Handschuhen verhüllt, bald wieder entblößrt, so auch die guten Werke bald der Demut halber im verborgenen, bald des guten Beispiels wegen in der Öffentlichkeit üben ${ }^{3}$. Durandus sieht in Anlehnung an diese Deutung in den Handschuhen das Symbol jener Behutsamkeit, kraft deren man es sich angelegen sein läßt, die guten Werke in demütiger Gesinnung zu verrichten, auf daßs sie auch dann, wenn sie öffentlich geschehen müssen, wenigstens was die Absicht anlangt, gleichsam im verborgenen bleiben * Nach dem Speculum erimmern die Handschuhe an die Taten der Heiligen, die der Bischof in seinen Werken zum Vorbild nehmen muf. Zugleich sollen sie diesen auffordern, sein Tun von aller Makel frei zu halten ${ }^{5}$.

Der erste, welcher die Pontifikalhandschuhe auf Christus deutet, ist Innozenz III. Er vergleicht sie mit den Ziegenfellchen, mit denen Rebekka die Hände Jakobs umgab, und betrachtet sie wie diese als Sinnbilder der sündenähnlichen Menschennatur, mit welcher der Gottessohn durch die Kraft des Heiligen Geistes bekleidet ward".

In dem Gebete, welches der Bischof nach der Anweisung der Missa Illyrica bei Anlegung der Handschuhe verrichten soll, fleht derselbe, Gott möge ihn mit dem Gewande der Gerechtigkeit und Freude umkleiden, auf daß er verdiene, mit reiner Seele vor sein Angesicht zu treten?. Das Ornatstück erscheint hier als Sinnbild der Herzensreinheit, welche den christlichen Hohenpriester schmücken muf, wenn er sich zum heiligen Opfer anschickt. Eine ähnliche Anschauung begegnet uns in den Worten, welche der Bischof nach dem Sakramentar von Corbie zu sprechen hatte, wenn ihm der Minister die Handschuhe überreichtes, nur dak diese hier im Sinne Brunos von Segni auf die Reinheit der Hünde gedeutet werden. Die beiden

1 Gewisse Häretiker verglichen, wie Durandus (Rationale 1. 3, c. 13; f. 75) erzählt, den Bischof, dessen Haupt die Mitra schmücke, mit der zweihörnigen Bestio, von welcher Off b 13, 11 die Rede ist.

- Vat. lat. 4730 und Vat. Ottob. 27.

s So Honorius u. a.

* Rationale 1. 3, c. 13; f. 75 .
5 C. 6 (M. 177, 354).

${ }^{6}$ Die Auslegung der Bockfellchen, mit denen Jakobs Hiinde umkleidet wurden, auf die sündenbeladene Menschennatur findet sich schon beim hl. A ugustinus (De mendacio c. 10, п. 24 [M. 40,534$])$.

7 Mart. I. 1, c. 4, art. 12, ordo 4; I 177.

8 Ebd. ordo 11; I 203. 
Gebete bieten die ãlteste Symbolik der pontifikalen chirothecae. Ein Pontifikale des 15. Jahrhunderts sieht in den Handschuhen das Sinnbild einer reinen Meinung, wenn es den Bischof beim Anziehen derselben beten heift: „Beschirme mit den Handschuhen einer reinen Meinung mein Wirken, auf dafs ich dir, allmächtiger Gott, nach Willen und Tat gefalle."

Das Gebet, welches nach älteren Pontifikalien gesprochen wurde, während der Archidiakon in Gegenwart zweier Bischöfe, der Mitkonsekratoren, und unter Beihilfe der Subdiakonen den Konsekranden mit den Pontifikalhandschuhen ansstattete, lautet: "Allmächtiger, mildreichster Gott, wir bitten deine unermefliche Güte, du wollest die Hände dieses deines Dieners, unseres Mitbruders, so wie sie äuferlich mit diesen Handschuhen umhüllt werden, innerlich mit deines Degens Tau besprengen, auf daf3, was sie immer zu segnen oder zu weihen haben, durch dich gesegnet und geweiht werde." 2 Die Handschuhe erscheinen in ihm als Sinnbild der übernatürlichen Segenskraft des Bischofs, eine Deutung, welche sich bei den Liturgikern des 12. und 13. Jahrhunderts nirgends findet. Das Gebet, welches der Konsekrator nach Pontifikalien des späten Mittelalters bei jener Zeremonie sprechen mufste, schliefst sich der Symbolik an, welche Innozenz III. mit den Handschuhen verknüpft. Es ist dasselbe, welches noch jetzt nach dem römischen Pontifikale bei der Bischofsweihe gebetet und auch bei dem Pontifikalamt vom Bischof während des Anziehens der Handschuhe verrichtet wird.

Von der mystischen Bedeutung der Caliga e handeln die mittelalterlichen Liturgiker nur wenig. Nach Amalar versinnbildet die linnene Umhüllung des Fußses die Zucht der Füße, kraft deren diese gehindert werden, zum Bösen zu eilen. Ivo von Chartres sieht in den aus weifem Byssus oder Linnen angefertigten Caligae eine Mahnung für den Träger, den rechten Weg zu wandeln. Den Umstand, daß die Strümpfe am Knie mit Bündern befestigt wurden, betrachtet er als eine Aufforderung an den Bischof, die etwa durch allerlei Nachlässigkeiten geschwächten Knie zu stärken und so zur Verkündigung des Evangeliums zu eilen. Auch dem Speculum zufolge symbolisiert die Anlegung der Pontifikalstrümpfe die Vorbereitung auf die Reise zur Predigt des Wortes Gottes; nach Sicard sind die Caligae ein Bild der Reinheit des Wandels, die den Boden des Heiles zieren muf.

Wenn die Liturgiker die Caligae auf die Makellosigkeit des Lebens deuten, so tun sie das mit Rücksicht auf deren weike Farbe. Wenn sie aber in der Auslegung derselben auf das Predigtamt des Bischofs Bezug nehmen, so hängt das mit dem Umstand zusammen, daf die Caligae als Beigabe und als Zubehör zu den Pontifikalschuhen galten, die letzteren aber seit dem 9. Jahrhundert von den Liturgikern stets und allgemein als Hinweis auf die Verkündigung des Wortes Gottes angesehen wurden. Hraban ist der erste, welcher im Anschluß an Bedas Erklärung zu Mk 6, 9 die Sandalen auf die Predigttätigkeit bezieht.

Ihm ist der Fuf, welcher den Glaubensboten hinausträgt, Sinnbild des Evangeliums, welches gepredigt wird. Daher sollen die oben offenen, nach dem Boden zu mit fester Sohle versehenen pontifikalen Schuhe andeuten, erstens ut nee occultetur evangelium, nee terrenis commodis initatur, daß 3 also das Wort Gottes nicht unter dem Scheffel bleiben und anderseits der Prediger sich ebensowenig von zeitlichen Vorteilen hei Ausübung seiner hohen Aufgabe leiten lassen dürfe; zweitens daf der Bote Gottes die Wahrheiten des Evangeliums teils unerschlossen lassen, teils offen verkünden müsse, damit die gläubigen und frommen Seelen im Glanben hinreichend unterrichtet seien, die Ungläubigen und Spötter aber keinen Stoff zu ihren Lästerungen hätten. Mit andern Worten: Hraban sieht in den Sandalen die Mahnung zu eifriger, uneigennütziger und umsichtiger Verwaltung des mit den priesterlichen Funktionen innig zusammenhängenden Predigtamtes.

Weit eingehender als Hraban behandelt Amalar die Pontifikalschuhe; ja es ist, als ob dieser bei ihnen mehr noch wie bei allen andern liturgischen Gewändern seinen

1 Vat. lat. 1145. 2 $\mathrm{H}$ itt. 109. Vgl. M art. 1. 1, c. 8, art. 11, ordo 16; II 82. Braun, Die liturgische Gewandung. 
Scharfsinn und seine Deutungsgabe spielen lasse, damit nur gar nichts unausgelegt bleibe,

Die Sindalen exinnern nach Amalar den Prediger daran, dafs er zur Verkündigung des Wortes Gottes umherziehen müsse. Die Sohle ermahne ihn, sich nicht in irdische Angelegenheiten zu verwickeln, das weiße Leder zwischen Fuf und Sohle aber weise ihn darauf hin, daf dieses Fernhalten von der Welt aufrichtig und ernst gemeint sein miisse. Die Kappe der Sandale stellt nach Amalar die Zunge derjenigen dar, welche dem Prediger ein gutes Leumundszeugnis zu geben haben, das Vorderleder dagegen die Zunge der geistlich gesinnten Männer, welche den Prediger ins Predigtamt einführen. Das weißse Leder, womit die Sandalen inwendig gefüttert waren, soll die reine Absicht des Heilsboten bezeichnen. die schwarze Farbe des Äußsern aber zum Ausdruck bringen, daf3 den Weltmenschen das Leben der Prediger wegen der vielen Bedrängnisse dieser Welt verächtlich vorkomme, Außen- und Innenleder sind an den Rändern mit vielen Fäden vernäht, um anzuzeigen, daf beim Verkündiger des Wortes Gottes die äuferen Werke und der innere Tugendglanz in Einklang stehen müssen. Das Vorderleder kann man nach Amalar auch als Sinnbild der eigenen Zunge des Predigers auffassen; dann mag der mittlere Streifen desselben die evangelische Vollkommenheit, den Gegenstand der Predigt, bedeuten, während die Streifen, welche von den Seiten zur Mitte hin laufen, als Symbol des Gesetzes und der Propheten, deren Ziel und Ende das Evangelium ist, betrachtet werden können. Unter den Riemen, die mit der Hand zum Zwecke der Bindung hierhin und dorthin geführt werden, meint Amalar, lasse sich die Arbeit verstehen, die Panlus zur Verkündigung des Evangeliums hinzu auf sich nahm, um seinen Lebensunterhalt zu verdienen. "Wit sicherem Schritt zieht der Prediger einher, welcher niemand zur Last fällt." So ähnlich der Metzer Chorbischof.

Was Amalar in der Deutung der Sandalen vorgebracht, taucht seitdem immer wieder bald in etwas vereinfachter, bald in teilweise erweiterter Form bis auf Durandus bei den Liturgikern auf. Auch in den Worten, welche der Bischof nach den mittelalterlichen Sakramentaren bei Anlegung der Sandalen zu sprechen hatte, wird die pontifikale Beschuhung auf die Verkündigung des Evangeliums ausgelegt Das gleiche geschieht in dem Gebete, unter welchem nach einzelnen alten Weiheordines die assistierenden Bischöfe den Electus mit den Pontifikalschuhen bekleideten.

Den Grund zu dieser Symbolik bilden, wie aus Hraban hervorgeht, die zwei Stellen in dem Evangelium des hl. Markus und dem Briefe des Apostels an die Ephesier. Nach jener $(6,9)$ sandte der Herr die Apostel aus zur Predigt des Reiches Gottes "mit Sandalen beschuht". Im 6. Kapitel des Ephesierbriefes aber schildert der hl. Paulus die Waffenrüstung des Christen und mahnt dabei die Gläubigen, unter anderem auch, an den Füßen beschuht zu sein mit der Bereitung des Friedensevangeliums".

Gebete, die man beim Anschuhen der Pontifikalsandalen sprach, kommen übrigens in den Sakramentaren und Pontifikalien verhältnismäßig nur selten vor. Es scheint das Gewöhnlichere gewesen zu sein, daß man das Anlegen der liturgischen Beschuhung während der Vorbereitungsgebete auf die Messe vornahm. Sicher war es so im 15. Jahrhundert zu Rom Brauch, wie ein Pontifikale der Vatikanischen Bibliothek ausdrücklich angibt! Daf es aber auch anderswo so gehalten wurde, ergibt sich z. B. aus einem Minoritenmissale ${ }^{2}$. Natürlich war, wo diese Sitte bestand, ein besonderes Anlegegebet überflüssig, ja nicht einmal am Platz. Am hänfigsten stoßen wir auf das Gebet, welches auch jetzt noch beim Anziehen der liturgischen Fufiłsekleidung gesprochen wird ${ }^{3}$. Daneben finden sich aber auch einige andere von allgemeinerer Fassung, wie z. B : „Mit den Sandalen deines Schutzes beschirme, o Herr, meine Füße, dafi ich nach der Heiligen Beispiel würdig deine Geheimnisse feiere "

1 Vat. lat. 1145: Melius tamen est, quod calcietur, dum dicit psalmos, ut citius expediatur, et sic fit in curia romana, et tunc nihil aliud dicit pontifex, dum. calciatur.
2 Vat. lat. 4743. Vgl. auch Vat, lat. 9340 (Pontifikale von Monte Cassino).

\& Siehe oben S. 385.

4 Vat. lat. 1145 . 
Die Worte, welche beim Anziehen der Sandalen gesprochen wurden, galten in der Regel auch für die Caligae, also für die ganze Fußsbekleidung, gerade wie gegenwärtig. Nur selten findet sich ein besonileres Gebet für die Pontifikalstrümpfe angegeben. So soll z. B. nach zwei Pontifikalien der Vaticana der Bischof beim Anziehen derselben flehen: "Ziehe mir an, o Herr, die Caligae der Freude und stärke meine schwachen Knie, auf daf ich, ohne zu ermüden, auf dem Weg deiner Gebote zu dir gelangen möge." 1 Das Gebet erinnert an die Symbolik, welche Ivo von Chartres mit den Caligae verbindet. Typisch aufgefaßt sind die Pontifikalschuhe nach Rupert von Deutz wie der Amikt ein Sinnbild der heiligen Menschheit Christi, wobei insbesondere das Bindwerk auf die geheimnisvolle Einigung der beiden Naturen hinweist. Durandus sieht näher in den Caligae das heilige Fleisch des Erlösers, in den Sandalen seine heilige Seele symbolisiert.

Dem päpstlichen F ano scheint eine besondere Symbolik nicht beigelegt worden zu sein. Wenn Innozenz III. und Durandus seiner Erwähnung tun, so geschieht es blof, um ihn als päpstliches Sondergewand zu bezeichnen, nicht aber, nm daran irgend eine symbolische Erörterung zu knüpfen.

Dagegen ist das Subcinctorium, das ja auch ein allgemeiner gebräuchliches Ornatstück war, melrfach mystisch gedeutet worden. Nach Robert Paululus und Honorius sinnbildet es den Eifer im Almosenspenden, wobei dieses jedoch im weiteren Sinne zu fassen ist. Der eine Streifen soll den Träger des Subcinctorium ermahnen, durch Vermeidung der Sünde an der eigenen Seele Erbarmen zu üben; der andere dem Nächsten durch Hilfe in dessen Nöten Barmherzigkeit zn erweisen. Bruno von. Segni und Innozenz III. sehen in dem Ornatstück einen Hinweis auf Gebet und Fasten als die beiden zur Bewahrung der Keuschheit so notwendigen Mittel. Für Durandus bedentet das Subcinctorium wie das Cingulum die Keuschheit. Wăhrend letzteres jedoch die castitas mentis symbolisiere, sei ersteres Sinnbild der castitas corporis, daher es denn auch an der linken, der minder ehrenvollen Seite aufgehängt werde; die geistige Keuschheit stehe ja hoher und sei vorzüglicher als die leibliche.

Das ist in der Hauptsache die Symbolik, welche die Liturgiker des 12. und 13. Jahrhunderts mit dem Subcinctorium verbanden. Ein Gebet dürfte man im Mittelalter bei Anlegung desselben nur selten gesprochen haben, wahrscheinlich, weil man es gewöhnlich zugleich mit dem Cingulum anlegte. Die Nissa Illyrica läßst den Bischof bei Annahme des praecinctorium flehen: "Umgürte mich, o Herr, mit Kraft und mache makellos meinen Wandel." Nach dem Sakramentar von Corbie soll der Pontifex, wenn ihm der Minister das Subcinctorium reicht, beten: „Ich bitte dich, höchster Gott der Heerscharen, heiliger Vater, du wollest mir gnärligst Keuschheit angürten und meine Lenden mit dem balteus deiner Furcht umgeben und meine Nieren mit dem Feuer deiner Liebe ausbrennen, auf dafi ich um Verzeihung meiner Sünden dich anzuflehen, für des umstehenden Volkes Vergehen Nachlafs zu verdienen und friedenbringende Opfergaben für alle einzelnen darzubringen vermag. " ? Das Gebet im Pontifikale von Cambrai (ad balteum) hat heinahe denselben Wortlat wie dasjenige des Corbieer Sakramentars. Die Symbolik, welche in diesen Gebeten zum Ausdruck kommt, ist die gleiche, welche mit dem Cingulum verknüpft zu werden pflegte. Angesichts der Bedeutung, welche man im Mittelalter mit dem Subcinctorium verband, versteht man, weshalb der hl. Karl Borromäus bestimmt, der Bischof solle ein Subcinctorium haben pro ratione mysterii, um seines mystischen Sinnes willen.

Von der offiziellen Symbolik des Palliums mufite schon früher geredet werden. Hier kann es sich also bloß um die mystische Betrachtung handeln, welche die Liturgiker zur Karolingerzeit sowie im 12. und 13. Jahrhundert dem über alle andern hervorragenden Ornatstück haben zu teil werden lassen.

I Ebd. 4730 und Vat. Ottob. 27 ; ein ähnliches Gebet in Vat. lat. 1145.

2 M art. 1. 1, c. 4, art. 12, ordo 11 ; I 20 ?. Hier lautet, wie im Original (Bibl. Nat. f. lat. 12052), das Gebet: Rogo te... ut me castigare digneris accingere et meos lumbos balteo tui timoris ambire. Castigare ist ein Schreibfehler für castitate, wie aus einem Vergleich mit der ursprünglichen Vorlage erhellt. 
Bei Hraban, Amalar und Pseudo-Alkuin halten sich die diesbezüglichen Ausführungen roch in mäßigen Grenzen. Es war ja auch das Pallium noch nicht offizielles Srmhol der plenitudo pontificalis officii. Im 12. Jahrhundert war das jedoch anders gerrorden, und darum sehen wir denn auch die späteren Liturgiker sich eingehender mit der mystischen Auslegung des Ornatstückes beschäftigen. Bald beziehen sie es auf das Leiden Christi, das der Inhaber des Gewandes durch Wort und Beispiel predigen müsse, bald moralisch anf die Zucht, mit welcher der Erzbischof sich selbst und die Untergebenen zu regieren habe. Veranlassung zur Deutung auf Christi Leiden boten die dem Pallium aufgenähten purpurnen Kreuze. Es ist nicht möglich, auf alle diese mystischen Betrachtungen einzugehen. Es muf zu ihrer Charakterisierung genügen, als Beispiel die Erörterungen anzuführen, welche Innozenz III. über die Bedeutung des Palliums anstellt. Das Pallium symbolisiert nach ihm die Zucht, in weleher der Träger sich selbst und seine Untergebenen halten soll. Die Wolle, aus der das Gewandstück gemacht ist, erinnert daran, daf es ihm nicht an Strenge, die weife Farbe desselben, dak es ihm aber auch nicht an Milde fehlen dürfe. Eben um des letzteren Umstandes willen werde es ja auch nicht aus dem Haar jedes beliebigen Tieres, sondern aus dem des sanftmütigen Lammes gemacht. Der sich um die Schultern ziehende Ring des Palliums sinnbildet nach Innozenz die Furcht des Herrn, welche vom Unerlaubten abhält und im Überfluß zum Maß̧halten führt. Die vier Kreuze vorn, hinten und auf den Schultern legt er auf die vier Kardinaltugenden aus; ihre Purpurfarbe soll darauf hinweisen, daf diese Tugenden gleichsam in Christi Blut gerötet, d. h. verübernatürlicht werden müssen, falls sie wahre Tugenden sein und zur ewigen Seligkeit führen sollen. In den beiden Streifen, die vom Ring herabhangen, sieht Innozenz das tätige und das beschauliche Leben, dessen sich der Träger des Palliums befleißigen soll. Beide ziehen sich nach unten, weil der Leib die Seele gleichsam beschwert und zur Erde niederdrückt. Auf der linken Schulter ist das Pallium gedoppelt, weil das Leben hienieden, das durch die linke Seite versinnbildet wird, voll ist von Mühsalen; auf der rechten ist es dagegen einfach, um anzudeuten, dafs das zukünftige, dessen Bild die rechte Seite darstellt, nur Ruhe und Friede ist. Doppelt ist es ferner auf der Linken, weil sein Träger stark sein muf, um die Widerwärtigkeiten dieses Lebens zu ertragen; einfach auf der Rechten, weil er mit allem Verlangen nach dem Himmel seufzen soll. Die drei Nadeln, welche dem Pallium vor der Brust, auf der linken Schulter und im Rücken angeheftet sind, bezeichnen das Mitleid mit dem Nächsten, die Verwaltung des Amtes und das zukünftige strenge Gericht. Denn das sind drei Dinge, welche die Seele stechen, das erste durch das Mitgefühl, das zweite durch die Mühe, das dritte durch die Furcht. Daf auf der rechten Schulter die Nadel fehlt, besagt, daß es im Himmel keinen Stachel der Betrübnis gibt. Daf die Nadel unten zwar spitz, oben aber abgerundet ist, soll daran erinnern, dak der gute Seelenhirt auf Erden in der Sorge um seine Herde allerdings viele Plagen hat, dafo er dafür aber auch einst im Himmel gekrönt und jene kostbare Perle besitzen wird, von weleher der Herr im Evangelium redet.

Diè Ausführungen Innozenz' III. zeigen zur Genüge, in welcher Weise die Liturgiker des 12. und 13. Jahrhunderts das Pallium symbolisch auszulegen pflegten. In die liturgischen Bücher haben ihre Deutungen keinen Eingang gefunden. Ein Gebet bei Anlegung des Palliums zu sprechen, ist nicht Brauch geworden.

\section{DIE SYMBOLISCHE BEDEUTUNG DES SUPERPELLICEUM, DER LEVITENGEW ÄNDER UND DES PLUVIALE.}

Es erührigt noch, auf die Symbolik des Superpelliceum, der Levitengewänder, der Dalmatik und der Tunicella, und des Pluviale einzugehen. Sie sind nur in geringem Mase Gegenstand mystischer Auslegung geworden. Am meisten haben sich die Liturgiker noch mit der Dalmatik beschäftigt. Ankleidegebete, welche die genannten Gewandstücke sinnbildlich deuten, waren zum Teil gar nicht, zum Teil nur in sehr beschränktem Maf in Gebrauch. 
Von der Symbolik des Superpelliceum sagt Durandus, es bezeichne wegen seiner Weige die Keuschheit. doch bedeute es auch die Unschuld überhaupt und mahne darum seinen dem Dienste Gottes geweihten Träger, sich alle Tage des Lebens durch schuldlosen Wandel hervorzutun. Wegen seiner Weite sinnbilde es die allumfassende Liebe. Über die profanen Kleider gezogen, erinnere es daran,

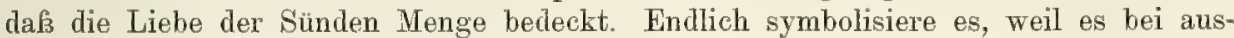
gebreiteten Ärmeln Kreuzesgestalt habe, Christi Kreuz und Leiden und ermahne denjenigen, der mit ihm bekleidet sei, sich selbst mit allen Fehlern und allen Gelüsten zu kreuzigen. Durandus' Auslegungen sind ein wenig gesucht, doch ansprechend. Seine Erfindung sind sie aber nicht. Wir finden sie schon bei Sicard, bei Arno und Gerhoh von Reichersberg, ja schon bei Anselm von Havelberg.

Die Symbolik der Dalmatik zeigt von der Karolingerzeit an bis auf Durandus immer wesentlich dasselbe Bild. Hraban legt das Gewand mit Rücksicht darauf, daf es Kreuzesform darstelle und vorn, auf dem Rücken und an den Ärmelsäumen mit roten Streifen besetzt sei, auf das Leiden Christi aus. Er findet demgemärs in ihm für den Diener Christi die Mahnung, seines hohen Amtes stets zu gedenken, auf daf er, wenn er im heiligen Opfer das Gedächtnis des Leidens des Herrn begehe, selbst dahei eine Gott wohlgefällige Opfergabe werde. Amalar deutet das Gewand auf die Reinheit und die Liebe zum Nächsten, welche dem Träger desselben eigen sein sollen. Ilie weife Farbe symbolisiere die Reinheit, die Purpurstreifen und Fransen, mit denen die Dalmatik geschmückt werde, die Liebe zum Nächsten. Den Umstand, daß sich diese Streifen sowohl von der rechten wie von der linken Schulter herabzogen, legt der Metzer Diakon dahin aus, dak die Liebe zum Nächsten sich im Glück (rechte Seite) wie im Unglück (linke Seite) bewähren müsse. Daf die Zierstreifen anf der Vorder- und Rückseite des Gewandes angebracht wurden, versinnbildet nach Amalar, daß das Gebot der Liebe im Alten wie im Neuen Bunde eingeschärft werde. Die Weite der Ärmel solle an freudige Freigebigkeit beim Spenden gemahnen.

Was die Folgezeit an Deutungen der Dalmatik bringt, bewegt sich im ganzen im Rahmen der Gedanken und Auffassungen Hrabans und namentlich Amalars. Man vergleiche z. B. nur, was Honorius, Robert Paululus, Sicard und Innozenz III. uns von ihrer Symbolik erzahlen. Nirgends findet sich etwas Neues, das irgendwie von Belang wäre. Nur Bruno von Segni geht in der Deutung des Crewandes seine eigenen Wege, wenn er dasselbe als Mahnung auffaft, nach dem von Leiden, Sorgen und Beschwerden freien Leben im Jenseits zu streben.

Gebete, die beim Anlegen der Dalmatik gesprochen wurden, begegnen uns nur selten in den liturgischen Büchern des Mittelalters, und selbst diese wenigen sind dem Wortlaut nach sehr verschieden, ein einziges ausgenommen. Dasselbe schlieEt sich an die Deutung Hrabans an und findet sich schon in der sog. Missa Illyrica. Es lantet: , Mit diesem nach dem Vorbild der früheren Väter in Kreuzesform gemachten und mit Purpurstreifen besetzten Gewande bekleidet, bitte ich demütig, o Herr, dafs ich dir durch die Begehung deines Leidens immerdar wohlgefällig sei." 1 In den andern Gebeten erscheint die Dalmatik als Gewand des Heiles, der Freude, der Gerechtigkeit oder als Abbild des neven Menschen, d. i. der übernatürlichen Heiligkeit. Der Grund für diese Symbolik mag bald ihre weiße Farbe, bald der Umstand gebildet haben, daf sie als Feierkleid galt. Das Gebet, welches jetzt der Bischof nach dem römischen Missale beim Anziehen des Gewandes zu beten hat, findet sich schon in einer Praeparatio ad missam der Vaticana aus dem 14. bis 15. Jahrhundert. Wo es bei der Diakonatsweihe üblich war, die Anlegung der Dalmatik mit einem Gebete zu begleiten, sprach der Bischof meistens entweder ähnlich wie jetzt: "Es bekleide dich der Herr mit dem Gewande des Heiles, mit dem Kleid der Freude und der Dalmatik der Gerechtigkeit", oder: "Es ziehe der Herr dir an den neuen Menschen, der nach Gott geschaffen ist in Gerechtigkeit und wahrer Heilig-

${ }^{1}$ Es kommt ferner vor in Vat. lat. 4746 und Vat. Ottob. 27; abgekürzt in Vat. lat. 1145. 
keit." 1 Die Symbolik ist in diesen Gebeten die gleiche wie in den vorhin erwähnten Ankleidegebeten.

Die Tunika hat nur wenige Ausleger gefunden. Sie wird bald auf die Tugenden gedentet, welche die Seele des Bischofs schmücken sollen, bald, weil tief herabfallend auf die Belarrlichkeit, bald endlich auf die Gerechtigkeit, die wie ein Panzer den Subdiakon umgeben soll. Die Ankleidegebete, die uns hie und da in den Pontifikalien begegnen, lassen die Tunika, ähnlich wio die Dalmatik, Symbol des Heiles, der Gerechtigkeit und der geistlichen Freude sein. Eigenartig ist das Gebet: „Bekleide mich, - Herr, mit der Strikta (anderer Name für Tunika) der Enthaltsamkeit von allem, was mir schadet, auf dafs ich in deinem Dienste beständig verharre." 2 Es klingt an die zweite der eben angeführten Deutungen an.

Wenn der Bischof sich bei der Subdiakonatsweihe unter der Überreichung der Tunika eines Gehetes bediente, pflegte er wohl am häufigsten zu sprechen: „Wit der Tunika der Wonne und dem Gewand der Freude bekleide dich der Herr." Es sind die Worte, welche heute bei dieser Zeremonie gebetet werden. Wir treffen sie schon bei Sicard von Cremona ${ }^{3}$ und in einem dem 12. Jahrhundert entstammenden Pontifikale von Besançon ${ }^{4}$ an. In andern Gebeten erscheint die Tunika als Gewand des Heiles und als Kleid der Gerechtigkeit, doch auch wohl als Tunika der Starkmut ${ }^{5}$.

Das Pluviale findet erst spät seine Deutung, weil es erst spät als liturgisches Gewand in Gebrauch kam. Es reicht aus, anzuführen, was Honorius uns von seiner Symbolik zu sagen weif. Das Gewand versinnbildet, wie dieser uns belehrt, einen heiligen Wandel. Daß es bis auf die Füße geht, legt der Liturgiker auf die Beharrlichkeit aus. In den Fransen am Saume des Gewandes sieht er die Mühen, welche mit dem Dienste Gottes verhunden sind. Daß es vorn offen ist, will bedeuten, dafs den Dienern Christi zum Lohn für ihren heiligen Lebenswandel der Himmel offen steht. In der Kapuze endlich, mit der die Cappa damals noch versehen war, findet Honorius einen Hinweis auf die Himmelsfreude.

Das wäre in der Hauptsache die mystische Bedeutung, welche man im Mittelalter seit den Tagen eines Hraban und Amalar den liturgischen Gewändern beizulegen pflegte. Wir sagen: in der Hauptsache; denn auf alle Einzelheiten einzugehen, war angesichts des zu Gebote stehenden Raumes unmöglich. Indessen reicht ja auch das Gebotene zu einer Charakterisierung der Symbolik, welche die Liturgiker und liturgischen Bücher im Mittelalter mit der heiligen Kleidung verbanden, völlig aus.

Auf die Ausdeutung, welche die liturgischen Gewänder seit dem Ausgang des 13. Jahrhunderts fanden, sind wir mit Absicht nur wenig eingegangen. Sie bietet nichts besonders Neues. Mit dem Ende des 13. Jahrhunderts war die Symbolik der Sakralgewandung, wie früher schon bemerkt wurde, im wesentlichen abgeschlossen. Mehr als man bis dahin darüber ersonnen und gesagt, liek sich in der Tat auch kaum ersinnen und sagen. Durandus hatte alles, was die frühere Zeit an Deutungen hervorgebracht hatte, mit Bienenfleif zusammengestellt. Bei ihm holten von da an alle den Honig mystischer Auslegung der liturgischen Kleidung. Nur sieht man von den vielen Einzelheiten ab, auf welche die Liturgiker der früheren Jahrhunderte einzugehen pflegten, und beschränkt sich auf den einen oder andern hervorstechenden Punkt. Beliebt war namentlich die Deutung auf das Leiden des Heilandes. In kurzen, aber festen Zïgen tritt uns diese Symbolik in einer Folge von Hexametern entgegen, welche wir einem Augsburger Missale

1 Vgl. z. B. einzelne der Weiheordines bei M a r t. 1. 1, c. 8, art. 5; II $31 \mathrm{ff}$. Ferner Vat. lat. 1152115357917114 ; Vat. Ottob. 27; Cod. Vat. Borgh. 99 u. a.
2 Cod. Vat. lat. 1145.

${ }^{3}$ Mitralis 1. 2, c. 2 (M. 213, 63).

4 Mart. 1. 1, c. 8, art. 12 , ordo 10 ; II 62.

5 Vat. lat. 7114. 
vom Jahre 1555 entnehmen. Sie verdienen es, daß wir sie zum Schluf abdrucken. Die Verse sind keineswegs klassisch; Poesie steckt auch nicht gerade in ihnen. Interessant, anmutend und erbaulich sind sie aber ohne Zweifel. Sie lauten übersetzt:
„Willst zum Altare du treten, das heilige Opfer zu feiern,
Oder willst anwohnen du dem übergroßen Geheimnis,
$O$ dann denke daran und frommen Sinnes erwäge,
Welche Kämpfe der Herr um deinetwillen bestanden.
Daßs man sein Haupt verhüllt, ihn höhnend, sagt der Amikt dir,
Ihn mit weifem Gewande zum Spotte bekleidet, die Albe.
Gurt und Manipel bedeuten die grausigen Ketten und Stricke;
An das Kreuz gemahnt, das Jesus getragen, die Stola,
Bild der klaffenden Wunden an Haupt, an Händen und Füßsen
Ist des Amiktes Zier mitsamt den Besätzen der Albe.
Schaust zur Kasel du hin, gedenke des purpurnen Mantels
Und der Ströme von Blut, so deinen Erlöser umflossen.
Eilt zum Altare der Priester, erwäge mit Andacht im Herzen,
Wie den Kalvarienberg aus Liube der Heiland erstiegen
Frei, um dort zu sterben am Kreuz zu deiner Erlösung.
Das beherzige fromm und klopf an die Brust voller Reue." 1

Man hat die Symbolik, welche das Mittelalter der liturgischon Gewandung beigelegt hat, sehr verschieden beurteilt. Begreiflich, der Geschmack ist sehr ungleich. Man vergifit indessen, wenn man über dieselbe den Stab bricht, nur zu oft, daf eine rechte und gerechte Würdigung derselben nur möglich ist, wenn man sich in die tiefgläubigen Anschauungen der Vorzeit hineinversetzt. Wer das nicht tun will oder das nicht zu tun vermag, der wird freilich sehen und doch nicht sehen.

Gewif soll nicht in Abrede gestellt werden, daß nicht weniges an den alten mystischen Deutungen gekünstelt, schwach und wertlos ist; allein es gibt in ihnen auch viele Goldkörner. Die Zeit hat die Schlacken davon entfernt. Was heute an Symbolik der liturgischen Gewandung vorgebracht zu werden pflegt, ist zumeist das geläuterte Gold aus den Schriften der alten Liturgiker.

1 Tu quicumque voles missam celebrare sacerdos :

Et quicumque voles tantis assistere sacris: Sis memor et tota devotus mente revolve, Qualia sit christus pro te certamina passus. Velatum capite et derisum signat amictus. Linea vestis item quod sit despectus in alba: Vincula significant fera tortaque zona manip]us: Est stola imago crucis: quam humeris gestavit jesus.

Cernis amictu atque inde quater tu cernis in alba

Signa terebrati capitis : manuumque pedumque.

Purpuree, spectans casulam, vestis memor esto:

Et rubeo ut fuerit perfusus sanguine christus.
Cumque sacerdotem properantem cernis ad aram :

Tunc animo volvas memori, ut conscenderit ultro

Calvarie montem, moriturus de cruce pro te. Omnia dicta pie memorando pectora tunde.

In etwas verkürzter Fassung finden sich die Verse in des Minoriten Stephan Brulefer ( $\dagger z w i s c h e n 1496$ und 1499) Altissimorum misteriorum misse brevis et utilissima declaratio, aus der sie bei Fran z, Die Messe 603, Anm. 4 abgedruckt sind. Die Stola erscheint hier, wie Cingulum und Manipe], als Sinnbild der Fesseln. Ausgelassen ist die Symbolik der Besätze des Amikts und der Albe. 


\section{DIE LITURGISCHEN FARBEN.}

\section{DIE LITURGISCHEN FARBEN NACH DER GEGENW ÄRTIGEN PRAXIS.}

Unter den liturgischen Farben versteht man die Farben, welche ron der Kirche je nach dem Charakter des Tages oder der gottesdienstlichen Funktion für die beim Kultus zur Verwendung kommenden Paramente vorgeschrieben sind. Sie sind gegenwärtig überall im Abendlande, mit Ausnahme von Mailand, das seinen besondern Farbenkanon hat, die gleichen.

Im ganzen gibt es heute im römischen Ritus fünf liturgische Farben: Weif, Rot, Grün, Violett und Schwarz. Sie sind durch das Missale Pius' V. endgültig festgestellt worden. Gelb und Blau gehören nicht zu dem liturgischen Farbenkanon, wie ihn dieses aufgenommen hat, weshalb denn auch durch wiederholte Entscheidungen der Ritenkongregation gelbe und blaue Paramente als durchaus unzulässig bezeichnet wurden ${ }^{1}$. Dagegen sind Paramente aus Gold- oder Silberstoff mit Rücksicht auf deren Kostbarkeit als erlaubt erklärt worden, und zwar können jene anstatt weißer, roter und grüner, diese anstatt weifer gebraucht werden ${ }^{2}$.

Der Sinn des liturgischen Farbenkanons erheischt übrigens nicht, dafs die Paramente nur eine Farbe aufweisen. Es dürfen vielmehr auch zweiund mehrfarbige Stoffe zu ihnen verwendet werden, wofern nur auf ihnen eine Farbe vorherrscht und diese Farbe zu den fünf liturgischen zählt ${ }^{3}$. Ausgeschlossen sind also erstens Zeuge ohne bestimmt erkennbare Hauptfarbe und zweitens Stoffe, die als Hauptfarbe eine nicht liturgische Farbe aufweisen. In einem gemusterten zwei- oder mehrfarbigen Gewebe gibt in der Regel die Farbe des Grundes den Hauptfarbenton an. Nur wenn das Muster so überwiegt, daf der Grund neben ihm nur mehr wenig zur Geltung kommt, wäre die Farbe der Musterung für die Bestimmung des Farbencharakters entscheidend. Ausdrücklich untersagt ist es, Paramente, die aus zwei- oder mehrfarbigen Zeugen gemacht sind, zugleich für die verschiedenen auf ihnen vorkommenden liturgischen Farben zu gebrauchen" ${ }^{4}$

Die Regeln über die Verwendung der liturgischen Farben sind in der Hauptsache folgende ${ }^{5}$ :

Weif müssen die Paramente sein am Dreifaltigkeitssonntag, an den Festen des Herrn mit Ausnahme derjenigen, welche dessen Leiden als solches zum Gegenstand haben, an allen Festtagen der allerseligsten Jungfrau, der heiligen Engel und Bekenner, der heiligen Jungfrauen und Frauen, welche nicht Märtyrerinnen sind, am Tag der Geburt des hl. Johannes Bapt. und dem Hauptfest des heiligen Evangelisten Johannes, an den Festen der Ketten- und Stuhlfeier Petri, der Bekehrung Pauli und Allerheiligen, bei der Kirch- und Altarweihe, am Jahrestag der Wahl und Krönung des Papstes sowie der Wahl und Weihe des Bischofs. Desgleichen verlangen die weiße Farbe die Oktaven der angeführten Feste und die Werktage zwischen Ostern und Pfingsten, wofern nicht Feste und Gelegenheiten einfallen, die eine besondere

1 Entscheidung vom 16. März 1838 , 23. Febr. 1839, 26. März 1859, 5. Dez. 1868, 23. Juni 1892 (Decret. auth. n. 27042788 308231913779 ).

2 Entscheidung vom 28. April 1866, 5. Dez. 1868, 20. Nov. 1885 (ebd. n. 314531913646 ).
${ }^{3}$ Entscheidung vom 23. Sept. 1837 (ebd. n. 2769).

4 Entscheidung vom 19. Dez. 1829, 12. Nov. 1831, 23. Sept. 1837 (ebd. n. 26752682 2769).

${ }_{5}$ Missale rom., Rubr. gen. tit. XVIII. 
Farbe erheischen, die Votivmessen von Geheimnissen und Heiligen, deren Festen Weif zukommt, und die Brautmesse.

Ferner sollen weif sein die Paramente, welche bei sakramentalen Prozessionen nnd bei Andachten vor ausgesetztem hochwürdigstem Gut zur Verwendung kommen, dann alle, welche in näherer Beziehung zum heiligsten Sakrament stehen, wie der Baldachin, die Bekleidung des Tabernakelinnern, das Ciboriummäntelchen, enàlich die Paramente, welche beim Begräbnis eines Kindes, das vor erlangtem Vernunftgebrauch starb, getragen werden, sowie die Stola, welche der Priester bei Ausspendung der heiligen Taufe, bei Erteilung der heiligen Wegzehrung und bei Einsegnung der Ehe gebraucht. Bis zur Abnahme des Glaubensbekenntnisses bedient sich der Priester bei den Taufzeremonien mit Rücksicht auf die Exorzismen, die er vornimmt, einer violetten Stola. Spendet der Priester in der Kirche aufer der Messe die heilige Kommunion, so kann sich die Farbe der Stola auch nach der Tagesfarbe richten ".

Rote Paramente sind vorgeschrieben am Samstag vor Pfingsten, am Pfingstfest und während dessen Oktav, an den Festen des Herrn, an welchen die Erinnerung an sein Leiden begangen wird, wie den Festen der heiligen Leidenswerkzeuge, des kostharen Blutes, der Auffindung und Erhöhung des heiligen Kreuzes, an allen Apostelfesten mit Ausnahme der wenigen schon genannten Tage, an welchen man sich weiker Paramente zu bedienen hat, an den Festen der heiligen Murtyrer, gleichviel welchen Alters und Geschlechtes sie sind, sowie bei der Messe um eine glïckliche Papstwahl. Auch den Votivmessen der genannten Feste und ihren Oktaven eignet die rote Farhe. Am Feste der unschuldigen Kinder bedient man sich roter Paramente, wenn es auf einen Sonntag, violetter, wenn es auf einen Wochentag fällt; sein Oktavtag verlangt jedoch stets Rot.

Die grüne Farbe haben die Sonn- und Werktage zwischen Epiphanie und Septuagesima sowie zwischen Trinitatissonntag und Advent, an denen kein Fest einfällt. Eine Ausnahme bilden jedoch die in dieser Zeit eintreffenden Quatembertage und Vigilien, welche Fasttage sind und tenen stets Violett zukommt. Desgleichen machen die Sonntage, welche innerhalb einer Oktav liegen, eine Ausnahme, da sie sich hinsichtlich der Farbe der Paramente nach der Farbe eben dieser Oktav zu richten haben.

Violett erfordern der Advent, die Zeit zwisehen Septuagesima und Gründonnerstag, die Vigiltage, welche zugleich Fasttage sind, und die Quatembertage, ausgenommen die Vigil vor Pfingsten und die Quatembertage der Pfingstwoche. Ferner müssen violette Paramente gebraucht werden bei der Messe der Bittage, der Votivmesse vom Leiden des Herrn und gewissen Votivmessen von ausgesprochenem Bußoder Bittcharakter, bei Bittprozessionen, bei der Kerzensegnung am Lichtmeftag und bei der Taufwasserweihe. Ebenso muf die Stola. deren sich der Priester bei Spendung des Bufssakraments und der heiligen Ölung bedient, violett sein.

Schwarz ist die Farbe für die Totenmesse, für die Präsanktifikatenmesse am Karfreitag und für den Begräbnisritus sowie die Exequien aller, welche nach erlangtem Vernunftgebrauch gestorben sind.

\section{DAS ERSTE AUFTRETEN DES LITURGISCHEN FARBENKANONS.}

Ein vollständiger Farbenkanon begegnet uns zum ersten Male in der Schrift Innozenz' III. über das heilige Meksopfer, also gegen 1200. Er ist dem jetzt mafigebenden schon im wesentlichen gleich. Für die Feste KreuzErfindung und Kreuz-Erhöhung gibt der Papst neben Weif auch Rot an, empfiehlt aber ersteres als entsprechender. Für die Fasten- und Adventszeit verzeichnet er Schwarz, für Lätaresonntag Schwarz oder besser Violett. Am Fest der unschuldigen Kinder wurde zu Rom Violett gebraucht, während

1 Entscheidung vom 12. März 1836 (ebd. n. 2740). 
man anderswo schwarze oder rote Gewänder für passender hielt. Dem Rot endlich gesellt Innozenz Scharlach, dem Grün Gelb (croceus color), dem Schwarz Violett als Nebenfarben zu, fügt dabei aber zugleich an, dak einige den Crocus, d. i. Gelb, auf die Bekenner bezögen, wie die Rosen (Rot) auf die Mârtyrer und die Lilien (Weif) auf die Jungfrauen.

Eine eigentlich verpflichtende Kraft legt Innozenz III. dem Farbenkanon nicht bei. Er erörtert nur, wie es die römische Kirche, die hier im engeren Sinne zu nehmen ist und auch wohl curia romana genannt wird, hinsichtlich ler Farbe der liturgischen Gewänder halte. Abweichende Anschauungen und Gewohmheiten betrachtet er als statthaft, wie die Weise zeigt, in welcher sie von ihm besprochen werden. Gleichzeitig mit Innozenz III. erwähnt auch Sicard von Cremona das Bestehen eines liturgischen Farbenkanons, ohne jedoch denselben in seinen Einzelheiten mitzuteilen ${ }^{1}$. Er belehrt uns nur, es wechsle die Farbe der Kasel je nach der Zeit. So werde Ostern ein weißes, Pfingsten ein rotes Mefsgewand gebraucht.

Bei den übrigen Liturgikern des 12. Jahrhunderts, angefangen von Bruno von Segni, Honorius, Rupert von Deutz und Ivo von Chartres bis auf Johannes Beleth, herrscht bezüglich einer liturgischen Farbenregel ein Schweigen, das unter Annahme eines bereits bestehenden Farbenkanons ganz unerklärlich ist.

Ivo von Chartres redet ausführlich von den Farben der Sakralgewandung des mosaischen Kultus, dagegen tut er in seiner Deutung der heiligen Kleilung des Neuen Bundes irgendwelcher liturgischer Farben nicht die geringste Erwähnung. An einzelnen Stellen ist sein Verhalten besonders auffallig, so z. B., wenn er gelegentlich der Besprechung des jüdischen Ephod bemerkt: Quod autem nostrorum pontificum superhumerale (gemeint ist der Amikt) non est tot coloribus intextum, nec est tam pretiosis gemmis redimitum, nihil refert, cum christiana religio veritati serviens compendiosis figuris idem intellegi faciat, quod vetus observantia sumptuosis ${ }^{2}$.

Sehr bezeichnend für die Lage der Dinge ist, was Bruno von Segni hinsichtlich der Farbe der bischöflichen Tunika bemerkt: „Wenn sie weif ist, sinnbildet sie, daf alle, welche der Kirche die Speise des Gotteswortes reichen, rein und makellos sein müssen; hat sie eine andere Farbe, mag man sie anders deuten. ${ }^{3}$

Rupert hebt hervor, es habe bei den alttestamentlichen Kultkleidern alles, auch die Farbe, einen mystischen Sinn gehabt " nichtsdestoweniger läßjt er bei den Erörterungen über die liturgische Gewandung der Kirche deren Farbe ganz und gar unberührt.

Honorius schildert in der Gemma animae den Garten Gottes und vergleicht dabei die Märtyrer mit Rosen, die Jungfrauen mit Lilien, diejenigen, welche die Welt verachten, mit Veilchen, die Weisen mit grünen Kräutern s. Wer jedoch auf Grund hiervon erwartet, es werde Honorius, wenn er gleich darauf die heilige Kleidung der Bischöfe, Priester und übrigen Kleriker behandelt, auch der Farbe derselben ein Wort widmen, wird sich völlig enttäuscht sehen.

1 Mitralis 1. 2, c. 5 (M. 218, 77).

2 Sermo 3 (M. 162, 523); vgl. über die Farbe des Cingulum ebd. 521.

${ }^{3}$ De sacr. eccl. (M. 165, 1105).

4 De div. offic. 1.1 , c. 18 (M. 170, 22). Nach der Übersetzung, welche Rohault de Fleury (La Messe VIII 37) von dieser Stelle gibt, sollte man glauben, Rupert rede in ihr von liturgischen Farben der Kirche. Pohault hat indesisen Puperts Worte gänzlich mifuverstanden.
5. L. 1, c. 162 (M. 172, 594). Rohault de Fleury (a. a. O.) läfst Honorius in der Gemma animae sagen, die Farbe für die Märtyrer sei Rot, für die Jungfrauen Weik. In vielen Riten seien Grün und Gelb die Farbe für Bischöfe und Doctores, Violett die der Mönche und heiligen Frauen. Er ist jedoch auch in diesem Falle im Irrtum, da sich bei Honorius weder in der Stelle des Textes noch sonst das Geringste über eine liturgische Farbenregel findet. 
Das Sakramentarium erzählt uns ${ }^{1}$, der Panther habe sieben Farben: Schwarz, Weik, Grau, Gelb, Grün, Blau, Rot. Dann deutet es dieselben, doch nicht auf die Farbe der priesterlichen Kleider, sondern auf deren Zahl und die sieben Tugenden, die dem Priester eigen sein müfaten.

Das Speculum de mysteriis ecclesiae weif uns nur zu berichten: Coccinea planeta, qua induitur apostolicus, quocumque proficiscatur praedicando, martyrium declarat?

Robert Paululus beschränkt sich auf die Bemerkung, man trage von Karsamstag an bis zum Samstag nach Ostern weife Gewänder ${ }^{3}$. Johannes Beleth berichtet uns, vor der Matutin von Weihnachten und Ostern würten wohl drei Tücher auf den Altar gelegt, ein schwarzes, weißliches und rotes als Simnbilder der Zeit vor dem Gesetze, der Zeit unter dem Gesetze und der Zeit der Gnade, und dann nach jeder Nokturn bzw. nach den einzelnen Lektionen des Osteroffiziums eines weggenommen ${ }^{4}$. Das ist aber auch alles, was wir von ihm vernehmen.

Es kann hiernach nicht bezweifelt werden, dab der liturgische Farbenkanon erst in der zweiten Hälfte des 12. Jahrhunderts entstanden ist. Das allgemeine Schweigen der Liturgiker unter Unständen, unter denen man eine Erörterung iber eine etwa bestehende Regel hinsichtlich der Farbe der Meßggewandung notwendig erwarten müßste, kann um so weniger anders gedeutet werden, als uns auch sonst nichts von einem ausgebildeten Farbenkanon berichtet wird.

Es ist auffällig, am Ende des 12. Jahrhunderts scheinbar so ganz wie auf einmal eine fertige liturgische Farbenreihe vor sich zu sehen. In Wirklichkeit tritt der Kanon Innozenz' III. jedoch nicht so ganz unvermittelt auf, als man beim ersten Anblick glauben sollte. Schon in sehr früher Zeit zeigen sich im Abendland die ersten Keime zu einer liturgischen Farbenregel. So heist es bereits in der Erklärung der gallikanischen Messe: „Ostern zieht man weiß̧e Gewänder an, da die Engel am Grab in weib̌en Gewändern erschienen. Weiße Kleider bedeuten nämlich Freude." Es war demnach im gallikanischen Ritus Brauch, am Osterfeste beim Gottesdienste sich weilifarbiger Kleider zu bedienen. Wirklich werden, wie wir schon gelegentlich vernalımen, bei Gregor von Tours casulae candidae, quae per paschalia festa humeris sacerdotum imponuntur, erwähnt5. Ob auch die Erzählung der Biographie des hl. Cäsarius von Arles $(† 542)$ hierher bezogen werden könne, es habe der Heilige einem Armen eines Tages, da er sonst nichts besessen, casulam quam processoriam habebat albamque paschalem ${ }^{6}$ gegeben, mit der Weisung, sie an jemand aus dem Klerus zu verkaufen, muj auf sich beruhen bleiben; denn es ist unklar, ob in ihr unter alba eine Tunika oder mit Ergänzung von casula eine weife Osterkasel zu verstehen ist.

Wie es damals auferhalb Galliens zu Ostern in Bezug auf die Farbe des Mebgewandes gehalten wurde und ob auch hier dann mit Vorzug weife Kleidung getragen wurde, läbt sich nicht feststellen. Wenn nach einer Notiz der Vita des hl. Columba die Mönche des Klosters Hy an Festtagen beim Gottesdienst weiße Kleider trugen ', so ist nicht die liturgische Gewandung, sondern die Mönchstracht gemeint.

I C. 29 (X. 172, 762).

2 C. 45 (M. 177, 354).

${ }^{3}$ De off. eccl. 1. 3, c. 27 (ebd. 453).

4 Rationale c. 69115 (M. 202, 75 120).

Die Sitte, drei Tücher von verschiedener Farbe vor der Matutin von Weihnachten und Ostern auf den Altar zu legen und dann bei derselben nach einander wegzuholen, kennen schon die Consuetudines von Farfa (A 1 b e rs, Consuet. Farfens, 16) und Cluny (Udalrici Consuet. Cluniac. 1. 1, c. 11 [M. 149, 656]). 5 Vita Patrum c. 8, n. 5 (M. 71, 1045).

${ }^{6}$ L. 1, n. 32 (M. 67, 1017); vgl. oben S. 67 , Anm. 2.

${ }^{7}$ Adamani Vita S. Columbae 1. 3, in. 15 (M. 88, 765). 
Die ältesten Zeugnisse über irgend einen Farbenunterschied hinsichtlich der liturgischen Gewänder im römischen Ritus stammen erst aus karolingischer Zeit. Sie finden sich in dem von Duchesne veröffentlichten Ordo aus der Frühe des 9. Jahrhunderts, in der pseudoalkuinischen Schrift „De divinis officiis" und in dem St Gallener Kleiderverzeichnis.

Der Duchesnesche Ordo vermerkt für die Feier am Lichtmefitag: Interim ingreditur pontifex in sacrario (sic) et induit se vestimentis nigris et diaconi similiter planetas nigras induunt. Für den Karfreitag lautet die Vorschrift: Hora $V$ procedit ad ecclesiam omnis clerus et ingreditur archidiaconus cum aliis diaconibus in sacrario (sic) et induunt se planetas fuscas: für die Bittage: et ingreditur pontifex in sacrario (sic) seu et diaconi et induunt se planetas fuscas ${ }^{1}$. Mit diesen Angaben stimmt überein, was Pseudo-Alkuin bezüglich der gottesdienstlichen Kleidung bei der Lichtmefsprozession und den Karfreitagszeremonien sagt. Denn auch er verzeichnet für erstere vestes nigrae, für letztere planetae fuscae ${ }^{2}$. Man trug also in Rom im 9. Jahrhundert bei Gelegenheiten, welche den Charakter der Trauer oder Buße hatten, schwarze oder dunkle Sakralkleider, ganz nach altrömischer Anschauung, wonach weiße Gewänder Zeichen der Freude, dunkle aber Ausdruck der Trauer waren.

Das St Gallener Kleiderverzeichnis schreibt, wo es von der Sakralkleidung des Papstes handelt: In his diebus, natl. Dom., pascha, sci petri et die ordinationis suae (pontifex Romanus) aliud colere (colore) planeta induitur. Leider gibt der Verfasser nicht an, was das für eine andere Farbe gewesen, welche die liturgische Gewandung des Papstes am Weihnachtstage, Ostern, am Feste des Apostelfürsten und am Tag (Jahrestag) seiner Weihe zu haben pflegte. Am ehesten möchte man, weil auch Ostern unter den Tagen genannt ist, an Weiß denken. Jedenfalls bekundet die Notiz des Ordo, daf man zu Rom schon eine geraume Weile vor dem Entstehen des liturgischen Farbenkanons in irgend einer Weise einige Feste von andern durch die Farbe der liturgischen Gewandung unterschied.

Wann zu Rom der Brauch sich festsetzte, bei den Prozessionen am Lichtmeftage und an den Bittagen sowie bei den gottesdienstlichen Funktionen am Karfreitage dunkle bzw. schwarze Gewänder zu tragen, läßst sich nicht sagen. Da er indessen durchaus dem Charakter dieser Zeremonien entspricht und die denselben eigene Stimmung in ihm einen natürlichen Ausdruck findet, mag er so alt sein wie diese Kultakte. Wenigstens darf das hinsichtlich jener Prozessionen angenommen werden.

Im Beginn des 12. Jahrhunderts trug der Papst nach dem 11. Ordo Mabillons am Ostertag und in der Osterwoche beim Gottesdienst eine weife Planeta $^{3}$. Der 10. römische Ordo verzeichnet auch für den Gründonnerstag weife Gewänder. Für den Karfreitag schreibt derselbe Ordo den ornatus quadragesimalis, also gemäßs dem alten römischen Brauch schwarze oder doch dunkle Kleidung vor ${ }^{5}$. Als Kardinal Cencius Sabellius zwischen 1192 und 1198 seinen Ordo, den 12. Mabillons, verfaßte, gab es zu Rom schon einen Farbenkanon ${ }^{6}$.

1 Duch., Orig. 468474479.

2 De div, offic. c. 718 (M. 101, 1181 1208).

${ }^{3}$ N. 45 (M. 78, 1043).

1 N. 3 (ebd, 1010).

5 N. 13 (ebd, 1013).
${ }^{6}$ Nach dem 12. Ordo bediente sich der Papst am Stephanstage bei seinem Zuge nach S. Stefano einer weifen, bei der Messe aber einer roten Kasel. Für Lichtmek und Ostern notiert der Ordo ein weifes Mefgewand (c. 3515 [ebd. 106710691078 ). 
Die ersten Keime zu einer liturgischen Farbenregel reichen also in der Tat weit über das 12. Jahrhundert zurück. Sie blieben freilich bis dahin auch nur Keime. Es war dem späten 12. Jahrhundert vorbehalten, sie zu einem vollständigen Farbenkanon auszugestalten. Eine Regelung der Farbe der Kultgewänder lag in jener Zeit starker mystischer Tendenzen und ausgesprochener Neigung zum Symbolisieren gleichsam in der Luft. Neue liturgische Gewänder konnte man dem Mystizismus zulieb nicht schaffen, da an solchen sich kaum mehr Neues ersinnen lief. Anders verhielt es sich mit der Farbe der Kultkleidung. Hier war erst der Anfang gemacht; hier hatte also der Mystizismus Gelegenheit, sich schöpferisch zu betätigen.

Freilich waren auch die äuferen Umstände für die Bildung einer liturgischen Farbenregel weit günstiger als zu irgend einer früheren Zeit. Nicht blok die Theologie und Philosophie mit ihren scharfsinnigen Spekulationen, nicht blow das religiöse Leben mit seinem tiefen Mystizismus, auch die Kunst hatte sich auf allen Gebieten ihres Schaffens rasch in ungeahntem Mase entfaltet und mit ihr zugleich der Sinn für das Schöne und die Liebe zum Schönen. Dazu kam, daf nicht blof der hochgesteigerte Verkehr mit dem Orient größere Mengen farbiger Seidenzeuge als je dem Abendlande zuführte, sondern daß sich mittlerweile auch in diesem eine blühende Seidenindustrie entwickelt hatte, deren Erzeugnisse rasch in lebhafte Konkurrenz mit den byzantinischen und sarazenischen Geweben getreten waren. Die Folge hiervon war, daf an dem wichtigsten Faktor für die Ausbildung eines liturgischen Farbenkanons, an farbigen Stoffen, kein Mangel mehr herrschte.

Wir haben uns darum auch den Hergang nicht so zu denken, als ob sich zuerst zu Rom ein Farbenkanon gebildet habe und dieser damn auferhalb Roms adoptiert worden sei oder umgekehrt. Hier wie dort hat er sich infolge der gleichen geistigen Strömung des 12. Jahrhunderts und durch die Gunst der gleichen Verhältnisse in selbständiger Weise entwickelt. Dafs es aber dabei im wesentlichen zum gleichen Resultat kommen mußte, leuchtet sofort ein, wenn man bedenkt, daf die die Farbenregel bestimmenden Anschauungen bis zu einem gewissen Grade nicht wilkürlich waren, sondern ihren Grund in der Natur der Sache hatten.

Wirklich finden sich schon in der Frühe des 12. Jahrhunderts auch auferhalb Roms Ansätze zur Fixierung der liturgischen Farbe. So will das um 1130 durch Beroldus für die Kathedrale von Mailand zusammengestellte Ordinarium, daf in der Fastenzeit über Altar und Kanzel ein schwarzes, in der Passionszeit aber ein rotes Tuch ausgebreitet werde. Ferner lesen wir darin, daß die Kasel, welche der Bischof am Karfreitag bei der Lesung der Passion trug, von roter Farbe sein muste, und daf der Diakon am Gründonnerstag in alba rubea, d. i. in roter Tunika, die Lektion, die Epistel und das Evangelium zu singen hatte ${ }^{1}$. Ein Pontifikale von Besançon aus dem Beginn des 12. Jahrhunderts schreibt für den Karfreitag purpurne Kaseln vor ${ }^{2}$, während ein Ordinarium von Laon aus dem dritten Viertel desselben den Bischof in einer casula crocei coloris die Karfreitagszeremonien vornehmen läfst ${ }^{3}$.

1 M ur., Ant. IV 883889891901.

2 M a t. 1. 4, c. 23; III 135.

3 Chevalier, Ordinaires de l'église cathédrale de Laon 113. Das Ordinarium ist das Werk des Dekans Lisiardus (1153-1168), doch wurde es später interpoliert, da S. 53 das
Fest des 1170 ermordeten Thomas Becket erwähnt wird. Eine eigentümliche irische $A b$ handlung über die Farbe der Kasel bei Moran, Essay on the origin, doctrines and discipline of the early irish church, Dublin 1864; französisch bei Roh. VIII 29. Der 
Natürlich sind das nur vereinzelte Daten. Sie beweisen indessen, daf auch aufserhalb Roms die Neigung auf die Ausbildung einer liturgischen Farbenregel himausging. Das erklärt denn auch die Abweichungen, die schon zu Innozenz' III. Zeit hinsichtlich der Farbe einzelner Tage und Zeiten des Iirchenjahres bestanden und bald sich noch weit greller bemerkbar machten.

Man hat Innozenz III. selbst für den Urheber der Farbenordung angesehen, die er in seiner Schrift über das Meßopfer mitteilt. Allein ohne Grund. Man braucht nur mit ein wenig Aufmerksamkeit die Ausführungen des Papstes anzusehen, um zu erkennen, daf er beschreiben will, nicht was el selbst geschaffen, sondern nur was seinerzeit Brauch der römischen Kirche war. Es mur schon vor Innozenz III. die Farbe der gottesdienstlichen Gewänder, sei es durch den Usus oder durch irgend eine besondere Verordnung, eine Regelung erfahren haben. Das deutet auch zur Genüge der Umstand an, daßs bereits der unter Cölestin III. entstandene 12. Ordo den Papst am Stephanstage bei der Messe eine rote Kasel tragen läfst.

Dagegen ist unzweifelhaft Innozenz' III. Schrift für die anderwärtige Aufnahme des römischen Farbenkanons von größtem Einfluf gewesen. Einen nicht geringen Anteil an seiner Verbreitung hat um das Ende des 13. Jahrhunderts freilich auch Durandus durch sein weitverbreitetes Rationale und sein Pontifikale gehabt ${ }^{1}$.

Die Farbenregel, wie sie zu Rom in der zweiten Hälfte des 13. Jahrhunderts bestand, gibt aufer Durandus teilweise auch das auf Befehl Gregors X. herausgegebene Caeremoniale romanum ${ }^{2}$, diejenige des frühen 14 . Jahrhunderts der Ordo des Jacobus Gajetanus ${ }^{3}$. Zu Durandus Zeit war zu Rom noch als Nebenfarbe von Grün Gelb gebräuchlich. In dem Farbenkanon des 14. Ordo wird Gelb dagegen nicht mehr erwähnt. Allerdings werden noch in dem Inventar von St Peter aus dem Jahre 1361 im Einklang mit der Angabe des Durandus eine Anzahl gelber Paramente aufgeführt 4. Doch mögen auch zu Rom Theorie und Praxis sich nicht stets völlig gedeckt haben. Violett ist in der Farbenregel des 14. Ordo noch immer, wie auch bei Durandus, gleichwertig mit Schwarz; denn sie bezeichnet es als "nicht unpassend", daf man an den Tagen, denen Schwarz zukomme, violette Gewänder gebrauche. Es galten selbst noch im Beginn des 15. Jahrhunderts, wie eine Notiz des 15. Ordo beweist, Schwarz, Violett und Indigo als gleichwertig ${ }^{5}$.

In der Farbenregel, die Pius V. dem römischen Missale einfügen lieb, fehlt nicht nur Gelb, es sind auch Violett und Schwarz in ihr völlig geschieden.

Der älteste unter den bisher bekannt gewordenen auferrömischen Farhenkanones aus dem Mittelalter findet sich, wenn wir von den kurzen Andeutungen Sicards von Cremona absehen, in den Statuten Hugo Pateshulls, Bischofs von Lichfield in England (1239-1241). Er ist von besonderem Interesse; denn er trägt noch deutlich den Charakter des Entwicklungs-

Verfasser will, dak auf jeder Kasel sich finde Gelb, Blau, Weik, Grůn, Braun, Rot, Schwarz, Purpur, und führt das auf. Anordnung Moses' zurück. Für die Geschichte der liturgischen Farben hat die Schrift keine Bedeutung; immerhin verdient sie, wenigstens erwähnt zu werden.
1 L. 3, c. 18. M art. 1. 1, c. 4, art. 12, ordo 23 ; I 225.

2 N. $18 \mathrm{ff}$ (M. 78, $1116 \mathrm{f}$ ).

* C. $49 \mathrm{ff}$ (ebd, 1154f).

- II üntz e Frotlinglam. Il Tesoro di S. Pietro 39.

${ }^{5}$ C. 24 (M. 78, 1288). 
stadiums an sich und kennt erst drei festbestimmte Farben: Weik, Rot und Schwarz. Für das Weilnachtsfest merkt er an "pretiosiora indumenta". Für die Paramente beim Officium de tempore von Epiphanie bis Septuagesima und von Trinitatissonntag bis Advent, an den Festen der Geburt des hl. Johannes d. T., der Stuhlfeier Petri, der hl. Maria Magdalena, Allerheiligen und eines Bekenners gibt er noch keine Farbe an, sondern begnügt sich mit der umbestimmt gehaltenen Anweisung „varii coloris". Der Sakristan soll an diesen Tagen die Farbe der Gewänder nach seinem Gutdünken festsetzen ${ }^{1}$.

Daf in der Tat die liturgische Farbenregel in England um die Mitte des 13. Jahrhunderts erst im Beginn ibrer Aushildung stand, beweist Kap. 1 der 1240 abgehaltenen Synode von Worcester. Denn wenn dieses bestimmt, es sollten in jeder Kirche zwei Kaseln vorhanden sein, und zwar ohne irgend eine Bemerkung über deren Farbe zu machen², so setzt das offenbar voraus, dafs es damals in der Diözese Worcester noch keinen vollständigen Farbenkanon gab. Selbst die Farbenordnung des "Liber consuetudinarius" des Abtes Richard de Ware von Westminster (1258-1283) ist noch nicht in allen ihren Teilen fixiert ${ }^{3}$. So lautet z. B. die Anweisung für Pfingsten: In die vero et infra octavas Pentecostes erunt indumenta praedicta (Kasel, Dalmatik und Tunicella) diebus quibus brudata (mit Stickereien versehen) non sunt, scintillata aut rubea vel etiam crocei aut glauci coloris. Am Pfingstfest und in seiner Oktav konnte man also nach Belieben bestickte, funkenfarbige, rote, gelbe oder blaue Gewänder gebrauchen. Für das Fest des hl. Johannes vor dem latinischen Tore verzeichnet der "Liber consuetudinarius": capae cantorum ad vesperas albi coloris erunt et capae sacerdotum crocei sive glauci coloris. Für die Bekenner mangeln Angaben. Die englischen Farbenkanones aus dem 14. Jahrhundert erscheinen völlig ausgebildet.

Die Entwicklung der liturgischen Farben in England kamn als Beispiel der Ausgestaltung der kirchlichen Farbenordnung überhaupt gelten. Denn wie dort, wird es sich ähnlich auch anderswo verhalten haben. Hiernach haben wir uns die Entstehungsweise des liturgischen Farbenkanons wohl in folgender Weise zu denken. Anfänglich wurden nur die Feste von scharf ausgeprägtem Charakter durch eine ihrer Stimmung und ihrer Bedentung entsprechende besondere Farbe ausgezeichnet, und zwar kamen hierbei zunächst nur WVeili, Rot und Schwarz (Dunkel) zur Verwendung. Für die übrigen Tage blieb die Gewandfarbe noch unbestimmt. Dann aber hielt man es für passender, auch für diese eine Farbe zu fixieren. Man wählte dazu die Farben, die man als Mittelfarbe zwischen Weilß, Rot und Schwarz ansah, Grün oder Gelb, seltener Blau. Gleichzeitig wurde Violett wegen seines trüben Aussehens dem Schwarz als Nebenfarbe zugesellt, mit dem Unterschied, daf man es vornehmlich an jenen Bulatagen brauchte, an welchen die Bufstimmung in gemilderter Form zum Ausdruck kam. So war der Farbenkanon in seinen Grundzügen fertig.

Unter den Farbenregeln aus dem 16. Jahrhundert ist eine der bemerkenswertesten und eigenartigsten diejenige der Stiftskirche von Ellwangen, über welche der "Liber caeremoniarum ecclesiae Elvangensis. Anno Domini 1574,

I D ugdale, Monasticon angl. (nov. ed.) VI 3,1259 .

2 Hard. VII 331.

${ }^{3}$ Diese sowie noch verschiedene andere englische Farbenregeln aus dem Mittelalter bei Wi ck h m Legg, History of the eccl. colours, London 1882, und bei Chambers app. I und suppl. 
I. die mensis Marcii" 1 Aufschluf gibt. Es sind darin sieben Kirchenfarben verzeichnet: Weif, Rot, Grün, Gelb, Violett, Schwarz und Aschgrau.

Der aschgrauen Farbe bediente man sich beim Offizium am Aschermittwoch, der schwarzen im Advent, in der Zeit zwischen Septuagesima und Passionssonntag, an allen Vigilien, welche Fasttage waren, mit Ausnahme von Karsamstag und den Tigilien ror Pfingsten und Mariä Himmelfahrt, bei den Prophetien am Karsamstag und an der Pfingstvigil, bei den Prozessionen am Montag, Mittwoch und Freitag der Fastenzeit sowie endlich beim Gottesdienst für die Verstorbenen. Violette Gewänder trug man bei der ersten Vesper von Weihnachten, dem dritten Hochamt am Weihnachtstag, an den in die Oktav des Christlestes einfallenden Sonn- und Ferialtagen und endlich in der Zeit zwischen der Oktav von Epiphanie und Septuagesima.

Gelb war die Farbe für Lätare, das Fest der Beschneidung, Epiphanie, das Fest der heiligsten Dreifaltigkeit und den Sonntag innerhalb der Fronleichnamsoktav.

Grüne Paramente gebrauchte man bei der Weihe der Osterkerze, an den Festen der Bekenner, das Geburtsfest des hl. Johannes des Täufers miteingeschlossen, und an den Festtagen heiliger Witwen und Frauen, die nicht Jungfrauen und Märtyrinnen waren. Doch war für das Fest der hl. Anna und das der hl. Elisabeth von Thüringen Violett vorgeschrieben.

In Rot kleidete man sich bei der zweiten Messe am Weihnachtstag, am Feste des hl. Stephanus und der unschuldigen Kinder, an den Festen der heiligen Apostel und Märtyrer, in der Passionszeit, den Gründonnerstag nicht ausgenommen, an Pfingsten und ungewöhnlicherweise auch am Feste Nariä Heimsuchung. Für den Karfreitag sind casulae speciales angemerkt. Die beiden Kanoniker, welche an diesem Tage bei der Prozession zum heiligen Grab den mit einer roten Kasel bekleideten Leichnam Christi trugen, waren mit roter Stola versehen.

Die weife Farbe galt für die ganze Osterzeit, selbst den Markustag und die Bittprozessionen eingerechnet, das Fest Christi Himmelfahrt und Fronleichnam, die Feste Mariä und die Tage heiliger Jungfrauen. Aufierdem bediente man sich ihrer bei der ersten Messe des Christfestes und bei der Taufwasserweihe sowie der Messe am Karsamstag und an der Pfingstvigil.

Für die Sonntage nach Pfingsten fehlt eine Angabe über die Farbe. Wenn am Mittwoch und Freitag das officium dominicale der betreffenden Woche wiederholt wurde, so hatte man dabei schwarze Paramente zu gebrauchen.

Liturgische Farbenkanones aus dem Mittelalter sind selten, zumal solche aus dem 13. und 14. Jahrhundert. Verhältnismä6ig die meisten mittelalterlichen Farbenreihen sind aus englischen Kirchen bekannt geworden. Noch in der ersten Hälfte des 16. Jahrhunderts findet sich eine Anweisung über die Farbe der Paramente nur selten in den Missalien. Häufiger wird in diesen eine solche erst in dessen zweiter Hälfte, namentlich seitdem 1570 das offizielle römische Missale erschienen war. Im 17. Jahrhundert begegnet uns ein Farbenkanon fast regelmäßig in den Meß̧büchern, und zwar auch da, wo das römische Missale nicht rezipiert worden war.

Wo eine vom römischen Gebrauch bezüglich der liturgischen Farben abweichende Gewohnheit bestand, wurde sie noch nach Erscheinen des offiziellen römischen Meßsbuches anfänglich vielfach beibehalten, auch wenn man im übrigen den römischen Ritus adoptierte. Allmählich aber paliten sich selbst solche Missalien, die nach der Bestimmung Pius' V. unverändert hätten forthestehen können, wie hinsichtlich des sonstigen Ritus, so auch bezüglich der Farben dem römischen Missale an. In Mailand blieb zugleich mit dem ambrosianischen Ritus auch dessen besondere Farbenregel bis auf die Gegenwart in Kraft. Aber auch in Frankreich bestanden bis ins 19. Jahrhundert hinein in einer Reihe von Diözesen eigene und eigentümliche Farbenkanones.

\footnotetext{
1 Kirchenschmack XXV $29 \mathrm{ff}$.
} 


\section{MANNIGFALTIGKEIT DER LITURGISCHEN FARBENREGELN IN DER VERGANGENHEIT.}

Vergleicht man die Vorschriften über die Farbe der Sakralgewandung, wie sie uns seit dem 13. Jahrhundert zu den verschiedenen Zeiten und an den verschiedenen Orten begegnen, so sieht man sich einem äuberst wechselvollen Bilde gegenüber. Woher das?

Das liturgische Recht der Bischöfe hatte bis zum Tridentinum einen ungleich weiteren Umfang als jetzt. Rom lief, ja muste ihnen infolge der Umstände in vielen Stücken freie Hand lassen. Es konnte damals unmöglich eine so umfassende heilsame Kontrole in Sachen der Liturgie wie hentzutage ausüben. Daher die vielen Eigentümlichkeiten in den gottesdienstlichen Gebräuchen nicht nur der einzelnen Länder, sondern auch der einzelnen Diözesen, ja einzelner Kirchen, von denen wir jetzt kaum mehr eine Ahnung haben, und die uns bisweilen höchlichst befremden, wenn wir ihnen in einem alten Ordinarium begegnen. Daher aber auch die Verschiedenheiten bezüglich des kirchlichen Farbenkanons. Ja, weil Prom hinsichtlich der Farbe der Paramente am wenigsten gebietend auftrat, und weil auferdem zuletzt fast jeder Farbe verschiedene mystische Bedeutungen unterlegt werden können, multe sich in Bezug auf die liturgischen Farbenregeln erst recht eine üppige Mannigfaltigkeit entwickeln.

Überhaupt beruhte die liturgische Farbenordnung das ganze späte Mittelalter hindurch vielfach mehr auf einem allem Wechsel unterworfenen und von subjektivem Ermessen in hohem Mafe abhängigen Usus als auf bindenden Vorschriften. Auch nachdem schon längst Farbenregeln bestanden, war für die Benutzung der Paramente noch vielfach nicht deren Farbe, sondern ihre Qualität maßggebend. Sehr belehrend sind in dieser Beziehung die Inventare der Kapellen der Kathedrale von York von 1360. Die Zahl der Kaseln geht in den einzelnen Verzeichnissen kaum je über drei hinaus; Norm für ihren Gebrauch aber ist lediglich der Ritus des Offizium. So heibt es im Inventar der Kapelle des hl. Eduard: unum vestimentum pro festis duplicibus, unum vestimentum pro IX. lectionibus, tertium feriale und in den der Kapelle B.M.V. et s. Ioannis: unum vestimentum bonum et sufficiens pro diebus duplicibus et festis, unum vestimentum pro diebus ferialibus. Ähnlich wird im Schatzverzeichnis der Kathedrale von Cambrai von 1359 bezüglich der Verwendung der Paramente zwischen festa IX et III lectionum unterschieden. Sogar im 16. Jahrhundert war jenes Prinzip noch vielfach bestimmend, wie z. B. das sehr interessante Inventar von St Michael zu Zeitz (Sachsen) aus dem Jahre 1514 bekundet. Von den sieben darin verzeichneten Ornaten für die Apostelfeste sind zwei grün, zwei rot, zwei blau und einer braun; für die Ferialtage ist einer braun, einer rot und einer schwarz. Auffallend gering: ist in dem Verzeichnis die Zahl weifer Kaseln, deren es unter 32 nur vier gibt gegenüber 15 roten, und selbst von diesen vier werden drei als "Fastengereth" bezeichnet. Sogar im Inventar der Schloßkirche zu Heilsberg von 1581 finden sich noch Notizen wie diese: 1 braun atlas Casel, die man braucht, wenn es duplex, item 1 blaw Casell mit blumen, die man braucht in semiduplici festo, 1 rot quotidian Casel ${ }^{1}$.

1 Hipler, Schatzverzeichnisse 64. Sehr jostruktiv ist auch das Inventar der Stiftskirche zu Ecouis (Eure) von 1565.

Braun, Die liturgische Gewandung. 
Noch bezeichnender aber ist eine Meßigewandordnung des Klosters Eberbach im Rheingau aus dem 16. Jahrhundert, welche für das Amt an den einzeInen Festen des Jahres die Kasel bestimmt. Kaum, daf sich in ihr auch nur eine Spur eines Farbenkanons offenbart ${ }^{1}$. Sie ist es wert, hier abgedruckt zu werden. Wir lassen sie darum nachstehend folgen. Tabula denotans quibus sacris vestibus in festis totius anni utendum:

Translationis S. Benedicti, das alt rot sammet.

Mariae Magdalenae, das grün seiden mit Trauben.

Iacobi apli, das grün sammet.

Annae matris Mariae, das weif Damast.

Ad vincula S. Petri, das blow seiden mit Löwen.

Laurentii mart., das rot seiden.

Coronae spineae dni, das rot verblümbt sammet.

Assumptionis B. Mariae V., das weifs silberstück.

Bernardi abb., das grauenstück.

Bartholomaei apli, das grün sammet.

Augustini epi, das blow sammet.

Decollationis Iois, das blow seiden mit gülden Löwen.

Nativitatis Mariae, das alt weif gülden Stück mit Perlen.

Exaltationis S. Crucis, das rot seiden.

Matthiae apostoli, das grün.

Michaelis archangeli, das alt braun seiden widersehein.

Lucae Evang., das gelb sammet.

Undecim millium Virg, das alt gülden stück.

Simonis et Iuciae, das grün verblümbt sammet.

Omnium S.S, das grün gülden stück.

Omnium animarum, das schwarz Sammet.

Martini epi, das blow sammet.

Ceciliae virginis, das braun seiden mit laubwerk.

Catharinae V., das weir Damast.

Adventus dni, das alt gülden stück.

Andreae apostoli, das grün verblümt sammet.

Conceptionis Mariae, das Eselfarb güldenstück.

Thomae apostoli, das grün sammet.

In Vigilia Nat. dni, das braun seiden.

In sacra nocte, das grauenstück.

In aurora, das rot new gülden stück.

Ad summam missam, das grün güldenstück.

Circumcisionis dni, das roth new gülden Stück.

Epiphanie dni, das Eselfarb gülden stück.

Agnetis virginis, das roth verblümbt Sammet Ornament.

Conversionis Pauli, das blow Seiden mit gülden Löwen.

Purificationis Mariae, das alt weiß gülden Stück mit Perlen.

Agathae virginis, das grün seiden mit roten Träublen.

Cathedra S. Petri, das alt gelb Stück.

Matthiae apostoli, das grün Sammet.

Iosephi et Benedicti abbatis, das rot Sammet.

Annunciationis B. M. V., das weiß gülden stück mit Perlen.

Ambrosii episcopi, das blow sammet.

In die Palmarum, das roth verblümbt sammet.

In coena dni, das weif Damast.

Parasceve, das roth seiden.

${ }^{1}$ Roth. Geschichtsquellen aus Nassau III, Wiesbaden 1880, 457. 
Vigilia Paschae, das braun seiden verblümbt.

In die sancto, das weiß silber Stück.

Altero die Paschae, das grün verblümbt sammet.

Tertio die, das grün verblümbt sammet, ut supra.

Quarto die, das blow sammet.

In Octava Paschae, das blow seiden mit gülden Löwen.

Marci Evang., das gelb sammet.

Inventionis S. Crucis, das gülden Stück.

Dedicationis ecclesiae, das grauen Stück.

Vigilia Pentecost, sicut in vigilia Paschae.

In die Pentecost., das grün gülden Stück.

Feria 2, 3. et 4, sicut in feriis paschalibus.

SS. Trinitatis, das Eselfarb gülden Stück.

Corporis Chri, das rot new gülden Stück.

Nat. Iois Baptistae, das roth verblümbt sammet.

Visitationis Mariae, sicut SS. Trinitatis.

Petri et Pauli, sicut in secundo Paschae.

Stephani prothomart., das rot verblümbt sammet.

Iois Evang., das grün sammet.

In die S.S. Innocentum, das alt güldenstück.

Sehen wir von den Apostelfesten, für die in den meisten Fällen Grủn verzeichnet ist, und von den Marienfesten ab, so gibt es keine bestimmte Norm für den Gebrauch der Farbe in dieser Mefagewandordnung. Man beachte besonders, wie das Fest der hl. Agnes Rot hat, während für die Feste der Elftausend Jungfrauen, der hl. Cäcilia und der hl. Katharina Gold, Braun und Weifs vermerkt werden.

Im Jahre 1603 verordnete eine Synode von Brixen, es sollten Paramente von allen fünf liturgischen Farben in allen Kirchen vorhanden sein. Ähnlich eine Synode von Konstanz aus dem Jahre 16091.

Das bunte Farbenspiel in den Farbenordnungen der französischen Missalien des ausgehenden 17. wie des ganzen 18. Jahrhunderts hatte teils seinen Grund im Festhalten an mittelalterlichem Brauch, teils war es die Folge der gallikanischen Reformbestrebungen am Ausgang des 17. und im Beginn des 18. Jahrhunderts, indem manche Bischöfe die gegen Ende des 16. Jahrhunderts in sehr vielen Diözesen eingeführte römische Liturgie wieder abschafften und auf den früheren Ritus zurückgriffen. Natürlich gab man mit dem römischen Missale auch den römischen Farbenkanon preis.

Um einen Einblick in die Mannigfaltigkeit der liturgischen Farbenordnungen zu erhalten, empfiehlt es sich, einen Rundgang durch das Kirchenjahr zu machen und dabei die verschiedene Praxis in Bezug auf die Farbe der Paramente Revue passieren zu lassen ${ }^{2}$. Wir erhalten so ein anschauliches Bild des bunten Wechsels, der ehedem in Bezug auf die Farbe der liturgischen Kleidung bestand. Wir beginnen mit dem Advent.

Der Advent ist das Nachbild der Jahrtausende, in denen die Menschheit der Ankunfit dessen harrte, der sie aus Sündennot und Verderben retten sollte. Zugleich ist er die Vorbereitung auf den Jahrestag der leiblichen Geburt des Gottessohnes und auf die geistige Einkehr des Heilandes in die Seele. In beider Beziehung ist der Advent eine Zeit der Trauer und Bufe, weßhalb denn auch meist beim Advents-

1 Hartzh. VIII 565909.

2 Eine sehr fleifige Sammlung von Farbenordnungen aus England, Frankreich, Deutschland und Spanien in der schon erwähnten
Schrift Wi ckham Leggs, History of the eccl. colours; französische anch bei M a 1 a is, Des couleurs liturgiques, Dieppe 1879, englisehe bei $\mathrm{Chambers}$ app. I und suppl. 
gottesdienst Violett oder Schwarz gebraucht wurde. Doch kamen auch weike Gewänder zur Verwendung. So findet sich Weiß für den Advent verzeichnet in dem schon erwähnten Farbenkanon der Westminsterabtei, in einem Pariser Missale von 1666, einem Missale von Sigüenza in Spanien (1552) und von Auxerre (1738) u. a. Anderswo bediente man sich roter Paramente, so zu Salisbury in England (15. Jalrrhundert) und Mainz (MI [ = Missale $]$ von 1602). In den Statuten von Wells in England (14. Jahrhundert) ist für den Advent dunkelblau vorgeschrieben. Ein Franziskanermissale des 15. Jahrhunderts in der Vaticana ${ }^{1}$ vermerkt für die Adventszeit im allgemeinen Violett, für den Sonntag Gaudete aber Weif. Von rosafarbenen Paramenten, wie sie das römische Caeremoniale ${ }^{2}$ für das Hochant am dritten Adventssonntag vorsieht, findet sich in den mittelalterlichen römischen Ordines noch keine Spur.

An der Weihnachtsvigil war in Rom zu Innozenz'.III. Zeit, wie es scheint, Schwarz, seit etwa der zweiten Hälfte des 13. Jahrhunderts aber Violett gebräuchlich. Der Liber consuetudinarius von Westminster, Durandus (Rationale und Pontifikale), das erwähnte Franziskanermissale und das Missale eines Augustinerklosters zu Neapel aus dem Jahre $1506^{3}$ vermerken jedoch Weif für sie, in signum pudoris partus futuri, wie das Franziskanermissale erklïrend beifügt. Gelb war zu Eichstätt (ca 1600) ${ }^{4}$, Schwarz zu Ellwangen und überhaupt fast überall da im Gebrauch, wo im Advent schwarze Paramente getragen wurden, Rot zu Evesham in England ${ }^{5}$.

Dem Weihnachtsfest und der Weihnachtszeit eignete fast allenthalben Weif. In Ellwangen war es, wie wir bereits hörten, merkwürdigerweise Sitte, sich bei der ersten Messe am Feste weißser, bei der zweiten roter, bei der dritten sowie in der Oktav violetter Gewänder zu bedienen. In dem Lyoner Missale von 1771 war für die Messe in galli cantu Violett, für die zweite Weiß, für die dritte Rot vorgeschrieben. Zu Mainz (M 1602) wurde die erste. Messe in roten, die zweite in weißen Gewändern zelebriert. Für die dritte und die Oktav fehlt eine Angabe. Eine dem Mainzer Brauch ähnliche Sitte wird bei Martène auch für Corbie und St Germain-des-Prés zu Paris erwähnte. Die Statuten von Wells bestimmen: In die natalis Domini omnia alba praeter in secunda missa, geben jedoch nicht an, welcher Farbe man sich bei dieser Messe bediente. Zu Evesham war es Sitte, bei der missa magna am Weihnachtsfest eine große schwarze Kasel zu tragen, bei der missa in galli cantu aber eine alba casula diasperata (gemustert) et auro stragulata.

Es ist nicht klar, welches der Grund war, die Messen am Weihnachtsfeste alle oder teilweise in verschiedenen Farben zu feiern. Vielleicht daß die weife Farbe die menschgewordene Gottheit oder seine ewige Geburt, die rote seine heilige Menschheit bzw. seine zeitliche Geburt, Violett aber das Wort des Apostels: "Er hat sich selbst erniedrigt" (Phil 2,8) versinnbilden sollte.

Am Feste der Beschneidung des Herrn bediente man sich entweder weiser oder roter Paramente, weißer, um Christi unendliche Reinheit und Gotheit anzudeuten, roter, um an seine erste Blutvergiefung zu erinnern. Beides war gleich gebräuchlich. Der beiden Bräuchen zu Grunde liegenden Auffassung suchten in eigenartiger Weise die Statuten von Wells dadurch gerecht zu'werden, dak von den funktionierenden Geistlichen die einen in Rot, die andern in Weif auftraten. Das Mainzer Missale von 1602 verzeichnet für das Fest der Beschneidung Blau?

1 Vat. Capp. 206.

2 L. 2 , c. 13, n, 11.

3 Vat. Ottob. 221.

- Kirchenschmuck XXI 24.

s Offic. eccl. abbat. sec. usum Evesham. monast. (Bradshaw Soc., London 1893) 166. Verfakt zur Zeit Eduards III. oder Richards II.

- Mart., Mon. 1. 2, c. 4, n. 9 18; IV 95.

7. Die Angabe des 13. Ordo (n. 18): In aliis vero festis sequentibus (sc. festum Innocentium), sive festum confessorum sive virginum, utitur colore albo, rubeo in dominicis a Nativitate usque ad Octavam Epiphaniae, si facit de dominica non de aliquo festo utitur colore albo, ist ersichtlich fehlerhaft. Vielleicht ist zu lesen: utitur colore albo vel rubeo (je nachdem die virgo nämlich blok Jungfrau oder auch zugleich Märtyrin war). In dominicis etc. 
Dem Feste Epiphanie und seiner Oktav eignete wie Weihnachten vornehmlich Weif; jedoch wurden auch rote Gewänder gebraucht, so zu Toledo (M. 1550), Lichfield (13. Jahrhundert), Clermont in der Auvergne ${ }^{1}$. Gelb war die Farbe für Epiphanie zu Ellwangen und Toulouse (M. 1832), Violett zu Soissons (M. 1745). Zu Lisieux benutzte man entweder rote Paramente oder Paramente von Goldstoff? Eigenartig ist das Grün zu Le Mans (M. 1655).

In der Zeit von Epiphanie bis Septuagesima begegnen uns Weif, Rot, Violett und Grün. Weißs zu Paris (M. 1666), Sens (M. 1715), Auxerre (M. 1738), Bourges (M. 1741), Toledo (M. 1550), Toul (Caeremoniale 1700), Rot zu Lyon (M. 1771), Salisbury (14. und 15. Jahrh.), Wells (14. Jahrh.), Yainz (M. 1602), Gelb zu Palencia in Spanien (M. 1568) ${ }^{3}$, Violett zu Ellwangen und Le Mans (M. 1655). Am verbreitetsten war, wohl infolge des Einflusses des römischen Kanons, Grün. Wir begegnen ihn z. B. zu Soissons (M. 1745), in Sizilien (M. 1568), zu Mailand (LI. 1795), in dem Angustinermissale von Neapel (1506), dem vorhin erwähnten Minoritenmissale (15. Jahrh.), einem Caeremoniale episcoporum der Vaticana (15. Jahrh.) ${ }^{4}$, zu Eichstätt (M. 1600), Exeter (Ordinale von 1337), London (St Paul, Pontifikale des Bischof's Clifford [1406 bis 1426]), in einem Dominikanermissale aus dem Beginn des 16. Jahrhunderts $^{5}$, zu Köln (M. 1626), Trier (M. 1608) u. a. Wo man sich einer sonstigen Farbe bediente, lag das meist daran, daf man die Farbe der Weihnachtsoktav his Septuagesima beibehielt. Das Gelb zu Palencia erklärt sich vielleicht durch den Umstand, daf Gelb Nebenfarbe von Grün war. Hier und dort behielt man die Weihnachtsfarbe bis Lichtmefs bei und ging erst dann zu einer andern Farbe über. So will es z. B. das Pariser Missale von 1685; so war es auch zu Rouen üblich ${ }^{6}$. Dort trat Rot, hier Grün an die Stelle von Weif.

Von Septuagesima bis zur Fastenzeit herrschte die violette Farbe vor. Rot scheint im 13. und 14. Jahrhundert namentlich in England Brauch gewesen zu sein; später kommt es auch anderswo vor, so zu Mlainz (M. 1602) und Paris (M. 1666). Schwarz sei beispielsweise für Köln (M. 1626) sowie für Ellwangen und Gubbio (M. 14. bis 15. Jahrh. ${ }^{7}$ ) angemerkt.

In der Fastenzeit bediente man sich, wie schon früher bemerkt wurde, zu Rom noch im Beginn des 13. Jahrhunderts schwarzer Paramente, dann aber im Wechsel mit schwarzen auch violetter und indigofarbiger, nicht lange nachher aber nur violetter. Auferhalb Roms war teils Violett, teils Schwarz gebräuchlich, und zwar nicht blof im Mittelalter, sondern bis wenigstens in das 17. Jahrhundert hinein. Zu Köln muß nach Ausweis des Inventars von St Brigiden aus dem Jahre 1508, welches eine Anzahl weißer Paramente ausdrücklich als Fastengewänder bezeichnet, um das beginnende 16. Jahrhundert Weif die Farbe für die Fastenzeit gewesen sein ${ }^{8}$. Dafs die Kölner aber damit in jener Zeit nicht allein standen, erhellt aus der Aschermittwochspredigt des Osnabrücker Augustiners Gottschalk Holen (ca 1490), worin es heift: In hoc sciendum, quod casula quadragesimalis est alba et habet rubeam crucem ${ }^{9}$; ferner aus dem Inventar von Zeitz (1514), einem Inventar der Schlobkirche zu Heilsberg (1581), dem Inventar der St-Gertrudenkapelle zu Braunschweig: (Ende 15. Jahrh.), dem Inventar der Infirmary Chapel zu Peterborough (one vestiment of white fustian [Baumwolle] for Lent) u. a. ${ }^{10}$ Das Mainzer Missale verzeichnete für

1 Guyet, Heortologia III, Urbini 1728 , 928.

2 Malais, Des couleurs liturgiques 10 .

3 Vat. Burber. B X 1.

4 Vat. Reg. 280.

5 Bischöfliches Nuseum zu Haarlem.

6 Wickham Legg, History of the eccl. colours, London 1882, 1719.

7 Vat. lat. 4743.

8 Ditges, Eine Kölner Gerkammer im XVL. Jahrhundert in Annalen des historischen
Vereins XLV 120: Seven wisser vastengeger mit sees stoelen, 5 manipuln. Vunf vasten wiss $g$ (eger) mit alven, stoelen etc. Das Kölner Missale von 1626 schreibt schwarz für die Werktage der Fastenzeit vor, an den Sonntagen bediente man sich violetter Paramente.

9 Kirchenschmuck IX 58.

10 Im Preßburger Inventar von 1425 finden sich 2 casulae quadragesimales, quarum una est alba et una rubea. 
die Fasten Blau. Es scheint dieses ein Ersatz für Violett sein zu sollen, welches in der Mainzer Farbenordnung auffälligerweiser nicht erwähnt wird. In französischen Diözesen bediente man sich seit etwa' dem 16. Jahrhundert während der Fastenzeit vielenorts aschgrauer Gewänder, und zwar bis tief in die neueste Zeit hinein, so zu Paris (M. 1685), Bourges (M. 1741), Poitiers (M. 1767), Lyon (M. 1771), Fréjus (M. 1786), Pamiers (M. 1845), Meaux (M. 1845), Autun (M. 1845) u. a. Solche kamen aber auch anderswo vor, so zu Toledo (M. 1550) und Ellwangen. Selbst im Inventar von St Peter zu Rom aus dem Jahre 1441 finden wir eine tunicella, aalmatica, planeta cineritia ad usum primi diei quadragesimae.

War für die Zeit von Septuagesima bis zu den Fasten eine andere Farbe im Gebrauch wie in der Fastenzeit, so folgte der Aschermittwoch regelmäfigig der Farbe der letzteren. Eine Ausnahme hiervon scheint nur sehr selten gemacht worden zu sein, wie z. B. zu Paris am Ende des 17. Jahrhunderts, wo man die Fastenzeit erst mit dem Sonntag nach Aschermittwoch begann?"

An verschiedenen Orten waren schwarze Paramente nur an den Werktagen der Fastenzeit in Gebrauch, während man sich an den Sonntagen violetter bediente, so zu Köln (M. 1626), Sens (M. 1715) u. a. Nan wollte dadurch den Sonntag vor den Werktagen aus- und kennzeichnen und die feierlichere und gehobenere Sonntagsstimmung auch in der Farbe der liturgischen Gewandung einigermaßen zum Ausdruck bringen.

Für den Sonntag Laetare merkt das mehrfach genannte Franziskanermissale des 15. Jahrhunderts gerade wie für den Sonntag Gaudete Weißs an, in signum laetitiae et victoriae, wie es sagt. Auch zu Palencia (M. 1568) und Sigüenza (M. 1572) bediente man sich an Laetare weißer Paramente, während man zu Burgo de Osma rote, zu Ellwangen gelbe und zu Lyon grüne trug. Bezüglich der rosafarbenen Gewänder, welche das römische Caeremoniale, wenn möglich, an diesem Tage beim Amte getragen wissen will, gilt, was in Betreff derselben beim Sonntag Gaudete gesagt wurde. Schon zu Innozenz' III. Zeit zeichnete man den Sonntag Laetare zu Rom dadurch aus, daß man an ihm statt schwarzer Paramente wie sonst in der Fastenzeit violette gebrauchte.

Während der Passionszeit hielt man zu Rom an der Farbe der Fastenzeit fest. In vielen auferrömischen Diözesen hatte jene jedoch eine besondere liturgische Farbe. In Spanien scheint für sie Schwarz bevorzugt worden zu sein. Wir finden dieses in der Passionszeit z. B. zu Toledo (M. 1550), zu Sigüenza (M. 1553), zu Burgo de Osma (M. 1561) und zu Palencia (M. 1568) in Gebrauch. Auch ein Missale von Monte Cassino aus dem Jahre 1515 gibt für die beiden letzten Wochen vor Ostern Schwarz an. In Frankreich begegnet uns daselbe zu Cahors (M. 1760), Luçon (M. 1828), Toulouse (M. 1832), Autun (M. 1845), Pamiers (M. 1845) und Albi (M. 1848). Es scheint jedoch, daf der Gebrauch schwarzer Paramente in der Passionszeit hier durchweg sehr jungen Datums war.

Am verbreitetsten war Rot. Wir finden es ebensowohl in englischen (Wells, Westminster, Salisbury, Exeter, London) und deutschen (Köln, Mainz, Eichstätt, Trier, Salzburg) wie in französischen Kirchen. Besonders charakteristisch war es für Frankreich. Schon der 13. Ordo (zweite Hälfte des 13. Jahrhunderts) hebt ausdrücklich hervor, daß man sich im Gegensatz zum römischen Brauch in der gallikanischen Kirche vom Palmsonntag ab roter Paramente bediene ${ }^{3}$. Noch im 16., 17. und 18. Jahrhundert war Rot als Farbe für die Passionszeit in Frankreich sehr gebräuchlich, so z. B. zu Reims (M. 1553), Laon (Belotte, Ritus eccl. Laud. 1662), Le Mans (M. 1665), Besançon (Cérémoniel 1707), Sens (M. 1715), Auxerre (M. 1738), Bourges (M. 1741) น. ล。

Am Palmsonntag hatten die Gewänder bei der Messe die Farbe der Passionszeit. Anders verhielt es sich dagegen vielenorts bei der Palmweihe und

1 Müntz e Frothingham, ll Tesoro di S. Pietro 97.
2 De Moleon (Lebrun-Desmarettes), Iter liturg. 247. ${ }^{8}$ N. 21 (M. 78, 1117). 
der Palmprozession. Bei diesen war, wie schon Durandus hervorhebt, Weifs sehr verbreitet ${ }^{1}$. Eine Ausnahme ist es, wenn zu Eichstätt für sie Gelb vorgeschrieben war. Häufiger war Grün bei ihnen in Gebrauch, wohl wegen der Palmzweige, mit denen die Juden dem in Jerusalem einziehenden Heiland entgegenkamen, so zu Laon. Toledo, Sevilla (MI. 1507 und 1534) und Vienne 2. In Mailand trägt man bei der Palmprozession violette Paramente, während man sich bei der Messe roter bedient; ein Missale von Luçon von 1828 schreibt umgekehrt für die Nesse am Palmsonntag Violett, für die Palmprozession aber Rot vor. Ähnlich das Caeremoniale von Toul von 1700. Zu Cahors war nach dem Missale von 1760 bei der Messe Schwarz, bei der Palmweihe und Palmprozession aber Violett gebräuchlich.

Am Gründonnerstag waren im Gegensatz zur römischen Farbenregel, welche Weif verlangt, in deutschen, englischen und französischen Diözesen vielfach rote Paramente üblich. Verschiedene Missalien vermerken, es sollten weiße Gewänder nur gebraucht werden, falls in der Messe die Weihe cler heiligen (Öle statthabe, andernfalls aber rote, z. B. die Missalien von Toledo (M. 1550), Burgo de Osma (M. 1561), Palencia (M. 1568), Lyon (M. 1771). Ähnlich bemerkt das Ordinale des Bischofs Grandisson von Exeter (ca 1337): Secundum quostam in coena Domini, si Episcopus non celebrat, vestimentis rubeis est utendum, d. $\mathbf{i}$, wenn keine Ölweihe stattfindet. Es ist beachtenswert, wie schon in dem ältesten römischen Ordo angeordnet ist, es sollten die Ampullen mit dem zu weihenden Öle in ein weißes seidenes Tuch eingehüllt sein ${ }^{3}$. Von demselben Brauch berichtet uns im Beginn des 9. Jahrhunderts auch Amalar von Metz:

Zu Eichstätt bediente man sich um den Beginn des 17. Jahrhunderts am Gründonnerstag grüner Gewänder, vielleicht, um durch dieselben dem Namen des Tages gerecht zu werden. Dasselbe geschah nach Martène im Kloster des hl. Martin zu Lyon ${ }^{5}$. Zu Mainz trug der Diakon, welcher das Evangelium bei der Fufwaschung sang, eine grüne Dalmatik, während dort im übrigen am Grỉndonnerstag rote Paramente gebraucht wurden.

Am Karfreitag benützte man nach dem Beispiel der römischen Kirche vielfach schwarze Paramente. Doch waren rote an diesem Tage kaum minder beliebt, namentlich auch in Deutschland. Wir finden am Karfreitag solche z. B. zu Passau (M. 1522), Salzburg (M. 1507), Würzburg (Rituale von 1564), Mainz, Köln, Trier, Eichstätt. Selten kommt Violett vor, wie zu Lyon (1771), ganz vereinzelt Gelb (Laon, Belotte, Ritus eccl. Laudun. 1662) ${ }^{6}$. Zu Vienne trugen der praecentor und cantor, welche bei der adoratio crucis das Ecce lignum anhuben, eigentümlicherweise grüne Chorkappen, wohl im Hinblick auf den neues geistliches Leben sprossenden Kreuzesbaum?

Die Messe am Karsamstag pflegte, weil im Grunde Ostergottesdienst, wie im römischen Ritus meist in weißer Farbe gehalten zu werden. Zu Le Mans ${ }^{8}$ und Evesham bediente man sich bei ihr roter, zu Mainz blauer, zu Eichstätt gelber, zu Soissons (M. 1745) grüner Paramente. Mannigfaltig war der Brauch bezüglich der Farbe der Gewänder bei den der Messe vorausgehenden Zeremonien, der Feuerweihe, der Kerzenweihe, der Lesung der Propheten, der Segnung des Taufwassers und der Absingung der Litanei. Hier geschah alles das in Weiß wie zu Lyon (M. 1771), Sevilla (M. 1507), Burgo de Osma (M. 1561), dort galt der römische Brauch. Zu

1 Rationale 1. 3, c. 18, n. 9 ; f. 83.

${ }^{2}$ De Moleon a. a. O. 37. Statt Si papa hac die Palmarum celebraret, portare debet paramenta violacea vel viridis coloris sine perlis im 14. Ordo, c. 82 (M. 78, 1204) mufs es wohl, wie der 15. Ordo, c. 65 (ebd. 1301) schreibt, heifen, paramenta violacea vel indii coloris. Das dunkle Indigoblau wurde auch sonst als Ersatz für Violett betrachtet. Bei der Messe am Palmsonntag grüne Gewänder tragen, pakt durchaus nicht zum Geist des römischen Farbenkanons.

${ }^{3}$ N. 31 (M. 78, 952).

4 De eccl. offic. 1. 1, c. 12 (M. 105, 1017).

5 Mart. 1. 4, c. 22; III 126.

6 Vgl. auch schon das Ordinarium des Lisiardus bei Chevalier, Ordinaires de l'église cathédrale de Laon 113.

' Mart. 1. 4, c. 23; III 139.

${ }^{8} \mathrm{De}$ Moleon, Iter liturg. 222. 
Salisbury wurde die Fenerweihe in roten Paramenten vorgenommen. Ebenso wurde dort die Litanei in roter Cappa gesungen; wenn aber drei Geistliche sie sangen, so mukte der mittlere eine weife, die beiden andern eine rote tragen. Zu Mainz war für die Fenerweihe Rot, für die Kerzenweihe Grün, für die Taufwasserweihe Rot vorgeschrieben, zu Monte Cassino (M. 1515) für die Feuer- und Kerzensegnung Weif, für die übrigen Zeremonien Violett oder Blau. Zu Paris war Violett nur während der Lesung der Prophezien im Gebrauch. Alles übrige vollzog man in Weif.

Am Ostertage wie in der Osterwoche wurden nach uralter Sitte überall weiß̧e Paramente gebraucht. Es sind äußerst seltene Ausnahmen, wenn das Kalendarium ron Wells und der Liber Consuetudinarius von Westminster für Ostern und die Osteroktav Rot vermerken, das Missale von Soissons von 1745 aber Grün.

Der Osterzeit eigne ebenfalls fast allgemein Weiß. In Salisbury waren sogar an allen in sie einfallenden Festen, Kreuzerfindung allein ausgenommen, weifse Gewänder in Gebrauch. Grün treffen wir in der Osterzeit außer zu Soissons zu Köln (M. 1626), Mailand (M. 1795) und Rheims (M. 1688), Rot zu Westminster und Wells an.

Am Himmelfahrtsfeste und in dessen Oktav war wie an Ostern fast ausnahmslos Weís gebräuchlich. Auch Köln, Mailand, Wells und Westminster folgten hierin der allgemeinen Praxis. Eine Ausnahme machte mit seinem Grün Rheims und wohl auch Soissons.

Eine seltene Einmütigkeit herrschte bezüglich der Farbe des Pfingstfestes. Der Liber Consuetudinarius von Westminster läft zwar an diesem Tage auch Gelb und Blau zu, doch schlieft er Rot so wenig aus, daßs er es vielmehr vor diesen beiden Farben anführt.

Bunt, recht bunt sah es dagegen wieder am Trinitatissonntag aus. Hier trug man weißße, da gelbe, hier blaue, da violette, hier grüne, da rote Paramente. So gab es Violett zu Soissons (M. 1745), Blau zu Toledo (M. 1550) und Mainz (M. 1602), Grün zu Exeter (ca 1337), Gelb zu Ellwangen (M. 1574), Rot zu Paris (M. 1685), Le Mans (M. 1655), Siguienza (II. 1552), Eichstätt (II. 1600) u. a., Weif zu Palencia (M. 1568), Mailand (M. 1795), Lyon (M. 1771), in Sizilien (1568) u. a.

Am Fronleichnamsfest war die liturgische Kleidung vorherrschend von weißer Farbe; jedoch war an diesem Tage vielfach auch Rot gebräuchlich, zumal in Frankreich. Das Grün zu Eichstätt und zu Clermont " ist eine vereinzelte Erscheinung. Ein interessanter Brauch bestand zu Exeter. Nach dem Ordinale Grandissons sollte nämlich der Priester am Fronleichnamstag bei der Messe in Weif, der ihm assistierende Geistliche in Rot gekleidet sein. Ferner sollte der Diakon in roter Dalmatik, der Subdiakon aber in weißer Tunicella ministrieren. Es sollte dadurch das unter den Gestalten von Brot und Wein eingesetzte heilige Sakrament, Christi Leib und Blut sowie Christi Reinheit und Liebe symbolisiert werden: Propter similitudinem panis et vini et corporis et sanguinis Jesu Christi et qui candidus est et rubicundus.

Vom Dreifaltigkeitssonntag an bis zum Advent verlangte die römische Sitte im Officium de tempore Grün. In andern Kirchen war dagegen, soweit man nicht der römischen Sitte folgte, bald Rot oder Violett, bald Blau oder Gelb in Gerauch, also wiederum mit Ausnahme von Weiß und Schwarz alle Farben. Violette Paramente waren z. B. üblich zu Le Mans (M. 1665), blaue zu Toledo (M. 1550), gelbe zu Palencia (M. 1568) und Eichstätt. Sehr gebräuchlich war Rot, so z. B. zu Wells (14. Jahrh,), Westminster (13. Jahrh.), Salisbury (14. und 15. Jahrh.), Prag (Inventar von 1387), Würzburg (Inventar von 1448), Paris (M. 1685), Iyon (M. 1771), Toulouse (M. 1832), Coutances (Cérémoniel 1825), Le Puy (M. 1783), Mainz (M. 1602). Zu Mainz bediente man sich der roten Farbe bis zum dritten Sonntag im Oktober, dem. Kirchweihfest der Kathedrale, dann vertauschte man sie bis zum Advent mit Grün.

An den M u t tergottesfesten kamen mit verschwindenden Ausnahmen überall weike Paramente zur Verwendung. Blaue trug man zu Eichstätt an den Festen Mariä

1 Guyet, Heortologia III 29, 9. 
Lichtmef und Mariä Opferung, sowie bei der Samstagsmesse de Beata von Pfingsten bis zum Advent, rote zu Ellwangen am Feste Mariä Heimsuchung. Zu Prag unterschied man nach dem Inventar von 1387 zwischen Fest und Oktav. An den Festen wurde Weiß, in den Oktaven derselben Blau gebraucht.

Den Engelfesten eignete meistens, doch nicht ausschlieflich Weif. Aufer Rot (Mainz M. 1602, Le Mans M. 1665 u. a.) war namentlich auch Gelb an ihnen in Gebrauch (Le Puy M. 1783, Fréjus M. 1786, Poitiers M. 1767, Autun M. 1845 u. a.). Das Kalendarium von Wells notiert für das Fest des hl. Yichael Blau und Weif.

Am Allerheiligenfest trug man, wie schon Innozenz III. und Durandus angeben, bald weifse, bald rote, bald mehrfarbige Gewänder; letztere, um durch die verschiedenen Farben die Tugenden der Heiligen zu versinmbilden. Solche bunte Gewänder waren z. B. zu Toledo (M. 1550), Burgo de Osma (M. 1561), Sigüenza (M. 1552) und Mainz (M. 1602) gebräulich. Aùch wurde es wohl an Allerheiligen in das Belieben des Priesters gesetzt, zu bestimmen, was für Paramente er anziehen wolle. So sagt z. B. Grandissons Ordinale: In festo omnium sanctorum ... omnibus coloribus indifferenter, ita tamen, quod candidum et rubeum praeponantur, ad libitum est utendum. Annderswo überlief man dem Priester wenigstens, zwischen Weif und Rot zu wählen. Das mehrfach erwähnte Franziskanermissale aus dem 15. Jahrhundert will, dak Allerheiligen der Priester Weis, der Diakon Rot und der Subdiakon Grün oder Gelb trage, offenbar, um so alle Stände der Heiligen zu symbolisieren.

Am Feste der Geburt des hl. Johannes Baptist waren mit Rücksicht auf dessen Heiligung im Mutterschof vorzugsweise weike Gewänder iublich; griner bediente man sich zu Mainz, Le Mans, Toledo u. a., violetter zu Soissons (M. 1745) und Bourges (M. 1741), doch hier nur in der Kathedrale, blauer zu Wells.

Das Fest der Enthauptung des. Heiligen wurde wie ein Martyrfest behandelt. Violette Paramente schreiben für diesen Tag vor das Ordinale Grandissons von Exeter und das Pontifikale des Bischofs Clifford von London. Als Grund führen dieselben an: Quia ad limbum descendit. Der Martertod fuhrte den Vorläufer Christi noch nicht sogleich in den Himmel. Wohl infolge der gleichen Auffassung scheint zu Prag nach dem Inventar von 1387 Blau an diesem Tage üblich gewesen zu sejn.

An den Aposteltagen gebrauchte man in seltener Übereinstimmung rote Gewänder. Das Mainzer Missale verzeichnet Grün. Eine Ausnahme bildeten auch gewisse Nebenfeste der Apostel, wie Petri Stuhlfeier und Pauli Bekehrung, sowie das Hauptfest des heiligen Evangelisten Johannes. Man feierte an diesen Tagen nicht die Erinnerung an das Martyrium der betreffenden Apostel. Daher behandelte man sie meist nach Weise der Bekennerfeste und benutzte an ihnen grüne, weifse, blaue, violette oder gelbe Paramente, je nachdem die einen oder die andern in den betreffenden Kirchen an den Bekennertagen in Gebrauch waren. Petri Kettenfeier wurde bald wie ein Bekennerfest behandelt, bald bediente man sich an ihr roter Gewänder. Am Eeste des hl. Johannes ante portam latinam herrschte in Rücksicht auf das Martyrium des Apostels, dessen Andenken man dann beging, Rot vor. Weif begegnet uns an diesem Tage vorzüglich in einigen englischen Diözesen (Wells, Salisbury, Westminster). Für den Markus- und den Lukastag schreibt das Missale von Palencia (M. 1568) Weifs vor. Im übrigen war an diesen beiden Tagen Rot gebräuchlich, obwohl das Martyrium des hl. Lukas zweifelhaft ist.

Die Mârtyrerfeste sind neben den Festen der heiligen Jungfrauen, welche nicht zugleich Märtyrinnen waren, die wenigen Tage, an denen überall dieselbe Farbe in Kraft war. In allen liturgischen Farbenkanons wird den Märtyrern Rot, den Junfrauen Weif zugewiesen. Einigermaken schwankt der Brauch an den Festen der Jungfrauen, die zugleich als Märtyrinnen verehrt wurden. Zwar herrscht auch hier Rot vor, doch fehlt es nicht an Kirchen, in denen man Weiß gebrauchte, z. B. zu Lyon (M. 1771). Das Kalendar von Wels vermerkt: Quando de virgine et martyre rubea et alba, und Grandissons Ordinale bestimmt: In festis virginum et martyrum partim albis partim rubeis vel eisdem coloribus mixtis (est utendum). Wie das partim albis partim rubeis zu verstehen sei, darüber belehrt uns die Notiz, 
welche sich an die früher erwähnte Ferordnung des Ordinales über die Farbe der Paramente am Fronleichnamstage anschliefst: Eodem modo fiat de virginibus et martyribus.

Eine ungemeine Mannigfaltigkeit herrscht in den verschiedenen Farbenregeln hinsichtlich der Feste der Bekenner. Da finden wir geradezu alle Farben, Schwarz nicht ausgeschlossen. Am häufigsten kommen Weif, Grün, und Gelb vor. Blau gab es zu Prag (Inventar 1387) und Mainz (M. 1602), Schwarz im Dom von Eichstätt an den Festen der Bekenner, die nicht Bischöfe waren ${ }^{1}$, und in einem Karmelitermissale an den Gedächtnistagen heiliger Mönche ${ }^{2}$. Zu Evesham trug man Schwarz an den Festen der hll. Egwin und Wulstan ${ }^{3}$. Zu Lincoln waren im 13. Jahrhundert an den Bekennertagen auch braune und dunkle Gewänder (coloris fusci) in Gebrauch. In manchen Kirchen waren die Bekennerfeste geteilt, indem man an den Festen der Bekennerbischöfe sich andersfarbiger Paramente bediente, wie an den Tagen der gewöhnlichen Bekenner. Ja man unterschied sogar hie und da die heiligen Bekennerpäpste von den einfachen Bischöfen oder die Äbte und Mönche von den andern Bekennern, die nicht Bischöfe waren. Das mehrfach angeführte Minoritenmissale der Vaticana vermerkt für die Papstfeste Weif, für die Feste der Bekennerbischöfe Grün, für die Tage der heiligen Priester, Mönche und Einsiedler Gelb an. Das Missale von Palencia (1568), früher in der Barberinischen Bibliothek zu Rom, jetzt ebenfalls in der Vaticana, weist den Bischöfen Grün, den Nichtbischöfen Violett zu. Zu Mailand ist an den Festen heiliger Bischöfe, heiliger Kirchenlehrer und Priester Weiß, an denen heiliger Äbte und heiliger Laien Grün gebräuchlich. Zu Rouen trug man an den Festtagen von Bischöfen und Priestern weifse, an den Festen von Kirchenlehrern grüne, an den Tagen von Heiligen des Alten Bundes, von Äbten, Mönchen und sonstigen Bekennern violette Paramente. Am buntesten mag es aber zu Wells ausgesehen haben, wo es, ohne erkennbare Regel, im Kalendar bei dem einen Bekenner heift: omnis viridia et crocea, bei dem andern omnia crocea etc.

Die Feste heiliger Frauen wurden ähnlich wie die Feste heiliger Bekenner behandelt. Ein treffliches Beispiel, welche Mannigfaltigkeit hinsichtlich der Farbe der liturgischen Gewänder an ihnen herrschte, bietet die Notiz des Ordinale Grandissons bezüglich des Festes der heiligen Maria Magdalena: In festo Maria Magdalenae secundum quosdam vestimentis indici id est aerei coloris rel blavi, si pulchra habeantur, non inconvenienter indui possunt. In festo tamen Magdalene quidam albis, quidam croceis utuntur. Das Gewöhnlichste an den Festen heiliger Frauen war Violett; Grün war nach dem Inventar von 1387 zu Prag üblich *.

Bei der Kirchweihe wurden nach römischer Sitte weißße Paramente gebraucht. Aber auch außerhalb Roms wurde es fast allgemein so gehalten, propter nuptias Christi et ecclesiae, wie das Pontifikale des Bischofs Clifford von London nach dem Vorgang Innozenz' III. sagt. Entsprechend war denn auch am Jahrestag der Kirchweihe beinahe allenthalben Weif üblich. Zu Le Mans war für das Fest der Kirchweih Rot vorgeschrieben. Das Kalendar von Wells merkt für dasselbe Blau und Weifs an, während das Ordinale Grandissons erklärt, man könne an ihm alle Farben nach Belieben gebrauchen; jedoch möge man Rot und Weiß den Vorzug geben.

Bei den Exequien bediente man sich in der Regel schwarzer Paramente. So vor allem zu Rom, wo man nach dem gegen Ende des 15. Jahrhunderts entstandenen Ordo des Petrus Amelius selbst bei den Exequien des Papstes schwarze Gewänder trug ̊̃. Das Kalendar von Wells (14. Jahrh.) bestimmt ausdrücklich:

1 Kirchenschmuck XXI 24. Möglich, daf Schwarz auf einem Irrtum beruht, aber auch nur möglich. Ob aber dann, wie im Kirchenschmuck" gemeint wird, dafür Blau einzusetzen ist, scheint fraglich. Eine Stütze für diese An nahme kïnnte allerdings sein, dak auch das Fest der Commemoratio des bl. Paulus Blau hat.
2 Wickham Legg, History of the eccl. colours 33 .

s Offic. eccl. abbat. sec. usum Evesham. monasterii, 166.

4 A. PodIaha und E. Sittler, Chrámový poklad u Sv. Vita v Praze XXXVIII. s C. 146 (M. 78, 1353 f). 
Memorandum, quoties et quandocumque agitur pro defunctis, omnia erunt nigra et simplicia, licet agatur pro rege vel episcopo. Ein Missale von Salisbury (15. Jahrh.) bemerkt ähnlich: In omnibus missis pro defunctis per totum annum utuntur vestimentis nigris. Es kamen aber auch violette Paramente bei Exequien zur Verwendung, so besonders in Frankreich, wie zu Narbonne u. a. Auch im Ordinale Grandissons heift es: In solemnibus exequiis mortuorum et etiam sepulturis eorum satis congrue violaceo colore est utendum. Violette Paramente wurden namentlich bei Leichenfeierlichkeiten von Fürsten und Standespersonen gebraucht.

Es sind nur einige fünfzig Kanones, welche wir unsern Ausführungen haben zu Grunde legen können; sie bieten bei weitem kein vollständiges Bild, und doch welche Verschiedenheit. Kaum könnte man sich eine buntere Mannigfaltigkeit denken. Es lassen sich, wenn wir von dem römischen Farbenkanon absehen, nicht einmal bestimmte Typen unterscheiden. Wohl zeigen die Farbenregeln in den einzelnen Ländern, wie Spanien, Frankreich, England mehrfach eine gewisse Übereinstimmung; so herrscht z. B. in den gallikanischen Kirchen eine Neigung zu Rot vor, während in den englischen Farbenordnungen den Bekennern mit Vorliebe Gelb zugewiesen wird. Indessen gestattet eine solche größere oder geringere Verwandtschaft noch keineswegs von einem englischen, spanischen oder gallikanischen Typus zu sprechen. Dafür sind der Verschiedenheiten in andern Punkten zu viele und zu bedeutende.

Es wäre interessant, einmal alle Farbenkanones, die je im Gebrauche waren, beisammen zu haben. Welche Fülle von Auffassungen und Gewohnheiten würde uns dann nicht erst entgegentreten.

Waren doch nicht einmal in den einzelnen Diözesen überall dieselben Vorschriften über die liturgischen Farben in Kraft und das Vorbild der Metropolitankirche für die andern Kirchen des Bistums keineswegs immer mafsgebend. Nicht selten hatte die Kathedrale wie einzelne besondere Riten, so auch bezüglich der Farben ihre Eigenheiten. So war z. B. in der Oktav von Epiphanie zu Paris (1776) Gelb nur in Notre-Dame gebräuchlich ${ }^{1}$. Zu Eichstätt bediente man sich ca 1600 während des Advents im Dom der schwarzen, in der Diözese der violetten Farbe. Ebenso trug man daselbst an den Festen der Bekenner im Dom schwarze, in der Diözese grüne Paramente. Für die Sonntage nach Trinitatis war im Dom Gelb, in der Diözese Grün Regel. Am Fest des hl. Johannes Bapt. waren in der Metropolitankirche zu Bourges (M. 1741) violette Gewänder üblich, während in der Diözese weibe in Gebrauch waren.

Insbesondere folgten nicht nur die Ordenskirchen, die sehr gewöhnlich ihre eigenen Gebräuche hatten, sondern häufig auch die Stiftskirchen einem mehr oder weniger von dem der Kathedrale abweichenden Farbenkanon.

Nicht wenig ward die Mannigfaltigkeit, welche uns in den alten Farbenkanones entgegentritt, auch durch deren geringe Stabilität begïnstigt.

Leider gestattet die geringe Zahl der noch vorhandenen alten Farbenregeln nicht, deren Entwicklung und Umbildung in den einzelnen Kirchen oder Diözesen zu verfolgen. Was wir von ihrer Geschichte zu wissen bekommen, sind zuletzt nur vereinzelte Ausschnitte, die uns unmöglich ein Bild des Wechsels zu geben vermögen, der sich im Lauf der Zeit mit ihnen vollzog.

Es ist ein Vorzug der römischen Farbenregel, dak sie sich seit den Tagen Innozenz' III. wenigstens in Theorie stets gleich geblieben ist. Die

1 Migne, Origines et raison de la liturgie, Paris 1844, 443. 
Veränderungen, welche sie im Laufe der Zeit erfuhr, waren sehr unbedeutend und bezogen sich fast nur auf Ausscheidung des Gelb und scharfe Trennung ron Schwarz und Violett. Nicht so in den auferrömischen Farbenkanones, in denen die jeweiligen subjektiven Anschauungen einen weiten Spielraum hatten, ganz abgesehen von den Veränderungen, welche die Annäherung an den römischen Brauch manchenorts bewirkte.

Wenn irgendwo auf liturgischem Gebiet, dann tritt gerade in Bezug auf die liturgischen Farben in auffallender Weise ein übertriebener Subjektivismus zu Tage. Hier hielt man es so, dort so, je nachdem man aus den einzelnen Farben die eine oder andere Symbolik herauslas. Heute bevorzugte man für denselben Tag Grün, um sich morgen zu Gelb oder Weif zu wenden. Es macht in dem Wirrwarr der verschiedenen und oft so verschiedenartigen Farbenregeln wirklich einen wohltuenden Eindruck, wenn man sieht, wie auch hier sich die römische Kirche als festen Punkt erwies.

Man mag die Vorzeit in gewissem Sinne um ihre größere Freiheit bezüglich der liturgischen Farben beneiden. Und doch war es gut, daf Pius V. auch den römischen Farbenkanon in das Missale aufnahm und mit diesem überall da zur Norm machte, wo nicht bereits seit zweihundert Jahren ein eigenes Missale vorhanden war:

Als entscheidend für die Farbe der Paramente galt nicht etwa die Farbe der Musterung, sondern, wie auch natürlich, die Grundfarbe des Stoffes. Das geht klar aus den Inventaren hervor. Wo immer dieselben sich auf eine genauere Beschreibung der Gewänder einlassen, ersieht man, daf sie den liturgischen Farbenwert derselben nach der Grundfarbe des Materials, aus dem sie gemacht waren, bemessen. Man vergleiche beispielsweise die ausführlichen Angaben des Schatzverzeichnisses des Apostolischen Stuhles von 1295, das Inventar von St Peter aus dem Jahre 1361, das Inventar des Domes von Prag (1387), die Inventare der Kathedrale von Angers aus dem 14., 15. und 16. Jahrhundert usw. Ausdrücklich sagt Grandisson in seinem Ordinale: Colores vestimentorum sunt quatuor vel sex... et quilibet horum colorum ita considerandus est, si major pars, qui campus panni dicitur, huius fuerit, quamvis auro vel alio colore fuerit permixtus et quilibet horum colorum est utendus prout infra hic continetur. Also entscheidend für den Farbenwert war der campus panni, der Grund des Stoffes, nicht das goldene oder andersfarbige Dessin ${ }^{1}$. Bezüglich etwaiger Gewänder von bunter oder unbestimmter Färbung sagt das Ordinale: Si autem aliqua vestimenta varii et incerti coloris forte habeantur, juxta judicium seniorum secundum eorum pulchritudinem et valorem in usum ponantur, aliis vestibus interim parcendo.

Werfen wir zum Schluß einen kurzen Rückblick auf das Gesagte, indem wir die Hauptergebnisse unserer Untersuchung nochmals zusammenfassen. Ein liturgischer Farbenkanon hat sich erst im Verlauf, genauer in der zweiten Hälfte des 12. Jahrhunderts unter dem Einflufs des mächtiger auftretenden Mystizismus und unter der Gunst der äuferen Verhältnisse ausgebildet. Wohl kamen schon früh farbige Gewänder beim Gottesdienst zur Verwendung, doch gab es für ihren Gebrauch noch keine umfassende, auf religiöser Farbensymbolik beruhende Normen. Es sind bestenfalls keimhafte Ansätze zur späteren Farbenregel, was uns vor dem 12. Jahrhundert begegnet.

1 Man vgl. damit die inhaltlich ähnliche Entscheidung der Ritenkongregation in Sachen des Bischofs von Marsi vom 7. April 1883. 
In der römischen Kirche steht die liturgische Farbenreihe schon gegen $1200 \mathrm{im}$ wesentlichen fertig da. Dagegen bürgert sich auferhalb Roms eine solche zum Teil eine gute Weile später ein. Zu einer einheitlichen Praxis kam es in Bezug auf die Farbe der Paramente erst, als in dem zweiten Viertel des 19. Jahrhunderts die vielfach noch in Gebrauch stehenden besondern Farbenregeln abgeschafft und endgültig mit dem Farbenkanon des römischen Ritus vertauscht wurden. Nur der ambrosianische Ritus hielt wie an seiner alten Liturgie, so auch an der ihm eigenen, in ihren Anfängen schon im Beginn des 12. Jahrhunderts nachweisbaren liturgischen Farbenregel fest.

\section{URSPRUNG UND SYMBOLIK DER LITURGISCHEN FARBENREGEL.}

Man hat gesagt, die liturgische Farbenregel sei im Hinblick auf die Farben der alttestamentlichen Kultkleidung eingeführt worden und als Zeuge dessen Innozenz III. angeführt. Natürlich kann nur eine mittelbare Ableitung gemeint sein, indessen verkennt auch so jene Ansicht vollständig die wirkliche Entstehung des kirchlichen Farbenkanons. Zwischen ihm und den Farben der jüdischen Sakralgewandung besteht ein zu tiefgreifender Unterschied, als dafs man im Ernst ihn zu diesen in irgend eine verwandtschaftliche Beziehung setzen könnte.

Die alttestamentliche Farbenreihe setzte sich aus Weic, Scharlach und zwei Purpurarten, also aus Weif und drei Nuancen von Rot zusammen. Die Farben galten nicht gleichmäfrig für die ganze Kleidung, sondern waren für die einzelnen Gewänder verschieden. Hüftschurz und Tunika mufsten weif, der Gürtel weils, scharlachfarbig, rot- und blaupurpurn, die Obertunika, Meil, blaupurpurn, das Schulterkleid, Ephod, wiederum weils, scharlachfarbig, blau- und rotpurpurn, die Kopfbedeckung weib und das Band, mit der die goldene Stirnplatte über der Tiara des Hohenpriesters angebunden war, blaupurpurn sein. Die Verschiedenheit der Feste und Funktionen hatte auf die Farbe der Sakralgewandung keinen Einfluf; dieselbe war zu allen Zeiten und bei allen Gelegenheiten die gleiche für die einzelnen Kleider, ausgenommen den grokien Versöhnungstag, an welchem diese ausschlieflich von weifer Farbe sein mufiten.

Ganz anders verhielt es sich von Anfang an mit unserem liturgischen Farbenkanon. Hier haben wir Weis, Rot, Schwarz und Grün mit Violett, Blau und Gelb als Nebenfarben. Hier ist ein und dieselbe Farbe die gleiche bei allen Gewändern, für welche der Farbenkanon Geltung hatte; hier wechselt endlich die Farbe der Sakralkleidung stetig nach Zeiten, Festen und Funktionen, wobei der Charakter der letzteren Prinzip und Norm für den Gebrauch der einzelnen Farben ist. Es liegt auf der Hand, dak bei einer solchen Verschiedenheit der Farben und ihrer Verwendung von einer Verwandtschaft zwischen der Farbenvorschrift des mosaischen Kultus und dem liturgischen Farbenkanon, wie er sich im letzten Viertel des 12. Jahrhunderts zu Rom ausgestaltete. keine Rede sein kann. Es ist aber auch ganz unzutreffend, Innozenz III. als Gewährsmann dafür anzuführen, daß die Kirchenfarben im Hinblick auf das alttestamentliche Vorbild eingeführt worden seien. Wenn der Papst bei Besprechung der liturgischen Farbenregel bemerkt: "Es gibt vier Hauptfarben, durch welche die römische Kirche je nach der Eigentümlichkeit der Tage die liturgischen Kleider unterscheidet, Weif, Rot, Schwarz und Grün; denn auch im Alten Bunde hatte man für die heilige Kleidung vier Farben, Byssus, 
Purpur, Hyazinth (Blaupurpur) und Scharlach", so ist das nur eine der bei den alten Liturgikern so beliebten nachträglichen Gegenüberstellungen eines alt- und neutestamentlichen Brauches. Über das Verhältnis der beiden zueinander seben die Worte Innozenz' III. keinen Aufschluf. Wie wenig dieser an eine wirkliche Ableitung des liturgischen Farbenkanons von den Farben der jüdischen Kultkleidung denkt, ergibt sich auf das klarste aus der Weise, wie er die Einführung des Grün begründet.

Der Ursprung der liturgisehen Farbenregel liegt ganz anderswo als in einem Hinblick auf alttestamentlichen Brauch; sie ist a us dem Schof der symbolisierenden Tendenzen des 12. Jahrhunderts geboren worden. Auf die Entstehung der liturgischen Kleidung hat die Symbolik keinen Einfluf ausgeibt, dagegen ist der kirchliche Farbenkanon im eigentlichsten Sinne ihre Schöpfung. Er ist ganz und gar auf dem Boden jener mystischen Betrachtungen und Anschauungen erwachsen, welche eine gewisse Verwandtschaft fanden oder doch zu finden glaubten zwischen dem Charakter der einzelnen Farben und ihrer Wirkung auf das Gemüt einerseits und dem geistigen Kolorit der verschiedenen kirchlichen Feste und der diesen eigentümlichen religiösen Stimmung anderseits.

Die Symbolik, welche man in Rom um 1200 mit den liturgischen Farben verband, hat Innozenz IIL. weitläufig erörtert. Durandus hat dieselbe fast wörtlich in sein Rationale aufgenommen. Sie ist es ohne Zweifel, welche in Rom kurz vor den Tagen des großen Innozenz zur Feststellung der römischen Kirchenfarben geführt hat. Die mystischen Deutungen, welche dieser den einzelnen Farben gibt, bilden in ihrer Einfachheit und Natürlichkeit einen wohltuenden Gegensatz zu den überschwenglichen Auslegungen, welchen man heute nicht selten in erbaulichen, aber auch in liturgischen Schriften antrifft.

An den Festen der Bekenner und Jungfrauen, so belehrt uns Innozenz III., symbolisiere Weißs Unversehrtheit und Unschuld. Er führt dabei die Schriftworte an: Nam candidi facti sunt nazaraei eius ${ }^{1}$, und: Ambulabunt semper cum eo in albis. Virgines enim sunt et sequuntur Agnum, quocumque ierit ${ }^{2}$. Unter den nazaraei, Auserwählten, versteht er die Bekenner. Symbol makelloser Reinheit ist rie weil3e Farbe auch an den Festen der heiligen Engel, am Fest der Geburt des Vorläufers des Erlösers, des hl. Johannes, der zwar in Sünde empfangen, aber schon im Mutterschof geheiligt wurde, und zumal am Geburtsfest des Heilandes. Am Fest der Erscheinung des Herrn betrachtet der Papst dagegen die weife Farbe der Paramente als Erinnerung an den Glanz jenes wundersamen Sternes, welcher die Weisen zum menschgewordenen Gottessohne nach Bethlehem führte. Am Lichtmefatag sind es nach Innozenz zugleich Mariä jungfräuliche Reinheit und Christus als das Gotteslicht, zur Erleuchtung der Heiden und zur Verherrlichung seines Volkes Israel", welche durch das Weif des Festes versinnbildet werden. Am Gründonnerstag, hören wir, werde die weilße Farbe gehraucht sowohl um der Segnung des Chrisams willen, das zum Zweck der Rieinigung (Heiligung) der Seele geweiht werde, als auch, weil das Evangelium dieses Tages, das die Fufwaschung berichtet, die Reinheit der Seele in besonderem Maf3e anempfehle. Der Papst beruft sich auf die Worte, die der Herr zu Petrus sprach: Qui lotus est, non indiget, nisi ut pedes lavet, sed est mundus totus, und: Si non lavero te, non habebis partem mecum ${ }^{3}$. Ostern sollen uns die weilsen Paramente an die Boten der Auferstehung, die Engel, erinnern, die in weißem Kleid am Grabe des Auferstandenen den Frauen erschienen und ihnen die frohe Kunde brachten, dafs der Herr erstanden sei; am Himmelfahrtstag an die weiße Wolke, in der Christus zum Himmel auffuhr, wie auch an die heiden Engel in weiß3em Gewande, welche den auf dem Ölberg Versammelten erschienen und sie über die Auffahrt des Erlösers trösteten. Am Kirch-

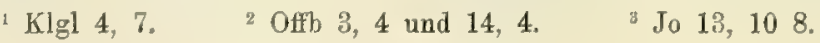


weihfest, so werden wir belehrt, symbolisiere die weißse Farbe. daf die Kirche die makellose Braut des Gottessohnes ist.

Rot erinnert nach Innozenz an den Festen der Apostel und Märtyrer, daf diese für Christus ihr Blut vergossen. Eine gleiche Symbolik hat für ihn die rote Farbe der Paramente an den Festen Kreuz-Erfindung und Kreuz-Erhöhung, wenngleich er lieber weiße an diesen beiden Tagen getragen sehen möchte, da an ihnen ja nicht sowohl das Andenken an das Leiden des Erlösers als vielmehr das freudige Gedächtnis der Auffindung und Erhöhung des Kreuzes Christi begangen werde. Pfingsten ist das Rot der liturgischen Gewänder Symbol der Feuerzungen, in Gestalt derer der Heilige Geist sich auf die Apostel niederließ. Am Festtag einer heiligen Jungfrau, die zugleich Märtyrin war, hält Innozenz rote Paramente für die passendsten, weil das Martyrium als Zeichen der vollkommensten Liebe (maiorem caritatem nemo habet, quam ut animam suam ponat quis pro amicis suis ${ }^{1}$ ) vor der Jungfräulichkeit den Vorzug habe. Dagegen belehrt er uns, daßs man sich an Allerheiligen zu Rom, abweichend vom Gebrauch an andern Orten, nicht roter, sondern weifer Gewänder bediene, weil „nicht sowohl an diesem Tag, sondern von diesem Tag die Kirche sage, es ständen nach der Offenbarung des hl. Johannes die Heiligen in weifen Gewändern. Palmen in den Händen vor dem Lamme*, d. h. weil an diesem Tage nicht der besondere Charakter der Seligen, sondern ihre Seligkeit im allgemeinen der Gegenstand der Festfeier sei.

Die schwarze Farbe beim Gottesclienst im. Advent, zwischen Septuagesima und Ostern und für die Verstorbenen erklärt Innozenz durch den Hinweis auf den Charakter der Trauer, Bußse und Sühne, den derselbe besitze. Auch am Tage der unschuldigen Kinder brauche man wohl schwarze Paramente, indem man dadurch die Trauer über deren Ermordung zum Ausdruck bringen wolle.

Für den Gebrauch des Violett gibt Innozenz keinen mystischen Grund an, sondern begnügt sich damit, es als Nebenfarbe und Ersatz für Schwarz zu hezeichnen. Wir finden ihn jedoch bei Durandus; derselbe belehrt uns nämlich, nachdem er die Tage verzeichnet hat, an denen man violette Paramente brauchte, man bediene sich an ihnen der violetten Farbe, weil sie pallidus et quasi lividus sei, $d$. $h$. weil dieselbe trüb und wie blutunterlaufen aussehe. Merkwürdig, wie eine Farbe, welche ehedem den ersten Rang unter allen Farben eingenommen hatte und die Kaiserfarbe im besondern Sinne gewesen war, im Lauf der Zeit den Charakter einer Trauerfarbe bekam.

Interessant und zugleich bedeutsam für die Entstehungsgeschichte des römischen Farbenkanons ist die Weise, wie der Papst das Grün begründet. Vom Grün der Hoffnung und ähnlichem, womit man heute gern die grüne Farbe der Paramente erklärt, sagt er kein Wort. Grün brauche man, belebrt er uns, quia viridis color medius est inter albedinem et nigredinem et ruborem. Innozenz will sagen: Es gibt Tage, die keinen bestimmt ausgesprochenen Charakter haben, so daß für sie weder Weif noch Rot noch Schwarz paßst. Sie sind weder Buftage, noch feiert man an ihnen das Andenken an Christi Leiden oder das Martyrium eines Heiligen, noch begeht man an ihnen das Gedächtnis an ein freudiges Geheimnis oder einen Heiligen, dessen Heiligkeit in Weif seinen entsprechenden Ausdruck fände. Man nimmt daher an diesen Tagen passend eine Farbe, die, was ihren Farbenwert anlangt, in der Mitte zwischen Weiß, Rot und Schwarz (Violett) steht, d. i. Grün. Die Erklärung ist weniger poetisch als manch spätere Deutung: sie gibt jedoch ohne Zweifel den richtigen Grund an, der dem Grün Aufnahme in den liturgischen Farbenkanon verschafft hat. Allerdings läßt sich, was Innozenz sagt, auch auf Gelb anwenden. Indessen hören wir ja von dem. Papst, daf man wirklich dieses wohl als Nebenfarbe von Grün behandelte.

Welche Bedeutung man da, wo man eine vom römischen Farbenkanon verschiedene Farbenregel beobachtete, den einzelnen Farben beilegte, ist gewöhnlich nicht gesagt, doch ist es in den meisten Fällen nicht schwer, die Symbolik zu erraten.

1 Ebd. 15, 13. 
Weif im Advent sollte z. B. auf die Makellosigkeit der Geburt des kommenden Gottessohnes und die jungfräuliche Reinheit derjenigen, die ihn gebären werde, hinweisen. Bei del Palmprozession war die weiße Farbe der Paramente der Ausdruck der Freude und des Jubels, mit dem einst die Bewohner Jerusalems den Heiland bei seinem feierlichen Einzug in die Stadt empfingen und ihn zum Tempel geleiteten. Ein anderey Grund für ihren Gebrauch bei der Prozession lag in dem Umstand, daßs man hei derselben wohl das heiligste Sakrament, d. i. den Erlöser unter sakramentaler Gestalt, umhertrug. Wenn man sich in der ganzen Zeit von Epiphanie bis Lichtmek bzw. Septuagesima weißer Gewänder beim Gottesdienst bediente, so lag das daran, daf3 man dieselbe noch als Teil der Weihnachtszeit ansah.

Rot in der Passionszeit erklärt sich leicht durch den Hinblick auf das Leiden des Erlösers und sein für uns vergossenes Blut. In der Weihnachtszeit und Weihnachten mochte es die Liebe versinnbilden sollen, die der Gottessohn durch seine Nenschwerdung zu uns bekundete. Am Allerheiligenfest trug man rote Paramente ob martyres, wie das alte Trierer Missale sagt, also mit Rücksicht auf die heiligen Märtyrer, die aus Liebe zu Christus ihr Blut vergossen hatten. Von Trinitatissonntag bis Advent war Rot darum wohl üblich, weil diese Zeit das Wirken des Heiligen Geistes in der Kirche darstellt. Eine verwandte Symbolik mag auch Ursache gewesen sein, daß man zu Ellwangen am Fest Mariä Heimsuchung rote Paramente trug. Wie es scheint, sollte dadurch ausgedrückt werden, dafs Elisabeth bei ihrer Begegnung mit Maria vom Heiligen Geist erfüllt und der hl. Johannes in ihrem Schofe geheiligt wurde. Warum man am Oktavtag der unschuldigen Kinder statt des Schwarz oder Violett des Festes rote Gewänder trug, sagt uns das Ordinale Grandissons von Exeter, wenn es bezüglich dieser Sitte bemerkt: Quia octava resurrectionem significat, weil der Oktavtag die Auferstehung berlente.

Der Gebrauch des Gelb am Fest der Erscheinung des Herrn geschah unzweifelhaft, um den goldigen Glanz des Sternes anzudeuten. Croceus auro similis fulgenti, heifst es im Ordinale Grandissons. Gelb an der Vigil vor Ostern, Pfingsten und Weihnachten, wie wir es zu Eichstätt antreffen, mochte seinen Grund darin haben, daE man diesen T'agen ihren Vigilcharakter zu wahren und doch sie zugleich vor den übrigen Vigilien auszuzeichnen suchte. An den Festen der Bekenner waren vielfach gelbe (grüne) Gewänder im Brauch, weil man die heiligen Bekenner weder als virgines noch als martyres behandeln wollte und darum einen color medius, wie Innozenz das Grün nennt, für das Geeignetste hielt.

Ein Minoritenmissale der vatikanischen Bibliothek sieht in dem Gelb der Bekennerfeste ein signum eorum abstinentiae et afflictionis ${ }^{1}$. Wenn man aber Grün an den Festen der Bekennerbischöfe und Gelb an denjenigen der übrigen Bekenner bzw. umgekehrt brauchte, so geschah das wohl lediglich, um die einen von den andern zu unterscheilen, wie ein Caeremoniale der Vaticana ${ }^{2}$ sagt: ad distinguendum (confessores non pontifices) a confessoribus pontificibus.

Warum man den color cinericius, die Farbe der Asche, den Paramenten am Aschermittwoch und in der Fastenzeit gab, liegt auf der Hand. Will man Violett am Weihnachtsfeste nicht durch den Hinweis auf die Erniedrigung erklären, in die sich Christus durch die Menschwerdung begab, so mag man vielleicht in ihm eine Reminiszenz an die Wertschätzung sehen, deren sich einst die violette Farbe zu erfreuen hatte. Bei Bekennern, zumal Äbten und Mönchen, bei heiligen Frauen und Witwen werden violette Gewänder Buße, Weltverachtung und Entsagung bedeutet haben.

Doch genug davon. Ein praktisches Interesse haben diese Deutungen, so interessant sie sind, ja doch nicht mehr. Sie gehören vergangenen Tagen an. Seit dem Verschwinden der nichtrömischen Farbenregeln hat auch deren Symbolik nur mehr einen geschichtlichen Wert. Als Probe, wie man einst die verschiedenen Farben deutete, und zugleich als Erklärung, wie es in den alten Farbenkanones zu so manchen Eigentümlichkeiten gekommen ist, reicht aber das Gesagte vollkommen aus.

$$
1 \text { Vat. Capp. 206. } 2 \text { Vat. Reg. } 280 .
$$




\section{DIE RITEN DES OSTENS UND DIE LITURGISCHEN FARBEN.}

In den Riten des Ostens gibt es keinen liturgischen Farbenkanon, ja die meisten kennen überhaupt keine liturgischen Farben. Man nimmt die Stoffe, wie man sie eben haben kann; doch pflegen, wenngleich keineswegs allgemein und ausnahmslos, die liturgischen Stauchen, der Gürtel, die Stola und der liturgische Mantel aus demselben Zeug gemacht zu werden, also von derselben Farbe zu sein. Nur im griechischen Ritus findet sich ein schwacher Anklang an eine liturgische Farbenregel. Im allgemeinen sind für die liturgische Kleidung alle Farben erlaubt, doch werden die hellen, glänzenden, leuchtenden bevorzugt. Von Ostern bis Christi Himmelfahrt ist Weif vorgeschrieben, und zwar selbst für die Begräbnisse 1. Während der großen vierzigtägigen Fasten haben die Gewänder gewöhnlich eine dunkle, und zwar meistens blaue oder violette Farbe. Doch trägt man in dieser Zeit bei der Liturgie auch wohl eine dunkelrote Gewandung, um an Christi Blut, das für uns vergossen ward, zu erinnern. Bei Begräbnissen wie am Karfreitag pflegt man sich der schwarzen Farbe zu bedienen. In der Kiewschen Metropole sind an den Aposteltagen Paramente aus Goldstoff, an den Märtyrertagen rote Kirchengewänder im Gebrauch. Das priesterliche Untergewand ist zwar nicht notwendig, aber doch gewöhnlich von weifer oder wenigstens heller Farbe. In Rußland wird in Hofkirchen häufig die sog. alexandrinische Mefakleidung getragen. Sie besteht aus grünem, mit Kreuzen geschmücktem Phelonion (Kasel), rotem Gürtel, roten Epimanikien (Stauchen), rotem Epigonation (Kniestück) und rotem Epitrachelion (Stola) 2 . Wie wenig übrigens selbst im griechischen Ritus von einer strikten Farbenregel die Rede sein kann, beweist klar die Tatsache, daf bei den Konzelebrationen, bei denen mehrere Priester gemeinschaftlich das heilige Opfer darbringen, die verschiedenen Priester keineswegs gehalten sind, Gewänder derselben Farbe zu tragen. Bei solchen Konzelebrationen kann man den einen Priester in einem grünen, den andern in einem blauen, einen dritten in einem violetten, den Hauptcelebrans aber in weikem Phelonion am Altar stehen sehen. Eine ausgebildete Farbenregel haben unter den Anhängern des griechischen Ritus nur die galizischen Ruthenen. Dieselbe ist indessen sehr jungen Datums, da es erst 1891 auf dem Provinzialkonzil von Lemberg zu ihrer Feststellung kam. Sie ist dem römischen Farbenkanon nachgebildet.

In der Ostkirche steht es also hinsichtlich einer liturgischen Farbenordnung noch jetzt so, wie es im Abendlande sich damit bis gegen das letzte Viertel des 12. Jahrhunderts verhielt.

Bezüglich der Geschichte der liturgischen Farben im griech is chen Ritus müssen wir uns kurz fassen, da soviel wie keine Nachrichten darüber vorliegen. Schon die unter dem Namen des hl. Sophronius gehende Mefierklärung kennt sowohl weiße wie rote Phelonien und weik auch für beide eine entsprechende Deutung ${ }^{3}$. Dagegen scheint ihr die Praxis, wonach rote Phelonien nur in der Fastenzeit und beim Leichengottesdienst getragen wurden, noch fremd zu sein. Indessen wird diese denn doch schon vom bulgarischen Erzbischof Demetrius Chomatenus in seinem Antwortschreiben an den Metropoliten von Dyrrhachium Konstantin Kabasilas erwähnt ${ }^{4}$, so dafis sie also spätestens

1 v. Maltzew, Fasten- und Blumen-Triodion LXXXv.

2 Nach gütiger Mitteilung des HerrnPropstes

v. Maltzew zu Berlin.

Braun, Die liturgische Gewandung. s $\mathrm{Mg} .87^{3}, 3988$.

1 Mg. 119, 949 und P itra, Analecta sacra et classica, Iuris eccl. graecorum selecta paralipomena, Paris. 1891, 634: 'Ev rénals ràp 48 
in der zweiten Hälfte des 12. Jahrhunderts aufgekommen sein muf. Im Beginn des 15. Jahrhunderts gedenkt ihrer Simeon von Saloniki ${ }^{1}$ und etwas später Kodinus?2.

Wie es in den übrigen Riten früher mit der Farbe der liturgischen Gewänder gehalten wurde, läßst sich nicht bestimmen. Ein unter dem Namen des lıl. Basilius gehender, jedenfalls aber späterer Kanon in der um die Mitte des 13. Jahrhunderts entstandenen koptischen Kanonessammlung des Ibu 'Assāl will, dafs die bei der Feier der Liturgie zur Verwendung kommenden Kleider weif, nicht aber gefärbt seien ${ }^{3}$. Wie weit ihm allerdings die Praxis entsprochen, muf dahingestellt bleiben.

\section{WEISS ALS LITURGISCHE FARBE IN DER VORKAROLINGISCHEN ZEIT.}

Es ist gesagt worden, in der ältesten Zeit sei Weif die ausschliefliche Farbe der liturgischen Gewandung und die alleinige liturgische Farbe gewesen, und zwar soll es so bis zum 9. Jahrhundert geblieben sein. Wir müssen etwas näher auf diese Frage eingehen. Natürlich kann es sich dabei nicht um die Farbe der liturgischen Untergewandung, des Humerale und der Albe, handeln; denn für diese blieb bis in die Gegenwart die weißse Farbe Brauch; es kommt vielmehr blof die Obergewandung, genauer die Kasel in Betracht. Denn von dem Pluviale kann vor der Karolingerzeit noch nicht die Rede sein, die diakonale und die subdiakonale Obertunika aber bewahrten ihre weife Farbe noch eine gute Weile über das 9. Jahrhundert hinaus. Farbige Dalmatiken und Tunicellen werden erst um die Wende des Jahrtausends gebräuchlich. Wir haben also, um eine richtige Antwort zu ermöglichen und nicht Gewänder mit Gewändern zu vermengen, die Frage genauer entweder zu formulieren: „War auch für die Ka sel vor dem 9. Jahrhundert die weife Farbe vorgeschrieben?" oder, was auf dasselbe hinauskommt: "Mufite bis dahin die ganze Kleidung des Liturgen beim Gottesdienst weiß sein?" Wird sie so gefaßst, so geht die oben angeführte Behauptung ohne Zweifel entschieden zu weit. Jedenfalls gilt das bezüglich des abendländischen Brauches in nachkonstantinischer Zeit.

Allerdings ist im Abendland vor dem 9. Jahrhundert wiederholt von weißen liturgischen Gewändern die Rede, doch handelt es sich in den meisten Fällen um die Tunika der Diakone oder des niederen Klerus. So ist die diakonale Tunika gemeint, wenn es in dem wohl mit Unrecht dem hl. Hieronymus abgesprochenen, jedenfalls aber vor dem Ende des 4. Jahrhunderts entstandenen Brief an den Diakon Präsidius von Piacenza heilit: "Beachte doch, was für eine schwierige Stellung es ist, des Stephanus oder Paulus Platz einzunehmen, eine Art englischen Dienstes auszuüben und auf das untergebene Volk in glänzendem (weißem) Gewande herabzuschauen." Von weifen Tuniken (albae)

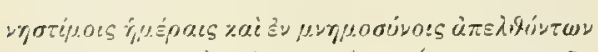

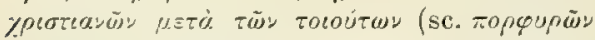

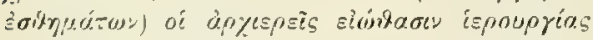

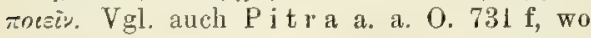
als Grund fiur den Gebrauch purpurner Gewänder in den Fasten der Bußcharakter dieser Zeit und die Erinnerung an das Purpurkleid des Heilandes angegeben wird.

1 De sacra ordinat. c. 83 (Mg. 155, 261).
2 De offic, eccl. c. 9 ( $\mathrm{Mg}, 157,83$ ).

s Renaudot, Liturg. orient. collect. I 160. Vgl. auch can. 99 der sog. Kanones des hl. Basilius bei W. Riedel, Die Kirchenrechtsquellen des Patriarchats Alexandrien, Leipzig 1890, 272, und can. 28 der sog. Kanones des hl. Athanasius, deren Mitteilung ich der Güte des Herrn Prof. Dx Riedel zu Greifswald verdanke. 
erzählt die Vita P. P. Emeritensium ${ }^{1}$. Eine Schar weißstrahlender Diakone begegnet uns bei Gregor von Tours in der Schrift De gloria confessorum 2, und eine Schar Diakone, die in Albae eine Bittprozession gegen Regen abhalten, in ebendesselben Vita S. Aridii ${ }^{3}$. Von einem Archidiakon, der am Weihnachtstage mit einer Alba bekleidet den zur Kirche kommenden Bischof in Empfang nimmt, erzählt uns die Historia Francorum Gregors * Von der Alba der Diakone und Lektoren handelt der 12. Kanon der Synode von Narbonne vom Jahre $589^{5}$, von der Alba der Diakone der 41. Kanon des sog. vierten Konzils von Karthago ${ }^{6}$.

Die wenigen Stellen, welche von der liturgischen Gewandung im allgemeinen oder dem priesterlichen Obergewande im besondern sprechen, beweisen höchstens, dafi man sich weifer Gewänder mit Vorzug oder bej bestimmten Gelegenheiten bedient habe, nicht aber, das Weif die ausschliefliche liturgische Farbe gewesen sei. So, wenn wir in Gregors von Tours Schrift De gloria confessorum ${ }^{7}$ lesen, daf bei der Einweihung einer Kapelle Priester und Leviten in vestibus albis erschienen seien; wemn wir in ebendesselben Vita Patrum ${ }^{8}$ von casulae candidae hörten, quae per paschalia festa humeris sacerdotum imponuntur, oder wenn die gallikanische Mefaerklärung uns berichtet, man trage am Ostertage weike Gewänder.

Wie es in Gallien für gewöhnlich gehalten wurde, ersehen wir aus dem Lobgedicht des Venantius Fortunatus auf den Klerus von Paris. Denn wenn es darin heifst:

Inde sacerdotes, leviticus hinc micat ordo.

Illos canities, hos stola pulchra tegit;

Illi iam senio, sed et hi bene vestibus albent,

so weist das zur Genüge darauf hin, daf eine weife Gewandung eine Eigentümlichkeit der Leviten war und daf die Priester für gewölnnlich nicht ganz in Weif erschienen ${ }^{9}$.

Auch die bekannten Worte des hl. Hieronymus: "Was für ein Unrecht gegen Gott soll darin liegen, wenn ich eine reinere Tunika habe und wenn der Bischof, die Priester, der Diakon und der übrige Klerus bei der Darbringung des heiligen Opfers in glänzendem Gewande (veste candida) aufziehen? "10, sind keineswegs ein Beweis, dafs damals Weif die ausschliefliche Farbe der liturgischen Kleidung war. Sie sind gegen die Pelagianer gerichtet, welche in stoischer Einseitigkeit die gloria vestium et ornamentorum, eine reiche Kleidung als Gott zuwider bezeichneten. Für ihr Verstänỏnis ist von Belang, was der Heilige, auf die Pelagianer anspielend, im Anschlul an die angefiuhrten Worte weiter bemerkt: "Ihr Geistliche, seht euch vor", ruft er aus, „seht euch vor, ihr Mönche, ihr (gottgeweihten) Jungfrauen und Witwen, ihr seid in Gefahr, wenn euch das Volk nicht in Schmutz und mit Lumpen bedeckt sieht. Von den Weltleuten ganz und gar zu schweigen, denen man offen Krieg ankündigt und die man zu Feinden Gottes stempelt, wenn sie sich kostbarer und glänzender Kleidung bedienen." Offenbar will Hieronymus keineswegs sagen, es seien zu seiner Zeit die liturgischen Gewänder ausschlieflich weil gewesen. Noch jetzt, da es doch verschiedene liturgische

1 C. 6 (M. 80,133$)$.

2 C. 61 (M. 71, 872).

${ }^{3}$ C. 8 (ebd. 1124).

- L. 4, c. 38 (ebd. 306).

5 Hard. III 493.
7 C. 20 (M. 71, 843).

${ }^{8}$ C. 8 , n. 5 (ebd. 104.5). Vgl. Cypriani Vita S. Caesar. 1. 1, c. 4 (M. 67, 1017).

9 Miscell. 1. 2, c. 13 (M. 88, 102).

10 Adv. Pelag. 1. 1, n. 29 (M. 23, 524). 
Farben gibt, könnte der Heilige dieselbe Sprache führen. Obendrein darf man nach dem Zusammenhang das Wort candidum nicht zu sehr pressen. Es hat hier offenbar nicht den speziellen Sinn von Weif, sondern mehr den allgemeineren von Glänzend. Auch ist nicht einmal sicher, ob die vestis candida, von der Hieronymus redet, das Obergewand oder die Tunika bedeutet. Für letzteres spricht nicht blof die tunica mundior, der unmittelbar vorher Erwähnung geschieht, sondern auch der Umstand, daf der Heilige ausdrücklich von der vestis candida aller Kleriker redet. Sollte aber wirklich unter ihr nur die Tunika zu verstehen sein, so leuchtet ein, dafs dann erst recht die Stelle nicht zum Beweis herangezogen werden kann. Denn auch heute muf die Albe stets weif sein.

Wie es sich tatsächlich im ausgehenden 5., im 6., 7., 8. und 9. Jahrhundert verhielt, ersehen wir aus den Monumenten aus jener Zeit. Sitte und Brauch, wie sie damals bestanden, haben auf denselben einen unzweifelhaften Ausdruck gefunden. Fast ausnahmslos sind auf ihnen, soweit sie wenigstens dem Abendlande angehören, die Bischöfe und Priester in farbiger Planeta dargestellt. So auf dem Mosaik der Kapelle des hl. Satyrus bei S. Ambrogio zu Mailand (Ende des 5. Jahrhunderts), den ravennatischen Mosaiken des 6. Jahrhunderts, einem Fresko in der Katakombe des Pontian zu Rom (6. Jahrhundert), den römischen Mosaiken des 7. und 9. Jahrhunderts, einem wohl noch ins 7. Jahrhundert reichenden, die hll. Kornelius, Cyprianus Xystus und Optatus darstellenden Fresko in der Katakombe von S. Callisto zu Rom, dem Diptychon zu Brescia mit den Bildern des hl. Hieronymus, Augustinus und Gregor d. Gr. (8. Jahrhundert) und dem noch zu Lebzeiten des grofen Gregor in dem von ihm gestifteten Kloster auf dem Clivus Scauri gemalten Porträt des Papstes, von dem Johannes Diakonus eine eingehende Beschreibung hinterlassen hat. Bald ist die Planeta auf diesen Monumenten von kastanienbrauner, bald von gelber, violettpurpurner, grünlicher, roter oder blauer Farbe. In weifer Planeta erscheint einzig Papst Pelagius auf dem Triumphbogenmosaik in S. Lorenzo fuori le Mura zu Rom. Aber gerade die Figur dieses Papstes ist auf dem betreffenden Mosaik eine vollständig neue ${ }^{1}$.

1 Auf die Farbe der Obergewänder der Bischöfe und Priester auf den Mosaiken und Fresken des 5.-9. Jahrhunderts hatte der Verfasser schon in einem Aufsatz der Inns. brucker Zeitschrift für katholische Theologie $(1901,157)$ als Beweis hingewiesen, daf in jener Zeit nicht ausschließlich Weiß die liturgische Farbe gebildet habe. Dazu bemerkt nun H. Kellner (Heortologie, Freiburg 1906, 52, Anm. 1): "Braun bestreitet, daßs Weif die einzige Kultfarbe gewesen sei, und beruft sich auf einzelne Bildwerke aus dem 5.-9. Jahrhundert (nicht Miniaturen), auf welchen gelbe, braune und andere Farben erscheinen. Allein "Weif" braucht nicht gerade schneeweik zu sein und die Naturfarbe der Seide spielt bekanntlich ins Gelbliche. Auch können die Bildwerke nachgedunkelt oder spàter úbermalt sein. Jedenfalls ist sein Beweismaterial nicht kräftig genug, um gegen die vielen Aussprüche der Quellen, die für die herrschende Ansicht sind, aufzukommen." Hierauf dürfte indessen zu erwidern sein: 1. Bei Prüfung und Wertung der keineswegs vielen schriftlichen Zeugnisse muf man durchaus Land, Zeit und Gowand unterscheiden, 2. Weif braucht gewif3 nicht schneeweic za sein, aber unmöglich können Kastanienbraun, Purpurviolett, Dunkelblau, Grün als, "Weiß” gelten. 3. Bei Mosaiken und Fresken kann von einem Nachdunkeln nicht die Rede sein; Fresken pflegen im Gegenteil zu verbleichen. Auch darf man wohl fragen, warum nur die Planeta ihre Farbe verändert haben soll, während doch die Tunika und Dalmatik ihr Weis in aller Frische behielt. 4. Keine der im Text angeführten Darstellungen ist in späterer Zeit übermalt worden, was bei den Mosaiken ohnehin ausgeschlossen ist. 
Wie wenig man sagen kann, es sei im Okzident bis zum 9. Jahrhundert Weif ausschlieblich die liturgische Farbe gewesen, erhellt auch aus dem schon in der Frühe des 7. Jahrhunderts sich geltend machenden Bestreben spanischer Diakone, farbige Orarien einzuführen. "Caveat", so verordnet das vierte Konzil von Toledo 633 in seinem 40. Kanon, „amodo levita gemino uti orario, sed uno tantum et puro nec ullis coloribus aut auro ornato." 1

Man vergesse doch auch nicht die Verhältnisse, in denen sich die Kirche in der uns hier beschäftigenden Zeit befand. Sie hatte durch Konstantin den Frieden erlangt und konnte ungehindert den Gottesdienst mit dem seiner Würde entsprechenden Glanz umgeben. Es fehlte ihr auch keineswegs dazu an den nötigen Mitteln; denn die christlich gewordene Welt, geistlich wie weltlich, legte mit höchster Freigebigkeit ihre Gaben auf die Altäre nieder. Es erstanden die herrlichen von Marmor strahlenden Basiliken mit ihren von Gold und Farbe leuchtenden Mosaiken, mit ihrem reichen Altargerät, mit ihren Lichterkronen, Bildwerken, Altarbekleidungen aus edeln Metallen und kostbarem Gestein und ihren purpurnen, grimen oder golddurchwirkten Altarund Wandbehängen aus prächtigen orientalischen und byzantinischen Seidenstoffen, oft das Werk eines Gebers. Man vergleiche nur die so wichtige Carta Cornutiana und die Angaben, welche sie enthält ${ }^{2}$. Es wäre wahrlich ein Wunder gewesen, hätte man die kostbaren farbigen Stoffe, mit denen man die Mauern bekleidete, zwischen den Säulen des Schiffes eine Folge glänzendster Draperien bildete und selbst den Altar umgab, nicht auch zur Herstellung der liturgischen Kleidung verwendet.

Etwas anders wie im Abendlande scheint es sich im Orient verhalten zu haben. Hier dürfte in der Tat hie und da Weis als die eigentliche Farbe der liturgischen Gewandung gegolten haben. Denn es lassen nicht blof die sog. Apostolischen Konstitutionen den Bischof in einer iaunpì è oil's zum Altare gehen ${ }^{3}$, sondern es sagt auch der 37. der sog. Kanones des Hippolyt: "So oft der Priester die Mysterien genieben will, sollen sich die Diakone und Priester in weifen, ganz vorzüglich reinen Gewändern, die schöner sind als die des ganzen übrigen Volkes, bei ihm versammeln*. Auch der 99. der sog. Kanones des hl. Basilius ${ }^{5}$ und der 28. der sog. Athanasianischen Kanones ${ }^{6}$ wollten, daß die liturgische Kleidung weif sei. „Die Gewandung, worin die Priester zelebrieren, soll weiß und gewaschen sein", sagt dieser; jener aber bestimmt: „Die Kleider, welche sich für das Priestertum ziemen, sollen weifs sein, nicht mit Farben gefärbt." 7 Allerdings ist durchaus nicht sicher, ob die beiden letztgenannten Kanones noch in die altchristliche Zeit hinaufreichen.

1 Hard. III 588.

2 Die Carta Cornutiana (D u c h., L. P. I, CXLVII), die Stiftungsurkunde einer Kirche bei Tivoli, stammt aus dem Jahre 471. Sie erwähnt unter andern: vela blattea auroclava paragandata, vela tramosirica prasinopurpura, vela tramosirica leucorodina, vela tramosirica leucoporphyra, vela olosirica coccoprasina etc. Und alles das befand sich nicht in einer der grofen Kirchen Roms, sondern in einer Landkirche.

${ }^{3}$ L. 8, c. 12 (Mg. 1, 1092).

4 Mg. 10, 962. Vgl. auch $\mathrm{R}$ i e de 1, Die Kirchenrechtsquellen des Patriarchats Alexaudrien 224.

\section{Ebd. $272 . \quad 6$ S. oben S. 754.}

7 Wenn das Testamentum D. N. Iesu Christi (1. 1, c. 24 [ed. R a h mani 83]) bestimmt:, Wer unter den. Diakonen durch Fleif und Verwaltungstüchtigkeit hervorragt, soll mit der Aufnahme der Fremden betraut werden und in dem in der Kirche befindlichen Hospiz weilen, wobei er mit weikem Gewand bekleidet $z u$ sein and auf der Schulter das Orarium zo tragen hat", so ist unter dem weifen Gewand unzweifelhaft die Tunika zu verstehen. Blof von der diakonalen Tunika redet auch der hl. Johannes Chrysostomus in der 82 . Homilie zu Matthäus, wenn er den Diakonen zuruft : "Das 
Übrigens darf man auf den angeführten Stellen nicht allzuweit gehende Folgerungen aufbauen. Denn erstens hat wohl keine der genannten Bestimmungen jemals allyememe Geltung besessen. Auberdem ist zweitens fraglich, ob der Theorie auch wirklich die Praxis entsprochen habe. Schon Theodoret erzählt uns von einem kostbaren, aus Goldstoff gemachten Gewand, welches Konstantin dem Bischof Makarius von Jerusalem für die Vornahme der Taufliturgie

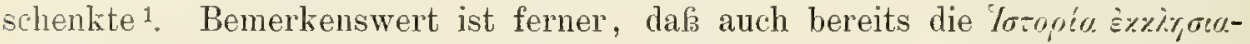
arxir. welche doch noch vor dem 9. Jahrhundert entstand, von einem roten Phelonion des Bischofs redet. Es wäre in der Tat zu auffallend, wenn man die Prachtgewebe, die in Byzanz, in Syrien, Ägypten usw. geschaffen wurden, so ganz und gar bej Herstellung der liturgischen Gewandung verschmäht hätte. Schwerlich ist auch die Schenkung Konstantins an Bischof Makarius ein ganz allein stehendes Ereignis geblieben.

Leider lassen uns die griechischen Monumente in unserer Frage fast ganz im Stich. Die Kasel, welche Bischof Eusebius auf einer Miniatur des syrischen Evangeliar der Laurentiana zu Florenz trägt (6. Jahrhundert), ist braun; jedoch ist es fraglich, ob es sich hier bei dem Gewand um ein liturgisches Kleidungsstück handelt. Welche Farbe das Phelonion des Bischofs Philippus und des Presbyter Romanus auf den Mosaiken der ehemaligen St Georgskirche (jetzt Moschee) zu Saloniki hat, lassen die davon vorliegenden Reproduktionen nicht mit Sicherheit erkennen"2. Das Obergewand des Patriarchen Theophilus auf den Miniaturen der früher erwähnten alexandrinischen Weltchronik ${ }^{3}$ ist rotbraun bzw. blauviolett. Es sind die einzigen Bildwerke, die etwa hier in Betracht kommen könnten.

Die bisherigen Erörterungen galten der nachkonstantinischen Zeit. Wie es sich in vorkonstantinischer hinsichtlich der Farbe der liturgischen Gewänder verhielt, darüber fehlen alle Zeugnisse, wenn man nicht etwa gegen alle Wahrscheinlichkeit den 37. der sog. Kanones des Hippolyt als wirklich von diesem herrührend ansehen sollte. Wir erhalten weder aus dem Osten noch dem Westen eine Nachricht, welche uns berechtigte, Weiß als die Farbe zu bezeichnen, die in der Frühzeit des Christentums mit Ausschlußs aller andern für die liturgischen Gewänder gebraucht werden mußite.

Man beruft sich freilich auf Äukerungen Klemens' von Alexandrien* und Tertullians ${ }^{5}$, in welchen diese gegen bunte und gefärbte Kleider eifern, die Wollfärber verbannt sehen möchten und weife bzw. naturfarbene Kleider zu tragen empfehlen. Indessen sind das nur Philippiken gegen den Kleiderprunk, den Luxus und die damit zusammenhängende Zügel- und Sittenlosig-

ist eure Würde, das eure Sicherheit und Krone (d. i. zu unterscheiden, wen sie zum Tisch des Herra zulassen können), nicht in weifer, glänzender Tunika herumzugehen" (Mg. 58, 745). Wenn aber in des Palladius Dialog iiber das Leben des hl. Johannes Chry sostomus erzählt wird (Mg. 47, 38), es habe sich der Heilige auf dem Wege in die Verbannung, da er sein Ende nahe gefühlt, zu einem bei der Stadt Comana gelegenen Martyrium (Kapelle utber einem Märtyrergrab) hringen lassen, dort seine Kleider mit glänzenden, seines Standes würdigen Gewändern

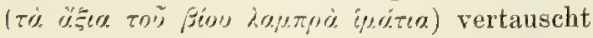

und so die heilige Wegzehrung empfangen, so ist wiederum nicht klar, ob hier $\lambda x \mu \pi \rho o ́ s$ ausschließlich weiß bedeutet. Keinesfalls aber folgt aus dem Bericht; daß3 zu des Heiligen Zeiten, also um 400, in der Ostkirche Weifs ausschlieflich Kultfarbe gewesen sei.

1 Hist. eccl. 1. 2, c. 23 (Mg. 82, 1066).

2 Abbildungen nach $T$ ex $\mathrm{i}$ e $\mathrm{r}$ und $\mathrm{P}$ u 11 a (Architect. Byzant. pl. $\mathrm{xxx}$ ) bei M a r r. pl. xviII $\mathrm{xx}$.

3 S. oben S. 236.

4 L. 2, c. 10 ; 1. 3, c. 11 (Mg. 8, $521 \mathrm{ff} 627 \mathrm{ff})$.

5 De cultu femin. 1. 1, c. 8; 1. 2, c. 12 (M. 1, 1312 1330). 
keit. Auf keinen Fall kann man aus diesen nicht wenig von einseitigem Rigorismus getragenen Auslassungen berechtigterweise einen Schluf auf die gottesdienstliche Praxis der Kirche machen, ja auch nur dieselben als der allgemeinen Anschauung der alten Kirche entsprechend hinstellen und aus ihnen folgern, es hätten sich die Christen des 2. und 3. Jahrhunderts prinzipiell nur weifer oder naturfarbener Gewänder bedient. Ebensowenig ist für unsere Frage von entscheidendem Belang die Bemerkung der Stromata, man müsse gewaschen, rein und glänzend zur Teilnahme an der Opferfeier kommen, und zwar, wie aus dem Zusammenhang folgt, nicht blof im Sinne körperlicher und moralischer Reinheit, sondern auch in dem einer saubern Kleidung ${ }^{1}$; denn es ist in ihr nicht an die Priester, sondern an die Gläubigen gedacht. Allerdings könnte man schlief3en: wenn Kilemens schon von den Laien verlangt, in lichter Gewandung bei der Liturgie zu erscheinen, um wieviel mehr wird er dann gefordert haben, dafi der Klerus selbst bei seinen Funktionen sich einer solchen bediene. Gewiß; indessen liegt auf der Hand, daf mit dieser Folgerung noch keineswegs bewiesen ist, es sei zur Zeit des Alexandriners wirklich feststehender Brauch gewesen, die liturgischen Verrichtungen mit Ausschlıß jeder andern in weiker Gewandung zu vollziehen, und das ist es ja doch, um dessen Nachweis es sich handelt. Inwieweit haben überhaupt die Zeitgenossen des Klemens dessen Anschauungen geteilt und inwieweit hat man ihnen in der Praxis entsprochen?

Was man bestenfalls aus den angeführten Stellen folgern darf, ist eine gewisse Bevorzugung weifer Kleider bei Vornahme der gottesdienstlichen Verrichtungen. Eine solche kann nun freilich im altchristlichen Kútus nicht auffallen. In Kleidern weils wie Schnee, so weils wie kein Walker auf Erden sie machen kann, erschien der Heiland bei der Verklärung auf Tabor. Weife Gewandung umflof die Engel, welche den Frauen des Herrn Auferstehung verkündeten, weife Gewandung die Himmelsboten, welche die Apostel und Jünger nach des Herrn Auffahrt trösteten. Weỉ gekleidet waren die Scharen der Seligen, welche Johannes vor dem Throne des Lammes schaute; sie kamen aus grolier Trübsal und hatten ihre Kleider gewaschen und weif gemacht in des Lammes Blut. Weif ist die Ǩleidung, welche die vierundzwanzig Ältesten am Throne des Herrn tragen; glänzender Byssus deckt in der Vision des Apokalyptikers die Braut des Lammes, weiker Byssus das Heer, das auf weiken Rossen dem himmlischen Reiter folgt. Weiße Gewandung wird den Auserwählten als Siegeslohn verheißen.

Dazu kommt, daf Weif, wie es im jüdischen Kultus eine so bedeutungsvolle Stellung eingenommen hatte, so auch in den heidnischen Kulten wenn auch keine ausschliefiliche, doch eine hervorragende Verwendung fand. Aufserdem war Weif, bekanntlich bis wenigstens zum 4. christlichen Jahrhundert die vorzüglichste Farbe der Festgewandung in der griechisch-römischen Welt.

Indessen handelt es sich ja nicht darum, ob man in altchristlicher Zeit bei der Kleidung des Liturgen Weif bevorzugt habe -- das konnte geschehen, weil auch im gewöhnlichen Leben bei besseren Gewändern Weif; vorherrschte -, sondern darum, ob jene nach Brauch und Herkommen weif sein $\mathrm{mu}$ u te oder doch tatsächlich stets weif war. Denn nur in diesem Falle kann man von Weif als von einer wirklich liturgischen Farbe reden.

Übrigens wird die Bevorzugung der weißen Kleidung bei den gottesdienstlichen Verrichtungen sehr von den äußeren Umständen und von dem

${ }^{1}$ L. 4, c. 22 (Mg. 8, 1351). 
Brauch der verschiedenen Länder abgehangen haben. Wie die Gewandung der Liturgen sich von der profanen Tracht bezüglich der Form noch nicht unterschied und über diese noch keine besondern Vorschriften bestanden, so wird es anch hinsichtlich der Farbe derselben gewesen sein: man wird sich in den verschiedenen Gegenden nach des Landes Herkommen und Sitte wie auch nach den augenblicklichen Verhältnissen gerichtet haben.

Monumente, die uns Aufschlußs geben könnten, fehlen aus vorkonstantinischer Zeit so gut wie völlig. Das einzige Bildwerk, welches etwa in Betracht kommt, ist das bekannte Fresko in der Katakombe von S. Priscilla, welches gewöhnlich als Einkleidung einer gottgeweihten Jungfrau erklärt wird. Der Bischof, welcher die Zeremonie vornimmt, trägt über einer mit schwärzlichem Clavus verzierten Ärmeltunika eine gelblich braune Pänula (Kasel), der Diakon aber, welcher als dessen Minister fungiert, eine grünliche Tunika. Es scheinen also im 3. Jahrhundert, welchem das Bild zugeschrieben wird, zu Rom nicht ausschließlich weiße Gewänder bei liturgischen Akten getragen worden zu sein. Allein, gibt das Bild die Wirklichkeit wieder? Es liegt kein Grund vor, daran zu zweifeln. Denn wäre Weif ausschlieflich die Farbe der Kultkleidung gewesen, so würde der Maler den Bischof und seinen Diakon wohl schwerlich anders als in Weif dargestellt haben.

\section{DRIT'TES KAPITEL.}

\section{SEGNUNG DER LITURGISCHEN GEWÄNDER.}

Alles, was die Kirche in den nächsten Dienst der heiligen Geheimnisse zieht, pflegt sie durch ihre Segnungen dem profanen Gebrauch zu entziehen, dem Allerhöchsten und seinem Kultus zu weihen und dem erhabenen Zweck gemäf, zu dem es verwendet werden soll, einen heiligen Charakter zu verleihen. So das Gotteshaus, so den Altar, so Kelch und Patene, so das Altarlinnen, so auch die liturgischen Gewänder. Allerdings ist, was die letzteren anlangt, die Benediktion nicht für alle in gleichem Mafie vorgeschrieben. Alle können gesegnet werden; ja es darf als durchaus angemessen bezeichnet werden, daf alle durch die kirchlichen Segnungen zu res sacrae gemacht werden, eine strenge Pflicht ist das jedoch nur bezüglich des Amikts, der Albe, des Manipels, der Stola, der Kasel und, wie es scheint, auch des Cingulum, also bezüglich der priesterlichen Meßggewandung.

Die Vollmacht, die liturgischen Gewänder zu segnen, ist ein Vorrecht der Bischöfe; Priester können nur dann die Benediktion derselben vornehmen, wenn sie, was freilich sehr häufig geschieht, zu ihr besonders ermächtigt werden. Selbst im Notfall ist ihnen ohne besondere Delegation die Segnung nicht gestattet. Auch wird ein Parament, das im Notfalle oder im guten Glauhen bei der Messe gebraucht wurde, ohne vorher benediziert zu sein, nicht schon durch diese Verwendung zu einer res sacra, die einer Benediktion nicht weiter bedarf. Es muf vielmehr auch so noch vom Bischof oder dessen Stellvertreter gesegnet werden ${ }^{1}$.

Die Formulare, deren sich der Bischof bei der Segnung der liturgischen Kleider zu hedienen hat, finden sich im Pontifikale ${ }^{2}$. Es sind ihrer zwei. Das eine, allgemcinere, in welchem bestimmte Gewänder nicht genannt werden, umfaist zwei Gebete, von denen das erste mit den Worten beginnt: Omnipotens,

\footnotetext{
${ }^{1}$ C. R. 31. Aug. 1867 (Decret. auth. 3162). 2 Pontif. rom. p. II, De Benedict.
} 
sempiterne Deus, qui per Moysen famulum tuum etc., das zweite: Deus invictae virtutis triumphator et omnium rerum creator etc. Das andere ist Benedictio specialis cuiuslibet indumenti überschrieben und besteht nur aus einem Gebet, in dem die zu weihenden Gegenstände ausdrücklich angeführt werden. Priester, welche die Vollmacht erhielten, die Segnung vorzunehmen, haben sich des aus drei Gebeten bestehenden Formulars zu bedienen, welches im römischen Rituale enthalten ist ${ }^{1}$. Die beiden ersten Gebete sind eins mit den beiden, welche das erste Benediktionsformular des Pontifikale bilden, das dritte, gleichfalls allgemein lautende, hebt an: Domine Deus omnipotens, qui vestimenta pontificibus, sacerdotibus et levitis ete. Es wurde im Mittelalter namentlich zur Segnung der Stola und der Kasel verwendet, zumal aber der Stola, woran noch jetzt die Bitte erinnert, mit der es schliefst: Atque ministros altaris tui, qui ea induerint (sc. vestimenta), septiformis gratia dignanter repleri atque castitatis stola beata facias cum bonorum fructu operum ministerii congruentis immortalitate vestiri.

Das Alter des Brauches, die liturgische Gewandung zu segnen, ist nicht bestimmbar. Wie für manches andere fehlt es auch hierfür an Nachrichten. Aber auch auf aprioristischem Wege läbt sich die Zeit nicht feststellen. Denn mag es auch angemessen sein, dafo die Sakralkleider durch die Segnung über das Niveau der profanen Gewandung erhoben und für den heiligen Dienst ausgeschieden werden, so ist solches doch weder durch die Natur der Sache noch kraft eines positiven göttlichen Gebotes unbedingt erforderlich. Liegt doch noch heute keine strenge Pflicht vor, die Tunicella, die Dalmatik, das Pluviale und das Superpelliceum zu segnen. Und dann erhält ja ein Gewand schon dadurch, dafis es zu gottesdienstlichem Zwecke und nur zu diesem bestimmt ist, wenn auch nicht den Charakter einer gesegneten Sache, so doch eine gewisse Heiligkeit und Würde.

Man hat an die ispò otuìn erinnert, welche nach Theodoret Konstantin dem Bischof Makarius von Jerusalem zum Geschenk machte ${ }^{2}$; allein mit Unrecht. Theodoret konnte das Gewand heilig nennen, weil es für die Verwendung bei gottesdienstlichen Verrichtungen gespendet und dann auch bei diesen gebraucht worden war. Noch weniger beweist der üros novinons, von dem Eusebius in seiner bei der Einweihung der Basilika zu Tyrus gehaltenen Rede spricht ${ }^{3}$; gar nichts der auf Grund einer Notiz in der Vita Stephans I. von Pseudo-Isidor gefälschte Brief des Papstes an den Bischof Hilarius, in welchem es heist: Vestimenta ecclesiastica, quibus Domino ministratur, et sacrata debent esse et honesta ${ }^{4}$, Worte, die bekanntlich auch ins kanonische Recht Aufnahme fanden.

Immerhin soll schon wenigstens im Beginn des 6. Jahrhunderts die Segnung der liturgischen Gewänder zu Rom in Übung gewesen sein. Das im ersten Teil des Papstbuches, welcher um jene Zeit entstand, mitgeteilte angebliche Dekret Stephans I. (254-257): Hic constituit sacerdotes et levitas, ut vestes sacratas in usu cotidiano non uti nisi in ecclesia ${ }^{5}$, tue das dar, meint man. In der Tat kann kein Zweifel sein, daß damals wirklich bereits eine Benediktion der liturgischen Kleidung bekannt war und in Brauch stand, wofern unter den vestes sacratae jener Verordnung nicht blok heilige

1 Rituale Rom. tit. VIII, c. 20.

2 Hist. eccI. 1. 2, c. 23 ( $\mathrm{Mg} .82,1066)$.

s S. oben S. 95.

4. Hins chi us, Decret. Pseudo-Isidorianae, Lipsiae 1863, 183.

D D ch., L. P. I 154 . 
Gewänder im Sinne ron vestes sacrae, d. i. Gewänder, die durch Zweck und Gebranch geheiligt waren, zu verstehen sind, sondern durch eine besondere Segnung geheiligte Ornatstücke. Allein angesichts der mehrfachen Bedeutung, die man mit dem Worte sacratus zu verbinden pflegte ${ }^{1}$, ist eben dieses sehr unsicher. Jedenfalls wird man dem Sinne der Stelle schon dann röllig gerecht, wenn man unter den vestes sacratae Gewänder versteht, welche durch die Verwendung bei der Feier der Liturgie einen sakralen Charakter im weiteren Sinn erhalten hatten. Beachtenswert ist, daf Hieronymus und Augustinus selbst die Heiligkeit der mit den heiligen Geheimnissen in nächste Berührung kommenden Altargeräte, der Kelche und Altartücher, nicht aus einer Weihe, sondern aus deren gottesdienstlichem Gebrauch herleiten ${ }^{2}$. Was gegen die Auffassung der vestes sacratae als gesegneter Kleider spricht, ist namentlich der Umstand, dab weder das gelasianische, noch das gregorianische Sakramentar in seiner älteren Gestalt eine benedictio vestum sacerdotalium kennt, obschon doch bereits das Gelasianum außer den Segensgebeten für die Weihe des Kelches, der Patene und Korporalien sogar eine benedictio vestimentorum virginum enthält. Allerdings enthält das gelasianische Sakramentar auch eine Segensformel für alles, was zum Gebrauche der Kirche dient, doch ist diese erstens schwerlich ursprünglich und dann scheint bei ihr nur an kirchliche Gerätschaften gedacht zu sein.

Die früheste sichere Nachricht über eine Segnung der Sakralgewänder erhalten wir erst im 9. Jahrhundert, woraus freilich nicht folgt, daf sie erst damals in Brauch kam. Sie mag vielmehr schon eine geraume Zeit in Übung gewesen sein, nur fehlt es an diesbezüglichen Angaben. Es sind PseudoIsidor und Benedikt Levita, die zuerst von ihr sprechen, jener in dem schon angeführten gefälschten Schreiben Stephans I., dieser in ]. 3, c. 431 seiner Kapitularensammlung ${ }^{3}$. Um das Ende des 9. Jahrhunderts begegnen uns in dem Ordo der Kirchweihe eines Sakramentars der Kathedrale zu Reims zwei Gebete für die Segnung der Stola, der Planeta und des Cingulum 4 . Sie sind, wenn die Datierung des Pontifikale bei Martène richtig ist, die ältesten bekannten Beispiele vou Benediktionsformularen; denn das sog. Egbertspontifikale, welches in dem Weiheritus nicht weniger denn vier verschiedene Gebete für die Segnung der liturgischen Kleider enthält, stammt in seiner jetzigen Form nicht aus der Zeit Egberts von York ( $†$ 766) wie Hefele, Krieg, Thalhofer u. a. irrtümlich glaubten, sondern frühestens aus der Mitte des 10. Jahrhunderts. $\mathrm{Zu}$ den Bereicherungen, die sein Inhalt damals erfuhr, gehört auch die Benedictio ad stolas vel planetas, quando levitae seu presbyteri ordinandi sunt aut ordinati quidem reperiuntur ${ }^{\overline{ }}$, ersichtlich ein späteres Einschiebsel in den ursprünglichen Ordo. Ihre merkwürdige verworrene Stellung im Weiheritus sowohl als ein Vergleich des Pontifikale mit andern gleichartigen wie mit dem Pontifikale von Aletis oder Jumièges in der Stadtbibliothek zu Rouen und dem St Dunstans-Pontifikale der Pariser Nationalbibliothek (jenes aus dem Ende des 10., dieses aus dem Beginn des 11. Jahrhunderts) lassen keinen

1 Vgl. z. B. den Index zum Register Gregors d. Gr. sub sacratus und sacrare bei M. G. Epp. II 587.

2 A u g u stin., Enarrat. in psalm. 113, sermo 2, n. 6 (M. 37, 1484); Hieron., Epist. 114 ad Theoph. n. 2 (M. 22, 934). Die Unterscheidung des hl. Ambrosius zwischen vasa initiata und nova et nequaquam initiata (De eccl. ministr. 1. 2, c. 28 [M. 16, 142]) läßst es zweifelhaft, $o b$ die Weihe durch den Gebrauch oder eine Segnung erfolgte.

${ }^{8}$ M. 97,853; M.G.LL. (ed.Pertz) II p. alt.129.

4 Mart. 1. 2, c. 13, ordo 5; II 260.

${ }_{5}$ Ebd. 1. 1, e. 8, art. 11, ordo 2; II 34. 
ernsten Zweifel daran. Die Benediktionsgebete, deren in diesen beiden nur drei vorkommen, sind in ihnen dem Ordo der Kirchweihe eingefügt, wo sie auch sonst in den mittelalterlichen Pontifikalien zu stehen pflegen. Welche Verbreitung der Brauch, die liturgischen Gewänder zu segnen, im 9. Jahrhundert besaf, ist bei den wenigen Angaben, die wir aus jener Zeit über ilhn erhalten, nicht festzustellen. Immerhin läßt der Umstand, daf Pseudo-Isidor und Benedikt Levita ihn wie eine allbekannte Sache behandelt, darauf schlieben, daf er damals weder etwas Neues noch eine seltene Erscheinung war.

Die Gebete, durch welche nach dem römischen Pontifikale und Rituale die Segnung der Sakralkleider vollzogen wird, lassen sich alle schon bald, nachdem wir zum erstenmal sichere Nachrichten über diese Zeremonie erhalten haben, in den liturgischen Büchern, den Sakramentaren und Pontifikalien, nachweisen. So findet sich das beiden eigene Omnipotens sempiterne Deus, qui per Moysen famulum tuum etc., schon in dem sog. Egbertspontifikale, ferner in dem Pontifikale St Dunstans ${ }^{1}$, dem Pontifikale von Aletis ${ }^{2}$, einem Reichenauer Pontifikale des 12. Jahrhunderts ${ }^{3}$. Das Gebet Deus invictae virtutis triumphator begegnet uns in einem Pontifikale der Barberiniana (11.-12. Jahrh.) ${ }^{4}$, dem Sakramentar Leofriks (11. Jahrh.) ${ }^{5}$, dem Egbertpontifikale, einem Pontifikale von Cahors (9.-10. Jahrl.) ${ }^{6}$, einem Salzlourger Pontifikale (12. Jahrh.) ${ }^{7}$ u. a. Die dritte Oration des Segensformulars in Rituale treffen wir in dem ebengenannten Pontifikale der Barberiniana, dem Pontifikale von Cahors ${ }^{8}$, einem Wiener Kodex bei Gerbert ${ }^{9}$ u. a. an. Das Gebet des zweiten Benediktionsformulars im römischen Pontifikale kommt seltener vor, so in den zu einem Typus gehörenden Pontifikalien St Dunstans und Egberts und dem verwandten Pontifikale von Aletis.

Wie in Bezug auf so manches andere, so herrscht auch in Bezug auf die Formulare für die Segnung der liturgischen Gewänder in den mittelalterlichen Pontifikalien wenig Übereinstimnung. Hier sind die Gebete merkwürdig gehäuft, dort beschränkt man sich auf zwei oder nur eines; anderswo wieder ist für Gewänder und Geräte ein und dasselbe Gebet angegeben ${ }^{10}$. Im späten Mittelalter kommen auch Segensformulare vor, bei denen jedes Gewand ein eigenes, seiner mystischen Bedeutung angepafstes Gebet hat. Sehr interessante Beispiele bieten ein Pontifikale der Vaticana ${ }^{11}$ und ein bei Martène abgedruckter Auszug aus einem Pontifikale von Sées ${ }^{12}$. Die Gebete des letzteren schliefsen sich an die moralische Symbolik an, die man mit den liturgischen Gewändern verband, die des ersteren dagegen auch an jene typische Deutung, bei welcher man den Priester als Abbild des leidenden Heilandes und die Gewänder als Bilder der Leidenswerkzeuge betrachtete. So wird der Amikt auf das Schweiftuch bezogen, womit das Angesicht des Erlösers nach dem von Kaiphas gefällten Urteilsspruch verhüllt wurde, die Albe auf das weiße Spottkleid, das Cingulum auf die Stricke, mit denen der Herr an die Säule gebunden wurde, usw.

1 Ebd. 1. 2, c. 13, ordo 4; II 257.

2 Ehd. ordo 3; II 252.

${ }^{3}$ Gerbert, Monumenta vet. liturg. alem.

II, St Blasien 1779, 52 .

Cod. Vat. Barber. 1869.

5 Ed. W arren 215.

- M a rt. 1. 1, c. 8, art. 9, ordo 5; II 45 .

7 Ebd. ordo 8; II 52.

8 Ebd. I. 2, c. 13, ordo 7; II 263.
9 Gerbert a. a. O. 55.

10 So die Pontifikalien von Narbonne und Lyon bei M a rt. 1. 2, c. 13 , ordo 89 ; II 266270.

11 Vat. Ottob. 221, f. $257^{\vee}$ ff (1506). Vgl. auch die verwandten Benediktionsgebete im Offic, eccl, abb. in Evenham. monast. (Bradshaw Society), London 1893, c. $51 \mathrm{ff}$.

${ }^{12} \mathrm{M}$ art. 1. 3, c. 23 ; II 300. 
Das Recht, die liturgischen Gewänder zu segnen. scheint von jeher als bischöfliches Privileg gegolten zu haben. Es ist nicht erst Innozenz III, der ihre Benediktion unter den Vollmachten aufführt ${ }^{1}$, welche den Bischöfen vor den Priestern eignen. Schon fast ein Jahrhundert früher schreibt Gilbert von Limerick: Consecrat autem episcopus utensilia ecclesiae, vestimenta videlicet sacerdotalia et pontificalia, altaris velamenta etc. ${ }^{2}$, während $u m$ dieselbe Zeit die Synode von Poitiers allen Nichtbischöfen durchaus die Segnung der priesterlichen Kleider untersagt: Ut nullus vestimenta sacerdotalia praeter episcopum benedicere praesumat ${ }^{3}$, ein Kanon, der gegen die Übergriffe einzelner Äbte gerichtet gewesen zu sein scheint. Es war sogar schon im 9. Jahrhundert ein bischöfliches Vorrecht, die liturgischen Gewänder zu segnen. Denn in der Kapitularensammlung des Benedikt Levita heibt es: Sunt etiam ab episcopo consecranda et benedicenda corporales, pallae et alia vestimenta sacerdotalia. Der Grund, warum die Segnung der liturgischen Kleidung den Bischöfen vorbehalten war, liegt wohl darin, daßs sie eine Ergänzung der nur diesen zustehenden Weihe der Kirche bildete.

Auch in den Riten des Ostens ist eine Segnung der liturgischen Kleidung, wie sie im Abendland Brauch ist, üblich, ausgenommen vielleicht bei den Nestorianern. Außerdem aber werden im griechischen und koptischen die Gewänder auch noch jedesmal beim Anziehen vom zelebrierenden Bischof oder Priester gesegnet". Die Benediktionsgebete, welche im griechischen Ritus bei der Segnung der liturgischen Kleider verrichtet werden ${ }^{5}$, haben große Verwandtschaft mit denjenigen des lateinischen Ritus. Leider fehlt es an Material, um einen etwaigen Zusammenhang zwischen beiden näher bestimmen zu können. Im griechischen Ritus ist die Segnung erst um 1400 nachweisbar, was natürlich nicht ausschliefst, dals sie weit älter ist. Sie ist in ihm keine den Bischöfen vorbehaltene Handlung. Schon aus einer Angabe Simeons von Saloniki erhellt, daß auch die Priester sie vornehmen durften, wenigstens im Notfall ${ }^{6}$.

${ }^{1}$ De sacro altaris mysterio 1.1 , c. 9 (M. $217,779)$.

2 M. 159, 1002.

${ }^{3}$ C. 3 (Sdralek, Wolfenbüttler Fragm., Münster 1891, 136).

${ }^{4}$ Ein Gegenstück zur griechischen Sitte findet sich im Sakramentar von Corbie (Mart. 1. 1, c. 4 , art. 12 , ordo 11 ; I 202), wo die einzelnen Ankleidegebete des Bischofs durch ein Iube domne benedicere des Diakons eingeleitet werden.

${ }^{5}$ Das Formular ist abgedruckt bei v. MaItzew, Bitt-, Dank- und Weihegottesdienst, Berlin 1897, $987 \mathrm{ff}$.

${ }^{6}$ Resp. ad Gabr. Pentap. q. 17 (Mg. 155, 868). 


\section{SCHLUSSABSCHNITT.}

\section{DIE LITURGISCHE GEWANDUNG IN IHRER GESAMT- ENTWICKLUNG.}

\section{DIE LITURGISCHE KLEIDUNG IN IHRER BEZIEHUNG ZUR ALT- TESTAMENTLICHEN KULTTRACHT.}

Christus hat in seiner Kirche nicht einen bis in die kleinsten Teile geregelten Gottesdienst angeordnet; er gab die wesentlichen, unwandelbaren Grundlagen und überlief es seiner Stellvertreterin, nach Ort und Zeit, nach Bedürfnis und Zweckmäßsigkeit die äuferen Kultformen zur Entwicklung und Entfaltung zu bringen. Nichts ist daher unrichtiger, als die frủhere Zeit einfachhin an der Gegenwart zu messen und die gottesdienstlichen Zeremonien und Riten, wie sie jetzt im Gebrauch sind, unverändert auf frühere Tage zu übertragen. Alle Jahrhunderte haben ihre Eigentümlichkeiten auch im Kultus gehabt; nie ist der Gottesdienst eine bloke Schablone und ein totes, starres Etwas gewesen. Das göttliche Leben, das den mystischen Leib Christi durchzieht, hat auch in der Ausgestaltung der Kultusformen stets seine treibende Kraft bewährt. Das muß auch derjenige vor Augen behalten, welcher die liturgische Kleidung in Gegenwart und Vergangenheit zum Gegenstande seiner Forschungen macht. Auch bei ihr gab es eine Entwicklung. Anders verhält es sich in der jetzigen Zeit, anders stand es im Mittelalter, anders in den Tagen der Karolinger und wieder anders in der Jugendzeit der Kirche. Die bisherigen Untersuchungen betreffs der einzelnen liturgischen Gewänder haben das klar gezeigt. Noch deutlicher wird das indessen zu Tage treten, wenn wir auf Grund der bisherigen Resultate über die Gesamtentwicklung der Sakralgewandung eine Überschau halten. Scharf abgegrenzte Abschnitte lassen sich für dieselbe allerdings nicht feststellen, da die Ausbildung der liturgischen Kleidung nicht überall gleichen Schritt hielt oder doch über dieselbe für die verschiedenen Länder nicht in gleichem Maßs Nachrichten vorliegen. Immerhin kann man unterscheiden die Zeit bis zur Freierklärung der Kirche, die Zeit von Konstantin bis zur karolingischen Reform, die Zeit von Karl d. Gr. bis zum 13. Jahrhundert und endlich die Zeit vom 13. Jahrhundert bis zur Gegenwart. Bevor wir indessen auf diese einzelnen Phasen in der Entwicklung der liturgischen Kleidung näher eingehen, müssen wir in Kürze das Verhältnis der neutestamentlichen zur alttestamentlichen $\mathrm{Kulttracht}$ betrachten.

Nach der Vorschrift, die Gott der Herr Moses betreffs der Opferkleidung der jüdischen Priester gab, sollte die heilige Gewandung des Hohenpriesters in den Michnasim, der Kethonet, dem Abnet, dem Meïl, dem Ephod, dem Choschen und der Miznephet mit dem Ziz bestehen. Die niederen Priester sollten nur die Michnasim, die Kethonet, den Abnet und die Migbaoth tragen ${ }^{1}$.

1 Ex c. 28 und 39. Vgl. auch Flav. Ios., Antiq. 1. 3, c. 7, und H ieron, Epist. 64 ad Fabiol. (M. 22, 607). 
Die Michnasim (feminalia) waren eine Art Hose oder Leibschurz; sie deckten den Unterleib von den Hüften an bis zu den Oberschenkeln herab und muß̉ten aus Linnen verfertigt sein. Die Kethonet (linea subucula, linea stricta) bestand in einem eng anschlielienden Leibrock, der ebenfalls aus Linnen gemacht sein sollte. Nach - Tosephus, dem hl. Hieronymus und den Rabbinen reichte er bis zu den Knöcheln. Der Abnet (baltens) war ein Gürtel, der über der Linnentunika getragen wurde. Er diente vor allem dem praktischen Zweck des Aufschürzens; doch war er auch ein Schmuckstuick des Priesters 1. Derjenige des Hohenpriesters wird ausdrücklich als das Werk des Rokem (des Buntwirkers) bezeichnet; es scheint aber, daß auch die gewöhnlichen Priester mit dem vierfarbigen (Weiß, Blaupurpur, Rotpurpur und Scharlach) Gürtel ausgestattet waren. Nach Josephus glich der vier Finger breite Abnet einer Schlangenhaut und war allerlei Blumenwerk in den eben genannten Farben in ihn hineingewebt. Zu Christi Zeiten muß der Gürtel eine bedeutende Länge gehabt haben. Denn er wurde nach des Josephus Angabe beim Anlegen einigemal in der Brustgegend 11m den Körper gewickelt, und doch hingen alsdann noch seine Enden vorn bis zu den Fußknöcheln herab, so daßs die Priester während des Opferdienstes gezwungen waren, dieselben über die linke Schulter zu werfen, um nicht durch sie behindert zu sein. Der Meil (tunica) war eine Obertunika aus Blaupurpur. Er war an seinem unteren Saum mit Granatäpfeln und Schellchen geziert und ging nach Josephus bis auf die Füßse. Oben hatte das Kleid einen Schlitz zum Durchlassen des Kopfes, an den Seiten aber Armlöcher. Der Ephod (superhumerale) mit dem Choschen (rationale), ein besonderer Schmuck des Hohenpriesters, war eine Art Schultergewand aus kostbarem, buntfarbigem Stoff (Gold, Weiß, Blau- und Rotpurpur sowie Scharlach). Wie dasselbe formell beschaffen war, läßst sich aus der Heiligen Schrift nicht mit Sicherheit ersehen; Josephus beschreibt den Ephod seiner Zeit als eine Art von kurzer Ärmeltunika, die vorn einen Ausschnitt zur Aufnahme des Choschen hatte. Dieser, der Richterschmuck, dessen prächtige Folie der Ephod gleichsam bildete, war, wie es scheint, eine Art Tasche aus demselben Material, aus dem das Schulterkleid angefertigt war, und mit zwölf in Gold gefafsten und mit dem Namen der zwölf Stämme versehenen Edelsteinen besetzt. Miznephet und Migbaoth (tiarae) hießs die turban- oder mützenartige Kopfbedeckung des Hohenpriesters bzw. der Priester?. Der Ziz (lamina), ein Goldblech, dem die Worte "Heilig dem Herrn" eingegraben sein sollten, war eine Auszeichnung des Hohenpriesters, der ihn über der Tiara trug.

Auch wenn wir nichts über den wirklichen Ursprung der liturgischen Kleidung des Neuen Bundes wüliten, würde ein bloß oberflächlicher Vergleich derselben mit der jüdischen Kultgewandung alsbald mit aller Bestimmtheit dartun, dak sie so, wie sie sich in der Kirche ausgebildet hat, unmöglich aus dem Alten Bunde herübergekommen sein kann. Ja für Stola, Manipel und Pallium, für Amikt und Kasel, für Dalmatik und Tunicella, für Fano und Subcinctorium, für die pontifikalen Strümpfe, Schuhe und Handschuhe, für Epimanikien, Epigonation und Sakkos fehlen in der aaronitischen Kultkleidung so sehr die Gegenstücke, daß wir jene nicht einmal als spätere Nachbildungen alttestamentlicher Gewänder zu betrachten vermögen. Die einzigen Gewandteile, bei denen man allenfalls an irgend eine vorbildliche Beeinflussung durch die entsprechenden Stücke der jüdischen Sakralkleidung denken könnte, sind Albe, Mitra und Rationale. Indessen war selbst bei diesen eine solche jedenfalls nur sehr gering und nur von geringer Bedeutung. Bei der Albe, die unmittelhar unzweifelhaft auf die Tunika des Alltagslebens zurückzuführen ist, mag sie vielleicht darin bestanden haben, daß man die im bürgerlichen Verkehr gebräuchlich gewordene Talartunika namentlich auch mit Rücksicht auf den poderes des Alten Bundes für die gottesdienstlichen Verrichtungen 
bevorzugte. Wir erinnnern an die Rede des Eusebius bei der Einweihung der Basilika zu Tyrus. Ist der poderes hier auch nur symbolisch aufzufassen ${ }^{1}$, so bekundet die Stelle doch, daf der Gedanke an die Talartunika des aaronitischen Priestertums dem Ideenkreis in damaliger Zeit keineswegs fern lag. Ausdrücklich weist auf den alttestamentlichen poderes der hl. Martin, Bischof von Braga ( $† 580)$, im 66. seiner Kapitel mit den Worten hin: Non oportet clericos comam nutrire et sic ministrare ... et secundum Aaron talarem vestem induere, ut sint in habitu ordinato ${ }^{2}$. Was die Mitra anlangt, so kann sich ein etwaiger Einfluß3 höchstens im allgemeinen auf die Ingebrauchnahme eines pontifikalen Kopfschmuckes bezogen haben, nicht aber auch auf die Form. Indessen liegt nicht einmal für das erstere ein Anhalt vor. Jedenfalls war der Hinblick auf die Kopfbedeckung der alttestamentlichen Priester nicht der einzige und noch weniger der Hauptanlafs zur Einführung des liturgischen Kopfschmuckes unserer Bischöfe. Am meisten noch dürfte in Bezug auf den Ursprung des Rationale (Superhumerale) einige vorbildliche Einwirkung des parallelen Schmuckes des alttestamentlichen Hohenpriesters anzunehmen sein; doch verdankt selbst dieses sein Entstehen nicht einer solchen allein und mit Ausschluf, jedes andern Faktors. Etwas anderes aber als die Ableitung der einzelnen Gewänder des christlichen Kultus von der mosaischen Sakraltracht ist die Annahme eines blof allgemeinen Einflusses der letzteren auf die Entstehung der liturgischen Gewandung des Christentums. Eine derartige nur ganz im allgemeinen auf die Einführung einer besondern Kleidung im Gottesdienst des Nenen Bundes hinzielende Einwirkung der alttestamentlichen heiligen Gewandung dürfte sich schwerlich kurzer Hand abweisen lassen. Denn es kann wohl nicht bezweifelt werden, dafs die Judenchristen aus dem Judentum jene Überzeugung mitbrachten, welche der hl. Hieronymus in die Worte kleidet: „Die göttliche Religion hat ein anderes Gewand im heiligen Dienst, ein anderes im gewöhnlichen Verkehr und Leben." 3 Diese Anschauung, welche auch den Heidenchristen durch die stets wiederholte Lesung der heiligen Schriften sich aufdrängen mulite, konnte um so weniger ohne Einfluf auf die Unterseheidung zwischen Altar- und Alltagstracht und die allmähliche Bildung einer ausschließlichen Kultgewandung bleiben, als ja der Neue Bund die Erfüllung des Alten und die Wirklichkeit war, auf welche der Schatten des mosaischen Kultus hingewiesen hatte. Ist also auch die Sakralkleidung des letzteren nicht in dem Sinn Prototyp der liturgischen Gewandung des Neuen Bundes, dafs sie für die einzelnen Bestandteile derselben, wie diese sich geschichtlich herausgebildet haben und noch jetzt in Gebrauch sind, vorbildlich wurde, se kann anderseits doch wohl kaum bezweifelt werden, dab die Erinnerung an sie immerhin wenigstens im allgemeinen und bis zu einem gewissen Grad anregend und fördernd eingewirkt hat auf die Ausscheidung einer besondern, der Feier des Gottesdienstes vorbehaltenen Kleidung der christlichen Liturgen.

\section{DIE LITURGISCHE GEWANDUNG IN VORKONSTANTINISCHER ZEIT.}

Daß es in vorkonstantinischer Zeit, d. i. in den drei ersten Jahrhunderten der christlichen Kirche, noch keine nach Form und Ausstattung von der nichtliturgischen Tracht unterschiedene Sakralkleidung gegeben

$$
1 \text { S. oben S. } 95 . \quad 2 \text { M. 84, } 583 .{ }^{3} \text { In Ez. 1. 13, c. } 44 \text { (M. 25, 437). }
$$


habe, ist jetzt allgemein zugestanden. Sollte es doch noch Jahrhunderte dauern, bis es zu einer derartigen Kultgewandung kam. Gab es schon damals eine besondere liturgische Kleidung, so kann das höchstens im Sinn einer lediglich bei den gottesdienstlichen Funktionen gebräuchlichen und ausschlief3lich für diese bestimmten Gewandung verstanden werden. Aber nicht einmal das ]älit sich mit Sicherheit nachweisen. Das einzige Zeugnis, welches wir darïber besitzen, ist das vom Papstbuch mitgetejlte Dekret Stephans I. ${ }^{1}$ Tnzweifelhaft ist, dafs die darin erwähnten vestes sacratae wenigstens ausschließlich für den Gebrauch beim Gottesdienst bestimmte Gewänder bezeichnen. Allein wie schon früher gesagt wurde, ist es sehr unsicher, ob jene $\mathrm{Be}$ stimmung wirklich vom Papst Stephan, ja überhaupt aus vorkonstantinischer Zeit herrührt. Unmöglich ist das freilich nicht. Denn vestes sacratae in der Bedeutung von Gewändern, welche nur bei der Feier der Liturgie verwendet werden durften, nach Schnitt und Beschaffenheit aber den gewöhnlichen Kleidern gleich waren, konnten selbstverständlich auch zur Zeit Valerians auf der Straße getragen werden, ohne aufzufallen. Allein es genügt offenbar nicht, daß der Inhalt des fraglichen Dekretes der Zeit Stephans I. nicht widerspricht. Solange nicht feststeht, dafs selbiges in Wirklichkeit von diesem herstammt, ist es für unsere Frage ohne Belang.

Auch a priori, d. i. aus der Natur der Sache, läfst sich nicht dartun, dafs bereits in vorkonstantinischer Zeit eine besondere liturgische Gewandung in dem vorhin angegebenen weiteren Sinn Verwendung gefunden habe. Wenn wir später eine solche in Gebrauch antreffen, so folgt daraus keineswegs, dab schon an sich und abgesehen von jeder positiven Bestimmung der Kirche oder einer diesbezüglichen rechtskräftigen Gewohnheit unter allen Umständen für den Gottesdienst eine eigene, ihm ausschlieflich vorbehaltene Kleidung nötig sei. Denn der den heiligen Geheimnissen gegenüber schuldigen Ehrfurcht genügt zweifellos beim Mangel ausdrücklicher Anordnungen jede reine, würdige Gewandung. Sonst müßste man zuletzt verlangen, dafs auch der Talar, den der Priester unter der Albe zu tragen hat, und die Schuhe, welche seine Füße bedecken sollen, lediglich bei der Messe benutzt werden.

Es liegt aber auch keine Erklärung des kirchlichen Lehramtes vor, aus welcher hervorginge, das die Heiligkeit der Kultakte schon an sich notwendig:

1 S. oben S. 65. Man hat sich auch auf die Angabe des Bischofs Polykrates vou Ephesus und des Epiphanius, es hätten der hl. Johannes bzw. der hl. Jakobus das PetaIon (die goldene Stirnplatte des jüdischen Hohenpristers) getragen (s. oben S. 488), sowie auf die Erzählung del Vita S. Silvestri vom Colobium des hl. Jakobus (s. oben S. 68) berufen. Es mag hier genügen, gegenüber solchen Beweisversuchen wie auch rücksichtlich gewisser Reliquien aus der Frühzeit der Kirche - liturgische Gewänder oder Reste von solchen - auf die diesbezủglichen früheren Ausführungen dieses Werkes (S. $12 \mathrm{f}$ 68) sowie auf das in den ${ }_{7}$ Stimmen aus Maria-Laach * LIV (1898), $401 \mathrm{f}$ Gesagte hinzuweisen. Weder jene angezogenen Stellen, noch jene Reliquien sind für die hier uns beschäftigende Frage von irgend einer Bedeutung. Ohne Wert ist für sie auch die bisweilen angeführte Notiz des Hegesippus bei Eusebius, es habe der hl. Johannes linmene, nicht wollene Kleider getragen, und darum sei es ihm allein erlaubt gewesen, in das Tempelheilige einzutreten (Hist. eccl. 1. 2, c. 23 (Mg. 20, 197). Wie es immer um deren Richtigkeit stehen mag, jedenfalls folgt aus ihr nicht, daf der Apostel sich bei der Feier der heiligen Geheimnisse, die er sicher nicht im Heiligen des Tempels vornahm, irgend einer besondern Tracht oder auch nur einer besseren als der Alltagskleidung bedient habe, und noch viel weniger, daf damals a $11 \mathrm{~g}$ e m e in bei der Liturgie eine eigene Gewandung gebraucht wurde. Aus den Worten des Hegesippus geht sogar hervor, daf nur Jakobus gewohnt war, sich in Linnen zu kleiden, nicht auch die übrigen Apostel, weshalb auch er allein ins Heilige hineingehen durfte. 
eine besondere Kleidung beim Gottesdienst erheische; ebensowenig hat dasselbe je entschieden, daß die im katholischen Kultus übliche Sakralgewandung: auf göttlicher Anordnung beruhe oder doch bereits von den Aposteln zur Wahrung der Würde des Gottesdienstes eingeführt worden sei. Zwar erklärt das Konzil von Trient im 5. Kapitel der 22. Sitzung: "Weil die menschliche Natur so beschaffen ist, daf sie sich nicht leicht ohne äuferliche Beihilfe zur Betrachtung göttlicher Dinge zu erheben vermag..., so ordnete die Kirche nach der apostolischen Disziplin und Überlieferung Zeremonien an, wie mystische Segnungen, Lichter, Räucherungen, Gewänder und vieles andere der Art, sowohl um die Herrlichkeit dieses so grofen Opfers dadurch anzuzeigen, als auch um die Gemiiter der Gläubigen durch diese sichtbaren Zeichen der Religion und Frömmigkeit zur Betrachtung der hocherhabenen Geheimnisse anzuregen, welche in diesem Opfer verborgen sind." Jedoch will es damit nur sagen, daf die Kirche nicht willkürlich die Opferfeier mit mannigfachen Zeremonien usw. umgeben habe, wie die Reformatoren behaupteten, sondern gemäß ihrer in apostolischer Disziplin und Tradition begründeten Stellung als Hüterin der heiligen Geheimnisse und gemär des ihr durch eben diese Lehrüberlieferung gewordenen Auftrags, das Heilige heilig zu halten, die Gläubigen mit Ehrfurcht gegen die Mysterien des Glaubens zu erfüllen und zu erbauen. Die Worte des 5 . Kapitels sprechen positiv aus, was im 7. Kanon derselben Sitzung negativ zum Ausdruck kommt, wemn es darin heibt: „Wenn jemand sagt, die Zeremonien, Gewänder und äufarlichen Zeichen, deren sich die Kirche bei der Feier der heiligen Messe bedient, seien eher Reizmittel zur Gottlosigkeit als Erweise der Frömmigkeit, so sei er im Banne." Es läbt sich aber aus ihnen nicht folgern, dab schon die Apostel eine von der profanen Tracht durchaus verschiedene liturgische Kleidung vorschrieben oder auch nur verordneten, dafs sich der Priester bei der Feier des heiligen Opfers einer lediglich bei der Liturgie zu verwendenden Gewandung bedienen müsse.

Mit Sicherheit ist alșo eine besondere gottesdienstliche Kleidung in keinem Sinne für die vorkonstantinische Zeit nachweisbar, weder mit historischen Belegen noch mit dogmatischen Zeugnissen noch endlich aus der Natur der Sache. Immerhin darf es als wahrscheinlich betrachtet werden, daf man bereits vor den Tagen Konstantins begann, wo immer die Verhältnisse das ermöglichten, einen Unterschied zwischen der Alltags- und der Altartracht zu machen. Es ist schwer glaubhaft, daf die Anfänge einer christlichen Sakralgewandung erst in das 4. Jahrhundert fallen sollen. Denn die Gründe, um derentwillen man später bei den gottesdienstlichen Verrichtungen sich einer nur bei diesen zur Verwendung kommenden Kleidung bediente, die Ehrfurcht gegen die heiligen Geheimnisse, die Pflicht der kirchlichen Vorsteher, in den Gläubigen die Hochschätzung gegen das vom Gottessohne der Kirche hinterlassene unblutige Opfer des Neuen Bundes zu wecken und zu befördern, hatten doch auch schon in der Jugendzeit des Christentums Bedeutung; ja damals vielleicht in besonderem Make, weil es galt, den für die christliche Lehre gewonnenen Juden und Heiden Hochachtung vor den Geheimnissen des Glaubens und den Mysterien des Neuen Bundes einzuflößen. Insbesondere, scheint es, hätte die Auferachtlassung jeden Unterschiedes zwischen Kult- und Alltagskleidung den Judenchristen zum großen Ärgernis gereichen müssen, denen die Idee einer Opfergewandung in der ersten Zeit noch durch persönliche Anschauung, nach Zerstörung des Tempels aber 
wenigstens durch die Lesung der heiligen Schriften vertraut war. Auch waren ja die drei ersten Jahrhunderte keineswegs eine Zeit ohne Unterbrechung sich hinziehender Verfolgungen. 7wischen Perioden der heftigsten Bedrängnisse gab es wiederholt solche des Friedens und der Ruhe, namentlich im 3. Tahrhundert. Ebenso wütete der Kampf nicht immer an allen Orten und in allen Gegenden des weiten römischen Reiches in gleichem Mafe. Jellenfalls darf als sehr wahrscheinlich gelten, daf man schon in vorkonstantinischer Zeit wenigstens insofern einen Unterschied zwischen der Alltagsund Altarkleidung machte, als man bei der Feier der Liturgie, wo immer solches anging, bessere oder doch anständige Gewänder benutzte. Denn wenn Klemens von Alexandrien sagt, man müsse gewaschen, rein und glänzend zu den Opferfeiern und Gebeten erscheinen ${ }^{1}$ - er versteht das aber, wie aus seinen folgenden Ausführungen hervorgeht, insbesondere auch mit Bezug auf die Kleidung - , und wenn er verlangt, es müsse Mann und Weib in ordentlicher Gewandung zur gottesdienstlichen Versammlung kommen ${ }^{2}$, so wird es erst recht für schicklich gegolten haben, daf der Liturg und seine Gehilfen bei der Feier des heiligen Opfers in anderer als der gewöhnlichen Haus-. Strafen- und Arbeitstracht am Altar erschienen. Es wäre den Gläubigen, die selbst die Kleider wechselten, ehe sie zum Gottesdienste gingen, sicherlich ein Anstob gewesen, hätten sie den Bischof, die Priester und Diakone in bestaubter, beschmutzter oder abgegriffener Alltagstracht ihres hohen Amtes walten sehen.

Wir sagen: wo immer es anging; denn wenn man während der Tage der Verfolgung im Drange der Not in Grüften und Höhlen, ja selbst in Kerkern die heiligen Geheimnisse zu feiern sich gezwungen sah, oder wenn die Boten des Evangeliums unter den ungünstigsten Verhältnissen in die Welt hinauszogen, um Christi Lehre zu verkünden, so konnte natürlich hier wie dort bei der Feier der heiligen Geheimnisse nicht alles durchgeführt werien, was an sich passend und in andern Lagen und Umständen möglich war. In normalen Zeiten und in den Tagen der Ruhe war sicher auch schon vor dem 4. Jahrhundert die Anschauung malígebend, welche in den sog. Kanones des Hippolyt ihren Ausdruck findet in der Bestimmung: „So oft der Bischof die Mysterien genieken will, sollen sich die Diakone und Priester, angetan mit weißen, ganz vorzüglich reinen Kleidern, die schöner als die des übrigen Volkes sind, bei ihm versammeln.... Auch die Vorleser sollen wie jene Festkleider haben" 3; eine Anschauung, die von Hieronymus in seiner Erklärung von Ez 44, 19 in die Worte gefaśt wird: "Hieraus lernen wir, daf wir nicht in den alltäglichen oder in sonst welchen, durch das gewöhn-

i. Strom. 1. 4, c. 22 (Mg. 8, 1352).

2 Paedag. 1. 3, c. 11 (ebd. 657). Aus den weiteren Worten an dieser Stelle geht hervor, daB die Gläubigen in der 'Tat andere Kleider anlegten, ehe sie zum Gottesdienste gingen. Klemens tadelt dieselben nämlich, dak sie bei der Heimkehr von der Kirche zugleich mit der Kleidung die Sitten wechselten und statt der Würde und des Ernstes, die sie im Gotteshause bekundeten, sich Leichtfertigkeiten aller Art erlaubten. Man trug also bei der Teilnahme an der Liturgie nicht die gewöhnlichen Haus- und Arbeits- kleider, sondern pflegte für dieselbe eine bessere Gewandung anzuziehen.

3 Can. 37 (Mg. 10, 962). A chel is, Die Canones Hippolyti (Texte und Untersuchungen VI, Hft 4, Leipzig 1891, 118); R i e d e 1, Die Kirchenrechtsquellen des Patriarchats Alexandrien 224. Über das Alter der Kanones, für deren nichthippolytaniscben $U \mathrm{r}$ sprung F. X. Funk gegen Achelis entschieden und mit guten Gründen eintritt, vgl. Bardenhewer, Geschichte der altkirchlichen Literatur II, Freiburg 1908, 541 ff, wo auch die einschlägige Literatur angegeben ist. 
liche Leben und Treiben beschmutzten Gewändern in das Allerheiligste eintreten, sondern mit reinem Herzen und reinen Kleidern an den Geheimnissen des Herrn teilnehmen sollen." 1

Die Gewänder, in denen wir uns die Bischöfe und Priester in vorkonstantinischer Zeit bei ihren Funktionen zu denken haben, waren die Tunika, dann, wo es Brauch war, die Tunika zu schürzen, ein Gürtel und endlich ein Mantel, welcher im Orient vielleicht schon früh, zu Rom wie iberhaupt in Italien aber seit etwa dem Verlauf des 3. Jahrhunderts in der Pänula bestanden haben dürfte. Bei den Diakonen mag der Mantel vielfach gefehlt haben, weil das für sie bei den mannigfachen Verrichtungen ihres Dienstes bequemer war. Die übrigen Kleriker werden wohl für gewöhnlich die gleiche Gewandung wie die Priester gehabt haben. War doch zu Rom noch im 8. Jahrhundert die Gewandung der Subdiakone und der andern Minoristen fast dieselbe wie diejenige der Priester, während wir im griechischen Ritus noch bis ins zweite Jahrtausend hinein bei jenen ebenso wie bei diesen aulier der Tunika ein Phelonion antreffen. In Bezug auf Schnitt, Ausstattung und ähnliches war für die Altarkleidung an den verschiedenen Orten natürlich die für die profane Tracht geltende Sitte mafagebend. Ob es auch schon in vorkonstantinischer Zeit oder doch wenigstens im 3. Jahrhundert ein liturgisches Distinktivum (Stola, Orarium, Omophorion, Pallium) zur Unterscheidung der fungierenden Geistlichen voneinander und von den Laien gegeben habe, muf dahingestellt bleiben?

\section{DIE LITURGISGHE KLEIDUNG VOM IV. BIS IX. JAHRHUNDERT.}

Die Zeit vom 4. bis 9. Jahrhundert bildet den bedentungsvollsten Abschnitt in der Geschichte der liturgischen Gewandung. Zwar ist die Entwicklung der letzteren mit ihm noch keineswegs abgeschlossen; immerhin gelangt die Sakraltracht, wie sie heute besteht, bereits in dieser zweiten Periode in ihren wesentlichen Bestandteilen und Eigentümlichkeiten zur Vollendung. Die Nachrichten, die wir aus dieser Zeit über die beim Gottesdienst gebräuchlichen Gewänder erhalten, sind allerdings noch immer recht unvollständig und mangelhaft; für einige Bestandteile der liturgischen Kleidung fliefen sogar auch jetzt noch die schriftlichen und monumentalen Quellen äuferst sparsam. Immerhin gestattet, was an Monumenten und schriftlichen Angaben vorliegt, den Werdegang der Sakralkleidung in diesem Abschnitt ihrer Geschichte wenigstens im großen und ganzen genügend zu verfolgen.

Bei der Ausbildung, welche die liturgische Kleidung während der zweiten Periode ihrer Entwicklung erfährt, lassen sich fünf verschiedene Momente unterscheiden: 1. Ausscheiden der bei den gottesdienstlichen Funktionen gebräuchlichen Kleidung aus allem auferliturgischen Gebrauch, 2. Auswahl und Festlegung bestimmter Gewänder für die liturgischen Verrichtungen, 3. Einführung sakraler Distinktiva in Gestalt des Palliums bzw. des Omophorion und der Stola bzw. des Orarium, 4. Verwendung der für den Gottesdienst bestimmten Gewänder unter Beibehaltung der auferliturgischen Kleidung, also über dieser, nicht mehr anstatt derselben, 5. endlich Einführung der Sitte, die zum Kultornat gehörenden Kleider durch eine besondere Segnung für ihren erhabenen Gebrauch zu heiligen.

1 In Ezech. 1. 13, c. 44 (M. 25, 436).

2 Über die Dalmatik im Kultus zu vorkonstantinischer Zeit vgl. oben S. 250. 
Die Scheidung zwischen liturgischer und auferliturgischer Tracht in dem im vorigen Paragraphen dargelegten Sinne begann wahrscheinlich schon in vorkonstantinischer Zeit. Sicher aber wird dies bald geschehen sein, nachdem der Kirche die Freiheit geworden war, da nun ja die Kirche ohne alle Hindernisse in der Öffentlichkeit auftreten konnte und die Umstände weggefallen waren ${ }^{1}$, welche vordem jene Unterscheidung erschwerten, ja in manchen Fällen unmöglich machten. Aber auch die Fixierung bestimmter Gewänder zum Gebrauch bei den gottesdienstlichen Funktionen dürfte schon im 4. Jahrhundert begonnen haben. Erinnert sei an die Dalmatik der römischen und an die Tunika der griechischen Diakone, von welch letzterer ja bereits Johannes Chrysostomus redet. Jedenfalls waren bereits im 6. Jahrhundert die hauptsächlichsten Bestandteile der liturgischen Gewandung festgesetzt. Für Rom und Italien ergibt sich das aus den Mosaiken und Fresken zu Mailand, Rom und Ravenna, für Spanien aus den früher erwähnten Kanones der 2. Synode von Braga und der 4. Synode von Toledo ${ }^{2}$, von denen die letzte zwar erst dem zweiten Viertel des 7. Jahrhunderts angehört, aber ersichtlich nichts Neues bietet, sondern nur, was dem Herkommen entsprach. Daß im gallikanischen Ritus im 6. Jahrhundert eine aus bestimmten Bestandteilen sich zusammensetzende Sakralkleidung in Gebrauch war, beweisen, abgesehen von vereinzelten Notizen bei Gregor von Tours u. a. ${ }^{3}$, die früher erwähnten Verordnungen der Statuta ecclesiae antiqua und der Synode von Narbonne ${ }^{4}$, sowie namentlich die gallikanische Meßserklärung. Für den Orient sei an die Darstellung des Bischofs Theophylus von Alexandrien auf einem Papyrus, der wahrscheinlich noch in das 5. Jahrhundert hinaufreicht, und an die Trierer Elfenbeintafel erinnert ${ }^{5}$. Auch der Umstand, dafs im Osten so früh schon sich liturgische Abzeichen in Gestalt des Orarium und des Omophorion einbürgerten, läbt vermuten, dafi dort bald eine bestimmte Kleidung für den Liturgen und seine Gehilfen festgelegt worden sei.

Liturgische Distinktiva treffen wir im Orient schon im 4. Jahrhundert an. Im Abendland begegnen sie uns erst eine Weile später. Zu Rom läßst sich mit Sicherheit ein sakrales Abzeichen - das päpstliche Pallium - erst für das 5. Jahrhundert nachweisen, in Spanien und Gallien ein solches - Stola, Orarium - aber erst für das 6., woraus freilich nicht folgt, dak es nicht auch schon früher daselbst diese Distinktiva gegeben habe.

Unbestimmbar ist, seit wann man anfing, die liturgische Gewandung über die Alltagskleider anzuziehen. Die Frage nach dem Alter dieser Sitte hängt mit der andern zusammen, seit welcher Zeit man begonnen habe, erst im Sekretarium sich für die Feier des Gottesdienstes anzukleiden. Denn eine Anlegung der liturgischen Kleider, welche im Sekretarium vorgenommen wurde, kann offenbar nur von einem Anziehen derselben verstanden werden, bei welchem wenigstens die Unterkleider der Alltagstracht beibehalten wurden. Die erste zuverlässige Nachricht über den Kleiderwechsel im Sekretarium

1 Vgl. z. B. Palladii Vita S. Ioan. Chrysust. (M. 47, 38), wo erzählt wixd, als der Heilige auf seinem Wege in die Verbannung

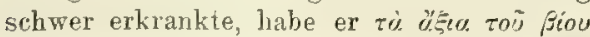

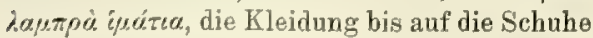
gewechselt und dann die heiligen Geheimnisse empfangen. Bei The od or von Trimuthis (De vita et exilio S. Ioan. Chrysost. n. 25
(Mg, 47, Lxxıx) heißen die Gewänder, welche der Heilige anstatt der gewöhnlichen an-

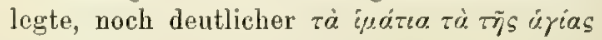
istrouprias.

2 Vgl. oben S. 155253.

3 Vgl. oben S. 66156754 .

$4 \mathrm{Vgl}$, oben S. 156253 .

s Vgl. oben S. 236. 
bringt der erste römische Ordo. In ihm hätten wir demnach zugleich das erste sichere Zeugnis für den Brauch, die liturgische Kleidung über den vestes communes zu tragen. Indessen wird dieser zweifelsohne weit höher als bis ins 8. Jahrhundert hinaufgehen. Wahrscheinlich hat er sich sogar schon bald gebildet, nachdem man begonnen hatte, zwischen liturgischer und auferliturgischer Gewandung streng zu unterscheiden. Es konnten darum auch im 6. Jahrhundert die gallischen Diakone und Lektoren schon vor Ende der Messe sich ihres sakralen Obergewandes, der Alba, die wir uns offenbar über der gewöhnlichen Kleidung befindlich zu denken haben, ohne alle Schwierigkeit entledigen ${ }^{1}$.

Über die Zeit, zu der es Sitte wurde, durch eine besondere Segnung die liturgischen Gewänder aller profanen Verwendung zu entziehen, wurde früher des näheren gehandelt. Bestimmt nachweisen läbt sich die benedictio vestium erst gegen Ende der uns beschäftigenden Periode, und zwar selbst dann nur für das Abendland, genauer für den römischen Ritus.

Inwieweit die Ausbildung einer liturgischen Kleidung sich vollzog auf dem Wege der blofien Gew ohn heit und inwieweit durch die positive kirchliche Gesetzgebung, läbt sich nicht abmessen. Als sicher darf es jedoch gelten, dab es nicht lediglich durch Brauch und Sitte zu einer Sakralkleidung kam. Insbesondere ist die Einführung liturgischer Abzeichen ohne Kweifel das Werk positiver Verordnungen. Aber auch bezüglich sonstiger Gewandstücke sowie der Sakralgewandung im allgemeinen war die kirchliche Gesetzgebung mit ausdrücklichen Bestimmungen an der Ausbildung der liturgischen Kleidung beteiligt. Wir ersehen das z. B. aus den Angaben des L. P., wonach Silvester I. die Diakone Dalmatik und Mappula tragen hiefs und Stephan I. den Gebrauch der vestes sacratae in gewöhnlichen Lehen zu gebrauchen verbot. Ist es auch fraglich, ob die beiden Dekrete wirklich von Silvester I. bzw. Stephan I. herstammen, so zeigen sie doch wenigstens, daf: auch die positive Gesetzgebung, wie übrigens natiurlich, zu den Faktoren gehörte, welche bei der Ausgestaltung einer besondern liturgischen Kleidung und ihrer einzelnen Bestandteile tätig waren?

Auf keinen Fall haben wir uns übrigens die Fixierung und Ausgestaltung der Sakralkleidung als allenthalben in gleichem Schritt geschehen zu denken. Es ging damit wie mit der Ausbildung so mancher liturgischen Zeremonien. Hier vollzog sich der Prozef rascher, dort langsamer. Aufierdem aber mufs zwischen Theorie und Praxis unterschieden werden. Auch bezüglich der Verwendung einer liturgischen Gewandung standen diese keineswegs überall in voller Übereinstimmung. Der Umstand, dafi die Idee einer besondern Sakralkleidung sich bereits in der Theorie vollständig durchgerungen hatte, bedeutete noch nicht, daf solches ebenso schon in durchgreifender Weise in der Praxis der Fall war. So sahen sich die Statuta ecclesiae antiqua veranlabit, den Diakonen zu untersagen, die Alba aufierhalb ihrer gottesdienstlichen Verrichtungen anzuziehen. Vom hl. Fulgentius ( $†$ 535) aber teilt uns dessen Biograph die bezeichnende Tatsache mit, der Heilige habe in derselben Tunika, in welcher er geschlafen, das heilige Opfer dargebracht. Zur Begründung und Rechtfertigung dieses Verhaltens habe derselbe bemerkt, man

1 Vgl. c. 12 der Synode von Narbonne vom Jahre 589 (s. oben S. 253).

$2 \mathrm{Vgl}$. auch c. 12 der Synode von Narbonne, c. 41 der Statuta ecclesiae antiqua, c. 9 der 2. Synode von Braga, c. 28 und 40 des 4. Konzils von Toledo, c. 22 des Konzils von Laodicea, c. 66 der Kapitel Martins von Braga u. a. 
solle zur Zeit des Opfer's lieber die Herzen als die Kleider wechseln ${ }^{1}$. Selbst zur Karolingerzeit war die Unterscheidung zwischen liturgischen und auferliturgischen Gewändern in der Praxis noch keineswegs vollständig durchgedrungen, wie die früher angeführten Verordnungen über den Gebrauch der Albe beweisen ${ }^{2}$. Auch die entschiedene Betonung des angeblichen Dekretes Stephans I. bei Pseudo-Isidor ${ }^{3}$ läßst vermuten, dab im Frankenreiche damals Theorie und Praxis in Bezug auf die Verwendung der gottesdienstlichen Gewandung nicht immer übereinstimmten. Am längsten dauerte es in einigen Sekten des Orients, bis die Idee einer besondern Sakraltracht sich in Auffassung wie Brauch Geltung verschaffit hatte. Für die Anschauung, welche bei den Nestorianern noch um das 9. Jahrhundert in Betreff der Verwendung einer besondern liturgischen Gewandung herrschte, ist die Antwort bezeichnend, welche Patriarch Johannes Bar Abgar († 905) auf die Frage gab, ob der Priester mit Schuhen an den Altar treten könne, die er auf dem Markte getragen. Billig und recht wäre es freilich, meinte er, wenn die Priester in besondern Gewändern und Schuhen zum kirchlichen Dienst hinzuträten. Falls aber die Notwendigkeit es anders anrate oder die Priester zu arm seien, stehe nichts im Wege, solches in den Schuhen und Kleidern zu tun, diesie in ihrer Werkstatt und bei ihrer gewöhnlichen Beschäftigung gebrauchten ${ }^{4}$. Bei den Armeniern wurde für die Abhaltung der Liturgie vielfach selbst noch im 12. Jahrhundert die Kleidung nicht gewechselt, wie der Katholikos Isaak in seinen Invectivae adversus Armenos bezengt und auch Nerses von Lampron in seinem Kommentar zur göttlichen und heiligen Liturgie andeutet ${ }^{5}$. Vielleicht war übrigens eine solche laxe Auffassung in jenen orientalischen Sekten nur ein Abirren von früheren, strengeren Anschauungen und Grundsätzen bezüglich der Unterscheidung zwischen der liturgischen und der Alltagsgewandung.

In formeller Hinsicht bestand, wenn wir von den liturgischen $\mathrm{Ab}$ zeichen absehen, auch nachdem die Kirche die Freiheit erlangt hatte, noch mehrere Jahrhunderte kein wesentlicher Unterschied zwischen der liturgischen Kleidung und der besseren bürgerlichen Tracht, zumal der bürgerlichen Festtagskleidung. Die Gewandstücke, deren man sich am Altare bediente, begegnen uns noch eine gute Weile ebenso bei Laien und noch weit länger in der aukerliturgischen klerikalen Gewandung. Selbst zu Rom waren sie noch im 6. Jahrhundert der Art, dafs man sie im gewöhnlichen Leben tragen konnte, ohne aufzufallen. Es erhellt das z. B. aus der Überschrift, welche Dionysius Exiguus in seiner Sammlung von Papstbriefen dem bekannten Schreiben Cölestins I. (423-432) an die gallischen Bischöfe gab. Indem er nämlich die Worte Cölestins: Discernendi sumus a plebe vel ceteris doctrina, non veste, conversatione, non habitu, mentis puritate, non cultu ${ }^{6}$, auf die Altarkleidung bezieht (nicht, wie es richtig hätte geschehen sollen, auf die aufierliturgische geistliche Gewandung), bekundet er, daf zu seiner Zeit, also um 5.30, zu Rom die liturgische Kleidung noch keineswegs von der laikalen formell wesentlich verschieden war. Sehr lehrreich ist in dieser Beziehung auch die Beschreibung, welche Johannes Diakonus von den noch zu Lebzeiten

I C. 18 (M. 65, 136).

- Vgl, oben S, 62.

Steph. I., Eipt n. 3 (H inschius, Decret. Pseudoisid. 183)

As s., Bibl. III I 251. Vgl, auch W a lafried, De exordiis et incrementis c. 24 (M.
114, 952): Primis temporibus communi indumento vestiti missas agebant, sicut et hactenus quidamorientales facere perhibentur. $\quad 5$ Vgl. oben S. 98.

${ }^{B}$ C. 1 (M. 50, 430). Vgl. auch oben S. 620 Anm, 1. 
Gregors d. Gr. gemachten Bildern des Vaters Gregors, Gordianus, und des Papstes selbst gibt. Nur das Pallium unterschied Vater und Sohn.

Ein durchgreifenderer Unterschied zwischen der laikalen und der liturgischen Tracht trat erst ein, als im profanen Leben die im 3. Jahrhundert in Aufnahme gekommene Talartunika wieder der kurzen Tunika und die nicht gerade bequeme Pänula dem offenen Mantel weichen mufite, die Kirche aber an beiden als Bestandteilen sowohl der auferliturgischen wie namentlich der liturgischen Kleidung der Geistlichen festhielt.

Es war kein öder Konservativismus, der sie dazu veranlalste, sondern die Erwägung und Erkenntnis, dafo eben diese Gewandung sich besser als jede andere für den Klerus im täglichen Leben wie am Altar eigne, weil sie der ihm eigenen Würde wie auch der Würde der gottesdienstlichen Funktionen angemessener erschien. Auferdem aber hat darauf zweifelsohne die Tendenz eingewirkt, den Klerus auch in seiner Kleidung, und zwar sowohl im täglichen Leben als namentlich am Altare, von den Gläubigen möglichst sinnfällig zu unterscheiden, eine Tendenz, die im Osten schon im 4. Jahrhundert zu liturgischen Distinktiva in Gestalt des Orarium und des Omophorion geführt hatte. Auf das Festhalten an der Talartunika mag obendrein, wie früher gesagt wurde, die Erinnerung an den poderes des jüdischen Kultus von Einflußs gewesen sein.

Man hat den eben erwähnten Weclisel in der profanen Kleidung mit dem Einbruch der germanischen Völker zu erklären gesucht und in der kurzen Tunika und dem offenen Mantel eine Nachbildung der germanischen Soldatentracht sehen wollen ${ }^{1}$. Ohne Grund. Sowohl die offenen Mäntel wie die kurzen Tuniken waren bei einem großen, die letzteren sogar bei dem gröläten Teil der Bevölkerung nie aufer Gebrauch gekommen. Inshesondere aber waren die einen wie die andern stets dem Militär und der Mehrzahl der kaiserlichen Beamten eigen. Es bedurfte darum nicht erst eines vorbildlichen Einflusses der Gewandung der nordischen Barbaren, um die Talartunika und die Pänula im bürgerlichen Leben wieder aufer Verwendung zu bringen und an ihre Stelle die kurze Tunika und den offenen Mantel treten zu lassen. Die Talartunika und die Pänula waren eine Mode, wie es deren so viele schon gegeben hatte. Sie erschienen im 3. bzw. 4. Jahrhundert auf dem Plan und verschwanden dann wieder, als ihre Zeit um war, als sie nicht mehr gefielen, als sie sich gleichsam ausgelebt hatten.

Im Orient erhielten sich die tunica talaris und die paenula, den Bildwerken nach zu urteilen, länger im allgemeinen Gebrauch. Es kam darum hier erst in viel späterer Zeit zu einer liturgischen Gewandung, die auch nach ihrer

${ }^{1} \mathrm{Vgl}$. Marr. xLvi, und im Anschluß an diesen Realenc. II 182. Marriott beruft sich namentlich auf die Bemerkung des Johannes Diakonus (9. Jahrhundert): Nullus pontifici (sc. Gregor d. Gr.) famulantium a minimo usque ad maximum barbarum quodlibet in sermone vel habitu praeferebat, sed togata Quiritium more vel trabeata latinitas suum Latium in ipso Latiali palatio singulariter obtinebat (Vita Greg. M. 1. 2, c. 13 [M. 75, 92]). Allein wie kann man, dürfen wir wohl fragen, diese Angabe des Biographen Gregors auf das Ausscheiden der Talartunika und der Pänula aus der Tracht des bürgerlichen
Lebens anwenden? Oder waren etwa die kurze Tunika, die Chlamys und die Lacerna unro̊mische, den nordischen Barbaren entlehnte Gewänder? Völlig unverständlich ist, wie Kraus (Kunstgeschichte I 533) schreiben konnte: "Auf den Mosaiken von S. Vitale zu Ravenna ist die Tracht der einfachen Geistlichen noch nicht wesentlich von der der Hofbeamten des Kaisers Justinian verschieden." Die kurze Tunika und die Chlanys der Hofbeamten sind denn doch etwas ganz anderes als die Dalmatik und die Planeta Maximians und als die Dalmatik der Diakone des Erzbischofs (vgl. oben B.ld 63, S. 159). 
formellen Seite hin von der Alltagskleidung verschieden war. Vielleicht erklärt sich daraus auch, warum Walafried im Anschluf an die Worte: Primis temporibus communi indumento (Volkstracht) induti missas agebant, mit Bezug auf den Osten fortfihrt: Sicut et hactenus quidam orientales facere perhibentur ${ }^{1}$.

Betont muf werden, daf die liturgische Kleidung aus dem Boden jener Gerrandung erwuchs, welche seit etwa dem 4 . Jahrhundert das Gemeingut der römisch-griechis chen Welt geworden war, nicht aber ausschlieblich aus demjenigen der römischen Tracht oder der Tracht des Ostens. Ebendarum denn auch die wesentliche Übereinstimmung in Bezug auf die liturgische Kleidung zu Rom und in den von dem römischen Ritus abhängigen Provinzen des Abendlandes einerseits und in den verschiedenen Landesteilen des weiten Ostens anderseits. Daf3 bei jenem Entwicklungsprozef der Sakralgewandung Rom und der römische Brauch einen bestimmenden oder vorbildlichen Einflufs auf den Orient ausgeübt habe, ist zwar behauptet, aber nicht bewiesen worden und unseres Erachtens auch nicht einmal wahrscheinlich. Wohl aber kann man umgekehrt von einer Einwirkung des Ostens auf den Westen reden. Namentlich darf eine solche für Spanien und Gallien angenommen werden. Die Übereinstimmung, welche zwischen der Sakralgewandung des griechischen Ritus und derjenigen der gallikanischen und altspanischen Kirche besteht, ist zu auffällig, als daf man sie als bloßen Zufall zu deuten hätte. Allein selbst zu Rom dürfte griechischer Brauch nicht ganz ohne Nachahmung geblieben sein. Wenigstens ist es keineswegs so ganz unwahrscheinlich, daß das Pallium und die Stola dorthin aus dem griechischen Ritus ihren Weg genommen haben. Im übrigen war die Entwicklung der liturgischen Gewandung zu Rom freilich eine durchaus selbständige. Man denke nur an das Schultertuch, die Mappula, die Dalmatik und die liturgische Beschuhung. Aber auch in der Neigung, die Gewandstücke zu häufen, zeigt sich schon in der uns hier beschäftigenden Periode der Geschichte der Sakraltracht eine charakteristische Eigenart der römischen Kultkleidung. Eine teilweise Einwirkung des römischen Brauches auf die liturgische Kleidung in Gallien setzte bereits im 6. Jahrhundert durch Verleihung des Palliums und die Erteilung des Privilegs, die Dalmatik zu tragen, ein; durchgreifend wurde sie jedoch erst zur Karolingerzeit.

Was die Gewänder anlangt, aus denen sich die liturgische Kleidung zusammensetzte, so bestand diese um den Beginn des 7. Jahrhunderts in Spanien bei den Subdiakonen bloG aus einer Tunika, bei den Diakonen aus Alba und Orarium, bei den Priestern und Bischöfen aus Alba, Gürtel, Orarium und Planeta, in Gallien bei den niedern Klerikern aus der Alba, bei den Diakonen aus Alba und Stola, bei den Priestern und Bischöfen aus Tunika, Gürtel, Stauchen, Stola (pallium) und Kasel. Zu Rom bedienten sich damals die Minoristen, die Subdiakone eingeschlossen, der Alba und Planeta, wie es scheint, ob auch schon der Mappula, ist fraglich, die Diakone der udones, der campagi, der Dalmatik und der Mappula, sowie auch wohl einer unteren Tunika (Albe). Über die liturgische Tracht der römischen Priester fehlen für den Beginn des 7. Jahrhunderts genügende Angaben; wir dürften indessen kaum irregehen, wenn wir uns dieselben mit Albe, Cingulum, Mappula und Kasel bekleidet denken. Der Papst trug udones, campagi, Albe und Cingulum,

${ }^{1}$ De exordiis et incrementis c. 24 (M. 114, 952). 
Dalmatik, Planeta, Mappula und Pallium. Unsicher ist, ob er auch schon die Tunika oder dalmatica linea hatte. Wegen des Gebrauches des Orarium seitens der Diakone, der Priester und des Papstes ist nachzusehen, was darüber bei Besprechung des Alters der Stola gesagt wurde. A u berhalb Roms wurde es überall da, wo der römische Ritus mafigebend war, ohne Zweifel mit der liturgischen Gewandung im grofen und ganzen gerade so gehalten wie zu Rom selbst. Man vergleiche z. B. die Mosaiken von S. Vitale zu Ravenna und von S. Apollinare in Classe. Die Mappula und die liturgische Beschuhung waren natülich im Anfang des 7. Jahrhunderts nur wenig verbreitet, da der römische Ḱlerus diese noch als sein besonderes Vorrecht betrachtete und demgemäß wachsamen Auges behütete. Dagegen war die Dalmatik wohl bereits allgemein bei den Diakonen und Bischöfen des römischen Ritus in Gebrauch. Des Palliums durften sich selbstverständlich nur jene Bischöfe bedienen, welche vom Papste mit demselben ausgezeichnet worden waren.

Im Orient finden wir zu Beginn des 7. Jahrhunderts bei den Diakonen das Sticharion und das Orarium, bei den Bischöfen das gegürtete Sticharion, das Epitrachelion, das Phelonion und Omophorion. Vom Epitrachelion hören wir freilich erst in der Yotopé; immerhin darf unbedenklich auch schon für das frühe 7. seine Verwendung angenommen werden. Beziiglich der liturgischen Kleidung der niedern Kleriker und der Priester liegen für diese Zeit keine Nachrichten vor. Wenn jene indessen noch um das Ende des Jahrtausends ein gegürtetes Sticharion und das Phelonion trugen, so wird es auch im 7. Jahrhundert wohl so gewesen sein, und wenn die priesterliche Tracht, wie nicht zweifelhaft, nur eine vereinfachte bischöfliche Kleidung darstellte, so haben die Priester damals wohl in gegiirtetem Sticharion, im Epitrachelion und im Phelonion ihres Amtes gewaltet.

Über den Verlauf, welchen die Entwicklung der liturgischen Kileidung: im Lauf des 7. und 8. Jahrhunderts nahm, sind wir im einzelnen nicht näher unterrichtet. In Gallien und Spanien bereitete sich die Aufnahme des römischen Brauches vor. In griechischen Ritus scheint sich im 8. Jahrhundert den liturgischen Ornatstücken der Bischöfe das Enchirion, das liturgische Etikettetuch, zugesellt zu haben. Besonders reich gestaltete sich aber in dieser Zeit die Sakralgewandung zu Rom aus, wo allerdings die ungemein einflufreiche Stellung und die hohe Bedeutung, welche Papst und Klerus inzwischen dort erlangt hatten, eine solche Entfaltung in hervorragendem Mafie begünstigten, ja fast notwendig herbeiführen muften. Thr Ergebnis kommt im 1. und 3. römischen Ordo, namentlich aber im S. G. K. zum Ausdruck. Dort ist es vornehmlich die päpstliche Gewandung, über die wir Aufschlub erhalten. Hier wird uns eine erschöpfende Zusammenstellung des gottesdienstlichen Ornates aller einzelnen Stufen des römischen Klerus geboten, die etwa den Stand der Dinge im 2. Viertel des 9. Jahrhunderts wiedergibt. Ebendeshalb lassen wir das für die Geschichte der liturgischen Gewandung des römischen Ritus so wichtige Verzeichnis in einem neuen, auf den handschriftlichen Text sich stïtzenden, durchaus korrekten Abdruck folgen.

De vestimento pontificis. Inprimis camisia et cingitur supra, deinde linea cum costis (sic) serica et cingitur, post haec mittitur anagolaium (sic), exinde dalmatica minore, postea maiore dalmatica et super orarium, post haec planeta et super mittitur pallium. Nam in his diebus, natali Dm̄i, pascha, sci. Petri et die ordinationis suae aliud colere (colore) planeta induitur. Sestace in manu portat; item calciamenta, inprimis odhones, deinde campagos. 
Item de vestimento alii romani episcopi. Inprimis camisia et cingitur, postea tunica alba, deinde orarium, post haee planeta et sestace in manu. Calciamenta, odhones et campagos.

Presbyter romanus similiter praeter tantum subtulares ${ }^{2}$, quos mittit presbyter ${ }^{2}$

Di a con us inprimis camisia et super cingitur, postea tonica (sic) alba et cingitur, deinde anagolagium, post hoe brachiale in dextra manu, dalmatica minore et maiore et planeta usque dum venitur presbyterio, ibidem tollitur ab acolito. Calciamenta sicut pontifex.

Subdiaconus. Camisia et cingitur, deinde anagolagium et tunica alba, orarium et sestace in sinistra manu.

Acoliti. Camisia et cingitur, sestace in sinistra latere ad cingulum pendens (pendit?), tonica (sic) alba et orarium ad collum et planeta, et quando in gradu psallitur, planeta abstollitur et orarium portat in manu. Calciamenta, odhones et subtulares sicut et subdiaconus.

Reliqui vero inferiores gradu ecelesiae, qui in gradu psallunt sicut et acoliti, illi vero qui in ammone (ambone) non psallunt, si habuerint, similiter induantur. Sin autem non potuerint..

Item cottidianis diebus qualiter pontifex induitur. Inprimis camisia et cingitur. Deinde tonica serica, orarium, planeta et pallium, sestace in manu. Calciamenta vero tam pontifex quam etiam et omnes reliqui sive festis diebus sive cottidianis suo modo induuntur. Item diaconi $\mathbf{i}^{3}$.

Eines Kommentars bedarf das Verzeichnis nicht, da an manchen Stellen dieses Werkes, auf die hier verwiesen werden kann, auf dasselbe Bezug genommen wurde. Es sei daher nur auf die eigenartige Häufung der liturgischen Ornatstücke aufmerksam gemacht, wie sie uns in dem S. G. K. entgegentritt, und zwar nicht blof beim Papst, sondern selbst bei den Akolythen. Dabei ist bemerkenswert, daf die Gewandung der römischen Hebdomadarbischöfe und Priester im Vergleich mit derjenigen der übrigen Ordines auffallend einfach ist. Am reichsten ausgestattet ist der liturgische Ornat des Papstes und der Diakone; begreiflich, da eben diese zu Rom die hervorragendste Stelle einnahmen, der Papst als summus pontifex, die Diakone als seine nächsten Ministri und zugleich als die papabili. Beachtung verdient auch der Umstand, daß der Papst beim Gottesdienst an gewöhnlichen Tagen eine einfachere Gewandung trug als an den hohen Festen, an denen er in vollem Glanz pontifizierte.

Charakteristisch ist für die hier in Frage kommende Periode die grobe Schlichtheit der liturgischen Gewänder. Dieselben erscheinen auf den Bildwerken stets ungemustert, und, wenn wir die Dalmatik mit ihren traditionellen clavi ausnehmen, fast immer ohne allen Zierbesatz. Es liegt aber kein Grund vor, welcher uns berechtigte, die Monumente in Bezug auf diesen Punkt als der Wirklichkeit nicht entsprechend zu betrachten. Indessen bedurfte es ja auch bei der weiten, vollen, faltenreichen Form der Gewänder keineswegs eines reichen Schmuckes derselben, um den Liturgen und seinen Gehilfen ihrer erhabenen Stellung gemäßs auszuzeichnen. Auch ohne besonderes Ornament auf ihrer Gewandung waren diese, wie die römischen und ravennatischen Mosaiken so simnfällig bekunden, ungemein würdevolle Erscheinungen.

1 In der Handschrift steht subtula und dann in der folgenden Zeile mit Wiederholung von la lares, offenbar ein Irrtum des Schreibers.

2 Das Manuskript hat pbs $=$ presbyteres.

3 Bei der Wiedergabe des Kataloges wurden a) statt der Punkte jnnerhalb der Sätze als
Trennungszeichen Kommata gesetzt, b) die Worte einheitlich, sofern es sich nicht um den Satzanfang handelt, mit kleinen Anfaugsbuchstaben geschrieben, c) die Abkiirzungen aufgelöst, d) zwei evidente Schreibfehler verbessert. In allem übrigen ist der Text mit aller Treue wiedergegeben. 
IV. DIE LITURGISCHE GEWANDUNG VOM IX. BIS XIII.JAHRHUNDERT.

Seit dem 9. Jahrhundert war die römische Sakralkleidung im ganzen Abendland herrschend. Für Spanien bezeugen das die Inventare; sie muls hier spätestens im 8. Jahrhundert Aufnahme gefunden haben. Nach England war sie zugleich mit den römischen Glaubenshoten gekommen, die Gregor d. Gr. dorthin geschickt und mit dem zur Feier der Liturgie nütigen Apparat ansgerüstet hatte. In Gallien hatte die karolingische Reform die liturgische Gewandung, wie sie zu Rom in Gebrauch war, endgültig eingebürgert. Was Hraban, Amalar, Pseudo-Alkuin, Walafried und die fränkischen Inventare des 9. Jahrhunderts an liturgischen Gewändern aufzählen, ist durchaus die Sakralkleidung des römischen Ritus. Daf diese in Italien gebräuchlich war, braucht kaum ausdrücklich bemerkt zu werden. Selbst im Süden, wo sich griechischer Einflus geltend machte, und zu Mailand waren die Abweichungen unbedeutend. Fraglich ist, wie es im 9. Jahrhundert in Irland stand. Wir haben darüber für diese Zeit keine Nachrichten. Erst um 1100 erfahren wir Näheres über die daselbst übliche gottesdienstliche Kleidung. Damals war in Bezug auf diese in Irland römische Sitte mafigebend.

Natürlich haben wir die Aufnahme römischen Brauches nicht dahin aufzufassen, als ob die römische Sakralkleidung bis in ihre kleinsten Einzelheiten kopiert worden wäre. Für die damalige Zeit mit ihrer Weitherzigkeit und ihrer Freiheit in liturgischen Dingen wäre das ein Ding der Unmöglichkeit gewesen. Es waren aber nur nebensächliche Punkte, in ilenen man von Rom abwich. Insbesondere war die Kleidung der Minoristen einfacher als zu Rom; das Orarium scheint auberhalb Roms bei denselben nie gebräuchlich gewesen zu sein, die Mappula nur bei den Subdiakonen. Die Bischöfe bedienten sich nach dem Vorbild der römischen Hebrlomadarbischöfe wohl meist nur einer Obertunika, also nicht zugleich der Dalmatik und Tunika, die Diakone zu Mailand und in Süditalien aber behielten die Gepflogenheit bei, die Stola über der Dalmatik zu tragen. Volle Übereinstimmung bestand in Bezug auf die priesterliche Kleidung, höchstens daf in Bezug auf den Gebrauch des Amikts zwar nicht in der Theorie, so doch in der Praxis einiges Schwanken herrschte. Abweichungen hinsichtlich der Form und Beschaffenheit der Paramente machen sich im 9. Jahrhundert nur wenige bemerklich. Am deutlichsten treten solche bei der Dalmatik auf, und zwar sowohl hinsichtlich der Länge als der Verzierung derselben. Auferhalb Roms, und zwar im Norden, war es auch wohl, wo die Mappula sich am frühesten zum bloßen Zierstreifen umbildete.

Die Entwicklung, welche die liturgische Kleidung seit dem 9. Jahrhundert nahm, äukerte sich namentlich nach zwei Richtungen hin, erstens in der Modifizierung der Verwendung einzelner Gewandstücke im Sinne des heute bestehenden Brauches und dann in der Erweiterung der Sakraltracht durch Einführung neuer Bestandteile.

Die Kasel, die Stola und die Mappula kamen bei den Akolythen, die Kasel und Stola bei den Subdiakonen allenthalben in Abgang; die Kasel wurde spezifisches Mekgewand, der Manipel Insignie der Subdiakone und mit der Tunicella die eigentlich subdiakonale Gewandung.

Gewänder, die neu in Gebrauch kamen, waren die Cappa und das Superpelliceum. Insbesondere aber erfuhr die pontifikale Kleidung durch Aufnahme neuer Stïcke eine weitere Ausgestaltung. Schon um die Wende des 
9. Jahrhunderts begegnen uns die Pontifikalhandschuhe, die wir dann bald allgemein in Gebrauch gewahren. Das 10. Jahrhundert sieht die liturgische Mitra entstehen. In Süditalien schon im ersten Viertel des 11. Jahrhunderts beim Erzbischof ron Bari Verwendung findend, wird sie 1049 auch in Deutschland und dann rasch überall heimisch. Ferner kommen im 10. Jahrhundert das bischöfliche Subcinctorium und das Rationale auf, welch letzteres allerding fast ausschließlich auf deutschen Boden beschränkt bleibt. Zur gleichen Zeit wird die liturgische Fubbekleidung, die vordem, wenngleich mit gewissen Modifikationen, bei allen Weihestufen des römischen Klerus Verwendung fand, eine spezifische Eigentiumlichkeit und ein Privileg der Kardinäle und Bischöfe. Auch die Anfänge des Biretts fallen in diese Periode.

Die Veränderungen, welche in Bezug auf die Form der liturgischen Gewänder vor sich geht, sind noch unbedeutend. Bei der Tunicella und der Dalmatik machen sich auch weiterhin auf Verkürzung derselben hinausgehende Tendenzen geltend. Die Pontifikalsandalen bilden sich gegen Ende der Periode zu einem Schuh um. Die Mitra, ursprünglich eine konische Mütze, erhält nach mehrfachem Schwanken im wesentlichen ihre endgültige Form. Die Mappula verkümmert allgemein und für immer zum Zierstreifen. Stola und Manipel werden üluerschmale Bänder, die an den Enden gern mit trapezartigen Ansätzen abschließen. An Amikt und Albe bürgern sich im Laufe des 12. Jahrhunderts die Paruren ein. Als letzte Frucht aber schafft dasselbe Jahrhundert den Jiturgischen Farbenkanon. Besonderer Wert - größerer wohl als je zuvor - wird auf die reiche Beschaffenheit und kostbare A usstattung der liturgischen Gewänder gelegt. Man betrachte nur die Bildwerke, auf denen diese bis zur Karolingerzeit, ja selbst noch bis zur Wende des Jahrtausends eine auffallende Schlichtheit zur Schau tragen. Sie spiegeln seit dem 11. Jahrhundert allenthalben deutlich die der sakralen Kleidung inzwischen zu teil gewordene gesteigerte Prachtentfaltung wider.

Zwei Punkte sind für die Geschichte der Ausbildung der liturgischen Kleidung in der Zeit vom 9. bis 13. Jahrhundert charakteristisch. Erstens ist es nicht Rom allein, welches die neuen Gewänder schafft und gibt. Die Pontifikalhandschuhe, die Cappa, das Supperpelliceum und wohl auch das Subcinctorium sind nicht römischen Ursprungs. Sie kamen von auswärts nach Rom. Auch der liturgische Farbenkanon ist nichts spezifisch Römisches. Wie früher gesagt wurde, lag er in der Zeit und trat darum auch gleichzeitig zu Rom und aufierhalb Roms ins Dasein; am wenigsten römisch ist das Rationale. Nur die Mitra ist eigentlich römischer Herkunft und von Rom aus in das übrige Abendland importiert worden. Ähnlich wie mit den genannten neuen Ornatstücken verhielt es sich mit den Namen der liturgischen Gewänder. Die alten römischen Bezeichnungen kamen zum größsten Teil auß̉er Gebrauch und machten andern Platz, die von aufien nach Rom gebracht worden waren. Die Beziehungen des übrigen Abendlandes zu Rom als dem Mittelpunkte der Kirche waren innigere, der Verkehr zwischen beiden ein ungleich lebendigerer geworden. Rom gab, aber es wubte auch das Gute zu schätzen, was es anderswo fand; zugleich war es weitherzig genug, solches Gute in seinen eigenen Brauch aufzunehmen.

\%weitens muk auffallen, dafs es gerade die Pontifikalgewandung ist, welche in dieser Periode sich im besondern Más ausgestaltete. Ohne Zweifel hängt das mit dem mächtigen Wachstum zusammen, welches das äufiere Ansehen der Bischöfe seit der Karolingerzeit erfahren hatte. Allerdings hatten 
diese nicht überall die hohe, selbst in weltlichen Beziehungen so einflufisreiche Stellung erlangt, welche ihnen auf deutschem Boden zu teil geworden war; doch war auch anderswo ihre Bedeutung nach aufen um ein Vieles gewachsen. Begreiflich also, dak gerade die Pontifikalkleidung eine besondere Ausbildung erfuhr.

Es ist gesagt worden ${ }^{1}$, daf diese Erweiterung der pontifikalen Tracht unter dem Einflub der alten Liturgiker erfolgt sei. Wir können diese Ansicht nicht teilen. Denn die Liturgiker der Karolingerzeit wissen noch gar nichts von den neuen bischöflichen Gewandstücken; auch findet sich bei ihnen nicht die geringste Tendenz auf Erweiterung der Pontifikaltracht. Die Liturgiker des ausgehenden 11. und 12. Jahrhunderts aber sahen schon die neuen Bestandteile der bischöflichen liturgischen Kleidung allesamt fertig vor sich. Wie unter solchen Umständen die Liturgiker auf die Ausgestaltung der Pontifikaltracht eine Einwirkung ausgeïht haben, ist sonach schwer verständlich.

Als Amalar seine Schrift De officiis ecclesiasticis schrieb, zählten zur liturgischen Gewandung folgende Stücke: Amikt, Albe, Cingulum, Manipel, Stola, Tunika, Dalmatik, Kasel, Pontifikalschuhe samt Pontifikalstrümpfen und Pallium. Es waren ihrer im ganzen elf. Am Ende der Periode, d. i. um 1200, gehörten außerdem noch zu ihr Cappa, Superpelliceum, Handschuhe, Subcinctorium, Mitra und Rationale, vom päpstlichen Fano oder Orale, damals noch lediglich Amikt, ganz abgesehen. Es waren also nou hinzugekommen nicht weniger denn sechs Gewänder. Damit hatte dann freilich die Ausbildung ihren naturgemäsen Abschluls erreicht. Es wäre in der Tat auch schon schwer geworden, ein weiteres Gewand zu ersinnen.

Was die Riten des Ostens anlangt, so läst sich nur im griechischen Ritus für die Zeit vom 9. bis 13. Jahrhundert die Entwicklung der Gewandung einigermaßen verfolgen. Sie betrifft lediglich die Pontifikalkleidung, welche um die Epimanikien und, falls solches nicht schon vor dem 9. Jahrhundert geschehen sein sollte, jedenfalls noch vor 1000 um das Enchirion bereichert wird. Außerdem kommt bei den Patriarchen im Laufe des 11. Jahrhunderts der allem Anschein nach der byzantinischen Hoftracht, genauer der kaiserlichen Gewandkammer, entlehnte Sakkos in Gebrauch. Eine formelle Veränderung läßst sich in der hier in Frage stehenden Periode nur beim Enchirion feststellen. Sie hatte frühestens im Verlauf des 12. Jahrhunderts statt. Das Enchirion wurde dabei aus einem Tuche ein rautenförmiges, gesteiftes Zierstück.

\section{DIE LITURGISCHE GEWANDUNG IM SPÄTEN MITTELALTER UND IN DER NEUZEIT.}

Seit Beginn des 13. Jahrhunderts erscheint die Ausbildung der liturgischen Gewandung, was Zahl und Charakter ihrer einzelnen Bestandteile anlangt, abgeschlossen. Kein weiteres Gewand kam in der Folge zu dem Kanon der Sakralkleidung, wie er zu Innozenz' III. Zeit bestand, hinzu, ebensowenig aber schied irgend eines der verschiedenen Ornatstücke völlig aus dem Gebrauch aus. Denn wenn auch der päpstliche Fano dadurch, dafs der Papst zu ihm hinzu den gewöhnljchen Amikt annahm, seine praktische Bedeutung verlor und zum blofen Zierstïck wurde, so fand er doch nach wie

1 Realenc. II 184. 
vor Verwendung; und wenn das Subcinctorium bei den Bischöfen in Abgang kam, so blieb es doch bis auf die Gegenwart ein Bestandteil der päpstlichen Pontifikaltracht. Sellost das Rationale erhielt sich, obschon es nie eine weite Verbreitung gefunden hatte, vereinzelt bis auf unsere Tage.

Auch bezäglich der Verwendung der liturgischen Gewänder brachte das späte Mittelalter und die Neuzeit keine andere bemerkenswerte Veränderung, als dafo seit dem 13. Jahrhundert das Superpelliceum immer mehr an Stelle der Albe in Gebrauch kam und namentlich an deren Statt das liturgische Kleid der niedern Kleriker wurde.

Die Geschichte der Sakralkleidung geht demnach seit dem 13. Jahrhundert fast ganz auf in der Geschichte ihrer formellen Umbildung, ihrer stofflichen Beschaffenheit und ihrer Ausstattung. Es würde selbstverständlich zu weit führen, hier auf einzelnes näher einzugehen; es muf und kann ja auch auf das, was darüber bei Besprechung der verschiedenen Gewänder gesagt wurde, verwiesen werden. Wir beschränken uns daher an dieser Stelle auf einige allgemeine Gedanken.

Für die formelle Umbildung im späten Mittelalter, namentlich aber seit dem 16. Jahrhundert, ist bezeichnend die allgemeine und rapid zunehmende Tendenz, die Gewänder immer mehr zu verkürzen. Verkürzungen kamen freilich bei einzelnen derselben auch schon früher vor, sie blieben aber recht bescheiden und waren keineswegs grundsätzlicher Art, während das Zustutzen in der letzten Periode der Geschichte der Sakralkleidung Prinzip, Grundton der Entwicklung ist. Manipel. Stola und Pallium, Tunicella, Dalmatik und Superpelliceum, die Kasel und selbst die Albe mufsten es an sich erfahren. Am übelsten wurde der Kasel mitgespielt, die aus dem weiten, glockenförmigen Mantel, den sie noch um 1200 darstellte, zuletzt zu einer Art von Skapulier wurde. Unberührt blieben, wenn wir von Amikt, Cingulum und Subcinctorium, den Pontifikalhandschuhen und der pontifikalen Fukbekleidung absehen, Gewandstücke, bei denen es nichts zu verkürzen gab, nur das Pluviale und die Mitra. Ja es machte sich bei diesen sogar eigentümlicherweise ein gegenteiliges Bestreben geltend. Beim Pluviale wurde der Schild allmählich so sehr vergrößert, daß3 zwischen ihm und dem Gewande jedes entsprechende Verhältnis schwand. Die Mitra aber lief man zu einer solchen Höhe und Breite anwachsen, dafi sie zum förmlichen, jedes Maßses entbehrenden Turm wurde. Alles in allem war es keine weitere Ausgestaltung der liturgischen Gewänder, was mit diesen seit dem 13. Jahrhundert in formeller Hinsicht vor sich ging, sondern eine beklagenswerte Verbildung derselben.

Ungleich erfreulicher ist das Bild, welches die Sakralgewandung seit dem 13. Jahrhundert nach ihrer stofflichen Beschaffenheit und nach ihrer Ausstattung bietet; weniger freilich in der Neuzeit als im späten Mittelalter. Allerdings hatte es schon vorher manchen kostbaren Ornat gegeben: den Beweis liefern die Inventare sowohl wie die noch vorhandenen Gewandstücke aus der Frühe des Jahrtausends. Allein was die Menge der prächtigsten Gewänder, die Qualität der zu ihnen verwendeten Stoffe und ihre reiche Ornamentierung mittels Perlen, Edelsteinen, Plättchen aus edeln Metallen und Emails, namentlich aber mittels grobartiger, kunstvollster Stickereien anlangt, hält die Zeit vor dem 13. Jahrhundert mit dem späten Mittelalter im ganzen genommen keinen Vergleich aus. Freilich war alles in diesem der Pflege der Paramentik ungleich günstiger als je zuvor. Die mächtig: aufgeblühten und alle Schichten interessierenden Kunstbestrebungen; der ge- 
steigerte religiöse Sinn, der überall heilige Bilder zu sehen liebte, um sich an ihnen zu erbauen; die staunenswerte Opferfreudigkeit des späten Wittelalters, wo es galt, die Ehre Gottes zu fördern und die Zierde seines Hauses zu mehren, in Verbindung mit dem um ein bedeutendes gestiegenen allgemeinen Wohlstand und der in weiten Kreisen heimisch gewordenen Bildung und Lebensverfeinerung: das rasche frische Aufblühen der Seidenindustrie in Mittel- und Norditalien und dann auch diesseits der Alpen in Flandern und Frankreich; die dadurch ermöglichte Leichtigkeit in Beschaffung glänzender Paramentenstoffe; die nach Technik und künstlerischer Durchbildung aufs höchste vervollkommnete Stickkunst und manche andere Faktoren wirkten zusammen, um das späte Mittelalter zum goldenen Zeitalter der stofflichen Beschaffenheit und der Verzierung der Paramente zu machen.

Das 16. und 17. Jahrhundert folgte, was Material und Ausstattung der liturgischen Gewänder anlangt, im ganzen noch mehr oder minder den spätmittelalterlichen Traditionen; doch begann bereits im Lanf des 17. auch in Bezug auf jene der traurige Verfall, welcher hinsichtlich der Form schon eine gute Weile früher eingesetzt hatte. Er nahm rasch zu und erreichte zur Zeit einer nüchternen Aufklärung in den Ornaten aus Leder und Stroh, aus Sopha- und Kleiderzengen seinen tiefsten Stand. So verblieb es, bis im zweiten Viertel des 19. Jahrhunderts das neu aufblühende kirchliche Leben und mächtig erwachte religiöse Bewufstsein eine glückliche Reform der liturgischen Gewandung, wenn auch vornehmlich nur nach Stoff und Ornamentierung, herbeiführten.

In Bezug auf die liturgische Kleidung im griechischen Ritus — von den übrigen orientalischen Riten müssen wir auch hier wieder absehen hatte in der Zeit von 1200 bis in die Gegenwart eine eigentliche Entwicklung nicht statt. Die Monumente des 13, des 15., des 17., ja des 19. Jahrhunderts gewähren dasselbe Bild der Sakraltracht bei den verschiedenen Weihestufen wie die des 11. Das einzige Ornatstück, welches zu den bereits vorhandenen hinzukommt, ist die im Lauf des 15. oder 16. Jahrhunderts eingeführte bischöfliche Mitra.

Was die Verwendung der Gewänder anlangt, blieb es im wesentlichen beim alten. Denn es kann wohl kaum eine bedeutende Veränderung genannt werden, wenn der Sakkos auch bei den Metropoliten und in einzelnen Zweigen des griechischen Ritus selbst bei den Bischöfen sich einbürgerte, wenn das Epigonation allmählich niedern Prälaten als Auszeichnung verliehen wurde und die Epimanikien bei den Priestern, ja bei den Diakonen in Gebrauch kamen. Der Mangel an Leben und Entwicklung, der im Osten seit einem Jahrtausend für die Riten als solche charakteristisch ist, offenbart sich daselbst auch in Bezug auf die liturgische Gewandung ?

Man kann an das Studum der liturgischen Gewänder unter mancherlei Gesichtspunkten herantreten. Von welchem Standpunkte man sich aber auch

1 Wir fügen einen kleinen Nachtrag an. S. 6 wird der 10. Ordo Mabillons als dem 11.-12. Jahrhundert angehörend bezeichnet; genauer wird man ihn wohl der zweiten Hälfte des 12. Jahrhunderts zuschreiben. Übrigens ist der Ordo für die Geschichte der liturgischen Gewandung von wenig Bedeutung. Der koptische Patriarch Gabriel ferner, der S. 51 und 99 als Gewährsmann angeführt wird, hatte den Patriarehalstuhl von Alexandrien 1409-1427 inne. Sein Rituale stammt aus dem Jahre 1411 (Renaudot, Liturg. orient. coll. I 158). S. 51, Zeile 1 von unten und S. 99 , Zeile 11 von oben muf es daher 15. Jahrh. heißen, nicht, wie infolge eines Versehens, 12. Jahrh. 
mit ihnen beschäftigen mag, immer bieten sie eine reiche Fülle des Wissenswerten und Interessanten. Die Sakralkleidung ist das Produkt jenes Lebens, das den mystischen Leib Christi durchzieht und ihn so wunderbar fruchtbar und schöpferisch macht. Wie aus diesem Quell Dogma und Moral ihre herrliche Entfaltung schöpften, und wie diesem Leben je nach den Zeiten und Verhältnissen die äufieren Formen des Gottesdienstes und eine reichste Fülle der bedentungsvollsten und erbaulichsten Zeremonien entsprossen, so hat auch unter dem Einflus derselben treibenden Kraft die gottesdienstliche Kleidung im Laufe der Jahrhunderte ihr Dasein und ihre bestimmte Gestalt erhalten. Die heiligen Gewänder sind weder das Ergebnis des Zufalls noch die Frucht der Willkür oder spielender Phantasie. Sie sind das Werk der Kirche, der Verwalterin der heiligen Geheimnisse, welche sie kraft der ihr von Christus verliehenen Gewalt und in treuer Sorge für die Zierde des Gotteshauses und des Kultes in langsamer, aber stetiger Entwicklung aus der Festagskleidung der alten griechischrömischen Welt sich herausbilden lief. Die Kirche ist es, unter deren wachenden Augen die heiligen Gewänder nach und nach ihre eigenartige Gestalt gewannen. Sie ist es, die wie im großen, so im kleinen die Verwendung der Sakralgewandung bei den verschiedenen Funktionen unter Berücksichtigung der örtlichen und zeitlichen Bedürfnisse wie des religiösen Dekors zu allen Zeiten sorgsam regelte und noch immer regelt. Ebendarum aber spiegelt sich ganz naturgemäßs in der Geschichte der liturgischen Kleidung das Leben der Kirche in den verschiedenen Zeiten in aller Deutlichkeit wider. Jugendzeit und Mannesalter der Kirche, Flut und Ebbe, welche das Leben und Wirken der Kirche im Laufe der Jahrhunderte infolge der mannigfaltigsten inneren und äuferen Einflüsse erfuhren, liaben ihre Spuren auch der Kultkleidung aufgedrückt.

Allerdings darf auch der Einflufa außerkirchlicher Faktoren in dem Entwicklungsprozeb der liturgischen Gewandung keineswegs verkannt werden. Zwischen der Kirche, die für die Menschen da ist und aus Menschen besteht, und der Welt, in deren Strom sie sich bewegt und wirkt, gibt es ja mancherlei Berührungspunkte und wechselseitige Beziehungen. Die Geschichte der einzelnen Gewänder bietet in der Tat mehr als einen Beleg für die Einwirkung, welche die äuferen Verhältnisse auf Ausgestaltung der liturgischen Tracht nach Form, Stoff und Verzierung ausübten. Allein welcher Art dieselbe auch war und in welchem Mafe sie sich geltend machte, immer bleibt dabei wahr, dafi wie die Zeremonien, welche die gottesdienstlichen Verrichtungen als ebensoviele Variationen ihres einen grofen Grundgedankens umspielen, so in gleicher Weise die Gewandung der Diener des Heiligtums zuletzt das eigenste Werk der Braut Christi auf Erden ist. Wenn aber die Kirche jenen eine besondere Kleidung gab, wenn sie diese Kleidung durch ihren Segen heiligte, wenn sie wollte, das die Sakralgewandung rein und geziemend ausgeschmückt sei, so geschah alles das in der Absicht, die Liturgen am Altare auch in ihrem Äußern über die Sphäre des alltäglichen, gewöhnlichen Lebens zu erheben und mit einem Glanze auszustatten, welcher den inneren Wert der göttlichen Geheimnisse, ihre Würde und Erhabenheit zwar nimmer voll zum Ausdruck zu bringen vermag, aber immerhin einigermaßen sinnfällig in die Erscheinung treten läkst.

Schlielien wir mit den begeisterten Worten, in denen Jesus Ben Sirach (Kap. 50, Vers 8-11) den Hohenpriester Simon, des Onias Sohn, im Glanz seiner pontifikalen Kleidung schildert, "Wie der Regenbogen glänzet zwischen herrlichen Wolken", so sagt er, "wie blühende Rosen in den Tagen des 
Frühlings, wie Lilien an Wasserbächen, wie duftende Weihrauchstauden in den Tagen des Sommers, wie leuchtendes Feuer und im Feuer entzündeter' Weihrauch, wie ein Gefäßs von gediegenem Gold mit allerlei kostbaren Steinen geziert, wie ein fruchtbarer Ölbaum, wie eine in die Höhe aufsteigende Cypresse, so war er, wenn er das Ehrenkleid anzog und mit allem Schmuck bekleidet war."

Es muls in der Tat ein herrlicher Anblick gewesen sein, wenn der Hohepriester, umgeben von einer Schar weif gekleideter Priester und Leviten, in der von Moses auf Geheifs des Herrn angeordneten Prachtgewandung ins Heilige einzog, um dort am Opferaltar als Mittler zwischen Gott und dem Volke der Auserwählung seines erhabenen Amtes zu walten, bekleidet mit der bis auf die Füßse herabwallenden, weibglänzenden, mit buntfarbigem Gürtel geschürzten Kethonet, darüber die blaupurpurne, am Saum mit purpurnen und scharlachnen Granatäpfeln und goldenen Schellchen besetzte Obertunika, auf dem Oberkörper den vierfarbigen, mit Gold reich durchwirkten Ephod, auf jeder Schulter in goldener Fassung einen kostbaren Edelstein mit den Namen von sechs Söhnen Israels, vor der Brust das goldstrahlende Rationale mit seinen zwölf Edelsteinen und seinen Ketten aus lauterem Golde, auf dem Haupte endlich die weibglänzende Mitra mit der goldenen stimplatte. Und doch, ob nicht der gottbegeisterte Erguf des Sohnes Sirachs in ungleich höherem Maß3e und mit weit gröberem Recht von dem christlichen Hohenpriester, dem Bischofe, gilt, wenn dieser inmitten seines Klerus, alle geschmückt mit auserlesenc' heiliger Kleidung, er selbst sogar an Hand und Ful. strahlend, zur Opferstaitte des Neuen Bundes schreitet, um dort gemäl des Erlösers letztem Willen das Gedächtnis an die wunderbare Opfertat auf Golgatha feierlich zu begehen und dabei zugleich als Stellvertreter Christi und im Namen der Kirche statt der Vorbilder und der Schatten von einst, die erhabenste Wirklichkeit, das Lamm, das am Kreuz sein Leben zum Heil der Welt hingab, auf geheimnisvolle, unblutige Weise dem Allerhöchsten von neuem für das ganze glüubige Volk darzubringen als würdigstes Lob-, heiligstes Dank-, gnadenvollstes Bitt- und kräftigstes Sühnopfer?

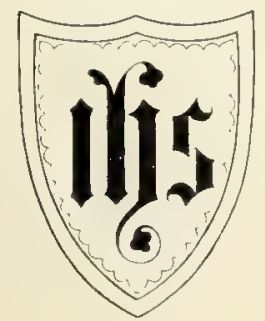





\section{VERZEICHNIS DER BESPROCHENEN ALTEN GEWÄNDER'.}

Aachen (Münster) : Handschuhe 362 ; Kasel 220; Manipel 542; Pluvialschließen 324 ; Stola 599.

Admont: Mitra 481.

Altenburg (Tirol): Kasel 188. Ambazac: Dalmatik 269.

Amiens (Stadtbiblioth.) : Handschuh 370 ; Mitra 479.

Anagni (Kathedrale): Dalmatiken 271272 ; Kasel 225; Manipel 541; Mitren 467 468; Pluviale 272341 ; Stola 598: Tunicella 272

Andechs: Cingulum 110; Manipel 540 ; Stola 599.

Arles (St-'Trophime): Cingulum 103 105; Stola 572 591; Pallien 643.

Arlon (St-Donat): Kasel 179; Manipel 539; Stola 592.

Arras (Kath.): Rochett 132.

Aschaffenburg (Schlofkirche): Kasel 178211; (Stiftskirche): Stola 572591597.

Ascoli (Kath.): Pluviale 339. Assisi (S. Chiara): Albe 77 8287.

Augsburg (Dommuseum) : Cingulum 110111 ; Kaseln 178 211; (St Ulrich) : Dalmatik 269 ; Kasel 178.

Avignon (St-Pierre) : Dalmatik 280.

Ragnoreo (Collegio delle Missioni): Mitra 476.

Bamberg (Dom): Kaseln 178 185225227 228: Mantel 230; Mitra 468; Rationale 680 688; (St Michael) : Kasel 468; Mitra 468.

Barcelona (Kath.) : Mitra 468.
Bayeux (Kath.) : Kasel 174211; Manipel 539; Stola 598.

Beauvais (Museum) : Mitra 467; (Privatbesitz): Dalmatik 277.

Berlin (k. Kunstgewerbe-Museum): Albenparura 87; Dalmatik 276282 ; Kaseln 207 ; Kaselkreuze 218221 ; Manipel 539 ; Mitren 481; Pluvialschließse 326 ; Sandalen 414.

Bern (Hist, Museum): DaImatiken 275277279280 : Kaseln 187; Pluviale 338 ; Stola 599; Tunicellen 290293.

Besançon (Kath.): Kasel 193; Mitra 478.

Billerbeck: Kasel 207.

Biville: Kasel180 187; Stola598

Bologna (Dom): Mitren 438 476; (Museo civico): Pluviale 344.

Brandenburg (Dom): Albe 77 87: Dalmatiken 275277280 : Kaseln 188; Tunicellen 290. Braunschweig (Herz, Museum): Dalmatik 270; Kaseln 188; Mantel 225.

Brauweiler: Kasel 178211.

Briennon: Kasel 187.

Brignoles (Var.): Dalmatik 277; Haudschuhe 369 ; Mitra 479.

Brixen (Dom): Handschuhe 370 375376 : Kaseln 174 ; Mitren 468 480; Sandalen 412.

Brüssel (MuséeCinquant.) : Pluvialbesatz 334 ; Sandalen 403.

Cahor's (Kath.): Handschuhplättchen 375 .

Capua (Dom): Mitra 438468.

Castel S. Elia: Alben 75; Dalmatiken (Tunicellen) 276;
Kaseln 180188193 f 216 :

Mitren 468; Sandalen 402. Châlons-sur - Marne (Kath.) : Sandale 408; Mitra 479.

Chelles: Sandalen 403.

Cividale (Dom) : Mitra 438476 Comminges (St-Bertrand): Albe 77: Handschuhe 370376 Vitra 467: Pluviale 342: Sandalen 412.

Conflens: Handschuhe 370.

Courtrai (St-Michel): Kasel 179

Danzig (St Marien): Alben 768287 ; Albenparuren 87: Amikt 36; 1 miktparuren 38 Cingula 108112; Dalmatiken 270275 ; Dalmatikfliigel 277 278; Kaseln 188215216 Manipel 541; Pluvialien 333 Stolen592599:Tunicellen293.

Darmstadt (Museum): Pluvialschließse 336 .

Delkhofen: Kasel 207.

Delsberg: Caligae 401; Sandalen 395.

Deutz: Kasel 178.

Dokkum: Kasel 174.

Durham (Kath.): Cingulum 110; Manipel 53\%; Stola 596.

Düsseldorf (Kunstgewerbe-Museum): Epigonation 551; Stola, arm.603; Stola, griech. 607 ; Tunika, arm. 95.

Fichstätt (Dom) : Albe 7787 . Amikt 36: Kasel 188: Rationale 688: (Bischöfl. Palais): Kasel 207; (St Walburga): Kasel 188.

Einsiedeln: Kasel 192.

Elten: Pluvialschliefse 323.

Essen: Pluvialschließse 323.

1 Aufgenommen sind in das Verzeichnis nur solche Gewänder, die noch vorhanden sind, nicht aber solche, über die nur noch Berichte vorliegen, die jedoch inzwischen zu Grunde gegangen sind. Uber die mittelalterlichen Paramente, welche sich unter den in der Kapelle Sancta sanctorum durch P. Grisar wiederaufgefundenen Schätzen befinden sollen, vermochte ich keine Auskunft zu erhalten, wie sie für diese Arbeit notwendig gewesen wäre. Sie blieben deshalb unberücksichtigt. Die mir von dem Entdecker freundlichst angebotenen Klischees verschiedener hochinteressanter Textilien des Schatzes mulate ich leider mit herzlichstem Dank ablehnen, teils weil der Druck der Arbeit bereits zu weit fortgeschritten war, als daks ich sie noch hätte erwarten können, teils weil es sich nicht um eigentliche Gewandreste handelte. 
Evreux (Museum): Mitra tis. Exaeten (Canisius-Kolleg): Kasel 191.

Ferentino (Kath): Mitra 468. Florenz (Museo degli Arrazzi): Dalmatik 280; (Opera del Dumo): Kasel 192 233; (S. Trinita): Handschuh 369 376: Kasel 180; Mitra 467.

Frankfurt a. M. (Dom): Pluvialschließse 326; (Rothschildmuseum) : Pluvialschließen 326; (Städt. Histor. Museum): Sandalen 414.

Freiburg (Münster): Handschuhe 372; Mitren 485; Sandalen 414

Tök: Albe 90: Dalmatik 272 273; Kasel 179 232: Pluviale 338 ; Tunicella 293.

Gran (Dom): Mitra 483.

Grottaferrata: Omophorion 671.

Haiberstadt (Dom): Amikt 36 . Amiktparura 37; Caligae 411; Cingula 107 108; Dalmatiken $270271275 \quad 280$ : Handschuhe 370 376: Kaseln $185 \quad 188 \quad 193 \quad 202 \quad 222$ 225; Manjpel 541; Mitren 468480481 : Pluvialien 333 ; Sandalen 412 413; Stolen 592597599 ; Tunicellen 290.

Hamont: Pluvialschliefe 325.

Hannover (Provinzialmuseum): Alben 7789.

Heriord (Johanniskiuche): Pluvialschlieke 326

Hildesheim (Dom) : Kasel 178; Sandalen 402; (St Godehard): Kasel 178 225; Sandalen 414.

Husaby: Kasel 203.

Iburg: Kasel 178.

Kamp (Niederrhein): Handschuhe 372; Mitra 484.

Kempen: Pluvialschlieke 323.

Kendenich: Kasel 207.

KöIn (Dom): Kasel 234; Mitren 485; (Sammlung Schnütgen): Kasel 179; (St Andreas): Kasel 599; Manipel 541; Stola 599; (St Mariä Himmelfahrtskirche) : Kasel 222; (St Ursula): Pluvialschließse 325 .

Kopenhagen (Nationalmusenm): Mitra 480; Sandalen 412.

Krakan (Dom): Kasel 219: Mitra 481; Rationale 685 692.

Kremsbrücken: Dalmatik 282.

Lausanne (Museum): Sandale 403.
Limburg (Dom): Mitra 483.

Limerick (Kathedrale): Mitra 480.

Lisieux (Hospiz): Albe 74 88; Dalmatiken 275.

London (Corpus Christ House) Pluviale 343; (Kensington Museum):Albe 7788 ; Manipel 540; Mitra 48\%; Pluvialien 340341 ; Stolen 599.

Louannec: Kasel 180.

Lyon (Kathedrale) : Mitren 467 478.

Mastricht (Liebfrauen): Tunika 261.

Madrid (Museum): Pluviale 340.

Majland (S. Ambrogio): Dalmatik 261: Kasel 190218

Mainz (St Stephan): Kasel 178 183.

Marienberg: Kasel 179232 ; Stola 597.

Martinsberg: Kasel 179230.

Maubenge: Kasel 180.

Melk: Kasel 179216.

Mochenwangen: Kasel 207.

Mondovi (Kathedrale): Caligae 411 ; Sandalen 413.

Mons (St-Nicolas): Pluviale 334.

Monza (Dom): Mitren 467.

Moskau: Mitren 492; Omophorien 672; Sakkos 305

Moutiers (Kathedrale): Handschuhe 377 .

Moyen-Moutier: Dalmatik 260.

München (Liebfrauen): Kasel 179; Mitra 468; (Nationalmuseum) : Albe 77 78; Handschuhe 372: Kaseln 178189 211: Pluvialschliefe 326; Rationale 691; Tunika 230.

Münster (Diözesanmuseum): Kaseln 174183 207; San. dalen 414 .

Namur (Kloster U. L. Frau): Manipel 538; Mitren 468.

Narni (Dom): Handschuhe 377

Neresheim (Schloßkirche): Albe 77: Amikt 36 .

Niederaltaich: Cingulum 109 112; Kasel 178; Sandale 402 .

Nürnberg (Germ. Museum): Kasel 207; Mitra 468.

Oberwesel (Stiftskirche) : Dalmatik 282.

Ofen (Kronschatz): Kasel 179 229.

Oppenweiler (Schlokkapelle) Kasel 207

Orvieto (Opera del Duomo) Dalmatik 280.

Osnabriick (Dom): Pluvialbesatz 334
Oxford (Maria Magdalena-Kolleg): Caligae 411; Sandalen 412; (New College): Handschuhe 377 380; Mitra 480.

Paderborn (Bufsdorfkirche) Kasel 178211 ; (Dom): Pluvialschlieke 325; Rationale 677687.

Paris (Cluny-Museum) : Caligae 411; Handschuh 370; Mitren 478 479; Sandalen 403414 ; (Sammlung Hochon): Pluvialschild 332.

Perugia (Universität): Pluviale 334

Petersburg (k. Zeichenschule): Pluvialschliefe 326.

Pienza (Kathedrale): Pluviale 346.

Pisa (Museo civico): Pluviale 344.

Pleasington: Pluviale 346

Pontigny: Manipel 539; Mitra 467; Sandalen 403; Stola 597.

Prag (Dom): Albenparuren 88 89: Handschuh 370375378 ; Kasel 208; Mitren 480485 ; (Goldschmiedegilde): Mitra 438.

Provins: Kasel 180 211; Manipel 539 ; Stola 597

Raab (Dom): Mitra 483.

Ratzeburg (Dom): Alben 7787.

Ravenna (Dom): Kasel 174 225; (Nuseo civico): Mitra 476.

Regensburg (Alte Kapelle): Dalmatiken 269 280; Kaseln 188; Tunicellen 290 293; (Dom): Kasel 179; Rationale 690; (St Emmeram): Kasel 178 211: Mitra 438468.

Reims (Kathedrale): Kaseln 212.

Rivadeo: Sandalen 403.

Robecco (Sammlung Visconti): Kaseln 203216.

Rom (S. Giovanni): Pluviale 346; (S. Maria Maggiore) Dalmatiken 281; Kaseln 190 218; Manipel 542; (S. Martino ai Monti): Mitra 438 477: Sandalen 395: (St Peter): Sakkos 304; (S. Pietro in Vincoli): Mitra 476; ( $\mathrm{Va}$ tikan, Museo cristiano): Mitra 476.

Rostock (Museum): Amikt 36 .

Salzburg (Dom): Mitren 468 (St Peter): Cingula 109; Ka sel 179; Mitra 482.

Saragossa (Kathedrale) : Mitra 478.

Sens (Kathedrale) : Albe 7387 Albenparuren 88; Amiktparura 37; Cingulum 106 
107111 ; Dalmatik 474475 ; Kaseln 174 180 211: Manipel 538 ; Nitren 467 ; Stolen 547598.

Siegburg: Pallien 643.

Siena (Dom): Kasel 192233 ; (Opera del Duomo): Kasel 187; Manjpel 541.

Sigmaringen (Hohenzoll. Museum): Pluvialschlieke 326.

Spalato (Dom): Handschuhstulpen 372 .

Speier (Dom): Handschuhscheibchen 369376.

St-Gildas-de-Ruis: Mitra 438.

St-Hubert: Stola 591596

St-Lizier-de-Consérans: Mitra 467.

St-Maximin: Pluviale 340.

St Paul (Kärnten): Kasel 179 230; Pluviale 318319338.

St-Rambert-sur-Loire: Kasel 180.

Steeple-Aston: Pluviale 343

Stockholm (Nationalmuseum) : Mitra 479.

Straß̧burg (Sammlung Forrer): Kasel 203 .

Strengnäs (Kathedrale): Sandale 412 .

Stuttgart (Altertumssammlung): Kasel 207.
Taben: Dalmatik 261.

Toledo (Kathedrale): Mitra 478; Pluviale 346.

Tongern: Pluvialschliefsen 324 .

Toul (St-Gengoul): Sandale 395.

Toulouse (St-Sernin): Haadschuhe 375; Kaseln 180187 216; Mitra 438

Tournai (Kathedrale): Kasel 179.

Trier (Dommuseum): Handschuhscheibchen 376 ; Kaselfragmente 225; Manipel536; Palliumfragmente 648; Sandale $402403415 \mathrm{f}$; Stola 592 598; (Liebfrauen): Stola 592598

Troyes (Kathedrale): Handschuhscheibchen 376: Manipel 539 .

Utrecht (jansen. Ordinariat): Albe 73 81; Manipel 535; Stola 591596.

Valencia: Kasel 183187188 Valsainte: Albe 77 88: Amikt 37: Manipel 540; Stola 598

Venedig (S. Marco): Kaseln 183.218

Verona (S. Zeno): Mitra 438 461468
Vich (Museo episcopal): Mitren 468 477; Pluviale 346.

Villingen: Pluvialschliebe 326. Viterbo (Dom): Albe 77.

Vreden: Dalmatik 280.

Waldsee: Superpelliceum 148.

Westerås (Kathedrale): Mitra 479

Wien (Hofburg): Caligae 401; Cingulum 109; Dalmatik 273 274: Kasel 232; Pluvialien 346 ; Sandalen 404; Tunicella 293; (Museum für Kunst und Industrje) : Albenparuren 8. : Mitra 481.

Worms (Museum): Sandalen 402.

Würzburg (Dom) : Handschuhe 372: Kaseln 178 230; Mitra 482; Sandalen 414; (Histor. Verein): Sandalen 414

Xanten (Dom): Albemparura 87: Dalmatiken 278280 ; Kaseln 178193 211; Manipel 541; Pluvialien 334; Stola 599; Tunicellen 293.

Zürich (Landesmuseum): Kaseln 207.

\section{II. ÜBERSICHT ÜBER DIE DEM WERK ZU GRUNDE LIEGENDEN MONUMENTALEN UND SCHRIFTLICHEN QUELLEN 1.}

\section{A. MONUMENTE.}

Elfenbeinarbeiten $62 \quad 167 \quad 169$ $\begin{array}{llllll}170 & 174 & 176 & 177 & 209 & 236\end{array}$ $\begin{array}{llllll}266 & 268 & 284 & 300 & 305 & 312\end{array}$ $\begin{array}{llllll}423 & 435 & 465 & 517 & 5822 & 545\end{array}$ $\begin{array}{llllll}559 & 646 & 652 & 660 & 669 & 679\end{array}$ 688.

Clasgemälde 681 .

Goldgläser 611612655 .

Grabmonumente 4142435490

$\begin{array}{lllllll}112 & 190 & 193 & 215 & 216 & 241\end{array}$

$\begin{array}{llllll}242 & 357 & 401 & 413 & 414 & 417\end{array}$

$\begin{array}{llllll}418 & 462 & 465 & 466 & 491 & 500\end{array}$

$\begin{array}{llllll}501 & 502 & 503 & 504 & 505 & 509\end{array}$

$\begin{array}{llllll}512 & 514 & 536 & 586 & 649 & 651\end{array}$

$680681688 \quad 690693$.
Katakombenfresken 6372159 $\begin{array}{llllll}173 & 241 & 251 & 254 & 258 & 259\end{array}$ $\begin{array}{lllllll}260 & 388 & 392 & 423 & 435 & 559\end{array}$ 649658660756760 .

Metallarbeiten 6273262269 $\begin{array}{llllll}268 & 284 & 305 & 351 & 366 & 423\end{array}$ $\begin{array}{llllll}435 & 459 & 463 & 465 & 466 & 501\end{array}$ $\begin{array}{llllll}502 & 503 & 505 & 521 & 552 & 585\end{array}$ 646684698 .

Miniaturen $27 \quad 50 \quad 62 \quad 73 \quad 97$ 99101106114116141145 $\begin{array}{llllll}167 & 169 & 170 & 174 & 176 & 177\end{array}$ $\begin{array}{llllll}209 & 210 & 213 & 236 & 237 & 238\end{array}$ $\begin{array}{llllll}239 & 242 & 255 & 262 & 263 & 265\end{array}$ $\begin{array}{llllll}266 & 267 & 268 & 289 & 294 & 302\end{array}$ $\begin{array}{llllll}305 & 312 & 313 & 314 & 316 & 318\end{array}$ $\begin{array}{llllll}355 & 367 & 395 & 435 & 448 & 450\end{array}$ $\begin{array}{llllll}459 & 460 & 461 & 462 & 463 & 465\end{array}$ $\begin{array}{llllll}466 & 490 & 492 & 501 & 522 & 532\end{array}$ $\begin{array}{lllllll}533 & 536 & 543 & 544 & 546 & 5.12\end{array}$ $\begin{array}{llllll}553 & 559 & 582 & 583 & 584 & 585\end{array}$ $\begin{array}{llllll}587 & 588 & 593 & 601 & 606 & 615\end{array}$ $\begin{array}{llllll}646 & 648 & 660 & 669 & 670 & 673\end{array}$ $\begin{array}{lllll}679 & 681 & 682 & 756 & 758\end{array}$

Tosaiken 43577290146158 $\begin{array}{llllll}159 & 173 & 174 & 175 & 192 & 209\end{array}$ $\begin{array}{llllll}218 & 235 & 242 & 252 & 254 & 258\end{array}$ $\begin{array}{llllll}259 & 260 & 265 & 266 & 267 & 303\end{array}$ $\begin{array}{llllll}304 & 348 & 351 & 387 & 388 & 389\end{array}$ $\begin{array}{llllll}392 & 393 & 417 & 423 & 435 & 501\end{array}$ $\begin{array}{llllll}502 & 503 & 552 & 559 & 576 & 585\end{array}$

1 Die beiden nachfolgenden Verzeichnisse bezwecken bloß, eine Übersicht über die benutzten Quellen zu ermöglichen. Einzeln angeführt wurden aufer den römischen Ordines nur die Autoren. Einen detaillierten Nachweis auch füx die Monumente, Konzilien, Bullen. Sakramentare, Inventare und ähnliches zu geben, wie anfänglich beahsichtigt war, zeigte sich leider als schlechthin untunlich, da solches zu viele Seiten in Anspruch genommen haben wïrde. Die bei den betreffenden Stichworten vermerkten Zahlen bezeichnen daher nur die Seiten, auf denen überhaupt Monumente, Konzilien usw. erwähnt werden. 
790 II. Übersicht über die dem Werke zu Grunde liegenden monument. u. schriftl. Quellen.

$\begin{array}{llllllllllll}611 & 612 & 613 & 626 & 643 & 644 & \text { Skulpturen } & 43 & 45 & 46 & 53 & 70\end{array}$ $\begin{array}{llll}645 & 646 & 756 & 758 .\end{array}$

Münzen 463497499 .

Siegel $34 \quad 263 \quad 367 \quad 435 \quad 450$ $\begin{array}{llllll}451 & 457 & 461 & 463 & 464 & 465\end{array}$ $\begin{array}{llllll}466 & 648 & 680 & 682 & 683 & 684\end{array}$ 685690691692698 $\begin{array}{llllll}140 & 216 & 240 & 241 & 242 & 243\end{array}$

$\begin{array}{llllll}300 & 348 & 367 & 369 & 417 & 462\end{array}$

$\begin{array}{llllll}466 & 501 & 502 & 503 & 577 & 586\end{array}$

$\begin{array}{lllllll}587 & 619 & 659 & 681 & 683 & 698 .\end{array}$

Tafelgemälde $5455111 \quad 145$ 148278304436502561648 .
Wandgemälde $43 \quad 54 \quad 55 \quad 90$ $\begin{array}{llllll}111 & 112 & 133 & 144 & 146 & 158\end{array}$ $\begin{array}{llllll}175 & 266 & 274 & 275 & 304 & 353\end{array}$ $\begin{array}{llllll}354 & 450 & 459 & 500 & 501 & 502\end{array}$ $\begin{array}{llllll}509 & 536 & 544 & 588 & 626 & 645\end{array}$ $\begin{array}{lllll}646 & 649 & 669 & 674 & 756 .\end{array}$

\section{B. SCHRIFTLICHE QUELLEN.}

Abälard 535.

Absalom von Lund 137.

Acta s. Chroniken.

Adalhard von Corbie 383.

Adam von Bremen 287.

- Prämonstr. 137.

Adamanus 731.

Ademar von Chavannes 318.

Admonitio synodalis (Synodalermahnung) $26 \quad 61 \quad 102 \quad 155$ 391520566582

Aelfrik 445519

Agnellus 308386577635641 653.

Aldhelmus 428.

Alkuin 307582.

Amalar $26 \quad 2961 \quad 72 \quad 102 \quad 155$ $\begin{array}{llllll}163 & 166 & 167 & 169 & 283 & 284\end{array}$ $\begin{array}{llllll}291 & 363 & 391 & 392 & 393 & 394\end{array}$ $\begin{array}{llllll}433 & 441 & 518 & 520 & 521 & 531\end{array}$ $\begin{array}{llllll}555 & 566 & 575 & 578 & 579 & 580\end{array}$ $\begin{array}{llllll}586 & 589 & 641 & 708 & 706 & 711\end{array}$ $\begin{array}{llllll}713 & 714 & 716 & 718 & 721 & 722\end{array}$ 724725743 .

Ambrosius 426564762 .

Ammianus Marcellinus 439.

Ammonius von Alexandrien 564.

Amiru 50.

Andreas Praeval. 440.

Ansegisus 383.

Anselm von Havelberg 137143 .

Apostol. Konstitutionen 614.

Arabisch-nicänische Kanones 116.

Arno von Rejchersberg 137 143.

Arnulf von Luxeuil 351.

Arsenius von Elas, 491.

Artemidor 245.

Asterius von Amasea 13.

Athanasius 95440.

Athelstan 443.

Augustinus 70157564720762 .

Auslegung des Amts der heiligen Messe 186.

Bar Abgar Johannes, nestor. Patr. 774

Barhebräus 50.

Balsamon $100 \quad 287 \quad 302 \quad 490$ 494551565608

Beda Venerab. $389 \quad 390 \quad 393$ 440444497721

Beleth Ioan. 118425548706 711713731.

Benedict. Anian. 388389.
Benedikt Levita 391762764 .

Benzo von Alta 504.

Bernhard von Clairvaux 122 369449454.

Beroldus 60291449733.

Berthold von Chiemsee 704 .

-. von Regensburg 155186 705719 .

Blastares 565 .

Bonifatius 156427627629 .

Bonizo von Sutri 455 .

Braulio 440.

Bromyard 588 .

Brulefer Steph. 727.

Bruno von Köln 311.

_ von Segni 29118291297 $\begin{array}{llllll}366 & 378 & 384 & 396 & 429 & 449\end{array}$ $\begin{array}{llllll}458 & 544 & 567 & 583 & 588 & 646\end{array}$ $\begin{array}{llllll}651 & 711 & 715 & 719 & 720 & 723\end{array}$ 730.

Buch der Väter 50494605709.

Bullen und Papstbriefe 121 $\begin{array}{llllll}122 & 128 & 135 & 136 & 143 & 144\end{array}$ $\begin{array}{llllll}146 & 147 & 251 & 252 & 256 & 257\end{array}$ $\begin{array}{llllll}286 & 356 & 365 & 367 & 380 & 385\end{array}$ $\begin{array}{llllll}398 & 399 & 408 & 419 & 427 & 428\end{array}$ $\begin{array}{llllll}447 & 448 & 449 & 452 & 453 & 454\end{array}$ $\begin{array}{llllll}455 & 456 & 457 & 511 & 527 & 620\end{array}$ $\begin{array}{llllll}621 & 625 & 626 & 627 & 628 & 629\end{array}$ $\begin{array}{llllll}630 & 631 & 633 & 634 & 635 & 636\end{array}$ $\begin{array}{llllll}637 & 638 & 639 & 640 & 641 & 642\end{array}$ $\begin{array}{llllll}644 & 668 & 677 & 678 & 682 & 683\end{array}$ 684685696.

Burchard von Straßburg 30.

Caeremoniale episc. 124128 $\begin{array}{llllll}165 & 171 & 200 & 247 & 289 & 290\end{array}$ $\begin{array}{llllll}297 & 306 & 307 & 360 & 384 & 429\end{array}$ $\begin{array}{llllll}440 & 516 & 517 & 563 & 621 & 740\end{array}$ 742 .

Cäremonialien s. Ritualien.

Carta Cornutiana 757.

Cäsar 426 .

Cassian 157245301.

C'ellini Benv. 507.

Chrodegang 160307.

Chronicon paschale 287245.

Chroniken: Gesta, Acta Historiae $\begin{array}{llllll}33 & 80 & 81 & 118 & 119\end{array}$ $\begin{array}{llllll}122 & 131 & 136 & 138 & 140 & 153\end{array}$ $\begin{array}{llllll}154 & 155 & 168 & 201 & 213 & 214\end{array}$ $\begin{array}{llllll}253 & 287 & 291 & 292 & 293 & 296\end{array}$ $\begin{array}{llllll}308 & 311 & 316 & 318 & 327 & 329\end{array}$ $\begin{array}{llllll}351 & 364 & 379 & 386 & 388 & 390\end{array}$ $\begin{array}{llllll}396 & 425 & 427 & 457 & 493 & 510\end{array}$ $\begin{array}{llllll}511 & 519 & 534 & 538 & 564 & 571\end{array}$ 633682686
Cicero 244426427.

Constitutum Constantini 352 387496527624.

Consuetudinare s. Mönchsregeln.

Corpus iur. can. 431621628. - jur. civ. 426.

Cyrillus von Jerusalem 614.

Decreta authentica 728729 748760 .

Demetrius Chomatenus 237 303753.

Diokletian (Maximaltarif) 244 300301388565.

Dionysius Exiguus 620774 .

Dorotheus 301.

Dunstan St 314.

Durandus 30325583102118 $\begin{array}{llllll}138 & 139 & 164 & 166 & 169 & 171\end{array}$ $\begin{array}{llllll}173 & 287 & 400 & 429 & 472 & 486\end{array}$ $\begin{array}{llllll}520 & 544 & 546 & 547 & 548 & 567\end{array}$ $\begin{array}{llllll}586 & 588 & 610 & 646 & 650 & 706\end{array}$ $\begin{array}{llllll}712 & 713 & 719 & 720 & 723 & 725\end{array}$ 740 .

Eadmerus 316633 .

Ebedjesu 50.

Eberhard von Bamberg 352.

Ebroin von Bourges 441.

Ekkehard IV. 287293311.

Ennodius 440.

Epiktet 245.

Epiphanius 488

Eucherius von Lyon 243247.

Eusebius von Câsarea 95302 488564761768 .

Eustratius 666668

Ferrandus Fulgentius 574.

Festus 426 .

Flavius Josephus 424765. - Vopiscus 564.

Flodoard 427571633 .

Florianus abb. 440.

Florus von Lyon 703 .

Folcuin 311.

Crabriel Biel 704.

- kopt. Patr. 5199783.

Gallikanische Meferklärung 25 $6067 \quad 103 \quad 152 \quad 156 \quad 253 \quad 362$ 565572702731.

Georg von Arbela 50.

Gerhoh von Reichersberg 131 143352 
Gerland Joh. 139153.

Gesetze s. Kapitulare.

Gesta s. Chroniken.

Gilbert von Limerick 27121 $\begin{array}{llllll}131 & 141 & 164 & 285 & 366 & 397\end{array}$ 449520548764.

Grandisson, Bischof von Exeter

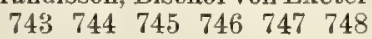
752 .

Gregor von Antivari 137.

- d. Gr. 153250251254283 $\begin{array}{llllll}386 & 526 & 528 & 626 & 627 & 629\end{array}$ $\begin{array}{llllll}631 & 632 & 637 & 638 & 640 & 642\end{array}$ 644654.

- von Nazianz 95488.

- von Tours 156284307564 731755

Gualterus Cancell. 136.

Helgaud 227311

Herard von Tours 391444.

Heribertus monach. cistere 122.

- de Boseham 584

Hermannus Contractus 396.

Hieronymus $47 \quad 66 \quad 247 \quad 425$ $\begin{array}{llllll}440 & 508 & 564 & 654 & 755 & 762\end{array}$ $765767 \quad 771$.

Hildebert von Le Mans 441.

Hildward von Halberstadt 678.

Hinkmar von Reims 445633 .

Hippolytus (Kanones) 757770.

Holen Gottschalk 741.

Honorius $29 \quad 32 \quad 118 \quad 131 \quad 141$ $\begin{array}{llllll}166 & 174 & 285 & 287 & 288 & 295\end{array}$ $\begin{array}{llllll}315 & 366 & 369 & 396 & 400 & 425\end{array}$ $\begin{array}{llllll}426 & 429 & 449 & 495 & 510 & 518\end{array}$ $\begin{array}{llllll}523 & 531 & 547 & 586 & 588 & 610\end{array}$ $\begin{array}{llllll}641 & 678 & 698 & 711 & 719 & 723\end{array}$ 726730 .

Hraban $26296172 \quad 102 \quad 155$ $\begin{array}{llllll}363 & 391 & 394 & 432 & 517 & 519\end{array}$ $\begin{array}{llllll}520 & 563 & 566 & 567 & 574 & 578\end{array}$ $\begin{array}{llllll}579 & 641 & 650 & 702 & 711 & 713\end{array}$ $714716718 \quad 721724725$.

Hugo, Erzb. von Benevent 498. - Metellus 137.

- von Pateshull 734.

Ibn 'Assal 96754.

Ibn Sabaa 1052

Innozenz III. 283253 อ๊ 83 $\begin{array}{llllll}118 & 171 & 285 & 366 & 374 & 382\end{array}$ $\begin{array}{llllll}396 & 400 & 454 & 457 & 458 & 493\end{array}$ $\begin{array}{llllll}520 & 531 & 544 & 546 & 548 & 567\end{array}$ $\begin{array}{llllll}588 & 641 & 646 & 650 & 651 & 705\end{array}$ $\begin{array}{llllll}719 & 720 & 723 & 724 & 729 & 742\end{array}$ 750751 .

Inventare $26 \quad 30 \quad 31 \quad 32 \quad 36 \quad 39$ $\begin{array}{llllllll}40 & 41 & 42 & 55 & 60 & 61 & 69 & 79\end{array}$ $\begin{array}{llllllll}80 & 81 & 82 & 84 & 85 & 86 & 90 & 106\end{array}$ $\begin{array}{llllll}113 & 114 & 119 & 121 & 127 & 153\end{array}$ $\begin{array}{llllll}154 & 201 & 202 & 227 & 264 & 265\end{array}$ $\begin{array}{llllll}278 & 279 & 283 & 286 & 287 & 288\end{array}$ $\begin{array}{llllll}289 & 291 & 292 & 296 & 307 & 308\end{array}$ $\begin{array}{llllll}310 & 311 & 321 & 322 & 327 & 330\end{array}$ $\begin{array}{llllll}331 & 385 & 336 & 338 & 359 & 362\end{array}$ $\begin{array}{llllll}364 & 378 & 418 & 473 & 474 & 517\end{array}$ $\begin{array}{llllll}518 & 519 & 533 & 534 & 537 & 560\end{array}$ $\begin{array}{llllll}566 & 567 & 568 & 569 & 592 & 593\end{array}$

$\begin{array}{llllll}594 & 651 & 683 & 692 & 734 & 737\end{array}$ $\begin{array}{lllllll}741 & 742 & 744 & 745 & 746 & 748 .\end{array}$

Irenäus 65 .

Isaak, arm. Katholikos 5098 239493774.

Isidor von Pelusium 605613 $\begin{array}{llllll}666 & 667 & 668 & 669 & 701\end{array}$

- von Sevilla $122 \quad 154 \quad 243$ $\begin{array}{llllll}252 & 253 & 301 & 307 & 363 & 425\end{array}$ 564573624702.

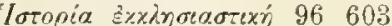
707758777 .

Itinerarium Hierosolymit. 252.

Ivo von Chartres $29 \quad 32 \quad 285$ $\begin{array}{llllll}291 & 366 & 391 & 396 & 400 & 449\end{array}$ $\begin{array}{llllll}544 & 547 & 563 & 588 & 633 & 678\end{array}$ $\begin{array}{llllll}698 & 700 & 711 & 714 & 716 & 721\end{array}$ 730.

Johannes von Avranches 2729 69138164166269291520. - Balbis 122

- von Bayon 119.

- Chrysostomus 96247.

- Cluniac. 584.

- Diakonus 104157158527 644645775 .

- Longus 364438.

- von Ravenna 526.

- von Salisbury 121.

Julius Pollux 245.

Justinus 65.

Kapitulare, Gesetze 126131 $\begin{array}{llllll}138 & 139 & 363 & 383 & 390 & 391\end{array}$ 581.

Karl d. Gr. 120.

Klemens von Alexandrien 758 770.

Kodinus 673754 .

Konrad von Mainz 452.

Konzilien, Synodalstatuten 27 424458606672789010 8 104112118120121126127 $\begin{array}{llllll}128 & 129 & 130 & 132 & 137 & 138\end{array}$ $\begin{array}{llllll}139 & 146 & 147 & 153 & 154 & 155\end{array}$ $\begin{array}{llllll}160 & 191 & 198 & 217 & 253 & 284\end{array}$ $\begin{array}{llllll}289 & 297 & 307 & 308 & 352 & 355\end{array}$ $\begin{array}{llllll}357 & 358 & 369 & 380 & 390 & 425\end{array}$ $\begin{array}{llllll}510 & 511 & 512 & 513 & 523 & 585\end{array}$ $\begin{array}{llllll}542 & 543 & 547 & 561 & 565 & 566\end{array}$ $\begin{array}{llllll}567 & 568 & 569 & 570 & 571 & 572\end{array}$ $\begin{array}{llllll}573 & 581 & 582 & 595 & 600 & 604\end{array}$ $\begin{array}{llllll}614 & 628 & 633 & 666 & 667 & 668\end{array}$ $\begin{array}{llllll}675 & 703 & 734 & 735 & 739 & 740\end{array}$ $\begin{array}{llllll}742 & 743 & 744 & 745 & 746 & 747\end{array}$ $\begin{array}{llllll}748 & 752 & 753 & 755 & 757 & 764\end{array}$ 769773.

Lampridius 244.

Lanfrank $69314 \quad 315316522$ 545549 .

Leo Grammat. 673 .

- von Ostia 122131

Leodebod von Aniane 350390. Liber diurnus 631640641 .

- Pontificalis $65 \quad 68 \quad 79 \quad 111$ $\begin{array}{llllll}238 & 249 & 301 & 385 & 424 & 444\end{array}$ $\begin{array}{llllll}496 & 498 & 499 & 523 & 524 & 526\end{array}$ $\begin{array}{llllll}574 & 575 & 624 & 625 & 631 & 640\end{array}$ $761768 \quad 773$

Liberatus 639644666668670 .

Liturgische Bücher der orient. Riten $\begin{array}{lllll}94 & 98 & 117 & 237 & 239\end{array}$ 550601603709710 .

Liutprand von Cremona 639 666.

Livius 426 .

Lucanus 426.

Lydus 237245422.

Liyndwoode 127.

Marcellus Christoph. 55.

Marculfus 440.

Martial 122244

Martin von Braga 767.

Menander 237245.

Mefserklärung, deutsche, gereimte 705711

Micrologus 164.

Missale rom. $22 \quad 125 \quad 150 \quad 165$ 248306385517728.

Missalien s. Sakramentare.

Mönchsregeln, Consuetudinare, Statuten von Orden, Kathedral- und Stiftskirchen 47 $\begin{array}{llllll}61 & 69 & 128 & 137 & 140 & 143\end{array}$ $\begin{array}{llllll}144 & 147 & 153 & 160 & 166 & 201\end{array}$ $\begin{array}{llllll}286 & 296 & 307 & 313 & 314 & 315\end{array}$ $\begin{array}{llllll}316 & 329 & 354 & 355 & 356 & 363\end{array}$ $\begin{array}{llllll}381 & 383 & 388 & 389 & 425 & 439\end{array}$ $\begin{array}{llllll}511 & 522 & 535 & 545 & 560 & 564\end{array}$ $\begin{array}{llllll}567 & 573 & 583 & 693 & 731 & 735\end{array}$ $\begin{array}{llllll}738 & 740 & 741 & 742 & 743 & 744\end{array}$ 745746763 .

Moschos 158666 .

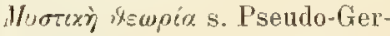
manus.

Yagoldus 309584 .

Nebridius von Mündelheim 136.

Nerses von Lampron 509899 239550551606774.

Nicephorus von Konstantinopel 96531552578603.

Nicetas Paphlag. 668.

Nikolaus von Clairvaux 486

Notker von St Gallen 519.

Obituarium der Sorbonne 287 Odilo 427.

Optatus von Mileve 425

Ordinare s. Ritualien.

Ordines romani Hittorps 6080 $\begin{array}{llllll}162 & 163 & 285 & 294 & 295 & 298\end{array}$ $\begin{array}{llllll}359 & 361 & 366 & 382 & 389 & 419\end{array}$ 548549721

Ordines romani Mabillons: Ordo $123285661157 \quad 161$ $\begin{array}{llllll}163 & 167 & 168 & 171 & 259 & 283\end{array}$ $\begin{array}{llllll}284 & 296 & 361 & 432 & 517 & 520\end{array}$ $\begin{array}{llllll}530 & 543 & 546 & 567 & 574 & 578\end{array}$ 644 743; II $161 \quad 167263$ $361 \quad 441521 \quad 546$; III 26 $\begin{array}{lllllll}28 & 56 & 60 & 61 & 161 & 171 & 263\end{array}$ $\begin{array}{llllll}361 & 432 & 517 & 520 & 546: & \text { VI }\end{array}$ $\begin{array}{llllll}162 & 163 & 255 & 309 & 317 & 543\end{array}$ 
544; VIII $157163 \quad 172297$ $574 \quad 579 \quad 580 \quad 589 ; \quad$ IX 28 $\begin{array}{llllll}297 & 429 & 497 & 499 & 521 & 579\end{array}$ $580584589590617:$ X 295 $\begin{array}{lllll}309 & 317 & 419 & 732: & \text { XI } 309\end{array}$ $317429456 \quad 732 ;$ XII 317 $\begin{array}{llllll}351 & 352 & 429 & 456 & 472 & 499\end{array}$ 683051732 : XIII $28 \quad 48$ $\begin{array}{lllllll}53 & \text { f } & 60 & 130 & 135 & 171 & 173\end{array}$ $\begin{array}{llllll}289 & 294 & 351 & 357 & 366 & 379\end{array}$ $\begin{array}{llllll}381 & 397 & 400 & 419 & 420 & 456\end{array}$ $\begin{array}{llllll}472 & 485 & 520 & 523 & 633 & 734\end{array}$ $740 \quad 742$; XIV 28304853 $\begin{array}{llllll}60 & 118 & 120 & 124 & 127 & 129\end{array}$ $\begin{array}{llllll}130 & 136 & 143 & 166 & 171 & 299\end{array}$ $\begin{array}{llllll}353 & 366 & 380 & 381 & 397 & 419\end{array}$ $\begin{array}{llllll}420 & 425 & 456 & 457 & 485 & 509\end{array}$ $512 \quad 545 \quad 588593 \quad 651734$ : $\begin{array}{lllllll}\mathrm{XV} & 28 & 48 & 53 & 60 & 69 & \mathbf{1 2 0}\end{array}$ $\begin{array}{llllll}128 & 351 & 352 & 353 & 380 & 381\end{array}$ $\begin{array}{llllll}418 & 419 & 485 & 509 & 512 & 734\end{array}$ 746.

Ordo romanus Duchesnes 2429 $\begin{array}{llllll}163 & 169 & 283 & 295 & 296 & 361\end{array}$ 432589732.

Otto von Freising 457.

Palladius $116 \quad 668 \quad 669 \quad 673$ 772.

Papstbriefe s. Bullen.

Paschasius Lilybet. 440 .

Passiones s. Vitae.

Paulinus Nol. 440445446.

- von Périguenx 158.

Pelagius 247.

Persius 243.

Pertinax 299.

Peter von Blois 454.

Petrus Cantor 454.

- Cellensis 699.

- Damiani 351427428.

- Diakonus 351.

- Malleus 642.

- Patr. von Antiochien 99 551606.

Philotheus Patr. Const. 603608.

Photius 666668 .

Plautus 244.

Polykiates 488768.

Pontificale rom. $128 \quad 142 \quad 149$ 360431621 .

Pontifikalien $28 \quad 29606168$ $\begin{array}{llllll}118 & 119 & 121 & 129 & 142 & 143\end{array}$ $\begin{array}{llllll}162 & 170 & 171 & 172 & 173 & 285\end{array}$ $\begin{array}{llllll}289 & 294 & 295 & 298 & 299 & 314\end{array}$ $\begin{array}{llllll}316 & 359 & 366 & 380 & 381 & 382\end{array}$ $\begin{array}{llllll}389 & 419 & 420 & 421 & 472 & 486\end{array}$ $\begin{array}{llllll}517 & 518 & 523 & 545 & 546 & 549\end{array}$ $\begin{array}{llllll}550 & 566 & 582 & 588 & 589 & 590\end{array}$ $\begin{array}{llllll}706 & 712 & 713 & 714 & 715 & 716\end{array}$ $\begin{array}{llllll}717 & 718 & 721 & 722 & 723 & 725\end{array}$ $\begin{array}{llllll}726 & 740 & 741 & 745 & 746 & 762\end{array}$ 763.

Prokop 157.

Prudentius 427564

Pseudo-Alkuin 2629105155 $\begin{array}{llllll}163 & 166 & 295 & 391 & 434 & 489\end{array}$ $\begin{array}{llllll}517 & 531 & 559 & 563 & 567 & 609\end{array}$ 641711713724732 .
Pseudo-Athanasius 754757.

Pseudo-Basilius 754757.

Pseudo-Beda 242629155163 166175563.

Pseudo-Germanus 96116551 603669708

Pseudo-Isidor $352 \quad 387 \quad 496$

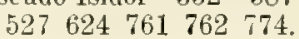

Pseudo-Sophronius $116 \quad 551$ $554666 \quad 669708753$.

Quaestiones Vet. et Nov. Test. 249556558614

Radulf von Bayeux 355

Ratherius von Verona 567583. Ratramnus 489.

Reginald von Durham 406442. Regino von Prüm 61 $62 \quad 155$ 518520582.

Riculf von Soissons 2661103 155201391518520566.

Rinthon 245.

Ritenkongregation, Dekrete 21

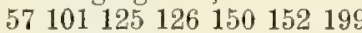
$\begin{array}{llllll}248 & 249 & 357 & 360 & 383 & 430\end{array}$ 516517563 .

Ritualien, Ordinare, Cäremonialien 131141147172196 $\begin{array}{llllll}285 & 288 & 294 & 296 & 314 & 316\end{array}$ $\begin{array}{llllll}318 & 354 & 355 & 380 & 381 & 425\end{array}$ $\begin{array}{llllll}733 & 735 & 740 & 741 & 742 & 743\end{array}$ 744746752.

Robert Paululus $30 \quad 32 \quad 118$ $\begin{array}{llllll}164 & 166 & 285 & 366 & 396 & 426\end{array}$ $\begin{array}{llllll}429 & 495 & 518 & 531 & 547 & 563\end{array}$ 641650719723731.

Romuald von Salerno 153.

Rufinus 301497.

Ruotgerus monach. Colon, 634.

Rupert von Deutz $2969 \quad 164$ $\begin{array}{llllll}174 & 175 & 285 & 307 & 396 & 400\end{array}$ $\begin{array}{llllll}426 & 520 & 535 & 641 & 705 & 711\end{array}$ 716718730 .

Sakramentare, Missalien 61 $\begin{array}{lllllll}67 & 68 & 103 & 121 & 122 & 129 & 153\end{array}$ $\begin{array}{llllll}162 & 164 & 172 & 285 & 287 & 288\end{array}$ $\begin{array}{llllll}359 & 365 & 381 & 384 & 421 & 434\end{array}$ $\begin{array}{llllll}517 & 518 & 548 & 566 & 567 & 582\end{array}$ $\begin{array}{llllll}589 & 679 & 702 & 706 & 707 & 710\end{array}$ $\begin{array}{llllll}711 & 712 & 713 & 714 & 715 & 717\end{array}$ $\begin{array}{llllll}718 & 720 & 721 & 723 & 725 & 727\end{array}$ $\begin{array}{llllll}740 & 741 & 742 & 743 & 744 & 745\end{array}$ 746747763764 .

S. G. K. (St Gallener Kleiderkatalog) $23 \quad 28 \quad 56 \quad 61 \quad 130$ $\begin{array}{llllll}163 & 167 & 255 & 263 & 286 & 294\end{array}$ $\begin{array}{llllll}387 & 432 & 519 & 545 & 546 & 548\end{array}$ $\begin{array}{llllll}574 & 579 & 580 & 584 & 586 & 723\end{array}$ 777778.

Seneca 427.

Sermo XIV 131153548714 . Servius Honoratus 426624 .

Severian von Gabala 605708.

Sicard von Cremona 3032118 $\begin{array}{llllll}131 & 136 & 137 & 143 & 171 & 285\end{array}$ $\begin{array}{llllll}287 & 291 & 299 & 366 & 369 & 382\end{array}$ $\begin{array}{llllll}396 & 400 & 425 & 426 & 429 & 458\end{array}$ $\begin{array}{llllll}493 & 495 & 518 & 520 & 531 & 545\end{array}$ $\begin{array}{llllll}548 & 549 & 567 & 583 & 610 & 646\end{array}$ 698705726730.

Sidonius 440 .

Siegfried von Mainz 452.

Sigehard monach. Trev. 625.

Simeon von Saloniki $96 \quad 100$

$\begin{array}{llllll}116 & 117 & 287 & 239 & 303 & 490\end{array}$

$\begin{array}{llllll}494 & 554 & 565 & 603 & 607 & 608\end{array}$ 667669708754764.

Simokattes 237245 .

Speculum de myst. eccl. 153 $\begin{array}{llllll}264 & 269 & 291 & 366 & 396 & 400\end{array}$ $\begin{array}{llllll}449 & 458 & 547 & 563 & 711 & 719\end{array}$ 720731.

Statuten von Orden und Stiftskirchen s. Mönchsregeln.

Stephan von Tournai 136137. Sueton 244

Suger von St-Denis 499.

Suidas 616 .

Sulpicius Severus 67152.

Symmachus 251.

Synodalstatuten s. Konzilien.

Tacitus 244

Tertullian $65244247426 \quad 445$ 657.

Testamentum D. N. I. Christi 604614615757

Thegan 120519 .

Theodemar von Monte Cassino 307.

Theodor von Canterbury 369 389.

- Lector 666668.

- von Trimithus 497772.

Theodoret 758761 .

Theodosius d. Gr. 245301619 656664

- monach. 386

- von Jerusalem 488

Theodulf von Orléans 61391 392393420433

Theophanes 497668 .

Theophylakt 122.

Thomas Cantiprat. 454

- von Aquin 118123.

- von Kempen 217.

Tractatus de sacr. altaris 30 $\begin{array}{llllll}285 & 291 & 299 & 396 & 449 & 548\end{array}$ 549719.

Translationes s. Vitae.

Trebellius Pollio 564.

Ulpian 244389.

Urban V. 129

Varro 244624.

Venantius Fortunatus 153440 755.

Viktor von Karthago 675 .

Vincentius von Lerin 440 .

Virgil 426.

Vitae, Translationes, Passiones $\begin{array}{lllllll}26 & 67 & 68 & 103 & 104 & 120 & 122\end{array}$ $\begin{array}{llllll}137 & 142 & 153 & 156 & 157 & 158\end{array}$ 
$\begin{array}{llllll}162 & 190 & 198 & 227 & 245 & 250\end{array}$

$\begin{array}{llllll}251 & 253 & 284 & 307 & 309 & 313\end{array}$

$\begin{array}{llllll}317 & 361 & 362 & 363 & 385 & 386\end{array}$

$\begin{array}{llllll}389 & 406 & 426 & 427 & 428 & 442\end{array}$

$\begin{array}{llllll}443 & 444 & 445 & 446 & 456 & 499\end{array}$

$\begin{array}{llllll}530 & 564 & 566 & 573 & 583 & 584\end{array}$ $\begin{array}{llllll}613 & 625 & 634 & 666 & 675 & 682\end{array}$ $686 \quad 698731755773$.

Walafried Strabo .26 $61 \quad 102$ $\begin{array}{llllll}155 & 363 & 391 & 433 & 517 & 520\end{array}$ 567774776 .
Wilhelm von Malmesbury 136 140.

Willegis von Mainz 319428 510 .

William de Chambre 129

Wipert von Toul 566 .

\section{SACHREGISTER.}

Abnet 766 .

Alba im gallikanischen und spanischen Ritus 67 252; alba romana 59; = Rochett 128 . alba = Tunicella 288 .

Albe: in der Gegenwart $57 \mathrm{f}$; Namen $59 \mathrm{f}$; in karolingischer Zeit $61 \mathrm{f}$; in vorkarolingischer Zeit $63 \mathrm{f}$; Verwendung $68 \mathrm{f}$; jm Gebrauch bei den Mönchen 69; Form $69 \mathrm{f}$. Stoff $78 \mathrm{f}$; Ausstattung $80 \mathrm{f}$.

Almucia: Alter 355; Form 355 f: Vexzierung 356: Name 358

Alttestamentliche Kultzleidung: ihre Bestandteile 765 ; Farbe 749; Beziehung zur christlichen $766 \mathrm{f}$.

Amikt: nach heutigem Brauch $21 \mathrm{f}$; Tragweise nach Lyoner Brauch 22 28; nach Mailänder Brauch 22 28; im Ritus der Subdiakonats. weihe 28 30; Alter im römischen Ritus $23 \mathbf{f}$; Alter außerhalb Roms 24 f; Tragweise nach mittelalterlichem Brauch 28 f; über dem Rochett (Superpelliceum) 28; Form 32; Ausstattung im Mittelalter $32 \mathrm{f}$; Stoff 43 ; Ursprung 44; Namen 48.

Amiktbesatz: Beschaffenheit 33; Form 34 f; Ursprung und Alter 35; Namen 36

Amiktkragen nach Lyoner, Mailänder und spanischem Branch 22.

amphibalus: Iaikaler Mantel 153; liturgischer Mantel s. Kasel; klerikaler Mantel 153. anabolagium (ambolagium) 23 48.

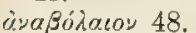

anagolagium (anagolaium) = anabolagium.

Ärmeltunika 70 .

aurifrisium (auriphrygium) = Parura 36 81; Besatz der Mitra 470.

aurum filatum 39 .

- tractitium 39.

Balteus: Gürtel der alttest. Priester 105; = Schwertkoppel120; = subcinctorium $120 \mathrm{f}$.
Bänder am Amikt 22.

Barockkasel 175196.

batraschil, Stola im koptischen Ritus 601.

Bearbeitungen der Gesch. der lit. Gew.: im 16. und 17. Jahrh. 15 f; im 19.Jahrh. 17 ff.

Behänge der Mitra 459460 471; ihre Entstehung 460.

Benediktion der liturgischen Gewänder s. Segnung.

Bernarduskasel 198.

Beschuhung: pontifikale, in der Gegenwart $384 \mathrm{f}$; zu Rom bis zum 2. Jahrtausend $385 \mathrm{f}$; Namen 388; auferhalb Roms bis zum 2. Jahrtansend $389 \mathrm{f}$; Bestandteile (Schuhe und Strümpfe) 391 f; Beschaffen heit bis zum 2. Jahrtausend 393 f; eit spezifisch bischöfl. Schmuck 396; bei den Kardinälen $396 \mathrm{f}$; Verleihung an Ảbte und andere Geistliche 398 f: Peschaffenheit bis zum 14. Jahrh. 399 f; Beschaffenheit seit dem 14. Jahr'h. 410 f; Verwendung 419 f; Ursprung $421 \mathrm{f}$.

Bildstickereien $\begin{array}{llll}33 & 37 & 38 & 39\end{array}$

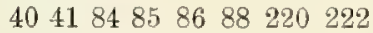
$\begin{array}{llllll}227 & 233 & 272 & 273 & 279 & 305\end{array}$ $331332 \quad 333-347 \quad 372 \quad 470$ $477-482535537-541542$ 551671688.

Birett: Alter $510 \mathrm{f}$; Entwicklung $512 \mathrm{f}$.

biruna, Amikt der Nestorianel' 50488494

Borromäuskasel 198.

Brederken $=$ Parura des Amikts 36 ; der Albe 82.

burnos, Mefgewand im koptischen Ritus 285.

Calceus senatorius $422 \mathrm{f}$.

Caligä (Pontifikalstrümpfe) s. Beschuhung.

Caligae in Nadelarbeit 401; aus Seidenstücken 402410 .

camelaucum: Kopfbedeckung des Papstes $496 \mathbf{f}$; profane Kopfbedeckung 497.

camilli (Opferdiener) 557613 615.

camisia $=$ Albe 59; $=$ Decke 79 ; = Rochett 126128. campagus, liturgischer Schuh 385 f 388422 f.

capitium $=$ Kopfdurchlaß der Albe 73; - Kapuze der Cappa 318.

Cappa cantorum 315; choralis 308353 : clericalis 307317 : magna 352; manicata 308; der Mönche 307 ; professionis 329 ; romana 307 ; rubea 352. - Pluviale : nach heutigem Gebrauch 306; Namen $307 \mathrm{f}$; Alter $310 \mathrm{f}$; Entwicklung ihrer Verwendung beim Gottesdienst $314 \mathrm{f}$; Form und Beschaffenheit $317 \mathrm{f}$; Kapuze $318 \mathrm{f}$; Schild $320 \mathrm{f}$ : Schliefse $321 \mathrm{f}$; Stoff $326 \mathrm{f}$;

Verzierung $329 \mathrm{f}$.

casula diptycha 16 .

- Etymologie 154.

catexamitum s. examitum.

cauda der Cappa magna 353. caudatarius 353.

chirotheca, Alter des Namens 362.

- inconsutiles 369 .

Chlamys 245656.

Chorkappe $=$ Cappa (Pluviale). choschen 766 .

cidaris = Mitra 428.

Cingulum: in der Gegenwart $101 \mathrm{f}$; in vorkarolingischer Zeit 102 f; seit dem 9. Jahrh., Form 105 f; Material 112; Verzierung $113 \mathbf{f}$

- in den orientalischen Riten 115; seine Geschichte 116 . circulus der Mitra 469472.

collare s. Parura des Amikts. collarín, spanischer Amiktkragen 22.

collet, colletin, Lyoner Amiktkragen 22.

compassus 336 .

contabulatio 659 .

cornua der Mitra $458 \mathrm{f}$.

corona als Anrede 440; =

Tiara 429485499

Cotta = Superpelliceum 136. cottus (cottis), Rock 137. cuphia = Mitra 428 .

Dalmatik: nach gegenwärtigem Gebrauch 247 f; Altel' 249f; spezifisches Gewand des römischen Ritus 251 f; Ver- 
leihung an auswärtige $\mathrm{Bi}$ schöfe und Diakone 251; als Decke der Bahre gebraucht 254; bei den römischen Kardinalpriestern 255; Verleihung an Äbte 256; Verleihung an sonstige Priester 257: Beschaffenheit in vorkarolingischer Zeit $258 \mathrm{f}$; in nachkarolingischer Zeit $261 \mathrm{f}$; im späten Mittelalter $270 \mathrm{f}$; in der Neuzeit $280 \mathrm{f}$; ihre liturgische Verwendung $293 \mathrm{f}$; ihr Gebrauch an Bußtagen 294; am Grûndonnerstag 295; bei Totenmessen 296 ; bei der Diakonenweihe 297.

Dalmatik: Clavi 259 265; Farbe 258 264; Flïgel (scapularia) 278; Fransen 260 277 ; Flöckchen 266 ; Quasten 274; seitliche Schlitze 260 274 281; seitliche Ausschnitte 262; Stoff 259263 270 ; Zierbesätze 276.

delicati (Tafeldiener) 557613 615.

dien- (Dienst-) rock (= Tunicella) 289 .

Diensttuch, diakonales $556 \mathrm{f}$. doigtier 561 .

Ggbertpontifikale: Alter 519 549.

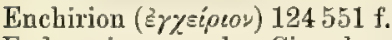

Endverzierung: des Cingulum 114; des Manipels 5:3 5:36; der Stola 595; des Palliums 651.

Entwicklung der liturgischen Gewandung: in vorkonstantinischer Zeit $767 \mathrm{f}$; vom 4. bis 9. Jahrh. $771 \mathrm{f}$; vom 9. bis 13 . Jahrh. $779 \mathrm{f}$ : vom 13 . bis 20. Jahrh. $781 \mathrm{f}$

Entwicklungsformen: des Biretts 513; der Kasel 195; der Mitra 475; des Palliums 649. ephod 653695766.

Epigonation: Form und Aus stattung 550; Charakter (Gegenstiick des Manipels) 550 560: Alter und $\mathrm{Ab}$ leitung $551 \mathrm{f}$; zum Tragen des Epigonation Berechtigte $553 \mathrm{f}$.

Epimanikien: Form 98: Farbe 99; Alter und Ursprung $99 \mathrm{f}$.

Ė griechische Priesterstola 601 603.

Etikettetuch 559.

examitum (samitum) 225.

Facistergia (facistercula) 560 561.

fano = Amikt 49; =- Behang der Mitra 459; = Fanone $52 ;=$ Manipel 518 .
Fanone (Fano), päpstlicher Ornat: Beschaffenheit 5255 ; Form 52; Verwendung $53 \mathrm{f}$; Alter 56.

Farben, liturgische: nach heutigem Brauch 728f; Alter der liturgischen Farbenregeln 729 f; ihr Uxheber 734; ihre frühere Mannigfaltigkeit 737 f; Norm für die Bestimmung dex Farben 748; Ursprung der Farbenregeln $749 \mathrm{f}$; Symbolik der verschiedenen Farben $750 \mathrm{f}$; liturgische Farben in den Riten des Ostens 753 f; Weif als liturgische Farbe in vorkarolingischer Zeit $754 \mathrm{f}$.

fasciae der Mitra s. Behänge. femoralia der jüdischen Priester (michnasim) 123766.

festa in albis 69 .

fibula: der Cappa s. Pluvialschliebe; als Verzierungsmittel s. Zierplättchen.

fimbriae: des Amikts, der Albe s. Parura; der Mitra s. Behänge; der Mitra, der Dalmatik, des Manipels, der Stola s. Fransen.

firmale (firmarium) s. Pluvialschliefze.

flatterchen, los hangende Verzierungen aus Metall 37.

Flügelrock, eine Art Superpelliceum 145 .

Fransen (Quästchen, Glöckchen): des Cingulum 112; der Dalmatik 260266277 ; des Manipels 516534536 ; der Mitrabehänge 429458 472; des Pluviale 329; der Stola 593 600; des Palliums 651.

frigium (phrygium) = tiara 497499.

frisium (frixium) $=$ Parura 3681.

Fußkuß 418.

Futter der Kasel 211.

Gabelkreuzförmiger Besatz: auf Laienkaseln 209; auf liturgischen Kaseln: Alter 209; Charakter 213 f; Blintezeit 215; Entartung 216; auf den Pontifikalschuhen 401.

Gallikanische Meferkläıung: A]ter 7.

Gebetsmanteltheorie 611.

gemma s. Parura.

Girenalbe 59.

Glockenkasel: Form $180 \mathrm{f}$; Schnitt und Herstellung 182 ; Schlitze in den Seiten $182 \mathrm{f}$; Schnüre zum Aufziehen 183.

Goldfaden 219; sog. cyprischer 39219 grammata s. Parura.

Granatapfel 206.

Gremiale 123.

Guipé (Hochstickerei in Gold oder Silber) 223234.

Guipuren (Spitzen) 92.

Gürtelschliefse, gallische 103 105.

Halstuch, profanes: auf Monumenten 45; bei den Schriftstellern 46 .

bandlin = Manipel 519.

Handschuhe: Namen 359; nach heutigem Gebrauch $359 \mathrm{f}$; Alter 361 f; Verbreitung im 12. and 13. Jahrh. $366 \mathrm{f}$; Verleihung an Nichtbischöfe $367 \mathrm{f}$; Form 369; Herstellungsweise $370 \mathrm{f}$; Stulpen 372; Verzierung $374 \mathrm{f}$; Stoff 378; Farbe $379 \mathrm{f}$; Verwendung $380 \mathrm{f}$; im Weiheritus 382; Ursprung 383.

Handvelum $554 \mathrm{f}$.

hantfane (hantfano) 518.

heubtdoech $=$ Amikt 30 .

Hörner der Mitra s. cornua.

Humerale $=$ Amikt 2148.

Immantatio des erwählten Papstes 351.

infula: Bedeutung $426 \mathrm{f} 444 \mathrm{f}$ 619; = casula 153.

infulae der Mitra $s$. Behänge der Mitra.

Inventare als Quelle für die Gesch. der lit. Gew. 10.

Inschriften: arabische $205 \mathrm{f}$; auf dem Cingulum 113.

Isispriesterinnen 659663 .

"Iazopía: Alter 10603.

Kalotte, Scheitelkäppchen 509.

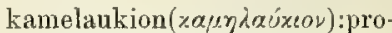
fane Kopfbedeckung 497 ; klerikale Kopfbedeckung 50. xápлayos, profaner Standesschuh 422.

Kapuze : an der Kasel 176 f 188 ; der Cappa 318.

Kasel (Amphibalus, Planeta): nach gegenwärtigem Gebrauch 149; planeta plicata 149; moderne Kaseltypen 150 f; Namen der Kasel 152 f; Alter $155 \mathrm{f}$; Gebrauch seitens der Subdiakone und Minoristen 160 f; Gebrauch seitens der Diakone $163 \mathrm{f}$ : Tragweise bei den Diakonen, Subdiakonen und Minoristen $166 \mathrm{f}$; Verwendung bei den gottesdienstlichen Funktionen $169 \mathrm{f}$; Verwendung im Weiheritus $172 \mathrm{f}$; Form bis zum 13. Jahrh. $173 \mathrm{f}$; Änderung der Form 184 f; Ver- 
such der Wiedereinfuihrung der spätmittelalterlichen $\mathrm{Ka}$ selform $197 \mathrm{f}$; Stoff 152 $200 \mathrm{f}$; Verzierung $209 \mathrm{f}$; Ursprung $239 \mathrm{f}$.

Kasel bei Buddhastatuen 243.

Kaselbesatztypus: nordischer (Gabelkreuz) 212 f; italienischer 217.

Kasel, gotische 198.

Kaselkreuzarten: Gabelkreuz $209213 \mathrm{f}$; schrägarmiges 215 ; horizontalarmiges 216.

Kasel (Amphibalus, Planeta): Teil der klerikalen 'Tracht 153 160; der Lajentracht 153157 ; der Mönclıskleidung 153157.

Kaseltypus: deutscher 151 . französischer $151 \mathrm{f}$ : römischer 150; spanischer 151 .

- Verwendung bei dem prot. Gottesdienst 197.

kethonet 766.

Klerikale Tracht 72.

Kölner Borten 221.

Kolobium 68301.

Kolobiumförniges Superpelliceum 146.

Kopfbedeckung, liturgische: im Abendland s. Mitra: im Orient $487 \mathrm{f}$; im griechischen Ritus $490 \mathrm{f}$; im syrischen 492; im armenischen 493; im chaldäischen 494: im koptischen 494.

Koptische Grabfunde, Bedeutung und Irrtümer in Bezug auf dieselben 13447550643 .

- Verzierungen der Tunika 8397694

korerock = T'unicella 289.

Kreuzchen: auf dem Manipel 516 536: den Sandalen 393 $416 \mathrm{f}$ : der Stola $593 \mathrm{f}$; dem Pallium $649 \mathrm{f}$.

kuklion, Mefgewand der Kopten 235.

Lacerna 348.

lamina, Stirnplatte des jüdischen Hohenpriesters 488 766.

Lederkaseln 207.

Leinwand (Baumwollzeug) : als Kaselstoff 202: bedruckte 203.

less- (leis-) rock $=$ Tunicella 289.

Liber Pontificalis, Alter 250.

licinum, Name des Pontifikalstrumpfes 398.

ligulae (linguae) der Mitra s. Behänge der Mitra.

linea (tunica linea) $=$ Albe 59: $=$ Tunicella 288.

lingula $=$ Bindevorrichtung der Albe 73 .

Linnenkaseln 202.
Liturgiker: der Karolingerzeit $8 \mathrm{f}$ : des 11., 12. und 13. Jahrh. 9

Liturgische Bücher als Quelle der Gesch. der lit. Gew. 6

- Gewänder, alte: Irrtïmer in Bezug auf ihre Datierung 13; Quellen für die Gesch. der lit. Gew. $12 \mathrm{ff}$

- Gewandung: Begriff 1 : Übersicht uber ihre Bestandteile in dem lat. Ritus 1; in den orientalischen Riten $1 \mathbf{f}$.

2woía: Besätze der Tunika 100 lorum $=$ Pallium 624 .

Maaphra des nestorianjschen Ritus = Kopfschleier 50494 = Mefogewand 235.

macnaftâ, Schultertuch des syrischen Ritus $49 \mathrm{f} 493$.

mandyas (uaviúas), Mante der griechischen Bischöfe 350 .

manica $=$ Handschuh 359363 = Stauche 101362.

Manipel:in der Gegenwart $515 f$ Namen $517 \mathrm{f}$; der Manipel zu und seit der Karolingerzeit 520 f 531 : im Gebrauch bei Mönchen 522: in vorkarolingischer Zeit $523 \mathrm{f}$; Umbildung zum Zierstreifen $531 \mathrm{f}$; Stoff und Verzierung bis zum 13. Jahrh. $534 \mathrm{f}$ : Beschaffenheit seit dem 12 . Jahrh. $535 \mathbf{f :}$ in der Neuzeit $541 \mathrm{f}$ : Tragweise in ältester Zeit 543: Anderung in der Tragweise 544; liturgischer Gebrauch 545f:Zeitpunkt der Anlegung $545 \mathrm{f}$ : Verwendung im Weiheritus $548 \mathrm{f}$ : der $\mathrm{M}_{\mathrm{a}}$ nipel im armenischen Ritus 550; Ursprung $554 \mathrm{f}$.

manipulus, Bedeutung 519

mantile = Manipel 519; = Serviette, Handtuch 519558.

Vantum 351

manuale $=$ Manipel 519: $=$ Stauche 362.

mapilla 527.

mappa, Bedeutung 517559.

Mappula $=$ Manipel 517520 526 f $530 \mathrm{f:}-$ Halstuch Schweiftuch, Baldachin 517 Velum 517530 .

- (mappulus) = Schabracke 526.

mappularii 317.

meil 766

meszachel (missahachul, masse hacele) $=$ Kasel 155 .

Mefogewand im armenischen, syrischen, chaldäischen und koptischen Ritus 235239.

Methode in der Behandlung der Gesch. der lit. Gew. 4. michnasim 766 . migba'ah 424766 .

Missa Illyrica, Alter 122.

Mitra: Namen des Ornatstiuckes $424 \mathrm{f}$; Bedeutung des Wortes mitra 425; die Mitra im heutigen Gebrauch 429 f: ihr Alter $431 \mathrm{f}$; die ersten Verleihungen an Bischöfe $447 \mathrm{f}$; bischöflicher Ornat 449: bei Kanonikern 452; bei Äbten $453 \mathrm{f}$ : bei den Kardinälen $455 \mathrm{f}$; bei weltlichen Fürsten 456: bei dem Kaiser (der Kaiserin) 457.

Form und Beschaffenheit: Kegrel-(Kalotten-) form $458 \mathrm{f}$ : angeblich ursprïnglich Kopftuch 462 : mit seitlichen Hörnern $463 \mathrm{f}$; mit Hörnern über Stirn und Hinterhaupt $464 \mathrm{f}$ : Herstellungsweise im 12. und 13. Jahrh. 469: Verzierung im 12 und 13. Jahrh. $470 \mathrm{f}$; Arten der Mitra 472: Form und Ausstattung im späten Mittelalter und in der Neuzeit $474 \mathrm{f}$; zur Zeit des Barocks 483; des Rokoko 484 ; liturgischer Gebrauch $485 \mathrm{f}$; Verwendung im Ritus der Bischofsweihe 486:Ursprung $495 \mathrm{f}$.

mitra : cum aurifrisio in circulo et titulo 472: cum aurifrisio in titulo sine circulo 472 . auriphrygiata 429472 ; pretiosa 429; simplex 429472 .

Mitra in den Riten des Ostens s. Kopfbedeckung, liturg.

miznephet 51424766 .

Mönchsgürtel 104116.

Monumente: als Quellen für die Gesch, der lit. Gew. 11 f: Regeln für ihre Verwertung $11 \mathrm{f}$. morsus, Pluvialschließ3e 321.

Mozzetta: Form, Alter 357 Ableitung 358.

Naccus (nattus) = Schabracke 527.

Nadeln zur Befestigung des Palliums 644651 .

Offertorium = Mappula 521.

Offizialen, Tracht 245656.

Omophorion, profanes 668673. sakrales: griechisches und armenisches 665 ; syrisches 665: Alter 666: Symbolik und Charakter $667 \mathrm{f}$ : Beschaffenheit 665 668: Tragweise $670 \mathrm{f}$; Ursprung $672 \mathrm{f}$,

opus anglicanum, romanum etc. 41221347.

òpáoı, griechische Diakonenstola 565601 .

Orarium : Etymologie 563567 : $=$ Pallium 574; $=$ profanes Tuch 564573 ; = Stola $565 \mathrm{f}$. 
Ordines, römische, Mabillons, Alter $6256497 \quad 788$.

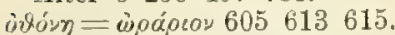
ourraige de Fleurence (opus Florentinum) 347.

Paenula 243.

Palla, Frauenmantel 659.

Pallium, Bedeutung des Wortes 624656 .

pallium: gallicanum 25572 573675 f 695 ; linostimum 524574.

Pallium, liturgisches, nach heutigem Gebrauch: Segnung 620: Charakter 621; Gebrauch $621 \mathrm{f}$ : Bedeutung $622 \mathrm{f}$ : Ritus der Übergabe 623 .

- Geschichte: Alter $624 \mathrm{f}$; Verleihungen an päpstliche Vikare n. Metropoliten $626 \mathrm{f}$; Verpflichtung der Metropoliten, um das Pallium nachzusuchen $627 \mathrm{f}$; Verleihung an Suffragane $629 \mathrm{f}$; Übersendung und persönliche Inempfangnahme 630: Pailiumsporteln 631 ; professio fidei und Treueid vor Empfang 631 ; sakraler Charakter $631 \mathrm{f}$; Verwendung $632 \mathrm{f}$; Stellung der weltlichen Fürsten zu den Palliumverleiliungen $624 \mathrm{f}$ : Interventionen weltlicher Füirsten 638 f: Bedeutung des Palliums $639 \mathrm{f}$; älteste Form desselben $642 \mathrm{f}$; Stoff 644 : Nadeln zur Befestigung 644651 ; Änderung in der Form 645 f; Kreuze auf dem Pallium 649 f; Farbe der Kreuze 650; Endstiicke und Fransen 651.

- Ursprung vom Kaiser verliehene Insignie 652; $\mathrm{Ab}$ leitung vom Ephod des Alten Bundes 653; Ableitung von einem Mantel des hl. Petrus 654: Ableitung von einem sakralen Mantelpallium 655; Ableitung von einem profanen Mantelpallium $657 \mathrm{f}$; als Insignie eingeführt $661 \mathrm{f}$.

- in Gallien, Spanien, Afrika $674 \mathrm{f}$.

- profaner Mantel 64656 $657 \mathrm{f}$.

Paruia, paratura: des Amikts $33 \mathrm{f}$ : der Albe $81 \mathrm{f}$; der Dalmatik 276

pedules, Strümpfe, Pontifikalstrumpfe 389398.

pellicea (Pelzkleid) $139 \mathrm{f}$.

penduli der Mitra s. Behănge der Mitra.

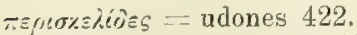

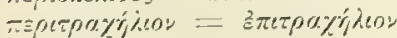
60)?.
Perlenstickereien $3738 \quad 3988$ $\begin{array}{llllll}212 & 233 & 374 & 377 & 470 & 473\end{array}$ $\begin{array}{llllll}474 & 477 & 478 & 480 & 481 & 482\end{array}$ 483537.

Pestkaseln-208.

phaina, Mefgewand des syrischen Ritus 225.

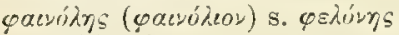
(oshóveov).

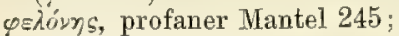
$=$ Buchhïlle 247.

Phelonion ( $\varphi$ shóveov, $\varphi \leftleftarrows \lambda o ́ v \eta s)$, Meßsgewand des griechischen Ritus: Form 234: - Stoff 235; Geschichte 236 ; Träger 238.

Philosophentracht $64 \mathrm{f}$.

Pileolus 509

pileus cantorum 319510 .

- = Mitra 428

plaga, plagula s. Parura.

Planeta s. Kasel.

planeta, Etymologie. 154.

- plicata $149166 \mathrm{f}$.

Pluvialagraffe s. Plnvialschliefse.

Pluviale s. Cappa.

pluviale, Etymologie 309.

Pluvialschliefe $321 \mathrm{f}$.

poderes $=$ Albe 59; = Talartunika der jüdischen Priester 95767.

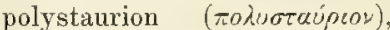
mit Kreuzen verziertes Me6gewand 237.

тотано'́ 9496350.

praecinctorium $=$ subcinctorium 120.

praetexta s. Parura.

presbyterium, Geldspende 135. procedere (Bedeutung) 528.

Pseudo-Beda: Alter 8.

Pseudo-Germanus: Alter 10.

Pseudo-Sophronius: Alter 10.

Quaestiones Vet. et Novi Test.: Alter 249.

Quellen für die Gesch. der lit. Gew. 5.

Rationale des jüdischen $\mathrm{Ho}_{0}$ henpriesters 653766 .

- pontifikales Schultergewand in der Gegenwart $676 \mathrm{f}$; Altex $678 \mathrm{f}$; Verbreitung $680 \mathrm{f}$ Charakter 686; Beschaffenheit $687 \mathrm{f}$; Typen 693; Ursprung $694 \mathrm{f}$; pontifikaler Brustschmuck $697 \mathrm{f}$.

Rauchmantel $=$ Cappa 306 .

Reformversuch Pauls IV. 190. regnum = Tiara $497499 \mathrm{f}$.

Religiöse Bilder auf profanen Gew. 13.

roceus = Tunicella 288

Rochett: Unterschied vom Superpelliceum: Form 125: Namen 126 f; Charakter iles fiewandes $129 \mathrm{f}$ : Alter
$130 \mathrm{f}$; Beschaffenheit $132 \mathrm{f}$ :

Verzierung (Spitzen) 135.

romanum (opus) = de Romania

(Griechenland) 221.

saghavart, Kopfbedeckung des armenischen Ritus 487493.

Sakkos: Charakter und Beschaffenheit 302; Alter 302 ; Tråger 303; Ursprung 305. samitum 225.

Sandalen s. Beschuhung.

- Farbe 393405 418; Löchlein im Oberstoff 406; $\mathrm{Ma}$ terial 405; Typen im Mittelalter 393404 412; in der Neuzeit $413 \mathrm{f}$; in Stiefelform 414 .

sarcos (saroht, sarcotium, sarrotus) = Rochett 127 .

scapularia s. Dalmatikflügel.

Schabracke, weife, als Auszeichnung verliehen $526 \mathrm{f}$.

Schärpen 619659663.

Schaufäden 611.

Schaufelmanipel 542.

Schaufelstola 600 .

Schild = Parura 36; des Pluviale $320 \mathrm{f}$

Schultertuch im gewöhnlichen Leben s. Halstuch

- im armenischen 49; chal. däischen 50; koptischen 49 51 ; syrischen Ritus 4950 f. schurtschar, Mefigewand des armenischen Ritus 235.

Schweiftuch 558 f 561 .

segmenta, Verzierung der Tunika 83.

Segnung der liturgischen Gewänder: nach heutigem Gebrauch 760; Alter $761 \mathrm{f}$; Formulare 762; ein bischöfliches Vorrecht 764: in den Riten des Ostens 764.

semicinctium $=$ Hüfttuch 122 ; = Subcinctorium 122.

Senatorenschul s. calceus senatorius.

Senatorentracht 245 .

Sermo XIV: Alter 9.

sestace $=$ Nanipel 519

sigilla, Verzierung der Tunika 83.

Soli-Deo $=$ Pileolus 509

sotularis = Caliga 388 .

Spange s. Zierplättchen.

Spatelalbe 59 .

Speculum de myst. eccl.: Alter 9719.

Spitzen : bei der Albe 91; beim Rochett 135; beim Super. pelliceum 148.

Statuta ecelesiae antiqua (Cone. Carth. IV vulg.), Alter 253.

Staurophor 554 .

Stoffe, bedruckte 203

Stoffmuster: in der Frühe des zweiten Jahrtausends 204: 
im 13. und 14. Jahrh. 205; im 15. Jahrh. 206.

Stola: nach heutigem Branch 562; als Insignie 563; Namen $563 \mathrm{f}$ : Ursprung des Namens Stola 568; Alter $569 \mathrm{f}$ : zur Karolingerzeit $578 \mathrm{f}$; als Insignie $580 \mathrm{f}$ : Verwendung $582 \mathrm{f}$; Tragweise $584 \mathrm{f}$ : im Weiheritus $589 \mathrm{f}$ : Beschaffenheit in vorkarolingischer Zeit 590 f; seit dem 9. Jahrh. 591 f: Fransen (Glöckchen) 593 ; Kreuze 593 f: Farbe 594 : Endstücke 595; Ursprung 608 f.

- in den Riten des Ostens: Form $601 \mathrm{f}$; Tragweise 602 : Verwendung 602 f 608 ; Geschichte $603 \mathrm{f}$.

- latior (stolone) 150

- = Matronengewand 609 .

Stowe-Missale, Alter 7

stricta $=$ Tunicella 288 .

Strohkasel 208.

Stulpen an den Handschuhen 372.

subbiretum $=$ Pileolus 509

subcingulum $=$ Subcinctorium 118.

Subcinctorium: nach gegenwärtigem Gebrauch 117; Alter 118: Beschaffenheit, Ausstattung, Tragweise 119;

Namen $120 \mathrm{f}$ : Ursprung $123 \mathrm{f}$. submitiale $=$ Pileolus 509. subtalaris = campagus 388 . subtile $=$ Tunicella 287.

succa, sucta, subta $=$ Rochett 128.

sudarium $=$ Manipel $518558 \mathrm{f}$. superhumerale = Amikt 48.

Superpelliceum: Alter $135 \mathrm{f}$; Namen $136 \mathrm{f}$ : Gebrauch 138 . Ursprung des Namens 139 f; des Gewandes $140 \mathrm{f}$ : Verwendung im Ordinationsritus 142: älteste Form $143 \mathrm{f}$ : Änderungen in der Form $144 \mathrm{f}$; Verzierung (Spitzen) $147 \mathrm{f}$; Fältelung 148.

Symbolik, Arten: moralische 700 ; dogmatisch - typische 700705 ; dogmatisch-repräsentative 705: allegorische $705 \mathrm{f}$.

- in den Stoffmustern 206.
Symbolische Deutung der liturgisehen Gewänder im Abendland: in vorkarolingischer Zeit 702; zur Karolingerzeit 702 f; im 12 . und 13. Jahrh. 704; im späten Mittelalter 704.

- im griechischen Ritus 707: im nestorianischen 709; im syrischen 709; im armenischen $709 \mathrm{f}$.

- des Schultertuches 710 der Albe 712; des Cingulum 713; des Manipels 714; der Stola 716: der Kasel 718: der Mitra 719: der Pontifikalhandschuhe 720: der Caligae und Pontifikalschuhe 721 : des Subcioctorium 723 des Pallium $723 \mathrm{f}$; des Superpellieeum 725: der Dalmatik (Tunicella) 725; des Pluviale 726; der liturgischen Farhen 750 .

\section{Túsica 350656}

talaris tunica $=$ Albe 59

Talartunika 71

Tallith (Talles), jüdischer Gebetsmantel 564611 .

Taschenmanipel 542.

tassellus s. Zierplättchen und Pluvialschliefe.

Tiara: ohne Kronreifen 498: mit einem Kronreifen $499 \mathrm{f}$ : mit gezacktem Kronreifen 500: Behänge 501: Beschaf fenheit 502; mit zwei Kronen 508: mit drei Kronen 504 f; oberer Abschluf3 506; Ausschmückung $506 \mathrm{f}$; Ursprung 508

tiara = Mitra 498

titulus der Mitra 469

Toga 652657658664 .

Totentanzdarstellung 334.

Tractatus de sacr. altaris, $\mathrm{Al}$ ter 9719

trica, Dalmatikverzierung 279 triregnum = Tiara $504 \mathrm{f}$

truncus s. Parura.

Tüllspitzen 92.

tunica epistolaria $=$ Tunicella 288.

Tunicella: nach gegenwärtigem Gebrauch $247 \mathrm{f}$ : Alter ihrer Verwendung $283 \mathrm{f}$; bei Ako- lythen 285: bei Ahten 286: Namen $287 \mathrm{f}$; Beschaffenheit in dem Mittelalter und der Nenzeit $289 \mathrm{f}$; liturgische Verwendung $293 \mathrm{f}$; an Bußtagen 294; am Gründonnerstag 295; bei'Totenmessen 296: bei der Subdiakonenweihe 298: Farbe 291: Form $289 \mathrm{f}$ : Stoff 290: Verzierung 292.

Tunika in den orientalischen Riten: Form 92 ; Farbe, Ver zierung 93; Gebrauch 94: Verwendung im Weiheritus 94; Geschichte $95 \mathrm{f}$.

- des Liturgen in vorkonstantinischer Zeit $63 \mathrm{ff}$.

- profane, im Altertum $70 \mathrm{f}$

Udo: Pontifikalstrumpf $385 \mathrm{f}$ 422 , profane Fufbekleidung 387422.

umbral = humerale 48711

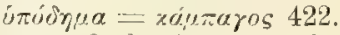

urar, Stola im armenischen Ritus 601.

uroro, Stola im syrischen Ritus 601.

Ursprung der liturgischen Gewandung 765 f 776 .

Vakas, Schultertuch im armenischen Ritus 49.

vellus, Bedeutung 362 .

Verhältnis: der lit. Gew. des lat. Ritus zu der der orient. Riten 1: der lit. Gew. der orient. Riten zueinander 2. Vespermantel $=$ cappa 306.

vittae der Mitra s. Behảnge der Mitra.

Vorspan (Fürspan) = Zierplättchen 41 .

$\mathbf{W}$ antus = Handschuh 359. wardecor = Dalmatik 287.

Weihetuch 619.

Zierplättchen(Scheibchen):als Verzierung der Handschuhe 375 376; bei sonstigen Paramenten $\begin{array}{lllll}36 & 37 & 40 & 41 & 114\end{array}$ $\begin{array}{lllll}221 & 278 & 476 & 477 & 480 .\end{array}$

ziz = lamina 424766 .

zizith, Quasten am jüdischen

Obergewand 611 .

zona romana 105 . 

Von demselben Verfasser sind in der Herdersehen Verlagshandlung zu Freiburg im Breisgau erschienen und können durch alle Buchhandlungen bezogen werden:

\section{Vorlagen für Paramentenstickereien, entworfen} nach Motiven mittelalterlicher Kunst. 28 Tafen nebst Text. 7 weite, vermehrte Auflage. Größe der Tafeln $52 \times 70 \mathrm{~cm}$. Text: Lex. $-8^{0}$ (VI u. 26) In Halbleinwand-Mappe $M$ 18.-

Dasselbe Werk ist auch in französischer und englischer Ausgahe erschienen.

„Im Vorjahre bereits hatten wir Anlaßs genommen, auf dieses ganz ausgezeichnete Werk hinzuweisen, und in $\mathrm{Nr} 2$ des laufenden Jahrgangs unseres Blattes ist ja unsern Lesern Gelegenheit geworden, den in dieser Materie wohlbewanderten Autor in seimen eigenen Ausführungen kennen zu lernen. Nach kaum mehr denn Jahresfrist liegt uns nun sein Hauptwerk bereits in Zweitauflage vor, der beste Beweis dafur, daf in jenen Kreisen, welche für dieses Fach beschäftigt oder sonst irgendwie interessiert sind, diese Motivenmappe sich entsprechende Wertschätzung errungen hat. Dieser gute Erfolg hat denn auch P. Brann ermuntert, die Erstausgabe um vier Tafeln - mit 50 Vorlagen - zu vermehren; dieselben beziehen sich auf die kûnstlerische Ausschmückung von Kirchenwảsche verschiedener Bestimmung, von Kaseln, Pluvialen, Schultervelen und Dalmatiken, eine gewif vielfach dankenswert empfundene Pereicherung des gebotenen Stoffes. Die hierzu gebrachten Motive zeichnen sich durch Gefälligkeit wie auch durch grol3e Verschiedenartigkeit aus, die Gröfse ihrer Darstellung erleichtert wesentlich ihre Verwendung in den verschiedenen Bearbeitungsformen. Damit ist zweifellos ein höchst beachtenswertes Hilfswerk zur Betätigung dieses Zweiges kirchlicher Kunstpflege geschaffen : möge ihm auch die verdiente Wertschätzung nicht vorenthalten bleiben." (Der Kunstfreund, Innsbruck 1904, Nr 5 )

,Unter den 200 Vorlagen der Sammlung befinden sich 14 bzw. 16 Entwürfe zu Kaselkreuzen, 5 bzw. 6 zu Pluvialausstattungen, 7 zu Dalmatikbesätzen, 7 zur Verzierung von Segensvelen, 11 zu Stolen, mehr denn 40 zu Bordüren für Alben, Altartücher, Superpellicien, etwa 15 zum Besticken von Baldachinbehängen, 24 zur Verzierung von Pallen usw. Das sehr bedeutende Material kann noch erhöt werden durch passende Vergrößerung oder Verkleinerung mancher Vorlagen oder durch geeignete Kombinationen derselben. Die Vorlagen sind teils im romanischen, vorzugsweise im gotischen Stile gebalten, viele originell und von bervorragender Schönheit, alle tragen echt kirchlichen Charakter. Das Werk hat bereits in seiner ersten Auflage sowohl seitens fachkundiger Gelehrten wie praktisch tätiger Stickerinnen von hervorragenden Leistungen ungeteilte Anerkennung gefunden. Von ersteren nennen wir nur den hochw. Herrn Domkapitular Prof. Dr Schnütgen, einen der vorzüglichsten Kenner und Förderer der mittelalterlichen Kunst und zumal der mittelalterlichen Paramentik. Der. Sammlung ein weiteres Wort der Empfehlung beizugeben, halten wir für unnätig: ilre Zeitgemäfheit wie ihre Brauchbarkeit beweist am besten die innerbalb eines Jahres notwendig gewordene zweite Auflage. Dem Verfasser gebührt für seine Mühewaltung der wärmste Dank. Die Fundgrube von Vorlagen ist eine in hohem Grade brauchbare Beihilfe zur würdigen Ausstattung der dem Dienste des Allerhöchsten und des Lammes geweihten Gewandung und Paramente.“ (Pastoralblatt, Köln 1904, Nr 6.)

"Schon die erste Auflage dieses wertvollen Paramentenschatzes hat wegen der schönen Ausführung und praktischen Verwendbarkeit der Vorlagen allseitige Anerkennung und günstige Aufnahme gefunden, so dafs schon nach Jahresfrist eine Neuauflage nötig wurde. Diese neue Auflage ist um vier Tafeln mit über 50 neuen Vorlagen vermehrt worden und bietet nun eine außserordentlich reiche Auswahl hübscher und stilvoller Motive für Paramentenstickereien, teils romanisch, meist aber in den mannigfaltigen und effektvollen Formen der Gotik gehalten. Über die Verwendung der einzelnen Muster und die Art der Ausfuhrung belehrt ein separat gedruckter Text, der zu jeder Tafel und Nummer die nötigen Angaben enthält. Der Verfasser, der über eine genaue Kenntnis der mittelalterlichen 'Lierformen verfügt, hat mit der Herausgabe dieser Vorlagen der kirchlichen Kunst einen wichtigen Dienst geleistet. Wir winschen auch dieser neuen, bereicherten Ausgabe seines Werkes weiteste Verbreitung."

Alte und Neue Welt, Einsiodeln 1904, Nr 21.)

\section{Winke für die Anfertigung und Verzierung der} Palamente. Mit 2 Tafeln und 74 Abbildungen im Text. Ergänzung zu der Sammlung von "Vorlagen für Paramentenstickereien“. Mit oberhirtlicher Approbation. Lex.-80 (XII u. 188) M 6.40; geb. in Leinw. M 8.-

„P. Braun ist zur Zeit wohl der erste Kenner der Paramentik sowohl nach der historischen wie auch nach der ästhetischen Seite des Gegenstandes. - Vorliegender Band, wie der Titel anzeigt, inshesondere als Lrgänzung zu des Verfassers, Vorlagen' gedacht, entbält eingebende Unterweisungen über Stoff und Bearbeitung wie über Aufbewahrung und Reparatur der Paramente. Künstler, Archäolog und Praktiker in einer Person, hat Verfasser ein äuß̉erst nützliches Werk geboten, das volle Beachtung aller beteiligten Kreise verdient. Gewif3 wird es weite Verbreitung finden und somit auch noch manche Auflagen erleben. ..." 
In der Herderschen Verlagshandlung zu Freiburg im Breisgau ist erschienen und kamn durch alle Buchhandlungen bezogen werden:

\section{Geschichte}

\section{der \\ Christlichen Kunst.}

Von

Franz Xaver Kraus.

In zwei Bänden. Mit zahlreichen Illustrationen. Lex.-80

Erster Band: Die hellenistisch-römische Kunst der alten Christen. Die byzantinische Kunst. Anfänge der Kunst bei den Völkern des Nordens. Mit Titelbild in Farbendruck und 484 Abbildungen im Text. (XX u. 622) $M$ 16.-; geb. in Orig.-Einb.: Halbsaffian $M$ 21.—; Einbanddecke $M 3 .-$

Zwe it er Band: Die Kunst des Mittelalters, der Renaissance und der Yeuzeit.

Erste Abteilung: Mittelalter. Mit Titelbild in Heliograviure und 306 Abbildungen im Text. (XII u. 512) $M$ 14.--; geb. $M$ 19.- Einbanddecke $M$ 3.-

Zweite Abteilung: Renaissance und Nenzeit. Erste Hälfte. Mit 132 Abbildungen. (IV u. S. 1-282) $M 8$.-

Die zweite, das Werk abschliefende Hälfte von Band II, 2. Abteilung wird im Sommer 1907 erscheinen.

„... Kraus gibt uns eine, Geschichte der christlichen Kunst', worin nur die Werke christlicher Meister ins Auge gefafit werden, aber auch unter diesen nur jene, welche religiös sind oder sein sollen, nicht also bürgerlicbe Baukunst, Ausstattung von Schlössern $u$. dgl. Überdies betont er die geschichtliche Ausbildung des Inhaltes der Kunstvorstellungen, die Einwirkung der gesellschaftlichen und literarischen Kultur auf die Kunsttätigkeit. Seine Ausführungen gründen sich, wie man dies bei allen seinen Arbeiten zu finden gewohnt ist, auf eine ausgedehnte, Staunen erregende Kenntnis der älteren und neueren Forschungen. Sie berücksichtigen mit Vorliebe alle jene Fragen, welche durch die so lebhaft geförderte Kunstforschung unserer. 'T'age in den Vordergrund geschrben und kïhn aufgestellt, mit Eifer verfochten und vorschnell angenommen oder auch rasch abgewiesen werden....

„Die Kritik hat von allen Seiten her sein Buch als eine hervorragende Leistung anerkannt. Auch Männer, welche dessen bekannte kirchenpolitischen Ansichten nicht teilen, haben freigebiges Lob ausgesprochen. Der geistreiche Bischof von Rottenburg nannte das Werk ,eine literarische Grofitat, auf welche das katholische Deutschland stolz sein darf, Professor Neumann einen mächtigen Bau, welcher, auf lange Zeit hin als das Hauptwerk (dieser Art) gelten wird", die "Studien aus dem Benediktiner- und Cistercienserorden", eine wissenschaftlicbe Leistung ersten Ranges'...." 




